Croyss Lessons ind Manual of Botany REVISD EDITON 


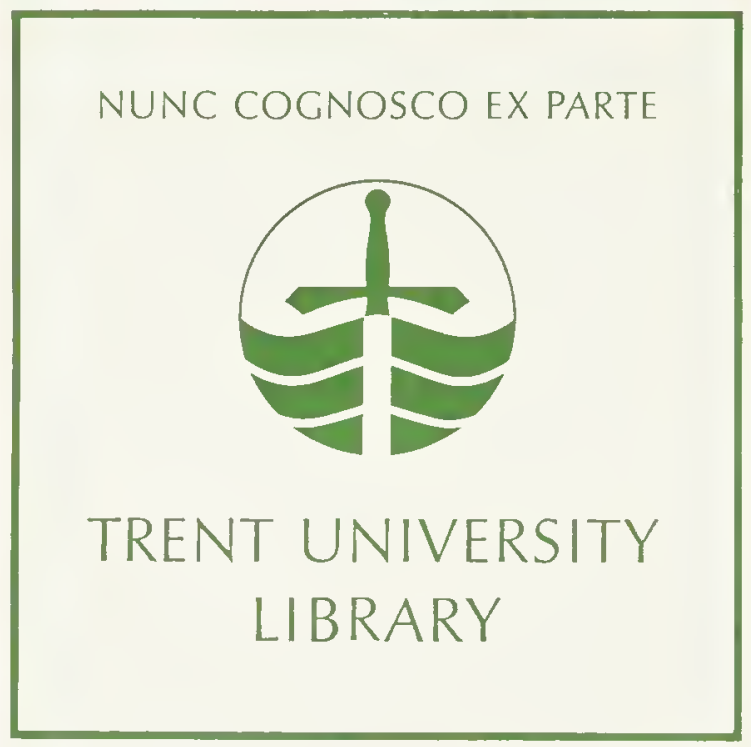

PRESENTED BY

Mrs. H.H. Graham 


Digitized by the Internet Archive in 2019 with funding from Kahle/Austin Foundation 



\title{
GRAY'S LESSONS IN BOTANY
}

\author{
REVISED EDITION
}

\section{THE}

\section{ELEMENTS OF BOTANY}

FOR BEGINNERS AND FOR SCHOOLS

\author{
BY ASA GRAY
}

NEW YORK $\cdot:$ CINCTNNATI $\cdot:$ CHIC $A_{A}$ 


\section{GRAY'S BOTANICAL SERIES}

Gray's How Plants Grow Gray's How Plants Behave

Gray's Lessons in Botany Gray's Field, Forest, and Garden Botany (Flora only)

Gray's School and Field Book of Botany (Lessons and Flora)

Gray's Manual of Botany. (Flora only)

Gray's Lessons and Manual of Botany Gray's Botanical Text-Book

I. Gray's Structural Bctany

II. Goodale's Physiological Botany

Coulter's Manual of Botany of the Rocky Mountains

Gray and Coulter's Text-Book of Western Botany

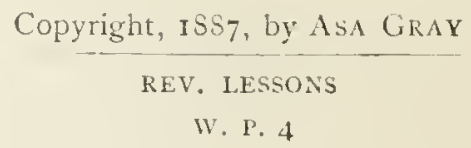




\section{PREFACE.}

\section{This volume takes the place of the author's Lessons IN Botany}

and Vegetable Physiologr, published over a quarter of a century ago. It is constructed on the same lines, and is a kind of new and much revised edition of that successiul work. While in some respects more extended, it is also more concise and terse than its predecessor. This should the better fit it for its purpose now that competent teachicrs are common. They may in many cases develop paragraphs into lectures, and fully illustrate points which are barely, but it is hoped clearly, stated. Indeed, cren for those without a teacher, it may be that a condensed is hetter than a diffuse exposition.

The book is adapted to the higher schools, "How Plants Grow and Behave" being the "Botany for Young People and Common Schools." It is intended to ground beginners in Structural Botany and the principles of vegetable life, mainly as concerns Flowering or Phanerogamous plants, with which botanical instruction should always begin; also to be a companion and interpreter to the Manuals and Floras by which the stucient threads his flowery way to a clear knowledge of the surrounding vegetable creation. Such a book, like a gramniar, must needs abound in technical words, which thus arrayed may seem formidable; neverthcless, if rightly apprehended, this treatisc should teach that the study of botany is not the learning of names and terms, but the acquisition of knowledge and ideas. No effort should be made to commit technical terms to mcmory. Any term used in describing a plant or explaining its structure can be lookcl up when it is wanted, and that should suffice. On the other hand, plans of 
structure, types, adaptations, and modifications, once understood, are not readily forgotten; and they give meaning and interest to the technieal terins used in explaining them.

In these "Elements" naturally no mention has been made of eertain terms and names which recent eryptogamieally-minded botanists, with laek of proportion and just perspeetive, are endeavoring to introduce into phanerogamous botany, and which are not needed nor appropriate, even in more advaneed works, for the adequatc recognition of the aseertained analogies and homologies.

As this volume will be the grammar and dictionary to more than one or two Manuals, Floras, ete., the particular direetions for procedure which were given in the "First Lessons" are now relegated to those works themsclves, which in their new editions will provide the requisite explanations. On the other hand, in view of sueh extended use, the Glossary at the end of this book has been considerably enlarged. It will be found to inelude not merely the common terms of botanical deseription but also many which are unusual or obsolete; yet any of them may now and then be encountered. Moreover, no small number of the Latin and Greek words whieh form the whole or part of the eommoner specific names are added to this Glossary, some in an Anglieized, others in thcir Latin form. This may be helpful to students with small Latin and less Greek, in eatehing the meaning of a botanieal name or term.

The illustrations in this volume are largely increased in number. They are mostly from the hand of Isaae Sprague.

It happens that the title ehosen for this book is that of the author's earliest publication, in the Jear 1836, of which copies are rarely seen; so that no ineonvenience is likely to arise from the present usc of the name.

ASA GRAY.

Cambridge, Massachusetts, March, 1887. 


\section{CONTENTS.}

\section{SEC TION I. INTRODUCTORY}

SECTION II. FLAX AS A PATTERN PLANT . . . . . 11

Growth from the Seed, Organs of Vegetation . . . . . . 11

Blossoming, Flower, \&c. . . . . . . . . . . . . 14

SECTION III. MORPHOLOGY OF SEEDLINGS . . . . . . 15

Germinating Maples . . . . . . . . . . . . 15

Cotyledons thickened, hypogæous in germination . . . . . 18

Store of Food external to the Embryo . . . . . . . . , 20

Cotyledons as to number . . . . . . . . . . . . . . 22

Dicotyledonous and Polycotyledonous . . . . . . . . 28

Monocotyledonous . . . . . . . . . . . . . . . 24

Simple-stemmed Plants . . . . . . . . . . . . 26

SECTION IV. GROWTH FROM BUDS; BRANCHING . . . 27

Buds, sitnation and kinds . . . . . . . . . . . . . 27

Vigorous vegetation from strong Buds . . . . . . . . 28

Arrangement of Branches . . . . . . . . . . . . . . 29

Non-developed, Latent, and Accessury Buds . . . . . . 30

Enumeration of kinds of Buls . . . . . . . . . . . . 31

Definite and Indefinite growth; Deliquescent and Excurrent . 31

SECTION V. ROOTS . . . . . . . . . . . 33

Primary and Secondary. Contrast between Stem and Root . 34

Fibrous and Fleshy lioots; names of kinds . . . . . . . 34

Anomalous Roots. Epiphytic and Parasitic Plants . . . 36

Duration: Annuals, Biennials, Perennials . . . . . . . 37

SECTION VI. STEMS . . . . . . . . . . . . . 38

Those alove Ground: kinis and modifications . . . . . . 39

Subterranean Stems and Branches . . . . . . . 42

Rootstock, 42. Tuher, 44. Corm, 45. Bulb and Bulblets . , 46

Consolidaterl Vegetation . . . . . . . . . . . . 47

SECTION VII, LEAVES. . . . . . . . . . . 49

$\S 1$. Leavits as Foliage . . . . . . . . . . . 49

Parts and Venation. . . . . . . . . . 50

Forms as to general ontline . . . . . . . . . . . 52

is to apex and narticular outline . . . . . . . . 53 
As to lobing or division . . . . . . . , 58

Compound, Perfoliate, and Equitant Leaves . . . . . . 57

With no distinction of Petiole and Blade, Phyllodia, \&c. . . . 61

§2. Leaves of Special Conformatron and Use . . . 62

Leaves for storage . . . . . . . . . . . . . . . 62

Leaves as bud-scales, 63 , Spines, 64 , and for Jlimbing . . 64

Pitchers, 64, and Fly-traps . . . . . . . . . . 65

6. Stipules ... . . . . . . 66

\$4. The Arrangement of Leates . . . . . . . . 67

Phyllotaxy, 67, of Alternate Leaves . . . . . . . . 69

Of Opposite and Whorled Leaves . . . . . . . . . . . 71

Venation or Præfoliation . . . . . . . . . 71

BECTION VIII. FLOWERS . . . . . . . . . . 72

\$ 1. Position and Arrangement, Inflorescence . . . . 73

Raceme, 73, Corymb, Umbel, Spike, Head . . . . . . 74

Spadix, Catkin, or Ament . . . . . . . . . . . 75

Panicle: Determinate Infloreseence . . . . . . . . . . 76

Cyme, Fascicle, Glomerule, Scorpioid or Helicoid Cymes . . 77

Mixed Inflorescence . . . . . . . . . . . . 78

§2. Parts or Organs of the Flower . . . . . . . 79

Floral Envelopes : Perianth, Calyx, Corolla . . . . . . 79

Essential Organs: Stamen, Pistil . . . . . . . . 80

Torus or Receptacle . . . . . . . . . . . . . . . 81

\$3. Plan of the Flower . . . . . . . . . . 81

When perfect, complete, regular, or symmetrical . . . . 81

Numerical Plan and Alternation of Organs . . . . . . . . 82

Flowers are altered branches . . . . . . . . 83

§4. Modifications of the Trpe . . . . . . . . . . 85

Unisexual or diclinous . . . . . . . . . . . . . . . 85

Incomplete, Irregular, and Unsymmetrical . . . . . 86

Flowers with Multiplication of Parts . . . . . . . . 88

Flowers with Union of Parts: Coalescence . . . . . 88

Regular Forms, 89, Irregular Forms . . . . . . . . 90

Papilionaceous, 91, Labiate, 92, and Ligulate Corollas. . . . 93

Adnation or Consolidation . . . . . . . . . . . . . 94

Position of Flower or of its Parts . . . . . . . . . . . 96

§5. Arrangement of Parta in tue Bud . . . . . . 87

Estivation or Præfloration, its kinds . . . . . . . . . . 87

SECTION IX, STAMENS IN PARTICULAR . . . . . . 98

Andrœcium, 98, Insertion, Relation, \&c. . . . . . . . . 99

Anther and Filament. Pollen. . . . . . . . 101

SECTION X. PISTILS IN PARTICULAR. . . . . . . 103

$\$ 1$ Angiospermods or Ordinary Gynecium . . . . 105

Parts of a complete Pistil . . . . . . . . . 105

Carpels. Simple Pistil . . . . . . . . . . 106 
Compound Pistil with Cells and Axile Placentæ . . . . $; 07$

fine-celled with Free Central Placenta . . . . . . . 108

One-celled with Parietal Placentæ . . . . . . . . 108

§ 2. Gyanospermous Graecium . . . . • • . . 109

SEC'TION XI. OVULES . . . . . . . . . . . . . 110

Their Parts, Insertion, and Kinds. . . . . . . . . 111

SECTION XII. MODIFICATIONS OF TIIE RECEPTACLE . . 112

Torus, Stipe, Carpophore, Disk . . . . . . . . . 113

SECTION XIII. FERTILIZATION . . . . . . . . . . 114

\$1. Adaptations for Pollination of the Stigma . . 114

Close and Cross Fertilization, Anemoplilous and Entomophilous 115

Dichogamy and Heterogony . . . . . . . . . . 116

§2. Action of the Pollen and Formation of the Embryo 117

SECTION XIV. THE FRUIT. . . . . . . . . 117

Nature and kinds . . . . . . . . . . 118

Berly, l’epo, l’ome. . . . . . . . . . . 119

Drupe and Akene . . . . . . . . . . . . 120

Cremocalp, Caryopsis, Nut . . . . . . . . . 121

Follicle, Legume, Capsulc . . . . . . . . . . . 122

Capsular Deliscence, Silique and Silicle . . . . . . 123

Pyxis, Strobile or Cone . . . . . . . . . . . 124

SECTION XV. THE SEED . . . . . . . . 125

Seed-coats and their appendages . . . . . . . . . 125

The Kernel or Nucleus, Embryo and its parts, Albumen . . 127

SECTION XVI. VEGETABLE LIFE AND WORK . • . 128

§1. Anatomical Structure and Growth •. •. . . 129

Nature of Growth, Protoplasm . . . . . . . . . 129

Cells and Cell-walls. Cellular Structure or Tissue . . . 130

Strengthening Cells. Wood, Wood-cells, Vesscls or Ducts . 132

§ 2. Cell-Contents . . . . . . . . . . . . 136

Sap, Chlorophyll, Starclı . . • . . . . . . 136

Crystals, Rliaphides . . . . . . . . . . 137

§3. Anatomy of Roots And Stems . • • • • . . 138

Findogenous and Exogenous Stems . . . . . . . . 139

Particular structure of the latter . . . . . . . . 140

Wood, Sapwood and Heart-wood. The living parts of a Tree 141

§4. Anatomy of Leaves . . . . . . . . . 142

Epidermis, Stomata or Breathing pores . . . . . . 143

§5. Plant Food and Assimllation . . . . . . . 144

§6. Plant Work and Mofedent . . . . . . . . 149

Movements in Cells or Cyclosis . . . . . . . . 149

Transference from Cell to Cell . . . . . . . . . 150 
Movements of Organs, Twining Stems, Leaf-movements , , 150

Movements of Tendrils, Sensitiveness . . . . . . . . 152

Movements in Flowers . . . . . . . . 153

Movements for capture of Inseets . . . . . . . . 154

Work costs, using up Material and Energy . . . . . • 155

, SECTION XVII. CRYPTOGAMOUS OR FLO WERLESS PLANTS 156

Vascular Cryptogams, Pteridophytes . . . . . . . 156

Horsetails (Equisetaceæ), Ferns . . . . . . . . . . 157

Club-Mosses (Lycoporlium), \&c. . . . . . . . . 161

Quillworts (Isoc̈tes), I'illworts (Marsilia) . • . . . . . 161

Azolla. Cellular Cryptogams . . . . . . . . . . 162

Bryophytes. Mosses (Musci) . . . . . . . . 163

Liverworts (IIepaticæ) . . . . . . . • . . . . 164

Thallophytes . . . . . . . . . . . . . . 165

Claracez . . . . . . . . . . . . . . 167

Algre, Scaweeds, \&c. . . . . . . . . . . . . . . 168

Lichenes or Lichens . . . . . . . . . . . . 171

Fungi . . . . . . . . . . . . . . 172

SECTION XVIII. CLASSIFICATION AND NONENCLATURE 175

§1. Kinds AND Relationship . . . . . . . . . 175

Species, Varieties, Individuals . . . . . . . . . 176

Genera, Orders, Classes, \&e. . . . . . . . . 177

\$2. Names, Terms, axd Characters . . . . . . . 178

Nomenclature of Genera, Species, and Varieties . . . . 179

Nomenclature of Orders, Classes, \&c. 'Terminology . • • . 180

§3. Srstem . . . . . . . . . . . . . . 181

Artificial and Natural . . . . . . . . . . . 182

Synopsis of Series, Classes, \&c. . . . . . . . . 183

SECTION XIX. BO'TANICAI, WORK • • . • • • • . 184

§1. Collection or llerborization . . . • • • • . 184

\$2. Herbarium . . . . . . . . . . . . . . . 186

\$3. Intestigation and Determination of Plants • • 187

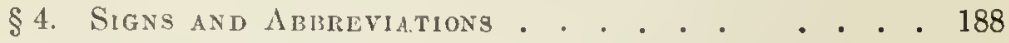

Abireviatioxs of the Namis of Botanists . . . . . . 190

Glossary combined with Index . . . . . . . . . . 108 


\section{ELEMENTS OF BOTANY.}

\section{Section I. INTRODUCTORY.}

1. Botany is the name of the science of the regetable kingdom in general; tlat is, of plants.

2. Plants may be studied as to their kinds and relationships. This study is Systematic Botany. An enumeration of the kinds of vegetahles, as far as known, classificd according to their various degrecs of resemblance or difference, constitutes a general System of plants. A similar account of the vegctables of any particular country or district is called a Flora.

3. Plants may be studied as to thcir structure and parts. This is Structural Botany, or Organograpiy. The study of the organs or parts of plants in regrird to the different forms and different uses which the same kind of organ may assumc, - the comparison, for instance, of a flower-lcaf or a bud-scale with a rommon leaf, - is Vegetable Morpiology, or Morpiogogical Botasy. The study of the minute stricture of the parts, to learn by the microscope what they themselves are formed of, is Vegetable Anatomy, or IIistology; in otlier words, it is Micioscopical Structural Botany. The sturly of the actions of plants or of their parts, of the ways in which a plant lires, grows, and acts, is the province of Piysiological Botany, or Vegetable Pirsiology.

4. Thlis book is to teacli the ontlines of Structural Botany and of the simpler parts of the physiology of plants, that it may be known how plants are constructed and adapted to their surromadings, and how they live, move, propagate, and have their being in an existence no less real, although more simplc, than that of the animal creation which they support. Particularly, this book is to teach the principles of the structure and relationships of plants, the nature and names of their parts and their modifications, and so to prepare for the study of Srstematic Botany; in which the learner may ascertain the name and the place in the system of any or all of the ordinary plants within reacli, whether wild or cultivated. And in ascertaining the mane of any plant, the student, if lightly tanght, will come to know all about its general or particular structure, rank, and relationship to other plants. 
5 The vegetable kingdom is so vast and various, and the difference is so wide between ordinary trees, shrubs, and herbs on the one hand, and mosscs, moulds, and such like on the other, that it is hardly possille to frame an intelligible account of p'ants as a whole without contradictions or misstatements, or endless and troublesome qualifications. If we say that plants come from seeds, bear flowers, and have roots, stems, and leaves, this is not true of the lower orders. It is best for the beginner, therefore, to treat of the higher orders of plants by themselves, without partieular refercuce to the lower.

6. Let it be understood, aceordingly, that there is a higher and a lower series of plants; namely:-

Pifaneroganous Plants, which come from secd and bear flowers, es. sentially stamens and pistils, through the co-operation of which seed is produced. For shortness, these are commonly called Phanerogams, or Phanogams, or by the equivalent English name of Flowering Plants.

Cryptoganous Plants, or Cryptogans, come from minnte bodies, which answer to seeds, but are of mueh simpler strueture, and suel plants have not stamens and pistils. Therefore they are called in English FLowerLess Plants. Such are Ferns, Mosses, Algæ or Seawceds, Fungi, etc. These sorts have eaeh to be stndied separately, for each class or order has a plan of its own.

7. But Phanerogamons, or Flowering, Plants are all constructed on one plan, or type. That is, taking almost any ordinary herb, shrub, or tree for a pattern, it will exemplify the whole series: the parts of one plant answer to the parts of any otlicr, with only certain differenees in particulars. And the occupation and the delight of the scientific botanist is in tracing out this comnon plan, in detecting the likenesses under all the diversities, and in noting the meaning of these manifold diversities. So the attentive study of any one plant, from its growth ont of the seed to the flowering and fruiting state and the produetion of seed like to that from whieh the plant grcw, would not only give a correct general idea of the structure, growth, and characteristics of Flowering Plants in general, but also scrve as a pattem or standard of comparison. Some plants will serre this purpose of a pattern mueh better than others. A proper patterm will be one that is perfect in the sense of having all the principal parts of a phanerogamons plant, and simple and regular in laving these parts free from complieations or disguises. The common Flax-plant may very well serve this purpose. Being an ammal, it has the advantage of bcing casily raiscd and carried in a short time through its circle of existence, from seedling to fruit and seed.

1 The riane is sometimes Phanerogamous, sometimes Phanogamous (Phanero. gams, or Phomigams), terms of the same meaning etymologically; the former of preferable form, but the latter shorter. The meaning of such terms is explained in the Glossurv 


\section{SEction II. FLAX AS A PATTERN PLANT.}

8. Growth from the Seed. Phanerogamous plants grow from seed, and their flowers are destincd to the production of seeds. A seed las a rudimcntary plant ready formed in it, - sometimes with the two most essential parts, i. c. stem and leaf, plainly discernible; sometimes with no obvious distinction of organs until gelmination begins. This incipient plant is called an EMbryo.

9. In this section the Flax-plant is taken as a speeimen, or type, and the development and history of common plants in gencral is illustrated by it. In flax-seed the embryo nearly fills the coats, but not quite. 'There is a small deposit of nourishment betrcen the secd-coat and the embryo: this may for the prescut be left out of the account. 'This embryo consists of a pair of leaves, pressed togetler face to face, and attached to an extremely short stem. (Fig. 2-4.) In this rudimentary condition the real nature of the parts is not at once apparent; but when the seed grows they promptly reveal their character, - as the accompanying figures (Fig. 5-7) show.

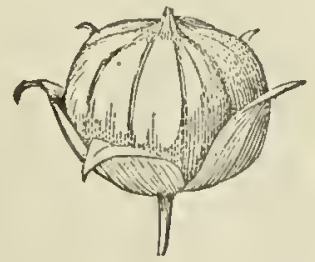

1

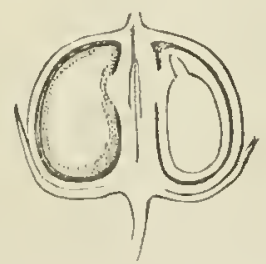

2

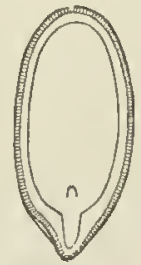

3

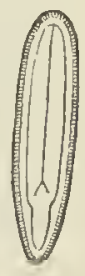

4

10. Before the nature of these parts in the seed was altogether understood, technical names were given to them, which are still in use. These intial leares were named Cotyurnons. The initial stem oil which they stand was called the RADICLE. That was because it gives rise to the first root; but, as it is really the begimning of the stem, and bceause it is the stem that produces the root and not the root that produces the stem, it is better to name it the Cauliche. Recently it has been named IIypocotyle; which signifies something below the cotyledons, without pronouncing what its nature is.

Fio. 1. Por of Flnx. 2. Section lengthwise, showing two of the seerls; one whole, the other cut half away, bringing contained embryo into view. 3. Similar seetion of a flax-seed nore magnified and diviled flatwise: tumed round, so that the stem-end (canlicle) of the enulngo is below: the whole broal upper part is the imer face of one of the cutylerlons; the minute niels at its lase is the plnnule. 4. Similar section through a sced turnel engewise, showing the thickness of the cotyledons, and the minute plumule between them, $\mathrm{i}$. e. the ninute bud on the upper end of the caulicte. 
11. On committing these seeds to moist and warm soil they soon sprout, 1. e. germinate. 'The very short stem-part of the embryo is the first to grow. It lengthens, protrudes its root-end; this turns downward, if not already pointing in that direction, and while it is lengthening a root forms at its point and grows downward into the ground. This root continues to grow on from its lower cnd, and thus insinuates itselt and penetrates into the soil. The stem meanwhile is adding to its length throughout; it erects itself, and, s.cking the light, brings the seed up out of the ground. The materials for this growth have been supplied by the eotyledo:s or seed-leaves, still in the seed: it was the store of nomishing material they held which gave them their thickish shape, so unlike that of ordinary leaves. Now, relieved of a part of this store of lood, which has formed the growth by which they have becn raised into the air and light, they appropriate the remainder to their own growth. In enlarging they open and throw off the seed-lusk; they expand, diverge into a horizontal position, turn green, and thus become a pair of evident lcaves, the first foliage of a tiny plant. This scedling, although diminutive and most simple, possesses and puts into use, all the Organs of Vegetation, namely, root, stem, and leaves, each in its proper element, - the root in the soil, the stem rising out of it, the leaves in the light and open air. It now draws in moisture and some

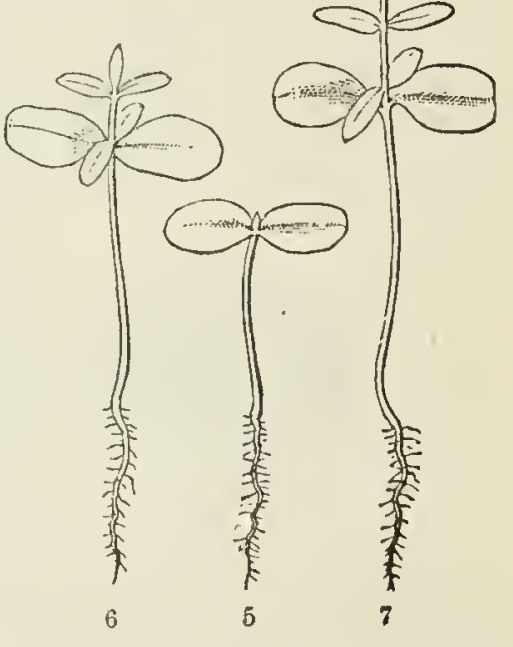
fond-materials from the soil by its root, conveys this through the stem into the leaves, where these materials, along with other crude food which these inbibe from the air, are assimilated into vegetable matter, i. e. into the inaterial for further growth.

12. Further Growth soon proeeeds to the formation of new parts, dowirward in the production of nore root, or of branehes of the main root, upward in the development of more stem and leaves. That from which a stem with its leaves is continued, or a new stem (i. e. braneh) originated, is a BUD. 'The most eorspicuous and familiar buds are those of most shrubs and trees, bearing buds formed in summer or autumn, to grow the following

FIa. 5. Farly Flax seedling; stem (canlicle), root at lower end, expanted seerlleaves (cotyledons) at the other: minute bul (plumule) hetween these. 6. Same later; the bud developer into second pair of leaves, with hardly any stem-part helow them; then into a thirl pair of leaves, raiserl on a short foint of stem; and a fiftl leaf also slowing. 7. Same still oliler, with more lenves rlevelopel, but these singly (one after another), and with joints of stem between thr.m 
spring. But every sucl point for new growth may equally bear the нame. When there is such a bud between the cotyleduis 112 the secd or scedlung it is ealled the PLumbe. 'T'his is eonspicuous enough in a bean (Figg. 29.), where the young leal ol the new grow h louks like a little plume, whenee the name, plumule. In flix-secu this is very minute indeed, but is discernible with a magnilier, and in the seedling it shows itself distinetly (Fig. 5, 6, i)

13. As it grows it slapes itseli iuto a secoud pair of leaves, which of course rests on a secoud joint, of stem, although in this instance that remains too sliort to be well seen. Upon its summit appears the third pair of leaves, soou to be raised upon its proper joint of stem; the next leaf is single, aud is carried up still futher upon its supporting joint of stem ; and so on. The root, meanwhile, continues to grow underground, not joint after joint, but continuously, from its lower end; and commonly it before long multiplies itself by branches, which lengthen by the same continuous growth. But stems are built up by a succession of leaf-bearing growths, such as are strongly marked in a reed or cornstalk, and less so in such an herb as Flax. The word "joint" is ambiguous: it may mean either the portion betwcen successive leaves, or their iunction, where the leares are attached. For precision, therefore, the place where the leaf or leaves are borne is called a Nops, and the naked interval between two nodes, an IxTERNODE.

14. In this way a simple stem with its garniture of leaves is de. veloped from the seed. But besides

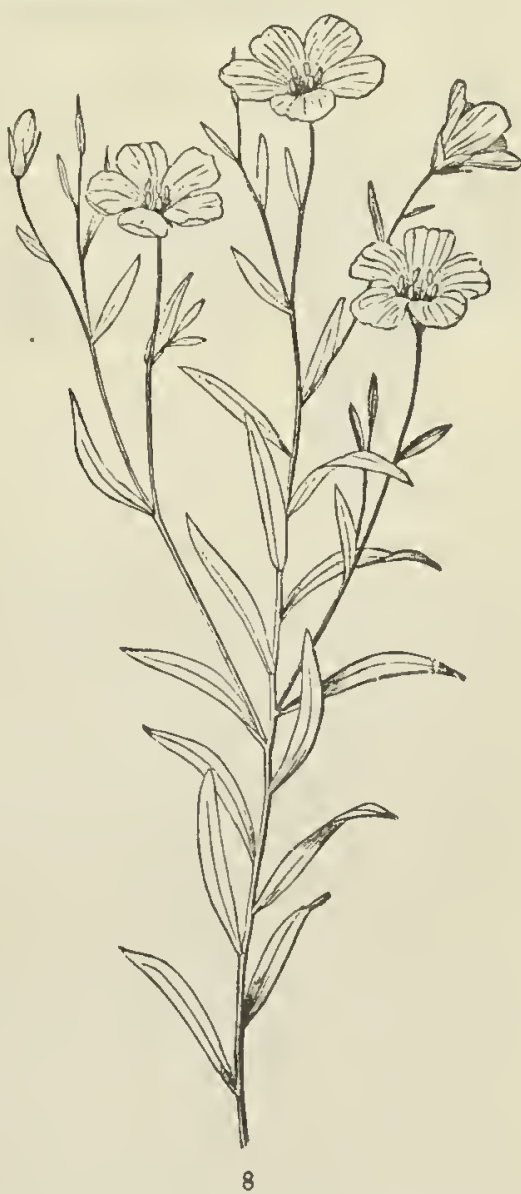

this direct enntinuation, buds may form and develop into lateral stems, that is, into branches, from any node. The proper origin of branches is liom the Axic of a leaf, i. e. the angle between leat and stem on the upper side; and branehes may again braneh, so building up the herb. shrub, or trec. But, sooner or later, and without long delay in an amnual like Flax, instead of this continuanee of mere regetation, reproduction is prepared for hy 
15. Blossoming. In Flax the flowers make their appearance at the end of the stem and branches. The growtl, which otherwise migbt continue them farther or indefinitely, now takes the form of blossom, and is subservient to the production of seed.

16. The Flower of Flax consists, first, of five small green leaves, crowded into a circle: this is the CALYX, or flower-cup. When its separate leaves are relerred to they are calied SePals, a name which distinguishes them from foliage-leaves on the one hand, and from petals on the otlier. Then some five delicate and colored leaves (in the Flax, blue), wlich form the Corolla, and its leaves are Petals; then a circle of organs, in
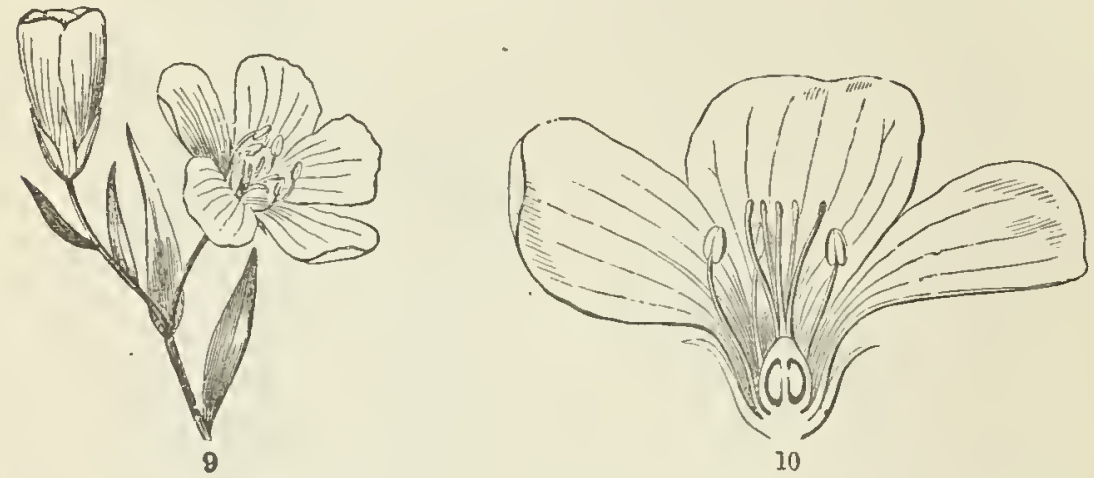

which all likeness to leaves is lost, consisting of slender stalks with a knob at summit, the Stamens; and lastly, in the centre, the rounded body, which hecomes a pod, surmounted by five slender or stalk-like bodies. This, all together, is the PIstiL. The lower part of it, which is to contain the seeds, is the Ovary; the slender organs surmounting this are STYLES; the knob borne on the apex of each style is a Stigua. Going back to the sta. mens, these are of two parts, viz. the stalk, called Filament, and the body it bears, the Axture. Anthers are filled with I'ollen, a powdery substance made up of minute grains.

17. The pollen shed from the anthers when they open falls upon or is conveyed to the stigmas; then the pollen-grains set up a kind of growtl (to be discerned only by aid of a good microscope), which penctrates the style: this growth takes the form of a thread more delicate than the finest spider's web, and reaches the bodics which are to become sceds (Orules they are called until this change oceurs): these, tonched by this influcnee, are incited to a new growth within, which beeomes an embryo. So, as the ovary ripens into the secd-pod or capsule (Fig. 1, ete.) containing seeds, each seed enclosing a rudimentary new plantlet, the round of this regetable existence is completed.

FIG. 8. Flax-flowers aljout natural size. 1n. Section of a flower moderately enlarged, showing a part of the petals and stamens, all five styles, and a section of ovary with two ovules or rudimentary seeds. 


\section{Section III. MORPHOLOGY OF SEEDLINGS.}

18. Having obtained a general idca of the growth and parts of a pha. nerogamous plant from the common Flax of the field, the seeds and seed. lings of other familiar plants may be taken up, and their variations from the assumed pattern examined.

19. Germinating Maples are cxcellent to begin with, the parts being so much larger than in Flax that a common magnifying glass, although convenient, is hardly necessary. The only disadvantage is that fresh seeds are not readily to be had at all seasons.

20. The sceds of Sugar Maple ripen at the end of summer, and germinate in early spring. The em. bryo fills the whole seed, in which it is nicely packed; and the nature of the parts is obvious even before growth begins. There is a stemlet (caulicle) and a pair of long and narrow seed-

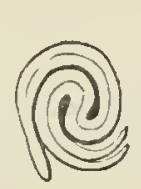

11

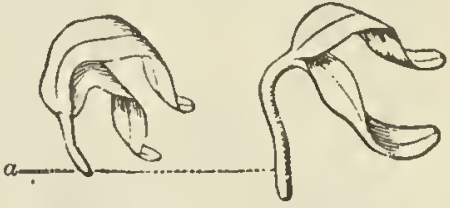

12

13 germination at once unfolding into the first pair of foliage-leaves, though of shape quite unlike those that follow.

21. Red Maple seeds are ripe and ready to germinate at the beginning of summer, and are therefore morc convenient for study. The cotyledons are crumpled in the seed, and not ensy to straighten out until they unfold themselves in germination. The story of thcir development into the seedling is told by the accompanying Fig. 14-20; and that of Sugar Maple is closely similar. No plumule or bud appcars in the enbryo of these two Maples until the secd-leavcs have nearly attained their full growth and are acting as follagc-leaves, and until a root is formed below. There is no great store of nourishment in these thin colyledons; so further growth has to wait until the root and secd-leaves have collected and elaborated sufficient ma. terial for the formation of the sccond internode and its pair of leaves, which lending their help the third pair is more promptly produced, and so on.

22. Some change in the plan comes with the Silver or Soft Whitc Maple. (Fig. 21-25). This blossoms in carliest spring, and it drops its large and ripened kcys only a few wceks later. Its cotyledons liave not at all the appearance of leares; they are short and broad, and (as there is no room to be saved by folding) they are straiglit, except a small fold at the top, a vestigc of the liabit of Maples in general. Their unusual thickness is due

Fig. 11. Embryo of Sugnr Maple, cut through lengthwise and taken out of the seed. 12, 13. Whole embryo of same just beginning to grow; $a$, the stemlet or caulicle, which in 13 has cousiderably lengthened. 
to the large store of nutritive matter they contain, and this prevents their developing into actual leaves. Correspondingly, thieir caulicle does not lengthen to elevate them abore the surfaee of the soil; the growth below the cotyledons is nearly all of root. It is the little plumule or bud between

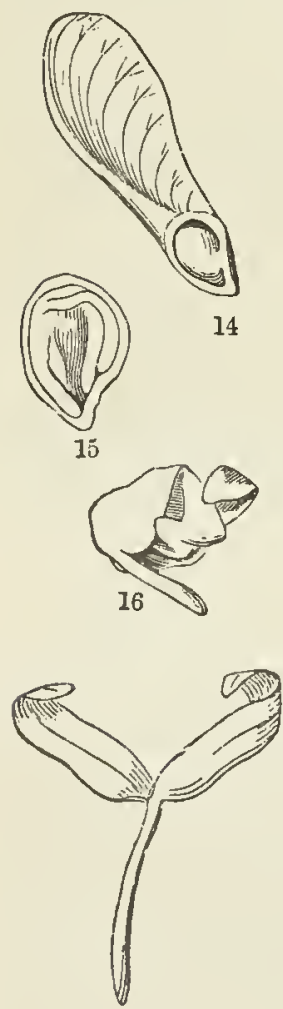

17

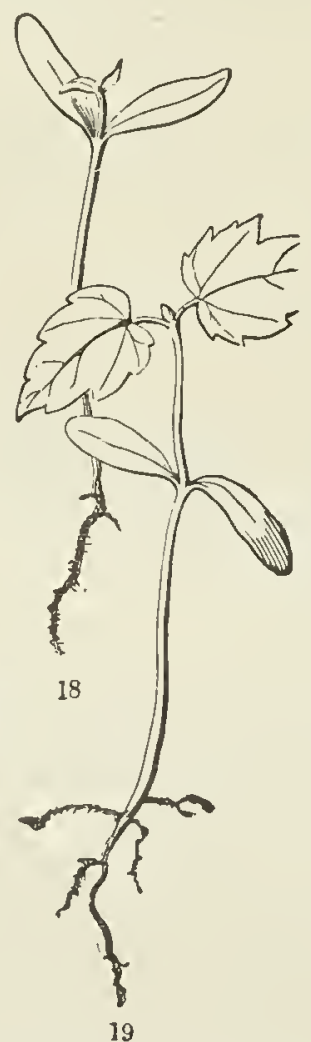

19

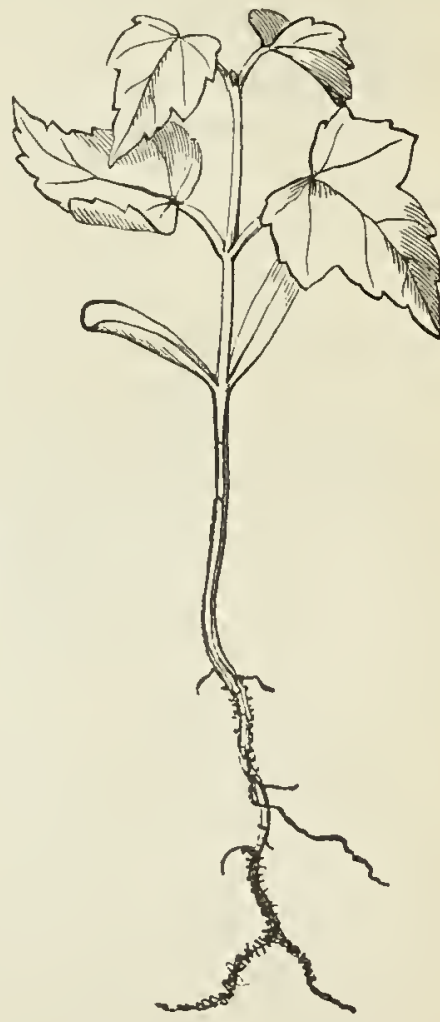

20

them which makes the upward growth, and which, being well fed by the cotyledons, rapidly develops the next pair of leares and ritises them upon a long internode, and so on. Thie cotyledons all the while remain below, in the husk of the fruit and seed, and perish when they have yielded up the store of food whieh they contained.

23. So, even in plants so much alike as Maples, there is considerable difference in the amount of food stored up in the cotyledons by which the growth is to be made; and there are corrcsponding differenees in the ger-

FIa. 14. One of the pair of keys or winged fruits of Red Maple; the seed-bear. ing portion cut open to show the seed. 15. Seed enlarged, and cliviled to show the crumpled embryo which fills it. 16. Embryo taken ont and partly opened. 17. Embryn which las unfohled in early stage of germination and begun to grow. 18. Seedling with next joint of stem and leaves apparent; and 19 with these parts full-growm, and bud at apex for further growth. 20. Seedling with another joint of stem and pair of leaves. 
mination. The larger the supply to draw upon, the stronger the growth: and the quicker the formation of root below and of stem and leaves above. This deposit of food thickens the cotyledons, and renders them less and less leaf-like in proportion to its amount.

24. Examples of Embryos with thickened Cotyledons. In the Pumpkin and Squash (Fig. $26,27)$, the cotyledons are well supplied with nourisling matter, as their sweet tastc demonstrates. Still, they are flat and not very thick. In germination this store is promptly utilized in the development of the cauliclc to twenty or thirty timer its length in the seed, and to corresponding thickness, in the formation of a cluster of roots at its lower end, and the early production of the incipient plumule; also in their own growth into efficient green leaves. The case of our common Be'nu (Phaseolus vulgaris, Fig. 28-30) is nearly the same, except that the cotyledons

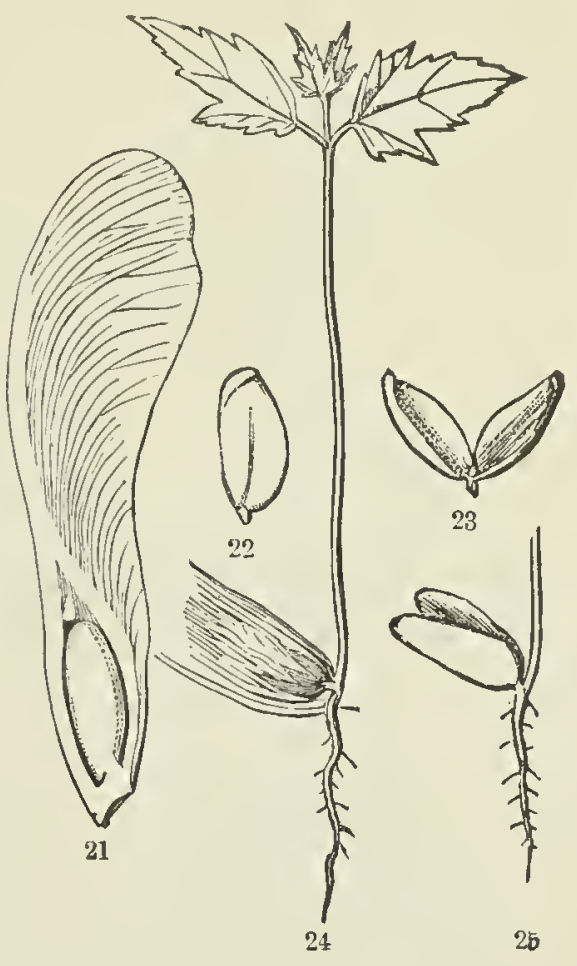
are much more gorged; so that, although carried up into the air and light upon the lengthening caulicle, and there acquiring a green color, they nevcr expand into useful leaves. Instead of this, they nourish into rapid growth the plumule, which is plainly visible in the seed, as a pair of incipient leaves; and these form the first actual foliage.

25. Very similar is the germination of the Beech (Fig. 31-33), except that the caulicle lengthens less, hardly raising the cotyledons out of the ground. Nothing would be gained by clevating them, as they never grow out into efficient leaves; but the joint of stem belonging to the plumule lengthens well, earrying up its pair of real foliage-leaves.

26. It is nearly the same in the Bean of the Old World (Vicia Faba, here called Horse Bean and Windsor Benn): the caulicle lengthens very little, does not undertake to elevate the heary secd, which is left below or

Fig. 21. Fruit (one key) of Silver Maple, Acer dasycarpum, of naturnl size, the seed-benring portion diviled to show the seed. 22. Embryo of the seed taken out. 23. Same opened out, to show the thick cotyledons and the little plumule or buil between them. 24. Gernination of Silver Maple, natural size; merely the base of the fruit, containing the seed, is shown. 25. Embryo of same, taken out of the husk; upper part of growing stem cut off, for want of ronm. 
upon the surface of the soil, the flat but thick cotyledons remaining in it, and supplying food for the growth of the root below and the plumule above. In its near relative, the Pea (Fig. 34, 35), this use of eotyledons
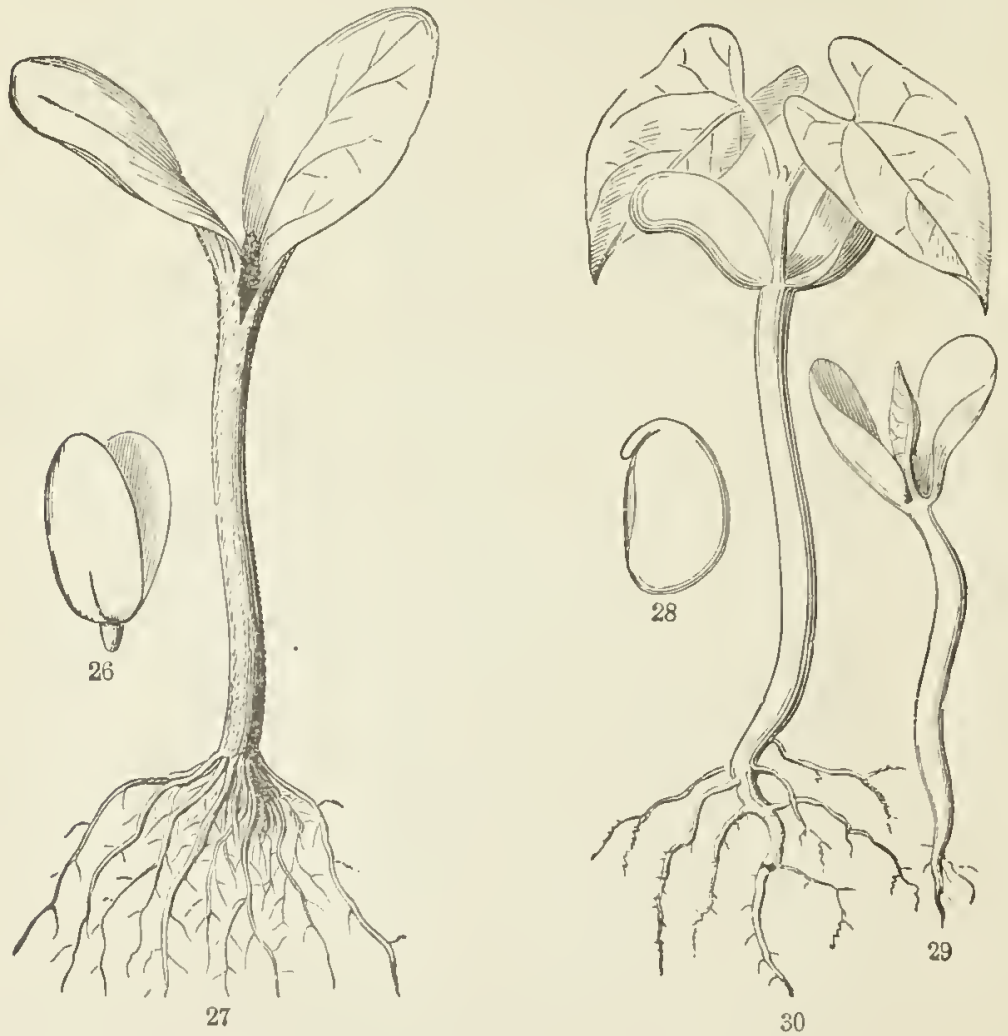

for storage only is most completely earried out. For they are thiekened to the utmost, even into hemispheres; the eauliele does not lengthen at all; merely sends out roots from the lower end, and develops its strong plumule from the upper, the seed remaining unmoved undergrouud. 'That is, in teelmieal language, the grermination is hypogrous.

27. There is suffeieut nourislment in the eotyledons of a pea to make a very considerable growth before any aetual foliage is required. So it is the stem-portion of the plumule whieh is at first eonspicuous and stronggrowing. Here, as scen in Fig. 35, its lotrer nodes bear eaeh a useless leaf-seale instead of an efficient leaf, and only the later ones bear leares fitted for foliage.

Fig. 26. Embryo of Pumpkin-sech. partly openet. 27. Tomug seciling of same.

Fig. 28. Embryo of (ommon [iean (['haseolus vulgaris): caulicle bent down over edge of cotyletons. 2y. Sime germinating : caulicle well lengthened and root beginning; thick cotyletons pratly sprenling; and plumule (pair of leaves) growing between them. 30. Same, older, with juluwule developed into internode and pair of leaves. 
28. This hypogcous germination is exemplified on a larger scale by the Oak (Fig. 36, 37) and IIorse-chestnut (Fig. 35, 39); but in these the dowuward growth is wholly a stout tap-root. It is not the cauliele; for

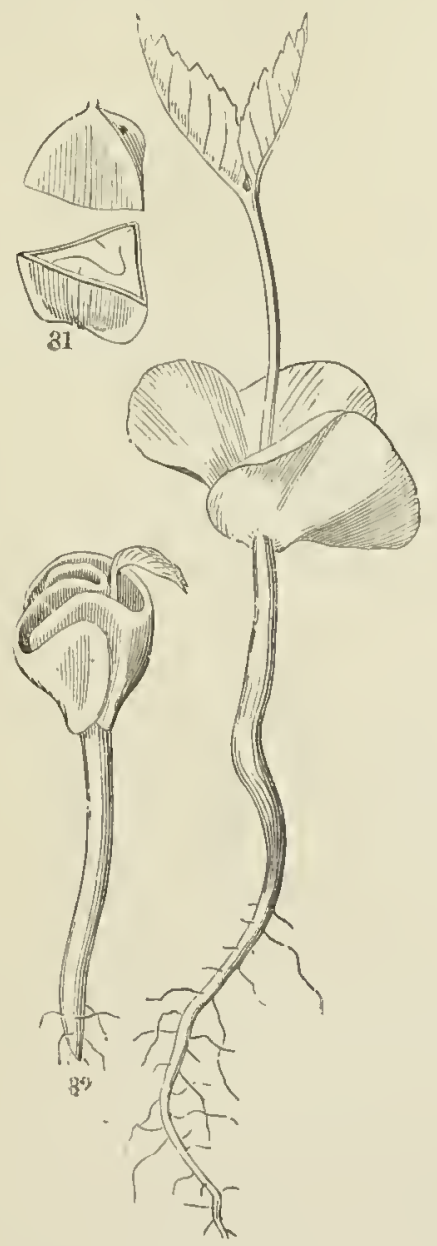

33

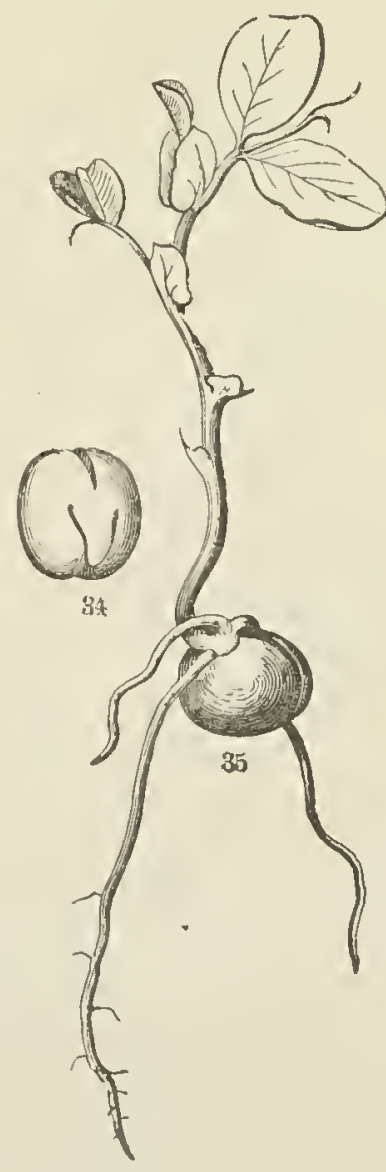

this lengthens hardly any. Indeed, the earliest growth whieh carries she very short eaulicle out of the shell comes from the formation of foot. stalks to the eotyledons; above these develops the strong plumule, below grows the stout root. The growth is at first entirely, for a long time

FIG. 31. A Bech-nut, cut across. 32. Beginning gemination of the Beech, slowing the plumule growing hefore the cotyleilons have opuned or the root has scareely formel. 33. 'The samc, a little later', with the flumule-leares developing, and a esvated on a long internoile.

Fis. 3t. Funhyo of Pea, i. e. a pea with the conts remover; the short and thick canlicle presenterl to view. 35. Same in alvancel gemnination: the plumule nus developed four or five internodes, bearing single leaves; but the first and sec. ond leaves are mere scales, the third hegins to serve as foliage; the next more so. 
mainly, at the expense of the great store of food in the cotyledons. These, after serving their purposc, decay and fall away.

29. Such thick cotyledons never separate; indeed, they sometimes grow together by some part of their contiguous faces; so that the germination

37
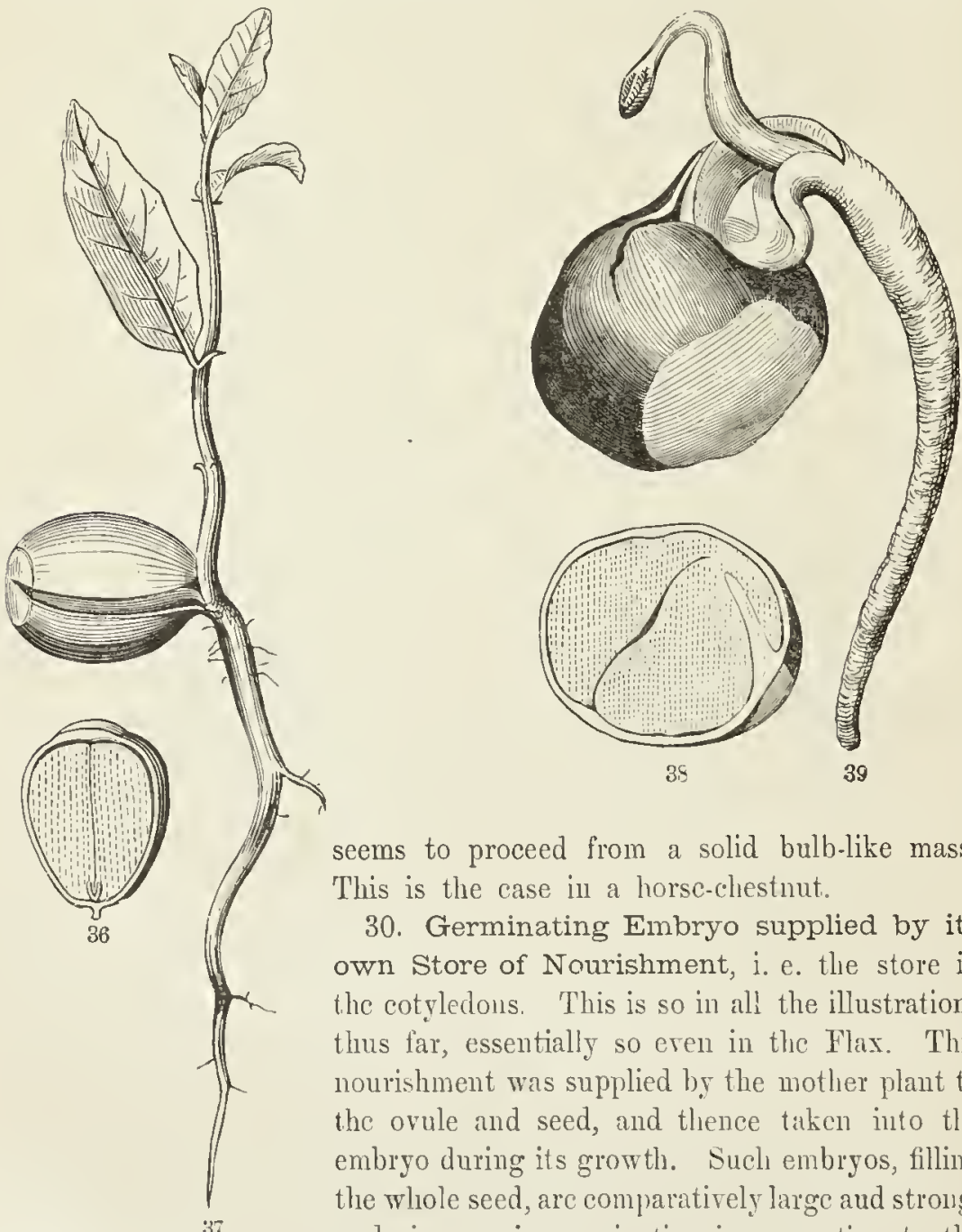

seems to proceed from a solid bulb-like mass. This is the case in a horse-chestnut.

30. Germinating Embryo supplied by its own Store of Nourishment, i. e. the store in the cotyledons. This is so in all the illustrations thus far, essentially so eren in the Flax. This nourishment was supplied by the mother plant to the ovule and seed, and thence taken into the embryo during its growth. Such embryos, filling the whole seed, arc comparatively large aud strong. and vigorous in germination in proportion to the amount of their growth while connected with the parent plant.

31. Germinating Embryo supplied from a Deposit outside of Itself. This is as common as the other mode; and it vccurs in all degrecs.

F1G. 36. Half of an acom, cnt lengthwise, filled by the very thick cotyledons, the base of which encloses the minute caulicle. 37. Oak-seenling.

Fra. 38. Half of a horse-chestunt, similarly cut; the caulicle is curved down on the side of one of the thick cotylerlons. 39. Horse-chestmut in germination; footstalks are formed to the cotylerlons, pushing out in their lengthening the growing parts. 
Some seeds have very little of this deposit, but a comparatively large embryo, with its parts more or less developed and recognizable. In others this deposit forms the main bulk of the seed, and the embryo is small or minute, and comparativcly rudimentary. The following illustrations exemplify these various grades. When an embryo in a seed is thus surrounded by a white substance, it was natural to liken the latter to the white of an egg, and the cmbryo or germ to the yolk. So the matter around or by the side of the embryo was called the Albumen, i. e. the white of the seed. The analogy is not very good; and to avoid ambiguity some botanists call it the ENDosperm. As that meaus in English merely the inwards of a sced, the new name is little better than the old one; and, since we do not change names in botany except when it cannot be avoided, this name of allumen is generally kept up. A seed with such a deposit is albuminous, one with none is exalbuminous.

32. The Albures forms the main bulk of the seed in whent, maize, rice, buckwheat, and the likc. It is the floury part of the seed. Also of the cocoa-nut, of coffee (where it is dense and hard), etc.; while in peas, bcans, almonds, and in most edible nuts, the store of food, although essentially the same in wature and in use, is in the embryo itself, and therefore is not counted as anything to be separately named. In both forms this concentrated food for the germinating plant is food also for man and for
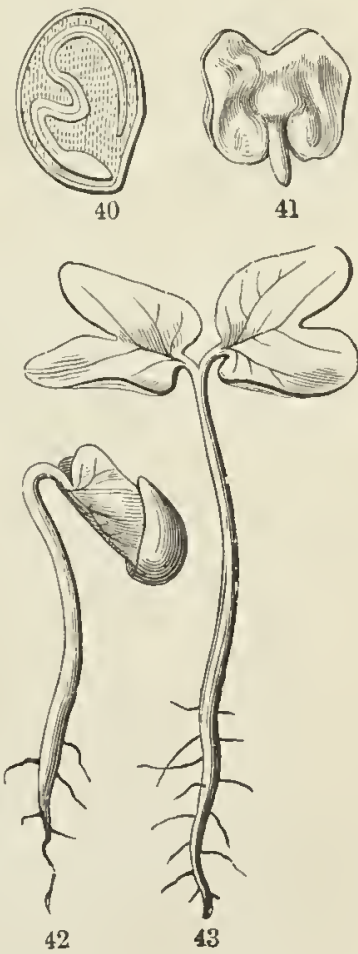
animals.

33. For an albuminous sced with a well-developed embryo, the common Morning Glory (lpomœa purpurea, Fig. 40-43) is a convenient example, being easy and prompt to grow, and having all the parts well apparent. The seeds (duly soaked for examination) and the grermination should be compared with those of Sugar and Red Maple (19-21). The only essential difference is that here the embryo is surrounded by and crumpled up in the albumen. This substance, which is pulpy or mucilaginous in fresh and young seeds, hardens as the seed ripcns, but becomes again pulpy in germination; and, as it liquifies, the thin cotyledons absorb it by their

FIG. 40. Seed of Morning Glory divided, moderately magnified; shows a longitudiual section through the eentre of the embryo as it lies crunpled in the albumen. 41. Embryo taken out whole aud unfolded; the broad and very thin cotyledons notched at summit; the canlicle below. 42. Early state of germinar ion. 43. Same, more advanced; caulicle or primary stem, cotyledous or seed'eaves, and below, the root, well developed. 
whole surface. It supplements the nutritive matter contained in the embryo. Both together form no large store, but suffieient for establishing the seedling, with tiny root, stem, and pair of leaves for initiating its independent growth; which in due time proceeds as in Fig. 44, 45.

34. Smaller embryos, iess developed in the seed, are more dependent upon the extraneous supply of food. The figures $46-53$ illustrate fou.
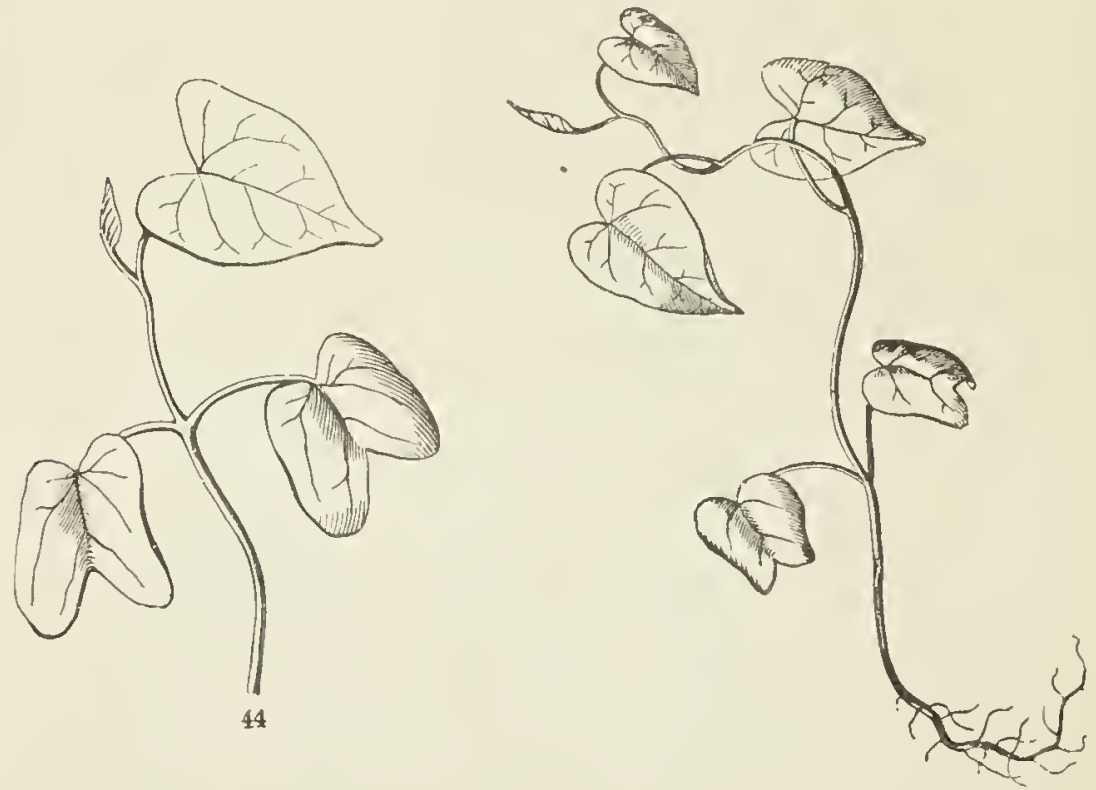

45

grades in this respect. The smallest, that of the Peony, is still large enough to be seen with a hand magnifying glass, and even its cotyledons may be discerned by the aid of a simple stage microscope.

35. The broad cotyledons of Mirabilis, or Four-o'clock (Fig. 52, 53), with the slender cauliele almost encircle and enclose the floury albumen, instead of being enclosed in it, as in the other illustrations. Evidently bere the germinating embryo is principally fed by one of the lcaf-like cotyledons, the other being out of contact with the supply. In the cmbryo of Abronia (Fig. 54,55), a near relative of Mirabilis, there is a singular modification; one cotyledon is almost wanting, being reduced to a rudiment, leaving it for the other to do the work. This leads to the question of the

36. Number of Cotyledons. In all the preeding illustrations, the embryo, however different in sliape and degree of derclopment, is evidently

Fia. 44. Seedling of Morning Glory more adranced (root cut away); cotyledons well cieveloperl into foliage-leaves: succeeding internode and leaf well developed, and the next forming. 45. Seedling more advanced; reduced to much below natural size. 
constructed upon one and the same plan, namely, that of two leaves on a cauliele or initial stem, - a plan whiel is obvious even when one cotyledon becomes very mueh smaller than the other, as in the rare instanee of Abro. nia (Fig. 54, 55). In other words, the embryos so far examined are all

37. Dicotyledonous, that is, two-cotyledoned. Plants whieh are thus similar in the plan of the embryo agree likewise in the seneral strueture of
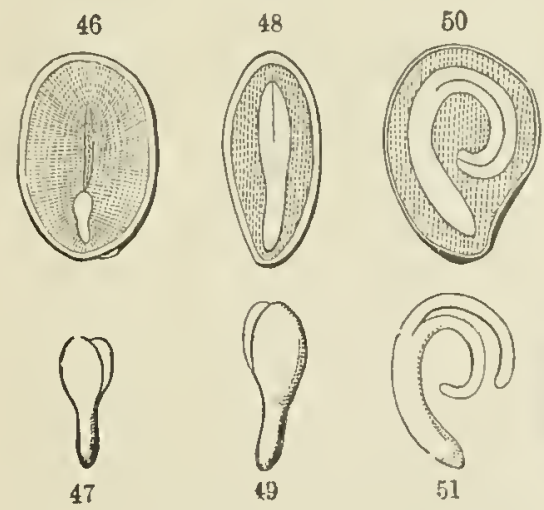

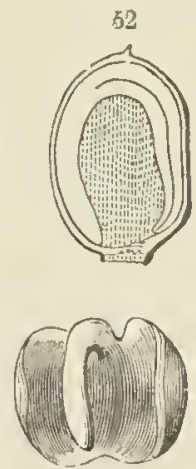

53

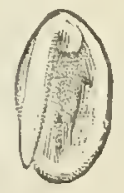

54

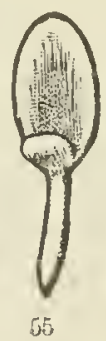

55

their stems, leaves, and blossoms; and thus form a class, named from their embryo Dicotyle dones, or in English, Dicotruedonous Plants. So long a name being ineonvenient, it may be shortened into Dicotyls.

39. Polycotylectonous is a name employed for the less usual ease in which there are more than two cotyledons. The Pine is the most familiar ease. This oeeurs in all Pines, the number of eotyledons varying from three to twelve; in Fig. 56, 57 they are six. Note that they are all on the same level, that is, belong to the same node, so as to form a eirele or whorl at the summit of the eauliele. When there are only thrce eotyledons, they divide the spaee equally, are one third of the eirele apart. When only two they are $180^{\circ}$ apart, that is, are opposite.

39. The ease of three or more eotyledons, whieh is eonstant in Pines and in some of their relatives (but not in all of them), is oecasional among Dieotyls. And the polyeotyledonous is only a variation of the dicotyledonous type, - a differenee in the number of leaves in the whorl; for a pair is a whorl reduced to two members. Some suppose that there are really only

FIG. 46. Sestion of a seed of a Peony, showing a very small embryo in the albumen, wear one ent. 47. This embryo detacherl, and more magnilied.

Fig. 48. Section of a seel of Barberry, showing the straiglat embryo in the middle of the albumen. 49. Its embryo detached.

F1G. 50. Section of a Potato-seed, showing the embryo coiled in the albumen. 51. Its embryo detached.

FIa. 52. Section of the seed of Mirabilis or Four-o'clock, sliowing the embryo coiled round the outsile of the albumen. 53. Embryo detached; showing the very broad and leaf-like cotyleslons, applierl face to face, and the pair incurved.

F1G. 54. Embryo of Abronia umbellata; one of the cotyledons very small 55. Same straightened out 
two cotyledons even in a Pine-embryo, but these divided or split up congenitally so as to imitate a greater number. But as leaves are often in whorls on ordinary stems, they may be si) at the very begimning.

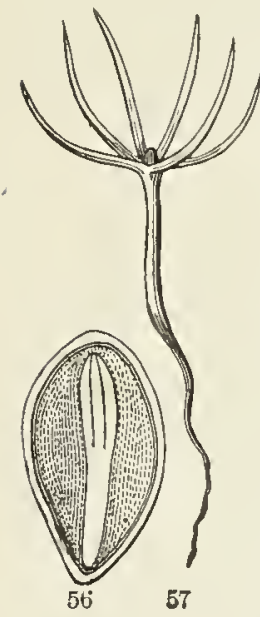

40. Monocotyledonous (meaning with single cotyledon) is the same of the one-cotyledoned sort of embry.). This goes along with peculiarities in sten, leaves, and flowers; which all together asso; iate snch plants into a great class, called Monocotyledonous Plants, or, for shortness, Момосотүls. It means merely that the leaves are alternate from the very first.

41. In Iris (Fig. 58, 59) the embryo in the seed is a small cylinder at one end of the mass of the alburnen, with no apparent distinction of parts. The end which almost touches the seert-coat is canlicle; the other end belongs to the solitary cotyledon. In germination the whole leugthens (but mainly the cotyledon) only enough to pnsh the proximate end fairly ont of the seed: from this end the root is formed; and from a little higher the plumnle later emerges. It would appear, therefore, that the cotyledon answers to a minute leaf rolled up, and that a chink through which the plumule grows out is a part of the in rolled edges. The embryo of Iudian Corn shors these parts on a larger scale and in a more open statc (Fig. 6663). There, in the seed, the cotyledon remains, imbibing nourishment from the softened albumen, and transmitting it to be growing loot below and new-forming leaves above.

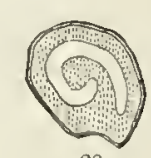

60

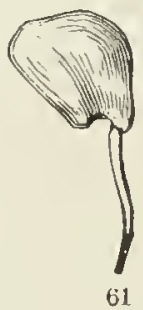

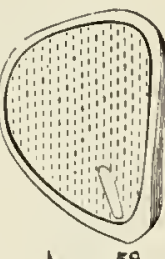

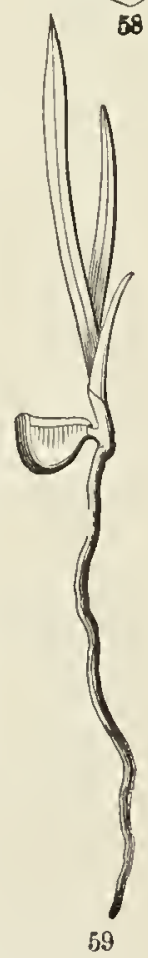

42. The general plan is the sime in the Onion (Fig. 60-65), but witn a striking difference. The embryo is long, and coiled in the albumen of the seed. To ordinary examination $i$, shows no distinction of parts. Bnt germination plainly shows that all except the lower end of it is cotyledon. For after it has lengthened into a long thread, the chink from which the

Fig. 56. Section of a Pine-seed, showing its polycotyledonons embryo in the centre of the albumen; moderately magnified. 57. Sectling of same, showing the freshly expanded six cotyledons in a whorl, anil the plumule just aypearing.

Fig. 58. Section of a seerl of thr Iris, or Flower-rle-Luce, enlarget, showing its small embryo in the albumen, near the bottom. 59. A germinating seerlling of the same, its plumule developed into the first four leaves (alternate), the first one mdimentary; the cotyledon remains in the seerl.

Fra. 60. Section of an Onion-seerl, showing the slenter and coiler embryo in the alhumen: mocterately magnified. 61. Seed of same in carly germination. 
plumule in time emerges is seen at the base, or near it; so the caulicle is
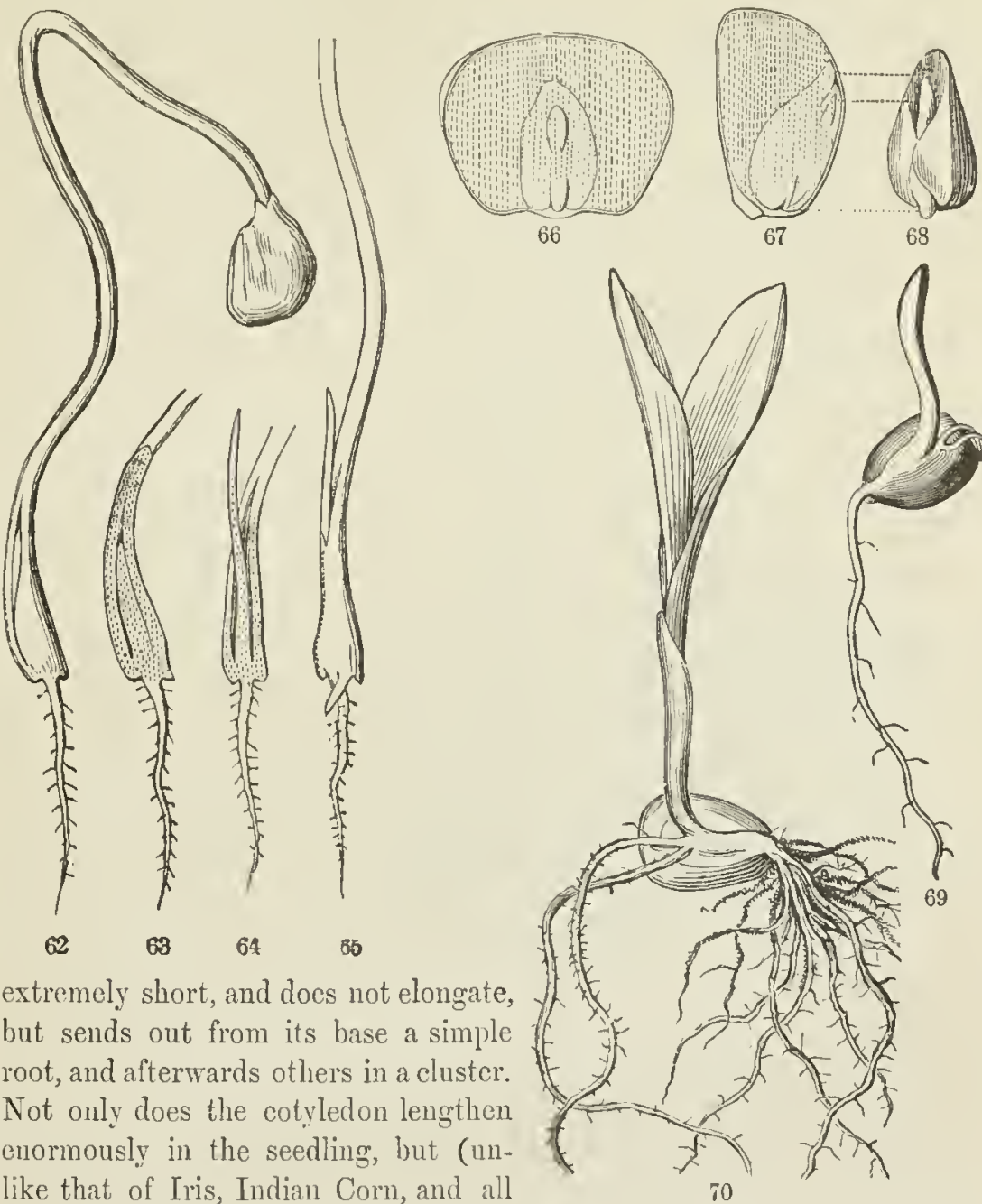

extremely short, and does not elongate, but sends out from its base a simple root, and afterwards others in a cluster. Not only does the cotyledon lengthen enormously in the seedling, but (unlike that of Iris, Indian Corn, and all

FIG. 62. Germinating Onion, more advanced; the chink at base of cotyledon opening for the protrusion of the plumule, consisting of a threal-shaped leaf. 63. Section of base of Fig. 62, showing plumule enclosed. 64. Section of same later; plumule emerging. 65. Later stage of 62; upper part cut off. 66. A grain of Indian Corn, flatwise, cut away a Iittle, so as to show the embryo, lying on the albumen, which makes the principal bulk of the seed. 67. A grain cut through the midale in the opposite direction, diviling the embryo through its thick cotyledon and its plumule, the latter consisting of two leaves, one enclosing the other. 68. The embryo, taken ont whole: the thick mass is the cotyledon; the narrow hody partly enclosed by it is the plumule; the little projection at its base is the rery short radicle enclosed in the sheathing hase of the first leaf of the plumule.

FIG. 69. Grain of Indian Corn in germination; the ascending sprout is the first leaf of the plumule, enclosing the younger leaves within; at its base the primary root has broken throngl. 70. The same, advanced; the second and third lenses developing, while the rienthing first leaf does not further develop 
the cereal grains) it raises the comparatively light seed into the air, the tip still remainiug in the secd and feeding upon the albumen. Whon this food is exhausted and tbe seedling is well es-

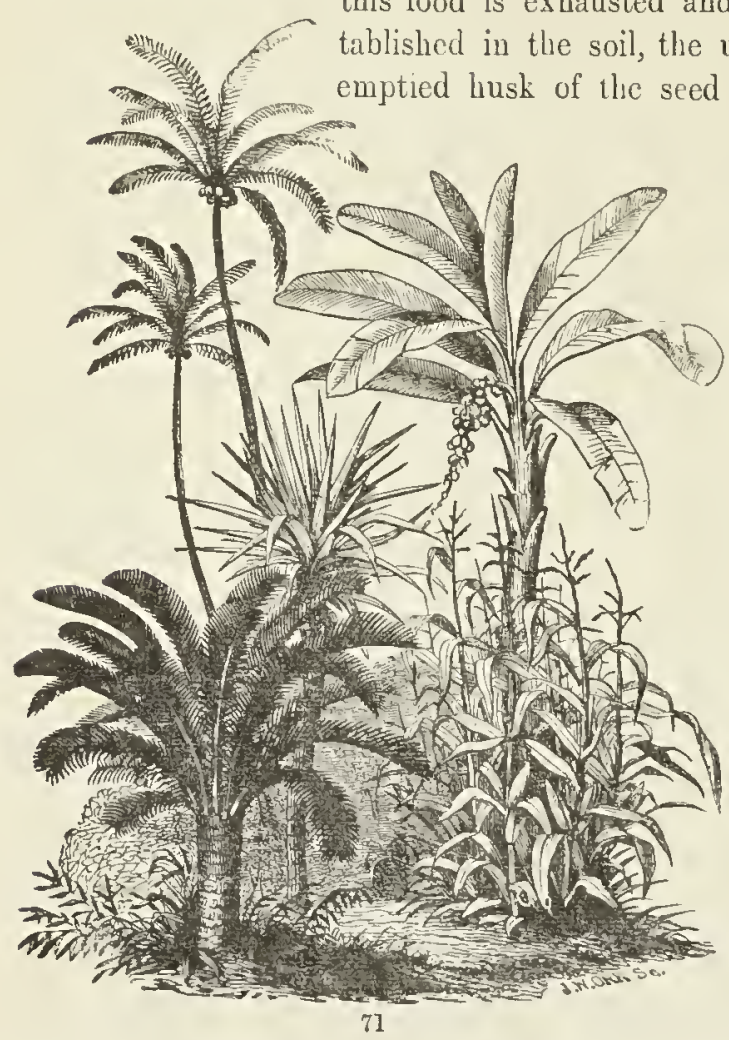

In Maize or In dian Corn (Fig. 66-70), the embryo is more de. veloped in the seed, and its parts can be made out. It lies against the starchy albumen, but is not enclosed thercin. The larger part of it is the cotyledon, thickish, its edges involute, and its back in contact with the albumen; partly enclosed by it is the well-devel. oped plumule or bud which is to grow. For the cotyledon rcmains in the seed to fulfil its office of imbibing nourishment from the softened albumen, which it convess to the growing sprout; the part of this sprout which is visible is the first leaf of the plumule rolled up into a sheath and enclosing the rudiments of the succeeding leaves, at the base enclosing even the minute cauliclc. In germination the first leaf of the plumule develops only as a sort of slieath, protecting the tender parts within; the second and the third form the first foliagc. The caulicle nerer lengthens: the first root, which is formed at its lower end, or from any part of it, has to break through the enclosing slieatl ; and succeeding roots soon spring from all or any of the nodes of the plumulc.

44. Simple-stemmed Plants are thus built up, by the continuous production of one leaf-bearing portion of stem from the summit of the preceding one, beginning with the initial stem (or caulicle) in the embryo. Some Dicotyls and many Monocotyls develop only in this single line of gromth (as to parts above ground) until the floweriug state is approached. For some examples, sec Cyeas (Fig. 71, front, at the left); a tall Yucea or Spanish Bayonet, and two Cocon-mut Palms behind; at the right, a group of Sugarcanes, and a Banana behint. 


\section{SEction IV. GROWTH FRON BUDS: BRANCHING.}

45. Most plants increase the amount of their vegetation by branching, thit is, by producing lateral shoots.

46. Roots branch from any part and usually without definite order. Stems normally give rise to branelies only at definite points, namely, at the nodes, and there only from the axils of leaves.

47. Buds (Fig. 72, 73). Every incipient shoot is a $B$ bod (12). A stem continues its growth by its terminal bud; it branches by the formation and devclopment of lateral buds. As normal lateral buds oecupy the axils of leaves, they are called axillary buds. As leaves are symmetrically arranged on the stcm, the buds in their axils and the branches into which axillary buds grow partake of this symmetry. The most conspieuous buds are the scaly winterbuds of most shrubs and trees of temperate and cold climates; but the name belongs as well to the forming shoot or branch of any herb.

48. The Terminal Bud, in the most general sense, may be said to exist in the cmbryo, - as cotyledons, or the cotyledons and plumule, - and to crown each sueecssive growth of the simple stem so long as the summit is eapable of growth The whole ascending growth of the Palın, Cycas, and the like (such as in Fig. 71) is from a terminal bud. Branches, being repetitions of the main stem and growing in the same way, are also lengthened by terminal buds. Those of Horsc-ehestnut, Hickory, Maples, and such trees, being the resting buds of winter, are conspicuous by their protective covering of scales. These bud-seales, as will hercafter be shown, are themselves a kind of leares.

49. Axillary Buds were formed on these annual shoots cally in the summer. Occasion-

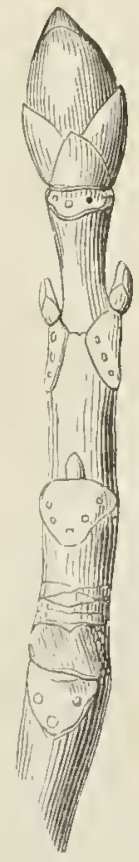

72

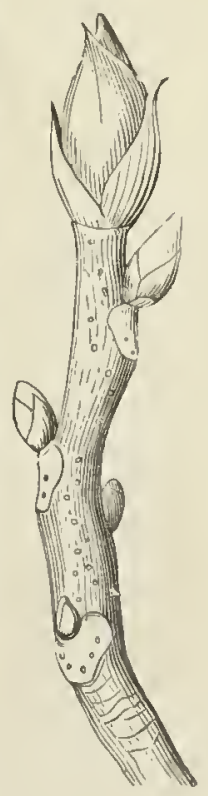

73 ally they grow the same season into branches; at least, some of them are pretty sure to do so whenever the growing terminial bud at the end of the shoot is injured or destroyed. Otherwise they may lie dormant until the following spring. In many trees or shrubs these axillary buds do not show themselves until spring; but if scarched for, they may be defected, though of small size, hidden under the bark. Somctimes, although early

Fia. 72. Shoot of Horse-chestnut, of one year's growtli, taken in autumn after the 'eaves have fallen; showing the large terminal bud and snsaller axillary buds.

Fra. 73. Similar shoot of Shagbark Hickory, Carya alba. 
formed, they are coneealed all summer long under the base of the leaf-stalk, which is then hollowed out into a sort of inverted cup, like a candle. extinguisher, to eover them; as irı the Locust, the Yellow-wood, or more strikingly in the Button-wood or Plane-tree (Fig. 74).

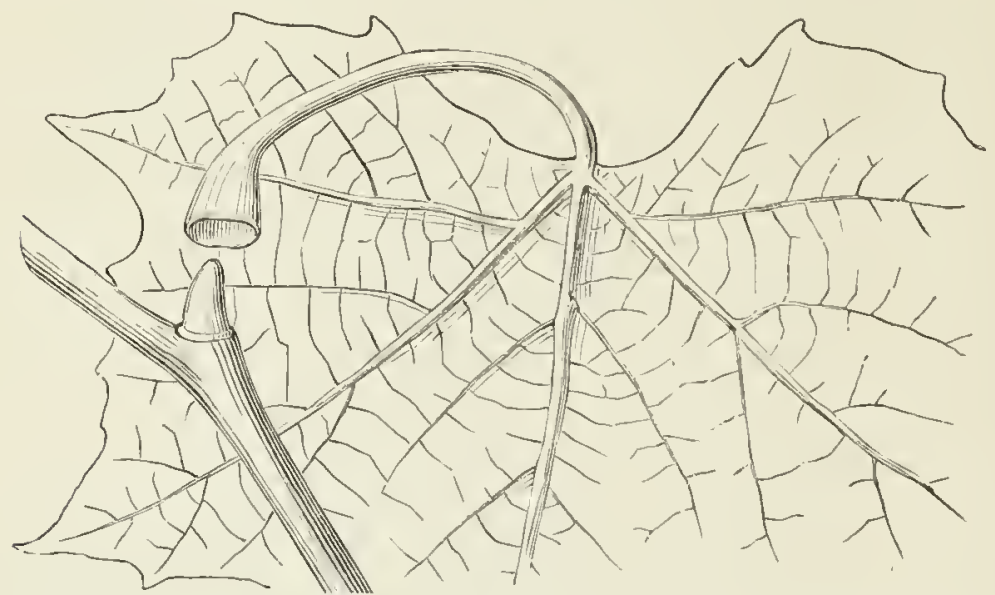

74

50. The leaf-scars, so conspieuous in Fig. 72, 73, under each axillary bud, mark the place where the staik of the subtending leaf was attached until it fell in autumn.

51. Scaly Buds, whieh are well represented in Fig. 72, 73, commonly belong to trees and shrubs of countries in whiel growth is suspended during winter. The scaly corerings protect the tender young parts beneath, not so much by keeping out the cold, which of course would penctratc the bud in time, as by shielding the interior from the effects of sudden elianges. There are all gradations between these and

52. Naked Buds, in whiel these scales are ineonspicuous or wanting, as in most herbs, at lcast above ground, and most tropieal trees and slurubs. But nearly related plants of the same climate may cliller widely in this respect. Rhododendrons have strong and sealy winter-buds; while in Kalmia they are naked. One speeies of Tiburnum, the Ilobblc-bush, has completely naked buds, what would be a pair of seales developing into the first leaves in spring; while another (the Snowhall) has eonspicuous scaly buds.

53. Vigor of Vegetation from strong buds. Large and strong luds, like those of the IIorsc-ehestnut, Hickory, and the likc, contrin screral leaves, or pairs of leaves, ready formed, folled and paeked away in small compass, just as the sced-leares of a slrong embryo are packed away in the seed: they may even contain all the blossoms of the ensuing season, plainly visible as small buds. And the stems upon which these buds rest are filled with abundant nourishment, which was deposited the summer before in the

Flg. 74. An axillary burl, coneealed under the kollowed base of the leafstalk. in Euttonwool or Plane-tree. 
wood or in the bark. Under the surface of the soil, or on it covered with the fallen leaves of autumu, similar strong buds of our perenuial lierbs may be found; while bencath are thick roots, rootstocks, or tinbers, cliarged with a great store of nourishment for their use. This explains how it is that vegetation from such buds shoots forth so vigorously in the spring of the year, and clothes the bare and lately frozen surfice of the soil, as well as the naked boughs of trees, very promptly with a coveriug of fresh green, and often with brilliant blossoms. Everything was prepared, and even formed, beforehand: the short joints of stem in the bnd have only to lengthen, and to scparate the leaves from each othcr so that they may nn. fold and grow. Only a small part of the vegetation of the season comes direetly trom the seed, and none of the earliest vernal vegetation. This is all from bnds which have lived through the winter.

54. The Arrangement of Branches, being that of axillar'y buds, anstwers to that of the leaves. Now leaves priucipally are either opposite or alternate. Leaves are opposite when there are two from the same joint of stem, as in Maples (Fig. 20), the two being on opposite sides of the stem; and so the axillary buds and branches are opposite, as in Fig. 75. Leaves are alternate when there is only onc from each joint of stem, as in the Oak, Lime. tree, Poplar, Button-wood (Fig. 74), Morning-Glory (Fig. 45, - uot counting the seed-leaves, which of course are opposite, there being a pair of them); also in [ndian Corn (Fig. 70), and Iris (Fig. 59). Consequently the axillary bnds are also alternate, as in Hickory (Fig. 73); and the branches they form alternate, - making a different kind of spray from the other mode, one branch shooting on one side of the stem and the next on some other. For in the alternate arrangement no leaf is on the same side of the stem as the one next above or next below it.

55. But the symmetry of branches (unlike that of the leaves) is rarely complete. This is due to sereral causcs, and most commonly to the

56. Non-development of buds. It never happens that all the buds grow. If they did, there might be as many branches in any year as there were lcaves the year before. And of those which do begin to grow, a arge portion perish, sooner or later, for want of nourishment, or for waut of light, or because those which first begin to grow have an advantage, which they arc apt to keep, taking to thenselves the nourishment of the stcm, and starviug the weaker buds. In the Horsc-elestnut (Fig. 72), Hickory (Fig. 73), Magnolia, and most other trees with large scaly buds, the terminal bud is the strongest, and lias the advantage in growth; and next in strength are the upper axillary buds: while the former continues the shoot of the last year, some of the latter give risc to branches, and the rest fail to grow. In the Lilac also (Fig. 75), the uppcrmost axillary buds are stronger than the lower; but the terminal bud rarely appears at all; 111 its place the uppermost pair of axillary buds grow, and so each stem branches every year into two, - making a repeatedly two-forked ramification, as in Fig. 76 . 
57. Latent Buds. Axillary buds that do not grow at the proper season and especially those which make no appearance externally, may long remain latent, aud at length upon a favorable occasion start iuto growth, so form-

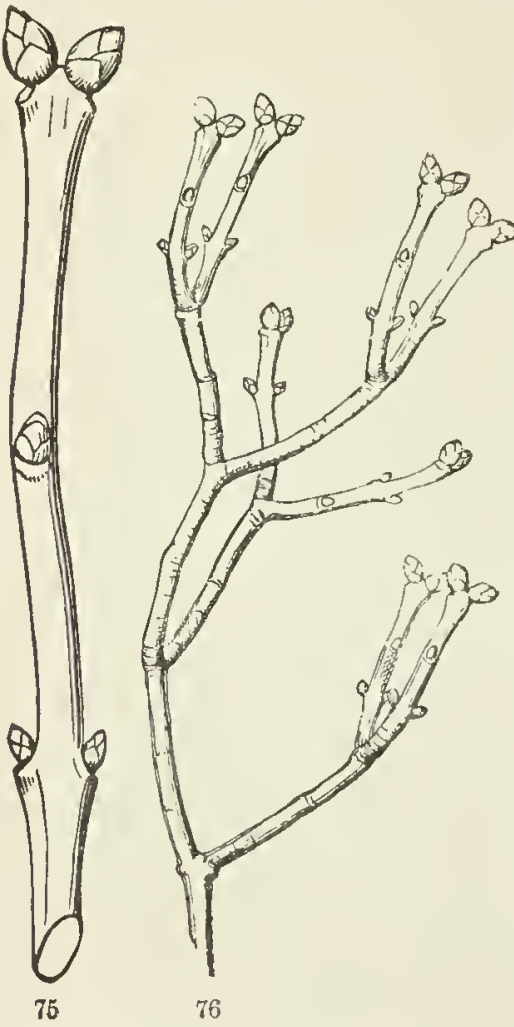
ing branches apparently out of place as they are out of time. The new shoots seen springing directly out of large stems uay sometimes orig. inate from such latent buds, whick have preserved their life for years. But commonly these arise from

58. Adventitious Buds. These are buds which certain shrubs and trees produce auywhere on the sur. face of the wood, especially where it has been injured. They give rise to the slcuder twigs which often featue: the sides of great branches of our Americau Elms. They sometimes form on the root, which uaturally is destitute of buds; they are even fouud upon some leaves; and they are sure to appear on the trunks and roots of Willows, Poplars, and Chestnuts, when these are wounded or mutilated. Indeed Osier-Willows are pollarded, or cut off, from time to time, by the cultivator, for the purpose of producing a crop of slender adventitious twigs, suitable for basket-work. Such branches, being altogether irregular, of course interfere with the natural symmetry of the tree. Another cause of irregularity, in certain trees and slirubs, is the formation of what are called

59. Accessory or Supernumerary Buds. 'There are cases where two, thrce, or more buds spring from the axil of a leaf, instead of the single ouc which is ordinarily found there. Sometimes they are placed one over the other, as in the Aris-

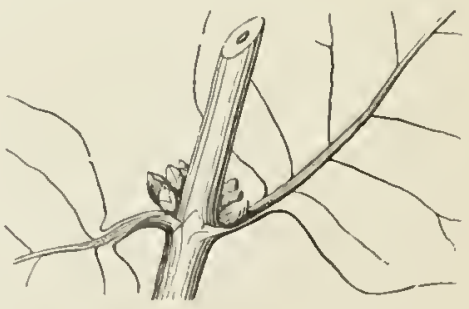

77 tolochia or Pipe-Vine, and in the Tartarean Honeysuckle (Fig. 77); also in the Honey-Locust, and in the Walnut and Butternut (Fig. 78), where

FIa. 75. Shoot of Lilac, with winter buds; the two uppermost axillary ones strong; the terminal not developed. 76. Forking ramification of Lilac; reduced in size.

FIa. 77. Tartarean Honeysuckle, with three accessory buds in each axil. 
the upper supernumerary bud is a good way out of the axil and above the others. And this is here stronger than the others, and grows into a branch which is considerably out of the axil, while the lower and smaller ones commonly do not grow at all. In other cases three buds stand side by side in the axil, as in the Hawthorn, and the Red Maple (Fig. 79.) If these were all to grow into brauches, they would stifle each other. But some of them are commonly flower-buds : in the Red Maple, only the middle one is a leaf-bud, and it does not grow until after those on cach side of it liave expanded the blossoms they contain.

60. Sorts of Buds. It may be useful to enumerate the kinds of buds which have been deseribed or unentioned. Thicy are

Terminal, when they occupy the summit of (or terminate) a stem,

Lateral, when they are borne on the side of a stem; of which the regular kind is the

Axillary, situated in the axil of a leaf. These are

Accessory or Supernumerary, when they are in addition to the normal solitary bud; and these are Collateral, when side by side; Superposed, when one abore another;

Extra-axillary, when they appear above the axil, as some do when superposed, and as oceasionally is the case when single.

Naked buds; those which have no protecting seales. Scaly buds; those which have protecting scales, which are altered leaves or bases of leaves.

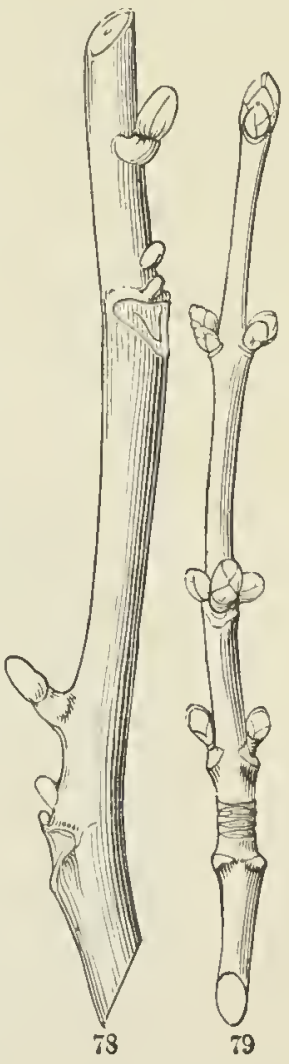

Leaf-buds, contain or give rise to leaves, and develop into a leafy shoot.

Flower-buds, contain or consist of blossoms, and no leaves.

Mixed buds, contain both leaves and blossoms.

61. Definite annual Growth from winter buds is marked in most of the shoots from strong buds, sueli as those of the Horse-ehestnut and Hickory (Fig. 72, 73). Such a bud generally contains, already formed in miniature, all or a great part of the leaves and joints of stem it is to produee, makes its whole growth in length in the course of a few weeks, or sometimes even in a ferv days, and ther forms and ripens its buds for the next year's similar' growtl.

62. Indefinite annual Growth, on the other hand, is well marked in such trees or shrubs as the IIoncy-Loeust, Sumac, and in sterile shoots of

Fig. 78. Butternut branch, with accessory burls, the uppernost above the axil.

FIg. 79. Reil-1Iaple branch, with aceessory buls placed side by sile. The annular lines toward the base in this and in Fig. 72 are scars of the bud-seales, and indicate the place of the winter-bud of the preceding year. 
the Rose, Blackberry, and Raspberry. That is, these shoots are apt to grow all summer long, until stopped by the frosts of autumn or some other cause. Consequently they form and ripen no terminal bud protected by scales, and the upper axillary buds are produced so late in the season that they have no time to matnre, nor has their wood time to solidify and ripen. Such stems therefore commonly die back from the top in winter, or at least all their upper bnds are small and feeble; so the growth of the succeeding year takes place mainly from the lower axillary buds, which are more mature.

63. Deliquescent and Excurrent Growth. In the former case, and wherever axillary buds take the lead, there is, of course, no single main stem, continued year after year in a direct line, but the trunk is soon lost

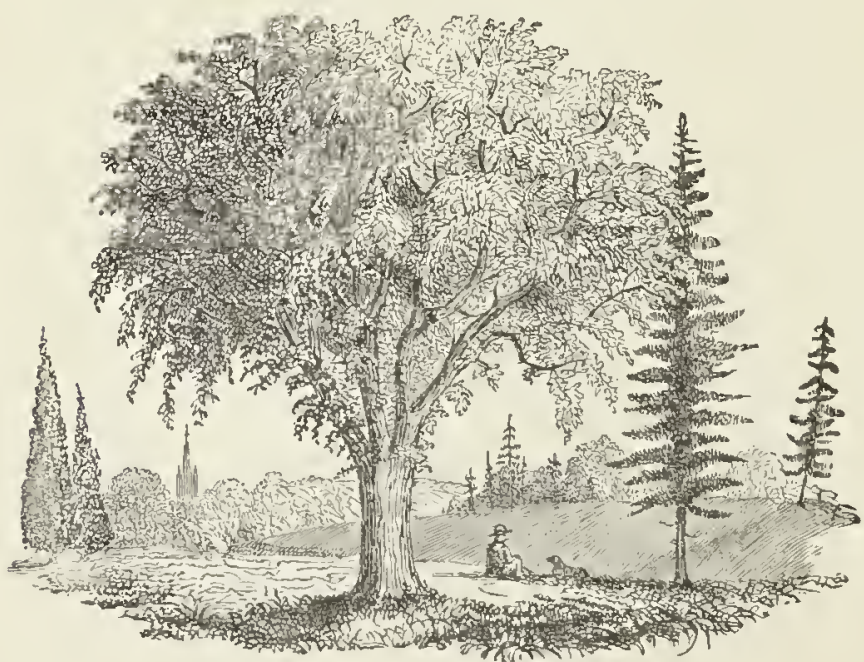

80

in the branches. Trees so formed commonly have rounded or spreading tops. Of such trees with deliquescent stems, - that is, with the trunk dissolved, as it were, into the suecessively divided branches, - the common American Elm (Fig. 80) is a good illustration.

64. On the other hand, the main stem of Firs and Spruces, unless destroyed by some injury, is carricd on in a direct hine throughout the whole growtl of the tree, by the development year after year of a terminal bud: this forms a single, unintermpted shaft, - an excurrent trunk, which cannot be confonnded with the branches that procecd from it. Of such spiry or spire-shaped trees, the Firs or Spruces are characteristic and finmiliar examples There are all gradations between the two modes.

Fig. 80. An American Elm, with Spruce-trees, and on the left Arbor Vitæ. 


\section{Bection V. ROOTS.}

65. It is a property of stems to produce roots. Stems do not spring from roois in ordinary cases, as is generally thought, but roots from stems. When perennial herbs arise from the ground, as they do at spring-time, they rise from subterranean steus.

60. The Primary Root is a downward growth from the root-end of the eaulicle, that is, of the initial stem of the embryo (Fig. 5-7, 81). If it goes on to grow it makes a main or tap-root, as in Fig. 37, etc. Some plants keep this main root throughout their whole life, and send off only small side branches; as in the Carrot and Radish : and in various trees, like the Oak, it takes the lead of the side-branches for several years, unless accidentally injured, as a strong taproot. But commonly the main root divides off very soon, and is lost in the branches. Multiple primary roots now and then occur, as in the seedling of Pumpkin (Fig. 27), wherc a cluster is formed even at the first, from the root-end of the caulicle.

67. Secondary Roots are those which arisc from other parts of the stem. Any part of the stem may

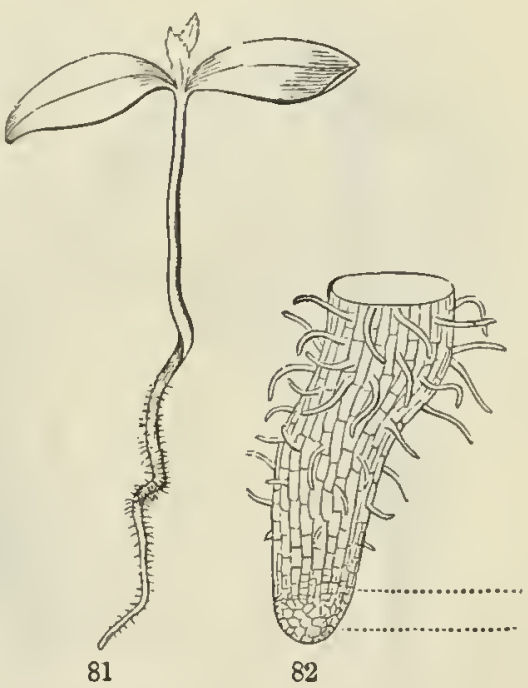
produce them, but they most readily come from the nodes. As a general rule they naturally spring, or may be inade to spring, from almost any young stem, when placed in favorable circumstances, - that is, when placed in the soil, or otherwise supplied with moisture and screened from the light. For the special tendency of the root is to aroid the light, seek moisture, and therefore to bnry itself in the soil. Propagation by division, which is so common and so very important in cultivation, depends upon the proclivity of stems to strike root. Stems or branches which remain under ground give out roots as freely as roots themselves give off branches. Stems which creep on the ground most commonly root at the joints; so will most branclies when bent to the ground, as in propagation by layer. ing; and propagation by cuttings equally depends upon the tendency of the cut cnd of a shoot to produce roots. Thus, a piecc of a plant which has stem and leaves, either developed or in the bud, may be made to produce roots, and so become an independent plant.

Fin. 81. Seelling Maple, of the natural size; the root well supplied with root-hairs, here large enough to be seen by the naked cye. 82. Lower ent of this root, magni. fied, the root scen just as root-hairs are beginning to form a little behind the tip. 
68. Contrast between Stem and Root. Stems are aseending axes; roots are deseending axes. Stems grow by the suceessive development of
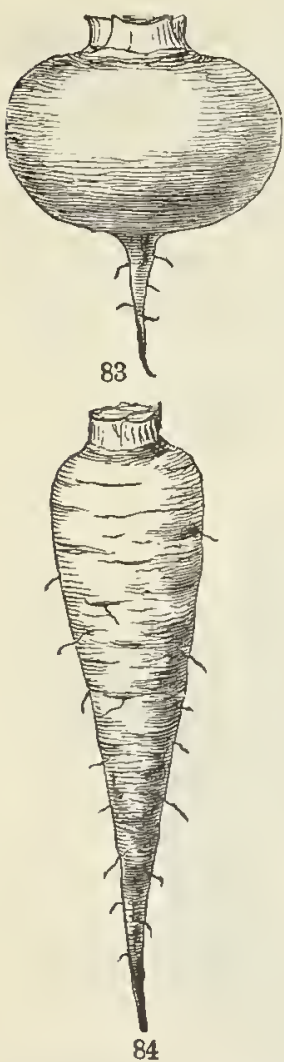
internodes (13), one after another, each leaf-bearing at its summit (or node); so that it is of the essential nature of a sten to bear leaves. Roots bear 10 leaves, are not distinguisluable into nodes and internodes, but grow on eontinuously from the lower end. They eommonly braneh freely, but not from any fixed points nor in definite order.

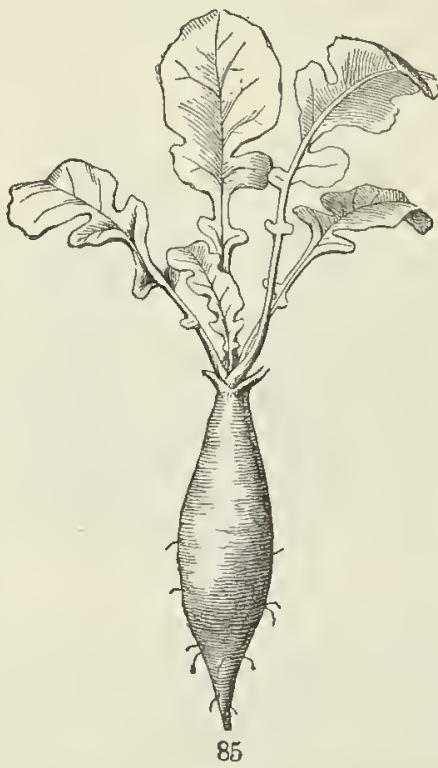

69. Although roots generally do not give rise to stems, and therefore do not propagate the plant, exeeptions are not uneommon. For as stems may produee adveutitious buds, so also may roots. The roots of the Sweet Potato among herbs, and of the Osage Orange among trees freely produee adventitious buds, developing into leafy shoots; and so these plants are propagated by root-cuttings. But most growths of subterranean origin whieh pass for roots are forms of stems, the common Potato for example.

70. Roots of ordinary kinds and uses may be roughly elassed into fibrous and fleshy.

71. Fibrous Roots, sueh as those of Indian Corn (Fig. 70), of most annuals, and of many perennials, serve only for absorption: these are slender or thread-like. Fine roots of this kind, and the fine branehes whieh most roots send out are ealled RooTLETs.

72. The whole surfaee of a root absorbs moisture from the soil while fresh and new; and the newer roots and rootlets are, the more freely do they imbibe. Aeeordingly, as long as the plant grows above ground, and expands fresh foliage, from whieh moisture largely eseapes into the air, so long it continues to extend and multiply its roots in the soil beneath, renewing and inereasing the fresh surface for absorbing moisture, in proportion to the demand fiom above. And when growth eenses above ground, and the leaves die and fall, or no longer aet, then the roots grenerally stop growing, 
aud their soft aud tender tips harden. From this period, therefore, uutil growth begins auew the next spring. is the best time for transplanting: especially for trees and shrubs.

73. The absorbing surface of young roots is much increased by the formation, near their tips, of Root-Hairs (Fig. 81, 82), which are delieate

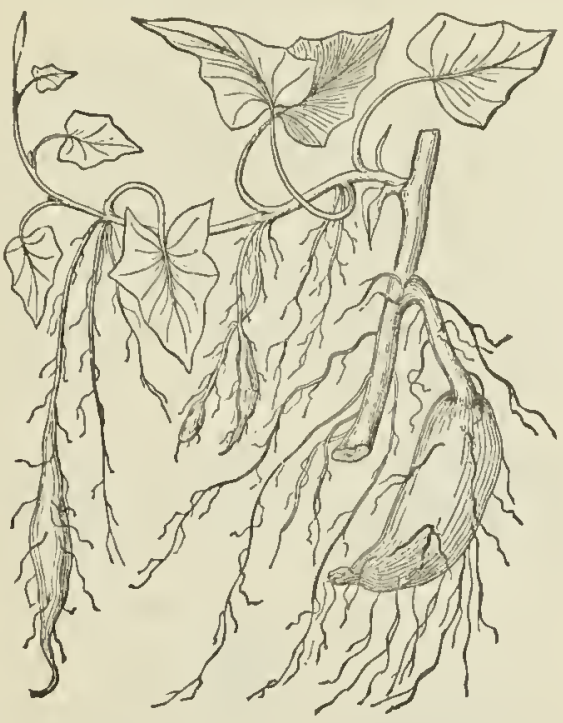

86

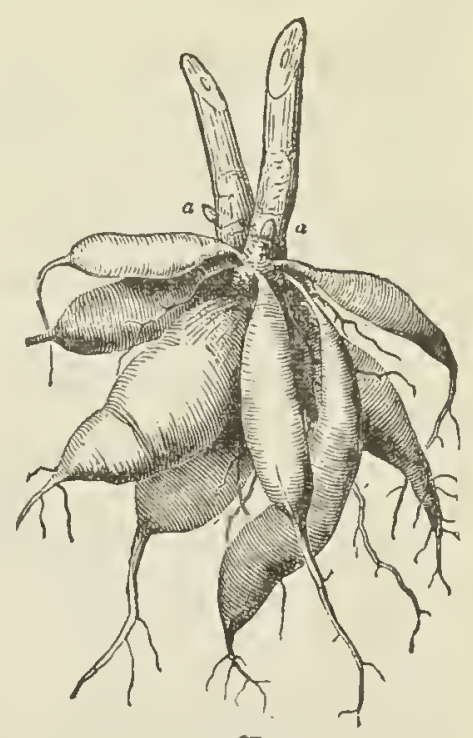

87

tubular outgrowths from the surface, through the delicate walls of which moisture is promptly imbibed.

74. Fleshy Roots are those in which the root becomes a storelıouse of nourishment. Typical roots of this kind are those of such bicmials as the turnip and carrot; in which the food created in the first season's vegetation is accumulated, to be expended the next season in a vigorous growtl and a rapid development of flowers, fruit, and secd. By the time the seed is matured the exhausted root dies, and with it the whole plant.

75. Fleshy roots may be single or multiple. The single root of the commoner biemials is the prinury root, or tap-root, which begins to thicken in the seedling. Names are given to its shapes, such as

Conical, when it thickeus most at the crowu, or where it joins the stem, and tapers regularly downwards to a point, as in the Parsnip and Carrot (Fig. S4);

Turnip-shaped or napiform, when greatly thiekened above, but abruptly becoming stender below; as the Turnip (Fig. 5.3); and

FIG. 86. Sweet-Potato plant forming thickened loots. Some in the midule are just beginning to thicken; one at the left has grown nore; one at the right is still larger.

Fic. 87. Fascicled fusiform roots of a Dahlia : $a, a$, buds on base of stem. 
Spindle-shaped, or Fusiform, when thickest in the middle and tapering to both ends; as the eommon Radish (Fig. 85).

76. T'liese exantples are of primary roots. It will be seen that turuips, earrots, and the like, are not pure root throughout; for the cauliele, from the lower end of which the root grew, partakes of the thickening, perhaps also some joints of stem above: so the bud-beariug and growing top is stem.

77. A fine example of secondary roots (67), some of which remain fibrous for absorption, while a few thieken and store up food for the next season's growth, is furnished by thic Sweet Potato (Fig. 86). As stated above, these are used for propagation by euttings; for any part will produce adventitious buds and shoots. The Dahlia produces fuscicled (i. e. elustered) fusiform roots of the sane kind, at the base of the stem (Fig. 87): but these, like most roots, do not produce adventitious buds. T'he buds by which Dahlias are propagated belong to the surviving base of the stem above.

78. Anomalous Roots, as they may be called, are those which subscrve other uses than absorption, food-storing, and fixing the plant to the soil.

Aerial Roots, i. e. those that strike from stems in the open air, are common in moist and warm elimates, as in the Mangrove which reaclies the coast of Florida, the Banyan, and, less strikingly, in some herbaceous plants, such as Sugar Cane, and even in Indian Corn. Such roots reach the ground at length, or tend to do so.

Aerial Rootlets are abundantly produced by many climbing plants, such as the Ivy, Poison Ivy, Trumpet Creeper, ete., springing from the side of stems, which they fusten to trunks of trees, walls, or other supports. These are used by the plant for climbing.

79. Epiphytes, or Air-

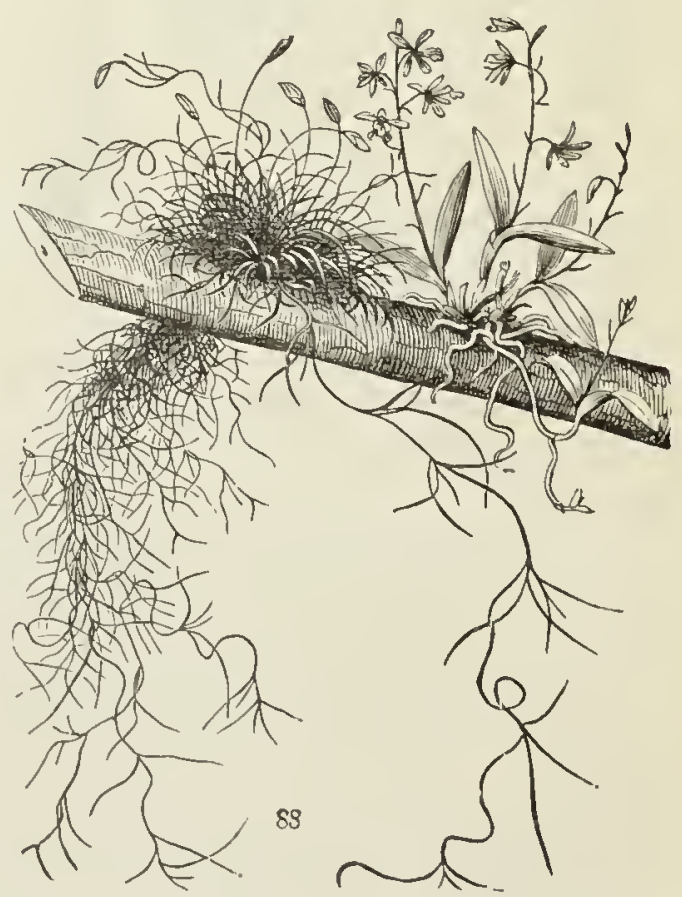
Plants (Fig. S8), are ealled by the former name becausc commonly growing

Fra. 88. Fpiphytes of Florida and Georgia, viz., Epilendrum conopseum, a small Orehil, aut Tillanlsia usneoides, the sn-called Long Moss n. Black Moss, which is no moss, but a flowering plant, also T. recurvata; ou a hough of Live Oak, 
upon the trunks o: limbs of other plants; by the latter beeause, having no conncetion with the soil, they must derive their sustenanee from the air only. They have aerial roots, which do not reaeh the ground, but are used to fix the plant to the surfaee upon which the plant grows: they also take a part in absorbing moisture from the air.

80. Parasitic Plants, of whieh there are various kinds, strike their roots, or what answer to roots, into the tissue of foster plants, or form attrehments with their surfaec, so as to prey upon their jujees. Of this sort is the Mistletoe, the seed of which germinates on the bough where it falls or is left by birds; and the forming root penetrates the bark and engrafts itself into the wood, to whiel it becomes united as firmly as a natural braneh to its parent stem; and indeed the parasite lives just as if it were a braneh of the tree it grows and feeds on. A most eommon parasitie herb is the Dodder; which abounds in low grounds in summer, and eoils its long and slender, leatless, yellowish stems -.- resembling tangled threads of yarn - round and round the stalks of other plants; wherever they toueh piereing the bark with minute and very short rootlets in the form of suekers, which draw out the nourishing juices of the plants laid hold of. Other parasitie plants, like the Becch-drops and Pine-sap, fasten tlıeir roots under ground upon the roots of neigliboring plants, and rob them of their juiees.

S1. Some plants are partly parasitie; while most of their roots aet in the ordinary way, others make suekers at their tips which grow fast to the

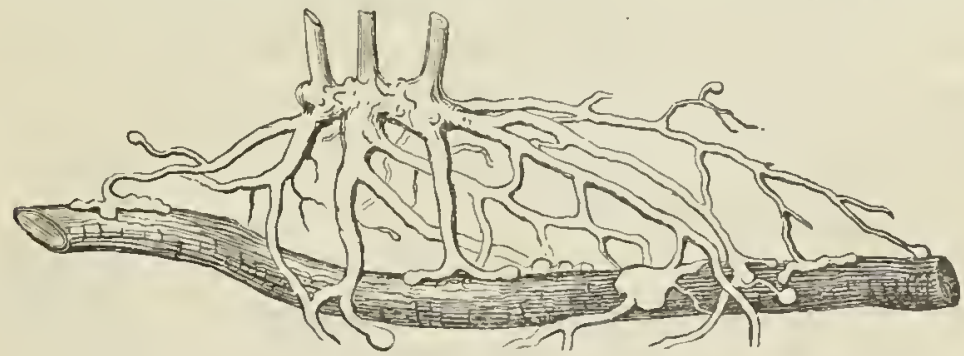

89

roots of other plants and rob them of nourishment. Some of our species of Gerardia do this (Fig. 89).

82. There are phanerogamous plants, like Monotropa or Indian Pipe, the roots of whieh feed mainly on dcearing vegetable matter in the soil. These are SAprophytes, and they imitate Mushrooms and other Fungi in their mode of life.

83. Duration of Roots, etc. Roots are said to be either annual, bien. nial, or perennial. As respects the first and seeond, these terms may be applied either to the root or to the plant.

84. Annuals, as the name denotes, live for only one year, generally for

FIG. 89. Rnots of Yellow Gerardia, snme attacher to and feeding on the root of 
only a part of the year. They are of course herbs; they spring from the seed, blossom, mature their fruit and seed, and then die, root and all. An. nuals of our temperate climates with severe winters start from the secd in spring, and perish at or before autumn. Where the winter is a moist and growing season and the summer is dry, winter annuals prevail; their seeds germinate under autumn or winter raius, grow more or less duriug winter, blossom, fructify, and perish in the following spring or summer. Annuals are fibrous-rooted.

85. Biennials, of whieh the Turnip, Beet, and Carrot are familiar examples, grow the first season without blossoming, usually thieken their roots, laying up in them a stock of nourishment, arc quiescent duriug the winter, bnt shoot vigorously, blossom, and seed the next spring or summer, maiuly at the expeuse of the food stored up, and then die completely. Annuals and bienuials flower only ouce; hence they have been called Monocarpic (that is, onee-fruiting) plants.

86. Perennials live and blossom year after year. A percmnial herb, in a temperate or eooler climate, usually dies down to the ground at the end of the season's growth. But subterrauean portions of stem, eliarged with buds, survive to renew the development. Shrubs and trees are of course peremial; cven the stcms aud branches above ground live on and grow year after year.

87. There are all gradations between anuuals and biemnials, ana between these and perennials, as also between herbs and slrubs; and the distinction between shrubs and trees is quite arbitrary. There are peremnial herbs and eveu slnubs of warm elimates which are auunals when raised in a climate which has a winter, - being destroyed by frost. The Castor-oil plant is an example. There are peromial lierbs of which ouly suall portions survive, as off-shoots, or, iu the Potato, as tubers, etc.

\section{SECTION VI. STEMS.}

88. The Stem is the axis of the plant, the part which bears all the other organs. Branches are seeondary stems, that is, stems growing out of stems. The stem at the very begimning produces roots, in most plants a single ront from the base of the embryo-stem, or caulicle. As this root bccomes a descending axis, so the stem, whieh grows in the opposite dircetion is called the ascending axis. Rising out of the soil, the stem bears leaves; and leaf-bearing is the partieular characteristic of the stem. But there are forms of stems that remain underground, or make a part of their growth there. These do not bear leaves, in the common sense; yet they benr rudiments of leaves, or what answers to leaves, althougl not in the form of folinge. The so-called stemless or acaulescent plants are those which bear no obvious stem (caulis) above ground, but ouly flower-stalks, and the like. 
89. Stems above ground, through differences in durat. on, texture, and size, form herbs, shrubs, trces, etc., or in other terms are

Herbaceous, dying down to the ground every year, or after blossoming.

Suffrutescent, slightly woody below, thcre surviving from year to year.

Suffruticose or Frutescent, when low stems are decidedly woody below, but herbaceous above.

Fruticose or Shrubby, woody, living from year to year, and of considerable size, - not, however, more than three or four times the height of a man.

Arborescent, when tree-like in appearance or mode of growth, or approaching a tree in size.

Arboreous, when forming a proper tree-trunk.

90. As to direction takcn in growing, stems may, instead of growing upright or erect, be

Diffuse, that is, loosely spreading in all directions.

Declined, when turned or bending over to one side.

Decumbent, reclining on the ground, as if too weak to stand.

Assurgent or Ascending, rising obliquely upwards.

Procumbent or Prostrate, lying flat on the ground from the first.

Creeping or Repent, prostrate on or just beneath the ground, and striking root, as does the White Clover, the Partridge-berry, etc.

Climbing or Scandent, ascending by clinging to other objects for support, whether by tendrils, as do the Pea, Grape-Vine, and Passion-flower and Virginia Creeper (Fig. 92, 93); by theil twisting leaf-stalks, as the Virgin's Bower; or by rootlets, like the Ivy, Poison Ivy, and Trumpet Creeper.

Twining or Voluble, when coiling spirally around other stems or supports; like the Morning-Glory (Fig. 90) and the Hop.

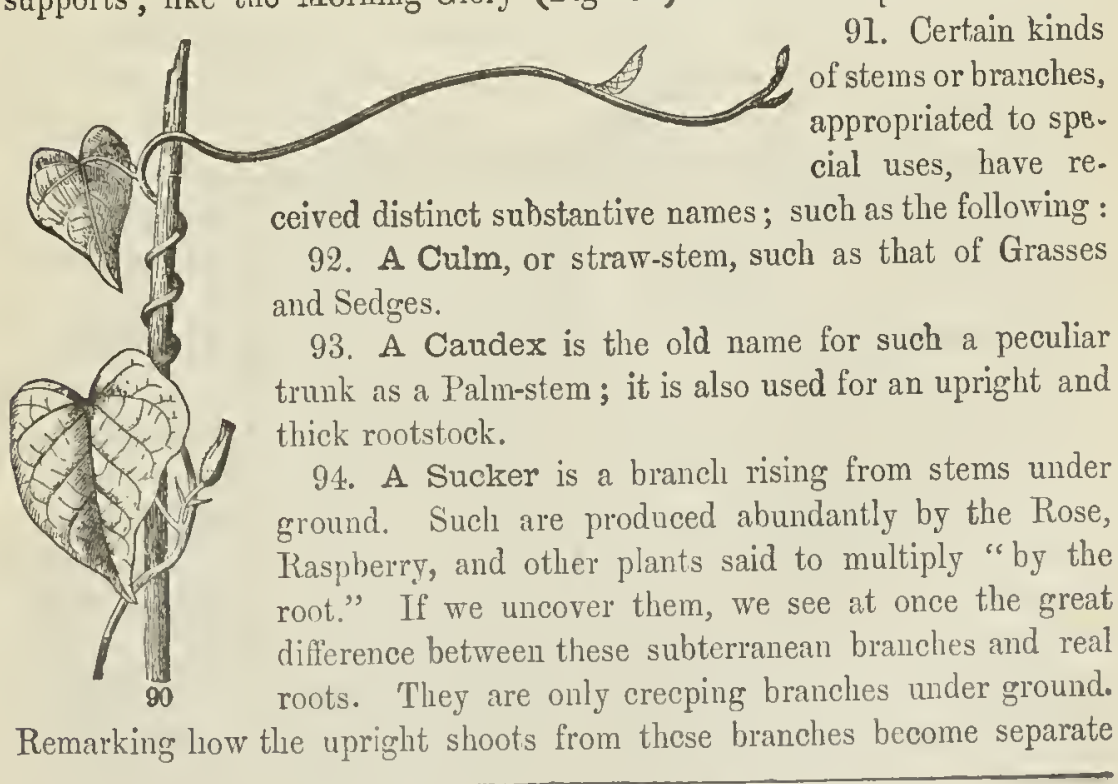


plants, simply by the dying off of the connecting under-ground stems, the gardener expedites the result by cutting them through with his spade. That is, he propagates the plant "by division."

95. A Stolon is a branch from above ground, which reclines or becomes prostrate and strikes root (usually from the nodes) wherever it rests on the soil. Thence it may send up a vigorous shoot, which has roots of its own, and becomes an independent plant when the connecting part dies, as it does after a while. The Currant and the Gooseberry naturally multiply in this way, as well as by suckers (which are the same thing, only the connecting part is concealed under ground). Stolons must have suggrested the operation of layering by bending down and covering with soil branches which do not naturally make stolons; and after they have taken root, as they almost always will, the gardener cuts through the connecting stem, and so converts a rooting branch into a separate plant.

96. An Offset is a short stolon, or sucker, with a crown of leaves at the end, as in the Houseleek (Fig. 91), whiclı propagates abundantly in this way.

97. A Runner, of which the Strawberry presents the most familiar and characteristic examplc, is a long and slender, tendrill-likc stolon, or branch from next the ground, destitute of conspicuous leaves. Each rumer of the Straw. berry, after having grown to its full

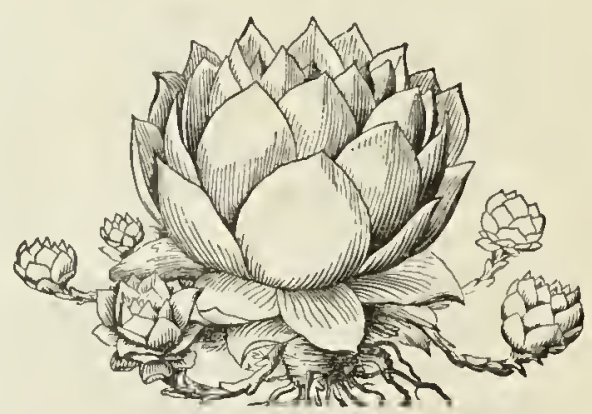

91 length, strikes root from the tip, which fixes it to the ground, then forms a bud there, which develops into a tuft of leaves, and so gives rise to a ncw plant, which sends out new runners to act in the same way. In this manner a single Strawberry plant will spread over a large space, or produce a great number of plants, in the course of the summer, all connected at first by the slender rumers; but these die in the following winter, if not before, and leave the plants as so many separate individuals.

98. Tendrils are brancles of a very slender sort, like rumners, not destined like them for propagation, and thereforc always destitute of buds or leaves, being intended only for elimbing. Simple tendrils are such as those of Passion-flowers (Fig. 92). Componnd or branching tendrils are borne by the Cucumber and Pumpkin, by the Grape-Vinc, Virginia Creeper, etc.

99. A tendril commonly grows straight and outstretched until it reaches some neighboring support, such as a stem, whon its apex hooks around it to secure a hold; then the whole tendril shortens itself by coiling up spirally, and so draws the shoot of the growing plant nearer to the supporting object. But the tendrils of the Virginia Creeper (Ampelopsis, Fig. 
93), as also the shorter ones of the Japanese species, effect the object differently, namely, by expanding the tips of the tendrils into a flat disk, with an adhesive face. This is applied to the supporting objcet, and it adheres

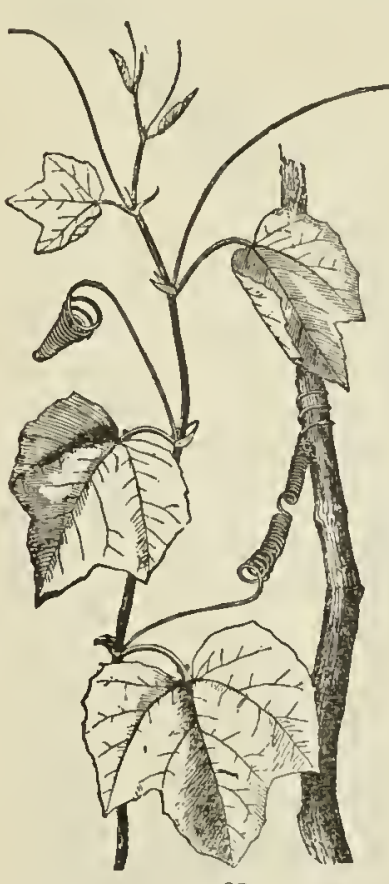

92

its branches by coiling brings up the growing shoot close to the support. This is all adaptation for climbing mural rocks or walls, or the trunks of trees, to which ordinary tendrils are unable to cling. The Iry and Poison Lvy attain the same result by means of aerial rootlets (78).

100. Some tendrils are leares or parts of leaves, as those of the Pea (Fig. 35). The nature of the tendril is known by its position. A tendril from the axil of a leaf, like that of Passion-flowers (Fig. 92) is of course a stem, i. e. a branch. So is one which terninates a stem, as in the Grape-Vine.

101. Spines or Thorns (Fig. 95, 96) are commonly stunted and hardened branches or tips of stems or branches, as arc those of Hawthorn, Honey-Locust, etc. In the Pear and Sloe all gradations oecur betwecn spines and spine-like (spincseent) branches. Spines

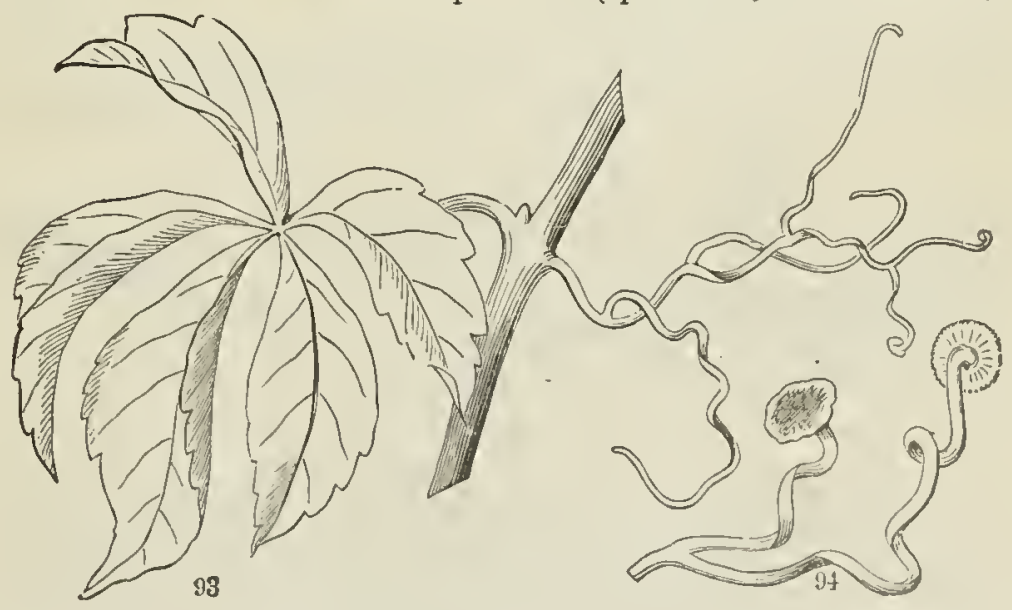

vay be reduced and indurated leares; as in the Barberry, where ilsein nature is revealed by thcir situation, underneath an axillary bud. But

Fig. 92. A small Passion-flower (Passiffore sicynides), showing the tendrils.

Fig. 93. Piece of the stem of Tirginia Creeper, bearing a leaf and \& tendril. 94. Tips of a tendril, about the natural size, showing the disks by which they hold fast to walls, etc. 
prickles, such as those of Blackberry and Roses, are only excrescences of the bark, and not branches.

102. Equally strange forms of stems are characteristic of the Cactus family (Fig. 111). These may be better understood by comparison with

103. Subterranean Stems and Branches. 'These are very numerons and various; but they are commonly overlooked, or else are confounded with roots. From their situation they are out of ordinary sight; but they will well repay examination. For the vegetation that is carried on under ground is hardly less varied or important than that above ground. All their forms may be referred to four principal kinds: namely, the Rhizoma (Rhizome) or Rootstock, the Tuber, the Corm or solid bulb, and the true Bulb.

104. The Rootstock, or Rhizoma, in its simplest form, is merely a crecping stem or branch

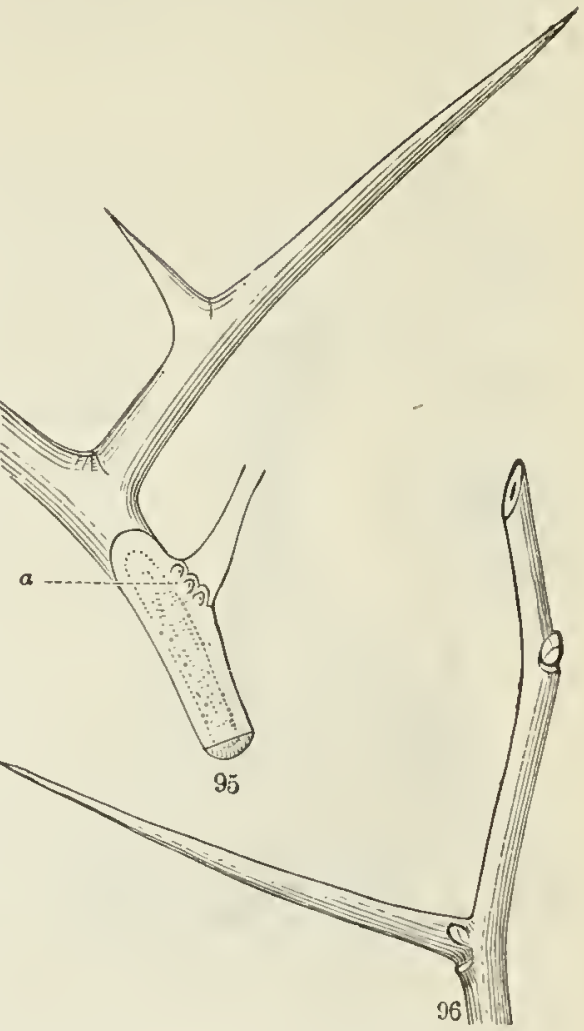
growing beneath the surface of the soil, or partly covered by it. Of this kind are the so-called creeping, running, or scaly roots, such as those

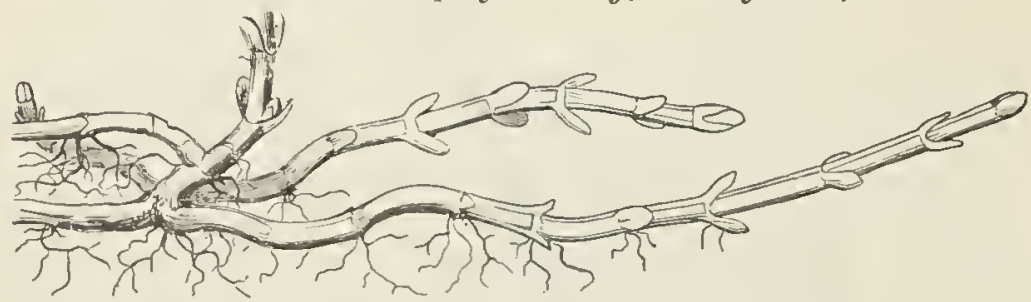

97

by which the Mint (Fig. 97), the Couch-grass, or Quick-grass, and many other plants, spread so rapidly and widely, - "by the root," as it is said. That these are really stems, and not roots, is evident from the way in which

FIG. 95. A branching thorn of Honey Locnst, being an imlnrated leafless branch developel from an accessory bul far above the axil: at the cut portion helow, three other buts $(a)$ are concealeul unirr the petiole.

Fia. 96. Spine of Cockspur Thorn, developed from an axillary buil, as the leaf scar below witnesses: an accessory leaf-bnd is seen at its base.

FIG. 97. Rootstocks, or creeping subterranean branches, of the Peppermint. 
they grow; from their consisting of a succession of joints; and from the leaves which they bear on each node, in the form of small seales, just like the lowest ones on the upright stem next the ground. They also producc buds in the axils of these seales, showing the scales to be leaves; whereas real roots bear neither leaves nor axillary buds. Placed as they are in the damp and dark soil, such stems naturally produce roots, just as the crecping stem does where it lies on the surface of the ground.

105. It is easy to see why plants with these running rootstocks take such rapid and wide possession of the soil, and why they are so hard to get rid of. They are alrays perennials; the subterranean shoots live over the first winter, if not longer, and are provided with rigorous buds at every joint. Some of these buds grow in spring into upright stems, bearing foliage, to elaborate nourishment, and at length produce blossoms for re. production by seed; while many others, fed by nour. ishment supplied from above, form a new generation of subtcrranean slioots; and this is repeated over and over in the course of the season or in suceecding years. Neanwhile, as the subterrancan shoots in. crease in number, the older ones, comnecting the successive growths, die of year by year, liberating the

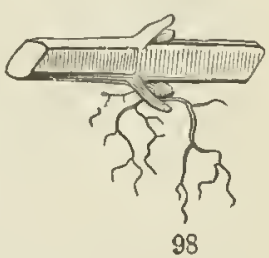
already rooted side-branches as so many separate plants; and so on indefinitely. Cutting these running rootstocks into pices, therefore, by the hoe or the plougl, far from destroying the plant, only accelerates the propagation; it converts one many-branched plant into a great number of separate individuals. Cutting into pieces only multiplies the pest; for each piece (Fig. 98) is already a plantlet, with its roots and with a bud in the axil of its scale-like leaf (either latent or apparent), and with prepared nourishnent enough to develop this bud into a leafy stem; and so a single plant is all the more speedily converted into a multitude. Whereas, when the subterranean parts are only roots, cutting away the stem completely destroys the plant, except in the rather rare cases where the root freely produces adventitious louds.

106. Rootstocks are more commonly thiekencd by the storing up of considerable nourishing matter in their tissue. The common species of Iris (Fig. 164) in the gardens have stout rootstoeks, which are only partly corered by the soil, and which bear folinge-leaves instend of mere seiles, closely covering the upper part, while the lower produces roots. As the leaves die, year by yeal, and deeay, a sear left in the from of a riug marks the plaee where each leaf was attached, that is, marks so many nodes, separated by rery short interuorles.

107. Some rootstoeks are marked with large round scars of a different

Fro. 9S. A piece of the runuing rontstock of the Peppermint, with its node or ioint, and an axillary bud reacly to grow. 
sort, like those of the Solomon's Seal (Fig. 99), whieh gave this name to the plant, from their looking somewhat like the impression of a seal upon

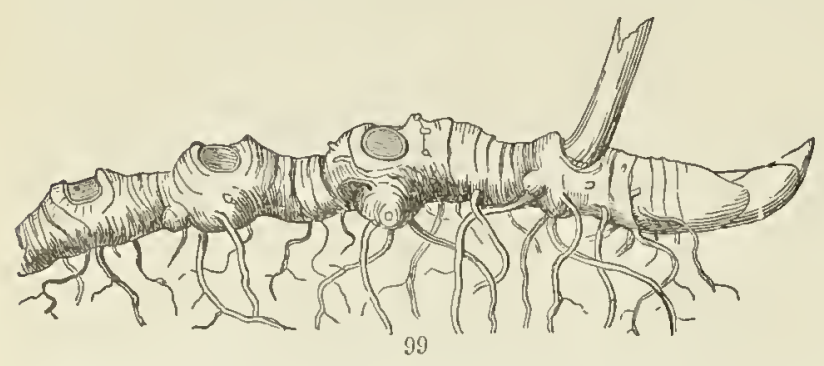

wax. Here the rootstoek sends np every spring an herbaeeons stalk or stem, whieh bears the foliage aud flowers, and dies in autumn. The seal is the eireular sear left by the death and separation of the base of the stout stalk from the living rootstoek. As bnt one of these is formed each year, they mark the limits of a year's growth. The bud at the end of the rootstoek in the fgure (whieh was taken in summer) will grow the next spring into the stakk of the seasom, whieh, dying in antumn, will leave a similar sear, while another bud will be formed farther on, ersmuing the ever-advaneing summit or growing end of the stem.

108. As eaeh year's growth of stem makes its own roots, it soon becomes independent of the older parts. And after a eertain age, a portion annually dies off behind, about as fast as it inereases at the growing end, death following life with equal and eertain step, with only a narrow interval. In vigorons plants of Solomon's Seal or Iris, the liring rootstock is sereral inehes or a foot in length; while in the short rnotstoek of Trillium or Birthroot (Fig. 100)

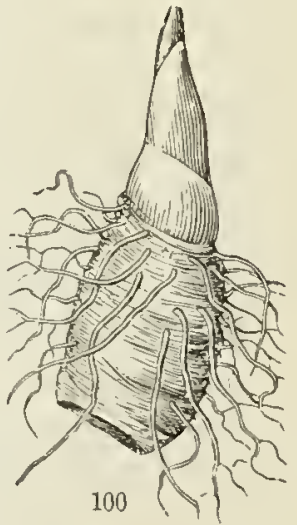
life is redueed to a narrower span.

109. An upright or short rootstoek, like this of Trillium, is eommonly called a CAUDEX (93); or when more shortened and thiekened it would beeome a eorm.

110. A Tuber may be understood to be a portion of a rootstoek thiek. ened, and with buts (eyes) on the sides. Of eonrse, there are all grada. tions between a tuber and a rotstoek. Helianthus tuberosus, the so-ealled Jerusalem Artichoke (Fig. 101), and the eommon Potato, are typieal and familiar examples of the tuber. The stalks by whieh the tubers are at. taeled to the parent stem are at once seen to be difierent from the roots, both in appearanee and manner of growth. The seales on the tubers are the rudiments of leares; the cyes are the buds in their axils. The Potato-plant

Fia. 99. Rontstock of Solomon's seal, with the bottom of the stalk of the season, and the hud for the next year's growth.

FIG. 100. The very short rootstock and stroug terminal bud of a Trillium or Birthroot. 
has three forms of branches: 1. Those that bcar ordinary leaves expanded in the air, to digest what they gather from it aud what the roots gather from the soil, and eonvert it into uourishment. 2. After a while a second set of branehes at the summit of the plant bear flowers, which form fruit and seed out of a portion of the uourishment which the leaves have prepared. 3. But a larger part of this nourishment, while in a liquid statc, is earricd clown the stem, into a third sort of branches under ground, and accumulated in the form of starch at their extremities, which become tu. bers, or depositories of prepared solid food, - just as in the Turnip, Carrot, and Dah. lia (Fig. 83-87), it is deposited in

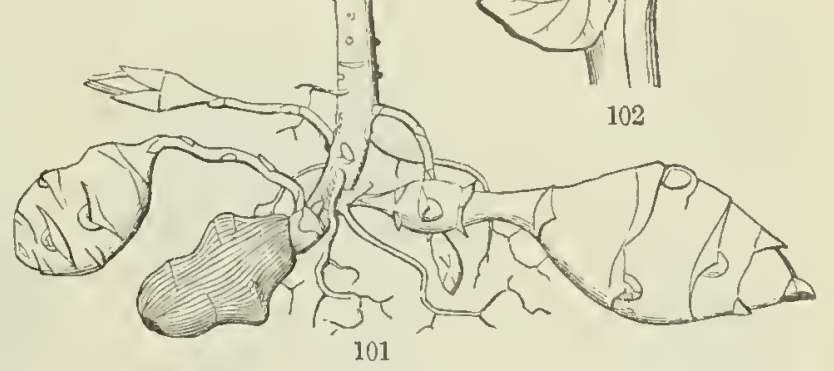
the root. The usc of the store of food is obvious enough. In the autumn the whole plant dies, cxcept the seeàs (if it formed them) and the tubers; and the littcr are left disconneeted in the grouud. Just as that small portion of nourishing matter which is deposited in the sced feeds the embryo when it germinates, so the much larger portiou deposited in the tuber nourishes its buds, or cyes, when they likewise grow, the next spring, into new plants. And the great supply cnables them to shoot with a greater vigor at the begimning, and to produce a greater amount of vegctalion than the secdling plant could do in the same space of time; which vegetation in turn may prepare and store up, in the course of a few weeks or months, the largest quantity of solid nourishing material, in a form most available for food. 'Taking arvantage of this, man has transported the Potato from the eool $\Lambda$ undes of Chili to other cool climates, and makes it yield him a copious supply of food, especially important in eountries where the season is too short, or the summer's lieat too little, for profitably cultirating the principal grain-plants.

111. The Corm or Solid Bulb, like that of Cyclamen (Fig. 10:3), and of Inctian Turnip (Fig. 10\%), is a very short and thick fleshy subterranean stem, often broader than high. It sends off roots from its lower end, or rather face, leaves aud stalks from its upper. The corm of Cyclamen gocs on to enlarge and to produec a succession of flowers and leaves ycal' after ycar.

FIG. 101. Tubers of Ilelianthus tuberosus, called "artichokes."

FIa. 102. Bulblet-like tubers, such as are occasionally formed on the stem of a Potato-plant above ground. 
That of Indian Turnip is formed one year and is consumed the next. Fig. 101 represents it in early summer, having below the corm of last year, from which the roots have fallem. It is partly consumed by the growth of the

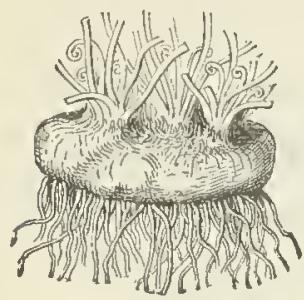

103

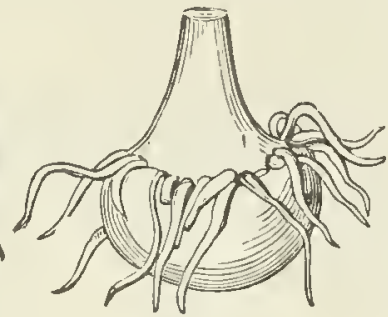

104 stem for the season, and the corm of the year is forming at base of the stem above the line of roots.

112. The corm of Crocus (Fig. 105, 106), like that of its relative Gladiolus, is also reproduced annually, the new ones forming upon the summit and sides of the old. Such a corm is like a tuber in budding from the sides, i. e. from the axils of leaves; but these leaves, instead of being small scales, are the sheathing bases of foliage-leaves which covered the surface. It resembles a true bulb in having these sheaths or broad scales; but in the corm or solid bulb, this solid part or stem makes up the prineipal bulk.

113. The Bulb, strictly so-called, is a stem like a reduecd corm as to its solid part (or plate); while the main body consists of thickened segles, which are leaves or leaf-bases. These are like budseales; so that in fact a bulb is a bud with feshy scales on an cxceedingly short stem. Compare a White Lily bulb (Fig. 107) with the strong sealy buds of the Hickory and Horse-chestnut (Fig. 72 and 73), and the resemblance will appear. In corms, as in tubers and rootstoeks, the store of food for future growth is deposited in the stem; while in the bulb, the greater part is deposited in the bases of the leares, elanging them into thick scales, which closely overlan or enclose one another.

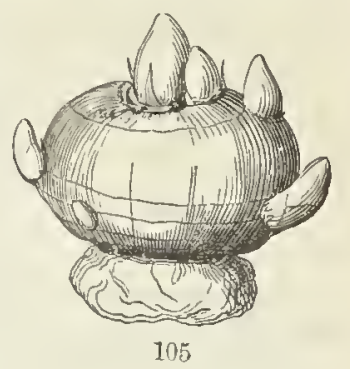

114. A Scaly Bulb (like that of the Lily, Fig. 107, 108) is one in which the scales are thick but comparatively narrow.

115. A Tunicated or Coated Bulb is one in which the seales enwrap each other, forming conecntric coats or laycrs, as in Hyacinth and Onion.

Fig. 103. Corm of Cyclamen, mucl reduced in size : roots from lower face, leafstalks and flower-stalks from the mper.

Fig. 104. Corm of Indian 'Tumip' (A rismma).

FIG. 105 Corm of a Crocus, the investing sheaths or dead leaf-bases stripped off. The faint cross-lines represent the sears, where the leaves were attached, i. e. the nories: the spaces between are the internoles. The exhausted corm of the

previous year is underneath; forming ones for next year on the summit and sides
FIo. 106. Seetion of the same. 
116. Bulblets are very small bulbs growing out of larger ones; or small bulbs produced above ground on some plants, as in the axils of the leaves of the bulbiferous Lilies of the gardens (Fig. 110), and often in the flower-clusters of the Leek and Omion. They arc plainly buds" with thickened scales. They never grow into branches, but detach themselves wisen full grown, fall to the ground, and take root there to form new plants.

117. Consolidated Vegetation. An ordinary herb, shrub, or tree is evidently constructed on the plan developing an extensive surface. In fleshy rootstocks,

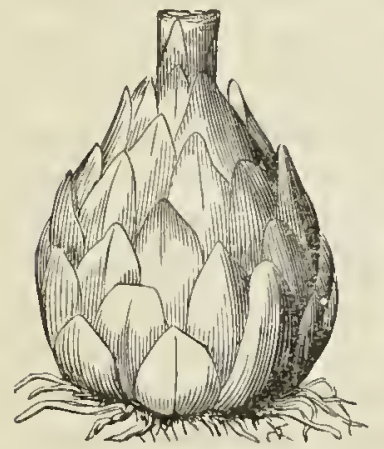

107

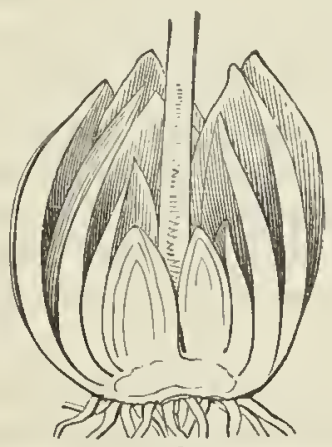

108

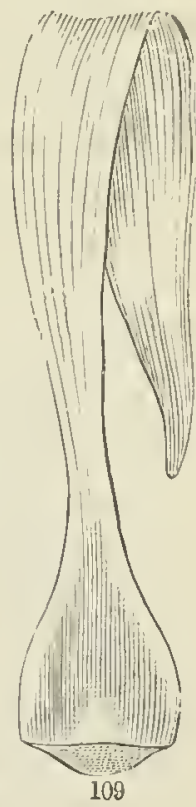

tubers, corms, and bullos, the more enduring portion of the plant is concentrated, and reduced for the time of struggle (as against drought, heat, or cold) to a small amount of exposed surface, and this mostly sheltered in the soil. There are many similar consolidatcd forms which are not subterranean. Thus plants like the Houseleek (Fig. 91) imitate a bulb. Among Cactuses the columnar species of Cereus (Fig. 111, b), may be lik-

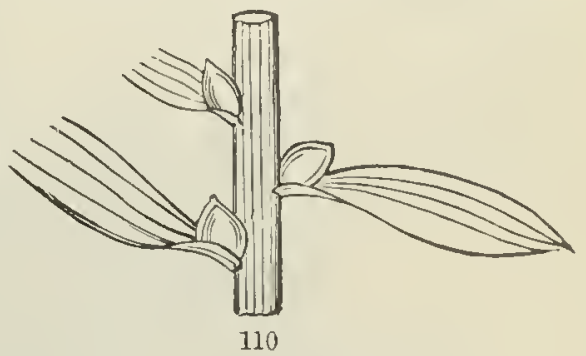
ened to rootstocks. A grcen rind serves the purpose of foliage; but the surface is as nothing compared with an ordinary leafy plant of the same bulk. Conpare, for instance, the largest Cactus known, the Giant Cerens of the Gila River (Fig. 111, in the background), which rises to the lieight of fifty or sixty feet, with a common leafy trec of the same hcight, such as that in Fig. 89, and cstimate how vastly grcater, even without the foliage, the surfacc of the latter is than that of the formcr. Compare, in the

FIG. 107. Bulb of a will Lily. 108. The same divided lengthwise, showing two forming buds of the next generation.

Frg. 109. A ground leaf of White Lily, its base (cut across) thickened into a oulb-scale. This plainly shows that bulb-scales are lcaves.

FrG. 110. Bulblets in the axils of leaves of a Tiger Lily. 
same view, an Opuntia or Priekly-Pear Cactus, its stem and branelies formed of a suceession of thiek and flattened joints (Fig. 111, a), whieh may be likened to tubers, or an Epiphyllum (d), laving short and fiat joints, with an ordinary leafy shrub or herb of equal size. And finally, in Melon-Caetuses, Echinoenetus (c), or other globose forms (whieh may be likened to permanent corms), with their globular or bulb-like sliapes, we have plants in the eompaetest shape; their spherieal figure leeing sueh as to expose the least possible amount of substanee to the ail. These are adaptations to elimates whieh are very dry, either throughout or for a part of the vear. Similarly, bulbous and eorm-bearing plants, and the like, are examples of a form of vegetation whieh in the growing season may expand a large surface to the air and light, while during the period of rest the living vegetable is redneed to a globe, or solid form of the least possible surface; and this proteeted by its outer coats of dead and dry scales, as well as by its situation under ground. Such are also adapted to a season of drought. They largely belong to countries which have a long hot season of little or no rain, when, their stalks and foliage above and their roots beneath early perishing, the plants rest seeurely in their eompaet bulbs, filled with nourishment and retilining their moisture with great tenaeity, until the rainy season comes round. Then they shoot forth leaves and flowers with wonderful rapidity, and what was perhaps a desert of arid sand becomes green with foliage and gay with blossoms, almost in a day.

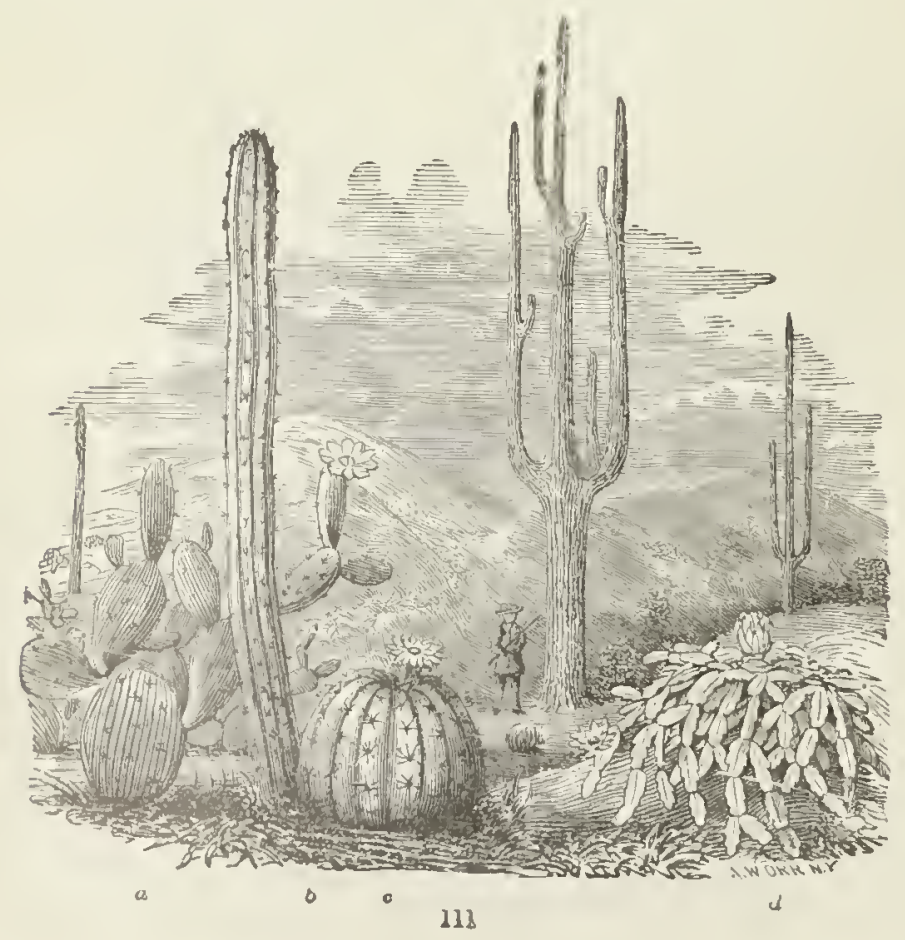




\section{SECTION VII. LEAVES.}

118. Stems bear leaves, at definite points (nodes, 13); and these are produced in a great variety of forms, and snbserve varions nses. 'i he commonest kind of leaf, which therefore may be taken as the type or pattern, is an expanded green body, by means of which the plant exposes to the air and light the matters which it imbibes, exhales ccrtain portions. and assimilates the residue into vegetable matter for its nourishment and glowth.

119. But the fact is already familiar (10-30) that leaves occur under other forms and serve for other nses, - for the storage of food already assimilated, as in thickened seed-lcaves and bulb-scales; for covering, as in bud-scales; and still othcr uses are to be pointed out. Indeed, sometimes they are of no service to the plant, being rednced to mere scales or rndiments, snch as those on the rootstocks of Peppermint (Fig. 97) or the tnbers of Jerusalem Artichoke (Fig. 101). These may be said to be of service only to the botanist, in explaining to him the plan upon which a plant is constrncted.

120. Accordingly, just as a rootstock, or a tuber, or a tendril is a kina of stem, so a bud-scale, or a bulb-scale, or a cotyledon, or a petal of a flower, is a kind of leaf. Even in respcet to ordinary leaves, it is natural to use the word either in a wider or in a narrower sense; as when in one sense we say that a leaf consists of blide and petiole or leaf-stalk, and in another scnse say that a leaf is petioled, or that the leaf of Hepatica is threc-lobed. The comncction should make it plain whether by leaf we mean leaf-blade only, or the blade with any other parts it may have. And the student will rcadily nuderstand that by leaf in its largest or morphological sensc, the botanist means the organ which occupies the place of a leaf, whatever bc its form or its function.

\section{§ 1. LEAVES AS FOLIAGE.}

121. This is tantological; for foliage is simply leaves: but it is very convenient to speak of typical leaves, or those which serve the plant for assimilation, as foliage-leares, or ordinary leaves. These may first be considered.

122. The Parts of a Leaf. The ordinary lcaf, complete in its parts, consists of blade, foot-stalk, or petiole, and a pair of stimules.

123. First the Blade or Iramina, which is the essential part of ordinary leaves, that is, of such as serve the purpose of foliage. In structure it consists of a softer part, the green pulp, called parenchyma, which is traversed and snpported by a fibrous frame, the parts of which are called ribs or veins, on account of a certain likeness in arrangement to the veins of animals. 
The whole surface is covered by a transparent skin, the Epidermis, not unlike that which eovers the surface of all fresh shoots.

124. Note that the leaf-blade expands horizontally, — that is, normally presents its faces one to the sky, the other to the ground, ol when the leaf is erect the upper face looks toward the stem that bears it, the lower faee away from it. Whenever this is not the case there is something to be explained.

125. The framework consists of wood, - a fibrous and tough material which rums from the stem through the leaf-stalk, when there is one, in the

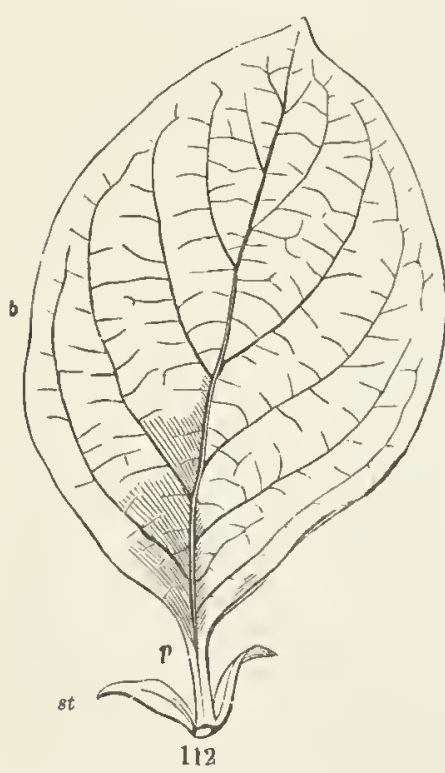
form of parallel threads or bundles of fibres; and in the blade these spread out in a lorizontal direetion, to form the rits and veins of the leaf. The stont main branehes of the framework are ealled the Rivs. When there is only one, as in Fig. 112, 114, or a middle one decidedly larger than the rest, it is ealled the Midrib. The smaller divisions are termed Veins; and their still smaller subdivisions, $V$ einlets. The latter subdivide again and again, until they beeome so fine that they are invisible to the naked eye. The fibres of which they are composed are hollow; forming tubes by which the sap is brought into the leaves and earried to every part.

126. Venation is the name of the mode of veining, that is, of the way in whieh the veins are distributed in the blade. This is of two principal kinds; namely, the parallel-veined, and the netted-veined.

127. In Netted-veined (also ealled Reticulated) leares, the veins branch off from the main rib or ribs, divide into finer and finer reinlets, and the branches unite with eaeh other to form meshes of network. 'That is, they anastomose, as antatomists say of the veins and arteries of the body. The Quinee-leaf, in Fig. 112, shows this kind of veining in a leaf with a single rib. The Maple, Basswood, Plane or Buttonwood (Fig. 74) show it in leaves of several ribs.

128. In parallel-veined leaves, the whole framework eonsists of slender ribs or veins, whieh run parallel with eaeh other, or nearly so, from the base to the point of the leaf, - not dividing and subdividing, nor forming meshes, except by minute eross-reinlets. The leaf of any grass, or that of the Lily of the Valley (Fig. 113) will furnish a good illustration. Such narallel veins Limnacus ealled Nerves, and parallel-reined leares are still commonlv called nerved leaves, while those of the other kind are said to be

Fra. 112. Leaf of the Quince: $b$, blade; $p$, petiole; st, stipules. 
veined, - terms which it is convenient to use, although these "nerves" and "veins" are all the same thing, and have no likeness to the nerves and little to the veins of animals.

129. Netted-veined leaves belong to plants whieh have a pair of seed. leaves or cotyledons, such as the Maple (Fig. 20, 24,), Beech (Fig. 33), and

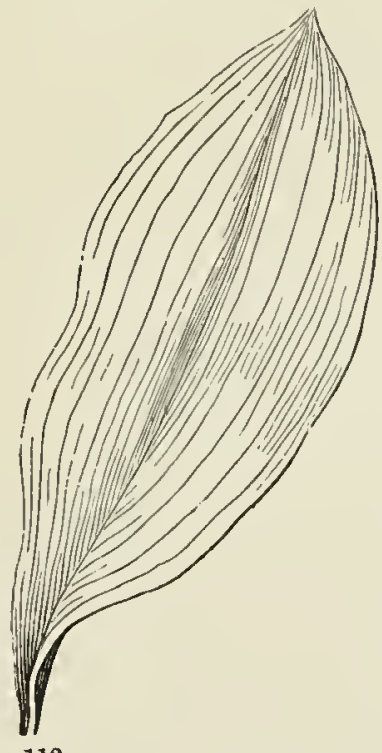

113

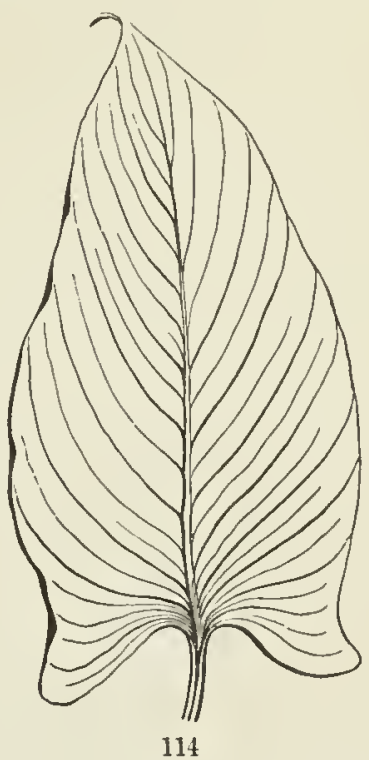

114

the like; wille parallı-veined or nerved leaves belong to plants with one cotyledon or true seed-leaf; such as the Iris (Fig. 59), and Indian Corn (Fig. 70). So that a nere glanee at the leaves generally tells what the structure of the embryo is, and refers the plant to one or the other of these two graud classes, - which is a great convenience. For when plants differ from each other in some oue important respect, they usually differ corres. pondingly in other respects also.

130. Parallel-veined leaves are of two sorts, - one kind, and the conmonest, having the ribs or nerves all rumning from the base to the point of the leaf, as in the examples already given; while in another kind they rum from a midrib to the margin, as in the common Piekerel-weed of our ponds, in the Bauana, in Calla (Fig. 114), and many similar plants of warm climates.

131. Netted-reined leaves are also of two sorts, as in the examples already referred to. In one ease the veins all rise from a single rib (the midrib), as in Fig. 112, 116-127. Such leaves are called Feather-veined or Perni-veined, i. e. Pinnately-veined; both terms meaning the same thing, namely, that the veins arc arranged on the sides of the rib like the plume of a feather ou eaeh side of the shaft.

Fig. 113. A (parallel-veined) leaf of the Lily of the Valley. 114. One of the Calla Lily. 
132. In the other case (as in Fig. 74, 129-132), the veins branch off from three, five, seven, or nine ribs, which spread from the top of the leat: stalk, and run through the blade like the tocs of a web-footed bird. Hence these are said to be Palmately or Digitately veined, or (sinee the ribs diverge like rays from a ecntre) Radiate-veined.

133. Since the general outline of leaves aceords with the frame-work or skeleton, it is plain that feather-veined (or penni-veined) leaves will inchine to elongated shapes, or at least to be longer than broad; while in radiateveined leaves more rounded forms are to be expected. A glance at the following figures shows this.

134. Forms of Leaves as to General Outline. It is necessary to give names to the principal shapes, and to define them rather precisely, since they afford easy marks for distinguishing speeies. The same terms are used

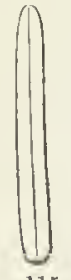

115
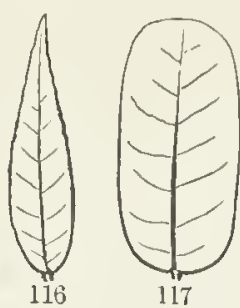

117

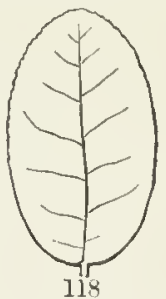

118

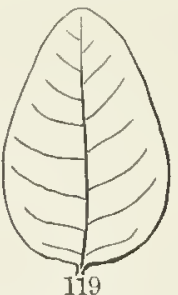

119

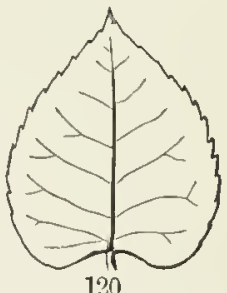

120

for all other flattened parts as well, such as petals; so that they make up a great part of the deseriptive language of Botany. It will be a good exercise for young students to look up leaves answering to these names and definitions. Beginning with the narrower and proceeding to the broadest forms, a leaf is said to be

Linear (Fig. 115), when narrow, several times longer than wide, and of the same breadth throughout.

Lanceolate, or Lance-shaped, when eonspicuously longer than wide, and tapering upwards (Fig, 116), or both upwards and downwards.

Oblong (Fig. 117), when nearly twiee or thrice as long as broad.

Elliptical (Fig. 118) is oblong with a flowing outline, the two ends alike in width.

Oval is the same as broadly clliptieal, or elliptical with the breadth eonsiderably more than laalf the lengtli.

Ovate (Fig. 119), when the outline is like a seetion of a hen's egg lengthwise, tlie broader end downward.

Orbicular, or Rotund (Fig. 132), cireular in outline, or nearly so.

135. A leaf which tapers toward the base instead of toward the apex may be

Oblanceolate (Fig. 121) when of the lanee-shaped form, only more tapering toward the base than in the opposite direction.

Spatulate (Fig. 122) when more rounder above, but tapering thenec to a narrow base, like an old-fashioned spatula, 
Obovate (Fig. 123) or inversely ovate, that is, ovate with the narrower end down.

Cuneate or Cuneiform, that is, Wedge-shaped (Fig. 12t), broad above and tapering by nearly straight lines to an acute angle at the base.

136. As to the Base, its shape characterizes several forms, such as

Cordate or Heart-shaped (Fig.
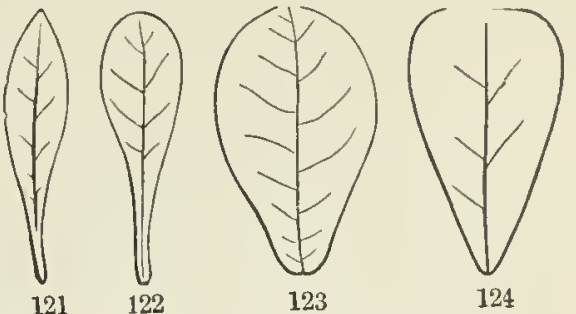
$120,129)$, when a leaf of an ovate form, or something like it, has the out-

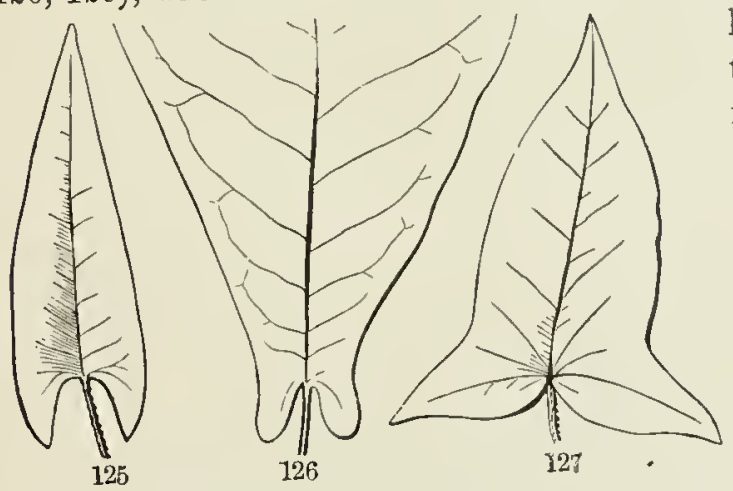
line of its rounded base turned in (forming a notch or sinus) where the stalk is attached.

Reniform, or Kidneyshaped (Fig. 131), like the last, only rounder and broader than long.

Auriculate, or Eared, having a pair of small and blunt projections, or ears, at the base, as in one species of Magnolia (Fig. 126).

Sagittate, or arrow-shaped, where snch ears are acute and turned downwards, while the main body of the blade tapers upwards to a point, as in the common Sagittaria or Arrow-head, and in the Arrow-leaved Polygonum (Fig. 125).

Hastate, or Halberd-shaped, when such lobes at the base point outwards, giving the shape of the halberd of the olden time, as in another
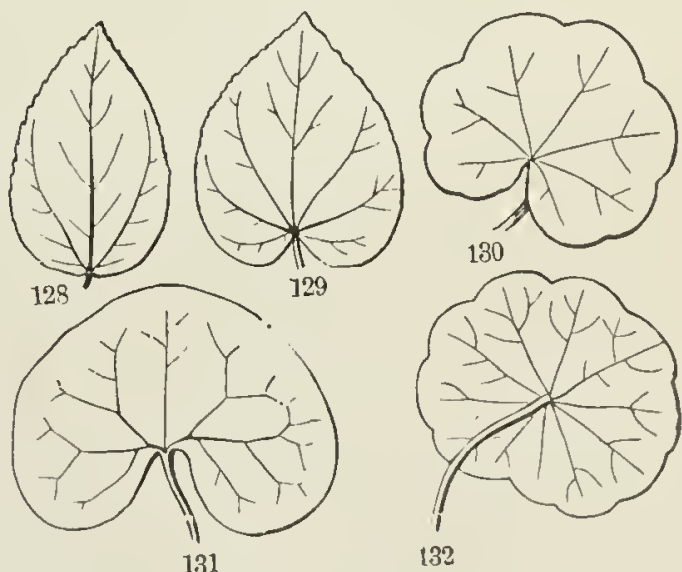
Polygonum (Fig. 127).

Peltate, or Shicld-shaped (Fig. 132), is the name applied to a curions modification of the leaf, commonly of a rounded form, where the footstalk is attached to the lower surface, instead of the basc, and therefore is natu.

FIG. 121, oblanceolate; 122, spatulate; 123, obovate; and 124, wedge-shaped, feather-veined, leaves.

FIG. 125, sagittate ; 126, auriculate ; and 127, halberd-shaped or hastate leaves.

FIG. 128-132. Various forms of radiate-veined leaves. 
rally likened to a shield borne by the outstretehed arm. The eommon Watershield, the Nelumbium, and the White Water-lily, and also the Mandrake, exlibit this sort of leaf. On eomparing the shicld-shaped leaf of the eommon Marsh Pennywort (Fig. 132) with that of another common species (Fig. 130), it is at onee seen that a shield-shaped leaf is like a kidney-shaped (Fig. 130, 131) or other rounded leaf, with the margins at the base brought together and united.

137. As to the Apex, the following terms express the prineipal variations : -

Acuminate, Pointed, or Taper-pointed, when the summit is more or less prolonged into a narrowed or tapering point; as in Fig. 133.

Acute, ending in an acute angle or not prolonged point; Iig. 134.

Obtuse, with a blunt or rounded apex; as in Fig. 135, ete.

Truncate, with the end as if eut off square ; as in Fig. 136.

Retuse, with rounded summit slightly indented, forming a very shallow noteh, as in Fig. 137.

Emarginate, or Notched, indented at the end more deeidedly; as in Fig. 138.

Obcordate, that is, inversely heart-shaped, where an obovate leaf is more deeply notehed at the end (Fig. 139), as in White Clover and Wood-sorrel; so as to resemble a eordate leaf inverted.

Cuspidute, tipped with a sharp and rigid point; as in Fig. 140.

Mucronate, abruptly tipped with a small and short point, like a mere projection of the midrib; as in Fig. 141.

Aristate, Alon-pointed, and Bristle-pointed, are terms used when this mucronate point is extended into a longer bristle-form or slender appendage.

The first six of these terms can be applied to the lower as well as to the upper end of a leaf or other organ. The others belong to the apex ouly.

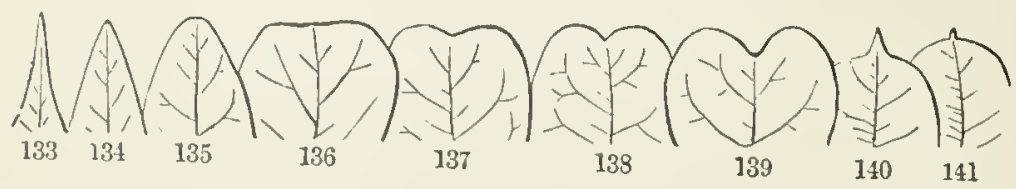

138. As to degree and nature of Division, there is first of all the ditference between

Simple Leaves, those in whieh the blade is of one piee, however mueh it may be eut up, and

Compound Leaves, those in whieh the hlade consists of two or more separate picees, upon a common leaf-stalk or support. Yet between these two kinds every intermediate gradution is to be met with.

139. As to Partioular Outlines of Simple Leaves (and the same applies to their separate parts), they are 
Entire, when their general outline is completely filled out, so that the margin is an even line, without teeth or notches.

Serrate, or Saw-toothed, when the margin only is cut into sharp teeth, like those of a saw, and pointing forwards : as in Fig. 142.

Dentate, or Toothed, when such teeth point outwards, instead of forwards; as in Fig. 143.

Crenate, or Scal. loped, when the teeth are broad and rounded; as in Fig. 144.

Repand, Uvalulate, or Wavy, when the margin of the leaf forms a wavy line, bending slightly in.

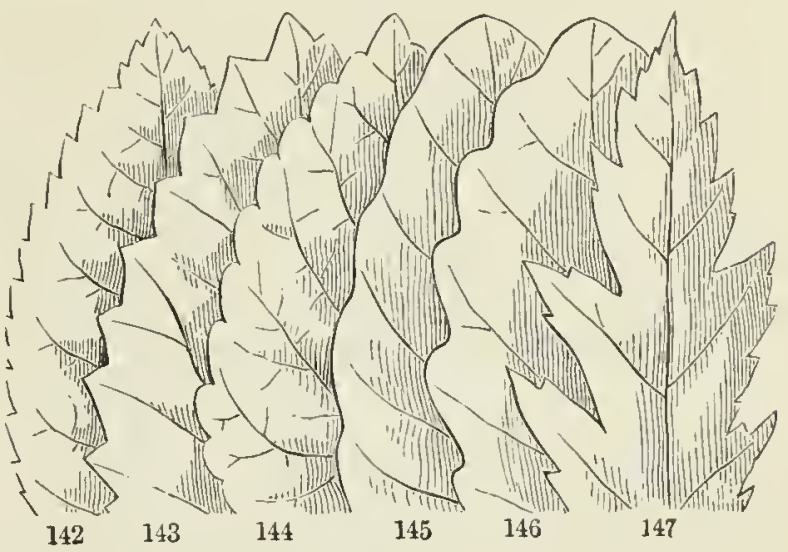
wards and outwards in succession; as in Fig. 145.

Sinuate, when the margin is more strongly sinuous or turned inwards and outwards; as in Fig. 146.

Incised, Cut, or Jagged, when the margin is cut into sharp, deep, and irregular teeth or incisions; as in Fig. 147.

Lobed, when dceply cut. Then the pieces are in a general way called LoBes. The number of the lobes is briefly expressed by the phrase troolobed, three-lobed, five-lobed, many-lobed, etc., as thc case may be.

140. When the depth and character of the lobing needs to be nore particularly specified, the following terms are employed, viz. :-

Lobed, in a special sense, when the incisions do not extend deeper than about lialf-way between the margin and the centre of the blade, if so far, and are more or less rounded; as in the leaves of the Post-Oak, Fig. 148, and the Hepatica, Fig. 152.

Cleft, when the incisions extcnd half way down or more, and especially when they are sharp; as in Fig. 149, 153. And the phrases tzco-cleft, or, in the Latin form, bifid, three-cleft or trifid, four-cleft or quadrifid, fivecleft or quinfuefid, etc., or many-cleft, in the Latin form, multifid, - express the number of the Segments, or portions.

Parted, when the incisions arc still deeper, but yct do not quite reach to the midrib or the base of the blade; as in Fig. 150, 154. And the terms two-parted, three-parted, etc., express the number of such divisions.

Divided, when the incisions extend quite to the midrib, as in the lower part of Fig. 151, or to the leaf-stalk, as in Fig. 155 ; which really makes the 
leaf compound. Here, using the Latin form, the leaf is said to be bisected, trisected (Fig. 155), ete., aeeording to the number of the divisions.

141. The Mode of Lobing or Division eorresponds to that of the veining, whether pinnately veined or palmately veined. In the former the notehes or ineisions, or sinuses, eoming between the prineipal veins or ribs are direeted toward the midrib: in the latter they are direeted toward the apex of the petiole; as the figures show.

142. So degree and mode of division may be tersely expressed in brief phrases. Thus, in the four upper figures of pinnately veined leaves, the first is said to be pinnately lobed (in the speeial sense), the seeond pinnatcly cleft (or pinnatifid in Latin form), the third pinnately parted, the fourth pinnately divided, or pinnatisected.

143. Correspondingly in the lower row, of palmately veined leaves, the first is palmately lobed, the seeond palmaiely cleft, the third palmately parted, the fourth palmately divided. Or, in other language of the same meaning (but now less eommonly employed), they are said to be digitately lobed, cleft, parted, or divided.

144. The number of the divisions or lobes may come into the phrase. Thus in the four last named figures the leaves are respeetively patmately

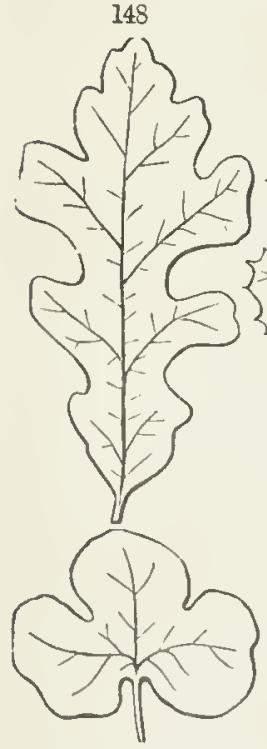

152

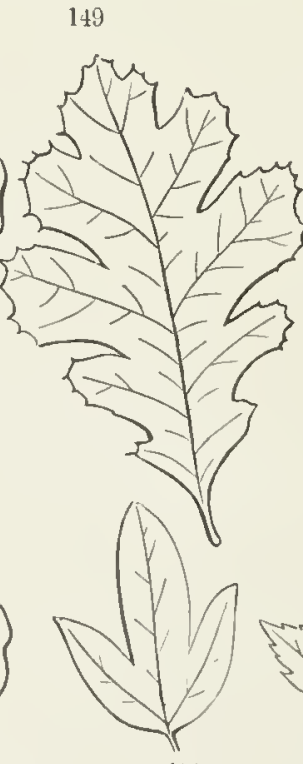

153

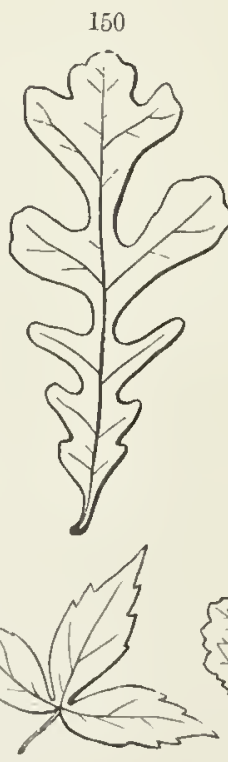

154

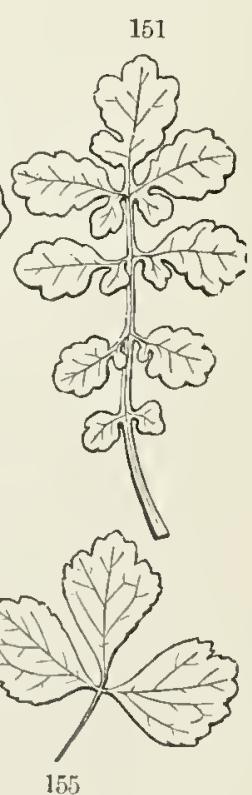

155

three-lobed, three-cleft (or trifid), three-parted, three-divided, or better (in Latin form), trisected. And so for higher numbers, as five-lobed, five-cleft,

Fia. 148, pinnately lobed; 1 s9, pinnately cleft; 150, pimnately parted; 151 ,

FiG. 152, Iralmately three-lobed ; 153, malmately three-cleft; 154, palmately three-parterl: 155 , nalmately three-divided or trisected, leaves 
etc., up to many-lubed, many-cleft or multifid, etc. The same mode of ex. pression may be used for pinnately lobed leaves, as pinnately 7-lobed, -cleft, -parted, etc.

145. The divisions, lobes, etc., may themselves be entire (without teeth or notches), or serrate, or otherwise toothed or incised; or lobed, cleft, parted, etc.: in the latter cases making twice pinnatifid, twice palmately or pinnately lobed, parted, or divided leaves, etc. From these illustrations one will perceive how thic botanist, in two or three words, may describe any one of the almost endlessly divcrsificd shapes of leaves, so as to give a clear and definite idca of it.

146. Compound Leaves. A compound leaf is one which has its biade in entirely separate parts, cacl usually with a stalklet of its own; and the stalklet is often jointed (or articulated) with the main leaf-stalk, just as this
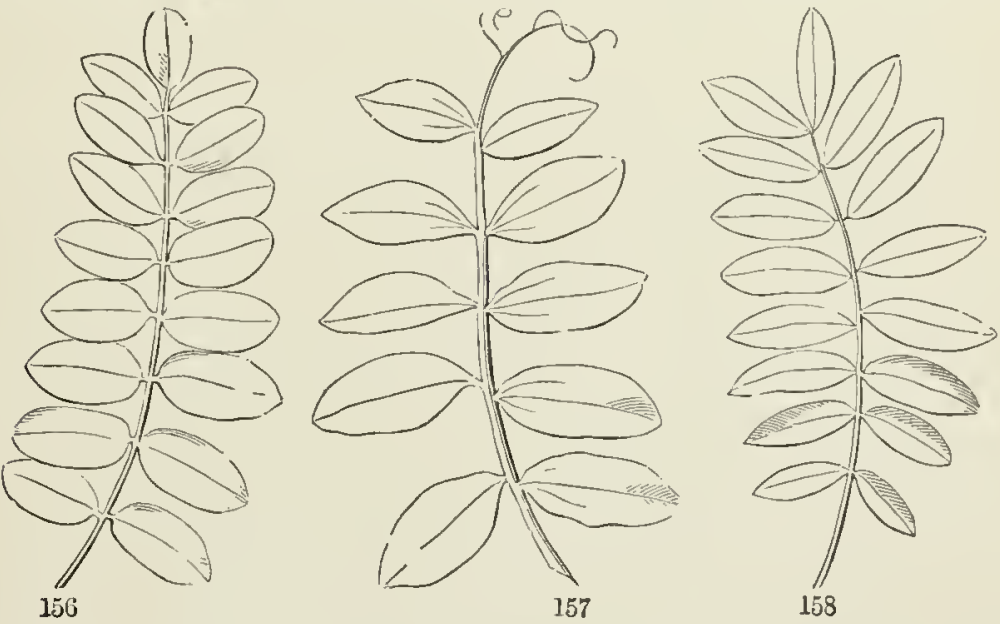

is jointed with the stem. When this is the case, there is no doubt that the leaf is compound. But when the pieces lave no stalklcts, and are not jointed with the main leaf-stalk, it may be considered eitler as a divided simple leaf, or a compound leaf, according to the circumstances. This is a matter of names where all interncdiatc forms may be expected.

147. While the pieces or projecting parts of a simple leaf-blade arc called Lobes, or in deeply cut leaves, etc., Segments; or Divisions, the separate pieces or blades of a compound leaf are called LeafLiets.

148. Compound leaves are of two principal kinds, namely, the Pinnate and the Palmate; answering to the two modes of veining in reticulated leaves. and to the two sorts of lobed or divided leares (141).

149. Pinnate leaves arc those in which the leaflets are arranged on the sides of a main leaf-stalk: as in Fig. 156-15S. They answer to the

FIc. 156-158. Pinnate leaves, the first with an odd leafiet (odd-pinnate); the second with a tendril in place of uppermost leaflets; the third abruptly pinnate, or of even pairs. 
feather-veined (i. e. pinnately-veined) simple leaf; as will be seen at onee on eompariug the forms. The leaflets of the former answer to the lobes or divisions of the latter; and the eontinuation of the petiole, along whieh the leallets are arrauged, answers to the midrib of the simple leaf.

150. Three sorts of pimnate leaves are here given. Fig. 156 is pinnate "with an odd or end leaflet, as in the Common Loeust and the Ash. Fig. 157 is pinnate with a tendril at the end, iu place of the odd leaflet, as in the Vetehes and the Pea. Fig. 158 is evenly or abruptly pinnate, as in the Honey-Loeust.

151. Palmate (also named Digitate) leaves are those in whieh the leaf-

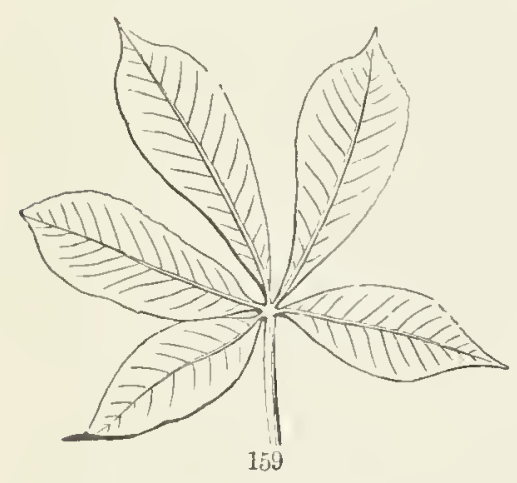
lets are all borne on the tip of the leaf. stalk, as in the Lupine, the Common Clover, the Virginia Creeper (Fig. 93), and the Horse-eliestnut and Buekeye (Fig. 159). They evidently answer to the radiate-veined or palmately-reined simple leaf. That is, the Clover-leaf of three leaflets is the same as a palmately three-ribbed leaf eut into three separate leallets. And suelı a simple five-lobed leaf as that of the Sugar-Maple, if more eut, so as to separate the parts, would produce a palmate leaf of five leaflets, like that of the Horse-cliestriut or Buekeye.

152. Either sort of eompound leaf may have any number of leaflets; yet palmate leaves cannot well liave a great many, sinee they are all crowded together ou the end of the main leaf-stalk. Some Lupines have nine or clcven; the Horse-ehestrut las seven, the Sweet Buckeye more eommonly five, the Clover three. A jimuate leaf often has only seven or five leaflets, or only three, as in Beans of the genus Phaseolus, ete.; in some rarer eases only t."o; in the Orange and Lemon and also in the eommon Barberry there ss unly one! Thle joint at the place where the leallet is united with the petiole distinguishes this last ease from a simple leaf. In other specier of these genera the lateral leaflets also are present.

153. The leaflets of a eompound leaf may be either entire (as in Fig. 126-128), or serrate, or lobed, eleft, parted, ete.; in fact, may present all the variations of simple leaves, and the same terms equally apply to them.

154. When the dirision is earried so far as to separate what wonld be one leaflct into two, three, or sereral, the leaf beeomes doubly or terice compound, citlier pimately or palmately, as the ease may be. For example, while the elustcred leaves of the IIoney-Inoust are simply pinnate, that is, once pimnate, those on new shoots are bipimate, or treice pinnate, as in Fig. 160. When these leaflets are again divided in the same, way, the leaf 
becomes thrice pinnate, or tripinnale, as in many Acacias. The first divisions are called Pinnee; the others, Pinnules; and the last, or little blades themselves, Leaflets.

155. So the palmate leaf, if again compounded in the same way, becomes troice palmate, or, as we say when the divisions are in threes, twice ternate (in Latiu form biternate); if a third time compounded, thrice ternate or triternate. But if the division goes still further, or if the degree is variable, we simply say thiat the leaf is decompound; either palmately or pinnately decompound, as the ease may be. Thus, Fig. 161 represents a four times ternately com. pound (in otleer words a ternately decompound) leaf of a common Meadow Rue.

156. When the botanist, in deseribing leaves, wishes to express the number of the leaflets, he may use terms like these:-

Unifoliolate, for a compound leaf of a single leaflet; from the Latin unum, one, and foliolum,

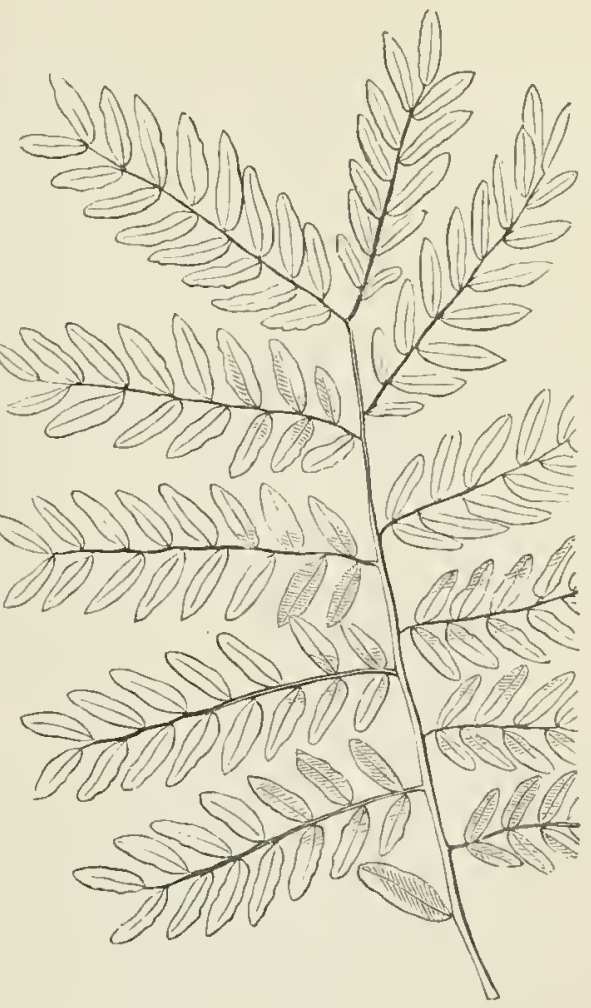

160 leaflet.

Bifoliolate, of two leaflets, from the Latin bis, twice, and foliolum, leaflet.

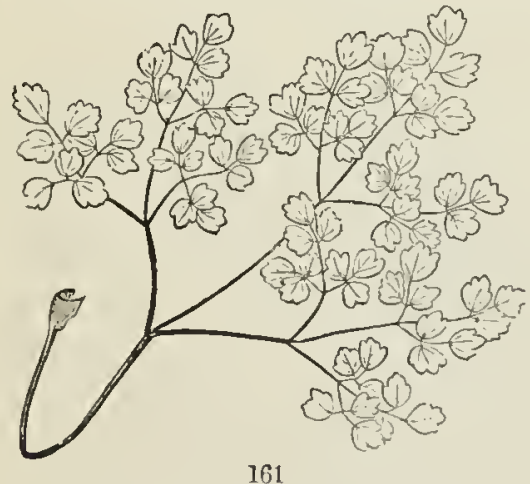

161

Trifoliolate (or ternato), of three leaflets, as the Clover; and so on.

Palmatel.y bifoliolate, trifuliolate, quadrifuliate, plurifoliolate (of several leaticts), ete. : or else

Pinnately bi-, lri-, quadri-, or plurifoliolale (that is, of two, three, four, five, or several leaflets), as the ease may be: these are terse ways of denoting in single plimses both the num. ber of leaflets and the kind of eom. pounding.

157. Of foliage-leares having certain peculiarities in structure, the following may be noted :- 
153. Perfoliate Leaves. In these the stem that bears them seems to run through the blade of the leaf, more or less above its base. A common
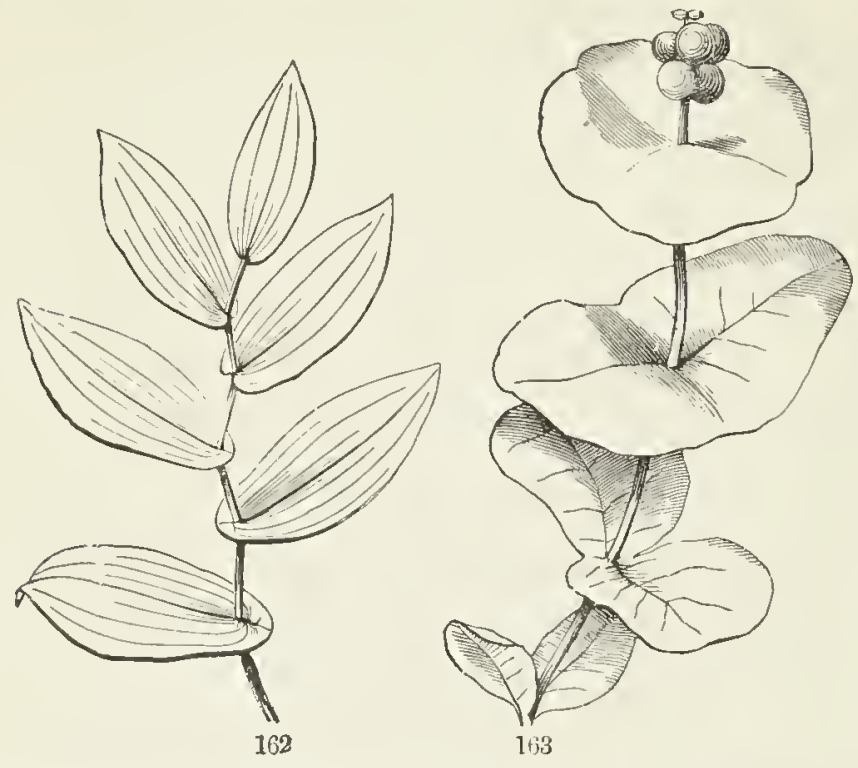

Bellwort (Uvularia perfoliata, Fi: $162)$ is a familiar illustration. The lower and earlier leaves show it distinctly. Later, the plant is apt to produce some leaves merely clasping the stem by the sessile and heart-shaped base, and the latest may be merely sessile. So the serics explains the peculiarity : in the formation of the leaf the

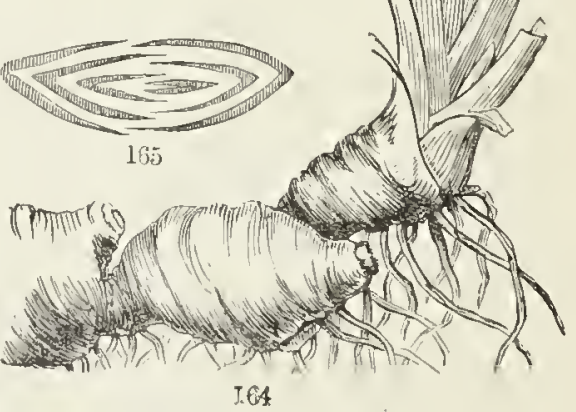
bases, meeting around the stem, grow together there.

159. Connate-perfoliate. Sueh are the upper leaves of true Honeysuckics. IIere (Fig. 163) of the opposite and sessile leaves, some pairs, especially the uppermost, in the course of their formation unite around the stem, which thus seens to run throngh the disk formed by their union.

160. Equitant Leaves. While ordinary leaves spread lorizontally, and present one face to the sky and the other to the earth, there are some that present, their tip to the sky, and their faces right and left to the horizon. Among these are the equitunt leares of the Iris or Flower-de-Luec. Inspection shows that each leaf was formed as if folded together lengthoise,

F10. 162. A smmuer hrancl of Uvularia perfoliata; lower leaves perfoliate, upper cordate-claspuing, upperinost simply scssile.

Fig. 163. Bianch of a Iloneysuclile, with connate-perfoliate leaves.

Fig. 164. Rontstock an!] cquitant lenves of Iris. 165. A scction across the cluster of leares at the bottom, showing the equitation. 
so that what would be the upper surface is within, and all grown together, exeept next the bottom, where eaeh leaf eovers the next younger one. It was from their straduling over eael other, like a man on horsebaek (as is seen in the eross-section, Fig. 165), that Limnæus, with his lively faney, ealled these Equitant leaves.

161. Leaves with no distinction of Petiole and Blade. The leares of Iris just mentioned show one form of this. The flat but narrow leaves of Jonquils, Dalfodils, and the eylindrieal leaf of Onions are other instanees. Needle-shaped leaves, like those of the Pine, Lareli, and Spruee, and the awol-shaped as well as the scale-shaped leaves of Junipers, Red Cedar, and Arbor-Vitæ (Fig. 166), are examples.

102. Phyllodia. Sometimes an expanded petiole takes the place of the blade; as in numerous New Holland Aeaeias, some of whieh are now eommon in greenhouses. Such eounterfeit blades are ealled phyllodia, - meaniug leaf-like bodies. They may be known from true blades by their standing edgewise, their margins being direeted upwards and downwards; while in true blades the faces look upwards and downrards; exeepting in equitant leaves, as already explained.

163. Falsely Vertical Leaves. These are apparent exeeptions to the rule, the blade standing edgewise instead of flatwise to the stem; but this position eomes
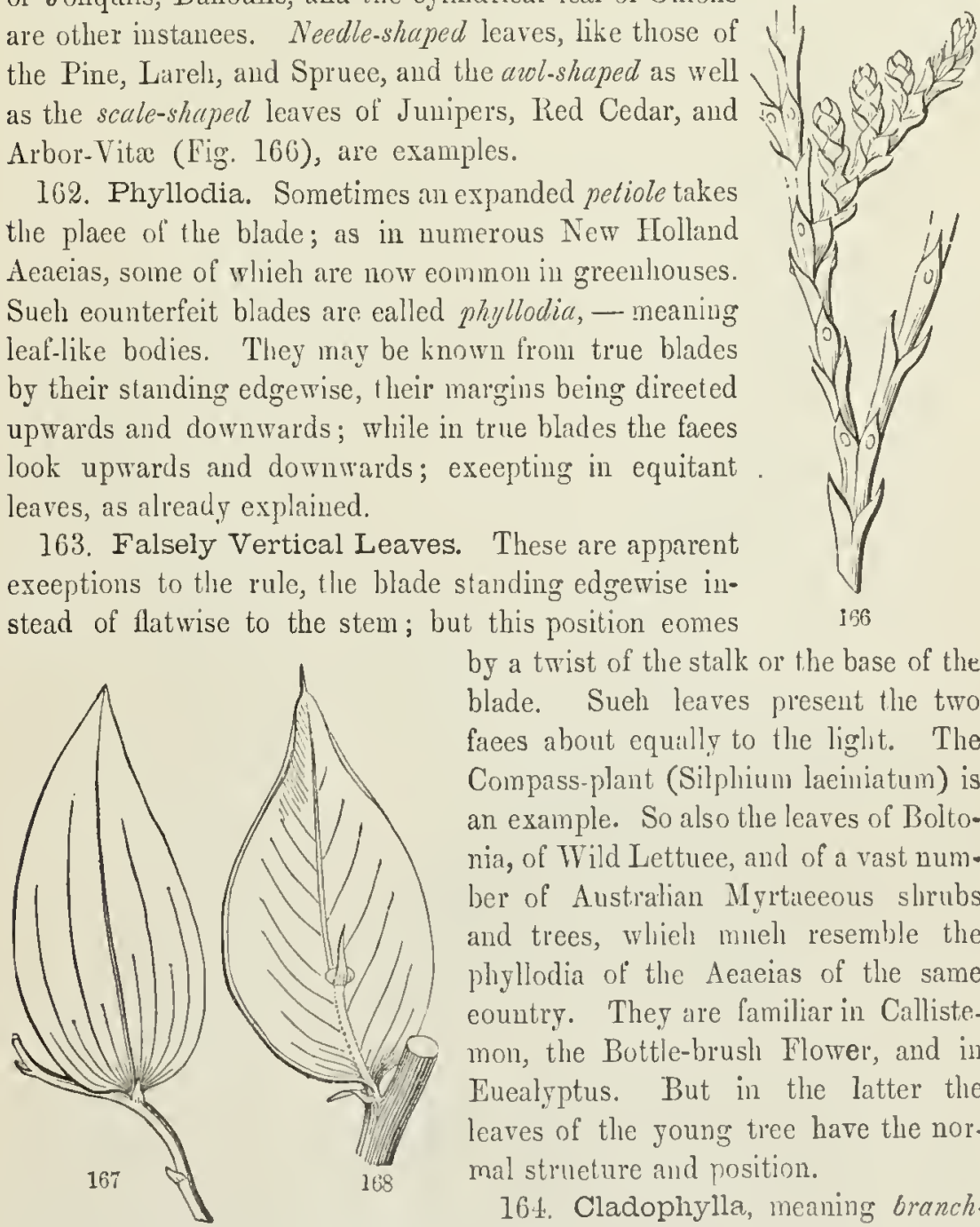

by a twist of the stalk or the base of the blade. Sueh leares present the two faees about equilly to the liglit. The Compass-plant (Silphium laeiniatum) is an example. So also the leaves of Bolto* nia, of Wild Lettuee, and of a vast num. ber of Australian Myrticeous slorubs and trees, whieh mueh resemble the phyllodia of the Aeaeias of the same country. They are familiar in Callistemon, the Bottle-brush Flower, and in Euealyptus. But in the latter the leaves of the young tree have the normal structure and position.

164. Cladophylla, meaning branchleaves. The foliage of Ruseus (the Buteher's Bronm of Lurope) and of Myrsiphyllum of South Afriea (eultivated for deeoration under the false

Fic. 166. Branch of Arhor-Vitæ, with awl-shaped and scale-shaperl leavez.

Fig. 167. The ambiguous leaf? (cladophyllum) of Myrsiphyllum.

Fic. 168. Same of Ruscus, or Butcher's Broom. 
name of Smilax) is peeuliar and puzzling. If these blades (Fig. 167, 168) are really leaves, they are most anomalous in neeupying the axil of another leaf, redueed to a little seale. Yet they have an upper and lower face, as leaves should, although they soon twist, so as to stand more or less eagewise. If they are branehes wheh have assuned exactly the form and offiee of leaves, they are equally extraordnary in not making any further development. But in Ruseus, flowers are borne on one faee, in the axil of a little seale: and this would seem to settle that they are branehes. Ir Asparagus just the same things as to position tre thread-shaped and braneh-like.

\section{§ 2. LEAVES OF SPECIAL CONFORMATION AND USE.}

165. Leaves for Storage. A leaf may at the same time serve both ordinary and speeial uses. Thus in those leares of Lilies, sueh as the common White Lily, whieh spring from the bulb, the upper and green part

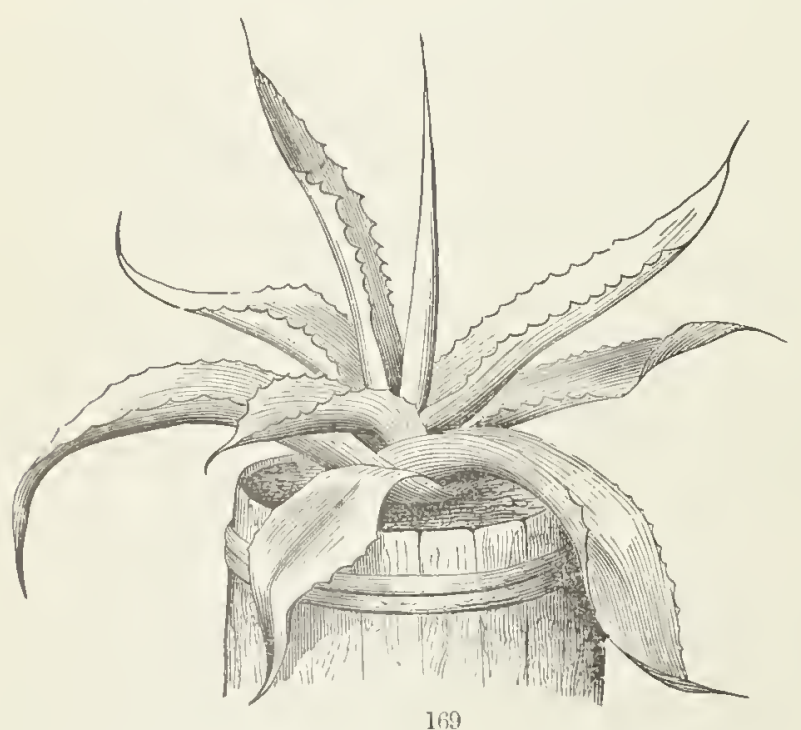

serres for foliage and elaborates nourishment, while the thiekened por. tion or bud-seale beneath serves for the storage of this nourishment. The thread-shaped leaf of the Onion ful. fils the same offiee, and the nourishing matter it prepares is depositerl in its sheathing base, forming one of the eoneentrie layers of the onion. When

these layers, so thiek and sueeulent, have given up their store to the growing parts within, they are left as thin and dry luusks. In a Houseleek, an Aloe or an Agave, the green color of the surface of the fleshy leaf indieates that it is doing the rork of foliage; the deeprer-seated white portion within is the storehouse of the nonrishment whiels the green surface has elahorated. So, also, the seed-leaves or eotyledons are eommonly used for stomge. Some, as in one of the Maples, the Pea, Horse-eliestnut, Oak, ete, are for nothing else. Others, as in Beeeh and in our eommon 
Beans, give faint indications of service as foliage also, chiefly in vain. Still others, as in the Pumpkin and Flax, having scrved for storage, develop

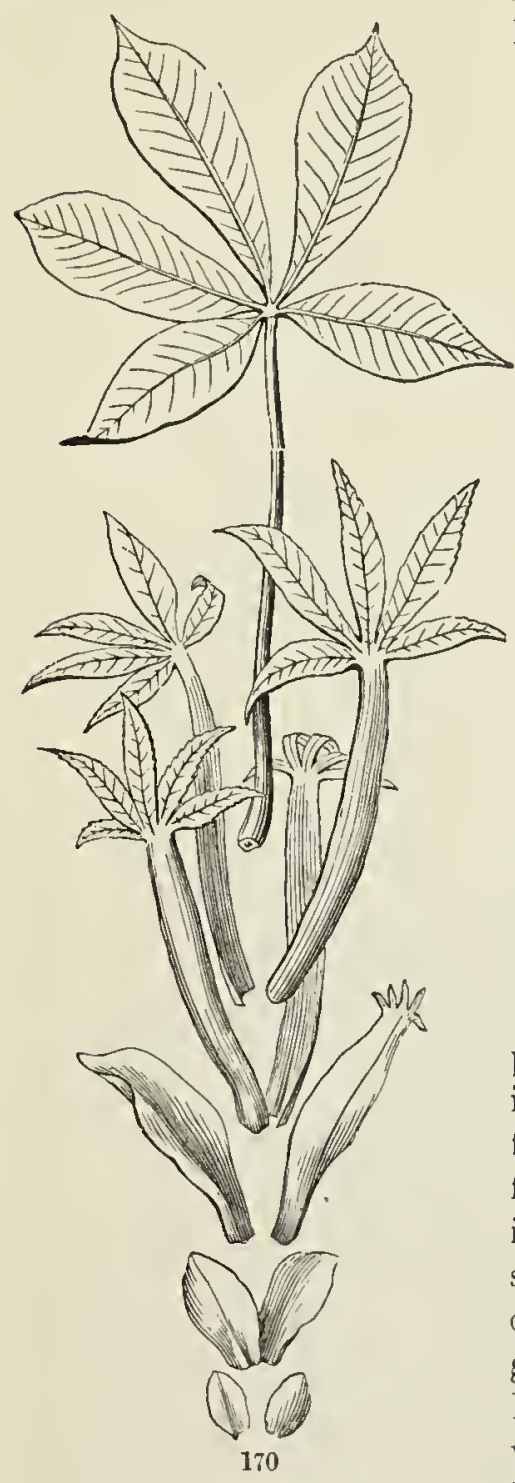
iuto the first efficient foliage. Compare $11,22-30$, and the accompanying figures.

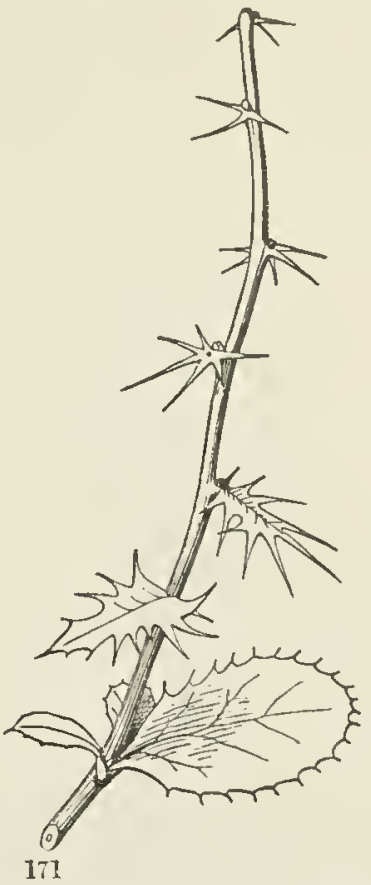

166. Leaves as Bud-Scales serve to protect thic forming parts within. Having fulfilled this purpose they commonly fall off when the shoot develops and foliage-leaves appear. Occasionally, as in Fig. 170, therc is a transition of budscales to leaves, which reveals the nature of the former. The Lilac also shows a gradation from bud-scalc to simple leaf. In Cornus florida (the Flowering Dogwood), the four bud-scales which through the winter protect the licad of forming flowers remain until blossoming, and then the base of each grows out into

FIG. 170. Series of bud-scales and foliage-leaves from a developing but of the Low Sweet Buckeye (Esculus parviflora), showing nearly complete gralation, from a scale to a compound leaf of five leaflets; and that the scales answer to reduced petioles.

Fra. 171. Shoot of common Barberry, showing transition of toliage-leaves to spines. 
a large and very showy petal-like leaf; the original dry scale is apparcnt in the notch at the apex.

167. Leaves as Spines occur in several plants. A familiar instance is that of the common Barberry (Fig. 171). In almost any summer shoot, most of the gradations may be secn between the ordinary leaves, with sharp bristly tecth, and leaves which are reduced to a branching spine or thorn. The fact that the spines of the Barberry produce a leaf-bud in their axil also proves them to be leaves.
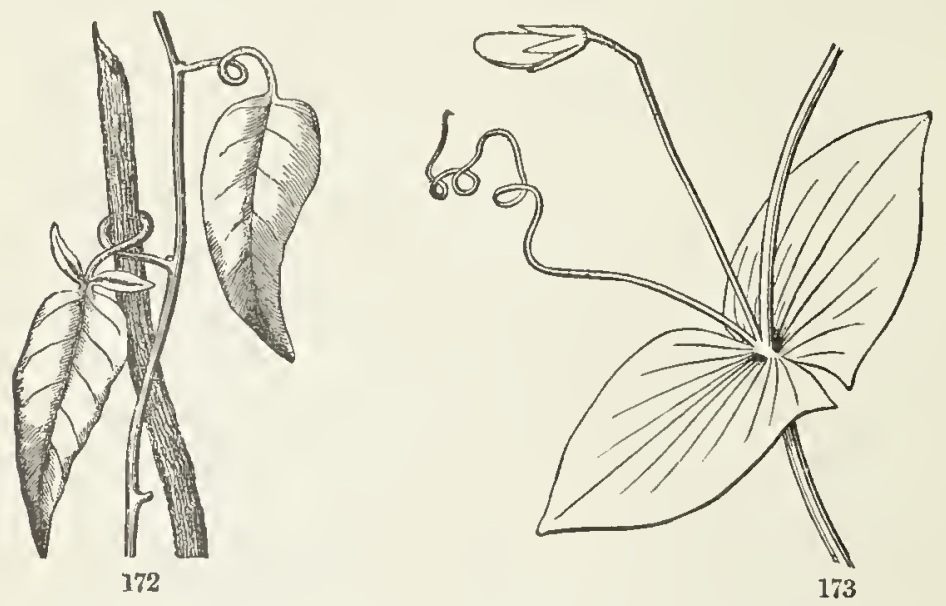

168. Leaves for Climbing are various in adaptation. True foliage leaves serve this purpose; as in Gloriosa, where the attenuated tip of a sim. ple lcaf (otherwise like that of a Lily) hooks around a supporting object; or in Solanum jasminoides of the gardens (Fig. 172), and in Naurandia, etc., where the leaf-stalk coils round and clings to a support; or in the compound leaves of Clematis and of Adlumia, in which both the leaflets and their stalks lrook or coil around the support.

169. Or in a compound leaf, as in the Pea and most Vetches, and in Cobxa, while the lower leaflets scrve for foliage, some of the uppermost are developed as tendrils for climbing (Fig. 167). In the common Pca this is so with all but onc or tro pairs of leaflets.

170. In one Europcan Veteh, the leaflets are wanting and the whole petiole is a tendril, while the stipules become the only foliage (Fig. 173).

171. Leaves as Pitchers, or hollow tubes, are familiar in the common Pitcher-plant or Sicle-saldelle Flower (Sarmeenia, Fig. 174) of our bogs. These pitchers are generally lialf full of water, in which flics and other inscets are drowncel, often in such numbers as to make a rich manure for the plant. More curious aro some of the southern species of Sarracenia, which scem to be specially adapted to the capture and destruction of flies and other insects.

Fig. 172. Leaves of Solanmm jasminoides, the petiole arlapter for climbing.

Fig. 173. Leaf of Lathyrus A pliacn, consisting of a pair of stipules and a tendril. 
172. The leaf of Nepenthes (Fig. 175) combines three structures and uses. The expanded part below is foliage: this tapers into a tendril for

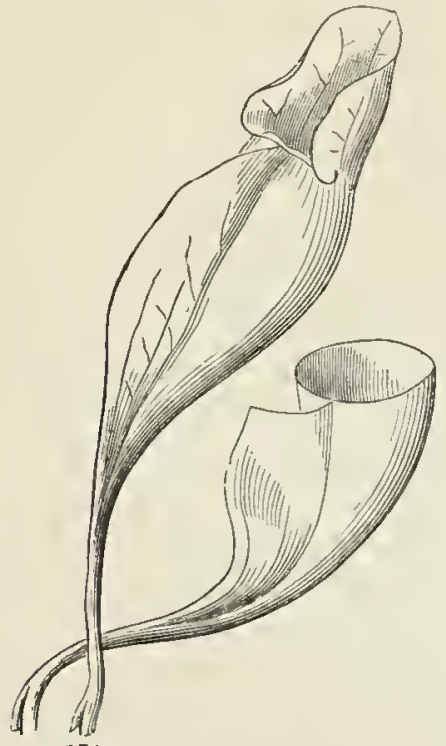

174

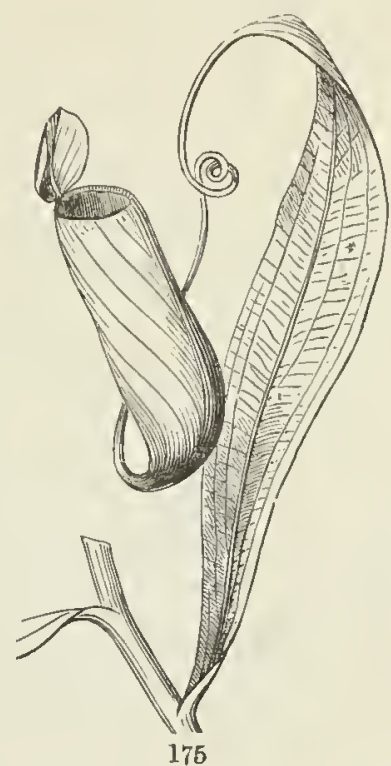

climbing; and this bears a pitcher with a lid. Insects are caught, and per. haps digested, in the pitcher.

173. Leaves as Fly-traps. Insects are caught in another way, and more expertly, by the most extraordinary of all the plants of this country, the Dionæa or Venus's Fly. trap, which grows in the sandy bogs around Wilmington, North Carolina. Here (Fig. 176) cach lcaf bears at its summit an appendage which opens and shuts, in shape something like a stcel-trap, and operating much like one. For when open, no sooner docs a fly alight on its surface, and brush against any one of the two or three bristles that grow there, than the trap suddenly closes, capturing the intruder. If the fly cscapes, the trap soon slowly opens, and is ready for another capture. When retained, the inscet is after a time moistened by a sceretion from miwute glands of thic inner surface, and is

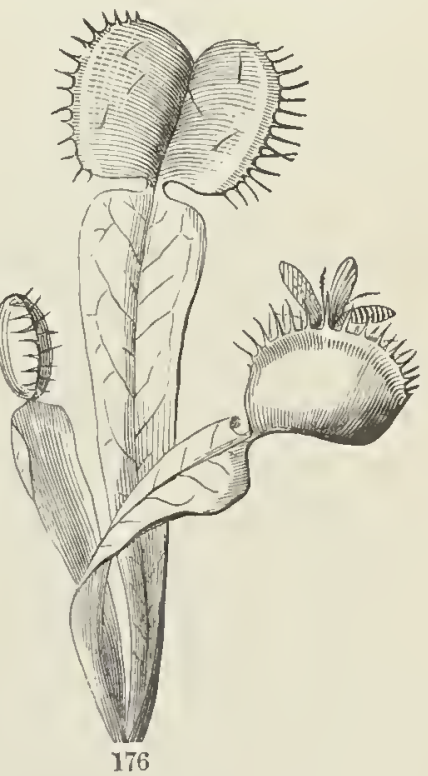
digested. In the various species of Drosera or Sundew, insects are caught

F1G. 174. Leaf of Sarracenia purpurea, entire, and another with the upper part eut off.

FIG. 175. Leaf of Nepenthes; foliage, tendril, and pitcher combined.

F1G. 176. Leaves of Dionæa; the trap in one of them open, in the others closed. 
by stickrre fast to very viscid glands at the tip of strong bristles, aided by adjacent gland-tipped bristles which bend slowly toward the captive The use of such adaptations and operations may be explained in another place.

\section{STIPULES,}

174. A leaf complete in its parts consists of blade, leaf-stalk or petiole, and a pair of stipules. But most leaves have either fugacious or minute stipules or none at all; many have no petiole (the blade being sesilile or stalkless); some have no clear distinetion of blade and petiole; and many

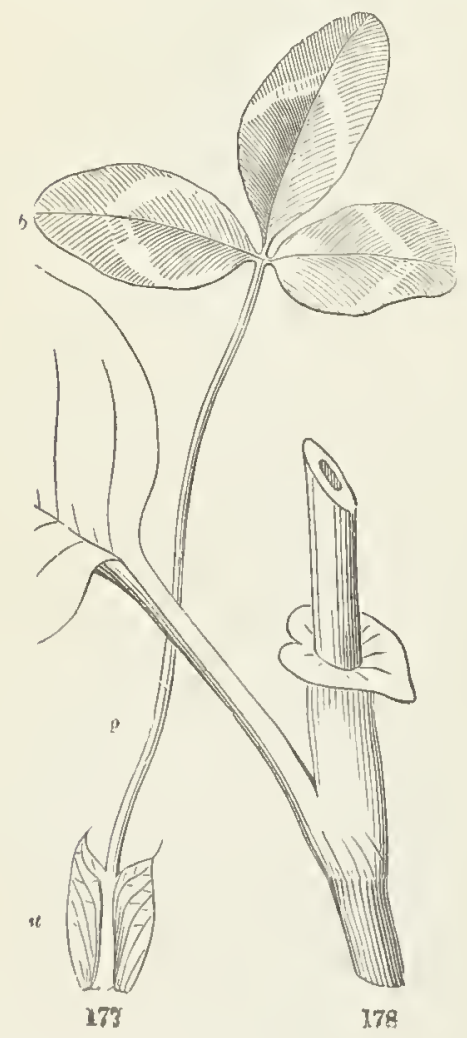
of these, sueh as those of the Onion and all phyllodia (166), consist of petiole only 175. The base of the petiole is apt to be broadened and flattened, sometimes into thin margins, sonetimes into a sheath which cmbraces the stem at the point of attachment.

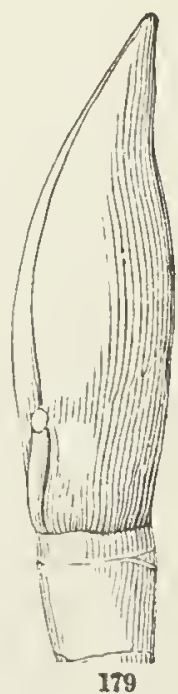

179

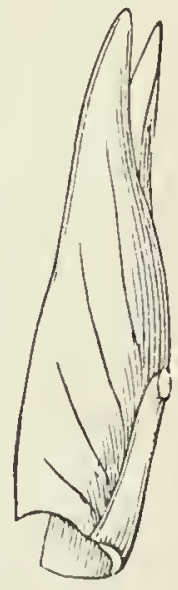

180

176. Stipules are sueh appendages, either wholly or partly separatea from the petiole. When quite separate they are said to be free, as in Fig. 112. When attaelied to the base of the petiole, as in the Rose and in

FIG. 177. Leaf of Red Clover: st, stipules, adhering to the base of $p$, the petiole; i, blarle of three leallets.

FIa. 178. Part of stem and leaf of Prince's-Feather (Polygonum orientale) with the united sheathing stipules forming a sheath or verea.

Fig. 179. Terminal winter bud of Magnolia Umbrella, natural size. 180. Outermost bud-scale (yair of stipules) detached. 
Clover (Fig. 177), they are adnate. When the two stipules unite and sheathe the stem above the insertion, as in Polygonum (Fig. 178), this sheath is called an Ocrea, from its likeness to a greave or leggin.

177. In Grasses, when the sheathing base of the leaf may answer to petiole, the summit of the sheatlo commonty projects as a thin and short membrane, like an ocreal this is calted a Ligula or Ligule.

178. When stipules are green and lear-like they act as so much foliage. In the Pea they make up no small part of the actual foliage. In a related plant (Lathyrus Aphaea, Fig. 173), they make the whole of it, the remainder of the leaf being tendril.

179. In many trees the stipules are the bud-scales, as in the Beech, and very conspicuously in the Fig-tıce, 'lulip-tree, and Magnolia (Fig. 179). 'These fall off as thie leaves unfold.

180. The stipules are spines or prickles in Locust and several other Leguminous trees and slurubs; they are tendrils in Smilax or Greenbrier

\section{\$ 4. THE ARRANGEMENT OF LEAVES.}

181. Phyllotaxy, meaning leaf-arrangement, is the study of the position $o^{f}$ leaves, or parts answering to leaves, upon the stenn.

182. The technical name for the attachment of leaves to the stem is

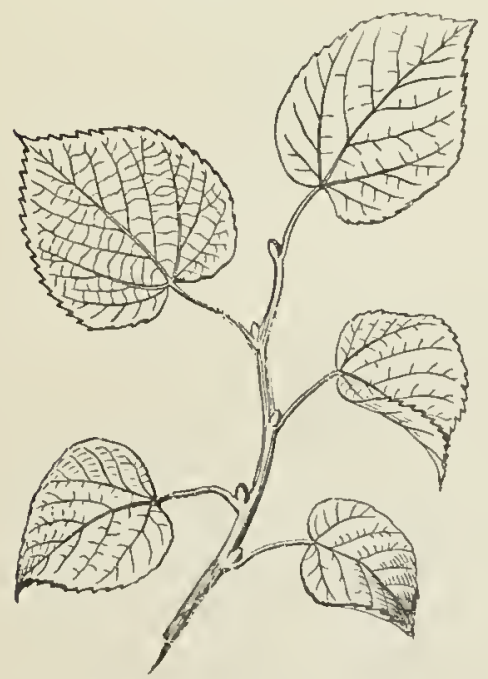

181

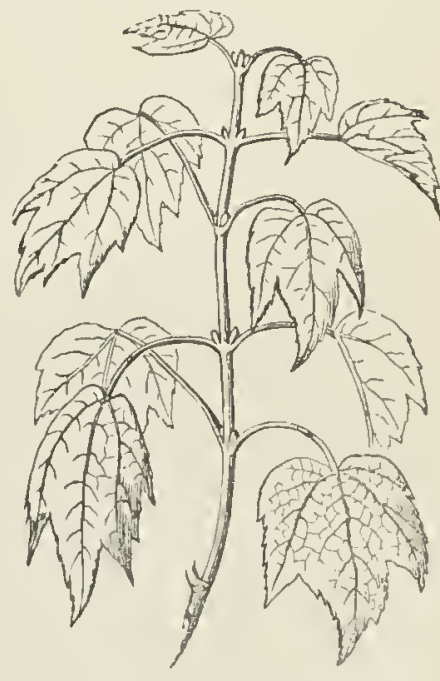

182

the insertion. Lcaves (as already noticed, 54) are inserted in threc modes. They arc

Alternate (Fig. 181), that is, one after another, or in other words, with only a single leaf to each node; 
Oppsite (Fig. 182), when there is a pair to each node, the two leaves in this case being always on opposite sides of the stem;

Whorled or Verticillate (Fig. 183) when there are more than two leaves on a node, in which case they divide the circle

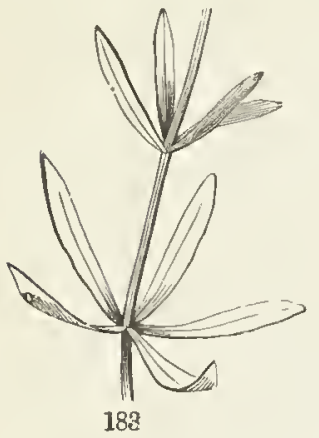
equally between them, forming a Verticel or whorl. When there are three leaves in the whorl, the leaves are one third of the circumference apart; when four, one quarter, and so on. So the plan of opposite leaves, which is very common, is merely that of whorled leaves, with the fewest leaves to the whorl, namely, two.

183. In both modes and in all their modifications, the arraugement is such as to distribute the leaves systematically and in a way to give them a gocd exposure to the light.

184. No two or more leaves ever grow from the same point. The socalled Fascicied or Clustered leaves are the leaves of a brauch the nodes of which are very close, just as they are in the bud, so kecping the leaves in a eluster. This is evident in the Larch (Fig. 184), in which examination shows each cluster to be made up of numerous leaves crowded on a spur or short axis. In spring there are only such clinstcrs; but in summer some of them lengthen into ordinary shoots with seattered alteruate leaves. So, likewise, each cluster of two or three needle-

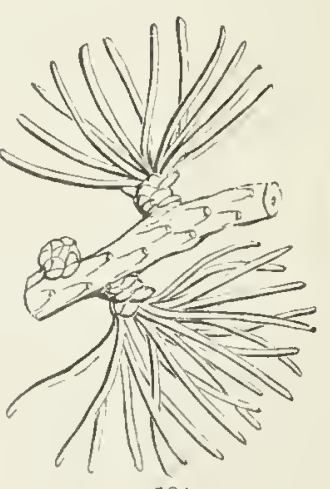

184 shapcd leaves in Fitch Piues (as in ligg. 185), or of five leaves in White Pine, answer's to a similar extremely short branch, springing from the axil of a thin and slender scale, which represents a leaf of the main shoot. For Pines produce two kinds of leaves, -1 . primary, the proper leaves of the shoots, not as foliage, but in the shape of dclicate scales in spring, which soon fall away; and 2. secondary, the fascicled leaves, from buds in the axils of the former, and these form the actual foliage.

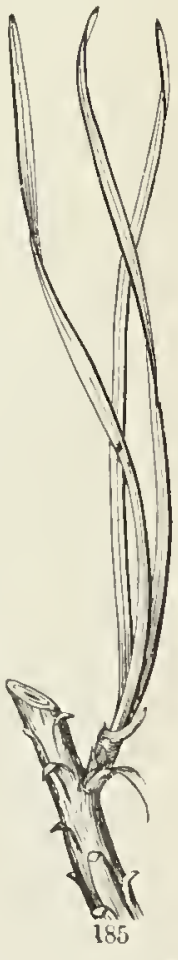

Fig. 183. Whorled leaves of Galium.

FIo. 18t. A piece of sten of Larch with two clusters (fascicles) of numerous lcaves.

FI0. 185. Piece of a branch of Pitch l'ine, with three leaves in a fascicle or bun. dle, in the axil of a thin scale which answers to a primary leaf. The buidle is surrounded at the base by a short sheatl, formud of the delicatc scales of the axillary bud. 
185. Phyllotaxy of Alternate Leaves. Alternate leaves are distrib. uted along the sten in an order which is uniform for each species. The arrangement in all its modifications is said to be spiral, because, if we draw a line from the insertion (i. e. the point of attacliment) of one leaf to that of the next, and so on, this line will wind spirally around the stcm as it rises, and in the same spccies will always bear the sane number of leaves for cach turn round the stem. That is, any two successive leaves will always be separated from each other by an equal portion of the circumference of the stem. The distance in height between any two leaves may vary greatly, even on the same shoot, for that depends upon the length of the internodes, or spaces between the lenves; but the distance as mcasured around the circumference (in other words, the Angular Divergence, or angle formed by any two successive leaves) is uniformly the sime.

186. Two-ranked. The grcatest possible divergence is, of coursc, wherc the sccond leaf stands on exactly the opposite side of the stem from the first, the third on the side opposite the second, and therefore over the first, and the fourth over the second. This brings all the leaves into two ranks, one on one side of the stem and one on the other, and is therefore called the Two-ranked arrangement. It occurs in all Grasses, - in Indian Corn, for instance; also, in the Basswood (Eig. 181). 'This is the simplest of all arrangcments, and the one which most widely distributes successive leares, but which therefore gives the fewest vertical ranks. Next is the

187. Three-ranked arrangcment, — that of all Sedges, and of White IIellcbore. Helc the second

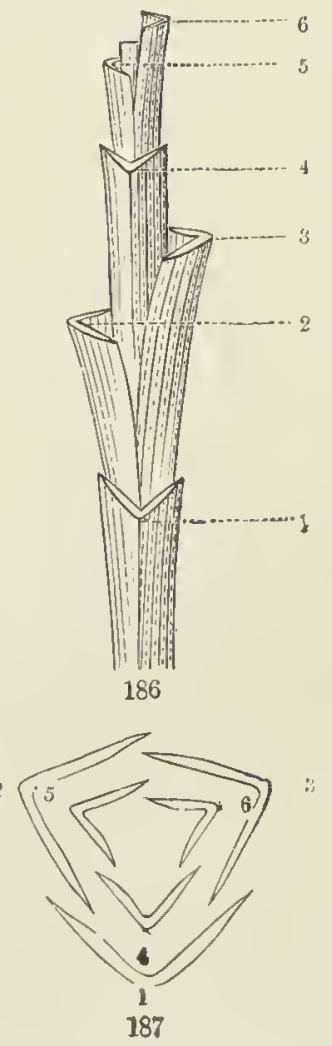
186

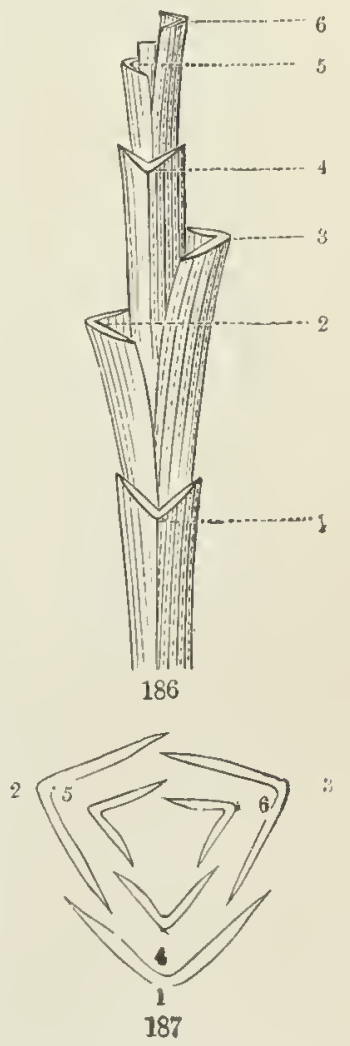
leat is placed one third of the way round the stem, the third leaf two thirds of the way round, the fourth leaf accordingly directly over the first, the fifth over the second, and so on. That is, three lcaves occur in each turn round the stem, and they arc separated from each other by one third of the circumference. (Fig. 186, 187.)

188. Five-ranked is the next in the series, and the most common. It is secn in the Apple (Fig. 188), Cherry, Poplar, and the greater number of trees and slrubs. In this case the line traced from lcaf to leaf will pass twicc round the stcm beforc it reaches a lcaf

FIG. 186. Three-ranked arrangement, shown in a piece of the stalk of a Sedge, with the leaves cnt off above their bases; the leaves are numbered in order, from 1 to 6. 1-i. Ditgram or cross-section of the same, in one plane; the learec similarly numbere:l; showner two cycles of threc. 
situated directly over any below (Fig. 189). Here the sixth leaf is over the first; the leaves stand in five perpendicular ranks, with equal angular distauce from each other; and this distanee between any two suecessitt leaves is just two fifths of the circumferenee of the stem.

189. The five-ranked arrangement is expressed by the fraction $\frac{2}{5}$. TLL

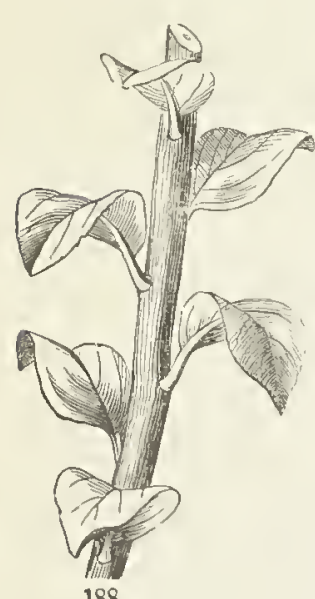

fraction denotes the divergence of the suceessive leaves, $i, e$, the angle they form with each other: the numerator also expresses the number of turns made round the stem by the spiral line in completing one eyele or set of leaves, namely, two; and the denominator gives the number of leaves iu each eycle, or the number of perpendicular ranks, namely, five. In the same way the fraction $\frac{1}{2}$ stands for the two-ranked mode, and $\frac{1}{3}$ for the three-ranked: and so these different sorts are expressed by

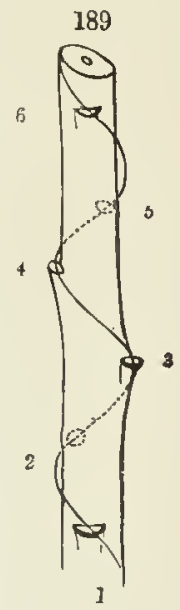
we series of fractions $\frac{1}{2}, \frac{1}{3}, \frac{2}{5}$. Other eases follow in the same numerieal progression, the next being the

190. Eight-ranleed arrangemeut. In this the nintb leaf stands over the first, and three turns are made around the stem to reach it; so it is expressed by the fration $\frac{3}{8}$. This is seen in the Holly, aud in the common Phantain. Then comes the

191. Thirteen-ranked arrangement, in whieh the

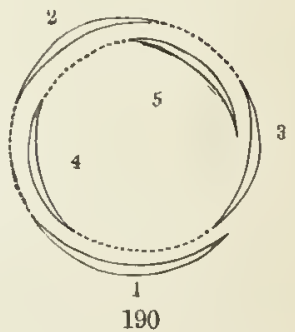
fourtecnth leal is over the first, after five turns around the stem. The eommon Houseleek (Fig. 191) is a good example.

192. The scries so far, then, is $\frac{1}{2}, \frac{1}{3}, \frac{2}{5}, \frac{3}{8}, \frac{5}{13}$; the numerator and the denominator of cach fraction being those of the two next preceding ones added together. At this rate the next higher should be $\frac{8}{21}$, then $\frac{13}{3} \frac{3}{2}$, and so on; and in faet just such cases are met with, and (commonly) no others. 'These lighler sorts are found in the Pinc Family, both in the leaves and the eoncs and in many other plauts with small and crowded leaves. But in those the number of the ranks, or of lcaves in cach cyele, ean only rarely

F1G. 188. Shoot with its leares 5-ranked, the sixth leaf over the first; as in the Apple-tree.

FIa. 189. Dingram of this arangement, with a spiral line drawn from the attaeh. ment of one leaf to the next, and so on; the parts on the sile tumed from the eye are fainter.

FIs. 190. A ground-plan of the same; the section of the leaves similarly num. bered; a dotted liue clrawn from the edge of one leaf to that of the next marks out tlie spiral. 
be made out by direct inspection. They may be indirectly ascertained, however, by studying the secondary spirals, as they are called, whieh usually become conspieuous, at least two series of them, one turning to the right and one to the left, as shown in Fig. 191. For an aceount of the way in whieh the character of the phyllotaxy may be deduced from the secondary spirals, see Structural Botany, Cliapter IV.

193. Phyllotaxy of Opposite and whorled Leaves. This is simple and comparatively uniform. The leaves of each pair or whorl are placed over the intervals between those of the preceding, and therefore under the intervals of the pair or whorl next abore. The whorls or pairs altcrnate or cross caelı other, usually at right angles, that is, they decussate. Opposite leaves, that is, whorls of two leares only, are far commoner than whorls of three or four or inore members. This arrangement in suecessive decussating pairs gives an advantageous distribution on the stem in four vertical ranks. Whorls of three give six vertical ranks, and so on: Note that in descriptive botany leaves in whorls of two are simply called opposite leaves; and that the term verticillate or zoliorled, is cmployed only for cases of more than two, unless the latter number is specificd.

194. Vernation or Præfoliation, the disposition of the leaf-blades in the bud, comprises two things ; 1st, the way in which each separate leaf is folded, eoiled, or paeked up in the bud; and $2 \mathrm{l}$, the arrangement of the leaves in the bud with respect to one another. The latter of course depends very much upon the

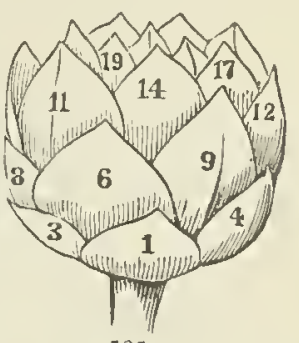

191

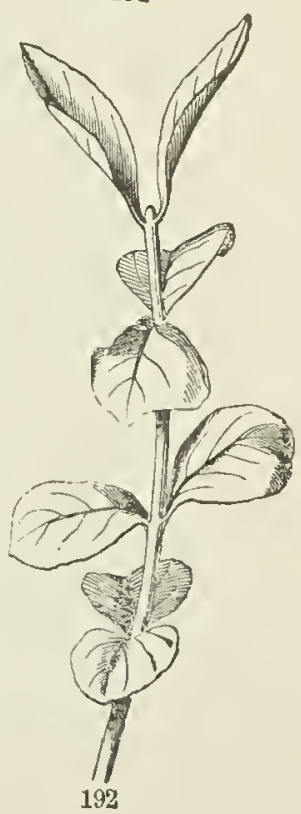
plyyllotaxy, i. e. the position and order of the leaves upon the stem. The same tcrms are used for it as for the arrangement of the leaves of the flower in the flower-bud. Sce, therefore, "Estivation, or Præfloration."

195. As to each leaf separately, it is sometimes straight and open in vernation, but more commonly it is either bent, folded, or rolled up. When the upper part is bent down upon the lower, as the young blade in the Tulip-trec is bent upon the leafstalk, it is said to be Inflexed or Reclined in veruation. When folded by the midrib so that the two halves are placed face to face, it is Conduplicate (Fig. 193), as in the Magnolia, the Cherry, and the Oak. When folded baek and forth like the plaits of a fan, it is

Fig. 191. A young plant of the Houseleek, with the leaves (not yet expanded) numbered, and exhiliting the 13-ranked arrangement; and showing secondary spirals.

FIG. 192. Opposite leaves of Euonymus, or Spindle-tree, showing the successive pairs crossing each other at right angles. 
Plicate or Plaited (Fig. 194), as in the Maple and Currant. If rolled, it may be so either from the tip downwards, as in Ferns and the Sundew
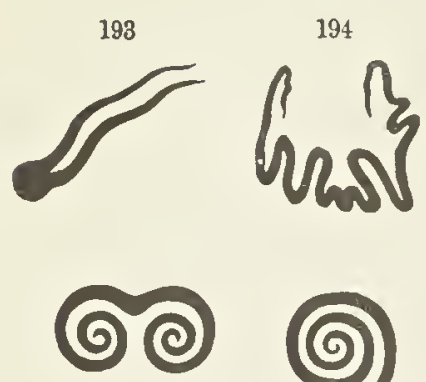

196

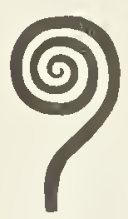

197
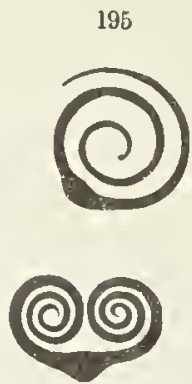

198

(Fig. 197), when in unrolling it resembles the head of a erosier, and is said to be Circinate; or it may be rolled up parallel with the axis, either from one edge into a eoil, when it is Convolute (Fig. 195), as in the Aprieot and Plum; or rolled from both edges towards the midrib, - sometimes inwards, when it is Involute (Fig. 199), as in the Violet and Water-Lily; sometimes outwards, when it is Revolute (Fig. 196), in the Rosemary and Azalea. The figures are diagrams, representing seetions through the leaf, in the way they were represented by Linnæus.

\section{Section VIII. FLOWERS.}

196. Flowers are for the production of seed (16). Stems and branches, which for a time put forth leaves for vegetation, may at length put forth flowers for reproduetion.

\section{POSITION AND ARRANGEMENT OF FLOWERS, OR INFLOR- ESCENCE.}

197. Flower-buds appear just where lenf-buds appear; that is, they are either terminal or axillary (47-49). Morphologieally, flowers answer to shoots or branehes, and their parts to leaves.

198. In the same speeies the flowers are usually from axillary buds only, or from terminal buds only; but in some they are both axillary and terminal.

199. Inflorescence, whiel is the name used by Limnæus to signify mode of flower-arrangement, is aceordingly of three elasses: namely, Indeterminate, when the flowers are in the axils of leaves, that is, are from axillary buds; Determinate, when they are from terminal buds, and so terminate a stem or branch; and Mixed, when these two are eombined.

200. Indeterminate Inflorescence (likewise, and for the same reason, called indefinite inflorescence) is so named beeause, as the flowers all come from axillary buds, the terminal bud may keep on growing and prolong the stem indefinitely. This is so in Monerwort (Fig. 199) 
201. When Howers thus arise singly from the axils of ordinary leaves, they are axillary and solitary, not collected into flowel-clusters.

202. But when several or many flowers are produced near each other, the accompanying leaves arc apt to be of smaller size, or of different shape or charactcr: then they are called Bricts, and the flowers thus brought together form a cluster. The kinds of flower-clusters of the indeterminate class have re-

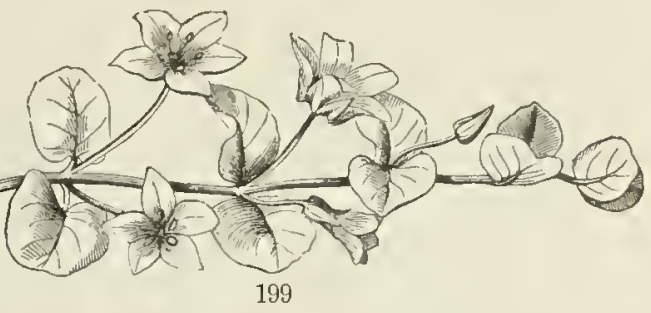
ceived distinct names, according to their form and disposition. They are principally Raceme, Corymb, Unebel, Spike, Head, Spadix, Catkin, and Panicle.

203. In defining these it will be necessary to use some of the following terms of descriptive botany which relate to inflorescence. If a flower is stalkless, i. e. sits directly in the axil or other support, it is said to be sessile. If raised on a naked stalk of its own (as in Fig. 199) it is pechunculate, and the stalk is a PEDUNCLE.

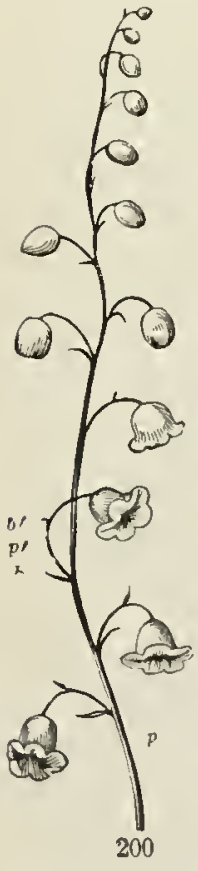

204. A peduncle on wlich a flower-cluster is raised is a Common peduncle. That which supports each separate flower of the cluster is a Partial peduncle, and is generally called a Pedicel. The portion of the general stalk along which flowers are disposed is called the Axis of inflorescence, or, when covered with sessile flowers, the Rhachis (back-bone), and sometimes the Receptacle. The leaves of a flower-cluster generally are termed Bracts. But when bracts of different orders are to be distinguished, those ou the common peduncle or axis, and which have a flower in their axil, keep the name of bracts; and those on the pedicels or partial flower. stalks, if any, that of Bractlets o1 Bracteoles. The former is the preferable English name.

205. A Raceme (Fig. 200) is that form of flower-cluster in which the flowers, each on their own foot-stalk or pedicel. are arranged along the sides of a common stalk or axis of inflorescence; as in the Lily of the Valley, Currant, Barberry, one section of Cherry, etc. Each flower comes from the axil of a small leaf, or bract, which, however, is often so small that it might escape notice, and even sometimes (as in the Mustard Family) disappears altogefluer. The lowest biossoms of a

F1G. 199. Piece of a flowering-stem of Moncywort (Lysinachia nummularia,) with single flowers successively produced in the axils of the leaves, from below upwards, as the stem grows on.

FIG. 200. A raceme, with a general peduncle $(p)$, perlicels $\left(p^{\prime}\right)$, hracts $(b)$, and bractlets $\left(b^{\prime}\right)$. Plainly the bracts here answer to the leaves in Fig. 199 
raceme are of course the oldest, and therefore open first, and the order of blossoming is ascending from the bottom to the top. The summit, never being stopped by a terminal flower, may go on to grow, and often does so (as in the common Shepherd's Purse), produciug lateral flowers one after auother for many weeks.

206. A Corymb (Fig. 202) is the same as a raccme, except that it is flat and broad, citler eonvex, or level-topped. That is, a raceme beeomes a corymb by lengthening the lower pedieels while the uppermost remain

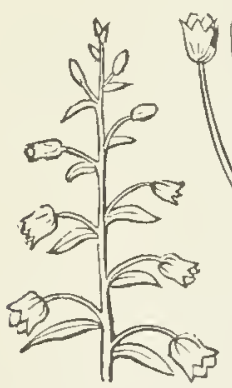

201

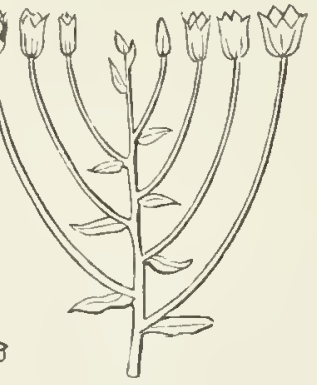

202

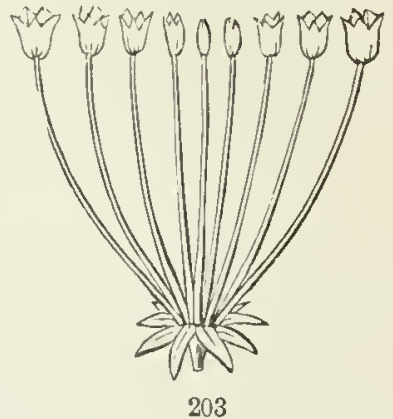

203

shorter. The axis of a corymb is short in proportion to the lower pedicels By extreme shortening of the axis the eorymb may be converted into

207. An Umbel (Fig. 203) as in the Milkweed, a sort of flower-eluster where the pedieels all spring apparently from the same point, from the top of the peduncle, so as to resemble, when spreading, the rays of an umbrella;

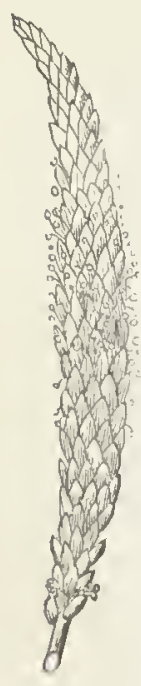

204 whenee the name. Here the pedicels are sometimes called the Rays of the umbel. And the bracts, when bronght in this way into a cluster or cirele, form what is called an Irrolucre.

208. The corymb and the umbel being nore or less leveltopped, bringing the flowers into a lorizontal plane or a couvex form, the ascending order of development appears as Centripetal. T'lat is, the flowering prueceds from the margin or circunferenec regularly towards the ecutre; the lower flowers of the former answering to the outer ones of the latter.

209. In these three kinds of flower-elusters, the flowers are raised on conspicuous pedicels (204) or stalks of their orm. 'The shortening of these pedicels, so as in render the flowers sessile or nearly so, converts a raceme into a spike, and a corymb or an umbel into a Head.

210. A Spike is a flower-cluster with a more or less lengthened axis, along which the flowers are sessile or nearly so; as in the I'lintain (Fig. 204).

211. A Head (Cupitulum) is a round or roundish chuster of flowers, 
which are sessile on a very short axis or reeptaele, as in the Button-ball, Button-bush (Fig. 205), and Red Clover. It is just what a spike would

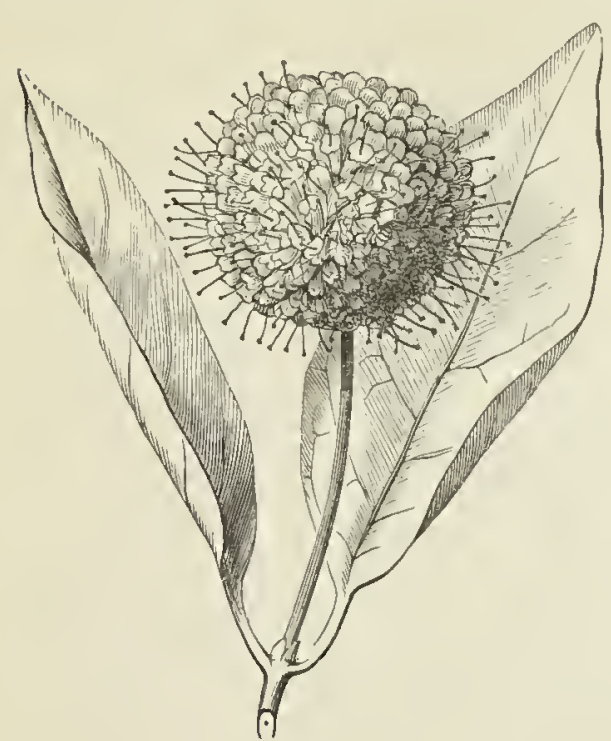

205

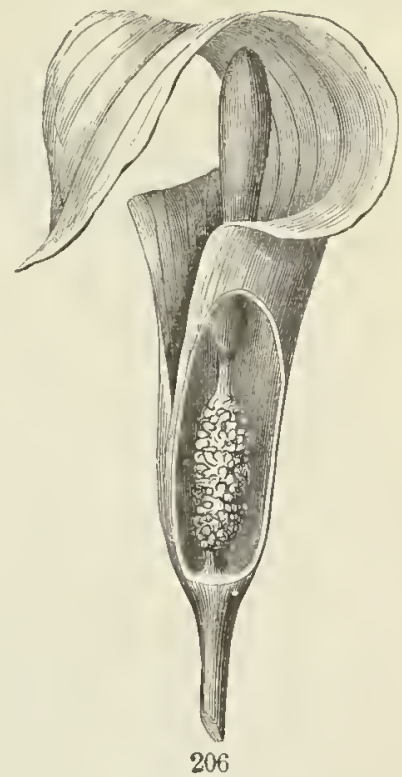

206

beeome if its axis werz shortened; or an umbel, if its pedieels were all shortened until the flowers beeame sessile. The head of the Button-bush is naked; but that of the Thistle, of the Dandelion, and the like, is surrounded by empty brats, whieh form an Incoluere. Two partieular forms of the spike and the head lave reeeived partieular names, namely, the Spadix and the Cathin.

212. A Spadix is a fleshy spike or head, with smatl and often imperfect flowers, as in the Calla, Indian Turnip, (Fig. 206), Sweet Flag, ete. It is commonly surrounded or embraced by a peeuliar enveloping leaf, ealled a Spatile.

213. A Catkin, or Ament, is the name given to the sealy sort of spike of the Bireh (Fig. 207) and Alder, the Willow and Poplar, and one sort of flower-elusters of the Oak, Hiekory, and the like, — the so-ealled Amentaceous trees.

214. Compound flower-elusters of these kinds are not uneommon. When the stalks whieh in the simple umbel are the pedieels of single flowers themselves braneh into an umbel, a Compound Umbel is formed.

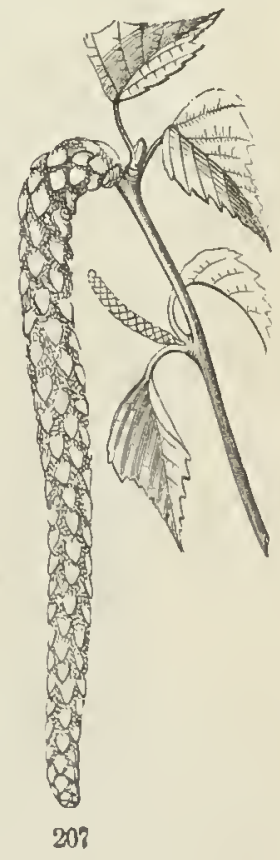

FIG. 205. Head of the Button-bush (Cephalanthus).

FIg. 206. Spadix and spathe of the Indian Turnip; the latter cnt through belesw. FIG. 207. Catlin, or Ament, of Birch. 
This is the inflorescence of Caraway (Fig. 208), Parsnip, and almost all of the great family of Umbclliferous (umbel-bearing) plants.

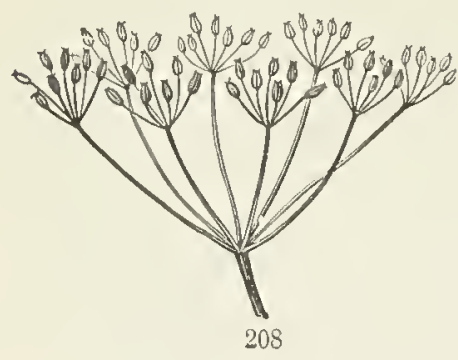

215. The secondary or partial umbels of a compound um. bel arc Unibellets. When the umbellets are subtended by an involucre, this secondary involucre is called an INvoLuce L.

216. A Compound raceme is a cluster of racemes racemosely arranged, as in Suilacina racemosa. A compound corymb is a corymb some branches of which branch again in the same way, as in Mountain Ash. A compound spite is a spicately disposed cluster of spikes.

217. A Fanicle, such as that of Oats and many Grasscs, is a compound flower-cluster of a more or less open sort which bramches with apparent irregularity, neither into corymbs nor racemes. Fig. 209 represents the simplest panicle. It is, as it were, a raccme of which some of the pedicels have branched so as to bear a few flowers on pedicels of their own, while others remain simple. A compound panicle is ove that branches in this vay again and again.

218. Determinate Inflorescence is that in which the flowers are from terminal buds. The simplest case is that of a solitary terminal flower, as

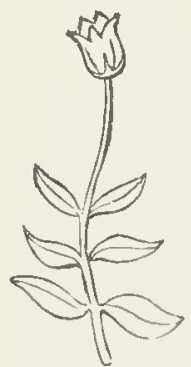

210

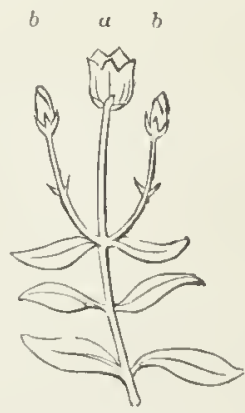

211

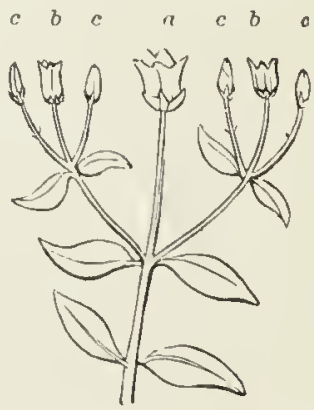

212

in Fig. 210. This stops the growth of the stem; for its terminal bud, be. coming a blossom, can $n$ more lengthen in the manncr of a leaf-bud. Any

Fig. 208. Compound Umbel of Caraway.

FIG. 209. Diagram of a simple panicle.

FIG. 210. Diagram of an opposite-leaverl plant, with a single terminal fower. 211. Same, with a cyme of three flowers; $a$, the first flower, of the main axis: $b b$. those of branches. 212. Same. with flowers also of the thirel orler, $c$ c. 
further growth must be from axillary buds developing into branches. If such branches are leafy shoots, at length terminated by single blossoms, the inflorescence still consists of solitary flowers at the summit of stem and branches. But if the flowering branches bear only bracts in place of ordinary leaves, the result is the kind of flower-cluster called

219. A Cyme. This is commonly a flat-topped or convex flower-cluster, like a corymb, only the blossoms are from terminal buds. Fig. 211 illustrates the simplest cyme in a plant with oppo. site leaves, namely, with three flowers. The middle flower, $a$, terminates the stem; the two othcrs, $b \quad b$, terminatc branches, one from the axil of each of the uppermost leaves; and being later than the middle one, the flowering proceeds from the centre outwards, or is Centrifugal. This is the opposite of the indeterminate mode, or that where all the flower-buds are axillary. If flowering branches appear from the axils below, the lower ones are the later, so that the order of olossoming continues centrifugal or, which is the same thing, descending, as in Fig. 213, making a sort of reversed raceme or false ra. ceme, - a kind of cluster which is to the true raceme just what the flat cymc is to the corymb.

220. Wherever there are bracts or leaves, buds may be

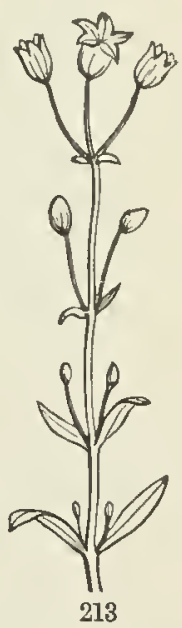
produced from their axils and appear as flowers. Fig. 212 represents the case where the branches, $b$, of Fig. 211, each with a pair of small leaves or bracts about thcir middle, have branched again, and produced the branchlets and flowers $c c$, on each side. It is the continucd repetition of this which forms the full or compound cyme, such as that of the Laurestinus, Hobble-bush, Dogwood, and Hydrangea (Fig. 214).

221. A Fascicle (meaning a bundle), like that of the Sweet William and Lychnis of the gardens, is only a cyme with the flowers much crowded.

222. A Glomerule is a cyme still more compacted, so as to imitate a head. It may be known from a true head hy the flowers not expanding centripetally, that is, not from the circumference towards the centre.

223. Thic illustrations of determinate or cymose inflorescence have been taken from plants with opposite leaves, which give rise to the most regular cymes. But the Rose, Cinquefoil, Buttercup, etc., with alternate leaves, furnish also good examples of cymose inflorescence.

224. A Cymule (or diminutive cyme) is either a reduced small cyme of few flowers, or a branch of a compound cyme, i. e. a partial cyme.

225. Scorpioid o1 Helicoid Cymes, of various sorts, are forms of determinate inflorescence (often puzzling to the student) in which one half of the ramification fails to appear. So that they may be called incomplete cymes. The commoner forms may be understood by comparing a complete

Fig. 213. Diagram of a simple cyme in which the axis lengthens, so as to take the form of a raceme. 
cyme, like that of Fig. 215 with Fig. 216, the diagram of a cyme of an opposite-leaved plant, having a series of terminal flowers and the axis con-

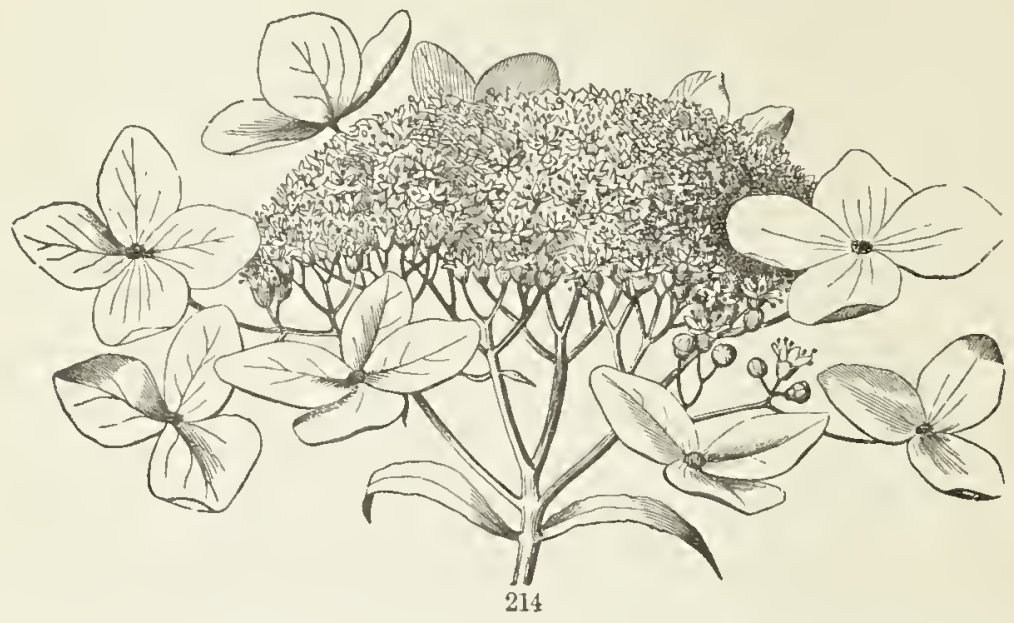

tinued by the development of a branch in the axil of only one of the leares at each node. The dotted lines on the left indicate the place of the wanting

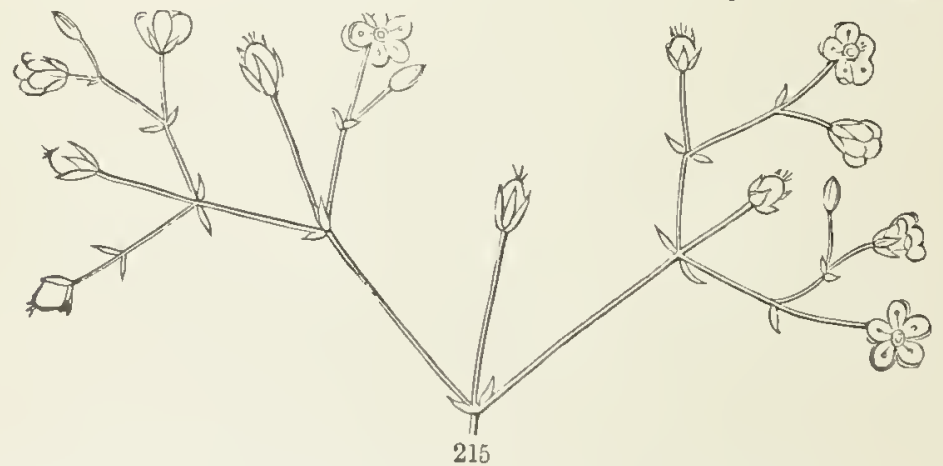

branches, which if present would convert this srorpioid cyme into the completc one of Fig. 215. Fig. 217 is a diagram of similar inflorescence with alternate leaves. Both are kinds of false racemes (219). When the bracts are also wanting in such cases, as in many Borragineous plants, the true nature of the inflorescence is very much disguised.

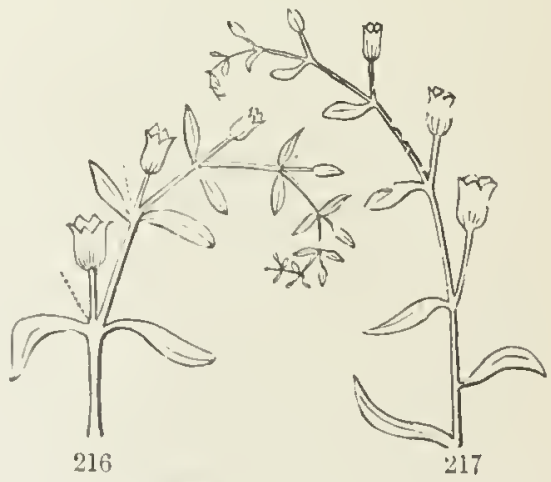

Fia. 214. Complound cyme of Hydrangea arborescens, wim nential enlarged Howers roumd the circumference.

FIG. 215. A complete forking cyme of an Arenaria, or Chickweed.

FIG. 216. Diagram of a scorjioid cyme, with opposite leaves or bracts.

Fra. 217. Diagram of analogous scorpioid cyme, witl alternate leaves or bracts. 
226. These distinctions between determinate and indetermnate inflores. cence, between corymbs and cymes, and between the true and the false raceme and spike, were not recognized by botanists much more than half a century ago, and even now are not always attended to in descriptions. It is still usual and convenient to describe rounded or flat-topped and open ramification as corymbose, even when essentially cymose; also to call the revcrsed or false racemes or spikes by these (strictly incorrcet) names.

227. Mixed Inflorescence is that in which the two plans are mixed or - mbined in compound clusters. A mixed panicle is one in which, while we primary ramification is of the indeterminate order, the secondary or ultimate is wholly or partly of the determinate order. A contracted or elongated inflorescence of this sort is called a THyrsus. Lilac and Horsechestnut afford common examples of nixed inflorescence of this sort. When loose and open such flowcr-clusters are called by the general name of Panicles. The heads of Compositx are centripetal; but the branches or peduncles which bear the heads are usually of centrifugal order.

\section{§2. PARTS OR ORGANS OF THE FLOWER。}

228. These were simply indicated in Section II. 16. Some parts are necessary to seed-bearing; these are Essentiul Organs, namely, the Stamens and Pistils. Others serve for protection or for attraction, often for both. Such are the leaves of the Flower, or the Floral Envelopes.

229. The Floral Envelopes, taken together, are sometimes called the Pertantir, also Perigone, in Latin form Perigonium. In a flower which posscsses its full number of organs, the floral cnvelopes are of two kinds, namely, an outer circle, the CALYx, and an inner, the Conolia.

230. The Calyx is commonly a circle of green or greenish leaves, but not always. It may be the most brightly colored part of the blossom. Each calyx-leaf or piece is called a SEPaL.

231. The Corolla is the inner circle of floral envelopes or flower-leaves, usually of delicate texture and colored, that is, of some other color than green. Each corolla-leaf is called a Petal.

232. There are flowers in abundance whi-h consist wholly of floral envelopes. Such arc the so-called full double flowers, of which the choicer roses and camellias of the cultivator are familiar examples. In them, under the gardener's care and selection, petals have taken the place of botli stamens and pistils. These are monstrous or unnatural flowers, incapable of producing sced, and subservicnt only to human gratification. Their common name of double flowers is not a sensible one: except that it is fixed by custom, it were better to translate their Latin name, flores pleni, and call them full flowers, meaning full of leaves.

233. Moreover, certain plants regularly produce neutral flowers, consisting of floral envelopes only. In Fig. 214, some are scen around the margin 
of the cyme in Hydrangea. They are likewise familiar in the Hobble-bush and in Wild-Cranberry tree, Viburnum Oxycoccus; where they form an attractive setting to the cluster of small and comparatively inconspicuous

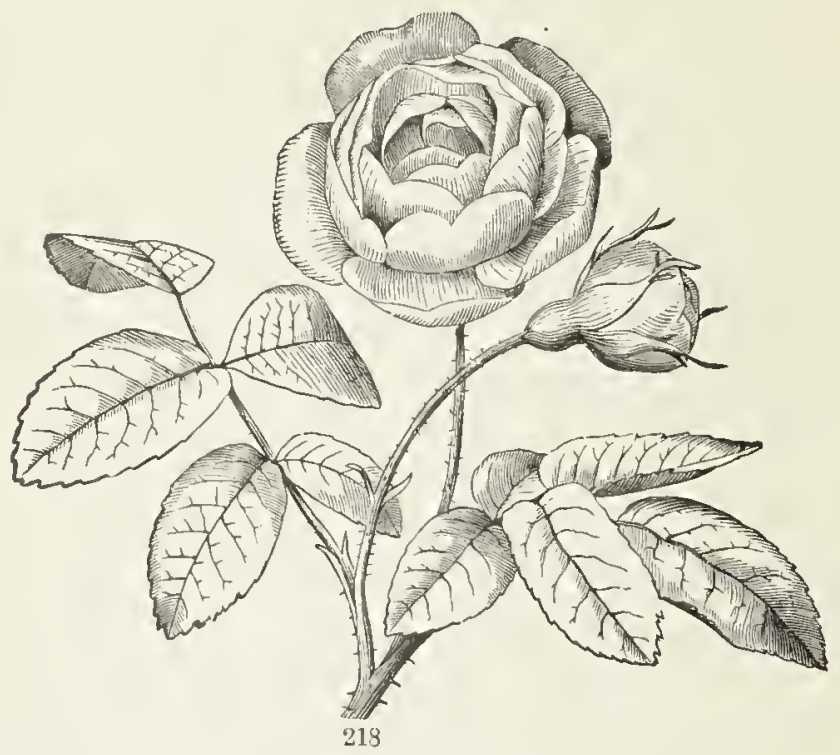

perfect flowers which they adorn. In the Guelder Rose, or Snow-ball of ornamental cultivation, all or most of the blossoms of this same shrnb are transformed into neutral flowers.

234. The Essential Organs are likewise of two kinds, placed one above or within the other; namely, first, the Stamens or fertilizing organs, and second, the Pistius, which are to be fertilized and bear the seeds.

235. A Stamen consists of two parts, namely, the Filament or stalk (Fig. 219 a), and the Anther (b). The latter is the only

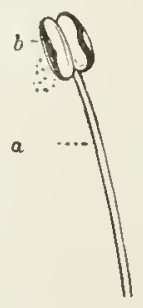

219

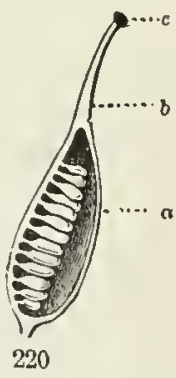
essential part. It is a case, commonly with two lobes or cells, each opening lengthwise by a slit, at the proper time, and discharging a powder or dustlike substance, usually of a yeliow color. This powder is the Poluen, or fertilizing matter, to produce which is the office of the stamen.

236. A Pistil (Fig. 220, 221) when complete, has three parts; Ovary, Style, and Stigira. The Ovary, at base, is the hollow portion, which contains one or morc Ovules or rudimentary seeds. The Style is the tapering

FIG. 218. A flos plenus, namely, a full double flower of Rose.

FIG. 219. A stamen: $a$ filament: $b$, anther, discharging pollen.

FIG. 220. A pistil; with ovary, $a$, half cut away, to show the contained orules; $b$, style; a, stigma 
portion above: the Stigma is a portion of the style, usually its tip, witb moist naked surface, upon whicl grains of pollen may lodge and alhere, and thence make a growth which extends down to the ovules. When there is no style then the stigma oceupies the tip of the ovary.

237. The Torus or Receptacle is the end of the Hower-stalk, or the portion of axis or stem out of which the several organs of the flower grow, upon which they are borne (Fig. 223).

23s. The parts of the flower are thus disposed on the reeeptacle or axis essentially as are leaves upon a very short stem; first the sepals, or outer floral leaves; then the petals or inner floral leaves; then the stamens; lastly, at summit or centre, the pistils, when there are two or more of them, or the single pistil, when only one. Fig. 223 shows the organs displayed, two of each kind, of such a simple and symmetrical flower as that of a Sedum or Stoueerop, Fig. 222.

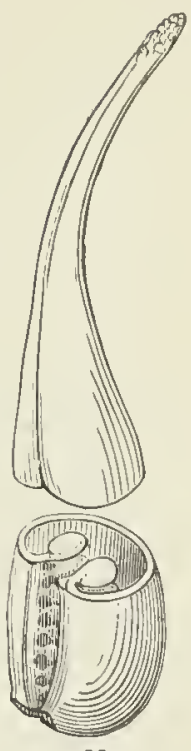

221

\section{§ 3. PLAN OF FLOWER.}

239. All flowers are formed upon one general plan, but with almost in. funite variations, and many disguises. This common plan is best understood by taking for a type, or standard for comparison, some perfect, complete,

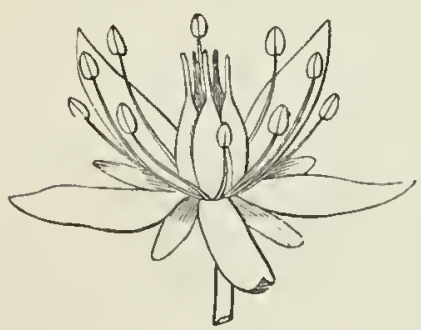

222

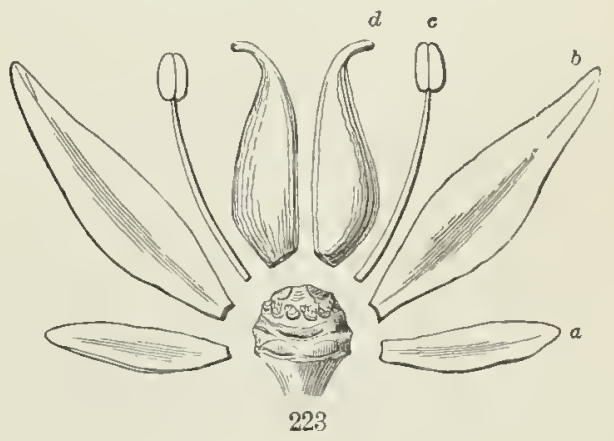

regular, and symmetrical blossom, and one as simple as such a blossom could well be. Flowers are saill to be

Perfect (hermaphrodite), when provided with both kinds of essential organs, i. e. witlı botlı stantens and pistils.

Complete, when, besides, they have the two sets of floral envelopes, namely,

Fia. 221. Model of a simple pistil, with ovary cut across and slightly opened ventrally, to show the ovules and their attachment.

FIg. 222. Flower of Sedum ternatum, a Stonecrop.

FIG. 223. Parts of same, two of each kind, separater and displayed; the torus or receptacle in the centre; $a$, a sepal; $b$, a petal ; $c$, a stamen; $d$, a pistil. 
calyx and corolla. Such are completely furnished with all that belongs to a flower.

Regular, when all the parts of cach sct are alike in shape and size.

Symmetrical, when thcre is an equal number of parts meach set or circle of organs.

240. Flax-flowers were taken for a pattern in Section II. 16. But in them the five pistils have their ovaries as it were consolidated into one body.

224
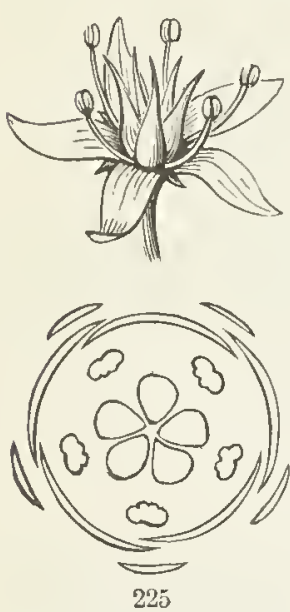
Scdum, Fig. 222, has the pistils and all the other parts frce from such conbination. 'The flower is perfect, complete, regular, and symmetrical, but is not quite as simple as it might be; for there are twicc as many stamcus as there are of the other orgaus. Crassula, a relative of Sedum, cultivated in the conservatories for winter blossoming (Fig. 224) is simpler, being isostemonous, or with just as many stamens as petals or scpals, while Sedun is diplostemonous, having double that number: it las, indecd, two sets of stamens.

24\%. Numerical Plan. A ccrtain number eitler runs through the flower or is discernible in some of its parts. This number is most commonly either five or three, not very rarely four, occasionally two. Thus the ground-plan of the flowcrs thus far used for illustration is five. That of Trillium (Fig. 226, 227) is threc, as it likewisc is as really, if not as plainly, in Tulips and Lilies, Crocus, Iris, and all that class of blossons. In some Scdums all the flowers are in fours. In others the first flowers are on the plan of five, the rest mostly on the plan of four, that is, with four scpals, four petals, cight stamens (i. e. twice four), and fom pistils. Whatever the ground number may be, it runs through the whole in symmetrical blossoms.

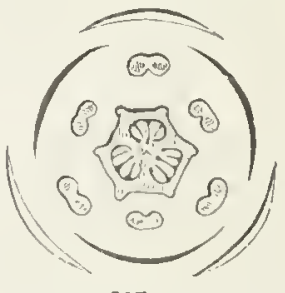

227

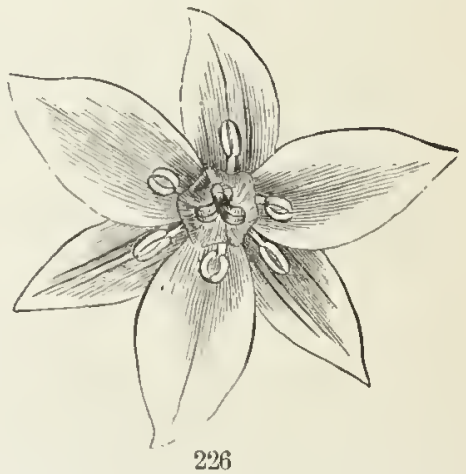

226

242. Alternation of the successive Circles. In these flowers the parts of the successive circles alternate; and sucl is the rule. That is,

Fig. 224. Flower of a Crassula. 225. Diagram or gromul-plan of same.

FIg. 226. Flower of a Trillium; its parts in threes.

FIa. 227. Dingran of flower of Trillium. In this, as in all such diagrams of crossscction of blossoms, the frarts of the outer circle represent the calyx; the next, corolla; within, stanens (here in two circles of threc each, and the cross-scction is through the anthers); in the centre, section of three oraries joined into a compound sne of three cells 
the petals stand over the intervals between the sepals; the stamens, when of the same number, stand over the intervals between the petals; or when twice as many, as in the Trillium, the outer set alternates with the petals, and the inner set, alternating with the other, of course stands before the petals; and the pistils alternate with these. This is just as it should be on the theory that the circles of the blossom answer to whorls of leaves, which alternate in this way. While in such flowcrs the circles are to be regarded as whorls, in others they are rather to be regarded as condensed spirats of alternate leaves. But, however this may be, in the mind of a morphological botanist,

243. Flowers are altered Branches, and their parts, therefore, altered leaves. That is, certain buds, which might lave grown and lengthened into a leafy brancl, do, under other circumstances and to accomplish other purposes, develop into blossoms. In these the axis remains short, nearly as it is in the bud; the leaves therefore remain close together in sets or circles; the outcr ones, thosc of the calyx, generally partake more or less of the character of foliage; the next set are more delicate, and form the corolla, while the rest, the stamens and pistils, appear under forms very different from those of ordinary leaves, and are concerned in the production of seed. This view gives to Botany an interest which one who merely no. tices the shape and counts the parts of blossoms, without understanding their plan, has no conception of.

244. That flowers answer to branches may be shown, first, from their position. As explained in the section on Inflorescence, flowers arise from the same places as branches, and from no other; flower-buds, like leaf-buds, appear either on the summit of a stem, that is, as a terminal bud, or in the axil of a leaf, as an axillary bud. And, as the plan of a symmetrical flower shows, the arrangement of the parts on their axis or receptacle is that of leaves upon the stem.

245. That the sepals and petals are of the nature of leaves is evident from their appearance; they are commonly called the leaves of thie flower. The calyx is most generally green in color, and foliaceous (aaf-like) in texturc. And though the corolla is rarely green, yet neither are proper leaves always grecn. In our wild Painted-cup, and in some scarlct Sages, coinmon in gardens, the leares just under the flowers are of the brightest red or scarlet, often much brighter-colored than the corolla itsclf. And sometimes (as in many Cactuses, and in Carolina Allspice) there is such a regular gradation from the last leaves of the plant (bracts or bractlets) into the leaves of the calyx, that it is impossible to say where the one cuds and the other begins. If sepals are leaves, so also are petals; for there is no clearly fixed limit between them. Not only in the Carolina Allspice and Cactus (Fig. 229), but in the Water-Lily (Fig. 22s) and in a variety of Howers with more than one row of petals, there is such a complete transition betwecn caly $\mathrm{x}$ and corolla that no one can surely tell how many of the leaves belong to the one and how many to the other. 
246. That stamens are of the same general nature as petals, and therefore a modification of leaves, is shown by the gradual transitions that occur

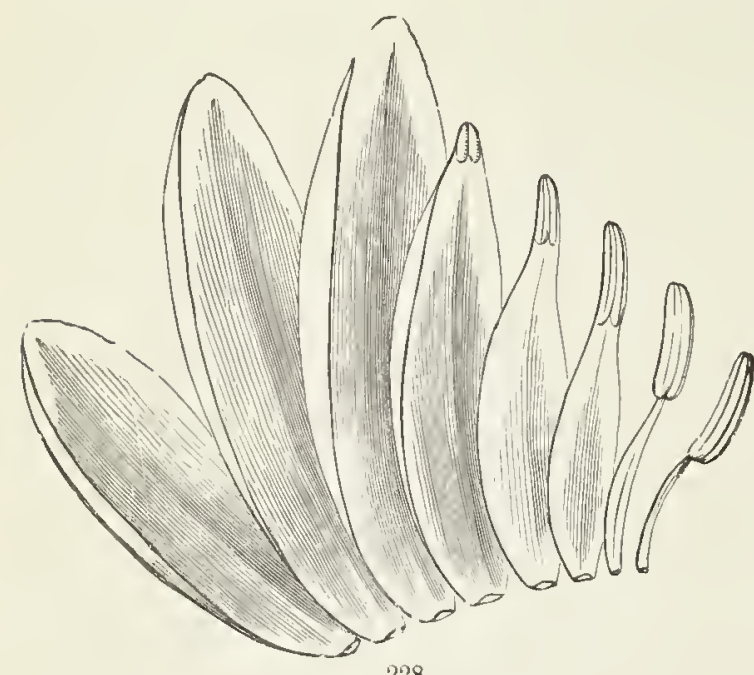

228

between the one and the other in many blossoms; especially in cultivated flowers, such as Roses and Camellias, when they begin to double, that is, to change their stamens into petals. Some wild and natural flowers show the same interesting transitions. The Carolina Allspice and the White Water-Lily exhibit complete gradntions not only between sepals and petals, but

between petals and stanens. The sepals of our Water-Lily are green outside, but white and petal-like on the inside; the petals, in many rows, gradually grow narrower towards the centre of the Hower; some of these are tipped with a trace of a yellow anther, but still are petals; the next are more contracted and stamen-like, but with a flat petal-like filament; and a further narrowing of this completes the genuine stamen.

247. Pistils and stamens now and then change into ench other in some Willows; pistils often turn into petals in cultivated flowers; and in the Double Cherry they are occasionally replaced by small green leaves. Sometimes a whole blossom cliauges into a cluster of green leares, as in the "green roses" occasioually noticed in gar-

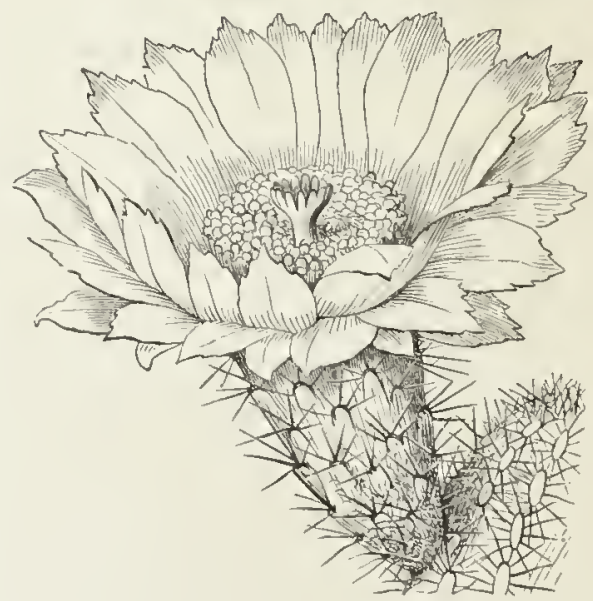

229 dens, and sometimes it degenerates into a leafy branch So the botanist regards pistils also as answering to leaves; that is, to single leaves when simple and separate, to a whorl of leaves whien conjoined.

F1G. 22. Series of sepals, petals, and stamens of White Water-Lily, showing the transitions.

Fia. 229. A Caetus blossom. 


\section{$\S$ 4. MODIFICATIONS OF THE TYPE.}

248. The Deviations, as they may be ealled, from the assumed type or pattern of flower are most various and extensive. The diferenees between one speeies and another of the same genus are eomparatively insignifieant; those between different genera are more striking; those between different families and elasses of plants more and more profound. They represent different adaptations to eonditions or modes of life, some of whieh have obvious or probable utilities, although others are beyond partieular explanation. The prineipal modifieations may be eonveniently elassified. Finst those which in place of perfeet (otherwise ealled hermaphrodite or bisexual) flowers, give origin to

249. Unisexual, or Separated, or Diclinous Flowers, imperfect flow. ers, as they liave been called in contradistinelion to perfeet llowers; but that
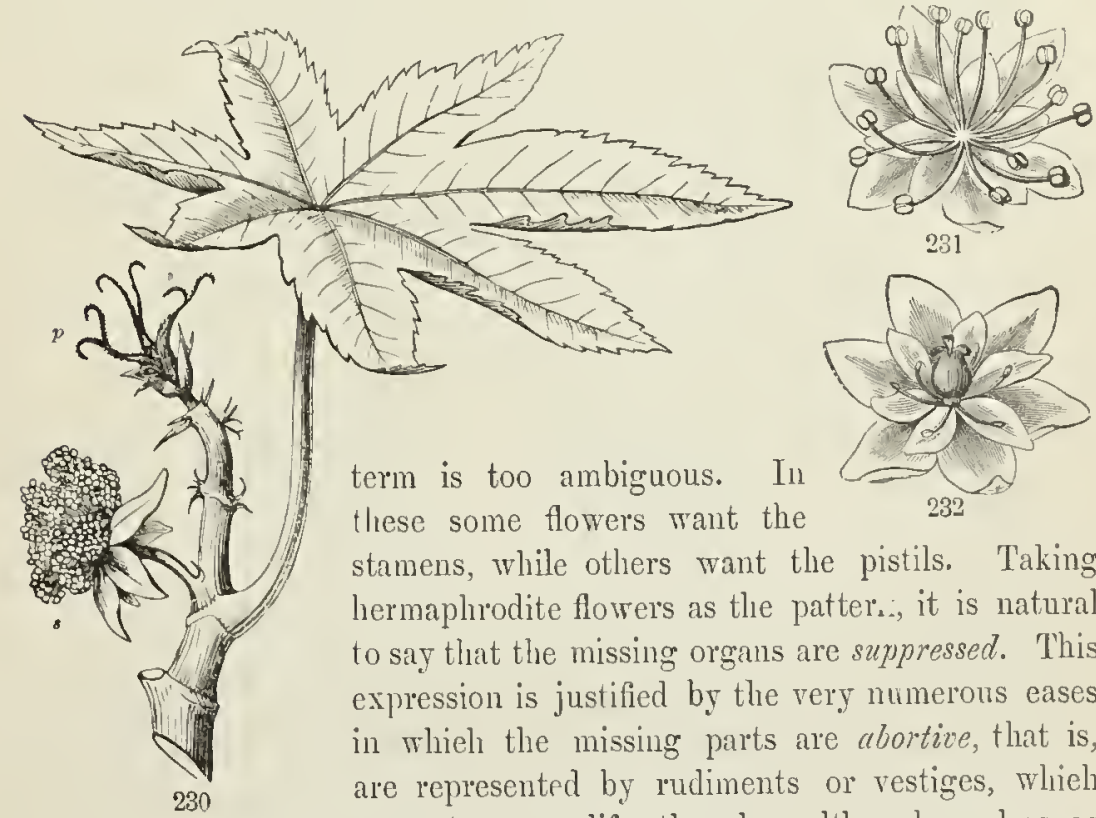

231

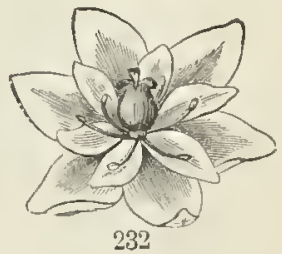

term is too ambiguous. In these some flowers want the 232 stamens, while others want the pistils. Taking hermaphrodite flowers as the patter.; it is natural to say that the missing organs are suppressed. This expression is justified by the very numerous eases in whieh the missing parts are abortive, that is, are represented by rudiments or vestiges, which serve to exemplify the plan, although useless as

to office. Unisexual fiower's are

Monocious (or Monoicous, i. e. of one liousehold), when flowers of botl: sorts or sexes are produeed by the same individual plant, as in the Ricinus or Castor-oil Plant, Fig. 230.

Diocious (or Dioicous, i. e. of separate houselıolds), when the two kinds are borne on different plants; as in Willows, Poplars, Hemp, and Noon. seed, Fig. 231, 232.

Polygamous, when the flowers are some of them perfect, and some staminate $n \Gamma^{*}$ pistillate only.

FIG. 230. Unisexual flowers of Castor-oil plant: $s$, staminate flower ; $p$, pistillate flower.

FIG. 231, staminate, and 232, pistillate flower of Moonseed. 
250. A blossom having stamens and no pistil is a Staminate or Male flower. Sometimes it is called a Sterile flower, not appropriately, for other flowers may equally be sterile. Onc laving pistil but no stamens is a Pistillate or Female flower.

251. Incomplete Flowers are so named in eontradistinction to complete: they want either one or both of the floral envelopes. Those of Fig. 230 are ineomplete, having calyx but no eorolla. So is the flower of Ancm-

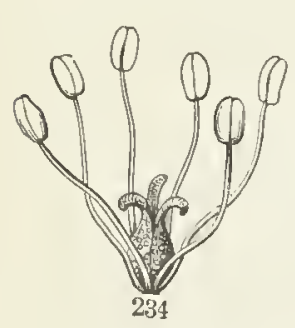
one (Fig. 233), although its ealyx is colored like a corolla. The flowers of Saururus or Lizard's-tail,

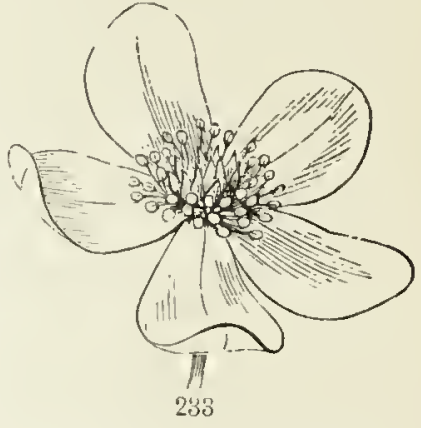
although perfect, have neither calyx nor corolla (Fig. 234). Incomplete flowers, accordingly, are

Naked or Achlanydeous, destitute of both floral cnvelopes, as in Fig. 234, or

Apetalous, when wanting only the corolla. The ease of eorolla present and ealyx wholly wanting is extremely rare, although there are seeming instanees. In fact, a single or simple perianth is taken to be a calyx, unless the absenee or abortion of a calyx can be made evident.
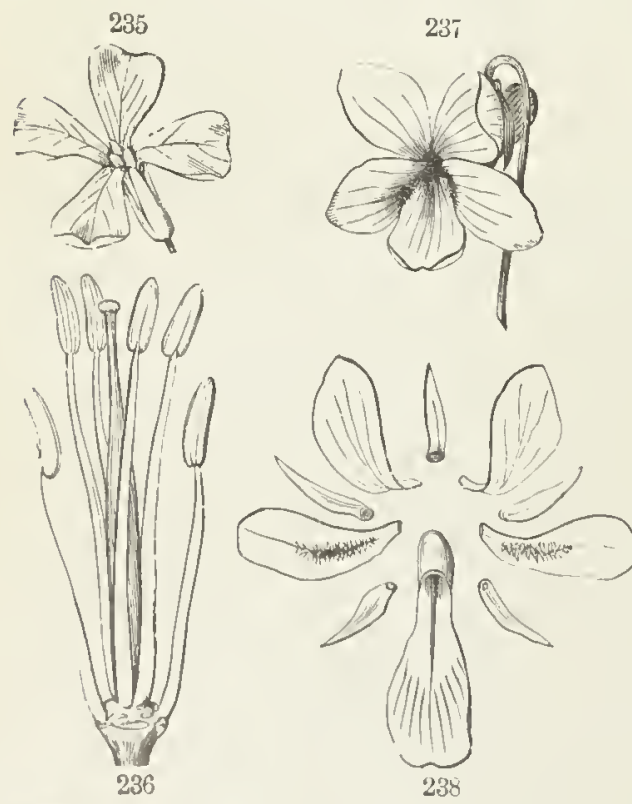

252. In contradistinction to regular and symmetrical, very many flowers are

Irvegulur, that is, with the members of some or all of the floral circles unequal or dissimilar, and

Unsymmetrical, that is, when the cirelcs of the flower or some of them differ in the number of their members. (Symmetrical and unsymmetrical are nsed in a different sense in somc reeent books, but the older use should be adhered to.) Wint of numerieal symmetry and ilregularity commonly go together; and both are common. Indeed, few flowers are entircly

FIG. 233. Flower of Anemone Pennsylvanica; apetalous, hermaphrodite.

FIG. 231. Flower of Sanmus or Lizard's-tail; nakerl, bnt hermaplirolite.

FIG. 235. Flower of Mustard. 236. Its stamens and pistil separate and enlarged.

FIG. 237. Flower of a Violet. 238. Its calyx and corolla clisplayed: the five smaller parts are tlie seprals; the five intervening larger ones are the petals. 
symmetrical beyond calyx, corolla, and perhaps stamens; and probably no irregular blossoms are quite symmetrical.

253. Irregular and Unsymmetrical Flowers may therefore be illus.
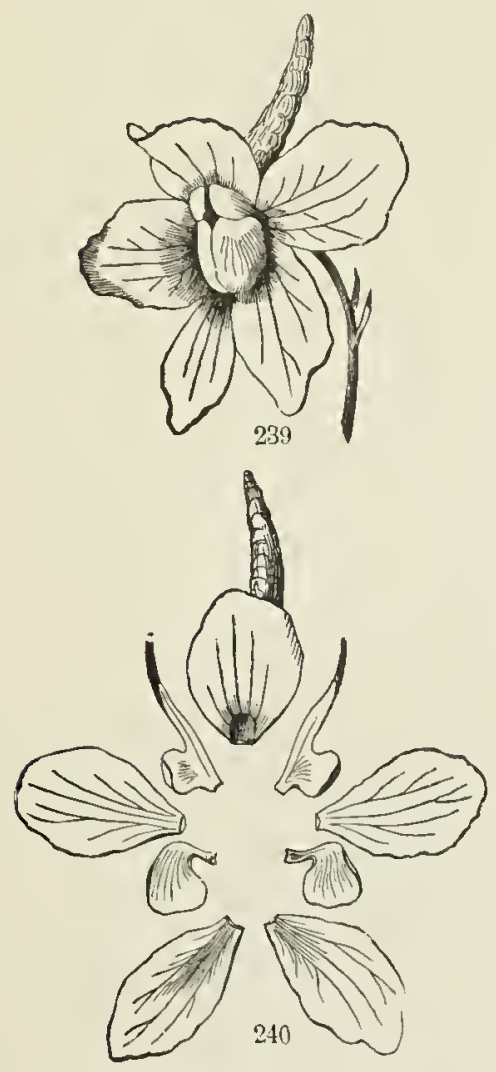

trated together, beginning with cases which are comparatively free from other complications. The blossom of Mustard, and of all the very natural family which it represents (Fig. 235, 236), is regular but unsymmetrical in the stamens. There are four equal sepals, four equal petals ; but six stamens, and only two members in the pistil, which for the present may

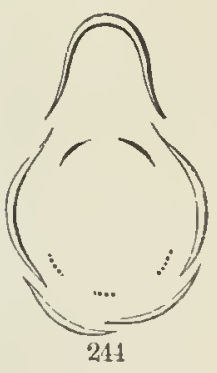

FIG. 239. Flower of a Larkspur. 240. Its calyx and corolla displayed; the five larger parts are the sepals; the four smaller, of two shapes, are the petals; the place of the fifth petal is vacant. 211. Diagram of the same; the place for the missing petal marked by a dotted line.

FIG. 242. Flower of a Monkshood. 243. Its parts displayed; five sepals, the up per forming the hood; the two lateral alike, broad and flat; the two lower small. The two pieces under the hood represent the corolla, reduced to two odd-shaped petals; in centre the numcrous starnens and three pistils. 244. Diagran of the calyx and cornlla: the three dotted lines in the place of missing petals. 
be left out of view. The want of symmetry is in the stamens. These are in two circles, an outer and an imer. The outer circle consists of two stamens only; the inner has its proper number of four. The flower of Violet, which is on the plan of five, is symmetrical in calyx, corolla, and stamens, inasmuch as each of these circles consists of five members; but it is conspicuously irregular in the corolla, one of the petals being very dillerent from the l'est.

254. The flowers of Larkspur, and of Monkshood or Aconite, which arc nearly related, are both strikingly irregular in calyx and corolla, and considerably unsymmetrical. In Larkspur (Fig. 239-241) the irregular caly consists of five sepals, one of which, larger than the rest, is prolonged beLimd into a large sac or spur; but the corolla is of only four petals (of two shapes), - the fiftl, needed to complete the symmetry, being left out. And the Monkshood (Fig. 242-244) has fve very dissiniliar sepals, and a corolla of only two very small and curiously-shaped petals, - the three needed to make up the symmetry being left out. The stamens in both are out of symmetry with the ground-plan, being numerous. So are the pistils, which are usually diminished to three, sometimes to two or to one.

255. Flowers with Multiplication of Parts are very common. The

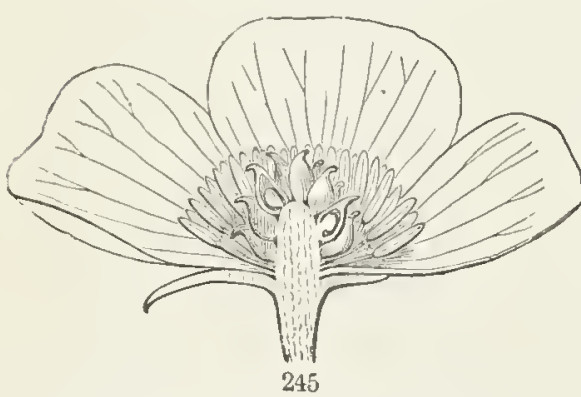
stamens are indefinitely numerous in Larkspur and in Monkshood (Fig. 242, 243), while the pistils are fewer than the ground-plan suggests, Most Cactus-flowers liave all the olgans much increased in number (Fig. 229), and so of thic Water-Lily. In Anemone (Fig. 233) the stamens and pistils are multiplied while the petals are left out. In Buttercups or Crow Joot, while the scpals and petals conlorm to the ground-plan of five, both stamens and pistils are indefnitely multiplied (Fig. 245).

256. Flowers modified by Union of Parts, so that these parts more or less lose the appearance of separate leaves or other organs growing ont of the end of the stem or receptacle, are extremely common. There are two kinds of such union, namely :-

Cualescence of parts of the same circle by their contiguous margins; and Adnation, or the mion of adjacent circles or unlike parts.

257. Coalescence is not rave in leaves, as in the upper pairs of Honeysuekles, Fig. 163. It may all the more be expected in the crowded circles or whorls of flower-leaves. Datuma or Stramonium (Fig. 246) shows this coalescence both in ealyx and corolla, the five sepals and the five petals being thus united to near their tips, each into a tube or loug and narrow cup. These unions make needful the following terms : - 
Gumopetalous, said of a corolla the petals of which are thus eoalescent into one body, whether only at base or higher. The union may extend to the very summit, as in Morning Glory and the like (Fig. 247), so that the number of petals in it may not be apparent. The old name for this was Monopetalous, but that means "one-petalled;" while gamopetalous means "petals minted," and therefore is the proper term.

Polypetalous is the eounterpart term, to denote a eorolla of distinct, that is, separate petals. As it means "many petalled," it is not the best possible name, but it is the old one and in almost universal use.

Gamosepalous applies to the calyx when the sepals are in this way united.

Polysepalous, to the calyx when of separate sepals or calyx-lcaves.

258. Degree of union or of separation in descriptive botany is expressed in the same way as is the lobing of leaves (139). See Fig. 249-253, and the explanations.

259. A corolla when gamopetalous eommonly slows a distinetion (well marked in

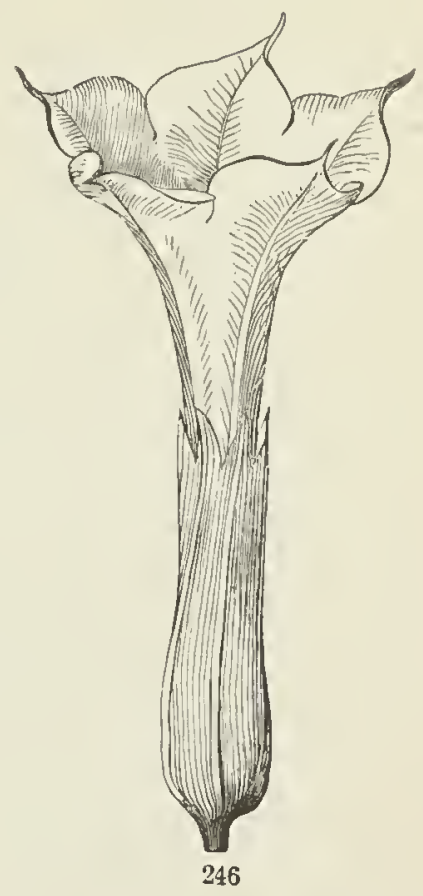
Fig. 249-251) between a contraeted tubular portion below, the TuBE, and the spreading part above, the Border or Limis. The junetion between tube and limb, or a morc or less enlarged upper portion of the tube between the two, is the Tirroat. The same is true of the calyx.

260. Some names are given to partic. ular forms of thic gamopetalous eorolla, applicable also to a gamosepalous calyx, such as

Wheel-shaped, or Rotate; when spreading out at onee, without a tube or with a very short one, something in the shape of a wleel or of its diverging spokes, Fig. $252,253$.

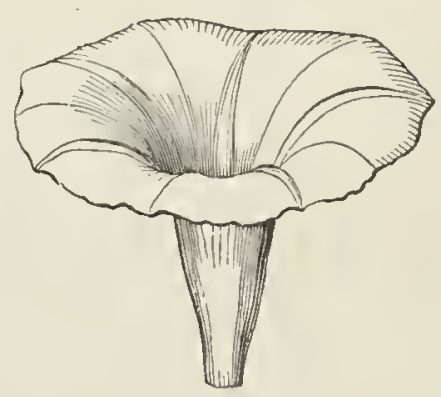

Salver-shaped, or Salver-form; when a flat-spreading border is raised on

FIG. 246. Flower of Datura Stramonium; gamosepalous anil gamopetalous.

FIG. 247. Funnelform corolla of a common Morning Glory, detached from its polysepalous calyx. 
a narrow tube, from which it diverges at right angles, like the salver rep

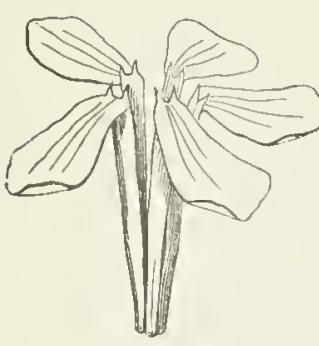

248
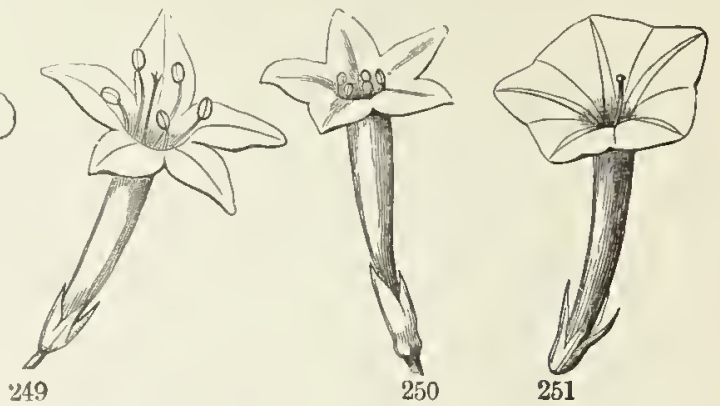

resented in old pietures, with a slender handle beneath, Fig. 249-251, 255.

Bell-shaped, or Campanulate; where a short and broad tube widens upward, in the shape of a bell; as in Fig. 254.

Funnel-shaped, or Funnel-form; grad-

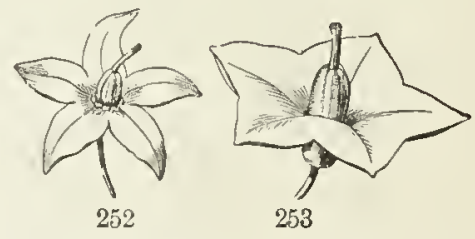
ually spreading at the summit of a tube whieh is narrow below, in the

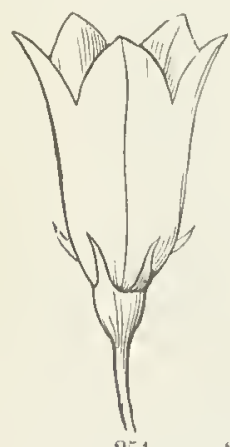

254

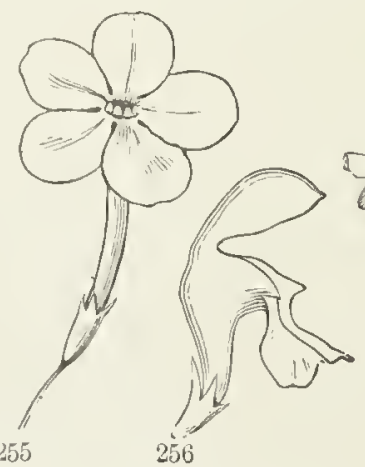

256

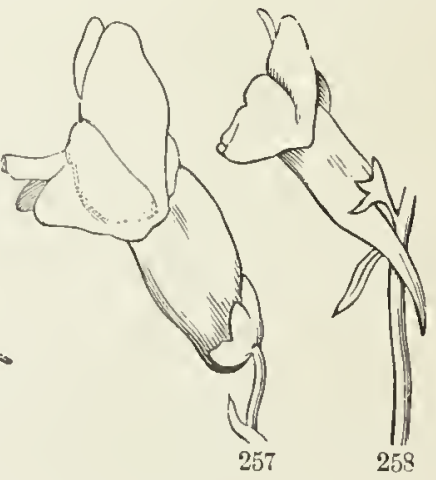

257

258

shape of a funnel or tumel, as in the corolla of the eommon Morning Glory (Fig. 217) and of the Stranonium (Fig. 246).

Fia. 248. Polypetalous corolla of Snapwort, of five petals with long claws or stalk-like bases.

FlG. 249. Flower of Standing Cypress (Gilia coronopifolia); grmopetalous: the whe answering to the long claws in 248 , except that they are conlescent: the limb ur border (the sprealing part above) is fwe-parted, that is, the petals not there united excent at very hase.

Fig. 250. Flower of Cypress-vine (I pomona Quamoclit); like preceding, but limb five l,bed.

FIG. 251. Flower of Ipomma coccinea; limb almost entire.

Fro. 252. Whecl-shajerl or rotate and five-parterl corolla of Bittersweet, Solanum Dulcamara. 253. Wheel-shaped and five-loberi corolla of l'otato.

FIa. 251. l'lower of a Caminula or llarebell, witl a campanulate or bell-slnaped corolla; 2:5, of a Ihilox, with salver-shaped corolla; 256. of Dear-Nettle (Lanium), with labiats ringent (or gaping) corolla; 257, of Snapulugon, with labiate person ate corolla; 25, of toml-Flax, with a similar corolla spurred at the base. 
Tubular; when prolonged into a tube, with little or no spreading at the border, as in the eorolla of the Trumpet Honeysuckle, the calyx of Stramoninm (Fig. 246), ete.

261. Although sepals and petals are usually all blade or lamina (123), like a sessile leaf, yet they may have a eontracted and stalk-like base, an-

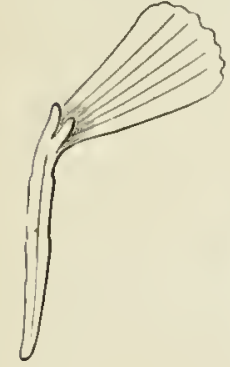

259

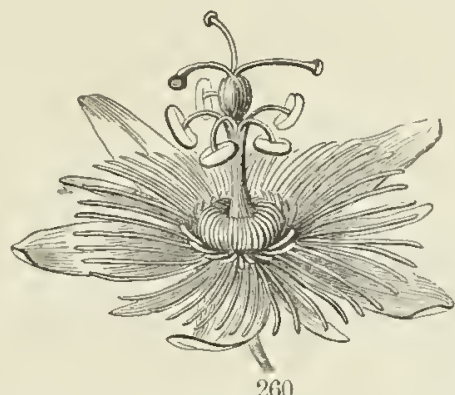

260 swering to petiole. This is called its CLAW, in Latill Unguis. Unguiculate petals are universal and strongly marked in the Pink tribe, as in Soapwort (Fig. 248).

262. Sucli petals, and various others, may have an outgrowth of the inner face into an appendage or lringe, as in Soapwort, and in Silene (Fig. 259), where it is at the junction of elaw and blade. This is called a Crown, or Corona. In Passionflowers (Fig. 260) the crown eonsists of mumerons threads on the base of each petal.

263. Irregular Flowers may be polypetalous, or nearly so, as in the papilionaceous eorolla; but most of them are irregular through coaleseence, which often mneh disguises the numerieal symmetry also. As affecting the eorolla the following forms hare reecired particular names:

264. Papilionaceous Corolla, Fig. 261, 262. This is polypetalous, exeept that two of the petals coliere, usually but slightly. It belongs only to the Leguminous or Pulse family. The name means butterfly-like; but the likeness is hardly obvious. The names of the five petals of the papilionaceous enrolla are cnrionsly ineongruous. They are,
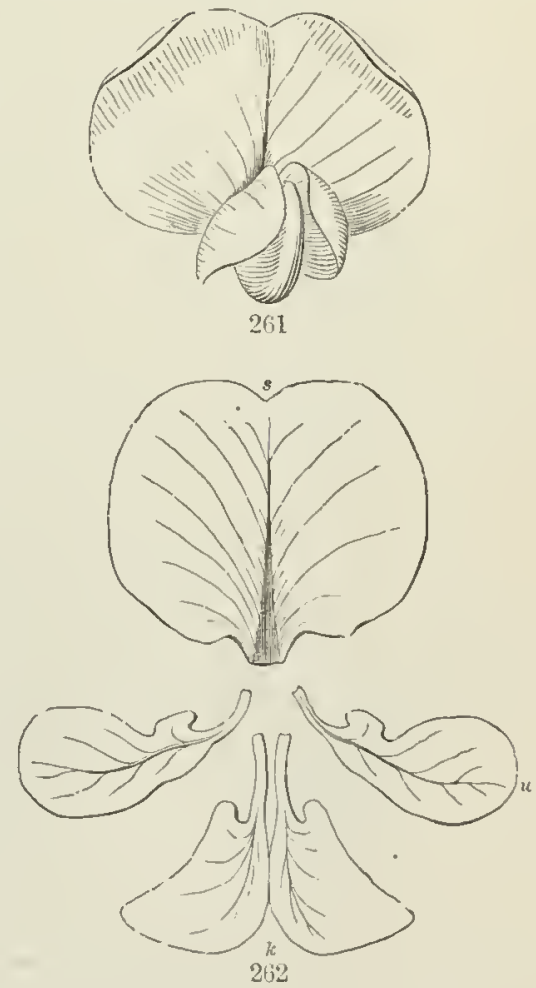

FIa. 259. Unguiculate (clawed) petal of a Silene; with a two-parted crown.

Fig. 260. A small Passinn-flnwer, with crown of slender threads.

FIg. 261. Front view of a piapilionareous corolla. 262. The parts of the same, displayed: $s$, Stanlard, or Vexillum; $v$, Wings, or Alæ; $k$; Keel, or Carina. 
The Standard or Banner (Vexillum), the large upper petal which is external in the bud and wrapped around the others.

The Wings (Ale), the pair of side petals, of quite different shape from the standard.

The Keet (Carina), the two lower and usually smallest petals; these are lightly coalescent into a body which bears some likeness, not to the keel, but to the prow of a boat; and this encloses the stamens and pistil. A Pea-blossom is a typical example; the present illustration is from a species of Locust, Robinia lispida.

265. Labiate Corolla (Fig. 256-25\$), which would more properly lave

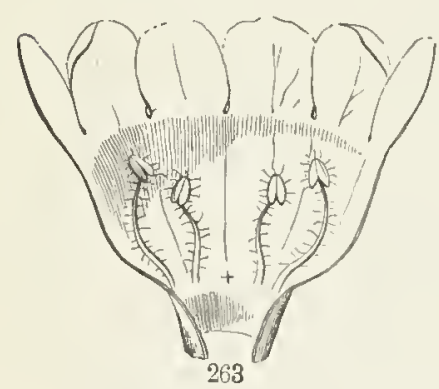
been called Bilabiate, that is, two-lipped. This is a common form of gamopetalous corolla; and the calyx is oftcn bilabiate also. These flowers are all on the plan of five; and the irregularity in the corolla is owing to unequal union of the petals as well as to diversity of form. The two petals of the upper or posterior side of the flower unite with each other highcr up than with the lateral petals (in Fig. 256, quite to the top),

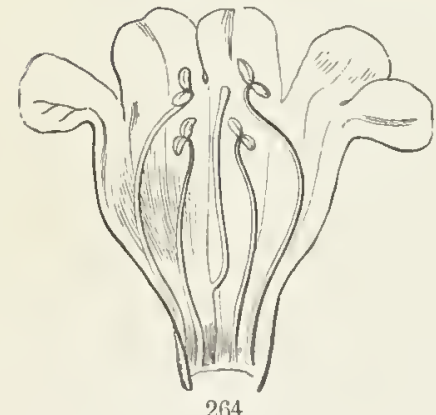

264

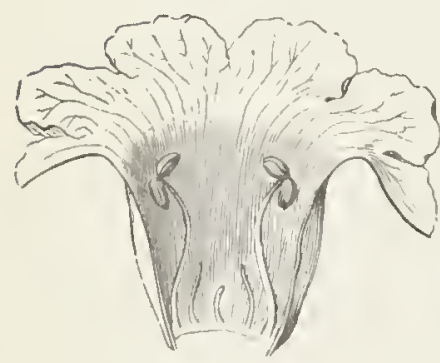

265 forming the Upper lip: the lateral and the lower similarly unite to form the Lower lip. The single noteh which is generally found at the summit of the upper lip, and the two notehes of the lower lip, or in other words the two lobes of the upper and the thrce of the lowrer lip, reveal the real composition. So also docs the altcrnation of these fire parts with those of the calyx outside. When the ealyx is also bilabiate, as in the Sage, this alternation gives three lobes or sepals to the upper and two to the lower lip. 'T'wo forms of the labiate corolla have been designated, viz.:-

Ringent or Gaping, when the orifice is wide open, as in Fig. 256.

Personute or Masked, when a protuberance or intrusion of the base of the lower lip (called a Palate) projects orer or eloses the orifice, as in Suipdrugon and Tond-Flax, Fig. 257, 258 .

F1g. 263. Corolla of a purple Geranlia laid open, showing the four stamens; the cross shows where the fifth stamen would be, if present.

Fig. 264. Corolla, laid open, and stamens of Pentstemon grandiflorus, with a sterile filanent in the place of the fiftl stamen, and representing it.

FIG, 265. Corolla of Catalpa laid open, displaying two good stamens and three abortive ones or vestiges. 
266. There are all gradations between labiate and regular corollas. In those of Gerardia, of some species of Pentstemon, and of Catalpa (Fig. 263-265), the labiate character is slight, but is manifest on close inspection. In almost all such flowers the plan of five, which is obvious or ascertain. able in the calyx and corolla, is obscured in the stamens by the abortion or suppression of one or three of their number.

267. Ligulate Corolla. 'Ihe ligulate or Strap-shaped corolla mainly belougs to the fromily of Compositæ, in which numerous small flowers are

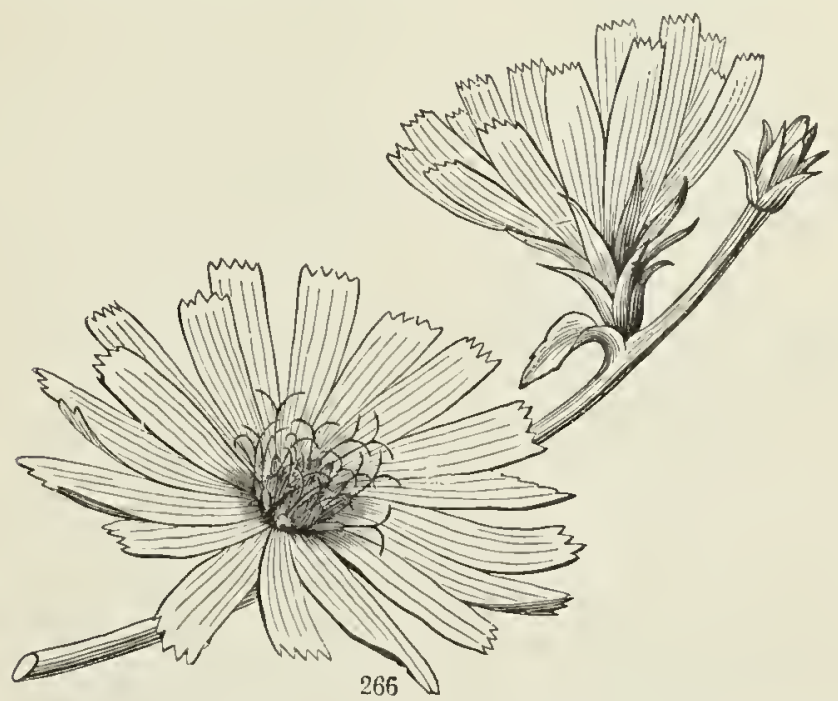

gathered into a head, within an involucre that imitates a calyx. It is besi exemplified in the Dandelion and in Chiccory (Fig. 266). Each one of these straps or Ligules, looking like so many petals, is the corolla of a dis-

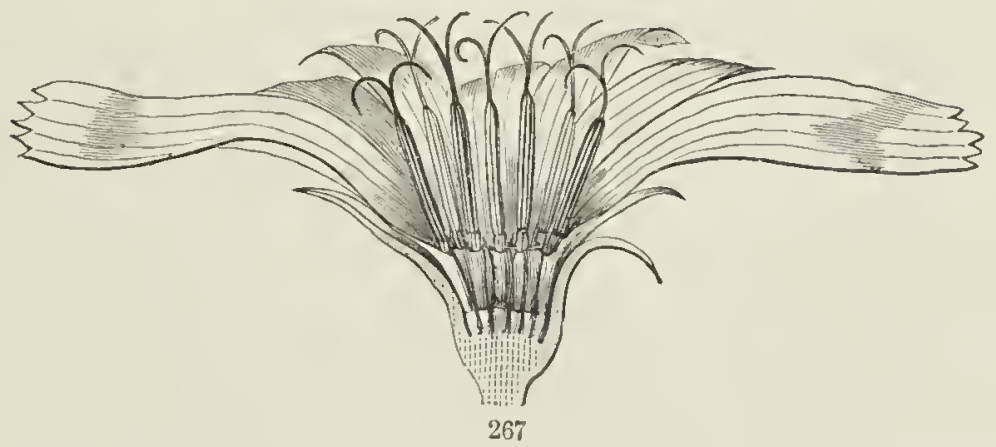

tinct flower: the base is a short tube, which opens out into the ligule: the five minute teeth at the end indicate the number of constituent petals. So this is a kitd of gamopetalous corolla, which is open aiong one side nearly 
to the base, and outspread. The nature of such a corolla (and of the sta. mens also, to be explained in the next section) is illustrated by the flower of a Lobelia, Fig. 255.

268. In Aster's, Daisies, Sunflower, Coreopsis (Fig. 268), and the like, only the marginal (or $R(y)$ ) corollas are ligulate; the rest (those of the

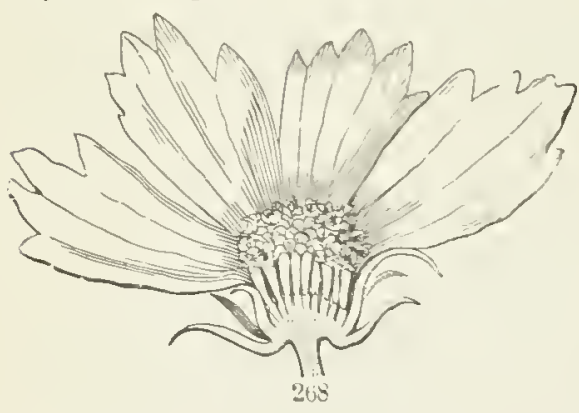
Disk) are regularly gamopetalous, tubular, and five-lobed at summit; but they are small and individually inconspicuous, only the ray-flowers making a show. In fact, those of Coreopsis and of Sunflower are simply for show, these ray-flowers being not only sterile, but neutral, that is, having neither stamens nor pistil. But in Asters, Daisies, Golden-rods, and the like, these ray-flowers are pistillate and fertile, serving

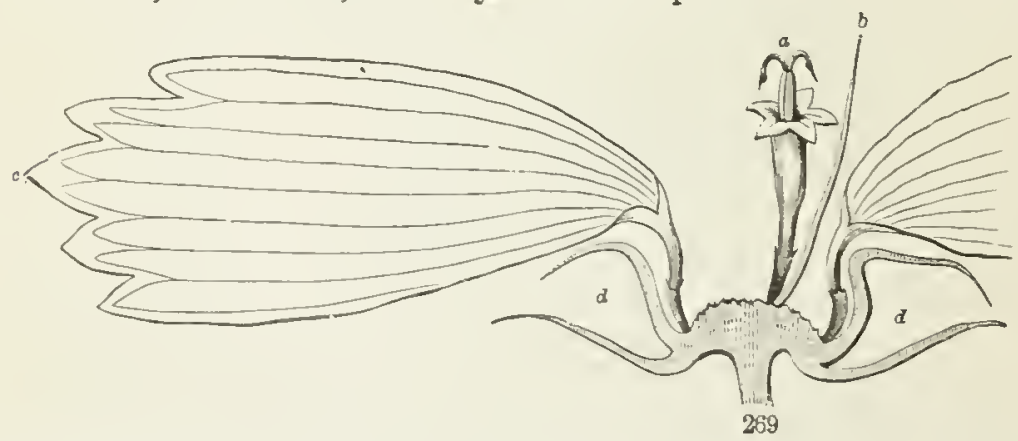

therefore for seed-bearing as well as for show. Let it not be supposed tina the show is useless. See Section XIII.

269. Adnation, or Consolidation, is the union of the members of parts belonging to different circles of the flower (256). It is of course understood that in this (as likewise in coalescence) the parts are not formed and then conjoined, but are produced iu union. They are born united, as the term adnate implies. To illustrate this kind of union, take the accompany. ing series of flowers (Fig. 270-274), shown in rertical section. In the List, Fig. 270, Flax-flomer, there is no adnation; sepals, petals, and sta mens, are free as well as distinct, being separately borme on the receptacle, one circle within or above the next; only the five pisti's bave their ovaries coalescent. In Figr. 271, a Cherry florrer, the petals and stamens are borne on the throat of the calry-tube; that is, the sepals are coalescent into a cup, and the petals and stamens are aduate to the imner face of this; in other

FIG. 268. Head of flowers of a Coreopsis, divided lengthwise.

Fia. 269. A slice of the preceding more enlarger, with one tubular perfect flower (a) left stamling on the recentacle, with its bractlet or chaff $(b)$, one ligulate and nentral ray flower $(c c)$, and part of arouther; del, section of bracts or leaves of the involucre. 
words, the sepals, petals, and stamens are all consolidated up to a certain height. In Fig. 272, a Purslane-flower, the same parts are adnate to or eonsolidated with the ovary up to its middle. In Fig. 273, a Hawthorn-flower, the consolidation has extended over the whole ovary; and petals and stamens are adnate to the calyx still further. In Fig. 274, a Cranberry-blossom, it is the same except that all the parts are free at the same height; all seem to arise from the top of the ovary.

270. In botanical description, to express tersely such differences in the relation of these organs to the pistil, thcy are said to be

Hypogynous (i. e. under the pistil) when they are all free, that is, not adnate to pistil nor connate with each other, as in Fig. 270.

Perigynous (around the pistil) when eonuate with eaeh other, that is, when petals and stamens are inserted or borne on the calyx, whether as in Cherry-flowers (Fig. 271) they are free from the pistil, or as in Purslane and Hawthorn (Fig. 272, 273) they are also adnate below to the ovary.

Epigynous (on the ovary) when so aduate that all these parts ap-
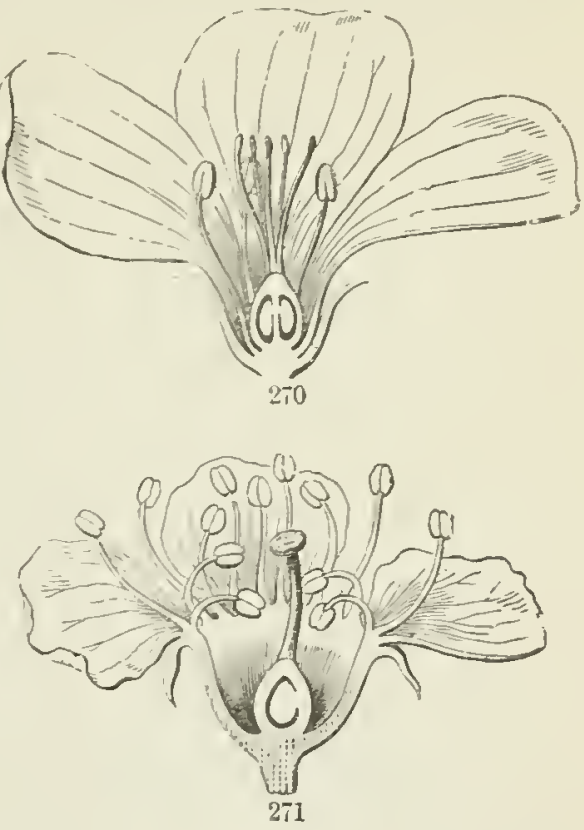
pear to arise from the very summit of the ovary, as in Fig. 274. The last two terms are not very definitely distinguished.

271. Another and a simpler form of expression is to describe parts of the flower as being

Free, when not united with or insertea upon other parts.

Distinct, when parts of the same kind are not united. This term is the counterpart of coalescent, as free is the counterpart of adnate. Many writers use the term "free" indiscriminately for both; but it is better to distinguish them.

F1a. 270 Flax-flower in section; the parts all free, - hypogynous,

Fia. 271. Cherry-flower in section; petals and stamens adnate to tube of caiyz, perigynons.

FIG. 272. Purslane-flower in section; calyx, petals, stamens, all adnato to lower half of ovary, - perigynous. 
Connate is a term eommon for either not free or not distinet, that is, for parts united eongenitally, whether of same or of different kinds.

$\boldsymbol{A}$ dnate, as properly used, relates to the union of dissinilar parts.
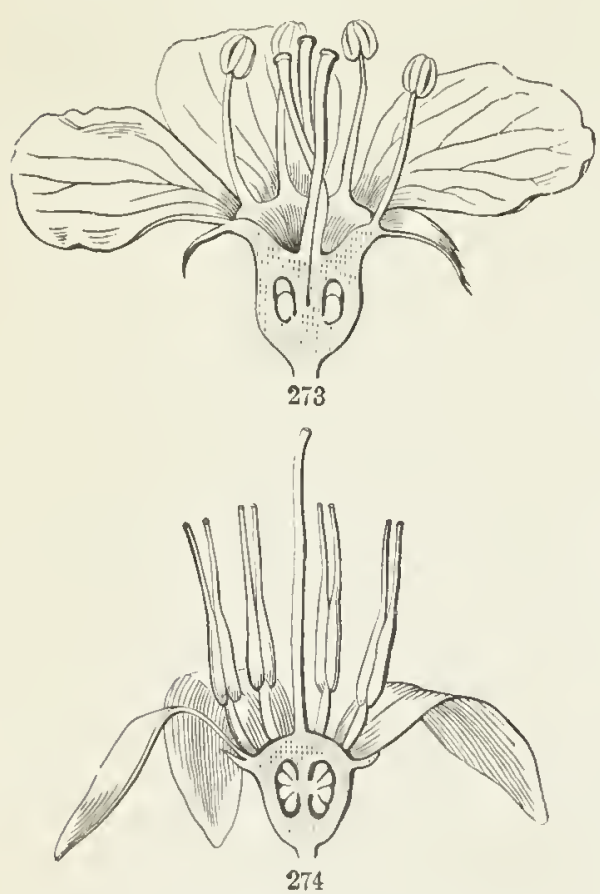

272. In still another form of $\mathrm{ex}$. pression, the terms superior and inferior have been mueh used in the sense of above and below.

Superior is said of the ovary of Flax-flower, Cherry, ete., beeause above the other parts; it is equivalent to "ovary free." Or it is said of the ealyx, etc., when above the ovary, as in Fig. 273-275.

Inferior, when applied to the ovary, means the same as "calyx adnate;" when applied to the floral envelores, it means that they are free.

273. I osition of Flower or of its Parts. The terms superior and inferior, or upper and lower, are also used to indieate the relative position of the parts of a flower in referenee to the axis of infloresrenee. An axillary flower stands between the braet or leaf whieh subtends it and the axis or stem whieh bears this braet

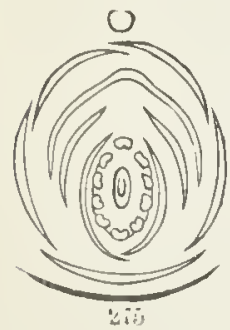

or leaf. This is represented in seetional diagrams (as in Fig. 275, 276) by a transverse line for the braet, and a snall eirele for the axis of infloreseenee. Now the side of the blossom which faees the bract is the

Anterior, or Inferior, or Lower side ; whitc the side next the axis is the

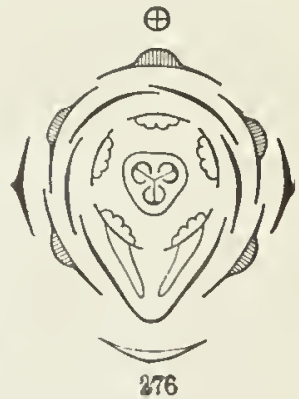

276

Posterior, or Superior, or Uppr side of the flower.

274. So, in the labiate corolla (Fig. 256-258), the lip whieh is eomposea of thrce of the five petals is the anterior, or inferior, or lover lip; the other is the posterior, or superior, or upper lip.

FIG. 273. Hawtlom-blossom in scction; parts alnate to whole face of ovary, and with each other lieyond; another grale of jerigynous.

Fia. 274. Cranberry-blosson in section; parts ejigynous.

Fra. 275. Diagram of papilionaceous flower (Robinia, Fig. 261), with bract below; axis of inflorescence alove.

Fia. 276. Diagram of Violet-flower; showing the relation of parts to bract and axis 
275. In Violets (Fig. 238, 276), the odd sepal is posterior (next the axis); the odd petal is therefore anterior, or next the subtending leaf. In the papilionaceous flower (Fig. 261, and diagram, Fig. 275), the odd sepal is anterior, and so two sepals are posterior; consequeutly, by the alternation, the odd petal (the standard) is posterior or upper, and the two petals forming the keel are anterior or lower.

\section{\$ 5. ARRANGEMENT OF PARTS IN THE BUD.}

276. IEstivation was the fanciful name given by Linnæus to denote the disposition of the parts, especially the leaves of the flower, before $A n$ thesis, i. e. before the blossom opens. Prefforation, a better term, is somctimes used. T'his is of importance in distinguishing different families or genera of plants, being generally uniform in each. The æstivation is best seen by making a slice across the flower-bud; and it nay be expressed in diagrams, as in the accompanying tigures.

277. The pieces of the calyx or the corolla either overlap each other in the bud, or they do not. When they do not overlap, the æstivation is

$V$ alcute, when the pieces meet each other by their abrupt edges, without any infolding or overlapping; as the calyx of the Linden or Basswood (Fig. 277).

Tnduplicate, which is valvate with the margins of each piece projecting inwards, as in the calyx of a common Virgin's-bower, Fig. 278, or

Involute, which is the same but the margins rolled inward, as in most of the large-flowered species of

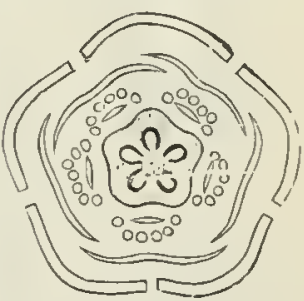

277 Clematis, Fig. 279.

keduplicate, a rarer modification of valvate, is similar but with margins projecting outward.

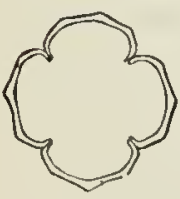

278

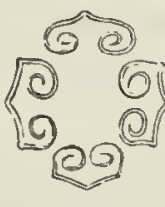

279

Open, the parts not touching in the bud, as the calyx of Mignonette.

279. When the picces overlap in the bud, it is in one of two ways; either every piece has one edge in and one edge out, or some pieces are wholly outside and other's wholly inside. In

the first case the restiration is

Convolute, also named Contorted or Tristed, as in Fig. 280, a cross-section of a corolla very strongly thus convolute or rolled up together, and in the corolla of a Flax-flower (Fig. 2S1), where the petals only moderately overlap in this way. Here one edge of every petal covers the next before

FIG. 277. Dingram of a flower of Linden, showing the calyx valvate and corolla $1 \mathrm{mbricate}$ in the bud, atc.

FIr. 278. Valvate-induplicate astivation of calyx of common Virgin's-hower. Fig. 279 Valvate-involute æstivation of same in Vine-bower, Clematis Vitialla. 
it, while its other edge is covered by the next behind it. The other mode is the

Imbricate or Imbricated, in which the outer parts cover or overlap the

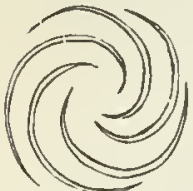

280 inuer so as to "break joints," like tiles or shingles on a roof; whence the name. Whon the parts are three, the first or outermost is wholly external, the third wholly internal, the second has one margin covered by the first while the other overlaps the third or imnermost piece: this is the arrangement of alternate three-

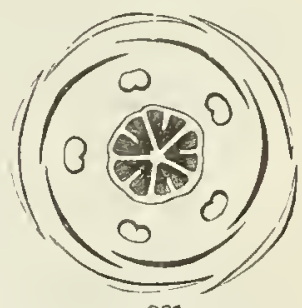

281 ranked leaves (187). When there are five pieces, as in the corolla of Fig. 225, and calyx of Fig. 281, as also of Fig. 241, 276, two are external, two are internal, and one (the third in the spiral) has one edge covered

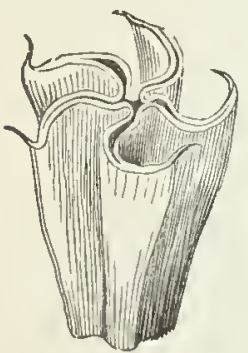
by the outermost, while its other edge covers the innermost; which is just the five-ranked arrangement of alternate leaves (ISS). When the picces are four, two are outer and two are inner; which answers to the arrangement of opposite leaves.

279. The imbricate and the convolute modes some. times vary one into the other, especially in the corolla.

280. In a gamopetalous corolla or ga mosepalous calyx, the shape of the tube in the bud may sometimes he notice-

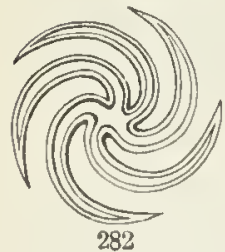
able. It may be

Plicate or Plaited, that is, folded lengthwise; and the plaits may either he turned outwards, forming projecting ridges, as in the corolla of Crmpanula; or tumed inwards, as in that of Gentian Belladonna; or

Sxpervolute, when the plaits are convolutely trapped round each other, us in the corolla of Morning Glory and of Stramonium, Fig. 282.

\section{SECTION IX. STAMENS IN PARTICULAR}

231. Androctum is a technical name for the staminate system of a fower (that is, for the stamens taken together), which it is sometimes convenient to use. The preceding section has dealt with modifications of the flower pertaining mainly to calyx and corolla. Those relating to the stamens are now to be indicated. First as to

FIG. 280. Convolute anstivation, as in the corolla-lohes of Oleander.

Fig. 281. Diagram of a Flax-flower; calyx inbricated and corolla convolute in the bud.

Fig. 282. Upner part of corolla of Datura Stramonium in the bud; and below - section showing the convolution of the plaits. 
282. Insertion, or place of attachment. The stamens usually go with the petals. Nut rarely they are at base

Epipetalous, that is, inserted on (or aduate to) the corolla, as in Fig. 283. When free from the corolla, they may be

Hypogynous, inserted on the receptacie under the pistil or gynocium.

Perigynous, inserted on the calyx, that is, with the lower part of filament adnate to the calyx-tube.

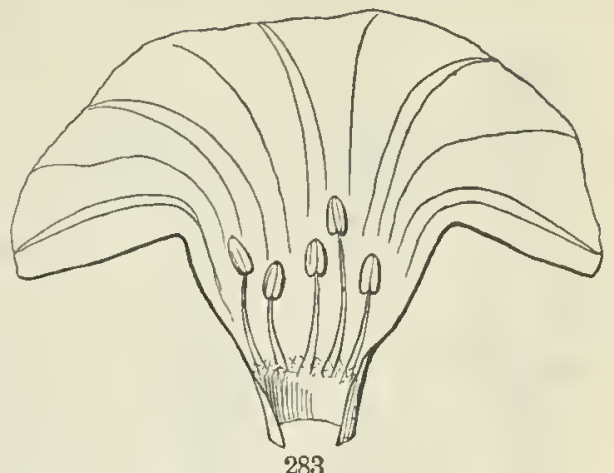

Epigynous, borne apparently on the top of the ovary; all which is explained in Fig. 270-274.

Gynandrous is another term relating to insertion of rarer occurrence,

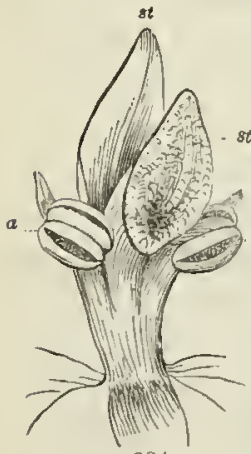

284 that is, where the stamens are inserted on (in other words, aduate to) the style, as in Lady's Slipper (Fig. 284), and in the Orchis family generally. 2S3. In Relation to each ${ }^{a}$ Other, stamens are more commonly

Distinct, that is, without any union with each other. But when united, the following technicul terms of long use

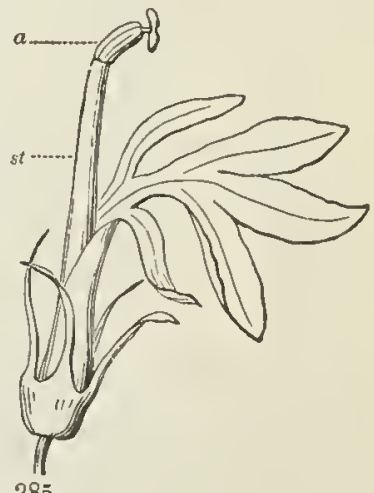

indieate their modes of mutual connection:-

Monadelphous (from two Greck words, meaning "in one brotlierhood "), when united by their filaments into one set, usually into a ring or cup below, or into a tube, as in the Mallow Family (Fig. 286), the Passionflower (Fig. 260), the Lupine (Fig. 297), and in Lobelia (Fig. 285).

Diadelphous (meaning in two brotherhoods), when united by the filaments into two scts, as in the Peat and most of its near relatives (Fig. 288), usually nine in one set, and one in the other.

Triadelphous (three brotherhoods), when the filaments are united in three sets or clusters, as in most species of Hypericunı.

FrG. 2S3. Corolla of Morning Glory lain open, to show the five stamens inserted on it, near the base.

FIG. 291. Style of a Lady's Slipper (Cypriperlinm), and stamens united with it; $a, \alpha$, the anthers of the two gnorl stamens; st, sur arortive stamen, what should be its anther changerl into a petal-like louly; stin, 1 he stigna.

FIG. 285. Flower of Lobelia carlinalis, (thrinal Hower; corolla making approach to the ligulate form; filaments (st) monadelphous, and anthers $(a)$ syngenesious. 
Pentadelphous (five brotherhoods), whell in five sets, as in some species of Hyperieum and in Anerieun Linden (1'gr. 277, 259).

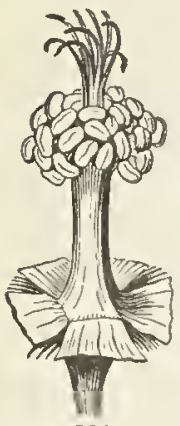

286

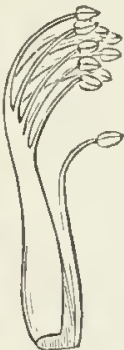

288

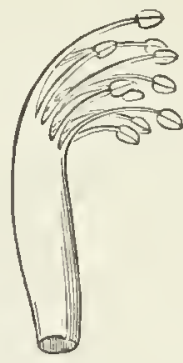

287 Polyudelphous (many or several brotherhoods) is the turw grenerully employed when these sets are several, ol even nore than two, and the par. tieulin number is lelt unspeenlied. I'hese terms all relate to the liliamellts.

Syngenesious is the term to denote that stanens have their anther's united, couleseent into a ring or tube; as in Lobelia (Fig. 285), in Viulets, and in all of the great limily of Compositæ.

294. Their Number in a flower is eominowly expressed direelly, but sometimes adjeetively, by a series of terms whieh were the name of elasses in the Limmen artifieial system, of which the foilowing names, as also the preecding, are a survival :-

Monandrous, i. e. solitary-stamened, when the flower has only one stamen,

Diandrous, when it has two stamens only,

Triandrous, when it bas three stamens,

Tetrandrous, when it has four stamens,

Pentandrous, whell it las five stamens,

Hexandrous, when with six stamens, and so on to

Polyandrous, when it has

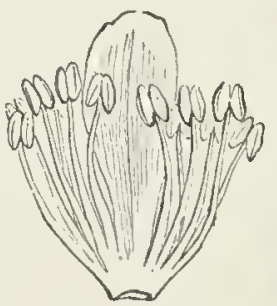

289

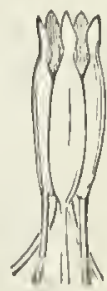

290

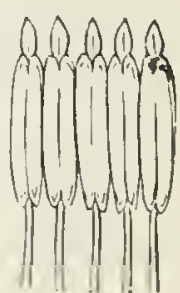

291 many stamens, or more than a dozen.

235. For which terms, sec the Glossarv. They are all Greek numerals prefixed to -andria (finm the Greck), whieh Limmeus used for andionsium, and are marle into an English adjcetive, androus. Two other terms, of - same origin, designate particular cases of number (lour or six) in eonnection with unequal length. Nimely, the stamens are

Dirlynamous, when, heing only four, they form two pairs. one pair longer than the other, as in the Trumpet Crerper, in Gerardia (Fig. 2033), ete.

FIG. 2S6. Flower of at Mallow, with calyx and corolla cht away ; slowing monadelphons stmmens.

FIG. 287. Monadelybous stamens of Lupine. 288. Diadelphous stamens (9 and 1) of a l'en-linssom.

Fig. 2S9. One of the five stamen-clusters of the flower of American Jinden, with accompanying scale. The five clusters are shown in section in the diagram of this flower, Fig. 277.

Fig. 290. Five syngenesious stamens of a Coreopsis. 291. Same, with tube laid open and displayed. 
Tetradynamous, when, being only six, four of them surpass the other two, as in the Mustard-flower and all the Crueiferous family, Fig. 235.

256. The Filament is a kind of stalk to the antlier, commonly slender or thread-like: it is to the anther nearly what the petiole is to the blade of a leaf. 'l'herefore it is not an essential part. As a leaf may be without a stalk, so the auther may be Sessile, or without a filament.

287. The Anther is the essential part of the stamen. It is a sort of case, tilled with a line powder, the Pollen, which scrves to fertilize the pistil, so that it may perlect secds. 'The anther is said to be

Innate (as in Fig. 292), when it is attilelied by its base to the very apex of the filament, turning neither inward nor outward;

Adnate (as in Fig. 293), when atticlied as it were by one lace, usually for its whole length, to the sidc of a continuation of the filament; and

Versatile (as in Fig. 291), when fixed by or near its niddle only to the very point of the filament, so as to swing loosely, as in the Lily, in Grasses, etc. Versatile or adnate antliers are

Introrse, or Incumbent, when faeing inward, that is, toward the eentrc of the flowel, as in Magnolia, Water-Lily, ete.
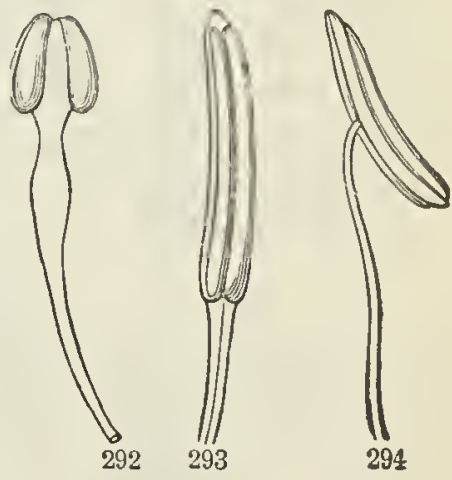

Extrorse, when facing outwildly, as in the Tulip-tree.

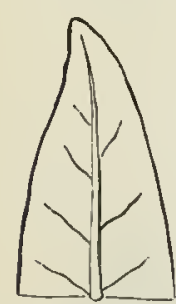

285. Rarely does a stamen bear any resemblance to a leaf, or cven to a petal or flower-leaf. Nevertlieless, the botanist's idea of a stamen is that it answers to a leaf developed in a peculiar form and for a speeial purpose. In the filament he sees the stalk of the leaf; in the anther, the blade. The blade of a leaf consists of two-similar sides; so the anther consists of two LoBEs or CELLS, one answering to the left, the other to the right, side of the blade. The two lobes are often

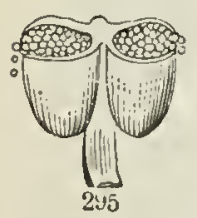
connected by a prolongation of the filament, which answers to the midrib of a leaf; this is called the Connective. This is conspieuous in Fig. 292, where the eomnective is so broad that it separates the two cells of the anther to some distance.

239. A simple eonception of the morphologieal relution of an anther to a leaf is given in Fig. 295, an ideal figure, the lower part rcpresenting a stameu with the top of its anther cut away; the upper, the corresponding upper part of a leaf.

F1G. 292. Stamen of lsolyrum, with inuate anther. 293. Of Tulip-tree, with adnate (and extrorse) anther. 291. Of Evening Primrose, with versatile anther.

FIG. 295. Diasram of the lower part of an anther, cut across ahove, and the upper part of a leaf, to slonw how the one answers to the other; the filament to petiole, the connective to midivib; the two cells to the right and left halves of the blade. 
290. So anthers are generally two-celled. But as the pollen begins to form in two parts of each cell (the anterior and the posterior), sometimes these two strata are not confluent, and the anther even at maturity may be four-celled, as in Moonseed (Fig. 296); or rather, in that case (the word

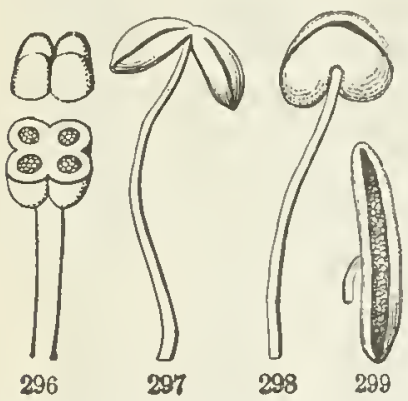
cell being used for cach lateral lialf of the organ), it is two-celled, but the cells bilocellate.

291. But anthers may become one-celled, and that either by confluence or by suppres. sion.

292. By confluence, when the two cells run together into one, as they nearly do in most species of Pentstemon (Fig. 297), more so in Monarda (Fig. 300), and completely in the Mallow (Fig. 298) and all the Nallow family.

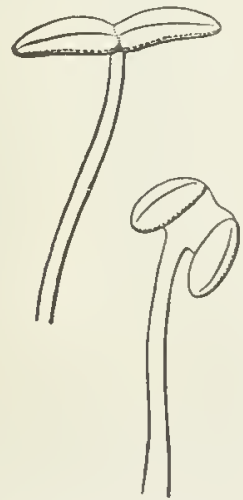

800

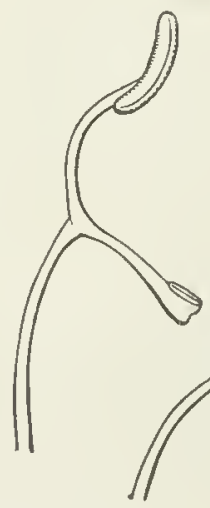

302

301

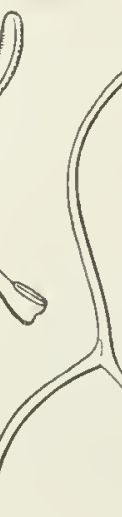

303

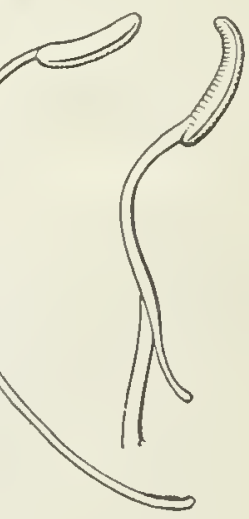

304

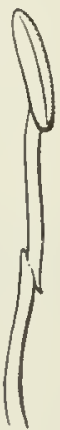

305

Fia. 296. Stamen of Moonseed, with anther cut across; this 4-celled, or rather 4locellate.

Fro. 297. Stamen of Pentstemon pubescens; the two anther-cells diverging, and almost confluent.

Fro. 293. Stamen of Mallow ; the anther supposed to answer to that of Fig. 297, but the cells completely confluent into one.

Fic. 299. Stamen of Globe Amaranth; very short filament bearing a single anther-cell; it is open from top to bottom, showing the pollen within.

Fia. 300-305. Stanens of sereral plants of the Labiate or Mint Fanily. Fia. 300. Of a Monarda: the two anther-cells with bases divergent so that they are transverse to the filament, and their contiguous tips confuent, so as to form one cell opening by a continuons line. FIG. 301. Of a Calamintha: the broad connective separating the two cells. Fla. 302. Of a Sage (Salvia Texana ; with long and slender comective resembling forks of the filanent, one hearing a good anther-cell; the other an ahortive or poor one. FIG. 303. Another Sage (S. eoccinea), with connective longer and more thread-shapel, the lower fork having its antlier-cell wholly wanting. FIo. 304. Of a Wlite Sage, Aulibertia grandiflora; the lower fork of connective a niere vestige. FIG. 305. Of another White Sage (A. stachy. nides), the lower fork of connective suypressed. 
293. By suppression in certain cases the anther may be reduced to one cell or halved. In Globe Amarauth (Fig. 299) there is a single cell without vestige of any other. Difierent speeies of Sage and of the White Sages of California show various grades of abortion of one of the anther-cells, aloug with a singular lengthening of the eounective (Fig. 302-305).

294. The splitting open of an anther for the discharge of its pollen is termed its Dehiscence.

295. As the figures show, this is commonly by a line along the whole lengtls of each cell, either lateral or, when the authers are extrorse, often along the outer face, and when introrse, along the inner face of each cell. Sometimes the opening is only by a elink, liole, or porc at the top, as in the Azalea, l'yrola (Fig. 307), etc.; sometimes a part of the facc separates as a sort of trap-door (or valve), limged at the top, and opening to allow the escape of the pollen,

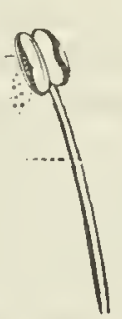

306

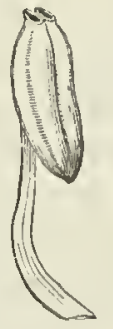

307

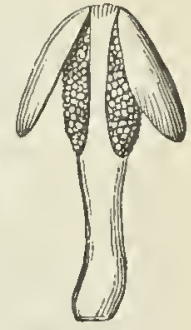

308 as in the Sassafiras, Spiee-bush, and Barberry (Fig. 308).

296. Pollen. This is the powdery matter, commonly of a yellow color, which fills the cells of the anther, and is discliarged during blossoming,

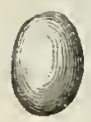

309

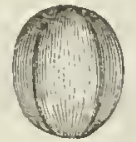

310

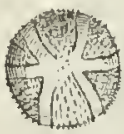

811

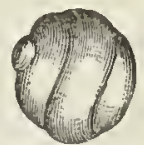

312

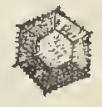

313

after which the stamens geueraily fall or wither away. Under the microscope it is found to consis. of grains, usually round or oval, and all alike in the same species, but very different in different plants. So that the

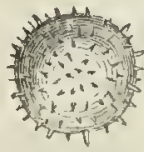

314

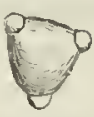

315

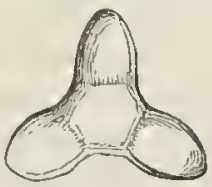

316

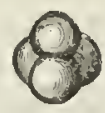

317

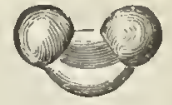

318

p'ant may sometimes be reengnized from the polleu alone. Several forms are snown in the accompanying figures.

FIG. 306. Stamen with the usual dehiscence of anther dowr. the side of each cell.

Frg. 307. Stamen of Pyrola; cells rpening by a terminal hole.

Fig. 308. Stamen of Barberry; cells of anther each opening hy an uplifted valve.

Fig. 309. Magnificl pollen of a Lily, smooth and oval; 310, of Echinocystis, grooved lengthwise; 311, of Sicyos, with bristly points and snooth bands; 312, of Musk Plant (Minulns), with spiral grooves; 313, of Succory, twelve-sided and dottel.

Fld. 314. Magnified pollen of Hihiseus and other Mallow-plants, beset with prickly projections ; 315 , of Circea, with angles bearing little lobes; 316 , of Fveu. 
297. An ordinary poilen-grain has two coats; the outer coat ihickisl. but weak, and frequently adorned with lines or bands, or studded with points; the inner coat is extremely thin and delicate, but extensible, and its cavity when fresh contains a thickish protoplasmic fluid, often rendered turbid by an immense number of minute particles that float in it. As the pollen matures this thuid usually dries up, but the protoplasm does not lose its vitality. When the grain is wetted it absorbs water, swells up, and is apt to burst, discharging the contents. But when weak syrup is used it absorbs this slowly, and the tough inner coat will sometimes brcak through the outer and begin a kind of growth, like that which takes place when the pollen is placed upon the stigma.

298. Some pollen-grains are, as it were, lobed (as in Fig. 315, 316), or formed of four grains united (as in the Heath family, Fig. 317): that of Pine (Fig. 318) has a large rounded and empty bladder-like expansion upon each side. This renders such pollen very buoyant, and capable of being transported to a great distance by the wind.

299. In species of Acreia simple grains lightly cohere into globular peliets. In Milkweeds and in most Orchids all the pollen of an

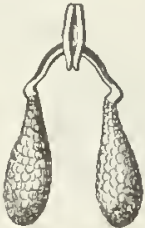

31.9

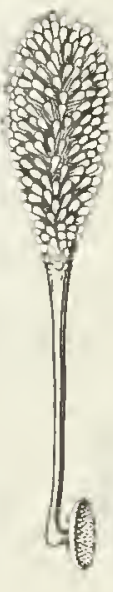

320

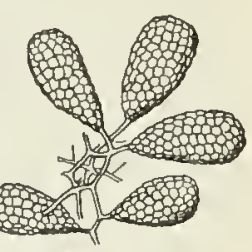

821

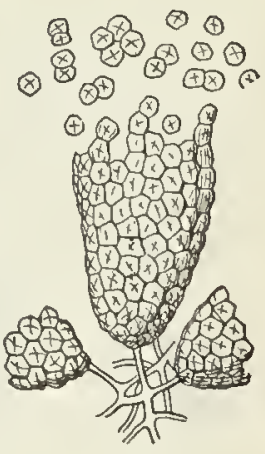

222 anther-cell is compacted or coherent into one mass, called a Pollen-mass, o: Pollinium, plural Pollinia. (Fig. 319-322.)

ing Primrose, the three lobes as large as the central borly; 317 , of Kalmia, four grains united, as in most of the Heath fanily; 318 , of Pine, as it were of three grains or cells united; the lateral enıpty and light.

Fig. 319. Pollen, a pair of pollinia of a Milkweed, Asclepias, attached by stalks to a gland; moderately magnified.

Fic. 320. Pollinium of an Orchis (IInhenaria), with its stalk attached to a sticky gland; magnified. 321. Sume of the packets or partial pollinia, of wlich Fig. 320 is marle up, more magnifier.

Fra. 322. One of the pratial pollinia, torn up at top to show the grains (which are each composed of four), and highly ur:agnified. 


\section{Section X. PISTILS IN PARTICULAR.}

\section{§ 1. ANGIOSPERMOUS OR ORDINARY GYNECIUM.}

300. Gynœcium is the technical name for the pistil or pistils of a flower taken collectively, or for whatever stands in place of these. The various modifications of the gynocium and the terms which relate to them require particular attention.

301. The Pistil, when only one, occupies the centre of the flower; when there are two pistils, they stand facing each other in the centre of the flower; when several, they commonly form a ring or circle; and when very numerous, they are generally erowded in rows or spirals on the surface of a more or less cnlarged or elongated receptaclc. Their number gives rise to certain terms, the counterpart of those used for stancns (284), which are survivals of the names of orders in the Linnæan artificial system. The mames werc coined by prefixing Greek numerals to -gynia used for gynœcium, and changed into adjectives in the form of -gynous. That is, a flower is

Monogyrous, when it has a single pistil, whether that be simple or compound;

Digynous, when it has only two pistils; Trigynous, when with threc; Tetragynous, with four; Pentayynous, with five; Hexagynous, with six; and so on to Polygynous, with milly pistils.

302. The Parts of a Complete Pistil, as already twice explained (16, 236), are the Ovary, the Strle, and the Stigin. The ovary is onc esseutial part: it contains the rudiments of seeds, called Orules. The stigma at the summit is also essential: it receives the pollen, which fertilizes the ovules in order that they may become seeds. But the style, commonly a tapering or slender column borne on the summit of the ovary, and bearing the stigna on its apex or its side, is no more necessary to a pistil I lian the filament is to the stamen. Accordingly, there is no style in many piscils: in these the stigma is sessile, that is, rests directly on the ovary (as ir Fig. 326). The stigma is very various in shape and appenrance, being sometimes a little knob (as in the Cherry, Fig. 2il), sometimes a point or small surface of bare tissue (as in Fig. $327-330$ ), and sometimes a longitudinal crest or line (as in Fig. 32t, 3t1-343), or it may occupy the whole length of the style, as in Fig. 331.

303. The word Pistil (Latin, Pistillum) mcans a pestle. It came into use in the first place for such flowers as those of Crown Impcrial, or Lily, in which the pistil in the centre was likened to the pestle, and the perianth around it to the mortar, of the apotheeary.

304. A pistil is either simple or compound. It is simple when it answers to a single flower-leaf, compound when it answers to two or three, or a fuller circle of such leaves conjoined. 
305. Carpels. It is convenient to have a name for each flower-leaf of the gynocium; so it is called a Carpel, in Latin Carpellum or Carpidium. A simple pistil is a carpel. Each component flower-leaf of a compound pistil is likenise a earpel. When a flower has two or more pistils, thesc of course are simple pistils, that is, separate carpels or pistil-leaves. 'There may be only a single simple pistil to the flower, as in a Pea or Cherry blossom (Fig. 271); there may be two such, as in many Saxifrages; or many, as in the Strawberry. Nore commonly the single pistil in the centre of a blossom is a compound one. Then there is seldom much dificulty in ascertaining the number of carpels or pistil-lcaves that eompose it.

306. The Simple Pistil, viewed morplologically, answers to a leaf. blade with mingins incurved and united where they mect, so forming a closed case or pod (the ovary), aud bearing ovules at the suture or junction of these margins: a tapering upper portion with margins similarly inrolled, is supposed to form the stylc; and these same margins, cxposed at the tip or for a portion of the length, hecome the stigma. Compare, under this riew, the three accompanying figures.

307. So a simple pistil should have a one-celled ovary, only one line of

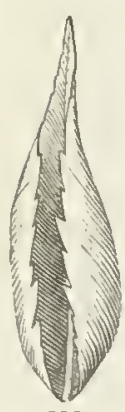

323

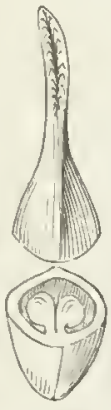

324

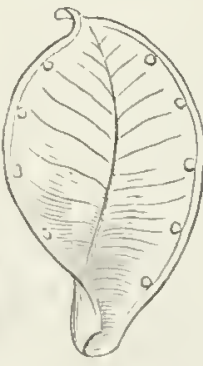

325 attacliment for the ovules, a siugle style, and a single stigma. Certain variations from this normal condition which sometimes occur do not invalidate this morphological conceprion. For instance, the stigma may become two-lubed or twolidged, because it consists of two leat: margins, as Fig. 324 sloors; it may become 2-locellate by the turuing or growing inward of onc of the sutures, so as to divide the carity.

308. There are two or three terms which primarily relate to the parts of a simple pistil or carpel, and are thence carried on to the compound pistil, riz.:-

Tentral Suture, the line which answers to the united margins of the carpel-lcaf, therefore naturally called a suturc or scam, and the ventral or inner onc, because in the circle of carpcl-leaves it looks inward or to the centre of the flower.

Dorsal Suture is the line down the back of the carpcl, answering to

Fic. 323. An inrolled small leaf, such as in double-flowered cherry blossoms is often seen to ncenpy the jlace of a pistil.

FIG. 324. A simple pistil (of Isourrmon), with orary cut across; the inner (rentral) face turned towini the eve: the ornles seem to he home on the ventral suture, answering to leaf-margins: the stigna above sepn also to answer to leaf-margins.

FIg. 325. Pol or simple pistil of Caltha or Marsh-1Iarigold, which has opened sod shel its seeds 
the midrib of the leaf, - not a seam therefore; bnt at maturity many fruits, sueh as pea-pods, open by this dorsal as well as by the ventral line.

Placenta, a name given to the surface, whatever it be, whieh bears the ovules and sceds. The name may be needless when the ovules grow directly on the ventral suture, or from its top or bottom; bnt when therc are many ovnles therc is usually some expansion of an ovnle-bearing or seed-bearing surface; as is seen in onr Mandrake or Podophyllum, Fig. 326.

309. A Compound Pistil is a combination of two, three, or a greater number of pistil-leaves or carpels in a circle, united into one body, at least

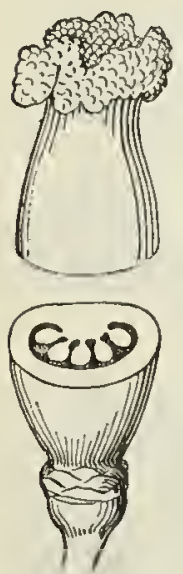

326
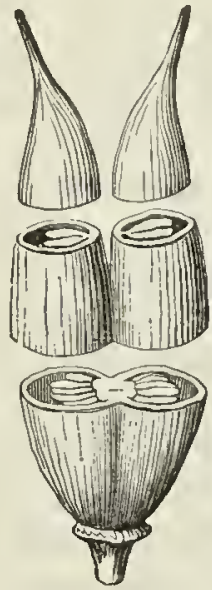

327

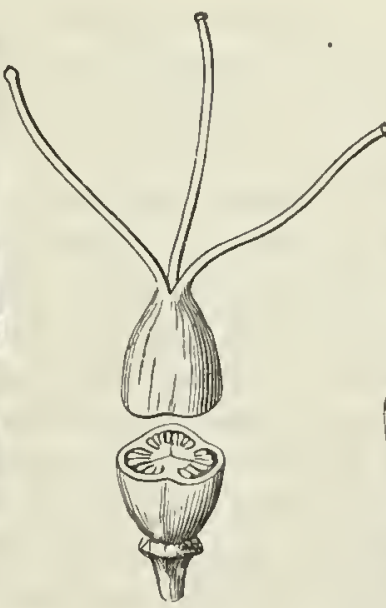

328

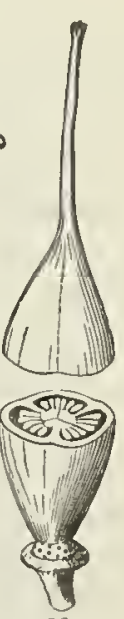

329

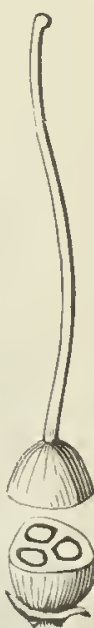

330

by their ovaries. The annexed figures should make it clear. A series of Saxifrages might be selected the gynocium of which would show every gradation between two simple pistils, or separate carpels, and their complete coalescence into one compound and two-celled ovary. Even when the constituent styles and stigmas are completely coalescent into one, the nature of the combination is usually revealed by some external lines or grooves, or (as in Fig. 328-330) by the internal partitions, or the number of the placentx. The simplest casc of compound pistil is that

310. With two or more Cells and Axile Placentæ, namely, with as many cells as there are carpels, that have united to compose the organ.

FIG. 326. Simple pistil of Podophyllum, cut across, showing ovules borme on placenta.

FIG. 327. Pistil of a Saxifrage, of two simple carpels or pistil-leaves, united at the base only, cut across both above and below.

FIG. 328. Compound 3-carpellary pistil of common St. John's-wort, cut across: the three styles scparate.

Fia. 329. The same of shrubby St. John's-wort; the three styles as well as ovaries here united into one.

Fig. 330. Compound 3-carpellary pistil of Tradescantia or Spiderwort; the three stigmas as well as styles and ovary completely coalescent into one. 
Such a pistil is just what would be formed if the simple pistils (two, three, or fire in a circle, as the case may bc), like those of a Prony or Stonecrop (Fig. 22t, 225), pressed together in the centre of the flower, were to colhere by thcir contiguous parts. In such a case the plincentre are niturally axile, or all brought together in the axis or ecntre; and the ovary has as many Dissepiarexts, or internil Partitions, as there are carpels in its composition. For these are the contignous and conlescent walls or sides of the component cal'pels. When such pistils ripen into pods, they often separate along these lines into thcir elementary carpels.

311. One-celled, with free Central Placenta. The commoner case is thit of Purslaue (Fig. 272) and of the Pink and Chickweed familics (Fig. 331, 332). This is explaincl by supposing that the partitions (such ats those of Fig. 329) hare early vanished or have been suppressed. In-

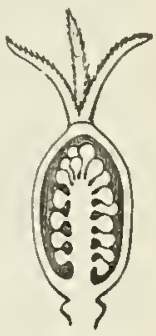

231

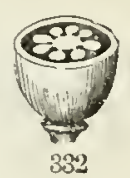
deed, traces of them may often be deterted in Pinks. On the other lana. it is equilly supposable that in the Primuli lamily the free central is de rived from parietal placentation by the carpels bearing orules only at base, and forming a consolidated common placenta in the axis. Mitella and Dionea help out this conception.

312. One-celled, with Parietal Placentæ. In this not uncommon case it is conceived that the two or thice or. more carpel-leares of such a compound pistil coalesce by their adjacent edges, just as sepal-leaves do to form a gamo-

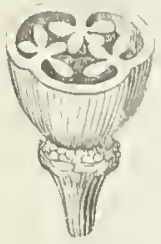

334

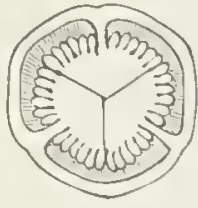

335

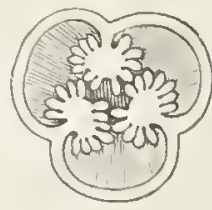

336 sepalous calyx, or petils to form a gamopetalous corolla, and as is shown in the d i a gr a m, Fin. 333 , and in an actual cross-sec-
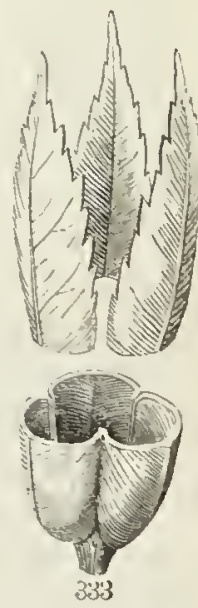

tion, rigr. 33t. Herc cach carpel is an open leat, nr witl some introflexion. bearing ovules along its margins; and cach placenta consists of the con-

FIg. 331, 332. Pistil of a Sundwort, with vertical and transicrse section of the ovary : fiee central placenta.

FIG. 333. I'lan of a one-celled ovary of three carpel-leaves, with parietal pla. cente, cut across below, where it is complete; the upper part showing the top of the three leases it is comproserl of, approaching, hut not united.

FIG. 33.4. Cross section of the ovary of Frost-weed (Helianthemmm), with three pariefal jucentre, heraing ormles.

FIf. 335. Crox suction of an orary of Hyjericum grareolens, the three large pla pentse mereting in the contre, so as to form a three celled ovary. 336. Same in truit, the placentie now separate and rounded 
tiguous margins of two pistil-leaves growu together. There is every grada. tion between this and the three-eelled ovary with the plaeentæ in the axis, even in the same genus, sometimes even in diffrent stages in the sane pistil (Fig. 335, 336).

\section{§ 2. GYMNOSPERMOUS GYNCECIUM.}

313. The ordinary pistil has a elosed ovary, and aceordugig the pollen can aet upon the contained ovulcs only indircetly, through the stigma This is expressed in a term of Greek derivation, viz.:-

Angiospernous, meaning that the seeds arc borme in a sae or elosed vessel. 'The counterpart term is

Gynnospermous, meaning naked-seeded. This kind of pistil, or gruœcium, the simplest of all, yet the most peeulial, eliaraterizes the Pine family and its relatives.

314. While the ordinary simple pistil is eonceived by the botanist to

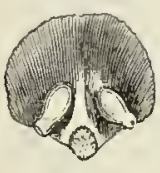

3.77 be a leaf rolled together into a elosed pod (306), those of the Pine, Larch (Fig. 337), Cedar, and Arbor-Viro (Fig. 338, 339) arc open leaves, in the form of scales, each bearing two or more ovules on the inner fiee, next the base. At the time of blossoning, these pistil-leaves of the young eone diverge, and the pollen, so abuudantly shed from the staminate blossoms, falls dircetly upon the exposcd ovules. Aftcrward the scales elose over each other unti' the seeds are ripe. Then they sepa. rate that the sceds may be shed. As the pollen acts direetly on the ovules, suel pistil (or orgin aeting as pistil) las no stiyma.

315. In the Yew, and in Torreya and Gingko, the grnœeium is redueed to ex/remest simplieity', that is, to a naked ovule, willout any visible: carnel.

316. In Cyeas the large naked ovules are borne

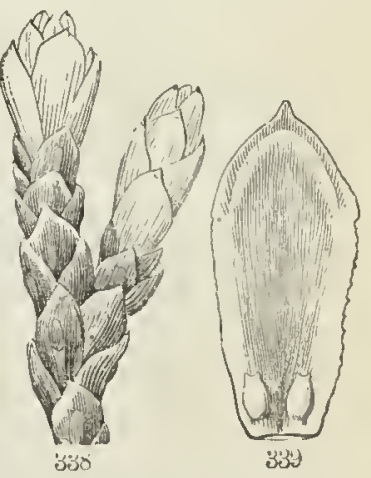
on the margins or lobes of an obvinus open leaf. All Gymnosperuous plants have other peeuliarities, also dislinguishing them, as a class, from. Angiosperyous plants.

FIG. 337. A pistil, that is, a scale of the cone, of a Larch, at the time of flowering; insirle view. slowing its pair of naker nrules.

FIG. 338. Branchlet of the American Arbor-Vitæ, considerahly larger than in nature, terminated by its pistillate flowers, each consisting of a single scale (an spen pistil), tngether furming a small cone.

EIG. 339. One of the scales or carpels of the last, removerl and more enlarged. she iuside exposed to view, showng a pair of ovules on its base- 


\section{SECTION XI. OVULES.}

317. Ovale (from the Latin, meaning a little egg) is the technical name of that which in the flower answers to and beeomes the seed.

318. Orules are naked in gymnospermous plants (as just deseribed); in all others they are enclosed in the ovary. They may be produced along the

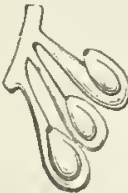

310 whole length of the cell or cells of the ovary, and then they are apt to be numerous; or only from some part of it, generally the top or the bottom. In this case they are usually few or single (solitary, as in Fig. 341-343). They may be sessile, i. e. without stalk, or they may be attaelied by a distinet stalk, the Funicle or Funiculus (Fig. 340).

319. Considered as to their position and direetion in the ovary, they are Horizontal, when they are neither tmrned upward nor downward, as in Podophyllnm (Fig. 326);

Ascending, when rising obliquely upwards, usually from the side of the cell, not from its very base, as in the Buttercup (Fig. 341), and the Purslane (Fig. 272);

Erect, when rising upright from the very base of the cell, as in the Buck. wheat (Fig. 342);

Pendulous, when hanging from the

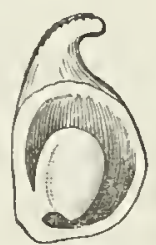

341

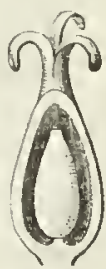

342

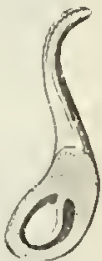

343 side or from near the top, as in the Flax (Fig. 2r0); and

Suspended, when lianging perpendicularly from the very summit of the cell, as in the Anemone (Fig. 343). All these terms equally apply to seeds.

320. In structure an ovule is a pulpy mass of tissue, usually with one or two coats or coverings. The following parts are to be noted; viz: -

Kernel or Nucueus, the body of the oville. In the Mistletoe and some related plants, there is only this melens, the eoats heing wanting.

Tegumexts, or coats, sometimes only one, more comnonly two. Then two, one has becn ealled Primixe, the other Secuninse. It will serve all purposes to eall them simply outel and inner ornle-coats.

Orifice, or Fonumes, an opening through the coats at the organic apex of the orule. In the seed it is Micropyle.

Chalaza, the place where the coats and the kernel of the ornle blend.

Hisum, the place of junetion of the funiculus with the body of the ornle.

FIG. 340. A cluster of ornles, pendulons on their funicles.

FIg. 341. Section of the orary of a Buttercup, lengthwise, showing its ascenling ovule.

F10. 342. Section of the ovary of Bnckwheat, showing the erect orule

FIa. 343. Section of the ovary of Anemone, showing its susperded orule. 
321. The Kinds of Ovules. The orules in their growth develop in thrce or four different ways, and thereby are distinguished into

Orthotropous or Straight, those which develop without curving or turn-

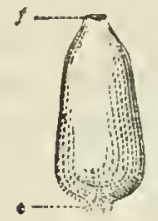

344

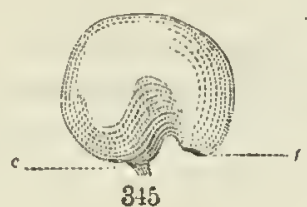

315

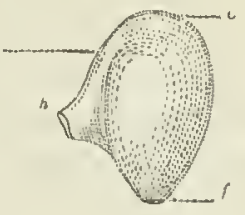

346

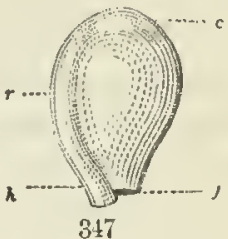

$3 \pm 7$

ing, as in Fig. 344. The chalaza is at the insertion or base; the foramen or orifice is at the apex. This is the simplest, but the least common kind of ovule.

Campylotropous or Incurved, in which, by the greater growth of one side,

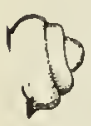

348

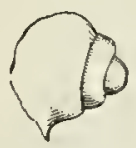

349

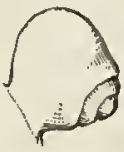

350

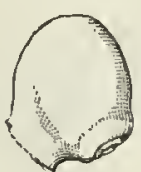

351

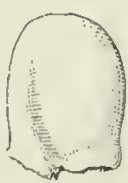

352

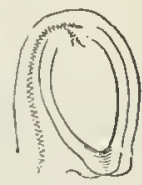

353

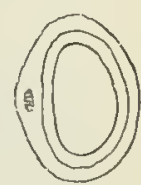

354

the ovule curves into a kidney-shaped outline, so bringing the orifice down close to the base or chalazil; as in Fig. 345.

Amphitropous or IIalf-Interted, Fig. 346 . Here the forming ovule, instcad of curving perceptibly, keeps its axis nearly straight, and, as it grows, turns round upon its base so far as to become transverse to its funiculus, and adsate to its upper part for some distance. 'Tliercfore in this casc the attachment of the funiculus or stalk is about the middle, the chalaza is at onc end, the orifice at the other.

Anatropous or Inverted, as in Fig. $34 \pi$, the commoncst kind, so called because in its growth it has

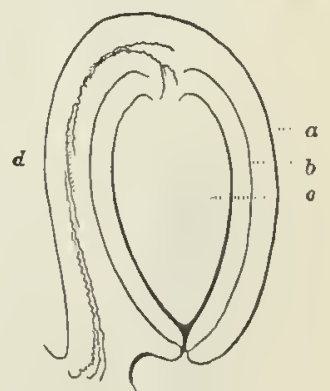

355 as it were turncd over upon its stalk, to which it has continued adnate. The organic base, or chalaza, thus becomcs the apparent summit, and the

FIG. 344. Orthotropons ovnle of Buckwheat : $c$, hilum and chalaza; $f$, orifice.

FIG. 345. Campylotropons ovule of a Chickweel: $c$, hilum and chalaza: $f$, orifiee.

Fig. 346. Amphitropous ovule of Mallow: $f$, orifice; $h$, lilum; $r$, rhaphe; $c$, chalaza.

FIG. 347. Anatropous ovule of a Violet; the parts lettered as in the last.

FIg. 348-350. Three early stages in the growth of ovule of a Magnolia, showing the forming outcr and inner coats, which, even in the later figure have not yet completely enclosel the nuclens; 351, further alvaneed, awd 352, completely anatropons ovule.

FIG. 353. Longitudinal seetion, and 354 , transverse section of 352 .

FIG. 355. Same as 353, enlarged, showing the parts in seetion : $a$, outer coat:

$b$, inner coat; $c$, vueleus: $d$, rhaphe. 
orifice is at the base, by the side of the hilum or place of attachment. The aduate portion of the funiculus, which appears as a ridge or cord extending from the hilum to the chalaza, and which distinguishes this kind of ovule, is called the RндPнe. The amplitropous ovule (Fig. 346) has a short or incomplete rhaphe.

322. Fig. 348-352 show the stages through which an ovule becomes anatropous in the course of its growth. The annexed two figures are sections of such an ovulc at maturity; and Fig. 355 is Fig. 353 enlarged, with the parts lettered.

\section{SECTION XII. MODIFICATIONS OF THE RECEPTACLE.}

323. The Torus or Receptacle of the flower (237, Fig. 223) is the portion which belongs to the stem or axis. In all preceding illustrations it is small and short. But it sometimes lengthens, sometimes thickens or variously enlarges, and takes on various forms. Some of thcse have received special names, very few of which are in common use. A lengthened portion of the receptacle is called

A Sripe. This name, which means simply a trunk or stalk, is used in

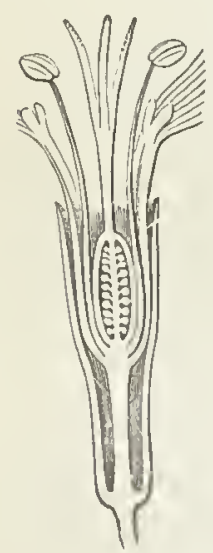

356

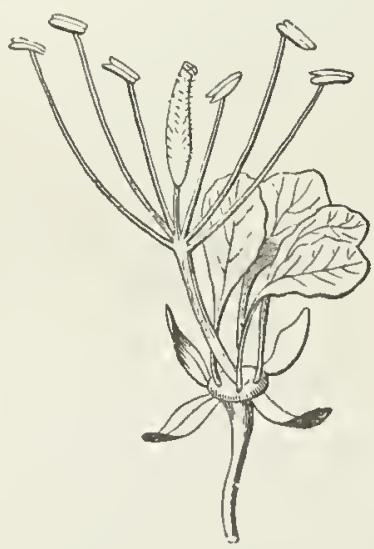

357

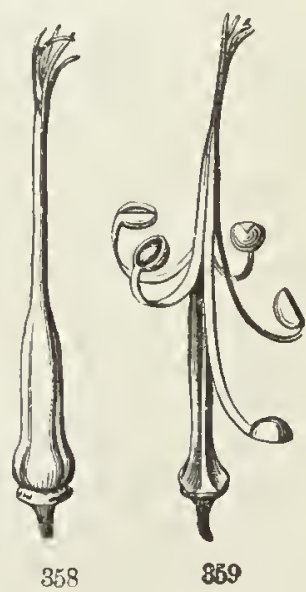

358

botany for various stalks, even for the lcaf-stalk in Ferns. It is also applied to the stalk or petiole of a carpel, in the rare cases when there is any, as in

FIG. 356. Longitudinal section of flower of Silene Pennsylvanica, showing stipe between calyx anil corolla.

Fia. 357. Flower of a Cleome of the scetion Gynandropsis, showing broadened receptaclc to hear petals, lengthened stipc bclow the stamens, and another between these aml pistil.

Fic. 35s. lintil of Geranimn or Crancsbill.

Fic. 3.59 The same, ripe, with the tive carpels splitting away from the long beak (carpoluhore), and hamging from its top by their recurving styles. 
Goldthread. Then it is teehnieally distinguished as a Thecapiere. When there is a stalk, or lengtlened internode of reeptrele, directly under a compound pistil, as in Stanleya and some other Crueiferx, it is called a Grnophore. When the stalk is developed below the stamens, as in most speeies of Silene (Fig. 356), it has been called an Anthopiore or GonopHore. In Fig. 357 the torus is dilated above the calyx where it bears the petals, then there is a long internode (gonophore) between it and the stamens; then a shorter one (grnophorc) between these and the pistil.

324. A Carpophore is a prolongation of receptacle or axis between the carpels and bearing them. Umbelliferous plants and Geranium (Fig. 358, 359) afford charaeteristie eximples.

325. Flowers with very numcrous simple pistils generally lave the reccptaele enlarged so as to give them room; sometimes beeoming broad and Hat, as in the Flowering Raspberry, sometimes elougated, as in the Black-
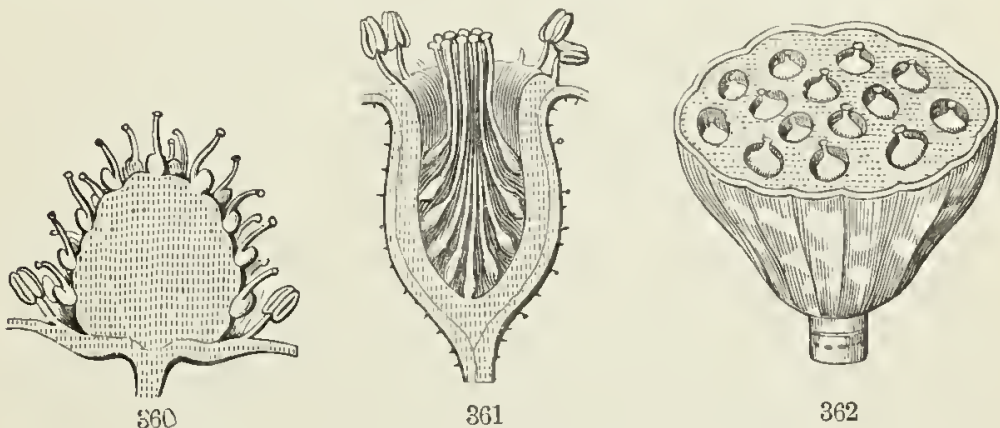

berry, the Mawnolia, etc. It is the receptaele in the Strawherry (Fig. 360), much enlarged and pulpy when ripe, which forms the eatable part of the fruit, and bears the small seed-like pistils on its surface. In the Rose (Fig. 361), instead of being eonvex or conieal, the receptaele is deeply concave, or urn-slaped. Indeed, a Rose-hip may be likened to a strawberry turned insicle out, likc the finger of a glove reversed, and the whole eovered by the adhercnt tube of the ealyx. The calyx rcmins beneath in the strawberry.

326. In Nelumbium, of the Water-Lily family, the singular and greatly cularged reeeptaclc is shaped like a top, and bcars the small pistils inmersed in separatc carities of its flat upper surface (Fig. 362).

327. A Disk is an enlarged low reeeptacle or an ont. growth from it, hypogynous whon underneath the pistil, as in Rue and the Orange (Fig. 363), and perigynous when adnate

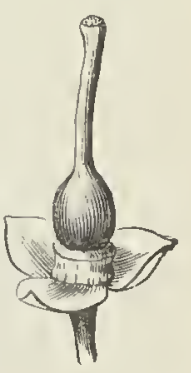

363 to ealyx-tube (as in Buekthorn, Kirg. 36t, 365), and Cherry (Fig. 271), or

Fig. 360. Longitudinal section of a young strawberry, enlarged.

Fig. 361. Similar section of a young Rose-hip.

Fig. 362. Enlarged and top-shaped receptacle of Nelumbium, at maturity

Fig. 363. Hypogynous disk in Orange. 
to both calyx-tube and ovary, as in Hawthorn (Fig. 273). A flattened

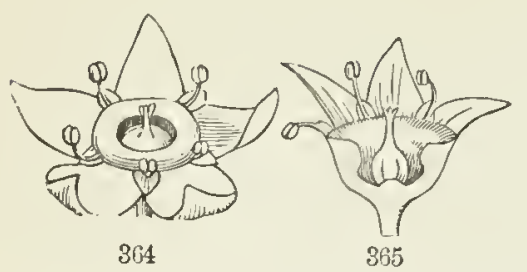
hypogynous disk, underlying the ovary or ovaries, and from which they fall away at maturity, is sometimes called a Grobase, as in the Rue family. Ill some Borragineous flowers, sueh as Houndstongue, the gynobase runs up in the eentre between the earpels into a earpophore. The so-called epigynous disk (or STrLorodrum) crowning the summit of the ovary in flowers of Umbelliferæ, etc., cannot be said to belong to the receptacle.

\section{Section XIII. FERTILIZATION,}

328. The end of the flower is attained when the orules becone seeds. A flower remains for a certain time (longer or sliorter according to the species) in anthesis, that is, in the proper state for the fulfilment of this end. During anthesis, the orules hare to be lertilized by the pollen; or at least some pollen has to reach the stigma, or in gymmospermy the ovule itself, and to set up the peculiar growth upon its moist and permeable tissue, which has for result the production of an embryo in the ovules. By this the ovules are said to be fertilized. The first step is pollination, or, so to say, the sowing of the proper pollen upon the stigma, where it is to germinate.

\section{\$1. ADAPTATIONS FOR POLLINATION OF THE STIGMA.}

329. These various and ever-interesting adıptations and processes are illustrated in the "Botanical Text Book, Structural Botany," chap. VI. sect. iv., also in a brief and simple way in "Botany for Young People, How Plants Behave." So mere outlines only are given here.

330. Sometines the application of pollen to the stigma is left to ehanee, as in diøeious wind-fertilized flowers; sometimes it is rendered very sure, as in flowers that are fertilized in the bud; sometimes the pollen is prevented from reaching the stigma of the same flower, although placed very near to it, but then there are always arrangements for its transferenec to the stigma of some other blossom of the kind. It is among these last that the most exquisite adaptations are met with.

331. Aceordingly, some flowers are particularly adapted to close or selffertilization; others to cross fertilization; some for either, according to cireunstances.

Fro. 364. Flower of a Puckthorn showing a conspicuous perigynous disk.

FIg. 365. Vertical section of same flower. 
Close Fertilization occurs when the pollen reaches and acts upon a stigma of the very same flower (this is also called scli-fertilization), or, less closely, upon other blossoms of the same cluster or the same individual plant.

Cross Pertilization occurs when ovules are fertilized by pollen of other individuals of the same species.

IIybridization occurs when ovules are fertilized by pollen of some other (uecessarily some nearly rclated) species.

332. Close Fertilization would seem to be the natural result in ordinary hermaphrudite fluwers; but it is by no means so in all of them. More commonly the arrangements are such that it takes place ouly after some opportunity for cross fertilization has been afforded. But close fertilization is inevitable in what are called

Cleistogamous Flowers, that is, in those which are fertilized in the flower. bud, while still mopened. Most flowers of this kind, indeed, never open at all; but the closed floral coverings are forced off by the growth of the precocionsly fertilized pistil. Conmon examples of this are fonnd in the earlier blossons of Speculinia perfoliata, in the later oncs of most Violets, especially the stcmless specics, in om wild Jewcl weeds or Impatiens, in the subterranean shoots of Amphicarpæa. Every plant which produces these cleistogamnous or bud-fertilized flowers bear's also more conspicuous and open tlowers, usually of bright colors. The latter very commonly fail to set seed, but the former are prolific.

333. Cross Fertilization is naturally provided for in diœcions plants (249), is much favored in monocious plants (249), and liardly less so in dichogamous and in heterogonous flowcrs (33S). Cross fertilization depends upon the transportation of pollen; and the two principal agents of conveyance are winds and inscets. Most flowers are in their whole strncture adapted cither to the one or to the other.

334. Wind-fertilizable or Anemophilous flowers are morc commonly diøcious or monœcious, as in Pines and all coniferous trees, Oaks, and Birches, and Sedges; yet sometimes hermaphrodite, as in Plantrins and most Grasses; they produce a superabundance of very light pollen, adapted to be wind-borne; and they offer neitleer nectar to fecd winged insects, nor fragrance nor bright colors to attract them.

335. Insect-fertilizable or Entomophilous flowers are those which are sought by insects, for pollen or for nectar, or for botls. "illirough their visits pollen is conveyed from one flower and from one plant to another. Insects are attracted to such blossoms by their bright colors, or their fragrance, or by the nectar (the material of honey) there provided for them. Whilc supplying their own needs, they carry pollen from antleers to stigmis and from plant to plant, thus bringing about a certain amonnt of cross fertilizition. Willows and some other diœcious flowers arc so fertilizcd, chiclly by bees. But most inseet-visited flowers have the stamens and pistils associated cither in the same or in cuntiguons blossoms. Even when in the same blossom, anthers and stigmas are very commonly so situated 
that under insect-visitation, some pollen is more likely to be deposited upor: other than upon own stigmas, so giving a cliance for cross as well as for close fertilization. On the other hand, mumerous flowers, of very various kinds, have their parts so arranged tlat they must almost necessarily be crossfertilized or be barren, and are therefore dependent upon the aid of insects. This aid is secured by different exquisite adaptations and contrivances. which would need a volume for full illustration. Indecd, there is a good number of volumes devoted to this subject. ${ }^{1}$

336. Some of the adaptations which favor or ensure cross fertilization are peculiar to the particular kind of blossom. Orchids, Milkweeds, Kalmia, Iris, and papilionaccous flowers each have their own special contrivances, quite different for each.

337. Irregular flowers (25:) and especially irregular corollas are usu ally adaptations to insect-visitation. So are all Nectaries, whether hollow spurs, sacs, or other concavities in which nectar is secreted, and all nectariferous glands.

338. Moreover, there are two arrangements for cross fertilization common to hermaphrodite flowers in various different families of plants, which have reccived special names, Dichogamy and Heterogony.

339. Dichogamy is the commoner case. Flowers are dichogamous when the anthers discharge their pollen either before or after the stigmas of that flower are in a condition to receive it. Such flowers are

Proterandrous, when the anthers are earlicr than the stigmas, as in Gelltians, Campanula, Epilobium, ete.

Proterogynous, when the stigmas are mature and moistened for the reception of yollen, before the anthers of that blossom arc ready to supply it, and are withered before that pollen can be supplied. Plantains or Ribworts (mostly wind-fertilized) are strikiugly proterogymous : so is Amorpha, our Papaws, Scrophularia, and in a less degrce the blossom of Pears, Tlawthorms, and Horsc-chestuut.

340. In Sabbatia, the large-flowered species of Epilobium, and strikingly in Clerodendron, the dichogamy is supplemented and perlected by movenents of the stamens and style, onc or both, adjusted to make sure of cross fertilization.

341. Heterogony. This is the case in mhich lermaphrodite and fertile flowers ol two sorts are produced ou different individuals of the same species; one solt laring ligher anthers and lower stigmas, the other liav. ing higher stigmas and lower antlers. Thuns reciprocally disposed, a visit. yng jusect carrics pollen from the high anthers of the one to the high stigma of the other, and from the low anthers of the one to the low stigma of the other. These plants are practically as if dicecious, with the advantage that

1 Begiuning with one by C. C. Sprengel in 1793, and again in our day with Darwin, "On the Various Contrivances by which Orchids are fertilized by Inscets," and in sueceding works. 
both kinds are fruitful. Honstonia and Mitchella, or Partridge-berry, are excellent and familiar examples. These are eases of

Heterogone Dimorphism, the relative lengths bcing only short and long reciproeally.

Heterogone Trimorphism, in which there is a mid-length as well as a long and a short set of stamens and style; occurs in Lythrmm Salicaria and some speeies of Oxalis.

342. There mnst be some essential advantage in cross fertilization or eross breeding. Otherwise all these various, elaborate, and exquisitely adjusted adaptations wonld be aimless. Doubtless the advantage is the same as that whieh is realized in all the ligher animals by the distinction of sexes.

\section{§2. ACTION OF POLLEN, AND FORMATION OF THE EMBRYO.}

343. Pollen-growth. A grain of pollen may be justly likened to one of the simple bodies (spores) whieh answer for seeds in Cryptogamons plants. Like one of these, it is capable of germination. When deposited upon the moist surfaee of the stigma (or in some cases even when at a ccrtain distance) it grows from some point, its living inner coat breaking through the inert outer coat, and protruding in the form of a delieate tube. This as it lengthens penetrates the lonse tissue of the stigma and of a loose conducting tissne in the style, feeds upon the nourishing liquid matter there provided, reaelies the eavity of the ovary, enters the orifiee of an ovule, and attaehes its extremity to a sac, or the lining of a definite eavity, in the ovule, called the Fimbryo-Sac.

344. Origination of the Embryo. A globule of living matter in the cmbryo-sac is formed, and is in some way plaeed in elose proximity to the apex of the pollen tube; it probably absorbs the contents of the latter; it then sets up a special growth, and the Embryo (8-10) or rudimentary plantlet in the seed is the result.

\section{SECTION XIV. 'THE FRUIT.}

345. Its Nature. The orary matnres into the Fruit. In the strictest sense the fruit is the seed-vessel, trehnically named the Pertcarp. But practically it may inehde other parts organically eonneeted with the pericarp. Especially the calyx, or a part of it, is often incorporated with the ovary, so as to be undistinguishably a portion of the periearp, and it even forms along with the reeptaele the whole hulk of sueh edible fruits as apples and pears. The reeptacle is an obvions part in blackberries, and is the whole edible portion in the strawherry.

346. Also a eluster of distinet earpels may, in ripening, be consolidated or eompacted, so as practically to be taken for onc fruit. Sneh are raspber- 
ries, blackberries, the Magnolia frnit, etc. Moreover, the ripened product of many flowers may be compacted or grown together so as to form a single componind fruit.

347. Its kinds have therefore to be distinguished. Also various names of common use in descriptive botany lave to be mentioned and defined. into

348. In respect to composition, accordingly, fruits may be classified

Simple, those which result from the ripening of a single pistil, and con. sist only of the matnred ovary, either by itself, as in a cherry, or with calyx-tubc completely incorporated with it, as in a gooseberry or cranberry.

Aggregute, when a cluster of carpels of the same flower are crowded into a mass; as in raspberries and blackberrics.

Accessory or Anthocarpous, when the surroundings or supports of the
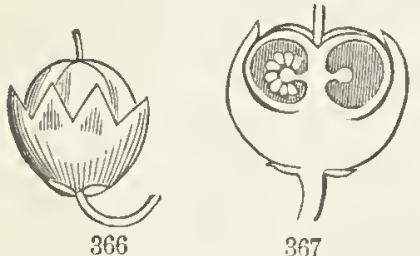
pistil make up a part of the mass; as does the loose calyx changed into a fleshy and berry-like envelope of on Wintergreen (Gaultheria, Fig. 366, 367) and Buffalo. berry, which are otherwise simple fruits. In an aggregate frnit such as the strawberry the great mass is receptacle (Fig. 360,368 ) ; and in the blackberry (Fig. 369 ) the juicy receptacle forms the central part of the savory mass.

Multiple or Collective, when formed from several flowers consolidated

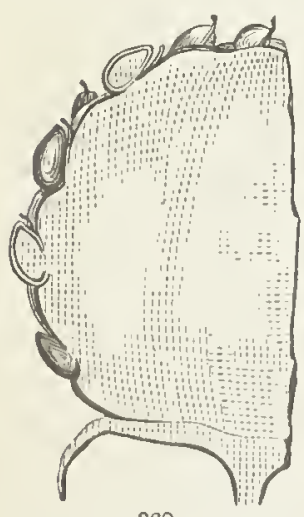

368

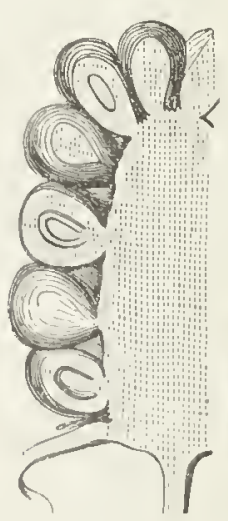

369 into one mass, of which the common receptacle or axis of inflorescence, the floral enrelopes, and even the bracts, etc., make a part. $\Lambda$ mulberry (Fig. 408, which superficially

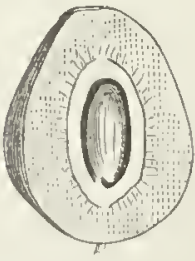

370 much resembles a blackberry) is of this multiple sort. A pineapple is another exanplc.

3.9. In respect to texture or consist. ence, fruits may be

distinguished into three kinds, viz.:-

Fleshy Fruits, those which are more or less soft and juicy throughout;

Fra. 366. Forming fruit (capsule) of Ganltheria, with calyx thickening around its base. 367. Section of same mature, the berry-like calyx nearly enclosing the capsule.

Fra. 368. Section of a part of a strawberry. Compare with Fig. 360.

Fia. 369. Similar section of part of a blackherry. 370. One of its cnmponent simple fruits (Irupe) in section, showing the pulp, stone, and contained send. more enlargerl. Compare witl Fig. 375. 
Stone Fruits, or Drupaceous, the outer part fleshy like a berry, the inner hard or stong, like a nut; and

Dry Fruits, those which have no flesh or pulp.

350 . In reference to the way of disseminating the coutained seed, fruits are said to be

Indehiscent when they do not open at maturity. Fleshy fruits and stone fruits are of course indehiscent. The sced becomes frcc only through decay or by being fed upon by animals. Those which escape digestion are thus disseminated by the latter. Of dry fruits mally are indeliscent; and these are variously arranged to bc transported by auinals. Some burst irregularly; many are

Dehiscent, that is, they split open regularly along certain lincs, and discharge the seeds. A dehiscent fruit almost always coutains many or

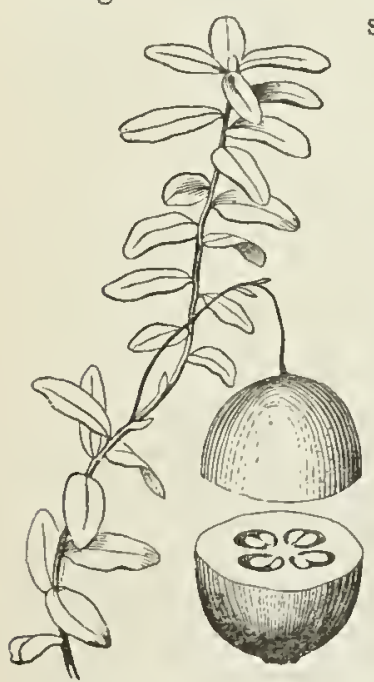

371

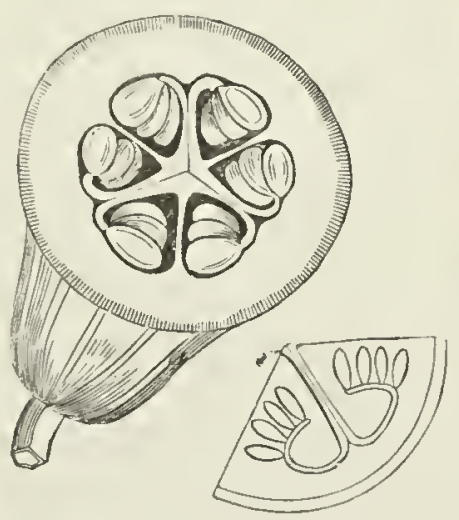

372

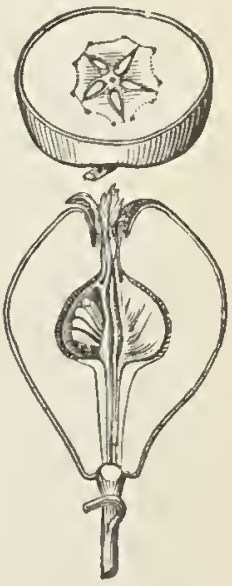

374

351. The principal kinds of fruit which have received substantive names and are of common use in descriptive botany are the following. Of fleshy fruits the leading kind is

352. The Berry, such as the gooseoerry and currant, the blueberry and cranberry (Fig. 371), the tsinato, and the grape. Here the whole flesh is soft thiroughout. The orange is a berry with a leathery riud.

353. The Pepo, or Gourd-fruit, is a lard-rinded berry, belonging to the Gourd family, such as the pumpkin, squasl, cucumber, and melon, Eig. $372,373$.

354. The Pome is a name applied to the apple, pear (Fig. 374), and quince; Heshy fruits, like a berry, but the principal thickness is calyx, only

FIG. 371. Leafy shoot and berry (cut across) of the larger Cranberry, Vaccinium macrocarpon

Fig. 372. Pepo of Gourd, in section. 373. One carpel of same in diagram.

FIG. 374. Longitudinal and transverse sections of a pear (pome). 
the papery pods arranged like a star in the core really belonging to the carpels. The fruit of the Hawthorn is a drupaceous pome, something between pome and drupe.

355. Of fruits which are externally fleshy and internally hard the lead. ing kind is

356. The Drupe, or Stone-fruit; of which the cherry, plum, and peach

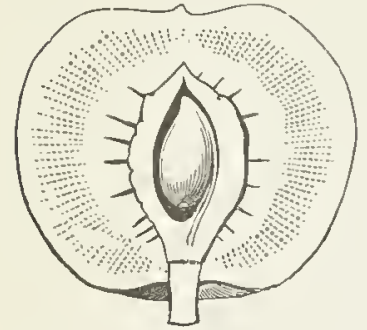

375

(Fig. 375) are familiar examples. In this the outer part of the thickness of the pericarp be. comes fleshy, or softens like a berry, while the inner hardens, like a nut. From the way in which the pistil is construeted, it is evident that the fleshy part here answers to the lower, and the stone to the upper face of the component leaf. The layers or concentrie portions of a drupe, or of any pericarp which is thus separable, are named, when thus distinguishable into three portions, -Epicarp, the external layer, often the mere skin of the fruit, Mesocarp, the middle layer, which is commonly the fleshy part, and Endocarp, the innermost layer, the stone. But nore commonly only two portions of a drupe are distinguished, and are named, the onter one

Sarcocarp or Exocarp, for the flesh, the first name referring to the fleshy character, the second to its being all external layer; and

Putamen or Endocarp, the Stone, within.

357. The typical or true drupe is of a single carpel. But, not to multiply teehnical names, this name is extended to all such fruits when fleshy without and stony within, although of compound pistil, - even to those having several or separable stones, sueb as the fruit of Holly. These stones in such drupes, or drupaceous fruits, are ealled Pyrence, or Nucules, or simply Nutlets of the drupe.

35s. Of Dry fruits, there is a greater diversity of kinds having disinet names. The indehiscent sorts are commonly oneseeded.

359. The Akene or Achenium is a small, dry and indehiscent one-seeded fruit, often so seed-like in appearance that it is popularly taken for a uakcd seed. The fruit of the Butter cup or Crowfoot

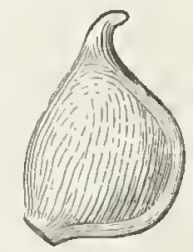

376

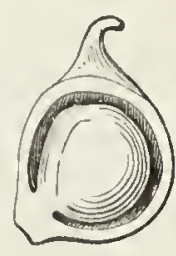

377

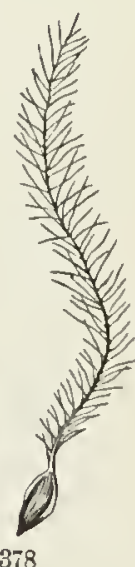

378 - Its nature, as a ripened pistil (in this

FIG. 375. Longitudinal section of a peach, showing flesh, stone, and seed.

Fio. 376. Akene of a Buttercup. 377. The same, divided lengthwise, to show the contained seed.

FIG. 378. Akene of Virgin's-bower, retaining the feathered style, which aids in dissemination. 
case a simple carpel), is apparent by its bearing the remains of a style or stigma, or a scar from which this has fallen. It may retain the style and use it in various ways for dissemination (Fig. 378).

360. The fruit of Compositæ (though not of a single carpel) is also an akene. In this case the pericarp is invested by an adherent calyx-tube; the limb of which, when it has any, is called the Pappus. This name was first given to the down like that of the Thistle, but is applied to all forms under which the limb of the calyx of the "compound flower" appears. In Lettuce, Dandelion (Fig.

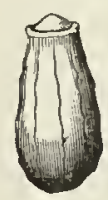

379

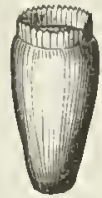

380

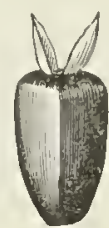

381

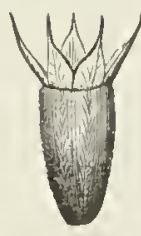

382

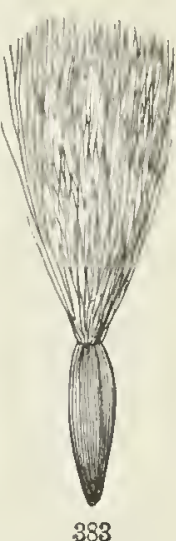

383

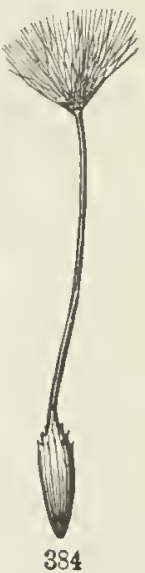

384

384), and the like, the achenium as it matures tapers upwards into a slendes beak, like a stalk to the pappus.

361. A Cremocarp (Fig. 385), a name given to the iruit of Umbelli feræ, consists as it were of a pair of akenes united com-

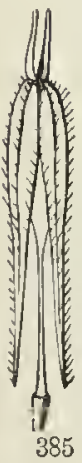
pletely in the blossom, but splitting apart when ripe into the two closed carpels. Each of these is a Mericarp or Hemicarp, namcs seldom used.

362. A Utricle is the same as an akene, but with a thin and bladdery loose pericarp; like that of the Goosefoot or Pigweed (Fig. 356). Then ripe it may burst open irregularly to discharge the sced; or it may open by a circular line all round, the upper part falling off like a lid; as in the Amaranth (Fig. 387).

363. A Caryopsis, or Grain, is like an akene with the seed adhering to the thin pericarp throughout, so

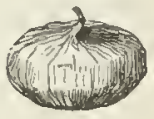

386

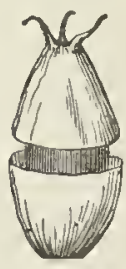

387 that fruit and seed are incorporated into one body; as in wheat, Indian corn, and other kinds of grain.

364. A Nut is a dry and indehiscent fruit, commonly one-celled and one.

Fig. 379. Akene of Mayweed (no pappus). 380. That of Succory (its pappus a 3hallow cup). 381. Of Sunflower (pappus of two deciduous scales). 382. Of Sneezeweel (Helenium), with its pappus of five scales. 383. Of Sow-Thistle, with its pappus of delicate downy hairs. 384. Of the Dandelion, its pappus raised on a long beak.

FIG. 385. Fruit (cremocarp) of Osmorrhiza; the two akene-like ripe carpels separating at maturity from a slender axis or carpophorse.

FIG. 386. Utricle of the common Pigweed (Chenopodium album).

FIG. 387. Utricle (pyxis) of Amaranth, opening all round (circumscissile). 
seeded, with a hard, crustaceous, or bony wall, such as the cocoanut, hazel-

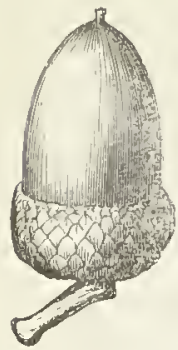

388 nut, ehestnut, and the acom (Fig. 37, 389.) Here the involucre, in the form of a cup at the base, is called the Cupole. In the Cliestnut the cupulc forms the bur; in the Hazel, a leafy husk.

365. A Samara, or Key-fruit, is either a nut or an akcue, or auy other indehiscent fruit, furnished witl a wing, like that of Ash (Fig. 389), and Elm (Fig. 390). The Maple-fruit is a pair of keys (Fig. 391).

366. Dehiscent Fruits, or Pods, are of two classes, viz., those of a simple pistil or carpel, and those of a compound pistil. Two commou sorts of the first are named as follows:-

367. The Follicle is a fruit of a simple earpel, which dchisces down one side only, i. e. by the inner or ventral suture. The fruits of Marsh Marigold (Fig. 392), Pæony, Larkspur, and Milkweed are of this kind.

368. The Legume or true Pod, such as the peapod (Fig. 393), and the fruit of the Leguminous or Pulse family geverally, is one which opens aloug the dorsal as

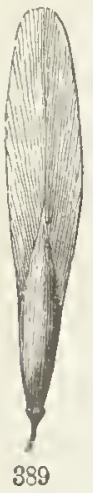
well as the ventral suture. The two pieces
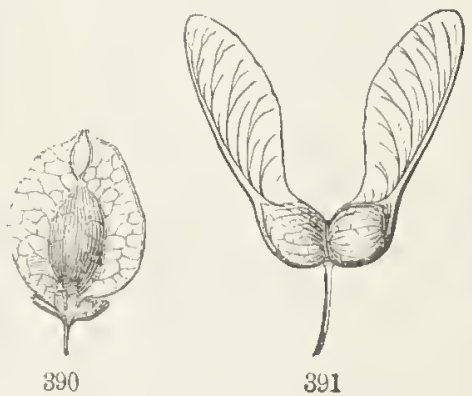

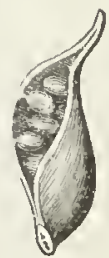

392

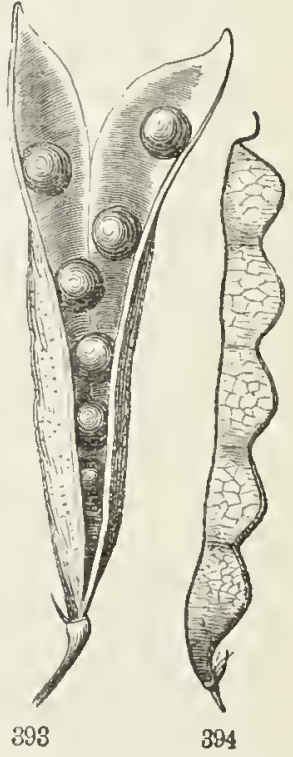

into whieh it splits are called Valves. A Lonext is a legume which is coustricled between the seeds, and at length breaks up crosswise into distinct joints, as in Fir. $39 \%$.

369. The pods or dehiscent fruits belouging to a compound ovary have several technien! names: but they all may be regarded as kinds of

370. The Capsule, the dry and deliseent fruit of any compound pistil. The capsule may diseharge its seeds throngh chinks or pores, as in the

Fig. 388. Nut (acorn) of the Oak, with its cup or cupule.

Fig. 38?. Samara or lieg of the White Ash, wingerl at end. 390. Samara of the American Elm, wingerl all rouml.

Flg. 391. Pair of samaras of Sugar Maple.

Fig. 392. Follicle of Marsl Marigold (Caltha palustris).

Fig. 393. Legume of a sweet Pea, opener.

FIG. 394. Loment or jointed legume of a Tick-Trefoil (Desmollium). 
Poppy, or burst irregularly in some part, as in Lobelia and the Snapdragon; but conmonly it splits open (or is dehiscent) lengthrvise into regular pieces, called VALves.

371. Regular Dehiscence in a capsule takes place in two ways, which are best illustrated in pods of two or three cells. It is eitlier

Loculicidal, or, splitting directly into the loculi or cells, that is, down the back (or the dorsal suture) of each cell or carpel, as in Iris (Fig. 395); or

Septicidul, that is, splitting through the partitions or septa, as in St. Joln's-wort (Fig. 396), Rhododendron, etc. This divides the capsule into its component earpels, which then open by their ventral suture.

372. In loculicidal dehiscence the vilves naturally bear the partitions on their iniddle; in the scpticidal, half the thickness of a partition is borne on the margin of cach valve. See the annexed dingrams. A variation of either mode occurs when the valves break away from the partitions, these remaining attached in the axis of the fruit. This is cal'ed Septifragaldehiscence. One form is seen in the Morning-Glory (Fig.

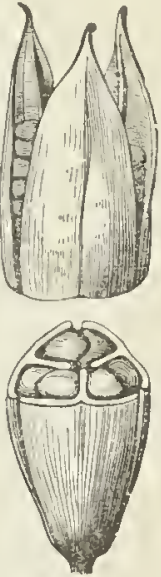

395 $400)$.

373. The capaules of Rue, Spurge, and some others, are both locul, cidal and septicidal, and so split into hall-carpellary valves or pieces.

374. The Silique (Fig. 401) is the technical name of the peculiar pod of the Mustard family; which is two-celled by a false partition stretcled across between two parictal placentx. It generally opens
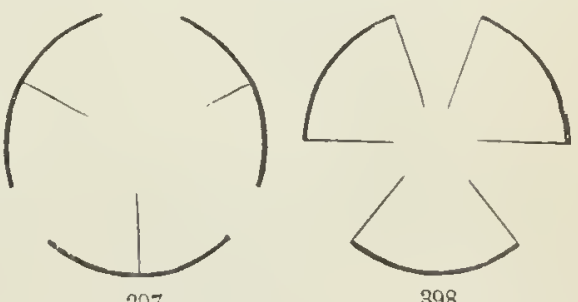

398 by two valves from below upward, and the placente with the partition are left behind when the valves fall off.

375. A Silicle or Pouch is only a short and broad silique, like that of the Shepherd's Purse, Fig. 402, 403.

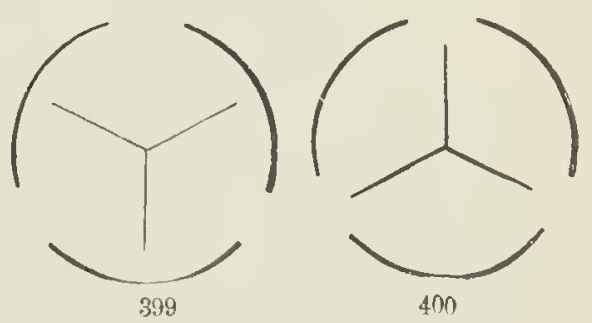

Fig. 395. Capsule of Iris, with loculicidal dehiscence; below, cut across.

Frg. 396. Pod of a Marsh St. John's-wort, with septicilal dehiscence.

Fig. 397, 398. Diagrams of the two modes.

Fra. 399. Diagram of septifragal dehiscence of the loculicidal type. 400. Same of the septicidal or marginicidal type. 
376. The Pyxis is a pod which opens by a circular horizontal lime, the upper part forming a lid, as in Purslane (Fig. 404), the Plantain, Hen-

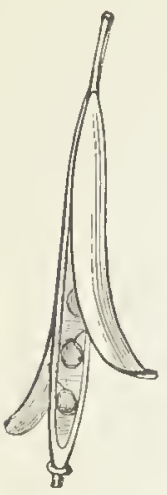

401 bane, ctc. In these the dehiscence cxtends all round, or is cir. cumscissile. So it does in Amarantlı (Fig. 357), forming a oneseeded utricnlar pyxis. In Jeffersonia, the line does not separate quite round, but lcaves a portion for a linge to the lid.

377. Of MIultiple or Collective Fruits, which are properly

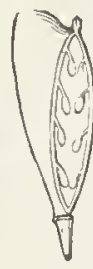

403

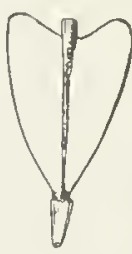

402

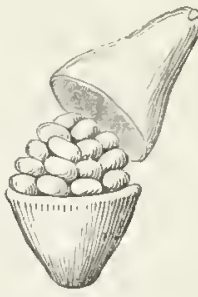

404 masses of fruits aggregated into one body (as is secr in the Nulberry (Fig. 408), Pineapple, etc.), there are two kinds with special names and of peculiar strueture.

378. The Syconium or Figfruit (Fig. 405, 406) is a flesliy axis or summit of stem, hollored out, and lined within by a multitude of minute flowers, the whole becoming pulpy, and in the comnon figr, luscious.

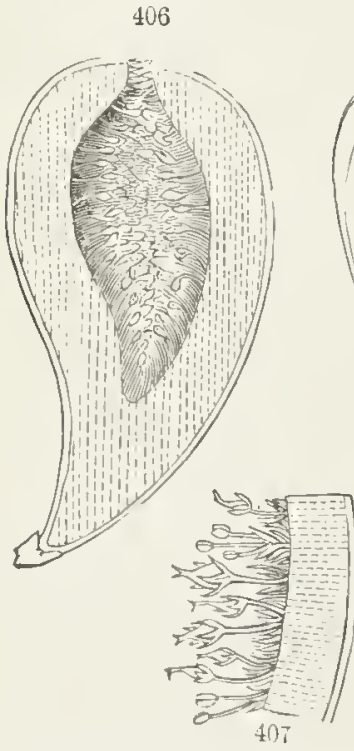
405
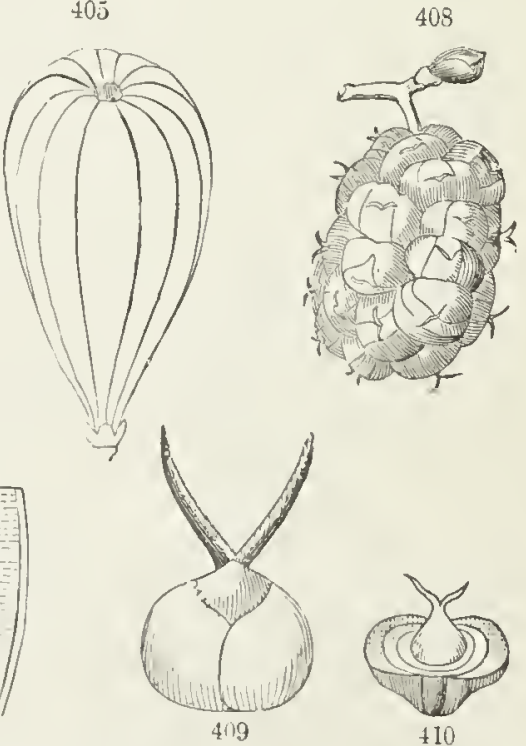

379. The Strobile or Cone (Fig, 411), is the peculiar multiple fruit of Pines, Cypresses, and the like: hence named Coniferre, riz. cone-beariner

FIG. 101. Silique of a Carlanine or Spring Cress.

Fia. 402. Silicle of Slieplierl's Purse. 403. Same, with one valre renoved.

FIg. 40t. Pyxis of Purslane, the liul detaching.

FIg. 105. A fig-fruit when young. 406. Same in section. 407. Magnified por. tion, a slice, slowing some of the flowers.

FIG. 408. A mullerery. 409. One of the grains younger, enlarged; seen to ba a listillate flower witl calyx becoming fleshy. 410. Same, with fleshy calyx cat zcross. 
plants. As already shown (313), these eones are open pistils, mostly in

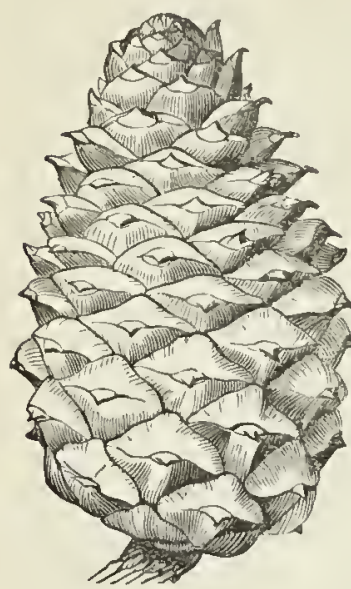

411 the form of flat seales, regularly overlying each other, and pressed together in a spike or head. Each seale bears one or two naked seeds on its inner faee. When ripe and dry, the seales turn baek or diverge, and in the Pine the seed peels ofl and falls, generally earrying with it a wing, a part of the lining of the seale,

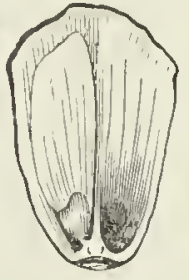

412

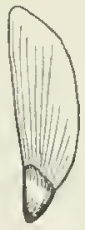

413 whieh facilitates the dispersion of the seeds by the wind (Fig. 412, 413). In ArborVitæ, the seales of the small cone are few, and not very unlike the leaves. In $\mathrm{Cy}$ press they are very thiek at the top and narrow at the base, so as to make a peculiar sort of elosed eone. In Juniper and Red Cedar, the few seales of the very small eone become fleshy, and ripen into a fruit which elosely resembles a berry.

\section{Section XV. THE SEED.}

380. Seeds are the final produet of the flower, to which all its parts and offiees are subservient. Like the ovule from which it originates, a seed consists of eoats and kemel.

381. The Seed-coats are commonly two (320), the outer and the inner. Fig. 414 slows the two, in a seed eut through lengthwise. The outer eoat is often hard or erustaecous, whenee it is called the Testa, or shell of the sced; the imer is almost always thin and delieate.

352. The sliape and the markings, so various in different seeds, depend mostly on the outer eoat. Sometimes this fits

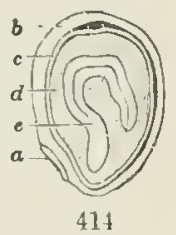

411 the kernel elosely; sometimes it is expanded into a wing, as in the Trum. pet-Creeper (Fig. 415), and oeeasionally this wing is eut up into shreds or tufts, as in the Catalpa (Fig. 410); or instead of a wing it may bear a Coma, or tuft of long and soft hairs, as in the Milkweed or Silkweed (Fig. 417). The use of wings, or downy tufts is to render the seeds buoyant

FIG. 411. Cone of a common Pitch Pine. 412. Inside view of a separated scale or open carpcl; one seed in place: 413 , the other seed.

FIG. 414. Seed of a Linden or Basswood cnt through lengthwise, and magnified, the parts lettered: $a$, the hilum or scar; $b$, the outer coat; $c$, the inwer; $a$, the allumen; $e$, the embryo. 
for dispersion by the winds. This is elear, not only from their evident adaptation to this purpose, but also from the fact that winged and tufted seeds are found only in fruits that split open at maturity, never in those

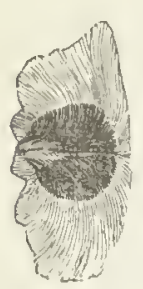

415 that remain closed. The coat of some seeds is beset wit: long laairs or wool. Cotton, one of the most importaut regetable products, since it forins the principal elothing of the

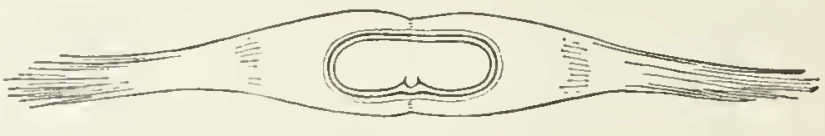

416

larger part of the human race, consists of the long and woolly hairs which thickly eover the whole surface of the seed. There are also crests or other

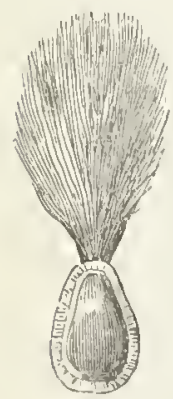

417 appendages of various sorts on certain seeds. A few seeds have an additional, but more or less incomplete covering, outside of the real seed-coats ealled an

393. Aril, or Arillus. The loose and transparent bag which eneloses the seed of the White Water-Lily (Fig. 418) is of this kind. So is the mace of the nutmeg; and also the searlet pulp around the seeds of the Waxwork (Celastrus) and Strawberry-bush (Euonymus). The aril is a growth from the ex. tremity of the seed-stalk, or from the placenta when

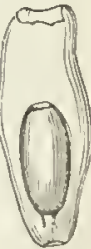

418 there is no seed-stalk.

384. A short and thickish appendage at or elose to the hilum in certain seeds is called a CARUNCLE or Sirrophiole (Fig. 419).

385 . The various terms which define the position or direetion of the ovule (erect, ascending, cte.) apply equally to the seed: so also the terms anatropous, orthotropous, campylotropous, ete., as already defined $(320,321)$, and such terms as

HrLum, or Scar left where the seed-stalk or funiculus falls away, or where the seed was attached directly to the placenta when there is no seed-stalk.

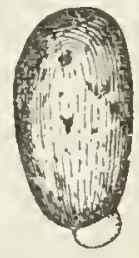

419

RIIPUE, the line or ridge which runs from the hilum to the clialaza in anatropous and amphitropous seeds.

Chabaza, thic place where the secd-coats and the kernei or nueleus are organienlly eomected, - at the hilum in orthotropous and eampylotropous seeds, at the extrenity of the rhaphe or tip of the seed in other kinds.

Micropyle, alswering to the Foramen or orifice of the orule. Compare the aecompanying figures and those of the ovules, Fig. $341-355$.

Fla. 415. A winged seel of the Trmmet-Creeper.

Fra. 416. One of Catalpa, the kernel eut to show the embryo.

Fig. 417. Seel of Mlilkweed, with a Coma or tuft of long silky hairs at one end.

Fra. 418. Seel of White Wrater-Lily, enclosed in its aril.

IG 419. Seed of Ricinus or Castor-vil plant, with caruncle. 
386. The Kernel, or Nucleus, is the wlole body of the seed within the coats. In many seeds the ker. nel is all Embryo; in others a large part of it is the $A l$. bumen. For example, in Fig. 423 , it is wholly embryo; in Fig. 422, all but the small

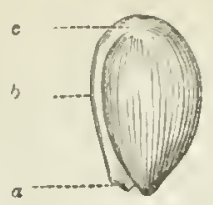

420

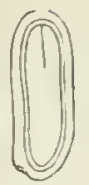

423

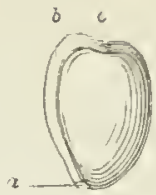

421

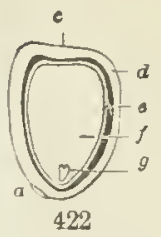

speek $(g)$ is albumen.

357. The Albumen or Endosperm of the seed is sufficiently charae. terized and its offiee explained in Scet. III., 31-35.

398. The Embryo or Germ, which is the rudinentary plantlet aud the final result of blossoming, and its development in geruination have been extensively illustrated in Sections II. and III. Its essential parts are the Radicle and the Cotyledons.

389. Its Radicle or Caulicle (the former is the term long and generally used in botanical descriptions, but the latter is the more correet one, for it is the initial stem, whieh merely gives origin to the rcot), as to its position in the seed, always points to and lies near the mieropyle. In relation to the pericarp it is

Superior, when it points to the apex of the fruit or eell, and

Inferior, when it points to its base, or downward.

390. The Cotyledons liave already been illustrated as re. spects their number, - giving the important distinetion of Dicoty. ledonous, Polycotyledonous and Monocotyledonous embryos (36-43), - also as recrards their thiekness, whethcr foliaceous or fleshy;

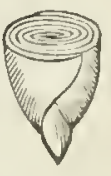

424 and sumc of the very various shapes and adaptutions to the seed lave been figured. They may be straight, or folded, or rolled up. In the latter case the eotyledons may be rolled up as it were from one margin, as

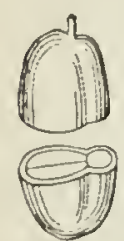

425 in Calycanthus (Fig. 424), or from apex to base in a flat spiral, or they may be both folded (plicate) and rolled up (convolute), as in Sugar Maple (Fig. 11.) In one very natural fumily, the Cruciferæ, two different modes prevail in the way the two eotyledons are brought round against the radiele. In one scries they are

FIG. 420. Seed of a Violet (anatropons): $a$, hilum; $b$, rharhe; chalaza.

FIa. 421. Seed of a Larkspur (also anatropous); the parts lettererl as in the last.

FIG. 422. The same, cut through lengthwise: $a$, the hilum; $c$, ehalaza; $d$, outer seed-coat; $e$, inner seerl-coat; $f$, the albumen; $g$, the minute embryo.

FIG. 423. Seed of a St. Jolin's-wort, diviled lengthwise; here the whole kerne] is embryo.

Fic. 424. Embryo of Calycantluus; upper part cut away, to show the convolute cotyletions.

FrG. 425. Seerl of Bitter Cress, Barbarea, cut across to show the accumbent cotyledons. 426. Embryo of same. whole. 
Accumbent, that is, the edges of the flat cotyledons lie against the radicle, as in Fig. 425, 426. In another they are

Incumbent, or with the plane of the cotyledons brought up in the opposite

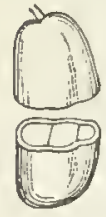

427

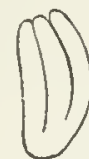

428 direction, so that the back of one of them lies against the radicle, as shown in Fig. 427, 428.

391. As to the situation of the embryo with respect to the albumen of the seed, when this is present in any quantity, the embryo may be Axile, that is occupying the axis or centre, either for most of its length, as in Violet (Fig. 429), Barberry (Fig. 4S), and

Pine (Fig. 56); and in these it is straight. But it may be variously curved or coiled in the albumen, as in Helianthemum (Fig. 430), in a Potato-seed (Fig. 50), or Onion-seed (Fig. 60), and Linden (Fig. 414); or it mas be coiled around

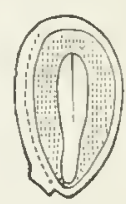

429

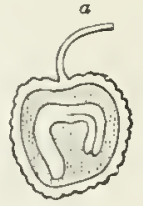

430

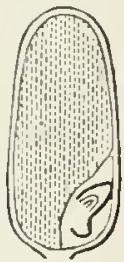

$430 a$ the outside of the albumen, partly or iuto a circle, as in Chickweed (Fig. 431, 432) and in Mirabilis (Fig. 52). The latter mode prevails in Campylo.

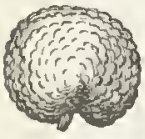

431

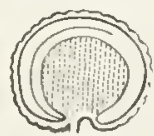

432 tropous secds. In the cereal grains, such as Indian Corn (Fig. 67) and Riee, 430 a), and in all other Grasses, the embryo is straight and applied to the outside of the abundant albumen.

392. The matured sced, with embryo ready to germinate and reproduce the kind, completes the cycle of the vegetable life in a phanerogamous plant, the account of which began with the seed and sccdling

\section{Section XVI. VEGETABLE LIFE AND WORK.}

393. The following simple outlines of the anatomy and physiology of plants (3) are added to the preceding structural part for the better preparatiou of students in descriptive and systematic botany; also to give to all learners some gencral idea of the life, growth, intimate structure, and action of the beings which compose so large a part of organic nature. Those who would exteud and verify the fuets and prineiples here outlined will use the Pliysiological Botany of the "Botanieal Text Book," by Professor Goodalc, or solne similar book.

FIG. 427. Seel of a Sisymbrium, cut across to show the incumbent cotyledons. 42S. Einbryo of the same, detacher? whole.

FIG. 429. Section of seel of Tiolet; anatropous with straight axile entbryo in the allnmen. 430. Section of seed of Rock Rose, Heliantliemum Canadense; orthotropous, with curved embryo in the albumen. $430 a$. Section of a grain of Rice, lengthwise, showing the embryo outside the albumen, which forms the principal bulk.

Fig, 431. Seed of a Chickweed, campylotropous. 432. Section of sane, show ing slender embryo coiled around the outside of the albumen of the kernel. 


\section{§ 1. ANATOMICAL STRUCTURE AND GPOWTH.}

394. Growth is the increase of a living thing in size and substance. It appears so uatural that plants and animals shonld grow, that one rarely thinks of it as requiring explanation. It seems enough to say that a tling is so becanse it grew so. Growth from the seed, the germination and development of an embryo into a plantlet, and at length into a mature plant (as illnstrated in Sections II. and III.), can be followed by ordinary observation. But the embryo is alrcady a miniature plantlet, sometimes with hardly any visible distinction of parts, but often one which lias already made ver'y considerable growth in the seed. To investigate the formation and growtl of the embryo itself requires well-trained eyes and hands, and the expert use of a good componnd microscope. So this is beyond the reach of a beginner.

395. Moreover, although o'oservation may show that a seedling, weighing only two or tliree grains, may donble its bulk and weiglıt every week of its early growtl, and may in time produce a linge amount of vegetable matter, it is still to be asked what this vegctable matter is, where it came from, and by what means plants are ablc to increase and accumulate it, and build it up into the fabric of herbs and slirubs and lofty trees.

396. Protoplasm. All this fabric was built np under life, bnt only a small portion of it is at any one time alive. As growtl proceeds, life is passed on from the old to the new parts, muclı as it has passed on from parent to offspring, from generation to gencration in unbroken continuity. Protoplasm is the common name of that plant-stuff in whicl life essentially resides. All growth depends upon it; fol it has the peculiar power of growing and mnltiplying and bnilding up a living structure, - the animal 'no less than the regetable structure, for it is essentially the same in both. Indeed, all the animal protoplasm comes primarily from the regetable, which las the prerogative of producing it; and the protoplasm of plants furuishes all that portion of the food of animals which forms their flesh and living fabric.

397. The rery simplest plants (if such may specifically be called plants rather than animals, ol one may say, the simplest living things) are mere particles, or pellets, or thrcads, or even indefinite masses of protoplasm of vague form, which possess powers of motion or of changing their shape, of imbibing water, air, and evell other matters, and of assimilating these into plant-stnff for their own growtl and multiplication. Their growth is increase in substance by incorporation of that whicl they take in and assimilate. Their multiplication is by spontaneous division of their substauce or body into two or mole, each capablc of continuing the proccss.

398. The embryo of a planerogamous plant at its beginning (344) is essentially snch a globule of protoplasm, which soon constricts itself into two and more such globules, which loold together inseparably in a row; then the last of the row divides without separation in the two other planes, to 
form a compound mass, cach grain or globule of which goes on to double itself as it grows; and the definite sliaping of this still increasing mass builds up the embryo into its form.

399. Cell-walls. Whilc this growtl was going on, each grain of the forming structure formed and clothed itself with a coat, thin and transparent, of something different from protoplasm, - something which hardly

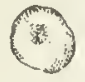

433

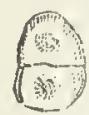

434

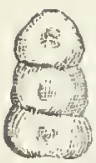

435

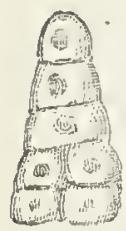

436 and only transiently, if at all, partakes of the life and action. The protoplasm forms the living organism; the eat is a kind of protective eovering or shell. The protoplasm, like the Alesh of animals which it gives rise to, is composed of four chemical elements: Carbon, Hydrogen, Oxygen, and Nitrogen. The coating is of the nature of wood (is, indeed, that which makes wood), and has only the three elements, Carbon, Ifydrogren, and Oxygen, in its composition.

400. Although the forming structure of an embryo in the fertilized ovale is very mimute and diffieult to see, there are many simple plants of lowest grade, abounding in pools of water, which more readily show the earlier stages or simplest states of plant-growtlı. One of these, which is common in early spring, requires only moderate magnifying power to bring to view what is shown in Fig. 437. In a slimy mass which holds all loosely together, little spheres of green vegetable matter are secn, assembled in fours, and these fours themselves in elusters of fours. A transient inspection shows, what prolonged watehing would confirm, that cach spleere divides first in one plane, then in the other, to make four, soon acquiring the size of the original, and so on, producing suecessive groups of fours. These pellets cach form on their surface a transparent wall, like that just described. The delicate wall is for some time eapable of expansive growth, but is from the first mnel firmer than the protoplasm within; through it the latter imbibes surrounding moisture, which becomes a watery sap, occupying vacuities in the protoplasmic mass which cularge or run together as the periphery increnses and distends. When full grown the protoplasm may become a mere lining
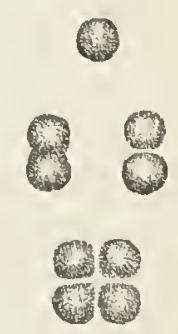
to the wall, or some of it central, as a nucleus, this usually eonnected with the wall-lining by delicate threads of the same substance. So, when full grown, the wall with its lining - a vesicle, eontaining liqnid or some

FIG. 433-436. Figures to illustrate the earlier stages in the formation of at embryo; a single mass of protoplasm (Fig. 433) dividing into two, three, and then into more incipient cells, which by continued multiplication build up an embryo.

F1a. 437. Magnified view of some of a simple fresh water Alga, the Tetraspora 'ubrica, each sphere of which may answer to an indivilual plant 
solid matters and in age moskly air - naturally came to be uamed a CeLL. But the name was suggested by, and first used ouly for, cells in combination or built up into a libbric, much as a wall is built of bricks, that is, into a

401. Cellular Structure or Tissue. Suppose numerous cells like those of Fig. 4.37 to be heapcd up like a pile of cannon-balls, and as they grew, to be coupacted together while soft aud yielding; they would flatten where they touched, and each sphere, beiug touched by twelve surrounding ones would become twelrc-sided. Fig. 435 would represent onc of them. Suppose the contiguous faces to be united into oue wall or partitiou betweeu adjacest cavities, and a cellular otructure would be formed, like that shown in F'ig. 439. Roots, stems, leares, and the whole of pliau. erogamous plauts are a fabric of countless numbers of suclr cells. No such cxact regularity iu sizc and shape is ever

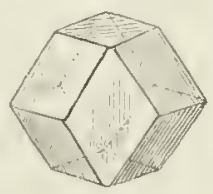

43.9

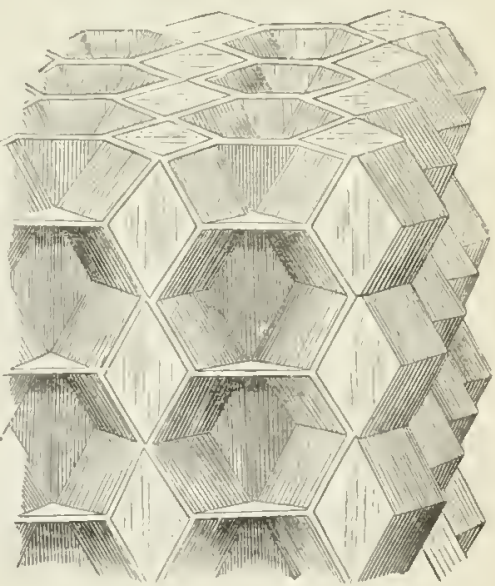

439 actually found; but a nearly truthful magnified view of a small portion of a slice of the flower-stalk of a Calla Lily (Fig. 440) shows a fairly corres

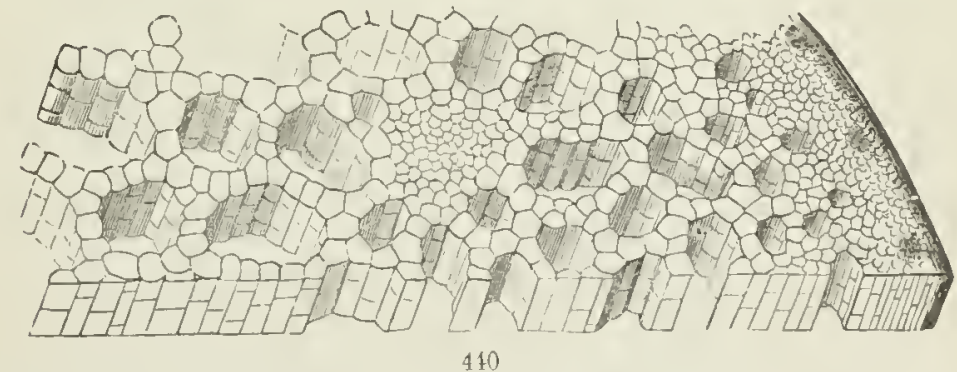

ponding structure; except that, orring to the great ail-spaces of the iuterior, the fabric may be likeucd rather to a stack of chimueys than to a solid fabric. In young and partly transparcnt parts oue may discern the cellular structure by looking down directly ou the surfacc, as of a forming root. (Fig. 82, 44I, 442).

4.02. The substance of which cell-walls are mainly composed is callcd Cellodose. It is esseutially the sane in the stem of a delicate leaf or petal and in the wood of an Oak, except that in the latter the walls are

FIG. 438. Diagran of a regetahle cell, such as it would be if when splerical it were equally pressed by sinilar surrounding cells in a heap.

FIG. 439. Teleal construction of celluiar tissuc so formed, in section.

Fif. 440. Magnified view of a portion of a transverse slice of stem of Calla

Lilv. The great spaces are tubular air-channels built up by the cells. 
much thickened and the calibre small. The protoplasm of each living cell appcars to be completely shut up and isolated in its shell of cellulose; but microscopic investigation has brought to view, in many cases, minute

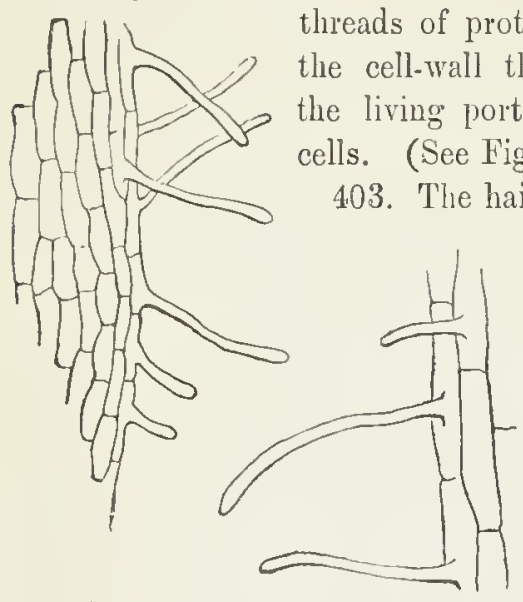

441

442 cells is from $\frac{1}{300}$ to $\frac{1}{500}$ of an inch; so that there may generally be from 27 to 125 millions of cells in the compass of a cubic inch!

405. Some parts are built up as a compact structure; in others cells are arranged so as to build up regular air. channels, as in the stems of aquatic and other watcr-loving plants (Fig. 4:10), or to leave irregular spaces, as in the lower part of most leaves, where the cells only here and there come into close contact (Fig. 443).

406. All such soft ccllular tissuc, like this of leaves, that of pith, and of the green bark, is.called Parexcirya, while fibrous and woody parts are composed of Proses. CIIYM, that is, of pcculiarly transformed

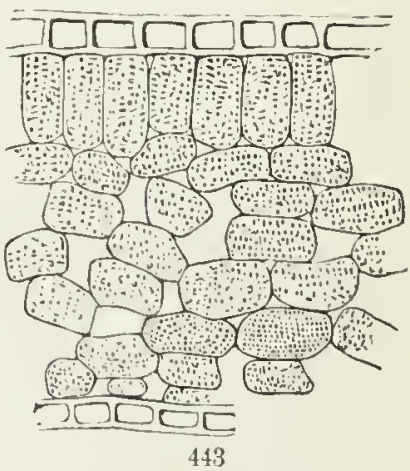

407. Strengthening Cells. Common eellular tissue, which makes up the whole structure of all vary young plants, and the whole of Mosses and other vegetables of the lowest grade, even when full grown, is too tender or too brittle to give needful strength and toughness for plants which are to rise to any considcrable height and support themselves. In these needfinl strength is imparted, and thic conveyance of sap through the plant is lacilitated, by the clrange, as they arc formed, of some cells into thieker-walled and tougher tubes, and by the ruming together of some of

FIG. 411. Much magnified small portion of young root of a seedling Maple (such as of Fig. S2); and 142, a few cells of sume more magnified. The prolonga. tions from the back of some of the cells are root-liairs.

FIG. 443. Magnified section throngh the thickness of a leaf of Florida Star. dissis. 
these, or the prolongation of others, into hollow fibres or tubes of varions size. Two sorts of such transformed cells go together, and essentially form the

408. Wood. This is found in all common herbs, as well as in shrubs and trees, but the former have much less of it in proportion to the softer cellular tissue. It is formed very early in the growth of the root, stem, and leaves, - traces of it appearing in large cmbryos even while yet in the seed. Those cells that lengthen, and at the same time thieken their walls form the proper Woony Fibre or Wood-cells; those of larger size and thinner walls, which are thickened only in certain parts so as to have peculiar markings, and which often are seen to be made up of a row of cylindrical cells, with the partitions between absorbed or broken away, are called Ducts, or sometimes Vessels. There are all gradations between wood-cells and ducts, and between both these and common cells. But in most plants the three kinds are fairly distinct.

409. The proper cellular tissue, or parenchyma, is the ground-work of root, stem, and leaves; this is traversed, chiefly lengthwise, by the strengthening and conducting tissuc, wood-cells and duct-cells, in the form of bundles or threads, which, in the stems and stalks of herbs are fewer and comparatively scattered, but in shrubs and trees so numerrous and crowded that in the stems and all permanent parts they make a solid mass of wood. They extend into and ramify in the leaves, spreading out in a horizontal plane, as the framework of ribs and veins, which supports the softer cellular portion or parenchyma.

410. Wood-Cells, or Woody Fibres, consist of tubes, conmonly between one and

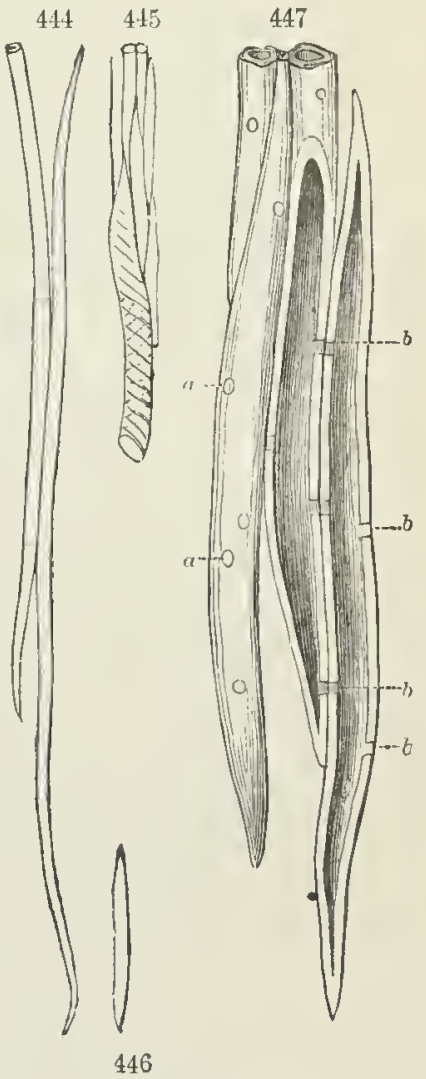
two thousandths, but in Pine-wood sometimes two or three hundredths, of an inch in diameter. Those from the tough bark of the Basswood,

FIG. 444. Magnified wood-cells of the bark (bast-cells) of Basswood, one and part of another. 445. Some wood-cells fron the wool (and below part of a duct); and 446, a detached wood-cell of the same; equally magnified.

Fig. 447. Some woor-cells from Buttonwooll, Platanus, highly magnified, a whole cell and lower end of another on the left; a cell cut half away lengthwise, and half of another on the right; some pores or pits $(a)$ seen on the left; whilo $b b$ mark sections through these on the cut surfaee. When living and young the protoplasm extends into these and by minuter perforations connects across them In age the pits become open passages, facilitating the passage of sap and air 
shown in Fig. 44t, are only the fiftecn-lundredth of an inch wide. Those of Buttonwood (Fig. 417) are larger, and are here highly magnified besides. The figures show the way wood-cells are commonly put together, nancly, with their tapering cuds overlapping each other, - - spliced together, as it were, - thus giving more strength and tonghness. In hard woods, snch as Hickory and Oak, the walls of these tubes arc very thick, as woll as dense; while in soft woods, such as White-Pine and Basswood, they are thimner.

411. Wood-cells in the bark are generally louger, finer, and tougher than those of the proper wood, and appear mole like fibres. For example, Fig. 446 represents a cell of the rrood of Basswood of arerage length, and Fig. 444 one (and part of another) of the fibrous bark, both drawn to the same scale. As these long cells form the principal part of fibrous bark, or bast, they are named Bast-cells or Bust-fibres. These give the great tonghness and llexibility to the iuner bark of Basswood (i. c. Bast-rrood) and of Leatherwood; and they furnish the invaluable fibres of llax and hemp;

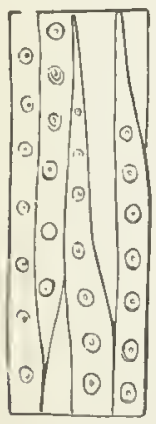

448

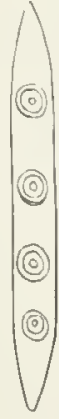

449

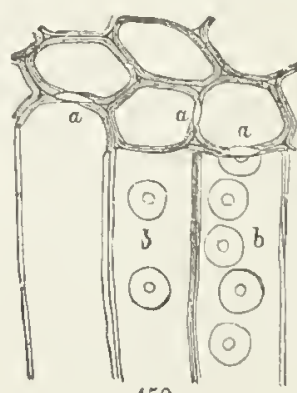

450 the proper wood of their stems being tender, brittle, and destroyed by the proccsses which separate for use the tough and sleuder bast-cells. In Leatherwood (Dirca) the bast-cells are remarkably slender. A ricw of one, if magnified on the scale of Fig. 4t.t, would be a foot and a half long.

412. The wood-cells of Pines, and more or less of all other Conifcrons trees, have on two of their sidcs very peculiar disk-shaped markings (Fig. $4 \pm S-450$ ) by which that kind of wood is recognizable.

4.13. Ducts, also called Vessecs, are mostly larger than wood-cells: indeed, some of them, as in Red Oak, have calibre large enough to be discerned on a cross section by the naked cye. They make the risible porosity of such linds of wood. This is particularly the case with

Dotted ducts (Fig. 451, 452), the surfitec of which appears as if riddlcd with lound or oral pores. Such ducts are commonly made up of a row of large cells more or less conflucnt into a tube.

Scalariform duets (Fig. 458, 459), common in Fcrus, and gencrally angled hy mutual pressure in the bundles,

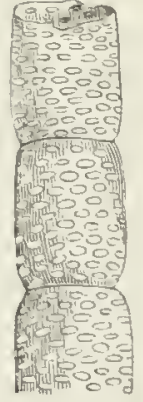

$4 j 1$

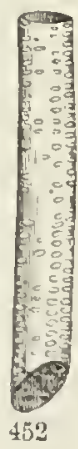

FIG. 448. Magnified lit of a pine-shaving: taken parallel with the silver grain 449. Separate whole wool-cell, more magnifiesl. 450 . Siame, still more magnified both sections represented: $a$, disks in section, $b$, in face.

FIa. 451, 452. A large and a snaller dotted duct from Grape-Tine. 
have transversely elongated thin places, parallel with each other, giving a ladder-like appearance, whence the name.

Annular ducts (Fig. 457) are marked with cross lines or rings, which are thickencd portions of the cell-wall.

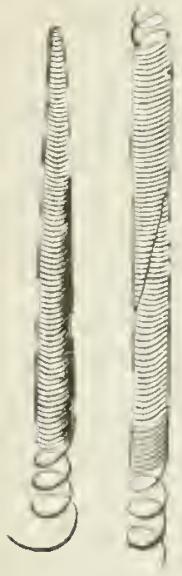

45.3
454

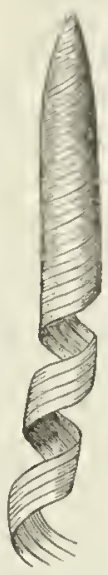

455

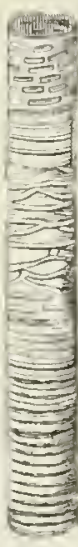

456

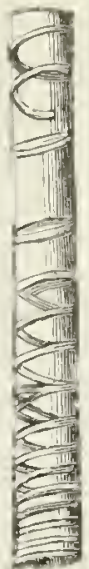

457

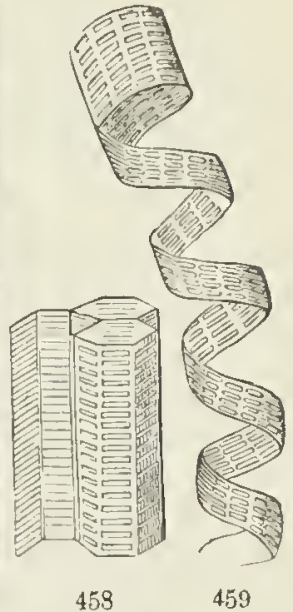

459

Spiral ducts or vessels (Tig. 453-455) liave thin walls, strengthened by a spiral fibre adherent within. This is as delicate and as strong as spiderweb : when uncoiled by pulling apart, it tears up and annihilates the cellwall. The uncoiled threads are seen by gently pulling apart many leaves, such as those of Amaryllis, or the stalk of a Strawberry leaflet.

Laticiferous ducts, Vessels of the Later, or Milk-vessels are peculiar branching tubes which hold latex or milky juice in certain plants. It is very difficult to sce them, and more so to make out their naturc. They

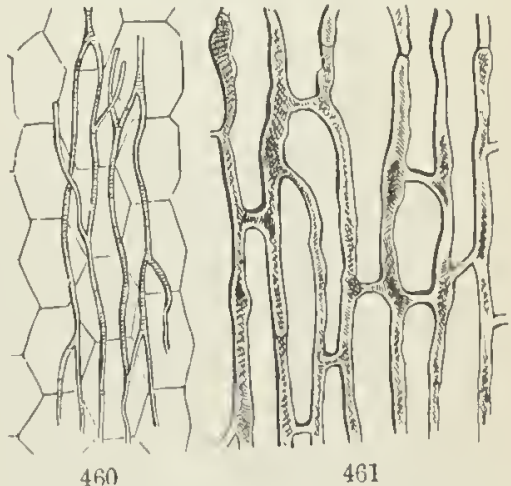
are peculiar in branching and inosculating, so as to make a net-work of tubes, ruming in among the cclular tissue; and they are very small, except when gorged and old (Fig. 460, 461).

FIG. 453, 454. Spiral ducts which uncoil into a single thread. 455. Spiral duct which tears up as a bank. 456. An amnular duct, with variations above. 457. Loose spiral duct passing into anmular. 458. Scalariform ducts of a Fern; part of a bundle, prismatic by pressure. 459. One torn into a band.

FIG. 460. Milk Vessels of Dandelion, with cells of the common cellular tissue. 461. Others from the same older and gorged with milky juice. All highly mag. nified. 


\section{§ 2. CELL-CONTENTS.}

414. The living contents of young and active cells are mainly protoplasm with water or watery sap which this has imbibed. Old and effete cells are often empty of solid matter, containing only water with whatever may be dissolved in it, or air, according to the time and circumstances. All the various products which plants in general elaborate, or which particular plants spccially elaborate, out of the common food which they derive from the soil and the air, are contained in the cells, and in the cells they are produced.

415. Sap is a general name for the principal lignid contents, -Crude sap, for that whieh the plant takes in, Elaborated sap for what it has digested or assinilated. They must be undistinguishably mixed in the cells.

416. Among the solid matters into which cells convert some of their elaborated sap two are general and most important. These are Chlorophyll and Starch.

417. Chlorophyll (meaning leaf-green) is what gives the green color to herbage. It consists of soft grains of rather complex natnre, partly waxlike, partly protoplasmic. These abound in the cells of all common leaves and the green rind of plants, wherever exposed to the light. The green color is seen through the transparent skin of the leaf and the walls of the eontaining cells. Chlorophyll is essential to ordinary assimilation in plants: by its mcans, under the influence of sunlight, the plant converts crude sap into vegetable matter.

418. Far the largest part of all vegetable matter prodnced is that which goes to build up the plant's fabric or cellnlar structnre, either directly or indirectly. There is no one good name for this most important product of vegetation. In its final state of cell-walls, the permanent fabric of lierb and shmb and trec, it is called Celluclose (405): in its most soluble form it is Sugar of one or another kind; in a less soluble form it is Dextrine, a kind of liquefied stallech: in the form of solid grains stored up in the cells it is Starch. By a scrics of slight clicmical changes (mainly a variation in the water entcring into the composition), one of these forms is converted
into another.

419. Starch (Farina or Fecula) is the form in which this common plant material is, as it were, laid by for future use. It consists of solid grains, somewhat different in form in different plants, in sizc varying from $\frac{1}{30}$ to $\frac{1}{4000}$ of an inch, partly translucent when wet, and of a pearly lustre. From the concentric lincs, which conmonly appcar under the microscope, the grains scem to be made up of layer over layer. When loose they are com. monly oval, as in potato-starch (Fig. 462): when much compacted the grains may beconc angular (Fig. 463).

420. 'The starch in a potato was produced in the foliage. In the soluble form of dextrine, or that of sugar, it was conveycd through the cells of the herbage and stalks to a sibterranean shoot, and therc stored up in the 
tuber. When the potato sprouts, the starch in the ricinity of developing buds or eyes is clianged back again, first into mucilaginous dextrine, then into sugar, dissolved in the sap, and in this form it is made to flow to the growing parts, wherc it is laid down into cellulose or cell-wall.

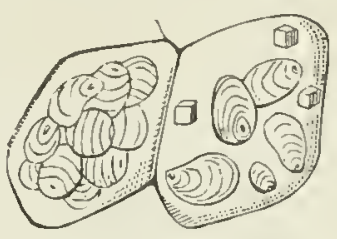

462

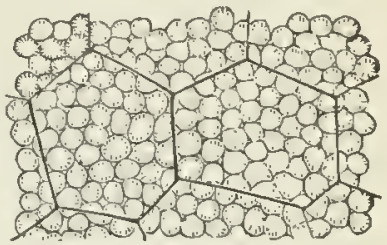

463

421. Besides these cell-contents which are in obvious and essential relation to nutritiou, there are others the use of which is problematical. Of such the conimonest are

422. Crystals. These when slender or needle-shaped are called RinAPHides. They are of inorganic matter, usually of oxalate or phosphate or sulphate of lime. Some, at least of the latter, may be direct crystalliza-

467

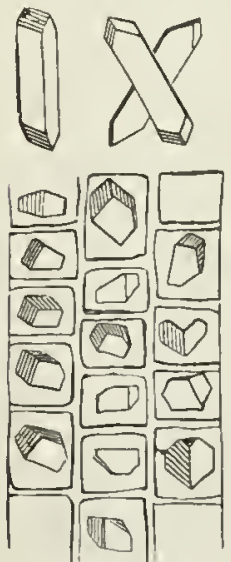

469
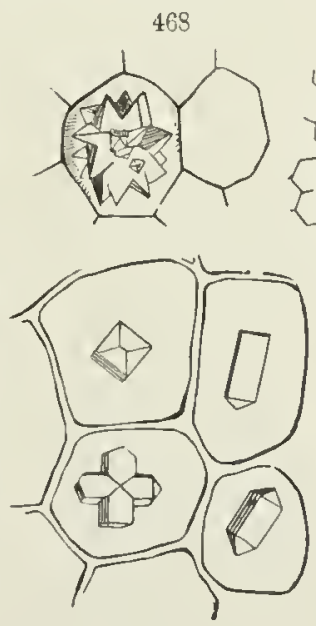

464

466

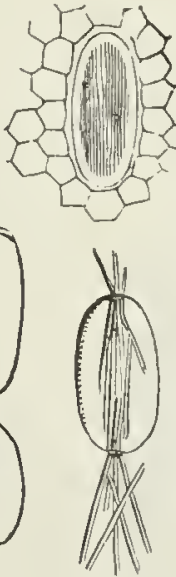

470

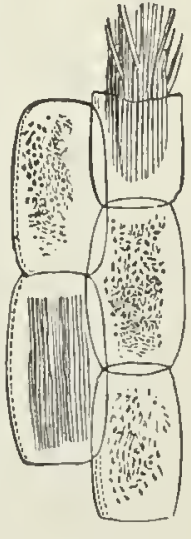

465

tions of what is taken in dissolved in the water absorbed, but others must be the rcsult of some elaboration in the plant. Some plants have hardly any; others abound in them, especially in the foliage and bark. In Locustbark almost every ccll holds a crystal; so that in a square inch not thicker than writing-paper there may be over a million and a half of them. When

FIG. 462. Some magnified starch-grains, in two cells of a potato. 463. Some cells of the albumen or floury part of Indian Corn, filled with starch-grains.

FIG. 464. Four cells from llrier Onion-peel, each holling a crystal of different shape, one of them twinnerl. 465. Some cells from stalk of Rhubarb-plant, three containing chlorophyll; two (one torn across) with rhaplides. 466. Rhaphides in a cell, from Arisæma, with small cells surrounding. 467. Prismatic crystals from the bark of Hickory. 46s. Glomerate crystal in a cell, from Beet-root. 469. A few cells of Locust-bark, a crystal in each. 470. A detached cell, with rhaphides being forced ont, as happens when put iu water. 
needle-shaped (rhaphides), as in stalks of Calla-Lily, Rhubarb, or Four. o'clock, they are usually packed in sheaf-like bundles. (Fig. 465, 466.)

\section{\$3. ANATOMY OF ROOTS AND STEMS.}

423. This is so nearly the same that an account of the internal structure of stems may serve for the root also.

424. At the beginning, either in the embryo or in an incipient shoot 'from a bud, the whole stem is of tender cellular tissue or parenchyma. But wood (consisting of wood-cells and ducts or vessels) begins to be formed in the earliest growth; and is from the first arranged in two ways, making two general kinds of wood. The differenec is obvious even in herbs, but is more conspicuous in the enduring stems of shrubs and trees.

425. On one or the other of these two types the stems of all plianerogamous plants are constructed. In one, the wood is marle up of separate threads, scattered herc and there throughout the whole diancter of the stem. In the other, the wood is all collected to form a layer (in a slice across the stem appearing as a ring) lictween a central cellular part which has none in it, the Pith, and an outer cellular part, the Bark.

426. An Asparagus-shoot and a Corn-stalk for leerbs, and a rattan for a

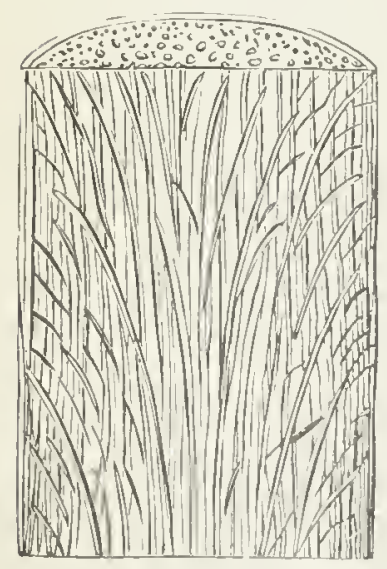

$4 \pi 1$ woody kind, represent the first kind. To it belong all plants with monocotyledonous em.

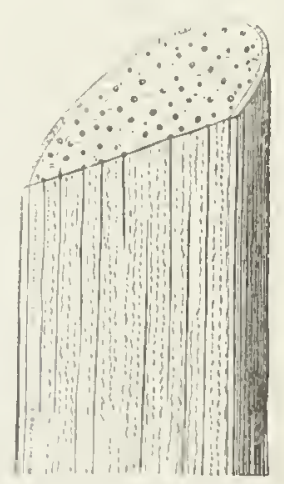

472 bryo (40). A Bean-stalk and the stem of any common shrub or tree represent the sccond; and

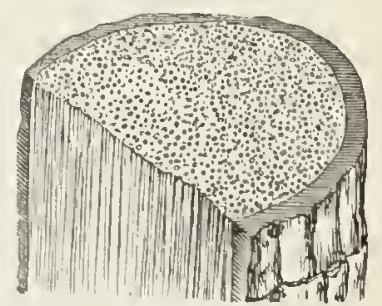

473

ito it belong all plints with dicotyledonons or polycotyledonous embryo. The first has been called, not very properly, Endogenous, which means irside-growing; the scend, properly enough, Errogenous, or outside-growing.

427. Endogenous Stems, those of MIonocotyls (10), attiin their greatest size and most chanacteristic development in Palms and Dragon. trees, thercfore elicfly in warm climates, although the Palmetto and some

Fig. 471. Diagrun of structure of Palm or Yucea. 472. Structure of a vald stalk, in transverse and longitulinal section. 473. Sane of a small Palm-sten. The dots on the cross sections represent cut ends of the woody bundes or threads. 
Yuceas becoine trees along the southern borders of the United States. Is such stems the woody bundles are more numerous and crowded toward the circumference, and so the hurder wood is outside; while iu an exogenous stem the oldest and hardest wood is torrard the centre. An endogeuous stem has no clear distinction of pith, bark, and wood, concentrically arranged, no silver grain, no anmual layers, no bark that peels of cleau from the wood. Yet old stcms of Yuccas and the like, that continuc to increase in diameter, do form a sort of layers and a kind of scaly bark when old. Yuecas show well the curving of the woody buudles (Fig. 471) which below taper out and are lost at the rind.

429. Exogenous Stems, those of Dicutyls (37), or of plants coming from dicotyledonous and also poly cotyledonous embryos, have a structure which is familiar iu the wood of our ordinary trees and shrubs. It is the same in an herbaceous shoot (such as a Flax-stcm, Fig. 474) as in a Maple-sten of the first year's growth, except that the woudy layer is commonly thinner or perhaps reduced to a circle of bundles. It was so in the tree-stem at the beginning. The wood all forms in a cylinder, - in cross scction a ring - around a cen.

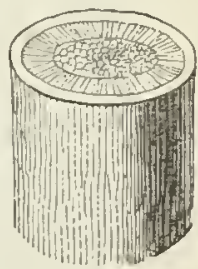

474 tral cellular part, dividing the cellular core within, the pith, from a cellu. lar bark without. As the wood-bundles increase in number and in size,

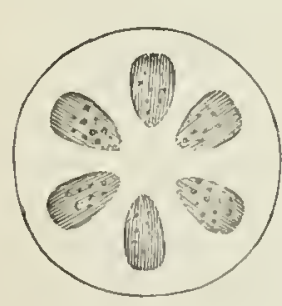

4.5)

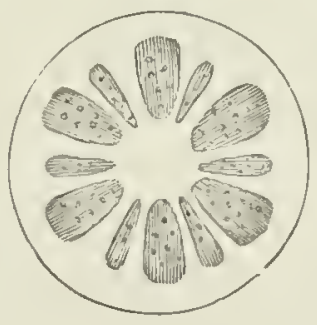

476

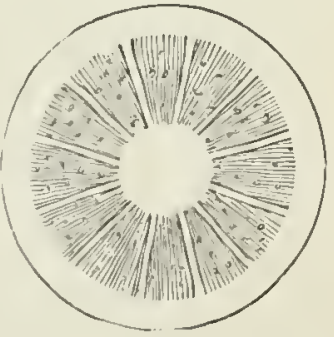

47

they press upon each other and bceome wedgc-shaped in the cross secfion; and they continue to grow from the outside, next the bark, so that they become very thin wedges or plates. Between the plates or wedges are very thin plates (in cross section lines) of much compressed cellular tissue, which connect the pith with the bark. The plan of a one-year-old wondy stem of this kind is cxhibited in the fignres, which are essentially diagrams.

429. When such a stem grows on from year to year, it adds annually a

Fic. 474. Short piece of stem of Flax, magnifiel, showing the bark, wood, and pith in a cross section.

FIc. 475. Dingram of a cross section of a very young exogenous stem, showing six woody bundles or werlges. 476. Same later, with werlges increaser to twelve. 477. Still later, the wollges filling the space, separated only by the thin lines, or medullary rays, running from yith to bark. 
layer of wood outside the preceding one, between that and the bark. This is exogenous growth, or outside-growing, as the name denotes.

430. Some new bark is formed every year, as wcll as new wood, the

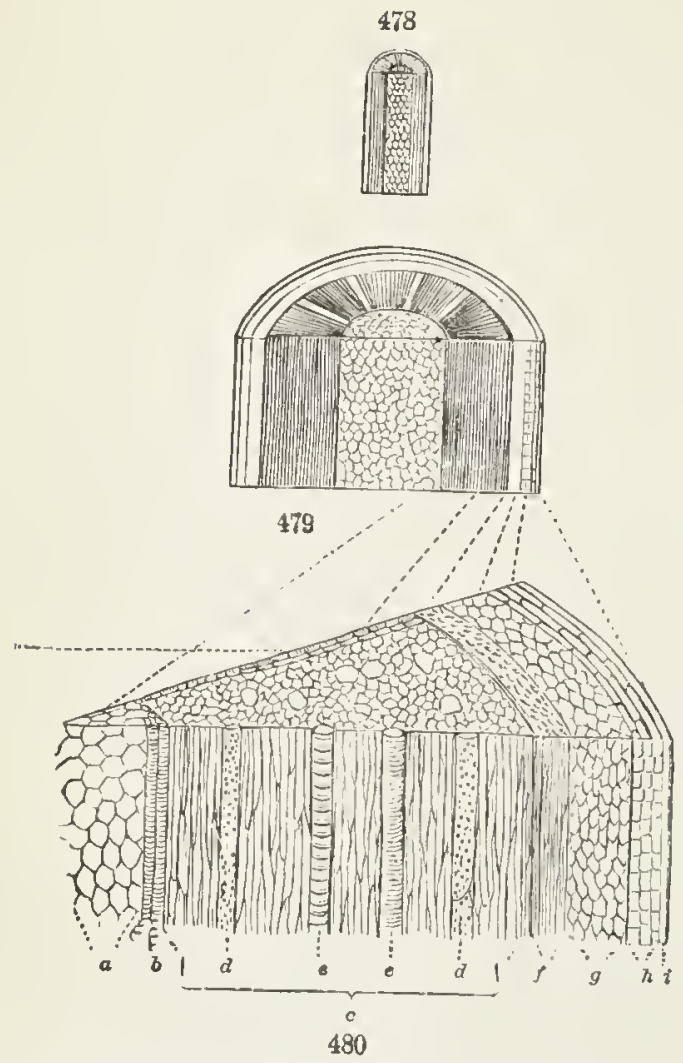
former inside, as the latter is outside of that of the year preccding. T'he ring or zone of tendel forming tissuc between the bark and the wood has been called the Cambium Layer. Camlium is an old name of the pliysiologists for nutritive juice. And this thin laver is so gorged with rich nutritive sap when spring growtlı is renewed, that the bark then seems to be loose from the wood and a layer of viscid sap (or cambium) to be poured out between the two. But there is all the while a connection of the bark and the wood by delicate cells, rapidly mul. tiplying and growing.

431. The Bark of a ycar-old stem consists of three parts, more or less distinct, nanely, - beginuing next the wood, -

1. The Liber or Fibrous Bark, the lmer Bark. 'This contains some wood-cells, or their equivalent, commonly in the form of bast or bast-cells (411, Fig. 414), such as those of Basswood or Linden, and amoigh herbs those of flax and lemp, which are spun and woven or made into cordage. It also contains cells which are named sieve-cells, on account of numerous slits and pores in their walls, by which the protoplasm of contiguous cells cominunicates. In woody stcms, whenever a new layer of wood is formed, some new liber or imner bark is also formed ontside of it. wise.

F1a. 478. Pieee of a stem of Soft Maple, of a year old, ent crosswise and length.

Fic. 479. A portion of the same, magnified.

Fig. 480. A small piece of the same, taken from nne sile, reaching from the bark to the pith, and highly magnified: $a$, a small lit of the lith; $b$, spiral ancts of what is called the medullary shecth; $c$, the wookl; $d, d$, dotted dnets in the woorl; $e, e$, annular ducts; $f$, the liber or inner hark; $g$, the green bark; $h$, the corky layer; $i$, the skin, or epilermis; $j$, one of the medullary rays, or plates of silver
grain, seen on the cross-seetion 
2. The Green Bark or Middle Bark. This eonsists of cellular tissne only, and contains the same green matter (chlorophyll, 417) as the leaves. In woody stems, before the season's growth is completed, it becomes covered by

3. The Corky Layer or Outer Bark, the eells of which contain no ehlorophyll, and are of the nature of cork. Common eork is the thick eorky layer of the bark of the Cork-Oak of Spain. It is this which gives to the stems or twigs of shrnbs and trees the aspeet and the color peculiar to each, - light gray in the Ash, purple in the Red Maple, red in severa] Dogwoods, ete.

4. The Epidermis, or skin of the plant, consisting of a layer of thicksided empty eells, which may be considered to be the outermost layer, or in most herbaceous stems the only layer, of cork-eells.

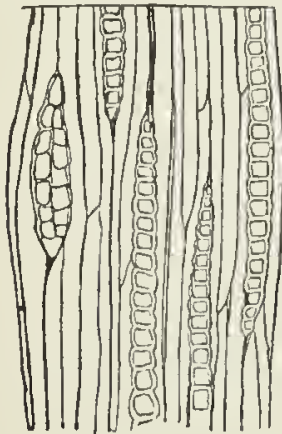

481

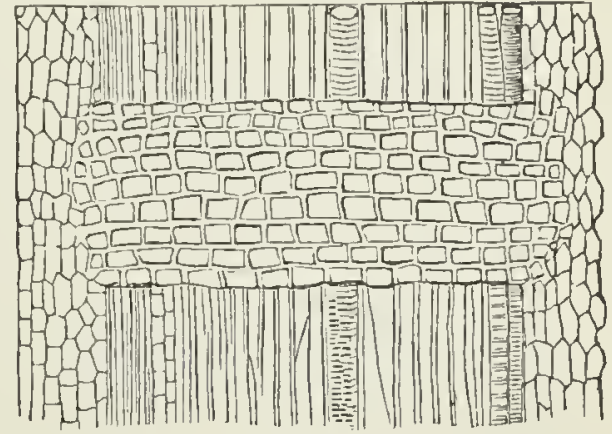

482

432. The green layer of bark seldom grows much after the first season. Sometimes the eorky layer grows and forms new layers, inside of the old, for years, as in the Cork-Oak, the Sweet Gum-tree, and the W'lite and the Paper Birel.. But it all dies after a while; and the continual enlargement of the wood within finally stretehes it mure than it can bear, and sooner or later eracks and l'ends it, while the weather acts powerfully upon its surface; so the older bark perishes and falls away pieecmeal year by year.

433. So on old trunks only the inner bark remains. This is renewed every year from within and so kept alive, wlite the older and onter layers die, are fissured and rent by the distending trunk, weathered and worn, and thrown off in fragments, - in some trees slowly, so that the bark of old trunks may aequire great thickness; in others, more rapidly. In Honeysuckles and Grape-Vines, the layers of liber loosen and die when only a year or two old. The annual layers of liber are sometimes as distinct as those of the wood, but often not so.

FIG. 481. Nagnified view of surface of a bit of young Maple wood from which the bark has been torn away, showing the wood-cells and the bark-ends of meduls lary rays.

FIG. 482. Section in the opposite direction, from bark (on the left) to beginning of pith (on the right), and a medullary ray extending from one to the other. 
434. The Wood of an exogenous trunk, having the old grow ths covered by the new, remains nearly unelianged in age, exeept from deeay. Wherever there is an annual suspension and renewal of growth, as in temperate cli. mates, the annual growths are more or less distinetly marked, in the form of eoneentric rings on the eross seetion, so that the age of the tree may bu known by counting them. Over twelve hundred layers have been counted on the stumps of Sequoias in California, and it is probable that some trees now living antedate the Christian cra.

435. The reason why the annual growths are distinguishable is, that the wood formed at the beginning of the season is more or less different in the size or charaeter of the eells from that of the close. In Oak, Chestnut, ete., the first wood of the season abounds in dotted ducts, the ealibre of whieh is many times greater than that of the proper wood-eells.

436. Sap-wood, or Alburnum. This is the newer wood, living or reeently alive, and taking part in the eonveyanee of sap. Sooner or later, eaelı layer, as it beeomes more and more deeply covered by the newer ones and farther from the region of growth, is eonverted into

437. Heart-wood, or Duramen. This is drier, harder, more solid, and mueh nore durable as timber, than sap-wood. It is generally of a different color, and it exhibits in different species the hue peeuliar to each, sueh as reddish in Red-Cedar, brown in Blaek-Walnut, blaek in Ebony, etc. The change of sap-wood into heart-wood results from the thiekening of the walls of the wond-eells by the deposition of hard matter, lining the tubes and diminishiug their calibre; and by the deposition of a vegetable eoloringmatter peeuliar' to cach species. 'The leart-wood, being no longer a living part, may decay, and often does so, without the least injury to the tree, except by diminishing the strength of the trunk, and so rendering it more liable to be overthrown.

438. The Living Parts of a Tree, of the exogenous kind, are only these: first, the rootlets at one extremity; seeond, the buds and leaves of the season at the other; and third, a zone eonsisting of the newest wood and the newest bark, eonneeting the rootlets with the bnds or leaves, however widely separated these may be, - in the tallest trees from two to four "hundrcd feet apart. And these parts of the tree arc all renewed every year. No wonder, therefore, that trees may live so long, since they annually re. produce everything that is essential to their life and growtb, and since only a very small part of their bulk is alive at onee. The tree survives, but nothing now living has been so long. In it, as elsewhere, life is a transitory thing, ever abandoning the old, and renewed in the young.

\section{ANATOMY OF LEAVES.}

439. The wood in leaves is the framework of ribs, veins, and veinlets (125), serving not only to strengthen them, but also to bring in the sap, and to distribute it flixoughout r very part. The ecllular portion is the 
green puip, and is nearly the same as the green laver of the bark. So that the leaf may properly enough be regarded as a sort of expansion of the îbrous and green layers of the bark. It has no proper corky layer; but the whole is covered by a transparent skin or epidermis, resembling that of the stem.

440. The cells of the leaf are of various forms, rarely so compact as to form a close cellular tissue, usually loosely arranged, at least in the lower part, so as to give copious intervening spaces or air passages, communicating throughout the wholc interior (Fig. 443, 483). The green color is given by the chlorophyll (417), seen through the very transparent walls of the cells and through the translueent epiderinis of the leaf.

441. In ordinary lcaves, laving an upper and under surface, the green cells form two distinct strata, of different arrangement. Those of the upper stratum are oblong or cylindrical, and stand endwise to the surface of the leaf, usually close together, leaving hardly any vacant spaces; those of the lower are commonly irregular in shape, most of them with their longer diameter parallel to the face of the leaf, and are very loosely arranged, leaving many and wide ail-chambers. The green color of the lower is therefore diluted, and paler than that of the upper face of the leaf. The upper part of the leaf is so constructed as to bear tlie direct action

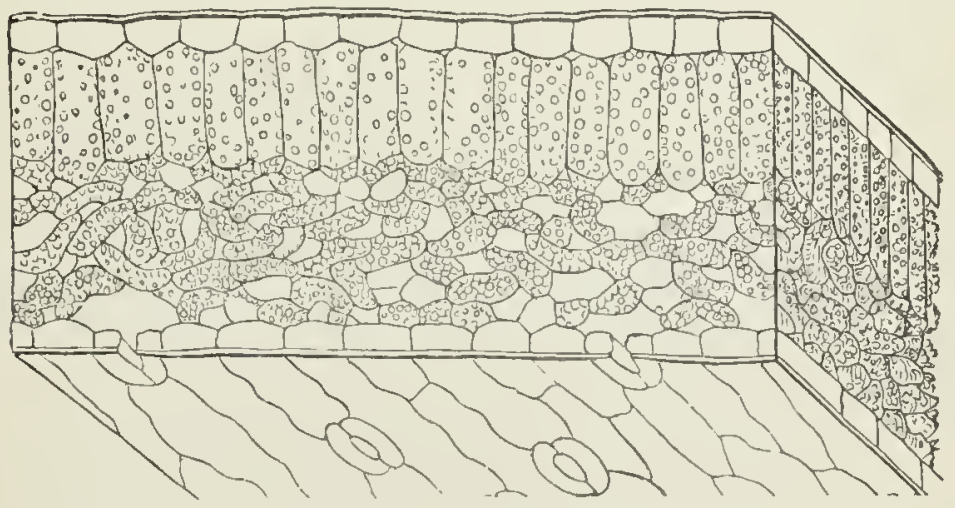

183

of the sunshine; the lower so as to afford freer circulation of air, and to facilitate transpiration. It communicates more directly thau the upper witl the external air by means of Stomates.

442. The Epidermis ol skin of leaves and all young shoots is best secn in the foliage. It may readily be stripped off from the surface of a Lily-leaf, and still more so from more fleshy and soft leares, such as those

FIG. 483. Mamniffed section of a leaf of White Lily, to erhibit the cellular structure, both of upper and lower stiatum, the air-passages of the lJwer, and the epidermis or skin, in section, also a little of that of the luwer faca, with soma of its stomatos 
of Houseleek. The epidermis is usually composed of a single layer, occasionally of two or three layers, of empty cells, mostly of irrcgular outline. The sinuous lines which traverse it, and may be dis-

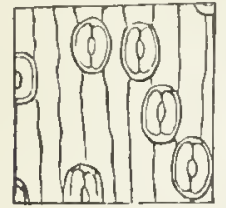

484

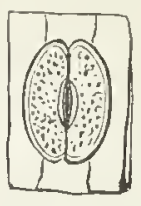

485

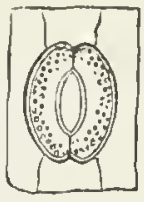

486

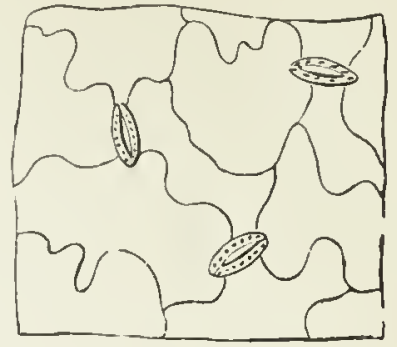

$48 ;$

cerned under low powers of the microscope (Fig. 487), are the boundaries of the epidermal cells.

443. Breathing-pores, or Stomates, Stomata (singular, a Stoma, litcrally, a mouth) are openings through the epidermis into the air-chambers or intercellular passages, always between and guarded by a pair of thinwalled guardian cells. Although most abundaut in leaves, cspecially on their lower face (tliat which is screened from direct sunlight), thicy are found on most other green parts. They establish a direct communication between the external air and that in the loose iutcrior of the leaf. Their guardian cells or lips, which are soft and delicate, like those of the green pulp within, by their greater or less turgidity open or close the orifice as the moisture or dryness varies.

444. In the Whitc Lily the stomata are so remarkably large that they may be seen by a simple microscope of moderate power, and may be discerned even by a good hand lens. Therc are about 60,000 of them to the square inch of the cpidermis of the lower face of this Lily-leaf, and only about 3000 to the same space on the upper face. It is computed that an average leaf of an Apple-tree has on its lower face about 100,000 of these mouths.

\section{§. PLANT FOOD AND ASSIMILATION.}

445. Only plants are capable of originating organizable matter, or the materials which compose the structure of vegetables and animals. The es. sential and peculiar work of plants is to takc up portions of eartl aud air (water belonging to both) upon which animals camnot live at all, and to convert them into something organizable; that is, into somcthing that, under life, may be built up into vegetable and animal structures. All the food of animals is produced by plants. Animals live upon vegctables,

Fig. 484. Snall portion of epidermis of the lower face of a White-Lily leaf, jith stomata.

FIG. 485. One of these, more magnified, in the closed state. 486. Another stoma, opren.

Frg. 487. Small portion of epidermis of the Garden Balsam, highly magnufied, showing very sinuous-walled cells, and three stomata. 
directly or at seeond hand, the earnivorous upon the herbivorous; and vegetables live upon earth and air, immediately or at seeond hand.

446. The Food of plants, then, prinarily, is earth and air. This is evident enough from the way in which they live. Many plunts will flourish in pure sand or powdered ehalk, or on the bare fice of a roek or wall, watered merely with rain. And almost any plant may be made to grow from the seed in moist sand, and inerease its weight many times, even if it will not eome to perfeetion. Many naturally live suspended from the branches of trees high in the air, and nourislied by it alone, never hav. ing any eonnection with the soil; and some which naturally grow on the ground, like the Live-forever of the gardens, when pulled up by the roots and hung in the air will often lourish the whole summer long.

447. It is true that fast-growing plants, or those which produce mueh vegetable matter in one season (especially in such concentrated form as to be useful as food for man or the higher animals) will eome to maturity ouly in an enriehed soil. But what is a rich soil? One which contains deeomposing vegetable matter, or some deeomposing animal matter; that is, in either ease, some deeomposing organie matter formerly produeed by plauts. Aided by this, grain-bearing and other important vegetables will grow more rapidly and vigorously, and make a greater amount of uenrishing matter, than they could if left to do the whole work at onee from the beginning. So that in these eases also all the organie or organizable matter was made by plants, and made out of earth aud air. Far the larger aud most essential part was air and water.

448. 'Two kinds of material are taken in and used by plants; of whieh the first, although more or less essential to perfeet plant-growth, are in a eertain sense subsidiary, if not aeeidental, viz.:-

Larthy constituents, those which are left iu the form of ashes when a leaf or a stick of wood is bumed in the open air. These consist of some potash (or soda in a marine plant), some silex (the same as flint), and a little lime, aiumine, or magnesia, iron or manganese, sulphur, phosphorus, ete., - some or all of these in variable and usually minute proportions. They are such materials as happen to be dissolved, in smill quantity, in the water taken up by the roots; and when that is eonsumed by the plant, or flies off pure (as it largely does) by exhalation, the earthy matter is lelt behind in the eells, - just as it is left inerusting the sides of a tenkettle in whieh mueh hard water has been boiled. Naturally, therefore, there is more earthy matter (i. e. more ashes) in the lenves than in any other part. (sometimes as much as seven per eent, when the wood eontains only two per eent); beeause it is through the leaves that most of the water escapes from the plant. Some of this eartliy matter incrusts the cell-watls, some goes to form erystals or rhaplides, which abound in many plants (122), some enters into eertain speeial vegetable produets, and some appcir's to be necessary to the well-being of the higher orders of plants, although forming no neeessary part of the proper vegetable structure. 
The essential constituents of the organic fabric are those which are dissipated into air and vapor in complete burning. 'They make up from 88 to 99 per ccnt of the leaf or stem, aud essentially the whole both of the cellu. lose of the walls and the protoplasm of the contents. Burning gives these materials of the plant's structure back to the air, mainly in the same condition jn which the plant took them, the sane condition which is reached more slowly in natural decay. The chemical elements of the cell-walls (or cellulose, 402), as also of starcli, sugar, and all that class of organizable cell-material, are carbon, hydrogen, and oxygen (399). The same, with nitrogen, are the constitucnts of protoplasm, or the truly vital part of vegetation.

449. 'These chemical elements out of which organic matters are composed are supplied to the plant by water, carbonic acid, and some combinations of nitiogen.

Water, lar more largely than anything else, is imbibed by the roots; also more or less by the folinge in the form of vipor. Water consists of oxygen and hydrogen; and cellulose or plant-wall, starch, sugar, etc., however different in their qualities, agree in containing these two elements in the same relative proportions as in water.

Carbonic acid gas (Carbon dioxidc) is one of the components of the atmosphere, - a small one, ordinarily only about $\frac{1}{25 \overline{0}}$ of its bulk, - sufficient for the supply of vegetation, but not enougle to be injurions to animals, as it would be if accumulated. Every current or breeze of air brings to the lcaves expanded in it a suceession of fresh atoms of carbonic acid, which it absorbs through its nultitudinous breathing-pores. This gas is also taken up by water. So it is brought to the ground by rain, and is absorbed by the roots of plants, either as dissolved in the water they inbibe, or in the form of gas in the interstices of the soil. Manured ground, that is, soil containing dccomposing vegetible or animal matters, is constantly giving out this gas into the interstiees of the soil, whence the roots of the growing clop absorb it. Carbonic acid thus supplied, primarily from the air, is the source of the carbon whieh forms nuch the largest part of the substance of every plant. 'The proportion of carbon may be ronghly estimated by charring some rood or foliage; that is, by heating it out of contact with the air, so as to decom. pose and drive ofl' all the other constituents us the fabric, leaviug the large bulk of chareoal or cirbon behind.

Nitrogen, the remaining plant-elcment, is a gas which makes up more than two thirels of the atmosphere, is brought into the foliage and also to the roots (being moderately soluble in water) in the same ways as is carbonic acid. The nitrogen which, mixed with oxygen, a little carbonic acid, and rapol of water, constitutes the air we breatlic, is the source of this fourth pliunt-element. But it is very doubtful if ordinary plants can use any nitrogen gus directly as food; that is, if they can directly cause it to combine with the other clements so as to form protoplism. But when com. bined with hydrogen (forming ammonia), or when combined with oxygen 
(uitric acid and nitrates) plants appropriate it with avidity. And several natural processes arc going on in which nitrogen of the air is so combined and supplied to the soil in forms directly available to the plant. The most efficient is nitrification, the formation of nitre (nitrate of potash) in the soil, especially in all fertile soils, through the action of a bacterial ferment.

450. Assimilation in plants is the conversion of these inorganic sub. stances - essentially, watcr, carbonic acid, and some form of combined or combinable nitrogen - into vegetable mattcr. 'This most dilute food the living plant concentrates and assinilates to itself. Only plants are capable of converting these mineral into organizuble matters; and this all-important work is done by them (so far as all ordiuary vegetation is concerned) only

451. Under the light of the sun, acting upon green parts or foliage, that is, npon the chlorophyll, or upon what answers to chlorophyll, which these parts contain. The sun in some way supplies a porrer which enables the living plant to originate these peculiar chenical combinations, - to organize matter into forms which are alone eapable of being endowed with life. The proof of this proposition is simple; and it shows at the same time, in the simplest way, what a plant does with the water and carbonic acid it consumes. Namely, 1st, it is only in sunshine or bright daylight that the green parts of plants give out oxygen gas, - then they regularly do so; and $2 \mathrm{~d}$, the giving out of this oxygen gas is required to render the chemical composition of water and carbonic acid the same as that of ccllulose, that is, of the plant's permanent fabric. This shows why plants spread ont so large a surface of foliage. Ieaves are so many workshops, full of machinery worked by smn-power. The emission of oxygen gas from any snn-lit foliage is scen by placing some of this under water, or by using an aquatic plant, by collecting the air bubbles which rise, and by noting that a raper bnrns brighter in this air. Or' a leafy plant in a glass globe may be supplied with a certain small percentage of carbonic acid gas, and after proper expositis to sunshine, the air on being tested will be fonud to contain less carbonic acid and just so much the more oxygen gas.

452. Now if the plant is making cellulose or any equivalent snbstance, - that is, is making the very materials of its fubric and growth, as mist generally be the case, - all this oxygen gas given off by the leaves comes from the decomposition of carbonic acid taken in by the plant. For cellu. lose, and also starch, dextrine, sugar, and the like are composed of carbon along witl oxygen and lydrogen in just the proportions to form water. And the carbonic acid and water taken in, less the oxygen which the carbon brought with it as carbonic acid, and which is giren off from the folinge in sumshine, just represents the manufnetured article, cellulose.

453. It comes to the same if the first prodnct of assimilation is sugrar, or dextrine which is a sort of soluble stareh, or starch itself. And in the plant all these forms are readily changed into one another. In the tiny seedlıng, as fast as this assimilated matter is formed it is used in growth, chat is, in the formation of cell-walls. After a time some or much of 
the product may be accumulated in store for future growth, as in the root of the turuip, or the tuber of the potato, or the seed of corn or pulse. This store is mainly in the form of starch. When growth begins anew, this starch is turned into dextrine or into sugar, in liquid form, and used to nourish and build up the germinating embryo or the new shoot, where it is at length converted into cellulose and used to build up plant-structure.

45.t. But that which builds plant-fabrie is not the cellular structure itself; the work is done by the living protoplasm which dwells within the walls. This atso has to take and to assimilate its proper food, for its own mainlenance and growtll. Protoplasm assimilates, along with the other three clements, the nitrogen of the plant's food. This comes primarily from the vast stock in the atmosphere, but mainly through the earth, where it is accumulated through various processes in a fertile soil, - mainly, so far as concerns crops, from the decomposition of former vegctables and animals. This protoplasm, which is furmed at the same time as the simpler cellulose, is essentially the same as the flesh of animals, and the source of it. It is the common basis of vegetable and of animal life.

45.5. So planl-assimilution produces all the food and fabric of animals. Starelı, sugar, the oils (which are, as it were, these fullinaceous matters more dcoxidated), clilorophyll, and the like, and even ccllulose itself, form the food of herbivorous animals and much of the food of man. When digested they enter into the blood, undergo various transformations, and are at length decomposed into carbonic acid and water, and exhaled from the lungs in respiration, -- in other words, are giveu back to the air by the ani. mall as the very same materials which the plant took from the air as its food, - are given back to the air in the same form that they would have tiken if the vegetable matter lad been left to decay where it grew, or if it liad been set on fire and burned; and with the same result, too, as to the heat, - the licat in this casc prodlucing and maintaining the proper temperature of the animal.

456. The protoplasm and otlicr products containing nitrogen (gluten, legumine, cte.), and which are most necumulited in grains and secds (for the nourishnent of their emblyos when they germinate), compose the most nutritious vegetable lood consumed by animals; they form their proper Hesh and sinews, while the cartliy constituents of the plant form the carthy matter of the bones, cte. At leugth decomposed, in the secretions and excretions, these uitrogenons constitucuts are through successive changes finally resolved into mincral matter, into carbonic acid, water, and ammonia or some nitrates, - intor exactly or essentivilly the same nuterials which the plants took up and assinilated. Animals depend upon vegetables absolutely and direetly for their subsistenec; also indirectly, heciuse

457. Plants purify the air for animuls. In the very process by which they create food they take fiom the air carbonic acid gas, injurions to animal res. piration, which is continually ponred into it by the brcathing of all aiamals, by all decay, by the burning of fucl and all other ordinary combustion; and 
they restore an equal bulk of life-sustaining oxygen necdful for the respiration of animals, - needful, also, in a eertain measure, for planto in any work they do. For in plauts, as well as in animals, work is done at a certain cost.

\section{PLANT WORK AND MOVEMENT.}

453. As the organie basis and truly living material of plants is identieat with that of animals, so is the life at botton essentially the same; but ir animals something is added at every rise from the lowest to highest organisms. Aetion and work in living beings require movement.

459. Living things move; those not living are only moved. Plants move as truly as do animals. The latter, nourished as they are upon organized food, which has been prepared for them by plants, and is found only here and there, must needs bave the power of going after it, of collecting it, or at least of taking it in; whieh requires them to mike spontaneous movements. But ordinary plants, with their wide-spread surface, always in contact with the earth and air on whieh they feed, - the latter everywhere the same, and the former very much so, - might be thought to have no need of movement. Ordinary plints, indeed, lave no locomotion; come float, but most are rooted to the spot where they grew. Yet probably all of them exceute various movements whieh inust be as truly self-eaused as are those of the lower grades of animals, - movements whieh are overlooked only because too slow to be dircetly observed. Nevertheless, the motion of the hour-hand and of the minute-hand of a wateh is not less real than that of the second-lind.

460. Locomotion. Morcover, many mieroseopic plants living in water are seen to move frecly, if not briskly, under the mieroseope; and so like. wise do more eonspieuous aquatic plants in their embryolike or secdling state. Even at maturity, speeics of Oseillaria (such as in Fig. 498, minute worm-shaped plants of fresh waters, taking this name from their oseillating motions) frecly

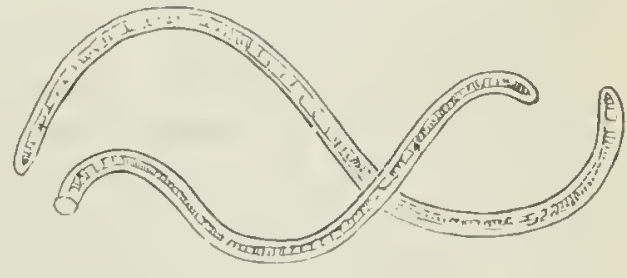

488 exceute three different kinds of movement, the very delieate investing eoat of celluluse not impeding the action of the living protoplasm within. Even when this eoat is firmer and hardened with a siliceous deposit, such eresecut-shaped or boat-shaped onc-eelled plants as Closlerium or Navicula are able in some way to move along from place to plise in the water.

461. Movements in Cells, or Cell-circulation, sometimes ealled $C y$ closis, hils been deteeted in so many plints, cspccially in comparatively

FIa. 488. Two indiviluals of an Osciliaria, mastified. 
transparent aquatie plants and in hairs on the surface of land plants (where it is easiest to observe), that it may be inferred to take place in all eelis during the most aetive part of their life. This motion is eommonly a

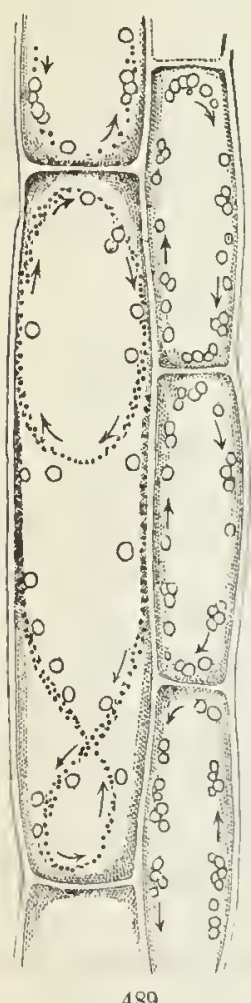

489 streaming movement of threads of protoplasm, earrying along solid granules by which the aetion may be observed and the rate measured, or in some eases it is a rotation of the whole protoplasmie eontents of the eell. A eomparatively low magnifying power will show it in the eells of Nitella and Chara (whieh are eryptogamous plants); and under a moderate power it is well seen in the Tape Grass of fresh water, Vallisneria, and in Naias flexilis (Fig. 489). Minnte partieles and larger greenish globules are seen to be earried along, as if in a euirent, around the eell, passing up one side, aeross the end, down the other and aeross the bottom, eompleting the eireuit sometimes within a minute or less when well warmed. To see it well in the eell, whieh like a string of beads form the hairs on the stamens of Spiderwort, a high magnifying power is needed.

462. Transference of Liquid from Cell to Cell, and so from place to plaee in the plant, the absorption of water by the rootlets, and the exhalation of the greater part of it from the foliage, - these and similar operations are governed by the plysieal laws which regulate the diffusion of fluids, but are eontrolled by the action of living protoplasm. Equally muder vital eontrol are the various ehemieal trausformations which attend assimilatiou and growth, and which involve not only moleeular movements but eonveyance. Growth itself, which is the formation and shaping of new parts, implies the direetion of internal activities to definite ends.

463. Movements of Organs. The living protoplasm, in all but the lowest grade of plants, is enelosed and to eommon appearanee isolated in separate eells, the walls of whieh ean only in their earliest state be said to be alive. Still plants are able to eause the protoplasm of adjacent eells to aet in eoneert, and by their eombined aetion to effeet movements in ronts, stems, or leaves, some of them very slow and gradual, some manifest ana striking. Sueh movements are brought about through individually minute ehanges in the form or tension in the protoplasm of the innumerable eells whieh make up the strueture of the organ. Some of the slower movements are effeeted during growth, and may be explained by inequality of growth on the two sides of the bending organ. But the more rapid hanges of position, and some of the slow ones, eannot be so explained.

FIG. 4\$9. A few cells of a leaf of Naias flexilis, hichly magnified: the arrows indicate the courses of this circulating currents 
464. Root-movements. In its growth a root turns or bends away from the light and toward the centre of the earth, so that in lengthening it buries itself in the soil whore it is to live and act. Every one must have observed this in the germination of seeds. Carclul observations liare shown that the tip of a growing root also makes little swceps or short movements from side to side. By this means it more readily insinuates itsclf into yielding portions of the soil. The root-tips will also turn toward moisture, and so secnre the most favorable positions in the soil.

465. Stem-movements. The root end of the caulicle or first joint of stem (that bclow the cotyledons) acts like the root, in turniug downward iu germination (makiug a complete bend to do so if it lappens to point upward as the seed lies in the ground), white the other end turns or points skyward. These opposite positions are taken iu complete darkness as readily as in the light, in dryness as much as in moisture: there forc, so far as these movements are physical, the two portions of the same internode appear to be oppositely affected by gravitation or other influences.

466. Rising into the air, the stem and green shoots generally, while young and pliable, bend or direct themselves toward the light, or toward the stronger light when uncqually illuminated; while roots tmru toward the darkness.

467. Many growing stems have also a movement of Nutation, that is, of nodding successively in different directions. This is brought about by a temporary increase of turgidity of the cells along one side, thus bowing the stem over to the opposite side; and this line of turgescence travels round the shoot continually, from right to left or from left to right accordiug to the species: thus the shoot bends to all points of the compass in successiou. Commonly this nutation is slight or hardly observable. It is most marked in

465. Twining Stems (Fig. 90). The growing upper end of such stems, as is familiar in the Hop, Pole Beaus, and Morning-Glory, turns over in an incliued or horizontal direction, thus stretching out to reach a neighboring support, and by the continual change in the direction of the nodding, sweeps the whole circle, the sweeps being the longer as the stem lengthens. When it strikes agaiıst a support, sueh as a stem or branch of a neighboring plant, the motion is arrested at the contact, but continues at the growing apex beyond, and this apex is thus made to wiud spirally around the supporting body.

469. Leaf-movements are all but universal. The presentation by most leaves of their upper surface to the light, from whatever direction that may come, is an instance; for when tnrmed upside down they twist or bcird round on the stalk to recorer this normal position. Leaves, and the leaflets of compound leaves, change this position at nightiffall, or whon the light is withdrawn; they then take what is culled their slecping posture, resuming the diurnal position when daylight returns This is very striking 
in Locust-trees, in the Scnsitive Plant (Fig. 490), and in Woodsorrel. Young secdlings droop or close their leaves at night in plants which are not thus affected in the aclult foliage. All this is thought to be a protec. tion against the cold by nocturnal radiation.

470. Various plants climb by a coiling movenent of their leaves or their ' leaf-stalks. Familiar examples are seen in Clematis, Maurandia, T'ropæolum, and in a Solanum which is much cultivated in greenhouses (Fig. 172). In the latter, and in other woody plants which climb in this way, the petioles thicken and harden after they have grasped their support, thus securing a very firm hold.

471. Tendril movements. Tendrils are either leaves or stems (98, 168), specially developed for climbing purposes. Cobrea is a good cxam. ple of partial transformation; some of the leaflets are normal, some of the same leaf are little tendrils, and some intermediate in character. The Passion-flowers give good examples of simple stem-tendrils (Fig. 92); Grape-Vines, of branched ones. Most tendrils make revolving sweeps, like those of twining stems. Those of some Passion-flowers, in sultry weather, are apt to move fast cnough for the movement actually to be seen for a part of the circuit, as plainly as that of the second-hand of a watch. Two herbaceous species, Passiflora gracilis and P. sicyoides (the first an anmual, the second a strong-rooted perenniel of the easiest cultivation), are admirable for illustration both of revolving movements and of sensitive coiling.

472. Movements under Irritation. The most familiar case is that of the Sensitive Plant (Fig. 490). The leaves suddenly take their nocturnal position when roughly touched or when shocked by a jar. The leaflets close in pairs, the four outspread par. tial petioles come closer together, and the common petiole is depressed. The seat of the movements is at the base of the leal-stalk and stalklets. Sclirankia, a near relative of the Sensitive Plant, acts in the same way, but is slower. These are not anomalous actions, but only

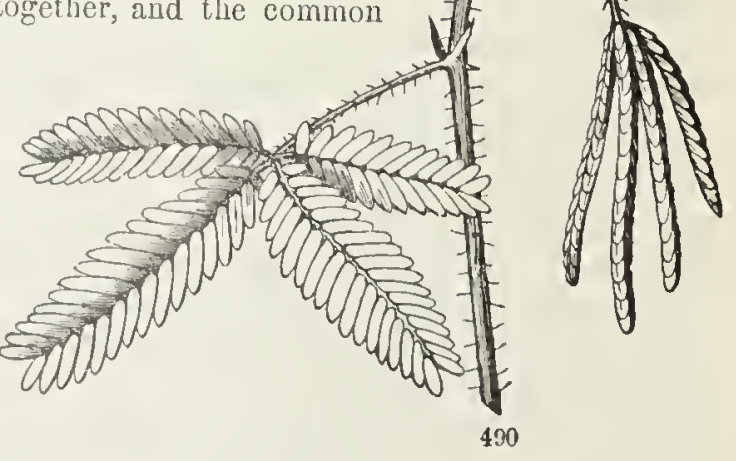
extreme manifestations of a faculty more or less common in foliage. In Locust and Thoucy-Locusts for example, repeated jars will slowly pro. duce similar effects. 
473. Leaf-stalks and tendrils are adapted to their uses in climbing by a similar sensitiveness. The coiling of the leaf-stalk is in response to a kind of irritation produced by contact with the supporting body. This may be shown by gentle rubbing or prolonged pressure upon the upper face of the leaf-stalk, which is soon followed by a curvature. T'endrils are still more sensitive to contact or light friction. 'I'lis causes the free end of the tendril to coil round the support, and the sensitiveness, propagated downward aloug the tendril, causes thit side of it to become less turgescent or the opposite side more so, thus throwing the tendril into coils. This shortening draws the plant up to the support. Tendrils which have not laid loold will at length commonly coil spontaneously, in a simple coil, from the free apex downward. In Sicyos, Echinocystis, and the above mentioned Passion-flower's (471), the tendril is so sensitive, under a high summer temperature, that it will curre and coil promptly after onc or two light stıokes by the hand.

474. Among spoutaneous movements the most siugular are those of Desmodiun gyrans of India, sometimes called Telegraphi-plant, which is cultivated on account of this action. Of its threc leaflets, the larger (terminal) one moves only by drooping at nightfall and rising with the dawn. But its two small Iateril leallets, when in a congenial ligh temperature, by day and by night move upward and dnwnward in a succession of jerks, stopping occasionally, as if to re. cover from exhaustion. In most plant-movements some obviously useful purpose is subservel : this

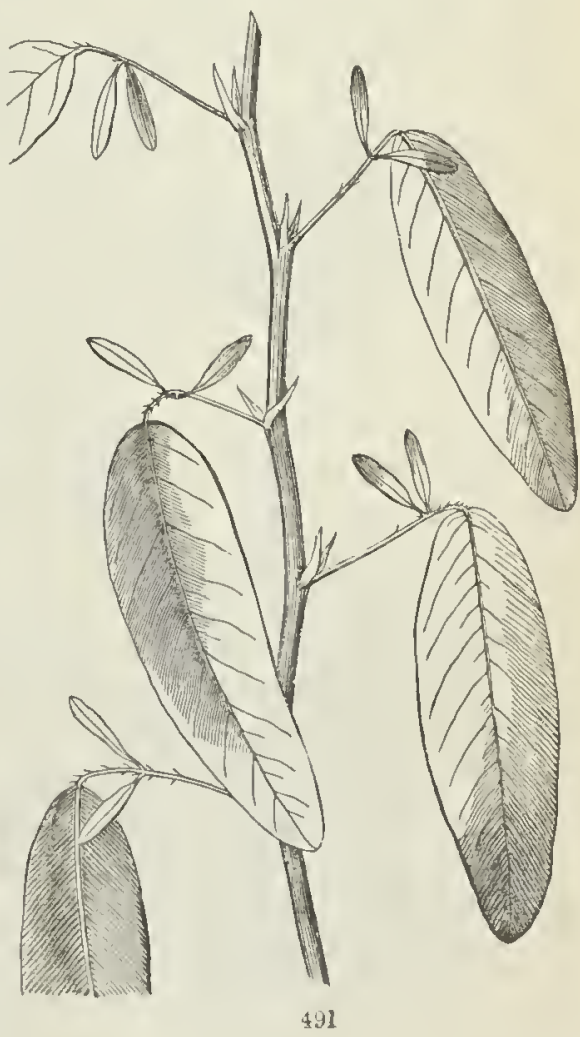
of Desmodium gyrans is a riddle.

475. Movements in Flowers are very various. The most remarkable are in some way comected with fertilization (Sect. XIII). Some nceur under irritation: the slamens of Barberry start formand when touched at the base inside: those of many polyandrous flowers (of Sparmannia very strikingly) spread ontwardly when lightly brushed: the two lips or lobes

FIG. 491. Portion of stem and leaves of Telegraph-plant (Desmodium gyrans), almost of natural size. 
of the stigma in Mimulus close after a touch. Some are automatic and are connected with dichogamy (339): the style of Sabbatia and of largeflowered speeics of $\mathbf{E}$ pilobium bends over strongly to one side or turns downward when the blossom opens, but slowly erects itsell a day or two later.

476. Extraordinary Movements connected with Capture of Insects. The most striking eases are those of Drosera and IDionæa; for an account of which see "How Plants Behave," and Goodule's "Pliysiological Botany."

477. The upper face of the leaves of the common species of Drosera, or Sundew, is beset with stout bristles, laving a glandular tip. This tip secretes a drop of a clcar but very viscid liquid, which glistens like a dewdrop in the sun; whence the popular name. When a fly or other small insect, attraeted by the liquid, alights upon the leaf, the viscid drops are so tenacions that they hold it fast. In struggrling it only beeomos more com-

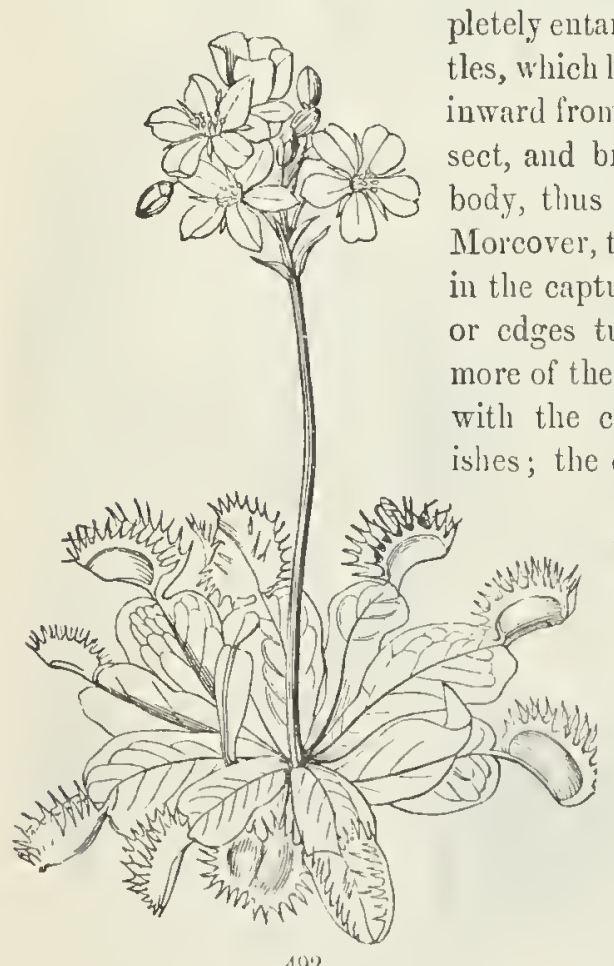

492 pletely entangled. Now the neighboring bristles, which have not been touehed, slowly bend inward from all sides toward the captured in. sect, and bring their sticky apex against its body, thus inereasing the number of bonds. Morcover, the blade of the leaf commonly aids in the capture by beeoming coneave, its sides or cdges turning inward, whieh brings still more of the gland-tipped bristles into contact with the captive's body. Thic inseet perishes; the elear liquid disappears, apparently by absorption into the tissuc of the leaf. It, is thought that the absorbed secretion takes with it some of the juices of tile insect or the products of its decomposition.

4.7. Dionæa muscipula, the most rcmarkill) vegetable fly -trap (Fig. 176,492$)$, is related to the Sundews, and lias a more special and active apparatus for fly. catching, formed of the summit of the leaf. The two halres of this rounded body move as if they were hinged upon the nidrib; their edges are fringed with sping but not glandular bristles, whieh interloek when the organ closes. Upon the face are two or three short and delicate bristles, which are sensitive. 'They do not themselves move when tonelied, but they propagate the sensitivencss to the organ itsclf, causing it to elose with a quick movement. In a fresh 
and vigorous leaf, under a high summer temperaturc, and when the trap lies widely open, a touch of any one of the minute bristles on the face, by the finger or any extraneous body, springs the trap (so to say), and it closes suddenly; but after an hour or so it opens again. When a fly or other small insect alights on the trap, it closes in the same manner, and so quickly that the intercrossing marginal bristles obstruct the egress of the insect, unless it be a small one and not worth taking. Afterwards and more slowly it completely closes, and presses down upon the prey; then some hidden glands ponr out a giairy liquid, which dissolves ont the juices of the insect's body; next all is re-absorbed nto the plant, and the trap opens to repeat the operation. But the same leaf perhaps never captures more than two or three insects. It ages instead, becomes more rigid and motionless, or decays away.

479. That some few plants should thus take animal food will appear less surprising when it is considercd that hosts of plants of the lower gr: te, known as Fungi, monlds, rusts, ferments, Bacteria, etc., live upon aninal or other organized natter, cither decaying or living. That plants shouid execnte movenents in order to accomplish the ends of their existence is less surprising now when it is known that the living substance of plants and animals is esscntially the same; that the beings of both kingdoms partake of a conmon life, to which, as they rise in the scale, other and higher endowments are successively superadded.

4S0. Work uses up material and energy in plants as well as in ani. mals. The latter live and work by the consumption and decomposition of that which plants have assimilated into organizable matter through an energy derived from the sun, and which is, so to say, stored $11 \mathrm{p}$ in the as. similated products. In every internal action, as well as in cvery movement and exertion, some portion of this assinilated matter is transformed and of its stored energy expended. The steam-engine is an organism for con. verting the sun's radiant encrgy, stored up by plants in the fuel, into mechanicul work. An animal is an cugine fed by regretable fuel in the same or other forms, from the same source, by the decomposition of which it also does mechanical work. The plant is the producer of food and accunulator of solar enelgy or force. But the plint, like the animal, is a consumer whenever and by so much as it does any work except its great work of assimilation. Erery internal change and movement, every transformition, such as that of starch into sugar aud of sugar into ccll-walls, as well as crery movement of parts which beeomes externally risible, is done at the expense of a certain amount of its assimilated matter and of its stored energy ; that is, by the decomposition or combustion of sugar or some such product into carbonic acid and water, which is given back to the air, just as in the animal it is given back to the air in respiration. So the respira. tion of plants is as real and as cssential as that of animals. But what plants consume or dccompose in their life and actiou is of insignificant amount in comparison with what they compose. 


\section{SECTION XVIT. CRYPTOGAMOUS OR FLOWERLESS PLANTS.}

481. Even the beginner in botany should have some general idea of what cryptogamous plants are, and what are the obvious distinctions of the principal fumilies. Although the lower grades are difieult, and need special books and good microseopes for their study, the highlier orders, such as Ferns, may be detcrmincd almost as rendily as planerogamous plants.

482. Linneus gave to this lowcr gratle of plints the name of Crypto gamia, thereby indicating that their organs answering to stamens and pistils, if they had any, wore recondite and unknown. There is no valid reuson why this long-faniliar name should not be kept up, along with the counterpart one of Phunerogamia (i), although organs analogous to stamens and pistil, or ratler 10 pollen and orule, have been discovered in all the ligglier and most of the lower grades of this serics of plants. So also the English synonymous name of Floverless Plants is both good and convenient: for they have not flowers in the proper sense. 'The essentials of flowers are stamens aud pistils, giving rise to secds, and the essential of a seed is an embrgo (S). Cryptogamous or Flowerless plants are propagated by SPores; and a spore is not an cmbrgo-plantlet, but mostly a single plint-cell (390).

4S3. Vascular Cryptogams, which compose the higher orders of this series of plants, have stems and (usuatly) lcaves, constructed upon the gencral plan of ordinary plants; that is, they lave wood (wood-cells and vessels, 4.08) in the stem aud leaves, in the latter as a frame work of veins. But the lower grades, laving only the more elementary cellular structure, are called Celtular Cryptogans. Fur the larger number of the former are Ferns: whicrefore that cliss lias becn called

454. Pteridophyta, Pteridophytes in English form, meaning Fern. plants, - that is, Fcrus and their relatives. They are mainly Itorsetails, Ferns, Club-Mlosses, and various aquatics which have been called Hydropterides, i. c. Water-Fcrus.

455. Horsetails, Equisedacece, is thic name of a family which consists only (among now-living plints) of Equisotum, the botanical name of Horsetail and Scomring Rush. They have hollow stems, with partitions at the nodes; the leaves consist ouly of a whorl of scales at each node, these coalescent into a sheath: from the axils of these leaf-scalcs, in many species, branches grow cut, which are similar to the stem hut on a much smaller scalc, clese-jointed, and wills the tips of the leaves more apparent. At the apex of the stem appears the fructification, as it is called lor lack of a better term, in the form of a short spike or head. This consists of a good num. ber of stalked shicids, brariug on their inner or under face several wedge. thaped spore-enses. The spore-cases when they ripen opeu down the inine 
side and discharge a great number of green spores of a size large enough to be well seen by a hand-glass. The spores are aided in their discharge
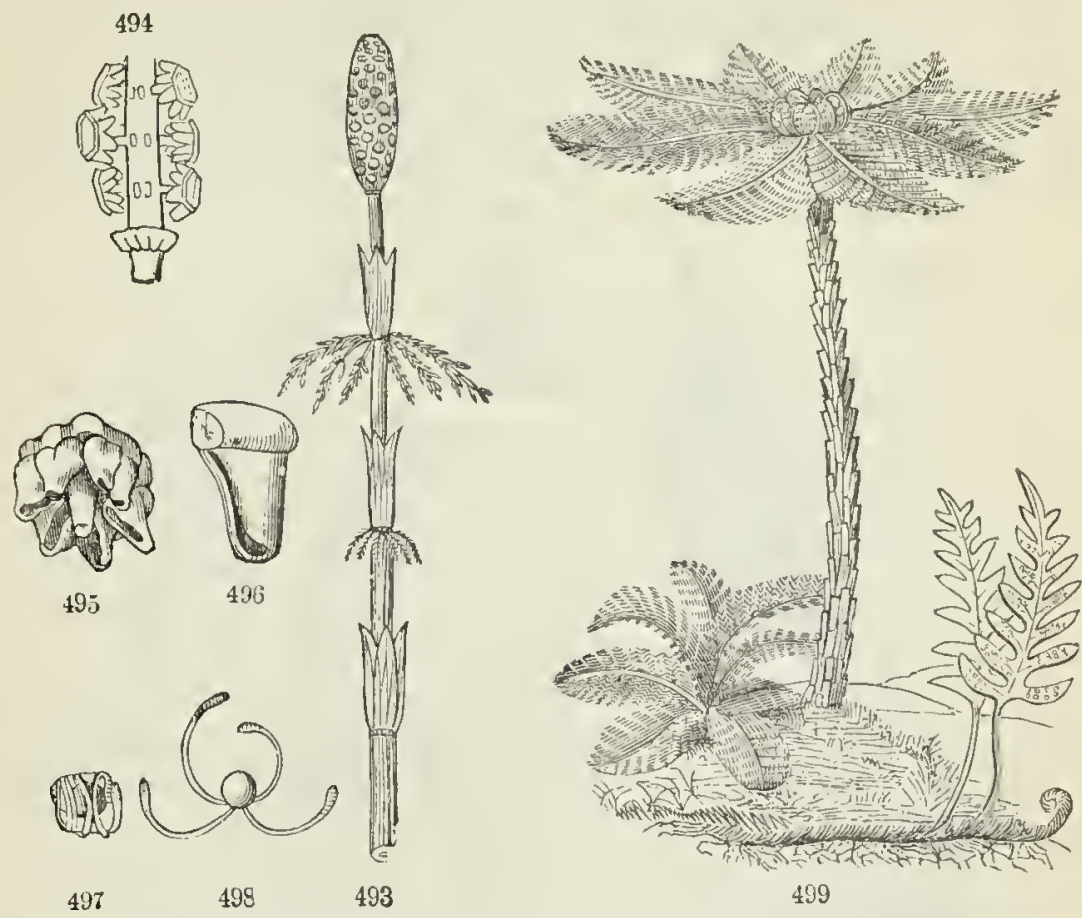

and dissemination by four elub-slinped thrcads attached to one part of thein These are hygrometrie: when moist they are rolled up over the spore; when diy they straighten, and exhibit lively movements, elosing over the spore when breathed upon, and unrolling promptly. a moment after as they dry. (See lig. 493-493.)

4.56. Ferns, or Filices, a most attraetive lamily of plants, are very uumerous and varied. In warn and equable elimates some rise into forest-trees, with labit of Palms; but most of them are percinnial herbs. The wood of a Fentu-trunk is very dif-

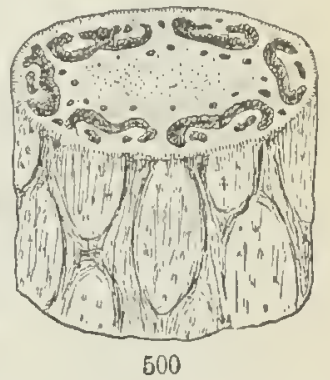
ferent, howerer, from that of a palm, or of any exogenous stem either. A section is represented in Fig. 500. 'Tlie curved plates of wood each ter-

Fag. 493. Upwer part of a stem of a Horsetail, Equisetun sylvaticum. 494. Part of the head or spike of spne-cases, with some of the latter taken off. 495. View (more enlurgeri) of uncler side of the shieli-shaped body, bearing a circle of sporecases. 496. One of the latter detached and more magnified. 497. A spore with the attached arms moistenerl. 495. Same when rly, the arms extended.

Fig. 499. A Tree-Fern, Dicksonia arborescens, with a youmg one near its base. In front a common lierbaceous Feru (Polypodium vulgare) with its creeping stem or rootstnck.

FIG. 500. A section of the trunk of a Tree-Fern. 
minate upward in a leaf-stalk. The subterranean trunk or stem of any strong-growing herhaccous Fern shows a similar structure. Most Ferns are circinate in the bud; that is, are rolled up in the manner shown in Fig. 197. Uncoiling as they grow, they lave some likeness to a crosier.

487. The fructification of Ferus is borne on the back or under side of the leave- The carly botanists thought this such a peculiarity that they

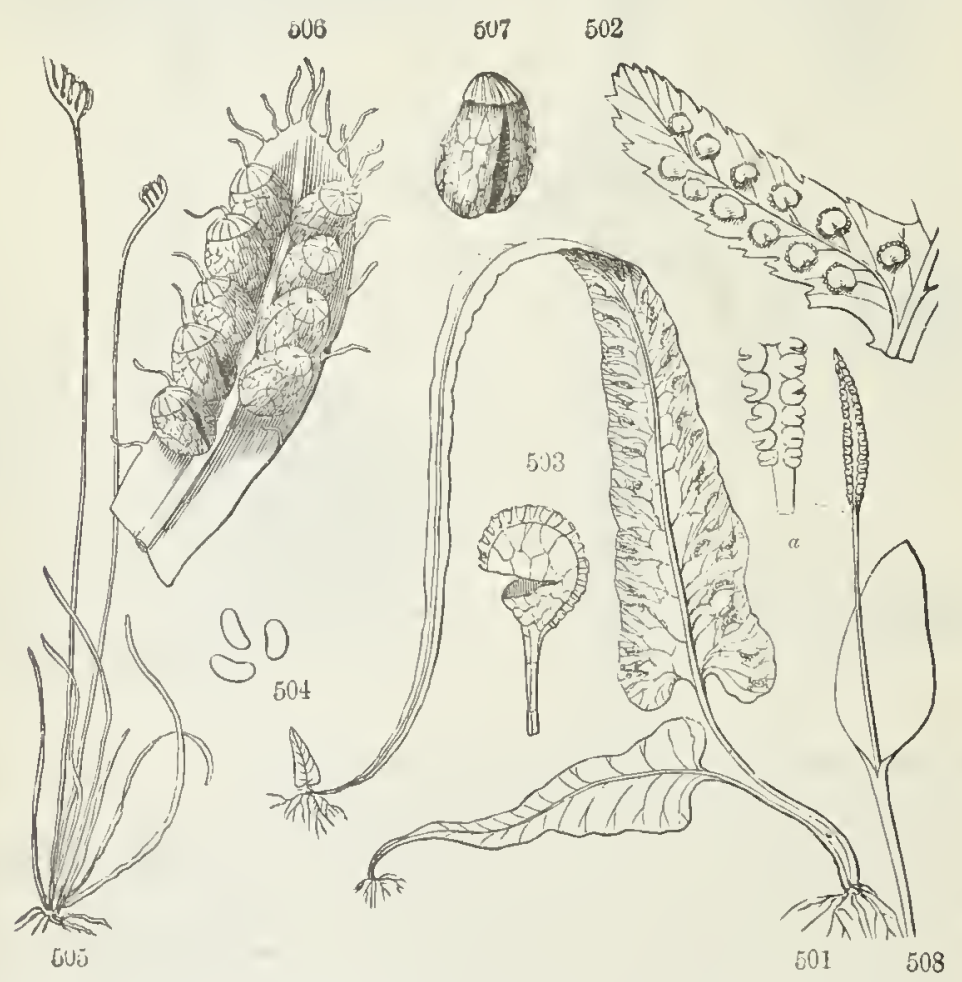

always called a Fern-leaf a Frond, and its petiole a STrPe. Usagre contimues these tcrins, although they are superluous. 'The fruit of Ferns consists of SPORE-Cases, technically Sporangia, which grow out of the veins of the leaf. Sometimes these are distributed over the whole lower

Frg. 501. The Walking-Fern, Camptosorts, rerlucel in size, showing its fruitdots on the veins aplroximater in pairs. 501. A smill piece (pimule) of a Shickl-Fern: a row of fruit-dots on ench side of the mithib, each corered hy its kichey-shaped indnsium. 503. A spore-ease from the latter, just bursting by the partial straightening of the iucomplete ring; well magnifiel. 501. Three of the spores of 509, more magnified. 505. Schizæa pusilin, a very small and simpleleaved Ferm, drawn noarly of matural size. 506. One of the loles of its fruitbearing portion, magnifiecl, bearing two rows of spore-cases. $50 \%$. Spore-ease of the latter, hetschert, opening lengthwise. 508. Adter-fongue, Ophioglossum: spore-cases in a kinkl of spike: a, a prortion of the fruiting part, alont natural aize; showing two rows of the firm spore-cases, which open transversely into two arlves. 
surface of the leaf or frond, or over the whole surface when there are no proper leaf-blades to the frond, but all is rediced to stalks. Commonly the sporc-cases occupy only detached spots or ines, each of which is called a Sorus, or 11 English merely a Fruit-chot. In many Ferns these fruit-dots arc naked; in others they are produced under a scale-like bit of membrane, called an Indusium. In Maidenhair-Ferns a little lobe of the leaf is folded back over each fruit-dot, to serve as its shield or indusium. In the true Brake or Bracken (Pteris) the whole edge of the fruit-bearing part of the leat is folded back over it like a hem.

488. The form and structure of the spore-cases can be made out with a common hand magnifyng glass. The commonest kind (shown in Fig. 50:3) has a stalk formed of a row of jointed cells, and is itself composed of a linger of thin-walled cells, but is incompletely surrounded by a border of thicker-walled cells, forming the Rivg. This extends from the stalk up one side of the spore-casc, round its summit, descends on the other side, but there gradually vanishes. In ripening and drying the shrinking of the cells of the ring on the outer side causes it to straighten; in doing so it tears the spore-case open on the weaker side and discharges the minute spores that fill it, commonly with a jerk which scatters them to the wind. Another kind of spore-case (Fig. 50\%) is stalkless, and has its

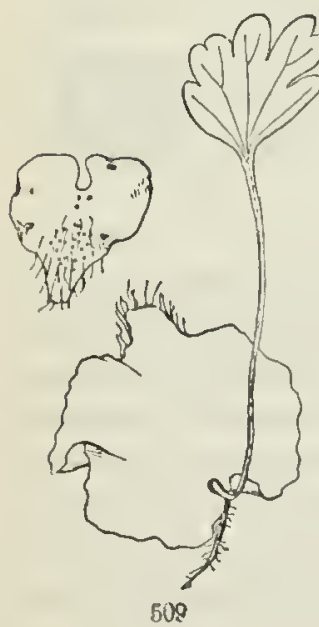
ring-cells forming a kind of cap at the top: at maturity it splits from top to bottom by a regular dehiscence. A third kind is of firm texture and opens across into two valves, like a clam-shell (Fig. 505 ${ }^{a}$ ): this kind makes an approach to the next family.

489. Thic spores germinate on moistened ground. In a conservatory they may be found germinating

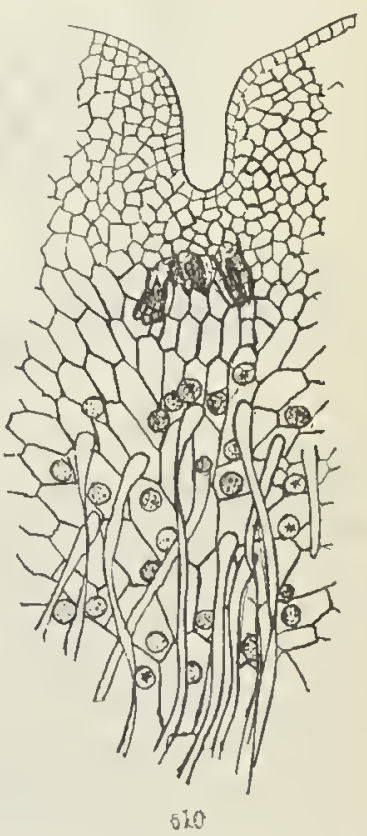

on a damp wall or on the cdges of a well-watered flower-pot. lustead of directly forming a fern-pliutlet, the spore grows first into a body which

FIc. 509. A young prothallus of a Maiden-hair, morlerately enlarged, and an older one with the first fern-leaf developed frem near the notch. 510. Millle portion of the young one, much mngnified, snowing below, partly among the rootlets, the antheridia or fertilizing orgaus, and above, near the notch, three pistillidia to be fertilized. 
ciosely resembles a small Liverwort. This is named a Prothailus (Fig 509): from some poiut of this a bud appears to originate, which produces the first fern-leaf, soon followed by a sccond and third, and so the stem and leaves of the plant are set up.

490. Investigation of this prothallus under the microscope resulted ir the discovary of a wholly unsuspected kind of fertilization, taking place at

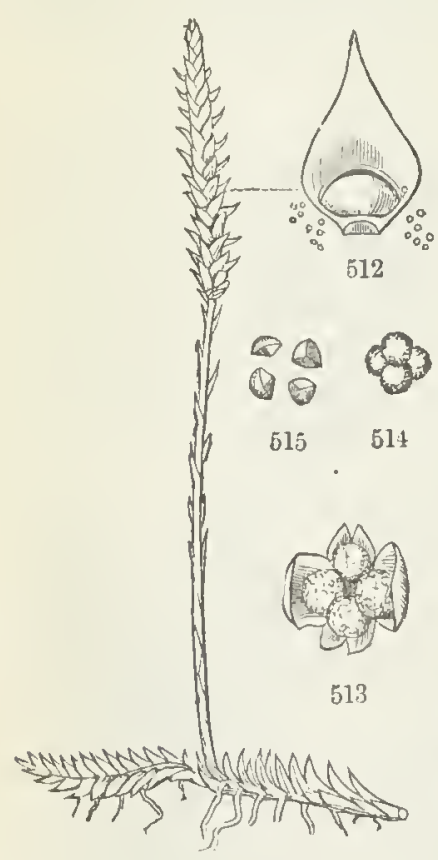

511

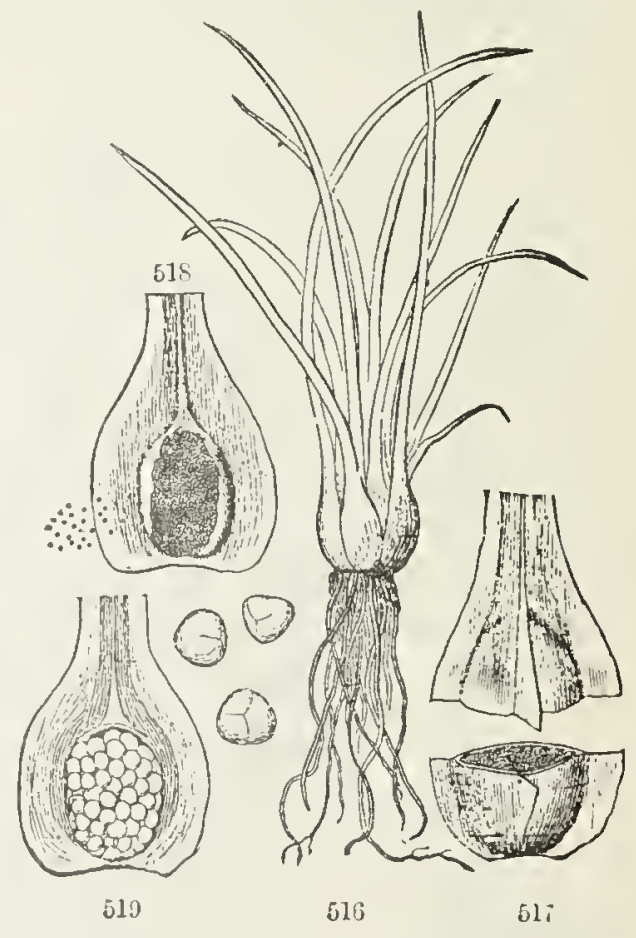

517

this germinating stage of the plant. On the under side of the prothallus two kinds of organs appear (Fig. 510). One may be likened to an open and depressed ovule, with a single cell at botton answering to nucleus; the ofher, to an anther; but instead of polten, it discharges corkscrewshaped inicroscopic filaments, which bear some cilia of extreme tenuity, by the rapid vibration of which the filaments more ficely over a wet surface. These filaments travel over the surfnee of the prothallus, and cven to other prothalli (for there are natural hybrid Ferns), reach and cuter the ovule

Fig. 511. Lyeopodium Carolinianum, of nearly natural size. 512. Inside view of one of the braets and spore-ease, magnified.

Fia. 513. Open 4-valver spore-ease of a Selaginella, and its four large spores (ninerospores), mignifiel. 51t. Maerospores of another Selaginella. 515. Same separaterl.

Fio. 516. Plant of Isoctes. 517. Base of a leaf and containeil sporocarp filled with mierospores ent across, magnified 51S. Same divided lengthwise, equally magnified; some microspores seen at the left. 519. Section of a spore-case contain. lug macrospores, efually magnitied: at the right three macrospores more nagnifiea 
like carities, and fertilize the cell. This thercupon sets up a growth, forms a regetable bud, and so develops the new plant.

491. An essentially similar process of fertilization lias been discovered in the preceding and the following families of Pteridophytes; but it is mostly subterranean and very diffieult to observe.

492. Club-Mosses or Lycopodiums. Some of the common kinds, called Ground Pine, are familiar, being larrgely used for Christmas wreaths and other decoration. They are low evergreens, somc creeping, all with considerable wood in their stems: this thickly beset with small leaves. In the axils of some of these leaves, or more commonly, in the axils of pecu. liar leaves ehanged into bracts (as in Fig. 511, 512) spore-cases appear, as roundish or kidney-shaped bodies, of firm texture, opening round the top into two valves, and discharging a great quantity of a very fine yellow powder, the spores.

493. The Selaginellas lave been separated from Lycopodium, which they much resemble, because they produce two kinds of spores, in separate spore-cases. One kind (Microspores) is just that of Lycopodium; the other consists of only four large spores (MaCroSPORES), in a spore-case which usually breaks in pieces at maturity (Fig. $513-515)$.

494. The Quillworts, Isoetes (Fig. 516-519), are very unlike Club Mosses in aspect, but have been associated with them. They look more like Rushes, and live in water, or partly out of it. A very short stem, like a corm, bears a cluster of roots underneath; above it is covered by the broad bases of a cluster of awlshaped or thread-shaped leares. The spore-cases are immersed in the bases of the leares. The outer

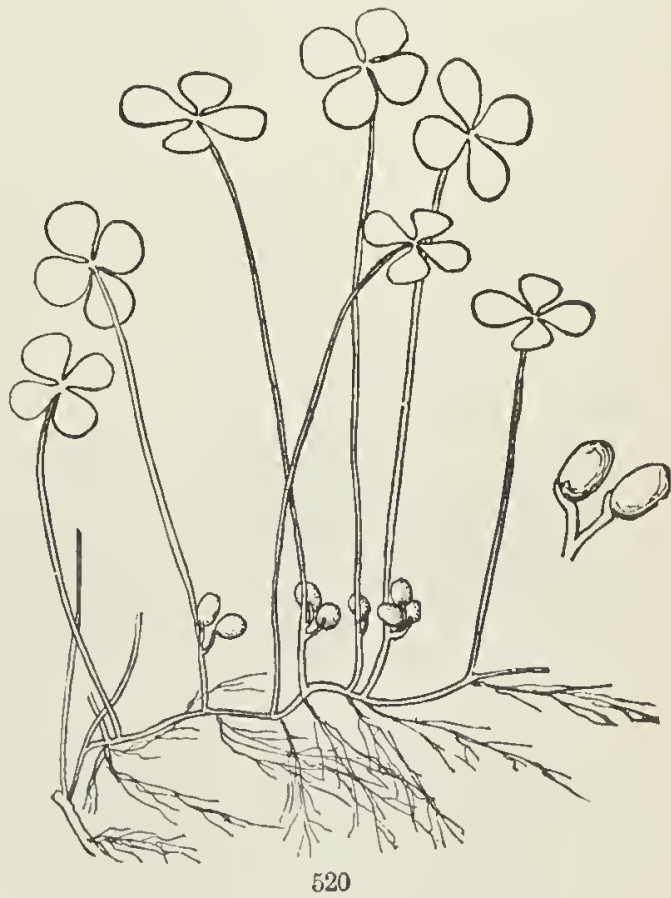
leaf-bascs contain numerous macrospores; the inner are fillcd with innumerable nicrospores.

495. The Pillworts (Marsilia and Pilulara) are low aquatics, which

Fig. 520. Plant of Marsilia quadrifoliata, reduced in size; at the right a pair of sporo-carps of about natural size. 
bei.r globular or pill-shaped fruit (SPorocarps) on the lower part of then leaf-stalks or on their slender creepiug stems. The leaves of the eommoner speeies of Marsilia might be taken for four-leaved Clover. (See Fig. 520.) The sporoearps are usually raised on a short stalk. Within they are divided leugthwise by a partition, and then erosswise by several partitions. These partitions bear uumerous delieate saes or spore-eases of two kinds, intermixed. The larger ones eontaiu eaeh a large spore, or maerospore; the smaller eoutain numerous mierospores, immersed in mueilage. At maturity the fruit bursts or splits open at top, and the two kinds of spores are diseharged. The large ones in germination produee a small prothallus; upon which the contents of the mierospores act in the same way as in Ferns, and with a similar result.

496. Azolla is a little floatiug plant, looking like a small Liverwort or Moss. Its branehes are eovered with minute and seale-shaped leaves. On the uuder side of the brauehes are found eggr-shaped thiu-walled sporoearps of two kiuds. The small ones open aeross and diseharge mierospores; the larger burst irregularly, and bring to view globose spore-eases, attaehed to the bottom of the sporoearp by a slender stalk. These delieate spore-cases burst and set free about four maerospores, which are ferti. lized at germination, in the manner of the Pillworts and Quillworts. (See Fig. 521-526.)

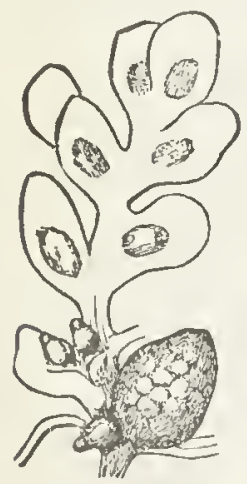

522

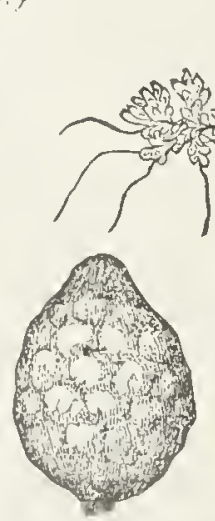

$52 t$
521

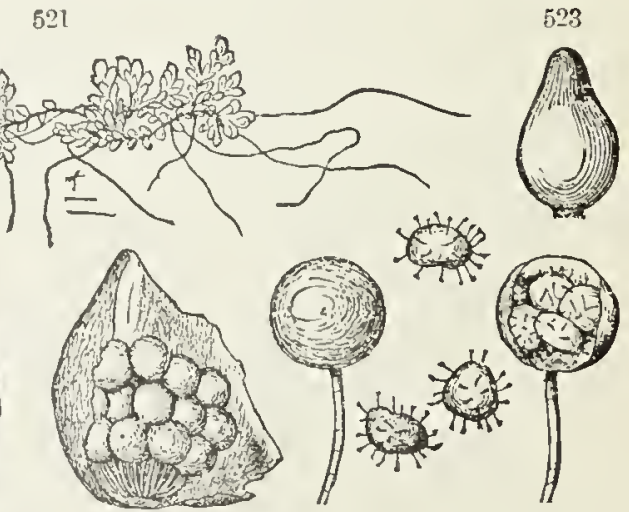

525

5215

497. Cellular Cryptogams (483) are so ealled beeause composed, even in their higher forms, of cellular tissue only, without proper woodeclls or vessels. Many of the lower kinds are mere plates, or ribbons, or simple rows of eclls, or even single eells. But their highest orders follow the plau of Ferus and phanerogamous plants in having stem and leaves for their upward growth, and eommonly roots, or at least rootlets,

Fia. 521. Sntall plant of Azolla Curoliniana. 522. Portion magnified, showing the two kinds of sporocarp; the small ones contain microspores; 523 represents one more magnifred. 52\%. The larger sporocarp more magnified. 525. Same more magnified anrl lutrst open, showing stalked spore-cases. 526. Two of the latter highly magnifiel ; one of them bursting shows four contained macrospores: between the two, three of these snores highly unagnified. 
to attach them to the soil, or to trunks, or to orner bodies on which they grow. Plants of this grade are chiefly Mosses. So as a whole they take the name of

498. Bryophyta, Bryophytes in English form, Bryum being the Greek name of a Moss. These plants are of two principal kinds: true Mosses (Musci, which is their Latin name in the plural); and Hepatic Mosses, or Liverworts (IIepaticre).

499. Mosses or M- גsci. The pale Peat-mosses (species of Sphagnum, the principal component of spluaguous bogs) and the stroug-growing Haireap Moss (Polytrichum) are anong the lalger and commoner represcutatives of this numerous family; while Fomtain Moss (Fontinilis) in rumning water sometimes attains the lengtl of a yard or more. On the other land, some are barely individually distingnishable to the naked cye. Fig. $52 i$ represents a common little Moss, cularged to about twelve times its natural size; and by its side is part of a leaf, much magnified, showing that it is composed of cellular tissue (parencliyma-cells) only. The leaves of Mosses are always simple, distinct, and sessilc on the stcm. The fructification is an urn-shapod spor-case, in this as in most cases raised on a slender stalk The spore-ease loosely bears on its summit a thin and pointed eap, like a candle-extinguisher, called a Calyptra. Detaching this, it is found that the spore-ease is like a pyxis (376), that is, the top at maturity eomes off as a lid (Operculum); and that the interior is filled with a grcen prowder, the spores, which are discharged through the open mouth. In most Mosses there is a fringe of one or two rows of teeth or membrane around this mouth

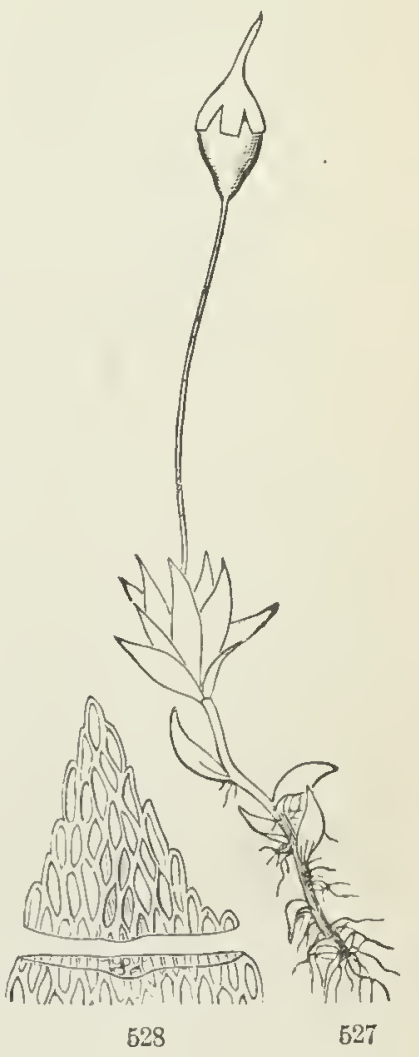
or orifice, the Peristone. When moist the peristome closes hygrometrieally over the orifice more or less; when drier the teeth or processes eommonly bend outward or reeurve; and then the spores more readily escape. In Hair-eap Moss a membrane is stretched quite across the mouth, like a drum-head, retaining the spores until this wears away. See Figures $527-541$ for details.

500. Fertilization in Mosses is by the analogues of stamens and pistils, which are hidden in the axils of leaves, or in the cluster of leaves at the

Fra. 527. Single plart of Physcomitrium pyriforme, magnified. 528. Top of a leaf. cut across; it consists of a single liyer of cella. 
end of the stcm. The analoguc of the anther (Antheridium) is a eellular sae, whieh in bursting cliseharges innumcrable delicate cells floating in a mueilaginous liquid; caeh of these bursts and sets frec a vibratile self631

534

$541 \quad 540$

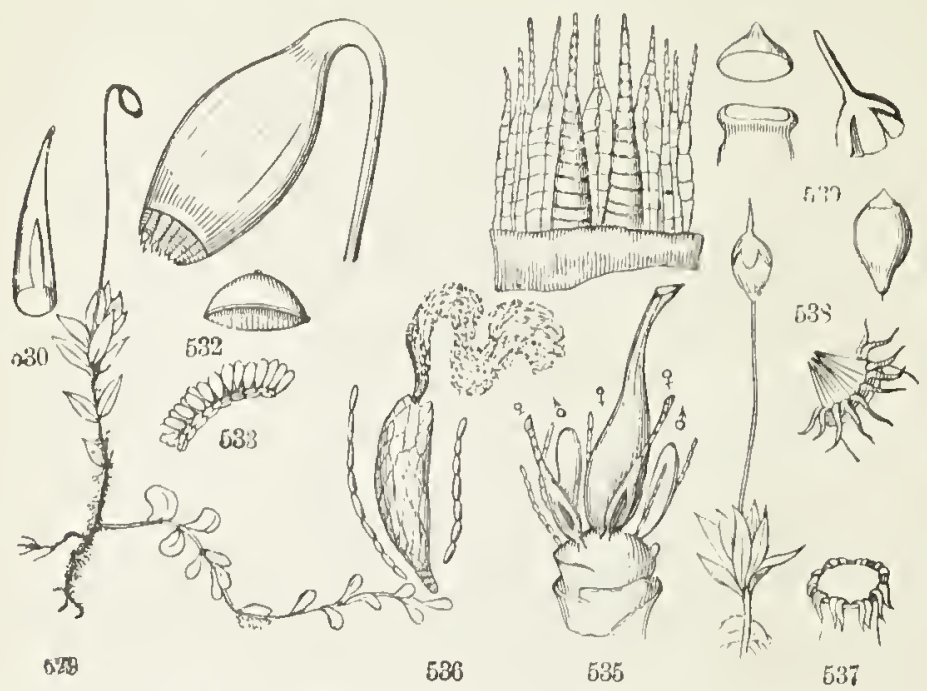

muving thrcad. These threads, one or more, reaeh the orifiec of the pistil. shaped body, the Pistillidium, and aet upon a particular cell at its base within. This cell in its growth develops into the spore-ease and its stalk (when therc is any), carrying on its summit the wall of the pistillidium, which beeomes the ealyptra.

501. Liverworts or Hepatic Mosses (IIepatice) in some kinds rescmble true Mosses, having distinct stem and leaves, althongh their leaves oecasionally run together; while in other's there is no distinction of stem and leaf, but the whole plint is a leaflike body, which produces rootlets on the lower face and its finetification on the upper. Those of the moss-like kind (sometimes ealted Scale-Mosses) have their tender sporc-cases splittiug into four valves; and with their spores are intermixed some slender spiral

Fig. 529. Anium cuspielatum, smaller thon nature. 530. Its caljptra, detacher, enlarged. 531. Its spore-cise, witle top of stalk, marnified, the licl (532) bering detached, the outer peristone appears. 533. I'ant of a cellular ring (umulus) which was uncle the licl, outside of the peristome, more nagnified. 63t. Some of the onter and of the inmer peristone (consisting of jointed teeth) mucl masnified. 53.5. Antheridia and a pistilliclium (the so-called flower) at end of a stem of same plant, the leaves torn away ( $\delta^{\prime \prime}$, mtheridia, $\$$, listillidium), magnified. 536. A bursting antherilium, and some of the accomplanying jointed threads, highly magnifiecl. 537. Summit of an open spole-easo of a Moss, which lias a peristone of 16 pairs of tecth. 538. "['le doulble peristome of a Hypulun. 539-541. Sprore-case, detached ealyptra, ancl top of more culargexl spore-caso and detachecl licl, of I'lysscomitrium pyriforme (Fig. $5: 7$ ) : orifiee shows that there is 110 joristome. 
and very liygrometrie threads (ealled Elaters) which are thought to aid in the dispersion of the spores. (Fig. 542-544.)

502. Marehautia, the eommonest aud largest of the true Liverworts, forms large green plates or fronds on tamp and shady ground, and sends up from some part of the upper faee a stout stalk, ending in a several-lobeu umbrella-shaped body, under the lobes of whieh hang several thin-walled spore-eases, whieh burst open and diseharge spores and elaters. Rieeia natans (Fig. 545) eonsists of wedge-shaped or heart-slaped fronds, whieh float free in pools of still water. The under face bears eopious rootlets; in the substance of the upper faee are the spore-eases, their pointed tips

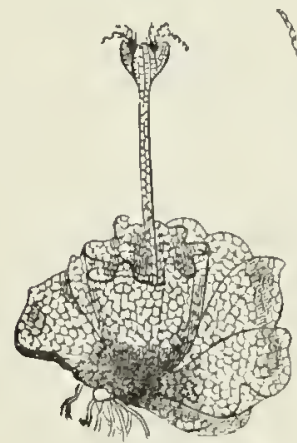

$6+2$

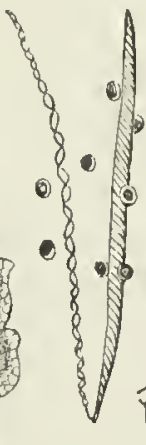

543

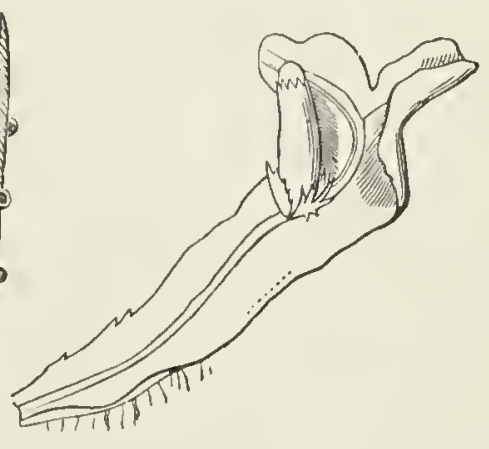

544

merely projeeting: there they burst open, and diseharge their spores These are eomparatively few and lirge, and are in fours; so they are very like the macrospores of Pillworts or Quillworts.

503. Thallophyta, or Thallophytes in English form. This is the name for the lower elass of Cellular Ciyptogams, - plants in whieh there is no marked distinetion into root, stem, and leaves. Roots in any proper sense they never lave, as organs for absorbing, attlough some of the larger Seaweeds (such as the Sea Colauder, Fig. 553) have them as holdfasts. Instead of axis and foliage, there is a stratimn of frond, in sueh plants commonly ealled a T'untuus (by a strained use of a Greek and Latin word whieh means a green shoot or bough), whielt may have any kind of form, leaf-like, stem-like, branelyy, extended to a flat phate, or gatliered into a spliere, or drawn out into threads, or ledueed to a single row of eells, or even redueed to single eells. Indeed, Thallophytes are so multifarious, so numerous in kinds, so protean in their stages and triusformations, so reeondite in their fruetifieation, and many so mieroseopie in size, either of

FlG. 542. Fructification of a Jungermamia, mannificil; its cellular spore-stalk, surrounded at base by some of the leaves, at smmmit the 4 -valver spore-ense opening, discharging spores and elatcrs. 543. Two elaters and some spores from the same, highly magnified.

FIG. 544. One of the frondose Liverworts, Steetzin, otherwise like a Juncer mannia; the spore-case not yet protruded from its sheath 
the plant itself or its essential organs, that they have to be elaborately deseribed in separate books and made subjects of special study.

504. Nevertheless, it may be well to try to give some general idea of what Algæe and Lichens and Fungi are. Linnæus had them all under the orders of Alge and liungi. Afterwards the Liehens were separated; but

545 546

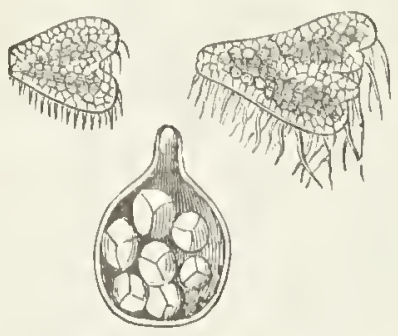

548
547

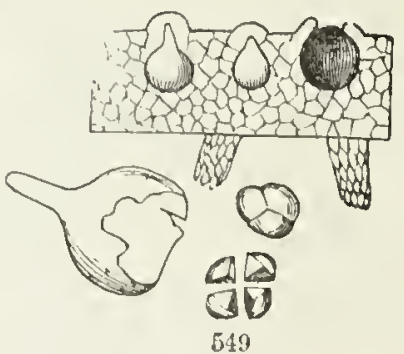

of late it has been made most probable that a Liehen eonsists of an Alga and a Fungus conjoined. At least it must be so in some of the ambiguous forms. Botanists are in the way of bringing out new elassifications of the Thallophytes, as they come to understand their structure and relations better. Here, it need only be said that

505. Liehens live in the air, that is, on the ground, or on roeks, trunks, walls, and the like, and grow when moistened by rains. 'l'hey assimilate air, water, and some cartly matter, just as do ordinary plants. Alga, or Sea-

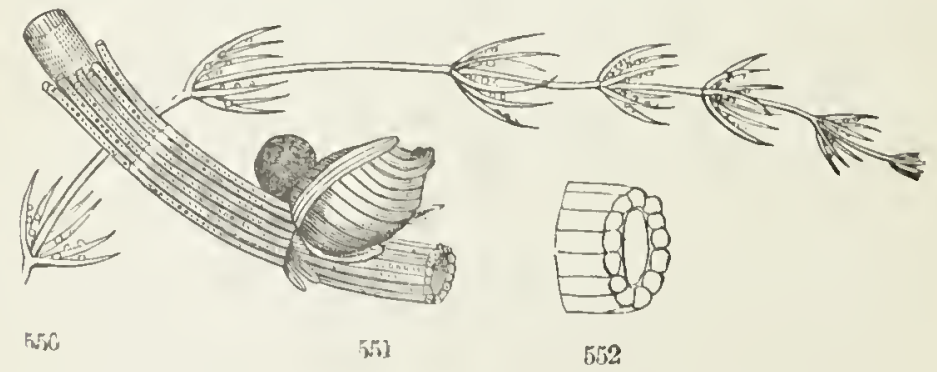

weeds, live in water, and live the same kind of life as do ordinary plants Fungi, whatever medium they inhabit, live as animals do, upon organie matter, - upon what other plants liave assimilated, or upon the products of

FIa. 545, 546. Two plants of Riccia natans, about uatural size. 547. Magnified section of a part of the fromd, showing two immcrsenl spore-cases, and one emptied space. 54. Magnified section of a sprore-case with sone spores. 549. Magnificd spore-case tom out, and sppores; one figure of the spores united; the other of the four scparatel.

FIa. 550. Branch of a Chara, about natural size. 551. A fruiting portion, magnified, showing the structure; a sporocn p, and an anthericlium. 552. Outlines of a portion of the stem in scction, showing the central cell and the outer or
cortical cells 
their decay. True as these general distinctions are, it is no less true that these orders run together in their lowest forms; and that Algæ and Fung: may be traced down into forms so low and simple that no clear line can he drawn between them; and even into forms of whieh it is uncertain whether they should be called plants or animals. It is as well to say that they are not high enough in rank to be distinctively either the one or: the other. On the other hand there is a peeuliar group of plants, which in simplicity of somposition resemble the simpler Algx, while in fructification and in the arrangements of their simple cells into stem and branches they seem to be of a higher order, viz. : -

506. Characeæ. These are aquatic herbs, of considerable size, abounding in ponds. The simpler kinds (Nitella) bave the stem formed of a single row of tubular cells, and at the nodes, or junction of the cells, a whorl of similar branches. Chara (Fig. 550-552) is the same, except that the cells which make up the stem and the prineipal brauches are strcngthened by a coating of many smaller tubular cells, applied to the surface

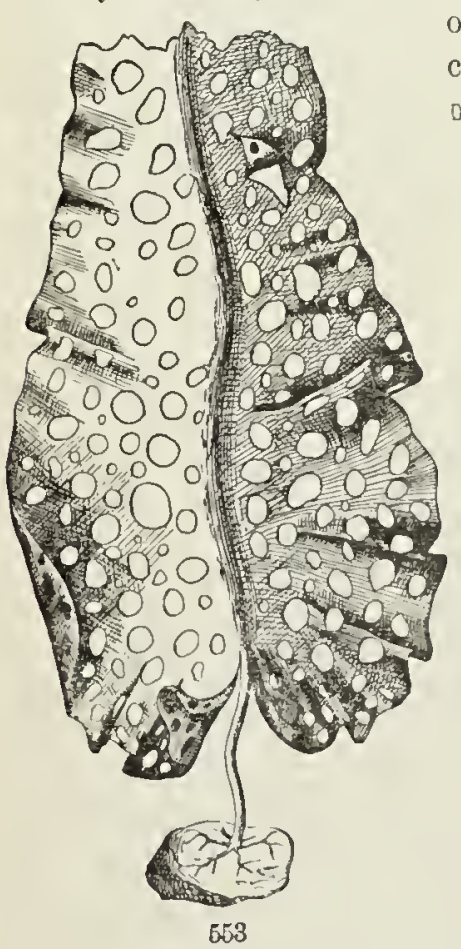
of the main or central cell. The fructif cation consists of a globular sporocarp of considerable size, which is spirally

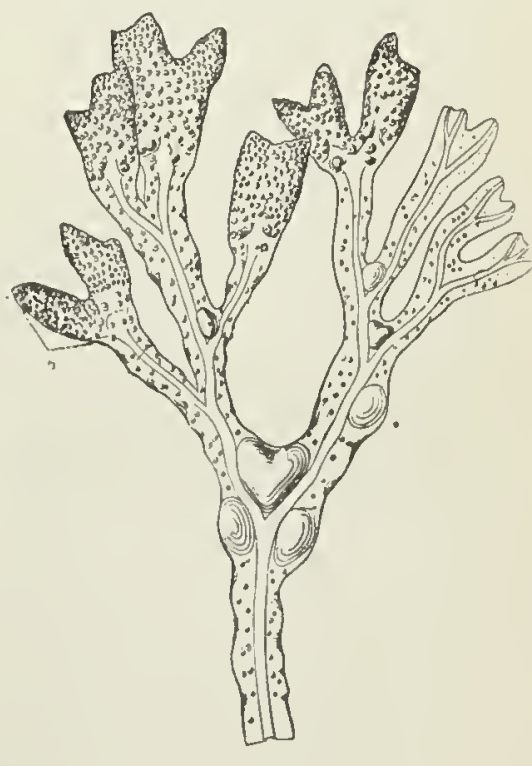

554

enwrapped by tubular cells twisted around it: by the sidc of this is a smaller and globular antheridium. The latter breaks up into eight shield-

FIa 553. Agarum Turneri, Sea Colancler (so callerl from the perforations with which the frond, as it grows, becomes riddled); very much reduced in size.

Fic. 554. Upper end of a Rockweed, Fucus vesiculosus, reduced half or more, $b$, the frustification. 
shaped preces, with an internal stalk, and bearing long and ribbon shaped filaments, which consist of a row of delicate cells, each of which discharges a free-moving microscopic thread (the analogue of the pollen or pollen-tube), nearly in the manner of Ferms and Mosses. One of these threads reaches and fertilizes a cell at the apex of the nucleus or solia body of the sporocarp. This subsequently germinates and forms a new individual.

507. Algæ or Seaweeds. The proper Seaweeds may be studied by the aid of Professor Farlow's "Marine Aigæ of New England;" the

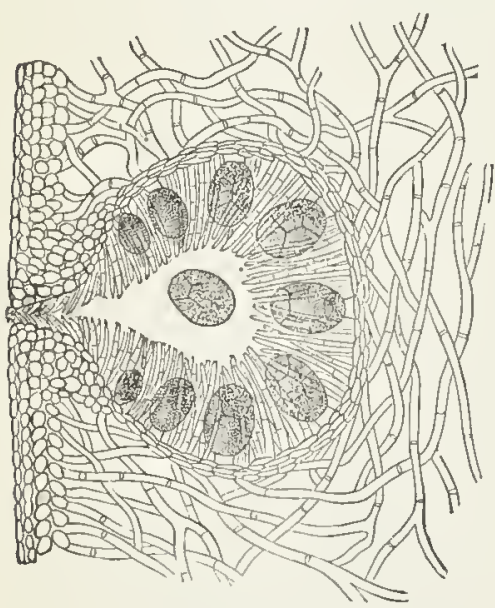

555

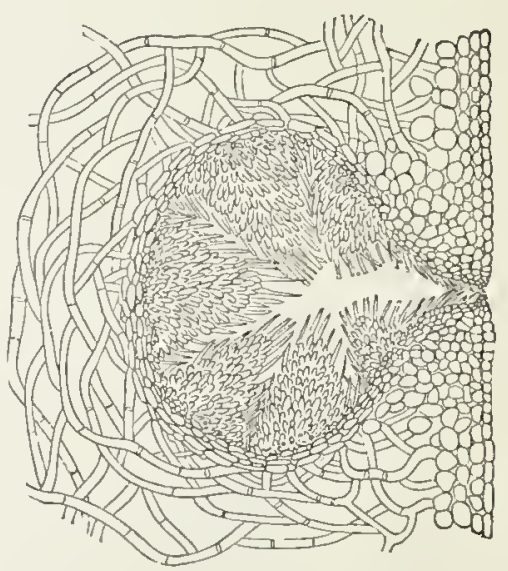

556

fresh-water species, by Prof. H. C. Woods's "Fresh-water Algæ of North America," a larger and less accessible volume. A few common forms are here very briefly mentioned and illustrated, to give an idea of the family. But they are of almost endless diversity.

508. The common Rockweed (Fucus vesiculosus, Fig. 554, abounding between high and low water mark on the coast), the rarer Sea Colander (Agarum Turneri, Fig. 553), and Laminaria, of which the larger forms are called Devil's A prons, are good representatives of the olive green or brownish Seaweeds. They are attached either by a lisk-like base or by root-like holdfasts to the rocks or stones on whieh they grow.

509. The hollow and inflated places in the Fucus vesiculosus or Rockweed (Fig. 554) arc air-bladder's for buoyaney. The fructification forms in the substance of the tips of the frond: the rough dots mark the places where the conceptacles open. The spores and the fertilizing cells are in different plants. Sections of the two kinds of conceptacles are giren in Fig. 555 and 556 . The contents of the conceptacles are discharged through

FIG. 555. Magnified section through a fertile conceptacle of Rockweed, showing the large spores in the midst of threals of cells. 556. Similar section of a sterile conceptacle, contuining slender antheridia, From Farlow's "Marine Alræ of Ner England." 
a small orifice which in cach figure is at the margin of the page. The large spores are formed eight together in a mother-eell. The minute motile filaments of the anthericlia fertilize the large spores after injection into the water : and then the latter promptly acquire a cell-wall and germinate.

510. The Floridex or Rose-red series of marine Algæ (whieh, however, are sometimes green or brownish) are the most attrietive to amateurs. The delieate Porphyra or Laver is in some countries eaten as a delicacy, and

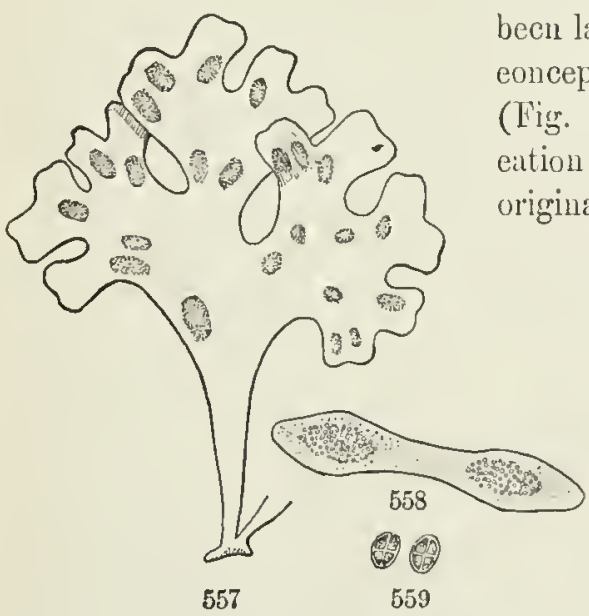
the cartilaginous Chondrus crispus has becn largely used for jelly. Besides their eonceptacles, whiels contain true spores (Fig. 560), they mostly have a fructifieation in Tetraspores, that is, of spores originating in fours (Fig. 559).

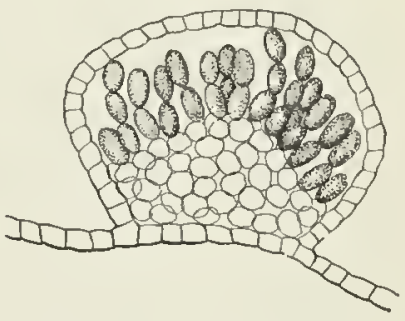

560

511. The Grass.rrreen Algre sometimes form broad membranous fronds, such as those of the common Ulva of the sea-shore, but most of them form
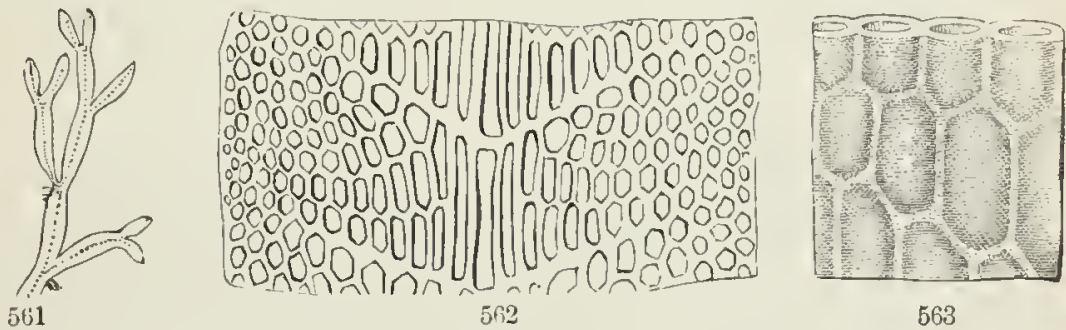

mere threads, either simple or branched. To this division belong almost

FIG. 557. Small plant of Chondrus erispns, or Carrageen Moss, reduced in size, in fruit; the spots represent the fructification, consisting of numerous tetraspores in bunches in the substance of the plant. 558. Section through the thickness of one of the lobes, magnified, passing through two of the imbedded fruit-clusters. 559. Two of its tetraspores (spores in fours), highly magnilied.

Fig. 560. Section throngh a conceptucle of Delesseria Leprieurei, mnch magnifierl, showing the spores, which are single specialized cells, two or three in a row.

Fig. 561. A piece of the rose-rerl Delesseria I epreinrei, double natural size. 562. A piecc cut out and much magnifierl, showing that it is coniposel of a laycr of cells. 563. A few of the cells morc highly magnified: the cells are gelatinous and thick-walled. 
all the Fresh-water Algæ, such as those which constitute the silky threads or green slime of rmming streams or standing pools, and which were all called Confervas bcfore their immense diversity was known. Some are formed of a single row of cells, developed each from the end of another. Others branch, the top of one cell prodncing more than one new one

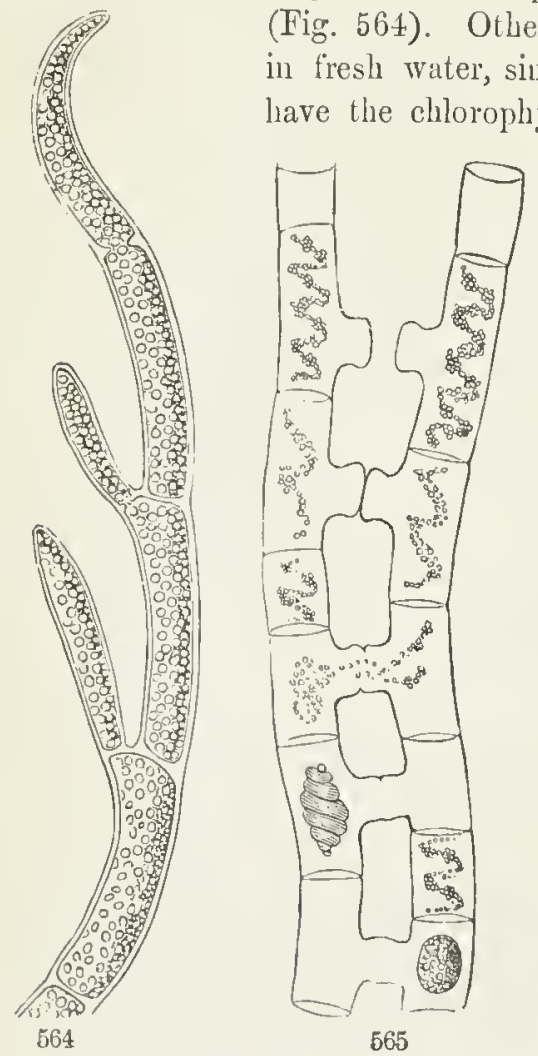

(Fig. 564). Others, of a kind which is very common in tresh water, simple tlireads made of a line of cells, liave the chlorophyll and protoplasm of each ccll arranged in spiral lines or bands.
They form spores in a peculiar
way, which gives to this family the designation of conjugating Algæ.

512. At a certain time two parallel threads approach each other more closely; contiguons parts of

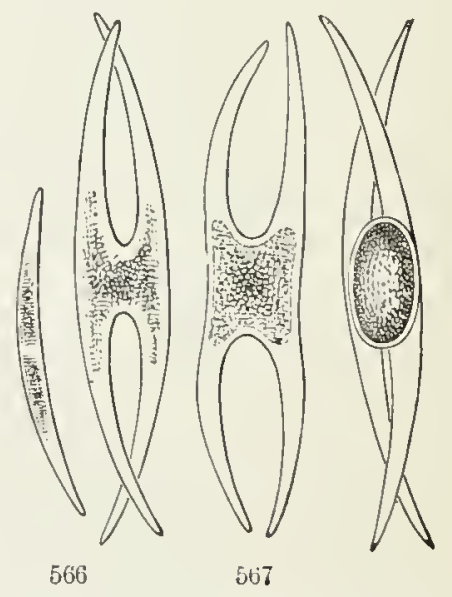

a cell of each thread bulge or grow out, and unite when they meet; the cell-wall partitions between them are absorbed so as to open a free communication; the spiral band of green matter in both cells breaks up; the whole of that of one cell passes over into the other; and of the united contents a large green spore is formed. Soon the old cells decay, and the spore

FIG. 564. The growing cnd of a braneling Conferva (Cladophora glomerata), mueh magnifierl; showing how, by a kind of budding growtl, a new cell is formed by a cross partition separating the newer tip from the older part below; also, how the branches arise.

FIG. 565. Two magnified individuals of a Spirogyra, forming spores by conjugation; a completel spore at base: alove, successive stages of the eonjugation are represented.

FIG. 566. Closterium acutum, a enmmon Desmid, moderately magnified. It is a single firm-walled cell, filled with green protoplasmic matter.

FIg. 567. More magnified view of three stages of the conjugation of a pair of the same. 
set free is ready to germinate. Fig. 565 represents several stages of the conjugating process, which, however, would never be found all together like this in one pair of threads.

513. Desmids and Diatomes, which are microscopic one-celled plauts of the same class, conjugate in the same way, as is slown in a Closterium by Fig. 566, 567. Here the whole living contents of two individuals are incorporated into one spore, for a fresk start. A reproduction which costs the life of two individuals to make a single new one would be fatal to the species if there were not a provision for multiplication by the prompt division of the new-formed individual into two, and these again into two, and so on in geometrical ratio. And the costly process would be meaningless if there were not some real advantage in such a fresh start, that is, in sexes.
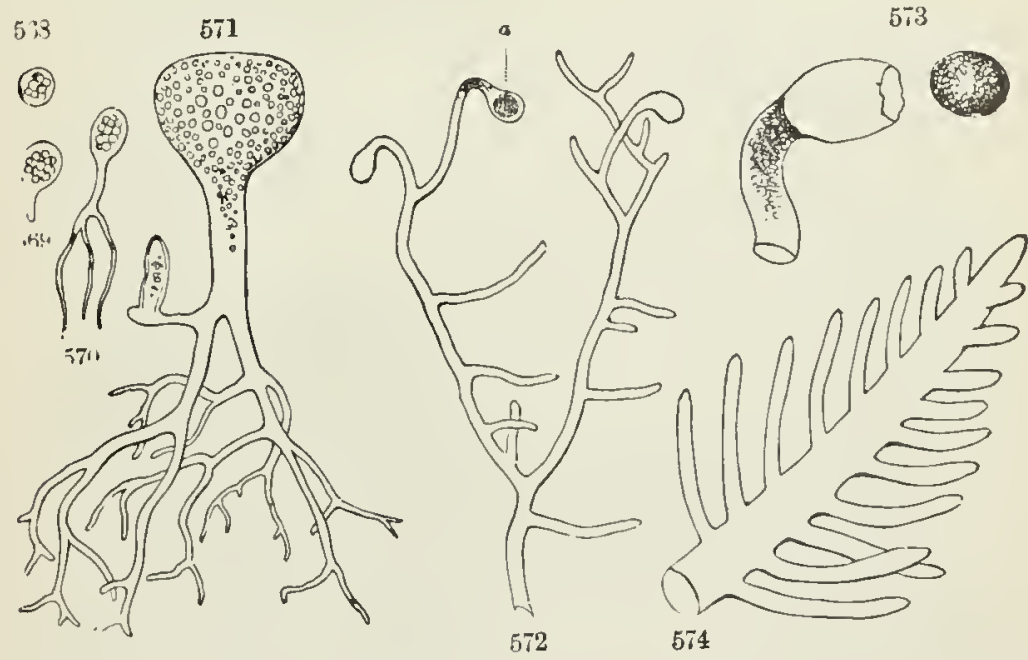

514. There are other Algæ of the grass-green series which consist of singlc cells, but which by continued growth form plants of considerable size. Three kinds of these are represented in Fig. 568-574.

515. Lichens, Latin Lichenes, are to be studied in the works of the late Professor Tuckerman, but a popular exposition is greatly necded. The subjoined illustrations (Fig. 575-580) may simply indicate what some of the commoner forms are like. The cup, or shicld-shaped spot, or knob, which bears the fructification is named the Apothecium. This is nainly

FIG. 568. Early stage of a species of Botrydium, a globose cell. 569, 570. Stages of growth. 571. Full-grown plant, extended and ramified below in a root-like way. 572. A Vancheria; single cell grown on into a much-branched thread; the end of some branches enlarging, and the green contents in one (11) there condensed into a spore. 573. More magnified view of $a$, and the mature spore escaping. 574. Bryopsis plumosa; apex of a stem with its branchlets; all the extension of one cell. Variously maguified. 
composed of slender sacs ( $A s c i$ ), haring thread-shaped cells intermixed; and each ascus contains few or several spores, which are commonly double or trcble. Most Lichens are flat expansions of grayish huc; some of them foliaceous in texture, but never of bright green color; more are crustaceous; some are wholly pulverulent and nearly formless. But in several the vegetation lengthens into an axis (as in Fig. 580), or imitates stem

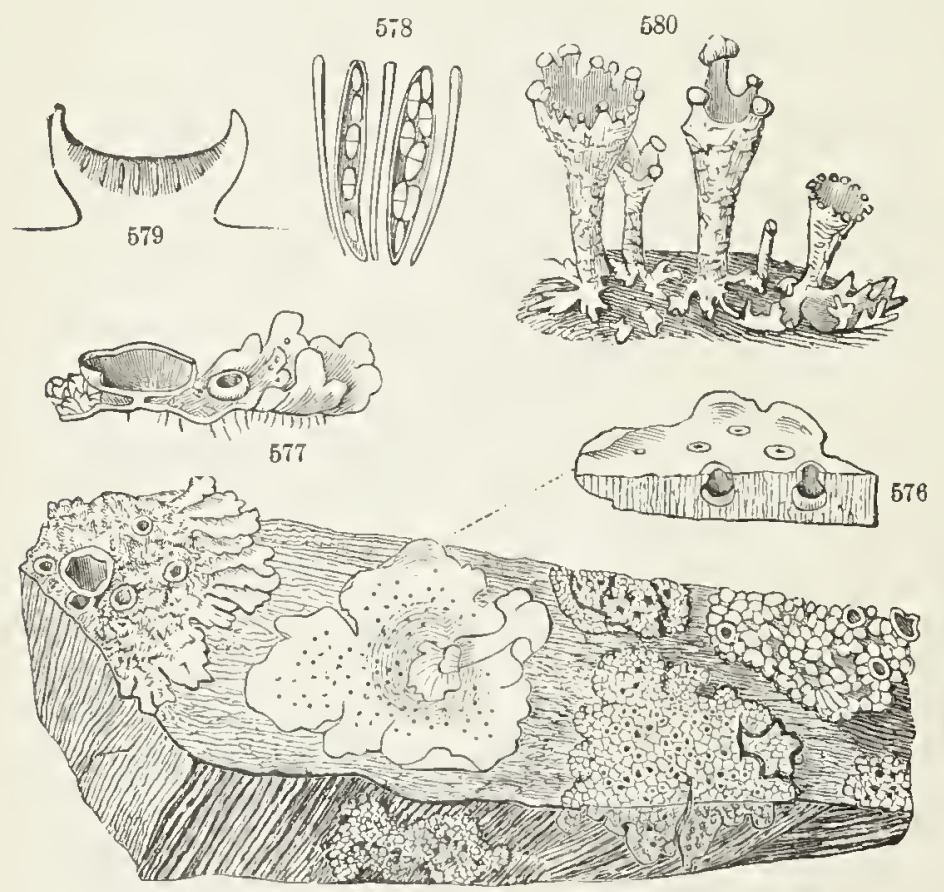

575

and branches or threads, as in the Reindeer-Moss on the ground in our northern woods, and the Usnea hanging from the boughs of old trees overhead.

516. Fungi. Tor this immense and grcatly diversilied class, it must here suffice to indicate the parts of a Mushroom, a Sphria, and of one or two common Moulds. The true vegetation of common Fungi consists of slcnder cells which form what is called a Mycelium. These filamentous

FIG. 575. A stone on which rarions Lichens are growing, such as (passing from left to riglit) a Parmelia, a Sticta, and nn the right, Lecilia geograplrica, so called from its patches resemluling the nutline of islands or continents as depicted upon maps. 576. Piece of thallus of Parmelia conspersa, with section through an apothecium. 577. Section of a smaller apothecion, enlargerl. 578. Two ase of same, and contained spores, and accompanying filanents; more magnified. 579. Piece of thallus of a Sticta, with section, showing the immersed apothecia; the small openings of these lot the surface. 580. Cladonia coccinea; the fructi. fication is in the scarlet lnobs, which surround the cups. 
cells lengthen and branch, growing by the absorption through their whole surface of the decaying, or organizable, or living matter which they feed upon. In a Mushroom (Agaricus), a knobby mass is at length formed, which develops into a stout stalk (Stipe), bearing the cap (Pileus): the under side of the cap is covered by the Hymenium, in this genus consisting of radiating plates, the gills or Lamelle; aud these bear the powdery spores in immense numbers. Under the microscope, the gills are found to be studded with projecting cells, each of which, at the top, produces four stalked spores. These form the powder which collects on a sheet of paper upon which a mature Mushroom is allowed to rest for a day or two. (Fig. 581-586.)

517. The esculent Morel, also Sphæria (Fig. 585, 586), and many other Fungi bear their spores in sacs (asci) exactly in the manner of Licbens (515)

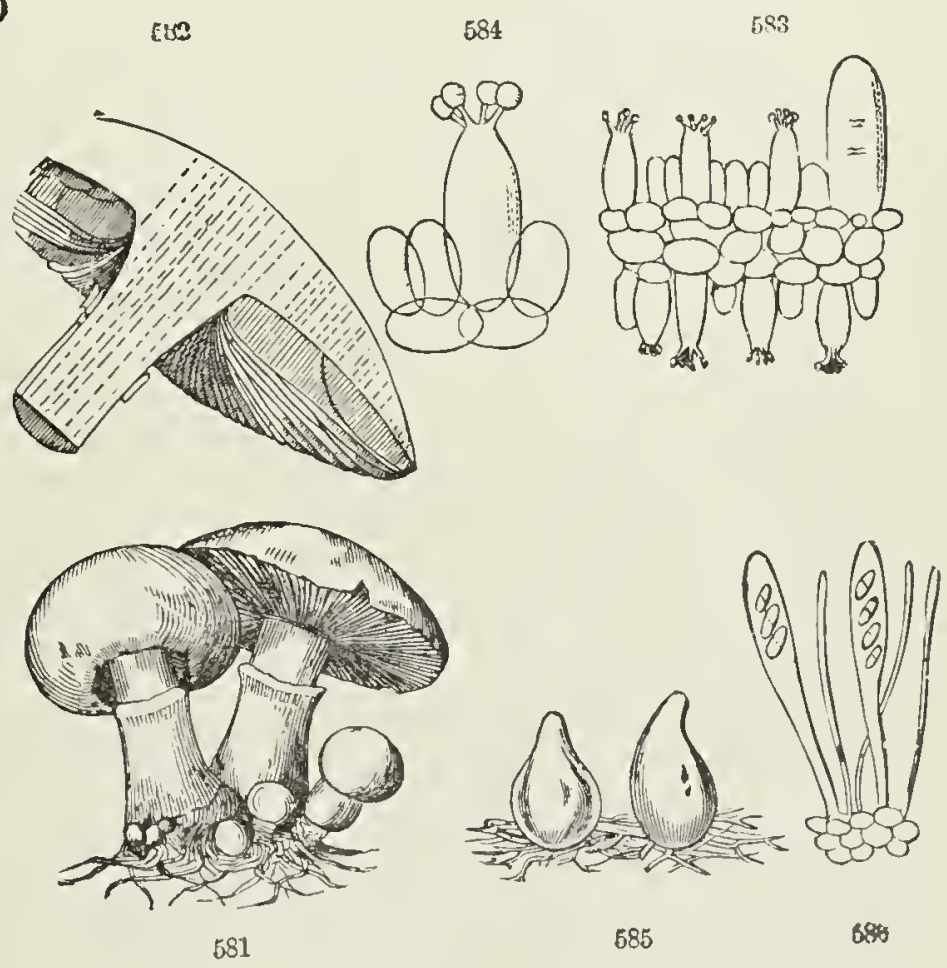

518. Of the Moulds, one of the commoner is the Bread Mould (Fig. 587). In fruiting it sends up a slender stalk, which bears a globular sac;

FIG. 581. Agaricus campestris, the common edible Mushroom. 582. Section of cap and stalk. 583. Minute portion of a section of a gill, showing some sporehearing cells, much magnified. 584. One of these, with its four spores, more magnified.

FIG. 585. Sphæria roselli. 586. Two of the asci and contained donble spores, auite like those of a Lichen; much magnified. 
this bursts at maturity and discharges innumerable spores. The blue Cheese-Mould (Fig. 588) bears a cluster of branches at top, each of which is a row of naked spores, like a string of beads, all breaking apart

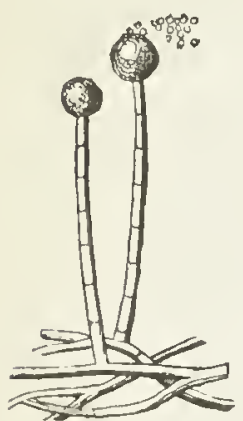

587

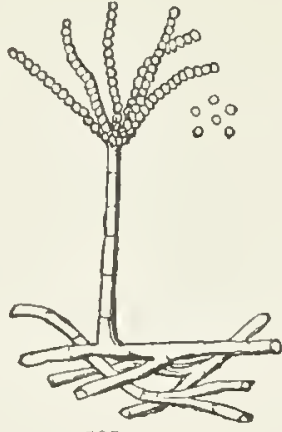

588

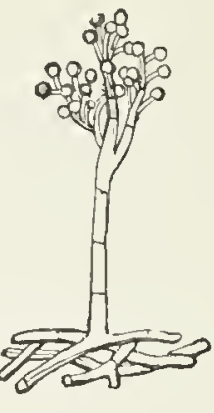

589 at matnrity. Botrytis (Fig. 589), the fruiting stalk of which branches, and cach branch is tipped with a spore, is one of the many moulds which live and feed upon the jnices of other plants or of animals, and are often very destructive. The extremely numerous kinds of smnt, mst, mildew, the ferments, bacteria, and the like, many of them very destrnctive to other vegetable and to animal life, are also low forms of the class of Fuugi. ${ }^{1}$

FIG. 587. Ascophora, the Bread-Monld. 588. Aspergillus glancus, the mould of cheese, but common on mouldy vegetables. 589. A species of Botrytis. All magnified.

1 The "Introduction to Cryptogamous Botany," or third volume of "The Botanical Text Book," now in preparation by the author's colleague, Professor Farlow, will be the proper guile in the esudy of the Mowerless Plents, espanially of the Algæ and F'vnæi 


\section{SECTION XVIII. CLASSIFICATION AND NOMENCLATURE.}

519. Classifieation, in botany, is the eonsideration of plants in respeet to their kinds and relationships. Some system of Nomenelature, or naming, is neeessary for fixing and expressing botanieal knowledge so as to make it available. The vast multiplieity of plants and the vinious degrees of their relationship imperatively require order and system, not only as to names for designating the kinds of plants, but also as to terms for defining their differenees. Nomenelature is eoneerned with the names of plants. Terminology supplies names of organs or parts, and terms to designate their differenees.

\section{§ 1. KINDS AND RELATIONSHIP.}

520. Plants and animals have two great peeuliarities: 1st, they form themselves; and $2 \mathrm{~d}$, they multiply themselves. They reproduce their kind in a continued suceession of

521. Individuals. Mineral things oeeur as masses, which are divisible into smaller and still smaller ones without alteration of properties. But organie things (vegetables and animals) exist as individual beings. Each owes its existenee to a parent, and produees similar individuals in its turn. So each individual is a link of a ehain; and to this chain the naturalhistorian applies the name of

522. Species. All the deseendants from the same stock therefore eompose one speeies. And it was from our observing that the several sorts of plants or animals stendily reproduee themselves, or, in otlıer words, keep up a sueecssion of similar individuals, that the idea of speeics originated. There are few speeies, however, in which man has actually observed the suceession for many generations. It could seldom be prover that all the White Pine trees or White Oaks of any forest eame from the same stock. But observation having familiarized us with the general fact that indivicluals proeceding from the same stoek are essentially alike, we infer from their elose resemblanee that these similar individuals belong to the same speeies. That is, we infer it when the individuals are as mneh like each other as those are which we know, or eonfidently suppose, to have sprung from the same stock.

523. Identity in speeies is inferred from elose similarity in all essential respeets, or whenever the differenees, however ensiderable, are not known or reasonably supposed to liave been originated in the eourse of time under elanged eonditions. No two individuals are exactly alike; a tendeney to variation pervades all living things. In eultivation, where variations are looked after and eared for, very striking differenees eome to light; and if in wild nature they are less eommon or less conspicuous, it is partly because they are uneared for. When such variant forms are pretty well marked they are ealled 
524. Varieties. The White Oak, for example, presents two or three varicties in the shape of the leaves, although they may be all alike upo!ı each partieular tree. The qurstion often arises, and it is often liard to answcr, whether the difference iu a particular ease is that of a variety, or is speeifie. If the former, it may eommonly be proved by finding sueh intermediate degrees of differenee in various individuals as to show that no elear distinetion can be drawn between them; or clse by observing the variety to vary back again in some of its offspring. The sorts of Apples, Pears, Potatoes, and the like, show that differences whieh are permanent in the individual, and eontinue unehanged through a long series of generations when propagated by division (as by ollsets, euttings, grafts, bulbs, tubers, ete.), alre not likely to be reproduecd by seed. Still they sometimes are so, and perhaps always tend in that direetion. For the fundamental law in organie nature is that offspring shall be like parent.

Races are such strongly marked varieties, eapable of coming true to seed. The different solts of Wheat, Maize, Peas, Radishes, ete, are familiar examples. By seleetimg those individuals of a speeies whieh have developed or inlserited any desirable peeuliarity, kecping them from mingling with their less promising brethen, and sclecting again the most pronising plants raised from their seeds, the eultivator may in a few generations render ahnost any variety transmissible by seed, so loug as it is cared for and kept apart. In finet, this is the way the eultivated domestieated races, so useful to mau, hare been fixed and preserved. Raees, in faet, ean lardly, if at all, be said to exist independently of man. But man does not really produce them. Such peculiarities--often surprising enough - now and then originate, we know not low (the plant sports, as the gardeners say); they are only preserved, propagated, and generally further developed, by the eultivator's skilful eare. If left alone, they are likely to dwindle and perish, or else revert to the original form of the speeies. Vegetable races are eonmonly anumals, which ean be kept up only by seed, or herbs of which a suceession of gencrations ean be had erery year or two, and so the education by selcetion be eompleted without great lapse of time. But all fruit-trees eould probably be fixed into raees in an equal number of generations.

BUD-VARIETIEs are those which spring from buds instead of sced. They are uneommon to any marked extent. They are sometimes ealled Sports, but this name is equally applied to variations among seedlings.

Cross-BrezDs, strictly so-ealled, are the variations whieh eome from eross-fertilizing one varicty of a speeies witl anotlere.

Hrbrids are the varicties, if they may he so ealled, whieh eome from the erossing of species (331). Only neatly related species ean be hybridized; and the resulting puogeny is usually self-slerile, hut not always. ITybrid plants, however, nuy often be fertilized and male prolific by the pollen of one or the other parent. This produces anofher kind of eross-breeds.

525 Speeies are the units iu elassification Varieties, altuough of 
utmost importanee in eultivation and of considerable eonsequenee in the flora of any country, are of less botanieal signifienuce. For they are apt to be indefinite and to shade off onc form into another. But species, the botanist expects to be distinet. Indeed, the practieal difference to the botanist between speeies and varietics is the definite limitation of the one and the indefuniteness of the otleer. 'The botanist's determination is partly a matter of observation, partly of judgment.

526. In an enlarged view, varieties may be incipient species; and nearly related speeics probably eame from a common stock in earlier times. For there is cvery reason to believe that cxisting regetation eame from the more or less changed vegetation of a preceding geological cra. However that may be, speeies are regarded as permanent and essentially unchanged in their succession of individuals through the actual ages.

527. There are, at nearly the lowest computation, as many as one hundred thousand speeics of planerogamous plants, and the cryptogamous specics are tlought to be still more numerous. They are all connected by resemblances or relationships, near and remote, whieh show that they are all parts of one systcm, realizations in nature, as we may affirm, of the eonception of One Mind. As we survey them, they do not form a single and conneeted eliain, stretehing from the lowest to the highest organized species, ulthough there obviously are lower and higher grades. But the speeics throughout group themselves, as it were, into clusters or constellations, and these into still more comprehensive clusters, and so on, with gaps between. It is this clustering which is the gromend of the recognition of kinds of speeies, that is, of groups of species of successive grades or degree of gencrality; such as that of similar species into Genera, of genera into Families or Orders, of orders into Classes. In classification the sequence, proeceding from ligher or more gencral to lower or special, is always Class, Order, Gexes, Species, Variety (if need be).

528. Genera (in the singular, Genus) are assemblages of closely related species, in which the essential parts are all eonstructed on the same particular type or plan. White Oak, Red Oak, Searlet Oak, Live Oak, etc., are so many species of the Oak genus (Latin, Quercus). The Chestnuts compose another geuns; the Bccelics another. The Apple, Pear, and Crab are species of one genus, the Quinec represents another, the various speeirs of IIawthom a third. In the animal kingdom the common eat, the wild-eat, the panther, the tiger, the leopard, and the lion are species of the cat kind or genus; while the dog, the jackal, the different species of wolf, and the foxes, compose another genus. Some gencra are represented by a rast number of species, others by few, very many by only onc known speeies. For the genus may be as perfeetly represented in one speeies as in several, althongh, if this were the case throughout, gencra and species would of eourse be identieal. The Beech genus and the Chestnut genus would be just as distinet from the Oak genus cren if but one Beeeh and one Chestnut were known: as indeed was once the case 
529. Orders are groups of genera that resemble eaeh other; that is, they are to genera what genera are to species. As familiar illustrations, the Oak, Chest:zut, and Beech genera, along with the Hazel genus and the Hornbeams, all belong to one order. The Birches and the Alders make another; the Poplars and Willows, another; the Walnuts (with the Buttermut) and the Hickories, still another. The Apple genus, the Quince and the Hawthorus, along with the Plums and Clieries and the Peacl, the Raspberry with the Blackberry, the Strawberry, the Rose, belong to a large order, whieh takes its name from the Rose. Most botanists use the names "Order" and "Family" synonymously; the latter more popularly, as "the Rose Family," the former more technically, as "Order Rosacea."

530. But when the two are distinguished, as is common in zoölogy, Fimily is of lower grade than Order.

531. Classes are still more comprehensive assemblages, or great groups. Thus, in modem botany, the Dicotyledonous pliuts compose one class, the Monoeotyledonous plants another (36-40).

532. These four grades, Class, Order, Genus, Species, are of universal use. Variety eomes in upon occasion. For, although a species may have no recognized varietics, a genus implies at least one specics belonging to it; cvery genus is of some order, and every order of some class.

533. But these grades by no means exhaust the resourees of clas. sifieation, nor suffiec for the elucidation of all the distinctions which botanists reeognize. In the first plaec, a ligher grade than that of eliss is needful for the most comprehensive of divisions, that of all plants into the two Series of Phanerogamous and Cryptogamous (6); and in natural history there are the two Kingdons or Realms, the Vegetable and the Animal.

534. Moreover, the stages of the scaffolding have been variously ex. tended, as required, by the reeognition of assemblages lower than class but lighler than order, viz. Subclass and Cohort; or lower than order, a Sub. order; or between this and genus, a Tribe; or between this and tribe, a Subtribe; or between genus and species, a Subgenus; and by some a species has been divided into Subspecies, and a rariety into Subvarieties. Last of all are Individuals. Suftice it to remember that the following are the principal grades in elassification, witl the proper sequenee; also that only those here printed in small capitals are fundamental and universal ill botany :-

SERIES,

Cuass, Subelass, Coliort,

Order, or Famri, Suborder, Tribe, Subtribe, Genus, Subgenus or Seetion, Species, Varicty. 


\section{§ 2. NAMES, TERMS, AND CHARACTERS.}

535. The name of a plant is the name of its genus followed by that of the specics. The name of the genus answers to the surmame (or family name); that of the specics to the baptismal name of a person. Thus Quercus is the name of the Oak genus; Quercus alba, that of the White Oak, Q. rubra, that of Red Oak, Q. nigra, that of the Black-Jack, cte. Botanical names being Latin or Latinized, the adjective name of the species comes aftcr that of the genus.

536. Names of Genera are of one word, a substantive. The older ones are mostly classical Latin, or Greek adopted into Latiu; sueh as Quercus for the Oak genus, Fagus for the Becel, Corylus, the Hazel, and the like. But as more genera became known, botanists had new names to make or borrow. Many are named from some appearance or property of the flowers, lcaves, or other parts of the plint. 'To take a few cxamples from the carly pages of the "Manual of the Botany of the Northern United States," - the genus Hepatica comes from the shape of the leaf, resembling that of the liver. Nyosurus means mousc-tail. Delphinium is from delphin, a dolphin, and alludes to the sliape of the flower, which was thought to resemble the classical figures of the dolphin. Ianthorhiza is from two Greck words meaning yelluw-root, the common name of the plant. Cimirifuga is formed of two Latiu words meaning to drive away bugs, i. e. Bugbane, the Siberian species being nsed to keep away such rermin. Sanguinaria, the Bloodroot, is named from the blood-like color of its juice. Other genera are dedicalcd to distinguished botanists or promoters of scienee, and bear their names: such are Magnoliu, which commemorates the early French botanist, Mingnol; and Jeffersonia, named after President Jefferson, who sent the first cxploring expedition over the Rocky Mountains. Others bear the name of the discoverer of the plant; as, Surracenia, dedicated to Dr. Sarrazin, of Quebec, who was one of the first to send the common Pitcher-plant to the botanists of Europe; and Claytonia, first made known by the early Virginian botanist Clayton.

537. Names of Species. The name of a species is also a single word, apponded to that of the genus. It is comnonly an adjective, and therefore agrees with the generic name in case, gender, etc. Sometimes it relates to the country the species iulabits; as, Claytonia Virginica, first made known from Virginia; Sanguinaria Canadensis, from Canada, etc. Nore commonly it denotes some obvious or characteristic trait of the species; as. for example, in Sarraeenia, our northern species is named purpurea, from the purple blossoms, while a more southern one is named fora, beenuse its petals arc ycllow; the species of Jeffersonia is called diphylla, meaning two-leaved, because its leaf is divided into two leaflets. Some speeies are named after the discoverer, or in compliment to a botanist who has made them known: as. Magnolia Fraseri, named after the botanist Fraser, one 
of the first to find this speeies; and Sarracenia Drummondii, for a Piteherplant found by Mr. Drummond in Florida. Suelı personal speeific names are of course written with a eapital initial letter. Oeensionally some old substantive name is used for the species; as Magnolia Umbrella, the Umbrella tree, and Ranunculus Flummula. These are also written with a eapital initial, and need not aecord with the generie name in gender. Geographieal speeifie names, such as Cunadensis, Caroliniuna, Americana, in the later usage are by some written without a eapital initial, but the older usage is better, or at least more aecordant with English orthography.

538. Varietal Names, when any are required, are made on the plan of speeifie names, and follow these, with the prefix vur. Ranumeulus Flammula, var. reptans, the erecping variety: R. abortirus, var. micranthus, the small-flowered variety of the speeies.

539. In recording the name of a plant it is usual to append the name, or an abbreviation of the name, of the botanist who first published it; and in a flora or other systematic work, this reference to the souree of the name is eompleted by a further eitation of the name of the book, the volume and page where it was first published. So "Ranunculus acris, L.," means that this Buttereup was hirst so named and deseribed by Linnæus; "R. mullifidus, Pursh," that this speeies was so named and pub. lished by Pursh. 'The suffix is no part of the nane, but is an abbreviated referenee, to be added or omitted as eonvenienee or definiteness may require. The authority for a generie name is similarly reeorded. Thus, "Ramencultes, L.," means that the genus was so named by Limncus; "Myosurus, Dill.," that the Mouse-tail was established as a genus under this name by Dillenius; Caulophyllum, Mielix., that the Blue Cohosh was published under this name by Miehaux. The full reference in the lastnamed instanee would be, "in Flora Boreali-1merieana, first volume, 205 th page," - in the eustomay abbreviation, "Miehx. Fl. i. 205."

540. Names of Orders are given in the plural number, and are com. monly formed by prolonging the nume of a genus of the group taken as a representative of it. For example, the order of whieh the Butterenp or Crowfoot genus, Ranunculus, is the representative, takes from it the name of Ranunculacere; meaning Plante Ranunculacee when written out in full, that is, Rinuneulaceous Plants. Some old deseriptire names of orders are kept up, sueh as Crucifere for the order to whieh Cress and Mustard beloug, from the erueiform appearanee of their expanded eorolla, and Umbellifere, from the flowers being in umbels.

541. Names of Tribes, also of suborder's, subtribes, and the like, are plurals of the name of the typieal genus, less prolonged, usually in ee, nece, idece, ete. Thus the proper Buttereup tribe is Ranunculea, of the Clematis tribe, Clemalidece. While the Rose fanily is Rosacee, the special Rose tribe is Rosere.

542. Names of Classes, etc. For these see the following synopsis $n^{i}$ the aetual elassifieation adopted, p. 183. 
543. So a plant is named in two words, the generic and the specific names, to which may be added a third, that of the variety, upon occasion. The generic name is peculiar: obviously it must not be used twice over in botany. The speeifie name must not be used twice over in the same genus, but is free for any other genus. A Quescus alba, or Whitc Oak, is no hindranee to Betula alba, or White Bireh; and so of other names.

544. Characters and Descriptions. Plunts are characterized by a terse statement, in botanieal terms, of their peculiarities or distinguishing marks. The charicter of the order should include nothing whieh is common to the whole class it belongs to; that of the grenus, notling which is eommon to the order; that of the species nothing which is shared with all other species of the genus; and so of other divisions. Descriptions may enter into complete details of the whole strueture.

545. Terminology, also called Glossoloyy, is nomenclature applied to organs or parts, and their forms or moditications. Each orgm or special part has a substantive name of its own: shapes and ollher modifications of an organ or part are designated by adjective terms, or, when the forms are peculiar, substantive names are given to then. By the correct use of sueh botanieal terms, and by proper suhordination of the characters under the order, genus, species, etc., plants may be described and determined with mueh preeision. The classieal lunguage of botany is Latin. While modern langnages have their own names and terms, these usually laek the precision of the Latin or Latinized botanical terminology. For. tunately, tlis Latinized terminology has been largely adopted and ineorporated into the English technieal language of botany, thus securing precision. And these terms are largety the basis of specific names of plauts.

546. A glossary or vocabulary of the prineipal botanical terms used in phanerogamous and vaseular cryptogamous botany is appended to this volume, to whieh the student may refer, as occasion arises.

\section{§3. SYSTEM.}

547. Two systems of classification used to be recognized in botany, - the artificial and the natural; but only the latter is now thought to deserve the name of il systeml.

51.9. Artifieial elassificatious have for object merely the asecrtaining of the name and place of a plant. They do not attempt to cxpress relationships, but serve as a kind of dietionary. They distribute the genera and species according to some one peculiarity or set of peculiarities (just as a dietionary distributes words acenrding to their first letters), disregrarding all other considerations. At present an artificial classification in botany is needed only as a key to the natural orters, - as an aid in referring an unknown plant to its proper family; and such kcys are still very needful, at least for the beginner. Former] not clearly madc out, an artifieial classification was required to lead the 
student down to the genus. Two sueh elassifieations were long in rogue: -First, that of Tournefort, founded mainly on the leaves of the flower, the calyx and eorolla: this was the prevalent system throughout the first half of the eighteenth eentury; but it las long since gone by. It was sueceeded by the well-known

549. Artificial System of Linnæus, which was founded on the stamens and pistils. It eonsists of twenty-four elasses, and of a variable number of orders; the elasses founded mainly on the number and disposition of the stamens; the orders partly upon the number of styles or stigmas, partly upon other considerations. Useful and popular as this system was down to a time within the memory of still surviving botanists, it is now eompletely obsolete. But the tradition of it survires in the names of its elasses, Monandria, Diandria, Triandria, ete., whicls are familiar in terminology in the adjeetive terms monandrous, diandrous, triandrous, ete. (2S4); also of the orders, Monogynia, Digynia, Trigynia, ete., preserved in the form of monogynous, digynous, trigynous, etc. (301); and in the name Crgptogamia, that of the 24 th elass, which is eontinued for the lower series in the natural elassification.

550. Natural System. A genuine system of botany consists of the order's or familics, duly arranged under their elasses, and having the tribes, the genera, and the species arranged in them aceording to their relationships. This, when properly carried out, is the Natural System; beeause it is intended to express, as well as possible, the various degrees of relationship among plants, as presented in nature; that is, to rank those speeies and those genera, cte., next to eaeh other in the elassifieation whieh are really most alike in all respects, or, in other words, which are eonstrueted most nearly on the same partieular plan.

551 . There ean be only one natural system of botany, if by this term is meant the plan aceording to which the vegetable ereation was ealled into being, with all its grades and diversities among the speeies, as well of past as of the present time. But there may be many natıral systems, if we mean the attempts of men to interpret and express that plan, - systems which will vary with advaneing knowledge, and with the jndgment and skill of diflerent botanists. These must all be rery imperfeet, bear the impress of individual minds, and be shaped by the enrrent philosophy of the age. But the endeavor always is to make the elassifieation answer to Nature, as far as any system ean which has to be expressed in a definite and serial arrangement.

552. So, although the classes, orders, genera, ete., are natural, or as natural as the systemiatist ean make them, their grouping or order of arrangement in a book, must necessarily be in great measure artificial. Indeed, it is quite impossible to arrange the orders, or even the few elasses, in il single series, and yet lave each group stand next to its nearest relatives onl botlı sides.

553. Especially it should be understood that, although phanerogamous 
plants are of higher grade than cryptogamous, and angiospermous or or. dinary phanerogamous higher than the gymnospermous, yet there is no. culmination in the vegetable kingdom, nor any highest or lowest order of phanerogamous plants.

554. The particular system most largely used at present in the classification of the orders is essentially the following:-

Series I. Phanerogamia: Phaneroganous or Flowering Plants.

Class I. DICOTYLEDONES ANGIOSPERMEA, called for shortness in English, Dicotyledons or Dicotyls. Ovules in a closed ovary, Embryo dicotyledonous. Stem with exogenous plan of growth. Leaves reticulate-veined,

Artificial Division I. Polypetale, with petals mostly present and distinct. Orders about 80 in number, Ranunculacere to Cornacece.

Artificial Division II. Gayopetale, with gamopetalous corolla. Orders about 45, Caprifolitceee to Plantaginacece.

Artificial Division III. Apetale or Incomplete, with perianth, when present, of calyx ouly. Orders about 35 in number, from Nyctaginacece to Salicacea.

Cuass II. DICOTYLEDONES GYMNOSPERMEe, in English GryxOSPERMS. No ovary or pericarp, but ovules and seeds naked, and no proper calyx nor corolla. Embryo dicotyledonous or polycotyledonous. Stem with exogenous plan of growth. Leaves mostly parallel-veined. Consists of order Gnetacee, which strictly connects with Angiospermous Dicotyls, of Conifere, and of Cycadacee.

Class III. MONOCOTYLEDONES, in English Moxocotyledons or Monocotyls. Angiospermous. Embryo monocotyledonous. Stem with endogenous plan of growtl. Leares mostly parallel-veiued.

Division I. Petaloides. Perianth complete, laving the equivalent of both calyx and corolla, and all the inner series corolline. About 18 orders.

Division II. CaLYCINex. Perianth complete (in two series) but not corolline, mostly thickish or glumaceous. Chiefly two orders, Juncacee, the true Rushes, and Palme, Palms.

Division III. Spadicirlore or Nudiflora. Perianth none, or rudimentary and incomplete: inflorescence spadiceous. Of five orders, Typhacee and Aroidece the principal.

Division $I V$. Guunacez. Periantls none, or very rudimentary : glumaceous bracts to the flowers. Orders mainly Cyperacea and Graninece.

Series II. Cryptogamia: Cryptogalous or Flowerless Plants

Class I. Pteridophyta, Pteridophytes (484).

Class II. BRYOPHYTA, Bryophytes (498).

Clase III. Thallophyta, Thallophites (503). 


\section{SECTION XIX. BOTANICAL WORK.}

555. Some hints and brief instruetions for the collection, examination, and preservation of specimens are added. They are especially intended for the assistance of those who have not the advantage of a teacher. They apply to phanerogamous plants and Ferns only, and to systematic botany. ${ }^{i}$

\section{§1. COLLECTION, OR HERBORIZATION.}

556. As mueh as possible, plants should be examined in the living state, or when freshly gathered. But dried specimens should be prepared for more leisurely examination and for comparison. To the working botanist good dried specimens are indispensable.

557. Botanical Specimens, to be complete, should have root or root. stoek, stem, leaves, flowers, both open and in bud, and fruit. Sometimes tinese may all be obtained at one gathering; more commonly two or three gatherings at different times are requisite, especially for trees and shrubs.

558. In Herborizing, a good knife and a narrow and strong trowel are needed; but a very strong knife will serve instead of a trowel or small piek for digging out bulbs, tubers, and the like. To carry the specimens, either the tin box (vasculume) or a portfolio, or both are required. The tin box is best for the collection of specimens to be used fresll, as in the elass-room; also for very thick or fleshy plants. The portfolio is indispensable for long expeditions, and is best for specimens which are to be preserved in the herbarium.

559. The Vasculum, or Botanical Collecting-box, is made of tin, in shape like a candle-box, only flatter, or the smaller sizes like an English sandwichcase; the lid opening for nearly the whole length of one side of the box. Any portable tin box of eonvenient size, and capable of holding specimens a foot or fifteen inehes long, will answer the purpose. The box should slut close, so that the specimens may not wilt : then it will keep leafy branches and inost flowers perfectly fresh for a day or two, especially if slightly moistencd. They should not be wet.

560. The Portfolio is best made of two pieces of solid binder's-board, covered with enamel cloth, which also forms the back, and fastencd by straps and buckles. It may be from a foot to twenty inelies long, from nine to eleven or twelve inches wille. It should contain a needful quantity of smooth but strong and pliable paper (thin so-ealled Manilla paper is best), cither fastened at, the back as in a book, or lonse in folued sheets when not very many specimens are required. As soon as gathered, the specimens should be scparately laid between the leaves or in the foldcd sheets, and kept under moderate pressure in the elosed portfolio. 374.

1 For fuller directions in many particulars, see "Structural Botany," pp. 370 . 
561. Of small herbs, especially annuals, the whole plant, root and all, should be taken for a specimen. Of larger ones branelies will suffice, with some leaves from near the root. Enough of the ront or subterranean part of the plant should be collected to show whether it is an annual, a biennial, or a perenuial. Thiek roots, bulbs, tubers, or branches of speeimens intended to be pressed slould be thimned with a knife, or cut into sliees. Keep the specimens within the lengtl of filteen or sixteen inches, by folding, or when that eannot be done, by eutting into lengths.

562. For Drying Specimens a good supply of soft and unsized paper is wanted; and some convenient neans of applying considerable pressure. To make good dried botanical specimens, dry them as rapidly as possible between many thicknesses of sun-dried paper to absorb their moisture, under as mueh pressure as erm be given without erushing the more delieate parts. This pressure may be had by a botanical press, of which various forms have been eontrived; or by weights placed upon a board, - from forty to eighty or a hundred pounds, according to the quantity of specimens drying at the time. For use while travelling, a good portable press may be made of thiek binders' boards for the sides, and the pressure may be applied by strong straps with buekles. Still better, on some aecounts, are portable presses made of wire network, which allow the dampness to eseape by evaporation between the meshes. For herborization in a small way, a light wire-press may be taken into the field and made to serve also as a portfolio.

563. It is well to lave two kinds of paper, namely, driers of bibulous paper, stitched into pads (or the pads may be of thick earpet-paper, cut to size) and thin smooth paper, folded once; the speeimens to be laid into the fold, either when gathered or on returning from the excursion. These sheets are to loold the speeimens until they are quite dig. Every day, c: at first even twiee a day, the specimens, left undisturbed in their sheets, are to be shilted into fire-dried or sun-dried fresh driers, and the pressure renewed, while the moist sheets are spread out to dry, so as to take their turn again at the next shilting. This course must be eontinued until the specimens are no longer moist to the touch. Good and comely specimens are either made or spoiled within the first trenty-four or thirty-six lours. After that, when plenty of driers are uscd, it may not be necessary to cliange tliem so frequently.

564. Succulent plants, which long refuse to part with life and moisture, and Spruces and some other evergreens which are apt to east off their leares, may be plunged for a moment into boiling water, all but the flowers. Dulicate flowers may be eneased in thin tissue paper when put into the press. Thick parts, like the heads of Sun-flowers and Thistles, may be eut in two or into slices.

565. Dried spccimens may be packed in bundles, either in folded paper or upon single half-sheets. It is better that sueh paper should not be bibulcus. The packages slould be well wrapped or kept in close eases. 
566. Poisoning is neeessary if speeimens are to be permanently pre served from the depredation of inseets. The usual applieation is an almost saturated solution of corrosive sublimate in 95 per eent aleohol, freely ap. plied with a large and soft brush, or the speeimens dipped into some of the solution poured into a large and flat dish; the wetted speeimens to be transferred for a short time to driers.

\section{§ 2. HERBARIUM.}

567. The botanist's colleetion of dried specimens, tieketed with their names, place, and time of eolleetion, and systematieally arranged under their genera, orders, ete., forms a Hortus Siccus or Herbarium. It com. prises not only the speeinens whiel the proprietor has himself eolleeted, but those which he aequires through friendly exelianges, or in other ways. The speeimens of an lierbarium may be kept in folded sheets of paper; or they may be fastened on half-sheets of thiek and white paper, either by gummed slips, or by glue applied to the speeimens themselves. The former is best for private and small herbaria; the latter for large ones whieh are mueh turned over. Eaeh sheet should be appropriated to one speeies; two or more different plants shonld never be attaehed to the same sheet. The generie and speeifie name of the plant should be added to the lower right-hand eorner, either written on the sheet, or on a tieket pasted down; and the time of eolleetion, the loeality, the eolor of the flowers, and any other information whieh the speeimens themselves do not afford, should be duly reeorded upon the sheet or the tieket. The sheets of the herbarium sliould all be of exaetly the same dimensions. The herbarium of Linnæus is on paper of the eommon foolseap size, about eleven inehes long and seven wide. This is too small. Sixteen and three eighths inehes by eleven and a lialf inehes is an approved size.

568. The sheets eontaining the speeies of eael genus are to be plaeed in genus-covers, made of a full sheet of thick paper (sueh as the strongest Manilla-hemp paper), to be when folded of the same dimensions as the speeies-sheet but slightly wider: the name of the genus is to be writ. ten on one of the lower eorners. These are to be arranged under the orders to which they beloug, and the whole kept in elosed eases or eabinets, either laid flat in eompartments, like "pigeon-holes," or else plaeed in thick portfolios, arranged like folio volumes. All should be kept, as mueh as praetieable, in dust-proof and inseet-proof eases or boxes.

569. Fruits, tubers, and other hard parts, too thiek for the herbarium, may be kept in pasteboard or light wooden boxes, in a collection apart. Small loose fruits, seeds, detaelied flowers, and the like nay be eonven. iently preserved in paper eapsules or envelopes, attaehed to the herbarium. shef ts. 


\section{§. INVESTIGATION AND DETERMINATION OF PLANTS.}

570. The Implements requircd are a hand magnifying glass, a pocket lens of an inch or two focus, or a glass of two lenses, onc of the lower and the other of the higher power; and a sharp penknife for dissection. With these and reasonable perseverance the structure of the flowers and fructification of most phanerogamous plants and Ferus can be made out. But for ease and comfort, as wcll as for certainty and right training, the student should have some kind of simple stage microscope, and under this make all dissections of small parts. Without it the student will be apt to fall into the bad habit of guessing where he ought to ascertain.

571. The simple microscope may be reduced to a good lens or doublet, of an inch focus, mounted over a glass scage, so that it can be moved up and down and also sidewisc, and with (or without) a little mirror underneath. A better one would have one or two additional lenses (say of half and of a quarter inch focus), a pretty large stage, on the glass of which several small objects can be placed and conveniently brought under the lens; and its height or that of the lens should be adjustable by a rackwork; also a swivel-mounted little mirror bcneath, which is needed for minute objects to be viewed by transmitted light.

572. For dissecting and displaying small parts on the stage of the microscope, besides a thin-bladed knife, the only tools nceded are a good stock of common needles of various sizes, mounted in handles, and one or more saddler's-needles, which, being triangular, may be ground to sharp edges convenient for dissection. Also a pair of delicate-pointed forceps; those with curved points used by the dentist are most convenient. A cup of clean water is indispensable, with which to moisten or wet, or in which occasionally to float delicate parts. Small flowers, buds, fruits, and seeds of dried specimens can be dissected quite as well as fresh ones. 'They have only to be soaked in warm or boiling water.

573. The compound microscope is rarcly neccssary except in cryptogamic botany and vegetable anatomy; but it is very useful and convenient, especially for the examination of pollen. To the advanced botanist it is a neccssity, to all students of botany an aid and delight.

574. Analysis. A few directions and hints may be given. The most important is this: In studying an unknown plant, make a complete examination of all its parts, and form a clear idea of its floral structure and that of its fruit, from pericarp down to the cmbryo, or as far as the materials in hand allow, before taking a step toward finding out its name and relationship by means of the keys or other helps which the Manuals and Floras provide. If it is the name merely that is wanted, the shorter way is to ask some one who already knows it. To verify the points of structure one by one as they happen to occur in an artificial key, without any preparatory investigation, is a usual but is not the best nor the surest 
ray. It is well to make drawings or outline sketches of the smaller parts, and cspecially diagrams of the plan of the flower, such as those of Fig $225,227,241,244,275-277$. For these, cross sections of the flower-bud or flower are to be made: and longitudinal seetions, suelı as Fig. 270-274, are equally important. The dissection even of small sceds is not difficuli after some praetiee. Commonly they need to be soaked or boiled.

575. The right appreciation of characters and terms used in description needs practice and calls for judgment. Plants do not grow exactly by rule and plummet, and measurements must be talicu loosely. Difference of soil and situation are responded to by considerable variations, and otlicr divergences occur whieh cannot be accounted for by the surroundings, nor be anticipated in gencral descriptions. Anuuals may be very depauperate in dry soils or seasons, or very large when particularly well nourished. Warm and arid situations promote, and wet ones arc apt to diminish pubescence. Salt water cruses increased succulenee. The color of flowers is apt to be lighter in shade, and brighter in open and elevated situations. A color or hue not normal to the species now and then occurs, which nothing in the conditions will account for. A volite-flowered variation of any other colored blossom may always be expected; this, though it may be notable, no more indicates a distinct variety of the species than an albino would a varicty of the human spccies. The numcrical plan is subject to variation in some flnwers; those on the plan of five may now and then vary to four or to six. Variatinns of the ontline or lobing of leaves are so familiar that they do not much mislead. Only wider and longer observation sut: fices to prevent or correct mistakes in botanieal study. But the weighing of evidence and the balaneing of probabilities, no less than the nse of the well-ordcred and logieal system of classification, give as excellent training to the judgment as the search for the facts themselves does to the observing powers.

\section{SIGNS AND ABBREVIATIONS.}

576. For a full aecount, of these, whether of former or actual use, see "Structural Botany" of the "Botanical Text Book," pp. 367, 392, as alsn for the prineiples whieh govern the aecentuation of names. It is needful here to explain nuly those used in the Manuals and Floras of this country, for which the present volume is an introduction and companion. They are not numerous.

577. In arranging the speeies, at lcast those of a large genus, the divisions are denoted and graduated as follows: The sign $\$$ is prefixed to see. tions of the highest rank: these scetions when they have names affixed to them (as Pronus $\$$ Crrasus) may be ealled suhgencra. When the divisions of a gonus are not of such importance, or when dirisions arc made under the subgenus itsclf, the most comprehensire ones are marked by as. terisks, * for the first, ** for the sccond, and so on Subdirisions are 
narked with a prefixed + ; those under this head with ++ ; and those under this with $=$, if there be so many grades. A similar notation is followed in the synopsis of the genera of an order.

578. The interrogation point is used in botany to indicatc doubt. Thus Evematis crispu, L.? expresses a doubt whether the plant in question is really the Clematis crispo of Linnicus. Clenatis? polypetala expresses a doubt whether the plaut so mamed is really a Clematis. On the other hand the exclannation point (!) is used to denote certainty whenever there is special need to aflim this.

579. For size or height, the common signs of degrees, minutes, and sceonds, have been used, thus, $1^{\circ}, 2^{\prime}, 3^{\prime \prime}$, stand respectively for a foot, two inches, and threc lines or twellitis of an inch. A better way, when such brevity is needed, is to write $]^{\text {ro }} .2^{\text {in }}$. $3^{1}$.

580. Signs for duration used by Linnæus were $\odot$ for an annual, to for a biennial, 4 for a percmial lierts, 5 for in shrub or trec. DeCandolle brought iu $\odot$ for a plant that died after once flowering, (1) if annual, (2) if bicunial.

581. To indicate sexes, J means staminate or male plant or blossom; Q , pistillate or femile; $\tilde{\wp}$, perfect or hermaphrodite.

582. To save roon it is not uncommon to use $\infty$ in place of "many ;" thus, "Stamens $\infty$," for stamens indefinitely numcrous: " $\infty$ flora " for pluriflora or many-flowered. Still more common is the form "Stamens 5-20," or "Calyx 4-5-parted," for stamens from fire to twenty, calyx four-parted or five-parted, and the like. Such abbreviations hardly uced cxplanation.

583. The same may be said of such abbreviations as Cal. for calyx, Cor, for corolla, Pet. for petils, St. for stamens, Pist. for pistil, Hab. for habitat, meaning place of growth, IIerb. for herbarium, Hort. for garden. Also $l$. e., loco citalo, which avoids repetition of volume and page.

584. "Structural Botany" has six pages of abbreriations of the names of botanists, mostly of botanical authors. As they are not of much consequence to the beginner, while the morc advanced botanist will know the names iu full, or know where to find them, only a sclection is here appended. 


\section{ABBREVIATIONS OF THE NAMES OF BOTANISTS}

\begin{tabular}{|c|c|c|c|}
\hline \multirow[b]{2}{*}{ Adans. } & & \\
\hline & $=$ Adanson. & Gmel. = & $=$ Gmelın. \\
\hline Alt. & Aiton. & Good. & Goodenough. \\
\hline All. & Allioni. & Grev. & Greville. \\
\hline$A n d r$. & Andrews. & Griseb. & Grisetaeh. \\
\hline Arn. & Alnott. & Gron. & \\
\hline$A u b$. & & Gronov. & us. \\
\hline Bartr. & Bartram. & IIall. & $\mathrm{Ha}$ \\
\hline Beauv. & Palisot de Beaurois. & IIartm. & Hartmann. \\
\hline Benth. & am. - am. & Hartu. & \\
\hline Bernh. & nardi. & IIarv. & Ha \\
\hline Bigel. & Bigelow. & Haw. & rth. \\
\hline Bong. & rd. & Ileyelm. & maier. \\
\hline Bonpl. & and. & IIemsl. & Hemsley, \\
\hline$B r$. or $R . B$ & Brown. & Ilerb. & art. \\
\hline Cass. & Cass & Hoffm. & Hoffmann. \\
\hline Cav. & les. & IIoffmans. & fmansegg. \\
\hline Cham. & sso. & Hook. & Ho \\
\hline Chapm. & aan. & Ilook. $f$. & J. D. Hooker. \\
\hline Chois. & Cho & Hornem. & nemann. \\
\hline Clayt. & $\mathrm{Cla}$ & IIuds. & Hudson. \\
\hline Curt. & & itumb. & Humboldt. [Kunth \\
\hline Curt. (MI.A. & 4.) $\mathrm{M}$. & $I I B K$. & Humboldt, Bonpaand, anc \\
\hline Darl. & Darlington. & Iacq. & in. \\
\hline$D C$ & & $J a c q \cdot f$ & J. F. Jaequin. \\
\hline DeCand. & & Juss. & Jussieu. \\
\hline A. $D C$ & Alphonse DeCandoll。. & A. Juss. & Adrien de Jussieu. \\
\hline Desc. & Descourtilz. & hit. & ibel. \\
\hline Desf. & Desfontaines. & L. or Linn. & Linnæus. \\
\hline Desv. & Desvi & Labill. & Labillardiere \\
\hline Dill. & Dille & Lag. & Lag \\
\hline Dongl. & Douglas. & Lam. & Lamarek. \\
\hline Duham. & Duhamel. & Ledeb. & Ledebour. \\
\hline Dun. & Junal. & Lehm. & Lehmann. \\
\hline Eat. & Eaton (Amos) or D. C. & Lesq. & Iesquereax. \\
\hline Ehrh. & Ehrhart & Less. & Lessing. \\
\hline Ell. & Elliot & Lestib. & Lestibudois. \\
\hline Endl. & Endl & L'Her. & L'Heritier. \\
\hline Engelm. & elmann. & Lindb. & Lindberg. \\
\hline Engl. & Engler. & Lindh. & Lindheimer. \\
\hline Fisch. & Fischer. & Lindl. & ley. \\
\hline Froel. & Frolich. & Lodd. & Loddiges. \\
\hline Gartn. & Gæituer. & Loud. & Loudon. \\
\hline Gaud. & & M. Bieb. & Marsehall von Bieberstein. \\
\hline Gaudich. & Gaudiehaud. & Marsh. & Ma \\
\hline Ging. & Gingins. & Mart. & Martius. \\
\hline
\end{tabular}


Mast. $=$ Masters.

Maxim. Maximowicz.

Meisn. Y Meisner or

Meissn. YMcissner.

Michx. or Mx. Michaux.

Michx.f. F. A. Michaux.

Mill. Miller.

Miq. Miquel.

Mitch. Mitchcll.

Moç. Moçino.

Moq. Moquin-Tandon.

Moric. Molicand.

Moris. Morison.

Mruell. Arg. J. Mueller.

Mfuell. $(F$.$) Ferdinand Mueller.$

suhl. Muhlenberg.

Murr. $\quad$ Murray.

Naud. Naudin.

Neck. Necker.

$\left.\begin{array}{l}\text { Nees } \\ N . a b \text { E. }\end{array}\right\}$ Nees von Esenbeck.

Nutt. Nuttall.

Ed. $\quad$ Eder.

Ort. Ortega.

P. de Beauv. Palisot de Beaurois.

Pall. Pallas.

Parl. Parlatore.

Pav. Pavon.

Pers. Persoon.

Planch. Planchon.

Pluk. Pluk॰net.

Plum. Plumier.

Poir. Poiret.

Radlk. Radlkofel.

Raf. Rafinesque.

Red. Redouté.

Reichenb. Reichcubach.

Rich. I. C. Richard.

Rich.f. or A. Achille Richard

Richards. Richardson.

Ridd.

Riddell.
Roem.\&.Schult. = Rœincr \& Schultcs.

Rottb. Rottbell.

Rupr. Ruprecht.

St. Hil. Saint-Hilaire.

Salisb. Salisbary.

Schk. Schkuhr.

Schlecht. Schlechtendal.

Schrad. Schrader.

Schreb. Schreber.

Schwein. Schweinitz.

Scop. Scopoli.

Spreng. Sprcugel.

Sternb. Stcrnberg.

Steud. Stcudel.

Sull. Sullivant.

Thunb. Thunberg.

Torr. Torrey.

Tourn. Tournefort.

Trautv. Trautvetter.

Trin. Trinius.

Tuck. Tuckerman.

Vaill. Vaillant.

Vent. Ventenat.

Vill. Villars.

Hahl. Wahlenberg.

Wralds. Waldstein.

ITall. Wallich.

Wallr. Walloth.

Walp. Walpers.

Walt. Walter.

II ang. Wangenbeim.

Irats. Screno Watson, unless other initials are given

Wedd. Weddell.

Trendl. Wendland.

Wiks. Wikstrom.

Willd. Wil]denow.

Fulf. Wulfen.

Zucc. Zuccarini.

Zuccag. Zuccagini. 



\section{GLOSSARY AND INDEX,}

OR

\section{DICTIONARY OF THE PRINCIPAL TERMS IN DESCRIPTIVE BOTAINY, COMBINED WITH AN INDEX.}

For the convenience of unclassical students, the commoner Latin aud Greek words (or their equivalents in English form) which enter into the composition of botanical names, as well as of technical terms, are added to this Glossary. The numbers refer to pages.

$\boldsymbol{A}$, at the beginning of words of Greek derivation, commonly signifies a negative, or the absence of sonething; as apetalous, without petals; aphyllous, leafless, \&c. In worls beginning with a vowel, the prefix is an; as anantherous, destitute of anther.

Abnormal, contrary to the usual or the natural stricture. A om rginal, original in the strictest sense; same as indigenous. Abortive, imperfectly formel, or rudimentary. Atortion, the imperfect foruation or the non-formation of some part. Abrupt, sudlenly terminating; as, for instance, Abruplly pinnale, pinnate without an odd leaflet at the end, 58.

Acantho-, sping. Acaulcscont (acculis), apparently stemless; the proper stem, bearing the leaves amil flowers, being very slort or subterranean. Accessory, sometling alditional; as Accessory buds, 30, 31 ; Accessory fruits, 118. A ccrescent, growing larger after flowering.

Accrcte, grown to.

Accumbent, lying against a thing. The cotyledons are accumbent when they lie with their edges against the radicle, 128.

Acephalous, headless.

Acerise, necille-shapert, as the leaves of Pines.

A cclabuliform, saucer-shaped.

Achonium, or Achenium (plural achcnia), a onc-seeded, seed-like fruit, 120.

Achlunydeous (Hower), withont floral cnvelopes, S6.

Acrcular, neelle-shaperl; more slender than acerose.

Acinaciform, scimitir-shapel, like some hean-pous.

Acines, the separate grains of a fruit, such as the raspberry.

Acirn, the nut of the Oak, 122.

Acotyledinous, destitute of cotyledions or seed-leaves.

Acroycnous, growing from the apex, as the stems of Ferns and Mosses. Acrogens, or $A$ cringenomes P'lents, a name for the vascular cryptogamous plants, 156.

Aculeale, armel with priekles, i. e. aculpi; as the Pose and Brier.

Aculenlate, armesl with smali prickles, or slightly jrickiy.

Acuminale, taper-pouted, 5 t.

cule, mealy shimp-bointed, or ending in a point less than a ruint angle, 54 , 
Adelphous (stamens), joined in a fraternity (adelphic); see monadelphous, \&c. Aden. Greek for gland. So Adenophorous, gland-bearing.

Adherent, sticking to, or more commonly, growing fast to another body.

Adnatc, literally, growing fast to, born allierent, 95 . The anther is adnate when fixed by its wholc length to the filament or its prolongation, 101 .

Adnation, the state of bcing ainate, 94.

Adpressed or appresscd, brought into contact witl, but not united.

Adscendent, asccndent, or ascending, rising gradually upwards, 39.

Adsurgent, or assurgent, same as ascending, 39.

Adventitious, out of the proper or usual place; e. g. Adventitious buds, 30.

Adventive, applied to foreign plants accidcntally or sparingly introduced into a country, but harkly to be called naturalizel.

Equilateral, equal-sided; opposed to oblique.

A erial roots, \&c., 36.

Aruginous, verdigris-colored.

Astival, produced in summer.

Estivation, the arrangement of parts in a flower-bud, 97.

Agamous, sexless.

Aggregate fruits, 118.

Agrestis, growing in fields.

A ir-cells or A ir-passages, spaces in the tissue of leaves and some stems, 131

Air-Plants, 36.

Akene or Alenium, 120.

Ala (plural, alce), a wing; the side-petals of a papilionaceous corolla, 92.

Alabastrum, a flower-hur?.

A? ar, situated in the forks of a stem.

Alate, winged.

Albescent, whitish, or turning white.

Albus, Latin for white.

Albumen of the seed, nourishing matter stored up with the embryo, 21, 127.

Albumen, a vegetable prolnct, of four elements.

Albuminous (seeds), furnishcd with albumen, 21.

Alburnum, young wood, sap-wood, 142.

Alliaceous, with odor of garlic.

Alloyamons, close fertilization.

Alpestrine, subalpine.

Alpine, lelonging to high mountains above the limit of forests.

Alternate (leaves), one after another, 29, 67. Petals are alternate with tho sepals, or stamens witl the petals, when they stand over the intervals between them, 82.

Alveolate, honeycomb-like.

Ament, the scaly spike of trees like the Birch and Willow, 75 .

Amentaceous, catkinl-like, or catkin-bearing.

Amorphous, shapeless, without any definite form.

Amphicarpous, prolucing two kinds of fruit.

Amphigatrium (plnral, amphigastvia), a peculiar stipule-like leaf of Liverworth

Amplitiopous, ovnles or seetls, 111.

Amphora, a pitcher-shapel organ.

Amplectant, enbracing. Amplexicaul (leaves), clasping the stem by the base.

Ampullaceous, swelling out like a botile or blalder (ampulla).

Amylaceous, Amyloid, composed of starch (amylum), or starch-like.

Anandrous, without stamens.

Anantherons, without anthers. Ananthous, restitnte of flowers ; flowerless.

Anastomosing, forming a net-work (anastomosis), as the vcins of leaves, 50

Anutrompus ovules or seetle, 111.

Ancipital (anceps), two-elget.

Andracium, a nanie for the stamens taken together, 98. 
andro-dicecrous, flowers staminate on one plant, perfect on anotber.

Androgynous, having both staminate and pistillate flowers in the same cluster.

Androphore, a column of united stamens, as in a Mallow.

Andrones, ol Ander, andra, andrum, Greek in compounds for male, or stamens.

Anemophilous, wivd-loving, sail of wind-fertilizable flowers, 113.

Anfructuose, bent hither and thither as the authers of the Squash, \&e.

Angiospermo, Angiospermous, with seeds formed in an ovary or pericarp, 109.

Anyular divergence of leaves, 69.

Anisos, unequal. Anisomerous, parts uncqual in number. Anisopetrlous, with unecrual petals. Anisophyllous, the leaves unequal in the pairs.

Annual (plant), flowering and fruiting the year it is raised from the seed, and then dying, 37.

Annular, in the form of a ring, or forming a circle.

Annulale, narked by rings; or furmisherl with an

Annulus, or ring, like that of the spore-case of most Ferns. In Mosses it is a ring of eells placed between the mouth of the spore-case and the lid in many species.

Annotinous, yearly, or in yearly growths.

Anterior, in the blossom, is the part next the bract, i. e. external; while the posterior sile is that next the axis of inflorescence. Thus, iu the Pea, \&e., the keel is anterior, and the standard posterior, 96.

Anthela, an open panieulate cyme.

Anther, the essential part of the stamen, which eontains the pollen, 14, 80, 101.

Antheridium (plural anthericlia), the organ in Cryptogams which answers to the anther of Flowering Plants, 150.

Antheriferous, anther-bearing.

Anthesis, the period or the act of the expansion of a flower.

Anthocarpus (fruits), 118.

Anthophore, a stipe betwcen calyx and corolla, 113.

An'hos. Greck for flower; in composition, Monanthous, one-flowered, \&c

Anticous, sante as anterior.

Antrorse, lireeted upwards or forwards.

Apetalous, destitute of petals, 86 .

Aphyllous, leattess.

Apical, belonging to the apex or point.

Apiculate, pointleted; tipper with a small point.

Apocarpous (pistils), when the several pistils of the same flower are separate.

Apophysis, any irregular swelling; the enlargement at the base of the spore-case of the Umbrella-Hoss.

Apothecium, the fructification of Tichens, 171.

Appendage, any superadiled part. Appendiculate, provided with appendages

Appressed, close pressed to the stem, Rc.

Apricus, growing in dry and sunny places.

Apterous, wingless.

Aquatic (Aquatilis), living or growing in water ; applier to plants whether growing uncler water, or with all but the base raised out of it.

Arachnoid, Araneose, eobwehby; elothed with, or eonsisting of, soft downy fibres.

Arboreous, Arborescent, tree-like, in size or form, 39.

Arburetum, a colleetion of trees.

Archegonium (plural archegonir), the organ in Mosses, \&c., which is analogous to the pistil of Flowering Plints.

Arcuate, bent or curved like a bow.

Arenose (Arenarius), growing in sand.

Areolate, marked out into little spaces or areohs.

Argenteous, or Argentale, silvery-like.

Argillose, growing in elay.

Argos, Greek for pure white; Argophyllous or Argyrophyllous, white-leaved, \&c.

Argutus, aentely dentate. 
Arillate (seeds) furnished with an aril.

Arillifurm, aril-like.

Arillus, or Aril, a Heshy growth from base of a seed, 126.

Aristate, awned, i. e. fumished with an arisia, like the beard of Barley, \&c., 54.

Aristulate, dinniuntive of the last; short-awned.

Arrect, brought into upright position.

Arrow-shaped or Arrow-heuded, same as sagittate, 53.

Articulated, jointel; furnishel with joints or articulations, where it ssparates or

inclines to do so. Articulated leaves, 57.

Artificiul Classification, 181.

Ascending (stens, \&c.), 39; (seeds or ovules) 110.

Ascidium, a pitcher-shaped body, like leaves of Sarracenia.

Ascus (asci), a sac, the spore-case of Lichens and some Fungi.

Aspergilliform, shapcd like the brush usel to spriukle holy water; as the stigmas of many Grasses.

Asperous, rough to touch.

Asimilation, 144, 147.

Assurgent, same as ascending, 39 .

Atropous or Atropal (ovules), same as orthotropous.

Aurantiacous, orange-colored.

Aureous, golden.

Auriculate, furnished with auricles or ear-like appondages, 53.

Autoyamy, self-fertilization, 115.

Awl-shaped, sharp-pointel from a broaler base, 61 .

$A w n$, the bristle or beurd of Barley, Oits, \&c.; or any similar appendage.

Awned or Awn-pointed, funished with an awn or long bristle-shaped tip, 54 .

Axil, the angle on the upper side between a leaf and the stem, 13 .

Axile, leelonging to the axis, or occupying the axis.

Axillary (buds, \&c.), occurring in au axil, 27.

Axis, the central line of any body; the organ round which others are attached; the root and stem. Ascending and Descending Axis, 38.

Baccate, berried, berry-like, of a pulpy-nature like a bcrry (bacca).

Budius, cliestmut-colorer.

Bımner, see Stamdarl, 92 .

Burbute, bearled; hearing tufts, spots, or lines of hairs.

Barbed, furnished with a barb or louhle hook; as the apex of the bristle on the fruit of Echinosfermum (Stickseer), \&c.

Burbellate, sail of the bristles of the pappus of some Conpositre when beset with short, stiff hairs, longer than when clenticulate, but shorter tban when plumose.

Barbellulate, liminntive of barhellatc.

$B u r k$, the covering of a stem ontsile of the rood, 138, 140.

$B a s u l$, belonging or attached to the

Buse, that extrenity of any organ by which it is attached to its suppres

Bisifixed, attacherl by its base.

Basl, Bust-fibres, 134 .

Bestied, enting in a prolonged narrow tip.

Beurded, see barbate. Beard is sometin.cs used for awn, more commonly for long or stiff hairs of any sort.

Brtl-shmped, of the shape of a hell, as the corolla of Harebell, 90.

Berry, a fruit pulpy or juicy tiroughout, as a graje, 119.

$B 2-\left\{0 r^{\circ} B\right.$ is), in compontul worls, twice; as

Burticulre, twice-jointerl, or two-jointerl; separating into two pieces.

Binuriculate, having two ears, as the leaf in fig. 120.

Bicnlluse, having two callosities or harler spots.

Bernrimate. two-keelet.

Bioupual (Biceps), two-liculcd; dividing into two parts. 
Biconjugate, twice paired, as when a petiole fer:ss twice.

Bidenute, huving two teeth (not twice or loubly dentate).

Biennial, of two year's' continumce; sIn'inging from the seed one scason, flowering and lying the next, 38.

Bifirenus, two-ranket; arranged iu two rows.

Bificl, two-cleft to about the niuldle.

Bifuliulite, a compuum] leal' of two leaflets, 59.

Bifurcate, twice lorkerl; or more commonly, forked into two branches.

Bijuyate, bearing two pairs (of leaflets, \&(".).

Bilubiate, two-lipped, as the corolla of Libliate.

Bilemellate, of two plates (lamelie), as the stigma of Mlimulus.

Biluber, the same as two-loberl.

Bilocillate, when a eell is diviled into two locelli.

Biloculur, two-celled; as most anthers, the jod of Foxglore, \&c.

Binary, in twos.

Binate, in eonples, two together. Bipartite, the Latin form of two-parted.

Binodal, of two norles.

Binomial, of two worls, as the name of genus and speeies taken together, 180 .

Bipalmate, twiee palmately divided.

Biparous, lhearing two.

Bipinnute (leat), twice pinnatc, 5S. Bipinnatifu, twice pinmatifid, 57.

Bipinatisect, twiee jinnately diviled.

Biplucute, twice folderl together.

Biseriul, or Biseriate, oceupying two rows, one within the other.

Biserrule, cloubly serrite, as when the teeth of a leaf are thenselves serrate.

Biscxurl, laving both stamens and pistil.

Biternate, twiee teruate; i. e. principal divisions three, each bearing three leaflets. 59

Bladdery, thin and inflated.

Blarle of a lear, its expranded portion, 49.

Blown, the whitish powler on some fruits, leaves, \&c.

Bo't-shaped, concave within and lieeled without, in shape like a small boat.

Burder of corolla, \&u., \$9.

Brachiate, with oplposite branehes at right angles to each other.

Brachy. short, as Brachycorpous, sliort-fluiterl, \&e.

Bract (Bractea), the leaf of an infliresccnee. Speeially, the hract is the small lea! or seale from the axil of which a flower or its peclicel proceeus, 73.

Bracteate, furnished with brincts.

Bracteolate, furnished with bractlets.

Bracteose, with numerous or ennspicuous bricts.

Brartlet (Bracteola), or Bracteole, is a bract seated on the pedicel or flower-stalk, 73.

Brinch, Branching, 27.

Breathing-pores, 144 .

Bristles, stiff, sharp hairs, or any very slender bodies of simitar appearance.

Bristly, beset with hristles. Birstle-pointed, 54 .

Brunneous, brown.

Brush-shaped, see aspergilliform.

Bryolosy, that part of botany which relates to Mosses.

Bry'pliyta, Bryophytes, 163.

$B u^{\prime}$, a branch in its ealliest or undeveloper state, 27 . Bud-scales, 63.

Bulb, a leaf-hul with fleshy seulcs, usually subterranenn, 46 .

Bulbils, liminutive bulbs.

Bulbiferous, hearing or prorlucing bulbs. Bulbose or bulbous, bntb-like in shape, \&c

Bulblets, sinall bulbs, borne above ground, 46 .

Bulb-scales, 46 .

Bullute, appenring as if blistererl or blarklery (from bulla, a bubble).

Byssaceous, coniposed of fine flax-like threacls. 
Caducous, dropping off very early, compared with other parts; as the calyx in the Poppy, falling when the flower opens.

Caruleous, blue. Corulescent, beconing bluish.

Caspituse, or Cespitose, growing in turf-like patches or tufts.

Calathiform, cup-shaped.

Calcarate, furnished with a spur (calcar), 86, 87.

Calceolate or Calceiform, slipper-shaped, like one petal of the Lady's Slipper.

Callose, lıardened; or furnished with callosities or thickened spots.

Calvons, bald or naked of hairs.

Calyciflurus, when petals and stamens are adrate to calyx.

Calycine, bulonging to the calyx.

Calyoulate, furnished with an outer accessory calyx (calyculus) or set of bracts looking like a calyx, as in true Pinks.

Calyptra, the hood or veil of the capsule of a Moss, 163.

Calyptrate, having a calyptra.

Calyptryform, shaped like a calyptra or candle-extingnisher.

Calyx, the onter set of the floral envelopes or leaves of the flower, $14,79$.

Cambium, Cambium-layer, 140.

Camprinulate, bell-shaped, 90 .

Campylotropous, or Campylotropal. curved ovules and seeds, 111. Campylospermous, applied to fruits of Umbelliferæ when the seel is curved in at the edges, forming a groove dowu the inner face; as in Sweet Cicely.

Canuliculate, channelled, or with a deep longitudinal groove.

Cancellate, latticed, resembling lattice-work.

Candidus, Latin for pure white.

Canescent, grayish-white; loary, usually because the surface is covered with fine white hairs. Incanous is whiter still.

Canous, whitened with pubescence; see incanous.

Capillaceous, Capillary, hair-like in shape; as fine as hair or slender bristles.

Capitute, having a giobular apex, like the head on a pin.

Capitellate, diminutive of capitate.

Cipitulum, a close rounder dense cluster or head of sessile flowers, 74 .

Capreolate, bearing tendrils (from capreolus, a tendril).

Capsule, a dry dehiscent seed-vessel of a compound pistil, 122.

C'psulnr, relating to, or like a capsule.

Capture of insects, 154.

Carina, a keel; the two anterior petals of a papilionaceous flower, 92.

Ca inate, keeled, furnished with a sharp ridge or projection on the lower side.

Cariopsis, or Caryopsis, the one-seeder fruit or grain of Grasses, 121.

Carneous, Hesh-colorel; pale red. Carnose, theshy in texture.

Carpel, or Carpidium, a simple pistil or a pistil-leaf, 106 .

Carpeliary, pertaining to a carpel.

Carpoligy, that department of botany which relates to fruits.

Carpophore, the stalk or support of a pistil cxtending between its carpcls, 113.

Carpos, Greek for fruit.

Curtilnginous, or Cartilagineous, firm and tough in texture, like cartilage

Caruncle, an excrescence at the scar of some seeds, 126.

Carunculate, furnisherl with a caruncle.

Cary'phy/laceons, pink-like: applied to a corolla of 5 long-clawed petsis.

Cassileous, helmet-shaped.

Crssus, entpty and sterile.

Catenate, or Catenulate, end to end a in a chain.

Catkin, see Ament, 75.

Crutate, tailed, or tail-pointed.

Caudex, a sort of trunk, snch as that of Pa'ms; an upright rootstock, 39, 4 .

Caudicle, the stalk of a pollen-mass, \&c.

Caulescent, having an obvious stem. 36. 
Caulicle, a little stem, or rudimentary stem (of a seedling), 11, 127.

Cauline, of or belonging to a stcm, 36. Caulis, Latin name of stem.

Caulocarpic, equivalent to perennial.

Caulome, the cauline parts of a plant.

Cell (diminutive, Cellule), the cavity of an anther, ovary, \&c.; one of the anatomical elements, 131.

Cellular Cryptogams, 162. Cellular tissue, 131.

Cellulose, 131. Cell-walls, 130.

Centrifugal (inflorescence), produced or expanding in succession from the centre outwards, 77.

Centripetal, the opposite of centrifugal, 74 .

Cephala, Greek for head. In compounds, Monocephalous, with one head, Microcephalous, small-headed, \&c.

Cereal, belonging to corn, or corn-plants.

Cernuous, nodding; the summit mure or less inclining.

Chceta, Greek for bristle.

Chaff, small membranous scales or bracts on the receptacle of Compositæ; the glumes, \&c., of grasses.

Chaffy, furnished with chaff, or of the texture of cbaff.

Chalaza, that part of the orule where all the parts grow together, 110, 126.

Channelled, hollowed out like a gutter; same as canuliculate.

Character, a phrase expressing the essential marks of a species, genus, \&c., 181

Chartaceous, of the texture of paper or parchment.

Chloros, Grcek for green, whence Chloranthous, green-Howered; Chlorocarpous, green-fruited, \&c.

Chlorophyll, leaf green, 136.

Chlorosis, a condition in which naturally colored parts turn green.

Choripetalous, same as polypetalous.

Chorisis, separation of the normally united parts, or where two or more parts take the place of one.

Chromule, coloring matter in plants, especially when not green, or when liquid.

Chrysos, Greek for golden yellow, whence Chrysanthous, yellow-flowered, \&c.

Cicatrix, the scar left by the fall of a leaf or other organ.

Ciliate, beset on the margin with a fringe of cilia, i. e. of hairs or bristles, like the eyelashes fringing the evelids, whence the name.

Cinereous, or Cineraceous, ash-grayish; of the color of ashes.

Circinate, rolled inwards from the top, 72.

Circumscissile, or Circumcissile, divided by a circular line round the sides, as the pods of Purslane, Plantain, \&c., 124.

Circumscription, general outline.

Cirrhiferous, or Cirrhose, furnished with a tendril (Latin, Cirrhus); as the Grape vine. Cirrhose also means rescmbling or coiling like tendrils, as the leaf. stalks of Virgin's-bower. More properly Cirrus and Cirrose.

Citreous, lemon-yellow.

Clados, Greek for branch. Cladophylla, 64 .

Class, 178, 183.

Clas.ification, 175, 183.

Clathrate, latticed; same as cancellate.

Clavate, club-shapcd; slender below and thickened upwards.

Clavellate, diminutive of clavate.

Claviculate, having Clavicula, or little tendrils or hooks.

Clicu, the narrow or stalk-like base of some petals, as of Pinks, 91.

Cleistogamous (Cleistogamy), fertilized in closed bud, 115.

Cleft, cut into lobes, 55 .

Close fertilization, 115.

Climbing, rising by clinging to other objects, 39, 151.

Club-shaped, see clavate.

Clustered, leaves, flowers, \&c., aggregated or collected into a bunca. 
C'ypeate, buckler-shaped.

Coadunate, same as connate, i. e. united.

Coalescent, growing together. Coalescence, 88.

Coarctate, contracted cr brought close together.

Coated, having an integument, or covered in layers. Coated buib, 46.

Cubwrbby, same as arachnoid; bearing hairs like cobwebs or gossamer.

Coccineous, scarlet-red.

Coccus (plural cucci), anciently a berry; now mostly used to denote the separable carpels or nutlets of a diy fruit.

Cochleuriforn, spoon-shaped.

Cuchleate, coiled or shaped like a snail-shell.

Celospermons, applied to those fruits of Umbellifere which have the seed bollowed on the inner face, by incurving of top and bottom; as in Coriander.

Coherent, ustrally the same as connate.

Cohort, name sometimes used for groups between order and class, 178.

Coleor/izan, a root-sheath.

Colleteral, side by side.

Collective fruits, 118.

Collum or Cullar, the neck or junction of stem and root.

Colored, parts of a plant which are other-colored than green.

Columella, the axis to which the carpels of a compound pistil are often attached, as in Geranium (112), or which is left when a pud opens, as in Azalea.

Column, the united stamens, as in Mallow, or the stanens and pistils united inte one bolly, as in the Orchis family.

Columnar, shaped like a column or pillar.

Coma, a tuft of any sort (literally, a head of hair), 125.

Comose, tufted; bcaring a tuft of hairs, as the seeds of Milkweed, 126.

Commissure, the line of junction of two carpels, as in the fruit of Umbelliferæ.

Complanate, flattenerl.

Compound lenf, 54.57. Compound pistil, 107. Compound umbel, 75, \&c.

Compli te (flower), 81.

Complicate, folded upon itself.

Compresserl, flattened on opposite sides.

Conctpracle, 168.

Concinnous, neat.

Concoler, all of one color.

Conchiform, slicll- or half-shell-shaped.

Conduplicate, folded upon itself lengthwise, 71.

Cone, the fruit of the Pine family, 12t. Coniferous, cone-bearing.

Confer/us, much crowded.

Conferruminate, stuck together, as the cotyledons in a horse-chestnut.

Confuent, blended together; or the same as cohesent

Cenfonmed, similar to another thing it is associated with or compared to; or closely fitted to it, as the skin to the kernel of a sced.

Compested, Conglomerente, crowded tonther.

Conglomerate, crowded into a glomernle.

Conjugnte, coupled; in single pairs. Conjugntion, 170.

Councite, united or frown together frem the first formation, 96.

Conurit-perfoliute, when a pair of leaves are connate round a stem, 60.

Connective, Cunnectivum, the part of the anther connccting its two cells, 101.

Comivent, contersing, or brought close together.

Consulirlation (florill), 94.

Consolidated forms of vegetation, 47 .

Contents of cells, 136 .

Continuous, the reverse of interrupted or articulated.

Contorted, twistal tocather. Contorted estivation, sane as convolute, 87.

Contortuplicate, twisted batk upon itself.

Contracterh eitlier narrowed or shortened. 
Contrary, turned in opposite direction to the ordinary.

Convolute, rolled up lengthwise, as the leaves of the Plum in vernation, 72. In astivation, same as contorted, 97 .

Cordate, heart-sluaped, 53.

Coriacerus, resembling leather in texture.

Corky, of the texture of cork. Corky linger of bark, 141.

Corm, a solid bulb, like that of Crocus, 45 .

Corneous, of the consistence or appearance of horn.

Corniculate, furnished with a smill horn or spur.

Cornule, horned; bearingr a horn-like projection or appendage.

Corolla, the leares of the Hower within the calyx, 14,79 .

Corollaceous, Corolline, like or bclonging to a corolla.

Corona, a cornet or crown; an appenlage at the top of the $\mathrm{cm}$ of some petals, 91

Curonate, erowned; fumished with a cruwn.

Cortex, bark. Cortical, belonging to the bark (cortex).

Corticute, coated with bark or bark-like covering.

Corymb, a flat or convex indeterminate flower-cluster, 74 .

Conymbifirous, bearing coryoubs.

Corymbose, in corymbs, apprnacling the form of a corrmb, or branched in that way

Costr, a rils; the inidrib of a leal, Sc. Costate, ribbed.

Cotyledins, the proper leaves of the emhryo, 11, 127.

Cratr rifurm, noblet-iliaped or deep siluccr-sliapcd.

Creeping (stcms). gruwiug fat on or bencath the tround and rooting, 39.

Cremocarp, a lialf-fruit, or one of the two carpels of Umbellifera, 121.

Crenate, or Crenelled, the edire scalloped into rounded teetli, 55.

Cren ilate, minutcly or slightily crenate.

Cresten, or Crisule, bciring any elevated appendagc like a crest.

Cretaceous, chalky or chalk-like.

Cribruse, or cribriform, pierced like a sieve with small apertures.

Cinnite, bearing lomar lairs.

Crispate, curled or crispy.

Croreous, suffrotl-colur, clecp reddish-rellow.

Cross-breeds, the proseny of intcrbed varteties, 178.

Cross fertilization, 115.

Crom, see corrona. Crouned, see coronate.

Crurinte, or Cruclfurm. clús-slıaped. Cruciform Corolla, 86.

Crustrcenus, harl and britle in texture; crustlilie.

Cryptogamous Plonts, Cryptoryms, 10, 156.

Cryptos, concealerl, as Cryptopetaluns, witl conccaled petals, \&c.

Crystruls in plante, 137.

Cucullnte, hoofled, or hond-shaper, rolles up like a cornet of paper, or a hood (cucullus), as the spathe of Indian Turnip, 75 .

Culm, a straw: the stem of Grass's and Setges, 39.

Coltrite, sliaperl like a trowel or hroatl knife.

Cunente, Cuneiform, werlge slialped, 53.

Cup-shaped, same as cyathiform or near it.

Cupule, a little cup; the cup to the acorn of the Oak, 122

Cupular, or Cupulate, provicled with a eupule.

Cupuliferous, cupulc-butring.

Curriveined, witl curved ribs or reins.

Curriserial, in oblique or spiral ranks.

Cushion, the cnlingement at the insertion or base of a petiole.

Cuspilate, tipped with a sharp and stiff point or cusp, 54 .

Cut, same as inciscd. or applied generally to any sharp and deep division, ,55.

Cuticle, the skin of plants, or more strictly its extcrnal pellicle.

Cynneous, bright bluc.

Cyulhiform, in the sluape of a cup, or particularly of a winc-glass

Cycle, one complete turn of a spire, or a circle, 70. 
Cyclical, rolled up eireularly, or coiled into a eomplete cirele.

Cyclosis, eireulation in closed eells, 149.

Cylindraceous, approaching to the Cylindrical form, terete and not tapering.

Cymbeform, or Cymbiform, same as boat-shaped.

Cyme, a cluster of centrifugal inflorescenee, 77.

Cymose, furnished with cymes, or like a cyme.

Cymule, a partial or diminutive cyme, 77 .

Decc- (in words of Greek derivation), ten; as

Decayynous, with 10 pistils or styles, Decamerous, of 10 parts, Decandrous, witb 10 stamens, dic.

Deciduous, falling off, or subject to fall; said of leaves whieh fall in autumn, and of a calyx and corolla which fall before the fruit forms.

Declimate, declined, turncd to one side, or downwards.

Decompound, several times compounded or divided, 59.

Decumbent, reclined on the ground, the summit tending to rise, 39.

Decurrent (leaves), prolongcd on the stem beneath the insertion, as in Thistles.

Decuss tte, arranged in pairs which suceessively eross each other, 71.

Decluplication, same as chorisis.

Definite, when of a uniform number, and not above twelve or so.

Definite Inforescence, 72 .

Defexed, bent downwards.

Deflorate, past the flowering state, as an anther after it has diseharged its pollen.

Deliscence, the regular splitting open of capunle or anther, 103, 119.

Dehiscent, opening by regular dehiscence, 119, 123.

Deliquescent, branching off so that the stem is lost in the branehes, 32 .

Delloid, of a triangular shape, like the Greek capital $\Delta$.

Demersed, growing below the surfaee of watcr.

Denolroirl, Dendritic, tree-like in form or appearance.

Dendron, Greek for tree.

Deni, ten together.

Dens, Latin for tooth.

Dentate, toothed, 55. Denticulate, furnished with denticulations, or little teeth.

Depauperate, imporerishcr or starved, and so below the natural size.

Depressed, flattened or as if pressed down from abore.

Derma, Greek for skin.

Descending, tending gradually downwards. Descending axis, the root.

Desmos, Greek for things connected or bound togetler.

Determinate Inflorescence, 72.

Dextrorse, turned to the right hand.

Di-Dis (in Greek enmpounds) two, as

Diadelphous (stamens), united by thcir filaments in two sets, 99 .

Dingnosis, a short distinguishing character or descriptive phrase.

Dirlypetulous, same as polypetalous.

Dianlrous, having two stamens, \&c.

Dinphanous, transparent or tianslucent.

Dicarpellary, of two carpels.

Dichlamydeous (flower), having both ealyx and corolla.

Dichogumous, Dichogamy, 116.

Dichotomous, two-forked.

Diclinnus, having the stamens in one flower, the pistils in another, $\mathbf{8 5 .}$

Diroccous (fruit), splitting into two cocci or closed earpels.

Dicutyls, 23.

Dicotyledonous (embryo), having a pair of cotyledons, 23. Dicotyledonows Plants. 25 182.

Didymous, twin.

Didynrmous (stamens), having four stamens in two pairs, 100 .

Diffuse. corregding widely and irregularly 
Digitate (fingered), where the leaflets of a compound leaf are all borne on the apex of the petiole, 58 .

Digynous (Hower), laving two pistils or styles, 105.

Dimerous, made up cf two parts, or its organs in twos.

Dimidiate, halved; as where a leaf ur leaflet has only one side developed.

Dimorphism, 117. Dimorphous, Dimorphic, of two forms, 117.

Diocious, or Divicous, with stancns and pistils on different plants, 85.

Dipetrilous, of two petals. Diphyllous, two-leaved. Dipterous, two-winged.

Diplo-, Grcck fur duable. as Diplustemonous, with two sets of stamens.

Discifirm or Disk-shaped, flat and circular, likc a disk or quoit.

Discuidal, or Discoia, belonging to (r like a disk.

Discolor, of two different colors or hues.

Discrete, separate, opposite of concrete.

Disepalous, of two sepals.

Disk, the face of any flat body; the central part of a head of flowers, like the Sun. flower, or Coreopsis, as upposed to the ray or margin; a fleshy expansion of the reccptacle of a fliwer, 113 .

Disk-flowers, those of the disk in Compositx.

Dissected, cut deeply into many lobes or divisions.

Dissepiments, the partitions of a compound ovary or a fruit, 108.

Dissilient, burstingr in pieces.

Distichous, two-ranked.

Distinct, uncombincd with each other, 95 .

Dithecous, of two theca or anther-cel's.

Divaricate, straddling; very widely divergent.

Divided (laves, \&c.), cut into diviuions down to the base or midrib, 55.

Dudeca, Greek for twelve; as Dodecagynous, with twelve pistils or styles, Dode. candrous, with twelve stamens.

Dodruns, span-long.

Dolibifform, axe-sliaped.

Dorsal, pertaining to the back (dorsum) of an organ. Dorsal Suture, 106.

Dotted Ducts, 148.

Duuble Flowers, where the petals are multiplied unduly, 79.

Downy, clothed with a coat of soft and short hairs.

Drupaceous, like or pertaining to a drupe.

Diupe, a stone-firit, 120. Drupelet or Drupel, a little drupe.

Ducts, the so-called ressels of plauts, $13 t$.

Dumose, bushy, or relating to bushes.

Duramen, the heart-rood, 142.

Dwarf, remarkably low in stature.

$E$-, as a prefix of Latin compound words, means destitute of; as ecostate, without a rib or miclrib; exulbuminous, without albumen, \&c.

Eared, see auriculate, 53.

Ebracteate, destitute of bracts. Ebracleolate, destitute of bractlcts.

Eburneous, ivory-white.

Echinate, armed with prickles (like a licdgelogg). Echinulate, a diminutive of it.

Edeniate, toothless.

Effete, past bearing. \&c.; said of anthers which have discharged their pollen.

Effuse, very lonsely branched and sprcading.

Eglnadulose, destitute of glands.

Elaters, threads mixed with the spores of Liverworts, 165.

Ellipsoiral, appronching an elliptical figure.

Elliptical, oval or oblong, with the ends regularly roundcd, 52

Emarginate, notched at the simmnit. 5t.

Embryo, the rudimentary plantlet in a seed, 11, 127.

Embryonal, belonging or relating to the embryo.

Embereosac. 117 
Emersed, raised out of water.

Endecayynous, with eleven pistils or styles. Fndecandrous, with eleven stamens

Endemic, peenliar to the count ry reographieally.

Endocurp. the inner lay"es of a pericarp or fruit, 120.

Endochmme, the coloring matter of Algie and the like.

Enlogenous Stems, 138. Indogenous plints, an old name for monocotyledons.

Endupleurr, inuer seed-eort.

Endinhizal, raclicle on root sleathed in germination.

Endosperm, the albunen "f a seed, 21.

Entostome, the orilice in the inner cout of an ovule.

Enner-, nine. Ennengynous, with nine petals ur styles. Enneandrous, nine-stamened

linstite, linsiform, sworcl-sliaped.

Entire, the margins not at all toothel, notehed, or divided, but even, 55.

Entomophilous, sait of flowers frequented and fertilized by iusects, 113.

Fphemeral, listing for a day or less, as the eorolla of Purslane, dic.

Ein-, Greck for uport.

Epicalyx, such an iwolucel as that of Malvaeen.

Epicurp, the outermost layer of a fruit, 120 .

Epidermal, relating to the Eyidermis, or skin of a plant, 50,141, 143 .

Epigoous, growing on the eattl, or close to the ground.

Evigynus, "pon the wary, 95, 99.

Eprpetalins, borne on the petals or the corolla, 99.

Epiphyllous, borne on a leaf.

Epiphyte, a plant grewing on another plant, but not nourished by it, 36 .

Epiphytic or lipijhytul, relating to Eipiphytes.

Epipterous, winged at top.

Eypisperm, the skin or coat of a seed, espceially the outer eoat.

Equal, alike in number or length.

Equally pinnate, same as abruptly pinnate, 57.

Equitunt (riding striddle), 60.

Eri, n, Greek for wool. Limanthous, woolly-flowered. Eriophorous, wool-bearing, \&c

Erose, eroded, as if guawed.

Erostrate, unc bealied.

Erythros, Greek for red. Erythrocarpous, red-fruited, \&c.

Essentivl Oigans of the flower, 80.

Estivation, see cestivatiun.

Eivolited, blanched by exeluding the light, as the stalks of Celery.

Eu, Greck prefix meaniug very, or much.

Evergreen, lolding the leares over winter and until new ones appear, or longer.

$E x$, latin pretix; privative in place of "e" when next letter is a rowel. So Ex. alate, wingless; lixulbuminous (seel), witlout allumen, 21.

Excurvent, rumiug out, as when a midrib prijects leyond the apex of a leaf, or a trunk is eontinued to the very top of a tree, 32 .

Ergums, pury.

Exilis, lank or meagre.

Eximius, distinguisicel for size or beanty.

Fxo-, in Greek compoumds, ontwind, as in

Exocriry, outer layer of a periearp, 120.

Exogenums, outwarel growiugs. Exogrnous stems, 139.

Exorkizal, rarliele in germinstion unt sleatled.

Exostome, the orifice in the onter enat of the ovule.

Explanate, spreal ol fattened out.

Exserted, protruling out of, as the stamens ont of the corolla.

Exstipulute, destitute of stipules.

Extine, outer eoat of a pollen-rirain.

Exturn-axillury, saisl of a branch or hud somewhat out of the axil, 31.

Extrorse, thried outwals: the antier is extrurse when fastened to the filament ot the side vext the matil, and opeuing on the outer sidw. 101 
Falcate, seythe-shaped; a flat body eurved, its edges parallel.

False Racemes, 78.

Fumily, in botany same as Order, 177.

Farma, meal or sturehy matter, 136.

Farinnceaus, mealy in texture. Furinose, envered with a mealy powder.

Fuscirte, banded; also applied to monstrous stems which grow flat.

Fascicle, a close cluster, 77.

Fuscicled, Fasciculated, growing in a bundle or tuft, as the leares of Lareh, 68, and roots of Peony, 35.

Fastiginte, close, parallel, and upright, as the branches of Lombardy Poplar.

Finux (plural, fauces), the throat of a calyx, corolla, \&e., 89.

Faveolate, Fucose, honeycombed; same as alceolate.

Feather-veined, with veins of a leaf all springing from the sides of a midrib, 51 .

Fecula or Feculn, starch, 136.

Femule flower or plint, une bearing pistils only.

Fenestrate, pierced with onc or more large holes, like windows.

Ferrugineous, or Ferruginous, resembling iron-rost; red-gravish.

Fertile, fruit-bearing, or capable of it; also said of anthers producing good pollen.

Fertilizatiun, the proeess by which pollen causes the embryo to be formed, 114.

Fibre (wooly), 133. Fibrous, containing much fibre, or composed of tibres.

Fibrilluse, formed of small fibres, or Fibrille.

Fibro-vrscular bundle or tissue, formed of tibres and ressels.

Fiddle-shuped, obovate with a deep recess on each side.

Fidus, Latiu suflix for eleft, as Biful, two-cleft.

Filiment, the stalk of a stamen, 1t, 80, 101; also any slender thread-shaped body.

Fil menluse, or Filumentous, bearing or formed of slender threads.

Filiform, thread-slaped; long, slender, and cyliudrical.

Fimbriate, fringed; furnislsed with fringes (fimbrice).

Fimbrillate, Fimbrilliferous, bearing small fimbrice, i. e. fimbrilla.

Fissiprous, multiplying by division of one body into two.

Fissus, Latur for split ot divided.

Fistulu, "r Fistulose, hollow and cylindrical, as the leaves of the Onion.

Flubelliforn, or Flabellate, fan-slaped.

Flagellate, or Flngelliform, long, narow, and flexible, like the thong of a whip; or like the runners (flagelle) of the Strawberry.

Flavescent, yellowish, or tuming yellow.

Flurus, Latin for yollow.

Fleshy, composer of firm pulp or flesh.

Flexuose, or Flexuous, bendiug in opposite directions, in a zigzag way.

Fluating, swimming on the surlace of water.

Floccose, composed of or bearing tufts of woolly or long and soft hairs.

Flora (the golless of flowers). the plants of a country or distriet, taken together, or a work systematically deseribing them, 9.

Floral Encelopes, "11' Flower-leaves, 79.

Floret, a dimimulive flower, one of a mass or eluster.

Floribunl, ahumlantly torifernus.

Flurula, the flora of a small distriet.

Flos, floris, Latin for llower.

Flusculus, dinintutive, same as forct.

Flower. the whole urgars of reproduetion of Phrnogamous plants, 14, 72.

Floner-bul, an sumpenserl flower.

Flowering Pltuts. 11, 156 . Flowerless Plants, 10, 156.

Fly-toup lentes, riis.

Fluiluns, latin :ol flonting. Flurintile, belonging to a river or stream.

Foluceous, holonsriute to, of of the texture or nature of, a leal fulinm).

Foline, providel with leares. I,atin pretixps denote the number of leaves, as bifo.

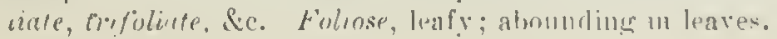

Foliol ile, relating to or bearing leaflets (fulioh); trijoliure, with three leaflets. So. 
Folium (plural, folia), Latin for leaf.

Fullicle, a simple pod, opening down the inner suture, 122.

Follicular, resembling or belonging to a follicle.

Food of Plants, 144.

Fout-stalk, either petiole or peduncle, 49.

Foramen, a holc or orilicc, as that of the ovule, $\mathbf{1 1 0 .}$

Foruminose, Furaminulose, pierced with holes.

Forked, branched in two or three or more.

Fonnicate bearing formices.

Furmix, little arched scales in the throat of some corollas, as of Comfrey.

Foveate, deeply pitted. Foveolate, diminutive of foveate.

$F^{\prime} r e e$, not united with any other parts of a different sort, 95 .

Fringed, the margin beset with slender appendages, bristies, \&c.

Frond, what answers to leares in Ferns, dic., 157; or to the stem and leaves fused into olle, as in Li erwort.

Frontescence, the bursting into leaf.

Frondose, frond-bearing, like a frond, or sometimes used for leafy.

Fructification, the state or result of fruiting.

Fructus, Latin for fruit.

F/unt, the matured ovary and all it contains or is connected with, 117.

Fruit-duts in lierns: scc Sorus.

Frustulese, consisting of a c hain of similar pieces, or Frustules.

Frutescent, somewliat shrubby ; becoming a shrub (Frutex), 39.

Fruticuluse, like a small shrub, or Fraticulus. Fruticose, slirubby, 39.

Fugacious, soon falling off or perishing.

Fulcrate, having accessory organs or fiulcra, i. e. props.

Fulcous, tawny; dull yellow with gray.

Fungus, Fungi, 172.

Funicle, Funiculus, the stalk of a seed or ovule, 110.

Funnel, iom, or funnel-shrped, expanding gradually upwards into an open mouth, like a funnel or tumel, 90.

Furcate, forked.

Furfurraceous, covered witl bron-like fine scurf.

Furowed, maked by longitudinal channels or grooves.

$F$ uscous, deep gray-lirown.

Fusiform, spindle-shaped, 36.

Galbulus, the fleshy or at length woody cone of Juniper and Cypress.

Galea, a helmet-shaped boty, as the ipper sepal of the Monkshood, 87.

Galeate, shaped like a ticlmet.

Gamepetulous, of united petals, 89.

Gamophyllons, formerl of united leaves. Gamosepalous, formed of united sepals, 89

Geminute, twin; in pairs.

Gemma, latin for a bul.

Gemmution, the state of budding; budding growth.

Gemmule, a small bud; the plumule, 6 .

Generr, plural of genus.

Geniculate, bent abmutly, like a knce (genu), as many stems.

Generic Nimes, 179.

Genus, a kind of a lank aborc species, 177.

Germ, a growing point; a young bud; sometimes the same as embryo, 127.

Germen, the old name for ovary.

Germinution, the derelopment. of a plantlet from the seed, 12.

Gerontogacous, inhabiting the Old World.

Gibbous, more tmmisl at one place or on one side than the other

Gilvous, dirty redllish-yellow.

Glubrate, becoming grahmous with age, or almost glabrous.

Glabrous. smoth, in the scnse of liaving no hairs, bristles, or other pubescence. 
Gladiate, sword-shaped, as the leaves of Iris.

Glands, small cellular organs which seerete oily or aromatic or other produets; they are sometimes sunk in the leaves or rind, as in the Orange, lrickly Asli, \&e.; sometimes on the surface as small projections; sometimes raised on hairs or bristles (glandular hairs, foc.), as in the Sweetbrier and Sundew. The name is also given to any small swellings, Se., whether they secrete anything or not; so that the word is loosely used.

Glandular, Glundulese, furnislsed witlı glands, or gland-like.

Glans (Gland), the acom or mast of Oak and similar fruits.

Glareose, growing in gravel.

Glaucescent, slightly glaucous, or bluish-gray.

Glaucous, covered with a bloom, viz. with a fine white powder of wax that rubs off, like that on a fresh plum, or a eabbage-leaf.

Globose, spherical in form, or nearly so. Glubular, nearly globose.

Gluchidinte, or Glochideous, (bristles) barbed; tipped with barbs, or with a double hooked point.

Glomerate, elosely aggregated into a dense cluster.

Glomerule, a dense head-like cluster, 77.

Glussology, the department of botany in which technical terms are explained.

Glunaceus, grlume-like, or glume-bearing.

Glume; Glumes are the husks or floril coverings of Grasses, or, partieularly, the onter husks or braets of each spikelet.

Glumelles, the inner husks of Ǵrasses.

Gonophore, a stipe below stamens, 113.

Gossypine, cottony, floceulent.

Gracilis, Latin for slender.

Grain, see Caryopsis, 121.

Gramineous, grass-like.

Granulur, eomposed of grains. Granule, a small grain.

Graveolent, heary-seented.

Griseous, gray ol bluish-gray.

Growth, 129.

Grumous, or Grumose, formed of coarse clustered grains.

Guttate, spotted, as if by drops of something colored.

Gymnos, Greck for naked, as

Gymnecarpons, naked-fruited. Gymnospermous, naked-seeded, 109.

Gymnospermons yyncecium, 109.

Gymnosperma, or Gymnospermous Planis, 18:.

Gynandrous, with stamens borne on, i. e. united with, the pistil, 99.

Gynocium, a name for the pistils of a thower tnken altogrether, 105.

Gynobase, a depressed reeeptacle or support of the pistil or carpels, 114.

Gynophore, a stalk raising a pistil above the stamens, 113.

Gynostegium, a sheatl around pistils, of whatever nature.

Gynosteminm, name of the eolumn in Orehids, Se., eonsistiug of style and stigma with stamens combined.

Gyrate, eoiled or moving cireularly.

Gyrose, strongly bent to and fro.

IIabit, the generai aspeet of a plant, or its mode of growth.

IIabitat, the situation or country in which a plant grows in a wild state.

Hairs, liair-like growtlis on the surface of plants.

Hairy, beset with hairs, especially longish ones.

Halberd-shaped, see hastrie, 53.

Ilalved, when appearing as if one linlf of the body were cut away.

Hamate, or Himmose, hooked; the end of a slender londy bent louind.

Hamulose, bearing a small look; a diminutive of the last.

Haplo- in Greek compounds, single; as Hoplostemonous, laving only one series of stamens. 
Ifastate, or Hasille, shaped like a balberd; furnished with a spreading lobe on each side at the base, 53 .

Lieud, eapitulum, a form of inflorescence. 74 .

IIerit-shuped, of the shape of a heart as painted on eards, 53.

Heart-uood, the oliler or matured wool of exogrenous trees, 142.

Helicoid, eniled like a helix or suail-shell, 77.

Helmet, the upper sejul of Monkshood is so ealled.

Ilelvolius, grayisl:-rellow.

IIemi-in eompounds from the Greek, half; e. g Hemisphericol, \&c.

Hemicarp, balf-fruit, one carpel of an Unbelliferous plint, 121.

Hemitropous (ovule or seed), nearly same as amphitropous, 123.

Ileptr- (in words of Greck origin), seven; as IIeptayynous, with seven pistils or styles. Heptumerous, its parts in sevens. Hrotandrous, having seren stamens

Ilerb, plant not workly, at least abure ground.

Herbictuus, of the texture of an herb: not wody, 39.

Herbarium, the butanist's arranged eolleetion of dried plants, 186.

Jle borization. 184.

Hermophrotite (Hower), having stamens and pistils in the same blossom, 81.

llesperidium. wange-fruit, a hard-rinded bery.

Heterm, in Greek compromis. means of two or more sorts, as

Jeterorarpous, bearing fruit of two linds or shapes.

Heferogamous, bearing two or more solts of flowers in one eluster.

Iheterngomy. Heterogone, or /leterngonme, with stansens and pistil reeiproeally of two sorts, 116. Ileternstyled is same.

Ih. leromorphous, of two wr more shapes.

Ileteropliyllous, with two sorts of leaves.

II. teritropous (ovule), the same as amplitiopous, 123.

IItxu- (in Greek (componnd:). six; as /lexagumul, six-angled. Mexnrynous, with six pistils or styles. Hexcmerous, its parts in sixes. Hexundrous, with six stamens. H(xip)terus, six-winged

Mibernaculum, al winter ind.

Hiemal, rulating to winter.

Hilar, belonging to the hilum.

Hilum, the -ciar of the sted; its plaee of attaehment, 110, 126.

Hippocreniform, lurseslue-shaped.

Mirsute, cluthed witlo stillish or beard-like hairs.

Ilitellines, minutcl! liilstlte.

Ilspin, bristiy, beset with stiff hairs. Mispiluluas, diminutive of hispia.

Ihistuluyy, 9 .

Ilminy. glayish.white; see ranescent, \&.e.

Indusiriceous, all over scriceous or silky.

Ilonno-, in Greek compouml-, all alike or of one sort.

Homorlromous, rumuing in one direction.

Homegumous, a heat or cluster witl fluwers all of one kind.

llomogeneous, tuifiorm in mattue : all of ome kind.

Himogone, or Hommogonous, comberpart of Ileterogone or Homnstyled.

Homologous, of sam type; thus petal and sepals are the lomologues of leaves.

Hommullous (leave, (Se.), originating all round an axis, but all bent or eurred to one sicle.

Jlomorpheres, all of one shilpe.

Homotropous (embryo), curved with the sced; enrved only one way.

Hord, same as helmit or gulen. Ilooded, hood-shaped; see cucullite.

Howked, same as hamente.

Horn, a spur or some sim lar appendare. Horny, of the texture of horn.

Ilortensis, pertainume to the gardent.

Hortus Siccus, an herbarium, or collection of dried plants, 201.

Humifuse, Humistrite, spread over the surfaee of the ground.

Uumilis. low in stature. 
Hyaline, transparent, or partly so.

Hybrid, a cross-breed between two allied species, 176.

Hydrophytes, water-plants.

Hyemal, see hiemal.

Bymenium of a Mushroom, 172.

Hypanthium, a hollow flower-receptacle, such as that of Rose.

Hypo-, Greek prefix for under, or underneath.

Hypocotyle, or Iypocotyl, part of stem below the cotyledons, 11 .

Hypocrateriform, properly Hypocraterimorphous, salver-shaped.

IIypogean, or Hypogeous, produced under ground, 19.

Hypogynous, inserted under the pistil, $95,99$.

Hysteranthous, with the blossoms developed earlier than the leaves.

Icosandrous, having 20 (or 12 or more) stamens inserted on the calyx.

Imberbis, Latin for beardless.

Imbricate, Imbricated, Imbricative, overlapping one another, like tiles or shingles on a roof, as the bud-scales of Horse-chestnut and Hickory, 27. In æstivation, where some leaves of the calyx or corolla are overlapped on both sides by others, 98.

Immarginate, destitute of a rim or border.

Inmersed, growing wholly under water.

Impari-pinnate, pinnate with a single leaflet at the apex, $\mathbf{5 7 .}$

Imperfect flowers, wanting either stamens or pistils, 85 .

Incequilateral, unequal-sided, as the leaf of a Begonia.

Inane, empty, said of an anther which produces no pollen, \&c.

Inappendiculate, not appendaged.

Incanous, Incanescent, hoary with soft white pubescence.

Incarnate, flesli-colored.

Incised, cut rather deeply and irregularly, 58.

Included, enclosed; when the part in question does not project beyond another.

Incomplete Flower, wanting calyx or corolla, 86.

Incrassated, thickened.

Incubous, with tip of one leaf lying flat over the base of the next above.

Incumbent, leaning or resting upon; the cotyledons are incumbent when the back of one of them lies against the radicle, 128; the anthers are incumbent when turned or looking inwards.

Incurved, gradually curving inwards.

Indefinite, not uniform in number, or too numerous to mention (over 12).

Indefinite or Indeterminate Inflorescence, 72.

Indehiscent, not splitting open; i. e. not dehiscent, 119.

Indigenous, native to the countiy.

Individuals, 175.

Indumentum, any hairy coating or pubescence.

Induplicate, with the edges turncd inwards, 97.

Induviate, clothed with old and withered parts or induvia.

Indusium, the shield or covering of a fruit-dot of a Fern, 159.

Inermis, Latin for unarmed, not prickly.

Inferior, growing below some other organ, 96 .

Infertile, not producing seed, or pollen, as the case may be.

Inflated, turgid and bladdery.

Inflexed, bent inwards.

Inflorescence, the arrangement of flowers on the stem, 72.

Infra-axillary, situated beneath the axil.

Infundibuliform or Infuntibular, funnel-shaped, 90.

Innate (anther), attacherl by its base to the very apex of the filament, 101.

Innovation, a young shoot, ol new growth.

Insertion, the place or the mode of attachment of an organ to its support, 95, 99

Integer, entire, not lobed. Integerrimus, quite entire, not serrate. 
Intercellular Passages or Spaces, 131, 143.

Interfuliaceous, between the leaves of a pair or whorl.

Internode, the part of a stem between two nodes, 13.

Interpetiolar, between petioles.

Interruptedy pinnate, pinnate with small leaflets intermixed with larger.

Intine, inner coat of a pollen grain.

Intrafoliaceous (stipules, \&c.), placed between the leaf or petiole and tbe stem.

Introrse, turned or facing inwards; i. e. towards the axis of the flower, 101.

Intruse, as it were pushed inwards.

Inversed or Inverted, where the apex is in the direction opposite to that of the organ it is compared with.

Involucel, a partial or small involucre, 76 .

Involucellate, furnished witl an involucel. Involucrate, furnished with an involucre.

Involucre, a whorl or set of bracts around a fower, umbel, or head, \&ce, 74, 75.

Involute, in vernation, 72 ; rolled inwards from the edges, 97.

Irregular Flowers, 86, 91.

Isos, Greek for equal in number. Isomerons, the same number in the successive circles or sets. Isostemonous, the stamens equal in number to the sepals or petals.

Jointed, separate or separable at one or more places into pieces, 64 , \&c.

Jugum (plural Juga), Latin for a pair, as of leaflets, - thus Unijugate, of a single pair ; Bijugate, of two pairs, \&.c.

Julaceus, like a catkin or Julus.

Keel, a projecting ridge on a surface, like the keel of a boat; the two anterion petals of a papilionaceous corolla, 92 .

Keeled, furnished with a keel or sharp longitudinal ridge.

Kermesine, Carnine-red.

Kernel of the ovule and seed, 110.

Key, or Key-fruit, a Samara, 122.

Kidney-shaped, resembling the outline of a kidrey, 53.

Labellum, the odd petal in the Orchis Family.

Labiate, same as bilabiate or two-lipped, 92.

Labintiforous, having flowers with bilabiate corolla.

Lnbium (plural, Labia), Latin for lip.

Lacerate, with margin appearing as if torn.

Laciniate, slashed; cut into deep narrow lobes or Lacinice.

Lactescent, produeing milky juice, as does the Milkweed, \&c.

Lacteus, Latin for milk-wlite.

Lacunose, full of holes or gaps.

Lacustrine, belonging to lakes.

Lavigate, smonth as if polished. Latin, Laeris, smooth, as opposed to rough.

Lageniform, gourd-sliaped.

Lagropous, Latin, hare-fonted; densely elothed with long soft hairs.

Lamella or Lamellate, consisting of flat plates, Lrmellee.

Lamina, a plate or blale, the blade of a leaf, \&c., 49.

Lanate, Lrinose, wonlly; clnthed with long and soft entangled hairs.

Lanceolate, lance-shaped, 52.

Lanuginous, cottony or woolly.

Latent buds, concealed or undereloped buis, 30 .

Lateral, belonging to the side.

Latex, the inilky juice, Sc., of plants, 135.

Lnx (Lnxus), linse in texture, or sparse; the opposite of crowdea.

Leaf', 49. Leaf-buds, 31 .

Leaflet, one of the divisions or blades of a compound leaf, 57.

Leaf-like, same as folincerus.

Leathery, of about the consistence of leather; coriaceous. 
Legume, a simple pod which dehisces in two pieces, like that of the Pea, 122.

Leguminous, belonging to legumes, or to the Leguminous Family.

Lenticular, lens-shaped; i. e. flattish and convex on both sides

Lappaceous, bur-like.

Lasio, Greck for woolly or liairy, as Lasianthus, woolly-flowered.

Lateritious, brick-colored.

Laticiferous, containing latex, 138.

Latus, Latin for broad, as Latifulius, broad-leaved.

Leaf-scar, Leaf stulk, petiole.

Lenticels, lenticular dots on young bark.

Lentiginose, as if freckled.

Lepal, a made-up word for a staminode.

Lepris, Greek for a scale, whence Lepidote, leprous; corered with scurfy scales.

Leptos, Greek for slcnder; so Leptophyllous, slender-leaved.

Leukos, Greek for white; whence Leucunthous, white-flowered, \&c.

liber, the inner bark of Exogenous stems, 140.

lill, see operculum.

Ligneous, or Lignose, woody in texture.

Ligulate, furnislich with a ligule, 93.

Ligule, Ligula, the strap-shaped corolla in many Compositæ, 93 ; the membranous appendage at the summit of the lcaf-slieatlis of most Grasses, 57.

Limb, the border of a corolla, \&c., 89 .

Limbate, bordered (latin, Limbus, a boriler).

Line, the twelfth of an inch; or French lines, the tenth.

Linear, narrow and flat, the margins parallel, 52.

Lineate, marked with parallel lines. Lineolate, marked with minute lines.

Jingulate, Linguiform, tongue-shaperl.

lip, the principal lobes of a bilabiate corolla or calyx, 92 .

Litoral or Littoral, belonging to the shore.

Livil, pale lead-colored.

Lobe, any projcction or division (espeeially a ronnder one) of a leaf, \&c. .

Lobed or Lnbate, cut iuto lobes, 55, 56; Lobulate, into small lobes.

Locellate, having Locelli, i. e. compartments in a cell: thus an anther-cell is oftep bilocellute.

Loculament, same ns loculus.

Loculur, rclating to the eell or compartment (Loculus) of an ovary, \&c.

Loculicidal (dehiscence), splitting down through the back of cach cell, 123.

Locustu, a name for the spikelet of Crisses.

Lodicule, one of the scalcs answering to perianth-leaves in Grass-flowers.

Loment, a pod which separates transicrsely into joints, 122.

Lomentaceous, pertaluing to or resembling a loment.

Jorate, thong-shaperl.

Lunate, crescent-shaped. Lunulate, diminutive of lunate.

Lupuline, like hops.

Jusus, Latin for a sport or abnormal variation.

Luteulus, yellowish; dininutive of

Luteus, Latin for yellow. Lutrscent, rerging to yellow.

Lyrate, lire-shajed: a pinuatiful lcaf of an obovate or spatulate outline, the end. lobe large and roundish, and the lower lobes small, as in lier. 149.

Macros, Greek for long, sometimes also uscd for large; thus Mfacrophyllous, long or large-leaved, \&c.

Macrospore, the large kind of spore, when there are two kinds, $160,161$.

Maculnte, spotted or blotched.

Male (flowers of plants), having stamens but no pistib.

Mammose, breast-shapel.

Marcescent, witherng without falling off.

Marginal, belongriug to margin. 
Marginate, margined with an edge different from the rest.

Harginicidal dehiscence, 123.

Maritime, belonging to sea-coasts.

Marmorate, marbled.

Mas., Masc., Musculine, male.

Masked, see personate.

Mealy, see farinaceons.

Median, Medial, belonging to the middle.

Medifixed, attached by the middle.

Medullary, belonging to or of the nature of, pith (Medulla); pithy

Medullury Ruys, the silver-grain of wood, 140, 141.

Medullary Sheuth, a set of ducts just around the pih, 140.

Meiostemonous, having fewer stamens than petals.

Membranaceous or Membranous, of the texture of membrane; thin and soft.

Meniscoid, crescent-shaped.

Mericarp. one carpel of the fruit of an Umbelliferous plant, 121.

Merismatic, separating into parts by the formation of partitions across.

Merous, from the Greek for part; used with numeral prefix to denote the number of pieces in a set or circle: as Monomerous, of only one, Dinevous, with two. Trimerous, with three parts (sepals, petals, stamens, \&c.) in each circle.

Jesocarp, the middle part of a pcricarp, when that is distinguishable into three layers, 120.

Mresophloeum, the middle or green bark.

Nicropyle, the closed orifice of the seed, 110, 126.

Aficrospore, the smaller kind of spore when there are two kinds, 161.

Ifidrib, the middle or main rib of a leaf, 50 .

Jilk-vessels, 138.

Miniate, vermilion-colored.

Mitriform, mitre-shaped: in the form of a peaked cap, or one cleft at the top.

Moniliform, necklace-shaped; a cylindrical body contracted at intervals.

Monocarpuc (duration), flowering and seeding but once, 38 .

Monochlamydeous, having only one floral euvelope.

Monocotyledonous (embryo), with only one cotyledon, 24.

Mfonocotyledonous Plants, 24. Mfonocotyls, 24.

Monceious, or Honoicous (flower), having stamens rr pistils only, 85 .

Monogynous (flower), having only one pistil, or one style, 105.

Monopetalons (flower), with the corolla of one piece, 89.

Ifonophyllous, ono-leaved, or of one piece.

Monos, Greek for solitary or only one; thus Monadelphous, stamens united by thelr filaments into one set, 99 ; ironandrous (flower), having on Iy one stamen, 100.

Monosepalous, a calyx of one piece; $\mathrm{i}$. e. witli the sepals united into one body.

Monospermous, one-seeded.

Monstrosity, an unnatural deviation from the usual structure or form.

Morphology, Morphalogicul Botany, 9; the department of botany which treats of the forms which an organ may assume.

Moschate, Musk-like in odor.

Morements, 149.

Mucronate, tipped with an ablupt short point (Mucro). 54.

If ucronulate, tipped with a minute abrupt point; a diminutive of the last.

If ulti-, in composition, many; as Multangular, many-angled; Multicipital, many. hended, \&c.; Multifurions, in many lows ol ranks; Mfultifid, many-cleft; Mul tilocular, many-celled; Multiserial, in many rows.

Multiple Fruits. 118, 124.

Afuricate, beset with short and hard or prickly points.

Muriforn, wall-like; resembling courses of bricks in a wall.

Muticous, pointless, blunt, unarmed.

Jycelium, the spawn of Fungi; $\mathbf{i}$. e. the filaments from which Mushrooms, Sc.; originate, 172. 
Naked, wanting some usual covering, as achlamydeous flowers, 86, gymnospermous secds, $109,125, \& c$.

Names in botany, 179.

Nanus, Latin for dwarf.

Napiform, turnip-shaped, 35.

Natural System, 182.

Naturalized, introduced from a foreign conntry, and flourishing wild.

Navicular, boat-shaped, like the glumes of most Grasses.

Necklace-shaped, looking like a string of beads; see moniliform.

Nectur, the sweet secretion in flowers from which bees make honey, \&c.

Nectariferous, loney-bearing; or having a nectary.

Nectary, the old name for petals and other parts of the flower when of unusual shape, especially when honey-bearing. So the hollow spur-shaped petals of Columbine were called nectaries; also the curious long-clawed petals of Monkshood, 87, \&c.

Needle-shaped, long, slender, and rigid, like the lcaves of Pines.

Nemorose or Nemoral, inhabiting groves.

Nerve, a name for the ribs or veins of lcares when simple and parallel, 50.

Nerved, furnished witl nerres, or simple and parallel ribs or reins, 50.

Nervose, conspicuously nerved. Nervulose, ninutely nervose.

Netted-veined, furnished with branching veins forming network, 50, 51

Neuter, Neutral, sexless. Neutral flower, 79.

Niger, Latin for blaek. Nigricans, Latin for verging to black.

Nitid, shining.

Nival, living in or ncar snow. Niveus, snow-white.

Nodding, bending so that the summit hangs downward.

Node, a knot; the "joints" of a stem, or the part whence a leaf or a pair of leaves springs, 13.

Nolose, knotty or knobby. Nodulose, furnished with little knobs or knots.

Nomenclature, $175,179$.

Normal, according to rulc, natural.

Notate, marked with spots or lines of a different color.

Nucamentaceous, relating to or resembling a small nut.

Nuciform, nut-shaped or nut-like.

Nucleus, the kernel of an ovulc (110) or seed (127) of a cell.

Nucule, same as nutlet.

Nude, (Latin, Nudus), naked. So Nudicaulis, naked-stemmed, \&c.

Nut, Latin Nux, a lıard, mostly one-seeded indehiscent fruit; as a chestnut, butternut, acorn, 121.

Nutant, nodding.

Nutlet, a little nut; or the stone of a drupe.

Ob- (meaning over against), when prefixed to words signifies inversion; as, $O b$ compressed, flattcned the opposite of the usual way; Obcordate, heart-shaped, with the broad and notehed cnd at the apex instead of the base, 54; Oblanceolate, lance-shaped with the tapering point downwards, 52 .

Obliquê, applied to leares, \&c., means unequal-sided.

Oblong, from two to four times as long as broad, 52.

Obovate, inversely ovate, the broad end upward, 53. Obovoid, solid obovate.

Obtuse, blnnt or round at the end, 54 .

Obverse, same as inverse.

Obvolute (in the bud), when the margins of one piece or leaf alternately overlap those of the opposite one.

Ocellate, with a circular colored pateh, like an eye.

Ochroleucous, yellowish-white; dull cream-eolor.

Ocreate, furnished with Ocree (boots), or stipules in the form of sheaths, 57.

Octo-, Latin for cight, enters into the composition of Octagynous, with eight pistils or styles; Octamerous, its parts in eights; Octandrous, with eight stamens, \&c. 
Oculate, with eye-shaped marking.

Officinal, used in medicine, thertfore kept in the shops.

Offset, short branches next the ground which take root, 40 .

Oides, termination, from the Greek, to denote likeness; so Dianthoides, Pink-like.

Oleraceous, esculent, as a pot-herb.

Oligos, Greek for few; thus Oliganthous, fer-flowered, \&c.

Olivaceous, olive-green.

Oophorilium, a name for spore-case continining macrospores.

Opaque, applied to a surface, means dull, not slining.

Operculate, fumished with a licl (Opcrculum), as the spore-case of MLoses, 163.

Opposite, said of leares and lranches when on opposite sides of the stem from each other (i. e. in pairs), 29, 68. Stamens are opposite the petals, \&c., when they stand before them.

Oppositifolius, situated opposite a leaf.

Orbicular, Orbiculate, cireular in outline, or nearly so, 52.

Order, group below class, 178 . Ordinal names, 180 .

Organ, airy member of the plant, as a leaf, a stamen, \&c.

Organography, study of organs, 9. Organugentsis, that of the development of organs.

Orgynlis, of the lieight of a man.

Orthes, Greek for straiglit; thus, Orthocarpous, with straight fruit; Orthostichous, straight-ranked.

Orthotropins (ovule or seed), 111.

Osseous, of a bony texture.

Outgrowths, growths from the surface of a leaf, petal, \&c.

Oval, broadly elliptical, 52.

Ovary, that part of the pistil containing the ovules or future seeds, $14,80,105$.

Ovate, shaped like an egg, with the broader end downwards; or, in plain surfaces, sucli as leares, like tlue section of an egg lengthwise, 52 .

Ovoid, ovate or oval in a solid form.

Ovule, the body which is destined to become a seed, 14, 80, 105, 110.

Ovuliferous, ovule-bearing.

Palate, a projection of the lower lip of a labiate corolla into the throat, as in Snapdragon, Sc.

Palea (plural palea), chaff; the inner luusks of Grasses; the cliaff or bracts on the receptacle of many Compositx, as Coreopsis, and Sunflower.

Paleaceons, furnished with chaff, or chaffy in texture.

Paleolate, having Paleuke or palex of a second order, or narrow palex.

Palet, English term for palea.

Pulmate, when leaflets or the divisions of a leaf all spread from the apex of the petiole, like the liand with the outspread fingers, $57,58$.

Palmately (veined, lobed, \&c.), in a palmate manner, $51,56$.

Palmatifid,-lubed, -sect, palmately cleft, or lobed, or divided.

Paludose, inhabiting nurshes. Palustrine, same.

Pandurifon, or I'thilurate, fiddle-shaped (which see).

Panicle, an open and branched cluster, 81.

Panicled, Puniculate, arranged in panicles, or like a panicle.

Pannose, covered with a felt of woolly lairs.

Papery, of about the consistence of letter-paper.

Papilionnceous, buttcrily-shnped; applied to such a corolla as that of the Pea, 91.

Papilla (plural papille), little nipple-slıaped mrotuberances.

Papillate, Papillose, corered with papillie.

Pappus, thistie-down. The down crowning the acheninn of the Thistle, Gronndsel, \&c., and whatever in Coupositie answers to calyx, whether liairs, teeth, or scales. 121.

Papymceous, like parclunent in texture.

Puralleb-veined or nerced (leaves), 50. 
Paraphyses, jointed filaments mixed with the antheridia of Mnsses

Parasutic, living as a parasite, i. e. on another plaut or animal, 37.

Parenchemytuus, composed of parenehyma.

Parenchymu, soft cellular tissue of plants, like the green pulp of leaves, 132.

Parietal (placentix, \&c.), attached to the walls (parietes) of the ovary.

Paripinnate, pinnate with an even number of leaflets.

Parted, separated or eleft into parts alınost to the base, 55 .

Parthenogenesis, producing seel without fertilization.

Partinl involucre, same as an incolucel; partial petiole, a division of a main leaf. stalk or the stalk of a leaflet; partial peduncle, a braneh of a pedunele; par. tical umbel, an umbellet, 76 .

Partition, a segment of al purted leaf; or an internal wall in an ovary, anther, \&e.

Patelliform, disk-slıaped, like the pritella or kneenau.

Patent, spreading, open. Patulous, molerately spreading.

Pauci, in composition, few; as pauciflorons, few-flowered, \&c.

Pear-shaped, solicl obovate, the shape of a pear.

Pectindie, pinnatifid or pinnately divided into narrow and close divisions, like the tectli of a comb.

Pedate, like a birl's foot; palmate or palmately eleft, with the side divisions again cleft, as in Viola pedata, \&e.

Pedicel, the stalk of each paticular flower of a cluster, 73.

Pedicellrite, Pedicelled, borne on a pedieel.

Pedalis, latin for a foot high or long.

Perduncle, a flower-stalk, whetler of a single flower or of a flower-cluste:, 73.

Peduncled, P'edunculute, furnished will a peduncle.

Pelorit, an abnormal return to regularity and symmetry in an irregular flower; com. monest in Snapdragon.

Peltate, shield-shaped; said of a leaf, whatever its shape, when the petiole is attached to the lower side, somewhere within the margin, 53.

Pelvifurm, basin-shaped.

Pendent, hansing. Pendulous, somewhat hanging or drooping.

Penicillate, Penicilliform, tipped with a tuft of tine hairs, like a painter's peneil; as the stigmas of some Giasses.

Pennate, same as pinnate. Penninerved and Penniveined, pinnatel $y$ veined, 51.

Penta-(in worls of Greek composition), tive; as Pentadelphous, 99; Pentagynous, witl tive pistils or styles; Pentanerous, witl its parts in fives, or on the plan of five; Pentenulrous, haviug tive stamens, 112; Pentastichous, in five ranks, \&e.

Pepo, a frnit like the Nelon and Cueumber, 119.

Perenninl, lasting from year to year, 38.

Perfect (Alower), having botll stamens and pistils, $\mathbf{9 1 .}$

Perfolme, passing thougl the leaf, in appearance, 60.

Perforate, pierced with holes, or with trinsparent dots resembling holes, as an Orange-leaf.

Peri-, Greek for around; from which are such terns as

Perianth, the leaves of the flower collectively, 79 .

Pericorp, the ripened ovary; the walls of the fruit, 117.

Pericripic, helonging to the pericarp.

Perigonium, Peroyne, same as perianth.

Perigynium, Indies around the pistil; applied to the elosed eup or bottle-shapea boty (of bracts) which encloses the ovary of Sedges, and to the bristles, littlo scales, ke. of the tlowers of some other Cyperacex.

Perigynous, the petals and stamens borne on the calyx, 95, 99.

Periphervic, aroumb the cut-icle, or periphery, of any organ.

Perisperm, a riame for the albumen of a seed.

Peristome, the fringre of teptlis to the spore-ease of Mnssea, 163.

Persistent, remaining beyond the perod when such parts commonly fall, as the leaves of evergreens, and the cally $\mathrm{x}$ of such flowers as persist during the growth oi the fruit. 
Personate, masked; a bilabiate eorolla with a palate in the throat, 92.

Pertuse, perforated with a hole or slit.

Perulate, having seales (Perulo), such as bud-scales.

Pes, pedis, Latin for the foot or support, whence Longipes, long-stalked, \&c.

Petal, a leaf of the corolla, 14, 79 .

Petalody, metamorphosis of stamens, \&e., into petals.

Petaloid, Petaline, petal-like; resembling or colored like petals.

Petiole, a footstalk of a leaf; a leaf stalk, 49.

Petioled. Petiolate, furnished with a petiole.

Petiolulnte, said of a leaflet when raised on its own partial leafstalk.

Petrœus, Latin for growing on rocks.

Phalanx, phalanges, bundles of stamens.

Phonogamous, or Phanerogamous, plants bearing flowers and produeing seede same as Flowering P'lants. Phonogams, Phanerogams, 10.

Phloum, Greek name for bark, whenee Endophlœum, inner bark, \&c.

Phoniceous, deep red rerging to searlet.

Phycology, the botany of Algr.

Phyllocladia, branches assuming the form and function of leaves.

Phyllodium (plural, phyllodia), a leaf where the seeming blade is a dilated petiole, as in New Holland Acaeias, 61.

Phyllome, foliar parts, those answering to leaves in their nature.

Phyllon (plural, phylla), Greek for leaf and leaves; used in many compound terms and names.

Phyllotaxis, or Phyllotaxy, the arrangement of leaves on the stem, 67 .

Physiological Botany, 9.

Phytography, relates to claracterizing and deseribing plants.

Phyton, or Phytomer, a name used to designate the piees which ty their repetition make up a plant, theoretieally, viz. a joint of stem with its lcaf or pair of leaves.

Pileus of a mushroom, 172.

Piliferous, bearing a slender bristle or hair (pilum), or beset with hairs.

Pilose, hairy; elothed with soft slender hairs.

Pinna, a primary division with its leaflets of a bipinnate or tripinnate leaf.

Pinnule, a secondary division of a bipimnate or tripinnate leaf, 66.

Pinnate (leaf), when leaflets are arranged along the sides of a common petiole, 57 .

Pinnately lobed, cleft, parted, divided, veined, 56.

Pinnatifid, Pinnatisect, same as pinnately eleft and pinnately parted, 56.

Pisifor"m, pea-shaped.

Pistil, the seed-bearing organ of the flower, 14, 80, 105.

Pistillate, having a pistil, 85 .

Pistillidium, the body which in Mosses answers to the pistil, 159, 164.

Pitchers, 64.

Pith, the cellular centre of an exogenous stem, 138.

Plicenta, the surface or part of the ovary to which the ovules are attached, 107.

Placentiform, nearly same as quoit-slaped.

Plaited (in the bud), ol Plicate, folded, 72, 98.

Platy-, Greek for broad, iu compounds, such as Platyphyllous, broad-leaved, Sc.

Pleio-, Greek for full or abounding, used in eompounds, such as Pleiopetalous, of many petals, $\& c$.

Plumbeus, lear-colored.

Plumose, feathery; when any slender body (such as a bristle of a pappus or a style) is beset with lairs along its sides, like the plume of a feather.

Plumule, the bud or first shoot of a germinating plantlet above the eotyledons, 13

Pluri-, in composition, many or several; as Plurifoliolate, witl several leaflets.

Pod, specially a legume, 122; also may be applied to any sort of capsule.

Podium, a footstalk or stipe, used only in Greek compounds, as (suffixed) Leptro podus, slender-stalked, or (prefixed) Podocephalus, witl a stalked head, and in Podosperm, a seed stalk or funiculus.

Pogon, Greek for bearl, comes into rarious compounds. 
Pointless, destitute of any pointed tip, such as a mucro, awn, acumination, \&c.

Pollen, the fertilizing powder contained in the anther, $14,80,103$.

Pollen-growth, 117. Pulleniferous, pollen-bearing.

Pollen-mass, Pollinium, the united mass of pollen, 104, as in Milkweed and Orehis.

Pollicaris, Latin for an inch long.

Pollination, the applieation of pollen to the stigma, 114.

Poly-, in compound words of Greek origin, same as multi-in those of Latin origin viz. many, as

Polyadelphous, stamens united by their filaments into several bundJes, 100 .

Polyandrous, with numerous stamens (inserted on the reeptacle), 100.

Polycarpic, term used by DeCandolle in the scuse of perennial.

Polycotyledonous, having many (more than two) cotyledons, as I'ines, 23.

Polygamous, having some perfeet and some unisexual flowers, 85 .

Polygonal, many-angled.

Polygynous, with many pistils or styles, 105.

Polymerous, formed of many parts of each set.

Polymorphous, of scveral or varying forms.

Polypetalous, when the petals are distinet or separate (whether few or many), 89.

Polyphyllous, many-leaved; rormed of sereral distinct pieces.

Polysepalous, same as the last when applied to the ealyx, 89.

Polyspermous, many-seeded.

Poine, the apple, pear, and similar fleshy fruits, 119.

Pomiferous, pone-bearing.

Porrect, outstretched.

Posterior side or portion of a flower (when axillary) is that toward the axis, 96.

Pouch, the silicle or short pod, as of Shepherd's Purse, 123.

Precocious (latin, procox), unusually early in development.

Prefloration, same as astivation, 97.

Prefoliation, same as vernation, 71 .

Promorse, ending abruptly, as if bitten off.

Pratensis, Latin for growing in meadows.

Prickles, sharp elevations of the bark, coming off with it, as of the Rose.

Prickly, bearing prickles, or sharp projeetions like them.

Primine, the outer eat of the covering of the ovule, 110.

Primordial, earliest formed; primordial leaves are the first after the cotyledons.

Prismatic, prism-shaped; having three or more angles bounding flat sides.

Procerous, tall, or tall and slim.

Process, any projeetion from the surfaee or edge of a body.

Procumbent, trailing on the ground, 39.

Procurrent, running throngl but not projecting.

Produced, extended or projeeting; the upper sepal of a Larkspur is produced above into a spur, 87.

Proliferous (literally, bearing offspring), where a new branch rises from an older one, or one head or cluster of flowers out of another.

Propaculum or Propagulum, a shoot for propagation.

Prosenchyma, a tissue of wood-cells.

Prostrate, lying flat on the ground, 39.

Protandrous or Proterandrous, the anthers first maturing, 116.

Proteranthous, flowering before leafing.

Proterogynous or Protogynous, the stigmas first to mature, 116.

Prothallium or Prothallus, 160.

Protoplasm, the soft nitrogenous lining or contents, or liring part, of cells, 129.

Protos, Greek for first; in various compounds.

Pruinose, Pruinate, frosted; covered with a powder like hoar-frost.

Psendo-, Grcek for false. Pseudo-bulb, the aerial corms of epiphytic Orchids. \&cc.

Psilos, Grcek for barc or naked, used in many compounds.

Pteridophyta, Pteridophytes, 156.

Reris, Greek tor wing, and general name for Fern, enters into many compounds. 
Puberulent, eovered with fine and short or almost impereeptible down.

Pubscent. hairy or downy, espeeially with fine and soft hairs or pubescence.

Pulverulent or Pulveraceous, as if dusted with fine powder.

Pulvinate, eushioneal, or shaped hike a eushion.

Pumilus, low or little.

Punctute, dotted, either with minute holes or what look as such.

l'uncticulate. minutely punetate.

l'ungent, prickly-tipped.

Funiceous, earmine-red.

Purpureus, originully l'ed or erimson, more used for duller or bluish-red.

Pusillus, weak and small, tiny.

Futamen, the stone of a drupe, or the shell of a nut, 120.

Pygmeus, latin for dware.

$I^{\prime} y$ remidul, sliaped like a pyramid.

Purene, Pyrenu, a seed-like nutlet or stone of a small drupe.

Syriform, pear-slaped.

'yucidare, furnished with a lid.

F.y

Qu adri-, in words of Latin origin, four; as Quallrangular, four-angled; Quadr foliate, four-leaved; Quadrifid, four-cleft. Quaternate in fours.

Quinute, in tives. Quingue, five.

Qincuncial, in a quineun; when the parts in xstivation are five, two of them outside, two inside, and one half out and half in.

Quintuple, tive-fold.

Kace, a marked variety whieh may be perpetuated from seed, 176.

haceme, a flower-cluster, with one-flowered pedieels arranged along the sides of a general pedunele, 73 .

Racemose, bearing racemes, or raeeme-like.

Riacres, see rhachis.

$R$ adial, belonging to the ray.

Radiate, cr Ridiant, furnished with ray-flowers, 94 .

Racliate-veined, 52.

Radical, belonging to the root, or apparently eoming from the root.

Radicant, rooting, taking root on or above the ground.

Radicels, little roots or rootlets.

Radicle, the stem part of the embryo, the lower end of which forms the root, 11, 127.

Rameal, belonging to a branch. Ramose, full of branches (rami).

Ramentrceous, beset with thin ehaffy seales (Ramenta), as the stalks of many Ferns.

Ramification, branehing, 27.

Rimulose, full of branchlets (vamuli).

Riphe, sce rhoiphe.

Ray, parts diverging from a centre, the marginal finwers of a head (as of Coreopsis, 94 ), or cluster, as of Hydrangea (78), when different from the rest, espeeially when lignlate and diverging (like rays or sunbeans); also the branehes of an umbel, 74 .

Ray-flowers, 94.

Receptracle, the axis or support of a fluwer, 81,112 ; also the common axis or sup port of a head of flowers, 73.

Reclined, turned or eurved downwards; nearly reeumbent.

Rectinerved, with straisht nerves or veins.

Recurverl, eurved outwards or backwards.

Reduplicate (in sestivation), valvate with the margins turned outwards, 97

Reflexed, bent cutwarls or backwards.

Refracted, bent sullenly, so as to appear broken at the bend.

Regular, all the parts similar in shape, 82 .

Reniform. kidney-sliaped, 53. 
Repand, wavy-margined, 55.

Repent, creeping, i. e. prostrate and rooting underneath.

Replum, the frame of some pods (as of Prickly Poppy and Cress), persistent after the valves fall away.

Reptont, same as repent.

Resupinate, inverted, or appearing as if upside down, or reversed.

Reticulated, the veins forming network, 50. Retiform, in network.

Retinered, reticulate-reined.

Retroflexed, bent backwards; same as refexed.

Retuse, blunted; the apex not only obtuse but somewhat indented, 54.

Revolute, rolled backwards, as the margins of many leaves, 72 .

Rhachis (the backbone), the axis of a spike or other body, 73 .

Rhaphe, the continuation of the seed-stalk along the side of an anatropous ovule or seed, 112, 126.

Rhaphides, crystals, especially needle-shaped ones, in the tissues of plants, 137 .

Rhizunthous, flowering from the root.

Rhizomn, Rhizome, a rootstock, $42-44$.

Rhombic, in the shape of a rhomb. Rhomboidal, approaching that shape.

Rib, the principal piece, or one of the principal pieces of the framework of a leaf, or any similar elerated line along a body, 49, 50 .

Rimose, having chiuks or cricks.

Ring, an elastic band on the spore-cases of Ferns, 159.

Ringent, grinning; gaping open, 92.

Riparzous, on river-banks.

Rivalis, Latin for growing along brooks; or Rivularis, in rivulets.

Root, 33 .

Root-hairs, 35 .

Rootlets, small roots, or root-branches, 33 .

$R$ notstock, root-like trunks or portions of stems on or under ground, 42.

Roridus, dewy.

Rosacfous, arranged like the petals of a rose.

Rostellate, bearing a small beak (Rostellum).

Rostrute, bearing a beak (Rustrum) or a prolonged appendage.

Rosulate, in a rosette or cluster of spreading leaves.

Rotate, whcel-shapel, 89.

Rotund, rounded or roundish in outline.

Ruber, Latin for red in general. Rubescent, Rubicund, reddish or blushing.

Rudimentary, imperfectly developerl, or in an early state of development.

Rufous, Rufescent, brownish-red or reddish-brown.

Rugose, wrinkled; roughened with wrinkles.

Ruminated (albumen), penetrated with irregular channels or pottions, as a nutmeg, looking as if chewed.

Runcinate, coarsely saw-tootled or cut, the pointed teeth turned towards the base of the leaf, as the leaf of a Dandelion.

Runner, a slender and prostrate branch, rooting at the end, or at the joints, 40.

Sabulose, growing in sand.

Sac, any closed monbrane, or a deep purse-shaped cavity.

Saccate, sac-shaped.

Sagittrate, arrowlicad-shaped, 53.

Salsuginous, growing in brackish soil.

Salver-shaped, or Sulter-form, with a border spreading at right angles to a slendel tube, 89.

Samara, a wing-fruit, or key, 122.

Samaroid, like a samara or key-fruit.

Sap, the juiccs of plants generally, 136. Saprood, 142.

Saprophytes, 37.

Sarcocarp, the fleshy part of a stone-fruit, 120 . 
8armentaceous, Sarmentose, bearing long and fexible twigs (Sarments), eithet spreading or procumbent.

Saw-toothed, see serrate, 55 .

Scabrous, rough or harsh to the toueh.

Scalariform, with eross-bands, resembling the steps of a ladder, 134.

Scales, of buds, 28 ; of bulbs, \&e., 46.

Scalloped, same as crenate, 55 .

Scaly, furnished with seales, or scale-like in texture.

Scandent, elimbing, 39.

Scape, a pedunele rising from the ground or near it, as in many Violets.

Scapiform, seape-like.

Scapigerous, seape-bearing.

Scar of the seed, 126. Leaf-scars, 27, 23.

Scarious or Scariose, thin, dry, and membranous.

Scion, a shoot or slip used for grafting.

Scleros, Greek for hard, henee Sclerocarpous, hard-fruited.

Scobiform, resembling sawdust.

Scorpivid or Scorpioidal, curved or eireinate at the end, 77.

Scrobiculate, pitted; exeavated into shallow pits.

Scurf, Scurfiness, minute scales on the surface of many leaves, as of Goosefoot.

Scutate, Scutiform, buekler-shaped.

Scutellate, or Scutelliform, saueer-shaped or platter-shaped.

Secund, cne-sided; i. e. where flowers, leaves, \&e., are all turned to one side.

Secundine, the inner coat of the ovule, 110.

Seed, 125. Seed-leaves, see cotyledons. Seed-vessel, 127.

Segment, a subdivision or lobe of any eleft body.

Segregate, separated from each other.

Semi-, in compound words of Latin origin, half; as

Seni-adherent, as the calyx or ovary of Purslane; Semicmdate, half-heart-shapea

Semilunar, like a half-moon; Semiovate, half-ovate, \&c.

Seminal, relating to the seed (Semen). Seminiferous, seed-bearing.

Sempervirent, evergreen.

Sensitiveness in plants, 149, 152.

Senary, in sixes.

Sepal, a leaf or division of the calyx, 14,79 .

Sepaloid, sepal-like. Sepaline, relating to the sepals.

Separated Flower's, those having stamens or pistils only, 85.

Septate, divided by partitions.

Septenate, with parts in sevens.

Septicidal, where dehiseenee is through the partitions, 123.

Septiferous, bearing the partition.

Septifragal, where the valres in dehiseence break away from the partitions, 123

Septum (plural septa), a partition or dissepiment.

Serial, or Seriate, in rows; as biserial, in two rows, \&c.

Sericeous, silky; elotled with satiny pubeseence.

Serotinous, late in the season,

Serrate, the margin ent into teeth (Serratures) pointing forwards, $\mathbf{5 5}$.

Serrulate, same as the last, but with fine teeth.

Sessile, sitting; without any stalk.

Sesqui-, Latin for one and a half; so Sesquipedalis, a foot and a half long.

Seta, a bristle, or a slender body or appendage resembling a bristle.

Setaceuus, bristle-like. Setiform, bristle-shaped.

Setigerous, bearing bristles. Setose, beset with bristles or bristly haIrs.

Setula, a diminutive bristle. Setulose, provided with suel.

Sex, six. Sexangular, six-angled. Sexfarious, six-faeed.

Sheath, the base of sueh leaves as those of Grasses, which are

Sheatling, wrapperl round the stem.

Shield-shmped same as scutate, or as peltate. 53. 
Shrub, Shrubby, 39.

Sieve-cells, 140.

Sigmoid, curved in two directions, like the letter S, or the Greek sagma.

Silicle, a pouch, or short pod of the Cress Family, 123.

Siliculose, bearing a silicle, or a fruit resembling it.

Silique, capsule of the Cress Family, 123.

Siliquose, bearing siliques or pods which resemble siliques.

Silky, glossy with a coat of fine and soft, close-pressed, straight hairs.

Silver-grain, the medullary rays of wood, 139.

Silvery, shining white or bluish-grav, usually from a silky pubescence.

Simple, of one piece; opposed to compound.

Sinistrorse, turned to the left.

Sinuate, with margin alternately bowed inwards and outwards, 55.

Sinus, a recess or bay; the re-entering angle between two lobes or projections.

Sleep of Plants (so called), 151.

Smooth, properly speaking not rough, but often used for glabrous, i. e. not pu bescent.

Soboliferous, bearing shoots (Soboles) from near the ground.

Solitary, single; not associated with others.

Sordid, dull or dirty in hue.

Sorediate, bearing patches on the surface.

Sorosis, name of a multiple fruit, like a pine-apple.

Sorus, a fruit-dot of Ferns, 159.

Spadiceous, chestnut-colored. Also spadix-bearing.

Spadix, a flcshy spike of flowers, 75 .

Span, the distance between the tip of the thumb and of little finger outstretched, six or seven inches.

Spathaceous, resembling or furnished with a

Spathe, a bract which inwrans an inflorescence, 75.

Spatulate, or Spathulate, shaped like a spatula, 52.

Species, 175.

Specific Numes, 179.

Specimens, 184.

Spermaphore, or Spermophore, one of the names of the placenta.

Spermum, Latin form of Greek word for seed; much used in composition.

Spica, Latin for spike; hence Spicate, in a spike, Spiciform, in shape resembling a spike.

Spike, an inflorescence like a raceme, only the flowers are sessile, $\mathbf{7 4}$.

Spikelet, a small or a secondary spike; the inflorescence of Grasses.

Spine, $41,64$.

Spindle-shaped, tapering to each end, like a radish, 36.

Spinescent, tipped by or degenerating into a thorn.

Spinose, or Spiniferous, thorny.

Spiral Vessels or ducts, 135.

Spithameous, span-high.

Spor't, Greek name for seed, used in compound words.

Sporadic, widely dispersed.

Sporangium, a spore-case in Ferns, \&c., 158.

Spore, a body resulting from the fructification of Cryptogamous plants, in them the analogue of a seed.

Spore-case (Sporangium), 158.

Sporocarp, 162.

Sport, a newly appeared variation, 176.

Sporule, same as a spore, or a small spore.

Smumescent, appearing like froth.

Spur, any projecting appendage of the flower, looking like a spur but hollow, as that of Larkspur, fig. 239.

Squamate, Squamose, or Squamaceous. furnished with scales (squamo). 
Squamellate, or Squamulose, furnished with little scales (Squamello, or Squamulae). Syuremiform, shaped like a scale.

Squarrose, where scales, leares, or any appendages spread widely from the axis on which they are thickly set.

Squarrulose, diminutive ol squarrose; slightly squarrose.

Stachys, Greck for spike.

Stalk, the stem, petiole, peduncle, \&e., as the ease may be.

Stamen, 14, 80, 98.

Staminate, furmished with stamens, 86. Stamineal, relating to the stamens,

Staninodiun, an abortire stamen, or other body in place of a stamen.

Standurd, the upper petal of a papilionaceous eorolla, 92.

Sturch, 136, 163.

Station, the particular kind of situation in which a plant naturally oceurs.

Stellate, Stellulur, stary or star-like; where several similar parts spread out from a common eentre, like a star.

Stem, 3y. Stemlet, diminutive stem.

Stemless, destitute or apparently destitute of stem.

Stenos, Greek for narrow; hence Stenophyllous, narrow-leaved, \&e.

Sterile, barren or imperiect.

Stigma, the part of the pistil which receires the pollen, 1f, 80, 105 .

Stiymatic, or Stigmatose, belonging to the stigma.

Stipe (Latin Stipes), the stalk of a pistil, \&c., when it has any, 112; also of a Fern,

158, and of a Mnsliroom, 172.

Stipel, a stipule of a leaflet, as of the Bean, \&c.

Sipellate, fumished wilh stipels, as in the Bean tribe.

Stipitate, furnished with a stipe.

Stipulaceous, belonging to stipules. Stipulate, furnished with stipules.

Stipules, the appendages one each side of the base of certain leaves, 66 .

Stirps (plural, stirpes), Latin for race.

Stock, used for race or source. Also for any root-like base from which the herb grows up.

Stole, or Stolon, a trailing or reclined and rooting shoot, 40 .

Stoloniferous, producing stolons.

Stomate (Latin Stoma, plural Stomata), the breathing-pores of leaves, 144.

Stone-J"uit, 119.

Storage-lentes, 62.

Stramineous, straw-like, or straw-colored.

Strap-shaped, long, fat, and narrow.

Striate, or Striated, maiked with slender longitudinal grooves or stripes.

Strict, close and narrow; straight and narrow.

Striyillose, Strignse, beset with stont and appressed, stiff or rigid bristles.

Strobilaceons, relating to or resembling a str bile.

Sirobile, a multiple fruit in the form of a cone or head, 124.

Strombuliform, twistel, like a spiral shell.

Strophivle, same as crruncle, 126. Strophiolate, furnished with a strophiole

Struma, a wen; a swelling or protuberanee of any organ.

Strumose, hearing a strmma.

Stupose, like tow.

Style, a stalk between ovary and stigma, 14, 80, 105 .

Styliferous, styluse, bearing styles or conspicuous ones.

Stylopodium, an epigyruns disk, or an enlarement at the base of the style.

Sub-, as a prefix, abont, nearly, somewhat; as Subcordate, slightly cordate; Subser. rate, slinhtly serrate; Subrrillary, jnst beneath the axil, \&e.

Subclass, Suborler, Sublribe, 178.

Suberose, corky or cork-like in texture.

Subulate, awl-shaped; talpering trom a broadish or thickish base to a sharp point.

Succise, as if cut off at lower end.

Succubous, when erowled leaves are each eovered by base of next above. 
Suckers, shoots from subterranean branehes, 39.

Suffirutescent, slightly shrubby or woody at the base only, 39.

Sulfiruticuse, ratlier more than suffruteseent, $37,39$.

Sulcate, grooved longitudinally witl deep furrows.

Superior, above, 96 ; sometimes equivalent to posterior, 96.

Supernumerary Buds, 30, 31.

Supervolute, plaited and convolute in bud, 97.

Supine, lying flat, with face ujward.

Supra-axillury, borne alrove the axil, as some buds, 31 .

supra-decompound, many times eompounded or divided.

Surculose, produeing suckers (Surculi) or shoots resenbling them.

Suspended, hanging down. Suspended ovtules or seeds lang from the rery summit of the cell which contains them.

Sutural, belonging or relatins to a suture.

Suture, the line of junction of contignous parts grown together, 106.

Sicord-shriped, applied to narrow leares, with acute parallel edges, tapering above.

Syconium, the fig-fruit, 124.

Sylrestrine, growing in wonds.

Symmetrical Flower, similar in the number of parts of eaeh set, 82.

Sympetalures, same as gamopetalous.

Sympode, sympodium, a stem composed of a series of superposed branches jn sueb a Way as to in itate a simple axis, as in Grape-rine.

Synontherous or Syngenesious, where stamens are united by their anthers, 100.

Śyncarpous (fruit or pistil), emmposed of sereral carpels consolidated into one.

Synonym, an equiralent sunersecled name.

Synsepalous, same as gamosepalous.

Śy.tem (artilieial and natural), 182, 183.

Systematic Botany, the study of plants after their kinds, 9 .

Tabescent, wasting or slirivelling.

Tuil, any long and sleuder prolongation of an organ.

Triper-pointed, same as acuminate, 54.

Tup $-r^{\circ}$ oot, a root witlı a stout tapeling body, 32-35.

Tacony, dull yellowish, with a tinge of brown.

Taxonomy, the part of butany which treats of classifieation.

Tegmen, a name for the inner" seed.coat.

Tendril, a threarl-shaped organ used for elimbing, 40 .

Terete, long and round; sane as cylindrical, only it may taper.

Terminal, borne at, or belunging to, the extremity or summit.

Terminology treats of technical terms; same as Cilossology, 181.

Ternate, Ternntely, in threes.

Tessellate, in eileeker-work.

Testu, the outer (and usualiy the harder) eoat or shell of the seed, 125.

Testaceous, the eolor of micriaged pottery.

Tetra- (in words of Greek composition), four; as, Tetrencocous, of fonr eneci.

Tetradynamous, where a flower has six stamens, two shorter than the four, 101.

Tetragonal, four-ingled. Tetrugynous, with four pistils or strles. Tetramerous with its parts or sets in fours. Tetrandrous, with fuur staniens, 100.

Tetraspure, a quadruple spore, 169.

Thalamaflrous, with petals and stamens inserted on the torus or Thalamus.

Thallophiyta, Thallophygtes, 165.

Thallus, a stratum, in place of stem and leaves, 165.

Theca, a ease; the eelli or lolos of the anther.

Thecaphore, the stipe of a earpul. 113.

Thurn, an induraterl pointel brancli, $\$ 1,42$.

Threal-shned, slender and round or roundish, like a thrend.

Throat, the opening or gorge of a monopetalous corvlla, Se., where the border and the tube join, and a little below. 89 . 
Thyrse or Thyrsus, a compact and pyramidal panicle of cymes or cymules, 79 .

Tomentose, clothed with matted woolly hairs (tomentum).

Tongue-shoped, long and flat, but thickish and blunt.

Toothed, furnished with teeth or short projections of any sort on the margin; used especially when these are sharp, like saw-teeth, and do not point forwards, 55 .

Top-shaped, shaped like a top, or a cone with apex dowawards.

Torose, Torulose, kubby ; where a cylindrical body is swollen at intervals.

Torus, the receptacle of the flower, 81,112 .

Trachea, a spiral duct.

Trachys, Gleek fol rough; used in componinds, as, Trachyspermous, rough-seeded.

Transverse, aeross, standing right and left instead of fore and aft.

Tri- (in composition), three; as,

Triadelphous, stamens united by their filaments into three bundles, 99 .

Triandrous, where the flower has three stamens, 112.

Tribe, 178.

Trichome, of the nature of hair or puhescence.

Trichotonuus, three-forked. Tricoccous, of three cocci or roundish carpels.

Tricolor, having threc colors. Tricostate, having three ribs.

Tricuspidate, three-pointed. Tridentate, three-toothed.

Triennial, lasting for three years.

Trifurious, iu three vertical rows; looking three ways.

Trifid, three-cleft, 56 .

Trifoliate, three-leaved. Trifoliolate, of three leaflets.

Trifurcate, three-forked. Trigonous, three-angled, or triangular.

Trigynous, with three pistils or styles, 116. Trijugate, in three pairs (jugi).

Trilobed or Trilobate, three-lobed, 55.

Trilocular, three-celled, as the pistils or pods in fig. 328-330.

Trimerous, with its parts in threcs. Trimorphism, 117. Trimorphic or Trimorphous, in three forms.

Trinervate, three-nerved, or with three slender ribs.

Triocious, where there are three sorts of flowers on the same or different individuals, as in Red Maple. A form of Polygamous.

Tripartible, separable into three pieces. Tripartite, three-parted, 55.

Tripetalous, having three petals.

Triphyllous, three-learcd; composed of three pieces.

Tripinnate, thrice pinnate, 59 . Tripinnatifid, thrice pinnately cleft, 57 .

Triple-ribbed, Triple-nerved, \&c., wherc a midrib branches into three, near the base of the leaf.

Triquetrous, sharply three-angled; and especially with the sides concave, like a bayonet.

Triserial, or Triseriate, in three rows, under each other.

Tristichous, in threc longitudinal or perpendicular ranks.

Tristigmatic, or Tristigmatose, having three stigmas.

Trisulcate, three-grooved.

Triternate, threc times ternate, 59 .

Trivial Name, the specific name.

Trochlear; pulley-shaped.

Trumpet-shriped, tubular; enlarged at or towards the summit.

Truncrte, as if cut of at the top.

Trunk, the main stem or general body of a stem or tree.

Tube (of corolla, \&c.), 89.

Tuber, a thickcncl portion of a subterrancan stem or branch, provided with eyes

(butds) on the sides, 44.

Tubercle, a small cxcrescence.

Tubercled, or Tuberculute, bearing cxcrescences or pimples.

Tubceform, trumpertsliajorl.

Tuberous, rescmbling a tuber. Tuberiferous, bearing tubers.

Tubular; hollow ant of an elongated form; hollowed like a pipe, 91. 
Tubuliflorous, bearing only tubular flowers.

Tunicate, coated; invested with layers, as an onion, 46 .

Turbinate, top-shaped.

Turio (plural turiones), strong young shoots or suckers springing out of the ground as Asparagus-shoots.

Turnip-shaped, broader than high, abruptly narrowed below, 35 .

Twining, ascending by coiling round a support, 39 .

Type, the ideal pattern, 10.

Typical, well exemplifying the characteristics of a species, genus, \&c.

Uliginose, growing in swamps.

$U$ mbel, the umbrella-like form of inflorescence, 74 .

Umbellate, in umbels. Umbelliferous, bearing umbels.

Umbellet (umbellula), a secondary or partial umbcl, 76 .

Umbilicate, depressed in the centre, like the ends of an apple; with a navel.

Umbonate, bossed; furnislied with a low, rounded projection like a boss (umbo)

Umbraculiform, umbrella-shaped.

Unarmed, destitute of spines, prickles, and the like.

Uncial, an inch (uncia) in length.

Uncinate, or Uncate, hook-shaped; hooked over at the end.

Under-shrub, partially shrubby, or a very low shrub.

Undulate, or Undate, wavy, or wary-margined, 55.

Unequally pinnate, pinnate with an odd number of leaflets, 65 .

Unguiculate, furnished with a claw (unguis), 91.

Uni-, in compound words, one; as Unicellular, one-celled.

Uniflorous, one-flowercd. Unifoliate, one-leavcl.

Unifuliolate, of one lcaflet, 59. Unijugate, of one pair.

Unilabiate, one-lipped. Unilateral, one-sided.

Unilocular, onc-celled. Uniovulate, laving only one ovule.

Uniserial, in one horizontal row:

Unisexual, having stamens or pistils only, 85.

Univalved, a pod of only one piece after dehiscence.

Unsymmetrical Flowers, 86.

Urceolate, urn-shaped.

Utricle, a sinall thin-walled, one-seeded fruit, as of Goosefoot, 121.

Utricular, like a small bladder.

Vaginate, sheathed, surrounded by a sheath (vagina).

Valve, one of the pieces (or doors) into which a debiscent pod, or any similar body splits, 122, 123.

Valvate, Valvular, opening by valves. Valvate, in æstivation, 97.

Variety, 176.

Vascular, containing vessels, or consisting of vessels or ducts, 134 .

Vascular Cryptogams, 156.

Vaulted, arched; same as fornicate.

Vegetable Life, \&c., 128. Vegetable anatomy, 129.

Veins, the small ribs or branches of the framework of leaves, \&c., 49, 50.

Veined, Veiny, furnished with evident veins. Veinless, destitute of reins.

$V$ einlets, the smaller ramifications of veins, 50.

Velate, furnished with a reil.

Velutinous, velrety to the touch.

$V$ enation, the veining of leares, \&c., 50.

Venenate, poisonous.

Venose, veiny; furnished with conspicuous veins.

Ventral, belonging to that side of a simple pistil, or other organ, which looks to wards the axis or centre of the flower; the opposite of dorsal; as the

Ventral Suture, 106.

Ventricose, inflated or swelled out on one side. 
Venulnse, furnished with reinlets.

Vermicular, worm-like, shaped like worms.

Vernal, belonging to spring.

Vernation, the arrangement of the leaves in thc bud, 71 .

Vernicose, the surface appearing as if rarnished.

$V$ errucose, warty; beset with little projections like warts.

Versatile, attached by one point, so that it may swing to and fro, $10_{2}$

Vertex, same as apex.

Verlical, upright, perpendicular to the horizon, lengthwise.

Verticil, a whorl, 68 . Verticillate, whorled, 68.

Verticillaster, a false whorl, formed of a pair of opposite cymes.

Vesicular, bladdery.

Vespertine, appearing or expanding at evening.

$V$ essels, ducts, \&c., 134.

Vexillary, Vexillar, relating to the

Vexillum, the standard of a papilicnaceous flower, 92 .

Villose, slaggy with long and soft hairs (Villosity).

Vimineous, producing slender twigs, such as those used for wicker-work.

Vine, in the American use, any trailing or climbing stem; as a Grape-vine

Virescent, Viridescent, greenish; turning green.

Virgate, wand-shape; as a long, straight, aud slender twig.

Viscous, Viscid, having a glutinous surface.

Vitta (plural vittoe), the oil-tubes of the fruit of Umbelliferg.

Vitelline, ysllow, of the hue of yolk of egg.

Viviparous, sprouting or germinating while attached to the parent plant.

Voluble, twining; as the stem of Hops and Beans, 39.

Volute, rolled up in any way.

Wavy, the surface or margin alternately convex and concave, 55 .

Waxy, resembling beeswax in texture or appearance.

Wedge-shiped, broad above, tapering by straight lines to a narrow base, $5 \delta$

Wheel-shaped, 89.

Whorl, an arrangement of leaves, \&c., in circles around the stem.

Whorled, arranged in wliorls, 68.

Wing, any membranous expansion. Wings of papilionaceous flowers, 92.

Winged, furnished with a wing; as the fruit of Ash and Elm, fig. 300, 301

Wood, 133, 142. Woody, of the texture or consisting of wood.

Woody Fibre, or Wood-Cells, 134.

Woully, clothed with long and entangled soft hairs.

Work in plants, $149,155$.

Xanthos, Greek for yellow, used in compounds; as Xanthocarpus, yellow-fruited.

Zygomorphous, said of a flower which can be bisected only in one plane into simila: halvew. 


\section{B O T A N Y OF}

THE NORTHERN UNITED STATES 



\section{MANUAL}

OF

THE B OTAN Y

ов ния

\section{NORTHERN UNITED STATES,}

INCLUDING THE DISTRICT EAST OF THE MISSISSIPPI AND NORTH OF NORTH CAROLINA AND TENNESSEE.

\section{By ASA GRAY,}

LATE FISHER PROFESSOR OF NATURAL HISTORY IN HARVARD UNIVERSITY.

\section{Sixty 造】ition.}

REVISED AND EXTENDED WESTWARD TO THE IOOth MERIDIAN, BI

SERENO WATSON, CURATOR OF THE GRAY HERBARIUM, HARVARD UNIVERSITY,

AND

JOHN M. COULTER, PROFESSOR OF BOTANY IN WABASH COLLEGE, ASSISTED BY SPECIALISTS IN CERTAIN GROUPS.

WITH TWENTY-FIVE PLATES, ILLUSTRATING THE SEDGES, GRASSES, FERNS, ETC. 
Copyright, i889, by The: President and Fellows of Harvard College GRAY'S MANUAL 


\section{O N T E N T S.}

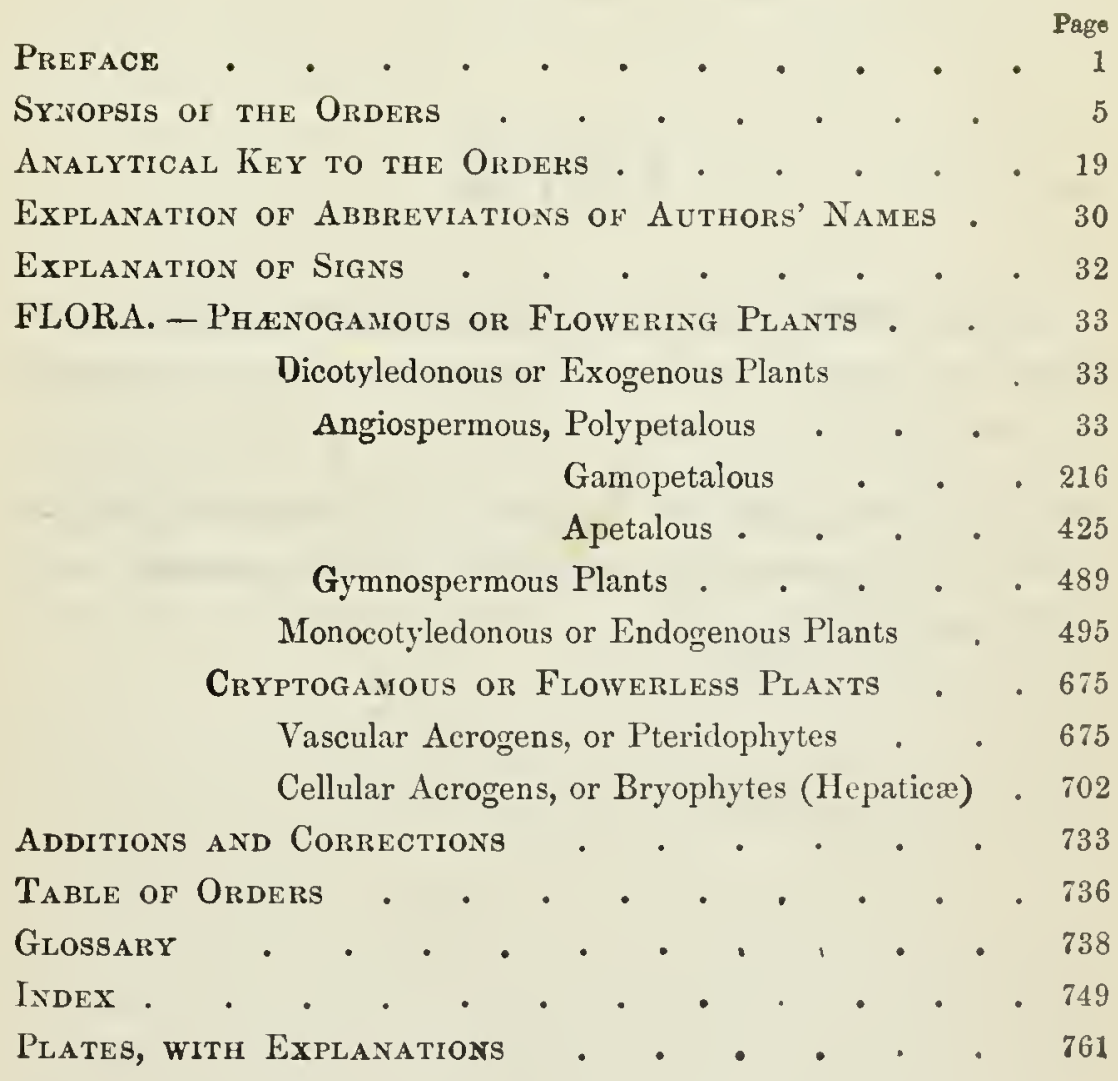




\section{N O T E.}

IN this second issue of the Manual are given all such needed emendations of every kind as have come to our notice. Wherever it could be conveniently done, these alterations have been made in the plates. The remainder will be found in supplementary "Additions and Corrections," near the end of the volume. 


\section{P R E F A C E.}

THe first edition of Gray's Manual was published in 1848. It was to a great extent rewritten and its range extended in 1856 , and it was again largely rewritten in 1867. The great advances that have since been made in systematic botany and in the knowledge of our flora have for several years past made another revision desirable, which Dr. Gray before his death was purposing to undertake.

The present editors, acting to the best of their ability in his stead, have endeavored throughout to follow his methods and views. The original plan, so long retained by Dr. Gray and so generally approved, has been closely adhered to, the characters and descriptions of the last edition have been left essentially unchanged so far as possible, and in the numerous alterations and additions that have been considered necessary or advisable, his conclusions and principles have governed in every matter of importance, so far as they could be known. The effort especially has been to maintain that high standard of excellence which has always made the Manual an authority among botanists.

In the treatment of the genera and species, Gray's Synoptical Flora has been made the basis in the revision of the Gamopetalous Orders, and his manuscript in continuation of that work, so far as prepared, for the Polypetalous Orders which precede Leguminosa (excepting Nuphar, the Cruciferc, Caryophyllacece, Vitis, and the small Orders numbered 18, 22, 23, 25-27, and 29). The genus Salix has been rewritten for this edition by M. S. Bebb, Esq., the genus Carex by Prof. L. H. Bailex, and the Ferns and allied orders by Prof. D. C. Eaton. For the rest, all known available sources of information have been made use of, and much willing help has been received from botanists in all parts of our territory. 
The increasing interest that is taken in the study of the Cellalar Cryptogams, and the desire to eneourage it, have led to the inelusion again of the Hepatieæ, whieh were omitted in the last edition. These have been prepared through the kindness of Prof. L. M. UNDErwood, though the limits of the volume have necessitated somewhat briefer descriptions than he considered desirable. The three fine plates illustrating the genera of these Orders, which were used in the early editions, are also added, with a supplementary one, as well as an additional one in illustration of the Grasses, thus increasing the number of plates to twenty-five. A Glossary of botanical terms is appended, to meet an expressed need of those who use the Manual alone, and a Synopsis of the Orders in their sequence is given, to contrast more clearly their charaeters, and to show the general principles which have determined their present arrangement. This should be a nseful adjunet to the nore artificially arranged Analytical Key.

Geographical Limits, and Distribution. - The southern limit of the territory covered by the present work is the same as in the later previous editions, viz. the southern boundary of Virginia and Kentucky. This coincides better than any other geographieal line with the natural division between the coolertemperate and the warm-temperate vegetation of the Atlantie States. The rapid inerease of population west of the Mississippi River, and the growing need of a Manual eovering the flora of that section, have seened a sufficient reason for the extcnsion of the limits of the work westward to the 100th meridian, thus connecting with the Manual of the Flora of the Rocky Mountain Region by Prof. Coulter. These limits, as well as that upon the north, have been in general strictly observed, very few speeies being admitted that are not known with some degree of eertainty to oceur within them. The extreme western flora is no doubt imperfeetly represented.

The distribution of the individual speeies is indicated somewhat more definitely than heretofore in many cases, so far as it could be satisfactorily aseertained. The extralimital range is also sometimes given, but the terms "northward," "southward," and "westward" are more frequently employed, signifying an indefinite range in those directions beyond the limits of the Manual. Where no definite habitat is specified, the spe- 
cies may be understood as found morc or less generally through. out the whole area, or at least to near the western limits.

Nomenclature, Accentuation of Names, ctc. - In casc ef question respecting the proper name to be adopted for any species, Dr. Gray's known and expressed views lave bcen followed, it is believed, throughout the work. While reasonable regard has been paid to the claims of priority, the purpose lias been to avoid unnecessary changes, in the bclief that such changes are in most cases an unmitigated evil. Synonyms are rarely given except where changes lave been made. As a guide to correct pronunciation, the long sound of the accented rowel (modified often in personal names) is indicated, as lieretofore, by the grave accent ('), and the short somnd by the acutc ('). In regard to the derivations of generic names, many valuable suggestions have been due to W. R. Gerard, Esq., of New York.

Prominest Characters are indicated by the use of Itulic type for the leading distinctions of the Orders, and generally in the specific descriptions for those points by which two or more nearly allied species nay be most readily distinguished. The ready discrimination of the genera is provided for by a Synopsis of their leading characters under each order. Whenever a genus comprises several species, pains have been taken to render important differences conspicuous by proper grouping, and when needed by a series of subordinate divisions and subdivisions. The headings of these various groups are to be considered as belonging to and forming a part of the specific characters of the several species under them, - a fact which the student should always bear in mind.

Arrangement of the Orders. - The Natural Orders are disposed in very close accordance with the method followed by Bentham and Hooker in the Genera Plantarum, the principles of which are concisely shown in the Synopsis of Orders which precedes the Analytical Key. The Gymnosperma are retained as a Subclass following the Angiospermous Dicotyledons, with which they have an obvious relationship, in preference to placing them, as some authorities would do, next before the Pteridophytes, to which their affinity, if no less certain, is nevertheless obscure. A more natural arrange. ment than either would be the withdrawal of the Endogens, placing them at the beginning, in perhaps an inverse order. 
Avalytical Key to the Orders. - As stated in Dr. Gray's Preface to the last edition, this is designed to euable the student to refer readily to its proper Order any of our plants, upon taking the pains to ascertain the structure of its flowers, and sometimes of the fruit, and by following out a series of easy steps in the analysis. It is founded upon the most obvious distinctions which will answer the purpose, and is so contrived as to provide for all or nearly all exceptional instances and variant cases. Referring to the Order which the Key leads him to, the student will find its most distinctive points brought together and printed in Italics in the first sentence of the ordinal description, and thus can verify his results. The Synopsis which follows will then lead him to the genus, to be veritied in tur'u by the full generic description in its place; and the progress thence to the species is facilitated, when there are several to choose from, by the arrangement under divisions and subdivisions, as already explained.

It will be seen that the Key directs the inquirer to ascertain, first, the Class of the plant under consideration, - which, even without the seeds, is revealed at once by the plan of the stem, as seen in a cross-section, and usually by the veining of the leaves, and is commonly confirmed by the numerical plan of the flower; - then, if of the first Class, the Subclass is at once determined by the pistil, whether of the ordinary kind, or an open scale bearing naked ovules. If the former, then the choice between the three Divisions is determined by the presence or absence of the petals, and whether separate or united. Each Division is subdivided by equally obvious characters, and, finally, a series of successively subordinated propositions, - each set more indented upon the page than the preceding, - leads to the name of the Order sought for, followed by the number of the page upon which it is described in the body of the work.

The book is now submitted to those for whose benefit it has been prepared, in the trust that its shortcomings will meet with fricndly indulgence, and with the earuest request that information be kindly given of any corrections or additions that may appear to be necessary.

Cambridge. Mass., Dec. 26, 1889. 


\title{
SYNOPSIS OF THE ORDERS OF PLANTS
}

\author{
DESCRIBED IN THIS WORK.
}

\section{SERIEs I. PH ANOGAMOUS or FLOTERING PLAN'TS: those} producing real flowers and seeds.

\section{Class I. DICOTYLEDONOUS on EXOGENOUS PLANTS.}

Stems formed of bark, wood, and pith; the wood forming a zone between the other two, and increasing, when the stem continues from year to year, by the annual addition of a new layer to the outside, next the bark. Leaves netted-veined. Embryo with a pair of opposite cotyledons, or in Subclass II. often three or more in a whorl. Parts of the flower mostly in fours or fives.

SubCLASS I. ANGIOSPERMIE. Pistil consisting of a closed ovary which contains the ovules and bccomes the fruit. Cotyledons only two.

Division I. POLYPETALOUS: the calyx and corolla both present; the latter of separate petals. (Apctalous fluwers occur in various Orders, as noted under the subdivisions.)

A. THALAMIFLOR X:. Stamens and petals hypogynons (free both from the calyx and from the superior ovary), upon a usually narrow receptacle (not glandular nor discoid, except in Reseda, sometimes stipe-like). (Sta mens and petals upon the partly inferior ovary in some Nymphæaceæ. ? Apetalous flowers occur in the Ranunculacex and Caryophyllacex.

* 1. Carpels solitary or distinct (or coherent in Magnoliacex); sepals and petals deciduous (except in Nymphæacex); leaves alternate or radical, without stipules (sometimes opposite or whorled and rarely stipular in Ranunculacex); embryo (except in Nelumbo) small, in fleshy albumen

1. Ranunculaceæ (p. 34). Sepals (3 or more), petals (as many, in regular flowers, or none), stamens (usually many), and carpels ( 1 - many) all distinct. Fruit achenes, follicles, or berries. Mostly herbs.

2. Magnoliaceæ (p. 49). Sepals and petals colored alike, in three or more rows of three, imbricate. Fruit cone-like, formed of the numerous cohering pistils. Trees.

3. Anonaceæ (p. 50). Sepals (3) and petals (6, in two rows) valvate. Fruit pulpy. Shrubs or small trees.

4. Menispermaceæ (p. 51). Sepals and petals in twos or threes, imbricate. Pistils becoming 1 -seeded drupes. Diœeious woody climbers, with pal mate or peltate leaves. 
5. Berberidaceæ (p. 52). Sepals and petals imbricate, each in two rows of three (rarely iu twos or fours). Stamens opposite the petals. Pistil solitary, becoming a berry or pod. Shrubs or low herbs.

6. Nymphæaceæ, in part (p. 54). Sepals and petals each 3, or many in several rows. Pistils becoming coriaceons and indehiscent. Aquatics: floating leaves peltate.

* 2. Carpels ( 2 or more) united into a componnd ovary with parietal, often nerve-like placenta (or the seeds covering the inner surface in Nymphaacex, and the placeutæ axile in Sarraceniacex). Herbs (some Cistaceæ somewhat shrubby).

- Fruit 5-mauy-celled; calyx or whole perianth jersistent; embryo small, at the base of fleslyy albumen.

6. Nymphæaceæ proper (p. 54). Sepals 2-6. Petals and stamens numerons, on a thick lypogynous receptacle or inserted upon the ovary. Capsule 8-30-celled. Aquatics, with peltate or cordate leaves.

7. Sarraceniaceæ (p. 57). Sepals aud petals 5. Capsule 5-celled. Marsh plants, with pitcher-shaped leaves.

+ + Fruit 1-celled, or spuriously 2 - more-celled by partitions connecting the placentix.

- Embryo minute at the base of fleshy albumen; perianth deciduous; sepals 2.

8. Papaveraceæ (p. 57.) Flowers regular. Sepals fugacions. Petals 412. Stamens and seeds numerous. Capsule 2-several-valved. Juice milky or colored.

9. Fumariacea (p. 59.) Flowers irregular. Petals 4, in dissimilar pairs. Stamens 6, diadelphous. Fruit 2-valver (indehiscent and 1 -seeded in Fumaria). Juice watery; leaves dissected.

+ + Albumen none; embryo curved or folded; perianth deciduous (sepals persistent in Resedacea).

10 Cruciferæ (p. 61). Sepals and petals 4. Stamens mostly 6, tetradynamons (two inserted lower and shorter). Pod 2-celled by a transverse partition, 2-valved, or sometimes indehiscent or transversely jointed. Bracts and stipules none.

11. Capparidaceæ (p. 74). Sepals and petals 4. Stamens 6 or more, nearly equal. Pod I-celled, 2-ralved. Embryo coiled. Leaves often palmately divided; bracts and stipules often preseut.

12. Resedacer (p. 75). Sepals and petals 4-7, irregular. Stamens indefiuite on an hypogynons disk, not covered in the bud. Pod I-celled, 3-6lobed, opening at tlie top.

+++ Embryo rather large in flesly albumen; placenta on the middle of the valves; calyx persistent.

13. Cistaceæ (p. 76). Flowers regular; sepals and petals 5 , the two onter sepals minute. Stamens indefinite. Pod l-celled, 3-5-ralved. Ovules orthotropous. Embryo curved. I.eaves entire, the lower often opposite.

14. Violaceæ (p. 78). Flowers irregular; sepals and petals 5 . Stamens 5 , with connivent introrse anthers. Style clavate. P'od l-celled, 3-valved. Ovules anatropous. Embryo straight. Stipules present. 
- 3. Ovary compound, l-celled, witl central placenta; embryo curved around mealy albumen (except in Dianthus) ; leaves entire ; stipules mostly none.

15. Caryophyllacere (p. 82). Sepals (5, rarely 4) distinct or united, persistent. l'etals as many, rarely none. Stamens as many or twice as many, rarely fewer. Sityles $2-5$. Leaves opposite:

16. Portulacaceæ (p. 90). Sepals 2. Petals 5. Stamens 5-20. Capsule 3-valved or circumscissile. Flesly herbs; leaves mostly alternate.

* 4. Calyx imbricate; stamens as many or twice as many as the petals or often indefinite; ovary compound, l-celled with parietal placenta or several-celled with the placenta mited in the axis; embryo straight or slightly curved; albumen none or scanty.

17. Elatinacea (p.91). Small marsh anuuals, with opposite leaves, memibranous stipnles, minute axillary flowers, few stanens, and pod 2 -5-celled.

18. Hypericaceæ (p. 92). Herbs or shrubs, with opposite entire dlotted leaves and no stipules. Flowers cymose or panicled. Stamens few or many, usually in 3 or more clusters. Pod 1-celled or 3-5-celled.

19. Ternstrœmiaceæ (p.95). 'Trees or slırubs, with alternate leaves and no stipules. Flowers large, axillary, solitary. Stamens numerons, more or less united together and with the base of the petals. I'od 3-5-celled.

* 5. Calyx valvate; stamens numerous, usually more or less mnited together and with the base of the petals; ovary 3 -many-celled with the placenta united in the axis (becoming l-celled and 1 -seeded in Tilia).

20. Malvacea (p. 96). Stamens monadelphous; anthers l-celled. Calyx persistent. Seeds kidney-shaped, with curved embryo and little albumen. llerbs or shruls, with alternate palmately veined stipular leaves.

21. Tiliacea (p. 101). Stamens polyadelphous or nearly distinct; anthers 2-celled. Calyx deciduons. Embryo nearly straight. Trees, with alter. nate leaves and deciduous stipules.

B. DISCIFLORA. Stamens as many as the petals or twice as many or fewer, inserted upon or at the onter or inner base of a more or less tumid hypogynons or perigynons disk, which is cushion-like or annular or divided into glands, sometimes obscure or minnte (or none in Linum, llex, some Geraniacere and Polygala); ovary superior (or half-inferior in some Rhamnacer); sepals more usually distinct. Petals wanting in some Rutacex, Rhamnacex, and Sapindacere.

* 1. Orules (mostly 1 or 2 in each cell) pendulous, with the rhaphe toward the axis of the ovary; disk often reduced to glands alternate with the petals or none; ovary often lobed or the carpels nearly distinct.

22. Linacez (p. 101). Flowers regnlar, usually 5-merous. Capsule not lobed, mostly 5-valved, spuriously 10 celled, 10-seederl. Stamens united at base. Disk none or 5 minute glands. Ilerbs, with entire alternate or opposite leaves; stipules gland-like or none.

23. Geraniaceze (p. 102). Flowers regular or irregular, 5-merous or 3. merous as to the stamens and pistils. Orary $3-5$-lobed, the cells $1-$ few. ovuled, and axis persistent. Disk of 5 glands or none. Herbs, with often lobed or divided mostly alternate leaves, with or without stipules. 
24. Rutaceæ (. 106). Flowers mostly regular, 3-5-merous, diccious or polygamous in our genera. Orary $2-5$-lobed or the carpels nearly distinct, upon a glandular disk; cells 2-ovuled. Mostly shrubs or trees, with glandular-punctate compouud leaves, without stipules.

* 2. Ovules ( 1 or 2) pendulous, the rhaphe away from the axis; disk none and ovary not lobed.

25. Hicinere (p. 107). Flowers small, diœciously polygamous, axillary, 48-merous. Fruit a 4-8-seeded berry-like drupe. Shrubs or trees, with simple alternate leaves and no stipules.

* 3. Ovules ( 1 or 2 in each cell) erect, the rhaphe toward the axis; disk fleshy, covering the base of the calyx; stamens as many as the petals, at the margin of the disk; flowers perfect or polygamo-dicecious ; albumen fleshy; shrubs or trees, with simple leaves (compound in some Vitaceæ).

26. Celastracea (1. 109). Sepals and petals imbricated, the stamens alternate with the petals. Fruit 2-5-celled; seeds arilled.

27. Khamnaceæ (p. 111). Calyx valvate. Petals small or none. Stameus alternate with the sepals. Fruit 2-5-celled; seeds solitary, not arilled.

28. Vitaceæ (p. 112). Calyx minute. Stamens upposite the valvate cadu cous petals. Climbing by tendrils opposite the alternate leaves.

* 4. Ovules ( 1 or 2) ascending or horizontal, or pendulous from a basal fuuicle; fleshy disk entire or lobed; stameus 5-10; shrubs or trees, with compound leares (simple in Acer) and mostly polygano-dicecions and often irregular flowers; petals imbricate (sometimes none in Sapindacer).

29. Sapindaceæ (p. 115). Flowers mostly unsymmetrical or irregular. Ovary 2-3-celled and -lobed.

30. Anacardiacea (p. 118). Flowers regular, 5-androns. Orary 1-celled, becoming a small dry drupe. Leaves alternate; juice milky or resinous.

* 5. Ovules solitary, pendulous from the summit of the 2-celled ovary; disk uone; flowers irregular (subpapilionaceons), hypogrnous; stamens monadelphous or diadelphous; anthers l-celled, opening by an apical pore.

31. Polygalaceæ (p. 120). Herbs, with perfect flowers and alternate or opposite or whorled entire leaves. Stamens 6-8. Seed carunculate.

C. CALYCIFLORA. Sepals rarely distinct; disk adnate to the base of the calyx, rarely tumid or conspicuous; petals and stamens on the calyx, perigynous or epigynous, the ovary being ofteu inferior (hypogynous in Drosera aud Parnassia, uearly so in some Leguminosæ and Crassulacex). Apetalous flowers iu Orders $33,35,36,38,39,41,42,47$, and 50 .

* I. Ovary usually superior, the pistils solitary, or several and distinct (sometimes more or less united but at least the styles distinct except in some Saxifragace $x)$.

32. Leguminosa (p. 122). Flowers papilionaceous or regular. Stamens usually 10, and mostly monadelphous or diadelphous. Pistil one, free, becoming a legume; style termiual. Albumeu none. Leaves mustly compound, alteruate, stipular.

33. Rosacez (p. 150). Flowers regular, with usually numerous distinct stamens, and 1 -many pistils, distinct or (in Pomex) uuited and combiued 
with the calyx-tube; style often lateral or basal. Calyx-lobes and petals mostly 5. Ovules mostly I or 2. Albumen mostly none. Trees, shrubs, or herbs; leaves usually alternate and stipulate, simple or compound.

34. Calycanthaceæ (p. 167). Calyx-lobes, petals, and stamens indefinite. listils numerous, becoming achenes in a hollow receptacle. Albumen none. A romatic slirubs, with opposite entire leares and no stipules.

35. Saxifragaceæ (p. 16s). Flowers regular, with 5-10 stamens (numerous in Philadelphus), few (mostly 2) more or less united, free or partially adnate carpels, and few - many ovules on axile or sometimes parietal pla. centæ. Seeds albuminous. Herbs or shrubs, with opposite or alternate leaves, with or without stipules.

36. Crassulaceæ (p. 170). Mostly fleshy herbs, with symmetrical flowers, the usually distinct mauy-seederl carpels as many as the sepals. Seeds albuminous. Leares alternate or opposite or whorled; stipules none.

37. Droseraceæ (p. 178). Glandular-haired scapose marsl herbs, with regular 5-merous hypogynous flowers. Capsule 1-celled, with 3-5 mauyseeded parietal placentr. Anthers extrorse. Leares circinate in vernation.

38. Hamamelideæ (p. 179). Shrubs or trees; flowers often polygamomonœcious, in clusters, heads, or spikes; petals often none. Seeds 2 or more, bony, in a 2-beaked woody pod opening above, the base adnate to the calyx-tube. Stamens few or many. I,eaves alteruate, simple.

39. Halorageæ (p. 180). Aquatic or marsh hesbs; flowers perfect or poJygamo-diœcious, small, axillary or spicate; petals often none. Stamens 1-8. Ovary inferior, the calyx-limb obsolete or very short. Fruit small, indehiscent, 1-4-celled, 1-4-seeded. Leaves alternate or opposite, the submersed often dissected.

- 2. Ovary inferior (except in Lythracex), 1-several-celled; style entire; flowers perfect, regular or vearly so, mostly 4-merous; herbs, with simple and inostly eutire leaves without stipules.

40. Melastomacez (p. 183). Calyx open. Stamens definite; anthers opening by an apical pore. Leares opposite,3-7-nerved; flowers cymose

41. Iythraceæ (p. 184). Calyx-Iobes valvate. Pod free, but enclosed in the calyx, membranous, 1 -4-celled, many-seeded with axile placentæ. Leavew mostly opposite; flowers axillary or whorled; petals crumpled, or none.

42. Onagraceæ (p. 186). Calyx-lobes valvate. Ovary 1 -4-celled, the cells 1 - many-oruled. Stamens 2,4 , or 8 . Petals 2 or 4 , convolute, or none Leaves opposite or alternate.

* 3. Ovary inferior (except iu Passifloracex and Ficoideæ), 1-celled with parietal placentæ or several-celled by the intrusion of the placentæ; flowers regular, perfect or unisexual; styles free or united; herbs.

- Embryo straight; cotyledons foliaceous; leaves alternate, often lobed.

43. Loasacex (p. 193). Flowers perfect. Stamens indefinite. Style entiro or 2-3-cleft. Capsule I-celled, with 2 or 3 many-seeded placentæ. Pubescence of hooked hairs.

44. Passifloraceæ (p. 194). Climbing by tendrils. Flowers perfect. Star mens 5, monadelphous. Ovary stalked, superior, becoming a l-celled many-seeded berry with 3 or 4 placentx. Styles 3, clavate. 
45. Cucurbitaceæ (p. 194). Tendril-bearing vines, with diœcious or monacious flowers. Corolla 5-lobed, often confluent with the calyx. Stamens 3 or 5, usually morc or less mnited and the anthers often tortnons. Fruit fleshy or nembrauous, 1-5-cclled, the placenta often produced to the axis and revolute. Seeds cxalbuminous.

+ + Embryo curved or coiled about central albnmen; leares entire.

46. Cactaceæ (p. 196). Fleshy and mostly leafless prickly plants, with sol itary sessile perfect flowers. Calyx-lobes and petals indefinite, imbricated, the numerons stamens on the tube. Fruit a l-celled many-seedcd berry

47. Ficoideæ (p. 198). Calyx-lobes or sepals 5 aud petals none in our gen. era. Capsule 3-5-cclled with axilc placcntæ, loculicilal or circnmscissile, mauy-seeded. Oftcu fleshy; leavcs mostly opposite or verticillate.

* 4. Flowers small, regular, perfect or polygamous; calyx-limb minnte or obsolete; ovary inferior, 2 -several-celled, with solitary pendnlons ovnles; petals and stancus mostly 4 or 5, on the margin of an epigynons disk surronuding the styles; albnmen copions.

48. Umbelliferæ (p. 198). Flowers iu nmbels or hcads. Pctals (inflexed) and stamens 5. Styles 2. Frnit of 2 dry scel-like carpels, the pericarp usually with oil-tubes. Herbs, with alternate mostly componnd lcaves.

49. Araliaceæ (p. 212). Flowers mostly in nmbcls aud nearly as in Umbelliferæ; petals not inflexed and styles 2 or morc. Fruit a 2 -several-celled drupe. Herbs or shrubs, with altcrnate mostly componnd learcs.

50. Cornaceæ (p. 213). Flowers not in nmbels; pctals (valvatc, or none) and stamens 4 or 5. Style 1. Ernit a 1 -2-seedcd drupe. Trecs, shrubs, or rarely herbs, with opposite or alternate simple and mostly entire leares

Division II. GAMIOPETALOUS: calyx and corolla both present, the latter of unitcd petals (cxcepting some Ericacex, Styracaceæ. and Oleacex, Galax, Statice, and Lysimachia). Apetalons flowers occn in Glaux and some Oleacex. Stipules present only in Rnbiaccæ and Loganiacex, or rarely in Caprifoliaceæ.

* 1. Ovary inferior; stamens borne upou the corolla, alternate with its lobcs.

- Stamens distinct; leaves opposite or whorled; seed albnminous except in Valerianacex.

51. Caprifoliaceæ (p. 216). Corolla mostly 5-lobed, regular or irregnlar, the stamens as many (one fewer iu Linnea, donbled in Adoxa) Ovary lseveral-cellcd; fruit a berry, drupe, or pod, l-several-sceded. Shrubs or herbs; leaves opposite, rarely stipular, not turning black in drying.

52. Rubiaceæ (p. 222). Flowcrs regular, 4-5-ncrous, the corolla mostly valvate. Ovary $2-4$-celled. Ifcrls or slirubs; leaves simple, entire, opposite with stipnlcs, or verticillate, usually turning black in drying.

53. Valerianace (p. 228). Stamcns $(1-4)$ fewer than the lobcs of the somewhat irregular corolla. Ovary with two abortive or empty cells and one containing a suspenderl ovule. Fruit dry and indehiscent. Herbs.

54. Dipsacere (p. 229). Fluwers mostly 4-merous and with 4 (rarely 2) sta. mens, involncellate in iuvolucrate heads; corolla-lobes imbricate Ovary simple, 1-celked, with a suspended ovule. Herbs. 
++ Anthers connate into a tube.

55. Compositæe (p. 230). Stamens as many as the valvate corolla-lobes. Ovary with a solitary erect ovule, becoming an achene. Albumen none. Calyx-limb reduced to a pappus or none. Flowers in involucrate heads.

* 2. Ovary inferior (or superior in most Ericacea and in Diapensiacea) ; stamens free from the corolla or nearly so (adnate in some Diapeusiacex), as many as the lobes and alternate with them, or twice as many; leaves alternate (upposite in some Ericacex); style 1.

- Juice milky; capsule 2-5-celled, many-seeded; herbs.

56. Lobeliaceze (p. 305). Corolla irregular, 5-lobed. Stamens urited, at least by the anthers. Capsule 2-cclled or with two placentæ.

57 Campanulaceæ (p. 307). Corolla regular, 5-lobed, valvate. Stamens usually distinct. Capsule 2-several-celled.

+ + Juice not milky nor acrid; capsule 3-10-celled.

58. Ericaceze (p. 309). Flowers mostly regular, 4-5-1nerous. Stamens distinct, more usually twice as many as the corolla-lobes or petals. Ovary inferior or superior. Herbs or shrubs.

59. Diapensiacere (p. 326). Flowers regular. Stamens 5, on the corolla, or monadelphous with 5 petaloid staminodia. Ovary superior, 3-celled.

* 3. Ovary superior; stamens as many as the corolla-lobes and opposite them.

60. Plumbaginacez (p. 327). Stamens 5, on the base of the petals. Styles 5. Fruit an achene or 1-seeded ntricle. Herbs; leaves radical.

61. Primulaceæ (p. 328). Stanens 4-8, perigynous. Style 1. Fruit a capsule with several seeds on a central placenta. Herbs; leaves radical or opposite or alternate.

62 Sapotaceæ (p. 332). Flowers small, 4-5-merous. Style 1. Ovary few-several-celled; fruit fleshy, bearing a single bony-coated seed. Shrubs or trees, with milky juice and alternate entire leaves.

* 4. Ovary superior or more or less adnate to the calyx, few-several-celled, the cells 1-ovuled; stamens twice as many as the corolla-lobes or more; trees or shrubs, with alternate leaves.

63. Ebenaceæ (p. 333). Flowers diceious or polygamous. Stamens on the corolla. Ovary superior. Styles distinct. Fruit fleshy, few-seeded.

64. Styracacez (p. 333). Flowers perfect. Stamens subhypogynous. Ovary more or less inferior. Style 1. Fruit dry or nearly so, 1-4-seeded.

* 5. Ovary superior, of two carpels (sometimes by division apparently 4-carpellary, sometimes of $3-5$ in Polemoniacer, Convolvulacex, and Solanacex); stamens on the corolla (except in apetalous Oleacex), alternate with its lobes, as many or fewer.

- Corolla not scarious and nerveless.

+ Corolla none, or regular and 4-cleft or -parted, the stamens fewer than its lobes; style 1 ; seeds $1-3$.

65. Oleacez (p. 335). Trees or shrubs, with opposite and pinnate or simple leaves. Flowers perfect or polygamo-diocious. Stamens mostly 2, alter nate with the usually 2-ovuled carpels. 
- Corolla regular, its lobes 4-5 or rarely more; stamens as many.

= Oraries 2, becoming follicles; stigmas and sometimes the styles united; herbs with milky juice, perfect 5-merous flowers, and simple entire leaves.

66. Apocyuaceæ (p. 337). Stamens distinct or the anthers merely connivent, with ordinary pollen. Style 1 .

67. Asclepiadaceæ (p. 338). Stamens monadelphous, the anthers permanently attached to a large stigmatic body; pollen mostly in waxy masses. Styles distinct below the stigma.

$==$ Ovary compound (ovaries two in Dichondra), with 2 or 3 (rarely 4 or 5) cells or placentæ; stameus distinct; mostly herbs.

a. Leaves opposite; corolla-lobes 4 or 5 or more.

68. Loganiaceæ (p. 345). Leaves entire, with stipules or a stipular line joining their bases. Capsule 2-celled, few-many-seeded. Herbs or woody twiners (our species).

69. Gentianaceæ (p. 346). Glabrous herbs; leaves entire, sessile and simple (except in Meuyanthes). Capsule 1-celled with 2 parietal placentæ or the whole inner surface ovuliferous, many-seeded.

b. Leaves alternate (sometimes opposite in Polemoniaceæ and Hydrophyllacex); corolla-lobes always 5 in our species.

70. Polemoniaceæ (p. 354). Capsule usually 3-celled, loculicidal; seeds 1 - many in each cell on the stout placental axis. Style 3-cleft or -lobed. Leaves opposite or alternate, simple or compound.

71. Hydrophyllacez (p. 357). Leaves often lobed or divided, and the inflorescence frequently scorpioid. Style 2-parted or 2-lobed. Capsule 1-celled, 2-valved with two parietal or iutroflexed placentæ, or sometimes 2-celled. Seeds 2 or more on each placenta.

72 Borraginacez (p. 360). Leaves mostly eutire and plants often roughhispid; inflorescence commonly scorpioid. Style 1. Ovary 4-ovulate, nsually 4-lobed and maturing as 4 separate or separable nntlets, or not lobed, $2-4$-cellerl and separating when ripe into 2 or 4 nutlets.

73. Convolvulaceæ (p. 367). Usually twining or trailing; flowers on axillary pednucles or cymose-glomerate. Corolla 5-lobed or 5-plaited, twisted in the bud. Styles 1 or 2. Ovary 2- (sometimes 3-or spuriously 4-) celled, bccoming a globular 4-6-seeded capsule (or ovaries two and distinct in Dichondra). Cotyledlons broad-foliaceous.

74. Solanacere (p.373). Style 1. Ovary 2-celled (rarely 3-5-celled), with numerous ovules on axillary placeuta, becoming a pod or berry. Cotyledons narrow.

++ ++ Corolla more or less bilabiately irregular (sometimes nearly regular), 5-lobed. Fertile stamens 4 and didynamous, or 2. Style 1. Ovary always of two carpels.

a. Ovules several or many.

75. Scrophulariaceæ (p. 377). Capsule 2-cellcd, with central placentæ. Seeds small, usually numerous. Herbs; leaves alternate or opposite.

76. Orobanchaceze (p. 393). Root-parasitce with no green foliage. Capsule 1-cellcd, with 2 simple or double parietal placentæ. Seeds mauy. 
77. Lentibulariaceæ (p. 395). Aquatic or marsh herbs, with scapes or scape-like peduncles, sometimes nearly leafless. Corolla personate and spurred. Capsule globular, 1-celled; placeuta central, free, many-seeded.

78. Bignoniaceæ (p. 398). Large-flowered trees or often climbing shrubs, with usually opposite simple or compound leaves. Capsule 2-celled by a partition between the 2 parietal placentre. Seeds uumerous, large, mostly winged.

79. Pedaliaccæ (p. 399). Herbs, with opposite simple leaves. Ovary 1. celled with two bilamellar parietal placentre, or 2-4-celled by their union, becoming drupaceous or capsular. Seeds few or many, wingless.

80. Acanthaceæ (p. 399). Herbs, with opposite simple leaves. Capsule 2-celled, loculicidal, with each axile placouta bearing $2-10$ flattish seeds.

b. Cells of the ovary 1-2-ovuled; herbs or low shrubs, with opposite leares

81. Verbenaçæ (p. 401). Ovary 2-4-celled, not lobed, the dry or clrupaceous fruit separating iuto 2 or 4 1-seeded nutlets (fruit 1-celled and 1 seeded in Phryma). Style terniual.

82. Labiatæ (p. 403). Ovary d-eply 4-lobed around the style, the lobes becoming dry seed-like nutlets. Stems square; aromatic.

+ + Corolla scarious and nerveless; flowers regular, 4-merous; style 1.

83. Plantaginaceæ (p. 422). Scapose herbs, with perfect or polygamodiccions or monœcious flowers in 1 -many-flowered spikes. Fruit a circumscissile 2-celled capsule, with one or more peltate seeds in each cell, or an achene.

Division III. APETALOUS EXOGENS. The corolla wanting (except in some Euphorbiacere, and sometimes also the calyx.

* 1. Ovary superior (though sometimes enclosed within the calyx), 1-celled with a solitary basal orule (several-celled in Phytolaccaceæ); embryo coiled or curved (uearly straight in Polygonacex) in or about mealy albumen (albumen none in some Chenopodiaceæ); herbs.

- Fruit the hardened or mcmbranous closed base of the corolla-like perianth enclosiug a utricle.

84. Nyctaginaceze (p. 425). Perianth tubular or funnelform. Stamens hypogynous. Fruit ribbed or winged. Leaves opposite; stipules none.

+ + Fruit a utricle; perianth mostly persistent, small, 4-5-lobed or -parted, ol' none.

85. Illecebraceæ (p. 426). Perianth herbaceous. Stamens perigynous. Leaves opposite; stipules scarious (none in Scleranthus).

86. Amarantaceæ (p. 427). Flowers sessile, bracteate, the bracts (usually 3) more or less dry and scarious, as wcll is the $3-5$ distinct sepals. Stamens 1-5, hypogynous. Utricle indehiscent or circumscissile. Embryo annular. Leaves mostly alternate, entire; stipules none.

87. Chenopodiaceæ (p. 430). Flowers sessile, not scarious-bracteate. Sepals greenish or succulent, 5 or fewer, or none. Stamens 5 or fewer, perigynous or hypogynous. Embryo annular or spiral or conduplicate. Leaves alternate; stipules none. 
+++ Ovary of several 1-ovuled carpels, in fruit a berry (in our genera).

88. Phytolaccacez (p. 435). Sepals $4-5$, petaloid or herbaceous. Stamens 5-30, hypogynous. Carpels 5-12. Einbryo annular. Leaves alteruate, entire; stipules none.

++++ Fruit a triaugular or lenticular achene.

89. Polygonacea (p. 436). Flowers on jointed pedicels. Calyx 3-6-lobed or -parted, more or less corolla-like. Stamens 4-12, on the calyx. Embryo nearly straight. Leaves alternate, with sheathing stipules or none.

* 2. Ovary compound, the cells many-ovuled (or l-ovuled in Piperacex); embryo minute in copious albumen; flowers perfect.

90. Podostemacea (p. 444). Aquatic, with the aspect of sea-iveeds or mosses, with minute naked flowers from a spathe-like iurolucre. Ovary superior; pod 2-3-cclled.

91. Aristolochiaceæ (1) 444). Terrestrial herbs or climbing shrubs. Calyx valvate, adnate at least at base to the 6-celled many-seeded ovary. Stamens 6-12, more or less united with the style. Leaves alternate, mostly cordate; stipules none.

92. Piperaceæ ( $\$$ Saurureæ), (p. 446). Marsh herb (our species). Perianth none. Carpels 3-4, distinct, with usually a siugle asceuding seed. Leaves alternate, entire.

* 3. Ovary superior, simple, l-celled, l-ovuled, forming a berry or drupe; trees or shrnbs, with mostly cutire leaves and no stipules.

93. Lauraceæ (p. 446). Flowers perfect or diøcious. Sepals 4 or 6 , in 2 rows. Stamens 9-12; anthers opening by 2 or 4 uplifted valves. Seed suspended; albumen none. Aromatic; leaves altcrmate.

94. Thymelæaceæ (p. 44s). Fluwers perfect. Calyx corolla-like, 4-5cleft. Stamens twice as many. Seed snspended, with little or no albumen. Acrid slirubs with rery tough bark; leaves altcrnate.

95. Elæagnaceæ (p.448). Flowers mostly diœcious. Calyx-tube becoming berry-like and enclosing the achene. Seed erect, albuminous. Leaves silvery-scurfy, opposite.

* 4. Ovary inferior, 1-celled, 1-3-ovuled (but 1-sceded); albumen without testa, bearing the embryo in a cavity at the apex; calyx-lobes valvate.

96. Loranthaceæ (p. 449). Parasitic on trees, witl jointed stems and opposite leares. Flowers diccious. Orule solitary, erect. Fruit a berry.

97. Santalaceæ (p. 450). Flowers perfect. Ovules 2-4, suspended from the apex of a ccutral placenta. Fruit dry, indehiscent. Leaves alternate.

* 5. Flowers all misexual (polygamous in some Urticacex and Empetracex, apparently perfect iu Euphorbia); cells 1-2-ovnled; embryo nearly as long as the albumen or filling the seed; calyx often wanting, corolla-like ouly in some Euphorbiacea and Empetracex; stipules often present.

$\leftarrow 1$. Orary superior, 3-celled (1-celled in Crotonopsis) with 1 or 2 pendulous ovules in each cell; herbs.

98. Euphorbiaceæ (p. 451). Flowers monœcions or dicecious (iuvolucrate and apparently perfect in Euphorbia). Mostly with milky juice, and usually alternate ofteu stipulate leaves. 
- 2. Ovary l-celled, l-seeded; trees or shrubs (except some Urticaceæ).

$\rightarrow$ Calyx regular, the stamens as many as the lobes and opposite them or fewer; ovary superior.

99. Urticaceæ (p. 461). Flowers monœcious, diœcions, or (in Ulmeæ) perfect. Seeds exalbuminous or nearly so. Inflorescence very various.

+ Perianth mostly none; at least the staminate flowers iu aments or spikes or dense heads; albumen none.

100. Platanaceæ (p. 466). Trees, with alternate palmately lobed leaves, sheathing stipules, and monœeious flowers in separate globose heaùs. Ovary superior; fruit a club-shaped nutlet.

101. Juglandaceæ (p. 467). Trees, with alternate piuuate leaves, no stipules, and monocious flowers, the staminate in aments. Ovary inferior; fruit a nut.

102. Myricaceæ (p. 469). Shrubs, with resinous-dotted leaves, with or without stipules, and monœcious or diœcious flowers, both kinds in slrort scaly aments. Ovary superior, becoming a small drupe-like nut.

+3 . Ovary 2-7-celled, with 1 or 2 suspencled ovules in each cell, bccoming l-celled and 1-seeded; calyx mostly none or adherent to the ovary; trees or shrubs with simple leaves.

103. Cupuliferæ (p. 470). Flowers monœcious. Fruit a nut surronnded by an involucre, or (in Betuleæ) a small winged or angled naked nutlet in the axils of the scales of an ament.

+ 4. Ovary l-celled, becoming a 2-valved pod with two parietal or basal placentæ bearing numerous small comose seeds; perianth none.

104. Salicaceæ (p. 480). Diocious trees or shrubs, with both kinds of flowers in aments, aud simple alternate stipulate leaves.

-5. Ovary several-celled, becoming a drupe containing 3-9 l-seeded nutlets; seed erect; low shrubby heath-like evergreeus.

105. Empetraceæ (p. 487). Flowers polygamous or diœcious, scaly-bracted. Sepals somewhat petaloid or none. Embryo axile in copious albumen.

-6. Ovary l-celled with a suspended ovule, becoming an achene; calyx none; aquatic herbs, with finely dissected whorled leaves.

106. Ceratophyllaceæ (p. 488). Flowers monœcious, minute, axillary and sessile. Albumen none; the seed filled with a highly developed embryo.

Subclass II. GYMNOSPERMOUS EXOGENS. Orules naked upon a seale, braet, or disk. Cotyledons two or more.

107. Coniferæ (p. 489). Rcsiniferous trees or shrubs, with mostly awlshaped or needle-shaped and evergreen leaves, and monœcious or diœcions flowers.

\section{Class II. MONOCOTYLEDONOUS PLANTS.}

Stems withut eentral pith or annular layers, but having the woody fibres distributed irregularly through them (a transverse slice showing the fibres as dots seattered through the cellular tissue). Embryo with a single cotyledon and the early leaves always alternate. Parts of the 
flower usually in threes (never in fives), and the leaves mostly paralle1veined. Our species herbaceous, excepting Smilax.

* Ovary inferior (superior in Bromeliaceæ, nearly so in some Hemodoraceæ); at least the inner lobes of the perianth petal-like.

+1 . Seeds without albumen, very numerous and minute.

108. Hydrocharidaceæ (p. 495). Aquatics, with diøcious or polygamous flowers from a spathe; outer periantl calyx-like, the iuner sometimes wanting. Stameus 3-12. Ovary l-celled with 3 parietal placentie or $6-9$-celled with axile placentæ.

109. Burmanniaceæ (p.496). Terrestrial, with scale-like cauline leaves and regular perfect triaudrous flowers. P'erianth corolla-like.

110. Orchidaceæ (p. 497). Terrestrial, with very irregular perfect flowers. Stamens and style connate; anthers 1 or 2. Capsule 1-celled; placentæ 3, parietal. Periauth corolla-like.

- 2. Seeds albuminous. (Ovary 3-celled and flowers regular in our genera.)

111. Bromeliaceæ (p. 511). Mostly epiphytes, with dry persistent scurfy leaves. Flowers 6-androus; outer perianth calyx-like.

112. Hemodoraceæ (p. 512). Fibrous-rooted, with equitant leaves aud perfect 3- or 6-androus flowers. Periauth persistent, woolly or scurfy outside. (Ovary sometimes uearly free; leaves flat in Aletris.)

113. Iridaceæ (p. 513). Root not bulbous; leaves equitant in two ranks. Flowers from a spathe. Stamens 3, opposite the outer lobes of the corolla-like periauth; authers extrorse.

114. Amaryllidaceæ (p. 515). Often bulbous-rooted and scapose. Periauth corolla-like. Stamens 6 ; anthers introrse.

115. Dioscoreaceæ (p. 517). Climbing, with net-veined leaves. Flowers diœcious, small, 6-androus; periantlı calyx-like. Ovules 1 or 2 iu each cell

* * Ovary superior (very rarely partially adnate to the calyx in Liliacex).

+1 . At least the inner periantlı corolla-like; ovary compound; seeds with copious albumen.

116. Liliaceæ (p. 517). Flowers perfect, 6-androus, the regular perianth corolla-like (diœcious in Smilax, dimerous iu Maianthemum, the outer divisions herbaceons in Trillium). Fruit a 3-celled capsule or berry.

117. Pontederiaceæ (p. 535). $\Lambda$ quatic, with more or less irregnlar perfect flowers from a spathe; periantl corolla-like. Stamens 3 or 6 , mostly unequal or dissimilar. Capsnle 1-celled or imperfectly 3-celled.

118. Xyridaceæ (p. 536). Rush-like, scapose. Flowers capitate, perfect, 3-androus, the calyx glumaceous. Capsule 1-celled.

119. Mayaceæ (p. 537). Moss-like aquatic. Flowers perfect, axillary, solitary, 3-androus; calyx herbaceons. Capsule 1-celled.

120. Commelinaceæ (p. 538). Flowers perfect, regllar or somewhat irregular, with 3 more or less herbaceous persistent sepals and 3 fugacious petals. Stamens 6 or some sterile. Capsule 2-3-celled.

127. Eriocaulea (p. 566). Scapose aquatic or marsh plants, with linear leaves and dense heads of monxcious (rarely diocious) minute flowers. Corolla tubular or none. Capsule 2-3-celled, 2-3-seeded. 
— 2. Perianth small, of 6 equal persistent glumaceous segments; flowers perfect; ovary compound.

121. Juncacez (p. 539). Rush-like. Stamens 3 or 6. Capsule 1-or 3 . celled, 3-valved.

4- 3. Fluwers without chaffy glumes, the perianth none or reduced to bristles or sepal-like scales; flowers often mon ceious or diocious ; carpels solitary or united.

+ H lowers capitate or upon a spike or spadix, with or without a spathe.

122. Typhaceæ (p. 547). Marsh or aquatic plants, with linear leaves, and monceious flowers without proper perianth, in heads or a naked spike.

123. Aracee (p. 548). Flowers pcrfect or monocions upon the same spadix, rarely diœcious, with 4 or 6 scale-like sepals or none.

$\mapsto+$ Flowers very miuute, one or few from the margin of a floating disklike frond.

.24. Lemnaceæ (p. 551). Plants very sinall, green, mostly lenticular or globose.

- 4. Perianth of 4 or 6 segments, the inner often petaloid, or none; carpels solitary or distinct (coherent in Triglochin); sceds without albumen; aquatic or marsh plants, often monœcious or dicecious.

125. Alismacez (p. 553). Perianth of 6 segments, the inner petal-like.

126. Naiadaceæ (p. 557). Periauth-segmeuts herbaceous or noue.

- 5. Flowers in the axils of chaffy scales or glumes arranged in spikes or spikelets, without evident perianth ; stamens $1-3$; ovary 1-celled, 1 -seeded; seed albuminous.

128. Cyperacee (p. 567). Scalcs single. Perianth none or replaced by bristles. Anthers basifixed. Fruit a triangular or leuticular achene. Stem solid, often triangular, with closed sheaths.

129. Graminez (p. 623). Glumes in pairs. Perianth replaced by minute scalcs. Authcrs versatile. Fruit a caryopsis. Culm usually hollow, terete; sheatlıs split to the base.

Skries II. CRYPTOGAMOUS or FLOWERLESS PLANTS; destitute of stamens and pistils, in fructification producing spores instead of sceds.

\section{Crass III. ACROGENOUS PLANTS.}

Cryptogamous plants with a distinet axis (stem and branches), growing from the apex only, and furnished for the most part with distinet leaves (sometimes taking the form of an expanded leaf-like usually prostrate thallus); reproduction by means of antheridia and archegonia, sometimes also by gemmation.

Subclass I. VASCULAR ACROGENS, or PTERIDOPHYTES. Stems (and foliage when present) containing both woody fibre and vessels; antheridia or archegonia, or both, borne on a minute prothallus, which is developed from the spore on germination. 
* Spores of only one kind; prothallus bearing antheridia and archegonia.

130. Equisetaceæ (p. 675). Cylindric jointed hollow-stemmed plants, with toothed sheatlis. Fructification in a terminal spike.

131. Filices (p. 678). Ferns, with fronds circinate in vernation, bearing the fructification on the under surface or beneath the margin.

132. Ophioglossaceæ (p. 693). Frouds often fern-like, erect in vernation Sporangia globose, coriaceous, 2-valved, in special spikes or panicles.

133. Lycopodiaceæ (p. 695). Low moss-like plants with elongated stems and small persistent entire several-ranked leaves. Sporangia solitary, axillary, 1 -3-celled, 2-3-valved.

* * Spores of two kinds, the macrospore producing a prothallus with archegonia, the microspore smaller and developing antheridia.

134. Selaginellaceæ (p. 697). Low leafy moss-like or marsh plants, with branching stems, and small 4-6-ranked leaves, or with a corm-like stem and basal linear-subulate leaves, the two kinds of spores in distinct solitary axillary 1-celled sporangia.

135. Marsiliaceæ (1). 700). The two kinds of spores in the same or different sporangia whicll are borne in a coriaceous peduncled sporocarp arising from a slender creeping rhizome. Fronds digitately 4-foliolate or filiform.

136. Salviniaceæ (p. 701). The two kinds of spores in separate thin-walled l-celled sporocarjs or conceptacles clustered beneath the small foating fronds; macrospores solitary.

Subclass 1I. CELLULAR ACROGENS, or BRYOPHYTES. Plants with cellular tissue only; both antheridia and archegunia borne upon the plant itself. - Including the Musci, or Mosses (which are not treated of here), never thallose, and bearing capsules which usually dehisce by a lid and contain spores only, and the HLPATICA, which bear capsules which dehisce by valves or irregularly and usually have claters mingled with the spores. The latter division comprises the following Orders.

* Capsule 4-valved; plant a leafy axis or sometimes a branching thallus.

137. Jungermanniaceæ (p. 702). Leaves, when present, without a midrib, 2-ranked, with often a third row beneath; pedicels slender.

* * Capsule 2-valved, or dehiscing irregularly, or indehiscent; plant a thallus or thalloid stem.

138. Anthocerotaceæ (p. 726). Thallus without epidermis, irregularly branching; pedicels stout or none. Capsule with a columella. Elaters mostly without fibres.

139. Marchantiaceæ (p. 727). Thallus radiate or dichotomous, the epidermis usually porose. Capsules borne on the under side of a pedunculate receptacle, irregularly dehiscent. Elaters 2-spiral.

140. Ricciace (p. 730). Thallus radiate or dichotomous, the epidermis eporose. Capsules immersed in the thallus or sessile upon it, indehiscent Elaters none. 


\section{ANALYTICAL KEY TO THE ORDERS.}

\section{Class I. DiCOTyledonous Plants. (See p. 5.)}

Subclass I. ANGIOSPERMÆ. Pistil consisting of a closed ovary. Cotyledons only two.

Division I. POLYPETALOUS: the calyx and corolla both present; the latter of separate petals.

A. Stamens numerous, at least more than 10 , and more than twice the sepals or labes of the calyx.

1. Calyx entirely free and separate from the pistil or pistils.

Pistils numerous but cohering over each other in a solid mass on

PaGE

an elongated receptacle. . . . . . Magnoliacex, 49

Pistils numerous, separate, but concealed in a hollow receptacle.

Leaves opposite, entire; no stipules. . . . Calycantracea, 167

Leaves alternate, with stipules. . . . . Rosa, in RosaCe e, 162

Pistils several, immersed in hollows of the upper surface of a

large top-shaped receptacle. . Nelumbo, in NrMPHжacE五, 55

Pistils more than one, separate, not enclosed in the receptacle.

Stamens inserted on the calyx, distinct. . . . . Rosaces, 150

Stamens united with the base of the petals, monadelphous. MaLvaCex, 96

Stamens inserted ou the receptacle.

Filaments much shorter than the anther; trees. . . Anonaces, 50

Filaments longer than the anther.

Flowers diœeious; twiners with alternate leaves. Menispermaces, 51 Flowers perfect; if climbers, the leaves opposite.

Leaves not peltate; petals deciduons. . RanunculaCeE, 34

Leaves peltate; petals persistent. Brasenia, in NrmpheACEE, 55

Pistils several-lobed, the ovaries united below the middle. Resedaces, 75

Pistils several, their ovaries cohering in a ring around an axis. MALvaCEE, 96 Pistils strictly one as to the ovary; the styles or stigmas may be several.

Leaves punctate under a leus with transparent dots. HYPERICACEE, 92

Leaves not punctate with transparent dots.

Ovary simple, 1-celled, 2-ovuled. . . . . Rosaces, 150

Ovary simple, 1-celled, with one parietal many-ovuled placenta.

Leaves 2-3-ternately compound or dissected. RANUnCULACE.E, 34

Leaves peltate, simply lobed. Podophyllum, in Berberidaces, 52

Ovary compound, 1-celled, with a central placenta. PORTULACACEE, 90 
Ovary compound, l-celled, with two or more parietal placentæ.

Calyx caducous; juice milky or colored. - . PAPAVERACE 2,57

Calyx deciduous, of 4 sepals. . . . C CAPparidace 4,74

Calyx persistent, of 3 or 5 sepals. . . . . Cistace 5,76

Ovary compound, several-celled.

Calyx valvate in the bud, and

Persistent; stamens monadelphous; anthers l-celled. Malvacex, 96

Deciduous; anthers 2-celled . . . . Tiliace 1,101

Calyx imbricated in the bud, persistent.

Shrubs; stamens on the base of the petals. Ternstremiace 2,95 Aquatic or marsh herbs; ovaries many,

On 5 placentæ in the axis. . . . Sarraceniace 57

On the 8-30 partitions. . . . . NYMPHєACE

2. Calyx more or less coherent with the surface of the (compound) ovary.

Ovary 8-30-celled; ovules many, on the partitions; aquatic. NYMPHÆACE 1,54 Ovary 10-celled; cells 1-ovuled. . . . A melanchier, in Ros $\triangle$ CEA, 166 Ovary $2-5$-celled.

Leaves alternate, with stipules. ․ . . Pomeæ, in RosACEx, 151

Leaves opposite, without stipules. . . Some SAxifragaced, 168

Leaves alternate, without stipules. . . . . STYRACACE 333

Ovary l-celled, with the ovules parietal.

Fleshy plants with no true foliage; petals many. $\quad$ CACtace 2,186

Rough-leaved plauts; petals 5 or $10 . \quad . \quad . \quad$ LOAsacE 193

Ovary one-celled, with the ovules rising from the base. Portulacace 2,90

B. Stamens of the same number as the petals and opposite them.

Pistils 3-6, separate; flowers diœcious; woody vines. Menispermace 5,51 Pistil only one.

Ovary one-celled; anthers opening by uplifted valves. BERBERIDACE $\mp, 52$ Ovary one-celled; anthers not opening by uplifted valves.

Style and stigma one; ovules more than one.

Style 1 ; stigmas 3 ; sepals 2 ; ovules several.

Primulaces, 328

Style twice or thrice forked; flowers monœcions.

Portulacace 290

Crotonopsis, in Euphorbiace 2,458

Styles 5; ovule and seed only one. . . . Plumbaginace $x, 327$ Ovary 2-4-celled.

Calyx-lobes minute or obsolete; petals valvate. . . VItaces, 112

Calyx 4-5-cleft, valvate in the bud; petals involute. Rhannacex, 111

C. Stamens not more than twrce as many as the petals, when of jist the number of the petals then alternate with them.

1. Calyx free from the ovary, i. e. the ovary wholly superior.

* Ovaries 2 or more, separate.

Stamens united with each other and with a large and thick

stigma common to the two ovaries. - AsCLEP1ADACE E, 338

Stamens unconnected, on the receptacle, free from the calyx.

Leaves punctate with pellucid dots. . . . . . RUTACE.⿱一⿻上丨, 106 
Leares not pellucid-punctate.

Tree, with pinnate leaves. . . Ailanthus, in Simarubace.s, 107

Low shrub, with pinnate leaves. Xanthorrhiza, in RANunculacese, 48

Herbs, not fleshy. . . . . . . Ranunculace 2 . 34

Herbs, with thick fleshy leaves. . . . . Crassulace 176

Stamens unconnected, inserted on the calyx.

Just twice as many as the pistils (flower symmetrical). Crassulace 176

Not just the number or twice the number of the pistils.

Leaves without stipules. . . . . . SAxifragace 168

Leaves with stipules. . . . . . . . ROSACEN, 150

* Ovaries 2-5, somewhat united at the base, separate above.

Leaves punctate with pellucid dots. . . . . . RUTACEA, 106

Leaves not pellucid-punctate.

Shrubs or trees with opposite leaves. . . . SAPINDACEF, 115

Terrestrial herls; the carpels fewer than the petals. SAxifragacex, 168

* * Ovaries or lobes of ovary 3 to 5, with a common style. Geraniacex, 102 * * * Ovary only one, and

- Simple, with one parietal placenta. LEguminose, 122

++ Compound, as shown by the number of cells, placento, styles, or stigmas.

Dvary one-celled.

Corolla irregular; petals 4; stamens 6. . . . . Fumariacex, 59

Corolla irregular; petals and stauens 5. . . . . VIOLACEA, 78

Corolla regular or nearly so.

Ovule solitary; shrubs or trees; stigmas 3. Anacardiace.e, 118

Ovnles solitary or few; herbs. . . Some anomalous Cruciferæe, 61

Ovules more than one, in the centre or bottom of the cell.

Petals not inserted on the calyx. . . . CAR YopHxLlaces, 82

Petals on the throat of a bell-shaped or tubular calyx. LrTHRACEs, 184 Ovnles several or many, on two or more parietal placentæ.

Leaves punctate with pellucid and dark dots. HYPERICACEA, 92

Leaves beset with reddish gland-tipped bristles. Droserace 178

Leaves neither punctate nor bristly-glandular.

Sepals 5, very unequal or only 3. . . . C Cistace 2,76

Sepals and petals 4 ; stamens 6. . . Anomalous CrdCiferæ, 61

Sepals and petals 5 ; stamens 5 or 10 .

Ovary and stamens raised on a stalk. PAssiflorace 4,194

Ovary sessile. . . . . . . SAxifragace 2,168

Ovary 2-several-celled.

Flowers irregular.

Anthers opening at the top,

Six or eight and 1-celled; ovary 2-celled, 2-ovuled. PolygalaCEA, 120

Ten and 2-celled; ovary 5-celled. Rhododendron, in ERICACEA, 286 Anthers opening lengthwise.

Stamens 12 and petals 6 on the throat of a tubular inflated or gibbous calyx. • • • Cuphea, in Lythraced, 186 
Stamens 5-8 or 10, and petals lypogynous, or nearly so.

Ovary 3-celled. . . . . . . SAPINDACEE, 11:

Ovary 5 celled. . . . Impatiens, \&c., in Geraniaces, 105

Elowers regular or uearly so.

Stamens neither just as many uor twice as many as the petals,

Triadelphous; petals 5. . . . . . HYPERICACE 2,92

Tetradynamous (or rarely only 2 or 4 ) ; petals 4 ; pun-

gent herbs. . . . . . Creclfere, 61

Distinct and fewer than the 4 petals. . . . OLEACE 2,335

Distinct and more uumerous than the petals. . SAPINDACEX, 115

Stamens just as many or twice as many as the petals.

Ovules and seeds only 1 or 2 in each cell.

Herbs; flowers moncecicis or diwcious.

EcPIIORBIACEN, 451

Herbs; flowers perfect and symmetrical.

Cells of the orary as many as the sepals, \&c. Geraxiacex, 102

Cells of the (divided) ovary twice as many as

the styles, sepals, \&c. . . . . LixacEx, 101

Shrubs or trees.

Leares 3-foliolate, pellucid-punctate. Ptelea, in Rutaceæ, 107

Leares palmately reined and fruit 2-winged, or

pinnate aud fruit a bery. . . . SAPINDACEe, 115

Leaves pinnately veined, simple, not punctate.

Calyx not minute; pod colored, dehiscent;

seeds enclosed in a pulpy aril. Celastrace $\$, 109$

Calyx minute; fruit a berry-like drupe. ILıcises, 107

Ovules (and usually seeds) several or many in each cell.

Stipnles between the opposite and simple leaves. Elatinaceæ, 9]

Stipules between the opposite and compound leaves

(but they are caducous). Staphylea, in Sapixdaces, 118

Stipules none when the leares are opposite.

Stamens 5, monadelphous in a 10 soothed tube or cup ;

leaves simple, all radical. Galax, in Diapexsiace. 320

Stameus 10, monadelphons at the base. Leaflcts 3,

inversely heart-shaped. Oxalis, in Geraxiace., 105

Stameus distinct, free from the calyx.

Style 1, undivided. . . . . . ERICacex, 309

Styles 2-5, separate. - . . Carrophrllacex, 82

Stamens distinct. inserted on the calyx.

Styles 2 (or 3), or splitting into 2 in fruit. SAxIFraGACE 168

Style 1 ; pod in the calyx, l-celled. LYTHRACE. 184

2. alyx-tube adherent to the ovary, at least to its lower half.

rendril-bearing and often snceulent herbs. . . . Cecuraitace $x, 194$

Not tendril-bearing.

Ovules and seeds more than one in each cell.

Ovary l-celled, inany-oruled from the base. - . Portulacaces, 90

Ovary 1-celled, with 2 or 3 parietal placeutæ. - SAxifragaces, 168

Ovary 2-several-celled.

Anthers opening by pores at the apex; style 1. MeLastomaced, 183 
Anthers not opening by pores.

Stanens on a flat disk which corers the ovary. Celastraceæe, 109 Stanens inserted on the calyx.

Eight or four (rarely five); style 1. . . Onagracese, 186 Five or ten; styles 2-3, distinct. . . Saximragacex, 168 Ovules and seeds only one in each cell.

Stamcus 10 or 5 (instead of many), - rarely in Cratægus, in RosACEe, 165 Stamens 2 or 8 ; style 1; stigma 2-4-lobed; herbs. ONaGracede, 186 Stamens 4 or 8 ; aquatics; styles or sessile stigmas 4. Halorages, 180 Perfect stamens 4 ; styles 2 ; slurub. . . Hamamelide 17,179 Stamens 4; style and stigme. 1; chiefly shrubs. . . Coratacex, 213 Stamens 5; flowers in unbels, or rarely in heads.

Fruit dry, splitting in two at maturity; styles 2. UMBELLIFERx, 198 Fruit berry-like; styles 2-5, separate or united. Araliaces, 212

=-rsion II. GAMOPETALOUS ealyx and corolla both present; the latter with its petals united more or less into one piece.

A. Stamens more numerous than the lobes of the corolla.

Ovary 1-celled with one parietal placenta.

LEGUMINOSA, 122 Ovary 1 -celled with two parietal placentæ. Adlumia, \&c., in Fumariace $E$, 60 Ovary 1-celled with the ovules at the centro or base. - Strracacex, 333 Ovary 2-celled with a single ovule in each eell. . . PoLyGaLACEe, 120 Ovary 3 - many-celled

Stamens free or nearly free from the eorolla; style single. Ericace $\mathbb{E}, 309$ Stamens free from the corolla; styles 5. Oxalis, in Geraniace ex, 105 Stamens inserted on the base or tube of the eorolla.

Filaments monadelphous; anthers l-celled, kidney-shaped. MaLraCese, 96 Filaments 1-5-adelphous at base; anthers 2-celled.

Calyx free from the ovary. . . . . Ternstremiace 2,95

Calyx coherent with the ovary or with its base. STrracace $\mathbb{2}, 333$

Filaments wholly distinct; calyx free, persistent. EBenaCE $\$, 333$ Filaments in pairs at each sinus; anthers 1-celled. CAprifolinces, 216

B. Stamens (fertile ones) as many as the lobes of the corolla and opposite them. Ovary 5-celled; corolla appendaged with scales inside.

Sapotacex, 332 Ovary 1-celled; pod several - many-seeded; style 1.

Primulaceit, 328 Ovary 1-celled; utricle 1-seeded; styles 5. . . Pumbaginace 327

C. Stamens as many as the lobes of the corolla and alternate with them, or fewer.

1. Ovary adherent to the calyx-tube (inferior).

Tendril-bearing herbs; anthers often united.

CuCurbitace 2,194 Tendrils none.

Stamens united by their anthers into a ring or tabe.

Flowers in an involucrate head.

Cosmposite, 230

Flowers separate, not involucrate; corolla irregular.

Lobeliacex, 305

Stamens sep $\because$ rate, free from the corolla or nearly so, as

many as its lobes: stipules none: juice milky. Campanulaces, 307 
Stamens separate, inserted on the corolla,

One to three, always fewer than the corolla-lobes. VALerianace $\boldsymbol{E}, 228$

Four or five; leaves opposite or whorled.

Ovary 1-eelled; flowers in a dense involucrate head. DIPSACEx, 229 Ovary 2-5-celled.

Leaves whorled and without stipules.

Leaves opposite or whorled, and with stipules.

RUBIACE $\mathbb{E}, 222$

Leares opposite without stipules (petioles sometimes with stipule-like appendages).

CAPrifoliacex, 216

2. Ovary free from the calyx (superior).

* Corolla irregular: stamens (with anthers) 4 and didynamous, or only 2.

Ovules and seeds solitary in the $(1-4)$ cells.

Ovary 4-lobed, the style rising from between the lobes.

Ovary not lobed, the style from its apex.

LABIATx, 403

Orules numerous or at least as many as 2 in each cell.

Ovary and pod 1-celled,

With a free central placenta; stamens 2.

With 2 or more parietal rery many-seeded placentæ;

stamens 4. . . . . . . Orobarchace 2,393

Ovary and fruit more or less $4-5$-celled. . . . Pedaliace 2,399

Ovary and pod 2-celled, but the 2 placentæ parietal. BIGNON1ACE 2,398

Ovary and pod 2-celled; placentæ in the axis.

Seeds rarely few, not on hooks, with albumen. Scrophulariace $\mathbb{E}, 377$

Seeds few, borne on hook-like or other projections of the placentæ: no albumen.

ACANThace $\mathbb{2}, 399$

* * Corolla somewhat irregular: stamens (with anthers) 5 .

Stamens free from the corolla; anthers with their cells opening by

a hole or chink at the top. Rhododendron, in ERICACE 20,320

Stamens inserted on the corolla.

Ovary deeply 4-lobed around the style. Echium, in BORRAGINACE $\mathbb{E}, 367$

Ovary not lobed; pod many-seeded.

Filaments or some of them woolly. Verbascum, Scropnudariace $\$$, 379 Filaments not woolly. . . . Hyoseyamus, Solanace 370 * * Corolla regular.

- Stamens as muny as the lobes of the corolla.

Ovaries 2, separate; their

Styles and stigmas also wholly separate. Dichondra, Cosrolvulace $\&, 368$ Stigmas and sometimes styles united into one.

Filaments distinct; pollen in ordinary grains.

Filaments monadelphons; pollen in masses. .

Apocracese, 337 - Asclepiadaces, 338

Ovary one, but deeply 4-lobed around the style (or 2-lobed in Heliotropium).

Leaves alternate.

Leaves opposite.

- Borraginaces, 360

Ovary one; pod 2-lobed or 2-horned at 'he summit.

Ovary one; not deeply lobed,

One-celled, one-ovuled, beeoming an achene. Mentha, in Labiate, 407

LOGANIACEe, 345

Plantaginace, 422 
One-celled, with ovnles parietal or on 2 parietal placentæ.

Leaves (or in Menyanthes three leaflets) entire. Genrianaced, 346

Leaves toothed, lobed, or pinnately compound. HYDROPHYLACEA, 357 Two- to ten-celled.

Leafless parasitic twining plants. Cuscuta, in Convolvulaces, 370

Leaves oppositc, their bases or petioles connected

by stipules or a stipular line. . . . Logandacese, 345

Leaves when opposite without stipules.

Stamens free from the corolla or nearly so; style 1. Fricaces, 309 Stamens almost free from the corolla; style none. . Ilicinede, 107 Stamens in the sinuses of the corolla; style 1. Diapexsiace As, 326

Stamens inserted on the tube of the corolla,

Four; pod 2-celled, circumscissile. . . Plantaginace 2,422

Four; ovary 2-4-celled; orules solitary. . VERBEAACEA, 401

Five or rarely more.

Fruit of two or four secd-like nutlets. - Borraginacede, 360

Fruit a few-seeded pod.

Calyx 5-cleft; style 3-lobed or -cleft. . Polemoniace 2,354

Sepals 5; styles 1 or 2, cutire or 2-clcft; seeds

large, only one or two in a cell. Cosvolvolaces, 367

Fruit a many-seeded pod or berry.

Styles 2. . . . Hydrolea, in Hrdrophyllace 2,360

Style single. . . . . . . . Solanace 373

- + Stamens fewer than the lobes of the corolla.

Stamens 4, didynamous.

Ovary 2-celled; the cells several-seeded. . . . ACANTHACE 399

Ovary 2-4-celled; the cells 1-seedcd. . . . Verbenacese, 401

Stamens only 2 with antlicrs; ovary 4-lobed. . Lycopus, in LABiat压, 408

Stamens 2, rarely 3 ; ovary 2 -celled.

Low lierbs; corolla scarious, withering on the pod. Plantaginaces, 422

Herbs; corolla rotate, or somewhat funnelform, and

slightly irregnlar. . . Veronica, in Scropidulariace

Sỉrubs or trees; corolla perfectly regular. . . . . OLEACE $\mathbb{\text { . }} 335$

DIVision III. APETALOUS : corolla (and sometimes calyx) wanting.

A. Flowers not in catkins.

1. Ovary or its cells containing many ovules.

Ovary and pod inferior (i. e. calyx-tube adherent to the ovary),

Six-celled; stamens 6-12. • . . . . Aristolochiace 2 , 444

Four-celled; stamens 4. . . . . Lndwigia, in ONAGRACEde, 187

One-celled, witl parietal placentre. Chrysosplenium, in SAXIrRAGACEA, 172 Ovary and pod wnolly naked (there being no calyx),

Two-celled, 2-beaked; flowers capitate; tree. - Hamamelinem, 179

Two-celled, many-ribbed; aquatic herb. . . . Podostemace\&. 444 
Ovary and pod superior, i. e. free from the calyx.

Five-celled and 5-beaked, opening across the beaks, which

fall off at maturity ; stamens 10 . Penthorum, in Crassclacex, 176

Three-celled and 3-valved, or 3-5-celled and circumscissile. Ficorde 2,198

Two-celled or one-celler; placentæ central.

Stamens inserted on the throat or tube of the calyx. Lrthraces, $18 t$

Stamens insertcd o: the receptacle or the base of the calyx,

Alternate with the 5 sepals. . . . Glaux, in Primdlaces, 331

Opposite the sepals when of the same number. Carrophyllace 2,82

One-celled, with one parietal placenta. $\}$. . . Randxculaces, 34

Ovaries 2 or more, separate, simple.

2. Ovary or its cells containing only 1 or 2 , rarely 3 or 4 , ovules.

* Pistils more than one, and distinct or nearly so.

Stamens inserted on the calyx; leares with stipules. . . ROSACE 150

Stamens inserted on the receptacle.

Lcaves punctate with pellucid dots. . Xanthoxylum, in Rutace $£, 106$

Leaves not dotted.

Calyx present, and usually colored or petal-like. Raxuxculacex, 34

Calyx absent; flowers entirely naked, perfect, spiked. Piperacex, 446

* Pistil one, either simple or compound.

Ovary partly inferior, the calyx coherent to its lower lalf,

2-celled; styles 2; stamens many. . . HAMAMELIDEE, 179

Ovary wholly inferior (in perfect or pistillate flowers).

Aquatic herbs; ovary 3-4-celled, or (Hippuris) I-celled. HALORAGEE, 180

Mostly woody plants; style or stigma one, entire; vrary l-celled.

Stigma running down one side of the style. Nyssa, in Corvacese, 215

Stigma terminal, with or without a style.

Parasitic on the branches of trees; anthers sessile. Loranthacex, 449

Not parasitic above ground; anthers on filaments. SAxtaLACEE, 450

Ovary really free from the calyx, but permanently invested by its

tube, or the basc of it, so as to seem inferior.

Shrubs, with scurfy leaves; flowers mostly diœcions. ELAAGGACE 4448

Herbs, with the calyx colored like a corolla.

Leaves opposite, simple. . . . .

Leaves alternate, piunate. . . . Poterium, in Rosaces, 161

Ovary plainly free from the calyx, which is sometimes wanting.

Stipules (ocrex) sheathing the stem at the nodes.

Tree; calyx none; flowers monœcious, in heads.

Platanace 466

Herbs; calyx present and commonly petal-like. Polygonace 4,436

Stipules not sheathing the stem, or none.

Aquatic herbs, submerged or nearly so.

Leaves whorled and dissected; style single. Ceratopin llace.e, 488

Leaves opposite, entire; styles 2; ovary 4-celled. Halorages, 180

Not aquatics, herbs.

Ovary 10-celled; berry 10-seeded. . . Purtolaccace 2,435

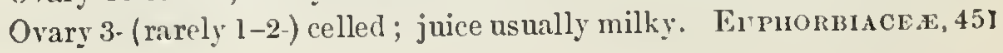


Ovary 1-celled; juice not milky.

Style, if any, and stigma only one; leares simple;

no searious bracts around the flowers. . URTICACE $\mathbb{E}, 461$

Styles 3 ; embryo straiglit; flowers involncrate.

Eriogonum, in Polrgoxaced, 436

Style or stigmas 2 or 3 ; embryọ coiled or curved.

Stipules not scarious, leaves palmately cleft or palmately compound. . . Camnabineæ, in Urticaces, 461

Stipules scarious (or none); leaves opposite. Illecebracee, 426

Stipules noue; but flowers with scarious bracts. Awaraxtace.e, 427

Stipules and scarious bracts none . . Chexoponiace玉, 430

Shrubs or trees.

Ovules a pair in each cell of the ovary.

Fruit 2-celled, a doulle samara. Acerinex, in Sapindaces, 115

Fruit a l-celled aud l-seeded samara or a clrupe. Oteace.e, 335

Ovules single iu each cell of the

Three-nine-celled orary; leares heatl-like. • EMPETRACEd, 487

Three-celled orary; leaves broad. . . . Rhamnaced, 111

One-two-celled ovary; styles or stigmas 2-cleft. UrílсACEÆ, 461 One-celled orary; style and stigma single and entire.

Anthers opening longitudiually. . . TrmmelæACE 448

Anthers opening by uplifted valves. . . . Laurace 1446

B. Flowers monocious or dixcious, one or both sorts in catkins.

1. Only one sort of flowers in cuthins or catkin-like heads.

Fe-tile flowers in a short catkin, head, or strobile. . . Urticaces, 461 Fertile flowers single or clustered; sterile in slender catkius (except in Fagus).

Leaves pimate; fertile flowers and fruit uaked. JUGLANDACE.E, 467

Leaves simple; fertile flowers $1-3$ in an involucre or cup. Cúpullere, 470

2. Both sterile and fertile flowers in catkins or cathin-like heads.

Ovary and pod 2-celled, mauy-seeded. I iquidambar, in Hanamelnew, 180 Ovary and pod l-celled, many-seeded; seeds furnished with

a downy tuft at one end. . . . . . Salicaceze, 480

Ovary I-2-celled, only one orule in each cell; fruit 1-seeded.

Parasitic ou trees; fruit a lerry. . . . . LoRantirace.e, 449

Trees or shrubs, not parasitic.

Calyx regular, in the fertile flower succulent in fruit. URTICACEx, 461

Calyx none, or rudimentary and scale-like.

Style and stigma one, simple; the flowers in heads. Platanaces, 466

Styles or long stigmas 2.

Fertile flowers 2 or 3 at each scale of the catkin. Cupulifere, 470

Fertile flowers single under each scale; nutlets

naked, waxy-coated or drupe like. . . . MrricaceEe, 469

Subciass IT. GYMNOSPERMAE. Pistil an open scale or altered leaf, beariug naked orules on its margin or its upper surface, or in Taxus entirely wanting. Flowers monøeious or diœcious. ConfFeræ, 489 


\section{Class II. MONOCOTYLEDONOUS PLANTS. (See p.15.)}

A. Spadiceods Division. Flowers aggregated on a spadix or fleshy axis, or sometimes scattered, destitute of calyx and corolla (excepting some Aracew and Naiadacex, where, however, they are on a spadix), and also without glumes (husky scales). Leaves sometimes with netted veins.

Little floating aquatics, with no distinction of stem and foliage. LEMNACE $₫, 551$ Immersed aquatics, brancling and leafy. . . . NAIADACE E, 557 Reed-like or Flag-like marsh herbs, witl linear and sessile

nerved leaves; flowers in spikes or leads.

Flowers monœcious, and quite destitute of floral envelopes. TrpHaces, 547

Flowers perfect, on a lateral spadix; sepals 6. Acorus, in Araces, 550 Terrestrial or marsh plants; leaves mostly with a distinct

netted-veined blade, petioled. . . . . . . Aracex, 548

B. Petaloideous Division. Flowers not collected on a spadix, furnished with floval envelopes (perianth) answering to caly $x$ or to both caly $x$ and corolla, either herbaceous or colored and petal-like (wholly glumaceous in Juneace ).

\section{Perianth adherent to the whole surface of the ovary.}

E lowers diøcious (or rarely perfect), regular.

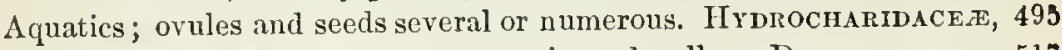

Cwiners; ovules and seeds one or two in each cell. Dioscoreaces, 517

Elowers perfect; ovules and seeds usually numerous.

Stamens only one or two; flower irregular, gynandrous. Orcindace $\mathbb{A}, 497$

Stamens three.

Anthers introrse, opening transversely. - . Burmanniace 2496

Anthers introrse or versatile, opening lengthwise. HAMODORACEx, 512 Anthers extrorse, opening lengthwise. . . . IRIDACE $\mathbf{A}, 513$

Stamens 6 ; flowers usually on a scape from a bulb. AMArYLLIDACE 515

2. Perianth adherent only to the base or lower half of the ovary.

Perianth woolly or roughish-mealy; leaves often equitant. HæMODORACE\&, 512 Perianth smooth; the leaves grass-like. Steuanthium, etc., in LiLIACE $\mathbb{E}, 517$

3. Perianth wholly free from the ovary.

Pistils numerous or few in a head or ring. . . . . Alismaces, 553 Pistil one, compound (cells or placentse mostly 3).

Perianth not glumaceous or chaffy; flowers not in dense heads.

Stamens 6 (in Maianthemum 4), sinilar and perfect.

Scurfy-leaved epiphyte; seeds hairy-tufted. . BromeliaCe $\boldsymbol{A}, 511$

Marsh herbs; earpels nearly distinct or separating closed from

the axis; seed without albumen. Juncagineæ, in NAIADACE 2,557

Terrestrial, not rush-like; seeds with albumen.

Periant h of similar divisions or lobes, mostly colored.

Perianth of 3 foliaceous and green sepals and 3 col- $\}$ Liliaces, 517 ored withering-persistent petals. Trillium in

Perianth of 3 persistent green sepals, and 3 epheme-

ral deliquescent petals. . . . . COMmelinaclide, 538 
Stamens 6, dissimiiar, or only three witl perfect anthers.

Sepals 3 , herbaceous; ephemeral petals 3 , unequal.

Commelinaceæ, 533

l'erianth tubular, 6-lobed. • . . . PontederiaceE, 535

Stamens 3, similar. Moss-like aquatic. . . . MaYaCe无, 537

Perianth wholly glumaceous, of 6 similar divisions. - JunCACE正, 539

Perianth partly glumaceous or chaff-like; flowers in very

dense heads. Rush-like or aquatic.

Flowers perfect; inner perianth of three yellow petals;

perfect stamens and plumose sterile filaments each

3 ; pod l-celled, many-seeded on 3 parietal placent $x$. XYr1DACE正, 536

Flowers monœcions or diœcious, whitish-bearded; sta-

mens 4 or 3; pod 2-3-celled, 2-3-seeded. . Eriocavlese, 566

C. Guumaceous Division. Flowers destitute of proper perianth, except sometimes small scales or bristles, but covered by scale-like bracts or glumes.

Glume a single scale-like bract with a flower in its axil. . CYPERACle, 567 Glumes in pairs, of two sorts.

Graminex, 623

\section{Class III. CRyptoganous ACROGENs. (See p. 17.)}

Subclass I. PTERIDOPHYTES: with woody fibres and vessels.

Spores of only one kind; spore-cases

Borne beneath shield-shaped scales in a terminal spike; stems naked, sheathed at the nodes. . . . . EQuisetacexa, 67

On the back or margin of fronds circinate in vernation. Filıces, 678

Bivalvular, in special spikcs or panicles ; fronds erect in vernation,

from short erect rootstocks. • • . OPHIOG LOSSACEN, 693

Solitary in the axils of leaves, $2-3$-ralved; low long-stemmed moss-

like evergreens; leaves small, in $4-16$ rauks. Lrcopodiaces, 695

Spores of two kinds, large and small; spore-cases

Solitary in the axils of small 4-ranked leaves, or in the bases of

linear radical leaves. . . . . Selaginellace 2,697

Enclosed in peduncled sporocarps; leares 4-foliolate. Marsiliace 2,700

Sporocarps sessile beneath the stem; small, floating, pinnately

branched, with minnte imbricate leaves. . S SALInIACE 101

Subclass II. BRYOPIITTES: with cellular tissue only. [Capsules not operculate, containing spores and usually elaters, in the following Orders.]

Capsule 4-valved, pedicellate; plants leafy-stemmed, rarely thallose.

JUNGERMANNIACE正, 702

Capsule 2-valved or valveless; plants thallose.

Thallus withont epidermis; capsule with a columella, short-pedicelled or sessile on the thallus. A ANтrocerotaced 726

Capsules borne beneatl a pedunculate receptacle. Marchastiaces, 727

Capsules immersed in the thallus or sessile upon it, indehiscent. 


\section{A B B REVIA TIONS}

\section{OF THE NAMES OF AUTHORS CITED IN THIS VOLUME.}

Adans. - Adanson, Michel.

Ait.-Aiton, William.

Ait.f.-Aiton, William Tornsend.

All. - Allioni, Carlo.

Anders.-Andersson, Nils Johan.

Arn. - Arnott, George A. Walker.

Aust. - Austin, Coe Finch.

Baldw. - Baldwin, William.

Bart. - Barton, Tilliam P. C.

Beauv.-Palisot de Beauvois, A. M. F.J.

Benth. - Bentham, George.

Benth. of IIook. - G. Benthain and J. D.

\section{Hooker.}

Bernh. - Bernhardi, Johann Jacob.

Bess. - Besser, Wilhelm S. J. G. von.

Bieb. - Bieberstein, F. A. M. ron.

Bigel. - Bigelow, Jacob.

Bisch. - Bischoff, Gottlieb Wilhelm.

Boeckl. - Boeckeler, Otto.

Boiss. - Boissier, Edmond.

Borkh.-Borkhausen, M. B.

Br., R. Br:-Brown, Robert.

Britt. - Britton, Nathaniel Lord.

Carr. - Carrière, Élie $\Lambda$ bel.

Carring. - Carrington, Benjamin.

Cass. - Cassini, Henri.

Cav. - Cavanilles, Antonio Jose.

Cerv. - Cervantes, Ticente.

Cham.-Chamisso, Adalbert ron.

Chapm. - Chapman, Alvan Wentwor'h.

Chois. - Choisy, Jacques Denis.

Clayt. - Clayton, Jolm.

Cogn.-Cogniaux, Alfred.

Coult. - Coulter, Jolin Merle.

Darl., Darling. - Darlington, Willam.

$D C$. - DeCandolle, Aurustin Pyranus.

A. DC. - DeGindollo, Alphonse.

Decsne. - Decaisne, Jorph.

Desf. - Desfontaines, Rén Louiche.

Desv. - Desvaux, Nicaise Augustin.
Dicks. - Dickson, Janes.

Dill. - Dillenius, Juhan Jacob.

Duugl. - Douglas, Davicl.

Dufi. - Dufresne, lierre.

Dumort. - Dumortier, Barthélemy C.

Eat.-Eaton, Amos.

Ehr.-Ehrhart, Friedrich.

Lll. - Elliott, Stephen.

Endl. - Endlicher, Stcphan L.

Engelm. - Engelmann, George.

Esch.-Eschscholtz, J. F.

Fisch.-Fischer, F. E. Ludwig ron.

Fong. - Fougeroux, Auguste Dcn is.

Forst. - Forster, J. R. and George.

Froel. - Froelich, Joscph Aloys.

Gaevtn. - Gaertner, Joscph.

Gaertn.f.-Gaertner, Carl Friedrich.

Gal.-Galeotti, Henri.

Goud.-Gaudichaud-Beaupre, Cliarlcs

Gey. - Geyer, Charles (Carl Andreas).

Ging. - Gingins de Lassaraz, F. C. J.

Glox. - Gloxin, Benjamin Peter.

Gmel.-Gmelin, Samuel Gottlieb.

Guoden.-Goodenough, Samuel.

Grev. - Greville, Robert Kaye.

Griseb.-Grisebach, Ifeinpich R. A.

Gronov. - Gronovius, Jan Fredrik.

Guss. - Gussone, Gioranni.

IItck. - Hackel, Eduard.

Martm. - Hartman, Carl Johann.

IIrssk. - Hasskarl, Justus Carl.

IIausskn. - Haussknecht, Carl.

II aw. - Haworth, durian Hardy.

II $B K$. - Humboldt, F. Alexander von

Aimé Bonpland, and C. S. Kunth.

Negelm. - Hegelmaier, Friedrich.

Herb. - Herbert, William.

IIochst. - Hochstetter, Christian F.

IIoffm. - Hoffman, Genrg Franz.

Holl. - Hollick, Arthur. 
Hook. - Hooker, William Jackson. Hook. f.-Hooker, Joseph Dalton. Hornem. - Hornemann, Jens Wilken. Huds. - Hudson, William. Huebn. - Hnebener, J. W. P. Jacq. - Jacquin, Nicolaus Joseph. Juss. - Jussieu, Antoine Laureut. A. Juss. - Jussieu, Adrien de.

L., Linn. - Iinnæus, Carolus, or Carl von Linné.

L. $f$. - Linné, Carl ron (the son).

L'Her. - L'Heritier de Brutelle, C. L. Lag. - Lagasca, Mariano.

Lam. - Lamarck, J. B. A. P. Monnet. Ledeb. - Ledebour, Carl F. von.

Lehm. - Lehmann, J, G. C.

Less. - Lessing, Chnistian Friedrich.

Light. - Lightfoct, John.

Lindb. - Lindberg, Sextus Otto.

Lindenb. - Lindenberg, Joliann B. W.

Lindl. - Lindley, John.

Loisel._Loiseleur-Deslougchamps, J.

Lour. - Loureiro, Juan.

[L. A.

Marsh. - Marshall, Humphrey.

Mart. - Martens, Martin.

Maxim. - Maximowicz, Carl Johann.

Medic. - Medicus, Friedrich Casimil.

Meisn. - Meisner, Carl Friedrich.

Mey. - Meyer, Ernst (Heinrich F.).

Mich. - Micheli, Pier" Autonio.

Michx, - Michaux. André.

Michx.f.-Michaux, Frauçois André.

Mill. - Miller, Philip.

Mitch. - Mitchell, J.

Mrtt.-Mitten, William.

Mont. - Montagne. (J. F.) Camille.

Moq. - Moquin-Tandon, Alfred.

Muell. - Mueller, Jean (of Aargau),

Afuhl. - Muhlenberg, Hemry (H. Ernst).

Murr. - Murray, Johann Audreas.

Neck. - Necker, Noel Joseph de.

'Nutt. - Nuttall, Thomas.

Pall. - Pallas, Peter Simon.

Pers. - Persoon, Christian Hendrik.

Planch. - Planchon, Jules Emile.

Poir. - Poiret, Jean Louis Marie.

Poll, - Pollich, Jolann Adan.

R. \& S. - Roemer, J. J., and Joseph August Schultes.

Raf. - Rafinesque-Schmaltz, C. S.

Reichenb. - Reichenbach, H. G. L.

Richards. - Richardson, John.
Roem. - Roemer, Jolınn Jacob.

Rostk. - Rostkovius, F. W' G.

Rotlb. - Rottboell, Christen Fries.

St. IIil. - St. Hilaire, Auguste de.

Sulisb. - Salisbury, Richard Authony.

Savtw. - Sartwell, Henry P.

Sav. - Savi, Graetano.

Schlecht. - Schlechtendal, D. F. L. von.

Schleich. - Schleicher, J. C.

Schleid.-Schleiden, Matthias Jacob.

Schrad. - Schrader, Heinrich A.

Schreb. - Schreber, Johann C. D.

Schum. - Schumacher, Chrstian F.

Schuein. - Schweinitz, Lew is David de.

Sc(p). - Scopoli, Johaun Anton.

Scribn. - Scribner, F. Lamson.

Shutlw. - Shuttleworth, Robert.

Sibih. - Sibthorp, Jolın.

Sieb. of Zucc. - Siebold, P. F. ron, and

J. G. Zuccarini.

Spreng. - Sprengel, Kurt.

Steph. - Stephani, F.

Steud. - Steudel, Ernst Gottlieb.

Sulliv. - Snllivant, Williau Starling.

Tayl. - Taylor, Thomas.

Thuill. - Thuillier, Jean Lonis.

Thunb. - Thunberg, Carl Peter.

Thurb. - Thurber, George.

Torr. - Torrey, John.

Tourn. - Tournefort, Joseph Pitton de.

Tratt. - Trattenick, Leopold.

Tuckerm. - Tuckerman, Edward.

Turcz. - Turczaninow, Nicolaus.

Undernc. - Underwood, Lucien $\mathbf{M}$.

Vaill, - Vaillant, Sébastien.

Vent, - Ventenat, Etienne Pierre.

rill. - Villars, Dominique.

Wuhl. - Wahlenberg, George.

$I^{r} a h l b$. - Wahlberg, Pelır Fredrik.

W"alp. - Walpers, Wilheln Gerbard.

Wult. - Walter, Thomas.

Wang. - Wangenheim, F. A. J. von

Web. - Weber, Friedrich.

Wiı. - Wiggers, F. H.

Hill, - Willdenow, Carl Ludwig.

Wils. - Wilson, William.

Wimm. - Wimmer, Friedrich.

With. - Withering, Willian.

Hormsk. - Wormskiold, M. von.

Wr. (Eat. of $W^{r} r$.) - Wright, John

Wulf. - Wulfen, Franz Xaver. 


\section{SIGNS USED IN THIS WORK.}

',',". The sign of degrees ( $\left.{ }^{\circ}\right)$ is used for feet; of minutes ('), for inches, of seconds ("), for lines, - the line being the twelfth part of an inch, and very nearly equivalent to two millimetres.

$\mu$. In microscopic measurements, the conventional sign for the micromillimetre or the one-thousandth part of a millimetre = one two-thousandth part of a line.

$\delta$ Bearing only stamens or antheridia.

P Pistillate or bearing archegonia.

? A mark of doubt.

! A mark of aftirmation or authentication.

Figures or words separated by a short dash (-) indicate the extremes of variation, as " $5-10$ " long, few-many-flowered," i. e. varying from 5 to 10 lines in length, and with from few to many flowers. 


\section{B O T A N Y}

OF THE

\section{NORTHERN UNITED STATES.}

\section{SERIES I.}

\section{PHÆNOGAMOUS OR FLOWERING PLANTS.}

VEGETABLES bearing proper flowers, that is, having stamens and pistils, and producing seeds, which contain an embryo.

\section{Class I. DICOTYLEDONOUS or EXOGENOUS PLANTS.}

Stems formed of bark, wood, and pith; the wood forming a layer between the other two, increasing, when the stem continues from year to year, by the annual addition of a new layer to the outside, next the bark. Leaves nettedveined. Embryo with a pair of opposite cotyledons, or rarely several in a whorl. Flowers having their parts usually in fives or fours.

\section{Subclass I. ANGIOSPÉRMIE.}

Pistil consisting of a closed ovary, which contains the ovules and forms the fruit. Cotyledons only two. 


\section{Division I. POLYPETALOUS EXOGENOUS PLANTS.}

Floral envelopes consisting of both calyx and corolla; tha petals not united with each other. (Sereral genera or species belonging to Polypetalous Orders are destitute of petals, or have them more or less united.)

\section{Order 1. RANUNCULACEA. (Crowfoot Family.)}

Herbs or some woody plants, with a colorless and usually acrid juice, polypetalous, or apetalous with the calyx often colored like a corolla, hypogy. nous; the sepals, petals, numerous stamens, and many or few (rarely single) pistils all distinct and unconnected. - Flower's regular or irregular. Sepals 3-15. Petals $3-15$, or wanting. Stamens indefinite, rarely few. Fruits either dry pods, or seed-like (aehenes), or berries. Sceds anatropous (when solitary and suspended the rhaphe dorsal), with hard albumen and a minute enbryo. - Leares often disseeted, their stalks dilated at the base, sometimes with stipule-like appendages. (A large family, including some acrid-uarcotic poisons.)

\section{Synopsis of the Genera.}

'Tribe I. CLEMATIDEA. Sepals normally t, petal-like, ralvate in the bud, or with the edges bent inward. Petals none, or small. Achenes numerous, tailed with the feathery or haily styles. Seed stispencled. - Leaves all opposite.

1. Clematis. Climbing by the leafstalks, or erect herbs.

Tribe II. ANE 1ONEA. Sepals 3-20, often petal-like, imbricated in the bud. Sta. meus mostly numerous. Achenes numerons or sereral, in a head or spike.-Herbs, never climbing; leares alternate, or radieal, the upper sometimes opposite or whorler.

* Petals none (rarely some staminodia). Seed suspended.

+ All but the lower leaves opposite or whorled Peduncles 1-flowered.

2. Snemone. Involucre leaf-like, rcmote from the flower. Leaves compound or dissected. Pistils very nany.

3. Hepatica. Involucre close to the flower, of 3 oval bracts, calyx-like. Leaves radical, simlle and lobed. Pistils several.

4. Anemonella. Stigma terminal, broad and flat. Radical leaves and involucre comnound. Peduncles rumbellate. Achencs $4-15$, mauy-ribbed.

+ - Leaves alternate, compound. Flowers panicled, nften diœcious.

¿Thalictrum. Sepals usually 4 , petal-like or greenish. Achenes fer.

* Petals none. Sepals $3-5$, caducous. Seed erect. Leaves alternate.

6. Trautretteria Achenes numerous, inflated, 4-angled. Flowers corjubose. Filaments white, clavate.

*** Petals evilent. Sepals usually 5. Achenes mans

7. Adonis. Sepals and rictals (5-16, crimson or searlet) flat, unappendaged. Seed suspended.

8. Myosurus. Sepals spurred. Petals 5, white. Acheries in a long spike. Scapes l-flowered. Sced suspended.

9. Ranunculus. Petals 5, yellow or white. with a scale or gland at base. Achenes capitate. Seed erect. 
Tribe 111. HELLEBOREAE. Sepals imbricated in the bud, rarely persistent, petallike. Petals often nectariferons or reduced to staminodia or none. Pods (follicles) or Lerries (in n. 20, 21) few, rarcly single, few - many-seeded. - Leaves alternate.

* Ovules and commonly seeds more than one pair. Herbs.

- Flowers regular, not racemose. Petals inconspicuous nectaries or slender or none. Sepals tardily deciduons.

10. Isopyrum. Petals none. Sepals broad, white. Pods few. Leaves compound.

11. Caltha. Petals none. Sepa!s broad, yellow. Leaves kidney-shaped, undirided.

12. Trollius. Petals 5-20, narrow, pitted above the base. Pods scssile. Leaves palmately lobed.

13. Coptis. Petals 5-6, small, lrollowed at apex, white. Pods long-stalked. Leaves radical, trifoliolate.

14. Helleborus. Petals sinall, tubular, 2-lipped, Serrals 5, broad, nersistent and turning green. Pods sessile.

15. Eranthis. Petals small 2-lipped nectaries. Sepals $5-8$, narrow, deciduous. Flower solitary, involucratc.

$$
\text { + + Sepals and large spur-shaped petals regular, each } 5 .
$$

16. Aquilegia. Pistils 5, witl slender stylcs. Leaves ternately compound.

$$
+++ \text { Flowers unsymmetrical and irlegular. Sepals } 5 .
$$

17. Delphinium. Upres sepal spurred. Petals 4, of two forms; the upper pair with long spurs, enclosed in the spir of tlie calyx.

18. Aconitum. Upper sepal looded, covering tle two long-clawed small netals.

$+\ldots++$ Flowers regular, racemose. Selvals caducous. Petals very small, stamen-like, or none. Leaves decompound.

19. Cimicifuga. Fluwers in long often paniculate racemes. Pistils $1-8$, becoming many-seeded pods.

20. Actzea. Flowers in a single short raceme. Pistil single, forming a many-seeded berry.

* Ovules a single pair. Flowers regular. Roots yellow and bitter.

21. Hydrastis. Flowers solitary. Sepals 3, netal-like, caducous. Petals none. Staunens nunerous. Pistils several, becoming 2-seeded berıies. Leaves sinule, lobed.

2. Xanthorrhiza. Flowers in coupound rilcenes. Sepals 5. Petals 5, small, 2-lobed, with claws. Stanens $5-10$. Pods 1 -seeled. Slurub with pinnate leaves.

\section{CLÉmAtis, I. Virgin's-Bower.}

Sepals 4, or rarely more, colored, the valvate margins turned inward in the bud. Petals none or small. Achenes numerous in a head, bearing the persistent styles as uaked, hairy, or plumose tails. - P'erenuial herbs or vines, mostly a little woody, and climbing by the hending or elasping of the leaf-

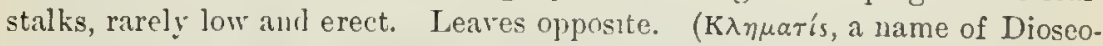
ricles for a climbing plant with long and lithe branches.)

$\S$ I. FLAMMULA. Flowers cymose-paniculate, rather small, in our species diacious. Sepals petaloid, whitish, spreading, thin. Petals none. Anthers short, blunt.

1. C. Virginiàna, I. (Commox Virgin's-Bower.) Smooth; leaves bearing 3 orate acute leaflets, which are cut or lobed, and somewhat heartshaped at the base; tails of the fruit plumose. - River-banks, ete., common, climbing over shrubs. July, August.

2. C. ligusticifolia, Nutt. Very similar, but the leaves 5-foliolate or quinate-ternate. - Long Pine, Neb., and west to the Pacific. 
§2. VIÓRNA. Flowers large, solitary on long peduncles, usually nodding. Sepals thich, erect and connivent at base, mostly dull purple. Petals none. Anthers linear.

- Stems climbing; leaves pinnate; calyx (and foliage) glabrous or puberulent.

3. C. Viórna, I. (Leather-Flower.) Calyx ovate and at length bell. shaped; the purplish sepals ( $I^{\prime}$ long) very thick and leathery, wholly connivent or only the tips recurved; long tails of the fruit very plumose; leaflets $3-7$, ovate or oblong, sometimes slightly cordate, $2-3$-lobed or entire; uppermost leaves often simple. - Rich soil, Penn. to Mo., and southward. May-Aug.

4. C. Pítcheri, Torr. \& Gray. Calyx bell-shaped; the dull purplish sepals with narrow and slightly margined recurved points; tails of the fruit filiform and naked or shortly villous; leaflets 3-9, orate or somewhat cordate, entire or 3-lobed, much reticulated; uppermost leaves often simple. $-\mathrm{S}$. Ind. to Kan., and Tex. June.

5. C. críspa, I. Calyx cylindraceous below, the upper half of the bluishpurple sepals ( $1-2^{\prime}$ long) dilated and widely spreading, with broad and wavy thin margins; tails of the fruit silly or glabrate; leaflets 5-9, thin, varying from ovate or cordate to lanceolate, entire or 3-5-parted. (C. cylindrica, Sims.) - Va. near Norfolk, and southward. May-Aug.

+ + Low and erect, mostly simple; flowers solitary, terminal; leaves sessile or nearly so, undivided, strongly reticulated.

6. C. ochroleùca, Ait. Leaves ovate, entire or sometimes 3-lobed, silky beneath; peduncles long; tails of the fruit very plumose. - Copses, Long Island to Penll, and Ga.; rare. MTay.

7. C. Fremónti, Watson. Teaves crowded, thick, often coarsely toothed, spariugly villous-tomentose; peduncles very short; tails villous or glabrate, not plumose. - Mo. and Kían.

§3. ATRAGENL. Some of the outer filaments enlarged and more or less petaloid; peduncles bearing single large flowers; the thin sepals widely spreading.

8. C. verticillàris, DC. Woody-stemmed climber, almost glabrous; leaves trifoliolate, with slencler common and partial petioles; leaflets ovate or slightly heart-shaped, pointed, entire, or sparingly toothed or lobed; flower bluish-purple, 2-3' across; tails of the fruit plumose. - Rocky places in mountainous districts, Maine and W. New Eng. to Va., Minn., and northwestwarl; rare. May. - A pair of leaves with a peduncie between them, devel= oped in spring from each of the opposite buds, gives the appearance of a whorl, whence the specific name.

\section{A N E M O N E, 'Tourn. ATÉmone. WiND-FLower.}

Sepals few or many, petal-like. Petals none, or in 11.1 resembling abortive stamens. Achenes pointed or tailed, Alattened, not ribbed. Seed suspended. - Percnnial herbs with radical leaves; those of the stem 2 or 3 together, opposite or whorled, and forming an involucre remote from the flower; peduncles l-flowered, solitary or umbellate. (The ancient Greek and Latin name, from

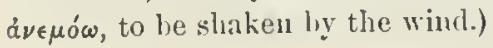


\$1. PULSATILLA. Carpels numerous in a head, with long hairy styles which in fruit form feathery tails, as in Clematis; flower large, usually with some minute or indistinct gland-like abortive stamens answering to petals.

1. A. pàtens, L., var. Nuttalliàna, Gray. (PAsque-flower.) Villous with loug silky hairs; peduncle solitary; flower erect, developed before the leaves, which are ternately divided, the lateral divisions 2-parted, the miclde one stalked and 3-parted, the segments deeply once or twice cleft into nar. rowly linear and acute lobes; lobes of the sessile involucre like those of the leaves, at the base all united into a sliallow cup; sepals 5-7, purplish or whitish ( $1-1 \frac{t^{\prime}}{2}$ long), spreading when in full anthesis. - Prairies, 1ll. aud Mo., thence northward and westward. March $-A$ pril. $-A$ span high. Tail of carpels $2^{\prime}$ long. (Eu., Siberia.)

§ 2. ANEMÒNE proper. Styles short, not plumose. Staminodia none.

* Achenes densely long-woolly, conpressed; involucre far below the flower. + Sten single, from a small tuber; sepals 10-20; style filiforn.

2. A. Caroliniana, Walt. Stem $3-6^{\prime}$ high; root-leaves once or twice 3-parted or cleft; involucre 3-parted, its wedge-slaped divisions 3-cleft; sepals $10-20$, oblong-linear, purple or whitish; head of fruit oblong. - Ill. to Neb. and southward. May.

+- Stems several; sepals 5-8; style filiform.

3. A. parviflora, Michx. Stem 3-12' ligh from a slender rootstock, l-flowered; root-leaves 3-parted, their broadly wedge-slaped divisions crenateincised or lobed; involucre 2-3-leaved; sepals 5 or 6, oval, white; head of fruit globular. - Lake Superior, nortliward and westward. May, June.

4. A. multífida, Poir. Stems from a brauching caudex, silky-haixy (6-12' high); principal involucre 2-3-leaved, bearing one naked and oue or two 2-leaved peduncles; leaves of the iuvolucre short-petioled, similar to the root-leaves, twice or thrice 3-parted and cleft, their divisions linear; sepals obtuse, red, sometimes greenish-yellow or whitish; head of fruit spherical or oval. - Rocks, etc., N. E. Maine to Lake Superior, north aud westward; rare. June.

++ + Taller, commonly branching above or producing two or more peduncles; involucral leaves long-petioled; sepals 5-8, silky or douny beneath (4-6"long), oval or oblony; style subulate.

5. A. cylíndrica, Gray. (Lovg-Fruted A.) Slender $\left(2^{\circ}\right.$ high $)$, silkypubescent; flowers 2-6, on very long upright naked peduncles; iuvolucral leaves twice or thrice as many as the peduncles, 3-divided; their divisions uedge-lanceolate, the lateral 2-parted, the midlle 3-cleft; lobes cut and toother at the apex; sepals 5 , rather obtuse, greenish-white; head of fruit cylindrical (1'long). - Dry woods, N. Eng. to Mo., and northwestward. May. - Peduncles 7-12' long, all from the same involucre and naked throughout, or one involucellate in the middle.

6. A. Virginiàna, L. More loosely pubescent or glabrate; involucral leaves 3, 3-parted ; their divisions orate-lanceolate, pointed, w-serrate, the lateral 2-parted, the middle 3-cleft; peduncles elongated, the earliest naked, the others with a 2-leaved involucel at the middle, repeatedly proliferous; sepals 5 , 
acute, greenish (in one variety white and obtuse); head of fruit oval or oblong. - Woods and meadows; common. June-August. - Plant $2-3^{\circ}$ high; the upright peduncles $6-12^{\prime}$ long.

* Achenes naked, orbicular, compressed, wing-margined; sepals 5, obovate; involucre sessile.

7. A. Pennsylvánica, L. Hairy, ratner low; primary involucre 3leaved, bearing a naked peduncle, and soon a pair of branches or peduncles with a 2-leaved involucre at the mittle, which branch similarly in turn; their leaves broadly wedge-shaped, 3-cleft, cut and toothed; radical leaves 5-7parted or cleft; sepals white $\left(6-9^{\prime \prime}\right.$ long $)$; head of fruit spherical. - W. New Eng. to Penu., Ill., aud northwestwarl. Juue-Aug.

* * * Achenes rather few, nearly nuked, orate-oblong; stems slender, 1-flowered; leares radical.

8. A. nemorósa, L. (WIND-Flower. Wood A.) Low, smoothish; stem perfectly simple, from a filiform rootstock; involucre of 3 long-petioled trifoliolute leaves, their leaflets werlge-sliaped or oblong, and toothed or cut, or the lateral oues (var. QtixqLefolis) 2-parted; a similar radical leaf in sterile plauts solitary from the rootstock; peduncle not longer thau the involucre; sepals $4-7$, oval, white, sometimes blue, or tinged with purple outside; carpels only 15-20, oblong, with a hooked beak. - Margin of woods. A pril, May.A (lelicate vemal species; the flower $\mathrm{I}^{\prime}$ broad. (Eu.)

9. A. nudicaùlis, Gray. Glabrous; rootstock filiform; radical leaves reniform, 3-parted, the divisions broally cuneate with rounded crenate-incised or -lobed summit; involucre of a single similar petiolate leaf or wanting; achenes glabrons, tipped with a slender-subulate hooked style. - North shore of Lake Superior near Sand Bay, Miun., in bogs. (Joseph C. Jones.) Imperfectly kuown.

\section{He Pá T I CA, Dill. Liver-leaf. Hepatica.}

Involucre simple and 3-leaved, very close to the flower, so as to resemble a calyx; otherwise as in Anemone. - Leares all radical, heart-shaped aud 3-lobed, thickish and persistent throngh the winter, the new ones appearing later than the flowers, which are single, on hairy scapes. (Name from a fancied resemblance to the liver in the shape of the leaves.)

1. H. tríloba, Chaix. Leaves with 3 orate obtuse or rounded lobes, those of the involucre also obtuse; sepals 6-12, blue, purplish, or nearly white, achenes several, in a small loose head, ovate-oblong, pointed, hairy. - Woods, common from the $\Lambda$ thantic to Mo., Minn., and northward, flowering soon after the snow leaves the ground in spring. (Eu.)

2. H. acutíloba, I)C. Leaves with 3 ovate and pointed lobes, or sometimes 5-lobed; those of the involucre acute or acutisly. - Passes iuto the other and has the same range.

\section{A NEMONÉLLA, Spach.}

Involucre compounct, at the base of an umbel of flowers. Scpals 5-10, white and conspicuous. l'etals none. Achenes $4-15$, ovoid, terete, strongly 8-10-ribbed, sessile. Stigma terminal, broad and depressed. - Low glabrous perenuial; leaves all radical, compouud. 
1. A. thalictroldes, Spach. (Rue-Anemone.) Stem and slender petiole of radical leaf (a spau ligh) rising from a cluster of thickicned tuberous roots; leares 2-3-temately compound; leaflets roundish, sonnewhat 3 -lobed at the end, cordate at the base, long-petiolulate, those of the 2-3-leared 1-2ternate involucre similar; flowers several in an umbel; sepals oval ( $\frac{1}{2}$ long, rarely pinkish), not early deciduous. (Thalictrum anemonoides, Mich $x$.) Woods, common, flowering in early spring with Anemone nemorosa, and considerably resembliug it. liarely the sepals are 3-lobed like the leaflets.

\section{THA LÍ TRUM, Tourn. MEADOw-Rue.}

Sepals 4-5, petal-like or greenish, usually cadncous. Petals uone. Achenes 4-15, grooved or ribbed, or else inflated. Stigna unilateral. Seed suspended. - Perennials, with alternate 2 -3-ternately compound leares, the dirisions and the leaflets stalked; petioles dilated at base. Flowers in corymbs or pauicles, often polygamous or diøcions. (Derivation obscure.)

* Flowers diccious or sometimes polygamous, in ample panicles; filaments slender; stigmas elongated, linear or subulate; achenes sessile or short-stipitate, oroid, pointed, strongly severul-angled and grooced.

1. T. diòicum, L. (EARLY MEsdow-lice.) Smooth and pale or glaucous, $1-2^{\circ}$ high; leaves $(2-3)$ all with general petioles; leaflets drooping, rounded and 3-7-lobed; flowers purplish and greenish, dioecious; the yellowish anthers linear, mucronate, drooping on fine capillary filaments. Rocky woods, etc.; common. A pril, May.

2. T. polýgamum, Muhl. (TALL M.) Smooth, not glandular, 4-8 high; stem-leares sessile; leaflets rather firm, roundish to ollong, commouly: with mucronate lobes or tips, sometimes puberulent beneath; panicles very compound; flowers white, the fertile ones with some stamels; anthers not drooping, small, oblong, hlunt, the mustly whte filaments decidedly thickened npwards. (T. Cornuti, Man., not L.) - Wet meadows and aloug rivulets, $\mathrm{N}$. Eng. to Ohio and southward; common. July-Sept.

3. T. purpuráscens, I. (Perplisn M.) Stem $\left(2-4^{\circ}\right.$ high) usually purplish; stem-leares sessile or nearly so; leatlets more veiny and reticulated beneath, with or without gland-tipped or glaudless hairs or waxy atoms; pauicles compouud; flowers (sepals, filaments, etc.) greenish and purplish, diocious; anthers linear or oblong-linear, mucronulate, drooping ou capillary filaments occasionally broadened at the summit. - Dry uplands and rocky hills, S. New Eng. to Minn., and southward. May, Juue.

* Flowers all perfect, corymbed; the flaments strongly club-shaped or inflated under the small and short anther; stigma short; achenes gibbous, long-stipitate.

4. T. clavàtum, DC. Size and appearauce of 11.1 ; leares only twice ternate; flowers white, fewer; achencs 5-10, flat, somewhat crescent-shaped, tapering iuto the slender stipe. - Mountaius of $\mathrm{Va}$. and southward. Juue.

\section{TRAUTVETTERIA, Fisch. \& Mey. False Begraxe.}

Sepals 3-5, usually 4, concave, petal-like, very caducous. Petals none. Achenes numerous, capitate, membranaceous, compressed-angled and inflated. Scel erect. - A percmial herb, with alternate palmately-lohed leares, and corymbose white flowers. (For Prof. Tranteller, a Russian botanist.) 
1. T. palmata, Fiseh. \& Mey. Stems $2-3^{\circ}$ high; root-leaves large, 5-11-lobed, the lobes toothed and cut. - Moist ground along streamlets, Mu. to S. Ind., and south to Ga.

\section{A D ÒN I S, Dill.}

Sepals and petals $(5-16)$ flat, unappendaged, deciduous. Achenes numer ous, in a head, rugose-reticulated. Seed suspended. - Herbs with finely dissected alteruate leares and showy flowers. ("A $\delta \omega \nu t s$, a farorite of Venus, after his death changed into a Hower.)

A. Autumsalis, I. A low leafy annual, with searlet or crimson flowers, darker in the centre. - Sparingly naturalized from Europe.

\section{M YOS Ù U S, Dill. Mouse-tall.}

Sepals 5, spurred at the base. Petals 5, small and narrow, raised on a slender elaw, at the summit of which is a nectariferous hollow. Stamens 5-20. Achenes numerous, somewhat 3 -sided, erowded on a very long and slender spike-like receptacle (whence the name, from $\mu \hat{v s, ~ a ~ m o u s e, ~ a n d ~ o u ̀ p a ́, ~ a ~}(a i l)$, the seed suspendal. - Little annuls, with tufted narrowly linear-spatulate root-leaves, and naked 1-flowered scapes. Flowers small, greenish.

1. M. mínimus, I. Fruiting spike 1-2' long; achenes quadrate, blunt. - Alluvial ground, 1ll. and $K y$, thence south and west. (Eu.)

\section{RA N Ú NCULUS, Tourn. Crowfoot. Buttercup.}

Sepals 5. Petals 5, flat, with a little pit or seale at the base inside. Achenes numerous, in a head, mostly flattened, pointed; the seed erect. - Annuals or perennials; stem-leaves alternate. Flowers solitary or somewhat corymlued, yellow, rarely white. (Sepals and petals rarely only 3 , the latter often more tlian 5. Stamens oceasionally few.) - ( $\Lambda$ Latin name for a little frog; a plylied by Pling to these plants, the aquatic species growing where frogs alomml.)

R. FicArid, l. (representing the SFowia), which has tuberous thickened routs, Caltha-like leares, and scape-like peduncles bearing a 3 -sepalous and 8 -9-petalous yellow Hower, has been found as an escape from gardens about New York and I'hiladelphia.

§ 1. BATRÁCIIUUM. Petals with a spot or naked pit at base, uhite, or only the claw yellow; achenes marginless, transversely wrinkled; aquatic or subaquatic perennials, with the immersed foliage repeatedly dissected (nostly by threes) into cupillary divisions; peduncles 1-flouered, opposite the leaves.

$$
\text { * Receptacle hairy. }
$$

1. R. circinatus, Sibth. (StrF WАTEr-Свошғопт.) Leaves all under water and sessile, with broad eonspicnons stipules, the divisions and subdvisions short, spreading in one roundish plane, rigid, wot collapsing when withdraten from the water. (R. divaricatus, Man., not Schrank.) - Ponds and slow streams, Miaine and Vt., to Iowa, north and westward, much rarer than the next. June-Ang. (Eu.)

2. R. aquátilis, I., var. trichophýllus, Gray. (Common Wuтs: WATER-CRowrooT.) Leares all under water and mostly petioled, their eapillary divisions and suldivisions rather long and sof, usully collapsing more or less when withdrum from the water: petinle rather narrowly dilated. - Com- 
mon, especially in slow-flowing waters, the eastern form with more soft and flaccid leares. June-Aug. (Eu.)

Var. cæspitosus, DC. $\Lambda$ dwarf terrestrial form, rooting at the nodes, the small leaves somewhat fleshy, with broader rigid divisions. - S. 111 . (Schneck), and westward.

$$
\text { * Receptacle glabrous; no submersed leaves. }
$$

R. HEDkRÁceus, L. Rooting freely in shallow water; leaves all reniform angulate-lobed. - Fresh-water marshes at Norfolk, Va. (Nat. from Eu.)

‘. IIALODES. Petals yellow, with nectariferous pit and scale; carpels thin-uculled, striate, in an oblong head; scapose, spreading by runners.

3. R. Cymbalària, Pursh. (SeA-side Crowfoot.) Glabrous; scapes 1-6' high, 1-7-flowered; leaves clustered at the root and on the joints of the long rooting runners, roundish-heart-shaped or kidney-shaped, crenate, rather fleshy, long-petioled; petals 5-8. - Sandy shores, from New Jersey northward, and along the Great Lakes to 11l., Kan. and westward; also at salt springs. June - Aug.

§3. RANUNCULL'S proper. Petals with a little scale at the base, yellow; achenes nerveless.

* Achenes smooth; mostly perennial.

+ Aquatic; immersed leaves filiformly dissected, as in \$ Batrachium.

4. R. multífidus, Pursh. (Yellow Water-Crowfoot.) Stems floating or immersed, with the leaves all repeatedly 3 -forked into long filiform divisions, or sometimes creeping in the mud (perennial by rooting from the nodes, if at all); emersed leaves with shorter and linear or werlge-shaped divisions, or else kidney-shaped and sparingly lobed or toothed; petals 5-8, deep bright yellow, 4-6" long, much larger than the calyx; carpels in a ronnd head, pointed with a straight beak. - F. New Eng. to S. Penn., Mo., and northward. May-July. - Out of water it is often pubescent, especially in

Var. terréstris, Gray. Stem rooting in the null or ascending from the base; leaves all smaller, coarsely dissected, round-reniform in ontline; flowers and fruit twice or thrice smaller. $-\mathrm{N}$. Olio to $\mathrm{N}$. Ill., Minn., and westward.

++ Terrestrial but growing in very wet places, glabrous or nearly so; leaves entire or barely toothed, all or else all but the lowest lanceolate or linear; carpels forming a globular head. (SPEARWORT.)

5. R. ámbigens, Watson. (Water Plantain Spearwort.) Stems ascending ( $1-2^{\circ}$ high), often rooting from the lower joints; leaves lanceolate or the lowest oblong, mostly denticulate $\left(3-5^{\prime}\right.$ long), contracted into a margined half-clasping petiole; petals $5-7$, bright yellow, oblong ( $2-3^{\prime \prime}$ long); carpels flattened, large ( $("$ long), pointed with a long narrow-subulate beak. (R. alismæfolius, Man., not Gey.) - N. Eng. to Ont., Minn. and southward; common, especially at the north. June-Aug.

6. R. Flámmula, L. (Sinaler Spearwort.) Stem reclining or ascending, luoting helow, leaves lanceolate or linear, or the lowest ovate. obloug to lanceolate, entire or nearly so, mostly petioled $\left(1-2^{\prime}\right.$ long), petals $5-7$, much longer than the calyx, bright yellow, carpels small, fattish but turgid, mucronate with a short abrupt point. - Only a small form (var. INTER. 
MÈDIs) met with in this country (shore of L. Ontario, and northward), a span high, with Howers $3-5^{\prime \prime}$ in diameter, passing into

Var. réptans, E. Meyer. (Crexpixig S.) Small, slender, the filiform creefing stems rooting at all the joints; leaves linear, spatulate, or oblong $\left(\frac{1}{6}-I^{\prime}\right.$ long); flowers small. - Gravelly or sandy banks; Newf. to Penn., north and westward. June-Sept. (En.)

7. R. oblongifòlius, Ell. L'snally annual; stem ereet or ascending, often pubescent below, slender $\left(1-2^{\circ}\right.$ high $)$, diffirsely branched above and many-flovered; leaves serrate or denticulate, lower long-petioled, ovate or oblong ( $\frac{1}{2}-1 \frac{1^{\prime}}{2}$ long), nppermost linear' ; Howers $3-5^{\prime \prime}$ broad; petals 5 , bright yellow, $1-3$ " long; carpels minnte, almost ylubular, the small style decidnous. - Wet prairies, I1l., Mo., and in S. States. Jnne.

8. R. pusíllus, Poir. Stem ascending, weak, loosely branching $\left(6-18^{\prime}\right.$ long) ; leaves entire or obseurely denticulate, the lowest ronnd-ovate or heartshaped ( $\frac{1}{2}$ long), long-petioled, the mpper oblong or lanceolate $\left(1-1 d^{\prime}\right.$ long); flowers zery small; petals $1-5$, yellowish; stamens $3-10$; carpels very turgid, smooth or slightly papillose, tipped with a minute sessile stigma. - Wet places, S. New York, and southward along the coast. June-Ang.

+++ Terrestrial, but often in uet places; leares mostly cleft or divided.

+ Root-leaves not divided to the very base; achenes marginless.

9. R. affinis, R. Br. Somewhat hairy or glabrous; low or slender, $1^{\circ}$ high or less; leares pedately cleft, the eauline with linear or narrow oblanceolate divisions; petals light yellow, 3-4" long or smaller; heads oblong; achenes turgid, with small and mostly recurred style, pubescent or glabrous. - And var. valdovs, Gray, stonter and with more fleshy leares, the lower mostly undivided and romilish, cordate, truneate or euneate at base, eoarsely crenate or more or less cleft. - Ninm., Iowa, north and westward.

10. R. rhomboideus, Goldie. Low $\left(3-8^{\prime}\right.$ high), hairy; root-leaves roundish or rhombic-ovute, rarely subeordate, toothed or crenate; lowest stemleaves similar or 3-5-lobed, the upper 3-5-parted, almost sessile, the lobes linear; carpels orlicular with a minute beak, in a globose heal; petuls large, deep yellow. - Prairies, Mich. to N. 11l., Minn., and northward. April, May.

i1. R. abortivus, L. (Suall-fiowered C.) Biennial, glabrous, branching, $6^{\prime}-2^{\circ}$ high; primary root-leares round heart-shaped or kidney-for $m$, barely crenate, the succeeding often 3-lohed or 3-parted; those of the stem and branches 3-5-parted or divided, subsessile, the divisions oblong or narrowly ivedge-form, mostly toothed; head globose; carjels mucronate, with a minute curied beak; petals pule yellou, shorter than the small reflexed calyx. - Shady hillsides and along lorooks, common. April-June.

Var. micránthus, Gray. Pubescent, roots often fusiform-thiekened; root-leaves seldom at all heart-shaped, some 3-parted or 3-divided; peduneles more slender and carpels fewer. - F. Mass. to 111., Minn., and westward.

12. R. sceleràtus, I. (Cursed C.) Anuual, glabrous; root-leaves 3-lobed, rounded; lower stem-leaves 3-parted, the lobes obtusely ent and toothed, the mppermost almost sessile, with the lobes oblong-linear and nearly entire; carpels burely mucronulate, very numerous, in oblong or cylindrical 
heads; petals scarcely exceding the calyx. - Wet ditches; appearing as if introduced. June- $\Lambda$ ug. - Stem thick and hollow, $1^{\circ}$ high; juice acrid and blistering; leaves thickish; flowers small, pale yellow. (Eu.)

+ + Leares variously cleft or divided; achenes in globular heads (except n. 17), compressed, with an evident jirm maryin; hirsute or pubescent.

$=$ Achenes with long recured beuk; root-leaves rarely divided.

13. R. recurvatus, Poir. (Hooken C.) Hirsute, 1-2 high; leaves of the root and stem nearly alike, long-petioled, deeply 3-cleft, large; the lober broudly wedge-shaped, 2-3-cleft, cut and toothed toward the apex; petals shorter than the reflexed calyx, pale. - Woods, common. May, June.

$==$ Style long and attenuate, stigmatose at the tip, persistent or the upper part usually deciduous: early root-lcares only 3-prarted, the later 3-5-joliolate; petals bright yellou.

14. R. fasciculàris, Muhl. (KıRL C.) I.ow, ascending, 5-9' high, pulsescent with close-pressed silky hairs; root a cluster of thichened fleshy fibres: radical leaves appearing pimnate, the long-stalked terminal division remote from the sessile lateral ones, itself 3-5-diviled or parted and 3-5-cleft, the lobes oblong or linear; pretals often 6 or 7 , spatulate-oblong, twice tle length of the spreading ealyx; curpels searcely murgined, tipped with a slender straight or rather ('nrverl beak. - Dry' or moist litls. April, May.

15. R. septentrionàlis, Yoir. Low, hairy or nearly glabrons; stems ascending, or in wet ground some of them mocumbent or forming long runners; leaves 3-divided, the divisions all stalked (or at leat the terminal one), broally wolge-shaped or ovate, meyually 3-cleft or parted and variously cnt, never pinnately compound; petals obovate, much larger than the spearling calyx; curpels stronyly murymed, pointed by a stout struightish beak. (R. repens, of Mamul, mainly.) - Moist or sharly places, ete, May-Ang. - Extremely variable in size aud foliage, commencing to Hower by upriglit stems in spring before any long runuers are formel.

$===$. vigle subulate, stigmatose along the inner margin, mostly persistent.

16. R. rèpens, L. In liabit and foliage closely similar to the last species; lears frequently white-raringated or spotted; commenciug to flowor somewhat later. - In low groumds; generally in waste grounds near the coast and probably introduced from kurope, hut indigenous westwarl.

17. R. Pennsylvánicus, L. f. (BrI*TL C.) Sitout and erect from ab usually annual root, lirsute with widely spreading bristly hairs, leafy to the top, $1-2^{\circ}$ high; leaves all termately divider or compound, the stalkerl leaflets unequally 3-cleft, shuply ent and tootled, acute; Howers inconspicuons; calyx reflexed ; heal of carpels oblong. - Wet places, conmon. JuneA 1 g.

18. R. hispidus, Mook. (not Michx, or I)C.). Resembling the last, but the ascencling or reclining stems few-leaved, rarely if ever routing, not always hirsute; petals (abont $3^{\prime \prime}$ long) snrpassing the harlly reflexed and soon deciduous calyx: achenes with a stout straight beak, in a globose or oval lread. ()n the iortlern shore of Lake Superior, and north and westward; probably in N. Minn. 


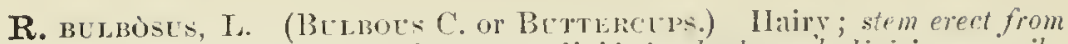
a bulb-like base, $1^{\circ}$ high; ratical leaves 3 -divided; the lutercil divisions sessile, the terminal stalked ind 3-parted, all wedge-shaped, cleft and tootherl; peduncles furrowed; petals round, welde-shaped at base; calyx reflexed; carpels tipped with a very sloot beak. - Fields; very abundant only in E. New ling-

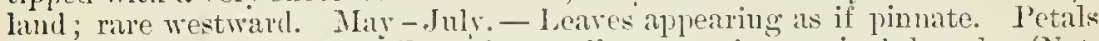
often 6 or 7 , deep glossy yellow, the corolla more thin an inch broad. (Nat. from Eu.)

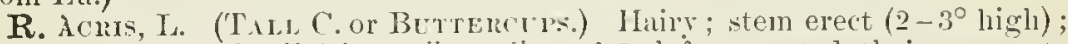
Jeaves 3-divided; the divisions all sessile and 3-cleft or parted, theil segments cut into lanceolate or linear crowded lobes; pechureles not furrowerl; petals obovate, much longer than the spreading calyx. - Fields; common, especially eastwarcl. Jume-Aug. - Flower notrly as large as the last, but not so deep yellow, - The Buttercups are avoictes by attle, on areumt of their very acrid or even blistering juice, which property, hwwever, is dissipated in drving when these plauts are cut with hay. (Nat. from Lu.)

\section{* * Achenes beset with rough points or small micleles; annuals.}

R. Muricitrs, L. Nearly glaliruns; luwer leares roundish or reniform, 3-lobed, coarsely crenate; the ulper 3-cleft, wedge-form at the lase; petals longer than the caly.r; carpels flat, spiny-tuberculute on the sides, strougly beaked, surrounded with a wide and sliarp smooth margin. - Lastern Virginia and sonthward. (Nat. from Ku.)

R. Panvilósts, I. Hairy, slender and liffuse; lower leaves roundishcordate, 3-cleft, consely toothed or cut; the upper. 3-5-parted: petals not longer than the culyx: "arpels mimutely hispid and rough, beaked, narrowly margined, - Norfolk, Va., and southward. (Nat. from En.)

\section{I SOPỲ RUM, L.}

Sepals 5, petal-like, decidnous. Fetals 5, minnte, wanting in the American species. Stamens $10-40$. I'istils $3-6$ or more, pointed with the styles. P'orls ovate or oblong, 2-several-seedeil. - Slender smoth perennial herhs, with 2-3-tcrnately compouml leaves; the leaflets 2-3-holed. Slowers axillary and terminal, white. (From íórvpov, the ancient uame of a Fumaria.)

1. I. biternàtum, Torr. \& Giray. l'etals none; filaments white, elubshapert; pistils $3-6$ (eommonly 4), divaricate in fruit, 2-3-scedect: seeds smooth. - Irist shady places, ()hio to Minm. and soutluwr. May. - Fihres of the root thickened heve and there into little tuhcrs. Aspect and size of the plant much as in Ancmonella.

\section{CÁLTHA, T. Mirsn Mirigold.}

Sepals 5-9, petal-like. Petals none. l'istils 5-10, with scareely any styles. Porlin (follicles) compressed, sprealing, many-seeterl. - Glabrous peremials, with round and leart-slaped or kilney-form, larew, unlivided leares. (An ancicut Latin nanne for the conmon Marigolı.)

1. C. palústris, l. Stem holluw, furrowel; leaves lomml or hilner: slaped, either crenate or rlentate or nearly entire; sepals hually oval (hright yellow). - Swanps and wet mealows, common morthwat. April, May.-()ften callerl incorrectly Conoslips; usel as a pot-her? in spring, when coning

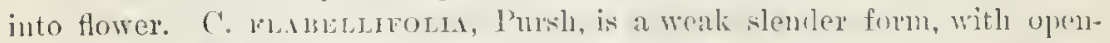
reniform leaves and smaller fowers ( $1^{\prime}$ broad or less), occurring in coll nuontain springs, X, Y. to MIT, (Eu.) 


\section{TRÓLIIUS, L. GLOEE-FLower.}

Sepals 5-15, petal-like. P'etals numerous, small, l-lipped, the conearity near the base. Stameus and pistils mumerous. Pods 9 or more, sessile, manyseeded. - Smooth perennials with palmately parted and cut leaves, like Ranunculus, and large solitary terminal flowers. (Nane thought to be derived from the old German word troll, a globe, or something round.)

1. T. láxus, Salisb. (Niresnixg Glone-Flower.) Leaves 5-7-parted; sepals 5-6, sprealing; petals $15-25$, inconspicuous, much shorter than the stimens.-Deep swamps, N. H. to Del, and Mich. May.-Flowers twice the size of the common Buttercup; the sepals spreading, so that the name is not appropriate, as it is to the European Globeflower of the gardens, nor is the blossom shory, being pale g"reenish-yellow, or nearly white.

\section{Cóptis, Salisb. Goluthrean.}

Sepals $5-7$, petal-like, deciduuts. Petals $5-7$, small, club-shaped, hollow at the apex. Stamens 15-25. P'istils $3-7$, on slender stalks. Pods divergent, membranaceus, pointed with the style, 4-8-seeded. - Low smooth perennials, with ternately divided root-leaves, and small white flowers on

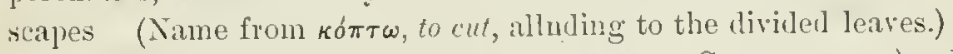

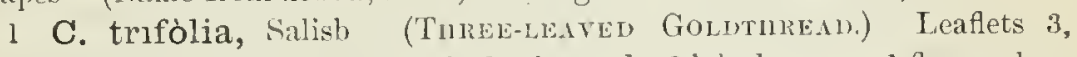
oborate-welge-form, sharply toothed, obscurely 3-lobed, scape 1-flowered.l3ogs, alsudiut northwari, extendiug south to Maryland along the mountaius, aud west to lowa. May. - lioot of long, bright yellow, bitter fibres. I.eaves evergreen, shining Scape naked, slender, 3-5' high. (Eu.)

\section{HEULFBoR U S T Tourn. Hellemere.}

Sepals 5, petal-like or greenish, persistent. Petals $8-10$, rery small, tubular, 2-lippecl. l'istils 3-10, scssile, forming coriaceous many-seeded pods.l'erennial herbs, with anple palnate or pedate leaves, and large, sulitary, nodkling, daly' vernal flowers. (An ancient name of unknown meaning.)

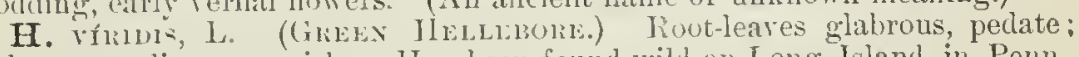
calyx sprealiug, greenisls. - Has been found wild on Long Island, in Peun., and IV Va. (Nily. from Eu.)

\section{ER Á N THIS, Salisb. Wister Acosite.}

Sepals 5-8, petal-like, deciduous. Petals small 2-lipped nectaries. Carpels few, stipitate, serpral-seeded. - J'eremial herls, with jalmately multifid radical leares, the scape bearing a single large yellow flower surrounded by an

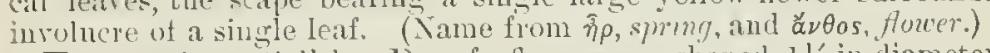

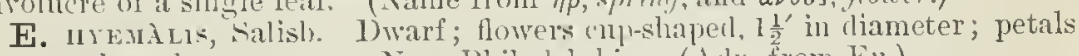
shorter than the stamens. - Near Philadelylia. (Als. from Eu.)

\section{A Q U I L E I A, Touru. Colvinise.}

Sepals :s, regular, colored like the petals. Petals 5, all alike, witl a short sprealing lip, produced lackward into large lollow spurs, much louger than the alyx. Pistils 5 , with slender styles. Pods erect, many-seeded.-Per. ennials, witl 2 -3-ternitely compound leares, the leaflets lobed. Flowers large and showy teminiting the hanches. (Name from ugulegus, water. drawing.) 
1. A. Canadénsis, L. (Wrli Coloubıne.) Spurs nearly straight; stamens and styles longer than the ovate sepals. - Rocks, common. $\Lambda_{\text {jull }}$ June. - Flowers 2' long, scarlet, yellow inside (or rarely all over), nodding, 6o that the spurs turn upward, but the stalk becones upright in frnit.

2. A. brevístyla, Hook. Flowers suall, line or purplish or nearly white; spurs incurved. - lied River valley, N. D.; Rocky Mts., northwarl.

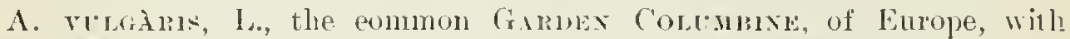
hooked spurs, is leginning to escape from coltivation in :ome places.

\section{DELPHÍNIU M, Tourn. Larkspur.}

Sepals 5, irregular, petal-like; the upper one prolonger into a spur at the base. Tetals 4, irregular, the upper pair eontinued haekward into long spurs which are enclosel in the spur of the calyx, the lower pair with short elaws: rarely only 2 , wited into one. Pistils $1-5$, forming many-seeded pods in fruit. - Leaves palmately divicied or cut. Flowers in terminal racemes. (Name from Delphin, in allusion to the slape of the flower, which is sometimes not unlike the elassical figures of the dolphin.)

$$
\text { * Perennials, indigenous; pistils } 3 .
$$

1. D. exaltàtum, Ait. (TALL LARksper.) Stem sleṇler, $2-5^{\circ}$ high ; leaves deeply 3 -5-cleft, the divisions narrow wedge-form, diverging, 3-eleft at the apex, aeute; rucemes wand-tike, panieled, many-flovered; flowers purplish-blne, downy; spur straight; pods erect. - Rich soil, Penn. to Miun. and sonthward. Jnly.

2. D. tricórne, Michx. (1)WARF I.) Leaves deeply 5-parted, their divisions unequally 3 -5-cleft; the lobes linear, aeutish; raceme feu-flowered. loose; spur straightish, ascending; pods strongly dilerying. - Wr. l'em. to Minn. and sonthward. April, May. - Root a tuberous cluster. Stem simple, $6^{\prime}-3^{\circ}$ high. Flowers bright blue, sometimes white, oeensionally numerous.

3. D. azùreum, Michx. Leaves deeply 3-5-parted, the divisions $2-3$ times eleft; the lobes all narrowly linear; raceme strict: spur ascending, usually eurved npward; pods erect. - Wise to the Dakotas and sonthward. May, Jume. - Stem $1-2^{\circ}$ high, slender, often softly pubeseent. Flowers slyblne or whitish.

* Anmul, introduced; petals 2 , united into me body; pistil single.

D. Coxsólid, I. (F1ELI) J.) Lenves tisseeted into narrow linear lobes ; infloreseenee loosely paniculate; perlicels shorter than the biacts; pol glatlrous. - Old grain-fields, Penn. and Va.; also sparingly along roalsicles firtler north. (Nat. from Eu.)

D. AJAcrs, L. Flowers more mumerons and spicately racemose; pols pubescent. - Sparingly escaped from gardens in K. Atlantie States. (Nat. from Eu.)

18. ACONITU M, Tourn. Acoxte. Moxkshoon. Wolfabaxe.

Sepals 5, petal-like, rery irregular; the upper one (helmet) hooded or hel. met-shaped, larger than the others. l'etals 2 (the is lower wanting entirely, or very uninte rubliments anong the stamens), consisting of small spur-shitped bodies raised on longe claws and concealed under the lelmet. l'istils $3-5$.

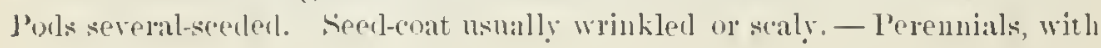


palmately cleft or dissected leares, and showy flowers in racenes or panicles. (The ancient Greek and Latin name, of uncertain origin.)

1. A. Noveboracénse, Glay. Erect from tuberous-thickened roots, $2^{\circ}$ highl, leafy, the summit and strict lousely flowered raceme mulescent; leares rather deeply parterl, the bromlly cuneate divisions 3-cleft and incised; flowers blue, the helmet gibbous-obovate with broad rounded summit anl short descend. ing beak, - Chenango and Orange Cos., N. Y.

2. A. uncinàtum, L. (W11, Moxksnoon.) Glabrous; stem slender, from tuberous-lhichened rooks, morl, hut weak and disposed to clinb; leares firmo deeply 3-5-lobed, petioled, the lobes ovate-lanceolate, coarsely toothed; flowers Uhe ; helmet erect, ohlusely comicul, connpressed, slightly heaked in front. — Rich shaty soil along streams, l'enu, and southward in the mountains; Wisc. June- Aug.

3. A. reclinàtum, Gray. (Thandso Wolfsinas.) Gilabrous; stems trailing $\left(3-8^{\circ} \mathrm{long}\right)$; leaves deeply $3-7$-cleft, petioled, the lower orbicular in ontline; the divisions wedge-form, incived, often 2-3-lobed; flowers uhite, in rery loose panicles; helmet som horizontal, elomgated-conical, with a straight heak in front. - Cheat Mountain, Va., and sonthward in the MIleghanies. Aug. - Lower leares 5-6' wide. Flowers 9" long, nearly glabrous.

\section{CIMICÍFU G A, L. BLGBAN.}

Sepals 4 or 5 , falling off soon after the flower expauds. Petals, or rather transformed stamens, 1-8, small, on claws, 2-horned at the apex. Stamens as in Actad. T'istils $1-8$, forming dry dehiscent porls in fruit. - Terennials, with 2-3-termately-rlivicled leaves, the leaflets cut-serrate, and white flowers in elongated wand-like racemes. (Nime from cimex, a bug, and fugo, to drive away.)

$\$ 1$ CIMICIFUGA proper. Pistils 3-8, stipitute; seeds fluttened laterally, corered with chaffy scales, in one row in the membranacoous pods; style aul-shaped; stigma minute.

1. C. Americàna, Michx. ( Muericax Bçax́.) Stem 2-40 highl; racemes slender, punicled, oraries mostly 5 , golabrous; pods flattened, veiny, 6-8-seeled. - Mountains of S. Penn. and southwarl. Ang.-Sept.

\$2. MACRÒTYS. Pistil solitury, sometimes 2-3, sessile; seeds smooth, fattened and packed horizontally in the pod in two rows, as in Actaa; stigma broed and flut.

2. C. racemósa, Nutt. (Bцаск Sxakrzoot. Bгаск Cohosi.) Sten $3-8^{\circ}$ high, from a thick knotted rootstock; racemes in frnit becoming $1-3^{\circ}$ long; porls ovoil. - Rich woods, Maine to Wisc., and southward. July.Val msisecta, Gray. Leaves irregnlarly pinnately decompound, the rather sulitl leaflets incised. - Centreville, Del. (Commons.)

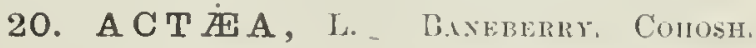

Sepals 4 or 5 , filling off when the flower ('xpands. l'etals $4-10$, small, flat, spatnlate, on sluder claws. Stanens numerous, with slender white filaments. Pistil single; stigma sessile, depressed, 2-lobed. Fruit a many-seeded berry. 
Seeds smooth, flattened, aud packed horizontally in 2 rows. - Perennials, with ample 2-3-ternately compound leaves, the ovate leaflets sharply cleft and

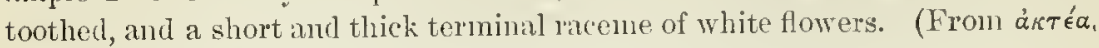
actca, ancient names of the elder, transfcrred by Linneus.)

1. A. spicàta, L., var. rubra, $\Lambda$ it. (Red Buxrırnir.) Raceme orale; petals rhombic-spatulate, much shorter than the stamens; pedicels slender; berries cherry-red, or sometimes white, oral. - Rich wools, common, especially northward. April, May, - Plant $2^{\circ}$ high. (Eu.)

2. A. álba, Bigel. (White Baxenerry.) Leaflets more incised anà sharply toothed; raceme. oblong; petals slender, mostly truncate at the end, appearing to be transformed stamens; pedicels theliencel in fruit, as large as the peduncle and red, the globular-oral beries uhite.- lich woorls, flowering a week or two later than the other, and more common westward and soutl. warl. - White berries racly occur with slender perlicels, also red berries with thick pedicels; but these are perhajs the result of chossing.

\section{HY D RÁ STIS, Filis. Orangernot. Yellow Peccnox.}

Sepals 3, petal-like, falling away when the flower opens. Petals none. Pistils 12 or more in a hear, 2-ovuled; stigma flat, 2-lipped. ()Taries becoming a heal of crimson 1 - 2-seeded lerries in fruit. - A low perennial herl, sembling up in early spring, fron a thick and knotterl yellow rootstock, a single radical leaf and a simple hairy stem, which is 2-leared near the summit and terminated by a single greenish-white fower. (Name numeaning.)

1. H. Canadénsis, I. (Gornw stes, ete.) Leares rounder, heartshaperl at the base, 5-7-lobed, donlyly serrate, reing, when full grown in summer $4-9^{\prime}$ widle. - Kich woods, N. Y. to Minn., and southward.

\section{XANTHORRHIZA, Marshall. Smiт Yellow-zоот.}

Sepals 5, regular, spreading, deciluous. Petals 5, much smaller than the sepals, concave and obscurely 2-lober, raisel on a claw. Stamens 5 to 10. P'istils 5-15, with 2 pendulous ovules. I'orls 1 -seederl, oblong, the short style becoming dorsal. $-\Lambda$ low shrubby plant; the bark and long roots dcep yellow and bitter. Flowers polygamons, bruw purple, in compond drooping racemes, appearing along with the 1 -2-pinnate lenves from large terminai

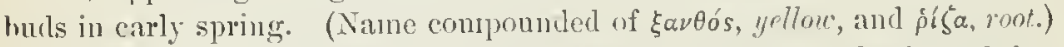

1. X. apiifolia, L'Iler. Stems clnstered, $1-2^{\circ}$ high; leaflets cleft and tootherl. - Shady lanks of streams, Pem. to $\mathbb{S} W^{\circ}$. Sew York and Ky., and sonth in the monutains. The rootstocks of this, ancl also of the last plant, were used as a yellow dye by the alorigines.

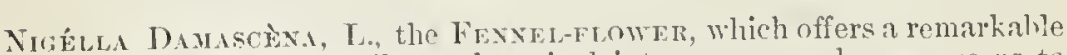
exception in having the pistils partly mited into a componnd orary, so as to form a several celled capsule, grows nearly spontmeously around gardens. 


\section{Order 2. MAGNOLIACEAE. (Magnola Famru.)}

Trees or shrubs, with the leaf-buds covered by membranous stipules, polypetulous, hypogynous, polyandrous, polygymous; the calyx and corolla colored alike, in three or more rours of three, and imbricated (rarely conrolute) in the bur. - Sepals and petals deciduous. Anthers adnate. l'istils many, mostly packed together and covering the prolonged receptacle, cohcring with each other, and in fruit forming a sort of fleshy or dry cone. Seeds 1 or $\cong$ in each carpel, anatropous; albumen fleshy; embryo minute. - Leaves altemate, not toothed, marked with minute transparent dots, feather-veined. Flower's single, large. Bark aromatic and bitter.

\section{MA G N ÒIIA, I.}

Sepals 3. Petals 6-9. Stamens imbricated, witl very short filaments, and long anthers opening inward. Pistils coherent, forming a fleshy and rather woody monelike red fruit; each carpel at maturity opening on the back, from which the 1 or 2 berrylike seeds liang ly an extensile thread composed of umrolled spiral resscls. Innel seed-coat bony. - Buds conical, the coverings formed of the sucressive pair's of stipules, earh pair enveloping the leaf next ahove, which is folded lengthwise and applied straight against the side of the next stipular sleath, and so on. (Named after Magmol, Professor of Botany at Montpellier in the 1 th ceutury.)

* Leares all srattered along the hranches; leaf-buds silky.

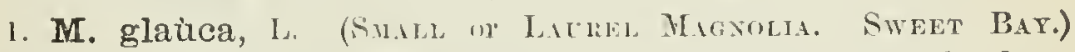
Leaves oval to broally lanceolate, 3-6' loug, obtuse, glumcons benealh ; fower ylobular, white, 2' long, rery fiogrent: petals lnowl; cone of fruit sulnall, oblong. - Swamp, from near (ape $\Lambda$ n and X. Y. sonthward, near the coast; in Penn. as far west as Cumberlund Co. Jnme- $1 \mathrm{ug}$. - Shub $4-20^{\circ}$ high, with thickish leaves, which fintler sonth are evergreen.

2! M. acuminàta, I. (CINImR-TiEe.) Lerres thin, ollong, pointed, green :und a little pubesecnt leueatl, 5-10' long; foucer ollong bell-shaped, glaucous-yreen tinged with ycllow, '2 long; cone of frnit $2-3^{\prime}$ long, cylindri(al. - Ricl woods, western N. Y. to Ill., and southward. May, June. - Tree $60-90^{\circ}$ higl. Fruit when young slightly resumbling a small cucumber, whence the common name.

3. M. macrophýlla, Michx (Gueat-haven Macrolia.) Leaves ohorate-oblong, cordule at the narrowed hase, puldescent and white benealle; flower open bell-shcrped, while, with a purple spol ut buse; petals orate, $6^{\circ}$ long; cone of fruit oroil. - S. E. Ky. and southwari. May, June.-Tree 20-40 high. Leaves $1-3^{\circ} \mathrm{long}$, soniewhat clnstered on the flowering branches.

* * Leates rrouded on the summit uf the flowerin! branches in an umbrellatike circle; leaf-buds glubrous: Houers white, slightly scented.

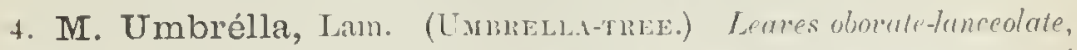
poined at bolle enels, soon glalırous, 1-20 long; petals obowate-oblong, 4-5' long, - S. l'eun. to líg. and southward. May, - I small tree. Fruit rose[olor, 4-5' long, woid-oblong. 
5. M. Fràseri, Walt. (Far-LEaven Limblata-traf.) Leaces oblong. oborate or spatulate, auriculate at the base, glabrous, 8-20' long; petals obovate. spatulate, with narrow claws, $4^{\prime}$ long. - Va. and $K y$, along the Alleghanies, and sonthward. April, May. $-\Lambda$ slender tree $30-50^{\circ}$ high. Flower more graceful and cone of fruit smaller than in the preceding.

\section{LIRIODÉ N D RON, I. T' Tlip-TREe.}

Sepals 3, reflexed. Petals 6 , in two rows, making a bell-shaped eorolla Anthers linear, opening cutward. l'istils flat and scile-form, long and narrow, imbrieating and cohering together in an elnngaterl cone, dry, separating from eaeh otlee and from the loner and slencler axis in fruit, and falling away whole, like a samara or ker, indeliscent, 1 -2-seeded in the small carity at the base. Buds flat, sheathed ly the snecrsive pairs of flat and hroad stipnles joiner? at their edges, the follecl leaves bent down on the petiole so that the apex points to the base of the hud. (Name from díptov, lily or qulip, and $\delta \varepsilon^{\prime} \delta \rho o v$, tree.)

1. L. Tulipífera, 1. - Rich soil, S. New Eng. to Miel., Wisc., and sonthward. May, June, $-\Lambda$ most beautiful tree, sometimes $140^{\circ}$ high and $8-9^{\circ}$ in diameter in the Wrestern States, where it is wrongly called Wunt I'opLAR. Leaves very smooth, with 2 lateral lobes near the base, and 2 at the apex, which appears as if cut off abruptly by a broal shallow noteh. I'etals $2^{\prime}$ long, greenishyellow markel with orange. Cone of fruit $3^{\prime}$ long.

\section{Order 3. ANONACEAS. (Custard-Apref Famir.)}

Trees or shrubs, with naked buls and no stipules, a calyx of 3 sepals, and a corolla of f petuls in two rows, valcate in the bul, hypogynous, polyandrous. - Petals thickish. Inthers aduate, opeuing outward; filaments very short. Pistils several or many, separate or cohering in a mass, fleshy or pulpy in fruit. Seeds anatropous, large, with a rrustaceous seetl-coat, and a minute embryo at the hase of the ruminated albumen, - Leares alternate, entire, feather-reined. Elowers axillary, solitary. - I tropical family, exeepting the following genus: -

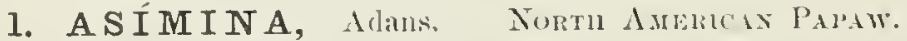

Petals 6 , increasing after the loul opens; the outer set larger than the inner. Stamens numerous in a globular mass. l'istils few, ripenning $1-4$ large and vblong pulpy sereral-seederl fruits. Seerls horizontal, that, enclosed in a fleshy" aril. - Shrubs or small trees with mupleasant odor when hrused; the lurid flowers solitary from the axils of last year's leaves. (Name from Asiminier, of the French colouists, from the Inclian name assimin.)

1. A. tríloba, Innal. (Cuммох P'ıмw.) Teaves thin, obovate-lauceolate, pointed; petals lull-purple, reiny, romul-ovate, the outer ones $3-4$ times as loug as the ealyx. - lianks of streams in liubl soil, wesiern N. Y. anc: l'enn. to 111., S. I. Neh., and southwarl. A pril, May. - Tree 10-20 ligh; the young shoots and expandiug leaves clothed with a rusty down, son gla-

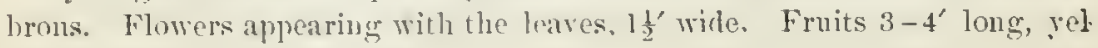
luwisli, swet and exlible in antmun. 


\section{OrDer 4. MIENISPICRIIACEAE. (MOONSEFD FamLY.)}

Woody climbers, with palmate ar peltate alternate leaves, no strpwles, the sepals and petals similar, in three or more rous, imbricated in the bud; hypogynous, dicecious, 3-6-gynous: fruil a 1-secderl drupe, with a lruge of long curved embryo in scanty allumen. - Flowers small. Stamens several. Ovaries nearly straight, with the stigma at the apex, but often incurved in fruiting, so that the seed and embry are bent into a cres. cent or ringr. - Chiefly a tropical family.

* Seprals and pretals present. Anthers t-celled. Sierl incurved.

1. Cocculus. Stamens, petals, ani serals each 6.

2. Menispermum. Stanens $12-24$, slender. Petals $6-s$.

* * Petals none. Antlers 2-celled. Seed sancer-shaped.

3. Calycoearpum. Stamens in the strile fowers 12 ; in tle fortile Howers 6 , aboltive.

\section{Có C U I US, 1)C.}

Sepals, petals, aml stamens 6 , alternating in threes, the two latter short. Antliers 4-celled. I'istils $3-6$ in the fertile flowers; style pointerl. Irupe ancl seed as in Menispermm. - Flowers in axillary racenes or panicles. (An old name, a dinimutive of corcrss, кókкos, a berry.)

1. C. Carolinus, I). Mimutely pulsescent; leaves downy beneath, ovate or corfate, entire or siuuately or hastately lobed, valialble in shape; fowers greenish, the petals in the sterile ones an riculate-inflexen below around the filaments; drupe red (as large as a snall pea). - River-banks, Va. to s'. Ill., Kan., and southward. July, Ang.

\section{M E N I P ER M U M, I. MoOxeEL.}

Sepals 4-8. Petals $6-8$, short. Stamens 12-2t in the sterile flowers, as long as the sepals; anthers t-celled. I'istils $2-4$ in the fertile flowers, raised on a short common receptacle; stigna broarl and flat. Drnpe globular, the mark of the stigma neas the bise, the ovary in its growth after flowering heing strongly incurved, so that the (wrinkled and gronved) laterally flattened stone takes the form of a large rrescent or ring. The slender cmlnryo therefore is horseshoe-shaperl; cotyledons filiforn. - Flowers white, in small and loose

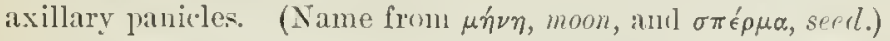

1. M. Canadénse, I. Leaves peltate near the edge, 3-i-angled or lobel. - Banks of streams; (omnon. June, July. - Drupes black witl a bloom, ripe in September, loxking like frost grapes.

\section{CALYCOCÁRPU M, İutt. Curseñ.}

Sepals 6, petaloid. Petals none. Stamens 1: in the sterile fluwers, short; anthers 2-celled. I'istils 3, spindle-shaped, tipled with a raliate many-cleft stigma. I rupe globnlar; the thin crustaceons putamen hollowerl ont like a cup on one side. Embryo foliacens, heart-sliaped. - Flowers greenisli-white,

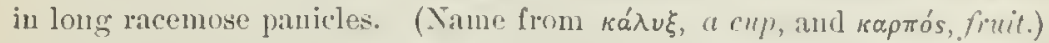

1. C. Lyoni, Nutt. Lenves large, thin, deeply 3-5-loberl, cordate at the lase; the lobess armminate; drupe an inch long, liach when rije; the shell 
crested-toothed on the edge of the carity. - Kich soil, Ky. to S. Ill. and Kan., and southwart. Nay. - Stems elimbing to the tops of trees.

\section{Order 5, BERBERIDÃCEAE. (Barmerry Famiy.)}

Shrubs or herbs, with the sepals and petals both imtricated in the but, usually in two rows of 3 (ravel!y 2 or 4 ) cach ; the hypoy!ynous stamens as mu!n as the pelals and opposite to them; anthers opening by 2 valves or lids hingerl at the top. (Podophyllum is an exeeption, and Jeffersonia as respects the sepals in one row.) Pisil single. Filaments short. Style reit or none. Fruit a berly or a pod. Seeds few or sereral, anatropous, with albumen. Embryo small, except in Berberis. Leares alternate, with diliated bases $01^{\circ}$ stipulate.

* Petals and stamens 6. Fruit fer-seeded.

1. Berberis. Shrubs, with yellow tlowers and wood; a pair of glandular spots on the base of each petal. Fruit a berry.

2. Caulophyllnm. Ilerb, with greenish flowers; petals thick, much slorter than the seluals. Orary soon bursting; tle two seeds leit naked.

3. Diplyglleia. Herb with white Howers; petals much longer than the sepals, Berry 24 -seeded.

* Petals 6-9. Stamens 8 - 18. Fruit many-secled. Herbs.

4. Jeffersonia. Petals and stamens usually 8 ; anther's olening by unlifted valves. Poul opening by a lid.

5. Podoply llum. Petals 6-9. Stamens 12-18; anthels not opening by uplifter ralves Fruit a larce berry

\section{BÉRBEIS, L. Bamerry.}

Sepals 6 , roundish, with $2-6$ bractlets ontside. Petals 6 , oborate, encave, with two glandular spots inside above the short claw. Stamens 6 . Stignua cirenlar, depressed. Frnit a 1 -few-seeded berry. Seeds ereet, with a erust:1ceons integument. - Shruls, with yellow wood and inner bark, yellow flowers in crooping racemes, sour berries, and l-9-foliolate leares. Stamens irritable. (1)erived from Berlinys, the Alabie name of the fruit.)

1. B. Canadénsis, Pnrsh. (Awericax B.ruerry.) Leaves repandly touthed, the teeth less luristly-pointed; recemes fru-floured: petals notcher at the apex; berries ord; otherwise as in the next. - Alleghanies of Va. and sonthward; not in Canala. June - Shrnb $1-3^{\circ}$ himl.

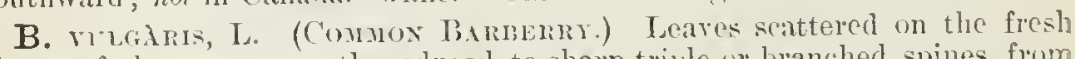
shoots of the season, mostly redncel to sharp triple or branched spines, from the axils of whicls the next season proceed rosettes or fascicles of obovate oblong clusely bristly-toothed leaves (the shont petiole jointed!), and drooping

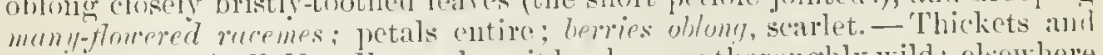
wate grom in E. New Eng., where it has become thoronghly wild; elsewhere becatsionally spontaneons. May, Jnnr. (Nat. from Eu.)

\section{CAULOPHÝLLUM, Michix. BLte Conosir.}

Sepals 6 , with 3 or 4 small bractlets at the base, orate-oblong. I'etals 6 thick und gland-like somewhat kidney-shaped or hooled hodies, with short daws, murly smaller than the sepals, one at the hase of each of them. Stamens 6 ; anthers oblong. l'istil gilbous; style slort; stigna minute and nuilateral; 
ovary bursting soon after flowering by the pressure of the 2 erect, enlarging seeds, and withering away; the spherical seeds naked on their thick seed-stalks, looking like drupes, the fleshy integument turning blue; albumen horny. A perennial glabrous herb, with matted knotty rootstocks, sencling up in early spring a simple and naked stem, terminated by a small raceme or panicle of yellowish-green flowers, and a little below bearing a large triternately com-

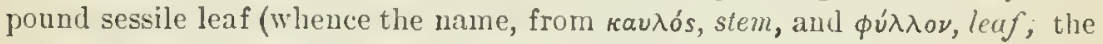
stem seeming to form a stalk for the great leaf.)

1. C. thalictroides, Michx. (Also called PAproose-root.) Stems $1-2 \frac{1}{2}^{\circ}$ high ; leaflets obovate wedge-form, 2-3-lobed, a smaller biternate leaf often at the base of the panicle; flowers appearing while the leaf is yet small. - Deep rich woods; commou westward. A pril, May: - Whole plant glaucous when young, as also the seeds, which are as large as peas.

\section{DIPHYLIEIA, Michx. CMbRella-Leaf.}

Sepals 6, fugacious. Petals 6, oval, fat, larger than the septls. Stamens 6 ; anthers oblong. Ovary oblong; style hardly auy; stigina depressed. Orules 5 or 6 , attached to one side of the cell below the middle. Berry globose, fewseeded. Seeds oblong, with no aril. $-\Lambda$ perennial glabrous herb, with thick horizontal rootstocks, sending up each year either a luge centrally peltate and cnt-lobed, rounded, umbrella-like radical leaf, on a stout stalk, or a flowering stem bearing two similar (but smaller and more 2-cleft) alteruate leares which are peltate near one margin, and terminated by a cyme of white flowers.

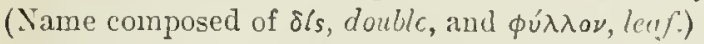

1. D. cymòsa, Michx. Root-leares $1-2^{\circ}$ in diameter, 2-cleft, each division 5-7-lobed; lobes toothed; berries blue. - Wet or springy places, mountains of Va. and southward. Mlay.

\section{JEFFERSONIA, Barton. TwL-LEAF.}

Sepals 4, fugacious. Petals 8, oblong, fat. Stamens 8; anthers oblonglinear, on slende filaments. Orary oroid, soon gibbous, pointed, stigma 2 lobel. Pod pear-shaped, opening half-way round horizontally, the upper part making a litl. Seeds mauy in sereral rows ou the lateral placenta, with a Heshy lacerate aril on one side. $-A$ pereunial glabrous herb, with matted fibrous roots, long-petioled root-leares, parted into 2 half-ovate leafiets, and simple naked l-Howererl scapes. (Named in honor of Thomas Jefferson.)

l. J. diphylla, l'ers. Low; flower white, $I^{\prime}$ broad, the parts rarely in threes or fives. - Woods, western N. Y. to Wisc. and southward. April, May. - Called Rheumatism-root in sone places.

\section{PODOPHÝYLUM, L. MAY-Appe. Maxdrake.}

Flower-bud with three green bractlets, which early fall away Sepals 6, fugacious. Petals 6 or 3. ohorate. Stamens twice as many as the petals in our species; anthers linear-ollong, not opening by uplifted valres Orary oroid; stigma sessile, large, thick and undulate. Fruit a large fleshy berry. seeds covering the very large lateral placenta, in many rows, each seed enclosed in a pulpy aril, all forming a mass which fills the carity of the fruit. Perennial lerbs, with creeping rootstocks and thick fibrous roots. Stems 


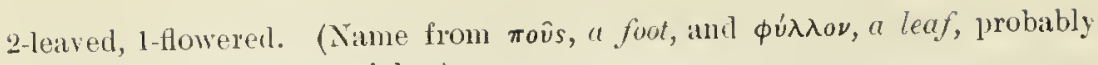
referring to the stout petioles.)

1. P. peltàtum, 1. Stamens $12-18$; leaves $5-9$-1 arted, the lobes obloug, rather welge-shaped, somewhat lobed am toothed at the apex. - Rich wook, commou. May. - Flowerless stems terminated by a kige ronnd 7 -9lobed leat, peltate in the midule like an umbrella. Flowering stems benring two one-sided leases, with the stalk fixed near their inner edge; the nodding white flower from the fork nearly $2^{\prime}$ lnoul. Fronit woid, $1-2^{\prime}$ long, ripe in Jnly, sweet and slightly acid, edible. The leares and roots are drastic aud poisonous! - Found xcasionally with from 22 to 6 carpels !

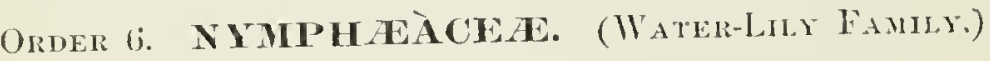

Aquatic perenniul herbs, with horizontal roolstochs and peltate or sometimes only cordute leaves floating or emersed; the ovules borne on the sides or buck (or when solitary hanging fiom the summit) of the cells, not on the ventral suture: the embryo enclosed in a little bay at the end of the albumen next the hilum, exe'pt in Nelmubium, which has no albumen. Radicle hardly any; cotyleclons thek and fleshy, enclosing a well-elereloped plumule. - Flowers axillary, solitary. Fernation inrolnte. Rootstocks appiurently endogenons. - The few genera differ so much in the flower and fruit that they are separated into the three following suborders.

Suborder: T. Cabómbeac. Sepals and petals each 3 or sometimes 4, hỵogrnons and persistent. Stamens definite $(3-18)$. Pistils $2-18$, free and distinct, eoriareons and indehiscent, 1 -3-sceded on the dorsal sntme. - Stems slencler, leafy, coated with mueilage. Flowers small.

1. Cabomba. Stamens 3-4. Carpels 2-3. Submersed ieaves capillary-multifil.

2. Horasenia. Stamens $12-18$. Curpels $4-18$. Leaves all pultate.

Strorder: II. Nelumbonear. Sepals and petals munerous in several rows, passing gratually into each other, and with the indefinitely numerous stamens hypogrnous and decidnous. J'istils several, 1-ovuled, seprately immersed in the obeonical receptarle, which is much enlarged and hroadly top-shaperl at maturity, the imberled mut-like fruits resembling small acorns. Embryo large; 110 allumen. - Petioles and peelunsles all from the tulnorous rootstock, the centrally peltate leaves and the flowers larere.

3. Nelumbo. Chisacter of the Suborler.

SUmolizer 11I. Nymphacacea proper. Sepals 4-6, ame petals numerous in many rows, persistent or decaying away, either lypogynoms or varionsly achate to the surface of the componnd 8-30-eelled orary, which is formed hy the union of as many eaplels: the numerons ovnles inserter over the whole inner face of the cells, except at the ventral suture. Stignas radiate as in l'oply. Frut baccate, with a firm rind. Petioles and pedumeles from a thirek rootstock.

4. Nymphzea. Petuls armate to the oxiry, litge ; the stumens on its summit.

5. Nuphar. l'utils (Very smill and stinmen-like) aml stamens inserted under the ovary. 


\section{1. С A B Ó M B A, Anblet.}

Sepals 3. Petals 3 , oral, bi-aurieulate alove the very short claw. Stamens 3-6; antliers short, extrorse. I'istils 2-4, with mall terminal stigmas. Seeds 3, pendnlous. - Sleuder, mainly submersed, with opposite or verticillate capillary-dissected leaves, a few floating, alternate and centrally peltate. Flowers single on long axillary peduncles. (Probably an aboriginal name.)

1. C. Caroliniàna, Gray. Floating leaves linear-ollongrg or -ohorate, often with a basal notch; flowers $6-8^{\prime \prime}$ hroasl, white with yellow spots at base; stamens 6.-P'onds, S. Ill. (May-Sept, schuerk) to Fla. and Tex.

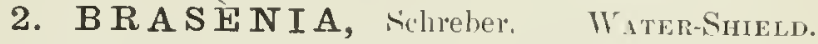

Sepals 3 or 4 . Petals 3 or 4 , linear, sessile. Stamens 12-18; filaments filiform; anthers innate. I'istils 4-18, forming little clnl-shaped indehiscent pods; stigmas linear. Seeds 1-2, pendnlons on the dorsal suture!- hootstuck creeping. Loaves alternate, long-petioled, centrally peltate, oral, Hoating. Flowers axillary, sulall, dull-purple. (Name of meertain origin.)

1. B. peltàta, l'urslt. Teaves entire, $1-4^{\prime}$ across. - l'onds ancl slow streams. June-Ang. (Asia, Aficica and Anstrilia.)

3. NELÚ M B O, Tourn. SACren Beax.

The only genus of the suborler. (Netumbo is the Ceylonese name of the East Indian species, the pink-thowered $\mathrm{N}$. speciosa.)

1. N. lutea, Pers. (Ieluow Nemino, or Whter Cinsorapix.) Leaves usually raised ligh ont of the water, circular, with the eentre lepressed $\mathrm{or}^{\circ}$ cupped, $1-2^{\circ}$ in dianeter ; Hower pale yellow, 5 - 10' bcoal ; anthers tipped with a sleuder hooked appendage. (Nelumbium lnteum, Willd.) - S. Conm. (probalsly of Indian introduction) to Lake Ontario, Micls., Minn., E. Neb., and sontlward; rave in the Mirdle States. - Thuers farinaceous and edible. Seeds also eatable. Embryo like that of Nymphar on a large scale; cotyledons thiek and fleshy, enclosing a plummle of 1 in 2 well-formed young leaves, cuclosed in a delieate stipule-like sheatl.

\section{NYMPH 庄A, Tourm. WATER-A'YMPI. WATER-LILY,}

Sepals 4, green ontside, nearly free. Petals numerons, in many rows, the innermost gradually passing into stamens, imbrieately iuserted all over the orary. Stamens indefinite, inserted on the owar, the onter witl dilated filaments. Ovary $12-35$-eelled, the concave snmunit tipjed with a globular projection at the centre, around whieh are the radiate stigmas; these project at the nargin, and are extended into linear and incurved sterile appendages. Fruit depressed-globular, eorererl with the bases of the decayed petals, maturing unter water. Seerls envelopor by a sac-like aril. - Flowers white, pink, yellow, or lilue, very shomy. (1)edieated by the Greeks to the Water-1Yynphs.)

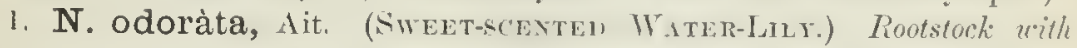
few and persistent branches: leaves orbienlar, cordate-cleft at the base to the petiole (5-9' wide), the margin entire; stipules hroally triangular or almost kiduey-shaped, noteherl at the apex, appressed to the rontstock; flower white, iery supet srented (often as much as $5 \frac{1}{2}$ in diameter when fully expauded, opening early in the morning, elosing in the afterunon); getals obtuse; anthers 
blunt; aril mnch longer than the distinctly stipitate ollong seeds (these about $1 \frac{1}{2}$ " long). - P'onds and still or slow-flowing water; common. June-Sept. Varies with pinkish-tinged and rarely with bright pink-red flowers (especially at Barustable, Mass.), the leaves ofteu crimson underneath, - and in size by gradations iuto

Var. minor, Sims, witl leaves only $2-5^{\prime}$ and flowers $2-3^{\prime}$ broad. - Shallow water, in cold bogs aud in sandy soil.

2. N. renifórmis, DC. (Tumin-bearixg WV.) Leaves reniform-orbicular, mostly larger (8-15' wide) and more prominently ribbed than the last, rarely purplish beneath; rootstock bearing numerous spontuneously detaching often compound tubers; flower scentless (or with a slight odor as of apples), white, never pinkislı, $4 \frac{2}{2}-9^{\prime}$ in diameter, the petals proportioually broader and blunter than in 11.1 ; the frnit more depressed, and with fewer but much larger (i. e.twice as broad) globular-ovoid seeds, which when mature are barely enclosed by the aril and not stipitate. (N. tuberosa, Paine.) - Lakes, slow rivers, etc, westeru N. Y. (from Oneida Lake, Paine) and near Meadville, Penu., to Mich., E. Neb., and probably iu the Sonthern States. July-Sept.

\section{N Ù P H A R, Smith. Yellow Pond-Lily. SPater-Dock.}

Sepals 5,6, or sometimes more, colored, or partly green outside, rouudish, concave. P'etals numerous, small and thickish, stamen-like or scale-like, inserted with the very numerous short stamens on the receptacle under the oxary, not surpassing the disk-like 8-24-rayed sessile stigma, persistent and at length recurved. Fruit ovoid, maker, usually ripening above water. Aril noue. - Rootstock creeping, cylindrical. Leaves with a deep sinus at the hase. Flowers yellow or sometimes tinged with purple, produced all summer (Name said to be of Arabic origin.)

1. N. advena, $\Lambda$ it. f. Sepuls 6 , unequal; petals shorter than the stamens and resenbling them, thick and fleshy, truncate; stigma vearly entire, 12-24rayed, pale red; ovary and fruit ( $\left.1 \frac{1}{2}^{\prime} \mathrm{long}\right)$ ovate, not contracted above into a narrow ueck; thin submersel leares seldom preseut; floating or emersed and erect leares thick $\left(6-12^{\prime}\right.$ long $)$, from roundish to orate or almost oblong, the sinus open, or closed or uarrow. - Very common, in still or staguant warer; stont and cuarse; fluwer often partly purplish (var. valikgatum, lingeln.).

Var. minus, Morong. Nore slenter; leaves somewhat smaller (3-S' long); flowers usually smaller (sepals $12-15^{\prime \prime}$ loug); petals spatulate; stignas 9-13-rayed, crenately toothed, lrright red or crimson; fruit l' loug, contracted ahore. (N. rubrodiscum, Morong. N. lutem, Man,; not Smith.) - N. V't. to Mich. aud Penm. l'robably a lyblid between this and the next species.

2. N. Kalmiànum, Ait. Very slender and with slender rootstock: snbmersed leares thin, round-reniform, the floating broadly elliptical with a leep narrow sints, $2-4$ ' long; sepals usually 5 , the flowers an inch broad or less; petals spatulate or obovate; stigrmas 7 -10-rayed, lark red ; fruit globular with a short neck $\left(6-9^{\prime \prime}\right.$ in diancter $)$. (N. luteum, var. pumilum, Man.) - Mlaine to Femn. and Minn., and northwarl.

3. N. Sagittifolıum, l'ulshl. Routstock stont; leares narrowly obloug to oblong lincerolate with a slor't sinus, 6-15' loug; Howers small (1' broad). - S. Ind. and 1ll. (sihneck), aud southward. 


\section{Order 7. SAIRACENIACEAE. (Pitchei-Plants.)}

Poïyantrous and lypogynous boy-plants, with hollow pitcher-form or trumpet-shaped leaves, - comprising one plant in the mountains of Guiana, another (Darlingtonia, Torr.) in California, and the following genus in the Atlantie United States.

\section{SARRA E E $\mathbf{A} \mathbf{A}$, Tourn. SinE-Sidde Flowlir.}

Sepals 5, with 3 braetlets at the base, colored, persistent. Petals 5, ollong or ohorate, meurved, deednous. Stamens numerous, hypogynous. Ovary compound, 5-celled, globose, crownerl with a short style, which is expanded at the summit nto a very broal and petal-like, 5-angled, 5-layed, umbrella-shaped body, the 5 delicate rays terninating under the angles in as many little looked stigmas. Capsule with a gr:mular surface, 5-celled, with many-seeded placenta in the axis, loculicilally 5-ralved. Seels anatropous, with a small embryo at the base of fleshy albumeis. - Peremials, yellowish-yreen and purplish; the hollow leaves all ractical, with a wing on one side, and a rounded arching hood at the apex. Seape naked, l-flowered; flower nodding. (Named by Tonmefort in honor of Dr. Sarrasin of (Lnebec, who first sent our Northern speeies, and a botamcal account of it, to Furope.)

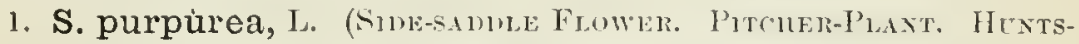
sax's Cur.) Leares pitcher-sherped, ascending, curved, broally winged; tho hood ereet, open, round licart-shaped; flower deep purple; the fiddle-shaped petals arched over the greenish-yellow style. - Varies rarely with greenishyellow flowers, and without purple veins in the foliage. - Peat-logrs; common from $\mathrm{N}$ Eng. to Minn., N. F. Iowa, and southward east of the Alleghanies. June. - The curious leaves are usually half filled with water and drowned insects. The inner faee of the hood is clotherl with stiff lnoistles pointing duwnward. Flower globose, nodkling on a seape a foot high; it is clifficult to fancy any resemblanee between its shape and a side-saddle, but it is not very unlike a pillion.

2. S. flàva, I. (Trumprs.) Leaves long $\left(1-3^{\circ}\right)$ and immpet-shriped, erect, with an open mouth, the ereet hood ronnled, narrow at the base; wing almost none: Hower yellow, the petals beeonning long and drooping. - Bogs, Va and sonthward, April.

\section{Order 8. PAPAVERACEA. (Poppi Famit.)}

IIerths with mithy or colored juice, regular fowers with the parts in twos or fours, fugacious sepals, polyandrous, hyponynous, the ovary 1-celled with two or more puriflal placentce. - Sepals 2 , rarely 3 , falling when the flower expands. Petals $4-12$, sprearling, imbricaterl and often crumpled in the bud, early deeiduous. Stamens rarely as few as 16 , distinct. Fruit a dry 1-celled pod (in the I'oppy inperfectly many-celled, in Glancium 2-celled). Seeds numerous, anatropous, of ten crested, with a minute embryo at the hase of fleshy and oily allumen. - Leaves alternate, without stipules. Peduncles inost? 1 -llowered. Juice nareotic or acrid. 
* Petals $8-12$, not crumpled in the bui, white. Poil 1-celled, 2-valved.

1. Sanguinaria. Petals white. Leaves and 1-flowered scape from a short rootstock.

* Petals 4, crimpler in the bud. Pod 2-valved or more.

- Pod 2-4-valved, the valves seqariting to the base from the placentas. Leaves pinnately parterl. Flowers yellow.

2. Stylophormm. Pod bristly; style distinct; stigmas and placentis $3-4$.

3. Chelidomium. Pod lincar, smooth; style almost uone; stigmas and placentas 2.

4. Glaucium. Pollongl, long-linear, 2-celled by a spongy fartition; style none.

+ + Pod +-20-valved, dehiscent only at the top or to the midelle.

5. Papaver. Ovary incompletely many-celled; stigmas mited into a radiate sessile

(rown.

6. Argemone. Stigmas (scssile) and placentas 4-6. Por and leaves prickly.

\section{S A N G U I N À R I A, Dill. BLоOก-RoюT.}

Sepals 2. Petals 8-12, spatulate-ublong, the immer nartower. Stamens about 24. Nityle short; stigna 2-grouved. Pod oblong, turgid, l-celled, 2ralved. Seeds with a large crest. - I low perennial, with thick prostrate premorse rootstocks, surcharged with red-orange acrid juice, sending up in earliest spring a rounded palmate-lobed leaf, mil a l-flowered naked scape. Flower white, handsome, the bul erect, the petals not crumpled. (Name from the color of the juice.)

1. S. Canadénsis, 1.-Open rich woots; common. April, May.

\section{STYLÓPHORUM, Nutt. ('WAxpre Porr's.}

Gepals 2, hairy. Petals t. Sityle rlistinct, colmunar; stigma 2-4-lobed. l'ods hristly, 2-4-ialred to the bise. Seenls conspicumsly crested. - Perennial low herhs, with stems naked helow and oppositely 2-leaved, or sometimes 1-3-leared, and mubellately 1 -few-Howered at the sumnit; the flower-buds and the pouls nolding. Leaves pimately parted or divided. Juice yellow.

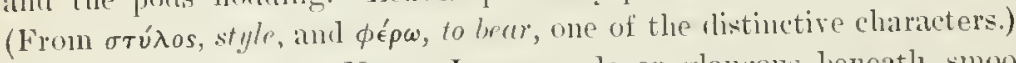

1. S. diphýlum, Nutt. Leares pale or \&lancous beneatl, smoothish, leeply pimmatificl inte 5 or 7 oblum simute-lobed livisions, and the root-leaves often with a pair of smaller and distinct leathets; perluncles equalling the pretioles; Hower deep yellow ( $\underline{Q}^{\prime}$ Lroal) ; stigmas 3 or 4 ; porl oril. - Dimp woods, W. Pem. to Wisc. aud Tenu. May. - Foliage and flower resembling Celandine.

\section{CHELIDÒ I U M, L. C'L.MNINk.}

Scomals 2. I'etals t. Stamens $16-24$. Strle narly none; stigna 2-lobel. Pod linear, slender, smooth, 2-valved, the valves "pentum from the bottom upwarl. Seeds erestexl. - Bimmial herl, with brittle stems, saffron-colored acrin

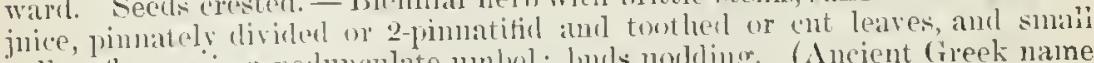

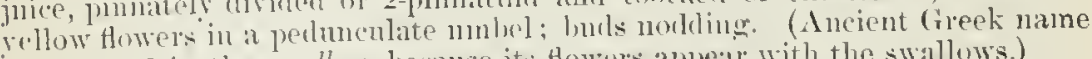
from $\chi \in \lambda\llcorner\delta \dot{\omega} \nu$, the snellour, becallse its flowers appear with the swallows.)

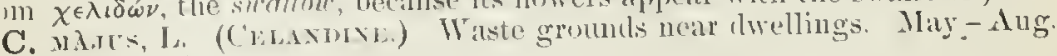
(Shr. frum Lin.)

\section{G L A U CI U M, 'Tomrn. Ilonx-l'opry.}

Sepals 2. Potals t. Style none: stigma 2-loherl or 2-homed. Pod very long and linear, completely a-celled ly it spming false partition; seeds crest- 
less. - Annuals or liemnials, with saffron-colored juice, clasping leaves, and solitary vellow Howers. ('The Greek name, ydaúktov, from the glaucous foliagre.)

G. Lùtrar, Scop. lower leaves pimnatifid; nuper ones simuate-loberl ams: toothed, eordate-clasping; mols rowgh $\left(6-10^{\prime}\right.$ long). - Waste places S. L. New Eng., Md., and Va.; not common. (Adr. from Eu.)

\section{P A P A V E R, Tourn. l'opr.}

Sepals mostly 2. l'etals mostly 4. Stignas uniter in a flat $4-20$-raverl crown, resting on the summit of the varly and calsusule; the latter shont and turgid, nith 4-20 many-seeded placenta projecting like imperfoct partitions, opening hy as many pores or chinks moler the eilge of the stigna.Herls with a white jnice; the flower-huls molding. (Derivation olsscure.) Three annul species of the ()ld World are slaringly antrentiye; viz.

P. somxilercm, H. (('ommox l'orry.) Smoth, glaucous; leares clasping, ways, incised and toutleel; pod globose: corolla mostly white or jurple. - Near dwellings in some places. ( Idr. from kn.)

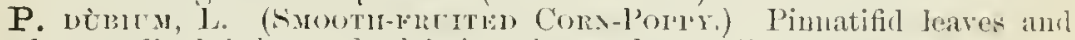
the long stalks bristly; pods club-shaped, smooth; corolla light scarlet. — C'nlt. grounds, W'estchester, l'enn., and southwarl ; rare. (Mrly. from Eu.)

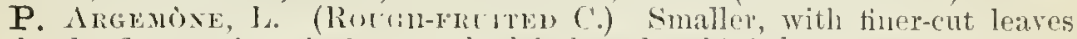
and paler flowers than the last; pods rluh-shaped and bristly. - 11 aste grounds, near Philadelphia. ( $\Lambda$ dr. from En.)

\section{A R G E O N E, I. Prexry Porry.}

Sepals 2 or 3, often prickly. Petals 4-6. Style almost none; stigmas $3-6$, raliate. Pod oblong, prickly, opening $l y-6$ valves at the top. Seeds crested. - Ammals or hiembials, with prickly bristles and yellow juice. Leaves sessile, sinnate-lober, and witl prickly teetl, often libteleer with white. Flower-luds crect, slurt-peduncled. (Name liom ăp $\gamma \in \mu \alpha$, a discase of the eye, for which the juice of a plant so called by the Greeks was a supposerl remerly.)

1. A. platýceras, link \& Otto. Setose-hisplud all over; petils white,

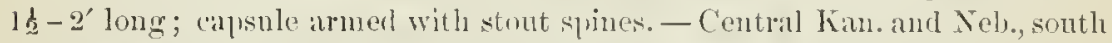
and westward.

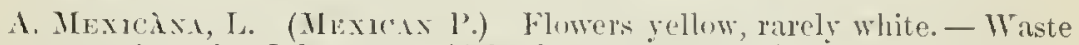
places, southwarl. July-1).t. (1/k. from troj). Aner.)

\section{Orne: 9. FUMARIACIAA. (Fumtory FamLi.)}

Delicate smooth lerbs, will wertery juice, impound dissected leates, irregular flowers, with 4 somewhat mited petuls: 6 diadelphous stamens, rud 2-merous porls and sceds lilie those of the Poppy Family. - Sepals 2, small and scale-like. Corolla flattened, closed; the 4 petals in two pairs; the outer with spealing tips, and one or both of them spurred or saceate at the base; inner pair narrower, and their callous erested tips united over the stigma. Stamens in two sets of 3 each, placed opposite the larger petals. hypogyons; their filaments of ten mited; middle anther of rach sed 2-celled, the lateral ones 1-celled. Porl 1-celled, cither 1-seeded and indehiscent. or several-seederl with 2 parictal placenta and leeiduous valves. - Leaves delieate, usually alternate, without stipules. Slightly bitter', inumerent plants. 
* Curolla bigibunus or 2-spurrerl, the 2 outer petals alike. Pod sereral-secded.

1 A dlumia. Petals uniter into a spongy persistent subentate corolla. Sceds crestless.

2. Dicentra. Corolla cordate or 2-spurred at base, less united. Seeds crested.

* Corolla with but one petal spurred at base, deciduous.

3. Corydalis. Pod with few to many crested or arilled seeds.

4 Fumaria. Fruit a globular 1-seeded nutlet. Seed crestless.

\section{A DI ÙMIA, Raf. Chimsf: Fumitory.}

Jetals all permanently united in a cordate-orate corolla, beconing spongy. cellular and persistent, enclosing the small, few-seeded pod. Seeds not erested. Stigma 2-crested. Filanents monadelphons below in a tube which is atherent to the corolla, diadelphous at the smmmit - A climbing hiennial, with thricepimnate leaves, cut-lobed delicate leatlets, am ample panicles of drooping white or purplish flowers. (1)edicated by Rafinesque to Major Adlum.)

1. A. cirrhòsa, Raf. - Wet wouls; N. Eng. to Wisc, E. Faun., and sonthward. June-Oct. - $\lambda$ handsome vine, with delicate foliage, climbing hy the slender young leaf-stalks over high bushes; often cultivated.

\section{DI CÉ N T R A, Borkh. Dutchma's Breeches.}

Petals slightly cohering into a heart-shaped or a-spurred corolla, either docidnons or withering-persistent. Stigma 2-crested and sometimes 2-1orned. Filaments slightly united in two sets. Pod 10-20-seeded. Seeds crested. I.ow, stemless pereminials (as to our wild species) with temately compound and dissected leaves, and racemose nodding flowers. l'elicels 2-bracted. (Name

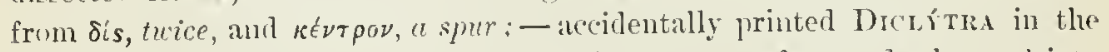
first instance, which by an erroneous conjecture was afterwards changerl into I) İ́LYTRA.)

$$
\text { * Raceme simple, feu-fowered. }
$$

1. D. Cucullària, DC. (Dutrinas's Bremcines.) Scape and slender-petioled leaves from a sort of gramulate bulh; lobes of leaves linear; corolla with 2 divergent spurs longer than the pedicel; crest of the inner petals mimute. - Rich woods, especially westward. $-\Lambda$ very delicate plant, sending np in early spring, from the cluster of grain-like tuhers cowderl together in the form of a scaly bull, the finely cut luaves and the slender scape, bearing 4-10 pretty, but odi, white Hower's tipped with cream-color.

2. D. Canadénsis, DC. (Srmuer Corx.) Snbterranean sloots bearing scattered grain-like tubers (resembling peas or grains of Indiau corn, yellow); leares as in n. I; corolla merely heart-shaped, the spurs very short and ronnded; crest of the inner petals ronspicuous, mojecting. - Rich woods, especially northward. April, May - Flowers greenish-white tinged with rose, with the fragrance of Ilyacinths.

$$
\text { * Retermes compound, clustered. }
$$

3. D. eximia, I)C. Snloterlanean shoots sealy; divisions and lobes of the leaves broarlly ohlong; corolla oblong, 2-saccate at the base; crest of the inner petals projecting. - Rocks, westem $\mathrm{N}^{+}$. Y., lare, and Alleglianies of Va. May - $\mathrm{dug}$ - Coarser-leaved than the other's; sapes 6-10' high. 


\section{CORÝDALIS, Vent.}

Corolla 1-spured at the base (on the upper sille), deciluons. Style persistent. Pod many-seederl. Seeds crested or arilled. Flowers in racemes. Onr species are biemial, leafy-stemmed, and pale or glaucous. (The ancient Grcek name for the crested lark.)

* Stem strict: flowers purplish or rose-color with yellow tips.

1. C. glaùca, I'nlsh. (PAle Corrdilis.) liacemes panicled; spur of the corolla very short and rounded; pods erect, slender, elongated. - Rocky places; common; $6^{\prime}-2^{\circ}$ high. May $-\Lambda 11 g$.

* Lox', ascending; flowers yellou.

+ Outer petals uing-crested on the back.

2. C. flávula, I)C. Petlicels slender, conspicuonsly bracted : corolla pale yellow, 3-4" long, spur very short; tips of the onter petals pointed, longer than the inner; crest 3-4-tootherl; pods torulose, pendulons or spreading; seeds acutely margined, rugose-reticulated; aril loose. - Penu. to Minn., and sonthward.

3. C. micrántha, Giạy. Peliecls short and hracts small; corolla pale yellow, 4" long, with short sjur and cntire crest, or flowers often cleistogamous and much smaller, withont spur or crest, pods ascending, torulose; sceds olstuse-margined, smooth and shining. - K. ('ar., Mil., Minn., and sonthward.

4. C. crystállina, Enggelm. l'ellicels short, erect; corolla bright yellow, 8" long, the spur ncarly as long as the boly; "lest very broad, usually tootlied; pods terete, erect, densely" covered with transparent resicles, seeds acutcly margined, tuberculate. - - . W. Mo. aud sonthward.

+ + Outer petals merely carinate m the back, not crested.

5. C. aùrea, Willd. (Gounex C.) Corolla gollen-yellow, 尔' long, the slightly decnrved spur about half as long, shorter thau the pedicel; pods sprealing or pendulons, beeoming tornlose; secds obtuse-margined. - Rocky banks, V't. to Penn., Mo., Minn., and westward.

Var. occidentàlis, Engelm. Flowers rither larger, the spur nearly as long as the body; pods less torulose, on short pedicels; sceds acutish on tho margin. - Neb. and Kan. to W. Tex. and Westwarl.

\section{FU M A RIA, 'Touru. Fumtory.}

Corolla 1-spurred at the base. Style deciluons. Fruit indehiscent, small, glohnlar, l-scederl. Secds crestless. - Branched and leafy-stemmed annuals, with finely dissecterl compound leaves, and small flowers in dense racemes or spikes. (Nime from fumms, smoke.)

F. officindlis, L. (Commox Fumtorr.) Siepals ovate-lanceolate, acute, sharply toothed, narrower and shorter than the corolla (which is flesh-color tipped with (rimson); fruit slight? notched. - Waste places, about dwellings. (Adr. from Eu.)

\section{Order 10. CRUCÍFERAE. (Mustard Family.)}

Ilerbs, with a pungent watery juce and cruciform tetradynamous flowers; fruit a silique or silicle. - Sepals 4, deciduous. Petals 4, hypogynous, regular, placed opposite each other in pairs, their spreading limbs form- 
ing a cross. Stamens 6, two of them inserted lower down and shorter (rarely only 4 or 2 ). Pod usually z-celled by a thin partition stretched between the two marginal placentie, from which when ripe the valves separate, either much longer than broarl (a silique), or short (a silicle), sometimes indehiscent and nut-like (mucumentaceous), or separating acros: into 1-sceded joints (lomentaceous). Seeds campy lotropous, withont albumen, filled by the large embryo, which is cmverl or folded in rarious ways : i. e. the cotyledons accumbent, viz., their maryins on one side applied to the radielc, so that the cross-section of the seed appears thus $0=$; or else incumbent, viz, the back of one cotrlerton applied to the radicle, thus oll. In these cases the cotyledons are plane; but they may be folded upon themselves and round the radicle, as in Mustard, where they are conduplicate, thus $0>>$. In Leavenworthia alone the whole embryo is straight. - Leaves alternate, no stipules. Flowers in terminal racenes or corymbs; peedicels rarely bracted. - A large and very natural family, of pungent or acril, lut not poisonous plants. (The claracters of the? genera are taken almost wholly from the poils and seeds: the flowers being nearly alike in all.)

SERIES I. Pod 2-celled, regularly dehiscent by 2 valves.

* Pod compressed parallel to the broal partition. Seeds flat or flattish, orbicular or oral ; cotyledous acemubent or nearly so.

- Porl large, oblong-elliptical, values nerveless. Seets in ?2 rows. Flowers yellow.

1. Selenia. Leaves pinuatiscet, Racenc leafy-bracteate. Secds winged

+ + Pod linear; valves nerveless. Seeds in one rom. Flowers yellow only in n. 2.

2. Leavenworthia. Sced winged; cmbryo straight or rearly sn. Amual; stem often seapose, 1-few-flowered.

3. Dentaria. Stem naked below, 2--)-leaved. Pod coriaccous, with thick placentas, ling-styled. Secds wingless; cotyledons thick, very unequal.

4. Cardamine. Stem leafy. Pod coriacens, with thick placentas. Seeds wingless, rotyledons flattened, equal.

+ + + Pol linear, ol oblong, or orbienlar; valves 1-nerved or nerveless. Seeds in 2 rows (excopt. in species of $n .5)$.

5. Arabis. Pol long-linear, the Hitt or flattish valves more or less 1-nerved. Seents winged or wingless. Flowers whito to purple. Stems leafy, at least below.

6. Draba. Pol whal on nizrowly oblong or lanceolite; vilves flat or flattisle, faintly nelved or veined. Seerls wingless, numerous.

7. Alyssum. Pol orbienlar: valves veinless, somewlut convex with flattened margin. Seerls wingless, a-4.

* Pod terete or tulmid, or t-angled by the prominent midnerves. Suculs wingless, more or less turrid.

- Pokls short. (bee also n. 11.)

8. Iesquerellar. Porl glubular-inflatel, aloul 4-seederl; valves nerveless. Cotyledons iccumbent. Flowers yellow.

9. Camelina. Porl oboroil, many-sceded, Wulves l-nerverl, style slender. Cotyledous incumbent. Fluwers yellow.

10. Subularia. Pod oroid or globnlar, few-seched valves 1-nerved style none. Coty. lerlous long. folled transversely. Flowers white. Dworf stemless aquatic. 
++ Pod linear (or oblong or even globular in n. 11).

+ Cotyledons aceumbent.

11. Nasturtium. Pod often sliort: valves strongly eonvex, uerveless. Seeds small, in 2 rows in cach cell. Flowers yellow or white.

12. Barbarea. Pod somewhat 4 -sidel ; valves strongly 1 -nerved. Seeds in 7 row. Flowers yellow.

$$
\text { + + Cotyledons incmubent or partially so. }
$$

13. Hesperis. Pod terete, elongated; stigna-lobes narrow, erect. Flowers large, purple.

14. Erysimum. Pod 4-sided; ralves strongly 1-nerved; stigna broadly 2-lobed. Pu bescence of appressed 2-3-parted lairs. Flowers yellow.

15 Sisymbrium. Pod angled or teretish; valves 1-3-nerved; stigma snall. Flowers yellow or white, small.

16. Thelypodium. Pod teretish; ralves l-nerved; stigma entire. Cotyledons obliquely incumbent. Flowers rose-eolor, Leaves aurieler?.

+++ Cotyledons eonduplicate.

17. Brassiea. Por beaked or pointed beyond the end of the valves, or tipped with a rigid style, nearly terete, or 4 -sided. Flowers yellow or whitish.

- * Pod short; the boat-shajed valves conduplicate or much flattened contrary to the narrow partition. Flowers white.

18. Capsella. Pod many-seeded, obcordate-triangular, wingless. Cotyledons incumbent.

19. Thlaspi. Pod several-seeded, obovate or obcordate, winged. Cotyledons accumbent.

20. Lepidium. Pod 2-seeded, flat, scale-shaped. Cotyledons ineumbent or aceunibent.

21. Senebiera. Pod s-secded, didymous; the valves rngose, separating at maturity from the little partition as 2 elosed 1-seeded nutlets. Cotyledons incumbent, narrow.

SERIES 1I. Pods indehiscent, continuons or transversely jointed; joints i-celled.

22. Cakile. l'od short, 2-jointed : joints 1-seeded. Cotyledons plane, accumbent.

23 Raphanus. Pod elongated, several-seeded, continuous, or constricted between the seeds and moniliform. Cotyledons condullicate.

\section{SELENIA, Nutt.}

Pod large, oblongrelliptical, flat; the valves nerveless. Seeds in 2 rows in each cell, rombed, lroadly wingerl; cotyledons accunbent; radicle short. A low annual, with once or twice pimatifid leaves and leafy-bracteate racemes of yellow Howers. (Name fron $\sigma \in \lambda \dot{n} \nu \eta$, the mom, with allusion to Lunaria, which it somewhat resembles in its porls.)

1. S. aurea, Nutt. Loless of the simply pinnatifil leaves entire or cootled ; pod $\frac{1}{2}$ long, on elongated spreading pedicels, beaked by the long slender style. - Mo. and Kian. to Tex.

\section{LEAVENWÓRTHIA, Torr.}

Pod broally linear or ollong, flat; the valves nerveless, lut minutely re. ticulate-veined. Seeds in a single row in each cell, flat, surrounded by a thick wing. Embryo straight! or the short radicle only sliglitly bent in the direc. tion which if continued wonld make the orlicular cotyledons accumbent.Little winter anmuls, glabrous and often stemless, with lyrate leaves and short 1 -few-flowered scape-like peduncles. (Nimned in honor of the late M.C. Lenienuorth.)

1. I. Michaùxii, Torr. Srapes 2-6' high; leaf-lohes usually numerous $(7-15)$; petals murplish or nearly white with a yellowish base, obtuse: 
pods not tornlose, olloug to linear $\left(6-15^{\prime \prime}\right.$ long); style short. - S. Ind. to Tenn. and Mo.

2. I. torulósa, Gray. Similar, hut porls torulose even when young, linear; style $1-2^{\prime \prime}$ long; sceds acutely margined rather than winged; petals emarginate. - Parreus of $\mathrm{K} y$. and 'Tenn.

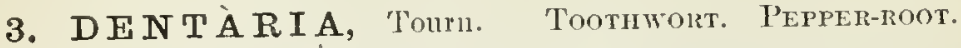

Pod lanceolate, flat, as in Cardamine. Style elongated. Seeds in one row, wingless, the stalks broad and flat. Cotyledons petioled, thick and rery unequal, their margins somewhat infolding each other.-Perennials, of damp woodlands, with long, horizontal, fleslyy, sometimes interrupted, scaly or toothed rootstoeks, of a pleasant pungent taste; the simple stems leafless below, bearing 2 or 3 petioled compominl leares abont or ahove the middle, and terminated by a single corymb or short raceme of large white or purple flowers. Flowers larger, pods broader, and seeds larger than is nsnal in Cardamine. (Name from dens, a tooth.)

* Rootstock elongated; leares 3-foliolate.

1. D. diphýlla, I. Rootstock long and eontinuons, often branehed, toothed; stem-leares 2, similar to the radieal ones, close together; leaflets rhombic-ovate or ohlong-ovate, shortly petiolate, coarsely crenate, the teeth abruptly acnte; petals white.- Rich woods, Maine to Minn. and Ky. Mav. - Rootstocks $5-10^{\prime}$ long, crisp, tasting like Water-Cress.

* Tootstoch tuberous, more or less moniliform; leares 3-fololate or 3-parted.

2. D. laciniàta, Mnhl. Tnhers deep-sented, usually not jointed nor prominently tubercled; root-leaves often none; stem-leares 3-parted, the lateral segments often 2-lobed, all hroarlly oblong to linear, more ol less gashtoothed ; flowers white or rose-color. - N. Eng. to Minn., Kan., and southward. A pril, May, - Var. xuLtffiD., a slender form with the narrowly linear segments usnally more or less divided into linear lubes. (D. mnltifida, Muhl.) Southwarl, scarcely if at all within our linits.

3. D. heterophýlla, Nutt. 'Tuhers vear the surface, jointed, narrowly oblong or thick-clarate, prominently tubercled; leares 3-foliolate, the leaflets distinctly petiolate, oblong-lanceolate to linear, entire to rather deeply erenate, rarely laeiniate or lobed; root-leaves with ovate or lanceolate and usually lobed leatlets. - Penu. to Kr. and sonthwinl. Blooning a little later thin the last.

4. D. máxima, Nutt. 'Inbers jointed, strongly tubercled; sten-leaves nsually alternate, 3-foliolate; leaflet's ovate or oblong-n rate, coarsely toothed and sonewliat cleft or lobed. - T't to western N. I. and I'enn. May.

\section{C A R D A M İ N E, Touru. Bitren Cress.}

Por linear, flattenerl, nsually opening elastically from the hase; the ralves nerveless and reinless, or nearly so; placentas and partition thick. Seeds in a single row in each cell, wingless; their stalks slender. Cotyledons acenmbent, flattened, eyuul or nearly so, petiolate - Mnstly gliblous perenuials, aafy-stemmed, growing aloug watercourses and in wet places. Flowers white or purple. ( 1 (ireek name, in Dioscorides, for sume eress, from its cordial or carcilical (pualities.) 
* Tiont jerennial; leazes simple.

1. C. rhomboidea, DC. (Spung Cress.) Stems upright from a tuberous base and slender rootstork bearing small tubers, simple; root-leaves round and often heart-slapeel; lower stem-leaves ovate or rhombic-oblong, somewhat petioled, the upper alnost lanceolate, sessile, all often sparingly toothed; pous linear-lanceolate, pointed with a sleuder style tipped with a consplicuous stigma; seeds round-oxal. - Wet mealows and springs; common. April-June.Elowers large, white.

Var. purpùrea, Torr. Lower $\left(4-6^{\prime}\right.$ ligh), and usually slightly pubescent; flowers rose-purple, appearing earlier. - Along streams in rich soil. Western N. Y. to Ml. and Wise.

2. C. rotundifolia, Miclix, (Mouxtas Wateli-Cises.) Stems tranching, weuk or decumbent, making long runners: rot fibrous: leaves all much alike, roundish, somewhat angled, often heart-shaped at the hase, petioled: pods small, linear-awl-shaped, pointed with the slender style; stigma minute; seeds oral-oblong. - Cool shaded springs, N.J. (Middletown, Willis) to Ky. and southward along the momutains. May, June. - Flowers white, smaller than in $\mathrm{n} . \mathrm{l}$.

3. C. bellidifòlia, L. Duarf (2-3' liggh), alpine, tufted; leaves orate, entire, or sometimes with a blunt lateral tootl ( $f^{\prime \prime}$ long), on long petioles, pods I' long, upright, linear"; style neurly none, stout. - Simmits of the W'hite Mountains and Katahclin, Maine. Jnly-Flowers I-5, white. (Eu.)

$$
\text { * Root perennial; leaves pinnate; flouers showy. }
$$

4. C. praténsis, L. (Cucroo Fuwli.) Stem ascencling from a short rootstock, sinple; leaflets $7-13$, those of the lower leaves romuled and stalked, of the upper oblong or linear, entire, or slightly angled-tootletl : petals (white or rose-color) thrice the lengtlı of the calyx; pod 9-15" long, I" broal ; style short. - Wet places and bogs, l't. to X.J, Wisc, and northward; rare. May. (Eu.)

* * Loot mostly tiennial or anmual; leaves pimnute; flouers smull, urhite.

5. C. hirsùta, I. (Simll Bitser Cress.) Glabrons or heset with scattered lairs; stems $\left(3^{\prime}-2^{\circ}\right.$ highl $)$ erect or ascending from the spreading cluster of root-leares; their leaflets rounded, those of the upjer leaves oblong or linear aurl often conflnent, all either tootled, angled, or entire; pods linear, very narrow, erect or asceuling; style virialle. - Wtet places; conmon. May-July. The ordinary form corresponds closely to the Enopean var. sruvátıci, Gaud. 'Tle typieal imperfectly developed anmul form, with only 4 stamens and ratler strict pols, occurs very rarely. A form answering to $\mathrm{C}$. parviflora of Eurnee, with nustly linear leaflets and pods often erect on spread. ing pedicels, is occasionally fonnd in drier localities. (En, Asia.)

\section{5. Á R A BIS, I. liock Cress.}

Pod lincar, flattened; placentas not thickenerl; the valves plane or convex, more or less l-nerved in the middle, or longitudinally veiny. Seerls msually margined or winged. Cotyledons accumbent or a little oblique. - Leares seluom divided. Flowers white or purple. (A tune from the country, Arabia. see Lim. Plil. Bot. \$2.35.) 
\$1. ARABIS proper. Seeds in one row in eacle rell, orbicular or nearly so, nore or less wing-maryined; cotyledons strictly accumbent.

* Low, rhiefly biennials, diffuse or spreading from the base.

1. A. Ludoviciàna, Meyer. Nearly glabrons, often annual; leaves all pinnately parted into oblong or linear few-toothed or entire divisions, those of the lower leaves munerous; pedicels rery slort; flowers small, white; pods rather broadly linear, sprearling, flat; seeds winged. - Open gromnds, Va. to Mlo, and southwart.

* Erect and simple leafy-stemmed biennials, with simple leaves, white or whitish flowers, nurrou but fattened ascending or erect pods, and nearly uinyless seeds.

2. A. pàtens, fulliv. Downy with sprearling hairs, erect (1-2o ligh); stem-leares oblung-orate, acutish, coarsely tootled or the upperinost entire,

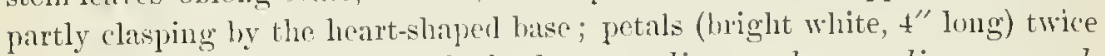
the lengtl of the calyx; pedicels slender, spreading: pods smeading or ascending, lipped with a distinct style. - P'enn. to eentral Ohio and sonthward; Mlinn. April, May.

3. A. hirsuta, א́cop. Rongh-lairy, sometines smoothish, strictly erect (1-20 high); stenl-leares oblong on lanceolate, entire or toothed, partly elasping ly a somewhat arrow-sliaped or leart-shaperl hase; petals (greenisli-white) small, but louger than the calyx; pedicels and pods strictly npright; style scurcely any: immature seeds somewhint 2-rowed. - liocks, common, especially nortliward. May, June. (Eu.)

* * * Erect and simple leafy-stemmed birmials ( $1-3^{\circ}$ high), with small uhitish

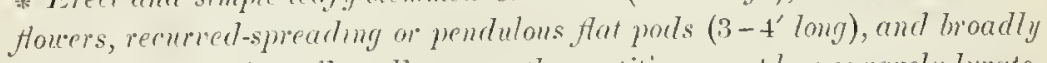
winged sceds, their stallss radherent to the partitiom; root-lecues rarely lyrate.

4 A. lævigàta, l'vir. Smootl and glancons, unright'; stem-leaves purtly clusping by the arjow-shaped hase, lancenlate or linear, sparingly ent-toothed or entire; petals scarcely longer than the cally : pods long and nurrou, recuredsprealing on aserndiug or merely spreading perlicels. - Rocky places, Maine to Minn. and soutlwarl. May.

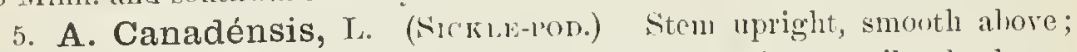
stem-lenves pubesrent, pointed at both cuds, oblong-laneeolate, sessile, the lower toothed; petals twice the length of the calyx, oblong-linear; pods revy flat, scythe-shaped, hanging on rough-hairy pedicels (2" wide). - Woods and rarines; not rare, especially westwark. June-Aug.

§2. 'TLRRITIS. Seeds not so broad as the partition, in tuo more or less distinct rou's in each rell, at least when young; strict and rery leafystemmed bieminls; cauline leaves partly clasping by a sagittate base. (Our speries rery glubrous, exeept the mostly hirsute buse of the stem and the lourev leares.)

6. A. perfoliata, Lam. ('Tower Mustrin.) Tall ( $2-4^{\circ}$ high), glancous; stem-lenves oblong or ovate-laneeolate, entire; petals yellonishwhite, little lonerr than the calyr: pods rery nurrou ( $3^{\prime}$ long) and pedicels strictly erert: secels marginless; cotyledlons often oblique. - Rocks and fields, N. Hing. to Minn. (rin), north and westwand. (Ku.) 
7. A. confinis, Watson. Scarcely glancous, 1-30 high; pubescence beluw finely stellate; stem-leuves lanccolute or oblong-linear, entine (1-2' long), witl narrow auricles, or the lowest spatulate and toothed; petals white or rose-color, fully twice the length of the calyx; perlicels and flat pods loosely erect, or ascending, or even sprcading; sceds wing-margined, when mature little nar. rower than the partition. (A. I)rummondii, Man.) - From the lower St. Iawrence to Minn., soutl to Conu., N. Y., and Ill. - Pods $2 \frac{1}{2}-3 \frac{1}{2}^{\prime}$ loug, or in a var. (T. brachyearpa, Torr. \&. Giray) only 1-2' long.

\$ 3. PSETDARABIS. Siceds oblong or elliptiral, rery small, wingless, in one row; cotyledons oflen wore or less oblique. Bifnnial or peremial, branching fiom the base.

8. A. lyràta, I. Mostly glabrous, exrept the lyrute-pinnatifid ront-leaves: stem-leaves seattered, spatulate or linear with a tapering hase, sproingly toothed or entive; petals uhte, much longer than the yellowish calyx; pods long and slenrler, flat, ascending or spreanling. - l)n locks or sandy shores, New Eng. to Ky. along the mountains, Minn., anel northward. April-July. - Usually hiennial, but soutlwand in the monntains decidenly perennial.

9. A. dentàta, Torr. \& Glay. Longhish-pubescent, slencler (I-20 high); lecres oblong, very obtuse, merually and sharply toother, those of the stem numerous, half-clusping and cured at the base, of the root broader and tapering into a slort petiole; petals (whitish) scarcely exceeding the calyx; pods widely spreading, rory slender, short-stalked; style seurely any.- N. Y. to Mich., Minn., and southward. May, dune.

\section{DR A B A, Dill. Whitlow-Grass.}

Pou ovat, oblong, or even lisear, that; the valves plane or slightly convex; the partition broarl. Sieels sereral or nunerons, in 22 rows in each rell, marginless. Cotyleclons accumbent. Filaments not toothed. - Low herhs with entire or toothed leaves, and white or yellw flowers; puhescence often stellate. (Name from $\delta \rho \alpha \beta \beta \eta$, applied by l Dioscolicles to some cross; meaning muknown.)

§ 1. DRABALA. Petals not notrhed or cleft; perenniul or biennial, leafystemmed; flowers uhite: pods weisted wherit ripe.

1. D. ramosíssima, Desv. Diffuscly much bronched and formiug many radical tufts, perennial $\left(5-s^{\prime}\right.$ highl $)$, pubescent; lenes laciniule-tonthed, linearlanceolate, the lower oblanceolate; racones corymboscly-branched; pods hairy, wal-oblong or lanceolate $(\not 2-5)^{\prime \prime}$ ] $\mathrm{ng}$ ), on slender sprearling perlicels, tipped with a long style. - Cliffs, llarper's Ferry, Natural Briclge, etc., Va, to Kentucky River, and southwarl. A pril, May.

2. D. incàna, 1. Hoary-pubescent, hienuial or somewhat perenial, the radical tuft scldon branching; leaves oblanceolate ov the cauline lanceolate to orate, few-toothed or entire; purk oblong to lancolute, usually racutc and straight, oficn pubescent, on short elect pedicels; style very slunt or none. - Iry rocks, Willougluby Monntain, Vt.; alio northwarl and far westwarl. (Fin.)

Var. arábisans, Watsou. Caudex much branched; pod glahrons, acnminate or acnte, twisted, beaked with a longel listinct style. (D) arabisans. Michx.) - Y. Vt. to western X. Y. and the shores of the uper lakes. 
82. DRABÉLLA. Winter anmals; leafy stems short; flowers white (yellow in $\mathrm{n} .5)$; style none. (Leaves oblong or oborate, hairy, sessile.)

3. D. Caroliniảna, Walt. Small $\left(1-5^{\prime}\right.$ high $)$; leaves obovate, entire: peduncles scape-like; petals usually twice the length of the calyx; raceme

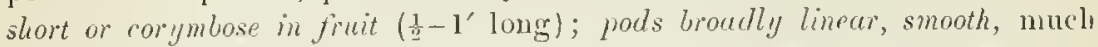
longer than the ascending pedicels. - Sandy and waste fields, E. Mass. to Minn., and southward. March-May. - Petals often wanting in the later racemes, especially in the var. ucrixms, Gray, with minutely rougl-hairy pods, which is foumd with the other, westward.

4. D. cuneifolia, Nutt. Leaves obovate, werlge-shaped, or the lowest spatulate, toothed; raceme somer.hut elonguted in fruit $\left(1-3^{\prime}\right)$, at lengtl equalling the naked perluncle; petals emarginate, much longer than the calyx; pods oblong-linear, mimutely hary, longer than the horizontal pedicels. - Grassy places, Ill. to E. Kan, and southward. March, April.

5. D. brachycárpa, Nutt. Low (2-4' hight), minutely pubeseent; stems leafy to the base of the dense at length elongated racene; leares narrowly obloug or the lowest ovate $\left(2-4{ }^{\prime \prime}\right.$ long), few toothel or entire; Howers small; pods smooth, narrouly oblong, acutish (2" lung), wout the length of the asrending or spreading pedicels. - Iry lills, IIl., Ky., Va. (A. H. Curtiss), and southward. April. - Petals sometimes minute, sometines none.

6. D. nemoròsa, 1 . Leaves oblong or somewhat lanceolate, more or less toothed; racemes elonguted $(4-8$ ' long in fruit) ; petals cmarginate, small; pods elliptical-oblong, half the length of the horizontal or widely-spreading redi. cels, pubescent or smooth. - Fort Gratiot, Mich., N. Minn., and westward. (Eu.)

§3. ERÓPIIILA. Petals 2-cleft. (Annual or biennial; flowers white.)

D. véraA, I. (Wuntow-Grass.) small (scapes 1-3' high); leaves all raclical, oblong or lanceolate; racemes elougated in fruit: pods rarying frum round-oval to oblong-lanceolate, smooth, shorter than the pedicels. - Saudy waste places and rualsides. April, May. (Nat. from Eu.)

\section{ALÝS SUM, Tourn.}

Pol small, orhicular, with only one or two wingless seeds in a ecll; valyes nervess, somewhat convex, the matgin flattened. Flowers yellow ur white Filanents often toother. Cotyledons accumbent. (Greek riame of a plant reputed to (heck the hiceup, as the etymology denutes.)

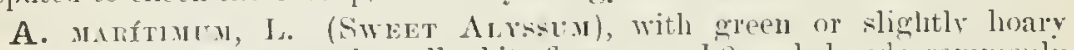
linear laves, honey-scenterl small white fowers, and 2-secled pods, commonly (cult., legins to be sipontaneons southward. (Arlv. from Eir.)

A. cox'ixu, l., a dwarf hoary annual, with linear-spatulate leaves, pale yellow or whitish petals little exceeding the persistent cilly, and orbicular sliarp margined 4 -seeded porl, the style minute, vecurs vecasionally in grassland. (Ldr. from Eu.)

\section{LESQUERELLA, Watson.}

Pol mostly glohular or inflated, with a hroal orbicular to orate hyaline partition nervel to the middle, the hemisphericil or convex thin valves nerveJuss. Seeds few or soreral, in 2 rows, flit. Cotyleflons aremmlent. Filaments

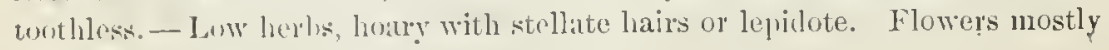
yellow (Nansed for Joco Jespuereux.) 
1. L. globòsa, Watson. Minutely hoary all orer; stems spreading or deeumbent from an annual or bienuial root; leaves oblong or lanceolate with a tapering base, repand-toothed or neally entire; racene at length elongated, with filiform diverging pedicels; petals light rellow; style filiform, much longer than the small globose, acntish, abont 4 -seeded pod; seeds minginless. (Vesicaria Shortii, Torr.) - Roeky banks, Ky. to Teum. and Mo. May, Jame.

2. L. grácilis, Watson. Amuıl, slender; pubescence very fine; leaves narrowly oblanceolate; pods ghlabroms, suberect on ascending or curved pedicels, stipitate; style long. (Vesicaria gracilis, Monk.) - S. Kan. to Tex.

3. L. Ludoviciàna, Watson. Biennial or perennial; pmbescence compact; leares linear-oblanceolate, mostly entire; pods pulescent, pendulous on recurved perlicels; style loug. (Vesicaria Ludoricinna, DC:) - Minn. to Neb. and sonthwestward.

\section{CAM ÉLINA, Crantz. FAlse Flax.}

Pod oboroid or pear-shipred, pointed, flattish pauallel to the broal partition; valves 1-nerved. Sieeds numerons, oblong. ('otyledons incmubent.

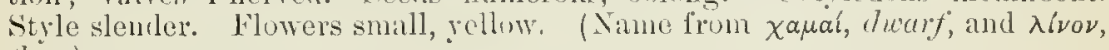
$f(i x$.

C. sirtr, Crantz. Anutal; lanves lanceolate and arrow-shaped; pods margined, large. $\Lambda$ weed in thax-fichls, etc. (Adv. from Eu.)

\section{SU BU L À R I A, I. AwLworT.}

Pod ovoid or globular, with a loroad partition; the turgid ralves I-nerved. Seeds sereral. Cotyledons long and narow, incumbently folded transversely, i. e., the cleft extenrling to the radicular side of the currature. Style none. A dwarf stemless perennial, aquatic; the tufted leares awl-shaped (whence the name). Scape naked, few-flowererl, 1-3' highl. Flowers minute, white.

1. S. aquática, L. Margin of lahes in Maine; Eeho Like, Franeonia, N. II; also in alpine regions of the westem momtains. June, Jnly. (Eu.)

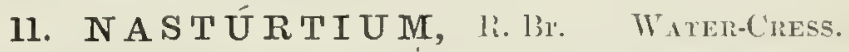

l'od a short silupue ol a silicle, varying from ublong-linear to globular, terete or nearly so; valves strongly convex, nerreless. Seels usually umerons, small, turgitl, marginless, in 2 irdegulau rows in each cell (except in $\mathbf{X}$. sylrestre). Cotyledons accumlent. - A puatic or mas ly plants, with yellow or white flowers, and commonly jimate ol pinatifid leaves, manly glahues. (Name from Nusus tortus, a convulsed nuse, alluding to the effect of its prugent qualitics.)

\$1. Petals white, wice the length of the calyx: porls linear : leaves pimute.

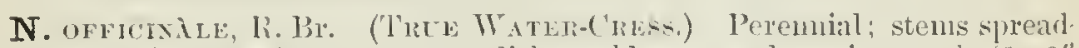

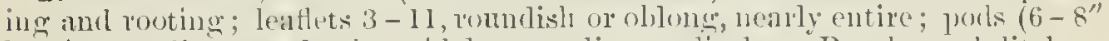
long) ascending on slender widely spreading peticels. - Brockis and ditches; escaped from cultisation. (Nat. Pom Eu.)

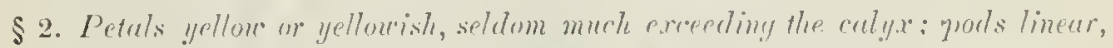

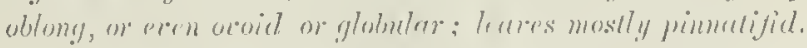

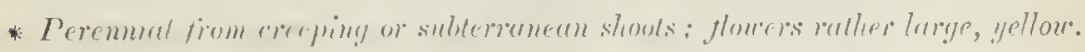

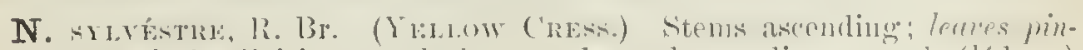

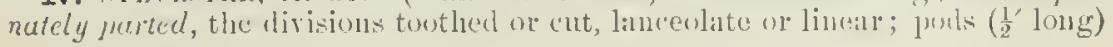


nn stencler pedicels, linear and ninrow, bringing the seets into one row; style rery short. - Wet meaduws, Mass to Va.; lare. (Nat. from Eu.)

1. N. sinuàtum, Nutt. Sitems low, cliffuse; leares pimately cleft, tho shont lobes nearly entive, linear-oblong; porls linear-oblong $\left(4-6^{\prime \prime}\right.$ long $)$, on slender pedicels; style slender. - Banks of the Mississipyi and westward. Junc.

* A Ammal ar biemnial, rarely peremial (?), uith simple fibrous roots; fluuers small or mimute, greenish or yellowish; leaces somerhat lyrate.

2 N. sessiliflorum, Nint. Ntems erect, rather simple; leares obtusely

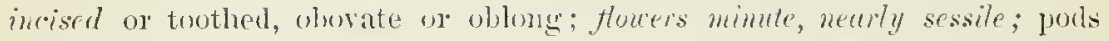
elongated-oblong (5-6" long), thick; style very short. - W. I1l. to W. Kan., 'Temm, and sonthward, April-Juue.

3. N. obtusum, Nintt. Stens much loanched, diffusely sprcaling; ieares pimmety puted or alicided, the divisions romdish and obtusely toothed

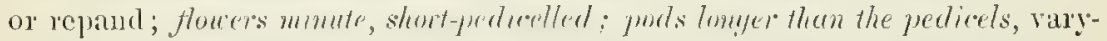
ing from linear-ohlong to short-oral ; style short. - With 11.1 and ‥

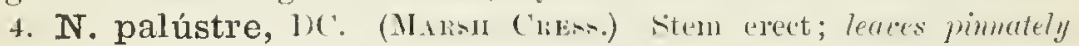
cleft or parted, or the upper laciniate; the lohes ollong, cont-tuothed; pedieds about as lony as the small flourers and mostly longer than the oblong, ellipsoid, or ovoid pods; style short. - Wet places or in shallow water; common.

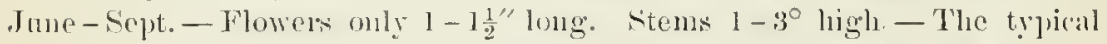
form with oblong pols is lare. Sllort pods and hirsute stems and leares are

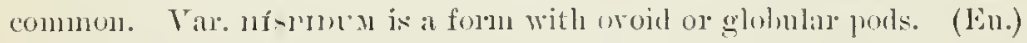

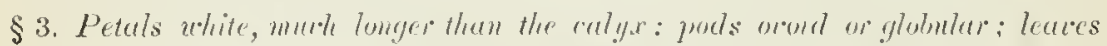
undicided, or the lorrey ones pumalifill; rout perennial.

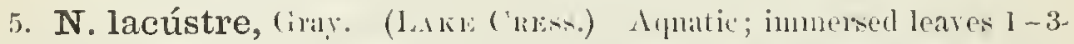
pinnately dissected into numerons alpillany divisions; (nnersed leaves oblong,

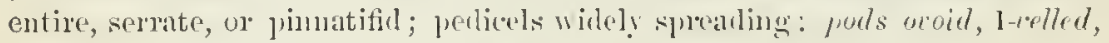
a little lomger then the style. - Lakes and livers, X. L. Sew York to X. J., Minn, and sonthwestwal. July- lug. - Neal X. auphihinn.

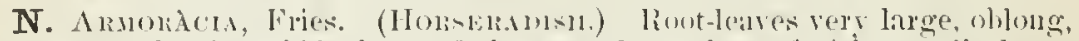

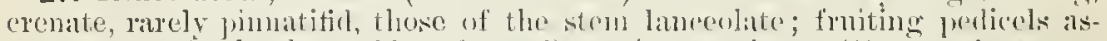

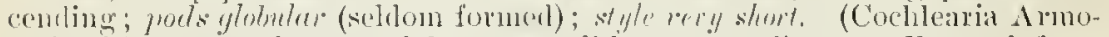

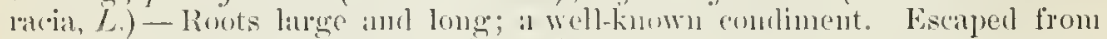
cultivation into moist ground. (Alv. l'rom lin.)

\section{B A R B A R E A, li. lir. Wirtir C'Ress.}

l'oul linear, terete a somewhat 4-silded, the values being kecled by a mirl-

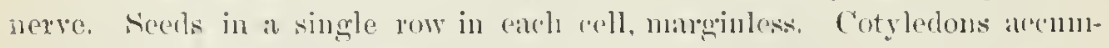
bent. - Mostly hiemials, pesembling Nastutinm; flowers yellow. (Anciently allerl the Herth of Sit. Barbatra.)

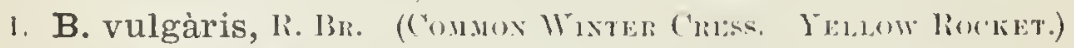
Simoth; lower leaves lyate, the terminal division romul and nsmally large,

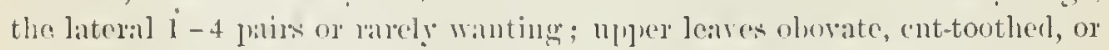
pinnatiful at the bise; pols areet or slightly spealing or in var. stmets.

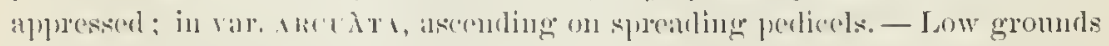
and ranlsides; appanently intruduced, but iudigenous from L. Suserior northwallat aud westwatel. (Eu.) 
B. PRdecox, R. Br. (LARLY Winter C.), with 5-8 pairs of lateral lobes to the leaves, and louger pods on very thick pedicels, - yet probably only a variety of the other, - somewhat cultivated from $\mathrm{N}$. I. sonthward as a winter sulad, under the namo of Sctrvi-Grass, - is begining to run wild. (Kin.)

\section{HésPERS, Tourn. Rechet.}

Pod linear, nearly cylindrical; stigma lohed, erect. Seeds in l row in each cell, ublong, narginless. Cutyledous incumbent. - Biennial or perennial, with serrate sessile or petiulate leaves, and large purple flowers. (Name from

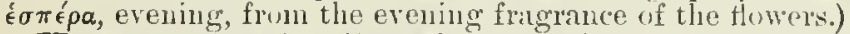

H. мatmoxils, I. (D.mu's Tion:t.) 'Tall; leaves lanceolate, acumiuate, mostly petiolate; pods $2-4^{\prime}$ loug, spreadiug. - S jaringly naturalized. (Nat. from Eu.)

\section{ERÝ S I M U M, Tourn. Treacle Mustard.}

Pod linear, 4-xided, the valves keeled with a strong midrib; stigma loroadly lobed. Seeds in I row in each cell, oblong, marginless. Cotyledons (often obliquely) incumbent. - Chiefly licmials, with yellow flowers; the leares not clasping. I'ubescence of appressed 2-3-parted hairs. (Name from épúw, to draw blisters.)

1. E. ásperum, DC. (Westerx Wall-Flower.) Minntely roughishhoary; stem simple, leaves lanceolate to linear, entire or somewhat touthed; fods nearly erert or widely s]readiug on short predicels, elongated (3-4' loug), exactly 4-siled; stigma 2-lobed. - Ohio (on limestone (cliffs) to Ill., Ark, S. D., and common westwarl. June, July. - Plant stout, $1-2^{\circ}$ high; the crowded bright orange-yellow flowers as large as those of the Wall-flower. Petals orbicular, on very slender claws.

2. E. cheiranthoides, L. (Worm-slED M('STARD.) Ninutely roughish, branching, slencler; leaves lanceolate, scarcely toothed; flowers small; pods smull and stort ( $7-12$ " long), very oltusely angled, ascenting on slender divergent pedicels. - Bauks of streams, Mass. to Peun., Mliun., aud northward. July. (Eu.)

3. E. parviflolum, Nutt. Stem erect, often simple; leaves liuearoblanceolate, entire or the lowest "ousely toother; flowers suall ( 3 "loug); porls narrow, $1-2 \frac{2}{2}$ long, ascendiug on short pedicels. - Miun. to lian. aud westward.

\section{S ISÝ M BR I U M, Tourn. Henge Místard.}

Pod terete, flattish or $4-6$-siderl, the valves 1 -3-nerved; stigma small, entire. Seeds oblong, marginless, in 1 or 2 rows in each cell. Cotyledous incmbent. Calyx open.-Flowers small, white or yellow. Pubescence sprealing. (An ancient Greek name for some plant of this family) Uurs are mostly ammals or biemials

1. S. humile, Meyer. Perennial, brancling from the hase, sparingly pubescent, $6^{\prime}$ high or less; leaves uarrowly ohlanceolate, mostly coarsely and sharply tonther, flowers white or rose-color: pods very narrow, subterete, $4-9^{\prime \prime}$ long, ascending on short pedicels, heaked with a short style; seeds I-ranked. (Aralis petrea, M/an., not Lam.) - Willoughby Mountain, Vt.; Canada and westward. (N. Asia.) 
2. S. canéscens, Nutt. (TAxsy Mustırd.) Leures 2-pinnatifid, often hoary or dowy, the divisions small and toothed; flowers yellowish, very small; pods in long racenes, oblong-cluh-shaped or oblong-linear, shorter than their mostly horizontal perlicels; seeds 2-ranked in each cell. - l'enn and $\mathrm{X}$. Y. to Lake Superior, thence southward and westward. June-Ang.

S. Sifpur., I. I similar hoary species, with decompound leaves; pods slender, 6-15" loug, ascending; seeds I-ranked, - Sparingly naturalized from Europe.

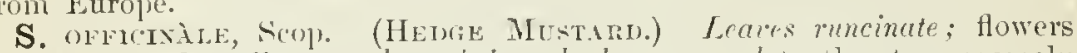
very small, pale yellow; prots an/-shayed, rlose pressed to the stem, scarcely. staiked. - Waste places. May - Sept. - In mosightly branched weed, $2-3^{\circ}$ higl. (Nat. from Iitu.)

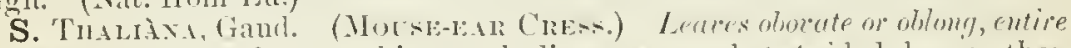

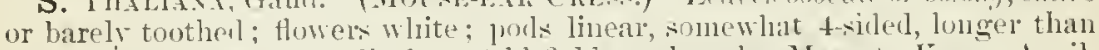
the sleniler spreading pedicels. Old fields and rocks, Mass to Kin. April, Ifay. - A span ligh, semler, hranched, hairy at the hase. (Nat. from Eu.)

S. Aludis, scop. Stont, erect; leaves reniform to orate-cordate, coarsely repand-dentate; flowers white; porls tapering, l-2' long, ascending on rery stont sprealing peiticels. - Near (iengetown, D. C. (Nat from Eir.)

\section{THELYPÒ D U M, Enell.}

Iod terete or teretisli; valres l-nerverl; stigma mostly entire. Seeds in 1 row in each cell, oblong, marginless. Cotyleduns olliquely incmubent. Stout biennials or perennials, with nostly liarge purplish or white Howers. Leaves or petioles often anricled at hase. (Name from $\theta \hat{n} \lambda u s$, femule, and moús, fout, the ovary in some species loeing stipitate.)

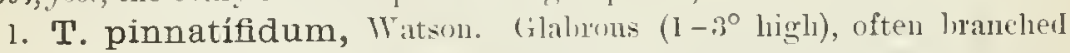

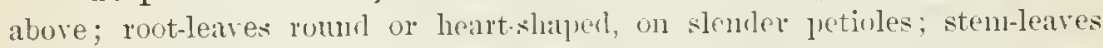
auricled, ovate-oblong and svate-lancenlate $\left(2-6^{\prime}\right.$ lomg), sharply aur often doubly tootherl, tapering to each encl, the lower into a winged petiole, rarely bearing a pair or two of small lateral lohes; fowers purplish; pods 1 - 1 $\frac{1}{2}$ long, on slurt diverging perlicels, pointed hy a short style. (Arabis lesperibloides, (rouly) Alluvial river-banks, W. Pa. to Minn., Mo., and soutlwestward. May, June.

17. B R ÁS SICA (Biassica and Simpis), Tourn.

Pod linear or oblong, near]y terete or t-sided, with a stont l-seeded lueak or a rigid style; valves 1-5-nerverl. Seeds grobuse, 1-rowel. cotyledons

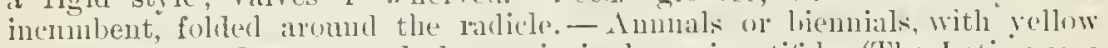
Howers. Lower leares mostly lyate, incisel, or pimatifisl. (The Latiil name of the Cabbage. Sinapis is the Greek oivani, which is saicl to come from the Celtic unp, a turnip.)

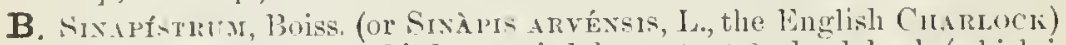
with knotty pork, fully one third occmpied ly a stout 2-edged beak (whieh is eitler empty or 1-seeded), the nlper leaves larely toothed, is a noxious weed in grabil-fielrs, from X. Eng. to P'enn. and X. Y. westward. (Aw. from Eir.)

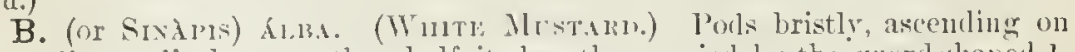
spreading pedicels, more than half its lengtl ocupied ly the sword-shaped 1-

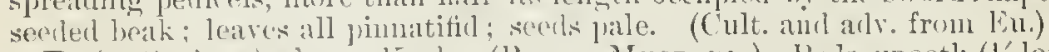

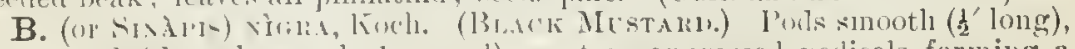
4-cornered (the vilves only l-nerved), erect on appressed pedicels forming a sender raceme, tipped with a stout persistent style; seeds dark brown, smaller 
and more pungent than in the last; lower leaves witl a large terminal lobe and a few small lateral ones. - Fielks and waste places. (Aclr. from liu.)

B. CAMPÉstris, L., in the form of the R'TABIGs and the Turvip, sometimes persists a year or two in neglerted groumls.

\section{C A P S Él I A, Medie, Surpierd's P'Urse.}

l'ol oheorlate-triangular, flattened contriry to the narrow partition; the valves hoat-shaperl, wingless. Seeds numerous. Cotyledons incumlent.-Amuals; Howers surall, white. (Name a riminutive of capsen, a bros.)

C. Bursi-r.stóns, Hoench. Lont-leaves cInstered, pinnatifid or touthert; stem-leaves arrow-shaperl, sessile. - Waste placess the commonest of weedo. April-sept. (Nit. from Ens.)

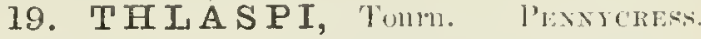

lerl orlicnlar, olovate, or obcorclate, Hattened contrary to the narrow partition, the nidril, or keel of the hoat-shalperl valves extenderl into a wing. Sceeds $2-8$ in eacli cell. Cotyledms accumbent. I'etals emal. - Low plants, with root-leaves unlivided, sten-leaves amow-shaped and cldsping, and small white or pupplish flowers. (Ancient Greek name, from $\theta \lambda a ́ \omega$, to crush, from the flattenerl pul.)

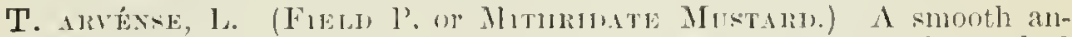
nual, witl broarly wingerl porl $\frac{1}{2}$ ' in cliameter, several-seederl, deeply notched at top; style minute. - Waste places; rarely naturalized. (Nat. from Eu.)

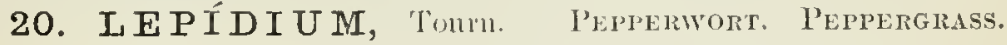

Pof roundisl, much flattened contrary to the narrow partition; the valves boat-shaped and keeled. Feeds solitary in each roll, pendulons. Cotyledons incumbent, or in 11.1 accumbent! Flowers small, white or greenish. (Name from $\lambda \in \pi i \delta ı v$, a little scale, alluding to the small flat pods.) - Ours are annuals or hiennials, except the last.

* Leares all with a tapering base, the upper linear or lancealate and entire, the lover and often the middle ones meised or pimatifid: pods orbicular or oval, with a small notch at the top; the style minute or none; stamens only 2.

1. L. Virgínicum, I. (Wild PEPIER(iRass.) Cotyledons accumbent and seed minutely margined; pod marginless or obscurely margined at the toip; petals present, except in some of the later flowers. - June-Sept. $\Lambda$ common roadside weed, which has immigrated from farther suth.

2. L. intermedium, Gray. Cotyledons incumbent as in the following; pod minutely wing-margined at the top'; petals ustually minute or wanting; otlerwise nearly as in n. 1. - Dry places, from western $\mathrm{N}$. Y. and $\mathrm{N}$. Ill., north and westward.

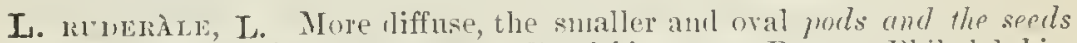
marginless; petuls ulunys untmy. - Roanlsiles, near Boston, Philatelphia, etc.; not common. (Ailv. from Eu.)

* * Sitem-leaves uith usugitute partly rlaspming brise, ruther crouded.

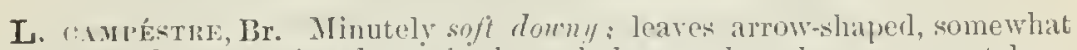
toothed ; porls orate, eringed, rongh, the stylo longer than the narruw notch. Old fielils, Mass. anil N. Y. to Va.; rare." (Nat. from liu.)

L. Drגas, L. Perennial, obscurety houry; liaves oval or oblong, the

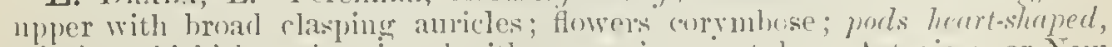
wingless, thickish, cutire, tipperl with a consplicunds style. - Asturia, near New York, I). ('. Euton. (Ailv. from Eu.) 
21. SENEBIERAa. DC. Wart-Cress. Swise-Cress.

Pod flattened contraly to the narrow jartition; the two cells indehiscent and falling away at maturity from the partition as closed nutlets, strongly wrinklerl or tuberculate, 1 -seederl. Cotylerlons narrow arsh incumbently folded transversely. Low and diffuse or prostrate amnals or biemnials, with minnte whitish Howers. Stanens often only 2. (1)edicated to J. Senebier, a distinguished vegetable physiologist.)

S. Dfurm, Pers. Leaves 1-2-pinnately parted; pods notched at the aper, rongh-wrinkled. - Waste places, at polts, L. Mass. to Ya, ete. ; an immigrant from farther soutl.

S. Colonòvs, I)C. Leaves less divided, with narrower lobes; pords not

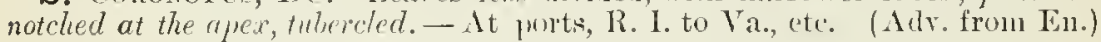

\section{C A K I L E, 'Tonrn. Sir-liockit.}

Pul short, 2-jointed across, fleshy, the upper joint separating at maturity; each indehiseent, l-celled and l-seeded, or the lower sometimes seedless. Feet erect in the upper, suspended in the lower joint. Cotyledons oljlipuely acembent. - Seaside fleshy ammals. Flowers purplish. (An old Arabic nane.)

1. C. Americána, Nutt. (Ankicix SEA-liocikto) Leaves oborate, simuate and toothed; lower joint of the fruit obovoid, entrginate; the nper wate, flattish at the apex - Const of the Northern States and of the Great Lakes. July-Sept. - Joints nearly eren and fleshy when fresh; the upper one 4-imgled and ippearing more beaked wheu dry.

\section{RÁ P H A N S, 'Tourn. RıDisı.}

Pods linear or whlong, tapering npwarl, indeliscent, several-seeded, eontiunous and spongy within between the seeds, or secklace-form by constriction betreen the secdis, with no proper partition. Style long. Seers spherical and cotyledoms combluplicate, as in Brassica. - Anmuals or biemulals, (Tlue an cient Greek name from $\rho \alpha$, quickly, and $\phi$ aivw, to apjear, alluding to the rapicl germination.)

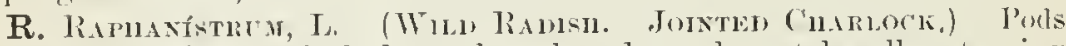
necklace-form, lomo-beaked ; leaves lyre-shaped, rongh: petals yellow, turning

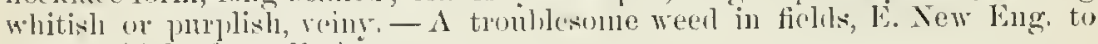
J'en11. (Adr. from lin.)

\section{OHDER 11. CAPPARIIACEAE. (CANGR FAMLY)}

Ilerbs (when in northern regions), with cruciform flowers, lut 6 or more not tetradynamous. stamens, a 1-celled porl uith 2 parietal placenta, and libiney-shaper seels. - Pod as in Crumifure. hut with no partition; seeds sinilar, lut the cmbryo coiled rather than folderl. Leaves alternate, mostly palmatcly componnt. - Often with the acriul or pungent qualities of Cruciferse (as in capers, the llower-bunls of Cáplunis spinòsa).

1 Polanisia. Stamens 8 or more Pol many-seculen, mot or sarcely stipitate.

2. Cleome. stamens 6. Pod linear, many-scesled, long-stipitute.

3. Cleomella. Stanens 6 . Pod rery short, rlomboidal, few-seedor, long-stipitate.

\section{POLA NÍSIA, Raf.}

l'etals with chus, notched at the apex. Stamens $8-32$, mequal. Receptacle not elongated, hearing a glaud behind the hase of the ovary. Pod linear 
or oblong, veiny, turgid, many-seeded. - Feticl anmals, with glandular or clammy hairs. Flowers in leafy racemes. (Name from todús, many, and

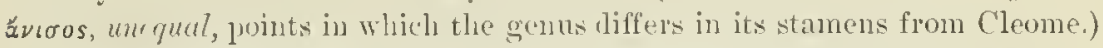

1. P. gravèolens, Raf. Leaves with 3 oblong leafiets; stamens about 11, scarcely exceeling the petals; strle short; porl slightly stipitate. - Grav-

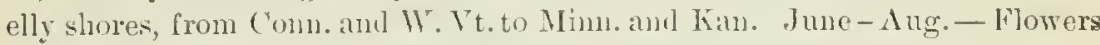
small (2-3" long); (alyx and filuments pumplish; potals yellowish-white.

2. P. trachyspérma, "T"un. \& (iray. llower' langer ( $t-5$ "long), the stamens $(12-16)$ long-exserterl; style $2-3$ " loug; joul sessile; seeds usually rougli, - Iowa to lítn. and westratrel.

\section{CIE ÒME, I.}

P'etals entire, witl claws. Stamens 6 . Receptacle somewliat produced between the petals and stamens, and hearing a gland behind the stipitate ovary. Fod linear to ollong, many-seeded. - Our species a glabrous anumi, with 3-foliolate leaves, leafy-lurcteate racemes, and rose-colored or white flowers. (Name of uncertan derivation, early applied to some mustard-like plaut.)

․ C. integrifolia, Torr. \& Gray. Calyx 4-cleft; petals witl very short claws, leaftets narpowly linceolate to oblonger bracts simple; por ollong to linear, $1-2^{\prime}$ long, the stipe as long as the pedicel. - Minn. to Kan. aud west.

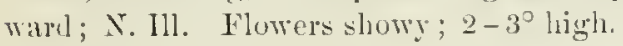

\section{CLEOMELLA, DC.}

Differing from Cleome in the clawless petuls, glanclless receptacle, and the short fer-seeded pou with nore or less distended or eren conical ralves. Flowers small, yellow. (Name a diminutive of Clrome.)

I. C. angustifòlia, 'Turr. (xlatrons, $1-2^{\circ}$ hight ; leaflets (3) and simple bracts linear to linear-lancenlate, acute; pod rhomboidal, the valves very bluntly conical; stipe shorter than the pedicel. - Kan. to 'Tex. and westward.

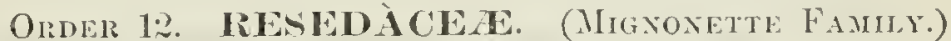

ILerts, with unsymmetrical 4 - i-merous small flowers, a flesty 1-sided hypogynous disk between the pretals am the $(3-40)$ stameis, bearing the latter. C'ulyx not closed in the but. C'upsule 3-6-loberl, 3-ti-torned, 1 celled with 3-6-purietal placenta, opening ut the top before llie seerls (which are as in Order 11) are full gromen. - Leares alternate. witl only glands for stipules. Flowers in terminal spikesor racenses. - A small and unim portant fasmily, of the Old Work, represented by the Mignonette (lieseda orlorata) ant the 1)yer's Meerl.

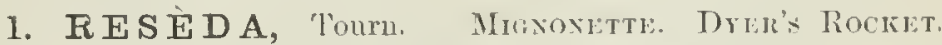

l'etals $4-\boldsymbol{i}$, cleft, mexpul. Stamens 12-40, on one side of the flower. (Name from resedo, to calnu, in allusion to suppused sedative properties.)

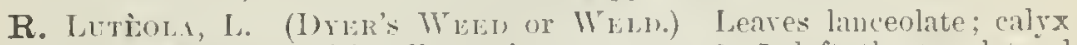
4-parterl petals 4, greenish-yellow; the upper one is-5-cheft, the two lateral 3-cleft, the lower me linenr aurl entire; capsule dlepresserl. - Roarlsides, N. Y.,

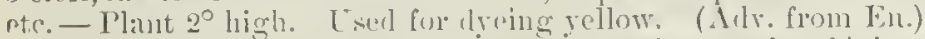

R. Lirtis, Y. I.eaves irregularly pinnately parted or hipinuitificl; sepals aud petals 6 , stamens $15-20$. - Tantucket, Mass, and ballist-grounds. 


\section{Order 13. Cistàcead. (Rock-rose Family.)}

Low shrubs or herls, with reyular flowers, distinct and hypogynous mostly indefinite stamens, a persistent calyx, a 1-celled 3-5-valved capsule with as many parietal placenta bome on the middle of the valves, and orthotropous albuminous seeds. - Sepals 5 ; the two external much smaller, bract-like, or sometimes wanting; the threc others a little twisted in the bud. Petals 3 or 5 , convolute in the opposite direction from the calyx in the bud. Anthers short, innate, on slender filaments. Style single or none. Ovules few or many, on slender stalks, with the orifice at the apex. Embryo long and slender, straightish or eurved, in mealy albumen; cotylerions narrow. - Leaves simple and mostly entire, the lower usually opposite; and the upper alternate. Inert plants.

1. Helianthemnm. I'etals 5, (1)umpled in the bud, fugacions (or molle). Stigma nearly sessile. Stimens and ovules numerous in llo pretal-bearing fowers.

2. Hndsonia. Petals 5, fugacious. Stamens 9-30. style lung und slender. Pod strictiy 1-relled, 2-ti-secled. Heath-like.

3. Lechea. Petals 3, persistent. Stampus 3-1\%. Style none. Pod partly 3-celled, the injerfect partitious benring boad :-sceted placentid.

\section{HELIÁ N TH F M U M, Tomm. Rock-Rosi.}

Petals 5, crumpled in the hod, fugacions. Styles short on none in our speries; stigna 3-lobed. Capsule strictly 1-crllorl. Embryo curved in the form of a look or ring. - Flowers in most X. American speejes of two sorts, riz., mimary or earlicr ones, with liurge petals, indefinitely mumerous stanens, and many-seeded pods; and secondury, wr later ones, which are much smaller and in clusters, with small petils or nume, :3-10 stanems, and much smaller :3few-sceded porls. 'The yellow flowers open only once, in sunshine, and cast thein petals by the next daly. (Name from

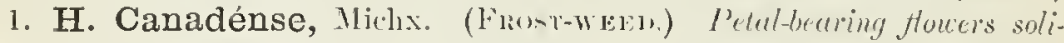
tury; the small secondury flowers clustered in the axis of the lences, neanly sessile; calyx of the large flowers hatiry pubesecent, of the small ones hoary, like the stem and lower side of the lanewlate-oblong leawes. - Samdy on gravelly dry soil, Maine to Minn. and sontlowarl. Jnne- \ng. - Sitems at first simple.

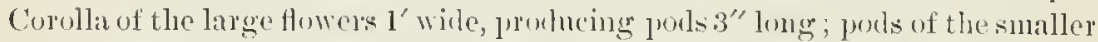
Howers not larger than a pin's hearl. A variety is more loury, and witlo a

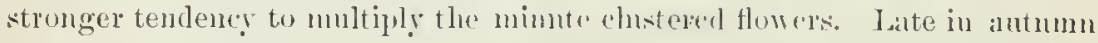
crystals of ice shoot from the erachenl lark at the reot, whence the popmlar nalle.

". H. corymbosum, Miclix. Flourers all clustered at the summit of the stem or branches, the petal-bearing ones at length on slencler stalks; calyx woolly. - I'ine batrens, N. J. and sonthward along the coalst.

\section{H U D S O N I A, I.}

Petals 5, fugacions (lasting but a day), unch larger than the calyx. Stamens $9-30$. Sityle long and slencer; stignia minte. I'od ohlong, enclosed in the calyx, strictly 1 -celled, with 1 or 2 sceds attached ncar the hase of each nervelike placenta. Emloryo cuiled into the form of a clused houk. - Busliy" 
heath-like little shrubs (sellom a font high), covered all over with the small awl-shaped or scalc-like alternate persistent downy leaves, producing numerous (small but showy) bright yellow flowers erowded along the npper part of the branches. (Named in honor of $I^{\top} m$. Hudson, an early English botanist.)

1. H. ericoides, L. Downy but greenish; leaves slenter, awl-shaped, loose; Howers on slender naked stalks; ovary hairy. - Dry sandy soil near the coast, E. Maine to Va.; N. Conway, N. H. (Miss Mims.) May.

2. H. tomentòsa, Nutt. 1Loary with dowu; leaves oval or narrowly obloug, l" long, close-pressed and imbricated ; flowers sessile or some shortpeduncled. - Saudy shores, Maine to Ma., and along the Great Lakes to Minn, ; rarely on banlis of streams inland. May, June.

\section{L ÉCHEA, Kaln. P'ixwen.}

Petals 3, narrow, flat in the bud, not longer than the calyx, withering-persistent. Stamens 3-12. Style searcely any; stigmas 3, plumose. l'od globular, partly 3-celled; the 3 hroad and thin placentae borne on imperfect partitions, each bearing 2 seeds on the face towarl the valve; in our species the placentæe cure backward and partly enclose the seeds. Embryo straightish. - Homely peremuial herbs, with very small greenish $01^{\circ}$ mrplish flowers, in summer. (Nanned in honor of John Leche, a Sivedish hotanist.)

* Pubescence villous, spreading; leares oblony; flowers very short-pedicelled in cymulose clusters.

1. L. màjor, Michx, Stem upright $\left(1-2^{\circ}\right.$ high $)$, stout, simple, very leafy, producing slender prostrate branches from the base; leaves elliptical, inucronate-pointed, alternate and opposite or sometimes whorled; flowers deusely crowded; pedicels shorter than the very small depressed-glulose pod; sepals narrower than its valves. - Sterile gromuls; common, especially southward.

* * Pubescence appressed, leazes nomorer ; flowers paniculate.

+ Lenves comparatively short, broad, and thin; panicles leafy.

2. L. thymifolia, Michx. Erect, abont $2^{\circ}$ high ; sten-leaves oval or oblong (3-6" long), commonly somewhat hairy, some whorled or opposite, those of the rather erowled panicles more linear; pod obuvate-glubose, one of the narrow onter sepals often longer. (L. Novix-Casarea, Austin.) -Dry grounds near the coast, E. Mass. to Fla.

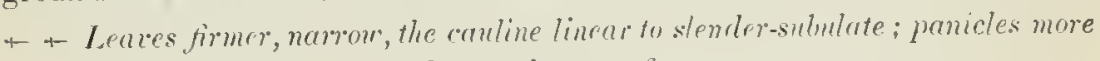
maked and racem! form.

+ Frniting calyx globulur or broally ound: pod rather large, nourly glabose.

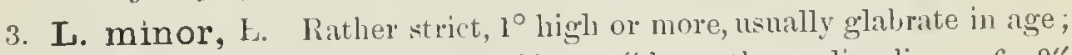
leaves of radical shoots lanceolate, rigil, $2-3^{\prime \prime} \operatorname{loug}$, the cauline linear, $6-9$ " loug; pod abont l" higl. - Dry and sterile gromur; common.

Var. marítima, (ilay in lierl). Stouter and more rigid, leaves of radical shoots thicker, linear, hoary, the canline puberulent or glabrons; calyx canescent. (L. thymifulia, Pursh.: L. maritima, Leggett.) - Sandy soil near the coast, Miss. to Gia.

4. L. tenuifolia, Michx. Low, slender aud cliffuse, minutely pubeseent or glabruts; leaves all small and very narrow, fluwers nostly on very short 
pedicels, diffusely ranemosi-juiculate; sepals without literal ribs; pod ovoid glubuse. - Dry, sterile suil, E. Mass. to Mo, and southwarl.

+ + Smaller-flowered; frutiny culyx nurrouer; pod ellipsoidal.

5. L. racemulosa, Lam. Erect, solt-jubescent when young, soon nearly glabrons; leaves of raclical slouts namowly oblong, the cauline obloug-linear, 4-6" long; inflorescence loose and diffuse; fruiting ealyx glalnous. - Iny and rocky soil, Lomg Island to Ky., and siuthward.

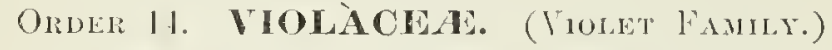

ITerbs, will a somewhat irregular 1-ximured corolla of 5 petals, 5 hypogynous stamens with adnate introrse anthers connicing over the pistil. and a 1-celled 3-raled pol with 3 parielal placenla. - Sepals j, persistent. Petals iubritater in the bud. Stamens with their short aud lonoad filanents eontinued beyond the anther-cells, and often coherent with each wther. Style usually chb-shapexl, with the simple stigma turned to one sile. Valves of the capsule bearing the sevaral-seederl placenta on their middle; after opening, each valve as it dries folds together lenetlowise firmly, projecting the secels. seeds anatropous, rather large, with a hard seed-eont, and a lange and straight mbryo nearly as long as the allumen; entyledons 1lat. - leaves alternate, with stipules. Flowers axillary, nodding. (lioots sligltly acrid or 'metic.)

1. Viola. Sepals aurteded. Lower netal spureal. Stamens rlistinct, the 2 lower spured

2. Solea. Sepals not atuiclerl. Petals erpul in lengtls, Stanens united into a sheath.

3. Ionidium. Sepals not auricled. Petals very unequal. Filaments clistinct, the anthers nerely comnivent.

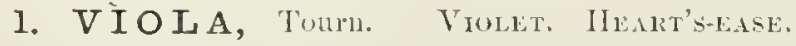

Sepals extended into ears at the lase. P'etals somewhat nuequal, the lower one spurred at the base. Stamens closely surrounling the vrary, of teu slightly. eohering with each other; the two lower hearing spurs whels project into the spur of the corolla. liesiles these amspicuous lolussous, which apjeat in spring, others are problued later (expecially in the stemless species), on shustur

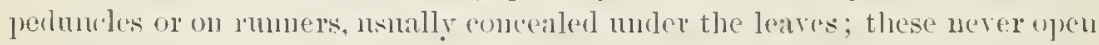
nor develop petals, lut ane fertilized in the luml, and are fin more frutful than the ordiuaty blussenus. ('l'he ancient latin name of tlue genus.)

$\$ 1$. Peremmals; stipules never lenflilie, the loure more or less scarions. * Sirmless, the leaves and scupes diverlly fiom "routstock or from rumers.

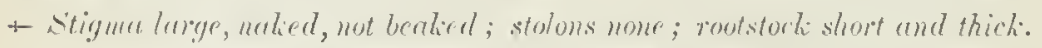

1. V. pedata, I. (131k1-Foor T.) Nearly sllumtl ; rootstock erect, not scaly ; lenes all :3-5-divided, or the earliest only parted, the lateral clivisions 2-i3-parterl, all linear or narrowly spatulate, sometimes 2-3-tootled or colt at

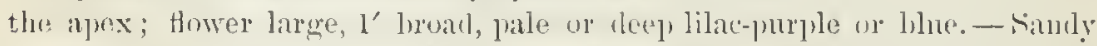

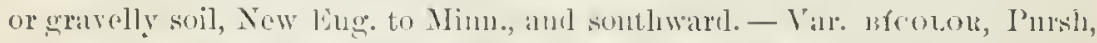
at very lamelsone valuty, with the two npler potals decp violet, and as it were

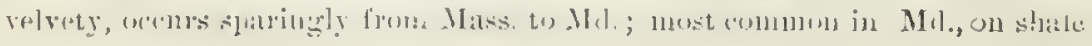


+ +t sitigma small, naked, oficn beaked or pointrol.

+ Rootstock fleshy and thickened, never filiform nor producing rumers; flouers violet or purple (rarely white); lateral petuls bearded.

2. V. pedatífida, G. 1)on. Leares all palunately or peditely 5 - 7 -parted; divisions 2-3-cleft; lubes linear; otherwise like n. 3. (V. dehlinifolia, Nuth.) - Kich prairies, or more often in dry poor laud, 1ll, to Kam, and Minm.

3. V. palmàta, L. (Comos But V.) Glabrous to villous-pubescent; anly leaves romelish-eordate or reniform and merely crenate, the siles rolled inward when young, the liter rery various, palmately or pedately or lastately lobed or parted, the segments oburate to linear. (V. cucullata, var. palmata, Gray.) - Nuist or dryish, especially sterile, ground; rery common.

Var. cucullàta, Gray. Later leares nierely crenate, not lobed. (V. cucullata, Lit.) - Iow groumds; commou everywhere. Botli forms are very variable in the size and shape of the leaves and sepals, and in the size and color of the flowers, which are deep or pale violet-blue or purple, sometimes white or viriegated witl white.

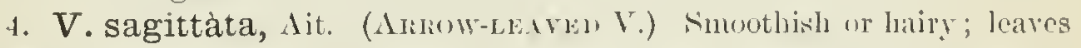
on short and margined, or the later often on long and naked petioles, varying from oblong-heant-shayed to haberd-shaped, arrow-shaperl, oblong-lancenlate. or orate, denticulate, sonctimes cut-toothed near the base, the lateral or oreasionally all the (mither large purple-blue) petals bearded; spur short aurl thick; stigma leaked. - I ry or noist sandy places, New Eng, to Minn., and soutluward. Sone forms paiss into the last.

$$
\begin{gathered}
+++ \text { Lootstocks long and filiform, extensively creeping. } \\
=\text { Flowers blue or purple. }
\end{gathered}
$$

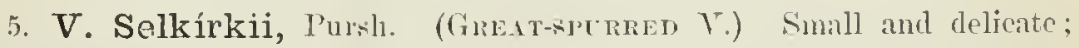
the filiforu rootstock fitrose-rootel, no rumers above ground; smooth, exeept the romd-heart-shaped crenate leaves, which are mimntely hairy on the ipper suface and have a deep narrowed sinns; spur very lurge, thickened at the encl, almost as long as the liearlless pale violet petals. - Damp and shady soil, N. Matine to Wr. Mass., centlal N. Y., I, Snejeriol (Robbins), anıl northwated ; rare. - Scatpes and petioles 1-2', the leaf $\frac{1}{2}-1 \frac{1}{1}$ long, thin ; the spur 3" long. (En.)

6. V. palústris, I. (Mhlisu T.) Sinooth; leaves lound-heart-shaped and kirlney-form, slightly crenate: flowers (small) pale lilac witl purple streaks, nearly hearlless; spur wry short and ohtuse. - Mlpine sumnits of the White Momutains, N. Il., and ligh morthwarl. June. (Eu.)

V. onomita, I. (Siwter V'roffT), cultirated in rardens, from Europe, belungs near this group, and is sparingly spontanesus in some places.

$==$ Flowers rhite (smull, short-spurred), mostly with broun-purple veins; lateral petuls becurded or butrdless. Species apparemtly ennfluent.

7. V.blánda, Wille. (Awis: Winte Y.) Commonly grlahnons; leaves round-heart-shaped ur kiduey-forun; protals mostly lonelless, the lower strongly reined. - I anup places, creywliere. Flowers faintly swort-kented.

Var. palustriformis, (iray. The larger form; upper surface of the

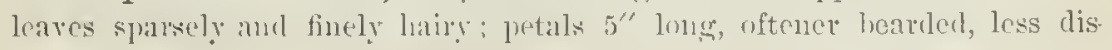

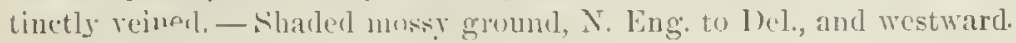


Var. renifolia, Grar. Slightly or strongly pubescent with soft spread. ing hairs; leaves romnd-reniform; petals usial]y learlless. (V. renifulia, Gray.) - Maine to Miss., Western X. Y., Lake Buperior, ete.

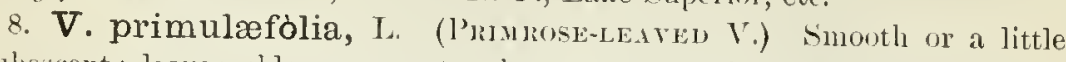
pubscent; leaves oblong wr orate, abrupt or somewliat lieart-shaped at the hase; petals often acute, the lateral ones usually sparingly bearded. - Damp or dry soil, N. Eng. to Ir]a., towarel the coast.

9. V. lanceolàta, I. (LAsck-Livil, Vrofli.) Smootli; leaves lanceolate, erect, blunt, tajering into a long-marginel jectiole, alnost entire; petals beardless. - Damp soil ; common, especially eastward.

$$
==\text { Filouers yellou. }
$$

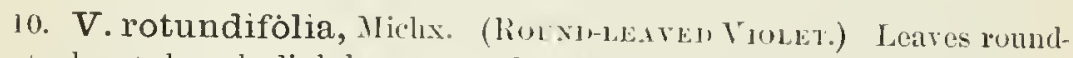
ovate, heart-shaped, slightly crenate; lateral petals hearded and marked with brown lines; spur very short. - Cold workls, Maine to Minn, and sonth along the Alleghanies. - Sunvotlish, leares $1^{\prime}$ loroad at flowering, increasing to 3 or 4 ' in the summer, then lying flat on the ground, shrining above.

* Leafiy-stemmed; all peremial with short roolstocks:

+ Low, at first nearly stemless; flowers yellow; stigma concare, bearded.

11. V. Nuttàllii, l’ursli. I'nbescent ur nearly glabrous; leares ovate to oblong-lanceolate, obtuse, entire or slightly crenate, decurrent on the petiole. - Central Kansas and westward.

+t +- Stems erect, without root-leares: stipules entire; spur rery short; stigma beakless, pubescut.

++ Stems naked belou; Houcers yellow.

12. V. pubéscens, Ait. (Dowsy IELLow V.) Suftly pubescent (6$12^{\prime}$ high); leares very broadly heart-shaped, tootherl, sonewliat pointerl; stipules vrate or ovate-lanceolate, large; lower petals veined with purple, capsus]e oblong to globular, glabrous or tomentose. - Wouls; common. - Var. Ac. mwitscrta, Torr. \& Gray, smaller and greener, sliglitly pubescent $\left(4-10^{\prime}\right.$ high). - R. I. to Ky, and sonthwestwart.

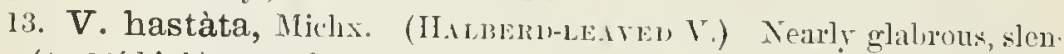
der $\left(4-10^{\prime}\right.$ high $)$; stem-leares halberd-shaped or oblong-heart-shajed, slight]y serrate, acute; stipules orate, small. - Woxls, N. O)lio (near I'ainesville, Miss Shattuck), monntains of P'enn, and sontleward; l'are.

+t+ Stems more lenfy and molonged; flowers uhite or purplish

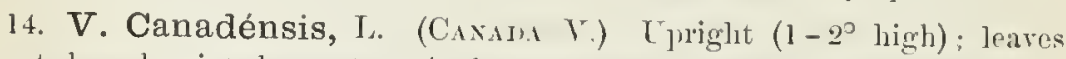
heart-shajed, pointerl, surate; stipules ovate-lanceolite, entire; petals white or whitish inside, the njuer ones nustly tingerl with siolet leneath, the lateral hearted. - Rich woods; common northwarl and along the Alleghanies. May - Aug.

+ + + Stems erert or spreating (at first nearly araulesernt) : stipules fringe. toothed; spure whlong to cylindricul; stigma nalied.

15. V.striàta, $\Lambda$ it. (l'A LE V.) Stems angular, ascending $\left(6-10^{\prime}\right.$ high $)$; leaves heart-shajeci, fincly scrrate, often aente; stipules oblong-lanceolate, large; spur thachish, much shorter thun the rorim-rolored or white petals, the 
lateral ones bearded, the Iower striped with jurplish lines; stigma liealied. Low grounds, W. New Eng. to Minn. and Mo., and soutluadrd in the mountains. April-Oct.

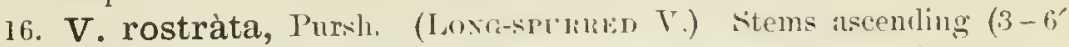
ligh); leaves roumbish-heart-shaperl, serrate, the upper acute; stipules lan-

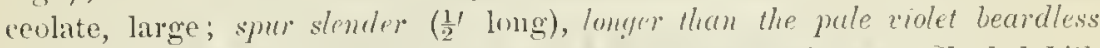
petals; style straight and slemiler' stigna teminal, heakless. - Shaded hillsides, N. New Eng. to Mich., and southwat iu the Alleghanies; rather rare Jume, July.

17. V. canina, I, var. Muhlenbérgii, Grạ. (Dor T.) I.ow (3-8 high), mostly gliblous; stems ascending, mostly simple, from the base at length prolucing 'reeping luanclues; leaves leart-shaped, or the lowest kidney-form, crenate, the uppermost slightly jointerl; stipulcs lanceolate; spur cylindricul, hulf the lenyth of the light riotet petuls, the lateral ones slightly bearded; stigma heaked. - Damp or wet sharly places; common. May-

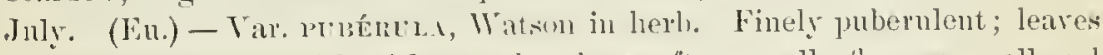
mostly ovate and acutisl with a corlate lase, ofteu small ; Howers small and mostly cleistogamous. - Simdy or stomy shores and islamds of Lakes lluron and

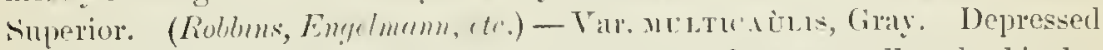
and stoloniferons; flowers mosty cleistogamous; leaves small, suborbicular to reniform. - Kyy. to Filı. and 'linx.

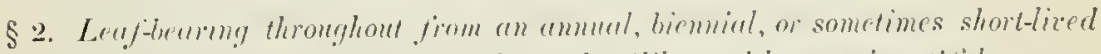
peremmal ront: the stipmles large, loriftilie and lyrate-pimatifid.

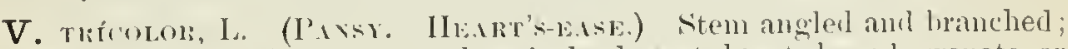
leaves rommlish, or the upler oval amcl the lowest heart-shaped, crenate or cutire; petals variable in ("ulor ur a aregated (yellow, whitish, violet-b) ane and

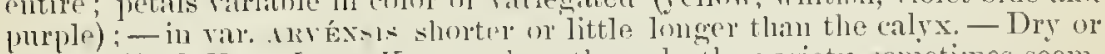
sandy soil, X. I. to Iowa, Kin., and somthwart; the varety sometimes seeming like a native plaut. I pull-sept. (Nat. from lin.)

\section{S Ò L $\mathbf{E A}$, siremg., in part. Grees V'rolet.}

Sepals not prolongerl at the hise. l'etals neuly equal in length, but the lower one langer and gibhoum or silcuate at the lise. more notclued than the others at the apex. Stamens completely miterl into a sheath enclosing the ovary, and hearing a liroal gland on the lower side. Style hooked at the summit. - I lonely jeremnial herl, with stens leafy to the top, and $1-3$ small greenish-white flowers in the axils, on short reeurver pedicels. (Named in honor of 11 . wiole, anthor of an essay on the Britisl Mints.) .

1. S. cóncolor, Ging. l'lant $1-2^{\circ} \mathrm{lighl}$; leives oblung, pointed at hoth encls, entire; poul I'long. - Wools, N. I. to Kam., and southward. June.

\section{I O N I D U M, Tent.}

Sepals not prolongerl at hase. Petals very nnequal, the two upper shorter, the lower longest and larnest, concave at base, contracted in the midlle, Filaments distinct, the two lower witl a scale-like gland or spur at base; anthers merely comnivent. - l'eremials, branching and leafy, with alternate and opposite leaves, and small axillary flowers. (Name from tov, violet, and eioss, uppearance.) 
I. I. polygalæfolium, Vent. Stems low, from a woody hase; leaves linear to oblanceolate, or the lower obuvate, entire, the stipules leaf-like or small or none; Howers solitary, nodling, $2^{\prime \prime} \mathrm{long}$, white. (I. lineare, Torr.) - lian. anl sunthwestward.

\section{ORder 15. CARYOPHYLIACLAC. (PINK FAMLY)}

Herbs, with opposite entire leaves, symmetrical 4-5-merous flowers, with or without petals; the distinct stamens no move than twice the number of the sepals, either hypogynous or perigynous; styles $2-5$ (or ravely united into one); seeds several or usually many, attached to the base or to the central column of the 1-celled (rarely 3-5-celled) prod, wilh a slender embryo coiled or curved around the outside of mealy ulbumen, in Dianthus nearly straight. - Bland herbs; the stems usually swolken at the joints; uppermost leaves rarely alternate. Leaves often united at the basc. Calyx persistent. Styles stigmatic along the inside. Seeds amphitropous or campylotropous.

Tribe I. SILENEA. Sepals unitel into a tube or cup. Petals (mostly convolute in the bud) and stamens (10) borne on the stipe or stalk of the ovary, the former with slender cluws, to the hase of which the corresponding filaments often adhere, ineluded in the enlyx-tube. Seesls numerous. - Stipules none. Fluwers often large and showy.

* Calyx with sealy bractlets no small leaves at the base. Sceth llattener on the back, attached ly their face: embryo nearly straight.

1. Dianthus. Calyx tepete, mostly cylindrical. Styles ¿.

* *alyx naked. Seeds globular or kirlney-shaned; eminryo curved or coiletl.

2. Gyusopbila. Calyx top-shaped or campanulate. Pod deoply 4-valved Styles 2.

3. Saponaria. Colyx oblong-eglindrical, obscurely nerverl, terete on s-inglerl. Pod slontly 4-valverl. Styles 2.

4. Silene. Caly 5-tuothed, 10-nerved. Styles 3.

5. Lychnis. Calyx 5-tootherl, 10-nerverl. Styles 5, rarely 4.

Tribe I1. ALSINFA. Sepals distinct or nenly so, imbricated in the lum. Petals when flesent withont elaws, mostly imbrieatul, and with the stamens inserter at tho base of the sessile ovary, or into a little disk. Poxl splitting into valves or teeth, severalminy-seeded. Strmens opposite the sepals, when not more in mumber. - Low herbs.

* Stịnules nome.

- Styles opposite the sepals, or, when fewer, opposite those which are exterior in the bul. th Por short, splitting into as many vialyes as styles: valyes often hitil or 2-parteil.

6. Arenaria. Petals chtire. Styles usually 3. Valves of the pol entire, hificl, or 2-purted.

7. Stellaria. Petals 2erleft nu none. Styles usually 3. Valves hiful or 2-parted.

++ Pod eylimlrieal, dehiscent hy twive as many rqunal tertl as styles.

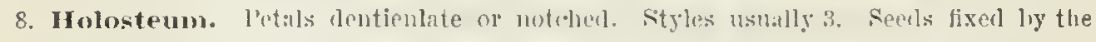
face.

9. Cerastium. Potals notehed or 2-eleft. Styles 5 or t. Speds fixed elgewise. +- + Styles alteruate with the sepuls. Stinıns is many, or twiee as many.

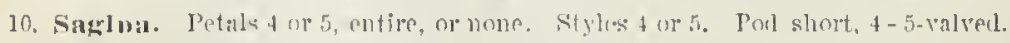
* Etipunles prosent. roul slinrt.

11. Burla. Styles 3. Pol 3.ralved. Leaves oplosite.

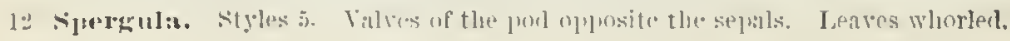




\section{DI Á. - IUUS, L. P'NK, CARATION.}

Calyx rylinlrical, ucrvat or striate, 5-toothed, subtended ly 22 or more imbricated hiatlets. Stameas 10 . Sityles 2. T'url 1 -celled, 4-ralied at the apex.

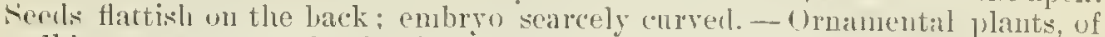
well-known aspect aud value in cultivation. (Nane from $\Delta$ ós, of Jupiter, aud

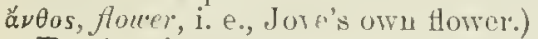

D. Armìnia, L. (Dertforu I’ıк.) Anmual; flowers clustered; bractlets of the calyx aud brarts lume-anr-form, licrlaceons, downy, as long as the tube; leaves linear, hairy; jetals smill, rose-color with white clots, crenate. Ficlds, etc., eastward. July. (Adr. from Eu.)

D. puólffer, I. Annual, smouth, slenter; flowers elusteresl; bractlets orute, $d r y$, concealing the calyx; leaves few; narow, linear, elect; petals small, piuk, - N. J. and E. l'enin. (A (h. from Eu.)

D. Díltoldes, L. (MAmex I'ixk.) l'erennial; leaves short, narowly lanceolate, clowny and roughish; flowers solitary; loracts ovate, lablf as long as the tube; petils ruse-color or white, toothect. - Micls., L. II. Bailey. (Nat. from Eu.)

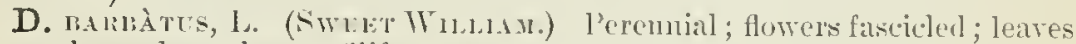
large, lanceolate; bracts filiform-attennate, equalling the ealyx. - - juaringly spuntancols. (Aclv, from lin.)

\section{GYPSÓPHILA, L.}

Calyx narrowly top-shaped or (:mupanulate, 5-nerverl, 5-tootlied, naked at base. I'etals not crownerl. Staneur 10. S'tyles 2. I'od 1-erelled, 4-ralved at the apes, sessile. - Slenrler glancons ammuls or perennials, witl numerous

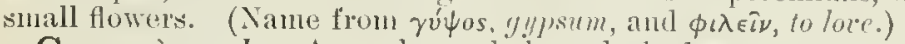

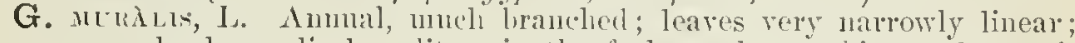
flowers on slender pedieels, solitary in the forks; calyx turbinate, the teetli short, olntuse; petals purplish, crenate or enarginate. - Siparingly naturalized. (Nat. from Lu.)

\section{SAPO N À R I A, I.}

Calyx narrowly oroid or whlong, 5-tootlued, ohsenrely nerred, naked. Sta-

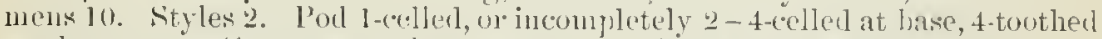
at the apex. - Coarse ammals or perennial, with large flowers. (Nime from supo, soup, the mucilaginous juice forming a lather with water.)

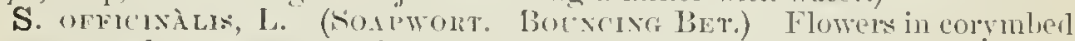
clusters ; calyx terete; petals clowned with an appendage at the top of the claw; leaves oval-linceolate. - Roadsides, etr. July - Sejet. - A stout perennial, with large rose-eolored flowers, commonly double. (Aelv. from liu.)

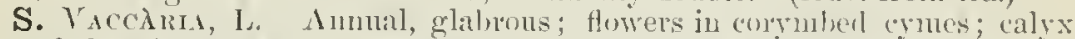
5-angled, enlarged and wing-angled in fruit; petals pale red, not crowued; laves orate-lanceolate. (Vaccaria vulgaris, /Iost.) - Uccasionally spontaneots. (Aclv. from Iin.)

\section{SILENE, I. CATrnly. CMmon.}

Calyx 5-tontled, 10-many-nerved, naked at the hase. Stamens 10. Styles 3, rarely 4. Porl 1-celled, sometimes 3-eelled at lenst at the lase, opening by 3 or 6 tectl at the apex.- Flowers sulitu'y or in cymes. I'ctals mostly

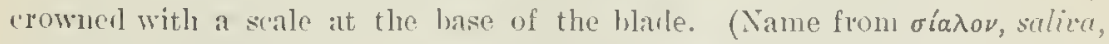
from the viscil exulation on the stems and calyx of many species. 'The English nane Cutchfly allules to the same peculiarity.)

* Ducarf, alpine, tujted, smooth, premial; flowering shoots I-flonered.

1. S. acaùlis, 1. (Moss Campos.) 'Tufted like a moss (1-2' lighli);

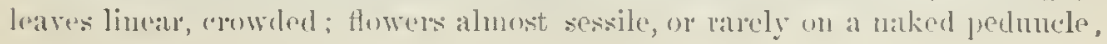


petals purple or rarely white, notched or entire, crownel. $-\Lambda$ pine summits of the White Mountauns, X. II. July. (Lu.)

* Calyx Uhuldery-inflated; peremial; flowers panicled, white, in summer.

2 S. stellàta, Ait. (Sxarny Campox.) Lentes in whorls of 4 , watelenreolufe, taper-pointerl ; calyx bell-slaped ; petuls cut info a fringe, crounless. - Woorled lanks, li. I. to Minn., ans sonthward. — Stem $3^{\circ}$ high, witl a large

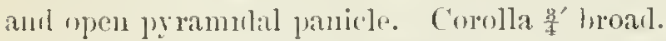

$3^{\circ}$ S. nivea, (1)th. Leares opprosite, lanceolate or oblong, taper-pointed; calyx whlong: prets uertge-form, 2-rleft, mimutely cromed. - Penn. to Iowa aul Mimn: rare - Sitem $1-2^{\circ}$ highl, almost smonth. Flowers few, larger than in the last.

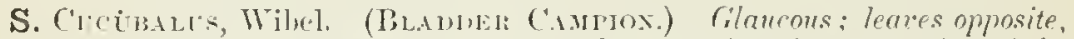

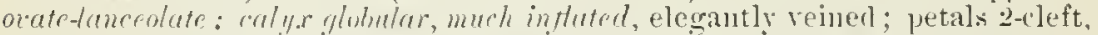
nearly (cownless. (S. inflata, smith.) - Fields and roarlsiles, ls. New Eng. to [11. - A foot lugh. Flowers lonsty (ymose. (Nat. from Eu.)

* * Calyx clongated or club-shaped. not inflated exropt by the enlarging pod;

flowers cymose or clustered : perennial, pubsecent with viscid hairs, rspecially the calyx: petuls round, red or roserestor.

4. S. Pennsylvánica, Miclı. (Wni Pıк.) Stems low $\left(4-8^{\prime}\right)$; root-leaves narowly spatulate, unarly glabous, tapering into hairy petioles; stem-lences (2 or 3 pairs) lunceolute: flowers clistered, short-stalked; calyx (lub-shaped; protuls werlye-form, slightly wotrhed and moded, pink. - Gravelly: places, E. New ling. tu N. Y., Ky, and sonthwarl. April-.Jume.

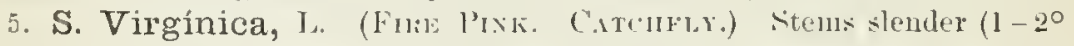
ligh); leares thin, spatulate, or the uppor oblong-lancrolate: flovers feut and loosely cymose, pedmuclen; calyx oblong-cylindrical, soun obeonical ; jetuls ublong, 2-rleft, deep rimson: the limb l' long. - Open wouds, westeru X. I. tu Minn., and soutluarel. June-Aug.

6. S. règia, Sims. (Iioral, C.trurter.) Stem roughish, erect $\left(3-4^{\circ}\right.$ high); lerares thickish, orate-lanceolate, acute; floners mumerous, short-stalled, in clusters, forming a strict panicle; cal rx orvid-elul,-shapen in fruit; prtals

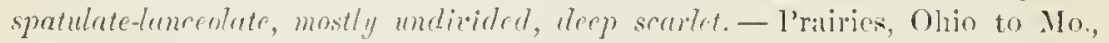
and sontliward. Jnly.

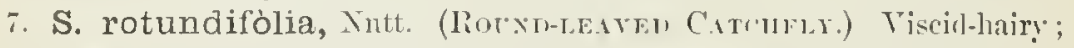

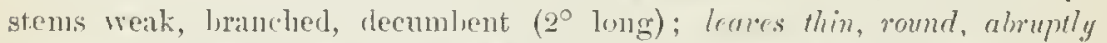
pointed, the lower olowate; flowers few, loosely cymose, stalked; calyx elon-

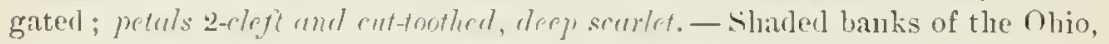
and in Kiy. Jume-Ang. - Leaves mul flowers large.

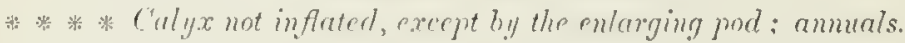

+ Cilchous, a portion of cach joint of the siom glutinous ; flowers pink.

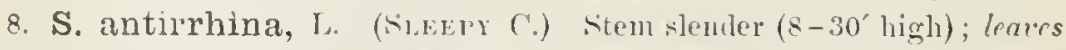
lanceolate or linere; flowers small, panicnlate; raly.r moid: petals obcorclate, crowned, opening transiently in sunsline.-1)ry snil; common in waste places. Inue-siept.

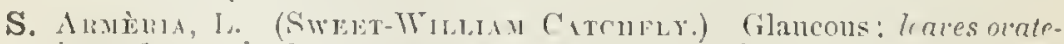
lomerolate; flowers in that eymes, olen ill sumshine; calyx club-shaped: petals notcherl, crowned with awl-shaped scales. - Lscaped from gardens; rare. (Adr. from En.) 
L t Hiscid-pubeseent; flowers white or nearly so, oprening at night, sueet-scenterl.

S. Noctúns, l. (Nignt C.) Leaves slort, the lower spatulate, the upper linear; floners small, altermute in a 1-sided spilie; petals 2-parted. Introduced sparingly in l'a., according to schueinita. (Adv. from Eus.)

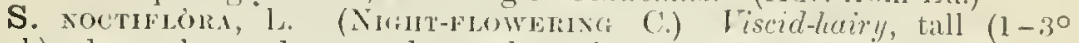
high); lower leaves large and spatulate, the upper lancelate; Howers for, peduneled; calyx-tule elongated (over l' long), soon ovoid, with awl-shaped teetlı; petals rather large, 2-parted, crowned. - Cultivated grounds.

\section{I Ý CH N I S, 'Tourn. C'оскL:}

Sityles 5, rarely 4, and pod opening by as many or twice as many teeth, ctherwise nearly as in vilene. Calyx in one sjecies witl leaf-like lobes.

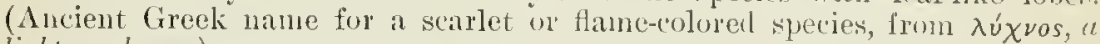
light or lampr).

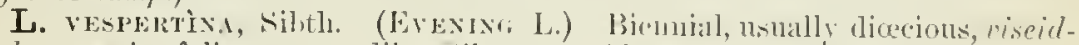
pubeseent, in foliuge, ete, like silene noctiflüa but 5 styles, ealyx much shorter (7-9" long), with lance-linenr teeth, and flume's white or pinkish, opens ing at evening. - (ult. or waste gromuls; scarce. (Mdv. from lun.)

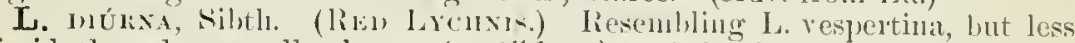
viscid, the calyx usually slorter $(t-6$ " long), and the Howers red, opening in the morning. - Ramely" spontanenus. (Adr. from lin.)

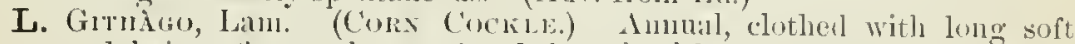
appressed hairs; Howers long-pednucled; culy.x-lubes similar th the lomig and lineur leaves, surpatssing the brual and crownless purple-red petuls, falling off

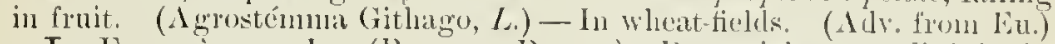

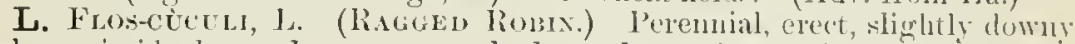
below, viscid above; leaves narrowly lanceolate; flowers in loose janicles; calyx sloort, glabrous; petals red, 4-lobed, lobes linear. - Moist or marshy places; New Eng. and N. Y. (Adr. from Eu.)

\section{A RENARIA, L. S.кинопт.}

Sepals 5. P'etils 5, entire, sometines barely notelecl, rarcly wanting. Stamens 10. Styles 3, rarely more or fewer, oplrosite as nany sepals. I"ud short, splitting into as many or twice as many valves as there are styles, few-manyseeded. - low, usually tufted herbs, with sesile exstipulate leaves and smill white flowers. (Name from arena, sand, in which many of the species grow.) - The following sections are by many hotanists taken for gencra.

\$1. ARENARIA proper. Pod splitting wholly or partucay dencn into $3 \mathrm{or}$ at length into 6 ratees; seeds many, nuked at the hilum.

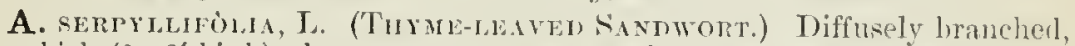
roughish $\left(2-6^{\prime}\right.$ high) ; leaves ovate, alcute, suall; cymes leafy; sepals lancenlate, pointerl, 3-5-11erverl, ahout equalling the petals and 6-tiothed pod. - A low annual; sandy waste places. June- $\Lambda \mathrm{ng}$. (Nat. from En.)

\$2. ALStNe. Pud splitting to the base into 3 entive valces; seeds many, usually rough, naked at the hilum; fowers sulitury and tcrminal or cymose; root in our species perennial, except in $\mathrm{n} .4$.

* Lerees small, rigid, and-shaped or bristle-shaped.

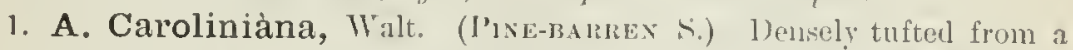
deep perpendicular root; Iours slosely imbricated, hut sprealing, aul-slerperl, short, chunnelled; branches naked and inimutely glandular above, several-fowered; sepuls obtuse, ovate, slorter than the purl. (1. spuaruesa, Miclir.) - In pure sand, s. New York, X. J., and southwarl along the coast. May - July.

2. A. Michauxii, Ilook. f. Erect, or usually diffusely sprealing from a small root, smootlı; leaves slender, between awl-shaped and bristle-form, with 
many nthers clustered in the axils; eyme diffuse, naked, many-flowered ; sepals minted, 3-ribbed, orate, as long as the pol. (A. stricta, Michx.) - liocks and dry wooded banks, Vt. and Penn. to Miml, Mo, aul southwestmard. July.

3. A. vérna, L. Dwarf, alpine, densely matted, glabrous or (var. mirs) somewhat pubescent, 1-3' high; leaves narrowly linear or awl-shaped; flowers loosely eymose; sepals lauceolate. pointerl, 3-nerred, shorter than the pod.

- Smuggler's Noteh, Irt. (Pringle); north and westward. (En.)

* Leares soft and herbaceous, filiform-linear; petuls retuse or notched.

4. A. pátula, Michx. Diffnsely limelsed from the slender root; stems filiform $\left(6-10^{\prime}\right.$ long); lmanches of the cyme diverging: peduncles long; sepals lanceolate, acuminate, 3-5-nered. (1. I'iteheri, Nutt.)-S. IT. Ta. to Kr., ill., Kan., and sontliw:arel.

5. A. Grœnlándica, spreng: (Morstax s.) Densely tufted from slender roots, smootls; Howering stens filiform, ereet (2-t' high), few-flowered; sepals oblong, uhtuse, nereless. - snmmit of thr shawangunk, Catskill, and Adiroulack Mountans, N. I., of the higher monutains of New Fug., and nortlinard: alpine ol subalpine, At Bath, Minine, on rirer-banks near the sea, and near Mlichlletown, Ct. June-Ing, - Leares and pelnucles $3-6^{\prime \prime}$ long; flowers large in proportion.

\$3. MeEHRfxGLA. Parts of the flower sometimes in fours: pod as in $\$ 1$, but the youny orury 3-celled: sects rather fex, smooth, with a thiekish uppendage (strophioh) at the hilum; premnials, with flaccid broadish laves.

6. A. lateriflora, l. Aparingly branched, erect, minutely pubeseent:

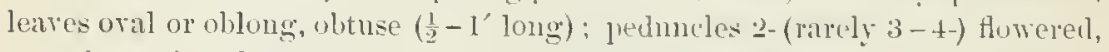
soon becoming lateril; sepals oblong, obtuse, - Gravelly shores, ete, New Eng. to P'enn., Mo., Minn., and uorthward. May, June, (Eu.)

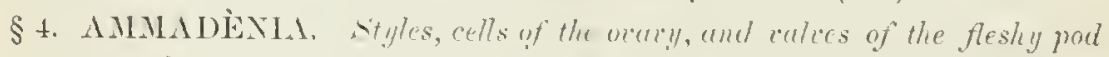
3 , ravely 4 or 5 ; sceds fex, smooth, short-beukut at the naked hilum; disk: under the orary more promment than usual, ylandular, 10-lobed; flowers almost sessite in the axits, sometimes diucions or polyyumous; root perennial.

7. A. peploides, l. Sitems (simple or forking from long rootstocks,

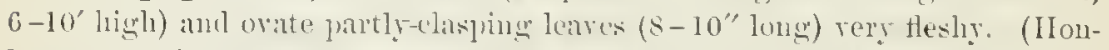

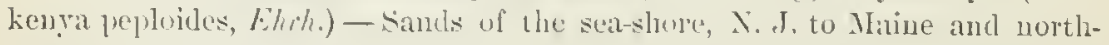
warl. Junce. (Eu.)

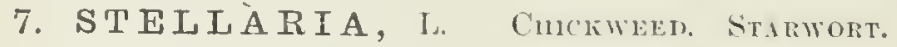

Sepals $4-5$. Petuls $4-5$, dreply 2-choft, sometimes none. Stamens 8,10 ,

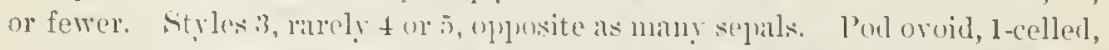
"pening by twice als many values as there are styles, several-many-seeded.

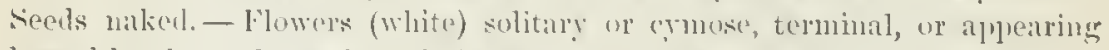
lateral by the prolongation of the stem from the upler axils. (Name from stella, a star, in allusion to lhe star-shap ped Howers.)

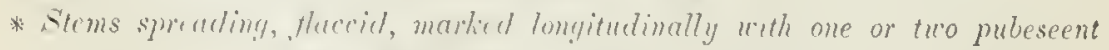

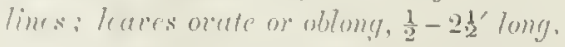

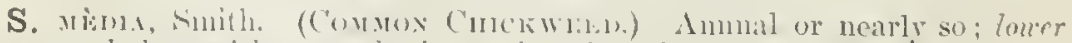

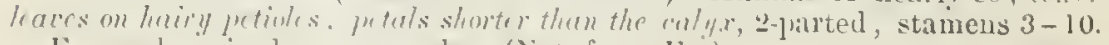
- Everywhere in elane anomels. (Nat. from liu.) 


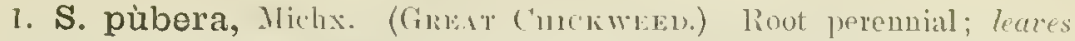
all sessile; petuls lunger than the caly.x, decply 2-cleft; stamens 10. - Slauded rocks, Penn. to lnd., and southward. May.

* * Stems erect or spreadiny: uholly glabruns peremials, with sessile and nar. rou or small leures; stamens usually 10, wrigynous.

+ Sraly-lracted; petals 2-parted, equalling or surpassing the calyx.

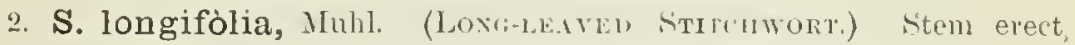
weak, often with rough angles (8-18' high); hates limear, acutish at both ends, spreading; cymes melied and at lenyth iateral, pulumeled, maly-Howered, the stender pedicels spmeading; petals 2-parterl, longer than the colyx; seeds smooth. - Grassy pliacs; (common, especially noutluwarl. June, July. (Eu.)

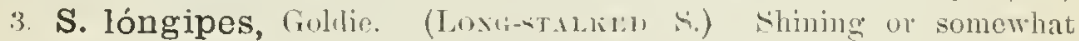

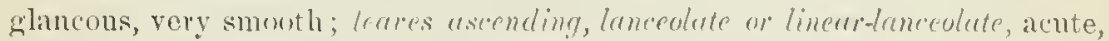
bruadest at the base, lather riginl; cyme terminal, few-flowered, the long pedicets strictly erect: petals lonere than the cally; seeds smooth. - Maine to Minn, rare; comurun fartler north. (Wu.)

S. Gianfxis, I. liesembling the last; leares linear-lanceolate, broodest abore the buse; pedienls midely spreading: seeds strongly but minntely rugose. - Becoming rather frepuent." (Int. frim Liu.)

4. S. uliginósa, Murr. (kwм. S.) Stems weak, decumbeut or diffuse, at leugth prolungel, leaving the naked and usually scssile cymes lateral; leaves lenerulute or oblong, beiny; petals and ripe jods as long as the calyx; seds ronghened. - Swamps aul rills, Ml. to X. ling, and northward; rare. (Eu.)

+ + Flowers terminal or in the forks of the stem or of leafy branches: bracts foliaceons; petals 2-purted, smull or often none; styles 3-4; pod longer than the ealy.r.

5. S. crassifolia, Ehrh. Stems diffus or crect. flaccid; leares rather

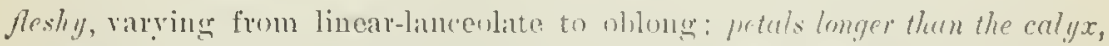
or wanting; seeds rugose-roughomed. - Siringr blaces, eastern liy. (Short), Riugwoul, Ill. (Tisey), and uorthwitul. April-June. (Eu.)

6. S. borealis, Bigel. (Nortnitis S.) stems erect or sprearling, flaceil, many times forked, at leugth resulved into a leafy "yme; leaves varying from

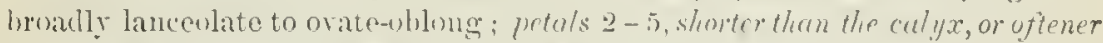
none: sepals acute; styles usually t; sffeds smonth. - Shaded or wet places,

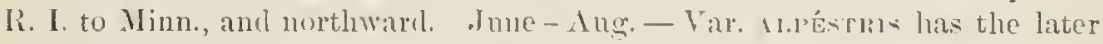
fowers more egmuse, aul their lincts small and partly scarions, also the seeds Juscurely retieulated or romghish. - Ialie superior, Dr. Robhins. (Eu.)

7. S. humifusa, Rutth. Aprealiug ur repring; steus or branches (2' high) 1-3-fowered; leares fleshy, orate on ublong (2-3" long); petuls a hatle longer than the calyx: seeds smooth. - Northern borter of Maine on the St. John's ( $\left(\dot{r}, L_{\text {. }}\right.$ (ioodule), and high uorthwite. June. (Lis.)

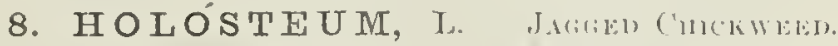

Sepals s. l'etals 5, msually jagred or denti"ulate at the point. Stamens

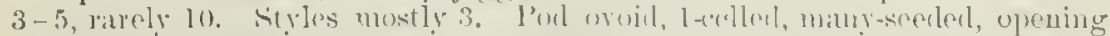

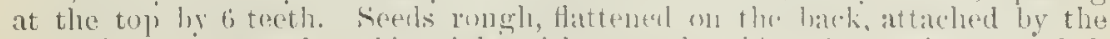

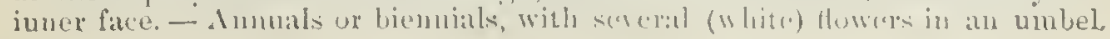


borne on a long terminal peduncle. (Name composed of ö $\lambda$ os, all, and $\dot{o} \sigma \dot{\tau} \dot{o \nu}$, bone, by antiphrasis, these plants being soft and tender.)

H. UMBELLAtin, L. Leares ollong; peduncle and upper part of the stem glandular-pubescent; pedicels reflexed after flowering. - lillls around laneaster, Penu., Prof. Porter, and Morris Co., N.J., C.F. Austin. (Nat. from Eu.)

\section{CERÁstium, L. Mouse-ear Chickweed.}

Sepals 5, rarely t. P'etals as many, 2-lobed or cleft, rarely entire. Stamens twice as many, or fewer. Styles equal in number to the sepals and opposite them. Pod 1-celled, usually elougated, membranaceons, opeuing at the apex by twice as many teeth as there were styles, many-seeded. Seeds rough. Flower's white, in terminal cymes. Our species have the petals 2-cleft or obcorlate, the parts of the flower always in fives, and the exserted pods more or less curved. (Name from répas, a hom, alluding to the shape of the pod in many species.)

C. Viscostu, I. (Molse-ear Cuicrweed.) Anmul, hairy and rather clammy, nearly erect ( $4-9^{\prime}$ high); leares ovate or obovate to oblong-spatulate: bracts herbaceons; flowers small in close clusters at first, pedicels even in fruit not longer than the acute sepuls; petals shorter than the calyx. (C. rnl. gatum, L. Kerb., and Man. The names of this aud the next were transposed in the fimnean herbarimm, which has cansed much confusion. They are liere applied as originally ly Limuans, and by numy recent botanists. (Uther's substitute for this the later name, C. glomeràtum, Thuill.) - Grassy places, eastwarl and southward; not common. May-July. - Stamens often 5. (Nat. from liu.)

C. Velratca, I. (LARger M.) Perenuial; stems clammy-hairy, sprealing $\left(6-15^{\prime} \operatorname{long}\right)$; leares oblong; npler hracts scanious-margined; flowers lurger (sepals $2-3$ " long), at first clusterert, the fruiting pedicels longer, the carlier ones mostly much longer than the obtuse sepals; pretals equalling the calyx. (C. viscosum, L. Herb., and Mun. C. triviale, Link.) - Fields and copses; common, perhaps indigenous. May-July. (Tat. from Eu.)

I. C. nùtans, Raf. Anmual, very clammy-pubesceut; stems erect, slender, grooved, diffusely branched (6-20' lighl); cyme loose and open, manyflowered: leares oblong-lanceolute, acute, the lowest spatulate; peduncles mostly elongated; petals longer than the calyx; pods nodding on the stulks, curved upuetrd, thrice the length of the culy.x. - Muist plaees, Vt. to Minn., and southward. May-July.

2. C. arvénse, I. (Fnı, CHIKWLEn.) l'erennial; stems ascending or erect, tufterl, downy or nearly smooth, slender ( $4-8^{\prime}$ ligh $)$, naked and fewseveral-flocered at the smmmit; lenes linew or nurrouly lanceolute; petals obconlate, more than twice the lengtli of the calyx; pods srarcely longer than the calyx. - 1)ry or rocky places. May - Jnly. (En.)

Var. oblongifolium, 1loll. \& Britt. ¿sually taller, pubescent; leares narrowly or broally ollong or ollong-lanceolate; por abont twice longer than the calyx. (C) oblomgifolium, Tom.) - locky places, X. Y. to Minn., and southward. - Viur. vinó-Lu, IIoll. \& Britt. Similar hut densely villous-pubescent, aud the lawes lancenlate to wate-lancenlate - F. l'em.

\section{SA G I N A, L. I'lahwort.}

Sepals 4 or $5 . \quad$ l'etals 4 or 5 , mulivided, or often none. Stamens as many as the repals, rarely twice as many. Styles as many as the sepals and alterpate with them. lou many-seeded, 4-5-ralred to the base; ralres opposite 
the sepals- - Little, matted lierbs, with threal-like or awl-shaped leates, no stipules, and small flowers termilating the stems or branches; in summer. (Name from sagına, fattening; previonsly applied to the spulry.)

* Parts of the flower in fontrs, retrely with some fow in fircs.

1. S. procúmbens, L. Ammal or pereunial, depressed or spreuding on the ground, glabrons; leaves linear-thread-slutjed; "pex of the peduncle offen hooked soon after thowering; petals shorter then the hroatly orate ohtuse sepuls, sometines none. - springy places and damp rocks, coast of Maine to I'emu. (Eu.)

2. S. apétala, I. Ammul, erect or ascending; leaves ciliate at loase or glabrous; petuls none or rery small; peduncles uherays erect. - Dry soil, Mass. to Peun.; scaree, seemiugly native! (Fu.)

* * P'trts of the flower in fives, the stumens not ramely 10.

3. S. decúmbens, Torr. \& Gray. Ainual, ascending; the peduncles and caly with the margins of the mper leaves at first ghundular-pubscent; leares short, often bristly-tipled, not fascieled in the axils; pedunclesslender ; pelals equalling or shorter than the calyr: jout oblong-olate, nearly twice longer than the acutislo sepals. (S. sululata, Mom., not Mimm.) - E. Mals.s, to Ill., Mu.,

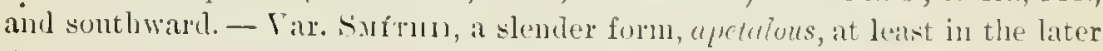
flowers. - Near Philadelphia, in waste gromu, ambl in sandy fichls at foners' l'oint, N. .J., C'. F. s゙mith. Seeds minntely rongheneel.

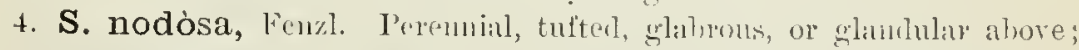

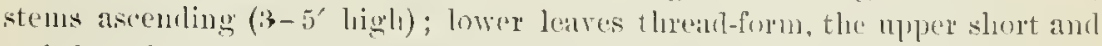

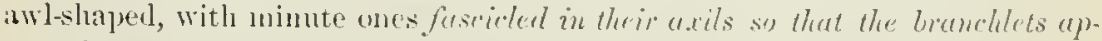

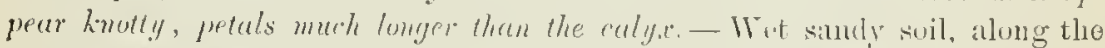
coast of Maine amel X. H., also Lake Superior, and morthward. (Eiu.)

\section{B Ù D A, Mlans. SAxu-soterlir.}

Sepals . T. Petals 5, entire. Stamens 2-10. Styles and valfes of the many-

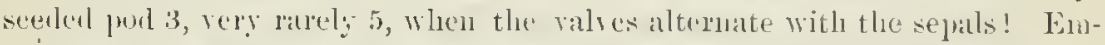
bryo not colled into a complete ring - Low heriss, mostly on or near the sea.

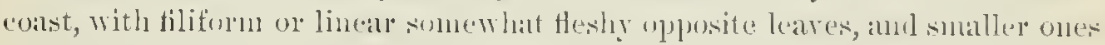

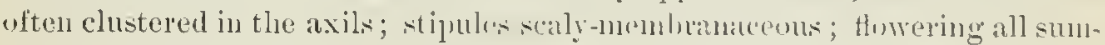

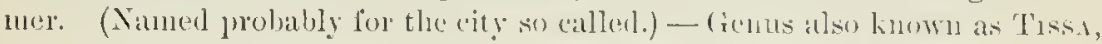

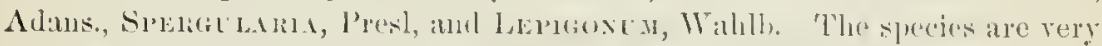

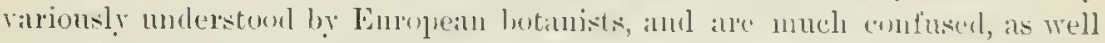
as the simonymy. Onl forms are anmat, or at the most linminal.

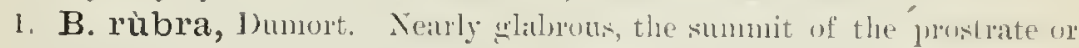

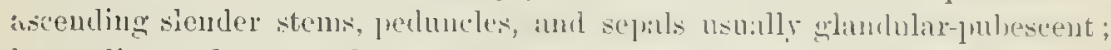
leaves linear, flat, scancely llasly; ; stipules lanceolate, rantire on clcft; peelicels

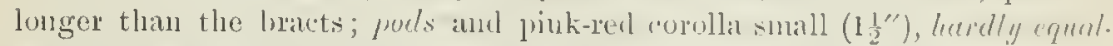
ling or cacededing the calyx; sceds rough with projerting points, semi-aborate or

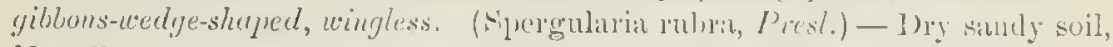
New Eng. to Ta., along and neall the coast, but ratrely maritine. (lin.)

2. B. marina, 1)unort. More decielelly fleshy than the preeceling, erect o! ascending, usually pubescent, with orate stipules, terete leaves, and pedi-

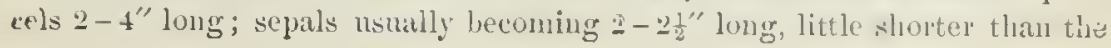


pod; petals pale; sects oboute-roundert and rouglemed with points, wingless or narrow-winged. (Spergularia salina, Pres. Tissa marina, Britt.) - Brackish sands, cte., coanst of $\mathrm{N}$. king. to Ya., and wonthward. A form with smooth seeds is var. Lentosprem, N. E. Brown. ('s. media, l'rest.) (Eu.)

Var. (?) minor, Watson. Small, iscending or decumbent ; flowers smaller, on shorter pedicels (milely $2^{\prime \prime}$ long), the sepals and pod $1-1 \frac{1}{2}{ }^{\prime \prime}$ long ; sceds wingless, usually papillose. - Coast of X. 11 . and Mass.

3. B. boreàlis, Watson. Diffusely hancherl, glalurms; pedicels nsually 2-4" long"; petals whitr; porl wate, 2" loug, alknit twice longer than the sepals; secus nsually wingless, smooth or uearly so. (Tissa salina, Britt.) On the coast, E. Maine to Labrator.

\section{SPERGUIA， L. SPritir.}

Stamens 5 m 10. Styles 5. The 5 valves of the poil opposite the sepals Jombryo spirally" inumlar. Leaves in whorls. Otherwise as in Buda. (Namm from spargo, to scatter, from the: eds.)

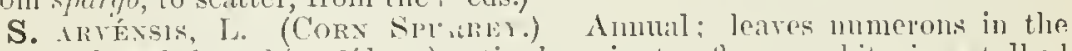
whorls, thread-shaped (1-2' long); stipules minuts: flowers white, in a stalked panicled cyme, seeds rough. - Grain-fields. (Aḷt. from lin.)

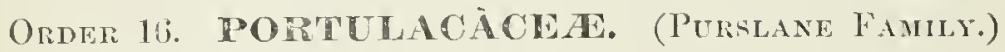

Herbs, with suesulent leaves, and regular but unsymmetrical flowers. viz.. sepuls fever than the petals; the stamenss opposite the petuls uthen of the same number, but often indefinite, ollerwise nearly.as ChickweedsSeprals 2. Petals 5, or sometimes none. Stamens mostly 5-20. Styles 2-8, united below, or distinet. stigmatic along the inside. Pod 1-cellech with few or many canplotropous seets rising on stalks from the hase. Embryo curved aromel mealy allumen. - Insipid and inuocent lecrls. with entire leaves. Corolla opening unly in sunshine, mostly ephemeral, then sluivelling.

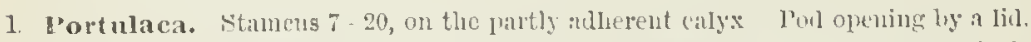

2. Talinum. Stamens more numerons than the petals, lyghygnons Calyx deciduous. Pot many-sected.

3. Claytonia. Stamens as many as the hypogyons petals, anul attached to their base. Calyx persistent. Pod $3-6$-semled.

\section{P ORTULÀ CA, Tourn. l'untane.}

Calyx 2-cleft; the tule colering with the orary loclow. Petals 5, rarely 6. inserted on the caly $x$ with the $7-20$ stamens, fugacions. Style mostly $3-8$. parted. P'nd l-celled, globular, many-secoled, opening transtersely, the mper

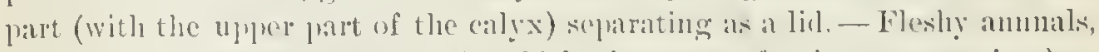
with mostly sattered leares. (Au olel hatin name, of moknown meaning.)

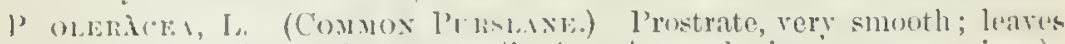

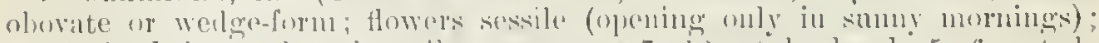

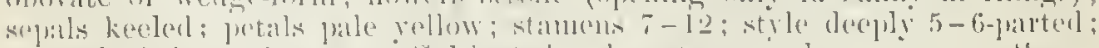

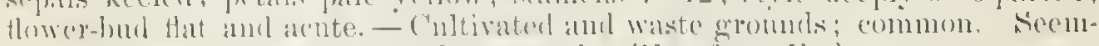
ingly indigranus west and sontluestwanl. (Natt. from lin.)

1. P. retusa, lingelun. Leaves often retuse: cally-lobes olluse in tho bud; petals sunall or minute; style slurter, 3-4-cleft; seeds larger, sharply 
tuherculate; otherwise like the last. - Mrk. to Tex. and westwarl; rejorted from Kan., Iowa, ancl Minı.

2. P. pilosa, I. Aseending or sprealing, eopinusly latry in the axils; leaves linear-subnate, nearly terete, $3-6^{\prime \prime}$ long; petals red or purple. - Kius. to 'Tex., etc.

\section{TALI N U M, Alans.}

Sepals 2, rlistinct aud free, reciduous. l'etals 5, ephemeral, Stameus 1030. Style 3-lobed at the ajex. l'ol 3-3elled at the hise when young, is-valverl, witl many seeds on a glolular stalkerl placenta. (1)erivation olscure.)

1. T. teretifolium, I'ursh. l'erennial; leafy stems low, tuherous at base; leaver linear, c'ylindrical; peduncle long (3-6') and naked, bearing an open erme of pink flowers (g' loroul); stameus 15-20. - Serpentiue rocks, l'enn., to hud, Minn., and southward. June- $\mathrm{Aug}$.

\section{CLA Y TO NIA, Gronuv. Sprixg-Biati}

Sepals 2, ovite, free, persistent. Stamens 5, arlhering to the short claws of the petals. Style 3-cleft at the apex. Forl 1-cellecl, 3-valverl, 3-6-seceled.Our two specios are perennials, sonding up simple stems in early spring from a suall decp tulne, bearing a pair of opposite leaves, and a lonse racene of pretty flowers. Corolla rose-color with leeper reins, opening for more than one day! (Nimed in honor of Di .John Clayfon, one of our calliest botanists, who contributed to Gronovins the materials lon the Flora Virginica.)

1. C. Virgínica, I. Leaves linear-lancenlate, elongaterl (3-6' long). Mloist open wooks; common, especially westward and sonthwarel.

2. C. Caroliniàna, Michx. Flowers rather smaller and fewer; leaves Fpatulate-oblong or oval-linceolate (1-2' long). - Maine to Minn., and soutlwarl along the Alleghanies.

\section{ORDER 17, ERATINACLAE. (WATER-WORT FAMIL.)}

Litlle mursh annuals, will memlwanaceons slipules between the opposite dolless leures, minute axillary flouers lite those of the Clinckweeds, but the pod 2-5-celled, and the seeds as in st. Joln's-wort. 'The principal genus is

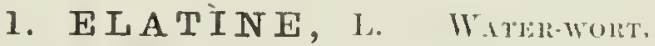

Siepals $2-4$, persistent. l'etals $2-4$, hypggyous. Stamens as many, rarely twice as many, as the petals. Sityles, or scsile capitate stigmas, $2-4$. l'orl membranacens, glohose, 2-4-celled, several-many-seculed, 2-4-ralred ; the partitions left attacled to the axis, or evanesent. Seeds cylindical, straight-

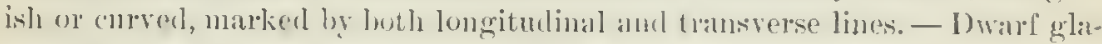
mons plants, usually rooting at the nodes, aquatic or teroestrial. (A Grers mane for sone ohscure herb.)

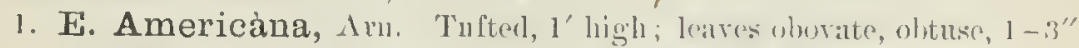
long; flowers sessile, varely opening in the anutice form; sepals, petals, sta-

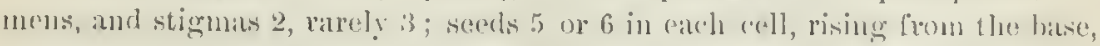

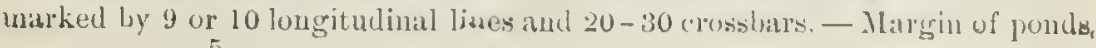


ete., N. II. to Ill., Va., and southwestward. Pod very thin and delieate; the seeds large in proportion, straightish.

2. E. triándra, Schkulır. Leaves oblanceolate or nearly lanceolate; petals and stamens commonly 3; seeds more slender, covering the axis Ponds, Ill., Neb., and westward. (Eu.)

3. E. brachyspérma, Gray. Leaves oblong or oval with narrowed base; flowers mostly dimerons; seeds shurt-oblong, with 6 or 7 longitudinal lines and $10-12$ erossbars. - III. and southwestward.

\section{Order 18. HYPERICACHAE. (ST, JonN" Wort Famit.)}

Herls or shrubs, with opposite entirp dotted leaves and no stipules, regular hyporymous flowers, the petuls mostl! uhlique and com:olute in the bud, and many or for stamens commonly collected in 3 or more clusters or bundles. Pod 1-celled with 2-5 parictal piacente, and as many styles, or 3-7-celled by the union of the placente in the centre; alehiscence mostly septicinlal. Sepals $4 \mathrm{or}^{\circ} 5$, imbricated in the lud, herbaceons, pel'sistent. I'etals 4 or 5, mostly deciduous. Styles perristent, at first sometimes united. Seeds numerous, small, anatropous, with no albumen. Embryo cylindrical. l'ants with a resinous juice, dotted with pellucid or dark glands, usually smooth. Leav's mostly sessile. Flowers solitary or eymose.

* Petils ubligue, convolute, jelluw; lignogynous glinds none.

1. Asryrum. Sejuls 4 , in g rery unequal pairs. Petals 4. Stanens many, distinct.

2. Hypericum. Sepals 5, alike. Petals 5. Stanens ustally numy and in 3 or 5 clusters.

* * Petals equal, inubricate, purplish; glands altenating with the :3 stmen-chusters.

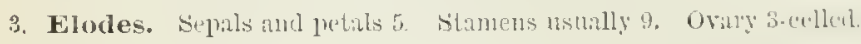

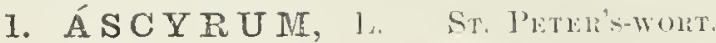

Sepals 4 ; the two onter very loran and leaf-like; the inner much smaller. Petals 4 , oblique, very deciduous, convolute in the bud. Stamens numerous; the filanents distinct and scarcely in rlnsters. I'oul strictly l-celled, 2-4valvenl. - Low, rather shrubly, smooth plants, with pale black-dotted leaves, and nearly solitiry light yellow flowers. (An ancient Greek name of some

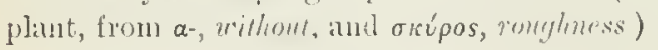

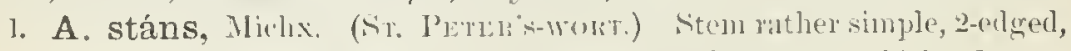
1-20 high, stout; lenres oral or whomy, srmm rchul rlusping, thickish; flowers

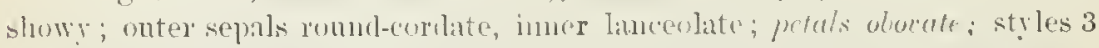
er 4. - l'ine larrens, long Island to l'enu, and sonthward. July. Aug.

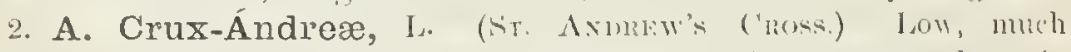

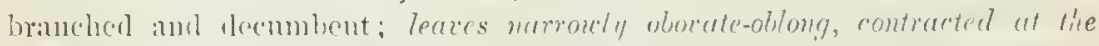
brise, thin; petrls linear-oblong: styles 2, vely slurt; por flat - Nantucket:

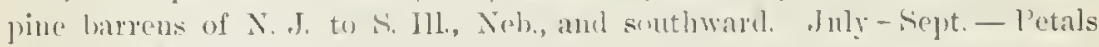

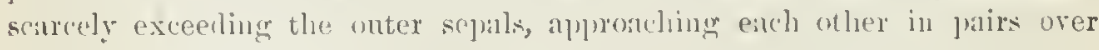

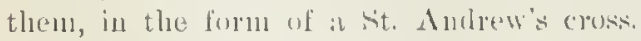

\section{HYPERICUIM, 'lomm. ST. Jonx's-moner.}

Sepals 5, somewhat c(pual, I'etals 5, oblique. convolute in the birl sitamens commonly united or clustered 111 3 $3-5$ parcels; no iuterposed glands. 
Pod 1-celled ur 3-5-celled. Seerls usnally rylindrical. - IIerls or shrubs, with eymose ycllow flowers. (An ancient Greek llame, of obscure meaning.)

\$1. Stumens very numerous:, 5-adelphous; styles 5, united below, the stigmas capitute; pod s-celled, the placenter turned fur back into the cells; perennial herb; flowers very large.

1. H. Áscyron, L. (Grest ST. Jonx's-wolt.) Sitems 2-50 high; branches 2-4-angled ; leares (2-5' hong) orate-olulung, partly clasping; petals nar rowly olsurate (I'long), not deciduous mutil after they wither; pou g' long, conical. (II. prramidatum, Lit.) - Banks of rires, New Eng. and I'eun. to Iowa and Minn. July.

\$2. Stamens rery numerous, obsrurely if al all chustered; styles 3 (n. 2 ex. cepted), more or less anitad into one, the stigmas not capitate except in $\mathbf{n} .10$ sepals mostly folitecous.

* Bushy shruls, 1 - 6 o high, lenfy to the top.

- Silyles 5 ; pod rompletrly 5-relled.

2. .H. Kalmiànum, I. (KALx's Sr. Jons's-wort.) Branches 4angled; branchlets 2-chged; leaves crowichl, glaucuns, linear to oblanceolate ( $1-2$ ' long); fluwers few in a cluster ( $l^{\prime}$ wide); pock ovate. - Wet rocks, Niagara Falls aut northern lakes. Aug.

$$
\text { +- styles } 3 \text {; pod completely 3-celled. }
$$

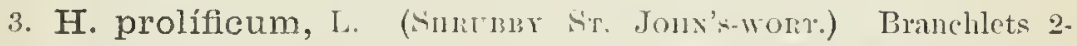
edged; leaves nurowly ollong (I - 2' long), mostly obtuse, narrowed at the base; flowers numerous, in single or compound clusters; pods lanceolite to wate, $4-6^{\prime \prime} \operatorname{long}$ - N. J. to Mich., Minn., and soutluarl. July-sept. Varies greatly in size, etc.

4. H. densiflorum, Pursh. Fxceedingly hranches abore, $1-6^{\circ}$ high, the branches slender and crowded with smaller leaves; fluwers smaller $\left(\frac{1}{2}-\frac{2}{3}\right.$ in diameter) and nore numerons, in crowder compond cymes; porl $2-3$ " long. (I1. prolificum, viu. densiform, Gray.) - Tine barrens of. X. J. to griules of Iìr., Ark., and sonthwart.

* Peremial herbs or a little uoody at the base.

+- Porl incompletely 3-4-celled.

5. H. galioides, Lam. Alender, branching, woody helow; leares linear whlunceulute, narrowed lownwarl, $\frac{1}{2}-3^{\prime}$ long, mostly acute; flowers small in terminal and axillay cynes; sepals very narrow, $1 \frac{1}{2}-3^{\prime \prime}$ long; fool as long, wate. - l)el. to Gat. and E. Tem.

6. H. adpréssum, l3altou. Sitcm simple, lerbacenus, from a sliglitly wooly creeping hase ( $1-20$ high), olsculely 4 -ingled below and 2-elged above; lemes aseculiny, lancelufe or linear-ohlong, often acute, thin; "rme terminal, luafy at the base, few-flowered; sepals linear-lanceolate, pods ovoil-n)long.Muist places, Nautucket and li. I. to P'eun, and southwestward. July- $\Delta$ ug. - Leaves $1 \frac{1}{2}$ ' long. I'etals lnighlit yelluw, 3-5" long.

$$
\text { + + Turl 1-rellid wilh } 3 \text { purietal placenter. }
$$

7. H. dolabrifórme, Vent. Sitems lranchél from the duemmexut hase, wondy hrow $(0-20$ high $)$, terete; leares linear-luncelute, wilkely spreading, 
veinless; eyme leafy, few-flowered; sepals oblong or orate-lanceolate, abont the lengtl of the very bblique petals $\left(5-6^{\prime \prime}\right.$ long); porls orcute-conicul, pointed, the walls very thick and hard. - Dry hills aud rocks, barrens of ky, and 'lenn. June-Ang.

8. H. cistifòlium, Lam.! Stems mostly simple, herbaceons, with a somewhat woody base, angled with 4 very narrow salient lines ( $1-2^{\circ}$ high); leaves uarrowly oblong to nearly linear (1-3' long), sessile with a somewhat elasping base; the cyme naked, compound, nsually many-flowered; sepuls ovate; pods depressed-globular or ovoid-conical; seeds large, ublong, very rougli-pitted. (H. sphicrocarpon, Michx.) - Rocky viver-banks, S. W. Uhio, to lowa and sonthward. July-Sept. - Flowers small.

9. H. ellípticum, Hook. Stem simple, herlaceuts $\left(10-20^{\prime}\right.$ ligh $)$, obscurely 4-angled; leares spreading, ellipticul-oblong, obtuse, usaally narrower towart the subchasping base, thin; cyme nearly naked, rather few-flowered; sepals oblong: pods ovoid, very obtuse; seeds minutely striate. - Wet places, New Eng. and Penn. to Minn., and northward. July, Aug. - Petals light yellow, $3^{\prime \prime} \operatorname{long}$.

10. H. virgàtum, Iam. Stem slenler, strict, simple, sharply 4-angled, herlaceons (1-20 high); leares ascending, opagne, orate or ollong-lanceolate, acute $\left(\frac{1}{2}-l^{\prime} \operatorname{long}\right)$, closely sersile hy a broad hase; crme compound, naked, the scattered flowers racemose on its ascending branches; sepals herbaceous, erect, enclosing the oroid joul styles 3 , separate, with capitate stignas. (11. angulosum, Michx.) - Wet pine barrens of X.J. and southward; Ky. July-Sept. - l'etals copper-yellow, $4-5$ " long.

\$ 3. Stamens rery many, in 3 or 5 clusters ; styles 3 , separate and usually direrg. ing; pod 3-celled; calyx erect; petals and anthers with black dots; perennials.

H. Ṕrforàtum, L. (Commox St. Jonx's-wont.) Stem much branched and cormbed, somewhat 2-edged (prolncing runners from the hase); leaves ellipticil-oblong or linear-oblong, witl pellneid dots; petals (deep yellow) twice the length of the lancolote aronte sepals; flowers numerons, in open leafy crmes. - Fields, etc. Jume-Sept. - Too well kuown as a pernicions weed, which it is difficult to extirpate. Juice very alcrid. (Nat, from Eu.)

11. H. maculàtum, Walt. Comspicuously marked with both black and pellucil dots; stem terete, sparingly loranched; leaves oblung or lance-ovate, the hase either obtuse or somewhat clasping; flomers rromed (small); petals pole yellore, much longer than the oblomg sepuls, styles mostly not longer than the pol. (H. corymbosum, Muhl.) - 1)amp places; commun. July-sept. - Leaves larger mul flowers much smaller that in the last; petals $2-3$ " loug. market with black lines as well as lots. The orlinary northeru form differs from the typical southern one in the shorter style and the more oblong less clasping leares.

\$4. Ntumens 5-12, distinct or in 3 clusters: pod 1-celled, with 3 strictly parietal plucenter; styles short, distimet, with comitute stigmas ; petuls oblony or linear; spouls nerrow, erect; slender annumls, with t-angular brameres: flowering oll summer.

* Stem simple or loosely branched; leares linear to ourte, spreading.

12. H. mùtilum, I. Stem flacoil, wjilely branching $\left(6-20^{\prime}\right.$ higgh $)$;

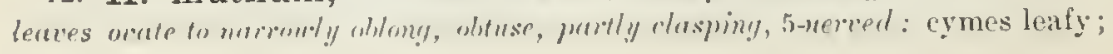


flowers $2^{\prime \prime}$ liroal; pods oxatp-conical, rather longer than the culyx. - Low grounds, everywhere.

13. H. gymnánthum, Engelm. \& Gray. Almost simple, with strict stem and branches ( $1-3^{\circ}$ high $)$; leaves elasping, heart-shaped, acute or obtuse ; crme naked, the floral leaves reduced to small awl-shaped bracts; in aspect approaching the next. (II. mntihun, var. gymnautlum, Gray.) - J)el. and I'enu. to Minn., and sontlward.

14. H. Canadénse, L. Sitem strict $\left(6-15^{\prime}\right.$ higlı), with the lranches erect; leures lineur, 3-nerred at the hase, obtuse; 'ymes naked; flowers deep yellow, 2-3" broad when expluded ; jods conical-oblong, usually much longer than the calyx. - Wret, sandy soil ; common. June-Oet. - Var. MÀn's, Gray, is a large form, $1-2^{\circ} \mathrm{higl}$, with lanceolate leaves $1 \frac{1}{2}^{\prime} \mathrm{long}, 3^{\prime \prime}$ wide, the npper acnte. I. Sinperior, Lobbins; S. New Tork and sonthward. - Var. Mnnutu, Chois., a simple few-flowered form, 1-3' high, with oblong obtuse leares. On wet rocks, W ince, and northward.

* Stems fustigiately uranched; leaves linear or bract-like, ascending or appressed.

15. H. Drummóndii, Torr. \& Gray. Stem and the mostly alternate hushy branches rigid, erect $\left(10-18^{\prime}\right.$ high $)$; lcures linear-subulute, mearly erect, I-nervel (3-9" long); flowers scattered along the upper part of the leafy hranches, short-pedicelled; porls oroid, not longer than the culyx. $-\mathrm{II}^{r}$. Ill., lowa, lian., and sontloward, in dly soil.

16. H. nudicaùle, Walt. (Otsxak-(ilsss. J'NE-wlizb) Stem and hushy hauches threarl-like, wiry ( $t-9^{\prime}$ ligh $)$; leares mimute arr-shaped scales, appressed ; flower's mimute, mostly sessile and scattered along the erect branches; pods ovate-luncolate, acute, much longer then the caly.x. (II. Sarothra, 1Fichx.) - Sandy fields, N. Eng.to 11., Mo., and sonthwatd ; common. Jume-Oct.

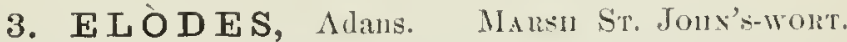

Sepals 5, equil, erect. J'etals 5, equal-sided, oblong, naked, inbricated in the bucl. Stamens 9 (rarely more), mited in 3 sets; the sets seprarated ly as mauy large orange-colored glauds Poul 3-celled, oblong: styles ristinct. l'erennial herbs, in marshes or shallow water, with smill rlose clnsters of flesh-colored flowers in the axils of the leaves aul at the summit of the stem.

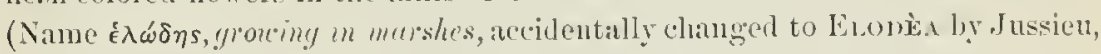
who was followed ly Pursh, etc.)

1. E. campanulàta, I'urshls. Lences closely sessile or closping by a hrourl lusse, oblong or ovate, very olstuse; filanents united below the midlle. (Is. Vircrinica, Nutt.) - ('ommon in swamps; $1-2^{\circ}$ highl. July, $\Lambda u g$.

2. E. petiolàta, I'nrsl. Taller, more luancling; leares tujering into a shor petiole, oblony: filaments mited beyoud the middle. - From Va. south and westward.

\section{OrDer 19. TERNSTROLMIACTAE. (TeA OR CAMELLIA}

\section{FAMILY.)}

Trees or shrubs, wilh allermute simple faulher-reined leares, and no stipules, the regulur jlowers hypoyynous and polyandrous, the scpals and petals 
both imbricated in wstitation, the stamens more or less mited at the base with euch other (monadelphous or 3-5-udelphous) and with the base of the petals. - Anthers 2-celled, introrse. Fruit a woorly 3-5-celled loculicidal pod. Seeds few, with little or no allomen. Limbryo large, with broal cotyledons. $-\Lambda$ fanily with showy flowers, the types of which are the well-known CANLLLIA and the more important TEA P'LANT, - rep resented in this country by the two following genera.

\section{STUÚ́ RTIA, I.}

Sepals 5, rarely 6, ovate or lanceolate. Pctals 5, rarely 6, oborate, cremulate. Stamens monarlelphous below. Por 5-celled. Seeds $101^{\circ} 2$ in each eell, crnstatceons, anatropous, ascending. Embryostraight, nearly as loug as the albumen; rarlicle longer than thr cotyledons. - Silnoubs with mentmanaceous rlecilnons oblong-orate sermlate leaves, soft-lowny beneath, and litrge short-peduncled flowers solitary in their axils. (Named for Joln sifurt, Matruis of Bute.)

1. S. Virgínica, Cav. I'etals 5, white (1' longr); sepls ovate; style 1; stigma 5-toothed; pod globular, blunt; seels not margined. - Woorls, Va., and sonthwarl.

2. S. pentágyna, L'Tler. I.eaves larger, 5-6' lomg; kepals acute; petils often 6 ; styles 5 , distinct ; porl angled, pointed; seeds wing-margined. - Mountains of ky., Car., and sonthwart.

\section{GORDONIA, Ellis. Lomboly B.r.}

Sepals 5, rounctel, concare. I'etils 5, oburate. Stamens 5-allelphous, one eluster adhering to the hase of each petal. Style 1. I'oxl ovoil, 5-ralred; the valves separating from the persistent axis; cells $2-8$-sceded. Sceds penhlulous. Embloryo straightish, with a short radicle, and thin longiturimally pliniterl cotyledons. - Slnubs ur small trees, with lare and showy white flowers on axillary perluncles. (Dedicated by 1)r. Gamen to his "old master", I). Jumes Cordon of Aberdeen," and by Ellis to a London nurseryman of the same name.)

1. G. Iasiánthus, L. (Lomlonly BAY) Leares coriaceous and persistent, lanceolate-ollong, narowed it the hase, mimtely serrate, smontl and shining; pod pointed; sects winger alowe. - Swanps near the coast, Va. and southwarl. May-July. - Petals $1 \frac{1}{2}{ }^{\prime} \operatorname{long}$.

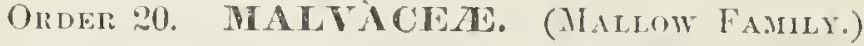

Ilerls or shruls, with allemate shipulate leares and regular flowers, the calyx valuate and the corolla comblute in the bud, munerous stamens monatdelphous in a column. and united at base uth the short clanes of the pretals,

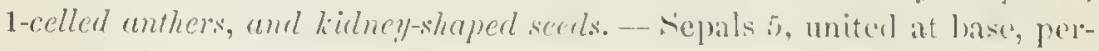
sistent, often involucellate with a whorl of huatetes formines a sort of exterior calyx. l'etals 5. Antheres kidney-shaped, openiner aloner the top. Jistils several, the ovaries mited in a ring or forming a severalcellet port. Seeds with little allumen; ('mulnyou "urved, the leafy" cotyle-

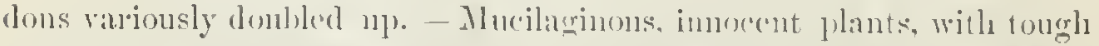
bark and palmatrely-remed leaves. Flower-stallis with a joint, axillary. 
Tribe I. MATVEAE. Columns of stamens anther-hearing at the top. Ovaries and cancls 5 - 20 or nore, closely united in a rin's around a central axis, from which they separate after ripeaing.

* Stignas oceupying the inner face of the styles; carpels l-seeded, falling away separately.

1. Althaea. luvolucel of 6 to 9 bractlets.

2. Malva. Involun of 3 bractlets. Pululs obcorlate. Carpels roundel, beakless.

3. Callirrioe. Insolncel of $1-3$ loractlets or none. Petals truneate. Carpels beaked.

1. Napoa. Involucel nonc Flowersdioeious. Stamens few (15-20). Carpels beakless. * Stigmas terminal, cayitate; carpels 1 - few-seeded, usually dehiscent.

5. Malvastrum. lirvolucel of 3 bractlets or none. Seed solitary, filling the cell, ascending.

6. Sida. Involneel none. Seed solitary in the cells, pendulous.

7. Spliaeralcea. Brictlets 3. Seeds 2 or 3 in eacli cell.

8. Abutilon. Involucel none. Seels $3-9$ in eacli cell.

9. Modiola. Bractlets 3. Seeds 2 in each ecll, with a transterse partition between them.

Tribe II. HIBISCEAE. Columm of stanens anther-henring for a considerable part of its lengtli, naked and 5-tootleel at the rery apex. Pod mostly 5-celled, loculiciclal, leaving scarcely any axis in the centre after opening.

10. IÉsteletzya. Involucel of severnl bractlets. Pod 5-celled, 5-secled.

11. Ifibiscus. Involuet of many bractlets. Pol 5-celled, niny-seederl.

\section{A LTH 罡 A, I。 Marsh-Mallow.}

Calyx surrounded by a $6-9-(\mathrm{left}$ involneel. Otherwise as in Malva. (Old Greck anı Latin name, from à $\lambda \theta \omega$, m cure, $n$ allusion to its healing properties.)

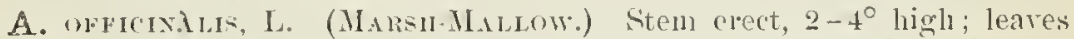
orate or slightly heart-shaped, toothed, sonetimes 3-lobed, felvety-downy; p.luncles axillary, many-Howerest flower's pale rose-colol: - salt marshes, coast of N. Eng. and $\mathrm{X}^{*} \mathrm{Y}$. A I g., Sept. - I'ereminal root thick, abounding in mucilage, the hasis of the Pâtes de Guimanue. (Nat. from liu.)

\section{M Á L $\mathbf{A}$, I. MALLOW.}

Calyx with a 3-leared inrolucel at the base, like an outer calyx. Petals obcorlate. Styles mmmerons, stigmatic down the inner side. Fruit depressed, sepating at maturity into as many l-seederl and indehiscent round kidneyshaped binnt carjels is there are styles. liallicle pointing downwarl. (fin ohl Latiu name, from the Greek nime, $\mu a \lambda \alpha ́ \chi \eta$, having al]usion to the cnollicnt leares.)

\section{* Flowers fuscicled in the axils.}

M. Rotundfóla, Is. (Commos M.iLlow.) Stems procumbent from a deep hiemuial root; leaves round-heart-shaped, on very long petioles, crenate, obsurely-lobed: petals twice the length of the calyx, whitish; carpels pubesrent, even. - Warsiles anl cultivated grounds; common. (Nat. from En.)

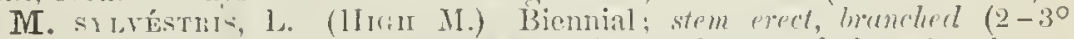
high); lemes sherply $5-7$-loled: petals thrice the length of the calyx, large, purple and rose-color ; carpels whinkled-reiny. - IVassides. (Adr. from Iiu.)

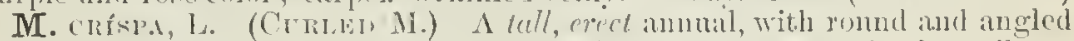
tnothed and risped leures, and small sessile floneres croweled in the axils. riparingly escajed from old garlens. (Adr. from Lu.)

* * Fincers only in the upper axils, somerchat racemose or preniculate.

M. mosendre, 1. (Hrsk M.) A low perenuial, with the stm-teares 5-perted, and the dirisions one or lure parted "ur reft into linear lohes, faintly

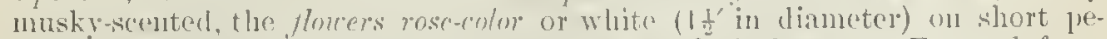

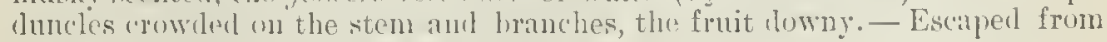
gardens to waysides. (Adr. from Eu.) 
M. S LCEA, L., with the stem-leaves only once 5-parted or cleft, the lobes incised, large flowers like the last, but the fruit smooth, and bractlets of the involucel orate, has escaped from gardens. ( $\Lambda \mathrm{dr}$. from Eu.)

\section{C A LIIRRHOE, Nutt.}

Calyx either naked or with a 3-leaved involucel at its lase. Petals wedgeshaped and trumeate (usually red-purple). Styles, etc, as in Malva. Carpels 10-20, straightish, with a short empty heak, separated witlin from the Iseeded cell by a narrow projection, indehiscent or partly 2-valved. Radicle pointing downward. (Name drawn from Greek mythology.)

* Iniolucel 3-leared.

1. C. triangulàta, Gray. Ilairy-pubescent; stems nearly erect (20 ligh) from a fusiform root; leares triangular or halberd-shaped, or the lowest rather heart-shaped, coarsely crenate; the upper incised or 3-5-cleft; flowers panicled, short-perlicelled (purple); involucel as long as the 5-cleft 5-nerred calyx; carpels not rugose. - Dry prairies, Inul. to Mimn., and southward,

2. C. involucràta, Gray. Ilirsute or lispisl, procumbent; leares rounded, 5-7-parted or -deft, the segurents incrsely lobed : peduncles elongated, 1-flowered; calyx 5-parted, the lanceolate 3-5-nerved sepals twice as Iong as the involucel; petals red or purplish, carpels indehiscent, rugoseretinulated. - Minu. to 'Tex.

* * Involucel none; caly.r 5-parted; carpuls stronyly rugose.

3. C. alcæoides, Gray. Strigose-pmbeseent; stems slender (10 ligh), ereet from a peremial root; lower leaves triangular heart-shaped, incised, the upper 5-7-parted, laciniate, the uppemost divided into linear segments; flowers (rose-color or white) eorymbuse, on slender peduncles - Barren oaklands, S. Ky. to Kían. and Neb.

4. C. digitàta, Nutt. Sparsely liirsute or glatrous, erect; Ieaves few, rounl-endate, 5-7-parted, the canline commonly with linear divisions; peduncles subraeemose, long, filiform; Howers red-purple to white- Kan. to T'ex.

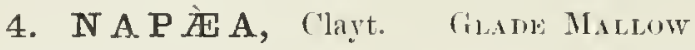

Calyx naked at the hase, 5-toothed. P'atals entire. Flouers diocions; the staminate flowers destitute of pistils, with 15-20 anthers; the fertile with a short column of filaments lont usually no authers. Sityles 8-10, stiguatic along the inside. Frnit depressed-globular, separating when ripe into as many kirlney-shaped 1-seeded leakless and scarcely deliscent carpels as there are styles. Radicle pointing downarl. $-\Lambda$ tall rouglish peremnial herl, with very large 9-11-parted lower leaves, the pointed lobes pinnatifid-cut and toothed, and with small white flowe's in panicled clustered corymbs. (Named from $\nu a ́ \pi \eta$, a glade or dell, or, poetically, a nỵnph of the glades.)

1. N. dioica, I. Stems nearly simple, 5-9o higlı - Y'enn. to Ya., and west to lowa and Mimn, rare. July.

\section{M A L VÁSTRUM, Gray. Fase Mallow.}

Calyx witl an involucel of $20 \mathrm{or} 3$ luactlets, or none. l'etals noteled at the end or entire. Sityles 5 or more; stignas capitate. ('arels ats in Malva, or 
else as in Sirla, lnt the solitary kidney-shaped seed ascending and the radicle pointing downwarl, as in the former. (Name altered from Mulea.)

I. M. angústum, (iray. Ammul, shightly lairy, erect $\left(6^{\prime}-1^{\circ}\right.$ ligh $)$; leaves lance-oblong or linein, witl scattered fine callous teetlı; flowers in the npjer axils, on peluncles shorter than the loroally ovate-tringular sepals; bractlets and stipules setaceons; petals yellow, scarcely exceeding the calyx; carpels 5, kidney-shaped, smootls, at length 2-ralvod. - W. 'Yenn. to lowa and lian. Ang.

2 M. coccíneum, Gray. P'cmuial, low and hoary; leaves 5-parted or perlate, flowers in short spikes or ralemes, the pink-red petals very much longer than the calyx; carpels 10 or mote, reticulaterl on the sieles and indehiscent. - Minn to W. Tex., and westward.

\section{S İ D A, L.}

Calyx maked at the base, 5-cleft. P'etals cutire, usually ollique. Styles 5 or nore, tipped with eapitate stiguas: the ripe frotit separating into as many l-seeded cirpels, which are clused, wr commonly 2-valved at the top, and tardily sepante fou the axis. Sied pemlulous. Embryo abruptly bent; the ladicle pointing mord. (A nime used ly Theophrastus.)

1. S. Napæaa, (av. A suooth, tall ( $t-10^{\circ}$ ligh h) jerennial; leates 3-7cleft, the lobes oblong and peinted, toothed : flowers (uhite) umbellute-corymbed, I'wile; calpels 10, pointerl. - lacky river-hanks, along the Alleghanies, Penn. to Va.; rare. (Cultivated in old gardens.)

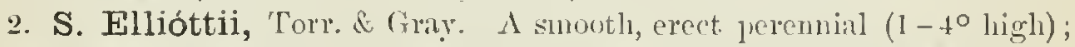
leaves linear, serrate, short-petioled; pednucles axillary, l-flowered, short; fowers (yellore) ratlier large; curprls 9-10, slightly and abruptly pointed,

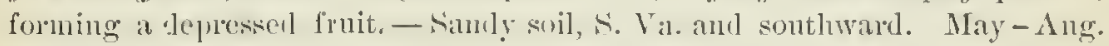

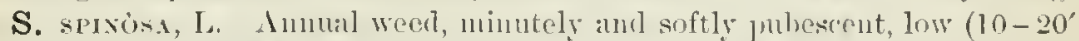

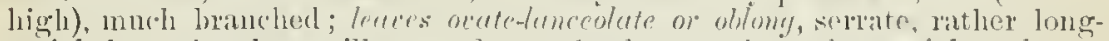
petioled; pedumeles axillary, I-flowered, shouter thail the petioln; forrers (yellow) smiall; ravels 5, combined into an orate fruit, earle splitting at the (ii) into 2 breks. - I little tulnercle at the hase uf the leaves on the strouger plants gives the sperific name, hut it cannot be called a spine - Waste places, S. New York to lowa, and common southward. (Nat. from the trojici.).

\section{SPH Æ $\mathrm{EÁ}$ LCEA, St. llil.}

Ormles ancl seecls usually 2 or 3 in each cell. Characters otherwise as in

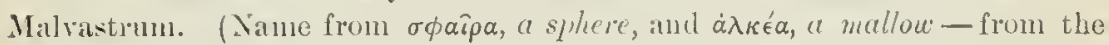
cummonly spherical fruit.)

1. S. acerifolia, Nutt. Perennial, erect, $2-6^{\circ}$ ligh, stellately pubescent or ghlah:ite; leaves maple-slaped, 3-7-cleft; flowers clustered in the upjer axils and subspicate, rose-color to white. - Kankikce Co., 11l., L.. J. Hill; Dak. and westwarl.

\section{A B ÙTILON, Tonm. Trmix MLLow.}

Carpels 2-9-seeded, at length 2-ralved. Radicle ascending or pointing inwarl. (Otherwise als in sicli. (Name of unknown origin.)

A. Avicherve, Gaertu. (Vengt-Lenfo) Tall aunal ( $4^{\circ}$ lighli); leaves roumdish-heart-shaped, taper-printed, velvety; pedundes shorter than the leaf.

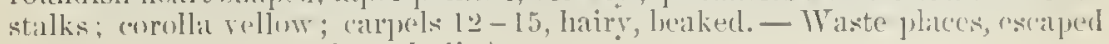
frum giarlens. (Ailro from Inclia.) 


\section{MODİOLA, Nirencli.}

Calyx with a 3-leared iurolucel. Petuls oborate. Stamens 10-20. Stigmas capitate. Carpels $14-20$, kidney-shaped, pointed, and at length 2-valved at the top; the cavity divicled into two by a cross partition, with a single seed in each cell. - Humble, procumbent or creeping annuals or biennials, with cut leaves and small purplish flowers solitary in the axils. (Nane from modiolus, the broad and depressed fruit resenbling in shape the Roman neasure of that name.)

I. MI. multífida, Moench. Iairy; leaves 3-5-cleft and incised; stamens 15-20; fruit hispid at the top.- I Low grounds, Ta. aud southward.

\section{KOSTELFTZKYA, Presl.}

Pod depressed, with a single seed in each cell. Otherwise as Ilibiscas. (Named after $J$. F. Kosteletaly, a Tohemian botanist.)

1. K. Virgínica, Gray. Roughish-hairy perenuial $\left(2-4^{\circ}\right.$ high $)$; leaves halberd-shaped and heart-shaped, the lower 3-lulsed; corolla $2^{\prime}$ wide, rosecolor; colmun slender. - Marshes on the coast, $\mathrm{N}$. Y. and soutlward. Aug.

\section{HIBÍSCUS, I. Rosk-Mallow.}

Calyx involucellate at the base by a row of numerons bractlets, 5-cleft. Column of stamens loug, beariug anthers for much of its lengtl. Styles united, stigmas 5, capitate. Fruit a 5-celled loculiciulal pod. Seeds several or many iu each cell. - Herhs or slu'uls, usnally with large and showy Howers. (An old Greek and Latin name of unknowu meaning.)

* Indigenous tall perennials ( $\left.1-8^{\circ} \mathrm{high}\right)$, flowering late in summer.

1. H. Moscheùtos, L. (SWM Rosw-Mnl.om.) Leaces arate, pointed, toothed, the lower 3-lohed, the uppernost oblong-lanceolate, all whitened underneatll with a fine suft down, glahnons or slightly downy above; the 1 -flowered pednucles sometimes united at the hrse with the petioles; bractlets not hairy; calyx not inflated; pod and seeds smooth or nenrly so. - Brackish markhes alung the coast, from F. Mass. southward, and lake sloores and swanns westward to Ill. and Mlo., especially within the influence of salt springs. - Corolla 5-6' in dianeter, light rose-color or white, with or withont a crimsun eye.

2. H. lasiocárpus, Car. Leavessoit-domy buth sicles, the lower burally orate and heart-shaped ; lractlets ciliatt:; pot hirsute; - otherwise resembling the last. (II. grandiforms, M/irh.r.) - Imrl, to Mo., ant southward.

3. H. militàris, ('al. (H unbru-Lurves, R.) Smoth thronghout; lower

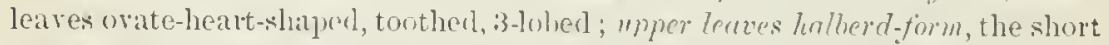
lateral lobes sprearling at the hase, the miclile one prolonged and taper-pointed; perluncles slender; foniting ruly.r infleted; sceds hairy. - River-hanks, Penn.

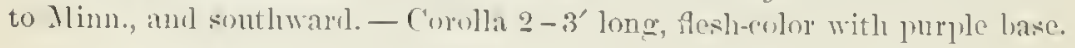

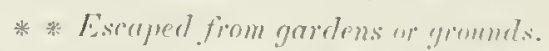

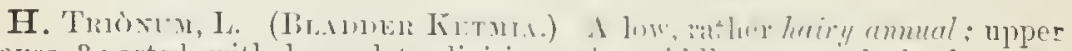
leaves 3-1arted, with lanceolate divisions, the michle one mull the longest;

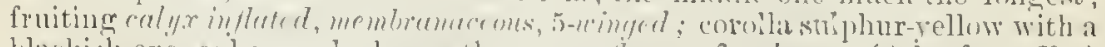

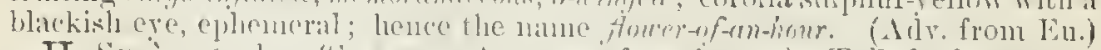

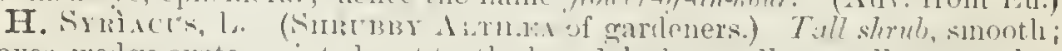

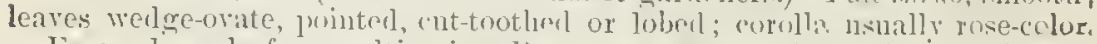
- Escaped rarely from cultivation, l'enn., cte. Sipt. (Allv. froin Eu.) 


\section{ORDER 21. MILIACEA. (LANDEX FAMIY\%)}

T'rees (retrely herbs), with the mucilarinous properties, filrous burk. valcate calyx, etc, of the Mallow Fanily; but the sopols decidnous, petals imbricated in the but. the stamens usually poigrelelphous, und the anthers 2-celled. Represented in Northern rergions vily ly the genus,

\section{TÍLIA, Tourn. Lixiex. Basswood.}

Sepals 5. Petils 5, spatulate-oblong. Stamens numerous ; filaments coliering in 5 clusters with tacll other (in Luropean species), or with the hase of a spotulate petal-like boly plated oplysite each of the real petals. Pistil with a 5-celled oviry, and 2 half-anatropuns ovules in eaclu cell, a single style, and a 5-trothed stigma. F'ruit dry and wouly, indeliscent-globulill, becoming Icelled and 1-2-seeded. Embryo in hard albumen; cotyledons lroal and thin, 5-lobed, crmmpled. - Fine trees, with soft and white wool, very fibrous and tough inner bark, more or less heart-shaped and serrate alternate leaves (oblique and olten truncate at the base), (leciduons stipules, and small cymes of Howers, langing on an axillary peduncle which is united to a ligulate menbranaceous lirat. Flower's cream-color, honey-bearing, fragrant. (The classical Latin name.)

1. T. Americàna, L. (B.ıswoon.) Leaves large, green and glabrous or nearly so, thickish; flomal bratet nsmally tapering at hase; frut ovoid. -

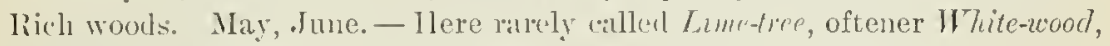
commonly linssumor ; the latter nume now ohsolete in Fingland.

2. T. pubéscens, Ait. Ieaves smalle' (2-3' long $)$, thinner, and rather pulescent bencath; floral bract ustally rounderl at bise; fruit globose, smaller (3" broici). (T. Americaua, var. pubesems, .Mun.) - N. Y. to Fla., and westwari.

3. T. heterophýlla, Vent. (Wurt: BAsswood.) Leaves harger, smooth and hright green above, silvery-whitened with a fine down underneath. - Mountains of l'(1m, to s. Ill., and southw:1l.

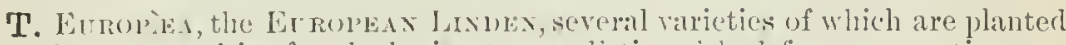
in amb near onr cities for shate, is at once distingushed from any native spe-

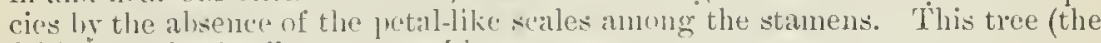
Lin) gave the family name to Limmus.

\section{Ordi: 总. LINACEA. (Flax Famm.)}

Herbs (rarety shrubs) with the regular and symmetrical hypogynons flowers 4-b-merous throughout, strongly imbricaled calyx and convolute petals, 5 stamens monadelphous at base, and an 8 -10-sceded pod, having wice as many cells as there are styles. Represented by the grenus,

\section{L İ N U M., Tuurn. liLix.}

Sepals (persistent), petals, stamens, anıl styles 5, regularly alternate with each other. Pod of 5 uniterl carpels (into which it splits in dehiscence) and 5 -celled. with 2 seeds hanging from the summit of each cell, which is partly or completely divided into two hy a falsn purtition projecting from the back of the carpel, the pod thus hecoming 10-celled. Seeds anatropons, mucilaginous, flattened. 
containing a large embryo with plano-convex cotyledons. - Herbs, with tough fibrous bark, simple and sessile entire leaves (alternate or often opposite), without stipules, but often with glands in their place, and with corymbose or panicled flowers. Corolla nsually ephemerat. (The classical name of the Flax.)

$$
\text { * Flouers rather small, yellow; glabrous, } 1-20 \text { high. }
$$

1. L. Virginianum, L. Stem erect from the base and with the corymbose spreading or recurving brunches terete and even; 10 stipular glands; leaves cublong or lanceolate, or the lower spatulate and often opposite; flowers scattered, small (barely $3^{\prime \prime} \mathrm{long}^{\circ}$ ); sepals ovate, pointed, smooth-edged or nearly so, equalling the depressed 10-celled perd; styles distinct. - Dry woods; common. - lioot apparently annual; but the plant propagates ly suckers from the hase of the stem.

L. Fondodxu, 'Trelease, of rather stricter lialit and the pods broadly ovate and obtuse, appears to have been fomml in $\mathrm{S}$. Ill.

2. L. striàtum, Walt. Stems gregarious, erect or ascenling from a creeping or decumbent base, slightly viscid, and with the mostly racemose short branehes striate with about 4 sharp wing-like angles decurrent from the leaves; these hroader than in the last, and mostly ol,long, usually with all the lower ones opposite; flowers more crowded; sepals searcely equalliug the very small suloglobose brownish pod; otlerwise nearly as n. . - Wet or boggy grounds, E. Mass to Lakes Ontario and Iluron, Mll., and sontliward.

3. L. sulcàtum, Riddell. Stem strictly erect from an annual root, and with the upright or ascending branches wing-angled or grooved; leaves alteruate, linear, acnte, the upjer sululate and glandular-serrulate; a pair of dark glands in phere of stipules; sepals wate-lanceulate and sharp-pointed, strongly 3-nerverl and with rough-bristly-glandular margins, scarcely longer than the ovoil-grohose incompletely 10 -celled pod; styles united almost to the middle.-Dry soils, li. Miss. to Minn., aud sonthwestward. - Flowers and porls twice as lange as in the precerling.

4. L. rígidum, l'msh. Glau'ous, sometimes slightly puberulent, often low and cespitose, the rimid branches angled, leaves narrow, erect, usually with stipular glands; flowers large; sepals lancelate, glandular-serrulate; styles united; capsule oroid, 5-valved. - Minn. to Kau, and sonthwarl.

$$
\text { * Flovers large, blue. }
$$

5. L. perénne, T., var. Lewísii, Kat. \& Wight. Terennial, glabrous and glancons, $1-3^{\circ}$ high; leaves linear, acnte; flowers ratler few on long perhucles; sepals olstuse or acutisl, not glauchular-sorrulate; styles distinct; porl wate. - Minn. to Neh., and westwart. (litl., Asia.)

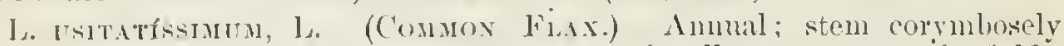
lorancherl at fop); sepals acute, ciliate. - Occasionally spontaneous in fields. (Aclv. from Eu.)

\section{Order 2:3. GERANIACEAE. (Ghaniua Famir.)}

I'lants (chiefly herbs) with perfect and generally symmetrical hypogynous flowers; the stamens, counting sterite filuments, as many or commonly twice as many, and the lobes or cells (1-few-ovuled) of the orary as many, as the sepals, the axis of the dry fruit persisting. - Seenls withont albumen 
except in Oxalis. Flowers mostly 5-merous and the sepals usually distinct. Leaves never punctate. An order not easily defined, and including several strongly marked tribes or suborders which hare been regarded by many botanists as distinct.

Tribe I. GERANi EAE. (Geraniun Family proper.) Flowers regular, 5-merots, the sepals imbrieate in the bud, persistent. Glanls of the disk 5, alternate with the petals. Stamens somewhat uniterl. Ovary deeply lobed; carlels 5, 2-ovuled, 1-seeded, sejarating elastieally with their long styles, when mature, from the elongated axis. Co. tyledons plicate, incumbent on the radicle. - llerbs (our species) with more or less lohed or divided leaves, stipules, and astringent roots.

1. Geranium. Stamens with anthers 10 , rarely 5 . The recurving bases of the styles or tails of the earpels in fruit naked inside.

2. Erodium. Stamens with anthers only 5. Tails of the carpels in fruit hearded inside, often spirally twisted.

Tribe II. LIMNÁNTHËL. Flowers regular, 3.merous (in Floerken), tlie persistent sepals valvate. Glands alteruate with the petals. Stamens distinct. Carpels nearly distinct, with a common style, 1 -ovuled, 1 -seeded, at length fleshy aul indeliseent, not beaked, separating from the very short axis. Embryo straight; cotyledons very thisli; radicke very short,-- Low tender annuals, with alternate pinnate leaves and no stipules.

3. Flcerkea. Sepals, minute pistils, and loves of the ovary $3:$ stamens 6 .

Tribe III. OXALIDEA. (Sorrel Fanily) Flowets regular, 5-metous, the persistent sepals imbreate. Glanls nonc. Stamens 10 , often united at lase. Stigmas capitate. Fruit a 5-celled loculicidal pod (in Oxalis): cclls 2-several-seeded. Embryo struight, in a little fleshy albumen. - Lenves compound (3-foliolate in onr species): juice sour.

4. Oxalis. Styles 5, separate. Pod oblong; the valves not, falling away. Leaftets usually obcorilate.

Tribe IV. BaLsaminede. (Balsam Family.) Flowers irtegular (5-mernis as to the stamens and pistil), the petals and colored sepals fewer in nunber, ceciduons, the larger sepal witlı a large sae or spur. Glands none. Stamens 5, distinet, short. Frnit a fleshy 5-eelled lind (in Impatiens); cells several-seeded. Embryo straight. - Tender and very suceulent herbs, with simple leaves and no stipules.

5. Impariens. Lateral petals unequally 2-lobed. Pod tursting elastically into 5 valves.

\section{G E R À N I U M, Tonru. Cravesbill.}

Stamens 10 (snmetimes only 5 in $\mathrm{n} .3$ ), all with perfect anthers, the 5 longer with glauds at their base (alternate with the petals). Styles smooth inside in fruit when they separate from the axis. - Stems forking. Peluncles 1-3fowered. (An old Greek name, from répavos, a crane; the loug fruit-bearing beak thouglit to resemble the bill of that birl.)

$$
\text { * Rootstock peremial. }
$$

1. G. maculàtum, L. (Wilo Craxesbill.) Stem erect, hairy; leares alout 5-parted, the wedge-shaped divisions lohed and ent at the end; sepals

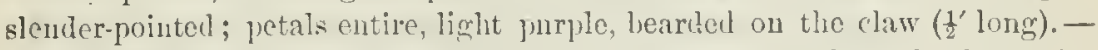
Open wooks and fields. April-July. - Leaves somewhat blotched with whitish as they grow old.

$$
\begin{aligned}
& \text { * Root biennial or anmual; flowers small. } \\
& \text { + Leaves ternately mueh-dissected; heavy scented. }
\end{aligned}
$$

2. G. Robertiànum, I. (llerb Ronert.) Sparsely hairy, diffnse, strong-scented; leaves 3-divided or pedately 5-livided, the divisions twice pin- 
natifid; sepals awned, shorter than the (recl-purple) petals; carpeis winkied; seels smooth. - Moist wools and shaded ravines; $\mathbf{X}$. Ling. to Mo., and northward. June-Oct. (Eu.)

\section{+ + Leares palmately lobed or disserted.}

3. G. Caroliniànum, L. Stems at filst erect, diffusely branched from the hase, hairy ; leaves abont 5-parten, the divisions cleft and cut into numerous oblong-linear lobes; pednucles and pelicels short; scpuls aun-pointer, as long as the emarginate (pale rose-colored) petals; carpels hairy; seeds ovnid-oblong, very minutely reticulated. - Barren soil aud waste places; common. MayAng. - Depauperate forms, except lyg the seeds, are hardly distingnishable from

G. Disséctum, I. More slender and spreading, with narrower lobes to the crowded leaves, and smaller red-purple petals notched at the end; seeds short-ovoid or globelar, finely and deeply putted. - Waste grounds, rare. (Nat. from Eu.)

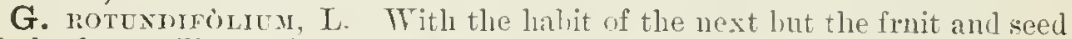
of the last; villous witl long white hairs tipped with puple glands; leares short-lobed. - Rare. (Nat. from Eu.)

G. PCsílum, I. Stems procumlient, slender, minutely pubescent; leares rounded hidney-form, 5-i-parted, the divisions werlge-shajed, mostly 3-lobed; sepals aunless, about as long as the (purplish) petals; stamens 5: fruit pulsescent; seeds smooth. - Waste places, Mass. to Penn.; rare. (Nat. from En.)

G. Mólce, L. Like the last; more juhescent; flowers dark purple; stamens 10 ; carpels transversely wrinkled; seed slightly striate. - Uccasionally ipontaneous. (Nat. from Eil.)

G. Coltumisu. (Loxg-staked C) Mimtely hairy, with very slender decumbent stems; leaves 5-7-parted and cut into narow linear libes; pesuncles and pedirels, filform and elongated; sepals alwned, alout equalling the purple petals, enlarging after flowering; rurpels ghubrons; seeds nearly as in G. dissectum, - Rarely introdnced; Penu. and suththward. June, July." (Nat. from Fur.)

G. Sibfricum, L. Slender, repentedly forked, short-rillous; leares 3-cleft with serrate livisions; flowers chu]]-rhite, inostly solitary; sepals anned; seeds minntely reticulate. - Rars. (Nit. from En.)

\section{ERÒdU M, L'Fier, Storkabill.}

The 5 shorter stamens sterile or wanting. Strles in fruit twisting spirally, bearled inside. Utherwise as Geranimm. (Name from épwóós, a heron.)

E. cicutàru, L'ller. Annual, hairy: stems low, spreading; stipnles acnte; leaves pinnate, the leaflets sessile, 1 - - - pinnatifil; peduncles sereralHowered. - N. Y., I'enn., etc.; scarce. ( Wels from Eu.)

\section{FLǴRKEA, Willit. Fils: Mermaid.}

Sepals 3. Petals 3, slorter than the alyx, oblong. Sitamens 6. Ovaries 3 , oprusite the sepals, mited only at the base; the style rising in the centre; stigmas :3. Frnit of :3 (or 1 - 2) ronghish fleshy achenes. Seed auatropous, erect, filled by the large embryo with its hemispherical fleshy cotyledons. A small and inconspicuons asunal, with minute solitary Howers on axillary pelumcles. (Named after Florrhe, a German botanist.)

1. F. proserpinacoides, Willd. Leatlets $3-5$, lauceolate, sometimes 2-3-cleft. - Marshes an? river-luaks, W. New Eng. to Penu., Ky, Wisc., and westward. April-oune. Taste slingly pungent. 


\section{4. ÓXALIS, I. WoOd-SOrRel.}

Sepals 5, persistent. Petals 5, sometimes nuited at base, withering after expansion. Stamens 10, usmally monalelplous at base, altemately shorter. Styles 5, distinct. I'od ohlong, membranaceons, 5-celled, more or less 5-luberl, each cell opening on the back; ralves persistent, leing fixel to the axis by the partitions. Seeds 2 or more in each cell, penduluns from the axis, anatropons, their ontel coat loose and separating. Innluryo large and straight in fleshy albumen; cotyledons Hit, - Ilerls, with sour watery juice, alteruate or radical leares, mostly of 3 ubeordate leaflets, which close and droop at nightfall. Several species produce small peculiar flowers, precocionsly fertilized in the bud and particularly funitul; and the ordinary flowers are often dimorphous or even trinorphons in the relative length of the stamens and styles. (Name from òłús, sour.)

* Stemless perennials ; leaves and scupes uivinif firm a rootstock or bulb; leaflets broadly obcordate; flowers nearly l'broud; cells of the porl few-seeded.

1. O. Acetosélla, I. (Commox Wood-Sonner..) Rootstock creeping and scialy-tonthed; scape I-flucered (2-5' high); petals white with reddish veins, uften notched. - Deep culd woods, Mass. to l'enn., T. Snperior, and northward; also sunthward in the Alleghanies. June. (Lu.)

2. O. violàcea, I. (Vrolfir W.) Nearly smooth; bulb scaly; scapes umbellutely srreral-floured (5-9' high), longer than the leares; petals violet. - Rocky places ani open wouls; most common sonthwari. May, June.

* Stems leafy, branching; poduncles axillary; flowers yellow; cells severalsecrled.

3. O. corniculàta, L. (TELLow W.) Aunual or perenuial by ruming sulterramean shouti, erect or procmmhent, strigose-pulsescent; stipnles round or truncate, ciliate; peduncles 2-6-fowerecl, longer than the leaves; pods clungaterl, erect in fruit. - liare; (m ballast, ete; ; indigenons in Mo. (Bush), and sunthwestward. (Cosmopolitum.)

Var. strícta, Silv. Sten erect, somewhat glalırons to very villons; stipules none. (O. stricta, L.) - Common, May-Sept. Varies greatly.

4. O. recúrva, Ell. Like var. stricta of $n .3$; leaflets larger $\left(\frac{1}{2}-1 \frac{1}{3}\right.$ hroal), nsmally with a lorownish margin ; fowers larger $\left(6-8^{\prime \prime}\right.$ long). - Peun. to $\mathrm{S}$. 11l., and sonthward.

\section{I MPÀTIENS, I. JALSM. TLWEL-WEEN.}

("alyx and corolla colored alike and not clearly distinguishable. Sepals apjarenty unly 4 ; the anterior one notehed at the apex and probahly consisting of two combinel ; the posteriur one (appearing anterior as the Hower langs on its stalk) largest, and forming a spurred sac. Petals 2, meqnalsided and 2-lobed (each consisting of a pair mited). Stamens 5, short; filaments appendiged with a scule on the immer sile, the 5 scales comivent and united wrel the stigma; anthers opening on the inner face. Orary s-elled; stigma sessile. I'od with evmescont partitions, and a thick axis hearing several anatropons seeds, 5-rulvel, the valves coiling elastically ancl projecting the seeds in hnrsting. Embryo straight; alhmen none. - I.ences simple, alternate, withunt stipnles, in unr species orate or oval, coarsely tuothed, peti- 
oled. Flowers axillary or panieled, often of two sorts, viz.., - the larger ones, which seldom ripen seeds; - and rery small ones, which are fertilized early in the bud; their floral envelopes never expand, lut are forced off by the growing pod and carried npward on its apex. (Name from the sudden bursting of the pods when touched, whence also the popular appellation, $T$ ouchme-not, or snap-reed.)

1. I. pállida, Nutt. (РАLE Tогсn-ме-хот.) Flowers pale-yellow, sparingly dotted with brownisli-red; sae dilated and very obtuse, broader than long, tipled witl a short incurved spur. - Mloist shady places and along rills, in rich soil; most common northward. July-Sept. - Larger and greener than the next, with larger flowers, and less frequent.

2. I. fúlva, Nutt. (SeotreD Tor'nl-ne-xot.) Flouers orange-color, thiclly spotted with reddish-broun: sac longer than lroarl, acutely conical, tapering into a strongly inflexed spur half as loug as the sale. - Rills and shady moist places : eommon, espeeially southwark. .June-Sept. - Plant $2-4^{\circ}$ ligh ; the flowers loosely panicled, hanging graeefully on their slender nodling stalks, the open mouth of the cornucopiac-sliaped sepal upward. Spur rarely wanting. Spotless forms of botli species occur.

\section{Order: 24. IRUTACEA. (Rue Famil.)}

Plants with simple or eompound leures, dolted with pellucid glands and abounding with a pungent or bilter-aromatie aerid volatile oil, produeing hypogynous almost always regular 3-5-merous flowers, the stamens as many or twice as many as the sepals (ravely more numerous); the $2-5$ pistils separate or eombined into a eompound onary of as many cells, raised on a prolongation of the reeeptacle (gynophore) or glandular dish. - Embryo large, curver or straight, usually in lleshy albumen. Styles commonly united or colneing, cren when the oralies are distinct. Frut usually capsular. Leaves alternate or opposite. Stipules none. $-\Lambda$ large family, chictly of the Olil World and the southern hemisphere; our two indigenous genera are

1. Xanthoxylum. Flowers dioecious; nvaries $3-5$, separate, forming fleshy pods.

2. P'telea. Flowers polyganous; ovary 2-t'elled, forming a saman, like that of Elm.

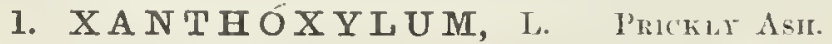

Flowers dinceions. Sepals 4 or 5 , olsolete in one species. Petals 4 or 5 , imbricated in the bud. Stamens 4 or 5 in the sterile flowers, alternate with the pretals. Pistils 2-5, separate, lut their styles ('onniving or sliglitly united, l'uls thick and fleshy, 2-valved, 1-2-seeded. Seed-roat crustaceous, black, smouth :urt shining. Embryo straight, with broad cotyledons. - S Shrubs or treas, with mustly pimnate leaves, the stems and often the leafstalks prickly.

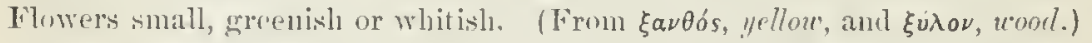

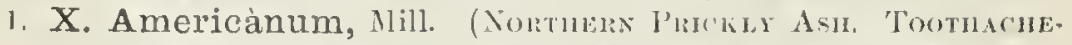
тuю.) Leaves and flowers in sessile axillary nubelate elusters; leaflets $2-4$ pairs and an ohtel one, ovate-olnlone, down when young; (alyx none; petals 4-5; pistils 3-5, with slender styles; pols short-stalkerl. - Rocky wools and river-banks; common, especially northward. April, May. $-A$ slirub, with 
yellowish-green flowers appearing befure the leaves. Bark, leaves, and podo very pungent and aromatic.

2. X. Clàva-Hérculis, I. (Soctuerx P.) Glabrous; leaflets 3-8 pairs anr an odd one, ovate or ovate-lanceolate, oblique, shining above; flowers in an ample terminal crne, appearing after the leares; sepals and petals 5; pistils 2-3, with short styles; pouls sessile. ( $\mathrm{X}$. Caruliniaum, Lum.) Sancly coast of Virginia, and southward. Juue. $-A$ small tree with very sharp prickles.

2. PTELEA, I. SHRLBuY TrEFon. Hop-tree.

Flowers polygamous. Sepals $3-5$. Petals $3-5$, imbricated in the bud. Stamens as many. Orary 2-celled; style short; stigmas 2. Fruit a 2-celled aurl 2-seeded samara, winged all round, uearly orlicular. - Slrubs, with 3-foliolate leares, and greenisli-white small flowers in compound teminal cymes. (The Greek name of the lim, here applied to a genus with similar fruit.)

1. P. trifoliàta, L. Ieaflets vrate, pointed, downy when young. Rocky places, Long Istand to Minn., aud southward. June. - I tall shrub. Fruit bitter, used as a sulstitute for hops. Odor of the flowers disagreeable.

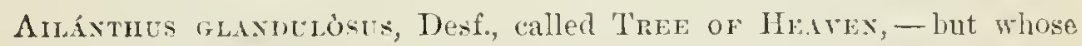
hlossoms, especially the staminate ones, are redoleut of anytling but "airs from heaven," - is much planted as a shade-tree, especially in toms, and is inclined to spread from sech. It helougs to the order Smatemacris, which differs from Rutacea in the abserce of dots in the leaves. The tree is known by its rery long pinnate leares of many leaflets, and small polygamous greenish firers iu panicles, the female prodneing $2-5$ thin, linear-oblong, reiny samaras. (Adv. from China.)

\section{ORDER 25. TLICINEAE. (TOLLY FAMLY.)}

Trees or shrubs, with small axillary $4-8$-merous flowers, a minute calyx free from the 4-8-eelled ovary and the 4-8-sected berry-like drupe: the stamens as many as the divisions of the almosi or quite 4-8-petalled corolla and alternate with them, alluherl to their very buse. - Corolla imbrivaterl in the bud. Anthers opening lengthwise. Stigmas $4-8$, or mited into one, nearly sessile. Seeds suspended and solitary in each cell, auatropons, with a minute embryo in fleshy allumen. Lexives simple, mostly alternate. Flowers white or greenish. -1 small family nearly related to the Gamopetalous order Ebenareer.

1. Ilex, Petuls or corolla-lubes oral ol obnrate. Pedicels mostly clustered.

2. Nemopanthes. Petals lincar. Pellicels solitary.

\section{I LEX, \% . Hortr.}

Flowers more or less dicciously polygamons. Calyx 4-6-toothed. Petals $4-6$, separate, or mited only at the base, nwal or obovate, oltnise, spreading. Stamens $4-6$. The berry-like drupe containing $4-6$ littlo nutlets. - Leares alternate. Fertile flowers inclined to be solitary, and the merile or partly 
sterile flowers to be clustered in the axils. (The aucient Latin name of the Ifolly-Oak, rather that of the 1Iolly.)

§ 1. AQUIFOLILH. Purm of the fower commonly in fours, sometimes in fives or sixes; drupered, its nutlets ribbed, reiny, or 1-grooved on the back; leaves (mostly smooth) coriuceous and cvergreen.

* Leaves armed with spiny teeth; trees.

1. I. opaca, Ait. (AnERICAx Holur.) Leaves oral, flat, the wary margins with seattered spiny tecth; flowers in lonse clusters along the base of the young branches and in the ixils; ; 'ily x-teeth ancute. - Moist woodlauds, Maine to N. J., near the coast, west to s. Mo, and southwark. Jme. - Tree $20-40^{\circ}$ high; the deep green foliage less glossy than in the European Ilolly (I. Aevifoliux, L.), the berries nut so bright red, ancl nutlets not so reiny.

* Leoves serrote or entive, not spiny; shrubs.

2. 1. Cassine, I. (CAssexi. Yarox.) Lences lance-ovate or elliptical, crenate $\left(1-1 \frac{1^{\prime}}{2} \mathrm{long}\right)$; flower-clustes ncarly sessile, smonth ; colyx-teeth olituse. - Virginia and sonthward along the coist. May. - I eares used for tea by the people almg the coast, as they were to make the celebrated blach drink of the North Carolina Indians.

3. I. Dahóon, Walt. (I) nnoos HoLly.) Leares oblanceolute or oblong, entire, on sharhly serrate tuward the apex, with revolute margins ( $2-3^{\prime}$ long), the midrito ond pedmeles pulescent: calyx-teeth acule. - Swamps, const of Va. and southward. May, June.

Var. myrtifolia, clapun. Leaves smaller ( $l^{\prime}$ long or less) and narrower. (I. myrtifulia, Halt.) - Sime halitat. Mlas.

§ 2. I'RINUIDESS. I'arts of the (polygumons or aliccions) flouers in fours or fives (rarely in sixes); drupe red or purple, the nulcts striate-many-ribbed on the back; leaces decidnous; shmbs.

4. I. decídua, Walt. Leares ucdye-ollowy or lance-uluacale, oblusely serrate, douny on the midrib beneath, shining abore, becoming thickish ; pednucles of the sterile flowers longer than the petioles, of the fertile short; calyx-teeth smooth, acute. - Wet gromuls, liz. to Mlo., kim., and sonthward. Miy.

5. I. montícola, (iriy. Leeres orate or lunce-ollong, ample $\left(3-5^{\prime}\right.$ long): taper-pointerl, thin-mentranaceons, smoth, slumply semole: fertile flowers very short-peduncled; (alyx riliate. - 1)imup wersls, Taconic and Catskill Mountains, and Cattariugus ('o., N. Y., through l'ene. (east to Nurthampton (o.), ancl southward along the Alleghlunics. May.

6. I. móllis, Graỵ. Learess soff domyy lwenth, oval, ovate, or oblong taper-pointed at botle cids, especially at the apex, hlin-membranaceuts, sharply serrulate; sterile flowers rery mumerous in mulul-like rlusters, the pollicels

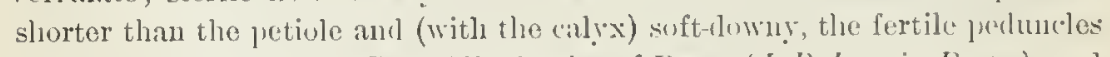
rery short. - Burgoon's Gap, Alleghinies of I'cnn. (.I. R. Loucrie, Porter), and along the mountains in the Southern States. - Resemliles the last.

\$3. PRINOS. J'urts of the sterile floners commonly in fours, fives, or sixes, those of the fertile glouers commonly in sixes (rarely in fires, secens, or eights); mutlets smooth and exen; shrubs. 
* Leaves deciduous; flowers in sessile clusters, or the fertile solitary; fruit bright red.

7. I. verticillàta, Gray. (Biack Alder. Winterberry.) Leaves oval, oborate, or wedge-lanceolate, jointed, acnte at base, serrate, douny on the veins beneath; jlowers all very short-peduncled. - Low grounds; eommon. Nay, June.

8. I. lævigàta, Gray. (Syootu Winterberry.) Leaves lanceolate or oblong-lanceulate, pointed at both ends, appressed-serrulate, shining above, beneath mostly glubrous; sterile flouers long-peduncled. - Wet grounds, Maine to the mountains of Ya. June. - Fruit larger than in the last, ripening earlier in the autumn.

* * Leaves coriaceous, evergreen and shining, often black-dotted beneath; fruit black.

9. I. glàbra, Gray. (IxkвьrRr.) Leaves wedge-lanceolate or oblong, sparingly tonther toward the apex, smooth; peduncles $\left(\frac{1}{2}\right.$ long $)$ of the sterile flowers 3-6-flowered, of the fertile 1-flowered; calyx-teeth rather blunt. Sandy grounds, Cape Ann, Mass, to Yra., and sonthward near tlie eoast. June. - Shrub $2-3^{\circ}$ high.

\section{NEMOPÁnTHES, Raf. Mountain Holly.}

Flowers polrgano-diocions. Calyx in the sterile flowers of $4-5$ minute decilluous tecth, in the fertile ones obsulete. Petals $4-5$, oblung-linear, spreading, distinct. Stamens $4-5$; filaments slender. Drupe witl $4-5$ bony nutlets, light rel. - A much-hranchel shrul, with ash-gray bark, alternate and oblong deciduous leaves on slender petioles, entire or slightly toothed, smootli. Flowers on long slender axillary peiluncles, solitary or sparingly clustered. (Name said by the anthor to mean "flower with a filiform peduncle," therefore prob-

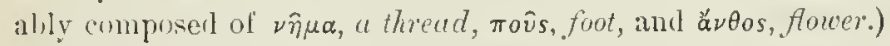

1. T. fasciculàris, Raf. (N. Canarlensis, $D C$.) - Damp cold woods, from the mountains of Va. to Maine, Ind., Wisc., and northward. May.

\section{Ordel: 26. CELASTRACEA. (StafF-tree Famir.)}

Shrubs with simple leares, and small regular flowers, the sepals and the petals both imlricater in the bud, the 4 or 5 peritynous stamens as many as the petals and alternate with them, inserted on a disk which fills the bottom of the caly.x and sometimes covers the ovary. Seeds arilled. - Ovules one or few (erect or pendulous) in each cell, anatropous; styles united into one. Fruit 2-5-cellel, free from the calyx. Lmbryo litrge, in theshy albumen; cotyledons broad and thin. Stipules minute and fugraeious. Pedicels jointed.

\section{* Leaves alternate. Flowers in terminal lacemes.}

1 Celanturs. A slurubby clinuber. Fruit globose, orange, 3-valved. Aril scarlet.

* Lenves opjosite. lilowers in axillary cyues or solitary.

2. Euonymus. Erectslumbs. Leaves deciduous. Fruit 3-5-10bed,3-5-ralved. Aril red.

2. Paclystima. Dwarf evergreen shrub. Whowers very small. Finit ublong, 2-valved. Arll whitom 


\section{Cetástru S, L. Staff-tree. Sirrmby Brtrer-Sweet.}

Flowers polygamo-diacions. Petals (crenulate) and stamens 5, inserted on the margin of a ("mp-shaped disk which hines the base of the aty. $x$. l'od globose (orange-color and berry-like), 3-celled, 3-valved, lexulicital. Seels 1 or 2 in each coll, erect, encluserl in a pll pre searlet aril. - Leares alternate. Flowers snall, greenish, in lacene-like clusters terninating the branches. (An ancient Greek name for some erergreen, which om plant is not.)

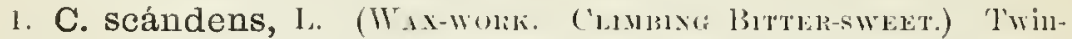
ing shrub; leares ovate-oblong, fucly serrate, pointed. - Mlong streans and thickets. June. - The opening orange-culored pods, displaying the scarlet covering of the seeds, are very urmanental in autumm.

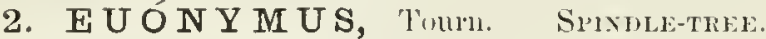

Flowers perfect. Sepals 4 or 5, united at the hase, forming a short and flat calyx. Petals 4-5, rounded, spreading, Stamens very short, inserted on the edge or face of a broal and flat 4-5-angled disk, which coheres with the calyx and is stretched over the ovary, alhering to it more or less. Style short or none. Pod 3-5-lobed, 3-5-valved, loculicidal. Secels $1-4$ in earch cell, enclosed in a red aril. - Shubs, with 4 -xided lnanchlets, opposite serrate leaves, and loose cymes of small flowers on axillary peduncles. (1)erivation from $\epsilon \bar{v}$, good, and ớ $\nu$ $\mu$ a, name, because it has the bad reputation of poisoning cattle. Tourn.)

1. E. atropurpùreus, Jacq. (Bunxivg-Busn. Wranoo.) Shrub tall $\left(6-1 t^{\circ}\right.$ high) and upright; leuces petioled, oval-oblung, pointed ; parts of the (dark-purple) flower conmonly in fours; pods smonth, deeply lobed. - N. Y. to Wrise., Neb., and southward; also cultivated. June. - Unnamental in antumn, by its copious crimson fruit, drooping on long peduncles.

2. E. Americànus, L. (STraweerry Busr.) Shrub low, upright or straggling $\left(2-5^{\circ}\right.$ high); leaves almost sessile, thickish, bright green, varying from orate to oblong-lanceolate, acute or pointed; parts of the greenish-purple Howers mostly in fives; porls rongh-urerty, depressed, crimson when ripe; the aril and clissepiments scarlet. - Wooderl rirer-banks, N. Y. to Ill., and southward. June.

Var. obovàtus, Torr. \& Gray. Trailing, with rooting branches; Howering stems $1-2^{\circ}$ high; leaves thin and dnll, obovate or oblung. - Low ur wet places; the commoner form.

\section{PA CH Ý S I M A, Raf.}

Flowers perfect. Sepals and petals 4. Stamens 4, on the edge of the broad (lisk lining the calyx-tube. Orang fuec; style very sluort. Pod small, oblong, D-eclled, lucnlicidally 2-valved. Seerls 1 or 2, enclused in a white membranacents nayy-cleft aril. - Low evergreen shrmbs, with smooth serrulate coria("ens opposite leaves and rery small green flowers solitary or fascieled in the axils. (1) (1)ivation olseure.)

1. P. Cánbyi, (iray. Leaves lincar to linear-oblong or oblong-obovate, obtuse, $3^{\prime \prime}-l^{\prime}$ long; perlicels very slender, often solitary, shorter than the leaves; fruit 2" long. - Mountains of s. Ir. Ia. 


\section{Order 27. RHAMNÀCEA. (Buckthory Family.)}

Shrubs or small trees, with simple leaves, small and regular flowers (sometimes apetalous), with the 4 or 5 perigynous stamens as many as the valvate sepals and alternate with them, accordingly opposite the petals! Drupe or pod with only one erect seed in each cell, not arilled. - Petals folded inwards in the bud, hooded ur coneave, inserted along with the stamens into the edge of the fleshy disk which lines the short tube of the ealyx and sometimes unites it to the lower part of the 2-5-eelled ovary Orules solitary, anatropous. Stigmas 2-5. Embryo large, with broad cotyledons, in sparing fleshy albumen. - Flowers often polygamous, sometimes diøcious. Leaves mostly alternate; stipules small or obsolete. Branehes often thorny. (Slightly bitter and astringent; the fruit often mucilaginous, commonly rather nauseous or drastic.)

* Calyx and disli free from the ovary.

1. Herchemia. Petals sessile, entire, as long as the calyx. Drupe with thin flesh and a 2-rellel bony putamen.

2. Rhammus. Prtals small, short-elawed, notehed, or none. Drupe berry-like, with 2-4 seprarate seed-like nutlets.

* * Calyx with the disk adherent to the base of the ovary.

3. Ceanotins. Petals long-clawed, hooden. Fruit dry, at lengrth deliseent.

\section{BERCH EIA, Necker. Suprefack.}

Calyx with a very short and roundish tube; its lobes equalliug the 5 oblong sessile acute petals, Ionger than the stamens. I )isk rejy thick and flat, filling the calyx-tube and eovering the ovary. I)mpe ob]ong, with thin flesh and a bony 2-celled putmuen. - Wooly high-climbing twiners, with the pinnate veins of the leares straight and parallel, the small greenish-white flowers in small panicles. (Name unexplainerl, probably personal.)

1. B. volùbilis, I)C. Glabrous; leaves oblongrovate, arute, scareely sermlate; style slont. - l)amp soils, Ta. to Ky. aul Mo., and southward. June. $-\Lambda$ scenching tall trees. Stems tough and very lithe, whence the popnlar name.

\section{RHÁ M N US, Tourn. Brektmors.}

CaIyx 4-5-cleft; the tube campanulate, lined with the disk. I'etals small, short-elawed, notched at the end, wrapped aronnd the short stanens, or sometimes none. Ovary free, 2-4-celled. Drupe berry-like (black), containing 2 -4 separate seed-like nutlets, of cartilaginous texture. - Shrubs or small trees, with loosely pinnately reined leaves, and greenish polyganous or diucious flowers, in axillary cInsters. (The ancient Greek name.)

\$ 1. RIIAMNTS proper. Flowers usually dixcious; nutlets and seeds deeply grooved on the back; rhuphe dorsal; cotyledons foliaceons, the margins revolute.

* Calyx-lobes and stamens 5 ; petals wantiny.

1. R. alnifolia, L'Her. A Iow shrub; leares oral, acute, serrate, nearly straight-veined; fruit 3-seeded. - Swamps, Maine to I'enn., Neb., and northward. June 
* Calyx-lobes, petals, and stamens 4 .

R. C.ithártica, L. (Commox весктиor:) Leques orate, minutely serrate; fiuit 3-4-seeded; branchlets thorny.-Oultivated for hedges ; sparingly naturalized eastward. May, June. (Nat, from Eu.)

-2. R. lanceolàta, Pirsh. Leares oblong-lanceolate and acute, or on flowering shoots oblong aud obtuse, finely serrulate, smooth or minutely downy heneath; petals deeply notched; fruit 2-seeded. - Hills aud river-lanks, Penn. (Mercersburg, Green) to Ill., Teun., and westward. May. - Shrub tall, not thorny"; the yellowish-green flowers of two forms on distinct plants, both perfect; one with short pedicels clustered in the axils and with a short included style; the otler with pedicels oftener solitary, the style longer and exserted.

§2. FRÁNGULA. Flowers perfect; nutlets and seeds not furroued; cotyledons flat, thick; rhaphe lateral.

3. R. Caroliniàna, Walt. 'Thomless shrub or small tree; leaves (3-5' long) oblong, obscurcly serrulate, nearly glabrous, deciduons; flowers 5-merous, in one form umbclled, in another solitary in the axils, short-peduncled; drupe globose, 3-seeded. (Frangula Caroliniana, firry.) - swamps and river-bauks, న. J., Ta. to Kị., and southward. Juue.

\section{CEA N ÒTHUS, I. New Jerser Tea. Red-root.}

Calyx 5-lobed, imcureal; the lower part cohering with the thick disk to the orary, the upper separating across in fruit. I'etals looded, spreading, on slender claws longer than the calyx. Filaments elongated. Fruit 3-lubed, dry and splitting into its 3 carpels when ripe. Seed as in \$ Frangula. - Sihrubby plauts; f fowers in little umbel-like clusters, forming dense panicles or corymbs at the summit of naked flower-branches; caly and pedicels colored like the petals. (An obscure name iu Theophrastus, probably misspelled.)

1. C. Americánus, L. (NEW Jerser TEA.) Lcaves orate or oblongovate, 3-ribbed, serrate, more or less pubesceut, often slightly heart-shaped at base; common peduncles elongated. - Dry moodlands. July. - Stems $1-3^{\circ}$ high from a lark red root; branches downy. Flowers in pretty white clusters, on leafy shoots of the same year. 'The leares were used for tea during the American Revolution.

2. C. ovàtus, I)esf. Leares nalrowly oval or elliptical-lanceolate, fincly. glandular-serrate, glabrous or nearly so, as well as the short comnou peduncles. (C. ovalis, Bigel.) - Dry rocks, W. Vt. and Mass. to Minn., Ill., and sonthwestwarl; rare eastward. May.

\section{Order 28. VTTACTAE. (Tinz: Famlo.)}

Shmubs with watery juice, usually climbing ly tendrils, with small regulur fovers, a minute or truncated calyr, its limb moslly olsolete, and the stamens as many as the valcate petals and opposite them! Berry 2-celled, usually 4-seeded. - Petals 4-5, very deciluous, liyporynous or perigynous. Filaments slender; anthers introrse. Pistil with a short style or none, and a slightly 2-lobed stigma; orary 2-celled, with 2 erect anatropous ovules from the base of eacle cell. Seeds bony, witl a minute 
cmbryo at the base of the hard albumen, which is grooved on one side. -- Stipules deciluous. Leaves alternate, palmately veined or compound; tembinils and flower-clusters opposite the leaves. Flowers small, greenish, commonly polyganous. (Joung sloots, foliage, etc., acid.)

* Urary surroumded by a nectariferous w orlanduliferour disk ; plants climbing by the conling of naked-tipurel tendrils.

1. Vitis. Corolla caducons witlont exlanding. Ifyongyous glonds 5, alternate with the stamens. Fruit pulpy Leaves simple.

2. Cissus. Corolla explanding. Disk cupular. Berry with seanty pulp, inedible. Leares simple or pimately compound.

* No distinet liylogynous disk; plants elimbing by the adluesion of the dilated tips of the tendrit-hanches.

3. Ampelopkis. Corulla expranding. Leaves digitate.

\section{VITTS, Tourn. Grapk.}

Flowers polygano-dicecions (some plants with perfect flowers, others staminate with at most a momentary wary), 5-merons. ('aly very short, usually with a nearly entire horler or none at all. Petals separating only at hase and falling off without expanling. Hypogyuous risk of 5 nectariferous glands alternate with the stamens. IBerry pulp. Seeds pyriform, with beak-like hase. - l'lants climbing by the coiling of naked-tipped tendrils. Flowers in a compound thyrse, very fragrant; jedicels motly umbellate-clnstered. Leaves smple, rombled and heart-shaped. (The classical Latin name.)

\$1. VITIS proper. Burk loose and shreddy; tendrils forked; nodes solid. + Atendril (or inforescence) opposite peich louf.

1. V. Labrúsca, L. (Nortuenex Fox-(Fkape.) Branchlets and young seaves very woully; leaves large, entire or deeply lohed, slightly dentate, coutinuing rnsty-wolly beneath : fertile panicles compact ; berries large. - Moist thickets, X. Ing. to the Alleghany Mountains, and sonth to $\therefore$. Car. June. Fruit ripe in Sept. or ()ct., dark purple or imber-color, with a tough musky pulp. Improvel ly cultivation, it las given rise to the Isabella, Catawba, Concord ant other varieties.

$$
++ \text { Tendrils intermittent (none opposite ench third leaf). }
$$

- Leares pubescent and flocrose, especially benerth and when young.

2. V. restivális, Michx. (Sumar Grape.) Brauchlets terete; leaves large, entire or more or less deeply aud obtusely 3-5-lobed, with short broal teeth, very woolly and mostly red or rusty when young; berries middle-sized, black with a bloom, in compact bunches. - Thickets; common. May, June. lierries pleasant, ripe in Sept. - V.131color, LeConte, has its leaves smoothish when old and pale or glancous beneath; common north and westward.

3. V. cinèrea, Engeln. (Dowry Grare.) Brancllets augular; pu. bescence whitish or gray isl, persistent; leaves entire or slightly 3-lobed; influrescence large and loose; berries small, black without bloom. - Central Ill. to Finn. and Tex.

++ Leaves glabrous and mostly shining, or short-hairy especzally on the ribs beneath, inrisely lobed or undivided.

4. V. cordifolia, Michix. (Frost or Cmekr. Grame) Leaves 3-4' wide, not lobed or slightly 3 lobed, cordate with a deep acute sinus, acuminate. 
coarsely and sharply toothed; stipules small; inflorescence ample, loose; herries small, black and shining, very acerb, ripening after frosts; seeds 1 or \& rather large, with a prominent rlaphe. - Thickets and strean-bauks, New ling. to central 11l., Mo., Neb., and southward. MLay", June.

5. V. riparia, Michx. I)ffering from the last in the larger and more persistent stipules (2-3" long), more slining and more nsually-3-lobed leaves with a broal rounded or truncate sims and large aeute or acmminate teetl, smaller (omilact inflorescence, and beries $\left(4-5{ }^{\prime \prime}\right.$ lroad) with a bloom, sweet and very juicy, ripening from .July to Sept. ; seeds very small; rhiphe indistinct. ( $r$. cordifolia, var. riparia, Groy.) - Stream-banks or near water, W. New Eng. to Prnm., west to Minn. and Kan. Eastward the berres ale sour and ripen late.

6. V.palmàta, Viahl. Branches bright red; leares dark green and dnll, 3-5-lohed, with a broal sinus, the lobes usually long-acuminate; inflorescence lauge aud loose; berries black, withont bloom, ripening late; seeds rery large and rounded; otherwise like 2. 5. (V'. rubra, MLich $x_{\text {. }}$ - Ill. and No.

7. V. rupéstris, scheele. (S.s. or Strul Grape.) Lsnally low and buslıy, often withunt tendrils; leaves rather small, shiniug, broadly eordate, abruptly pointed, with hroad coarse teeth, rarely slightly lobed; berries rather small, sweet, in rery small close bunches, ripe in $\mathrm{Mug}$ - Mo. to Tex; ; also found in Tenn., and reported from banks of the Potomac, near Washington.

\$2. MUSCADINIA. Bark rosely adherent on the branches; pith continuous thromgh the nodrs; tendrils simple, internittent; secds with tronsererso winkles on both sistes.

\&. V. rotundifòlia, Miclx. (Mrschns, Brulate, or Soltuenx Fox-Gistre.) Jeaves shining both sidese, small, l'ounded with a leart-shaped base, very coarsely toothed with hrom and hintish teeth, seldom loberl;

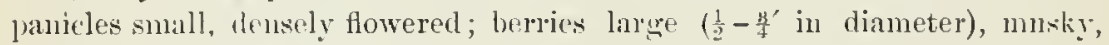
jurplish withont a bloom, with a thick and tongl skin, lipe early in autumu. (V. vulpina, M/m., not L.?) - River-hinks, Mol. to Ky., Mo., Kan., and sonthward. Mly - Branchlets minutely warty. This is the original of the semplermong (iriple, atc.

\section{CÍSSUS, I.}

Flowers perfect or sometines polygamous, 4-merums or (in ours) 5-merons. letals expanding. Disk cup-shaperl, surromding the base of the orary. Berry inedible, with scanty pulp. Seels nsually triangular-oborate. - Ten* drils in our species few and mustly in the inflorescence. I rast genus, mainly tropical. (Greek name of the liy.)

1. C. Ampelópsis, l'ers. Nearly glabrons; leares herret-yaped or trun eate at the hase, coarsely and sharply toothed, acmminate, not lobed; panicle small and loose; style slender; berries of the size of a pea, 1 -3-seeted, blnish or greenish. (Vitis indivisa, Willd.) - River-banks, Va. to lll., ant southward. June.

2. C. stans, l'urs. Nenly glilurons, bushy and rather upright; lraves turce prmate or ternate, tho leaflets cut-toothed; flowers rymose; ealyx is. roothed; disk very thick, allierent to the ovary; berries black, obovate (Vitis bipinuati, Torr. \&. Gray.) - Rich seils, Va. to Mo., and sonthward. 


\section{A MPELó PSis, Miclix. Virgiviax Creeper.}

Calyx slightly 5-toothed. Petals concare, thick, expanding hefore they fall. I)isk none. - Leares digitate, with $5(3-7)$ wlong-lanceolate sparingly serrate leaflets. H'lower-clusters cymuse. Tendrils fixing themselves to trunks or walls by dilated sucker-like disks at their tips. (Name from $a \mu \pi \in \lambda$ os, a vine, and ü $\psi$ ss, appearance.)

1. A. quinquefólia, Michx. A common wooly rine, in low or ricle grounds, climbing extensively, sometimes ly rootlets as well as by its diskbearing tendrils, blossoming in July, ripening its small blackish berries in October. Also called American $I^{\prime} y$, aul still less appropriately, Woodline. Leaves turning bright crimson in autumn.

\section{Order 99. SAPINDACEAE. (Sodpherty Family.)}

Trees or shrubs, with simple or compound leaves, mostly unsymmetrical and often irregular flowers; the $4-5$ sepals and petals imbricated in astivation; the 5-10 stamens inserted on a fleshy (perigynous or hypogynous) dish; a 2-3-celled and-lobed ovury, with 1-2 (rarely more) ovules in each cell; and the embryo ('xcept Staphylea) curced or convolute, without albumen. - A large and diverse order.

Suboridr I. Sapindeae. Flowers (often polyomous) mostly unsymmetrieal and irregular. Stamens commonly more numerous than the petals, ralely twice as many. Orules 1 or 2 in earh cell. Embryo eurved or eonvolute, rarely straight ; eotyledons thick and lleshy. - Leares alternate or sometimes opposite, without stipules, mostly compound.

1. Asculus. Flowers irregular. Calyx 5-lobed. Petals 4 or 5. Stamens commonly 7. Fruit a leathery 3.valved pod Leaves opposite, digitate.

2. Sapindus. Flowers regulir. Sepals $4-5$, in two rows. Petals $4-5$. Stamens $8-10$. Fruit a globose or 2-3-lobed berry Leaves alteruate, pinnate.

Suborder II. Acerineae. (Maple Family) Flowers (polygamous or diweious) small, regular, but usually unsymmctrieal. Petals often wanting. Ovary 2-lobed and 2-celled, with a pair of ovules in eaeh cell. Fruits winged, 1-seeded. Embryo eoiled or folded; the cotyledons long and thin. - Leaves opposite, simple or compound.

3. Acer. Flowers polyganous. Leares simple.

4. Negundo. Flowers diœcions. Leaves fiumate, with $3-5$ leaflets.

Strorder III. Staphyleae. (Bladner-Ntt Family.) Flowers (perfect) recrular; stamens as many as the petals. Ovules $1-8$ in each cell. Seeds bony, with a straight embryo in seanty albumen. - Shrubs with opposite pinnately compound leares, both stipulate and stipellate.

5. Staphylea. Lobes of the colored ealyx and petals 5, erect. Stamens 5. Frnit a 3 celled bladdery-inflated poul.

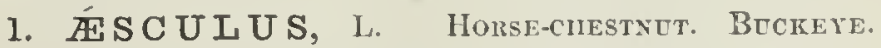

Calyx tuhular, 5-lobed, often oblique or gibbous at base. Petals $4-5$, more or less uuequal, with claws, nearly hypogynous. Stamens 7 (rarely 6 or 8); 
filaments long. slender, often unequal. Style 1; ovary 3-eelled, with 2 ornles in each cell. Fruit a leathery pod, 3-celled and 3-seeded, or usually by abortion 1-celled and 1-seetled, locnlicidally 3-valved. Seed very large, with thick shining eoat, and a large round pale scar. Cotyledons rery thick and fleshy, their contiguous faces coherent, remaining under ground in germination: plumule 2-leaved; radicle curved. - Trees or shruls. Leares opposite, digitate; leaflets serrate, straight-reined, like a Clıestnut-leaf. Flowers in a terminal thyrse or dense panicle, often polygamons, most of them with imperfect pistils and sterile; pedicels jointed. Seeds farinaceous, but imbned with a bitter and narcotic principle. (The ancient name of some Oak or other mast-bearing tree.)

\$ 1. ASCULUS proper. Frut covered with prickles when young.

王. Huppocastanum, L. (Commox Horse-Cuestrit.) Corolla spreading, white spotted with purple and yellow, of 5 petals; stamens declined; leaflets 7. - Commonly planted. ( $\Lambda \mathrm{dr}$. from $\Lambda$ sia via Iin.)

1. 尼. glàbra, Willd. (Fetid or ()mo Bcekre.) Stamens curved, longer than the pale yellow corolla of 4 upright petals; leaflets usually 5. River-banks, W. Penn. to Mich., Mo., Kan, and southward. June. $-\mathbf{A}$ large tree; the bark exhaling an nnpleasant odor, as in the rest of the genus. Flower's small, not showy.

§ 2. IAVIA. Frut smooth; petals 4, conmuing; the 2 upper smaller and longer than the others, with a small ronnded blade on a very long cluw.

2. Af. flàva, Ait. (Sweet Bucrere.) Stumens included in the yellow eorolla; caly $x$ oblong-campanulate; leaflets 5 , sometimes $\bar{i}$, glabrous, or ofterr minutely downy underneatl. - Rich woods, Va. to ()hio, Mo., and southward. May. A large tree or a shrub.

Var purpuráscens, Gray. Calyx and corolla tinged with flesh-eolor or dull purple; leaflets commonly lowny beneath. - From Wr. Va., sonth and westward.

3. 王. Pàvia, I. (Rev Buckire.) Stamens not longer than the corolla, which is bright red, as well as the tubular ralyx; leatlets glabrous or soft-downy beneath. - Fertile valleys, Va., Ky., Mo., and sonthward. Mặ A shrub or small tree.

\section{SA P I N D U S, I. SolP-BERrT.}

Flowers regular, polygamons. Sepals $4-5$, imbricated in 2 rows. Petals $4-5$, with a scale at the base. Stamens 8-10, upon the hypogynons disk. Ovary 3-celled, witl an ascending orule in each cell. Fruit a globose or 2-3lobed herry, 1-3-seeded. Seed cmstaceous, gloluse. - Trees or slumbs, with alternate abruptly pinnate leares, and small flowers in terminal or axillary. raeenes or panicles. (Name a contraction of supn) Indicus, Indian suap, laaiing reference to the saponaceous chancter of the berries.)

1. S. acuminàtus, liaf. A tree $20-60^{\circ}$ ligh ; leaflets $4-9$ pairs, obliquely lanceolate, sliarly acuminate, 'ntire, $1 \frac{1}{2}-3^{\prime}$ long; the rhachis of the leaf not winged; flower's whice, in a large panicle; fruit nostly globose, 6" broad. (S. marginatus of anthors, not Willd.) -S. Kan, to La., Fla., and Mex. 


\section{3. ÀCER, Tourn. Maple.}

Flowers polygano-diceions. Calyx colned, 5- (rarely 4-12-) lobed or parted. l'etals either none or as namy as the lubes of the calyx, equal, with short elaws if any, inserted on the mingin of the lobed disk, which is either

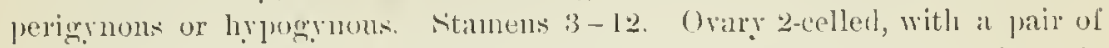
ormles in each cell; styles 2, long and slender, united only below, stigmatic down the inside. From the back of each calpel grows a wing, converting the fruit into two l-seceled, at length separalle sumaris or keys. Embryo variously coiled or folded, with large and thin cotyledors. - l'rees, or sometimes shrubs, with opposite palmately-lobed leaves, and snmil Howers. l'edicels not juinted. (The classical namos, from the ('eltic: ar, lard.)

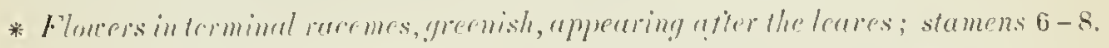

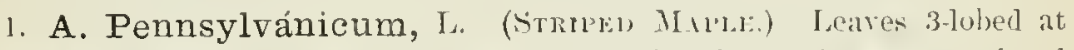
the apex, futely and sharply donbly sermate, the short lobes titper-pointer and alse serrate; aremes deomping, loose: pretuls oborete: fluit with large

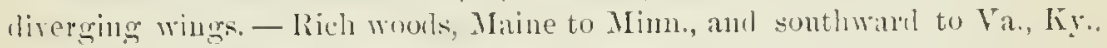
and Mo. June. - A small and slenter tree, with light-green birk striped with dak lines, and greenish flowers and fruit. Also called Sirnod Dorg-

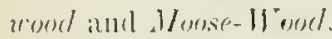

2. A. spicàtum, lam. (Morxtus .I.) Leaves dowm beneatl, 3- for slighty .x-) lohed, coalscly serrate, the lobes taper-puinted; raremes upright, dense, somewhat componul; phlsk linear-spundule: fruit with small erect or divergent wings - Moist wouks, with the sane range as n. 1. Jnne. $-\Lambda$ tall shrul, forming clumps.

* Floners in nearly sessile terminul and luterul umbellate-corymbs, greenishyellowe, "rjpenting with the leceres.

3. A. saccharinum, Wang. (Norit or lexk M.) Leaves -5 lobed, with romuled sinuses and pointed sparingly sinute tonthed lobes, either heartslaped or nearly trumeate at the hase, whitish and smonth ol a little rlowny on the veins beneath; flowers lirom teminal leaf-bearing and lateral leatiess buds, dromping on very slenler hairy pexlicels; caly $x$ hairy at the apex ; petals none; wing of the fruit hoal, nsmally slightly diverging - Rich wouk, wpecially northward and along the monntains southward. A juril, hisy- $-\Lambda$ large and habdiome tree.

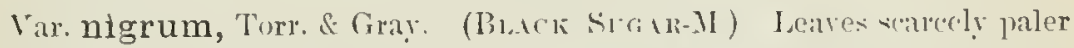
beneath, lnut often minutely diwny, the lobes willer, often -lonter aud entire, the simms at the hase often closed. - With the ordinary form; quite variable, sometimes appearing distinct.

* * Hluwers in umbel-lilie clusiers arising fiom sepiarde lateml buds, and much preceding the leaves; stumens: $3-6$

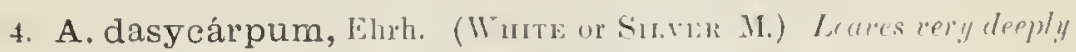
5toled with the sinuses rather acute, silvery-white (and when yomg downy) underneatl, the divisions narow, cut-lobed and tonthed; fluwers (sreenishyellow) on short peedicels; petrels none; fimit weolly whn youm, with large divergent wings - River-lauks; most common southwarl aud westward. Marcl - April. - A fine ornamental tree. 
5. A. rubrum, I. (RED or Swane M.) Laters 3-5lobed, with aente sinuses, whitish underneath; the lobes irregularly serrate and notched, aente, the middle one usually longest; petuls linear-oblong; flowers (scarlet, crimson, or sometimes vellowish) on very short pedicels; but the smonth, fruit on prolonged dlooping prelicels. _ Swamps and wet woorls. April. - I small tree, with reldish twigs; the leares rarying greatly in slape, tuming bright crimson in early autumu.

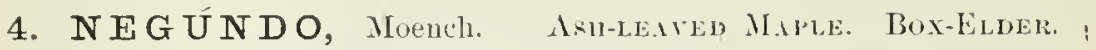

Flowers cliacions. Calyx minute, 4-j-eleft. letak mone. Stamens $4-5$. bisk none. - Sterile fluwers in clusters on capilliny perlicels, the fertile in (lrooping racemes, from lateral buls. Leares pimite, with 3 or 5 leaflets. Fluit as in Acer. (Name mumeaning.)

1. $\mathbf{N}$. aceroides, Mornch. Leaflets smoothish when old, rery reiny, wate, pointed, toothel ; fruit sunooth, with large rather incurred wings. River-banks, W. New Eng. to the Dakotas, south and westwarl. A pril. - A small int handsome tree, with light-green twigs, and very delicate drooping chsters of small greenish flowers, rather earlicr than the leaves.

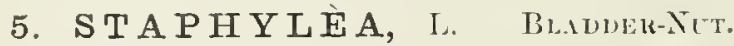

Caly reeply 5-parterl, the lobes erect, whitisl. Petals 5, erect, spatulate, inserterl on the maroin of the thick perigrnons rlisk which lines the base of the aly. Stamens , altermate with the petals. P'istil of 3 seremal-ownlest ("alpuls, nuted in the axis, thoir long styles lightly cohering. Pod large,

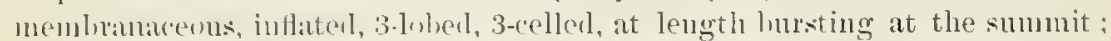
the cells containiner I +4 boug anatropous seeds. Aril none. Embryo larege aud straight, in seanty albumen, cotyledons broul aud thin. - L pright shoruls, with opposite pinuate leaves of 3 or 5 serute leaflets, and white towers in lrouping raceme-like clustels, teminating the branchlets. Stipules and stipels

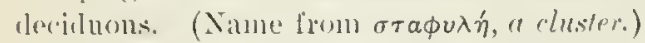

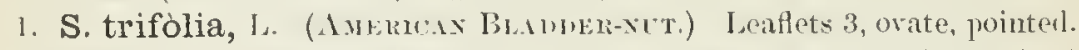
- Thickets, in molst soil. May, - Shrul, $10^{\circ}$ high, with greenish striped britlches.

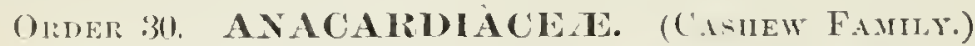

Trees or shrubs, with resinous or milliy acrid juice. dotless alternate leares, and smatl, often polygamons, regular, 5-merous flowers, but the ovary 1-celled and 1-oculed, with 3 styles or sligmas. - P'ctals imbrieated in the bud. Frut mosty drupareons. Serd withont albumen, bolne on a rmrerl stalk that rises from the base of the eell. Sitiules none. Juice or exlatations often poisonons.

\section{RHÚS, I. кіхими.}

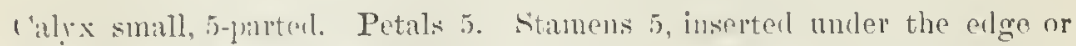
hetween the lobes of a flattened clisk in the lottom of the calyx. Fruit sulall

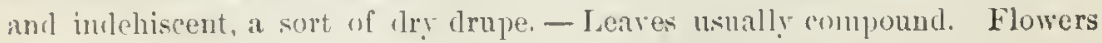
greenisli-white or yellowislı. (The old Greek and Latin name.) 
§1. RHUS proper. Fruit symmetrical, with the styles terminal.

* Flouers polygamous, in a terminal thyrsoid panicle; finit globular, clothed with acid crimson hairs; stone smooth; leaces odd-yimute. (Not poisonons.) - (S SUMAC, 1)C.)

1. R. týphina, 1. (STiguorx Siunul) Branches and stalks densely velety-hairy: leaflets 11 -31, pale beneath, wblong-lanceulate, puinted, serrate, rarely laciniate. - Hillsiles. June. - Shmub or tree $10-30^{\circ}$ hish, with orange. colored wook. Apparently lỵbidizes with the next.

2. R. glàbra, L. (Smootr.s.) Smooth, somercht gluucous; leatlets 11 31, whitenel beneath, lanceslate-ohloug, pointed, serrate. - Rocky or barren soil. June, Jnly - Nhruh $2-12^{\circ}$ high. A var. has laciniate leafiets.

3. R. copallina, L. (1)war S.) Brunches and stulks dowy: petoles wing-margined between the 9-21 bblong w wate-lanceolate (often entire) leaflets, which are oblique or uneynal at the base, smouth ant shining above. Rocky hills. July, - Shrub $1-7^{\circ}$ higl, with running roots.

* Flowers polyyamous, in loose and sleuder axillar! panicles ; fruit glubular. ylubrous, whitish or dun-colored; the stone striate; leates odd-pimate or 3-

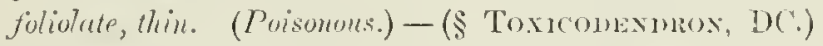

4. R. venenàta, DC. (Porsux S. or l)orwou.) Smooth, or nearly: so; leaffets $7-13$, oboxute-ablony, entire. - Swamps. Junc. Shrub 6-18 high. The most poisonous species; also callen] Prisom Lileter.

5. R. Toxicodéndron, I. (Puson Ir. Porsox ()ik.) Climbing by rootlets urer rocks, etc, or ascencling trees, or sometimes low and erect; lerbfets 3, womluc-oucte, mostly pointed, and rather downy beneath, variously notched, sinuate, or cut-lobed, - high-climbing plants (li. raclicans, L.) baving nsually nore entire leaves. - Thickets, low gronnds, etc. June.

* * *lowers polygumo-diuerous, in smull solitury or clustered spilies or heads which develop in spring butine the lentes: leares 3-foliolute; finit us in first

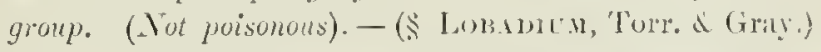

6. R. Canadénsis, Marsh. Leares soft-pubescent when young, becoming glabrate; leaflets rhomlic-obovate or orate, nnequally cut-toothed, 1-3' long, the terminal one cmeate at base and sometimes 3-cleft; flowers pale yellow. (12. aromatica, .lit.) - Dry rocky banks, WT. Vt, to Minn., and southwarl. - I straggling bush, 3-7० high; the crushed leaves not unpleasiutly scented.

Var. trilobàta, Gray. With smaller leaflets ( $\frac{1}{2}-I^{\prime}$ long), crenately ferrlobed or incised toward the summit. - Long l'ine, Neb., and common westwarl. Unpleasantly scented.

\$. CO'T1NUS. Ovary becoming very gibbous in frut, with the remains of the styles lateral; flowers in loose ample punicles, the pedicels elonguting and becoming plumose; teures simple, entire.

7. R. cotinoldes, Nint. Glabruns or nearly so; leaves thin, oral, $3-\epsilon^{\prime}$ loug; flowers and fruit as in the cultivated Smoke-tree (R. Cotinus). - Mo. to 'Tenn., and southward. $-\triangle$ tree, $25-40^{\circ}$ high. 


\section{Order 31. POLYGaläceat. (Minkort Family.)}

Plants with irregular hypogynous flowers, $4-8$ dialelphous or manadelphous stumens, their 1-celled anthers opening at the top by a pore or chink: the fruit a 2-celled and 2-seeded pod.

\section{POLÝGALA, Tourn. Mnковт.}

Flower very irregular. Calyx persistent, of 5 sepals, of which 3 (the upper and the 2 lower) are small and often greenish, while the two lateral or inner (called ungs) are much larger, and colored like the petals. P'tals 3, hypogynous, connected with each other and with the stamen-tule, the middle (lower) one keel-shaped and often crested on the back. Stameus 6 or 8 ; their filaments united below into a split sheath, or into 2 sets, colering more or less with the petals, free above; anthers l-celled, often cup-shaped, opening by a hule or lroal chink at the apex. Ovary 2-celled, with a single anatropous orule pendulous in each cell; strle prolonged and curred; stigma rarious. Fruit a small, loculicrlal 2-seeded porl, nsually rounded and notched at the apex, much flattened contrary to the very narrow partition. Seeds carumculate. Linbryo large, stranght, with flat and broad cotyledons, in scanty allumen. - Bitter plants (low herls in temperate regions), with simple entire often lutted leares, and no stipules; sometimes (as in the first two species) bearing clesstugamous flowers next the gronnu. (An old name composed of modús, much, and $\gamma \alpha \dot{\alpha} \lambda \alpha$, milh, from a fancied property of its increasing this secretion.)

* Perennial or biennial; flowers purple or uhite; leaves alternate.

- Flowers shoucy, rose-purple, conspiruously crested; also bearing inconspicuous colorless cleistogamons flower's on subterranean branches.

1. P. paucifolia, Willd. Permmial: flowering stems short (3-4' high), from long slenter prostrate or sultermeau shoots, which also bear concealed fertile Howers; lower leaves small and scale-like, scattered, the upper orute,

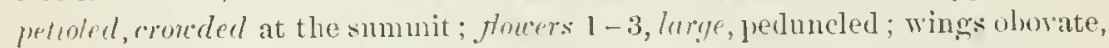
rather shorter than the fringe-crested keel; stamens 6 ; caruncle of 2 or 3 awshapeel lolses longer than the seed. - Wools, in light soil, N. Eng. to Mimm., I11., and sonthward along the Alleghanis. May. -1 delicate plant, witla rery handsome flowers, 9" long, rose purple, or rarely pure white. Sometimes

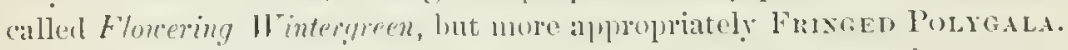

2. P. polýgama, Walt. Stems numerous from the hennial root, mostly

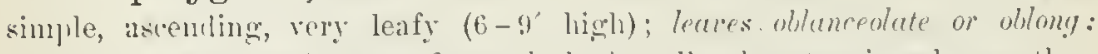
terminal mer me fowsely many-fourecel, the broudly oluovate wings longer than the keel; stamens 8; radieal flowers racentel on sliort subterranean rumers; lobes of the (arnncle 2, scale-like, shorter than the seet. - Dry sandy suil; common. July.

+ + Floncers uhite, in a solitary close spike; none cleistogamous.

3. P. Sénega, I. (Sexeca Sxakeroot.) Stems several from thick and hard knotty' rootstocks, simple $\left(6-12^{\prime}\right.$ lighli $)$; leares lanceolate or oblonglanceolate, with rough margins; wings rouml-oburate, concave; crest short; caruncle nearly ins long as the reed. - Rucky suil, W. New Fog. to Minn., and southward. Mar, Juse. 
Var. latifolia, Torr. \& Grar. Taller, snmetimes branched; leares orate or orate-lanceolate, $2-4^{\prime}$ long, tapering to earch end. $-\mathbf{M}$ d. to Mich. and $\mathrm{K}$.

4. P. álba, Nutt. Stems several from a lard ruotstock, $1^{\circ}$ high; leaves narrowly linear, $3-12^{\prime \prime}$ long, acute; wings ohlong-oborate; crest small; lubes of the caruncle half the length of the appressed-silky seed. - Neb. and Kan. to' 'Tex.

* * Annuals, with all the leaves alternate; fourers in terminal spikes, heads or racemes, purple or rase-rolur, in summer; none subterranean.

:- Keel conspicuously crested; claurs of the true petals mited into a long and slender cleft tube much surpassing the wings.

5. P. incarnàta, L. Glancons; stem slender, sparingly lurancherl; leares miunte and linear-awl-shaped; spike cylindrical ; flowers flesh-color; caruncle longer than the narrow stalk of the hairy seed. - Dry soil, Penn. to Wisc., Iowa, Neb., aud southward; rather rare.

+ + Keel minutely or inconspicuously crested; the true petals not longer but mostly shorter than the wings; seed pear-shaped.

6. P. sanguinea, L. Stem sparingly branched abore, leafy to the top ; leares oblong-linear; heads ylubular, at length oblung, very dense ( $t-5$ " thick), bright red-purple (rarely paler or eren white); perlicels scarcely any; wings broadly orate, rlosely sessile, longer thin the pod; the 2-parted caruncle almost equalling the seed. - Sandy and moist ground; common.

7. P. fastigiàta, Nutt. Stem slender, at length corymbosely luranched; leares narrouly linear, acute, $3-8^{\prime \prime}$ long; spikes short and dense ( $3^{\prime \prime}$ in diameter); the small rose-purple flowers on pedicels of about the length of the pod; wings obovate- or oral-oblong, narrowed at the lase, scarcely exceeding the pod; bracts deciduons with the flowers or fruits; caruncle as long as and nearly enveloping the stalk-like base of the minutely hairy seed. - I'ine barrens of N. J. and Del. to liy., and soluthward.

8. P. Nuttàllii, Torr. \& Gray. Resembles the last, but nsually lower; spikes cylindrical, narrow; flowers duller or greenish purple, on very shurt pedicels: the awl-shaped scaly bracts persistent on the axis after the flowers or fruits fall; seed rery hairy, the cartuncle smaller. - 1)ry sandy suil, const of Mass. to Mo., and sonthward. - Spike sometimes rather loose.

9. P. Curtíssii, Gin:1y. Slencler $\left(9^{\prime}\right.$ highl), leaves, etce, as in the two preceding, flowers rose-pmrple, in usnally short racemes; perticels ahout equalling or exceeding the persistent bracts; the nurrou oblong erect arings fully tuce the length of the porl: carnucle small, on one side of the stalk-like hase of the very hairy seed, which is conspicuonsly apirulate at the broader end. - IId. to Ga. The species was founded upron an ahnormal form with elongated racemes and pedicels.

*** Ammals with at least the lourer stem-lentes whorled in fours, sometimes in

fives; spikes terminating the stem and branchis; fl. summer and cutumn.

- Spikes short and thek ( +-9 "in dhameter); brats persisting after the fall of the (middle-stzed) rose or greenish purple flowers; crest small.

10. P. cruciàta, L. Stems $\left(3-10^{\prime}\right.$ high $)$ alnost winged alt the angles, with sprealing opposite hranches; leares nearly all in funrs, linear and sumewhat spatulate or oblanceolate; spikes sessile or mearly sn; wings lroadiy 
deltoid-orate, slightly heart-shaped, tapering to a bristly point or rarely pointless; caruucle nearly as long as the seel. - Margin of swamps, Maine to Va. and sonthwarl near the coast, and west to Minn. and Neb.

11. P. brevifolia, Nutt. Rather slender, branchel ahore; leaves scattered on the branches, narrower; spikes peduncled: wings lanceolute-orate, pointless or barely mucronate. - Margin of sandy bogs, li. I., N. J., and southward.

+ + Spilies slender (about $2^{\prime \prime}$ thacli), the bracts falling with the flowers, which are small, greenish-white or bavely tinged with purple, the crest of the here larger.

12. P. verticillàta, L. Slender $\left(6-10^{\prime}\right.$ high $)$, much hrancheel; stemleares all whorled, those of the (mostly opposite) luanches scattered, linear, acute; spikes peduncled, nsually short and dense, acnte; wings romnd, clawed; the 2-lobed caruncle half the length of the seed. - Inry soil; common.

Var, ambigua. Leaves (and luranches) all seattered or the lowest in fours; spikes long-peduncled, more slender, the flowers often purplish and scattered. (1'. ambigua, Nitl.) - N. Y. to Mo., and southward.

* * * Biennials or ammals, wh alternate leaces, and yellow fourers, which are disposed to turn greenish in drying; crest smull; foucering all summer.

13. P. lùtea, I. Luw ; flowers (briglt orange-yellow) in solitury ocate or ollong hearls (年' thick) terminatiug the stem or simple branches; leaves ( $1-2^{\prime}$ long) ubovate or spatulate; lobes of the carumele necurly as lony as the sed.Sandy swanls, N.J. and southward, near the coast.

14. P. ramosa, Ell. Flouer's (ritron-yellow') in mumerous sliort and dense spilie-like ruremes collerter in a flat-topped componud cyme: leaves oblonglinear, the lowest spatulate or obovite; seeds ovoid, minutely hairy, tuice the lemgth of the curnucle.-1)amp pinc-barrens, Del. and sonthward.

15. P. cymósa, Walt. Stem short, naked abore, the numerous racemes in a usually nearly simple crme; leaves narrow, acuminate; seeds globose, without caruncle. - Del, and sonthward.

\section{Order 3:. Leguminòs a . (Pulge Famly.)}

Plants with permlionnceous or sometimes regular flowers, 10 (rarely 5 and sometimes many) monarlelplous, diaclelphous, or rarely disfinct stamens, and "single simple fice pistil, lecoming a legume in fruit. Sceds mostly uithout allumen. Lortes alternate, uith stijules, usually compound. One of the surals inferior (i. e. next the bract); one of the petals superior (i.e. next the axis of the inforescence). $-A$ very large order (nearly free from noxious qualities), of which the principal representatives in nortlim temperate regions belong to the first of the three suborders it eomprises.

Strorder T. P'apilionacer. Calyx of 5 sepals, more or less united, often unequally so. Corolla inserted into the hase of the calyx, of 5 irregular letals (or very rarely fewer), more or less distinctly papil-

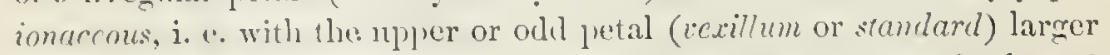
than the others and enclowing them in the but, wsully tmmed harkward 
or spreading; the two lateral ones (wings) oblique and exterior to the two lower, which last are connivent and commonly more or less coherent by their anterior edges, forming the carina or heel, which usually encloses the stanens and pistil. Stamens 10, rery rarely 5, inserted with the corolla, monadelphous, diadelphous (mostly with 9 united into a tube which is eleft on the upper sicle, and the tenth or upper one separate), or oceasionally distinct. Orary 1-eelled, sometimes 2-ecelled by in intrusion of one of the sutures, or transversely 2-many-eelled by cross-division into joints; style simple; orn!es amphitropous, rarely aratropous. Co tyledons large, thick or thekish; radicle incurved. - Lcaves simple or smply compound, the earlicst ones in germination usually opposite, the rest alternate; leallets ahmost always quite entire. Flowers perfect, solitary and axillary, or in spikes, racenes, or panicles.

I. Staneus (10) distiuct.

* Leares palmately 3 -folinhate or simple ; calyx 4-5-lobed; herbs. (POD -- RIE.E.)

1 Baptisia. l'od inflated

2. Thermopsis. Dorl flat, linear.

* Leaves pinuate; calyx-teeth sliort. (SopHone...)

3. Cladrast is. Forvers panicled, white. Pod flat. A tree.

4. Sophora. Flowers lacemuse, white. Pod terete, moniliform. Itubaceous.

1I. Stanens monadelphous, or diatelphous (9 and 1, ramely 5 and 5 ); nearly distinct in $\mathrm{n} .14$.

- Antliers of two forms; stamens monadelphous; leaves digitate or simple; leaflets entire.

$$
\text { (GENISTE.K.) }
$$

5 Crotalaria. Calyx 5-lober. Pod intlated. Leaves simple.

6. Genista. Calyx 2-lipped. l'ur flut, Seed estrophiolate. Lenves simple. Slumbby.

7. Cytisus. Calyx 2-lipled. Pud flat. Seen strophiolate. Leares 1-3-foliolate. Shrubby.

5. Lupinus. Calyxiderely 2-lipped. Pod flat. Leaves 7 -11-foliolate.

* Authers unifurm (except in 11.13 and 29).

- Leaves digitutely (rirely pimately) 3-foliolate: leaflets dentienlate or serrulate : stamens diadelplunus; porls small, 1 -few-seeded, often enclosed in the ealyx or curved or collal. (TRTFLELE.)

9. Trifoliun. Flowers capitate. Pods membranaceous, 1-G-seeded. Petalsadjerent to the stamen-tube

10. Melilotus. Flowers racenteu. Poul coriaeons, wrinklerl, 1-2-secded.

11. Medicago. Howers raeemed or spilied. Pods curvel or coiled, 1 - few-seeded.

+ + Leaves unequilly linuate (or digitate in n. 13); pod not jointed; not twining nor climbing (except 11. 20).

++ l'lowers umbellate (solitary in ours) on axillary pedmeles. (Toteš.)

22. Hosackia. Leaves 1 - 3-foliolate. Peduncle leafy-bracteate. Ponl linear.

$$
++++ \text { Flowers in spikes, raremes, or heals. (Galegex.s) }
$$

- Herbare glandular-dotted; stamens mostly monadelphous; pod small, indehiseent, mostly 1-seceled ; leaves pinate (except in 11.13 ).

13. Psoralea. Comolla truly papilionaceous, stamens 10 , half of the anthers often smaller or less perfect. Leaves inostly palmately 3 - 5-foliolate.

14. Amorplia. Corolla of one petal ? Stamens 10, monadelphous at hase.

15. Dalea. Cornlla imperfectly papilionaceous. Stamens 9 or 10 ; the cleft tube of filaments lrearing 4 of tlie petals abont its niddle.

16. Petalostemon. Copolla scureely at all papilinnacenus. Stamens 5 ; the eleft tube of flaments beariug 4 of the petals on its summit. 
$==$ Herbage not glandular-dotted (except in $\mathrm{n}$. 23); stameus mostly diarlelpnous: pnor ¿-valved, several-seeded; leates pinnately several-fololate; nowers racemost.

a. Wings collering with the keel; lod flat or 4-angled; hoary peremial herbs.

17. Tephrosia. Standard broad. Fod flat. Leaflets pinnately veinerl.

18. Indigofera. Calyx and standard suall. Pod 4-angled. Leaftets olscurely veined. b. Flowers larce and slowy; standard hroad; wings free; woody; leatlets stipeilate.

19. Robinia. Pod flat, thin, margined on one edge. Trees or shruls.

20. Wistaria. l'od tumil, marginless. Woody twiners ; leaflets obsenrely stipellate. c. Standard narrow, erect; pod turgid or iuflated; perennial herbs.

21. Astragalus. lieel not tipped with a point or sharp apryendige. Pud with ne or buth the sutures turned in, sometimes dividing the cell lengthwise into two.

22. Oxytropis. Keel tipped with an erest point; otherwise as Astragalus.

23. Glycyrrhiza. Flowers, etc, of Astragalus. Antherecells confluent. Pod prickly os muricate, short, nearly indehiscent.

+++ Herbs with pinnate or pinnately $1-3$-foliolate leaves; no tendrils ; pod transversely 2 -several-jointed, the reticulated l-seeded juints indehiscent, or sometines reduced to one such joint. (IIEDYSARE.E.) $=$ Leaves pinnate, with several leaflets, not stipellite.

24 Eschynomene. Stamens equally diadelphous (5 and 5). Calyx 2-lipped. Pod several. jointed; joints square.

25. Coronilla. Stanens nuequally diadel phous $(9$ and 1$)$, Caly $\times 5$-toothed. Joints oblong. 4-angled. Flowers umbellate.

26. Hedysarum. Stauens unequally diadel jhous (9 aud 1). Calyx 5-cleft. Pod severaljointed ; joints roundish.

$$
==\text { Leaves pirnately 3-foliolate, rarely } 1 \text {-foliolate. }
$$

27. Desmodium. Stamens diadelphots (? and 1) or monadelphous below. Calyx 2-lipped. $P^{\prime}(u l$ several-jointed. Flowers all of ne sort and complete. Leaflets stipellate.

28. Lespedeza. Stamens diadelphous (9 and 1): anthers uniform. Pod 1-2-jointcu. Flowers often of 2 sorts, the more fertile mes apetalous. Leaflets unt stipellate.

29. Stylosanthes. Stamens monalelpluns; anthers of 2 sorts. P'od 1-2-jointed. Calyx deciduous, the tube narrow and stalk-like. Leaflets not stipellate.

++++ Herbs with abrultly pirmate leaves, terminated by a tentril or bristle: stamens fliadelphons: poul continuous, 2-valved, few-several-sceded. (Vicies-)

30. Vicia. Wings adherent to the keel. Style filiform, hearded with a tuft or ring of lasirs at the apex.

31. Lathyrus. Wings nearly free. Style somewhat dilated aurl fluttened upwards, bearded down the inner face.

$+\ldots+++$ Twining (sometimes only trailing) herbs; leaves pinnately 3- (rarely 1- or 5-7-) folioliate; no tendrils; peduneles or flowers axillary pou not jointed, 2-valved. (Phaseoleme.)

$$
=\text { Leaves pinuate. }
$$

32 Apios. Herbaceous twiner; leaftets $5-7$. Keel slender and much incurved or coiled. $==$ Leaves 3 -foliolate. Orules and seeds sereral. Flowers not yellow.

33. Phaseolus. Kecl spirally coiled : staudurl recurved-spreading. Style bearded length. wise. Flowers maremose. Sewls rouml-reniform.

34. St rophostyles. Reel long, strongly incurved. style bearded lengthwise. Flowers sessile, capitate, few. Seeds ollumg, mostly mbescent.

35. Centrosema. Culyx short, 5-cleft. Stanclard with a spur at the base; keel broad, merely ineurved style minutely beardul next the stigma.

36. Clitoria. Calyx tubular, 5-lnherl, stanclaril ereet, spurless; keel seythe-slıaped. Style beardicl down the inner line.

37. Amphicarpira. Calyx tuhular, $4-j$-tonthed. Standarl trect; keel almost straight Stỵle beardless some nearly apetalous fertile flowers next the grouud. 
38. Galactia. Calyx 4-cleft, the upper lobe broadest and entire. Style beardless, Bract and bractlets minute, mostly deciduous.

$===$ Leaves $1-3$-foliolate. Ovules and seeds only one or two. Flowers ycllow.

37. Rhynchosia. Keel scythe-shaped. Calyx 4-5-parted. Pod short.

Suborder II. Caesalpiniere. (Brasilfito Famir.) Corolla imperfectly or not at all papilionaceous, sometimes nearly regular, imbricated in the bud, the upper or odd petal inside and enclosed by the other: Stamens 10 or fewer, commonly distinet, inserted on the calyx. Seeds anatropous, often with albumen. Embryo straight.

* Flowers imperfectly papilionaceous, perfect. Trees.

40. Cercis. Calyx campanulate, 5-toothed. Pod flat, wing-margined. Leaves simple.

* Flowers not at all papilionaceous, perfect. Calyx 5-parted. Herbs.

41. Cassia. Leaves simply and abruptly pinnate, not glandular-punctate.

42. Hoffimanseggia. Leaves bipinnate, glandular-punctate.

* *lowers not at all papilionaceous, polygamous or diœcious. Trees.

43. Gymmocladus. Leaves all doubly pinuate. Calyx-tube elongated, at its stmmit bearing 5 petals resembling the calyx-lobes. Stamens 10 .

44. Gleditschia. Thorny ; leavessimply and doubly pinnate. Calyx-tube short; its lobes, petals, and the stamens $3-5$.

Suborder 1II. Mimosere. (Mmosa Family.) Flower regular, small. Corolla valvate in rstivation, often united into a $4-5$-lobed eup, hypogynous, as are the (often very numerous) exserted stamens. Embryo straight. Leaves twice pinnate.

45. Desmanthus. Petals distinct. Stamens 5 or 10. Pod smooth.

46. Schrankia. Petals united below into a cup. Stanens $S$ or 10. Pod covered with sinall prickles or rough projections.

\section{BA PTÍSIA, Vent. False Irdigo.}

Calyx 4-5-toothed. Standard not longer than the wings, its sides reflexed; keel-petals nearly separate, and, like the wings, straight. Stanens 10, distinct. l'od stalker in the persistent calyx, rumdish or oblong, inflated, pointed, many-seeded. - Perennial herbs, with palnately 3-foliolate (rarely simple) leaves, which generally blacken in dryng, and racemed flowers. Named from $\beta a \pi \tau l \zeta \omega$, to dye, from the economical use of some species, which vield a poor indigo.)

* Racemes many, short and loose, terminal, often leafy at base, flouers yellow.

1. B. tinctoria, R. Br. (WiLn Irnıoo.) Smooth and slender $\left(2-3^{\circ}\right.$ high), rather glancous; leaves almost sessile, leaflets rounded wedge-obovate $\left(\frac{1}{2}-1 \frac{1^{\prime}}{2}\right.$ long); stipnles and bracts minute and deciduous; pords oral-globose, on a stalk longer than the calyx. - Sandy dry soil, N. Eng. to Fla., west to Minn. and La.

$$
\begin{aligned}
& \text { * Racemes fewer, opposite the leaves. } \\
& + \text { Flowers yellor. }
\end{aligned}
$$

2. B. villosa, E1l. Sometimes suft-hairy, nsually minutely pubescent when young, erert $\left(2-3^{\circ}\right.$ ligh) with divergent branches; leares almost see- 
sile; leaflets wedge-lanceolate or obovate; lower stipules lanceolate and persistent, on the branchlets often small and subulate; racenes many-flowered; pedicels short; bracts subulate, mostly deciduous; pods oroid-oblong and taper-pointer, minutely pubescent. - Va. to N. C. and Ark.

$$
+ \text { t- Flowers white or ream-color. }
$$

3. B. leucophæa, Nutt. IIairy, /ow (1 ${ }^{\circ}$ higrli), with dirergent branches; leares almost sessile, leaflets narrowly oblong-obovate or spatulate; stipules and bracts lurye and lenfy, persistent; meness long (uften $1^{\circ}$ ), redined; flowers on elongated pedicels, cream-casr: porls pointed at both ends, hoary. - Mich. to Minn., soutl to Tex. A pril, May.

4. B. leucántha, Torr. \& Gray. Smooth: stents, leaves, and racemes as in n. 6 ; stipules eurly deciduous; flowers white: jods orul-ohlong, ruised on a stalk filly ture the length of the calyx. - Alluvial soil, ()nt. and Ohio to Minn., sonth to Fla. and La.

5. B. álba, R. Br. Smooth (1-30 ligh), the brancless slender and widely sprealing; petioles slender; stipules and bructs minute and decidnons; leaffets oblong or oblancenlate; racemes slender on a long naked peduncle; pods

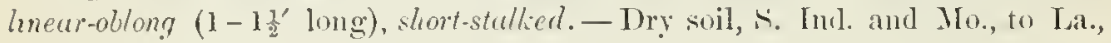
N. C., and Fla. July.

$$
++ \text { t- Flovers indign-b/ue. }
$$

6. B. austràlis, li. Br. (Burf Fuse-Mnifio.) Smooth, tall and stout $(t-.5 c)$; leafletsolilomg-welge-form, obtuse; stipules lanceolate, as long as the petioles, rather persistent; raceme alongatel $\left(1-2^{\circ}\right)$ and many-flowered, erect; bracts deciduous; stalk of the oral-ohlong pous about the length of the calyx. - Alluvial soil, l'enu. to Ga., west to S. Ind., Mo., ancl .trk.

\section{THERMÓPSIS, li. Br.}

Pod sessile or shortly stupltate in the calyx, flat, linear, straight or chirved. otherwise nearly as Baptisia. - l'erennial lerhs, with palmately 3-foliolate leaves ind foliaceous stıpules, not hlackening in frying, and yellow flowers in terminal racemes. (Name from ófpuos, the lupine, and ófis, resemblance.)

1. T. móllıs, M. A Curtis. Finely appressed-pubescent, 2-3 $3^{\circ}$ high; loaflets rhombic-lancenlate, $1-3^{\prime}$ long; stipules narm, mostly shorter than the petiole. raceme elongated; poils narrow, short-stipitate, somewhat cured, $2-+$ lmmg, - Mluntains of S. Ya. and X. C.

2 T. rhombifolia, Nutt. Low, with smaller leatres and loroad conspic uous stupules; racomes short, few-flowered; pols lowadly linear, spreading, usually strongly curved. - Sask. to Is, Col., near or in the muntains, reported from central lian.

\section{CLADRÁ STIS, Raf. YEnow-Woon.}

Calyx 5-tonthed. Sitaularel large, roumlish, reflexed; the distinet keel-petals aud wings strught, oblung. Stamens 10, listinct; filaments slender, inemred above. Poul short-stalkel above the calyx, linear, flat, thin, marexinless, 4-6seeded. at length 2. valved - A handsome tree, with yellow wood, smooth bark, nearly smootl pimate leaves of $7-11$ oval or ovate leaflets, and ample panicled racemes $\left(10-20^{\prime}\right.$ lung $)$ of showy white flowers drooping from the ends of 
the branches. Stipnles obsolete. Base of the petioles hollow, enclosing the leaf-bnds of the next year. Bracts minute and fngacions. (Name from $\kappa \lambda a ́ \delta$ s, a branch, and epavotós, brittle.)

1. C. tinctòria, Raf. Sometimes $50^{\circ}$ ligh ; porls $3-t^{\prime}$ long. - Rich hillsides, central Ky. and 'Tenn. to N. C. Also in cultivation. 'The woul yielcls a yellow dye.

\section{SOPH Ò $\mathbf{A}, \mathrm{T}_{\text {. }}$}

Calyx bell-shaped, shortly 5-tootled. Standard rounded; keel nearly straight. Stamens distiuct or nearly so. Pod coriaceous, stipitate, terete, more or less constricted between the seeds, indehiscent. Seeds subglobose. Shrnbby or onrs an herbaceons perennial, the leaves pinnate with nnmerous leaflets, and flowers white or yellow in terminal racemes. (Said by Linnæus to be the ancient name of an allied plant.)

1. S. serícea, Nitt. Silky-cunescent, erect, $1^{\circ}$ high or less; leaflets ollong-obovate, 3-6" long; flowers white; pods few-seeded. - Central Kían. to Col., Tex., and $A$ riz.

\section{CROTALÀ RIA, L. RAtTLE-Box.}

Calyx 5-cleft, scarcely 2-lipped. Standard large, heart-shaped; keel scytheshaped. Sheatl of the monadelphous stamens cleft on the npper side; 5 of the anthers smaller and roundish. Por inflated, oblong, many-seeded. - Herhs

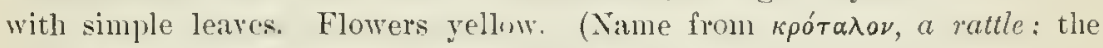
loose seeds rattling in the coriaceous inflated pols.)

1. C. sagittàlis, I. Annual, lairy $\left(3-6^{\prime}\right.$ lighlı); leares oral or oblonglanceolate, scarcely petioled, stipules united and decurrent on the stem, so as to be inversely aruw-slaped; perluncles few-flowered; corolla not longer than the calyx; pol blackish._- Minly suil ; Maine to Mll., Minn., lian., and sontliwarl.

\section{GENISTA, L. Woแ-WAxex. Wux.}

Calyx 2-lipperl. Standinl ollong-oval, spreading, keel oblong, straight, deflexed. Stamens monalelphous, the sheath entire; 5 alternate anther: shorter. l'od mostly flat and several-seeded. - Shrubby plants, witl simple leaves, and yellow flowers. (Name from the Celtic yen, it huslı.)

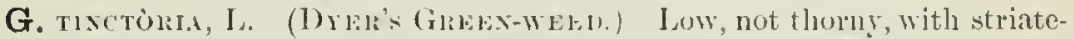
angled erect hran'hes; leaves lanceolate; Howers in spiked racemes. - Established on sterile hills, eastern N. I. and Mass. (Adr. from En.)

\section{7. СÝTISUS, Tonm. , B1:00ณ.}

Calyx campanmate, with 2 short broal lips. l'etals broal, the keel obtuse and slightly incurved. Stanens monalelphous. I'oul flat, much longer than the calyx. Seeds several, with a strophiole at the hilum. _- sluruls, with stiff green branclies, leaves mostly digitately 3 -foliolate, and large mirrlit yellow Howers. ('l'le ancient linnin name of a plant, probalsly a Medicago.)

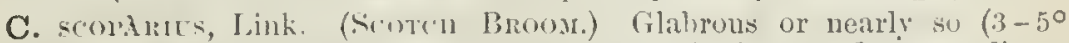
high); leaflets small, olwwate, uften rednced to a single one; fluwer's sulitary: or in laim, on slomer perlicels, in the axils of the old leaves, forming leafy racemes along the njper hanches; style very long and spirally incurved. Vit. and sinuthwarl. (Nat. from lin.) 


\section{L U P İ N US, Tourn. Lurine.}

Calyx very deeply 2-lipped. Sides of the standard reflexed; keel scythe shaped, pointed. Sheath of the monadelphous stamens entire; anthers alternately oblong and roundish. Iod oblong, flattened, often knotty by constrictions between the seeds. Cotyledons thick and fleshy.-Herls, with jalmately $\mathbf{l}$ - I5-foliolate leaves, stipules adnate to base of the petiole, and showy flowers in terminal racemes or spikes. (Name from Lupus, a wolf because these pliunts were thought to derour the fertility of the soil.)

1. I. perénnis, L. (WILd Lrixe.) Peremial, somewhat hairy ; stem erect $\left(1-2^{\circ}\right)$; Ieatlets $7-11$, oblanceolate; flowers in a long raceme, showy, purplish-blue (rarely pale); pods broad, rery hairy, 5-6-seeded. - Sandy soil, N. Eing. to Mimn., Mo., and sonth to the Gulf. - Var. occnestàlis, Watson, has stems and petioles more villons. - Mich. and Wisce.

2. L. pusillus, I’ursh. Annual, low, villons; leaflets usually 5 ; racemes short, sessile; flowers purple or rose-color; pods oval, hirsute, 2-seeded. Central part of the Dakotas and Kan., and westward.

\section{TR I F Òl I M, Tourn. Clover. Trefoll.}

Calyx persistent, 5-cleft, the teetl bristle-form. Corolla mostly withering or persistent; the claws of all the petals, or of all except the oblong or ovate standard, more or less united helow with the stamen-tube; keel short and obtuse. Tenth stamen nore or less separate. P'ods small and membranous, often included in the calyx, 1 -6-seederl, indehiscent, or opening by one of the sutures. - Tufter or diffuse herbs. Leares mostly palmately, sometimes pinnately 3 -foliolate; leaflets nsnally toothed. Stipules mited with the petiole. Flowers in hears or spikes. (Name from tres, three, and folium, a leaf.)

* Flowers sessile in dense herds; corolla purple or purplish, withering uwa!y after flowering, tubular below, the petals more or less coherent with each other.

+ Calyx-teeth silky-plumose, longer than the whitish corolla; root anmual.

T. Arvéxsis, L. (RABnit-foot or STove Clover.) Silky, branching (5-10 high); leaflets oblanceolate; heads becoming very soft-silky and grayish, oblong or cylindrical. - Old fields, etc. (Nat. from Eu.)

+ + Calyx scarcely hairy excent a bearded ring in the throat, shorter than the rosepurple elongated-tubular corolla. (Short-lived perennials; flowers sueet-scented.)

T. pratéxse, L. (REn C.) Stems ascending, sumewhat hairy; leaflets oval or oborate, offen notched at the end and marked on the upper sicle with a pale spot; stipules broad, bristle-pointed; heads orate, sessile. - Fields and mearlows; largely cultivated. (Allv. from Eu.)

T. MÉnta, L. (Ziczar C.) Sitems zigzag, smoothish; leuflets oblong, entire, and spotless; heuls mostly stalked; Howers leeper purple, otherwise too like the last. - Dry hills, N. Scotia to L. Mass. ( $\mathrm{d} d \mathrm{r}$. from Lu.)

* Flowers pedicelled in umbel-like round heads on a naked peduncle, their short pedicels reflexed when old; corolla white or rose-color, withering-persistent and turning bronnish in fading; the tubular portion short.

1. T. refléxum, L. (Brfraco C.) Annual or hienial; stems ascending, downy; leaflets obovatemblong, finely toother; stipules thin, ovate; standard rose-red, wings and keel whitish; calyx-teeth hairy; pods 3-5-seededWestern I. Y. and Ont. to Iowa, Kan., and southward. 
2. T. stoloníferum, Muhl. (Revrixg Bufralo-C.) Smooth, perennial; stems with long runners from the base; leaflets brondly oborate or ubcordate, minutely tonthel; heads loose; flowers white, tinged with purple; pols 2seeded. - Open woodlands and prairies, Ohin and li y, west to Iowa and han.

3. T. repens, 1. (Write C.) Smooth, perennial: the slender stems spreadiny and creeping; leaflets inversely heart-shuped or merely nutehed, ob). scurely toutlied; stipules scale-like, narrow; petioles and especially the peduncles very long; heads small and loose; calyx much shorter thon the white corollu: pods about 4 -seeled. - Fields and copses, ererywhere. Indigenous only in the northeru part of our range, if at all.

4. T. Carolinianum, Aichx. Somewhat pulescent small perennial, procumbent, in tufts; leaffets werlge-olovate and slightly notched; stipules ovate, foliaceous; heads small on slender peduncles; calyx-teeth lanceolate, nearly equalling the purplish corolla; strulurd pointed: pods 4-seeded. - Waste ground near Philadelphia, south to V'a., F'la., anrl Tex.

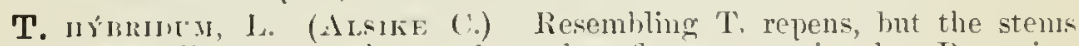
erect or ascencling, not rooting at the nodes; flowers rose-tinted. - Becoming commun. (Nat. from Eur.)

* * Flouers slont-predirelled in rlose heads, veftexed uhen old: corolla yellour, persistent, turning dry and chestnut-hroun with age, the standard becoming hood-shaped; ammals, fl. in smmmer.

T. Arkdricu, L. (YkLlow or Hop-C.) smoothish, somenlat upright

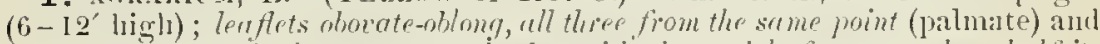
nearly sessile; stimules nurrow, coliering with the protiole for mone than half its lengtli. - Sandy fields and roarlsiles; $\mathrm{X}$. Scotia to Va.; also in western N. Y. (Niat. from Eui.)

T. proctums, I. (Low Hop-C.) Stems spreatling or ascenting, jubescent $\left(3-t^{\prime}\right.$ lighli); leaflots wedge-ohoerate, notched at the end, the lateral at a small disfume fiom the other (jinnately 3-foliolate); stipnles ovate, short. samly fielils and roalsiles, common. - Var. whrs, Gray, has smaller heads, the standard not much striate with age. (Kat. fron En.)

\section{MELILOTUS, Tomm. Mrulut. Siret Clorer.}

Flowers much as in Trifolium, lut in spike-like racemes, small; eorolla deciduons, free from the stamen-tube. Pod woid, coniaceous, wrinkled, longer than the calyx, scarcely dehiscent, 1-2-seederl. - Innual or biennial herbs, fragrant in drying, with pinnately 3-foliolate leaves, leaflets toothed. (Nams: from $\mu \epsilon^{\prime} \iota_{b}$, honey, and $\lambda \omega \tau o ́ s$, sonje leguminous plant.)

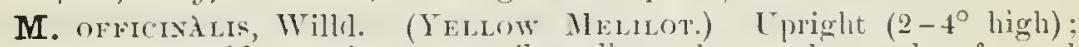
leaflets obovate-oblong, obtuse; corolla yellon: the petals nearly of equal length. - Waste or cultivated gromels. (Arlv. from Eu.)

M. Áns, Lam. (WuIts II.) Leatlets truncate; corolla white; the standard louger than the other petals. - ln similar places. (Adv. from Eu.)

\section{MEDICA GO, Tom'n. MEntr.}

Flowers nearly as in Molilotus. Porl 1-several-keeded, scythe-shaped, incurved, or varionsly coiled. - Leaves pimately 3-foliolate; leaflets toothed;

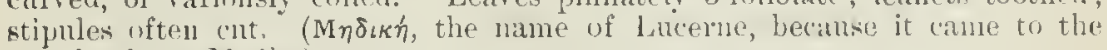
Greeks fron Media.)

M. sitiva, L. (Luckise. Arfalfa.) Upright, smooth, peremial; leaflets obovate-oblong, towthed; flowers (purple) rucemed; pouls spinally twisted. - Cultivater for green fodeler; spontaneous from Mass. to Minn. and Lan. (Adv. from Eu.) 
M. Luplolixi, L, (Brirk Medick. Noxestcir.) Proeumbent, pubescent, anmual; leitlets werlge-obovate, tootherl at the apex; flowers in short spilic: (yellow); pods kidney-form, 1-seeded. - Waste places, N. Eng. to Fla., west to Mich., Jowa, ani Mo. (Ndv. from Fur.)

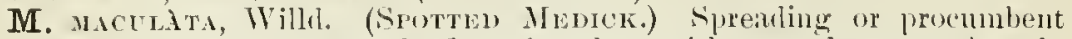
ammual, somewhat pubescent; lcaflets obcordate, witl a purple spot, minutely

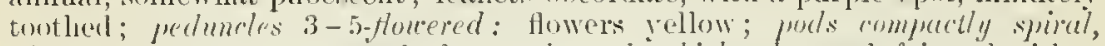
of 2 or 3 tul'ns, compressed, furromed on the thich edge, and fringed with a

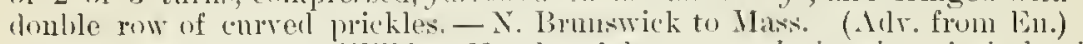

M. Instred dita, Willd. Nearly glalnous; pods loosely spiral, deeply reliculated, and with a thin keeled edge; otherwise like the last, and with the same range. (Adr. from Liu.)

\section{H O S Á C K I A, 1)ouglá.}

Calys-teeth nearly equal. l'etals free from the diuld phous stamens, stanclard orate or romulish, its claw often remote from the othens; wings oborate ur ollong; keel incurvel. P'ol linear, compressed or ommewhat terete, scssile, several-seeded. - Ilerls, with pimate leaves (in onrs l -3-foliolate, with glandlike stipnles), and snall yellow or redulish flowers in umbels (onrs solitary) upon axillary leafy-bracteate pehuncles. (Named for Dr. Havid IIosuch, of New lork.)

1. H. Purshiàna, Benth. Annut, more 01 less silky-villous or glabrons, often $1^{\circ}$ higl or more; leares nearly sessile, the $1-3$ leaflets wate to lanceolate $\left(3-9^{\prime \prime}\right.$ long); peduncles often short, bracteate with a single leaflet. - N. C.; S. W. Mimn. to Ark., and west to the I'arific. Very rariable.

\section{PSORÀLFA, I.}

Calyx 5-cleft, persistent, the lowe lobe longest. Stamens diadelphoms or sometimes monadelphons. P'od seldom longer thim the calyx, thick, often wrinkled, indeliscent, l-seeded. - l'erennial herls, nsually sprinkled all wer or ronghened (especially the calyx, pods, ete.) with glindnlan dots or points. Leaves mostly 3-5-foliolate. Flowers spiked or racemed, white or mustly

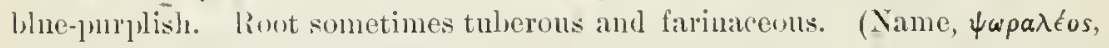
scury,y, from the glanris or dots.)

\section{* Leares pinnately 3-foliolate.}

1. P. Onóbrychis, Nutt. Nearly smooth and fiee from glands, erert

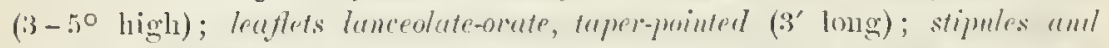
lmorts an/-shoped; ricemes elongated; peluncle shorter than the leares; ports

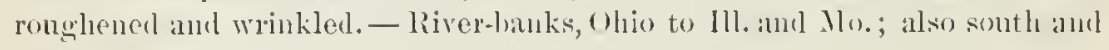
east to S. C. July.

2. P. stipulàta, 'Torred Gray. Nearly smontlu and grlandlexs'; slems dlif-

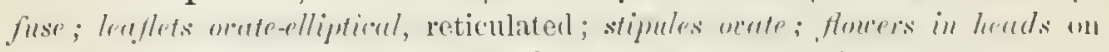

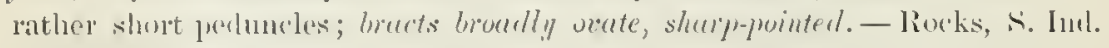
and liy. Junr, July.

3. P. melilotoides, Michx. Somewliat pubescent, more or less grimu-

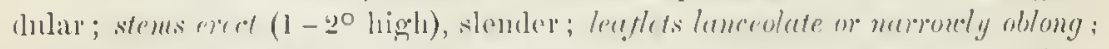

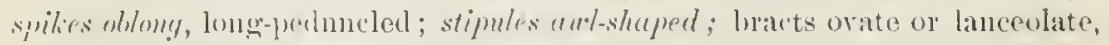
taper-pointed ; puls strongly wrinkled transrersely, - Dry soil, Fla. to Teun.. $\therefore$. Ind. and lian. June. 
* Leaves palmately $3-5$-joliolute; roots not mberous.

4. P. tonuiflòra, Pursh. Slender, erect, much branched and bush! ( $2-4^{\circ}$ high), mimutely hoary-pubescent when young; leaflets varying from linear to obovate-oblong $\left(\frac{1}{2}-1 \frac{1}{2}^{\prime} \mathrm{long}\right)$, glandular-dotted; florer's (2-3" long) in loose racemes; lobes of the caly atul hracts orate, acute; poul glitulular. (1'. floribunda, Vutl.) - Prairies, Minn. to Ill., Tex, and westward. Junesept.

5. P. argophýlla, I'ursh. silvery silky-uhite all over, erect, divergently" branched (1-30 ligh); leaflets elliptical-lancolate: spikes intempted: lobes of the ealyx and boucts lanecolute. - Iligh plains, N. Wisc. to Iowa, han., and westward. June. - Flowers $4-5$ "long.

6. P. digitàta, Nutt. More slentler anul less lum y, 1-20 high ; leaflets linear-ol)lanceolate; bracts of the interrupteil spike olvordate: calyx-lobes ohlong, acute. - Central Kan. to Col. and Tex.

7. P. lanceolàta, Pursh. Glabrous or nearly so, yellowish green, densely punctate; leaflets 3 , limear to oblanceolate; Howers sulnall, in very short spikes: "alyx l" long, with short broad teeth. - Central Kan. to the sask. and westward.

* * Leuces pulmately 5-fuliolute; root tuberones: spilie-like rucemes dense.

8. P. esculénta, Pursh. Roughish hairy all over; stem stont $(5-15$ ' higli) aul erect from a tuberous or turuip-shapen fillinaceous ruot; leaflets obovate- or lanceolate-oblong; spikes oblong, long-perluncled; lobes of the

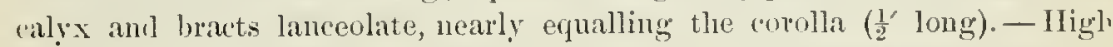
plains, Sask. to Wisc, Iowa, and 'lex. June. 'T'he l'oumb BLAxcue, or' PounE ne l'RAlili, of the royigents.

9. P. hypogiea, Nint. Tuber small; nearly acaulescent, hoary with appressen hairs; leaflets linear; spikes short-capitate, on pentuncles $\frac{1}{2}-2$ ' loug; calyx narrow, 3-6" loug. - Central Kan. to Col. and 'Tex.

10. P. cuspidàta, P’urslı. Stont, tall, from a deep-neated tnher, hoary with appressed laairs; leaflets nsually hoally oblanceolate, obtuse; flower's large, the petals $\left(6-8^{\prime \prime}\right.$ long) exceeling the linceolate-lobed calyx - Central líuı, to Col. and Tex.

\section{A M ÓRPHA, I. False INDrgo}

Calyx inversely conical, 5-toothed, persistent. Standard (the other petals entirely wanting!) wrapped around the strmens and style. Stamens 10 , monalelphons at the rery lose, otherwise distinct. l'oxl oblong: longer than the calyx, I-2-seederl, runghened, tardily dehisent. - Slunhs, with odelpimate leares; the leaflets natked with minnte dots, usually stipellate, the milvein excmrent. Flowers violet or puiple, clowrled in clusterel teminal spikes. (Name, ăuopфos, dejormed, from the absence of four uf the petals.)

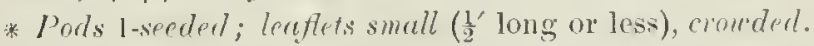

1. A. canéscens, Nitt. (Llist-PLast.) Ithitened with houry dou'n ( $1-3^{\circ}$ higll); leaflets 1.5-25 pairs, oblong-elliptical, becoming smoothish ahore; spikes usually chusterel at the summit. - Sask. to Ind. and Tex, west to the Rocky Mts.; also eastward to Ga.

2. A. microphýlla, I'urslı. Nearly glabrous throughout, $1^{\circ}$ high or $^{\circ}$ less; leaflets rather rigit; spikes usmally solitary. - Sask. to Minm. and lowa, west to the lincky. IIts. 


\section{* Pods 2-seeded: leaflets larger, scattered.}

5 A. fruticosa, L. (EAlse Irifio.) A tall shrub, rather pubescent or smouthish, leaflets $8-12$ pairs, obloug to broadly elliptical. - River-banks, S l'em to Fla., west to Sask., Tex., and the Rocky Mts. Very variable.

\section{D A L E A, L.}

Calyx 5-cleft or toothed. Corolla imperfectly papilionaeeous; petals all on claws; the standarl heart-shaped, iuserted in the bottom of the calyx; the keel and wings borne on the middle of the monalelphous sheath of filaments, which is cleft duwn one sile. Stanens 10 , rarely 9. Pod membranaceous, I-seeded, inclehiscent, enclused in the persistent calyx, - Mostly herbs, more or less glindular-dotted, with minute stipules; the small flowers in terminal spikes or heals (Named for Sumuel Dule, an English botanist.)

* Giluluons: Hourers uhite or rose-color: leaftets $4-20$ pairs ; ammuls.

1. D. alopecuroides, Willl. Frect $(1-20$ high $)$; leaflets $10-20$ pairs. linear-ohlong; flowers light rose-color or whitish, in cylindrical spikes; hrats wate-lanceolate, acmuluate, recilnous; aly very villous, with long sleucler teeth. - Mlluvial suil, Mimm. to 111. anr Mla., west to the liocky Mts.

2. D. laxiflora, l'nrsh. Erest $\left(1-t^{\circ}\right.$ higli), branehing; leaflets $3-5$ pails, linear, 2-3" long; spikes loosely-Howered; brats conspicnons, persistent, almost orbuculat and rery obtuse; petals white; calyx densely villous, the long teeth beantifully plumose. - Iowa and Mo. to Tex., west to Col.

$$
\text { * * Inlessent: leuftets } 3-4 \text { puirs: perennial herbs. }
$$

3 D. aùrea, Nutt. Sitens erect and simple, $1-3^{\circ}$ high ; leaflets oblong. obovate to linear-ollowg, more or less silky-pubescent; spikes solitary, oblongwate, rery conpact and lensely silky; bracts short, rhombie-owate; petals rellow, - on the plitins, In. to 'Tex., and westwarl.

4. D. lanáta, spreng. Very pubescent thoughout, 1-20 high, branching; leaflets obovate to ollong-ohovite, 2-3" long; spikes slender, rather bose, the olurate acute bracts equalling the small short-toothed calyx; petals short, pulple. - central Kian. to 'Tex., and westwaril.

\section{PETALOSTEMON, Michx. Mrmin Clover.}

Cally 5-tuothed. Corolla indistinctly papilionaceous; petals all on threadshapest chas, 4 of them nenrly sinilar and sprearling, horne on the top of the muadelphons and cleft sheath of filaments, alternate with the 5 anthers; the fifth (stmulard) inserted in the hottom of the calyx, heart-shaped or oblong. l'orl membranaceons, enclosed in the calyx, indehiscent, 1-2-seerled. - Chiefly

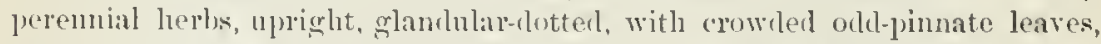
mimte stipules, and small flowers in very rlense terminal and peduncled hearls or spikes. (Nane combined of the two (ipeck works for petal and stamen, alluting to the peculiar mion of these organs in this genus.)

1. P. violàceus, Michx. Nimollish; lentlets 5, narrorly linear; heads globose-orute, or olilung-cylindrical when old; bracts pointed, not longer than the silky-hoary "alyx; corolla ruse-purple. - Dry prairies, Minn. to Ind. and Tex., west to the liockị Mts July. 
2. P. cándidus, Michx. Sinooth; leaflets $7-9$, lanceolate or linear-ablong; heads oblony, when old cylindrical; bracts awned, longer than the nearly. glabrous calyx; curulla white. - With w. 1.

3. P. villòsus, Nutt. Softi-douny or sillyy all over; leuflets $13-17$, linear or oblong, small ( $4-5^{\prime \prime}$ long); sprites cylindicul ( $1-5^{\prime}$ long), short-peduncled, soft-villous; corolla rose-culur. - Wisc. to MIo., west to the Rocky Mits.

4. P. foliòsus, Gray. Sinouth, very leafy; leaflets 15-29, linear-oblong; spikes cylindricul, short-peluncled; bracts slender-awned from a lanceolate base, exceeding the glabrous calyx; petals rose-culor. - River-bunks, Ill. and Tenn.

5. P. multiflòrus, Nutt. Glabrous thoughout, erect, branching; leaflets 3-9, linear to oblong; spikes globose, the subnlite-setaceous bracts much shorter thin the acutely toothed calyx; petals white. - Kill. to 'Tex.

\section{TEPHRÓSIA, P'el's. JloARY P'EA.}

Calyx about equally 5-cleft. Standard romulish, usilally silky outside, turned back, scarcely longer than the colserent wings and keel. Stamens monadelphons or diadelplous. I'od linear, flat, several-seederl, 2ralved. - Hoary perennial herbs, with odd-pinuate leares, and white or puplish ratemed flowers. Leaflets mucromate, veiny. (Name from $\tau \in \phi \rho o s$, ash weolured or loury.)

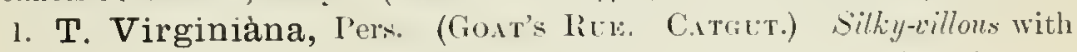
whitish hairs when young; stem erect and simple (1 - 20 high), leufy to the top); leaflets $17-29$, linear-oblong; fowers large and numerons, clustered in a terminal oblong dense raceme or prmicle, vellowish-wlite marked with purple. Dry sandy soil. June, July - Roots long and slender, very tough.

2. T. spicàta, Torr. \& Gray. Tillous wh rusfy huirs; stems branched below, straggling or ascending $(2 \circ \mathrm{long})$, few-lerterl; leaflets $9-15$, ohnrate or oblong welge-shaped, often notehed; flowers fer, in a louse and interrupted rery long-peduncled spike, redelish. - Dry soil, from Del. and Va. to Fla. and Miss. July.

3. T. hispidula, Pers. ITairy with some long and rusty or only minute and appresserl pubescenee; stems slender $\left(9-2 t^{\prime}\right.$ long), divergently luanched, straggling; leaflets 5-15, oblong, varying to obovite-werlge-shaperl and oblaneeolate; peduncles longer than the leaves, 2-4-flowered; flowers reddishpurple. - Dry sandy suil, Va. to Fla. and Ala.

\section{I N DIGOFERA, T. IxDIgo.}

Calyx small, equally 5-cleft. Staudard rounlish, silky ontside, wings coherent; keel erect, giblons or spured at base. Stamens diarlelpluns; enuneetive gland-like. Pod 1 -several-seded, septate within hetween the sechls. - Herbs or shruhs, mosty canescent with appressed hairs fixell by the micllle. with odd-pinnate faintly-nerved leaves, and pink or lnuplish fowers in nakinl axillary spikes. (tio named beeause some of the species yield the indigo of commerce.)

1. I. leptosépala, Nutt. A peremial herl, $\frac{1}{2}-20$ higls; leaflets $5-9$, oblanceulate; spikes very lonsc; pods linear, 6-9-seeded, obtusely t-ingled, reflexel, 1' long. - Kan. to Tex. aud Fla. 


\section{ROBINIA, I. LOCEst-trie.}

Catlyx short, 5-toothed, slightly 2-lipped. Standard large and rounded, turned back, scarcely longer than the wings and keel. Stamens diadelphons. l'od linear, Hat, several-seeled, margined on the seed-lyearing elge, at length 2-valved. - Trees or shrubs, often with prickly spincs for stipnles. Jeares odi-pinnate, the ovate or ublong leaflets stipellate. Flowers showy, in hanging axillary racemes. Base of the leat-stalks covering the buls of the next year. (Named in honor of John Lobin, lerbalist to Ilenry IV. of France, and his son Fespusiun Rubin, who first cultivated the Locust-tree in Europe.)

I. R. Pseudacàcia, L. (Comion Locust or Filse Achera.) Branches naked ; racemes slender, luose; Howers white, fragrant; jod smooth. - S. I'enu. to Ind., Iowa, and sonthward. ('ommonly cultivated as an ornamental tree, and for its valuable timber; naturalized in many places. June.

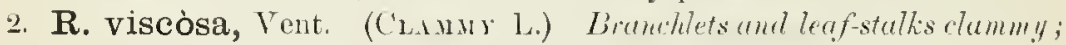
flowers crouded in ublong racemes, tinged with rose-color, nearly inodorous; por glandnlar-hispid. - Va. to N. C. and Ga., in the mountains. Cultivated, like the last, and often escaped. June.

3. R. híspida, L. (Bristu L. or Rose Aracin.) Shrub 3-80 high; branchlets and stulks bratly: flowers large and dee] rose-color, inodorons; porls glandulathispid. - Varies with less bristly or nealy naked branchlets; also with smitler flowers, etc. - Mts. of Via to N. C. and Ga. May, June.

\section{WISTARIA, Nutt.}

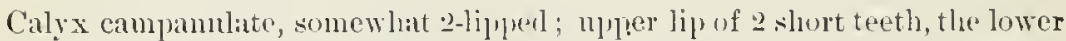
of 3 longer ones. Staudard lonulis], lange, turned batck, witl 2 callosities at its hase; keel siythe-shajed; wings donbly andeled at the base. Stamens dialchphous. Pods elongated, thickisll, kmol)y, stipitate, may-seeded, at length 2-valverl. Seeds large. - Woody twiners, chimbing ligh, with minute stipules, pinnate leaves of $9-13$ ovate-lanceolate lattets. with or witlout minute stipels, and lense racemes of lawge and showy lilai-jurple Howers. (Dedicated to the late Prufessor Iristar, of l'hilalelphia.)

1. W. frutéscens, loir. 1)owny or sumothish when old; wings of the

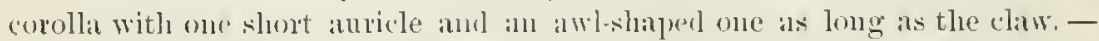

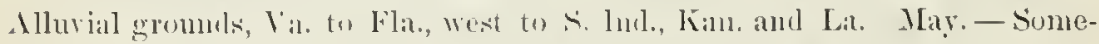
times enltivatel for ormament, as is the still hamblomer Chinese species.

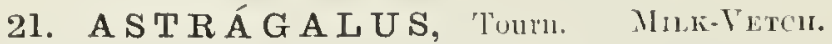

Calyx 5-toothed. Corollat usually lomg and narow; staudard narrow, equalling or exceeding the wings and l,lut keel, its silles reflexed or sprealling.

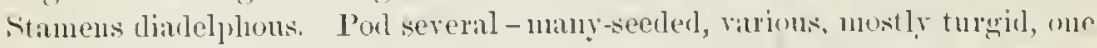
1) hotlı sutures usually projecting into the cell, eitler slightly or so : as to divide the cavity lengthwise into two, - Chiety herbs (ours peremials), with

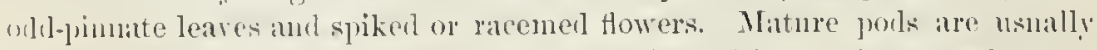

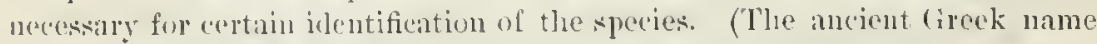
of a legruninums plant, als also of the ankle-bone; lut the comnection between the two is past all guess.) 
I. Pod turgid, completely or imperfectly 2-celled by the intrision of the dorsul suture, the ventral suture being not at all or less deeply inflexed. - AsrraGalus proper.

* Pod plum-shaped, succulent, becoming thirk and flesliy, indeliscent, not stipitute, completely 2-celled.

1. A. caryocárpus, lier. (Grounu l'ı I.) l'ale and mimitely appressed-pubescent; leatlets narrowly oblong; Howers in a slort spike-like

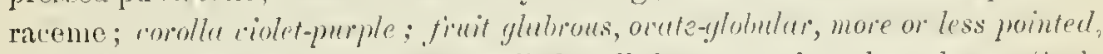

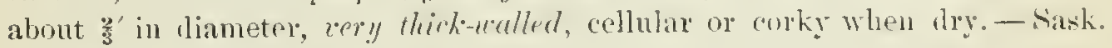
and Minn. to Mo., Cul, and Tex. May.

2. A. Mexicànus, 1. 1)C. Sinootler, or luthesunt with looser hairs, Larger: Ieatlets ronuclish, olorate, or ohlong": Howers larger (10-12" long);

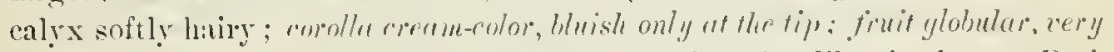
obtuse and puintless, l' or more in diameter; otlerwise like the last. - Prairies and open plains, Inl. to lian., sonth to 'l'ex. The unripe fruits of both resemble eneen plnms - whence the popmlar name - and are eaten, raw or cookerl, by travellers.

3. A. Platténsis, Nontt. Lonscly villons; stipules conspicuous; leaflets olylong, often glahrous ahove; flowers crowderl in a short spike or oblong hear, cream-color often tinged or tipped with purple; finit orrote, pointed, and witl the calyx villous. - Grarelly or sumly hauks, Minn. to Ind. and $A$ la., west to ('ol, and 'l'ex. - Var. 'Tlexsesséssic, Gray, has the pod oblong and slightly curverl, and much less fleshy. May.

* Pod dry, coriaceons, cartilaginous or membrunous, deliscent.

+- Pod completely 2-celled, sessile.

4. A. mollissimus, Torr. Stout, decumbent, donsely silky-villous throughout and tomentose; leaflets 19-29, orate-oblong; peduncles elongated; spikes dense, with rather large violet flovers $\left(6-12^{\prime \prime}\right.$ long); pod natrow-rblong (59" long), glabrons, somewhat obconpressed and sulrute at both sumpes, at length incurverl. - Neh. to Kan. and Tex., west to Col. "The most common "loco"plant, and said to he rery poisonous to cattle.

5. A. Canadénsis, L. Trll and reet $\left(1-4^{0}\right.$ highl $)$, someulut pubescent

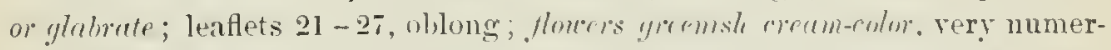
ous, in long dense spikes; pods "rowled, uhlong (b" long), glabrous, terete, scurely sulcorte and only on the bark, nearly straiglut. - River-banks, westeru N. Y. to N. Cis., and far westward.

6. A. adsúrgens, l'all. Ascencling or decumbent ( $1-18^{\prime}$ ligh), ('inereous whit minte appressed pubescence or crlabute: leaflets ahout 21, namowly or linear-oblong; spike dense, with melium-sized pale or purplish flowers; $f^{\prime \prime}$ -

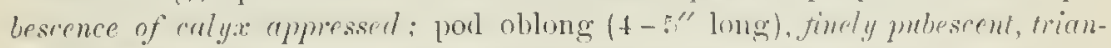
gular-compressed, with a deep dorsul furrou, struight. - Rerl River valley, MLinn., to W. Kan., aud westward. (Asia.)

7. A. hypoglóttis, I. Slender $\left(6^{\prime}-2^{\circ}\right.$ long $)$, diffusely procumbent or ascending, with " rather loose pubsscence or nearly glabrous; leaflets 15-21,

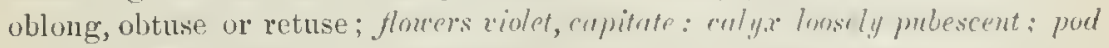
as in the last, but oute and silhy-cillous. - lied liver valley, Minn., to central lian. and westward. 
++ Pod not completely 2-celled.

+ Pod stipitate, pendent.

8. A. alpinus, I. Diffuse $\left(6-12^{\prime}\right.$ high $)$, smooth or slightly hairy; leaflets $13-25$; Howers ziolet-purple, or at least the keel tipped with violet or blue; calyx campanulate; pod narrowly oblong, short-acuminate, lack-pubescent, triangular-turgid, leeply grooved on the back, straight or curved, its stipe usually rather exceeding the calyx. - liocky banks, Lab. to Maine and X. I't.

9. A. Robbínsii, Gray. Nearly smooth and erect ( ${ }^{\circ}$ high), slender; leaflets 7 - Il; calyx more oblong; flovers white; poul oblong (6" loug), ob. tuse or acntish, minutely duikish-pubescent, somewhat latera'iy compressed, not dorsully sulcate or obsoletely so, straight or somewliat incurved, rather abruptly narrowerl at base into the often included stipe. - Rocky ledges, Vt.

10. A. racemòsus, Pursh. Sitout $\left(1-2^{\circ}\right.$ ligh $)$, erect or ascending, appressed-pubescent or glahate; leaflets 13-25; flowers numerous, white, penflent; calyx campanulate, gibbous, white-pubescent; jod straight, narrow, $l^{\prime}$ long, acute at both euds, triaugular-compressed, deeply groover on the back, the ventraI edge acute. - Neb. to Mo, and westward.

$$
\text { ++ +r Pod sessile. }
$$

11. A. grácilis, Nutt. Subcinereons, slender (10 high or more); leaflets $11-17$, linear, olstuse or retuse ; racenes loose; flowers small (3" long); pods pemlent, 2-3" long, curiaceous, elliptic-ovate, concace on the buck, the rentral suture prominent, white-hairy, at length glabrous, trunstersely cemed. - Minn. to Nel. and Mo., and westwark.

12. A. distórtus, Torr. \& Gray. Low, diffuse, many-stemmet, sulgrglaurons; leaflets 17 - 25, oblong, emarginate; flowers in a short spike, pale-purple ; porl ovate- or lance-oblong, curved, 6-9" long, glabrons, thick-eoriaceous, somewhat grooved on the back, the ventral sntme nearly flat. - Ill. to Iowa, Mo., Ark. and Tex.

13. A. Iotiflorus, Iook. llory or cinereons with appressed hairs ; stems very short; leatlets $7-13$, lance-oblong; flowers yellowish, in few-flowered heals, witl peluncles exceeling the leaves or very short; calyx campumlute, the subulate teeth exceeding the lube; porl oblong-orate, 9-12" long, acmminate, acute at basp, eanescent, the back inore or less inpresserl, the acute ventral suture nearly straight. - Sask. to Nel. and Tex, west to the mountains

14. A. Missouriénsis, Nutt. Short-eanlescent, hoary with a closely appresserl silky pulxescence; leaflets 5-15, oblong, clliphic or obovate; flowers

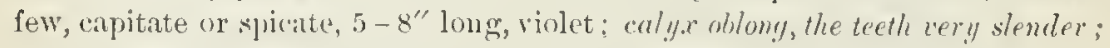
por ohlomg ( $\mathbf{l}^{\prime}$ lomg), acute, obtuse at base, pulescent, nearly straiglit, obcompressed or olscompressed-triangular, depressed on the back and the ventral snture more or less prominent, transversely rugulose. - Sask to Neb. and N. Mex.

II. Pod 1-relled, neither suture being inflexed or the ventral more intruded than the dorsal. - Prica.

15. A. Coòperi, Gray. Nearly smooth, erect (1-2o high); leaflets $11-21$, elliptical or ohlong, sonewhat retuse, mimntely houly beneath ; flowers white, rather numerous in a short spike; "alyx dank-pubescent; jow coriaceous, inAlated, orate-globose $(6-9$ "long), arute, glabrous, slightly sulcate on both sides, carity webly. - Ont. and westeru $X_{\text {, }}$ I. to Min!. and Iowa. 
16. A. flexuósus, bougl. Ashy-pnberulent, ascending $\left(1-2^{\circ}\right.$ high $)$; leaflets 11-21, mostly narrow; flowers smahl, in loose racemes; pod thin-coriaceous, cylindric (8-11" long, 2" loroal), pointed, straight or curvesl, puberulent, very slortly stipitate. - Red River Valley, Minu., to Col.

\section{OXÝTROPIS, DC.}

Kerl tipporl with a sharp pojecting point or apjendage; otherwise as in Astragalns. Pod often more or less 2-eelled hy the intrusion of the rentral suture. - fonr species are low, nearly acaulescent perennials, with tufts of numerons rery short stems from a liard and thick root or rootstock, covered with scaly alnate stipules; pinnate leaves of uany leaflets; peluncles scapelike, learing a head or short spike of flower's. (Name from ö $\xi \dot{u} s$, sharp, and $\tau$ тómıs, licel.)

$$
\text { * Leares simply jimute. }
$$

1. O. campéstris, DC., rar. cæerùlea, Koch. I'ulossent or smoothish; leaflets lanceolate or oblong; flowers violet or line, sometimes pure white; pols ovate or oblong-lanceolate, of a thin or papery texture, - N. Maine to Laluntor.

2. O. Lambérti, Pursh. Silh!l whl fine appressed hairs; leaflets mostly linear; flowers linger, purple, violet, or sometimes white; prods cortiluginous or firm-cmiarous in texture, silky-pulsescent, strictly erect, cylindraceous-lanceolate and long-pointed, almost 2-celled ly intrusion of the ventral suture.1)ry plains, Sask. and Minn. to Mo and l'ex., Nest to the mountains.

* * Leaflets numerous, mostly in fuscicles of 3 or + or more along the rhachis.

3. O. spléndens, Dongl Silvery silky-rillons $(6-12$ high $)$; scape spicately several to many-flowered: flowers erect-sprealing; porl ovate, erect, 2celled, harlly surpasing the very villous cally - I'lains of Sink, and Wr. Minn., to N. Mex. and the Rocky Mts.

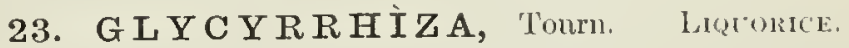

Calyx with the two upper lohes shorter or partly united Antler-cells confluent at the apes, the alteruate ones smaller. Poul orate or ollong-linear, compressed, often 'nrved, clothed with rough golands or short prickles, scarcely dehiscent, few-seederl. The flower, etc., othorwise as in A.straglus - Long

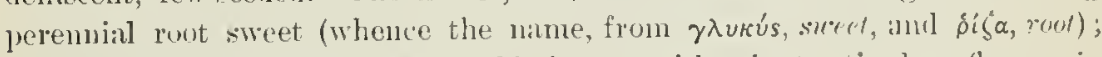
herlage glandular-riscid; leares whl-pinate, with minute stipules; flowers in axillary spikes, white or hlush.

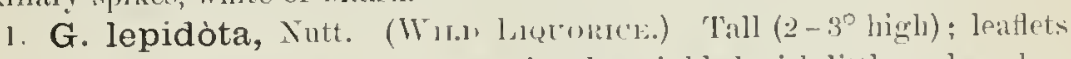
15-19, oblong-lanceolate, nucromate-pointerl, spoinkled with little scules when young, and with corresponding dots when old; spikes peduncled, short ; fowers whitish; porls oblong, beset with looked prickles, so as to resemble the fruit of Xanthium on a smaller scile. - Mimn. to Iowa and Mo., and westward; lit. Erie, Ont.

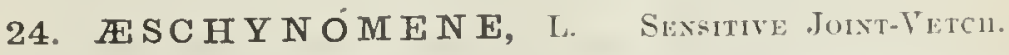

Calyx 2-lipped; the upper lip 2-, the lower 3-cleft. Stanclard roundish: keel boat-shaped. Stamens diadehplous in two sets of se eich. I'orl flattenet, 
eompused of sereral casily separable joints. - Leaves odd-pinnate, with several jairs of leaflets, sometimes sensitive, as if shrinking from the touch (whence

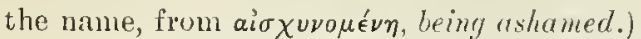

1. A. híspida, Willd. Erect, rongh-bristly annual; leaflets $37-51$, linear; racemes few-Howered ; flowers yellow, reddish externally; pod stalked, 6-10-jointed. - Along rivers, S. l'enn. to Fla. anl Miss. Aug.

\section{CORONÍLA, 1.}

Calyx 5-toothed. Stanulud orbicular ; keel incurved. Staneus diadelplon: 3 and 1. Pol terete or 4-angled, juinted; the joints oblung. - Glabrons hert or sluubs, with pinnate leares, and the flowers in mulels terminating axillary peduncles (Diminutive of romu, " $\%$ ou, alluding to the inflorescence.)

C. varu, L. A prennial herb with ascending stens; leaves sessile; leaflets 15-25, oblong; Howers rose-color; pols coriaceous. 3 - 7 -joiuted, the 4 -angled joints 3-4" long. - Coun. to N. J. (Nat. from Ëu.)

\section{HE D Ý S A R U M, Tourn.}

Calyx 5-cleft, the lobes awl-shaped and nearly equal. Keel nearly straight, obliquely truncate, not appendaged, longer than the wings. Stameus rliarlelphous, 9 and 1. loul Hattened, composed of sereral equal-sided separable romdish joints comected in the middle. - Perenuial herbs; leaves ord-pin-

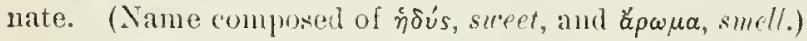

i. H. boreàle, Nutt. Leaflets 13-21, oblong or lauceolate, nearly glabrous; stipnles scaly, mited opposite the petiole; raceme of many deflexed purple flowers; staulatu shorter than the keel; joints of the pod 3 or 4 , smooth. reticulated. - Lahs. to northern Maine and Vt.; north shore of L. Superior, and north and westward.

\section{DE S M Ò I U M, Desv. Tick-Trefoll.}

Calyx usualy more or less 2-lipped. Standard oburate; wiugs adherent to the straight or straightish aud usually truncate keel, hy means of a little transrerse appendage on each sile of the latter. Stamens diadelphous, 9 and 1 , or monadelphons lielow. l'ol Hat, deeply lobed on the lower mangin, separating mto few or many flat reticulated joints (mostly rouglened with minute houked hairs, hy which they adhere to the tleece of aninals on to clothing). - l'eremnial herhs, with pimately 3-foliolate (rarely 1 -foliolate) leares, stipellate. Flowers (in smmmer) in axillary tu temunal racenes, often panicled, and 2 or 3 from each hract, purple or purplish, often turning encen in withering. Stipnles amel bracts scale-like, often striate (Xime fiom $\delta \in \sigma \mu$ ś $^{2}$ a bond or chain, from the commerted juints of the pouls.)

\$1. Pod raised on "stalk (stipe) men!y times Ionger than the slightly toothed calyx and nearly as long as the pedicel, struightish on the upper margin, deeply sinnate on the lourer; the 1-4 joints mostly halfoborate and concave on the back; stamens monadelphous belore; plunts nearly glubruns: stems erect or ascending; raceme terminal, panieled; stipules bristle-firm, decidrous.

1. D. nudiflorum, DC Leaves all crouded at the summit of sterile stems: leaflet, loroadly orate, bluntish, whitish heneath: rureme elongated on an ascend. ing mostly leafess stalk or scape from the root, $2^{\circ}$ long. - Dry woods, common. 
2. D. acuminatum, 1)C. Leures all crouded at the summit of the stem from uhul arises the elongated nuked raceme or panicle; leaflets round-orate. taper-pointed, green both sides, the end one round ( $t-5^{\prime}$ long). - Rich woods, from Cauada to the Gulf.

3. D. pauciflorum, 1)C. Leares scutkert along the low (8-15' high) ascencling stens; leatiets rhombic-orate, bluntish, pale bencath; raceme ferflonered, terminal. - Woods, Ont. to Penn., Mich., Kan., and southward.

$\$ 2$. Pod raised on at stalk (stipe) little if at all surpassing the deeply cleft calyx; stems long and mostrate or decumbent; racemes axillary and terminal.

* Stipules conspricuous, wate, attomute, striate, persistent; racemes mostly simple.

4. D. rotundifolium, I)C. Softhairy all over, truly prostrate; leaflets mbicular, or the ould one slightly rhumboid; flowers mirple; pods almost equally sinuate on both edges, $3-5$-jointel ; the joints rhomboid-oval. - I) ry rocky Woods, N. Lug. to Fla., west to Minu., Mo, anel La.

Var. glabràtum, Gray, is almost glabrous, otherwise nearly as the ordiuary form. - Mass, aud N. Y.

5. D. ochroleùcum, M. A. Curtis. S̈lems spursely hairy, ilecumbent; leaflets nearly glabrous, ovate, acute or obtuse, trausversely reticulated beneath, the lateral ones smaller or sometimes wanting; racemes mucli elongated ; comoller whitish; pols le isted, 2-4-jointed, the large rhomboid joints smooth and reticnlated lut the margins dowyy.- IToodlands, Mrl. and Va.

* * Slipules smaller, lancolate and ant-shaped, less persistent: racemes panicled.

6. D. humifusum, Beck. Cilabrous or nearly so, procumbent; leaflets urate or orate-ublung, rather obtuse, mneh smaller thin in the two preceding

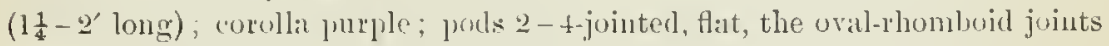
minutely scalsous thronghont. - 1)y simty soil, S. Penn. to Md.

\$3. I'vel slightly if al all stullied in the ralyx; racemes panicled.

* Sitems tull $\left(3-5^{\circ}\right)$ and erect: the persistent stiputes and deciduous bracts larye and conspicuous, wrate wr weute-lanceolute, taper-pointed; flouers ruther large.

+ Pods of +-7 unerquel-sided rhomlir juints, uhich are considerably longer than brocerl (alume $6^{\prime \prime}$ long).

7. D. canéscens, DC. Stem loosely luanched, huiry; loafots oiute, bluntish, about the length of the pwinks, whitish and retiruluted beneath, both sides ronghish with a close fine pubeseence joints of the pod rery arlhesire. Moist grounds, Mass. and Vt. to Minu, and sonthward, chiety westrarel. Branches clethed with botl minute and hooked, and longer, spreading, mather

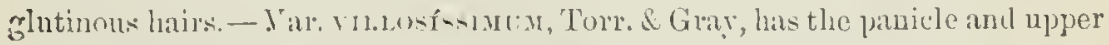
part of the sten rey rilloms, and leatlets oblong-orate. - Mo.

S. D. cuspidatum, Torr. \& Giry. Fry smonth except the panicle; stem ctraight; lereflets laneolate-ocute und ruper-pointed, green both sides, longer than the petiole $\left(3-5^{\prime}\right)$; juints of the pod rhomloid-oblung, smoothish. Thickets, common. The conspicuous bracts and stipules $\frac{x^{\prime}}{4}$ long.

$$
\text { +t + Pods of } 3-\text { s oecal joints (not orer 3" lomg). }
$$

9. D. Illinoénse, Gray. Erect $\left(3-5^{\circ}\right.$ high $)$; stem and leaves with short rough pubesceuce; leaflets ovate-ohlong or orite-lanceolate $\left(2-4^{\prime}\right.$ long), obtuse, snbcoriacous "incrous beneath, reins and reinlets prominent, strongly retie- 
ulated, the lower leaflets nearly equalling the petiole; pods scarcely over l' long. sinuate on both margins (deeper below). - Dry ground, Ill. to Iowa and Kan.

* * Stens $(2-50$ high) erect; stijules and bracts mostly deciduous, small and inconspricuous; joints of the pod 3-5, trianyular or half-rhombic or very un"qual-sided rhomboidal, longer than broad, 3" or less in length; Howers middle-sized.

10. D. lævigàtum, I)C. Sinoolh or nearly so tluoughout; stem straight; leaflets ovate, blutish, pale beneath (2-3' longr); panicles minutely roughpubescent. - l'ine woorls, N. J. to Fla., west to Mo. and 'Tex.

11. D. viridiflorum, Beck. Sten cery douny, rough at the summit, leaflets broadly ocate, very obtuse, rougl above, whitened with a soft welly down underneuth (2-3' long). - Southern N. Y. to N. J. and Fla., west to Mich., Mo., and Tex.

12. D. Dillèni, Darlingt. Stem pubescent ; leaflets oblong or ublong-ourte, conmonly bluntish, pale beneatl, soflly and finely pubescent, nustly thin (2-3' long). - (o pren woullauds, common.

13. D. paniculàtum, DC. Neurl!! smoolh throughout; stem slender.

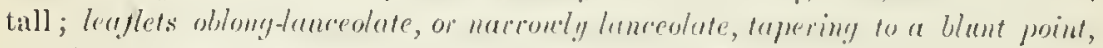

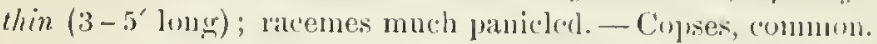

14. D. stríctum, ])C. Steu rey straight and slenler, simple (z-:?०

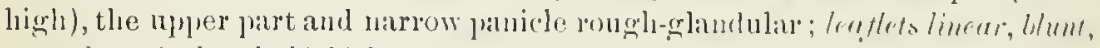
stromgly reliculaterl, thickish, rery smoulh (1-2' long, $\frac{1}{4}$ wide); joints of the pord 1-3, semi-oburate or very gihlsous (unly ." long). - l'ine wools, X. J. to lila. and La.

* * Stipules suall and incousyicuons, mostly deridnons ; pods of fre roundish or obliquely orul or sometimes roundish-rhombohdal joints, $1 \frac{1}{2}-2 \frac{2}{2}$ long.

+ Stems erect: biacts before flowering conspicuous; caremes densely flowered.

15. D. Canadénse, I)C. Stem hairy (3-60 lighli); lenflets whlong-tancenlate or ovate-lancenlate, olituse, with vumerous straightish veins, much longer than the petiole (1 $\left.\frac{1}{2}-3^{\prime} \operatorname{long}\right)$; flover's shomy, larger than in any other species $\left(\frac{1}{2}-\frac{y^{\prime}}{8}\right.$ long). - Dry rich woods, N. Brumswick to X. C., Minn., and Fiun.

16. D. sessilifòlium, 'Turr. \& Glay. Stem pullescent $\left(2-4^{\circ}\right.$ lighl $)$; leaves nearly sessile; leaflets limen or linear-ohlung, blunt, thickish, reticulated, rough above, downy bencatli; luancles of the pindele long: flumers smell. Copses, l'enn. and Ky, west to Mich., luwa, Mo., and 'lex.

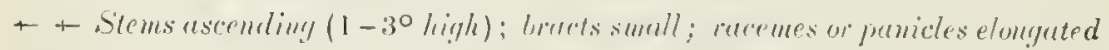
and loasely flowered: Houre's suall.

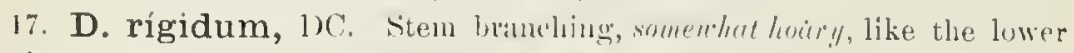

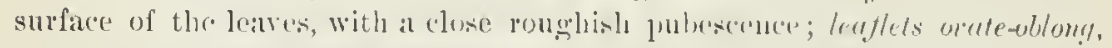

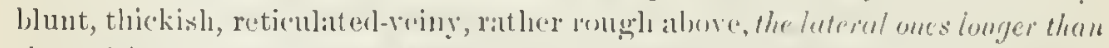

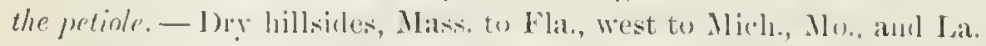

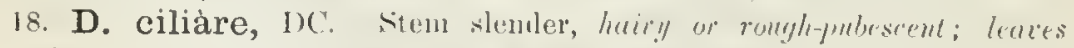
crouded, on eery shont hariry petioles; herflets combl-oente or oral, thichish, more or less hairy on the margius and underneath $\left(\frac{1}{2}-1^{\prime}\right.$ longr $)$ - I ly liblls aud saumly ficlels, N. ling. to Fla., west to Mich., Mo, and 'l'ex.

19. D. Marilándicum, F. l3outt. Vearly s'morth throughout, slemeler, ieaflets ocute or rundish, very obtuse, thin, the lateral ones clumt the length of 
.re slender petiole; otherwise resembling the preceling. - Copses, N. Eng. to rea., west to Mich., Mo., and La.

+t + + Stems reclining or prostrate: racemes Inosely flonered.

20. D. lineàtum, 1)C. Stem minutely puhescent, striate-angled; leaf-

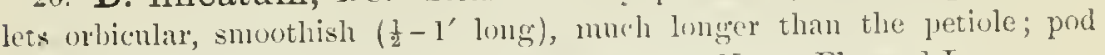
scarcely stalked in the calyx. - Dry soil, Mu. and Va. to Flit. and La.

\section{LESPEDEZA, Michx. Besh-Chover.}

Calyx 5-cleft; the lobes nearly equal, slemder. Stanens diadelphous (9 and 1): anthers all alike. Pools of a single 1 -seeted joint (sometimes 2-jointed, with the lower joint empty and stalk-like), oral or roundish, flat, reticulated. - Herhs with pimately 3-foliolate Jeaves, not stipellate. Flowe's often polyganous, in stummer and autumn. (Dedicated to Lespedes, the Spanish govemor of Florida in the time of Miehanx.)

$\$ 1$. Stipules subulate-setuceous: bracts minute; calyx-lobes attemute; perpnnial.

* Floners uf two sorts, the hurger (ciolet-purple) perfect, but seldem frut ful, pumicled or chustered; with smuller pistillate and fertile but mostly apetalons unes intermired or in smull subsessile clusters ; cally.x 1-2" long: pod exserfed.

1. L. procúmbens, Michx. Slender, trailiny and prosterte, minutely appressed-hairy to soft-rlowny; leaflets oval or obovate-ellipticill, 3-9" long; peduncles very slender, feu-fouered: keel equalling the wings; pod small, ronurlish, ohtuse or acute. (Incl. I. repers, Bur.) - I)ry salirly soil ; common.

2. L. violácea, Pers. stems upright or spreading, slender, branched, rather spursely ieryil and sparingly pubescent; leuflets thin, broully oral or abiony, fulely aplressed-puliescent heneath; peduneles rery slender, loosely feu- Aorred, incstly longer tlum the leaves; flowers $3-4$ "long, the keel often the lingest; purl orrte, 2-3" long, nearly glabrous. - Iry copses, X. Eug. to Minu. and L. Kiul, south to Fla. and La.

3. L. reticulàta, Pers. Stouter, evert, veryleafy: leafels thickish, linear to lineur-oblony, 6-15" long, finely appressed-puhescent; floners (scarcely 3" lomg) chustered on pedundes much shorter thun the lenres, the keel shurter than the standarl; pods ocrte, arue, 2" long, appressed-subphlesecent. (J), violacea, var. angustifolia, Torr. d. (moy.) - Mass. to Mimu., and soutlwarl.

4. L. Stùvei, Nutt. Situs upright-splealing, very leri\%, sinple or some-

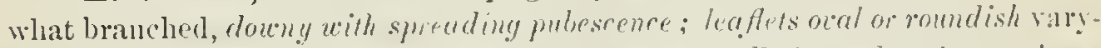
ing to oblung or rarely linear-olblong, sithy or whitr-uodly beneutl and sometinies

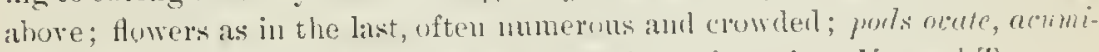

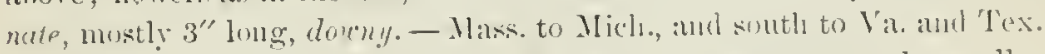

Var. intermedia, Watson. l'ubescence mure seanty and usually fine and appresserl as in 11.3 , hut the leatlets oral to oblong; inforescence often more open; pod of $n .4$ or of 11.3 . (I. violateal, var. sessiliftora, of Man., maiuly.) - Mass. to Fla., and west to Mich., Mll., li. Kian, and Ark.

* * Fluners all alike and perfect, in close spities or heads; corolla whitish or crram-eolor with a purple spot on the standurd, about the length of the doun! 5 -purted calyx; pod included: stems upright, uandtite $\left(2-4^{\circ}\right.$ high).

5. I. polystàchya, Michx. Stem with mostly sprealing pubescence; petioles $2-6$ "l lony; leufets fiom orbicular to oblong ovate, hairy; spilies oblong, 
on elongated peduncles: pod (at maturity) oblong-orate, pubescent, nearly $3^{\prime \prime}$ long, hardly stiorter than the raly.x. (L. hirta, Ell.) - Iry lills, common.

6. I. capitàta, Michx. Stens rigid, woolly; potioles very short: leuftets oblong to narrowly oblony, thickish, retieulated and mostly smooth above, silky or sometimes downy beneath; heads of floners glolulur, on peduncles shorter than the leaces; pod oblong-orate, pulicscent, much shorter than the calyx. - I)ry and sandy soil, N. Eng. to Fla, west to Mlinu., Mo., aut lat.

7. L. angustifolia, Ell. Like the last, but mostly appressed-silky, the leaflets linear, the smuller often oblong heads on distinet and sometimes slender

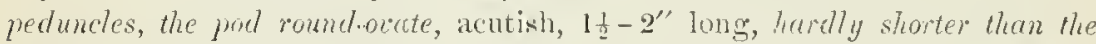
calyx. (L. capitata, war. angustifolia, Pursh.) - N. J. to Fla., west to Micll., Iowa, and Lat.

8. L. leptostàchya, Gray. Clothed with appressod silky pubescence; stems often branched, sleucler; leaflets linear to nalvowly oblung; spikes slender, somerthat loosely-flowered, on peduncles as long as the leares; pod orute, small (11" long), aboul equalling the calyx, demsely pubescent. - I1l., Iowa, and Minn.

$\$ 2$. Stipules and bracts broad and scarious; calyx-loles broad: anmual.

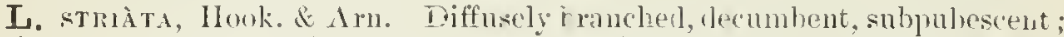
petioles very short; leaflets ohlong-obcrate, $5^{\prime \prime}$ long or less; pednncles very short, 1-5-flowered; pod small, lithe exceeding the calyx, - Common in the Sonthern States, extending into Mo. (Nat. from lis. Asiic.)

\section{STYLOSÁ N THES, Swartz.}

Calyx cally decidnous; tuhe slemeler aud stalk-like; limb unequally 4-5cleft, the lower lobe more distinct. Corolla and monalelphons stamens inserted at the summit of the calyx-tuhe; standard orbicular; kecl incurverl. Anthers 10, the 5 Ionger ones fixed near their base, and the 5 alternate shortur ones fixed ly the midlle. Style filiform, its npper part falling off after Howering, the lower port incurved ol hooked, persistent on the 1 - 2-jointed snall au! slort reticulated forl; the lower joint when present enpty and stalk-like. I ww peremials, blanded from the base, with wiry stems, pinnately 3-foliolate leares, the sheathing stipnles united to the petiole, no stipols, and small, yellow. flowers in terminal leads or short spikes. (Name composed of oqúxos, a col-

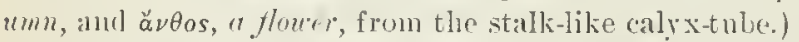

1. S. elàtior, swart\%. Tuftel; leaflets lanceolate, strongly straigl:treincd : heads or clusters small and few-flowered. - l'iue harreus. Long Island and X.J. to Fla., west to S. Ind., Kan, and $\Lambda$ rk.

\section{VÍCIA, Tonru. Vetch. TARE.}

("aly 5-cleft a) 5.tonthel, the 2 upper tecth often shorter, or the lowest longer. Wings of the corolla alluering to the middle of the keel. Situneus:

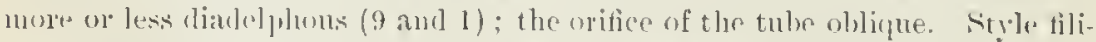

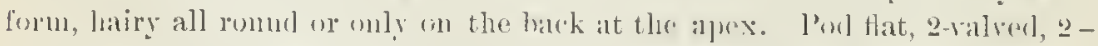

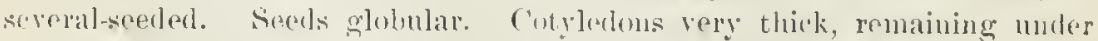

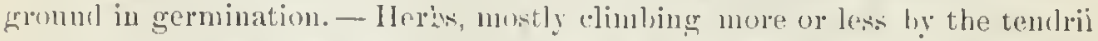
at the end of the pinnate leaves. Sitipules half-kigittate. Flowers or perluncles axillary. ("l'he clasisical I atin name.) 
* Annual; Aloueres 1 or 2 in the axils, nearly sessile, large, violet-puryle.

V. nivi, L. (Comuon VuTcu or Tuls.) simpwhat pubescent; stem simple; leattets 5 - 7 pairs, varying from obovate-ol, long to linear, notcheri and mucronate at the apex: pod linear, several-senled. - Cultivated fields and Waste places, N. Eng. to N. J. and sonthwart, west to Mich. and Minn.-

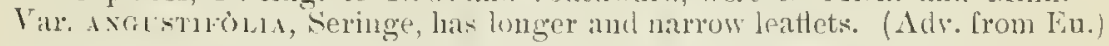

* Anmual, stender; pedunrles elonguted : floucers small.

V. титиıspéruı, L. P'elmeles I-2-flowered: leaflets $4-6$ pairs, linearohlong, obtuse; calyx-teeth mequal; corolla whitish; pods numon, 4-seedef, smooth. - Waste places, wear the coalst, N. Scotia to N. J. (Nat. from Eu.)

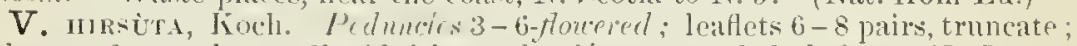
(alyx-teeth equal; corollat bluish; pods obloni, 2-speded, hariy. - N. Brunswick to Mass. and Via. (Nat. Lrm En.)

* * * Perenniar; peduncles clonguled; calyx-teeth uneryual; poul several-seeded.

1. V. Crácca, I. I)owuy-[ubescent; laftets 20- 2t, ollong-lunceolate, shongiy mucronute; spites denscly many-flowerod, 1-xided; flowers blue, turning purple, 6" long, reflexerl; caly:x-teeth shorter than the tube. - Borders of thickets, Newf. to N. J., west to Ky. Towa, and Mimn. (Wu.)

2. V. Caroliniàna, Wialt. Nearly smooth ; leaflets $\mathrm{S}-24$, ollong, obuse, soncely mucronale: peduncles loosely-fonered: fiowers small, more scattered than in the preceling, whitish, the keel tipjed with blue; callx-teeth very short. - River-1)anks, Ont. and X. Y. to Ga., West to Mimn. and Kan.

3. V. Americàna, Mull. (ilabrous; leceflets $10-1+$, dliptical or ornteolfong, verg oltuse, many-reines; pedincles $4-8$-foncered: Howers purpish (s" long). - MList soil, X. Y. and X. J., to Kran., Minn., anl westwart. - Var.

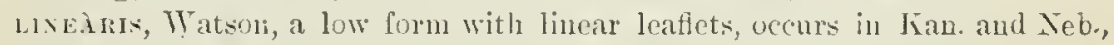
and is conmon westwarl.

\section{LÁth Y R US, Toum. Tetchlixi. Evlreasting Pea.}

Sityle flattisl, dilated and flattish (not grooved) above, hairy along tice inner side (next tlie free stamen). Silieath of the filaments sareely obliqne at the apex. Otherwise nearly as in Vicia. - Cur species are peremial and mostly. smooth plants, the rlachis of the leaves in some not prodncel into a tendril.

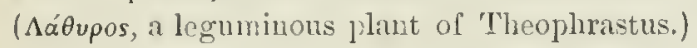

* Tendrils present; stipules large and broud: ieufets $3-5$ pairs.

1. L. marítimus, Bigelow: (BEAcn PEA.) sitont (10 ligh or more); stipules broadly oralc and halberd-shaped, wourity us iurge as the leaflets, tine lower lobe larger and usually coarsely touthed; leaflets thech, ovate-oblong (i-2' long); peduncles a little shorter than the leaves, 6 - 10-fowered, floners large ( $9^{\prime \prime}$ long), merple. - Seatshore from X..T. and Oregon to the Aretic Sen; also on the Great Isikes. (Eu.)

2. I. ochroleủeus, Hook. Stem slender $\left(1-3^{\circ}\right.$ high $)$; stipules semicordate, half us lurge as the thin ovute leaflets; peduncles 7 - 10-flowered: flowers smaller, yellaxish-white. - Ilillsiles, N. Eng. to Minn., Lowa, and westwarl.

* Tendrits present: stipules narron, semi-sugittate acuminate.

- Flowers mirple: leupats snerui pairs.

3. L. venòsus, Muhl. viou, climbing, usually somewhat downy; stipules rery small and mostly slender; leafets $t-6$ pars, oblong orate. mostly 
obtuse (abont 2'long); peduncles man!y-fouered; fowers $6-8^{\prime \prime}$ long. - Shady banks, l'enn. to Ga, west to Kan. and Minn.

4. L. palústris, I. Slender, glabrous or somewlat pubescent; stem often winged; stipnles lanceolate, slarpl-pointed at both ends; lenflets 2-4 pairs, narrowly oblong to linear, acutr (1-2' long); peduncles 2-6-flowerd: flowers $6^{\prime \prime}$ long. - Moist places, N. Sicotiat to N. J., and westwarl across the contineut. (liu.)

Var. myrtifòlius, Grạ. Sitipules usually broader anul larger; leaflets orate to oblong ( $l^{\prime}$ long or less). - Same range, and extenrling sonth to $\mathrm{N}$. C.

$$
\text { + Flowers yellow: leuflets a single puir. }
$$

L. PRAtÉssı, L. Low and straggling; leaflets narruwlik lanceolate to linear, acute; pedumcles several-flowered. - Spontaneous in Miass., N. Y., and ()it. (Nat. from Eur.)

* * * Tendrils usully uenting; lou, mostly erect; slipules semi-sagittale; flowers rery laige, purple: pod stipitste in the ralyx.

5. L. polymórphus, Nutt. I,eaflets $3-6$ fairs, marrowly oblong to linear, thick and strongly nerved, $1-2^{\prime}$ long; seets with a uarow footstalk aud short hilum. - Mo., Kau., and westward.

5. I. ornàtus, Nitt. Like the last, but leaflets alwars narrow, 3-12" long: sceds with a very hroad footstalk and long hilum. - Kan. to Col. and the 1)aliotas. Scarcely $1^{\circ}$ high.

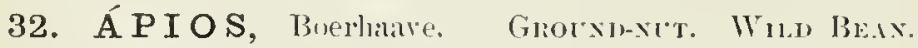

Calyx somewhat 2-lipped, the 2 lateral teeth being nearly obsolete, the upper - very slort, the lower one lomgent. Stumblar rery broarl, reflexerl; the long scythe-shaped keel strongly incurvel, at length coiled. Stamens diarlelphous.

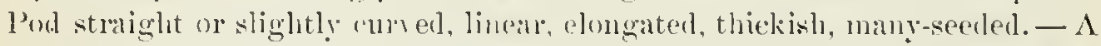
perennial herl, (witl some milky juice!), twining and climbing over bushes, and bearing edlible tubers on mulergemul shonts. Leathets $3-7$, orate-lancenlate, obscurely stipellate. Flowers in denso and short, often branching racemes. (Name from \&atov, "frer, from the sliajo of the tubers.)

1. A. tuberósa, Moench. Flowers hrow-puple or clucolate-eolor, violetscenter. - Low gromels. N. Brunswiek to Fla., West to Mim., Kim., and La.

\section{PHA SEOLUS, 'Tourn. linger BeAN.}

Calyx 5-toothen or 5.cleft, the two upled teeth often higher nnited. Keel of the corolla, with the included stamens and style, spinaly coiled. Stamens diadelphous. Style bearded along the mper sille; stigna ulligue or hateral. l'ol scythe-shaped, ser'mal-man-sected, tipjed with the latrlened base of the style. Seeds rounl-reniform, with very short lilum. (otyledous thick and Heshy, rising ont of the gromel nearly. unchanged in gernination. - Twining herbs, with pinnately 3 -fuliolate stipellate leaves. Flowers racenose, prodnced in summer and antumn. ('The ancient name of the Kiclucy. Bean.)

1. P. perénnis, Walt. (WLD likx.) Sten climbing higl from a pereunial root; leaflets roundish-ovate, short-pointed; flowm purple, landgome, but small; pols drooping, strongly curved, 4-5-seeded.-Copses, $\mathbf{N}$. Eng. to Fla, west to Minn. and La. 


\section{STROPHOSTỲLES, EH.}

Keel of the corolla with the included stamens and style elongated, strongly incurved, not spirally coiled. Porl linear, terte or flattish, straight or nearly so. Seeds quallate or obloug with trmucate end, mealy-pubescent or ghabrate; hilum linear, Flowers few, sessile and capitate-clustereal on the mostly long fechncles. Otherwise as Phaseolus. - Stems prostrate or climbing, more or

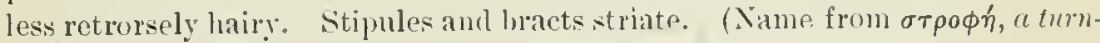
$i n \eta$, and $\sigma \tau \hat{v} \lambda$ os, a style.)

1. S. angulòsa, Ell. Imnuel: stems branched, 1-6 long; leaflets orate to oblong-ovate (maly linear-olbong), with a more or less prominent rounded lobe toward the luse (the terminal 2-tobed), or some or al] often entire, about l' $\left(6-20^{\prime \prime}\right)$ long; corolla greenish-white and pmrplish ; pod terete, $2-3^{\prime}$ long by 3 "wide, 4-8-seeded, nearly glabrons ; seeds oblong, about $3^{\prime \prime}$ lomg, uswally very pubescent. (1'haseolus diversifolins, Pers. I'. helvolus, L.) - Samly shores and river-binks; coast of Mass. and southward, aloug the Great Lakes to Minn., and soluth to lian. and 'Tex.

Var. Missouriénsis, Watson in herb. (limbing high $\left(10-30^{\circ}\right)$; leaves often $3^{\prime}$ long, rhombic-ovate, rarely at all bohed ; seeds $3-4$ " long. - Riverbottoms near Indepenlence, Mo, incarly two months later. (F. Bush.)

2. S. pedunculàris, lill. Stems more slenter, from a perennial rootstock, "2- $-4^{\circ} \operatorname{lnng}$; loaflets wate to whong-linear, rarely at all lobed, $1^{\prime}$ long or less; porl 12-2’ long and sertrely 2" wile; seeds much smaller, $1 \frac{1}{2}-2^{\prime \prime}$ long, short-oblong to quarirate. (Phasenlus helrolus, Man., ete, not L.) - Sandy ground, Tong lsland and X. J. to Flis, west to S. Inrl., Ky., and La.

3. S. pauciflorus, Witson in herl. Ammal, slenfler, low-climbing, pubescent ; leaflets ol, long-lanceolate or ovate-oblong to linear, not lobed, l' long; porl pubescent, I' long, flattish; sephs as in the last, rery finely mealy, soon

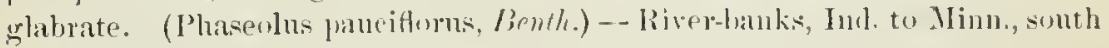
to Miss. and Tex.

\section{CENTROSEM A, JuC. Spuran Butterfly-Pea.}

Calyx short, 5-cleft. Corolla, "te., much as in Clitoria, lut the spreading standard with a spur-shaperl projection on the baek near the base: keel broad. Style bearded at the apex around the terminal stigna. Porl long and linear, flat, pointerl with the awl-shaperl style, many-seefled, thickened at the erlges, the ralves marked with a raised line on each side next the mangin. - Twining perennials, with 3-foliolate stipellate leaves, and large showy flowers, sitipules, hracts, and bractlets striate, the latter longer than the caly. (Name from

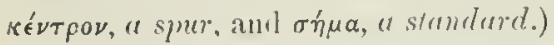

1. C. Virginiànum, Benth. Rather rongh with minnte hairs; leaflets rarying from oblong-ovate to lancolate and linear, very veiny, shining; peluncles $1-4$-flowered; ealy-x-teeth linear-awl-shaped; corolla riolet, $\mathbf{l}^{\prime}$ long; pods straight, 4-5' long. - Sandy woorls, Md. to Fla, and Ark. (Trop. Am.)

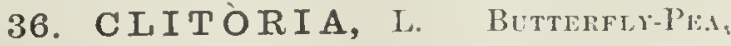

Calyx tubular, 5-toothed. Standard mueh larger than the rest of the flower, ereet, rounded, notehed at the top, not spurred on the lack: keel small, shorter 
than the wings, incurved, acute. Stamens monadelphous helow. Style bearded down the immer faee. Porl linear-oblong, flattish, knotty, several-seeded, pointed with the base of the style, - Erect or twining perennials, with mostly pinnately 3-foliolate stipellate leaves, and very large flowers. l'eluncles 1 -3-flowered; mactlets opposite, striate. (Derivation recondite.)

1. C. Mariàna, T. Low, ascending or twining, snooth; leatlets oblongorate or orate-lanceolate; stipules aud bracts awl-shaped; perluncles short; the showy pale-blue flowers $2^{\prime}$ long, - Dyy banks, $\mathrm{X}$. Y. to Ta. and Fla, west to Mo. and Tex.

\section{A I P P I A R P A, Fll. Hor PE.Ner.}

Flowers of 2 kinds; those of the racenes from the uppra hranches perfect, but seldom ripening fruit; those near the bise and on filiforn creeping hanehes with the corolla none or rulimentaly, and fow free stamens, hut firuitful. Calyx about equally 4- (marely 5-) toothed; bractlets none or minute. Fieel ancl wing getals similar, ahmost straight: the standard partly folded round them. Stamens diadelphous. Style bearlless. P'ols of the npper flowers, when formed, somewlat seymetar-slaped, stipitate, $3-4$-seeded of the lower ones rommonly subterianean and fleshy, obowate or pear-shaped, ripening usually but one lange seed. - Low and slender perennials; the twining stens clotlect witl brownish hairs. Laves pinnately ä-foliolate; latlets rlombic-orate, sti. pellate. Flowers in simple or compumul racemes, purplish. Bracts persistent, round, partly clasping, striate, as well is the stipules. (Nane from ảuqí, both. and raptós, fimit, in allusion to the two kincts of pork.)

I. A. monóica, Nutt. L.eaftets thiu, $\frac{1}{2}-\underline{2}$ long; racenes nodding:

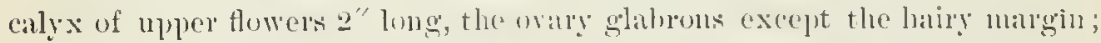

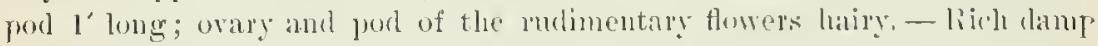
workllauls, commonom. Alng., Sept.

․ A. Pítcheri, 'Torr. \& Griy. Laflets usually 2-4' long; rlachis of the racemes msnally villous; caly: $3^{\prime \prime}$ long, the teeth acmunate: ovary hairy.

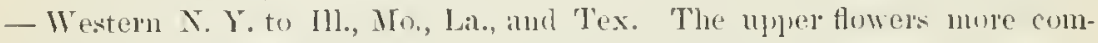
monly fortile; anparenty prochucing subterauean fint hut rarely.

\section{GA LÁ C T I I'. Browne. Mıк-I'kA.}

('alyx 4-cleft; the lohes acute, the npper one hroadest, entire. Feel scarcely" incurved. Stamens diadelphous or nearly su. Style beatlless. F'ul linear, Hat, several-seeded (some few of them larely partly subteranean and fleshy ur deformed). - Iow, mostly prostrate or twiung pereunial herbs. I Leaflets nsually 3, stipellate. Flowers in somewhat interlupted or kuntty racenes, purplish:

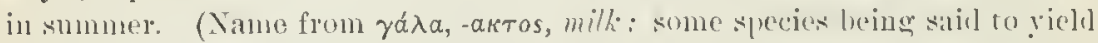
a milky juice, which is mulikely.)

1. G. glabélla, Michx. Slems mourly smooth, prostrate; leaflets elliptical or orate-oblong, sometimes slightly hairy heneatl, racenes short, 4-8-flowererl; pods somewhat hairy - Simly wouls, sulthem N. Y. to Va., Flin, and Miss.

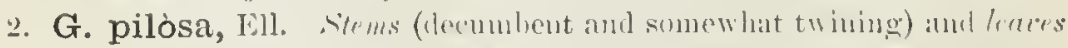

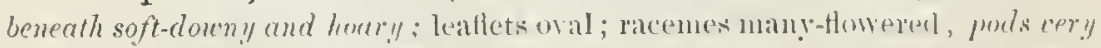
downy. (G. mollis, Groy, Manual; not Mirlex.) - l'enu. to Flat. and Miss. 


\section{RH Y N C H Ò I A, Lی11.}

Calyx somewhat 2-lipped, or depply 4-5-parted. Ki+1 seythe-shaped, or in-

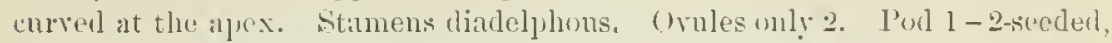
short and Hat, 2-valved. - Usually twining or trailing peremial herlss, pinnately 3-foliolate, or with a single leattet, not stipellate. Flowers yellow, lanemuse or clustered. (Name from púryos, a beuli, from the shape of the keel.)

1. R. tomentòsa, IIook. \& Aru. Tiulting aml trining, the stem and loaven more or less mbescent with sprending huirs; leatlets 3 , roundish on round3.hombir, acute or acntisln; rucemes few-Howered, almost sessite in the axils; anlyx alwont as long as the corolla, 4-pneted, the nppex lobe 2-cleft; pud oblong.

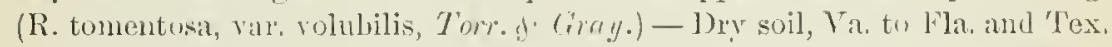

2. R. erécta, 1) : Erert, 1-20 highl, stent and leaves mone or less tomentose ; leaflets 3 , orel on oblong, obtnse or acutish; racenes short and shortly pe-

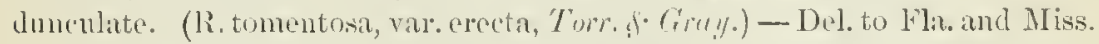

3. R. renifórmis, D(. Decof and upright, 3-8' high ; puluesecuce spreadiuy: lenfels solitury (rarely 3), round-reniform, very obtuse or apieulate; raeemes few-flowered, sessile in the axils. (li. tomentosa, lau. monophylla; Torr. fir (ivy.) - Va. to Fla. aud Misis.

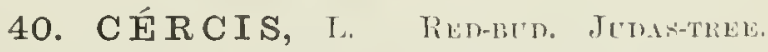

Calyx s-tootherl. Corolla imperfectly lapilionaceous; standared smaller than

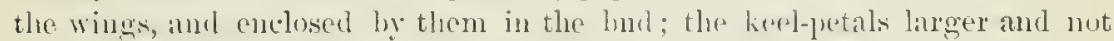
mitel. Stanens 10, distinct, declinerl. l'od nhlonge, Hat, mamy-seeded, the

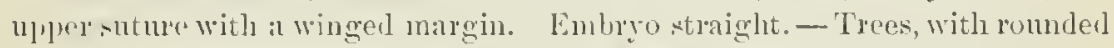
heart-shaped simple leaves, calucous stipules, and red-purple thwers in umbellike clusters along the branches of the last or preceding years, appearing before the leaves, acisl to the taste. (The ancient name of the Oriental . Tudus-frep.)

1. C. Canadénsis, I. (Ren-1згn.) Leaves pointed; pols nearly sessile abuve the "ilyx. - Rirh soil, N. Y. ant N. I. to Fla., west to S. Minu., Kian, and Lat. A small ormanental tree, often cultivated.

\section{C Á S S I A, Toulı. SExra.}

Sepals 5, scarecly united at base. l'otals 5, little mequal, spreading. Sta-

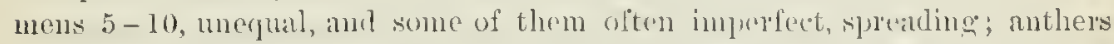

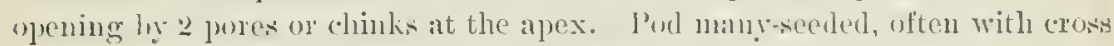
partitions. - Ilerls (in the linited States), with simply and almutly piunate Inaves, and mostly yellow flowers. (An ancient name of obscure derivation.)

* Leteflets lerere; stipules deciduous; the theren upper andhers de formed and im-

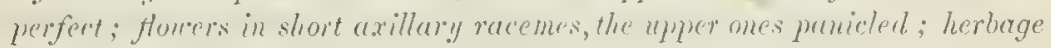
glabrous.

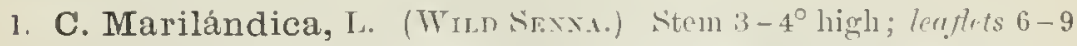
pairs, lanecolale-oldony, obluse: petiole with a clnb-sllaped gland near the base; pouls linear, sligntly ('urved, flat, at furst hairy $\left(2-t^{\prime}\right.$ loug $)$; rot peremial. -

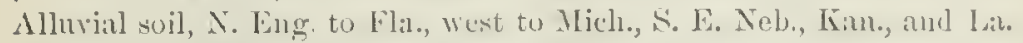

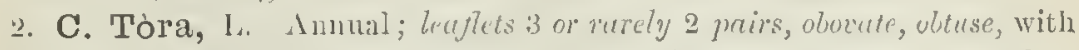
an elongrited gland hetween those of the lower pairs or lowest pair; puls slen- 
der, 6' Jong, curved. (C. obtusifolia, L.) - River-banks, S. Va. to Fla., west to S. Ind, Mo., and $\Lambda$ rk.

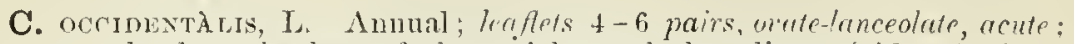
an ovate gland at the hase of the petiole; pods long-linear $\left(5^{\prime}\right.$ long) with a tumid horder, glabrous. - Via., S. Ind., and sonthwarl. (Adr. from Trop. Amer.)

* * Leaflets snull, somerrlat sensitire to the tonch; stipules striute, persistemt: a cup-shaped gland beneath the lowest prir of leaftets; amthers all perfeet flowers in small clusters wbote the axils; ports flat; root annual.

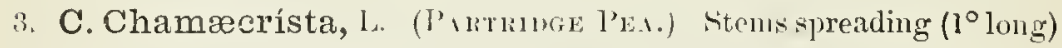
leatlets 10-15 pairs, linear-sblung, whicpe at the lase ; flouers (large) on ston. der predieds, 2 or 3 of the showy yellew potals of ten with a purple spot at base; unthers 10, eloniguled, unequal (t of them yellow, the others jurple); style slender. - Siandy fields; (onmm, especially southwarl.

t. C. níctitans, L. (WhL NExiture-PLAxт.) Leaflets $10-20$ pairs, oblong-linear; flowers (very small) on wry short pedicels ; anthers 5, nearly equal; style short. - Sandy ficlds, N. Eng. to Fla., west to Ind., Kan., and Ia.

\section{HOFFM A N E G GIA, Cav.}

Calyx 5-parted. Petals 5, nearly equal, nhlong or oral. Stamens 10, distinct, slightly declined; anthers deluscing longitudinally. Pod flat, olslong, often falcate, few-several-scederl. - Iow perenuial herbs, or wooly at hase, punctate with liack golands, with hipinnate leaves, and naked racemes of yellow fower's opposite the leares or terminal. (Named fur Count ron IIoffimanseg!y, a German hotanist.)

1. H. Jamèsii, 'Tol'r. \& Gray. Herhaceons, funcly pubescent; pinna 2 or 3 pairs with an odld one, the small oblong leaflets i) -9 pairs: porls loroarl, falcate, l' long, 2-3-secerlerl- Central Kan, to Tex., Ariz, and Mex.

\section{G Y M N Ó C L A D S, Lam. Kextreky Cofreli-trer.}

Flowers dioecions or polygamous, regular. Calyx elongated-tulmlar helow. 5-cleft. Petals 5, oblong, equal, inserted on the summit of the calyx-tube. Stamens 10, distinct, short, inserted with the petals. Iod oblong, flattened, hard, pulpy inside, several-seederl. Sceds flattish. - A large tall tree, with romgh bark, stont hranclilets, not thomy, and large mequally twice-pinnate leares; the leaflets standing rertionlly- - Flowers whitish, in terminal racennes

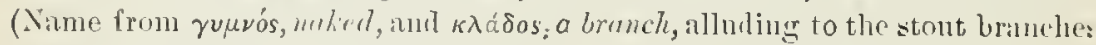
destitute of spriay.)

1. G. Canadénsis, Lam. Leares $2-3^{\circ}$ loug, witl several large partial Leafstalks hoaring $7-1.3$ orate stalked leaflets, the lowest pair with single leaflets; stipnles wanting; pod $6-10^{\prime}$ long, $2^{\prime}$ broad ; the seeds over $\frac{1}{2}$ across. lich woods, western X. I. and l'enn. to Minn., E. Neb., and Ark.

\section{GLEDÍTSCHIA, I. HoNer-Locest.}

Flowers polyamous. Calyx slont, 3-5-eleft, the lohes spreacling. Petals as many as the sepals and erpulling them, the 2 lower sonetimes united. Stamens $3-10$, distinct, inserted with the petals on the base of the calyx. Pod flat, 
1-many-seeded. Seeds flat. - Thorny trees, with abruptly once or twice pinnate leares, and inconspicuous greenish Howers in small spikes. Thorns abure the axils. (Named in honor of $J . G$. Gleditsch, a botanist contemporary wit? Linnxus.)

1. G. triacánthos, L. (Threw-Thorsed ACACL, or Honey-Locust.) Thorns stout, often triple or compound; leaflets lanceolate-oblong, somewlat serrate; pods linear, elongated ( $\left.1-1 \frac{1}{2}{ }^{\circ} \mathrm{long}\right)$, often twisted, fillerl witl sweet pnlp betwcen the seeds. - Rich woods, western N. T. and Penn. to Ga., west to Mich., E. Neb., Kan., and La. A large tree, common in cultivation, with very liard and heary wood.

2. G. aquática, Marsh. (WAtwi-Locust.) Thorns slender, most]y simple; leaflets orate or oblong; pods oral, ]-seeded, pulpless. (G. monosperma, Walt.) - Deep swamps, MIo. to S. Ind., S. Car., and southward. A smaller tree, $30-40^{\circ}$ high.

\section{DES MÍ́NTHUS, Willd.}

Flowers perfect or polygamous, regular. Calyx campanulate, 5-toothed. Petals 5, distinct. Stamens 5 or 10. I'od flat, membranaceous or somewhat coriaceous, several-seeded, 2-ralved, smuoth. - Herhs, with twice-pimnate leares of numerous small leaflets, and with one or more glands on the petiole, setaceous stipulcs, and axillary jeduncles bearing a head of small greenish-white

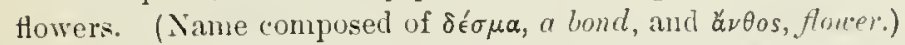

1. D. brachýlobus, Benth. Nearly glahous jeremial, erect $\left(1-4^{\circ}\right.$ high); pinux 6-15 pairs; lcaflets 20 - 30 pairs ; pednncles 1 - $3^{\prime}$ long; stamens 5 ; pods numerous in dense glohose heuds, oblong or iunecoiule, curved, scarcely l'long, 2-6-seeded. - Prairies and alluvial banks, lnd and Ky to Minn., Mu., and 'Tex.; also in Fla.

2. D. leptólobus, Torr. \& Gray. I'innx 5-8 pairs; leaflets $10-20$ pairs; peduncles 1' long or less; heads rather loose, stamens 5 ; pouls usually few, narrowly linear, erect, 1 -2' long. - Central Kian. to Tex.

\section{SCH R Á N K I A, Willd. Sensitive Briar.}

Flowers polyganous, regular. Calyx minute, 5-toothed. I'etals united into a funnel-form 5-cleft corolla. Stancis $10-12$, distinct, or the filaments united at base. Pods long and nurow, ruugh-prickly, several-seeded, 4-ralved, $i$, en the two narrow valves separating on cach side from a thickench margin. - I'e rennial herbs, nearly related to the true Sensitirc l'ants (Aimosa); the procum. bent stems and petioles recurved-prickly, with twice-pinnate scusitive leaves of many small leaflets, and axillary pedmeles bearing round heads of small rosecolored flurers. (Named for F. P. Schrank, a German botanist.)

1. S. uncinàta, Willd. P'rickles hooked; pinnse 4-6 pairs; leuflets ellipticul, reticulated with strong veins beneath; pods oblong-linear, nearly tereteshort-pointed, denscly prickly (2' long). - Dry sandy soil, Va. to Fla., west to S. Ill., Kan., and Tex.

2. S. angustàta, Torr. \& Gray. Leaflets oblony-linear, scarcely reined; pors slender, taper-pointed, spariugly prickly (about $4^{\prime}$ long). $-\mathrm{S}$. I'a. (l) to Fla., Tenn., and Tex. 


\section{Order 33. ROSACEA. (Rosk Family.)}

Plants with regular flowers, numerous (rarely few) distinct stamens in. sertert on the calyx, and 1 -muny pistits, which are quitc slistinct, or (in the last tribe) unted and combined with the calyx-tube. Seeds (anutropous) 1-few in each ockry, almost always without albumen. Eimbryo straighte, wilh latrge and thick colyledons. Leaves athernute, with stipules, these sometimes caducous, ranely obsolete or wanting. - Calyx of 5 or rarely 3-48 semals (the odd one superior), united at the base, of ten appearing double by a row of bractlets outside. Petals as many as the sepals (rarely wanto 1119), mostly imbricated in the bud, and inserted with the stamens on the "rlge of a disk that lines the calyx-tube. Trees, shrubs, or herbs. - A lare and mportant orler, almost destitute of noxious qualities, and producing the most valuahle fruits. Very intimatery connected with Leguminosie on one hand, and with saxifragacex on the other.

I. Ovary superor and not enclused in the caly-tube at maturity.

* Calyx decidnous, without bractlets : pistil solitiely, beroning a drupn.

Tribe I. PRUNEAs. Trees or slumbs, with simple mostly serrate leaves. Orules ?, lendulums, but seed almost always solitay. Style trininal.

i. Prunus. Flowers perfert. Lolses of calyx and enroila 5. Stone of the drupe bony.

* Calyx mostly persistent : juistils few to many (rarely solitany).

+ Calyx without buctlets : ovules 2-mans.

Trile I1. SPIIAEEI. Pistils mostly 5, heconing 2-several-seeded follicles. Shrubg or perennial herbs.

a. Cilyx short, j-eleft. Petils obovate, ecjual.

2. Civiraea. Flowers perfect or dicecinus. Pols 1-valvel. Herbs or shrubs; leaves stra. jile on pinuate.

i. Plysocarpus. Pods infinted, 2-rnlved. Slurub: leaves palnately lobed.

b. Calyx elongated, 5-toothed. Petals slewrler, uneunal.

4. Gillenia, Merbs; leaves 3 -foliolite.

Tribe III. RUIBER. Pistils several or numerous, beconing cirunelets in fouit. Ovules. 2 and pendulous, but sced solitary. Peremnials, herhacous or with bienuial soft-woody strins:

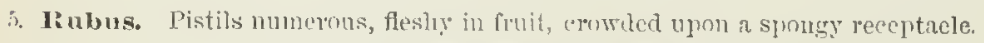

6. Daliluarda. Y'istils $5-10$, in the intton of the alyx, nearly dry in truit. - + Cilyx-holves mostly witl bractlets; ovule solitury.

Tribe IV. POTEXTILLE.E. Pistils few - maty, l-oruled, bermuity dy achenes. Herhs

r. Styles persisfent and elougited after antlıesis, often plumese or jointed.

7. Coum. Calyx-lobes usublly with 5 altemating small brartlots, Stamms ancl carpels nu. merous styles becoming jlumose or lairy tals, or hizliul ancl strairlit or jointed.

7. Styles not elongated after anthesis, mostly leciluous.

S. Waldsteinia. Letils and calyx-lulus 5 ; smill or no brictlets, stameus numerous Achenes $2-6$; styles leciluous flom the base.

9. Fragaria. Flower as in Potentilla, Receptacle much onliuged and pulpy in fruit.

10. Potentilla. I'tals 5 (rarely 4), conspirmons. Calyx-lubes as maly, with an alternat. ing set of bractletis. Stamens and melemes numerous: tho latter licaped on a dry re. ceptrele. Styles commonly more no less linteral, decisunous or not enlarging in fruit.

11. Sibloaldia. Tetals minute: stamens and achenes 5-10; otherwise as Potentilla. 
Ir. Ovaries inferior or "nclosed in the calyx-tube.

Tribe V. POTERIEA. Pistils $1-t$, hecoming arlenes, conpletely enelosed in the dry and firm ealyx-tube, whirch is constricted or nearly closed at the tluroat. Fierbs with compound or lobed leaves. Petals uften none.

22. Alchemillat. Calyx urceolite, bracteolate. Petals none. Stamens $1-4$. Flowers minute, clustererl.

1:5 Arimonia. Calyx turbinate, with a margin of looked prickles. Staneus $5-12$. Flowers yellow, in long racemes.

14. Poterium. Calyx-lobes petaloid; tube t-angled, naked l'etals none. Flowers densely eapitate or spiciate.

Tribe VI. ROSEA. Pistils many, beemning bony allenes, enchsed in the globose or

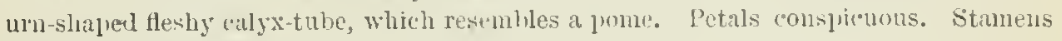
numerous.

15. Rosa. The only genus, Prickly shrubs with piunte leaves.

Tribe VI. FonIEA. Carpels $2-5$, enclosed in and coalescent with the fleshy or berrylike calys, in fruit, leconing a 2 -severul-celled pome. Trees or shmbs, with stipules free from the petiole.

a. Cells of the componnd ovary as many as the styles (2-5), enth "-- (rarely several-) ovuled.

16. Pyrus. Pone contaibing $2-5$ papery or cartilaginous carquels.

17. Cratregus. Poure drupe-like, with $1-5$ bouy stones or kernels. Usually thorny.

6. Cells of the romponnd orary beconing twice as many as the styles, eatch 1-oruled.

18. Amelanchier. Pome ustrally of a eapels; each becomes incompletely 2-celled by a Jrojection from its back; otherwise as Pyorus.

\section{PRU U U S, Tourl. Peru, Chenry, etc.}

Calyx 5-cloft; the tube bell-shaped, mon-shaped or tulutar-ohennical, deciduous after flomering. "'etals 5, sprealing. Stamens $15-20$. Pistil solitary, with 2 peudulus orules. Drupe floshy, with a lwny stone. - Simall trees or whubs, with mostly echible fruit. ('lhe ancient Latin name.)

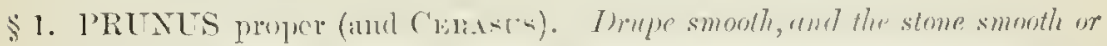

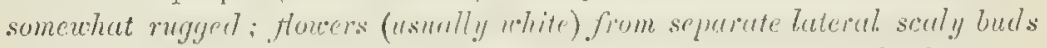
in early spring, yrencoting or rortuneous with the leares; the pedicels few or several in simjle umbel-lilie chusters.

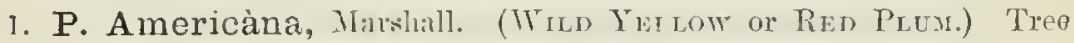

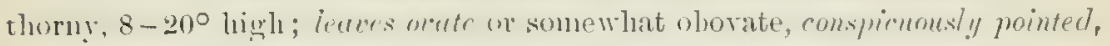

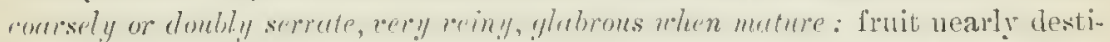

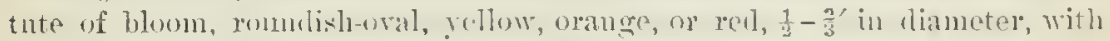

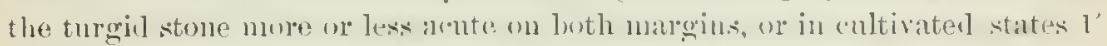

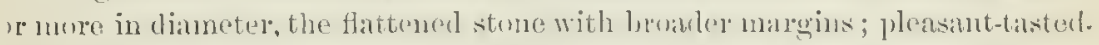

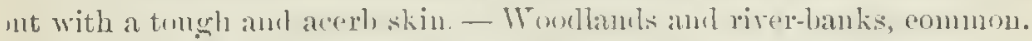

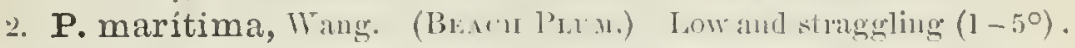

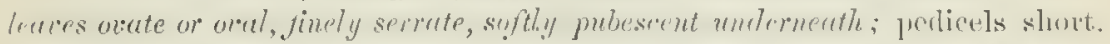

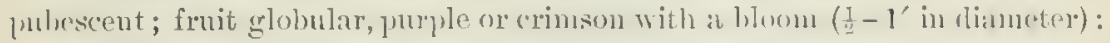

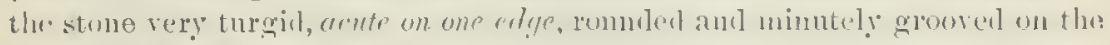

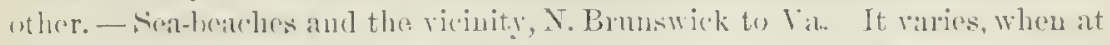
sonde distance [lon the coast (N. J. and sonthward), with the loaves smoothere and thimer ant] the fruit sumsller.

3. P. Alleghaniénsis, l'urter. A low stuggring shrul, or small tree

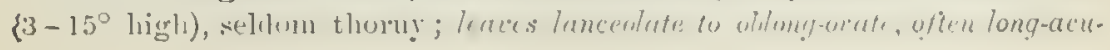


minate, finely and sharply serrule, softly pubescent when young, glabrate with age; fruit globose-ovoid, very durk purple with a bloom (less than $\frac{1}{2}$ ' in diameter); stone turgid, a shallow groove on one side and a broad flat ridge on the other. - Bluffs of the Alleglany Mts., Pemn.

4. P. Chicàsa, Michx. (Chicrasaw Plum.) Stem scarcely thorny (8-150 high); leaves nearly lanceolate, finely sermlate, glabrous: fruit globular, red, nearly destitute of bloom ( $\frac{1}{2}-\frac{2}{2}$ in diameter); the oroid stone alnost as thick as wide, rounded at both sutures, one of them minutely grooved.Mcl. to Fla., west to s. Ind., Kan., and 'Tex.

5. P. grácilis, Engeln. \& Gray. Soft-pulescent, 1-40 high; leaves oblongianceolate to ovate, acute, sharply serrate, becoming nearly glabrous above, 1 - 2 ' long; pedicels and caly $x$ pubescent; frnit less than $\frac{1^{\prime}}{2}$ in diameter; stone rather turgid, suborbicular, - l'rainies and sandy places, s. Kan. to Tex, and 'Tem.

6. P. pùmila, L. (Dwakr Cnlirr. Snx C.) Smooth, depressed and trailing $\left(6^{\prime}-6^{\circ}\right.$ high $)$; leares whorate-lunceolate, tapering to the base, somewhat toothed uear the apex, pule underneath: Howers 2-4 together; fiuit wroid, dark red or nearly black when ripe, withont bloom; stone ovoid, marginless, of the size of a large pea. - Rocks or sanly lanks, X. Brunswick to $Y^{r}$ r., west to Minu. and Ḱan. Fruit usually sour anu astringent.

7. P. Pennsylvánica, L. f. (Whin Ren Chenur.) Tree 20-30 highl, with light red-brow bark; leaves oblong-lanceolute, pointed, finely and slurply serate, shinimg, green and smoth both sides; flowers many in a cluster, on long perlicels; fruit glolose, light rerl, very small, with thin and sour flesh; stone grobnlan. - Rocky wools, Newf. to N. C., West to Minu. and Mo.

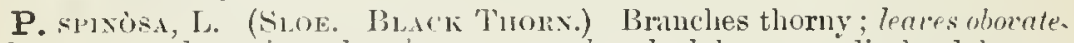
whong or ocate-lancedute, sharply serrate, at lempll glabrous; pedicels grlinhrons; finit small, globnlar, black with a hloom, the stone turgid, acute on une edge.

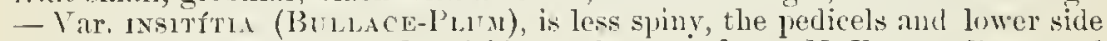
uf the leaves pubescent. - Ciondsides and waste places, N. Eng. to l'enn. and X... (All. from Eu.)

\$2. PADLS. Dimpe small, globose, withont bloom; the stone turgid-orate, marginless; forrors in racemes terminuting leafy branches, therefore aplearing "fter the leaves, lute in spring.

8. P. Virginiàna, I. (Cnoke-Cuerrr.) A tall shrub, with grayish bark; Teures ovul, oblong, or obocute, alnuptly pointed, rer"y sharply (often doubly) serrute with slender teeth, thin; petals roundish ; frnit red turning to dark crintson ; stone smooth. - Kiver-banks, Newf. to Ga., west to Mimu., L. Neh., an! 'lex. - Frnit very austere and astringent. A variety with rey short dense racemes and sweeter yellowish fruit has been found at Dellham, Mass.

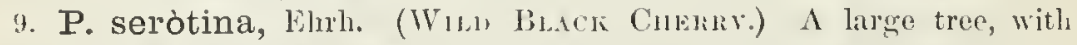

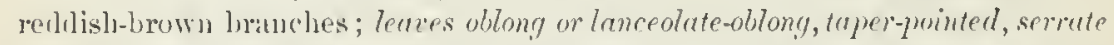
with inrumed shomt and rallous teeth, thickish, shining above; racemes elonsated; petals olwurate; frut purplish-black. - Winols, N. Neotia to Fla., west

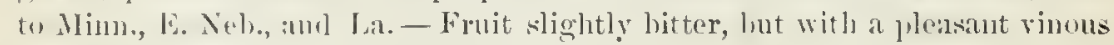
Haror.

10. P. demissa, Walp. Tow lut tree-like in habit, 3-1:0 ligh, resem-

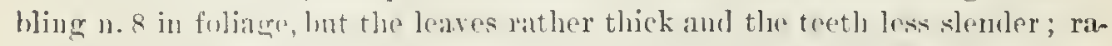
cemes often elongated; fruit purplish-black, sweet and but slightly astringent. - central Kan. and Neb. to New Mex., S. I)ak., and westward. 


\section{SPIR 望A, I. MLADOW-SWEET.}

Calyx 5-cleft, short, persistent. Petals 5, olmvate, equal, inbricated in the bud. Stamens $10-50$. Pocls (tollicles) 5-8, nut inflated, few-sereral-seeded. Seeds linear, with a thin or lonse coat and no allunen. - Shmbs w perennial herbs, with simple or pimate lares, and white or rose-colorel flowers in curyuls or panicles. (The Greek mane, from $\sigma \pi \in \iota \rho$ a $\omega$, to lwist, from the twisting of the pools in the original species.)

\$ 1. SPIRALA proper. Erect shubs, with simple leares; stipules obsolete; pods mostly 5 , secral-seeded.

1 S. betulæéolia, Pall., var. corymbósa, Watson. Nearly smooth (1? high) ; lenves owal or orate, cut-tunthed toward the apex; corymbs large, flut, several times compound; flocers uhite. (S. corymbosa, Reff.) - Mountaius of Penn. and N. J. to Ga., west to ky and Mo.

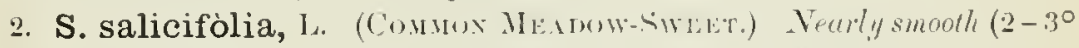
himll); leaves wedge-lanceolate, simply or donhly serrate; forers in a crourled prmmle, white or flesh-color; pods smootl. - Wet or low gromuls, Newf. to the mountains of Ga., west to Minn. and Mo.; also to the far northwest. (En.)

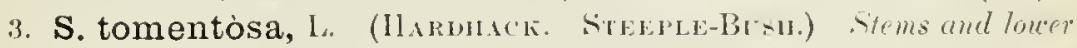
suffure of the ovate or oblung sermate leaces zery woolly; flowers in short racemes crowled in a lense panicle, rose-color, rancly white; porls woolly. - Low (reomds, N. Sicotia to the mountains of Ga, west to Minn. and Lian.

\$ุ. ULMARIA. I'erenniral herbs, with pimme leares and panicled cymose flovers; stipules kidney-form; pods 5-8, 1 -2-sected.

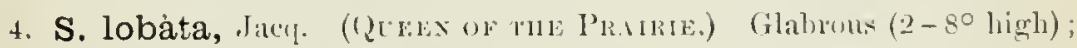
leaves interruptedly pimate; the teminal leaflet vary large, 7 -9-parted,

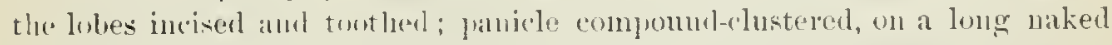

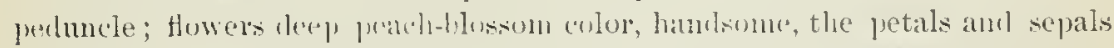
"ften in fours. - Mealows and prairies, Penu. to Gia, west to Mich., Ky., and Inw:

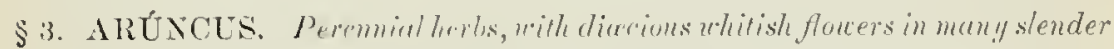

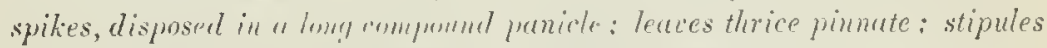

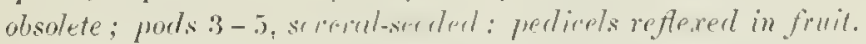

5. S. Arúncus, 1. (Goll's-131:1r5.) snootl, tall; leatlets thin, lan('colate-oblong, or the terminal ones ovate-lanceolate, taper-jointerl, slumply cut and serrate. - Ricll wools, N. Y. and l'enn. to (ia. in the momitainis, west to Iowa and Mo.

\section{PHYSOCÁRPUS, Maxim. Nisk-1вk.}

('arpels 1-5, inflated, 2-valverl; wules -2 - t. Seeds roundish, with a smouth and shining crustacens testa and copious allumen. Stanens 30-40. Otherwise as Spirea. - Shrubs, with sinple palnately-lubed leaves am mmbel-like

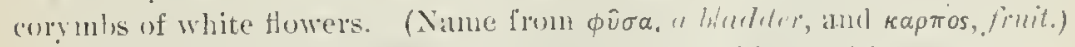

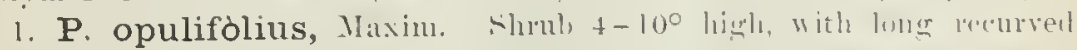

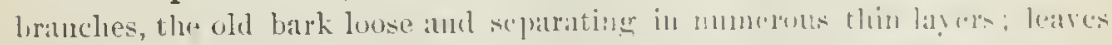

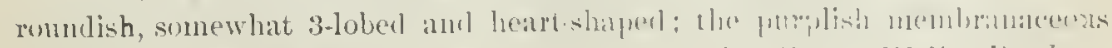

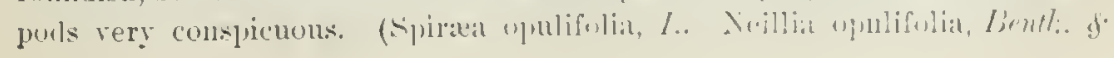


Hook.) - Rocky biuls of streams, N. Eng. to Fla., west to Mo., and the I'acific northward. Oftels, cultirated.

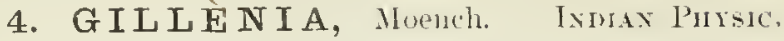

Calyx narow, somew lat constricted at the throat, 5-toothel ; teeth erect Petals 5, rather unepmal, linear-lancoulate, inserted in the throut of the ealyx, (onvolute in the lum. Sitanems 10-20, included. l'ols .5, included, at first lightly cohering with ach other, $2-4$-seteded. Secols ascending, with a cluse coriacens cont, and some allnumen, - P'eremulal holls, with almost sessilu 3-foliolate leaves: the thin leatlets donbly serratc and ineised. Flowers loosely

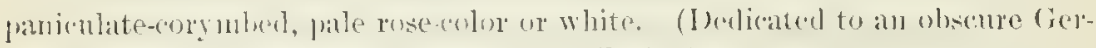

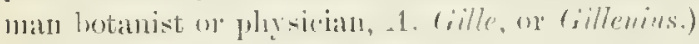

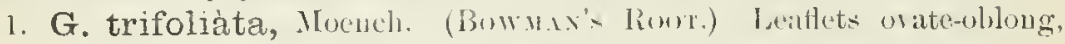
pointed, cut-serrate; stipules small, awl-shaped, entice--Rich woyls, N. I.

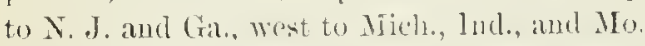

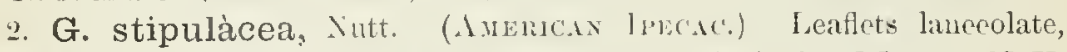
deeply incised; stipules large and leaflike, loubly incised. - Western N. Y. and Penn. to s. Ind. and Kan., soutl to Mla. and La.

\section{R U B U S, Tourn. BimbLe.}

Calyx J-parted, without bractlets. l'etals 5, decilnous. Stamens numerons. Achenes usually muny, collected on a spongy or sncculent reeeptacle, heeoming surall drupes; styles nearly terminal. - P'erennial herbs, or somewhat shrubby plants, with white (rarely redishlı) flowers, and edible fruit. (The Roman name, kiudred with meter, red.)

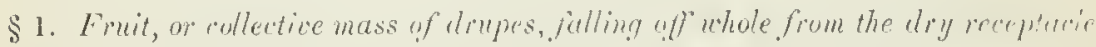
when ripe, of of few grains which full separately. - R.tal'usins:

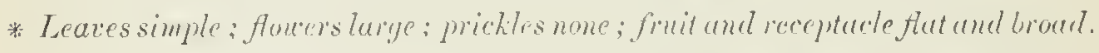

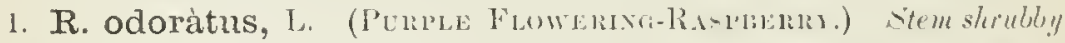

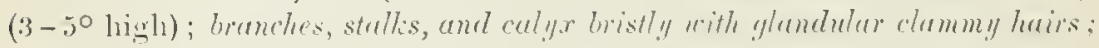
leaves 3-5-lobel, the lobes pointed and minutely tunthed, the nidule ome proIonged; peduncles matuy-flowered; Howers showy (2' hroal); (alyx-lohes

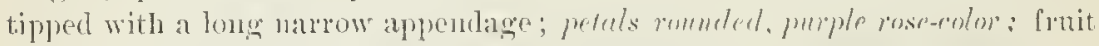
reddish. - N. Sontia to X. J. and Ga, West to Mirh.

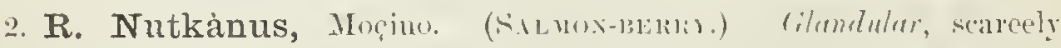
luistly; leares aluost equally 5-lobed, coal'sely tonthol; peluncles few-fluwcreel; petuls orel, white. - L plup Mich., Mim., and westward.

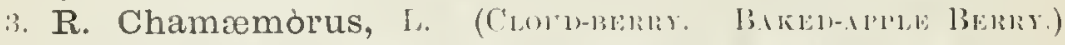

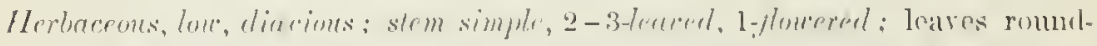

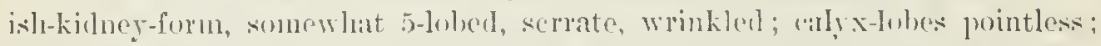

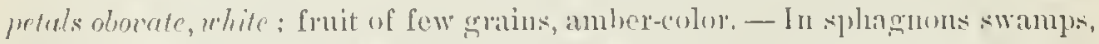
highest peaks of White Mts., coast of E. Maime, ambl nowll and west to the Aretie regions. (Eu.)

* * Leaflels (pimnately or pedately) 3-5; petals small, erert, white.

t- Stems ammul, herbarenus, not prickly; jinit of few soparate grains.

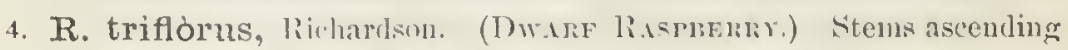
$\left(6-12^{\prime}\right.$ high) w trailing; lenflets 3 (or pedately .5). phombicosate or ovate- 
lanceolate, acute at buth culls, coarsely donlly serrate, thin, smooth; perluncle I-3-tlowered. - Wouted lillsides, Lab. to N. J., west to Minn. and Iowa. Sepals aud petals often 6 ox 7 . 'This appears to be more properly a blackberry.

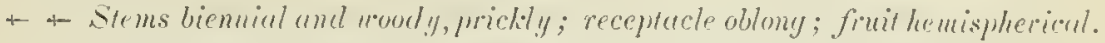

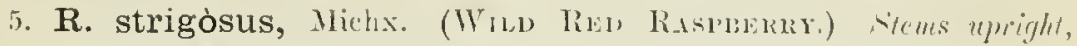
aud with the stalks, etce, heset wilh stiff strenght hristles (or a few becoming weak hooked prickles), grludular when youmg, somewhat gliurous; leathets 3-5, oblung-ovate, pointed, cut-sernate, whitish-clowny underneatle, the lateral ones sessile; petals as long as the sepals; fimit light rod. - 'Tluickets and hills, Libl. to N. J., aud sonth in the nonutins to X. C., West to Miun. and Mo.

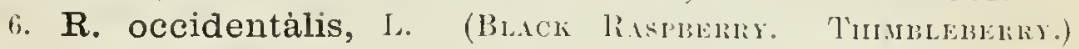

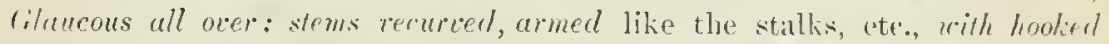
prickles, not lrisly; leatlets 3 (rarely 5), wate, pointel, consely loubly serrate, whitened-dowy molemeath, the lateral ones sonewhat stalked; petats shorter than the sepals: finil purple-black (rarely a whitish ralrexy), ripe early" in .July. - Comnon, especially northward. - Au applarent lylud (li. neglectus, Peck) between this and the last species oceurs, witl cluaracters intermediate between the two, and growing with them.

\$. Fruit, or collective drupes, not sejurating fiom the juicy prolonged rereptacle, mostly ovate or oblong, blackish; stems prickly and flowers whire.BLACKBERTY.

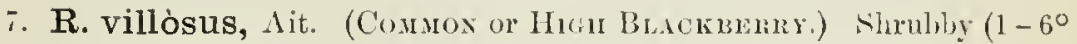
high), furrowed, upright or reclining, armed with stout mured prickles: branchlets, stalks, aud lower surface of the leaves hriry and glundular: leatlets 3 (or pedately 5), orate, printed, mennally seroute, the terminal wes somewhat heart-shaped, conspicnonsly stalked : fleners momed, numerous: hracts short; sepals linear-pointerl, much shorter than the ohorate-thlong spreacling petals. - Borders of thickets, etco, common, and rery raviable in size, aspect, and

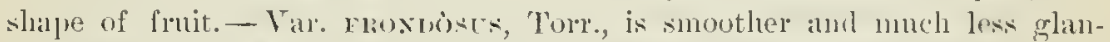
flular, with flowers nure corymlsose, leafy brates and roundish petals. Witlı the type, more common at the nortl. - Var. monlousu, Turr. \& Gray, is smaller and trailing, with peduncles few-flowered. Mure common sontlurard, and commerting with the next species.

8. R. Canadénsis, L. (Low HuackmRry, 1)ewnemr.) Shruby, ratensively trailing, slighlly prickly: leaflets 3 (or pedately 5-7), oral or ovatelanceolate, mostly pointed, thin, nearly smooh, sharply cut-serate; flowers racemed, with leaf-like bracts, - Dry fields, common; Newf. to Vil, west to central Minn. and E. lian.

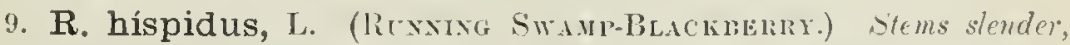
strecely woody, extensicely promumlemt, beset with smull reflexed mickles; leafluts is (or rarely pelately 5), smooth, thickish, mestly persistent, ubovate, obtuse, warsely serrate, entire toward the base; pedmules lenfess, several-flowered, ofin bristly: flowers small: fruit of few grains, black. - In low wouds or swampy grasy grourl, N. Scotia to Ga., west to Minn. and R. Kan.

10. R. cuneifòlius, I'nrsh. (SAsp Buckiliri.) shrubly (1-30

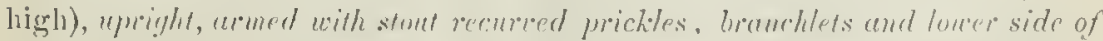
the leares whitish-uroolly: leatlets i-5, wedge-obovate, thickish, screrate alove; 
peduncles 2-4-Howered; petals large. - Sandy wools, sonthern N. Y. and l'enn. to Fla., west to Mo, and Ia.

11. R. triviàlis, Miclux. (Low Busn-BlackuEnkr.) Shrubly, procumlent, bristly and prickly ; leaces evergreen, coriuceous, neurly glabrous ; leaflets 3 (or pedately 5), ovate-oblong or lanceolate, sharply serrate; peduncles 1 - 3 flowered; petals large. - Sandy soil, Va. to Fla., west to Mo. and Tex.

\section{DALIBÁRDA, L.}

Calyx deeply 5-6-parted, 3 of the divisions larger and toothed. l'etals 5, sessile, deciduous. Stamens mauy. Oraries 5-10, becoming wearly dry seedlike drupes; styles terminal, deciduous. - Low peremidls, with rreeping and densely tuftel stems or rootstocks, and roundish-heart-shaped crenate leaves on slender petioles. Flowers 1 or 2 , white, on scape-like peinncles. (Named in honor of Thomes Lulibard, a French botanist of the time of Limnans.)

1. D. rèpens, L. Downy; sepals sprealing in the flower, converging and enclosing the fruit. - Wooled banks; common northward. June-Aug. - In aspect and foliage resembling a stemless Violet.

\section{G EU M, L. ArEss.}

Calyx bell-shaped or flattish, leeply 5-cleft, usially with 5 small bractlets at the sinuses. Petals 5. Stanens many. Achenes numerous, heaped on a coni(al or cylindrical dry receptacle, the long persistent styles forming hairy or nitkel and straight or jointed tails. Seed evect; raclicle inferior. - Perennial lucrbs, with pinnate or lyrate leaves. (A name used by Pliny, of unknown me:tuing.)

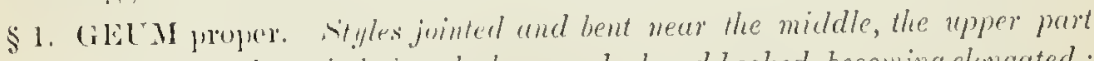
deciduous and mostl., hav'y, the lower nuked and hooked, becoming elangated; head of finit sessile in the ralyx'; calyx-lobes reflered.

* Petuls white or pule greenish-yellou', small, spatulate or ublon!l; stipules small.

1. G. álbum, Cinclin. Smouthish or softly puluesent; stem slender (20 high 1 ; root-leares of $3-5$ leaftets, or simple and rounder, with a few minute leaflets on the petiole lelow; those of the stem 3-divicles or loled, or only toutled; hairs mpon the long slenter peduncles asceuling or spreadiug; recep-

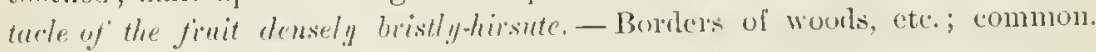
May - Aug.

2. G. Virginiànum, I. Bristly-hairy, especially the stont stem; lower and Jeot-leaves pimate, very varints, the upper mostly 3.parted or divided,

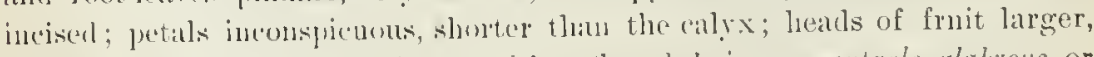

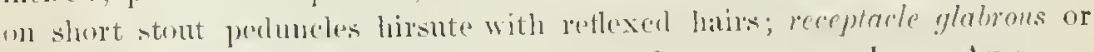

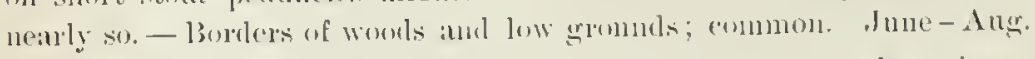

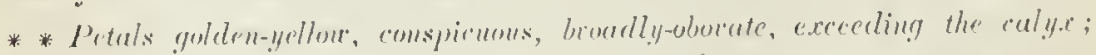
stipules largere and all alerply cut.

3. G. macrophýllum, Willd. Bristy-latiry, stout (1 - $3^{\circ}$ hicrli) ; lootleaves lyately and interneterlly pinate, with the lerminal lenflet very large

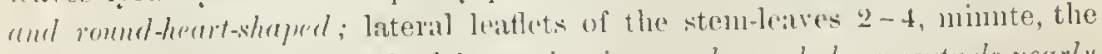

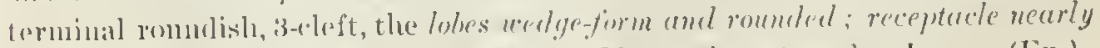
nelied. - X. Sicotia and X. Eng. to Minn., Mo., and westward. June. (Eu.) 
4. G. stríctum, \it. Smmewhat hairy $\left(3-5^{\circ}\right.$ high $)$; root-leaves interrupterlly pimate, the leatlots wedge-olonate; leaflets of the stom-leares $3-5$, rhombiconate or whong, arute: rereptucle dorny. - Moist meadows, Newf. to ‥J., west to Mim., Kan., and westward. Jnly, Aug. (En.)

\$2. STYYILIS. Styles smooth; head of finit conspricuously stalked in the calyx ; bactlets of the ralyx none: wheruise nearly as $\$ 1$.

5. G. vérnum, Torr. \& Giry. Somewhat pubescent; stems ascending, fen-leaved, slender ; ront-leaves roundish-heart-shaped, 3-5-hberl, or some of then pinnate, witl the lobes cut; petals yellow, about the length of the calyx, rexptacle smooth. - 'Thickets, l'em. to Ill., sontl to liy. and Tex. April-June.

\$3. CARI()PIIYLIAdTA. Style jointed and bent in the middle, the upper joint plumose; frowers large: calyx erect on sprending; petals erect.

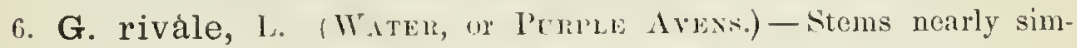
ple, several-flowerd ( 20 high); rout-leaves lyate and interuptedly pinnate, those of the stem few, 3-foliolate or 3-loberl; petals dilated-olyovate, retuse, contracter into a claw, jurplish-omange; hearl of fruit stalkel in the brownpmple calyx. - Bugs and wet nearlows, Newf. to X. J., west to Minu. and No. - Flowers nodling; pecherels erect in fruit. (Er:.)

\$. SIEVÉRSIA. Style mot jointed, wholly persistent and straight; head of fruit sessile; flovers lurye; calyx erect or spreading. (Flowering stems simple, and bearing only bracts or small lewes.)

i. G. triflórum, Pnrsh. Low, softly-hairy ; rot-leaves interuptedly pinnate; leaflets rery numerons and croweler, oblong-wedge-form, deeply enttootled; flowers 3 or more on long peduncles; brendets linear, longer than the purple culy.r, as long as the dilong pmoplish erert petuls: styles cery lony (2'), shongly plumose in finit. - Rocks, labb. and northern X. Fing., to Minn. ancl Mo. ; rare, April-June.

8. G. radiàtum, Michx. Ilirsutely hairy ur smootlish; root-leares rounded-hidhe y-shuped, radiate-veined (2-5' hroal), doul,ly or irregularly conttorthed and obsculely $5-7$-lobed, also a set of minute leaflets town the lomg protiole: stents (s-18' ligh) 1-5-fowered; bortlets mimute: petuls yellow.

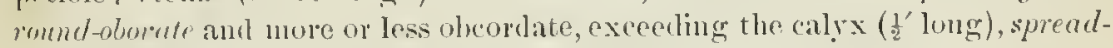
ing: styles molerd rexept the base. (Iligh momutaius of $\mathbf{X}$. C.)

Var. Péckii, Cimy. Nearly glabrons, or the stalks and reins of the leaves sparsely litrsite. - Alpine tops of the White Mts.

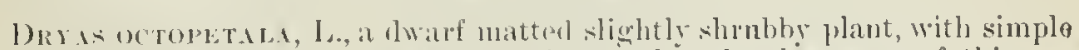
tootherl leaves and large white solitary Howel's, hats the characters of this sec

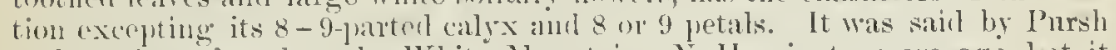
to have lesen founc on the White Mlomtains, N. H., ninety years ago, lat it is not known to have been seen there since.

\section{W A L D S T I N I A, Willd.}

Calyx-tuhe inversely conical ; the limb5-eleft, with 5 often ininute and deciduns bractlets. l'otals 5 . Stamens many, iuserterl into the chroat of the calyx. Achenes - -6 , minntely hairy; the terminal slender styles deciruous from the base by a joint. Seed erect; radicle inferior $\rightarrow$ Low peremial herbs, with 
chiefly radical 3-5-lohed or divilerl leaves, and small yellow thwers on bracted scapes. (Niuned in lonor of Francis con Waldstein, a Gernan botanist.)

1. W. fragarioides, Tratt. (BARrex Strawrenur.) Low; leaflets 3 , hroadly wedge-form, cut-toothed; scapes several-flowered; petals lunger than the calyx. - W voded hillsides, N. Eng. to Ga., west to Ind., Mich., and Him.

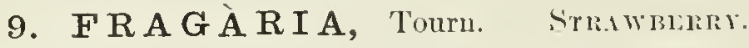

Flowers nearly as $m$ P'otentilla. Styles deeply lateral. Recejtacle in fruit nuch cularged and conical, beconing pulpy and scardet, bearing the minnte dry achenes scattered over its surface. - Stemless perennials, with rumers, and with white rymose flowers on seapes. Leaves radical; leatlets 3, whoratewedge-form, coarkoly serrate, stipules cohering with the base of the petioles, which with the scapes are usually latiry. (Name from the fragrance of the fruit.) - Flowering in sping. ('The species are indiscriminately called Winu STRA WBERRT.)

1. F. Virginiàna, Mill. dehenes imbedded in the deeply pitted firiting receplacle, which nsually has a narrow neck, calyx becoming erect after flowering and comnivent over the hairy receptacle when sterile or unfuctified; lenfiets of a firm or coriaceons texture: the hairs of the scapes, and especially of the pedicels, silk.y and appressed. - Moist or rich woollands, fields, ete. ; common.

Var. Illinoénsis, Gray, is a coarser or larger plant, with flowers more inclined to be polygamo-diocions, and the villous hairs of the scape and pedirels widely spreading. - Rich soil, western X. Y. to Mim., and westward.

2. F.vésca, L. Arhenes superficial on the glubrous comical or hemispherical finiting receptorle (not sunk in pits); calyx remaining spreading or reflexed; liatrs on the scape mostly widely spreading, on the perlicels appressed; leuftets thin, even the upper face strongly marked by the reins. - Fields and rocky places; less common. (Eu.)

F. Ixmca, L. differing from the true strawberries in having leafy rumuers, a calyx with incised leafy luactlets langer than the sepals, yellow petals, ant insipid frut, list become somewhat established near lliladelphia and in the s. states; an escape from cultivation. Flowers and fruit producel throngh the snmmer and antumn. ( $(d \mathrm{~d}$. from India.)

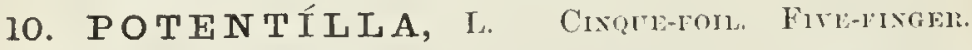

Calyx flat, deeply 5-cleft, with as many braetlets at the sinuses, thus appear. ing lo-eleft. Petals 5, nsually roundish. Stamens many Achemes many, collected in a heal on the dry nostly pubescent or liairy recentacle: styles lateral or terminal, lecistuous. Radicle superior. - IIerbs, or rately shrubs, with compound leares, and solitary or cymose flowers; their parts rarely iu iours. (Xame a diminutive from potens, poworful, originally applied to $I$ '. Anserina, from its once reputerl medicinal powers.)

$\$ 1$. Styles thichened and glamdular toutard the buse: achenes glabrous, numer$o u s$ : influrescence rymose.

* Style nearly basal; stamens 25-30 : perenniul glandular-villous herls, with pimale lomes, mol iother large white or yellow glowers.

1. P. arguta, l'nrslı. Stems erect, usually stont $\left(1-4^{\circ}\right.$ lighh), brownishhairy, clammy abue; leatlets $7-11$, oval or ovate, cut-serrate, down! beneath, 
"Yue striet and rather close; stamens mostly 30, on a thick glaudular disk.Rocky hills, N. Brnnswick to N. J., Minn., Kian., and wesward.

* * Style terminal; flowers small, yellow; leares pinnate or ternate.

- Innual or biennial; leaflets incisely serrate, not white-tomentose ; stamens 5- 20.

2. P. Norvégica, L. Stont, evect, hirsule (1-20 high); leaces ternate; leaflets ubovate or vblong-lanceolate; cyme rather close, leafy; caly $x$ large; staneus 15 (rarely 20). - Lah. to N. .., West to Mimn. and Kim. (En.)

3. P. rivàlis, Nutt. Wore slender and branched, sofll!y villuus; leaves pinnate, with tuo pairs of closely apmoximate leaftets, or a simgle pair and the ferminal leaflet 3-parted; leaflets cmueate-obovate or -ublong; cyme loose, often diffuse, less leafy; caly. smull; petals minute; stamens $10-20$ (rarely 5).Neb. to Mo. and N. Mex., and westward.

Var. millegrảna, Watson. Leaves all ternate; stems erect, or weak and ascending; achenes often small aud light-colored. - Minn. to Mo., N. Mex., and westwarl.

Var.pentándra, Watson. Leaves ternate, the lateral leaflets of the lower leaves parted nearly to the base; stanens 5 , opposite to the sepals. - Iowa, Mo., and Ark.

4. P. supina, L. Stems decumbent at buse or ereet, often stout, leafy, sulmillous ; leaflets pimately 5-11, oborate or oblong; ryme loose, leufy; stamens 20; achenes strongly gibbous on the central side. (I'. Jaradoxa, Lutt.) Winn. to NIo, and westward; also eastwart along the Great Lakes. - Var. Nicoltátrir, Watson. Slender; leaflets mostly but 3 ; inflorescenee nuch elongated, leafy, and falsely racemose. - Devil's Lake, Minn.

+ +Herbaceons perennials, more or less uhite-tomentose; leaflets incisely pinnatifid; bractlets and sepals nearly equal; stamens $20-25$.

5. P. Pennsylvánica, L. Stems erect or leeumbent at base $\left(\frac{1}{2}-2^{\circ}\right.$ ligh) ; lcaflets 5-9. white-tomentose beneatl, short-puhescent anil greener ahove, oblong, ohtuse, the linear segments slightly or not at all revolute; "gme fastigiate but rather open.-C Coast of Maine, $\mathbf{N}$. II, and the lower st. Lawrence, L. Superior, and westwarl. Jnly, Aug. - Tar. smincos, Lehm. stems $6-12^{\prime}$ ligh : silky-tomentose throughont; leatlets decply pimatifid, the margins of the narrow lubes revolute; "yme short and close. - Minn. and westwarrl.

\$2. Sityles filiform, not glandulur at base; inflorescence cymose.

* Style terminal; achenes glabrous; stamens 20 ; herbaceous perennials, with ruther lurge yellow flowers.

\section{+ Leares pinnate.}

6. P. Hippiàna, Jelum. Densoly white-tomentose anıl silky throughout, the upper surface of the leaves a little darker" stems ascenting ( $1-1 \frac{1}{2} \circ$ high $)$, slender, hranching above into a cliffue cyne; leaflets $5-11$, cuneate-oblong. in isely toothed at least toward the "pex, diminishing uniformly doun the petiole; (:irucels $10-30 .-$ N. WV. Minn., and westwanll.

-. P. effùsa, Dougl. Twmentose throughont, with scatterenl villous hairs; stums ascending $\left(4-12^{\prime}\right.$ high $)$, diffusely branched ahoro; leatlets 5 - 11 , interruptedly pimuale, llie altrmule mess smaller, cuneate-ohlonis, coursely-incised-serrate or dentate; "arpels 10. - Wr. Minn. to Mont. and Col. 
+ + Leaves palmate, of 3 or 5 leaflets; tomentose or villous.

8. P. argéntea, L. (Silyeri Crack-fon..) Stens ascending, pauicu. Jately brancherl at the summit, many-flowered, whitr-woolly; leaflets 5, wedgeoblong, ahnost pimatifirl, entire towarl the base, with levolute marcrins, green above, white with silvery wool beneath. - Dry barren fichls, ete., N. Seotia to X. J., west to Dak. and E. Kan. June-sept. (Eı.)

9. P. frígida, Vill. Dwarf $\left(I-3^{\prime}\right.$ highl $)$, tufterl, villums when young:

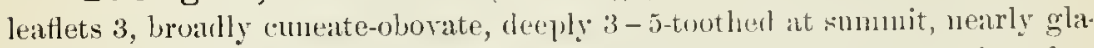
brous above; fowers mostly solitary, small, on very slender stems; bractlets aud sepals equal. - Alpine summits of the White Mits. (Fu.)

* * Style lateral i purple potals (shorter than the broad calyx) someuthat persist ent; disk thick and hairy; achenes glabrons; hairy receptacle becoming large and spong!y.

10. P. palústris, heop. (Maksi Fure-Fuxrkr.) Sitems stont, ascending from a deembent rooting perenuial base $\left(\frac{1}{2}-20\right.$ long $)$, glabrous helow; leaves pinnate; leaflets $5-7$, ollong, serrate, lighter colured and more or less pubescent beneatl, flowers few in an "pen cyme; calyx (1'broal) dark purple inside.-Cool hogs, N. J. to N. lukl., I11., Minn., and northward. (E11.)

* * Style attuched below the middle; achenes amd rroputurle densely villous: "roorly peremials.

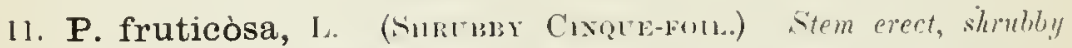
$\left(1-4^{\circ}\right.$ high), much hanched; loctes pimate; feuflets $5-7$, rowded, oblonglaneeolate, entire, silks, usmally whiter beneatl and the margins revolute; petals yellow, orhirular. - Wet inrounds, Lal. to X. .J., west to Minn., northeru lowa, and north and westwaril. June-sept. (Eu.)

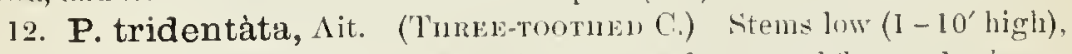
rather woody at hase, tufted, ascending, eymosely sereral-flowered; lecties palmate: leciffets :3, wedge-ohlong, nearly smooth, thick, coarsely 3-toothed at the apex: petuls white: aelienes and receptacle very hairy - Const of X. Eng. from Cape Corl northwarl, Norfulk, Ct. (Burbom), and mountain-tops of the Alleghanies; also slores of the upper Great Lakes, and N. Iowa, Wisce, and Minn.

\$3. Styles filiform, luteral; peduncles axillary, solitury, 1-flomered; achenes glabrous ; rereptacle very villouts: herbacrous peremnials, with yfllon yloneers.

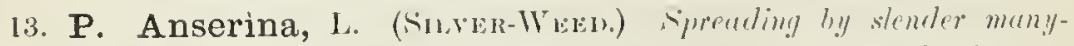

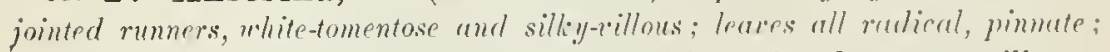
leaflets $7-21$, with smaller ones interposed, ollom, sharply serrite, silky tomentose at least heneath; hractlets and stipules often incisely cleft; perluncles elongated. - lirakish marshes, river-banks, etc., New Ling. to X. J., X. [ncl., Minn., and northward. (Eu.)

14. P. Canadénsis, I. (Commox Cixqr 15-1011, or Frve-Fisckis.) sitems slender and decumbent or prostrate, or sometimes erect; mbesernee villous, often scanty; leaves ternate, but apparently quinute by the parting of the lateral leaflets; leaflets cuneate-oblong or obovate, incisely serrate, nearly glabrons above; bractlets entire.-1)ry soil; eommon and varialle. A pr.-July.-Often produeing sumner runners. 


\section{S I B B Á L D I A, L.}

Calyx flattish, 5 cleft, with 5 hractlets. l'etals 5 , linear-oblong, minute. Stamens 5 , inserted alternate witl the petals into the margin of the woolly disk which lines the bise of the calyx. Achenes 5-10; styles lateral. - Low and depressed nunntain perennials; included by some in Potentilla. (Dedicaterl to I)". liebert sibuld, professor at Edinhurgh at the close of the 1ith century.)

1. S. procủmbens, L. Leaflets 3, werlge-shapel, 3-toothed at the apex; petals yellow.- Alpine summits of the White Mts., and northwarl. (Eu.)

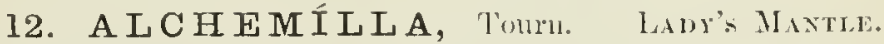

Calyx-tule inversely conical, contracter at the throat; linl, 4-parted with as rualur alternate acressory lobes. Petals none. Stanems 1-4. l'istils $1-4$, the slencler strle arising from near the base; achenes included in the tule of the persistent ealyx. - Low herls, with palnuately lobed or compound leares,

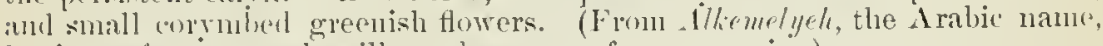
loving reforence to the silky pubesconce of some species.)

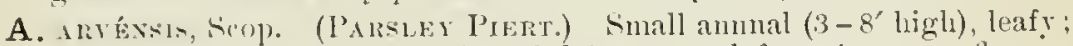
leaves 3-parterl, witl the wedge-sliaped lobes 2-3-cleft, pulsescent; Howers lascicled "plposite the axils. - Va. and N. C. (Adr. from En.)

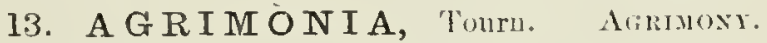

Calyx-tuhe topr-shaped, contracterl at the tliroat, heset witl hooker bristles above, indnuated in fruit and enclosing the 2 achenes; the linb 5-cleft, closed after fowering. l'etals 5. Stanens 5-15. Styesterminal. Seed suspended - l'eremuinl herls, with intermptedly pinate leaves, and yellow flowers in slenter spiked racenes; loracts 3 -cleft. (Name a corruption of Argemonia, of the same deriration as Irgenone, p.59.)

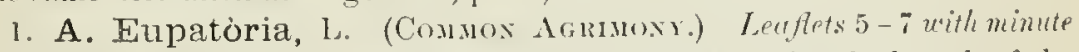
ones intrmixel, ollong-oborrale, comsely toothed; petals twice the length of the calyx. - Borders of woods, common. July-Sept. (Eu.)

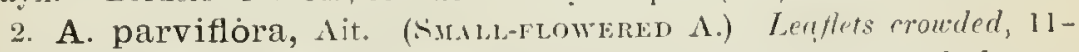
19, with smaller ones intermixed, lanceolute, acute, deeply and regularly cntserrate, as well as the stipules; petals small. - Woods and glades, $\mathbf{N}$. $\dot{Y}$. and Y. J. to Ga, west to Miclı, Kan, and La.

\section{POTERIUM, L. Birset.}

Calyx with a top-shaped tube, coustricted at the throat, persistent; the 4 lorul petal-like spreading lolus inbricated in the bud, decidnous. Petals none. Stamens 4-12 or more, with flaecil filanents and short anthers. P'istils $1-3$ : the slender terminal style tipped with a tufted or brush-like stigna. Achene (commonly solitary) enclosed in the 4-angled dry and thickish elosed calyx tnhe. Seed suspended. - Chiofy peremial herhs, with unerpally pinnate leaves, stipules coherent with the petiole, and small, often polygamous or di acious fowers crowled in a dense head or spike at the suminit of a long am naked pedumele, each bracteate and 2-bracteolate. (Name rorńpıv, a drinking. cup, the foliage of Burnet having been used in the preparation of some medicinal drink.) 
1. P. Canadénse, Benth. \& 1100k. (Cwxulx Brkxt.) Stamenst, longexserted, clubshatjerl, white, as is the whole of the elomgated and cylindrical spike; sten1 $3-6^{\circ}$ high ; leatfets numerons, wate or oblung-lanceolate, roarsely serrate, obtuse, leart sbajurl at hase, as if stipellate; stipules serrare. - Bogs and wet mealows, Newf. to momitains of Gal, west to Micli.

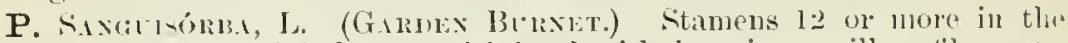
lower Howers of the globular greenish head, with tropping eapillary filaments, the upper flowers pistillate only; stems about 10 high ; leatlets numarous, small, ovate, deeply cut. - Fielis and rocks, N. Y. to Mll. (Ark. from lin.)

\section{ROS A, 'lomm. liost.}

Calyx-tule un-shaperl, contracted at the montl, heroming flesty in fruit. Petals 5, whovate or oherdate, inserterl with the many stamens into the edge of the hollow thin clisk that linos the calyx-tnbe and within hears the mumerons pistils lelow. Ovaries hairy, becoming bony achenes in fruit. - Shrubby and usmally spiuy or prickly, with odcl-pimate leaves, and stipules colering witl the petivle; stalks, foliage, etc., often bearing aromatic glands. Many of the species are rery rariable in their chancters, and are often indeterminable up) imperfect specimens. (The ancient Latin name.)

* Styles coliering in a motrudin! column, "ss lon!y as the stamens.

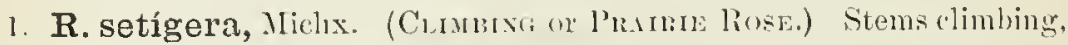
armed with stont nearly straight seatteres prokles, not hristly; leaflets $3-5$, wrate, acute, slurply serrate, smontl u dumy honeatlı; stalks and calyx Elandular ; flowers corymbed; sepals prointed ; jotak deep rose-color changing to white; funit (hip) golohlar. - Borders of praries and thickets, Ont. to ()hin, S. C., and Fla., west to Wike, Nel,., aml'lex. : also cultivated. July.'The unly Americau climbing rose, w with united protrnding styles; strong shoots growing $10-20^{\circ}$ in a season.

* * siples distinet; sepals comniermt ufter flomering and persistent; pedicals and reepeplereles malied.

+ Fruit oblong-obume to oblom!; infirestipulue spines nsually nome.

2. R. Engelmánni, Watson. Stems usually :3-40 ligh or less; iufra-

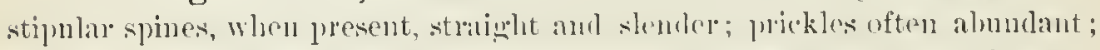

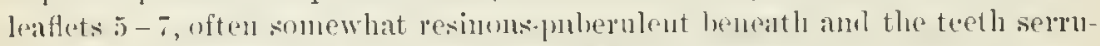

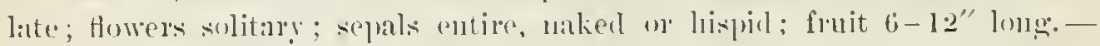
Whisky Islauml, L. Huron, shor's of L. Suprerior, and west to the Red liver valley, and in the momntains from N. Mlont. and N. Jabu to Col.

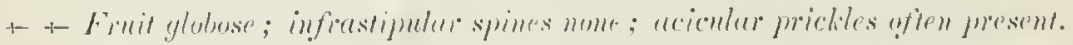

3. R. blánda, גit. Sitens 1 - 30 high, wholly mumed (occasionally witlı

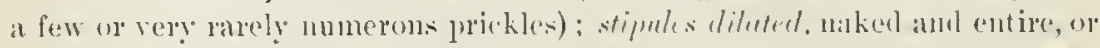

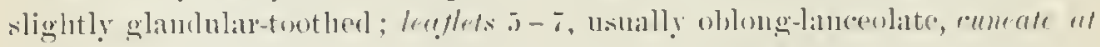

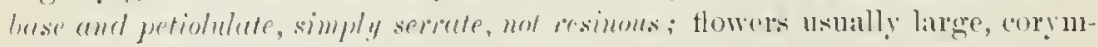
lese or solitary; sepuls lispid, entire - (1) rocks and rock! slopes, Newt. to

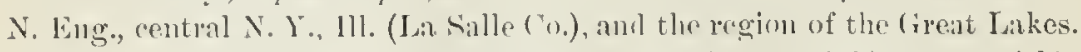

4. R. Sàyi, Sichwein. Stens nsnally low (1-20 high), ron! mirly! ;

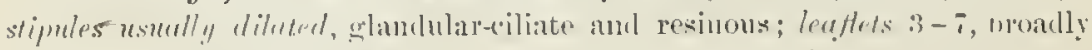

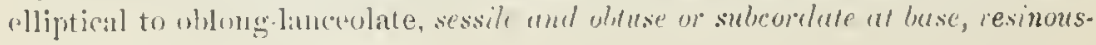


puberulent and teeth serrulale; Howers large, solitary (very rarely on or 3); vuter sepals usually with 1 or 2 narrow lateral lobes, not hispid. - X. Mich. and Wise, to Mimm. and Col.

5. R. Arkansàna, l'orter. Stems low, very prickly; stipules nurrou,

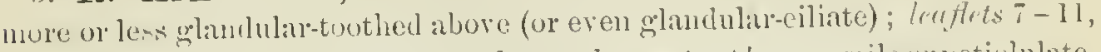

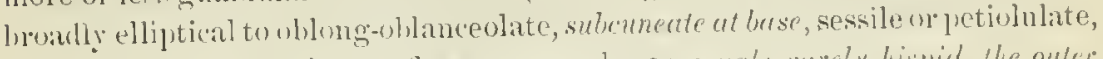

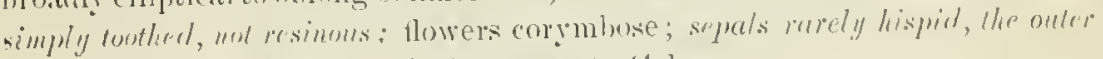
lobed.-Minn, to Mo, and Wr. Tex., west to Col.

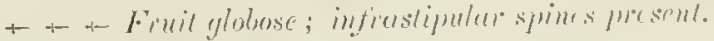

6. R. Woodsii, Lindl. Stems usually low $\left(\frac{1}{4}-30\right.$ lighlı), with slender straight or recurred spines, sometines with scattered prickles, wr wholly un-

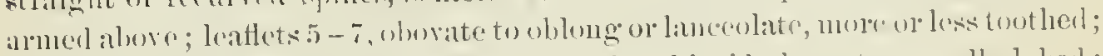

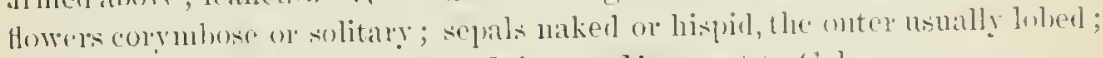
fruit gloluse with a short neck. - Minn. to Mo., west to (n).

* * Styles distinct; sepuls spreculing aftre Hourering and decidluous; infiastipular spines usually present, oglen with srattred pricliles; sepuls, globose receptacle, and pedicat usually hispid; Ireth simple; pubescence not resimous.

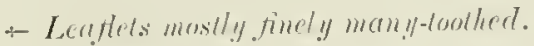

7. R. Carolina, L. Gtems usmally tall ( $1-7^{\circ}$ high $)$, with stout straight

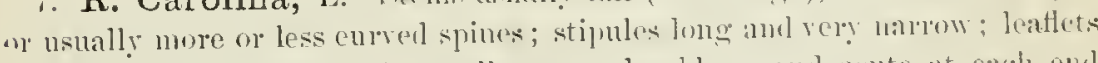

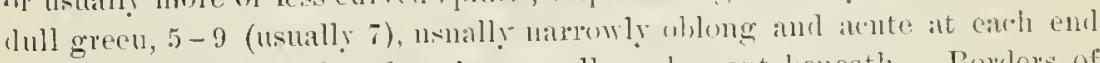
and petiolulate, hut often broaler, nsually pulescent heneath. - Borders of swamps and streams, N. Sicotia to Fla., west to Mimm. and Mlis.s.

+- + Leaflets coursely toolhed.

8. R. Iùcida, Ehrlı. Stems often tall and stont (a fer inehes to $6^{\circ}$ high), will at length stout and wsmully more or less hookrol spines; stipndes twally naked, more or less dilated; leafets (nustly i) lark green, rather thick, smoolh and ofien shining alove: Howers coryubose or solitary; onter seplals frecpuently with 1 or 2 small lobes. - Margins of swanps on must places, Newf. to N. Fing., N. Y., and E. Penn.

9. R. humilis, Marsl. Stems nsmally low $\left(1-3^{\circ}\right)$ and more slencler, less leafy, with straight slender spmes, sprealing or sometimes reflexerl; stipules nurou", rarely somewhat dilated; leaflets as in the last, lut nsually thin-

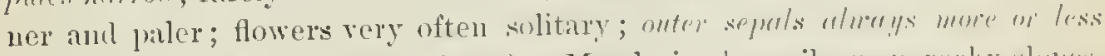

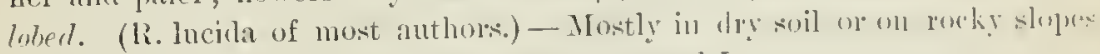
Maine to Ga., west to Minn., Mo., Ind. 'T'err., atul I.at.

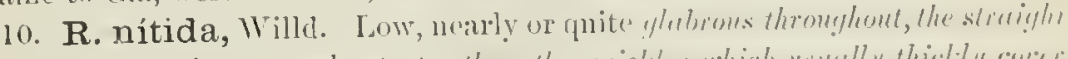

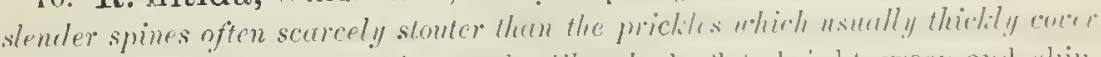

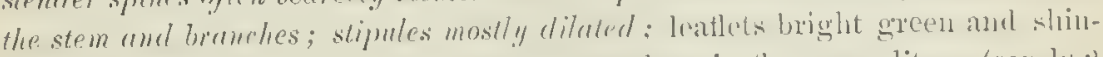

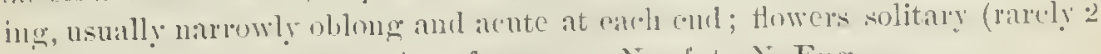
or 3) ; seprels entire. - Mareius of swamps, Newt. to X. Eug.

\section{Sulurelized speries.}

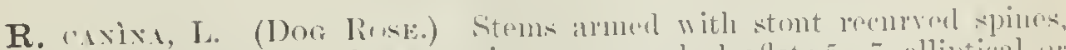

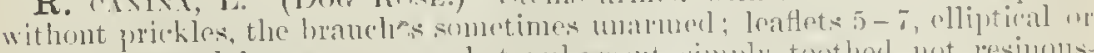

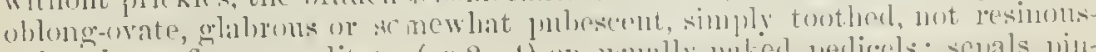

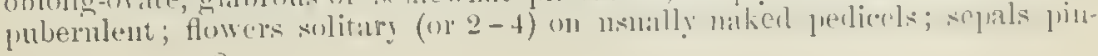


matibil, deciduons; fruit ol)long-ovate to uearly glolunlar. - Roarlsides, E. I'enn., 'l'enun., ete. (Int. from Fin.)

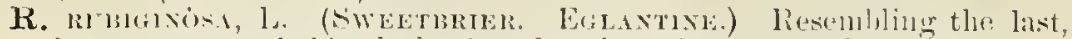

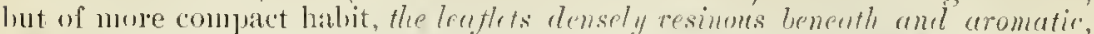

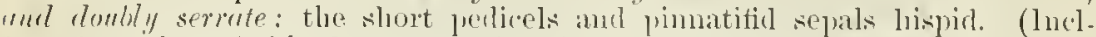
!. micrantha, smith: less armutic. with ohlong fruit and glabrous styles.) - X. S.cotia and Ont. tos. C. and T'mn. (Int. fron En.)

\section{PYR U S, L. I'LAR. APrL.}

('alyx-tube uru-shapel, the limb is-eleft. I'Ptals roundish or obovate. Sta-

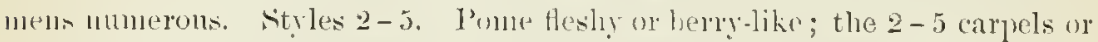
whis of a papery ar cartiliginoms texture, a-seeded. - Trees or shrubs, with hatudsome floters in corymbed cymes. (Vlue classilal name of the Pear-tree.)

\$1. MALLA (Arrus). Leuces simple: rymes simple and umbel-like; pome Heshy, globular, sunk: in at the attrichunent of the stull.

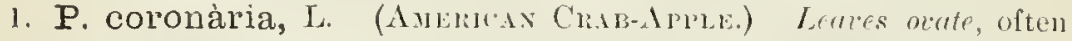

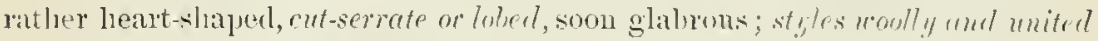
"lt luse. - Glades, Ont. and IV. Now York to X. C., west to Mimu, liam., and lat. May. - Tree 20 high, somewhat thormy, with latge rese-colored rery fragrant lolusoms, few in a colymly; fonit fragrant and greenisls.

2. P. angustifòlia, Ait. liesinlling the last, lut witl hrrers ollong or lemerolute, often areute at liase, mostly tootled, glaturous; styles disfinct. Giarles, Pem. to Fla., West to Ś. Inl., Kam., and la. April.

\$2. AI)ENORILAC'IIS. Leares simple, the midrib glandulat along the upper sirle; cymes componul: styles united at beese; finut berry-like, small.

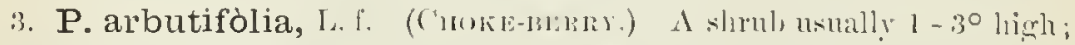
leaves oblong ol oblanceolate, mostly ande or acmuluate, finely glandular. serlate, tomentose beneath; cymo tomentose f fower's white or redhlish, fruit peal-shaped, or globose when ripe, small, red or purple. astringent. _ swamps sud danp thickets; rommon, from $\mathrm{N}$. Sicotia to Fla., and west to Minn., Hll, Mro., aurl La.

Var. melanocárpa, IIook. Tearly smootl tlurouglout, with larger liack fruit; leaves nsually less ante. - of apparently the sume range.

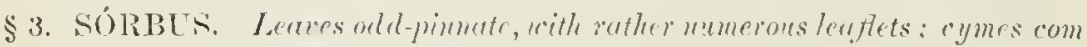
formal: styles separate : pome berry-like, small.

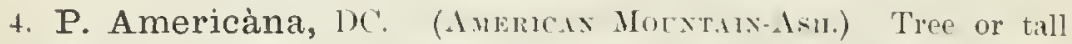

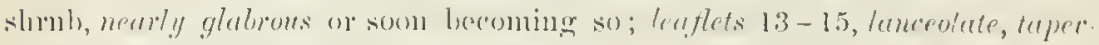

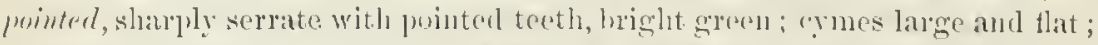
berrices globose, bright red, nut lingore than peas; feref-buels pointed, glabrous

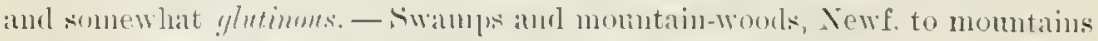
of X. C., West to X. Miel. and Mim. Oftem cultivated.

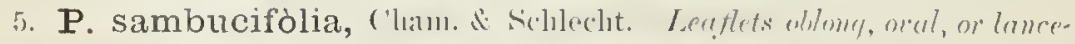

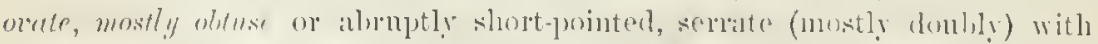
more spreading teeth, often pale loenath; cymes smaller' flowers and berries

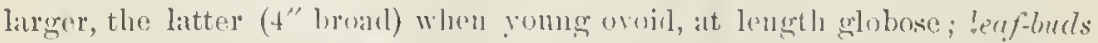
sparingly haing: ot luew ise uearly as the preceding. - Lab. to northern N Eng. and lake superior, and westwarl. 


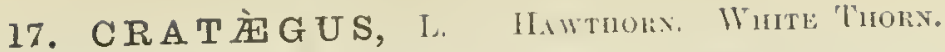

Caly-tube urn-shiperl, the limb s-cleft. P'utals 5, roumlish. Stamens mauy, or only 10-5. Styles 1-5. J'one drupe-like, containing 1-5 liony 1-seeded stones. - Thorny sluruls or smatl trees, with simple and mostly lobed leares, and white (rarely rose-(colored) blossoms. (Nime from кoátos, stiength, on account of the lialuless of the woul.)

\section{* Corymbs many-flowered.}

+ Fruit small, depressed-ylubose (not laryer than preas), bright red; flowers mostly small: calyx-treth short and broad (recegt in 11.3 ) ; styles 5 ; glabrous (except C. Pyiacantha) and ylundless.

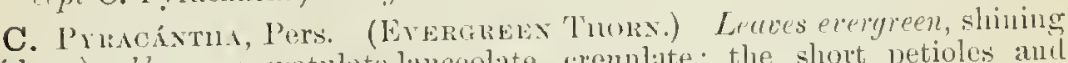
( $I^{\prime}$ long), oblony or slatulate-lanceolate, crenulate; the short petioles and voung branclilets puluscent; coryulis small. - Shrub, spontaneous near IVashiugton aml l'hilalelphia. (ills. from Eu.)

1. C. spathulàta, Michx. Shurub or tree, $10-25^{\circ}$ high; leaces thichish, shining, deciluous, sprutulute or oblanceolate, with a long tupreing base, crende alove, rarely cut-lobed, nealy sessile - Va. to Fla, wost to Mo. and Tex.

2. C. cordàta, Ait. (Wh-mxavox 'Tnowx) Trusk 15-250 ligh; lines brourlly orate or trimuguler, mostly trumcate or a little lieart-sliaped at the base, ou a slender petiole, ruriously 3-5-cleft or cut, serrute. - Va. to Gat. in the mountains, wrist to II $)$

3. C. víridis, L. A small tree, often marmed ; leaves orate to wateoblong or linceolate, or whlumg-oborate, mostly acute at both encls, on slender petioles, acutely serrate, often sumwhat lubed, and ofteu down in the axils; Howers larger, numerous; fruit hright red or rarely orange. (C. arburescens, I:ll.) -Mississippi buttoms from Sit. Lomis to the Gulf, and from S. Car. to Tex.

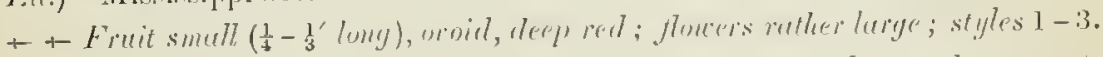

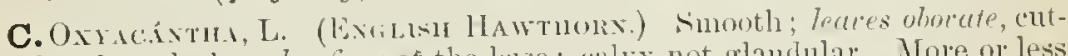
lohed and tootled, rerlyr-form at the hase; "alyx not glandular. More or less spontanfous as woll as cultivated. (1/v. from Eu.)

4. C. apiifolia, Michx. Solty pubesent when young; leares roundish, with a broal trumcate or slightly lueart-slaped base, pimulely 5 - 7 -cleft, the "rowded divisions cut-lohed and sharply ser'yte ; petioles slender; calyx-lobes griandular-toothed, slender. - S. Va. to Flil, west to Mo. and 'Tex.

+++ Fruit large $\left(\frac{1}{2}-1^{\prime}\right.$ long), red; flourrs lurge; styles and stones even in the sume speries $1-3$ (uhlurn the forvit is oroid or pent-shaped) or $4-5$ (in globular fmit) : stipules, culy.x-feth, brarts, pte. often beset with glands; shrubs or low trees. [Species as characterized ly Prof. C. S. Singext.]

5. C. coccínea, L. Branches reldish ; spines stout, chestnut-brown; villons-pulescent un the shoots, gimdular jedunclus, and calyx; leares on slemder putioles, thin, pubescent heneatl or often glalnons, rumb-orate, cuneate or subcorlate at hase, acutely glandular-tootherl, sometimes cut-lobed;

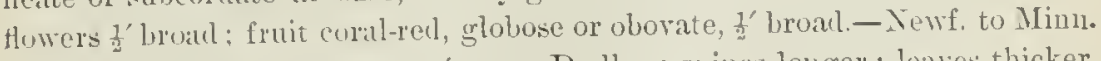

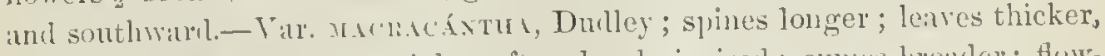
cuneate at bisc, on stout petioles, often deeply incised ; cymes broadler; flowers and fruit ratlur lander. - From the St. Lanrence and L. Miss. to Minn.

var. móllis, lorr. \& Cirny. Sluots deusely puluescent; leaves large, semler-prtinl(wl, cuneate, truncite or corlate at hise, usually with acute narrow" 
lobes, often subscalurous above, more or less densely pubescent beneath; flow('s I' broad, in broal cymes; fruit bright scarlet with a light bloom, I' broar. (C. tomentosa, var. mollis, Gray. C. subvillusi, Schrad.) - E. Mass. to Mo. and Tex. Sometimes $20-30^{\circ}$ higl, hlooming two weeks before the type.

f. C. tomentòsa, L. Branches gray, rarely witl stout gray spines; shots, pednncles, aud calyx villons-pubescent; glands none; leaves large, pale, prominently reined, densely puluscent beneatl, ovate or ovate-oblung, sharply serrate, usnally incisely lobed, contracted into a margined petiole;

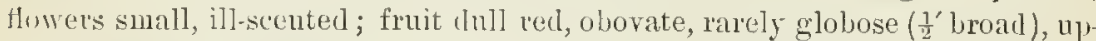
rimht. - Western N. Y. to Mich., Mu., and Ga. In fluwer 2-3 weeks after n. 5.

7. C. punctảta, Jacq. Branches lırizontal; glaucls none; leaves smaller, mostly wedge-ubovate, atteunate and entire below, megnally toothed above, rarely lobed, villons-pubescent becomiug smooth but dull, the many reins more inupressed, prominent leneatls; fruit globose ( $1^{\prime}$ broal), red or bright yellow. (C. tonentosa, var. punctata, Grey.) - Quebee to Ont. and south to Ga.

8. C. Crus-gálli, L. (Cocrisptr Thonx.) Brauches horizontal, with slender thorns often 4' long; glubrons; leares thick, dark green, shining abore, reelge-obovate and oblanrolate, tapering into a rery short petiole, sererate above the uniddle; fruit globular, dull reil (1' broad). - Thickets, common.

* Corymbs simple, few- $(1-6-)$ florered; calyx, bracts, etc., glandulur.

9. C. flàva, Ait. (Sumuer 1I.ı.) Tree 15-20 high, somewhat pu-

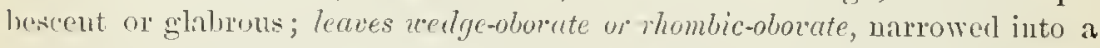
glimblular petiole, unerually toothed and someuthat cut above the uniddle, rather thim, the teetly glundulur; styles $4-5$; fruit somewhat pear-shaped, rellowish,

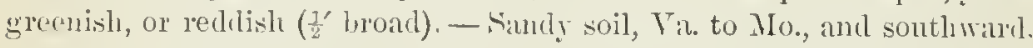

Var. pubéscens, Gray. Downy ol villous-pubescent when young: leaves

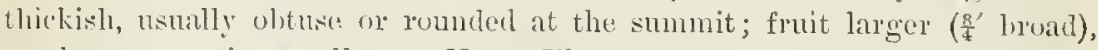
scarlet or sometimes yellow. - V'it. to Fla.

11. C. parvifolia, lit. (1)wan 'Inons.) Shlub 3-6 high, downy; lruers thick, whormle-spululute, cren'te-toothed $\left(\frac{1}{2}-1 \frac{f^{\prime}}{g} \operatorname{long}\right)$, almost sessile, the 11pures surface at length shining; flowers sulitary or $2-3$ together on rery short pectuncles: culy.x-lobes as long as the petals; styles 5 ; funit globular or pearshaperl, yellowish. - Sandy soil, N. J. to Fla. and Lat.

\section{A MELÁ N CHIER, Melic. Trxe-renr.}

Calyx s-cleft; lubes downy within. Peotals obloug, elonginted. Stamens mmmeruns, shont. Sityles 5, mited helow. Ovary 5-celled, each cell 2-ovuled,

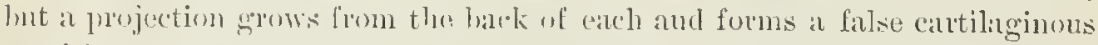

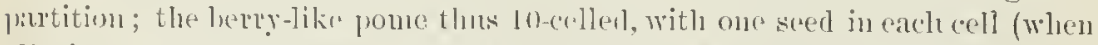
all ripen). - Stmall trees or shruls, with simple shanply sereated leaves, and

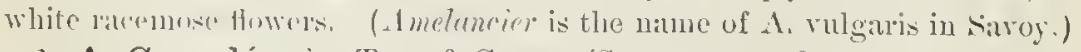

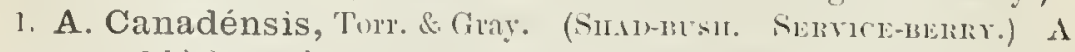
tree $10-30^{\circ}$ higgl, ucitry uc soun glithruns; leaves ovate to ovate-oblong, usually somewhat coplate at hase. printerl, very sharply serrate, 1 - $3 \frac{7}{2}$ long; brats

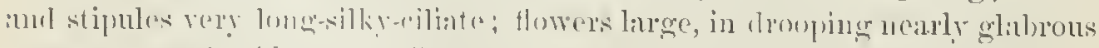

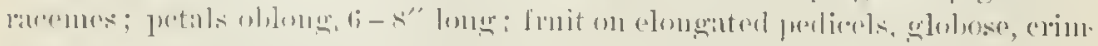

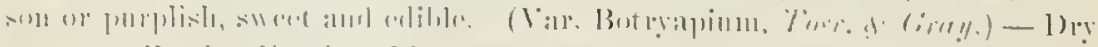

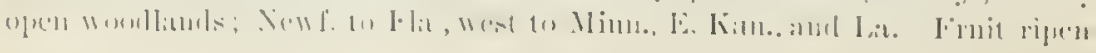


ing in June. - Var. Roterneobia, Torr. \& (iray, appears to he only a broadleaved form.

Tar. (?) oblongifolia, Torr. \& (iray, A smaller tree or shrub $\left(6-10^{\circ}\right.$ high), the youg leaves and ramemes densely white-tomentose; leares oblong or sometimes rather broally alliptical, acute, musty rounded at lase, finely

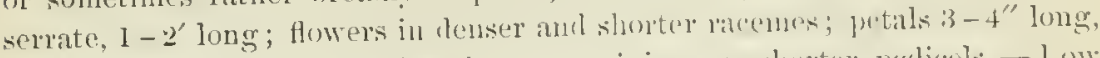
oblong-spatulate; fruit similar lut more juicy, on shorter pulicels- - low

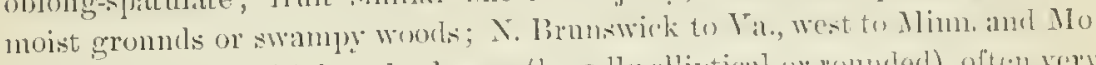
- $\Lambda$ form of this with broaler leates (broally elliptical or loluded), offen very

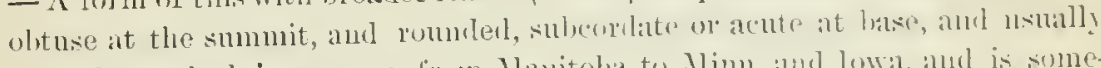

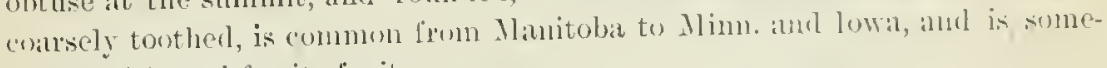
times cultivated for its fruit.

2. A. oligocárpa, lioen. A low shub $2-t^{\circ}$ highl, soon grlahous;

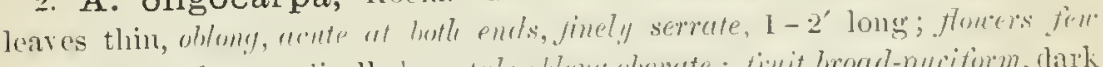

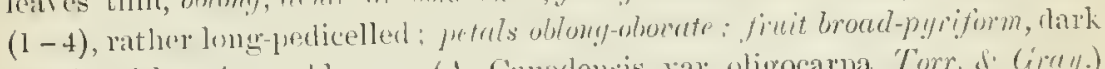

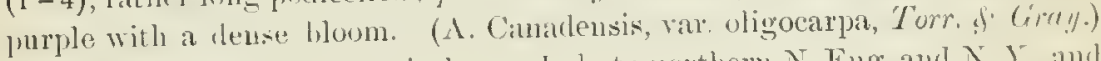
- Cold swamps and momitain bogs: Jab. to northern N. Eng. and N. Y., and the shores of Lake superior.

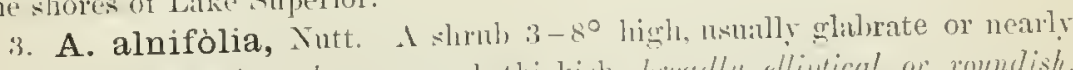

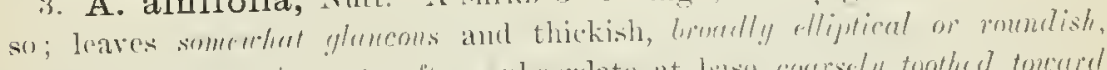

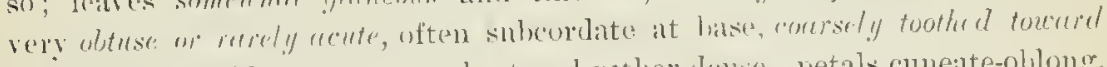
the summit, $\frac{1}{2}-2^{\prime}$ long : raceme short and rather denser, petals cumeate-oblong,

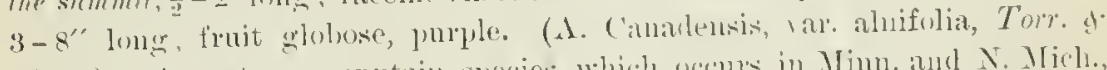

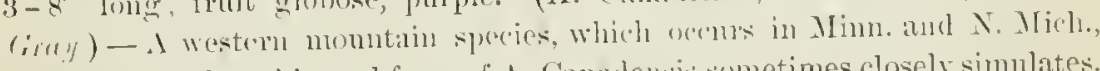
and which the brobleleavel form of $\mathrm{A}$. Canarlensis sometimes closely simulates.

\section{Order :34. CALYCANTHACEA. (CALYATITS FamLY)}

Sitrubs with opposite emtire leaves, no stipules, the sepats and potals similar

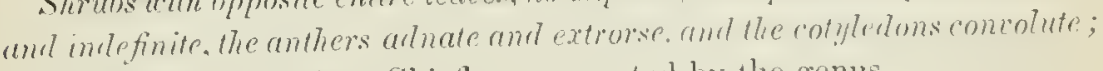
the finit lite a rose-lit?. Chiefly represented hy the genus

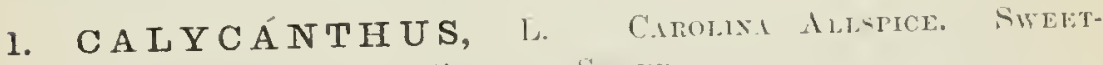 SAEXTLI SIIITH.}

(alyx of many sepals, united below into a fleshy inversely ('onical ('up) (with

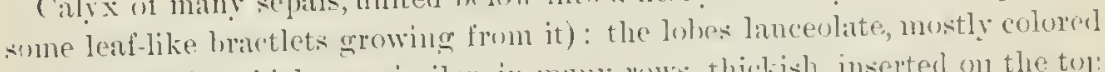
like the petals, which are similar, in many rows, thickish, inserted on the tol: of the closed calyx-tuhe. Stamens numerons, insorted just within the petals,

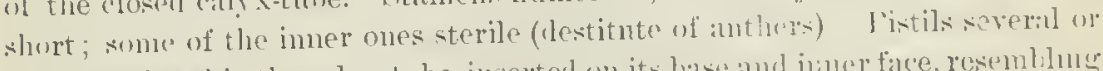

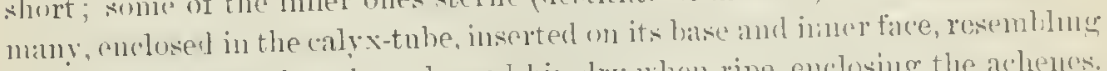
those of the hose; hut the enlarged hip dry whell ripe, enchusing the achencs. - The lnrid pmrple flowers terminating the leafy loranches. Bark and foliuge: aromatic; the crushed flowers exhaling more ur lest the fragranee of straw-

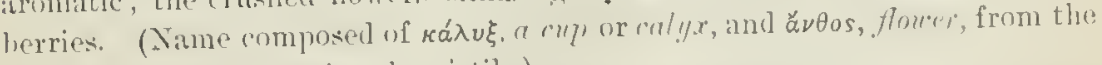
closed rup which (ontaius the pistils.)

1. C. flóridus, l. Lemes onel, sofi-downy underneath. - Virginia(?) aus

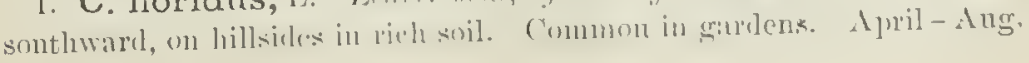


2. C. lævigàtus, Willı, Leaves oblong, thin, either blunt or taper-pointed, lirglit green and giulrous or nearly so on both sides, or rather pale beneatli; Howers smaller. - Momitains of Franklin Co., P'enn. (Prof'. Porter), and soutlward along the Alleghunies. May-Aug.

3. C. glaùcus, Willd. Leures ohlong-ovate or ovate-lanceolate, conspicuously taper-ponted, glancous-uchite be neall, loughish above, glabrous, large (4- ${ }^{\prime}$ long), probably a variety of the preceding. - Virginia (?) near the munutains and southward. May-Ang.

\section{Ordir 35. SAXIFRAGACEAE. (SAxifrage Famitr.)}

Herbs or shrubs, of various aspect, dsstinguishable from Rosacce by hating coprous albumen in the seeds, opposite as uell as alternate leares, and usually no stipules, the stamens mostly definite, und the corpels commonly fewer than the sepais, either separate or partly so, or all combined into one compound pistil. Calyx either free or alherent, usually persistent or withering away. Stamens and petals almost always inserted on the calyx. Ovules anatropous.

Tribe C. SAXIFIAGEA. Herbs. Leaves alternate (rarely opposite in n, 2 and 6). Fruit dry, calsular or follicular, the styles or tips of the carpels distinet.

* Ovary 2- (rarely 3-) celled with axile placentas, or of as many nearly distinet earpels.

1. Astilbe. Flowers polygamous, panieled. Stamens ( $S$ or 10$)$ twiee as many as the small petals. Seeds few. Leaves deempomd.

2. Saxifraga. Flowers perfeet. Petals 5 . Stamens in. Seeds numerous, with a elose eoat.

3. Boykinia. Flowers perfect. Stamens nuly as many as the petals, which are ennrolute in the bud and deciduous. Calyx-tuhe alherent to the ovary. Seed-eoat elose.

4. Snllivantia. Flowers perfect. Stancels 5. Calyx nearly free. Seeds wing-margined.

* * Ovary l-celle1, witl 2 parictal plueentas altemate with the stigmas. Sterile stamens none.

5. Tiarella. Calyx nearly free from the slemer orary. Petals entire. Stanens 10. I'acentas nearly hasal.

6. Mitella. Calyx frartly eohering with the depressed ovary. Petals small, pimuatifiu. Stamens 10.

7. Henchera. Calyx bell-shaperl, colnerent witl the ovary below. Petals small, cutire. Staniens 5.

S Clnryosplenium. Calyx-tube colnerent with the ovary. Petals noue. Stamens 10.

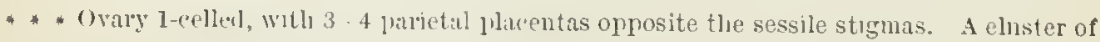
multerl sterile lilanents at the base of each petal.

9. Parnassia. Sepals, petals inut lurel stamens 5. Peluncle scape-like, 1-flowered.

Tribe II. IXDRANGEA. Slunhs. Leaves oplosite, simple Ovary 2-5-eelled; the eatyx colement at least with its base. Fruit eapsulare.

* Stanens $S$ or 10 .

10. Hydrangea. Caly-lobes miunte in complete flowers. I'etals valvate in the bud * *itaulens $20-40$.

11. Decumaria. Calyx-lobes small. Petals $7-10$, valvate in the bud. Filaments subnlate. sityle 1.

12. I'hiladelphus. Calyx-lobes conspicuons. Petals $4-5$, convolute in the bud. Filaments linen:. Styles : -5

Trihe III. ESCALLONI ER. Slurubs. Leaves alternate and simple. Ovary 2-5-

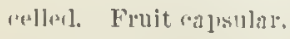

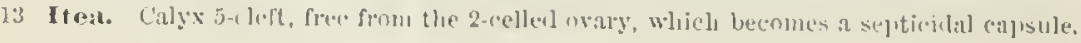


Tribe IV. RIBEsILA. Shubs. Leaves alternate anc simple, with stipules aduate to the petiole wr wanting. Fruit a berry:

14. Ribes. Cillyx-tube aluate to the 1-celled ovary. Placentas 2, parietal, many-secked.

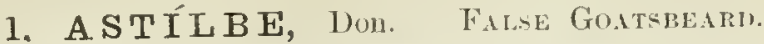

Flowers diceciously polygamous. Calyx 4-5-parted, small. T'etals 4-5, spatulate, small, withering-persistent. Stamens 8 or 10 . Ovary 2-celled, almost free, many-ovuled; styles 2, slort. Capsule 2-celled, separating into 2 follicles, each ripening few sceels. Seerl-coat luose and thin, tapering at each curl:Perennial herlss, with twice or thrice ternately-compound ample leaves, cut-lobed and toother leaflets, and small white or yellowish fowers in spilies or racemes, which are disposed in a cmmpund panicle. (Name composed of á- privative and $\sigma \tau i \lambda \beta \eta$, a bright surface, becantse the folinge is not shining.)

1. A. decándra, Don. Somewhat juhescent $\left(3-5^{\circ}\right.$ ligh 1 ); leaflets mustly heart-shaped; petals minute or wanting in the fertile flowers. stamens 10. - Rich woods; nountains of S. W. Ya. to N. C. and Ga. Closely initating Spirca Aruncus, lut coarser.

\section{SAXÍF $\mathbf{A}$ GA, I. SAXIFrage.}

Calyx either free from or collering with the base of the orary, 5-cleft or parted. Petals 5, entire, inluricated 111 the lud, commonly deciluous. Stamens 10. Sityles 2. ('apsule 2-beaked, 2-celled, opening down or between the beaks, or sometimes 2 alnust separate follicles. Seerls numerous, witl a close coat. - Chiefly peremial hurbs, with the root-leate's clustered, those of the stem mostly alternate. (Name from saxum, a rock, and finnyo, to break; man! species rooting in the clefts of rocks.)

* Stems prostrate, in tufts, lerfy; leares opmosite: caly $x$ free from the capsul?

1. S. oppositifólia, L. (Mocxtax Sixnfagk) Leares Heshy, ovat, keeled, ciliate, imbricated (n) the sterile luanches $\left(1-2^{\prime \prime}\right.$ long); flowers solitary, large: petals purple, whwate, much louger than the 5-cleft-calyx.Rocks, Willumglily Mountain, Vt., and nortlward. (Eu.)

* * Stems asremblmy: leares ultermate, calyx colierent below with the capisule.

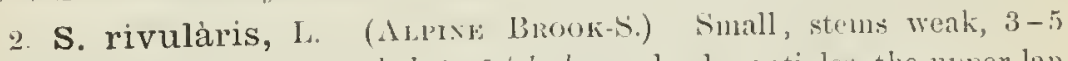
Howered; lower leaves rounded, 3-5-lobed, on slender petioles, the njper lan. (eulate; prals white, ocate - Mprine region of the White Its., to Lab. (Eu.)

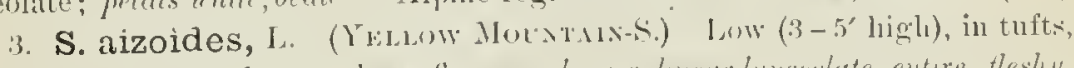
with fow or several corymhose flowers; lecurs limentanerolate, entre, fleshy, listantly spinulose-ciliate; preals yellene, spoted with orenge, oblong. - X. I't. to S. W. New York, N. Mich, ant nortlmanl. Jume. (Eu.)

4. S. trieuspidàta, Ret\% Sitens tufterl ( $t-8^{\prime}$ lighll), nakel ahove; flow-

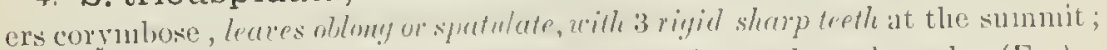

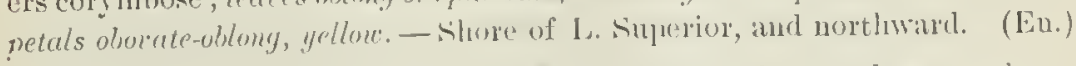

* * Leates clustered at the runt; secipe many-flurered, erect, clammy-pubescent.

+- Prials all alike.

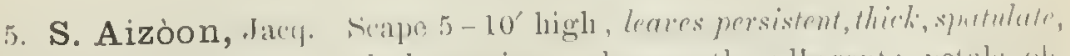

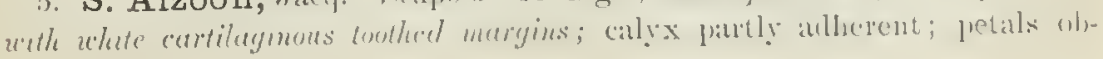


wate, ereantcolor, wften sjotted at the bitse. - Moist rocks, Lab. to $\mathrm{N}$. Vt, l. Siuperior, and northward. (bu.)

() S. Virginiénsis, Michx. (EARL S.) Low (t-9' high); leares oborate or onal-syalulate, narrowed into a lroal petiole, creuate-toothed, thickish: Howers in a clustered c!rne, which is at length open and loosely panicled; lobes "f the nearly free cully erect, not hulf the length of the whlong obtuse (white) pretuls ; follicles mited merely at the bise, divergent, jurplish. - Exposed rocks and (lry lillsides; N. Brumsick to Gia, and west to Minn., Ohio, and Tenur.; (")mmon, expecially northwarl. April-Jnne.

7. S. Pennsylvánica, l. (Nw.um S.) Large $\left(1-2^{\circ}\right.$ high) ; leuces ol-

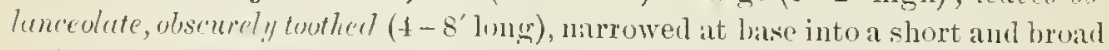
petiole; cymes in a litwe oljong linicle, at first clustered; lobes of the nearly

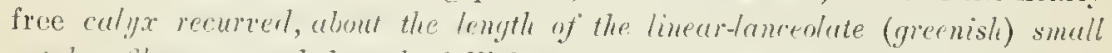
petrls; filuments aul-shaped; follicles at length divergent. - Bogs, N. Fing. to Val, west to Mimu. aud Iowa.

8. S. eròsa, I'ursh. (Lestrus. S.) Leaves oblong or oblancevlate, obtuse, shaiply foothed, tapering into a margined petiole (8-1.2' long); scape slenter $\left(1-3^{\circ}\right.$ ligh $)$; panicle elongated, looscly flowered; pedicels slender; ral y.x ro llexed, entirely froe, neremly us lony as the oral obtuse (uhite) petels; filcements chloshaped; follicles nearly se patute, diverging, nurrou, pointerl, $2-3$ "long. - (b)a mountain hruokir, Penu. to Va. and $\mathrm{N}$. C.

9. S. Forbèsii, Vasey. Sten stont, 2-40 high: Iruess denticulute, oral tn elongated ollong $\left(4-8^{\prime} \mathrm{long}\right)$; filuments filiform; fulliwes short weate; otherwise as in the last. - Shaded cliffs, near Makmuda, S. Ill. (Forbes); E. Mo. (L.cttermann.)

- - Petals unequal, with claus, white, all or some of them with a pair of yellow spots near the buse; leaces ublong, wedge-sherped or spatulate; calyx fire and reflexed.

10. S. leucanthemifolia, Michx. Leaves coarsely toothed or cut, tapering into a petiole; stems $\left(5-18^{\prime}\right.$ highl) bearing one or more leares or leafylusets and a loose, sprearling coryulose or paniculate cyme; petuls lanceolate, the 3 larger ones with a heart-sheped hase and a prir of spots, the 2 smaller

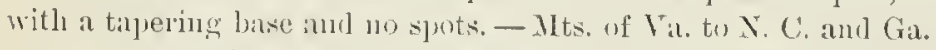

11. S. stellàris, I., r:ır. comòsa, Wihh. Jeavos wedge-shiped, nore or less toothed; scalpe ( $t-5^{\prime}$ high $\left.h_{1}\right)$ bearing a small eontracted junicle, many

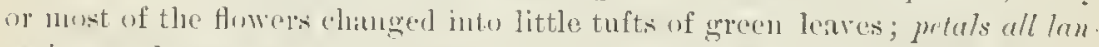
crolute and trepring into the chen. - Mt. Katahdin, Maine, north to Lab. and (ireenland. (ku.)

\section{BOYKÍ I A, Nutt.}

(alyx-tube top-shaped, colnerut with the 2-celled aud 2-beaked capsule. Stanems 5, as mauy as the decidums petals, these mostly convolute in the

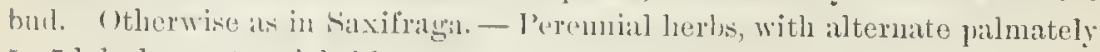
5 -7-lobed or cut pediuled leawes, and white Howers in eymes. (1)edicated to the late Dr. Boylin of (reorgia.)

1. B. aconitifolia, Nutt. Sitoul erlindular ( $\left(i-20^{\prime}\right.$ li

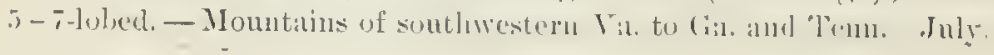




\section{SULLIVÁNTIA, 'Torr. \& Gray.}

Calyx bell-shaped, cohering below only with the bise of the ovary, 5-cleft. l'etals 5, oblanceolate, entire, acutish, withering-persistent. Stamens 5, shorter than the petals. Capsule 2-celled, 2-beaked, many-seeded, opening between the beaks, the seeds wing-nuargined, inbricated upward. $-A$ low and reclinedspreading peremnial lierb, with rounded and cut-toothed or slightly lobed smootl leaves, on slender petioles, and snall white Howers in a branched loosely crunose panicle, raised on a nearly leatless slender stem $\left(6-12^{\prime}\right.$ long). I'edum(les and calyx glumdular; perlicels recurved in frnit. (1)elicated to the distinguished bryologist who discovered our species.)

1. S. Ohionis, Torr. \& Gray- - Limestone eliffs, Ohio to Ind., Iowa, and sinn. June,

\section{TIA RÉLIA, 1. FALSE MITRE-WORT.}

Calyx bell-shaped, nearly free from the ovary, 5-parted. Petals 5, with claws, putire. Stameus 10, long and sleuder. Styles 2. Capsule membranaceons. 1-celled, 2-ralved; the valies mequal. Seeds few, at the base of each parietal placenta, glolular, smooth. - Perenuials; flowers white. (Name a diminutive from $\tau$ cápa, a tiura, or turban, from the form of the pod, or rather pistil, which is like that of Mitella, to which the name of Mitre-2cort properly belongs.)

I. T. cordifòlia, L. Leaves from the rootstock or suminer rumers heart-shaped, sharply lohed and toothed, sparsely hairy above, dowuy beneath; stem leatless or rarely with 1 ur 2 leaves (5-12' high) ; racene simple; petals whong, wfen sulserrate. - lich rocky woods, N. Eng. to Minn. and Ind., and sonthwarl in the mountains. Aproil, May.

\section{MITÉLLA, 'lourn. Mitie-wurt. Bismop's-Cap.}

Calyx short, coherent with the base of the orary, 5-cleft. Petals 5, slender, pinnatifid. Stamens 5 or 10, included. Styles 2, very short. Capsule short, 2-beaked, l-eelled, with 2 parietal or rather basal several-secded placentæ, 2 valved at the summit. Seerls smooth and shining. - Low and slender perennials, with rouml heart-sliaperl alternate leaves on the rootstock or runers, ou slender petioles; those on the flowerng stems opposite, if any. Flower: imall, in a simple slender raceme or spike Fruit soon widely dehiscent. (1)iminutive of murr, a cap, alluding to the form of the yommg pou.)

1 M. diphýlla, L. Hairy; leaves heurt-shaped, acule, somewhat 3-5lubed, toothed, those on the muny-flowered stem 2, opposite, newrly sessile, wit? interfoliar stipules; Howers white, in a raceme $6-8^{\prime}$ long; stamens 10 . llillsiles in rich woods; Ẋ. Eng. to N. C., west to Mlinn. and Mlo. Mlay.

2. M. nùda, 1. Sunall and slender; leares rounded or kidury-form, decply and donbly crenate; stem usully leafless, few-flocered, very slemler (4-6' high); Howers greenish; stamens 10. - 1)eep moist roouls, 111 moss, X. Wug. to X. Y. Mich., Minn, and northward. May-July.

\section{H E Ù C E E A, 1.. ALtM-Roor.}

Calyx bell-shaped, the tube coliering at the base with the ovary, 5-cleft. Petals 5, 8patulate, small, entire. Stamens 5 Styles 2, slender. Capsule 1-celled, 
with 2 parietal many-seeded placentx, 2-beaked, opening hetween the heaks. Feeds wal, with a rongh and elose seed-coat. - l'erennials, with the round leart-shaped leaves principally from the rootstock; those on the stems, if auy, alternate. Petioles with dilated margins or adherent stipnles at their base. Flowers in sniall clusters disposed in a prolonged and narrow panicle, greenish or purplish. (Naned in lionor of John IIenry Mencher, a German butanist of the beginning of the 18 th century.)

* Flowers small, loowely panieled; stamens and styles exserted; culyx regular.

1. H. villosa, Michx. Stems $\left(1-3^{\circ}\right.$ high $)$, petioles, and reins of the acutcly 7 -9-1obed leaves rillous with rusty hairs beneath; calyx $1 \frac{1}{2}$ " long; petals spatulate-linear, ubout as long as the stamens, soon twisted. - Rocks, MId. to Ga., west to Ind. and Mo. $\mathrm{lug}$., Sept.

2. II. Rugélii, Sluttlw. Stems slender, $\frac{1}{2}-2 \circ$ highl, glaudular-hirsnte, as well as the petioles, etc.; leaves round-renform, wilh $\bar{\tau}-9$ short and broad rounded lobes; flower's very small ( $l^{\prime \prime}$ long); petals linear-spatulate, twice as long as the calyx-lobes; fruit narrow, - Shaded cliffs, \$. 11l. to Tenn, aud N.C.

3. H. Americana, L. (Comon Alum-Tionr.) Stems (2-30 high), etc., glandular and nore or less hirsute with short hairs; leaves ronndish, with short rounded lobes and erenate teetl ; culy $x$ cery broad, $2^{\prime \prime}$ long, the sputulute petals not longer than its labes. - Rocky woodlands, Conn. to N. C., west to Minn, Mo., and Miss.

* * Flowers larger, in a very nurrow panicle; calyx (3-4"long) more or less oblique; stamens short; lerees rounded, sligletly 5-9-lobed.

4. H. híspida, Pursh. Stems 2-40 high; hispid or hirsute with long spreading hairs (occasionally almost glatrons), scarcely glaudular; stamens soon exserted, longer then the spatulute petuls. - Mountains of Va. and N. C., west to Mimn. and E. Kian. Nlay, June.

5. H. pubéscens, Pursh. Stem $\left(1-3^{\circ}\right.$ high) and petioles gramulurmubesent or glandular above, not hairy, helow often glahrous; stamens shorter thron the lobes of the caly $x$ and the spatulate petals. - Kich wools, in the monntains, from Penn. to liy, and southward. June, July.

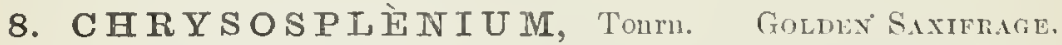

Calyx-tube coherent with the orary; the blunt lobes $t-5$, rellow within. Petals none. Sitanens 8-10, very short, inserterl on a conspicunns disk. Styles 2. Cajsule iuversely heart-shaped or 2-lobed, flattened, very short, 1celled with 2 parictal placentie, 2-ralved at the top, mauy-sechlest. - Low and small smooth herlss, with tender sncenlent leaves, and small solitary or leafy-

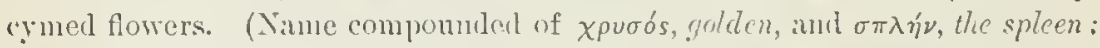
probaluly from some reputed melicinal qualities.)

1. C. Americanum, Schwein, Stems slender, dormbent and forking: leaves princijally oppesite, ronnelish or somerthat leart-shaped, obscurely cre-

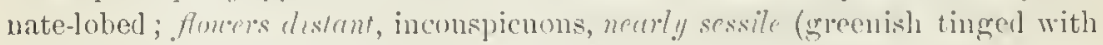
yellow or purple). - Cold wet places, N. Scotia to N. ( Sia, west. to Minn.

2. C. alternifolium, I. Sifems crest; Irapesultemate, reniform-cordate, doubly crenate or somewhat lobed; flowers com ymbose. - Decoral, forna, west to the Rocky. IIts., and north through Brit. Amer. (En., Asia.) 


\section{PaRNássia, Tourn. Grass of Parxassus.}

Siepals 5, imbricated in the bnd, slightly united at the base, and sometimes also with the base of the orary, persistent. I'etals 5, reiny, spreading, at length dereiduous, imbricated in the bud; a cluster of somewliat united gland-tipped sterile filaments at the base of each. Proper stamens 5, alternate with the petals, persistent; anthers introrse or subextrorse. Ovary 1-celled, with 4 projucting parietal placenta; stigmas 4, sessile, directly over the placentiz. ('apsnle t-ralred, the valves bearing the placeute on their middle. Seeds very numeroun, anatropous, with a thick wing like sced-coat and little if any albumen. Lumbryo straight; cotyledons very sliort. - I'erennial smooth herbs, witl entire leares, and solitary flowers on loug scape-like stems, which usnally bear a single sessile leaf. J'etals white, with greenish or yellowish veins. (Named from Mount l'arnissns; called Gralss of l'arnassus by Dioscorides.)

1. P. parviflora, 1$)$ C. Pctuls sessile, little longer than the calyx ( $3^{\prime \prime}$ long); sterile filuments about $i$ in euch set, slender; lecues orate or oblong, tapering at base. - Simdy bimks, Lab. to Mich., N. Minn., and westward.

2. P. palústris, L. Scapes $3-10^{\prime}$ high ; leaves heart-shaped; flower nearly l' broald; prtals sessile, rather longer than the culy, few-reined; sterile filaments 9 - 15 in each set, slender. - Same range as the last. (Eu.)

3. P. Caroliniàna, Michx. Scapes $9^{\prime}-2^{\circ}$ lighl ; flower $1-1 \frac{1}{2}^{\prime}$ broad; petals sessile, more than twice as long as the calyx, many-veined; sterile filaments 3 in each sct, stout, distinct ulmost to the buse: leaves thickish, ovate or rounded, often lieat-shaped, nsually bnt one low down on the scape and claspiug. - Wet hanks, X. Brmswick to Fla, west to Minn., Iowa, and La.

4. P. asarifòlia, Vent. Petuls abruptly contracted into a elaw at base; sterile filaments 3 in auch set: leaves rounded, kidney-shaped; otherwise as in the foregoing. - lligh mountains of T'a. and $\mathrm{N}$. C.

\section{H Y D R À N GEA, Gronov.}

Calyx-tube hemisplerical, $8-10$-ribbed, colnerent with the ovary; the limb 4-5.toothed. Petils orate, vilwate in the bur. Stamens $8-10$, slender. Cap. sule 15-ribbed, crowuel with $2-4$ direrging styles, 2 -celled below, many-seeded, opening by a hole between the styles. - Slutuls, witl opposite petioled leaves, no stipnles, and ummerous thwers in compound cynes. The marginal flowers are usually sterile and radiaut, consisting nerely of a show nembranaceous

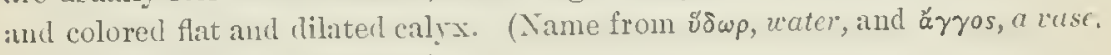
from the shape of the (apsule.)

1. H. arboréscens, L. (Wru, Hrumarea.) Glabrous or nearly so.

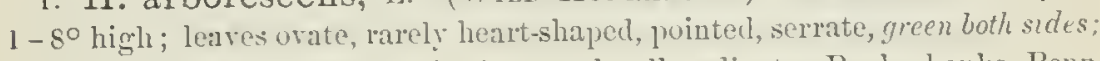
cynes flat; flowers often all fertile, rarely all radiant.-Rocky banks, Penn to Fla., west to lowa aud Mo.

2. H. radiàta, Walt. Leaves densely tomentose and paler or white be

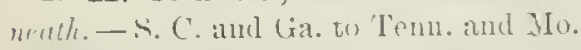

\section{DECUMARIA, L.}

Flowers all fertile. Calvi-tule turbinate, $z$-10-toothed, coherent with tho urary. Pretals oblong, valinte in the bud. Stamens $30-30$. Styles united 
into one, persistent Stigma thick, 7 -10-rayed. Capsule 10-15-ribbed, 7 lo-celled, many-seeded, bursting at the sides, the thin partitions at length separating into numerous chaffy scales. - A smooth climbing shrub, with opposite ovate or oblong entire or serrate leares, no stipules, and numerous fragraut white flowers in compound teminal cymes. (Name sild to he lerived frum decem, ten, referring to the fact of its being often 10-merous.)

1. D. bárbara, L. Leaves shining, sometimes pubesceut; capsule with the persistent style and stigma uru-shaped, pendulous. - Banks of streams: Dismal Swann. Ira, to Fla and La.

\section{PHILADÉPHUS, L. Moch ORAxge or Syrivga.}

Calyx-tube top-shiped, coherent with the ovary; the limb 4-5-parted, spread ing, persistent, valvate in the bud. Petals rounded or obovate, large, convolute iu the bud. Stanens 20-40. Styles 3-5. united below or nearly to the top Stigmas oblong or linear. Capsule 3 - 5-celled, splitting at length iuto as many pieces. Seeds very mmerous, ou thick placenta projecting frem the axis, pendulous, with a loose membranaceous coat prolonged at both ends. - Shrubs, with opposite ofteu toothed leaves, no stipules, and solitary or cymose-clustered showy white flowers. (Au ancient name, applied by limnæus to this genus for nu obvious reason.)

1. P. inodòrus, L. Glubrous; leaves ovate or ovate-oblong, pointed, entire or with some spreading teeth, flowers single or few at the ends of the diverging branches, pure white, sceutless: ralyxtobes acute, scarcely longer than the tube. - Nountains of V'a. to Ga. and Mla.

2. P. grandiflorus, Willd. A tall shrub, with long and recurved branches; like the last, but somewhat pubescent, with larger flowers, and the calyx-lobes long and taper-pointed. (P. modorus, var. grandiflorus, Gray.) Along streams, Va. to Fla. Often cultivated.

P. Coronarius, L., the common Mock Oraxge or Syraxga of cultivation, from S. Eu., with cream-colored odorous flowers, has sometimes escaped.

\section{3. ÍTEA, Gronov.}

Calyx 5-cleft, free from the ovary or nearly so. Petals 5, lanceolate, much longer than the calyx, and longer than the 5 stamens. Capsule oblong, 2. grouved, 2-celled, tipped witl the 2 mited styles, 2-parted (septicidal) when mature, several-seeded - Shrubs, wh simple, alternate, petivled leares, with. ont stipules, and small white flowers m smple racemes. (Greek name of the (Willow.)

I. I. Virgínica, L. Leares decidnons, oblong, lointed, minutely serrate; seeds oval, flattish, with a crustaceous coat. - Wet places, Penn and X.J to Fla., west to Mo, and La,

\section{Ri B E S, Is. Currant. Gooseberky.}

Calyx 5-lobel, often celorer ; the tube coherent with the ovary, l'etals 5, inserted in the throat of the calyx, small. Stamens 5 , alternate with the petals. ()ary 1-celled, with 2 parietal placentaz and 2 distinct or united styles. Berry rrowued with the shrivelled remains of the calyx, the surface of the numerous seeds swelliug into a gelatinous unter coat nvesting a crustaceous one. Enn- 
bryo minute at the base of hard albumen. - Low, sometimes priekly shrubs, with alternate and palmately-lobed leaves, which are plaited in the bud (exeept in one species), often fascieled on the branches; the small flowers from the same clusters, or from separate lateral buds. (From riebs, a German popular name for the currant. Grossularia was the proper name to have been adopted for the genus.)

\$1. GROSSULARIA. (GoOsEBERr.) Stems mostly bearing thorns at the base of the leafstulhs or clusters of leaves, and often with scattered bristly prickles; beries mickly or smooth. (Our species are indiscrminately called WILD Goosenzmil; the flouers greenish.)

* Peduncles 1-3-flowered; calyx as high as bruad; leaves roundish-heartshaped, 3-5-lobed.

- Calyx-lobes decidedly shorter thun the tule; berries apt to be prickly.

1. R. Cynósbati, L. Stamens and undivided style not longer than the broadly bell-shaped calyx; berries large, armed with long prickles or rarely smooth. - Rocky woods, X. Brunswick to the mountains of X. C., and west to Minn. and Mo.

+ Calyx-lobes dectedly longer than the short and ruther nurrow tube; berres smooth, purple, sueet und pleusunt.

2. R. grácile, Michx. (Mrssouri Gooseberry.) Spines often long, stout and red; peduncles long and slender: fourers whte or whitish; filaments (apillary, 4-6" lony, generally comnivent or closely parallel, soon conspicuously longer than the oblong-linear calyx-lobes. (K. rotundifolimm, M/an., in part.) Mieh. to Temn., west to Tex., Minu., and the Rocky Mlts.

3. R. rotundifolium, Michx. Spines short: peduncles short; flowers gremish or the lobes dull purplish; tilaments slender, $2-3^{\prime \prime}$ long, more or less exceding the narrowly oblong-sputulute ruly.x-lobes - W. Mass. and X. T., south in the Alleghanies to $\mathrm{X}$. C.

4. R. oxyacanthoides, I. Peduncles ver"y short, flowers greenish or clull purplish: stamens usually scarcely equalling the rather broadly oblong calyxlobes. (R. hirtellum, Mrchx.) - Newf. to К. J., west to Incl., Mlinu., and westward. The eommon smooth-frnited gooseberry of the north, the whitish spines often numerous.

$\because$ * Flowers several in a nodding raceme, small and flattish, grecmish.

5. R. lacústre, Poir. Foung stems clothed with bristly priekles anc with weak thorns; leaves heart-shaped, $3-5$-parted, with the lohes deeply cut; calyx broal and flat; stanens and style not longer than the petals; fruit bristly (small, unpleasint). - Cold woods and swamps, Newf. to $\mathrm{N}$. Eng., west to N. Y., Mieh., and Mimn.

§ 2. RIBESIA. (Cunkwr.) Thomless and prickless; racemes few-manyfluvered. stamens short.

6. R. prostràtum, I'ller. (FETid CurRaxt.) Stems reelined; leaves deeply heart-shaped, 5 - 7 -lohesl, smooth, the lobes ovate, acute, doubly serrate; racemes erect, sleuder, calyx flattish; pedicels and the (pale red),frit glandular- Gristly. - Cold clamp wools and rocks, Lab. to mountains of N. C., west to Mich., Minn., and the Rocky Mts. 
7. R. flóridum, L'Her. (Wild Black CurraxtT.) Leaves sprinkled with resinous dots, slightlly heart-shaped, sharply 3 -5-lobed, donbly serrate; racemes drooping, downy; bracts longer than the pedicels; flowers large, whitisls; caly $\mathrm{x}$ tubular-bell-shaped, smooth; fruit round-ovoid, Ulach, smooth. - Woorls, N. Eng. to Va., west to Ky., Iowa, and Minn.

8. R. rùbrum, L., var. subglandulòsum, Mixim, (REn Curravt.) Stems straggling or reclined; leaves somewhat heart-shaperl, obtnsely 3-5lobed, serrate, downy bencath when young; racemes, from lateral buds distinct from the leaf-buds, drooping; calyx flat (green or purplish); fruit globose, smooth, red. - Cold bogs and damp woods, N. ling. to N. J., west to Ind, and Minn.

§3. SIPIOÓCALYX. Thornless and prickless; leaves convolute in the bud; rucemes several-foucred; calyx-tube elongated; berry naked and glabrous.

9. R. aúreum, I'ursh. (Missociu or Buffalo Curraxt.) Shrub $5-12^{\circ}$ high; leaves 3-5-lobed, rarely at all cordate; racemes short; flowers golden-yellow, spicy-fragrant; tube of salverform calyx ( $6^{\prime \prime}$ long or less) 3 or 4 times longer than the oval lobes; stamens short; berries yellow or black. Bauks of streams, Mo. and Ark. to the Rocky Mts, and westward. Common in cultivation.

\section{Order 36. CRAssulaicta. (Orpine Family.)}

Succulent lierbs, with perfectly symmetricul flowers; viz, the petals and pistils erqualling the sepals in number $(3-20)$, and the stamens the same or double their number, - teehnically different from saxifraqca only in this complete symmetry, and in the earpels (in most of the grenera) being quite distinct from each other. Also, instead of a perigynous disk, there are usually little scales on the receptacle, one behind each carpel. Fruit dry and dehiseent; the pods (follicles) opening down the rentral suture. manyrarely few-seeded. - Stipules none. Flowers usually cymose, small. Leaves mostly sessile, in Penthorm not at all fleshy.

* Not succtilent : the carpels united, forming a 5-celled capsule.

1. Penthorum. Sepals 5. Petals none. Stamens 10. Fod 5-beaked, many-seeded. * Leaves, etc., thick and succnlent. Carpcls distinct.

D. Tillea. Sepals, petals, stamens, and pistils 3 or 4 . sieels few or many.

: Sedum. Sepals, putnls, and jistils 4 or 5 . Stamens $8-10$. Speds many.

\section{PÉ N THORUM, Gronov. Ditrit Stone-crop.}

Sepals 5. I'(ntals raw, if any, Stamens 10. P'istils 5, united loelow, forming a 5-angled, 5-holned. and 5-celled ('apsule, which opens ly the filling off of the beaks, many-sceded. - Cpriglat weel-like perenuials (not flesluy like the rest of the fanily), with seattred leaves, and yellowish-gren fluwers loosely spiked

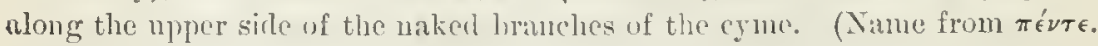
fiec, ancl ofos, a menk, from the quinary order of the flower.)

1. P. Sedoides, L. Leaves lanceulate, ar.ute at hoth ends, - Open wet

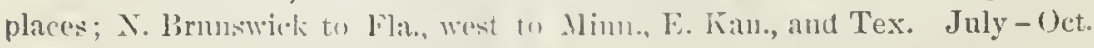
larts of the flowel larely in sixes o1 sorests. 


\section{TILL㐫A, Miel.}

Sepals, petils, stamens, and pistils 3 or 4. Pods 2-many-seeded.-Very snall tufted aunuals, with opposite entire leaves aud axillary fowers. (Named in honor of Mirhuel Angelo Tilli, an carly Italiau botanist.)

1. T. simplex, Nutt. Rootinir at the bise $\left(1-2^{\prime}\right.$ high $)$; leaves linearoblong; flowers solitary, nearly sessile; calyx half the length of the (greeuishwhite) petals and the narrow 8-10-seeded jods, the latter with a scale at the base of each. - Muddy river-banks, Mass. to Ma. July-Sept.

\section{SÉDU M, 'Touru. S'TOxL-Crol'. ORPINE.}

Sepals and petals 4 or 5 . Sitanens 8 or 10. Follicles many-seeded; a little scale at the hase of each. - Chiefly peremnial, smooth, and thick-lcaved herbs, witl the fluwers cyurese on one-sider. I'etals almost always narrow and acute or pointed. (Nane from sedeo, to sit, alluding to the manner in which these plants fix themselves upon rocks and walls.)

* Flowers perfect and sessili, as it were spiked aluny one side of spreading flowering branches or of the divisions of a scorpioid cyme, the first or central flower mostly 5-merous and 10-androus, the athers often 4-merous and 8-androus.

\section{- Flowers vilice or purple.}

1. S. pulchéllum, Michx. Stems ascending or trailing (4-12' ligh); leaves terete, linear-filiform, much crowded; spikes of the eyme several, densely Howered; petals rose-purple.-Va. to Ga., west to Ky., E. Kan., aud Tex.; also eultivated in gardens. July.

2. S. Névii, Gray. Stens spreading, simple (3-5' high); lenres all alternate, those of the sterile shoots aedge-oborate or spalulale, on flowering stems linear-spatulate and flattish; ryme about 3-spiked, densely flowered; petals white, more pointed than in the next; the flowering 3 or 4 weeks later; leaves and blossoms smaller. - Roeky eliffs, mountains of $\mathrm{Va}$. to Ala.

3. S. ternatum, Michx. Stems sprearling $\left(3-6^{\prime}\right.$ high $)$; leaves flal, the lower whorled in thres, uedge-oborute, the upperscatterod, oblong; cyme 3-spiked, leafy; petals white. - Roeky woods, I. Y. to Gil., west to Ind. aud Tenu.

$$
\text { + + Flourers yellou. }
$$

S. ACre, L. (Mossy Stone-Crop.) Spreadiug on the ground, moss-like; leaves very small, alternate, almost imbricated on the branehes, ovate, very thick; petals yellow. - Eseaped from cultiration to roeky roadsides, etc. July. (Nat. from En.)

4. S. Torrèyi, Don. Anmual; stems simple or branched from the base (2-4' high) ; leaves flat or teretish, seattered, ollong, 2-3" long; petals rather longer than the orale sepals; arpels at length widely divergent. - Mo. to Ark. and Tex.

* Flowers in a terminal naked and regular cyme ur cluster, morr or less pedurcled; leaves flat, abovate or oblong, mostly alternate.

+ Flawers perfect, 5-meruns, 10-undrous.

5. S. telephioides, Miehx. Stems ascending $\left(6-12^{\prime}\right.$ high $)$, stout, leafy to the top); leaves oblong or oral, entire or sparingly tootlied; cyme small; petals flesh-color, ovate-laneeolate, taper-pointed; follicles tupering into a slendor otyle. - Dry rocks, from western New Yulk to X. Ga. and S. Ind. June. 


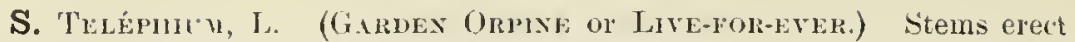
( $2^{\circ}$ high), stout; leives oral, obtuse, toothed; cymes eompound; pefals purple, (blong-lanceolate; follicles abnytly pointed with a short style. - Rocks and banks, eseaped fron cultivation in some places. July. (Adv. from En.)

S. Wertexum, I. Glabrous, ereet, $1^{\circ}$ high; leaies crouded, cylindric, subu. lute-tipper spreading or reflexed; flower's yellou, pedicelled. - Coast of Mass.; western N. Y.; rare. (Nat. from Eu.)

\section{+ + Flouers dicerions, mostly 4-merous and 8-androus.}

6. S. Rhodiola, DC. (Rosknour.) Stems erect $\left(5-10^{\prime}\right.$ high); leaves oblong or oral, smaller than in the preceling; flowers in a close cyme, greenishyellow, or the fertile tmming purplish. - Throughout Arctic America, extending southward to the coast of Mane, and chiffs of Delaware River; also in the western monntains. May, oune. (Eu.)

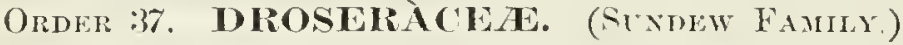

Bog-herbs, mostly glandular-haired, with regular hypogynous flowers, pen. tamerous and withering-persistent calyx, corolla. and stamens, the anther:s fixed by the middle and turned mulurd, and a 1-celled capsule with twice as many styles or stigmas as there are parietal placenta. - Calyx imbricated. Petals convolute. Secls numerons, anatiopous, with a short and minute embryo at the base of the albminen. - Leaves circinate in the bud, i. e., rolled up from the apex to the base as in Ferns. A small family of inseetivorous plants.

\section{DRÓ SERA, I. SuYnEw.}

Stamens 5. Styles 3, or sometimes 5, deeply 2-parted so that they are taken for 6 or 10, slender, stigmatose above on the inner face. Capsule 3- (rarely 5-) valved; the valves bearing the numerons seeds on their mickle for the whole length. - Tow puremials or liennials; the leaves clothed with reddish glandbearing bristles, in our species all in a tuft at the base; the naked seape bearing the flowers in a 1 -sited raceme-like inforescenee, which nods at the undevel operl apex, so that the fresh-blown flower (which opens only in sunshine) is always highest. The plants yield a purple stain to priper. (The glands of the leaves exude irops of a clen glutinous flnid, glittering like lew-drops, whenee the name, from $\delta p o \sigma \in \rho o s$, derly.)

1. D. rotundifòlia, I. (Round-LEaven Susiolw.) Leaves orbicular, abruptly narrowed into the sprearling hairy petioles; seeds spindle-shaped, the coat loose and chaff-like; flowers white, the parts sometimes in sixes. - l'eatbogs, Lab. to Minn., lnd., and southward; eommon. July, Ang. (Eu.)

2. D. intermèdia, Hayne, var. Americàna, 1)C. Lfaces sputuluteoblong, tapering into the long ratler eret naked petioles; seeds oblong, with a rongh (lose cout; Howers white. (D. longifolia, Groy, Manual.) - Bogrs, with the same range lut less common. Iune- $\Delta u g$. - Plant raised on its prolonged candex when growing in water. (Eu.)

3. D. lineàris, Gullie. (SLEvin Suxnew.) Leaves linear, obtuse, the biade (2-3' lon g, scarcely $2^{\prime \prime}$ wide) on naked erect petioles alont the same length; seeds oblong, with a smooth and perfectly close eoat; flowers white. - Shore of 1.. Superior, Mich., and Mina. 
4. D. Hlifórmis, Raf. (Thread-Leaved Scyuew.) Leaves rerylong and filifirm, erect, with no distinetion between blade and stalk; seeds spindleshaped; flowers numerous, purple rose-color ( $\frac{1}{2}$ broad ). - IVet sand, near the coast, Mass. to N. J. and Fli.

Diondea Muscfivia, Ellis, the Venus's Fry-TRAP, - So noted for the extraordinary irritability of its leaves, elosing quickly at the touch, - is a native of the sandy savanuas of the easter'n part of $\mathbf{N}$. C. "It differs in several resuects from the character of the order given above; the stanens being 15 , the styles muited into one, and the seeds all at the hase of the pod.

\section{Order: 38. HAMA MIELIDEAC. (Witchillazer, FAMIL.)}

Shrubs or trees, with alternatc simple leares and deciduous stipules; flowers in heads or spikes, often potygamous or moncecions: the calyx coliering with the base of the ovary, which consists of 2 pistits united below, and forms a 2-beaked, 2-celled woodly capsule, opening at the summe, with a single bony seed in each cell, or several, only one or two of them ripening. - Petals inserted on the calyx, narrow, valvate or involute in the bud, or often none at all. Stamens twice as many as the petals, and lialf of them sterile and ehanged into seales, or nunerous. Seeds anatrolıous. Embryo large and straight, in scanty albumen; cotyledons broad and flat.

* Flowers with a manifest caly’x, or calyx ancl corolla, and a single orule suspended from the summit of cach cell.

1. I amamelis. Petals 4, strap-shapel. Stamens and scales each 4 , short.

2. Fothergilla. Petals none. Stanens about 24 , long : filiments thickened upward.

* Flowers naked, with barely rudiments of a calyx and no corolla, crowiled ninto catkinlike heads. Ovules several or many in carh cell.

3. Liquidambar. Monoecious $0 l^{\prime}$ polygnmous. Stamens very mumerous. Capsules consolidated by their bases in a dense lieacl.

\section{HA M A I EIIS, I. WITCH.HAZEL.}

Flowers in little axillary elusters or hearls, nsmally surromsted by a scale-like 3-leaver inrolncre. Calyx 4-parterl, and with 2 or 3 lumctlets at its hase. l'etals 4 , strap-shaped, long and narow, spirally involute in the bucl. Stamens 8. very slort; the 4 alternate with the petals anther-bening, the others imperfect and scale-like. Styles 2, short. Capsule opening loculicilally from the top; the onter coat separating from the inner. which encloses the single large and bony seed in each cell, but soon bursts elastically into two pieces. - Tall shrubs, with straight-veined leaves, and yellow, perfect or polygamons flowers. (From an $\mu a$, "t the same time with, and $\mu \eta \lambda$ is, ch upple-tree; a name anciently applient to the Merllar, or some similar tree.)

1. H. Virginiàna, I. Leaves obovate or oval, wavy-tootherl, somewhat downy when yonng ; lossoming late in autumn, when the leares are falling, and naturing its seels the next summer.-Damp woods, X. Scotia to Fla, west to E. Mlinn. and La.

\section{FOTHERGÍLIA, L.}

Flowers in a terminal catkin-like spike, mostly perfect.

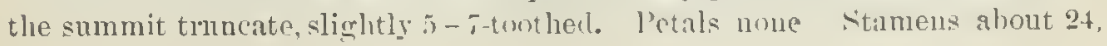


borne on the margin of the calyx in one row, all alike; filaments very long, thickened at the top (white). Styles 2, slender. Capsule cohering with the base of the calyx, 2-lobed, 2-cclled, with a siugle bony seed in each cell. - $A$ low shrub; the oval or obovate leaves smonth, or hoary underneath, toothed at the summit; the flowers appearing rather before the leaves, each partly corered by a scale-like bract. (Dedicated to the distinguished Li. John Folhergill.)

1. F. Gardèni, I. (F. alnifolia, L. f.) - Low grounds, Va. to N. C. April, May.

\section{LIQUID Á M B A R, L. Swevt-Gum Tree.}

Flowers usually monocious, in globular heals or catkins; the sterile arranged in a conical cluster, naked; stamens very munerous, intermixed with minute stales; filaments short. Fertile flower's consisting of many 2-celled 2-beaked ovaries, subtended by minute scales in place of a calyx, all more or less cohering together and hardening in fruit, forming a spherical catlin or head ; the capsules opening between the 2 awl-sliaped beaks. Styles 2, stigmatic down the inner side. Ovules many, but only one or two perfecting. Seeds with a wingangled seed-coat. - Catkins racemerl, nodding, in the bud enelosed by a 4-leared deeidnous involncre. (A mongrel name, from liquidus, fluid, and the Arabie amber, amber; in allusion to the fragrant terebinthine juice which exudes from the tree.)

1. L. Styraciflua, I. (Swert Gur. Bisston.) Leaves rounded, deeply 5-7-lobed, smootl and shining, glandnlar-serrate, the lobes pointed. Moist woods, fronl Coun. to S. I1l., and south to Fla. and Tex. April. $-\Lambda$ large and beautiful tree, with fine-graincd wood, the gray hark commonly with corky ridges on the branchlets. Leaves fragrant when hruised, turning leep crimson in antumn. The woody pods filled mostly with abortive seeds, resembling sawdust.

\section{Order 39. HatoräGEAE. (Thter-Nilfoil Famiy.)}

A quatic or marsh plants (at least in northern countries), with the inconspicuous symmetrical (perfect or unisexual) flowers sessile in the axils of leaves or bracts, calyx-tule coherent with the ovary (or calyx and corolla wanting in Callitriche), which consists of 2-4 more or less united carpels (or in Hippuris of only one carpel), the styles or sessile stigmas distinct. Jimb of the calyx obsolete or rery short in fertile flowers. l'etals small or none. Stamens 1-8. Fruit indehiscent, 1-4-celled, witlı a single anatropous sced suspended from the summit of each cell. Embryo in the axis of Aleshy albumen; cotyledons minute.

1. Myriophyllum. Flowers monoejous or polygnmous, the parts in fours, with or without petals. Stamens 4 or $\mathrm{S}$. Leaves often whorled, the immersed pinmately flissectel.

2. Proseruinaca. Flowers perfect, the parts in threes. Petals none. Leaves alternate, the inmerserl pinnately disserted.

3. II ippuris. Flowers usmally prifect. Petals none. Stamen, style, and cell of the ovary only one. Jeaves entire, in whorls.

4. Callitriche. Flowers monueious. Calyx and petals none. Stamen 1, Ovary 4-celled, with 2 fliform styles, Leives entire, opjonsite. 


\section{MYRIOPHÝLLUM, Taill. WATER-MILFoli.}

Flowers monocions or polygamons Calyx of the sterile flowers 4-parted, of the fertile 4-toother. Petals 4, or none. Stamens 4-8. Fruit nut-like, 4celled, deeply 4-loherl; stigmas 4, recurved. - l'erennial aquatics. Leares cruwled, often whorled; those unler water pinnately parted into capillary divisions. Flowers sessile in the axils of the upper leaves, usnally above water in summer; the uppermost staminate. (Name from $\mu v$ pios, a thousand, and

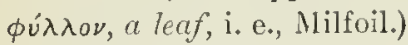

* Strumens 8 ; petals deciduons; carpels even; leaves whorted in threes or fours

1. M. spicàtum, L. Leaves all pinnately parted and capillary, except the floral omes or bincts: these orate, entre or toothed, and chifly shorter than the floners, which thus form an intermpted spike. - Deep water, Newf. to $\mathrm{N}$. Eng. and N. Y., west to Minus., Ark, and the P'acific. (Eu.)

2. M. verticillatum, I. Flowal leaves much longer than the flowers, pectinate-pinnatifid; otherwise nearly as n. 1.- Ponds, ete., common. (En.) * * Stamens 4; petals rather persistent; carpels 1-2-ridged and roughened on the back; leaves whorted in fours and fives, the lower with capillary divisions.

3. M. heterophyllum, Michx. Stem stont; floral leares orate and lanceolate, thick, crowded, sharply serrate, the lowest pimatifid ; fruit olscurely roughened. - Lakes and rivers, Ont. and N. Y. to Fli., west to Minn. and Tex.

4. M. scabràtum, Michx. Stem rather slender; lower leaves pinuately parted with few capillary divisions; floral lenies linear (rarely scattered), pectimate-toothed or ront-serrate: anpels strmyly 2-ridged and roughened on the back. — Shallow pouds, S. New Ling. to S. C., west to Mo. and La.

* * Sumens 4; petals rather prersistemt; curpets reven on the back, leaves chiefly scattered, or wating on the flowering stems.

5. M. ambiguum, Nutt. Immersed leares pinnately parted into abont 10 very delicate capillary divisions; the rmerging ones pectinate, or the "pper forul linear and sparingly toothed or entire; fouress mostly perfect: frnit (minute) smooth. - P'onds and ditches, Mass. to X. J. and I'eun.; also in Ind. - Var. CAllLACw: Torl. \& Gray, has stems floating, long and very slender, and leaves all immersed and capillary. Var. Luóum, Torr., is small, rooting in the mud, with leaves all linear, incised, toothed, or entire.

6. M. tenéllum, Bigelow. F"unering stoms nearly leafless and srape-tike $\left(3-10^{\prime}\right.$ high), erect, simple; the sterile shoots creeping and tufted, bracts small, entire; flowers alternute, momacious; fruit smooth. - Borders of ponds, Newf. to N. Eng., west to Mich.

\section{PROSERPINACA, L. Mermait)-TEen.}

Flowers perfect. Calyx-tube 3-silled, the limb 3-parted. I'etals none. Sta mens 3. Stimmas 3, cylindrical. Fruit bony, 3-angrled, 3-celled, 3-seeded, nutlike. - Low, perennial herls, with the stems creping at hase, alteluate leaves, and small flowers sessile in the axils, solitary or $3-4$ together, in summer. (Nane applied lyg P'liny to a Polygonum, meaning portuiming to Proserpine.)

1. P. palustris, I. Lerres lanceolute, shumly serote, the lower pectinate when under water; fruit sharply angled. - Wet swamps, N. Fng. to Fla., west to Minn. and Tex. 
2. P. pectinàcea, Lam. Leuces all pectimate, the divisions linear-aw-1. shaped; fruit rather obtusely angled. - Saudy swamps, near the coast, Mass. to Fla. and La.

\section{HIPPÜRIS, L. MARE'S 'TAIL.}

Flowers perfect or polygamous. Calyx entire. Petals none. Stamen one. inserted on the edge of the calyx. Style single, threal-shajed, stigmatic down one side, received in the groove hetween the lobes of the large anther. Fruit nut-like, 1-eelled, 1-seeded. - Perennial aquatics, witl simple entire leaves in whorls, aud minute flowers sessile in the axils in summer. (Name from a horse, and où á, a (uil.)

1. H. vulgàris, L. Stems simple $\left(1-2^{\circ}\right.$ highlı); leaves in whorls of 8 or 12, linear, acute; fruit nearly $\mathbf{I}^{\prime \prime}$ long. - Ponds and springs, Penn. to Ind. and Minu, and northward. (Eu.)

\section{CALLÍTRICHE, L. WATER-STARWort.}

Flowers monceious, solitary or 2 or 3 together in the axil of the same leaf, wholly naked or letween a pair of membranaceous lnacts. Sterile flower a single stamen; filanent bearing a lieart-shaped 4-celled antler, which by confuence beeomes 1-reller, and opens by a single slit. Fertile flower a siugle 4 celled ovary, either sessile or pedicclled, bearing 2 distinct and filiform sessile. usually persistent stigmas. Frnit nnt-like, compressed, 4-lobed, 4-celled, separating at maturity into as many closed 1-seeded portions. Seed pendulous, filling the cell; embryo slender, straight or slightly curved, nearly the length of the oily albmmen. - Low, stender and usmally tufted, glabrous, or beset with minnte (microscopic) stellate scales, with spatulate or linear entire leaves, loth forms of leaves often oecurring on the same stem. (Name from kaגos, beauiful, and $\theta \rho$ í, hair, from the often almost eapillary stems.)

* Small anmuls, forming tufts an motst soil, destute of stellate scules : leuces uniform, very small, obointe or oblanceulate, 3-rerved, croucled; bracts none.

1. C. defléxa, Brann, val. A ustini, Ilegeln. Stems $\frac{1}{2}-l^{\prime}$ high ; fruit small ( 1 " broad), broader than high, deeply notched above and below, on a pedieel often nearly of its nwn length or nearly sessile; lobes of the fruit nar rowly winged and with a deep growe between then ; persistent stigmas shorter than the fruit, spreading or rettexed] leaves 1-2" long. (C. Austini, Lingetm.) - On damp soil, $\mathrm{X}$. Y. and $\mathrm{X}$. J. to lll., Mo., and 'Tex. (S. Am.)

* Amphibrous perennials; leares uth stellate seales, the floating ones obovate and 3-nerved, the submersed lincer (all whiform and narrow in terrestrial forms) : flowers usually between a pair of bracts.

2. C. vérna, I. Funit ( $\left.\frac{1}{2} " \operatorname{lom} g\right)$ liggher than broal, obovate, sliglıtly obcordate, usually thickest at the hake, sessile, its lohes sharply kealed or very narrowly winged abore, and witl a wille sroore between tlem ; stignas slorter than the fruit, almost erect, usually deciduons; Hoating leaves crowded in a tuft, obovate, narrowel into a petiole.-Common in stagnant waters, New Fingland to Fla., west to Minn., 'Tex, ant the l'acific. (Fin.)

3. C. heterophýlla, Pursh, Frnit smaller, as luroal ol hoacer than

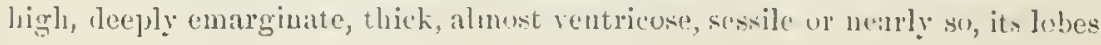


obtusely angled, with a small groove between them; stigmas as long as the fruit, erect, persistent; floating leaves crowded in a tuft, broadly spatulate, uften retuse, abruptly narrowed into a long petiole. - stagnant water, Mass. and N. J. to S. Ind, and Mo.

* * Submersed peremmal, unh numerors uniform linear 1-nerned leares; flowers without bructs; carpels separate nearly to the aris.

4. C. autumnàlis, L. Sitens 3-6' high ; fruit large (l' wide or more), flattened, circulin, reeply and narlowly notched, sessile or nearly so, its lober broadly winged, and with a very decp and narow growe between them; stigmas very long, reflexed, decidnous; leaves all linear from a broader base, retuse or notched at the tip $\left(2-6^{\prime \prime}\right.$ long $)$. - IV. Maks., Lake Champlain and N. New York, Lake Superior, and westward. (lin.)

\section{Order 40. MEIASTOMACHAE. (Melastoma Famil.)}

J'lants with opposite 3-7-ribbed leares, and lefinite stamens, the anthers opening by pores at the apex; otherwise nuch as in the Onagraces. - All tropieal, exrept the genus

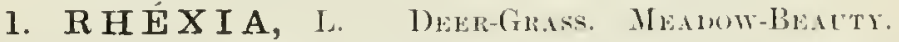

('aly-tulx urn-shaped, colserent with the orary lrehw, and continned above it, persistont, f-cleft at the apex. l'etals 4 , convolute in the bud, oblique, inserted along with the 8 stanens on the smmmit of the calyx-tube. Anthers long, l-cellorl, inverted un the bul. Fityle I; stigna 1. Capsule invested by the permanent calyx, 4-celled, with 4 many-seeder placenta projecting from the central axis. Siceds coiled like a suail-shell, without albunen. - Low per-

- enumal herlos, often bristly, with mostly sessile 3-5-nerved and bristly-edged leares, and large showy cymose flowers; in summer; the petals falling early.

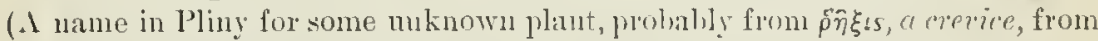
the place of growth.)

* Linthers linent, curved, with "mmute spur on the back at the atfachinem of the filument above its buse; fouress cyluose, peduncled.

1. R. Virgínica, I. Strm squur, with wing-like angles; lerers oeullanceolute, sessile, acute; caly-tube and pedicels more or less hispid with glandtipped hairs; petals briglit purple. - Sanrly swamps; coast of Maiue to Fla., west to northern X. Y., Ind., Mo, and La. Slender rootstorkis tuberiferous.

2. R. aristòsa, Britt. Branches sonewhat wing-anglerl; leaves linearohlong, sessile, not narrowed at base, naked or very sparsely latiry: hairs of the calyx mostly below the thrnat, not gland-tipped; petals sparsely villous, loright purple. - Iigg Iarlor City, N.J. (.I. E. Peters); also Simnter Co., si C. (J. D. Smith).

3. R. Mariàna, L. sitems cylindrical: leates linear-oblong, uarrowed below, mostly petiolate; petals paler. - Sandy swamps; N.J. to Fla., west to Mo. and La.

* Anthers oblong, struight, without any spur; flowers few, sessile.

4. R. ciliosa, Michx. Stem square, glibrous; leaves broadly ovate, ciliate with long hristles; calyx glabrous. - Md. to Fla, and La. 


\section{Order 41. LYTHRACEA. (Loosestrife Fanily.)}

Herbs, with mostly opposite entire leaves, no stipules, the calyx enclosing but free from the 1-4-celled many-seeded ovary and membranous capsule, ard bearing the 4-7 deciduous petals and 4-14 stamens on its throat; the latter lower down. Style 1; stigma capitate, or rarely 2-lobed. - Flowers axillary or whorled, rarely irregular, perfeet, sometimes dimorphous or even trimorphous, those on different plants with filuments and style reciprocally longer and shorter. Petals sometimes wanting. Capsule often 1-celled by the early breaking away of the thin partitions; placenta in the axis. Seeds anatropous, without albumen. - Branches nsually 4 -sided.

* Flowers regular or nearly so.

- Flowers mostly solitary in the axils of the leaves, sessile or nearly so.

1. Didiplis. Cilyx short, without appendages. Petals none. Stamens 4. Capsule indehiscent. Small aquatic.

2. Rotala. Calyx slort, the sinuses appendaged. Petals and stamens 4. Capsule septicidal, witl $: 3-4$ valves.

3 Ammannia. Flowers not trimorphous. Petals generally 4 or none. Stamens 4 . Capsule bursting irregularly.

- + Flowers in 3-many-flowered axillary cymes (rarely solitary).

4. Lythrum. Citlyx tubular. Petals usually 6 . Stameus mostly 6 or 12. Flowers cymose-spicate in one species.

5. Decodon. Flowers trimorphous. Petals 5 (rarely 4). Stamens 8-10. Capsule 3-4valved, loculicidal.

* Flowers irregular and unsymmetrical, with 6 jetals and 11 stamens.

6. Cuphea. Calyx spmrerl or enlarget on one side at base. Petals unequal.

\section{DIDÍPLIS, Raf. Water Purslaxe.}

Calyx short-camplinulate or semiglobose, with no appendages at the sinuses (or a mere callons point). Petals none. Stamens 4, short. Capsule globnlar, indehiscent, 2-celled. - Snbmersed aquatie (sometines terrestrial), rooting in the mud, with opposite linear leaves, and very smoll greenish flowers solitary in their axils. ("Didiplis means fuo doubling;" from $\delta$ s, twice, and $\delta เ \pi \lambda$ óos, double.)

1. D. lineàris, Raf. Leaves when submersed elongated, thin, closely: sessile by a broar base, when enersed shorter aul contrated at base; calyx with broal triangnlar lobes; style very short; capsules very small. (Anmmmnia Nuttalii, (imy.) - From Mlinn. and Wisc. to Tex., east to N. C. and Fla.

\section{ROTALA, I.}

Caly $\mathrm{x}$ short-campanulate or scmiglobose, with tooth-like appendages at the sinuses (abnormally, in our species). Yetals 4 (in ours). Stamens 4 , short. Capsule globulir, 4-celler, septicilal, the valves (under a strong lens) trans. versely and deusely striate. (Name a diminutive of rota, a wheel, from the whorled leaves of the original species.)

I. R. ramosior, lioehne. Leaves tapering at base or into a short petiole, linear-ublanceulate or somewhat spatulate; flowers solitary (rarely 3) in the axils and sessile; accessory teeth of calyx as long the the lobes or shorter. 
(Ammanuia humilis, Michr.) - Low or wet grouud, Mass. to Fla., west to Ind., Kan., and Tex. - With Ammannia-like lıabit, an exception in the genus.

\section{A M I I Á N NIA, Houston.}

Flowers in 3-many-flowered axillary cymes. Calyx globular or bell-shaped, 4-angled, 4-toothed, usually with a little horn-shaped appendage at each siuus. Petals 4 (purplish), small aurl rlecirluous, sometimes wanting. Stamens $4-8$. Capsule globnlar, 2-4-cellert, lnrstiug irregularly. - Low and inenspicuons: smooth herbs, with opposite narrow leaves, and small flowers in their axils, proruced all summer. (Named after Panl $A$ mmum, a German botanist ante'rior to Linnaus.)

1. A. coccínea, Rottb. Lenres linear-lanceolate $\left(2-3^{\prime} \operatorname{lon} g\right)$, with a lroad auricled sessile base; cymer subsessile, dense; petals purplish; stamen; more or less exserted; style usually slender; (apsule included. (A. latifolia, Gray, Mauual, not L.) - N. J. to Fla., west to S. Ind., Kan., and Tex. The style raries much in length, sometines in the sane specimen. Apparently the more developer forn of the southern 1 . latifolia, Linn., whieh, as limiter by lioehne, has apetalous flowers, with incheled stamens and short style.

\section{LÝ THR U M, L. LonsestrifF.}

Calyx cylindrical, striate, $5-7$-toothed, witl as many little processes in the sinuses. Petals 5-7. Stameus as many as the petals or twice the number, inserted low down on the calyx, commonly nearly equal. Capsule ollong, 2celled.-Slender leerls, with opposite or scattered mostly sessile leares, and

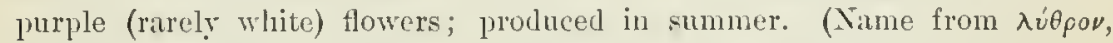
blood; perhaps from the styptic properties of some species.)

* Stamens and petals 5-7; flowers small, solitury and nearly sessile in the axits of the mostly scuttered upper leaves; proper calyx-tecth often shorter than the intermediate processes; plunts smooth.

1. I. Hyssopifòlia, l. Low annual (6-10' high), pale; leaves oblonglinear, obtuse, louger thau the inconspicuous flowers; petals pale-purple; stamens usnally 4-6, included. - Marshes, near the const, Maine to N. J. (En.)

2. L. lineàre, L. Stem slender and tall $\left(3-4^{\circ}\right.$ high), bushy at top, zilh 2 margined angles; Iraces linear, chiefly opposite: pet:ls whitish ; flowers with 6 included stamens and a short style, or the stanens exserted and style short; overy on a thick short stalk; no fleshy hypogynous ring. - Brackish marshes, N. J. to Flit. and Tex.

3. L. alàtum, Pursh. Tall and wand-like peremial; Uranches with margined angles; leares oblong-nrate to linear-lanceolute, arute, with a cordate or rounded bnse, the upper mostly alternate; calyr 2-4" long; jetals rather large, reep-purple; stamens of the short-styled fouers exserted; fleshy hypogynous ring prominent. — Ont. to Minn., sonth to Ga., $\Lambda$ rk., and Col.; also near Boston.

* Stamens 12 (rarely 8 or 10), twice the mumber of the petals, 6 longer and 6 shorter; flourers large, cronted and uhorled in an interrupted spitie.

L. Salicaria, L. (SPIKED Loosestrife.) More or less dowiy and tall; leares lanceolate, heart-shaped at hasc, sometimes wholled in threes; flowers purple, trimorphous in the relative lengths of the stanens and style. - Wet mealows, N. Scotia to Del. (Nat. from Eu.) 


\section{DÉCODON, Gmel. Swamp Loosestrife.}

Calyx short, broally bell-shaper or hemispherical, with $5-7$ erect teetl, and as many longer and spreading horn-like processes at the sinuses. Petals 5. Stamens 10 (rarely 8), exserted, of two lengths. Capsule globose, 3 - 5-celled, ioculicidal. - Peremial herbs or slightly shrubby plants, with opposite or whorled leaves, and axillary clusters of trimorplous flowers. (Name from

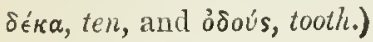

1. D. verticillàtus, Ell. Smooth or downy; stems recurvel $\left(2-8^{\circ}\right.$ long), 4-6-sided; leaves lanceolate, wearly sessile, oppusite or whorled, the upper with elustered flowers in their axils on short pedicels; petals 5 , wedge-

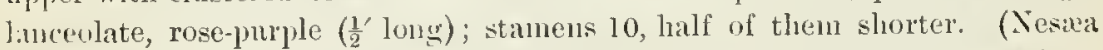

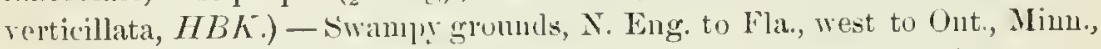
and La. Bark of the luwer part of the stem often spougy-thickened.

\section{C U P H E A, Jacq.}

Calyx tulular, 12-ribbed, somewhat inflated below, gibbous or spurred at the hise on the upper side, 6-toothed at the apex, and usually with as many little processes in the simuses. Petals 6 , very unequal. Stamens mostly 12 , approximitte in 2 sets, included, unequal. Orary with a eurved gland at the base next the spur of the calyx, 1-2-celled; style slender; stigma 2-lobed. Capsule oblumg, few-seeded, early ruptured though oue sille. - Flowers solitary or racenusse, stalked. (Nane from кuфós, gibbous, from the slape of the calyx.)

1. C. viscosíssima, Jacq. (Cцами Cepul..) Ammal, very viscidhairy, branching; leares orate-lanceolate; petals orite, short-clawed, purple; seeds flat, borne on one sicle of the placenta, which is early forced out of the ruptured capsule. - Dry fields, R. I. to Ga, west to Kan. and La.

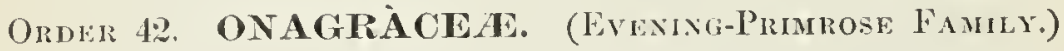

Herls, with 4-merous (sometimes 2-3-or 5-6-merous) perfect and symmetrical flowers; the tube of the cullyx eohering with the 2-4-eelled ovary, its lobes valuate in the bull, or obsolete, the petals convolute in the bud, sometimes wanting; and the stamens us momy or twice as many as the petals or calyx-lobes, inserted on the summit of the calyx-tube. Style singrle, slender; stigna 2-4-lobed or capitate. Pollen grains often connected by cobwebby theals. Seeds anatropons, small, without albumen, - Mostly herbs, with opposite or alternate leaves. Stipules none or glanduar.

* Parts of the llower in four's or morc.

- Fruit a many-seeded pou, usually loculiciul.

+. Calyx-limb divided to the summit of the ovary, persistent.

1. Jussicea. Petals 4-6. Stamens twice as many. Capsule elongated.

2. Ludwigia. Petals 4 or none. Stanens 4. Capsule sliort.

++ + Calyx-tube molonged beyond the ovary (scarcely so in 11 3) and deciduous from it. Flun ers 4-merous.

3. Fpllobium. Sends silly-tufterl. Flower's small, not jellow. Lower leaves often opposite.

4. OEnothera. Setals nalieul. Flowers mostly jellow. Leaves alternate 
+ + Fruit dry and indehiscent, 1-4-sceded. Leaves alternate.

5. Gaura. Calyx-tube obeonical. Filaments appendaged at base.

6. Stenosiphon. Calys-tube flliform. Filaments not appendaged.

* * Purts of the flower in twos. Leaves opposite.

7 Circaea. Petals 2, obcordate or 2-lolser. Stamens 2. Fruit 1-2-seeded, bristly.

\section{JUSSI 竎 A, L.}

(alyx-tule elongated, not at all prolonged beyond the ovary; the lobes 4 - 6 , lierbaceous and persistent. Petals $4-9$. Stamens twice as many as the petals. Capsule 4-6-celled, usually long, opening between the ribs. Seeds very numerous. - Herbs (ours glabrous perennials), with mostly entire and alternate leares, and axillary yellow flowers, in summer. (I)edicated to Bernard de Insien, the founder of the Natural system of Botany.)

1. J. decúrrens, DC. Stem erect $\left(1-2^{\circ}\right.$ high $)$, branching, winged by the lecurrent lanceolate leares; raly.x-lobes 4, as long as the petals; capsule oblongrlub-shaped, wing-angled: seels in sereral rows in cach cell - Wet places, Va. to Fli., west to S. Ill., Ark., and Ia.

2. J. rèpens, L. Stem creeping, or floating and rooting; leares oblong, tripring into a slender petiole; flowers large, long-pednucled; raíyx-lobes and o'mecute petals 5 ; pod woody, cylindrical, with a tapering base; seeds quadrate, in 1 row in each cell, adlierent to the spongy endocarp. - In water, Ill. and liy. to E. Kian., Ark., and 'T'e...

\section{LU D W I G I A, L. Linse Lousestifie.}

('alyx-tule not at all prolonged beyond the ovary; the lobes 4, usually persispent. Petals 4, often small or wanting. Stanens 4. Cilpsule short or cylindrical, nany-seeded. Śceds minute, naked. - P'eremial lerbs, with axillary (rarely (apitate) Howers, through summer and antmmn. (Naned for C. G. Luduig, Professol of Botany at Leipsic, contemporary with Linnans.)

* Leares all alternate, stssile or neurly so.

- Flovers peluncled in the upper axils, with conspicnous yellow petals $(4-8$ " long), equalling the orute ar lanceolate foliuceous lobes of the calyx.

1. L. alternifolia, L. (NELJ-10x.) Smooth or nearly so, branched (30 high) ; leares linnerulute folineur-lunceolate, acute or pointed at both ends; capsules culical, rounded at base, wing-angler. - Swamps, E. Mass. to Fli.. west to Mich., E. Kan., and la.

2. I. hirtélla, Raf. IIairy all over; stems nearly simple (1-20 high); Iraces oblong, or the upper lanceolate, blunt at both ends; capsules nearly as in the last. but scarcely wing-angled. - Moist pine barrens, X. J. to Fla. and Tex.

++ Flowers small, sessile (solitury mometimes clustered) in the axils, with very small greenish petals (in 11.5 ) nr mostly none; leaves mostly lanceolate or linear on the erect strms ( $1-3^{\circ}$ ligh) and munerous branches; but prostiate or creeping sterile shoots often produred from the base, thichly beset with shorter ot. ovate or spatulute leures. (Our species glabrous, except n. 3.)

3. L. sphærocárpa, Ell. Minutely pubescent, especially the calyx, or nearly glabrous: ; leaves lancenlate or liuear, acute, tapering at hase, those of the runners uhnate with a werlge-slitped base and glamblulir-alenticulate: 
Iractlets minute, obsolete, or none; rapsules glolular or depressed (sometimes acute at base), not longer than the calyx-lobes (less than $2^{\prime \prime}$ long). - Water or wet swamps, E. Mass. to Fla. and La. Bark below often spong.-thickened.

4. L. polycárpa, Short \& l'eter. Leaves narrowly lanceolate, acute at both ends, those of the runners oblong-spatulate, acute, entire ; lrartlets linearaxi-shriped and conspicuons on the base of the 4-sided somerchat top-shaped capsule, which is longer than the calyx-lobes. - Wet places, E. MIass. and Conn. to Mich., Minn., E. Kan., and Ky.

5. L. lineàris, Walt. Slender, mostly low; leaves narowly linear, those of the short runners obovate; minnte petals nsually present ; bractlets minute at the base of the elongated top-shaped 4-sided capsule, which is $3^{\prime \prime}$ long and much longer than the calyx-lobes. - Bogs, pine harrens of $\mathrm{N}$. J., and sonthward.

6. I. cylíndrica, Ell. Much branched; leaves oblong- or spatulatelanceolate, much tapering at the base or even petioled; liactlets very minute at the base of the cylindrical capsule, which is $3^{\prime \prime}$ longr, and several times exceeds the calyx-lobes. - Swamps, S. Ill. to Fla. and Tex.

$$
\text { * Leares all opposite; stems rreeping or floating. }
$$

7. L. palústris, EII. (WATER Pursuaxe.) Smooth; leaves ovate or oval, tapering into a slender petiole; petals none, or small and reddish when the plant grows out of water; calyx-lobes very short; capsules oblong, 4-sided, uot tapering at base, sessile in the axils (2" long). - Ditches, common. (Eu.)

8. L. arcuàta, Walt. Smootl, small and creeping: leares ublanceolate, nearly sessile; flowers solitary, loug-peduncled; petals yellow, exceeding the calyx ( $3^{\prime \prime}$ long) ; capsules obloug-club-shaperl, somewhat curved ( $\frac{l^{\prime}}{3}$ long). Swamps, Va. te Fla.

\section{EPIIOBIUM, L. WILOW-HERB.}

Calyx-tube not or scarcely prolonged heyond the ovary; the limb 4-cleft or -parterl, decilnous. l'etals 4 . Stamens 8 ; anthers slort. Capsule linear, many-seeded. Seers with a tuft of long hairs at the enrl. - Mostly pereunials, with nearly sessile leaves, anl violet, purple, or white Howers; in summer. A large genus, many of its species of rliticnlt limitation. 'The following provisional arrangenut has heen marle by Prof. Wr. 'TnLwsse, mainly in accordance with IIanssknecht's revision of the genus. (Nane composed of $\dot{\epsilon} \pi \dot{i}, u p o m$, and $\lambda \dot{\beta} \beta \iota \nu$, a little pod.)

$\$ 1$. Floxers large, purple, in a lony racrme: calyx-limb derply parfed; petals entire; stamens and style successively deflexed: stigma of + lony lolies.

1. E. angustifòlium, L. (Griat Wri,ow-лив. Fire-wenn.) Stem simple, tall $\left(4-7^{\circ}\right)$; leares scattered, ample, lanceolate, nearly entire. - Low grounds, especially in newly cleared lands; X. Eng. to X. C., west to Minn. and E. Fan., and fal north and restwarl. (Liu., Asia.)

\$2. Flowers mostly small and corymbed or panicled; malyx-limb 4-cleft; petals mostly deeply notched; stamens and style erect.

$$
\text { * Stigma t-parted; stem terete. }
$$

E. Husùruy, L. Densely soft-laairy, stont, hrauching $\left(3-5^{\circ}\right.$ high) ; leares mostly opposite, lance-oblong, sermlate, sessile flowers in the npper axils or 
in a leafy short racene; petals $6^{\prime \prime}$ long, rose-pnrple. - Waste grounds, Mass. to N. Y. and Ont. (Nat. from Eu.)

* Stigma clavate; stem terete, without decurrent lines (or with traces in n. 2): leaves numerous, the louer opposite, subentire, with revolute nargins.

2. E. lineàre, Mulll. Usually much branched above aud minutely hoarypubescent, $1-2^{\circ}$ high; leares linear-lanceolate, tapering to a short but distinct petiole, acutish; flowers numerous, pale; capsules hoary, on pedicels as long as the leaves. (F. palustre, var. lineare, Gray, mainly.) - Bogs, N. Eng. to lenn., Iowa, and northward.

3. E. stríctum, Mulhl. Freet, $1-2 \frac{1}{2}^{\circ}$ high, densely beset with soft spreading somewhat glandular white hairs; leaves hroader, more obtuse and with evident veins, very slort-petioled or sessile; pubescence of the capsule soft and sprearling. (1). molle, Torr.) - Bogs, Mass. to Minn., south to Va. and Ill.

* Stigma clarate; stem somewhat quadrangular with $2-4$ ridges or hairy lines decurrent from some of the leaves.

- Tall and mostly branching, many-flowered; leaves rather large, toothed, not revolute, the lower opposite; seeds papillose.

4. E. coloràtum, Muhl. Somewhat hoary-pubescent above or glandular, $1-3^{\circ}$ high ; leares lanceolate, sharply serrulate or denticulate, acute, narrowed to conspicuous petioles; flowers pale, nore or less nodding; peduncles shorter that the leaves; seeds dark, unappendaged; coma ciumamon-color. WV places, common.

5. E. adenocaùlon, Ilanssk. Differs in its nore glandular pubescence alsove, the often blunter and less toothed leaves abruptly contracted to shorter petioles, flowers erect, paler seeds with a slight prolongation at top, and a merely dingy coma. - Wet places throngh the Northern States.

6. E. glandulosum, Lehm. Subsimple; pubescence abore not gland. ular; leaves orate-lanceolate, mostly abruptly romded to a sessile base and more glandular-toothed; seeds larger. - Canada to the monntains of N. C. (fide Hansskuecht). (Asia.)

++ Mostly low, slender and simple (except forms of n. 10); leares chiefly opposite, less toothed: flowers feu, nodding; seeds appendayed at the apex.

+ Seeds areolate but not papillose; leniess not revolute.

¡. E. anagallidifolium, Lam. Glahrate, a span high or less; leares erect or ascending, ahout equalling the interunles, elliptical-oblong to narrowly obovate, entire or the upper denticulate, tapering to short petioles; flowers purple; sepals rather ubtuse: cupsules glabrous on perluncles exceeding the leaves. - White Mts. and Mrlirondacks (fide Haussknecht). (Eu.)

8. E. lactiflorum, Hanssk. Glabrous except the pubescent lines, 6-12' higl, with elongated internoles; leaves elliptical or the lowest round-obovate, slightly repanul-rlenticulate, olutuse, tapering into mostly elongated petioles; Howers smaller, white; sepals nore acute; seeds more prominently appendaged. - White Mts., and urthwam (fide Hanssknecht). (En.)

+t secels papillose-roughenerl.

9. E. Hornemánni, Reichenb. Glabrate, 8-18' high; leaves mostly horizontal, ovate, the upper acutiuh, remotely denticulate, abruptly contracted 
to winged petioles, not revolute; seeds often only slightly roughened, short and shortly appendager. (E. alpinum, Man.) - White Mts., dells of the Wisconsin River (Lapham), and northward. (Eu.)

10. E. palústre, I. Slender, $1^{\circ}$ high or less, often hranched, fively pubescent; leares erect or ascending, abont equalling or lunger than the internodes, sessile, linear to linear-lanceolate or elliptic-oblong, obtuse, with revolnte margins; capsules pubescent to nearly glalurons, nustly shorter thau the slender peduncles; seeds fusiform, with long beak. (E. jalustre, var. lineare, Man.. in part.) - Penn. to Mlimm and the White Mts., 120rth and westward. (Fu.)

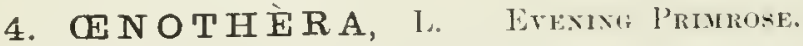

Calyx-tube prolonged leyond the oraty, decilnons; the lobes 4 , reflexed. Petals 4. Stamens 8 ; anthers mostly linear and rersatile. Capsule 4-ralverl. many-seeded. Seeds naked. - - Leares alternate. Flowers yellow, white or rose-color. (An old name, of unknown meaning, for a species of lipilobium.) \$1. Stigma-lobes linear, elongated (except in n. i) ; caly.r-tube linear, slightly dilated at the throat; anthers linear.

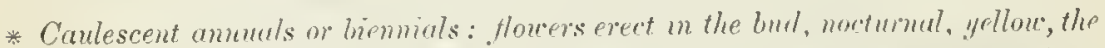
calyx-tips fiep; capsules sessile, corraceous; seeds in turo rous in wech cell.

- Flouers in a lenfy spitie: rupsules stont, oblong, slightly narmerd abore.

1. CE. biénnis, L. (Comms Fresixg PRmuosi.) Ratherstont, erect ( $1-5^{\circ}$ high), usually simple, more or less pubescent and hairy; leares lanceolate to oblong- or rarely orate-lanteolate ( $2-6$ ' long), acute ur acminate, repandly denticulate, the lowest petioled; caly-tube $1-2 \frac{1}{2}$ long, the tips of the sepals contiguous; petals $\frac{1}{2}-\frac{8^{\prime}}{4}$ long; 'aprsule more or less puluescent or lirsute.

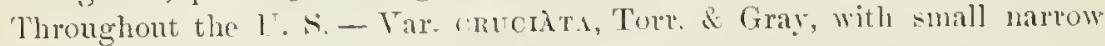
petals, appears to he merely a rare garden (?) sport. Li. Mlass.

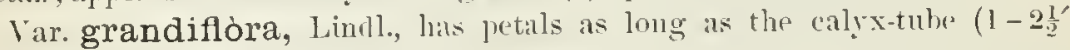
long). - Same range as the type, hut not so common east.

2. E. Oakesiàna, Robbins. Ammal, nore slender, not hairy, the puherulence manly appressel; calyx-tips not contiguous at hase; otherwise nearly as in the typical form of the last. ((E. biennis, var. Oakesiand, Cirmy.) - Dry places, E. Mass., R. 1., and Conn.

+ + Howers in a lerify sprite or arillary: ropsules lineur.

3. CE. rhombipétala, Nint. Rarely branching, appresied-puberulent aurl subcanescent: leaves matrowly lanceolate, acuminate. deuticulate, the lowest attemmate to a petiole and rarely pinnatifu, diminishing upward into the close, elongater, conspieuonsly bracted spike, ealyx silky-ranesernt (tube $11^{\prime}$ long) ; petals rlomlicerate $\left(6-10^{\prime}\right.$ long). - Int. to Mims. and Ark.

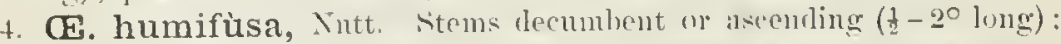
houry-pubesent with shom dense appressed hairs; leners natrowly lanceolate or

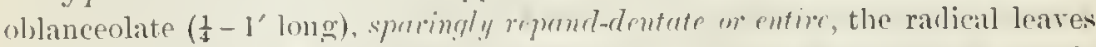

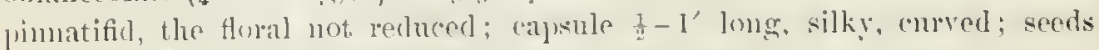
smootl. - (11 the searoast, N. J. to Flik.

5. E. sinuàta, 1. Stems ascenting or decumbent, simple or branched (10 ligh or more), mor or less strigose-pubescent and puberulent; leares oblong or lanceolate $\left(1-2^{\prime} \mathrm{long}\right)$, sinuctely toothed or often pinnatifid, the floral simi- 


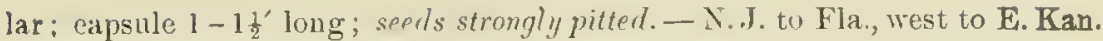
and Tex. Very variable.

* Caulescent perennial; flowers axillary, nodding in the bud, white turning rose-color; capsules sessile, linear; seeds in a single roue.

t. E. albicaùlis, Nutt. Stems erect ( $\frac{1}{2}-t^{\circ}$ high $)$, simple or branched, white and often shrelky, glatrons or puberulent; leaves linear to oblong-lan. cenlate ( $1-3^{\prime}$ long), entire 11 repand-denticulate, ol sinnate-pinultifil tomarl the base; calyx-tips free, throat naked; porls $\frac{1}{2}-2$ long, often curved or twisted; seeds lance-linear, smootl. - W. Minm. to N. Mex, and westward.

** Caulescent; floners diurnal, yellow and erect in the bud (except in n. 11): cupsules obovate or clavate, quadrangular, the alces ribled and the angles more or less strongly winged (except in 11.7 ).

7. E. linifòlia, Nutt. Anumal or biennial, crert, very slender, simple (1) diffuse $\left(6-15^{\prime}\right.$ high), glabrous, the hranchlets and capsules puberulent: radical leares oblanceolate, runline lineurfilyorm $\frac{1}{3}-\mathrm{l}^{\prime}$ long; spikes loosely Howered; coroll: 2-3" long; stigmus short; cupsules ubovate to oblong-clavate, 2-3" long, nol winged, neally ressile, - 11l. to E. Kan., La., and Tex.

8. E. pùmila, 1. Biemuial, puberulent, 1-20 high; leures mostly glabrous, entire, obtnse, the ladical slatulate, the curline nurrouly oblanceolate: flowers lousely sprilicel: corolla +-12 " loug; copsule glubrous, oblong-clavate, 3-6" long, sesile w on a short pedicel, slightly enged. (Incl. O*. ehrysantlia,

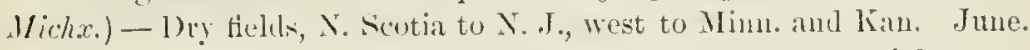

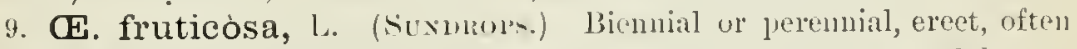
tall and stout $\left(1-3^{\circ}\right.$ high), villons-puhescent or puberulent or nearly glabrous; leares oblung-to lincar-lanceolate, mustly denturulute: receme rorymbed or loose:

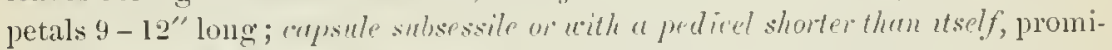
nently ribbed and strougly urmged. - (")munon and very variable.

Var. lineàris, Watron. Leares linear to linear-lanceolate; catpsnle nsually shorter than the perdicel, ratler less linadly winged. ((F. linearis of Man., in pirt. (F. riparia, Wull.) - (omm. to Fla., west to Mu. aud Ial.

Var. humifùsa, Allen. Low, decumbent, sonewhat wouly, diffusely brancled, puberulent; bratches slender, thesuous; leares narrow; flowers few, small; ("ipsules pubestent, alont equalling the penlicel. (CE. linearis of y/an., in 1:alt.) - suffulk Co., I. Island.

10. CE. glaùca, Michax. Perennial, erect (2-3ㄱighl), gholnous and glau-

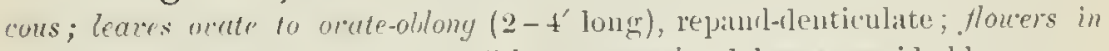

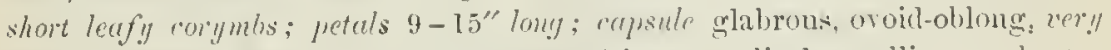
broudly winged, usually abruptly eontracted into a jeelicel equalling or shorter thar itself. - Mountains of Va. to Mli., west to Kiy and L. Kau.

11. CE. speciossa, Nutt. Perennial, sert or suldeeumbent, finely puheseent; leaves oblung-lanceolate to linear, repand-denticulate, or more or less leeply sinuate-pinnatifil ; fluvers larye, uhite or rose; capsule clavate-obovate, strongly 8-ribled, rigid, aeute, stontly pedicelled. - Mo. to Kim. and 'Tex.

* * * Capsule oblong to ocate or vibiculur, broudly uinged, ragud and sessile. + Acculescent or neurly so; flowers whte or rose-color.

12. CE. tríloba, Nutt. Biennial or perennial, nearly glabrous; leares $2-10^{\prime}$ long, somewhit ciliate hmg-petioled, mucinate-pimatificl or oblanceo- 
late and only simnate-toothed; calyx-tips free, the tube slender (2-4' long); petals $6-12^{\prime \prime}$ long; capsule orate, $\frac{1}{2}-I^{\prime}$ long, strongly winged, net-reined. Ky. to Miss. and Tex., west to the Pacific.

Var. (?) parviflora, Watson. Flowers very small (I - 2' long), fertilized in the bud and rarely fully opening; frnit abundant, forming at length a densely crowded hemispherical or cylindrical mass nearly $2^{\prime}$ in diameter and often 2-3' high. - Plains of Kan. and Neb.

+ + Low caulescent perennals; flowers axillury, yellow.

13. G. Missouriénsis, Sims. Stems decumbent; pubescence short and silky, closely appressed, sometimes dense or wholly wanting; lealves thick, oral to linear, mostly narrowly lanceolate ( $2-5^{\prime}$ long), acmminate, entire or repand-denticulate ; caly'x-tube $2-5^{\prime}$ long; petals broad, $1-2 \frac{1}{2}^{\prime}$ long ; capsules orbicular, very broadly winged ( $1-3^{\prime}$ long). - Mo. and Kan. to 'Tex.

14. F. Fremóntii, Watson. Hoary with appressed silky puluescence; leaves linear, pointed, entire; calyx-tube $1-2^{\prime} \operatorname{long}$; petals $\frac{7}{3}-1^{\prime}$ long; capsule hoars, oblong, narrowed at base, 9 " long. — Central Kan.

\$2. Stigma discoid; caly.x-tube more broadly dilated above; anthers oblonylinear; capsule mostly sessile, linear-cylindric ; peremial, someuhut woory, with axillary yellow flowers.

15. E. Hartwègi, Bentlı., var. lavandulæfòlia, Watson. Stenıs numerous from a woody base, $3-6^{\prime}$ high; leares numerous, hoctig-pulerulent, mostly linear, $\frac{1}{4}-I^{\prime}$ long; caly $x$-tuhe $1-2^{\prime}$ long; capsule 8-10" long. - Central Kan. to Col. and N. Mex.

16. CE. serrulàta, Nutt. Slender $\left(3-15^{\prime}\right.$ highl $)$, simple or brancherl, canescent or glalirous; leaves linear to lanceolate ( $1-3^{\prime} \mathrm{long}$ ), imegularly and sharply denticulute; caly:x-tube lrondly funnelform (2-4"lony), strongly nerved; petals broadiy oborate (3-4" long), crenulate; "apsule 9-15" long. - Wisc. and Minn. to Mo., Tex., and N. Mex.

\section{GA U R A, L}

Calyx-tube much prolonged beyond the ovary, deciduons; the lobes 4 (rarely 3), reflexed. Petals clawed, unequal or turned to the npper side. Stamens mostly 8 , often turued down, as is also the long style. $\Lambda$ small scale-like apjendage before the base of each filament. Stigna t-lobel, surronnded by a ring or cup-like border. Fruit hard and nut-like, 3 - f-ribbed or angled, indehiscent or nearly so, usually becoming l-celled and I-4-seeded. Sreds naked. - Ieaves alternate, sessile. Flowers rose-color or white, changing to reddish in fuling, in spikes or racemes, in our species quite small (so that the name, from raûpos, superb, does not seem appropriate).

\section{* Fruit sessite or nearly so.}

1. G. biénnis, I. Soft-hairy or downy $\left(3-8^{\circ}\right.$ high) ; leares oblongtancenlute, denticulate; spikes wandtike: finit oval or oblong, acute at both ends, 2-3" long, ribbed, downy. - Dry banks, N. Y. to Minn., and sonthwarl. Aug.

2. G. parviflora, Dougl. Suft-villous and puberulent, $2-5^{\circ}$ higl ; leaces orate-lanceolate, repand-denticulate, soft-pubesen'; spites dense; fruit ollong. clarate, narroved to both ends, 4-nerverl, obtusely augled above, $3-4$ " long. - Mo. to La. and restward. 
3. G. coccínea, Nutt. Canescent, puberulent or glabrate (6-12' high), very leafy; leaves lanceolate, limear-oblong or linear, repaud-denticulate or entire; flowers in simple spikes, rose-color turuing to scarlet; fruit terete below, 4 -sided and broader ulume, 2-3" long. - Minn. to Kan., and westwarl.

$$
\text { * Fruit slender-pedicelled. }
$$

4. G. fílipes, Spach. Tearly smooth; stem slender $\left(2-4^{\circ}\right.$ high); leaves linear, mostly twothed, tapering at base; banches of the panicle very slender, naked; fruit obovate-club-shaped, 4-angled at the summit.- Open places, Ta. to Fla., west to Ill., Kan., aul Ark.

\section{STENÓSIPHON, spach.}

Calyx prolonged beyoul the ovary into a filiform tube. Filaments ( 8 ) not appendaged at base. Fruit 1 -celled, 1 -seeded. Otherwise as Gaura, which it

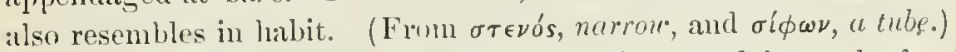

1. S. virgàtus, spacl. slender, 2-4high, glabrous, leafy, leaves narrowly lanceolate to linear, pointed, entire, much reduced above; fluwers numerous in an elongater spike, white, $\frac{1}{2} \operatorname{lomg}$; fruit pubescent, oblong-ovate, 8-ribhed, small. - E. Kan. to Col. aum Tex.

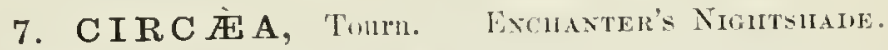

Calyx-tube slightly prolonged, the end filled by a cup-shaped disk, deciduous; lobes 2, reflexed. Petals 2, inversely heart-shaped. Stamens 2. Fruit indehiscent, small and bur-like, hristly with hooked hairs, 1 -2-celled; cells 1-seeded. - Low and inconspieuons peremials, in cool or lamp woods, with opposite thin leaves on slender petioles, and small whitish flowers in lacemes, produced in summer. (Named from Firce, the enchantress.)

1. C. Lutetiàna, L. 'Taller $\left(1-2^{\circ}\right.$ high $)$; lenres orute, slightly toothed; bracts none; hairs of the ronndish 2-celled finit bristly. - Very common. (Eu.)

2. C. alpina, I. Low $\left(3-8^{\prime}\right.$ high $)$, smooth and went: leares heart-shaped, thin, shining, contsely toothed; bracts minute; liairs of tle ohorate-oblong 1-relled fruit soft and slender. - Deep woods, N. Eng. to Ga., Ind., and Minn. (Fu.)

\section{Ornei: 43. LOASACEA. (Lohsa Family.)}

IIerbs, with a rough or stinging pubsesence, no stipules, the calyx-tube adherent to a 1-celled orary with 2 or 3 parietal placente; - represented here only by the genus

\section{MENTZELIA, Plnmier.}

Calyx-tube cylindrical or elub-shaped; the limb 5-parted, persistent. Petals 5 or 10 , regular, spreading, flat, convolute in the but, deciduons. Stamens indefinite, rarely few, inserted with the petals on the throat of the calyx. Styles 3 , more or less united into one; stignas terminal, miunte. Capsule at length dry and opening by valves or irregularly at the summit, few-many-seeded. Seeds flat, anatropuus, witl little albumen. - Stems erect. Leaves altermate, very adhesive by the barbed pubescence. Flowers terminal, solitary or cymoseclustererl. (Dedicated to C. Mentzel, an early (relman botanist.) 
* Seeds feu, ollong, not winged; petuls 5 , not large; filaments all filiform.

1. M. oligospérma, Nutt. Rough and alhesive $\left(1-3^{\circ}\right.$ high), muel branehed, the brittle branches spreading; leaves uvate and obloug, cut-toothed or angled, often petioled; flowers yellow ( $7-10^{\prime \prime}$ brond), opening in sunshine; petals wedge-oblong, pointed; stamens 20 or more; eapsule small, about 9 . seeded. - Prairies and plains, Ill. to Kan. and Col., south to Tex.

* Seeds numerous, rounded and wing-margined; petals 10, large and shoury; outer flaments pelaloid in 11.3 ; capsule large, oblong; leares sessile.

2. M. ornàta, 'Torr. \& Gray. Stout, 1-20 high; leaves oblong-lanceolate, deeply repand-toother or pinnatifid, the segnents acute; calyx-tulse leafy-luacteate; petals $2-3^{\prime}$ long, yellowish-white; filaments all filiform or the onter dilated below; eapsule 1z-2 long; seeds narowly marerined.-On the platins, western part of the Dakotas to central Kan. and 'Tex.

3. M. nùda, Torr. \& Gray. MIore slender, 1-50 high ; leares somewhat lanceolate, rather bluutly or shurtly repand-rlentate; flowers hatf as large as in the last : calyx not bracteate; onter filaments narrowly dilated, sterile; capsule about $\mathrm{l}^{\prime}$ long; seeds plainly winged. - I'lains, Dakotas to cen. Kan. and 'Tex.

\section{ORDer 44. PASSTFLORACEAE. (PAstox-Flower FAMILY.)}

Merths or wooly plants, climbing by tendrits, with perfect flowers, 5 monadephous stamens, uml a stalled 1-celled ovary fiee from the calyx, with 3 or 4 parietal placenter, and as many club-shaped styles.

\section{PASSIFLÒRA, L. PAS-IOA-FLOWER.}

Calyx of 5 sepals mited at the lase into a short cup, imbricated in the bud, nsnally colored like the petals, at least within; the throat crowned with a double or triple fringe. Petals 5 , on the throat of the calyx. Sitamens 5 ; filaments uniterl in a tube which sheathes the long stalk of the ovary, separate alove; athers large, fixed by the midrle. Berry (often elible) many-seeded; the anatropous albuminons seeds invested by a pully covering. Seed-coat brittle, groovel. - Leaves alternate, generally palmately lobed, with stipules. Peduncles axillary, jointed. Ours are perennial herlss. (An ataptation of Mos passionis, a translation of fior della pussione, the popmlar l talimn name early applied to the flower from a fancier resemblance of its parts to the implements of the (rucifixion.)

1. P. lùtea, I. Smonth, slouder ; leaves obtusely 3-lobed at the summit, lhe loles entire; petioles glaudless; Huwers greenish-yellow (l' broul); fruit to in dimmeter. - 1)inup thivkets, s. l'ont. to Fla., west to Ill., Mo., and Lat.

2. P. incarnàta, L. Pulesuent; leaces 3 -5-cleft, the lobes serrate, the hase bearing 2 glauds; flower lange ( 2 ' broad), nearly white, witl a triple lmrple and flesh-colored erown; involuere 3-leaved ; frnit as large as a lien's "rece. - Dry soil, Va. to Fla., west to Mo. and Ark. Fruit called maypops.

\section{OrDER 45. CUCURBTTACEAE. (YoURd FAMLY.)}

Mosily succulent herls with endrits, dicecious or monaccious (ofien gamoyetalous) flowers. the calyx-tube cohering with the 1 - 3-celled oring, and the 
5 or usually $2 \frac{1}{2}$ stumens (i.e., 1 with a 1-celled an 1 - with 2-celled anthers) commonly united by their often tortuous anthers, and sometimes also by the filaments. Fruit (pepo) fleshy, or sometimes membranaceous. - Limb of the calyx and corolla usually more or less combined. Stigmas 2 or 3. Seeds large, usually flat, anatropous, with no allumen. Cotyledons leaflike. Leaves alternate, palmately lobed or vinerl. - Mostly a tropical or subtropical orler; represented in cultivation by the Gourd (LAGEsíria vulgaris), Pumpkin and Squash (species of Cucurbita), Muskmelon (Cícumis Mèto), Cucumber (C. Satiros), and Watermelon (Citrúlius vulgàris).

* Fruit prickly. Seeds few, erect or pendulous. Flowers white. Annual.

- Ovary l-celled. Seed solitary, drentulous.

1. Sicyos. Corolla of the sterile flowers tlat and sprenling, 5-lobed. Fruit indeliscent. - ovary 2 -:-celled. Seeds few, crect or ascendiıg.

2. Echinocystis. Corolla of the sterile flowers flat aul sprealing, 6-parted. Anthers 3. Fruit blarklery, 2-celled, 4-seeded, bursting at the top.

3. Cyclanthera. Corolla 5-parted Anther 1, ammlar. Fuit oblique and gibbons.

* Fruit smonth. Ferds umemus, horizontal, attached to the $3-5$ parietal placentx. Pcrennial.

4 MeIothria. Flowers suall, greenislı; corolla 5-parted. Slender, elimbing. Fruat small, j. Cucurbita. Flowers large, jellow, tubular-eampanulate Prostrate. Fruit labge.

\section{SÍCYOS, I. ONE-SERHEn, BrR-CICUMHER.}

Flowers monocions. Protals 5, united beluw into a bell-shaperl or flattish corolla. Anthers cohering in a mass. Ovary l-cellerl, with a single suspemperl wrule; style stender ; stignas 3. Fruit ovate, dry and indehiscent, filled by the single seed, crrered with harbed prickly hristles which are readily detached. - Climbing annuals, with 3-forked tendrils, and small whitish flowers; the sterile and fertile nustly from the same axils, the former corymbed, the latter in a capitate cluster, long-pednncled. (Greek name for the Cnemmber.)

1. S. angulàtus, I. Leaves roundish heart-shaped, 5-angled or lobert, the lobes pointed; plaut clammy-liairy - River-banks, and a weed in damp yarks, X. II. and Quebec to Fla., west to Minn., E. Kan., and Tex. July-Sept.

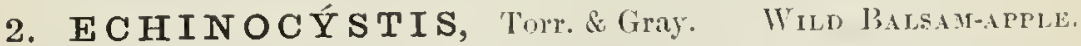

Flower's monocions. Petals 6 , lanceolate, united at the hase into an open surealing corolla. Anthers more or less unitel. Ovary a-cellerl, witl 2 erect wules in earlı cell; stigma broad. Fruit fleshy, at length dry, rlothed with weak prickles, bursting at the summit, 2-celled, 4-seeded, the inner lart fibromsnetted. Seeds large, flat, with a thickish hard and rougliened coat. - Tall rlimbing annual, nearly snootl, with 3 -forked tendrils, thin leaves, and very ummerous small greenish-white flowers; the sterile in componnd racemes often $10 \mathrm{long}$, the fertite in small clusters or solitary, from the same axils. (Name

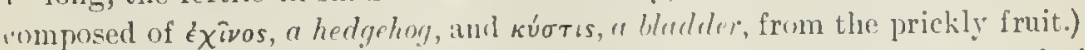

1 E. lobàta, Torr. \& (iray: Leaves deeply and sharply 5-lohed; fruit wal (2' long); seeds dark-colured. - kich soil along rivers, Wr. New Eng aud l'ent, to Minu., K. Kan., and 'Tex. Also cult. for arbors. duly-Uct. 


\section{CYCLANTHERA, Sclurad.}

Flowers monocious. Corolla rotate, reeply 5-parted. Stamens united iuto a ceutral columu, the anther solitary in our species aud annular. Ovary (1-3-) usmally 2-celled aud 4-locellate with 4 erect or ascenting orules. Fruit spiny, ohliquely ovoil and giblous, beaked, bursting irregularly. Seeds flattened. - Slender glabrous climbiug almuals or perenuials, with very small racemose or panicled white sterile flowers and a solitary fertile one in the same axil.

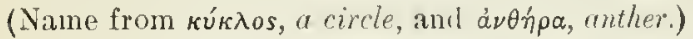

1. C. dissécta, Aru. Anumal ; leaves digitately 3 -7-foliolate, the oblong divisions somewhat lobed or toothed ; tendrils simple or lifid; fruit $l^{\prime}$ long, on a short perluncle. - Central hian. to 'T'ex. and Mex.

\section{M ELOTHRIA, I.}

Flowers polygamous or monocious; the sterile campaunlate, the corolla 5. lobed; the fertile with the calyx-tube coustricted above the orary, then campanulate. Antliers nore or less united. Berry small, pulpy, filled with unay flat and horizoutal seels. - l'endrils simple. Flowers rery small. (Altered from $\mu \dot{n} \lambda \omega \theta \rho o \nu$, an ancient uame for a sort of white grape.)

1. M. péndula, L. Slender, from a perennial root, climling; leaves small, roundisl and leart-shaped, 5-angled or lobed, roughish; stcrile flowers few in small racenes; the fertile solitary, greenish or yellowish; berry oval, green, 4-6" loug - Copses, Vis. to Fla., west to S. Iud. aur La.

\section{C U CÚ R BITA, L.}

lilowers mouncious, mostly solitary. Calyx-tule campanulate; corolla campannlate, 5-lobed to the midlle. Filaments distinct; anthers linear, miter, sigmoid. Ovary oblong, with short thick style, 3-5 2-lohed stigmas, and 3-5 parietal placentis, ovules numerous, horizontal. Fruit smooth, Heshy with a hard rind, indeliscent. - Prostrate scabrous vines, ruoting at the joints, with large yellow flowers and large fruit. ('The Latin name for the Gourl.)

1. C. fœtidíssima, IHBli. lioot rery lirge, fusiform; leaves thick, triangular-cordate; flowers 3-4' long; fruit globose or obovoid, $2-3$ ' in dianeter. (C. perennis, Croy.) - Central Neb. to Tex., and westward.

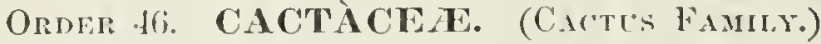

Fleshy and thickened mostly leufless plants, of peculiar aspect, globular or columnar and many-angled, or flattened and jointed, usually with prickles. Flowers solitary, sessile; the sepuls and petals nunerous, imbricated in several rows, the bases adlerent to the 1-celled orary. - Stamens numerous, with long and slender filaments, inserted on the inside of the tuhe or eup formed by the union of the sepals and petals. Style 1 ; stigmas numerous. Frut a 1-eelled berry, with numerous campylotropous seeds on several parietal placenta.

1. Mamillaria. Globose or oral plants, covered witl spine-hearing tubercles. Flowers from between the tulbereles. Ovary maked, leerry sueculent.

2. Opuntia. Branching or jointed plints, the joints flattened or cylindrieal. 


\section{M A MILLÀ RIA. Haw.}

Flowers about as long as wide, the tube campanulate or funnel-slaped. Ovary often hidden between the bases of the tubercles, naked, the succulent berry exserted. Seeds yellowish-brown to black, crustaceous. - Glohose or oval plants, covered with spine-hearing cylindrical, oval, or conical tubercles, the flowers from distinct woolly or bristly areoles at theit base. (Name from mamilla, a nipple, referring to the tubercles.)

1. M. vivípara, Haw, Simple or cespitose, $1-5$ ' high, the almost terete tubercles bearing bundles of $5-8$ reddish-brown spinus (10" long or less), surrounded by 15 - 20 grayish ones in a single series, all straight and very rigid; fowers purple, with lance-subulate petals and fuinged sepals; berry oval, green; seeds pitted, light brown. - Plains, l)akotas to kan., anc westward.

2. M. Missouriénsis, Sweet. Smiller. slobose, with fewer $(10-20)$ weaker ash-colored spines; flowers yellow, I-2' liroarl: berry subghobose, scarlet; seeds few, black, pitted. (11. Nuttallii, Enyflm.) - S. Lak. to central Kan., Tex, and westward.

\section{OPÚNTIA, Tonm. Prickix Prar. Ixindx Fig.}

Sepals and petals not united into a prolonged tube, sprealing, regular, the imner roundish. Berry often prickly. Seeds fat and inargined, covered with a white bony arillus. Embryo coiled aroumb albumen; cotyledons large, foliaceous in germination. - Stem composed of joints (Hattened in ons), learing rery snall awl-shaped and usually decidnoms lenves arranged in a spiral order, with clusters of barbed bristles and often spmes also in their axils. Flowers in onr species yellow, opening in sumshine for more than one lay. ( 1 name of Theoplurastus, originally belonging to smuce lifferent plant.)

$$
\text { * Spines small or none: fimit pulpy. }
$$

1. O. vulgàris, Nill. P'rostrate or spreadiug, light green; joints broadly

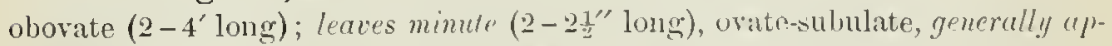
pressed; bristles short, greenish yellow, rarely with a few small spines; flower: pale yellow (nbont 2' broud), with chout \& yetals; fruit I' long. - Sandy fields and liry rocks, Nantucket to $\rightarrow$. C., near the coast; Falls of the P'otomac.

2. O. Rafinésquii, Encrelm. l'rostrate, deep green: joints broally olo. vate or orbicular $\left(3-5^{\prime}\right.$ long $)$; leal's $\left(3-4^{\prime \prime}\right.$ long $)$, spreading; loristles bright red-brown, with a few small spines and a single strong one $\left(9-12^{\prime \prime}\right.$ long) or none; flowers yellow $\left(2 \frac{1}{2}-3 \frac{1^{\prime}}{2}\right.$ Inored $)$, sometimes whle a reddish centre; petals 10-12; fruit $1 \frac{1}{3}^{\prime} \operatorname{loug}$, with an attematerl hase. - Sterile soil, Nantucket ancl sontlwward along the coast to Fla., and in the Mississippi valley, from Mieh. to Minn., and soutlı to Ky, and Ark.

$$
\text { * * Tery spuny, fiult diy and prickly. }
$$

3. O. Missouriénsis, DC. I'rostrate, jounts light green, broadly oborote, flat and tulerculate $\left(2-6\right.$ ' long), leaves small (1 $1 \frac{1}{2}-2^{\prime \prime}$ long) ; therr arils

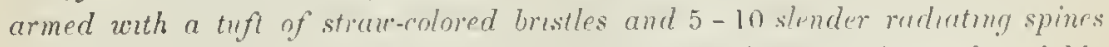
$\left(1-2^{\prime}\right.$ long); flowers light yellow $\left(2-3^{\prime}\right.$ broal $)$, fruit with spines of variable length. - Wise. to Mo, westward aeross the plains very variable.

4. O. frágilis, Haw. Sublecumbent; jomls small (I -2' long or less), ovate, compressed or tumid, or "en terete; leaves harlly I" long, red ; bristles" 
few, larger spines 1-4, wnciul", with 4-6 smaller white radiating ones below; flowers yellow - Minn. to Iowa and Kan., and westward.

\section{ORDER t7. FICOÍDEA.}

A miseellaneous group, chiefly of fleshy or succulent plants, with mostly opposite leares and no stipules. Differing from Caryophyllacex and l'ortulacaceæ by having the ovary and capsule 2-screral-eelled, and the stamens and petals sometimes numerous. at: in Cactaeca (but the latter wanting in most of the gencria), sterls, as in all these orders, witl the slender embryo enred about mealy albumen. Onr genera are apetalous and with the ealyx free from the oviry.

1. Sesuvium. Calyx-lobes 5, petaluid. Stunens j-60. Capsule circunscissile. Succulent.

2. Mollugo. Sejals 5. Stamens 3 or 5. Capsule 3-valved. Not succulent.

1. SES U V I U M, L. St:A P'LnSLAXE.

Calyx 5-partel, purplish inside, persistent, free. l'etals nune. Stameus 560, inserted on the (alyx. Styles 3-5, separate. Pool 3-5-celled, many-secded, circumscissile, the upher palt falling off as a licl. - LEmally prostrate maritime herbs, with succulent stems, "lposite leaves, and axillary or teminal flowers. (Ail unexplained name.)

1. S. pentándrum, lill. Anmul, procumbent or sonetimes erect; leaves oblong- to olwrate-spatulate, obtuse; flowers sessile; stamens $5 . \quad$ (S. Portulacastrum, (imy, Manual, not $L$.) - Sea-coast, N. J. to lila.

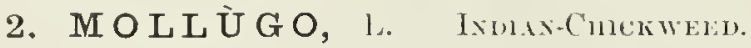

Sepals 5 , white inside. Stanems lyyogynous, 5 and alternate with the sepals, or 3 and alternate with the 3 eells of the orary. Stignas 3 . Capsule 3-celled. 3-valved, loculicifal, the partitions lneaking awa" fom the many-seeded axis. - Low homely annuals, much lnancherl; the stipules uhsolete. (Anuld Latin name for some suft plinit.)

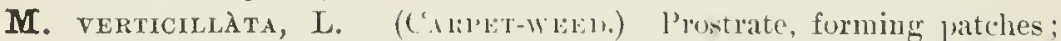
leaves spatulate, chusteren in whirk at the joints, where the l-flowered pedicels form a sort of sessile umbel; stane ns usually 3. - Sambly river-banks, and cultivated gromuls. June-sept. (.In innugrint form farther soutl.)

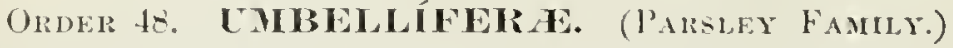

Herbs, with small flowers in umbels (or rardy in heads), the calyx entirely alhering to the 2-celled and 2-owuted ocury, the 5 petals and 5 stamens inserted on the dist that crouns the mory and surrounds the base of the: styles. Fruit consisting of 2 sert-like hy carpels. Limb of the calyx obsolete, or a mere 5-toothed horler. P'etals either imbricated in the bud or valvate with the point intlexed. 'l'he two rarjels (called mericurps) colering by their inner face (the commissure), when ripe separating from each other and usually suspended from the summit of a slender prolongation of the axis (carpophore); each carpel marked lengthwise with $\bar{y}$ wimary rils, and often with $t$ intermediate (secondary) ones; in the inter- 
stices or intervals between then are commonly lomgal the oil-tubes (icilu). whieh are longitudinal ranals in the substance of the fruit, eontainingr aromatie oil. (These are best seen in slices madr ackoss the fruit.) Seed suspended from the summit of the rell, anatrolous. with a minute embryo in hard albumen. - Stems usnally hollow. Leaves alternate, mostly eoupound, the petioles expranled or sheathing at base; rarely with true stipules. Lmbels usually componud, in which ease the seeondary ones are termed umbelles: the whorl of hacts which often subtends the gen"ral umbel is the imrolucre, and those of the nubellets the involueds. 'The base of the styles is fropuently thickenerl and cushion-like, and ralled the stylopodium. In many the flowers ane dirhoyamous, i. e. the styles are protruded from the bud some time before the anthers develop, - au arrangement for cross-fertilization. - A large family, some of the plants innocent and aromatie, otlers with rery poisonous (acrid-narcotic) proplertics. The flowers are much alike in all, and the fruits, inflorescenee, etc., likewise exhihit comparatively snall diversity. The family is con. sequently diflieult for the young stmdent.

1. Finit with the secondary ribs the most prouninent, wiuged and armed with larbed or hooked prickles, the primary ribs filiform and hristly.

1. Ditucus. C'alyx-teeth nosolete. Frnit Hattened dolsally. Serb-fared liat.

2. Caucalis. Calyx-tecth prominent. Funt flattened laterally. Seed-fite dueply sulcate.

11. Fruit with primary ribs only (hence but 3 rlursil ones on each carpel).

* Fruit strongly flattened lorsally, with the lateral riłs prominently winged.

- Caulescent branching plants, witl white flowers.

+. Lateral wings distinct; oil-tuhes usually nuore than whe in the intervals.

3. Angelica. Stylopodium mostly depressed, lut the lisk proninent and crenulate Dorsal ribs strong. Stout pereunials, with mostly coursely divilnd leaves.

4 Conioselinum. Stylopodium slightly conical. Dorsal ribs lmoninent. Tall salender grlabons perennial; leaves thin, finely pimately compound.

+. +- Lateral wings closely eontigunus; cil-tulus sulitayy ; stylogodiun thiek-conical.

5. Tiedenamua. Dorsal ribs apparently 5, filiforu. Kmonth swamp herbs witl leaves f(w or retlued to hollow eylindrical lretioles.

(i. Heracleum. Dorsal ribs tiliform, the broad wings with a manginal nerve. Oil-tubes obelavate. Petals conspipunus. Till stout perennials, with large leaves.

- Caulescent branching plants, witl repressed styolonlium and yellow flowers.

7 Pastinaca. Fruit with filiform rorsal ribs, thin wings, and solitary oil-tnbes.

¿. I'olytaenia. Fruit with a thiek corky marim, oliscure lousal ribs, and rery mumer. ulls oil-tubes.

- + - Acaulescent or nearly so, with filiform rlorsal ribs, thin wings, and no stylnpolium.

!). Peneedanum. Flnwers white or yellow. Lnw western plants, of dry groumd, with thick roots and finely lissected leaves.

* Frnit not flattened either way or but slightly. neither prickly nor sealy.

- Ribs all conspieuously winged; stylopodiutu depressed or wanting

it. Cymopterus. Low and glabrous, mostly cespitose prerennials, witlı pinnately eamjound leaves and white flowers. Oil-tubes 1 to severil. Westerll.

11 Thawpum. Tall perennials, with ternately disilenl or simple leaves, and yellow thow. ers (rimely purple). Oil-tuhus sulitary. 
+ + Ribs all prominent and equal but not winged; flowers white.

12. Ligusticum. Ribs acute, with broad intervals. Stylopodium conical. Oil-tubes nue merous. Smooth perennials, with large compound leaves.

13. AEthusa. Rils very broad aud corky, arute. Stylopodiun depressed. Oil-tubes solitary. Introlucen annual.

14. Colopleurum. Rilos thick, corky (mostly obtuse). Oil-tubes solitary, adherent to the seed, which is loose in the perieary. Stout glabrous sea-const perennial.

+++ Dorsal ribs filiform, the lateral very thick and corky; oil-tubes solitary.

15. Crantzia. Small glabrous erecling perenniuls, rooting in the mud, with snall simple umbels and leaves reducer to hollow cylindrical jointed petioles.

*** Fruit flattenerl laterally.

- Carpels de'pressed dorsally ; fruit short.

+- Seed-fare flit : flowers mostly yellow.

16. Fonienlum. Ribs prominent. Oil-tubes solitary. Stont aromatic herb, with filiforndissected leaves

17. Pimpinella. Rihs tiliform. Gil-táacs numerous. Glabrous perennials, with conlound leaves.

t+ t- Seed-fum concave; flowers white (yellow in n. 20); ribs filiform or obsolete.

1. Eulophus. Oil-tules numerous. Stylopodiun conical. Glabrous perennials from fascieled trbers, witn pinnately compound leaves.

39. Anthriscas. Fruit litear, long-beaked, without rils ur nil-tubes, and with conical stylopodium. Leaves ternately lecomponnd.

20. Bupleurum. Fruit ollong, with slender ribs, no nil-tubes, and lrominent flat stylopodimn. Leaves simple, perfoliate.

+ + Carlels tercte or slightly flatteued laterally: flowers white (except n. 24).

++ Seerl-fice flat (or somewhat concave in n. 28) : fruit short.

= Leaves 3 -foliolate : stylopodiun conieal; oil-tuhes solitary.

21. Cryptotrenia. Rils obtuse, exual : fruit linear-oblong.

$==$ Leares once pinnate; stylopolium depressed; oil-tnbes numerous. Aquatic perennials.

22. Sium. Fruit ovate to oblong ribs prouninent, corky, nearly equal.

2:?. Berula. Fruit nearly glohose; ribs inconspicuous; pericarp thick and corky.

$===$ Leares rlecomlound. Oil-tubes solitary (none in n. 25 ). Perennials.

24. Zizia. Ribs filiform; stylopodium none. Flowers yellow.

25. Carum. Rilus filiform or inconspienens; stylopodiun short-conical. Leaf-segments filiform. Roots tuberous.

24. Cicuta. Rils flittisli, corky, the lateral largest. Marsh perennials, witl serrate leaflets, the veins often rumning to the notches.

27. Acgopodium. 12ils fliforn; nil-tubes none; stylopodimm ennical. Leares bitemate. $====$ Leaves linely dissecterl; nil-tubes solitary. Very slender anumals.

2S. Ceptocaulis. Fruit bristly or tubcrulute, with rather proninent equal ribs.

23. Discopleura. Thorsal ribs filiform, the literal very thick and corky.

+* ++ Seed-face concave; fruit ovate, glabrous, with depressed stylopodium, and no oil-tubes.

30. Conium. An introluced biennial, with spotted stems, and large decompond leaves. $++\rightarrow$ Seerl-fuc encave. Fruit linear-oblong, with conical stylopodium.

31. Chaerophylnum. Fruit gliabrous, with small mostly solitary oil-tubes.

32. Osmorrhiza. Funt loristly, with oil-tubes obsolete. +++ Carpels (as woll as fruit) strongly flattencal laterally.

+ Seerl lunate, rleeply sulcatc ou the face: unbels compound, leafy-bractcul.

83. Frigenia. Fruit nearly orbicular, with numerous oil-tubes, Low, nearly acaulescent from a decp-sented tuber. Leaves ternatoly decomponnd. 
+++ Seed straight, not sulcate; $11 m b e=1$ simple.

34. Hydrocotyle. Fruit more or less orbieular, with nu oil-tubes, Low perennials, in $n$ near water, with creeping stems, and peltate or reniforn lenves.

* * * Fruit obovoid or globose, densely prickly or scaly.

35. Eryugium. Flowers sessile in dense bracteate heads, white or blue I.eaves mostly rigid and more or less spinose.

Sanicula. Flowers in irregularly compunnd few-rayed umbels, yellow, Leaves palmate.

\section{D A Ù C US, Tomm. Carrot.}

Calyr-teetl obsolete.

Fruit oblong, flattenerl dorsally; stylopodium depressed; carpel with 5 slenuler bristly primary ribs and 4 wingel secondary ones, each of the latter bearing a single row of barbed prickles; oil-tubes solitary under the secondaly ribs, two on the commiswuml side; seed-face somewhat concave or almost flat. - Bristly anmals or hienuials, with pinnately decompound leaves, foliaceons aud cleft involucral bracts, and white flowers in compound umbels which become strongly concave. ('The ancient Greek name.)

D. CAkót, I. Biennial ; stem lristly ; ultinate leaf-segments lauceolate and cuspidate; rays numerons. - Naturalized ererywlere, from Lu.

\section{CA U CALIS, L.}

Calyx-teeth prominent. Fruit orate or sblong, flattened laterally; styloporliuin conical; prickles barlued or hooked ; seerl-face deeply sulcate. (1therwise as Dancus. - Our species annul. (The ancient Greek name.)

C. xonosi, Hudion. Decumbent, hranching ouly at base, stems $1-2^{\circ}$ long, retrorsely hispid ; umbels naked, opposite the leaves and nearly sessile, of 2 or 3 very short rays. - Md., Iowa, and southward. (Nat. from Lu.)

C. Astunfseus, Indson, has 1-2-pinmate leaves with broad leaflets, and more regularly compounded umbels. - ()hio, etc. (Nat. from En.)

\section{A N G E LICA, L.}

Calyx-teeth obsolete. Fruit strongly flattened dorsally; prinary ribs rery prominent, the laterals extended into broad distinct wings, forming a doublewinged margin to the fruit; ril-tubes one to several in the intervals or indefinite, 2 to 10 on the connmissure. - Stont perennials, with temately or pinnately componud leaves, large terminal muleks, scanty or no involucres, small manyleaved involucels, and white or greenisls flowers. (Named angelir from its cordial and medicinal properties.)

* Seed adherent to the pericury: ait-tubes ome to several in the interculs; uppermost leares mostly iedured to largr inflated petioles.

1. A. Curtísii, Buckley. Glalirous ; leaves twice ternate or the divisions quinate; leaflets thin, orate-lanceolate ( $1-3^{\prime}$ brond), sharply and irregularly tonthed: fruit glabous, $1 \frac{1}{2}-3^{\prime \prime}$ broal ; oil-tulses mostly one in the intervals (sometimes 2 or 3). - Nlong the Alleghanies from Pemn. to N. C. Ang.

2. A. hirsuta, Mulll. Pubesemt above: leaves twice pimately or ternately divided; lenflets thirkish, limeeolate to oblong (5-10" uroud), serrate: fruit pubscent, $2^{\prime \prime}$ broad; vil-tubes $3-6$ in the intervals. (Archangelica hirsuta, Torr. \& Gruy.) - Dry ground, Coun. to Mimm., Tenu., aud Fla. July. * Seed loose; oiltubes indefinite (25-30); upper petioles not so prominent.

3. A. atropurpùrea, I. Very stont, glabrous throughout, with dark purple stem; leares 2-3-teruately divided, the pinnate segurnts of $5-7$ lan- 
ceolate to ovate leaflets ( $1-1 \frac{1^{\prime}}{2}$ broad), slarply mucronate-serrate. (Archangrelica atropurpurea. Hoffin.) - River-banks, Lah. to I)(l., Ill. and Minn. Jnne.

\section{CONIOSELIN U M, Fiscli. IIEMLOCK-PARSLET.}

Calyx-teeth obsolete. Stylopodium slightly conical. Fruit oral, Hattened dorsally, glabrous, the dursal ribs very prominent, the lateral ones extended into broad wings; oil-tubes $1-4$ in the intervals, $4-8$ on the commissure; seed slightly concave on the inner face. - Tall stender glabrous peremnial, with finely 2-3-pinuately compound leaves, few-leaved involucre or none, inrolueels of elongated linear-setaceons bractlets, and white flowers. (Conpounded of (onium and Selinum, from its resemblance to these genera.)

1. C. Canadénse, Torr. \& Gray. Leatlets pinnatitil; wings ne:urly as broad as the seed; oil-tubes $2-3$ in the interrals, sometimes 1 or 4 . - Swamps and cold cliffs, from Maine to Minu., southward to N. C. (in the higher mountains), Ind., Ill., and Mo. Aug.- Oet.

\section{TIEDEMÁ N N I A, I)C.}

Calyx-teeth frident. Fruit wrate to obovate, flattened dorsally ; dorsal ribs filiform, the lateral broully winged, clusely entiguons and strongly nerved next to the body (giving the appearanee of 5 dorsal ribs); oil-tubes solitary in the intervals, 2-6 on the commissnre; stylopolimm short, thiek-enical. Glahmens erect aquatic lerels, with leaves reduced to petioles or of few narrow leaflets; involncre : 11 l involucels present, and flowers white. (Dedicated to the anatomist $P_{i} \cdot y^{\circ}$. Tiedemunn, of Ileidelberg.)

1. T. teretifòlia, DC. Stem hollow, 2-6 high ; leuves redured to cylindricul hollow pointed noduse pefioles; oil-tubes filling the intervals. - Ponds and swamps, Dul. to Fla., and west to La. Aug., Seput.

2. T. rígida, Coult. \& Rose. (Cowlixi.) Stem 2-5o high; leaves simply pimute, with 3-9 linear to lanceolate entire ar remotely toothed leaflets; oil-tubes mostly smalt. (Archenora rigila, $D($.) - Swanes, N. Y. to Minn., south to the Cinlf. Aug. Puisonous: roots tuheriferous.

\section{HER A C LE U M, I. Cow-PARs}

Calyx-teeth minute. Firut broully oval or obovate, like Pastinaca, but with a thick conieal styloporlium, and the conspicuous olyclavate oil-tubes extending scareely below the midrlle. - Tall stunt peremial, witl large ternately conpound leaves, hroal mmbels, deciduons involucre, and many-leaved involucels, white flowers, and obeorlate petals, the onter ones eommonly larger and 2-cleft. (Dedicaterl to Mrerrules.)

1. H. lanàtum, Michx. Woolly; stem grooved, 4-80 high ; leatlet. broad, irregularly "ut-toothed. - Writ ground, Newf. to the Parific, and southward to N. C., Kị., andi lian. June.

\section{PASTINÀ CA, I. PARSKIP.}

Calyx-teeth obsolete. Fruit oval, very mucl flattened dorsally; dorsal ribs filiform, the lateral extenchl into lirond wings, which are strongly nerved toward the outer margin; oil-tubes small, solitary in the intervals. $2-4$ on the comnissure; stylnpulium dropessed. - Tall stout glabrons biemial. with pin- 
nately compound leares, mostly no involucre or involucels, and yellow thowers. (The Latin name, froul pastus, food.)

P. sxiri, L. Stem groored; leaflets ovate to oblong, cut-toothed.Introdueed everywhere. (itrv. from Lu.)

\section{POLYT 祖N I A , DC.}

Caly-teeth conspicuous. Fruit obovate to oval, much flattened dorsally; clorsal ribs small or obseure in the depresied back, the lateral with broad thick ("orky elosely contignons wings forming the margin of the fruit; oil-tubes $12-18$ about the sced and many scattered though the thick conky pericarp. A peremial mostly glathous herb, with 2-pinnate leaves (upper opposite and 3-cleft), the segments cuneate and incised, no involucre, narrow involncels, and b)ight yellow Hower's in May. (Named from moגús, mony, and raıvía, a fillet, alluling to the nuncrous oil-tules.)

1. P. Nuttàllii, DC. ['lant $2-3^{\circ}$ high ; perlicels anl invohcels probescent. - Barens, Mich. to N. Ala, west to the lively Mts.

\section{PEUCÉDANUM, L.}

Calyx-treth nustly obsolete. Frnit roumlish to ohlung, much flattened dorsally; lorsil ribs filiform and approxinate; the lateral extended into broad closely (c)herent wings; wil-tubes $1-4$ in the intervals, $2-6$ on the commissur - Dry ground acaulescent (or short canlescent) herds, with fusiform roots, lisisected leaves, no involucre, yellow or white fowers, and stylopodium depressed or wanting. (The aneient Greek name.)

1. P. nudicaùle, Nutt. P'ubeseent, with ledunc] les $3-8^{\prime}$ high ; leates

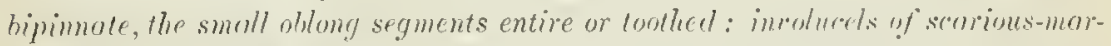

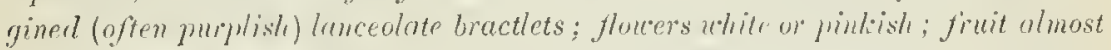
mound, emarginate al base, g/oluous, with wings landly as hroal as the body,

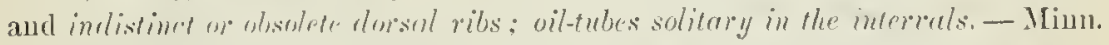
to Iow: and han., and westward. (Ine of the earliest spring bloomers.

2. P. fœniculàceum, Nutt. 'Tonentose or glalbrons, with perluncles 8-12' lung; leares jimly disserted, with short filiform seyments: incolucels

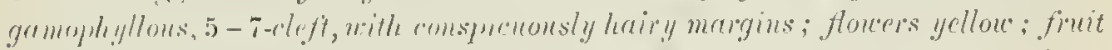
broully whony. glenluous, with wings half as hroad as the borly, and prominent dorsel ribs; oil-tubes $1-3$ in the intrenls. - Minn. to 'Tex. Mareh- $A$ pril.

3. P. villosum, Nutt. More or less puhescent throughout, 3-8' high;

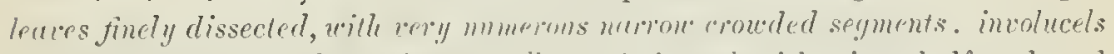
of orate to linear bractlets; flowers ywllowe: finit orol, with wings half as broad its the borly, and mominent dorsal ribs; oil-tubes 3 or 4 in the interrals. - Minn. to Neb. and the Dakotas, southwestward to Ariz. Root mueh elongated.

\section{CYMÓPTERUS, liaf.}

(alyx-teetl more a less proninent. Fruit usually globose, with all the ribs conspicuonsly winged; ail-tuhes one to several in the intervals, $2-8$ on the commissure. Stylopodimm dropessed. Seed-face slightly coneave. Mostlr low (often cespitose) glahrous perennials, from a thick elongated root, with more or less pinnately compouncl leaves, with or without an involucre, prominent involncels, and white fiowers (in ours). (From $\kappa \hat{v} \mu \alpha$, a wave, and

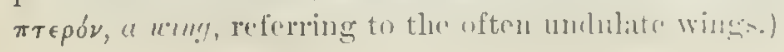


1. C. glomeràtus, Raf. Low $\left(3-8^{\prime}\right)$, with a short erect caudex bearing leaves and peduncles at the summit, glabrous; rays and pedicels very short, making a compuct cluster; incolucre none; involucel of a single palmately 5-7parted uratlet; fruit globose (3-4" in diam.); wings rather corky; oil-tules 4 or 5 in the intercals. - Minn, and Wisc. to Iowa and Ark., and westward.

2. C. montànus, Torr. \& Gray. Of similar labit $\left(1-6^{\prime}\right.$ high), glaucous and mostly glabrous; reys $3-9^{\prime \prime}$ long, pedicels very slort; imeoluree and ineo lucels of mostly broad membranaceous usually green-leined bructs (more or less united); fruit oblong to orbicnlar in outline $(3-6$ " loug); wings thin; oittubes $1-3$ in the intercals. - Neb, to central kin., T'ex., and westwarl. A pril.

\section{TH Á SPIU M, Nutt. MenmW-Parivil.}

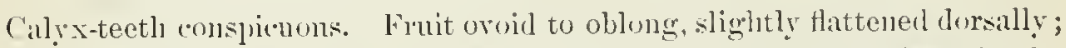
rarpel with 3 or 4 or all the ribs strongly wingerl; vil-tubes solitary in the intervals, 2 on the commissure. Sitylupodium wanting; styles long. - Perennials (2-50 high), with ternatuly divided leares (or the lower simple) and broad serrate or toothed leaflets, mostly yellow flowers, and all the fruit pedicelled. (Name al play upon Thapsia, so callerl l'um the island of Thapsus.)

1. T. aùreum, Xntt. Cilubrous; root-lectes mosily rurdute, serrate; stemleaves simply teructe (rareị biternate); leaflets wate to lanceolate, round or tapering at hase, serrate; Howers deen yellow: [ruit globose-owoid, alont $2^{\prime \prime}$ long, wll the ribs equally winged.- 'Thickets and woullands, throughont the Atlantic States and west into the Mliss. Valley. Fl. iu sumuer and nuaturing fruit in late smmmer or antnmn. Very rariable, an extreme form being

Var. trifoliàtum, Conlt. \& Rose. Leaves or leaflets crenate or crenately tonthed. (T. trifoliatum, Gircy, Mam., in part.) - ohio to Ill., westward to Oregon. 'Flie common w"ester'u form.

Var. atropurpùreum, Coult. \& liose. l'otals diuk-purple. ('I. trifoliatum, var. atropurpureum, (ivy, Mau.) - Same range as the species.

2. T. barbinode, Nutt. Irosely branched, puluscent on the joints, sometimes puberulent in the umbels; lanes 1 -3-ternate: leaftets otate lo lancedate, acute, witl cumeate hase, cuarsely cut-sermate, often teruately cleft or parted; flowers light yellow; fruit broally obloug, abont :3" long and 2" broal, with mostly 7 prominent uings. - Banks of streams, N. Y. to Mimn., and soutloward.

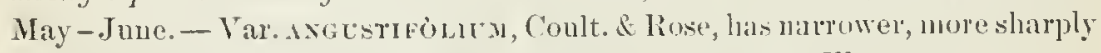
cit leaflets, aud fruit more or less puberulent. - l'eun. to 111.

3. T. pinnatifidum, (isay, Resembling the last, but pubrelent on the

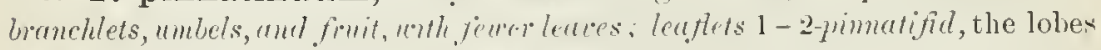
linear or oblong ; one or two leaves nea the base often reery large and long-

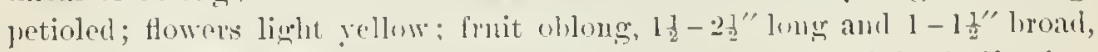
all the ribs unged, generally three of them narrowly so. (T. Walteri, shutteu.

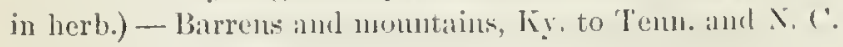

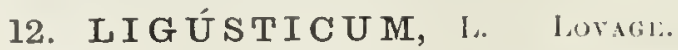

Cilyx-teeth obsolete. Fruit oblong or ovate, flattened laterally if at all, glabrous; carpels with prominent equal acnte rils and broad intervals; oiltubes 2-6 in the intervals, $6-10$ on the commissure. Styloporlium conical.

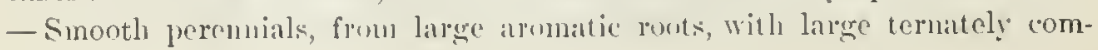


pound leaves, mostly no involucre, involucels of narrow bractlets, and white flowers in large many-rayed nmbels. (Named from the eountry Liguria, where the officinal Lorage of the gardens abounds.)

1. L. actæifolium, Michx. (Noxdo. Axaklico.) Sitem stout, branehed above $\left(2-6^{\circ}\right.$ high $)$; leaves very large, 3-4-termate; lenflets broully oblony (25 long), coarsely serrate: fruit orate $\left(2-3^{\prime \prime}\right.$ long) ; seed with angled back. Rieh ground, s. Penu, to Ky, sonthward to the Gulf.

2. L. Scóticum, L. (Ścotcr Lorage.) Stem simple (1-2o high); leaves biternate: leuflots orate $(1-2$ ' long), coarsely toothed: fiuit nurrouly oblong $(4-5$ "long); seed with roumd back. - Salt marshes, along the coast from E Conn. northwarl. Aug. (En.)

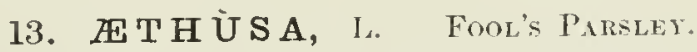

Calyx-teeth obsolete. Fruit ovate-globose, slightly flattened dorsally ; earpel with 5 thick sharp ribs; wil-tubes solitary in the intervals, 2 on the commissure. - Poisonous ammals, with 2 -3-termately componnd leaves, divisions pinmate, ultimate segments small and many cleft, 110 involncre, long narrow involucels, and white flowers. (Name from at $\theta \omega$, to bum, from the acrid taste.)

无. Crxapum, L. $\Lambda$ fetid, poisonous European herb, in cultivated grounds, from $N$. Eng. and I'enn. to Minn. June-Ang.

\section{C CELOPLE U R U M, Ledeb.}

Calyx-teeth obsolete. Fruit globose to oblong, with very prominent nearly equal thiek corky rilss (none of them winged); oil-tubes solitary in the intervals and minder the ribs, 2 on the commissure. Seed loose in the periearp. - Stont glalirons (or inflorescence puberulent) sea-const perennial, with $2-3$-ternate leaves on very large inflated petioles, few-leaved leciluous involucre, involucels of numerons small linear-lanceolate hractlets (rarely conspicuous or even leaf-like), and greenish-white flowers in many-1ayed mmbels. (From roîsos, hollow, and $\pi \lambda \epsilon u \rho o ́ v, a$ rib.)

1. C. Gmélini, Ledeb. Stem $1-3^{\circ}$ high ; leaflets ovate, irregularly cutserrate $\left(2-2 \frac{1}{2}^{\prime} \operatorname{long}\right)$; fruit $2-3 \frac{1}{2}^{\prime \prime}$ long. (Arehangelica Gmelini, DC.) Rocky eoasts, Mass, to Greenland.

\section{CRÁ NTZIA, Nutt.}

Calyx-teeth small. Fruit globose or slightly flattened laterally; dorsal ribs filiform, the lateral thick and corky; nil-tubes solitary in the intervals, 2 on the commissure. - Small perenuials, crepping and rooting in the mud, with hollow cylindrical or awl-shaped nodose petioles in place of leaves, simple fewHowered umlels, and white flowers. (Named for Prof. Henry John Crantz, an Austrian lotanist of the 18 th centnry.)

1. C. lineàta, Nutt. I eaves very obtuse, 1-3' long, 1-2" broad; fruit I" long, the thick lateral wings forming a corky margin. - In brackish marshes along the coast, from Mass. to Miss. July. Very wilely distributed.

\section{FENÍCULU M, A daus. Fexxis,}

Calyx-teeth obsolete. Frnit oblong, glabrous, with proninent rils ancl solitary vil-tuhes. - Stout glabrous aromatic herh, with lesves rlissected into 
numerons filiform segments, no involucre nor involucels, and latrge umbels of yellow flowers. (The Latin name, from fomum, luay.)

F. Officinale, All, the entivated fennel from Lurope, has berome naturalized along the shores of Md. and Va., and is a commun escape.

\section{P I M P I N ÉLLA, I.}

Calyx-tecth obsolete. Fruit oblong to wate, glalsun, with slender equal ribs, numerous oil-tubes, and lepressed or cushion-like stylopolinm. - Glabrots jerennials, witl ternately ol pimately componme leaves, involucre and involucels scanty or none, and white ar yellow flowers. (Name sairl to be formed from bipinnula, refering to the bipinnate leaves.)

1. P. integérrima, Benth. \& IIouk. Glancous, 1-3 high, slender, hranching; leaves 2 -3-ternate, witl lineeslate to wate entire leaflets; Howers yellow; fruit broadly oblong, 2" long; stylopolium sunall on wanting. (Zixia integerrina, $D($ ) - Rocky hillsides, Atlantic States to Mim., L. Kan, and Ark. May.

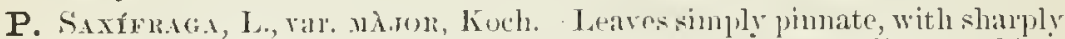
toothed leaflets; Howers white; frnit oblong, l" long; styopodiun cuslionlike. - Roeky shores of Delaware River; Sycanore, ( hio. (Nat. from Fu.)

\section{EÙ̃ O PHUS, Nutt.}

Calyx-teeth prominent. Frnit ovate or obloug, shlaln'ous, with equal filiform ribs; oil-tubes $1-5$ in the intervals; styloporimu conical, with long recurved styles; seerl-face hroally coneare, with a central longiturinal ridge. - Glatbrous perennials ( $3-50$ high) from deep-seated fascicled tuhers, with pinnately or ternately compoum leaver, involucels of numerons narmwly lanceolate acuminate bractlets, and long-poelnueled mulels of white flowers. (Nanne from

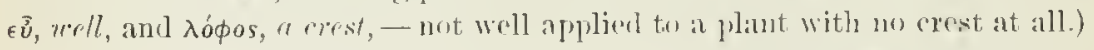

1. E. Americànus, Nutt. Rallical and lower stentures large, 1 - 2. pimnately couproud, witl leatlets cut into short nal'uw segments; upper stem. leaves termate, with narrowly linear elongater leaflots; fruit $2-3^{\prime \prime}$ long. ()hio to 11l, aml Mu., south tol Tenn. and Ark. July.

\section{A N T H R ÍS US, Hoffm. C'HERTI.,}

Galyx-teeth obsulete. Fruit lincar, untcherl at hase, hong-heaker, grablous,

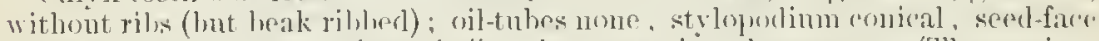

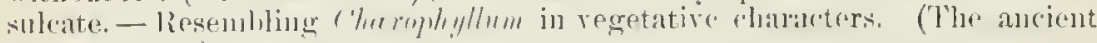
Vioman name.)

A. Corskobus, lloffm. Mature fruit smooth and shining, (Charo phyllum sativum, L..) - Naturalized in F. Penn. (l'rom liu.)

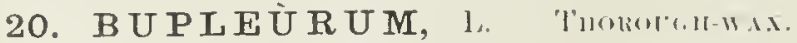

('alyx-teeth olsolete. Fruit obloner, with rery slender rilss, no oil-tules, defuressed styloporlium, ind seed-face somewhat coucave. - Sumoth aunual, with wate perfoliate entipe leaves, no involucre, involucels of 5 very eonspienous wate mucronate liactlets, and yellow flowers. (Name from Boùs, an ox, and $\pi \lambda \epsilon$ éóv, a rib.)

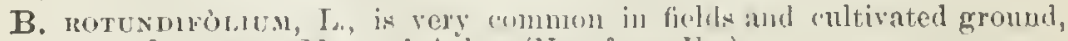
N. Y. to N. C, west to Mo. and $\Lambda$ rk. (Xit. from Jin.) 


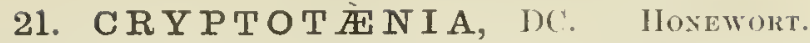

Calyx-teetlı obsolete. Fruit linear-obloug, glabrous, with obtuse equal rihs: oil-tubes solitary in the intervals and beneath each rib; stylopodium slenderconical; seed-face plane. $-\Lambda$ glalbrous perennial, with thin 3 -foliolate leaves, no involucre, involucels of minute bractlets or none, and white flowers. (Name

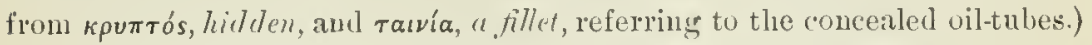

1. C. Canadénsis, I)C. Plant $1-3^{\circ}$ high; lenflets large, ovate $\left(2-4^{\prime}\right.$ longr), pointed, doubly serrate, often lobed; umbels irregular and unequally few-rayed; pedicels very une(ual ; fruit $2-3$ " long, often becoming curved. N. Brunswick to Ga., West to Mimn, E. Iian, and Tex. June-Sept.

\section{SIU IM, Tomm. WATER PARsil.}

Calyx-teeth minute. Fruit wate to ohlong, glabrous, with prominent conky nearly equal ribs; oil-tubes $1-3$ in the intervals; styloporlium depressed; seed-face plane. - Sunotl perennials, growiıg in water or wet places, with pinuate leaves and serrate or pinnatifid leaflets, involucre and involucels of mnmerous narrow linicts, and white flowers. (From oiov, the Greek name of some marsll plant.)

1. S. cicutæfolium, Gmelin. Sitout, 2-6 ligh; leaflets $3-8$ pairs, linear to lanceolate, shar'ply serrate ant mostly acuminate, $2-5$ long (lower leaves sometimes submersed and finely dissected, as in the next); frut $1 \frac{1}{2}$ long, with prominent ribs. (S. linene, Michx.) - Thuroughont $\mathrm{N}$. America.

2. S. Carsonii, Duraul. Weuk, 1-20 high; leaflets $1-3$ luirs, linear, s!larply serrate, 1 - 2'long; when suburised or floating, verg thin, orate to oblong, usually laciniutrly toothed or dissecterl, the leaf sometimes rechncel to the terminal leaflet; fimit about l" long. - Nass., R. 1., Comn, and Penn.

\section{B ÉRU L A, líoch.}

('alyx-teeth minute. Fruit nearly romnd, emarginate at base, glabrous; "allels nearly globuse, with very slenler incouspicnous ribs and thick corky ferienrp; oil-tubes ummerous and contiguons about the seed-rivity; seed terete. - Simootl aquatic peremnial, with simply pinmate lmacs ancl valiously cut leaflets, ustally conspicuons iuvoluce and involucels of narrow hrats, and white flowers. (The Latin name of the Water-cress, of Celtic origin.)

1. B. angustifolia, lincls. Lirect, $\frac{1}{2}-3^{\circ}$ high; loaflets $5-9$ pairs, linear to oblong or orate, ser'iate to ('ut-touthed, often laciniately lobed, sometimes

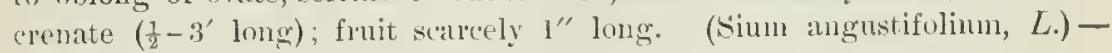
Tluronghont, the L. s. July, Ang.

\section{ZÍZI A, lioch.}

Calyx-teetl prominent. Fruit ovate to oblong, glalorous, with filiform ribs: nil-tubes large aud solitary in the loroal intervals, and a small one in each rib; stylopodium wanting; seed terete. - Smootlı peremials $\left(1-3^{\circ}\right.$ high), with mostly Thaspium-like leaves, nu involucre, involucels of small bractlets, yellow flowers, and the contral frut of each umbellet sessile. Flowering in early spring in open prairies and mplanl meadows. (Named for I. B. Ziz, a Rhen. ish botanist.) 
1. Z. aùrea, Koch. Leares (except the uppermost) 2-3-ternate, the radical very long-petioled; leaflets ovate to lanceolate, shiarply serrate; rays 15 25, stont (1-2' long); fruit oblong, ulout 2" long. (Thaspium aureum, rar. apternm, Gray, Manual.) - Atlantic States, west to Minu. and Tex.

Var. Bébbii, Conlt. \& Ruse. A more slender mountain form, with leaflets more coarsely serrate, the radical leaves smaller and more simple; rays "2 - 8, slender $\left(2-3\right.$ ' loug) ; fruit oval, $1-1 \frac{1}{2} "$ long. - W. Va. and Va. to Ga.

2. Z. cordàta, DC. Radical leaves mostly long-petioled, cordate or even rounder, crenately toothed, very larely lobed or divided; stemtences simply ternate or quinate, with the ovate or lancedate leaflets serrate, incised, or sometimes parted ; fiuit orate, $1 \frac{1}{2}$ " long. (Thaspium trifoliatum, var. apterun, Gray, Manual.) - Same rauge as the precelling, but extendiug farther westward.

\section{C A R U M, L. C.IRW Y.}

Calyx-teeth small. Fruit ovate or ollong, glabrous, with filiform or inconspicuous ribs; oil-tubes solitary; stylopodinm conical ; seed-face plane or nearly so. - Smooth erect slender herbs, with fusiform or tuberons roots, pinnate leaves, involucre and iuvolncels of few to many bracts, and white (or yellowish) flowers. (Name perhajs from the country, Caria.)

C. Cánur, J. (Cıkıway.) Leaves pimately componud, with filiform divisions. - Naturalized in many places, especially northward. (Nat. from En.)

C. Petrosedinum, Benth., the common Pinklex, from Europe, with 3pinnate leaves, orate 3-eleft leaflets, and greenish yellow flowers, is accasionally found as an escaje from cultivation. (Petroselinum sativum, Iloffm.)

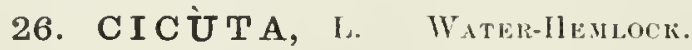

Calyx-teeth prominent. Fruit ollong to nearly orbicular, glabrous, with strong flattish corky ribs (the lateral largest) ; oil-tules conspicuous, solitary"; stylopodinm depresserl; seed nearly terete. - Snooth marsh perenuials, rery poisonons, with pinately compumbl leaves and sernate leaflets, involuere usnally none, involucels of several slender bractets, and white flowers. (The ancient Latin name of the Hemlock.)

1. C. maculàta, I. (Spotten Cowbane. Musquasm Root. BeaverPoison.) Stem stont, 2-6 high, streaked with purple; leaves 2-3-pinnate, the lower on long petioles; leaflets lanceolute to oblong-lanceolate ( $1-5$ ' long), acuminate, coasely serrate, the veins passing to the notches; perlicels in the umbellets mmerons, very unequal; fruit broally orate to oval, $1-1 \frac{1}{2}{ }^{\prime \prime}$ long. - Throngliont the U. S. Aug.

2. C. bulbifera, I. Ruther slender, 1-30 high; leaves 2-3-pinnate (sometimes appearing teruate); leafets linear, sparsely toothed (1-2' long); upper axils bearing clustered bulblets ; fruit (rare) scarcely 1" long. - Common in suanps, N. Scotia to Del, west to Minn. and Iowa.

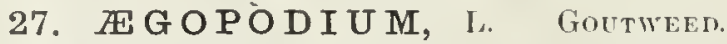

Calyx-teeth obsolete. Fruit ovate, glabrons, with equal filiform ribs, and no oil-tubes; stylopodium conical and prominent; seed nearly terete. - A coarse glabrous jeromial, with "repping rootstock, liternate leaves, sharply toothed ovate leathets, and rather large naked unbels of white Howers. (Nanie from ark, gort, and $\pi \delta \delta_{i o v}$ a litlle foot, probably from the shape of the leatlets.)

FE. Podagnini, I., a conmon and tronblesome weed in Europe, is ro ported from R. I. to Del. and K. l'enn. 


\section{LEPTOCA Ù L S, Nutt.}

Calyx-teeth obsolete. Fruit very suall, wate, usually bristly or tuberculate, with somewhat prominent rilss; oil-tubes solitury in the intervals; styloporlium conical; seed-face plane or somewhat concrve. - Very slender smooth branching annuals, with fincly dissected leaves (serments filiform or linear), and small white flowers in very nnequally few-rayed pechuculate umbels. (Name from $\lambda \in \pi \tau o ́ s$, slender, and kauגós, "t stem.)

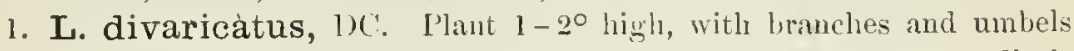
diffusely sprearling, the very slentel rays $\frac{1}{2}-l^{\prime}$ long and the longer pedicels often 3-6" long; fruit tuberculate, g" long. (A pium divaricatum, Benth. of Hook.) - N. C. to Fli.., west to Ark. and 'lex; reported from Kian. April.

2. L. pàtens, Nntt. (If similar haloit, lut the umbls shorter and more strict, the rays $3-6^{\prime \prime} \operatorname{long}$ or less and the pedicels short; fouit densely sharptuberculate or nearly smooth. (A piastrum patens, Conlt. \& Rose.)-Central Neb, to Tex. and N. Mcx.

\section{DISCOPLEÜRA, DC. МOCK BISOP.WEN.}

Calyx-teeth small or obsolete. Fruit ovate, glabrous: carpel with dorsal libs filiform to hroal and olstuse, the lateral very thick and corky, those of the two earpels closely contiguous and forming a lilated obtuse or acute corky hand; oil-tubes snlitary; stylopolim conical; sced nearly terete. - Sinooth branching anmuls, with finely dissected leaves, involuce of foliaceous bracts, involncels of prominent or minnte bractlets, and white flowers. (Name from $\delta i \sigma \kappa o s$, a disk, antl $\pi \lambda \in v \rho o ́ v$, " rił.)

1. D. capillàcea, DC. 1'laut $1-2^{\circ}$ high (or even $5-6^{\circ}$ ) ; leaves dissected into filiform divisions; umbel 5 - 20-rayed ; involucre of filiform bracts usually cleft or pated, and involncels nore or less prominent; fruit 1 - $1 \frac{1}{2}$ " long, orate, a'lite. - Wet gromud, Mass, to Fla., west to I11., Mo., and Tex. June-Oet.

2. D. Nuttallii, DC. Similar in habit; inrolucral bracts short and en.

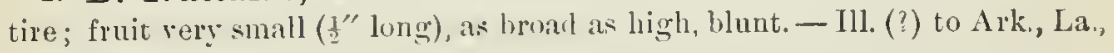
and Tex.

\section{CON İ U M, L. Polsox Ifemlock.}

Calyx-teeth obsolete. Frnit orate, somewhat flattened at the sides, glabrous, with prominent way libs: vil-tnbes none, but a layer of secreting cells next the seed, whose face is dreply and narrowly concave. - l'oisonous bien. nial, with spotted stens, linger decompound leaves with lanceolate pimnatifid leatlets, involucre and involucels of nurrow lnacts, and white flowers. (Kúvelov. the Greek mane of the Ilemlock, by wheh criminals and philosophers were jut to death at Atliens.)

C. Maculátur, I. A large branching kitupean herb, in waste places, N. Eng. to Penn., and west to Iowa and Mim

\section{CH王ROPHÝLLUM, L}

Calyx-teeth obsolete. Frnit narrowly oblong to linear, notchecl at lase, with short beak or nouc, ant equal rilss; oil-tulues solitary in tle interials; sced-face more or less deeply grooved. - Moist gronnd anmuals, with ternately decom jumd leaves, pimatifu leaflets with ohlong obtuse lohes, mostly mo invelucre, 
involueels of many bractlets, and white flowers. (Nime from xaipw, 10 glad den, and $\phi u ́ \lambda \lambda o v$, c leaf, allurling to the agreeable odor of the foliage.)

1. C. procúmbens, Crantz. More or less hairy ; stems slender, spread. ing $\left(6-18^{\prime}\right.$ high $)$; umbels few-rayert; fruit narrowly oblong ( $2 \frac{1}{2}-3 f^{\prime \prime}$ long). glabrous, contraeted but not tapering at the summit, the intervals luoader than the ribs. - N. Y. to N. C., west to Mieh., Jowa, Mrk., and Miss.

Var. Shórtii, Torr. \& Gray, las more broadly oblong to orate (ulten sumewhat pubeseent) fruit, not at all contraeted at the summit. - Ky. to Ark. and La.

\section{OSMORRHIZA, Raf. Swert Cicels.}

Calyx-teeth obsolete. Fruit linear to linear-oblong, with prominent caudate attenuation at base, rery bristly, with equal ribs; oil-tubes obsolete; seerl-face (uneave. - Glabrous to hirsute perennials ( $1-3^{\circ}$ higl $)$ from thick aromatic roots, with ternately compound leaves, ovate variously toothed leaflets, fewleaved involncres and involneels, aud white flowers in few-rayed and few-fruited

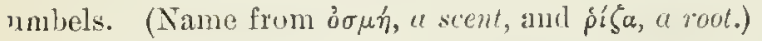

1. O. brevístylis, I)C. liather stout, cillous-pubescent; leaves $2-3$-ternate; leaflets 2-3' long, acuminate; fruit (not including the cauclate attenu. ation) 6" long; stylopodium und style $\frac{1^{\prime \prime}}{2}$ long. - From N. Seotia westwarel through the Northern States, and in the mountains to N. C. May, June.

2. O. longístylis, DC. Glabrous on slightly pubescent; like the last, but with the style $\mathrm{I}^{\prime \prime}$ lony or more, and the seed-face more deeply and broadly eoncare. - N. Sicotia to Va., and west to Tenn., L. Kan., and the Jakotas.

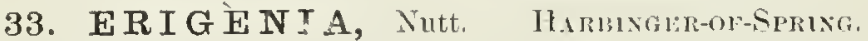

Calyx-teetl obsolete. Petals obovate or spatulite, flat, entire. Fruit diry mous, nearly orbicular and laterally flattened, the earpels incurver at top and bottom, nearly kidhey-form, with 5 very slenter ribs, anl several $(1-3)$ small wil-tules in the intervals; inner face of the seed lolluwerl into a hroarl deep cavity. - I small glalrons vernal plant, producing from a rleep round tuber a simple stem, bearing one or two 2-3-ternately diviled leares, and a somewhat imperfect and leafy-bracted compound umbel. Flowers few, white. (Name

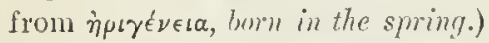

1. E. bulbòsa, Nutt. Stem 3-9' high; leaf-segments linear-oblong; fruit 1"long, 1 l’" lroal. - W. New York to Mrl.aul Tenn, and west to Wise, S. E. Minn., and lian.

\section{HYDROCÓTYLE, Tourn. Water Pennrort.}

Calyx-teetl obsolete. Fruit strongly flattened laterally, orlieular or slieldshaped; the "arpels 5-riblued, two of the ribs enlarged and often forming a thickened margin; wil-tubes nome, but nsually a conspientus oil-hening layer beneath the "pirlermis. - Iow, mostly smooth, marsh or aquatic premulals,

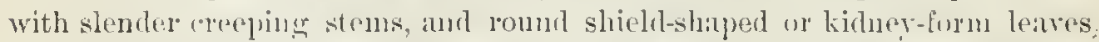
with seale-like stipules. Flower's small, white, in simple umbels or clusters, which are either singlo or prolifrous (one above another), appearing all sum-

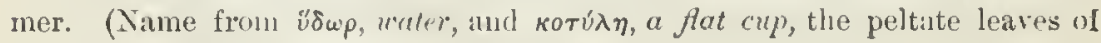
weveral speeies being sunewhit "mp-shaped.) 
* Pericarp thin except at the broad rorley dorsal and lateral ribs; leaves roundpeltate, crenate; peduncles as long as the petioles, from creeping rootstocks.

- Fruit notched at base and apex; intermediate ribs corky.

1. H. umbellàta, L. Umbels many-forered, simple (sonetimes proliferons); pedicels 2-6" long; fruit about lit" broad, strongly notched, the dorsal ribs prominent but obtnse. - Mass. to Minn., south to the Gulf.

2. H. Cánbyi, Conlt. \& Riose. Umbels 3-9-flowered. genercelly proliferous; pedicels very short, but distinct; fruit clbout 2 lincs broad: carpels broader and more flattened than in the preceding, sharper margined, the dorsal and lateral ribs mnch more prominent; seed-section much narrower. (H. umbellata, var.? ambigua, Crou, Manual). - N. J. to Mld.

\section{+ + Fuit not notrlesd: intermediute rils not rorky.}

3. H. verticillàta, Thunb. Umbels few-fowered, proliferous, forming an interrupted spike; pedicels very short or none; fruit $1 \frac{1}{2}-2^{\prime \prime}$ lroal; dorsal aul lateral rils very prominent. (II. intermpta, Mfull.) - Mass. to Fla.

* * Pericarp uniformly rorky-thicleened and rils all filiform: Ieromes not peltate; pertunctrs murh shorter than the petioles.

+ Fruit small, without secontury rils or reticulations; involucre small or none.

4. H. Americàna, L. Stems filiform, Inronching and creeping: leaves thin, rount-reniform, crenate-lobed and the lohes crenate, shining; few-flowered umbels axillary and almost sessile; fruit less than $1^{\prime \prime}$ lnoad; intermerliate ribs prominent; no oil-beariug layer; seecl-section broadly oral. - Common.

5. H. ranunculoides, L. f. Tsually florting; leares thicker, round-reniform, $3-7$-cleft, the lobes crenate; perluncles $1-3^{\prime}$ long, reflexed in frut ; capitate umbel 5-10-flowered; fruit 1-11" hroad; rils rather obsctue; seerl-section oblong. - E. Penn. to Fla, thence westwarl.

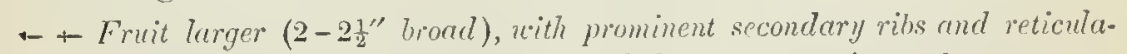
tions; the 2-4-flowered umbet subtended by tro conspicuns. bracts.

6. H. Asiática, L. P'etivles and peduncles (1-2’ long) clustered on creeping stems or runner's; leaves orate-comlate, repand-toothed, thickisls; seed-section narrowly oblong. (H. repanda, Pers.) - Md. to Fla. and Tex. (Widely distributed in the tropics and southern hemisphere.)

\section{ERÝ NGIUM, Tourn. ERYxgo.}

Calyx-teetl prominent, rigril anil persistent. Styles slender. Fruit ovate or ohovate, covered with little hyaline scales or tubercles, with no ribs, aurl ustally 5 slender oil-tubes on each carpel. - Chiefly perenuials, " ith coriaceuns,

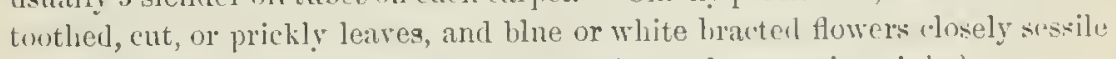
111 dense heads. ( $\mathrm{A}$ name nsed by lioscoriles, of uncertain origin.)

* Stout, with parallet-veined elongated linear thick leaves.

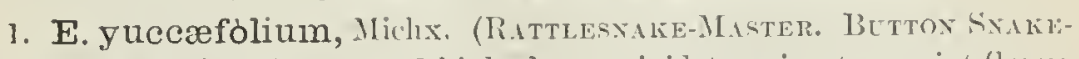
row.) Branching above, 1 - $6^{\circ}$ liigh ; leaves rigil, taporing to a point flower sometimes $2-3^{\circ}$ long), the margins remotely hristly" ; heads ovate-glubose ( $9^{\prime \prime}$ lung), with ovate-lanceolate montly entire chispilate-tipped bracts slorter than the hear, and similar hractlets.-Dry or damp soil, X. J. to Mimu, sontl to Fla. am Tex. July-sept. 
* Tall and often stout; leaves llick, not parallel-reined.

2. E. Virginiànum, Lam. Slender $\left(1-3^{\circ}\right.$ high); radical and lower stem-leaves linear- to oblong-lanceolate, on long (sometimes $10 \mathrm{loug}$ ) fistulous. petioles, entire or with small hooked teeth; upper leaves sessile, spiny-toothed or laciuiate; heads ovate-obloug ( $6^{\prime \prime}$ long $)$, with spiny-tonthed or entire reflexerl bracts, and bractlets with 3 spiny cusps (the middle one largest). - Margins of ponds and streams, X. J. to Fla. and Tex., near the coast. A Ing., Sept.

3. E. Leavenwórthii, Torr. \& (iriv. Stunt $\left(1-3^{\circ}\right.$ high $)$; lowest stemleaves broadly oblauceolate, spinosely toothed, the rest sessile and deeply palmately-parted into narrow incisely-pinnatifid spreading pungent segments: heads ovate-oblong $\left(1-1 \frac{1^{\prime}}{2}\right.$ long), with pinuatifid spinose bracts and $3-7$-cuspidate braetlets, the termimal ones very prominent and resembling the bracts. - Dry soil, E. Kan., Ark., and Tex.

* * Prostrate and slender, rooting at the joints, diffusely honched, with small thin unarmed leaves and very small heads.

4. E. prostràtum, Nutt. Lower leaves oblong, entire, few-toothed, or lobed at base; npyer leaves smallel, clustered at the rooting joints, wate, fewtoothed or entire (occisionally some additional trifid ones); reflexed bracts longer than the oblong hearls $\left(2-4^{\prime \prime}\right.$ long). - Wet places, S. No. to Fla. and 'Tex.

\section{SA N ÍCULA, 'Tomm. Santele. Bhack Syakhoot.}

Calyx-teeth manifest, persistent. Fmit globular; the earpels not separating spontaneously, ribless, thickly elothed with hooked prickles, each with 5 oiltubes. - Peremnial rather tall glabrous herbs, with few palmately-lobed or parted leaves, those from the root long-petioled. Umbels irregnlar or com. pound, the flowers (greenish or yellowish) capitate in the nmbellets, perfect, and with staninate ones intermixed. Involncre and involncels few-leaved. (Name said to be from sano, to heal; or perhaps from Son Nicolas)

1. S. Marylándica, L. Stem 1-30 high; leaves 3-7-parted, the divisions mostly sharply cut and serrate; sterile fowers numerous and long-pedicelled; fruit $1 \frac{1}{2}-2^{\prime \prime}$ long, the styles longer than the prickles. - Thronghont our lange, sonth to Ga. anl Tenu., west to E. Kan. and Minu. May - Mng.

Var. Canadénsis, Torr., lıs comparatively few and short-pedicelled sterile flowers, and styles shorter than the priekles. (S. Canadensis, $L$ ) With the last, but westward ouly to Minm. and E. lian.

\section{Orner 49. ARALTACEAE. (GINeFeng FAMILY)}

Ilerbs, shrubs, or trees, with much the same characters as Umbellifera. but with usually more than 2 styles, and the fruit a few-sereral-celled drupe. - Allumen mostly fleshy. Petals not inflexed.

\section{A R À I A, Tomm. Gixshag. Whin Sarsaparjula.}

Flowers more or less polygamous. Carlyx-tube coherent with the ovary, the teeth rery short or almost obsolete. l'etals 5 epigynous, oblong or obovate, lightly imbricater in the bud, decilnous. Stanens 5, epigynous, alteruate witl the petals. Styles $2-5$, nostly distiuct and slender, or in the sterile 
flowers short and united. Ovary $2-5$-celled, with a single anatrupus urule suspended from the top of each cell, ripening into a berry-like llupe, with as many seeds as cells. Embryo minute. - Leaves compound or decompound. Flowers white or greenish, in umbels. lioots (perennial), bark, fruit, etc., warm and aromatic. (Derivation obscure.)

\$ 1. ARALIA. Flouers monociously polygumons or perfect, the umbels usually in corymbs or panicles; styles and cells of the (blark or durk purple) finit 5 ; stems herbaceons or woody; ultimate divisions of the lentes pinnate.

* Umbels numerous in al large compound panicle; leates very larye, decompound.

1. A. spinòsa, L. (Axgelica-tree. Herculist' ('ulu.) Slerul, or u low tree; the stout stem and stalks prickly; leaflets ovatc, pointed, serrate, pale beneath. - River-banks, Penu. to Ind, and sonth to the Gulf. July, Aug*

2. A. racemósa, L. (SrikexinI.) Herbacenus; stem uidelybranched; leaflets heurt-ovate, pointed, doubly serrate, slightly downy; umbels racemose; styles united. - Rich woodlands, N. Brunswick to Minn., south to the mountains of Ga. July. Well known for its spicy-aromatic large roots.

* Umbels 2-7, corymbed; stem short, somewhat woody.

3. A. híspida, Vent. (Bristru Sarsaparill. Wh. Elder.) Stem $\left(1-2^{\circ}\right.$ high) bristly, leafy, terminating in a peduncle learing several umbels; leares twice pinnate; leaflets oblong-ovate, acute, cut-serrate. - Rocky and sandy places, Newf. to the Dakotas, south to the mountains of N. C. June.

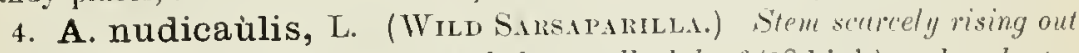
of the ground, smooth, bearing "single long-stulked leaf ( $1^{\circ}$ high) and a slorter naked scape, with $2-7$ umbels; leaflets olslong-ovate or oval, pointed, serrate, 5 on each of the 3 divisions. - Moist woodlands; range of n. 3. May, June. 'The long horizontal aromatic roots a sulstitute for officinal sarsaparilla.

\$2. GIXSENG. Floners diveionsly polygamons: styles and cells of the red or reddish frut 2 or 3 ; stem herbuceous, low, simple, bearing a whorl of 3 palmately 3-7-foliolate leuces, and a simple umbel on a slender peduncle.

5. A. quinquefòlia, Decsne. \& l'lanch. (Grsexc.) lioot lurge and spindle-shaped, of en forked (4-9' long, aromatic); stem $1^{\circ}$ high ; leaflets longstalked, mostly 5, linge and thin, obovate-oblong, pointed; styles 1nostly 2; fiuit bright red. - Rich and cool Hoods, V't. and W. Conn. to Minn., sonth to the mountains of Git. July.

6. A. trifòlia, Decsue. \& Planch. (I)warf Ginsexa. Grouxd-yut.) Root or tuber glolulur, deep in the ground (pungent to the taste, not aromatic); stems $4-8^{\prime}$ high ; leaflets $3-5$, sessile at the summit of the leafstalk, varrowly oblong, obtuse; styles usually 3 ; fruit yellowish. - Rich woods, N. Scotia to Minu., south to Ga. April, May.

\section{Order 50. COIRÁATAE. (Dogwood Family.)}

Shrubs or trees (incly herbaceous), with opposite or alternate simple leaves, the caly. $x$-tube coherent with the 1-2-celled wiary, its limb minute, the petals (calcate in the bud) and as many stamens borne on the margin of an epigynous alisk in the perfect flowers; style one: a siugle anutropous ovule hanging from the top of the cell: the fruit a 1-2-seeded drupe; embryo nearly 
as long as the albumen, with large foliacesus cotylestons. - Including two genera, of which Nyssa is partly apetalous. Bark bitter and tonic.

1. Cornus. Flowers perfect, 4-inerous. Leaves mostly opposite.

2. Nyssa. Flowers diøeiously polyganous, 5-merous. Leaves alternate.

\section{Có R N US, 'Tuurl. Curnel. Dogwoop.}

Flowers perfect (or in some foreigu species direcions). Calyx minutely 4toothed. Petals 4, ollung, spreading, Stanens 4; filaments slender. Style slender; stigma terminal, that or (apitate, Drupe small, with a 2-eelled aur 2-seeded stone. - Leaves opposite (except in one species), entire. Flowers small, in open naked cymes, or in close hearls snrronuled by a corolla-like involucre. (Yane from com, al horn; alluding to the liardness of the wood.) $\$ 1$. Flowers gremish, in a head or close cluster, surromeded by a lurge and shoncty, 4-leaved, curolln-like, white or rarely pinkish incolncie: finit bright red.

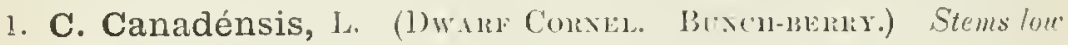
and simple $\left(5-\tau^{\prime}\right.$ high) from a stonder creeping aud sulterranean rather woody. trunk; leaves scarerly petiolem, the lower scale-lik', the upper crowded intu an apparent whorl in sixes or fonlrs, orate or oral, pointed; lenes of the imorlurve ovate; fruit globular. - Dinn l, cold woods, N. J. to Ind. and Mimno, and the far north and west. Jnue.

2. C. flórida, 1. (Fowling Dotiwoms.) Tree $12-40^{\circ}$ high ; leaves orate, pointed, acutisle at the hise; leares of the involure obcordute (1 11 long); fimit ocal. - Dry woods, from s. New kng. to Ont. al al s. Minn., sonth to Fla. and Tex. May, June. Very showy in Hower, scarcely less so in fruit.

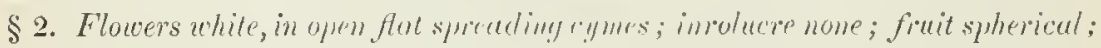
leares all opposite (exrept in 11.9).

* Pubescence roolly and more or less spreading.

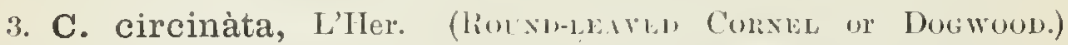

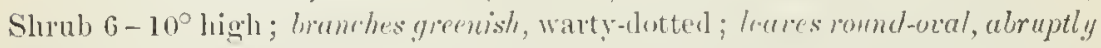
poimed, woully beneuth (2-5' hroad); (ynes Hat; fithit light blue. - Copses, in rich or sandy soil, or on rocks, N. Scotia to the Dakotas, south to Va. and 11o. June.

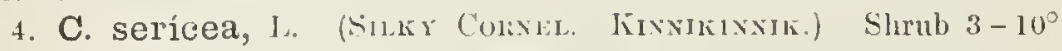
high; branches purplish; the bremchlets, stollis, und loner surjuce of the narrouly orate or ellipticul pointed leneses silliy-lonny (often rusty), pale and dull; cymes flatt, close; calyx-teeth lancelate; fruit pale U/ue. - Wet places, Canada to the Dakotas, soutli to Fla. aud La. June.

5. C. asperifolia, Mirlux. Bronches hromish; the bronchlets, etr., roughmbescent; leones oblomy on orute, on short petioles, pointed, romgh with a harsh pubescence abore, and donny benthth: alyx-teeth minnte; fruit white. (C. Drummondii, 1/ey.) - Dry or samly suil, N. shore of I. Frie to Minn. and the Gulf. May, June. A rather tall shrmb.

* * Pubescence descly "plymessed, straight and silk:y, or nome.

6. C. stolonifera, Michx. (R1:D-osien Dociwom1.) Branches, especially the osirv-litir shouts of the season, bright red-purple, smoth: leaves ozate, rounded at base, abrupt ly slont-pointed, roughish with a minute close pubescence 
on both sides, whitish underneuth: cymes smill and flat, rather few-flowered, smooth; fruit white or lead-color. - Wet plaees; common, especially northward. Multiplies freely by prostrate ol subterrumean suckers, aud forms broad clumps, 3-60 high. June.

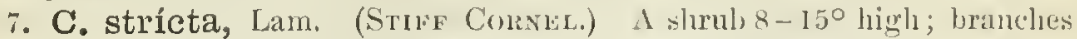
lirownish or reddish, smooth; lenes ovate or ovate-lunceolate, taper-pointerl, acutish at base, glabrons, of nearly the same hue both sides; cymes loose, fattish; conthers and fruit pule blue. - Swamps, Va. to Ga. aud Fla. April, May.

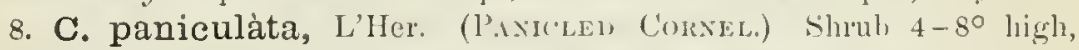

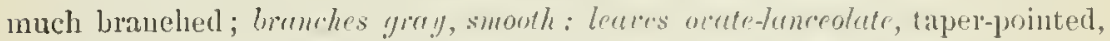
'acute at bass, whilish benceth lut not downy; rymes coner $x$, logse, often panicled; fruit white, depresserl-glohose. - Thickets and river-lunks. June.

9. C. alternifòlia, L. ๔. Sirul, or tree $8-25^{\circ}$ liggll; bronches gremish streaked with white, the altermute loness rlustered th the ends, ovate or oral, lougpointed, acute at base, whitish and minutely jubescent heneath; cymes rery broarl and open; fruil recp blue on reddish stallis. - Ilillsides in eopses, $\mathrm{X}$. Brunswick to Minu, south to Gia. and Mla. May, , June.

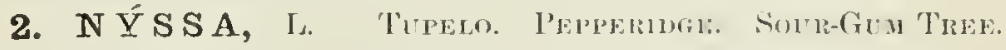

Flowers diacciously polyganous, clustered or rarely solitary at the smmmit of axilliry puhneles. Stum. Fl. numerous in a simple or componme dense cluster of fascicles. ('alyx sullil, 5-pinted. P'etals in in fertile flower or none. Sitamens 5-12, oftener 10, inserted on the ontside of a couvex disk; filaments slender ; anthors slort. No pistil. P'ist. F\% solitary, or 2-8, sessile in a bracted cluster, much latrer than the staninate Howers. Calyx with a very short respand-truncate ol minutely 5-toothed limb. l'etals rely small anil flesly, cleciduuns, or often wanting. Stamens 5-10, with perfect or imperfect antliers. Style elongated, revolute, stigmatic lown one sirle. Ovary l-eolled. Drupe oroid or oblong, with a hony and groover or striate l-celled and l-seeded stone. 'Trees with entire or sometimes angulate-tonther leaves, which are alternate, but mostly crowled at the culls of the luanclulets, and greenish flowers appearing with the leaves. (The name of al Nymull: "so calleil because it [the original species] grows in the water.")

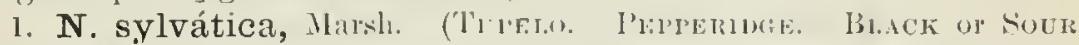
Grus.) Midlle-sized tree, with horizontal hrouldes; leatres oval or obovate, (ommonly acuminate, glabrous or villoms-pubesemet when young, at least on the margins and millib, slining alowe when whl (2) - 5) long ; jirfile flowers

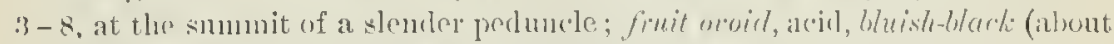

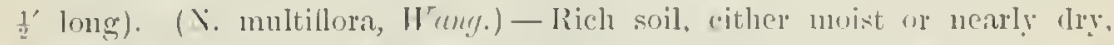

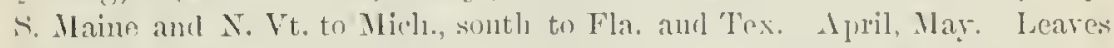
turning bright crimson in antmm. IVood tirm, elose-gratined and rery nu-

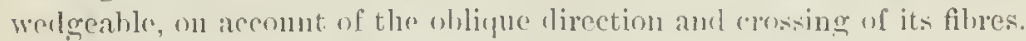

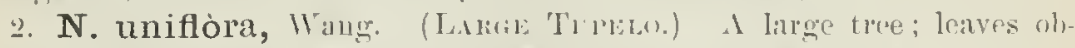

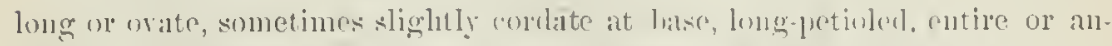
gnlate-tootled, pale and flowny-pubesernt heneath, all leist when young (4-12'

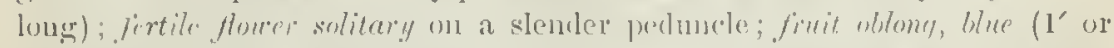
more in length). - Deep swamps, s. Va. to S. Hll. and Mlo, south to Fla and

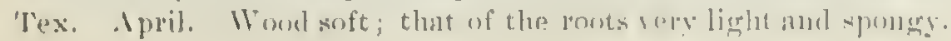




\section{Division II. GAMOPETALOUS DICOTYLEDONOUS PLANTS,}

Floral envelopes consisting of both calyx and corolla, the latter composed of more or less united petals, that is, gamopetalous. *

\section{Order 51. Caprifoliàceze. (Honfretchle Family.)}

Shrubs, or rarely herbs, with opposite leaves, no (genuine) stipules, the calyx-tube coherent with the 2-5-celled orary, the stamens as many as (one fewer in Linnea, donbled in Adoxa) the lobes of the tubular or rotate corolla, and inserted on its tube. - Fruit a berry, drupe, or pod, 1 - severalseeded. Seeds anatropous, with small embryo in theshy albumen.

Tribe I. SA MIBUCE E. Corolla wheel-shaped or uru-shaped, regular, deeply 5-lobed. Stiguas $3-5$, sessile or nearly so. Inflorescenee terminal and eynose.

* Dwarf herb, with stamens doubled and Howers in a capitate eluster.

1. Adoxa. Fruit a diy greenish drupe, witl $3-5$ cartilaginous mutlets. Canline leaves a single pair and ternate.

* * Shrubs, with stamens as many as corolla-lnbes and fluwers in broad compound eyınes.

2. Sambucus. Fruit bery-like, eontaining three small seerl-like nutlets. Leaves pinnate.

3. Viburnum. Fruit a l-relled 1 -seeded drupe, with a eompressed stone. Leaves simple.

Tribe II. LONICEREAE. Corolla tubular, often irregular, sometimes 2-lipped. Style slender ; stigma eapitate.

$$
\text { * Herbs, with axillary flowers. }
$$

4. Triosteum. Stamens 5. Corolla gibbous at the base. Frnit a 3-celled drupe. Erect; flowers sessile.

5. Linnaea. Stamens 4, one fewer than the lobes of the corolla. Fruit dry, 3-celled, hut only 1-seeded. Creeping, witlı long-pedunculate twin flowers.

* Erect or climbing slırubs, witlı scaly winter-buds.

6. Symphoricarpos. Stanens 4 or 5, as many as the lobes of the bell-shaped regular corolla. Berry 4-eelled, but only 2 -seeded; two of the eells sterile.

7. Lonicera. Stameus 5 , as many as the lobes of the tulubr and nore or less jrregular corolla. Berry severn-seeded; all the 2 or 3 cells fertile.

S. Diervilla. Stanens 5. Corolla funnel-form, nearly regrant. Pod 2-relled, ¿̀-valved, many-seeder, sleniler.

\section{A D Ó X A, L. Moschatel.}

Calyx-tube reaching not quite to the smmmit of the 3 -5-celled ovary ; limb of 3 or more teetl. ('orolla wheel-shaped, 4-6-cleft, learing at each sinus a pair of separate or partly mited stamens witl 1-celled anthers. Style 3-5parted. Dry drupe enrenish, witl i3-5 eartilaginous nutlets. - I lwarf persunial herb with sealy rootstock and ternately divided leaves, the cauline a siugle pair. An anomalous menus. (From abogos, olseme or insignificant.)

* In rertain families, as in Ericacene, otc., the petals in some genera are nearly or quite splurate. In Compositre ancl some others, the ealy is mostly reduced to a pappus, or a mere holder. or even to mothing more than a covering of the surface of the ovury. 'Tlue student miglit lonk for these in the first or the third clivision; but the artificial analysis prefixed to the volume provides for sucl anoinalies, and will lead him to the proper oriter. 
1. A. Moschatéllina, I. Smooth, musk-scented; radical leares 1-3ternate, the cauline 3-cleft or 3-parted ; leaflets obovate, 3-cleft ; flowers several in a close cluster on a slender peduncle, greenish or yellowish. - N. Iowa, Wisc., and Miun., and nortliward. (Eu., Asia.)

\section{S A M B Ù C U S, Tourn. Elder.}

Calyx-lohes minute or obsulete. Corolla opren urn-shaped, with a broadly spreading 5-cleft limb. Stamens 5. Stigmas 3. Fruit a herry-like juicy drupe, containing 3 small seed-like nutlets. - Slirnbly plints, with a rauk smell when bruised, pinnate leaves, serrate-prointed leaflets, anl numerous

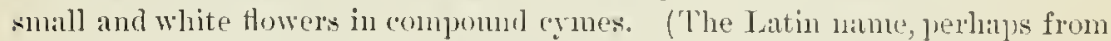
$\sigma \alpha \mu \beta \tilde{k} \eta$, an aucient musjcal instrument.)

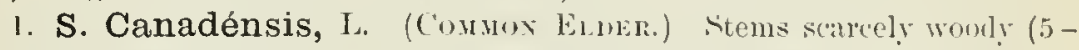
$10^{\circ}$ high); leaflets 5-11, oblomy, mostly smootl, the lower often 3-parted; rymes flat; fruit blark-pmple. - kich soil, in open places, throughout our range, and south and west. .June, Jnly. - l'ith white.

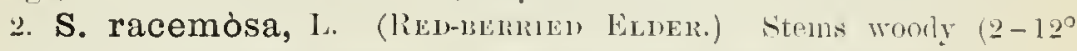

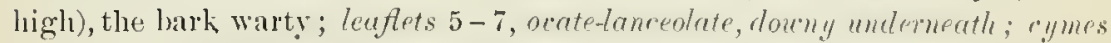
punicled, conrex or pyrumidul: finit brylt red (rarely white). (s. pubens, Mich.r.) - Rocky woods, N. Scotia to Ga., and westward acruss the continent. Iay ; the fruit ripening in Jume. - l'ith brown. Iboth specics oceur with the leaflets divided into $3-5$ linear-lanceolate 2-3-cleft or laciniate seguents.

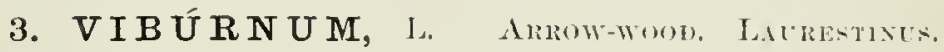

Calyx 5-toothed. Corolla spreading, deeply 5-lohed. Stanens 5. Stigmas 1-3. Fruit a 1-celled, 1-seeded drupe, with soft pulp and a thin-crustrecous (Hattened or tmmil) stone. - Shrmbs, with simple leaves, and white fluwers in Hat compound eymes. l'etioles sometimes leating little alpjemalages which are eviclently stipules. Leaf-londs naked, or with al jair of scales. (The clissical Latin name, of unknown meining.)

$\$ 1$. Cyme radiant, the maiginal floncers nentral, with yreatly anturyed flat corollas as in llydrangea; diupes coral-red tuming darker, not acid; stone sulcate; leares pimutrly iceined: uinter-buds naked.

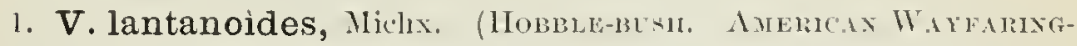

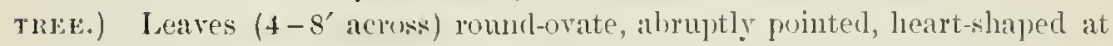
the base, closely serrate, the reins and veinlets beneath with the stalks anrl hranchlets very rusty-scurfy; crmes sessile, very hourl and flat. - Cold moist works, X. Brunswick to Ont, and I'ennl, and in the momutains to N. C. May. $\Lambda$ straggling shrub: the reclining hranches often taking ruot.

\$2. Cyme peduncled, radiant in n. 2; drupe light red, wiel, glolonse: stone rery flat, wbirular, not sulcate; leaves palmately reined: winter-buds scaly.

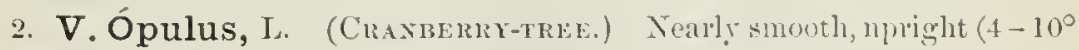
high); leaves 3-5-ribberl, strongly 3-loberl, hroully- weige-shaperl or truncate at lase, the sprearling lobes pointed, mostly lootherl on the silles, entire in the sinuses; petioles learing 2 glands at the apex. - Inw ground, along streams, from N. Brunswick far westward, and sontl to P'enn. June, July. - The acid

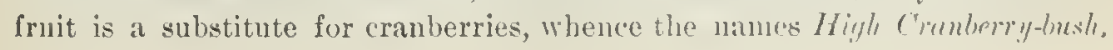


fte. The well-known Sxow-Buld Tree, or Gulubli-Rose, is a cultivated state, with the whole ayme tumed into showy sterile flowers. (Eu.)

3. V. pauciflorum, Pylaic. A low straggling shrub; leares glabrous (1) loosely pubescent beneath, 5-ribbed it base, unequally serrate nearly all round, with 3 short lobes at the sumnit; cyme few-flowered; stamens shorter than the corolla. - Cold woods, Newf. and Lab. to the mountains of N. Bing., Nestward to N. Micli. and the Rocky Mts.

\$3. Cyme never raliant; drupes blue, or dark-pmrple or black at maturity. * Leaces 3-ribbed fiom the rounded or sulcordate buse, sumeuhat 3-lobed; stij. ules birstle-shajed.

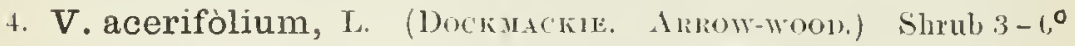
high; leaves soft-downy beneath, the pointed lohes diverging, unequally twotherl; cymes sulull, slenfler-peduncleil; stamens exserted; fruit crimson furning pnrple; stone lenticular, hardly sulcate. - Cnol rocky woods, from N. Brnnswick to N. C., and west to S. Minu.

* * Leares (with base inclined to heart-shaped) cours sty louthed, prominently pinnately veined; stipules narrouly subulute; no rusty scurf; fruit oroid, bluf or murple; the stone grooved; rymes peduncled.

+ Stone flut; leaves all short-petioled or sulusessile.

5. V. pubéscens, Pursh. (Dowxy A.) \ low, straggling shrub; leare. wate or oblong-ovate, acute or taper-pointed, the rins and teeth fewer and liss conspicnous than in the next, the lower surface and very short petioles soft-downy, at least when young; fruit dark-pulple; the stone lightly 2-snlcate on the faces. - Rocks, etc., Lower Canada to the mountains of Ga, west to lowa and Minn. June.

+t + Stone rery deeply sulcute rentrally; leaves ruther slender-petioled.

6. V. dentàtum, L. (Arrow-woon)) Simooth, 5-150 high, with ashcolored bark; leaves broadly ovate, very nmeronsly shupp-toothed and strongly reined; fruit 3" long; cross-section of stone between kidney-and horseshoeshaped. - Wet plikes, X. Brunswick to X. Ga, and west to Minu. June.'The pale leaves often witl latiry tufts in the axils of the straight veins.

7. V. mólle, Michx. Leares luroally oval, oborate or orate, scarcely puinted, coarsely crenate or repand-tootled, the lower surfice, hanchlets and rynes soft-lowy, the latter with stellate pubescence; fruit oily, larger ane more pointed, the stone as in 11.6 , but less deeply excavated. - Coint of $\mathrm{N}$. ling. (Martha's Vineyard), to 'Tex.

** * Leaves jinely serrute or entire, bright green; reins not prominent: stimule none; whole plant glabrous or with some minute rusty scurf; fruit black or with a bhe bloom, steet; stone very flut and even, broadly oval or orbicular.

- Cymes pedunded, ubout 5-royed; drupes globose-oroid, $3^{\prime \prime}$ lomg; shrubs 5-120 high, in swamps.

8. V. cassinoides, L. (Witul-Ron.) Shoots scurfy-punetate; leaves thickish and opaque or dull, orate to oblong, mostly with obtuse acumination, whsurely veiny ( $1-3^{\prime}$ long), with margins irvegularly cremulate-denticulate or sunutimes entire: proluncle shorter than the ryme. (V. nudum, var. eassinoides,"

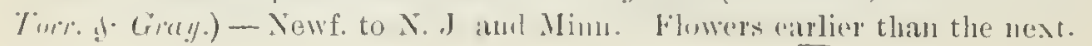


3. V. nudum, 1. Obscurely scurfy-punctato; leares more reiny, thickisb, oral, oblong or lancolate, entire or obsoletely denticulate, lucid abore (2t' loug); peduncle usually equalling the cyme. - N. J. to Fla.

+ + Compoum cymes sessile, 3-5-rayed; drupes oval, 5-7"long.

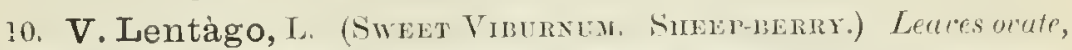
strungly pointed, (clusely and very shuply serrate; petioles long and margined; cyme large; froit oval, $\frac{1}{2}$ long or nore, ripe in antumn, edible; tree $15-30^{\circ}$ high. - Woods and banks of streans, from the $\Lambda$ tlantie to Mo., Minn., and northwart. Hi. in spring.

11. V. prunifolium, L. (Bнаск H.w.) Lenes oecal, obtuse or slightly pointed, finely and sharply serrote, smaller than in the preeding ( $1-2^{\prime} \operatorname{long}$ ); fruit similar or rather smallel. - Dry or moist gromed, N. Y. to Mich., Kan, ancl soutluwarl. Flowering early. - A tall slunb or sulall tree.

12. V. obovàtum, Walt. Sluuh ״- $-8^{\circ}$ high; leaves olovate or spatulate, olutuse, cutire or denticulate, thickish, small (1 - I long), shining; cymes small; frnit 5" longe, black. - liver-bauks and swanlss, Va. to Fla: May.

\section{TRIÓ S T E M, I. FEvil-Wont. Hons-Gextax.}

Calyx-lubes linear-lanceolate, leat-like, persistent. Corolla tulular, gibbous at base, somewhat equally 5-lohech, scarcely longer than the calyx. Stamens 5. ():ary mostly 3-celled, in fruit forning a rather dry drupe, containing as many

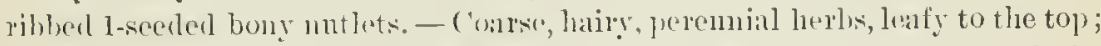
the ample entire pointed labres tapering to the base, but connate round the simple stent. Flowers sesile, solitary or chustered in the axils. (Nime an ablurevation of Triosteosermum, alluding to the three hony nutlets.)

1. T. perfoliàtum, I. Soffly nairy (2-4 high) ; liares oral, abruptly

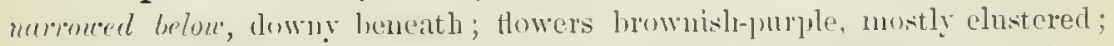
fruit orange-color, f’ long. - Rich wodilands, Cambula and N. Eng. to Minn.,

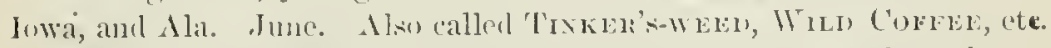

2. T. angustifolium, J. Sinaller, brislly-harin; fences lancolute, taper-

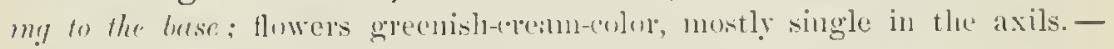
Sharly groumels, Viz. to Mll., Mo., and Mlil. May.

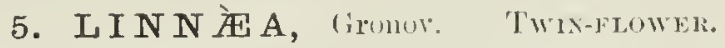

Calyx-tectl 5, awl-sliaped, leciluous. Corolla narrow bell-shaped, almost cyually 5-lobel. Stamess 4 , two of them shorter, inserted towarl the lase of the cornllat. Ovary and the small dry pod 3-celled, but only l-seeded, two of the cells liaring only abortive ovules. $-\Lambda$ slenter ereeping and trailing little erergreen, somewhit hairy, with rounded-oval sparingly crenate leares conthated at the base into short petioles, and threarlike npright pedumeles forking into 2 peelicels at the top, cach learing a delicate and fragrant nodding flower. Comblia purple and whitish, lairy insisle. (Dedicated to the immortal limue us, who first pointed out its cluaracters, and with whom this pret.y little plant was a special favorite.)

I. L. boreàlis, Linnens, - Noist nuossy wookts and cold bogs, N. Ling. to N. J. and the nomntains of Md., west to Minn.; also far north and west. June. (Lu.) 


\section{SYMPHORICÁR POS, Dill. Srowberry.}

Calyx-teeth short, persistent, Corolla bell-shajed, regularly $4-5$-lobed, with as many short stamens inserted into its throat. Ovary 4-celled, only 2 of the cells with a fertile ovule; the berry therefore 4-celled but only 2-seeded. Seeds bony. - Low and branching upright shrubs, witl oral short-petioled leaves, which are downy nuderueath and entire, or wary tootherl or lobed on the young sloots. Flowers white tinged with rose-color, in close slort spikes or clusters. (Name eomposed of $\sigma \nu \mu \phi o \rho \epsilon ́ \omega$, to beur together, and kaprós, fruit; from the clustered berries.)

* Style bearded; fruit red; flowers all in short dense axillary clusters.

1. S. vulgàris, Michx. (Ixplax Curraxt. Conal-Berry.) Flowers in the axils of nearly all the leaves; corolla sparingly bearded; berries small. - Rocky bauks, western N. Y. and l'enn. to the I)akotas, Neb., and 'Tex. July. * Style glabrous; fruit white; flowers in chusters or sometimes solitary.

2. S. occidentàlis, Hook. (WoLfBerri.) Flovers in dense terminal. and axillary spikes; corolla much bearded within; stamens anl style protruded. - Rocky ground, X. Mich. and Ill., west to the Rocky Mts. - Flowers larger and more funnel-form, aud stamens longer, thin in the next.

3. S. racemòsus, Michx. (Sxownemri.) Floners in a loose and somewhat leafy interrupted spike at the ent of the branches; corolla bearded insile; berries large, - Rocky banks, N. New King. and Y'em., to Minn. and westwatrl: common in cultivation. June-Sept, Berries ripe in antumn. - Var. P'Al'c1rooncs, Robbins. Low, diffusely brancher and spreading; leaves smaller (abont $I^{\prime}(0 n g)$, the spike rerluced to one or two flower's in the uppernost axils. - Mountains of Vt. and Penn. to Minn., the Dakotas, and westward.

\section{LONÍCERA, I. HoxeTstrLe. WoOdBNe.}

Calyx-teeth very short. Curolla tubular or funel-form, oftem gibbous at the base, irregulinly or alnost regularly 5-lobed. Sitamens 5. Orary 2-3celled. Berry several-seeder, - Leares entire. Fluwers olten slowy and fragrant. (Named in lonol of Adum Lomitas", latinized Lonicurus, a Germau herbalist of the 16th century)

\$1. XYLOSTEOx. Emight bushy slerubs; leares all distinet; peduncles axitlary, single, a-flowered at the summit; llie tro berries sometimes united into one; ealyx-tecth not persistent.

* Bracts (2 or sometimes 4) at the buse of the oraries minute.

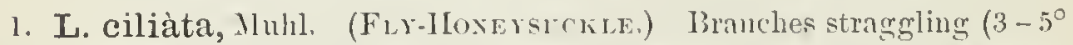

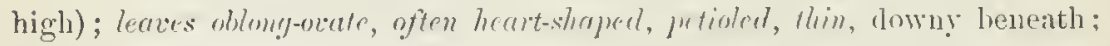
filiform peduncles shorter than the leurs: corolla fumel-form, almost spurred at the base (grecuis]lyellow, $\frac{g^{\prime}}{4}$ long), the lobes nearly erpual ; brories separate (red). - Rocky wools, N. Brmustrick to Penn, and Minn. May.

2. L. cærulea, 1. (Movntux F.) Low (1-.20 high); branches upriglit; leaves oval, downy when young; peduncles very short; brarts ant-shaped, Inmyer than the oberies, which are uniter into one (b/ue) berry; flowers yellowish. - Mountain woods and hogs, Lab. to R. I., Miun., and northward. May. (En.) 
3. L. oblongifòlia, Muhl. (Sw+MP F.) Shrnb 2-50 high, branches npright; leaves (2-3' long) oblong, downy when young, smooth when old; peduncles long and slender; bracts minute or deciduons; corolla deeply 2-lipped ( $\frac{1}{2}$ long, yellowish-white); berries (purple) united or nearly distinet. - Bogs, N. New Eng. and N. Y., to Mim. June.

* The tuo fourers incolucrute by 4 conspicuous and broad foliuceous bracts.

4. L. involucràta, Banks. Pnbescent, or leeoning glabrous; branclies 4-angular; leaves (2-5' long) ovate-oblong, mostly pointed, petioled, and with a strong midlil, exceeding the pednucle; corolla yellowish, riscid-pnbescent, cylindraceous $\left(6-8^{\prime \prime}\right.$ long); ovaries and globose dark-purple berries distinct. - Deep woods; slores of L. Superior, and north and westward.

\$2. CAPRIFOLILII. Thining slumbs, with the flowers in sosile whorled clusters fiom the axils of the (often connate) upper leaves, forming interrupted terminal spilies; calyx-teeth persistent on the (oed or orange) berry.

* Corolla trumpet-shaped, almost regular; stanens and style little exserted.

5. L. sempérvirens, dit. ('Trumpet Hoxersyckle.) Flowers in somewhat distaut whorls, scentless, nearly 2' long, deep red ontside, yellowish within or larely throughout; leaves oblong, smooth, the lower petioled, the nppermost pairs comnate. - Copses, Coun. to Ind., and soutluward; common in cultivation. May-Oct. - leares decirluons at the north.

* Corolla ringent; the louer lip nurrow, the upper broud and 4-lobed; stamens and style conspicuously exserted.

+ Corollatube an inch long, glabrous inside; stamens and style glabrous.

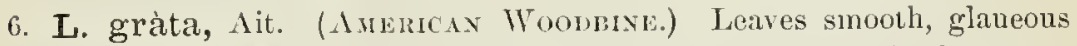
beneath, obovate, the 2 or 3 upper pairs uniterl flowers whorlel in the nppermost axils; corolla whitish with a purple tube, fading yellowish, not gibbous at base, fragrant. - liocky woodlands, N. J. and Penn. to Micl. and Mo., and sonthward; also cultirated. May.

\section{+ + Corollu hairy within, the tube $6^{\prime \prime}$ long or less.}

7. L. hirsùta, Eaton. (HAnr Hoxersuckle.) Twining and rather high-climbing; leares deep green abore, downy-hairy beneath, as well as the branches, veiny, clull, broadly oval, the uppermost united, the lower shortpetioled ; flowers in approximate whorls ; tube of the (otange-yellow) clammypubescent corolla gibbons at base, slender. - Damp eopses and roeks, Maine to Penn., Mieh., and Minn. July. - A coarse large-leaved speeies.

8. L. Sullivántii, Gray. At length much whitened with glaucous bloon, $3-6^{\circ}$ high, glabrons; leaves oral and oborate-oblong (2-4' long), sessile and mostly connate on the flowering stens, the uppermost into an orbicular disk: corolla pale yellow; filuments neavly ylabrous. (L. flava of former edition, mainly.) - Ohio to 111., Minn., aul I. Winnipes; also in Tenn. and N. C.

9. L. glaùca, llill. Clalirous, or lower leafsurface sometimes puberulent, 3-50 high ; leares oblong (2-3' long), glancous hut less whitened than in the last, the $1-4$ upper perirs connate; corolla greenish-yellow or purplish; tube only 3-4" long, within and also style and buse of filaments hirsute. (1. parviflóra, Lam., and part of var. Douglúsii. Cray.) - liucky grounds, N. Eng. and Penn, to Minm, nud northward. 


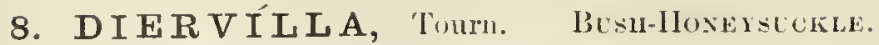

Calyx-tube tapering at the sumnit; the lobes slender, awl-shaped, persistent. Corolla funuel-form, 5-lubed, almost regular. Stanens 5. Pod oroid-oblong, pointed, 2-celled, 2-valved, septicidal, many-seeded. - Low upright shrubs, witl orate or oblong pointed serrate lenves, and cymosely 3 -several-tlowered pedmucles, from the upper axils or terminal. (Named in eompliment to $L \%$. Jiernille, who brought it from (amada to Touruefort.)

1. D. trífida, Moencl. Leaves oblong-ovate, taner-pointed, petioled ; peduncles mostly 3-flowered; pod long-beaked. - liocks, Newf. to the nountains of N. C., west to Minn. June-Aug. - Flowers loney-color, not showy, ats are the Japanese speeies eultivated under the name of WELivLA.

\section{Order 52. RUBIACLAE. (MAMER FAMLY.)}

Shrubs or herbs, with opposite entre leares connected by interposed stipules, or in whorls without apparent stipules, the calyx colcerent with the 2-4-celled veary, the stamens as many as the lobes of the regular corolla (4-5), and inserted on its tube. - Flowers perfect, but often dimorphous (as in Mitch(lla and Iloustonia). Fruit various. seeds anatropous or amphitropous. Embryo commonly pretty large, in copious lared albumen. - A very large fanily, the greater part, and all its most important plants (such as the Cuffee and Peruvian-Bark trees), tropical.

1. CINCHONEA: Ovules numerus in each cell; leaves opposite.

1. Honstonia. Corolla salvel-form ol fumel-form, 4-lobed. Seeds rather few, thimbleshaped or sameer-sliaped. Low lerbs.

2. Oldenlandia. Corolla wheel-shaped in our species, f-lobel. Seeds very mumerous and minute, angular. Low lierbs.

II. COFFEINEA. Grules solitiry in the cells; leaves mostly opposite. + Fluwers in a conse and globose long-pedmoled head. Fruit dry. Slırubs.

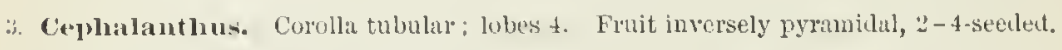
++ Flowers twin: theil ovaries united into ons. Fluit a 2 -eyed berry

4. Mitchella. Corolla funnel-form; its lobes 4 . A creeping lierb. + + + Flowers axillary, sejurate. Fruit dry when ripe. Herbs.

5. Sipermacoce. Corolla funuel-form ol salver-form: lobes 4. Frut seprating when ripe into 2 carlels, onc or butlu of them opening.

(i. Diodia. Frut separating into $201^{\circ}$ elosed and intohisent carpels; ntherwise as 13.5.

111. STHLLNTA: Ovules solitary; leaves in whorls, without stipules.

7 Galium. Corolla whec-slaped, 4-(or rarely 3-) partel. Culyx-tceth obsolete. Frnit twin, sephating into 2 indoliscent 1 -sectet carpels.

s. Sluevardia. Corolia fumbl-form. Calyx-lotes laneolate. Flowers subsessile. involuerate

\section{HOUSTONIA, I.}

Calyx 4-lobed, persistent; the Joles in frnit distant. Corolla salver-form ol

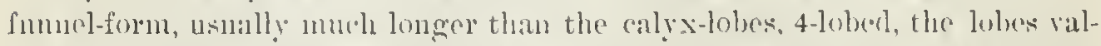
vate in the bud. Stamens 4 ; anthers linear or oblong. Sityle I : stignas 2. (Tary 2-celled. Pod top-shaperl, whlohlar, or didỵons, thin, its summ it or upper. half free from and projecting beyond the tube of the aly.x, loculicinlal ateruss 
the top. Seeds rather few (t-20 in each cell), peltate and saucer-shaped or globular-thimble-shaped, pitted. - Small lierbs, with short entire stipules connecting the petioles or narrowed bases of tho leares, and cymose or sulitary and peduncled flowers. These are limorplous, in some individuals with exserter anthers and short inclurled style; in others tho anthers included and the style

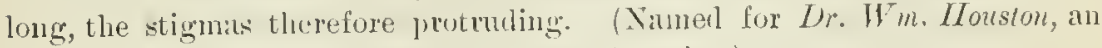
English botanist who collecter in (entral Anerica.)

* Simall and delicate, remal-flunering; pedurches 1-flourered; carolla salverform; npur half of the broud and someuliat 2-lubed pod fice; seeds globular, with a rery deep round carity occupying the inner face.

+ Perennial by delicule filiform crreping rootstock's or creeping stems; peduncles filiform, 1-2' long.

1. H. cærùlea, L. (Buters. Ixwoctace.) Glabrous; stemsered, slender, sparingly branched from the base ( $3-5$ high); leares oblong-spalulate (3$4^{\prime \prime}$ long) ; pednucle filiform, erect; corolla light blue, pale lilar or nearly white with a yellowish ere, with tube much longer than its lohes or than those of the calpx. - Mrist and grissy places, N. Jing. to Gal., west to Mich, and Ala. ; prodneing from early spring to mirlsummer its delicate little flowers.

2. H. serpyllifòlia, Miclx. Like the list, but filiform stems prostrute,

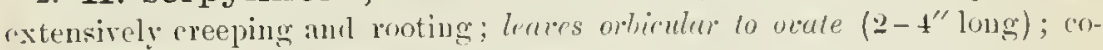
rollia rather larger, and depp riolet-llue. - \$long streamlets and on mountaintops, Va. to Temn. aurl s. C.

to t- Irinter-sumuls, branching firm the simple root: pedundes much shorter.

3. H. pàtens, Ell. In incle to at lengtle a span lighl, with ascentiug br:ucles aud erect perluncles; leaves spatulate to ovate; corolla much smaller thim that of $n$. 1, volet-blue or purplish withont yellowish eye, the tube longer Irum its lobes, twice the length of the calyx-lobes. - Dry or samly soil, F. Va. to Tex, and 111. (?)

4. H. mínima, Beck. More diffuse, rommonly scrubros ; stems at length much liranchel and spreading (1-t' high); lowest leaves ovate or spatinlate, the upper oblung or nearly linear; entier perluncles chngated and spreading in fruit, the later unes short ; lube of the purplish conollu not longer than its lobes

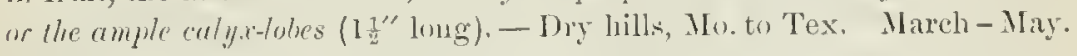

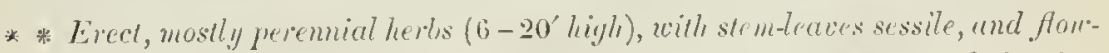
ors in sumll terminal cymes or clusters; corolla fumel-form, muptish, often lairy inside: serds moniscuidul, with a ridlye across the hollowed inmer firep.

5. H. purpùrea, T. Puliescent or smootlı (8-15' lighli); leazes rary ing from romelisl-orate to lemerolute, 3-5-rihbed; calyx-lobes longer than the halffree globulur pod. - Woollands, Mnl. to Ark., and sonthwarel. May-July. - Varying wonderfully, as into. -

Var. ciliolata, Gray. I spau ligh ; leaves only to long, thickish; cauline obloug-spatulate; radical oral or oblong, rosnlate, hirsute-ciliate; calyx-lobses a little longer thin the pod. - Rocky lanks, from the Great Lakes and Mimn. to lif. ; passing into

Var. longifolia, Gray. A span or two high, mostly stabrous, thinnerleaved; leaves ohlong-lanceulate to linear $\left.(6-20)^{\prime \prime} l o n g\right)$; radical oval or oblong, 
less rosulate, not ciliate. - Rocky or gravelly ground, Maine to Minn., south to Ga. and Mo.; also northward.

Var. tenuifolia, Gray. Slender, lix, diffuse, 6-12' high, with loose infloreseence, and almost filiform branches and peduncles; cauline leaves all linear, hardly over $1^{\prime \prime}$ wide. - S. E. Ohio to Va., N. C., and Tem.

Var. calycòsa, Gray. Almost $1^{\circ}$ high; leaves broadly lanceolate, thickish; calyx-lobes elongated $\left(2-4^{\prime \prime}\right.$ long), much surpassing the pod. - From Ill. (Hall) to Ark. and N. Ala.

6. H. angustifòlia, Michx. Stems tufted from a hard or wooly root; leaves narrowly linear, acnte, 1-ribbed, many of them fascicled; flowers crowded, short-pedicelled; lobes of the corolla densely bearded inside; pod oboroid, acute at base, only its summit free, opening first across the top, at leugth through the partition. - Barrens, 11l. to Kan., south to Tex., Tenn., aud Fla.

\section{OLDE N LÁ N D I A, P'lunier.}

Calyx 4-lobed, persistent. Corolla short, in our speeies wheel-shaped; the limb 4-parted, valvate in the bud. Stamens 4 ; anthers short. Style 1 or noue ; stigmas 2. Pod thin, 2-celled, many-seeded, opening locnlicidatly across the summit. Seeds very numerous, minute and angular. - Jow herls, with small stipules united to the petioles. (J)edicated to the memory of Oldenland, a German physician and botanist, who died early at the Cape of Good 11ope.)

1. O. glomeràta, Michx. An inconspicuous, pnbescent or smoothish, branched and sprealing annual (2-12' ligh); leaves orate to oblong; flowers in sessile axillary clusters; corolla nearly wheel-shaped (white), mnch shorter than the ealyx. - Wet places, near the eoast, N. Y. to Fla. and Tex.

\section{CEPHA LÁ N TH U S, I. Butron-izusir.}

Calyx-tube inversely pyramilal, the limb 4-toothed. Corolla tubular, 4tootled; the teeth imbricated in the bud. Style thread-form, much protruded. Stigma capitate. Fruit dry and hard, small, inversely 1yramidal, 2-4-eelled, at lengtl splitting from the base 11 pward into $2-4$ closed 1 -seeded portions. Shrubs, with the white flowers densely aggregated in spherical peduneled heads. (Name composed of $\kappa \epsilon \phi \alpha \lambda \eta$, a head, and ávos, a flourer.)

1. C. occidentàlis, L. Smooth or pubescent; leaves petioled, ovate or lanceolate-oblong, pointed, opposite or whorled in threes, with short intervening stipnles. - Swamps and along streans, throughout the continent. July, Aug

\section{MITCHÉLIA, L. JARTRDGL-BERR.}

Flowers in pairs, with their ovaries minted. Calyx 4-toothed. Corolla fun. nel-form, 4-lobed; the lobes spreating, densely bearded inside, valvate in the bud. Stamens 4. Style 1; stignas 4, linear. Fruit a bery-like doulle drupe, crowned with the ealyx-teetl of the two flowers, with 4 suall seed-like bony untlets to each flower. $-\Lambda$ smooth and trailing small evergreen herb, with ronnd-ovate and shining petioled loaves, minute stipules, white fragrant flow. crs often tinged with purple, and scarlet edible (but nearly tasteless) ber. ries, which remain over winter. Flowers occasionally 3-6-nerous, always dimorphons; all those of some individuals having exserted stamens and in. chred stigmas; of others, includer stamens and exserted style. (This very 
pretty plant commemorates Dr. John Mitchell, an early correspondent of Linnæus, and an execllent hotanist, who resided in Virginia.)

1. M. rèpens, I. - Dry woods, creeping about the foot of trees, espeeially Conifere, throughout our range and sonthward. June, July. - Ieares ofteu varlegated witl whitish lines. Rarely the two flowers are completely eonfluent into one, with a 10-lobed eorolla.

\section{SPER M A C Ò E, Dill. Buttos-weed.}

Calyx-tube short; the limb parted into 4 tecth. Corolla funuel-form or salver-form, valvate in the bud. Stamens 4. Stigma or style 2-cleft. Fruit small and dry, 2-eelled, 2-seederl, splitting when ripe into 2 carpels, one of them usually carrying with it the partition, and therefore closed, the other open on the mner face. - Small herbs, the bases of the leaves or petioles connected by a bristle-hearing stipular membrane. Flowers small, whitisll, crowded into sessile axillary whorled clusters or heads. (Name compounded of $\sigma \pi \epsilon$ p $\mu \alpha$, seed, and akwin, " point, probably from the pointerl calyx-tecth on the fruit.)

I. S. glàbra, Michx. Glabrous pereunial; stems spreading $\left(9-20^{\prime}\right.$ long); Ieaves oblong-lanceolate; heads many-flowered; corolla little exceeding the calyx, bearded in the throat, hearing the anthers at its base; filaments and style Lardly any. - River-banks, S. ()hio to Ark., Tex., and Fla. Ang.

\section{DI Ò D I A, Gronov. Butrox-ween.}

Calyx-teeth 2-5, often mequal. Fruit 2. (rarely 3 -) eelled; the crustaceous carpels into whieh it splits all closed and indehiscent. Flowers $\mathbf{l}-3$ in each axil. Otherwise resembling spermacoce. Flowering all stmmer. (Name

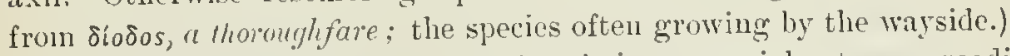

1. D. Virginiàna, L Smooth or hairy peremial; stems spreading (1 $2^{\circ}$ long); leaves lanceolate or oblong-laneeulate, sessile; corolla white ( $\frac{1}{2}$ long), the slender tube abruptly expanded into the large limb; style 2-parted; fruit oblong, strongly furroued, crowned mostly with 2 slender calyx-teeth - Low grounds along streams, southeru N. J to Fla., west to $\Lambda$ rk. and Tex.

2. D. tères, Walt. ILairy or minutely pubescent anunal; stem spreading (3-9' long), nearly terete; leaves linear-lanceolate, closely sessile, rigid; corolla funnel-form $\left(2-33^{\prime \prime}\right.$ long, whitish $)$, with short lobes, not exeeding the long bristles of the stipules; style undivided; finit obovate-turbinate, not furrowed, crowned with 4 short calyx-teeth. - Sandy soil, N .J.to Wr. 111., Fla, and Tex.

\section{GÀ I U M, L. Bedstraw. Cleavers.}

Calyx-tceth obsulete. Corolla 4-parted, rarely 3-parted, wheel-shaped, valvate in the bucl. Stamens 4, rarely 3, short. Styles 2. Fruit dry or fleshy, globular, twin, separating when ripe into the 2 seed-like, indehiscent, 1-seeded earpels. - Slender herbs, with small cymose flowers (produeed in summer), square stcms, and whorled leaves, the roots often containing a red coloring matter. (Name from $\gamma a \dot{\lambda} \alpha, m i l k$, which some species are nsed to curdle.)

\section{\$ 1. Naturalized species; fruit dry.}

G. Vèru, L. (Teliow Brostraw.) Terennial; stems smooth, erect; leaves 8 or sometimes 6 in the whorls, linear, loughish, soon heflexed; flower's 
very numerous, paniculate, yellow; fruit usually smooth. - Dry fields, E. Mass. (Nat. from Eu.)

G. Mollíro, I. Perennial, smooth throughout; stems ercet or cliffuse, 2 or $3^{\circ} \mathrm{long}$; leaves 8 , or 6 on the lunchlets, oblancculate to nearly linear; Howers very numerous in ample almost leafless pauicles; fruit sinootl. Roadsides and fields, N. Y. and I'enn. (Nat, from Eu.)

G. Áxglicum, IIuch. Annual, slender, diffuse, seldom $1^{\circ}$ high, glabrous: leaves $5-7$, oblancesolate to nearly linear ( $3^{\prime \prime}$ long), their margins and the angles of the stcm spinulose-scaluous; flowers rather few, cymulose on leafy branches, greenish-white, very small; fruit glabrons, more or lcss tuberculate - Roadsides, Bedford Co., Va. (Cumiss). (Nat. from Eu.)

G. Tricórve, Witl. Amual, resembling G. A parine, rather stont, with simple branches; lcaves 6 or 8 , ollanceolate, cuspictate-mucronate, the margins and stem retrorsely prickly-hispid; Howers mostly in clusters of 3, dull white; fruits rather large, tuberculate-graunlate, not hairy, pendulous. - Ficlds, east. ward. (Nat. from Eu.)

\$2. Indigenous species; fruit dry.

* Amual; leuves aboul $s$ in a whorl; peduncles 1 -3-flowered, axillary; feuil unistly with hooked mickles.

1. G. Aparine, L. (Clewrers. Goose-Grass.) Stem weak and recliniug, bristle-prickly lackward, hairy at the joints; leaves lanceolatc, tapering to the basc, short-prointed, rougl on the margins and midrib (1-2' long): Howers white. - Sharded grounds, throughout the continent; probably as an introduced plant eastward.

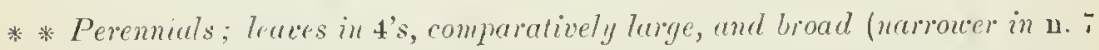
and 8), not cuspidule-poinled, more or less distinctly 3-nereed; fruit uncinateluspud (except in 11.6 and 7 ).

- Peduncles loosely 3-several-flucered; foners dull purple to yellowish-uhthe.

2. G. pilosum, Ait. Hairy; leaves oval, lotted, lairy ( $I^{\prime}$ long), the lateral nerves obscure; peduncles 2-3-forked, the flowers all pedicelled. - Dry. copses, R. I. and V't. to Ill., E. Kan., and southward.

Var. puncticulosum, Torr. \& Gray. Aluost glahrons; learcs varying to elliptical-oblong, hispidulons-ciliate. - Va. to Tex.

3. G. Kamtscháticum, steller. Stems weak, mainly glabrous $\left(1^{\circ}\right.$

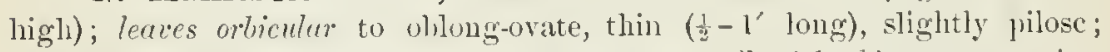
flowers slenterly pediccllate; covolla glabrous, yellowish-vthite, not turning lark, its lobes merely acute. (G. circazans, var. montaum, Torr. g. Gray.) Higlier mountains of N. Eng., L. Canada, aud far westward. (Asia.)

4. G. circiezans, Michx. (W11) Liquonick) Smooth or downy (10 high); leaves oval, varying to orite-ohlong, mostly obtuse, ciliate ( $1-1 \frac{y^{\prime}}{2}$ long), peduncles usually once forked, the branches elongated and widely diverging in fruit, bearing several remote flowers on very short lateral pedicels, reflexed in fruit; lobes of the greensh corolla haring outside, acute m acumimate. - Rich woods, N. Eng. to Minm., sontl to Fla. and Tex.

5. G. lanceolàtum, Torr. (Wu, Liqvoure.) Ncarly glabrous: leaves (exccpt the lowest) lancedale or neate-lancelate, tupering to the apex $\left(2^{\prime}\right.$ long); corollu glabrous, yellowesh turning dull furple, lobes more acuminate; otherwise like tho last. - 1)ry woods, N. Eng. to N. Mich. and Minn.

6. G. latifolium, Michx. Smooth $(1-20$ high); lenves lanceointe or

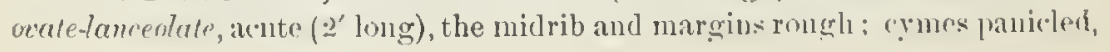


loosely many-flowered, the purple flowers on slender spreading palicels: fruit smoth, rather fleshy. - Dry woorls, momntains of Penn. to N. C. and Teun.

: G. Arkansànum, Gray. Similar but lower; leaves lanceolate to linear ( $\mathrm{I}^{\prime} \operatorname{lom}$ or less), the lateral nerves obscure or none. - S. Mo. and Ark.

+ + Leaves marrow; flowers bright white, numerous in a compact panicle.

8. G. boreàle, L. (Nontumex Bedstraw) Sinooth (1-20 high); leaves linear-linceolate; fruit minutely bristly, sometimes smootl. - Rock! banks of streams, Maine to Penu., Iowa, Minn., and westward. (Eu, $\Lambda$ sia.) * Leares in 4's, 5's, or 6's, small, 1-nerved; flourms uhite; finit smonth (flowers greenish and fruit hispid in 11 12.)

+- Leaves pointless

9. G. trífidum, 1. (SMAl, Benstraw) Sitems weak, ascending (520 high), branching, mostly roughened backwards on the angles; leares in whorls of +40 t, linear or oblanceolate, the margins ant mill rib rougli; peduncles scattered, 1-7-fouced ; corolla-lobes anl stumens often only 3. - Sphagnous bogs and wet ground, throughout the continent. Exceclingly variable - Var. pusf́ludr, Gray, the smallest forn ; leares only in 4 's, $3-4^{\prime \prime}$ long, narrow, in age often reflexed; peduncles 1-flowerel. In cold bogs, northward. - Var. LATrómu, "Torr, the larger and hromlest-leaverl form; leaves 6 or 7 " long, often 2" wille. From Canala, sonth and west. (Eu., Asia.)

10. G. concínnum, 'Torr. \& Gray. Sitens low and slender (6-12' high), witl minntely roughened angles; leaves all in 6 's, linerr, slighty pointed, veinless, the margins upwarlly ronghened; peduncles $2-3$ times forked, diffusely pam. irled; pedicels short. - Dry hills, Penn. to Va, west to Minn., Fowa, and Ark.

+ + Ceares cuspidately murronate or acuminate.

11. G. aspréllum, Michx. (Roriin Benstr.ı.) stem much branched, rough backwards with hooked prickles, leaning on bushes $\left(3-5^{\circ}\right.$ high); leures in whorls of 6 , or $4-5$ on the branchlets, mral-lancerdate, with almost prickly margins and millib; peduneles slort, 2-3 times forked. - Alluvial ground, N. Eng. to N. C., west to Minn., lowa, and Mo.

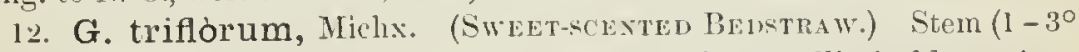
long) bristly-roughened backward on the angles; leaves elliptical-lanceolate, bristle-pointed, with slightly roughened margins (1-2' loug); peduncles 3flowered, the flowers all pedicelled, greenish; fruit beset with looked bristles. - lich woodlands, throughout the continent. Sweet-scented in drying. (Eu.)

\section{\$ 3. Perennial; finit a berry: leares in 4's, 1-nerved.}

13. G. hispidulum, Michx. Mirsute-pubeseent, scabrons, or sometines nearly smooth, 1-20 ligh, diffusely lrauched; leaves ollong or oval, mueronate $\left(3-6{ }^{\prime \prime}\right.$ long $)$, pellicels solitary or commonty 2 or 3 from the small inve incral whorl, all naked, or one of them luacteolate; flowers white; berr! purple, glabrate. - Dry or sudy soil, sonthern N. T. tu Fla, along the const.

\section{SHERÁRDIA, Dill.}

Calyx-lobes lanceolate, persistent. Corolla funnel-form, the limb 4-5-lobed. Stamens $4-5$. Style filiform, 2-cleft; stignas capitate. Fruit dry, twin, of 2

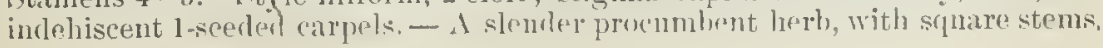


lanceolate pungent leaves in whorls of $4-6$, and small subsessile blue or pinkish flowers surrounded by a gamophyllous involncre. (Named for Dr. Hilliam Sherard, patron of Dillenius.)

S. ARvÉxsIs, L, The only species; sparingly natnralized from Eu.

\section{Order 53. VALERianiceae. (Valeriax Family.)}

Herbs, with opposite leaves and no stipules; the calyx-tube coherent with the ovary, which has one fertile 1-ovuled cell and two abortive or empty ones; the stamens distinct, 1-3, fewer than the lobes of the corolla, and inserted on its tube. - Corolla tubular , funnel-form, often irregular, mostly 5lobed, the lobes imbricated in the bud. Style slender; stignas 1-3. Fruit indehiscent, 1-celled (the two empty cells of the ovary disappearing), or 3-celled, two of them empty, the other 1-seeded. Seed suspended, anatropous, with a large embryo and no albumen. - Flowers in panicled or clustered cymes. (Roots often odorous and antispasmodic.)

\section{V A LER I À N A, Tonrn. Valeriax.}

Limb of the calyx of several plumose bristles (like a pappus) which are rolled up inward in flower, but mmoll and spread as the seed-like 1-celled fruit matures. Corolla commonly gibbous near the base, the 5-lohed limb nearly regular. Stamens 3. - Perennial herbs, with thickewed strong-scented roots, and simple or pinuate leaves. Flowers in many species imperfectly dicecious or dimorphons. (A medixval Latin name of uncertain origin.)

* Root spindle-shaped, large und deep (6-12'long); leaves thichish.

1. V. édulis, Nutt. Smooth, or minntely downy when very young; stem straight $\left(1-4^{\circ}\right.$ high $)$, few-leaved; leaves commonly minutely and densely ciliate, those of the root spatulate and lanceolate, of the stem pinnately parted into 3-7 loug and narrow divisions; Howers in a long and narrow interrupted panicle, nearly diocious; corolla whitish, obconical ( $\underline{z}^{\prime \prime}$ long). - Wet plains and prairies, Ohio and Ont. to Iowa, Minn., and westward. June.

* Root fibrous: leares thin. (Sients $1-3^{\circ}$ light.)

2. V. sylvática, Banks. Smooth or minutely pubescent; root-leares orate or oblong, entire, rarely with 2 sinall lobes; stem-leares pinnate, with 3 11 oblong-ovate or lanceolate nearly entire leaflets; cyme at first close, manyHowered; corolla inverscly conical ( $3^{\prime \prime}$ long, rose-colur or white). - Wet ground, Newf. to southern N. Y., N. Miclı, westwarl and northward. June.

3. V. pauciflora, Michx. Smooth, slender, surculose; root-leares ovate, heart-shaped, tootled, pointed, sometimes with 2 small lateral divisions; stemleaves pinnate, with $3-7$ orate tonthed leaflets; brauches of the panicled cyme few-flowered; tube of the (pale pink) corolla long and slender ( $f^{\prime}$ long). - Woods and alluvial banks, Penul. to.s. HII., Mo, and Tenu. June.

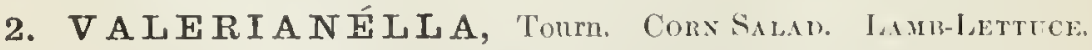

Limb of the calyx olsolete or merely toothed. ("orolla fumel-form, equally or unequally 5-lobed. Stamens 3, rarely 2. Fruit 3-celled, two of the cells empty and sometines confluent into one, the other l-seeded. - Amulals and 
hiennials, usually smooth, with forking stcms, tender and rather succulent leares (entire or eut-lobel towards the base), and white or whitish cymoseclustered aud bracted small flowers. - Our species all have the limb of the calyx obsolete, and are so much alike in aspect, flowers, etc., that good claracters are only to be takeu from the fruit. 'They all have a rather short corolla, the limb of which is nearly regular. (Name a dininutive of Valeriana.)

* Corolla blwish : finit with a corky mass at the back of the fertile cell.

V. olı́ória, Poll. Fruit flattish, obliqucly rhomboidal; cmpty cells as larme as the fertile, contiguous, the thin partition at lengtl breaking up. Old fielis, N. Y. to Penn. and Lil. (Nat. from Eu.)

* Corolla white; no corky mass behind the fertile cell.

+ Fertile cell broader than the empty ones; cross-section of fruit triangular.

1. V. chenopodifolia, 1)C. Stems with long interuodes and few forks; glomerate cymes few; slender-peduucled; bracts broadly lanceolate; frnit glahrons or pubescent, 2" long. (Fedia Fagopyrum, Torr. \& Gray.) - Moist grounds, western N. X. to Minu., soutlı to Va. and Ky.

+ + Fertile cell as broad as the empty ones, beaked; cross-section quadrate.

2. V. radiata, Dufr. Fruit ovate-tetragonal, downy-pubescent (sometimes glabrous); empty cells as thick as the oblong-ovate fertile one, or thicker, $a$ broad shallow groove between them. (Fedia raviata, Mich $x$.) - Low grounds, Penn. to Mimn., 'Tex., and Fla.

3. V. stenocárpa, Krok. Fruit oblong-tetragonal, commonly glabrous; oblong fertile cell thicker than the linear-oblong approximate empty ones. (Fedia stenocarpa, Engelm.) - W. Mo. aud L. Kan. to Tex.

+++ Fertile cell much the narrouest, dorsally 1-nerved; section roundish.

4. V. Woodsiàna, Walp. Frnit $1^{\prime \prime}$ long or more; fertile cell ovate, tipped with a tooth; empty oues inflated, with oblong lepression (sometimes an open cavity) in the middle. - Moist grounds, N. Y. and Penn. to Tex

Var. umbilicàta, Gray. Empty cells becoming confluent, vesicular by incurvation of the circular margin, forming a deep and round umbilication. (Fedia umbilicata, Sulliv.) - N. Y. to Ohio and soutluward.

Var. patellària, Gray. Fruit saucer-shaped, emarginate at base and apex, winged by the divergent cells. (Fedia patellaria, Sulliv.) - Same range.

\section{Order 54. DIPSȦCEA. (TeAsel FAMIL.)}

Ilerbs, with opposite or whorled leares, no stipules, and the flowers in dense heads, surrounded by an involucre, as in the Composite Family ; but the stamens are distinct, and the suspended seed has albumen. - Represented by the following introduced species and by the eultivated Sweet Scabious (Scabiosa atropurpurea).

\section{DÍPSACUS, Touru. Teasel.}

Involucre many-loaved, low ger than the chaffy leafy-tipped and pointed bracts among the densely capitate flowers; cach flower witl a 4-leaved calyx-like involucel investing the ovary aud fruit (achene). Caly-tube coherent with the ovary, the linh, cup-shaped, without a pappus. ('orolla nearly regular, 4-cleft. Stamens 4 , inserted on the corolla. Style slender. - Stout and coarse bien- 
nials, hairy or prickly, with large oblong heads. (Name from $\delta$ i $\psi a$ áw, to thirst, probably because the united cup-shaped bases of the leaves in some specres hold water.)

1. D. Sruxistris, Mill. (WH, Traseu.) Prickly; leares lance-oblong: leaves of the involucre sleuder, longer than the head; bracts (chatf) tapering into a loug flexilule awn with a straight point. - Roadsides; rather rare. (Nat. from Eu.) suspected to be the original of

2. D. Fulosicr, L., the Fulden's 'Tensel, which has a shorter involuere, and stiff chaff to the heads, with hooked points, used for raising a nap upon woollen cloth; it has escaped from cultivation in some places. ( $\Lambda \mathrm{dr}$. from Eu.)

\section{Order 55. COMH'ósitae. (Comosite Famiy.)}

Flowers in a close head (the eompound flower of the older botanists), on a common receptacle, surrounled by an involucre, with 5 (rarely 4) stamens inserted on the corolla, their anthers united in a tube (syngenesious). - Calyx-tube united with the 1-celled ovary, the limb (called a pappus) crowning its summit in the form of bristles, awns, scales, tectl, ete., or eup-shaped, or else entirely absent. Corolla either strap-shaped or tubular; in the latter ehiefly 5-loberl, valrate in the bud, the veins bordering the margins of the lobes. Style 2-eleft at the apex (in sterile flowers usually entire). Fruit seed-like (achene), dry, eontaining a single erect anatropous seed, with no albumen. - An immense family, in temperate regions chiefly herbs, without stipules, with perfect, polygamous, monœeions or diocions flowers. The flowers with a strap-shaped (ligulate) corolla are called rays or ray-flovers: the head which presents such flowers, either throughout or at the margin, is radiate. The tubular Alowers compose the dish; and a head which has no ray-flowers is said to be discoid. When the heal contains two sorts of flowers it is said to be heterogamous; when only one sort, homogamous. The leaves of the involucre, of whatever form or texture, are termed scales. 'The bracts or seales, which often grow on the receptacle among the flowers, are called the chaff; when these are wanting, the receptacle is said to be naked. - The largest oriler of l'hrenogamous plants. The genera are divided by the eorolla into three series, only two of which are represented in the Northern United States. The furst is mnch the larger.

\section{Systematic Synopsis.}

\section{SERTE T. TUBUIIFIORAE.}

Corolla tubular in all the perfect flowers, recularly 5- (ralely 3-4-) lobed, ligulate only in the marginal or ray-flowers, which when present are either pistillate only, or neutral (with neither stamens nor pistil).

Tribe I. VERyonIACEA. Ifuls riscoid; the thwers all alike, perfert and tubular, never yellow. Ibrnnches of the style, Inng and slender, terete, thread-slaphed, minutely bristly-hairy all over. - Leaves alternate or seattered.

1. Elephantopus. II cads 3 - 5-flowered, several crowded together into a compound head. Involucre of $S$ scales. Paputus of several chaffy bristles.

2. Vermonia. II atds several-many-flowered, sepirate. Iublucre of many scales. Papnus double, the inner capillary, the outer of minute chatly bristles. 
Tribe 1I. EUPATORIACE.T. Heads discoid, the towers all alike, perfect and tubular, never yellow. Branches of the stylc thickened upward or club-shaped, obtuse, very minutely and uniformly pulescent; the stigmatic lines indistinet.

* Pappus a row of hard scales.

3. Sclerolepis. Head nauy-Howered. Scalcs of the involucre cqual. Leaves whorled.

* Pappus of slender bristles.

- Achene 5-augled; bristles of the pappus roughish.

4. Mikania. Flowers and involucral scales only 4. Stems twiuing.

j. Empatorimm. Involuere of nore than 4 seales and the flowers few or many. Stems not twining.

- + Achene 10-ribbed; involucral seales striate-nerved.

6. Kuhnia. Pappus very strongly plumose. Scales of the involucre few.

7. Brickellia. Involucral scales in several series. Paplus merely scabrous.

8. Liatris. Paplus plumose or only barbellate. Corolla red-purple, strongly 5-lobed. IIeads spicate or racemose, the involncre well imbrisaterl.

9. Trilisa. Papjus minutely barbellate. Corolla row.jurple Heads corymbed or pan. icled, the involuere little imbrieated.

Tribe III. ASTLROIDEAC. Meads discoid, the Howers all alike and tubular ; or eltie radiate, the outer ones ligulate and pistillate. Anthers not caudate at base. Branches of the style in the perfect fowers flat, smooth up to where the conspicuous marginal stigmatic lines abruptly terminatc, and prolonged above this in to a flattened lance-sliaperl u' triangular alluenclage which is eveuly hairy or pubescent outside. - Leaves alternate. Recentacle naked (dcstitute of chaff) in all our species.

- 1. Ray-flowers yellow (in one species of Solidago whitish), or sometimes none at all.

- Pappus of not numerous sleuder bristles. 11eads radiate. luvolucre of firm scales witl greenish tips, commonly conten with resin. West of the Mississippi.

10. Gutierezia. Heals snall, numerous. Ray and disk-flowers 3 or 4 each, all fertile. Pupulus of several short chatfy scales. Suffutescent; leaves very uarrow.

11. Amphiachyris. Heads small. Ray-flowers 5-10; palyus corouiform. Disk-flowers infertile; pappus of several bristle-like scales. Anutual ; leaves very narrow.

12. Grindelia. Heads large, many-flowered. Flowers all fortile. Pappus of $2-8$ rigid calucous awns. Coarse luerbs with toothed leaves.

++ Pappus (at least of the disk) of copions slender or capillary bristles.

$$
=\text { Paplus double. }
$$

13. Heterothoca. Reserubling Chrysopsis, but the achenes of the ray thicker than those of the disk and without pappus or nearly so. Western.

14 Chrysopsis. Ileads many-flowered ; rays numerous. The outer pappus of very sman rhafy bristles, inuch shorter than the iuner of copious capillary bristles.

$$
==\text { Pajpus simple. }
$$

15. ApIopappus. Ileads many-flowered, unany-radiate. Involucre hemisplierical. Pap jus of many unequal bristles. Western.

16. Higelovia. Heats $8-4$-flowerol; rays nome. Receltacle awl-shaped. Pappus a single row of (:i) illaty bistles.

17. Solidago. Ifeals few-many-Howered; rays 1-16. Pappus of numerous slender and equal capilliary hristles.

18. Brachyehita. Heads $\$-10$-flowered, elustered; rays 4 or 5 . Pappus a row of miute bristles slorter than the acheue.

* 2. Ray-flowers white, blue, or purple, never yellow.

- Pajpus none or very slort, with or withnut a few awns.

* Receptacle conical. Awns nout.

19. Bellis. Achenes marninless, Rattencl; papjus mone. luvolucral stales equa

20. Aphanosteplus. Aelones prismatio; pappus cormiform. Guter stales shortex 
+* + Receptacle flat or convex. Pappus usually with awns.

21. Chatopappa. Achenes fusiform; pappus of 5 or fewer thin claff and alternating awns. Western.

22. Boltonia. Achenes very flat, thick-winged; pappus of short bristles and usually $2-4$ awus.

- Pappus of a single row of awns or coarse rigid bristles, or in the ray scale-like.

23. Townsendia. Low or stemless, with linear-spatulaté leaves and largo aster-like flowers. +++ Pappus of numerons long and capillary bristles; receptacle flat.

24. Sericocarpus. Heads $12-20$-flowered; rays 4 or 5 . Involucre ohlong or club-shaped imbricated, cartilaginous. Aclienes short, narrowed downward, silky.

25. Aster. Heads many-flowered, on leafy liceluncles. Involucral scales męjual, loosely or closely imbricated. Aclienes flattish; pappus simple (rarely donble), copious.

26. Erigeron. Heads many-flowered, on naked peduncles. Involucre of narrow equal scales, little imbricated. Achenes flattcued; pappus simple and rather scanty, or with some outer minute scales.

* 3. Rays none. Heads diœcious (all pistillate or all staminate).

27. Baccharis. Heads many-flowered. Pappus capillary. Smootl glntinons slirubs.

Tribe IV. INULOIDEA. Heads liscoid (radiate only in Iuula), the pistillate flowers mostly filiform and truncate. Anthers sagittate, the basal lobes attenuate into tails. Style-branelies with unappendaged obtuse or truncate naked tips. Pappus capillary or none.

* 1. Receptacle naked. Involucre not scarious, imbricated. Not woolly.

28. PIuchea. IIeads containing a few perfect but sterile flowers in the centre, and many pistillate fertile ones arouud them. Pappus capillary.

* 2. Receptacle chaffy. Involucral scales few, mostly scarious. Low floccose-woolly annuals ; flowers as iu n. 28.

29. Evax. Receptacle convex. Achenes obcompressed. Pappus none. Westeri.

30. Filago. Reccrtacle subulate. Achenes terete. Outer flowers witlout pappus.

* 3. Receptaclc naked. Involucral scales many, scarious. Floccose-woolly herhs.

31. Antennaria. Heads diøcious. Pappus of sterile flowers club-shaped, of the fertile united at base and deciduous together.

32. Anaphalis. Heads diœcious or nearly so. Pappus not thickeued above nor at all united at base.

33. Gnaphalium. IIeads all fertile throughout. Pappus all capillary.

* 4. Corollas all somewhat broadly tubular and lobed. Involucre not searious. Receptacle naked. Papjus none.

34. Adenocaulon. IIeal few-flowered and scales few; outer flowers pistillate. Somewhat woolly.

* 5. Heads ralliate. Receptacle nalied. Involucre herbaceons. Pappus copious.

35. Inula. Heals large, many-flowered. Flowers yellow. Stout percunial.

Tribe V. HELIANTIOIDEA. Heals radiate or discoid. Involnure not scarious (nut-like in fruit in $11,43,44$ ). Recptacle chaffy. Papuns never capillary, sometimes none. Anthers not caudate. Style-branches truncate or hairy-aplendiged.

*1. Ieads radiate (obscurely so in n. 41 , sometimes discoill in n. 36), the ray pistillate and fertile, the disk perfect but sterile.

+ Achenes turgid, triangular-obovoid; parpmonone.

36. Polynnla. Involueral scales in 2 rows, the 5 outer lcaf-like, the inmer small.

+ - Achenes flattened dorsally (obenmpressell).

97. Shphlum. Achenes wingruargined, in several rows; papms none or 2 teeth. Scules thick, to several rowes, 
35 Berlandiera. Achenes wingless, 5-12 in one row, without pappus. funer involucral scales obovate, outer smaller and more foliaceous. Western.

34. Chrysogonum. Achenes wingless, about 5; pappus a oue-sided 2 - 3-toothed crown Inner scales 5 , chaff-like, the 5 outer longer aud leaf-like.

40. Engelmannia. Achenes wingless, 8-10; pappus a scarious hispid crown. Outer scales (about 10) leaf-like, inner coriaceous with green tips. Western.

41. Parthenium. Rays 5, very short, persistent. Pappus of 2 small scales. Invulneral scales short, roundisli, in 2 rows.

* 2. Fertile flowers $1-5$, the corolla noue or reulucel to a tube; stamiuate corolla funnel-form. Pappus none.

+ Heads with $1-5$ pistillate flowers. Receptacle chaffy.

42. Iva. Achencs short, thick. Involncre of few roundish scales.

- + Heads of two sorts on the same plant, the upper staminate witl an open cup-shaped involncre, the lower pistillate, of $1-4$ flowers in a closed bur-like involucre.

4. Ambrosia. Scales of staminate involncre united. Fruit 1-seeded.

44. Xanthium. Scales of staninate involucre distinct. Fruit 1-4-celled, 1-4-beaked.

* 3. Heads radiate, or rarely discoid; disk-flowers all lerfect and fertile, dutlers blackish. Pappus none, or a crown or eup, or of one ol two ehaffy awns, never capillary, nor of several uniform chaffy scales. - Leaves move commonly opjosite,

- Involucre clouble; tlie onter forming a cup.

45. Tetragonotheca. Outer involucre 4-leaved. Achenes obovid; pappus none.

++ Involucre of one or nore rows of separate scales.

+ Cliaff of the flat receptacle bristle-shaped.

46. Eclipta. liay short. Involucral scales 10-12, in two rows, herbaceous. + + + Cliaff scale-]ike, embracing or subtending the achenes.

= Receptacle bigh, conical or columnar in fruit. Pappus none or a slort crowu.

47. Heliopsis. Rays fertile. Achenes 4-sider. Leaves opposite.

45. Echinacea. Rays rose-colorerl, pistillate, sterile. Acheues sbort, 4-sided. Chaff spinescent.

49. Rudbeckia. Rays nentral. Acbenes 4-sidcl, flat at the tol, margiuless.

50. Lepachys. Rays few, neutral. Achenes flattened laterally and margined.

$==$ Receptacle flat to convex. Achenes not winged nor very flat.

51. Borrichia. Achenes 3-4-angled; pappus a short 4-tootlied crown. Shrubby.

52. Iclianthus. Achenes flattencd, bearing 2 very deciduous chafry pointed scales.

$===$ Receptacle convex (rarely conical). Achenes flat-compressed laterally, winged or wingless, 2-awned. Leaves decurrent.

53. Verbcsina. Involucral scales closely inbricated in 2 or more rows.

54. Actinomeris. Scales few, soon deflexed. Achenes obovate, squarrosely spreading.

* 4. Rays few, ucutral, or wanting. Achenes obcompressed, i. e., flattened parallel with the seales of the involucre (rarely terete). Involucre double; the outer spreading aud ofteu foliaceons, Receptacle flat. Leaves opposite.

55. Coreopsis. Pappus of 2 (or larely nole) scales, teeth, or awus, which are nakel or barbed upward, sometimes obsolete or a mere crown.

56. Bidens. Pappus of $20 r^{\circ}$ more rigid and persistent downwardly barbed awns 01 teetl.

57. Thelesperma. Inner involurge connate to the middle. Acheues terete. Iwis retrorsely bearded.

* 5. Heads radiate or discoid; disk-flowers all perfect and fertile. Acheues turbinate, 5angled: pappus of several chaffy scales.

+ Leaves alternate, entire. Disk-flowers purplish.

55. Baldwinia. Rays numerous, long, neutral. Involucre much inbricated. Receptacl* deelvil lomey-eonher.

59. Marshallia Rays none. Involucre of uarow leafy equal scales. Receptacle chaff: 
++ Leaves opprosite, serrate. Wisk-flowers ycllow.

60. Galinsoga. Rays few, short, pistillate, whitish. [nvoluere of $4-5$ thin ovate scales Receptacle cliafiy.

Tribe VI. HELENIOIDEA. Nearly as Tribe V., but receptacle not chaffy (some. what so in n. 64). ln our gencra, tine disk-flowers perfect and fertile; the pappus a row of several chaffy scales (bristly-dissected in 1,65 ); the involucre hardly at all inbrieated (partly searious in 13.61 )

* Involucral scales distiuct, not glandular-punctate.

61. Hymenopappus. Rays none. Receltaule ftat. Involucre colorer. Western.

62. Actinella. Ratys fitile, 3-toothed. Receptacle elevated. Involuereappressed. Western.

(is. Heleniun. Rays fertile ol sterile, 3 -j-cleft. Receltacle elevater. Involnere small, reflexed. Leaves decurrent.

bit. Gaillardia. Ray 3-toothed, or nome. Receptacle usually beset with fine fimbrillate chatt. Outer involueral scales loose and leafy laplus-chaff tipped with the projecting midvein. Western.

* Dotted with oil-glands. Involucral seales mited into a cup.

6.5. Dysodia. Pappus a row of ehafty scales dissected into nany bristles.

Tribe VII. ANTIIEMTDE E. Distingnished from the last two tribes by the more or less dry and scarions inbricater seales of the involucre. Heads radiate (ray mostly white) or discoin, the perfeet flowers sometimes sterile and the pistillate rarely tubular. Achenes small; pappus a short crown or none, - Mostly strong-scented ; leaves alter'nate.

* Receptacle clatfy, at least in gart. lleads lokliate, manj-fluwered.

60. Anthemis. Achenes tercte, angled or ribbet. Ilculs hemispherical, rather large.

(iT. Aclrillea. Aclicnes obcompresied. I[earls small, cambunulate or obovate.

$$
\text { * Recepitacle nakeal. }
$$

+ Heads rabler limse, predumenlate, radiate or rarely rayless.

65. Matricaria. Rerentarle conical. Rays pistillate or none, Papyus crown-like or none

69 Chrysanthomum. Reecutacle 1lattish. Rays nany, pistillate. Pappus none. +f llumls mustly small, discoid, corymbed or panimlate.

70 Tanacotum. Ilumls coryubed. Achene with broad smmmit; pappus a short crown.

71. Artemisia. Ifouls in frulued spilies or racemes. Achrnes with narow summit; p']

Tribe VIII. SHNICIUNIDE.E. 1leats radiate or discoli, the involucre little or not at all jublicated, not scarious. Reeptacle nakel. Antlers talless. Pajpus capillary.

* Lleads nonocims or subdicecions, the perfect flowers mostly sterile, and the small (ligulate or tubular) lay-llowers iu more tluan one row (at least m the fertile lieads). Style.. branches obtuse, not a!prendager nor lispid. Leaves all ratical.

72. Tussilago. Ileal solitary, yellow-flowered, monceions.

73. Petasites. ITouls corymbenl, subdicecions. Flowe's white or purplish.

* Flowers all fertile. Stylo-branches truncate or capitellate, often appendaged. Involucral seales connivont-erest.

$$
\text { - Leares oprosite. }
$$

74. Arnicar. Heals showy. Paplus ratlere rigid, seabrous.

$$
++ \text { Leaves alternate. Palpus soft-capillary, copious. }
$$

75. Senecio. Invids nsurdly radiate. Corollas yellow, 5-toothed.

7; Cacalia. IIrasls discoid. Corollas white or eream-colored, 5-cleft.

7\%. Irechlites. Heads discoid. Flowers whitish, the onter pistillate with filiform corollas. 
Tribe IX. CYNAROIDEAE. Flowers all tubular and perfeet the outer ray-like and neutral in n. S2). lnvolucre much imbrieated. Anthers eaudate, long-apnendaged at tip. Style-branches short or united, obtuse, unalpnendaged, smooth, with often a pubescent ring below. Papnus mostly bristly. - Leaves alternate.

* Achenes attached by the base. l'lowers all alike.

+ Leaves not prickly. Style-branches partly distinet. Filaments glabrous.

7S. A retium. Involucral scales looked at the tip. Fappus of sliort rough bristles.

+ + Leaves prickly. Style-branches eoherent, usually a pubescent ring below.

79. Cnicus. Pannus-bristles plumose. Receptacle densely bristly.

80. Carduus. Panpus-bristles not plumose. Rerentacle densely bristly.

s1. Onopordon. Papnus-bristles nut plumose. liec"ptacle deeply honejeonbed.

* Achenes attacher obliquely. II Irginal fluwers often enlarged and ray-like.

S2. Centaurea. Involucral seales appenlaged. Pappus double and bristly, or very slort or none.

\section{Shries 11. LIGULIFLORAE. Tribe X. CICHOLIACEA.}

Corolla ligulate in all the flowers of the head, and all the flowers perfect. - Herbs, with milky juice. Leaves alternate.

$$
\text { * Pupluus none. }
$$

83. Laupsana. Involucre eylindrical, of s scales in a single row, 8-12-flowered.

$$
\text { * Pappus chaffy, or of both cliaff and bristies. }
$$

84. Krigia. Involuere simple, not enlyculate. Puppus of both chaff and bristles.

85. Cichorium. Involucre double. Paplus a small crown of many bristle-form scales.

$$
\text { * * Pilppus jilumose. }
$$

S6. Tragopogon. Involucre simple, not calyculate. Aehenes long-beaked. Stems leafy.

87. Leontodon. Involucre calyc:nlate. Achenes fusiform. Leaves radical.

ss. Picris. Outer involucral seales sprearling. Achenes terete. Stems leafy.

* * * Pappus composed entircly of capilliry bristles, not plumose.

+ Achenes not flattened, colunnar or terete, often slender.

- Achenes not beaked.

$=$ Flowers yellow or orange.

59. Hieraciun. Involucre inbricated. Papjus tuwy. Pilose perennials.

30. Crepis. Involueral seales in one row. Palyus white, soft. Not pilose. $==$ Flowers white or cream-color or pinkish. Involucre calyculate.

91. Prenantlies. Achenes short, blunt. Paluus tiwny or brown. Stems leafy and heads often nodding.

92. Lygodesnia. Achenes long, tapering. Pappus ivhite. Stems nearly leafless; headz ercct. Western.

$\leftrightarrow \rightarrow$ Achenes beaked (sometimes beakless in n. 93). Flowers yollow.

6.3. Troximon. Scapose. Involucre loosely imbricated. Aehenes 10-ribbed.

34. Taraxacum. Seapose. Involucre calyenlate. Achenes 4-5-ribleel.

9. Pyrrhopappus. Scapose or bianched. Pappus realdish, the buse starrounded by a

3f. Chondrilla. Stem branching, lenfy. Involucre few-flowered, calyculate. Pappus white.

- Achenes flat or flattisls. Pappus white, fine aud soft. Intolucre inbricated. Leafystemmed, with pauicled heads.

27. Tactuca. Achenes mole or less heaked. Flowers yellow on muplish.

9. Sonchua. Achenes lattish, not at all benked. Fluwers yellow. 
The technical characters of the tribes, taken from the styles, require a mag nifying-glass to make them out, and will not always be clear to the student The following artificial analysis, founded npon other and more obvious dis tinctions, will be useful to the beginner.

\section{Artificial Key to the Genera of the Tubuliflora.}

§ 1. Rays or ligulate flowers none; corollas all tulular (or rarely none).

* 1. Flowers of the head all perfect and alike.

Pappus composed of tristles:

Double, the outer of very short, the inner of longer bristles . . . . . No. a

simple, the bristles all of the same surt.

Heads few-flowered, themselves argregated iuto a componnd or dense clustcr . . 1

Heads seprarate, few-flowered or many-flowered.

Receptacle (when the flowers are pulled off) bristly-lairy . . . . 78, 79, 80,

Receptacle deeply honeycomb-like . . . . . . . . . . 81

Receptacle waked.

Pappus of plumose or bearded stiff bristles. Flowers purple . . . . 8

Pappus of very plnmose bristles. Flowers whitish . . . . . . 6

Pappns of slender but rather stiff rouglı bristles _ . . . 4 4, 5, 7, 9, 16

Pappus of very soft and weak naked bristles . . . . . . 76,77

Pappus composed of seales or chaff.

Receptacle naked. Leaves in whorls . . . . . . . . . . 3

Receptacle nakerl. Leares alternate, dissected . . . . . . . . 61

Receptacle bearing chaff anong the flowers . . . . . . . . 59,64

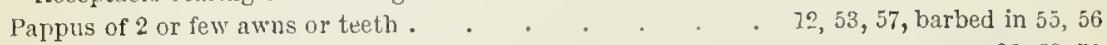

Pappus none, or a mere crown-like margin to the fruit . . . . . . 36,68,71

* 2. Flowers of two kinds in the same head.

Marginal flowers neutral and sterile, either conslicuous or inconspienons . . . 82

Marginal flowers pistillate and fertile.

Receptacle elongated and bearing broad chaff among the flowers . . . . 29, 30

Receptacle convex, cliaffy. Achene flat, 2-awneri . . . . . . . 52

licceptacle naked or bearing no conspicuous cliaff.

pappus of capillary lnistles. Involucre imbricated . . . . . 28, 32, 33

Pappus of captllary bristles. Involucre merely one row of seales . . . 26,73,77

Pappus a short, crown or none.

Achenes becomiug much longer than the involuere . . . . . . . 34

Achenes not exceding the involucrc . . . . . . . 42, 70, 71

* 3. Flowers of two kinds in sepurate heads, the one pistillate, the other staminate.

Heads diœcious: in both kinds many-flowered. Tappus capilliny $\quad$ • $\quad 27,31,32,79$

Heads monocions; the fertile 1 - 2-flowered and closed. Pillus nowe . • . 43, 44

\$2. Rays present; i. e. the mąrginal flowers or some of them with ligulate corollas.

* 1. Paprus of capillary bristies, at least in the disk. (Rays all pistillate.)

Rays occupying sereral rows . . . . . . . . . . . 26, 72, 70

Rays in one marginal row, and

White, purple or blue, never yellow . . . . . . 17, 24, 24, 26, 78

Yellow, of the same color as the disk.

Pappus (at least in the disk) double, the onter short and minute . . . 13,14

Papuns simple.

Scales of the involucre equal ancl all in one row. Leaves alternate.$\quad$. 75

Scales of the involucre in two rows. Leaves opposite . . . . . 74

Scales of the involuere inbricatel. Leares altermate . . . 10, 11, 15, 17, 35

* 2. Papuns a circle of awns or rigid bristles (at least in the disk).

Ray yellow, awns few $(2-8)$. . . . . . . . . . 12

Ray rose-color . . . . . . . . . . . . . . 23 
* 3. P'ilyus a circle of cliafy scales, dissected into bristles
* 4. Pappus a circle of thiu chaffy scales or short cliafly bristles.

Heads several-flowered. Recentacle cluaffy

Heads S-10-flowered. Reccptacle naked

$\cdot \cdot \cdot \cdot \cdot \cdot 18$

Heacls many-Howered. Receptacle deeply honejcombed . . • . • • . 58

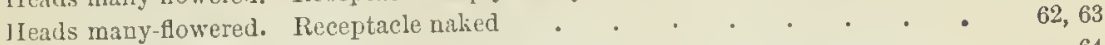

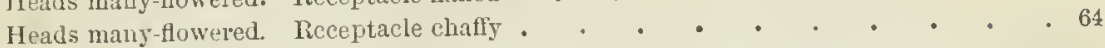

* 5. l'appus none, or a cup or crown, or of 2 or 3 awns, teeth, or chaffy scales corresponding with the edges or angles of the achene, often with interveniug minute bristles or scales.

- Recejtacle naked.

Achene flat, wing-margined. Palpus of separate littlc bristles and usually $2-4$ awns . 22 Achene flat, marginless. Pappus none. Receltacle conical . . . • . 19 Achene terete or angled. Pappus uone, livepptacle flattisi . . . . • . 69 lehene angled. Pappus a little cup or (rown (ur none). Recelstacle couical • . 20,68 Achene fusiform. Pappus of few scales, nsually with ilternating awns . . . . . 21

+ + Recentacle chafly.

Rays ncutral (rarely pistillate but sterile); the dist-Howers perfect and fertile.

Receptacle mostly elevated (varying from convex to columnar), and

Chaffy only at the sunmit; the chaft deciluous. Pappus none . . . . 66

Chafly throughout. Achene flattened laterally if at all . . . 48, 49, 50,52,54

Receptacle flat or flattish. Achene flattener parallel with the scales or chaff . 55,56

Receptacle flat. Achcne terete, 2-awnerl . • • • • • • • • • 57

Rays pistillate and fertile; the disk-flowers inso perfect and fertile.

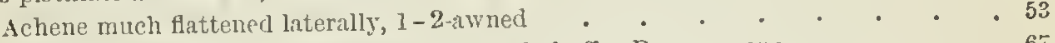

Achene flattcned parallel with the scales and chaff. Pappus nonc. $\quad$ - . . 67

Aclene 3-4-angular, terete or literally tlattish, awnless.

Reeentacle convex or conical. Leaves alternate, dissected . . . . . 66

Receptacle conical. Leares opposite, simple.

Achene obovid. Involucre a leafy cup

Achene 4-angrilar. Involucre of separate scales . . . . . . 47

Receptacle flat. Lcaves olposite and simple . . . . . . . 46,51

Rays pistillate and fertile; the disk-flowers staminate and sterile (pistil impcrfect).

Receptarle chnfly.

\section{FL}

Heads discoid, 2-5-flowered, several together clustered into a compound pedunculate head; flowers perfect. Involucre narow, flattened, of 8 oblong 11Y scales. Achenes 10-ribhed; pappus of stont bristles, chaffy-dilated at the hase. - lerennials, with altermate leaves and purplish flowers. (Name com-

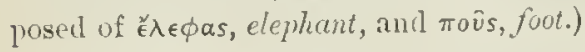

* Stem leafy; upper leaves very like the basal.

1. E. Caroliniànus, Willd. Somewhat hairy, corymbose, leafy; leaves ovate-oblong, thin. - Dry soil, Penn. to Ill. and Kan., and southward.

* Stem scape-like, with a few bract-like leares or naked.

2. E. tomentósus, L. Somewhat hairy; hasal leaves obovate to narrowly spatulate, silky and prominently veined beneath; heads large; pappusscales attemuate. - Va., Ky., and southward.

3. E. nudàtus, Gray. Strigose-puberulent; basal leaves thin, green, spatulate-oborate or ohlancoulite. not prominently veined beneath; heads smaller; paynus scales broull! ireltoid. - Del. and southward. 


\section{VER N Ò I A, Schreb. Irox-wEed.}

Heads discoid, 15-many-flowered, in corymbose crmes; Howers perfect Involucre shorter than the flowers, of many much imbricuted sinles. Recej. tacle naked. Achenes cylindrical, ribbed; pappus double, the outer of minute seale-like bristles, the inner of copions capillary bristles. - Pereunial herbs, with leafy stems, alternate and acuminate or very alente leares and mostly purple Howers. Species very ditticult. (Named for IVm. Kernon, an early linglish butanist who travelled in this country.)

$$
\text { * Heads large, } 50 \text { - 70-flouereel. }
$$

1. V. Arkansàna, DC. Tall, ratler glalırous; leaves linear-lanceolate, retrorsely denticnlate; involucre very squarrose, the scales with long filiform tips. - Mo., Kinn., and southward.

* Heads I high or less, $15-40$-fluwered.

- Leaves narrowly linear, glabrous, veinless, mostly entire.

2. V. Jamèsii, Torr. \& Gray. Low, nearly glabrous; lieads few-flow ered; scales obtuse or acute. - Plains of Neb. and suntlwarl.

+ + Leaves lnoader, mostly sharply denticulate or rigilly sermate, veined.

3. V. fasciculàta, Michx. Leavęs linear to oblong-lanceolate; leads many, crowled; scales close, obtuse or the uppermost mucronate; achene smooth. - Low grounds, Ohio and Ky to S. Dak., and southward. Ang.

4. V. altíssima, Nntt. Lsually tall; lenves lanceolate or lance-oblong; cyme loose; scales close, obtuse or mucronate; achenes hispidulous on the ribs. - Low grounds, WV. Penn. to 111., and soutlward. - Heads variable, 2$4^{\prime \prime}$ high and the scales in few or many ranks; the rar. Gruxufurora, Nutt., with large heads, the involucre of $35-40$ scales in many ranks.

5. V. Noveboracénsis, Willd. Rather tall; leaves long-lanceolate to lance-oblong; cyme open; involucre usually puplish; seales ovate and lanceorate tipped witl a slender cusp or awn. - Low grounds near the coast, Maine to Va., west to Minn., E. Kan., and soutlıward. Aug.

Var. latifolia, Gray. Learcs broader; hearls few; scales merely acute or acuminate. - Peun. to Ohig and southward.

6. V. Baldwínii, Torr. 'Tomentulose; heals sinall, at first globose; leaves lasce-oblong or -ovate; involncre hoary-tomentose, greenish, squarrose, the seales acute or acnminate. - T'rairies and harren hills; E. Mo. to lían. and Tex. Jnly, Ang. Passes into n. 4.

\section{SCLERÓLEPIS, Cass.}

Ifead discoid, many-flowered; flowers perfect. Involucral scales linear, equat, in 1 or 2 rows. Receptacle naked. Corolla 5-tontled. Achenes 5-angled; pappus a single row of 5 almost horny wal and obtuse scales. - I smooth perennial, with simple stems, rooting at the hase, lincar entire leaves in whorls of $4-6$, and a terminal head of flesh-colored flowers. (Name composed of $\sigma \kappa \lambda \eta p o ́ s$, hard, and $\lambda \in \pi i s, "$ secale, from the patpuns.)

1. S. verticillata, ('iss. - In water; pine burrells, New Jersey and southward. Aug. 


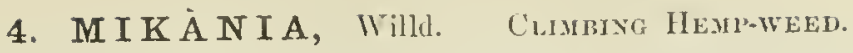

Heads diseoid, 4-flowerel. Involncre of 4 scales. Receptacle small. Flow. cris, achenes, etc., as in Eupatorium. - Twining perennials, elinbing bushes, with opposite eommonly heart-slaped and petioled leaves, and eorymbose-pauicled flesh-colored flowers. (Naned for Prof. Milin, of I'rague.)

1. M. scándens, L. Nearly smoth, twining; leaves somewliat triangular-heart-shalped or halberil-form, pointed, toothed at the hase. - Copses along streans, L. New Eng. to liy., and sunthwark. July-kept.

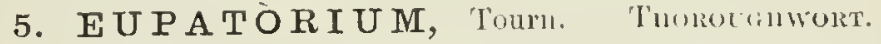

Heads discoid, 3-many-flowered; Howers perfect. Insolucre cylindrical or bell-shaped, of more than 4 scales. Receptacle flat or conical, naked. Corolla 5-toothed. Achenes 5-angled; pappus a single row of slender capillary harely roughish bristles. - Erect peremial lurols, often sprinkled with hitter resinons lots, with generally eorymbose heals of white, bluish, or purple hlossoms, appearing near the close of summer. (1)udicated to Euputor Mithidates, who is said to have used a species of the genus in medicine.)

\$ 1. ELT'TOTRIUM proper. Revepterle flut.

* Heads cylindricul, 5-15-fowered; the purplish scales munerous, closely im. bricated in several rows, of unequal length, slightly striate: stont herbs, with ample mostly whorled leaves, and flesh-colored flowers.

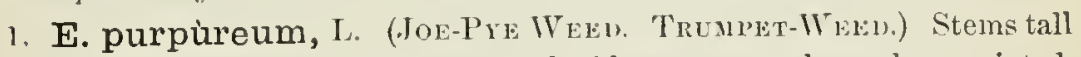
and stout, simple; leaves $3-6$ in a whorl, oblong-ovate or lanceulate, pointed, very veiuy, roughish, toothed; curyulss very dense and compound. - Varies greatly in size $\left(2-12^{\circ} \mathrm{high}\right)$, etc., aud with spotted or muspotter, often dotted stems, etc., - including several nomiual species. - Low grounds; eommon.

Var, amdenum, Gray. Low; lestes fewer, orate or oblong; heads few, 3-5-flowered. - Nountains of I'a. and N. I.

* Heads 3-20-flowered; incolurre of 8-15 more or less imbricuted and unequal scales, the outer ones shorter; flowers uhite.

- Leaves all alternate, mostly dissecterl; heads panicled, very small, 3-5-tlonered.

2. E. fœniculàceum, Willu. (Dog-Fensel.) Smootl or nearly so, paniculately much-branched $\left(3-10^{\circ}\right.$ high); leaves 1-2-pinnately parted, filiform. - Va., near the coast, and sunthwarl. Adv. near Philudelphia.

- + Leaves lony-yetiolerl, the upper ones alternate; heads 12-15-flumered, in rounpound corymbs.

3. E. serótinum, Mliclıx. Siten pulverulent-pubescent, bushy-branched $\left(3-7^{\circ}\right.$ high) ; leares ovate-lunceolate, tapering to a point, triple-nerved and veiny, coarsely serrate $\left(3-6^{\prime}\right.$ long); involncre rery pubescent. - Alluvial gromu, Md. to Minn., F. Kan., and southwaril.

+ + + Leaces sessile or nearly so, with a nurrow base, mostly opposite; heads mostly 5-flowered.

= Imolucral scules with white and scarious acute tips.

4. E. álbum, L. Komyhish-hairy ( $2^{\circ}$ high); leares oblong-lanceolate, coarsely touthed, miny: heals (lustered in the corymb; involucral scales close $v$ 
imbrieated, rigid, narrowly lanceolate, longer than the flouers. - Sandy and harren places, pine barrens of Long lsland to Va., and southward.

Var. subvenòum, Gray. Less rough; leares 1-2' long, finely toothed and less veiny. - Long Island and N. J.

5. E. leucólepis, Torr.\& Gray. Mimutely pubescent, simple ( $1-2^{\circ}$ high); leaves lineartanceolate, closely sessule, 1-nerved, obtuse, mimutely serrate, rough both sides; enrymb loary. - Sandy bogs, Loug Island, N. J., and southward. $==$ Scales not scarious or obscurely so, obtuse, at length shorter than the flowers.

6. E. hyssopifolium, L. Minutely pubescent $\left(1-2^{\circ}\right.$ high); leares narrow, linear or lunceolate, elongated, obtuse, 1 -3-nerved, entire, or the lower toothed, often erowded in the axils, acute at the base. - Sterile soil, Mass. to Va., E. Ky., and southward.

Var. laciniàtum, Gray. Leaves imegularly anl coarsely toothed or laciniate. - I'enu., liy., and southward.

7. E. semiserràtum, DC. Nlinntely velvety-puhescent, branching (2$3^{\circ}$ high); leaces lanceolate or ollong, triple-rzbled and zemy, scrrate above the mildle, tapering to the hase, the lower slightly petioled; heads small. (E. parviforum, Ell.) - Damp soil, Va. to Irk., and sonthward. - Leares sometimes whorled in threes, or the upper alternate.

8. E. altíssimum, I. Stem stout and till ( $3-7^{\circ}$ high), douny: leares lanceolate, tapering at both ends, conspicuously 3-nered, entire, or toothed abore the middle, the uppermost alternate; corymbs deuse; scales of the inrolucre obtuse, shorter than the flowers. - Dry soil, Penn. to Minn. and Ky. - Leaves 3-4' long, somewhat like those of a Solidago.

+ + + + Leares sessile or nearly so, wh a broad base, opposite or in threes; heads pubescent.

$=$ Heads 5-8-flowered: leaves not clasping.

9. E. teucrifolium, Willt. lioughish-pubescent $\left(2-8^{\circ}\right.$ ligh); leares ovate-oblong and ovate-lunceolate, obtuse or truncate at hase, slightly triplenerved, veiny, coarsely toothed or meised toumel the buse, the laner- shortly petioled, the upper alternate; branches of the (oryml) few, unequal; scales of the involucre oblony-lanceolate, at lenyth shorter than the flowers. - I Iow gromuds, Mass. to Va., and sonthward near the coast.

10. E. rotundifolium, L. Downy-pubescent ( $2^{\circ}$ high); lences roundishovate, obtuse, truncate or slightly luart-shaped at the base, deeply crenate-toothed, triple-nerved, veiny, rughish $\left(1-2^{\prime} l o n g\right)$; corymb large and dense; sules of

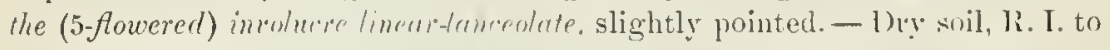
Va., near the coast, anl southward

Var. ovàtum, 'Tirr. Lsmally taller, leaves ovate, acute, hardly truncate at base, more strongly serate, lieads 5 -8.flowered. (E. pubescens, Muhl.) - Mass. to Ya., near the coast.

11. E. sessilifolium, L. (I'PLN1) BoxeskT.) Sten tall ( $t-6^{\circ}$ high), sinooth, branching; leaves oblong. or oratu-lancelate, tupering from neur the rounded sessile base to the shary poin, scriate, veiny, sucoth $\left(3-6^{\prime}\right.$ long) ; eorymb very componurl, pubescent; srates of the 5-flonered involucre oval and

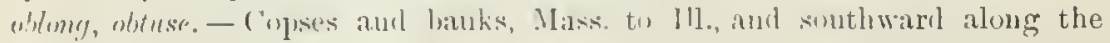
mulutinius 
$=$ Leaves opposite, clasping or united at the base, long, widety spreading; heads mostly 10-15-florcered; corymbs very compound and large.

12. E. perfoliàtum, L. (Thorol'Gnort. Boxeset.) Stem stout $\left(2-4^{\circ}\right.$ high), hairy; leaves lanceolate, mited at the base around the stem (comnateperfoliate), tapering to a slender puint, serrate, very veiny, wrinkled, downy bencath $\left(5-8^{\prime}\right.$ long $)$; scales of the involucre linear-lanceolate. - Low grounds ; common and well-known. - Varies with the lieads $30-40$-flowered, or with some or all of the leaves separated and truncate at base.

Var. cuneàtum, Engelm. Leaves smaller, narrowed at base and separate, and heads fewer-Howered. Perhaps a hybrid with n. 7.-Mo. and southward.

13. E. resinòsum, Torr. Mimutely reliety-downy $\left(2-3^{\circ}\right.$ high); lentes linear-lanceolate, elonguted, serrate, partly claspmy, tapering to the point, slightly veing beneath $\left(4-6^{\prime}\right.$ long); scales of the involucre oval, olstuse. - Wet pine barrens, N. J. - Name from the copious resinous globules of the leaves.

** Heads 8-30-flouered; inrolucral scales nearly equal, in one rou; leares opposite, ovute, petroled, wiple-nerved, not resinous-dotted; flowers white.

14. E. ageratoides, L. (White SNAKE-ROoT.) Smooth, branching ( $3^{\circ}$ high) ; leaves broally orate, pointed, coarsely und sharply toothed, lony-pretioled, thin $\left(3-5^{\prime}\right.$ long) ; corymbs componnd. - Rich woods; common northward.

15. E. aromáticum, r. Smooth or slightly downy; stems nearly simple; leaves on short petioles, wrate, rather obtusely toothed, not pointed, thickish. Copses, Mass. to Va., and southward, near the coast. - Lower and more slender than n. 14, with fewer, but nsually larger lreads; not aromatic.

\$2. CONOCLINIUM. Receptacle concal; involucral scales nearly equal, somewhat imbricuted.

16. E. colestinum, T. (Mrst-FLowEr.) Somewhat pnbescent $\left(1-2^{\circ}\right.$ high); leaves opposite, petiolate, triangular-ovate and slightly leart-shaped, coarsely and bluntly toothed; heals many-flowered, in compact cymes; flowers blue or violet. (Conoclinium colestinum, $J($.) - Rich soil, N. J. to Mich., Ill., and southward. Sept.

\section{KÙ H N I A, L.}

Heads discoid, 10-25-flowered; flowers perfect. Involucral scales thin, few and loosely imbricated, narrow, striate-nerved. Corolla slender, 5-toothed. Achenes cylindrical, 10-striate; pappus a siugle row of very plumose (white) bristles. - A perennial lierh, resinous-dotted, with mostly alternate leaves, and paniculate-corymbonse heads of cream-colored flowers. (Dedicated to Lr. Kulhn, of Pennsylvain, who carried the living plant to Linnæus.)

1. K. eupatorioides, 1. Stems $2-3^{\circ}$ high ; pubescence minute : leaves varying from broally lanceolate and toothed, to linear and entire. - I)ry soil. N.J.to Mimn. E. Kian, and sonthward. Sept. Very rariable. - Var. corsuisulosa, 'Torr: \& Gray, is a western form, stouter and somewhat more plubescent, the heads rather crowded.

\section{BRICKELLIA, Ell.}

Characters as in Kulnia; involueral scales more numerous, and the bristles of the pappns merely seabrous or at the most harbellatic or subplumose; leaves 
often all opposite. (Ir. Joln Brickell of Georgia, correspondent of Elliott and Muhlenberg.)

1. B. graudiflora, Nutt. Nearly glabrons, $2-3^{\circ}$ high; leaves deltoid; cordate, the upper deltoil-lanceolate, coarsely dentate-serrate, aemninate, 4' loug or less; heads about 40-flowered. - Shamon Co., Mo. (Bush), lian to Cul., New Mex., and westwarl.

\section{LIATRIS, Sehreb. Bitton Swakeroot. Buazicistali.}

llead diseoid, few-many-flowered; flowers perfect. Involueral seales well imbricated, appressed. Reeptaele naked. Corolla 5-lobed, the lobes lung and slemler. Achenes slender, tapering to the base, 10-ribled. Pappus ol $15-411$ (apillary bristles, manifestly plnmose or only barbellate. - P'eremial herls. often resinous-dotted, with simple stems from a roundish corm or tuher, rigic:

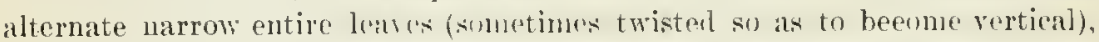
and spicate or raeement heals of hambome rose-pmrple fiowers, appearing late in summer or in autumn. (1)erivation of the name nnknown.)

* Prippus very plumose; scales of the 5-floueped menlurve uith nrate or lanceolate spreading petal-like (muple or somctimes uhite) lips, properding the flowers.

1. L. élegans, Willd. Stem $\left(2-3^{\circ}\right.$ high) and involure lairy; leares linear, short and spreading; spike or raceme compact $\left(3-20^{\prime}\right.$ long). - Barren soil, Ya. and southward.

* Pappus rery plumose; scrles of the cylindrial many-flouered involucre imbricated in many rous, the tijs rigid, not petallike: molla-lobes hairy within.

2. L. squarròsa, Willd. (13Lazixg-Strak, etc.) (Iften hairy $\left(6^{\prime}-2^{\circ}\right.$ higl1) ; leaves rigoil, lincar, elongated ; heads nsnally fow (1'long ; scales mostly with clongated and louftitie spreading tips. - Dry soil, Penn. to Mimn., and

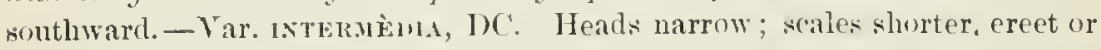
nearly so. - Ont. to Neb, and Tex.

3. L. cylindràcea, Michx. Commonly smooth $\left(6-18^{\prime}\right.$ high); leaves linear; herds few $\left(\frac{1}{2}-\frac{2^{\prime}}{3} \mathrm{long}\right)$; scales with short and rounded almuptly mucronate appressed tips. - Dry open places, Niagara Falls to Minn. and Mo.

* * Pappus rery plumose; heuds 4-6-floured; serales acuminate; corollalobes nated.

4. L. punctàta, IIook. Stout (10-30' high), from a branching or globose rootstock; leares narrowly linear or the mper aecrose, rigid; heats msually many in a dense spike. - Mimn to kian., and southwarl.

* * Papmes not olriomsly ylumose to the nalied eye: imenlle-lobes smonth inside.

5. L. Scariosa, Willu. Stem stont (2-50 highl), pnluscent or hoary; leaves (smooth, rongh, or puliescent) lumcenlate: the luwest mhlomg-lanceolute or obovate-oblong, tapering into a petiole; hearls fow or mamy, large, 2.5-40-flow-

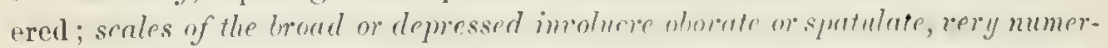
mus, with dry and scarions often colored tips or muryins. - Dry soil, New Eng. to Minn., and sonthwarl. - Widely variable; hearls I' or loss in diameter.

6. I. pyenostàchya, Michx. Hairy or smoothish; stem stont $\left(3-5^{\circ}\right.$ high), very leafy; leaves linear-lancenlate, the upper rery narrowly linear: spike thick and dense $\left(6-20^{\prime}\right.$ long); hearls about 5 -flowered ( $\frac{1}{2}$ long); scules 
of the rylindricul involucre ublong or lanceolate, with recured or spreading colored lips. - N'ralries, from Ind. to Nicnn., and sonthward.

7. L. spicàta, Willd. Smooth or somewhat hairy; stems very leafy, stout $\left(2-5^{\circ} \operatorname{ligh} 1\right)$; leaves linear, the lower 3 -5-nerved; heads 8 -12-flowered

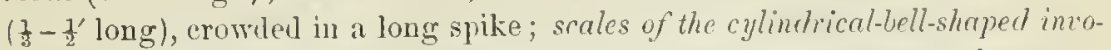
lacre oblong or oval, obtuse, apmessed, with slight margins; achenes puliescent or smoothish. - Moist grounds; common from Mass. to Minu., and sonthward. Involnere often resinous, very smootl.

Var, montàma, (iray. I d)w and stout; leares broader, obtuse; spike short and heals large. - Momutinis-tops, Va., and southward.

8. L. graminifolia, Will. llairy or smoothish; stem (1-30 ligh) slender, leafy; leaves linear, elongated, 1-11erverl ; heads sereral or numerons, in a spike or raceme, $\mathbf{i}-12$-tlowered ; sertes of the obronifal or oboroid in rolucre spatulate or oblong, obluse, or somenhat pointed, rigid, appressed ; achenes hairy. - Va. and sontliward. - Inflorescence sometimes panicled, especially in

Var. dùbia, Gray. Scales of the involnere narrower and less rigid, oblong, often ciliate. - Wet pine bairens, N. J., and southwarl.

\section{TRÍLIS A, ('ass.}

Ilearls discoid, 5-10-flowerch; flowers perfect. Involueral reales nearly equal, little inbricated. Receptacle naked. Corolla-lobes short-orate or oblong. Achenes 10-ribber; pappus of rather rigid hristles, not plumose.Peremial lierbs, fibrous-rooterl, with broarl entive leaves, obsenlely or not at all punctate, and cymules of smill heals in a thyse or panicle. Flowers rosepurple, in antumn. (Name an anagram of Liatis.)

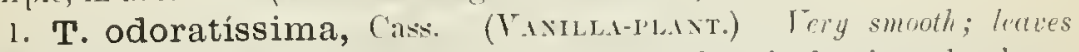
pale, thickish, oborate-spatulate, or the upper oral and clasping; heads corymbed. (Liatris oduratissima, Willd.) - Low pine barrens, Tra., and sontlward. - Leares exhaling the orlor of Vanilla when hruised.

2. T. paniculàta, Cass. Tiscid-hriry; leares narrowly oblong or lanceolate, smootlish, those of the stem partly clasping, heads panicled. (Liatris paniculata, Willd.) - Va. and sonthwirrl.

\section{GUTIERREZIA, Lag.}

Heads few-sereral-fluwered, varliate; rays $1-6$, pistillate. Involncre oblong-clarate; scitles coriaceous with green tips, closely imbricated, the outer shorter. Receptaclo small, naked. Achenes short, terete; pappus of about 9 chaffy scales, shorter in the ray-flowers. - Suffrutescent (our species), glabrons and often slutinous, much hranched, with narrowly linear entire alternate leaves, and small heals of yellow thowers in fastigiate or paniculate cymes. (Foul Gutiervez, a noblo Spanish family.)

1. G. Euthámize, 'Torr. \& Gray. Jow'; lcares ummerous, 1-2' long; heads nsually crowiled, the disk-and short ray-fowers nsually 3 or 4 eael. Dry plains, Mont. and Minn. to central Kan., sonthwarl and westward.

\section{A M P H Í CHYRIS, liutt.}

Heads hemisphoritul; rays 5-10. 1)isk-flowers perfect but infertile. Pappus of the la! minute, coroniform; of the disk-flowers of alluost bristir-like 
scales, more or less rlilated and united at base. - $\Lambda$ diffusely much-branehed annual, with heads solitary on the branchlets; otherwise as Gutierrezia. (From ả $\mu \phi i$, around, and ă $\chi$ vop, chaff.)

1. A. dracunculoides, Nutt. Rather low, slender; leaves narrowly linear, the upper filiform; disk-flowers $10-20$, their pappus of $5-8$ bristle-like chaff united at base and slightly dilated npward. - l'lains, lian. and southward.

\section{GRIN D E LIA, Willd.}

Heads many-flowered, radiate (or rayless); ray pistillate. Scales of the hemispherical involucre imbricated in several series, with slenter more or less spreading green tips. Achenes short and thiek, compressed or turgil, trumcate, glabrous; pappus of $2-8$ calucous awns. Coarse perennial or hieminil herbs, often resinous-riscid, ours glabrous and leafy with sessile or clasping alternate and spiunlose-serrate or laciniate rigid leaves, and large hearls telminating leafy braneles. Disk and ray yellow. (l'rof. Grindel, a Russian botanist.)

1. G. squarrósa, Dunal. Leaves spatulate- to linear-oblong; involucre squarrose; achenes not toothed; pappus-awus 2 or 3. - Prairies, Minu., southward and westward; Evanston, 11l. - Var. xùD.s, Gray. Rays wanting. $\Delta$ bout St. Louis and westward.

2. G. lanceolàta, Nutt. Leaves laneeolate or lincar; involncral scales ereet or the lower tips spreading; achenes with 1 or 2 short tecth at the summit; awns 2. - l'rulies, easteru Kam. to Ark., aul southward.

\section{HETEROTHECA, Cass.}

Characters as in Chrysopsis, but the aehenes of the lay thickish or triaugular, wathout pappus or obseurely crowned, and those of the disk compressed, with a double pappus, the inner of numerous loug bristles, the outer of many short and stont bristles. - (From Ẽ ¿ the unlike achenes.)

1. H. Lamárckii, Cass. Anumal or biennial, $1-3^{\circ}$ high, bearing numerons small heads; leaves oval or oblong, the lower with petioles auricled at base, the upper mostly subcordate-clasping. - S. L. Lian., and southward.

\section{CHRY SÓPSIS, Nutt. Golden $\Lambda$ ster.}

lleads many-flowerel, raliate; the rays numerous, pistillate. Involneral scales linear, imbricated, without herbaceons tips. Receptacle flat. Achenes obovate or linear-oblong, flattened, hairy; pappus in all the flowers double, the onter of very short and somewhat chaffy bristles, the inner of long capillary bristles. - Chiefly perenuial, low herbs, woolly or hairy, with rather large often corymlose heads terminating the branches. Disk and lay-flowers yellow:

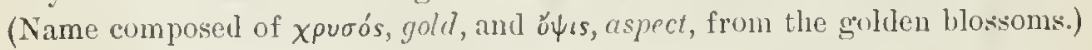

\section{* Leares narrouly laneenlate or linear; achenes linear.}

1. C. graminifolia, Nutt. Silvery-silly, with long close-pressed hairs: stem slender, often with rumers from the hase, naked above, hearing few lieads; leares lanceolute or linear, elonguted, gruss-like, nerverl, shining, entire. - Dry sandy soil, Del. to Va., and southwart. July-Oct. 
2. C. falcàta, E1l. Stems $\left(4-10^{\prime}\right.$ high) very woolly; leaves crouccet, lineur, vigid, about 3-nerved, entire, somewhat recurved or scythe-shaped, hary, or smooth when old, sessile; heads (small) eorrmbed. - 1)ry sandy soil on tre eoast, pine barrens of N. J. to Nantucket and Cape Cod, Mass. Aug. * Leaves oblong or lanceolate, cntire or slightly serrate, mostly sessile, veinea, not nerred: achenes obovate, flattened.

3. C. gossýpina, Nutt. Densely woolly ull over: leates spratulate or oblong, obuse $\left(1-2^{\prime} \operatorname{long}\right)$; heads larger than in the next. - l'ine larrens, Va., and soutliward, Ang.-Oct.

4. C. Mariàna, Nutt. Silky with long and weal lears, or when old smooth ish; leaves oblong; lieads corymbed, on glandular pellundes. - 1) by barrens. from s. New Fork and lemn., sonthward, near the coast. Aug.-Oct.

5. C. villòsa, Nutt. Ilirsule and villons-pulesrent; sten corymbosely branched, the branclies terminated by single slort-perluncled hcads; leares narrouly oblowy, hoary with rough jubescenee (as also the involurr(s), bretly-cillate toward the base. - I)ry plains ank prairics, Wisc. to Ky., an westward. July Sept. Very variable. - Var. nírides, Gray. Low, hirsute and híspld, not caneseent; heads small. Kan., west and sonthward. - Var. cAxéscexs, Gray. Wholly eanescent with short appressed pubcseence; leaves narrow, mostly ublanceolate. - lian, to Tex.

6. C. pilòsa, Nutt. Ammial, suft-hirsute or villous ; leares oblong-lanceolate; involucre viseid; outer pappus chaffy and eonspicuous. - Kan. and southward.

\section{A P L O P Á P P U S, Cass.}

lleads many-flowered, rarliate; rays many, pistillate. Iuvoluere hemispherical, of many closely inbricatel seales in several series. Receptacle flat. Aclienes short, turbinate to linear; pappus simple, of numcrons unequal bristles. - Mostly herbaceous perennials, with altemate rigid leaves. Ray-

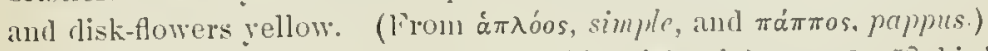

1. A. ciliatus, 1)C Anmual or biennial, glabrous, $2-5^{\circ}$ high, leafy ; leares oval (or lower obovate), obtuse, dentate with bristle-pointed teeth; lieals very large, few and elustered, the outer scales spreadiug; achenes gla. brons, the centril abortive. - Mo., Kan., and southward.

2. A. spinulòsus, DC. P'erennial, branching, puberulent or glalıate, low; lear cs narrow, pinnately or bipinnately parted, the lobes and teeth bristle tipped; heads small, the appressed scales bristle-tipped; achenes pubescent. - Minn. to kian., aud southwarl.

3. A. divaricàtus, Gray, Annual, 1-20 ligh, slender and diffusely paniculate, rough-pubcscent or glabrate; leaves rigid, narrow, entire or with a few spinulose tecth, much reluced above; heads small and sarrow, the appressed scales subnlate, attcuate; achenes silky. - Southern Kan.

\section{BIGELÒ V I A, DC. liYmLA GOLEN-Rod.}

Heals 3-4-Howered, the flowers all perfect and tulular Involurre clubshiped, yellowish; the rigid sonewhat glutinous scals lueal, ("losely imbri cated and aplyessen. lieeptacle narrow, with an awl-shapen prolongation in the contre. Achenes somewliat obeonical, hary: papplis a single row of 
(apillary bristles. - Flower's yellow. Leaves scattered, oblanceolate or linear, 1-3-nerved. A large westeru genus, few speeies approaching nur limits. (1)clieated by Do Caudulle to Dr. Jacob Bigelow, author of the Florula Bnstoniensis, and of the American Meclical Botany.)

1. B. nudata, DC. A smooth perennial; the slender stem (1 - 20 liggli) simple or branched from the base, naked abore, eoryubose at the summit, bearing small heads in a flat-topped corymb. - Low pine barrens, N. J. (rare), and southward. Sept.

\section{S O L I D A GO, L. GOLDEX-RO1\%.}

Heals few-many-thowered, radiate; the rays $1-16$, pistillate. Scales of the oblong involuere appressed, destitute of herbaceous tips (except $\mathrm{n} .1$ and 2). lieceptacle small, not ehaffy. Achenes many-ribhed, nearly terete; pappus simple, of equal capillary bristles. - Perennial herls, with mostly wand-like stems and nearly sessile stem-leaves, never hcart-shaped. Heals small, raremed or elustered; Howers both of the disk and ray (except n. 6) yellow. (Name from solidus and ago, to join, or make whole, in allusion to repnted vulnerary qualities.) Flowering in antumn.

\section{Conspectus of Groups.}

Heads small, sessile in flit-topped eorymbs; leaves linear _ . . . . . 41, 42

Heads all more or less pediceller.

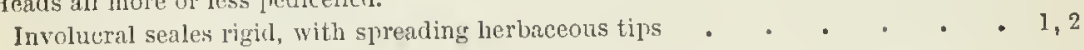

Involueral scales withont green tips.

Heads in a compound terminal corymb, not at all raeemose . . . . 37-40

Heads small, mostly clustered in the axils of feather-veined leares . . . 3-7

Heads mostly large, in a terminal thyrse; leaves feither-reined.

Western species . . . . . . . . . . . . 8, ?

Northern or nountain speeies . . . . . . . . . 10-12

Ireads mostly small or middle-sized : inflorescence pruiculate (sometimes tlygrsoidal).

Leaves 3-ribbed; heads in 1-sided spreading pracleri racemes.

Stem and leares smootlı and glabrous . . . . . . . . 29-32

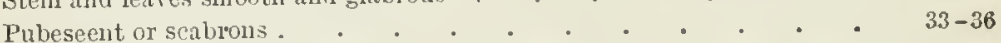

Leaves not 3-ribbed, or only obscurely triple-nerved.

Heads large; leaves thickish, very smnoth, entire. Seashore . . • . 13

Paniele virgate or thyrsoid : leaves nearly entire . . . . . 14-17

leads very small in a short broad panicle : leates nearly entire . . . 18-20

Heads racemosely paniculate; leaves ample, the lower serrite • . 21-28

§1. VIRGAÜREA. Rays mostly feucer than the disk-flowers; heads all more or less pedicelled.

* Scales of the much imbricated and rigid incolucre with abruptly spreading herbaceous tips; heads in clusters or glomerate racemes, disposed in a dense somewhat lenfy and intermpted wand-like compound spike.

1. S. squarròsa, Muhl. Stem stout $\left(2-5^{\circ}\right.$ high $)$, hairy above; leaves large, oblong, or the lower spatulate-oval and taperitg into a margined petiole. serrate, veiny; hrals numerous; sarales obtuse or acute; disk-flowers 16-24, the rays $12-16$. - liocky and wooled hills, Maine and Wr. Y't. to Penn., Ohio, aud the momutins of $\mathrm{V}$ a.; rather rare.

2. S. petiolàris, Ait. Minntely hoary or downy; sten strict, simple (1 $3^{\circ}$ high); leaves smill ( $\frac{1}{2}-2^{\prime}$ longr), oval or oblong, mucrenate, veiny, roughciliolate; the upper cutire and alunptly very short-jetioled, the lower often ser. 
rate and taperiug to the base; heads few, in a wand-like raceme or paniele, on slender bracted peclicels; rays about 10 , elongated; seales of the pubescent introluere laneeulate or linear-awl-shaped, the unter louse and sprealiug, more or less fuliaeeous. - S. W. Ill. to Kan. and southward. - The name is misleading, as the leaves are hardly petioled.

* Involueral scales without qreen tips and wholly appressed.

+ Meads small (3"long), clustered along the stem in the axils of the featherveined leaves, or the upper forming a thyrse.

+ dehenes pubescent.

3. S. cærsia, I. Smooth; stem terete, mostly glaueous, at length mneh branched and liffuse; leaves lanceolate or oblong-lanceolate, serrate, pointed, sessile; heads in rery short clusters, or somewhat racemose-panicled on the branches - Rich woollands, common; west to S. L. Minn., IHl., and Ky.

4. S. Iatifolia, I. Smooth or nearly so; stem angled, zigzag, simple or panienlate-branched ( $1-3^{\circ}$ high $)$; leaves broully ovate or or ul, very strongly and sharply serrate, conspicuously pointed at both ends (thiu, 3-6' long); heads In rery short axillary clusters, or the clusters somewhat prolonged at the end of the branches; rays 3-4. - Moist shaded hanks; common northward, and sonth along the monntains.

5. S. Curtísii, Torr. \& Gray. Smooth or nearly so; stem angled, nsnally branched; leaves obloug to long-lanceolate with narrowed entire base, serrate ahove with subulate teeth; hearls in small, louse clusters; lays 4-7. - Open woods at low elevations in the mountains of Va. and southwarl.

+* Achenes glabrons; infloresrence morr thyrsoid.

6. S. bícolor, 1. Howy or grazish with soft hairs; stem mostly simple; leaves oblong or elliptieal-lanceolate, acute at both ends, or the lower oval and talpering into a petiole, slightiy serrate; clusters or short racemes from the axils of the upper leares, forming an interrupted spike or crowled panicle; scales very ubtuse; rays $(5-14)$ small, rrem-color or nearly white. - Var. cóxcoLok, 'Torr. \& Gray, has the rays yellorr. - Dry copses, west to Miun. aur Mo.

7. S. monticola, Torr. \& Gray. Nearly glabrous; stem sleucler, $1-2^{\circ}$ high; leaves oblong-ovate to lanceolate, acute or taperiug at both ends, the lower sparingly serrate; heals small, the scales acutislı; rays 5-6. - Alleghany Mis., from MIl. southward.

+- + Heads mostly large (smaller in n. 12), many-flowered, forming an erect terminal thyrse; leaves feather-veined.

+ Leaves numerous, short, sessile, entire, uniform in size and shape; westem.

8. S. Bigelòvii, Gray. Cinereons-puberulent, „o high; leaves oval ancl ublong, mostly obtuse at both ends; thyrse rather loose; involuere broad. $\therefore$ Kan. and southward. Probnbly running into the next.

9. S. Lindheimeriàna, Scheele. Less puberulent; leaves lanceulate or oblong, more acute; lieads narrower and more deusely clustered; achenes glabruus. - S. Kan. and soutluward.

+* +. Sorthern or mountain species, bright green.

10. S. macrophylla, Pursh. Stem stout (1-40 high), wand-like, pubescent near the summit, simule; haves thin, neate, imegululy and cuarsely serrate 
with sharp salient leeth, large (lower $3-4^{\prime}$ long), all but the uppermost abruptly contracted into long and margined petioles; heads larye (5-6" long), manyHowered, crowded in an oblong or waud-like raceme or contracted panicle (2$18^{\prime}$ long); seales loose and thin, long, lanceolate, taper-pointed; rays 8-10, elongated; aehenes smooth. (S. thyrsoidea, E. Mey.) - Wooded sides of

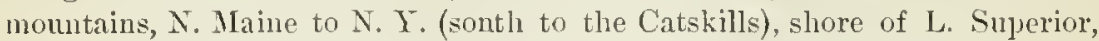
and northward. - Very near a Enropean form of $\mathbf{s}$. Virgaurea.

II. S. Virgaùrea, Linn. In extremely variable and confused species in the Old World, represented in North America by

Var. alpina, Bigel. Dwarf $\left(1-8^{\prime}\right.$ high), with few $(1-12)$ pretty large heads ( $3-4^{\prime \prime}$ long, becoming sualler as they increase in number); leares thickish, mostly smooth, spatulate or oborate, mostly olutuse, finely serrate or nearly entire, the nppermost lanceolate; heads few in a terminal chnster or subsolitary in the upper axils; scules laneeolate, acule on ucutish; rays abont 12. - Alpine summits of Alaine, N. II., and N. Y., and slure of L. Superior.

12. S. hùmilis, Pnrsh. Low $\left(6-12^{\prime \prime}\right.$ high) and smooth, bearing several or numerous loosely thyrsoid smaller heads, which, with the peduncles, etc., are mostly somewhat glutinons; scrles obtuse; lays $6-8$, short; upper leaves lanceolate to linear, entire, thic lower becoming spatulate and sparingly serrate. (S. Virganrea, var. humilis, Gray.) - Rocky banks, W. Yt., along the Great lakes, and northwarl; also on islands in the Susquehanna, near Lancaster, and at the Falls of the Potomac. $-\Lambda$ t the base of the White Mountains, on grarelly banks, occurs a form with the minutely pubescent stont stem $1-2^{\circ}$ hight, the leaves larger, broader, and coarsely toothed, and the heads rery numerous in an ample componnd raeme; rays occasionally almost white.

Var. Gillmàni, Gray. Larger (20 high), rigid, with compound ample panicle and laciniately toothed leaves. — Sand-hills of the lake-shores, N. Mich.

+++ Heads s'mall or middle-sizal (large in $\mathrm{n} .13$ und 17), panicled or sometimes thyrsoidal, not in a terminal corymbiforn cyme; not alpine.

+ Leaves veiny, not 3-ribbed, but sometimes obscurely triple-nerved.

$=1$. Heads commonly large; leaves thickish, wery smooth, entire, elongated.

13. S. sempérvirens, L. Smooth and stout $\left(1-8^{\circ}\right.$ highli); leaves lanceolate, slightly clasping, or the lower ones lanceolite-ohlong, obscurely triplenerved; raeemes short, in an open or contracted panicle. - Salt marshes, or rocks on the shore, Maine to Va. - Ileads slowy; the gollen rays $i-10$. Varies, in less brackish swamps, with thinner elongated linear-lanceolate leaves, tapering to each ent, and more erect rueemes in a narrower panicle.

$=2$. Heads small, in a narrou vingule or thyrsoid panicle; scales then, acule: leners necurly entire.

14. S. strícta, Ait. Tery smonth throughout; stem strict and simple, u'cud like $\left(2-4^{\circ}\right.$ high), slender, heset with small aud entire appressed lanceolateoblong thiekish leaves, gradually rednced upward to mere liracts, the lowest oblong-spatulate; heals crousted in a very narrow compromel spicate raceme: rays 5-7. (S. virgati, Mich.x.) - Damp pine harrens, N. .J. and sonthward.

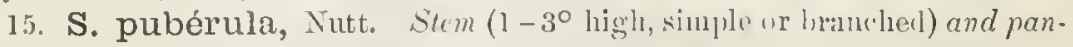
icle minutely hoary; stem-teares lanseolate, acute, lapmenng lo the betse smoothish; the lower wedge-lanceolate and sparingly toothed, heads rery numerons and 
sronciced in rumpuet short racemes forming " prolonyed and dense narcow or pyramiclal panicle; scales linear-anel-shuped, appressed; rags abont 10. Sandy soil, Maine to Va. and sonthward, mostly near the coast.

$=3$. Heads middle-sized, in a thyrsoid panicle; incoluchul scules ruther firm, obtuse; leaves entire or little serrate, smooth.

16. S. uliginosa, Nitt. Smooth nearly throughout; stem simple, strict $\left(2-3^{\circ}\right.$ high); leaves lanceolute, pointed, the lower tapering into winged petioles, partly sheathing at the base, sparsely serrulate or entire; racemes much rrovded and "prnossed in a clense wand-like panicle; scales linear-oblong; rays 5-6, small. (S. strieta, Man.) - Peat-bogs, Maine to L'enn., Minu., and northwarl. Root-leaves $6-10^{\prime}$ long. Flowers earlier than most species, beginning in July.

17. S. speciosa, Nutt. Stem stout $\left(3-6^{\circ}\right.$ high $)$, smooth; leares thickish. sinooth with rough margins, oval or ovate, slightly serrate, the uppermost oblong-lanceolate, the lower contracted into a margined petiole; heads somewhat crowded in numerous erect racemes, forming an ample pyramidal or thyrsiform panicle; peduncles and pedicels rongh-liairy ; scales of the cylintrical involucre ohlong; rays about 5, large. - Var. AxGuser rs, Torr. \& Gray, is a dwarf form, with the racemes short and clustered, forming a dense interrupted or compound spike. - Copses, Maine to Minn., and southward. - 1 very handsome species; the lower leares $4-6^{\prime}$ long and 2-4' wide in the larger forms.

$=4$. Heads very small in slender spreading secund clusters forming a mostly short and broad panicle; leazes entire or nearly so.

18. S. odora, Ait. (Swekt Golvex-Rod.) Smooth or nearly so thronghout; stem slender ( $2-3^{\circ}$ high), often reclined; leaves linear-lanceolate, entire, shining, pellucid-dotted; racemes spreading in a small one-sided panicle; rays 3-4, rather large. - Border of thickets in dry or sandy soil, Maine and Vt. to Ky., and southward. - The crushed leaves yiehl a pleasant anisate odor; but an occasional form is nearly scentless.

19. S. tortifolia, Ell. Stem scabrous-puherulent, 2-30 high; leaves linear, short, commonly twisted, roughish-pubernlent or glabrate; rays very short. - I)ry soil, coast of Va. and sonthward.

20. S. pilossa, Walt. Stem stout, upright (3-70 high), clothed with spreading hairs; hures ollong-lanceolate, roughish, hairy beneath, at least on the midrib, serrulate, the upper ovate-lanceolate or oblong and entire, closely sessile; racemes niany, recurverl, in a dense pyramidal panicle; rays $7-10$, very short. - Low grounds, pine barrens of $\mathrm{N}$. J. to Va. and sonthward.

$=5$. Ileads small or middle-sized, racemosely panienlate; leaves broad or ample, reiny, at least the lower serrate (or entire in 11.28$)$; involucral scales obtuse.

21. S. pátula, Muhl. Stem strongly anglod, smooth $\left(2-4^{\circ}\right.$ high) ; leares $\left(4-8^{\prime}\right.$ long) ovate, acnte, serrate, pale, very smowh and veiny underneath, but the upper surfuce rery rough, like shigreen; racemes rather short and utmerons on the spreading branches; heals rather large. - swamps; common.

22. S. rugòsa, Mill. Rouylh-liciry, esperiully the very leufy stem $\left(1-6^{\circ}\right.$ high); leaecs orate-lunceolate, ellipticul or oblong, often thickish and very rugose; racemes spreading; in rolucral scales linear; rays $6-9$; the disk-flowers $4-7$. (S. altisina, Torr. (hay, not $L$.) - Borders of fields and copses; very com- 
mon, presenting a great variety of forms; usually one of the lowest of the common Golden-rorls. It flower's early. Aug.-Sept.

23. S. ulmifolia, Muhl. Stem smooth, the branches hairy; leatrs thin, cllipticalovate or oblony-lanceolute, pointed, tapering to the base, iousely reined, beset with soft hairs beucath; racemes panicled, recurved-spreading; involucral scales lanceolate-oblung; rays abont 4. - Low copses; common. - Ton near the last; distinguished only by its smooth stem and thin larger leaves.

24. S. Ellióttii, Tur. \& Gray. Smooth; stem stont (1-30 high), et!y loufy; leaves elliptical or oblong-lanceolate, acnte (2-3' long), closely sessile, slightly serrate, strongly veined, thick, smooth both sides, shining above; heuds: in dense spreading raremes which are crowded in a close pyramidal panicle: veduncles and achenes strigose-pulescent. (s. elliptica, Torr. f. Gray, not 1it.) - Swamps (fresh or brackish) near the coast, Mass. to N. J. and southward. - lleals showy, 3" long; the rays $8-1 \cdot 2$.

25. S. neglécta, Torr. \& Gray. Smooth; stem stont $\left(2-4^{\circ}\right.$ high), less leafy; leave's thichish, smowh both sides, opaque; the upper oblong-lanceolate, mostly acute and nc:urly entire; the lower ovate-lanceolate or oblong, sharply serrate, tapering into a petiole; racemes short and dense, at length spreadiny. disposed in an elongated or pramidal close panicle; peduncles and achene: nearly glabrous. - Swamps, Maine to Ma., Wisc, and Minu. - lleads rather large, crowded; the racenes at first erect and suarcely one-sided. Vtry viriable, the forms approaching 11.16 and 27.

Var. linoides, Gray. 'The most slender for'm; radical leaves $4-8$ ' long and $4-6$ "wide, the upper rery small, erect; branches of panicle rather fen, one-sided ; rays 2-5. (s. linoiles, Tom. $\{$ Gray.) - Mass. to N. J.

26. S. Boottii, llook. Simonth, or scabrons-pnbescent or below hirsute, slemler, often hranched, 2-5o high; leaves rather fincly serrate, ovate to ohlong-lanceolate, pointed; the npper small, oblong to narrowly lanceolate, often entire; heals lousely racenose; rays 1 - 5 or none; achenes putescent. - 1)ry uronnds, Va. anl southwarl.

27. S. alguta, Ait. Smooth; stem angled: lerres (large and thin) ovute, and the nper elliptical-lanceolate, very shurply and stiongly serrate (entire only on the branches), pointed at both ends, the lowest un mirgined petioles; racemes pubescent, spreading, disposed in an elongated open penicle: ruys $6-7$, large ; achenes nsinlly glabrous. (s. Mnhlenbergii, Torr. d. Gru!.) - Copses and

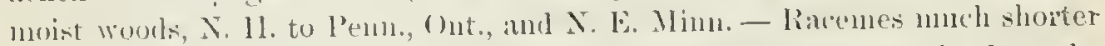
ant lonser than in the next; the involucal scales thin and more slenter; the hemls snnowhat larger, fully $3^{\prime \prime}$ long.

⒉8. S. júncea, Ait. Smooth throughout (1-30 highl); radical and lours

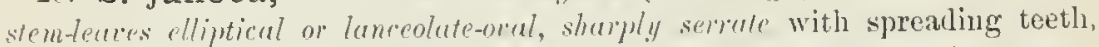
pointed, tapering into winged and ciliate petioles; the others luncrolate or narrouly ollong, slightly triple-nerved, tapering to each end, the uppermost mutire:

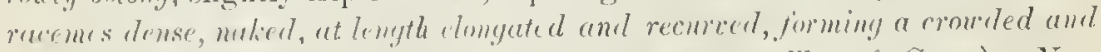

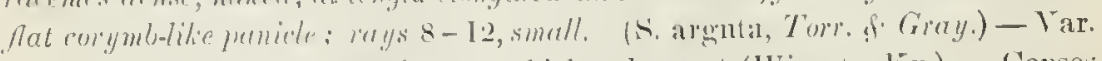

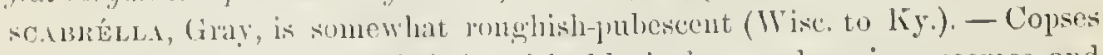
and banks; common. W $W^{\top}$ ell distinguished ly its long or llooping rateenes, and the closely appressed rigid scules of the involucre, small rays, etc. Heads sel. dom over 2 " long, the seales small and pale. 
+ Leares more or less plainly 3-ribled; heads in onc-sided spreading or recurved rucemes, forming an ample panicle. Tot maritime.

= Simooth and glabrons, at least the stem and bright green leaves.

a. Leaves firm and rather rigid; involucral scales thickish, obtuse, quite nnerual.

29. S. Missouriénsis, Nutt. Smooth throughout $\left(1-3^{\circ}\right.$ higlı); leares linerr-lanceolate, or the lower broadly lanceolate, tapering tro both ends, witl "ery rough margins; teeth, if any, sharp and rigid; heads and dense crowder racemes nearly as in $n .28$; achenes nearly glabrous. - Dry praries, from Wisc. and lnd. south and westward. - Heads $1 \frac{2}{2}-2^{\prime \prime}$ long.

30. S. Shórtii, Torr. \& Gray, Stem slender, simple $\left(2-4^{\circ}\right.$ lighh $)$, minutely roughish-pubescent above; leaves (the larger 2-3' long) oblomy-lanceolute, acute, the lower mostly serrate with a few fine teetl; racemes mostly short in a erowded panicle; achenes silky-pulescent. - Rocks at the Falls of the Ohio; Ark. - $\Lambda$ handsome species; heads $3^{\prime \prime}$ long, narrow.

b. Leaves thinner; imeolucrul scules thin, chiefly limear, wbluse.

31. S. serótina, Ait. Stem stout (2-70 high), smooth, yten glencous; lrues quite smooth both sides, lancenlate, taper-pointed, rery shalyly serrate, except the narrowed base, rough-ciliate; the ample paniclo pulescent; roys 7-It, rather long. (S. gigantea, of previous ed.) - Copses ant fence-rows: conmon, aud presenting many raricties. Seldom very tall.

Var. gigantèa, Gray. Communly tall, 5-80 ligh; leuses nore or less pubescent on hispidnlons beneath. (S. gigantea, Ait.; S. serotina of previous ed.) - Thickets and low yrounis, can. to Tex.

32. S. rupéstris, Raf. Stem smooth, slender, $2-3^{\circ}$ ligll; leares lineurlancedate, tapering both ways, entire or nearly so; panicle namow; heads very smell; rays 4-6, very short. - Rocky river-banks, W. Ta. to Ky and Ind.

$==$ Prbesrent (ut least the stem) or hispillulous-scubrous.

33. S. Canadénsis, 1 . Stem rongh-hairy, tall and stont $\left(3-6^{\circ}\right.$ high $)$; leares lanceolute, pointed, sharply surate (sometimes almost entire), more or less pubescent beneath and rough abore; hoads small: rugs very shont. - Borders of thickets and fields; rery common. - Varies greatly in the rom ghomess and hatriness of the stem and leaves, the latter oblong-lancenlite ar angated

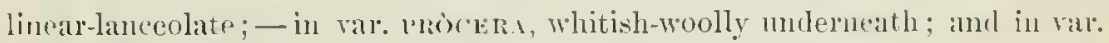

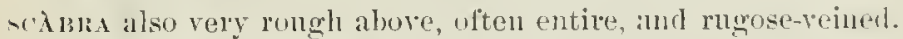

34. S. nemoràlis, Ait. Clothed with "mimute and close grayish-hour"! (soft or ronghisli) pulsescence: stem simple or coryuber at the summit $\left(\frac{1}{2}-2\right]^{\circ}$ high); leares ublunceolate or spatulate-oblong, the lower somewhat crenatetwothed ant tapering into a petiole; racemes numerous, dense, at length recurvel, forming a large and crowder compond raceme or panicle which is nsinally turned to one side; scales of the involucre linear-oblong, appressed; rays 5-9.-Dry sterile fields; very common. Flowers very lught yellow, hrginuing early in Ang. - Var. INcànt, Gray, of Minn, and westrard, is a dwarf form, with rigid oral or oblong leaves, rather strongly serrate or entire, and the clusters of hearls in a dense oblong or conical thyrse.

35. S. rádula, Nutt. Stem and oblong obovate-spatulate leaves rigid

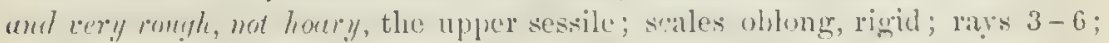
otherwise nearly as in n. 34. - Dry hills, W. 111., Minn., Kan., anl soutleward. 
36. S. Drummóndii, Torr. \& Gray. Stem (1-30 high) and lower sur. fare of the broudl! orate or oral someuhat triple-ribhed leares minulely reluetymubescent, some of the leares almost entire; racemes panicled, short; scales of the involucre oblong, obtuse; rays 4 or 5.-S. W. 111., Mo., and southwarl. +++ Heads in a compound corymb terminating the simple stem, not at all racemose; leaves mostly with a strony midrib.

- Leuves flat, not 3-nerecel.

37. S. rigida, L. Rough and somerhal horry with a minute pubescence; stem stout $\left(2-5^{\circ}\right.$ ligh $)$, very leafy ; corymb dense; lrures orct or ublong, copiunsly feather-veined, thick and rigid; the upper closely sessile by a hroal base, slightly serrate, the uppermost entire; heads large, orer 30 -flowered ; the rays - -10. - Dry soil, N. Fing. to Minn., and soutliwarl.

38. S. Ohioénsis, Riddell. Very smooth thronghout; stem wand-like, slenter, leafy $\left(2-3^{\circ}\right.$ high $)$; stem-leaves oblong-lancedate, flut, entire, obscurely feather-veined, closely sessile; the lower and radical unes elongated, slightly serrate towarl the apex, tapering into longr margined petioles; liearls nunerous, on smouth pedicels, small, 16 -20-flowered; the rays 6 or 7.- Moist meadows or prairies, W. New York to Inrl. and Wisc - Root-leaves $1^{\circ}$ long; the upper rednced to $1-2^{\prime}$, witl rough margins, like the rest.

+ + Leaves somewhat folded, entire, the lower slightly 3-nervea.

39. S. Riddéllii, Frank. Smoulh und stout $\left(2-4^{\circ}\right.$ high), very leafy, the branches of the dense corymb and pedicels rough-pubescent; leares linent-tancewhte, flongated ( $4-6^{\prime}$ long), acute, partly clasping or sheathing, mostly recured, the lowest elongater-lanceolate and tipering into a long keeled petiole ; heads ipry numerous, clustered, 20-30-towered; the rays $7-9$. - Wet grass. prairies, Ohio to Minn. and Mn.; Ft. Momroe, Va. - Ileads larger than in the last, 2-3" long. Stem-leaves upright and partly sheathing at the base, then gradually recurmen-spreading.

40. S. Houghtònii, Torr. \& Gray. Smooth; stem rulher low und slender $\left(1-2^{\circ}\right.$ high) : leares sintlered, lineur-lanceolate, acutish, tapering into a narrowed slightly elasping base, or the lower into margined petioles; heads few" or severul, 20-30-flowered; the rays $7-9$. - Swanls, north shore of Take Michigan; Genesee Co., N. Y. July, Aug. - leares rough-margined, 2-5' long, 2-4" wile, 1-nerved, or the lower olscurely 3-nervel above; reins obscure. Heads large, nearly $\frac{1}{2}$ long. Scales of the involucre obtuse.

\$2. EUT'IAMIA. Corymbosely murh branehed: lecuds small, sessile, in little clusters crowded in flut-topped rorymbs; the closely appressed imnolucrul scales somewhat glutinous; receptacle fimbrillate; ruys $6-20$, short, more numerous than the disk-flowers: leures narrou, entire, sessile.

41. S. lanceolàta, L. Leaves luncolntelinear, 3-5-nered: the nerves, margins, and ancles of the branches minutely rough-pulescent; heads obovoidrylindrical, in dense corymbed clnsters; rays $15-20$. - River-banks, etc., in nuist soil; common. - Stem 2-3 high; leaves 3-5' long.

42. S. tenuifolia, I'ursh. Smooth, slender; leaves zery narrowly linear, mostly 1-nered, dotted; heals obovoid-club-shapel, in numerous clusters of 2 or 3 , disposed in a loose corymb; rays 6-12. - Samly fields, Mass. to Ill., aut southward; common near the coast. 
18. BRACH Y CH 屈TA, Torr. \& Gray. False Goldex-Rod.

lleads and flowers nearly as in soliclago, rxcept the pappus, which is a row of minute rather scale-like bristles, shortcr than the achcne. - A perennial herb, with romuled or ovate serrate leaves, all the forer ones hear-shaped; the small yellow hearts in sessile clusters rinemed or spiked on the brinches. (Nane composect of $\beta \rho a \chi u ́ s$, short, and $\chi$ air $\eta$, hristle, from the pappus.)

1. B. cordàta, Torr. \& Gray. Wooded hills, S. Ind. and E. Kíy. to N. Ga. Oct. - l'lunt $2-4^{\circ}$ high, slender, more or less pubescent.

\section{BÉLIIS, Touru. DAISY.}

Heads many-flowered, radiate; the rays numerous, pistillate. Scales of the involucre herbaccous, cqual, iu about 2 rows. Receptacle conical, naked. Achenes obovate, flattenerl, wingless, and without auy pappus. - Low herhs (all but our single species natives of the Old World), either stemless, like the true Daisy, B. PERIXXIs (which is finnd as an occasional escape from cultivation), or leafy-stemuer, as is the following. (The Latin name, from bellus, pretty.)

1. B. integrifolia, Miclex. (Westers Disr.) Auntal or hiennial, diffusely hancher $\left(t^{\prime}-1^{\circ}\right.$ high), smoothish ; leaves lancenlate or oblong, the luwer spatulate-obvate; heads on slender peduncles; rays pale riolet-purple. - Prairies and banks, Ky. and southwestward. March-June.

\section{A PHA NÓSTEPHUS, DC.}

Involucral seales in few series, broally lanceolate, the outer shorter. Achenes prismatic, the broad truncate apex bearing a short coroniform pappus. Otherwise as Bellis. - Sonthwestern leafy-stemmed and branching puhescent lierbs, with solitary terminal daisy-like learls. ('A $\phi \alpha \nu n^{\prime}$, inconspicuous, and $\sigma \tau \hat{\phi} \phi$ os, crorn; in allusion to the pappus.)

1. A. Arkansànus, Gray. 1)iffuse, $1^{\circ}$ high; leaves oblong-spatulate to hroadly lauceolate, tho lower often toothed or lobed; rays white to purple, $\frac{1}{2}$ long; pappus mostly 4-5-lobed. - Plains of lian. aud sonthward.

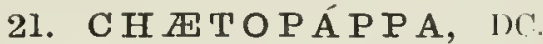

Heads sereral-flowerct, rarliate; lisk-flowers often sterile. Involucral bracts imbricated in 2 or more rows, the outer shorter. liceptacle flat, naked. Achenes fusiform or compressed; pappus of 5 or fower thin nerveless palea, alternating with rough bristly awns, or these wanting. - Low sonthwestern branching anumals, with narrow entire leaves and solitiry terminal hearls; ray white or purple. (Xaír , a bristle, and $\pi \alpha$ ámos, pappus.)

1. C. asteroides, DC. Slender, 2-10' high, pubescent; involncres narrow, 2" long; rays 5-12; achenes pubescent.-I)ry grounds, V'ernon Co., Mo., and sonthward.

\section{BOLTÒNIA, L’Her.}

Heads many-flowered, radiate; the rays numerons, pistillate. Scales of the hemispherical involucre imbricatch somewhat in 2 rows, appresserl, with narrow membranaceous margins. Jicceptacle concal or hemispherical, naked. Irhenes very flat, oborate or inversely beart-shaped, margined with a callotio 
wing, or in the ray 3-winged, crowned with a pappus of several minute bristles and usually $2-4$ longer awns. - Perennial and busly-branched smooth herlss, pale green, with the aspect of $\Lambda$ ster; the thickish leaves chiefly entire, often turned edgewise. Flowers autumnal ; lisk yellow; rays white or purplish. (Dedicated to fumes Bolton, an English botanist of the last century.)

$$
\text { * Heads middle-sized, loosely corymbal. }
$$

1. B. asteroides, L'Her. Stems $2-8^{\circ}$ high ; leacs lanceolate; involncral scales acuminate; pajpus of few or many minute bristles and 2 awns or none. (B. glastifolia, L'Iler., the awnert form.) - Moist places along

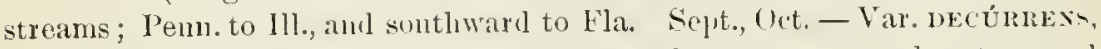
Engelm., a large form with the leaves alate-decurent upon the stem and branches. Mo. (Eyyert).

․ B. latisquàma, Gray. Heads rather larger; involucral scales oblong to orate, obtuse or nucronate-apiculate; pappus-awns conspicums. - W. Mu. and kin.

* Heads small, panicled on the slmulr bromlies.

3. B. diffùsa, l'ller. Sten diffusely branghed; leares lance-linear, those on the branchlets very small and awl-shaped; lays short, nostly white; paypus of several very short bristles and 2 short awns. - l'rairies of $\mathrm{s}$. 1ll. (l'isey), and southwestwat. Ing. - oet.

\section{TOW NSÉNDIA, llook.}

Ieads many-Howered, the numerous ray-flowers (violet to white) in a single selies, fertile. Involucre hroad, the lanceolate scirionsly margined scales in-

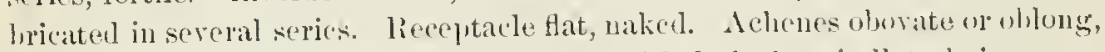
Hattened, with thickish margins and beset with forkecl-apitellate hairs: papfus a single row of long aw us or coarse rigid bristles, or redncel in the ray to chaffy scales. - I wow scarcely canlescent herlss, with linear to slutulate entire laves and large lieads. (Ximed for Ihovid Tounsend, botanical associate of Ir. Jarlington of l'enn.)

1. T. sericea, Ilook. Acaulescent silky-pulnescent peremial; luads sessile, solitary or few, $\frac{1}{2}-l^{\prime}$ high ; riy-pappos mostly bristly - l)ry llinits, central Yeh., inorth and westwarel. April, May.

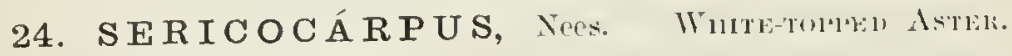

Ileals: $12-20$-tlywered, raliate: the rays abont 5, fertile (white). Involucore

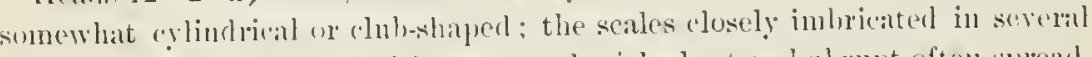
rows, cartilaginons and whitish, appressefl, wich short and alupt often spreatl. ing green tips. lieceptacle alvenlate-tontherl. Achenes short, imersely ry-

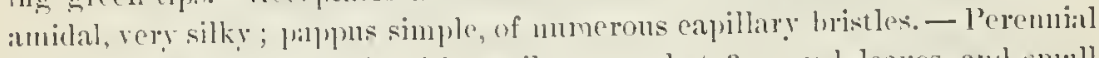

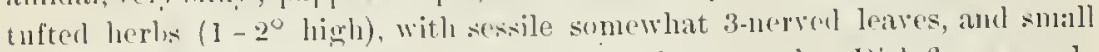
heals mostly in little rlusters, disposed in a fat corymb. Disk-flowers pale

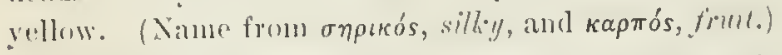

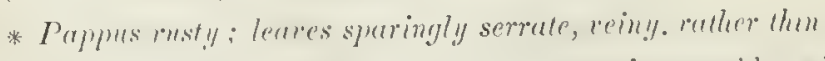

1. S. conyzoldes, Nees. Somewhat pubescent; leaves oblong.linuceolate or the lower spatulate, ciliate; heats rather loosely coryubed, obconical $(\$-b$ "

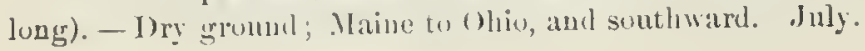


* Papms uhite: leazes entire, obscurely reined, firmer and smaller.

2. S. solidagíneus, Nees. Simooth, slenter; leaves linear, rigid, obtuse, with rongh margins, tapering to the hase; leats narow (i" long), in close

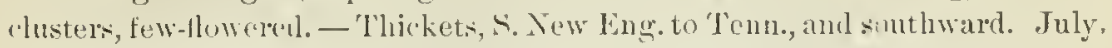

3. S. tortifolius, Nees. Iloally-phescent; leaves whurate or oblong-

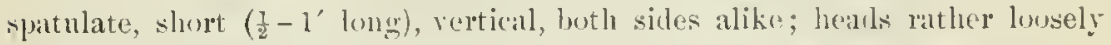
corymbed, oloroid $(t-5$ "long). - l'ine wools, Ya. and sunthward. Aug.

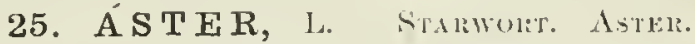

Heads many-flowered, ratiate; the ray-flowers in a single series, fertile. ficales of the involucre more or less imbricater, nstally with herbaceots or leaf-like tips. Receptacle flat, alvoolate. Achencs more or less thattened; pappus simple, of capillary bristles (double in $\$ \$ 4$ and 5). - I'eremnial herbs (ammul only in $\$ \$ 7$ and 8), with iorymbed, panicled, or racemose heads: Howering in autumn. Rays white, purple, w hlne; the disk yellow, often

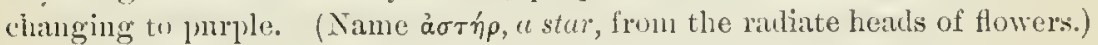

\section{Conspectus of Groups.}

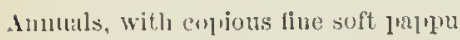

Papplus double

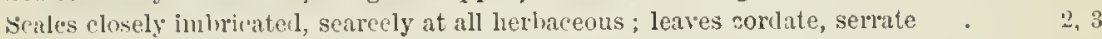

Sconles nearly rinil, rigil, more or less foliaceous; pappus-bristles rigid, some thickinel at top".

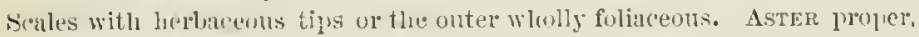

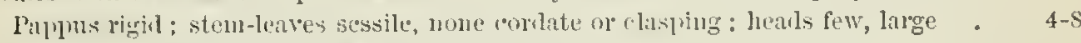

Jeaves silvery-silliy lutl sides, sessile, entire . . . . . . . . 14, 15

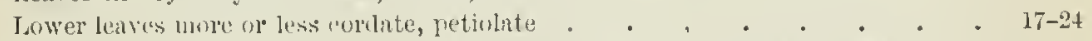

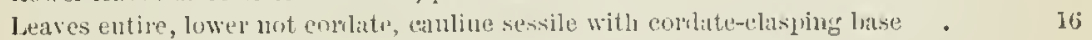

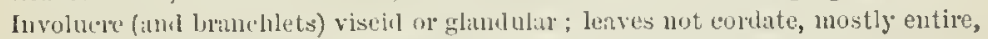

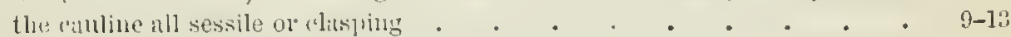

Lower leaves all achte at base; $16, \mathrm{t}$ glumlular nor viscill nor silky-eanesent.

Smootli and glalorous, nsually grlancuns; scales corjiceous at base; leaves firm, nisutlly entire

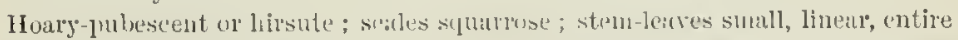

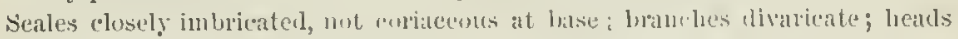
11:11, small

Remaining species; branches elect or ascenuling.

Stem-leaves amiculate-colasping or witl wingul-pefiole-like hase; involule lax $42-45$

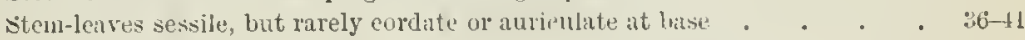

\$1. HELHÁTRLM. Papmus simple, course and rigid, the stronger hristles

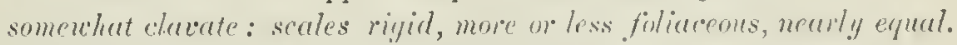

I. A. paludosus, Ait. Stems $1^{\circ}$ litgh; glalurons or nearly so; hearts $\frac{1}{2}$ ' high, ratlier few, racemose or spiente; outer scoles lax, foliacens; rays purple; leaves linear, entire. - Kan. to Tex., thence to Car. and riv.

\$2. BIOTIA. Inemuce whroid-bell-shaped: the sales regularly imbricuted in several rows, appressed, nearly destitute of herbuceous tips; ruys $6-18$ (white or nearly so); achenes stender: paplus slightly rigid, simple: lourer leares larye, heurt-shaped, petioled, conrsely serrale: heads in open corymbs.

2. A. corymbòsus, $\Lambda$ it. Stem slender, somewliat zigzig; leares thin, smouthish, crutsely and unequally serrate with sharp spreading teeth, taper-pointed, 
syate or orate-lanceolate, all but the uppermost heart-shaped at the base and on slender naked petioles; rays 6-9. - Woodlands; common; especially northwarl. July, Ang. - Plant $1-20$ high, with smaller heads, looser corymbs, rounder and less rigid exterior involncral sules, and thimer leaves than the next; not rongh, but sometimes pubescent.

3. A. macrophýllus, L. Stem stout and rigid $\left(2-3^{\circ}\right.$ lighh); leares thichish, rough, closely serrate, abruptly pointed; the lower heart-shaperl (4-10' long, 3-6' wide), long-petioled ; the upper ovate or ohlong, sessile or on margined petioles; heads in ample rigid corymbs; rays $10-15$ (white or bluish). - Moist woods; eommon northward, and southward along the mountains. Aug., Sept. - Involncre $\frac{1}{2}$ broad; the onter scales rigid, oblong or ovate-ob long, the innermost much larger and thinner.

\$3. ASTER proper. Scales imbricated in various degrees, with herbaceous or leaf-like summits, or the outer entively foliaceons; rays numerous; pappus simple, soft and nearly uniform (coarser and more rigid in the first group); achenes flattened. ( $\$ 11$ flowering late in summer or in autumn.)

* 1. Scales well imlricated, coriaceous, with short herbaceous mostly obtuse spreading tips; puphus of rigid bristles; stem-leares all sessile, none heart-shaped or clasping; heuds few, or when several corymhose, lurge and showy.

- Louest leaves orate or ovate-oblong, some rounded or subcordate at base.

4. A. Hervèy, Gray. Slightly scabrons, $1-2^{\circ}$ high, the summit and peduncles glandular-puberulent; leaves roughish, obscurely serrate, the lower ovate on nearly naked petioles, the upper lanceolate; heads loosely corymbose, $\frac{1}{2}$ high; involucre nearly hemispherical, the scales obscurely glandular, all erect, with very short or indistinct green tips; rays violet, $\frac{f^{\prime}}{2}$ long. - Borders of oak woods, in rather morist soil, E. Mass. and 12. I.; Mt. Desert. An ambiguous species, approaching the last.

+- + Radical leaces all tapering into maryined petioles; involucres squarrose (hardly so in 11. S); rootstocks slender.

5. A. spectábilis, Ait. Stens $1-2^{\circ}$ liggh, roughlish and glandularpubernlent above; leaves oblong-lanceolate, or tho lower spatulate-oblong, obscurely serrate or the upper entire; heals few, hemispherical, $\frac{1}{2}$ high ; scales glandular-puberulent and viscid; mostly with tho upper half herhaceous and spreading; rays about 20 , bright violet, nearly l' long. - Sandy suil, Mass. to Del., near the coast, aud perhaps southward. Sept.-Nov. One of the handsomest species of the genus.

6. A. surculosus, Michx. Stems $1^{0}$ high or less, from long filiform rootstocks; leares entire or nearly so, rigid, lanceolate or the upper linear; heads few or solitury, as iu the last but geuerally smoller; the scules hurdly glamdular. - Moist ground, coast of N. J., and southward.

7. A. grácilis, Nutt. Rootstocks occasionally tuberous-thickened ; stems slender, 10 high; leares oblong-lanceolate, entire or nearly so, small (1 - 2' long); heads few or several; involuce top-shaped, 3-4" long, glabrous, not glandular nor viscil, the coriaceons whitish scales with very short delloil or ovate tips: rays 9-12,3-6" long. - J'ine larrens, N. J. to N. C. F. Ky. and 'lenu.

8. A. rádula, Ait. Sitem simple or corymbose at the smmit, smooth or sparsely hairy, many-leaved $\left(1-3^{\circ}\right.$ ligh $)$; lentos ullong-lanceolute, ponted, 
sharply serrate in the middle, very rouyh both sides and myose-reinerl, closely sessile (2-3' long), nearly equal; scules of the bell-shaped inrolucre wblong, aypressed, with erery short and slightly spreading herbaceons tijs; achenes smouth. - Bogs and low grounds, Del. to Maine and northward, near the eoast; also l'oeono Mountain, P'enn. A dwarf form (val. strfctus, Gray) has oblong-to linear-lanceolate nearly entire leaves, and usually solitary hearts; White Monntains, N. H., to Lab. Aug. - Rays light violet. Involucre nearly smooth, except the eiliate margins.

* 2. Involucre and usually the branchlets viscidly or fruinose-glandular, uell imbricated or loose; pubescenee not silky; leaves entire (or the lower with few teeth), the cauline all sessile or elasping; mus showy, violet to purple.

- Ileads small; involuere not squarrose. Extreme western.

9. A. Féndleri, Gray. Rigid, $1^{\circ}$ high or less; leaves firm, linear, 1nerved, hispict-ciliate, $l^{\prime}$ long or mostly mucl less; heads scattered, $3^{\prime \prime}$ high ; seales linear-obIong, obtuse, or the inner acute. - Central Kau. (Ellis, Dr. L. IFatson) and sonthwestward.

+- Heads laryer; imolueral scales spreading, in few or many ranks.

10. A. grandiflòrus, 1. Rough with minute hispid hairs; stems slender, loosely much branched ( $1-3^{\circ}$ high); leuves very smull $\left(\frac{1}{4}-l^{\prime}\right.$ long), ohloninlinear, obtuse, rigil, the uppernost passing into scales of the hemispherical squarose many-raked involucre; rays bright violet ( $l^{\prime}$ long); achenes hair?. - Dry open places, Va. and sonthward. - lleads large aud very showy.

11. A. oblongifolius, Nntt. Minutely ylandular-puberulent, much brauched above, rigid, paniculate-corymbose ( 1 - 20 high); leaves narrouly ollong or lanceolute, mueronate-pointed, partly clisping, thickish (1-2' long by $2-5^{\prime \prime}$ wide); involncral seales nearly equal, broadly linear, appressed at the base; rass violet-pulple; achenes caneseent. - Banks of rivers, from Penn. and Va. to Mimn, ant Kan. - Ileads midle-sized or smaller.

Var. rigídulus, Gray. Łow, with more rigid and hispidulous seabrons leaves. - In trier places, Ill., Wrise, and sonthwestwarl.

12. A. Novæ-Ángliæ, 1. Stem stont, hairy (3-80 high), corymbed at the summit; leaves very numerous, lanceolate, entire, acute, auriculate-clasping. clothed with mimute pubeseewre, 2-5' long; sordes nearly equal, linerer-anc-shaped, loose, glandular-viscid, as well as the branchlets; lays violet-purple (in val. uoseus rose-purple), very mmerons; achenes hairy. - Moist gromuls; con. mon. - lleads large. A peconliar and hantisone species.

13. A. modéstus, lincl. Pnlescent or glabrate; sten slender, simple with few large heals terminating slender hanehlets; leaves lancenlate, rely acnte, narrowed to a sessile balse, sparingly serrate ol serrulate; scales linear. attennate, equal, mostly herbiceous; rạs hlne. — N. l)ak. and westwarl.

* 3. Leaves whitened, silvery-silly both sides, all sessile and entire, mueromulate; incolucre imbricated in 3 to sereral rows; roys showy, purple-violet.

14. A. sericeus, Vent. Stems slender, branched; leaves silver-white. lanceolate or oblong, heads mostly solitury, terminating the short branchlets; sorles of the globulur involucre similur to the leuces, spreading, except the short (oriaeeons base; achenes smooth, many-ribbed. - l'rairies and dry bauks, Wisc. and Minn. to ky. and southward. - Heads large; lays 20-30. 
15. A. cóncolor, L. Stems wand-like, nearly simple; leaves crowded, dblong or lanceolate, appressed, the upper reduced to little bracts; heads in " simple or compound wand-like raceme; scales of the olrovoid involncre closely: imbricated in several rows, appressed, rather rigicl, silky, lanceolate; achenes silky. - Dry sandy soil near the coast, R. I., N. J., and southward. - Plant 1 $3^{\circ}$ high, with the short leaves $l^{\prime}$ or less in length, grayish-silky both sides.

* 4. Leaves entire, the louer not leart-slaped, the eauline all with sessile and eordate-elasping base, the amricles generally meeting apound the stem.

16. A. pàtens, Ait. Rough-pubescent; stem lonsely panicled alove (1 $3^{\circ}$ high), with widely spreading branches, the hears mostly solitary, terminating slemler branchlets: leaves oblong-lanceolate or orate-ohlong, often contracterl below the middle, rough, especially above and on the margins; scales of the minutely roughish infolucre with spreading pointed tips; achenes silky. - Var. p'HLOGIFòlus, Nees, is a form of shady moist places, with larger and elongaterl thin scarcely rough leaves, downy muderneath, sometimes a little toothed abore, mostly much contracted below the mildle. - Dry ground; common, Mass. to Minn., and southward. Heads $\frac{y^{\prime}}{2}$ broat, with showy deep blue-purple rays.

* 5. Louer leares heart-shaped and petioled; no glandular or viscid pubescence: heads with short and appressed greon-tipped seales (except in $\mathrm{n} .17$ and 24), mostly small and numerous, raremose or panicled.

t- Heads middle-sized, with many rays, and squarrose foliaceons imelnere.

17. A. anómalus, Engeln. Somewhat pubescent and scabrous ; stems slender $\left(2-t^{\circ}\right.$ high), simple or racemose-branched above; leaves ovate or oratelincenlate, pointed, entire, the upper small and almost sessile; scales of the hemisplerical involucre imbricated in several rows, appressed, with linear spreading leafy tips; allenes smooth. - Limestone cliffs, IV. Ill. and Mo. to Ark. - Rays violet-purple.

++ Rerys it -20; meolucral scales appressed or erect.

$\rightarrow \rightarrow$ Leaves entire or slightly serrate; heads middle-sized: rays bright-blue.

18. A. azùreus, Liudl. Stem rather rough, erect, racemose-compound at the snmmit, the branches slenter and rigid; leaves rough, the lower oratelanceolute mo ollong, hrart-shoped, on long often hairy petides; the others lanceo. late or linear, sessile, on the branches awl-shaped; involucre inversely conical. - Copses and prairies, western X. Y., and Ohio to Mlinn., anl southwestward. Involncre much as in A. levis, hut smaller and slightly pulesent.

19. A. Shórtii, Hook. Sten slencler, spreading, nẹrly smootl, hearing very numerons heads in racemose prunicles: leares smooth abore, minutely pubescent underneuth, lanecolate or orate-taneolute, slonguted, tapering gradually to a slarep point, all but the uppermost wore or less hectrt-shaped at luse, and on unked petioles, none clasping; inrolnere bell-shaped. - Cliffs and banks, Ohin

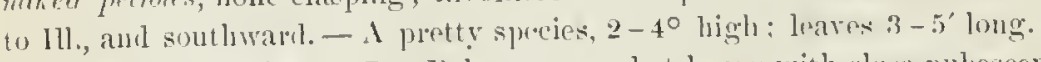

20. A. undulàtus, I. I'ale or somewhat hoary with clus? pubescence; stem sprealing, bearing numerous heads in racemose panicles; frues orate or orate-lanceolate, with wary or slightly toothed margins, ronghish above, downy underneath, the lowest heart-shaped on margined petioles, the others abruptly conwaeted into short broadly winged petioles which are diluted and rlusping at the 
fase, or directly sessile by a heart-shaped base; invulucre oboroid, the scales less rigid. - I)ry copses ; common.

+ + Leares conspicuously serrute; heads small; rays pale blue or nearly whitt.

21. A. cordifolius, I. Stem mueh branehed above, the spreading or direrging brenches bearing very numerous punicled heads; lower leaves all heartshaped, on slender and mostly naked ciliate petioles; scales of the imarsely

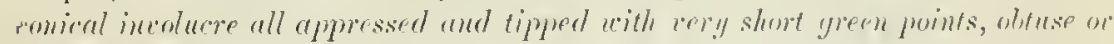
arntish. - Woodlands; rery common. - Ilears profnse, lut quitesmall. Varies with the stem and leares either smonth, rmghish, or sometimes hairy, also with the Ieaves all narmwer. Apparent hyluris with 11. 35 also (ecrur.

22. A. sagittifòlius, Willd. Stem rigirl, erect, with ascendiug hremehes

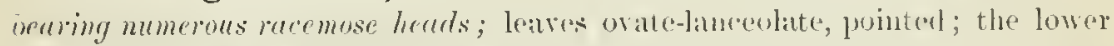
heart-shaper at base, on margined petioles; the upper lamerolate al lintar, pointed at both ends; srates of the oblong incoluene limere, tapering intes ant-

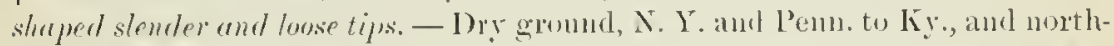

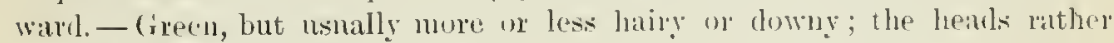
larger than in the last, almost sessile.

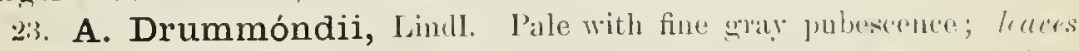
cordate to cordate-lancedate, mostly on meryiurd pretioles, the eppermenst lan(ex)late and sessile; scrules crute or acurish. - l'assing into the last. (Jpen gromul, etc., Ill. to Mimm, amkl lian.

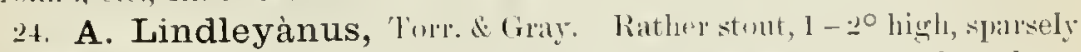

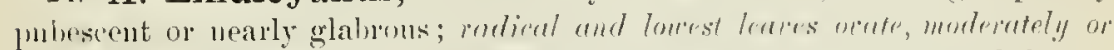

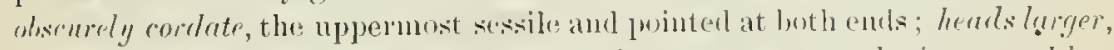

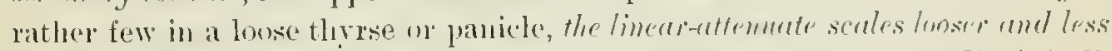
imlurcated; rays pale violet. - Lab. to L. Superior; Lishon, N. I1. (r'. I. Firom), aud Mit. Desert (liund).

* 6. Mrihout heart-shaped petinled leutes, the radical and loner all acute or attrmate at buse: not glamdular nor viscid, nor silky-canescent.

- Simooth and glabonus throughont (or nearly so, exropt forms of n. 30), and usually pale and ylourons; incolureal scales closely imbricated, firm and whitishcoriaceous bitur, greentipled; leares firm, usually entive.

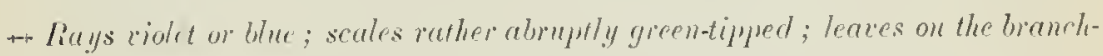
lefs reduerd to rigid subulate brarts.

2.). A. turbinéllus, Limll. Stenu slender, $3^{\circ}$ higlı, paniculately lurancherl; laves oblong to narrowly Ianceolate, tapering to each cucl, with rough margius;

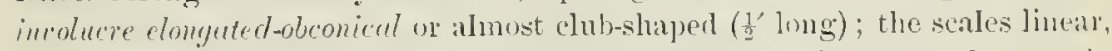
with very short and bint green tips; rays violet-l,lue; achenes nearly snowtl. - Dry hills, etc., 111., Mo., and sonthwestward. - Well-marked aud handsunte.

26. A. læevis, 1. Stonter, $2-4^{\circ}$ high; heads in a close panicle; leaves thickish, lancenlate or ovate-lanecolate, chicfly entire, the upper more or less (Iasping by an auricled or heart-shaper base; scales of the short-obmobl w" hemisphericul inroluce with short ahrupt green tips; rays sky-blue; achenes sncoth. - Borders of woollands; commun. A variable and elegant spectes.

27. A. virgàtus, Ell. Slender, strict and simple, with few or severil racemose or terminal heads, like those of the list; leaves lunceolar or lineur, the lover usually long and norrow. - S. W. Va., and southward. 
28. A. concínnus, Willd. Not glaucous, slender, 1-30 high; leave lanceolate, mostly somewhat serrate, the lowest spatulate-lanceulate on winged petivles; heads smaller than in the preceling, mumerous, panicled; rays violet. - Rare; Penn. and southward.

+ + Rays ulite or tuming purplish; scales nurrow, subulately green-tipped; leares mostly narrou, narroued at base, on the brancluets lax and attenuate.

29. A. polyphýllus, Willd. Often tall (4 or $5^{\circ}$ high), with virgate lranches; cauline leaves narrowly lanceolate or linear, 4 or 5 ' long; hears janiculate; scales lanceolate-subulate, the ontermost much shorter; rays 4" Jong. - N. Vt. to Wisce, and southward. Heads larger and flowering earlier than the next.

30. A. ericoides, L. Smooth or spariugly hairy $\left(1-3^{\circ}\right.$ high $)$; the simple branchlets or peduncles racemose along the mpper side of the wand-like spreading branches; lowest leaves oblong-spatulate, sometimes toother ; the other's linear-lancevlate or linear-awl-shajed; hearls $3^{\prime \prime}$ lighl or less; involncral scales often nearly equal, with attenuate or awl-shaperl green tips. - 1)ry open places, S. New Lug. to Minn., and southward. - Var. vilcosus, 'Torr. \& Gray, is a hairy form, often with broader leaves; chiefly in the Western States. Var. pusíluds, Gray, is a dwarf slender and glabrous form of the barrens of Lancaster, Penn. (Porter), with very narrow or filiform leaves aurl very small few-flowered heads. - Var. Príscler, Gray, a low strjet form, with few erect branches and latlıer small heads. About Lake Champlain.

++ Hoary-pubescent or lirsute; herbaceous tips of the inrolneral scales squarrose or spreading; cauline leaves small, linear, entire, scarcely narrowed at the sessile or partly clasping brise: lieads numerous, smull, rucemose.

31. A. amethýstinus, Nutt. 'Tall $\left(2-5^{\circ}\right.$ high $)$, uplight, much branched, pulor "ulent or somewhat hirsute; leaves not rigitl; lieads $3^{\prime \prime}$ high, the tips of the scales merely sprealing; rays light clear blue. - Moist grounds, E. Mass. to 11l. and Iowa. WVitl the habit of 11.11.

32. A. multiflorus, Ait. Pale or hoary with minute close pubescence (1* ligh), much branched and bushy; the heads much crowderl on the spreading lan lomose bratches; leaves rigid, crowder, spreading, with rough or ciliate margins, the uplumost passing into the spatulate obtuse scales; heals $2-3$ " ung; rays white wr raty bluish, 10-20. - Dry sandy soil; common.

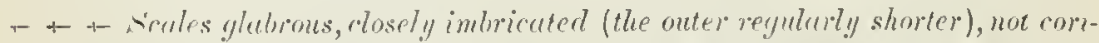
areons, with short apmessed ancen lips; branches slender, diraricute or dirergeat: leaves lunerolute to subulate; hends small (2-3" high) and memorous. + Heads scatlered, terminating minutely foliust slender brumblets.

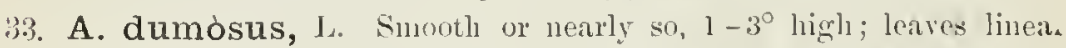
or the upper ohlong, crowderl, entire, with rough margins; scales linear-spatulite, obtuse, in $4-6$ rows. - Thickets; common. - I rarialule species, loosely hranched, with small leaves, especially the upper, and an ahounical or bellshaped involucer, with more uhmpt creen tips than auy of thr sucresting. Rays pale purple or blue, larger thau in 11.34 . Runs into several peculiu forms. +r + Herads racemosely milateral upon very short mimutely loufy bramehlets.

34. A. vimíneus, Laun. Smooth or smoothish, 2-50 high, hushy : leaves linear or nandowly lancenlate, elongated, the larger ones remonty serrate in 
the middle with fine sharp teeth; srales of the involucre narrouly linear, acute or aculsh, in 3 or 4 rows. (A. Trallescanti, of previous ed.) - Var. rounIosus, Glay, has linear entire leaves, the ascending brunches with more scattered paniculate heads. - Moist banks; very common. - Ieals rery numerous, and usually crowder, smaller than in the last. Rays white or neary so.

35. A. diffùsus, dit. More wess pubescent, much branched; leares linceolate or oblong-lanceolate, tapering or pointed at each end, sharnly serrule in the mildle; scales of the involucre lincar, acute or rather obtuse, imbricated in 3 or 4 rows. ( 1 . miser, of previons ed.) - Thickets, fields, etc.; very common, and extensively variable. Leaves larger than in either of the preceding $\left(2-5^{\prime}\right)$; the involuce intermediate between them, as to the form of the scales. lays mostly short, white or pale liluish-purple. - Var. turrsofDeus, Gray, with ovate-oblong to linceolate leaves, the hranches ascencling and often short, and the thyrsoid or spicate-glomerate heals less secund. N. Y. to Ill. - Var. nirsuticaturs, Gray, the slender stem and the midreins of the long narrow leaves very lirsute. N. Y.and Ky. - Var. ufruoss, Gray, a luxuriant form with large thin leaves and rather larger heads loosely disposed ou the spreading branches. Ky. to Ill.

++++ Involucre various, the heads when numerous densely or loosely paniculate on erect or ascending branches.

- Cauline leaves sessile, but the base not cordate nor auriculate (except in forms of $\mathrm{n} .+1)$, nor winged-petiole-like: glabrous or nearly so.

$=$ Heads small or middle-sized: scales narrow, in several lengths, the erect grcen tips not dilated.

36. A. Tradescánti, I. Stem much branched $\left(2-4^{\circ}\right.$ high); the numerous heals (2-3" high) somewhat panicled or racemed; leaves lanceolate to linear, tapering to a long slender point ( $2-6^{\prime}$ long), the lower somewhat serrate in the middle; involucral scales linear, acntish, partly green down the back. (A. tenuifolius, previous ell.) - Low grounds, Mass. to Minn., and soutl to Vil. and 111. Rays short and narrow, white or purplisls. Some forms approach 11. 32-34, others differ from $A$. panieulatus only in the smaller heads and shorter ray.

37. A. paniculàtus, Laum. Sitem $\left(2-8^{\circ}\right.$ high) much lranchel; the branclies and scattered heads (about 4 " high) loosely paniculate; leares longoblong to narrowly lanceolate, pointel, the lower serrate; seales namowly linear, with attenuate green tips or the ontermost wholly green. (A. simplex,

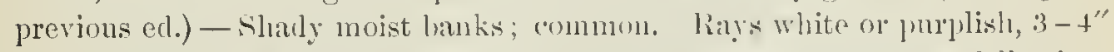
long. Aplproarches in its different forms the preceding and the two following. A slender form with linear leaves, in northern logs, resemhles n. 40.

38. A. salicifòlius, $\Lambda$ it. Like the last; the leaves commonly shurter, firmer, often scahnons, less serate or entire; involucre more imbricated, the firmer linear scules witl slorter acote or vitusish green tips; heals as lange,

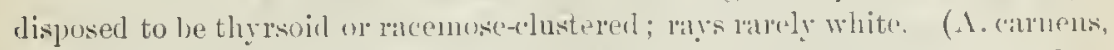
previous ed.) - Low gromuls, X. Eng. to Minn., and sunthwanl ; most alınclant

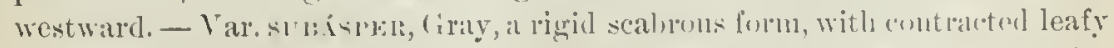
inflorscence, the broal heals nsually leafy-brateate and the malcre sules "fientl "litusin, Ill, to 'Tex. 
$==$ Heads small or middle-sized, the looser linear scales somewhat equal and reed, and the acute green tijs not ditated, the outer often wholly herbaceous.

39. A. júnceus, Ait. Slender, $1-3^{\circ}$ high, simple with few lrearls or

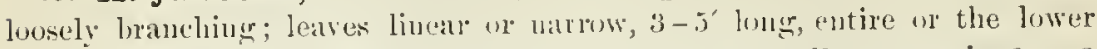
sparsely denticulite; leaks suall (3" high); scales small, narrow, in 2 or 3 rows, the onter more or less slurter; rays light purjle, 4-5" long. (A. axstivus, previous col, mininly.) - Wet mealows and coll hugs, N. Sicotia and Ni. I. to Mlich. and Mlun.

40. A. longifòlius, Lant. (nut of previons ed.) Siten $1-3^{\circ}$ hight, more or

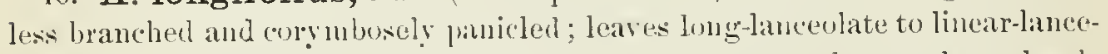

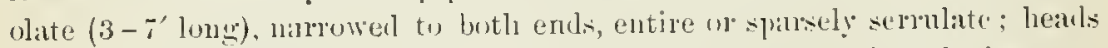
$4-5$ " highl, the scales nearly equal and nsually little imbricated, the onter

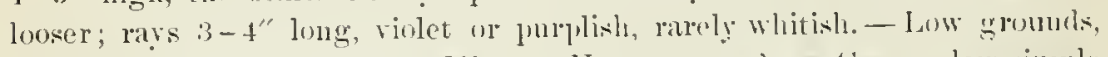

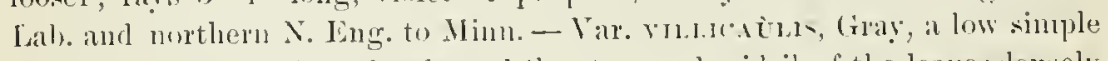
form, with few or solitary heads, and the sten and midib of the leaves densely white-rillous beneatl. X. Maine, at Fort lient (.Miss Furbish).

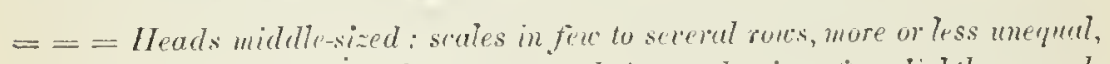

linear io spatulate, more herbaceus and firmer, the tips often slightly spreading or squurross.

41. A. Nòvi-Bélgii, l. liarely tall; leaves oblong to linear-lanceolate, mutire or sparsely seluate, the upper partly clasping and often somewhat anriculate; learks $4-5$ " long; rays bright bhe-viulet. (A. longifolins, previon : ed.) - N. Brmuswirk to Ill, and lia. The commonest laste-foweded Aster of

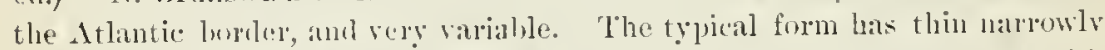
to oblong-lanceolate leaves, sometines scabous above, and lineat scales with

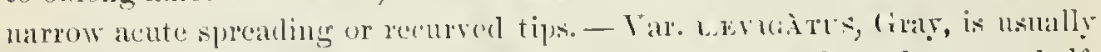
glatorous throughomt, the thin laves mostly oblong-lancenlate, the upper lualfclasping hy an abrupt base: s'ales nearly equal, lowscly erect, with short

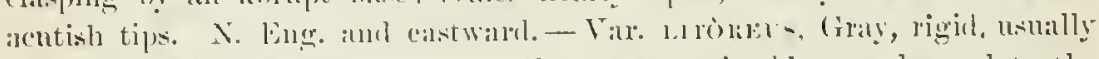
low, very leaf!; leates thickish, mally very smonth, whlong to linceolate, the upper sometimes amiculate: scales in several lowe rows, all hint the internost with hroalish whtuse tips, the unter usmally spatulate. Salt-marshes aud

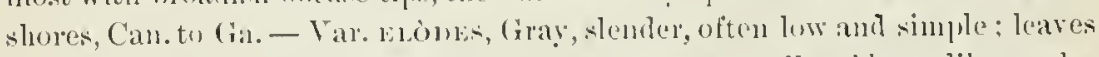
thick ish, long, na1rowly linear, entire, the "lplermest small and huet-like; scales llarrow, with slort and mostly suedeling acentish tips. Swamps, X. J. to Va.

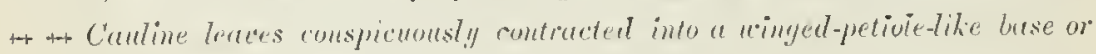
amirulate-clusping: ineluere lar.

42. A. pátulus, Lamn. Cilihous or subpubescent, 1-4o light: leaves wate- or oblong-lancenlate, sliarply. scrrate in the milllle, nurowed at both ends, the lower to a winged petiole, none amriculate or only obsenrely son; heads

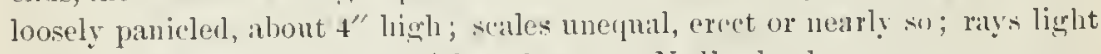
purple or whitr. - N. Bruuswiot aul eastern N. Englaurl.

43. A. tardiflorus, I. Glabrous or stem sonew lat pubescent (not hispul), 1-2 $2^{\circ}$ high; leaves lanceolate or oblong-lanceolate, icnninate, mostly with gradually narrowed and somewliat auricled base; heals often few, corymlose, 4-5" high; sc:ules stulyepual, the onter foliacents; rays pale violet. lab. to the Mass, coist and White Mts. Not late-tlowering. 
44. A. prenanthoides, Muhl. Sten 1-8, high, angmhse-pruicled, hairy above in lines; leaves rough above, smooth undroneatl, orate-lauceolate, sharply cut-toothed in the middle, comspicuonsly taper-pwinted, and rather abruptly narrowed to a long contracted entire portion, which is abruptly dilated into a conspicuonsly auricled base; heark nostly + " high, on short divergrent peduncles; scales narrowly linenr, tips recurved-surealing; rass light hue. - Borders of streams and rich woods, Wr. New Eng. to l'enn., Iowa, and Wise.

45. A. puníceus, I. Sitem till and stont $3-7^{\circ}$ high, lough-hairy" ali wer or in lines, usually purple below, panicled alowe; leaves oblong-lanceolate, not narrowed or but slightly so to the auricled hase, consely serrate to spar. indy denticulate in the miclle, rough above, nearly snooth beneath, printed, heark 4-6" high, sulsessile; scales narowly linear, acnte, louse, equal, in abou 2 rows; rays long and showy (lilac-b]ue, paler in slude). - Low thickets and

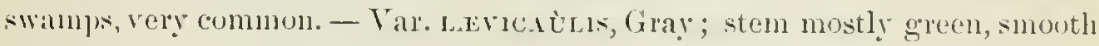
and naked below, sparsely hirsute above, 1-30 high; leaves sermate. - I ar. wefucul's, Gray; the very leafy stems glahrous or sparingly hispirlulous; leaves lanceolate, entire or slightly denticulate, glabrous and sonewhat shining; heads usually uumerous, the scales less loose and less attenuate.

\$. D)(ELINGERIA. Pappus manifestly double, the inner of long capillary bristles (some thickened at top), the outer of very short and rigid bristles; wroles short, without herbuceous tips; heuds small, corymbose or solitary; rugs rather few, white; leaves not rigid, veiny.

46. A. umbellàtus, Mill. Smouth, leafy to the top $\left(2-7^{\circ}\right.$ high $)$; leores funcrolute, elonguted, taper-pointed and tapering at the lase $\left(3-66^{\prime}\right.$ long); heads very nmmerous in compound flat corymbs; involucral scales rather close, obtusisli, scirecly longer than the achenes. (Diplopappus mubellatus, Tor of fircy.) - Moist thickets; common, especially northward. Ing. - Var. r'ímax, Gray ; the lower surface of the leaves and the brauchlets tomentulose.

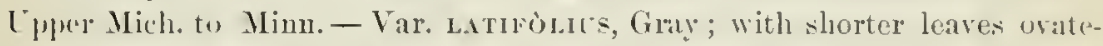
liuncerblite to wate, less narrowed or even rounded at base. (I). amygdalinus, Torr.f. (oruy.) l'ine barreus, etc., N. J., I'enn., and sontlwarl.

47. A. infírmus, Michx. Stem slender, often tlexnons, $1-3^{\circ}$ liggh, less leafy, hearing few or several heads on divergent peduncles; leaves obovate t, ovate ur whlong-lanceolate, narowed at base and ciliate, the midrib hairy be-

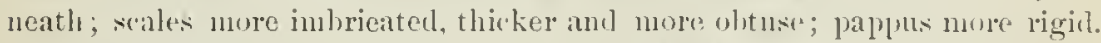
(1). cornifolius, Jur\%.) - Open woodlands, k. Masis, to 'Tenn., ant southwarl.

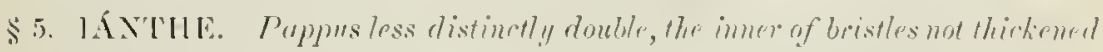
"t top, the onter shorter; seales well imbricuted, appuressed, whont herbureons tips, rays ridel: achenes namou, rillous; lecres munerous, righil, smull, limear, 1-mored and reinless.

45. A. linarifolius, I. Stems $3-20^{\prime}$ high, serral from a woody rout ; heads solitary or terminating simple branches, lather linge; leaves about $l^{\prime}$ long, rongli-nargined, fassing above into the rigit] acutish soales. (1). linariifolins, $I$ owh.) - Iry suil, common. Sept., Oct. Ray rarely white.

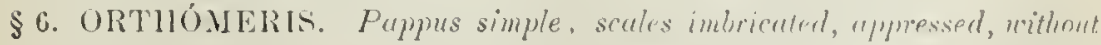
herbuceous tips, often scurions-edged or dry. Peremial, as all the prereding. 
49. A. ptarmicoides, Torr.\& Gray. Smooth or roughish ; stems clusicred $\left(6-20^{\prime}\right.$ ligh $)$, simple; leares linear-lanceolate, acute, rigid, entire, tapering to the base, 1-3-nerved, with rough margins (2-4' long); heorls small, in a Hat corymb: scales imbricated in 3 or 4 rows, short; rays white (2-t" lomg). - Dry roeks, W. New Lug. to Minn., along the Grout Lakes, and nortluward. Aug. - Var, y.tríscexs, Gray ; ràs small, pale yellow. - N. Ill. and Sask.

50. A. acuminàtus, Miehx. Somewhat hairy; steu (ahout $1^{\circ}$ high) simple, zigzag, panicled-eorymbose at the summit; peduncles slunler ; tereres whlong-lanceolate, conspicuonsly pointerl, coussly toothed above, wedge-form and entire at the hase: involueral scales few and lonsely imbriated, linne-lancerslite, pointed, thin $\left(3-5^{\prime \prime} \operatorname{long}\right)$; heark few or serelal; lays 12-18, white, or slightly purple. - Cool rich wouls; ; . Lab. to P'onn., and somthward along the Alleghauies. Ang. - There is a lepauperate nallow-leaved rariety on the White Mountains. A monstrous form oceurs in Mane, laving a chaffy receptacle and the flowers turned to tufts of chafl lateal.

51. A. nemoràis, Ait. Minutely ronghish-pulescent; sten slender, simple or corymbose at the summit, rery leafy (1 - 20 high); leures small (1 -

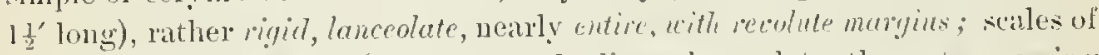
the inversely conical involuere narrowly linear-lanceolate, the outer passing into awl-shaped bracts; rays lilac-purple, elongated. - Bugs aud swaups, 1. J. to Newf. and Hudson's Bay. Sept.

52. A. tenuifolius, I. Very glabrous; stem often zigralg, simple or forked, $6^{\prime}-20$ high; heads rather la1'ge, terminal; leates fen, lung-linere, tupering to both cuds, rather thich and flrshy, entire, the upper sululate, pointed; involucre top-shaped, the scales sululate-lanceolate witl attenuate acute points;

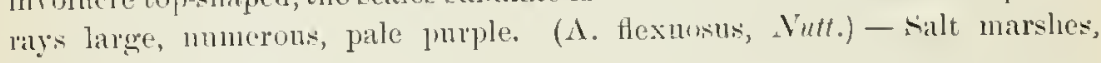
Mass. to lila. Siept.

\$. UXYTRIPOIAIM. Ineolucre as in $\$ 6$; pappos simple, fine and soft; glulvens ammals, braring memerous small heads and with narou entire leares.

53. A. subulàtus, Michx. Stem 6-24' highl, leaves lincar-lanceolate, pointerl, Hat, on the branches awl-shaped; seales of the obloug involucre linearawl-shaped, in few rows; rays somewhat in two rows, short, not projecting heyond the disk, more numerous than the disk-flowers, purplish. (A. linifolius. of previous ed.) - Salt marsles on the coast, Matine to Vil. Aug.-Oct.

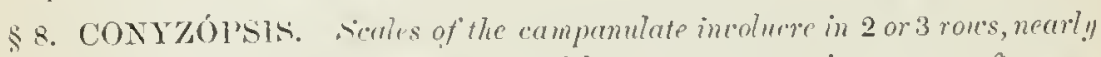
equal, linear, the unter fuliuccous and loose; pappus copious, very soft; rays very short or without ligules; low unnuals with mmerous rather small heads.

54. A. angústus, Torr. \& Gray. Branchiug, 6-20' high, nearly glabrons; leaves lincar, entire, more or lens short-ciliate; rar-flowers redueed to a tube much shorter than the elongated style. - Mimn. to Sask, and westward, spreading east to (hicigo, etc. (Siberia.)

\section{ERIGERON, I. FLемваNE.}

Heads many-flowered, ladiate, mostly flat or hemisphericul; the narrow rays very numierous, pistillate. Involueral scales narrow, (2) pual aud little im. micated, never coriaceous, foliaceons, uor green-tipperl. lieceptacle flat or conves, 1aked. Johemes fintened, usually pubescont and 2-nerved; pappus a 
single row of capillary luristles, with minuter ones intermixed, or with a listinct short outer pappus of little bristles or chaffy seales. - IIerhs, with entire or toothed and generally sessile leaves, and solitary or corymled naked-pedunculate hcals. Disk yellow; lay white of purple. (Nane from $\hat{n} \rho$, spring, and

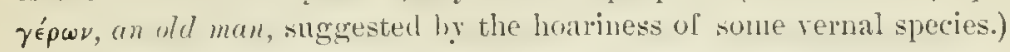

\$1. CANO'TUS. Rays inconspicuous, in seimel rous, searcely langer than the pappus; juppus simple; anmuals.

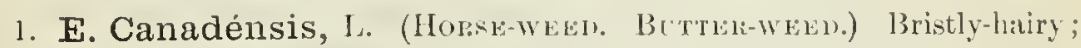
slem rrect, wand-lilir $\left(1-5^{\circ}\right.$ high $)$; leaves lincar, mostly entire, the radical eutlohed; leads very mumcrous and small, cylinclrical, punicled. - Waste places; a common weed, now wirlely diffused over the worlı. July-Oct. - Ligule of the ray-flowers much shorter than the tube, white.

2. E. divaricàtus, Miclıx. Llifjuse und decumbent $\left(3^{\prime}-1^{\circ}\right.$ high); leaves linear or awl-shaped, entire; heads loosely corymbed; roys purple; otherwise like n. 1.- Ind. to Minn., and sunthward.

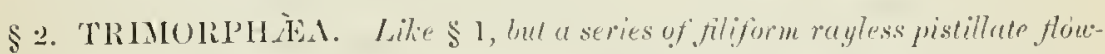
ers within the onter row of ray-flours; biennial mo sometimes perennial.

3. E. àcris, I. Hirsute-pubescent or sinuothish ; stem erect $(10-201$ ligh); leaves lanceolate or the lower spatulate-oblong, entire; hearls several or rather munerous, racemose or at length corymbose, nearly hemispherical (4-5" long), hirsute; rays purplish or bluish, equalling or a little exceeding the copious pappus. - Lower St. Lawrence, across the continent and northwatrl. The var. Drabscusisis, B!ytt, more glabrous and with the green iurolucre nearly or quite naked, occurs on the shores of l. Superior. (Eu.)

\$ 3. ERIGERON proper. lings elongrated (shost in a form of n. 5), crouded in whe or more rou's.

* Annuals (ar sometimes bienniul), leufy-stemmed and branching; puppus double, the outer a croun of minute scales, the imm of deciduous fragile bristles, "sually wantiug in the ray.

4. E. ánnuus, Pers. (Daisy Finabaxe. Sinet Scabious.) Stem stout $\left(3-5^{\circ} \operatorname{ligh}\right)$, branched, beset with spreading hairs; leanes coarsely and shurply toothed; the lowest ocute, tapering into a margined petiole, the npper ovite-lauceolate, acute and entire at hoth ends; heals corynbed; rays white, tinged with purple, not twice the length of the liristly involucre. - Fields and waste places; a very common weed. Jnme-Ang. (Nitt. in Eu.)

5. E. strigòsus, Mulıl. (Dast Fleanaxe.) sitem paniclerl-corymbose at the summit, roughish like the leaves with mimule appressed hairs, or I/most smooth: leares pntice or nearly so, the upper lanceolate, scattered, the lowest oblong or spatulate, tapering into a slender petiole; rays white, twice the lengtlı of the minutely hairy involucre. - Fiells, ete, common. JinneAug. - Stem smaller and nore simple than the list, witl smaller leads but longer rays. A form with the rays minute, scarcely exceeting the involucre, occurs in S. New England.

* Leafy-stemmed perennials: pappus simple (double in $\mathbf{n} .6)$.

6. E. glabéllus, Nutt. Stem $\left(6-15^{\prime}\right.$ high) stont, hairy ahove, the leafless summit heariug $1-7$ large heals; leaves nearly glabrous, except the 
margins, entire, the upper ollong-lanceolate and pointed, closely sessile or partly clasping, the lower spatulate and petioled; rays (more than 100, purple) more than twice the length of the hoary-hispid involuere; pappus double, the onter of ninute bristles. - Plaius of $\mathrm{N}$. Wisc, and westward. June.

7. F. hyssopifòlius, Michx. Nilightly pulescent, slenter (6-12' high), from filiform rutstucks: leaves short, rery numerons, narrowly linear; branches prolonged into slenter naked peduneles, bearing solitary small heads; rays 20-30, rose-purple or whitish. (Aster gruminifolius, Pursh.) Northeru borders of $N$. ling., L. Superior, and northwart.

8. E. bellidifolius, Muhl. (Robms's Plastass.) IHairy, producing offsets from the buse: stem simple, rather nated above, bearing few (1-9) large heads on slender peduncles; root-leares obovate and spatulate, sparingly tootled. the cauline distant, lanceolate-oblong, partly clasping, eutire; rays (about 50) rother broad, light bluish-purple. - Copses and moist hanks; common. May.

9. E. Philadélphicus, I. (Comox Fusasuxe.) Hairy; stem lenfy, corymbed, bearing sereral small heads; leaves thin, with a broad millrib, oblong; the upper smoothish, clasping by a heart-shaped lase, mostly entire, the Iowest spatulate, toothed; rays immumerable and very narrour, rose-purple or flesll-color. - Moist ground ; common. June- $\Lambda$ ug.

* * * Peremnial by rosulate offsets, with scape-like stems; pappus simple.

10. E. nudicaulis, Michx. Glabrous; leaves chustered at the rout, wal or spatulate; scape leatless, slender $\left(1-2^{\circ}\right.$ high), hearing $5-12$ small corymbed heals; rays white. (li, vernum, Torr. of Groy). - Low grounds, E. Va. and southwad. May.

\section{B Á C C H A R S, L. Grounusel-Trez.}

lleads many-flowered; the Howers all tubular, diccrious, i. e., the pistillate and staminate borne by different plats. Involuce inbricated. Corolla of the pistillate flowers very slender and thrend-like; of the stmmindte, larger and 5-loberl. Antlete tailless. Achenes ribhed; pappos of capillary bristles, in the sterile plant sciunty and tortuns; ;n the fertile very long and copious. - Slurubs, commonly smontl and resimons or glutimous. Flowers whitish or rellow, autumual. (Xiame of some slunb anciently dedicated to Bacchus.)

1. B. halimifolia, L. Smooth and sumewhit seurfy; branclues angled; leares obovate and werge-form, petiolate, coarsely touthed, or the nper entire; heals seattered or in leafy pancles: scales of the iuvolncre acutish. - Sea beaches, Mass to Va., and sonthwatrel - Shubl, 6-120 hicht ; the fertile plant "onspicuons in antumn ly its very long and white pappus.

2. B. glomeruliflòra, Pers. leaves spatulate-oblung, sessile or nearly so) heads latrore, scrsile in the axils or in clusters; scales of the lrell-shaped involuere brouler, very olsuse. - Pine biureus, li. Va. (?), anul southwarl.

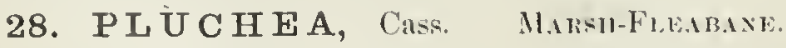

Heads many-flowered ; the flower's all tubnlar ; the central perfect, lut sterile. few, with a 5-cleft corolla; all the others with a thrcal-shaped truncate corolla, pristillate and fertile. lowolucre imbricated. Rerejtarle flat, nakerl. Anthers

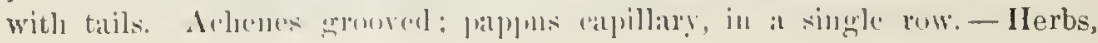


somewhat glandulu, enutting a strung or camploric ortur, the heals cymosely chatered. Flowers purplish, in smmmer. (Dedicated to the Abbe Pluche.)

1. P. bifrons, 1C. Perennial, $2-3^{\circ}$ high ; lences closely sessile ur halfrlosping, oblong to lanceolate, slarply lenticulate, reiny (only $2-3^{\prime}$ long); heads chustered in a corymb; scales lanceolate. - li ground, Cape May, X. J., and sontliwarrl.

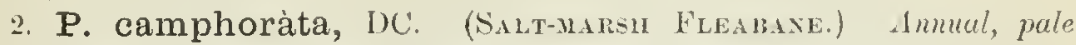
(2-50 high); leares scarcely yetioled, oblong-ovate or lanceolate, thickish, whscurely reiny, serrite; coryub flat; involucral scales ovate to lanceolate. (I'. fotida, $D C^{\prime}$.) - Salt marshes, Mass. to Va., and soutluwarl, and on riverloanks westward to Ki., I1l., and Neb. (?)

\section{9. 它 $\mathrm{VA} \mathrm{X,} \mathrm{(ialutu.}$}

Heals rather many-flowered, discoil ; flowers as in l'luehea, tho central unil-

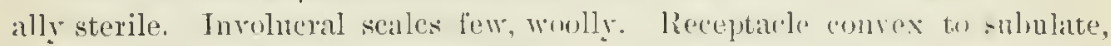
chaffy, the scarious chaff not embracing the smootl dorsally complensed

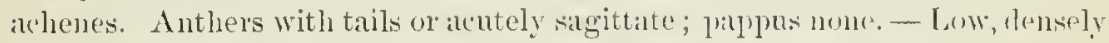
forense-woolly ammals; extrene western. (Name of uncertilu signification.)

1. E. prolifera, Nutt. A span high or less, simple or hranching from hase; leares mmerous, small and spatulate; heals in dense proliferons chnsters; receptacle convex; chaff subtenling sterile Huwers woolly-tipper, the rest more scarious anl naked, oral or oblong. - l)akotas and IV. Kan. to 'Tex.

\section{FI L Ä G O, 'T'ourn. Cormex-Ross.}

Ileads and Howers as in Grax. Receptarle clongated or top-shaped, naked at the summit, hut chaffy at the margins or toward the hase: the chaff resem. bling the propere involicral scales, each covering a single pistillate flower. Achenes terete; pappus of the central flowers capillary, of the vuter ones mostly nome. - Anumal, low, branching woolly herbs, with entire leaves, and small leads in capitate clusters. (Name from filum, a thread, in allusion tw the cottony hairs of these pliunts.)

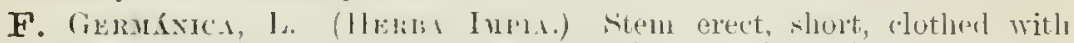
lanceslate and upright cowderl leares, producing a capitate cluster of woolly heads, from which rise one or more brinches, each terminated by a similar leatl, and so on ; - hence the common mame alpplied to it by the old botanists, as if the off:pring were undutifully ralting themselves above the parent. Dry fields, N. Y. to Va. July-l)it. (Nat. from Eu.)

\section{A N T E N N À R I A, Gaertu. Everlastiag.}

IIeads many-flowered, dicecious ; flowers all tubulan' ; pistillate corollas very -lender. Invilucre dry and rearions, white or colored, imbricated. Iiecejtacle convex on flat, not chaffy. Anthers caulate. Achenes terete or Hattish; fappus a single row of bristles, in the lertile flowers capillary, miter at base $\therefore 9$ as to fall in a ring, and in the sterile thickened and club-slaped or harbellate at the summit. - P'eremuial white-woolly herbs, with entiro leaves and coryubed (rarely single) heads. Corolla yellowish. (Name from the rcsemblance of the sterile puppus to the untenne of certinin insects.)

1. A. plantaginifólia, Ilook. (PLAxtAN-LLAYE1, WVERLAstixg.) Spreading by offsets and rumers, low $\left(3-18^{\prime}\right.$ high) ; leares silky-woolly when goung, at length irreen above and hoary beneath; those of the simple anch scape 
like flowering stems small, lanceolate, appressed; the radical obovate or ovalsjatulate, petioled, anple, 3-nerved; heads in a small crowded corymb; scales of the (mostly white) involucre obtuse in the sterile, and acutish and warrower in the fertile plant. - Sterile knoils and banks; common. March-May.

\section{A N ÁPHALIS, DC. Eimlastive.}

Characters as of Antemnaria, but tỉe pappus in tỉe sterile flower's not thickened at the sumnit or scarceiy so, and that of the fertile flowers not at ail nnited at base; fertile leads msuily with a few perfect but sterile tlowers in tìe centre. (hiaid to he an ancient Greek name of some similin piant.)

1. A. margaritàcea, Benth. \& llook. (PEAlly Eyerastro.) Stem erect ( $1-2^{\circ}$ highi $)$, coryuhose at the smmmit, with many heads, leafy; leaves brondiy to linear-lanceolate, taper-jointed, sessile, snon gुreen above; involncral seales jearly-wite, rery nmmerous, obtuse or rounded, raliating in age. (Antennaria margatitacea, li. Bro) - Dry hills and woods: common northward. Ang. (N. L. Asia.)

\section{G N A P H À I U M, L. Cuneen.}

Heads many-flowered; Howers ali tubular, the outer pistillate and rey slender, the central perfect. Scales of the involucre dry aud scarions, white or colored, imbricated in sererai lows. Reeptacle that, naked. Anthers caudate. Achenes terete or Hattisin; papplus a single row of capillary rongh bristles. Woolly herbs, with sessile or decurrent leaves, and chstered or corymbed heads; fl.in summer andi autumn. Corolla whitish or yellowish. (Name from $\gamma \nu a ́ \phi a \lambda o \nu$, a lock of wool, in allusion to the floccose down.)

\section{§. GNAPHALIUM proper. Bristles of the pappus distinct.}

1. G. polycéphalum, Michx. (Comuos EverLastixct.) Erect, woolly annual ( 1 - $3^{\circ}$ high), fragrant; leaves lanceolate, tupering at the base, with undulate margins, not decurent, smoothish above ; heuds clustered at the summit of the panicled-corymbose branches, ovate-conical before expansion, then obovate; scales (whitish) ovate and oblong, rather obtuse; perl'ect flowers few. - OId fields and wooks; comnon.

2. G. decúrrens, Ives. (Evknustrix.) Stout, erect ( $2^{\circ}$ highl), anuual or biennial, hranched at the toj, clammy-jubescent, white-woolly on the branches, bearing numerous heads in dense comymbed clusters: leares linearlanceolate, partly clasping, decurrent; scales yeliowish-white, oval, achtisis. llillsides, N. J. and Penn. to Maine, Mich., Minn., and northward.

3. G. uliginosum, I. (low CuDwend.) Diffusely lnanched, :lp)pressed-wonily anmul (3-6' highl); leaves sinatulate-oblanceolate or linear, not decurrent; leads (smull) in triminal sessile capilute ciusters subtended by leaves; scales brownisin, less inluricatent. - Low grounds; common, especialyy east and nortllward; perhạs introduced. (Lin.)

4. G. supinum, Vilims. (Morxtan Cumbin,) Dwarf and tufted peremial ( $2^{\prime}$ high); lenves lincul, wonlly; heals solitury or few and spiked on the slender simple fluwering stems; scales lorown, lanceolate, acnte, nearly: glahrons; achenes broader and flatter. - Alpine summit of Mount Wasining toll ; very rare. (Eu.) 
\$2. GAMOCHI'EA. Bristles of the pappus united at the rery base into at ring, so falling off all logether.

5. G. purpùreum, L. (Purplsil Cubwern.) Aunual, simple ar branelıed from the base, ascending ( $6-20^{\prime}$ high), silvery-canescent with dense white wool; leares oblung-spatulate, obtuse, not decurrent, green above; heads in sessile clusters in the axils of the upper leares, and spiked at the waul-like summit of the stem; seales tawy, the inner often marked with purple. Saudy or gravelly soil, coast of Maiue to Va., aud sonthward.

\section{A DE N O A Ù I O N, Hook.}

Ileads 5-10-flowered; the flowers all tubular and with similar corollas; the marginal ones pistillate, fertile; the others perfect lut sterile. Involueral scales few, equal, in a single row, not scarions. Receptacle Hat, naked. Anther's eandate. Achenes elongated at maturity, eluh-shaped, beset with stalked glanrls abore; papuns none. - Slender peremials, with the alternate thin and petioled leaves smootl anrl green abore, white-woolly beneath, and fow small (whitish) heads in a loose panicle, hoset with glanrls (whonce the name, from

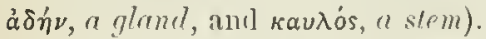

1. A. bícolor, Hook. Leares triangular, rather leart-shaped, with angu lar-toothed margins; petioles marginerl. - Moist woods, shore of Lake Superior, and westriard. Sitem $\mathbf{l}-3^{\circ}$ high.

\section{I I U I A, T. FLEAMUNE.}

Heads many-flowererl, radiate; disk-flowers perfect and fertile. Involucre imbricater, hemisplierical, the onter scales lierbaceous or leaf-like. Receytacle naked. Anthers candate. Achenes more or less 4-5-ribbel ; pappus simple, of capillary bristles. - Coarse herbs, not floccose-woolly, with alternate simple leares, aud large yellow flowers. (The ancient Latin iame.)

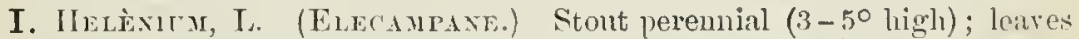
large, woolly boneath; those from the thick root orate, petioled, the uthers paitly clasping; rays very many, wawow, - Roadsides and diunp pastures. lug. - Hearls very large. Root mueilaginous. (Nat fron Fu.)

\section{POLÝMNIA, I. LEAF-CUP.}

Ileads broal, many-flowered, radiate, mys several (rarely abortive), pistil. late; disk-flowers perfect but sterile. Involncril seales in two rows; the outer about 5, leat-like, latre aud spreading; the inner small and nembranaceuns. partly cmbracing the thiek triangular-obovoid achenes. Receptacle flat, membranous-chaffy. Tappos none. - Tall branching peremnial herbs, viscid-hairy, exhaling a loary odlor. Leaves large and thin, opposite, or the uppermost altemate, lobed, and with dilated appendages like stipules at the base. Ileads in panieled eorymbs. Flowers light yellow; in summer and autumn. (Dedicaterl to the Muse, Polyhymniu, for no obrious teason.)

1. P. Canadénsis, L. Gummy-huiry, 2-50 high ; lower leares deeply pinnatifid, the: uppermust triangular-ovate and 3-5-lobed or angled, petioled: heals small; rays 5, obotate or uedge-form, shorter then the mrolucre, often ininute or abortive, whitish-yellow; achenes 3-costate, not striate. - Moist shaded rarines, Conu. to W. Vt., Minu, and sonthwart. - Tar. Rund t.1, Gray; ligules w re developed, 3-lobed, 3-G" long, whitish. Ill. to Kan., and southwark. 
2. P. Uvedàlia, L. Roughish-huiry, stout ( $t-10^{\circ}$ high); leaves broadly orate, angled and toothed, nearly sessile; the lower pal mately lobed, abruptly llarrowed into a winged petiole; onter involucral scales very large; rays $10-1.5$, lintti-oblong, much longer than the inner scales of the incolucre, yellow; achenes strongly striate. - Rich soil, W. New York and N. J. to Mo., and southward.

\section{S ÍLPHIU M, I. ROSWX-WEE.}

Heads many-flowered, radiate; rays numerons, pistillate and fertile, their In oad flat ovaries imbricated in 2 or 3 rows; disk-flowers apparently perfect, bnt with entire style and sterile. Scales of the broad and flattish iurolncre inbricated in several rows, thickish, broad and witl loose leaf-like smunits, except the innermost, which resemble the linear chaff of the flat receptacle. Achenes broad and flat, clorsally compressed, surrounded by a wing notched at the top, without pappus, or with 2 teeth conflnent with the wingerl margin. the achene aud its subtending chaff usually falling tugether; those of the clish sterile and stalk-like. - Coarse and tall rough perennial lerbs, with copious resinons jnice, and large corymbose-panicled yellow-Howered heals. (síxфiov. the ancient mame of some resinns plant, transferrel by Linuxus to this American genus.)

* Sicm terete, alternate-leaved (root rery lurge und thick).

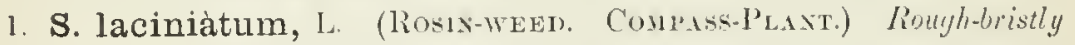
thrumgut. stem stunt (3-120 high), leafy ; leares pimutely purted, petioled lint dilaterl and clasping at the base; their divisions luncelate or liment, acute,

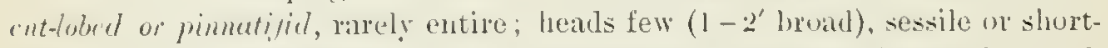

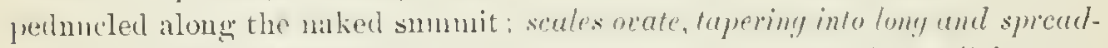
ing rigid points; achenes broadly winged aud deeply notched, 6" long. l'rairies, Mich. to the Dakotas, and southward. July. - Lower and root-lenves vertical, 12-30' long, orate in ontline; on the wide open prairies disposed to frrsent their edges uorth and south; hence called Compuss-Plant.

2. S. terebinthináceum, L. (1'kirit Dork.) sitem smouth, slenter

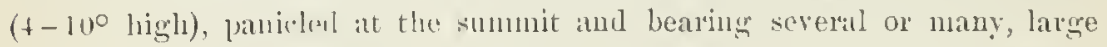
headr, leafless except wwart the base; leaves orole and orate-oblong, somewhat heart-shaperl, sr ronte-toothed, thick, rongh, especially lweneath (1-20 long,

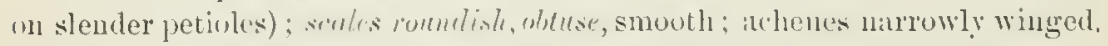

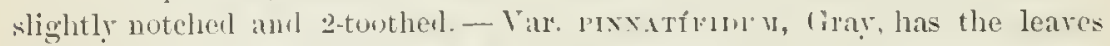
deeply cut or pimatiful, but varies into the ordinary form. - l'rairies and oali-

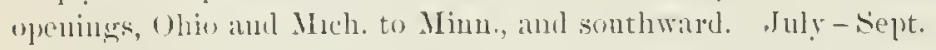

* * item terete or slightly t-angled, leafin: Irav's undivided (not large), some opposite.

3. S. trifoliàtum, L. Stem smooth, of fen glaucous, rather slentler $\left(4-7^{\circ}\right.$ high), branchel abore; stem-leuts luncculate, pointed, pntive or scarcely serrate, rough, short-petioled, in whorls of is or 4 , the uppermost opposite; hears loosely panicled; achenes rather lunuly winged, and shurply 2-toothed at the top. 1)ry plains and banks, l'enu. to ()hio, and sonthward. Aug.

4. S. Asteríscus, 1. sitem hispid $\left(2-4^{\circ}\right.$ high $)$ : leares opposite, or the

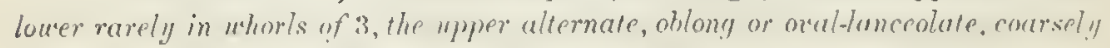

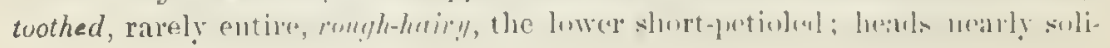


tary (large), squarrose; achenes obovate, winged, 2-toothed, the tecth usually. awu-like. - I)ry sandy soil, Va. and southward.

5. S. integrifòlium, Michx. Stem smooth or rough, ratler stout $\left(2-4^{\circ}\right.$ high), rigid, t-angular and groos erl; lenes ull opprosite, rigid, lanceolate-ovate, entire or denticnlite, tapering to a sharp point from a roundish heart-shaped and partly claspring buse, rong'l-pubesceut or nealy smooth, thick (3 - 5' long); heads in a close forking coryml, short-pedureled; acleues broadly winged, deeply notehed. - l'riries, Mich. to Minn, and southward. Angh.

* * Stem stpuare: leures upposite, connate (thin and laige, 6-15' long).

6. S. perfoliàtum, L. ('IP-P'LAxт.) sten stout, often branched abre $\left(t-8^{\circ}\right.$ high), leafy; leaves wate, cuarsely tootled, tho upper united by their bases and forming a cup-shaperl disk, the lower alonptly narowed into winged petioles which are commate ly their bases; heads corronbose; scales ovate; achenes winged and rarionsly notched, - Rich suil along streans, Mich. to Minu., and sonthward; comnon. $\Lambda$ lsu escaped from gardens eastward. July.

\section{BERLA N D ERA, IC.}

With the characters of Silphimm, but the $5-1$. fertile ray-flowers in a single series. Tnvolucral scales in about 3 series, thimner, the inner dilated obovate, exceeding the rlisk, the unter smaller and more foliaceons. Achenes obovate, not winged nor notched at the apex, and without pappus, decirluous with the subtending scale and 2 or 3 of the inner chaff. - Alteruateleaved perennials of the southeru and sonthwestern States; lear? perlunculate. (Xamed for .J. L. Berlunlier, a Swiss botanist who collecterl in 'Texas aud Mexico.)

1. B. Texàna, 1)C. Mirsute-tomentose or villons, $2-3^{\circ}$ high, very leafy ; leares crenate, the radical oblong, petiolate, the canline oblongrourdate to subcorchte-lanceolate, the upper clusely sessile; heads somewhat cymose, $\frac{1}{2}$ broad. - s. W. Mo, to La. and Tex.

\section{CHRY SÓ GO N U M, I.}

Ileads many-flowered, radiate; the lays abont 5, pistillate and fertile; the clisk-flowers perfect but sterile. Inumure of abut i onter leaf-like oblong scules, which exceer the disk, anl as many interior shorter aud chaff-like concavestales. Receptacle flat, with a linear chaff to eath disk-flow cr. Achenes all in the ray, obovate, oheompuresied, t-angled, eatch one paldy enclused by

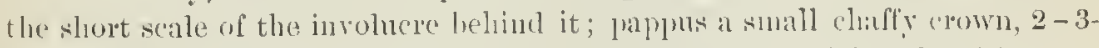

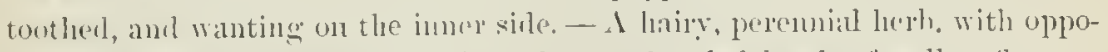
rite long-petioled leaves, and sultary long-perlumeled leats of yellow flowers, nearly stemless when it begins to fluwer, the flowerless slonts forming rumners. (The rireek name of sone plant, composed of xpurós, golden, and róvu, lines.)

1. C. Viroginiànum, L. ['sually low $\left(2-15^{\prime}\right.$ ligh 1 ) ; leaves orate, mostly olutuse, crenate, rarcly somewhat corlate, or the radical olorate with cumeate lase; rays I' long.-Dry soil, from southeru l'enu, to Fha. May-Aug. -

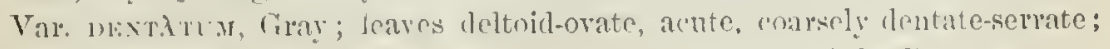
involucral scales more acte. - Iligh Island at the Falls of the I'otomac. 


\section{E N GELMÁ N N I A, Torr. \& Gray.}

Heads and flowers of the preeeding genera. Rays 8-10. Involncre of about 10 onter loose foliaeeous seales, more or less dilated and eorineeons at base, and several firm-coriaeeons, oval or obovate, eoncave inner ones with short abrupt green tips. Chaff of the flat receptacle tirn and persistent. Achenes Hat, ohovate, wingless, tarlily decidnous with the attached sealc and chaff; palpus a firm scarions hispid crown, more or less lobed. - A coarse hispirl peremial, with alternate deeply pinnatifid leaves, and somewhat paniculately disposed heads on slender naked pelnncles; flower's yellow. (Named for the eminent botanist, Dr. George Engelmann.)

1. F. pinnatífida, Torr. \& Griy. Stems 1-20 high ; heads $\frac{1}{2}$ broad, and rays $\frac{1}{2}$ long. - Central Kian. to La., and westward.

\section{PARTH亡 I U M, I.}

Heads many-flowered, ineonspjicuously radiate; ray-flowers 5, with rery short and broad obcortate ligules not projecting beyond the woolly disk, pistillate and fertile; disk-flowers staminate with imperfect styles, sterile. Inroluere hemispherieal, of 2 ranks of short orate or roundislı scales. Receptacle conical, chaffy. Achenes only in the ray, obcompresserl, surrounded by a slenter calluns margin, crowned with the persistent ray-corolla and a papjus of 2 small chaffy stales. - Leaves alternate. Heads small, corymbed; the fluwer's whitish. (An ancient name of some plant, from $\pi \alpha \rho \theta \dot{t} \nu o s$, virgin.)

1. P. integrifòlium, I. liongli-pubescent perennial ( $1-3^{\circ}$ highl); leares oblong or ovate, crenate-toothed, or the lower $\left(3-6^{\prime}\right.$ long) cut-lobed below the middle; heads many in a very dense flat eorymb. - I)ry soil, Md. to Ill, Minu., and sonthward. June- $\Lambda$ ug.

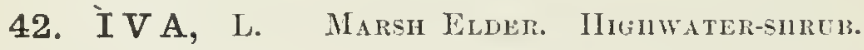

Heads several-flomeren, not radiate; the pistillate fertile and the staminato sterile flowers in the same heads, the former few (1-5) and marginal, with a small tubular or no corolla; the latter with a fumel-form 5-toothed corolla Anthers nearly separate. Seales of the iuroluere few, roundish. Rereptacle small, with narrow ehaff among the flowers. Achenes abovoid or lenticular. pappus none. - Herhaceons w shruhly (wane plunts, with thickish Jeares, the lower opposite, and small nodling (n)enish-white learls of flowers; in summer and autumu. (Name of unknown derivation.)

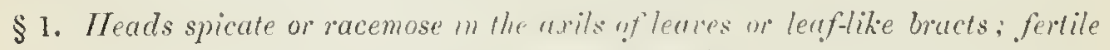
flowers with rident romollat.

1. I. frutéscens, L. Shrubly at the bus, newrly smooth (3-80 high); leaves oral or lanceolate, coarsoly and shaply toothed, wather fleshy, the uple ${ }^{\circ}$ rednced to linear hracts, in the axils of which the heals are disposed, in leafy panicled racemes; fertile flowers and sioles of the involure 5. - Sialt marshes, coast of Mass. to Va. aud sunthwilrd.

2. I. ciliàta, Willı. A mnual (2-60 high), rough and heriry ; iences ovate, puinted, coarsely toothed, domy beneath, on slender rilute petioles: heals in dense spikes, with conspicuous orate-lanceolate rongh-eiliate braets: scales of the involuce and fertile flowers $3-5-$ Moist wromul, flem I11. sontluward. 


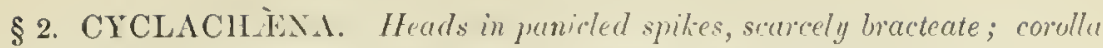
of the 5 fertile floucers a mere rudiment or none.

3. I. xanthiifolia, Nutt. Annual, tall, rouglish; leaves nearly all opposite, lıary with minute down, ovate, rhombic, or the lowest heart-shaped, doubly or cut-toothed, or obscurely lobed; heads small, crowded, in axillary and terminal panicles. - N. W. Wisc. to Minn., Kan., and westward.

\section{A M B R ÓSIA, Tourn. RAGWELD,}

Sterile and fertile flowersocruy ing different heads on the same plant; the fertile 1-3 together and stsile in the axil of leares or bracts, at the base of the racemes or spikes of sterile heals. Sterile involucres flattish or top-slaperd, of $7-12$ scales united iuto a cul, containing $5-20$ funnel-form staminate flowers, with slender chaff intermixid, on none. Anthers almost separate. Fertie involucre (fruit) oblong or top-sliaped, closer, pointed, resembling an achene (usually with $4-8$ tubercles or horns near the top in one row), and enclosing a single flower which consists of a pistil only; the elongated style-branches protrulling. Achenes ovoid; pappus nune. - Cuarse homely weeds, with opposite or alternate lobed or dissected leares, and inconspicuous greenish flowers, in late summer and autumn; ours ammals, except the last. (The Greek and later Latin uane of several plants, as well as of the food of the gods.)

$\$ 1$. Sterile herds spssile in a dense spilie, the top-shaped involucre extended on one side into clarge, lanceolate, hooded, bristly-hairy tooth or appendage; fertile involucre oblong and 4-angled.

1. A. bidentàta, Michx. Hairy ( $1-3^{\circ}$ highl), rery leafy; leares alternate, lanceolate, partly clasping, nearly entire, except a sloort lobe or tooth on eaclı side near the balse; fruit with 4 stont spincs and a central beak. - Prairies of Ill., Mo., and southward.

$\$ 2$. Sterile leads in single or panicled racemes or spikes, the involucre regular.

* Leaces opposite, only once luberl; sterile imvolurre 3-ribbed on one side.

2. A. trífida, 1. (Grist liakween.) Siten stout $\left(3-12^{\circ}\right.$ ligh $)$, rough-hairy, as are the large deeply 3-lobed leaves, the lolies oval-linumblate and serrate; petioles nurginel ; fruit obovate, $5-6$-ribled and tulserelerl. -

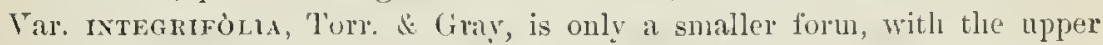
leaves, or all of them, undiviled, orate or oval. - Moist river-banks ; common.

* Lentes many of them alternate, all once or tuice pimatifid.

3. A. artemisizfolia, L. (RonAx Woruwoom. Hog-WeEn. Bit-

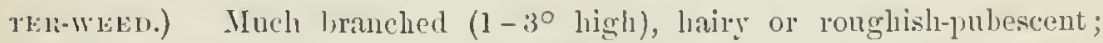
lenes thin, twire-pimatifid, smoothish above, paler or hoary beneath; fimit olownid or globular, armed will about 6 short acute teelh or spines. - Waste places everywhere. - Extremely rabinble, with finely cut leaves, on tho Hower. ing branches often undividerl: rarly tlur spikes bear all fertile leark.

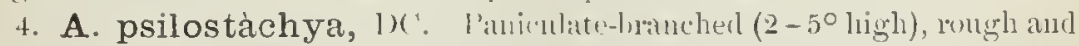
somewlat loary with slolt hispiel hairs; heres once pimutiful, thickish, the lobes acnte, those of the luwer leares often incised; fimit uluroid, withmet tubercles or with very small ones, pubescent. - l'rairies and plains, Ill., Wisc., Minn., and sonthwestward. Perenuial, with slender rumning rontstocks. 


\section{Xánthium, Tourn. Cochleber. Clotber.}

Sterile and fertile flowers oceupying different heads, the latter elustered lelow, the former in short spikes or racemes above. Sterile inwolneres and Howers as in Ambrosia, but the sciles separate and receptacle cylindrical. Fertile involnere closed, coriaceons, whing or ollong, clotherl with looked prickles so as to form a rough bur, 2-celled, 2 -Howered; the flower consisting of a pistil and slender threal-form corolla. Achenes oblong, fat, destitute of pappus. - Coarse and vile weeds, with ammonal roots, low and blanclings stout stems, and alternate toothed or loberl petioled leaves; flowering in summer and antmmı. (The Greek name of some plant that was used to dye the luair yellow; from $\xi \alpha \nu \theta o ́ s, y e l l o \iota^{\circ}$.)

\section{* Leaves attemute to both ends, with triple spines at the brase.}

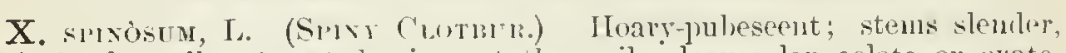
with slender yellow 3-parted shiues at the axils; leaves lanceolate or ovatelanceolate, tapering to a short protisle, white-rowny heneath, often $2-3$-luberl

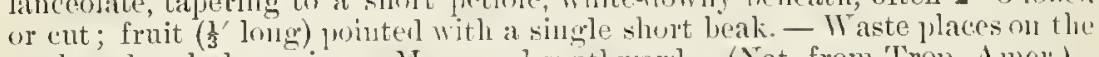
sea-board and along rivers, Mass. and sonthwarl. (Nat. from Trop. Amer.)

* Leares cordate or orate, 3-nererd, dentute and often lobed, long-petiolate; axils unarmed; fruit 2-beuked.

X. strundritu, L. Low $\left(1-2^{\circ}\right.$ liggli): fruit $6-8^{\prime \prime}$ long, glabrons or julhemint, with nsmally straight beaks and rather slender spines. $-\Lambda$ weed of harnyards, ete., sparingly nat. from Eir. (!) ur Ind. (?).

1. X. Canadénse, Mill. Sitouter', tlie stem uften lorown-punctate; fruit

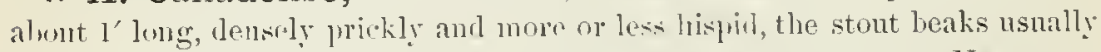
looked or incurved. - River-banks and waste places, common. - Var, lechlNATu, Gray, usmally low, with still denser and longer, eonspicnonsly hirsume or lispid prickles. Sandy sea-shores ant on the Great Lakes.

\section{TETRAGONOTHECA, Dill.}

lfearls many-flowered, radiate; the rays 6-9, fertile. luvolure louble. the onter of 4 large and leafy ovate seales, mited lrew hy therir margins incs a t-angled or winger cup; the inner of small chiffy sutulus, as many as the ray-flowers, and partly clasping their achenes. Receptacle convex or eoniear, with narrow and membranaceons cluaff. Achenes rery thick and obovoid, flat

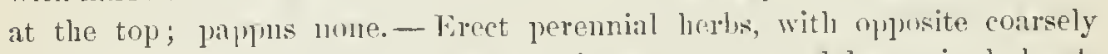
toothed leaves, their sessile hases sometimes comnate, ancl large single hearts of pale yellow flowers, on terminal perluneles. (Name compounded of $\tau \in \tau \rho \alpha$ ravos, four-angled, and $\theta \dot{n} \kappa \eta$, a case, from the shape of the involucre.)

1. T. helianthoides, I. Villons and somewhat viscill, $1-2^{\circ}$ high, simple; leaves orate or rliomlie-ollong, sessile ly a narrow base; involucral scales and rays abont l' long. - Samly soil, Va. aul southwarl. Tune.

\section{ECLÍP $\mathrm{A}$, I.}

Heads many-flownerl, rarlinte; rays short; disk-flowers perfect, 4-tonthed,

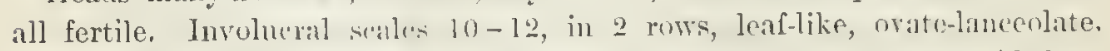
Reeptacle flat, with aluost hristle-form chaff. Achenos shomt, 3-t-xiderl, or in the disk laterally flattenerl, ronglened on the sides, hairy at the summit; pappus none, or an obseure denticulate erown. - An anmal rongh lierl, with 
slender stems and opposite leaves. Heads solitary, small. Flowers white; anthers brown. (Name from $\kappa^{\prime} \lambda \epsilon i \pi \omega$, to be deficient, alluding to the absence of pappus.)

1. E. álba, Ilassk. Kough with fine appressed hairs; stems procumbent, or ascending and $1-3^{\circ}$ ligh; leaves lanceolate or oblong, acute at each emil, mostly sessile, slightly serrate; rays equalling the disk. (F. procumbeus, Mirhx. - Wet river-bauks, N. J. to Ill. and southward. Peduncles rery rariable, (All tropical countries.)

\section{HELI Ó P S I S, Yers. OX-EXE.}

Heads many-flowererl, rarliate; rays 10 or more, fertile. Inrolncral scales in 2 or 3 rows, nearly equal; the onter leaf-like and somewhat spreadiug, the inner shorter than the disk. Receptacle conical; ehaff linear. Achenes surostl, thick, 4-augular, truncate; paplus uone, or a mere borter.- Perennial herbs, like Helinuthis. Ileads showy, peluneled, teminal. I,eares "prjusite, petioled, triple-ribbed, serrate. Flowers yellum. (Nime composerl of

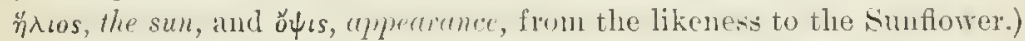

1. H. læovis, P'el's, Nearly smonth $\left(1-4^{\circ}\right.$ high $\left.{ }_{1}\right)$; leaves orate-lanceolate or oblung-ovate, rather narrowly pointed, occasionally ternate; scales (as in the noxt) with a rigid strongly nerverl hise; rays linear; pappus none or of $2-t$ 1) s'nre teeth. - Banks aud copses, N. I. to Ill. and sonthward. Ang.

2. H. scàbra, Dunal. Ronghish, especially the leares, which are rispuscl to be less narrowly pointed, the upjer sometimes entire; rays broadly chloug to linear or ollanceolite; pappus cotoniform and claffy or of 2 or 3 cumplicnous teeth. (Il. lavis, var. sealma, Tmr. Gray.) - Western N. Y. to Minil., Mo., and southward.

\section{ECHIN A C E A, Moench, Purle Coxi-frower.}

Ileads many-flowered, radiate; the rays rery long, drooping, pistillate but sterile. Scales of the iurolucre imbricated, lanceulate, spreading. Receptacle cunical ; the lanceolate carinate spiny-tipped chaff longer than the disk-fluwers. Achenes thick and short, 4-sided; pilppus a smill toothed border. - P'eremial herbs, with the stout aud uearly simple stems naked above and teminated by a single large head; leaves chiefly alteruate, 3-5-nerred. Rays rose-purple, rather persistent; disk purplish. (Name formed from é $\chi^{i v o s, ~ t h e ~ h e d g e h o g, ~ o r ~}$ sea-urchin, in allusion to the sping chatf of the disk.)

1. E. purpùrea, Moench. Leares rongh, often serrate; the lowest ocate, 5-nerved, reiny, long-petioled; the others ovate-lancelate; involncre inwrieater in 3-5 rows; stem smooth, or iu one form rough-bristly, as well at the leares. - P'viries and bauks, from WT. Penn. and Va. to Ioma, aud sontlwid ; occasionally adv, eastward. July. - Rays 15-20, dull purple (rarely whitish), 1-2' long or more. Root thick, llack, rery pungent to the taste, nwerl in popnlar mediciue under the name of Blach Sampison. - Tery rariable, and probably connects with

2. E. angustifolia, DC. Lcares, as well as the sleuder simple stem, Iristly-hairy, lanceolute and linear-lanceolate, allenuate at buse, 3-ncrzed, entire; involucre less imbricated and heads often sinaller; rays $12-15$ ( 2 ' long), rose color or red. - Plains from I11, aud Wise, sontlwestward. Jnne-Ang. 


\section{R U D BÉ CKIA, L. COXE-F LOWER.}

lleads many-flowered, raliate; the lays nentral. Soules of the involncre leaf-like, in about 2 rows, spreading. Receptacle contul or colnmmar; the short chaff concare, not rigid. Achenes t-anguhar (in our species), smooth, not margined, flat at the top, with no palpus, or a minute crown-like border. -Chiefly peremial herbs, with altermate leares, aud showy terminal heads; the rays generally long, yellow, often darker at base. (Named in honor of the Professors Rulbeck, father and son, predecessor's of Limnus at Lpsal.)

* Disk columnar in fruit, dull gremish-yellou"; leness divided and cut.

1. R. laciniàta, L. Stem smooth, brauching (-2 $-7^{\circ}$ high $)$; lewres smooth or ronghish, the lowest pimmate, with 5 - $;$ cut or 3 -lobed leaflets; upper leares irregularly 3-5-parted, the lolies ovate-lanceolate, pointed, or the uprermost undivirled; heads long-peduncled; wisk at first glohnlar or hemispherical; chaff truncate, downy at the tip; rays oblanceolate (1-2' long), drooping. Low thickets; common. July-sept. - Var. nưvis.s, Gray, low and glahrous, some of the radical leaves nudiviled or with roundish divisions; heads smaller ( $\frac{1^{\prime}}{2}$ high) and ray shorter. Mountains of Yra. and sonthwarl.

* Disli hemisplerical to oblong-ovoid in fiuit, dark purple or broun.

- Lower leares 3-lobed or jarted.

2. R. tríloba, I. IIairy, biennial, much branched $\left(2-5^{\circ}\right.$ high $)$, the branches sleuder anil spreading; npper leaves ovate-lanceolate, sparingly toother, the lower 3-loberl, tapering at the base, coarsely-sermate (those from the root pinnately parted or uudivided); rars 8 , oval or oblong; chaff of the black-purple depressert-globular disk smooth, awned. - Dry soil, Penn. to Mich., Mo., and southward. Aug. - Heads small, but mmerous and showy.

3. R. subtomentòsa, Pursh. Stem branching ahove $\left(3-4^{\circ}\right.$ high $)$, (lowny, as well as the petiolate ovate or orate-lanceolate serrate leaves beneath ; heads short-pednncled; disk globnlar, dull brown; receptacle sweet-scented: chaff downy at the blunt apex. - I'lairies, Wisc., 1ll., Mo., and sonthwarl.

$$
\text { + + Leaves undivided, rarely laciniately toothed. }
$$

4. R. hírta, I. Biemial, very rough and bristly-hairy throughout; stems simple or brancherl near the base, stont $\left(1-2^{\circ}\right.$ high $)$, naked above, bearing single large heads; leares nearly entire; the upper oblong or lanceolate, sessile: the lower spatnlate, triple-nerved, petioled; rays (abont 14) more or less ex-

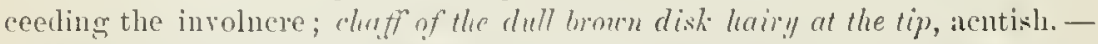
1) ry soil, westem $Y$. Y. to Wisc., and southward. Now common as a weed in eastern mealows, introrluced with clorer-seed from the West. Jnne$\Lambda \mathrm{ng}$.

5. R. fúlgida, Ait. Iairy, the branches nakel at the summit and bearing single heals; lenves spatulute-nblong or linceolate, purly clusping, triph-

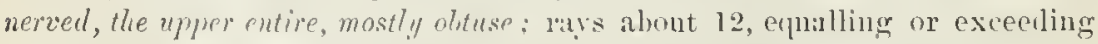

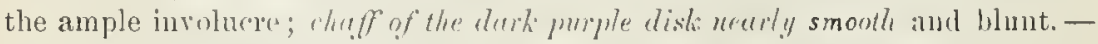
Dry soil, N. J. and l'enn. to Kr y., Mo, and sonthward. - Variable, l - $3^{\circ}$ high ; tlue rays oriange-yellow.

f. R. spathulàta, Michx. l'nhescence short and appresserl; slender, $x^{\prime}-33^{\circ}$ high; leaves olurate or spatulate or the upper orate to laneeolate, 
sonetimes all lanceolate or oblanceolate to linear, denticnlite; heads longpeduneled, smaller than in the preceding, the lays fewer and broader. - Pine woods, Va. to Tenn., and sonthward.

7. R. speciosa, Wenderoth. lioughish-hairy $(1-20$ higgli $)$, bruched; the branehes upright, elongated and naked above, terminated by siugle large heads; leaves lanceolate or ovate-lanceolate, pointed ut both ends, prtioled, 3-5nerved, coursfly and unequally toothed or incised; involucre much shorter than the numerous elongater $\left(1-1 \frac{1}{2}\right)$ rays; chaff of the durk purple disk acntish, smooth. - Dry soil, W. Penu. to Mich., Mo., and southward. Jnly.

\section{LÉ P A H Y R, Raf.}

Hearls many-flowered, radiate; the rays few, neutral. Involucral scales few and small, spreading. lieceptacle oblong or eolummar; the cliaff truneate, thickened and bearded at the tip, partly embracing the flattened and marginerl achenes. J'appus none or 2 teeth. - P'erennial herbs, with alternate pinnately divided leares; the groored stems or branches naked abore, bearing single showy heads. Ray's yellow or party-colored, drooping; disk grayish. (Name from $\lambda \in \pi i s, a$ scale, and $\pi \alpha \chi u$ s, thick, from the thickened tips of the chaff.)

1. L. pinnàta, Torı. \& Gray. Hoary witl minute appressed lairs, slender ( $4^{\circ}$ high), brancling; leaflets $3-7$, lanceolate, acnte; disk oblong, much shorter than the large aud drooping light-rellow rars (which are 2' long). Dry soil, western $\mathrm{N}$. Y. to Minn, and southward. July. - The receptaele exhales a pleasant anisate odor when bruised. Achenes slightly margined on the imner edge, obsenrely 2-toothed at the top.

2. L. columnaris, Torr. \& Gray. Branching from the base, $1-2^{\circ}$ high ; leuflets 5-9, oblong to narrowly linear', entire or 2-3-cleft; disk columuar, often $l^{\prime}$ loug or more; ray as loug ar shorter, yellow or (var. pulcuéruma, Torr. \& Gray) in part or wholly lnownpuple. - Miun. to Tex.

\section{BORRÍCHIA, Mlaus. Slé Ox-eris.}

Heals muny-flowererl, ratiate; ruys fertile. Scales of the hemispherical involucre imbricatel. lieceptacle Hat, covered witl lanceolate rigicl and persistent chaff. Aclienes somerhat werlge-shaped, 3-4-angled; pappus a short 4-toothed crown. - Shrubly low maritine plants, coriaceous or fleshy, with opposite uearly entire leares. and solitiry peduncled terminal heads of yellow flowers; anthers blackish. (Named for Oly limrich, a Danish botanist.)

1. B. frutéscens, I)C. Whitened with a miunte silky pubescence (6'$3^{\circ}$ high); leares oborate to spatulate-oblong or lanceolate, often toothed near the base; chaff rigidly pointed. $-V^{2}$ a. and sonthward.

\section{HELIÁNTHUS, L. ŚxTLOWEr.}

Ileads many-flowered, ladiate; rays sereral or many, nentral. Involucre imbricated, herbaceous or foliaceous. Receptacle flat or convex; the persistent chaff embracing the 4 -sided and laterally conpressed smooth achenes. which are neither winged nor magined. Pappus rery deciluous, of 2 thin chaffy scales on the principal angles, anl sonetines 2 or more small intermeriate scales. - Coalse and stout herls, with solitary or coryulyed hearls, and vellow rays; flowering toward autumu. LNannerl from $\eta_{\lambda}$ tos, the sun, and \&uous, a flower.) 
$\S 1$. Annuals; leaves mostly alternate, petiolate; receptacle flat; disk brownish.

1. H. ánnuus, L. (Commox Sonflower.) Tall, rough; leaves tripleribbed, ovate or the lower cordate, serrate; involneral scales broadly ovate to oblong, long-pointed, ciliate; disk usually l' broad or more. - Minn. to Tex., and westward; long eultivated, and occasionally found in waste grounds.

2. H. petiolàris, Nintt. More sleuder, $1-3^{\circ}$ high; leares oblong- or ovate-lauceolate, smaller ( $1-3^{\prime}$ long), mostly entire; seales laneeolate or oblong-lanceolate, seldom eiliate; disk $\frac{1}{2}$ ' broad or more. - Minn. to 'Tex., and westward.

\$2. Perennials; receptacle convex or at length low-conical; lower leaves usually opposite.

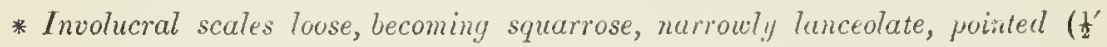
long); disk usually purple or brounish; leaves linear, 1-nerved.

3. H. orgyalis, DC. Stem glabrons, tall, very leafy; leares mostly alternate, linear to filiform aud entire, or the lowest lanceolate and serrulate; scales filiform-attenuate. - Dry plains, Mo. to Neb., sonth and westward.

4. H. angustifòlius, L. Stem slender $\left(2-6^{\circ}\right.$ high), usually scalırous; leaves long and linear, sessile, entire, with revolute margins; hearls luosely rorymbed, long-peduncled; scales acute or pointed. - Low pine barrens, N.J. to liy., and southward.

* Involucral scales closer, more imbricated, short, unequal and not foliareous; leaces lanceolate to orate, mostly oprosite and 3-nerced.

$$
\text { - Disk dark. }
$$

5. H. atròrubens, I. Rough-hairy; stem slender $\left(2-4^{\circ}\right.$ liggh $)$, smootl and naked and furking above; leaves thimish, ovute or ovel to oblong-lunceolute, (1) the lowest heart-shaped ( $3-6^{\prime}$ long), serrate, aloruptly eontracted into a margined petiole; heals small, curymbed; scales ovate, obtuse, ciliolate, a jpressed; rays 10-16; pappus of 2 friuged scales. - Dry soil, Va. to Ark., and sonthward.

6. H. rígidus, Desf. Stem stunt $\left(2-6^{\circ}\right.$ high or more), simple or sparingly branched, rough; feaves very thick and rigid, rough both sides, oblong-lan. ceolate, usually pointed at both ends, nearly sessile, entire or serrate, the lowest oval; heads nearly solitary, pretty large; scales ovate or ollong, obtuse, or mostly acnte, ciliate, appressed; rays 20-25, prapus of 2 large aud often sevelal small scales. - Dry prairies, Micl. to Tll., ancl westward.

$$
\text { + + Misk yellou. }
$$

7. H. lætiflorus, l'ers. Closely resemlling the last; leaves rather thiuner; heals siugle or corymberl; scales rather fewer (iu 2 or 3 rows), narrower and acute or mostly acuminate. - Dry open plaees, (Thio to Wise. and Minn., and southward. - Raỵs slowy, l-2' loug.

8. H. occidentàlis, lidllell. Lomewhat hairy, sten slenler, simple, naked above ( $1-3^{\circ}$ high, sending ont rnnners from the bise), bearing $1-5$ small heads on long perlunclus; lomest lruves oval or luncelate-mente, entire or obscnrely serrate, ronghish-juleseent beneuth, abruplly contructed into long havry petioles; the upper small and remote; scales ovate to lanceolate, acnte or pointed, sometimes ciliate. - Dry harrens, ()hio to Wisc, and Minn., and southward. 
* * Involucre looser, the scales more acuminute or elongated or foliaceous: disk yellow (anthers dark).

+ Leaves all opposite, sessile, semulute; pubescence ruther soft.

9. H. móllis, Lam. Stem simple, leafy to the top $\left(2-3^{\circ}\right.$ high $)$; leaves ovate to lanceolate, with broad eorlate clasping bise, pointed; scales lanceulate, seldom exceeding the disk. - 1)ry barrens, Olio to Iowa and southward. + + Leares mostly alternate and 3-nerced, soft-pubescent beneuth, scabrous abore; scales very long and loose, hairy; tips of chapl and corolla-lobes hirsute.

10. H. tomentosus, Michx. Stem lairy, stunt (4-80 high); leares oblong-lanceolate, or the lowest ovate, tapering at both ends, obscurely serrate, large $\left(5-12^{\prime}\right.$ loug), somewhat petioled; disk $I^{\prime}$ broal; rays $12-16$, about $1^{\prime}$ long. - Rich woods, lll.(?), Va., and soutlward aloug the mountains.

+++ Leaves nurrow, chirfly allenute, not 3-nerved, scrbrous borl sides; heads rather snall; srules loose, attenuate.

11. H. grósse-serràtus, Martens. Shem smooth and yluucous, $6-10^{\text {p }}$ high; leaves elongatrel-ancolale on wrate-lanceolate, taper-pointed, sharply serrate or denticulate, acnte or attenuate at base, pelioled, often whiter and finely pubescent beneath; scales lance-awl-shaperl, slightly ciliate. - Dry plains, Ohio to S. Dak., Mo., and southwestward. - Probably ruus into the next.

12. H. gigantèus, L. Srem hairy or rough $\left(3-10^{\circ}\right.$ highli), branched : bove; lewes lumreolute, pointed, minutely serrate or nearly entire, green both sides, narrowec and ciliate at base, bnt hewly sessile; scales long, linear-lanceulate, pointed, lıiry or strongly ciliate. - Var. smbicles, Torr. \& Gray; leaves mostly opyosite and clusely semsile ly an ubtuse base; perhaps a lyybrid with n. 17. - Low thiclsets and swamps; ; common. Ileads somewhat corymberl; the pale yellow rays 15-20; louts olten beewning tuber-like.

13. H. Maximiliani, halutu. Resembling the last; stout, often simple, $1-10^{\circ}$ ligh ; leaves becunning rigid and very scabrous, entire or sparingly denticulate; heads rather large, usually short-peduncled, terminal and in the upper. axils; scales longer attenuate, :nore rigicl. - I'rairies, Miun. to Tex.

++++ Leaves all or most wt them opposite, 3-nerved (faintly in 11. 15). + Heads very smull (about 4 "broud) ; ra!ys 5-8; scales feu", short, irregularly imbrivated, the outer with spreading foliaceous pointed $t i p s$; slems smoorh.

14. H. parviflorus, Berul. Stem 3-60 highl, with umerous slender lramches above; leates thin, orutr-lumeolate, tuper-pointed, somcwhat serinte, jetioled, rough above, pale and puberulent beneatli; jechncles slender, rough: sales ovate and ovate-lanceolite, (iliate. (II. microcephalus, Torr. \&. (incey.) - 'Thickets, Peuu. to Ill., and southward.

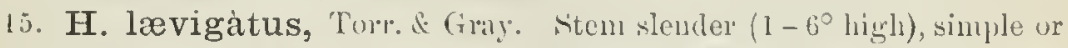

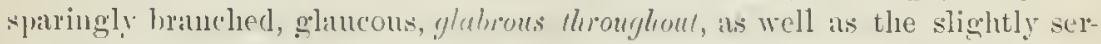
rate lancedute leares which are usually narow and attenuate to the base.1)'y soil, Alleghany Xls.s, and sunthwitrl.

+ + Meads larger; rays usually oner 10 ; spreuding by creepring rookstocks.

= Leares sessite nr subsessile to short-petiolute, sermulute or entire.

16. H. doronicoides, Lam. Finely pubesent aul roughish, 3-70

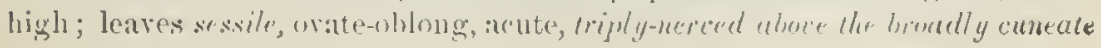


base, serrulate; scales loose, attennate, mostly $6-8^{\prime \prime}$ long, hairy. (H. cinerens, vall. Sullivantii, Torr. o. Gray.) - Dry gromul, (Jhio to Mo.

17. H. divaricatus, L. Stem simple or forked and corymbed at the top

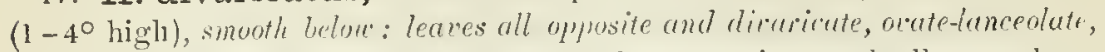
3-nered from the ronded or truncate sessile base, tapering gralually to a sharp point $\left(3-6^{\prime}\right.$ long), serrate, thickish, rough both sides: scales narrowly lanceolite, attenuate, ciliate, oqualling the disk; rạs 8 - 12. - Thickets and barrens; common. - Disk 6" wicle; rays $l^{\prime}$ long.

18. H. hirsutus, Ralf. Stem simple or forked above, stout ( $1-4^{\circ}$ high), bristly-hairy; leares all shoilly petioled, vecte-lanceolute, gradually pointed, slightly serrate, rounded or obtuse at the base, very rough al,ove, usmally roughhairy beneath; scales orate-lancevlate, printed, equalling the disk; rays about 12.- 1)y plains, Ohio to Wisc., and southward.

19. H. strumosus, L. Stem $\left(3-6^{\circ}\right.$ high) very smooth below, often glaucous; leates aretedancedute, tripering gradually to a point, or the lower ovate and acute, abruptly contracted into short margines petioles, rough above, ahitish and naked or mimuly douny underneath; scales lowally lauceolate witl spreading tips, ciliate, equalling the disk; rays $9-15 .-V$ ar. nobls, Torr. \& Gray, has the leaves downy miderneath, often sulsorlate, the scales looser and nore attenuate. - hiver-banks and low copses; common, especially westwark.

20. H. tracheliifolius, Willı. Like the last; leares thimner and nearly equally green both sibles, more sharply serrate, all distinctly petioled; scales all loose and spreading, excecling the disk, often much elongated.Copses, P'eun. and Uhio to Minn., and soutlwward.

$==$ Leaves longer-petiolate, thimnish or soft, coarsely serrate, commonly broad: scales loge, hirsute-ciliate.

21. H. decapétalus, I. Stem branching (2-50 high), smooth below; leaves smooth or roughish, orate, pointerl, almutly eontracted into margined petioles; scales lancenlate-linear, elongated, loosely sproarling, sometimes foliaceons, the onter longer than the disk; rays about 10 . - Copses and low banks uf streams; N. Fing. to Minn. and sonthward, common.

22. H. tuberósus, I. (Jerusalem Artichole.) I'uhescent or hirsute, $5-10^{\circ}$ high ; leares orate or subeorilate to oblong-lanceolate, acuminate, scubrous alove, minutely pulusent or cinereons beneath; scales lanceolate, attenuite, little exceeding the disk; rays 12-20. (11. doronicoides, former el.) - N. Y. to Mimm, and southward; often cultivated. - Var. SubCaxés r.as, Gray; Hstllly dwarf, the lower side of the leaves whitish with soft fine pulescence. Minn. to Mu.

\section{V ERB ESİNA, L. Crowrieard.}

Ieads several-many-floweved; the rays pistillate, or sometimes neutral and sterile, few, or sometimes none. Involucral scales imbricated in 2 or more rows. lieceptacle mither convex (conical in n.3); the chaff concave. Achenes flat (compressed laterally), winged or wingless, 2-awned. - Mostly perenuial herhs; the touther leares decmirent on the stem. Flowers mostly yelluw. ("Name metamorphosed from Verbena.") 
* Ileads nurrou, small, cymosely paniculate; rays jew, pistillate, usuclly fortile; incolucre evect.

1. V. occidentàlis, W:1t. Sitem tall, 4-winged; leures oppusite, ovate to oblong-lancenlate, triple-nerved, serrate, pointed at both ends, often jubescent heneatl (larow and thin); heals in compound corymbs; receptarle flattish; flowers y+llore; rays $1-5$, lanceolate; achenes wingless. (V. Siegesleckia, Mich.r.) - Rich suil, s. l'enn. to I1l., ind southward. July.

2. V. Virgínica, L. Siten marowly ol interrupterly wingerl, dounymbescent, like the lonet surfuce of the ovate-lancelate foather-reined alternate leares; heads in connenund rorymbs; receptacle convex; Houres uhite: rays 3-4, oval; achenes winged. - Iry soil, Penn. (!) to Ill, and sonthward. Aug.

* Heads liruader, solitary or feer.

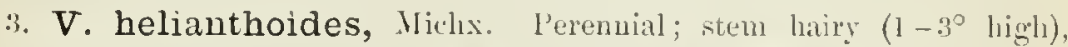
willely wingel by the uvate to the orate-lanceolate sessile alternate leaves, which are rough above and suft-liary heneath; involnce appressed; rays $8-15$, pistillate or nentral, nswally sterile; aclenes winged, tipped witl 2 fragile awns. (Artinomeris helianthoides, Vutt.) - I'rairies anl copses, Ohio to lowa and sonthward. July.

4. V. encelioides, Benth. \& llook. Amual, branching, 1-20 high, cinereous; leaves alternate, ovate or cordate to icltojil-lanceolate, the petioles mostly winged and anriculate at hase; involucral seales linear, equal, foliaceous, spreading; rays unneruns, fertile. - Kan. to Tex., and westward.

\section{ACTINómERIS, Nintt.}

lleads many-flowered; rays neutral, few or none. Involucral scales few, hrobraceous, nearly equal, soon deflexed beneath the grohnlar disk. Iicep1arle small, chaffy. Achenes flat, ohorate, wingerl or wingless, at matmity sprealing in all directions; palpus of 2 ur 3 smoutl persistent alwas. - Tall lmanching perenuiak, with surate feather-veined lenves, taperiug to the base ancl mostly decurreut on the stem. Heads corymbed; Howers chietly yellow. (Nane from áktis, " ru, and $\mu \in \rho$ s, a part; alluding to the irregularity of the rays.)

1. A. squarrosa, Nutt. Stem somewlat lairy, usually winged above $\left(4-8^{\circ}\right.$ high $)$; leaves alternate or the lower upjusitc, oblong wr ovate-lanceolite, pointed at botls ends; lays 2-8, irregular. - Tich soil, l'enn. and IV. New lork to Iowa, aud southward. Sejt.

\section{COREÓPSIS, L. Tichéen.}

Ifeads mauy-flowered, radiate; rays mostly 8, neutrul, rarely wanting. Involucre dumble; each of about 8 scales, the onter rather foliaceous and somewhat sprealing; the imer broader and appressed, nearly membranaceotis. Receptacle flat, with membranceons chaff deciluons with the frut. Achenes flat, obcompressed (i. e., parallel with the scales of the involuce), often wingerl, not narrowed at the top, 2-toothed or 2-awnerl, or sometimes naked at the sum. mit, the awns not barbed downardly. - Ilerbs, generally with opposite leaves and yellow or party-colored, rarely purple, rays. (Name from k'pis, a buy, and ots, resemblance; from the form of the achene.) 
\$. Style-tips Iruncate ur nearly so: onter involucre small and short; rays rose. color or yellow with brou'n brese; paprus an obscure border ar none.

1. C. ròsea, Nutt. Perennial; stem branching, leafy, smooth $\left(6-20^{\prime}\right.$ high); leaves linear, cutire; heads small, somewhat corymbed, on short pelumcles; rays rose-color, 3-toothed; achenes oblong, wingless. - Sandy grassy swamps, I'lymoutl, Mass., to X. J., aud sonthwarl; rare. Nug.

2. C. cardaminefolia, Tol'. \& Gray. Anumal, $0^{\prime}-20$ high; leaves I - 2-pinnately livided, the lobes oral to lanceolate or ahore linear ; rays yellow with brown-purple hase; achenes short, smouth or papillose, winged. kin. to La. and 'Tex.

3. C. tinctòria, Nutt. Amulal, glabrums, 2-30 high; leaves $1-2-p^{\text {in- }}$ nately divided, the lubes lanceolate to linear; achenes oblong, wingless; rays rellow with more or less of erimson-brown. - Minn. to 'Tex., etc.; common in cultivation.

\$.2. Style-tips abruplly cuspidute, lispid; involucres nearly equal; achenes roundish, winged, incurved, often pripillase and with a callus inside at base and apex; paphns 2 small teeth wr wone; ray mostly yellow and palmately lobed; perennials, with long-pedunculate heads; lover lences pctivlate.

4. C. lanceolàta, L. Smooth or hairy $\left(1-2^{\circ}\right.$ high $)$, tuftel, brancherl ouly at the base; leaves all entire (the lower rarely with a pair of small lateral lobes), lanceolate, the lowest oblanceolate or spatulate; outer scales ovatelanceslate. - Rich or damp soil, Mich. and Ill. to Yia., and sonthwarl. July. Also cultivated in gardens. Ileats showy; rays l' long. - Var. AxGretrloul, Torr. \& Gray, is a low form with crowded narrow leaves and elongated

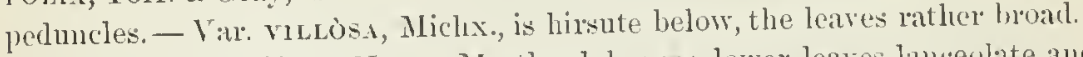

5. C. grandiflora, Nutt. Mostly glabrous; lower leaves lanceolate and spatulate, entire, the upper 3-5-purted with lunceolate to lineur and sometimes 2-3-puted lobes; heads as in the liast or larger. - S. Mo. to Tex. and Ga.

6. C. pubéscens, ili. Nore leafy, 1-4 high, pubescent or nearly ulibrous; leaves thickish, ohlong or the lower oval-obovate and the nuper ohlong-lanceolate, entire or with $2-4$ small lateral lobes; heals usually smaller. - Ya. to S. 111., Mo., amrl southward.

7. C. auriculàta, Lim. Pubescent or glabrous; stens $1-t^{\circ}$ high, banching, sonctines with rumers; leaves mostly petioled, the upper oblong 11. oral-lanceolate, "utire; the lower oval or roundish, some of them rariously 3-5-lobed or divided; wuter scales ohlong-lincar or lancenlate; achenes nar-, rowly winged and strongly involute. - Rich wools and lianks, Ya. to Inl., and southward. June-sept.

\$3. Style-tips cnspidate; achenes blong, nerrly straight, without callus, the wing narrow or none; rays yellow, mostly entive or sliylthly toothed.

* Outer scales nurvur, about the length of the inner, all. more or less united at base; rays mostly entire, acute; pappus 2-toothed or none; leaves opposite, sessile, mostly 3-divided, appearing as if whorled; peremial, $1-3^{\circ}$ high.

+ Leares 3-cleft, but not to the base.

8. C. palmàta, Nutt. Nearly smooth, simple; leares broadly wedgeshaped, rigill; the lohes Inoally linear, entire, or the midrle one 3-1obed. l'airies, Mlich. to Miun., anl southwestwarl. duly. 
+ + Leares rlicided to the base, uppermost and lourest sometimes simple.

9. C. senifòlia, Michx. I'lant minutely soft-pubescent; leares each divided into 3 sessile ocrite-lanceolate entire leuflets, therefore appearing like 6 in a Whorl. - Sindy wouds, Va. and southward. July.

Var. stellàta, 'Torr. \& Gray. Glabrous, and the leaves narrower. - Va., líy, aurl soutlwarl.

10. C. delphinifòlia, Lam. Glalıous or nearly so; leaves divided into 3 sessile leaflets which are 2-5-parted, the dr divisions leme-linear (1 - 3" broul), rather rigid; disk hownish. - I'ine woods, Vad and sonthward. July.

11. C. verticillàta, L. Glabrous; leaves divided into 3 sessile leaflets which are I-2-pinnately purted into nurrouly linear or filiform divisions. l)amp soil, from Ont. and Mich. to Md., Ark, and sonthward. Cultivated in oll gardens, but not slowy. July-Sejt.

* *uter scales narrou, shorter, all united at base; rays entire, ulutuse; pupms none; leures petiolate, pinnutely 3-5-divided; peremmial.

1.2. C. trípteris, I. (Tal Colvopsim.) simootli; stem simple $\left(t-9^{\text {? }}\right.$ lighl), (corymber at the top; leatlets lancoulate, acute, entire. - l'enn. to Wisc., lowa, and soutluward. Alug. - Sept. - Ileads exlialing the odor of anise when hruised; disk turning hrownish.

** * Scales mostly distinct, the outer leufy, reflexed or spreading; achencs flat, oboiate or chneate-oblong, 1-nerved on each face, 2-toothed or 2-auned (farely 4-awned); leares pctiolute, usully pinnately 3-7-divided, the lobes serrate; annuals (or biennial), branching. Approaching Bidens.

- Liuys conspicuous, golden yellow.

+t Achenes cuneute, obscurly ciliute or nuked; onler scales about 8.

13. C. aùrea, Lit. Nearly glabrons, $1-3^{\circ}$ hight; leares rniable, commonly 3-7-divided, ur some or all undivided, the segments inciscly serrate or

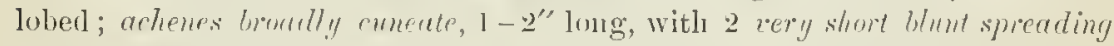

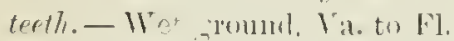

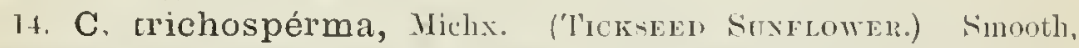
branclie.l; leaves short-petioled, nearly all 3- 7-rlivided; leaflets lanceolate or

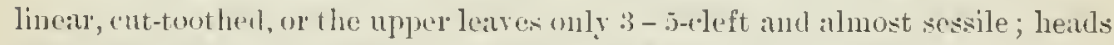

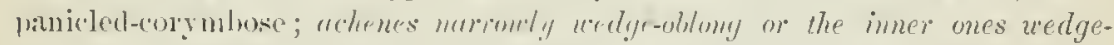
linear, abont $t^{\prime \prime}$ long, smooth wr slatsely hairy, marginless, rowned with 2

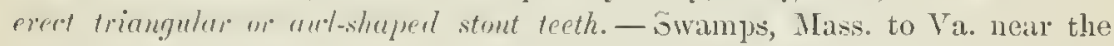
coast. Also Cayuga, X. Y., to Ill., where is a var. TLıcílob.l, Gray, with slorter achenes, approilluing the last. $\mathrm{Iug}$ - Oct.

++ Ichenes whoute, wy flat, with thin riliate margins.

15. C. aristosa, Michx. Somewhat pubescent; leaves I-2-pinnately 5 i-divided, petioled; leaflets lanceolate, cut-toothed or pinuatifil; heals pani. cled-corymbose; outer scales 8-10, not exceeling the inner, harely ciliate; achenes with" (rarely 4) long and slender diverying auns as long as the athene itself. - swamps, Uhio to Mich., Minn., and sonthwestward. Ang.-Oct. Var, uUn dhas two short divergent teeth or points in place of the awns. WV. Ill. and sonthwestwall. lon'us oecur witl the harls of the awns spread-

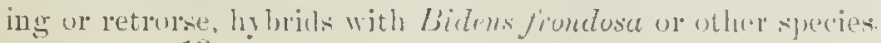


16. C. involucràta, Nutt. Heads rather larger, the outer scales 12-20, mostly exeeeding the inner, slender and hispid; aclienes with 2 short acnte teeth. - W. Ill. to Kian. and Tex.

+- + Rays none, or rarely rudimentury; outer scales usually 3-5, loose, leafy, commonly surpassing the shoit-pedunculate heads; achenes narrouly cuneate; plants glabrous, $1-30$ high; leares petiolute.

17. C. bidentoides, Nutt. Pauiculately branched; leares undivided, lanceolate, coarsely toothed, tapering at both euds; heads $6-10^{\prime \prime}$ long; achenes nearly subulate, bearing a pair of very slender upwardly roughened awns surpassing the corolla ( $t^{\prime \prime}$ long), but slorter than the achene, often also 2 minute teeth alternate with the awns. - Shores of Delaware River, near I'hilaul., and Delaware Bay, to Me. Hybridizes with Bidens frondose.

18. C. discoidea, Torr. \& Gray. Diffusely lunuched, $1-20$ high ; leares ternately divided, slender-petioled; leaflets orate-lanceolate, pointed, coarsely serrate; heads 2-3" long; achenes lineur-wedge-shaped (2-3" lo1'g), bearing a pair of short and stout upwardly-barbed auns of the length of the corolla. Wet banks and swamps, Comn. to (Hio, I11., and southward. July.

\section{BI D ENS, I. BEl-MIligoLD.}

Heads many-flowered; the rays when preseut 3-8, nentral. Iuvolucre double, the outer commonly large and foliaceous. Receptacle flattish; the chaff deciduons with the fruit. Achenes flattered parallel with the scales of the involncre, or slender and 4-sided, crowned with 2 or more rigid and persistent awus which are downwardy barbed. - Ammul or perennial leerbs, with opposite various leaves, and mostly yellow Howers. (Latin, bidens, two-toothed.)

* Achenes flat, not lapering at the summit; outer involucre foliaceous; annuals. + Icads erect, nearly rayless; leures mostly petiolate.

1. B. frondòsa, I. (Comox Beggar-ticks. Strok-тight.) Smooth or rather hairy, tall (2-6 ligh), brancling; lenres 3-5-diviced; leuflets

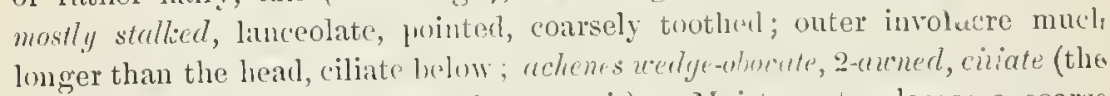
bristles ascending except near the summit). - Moist waste places; a coarse troublesome weed, the achenss, as in the other sperios, adhering to clothing,

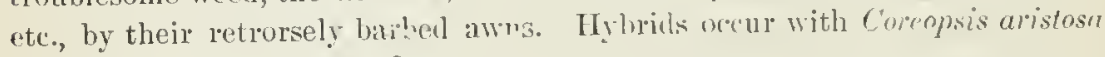
and other species. July-Oct.

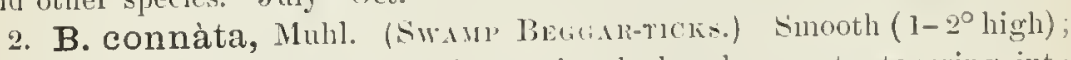
leaces lanceolute or oblong-lancolate, pointed, sharply serrate, tapering into margined slightly united petioles; the loue often :s-thided, the ir laterul dir:sions united at the buse and decuremt on the pthile: outer scales longer than the head, few, mostly obtuse; mys ume; arlemes marmonly wedge-form, 3- (24-) auned, the moryins minutely retrorsely ciliuto. - F. New Ling. to Minn., anto southward. - Var. conosi, Giay, is stonter, the leaves commonly all simple, upper ones nearly sessile, the hoaks larger and with rely lealy involucre. Ill., Ky., and restward. Aug.-()ct. - Van. 1יxir., Watson; leaves nearly all pinnately divided, the 5 - - narrow divisions spaldingly incised; acleues 4-awned. Henuepin Co., Minu. (F, L. Couillerd). 
- + Merds somuturt norldiny, commonly rudiute; Ionves sessile, undivided.

3. B. cérntia, 1. (Simuter 13ur-MAricoln.) Nearly smooth $\left(5^{\prime}-3^{\circ}\right.$ high); leares lancenlute, inequally serrute, sromely connute: heals nodding, with or without (light yellow) ruys; unter involucre longer than the head; aehenes werge-obovate, t-awnel, the margins rlownwardly barbed. - Wet places, $\mathrm{x}$. ling. to Va., Mu., Minn., and northwarl. July-Sept. - Rays, if any, smaller than in 11.4 , ant the onter involucre more leaf-like. (lin.)

4 B. chrysanthemoides, Michx. (Laroer Bur-Marmold.) Simooth, erect, or reclining at the base $\left(6^{\prime}-2^{\circ}\right.$ ligh $\left.g^{2}\right)$; leaces lanceolate, tajering at both ends, nore or less combate, regulurly serrate, onter involucre mostly shorter than the showy golden-yellow ( $l^{\prime}$ long) rays; achenes wedge-shajed, with almost prickly downwardly barbed margins; awns 2, 3, or 4. - Swamps; common. Ang - Oct

* Adenes linear, 4-sided, the imner lonyer and tapering upuard.

5. B. bipınnàta, L (SPArsir Neeples.) Smooth anmul, branehed; leares 1-3-pinnately parted, potioled; leaflets ovate-laneeolate, mostly wedgeshaped at the base; heats small, on slender peilnncles; outer involucre of linear scales equalling the short pale rellow rays, achenes t-grooved and angled, nearly smooth, 3-t-awned. - Damp soil, R. I. to N. Y., 1ll., and sonthward.

* * Achenes terete, truncate at both cnts, wh 3-6 rery long awns smooth below.

6 B. Béckil, Torr. (Whter Marigord.) Aquatic, perliaps peremial, smootlı; stens long and slender; immersed leares crowded, capillary, many times dissected, the few emerging ones lanceolate, slightly connate, toothed; hearls single, short-perlunclerl; involnere much shorter than the showy (gollen yelluw) rays; achenes thickish, smonth ( $\frac{1}{2}$ long), the stont divergent awns ( $I^{\prime}$ long) barbed only toward the apex. - Ponds and slow deep streans, Mass. to N. J., Mo., and northward. Aug. - Oet.

\section{THELE S P É R M A Less.}

Ileads many-flowered; rays ahout 8, neutral, or uone. Involuere as in Coreopsis, the imer comate to the midlle, scarious-margined. Reeeptaele flat, the scarious chaff falliug with the nearly terete wingless and beakless achenes; paypus of 2 stout sululate retrorsely hispid awns. - Smooth herbs, with opposite dissected leaves and pedunculate hearls of yellow flowers. (From $\theta \eta \lambda \dot{\eta}, a$ mpple, and $\sigma \pi \varepsilon^{\prime} \rho \alpha$, secd, on account of the papillose achenes.)

1. T. grácile, Gray. Perennial, rather rigil, I - $2^{\circ}$ high; leares with narrow or filiform divisions or the "p per entire; outer scales very short; rays slıort or usually none; achenes papillose. - Kan., sonth and westward.

\section{B A L D W I I A, Nutt.}

Heads globular, many-flowered, radiate; the long and narrowly wedge-shaped rays nentral. luvoluere short, of many thiek ish sumall scales imbricated in 3 or 4 rows, the outer ohowte and ohtuse. Receptacle strongly couvex, with deep honerconıb-like cells rontaining the olyconical or whlougs silky-villons achenes; pappus of $7-9$ lance-oblong erect chaffy scales. - A perennial herb, smoothish, with slender simple stems ( $2-3^{\circ}$ high), bearing alteruate oblanceolate leares, 
and a large showy lonig-pedunculate heal. Rays yellow ( $l^{\prime}$ longr); the disk ofteu turning lark purple. (Named for the late Li. Millium licklduin.)

1. B. uniflòra, Nutt. - Border's of swamps, Ya. (?) and sonthward. Aug.

\section{M A RSHÁLLIA, Schreb.}

Heads many-flowered; flowers all tulmlar and perfect, the corolla-lobes slender and spreading. Involucral scalcs linear-lanceolate, foliaceous, erect, in one yr two rows, nearly equal. Receptacle convex or conical, with nurowly linear rigid chaff. Achenes top-shaped, 5-ingled; pappus of 5 or 6 membranaceons and pointed chaffy scales. - Sinooth and low perennials, witl alternate entire 3-nerver leaves, and long-pedunculate heads (like those of a Sicalious) termiuating the simple sten or branches. Flowers purplislu; anthers blue. (Named

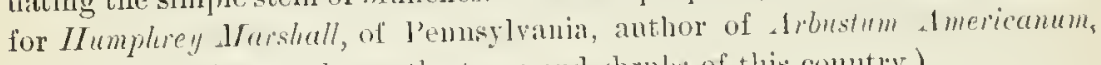
one of the earliest works on the trees and shruls of this conntry.)

1. M. latifòlia, l'ursh. Stems leafý; leaves ovate-lanceolate, pointed, sessile.-Dry soil, I a and sontluwirl.

2. M. cæespitosa, Nntt, Stem commonly leafy only at base; leaves narrowly oblauceolate to linear or the radical spatulate, obtnse. - Kan. to Tex.

\section{G A I I N S Ò G A, lủuiz \& l'aron.}

Heads several-thowered, radiute; rays $4-5$, small, roundish, pistillate. Invo lucre of 4 or 5 ovate thin seales. Receptacle conical, with narrow chaff. Achenes angled; pappus of small oblong cont-flinged chaffy scales (sometimes wanting). - Ammull lerbs, with opposite triple-nerved thin loares, and small

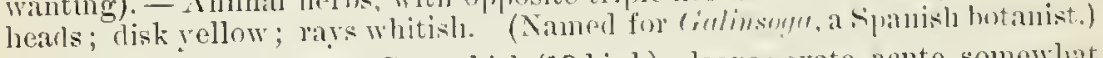

G. Parvation, Car. Smoothish (10 high); learos orate, acute, somewlat

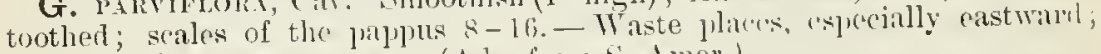
sprealing from gear to year. (Ady. from S. Amer.)

\section{H Y MENOPÁPPUS, L'Her.}

lleads many-flowered; flower's all tubular and perfect, with large revolute corolla-lobes. Involucral scales $6-12$, loose and broal, thin, the npper part petal-like (nsually white). lieceptacle small, naked. Achenes top-shaped, with a slender hase, striate; papplus of $15-20$ blunt seales $i n$ a single row,

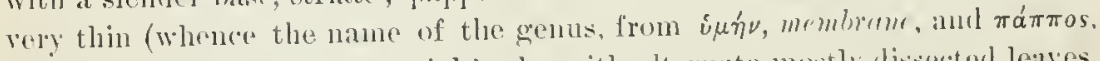
propus.) - Bienuial or pereunial herbs, with alternate mostly disiocted leaves. and corymber smatl heads of usulally whitish tlowers.

* Peppus of ery sumall roundish nereptese scules.

1. H. scabiosicus, L'Her. Somewhat flocculent-woolly when young, leafy to the top $\left(1-3^{\circ}\right.$ high); leares $1-2$-pinnitely parted into linear or ohlong lobes; imolucral scales roundish, mainly whitish. - Simly loarens, 111. and southward. May, Tumc.

2. H. corymbòsus, lorr. \& Gray. Mure slender, glaliate, naked above; scales obovate-ollong, petaloid at apex, - Neb. to A rk. and 'Tex.

* * Pappus of conspicuous spatulute l-nerved scales; incolucre fropuer.

3. H. tenuifolius, l'nrsh. Slightly tomentose or glahate, leufy, l-20 ligh; divisions of the leaves narrowly linear or filiform, revolnte; involucral scales ubovate-ubloug ; allones long-villous $\rightarrow$ Neb. to . I.h. and 'l'ex. 


\section{ACTINÉLLA, l'ers, Nintt.}

Heads many-flowered; rays several, wedge-olulong, 3-touthed, pistillate. Scales of the hemispherical involncre orate or lanceolite, menturanaceons or coriaceous, nearly equal, aplressed in 2 or 3 rinks, little shorter than the disk. Receptacle hemispherical or conical, nitied. Achenes top-shaped, flensely silky-villons; papjuns of 5 or nore ovate or lanceolate very thin chaffy scales. - Low herbs, with natrow alternate louves, dotted or sprinkled with resinous atoms as in the next genms ind hitter-inromatic; the solitary heads terminating scapes or slender naked peluncles; flowers yellow. (Nane a diminutive. of Actinea, from àktís, ray.)

* Ineolucre of numorous distinct not rigid scules; leaces mutire.

1. A. linearifolia, 'Torr. \& Gray. Ammal or biennial, villons or glabrate, $1^{\circ}$ high or less, simple or branched; leaves linear; peduncles filiform. -S. Kan. to Ia., and Tex.

2. A. acaulis, Nutt. Perenuial, densely cespitose, the lranches of the candex short and thick, with scapo-like peduncles, canescently villons or silky; leaves spatulate to linear, slort. - Ilills and plains bordering the Rocky Mts. aurl scarcely reaching our limits; the var. fidum, Gray (A. scaposa, var. glabra, M/an.), a greener glabrate form, las been found on au Iurlian mound near Joliet, Ill. The less densely cespitose A. scarosi, Nitt., more loosely villuus and the candex with more slender branches, is probably in s. Kín.

* Scales vigid, in 2 rours, the outer comnate at base; leures termately parted.

3. A. odoràta, Gray. Ammal, I-20 high, branching, leafy, somewhat floccose-woolly; heads small, scattered ; leaves I-3-pinuately divided, the lobes filiform. - Central Kan, to T'ex., and westward.

\section{HEI E N I U M, I. SXEE\%E-WELI,}

Hearls many-flowerol, radiate: ray several, wedge-shaped, 3 -5-cleft, fertile or rarely sterile. hurolucre small, reftrxel, the scales linear or awl-shapert. Receptacle glohose or oblong, naked. Achenes top-slaped, ribbed; jappns of $5-8$ thin and 1-nerved cluaff scales, the nerve usually extended into a bristle or point. - krect, hanching herls (ours perennial), with alteruate leaves tocurrent on the angled stem and hranches, which are terminated hy single or corymber (yellow, ranely purple) learls; often sprinhled with bitter aromatic resinoms glolnles. (The Greek name of some plant, saicl to be named after Ulelenus, son of J'rimu.)

1. H. nudiflòrum, Nutt. Somewlıat puherulent, 1-30 high; leaves narrowly lanceolate or oblong to linear, entire, or the radical spatulate and dentate; heads mostly small; disk brownish, globose; ray yellow or partly hrownpurple, sterile (ueutral or style abortive), shorter than or exceeding the disk. (Leptopoda brachypoda, Tor\%. G. Cry.) - Ill. and Mo. to N. Car. and Tex.; nat. near I'libalplinia. Iybrilizes with the next. Jnne-Ang.

2. H. autumnale, L. Nearly smootlı, $1-6^{\circ}$ high ; leaves mostly tootherl, linceolate to ovate-ollong; leads liuger (about 6" broad); risk yellow; ray fertile, yellow. - Alluvial river-banks ant wet ground, Comn. to Minn., soutl aud westward. Sept. 


\section{G A I LI ÁR DIA, Fong. .}

Heads many-flowered; rays 3-cleft or -toothed, neutral or sometimes fertile, or none. Involucral seales in $2-3$ rows, the outer larger, loose and folliaceons. Receptacle convex to globose, beset with bristle-like or silulate or sluort and soft ehaff. Achenes top-shaped, 5-costate, villous; palpus of $5-10$ long thiu reales, awn-tipped by the excurrent nerve. - Erect lierlss with alternate leaves and large showy heads of yellow or purplish fragrant flowers on terminal or scapiform peduncles. (Named after Gaillard de Merentomean.)

1. G. símplex, Scheele. Annual; leaves all radical, usually spatulate, pinnatifid to eutire; head globose on a naked scape, usually rayless. - ๖. Liau. to Tex.

2. G. lanceolàta, Michx. Anmal, leafy-stemmed, branched, $1-2^{\circ}$ high, finely pubescent; leaves oblauceolate to linear, mostly entire; rays rather few or none; chaff very short or ohsnlete. -S. Kan. to Tex. and Fla.

3. G. aristàta, Pursh. Ierennial, hirsute, often $2^{\circ}$ high ; leaves lanceolate to oblanceolate, broad or narrow, entire to coarsely pinnatific ; rays usually numerous and long; chaff bristly or subulate. - N. Dak., west aud southward.

\section{D Y SÒDIA, Car. Fetid Marigold.}

Heads many-flowered, usually radiate; rays pistillate. Involncre of one row of scales united into a firn cup, at the base some loose liractlets. Receptacle flat, not chaffy, lut heset with short chaffy bristles. Achenes slender, 4-angled; pappus a row of chaffy scales dissected into numerons rough lnistles. - I Ierls, mostly annuals or biennials, dotted with large pellucid glands, which give a strong odor (an in Tagètes, the Fuexcu Marigolo of the gardens, which belongs to the same group); heals terminating the branches; flowers yellow, (Name $\delta v \sigma \omega \delta l a$, an ill smell, which the plants exemplify.)

1. D. chrysanthemoides, lag. Nearly smooth, diffusely hranched (6$18^{\prime}$ high); leares opposite, pinnately parted, the narrow lobes bristly-toothed or eut; rays few, scarcely exceeling the involucre. - Roadsides, and banks of rivers, Minn. to Ill., 'Tenu., and southwestward. Ang. - Oct.

\section{6. Á NTHEMIS, L. Cinмomile.}

Heads many-flowered, radiate; rays pistillate or (in 11. 1) neutral. Involucre hemispherical, of many small imliricated dry and scarioms scales shorter than the disk. Receptacle conical, with sleuler chaff at least near the smmmit. Aehenes terete or ribled, glalurous, truncate; pappus none or a minnte crown. - Branching strong-scented herls, with finely punately dissected leares and solitary terminal heads; rays white; disk yellow. ('A $\nu \theta \in \mu$ is, the ancicnt Greek name of the Chamomile.)

A. Cótula, DC. (Mariweron.) Anmual, acrid; rilys mostly neutral; receptacle witlout chaff near the margin; pappus none; leares finely 3 -pinnately dissected. (Maruta Cotula, $B C$.) - Conmon by roidlsides. (Nat. from Eu.)

A. Anvensis, I. (Coms Cunmomile.) Pubescent ammul or biennial, resembling May-weel, but not ill-scented; leares less finely I-2-pinnately parted; chaff of the receptacle lanceslate, pointed; pappus i minte borier - Waste places; rare. (Air, from Eu.)

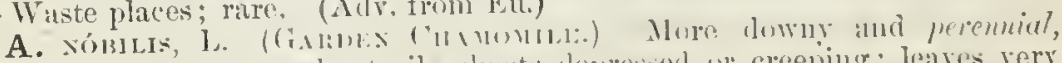

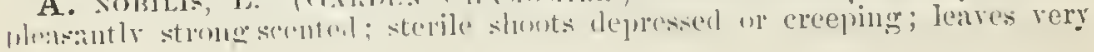


finely dissected; chaff of the receptacle blunt; pappus none.-Established near Lewiston, Delaware, Nuttall. ( $\mathrm{ddv}$. from Eu.)

\section{A CHILLEA，L. Yarrow.}

Heacs many-flowered, radiate; the rays few, fertile. Involucral scales imbricated, with scarious margins. Receptacle chaffy, flattislı. Achenes obloug, flattened, margined; pappus none.- Perenuial herbs, with small corymbose heads. (So named liecause its virtues are said to have been discovered by Achilles.)

1. A. Millefòlium, L. (Commox Yarrow or Mllfoll.) Stems simple; leaves twice-pinnutely purted; the divisions linear, 3-5-cleft, crowded; corymb componnd, flat-topped; involucre oblong; rays 4-5, short, white (sometimes rusecolor). - Fields ancl hills; commou. Green and more glabrate in fields in the Atlantic States, and perhaps in such cases introduced. Aug. (Eu.)

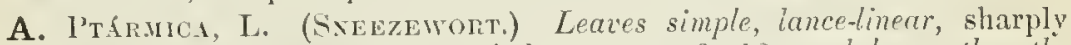
serrate with appressed teetli; corymb loose; rays $8-12$, much longer than the bronder rumpumulate incolncre; fluwers white. - Mass., Mich., etc.; rare. Apparently indigenous on the Lower St. Lawrence. ( $\mathrm{Al}$ v. from liu.)

\section{MATRICÁRIA, Tonm. Wum Cnamomue.}

Ilears many-flowered; rays pistillate, or wanting. Scales of the involncre imbricated, with scarious mirgins. Receptacle conical, at least in fruit, naked. Achenes 3-5-ribberl, wingless; papjus a membranaceons crown or borter, or none. - Smooth and branching herts (ours annuls or biennials) with finely divided leaves and single or corynued lieads. Rays white or noue; disk rellow. (Named for reputed medicinal virtues.)

M. wopòr., C. Leaves twice-pinnately divided into fine almost filifon'm lobes; heuds lurge, naked-perhuched, and with many long rays; achenes strougly 3-ribbed; pappus a sluert crown or border. - (Wild far northward.) Roalsides, Eastport, .laine, Trof. Terrill. Ang. (Arlv, from Eu.)

M. Inscónet, 1)C. Low $\left(6-9^{\prime}\right.$ high); leaves $2-3$-pinnately parted into short linear lubes; heads rayless, short-pedunclerl; scales oval, with broal margins, much slorter than the conical disk; achenes more terete; pappus obsulete. - Banks of the Mississippi upposite st. Louis. An imnigrant from Oregon, extenting eastward and becoming uaturalized near railroad stations; alsu established iu N. Europe. July - Sept.

\section{CHRYSÁNTHEM UM, Tourn. Ox-eye Daisr.}

Hearls many-flowered: rays numerous, fertile. Scales of the broad and flat involncre imbricated, with scarions margius. Receptacle flat or convex, nakerl. Disk-corollas with a thattened tulie. Achenes of disk and ray similar, striate. without pappus, - I'erennial herbs, with toothed, pinuatifid, or divided leaves, and single or corymber hears. Risys white; disk yellow. (O)d Greek name, $\chi p \nu \sigma a ́ \nu \theta \epsilon \mu o \nu$, i. e. golilen flower.)

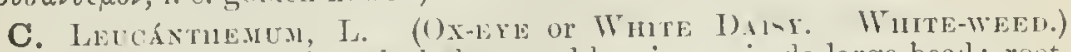
stem erect, nearly simple, nakel abore and bearing a single large heal ; rootleaves spatulate, jetioled, the others partly clasping, all cut or pinnatifil-tontherl; seales of the inrolucre with rusty-brown margins. (Lencanthenum rulgare, f.rm.) - Fields and meadows; ahundant eastward. June, July. A pernicious weenl, with large and showy lieads. It orcurs with abortive, deformed, or tubular and laciniate rays. (Nat. from Eu.)

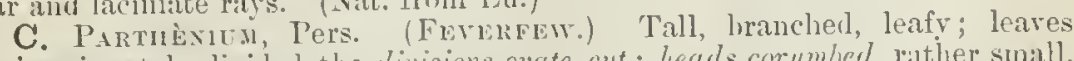
twice-pinnately divided, the divisions orate, cut; heads corymbed, rather small. (Lencanthemum l'antheuium, Godron.) - Escaped from garilens in some places. (Ahr frum Eu.) 


\section{TA NACETUM, L. TAxsY.}

Heads many-flowered, nearly discoitl ; flowers all fertile, the marginal ehiefy pistillate and 3-5-toothed. Invulucre imbricated, dry. Receptacle convex naked. Achenes angled or ribbed, with a large flat top; pappus a short crown. - Bitter and acrid strong-scented herbs (ours perennial), with 1-3-pinnately dissected leaves, and eorymbed heads. Flowers yellow; in summer. (Nant of uneertain derivation.)

T. vularir, L. (Comon 'Taxsr.) stem (2-40 high) smooth; leaflets and the wings of the petiole cut-toothed; coryml dense; pistillate florer's terete, with ollique 3-toothed limh; pappus 5-lobed. - Var. cuispun has the leaves more cut and crisped. - Eseaped from gardens to roadsirles; Atlantic States. (Nat. from Eu.)

1. T. Huronénse, Nutt. Ilairy or woolly when young, stout $\left(1-3^{\circ}\right.$

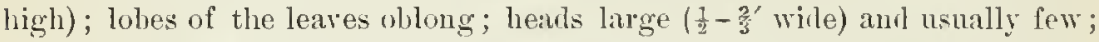
pistillate flowers flattened, 3-5-cleft; pappus toothed.-St. John's River, Maine ( $G$. L. Goodule), shores of the upper Great Jakes, and westward.

\section{ARTEMÍSIA, I. WORMWOOD.}

Ifeads discoid, few-many-flowered; flowers all tubular, the marginal ones pistillate, or sometimes all similar and perfect. I holucre imbricated, dry anci scarious. Receptable small and flattish, naket. Achenes oboroid, with a small summit and no pappus. - Herbs or shrubly plants, bitter and aromatic, with small eommonly nolding heads in panicled spikes or racemes; flowering in summer. Corolla yellow or purplish. (Aneient name of the Mugwort, in memory of Artemisia, wife of Mausolus.)

\$ 1. Receptacle smooth; marginal flowers pistillute and fertile; disk-flowers perfect but sterile, the style mostly entire; ront perennial, except in $\mathbf{n} . \mathbf{1}$.

\section{* Lerres dissected.}

1. A. caudata, Michx. Smooth $\left(2-5^{\circ}\right.$ high $)$; upper leaves pinnately, the lower 2-3-pinnately divided; the direisions threal-form, diverging; heads small, the racemes in te wallike elonguted punicle; root biennial. - Sandy soil, coast of N. H. to Va.; also Mich. to Minn., and sonthward.

2. A. Canadénsis, Michx. Smooth, or loary with silky down (1-20 high); lower leaves twice-pinnately divided, the upper 3-7-divided, the divisions linear, rather rigid: heads rather large, in panicled racemes. - Northern N. Eng. to the Great Lakes, Minn., and northward. (Eu.)

$$
\text { * *eares entire or some 3-cleft. }
$$

3. A. dracunculoides, P'ursh. Tall $\left(2-5^{\circ}\right)$, somewhat woorly at base, slightly hoary or glabrous; leaves linear and entire or the lower 3-cleft; heads small and numerous, panicled. - Sandy banks of streams, Minn. to I1l., Mo., and westwarl.

4. A. glaùca, Pall. Strict, $1-2^{\circ}$ high, somew hat wooly at base, nimutely silky-pubescent or glabrate; leaves linear- to oblong-lanceolate; heads as in the last. - Sask. to Minn. (Sil.)

5. A. filifolia, 'Torr. Snlfutione, finely canescent, $1-3^{\circ}$ lighl ; leaves all filiform, the lower commonly 3 -parted; heads very small and numerons, "rowded in a ling leaf paniele. - Central Kan. to Neb., and sonthwestward. 
\$2. Receptarle smonth; flowers all fertile, a few pistillate, the others perfect.

'Two cultivated slumbly species, from Enrope, with filifornly divided leaves, have oreasionally escapel from gardens and become spontaneous, viz., 1 . A13-

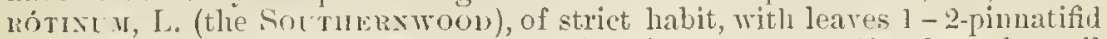
and pubescent heads, and A. PRócErs, L., with more spreading branches, all the leaves finely 2-pinnatifd, and heads glabrous.

* Tall $\left(1-5^{\circ}\right)$ and branching peremials, xhitened with fine and close-pressed uool; leads small, in leafy panicles.

6. A. serráta, Nutt. Yery leafy, 6-90 high, leaves lanceolate or the . ㄱ.per linear, scriate, white-tomentose beneath, green alove; heals greenish, oblong, 2" long ur less. - Ill. to S. Dak.

7. A. longifòlia, Nutt. Sten $2-5^{\circ}$ ligh ; leaves linear or lincar-lanceolate, entire, usullly glalurate alinve; hearls oblong; caneseent, 2-3" longYiun. to Nel,., ant westward.

8. A. Ludoviciàna, Ninte. (Westers Mugwont.) Hillened woolly thromgluat; leares laneeolute, the upper mostly ontire, the lower usually cutlohed, toothel or pinnatifid, the upjer surface sumetimes glabrate and green; heads campanulate, mostly sessile in nurrow paniclos. - Dry banks, Sask, to Miclı., Ill., Tex., and westwarl. Very variable.

A. vulginis, L. (Comox Mugwort.) Leares mostly glabrons and yreen aloce, beneath and the luanches white-wolly, all pinuatifid, with the ivisions often cut-loberl, linear-lancenlate; licals small in open panicles.Waste places, near dwellings. (Arlv. from Eu.)

* Whensely uhite-tomentose percmial; heads lurge, racemose-glomerate.

9. A. Stelleriàna, Bess. Stout, $1-2^{\circ}$ highl, from i ereeping base; feaves uburate or spatulate, pinnatificl, the lobes obtuse. - Sandy sea-beaehes, E. Mass, locally nat. from N. E. Asia?

* * * Less branched $\left(1-3^{\circ}\right)$, biennial or anmul, glabrous.

10. A. biénnis, Willd. Strict, $1-3^{\circ}$ high ; lower leaves twice-pinnately parted, the upper pimatifid; lobes linear, acute, in the lower leaves cuttouthed; heads in short axillury spikes o clusters, crowled in a narrow and glonerate leafy panicle. - Gravelly banks, Ohio to'Tenn., Mo., and northwestward; rapidly extending eastwatrd hy railroal to Buffalu, l'hilarlelphia, ete.

A. Axyc 1, L. Tall, much brancherl; lcaves 2-prinnately divided, the oblong scgments deeply pinuatifid; hearls small, in a lonse ample panicle. - Ind. to kian. (Nat. from ()], Wrorld.)

\$3. Receptacle hairy: flourers all fertile, the marginal ones pistillate.

A. Ansfriutu, 1, (Wormwood.) Rather shrubly (2-30 high), silky. loary; leaves 2-3-pinnately parted, lobes lanceolate; heals hemispherical, panicled. - lioadsides, escaped from gardens. (Arlr. from liu.)

11. A. frigida, Willd. I ow $\left(6-20^{\prime}\right.$ high $)$, in tufts, slightly woody at the base, white-silly ; leares pinnately parted and 3 -5-cleft, the divisions narrowlinear; hearls chlulose, lacemose. - Iny hills and rocks, sask. to Minn., W. l'ex., and westw:ul.

\section{TU S S I L À G O, 'Touru. CoLtsFoot.}

Head manc-flowered, ray-flowers in several lows, narrowly ligulate, pistillate, fertile; ilisk-flow's with undivided style, sterilr. Involucie nearly simple.

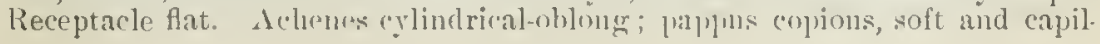


lary. - A low perennial, with horizontal creeping loulstorks, sending np simple scaly seapes in early spring, bearing a single lieud, and producing roundedheart-shaped angled or toothed leaves later in the seatson, woolly when yonng: Flowers yellow. (Name from tussis, a cough, for which the plant is a reputed remedy.)

T. FÁrfarı, I. - Wet places, and aloug brooks, N. Eng., N. Y., and Penn.; thoroughly wild. (Nat. from En.)

\section{PETASITES, Tourn. Sweet Coltsfoot.}

Heads many-flowered, somewhat dicecious; in the snbsterile plant with a single row of ligulate pistillate ray-llowers, and many tubular sterile ones in the disk; in the fertile plant wholly or ehiefly of pistillate flowers, tnbular or distinctly ligulate. Otlerwise as 'l'ussilago. - l'eremial woolly herlss, with the leares all from the rootstock, white-woolly beneatl, the scape with sheathing scaly bracts, bearing heads of purplish or whitislı fragrant flowers, in a

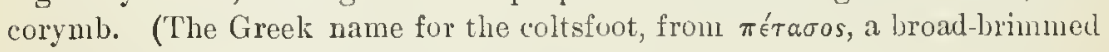
hat, on account of its large leaves.)

* Pistillate flowers ligulate; flowers whitish.

1. P. palmàta, Gray. Leares ronnded, somewlat kidney-form, palmately and deeply 5-7-lobed, the lobes toothed and cut. (Nardosmia palmata, / Kook.) - Swamps, Maine and Mass. to Mich., Minu., and northwestward; rare. A pril, May. - Full-grown leaves 6-10' broad.

2. P. sagittàta, Gray. Leaves deltoil-oblong to reniform-hastate, acute or obtuse, repand-dentate. - N. Minu. and westward.

$$
\text { * Ligules none; flowers jurplisl. }
$$

P. vulaAris, Desf. Rootstock very st.mit: leaves round-cordate, angulatedentate and denticulate. $-\Lambda$ bout Philadelphia. (Nat. from En.)

\section{4. Á R N I C A, ].}

Heads many-flowered, radiate; rays pistillate. Scales of the bell-shaped involucre lanceolate, equal, somewhat in 2 rows. Receptacle flat, fimbrillate. Achenes slender or spindle-shaped; pappus a single row of latler rigid and strongly ronghened-denticulate lristles. - Perennial herbs, chiefly of mountains and cold northern regions, witl simple stens, hearing single or corymled large heads and opposite leaves. Flowers yellow. (Name thought to be a corruption of Ptarmica.)

1. A. Chamissonis, Less. Softhairy ; stem leafy $\left(1-2^{\circ}\right.$ high $)$, hearing 1 to 5 heads; leaves thin, veiny, smoothish when old, toothed; the npper outelanceolate, closely sessile, the lower narower, tipering to a margined petiule: scales pointed; pappos almost plumose. (A. mollis, IIook.) - N. Maine, mum-

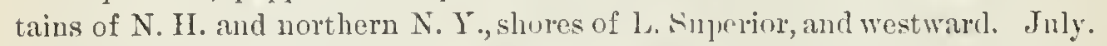

2. A. nudicaulis, Nutt. Ilairy and rather glandular $\left(1-3^{\circ}\right.$ high); leaves thichish, 3-5-nerved, ovate or oblong, all sfscile, mostly entire and near the root, the cauline small and only one or two pairs; heals several, corymbed, showy. - Damp pine barrens, S. Penn. and sonthwarl. A pril, May.

\section{SENECIO, Touru. GRol'NTs:L}

Ileads many-flowered; rays pistillate, or none: involucre cylintrical to bell. slaped, simple or with a few lina thets at the liase, the seales erect-eonnivent. 
Receptacle flat, naked. Pappus of numerous very soft and slender capillary bristles. - Herls, in the Luited States, with alternate leaves and solitary or corymbed heads. Flowers chiefly yellow. (Name from senex, an old man, alluding to the hoariness of many species, or to the white hairs of the pappus.)

* Root annual or in n. 3 biennial; heads severul or many in a corymb; herbage glabrous or soon becoming so.

+ Ruys none or minute.

S. velgaris, T. (Comuox Grovidesel.) Tow, corymbosely branched, clabrate; leaves pinnatifid and toothed; clasping tips of involucral scales Dlackish; ravs none. - Waste grounds. July-Sept. (Adv. from Eu.)

S. vicośs, L. Coarser, viscid-pubescent and strong-scented; leares 2piulutifid; scales not black-tipped; rays minute. - Waste gromnds, coast of N. Eng. (Nat. from Eu.)

\section{+- + Heads conspicuously radiate.}

1. S. lobàtus, l'ers. (ButTer-wEed.) liather tall; leaves somewhat fleshy, lyrate or pinnate, the divisions or leaflets crenate or cut-lobed, variable; heads small in a naked corymb; rays $6-12$, conspicuous. - Wet gronnds, $\boldsymbol{N}$. Car. to S. Ill., Mo, and sontliward. A pril-July.

2. S. palústris, Hook. Aunual or biennial, loosely woolly or glabrate; stem stout, $6^{\prime}-2^{\circ}$ high ; leares obloug-lanceolate, irregularly toothed or laciniate, the upper with a heart-shaped clasping base; rays 20 or more, short, pale yellow; pappus copious and beconing rery long. - Wet ground, Iowa to $\mathrm{N}$. Wise., Minm., and northward. June. (Eu.)

* Root perennial; heads small or middle-sized, in a nahed corymb.

3. S. aùreus, I. (Goldex Ragwort. Secaw-wed.) Smooth, or floccose-woolly when young $\left(1-3^{\circ}\right.$ high $)$; leaves thin, the radical simple and rounded, the larger ones mostly heart-sliaped, crenate-toothed, long-petioled; lower stem-leaces lyrule: upper ones lanceolate, cut-piunatifid, sessile or partly elasping; corymb umbel-like; rays 8-12. - Common everywhere. May, Jnne. Varies greatly.

Var. obovatus, Torr. \& Gray. Root-leaves tlicker, rumd-obovate with a cuneate or truncate base, or the earliest almost sessile iu rosulate tufts. ( $\mathrm{S}$. Elliottii, Tur. s. Gray.) - Open grounds, Can. to Ind. aud Ga.

Var. Balsámitæ, Torr. \& Gray. Less glabrate; root-leaves oblong, spatulate, or lancenlate, narrowed to the petiole, serrate, the upper ly rate-pinnatifid; heads rather small and numerous. - Common.

4. S. tomentòsus, Michx. (Woolur R.icwolit.) Clothed with scarcely

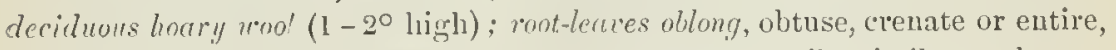
aften large, on elongated stunt petioles; the upper sessile, similar or ly ratepinnatifid; corymb llat-topped; lays 12-15. - Del. and mountains of l'enn. (I'mish.), to lila. and $A$ ik. May.

5. S. cànus, llook. L'sually low, persistently tomentose, rarely at all glabrate; leaves much smaller, spatulate to oblong, all entire or some cuttoothed or pinnatifil; achencs glabrous. - N. Miun., N. Dak, and westward.

6. S. integérrimus, Nutt. Woolly pubescent when yomng, sorn glahrate and green; leaves ohlong-lanceolate or oblong, entire or denticulate, the ipper bract-lik', attenuate from a broal basc; lieads ratliel large $\left(6^{\prime \prime}\right.$ ligh), witl grrent-tipled scales. — Sask. to Minn., and westward. 
7. S. lùgens, Richards. Like the last; leaves usnally repand- or callous. tenticulate; heals usually smaller, with mostly black-tipped scales. Z Subare. Amer. to New Mex., in the monntains; reported from Minn. and N. Iowa.

$$
\text { * * lioot peremiul; heads large and often solitary. }
$$

8. S. Pseùdo-Árnica, less. Lousely white-woolly, sometimes becoming glabrons; stem stont, $6-12^{\prime}$ high, leafy to the top ; leaves oblong, repand, tapering into a narrow petiole-like base; heads 1-4, orer an inch in diameter; rays 20 or more, large. - Grand Manan Island, off Maine (Prof. V'rrill), to Lab., and northward.

\section{Ca C À lia, L. Indian Plantain.}

Heads 5-many-flowered; the flowers all tubular and perfect. Inrolueral seales in a single row, ereet-connivent, with a few bractlets at the base. lieceptacle naked. Corolla deeply 5-cleft. Achenes obloug, smooth; pappus of numerous soft capillary bristles. - Smooth and tall perennial her bs, with alternate often petioled leaves, and rather large heads, in flat corymbs. Flowers white or whitish. (Au aucient nane, of nueertain meaning.)

* Involucre 25-30-flowered, with several bracts at its base; receptacle flat.

1. C. suavèolens, L. Sten grooved $\left(3-5^{\circ}\right.$ highl $)$; leutes triungulurianceolate, halberd-shaped, pointed, serrate, those of the stem on winged petioles. - Rich woods, Comn, to Mich., Iowa, and sonthward; rare. Sept.

* * Intolucre 5-leaced and 5-floreved, its bracts minute ar none; receptacle bearing a more or less ecident scule-like pointed appendage in the centre.

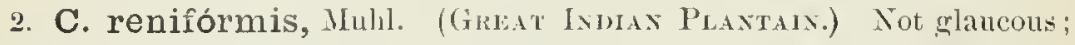
stem $\left(4-9^{\circ}\right.$ highl) grooverl and angled; leares green both sides, diluted funshaped, or the lourest lidhey-furm ( $1-2^{\circ}$ broull), repand-loothed and angled, palmately reined, petioled; the teeth pointed; corymls. large. - Rich damp woods, N. J. to 111., Minn., and sulthward along the monutains. Aug.

3. C. atriplicifólia, I. (PAll; Ixmax I'.) Cilancous; stem terete $\left(3-6^{\circ} \mathrm{high}\right)$; leaves palmately reind and angulate-lobed, the lower triangularkidney-form or slightly heart-shaped, the upner rhomboil or wedge-form,twothed. - Rich woollands, western N. Y. to Wisc., Minn., and sonthward. Ang.

4. C. tuberòsa, Nutt. (Temeror's Ixurux P.) Stem angled and grooved $\left(2-6^{\circ}\right.$ highl), lrom a thick or tuberous root; leutes green both sides, thick,

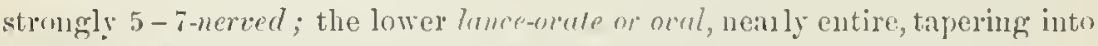
loug petioles; the upper on short margined petioles, snmetimes toothech at the apex. - Wet prairies, etc., Ohio to Wise, Mimm., ant southward. June.

\section{ERECHTITES, Ral. Fineween.}

Heads many-flowered; the flowers all ubbular and fertile; the marginal pistillate, with a slender corolla. Sicales of the cylindrical involucre in a single row, linear, acute, with a few small hractlets at the base. lieceptaele nakerl. Achemes ollong, tapering at the end; pappons copious, of very fine and white soft hairs. - lirect and coarse annnale, of rank smell, with alternate simple leares, and paniculate-corymberl heals of whitish flowers. (The ancient name of some species of GromdseI, probably (alled alfer Firchtheus.) 
1. E. hieracifolia, Raf. (FrREwElu.) (Jten hairy; stem groover $\left(1-6^{\circ}\right.$ ligh $)$; leaves lanceolate or oblong, acute, cht-tootled, sessile, the upper auricled at base. - Moist woods ; common, especially northward, and in recent clearings that have been burned over; whence the popular name. July - Sept.

\section{8. ÁRCTIUM, К. Bundock.}

Ileals many-flowered; flowers all tulular, perfect and similar. Involucre crlobular; the imbricated scales coriaceous and alpressed at base, attenuate to long stiff points with hooked tipns. licceptacle loristly. Achenes oblong, tlattened, wrinklerl transfersely; japjus short, of numerons rongly loristles, sepa-

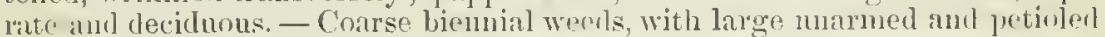
leaves, and small solitary or clusteral heads; flowers purple, ralely white. (Name probably from ápkros, "brete, from the rough involucre.)

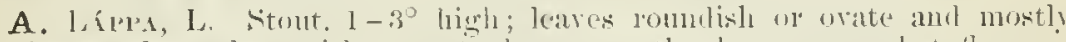
curdate, or lanceulate with cuneate hilse, smonth above, somewhat flocrosetomentuse beneatli, mustly simnate-denticulate. (Lappat officinalis, A/l.) 'The several reputerl species of the gents are scarcely distinguishable even as

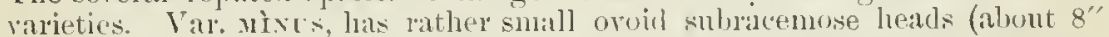

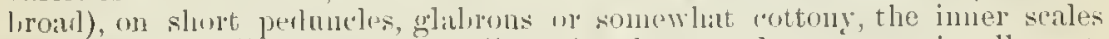
somewhat purplish-tipuol, equalling the flowers; leaves ocusionally cut-

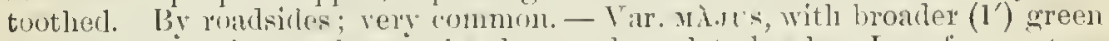
and glabrous sulacorymbose iather lung-pedunculate lieals. Less hrequent. Vau, romurosisu, it form of the last with more spherical webhed heads, with purplish scales shorter than the flower's. Rare. - July-oct. (Nat. from Eu.)

79. C N I C U S, 'I'ourn.

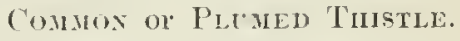

lleads many-fowered ; flowers all tnhnlar, perfect and similar, rarely inmerfectly diecions. Scales of the ovoil or splierical inrolncre imbricated in nuay. rows, tipper with a point or prickle. Recpltacle thickly clother with soft bristles or hairs. Achenes ol,ong, flattish, not ribled ; pappus of numerous Iristles united into a ring at the hase, plumose to the midlle, decidnous. llens, mostly biennial, witl sessile alternate lenves, often pinnatifid, prickly. Ileals usually large, terminal. Flowers reddish-purple, rarely white or yellowish; in slummer. (Latin name of the Saftuwer, from the Greek kvîkos.)

$$
\text { * Sirrles of the incolurre all liphed with spresuling prickles. }
$$

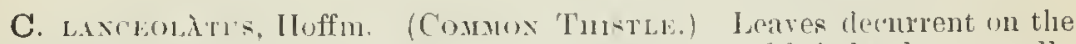
stem, forming puickly lohed wings, pinnatifil, rough and bristly above, woolly witl deciluous wchby hairs beneatl, prickly; Howers purple. (Cirsium, srop.) - Pastures aud roalsiles, everywhere, at the North. (Nat. from En.)

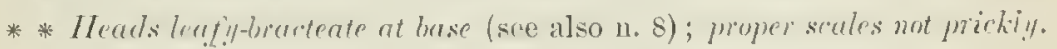

1. C. horrídulus, Pursh. (Yerum Tmstus.) Sitem stont (1 - $3^{\circ}$ highh)

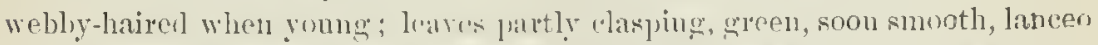
late, pinnatificl, the short tootlect ansl int luhes vely spiny with yellowish prickles; leals ( $1-1 \frac{y^{\prime}}{2}$ broad) surroumderl by hal-like and rery juickly bracts. which usually equal the narrow seales; fluwers pale yeilow or puple. (cirsium. Mich.r.) - Simuly fielels, Mass, to Vn., and sunthwarl, near the coast.

* * *eales appressed, the imner not at all prickly.

- Leaves white-roolly beneath, and sometimes also ahove: outer scales surcessively shorter, and tipped with short prichles.

2. C. Pitcheri, 'Torr. Whitercolly throughut, lew : stem very leafy, leaves all jimutrly parted inte rigid narrondy lineur und elungated, sometimes 
again pinnatifid divisions, with revolute margius; flowers cream-color. (Cir sium, Torr. of ( Gruy.) - Sandy shores of Lakes Michigan, Huron, and Superior:

3. C. undulàtus, Gray. White-woolly throughout, low and stout, leafy; leaves lanceulute-oldong, partly clasping, undivided, undulate-pinnatifid, or rarely pinnately parted, noderately prickly; flowers reldish-purple. (Cirsium, Spreng.) - Islands of L. Huron to Miun., Kan., aud westward. The heals vary much in size.

4. C. altissimus, Willd. Stem downy, branching $\left(3-10^{\circ}\right.$ high), lectif quite to the heads; leaves roughish-hairy above, whitened with close wool beneath, oblong-ovate to narrouly lunceolute, undivided, simuate-loothed, undulatepinnatifid, or twice pinnatifid, the lobes or teeth weakly prickly; heads $1 \frac{1}{2}-2^{\prime}$ high; flowers chiefly purple. (Cirsium, spreng.) - Fiells and copses, Mass. to Minn., and southward.

Var. discolor, Gray. Stem $2-6^{\circ}$ high; leaves nearly all deeply pinnatifid into lanceolate or linear lobes. (Cirsium discolor, Spreng.) - Common; N. Eng. to Ill., and southward.

5. C. Virginiànus, Pursl. Stem woolly, slender, simple or sparingly branched $\left(1-3^{\circ}\right.$ higli), the branches or long peduncles naked; leares lanceolute, green above, whitened with close wool beneath, ciliate with prickly bristles, entire or sparingly sinuate-lobed, sometimes the lower deeply sinuate-pinnatifid; heads small; outer scales scarcely prickly; flowers purple. (Cirsium, llich $x$.) - Woods and plains, Va., Ohio, and southward.

+ + Leaves green both sides, or only with loose cabueldy harrs underneath; heads large; scales scarcely prichly-pomted.

6. C. mùticus, Pursh. (Swamp Tristuz.) Stem tall (3-8 ligh), angled, smoothish, panicled at the summit; branches sparingly leafy, bearing single or few rather large heads; lenres somewhat hiary ahove, whitened with loose webby hairs beneath when young, deeply pimatifid, the dimsions lanreolate, aeute, cut-lobed, prickly-pointed; scales of the webly and glutinous (sometimes glabrate) involucre closely appressed, pointless or barely mucronate; flowers purple. (Cirsium, Mirhr.) - Swamps and low wools; common.

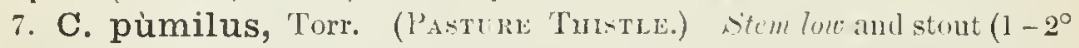
high), hairy, bearing $1-3$ rery linge hetds (1 $\frac{1}{2}$ lroad), which are often lenfybracted at the base; leaves yreen, lanceolate-oblong, partly clasping, someuhat

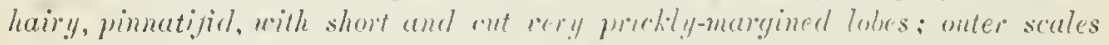
priclly-poimled, the innerery slender: fluwers purple ox rarely white (fragraut. 2 'long). (('irsinm, spromy.) - Mry' tielels, X. Fing, near the coast, to lenn.

**** Outer scales of the appressed involucre barely mickly-pminted; heads imperfectly dirrious, snall and numerous.

C. arvéxsis, Ifoffm. (Cixada Thrastu.) Perennial, slender, $1-2^{\circ}$ high, the roots extensively crepping; leaves obloug or lanceolate, smooth, or slightly woolly beneatl, simuate-pinnatifil, prickly-marequed; Howers mse-purple. (Cirsium, sirmp.) - Cultivatel ficlis, pastures, and roalsides, common; a nost tronblesome veed, extremely dificult to eralicite. (Nat. from ku.)

\section{C Á R D U U S, Tourn. Plumeless Tilstle.}

Bristles of the pajpus naked (not plumose), mere]y rongh or denticulate. Otherwise as in Cuicus. (The anciont Iatin name.) 
C. vưtaxs, I. (MIUsk Tuistle.) Biennial; leaves decurrent, sinuate, spiny; heads solitary, drooping; flowers purple. - Fields near Ilarrisburg, l'a., Prof. Purter. (Adv. from Eu.)

\section{O N O Pó RDON, Vaill. Cótrox or Scotch Tuistle.}

Receptacle deeply honeycombed, not setose. Pappus not plumose. Otherwise as Cnicus. - Coarse, branching annuals, or biemnials, with the stems winged by the decurrent hase of the lobed and toothed somewhat prickly leaves. lleads large; Howers purple. ('The aneient Greek name of the plint.)

O. Achisum. M, I. Stem $\left(2-4^{\circ}\right.$ high $)$ and leaves cotton-woolly; scales linear-awl-shaped. - Roadsides and waste places in the Atlantic States ; rather lare. July-Sept. (Adv. from Lu.)

\section{CENTA U R E A, L. Star-Tnistle.}

lleirls many-flowered; flowers all tubular, the marginal often much larger (as it were radiate) and sterile. Receptacle loristly. Involucre ovoid or globuse, imbricated, the scales margined ur appendaged. Achenes oboroid or ollung, attached ohliquely at wr wear the base; jappus setose or partly cliaffy or none. - llerbs with alternate leares aud single heads. (Named from the Centaur, Chiron, famous for lis skill in healing.)

* Achenes terete, 10-rlentate; pappus of 10 long bristles and 10 short inner ones.

C. BLEufors, L. Low branching annual, with clasping scarcely pinuatifil cut leaves, and lirge sessile leafy-bracted heads; flowers yellow. (Cnicus henedictus, i.) - lioadsides and waste grounds, S. Atlantic States; rare. (Adr. from Eu.)

* Achenes compressed or 4-angled: pappus rery short or none.

C. Cyaxs, L. (Butenotrt.e.) Scales of the glolular inrolucre fringemircrined; fulse ru!s: lump: linlpus very short; leaces linear, entire, or tonthed at the base; ront anmal. - linisisiles, escaped from garlens. July. - Hlowers blue, varying to purplish or white. (Aly. from Eu.)

C. Nigra, L. (lixipWErs.) ficales of the globular involucre appendaged, anl with a black pectinately ciliate fringe; rays wanting; papjus very short; lectes lanceolate, entire, or the lower lyrate-toothed, rough ; root pereunial. Wiste places, L. New Eng. Aug. - Flowers purple. (Adv. from Eu.)

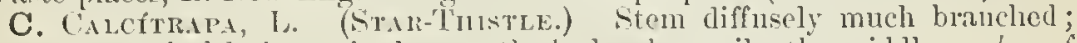
lmors pinnately lobed or spinulose-toothed; heads sessile, the middle scules of the oroid involucre spiny; papjus none; flowers purple; root annual. - Seaports, N. Y., and southwari. (Adr. from Eu.)

C. JACEA, L. Like the latst; heads ratler larger, the brownish scaleappendages lacerate; rays conspicuous, palmate. - Charlotte, Vt. (Pringle); near T. Y. , etc., on ballast. (Nat. from Lu.)

\section{L Á M P SA NA, Tourn. Niprle-wort.}

llemls 8-12-flowered. Seales of the cylindrical involucre 8 , erect, in one row. Receptacle naked. Achenes oljong; pappus none. - Slender branching aunuals, with angled or tonthor leaves, and loosely panicled sinall heads; Howers yellow. ('Tle $\lambda a \mu \psi \alpha \dot{\nu \eta}$ of I)iuscoricles was evidently a wild Mlustard.)

L. comurxs, L. Nearly smootl, $1-2^{\circ}$ light lower leaves ovate, sometimes ly re-shaped. - Roarsides, N. Ling. to N. Y. and L'enn. (Nat. from Eu.)

\section{KRÍGIA, Schreber. Dwarf Daxdelios.}

lleads seroral - many-flowered. Invulucral scales several, in about 2 rows, thin. Achenes short and truncate, top-shapell or columuar, terete ur angled; 
pappus double, the outer of thin pointless chaffy s'ales, the iuner of delieate bristles. - Small herbs, limuched from the hase; the leaves chicfly radical, lymate or tootled; the small lieads terminating the naked scapes or brauehes. Flowers yellow. (Nimed after D. Krieg, an early German hotanical coliector in this eountry.)

§i, KRIGIA proper. Adhenes turbinule, 5-angled; puppus of $5-7$ short roundish chaff' and as many alternating inistles. Immal.

1. K. Virgínica, Willd. Stems or scapes several (1 - lo' high), hecoming branched and leaty ; earlier leaves roundish aud entire, the others narrower and often pinnatificl. - New Eng. to Minn., and southward. April- Aug.

§2. CÝNTHLA. Achenes more slender: pappus of $10-15$ small oblong chaff and 1,i-20 bristles. P'erenniul.

2. K. Dandélion, Nutt. lioots slender, tuberiferons; scupes leafless, 6-18' high; leaves varying from spatulate-oblong to linear-lanceolate, entire or few-lobed. (Cyuthia, $L C$. $)$ - Moist ground, Md. tu lig., and southward. Narch - July.

3. K. amplexicảulis, Nutt. Konts fibrous; stem-leuers 1-3, ublong or oval, chasping. nustly entire; the radical oncs on short winged petioles, often toothed, rarely pimatifisl p peduncles $2-5$. (CJnthia Virginica, Don.) - Moist banks, Conn, to Minn., and southward. June, - Stem $1-2^{\circ}$ high.

\section{CICHORIUM, Tourn. Sirecoms or Cuscors,}

Heads several-flowered. Inrolucre domble, herbaceous, the inner of $8-10$ scales, the outer 5, slont and spealing. Achenes striate; papjus of numerous small cladfy scales, forming a short crown. - Branching peremials, with deep roots: the sessile healls g or 3 toretler, axillary atul terminal. Flowers bright hlur, varying to punple or pink, show. (Alterol from the Arabian name of the plinit.)

C. Axtruss, I. Stem-leares ohlong or lanceolate, partly clasping, the lowest runcinate, those of the rigin flowering hranehes minnt(', - lioalsiles; N. Eng. to Iowa and Minn. July-(1.t. (Nit. from Eu.)

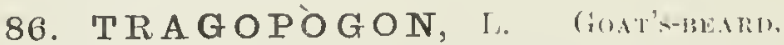

Ieals mamy-flowerod. Tnvolucres simple, of sereral erect lancenlate attonu ate equal realcs. Arbenes narmwly fusiform, 5-10-rib)ed, long-beaked;

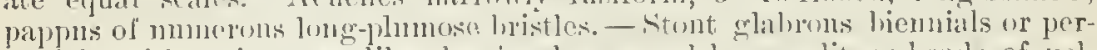

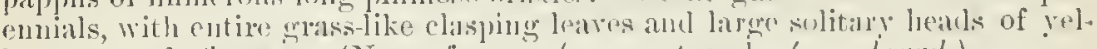

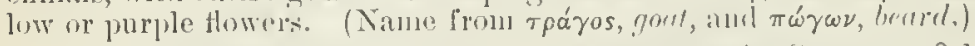

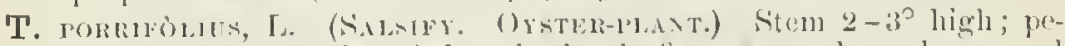
dumcle thickened and fistulons below the lead; flowers purple; achenes ant pappus $3^{\prime}$ long. - Sparingly escaped from cultivation. (Nat. from liu.)

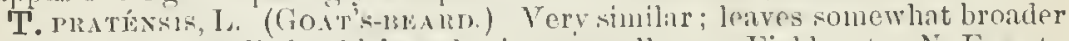
at base; penncle littlo thickenol; Hower's yellow. - Fields, ete. N. Eng, to N.J. and Mint. (Nit. from Iil.)

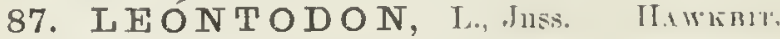

Heads many-flowered. Involncere scarcely imbricated, bnt with several bractlets at the base. Arlunes spiulle-shaper, striate, all alike; bappus persistent, composed of plumose bristles which al re enlarged and flattromel toward the base.

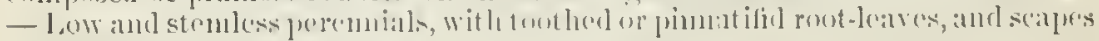


bearing one or more yellow heads. (Name from $\lambda \epsilon ́ \omega \nu$, a lion, and óôoús, a tooth, in allusion to the toothed leaves.) - The following belongs to the subgenus (Irontist, witl a tawny papjus of a single row of equal liristles.

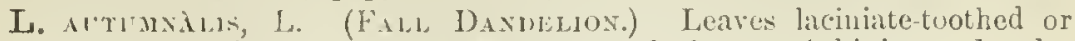
pimnatifi, somewhat pubescent; scape branched, 5-15' lighl ; peduncles thickened at the summit, scaly-bracteate. - Meadows and roadsides; N. Eng. to Penц. Juue-Nov, (Nat. from Eu.)

\section{PÍCRIS, L.}

Heads many-flowered, terminating leafy stems. Outer scules loose or spreading. Aclienes terete, with 5-10 ringuse ribs; pilppus of 1 or 2 rows of plumose bristles. - Coarse rough-bristly anumals or bienuials, with yellow Howers. (The Greek mane of some illied bitter herb, from $\pi$ เkpós, Lifter.)

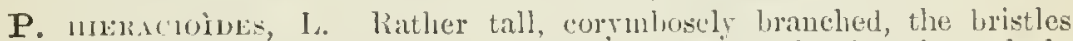
somewhat harbel at tip; leaves lanceolate or broader, clasping, irregularly toothed; achenes oblong, witl little or no beak. - Sparingly introdnced. (Nat. from Lu.)

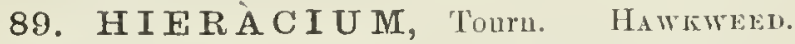

Heads 12-many-flowered. Involucre more or less imbricated. Achenes short, oblong or columwar, striate, not heaked ; pappus a single row of tawny and fragile capillary rough bristles. - IIispid or hirsute and often glandular perenuials, with entire or toothed leaves, and single or panicled heads of mostly Yellow flowers; summer and early autumn. (Nane from í́pak, a hark.)

\$1. Involucre not much imbricate, scarcly calyculate; achenes oblong; papmus not copions.

H. uravthacum, I.. Low, long-hirsute, above hispid and gltudular, the involucral hairs dark; leaves all near the hase of the simple pertuncle; heads "lustered; flowers deep, orange to lamc-color. - Roadsides and fields; N. Jing. to N. Y. (Nat. from Eu.)

H. PRARLTI, Vill. Glaucons, $2^{\circ}$ ligh, only the base and lanceolate leaves hairy; heads in an open cyme; flowers yellow. - N. New York ( $W$ crd $)$. (Nat. from Eu.)

\$2. Ileads large; involucre irregularly imbricated; achenes columnar; pappus copious, uncqual.

H. múnósum. T. Stem stape-like, low; leaves owal or oblong, obtuse, toothed towarl the suleorrlatr bise; lieads few, dark-glandular. - Open woods near Brooklyn, N. Y. (Nat. from Eu.)

1. H. Canadénse, Michx. Stems simple, leafy, corymbed at the summit $\left(1-3^{\circ}\right.$ high); leaves sessile, linceolate or ovate-oblong, acute, remotely and very eoarsely toothed, somewhat hairy, the nppermost slightly clasjing. - Dry woods, N. Eng. to I'enu., Mimn., and nortliward.

\$ 3. Ileads small ; inmlurre cylindrical, scarrely imbricatcd.

* Achenes columnar, not ultemute upurard when muture; panicle not virgute.

2. H. paniculàtum, 1 . , sem slender, lent!l, diffusely branrlicd, hairy only below $\left(1-3^{\circ}\right.$ highl $)$; leaves lanceolate, acnte at loth curk, slightly tootherl, smootly; hearls (rery small) in a lonse prmirels, on slcurler aud diverg ing perlicels, 12-20-floncred; achenes short.-0)en worsh; ratler common.

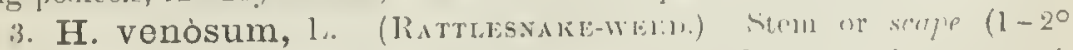

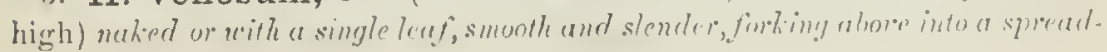


inu loose cor:/mb; leaves all radical or near the base, obovate or oblong, nearly entire, scarcely petioled, thin and pale, purplish and glancons underneath (often haily along the midrib), marlsed above with purple veins; pedicels very slender; involncre 12-35-flowered; achenes linecur. - Dry plains and pine woods; common from the Atlautic to Minu. and Iowa.

4. H. Marianum, Willt. Somewhit lecefy, $2-3^{\circ}$ high, hairy below; leares obovate-oblong, narrowed below, the radical petiolate, rarely purplishreiny; heads 20 -40-flowered in a very opeu cymose panicle, the slender inflorescence eommonly uhitish-tomentulose and sparingl!y glundular-hispid. - Open woods and clearings; R. I. to western N. Y., and sonthward. - Var. SPAтнLLAtum, Gray, a mountain form with leares all or mainly radical and very liairy. On Two-top Mountain, l'enn.

5. H. scàbrum, Michx. Stem rather stont $\left(1-3^{\circ}\right.$ higli $)$, leafy, roughhairy, the stiff panicle at first racemose, at length rather corymbose; the thickish perlicels and the hoary $40-50$-flowered involncre densely clotlied with dark glantlular bristles; leaves obovate or oval, nearly entire, hairy. - Dry open woods; common.

* * Achenes tapering upward; heads 15-30-flowered in a narrow or virgate panicle.

6. H. Gronòvii, L. (InArny 11.) Stem wand-like, mostly simple $\left(1-3^{\circ}\right.$ high), leaf!l and very hairy below, nuked above and forming a long and narrow panicle; leaves oblong or obovate, nearly entire, hairy; slender peduncles and involncre sparingly glandular-bristly; achenes with a cery taper summit. - Dry sterile soil; eommon, especially sonthward.

7. H. longípilum, Torr. (Lovg-bearned II.) Stem wand-like, simple, stout $\left(2-3^{\circ}\right.$ ligh), ver!l leaf!n tonerd the base, naked above, and bearing a small racemed panicle; the lower portion and both sides of the oblong-lanceolate or spatulate entire leaves thickly clothed with rery long and upright bristles (often $l^{\prime}$ long); peduncles and involucre glanduliu-bristly; achenes narrowed at the apex. - Prairies, Mich. to Minı., and sonthwestward.

\section{CRËPIS, L.}

Involncre few-many-flowered, commonly of a single row of equal scales, often becoming thickened at base. P'appus copious, white aud soft. $\Lambda$ unuals or biennials, not piluse. Otherwise as llieracium. (The Greek name of some plant, from $\kappa p \eta \pi i s, a$ s(mdel.).

C. BıÉxsis, L. Somewhat pulescent, $2^{\circ}$ highl, leafy ; leares runcinate-pinnatifil ; heals rather large, corymbose; achenes ollong, glabrous. -Vt., Mlass. ; rare. (Nat. from liu.)

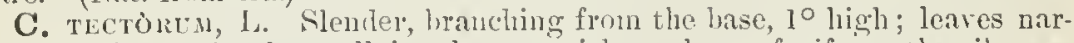
row, runcinate; heads small, in a loose pinicle; achenes fusiform, the ribs scabrons. - In fichls, Lansing, Mich., and on ballast. (Nat. from Eit.)

\section{PRENánthes, Vaill. Rattlesiake-root.}

Heads 5-30-fowerel. Involucre cylintrical, of 5 to 14 linear scales in a single row, and a few small bractlets at hase. Achenes slort, linear-oblong, striate or grooved, not contracted at the ajex. l'alputs of copions straw-color or brownish and rough (apillary bristles. - l'eremilat herlss, with upright leafy stems arising from spinulle shapol (extremely bitter) tubers, very variable 
leaves, and racemose-pauicled mostly nodding heads. Flowers greenish-whito or yellowish, often tinged with purple; late summer and autumu. Our species belong to the subgenus Nábalus. The original European species has soft

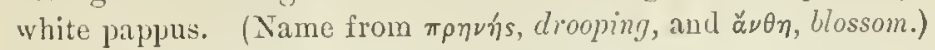

* Heads rather broad, 25-35-flowered, in a corymbose panicle.

1. P. crepidínea, Michx. Somewhat smooth; stem stout $\left(5-9^{\circ}\right.$ high), bearing numerous nodding heads in loose clusters; leaves large (6-12' long), broadly triangular-ovate or halberd-form, strongly-toothed, contracted intc winged petioles; pappus brown. (Nabalns, DC.) - Rich soil, Penu. and western N. Y. to Miun., aud sonthward. - F'lowcrs creant-color.

* Heads nurrow, 8-15-flowered, in a long raceme-like or thyrsoid inflorescence. stems simple; cauline leaves sessile; pappus straw-color.

- Inflorescence mbescent, strict; heads nearly erect, 12-15-flowered.

2. P. racemósa, Michx. Stem $2-50$ high, smooth and glaucous, as well as the oval or oblong-laneeolate denticulate leaves; the lower tapering into winged petioles (rarely cut-pinnatifil), the upjer partly clasping; lieads in crowled clusters ; flowers purplish. (Nabalus, DC.)-P'lains, N. Maine to N. J., Mo., and northward. - Var. PIxxatfrios, Gray, the leaves all lyrately pinnatifi.l. llackensack marshes, N.J.

3. P. áspera, Michx. Stem $2-4^{\circ}$ high, rough-puliescent, as well as the oval-oblong or broadly lanceolate toothed leaves; upper leaves not clasping; heads in small clusters; flowers larger, cream-color. (Nabalus asper, Torr. $\&$. Gray.) - Dry prairies and harrens, Ohio to Iowa, and southward.

+- Whole plant glabrous; heads nodding, 8-12-flowered; thyrse looser.

4. P. virgàta, Michx. (Slender Rattlessuke-root.) Slightly glaucons; stem $2-4^{\circ}$ high, prolonged into a naked and slender spiked raceme (1 $\frac{1}{2}-$ $2^{\circ}$ loug); hearls clinstered and mostly unilateral; leaves lanceolate, acute, closely sessile, the upper reducel to bracts, the lower toothed or piruatifid; involucre (purplish) of about 8 scales. (Nabalıs, DC.) - Sandy pine barreus, N. J. to Va., aud sonthward.

5. P. Mainénsis, Gray. Stem $2^{\circ}$ high, leafy; leares as in n. 2, but the radical ovate and more abriptly narowed to the short petiole; heads persistently drooping on slender pedicels. - St. Johu's River, N. Maine (Pringle). Perhaps a hybrid between n. 2 and 7 .

* * Ileads 5-18-flowered, racemose or paniculate, commonly pendulous: leaves varialle, mostly petiolate, the lower cordate or truncate or hastate at base.

+ Involucre cylindrical; scales scarions-margined, the onter very short, appressed.

+ Pappus reddish-broun; stem tall, generally purplish.

6. P. álba, L. (White Litucce. Rattlessine-root.) Simoothand glaucous $\left(2-4^{\circ}\right.$ high); stem corymbose-panicled at the smmmit: leaves angulate or triangular-halberd-form, sinuate-tnothed or 3 -5-clcft, the uppermost oblong and undivided; involucre (purplish) of alout 8 scales, 8-12-flowered (Nabalus, 11 ook.) - Burders of rich woots; common, especially northward.

++ + Puppus dirty struer-elor or uhitish; leners rery variable.

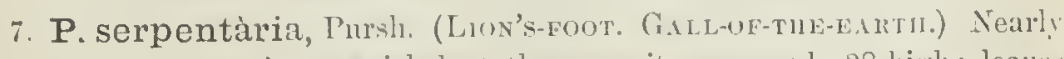
smoutl; stem corymbose-panicled at the summit, ('ommonly 20 high; leaver 
mostly deltoid, roughish; the lower variously 3 - 7-lobed, on nurgined petioles, the upper oblong-lanceolate, mostly undivided, nearly sessile; involncre (greenish, rarely purplish, sometimes slightly bristly) of alout 8 seales, $8-12$-flowered ; flowers purplish, greenish white, or cream-eolor. (Nabalus Fraseri, $D C^{\prime}$.) - Dry samery or sterile soil, New Eng. to Va., and sunthward.

Var. nàna, Gray. Stem inure simple and strict, $6-16^{\prime}$ high, smooth and glabrous: influrescence coutracted, the clusters often sessile in most of the

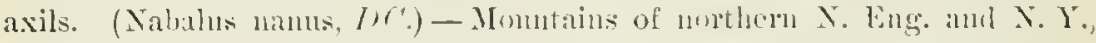
and uortheastwarl.

8. P. altissima, L. Smontl ; stem tall and slenter $\left(3-7^{\circ}\right.$ high $)$; the hears in small axilliny and terminal loose clusters forming a long and wandlike leafy panicle; leares memlırnnacems, all petioled, orate, heart-shaped, or triangular, and merely toothed or cleft, with naked or winged petioles, or frequently 3-5-parted, with the divisions entiro or again eleft; involnere slender (greenish), of 5 scales, 5-6-flowered. (Nahalus, /look.) - Rich moist woods; N. Eug. to Minn., and southwarl in the monntains to Ga.

4- + Inrolucre cumpanulate-oblong; secondary basul secules 2-3, hmear, loose.

9. P. Boottii, Gray. Stem simple, dwarf (5-6' high), pubeseent at the summit; the heads in an alnost simple racene; lowest leaves halberl-shaped or heart-shaped, the middle oblong, the upper lanceolate, nearly entire, tapering into a margined petiole; involnere (livid) $10-18$-flowered, the proper scales $10-15$, very obtuse; pappus straw-color. - Alpine region, mountaius of Maine, N. H., and N. New York.

\section{L Y GO DÉ S II A, Don.}

Heads and flowers $(5-10)$ nearly as in Nabalus; the cylindrieal involucre more elongaterl, and the achenes long and slender, tapering at the summit: pappus whitish. - Smooth, often glaucous, low perenuials, with single elect heads of rose-purple flower's terminating almost leafless or rush-like stems or

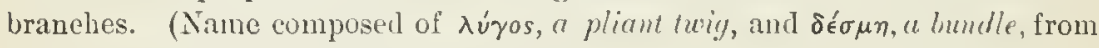
the fascicled twiggy or rusli-like steus.)

1. L. júncea, Don. Stems $\left(1^{\circ}\right.$ hig $\left.h_{1}\right)$ tufted, loranelıed, striate; lower leaves lanee-linear, $1-2^{\prime}$ long, rigid, the upper awl-shaped and minnte, heads 5-flowered. - St. Croix River, Wise, to Kan., and westwarl. July.

\section{TRÓXIMON, Nutt.}

Head large, solitary, many-flowererl. Scales of the bell-shaped involuere ovate or laneeolate, pointel, looscly imbricated in 2 or 3 rows. Achenes smooth, 10-ribled, with distinet beak a none. jappus longer than tho achene, white, of copious and mequal rigid capillary hristles. - T'erennial scapose lerbs, with olmgated linear tufterl root-loaves, and yellow Howers. (Name

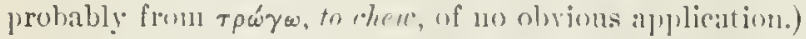

1. T. cuspidatum, I'ursh. S'ape $1^{\circ}$ lighl, from a thickener candex, leaves lancenlate, elongated, tilpering to a sharp point, entire, woolly on the margius; scales of the inwolnere linconlate, sharp-pointed; achene beakless - Prairies, Wisc., N. Ill., and westwarl. April. May. 
2. T. glaùcum, Nutt. Seape $1-2^{\circ}$ high; leares linear to lanceolate, entire to dentate or laciniate; head often pubescent or villous; achene longbeaked. - Minn. to Neb. and sontluwestward.

\section{T A R Á X A C U M, Haller. Daxielion.}

llead many-Howerel, large, solitary on a slender hollow scape. Involucre louble, the onter of short scales; the inner of long linear scales, erect in a single row. Aclenes ollong-ovate to fusiform, 4-5-ribled, the ribs roughened, the apex prolonged into a very slender beak, bearing the eopious soft and white capillary pappls. - l'ereunials or biennials; leaves radical, piunat. ifid or runcinate; flowers yelluw. (Name from $\tau a \rho \alpha \sigma \sigma \omega$, to disquiet or dismeler, in allnsion to medicinal furoperties.)

T. OFficisile, Weber. (Comnox I) Wrinliox.) Simooth, or at first pubescent; onter involucre reflexed. ('T. Dens-leonis, Desf.) - P'astures and fields everywhere. Intigenous forms occur northward and in the locky Mountains. A pril-Sept. - After hlossoming, the inner intolucre closes, and the slender beak elongates and raises up the pappus while the fruit is forming; the whole involucre is then reflexed, exposing to the wincl the naked fruits, with the pappus displayed in an open globnlar head. (Eu.)

\section{PYRRHOPÁPPUS, DC. False Danithox.}

Heads, etc., neturly as in Taraxacum, but the soft pappus reddish or rustyeolor, and surrounded at base by a soft-villons ring. - Nostly anmual or biennial herbs, seapose or often branching and leafy below. Heads solitary, terminating the naked summit of the stem or branches. Flowers deep yellow. (Name

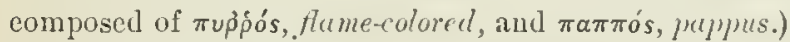

1. P. Caroliniànus, DC. Annual or biemial, stem branching $\left(1-2^{\circ}\right.$ high); leaves ollong or lanceolate, entire, cut, or pinnatifid, the stem-leares partly clasping. - Sandy fields, from Mirylant soutluwarl. April-July.

2. P. scapósus, I)C. Low, scapose, peremnial by roundish tubers; leaves all radieal, pinnatifu. - Prairies; Kan. to 'Tex.

\section{CHON DRÍLLA, Tourn.}

Heads few-flowered. Involnere cylindrical, of several narrow linear equal scales, ancl a row of small bractlets at hase. Achenes terete, sereral-ribbed, smooth below, roughened at the summit hy little scaly projections, from among which springs an alurupt slender beak; jappus of copious very fine and soft capillary bristles, bright white. - Herlss of the ()ld World, witl waud-like branching stems, and small heads of yellow flowers. (A mame of Dioscorides for some plant which exudes a gum.)

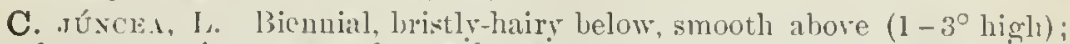
root-leaves runcinate; stem-leaves few and small, linear; heads scattereil on nearly leaHess hranches, $6-s^{\prime \prime}$ lonis. - Ficlds and roadsides, abundant in Md. and northem Va. Aug. (As. from Eu.)

\section{L A C T Ù C A, Tourn. Lettuce.}

Heads several-many-flowered. Involucre crlindrical or in fruit conical; scales imbricaterl in 2 or more sets of unequal lengtls. Achenes flat (obcompressed, parallel to the scales), ahnptly contracted into a beak, which is dilated w the apex, bearing a copinus and fugacious very soft and white capiliary pap- 
pus, its bristles falling separately. - Leafy-stemmed herbs, with panicled heads; Howers of variable color, produced in summer and autumn. (l'le ancient name of the Lettuce, L. sativa; from lac, nilk, in allusion to the milky juice.)

§ 1. SCARIOLA. Achenes very fat, orbicular to oblong, 1-nerved on each face, with a filiform beak: biemnial or annual; cauline leaves sagittate-clasping.

L. Scariola, I. (Prickly Lettrce.) Stem below sparsely pricklybristly, as also the midrib on the lower face of the ollong or lanceolate spinulose-denticulate verticai lcaves; panicle narow; heals sulall, (j-l-12-flowered; achenes striate. - Waste grounds and roadsicles, Atlantic States to Mo. and Minn. (Adv. from Eu.)

1. L. Canadénsis, L. (WViln Létтuck.) Mlostly tall $\left(4-9^{\circ}\right.$ higlı), very leafy, smooth or nearly so, glancons; leaves 6-12' long, pale beneath, mostly sinuate-pinuatifid, the npper lancenlate and entire (rarely all but the lower narrow and entire); heads abont 20-flowered, $3-6$ " long, numerous, in longr and narrow or diffuse panicles; flowers pale yellow; aclene oval, rather longer than the beak. -- Rich damp soil, borders of fields or thickets; common.

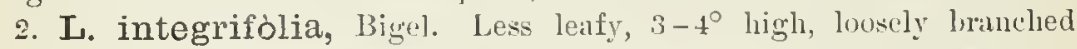
above or heads loosely panicled; leaves mulivided, oblong-lanceolate, pointed, denticulate or entire; flowers yellow or purplish. (L. Canaclensis, var. integrifolia, Torr. \&. Gray.) - N. Eng. to [ll., and southwa'd.

3. L. hirsùta, Muhl. Rather few-leaved, $2-3^{\circ}$ high, commonly hirsute at base; leaves hirsute both siles or only on the millib, mostly runcinate-pinnatifid; heads in a loose open panicle; achenes oblong-oral, abont as long as the beak; flowers yellow-purple, rarely whitish. (I. Canadensis, var. sanguinea, Torr. \&. Gra\%.) - E. Mass. to Minn., and southward.

4. L. Ludoviciàna, 1)C. Glabrous, leafy, $2-5^{\circ}$ high ; leares oblong, sinnate-pinnatifil and spinulosely dentate, ciliate; heads in an open panicle; involncre more imbricate; flower's ycllow. - Minn., Iowa, and southwestward.

§ 2. LACTLCÁSTRUMI. Achenes flut, lanceolate-oblong, tapering to a short slender beuk; perennial; flowers blue.

5. L. pulchélla, DC. P'ale or glancons; stem simple, $1-2^{\circ}$ highr; leares sessile, oblong- or linear-lanceolate, cutire, or the lower runcinate-pin natifid; heals few and large, racemose, erect on scaly-bracted perlnncles; in. volucral scales imbricated in 3 or 4 runks. (Mnlgedium, Nutt.) - Upper Mich. to Minn.; commou on the plains westward.

\$3. MULGiDDLII. Achenes thickish, oblong, contracter into a short thick beak or neck; ; umnual or biemial: flowers chiefly blue.

6. L. acuminàta, Gray. 'Tul] hicmial $\left(3-7^{\circ}\right.$ ligh $)$, witl mauy smali heads in a loose panicle, on diverging perluncles; leaves ovate to oblong-lan. ceolate, pointed, shaply and sometincs donl,ly seruate, sometimes hairy on the mitril, beneatl, contractes into a winged petiole, the lowest occasionaliy sinuate or cleft at base, and the cauline sagittate or luastate; achenes beakless; pappus white. (Mulgedinm, DC.) - Burders of woods, N. Y. to Ill. and Fla.

7. L. Floridàna, Gicrtn. Leaves all lyate or runcinate, tlie upper often with a heart-shaped chapung hase; lanicle larger; aclomes distinctly

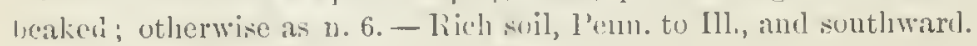


8. L. leucophæaa, Gray. Nearly smouth bienuial; stem tall $\left(3-12^{\circ}\right.$ ‘.ghlı), very laafy; leaves irregularly pimatifid, sometimes runcinate, coarsely tootlied, the upjer cauline sessile and auriculate, sometimes clasping; lieads in a large and dense compound panicle; flowers bluish to cream-culor; achene short-beaked; jappus tawny. (Mulgedium, I/C.) - Low grounds; rather common. - Var. intarifóla, Gray. Leaves undivided, or the lower sinuate-pinnatificl. Ohio to Ill.

\section{SÓ N CHUS, I. Sow-Turstle.}

Heads many-flowered, hecoming tumil at base. Iuvolucre more or less imbricateal. Achones obcompressed, ribbed or striate, not heaked ; pappus copious, of very white exceedingly soft and fine bristles mainly filling together. - Leafystemmed coarse weeds, chiefly sulooth and glaucous, with corymbed ol unbellate heads of yellow flowers; jroduced in summer and antumn. (The ancient Greek name.)

$$
\text { * Annual }\left(1-5^{\circ}\right. \text { high); fincers prile yellow. }
$$

S. oreracrus, T. (Commox Sow-Tustrl.) Sitem-leaves runcinate-pinnatificl, or rarely undivided, slightly toothed with soft spiny teetl, clasping by a heart-shaped hase, the auricles acute; involucre downy when young; achenes striate, also wrinkled transtersely. - Waste places iu nanmed soil and aromnd flwellings. (Nit. from Eu.)

S. Ás'er, Vill. (S'm,i-Leaven S.) Stem-leaves less divided and more spiny-toothed, the anricles of the clasping base rounled, achenes marrined, $3-$ nerved on each side, smootl. - With and like the last. (Nat. from Fu.)

* * Perennial, with creeping rootstocls; flow'rs bright yellow, m lnige heads.

S. ARvéxsis, L. (FELL S.) Leaves runcinate-pinnatifil, spiny-tootled, clasping by a heart-shaped base; peluncles and involucre liristly; achenes transversely wrinkled on the rilss. - Roadsides, ete., N. Eng. and N. Y.; becoming more common. (Nat. from Eu.)

\section{Order 56. LOBELiACEA. (Lobelia Famiz.)}

Herbs with acrid milky juice, alternate leaves, and scattered flowers, an irregular monopetalous 5-lobed corolla. the 5 stamens fiee fiom the corolla, and united into a tube commonly by their filaments and always by their anthers. - Calyx-tube adherent to the many-seeded pod. Style 1; stigma often fringed. Seeds anatropous, with a small straiglit embryo, in copious albumen. - Nearly passing into the following order.

\section{LOBELIA, L.}

Calyx 5-cleft, witl a short tube. Corolla with a straight tube, split down on the (apparently) upper side, somewhat 2-lipped ; the upper lip of in rather crect lobes, the lower lip spreading and 3 -cleft. Tro of the anthers in our species bearded at the top. Lod 2-celled, many-seeded, opening at the top. - Flowers axillary or chiefly in lracted racemes; in summer and early autumn. (I)edicated to Matthias De l'Obel, an early Flemish herbalist.)

$$
\text { * Flowers deep red, lurge: stem simple. }
$$

1. I. cardinalis, L. (CARDixat-1.owre.) Tall $\left(2-4^{\circ}\right.$ high), smoothish; leares oblung-lanceolate, slightly toothed; racene elongated, ratlicr l-sided, the pedicels much shorter tban the leaf-like bracts. - Low grounds, common 
- Perennial by offsets, with large and very showy intensely red flowers, vary. ing rarely to rose-color or even white. Hybrids with the next species alsu wecur.

$$
\text { * Flovers blue, or blue rariegated with white. }
$$

- Flowers vather large (corolla-tube 5-6" long), spicate-racemose; stems leafy, $1-3^{\circ}$ high ; perennial.

$\rightarrow$ Leaves ovate to lanceolate, numerous; lip of corolla glabrous.

2. L. syphilítica, L. (Gris Loвец.1.) Sumewhat hairy; leaves thin, acute at both ends (2-6' long), irregularly serrate; flowers (nearly $\mathrm{l}^{\circ}$ long) pedicelled, longer than the leafy bracts; callyx hirsute, the simuses uith consprcuous deftexed aurcles, the short tube hemisplerical. - Low grounds, common. - Flowers light blue, rarely white.

3. L. pubérula, Michx. Finely snft-pubescent; leaces tlickish, obtuse $\left(1-2^{\prime}\right.$ loug), witlı small glandular teetlı; spike rather 1-sided; hracts orate; inuses of the caly. $x$ with short and romeded or often inconspirums auricles, the iniry tube top-shaped. - Noist sandy gronnds, N. J. to Iowa, and sonth to Tex. and Fla. - Cornlla bright blue, $\frac{1}{2}$ long.

4. L. amœna, Miehx. Clubrous or nearly so; raceme virgate; leares narrower; hw'ts lanceolate or linear, often glandnlar-dentienlate; calyx-lobes long and very slender, usually withont auricles, the tube glabrous. $-\mathrm{S}$. Atliutic States, in swampis. - Var. glandefífera, Gray; a slonder form with seeund raceme, oval to lance-ollong ohtuse glani-toutherl leaves, and the bracts and calyx-teeth heset with slender wland-tipped teetl. S. Va. and soutliward.

+ + Leares long and narrom, syerise abore: lip of corolla pubescent at base.

5. L. glandulosa, Walt. Glabmus, or sparingly pubescent; leares, lracts, and nsually the lohes of the ealyx, strongly glandnlar-tonthed; ealy xtube densely hispiil, marely sparsely so or smoothish, the sinuses not anriculate. -Pine-barrell swamps, S. Va. to Fla.

$$
\text { + + Flowers smaller (corolla-tube not more than 2-3"long). }
$$

- Stem lenfy, mostly simple, continued into an elongated virgate spike-like raceme: leures lanceolate to obrowate, lurely denticu'ute or repand.

6. L. leptóstachys, A. DC. Sinooth ahove; leaves obtuse, denticulate, oblong-lanceolate, the mper gradually reduced to anl-shaped hracts; calyxlobes nearly equalling the corollis, with 10 roflered aw-shtuped appendages as long as the hemespherical thlie. _- Sandy soil, Olio to Ill. and MLo, also Va. (t) Gia.

7. L. spicàta, Lam. Strm slmuler, struet ( $1-4^{\circ}$ high) from a biemial (?) root, helow and the barely denticulite lenves minutely pubesenut; lower and root-leares olovate or spatnlate, the npper redured to linear or club-shaped bracts; calyx-tulse short, obeonical or heroming almost hemispherieal, sinuses not appendayerl. - Moist or dry, mostly gravelly or sandy soil, N. New Eng. to Sask, sonth to Ark. and La. Fl. througl sumuer. - Var. P.srvifLón, Gray, a small form, with ealyx-lohos hroarly sulmlate, and pale eorolla but $3^{\prime \prime}$ long. Swamps, Laneaster, l'enn. (l'orter); lecginning to flower in Jnue. -Var. murtílds, Gray; with somewhat seahrous puleserence, and minutely hirsuteciliate brats aul malyx-lohes. Cliefly towarl and hẹoml the Mississippi. 
$\rightarrow \rightarrow$ Stem leufy, often panieulately branched; flowers looscly racemose ; sinuses of calyx not appendaged; annual or bienmial.

= Leares chiefly linear, entire or denticulate; pod not inflated.

8. L. Cánbyi, Gray. Stem strict $\left(1-2^{\circ}\right.$ high 1$)$, minutely angled; pedirels shorter than the bracts and flowers, minntely rouglened under a lens; bractlets none; calyx-tube top-shaped, acule at base, only lulf the lcngth of the lobes (which, with the linear leares, are sparsely glandular-denticulate), in finit hecoming oblong, covering the whole pod; corolla deep blue (fully 5 "l long) more or less bearded in the throat. - Wet places, N. J., Del., and S. C.

9. L. Kálmii, L. Stem mostly low $\left(t-18^{\prime}\right.$ ligh $)$, minutely angled; pedicels filiform, not exceeding the linear or setaceous bructs but as long as the floxcer, minutely 2-bracteolate or 2-glandular above the middle; calyx-tube top-shuped or uboroid, fully half the length of the lobes, in fruit rather longer than ther, corering the whole pod; corolla light blue, $4-5$ " long. - Tet limestone rocks and banks, N. Eng. to I. WVinnipeg, sonth to P'enn., Ind., and Minn.

10. L. Nuttàllii, Roen. \& Scluult. Stem very slender $\left(1-2^{\circ}\right.$ high $)$, terete; pedicels mostly longer than the bract and shorter than the flower, usually with very minute bractlets near the base; calyx-tube very short, dcpressedhemespherical in fruit, the globular pod half free; corolla pale blue, barely $3^{\prime \prime}$ long. - Sandy swamps, N. .J. and P'enn. to Ga.

$==$ Leares orate or oblong, obtusely toothed; pod inflated, wholly inferior.

11. L. inflàta, I. (Ixpr.x Top.ıcon.) Stems paniculately much branched from an aumal ront, pubescent with spreadiug hairs $\left(1-2^{\circ}\right.$ ligh $)$; leares gradnally diminishing into leaf-like hracts, which exceed the lower short-pedi. celled fluwers; ealyx-tube oroid. - Dry open fields. - Corolla only $1 \frac{1}{2}-2$ " long. Plant poisonous and a noted quack medicine.

+++ Stcm scape-like, mostly simple, hollow ; leaves fleshy; fibrous-rooted peremnials, very glabrous, mostly aqnatic, with pale blue or whitish flowcrs.

12. L. paludòsa, Nuntt. Nearly smooth; stem slender (1-4 higls); leares fat, scattered near the base, finear-spatulnte or oblong-linear, glandulardenticnlate, mostly tapering into a petiole; lower lip of eorolla bearded in the milldle; calyx-tube about lalf the length of the short lobes, hemispherical in fruit. - In water (but foliage emerged), Del. to Fla. and La.

13. L. Dortmánna, L. (Watre Lobria.) Very smooth; scape thich1sh (5-12' high), fer-flowered; leates all tufted at the mot, linear, terete, hollow, with a partition lengthrwise; lower lip of cornlla slightly hairy; calyx-tube ahout as long as the lobes, in fruit much longer. - lowrlers of ponds (often immersed), N. Fing. to N. Penn., L. Superior, and northward. (En.)

\section{Order 57. Campanuláceas. (Campanula Famiy.)}

IIerbs, with milky juice, altcrmate leaves, and scattered flouecrs. calyx allherent to the orary; the regular 5-lubert corolla bell-shaperl, valuate in the lud ; the 5 stumchs usually fire from the corcllu and distinct. - Sityle 1, nsually heset witl collecting lairs aluve; stignas 2 or more. Capsule 2 - screral-rellerl, miny-sected. Seed small, anatropous, with a straight (mulnero in fleshy alhunen. Flowers generally blue and slowy. 


\section{SPECUIÀRIA, Heister. VENL's Looking-glass.}

Calyx 5-(or 3-4.) lobed. Corolla wheel-shaped, 5-lobed. Stamens 5, sepa. rate; the membranaceons hairy filameuts shorter than the anthers. Stignas 3. Capsule prismatie or elongated-oblong, 3-celled, opening by 3 small lateral valves. - Low annuals, with axillary blue or purplish flowers, in $\Lambda$ merican species dimorphous, the earlier being cleistoganous. (Name from Speculum Veneris, the early name of the eommon European speeies.)

1. S. perfoliata, A. DC. Somewhat hairy $\left(3-20^{\prime}\right.$ high $)$; leavcs roundish or ovate, clasping by the hcurt-shaped base, toothed; flowers sessile, solitary or 2-3 together in the axils, only the upper or later ones having a conspicuous and expanding corolla; capsile ollong, short, straiglet, opcning ruther below the middle; seeds lenticular. - Stcrile open ground; common. May-Angr.

2. S. leptocárpa, Gray. Minutely hirsute or nearly glabrous (6-12' high) ; leaves lanceolute, with flowers closely sessile in their axils; calyx-lobes of lower flowers 3 ; capsule nearly cylindrical $\left(6-9^{\prime \prime}\right.$ long, $1^{\prime \prime}$ thick), inclined to curve, opening by one or two uplifted valves near the summit; seeds oblong. W. Mo. and Ark. to Col. and W. Tex. Expanded eorolla 6-9" wide.

\section{CA $\mathbf{M}$ PÁ N U LA, Tourn. Bellflower.}

Calyx 5-cleft. Corolla generally bell shaped, 5-lobed. Stamens 5, separate; the filaments broad and membranaceous at the base. Stigmas and cells of the capsule 3 in our species, the short porl opening on the sides by as many valves or holes. - Herbs, with terminal or axillary flowers; in summer. ( $A$ diminutive of the Italian campana, a bell, from the shape of the corolla.)

* Style straight; openings of capsule below the middle.

- Coarse pubescent many-flowcred European species, sparingly naturalized; perennial.

C. Rapunceloines, I. Smoothish, slender, erect; stem-leaves ovate-laneeolate, pointed, the lower long-petioled and heart-shaped; flowers nodding, single in the axil of bracts, furning racemes; corolla oblong, $\mathrm{I}^{\prime}$ long. - Roadsides and fields, Canadin and N. Jing. to Penu.

C. gloumata, L. (Clusterki B.) Somewhat hairy, stont and erect, $1^{\circ}$ ligh; stem-leaves oblong or laneeolate, corlate-clasping; flowers sessile, clustered in the upper axils, forning a leafy head; corolla open-bell-sliaped, 1' long. - Roadsides, E. Mass.

+ - Slender perennals, mostly glabrous; flowers one or few, on slender peduncles.

1. C. rotundifòlia, I. (Harebell.) Slender, branching $\left(5-12^{\prime}\right.$ high), i-10-flowered; root-leaves round-lieart-shaped or ovate, mostly toothed or crenate, long-petioled, early withering away; stem-leaves numerous, linear or nur. sowly lanceolate, entire, smooth; calyx-lobes awl-shaped, from $\frac{1}{8}$ to $\frac{*}{3}$ the length of the brigint-bine corolla (which is $6-9^{\prime \prime}$ long); capsule nodding. - liocky shaded banks, throughout the northem part of our range, and sonthward in the mountains. $-\Lambda$ delicate and pretty species, but with a most inappropriate name, since the round root-leaves are rarely obvious. (Eu.)

Var. árctica, Lange. Stems more upright and rather rigid, lowest leaves spatulate; the very slender calyx-lobes soon spreading or deflexed ; corolla $3-I^{\prime}$ long. (C. rotundifolia, var. linifolia, of Man.) - Shores of the Great Lakes, and northward. (Eu.) 
Var. velutina, DC., has the whole herbage canescently pubescent. Sand-hills of Burt Lake, Mich. (E. J. Hill).

2. C. aparinoides, l'ursh. (Mursi Bellflower.) Stem simple and slender, weak (8-20' high), few-flowered, somewhat 3-angled, rough backward on the angles, as are the slightly toothed edges and midrib of the linear-lanceolate leares; peduncles diverging, slender; lobes of the calyx triangular, half the length of the bell-shaped nearly white corolla; capsule erect. - Wet grassy grouncls, througlrout onr range. With somewhat the habit of a Galium.

3. C. divaricàta, Miclix. Very smooth; stem loosely branched ( $1-3^{\circ}$ highl1); leaves oblong-lanceolate, pointed at both euds, coursely and sharply twothed; flowers numerous on the branches of the large compound panicle; "alyx-lobes awl-sluaped, about lialf the length of the pale-blue small corolla ( 3 " long); style exserted. - Dry wooks and rocks, mountains of Va., E. Ky., and southwarl.

* * Style declined and upwardly curved, much longer than the rotate corolla; openings of the cupsule close to the summit; inflorescence spicate.

4. C. Americàna, L. (Thli Bellelower.) Annual; stem mostly simple $\left(3-6^{\circ}\right.$ high $)$; leaves ovate and ovate-lanceolate, taper-poiuted, serrate, mostly on margined petioles, thin, somewhat lariry $\left(2 \frac{1}{2}-6^{\prime}\right.$ long); spike $1-2^{\circ}$ long; corolla light blue, 1' broad. - Moist rich soil, western N. I. to Minn., south to Ga. and Ark.

\section{Order 58. EricícEAe. (Heath Family.)}

Shrubs, sometimes herbs, with the flowers regular or nearly so; stamens as many or twice as many as the 4-5-lobed or 4-5-petalled corolla, free fiom hut inserted with it: anthers 2-celled, commonly appendaged, or opening ly terminal clunks or pores, introrse (exeept in Suborler 3); style 1 ; ovary 3-10-celled. Pollen compound, of 4 united grains (exeept in Suborler 4). Seerls small, anatropous. Embryo small, or sometimés minute, in tleshy albumen. - A large family, very various in many of the charaeters, eomprising four well-marked suborders, as follows:-

Suborner T. Vaccinieae. (Whortuaberr Famir.) Calyxtube adlenent to the ovary, which forms an edible berry or berry-like fruit, crowner with the short calyx-teetl. Anther-eells opening at the apex. - Shrubs or somewhat wooly plants, with scaly buds.

1. Gaylussacia. Ovary 10-celled, with a single orule in eacl cell. Fruit a berried drupe with 10 slutll seed-like mutlets.

2 Vaccinium. Berry 4-5-celled (or imperfeetly 8-10-celled by false partitions), manysestecl. Antlicr-rells tapering upwarl into a tube.

3. Chiogenes. Berry 4-cellerl, mang-seeder, its summit fiee. Anther-cells not prolonged into a thbe, but earch 2-pointed. slencler truiling evergreen.

Subordar II. Ericincie. (Ileatir Famis proper.) Calyx free from the ovary. Corolla gamopetalous, rarely polypetalous, hypogynous. - Slirubs or small trees.

Tribe I. Al:RUTEA. Fruit indeliseent, a berty or drupe. Corollin deciduous.

+ Arctostaphylos. Corolla urn-shaped. Drupe berry-like, 5-10-seeded. 
Tribe II. ANDROMEDEA. Fruit a loculieidal eapsule (berry-like in D. 6). Corolla deciduous.

* Anther-eells opening through their whole length, not appendaged.

5. Epigrea. Corolla salver-shaped. Calyx of 5 separate dry and lointed sepals.

* Antlier-eclls opeuing only at the top. Corolla not salver-shaped.

+ Calyx becoming enlarged and berry-like in fruit.

6. Gaultheria. Calys 5-cleft, in fruit cnclosing the eapsule. Antliers t-awned at top. + + Calyx dry, not becoming fleshy after fowering.

++ Corolla urecolate to eylindrical, 5-toothed; not heath-like.

7. Andromeda. Calyx valvate and very early open, naked. Capsule globular. Seeds mostly hanging on the eentral plaeenta.

8. Oxydendrum. Calyx short, early open, naked. Capsule oblong-pyranidal. Sceds all aseendiug. A small tree.

๑. Leueothoe. Calyx slightly or nuch imbricated, naked or bibracteate Corollia eylindraceous. Capsule delressed, 5-jobed, the valves entire.

10. Cassandra. Colyx of rigid imbricuted ovate sepals, bibracteate. Corolla cylindraecons. Capsule splitting wheu ripe into au outer and imer liyer, the inner of 10 valves.

+* ++ Corolla eampanulate, $t-5$-lobed or -parted; heath-like, with acerose inbricatel leaves.

11. Cassiope. Calyx of ovate imbricated sepals. Capsule globular-oroid, $4-5$-valved, the valves ?-cleft.

Tribe III. ERICE E. Corolla persistent, becomiug scarious. Capsule septividal.

12 Calluna. Corolla bell-shaped, 4-partel. Leaves minute, oplosite, imbricate.

Tribe IV. RHODODENDIEAE. lruit a septicidal eapsule. Corolla deciluous.

* Anther-eells opening by a loole or ehink at the tol.

- Flowers not from sealy buds; the bracts leaf-like or coriaceous.

19. Bryanthus. Corolla orate or uru-shaped. Leaves nurrow and heath-like.

14. Kalmia. Corolla broadly bell-shaped or wheel-shaped, with 10 pouches receiving as many anthers. Leaves oblong or linear.

+o + Flowers developed from large sealy buds, the scales or bracts eaducous.

15. Menziesia. Corolla globular-bell-shaped, 4-toothed. Stamens S. Leaves deciduous.

16. Rhododendron. Flowers usually 5-merous. Corolla bell-sliaped or funnel-form, lobed or liurted, often somewhat irregnlar. Leaves decidnons or evergreen.

17. Ledum. Corolla regular, all 5 petals nearly se jarate. Stameus $5-10$. Leaves evergreen.

* * Anther-cells opening lengthwise. Leaves evergreen. But-seales firm and persistent.

18. Leiophyll nm. Cornlla of 5 separate petals Stamens 10 , exserted.

19. Loiseleuria. Corolla deeply 5-cleft. Stamens 5, ineluderl.

Suborder III. Pyroleac. (PYrola Famis.) Calyx free from the ovary. Corolla polypetalous. Anthers extrorse in the bud, opening by pores at the base (inverted in the flower). Seeds with a loose and translucent cellular coat mueh larger than the nueleus.

Tribe I. CLETH REAs. shrubs or trees, with deeiduons foliage (in ours). Polleugrains simple. Capsule 3-celled.

20. Cletlura. Sepals and pretuls 5. Stamens 10. Style 3.cleft at the apex.

Tribe II. PYIOLEA. Herbs or nenty so, with evergreen foliage. Pollen-grains romponnd. Capsule 5- (rarely 4-) celled.

21. Chimaphila. Stems leafy. Flowers rorymbed or unbelled. Petals widely spreading. Style very short and top-shaped. Valves of the capsule smooth on the ediges.

22. Mroneses. Scape 1-flowercd. Petils widely sprending. Style strairltu, exserted; siignia snriyerl. Valves of the capmule smooth on the edges. 
-3. Pyrola, Amulescent. Flowers in a raceme. Petals not wirlely spreading. Filaments awl-shaperl. Styte long. Vatres of the capsule cobwebly on the erlores.

Suborder IV, Monotropere. (Indan-pipe Famluy.) Flow. ers nearly as in suborders 2 or 3 , but the plants herbaceuus, root-para sitic, entirely dustitute of green foliage, and with the aspect of Becch-drops. Seeds as in Suborder 3.

$$
\text { * Corolla monopetalous; anthers 2-celled. }
$$

24. Pterospora. Comolla ovate, 5-tootlied; anthers 2-awned on the back, opening lengtluwise. 25. Schweinitzia. Corolla broadly bell-slaped, 5-lobed; anthers npening at the top.

* * Corolla of 4 or 5 separate pretals; calyx imperfeet or bract-like

26. Monotropit. Petals narrow. Anthers kirney-shapech, opening ac'onss the top.

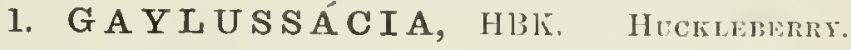

Corolla tubular, woid, or bell-shaped; the horler 5-eleft. Stamens 10 ; an. thers awnless; the cells tapering npward into noro or less of a tube, opening by a chink at the ent. Fruit a berry-like drupe, containing 10 seed-like nutlets. - Branching sluruls, with the aspect of Vaccininm, commonly sprinkled with rexinons dots; the flowers (white tinged with pmpple or red) in lateral and hracted racemes. (Naned for the distinguished clemist, Ciay-Lussac.)

* Lecures thich und evergicen, someuhat surrte, unt resmous-dotted.

1. G. brachýcera, Gray. (Box-IIocklabrar.) V'ery smooth (10 high); leares oval, finely erenate-toothed; racemes short and nearly sessile; pedicels rery short; corolla eylindrical-bell-shaped - Wooded hills, Perry Co., Penu, to Del. and Va. May - Leaves resembling those of the Box.

* Lorves decuduons, entire, sprintled more or less wuth resinous or waxy atoms.

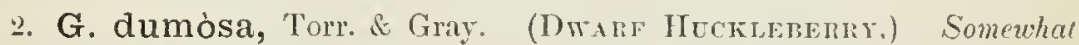
luiry and glandular, low ( $1-5^{\circ}$ high from a creeping base), bushy; leaves ob wate-oblong, mucronate. green bnth sules, rather thick and shining when old ricemes elongated ; Iracts leaflilie, oual, persistent, us lomg as the perlicels : orar"y lristly or glandular: corolla bell-klaped; fruit hlaek (insifid) - Var. mutéLLA has the young branchlets, racemes, aud of ten the leaves lairy - Sundy swamps. Newf., along the coist to Fla. and La.; the var. chiefly sonthwarl. Jume.

3. G. frondosa, Torr. \& Gray. (Bute Taxgle. I) axglibirk.) Smooth $\left(3-6^{\circ}\right.$ high); lranclies slender and divergent; leaves obovate-oblong, blunt, pale, ylancons beneath; racemes slender, loose, bracts oblong or linear, decidu. mos, shorter than the slender drooping pedicels; corolla globular-hell-shaped truit dark blue with a white bloom (sweet and edible) - Low copses, coast of X. Eng, and mountains of Penu, to Ky., sonth to La. and Fla. May. June

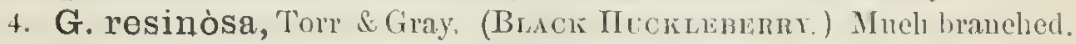
rigid, slightly meseent when young ( $1-3^{\circ}$ high) ; leaces oval, oblong-ovate, or obloug, thickly clothed aud at first clamm!n, ws well as the fowers, whe shmin!! resinous globules; racemes short, clustered, one-siled, pedicels about the length of the flowers ; bracts and bructlets (reddish) small and decuduous ; corolla oroid. conical, or at length eylindrical with an open mouth; fruit hlack, without bloom (plensant, very rarely white). - Rocky woodlands and swanps. Nenf to Minn. muth to N. Ga. May, June. - The eommon Hucklebery of the markets 


\section{V A CCín I U M, L. Buteberry. Bilmerry. Cramberry.}

Corolla various in shape; the limb $4-5$-cleft, revolute. Stamens 8 or 10 ; anthers sometimes 2-awned on the hack; the cells separate and prolonged upward into a tube, opening by a hole at the apex. Berry 4-5-celled, many-seeded, or sometimes $8-10$-celled by a false partition stretching from the back of each cell to the placeuta. - Shrubs with solitary, clustered, or racemed flowers; the corolla white or reddish. (Ancient Latin name, of obsenre derivation.)

§ 1. BATODÉNDRON. Corolla open-campanulate, 5-lobed; anthers with long tubes, and 2-awned on the back; berry (hardly edible) spuriously 10-celled; leaves deciduous but firm; flowcrs solitary or in leufy-bracted racemes, slender-pedicellcd.

1. V. arbòreum, Marshall. (FArkLe-Berry.) Tall (6-250 high), smoothish; leaves obovate to oblong, entire or denticulate, mucronate, luright green, shining above, at the south evergreen ; corolla white; anthers included; berries black, globose, small, many-seeded. - Sandy soil, S. Ill. to Tex., Fla., and N.C.

2. V. stamíneum, L. (Deerberry. Squaw Hichleberry.) Diffusely branched $\left(2-3^{\circ}\right.$ high), somewhat pubescent; leaves orate or oral, pale, glaucous or whitish underneath; corolla greenish-ulute or purplish; anthcrs mucle exserted; berries greenish or yellowish, globular or pear-shaped, largo, few-secded. - Dry woods, Maine to Miun., sonth to Fla. and La.

\$2. CYANOCOCCLS. (Buteberries.) Corolla cylindraceous to campanulate, 5-toothed; filaments luriry; anthers includcd, aunless; berry (sucet and edible) blue or black with bloom, completely or incompletcly 10-celled; flowers in firscicles or short raremes, short-pedicclled, appearing from large scaly buds with or before the leaves.

* Corolla cylindrareous when developed.

3. V. virgàtum, Ait. Low, more or less pulescent; leaves orate-ollong to cuneate-lanceolate, usually acute and minutely serrulate, thinnish, shining at least above; Hower-clusters sometimes virgate on naked loranches; corolla rose-color; berry black. - In swanps, south of our lange, but represented by

Var. tenéllum, Gray. Low form, mostly small-leaved, witl smaller nearly white flowers in shorter or closer clusters. - Va. to Ark., and soutluward. * Corolla shorter and brueder. (Tilueberias or Buce Huckileiberries.)

4. V. Pennsylvánicum, Jam. (Dwarf licikarerr.) Dwarf (6$15^{\prime}$ high), smooth, with green warty stems and hranches; leares lancedate or ablong, distinctly servulate with bristle-pomted tectl, smooth and shining hoth sides (or sometimes downy on the midril, underneath); corolla short, cylindriealbell-shaped; herries l,uish-black and glancous. - Dry hills, N. J. to Ill., north to Newf. and Sask. The lowest and earliest ripened of the blueherries. - Var. ANGUSTIFolidu, Gray ; a dwarfer high-mountain or northern form, with narrower lanceolate leaves. - White Mts. of N. II., Newf., and far northwarl.

5. V. Canadénse, Kalm. Low (1-20 high ); lerres oldong-lenceolate or elliptical, entire, douny both sidcs, as well as the crowled hranchlets; corolla shorter; otherwise as the last. - Swamps or moist woods, N. New Eng. to mountains of P'enn., Ill., Mivu., and morthward. 


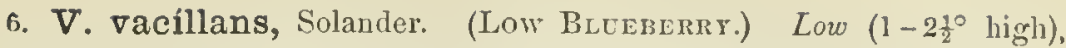
qlabrous, with yellowish-green branehlets; leaves obovate or oval, very pale or dull, glaucous, at least underneath, minutely eiliolate-serrulate or entire; eorolla between bell-shaped and eylindraceous, the month somewhat contraeted. - Dry places, especially in sandy soil, New Eng. to Mich. and Iowa, sonth to N. C. and Mo. - Berries ripeuing later than those of n. 4 .

7. V. corymbósum, L. (Common or Swanp-Bueberrry.) Tall (5$10^{\circ}$ high); leares orate, oral, oblony, or elliptical-lanceolate; corolla varying from turgid-ovate and cylindrical-uru-shaped to oblong-cyliudrical, $3-4^{\prime \prime}$ long. -Swamps and low thiekets, throughout our range and southward. This vields the common blueberny or blue luchleberry of the latter part of the season. 'The typical form has leares with naked eutire margius, and may be pubescent or glahrous (var. glìmom, Gray, Man.) Numerous gradations mite the following varieties:-

Var. amœnum, Gray. Leaves bristly-eiliate, shining above, green both sides, beneath somewhat pubeseent ou the veins. - Middle Atlantic States.

Var. pállidum, Gray. Leaves inostly glabrous, pale or whitish, gla neous especially underneath, serrulate with bristly teeth. - Common in the Alleghanies southwiard, mostly on the higher ridges.

Var. atrocóccum, Gray. The most distinet form; leaves entire, downy or woolly underueath eveu when old, as also the branchlets; berries smaller, black, without bloom. - New Lng. to l'enn.

§3. VACCINIUM proper. (Bilserieses.) Corolla ovate to globular, 4-5toothed; filaments glabrous; anthers 2-auned on the bach, inchuled; berry 4-5-celled; leaves deciduous; flowers on drooping pedicels, solitary or few together, appearing with or after the leaves; mostly glabrous.

* Parts of the flower mostly in fours; stamens 8.

8. V. uliginòsum, L. (Bog Bilberry.) Low and spreading $\left(4^{\prime}-2^{\circ}\right.$ high), tufted; leaves entire, dull, obovate or oblong, pale and slightly pubescent underneath; flowers single or 2-3 together from a scaly bud, almost sessile; corolla short, urn-shaped; berries black with a bloom, sweet. - Alpine tops of the high mountains of N. Eng. and N. Y., shore of L. Superior, aud northwestward. (Eu.)

* * Parts of the flower in fives; stamens 10 ; leaves membranaceous; flowers solitary on short axillary peduncles, norlding.

9. V. cæspitósum, Michx. Dwarf ( $3-6^{\prime}$ high $)$, tnfted, leaves obrarate, namowed at the base, smooth and shining, serrate: corolla oblong, slightly urnshaped; berries blue. - Alpine region of the White Mis., and high northward. - Var. cuneroulem, Nutt, is a foot high or less, bushy, witl cuneate-spatnlate leaves rounded at the apex, passing in one form to spatulate-lanceolate and aente. - Shores of I. Superior and westward.

10. V. myrtilloides, llook. Nlore erect, $1-5^{\circ}$ high; hranchlets somewhat angled; leaves mostly orate and acute or pointed, sharply and closely servulate, briglit green, nearly smootli; horder of the calyx alm st entire; corolla depressed-ylobular, rather large; berries large, black, rather acil. - 1)amp woods, shores of I. Superior, and northwestward. May, June. - Pedicels 3$6^{\prime \prime}$ long, drooping in flower, erect in fruit. 
11. V. ovalifölium, Snith. Straggling, $2-12^{\circ}$ high; leaves elliptical, obtuse, nearly entire, pale, mostly glancuns beneath, smooth; corolla ovoid, berries blue. - Peat-bogs, shores of L. Superior, and northwestward. May.

§4. VITIS-I1) ÀA. Corollu, berry, etc, as in $\$ 3$; filuments hairy; anthers. awnless; leaves coriaceous and persistent; fower's in clusters from separate buds, 4-merous (in our species); mostly glabrous; leaces 3-6" long.

12. V. Vitis-Idæa, L. (Conberry. Monjtaty Crayberry. FoxBERR 2.) Low ( $\left(6-10^{\prime}\right.$ high $)$; branchess erect from tufted creeping stems; leatres ohovate with revolnte margins, dark green, smooth and shining above, dotterl with blackish bristly points underneath; corolla bell-shaped, 4-cleft; herries rlark red, acil and rather bitter, edible when cooker. Coast and monntains of N. Eng. to X. shore of L. Superior, and far northwart. June. (En.)

\$5. OXYCóCCLs. Corolla derply t-pated or -cleft, with linear reftexed lobes; unthers exserted, awnless, with rery long terminal tubes; berry 4celled: flower's axillary or terminal, nodding on long filiform pedicels.

* Stem upriyht und leares deciduous, as in common Blueberries; flowers axillary and solitary; rorolla deeply 4-cleft; berries light red, turning purple, insipid.

13. V. erythrocárpon, Miclix. Smooth, divergently branched $\left(1-4^{\circ}\right.$ high); leaves oblong-lanceolate, taper-pointed, hristly serrate, thin. — Damp woods, higher Alleghanies, Va. to Ga. July.

* * Stems rery slender, creeping or truiling; leares small, cntire, whitened bcneath, evergreen; pedicels erect, the pale rose-colored flower nodding; coroller 4-parted: berries red, arid.-Cranierries.

14. V. Oxycóccus, L. (Simu. Cmaxberm). Stems very slender (4$9^{\prime}$ long) ; leness orrte, acute, with strongly revolute margins $\left(2-3^{\prime \prime} \mathrm{long}\right)$; pedicels $1-4$, terminal; filaments fully $\frac{1}{2}$ as long as the anthers. - Peat-logso, $x$. ling. and Penn. to Mimm., and nortluward. June. - Berry 3-4" lorotd, often spec(kled with white when young; seldom gathered for market. (En., A sia.)

1.5. V. macrocárpon, Ait. (Lamer or Americax Cranbirrr.) Stems elongated $\left(1-4^{\circ} \mathrm{long}\right)$, the flowering loranches ascencling; leares oblonm, obtuse. less revolute $\left(4-6^{\prime \prime}\right.$ long) ; pedicels several, locoming lateral ; filancuts scarcely one thirl the length of the anthers. - Peat-bogs, N C. to Minn., and crerywhere northwarl, hut scarcely westwart. June.-Berry $\frac{1}{2}-l^{\prime}$ loug.

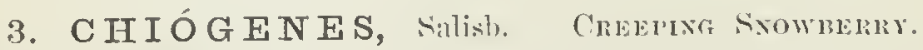

Caly-tube allerent to the orary ; limb 4-partel, persistent. Corolla hell shaped, deeply t-cleft. Stamens 8, includer, inserterl on an s-twothed disk.

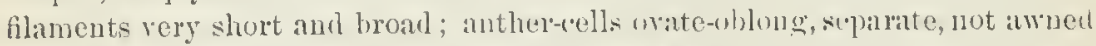
on the lack, but each minutely "2-pointed at the apex. and opening ly a large rhink down to the middle. Berry white, globular, rather dly, 4-celled, miny seeded. - I trailing and creeping evergreen, with rery slender and scarcely woody stems, and small Thyme-like, orate and pointerl leawes on short petioles. with revolute margins, smooth above, the lower surface and the hranches beset with rigicl rusty bristles. Fluwers rery small, solitaly in the axils, on short

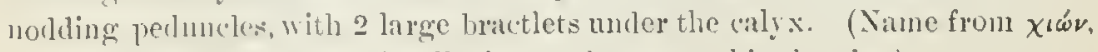

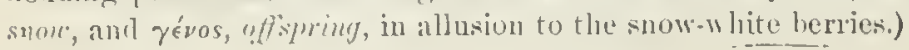


1. C. serpyllifolia, Salisb. Leaves $3-4$ "loug; berries 3 " broad, bright white. (C, hispirlula, Torr. \& Gray.) - Peat-bogs, and mossy woods, N. J. and Penn. to Minn., and nenthward; also southward in the Alleghanies to $\mathrm{N}$. C. llay. - Plant with the aromatie flarur of Gaultheria or sweet Bireh.

\section{A RCTOSTÁ PHYLOS, Nelans. Benrberm.}

Corolla orate and urn-shaped, with a slıort revolute 5-tuothed linb. Stamens 10 ,included; anthers with 2 reflexed awns on the back near the apex, opening hy terminal pores. 1)rupe berry-like, with 5 - 10 seed-like nutlets. - ilurubs, with alternate leaves, and sealy-bricted nearly white flowers in terminal racemes or clusters. Fruit austere. (Name eomposed of ápktos, a beur, am

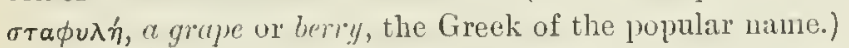

1. A. Ưva-úrsi, Spreng. (Bearbenur.) Trailing; leaves thick and evergreen, obovate ol spatulate, entive, smooth; fruit red.- Roeks and bare hills, N.J. and Penn. to Mo., and far north and westward. Maly. (Lu., Asia.)

உ. A. alpina, Spreug. (Alurixe Benriserry.) Dwarf, tufted and depressed; leaves deciduous, serrate, urinkled with strong netted veins, obovate: inut black. - Alpine summits in N. Eng., and high northward. (Arctic-alpino alound the world.)

\section{EPIG 势A, L。 Ground Euviel. Tranisg Arbutus.}

Corolla salver-form; the tube hairy inside, as long as the orate-lanecolate pointer and scale-like nearly distinct sepals. Stamens 10, with slender filaments; authers ollong annless, opening lengthwise. Style slender, its apex (as in Pyrola) forming a sort of ring or colliur aroumd and partly aduate to the i) little lobes of the stigma. Capsnle depressed-globnlar, 5-lobed, 5-celled, many-seeded. - I prostrate or trailing scarcely shrubby plint, bristly with rusty hairs, witl evergreen and reticulated lounded and hent-shaped alternate leaves, on slenter petioles, and with rose-colured flowers in small axillary rlusters, from sealy buats. (Name composed of $\epsilon^{\pi} i$, upon, and $\gamma \hat{\eta}$, the earth, flent the trailing growth.)

1. E. rèpens, 1. - Sumly works, or in rocky suil, especially in the shade uf pincs, Newt. to Minn., south to Fla., and Ky. - Flowers appearing in early spring, exhalling a rich spiey fragrance, dimorphous as to style and stamens inll suldiocious. In New Fingland called Mrifoower.

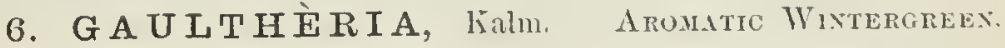

Corolla cylindrical-ovoid or a little mm-slated, 5-toothed, Stanens 10, inchuled; anther-cells each 2-awned at the sumnit, opening by a terminal pore. Capsule depressed, 5-lobed, 5-celled, 5-ral red, many-secded, cuclosed when rije hy the ealyx, which thickens and turns fleshy, so as to appent as a globnlar red herry! - Slurubs, or almost lierbaceous plants, with alteruate evergreen leaves and axillary (nearly white) flowers; peclicels with 2 bractlets. (Dedicated by Kalm to "Dr. Fralltier," of Quebee.)

1. G. procúmbens, L. (Creepixg Wistergreex.) Stems slender ind extensively creeping on or below the surfaee; the flowering branches as('mulines, leafy at the smmmit (3-5' high) ; leares obovate or oval, obseurely wrate; Howers few, mostly single in the axils, nochling. - Cool danp woorls, 
mostly in the shade of evergreens, Maine to Minn., aud southward to N. Ga. : also far northward. July. - The bright red berries (formed of the calyx) and the foliage have the well-known spicy-aromatic flavor of the Sweet Birch. Usually called Wintergreen, or sometines in the interior Tea-berry. Lastward it is often called Checkerberry or Purtridge-berry (names also applied to Mitch. ella, the latter especially so), also Boclerry.

\section{A NDRÓ MEDA, I.}

Calyx withont bractlets, of 5 nearly or partly distinct sepals, valvate in the bud, bnt very soon separate or open. Corolla urceolate (in ours), 5-toothed. Stamens 10; anthers fixed near the middle, the cells opening by a terminal pore. Capsule globular, 5-celled, 5-ralverl; the many-seeded placenta borne on the summit or middle of the columella. Seeds pendulons or spreading. Shrubs, with nmbelled, clustered, or panicled and lacemed (mostly white) Howers. (Fancifully mamed by Linnaus in allusion to the fable of a ndromeda.)

* Anthers auned; capsule more or less glubose; leves thick and evergreen.

1. A. polifolia, L. Glabrous, 6-18' high; leares linear to lanceolateoblong, strongly revolute, white beneath; flowers in terminal numbels; pedicels from axils of persistent scaly bracts; each anther-cell with a slender terminal ascending awn. - Wet bogs, N. J. and Penn. to Minn., and northward.

2. A. flolibúnda, Pursh. Very leafy, 2-6 high; young branchlets, etc., strigose-lıairy; leaves lancevlate-oblong, acute ol acuminate, ciliate-serrulate, glindular-dotted beneath ( $\left.2^{\prime} \mathrm{long}\right)$; rucemes crouded in short terminal panicles, densely flowered; each anther-cell with a slender deflexed awn on the back.-Moist hillsides, in the Alleghanies from Va. to Ga.

* Anthers aunless; capsule 5-angled, with a thickened riage at the dorsal sutures; leares thimish and deciduous.

3. A. Mariana, L. (StagGer-bush.) Mostly glabrous, 2-4 high, lcares olloug or oval $\left(1-3^{\prime} \mathrm{long}\right)$; frscicles of nodling flowers racemcse on

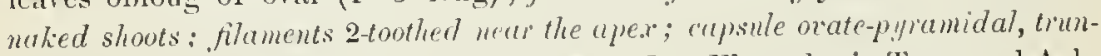
rate at the contracted apex. - Low grounls, R.I. to Flit.; also in 'Teun. and Ark. Foliage said to poison lambs and calves.

4. A. ligustrina, Inhl. Wimuty pubescent, 3-10 high; leares obo vate to lanceolate-oblong $(1-2$ ' long), serrulate or entire; racemes croucled in nuked or leafy panicles; filaments flat, not appendaged; capsule globular.Wet grounds, Canada to Fla. and Ark. - Var. Pubiscexs, Gray, is a form with dense soft pubescence, - Va. to Ga.

\section{OXYDENDRUM, DC. Somkt-TREF. Sovr-Wood.}

Calyx withont bractlets, of 5 almost distinct sepals, valvate in the bul. Corolla ovate, 5-toothed, puberulent. Stamens 10; anthers fixed near the hase, linear, awnless, the cells tapering upwarl and opening by a long chink. Capsule oblong-lyramidal, 5-celled, 5-valved; the miny-sceded placenta at the base of the cells. Sceds all ascending, slender, the thin and loose reticulited coat extended at both euds into awl-shaped appeudages. - A tree with deciluons, oblong-lanceolate, pointed, soon smooth, scrulate leaves, on slender petioles, and white flowers in long ontesided racemes clustered in an open pan 
icle, terminating the branches of the season. Bracts and bractlets minute, leciluous. Foliage acid (whenee the uame, from ógús, sour, and $\delta \epsilon^{\prime} \delta \rho \delta_{\nu}, t r e c$.)

1. O. arboreum, I)C. 'Tree $15-40^{\circ}$ high; leaves in size and shape like those of the peach. - Rich wools, from Peun. to Ind., aud southward, mostly along the Alleghanies, to Fla. June, July.

\section{LEUCÓTHOË, 1)on.}

Calyx of 5 nearly distinet sepals, imbricated in the bud. Corolla ovate or cyliudraceous, 5-toothed. Stamens 10 ; authers uakert, or the eells with 1 or 2 erect awus at the apex, opeuing by a pore. Capsule depressed, more or less 5-lohed, 5-celled, 5-valved, the sutures uot thickened; valves entire; the many. seeded placentre borne on the summit of the short eolumella. Seeds mostly pendulous. - Shruls with petioled and serrulate leaves, and white scaly-bracted Howers in dense axillary or terminal spiked raeemes. (A mythological uame.)

* Anthers awnless; stigma 5-raycd ; racemes scssilc, dense, with persistent bracts, in the axils of thick and shining evergreen leaves; caly $x$ not bracteolate.

1. L. axillàris, Don. Leaces lanceolate-oblong or oval, abruptly pointed or aeute, somewhat spinulose-serrulate, on very short petioles; sepals broudly ocute. - Low grounds, Va. to Fla. and Ala. Feb. - A pril. - Shrub $2-4^{\circ}$ high.

2. L. Catesbæ̀i, Gray. Learcs or:ate-lanceolate, taper-pointed, serrulate with eiliate-spiuulose appressed teeth, conspecuously petioled $\left(3-6^{\prime}\right.$ long) ; sepals ovate-oblony, often acute. - Moist banks of streams, Va. to Ga. along the mountains. May. - Shrub 2 $-4^{\circ}$ high, with loug spreading or reeurved branches. Flowers exhaling the unpleasaut seent of Chestnut-blossoms.

* Anthers awned; stigma simple; flowers very short-pedicelled, in long onesidcd racemes mostly terminating the branches; bracts deciduous: leaves membranaceous and deciduous, serrulate; calyx bibracteolate.

3. L. recúrva, Buekley. Branchcs and racemes recurved-spreading; leaves lanceolate or orate, taper-poiuted; sepals orate; anther-cells 1-anned; pod 5-lobed: seeds fut and cellular-winged. - Dry hills, Alleghanies of Va. to Sla. April. - Lower aud more straggling than the next.

4. L. racemósa, Gruy. Brunches and raremes mostly erect; leaves oblong or" oral-lanceolate, acnte; sepals ovate-luncelate; anther-cells each 2-awned; pod not lubed; sreds angled and uingless. - Moist thickets, Mass. to Fla. and La., near the coast. May, June. - Shrnb $t-10^{\circ}$ ligh. Corolla eyliudrical.

\section{CAs SÁ NDRA, Don. Leather-Leaf.}

Calyx of 5 distinct rigid orate and aeute sepals, imbrieaterl in the bud, aud with a pair of similar bractlets. Corolla cylindrical-oblong, 5-toothed. Stameus 10; anther-cells tapering juto a tubular beak, and opening by a pore at the apex, awnless. Capsule depressed, 5-celled, many-seeded, the pericarp of 2 lavers, the outcr 5-valved, the cartilaginous inner layer at length 10 -valved. Seeds flattened, wingless. - Low and much blanched shrubs, with nearly erer. green and coriaeeous leaves, which are scurfy, especially unflerneath. Flow ers white, in the axils of the upper small leaves, forming small l-sided leafy racemen. (Cussundra, a daughter of Priam and Hecuba.) 
1. C. calyculàta, Don. Leaves oblong, obtuse, flat.-Bogs, Newf, to Minn., and south to Ga.

\section{CAS S I O P E, Don.}

Calyx without bractlets, of 4 or 5 nearly distinct ovate sepals, imbrieated in the bud. Corolla broully campannlate, deeply +-5-cleft. Stamens 8 or 10: anthers fixed by the apex; the oroid cells cach opening by a large terminal pore, anr bearing a loug recurvel awn hehind. Cilpsule ovoil or glolutar, 4-5-celled, 4 -5-valved, the valves 2-cleit; placenta many-sechled, pendulumi from the summit of the columella. Feeds smootl and wiugless. - Smalt, arctie or alpine evergreen plants, resemlling Club-Mosses or Heaths. Flowers solitary, nodtling on slender erect peluncles, white or rose-color. (Cussiopu was the mother of Andromeda.)

1. C. hypnoides, Dou. 'Tufter and procumbent, moss-like ( $1-4$ ' high $)$; lenves needle-shaped, imbricated ; corolla j-cleft; style short aud conical. Alpine summits of N. New Eng. and N. Y., and high northward.

\section{C A L I U N A, Salisb. llertukn. Ima.}

Calyx of 4 colored sepals. Corolla bell-shaped, t-parterl, much shorter and less conspicuous thin the culyx, hoth hecoming scurions and persistent. Sitamens 8, distinct; anthers witls a pair of deflexed aplendages on the lack, the 'clls opening each ly a loug chink. Capsule t-colled, septicilally t-valved. Evergreen molershrul, with no scaly buck, opposite and minute leaves (mostly rstended at base inte 2 slar'p auricles), crowled and imbricated on the hranches. Flowers axillary, or terminating very short shoots and coweled on the luanches, forming close mostly one-silled sprikes ur spike-like racemes, rose-colored or simctimes white, small, bracted by 2 or 3 pairs of leares, the innermost of

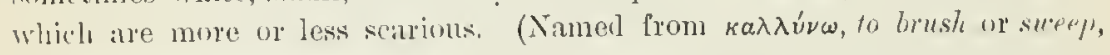
luxums lwim male of its twigs.)

1. C. vulgàris, Salish. Low grounds, Mass, at Tewksluty and WV Amlorer, Maine, at Cape Vilizalsetls; also N. Scotia, C. Breton, Newf., cte l'robably only introduced.

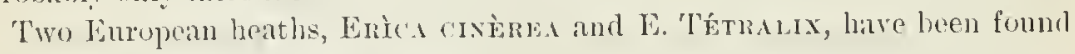
in small patches on Nantucket Islanul.

\section{BRYÁ $\mathbf{N} \mathbf{T} \mathbf{H}$, steller.}

("orolla urn-shaped or bell-shaped, 5-tontled or i-cleft, deciluons. Stamens 10. anthers pointless, shorter than the filaments, opening hy terminal porrs. (a)sule 5-celled, 5-valverl, septicilal (as are all the snoceding), many-sected.

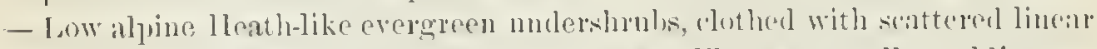

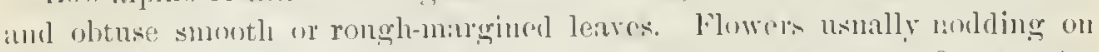
solitary or ambeller perlnucles at the smmmit of the lnanches. One specirs.

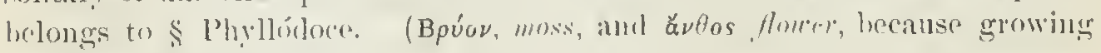
among mosses.)

1. B. taxifolius, Gray. (alyx puhesentit; corolla ohlong-nm-shatpmel, 5-tontled, purplish, smooth; style included. (Ply.Hodoce taxifolia, sulish.) Alpine summite of the monntains of $X$. II. aud Maine, and northward. July 


\section{K $\mathbf{A}$ L M A, L. American Lauled.}

Calyx 5-parted. Corolla between wheel-shaped and bell-shaped, 5-lobed, furnished with 10 depressions in which the 10 anthers are severally lodged; fil:unents long and thread-form. Cinsule globose, 5-celled, miny-seeded. livergreen mostly smooth shrubs, with alternate or opposite entire coriaceous leaves, naked buds, and showy flower's. (Dedicated to Peter Kalm, a pupil of linncus, who travelled in this comntry abont the michle of the last century, afterwarls l'rofessor at $\mathbf{M l o .}$

1. Flaners in simple or clustered maked umbet-tike corymbs; pedicels from the axils of small and firm foliacrous persistent bacts: calyx smaller than the prol, persistent; leaves and branches glabrous, or neutly so.

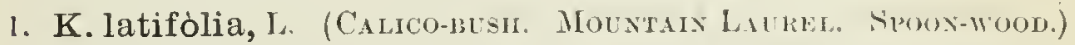
leaces moslly alternate, bright green both sides, ovute-lunceutute or whlong, acnte at each end, pctioled; flowers profuse, large and rery show!, varying from decp rose-color to nearly white; conymbs terminal, many-flowered, clammypubescent; pod depressed, glandular. - Rocky hills and damp soil, Canada and Maine, chiefly along the mountains to WT. Fla., West to Ohio, Ky, and 'Tenu. Lsually a shrub $4-8^{\circ}$ high, but in the mountains from Penn. southwarel forming dense thickets and often tree-like $\left(10-30^{\circ}\right.$ high $)$. May, June.

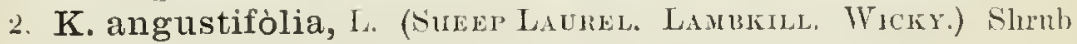
: $-3^{\circ}$ high; leares commonly opposite or in threes, pale or ulitish undermeath, light green abote, numouly oblong, obtuse, petioled; rorymbs lateral (appearing later than the slouts of the season), slightly glandular, many-flowered; pod depursed, nearly smootlı; pedicels recurved in finit. - Ilillsides, Newf. to Micl., soutl to N. Ga.; common. May, Tune. The flower's more erimson and two thirels smaller than in the last.

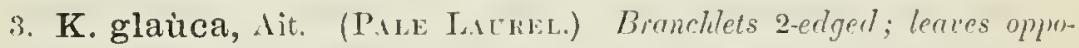
site, nerrly seswite, ablony, white-yluneus beneath, with revolute margins; corymbs terminal, few-fowered, smootli; lracts large; flowers I' hroad, lilae-purple; pod ovoil, smootl. - Cold peat-bogs and momutains, Newf. to Penn., Minn., and northward. May, June. - Stragghling, alwomt 10 liggh.

$\$ 2$. Floners srattered, solitury in the uxils; culy.x lonfy, larger than the pud, nearly equalling the corolla, decidnaus; laves and brumbes bristly-hariry.

4. K. hirsuta, Walt. Branches terete; leaves ohlong or lanceolate ( $t^{\prime \prime}$ long), becoming glabrous, - taurly pine-bumen swamps, s. E. I'a. to Fla. May - Sept. - Shlurul $1^{\circ}$ high; corollar rose-color.

\section{M E N Z I E S A , Suith.}

Calyx very small and flattish, 4 -tootled or 4-lobed. Corolla cylindraceousurn-slaped aud soon bell-sliaped, obtusely 4-lobed. Stamens 8, included; au. ther-cells opening at the tup by an oblinge pore. Capsnle ornir, woody, t-celled, t-ralred, many-sceded. Seeds narrow, with a loose cont. - I low shrub; the straggling brancles and the alternate decidnous leaves usually hairy and ciliate with rusty rather chaff-like bristles. Flower's snall, developed with the leares, in terminal clusters from scaly huts, greenislo-white aud purpilsh, nohling. (Nimed for Archibeld Menzies, who in l'ancouver's royage bronght the original speries from the Northwest Coast.) 
I. M. glabélla, Grạ: Strigose-chaffy scales mostly wanting; leares obovate, barely mucronate-tipped, glubrons or nearly so (1-2'long); filaments ciliate below; copsulc glabrous or nearly so; seeds lony-cundate at each end. Mimesota Point, L. Superior, and northwestwarl.

2. M. globulàris, Salisb. More or less chaffy, $2-5^{\circ}$ high ; leares obovate-oblong, prominently glandular-mncronate, strignest-hirsute especially ahove: filamcrts glabrous; capsule beset with short gland-tipped lristles; secds merely apiculate. (M. ferruginea, var. globularis, of Mauual.) - In the Alleghanies from Penn. to Ga.

\section{RHODODÉNDRON, L. Rose Bar, AzALEA, etc.}

Fluwers almost always 5-merons. Calyx mostly small or miunte, Corolla various (but not contracted at the orifice), lobed or cleft, or eren parted, often sumewliat irregular. Stamens sometimes as few as the corolla-lobes, more cummonly twice as mauy, usually cleclined; anther-cells opening by a ronnd terminal pore. Capsule 5-celled, 5-valved, many-seeded. Seeds scale-like, Shrubs or small trees, of diverse habit and character, with chiefly alternate entire leaves, and large and slowy flowers in umbelled clusters from large

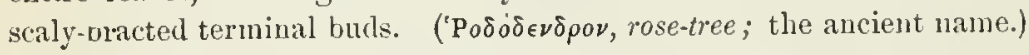

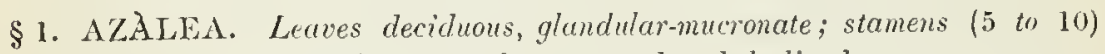
and style more or less exserted and declined.

* Flower-buds of numerous much imbricated scales; corolla with conspicuous. funnel-forn tube; stamens (chiefly 5) and style long-exserted; 3-10 high,. with leaves obovate to oblong-oblanceolate.

+ Flowers appearing after the leaves.

1. R. arboréscens, Torr. (\$моотн Azalea.) Branchlets smooth; leaves obovate, obtuse, rery smooth both sides, shining above, glancous beneath, the margins lristly-ciliate; calyx-lobes long and conspicuous . corollit slightly clanmy, (Azalea arborescens, Pursh. - Mountains of Penn, to N. C. June. Rose-colored flowers very fragrant.

2. R. viscòsum, Torr. (Chamm A. White Swamp-IIoverseckle.) Branchlets bristly, as well as the margins and midrib of the oblong-obovate otherwise smooth leaves; calyx-lobes minute; corolla clammy, the tube much longer than the lobes. (A zalea viscosa, L.) -Swamps, mostly near the coast. Cauada and Maine, to Fla. and Ark, June, July. - Var. GLıÙcux, Grạ. Leares paler, often white-glaucous underneath or on both siles, sometimes rongh-hairy. N. Eng, to Va.-Var. Nfтnex, Gray, Dwarf, with oblanceolate leaves green both sides. Mountaius, N. Y. to Va.

\section{++ Flowers appearing before or with the leaves.}

3. R. nudiflorum, Torr. (Purpee A. Pixxter-flower.) Leaves downy underneath; tube of the corolla scarcely longer than the ample lobes, slightly glandular. (Azalea nudiflora, L.) - Swamps, Canada to Fla., 1ll., Mo., and Tex. April, May. The slowy flowers vary from flesh-color to piuk and purple. There ire numberless varieties, some of them with 10 stamens.

4. R. calendulàceum, Torr. (Flame-Coloren AzA1. I.) Leares lairy; tube of the corolla shorter than the lobes, hairy. (Azalea calendulacea. 
Michx.) - Woods, mountains of Peun. to Ga. May. Covered just when the leaves appear with a profusion of large orange blossoms, usually turning to Hame-color, not fragrant.

* * Flower-ludls of fewer and early caducous scales; corolla ivregular, with short or hardly any tube, anteriorly divided to the base; the limb equalling the 10 stamens and style.

5. R. Rhodora, Don. Young parts sparingly strigose-hairy ( $1-2^{\circ}$ high $)$; leaves obloug, pale, mure or less pubescent; corolla lardly I' long, purplishrose-color, bilabiate, with the posterior lip 3-lobed, the anterior of 2 oblonglinear and recurving nearly or quite distinct petals. (Rlodora Canadensis, L.) - Cool bogs, Newt. and N. Lug. to mumutains of Penn.

\$2. RHODODÉNDRON proper. Leares coriaceous and persistent; stamens (commonly 10) and style rarely exserted, somewhat declined, or sometimes equally spreading.

6. R. máximum, L. (Great Laurel.) Leaves 4-10' long, very thick, flliptical-oblong or lance-oblong, acute, narrowed toward the base, very smooth, with somewhat revolnte margins; pedicels riscid; corolla bell-shaped, I' broad, pale rose-color or nearly white, greenish in the throat on the upper side, and spotted with yellow or redlish. - 1)amp deep woods, rare from Maine to Ohio, but very common through the Alleghanies from $\mathrm{X}$. Y. to Ga. July. - Shrub or tree $6-35^{\circ}$ high.

7. R. Catawbiénse, Michx. Leaves oral or oblong, rounded at both ends, smooth, pale beneatl $\left(3-5^{\prime}\right.$ long) ; corolla broadly bell-shaped, lilac-purple; pedicels rusty-downy. - lligh Alleghanies, Va. to Ga. June. Shrub 3-6 ${ }^{\circ}$ (rarely $20^{\circ}$ ) high.

8. R. Lappónicum, Wahl. Ducarf, prostrate in broad tufts ( $6^{\prime}$ high);

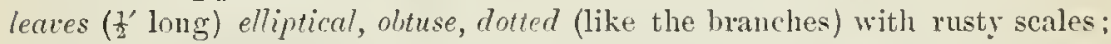
umbels few-flowered; corolla open bell-shaped, dotted, violet-purple; stamens 5-10. - Alpine summits of northern N. Y. and N. Fing., to the Arctic Coast. July. (Aret. Eu. aud Asia.)

\section{LÈ D M, L. Labrador Tea.}

Calyx 5-toothed, very small. Corolla of 5 obovate and spreading distinct petals. Stamens 5-10; anthers opening by terminal pores. Capsule 5-cellerl, splitting from the base upward, many-seeded; placenta borne on the summit of the columellia. - Low shrubs, with the alternate entire leaves clothed with rnsty wool underneath, persistent, the margins revolnte; lierbage slightly fragrant when bruiserl. Flowers white, small, in terminal umbel-like clusters from large scaly buds; bracts or sciales thin and caducous. ( $\Lambda \hat{\eta} \delta o \nu$, the ancient Greek name of the Cistns.)

1. L. latifólium, Ait. Erect, $1-3^{\circ}$ high ; leares oblong or linear-ohlong ( $1-2^{\prime}$ long), mostly $\frac{1}{2}^{\prime}$ wide, very obtuse; stamens $5-7$; capsule oblong, acutish. - N. Fing. to Penn., Mich., Minn., and northward, in cold bogs and mountain woods.

L. Palústre, L., with linear leaves, 10 stamens, and short-oval capsule, is found in Newfoundland and northwestward. (Eu.) 


\section{LEIOPH Ý LLU M, Pers. S.nd Mrrte.}

Calyx 5-partecl. Corolla of 5 distinct obovate-ololoug petals, spreading Stamens 10, exserterl; anthers opening lengthwise. Style filiform. Capsule 2 -3-celled, splitting from the apex downwarl, many-seeded. - A low nuchbranched evergreen, with the aspect, foliage, etc., of the last genus, but the crowled leaves sometimes opposite, scarcely petioled. Flowers small, white, in terminal umbel-like clusters. (Name formed of $\lambda \in \hat{\imath} o s$, smooth, and $\phi \dot{u} \lambda \lambda o \nu, l e u j$. )

1. L. buxifolium, Ell. Shrul, $6-10^{\prime}$ high; leaves oral or oblong, smooth and shining, $3-6^{\prime \prime}$ long. - Sandy pine barrens, N. J. to Fla. May.

\section{LOISELEÜRIA, Desl. Alpixe Azhes.}

('alyx 5-parted, nearly as long as the bell-shaped and deeply 5-cleft regular eorolla. Stamens 5, not declined, included; anthers opening lengthwise. Style short. Cipsule oroid, 2-3-celled, mauy seeded, 2-3-valred; ralves 2cleft from the apex; placenta bume on the midilc of the eolumella. -1 small depressed shrubly erergreen, much branched and tufted, smooth, witl coriaceons opposite elliptical leaves, on short petioles, with revolute margins. Flowers small, white or rose-color, 2 -5 in a cluster, from a terminal scaly bud; seales or bracts thick and persistent. (Named for Loiseleur-Delongchamps, a French botanist.)

1. L. procúmbens, Desi, $-\Lambda$ pline summits of the White Mountains, N. 11., and northward, June. (Ku., Asia.)

\section{CLETHRA, Gronov. Wnite Alder.}

Calyx of 5 sepals, inbricated in the bucl. Corolla of 5 distinct obovatc-ob. long petals. Stamens 10, often exserted; anthers arrow-shaped, erect in the bud, becoming inverted and opening by basal pores or short slits. Style slender, 3-cleft at the apex. Capsule 3-valred, 3-cellerl, many-seeded, encloser in the calyx. - Shrubs or trees, with alternate serrate decilluons leaves, and white

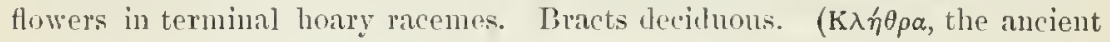
(ireek name of the Alder, which this genus somewhat resembles in foliage.)

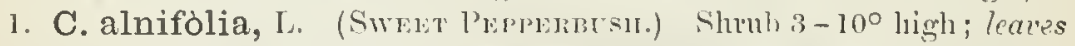
rerigp-olmonte, sharply serrate, entire toward the lase, mominently straightreined, smooth, green both sides; mesmes upright, panived ; bracts shorter than the flucers: filaments smooth. - Wet copses, Maine to Vra, near the coast, and sonthwart. Covered in .Jny and Angust with handsone fragrant hlossoms.

2. C. acuminàta, Michx. I tall shrub or small tree; lenies oxal or Jlong, pointor, thin, fucly serrate $\left(3-7^{\prime} \mathrm{long}\right)$, pale beneatl ; racemes solitary, drooping: lracts longer thon the fowers: filaments and pors hairy, - Woods in the Alleghanies, V'a. to Ga. Julỵ.

\section{CHIMÁ PHILA, Pursh, Pipsissewa.}

l'etals 5, concare, orhicular, willely spreading. Stamens 10 ; filaments enlarged and hairy in the midlle; anthers as in Pyrola, hut more or less conspicmonkly 2-homel. Style rery shont, inversely conical, nearly immersed in the depressed summit of the globular orary ; stigma broad and orbicular, tiskshaped, the borler 5-crenate. Capsule, ete, as in l'yrola, hut splittingr from 
the apex downward, the edges of the valyes not womly, - Low, nearly herba. ceous plants, with long running underground shouts, and evergreen thick and shining leaves, somew hat whorled or seattered along the short ascending stems ; the fragrant (white or pnlplish) flowers corymbed or nubeller on a terminal

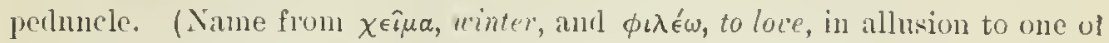
the populat uanes, viz., Wintergreen.)

1. C. umbellàta, Nutt. (Prixce's Prxe. I'Imisstwa) Leafy, 4-

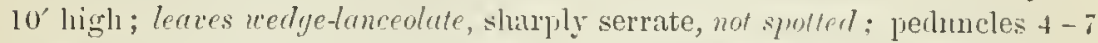
Alwered; petals flesh-color ; anthers violet. - Dry wouds, Nora ficotia to Gia. west to the l'acific. June, (Eu.)

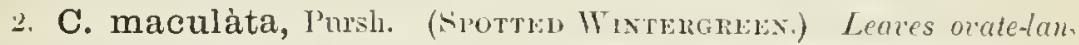
reolate, obtuse ut the base, remotely tootherl, the upper surfure variegated with white; peduncles 1-5-flowered. - 1)ry wools, N. Eng. to Ga, west to Minn. and Miss. June, Jnly, Plant $3-6^{\prime}$ ligh

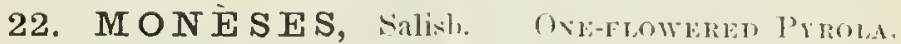

l'etals 5, widely spreading, ophicular. Filaments awl-shaper, naked; anthers as in l'yola, hut conspicmonsly 2-homed. Nyle straight, exserterl; stigua lauge, peltate, with 5 nalruw and conspicuons radiating lobes Valves of the capsule naked. (Flowers occasioually tetramerons.) Siaje l-flowered. itherwise as l'yrola; intermoliate hetween it and Chimaphila. (Name formed of $\mu \delta$ vos, single, and $\bar{\eta} \sigma s$, delight, from the pretty solitary flower.)

1. M. grandifiora, salisb. I small peremial, with the rounded anst reiny serlate thin leaves $\left(6-9^{\prime \prime}\right.$ long $)$ (hustered at the ascenting apex of creeping subterranean shoots; the $1-\underline{2}$-bracterl scape ( $\left(2-4^{\prime}\right.$ high) beariug a white or rose-colorerl teminal flower b" wille. (M. unitloril, Gray.) - Deep collt woods, Labraulor to P'enn., Ind., Minn., and westward. June. (Eu.)

\section{PÝrol A, 'Noull. Wintergren. Shin-lear.}

Calyx 5-parted, persistent. l'etals 5, (nneave and more or less converging, deciduons. Stamens 10; filaments awl-shaped, naked; anthers extrorse in the bud, lnt in the fower inverted by the infexion of the apex of the filat ment, more or less 4-celled, opening ly" a pair of pores at the blunt or somlewhat 2-hormerl base (by inversion the aplarent apex) style generally lung; stigna 5-lobel or j-rayed. Calsule depressed-globose, 5-loled, 5-celled, 5 batred from the base upward (loculicidal); the valves cobveby on the alges. Seerls minute, immumerahle, resembling sawelust, with a very lunsw allular-reticulated cont. - Low and smooth perenuil herbs, with rmunim subterranean slonts, hearing a cluster of rounded petioled evergreen rout leaves, and a simple raceme of nodiling flowers, on an upright more or less scaly-luracterl scape. (Name a dimintive of Pyms, the l'ear-tree, from some fancied resemblance in the foliage.)

* Style straight, much narrouer thun the peltate 5-rayed stigma; netals anil stamens erect and comivent; anthers not narrowed below the openings

1. P. minor, I. scape 5-10' high; leares round,sh, slightly crenulate. thickish, mostly longer than the margined petiole flowers suall. crowiled white or rose-color; calyx-lobes triangular-ovate, wery moh shorter than the 
nearly globose corollı: style short and included.-Cold woods, Lab., White Mts., L. Snperior, and northward.

2. P. secúnda, L. Subcanlescent, 3-6’ high; leutes ovate, thim, longer than the petiole, scattered, finely scrrate; racemes clense and spike-like, the numerous suall (greenish-white) flowers all turned to one side, scarcely noclling: calyx-lobes urate, very much shorter than the ollong-oval petals; style iong. exserted. - lich woods, Lab. to Minn., south to Md., and far northwarrl July (Eu.)

Var pùmila, Gray, is a smaller form, with ronnded leaves 6" or little more in dianeter, and 3-8-flowered scape. - High peat-bogs, X. Y. to L. Superior, and nortlward. Jnly, Ang.

* * style strongly declined, the apex curved upward, longer thun the connivent or spreading petals; stigma much narrower than the truncate excavated ring-like apex of the style; anthers contracted below the openings, forming "short neck; leaves denticulate or entire.

- Petuls and leaves acute, the latter ovate, coriaceous.

3. P. oxypétala, C. F. Anstin. Leaves orate, small ( $8-12$ " long), shorter than the slender petiole; scaje $\left(\overline{7}-8^{\prime}\right.$ high) several-flowered; flowers on ascending pedicels, not nodding; calyx-lobes triangular-ovate, acute, short; petals lanceolate-ollong, acuminate, greenish; anthers conspicnously mncronate at the apex, obtnsely 2 -horned at base, not inverted; style straightish, scarcely exsertel. - Wooded hill near Deprsit, Delaware Co., N. Y. (C.F. Austim, in 1860). Not since found; probally monstrons.

+ +- Petals and leares orbicular to oblong, very obtuse.

4. P. chlorántha, swartz. Leuces small ( $l^{\prime}$ long), roundish, thich, rull, shorter thun the petiole: scape few-flowered, naked $\left(5-8^{\prime} \mathrm{high}\right)$; cally $x$-lobes rorndish-oute, rery short: the elliptical petals converging (greenish-white); anther-cells contracted into a distinct neck; style little exserted. - Open woods, Jab. to Penn., Minn., north and westward. June, July.

5. P. ellíptica, Nutt. (Sinx-tenf.) Leares thin and dull, elliptical or olnvate-nval, longer than the margined petiole; raceme many-Howered; calyxioles orate, umute, not one fourth the length of the obovate rather spreading (greenish-white) petals : anther-rells blunt.-kich wooks, N. ling. to Ma, lowa, Minn, and northward. June.

6. P. rotundifòlia, I. Leares orbicular, thick, shining, nsually shorter than the petiole; scape many-bracted $\left(6-12^{\prime}\right.$ high) ; raceme elongaterl, manyHowered; rulyx-lobes lancelute or oblong-lancrolute, acutish, with somewhat jireading tips, one hulf or one third the length of the roundish-obovate rather anreading (chietly white) petuls: cuther-cells nearly blunt.- Damp or sandy worls, throughout the continent, sunth to $\mathcal{X}$. Ga. Exhibits many varieties, such as: Var. Ixcarsirı, I)C., with Hesh-colored to rose-pnrple flowers, and triangnlar-lancelate caly-x-loles. Cold woods and bogrs, N. Eng. to Minn.,

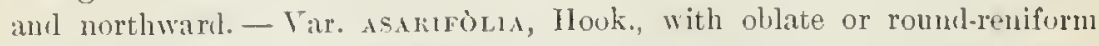
leaves, and shorter ovate caly'x-lobes; petals flesh-or rose-colored (rarely white) With same range - Var. LLigixosA, Gray, with short bromlly ovate calyx-lolves, subcordate to obovate dnll leaves, and rose-colored or pnr. ple finwers. Same range. (Eu.) 


\section{PTERós PORA, Nutt. PINe-Drops.}

Calyx 5-parted. Corolla ovate, urn-shaped, 5-toothed, persistent. Stamens 10 ; anthers 2-celled, awned on the back, opening lengthwise. Style short; stigma 5-lobed. Capsule globose, depressed, 5-lobed, 5-celled, loculicidal, but the valves cohering with the columella. Seeds very numerons, oroid, tapering to each end, the apex expanded into a broud reticulated wing nany tines larger than the body of the seed. - A stont ant simple purplish-brown clammy-pubescent root-parasitic herb $\left(1-2^{\circ}\right.$ high); the wand-like stem furnished towards the base with scattered lanceolate seales in place of leaves, above bearing many luorlding (white) flowers, in a long bracted racene. (Name from $\pi \tau \epsilon$ óv, a uing, and $\sigma \pi o p a ́$, seed, allucling to the singular wing borne by the seeils.)

1. P. Andromedè, Nutt. - Hard clay soil, parisitic apparently on the roots of pines, fron W. New kng. io N. Penn., N. Mich., and westward; rire.

\section{SCH WEINÍtZIA, Ehl. Swet PINe-sap.}

Calyx of 5 oblong-lanceolate acute scale-like sepals, erect, persistent. Corolla persistent, bell-shaped, rather fleshy, 5-lobed, slightly 5-gibbous at the base. Stanens 10; anthers much shorter than the filaments, fixer near the summit, awnless; the two sac-sluaped cells opening at the top. Capsule ovoid, 5-celled, with a short and thick style, and a large 5-augular stigmat. Seeds inummerable. - $\triangle$ low and smooth brownish plant, 3-4' ligh, with the aspect of Monotropi, scaly-bracted, the flowers several in a terminal spike, at first nokling, flesl-color, with the fragrance of violets. (Nimed for the late L. $D$. ron Schueinilz.)

1. S. odoràta, Ell. - Woods, parasitic oil the roots of herbs, Md. (near Baltimore) to N. C. April.

\section{Monótropa, L. Indax Pipe. Pine-sap.}

Calyx of 2-5 lanceolate bract-like scales, decidnous. Corolla of 4 or 5 separate erect spatulate or wedge-shaped scale-like petals, which are gibbous or saccate at the base, and tardily deciduous. Staneus 8 or 10 ; filaments awlshapel; anthers kidney-shaped, becoming l-celled, opening across the top. Style columuar; stigma disk-like, 4-5-1ayerl. Capsule oroid, 8-10-groover, 4-5-celled, loculicilal; the rery thick placente covered with innunerahle minute seeds, which lave a very loose coat. - Low and fleshy herbs, tawny, redrlish, or white, panasitic on loots, m growing on decomposing vegetable matter hike a Funşs; the clustered stens springing from a ball of matted fibrons rootlets, furuished with scales or bracts in place of leaves, 1 -sereralflowered; the summit at first uodding, in fruit erect. (Name composed of $\mu \delta v^{\prime}$, one, and $\tau \rho \delta$ osos, turn, from the summit of the stem turned to one side.)

\$ 1. MONOTROPA pioper. Plant inndorons, 1-flowered; caly $x$ of $2-4$ irregular scales or bracts; anthers transverse, opening equally by a chinks: siyle short and thich:

1. M. uniflora, L. (Ixulax Pipe. Corpse-Pudxt.) Smooth, waxywhite (turning blackish in drying, 3-8' high); stigma naked. - Dark and rich woods, nearly throughout the continent. June- Aus. (Asia.) 
\$2. HYPÓPITYS. Plant commonly fiagrant; flowers several in a scaly raceme; the terminal one usually 5-merous, the rest 3-4-merous; bract-like sepals mostly as many as the petals; unthers opening by a continuous line into 2 very unequal valves; style longer than the ouary, hollow.

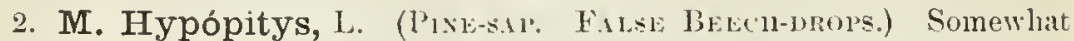

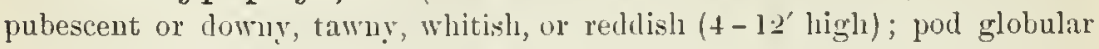
or oval; stigma ciliate. - Oak and pine woods, fron Cauada to Fla., west to Oregon. June-Aug. (Eu.)

\section{ORDER 5\%. DIALENSIACLAE.}

Low perennial herls or suffiruticulose tufted plants, glabrous or nearly so, with simple leaves, no stipules, regulur 5-merous, fourers (excent the 3celled ovary), stamens adnate to the corolla an.l sometimes mnnalelphous: (those opposite its lobes when present reducet to stwminodin); jollen simple; loculicidal capsule and scerls of Ericareac. - Flowers solitary or racemose. Style 1, with 3-lobed stigma. Distiumished from the Ericacese chiefly by the insertion of the stanchs upon the corolla.

Tribe I. DIAPENS1EAE. Dwarf woody erergrwens, with small entire erowded coriareons leaves. Staminodia none; filaments alnate to the canpanulate corolla up to the sinuses; anthers 2-celled. Calyx conspicunously bracteolate. Flowers solitary.

1. Pyxidinthera. Flowers sessile on short leafy banchlets. Antherells awi-pointed at base, opening trausversely.

2. Diapensia. Flower (or at lenst fruit) on it scape-like freduncle. Anther-cells blunt, ubliquely dehiscent.

Tribe II. GALACINEA. A Aulescunt, with trecping routstocks sending "], lungpetioled evergren leaves, and a 1 -several-flowerel seape. Staminodia present.

3. Galax. Calyx minutely 2-bracteolate. Stanens nonadehphous; anthers 1-celled.

\section{PYXIDA NTHERA, Michx.}

Sepals thin. Antler-cels awn-pwinted at base, "prening by a strictly transverse line. Otherwise much as in I lapensia. - l'ustrate and eveeping, with narrowly oblanceolate and awl-priuterl leaves, mostly alternate on the sterile lranches inl somewhat haily wea the base. Flowers solitary and sessile,

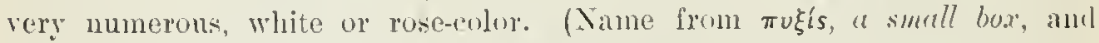
àvinpa, anther, the anther opening as if by a lisl.)

1. P. barbulàta, Michx. (Flowelisi Moss. I'rxik.) Leares 3" long. - Sandy pine larrens of X. J. to N. C. April, May.

\section{DIA PÉN SIA, I}

Calyx of 5 eoneave imbricated coriaceots sepals. ('mrolla bell-shaped, 5. lobed; lobes rounded. Filaments lnoid and flat, allherent to the corolla up to the sinuses, slort; anthers alnate, of 2 woicl pointless cells, liverging below, each opening therefore ly a trinsrersedescending hine. Capsule, enclosed it the ealyx, cartilaginous; cells few-seeded. - Alpine, growing in very dense (nuvex tufts, with the stems imbricated below with cartilaginons narrowly -patulate mostly opposite leaves, teminated ly a sape-like l-flowered pe-

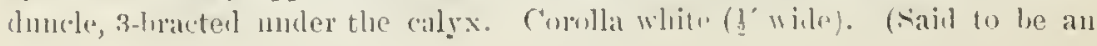


ancient Greek name of the Sanicle, of olscure meaning, strangely applied by Limnxus to this plant.)

1. D. Lappónica, L. Leaves 3 -5" long; peduncle at length 1 -2' long. Alpine summits of N. Eng. and N. Y., and nortlward to Lab. and the Aretie eoast. July. (Eu., Asia.)

\section{3. $\mathbf{G} \mathbf{A} L \mathbf{A} \mathbf{X}, \mathrm{I}$,}

Calyx 5-parted, imbricate, persistent. Petals 5, hypogynoms, oborate-spatulate, rather erect, deciluous, libaments united in a lo-toothed tuhe, slightly (ohering with the base of the petals, the 5 teeth opposite the petals naked, the altcrnate ones shorter and hearing roundish l-cellod anthers, which open across the top. Strle short. stigma 3-lobed. C'ansule oroid, 3-celled; columella none. Seerk numerous, the cellular louse cont tapering to each encl. Evergreen herl, with a thick matted tuft of scilly creeping rootstocks, brat with fibrous red roots, sending up romd-leart-shaped crenate-toothed am reiny shming leaves (about $2^{\prime}$ wille) on slender petioles, and a slender naked scape, $1-2^{\circ}$ high, bearing a waml-like spike or raceme of small and minutely-

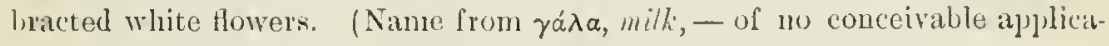
tiun to this plant.)

1. G. aphýlla, L. - Open woods, Va. to Ga. Jume.

\section{()RHER 60. PIUUIBAGINÄCEAE. (LEADWORT FamLy.)}

Martime herls, with regular 5-merous flowers, a plailed calyx, the 5 sfawens opposite the separate petals or the lolies of the corolla, and the free orary

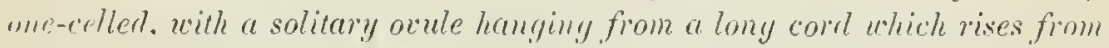
the luse of the cell. - Only the Statice or Marsi-Roskarar Trube is represented in our region, in gardens by the 'Thrift (A rmèria rulgùris). (o) the coast by a single species of

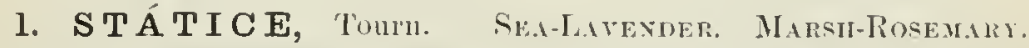

Flowers scattererl or lonsely spiked and i-sided wn the branches, 2-3-hracted. ('alyx fnmel-form, dry and memblanaseous, persistent. Corolla of 5 nearly ol' inite rlistinct petals, with loug claws, the 5 stancus sorerally attached to their hases. Sityles 5, ralely 3, separate. Frut membranoms and indehisernt, in the bottom of the calyx. Embryo straight, in mealy albumen. - Sea-sirle per"muials, with thick and stalked rarlisal leares; the naked fluwring stems (n)

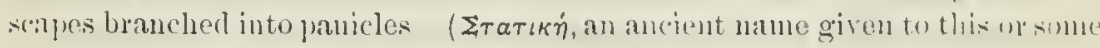
other herb, sn aceonut of its astrinecency)

I. S. Limonium, I. linot thick and woody, very astringent; leaves oblung, spatulato or ulwate-lanceolate, 1-ribhed, tipperl with a decislums hristly loint, petiolenl; scape nunch-branclied, corynbose-panicled (1-20 high); spilielets 1-3-floweresl: flowers lavender-color; ealy-tnbe hairy on the in! sales, the lobes orate-triangulas, with as many tecth in the sinnses. (Eu.)

Vir. Caroliniana, Gray, the plint of the Northeru Nitates, las more erect I ranches, rather panicled inflorescence with at length seattered Howers, and rery acute or acuminate calyx-lohes. - Salt marshes along the coast, from Lab. to Tex. Ing., Sept. 


\section{Order 61. PRtMuláceAe. (I'hmose Family.)}

Herbs, with simple leaves, and regular perfect flowers, the stamens as many as the lobes of the monopetalous (rarely polypetalous) corolla ana inserted opposite them (on the tube or base), and a 1-celled ovary with a central free placenta rising from the base, bearing several or many seeds. Calyx free from the ovary, or in Samolus partly coherent. (Corolla none in Glaux.) Stamens 4 or 5 , rarely 6 or 8 . Style and stigma one. Seeds with a small embryo in fleshy albumen. Ovules amphitropous, except in Tribe $\mathrm{I}$.

Tribe I. HOTTONIEA. Uvary wholly free; ovules anatropous. Aquatic; immersed leaves pectinate.

1. Hottonia. Cololla sliort salvel-form. Flowers verticillate and racenose.

'Fribe II. PRIMULEA. Ovary wholly fiee.

* Stemless, lutves all in a clnster from the ruot; calsule dehiscent by valves or teeth.

3. Dodecatheon. Corolla reflexed, 5-parted. Stamens exserted, connivent in a eone.

3. Primula. Corolla funnel-form or salver-sliaped, olen at the throat. Stanensinclnded

4. Androsace. Corolla short, very small, constricted at the throat. Stamens imelnded. * S Stems leafy ; corolla rotate (none in Glaux); leaves entire.

- Capsule dehiseent rertieally by valves or irregularly, mostly globose.

5 Trientalis. Corolla mostly 7 -parted. Stem leafy only at the summit.

6. Steironema. Corolla 5-parted. Five slender stamiuodia between the fertile stamens.

7. Lysimachia. Corolla 5-6-parted or 5-6-petalled. Staminodia none. Leaves dotted

8. Glaux. Corolla none; the calyx yetal-like. Flowers axillary.

- +Globose capsule circnmscissile, the top falling off as a lid : fowers axillary.

9. Anagallis. Corolla longer than the ealyx, 5-parted. Leaves opposite.

10. Centunculus. Corolla shorter this the caly $x, 4-5 \cdot$ cleft. Leaves alternate.

Tribe III. SA MOLEA. Ovary connate at base with the base of the calyx.

11. Samolns. Corolla bell-shaped, with 5 staminodia in the sinuses. Flowers racemose.

\section{HotTònIA, L. Featherfoll. Water Vholet.}

Calyx 5-parted, the divisions linear. Corolla salver-shaped, with a short tube, limb 5-parted. Stamens 5, included. Capsule many-seeded, 5-valved; the valves collering at the base and summit. Seeds anatropous. - Aquatic perennials, with pectinate inmersed leares, and the erect hollow flower-stems il nost leafless. Flowers white or whitish, whorled at the joints, forming an interrupted raceme. (Named for Prof. Hottom, a lotinist of Leyden.)

1. H. inflàta, Ell. Leares dissected into thread-like divisions, seattered on the floating and rooting stems, and crowded at the base of the cluster of peduncles, which are strongly inflated between the joints foften as thick its one's finger.); perlicels short. - P'vols and ditehes, Matss. to S. Ind., and suntl to the Gulf. Inne-Aug.

\section{DODECÀTHEON, L. Americax Cowslip.}

Calyx deeply. 5-cleft, the divisions lanceolate, reflexecl. Corolla with a very short tube, thickened throat, and 5-parted reflexed limb; the divisions long and narrow. Filanents short, munadelphous at hase; anthers long and linear, alproximate in a slender cone. - I'erenuial smooth herb, with fibrous ruots, a (inkter of chlong or spatulate leaves, and a simple naked scape, involucrate 
with small liacts at the summit, bearing an anple umbel of showy flowers, nodding on slender pelicels. Corolla rose-culor, or sometimes white. Name from $\delta a ́ \delta \epsilon \kappa a$, tuclece. and $\theta \epsilon o^{\prime}$, gods, griven by l'liny to the prinnrose, which was believech to be unrler the eare of the superior gods.)

1. D. Meadia, L. (ShootugG-STris.) lichl wooks, Pemu and Mcl, to WVisc., suuth to (ia. and Tex. May, Juue. - Very handsome in eultivation.

\section{PRÍ I U I A, L. P'rmmose. Cowsilp.}

Calyx tubular, angled, 5-cleft. Corolla salver-shajed, eularging above the insertion of the stamens; the 5 lubes often untched or inverscly heart-shaped. Stanens 5, included. C'apsule many-seeded, splitting at the top into 5 valves or 10 teeth. - Low perennial lierbs, produciug a tuft of veiny leaves at the root, and simple scapes, bearing the flowers in an umbel. (Name a diminutive of primus, from the flowering of the true l'rimrose in early spring.)

1. P. farinosa, L. (Bun's-erl: Prunlo-E.) Ácape $3-10^{\prime}$ ligh; leaves elliptical or obuvate-lanceolate, denticulate, the louer side aut the 3-20-flowered inelucre, etc., covered with a white menliness, at least when young; corolla pale lilac with a yellow eye. - Maine to $\mathrm{x}$. shore of L. Superior, and northward. June, July. (Ėı., Asia.)

2. P. Mistassínica, Michx. Sicape 2-6' high; leares spatulate or werlge-oblong, thin and veiny, not mealy; involucre 1 - s-fluwered; lobes of the flesli-eolured corolla hroadly and deeply obeordate. - Wet binks and shores, northern N. Kng. aud N. Y. to I. superior, aud northward. May. (Eu.)

\section{A N D RÓSACE, Tourn.}

Calyx 5-cleft; tube short. Corolla salver-shaped or funnel-form; the tube shorter than the ealyx, contrated at the throat; linb 5-parted. Stamens and stỵle included. Calpsule 5-valved, - Small herhs, with clustered root-leaves, and very small solitary or umbelled flowers. (An ancient Greek wane of a polyp, formerly believed to be a plant.)

1. A. occidentàlis, Pursh. Ninnothisl anumal; scalues diffuse $\left(2-4^{\prime}\right.$ high), many-flowered; leaves and leatlets of the involucre oblong-ovate, entire. sessile; calyx-lobes leafy, triangular-lanceolate, longer than the (white) corolla. - Bare hills, from Minn. to IIl. and Ark., and west to the monntains.

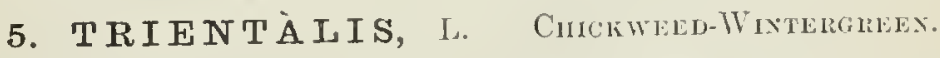

Calyx mostly ;-parted; the divisions liuear-lanceolate, pointed. Corulla mostly 7-parteil, sprealing, llat, withont tube. Filanents slender, mited in at ling at the base; anthers ohlong, revolute after Howering. Capsule few-seederl. - Low and smooth perennials, witl simple erent stens, bearing a few alternate nstually minute and scale-like l'aw (s) below, and a whorl of thin veing leaves at thro snmmit. Peduncles one wr more very slender, hearing a delicate white and star-shaped flower. (\$ Latin name, meaning the thircl part of a foot, alhuding to the lieight of the plant.)

1. T. Americàna, Pursh. (Nтан-plowkr.) Spreading by very slender elongated routstocks; leaves elongated-laneeolate, tapering to both ends; petals fircly pointel. - 1 amp colel woods, from Lab. to Minn., soutl to $N$. Ind., and the monutains of Va, Mag, - Rootstocks often $\downarrow-2$ long (Kitchings). 


\section{STEIRONEMA, Raf.}

Calyx 5-parterl Corolla rotate, with no proper tube, deeply 5-parted, the sinuses rounded; divisions ovate, cuspidate-pointed, erose-dentieulate above, each separately involute around its stamen. Filaments distinct or nearly so on the ring at liase of corolla, alternating with 5 subulate staminodia; anthers linear. Capsule 10- 20-seded. - Leafy-stemmed peremnials, glalrons except the ciliate petioles, not punctate, the leares all ojposite, but mustly in seeming whorls on the flowering branches. Peduncles slender, axillary, bearing y ellow

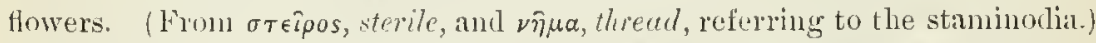

1. S. ciliàtum, liaf. Stem erert $\left(2-4^{\circ}\right.$ ligh $)$; lences lancculate-orate $\left(2-6^{\prime} \operatorname{long}\right)$, tapering to an achte point, runded or heart-shaped at base, all on long and fringerl petioles; corolla longer than the calys. (Lysimachia eiliata, L.) - Low gromuds aud thickets, common. July.

2. S. radicans, Gray. Stem slender, soon reclined, the elongated branches often rooting in the mud; fenves oute-lunceolute, mostly rounded at base, on slender petioles; corolla about the length of the calyx. (Lysimachia radicans, IJook.) - Swamp! river-hanks, W. Va. to Art. and La. - Leaves and flowers nearly one lall smaller than in the last.

3. S. lanceolàtum, Gray. stem erect $\left(10^{\prime}-2^{\circ}\right.$ ligh $)$; leaves lunceolate, rurying to ubluny and linear, nurrowed inlo a short murgined petiole or tapering lase, or the lowest short and broad on long petioles. (Lysimachia linceolata, Wall.) - Low groumls and thickets, Ont. to Fla the l)akotas, and Tex. Polymorphous; the extrenes are var. nh́ brudun, Gray, with cauline leaves from ollung to broadly linear, common north and west, - and var. AxGUsTIFòlus, (imy, with stems more brancluel, a span to $2^{\circ}$ hight, and the cauline leares linear, acute at hoth enls, nore sessile, 1-2" lireal ; nuinly southward.

t. S. longifòlium, Gray. Stem rect, t-ilnglerl, slender ( $1-3^{\circ}$ high $)$,

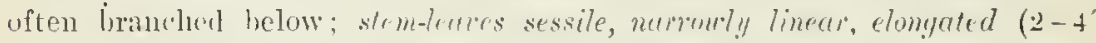
long, 2-3" wiln), smooth and shining, rather rigill, ol,tuse, the margins of ten a little revolute, the reins uherere; the lowest oblong or spatulate; corolla $\left(s-9^{\prime \prime}\right.$ lrual) longer than the "alyx, the lobes conspicuously pointed. (Lysimachia longlolia, l'msh.) - bauks of streams, from western $\mathrm{X}$. Y. to Va, Minn., ant lowal July-siept.

\section{LY S I M Á C H I A, 'Tumll. Loosestrifl.}

Cally 5-6-parted. Corolla rotate, the divisions entire, convolnte in bud. Filaments commonly mouadelphons at hase; anthers oblong or oval; stani. mulia none. Capsule few-severl-seelel. - Lenfy-stemmed perenuials, with

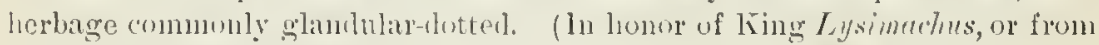

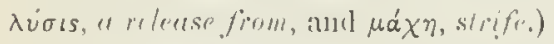

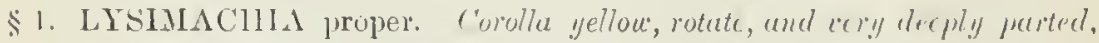
and with no teeth between the lobes; stamens more or less monudilyhous, ofien unequal; leaves opposite or whorled, or some abnormally allemute.

* Flowers (middle-sized) in a termmal leafy panicle; corolla without marks.

L. VllgÁris, L., a coarse aud tall limopean species, pubescent and branching, with orate-lanceolate distinctly petioled leaves, and glandular filaments mited to near the middle. - Naturalizerl in a few plares in E. Maws. 
* Flowers (small) in a rigate terminal ruceme or in the upper axils; corolln dark-dotted or streaked; filaments conspicuously monudelphous, unequal.

1. I. quadrifòlia, I. Somewhat hairy; sten simple (1-20 high); irrece whorled in fours or fires (sometimes in twos, threes, or sixes, rarely unly (1)posite or partly alternate), orate-lanceolate; flower's on long capillary pethucles from the axils of the leates; lobes of the corolla ovate-oblong. Meist or sambly soil, N. Brumswick to Mimn., and Ga. Jnue.

‥ I. stricta, $\Delta$ it. Stens $1-2^{\circ}$ high often bearing oblung or moniliform bublets in the axils; smooth, at length hranched, very leafy; leaces opposite or rarely alternite, lanceslate, acute at each end; flouers on slender pedicels in a long raceme $(5-12)$, leafy at base; lubes of the corolla lance-oblong. Low grounds, Newf. to Mlimn., Ark., and N. (ia. June-Aug.

*** Flowers (rather large) swlitary in the arits of ordinary leaves; curolla not darli-clotled nor streaked; filaments slighly monadelphons.

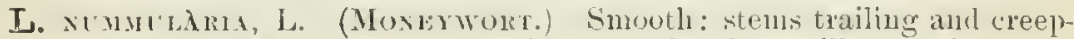
ing; leaves lomelish, small, short-petioled; peduucles axillary; l-flowered; clivisions of the corolla broally ovate, olutuse, longer than the lance-ovate calyxlohes and stancens. - Escaped from garlens juto damp gronnd in some places. Anly-Siejte (Nat. from En.)

\$. NAUMBÚRGIA. Corolla very deeply 5- (or 6-7-) parted into linear dicisions (somewhat purplish-dutted), with a small tooth in each sinus ; fildmeuts distinct, equal; leares opposite, the lou'est scalc-like.

3. L. thyrsiflòra, L. ('Tuftev Loosestrile.) Smootl; stem simple (1 - $2^{\circ}$ high); all but the lower. leaves lanceolate, the axils of one or two middle jairs bearing short-peduncled heat-like or spike-like elusters of small light yellow flowers. - Cold swamps, from Pem. to S. Ill., Iuwa, and nortliwestward. June, July. (Eu.)

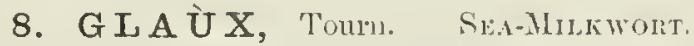

Calyx bell-shaped, 5-cleft; lobes ovate, petal-like. Corolla wanting. Stamens 5, on the lase of the cilly, alteruate with its lobes. Capsule 5-valred, few-seeded. - 1 low and leafy fleshy peremial, with opposite ohlong and entire sessile leaves, and solitary nearly sessile (purplish and white) fowers in their

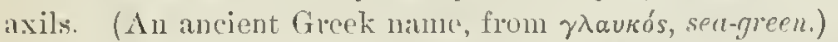

1. G. maritima, L. - Sci-shore of X. Ling. from Cape Cod northward. Also in subsaline soil, Mimu. to Neb., and westward. June. (Eu.)

\section{A N A GÁLIIS, 'Tourn. l'IMPEREL.}

Calyx 5-parted. Corolla wheel-shaped, with almost no tube, 5-parted, longer than the calr:; the divisions lurud. Stannens 5 ; filaments bearded. Capsule membranaceons, circmuscissile, the top falling off like a lid, many-seeded. Low, sprearling or furcumberit horls, mostly annuals, with opjosite or whorled entire leares, and solitary flowers on axillary peluncles. (The ancient Greek name, probably from àvá, (rygain, and á $\gamma a \dot{\lambda} \lambda \lambda \omega$, to delight in.)

A. Inveriss, L. (Commos P'mpenez.) Leaves ovate, sessile, shorter than the pednneles: petals nlwwate, oltuse, fringel with minnte teeth or stalked glinds. - Waste smuly fields. June-Ang. - Flowers variable in size, searlet, sometimes purple, line, or white, quiekly closing at the approach

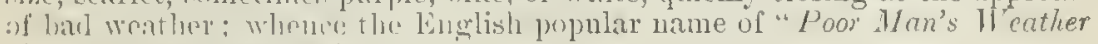
glass. (.iat. lioml liu.) 


\section{CENTÚ N C U L S, Dill. CHAFF'ED.}

Calyx 4-5-parted. Corolla shorter than the ealyx, 4-5-cleft, wheel-shaped, with an urn-shaped short tube, usually withering on the summit of the pod (which is like that of Inagallis). Stamens 4 or 5 ; filaments beardless. Small annuals, with alternate entire leaves, aud sulitary inconspieuous flowers in their axils. (Derivation obscure.)

1. C. mínimus, I. Stens ascending (2-6'long) ; leaves orate, oborate, or spatulate-oblong; flowers nearly sessile, the parts mostly in fours. - Low grounds, from 11l. and Minn. to Fla. and Tex., and westward. (Eu.)

\section{SÁ M OLU S, Tourn. Whter Pimperel. Bhook-Weed.}

Calyx 5-cleft; the tube adherent to the base of the orary. Corolla somewhat bell-shaped, 5-cleft, commonly with 5 sterile tilaments in the sinnses. 'True stamens 5, on the corchla-tube, included. Capsule glolose, 5-valverl at the smmmit, many-seeled. - Smouth herls, with alternate entire leaves, and small white racemed flowers. ("Aceording to Pliny" an ancient Druidieal name.")

1. S. Valerándi, L. Stem elect $\left(6-12^{\prime}\right.$ hish 1$)$, leafy; leaves uhovate or spatulate, the basal rosulate; bracts none; slender pedicels ascendiug. braeteolate in the midlle. (Eu.) - Var. Americànus, Gray. More slender', becoming diffuse; racemes often panicled, the pedicels longer and spreading. - Wet places, through the U.S. June-Siept.

\section{Order 62. SAPOTÁCEA. (SAPOILla FAMIL.)}

Trees or slerubs, mostly with a milky juice. simple and entire alternate leutes (often rusty-downy beneath), small and perfect regular flowers usually in axillury clusters; the calya free and persistent; the fertile stamens commonly as many as the lobes of the hypogynous short corolla and opposite them, inserted on its tube, alony with one or more rows of appendages and scales (or sterile stamens); anthers lurned outward; ovary 4-1\%celled, witle a single anatropous ovule in each cell; seeds large. - Albumen mostly none; but the large embryo witl thickened eotyledons. Style single, pointed. - A small, mostly tropical order. produeing the Sapodilla or Star-apple, and some other edible fruits.

\section{B U M E I A, swart\%.}

Calyx 5-parted. Corolla 5-eleft, with a pair of internal appendages at each sinus. Fertile stamens 5; anthers arruw-shaped. Sterile stimens 5, petallike, altemate with the lobes of the corolla. (bary 5-celled. Fruit small, resenbling a cherry, hack, containing a large ovoil and erect seed, with at romdish scar at its base. - Flowers small, white, in fascicles from the axils of the leares. Branches often sping. Leaves often fascicled on short spurs. Wool very hard. (The ancient name of a kind of ish.)

1. B. lycioides, Pers. (Nouturis Bromtnom.) Spiny $\left(10-25^{\circ}\right.$ high); leaves wedye-ollong vurying to ozul-lanceolute, with a tapering hase, often acute, retirulated, nearly glabrous (2-2' - long); clusters densely many-foucred, glabrous, fruit ovoid, - Moist groumd, Va. to S. Ill., Fla., and Tex. May, Jnue. 
2. B. lanuginòsa, Pers. Sping $\left(10-40^{\circ}\right.$ high $)$; leaves oblong-olovate on wedge-oborate, rusty-zoolly beneath, obtuse (1 $1 \frac{1}{2}-3^{\prime}$ loug); cluste'rs 6 - 12-flowered, pubescent; fruit globular. - Woods, s. Ill. to Fla. and Tex. July.

\section{Order 63. EBENÄCEA. (Eboxiy Family.)}

Trees or shrubs, with alternate entire leaves, and polygamous regular flou. ers which have a calyx fiee from the 3-12-celled atary: the stamens 2-4 limes as many as the lobes of the corolla, often in pairs before them, their anthers turned incard, and the fruit a sereval-celled berry. Orules 1 or 2, suspeniled from the summit of each cell. Seeds anatropous, mostly single in each cell, large and flat, with a smooth coriaceous integument; the embryo shorter than the hard albunen, with a long radicle and flat cotyledons. Styles wholly or partly separate. - Wood hard and dark. rolored. No milky juice. - A small family, chiefly tropical.

\section{Diospíros, I. DatePlun. Persmox.}

Calyx $4-6$-lobed. Corolla 4 -6-lohed, convolute in the hul. Stamens commonly 16 in the sterile Howers, and $\&$ in the fertile, in the latter imperfect. Berry large, globular, surromded at hase by the thickish calyx, 4 -8-elled, 4-8-seeded. - Flowers diœciously poly gamous, the fertile axillary and solitary, the sterile smaller ancl often clustered. (Name, $\Delta$ coss, of Jore, and mupós, grain.)

1. D. Virginiàna, L. (Сомmox Persimmox.) Leaves thickish, ovateothong, smooth or nearly so ; peduncles very short; calyx 4-parted; corolla pale rellow, thickish, hetween bell-shaped and urn-shaped, $6-8$ "long in the fertile flowers, much smaller in the sterile; styles 4 , two-lobed at the apex; orary 8-celled. - Woorts aud old fields, R. I. and X. Y. to Inwa, and sontl to Fla. and La. June. - Tree $20-70^{\circ}$ high, with very lard blackish wood; plmm-like fruit $l^{\prime}$ in thameter, exceedingly astringent when green, yellow when ripe, and sweet and edible after exposure to frost.

\section{Order 64. STYRACACEAE. (Storax Famlir.)}

Shrubs or trees, with alternate simple leaves destitute of stipules, and perfeet regular.fowers; the culy.x either free or adherent to the 2-5-cellert orary; the corolla of $4-8$ petals, commonly more or less united at base; the stamens twice us many as the petals or more numerous, monadelphous or polyalelphous at base; style $1 ;$ fruit dry or drupe-like, 1-5-celled, the cells commonly 1-seeded. - Seeds anatrojons. Embryo nearly the length of the albumen; rarliele slender, as long as or longer than the flat cotyle. dons. Corolla hypognous when the calyx is free; the stamens adherent to its base. ()viles 2 or more in each cell. - A small fanily, mostly" of warm countries, comprising two very distinct tribes.

Tribe 1. STYRACER. Calyx $4-8$-toothed or entire. Stanens $2-4$ times as mant as the petals, iu one series: anthers linear or oblong, adnate, introrse. Cotyledons flat. - Flowers white. handsone. Puhescence soft and stellate.

1. Styrax. Calyx coherent only with the base of the Barelled ovary. Corolla raostly 5-parted. Frutit l-celled, l-seeded. 
2. Halesia. Calyx colierent with the whole surface of the 2-4-celled ovary, which is 2-4-winger and 2-4-celled in fruit. Corolla 4 -lobed.

Tribe II. SYarPLOCINEzE. Calyx 5-cleft, imbricate. Stamens in several series; anthers short, innate. Embryo terete. Flowers yellow. Puibescence simple.

¿. Symplocos. Calyx coherent. Petals 5 , united merely at the base.

\section{STY $\mathbf{Y} \mathbf{A} \mathbf{X}$, Tourn. SтоRм.}

Calyx truncate, somewhat 5-tootherl, the base (in onr species) coherent with the hase of the 3-celled many-ovuled ovary. Corolla 5-parted (arely $t-8$ parted), large, the lobes mostly soft-downy. Stamens twice as many as the lobes of the corolla; filaments flat, united at the base into a short tube; anther's linear, adnate. Fruit globular, its hase surroumled ly the persistent calyx, I-celled, mostly I-seederl, dry, often 3-ralved. Seed crlobular, erect, with a liard cuat. - Shrubs or small trees, with commonly decilnuus leaves, and axillary or leafy-racemed white and showy flowers on drooping peduncles; produceal in spring. P'nluscence scurfy or stellate. (The ancient Greek nane of the tree which produces storu.

1. S. grandifòlia, Ait. Silnub $4-12^{\circ}$ hiph: leaves whorate, acute $u \mathrm{r}^{\circ}$ pointed, white-tomentose beneull (3-6' long); Honers maslly in elomyated mremes: corolla (l' long) eonrolute-imbricated in hul. - Wooks, S. Va. to Fla.

2. S. pulverulénta, Michx. Slunb $1-4^{\circ}$ lighn; leaves oval or olovite

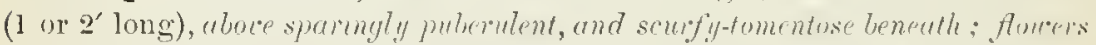

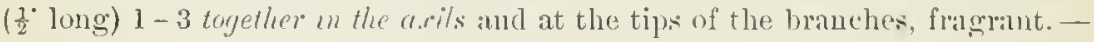
Low pine barrens, S. Va. to Fla. anıl Tex.

3. S. Americàna, Lam. Slıwh $4-80$ high; leaves obloug, acute at

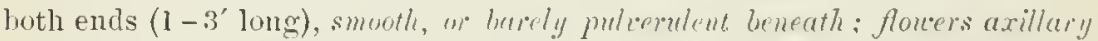

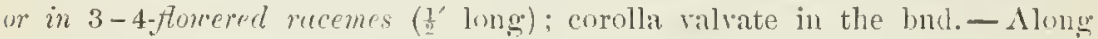
streams; V'a. to Fla., La., and Irk.

\section{H A LESI A, Ellis. SxownRoP or Silver-rell-TrEe.}

Calyx inversely conical, 4-toother ; the tube 4-ribberl, coherent with the $2-$ 4-enled ovary, l'etals 4, miterl at base, or oftener to the midlle, into an open loll-shaped corolla, convolnte or imbricaterl in the bucl. Stamens $8-16$; filainents united into a ring at base, and usually a little coherent with the hakp of the corolla; anthers linear-oblong. Orules 4 in cacle cell. Fruit large and dry, 2-4-wingerl, within hony ans I-4-celled. Sorks siugle, cylindrioal.Shrubs or sinall trees, with large and reiny pointerl decilluoms learus, and

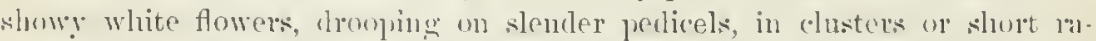
"woses, from axillary hurk of the precering real. L'uhescence partly stellate (Damed for Stephen IIcles, anthor of Vegetablo Statics, \&e.)

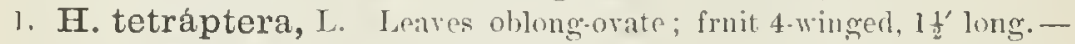
lianks of streams, WT. Va. to lll, sontl to Fla.

\section{S Ý M PLOCOS, Jacq. Swent-Leaf.}

Calyx 5-eleft, the tube coherent with the lower part of the 3-cellecl orary. Petals 5, imbricated in the bud, lightly mited at hase. Stamens rery mumerous, in 5 clnstera, once eoluering with the lase of ach petal; filaments sleu.

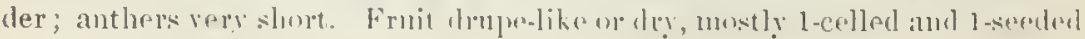


- Shrubs or small trees, the leares commonly turuing yellowish in dryiug, and furnishing a gellow dye. Fluwers in axillary clusters or racemes, yelluw (Name $\sigma u \mu \pi \lambda$ okos, comected, from the union of the stamens.)

1. S. tinctòria, L'Her (Ilonsk-StGal, \&c.) Leaver elongated-oblong, neute, olscurely toothed, thickish, almost persistent, nimutely pubescent aucl pale beneath (3-5'long); fluwers $6-14$, in close and bracted clusters, odorons. - Rich ground, Del. to Fla. aud La. April. - Leaves sweet, greedily eaten by cattle.

\section{ORDER (ij. OLEACIAE. (() Live FAMHY.)}

Trees or shruls, will opposite and pimnule or simple leares, a 4-cleft (or) sometimes obsolete) calyx, a regular 4-cleft or nearly or quite 4-petalous. corolla, sometimes apelalous; the stamens only 2 (varely or accidentally 3 (r. 4) ; lhe ov'ary 2-celled, with 2 (ravely more) ovules in each cell. - Secuin. anatropous, with a large straight embryo in hard fleshy albumen, or withont albumen. - The Olive is the type of the true Oleacer, to which belongs the Lilac (Syringa), ete; and the Jessanine (Jusminum) represents another division of the order.

Tribe I. FHAXINEA. Fruit dry, indelniceut, wingod, a samara. Leaves pinnate.

1. Frixinus. Fluwers diocions, mostly apetalons, sometimes also without calyx.

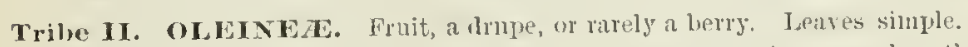

2 Forestiera. Flowers apetnlons, diocious or polyganons, from a scaly catkin-like bud. Stanens $2-4$.

3. Chionanthus. Flowers complete, sometines polygamus. Calyx anul corolla 4-merous, the latter with long and linear divisions.

4. Cigustrum. Corolla funnel-form, 4-cleft, the tube longer than the calyx.

\section{FRÁXINUS, Toum, Asir.}

Flowers polygamous or (in our species) dicecions. Calyx small and t-cleft, touher, or entire, or obsolete. Petals 4 , or altogether wantiug in our species. Stamens 2, sometimes 3 or 4 ; minthers linear or oblong, linge. Sityle single; stignni 2-cleft. Fruit a 1 -2-celled sumara or liry-finit, flattened, winged at thr apex, 1 - 2-seeded. Cotyledons clliptieal; radicle slender. - Light timbertrens, with petioled pinnate leaves of $:-15$ either toothed or entire leaflets; the small fowcrs in crowded punicles or racemes from the axils of last year's loisces. (The classical Latin nane.)

* Leaflets petrolulate; anthers lineur-oblung: arly.e small, persistent.

+ Fruit unged only at the upper purt of the terete or urerly terete body.

1. F. Americàna, L. (Wurre Asr.) Brumellets aud protioles glabrous: leaflets 7-9, ovate- or lance-ohloug, pointed, pale and either smonth or puhes'rnt underneatl, entire or sparingly serrate or denticulate; frut (about $1 \frac{1}{2}$

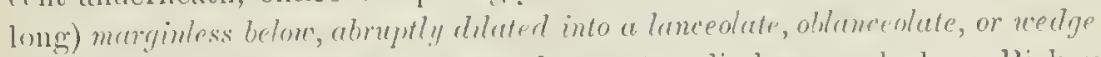
limere wing 2 or 3 times as lomg as the terete cylindraceous borly. - Rich or moist woods, common from the Atlantic to Minil., li. Neh. and liau. April, May. - A large and very valuable forest tree, with graly furrowed burk, smooth gray hranchlots and rusty-colored buds. Monocious Howers rarely ocenr. 
+ Body of fruit more slender, tapering gradually from summit to base, more or less margined upward by the decurrent wing.

2. F. pubéscens, Lam. (ReD Asir.) Branchlets and petioles velietypubescent; leaflets $7-9$, ovate or oblong-lanceclate, taper-pointed, almost entire, pale or more or less pubescent beueath; fruit $1 \frac{1}{2}-2^{\prime}$ long, the edyes gradually dilated into the linear or spatulate wing. - Low grounds, thronghout our lange; rare west of Ohio. - Tree of middle or large size; inner face of outer bark of the branches red or cinnamon-color when fresh.

3. F. víridis, Michx. f. (Greex Asir.) Glabrous throughout: leuftets $5-9$, ovate or oblong-laneeolate, often wedge-shaped at the base and serrate above, bright green both sides; fiut much as in n. 2. - Along streams; common. - Intermediate forms occur will paler leaves somewhat pubeseent beneath. A small or middle-sized tren.

+ + Fruit with compressed und wing-margined body.

4. F. platycárpa, Miehx. (WATER-Ash.) Branchlets terele, glabrous or pubescent; leaflets 5-7, ovate or oblong, acute at both euds, short-stalked; finit broadly winged (uot rarely 3-winged), oblong (9" wide), with a tapering base. - Deep river-swamps, Va, to La. March. 'Tree of middle size.

5. F. quadrangulàta, Michx. (Buve Asll.) Branchlets sifnuie, at least on vigorous shoots, glabrous; leaflets $7-9$, short-stalked, obloug-ovate or lanceolate, pointed, sharply serrate, green both sides; finit narrowly oblony, blunt, and of the same width at bothends, or slightly narrowed at the base, often notehed at the anex ( $1 \frac{1}{2}^{\prime}$ long, $3-4^{\prime \prime}$ wide). - I) ry or moist rich woods, () hio to Mich. and Minn., south to 'Temu. - Large timber tree, the inner bark rielding a blue color to water.

* * Lateral leaflets sessile; anthers short-oblong; flowers wholly nuked.

6. F. sambucifolia, Lam. (BLACK AsIr.) Brauchlets aui petioles glabrous; leaflets $7-11$, oblong-laneeolate, tapering to a point, scrrate, oltuse or rounderl at the base, green and smooth both sides, when young with some rusty hairs along the midrib; fruit linear-ollong or narrowly elliptical, blunt at both ends. - Swamps and wet bauks, $\mathrm{N}$. Scotia to Minl., south to Va. and Mo. - Small or middle-sized tree, with very tongh and fissile wood. Bruised foliage exhales the odor of Elder.

\section{FORESTIERA, Poir.}

Flowers dioeions, crowded in catkin-like scaly buds from the axils of last year's leares, imbricated with scales. Corolla none. Calyx of 4 minute se-

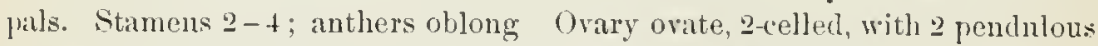
ornles in each cell; style slender; stigma somewhat 2-lohed. Drmpe small, oroid, 1-cellet, 1-seeded. - Shruls, with opposite and often fascicled deciduous leaves and small flowers. Fertile perluncles short, I-3-flowered. (Named for 1\%. Forestier, a French physician.)

1. F. acuminàta, 'oir. Glabrons, somewhat spiuescent, 5-100 high ; leaves thin, ollowg-ovate or ovate-lanceolate, acuminate at both ends, often serrulate; drupe elongated-oblong, nsually pointerl. - Wet river banks, S. W. Inil. to Mo, south to 'Tex. April. 


\section{CHIONÁ NTHUS, L. FMTGE-TREE.}

Calyx 4-parted, very small, persisteut. Corolla of 4 long and linear petals, which are barely united at base. Stanens 2 (rarely 3 or 4 ), on the very base of the corolla, :ery short. Stigna ustched. Drmpe fleshy, globular, becoming I-celled, 1-3-seeded. - Low trees or shrubs, with decidnons and entire petioled leaves, and delicate flowers in loose and drooping gracefnl panicles, from lateral buds. (Name from $\chi \iota \omega ́ \nu$, snon, and ápoos, blossom, alluding to the light and smow-white clusters of flowers.)

1. C. Virgínica, I. Leaves oval, oblong, or obovate-lanceolate; flowers on slender pedicels; petals l' lung, nartowly linear, acute, varying to 5 or 6 in number ; drupe purple, with a bloom, ovold $\left(6-8^{\prime \prime}\right.$ long). - River banks, N. J. and S. Penn. to Fla., Tex., and Mo.; very ormamental iu cultivation. June.

\section{L I G Ù S T R U M, Tonrn. Privet.}

Calyx short-tubular, 4-toothed, deciduous. Stamens 2, on the tube of the corolla, included. Berry -celled, 1-2-seeded. - Shrubs, with entire leaves and small white flowers in terminal panicles. ('The classical name.)

L. vulaAre, L. (Privet, or Prim.) Leaves very smooth; berries black. - Used for low hedges, and natmralized eastward; from Europe.

\section{OrDer 66. APOCYNACIAS. (DOGBANE FaMily.)}

Plants almost all with milhy acrid juice, entire (chiefly opposite) leaves without stipules, regular 5-merous and 5-androus flowers; the 5 lobes of the corolla convolute and twisted in the bud; the flaments distinct, inserted on the corolla, and the pollen granular; calyx free from the two ovaries, which (in our genera) are distinet (forming follicles), though their styles or stigmas are united into one. - reeds amphitropous or anatropous, with a large straight embryo in sparing albumen, often bearing a tuft of lown (comose). - Chicfly a tropical family (of acrid-poisonous plants), represented in gardens by the Oleander and Periwinkle.

1. Amsonia. Seeds naked. Corolla-tube hearded inside. Anthers longer than the filameuts. Leaves altemate.

2. Traclielospermun. Seeds comose. Corolla funnel-form, not appendaged. Filaments slender. Calyx glandular inside. Leaves opposite.

3. A pocynum. Seeds comose. Corolla bell-shaped, appendaged within. Filaments short, broad and flat. Calyx mot glanclular. Leaves opposite.

\section{A M S Ò N I A, Walt.}

Calyx 5-parted, small. Corolla with a narrow funnel-form tube bearded inside, especially at the throat; the limb divided into 5 long linear lobes. Stamens 5, inserted on the tube, included; anthers olutnse at both ends, longer than the filaments. Oxaries 2 ; style 1 ; stigma rounled, survomnderl with a cup-like membrane. Pod (follicles) 2, Inng and slender, many-secterl. Seeds cylindrical, abrupt at both ends, packed in one row, naked. - l'erennial herbs, with alternate leaves, and pale blne flowers in terminal panicled cymes. (Said to be named for a $M r$. Charles Amson.) 
1. A. Taberaæmontàna, iValt. Loosely juluescent or hairy wheu young, soou glabrous; leaves from ovate-lanceolate to linear-lanceolate, taperpointed; calyx-lobes short, awl-shiped; tube of the bluish corolla little lunger thau the lobes, the mpled part aither hairy when young or glabrous. - luw grounds, N. C. to S. Ind. and Mo., sunth to Fla. and 'Tex. May, Jnne.

\section{TRACHELOSPÉRMUM, Lemaïre.}

Calyx 5-parted, with 3-5 glands at its base insicle. Curolla funuel-form, not aphendager?; limb 5-lober. Stamens 5, inclurled; filaneuts slender; anther' mrow-shaped, with an inflexorl tip. L'uds (follicles) 2, slender, nanyseeterl. Seeds ohloug, with a tuft of down. - l'wiung plants, more or less worly, with opposite leaves and small flowers in rymes. (Name from

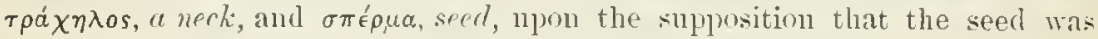
beaked.)

1. T. diffórme, Gray. Nearly herbaceous aud glalnous; leaves oval-lan. reolate, pointed, thin; calyx-lobes tiper-pointed; corolla pale yellow. (Forsteronia difformis, A. DC (.) - Dampl gromuls, Va to Fla. and Tex. $\Lambda$ pril.

\section{A PÓ Y Y U M, 'Tourt. Dograxi. Ixdax Heml.}

Calyx 5-parted, the lobes acute. Corolla bell-shaped, 5-cleft, bearing 5 triangular appentages below the throat opposite the lobes. Stamens 5, on the. very base of the corolla; filaments flat, shorter thau the arrow-slaped authers, which converge aromnd the stigna, and are slightly allerent to it. Style nune; stigma large, oroid, slightly 2 -lobed. Frut of $2 \operatorname{long}\left(2-7^{\prime}\right)$ and slen der follicles. Seets cumose, with a tuft of long silky down at the apex. l'ereunial herbs, with upright branching stems, opposite mucronate-pointed leaves, a tongh fihrous bark, and snall and pale cymose flowers on short perh.

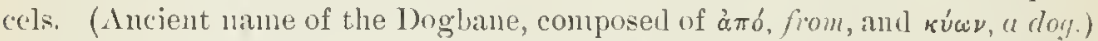

1. A. androsæmifólium, L. (SPRE.lping lograxe.) Smooth, w liurely soft-tomentose, brauched above; brunches dirergcully forking: leaves ounte, distunctly petiried: rymos loose, spreading, mostly longer thau the leaves; corolla (pale rose-culor, $4^{\prime \prime}$ broad) open-bell-shuped, with recolute lobes, the tube

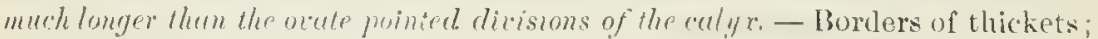
common. Jume, July.

․ A. cannábinum, L. (Ixmas Hemp.) Glabrous or more ur less suft-pubescent: sten and hranches uprught or ascending $\left(2-3^{\circ}\right.$ high), teruu nated by erect und elose many-flonered cymes, which are nsually shorter thau the lalves; leaves from oval to oblung and even lanceolate, short-petioled on sessile, with romuled or ulsomely cordate base; corollu (greenish-whte) with nearly erect lobes, the thise not longer llan the lancedate dewsions of the ralyx Moist grounds and hanks of streans; eommon. Very variable. July, Aug.

\section{Orner (77, ASCIEPIADACEAE. (MrLWEed FamLY.)}

Plants with milky juice, and opposite or wharled (ravely scattered) emtire leaves; the folliculur pods, seeds, anthers (connected mith the stigma), sensibte properties, etc. just as in the last fumily from whirh they differ in the 
commonly valuale corolla. and in the singular connection of the unlhers with the stigma, the colevion of the pollen into wax-like or granular masses (pollinia), etc.. as explained under the typical renus Asclepias.

l'erfPloci Grics, L., a woody climbing plant of the Old World, in ornatmental cultivation, and in one or two places inclined to be spuntaneous, represonts a tribe with granulose pollen loosely angregated in two masses in each anther-cell. It has a brownish rotate corolla, rery lairy within, and with 5 awuel seales in the thront.

Tribe I. OYNANCHEZE. Anthers tiphed witl an inflexed or sometimes erect scarions menbrane, the cells lower than the top of the stigna ; pollinin snspencled.

* Stems erect or merely decmubent.

I Isclepiodora. Corolla rotate, merely spreading. Crown of 5 hooled fleshy bodies, with a salinut wint in earll. Leaves alternate.

- Asclepias. C'mollil reflexed, deeply 5-parted. Crown as in n. 1, but with an incurved lorm rising fion the ravity of each hool. Leaves usually oplposite.

3. Acerates. Corollit reflexecl or merely sureadius. Crown as in n. 1, hut witl neither crest mo horm insirle. Learus mainly anternate.

* Stens twinimg. Leaves mostly njunsite.

4 Enslenia. Comla ereet. Crown uf 5 membramareous that bondies, terminated by a 2. cleft tail $\mathrm{nr}$ awn.

j. Vincetoxicum. Cornlla rotate, sprearlins. Crown a fleshy 5 -lo-lnhed ring or disk.

Tribe II. GONOLOBEA. Anthers witl short if any scarins tip, borne on the marwin of or "Inse under the disk of the stigma; mollinia horizontal.

6. Gonolobus. Corolla rotate. Crown a wary-lubet Heshy ring. Stens twining.

\section{A S CLEPIODORA, Gray.}

Nearly as in Asclepias. Int the enrolla-bolves ascending or spreading, and the hoods destitute of a horn, wisloly sprearling and somewhat incuryed, slip)per-shaped atud litterally enmpreseed, the cavity dividrel at the apex ly al crestlilie partition. - Y mbels solitary and terminal or corymhed, loosely-Anwered. lollicles olnlong on ovate, often somwhat mureate with soft spinous projec-

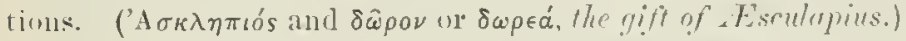

1 A. vílidis, Gray. Almost chlahrous; stems short ( $1^{\circ}$ highl); leaves alternate, short-petioled, ovate-ohlong to lanceolate, 1-2' wide; umbels sercanl in a elnster, short-pedunclel ; flowers large ( $l^{\prime}$ in diameter), green, witl a purplish crown. (Acerates paniculata, Jeraisne.) - I'rairies, Ill. to Tex. aull S. Car. June.

\section{A SCLEPIAS, I. MUKWRE. SHKWEED.}

Caly: 5-parted, persistent; the divisions small, reffexert. Corolla deeply 5.parted, the divisions valvate in the hul, reflexed, decidums. Croun of 5 hured borlies seated on the tube of stamens, each containing an incured horu. Stamens 5, inserted on the base of the corolla ; filaments mited in a tube which encloses the pistil; anthers adlherent to the stigma, eacll witlı 2 vertical cells, tipped with a membranaceons appendage, each cell containing a Hattened pearshaped and waxy pollen-mas; the two contignums pollen-mikses of auljacent antlers, forming pairs which lium by a slender prolongation of their summits from 5 cloven grlands that grow on the angles of the stigma (extricated from the cells by insects, anl directing copious pollen-tnhes into the point 
where the stigma joins the apex of the style). Ovarics 2, tapering into very short styles; the largo depressed 5-angled fleshy stigmatic disk common to the two. Follicles 2, one of them often abortive, suft, orate or lanceolate. Seech anatropons, flat, margined, bearing a tuft of loug silky hairs (roma) at the hilum, downwardly imbricated all over the large placenta, which separates from the snture at maturity. Embryo large, with broad foliaceons cotyledons in thin albumen. - Perennial upright lerbs, with thick and deep roots; peduncles terminal or lateral aul between the usually opposite petioles, bearing simple many-flowered umbels, in summer. (The Greek name of Asculapius, to whom the genus is dedicated.)

$\$ 1$. Corneous anther-uings broadest and usually angulate-truncate and salient at lase; horn conspicuous.

* Flowers orange-color: leaves mostly scattered; juice not milly.

1. A. tuberósa, L. (Buttekfly-ween. Pleurisy-koor.) Roughishhairy (1-20 high); stems erect or ascending, very leafy, branching at the summit, ard bearing usually numerous umbels in a terminal corymb; leaves from linear to oblong-lanceolate, sessile or slightly petioled; divisions of the (corolla oblong (greenish-orange); hoods narrowly oblong, bright orange, scarcely longer than the nearly erect and slender awl-shaped horns; pouk hoary, erect on deflexed pedicels. - Dry fields, common, especially southward. - Var. decúmuss, Pursh. Stems reclining; leaves broader and more commonly opposite, aurl umbels from most of the upper axils. - Ohio to Ga, etc.

* * Corolla bright red or purple; follicles naked, fusiform, etect on the de flexed pedicels (except in n. 5); leares opposite, mostly broad.

+ Flowers rather large: hoods about $3^{\prime \prime}$ long and exceding the anthers; leares transversely veined.

2. A. paupércula, Nichx. Glabrons; stem slender $\left(2-4^{\circ}\right.$ high); leares elongated-lanceolate or linear (5-10' long), tapering to both encls, slightly petioled; umbels 5-12-fouered : divisions of the red corolla narrowly oblong; the bright orange hoods broadly oblong, obtnse, mnch exceeding the incnrved horn. - Wet pine-barrens on the coast, N. J. to Fla. and Tex.

3. A. rùbra, I. Glabrous; leaves ovate or lancelate and tapering, from a rounded or heart-shuped base to a very acute point, sessile or nearly so (2-6) long, $\frac{1}{2}-2 y^{\prime}$ wide), hright green; umbels many-flowered; divisions of the co. rolla and hoods oblong-tanceolate, purple-red; the horn long and slender, straight. ish. - Wet pine-barrens, ete, N. .J. and Penu. to Fla., Ia., and Mo.

4. A. purpuráscens, L. (Pusue M.) Sitem rather slender $\left(1-3^{\circ}\right.$ high); leaves elliptical or ovele-ablong, the upper taper-pointed, minutely reliety. downy underneath, smooth above, contracted at base into a short petiole: predicels shorter than the peduncle, $3-4$ times the length of the dark purple lanceolateovate divisions of the corolla; hoods ollnug, abruptly narrowed above; the hom broadly scythe-shaped, with a narrow and abmptly inflered horizontal point. 1) ry gronnd, N. Fing. to Minu., Tenn, and suuthwarl. - Flowers 6" long.

t- +- Floucers smull; hoods 1" long, equalling the anthers; veins ascending.

5. A. incarnàta, L. (Swми Mикwвн) Smooth, or nearly so, iı the typical form, the stem with tro downy lines above and on the luanches 
of the peduneles $\left(2-3^{\circ}\right.$ high $)$, very leafy; leaves ulloug-lanceolate, acute or pointed, obtuse or obseurely heart-shaped at hase; flowers rose-purple; hoods searcely equalling the slender needle-pointed horn. - Swamps, common. Var, Púlcura, Pers. ; leaves broader and shorter-petioled, more or less hairypubeseent, as well as the stem. Milky juice seanty:- With the smooth form.

* * Flowers greenish, yellowish, white, or merdy purplish-tinged: leuves opposite or whorled, or the upper rarely scuttered.

+ Follicles eclinate with soft spinous processes, densely tomentose (smooth, and only minutely echinate at the apex in $\mathrm{n} .8)$, lurge $\left(3-5^{\prime}\right.$ long), ovute and acmminate, erect on deflexed pedicels: lear'es lurge and broad, short-petioled; umbels terminal and lateral.

6. A. speciosa, Torr. Finely cauescent-tomentose or glabrate, the manyflowered umbel and calyx densely tomentose; leaves subcordate-oral to oblong; corolla-lobes purplish, ovate-oblong, $4-5^{\prime \prime}$ long; hoods 5-6" long, with a short inflexed horn, the truncate summit abruptly produced into a very longlanceolateligulute appendage. - Along streams, Minn. to Ark., and westwart.

7. A. Cornùti, Decaisne. (Common Mirkwen or Snkwén.) Stem tall and stout, finely soft-pubescent; leaves oval-oblong ( $4-8^{\prime}$ long), pale, mimutely douny beneath, as well as the peduncles, etc.; corolla-lohes dull purple to white, 3-4" long; hoods rather longer than the anthers, ovate, obtuse, with a tooth each side of the short stout claw-like horm. - Rich gronnd, everywhere.

8. A. Sullivántii, Engelm. Very smooth throughont, tall; leaves orateoblong with a somewhat lieart-shaped base, nearly sessile; hoods obocate, entire, obtusely 2-eared at the base outside; flowers larger (9" long) and more purple than in the last; anther-wings 2-tootled at base; pod nearly glabrous, obseurely spiny chiefly on the beak. - Low grounds, Olio to Kau. aud Minn.

+- Follicles wholly unarmed, eiller glabrous or tomentulose-pubescent,

+- Erect or ascending on the deflexed or decurved fruiting pedicels.

= Umbel solitary, on a naked terminul pedumcle: leaves sessile, broad, transrersely reined, wary; glabrous and jale or glaucous.

9. A. obtusifolia, Michx. Sten $2-3^{\circ}$ high ; leaves oblong with a heart.

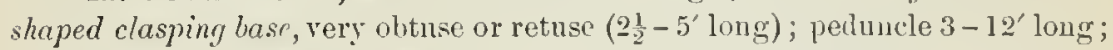
corolla pale greenish purple; loods truncatc, somewhat tootlied at the summit, shorter than the slender awl-pointed hom. - Sandy woods and fields, not rare, especially southward. A second nmbel at the base of the peduncle ocasionally ocelurs.

10. A. Meádii, Torr. Stem slender $\left(1-2^{\circ}\right.$ high $)$; leaves orate or oblong-

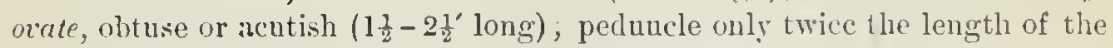
upper leaves, pedicels rather short; eorolla greenish-white; hoods ronndedtruncate at summit, and with a sharp tooth at eaeh margin, somewlat exeeding the stouter horn. - Dry ground, Ill, and Iowa. Jume.

$==$ Umbels mostly more than one; peduncle not overtopping the leaves.

a. Leaves larye, orbucular to oblong-lanceolate; hoods uroad, little if at all exceed. ing the anthers; glabrous or some minute mubscence on young parts.

11. A. Jamèsii, Torr. Stem stout ( ${ }^{\circ}$ high or more) : leaves about 5 pairs, approximate, remarkably thick, rounded or broally oral, fonen emarginate. 
subcordate at base, nearly sessile; umbels 2-3, densely nany-flowered, on short peduncles; corolla-lobes ovate, greenish; hoods truncate, entire. - Plaius of ("entral Kansas and sonthwestward.

12 A. phytolaccoldes, P'ursh. (Poke-Mhriweri), Stem $3-5^{\circ}$ high; leares broully arate, or the upper ocal-lanceolate and pointed at both ends, short-petioled, smooth or slightly downy underneath (s- $8^{\prime}$ long); lateral umhels several; pedicels loose rend noddini, numerous, long ind slender (1-3' long). crualling the perluncle; curollatobes urate-oblong, greenish; hoods (white) truncate, the margins 2-toothed at the summit, the hom with a long projecting 'tw'-shaped point. - Muist copses, N. Lug. to Minn., south to Ga. and Ark.

13. A. variegàta, L. Stem $1-20$ high; leuces $(t-5$ pair's) vecute, ocul, ar vborate, somewhat wary, contracted into short petioles, middle ones sometimes whorled; pedicels (mumerous and crouded) anil peducte short, dorny: divisious of the coralla orate (athite); hovels orbicular, entire, purplish or redalish, the horu semilunar with at horizontal point. - Dry woors, southern X. I. to - lucl, south to Fla., Ark, and TT. La. July.-Remarkable for its comprat unbels of nearly white flowers.

b. Leaves mostly pubescent or puberulent; hoods obluse, entire, twice or thrire the lenyth of the anthe's.

I4. A. ovalifolıa, Decaisue. Luw $\left(6-18^{\prime}\right.$ lighli), soft-downy, especially the lower surface of the ovate or lanceolate-oblong acute short-petioled learen $\left(1 \frac{1}{2}-3\right.$ long); mubels loosely $10-18$-thowered, scrsile or peduncled; pedicels slenter, hoods oblong, yellowish, with a small horn, athont the length of the owal greenish-whte corolla-lubes (tingerl with purple ontside). - Prairies and oak-openings, X. Ill. and Iuwa, tw Wisc. and S. Dak.

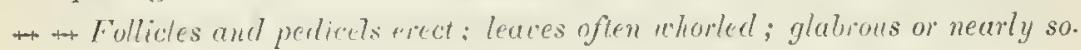

= Leares ocate to bruadly lanceulate, thin, rather slender-petioled.

15. A. quadrifòlia, L. Stem slender (1-20 high), mostly leafless helow, hearing nitully one or tuo whorls of four in the middle and one or two pair's of ovate or ovate-lanceolute talyer-pointerl petioled leares (2-4' long): peilicels slender; corolla-lobes (pule pink) oblong; low wh white, elliptical-orate. the incurved lorn short and thick. - Dry woods and hills, X. Eng. to Minn.. sontlo to X. C. and Ark.

16 A. perénnis, Tralt. Stems $\left(1-2^{\circ}\right.$ high $)$ persistent or someukut xomely

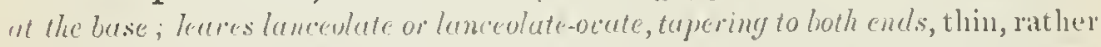
slender-petioled; flocess white, small; the small hoods of the crown shorter than the needle-shatperl horu; seeds sometimes lestitute of a coma! - Low sromds, S. Ind. and Ill. to Tex, and eastwarrl.

$==$ Leaves narrondy lineur tu filiform; horn subulute, exserted; column conspicuous.

17. A. verticillàta, L. Stems slender, simple or sparingly branched, very leafy to the summit; leaves filiform-linear, witls revolute margins (2-3" long, $1^{\prime \prime}$ wide), 3-6 in a whord; mulwels small, latteral and terminal; divisions of the comollar ovate (greenish-white); hoods ronndishtoral, alyout half the

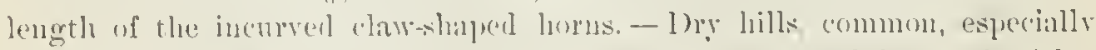

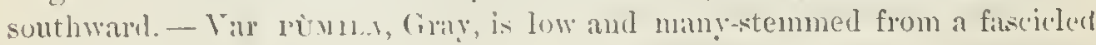

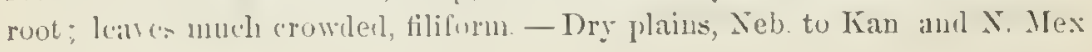


\$2. Anther-uings broudly rounded at base and conspicuously anriculate-notched just above it; hoods with u mimute horn exserted from the 2-lobed apex.

18. A. stenophýlla, Gris. P’uberulent, but foliage glabrous; stems slender (1-20 high), learcs narowly linear (3-7' long, 1-21" wide), the upper alternate, lower "ppusite; mulsels several, short-peduncled, $10-15$-flowered ; corolla-lohes whlong, greenish; hoods whitish, equalling the anther's, conduplicate-concare; follicles erect on ascending perlicels - Dry prairies, leb. to E. Kin., suntl and westwarl.

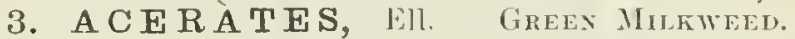

Nearly as in Asclepials; but the hoods destitute of crest or horn (whence the nante, from a privative, and képas, "hom). - Flower's greenish, in eompact many-flowered mulels. Leaves opjosite or irregularly alternite, short-petiolel ur sessile, I'ullen-masses slender-stalked. Follicles smouth, slender.

* Cronen upon a short irolumn and shorter than the globular mass of renthers and stivmo, leaces muinly altemate-scattered.

1. A. longifolia, Ell. Minutely roughish-lairy or smoothish; stem erect ( $1-3^{\circ}$ ligh $)$, very leafy ; leaves linear $\left(3-7^{\prime}\right.$ long); umbels lateral, on perluncles of alrout the lengtlo of the sleuder pedicels; flowers $3^{\prime \prime}$ long when expanded. - Moist prailies and pine-harrens, ()hio to Minu., south to Fla. and Tex. July-oct.

* Crom sessile, the oblong huods nearly equalling the anthers; lcares often opposite and broader.

2. A. viuidiflora, Ell. Minutely soft-douny, becoming smoothish; stems

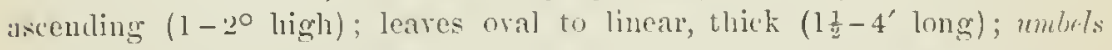
urrrly sessile, lateral, lense and glohose; Huw (when the corolla is reflexed) nearly" ${ }_{2}^{\prime} \operatorname{long}$, short-pedielled. - Dry soil, common, especially sonthwarr.

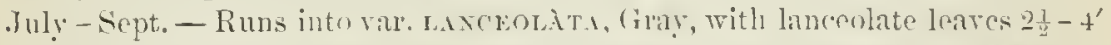

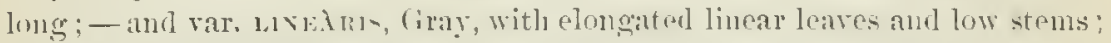
mulek often solitary. The latter form from Minn, N. Dak, ancl soutlward.

3. A. lanuginòsa, lecaisue. Hairy, low (j-12' high); leaves lanceoSite or wate-laneolate: Imblel solitery and triminal, peduncled: Howers suraller; perticels slender. - l'rairies, N. Tll. to MLim., and westward. July.

\section{ENSLENIA, Nutt.}

Calyx sparted. Corolla iplarted the clivisions elect, orate-lancenlate. Crown of 5 free membranacenus leatlets, which are truncate or uhscurcly lobod at the apex, where they hear a pair of flexnous awns united at loase. Anthers nearly as in Asclepias; pollen-masses chlong, olutuse at hoth ends, fixed helow

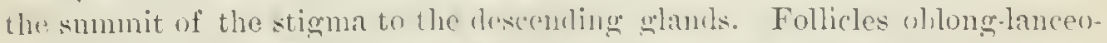
latc, smooth. seeds with a tult, as in Asclepias. - A pereminl twining herl, smouth, with opposite heart-owate and pointed long-potioled loaves, and small whitish flowers in racene-like clustror, on slemler axillary julumeles. (Dedicated to .1. Ensten, an Austrian hotanist who collected in the Gonthem Inited States early in the present century.)

1. E. álbida, Nutt. Climhing $8-120$ ligh; leaves $3-5^{\prime}$ wicle - River. baukis, S lenul. and Va to I11., Mo, and Tex July-Sept. 


\section{VINCETÓXICUM, Moench.}

Calyx 5-parted. Corolla 5-parted, wheel-shaperl. Crown flat and flesly, disk-like, 5-10-lobed, simple. Authers, smooth follicles and seeds mnch as iu Asclepias. - Herlss, often twining. (Nane from rincens, binding, and toxicum, poisoll.)

V. Nìgra, Moench. More or less twining, nearly smooth; leares orate or lance-ovate; flower's small, dark pnrple, in an axillary cInster, on a peduncle shorter than the leares. - N. Eng. to Penn.; a weed escaping from gardens. (Adv. from En.)

\section{GONÓLOBUS, Michx.}

Calyx 5-parted. Corolla 5-parted, wheel-shaped, sometimes reflexed-spreading; the lobes convolute in the bnd. Crown small and fleshy, anuular or cnpshaped, in the throat of the corolla. Anthers horizontal, partly hidden under the flattened stigna, oyening transversely. Pollen-masses 5 pairs, horizontal. Follicles turgid, mostly nuricate with soft warty projcctions, sometimes ribbed. Seeds with a coma. - Twining herbs or shrubs (ours herbaceous), with opposite heart-shaped leaves, and corymbose-umbelled greenish or dark purple flowers, on peinncles rising from between the petivles. Onr species belong to the typical section, with the crown simple and malpentaged, and the corolla nearly veinless. (Name composed of $\gamma \omega v i \alpha$, an angle, and $\lambda o \beta o s, a$ pod, from the angled follicles of some species.)

* Crown a low undulatcly 10-lobed fleshy disk; follicles unarmed, glabrous, 3-5costate or angled.

1. G. suberòsus, R. Br. Leaves cordate with an open shallow or some. times deeper and narrow sinus, pointed, glabrate or hairy (3-5' long); umbels 3-9-flowered, much shorter than the petiole; corolla broadly conical in bud, rbmptly pointed, twisted; lobes ovate or triangnlar-lanceolate, acnte, pubescent inside; calyx half as long. (G. macrophylhs, Chapman.) - Near the coast, $\checkmark$ a. to Fla.

2. G. læevis, Michx. Leaves oblong-cordate with a deep and narrow opeu sinus, conspicuonsly acuminate $\left(3-6^{\prime}\right.$ long); umbels 5-10-flowered, harely equalling the petiole; corolla clongated-conical in bud, not twisted; lobes narronly onlineru-lancelate, obtuse, glabrous inside, $3-4$ times as long as the rulyx. - South of our range. - Passes into var. Mcromíues, Gray, with larger broadly cordite lenes, the simus offen clused, finely pubescent beneath. (G. macrophyllus, Mirhr.) - River-banks, Va. to S. Ind., Mo., S. C., and 'Tex.

* Croun cup-shaped, as high as the anthers: follicles muricate, not costate.

t- Croun fleshy, merely 10-crenate, or the crenatures bidentute.

3. G. obliquus, R. Br. Leaves rounded-to ovatc-cordate with a narrow sinus, abruptly acmuninate $\left(3-8^{\prime} \mathrm{long}\right)$; umbel many-fouered; corolla m bud ollong-ronical; its lobes lineor-ligulate $\left(5-6^{\prime \prime}\right.$ long, l" wide), crimson-pnrple insirle, dull or greenisl and mimutly pubescent outside. - River-banks, monntains of Penn. and Va., to Ohio and Mo. Flowers said to be fragrant.

4. G. hirsutus, Michx. Commonly more hairy; leaves with the basal lobes sometimes overlipping; preduncles feuer-Anuered; corolla an bud orat, its lubes elliphicaloblong (3-4" long), barly puberulent autside, dull or brownishpurplo, - Ma, and Va. to Tenn. and Fla. 
- + Crown thinner, the border lobed or tonthed; leaves as in the preceding.

5. G. Shórtii, Gray. Resembles 11.3, but larger-leaved; corolla oblongconieal in bucl, dark crimson-purple, its lobes ligulate (fully 6" long); croun about 10-toothed, the alternate teeth thimner, narrouer and lonyer, either emarginate Ir 2-parted. - Along the mountains, E. Ky. (Short) to N. W. Ga. (Chapman).

6. G. Carolinénsis, 1R. Br. Flower-bud oblong; corolla brownishpurple; its lobes oblong or linear-ublong $(4-5$ " long); croun undulately and very obtusely 5tobed and with a longer bifid subulute process in each sinus. From Va. to La., extending worth to Ark. and central Mo.

\section{Order 68. LOGANiĀceae. (Logaxia Family.)}

IIerbs, shrubs, or trees, with opposite and entire leaves, and stipules or a stipular membrane or line between them, and with regular $4-5$-merous $4-5$ androus perfect flowers, the ovary fice from the calyx; a comnecting grouls between Gentianacea, I pocynacea, Scroplumariacea (from all which they are known by their stipulcs) and Rubiacex, from which they differ in their frce ovary; our representatives of the family arc ail most related to the Rubiacere, to which, indced, they have bcen appended.

* Woody twiners; leaves evergreen; stirnms 4.

1. Gelsemium. Corolla large, the 5 lobes imbricated in the bud. Style slender.

* Herbs ; stigrar single, entire or 2-lobed.

2. Polypremum. Corolla 4-lobed, not longer than the calyx, imbricated in the bud.

3. Spigelia. Corolla 5-lobed, valvate in the bud. Style single, jointed in the midulle.

4. Mitreola. Corolla 5-lobed, valvate in the bud. Styles 2, short, converging, united at the summit, and with a conmon stigma.

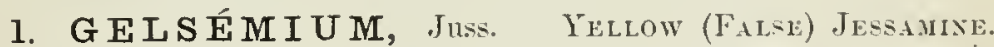

Calyx 5-parted. Corolla open-funnel-form, 5-lobed; the lobes imbricated in the bud. Stamens 5, with oblong sagittate anthers. Style long and slender; stigmas 2, cach 2-parted, the divisions linear. Capsule elliptical, flattened contrary to the narrow partition, 2-celled, septieidally 2-valved. Seeds many or sereral, winged. Embryo straight, in fleshy albumen; the orate flat cotyledoms mnch shorter than the slender radicle. - Smooth and twining slirubby jlants with orate or lanceolate leares, minute deciduons stipules, and showy rellow flowers, of two sorts as to relative length of stamens and style. (Gelso. minn, the Italian name of the Jessamine.)

1. G. sempérvirens, dit. (Yellow Jissumuse of the Soutl.) Stem "linbing high; leaves short-petiolel, shining, nearly persistent; flowers in shurt axillary clusters; pedicels scaly-bracted ; flowers very fragrant (the bright yellow corolla 1-1 $\frac{1}{2}$ long); (apsule flat, pointed. - Low grounds, E. Ta. to Fla. aud Tex. Mareh, April.

\section{POLYPRE M U M, L.}

Calyx 4-parted; the divisions awl-shaped from a broad scarious-margined hase. Corolla not longer than the calyx, almost wheel-shaped, bearded in the throat; the + lobes inbricated in the bnt. Stamens 4, very short; anthers grubulat. Style I, very short; stigna oroid, cutire. Capsule ovoid, a little 
flattened, notched at the apex, 2-celled, loculicidally 2-ralved, many-seeded. A smooth, diffuse, much-hranched, small annual, witl uarrowly linear or awlshaped leaves, eomected at hase by a slight stipular line; the small flowers :olitary aur sessile in the forks and at the ends of the branches; corolla incom-

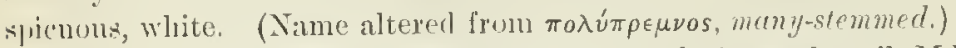

I. P. procúmbens, L. - Iry fields, mostly in sally soil, Mfl. to 'Tex.; also adrentive in l'em. June-Oet.

\section{SPIG ELIA, L. Pixli-Ront. Woragrass.}

Calyx 5-parted; the lobes slender. Corolla tulular-funnel-form, 5-lobed at the sumnit, ralvate in lond. Stamens 5; anthers linear. Style l, slender, hairy above, jointed near the mildle. Capsule short, 2-celled, twin, laterally Hattened, separating at maturity from a persistent lase into 2 carpels, which "pen loculicilally, few-seerled. — Chiefy herls, witl opposite leaves united by stipules, and the fowers spiked in one-sided cymes. (Named for Adrian spiegel, latinized spigflus, who wrote on botany curly in the litls century, and was perhaps the first to give directions for preparing an herbarium.)

1. S. Marilándica, L. (Marifaxp Priklioot.) Stems simple and (rect from a peremial rout $\left(6-18^{\prime} h i g h\right)$; leaves sessile, orate-lanceolate,

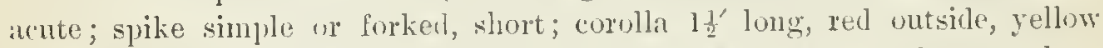
within; tube 4 times the length of the calyx, the lobes lanceolate; anthers ind style exserted. - Tich wools, X. I. to Wisc. and Tex. June, July. - A well-known oflicinal anthelmintic, and a showy plant.

\section{MITR 立OLA, L. Mitrewort.}

Calyx 5-parted. Corolla little longer tham the calys, somewhat funnel-form, 5-lubed, valvate in the hud. Stamens 5, included. Orary at the base slightly arluate to the bottom of the calyx, 2-celled; styles 2, short, converging and mited alove ly, a common stigniz. (apsule exserted, strongly 2-hormed or mitre-shaped, opening down the imer side of each lorn, many-scederl. - Annual smooth lierls, $6^{\prime}-2^{\circ}$ ligh, with small stipules hetween the leares, and small white flower's spikeal alongro me sile of the branches of a terminal petioles cyne. (Diminutive of mitre, a mitre, from the shapse of the port.)

1. M. petiolàta, 'Torr. \& Gray. leares tlin, oblung-lanceolate, petioled. - Dimup soil, from İ. V'a. to 'lex.

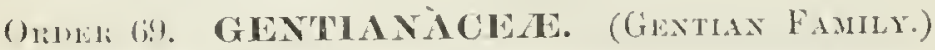

Sinooth herbs, with a colorless biller juiee, opposite and scssile entire and simple leaves (exespt in Tribe II.) without stipules, regular flowers with the samens as many as the lobes of the corolla. which are convolute (rarely imlricaterl and sometimes valvate) in the lunl, a 1-eelled oxury with 2 parietal placenta, or nearly the whole inner face of the outry oruliferous ; the fruit

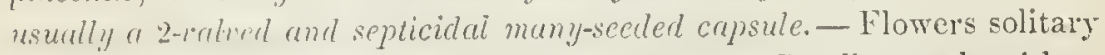

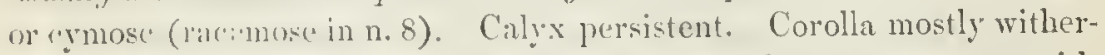
inl-persistent: the stamens inserted on its tube. Seeds anatropous, with

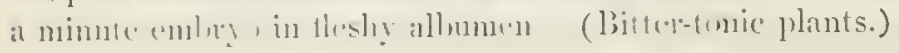


SUBorder I. Gentianeac. Leaves always simple and entire, sessile, never alternate. Estivation of eorolla never valvate.

* Lobes of eorolla convolute in the hur.

- Style filiform, usually deciduons; anthers oblong to linear, mostly twistiug or curving in age.

1. Erythrea. Pints of fluwer 5 or 4 ; corollat salver-form ; inthers twisting spirally.

2. Sabbatia. l'arts of fluwer $\tilde{5}-12$; eorolla rotate; authers reeurved or revolute.

3. Eustoma. Parts of flower 5 or 6 ; corolla eamprulate-funel-form ; anthers versatile, straight or reeurving; valyx-lobes long-acuminate.

+ +- Style stont and persistent or none; anthers remaining straight.

4. Gentiana. Corolla funnel-form or bell-shaped, mostly plaited in the sinuses, without spurs or glands. Calyx $4-5$-eleft.

5. Frasera. Corolla t-parted, rotate; a fringed glandular spot on each lobe.

6. Halenia. Corulla $t-j-1 \cdot f t$, cumplanulate, and $t-\bar{j}$-spourred at the base. * * Lobes of corolla inbricate in the bial; no almendages.

T. Bartonia. Calyx 4-parted. Conolla deeply 4 -cleft, somewhat campanulate.

S. Obolaria. Calyx of 2 foliacens sepals. Corolla 4-lober, olilong-eanjanulate.

Siinorder II. Mrengantheae. Leaves all alternate and mostly petiuled, sometimes trifoliolate or erenate. Estivation of eorolla indirplicite-valvate. Marsh or aquatic perennials.

9. Menyantles. Corolla bearded inside. Leaves 3-foliulate.

10. Limmanthemun. Corolli naked, or bearded un the margins only. Leaves simple, rounded.

\section{ERYTHR㐫A, Richard. Centaury.}

Calyx $4-5$-parted, the divisions slenter. Corolla funnel-form or salver-form, with slender tule and $4-5$-parted limb. Authers exserted, erect, twisting spirally. Style slendrr, single; stigma capitate or 2-lipued. - Tow and small

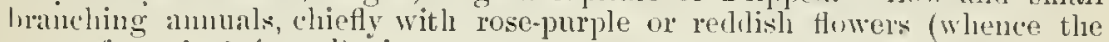
name, fronll éputpós, red); in summer.

E. Cextaúnum, l'ers. (Cwataury.) Stem upright (6-12' higli), corymbostly brencled above; leares oblong or elliptical, acutish, the basal rosulate, the ilplermost linear; cymes chustred, flat-topped, the flowers all noarly sessite: tube of the (purple-rose-colored) corolla not twice the length of the oval lobes. - Waste grounds, slores of Lakes (Mntario and Mlichiman. (Adv. from En.)

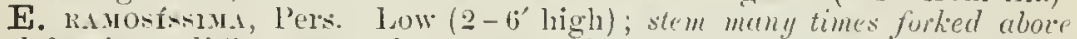
rmel forminy a difficse cyme; leaves orate-obloug or oral, not rosulate below; floures all on short pedicels; tube of the (pink-purple) corolla thrice the lengtli of the ellipticial-oblong lobes. - Wet or shady places, N. J., li. I'emn., and sonthward. (Nat. from Eu.)

E. splcdt, Pers. Sten strictly upright $\left(6-10^{\prime}\right.$ lighl $)$; the flowers sessile und spilied along one side of the simple or rarely forked brunches; leaves oval and olloug, rounded at base, acutish; tube of the (rose-colored or whitish) corolla scarcely longer than the calyx, the lobes oblong. - Sandy sea-slicre, Nautucliet, Mass., and Portsmouth, Vra. (Nat, from En.)

\section{SA B B À T I A, Adans.}

Calyx 5-12-parted, the divisions sleuder. Corolla 5-12-parted, wheelsliaped. Stamens 5-12; anthers soon recurved. Style 2-cleft or -parted, slender. - Biennials or annuals, with slender stems, and cymose-panicled laandsome (white or losepurple) fluwers; in summer. (1)edicated to L. Sab. buti, an carly lanlian lutauist.) 
* Corolla 5-parted, or rarely 6-7-parted.

+ Branches all opposite and stems more or less t-angled; flowers cymose; calyx with long and slender lubes.

+ Corolla white, often turning yellowish in drying.

1. S. paniculàta, Pursh. Stem brachiatel! much-branched (1-20 high); leaves linear or the louter ollong, obtuse, I-nerved, nearly equalling the internodes; calyx-lubes muel slorter than the corolla. - Low grounds, Va. to Fli.

2. S. lanceolàta, Torr. \& Gray. Stem simple $\left(2-3^{\circ}\right.$ high $)$ beariug a flat-topped cyme; lenves ovule-funceolute or ovate, 3-nerved, the upper acute, much shorter than the internodes; calyx-lobes longer and flowers larger than in n. 1. - Wet pine barrens, N. J. to Fla.

+ + Corolla rose-pink, rarely uhite, with a yelloucish or greenish eye.

3. S. brachiàta, Ell. Stem slighly angled, simple below (1-20 high); leares linear and linear-oblong, obuse, or the upper acute; branches rather fewflowered, forming an ohlong panicle; calyx-loles nealy half shorter than the corolla. - Dry or low places, Ind. and N. C. to Lat. anel Fla.

4. S. angulàris, Pursh. Stem someulut 4-ucinged-angled, much branched above (1-210 ligh), many-flowered; leares orule, acutish, 5-11erved, with a somewhat heurt-shaped clasping base; calyx-lobes one third or half the leugth of the corolla. - Rich soil, N. Y. to Ont. and Mich., south to Fla. and La.

++ Branches alternate (or the lower opposite in $\mathrm{n} .5$ ) ; peduncles 1-flowered.

+ Calyx-lobes foliaccous.

5. S. calycòsa, P’ursh. Diffusely forking, pale, ${ }^{\circ}$ high or less; leaves vblong or lance-oblong, narrowed at base; calyx-lobes spatulate-lanceolate $\left(3-I^{\prime}\right.$ loug), exceerling the rose-colored or almost white corolla. - Sea-coast and near it, Va. to 'Tex.

+ + Calyr-lohes slonder and tube very short (prominently costate in n. 6, and lom!ger, nearly or quite enclosing the retuse copsule).

6. S. campéstris, Nutt. Span or two high, dirergently branched albove; luaves orate with subcoldate clasping hase ( $\frac{1}{2}-I^{\prime}$ long $)$, on the branches lan-

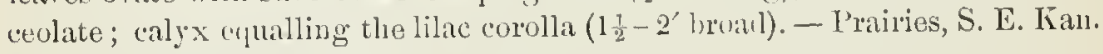
and W. Mo. to 'Tex.

7. S. stellàris, l'ursh. Luosely brancherl and forking; leaces oblong to lanceolate, the uliper narrowly linear; caly.tohes are-shapedtinear, rarying fiom half to nearly the length of the bright rose-purple corolla; style nearly 2 parterl. - salt marshes, Mass. to Fla. Appears to pass into the next; corolla in buth at tines pink or white.

8. S. grácilis, Salisb. Stem very slender, at length diffusely brauclied; luranclies and long peduncles filiform; leaves lineur, or the lower lance-linear, the uppermost sinilar to the setaccous caly.2-lubes, uhich equal the rose-purple corolla; style cleft to tlie niddle. - Brackish marshes, Nantucket, Mlass., and N. J., to lili. aud Iar.

9. S. Ellióttii, Stend. Iiffusely nuch lurancherl; leares small, lower (auline (6" long or less) thickish, from olsorate to lancrulate, upper narrowly lincar and ratler lunger, on the flowering branches subulate; calyxdubes shen- 
der-subulate, very much shorter than the white corollu; style 2-parted. - Pine barrens, s. Va. (?) to Fla.

$$
\text { * Corolla 8-12-parted, large (about 2' broad). }
$$

10. S. chloroides, Purslı. Stem ( $1-2^{\circ}$ higli), loosely panicled above; pednncles slender, 1-flowered: leaves oblong-lanceolate; calyx-lobes linear, half the length of the deep rose-colored (rarely white) corolla. - Borders of brackish ponds, Mass. to Fla, and Ala.

\section{E U S T O M A, Salisb.}

Calyx 5- (rarely 6-) parted; its lobes long-acuminate, with carinate midril). Corolla campaunlate-funnel-form, deeply 5 -6-lobed. Anthers oblong, versatile, straight or recurving in age. Style filiform, nearly persistent; stigma of 2 broad lancllix. - Gliucous large-flowered anunals, with nore or less clasping and comnate leares, and slender terminal and more or less paniculate 1-Howered pedunctes. (From $\epsilon \vec{v}$, nell, and $\sigma \tau \delta \mu a$, month, alluding to the openmouthed corollia.)

1. E. Russelliànum, Grisel,. One or two feet high ; leaves from ovateto lanceolate-oblong; lobes of lavender-purple corolla olovate (1 $\frac{1}{2}^{\prime}$ long), 4 times longer than the tube; anthers hardly curving in age. - Neb. to 'Tex.

\section{GE $\mathbf{N}$ T I À N A, Tourn. Gentian.}

Calyx 4-5-cleft. Corolla 4-5-lobed, regular, nsually with intermediate plasted folds, which bear appendages or teeth at the sinuses. Sityle short or none; stigmas 2, persistent. Cajsule ol)long, 2-ralved, the inumerable seeds either borue on placenta at or near the sutures, or in most of our species covering nearly the whole inner face of the pod.-Flowers solitary or cynose, showy, in late summer and autumu. (Name from Gentins, kiug of Illyria, who used some species mediciually.)

\$1. GENTIANELLA. Corolla (not rotute) destitnte of extended plats or tolies or teeth at the simuses: root anmul.

* (Frixgen Gextaxs.) Flouers lurge, solitury on long terminal peduncles, mostly 4-merous; corolla campanulate-fumel-form, its lobes usually fimbriute orese, not crouned; a row of glands between the bases of the filaments. Autumn-foucring.

1. G. crinita, Froel. Stem 1-20 high; leares lunceolate or orate-lanceofute from a partly herrit-shuper or rounded base; lobes of the 4-cleft calyx uneynal, ovate and lanceolate, as long as the bell-shaped tube of the blue corulla (2'long), the lukes of which are wedge-obovete, and strongly finged around the summit; ovary lanceolate. - Low grounds, N. Eng. to the Dakotas, south to lowa, Ohio, and in the mountains to Ga.

2. G. serràta, (iunner. Stem 3-18' high; leares linear or lanreolatelineer; lobes of the 4-(rarely 5-) cleft calyx unequal, orate or triangular and lanceolate, pointert; lo'ses of the sky-hlue corollu spatnlate-oblong, with ciliatefringed margins, the firinge shonter or ulmost ubsulete at the summit; ororn elliptiral or obocate. (G. detomsi, Hanual.) - Moist gromuls, Newf. and W. New York, to Iow: and Minn., north and westward. 
* Flowers smaller, 4-5-merous; corolla someuthat funnel-form or sulver-form, its lobes entire: peduncles short or none, terminal and lateral on the acuteangled stem.

3. G. Amarélla, L. Stems 2-20' high; leaves lanceolate to narrowly oblong, or the lowest obovate-spatulate, the margins minutely scabrous; ealyxlobes $(4-5)$ foliaceous, lanceolate or linear; corolla mostly blue, $\frac{1}{2}$ long ol more, "wh a fimbriate moun at the base of the oblong arute lobes; capsule sessite. - Var. acuta, Hook. f. Calyx almost 5-parted; crown nsually of fewer ani sometimes very few seta. - Lab. to N. Vt. and N. Minn., west and northwath.

4. G. quinqueflora, Lam. Stem rather slender, hranching (1-2o high); leaves ovate-lanceolate from a partly clisping and heart-shaped base, 3-i-nerved, tipped with a minute point; branches racemed or panicled, about 5-flowered at the summit; lobes of the small 5-cleft calyx awl-shapecl-linear; corolla pale blue, $6-9^{\prime \prime}$ long, its lobes trangular-orate, Imstle-ponted, wuthout crown, but the glands at the base of the slender obconical tube manjest; cupsulte stipitate. - Moist hills, Maine to Ont., Ill., and south along the mountains to Fla. - Var. occhextìls, Gray. Sometimes 2-30 high, and pauieulately much-branched; calyx-lubes more leaf-like, linear-lanecolate, reaching to the uniddle of the broader funnel-form corolla. - Va. and Ohio to Minu., soutlı to 'Tenn. and La.

\$2. PNEUMONANTllE. Cordlu (funnel-form or salver-form) with thinmembranaceous toothed or lubed plaits in the sinuses; no croun nor glands. capsule stipitate; autumn-flouering perennials, the floucrs large, sessile or short pedunculate and bibracteatc (cxcept in $\mathrm{n} .12$ ).

* Anthers unconnected or soon separate; leares rough-margined; seeds uingcai.

5. G. affinis, Griseb. Stems chustered, $1^{\circ}$ high or less, leaves ollong or lanceolate to linear; flowers numerous and thyrsoid-racemose or few or rarely almost solitary ; caly.r-lobes unequal, the longest rarely equalling the tulse, the shortest sometimes minute; corulla (blue or blnish) l' long or less, rather nurrouly funnel-form, with ovate sprealing lobes, the plaits with consficurnus lariniate uppondages sometimes equalling llie lobes - Minn. to the l'acifie.

6. G. pubérula, Michx. Stems (mostly solutury) erect or ascendings (8-16' high), mustly rough and minutely pubescent alove ; leares rigid, linearlanceolate to oblong-lanceolate $\left(1-2^{\prime}\right.$ long) ; flovers clustered, rarely sulitary . "alyx-lobes lanceolute, much shorter than the lifl-fumel-form open lright-blue "rolla, the sprealing ovate lobes of which are turice or thrice the length of the rut-toothed appendayes. - 1)ry prairies and barrens, western N Y. Obio, and Ky., to Minn. and Kan. Oct.

* Anthers cohering in a ring or slort tube; flowers in terminal and often axillary clusters.

- Calyx-lobes and bracts ciliolutr-scabrous; sceds ronspicuonsly winged; leares rough-margined.

7. G. Saponària, I. (Sonl'wort G.) Stem erect or ascenrling, sulouth, leaves ovate-lanceolate, oblong, or lanceolate-ohovate, uarrowed at the base. ruly.x-lolies linern or spatulute, acute, equalling or exceedung the tule, half the Jength of the ronolla; lobes of the club-bell-shaped light-lulne corolla obtuse, 
erect or converging, short and broad, but disfinct, and more or less longer than lhe ronspicuous 2-cleft and minutely toothed appendages. - Moist woods, N. Y. and N. J. to Minu., soutl to Fli. and La.

8. G. Andréwsii, Grisel). (Chosen G.) Stems upright, smooth; leaves ovate-lanceolate and linceolate from a narrower balse, gradually pointed ; caly $x$ lobes lanceolute to burte, recurverl, shorter than the top-shuped tube, and much shorter than the more oblong and truncate mostly blue corolla, which is closed at the mouth, its proper lubes obliferuled, the apparent lobes consisting of the hroad fringe-tootled and notched appendages. - Moist ground, N. ling. to Minn., sonth to N. Ga. Corolla blue with white plaits, or sometimes all white. + + Maryins of leaves, bracts, etc., smooth and naked; terminal flower-chuster leafy-inroluciute; seeds uinged.

9. G. álba, Mluhl. Stems upright, stout; flowers sessile and crowded in a (lense terminil cluster; leaves ovate-lanceolate from a licart-sliapel closely clisping base, gralually tapering; calyx-lobes orate or subcordate, many times shorter thin the tube of the corolla, reflexed-sprealing; corolla white nore or less tinged with greenish or yellowish, inflated-club-shaped, at length open, it short aul hroad orate lobes twice the length of the broal toothed appendages - Low grounls and mountain meadows, Ont. to Ill., Ky., and Va.

10. G. lineàris, Froel. Stems slender and strict, $1-2^{\circ}$ high; flowers $1-5$ in the terminal cluster; leaves linear or narrowly lanceolate, with somewhat dlarrowed base; bracts sometines very finely seabrous; calyx-lobes linear w lanceolate; corolla blue, narrow fumel-form, its erect roundish-ovate lobes little longer than the triangular acute appendages. (G. Saponaria, rar. linearis, (imy.) - Bogs, momtains of Md. to N. Y., N. Eng., and nortliwart.

Var. lanceolàta, Gray. Leaves lanceolate, or the upper and involucrate ones almost ovate-lanceolate, appendages of corolla sometimes very short and broad. - Minn. and I. Superior; also Herkimer Co., N. Y.

Var. latifolia, Gray. Stont; leaves closely sessile, not contracted at base, the lowest oblong-linear, the mpper orate-lanceolate; appendages broal, acute or subtruncate. - L. Superior; N. Brunswick (flowers blue).

+ + + Calys-lobes and bracts with smooth margins ar nearly so: seeds completely maryinless.

11. G. ochroleùca, Froel. Stems asconling, mostly smootl, leares ohovate-oblong, the lowest broally ohovate and obtuse, the uppermost somewhat lancenlate, all narrowed at base, calyx-lobes linear, unequal, much longer than its tule, rather shurter than the greenish-white npen corolla, which is painted insile with green veins and lilac-purple stripes; its lobes wate, very much exceeling the small and sparingly toothed oblique appenliages. - Dry or danp gromuls, P'enn. to Fla. and La.

* * Anthers not connerted: fluwers terminal, solitary, commonly peduncled and naked: seeds wingless.

12. G. angustifolia, Michx. Stems slender and ascending (6-15' high), mostly simple; leaves lincal or the lower oblanceulate, rigid ; corolla openfumel-form (2' long), azure-blue, also a greenish and white variety, about

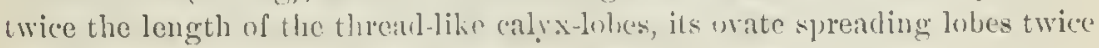
as long as the eut-turthed alpueudiges - Muist pine barrens, N. J. to Fla. 


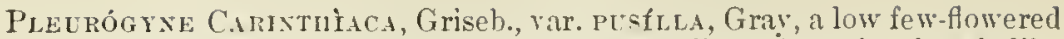
annual, with rotate hlue or bluish $4-5$ parted corollit and a pair of scule-like appendages on the base of its divisions, is fotand from the Aretic Coast to the lower St. Lawrence aud Newfoundland, and wis reported hy I'ursh from the summits of the Write Mountains, but has not since been found.

\section{FRÁserA, Walt. Avericix Colcibo.}

Calrx deeply t-parted. Corolla deeply t-parted, wheel-shaped, each division with a glandular aud fringed pit on the face. Filaments awl-shaped, usually somewhat monadelphous at base; anthers obloug, rersatile. Style persistent; stigna 2-lobed. Capsule oval, flattened, 4-14-seeded. Seeds linge and Hat, wing-marginerl. - Iall and showy herlss, with a thick root, upright and mostly simple stems, bearing whorled leaves, and numerous pedurcled Howers in open cymes, disposed in an ample elongaterl panicle. (Dedicated to John Fruser, an iuclefatigable collector in this conutry towaril the close of the last century.)

1. F. Carolinénsis, Walt. Smooth biennial or triennial $\left(3-8^{\circ} \operatorname{lig} \mathrm{h}_{1}\right)$ : leares mostly in fours, lance-oblung, the lowest spatulate, reiny; panicle pyranidal, loosely flowered; corolla (l' broad) light greenish-yellow, marked with small brown-purple dots, its divisious oblong, mucronate, longer than the narrowly lanceolate calyx-lobes, each with a litrge roumd gland below the niddle; capsule much flatteued parallel with the that valves. - Rich dry soil, western N. Y. to Wisc., soutl to Ga.

\section{HALE N I A, Borkh. Spurred Gextex.}

Calyx 4-5-parted. Corolla slort bell-shapel, 4-5-cleft, without folds or fringe, prolonged at the hase underueath the erect lobes iuto spurs, which are glandular in the bottom. Stigmas 2, sessile, persistent on the oblong fattish capsule. Seeds rather uumerous, ol,loug. - Sunall and upright herbs, with yellowish or purplish panicled-cymose flowers. (Named for Jolin IIalen, a German botanist.)

1. H. defléxa, Grisebach. Ieafy annual or biennial $\left(9-18^{\prime}\right.$ ligh $)$, simple or hranclied alove; leares 3-5-nerved, the lowest ollong-spatulate and petioled, the others oblong-lanceolate, acute; spurs cylindrical, obtuse, curved, descending, lalf the length of the acutely t-lobed eorolla. - I )amp and cool woods, from N. Maiue and W. Mass. to I. Superior, Minn., and uortluward.

\section{BARTÒNIA, Iıull.}

Calyx 4-parted. Corolla deeply 4-cleft, destitute of glands, fringes, or folds. Stamens short. Capsule oblong, flattenerl, pointel with a large persistent at Iength 2-lobed stiguna. Seeds minute, innmmerahle, corering the wlule inner surface of the pod. - Small annuals or hiennials $\left(3-10^{\prime}\right.$ higrls), with threadlike stems, and little awl-shaperl seales in place of leares. Flowers small, white, perluncled. (1)erlicaterl to Prof. Benjamin simith Barton, of 1'hilatelphia.)

1. B. tenélla, Mulıl. Stems branched above, the branches or peluncles mostly opposite, 1-3-Howered ; Intes of the corolla oblong, acutish, rather Innger than the caly $x$, or sometimes twice as long; anflers roundish: orary t-angled, the cell somewhat eruciform. - Open words, Newf. to Wisc., south to Va and I.a. Aug. - Scales aurl linuchos occisiunally alternate. 
2. B. vérna, Muhl. Sten 1-few-fluweled; flowers $3-t^{\prime \prime}$ long, larger; lobes of the corolla spatulate, ohtuse, spreading, thrice the length of the calyx; anthers oblong; ovary flat. - Bogs near the coast, S. Va. to Fla. aud La. March.

\section{OBOL A RIA, L.}

Calyx of 2 spatulate sprearling sepals, resembling the leares. Corolla tubular-bell-slaped, withering-persistent, 4 -cleft ; the lobes oval-oblong, or with age spatulate, imbricater in the bul]! Stamens inserted at the simses of the corolla, sliort. Style short, persistent; stigma 2-lipped. Capsule oroid, l-celled, the cell cruciform; the seels covering the whole face of the walls. $-\Lambda$ low and very smouth purplish-green perenuial $\left(3-8^{\prime}\right.$ high), with a simple or sparingly branched sten, opposite welge-ohovate leaves; the dull white or purplish flowers solitary or in clusters of three, terminal and axillary, nearly sessile; iu sprriug. (Name from ỏßoxós, a small Greek coin, from the thick monterl leaves.)

I. O. Virginica, L. Herbaceons and ratler fleshy, the lower leaves scale-like; flowers t" long. - Moist woods, N. J. to 111, south to Gir. and Tex.

\section{MENYANTHES, Toum. Búriban.}

Calyx 5-parted. Corolla short funnel-form, 5-cleft, decidnons, the whole upper surface white-bearded, valwate in the bud with the margins turned inwarl. Style slender, persistent; stigma 2-loled. Capsule bursting somewhat irregularly, many-seedled. Seel-coat liard, smouth, and shining. - A perennial alteruate-leaved herl, with a thickish creeping rootstock, sheathed by the membrauous bases of the long petioles, which bear 3 oval or oblong leaflets; the flowers racemed on the naked scape $\left(1^{\circ}\right.$ ligh), white or slightly reddish.

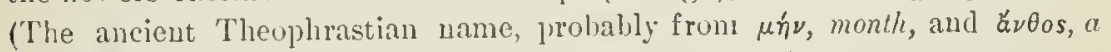
flocer, some say from its flowering for about that time.)

1. M. trifoliàta, L - Bogs, N. J. and Peun. to Ind. and Iown, aud far north and westward. May, June. (Lin., Asia.)

\section{L I M N Á N Them U M, Gmelin. Floating Heart.}

Calyx 5-parted. Corolla almost wheel-shaped, 5-parted, the divisions fringed or bearled at the hase or margins only, folded inward in the bud, bearing a glandular appentage near the hase. Style short or none; stigma 2-loberl, persistent. Capsule few-many-seederl, at lengtl bursting irregularly. Seerl-coat hard. - Terennial annatics, with romulen floating leaves on very long petioles, which, in most species, bear near the summit the umhel of (polygamous) fluwers, along with a cluster of short and spur-like roots, sometimes shooting forth new leares from the same place, and so spreading by a sort of proliferums stolons, flowering all smmmer. (Name componnded of $\lambda$ í $\mu \eta \eta$, a maish or pool, and a $\nu \theta \epsilon \mu \nu$, a blossom, from the situations where they grow.)

l. L. lacunòsum, Grischacl. Leaces entre, round-heart-shaped (1-2' broal), thiclish, petioles filifurus; lohes of the (white) corolla loroally oval, naked, except the crest-like yellowish gland at the lase, twice the length of the lancenlate calyx-lohes; style none: seeds smooth and even. - Shallow water, from Maine to Minn., south to Fla. and La. 
2. L. trachyspérmum, Gray. Leaves larger $\left(2-6^{\prime}\right.$ broad $)$ and rounder thieker, often wavy-margined or crenate, roughish and dark-punctate or pitted Deneath; petioles stouter; seeds glandular-roughened. - Ponds and streams, Md. and Va. to Fla. and Tex.

\section{Order 70, POlemoniàcea. (Polemonium Family.)}

Herbs, with alternate or opposile leaves, regular 5-merous and 5-androus flowers, the lobes of the corolla convolute in the bud, a 3-celled ovary and 3-lobed style; capsule 3-celled, 3-valied, loculicidal, few-many-seellet . the valves usually breaking atcay from the triangular central column.Seeds amphitropous, the coat frequently mucilaginous when moistened and emitting spiral threads. Embryo straight in the axis of copious albumen. Calyx persistent, imbricated. Corolla with a 5-parted border. Anthers introrse. (Insipid and innocent plants; many are ornamental in cultivation.)

1 Phlox. Corolla salver-form. Calyx narrow. Leaves opposite, entire.

2. Gilia. Corolla tubular-fumel-form or salver-form. Calyx narrow, partly searious. Lenves mostly alternate, entire.

:. Polemontum. Corolla open-bell-shaped. Calyx herbaceous, bell-shaped. Filaments slender, equal. Lenves alternate, linnate or pinuntely parted.

\section{PHLOX, L.}

Calyx narrow, somewhat prismatic, or plaited and angled. Corolla salverform. witl a long tube. Stamens very unequally inserted in the tube of thr. corolla, included. Capsule ovoirl, with sometimes 2 orules bnt ripening only a single seed in each cell. - I'eremials (except a few southern species, such as P. Drummondii of the garlens), with opposite and sessile perfectly entire leares, the foral often altemate. Flowers cymose, mostly bracted the open ('lusters terminal or erowden in the npper axils. ( $\Phi \lambda \hat{k} \xi$, fame, an aneient name of Iychnis, transferred to this Nortl American gents.) Most of onr species are cultivated in gardens.

\section{\$1. Herbaceous, with flul (broad or nutrou) leaves.}

* Stem strictly erect; panicle pyramidal or oblong, many-fouered; pedunctes and pedicels rery short; corollu-lobes entire. (l'ery rommon in gardens.)

1. P. paniculàta, L. Stem stont $\left(2-4^{\circ}\right.$ lıigh $)$, smootll; leaves oblunglanceolate and ovate-lanceolate, pointed, large, tapering at the base, the upper often heart-shaped at the base; panicle ample, pyramidal-corymbed: caly. $x$-treth ann-pointed: corolla pink-purple varying to white.-Open woods, Penn. to IIl., south to Flia. and I a. June, July:

2. P. maculàta, I. (Wh, Sweet-Wratan.) Smooth, or listely ronghish; stom spotted with purple, rather slender $\left(1-2^{\circ}\right.$ high $)$; lower leares lanceolate, the upper nearly orate-laneeolate, taperiug to the apex from the hroal and rounded or somewhat heint-shilped hase; ponirle numon, oblong,

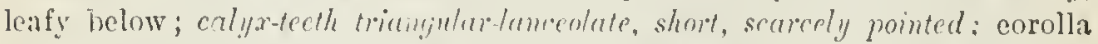
piuk-purple. - Rich womllands anl aloug streams, N. J. and N. I'enn. to Mimn, soutls to Fla. and Lrk, - Vau. Cixinn, Michx., is a white-flowered form, commonly with spotless stem. With the orlinary form. 
* Stems, at least the flowering ones, ascending or erect; flovers in corymbed or simple cymes; corolla-lobes obovate or obcordute.

+ Calyx-teeth triangular-subulate; corolla-lobes rounded, entire; glabrous or nearly so.

3. P. ovata, I. stems ascending ( $\frac{1}{2}-2^{\circ}$ high), often from a prostrate hase; leaces ublong-lunccolate, or the upper orate-ianceolate, and sometimes heart-shapes at the base, acute or pointed; flowers pink or rose-red, crowded, short-peduncled ; culyx-teeth short :uch broal, acute. (I'. Carolina, L.) - Open woods, in the mountain region from Penn. to Ala. June, Jnly.

4. P. glabérrima, I. Stems slender, erect ( $1-3^{\circ}$ high) ; leaves lineurlancenlate or ruml! whong-tancelate, very smooth (exeept the rough and some. times revolute margins), tapering gralually to a point (3-4' long); eymes few-flowered and loosely corymbed; flowers peduncled (pink or whitish); ralyx-teell narrower and rery shary-pointed. - l'rairies aud open woods, $\mathrm{N}$. Va. to Ohio and Mlim., sunth to Fla. and Mo. July.

+ + Calyx-teeth lony and slender: more or less hairy or glandular-pubescent.

+ To rumers or prostrate sterile shoots.

5. P. pilosa, L. Stems sleuler, nearly ereet $\left(1-11^{\circ}\right.$ high $)$, usually hairy, ats are the laneculute or lineur leaces $\left(1-4^{\prime}\right.$ long), which commonly laper to a sharp point; cymes at length open; culyx-leeth slender aw-shaped and aumlike, longer than the tube, loose or sureading; lobes of the pink-purple or rosered (rarely white) corolla obovate, cutire. - Dry or sandy wools, prairies, etc., X. J. to Minu, suntlu to F'li. and Tex. May, June.

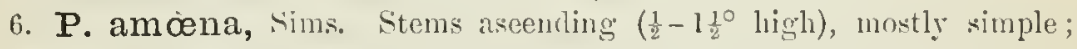
leares broadly linear, luncenlate or orcite-oblong, abruptly acnte or blunt $\left(\frac{1}{2}-1 \frac{1}{2}\right.$ long), on sterile shoots often ovate; cyme mostly compact and sessile, leafyInarted; calyx-leeth arrl-shuped or linear, sharp-pointed, but seldom awned, rather longer than the tube, straight; lobes of the cornlla obovate and entire (or rarely notehed), purple, pink, or sometimes white. (I'. proeumbens, Gray; not Lelem.) - Dry hills and barrens, Va. to Ky., sonth to Fila.

++ Sterile shoots from the base creeping or decumbent; leaves rather broad.

¡. P. réptans, Miehx. Rumers creeping, bearingr round ish-oborate smouthIsh and thickish leaves; flowering stems $\left(4-8^{\prime}\right.$ high) and their ollong or orate

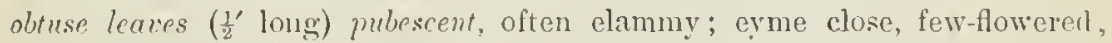
calyx-teetl linear-awl-shaped, about the length of the tube; lobes of the red. dish-purple corolla round-obouate, mostly entire. - Damp wools, in the Allegliany. region, Penn, to Ky. and Ga. May, June.

8. P. divaricàta, L. Stems spreading or ascending from a deeumbent hase $\left(9-18^{\prime}\right.$ ligh) ; lerues oblong-or lunce-ovate nu the lower olnong-laneeolate (1 $\frac{1}{2}^{\prime}$ long), acutish; erme cormmlose-panicled, spreading, loosely-flowered, alyx-teeth slender aw -shaped, lunger than the tube; lowes uf the prale lilue or

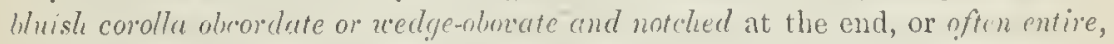
$\frac{1}{2}-z_{3}^{\prime}$ long, equalling or louger than the tube, with rather wille simuses between them. - Rocky damp wook, W. C'anala and N. Y. to Mimn., south to Fla. and Ark. Mlay. - I form oceurs near Crawforlsville, Ind., with reduced flow. ers, the narrow pntire acmuniute enolla-lobes searcely" half as long as the tuha. 
* * Stems lour, diffuse and branchiny; flouers scuthered or larely cymulose: corvilu-lubes nurrouly cuneate, bifid; calyx-lobes subulate-lanceolute.

9. P. bífida, Beck. Mimutely pubrecent; stems ascenling, branched (5-8'

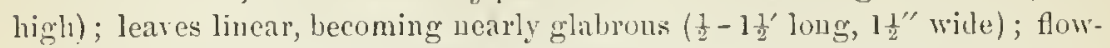
ers few, on slender peduncles; calyx-tceth awl-shaperl, abont as long as the tube; lubes of the pale purple corolla 2-cleft to or beloue the midrlle ( $t^{\prime \prime}$ long), equalling the tube, the dirisions inear-oblong. - Prairies of Ind. to Iowa and Mo.

10. P. Stellària, Gray. Téry glabrous; leaves bately somewluat ciliate at hase, linear ( $1-2^{\prime}$ long, $1^{\prime \prime}$ wille or more), acnte, rather rigid; flowers scattered, mostly loug-perluncled; loves of the pale bhe or almost uhite corolla hijid at the apex into barely oblong bobss - Cliffs of Ky. River (Short), S. Ill., aud 'Teun. (Guttinger). May.

S. Suffiuticulose and creping-cespitose, evergreen, uith mostly crouded and fascicled subulate and rigid leaves.

11. P. Subulàta, L. (Grotxi) or Moss J'ıк.) Depressed, in liroal mats, pubescent (glabrate when oll); leares awl-shaped, lanceolate, or narrowly linear $\left(3-6^{\prime \prime}\right.$ long) ; cyues few-flowered; calyx-teeth awl-shajed, rigil ; corolla pink-purple ur rose-color with a rlarker centre (sonctimes white) ; lobes wedge-shaped, notched, rarely cutire. - Dry rocky hills and sandy lanks, southern N. Y. to Mich., south to Fla. and Ky.

\section{GÍIA, Ruiz \&av.}

Calyx-lobes narow and acute, the tube searions below the sinnses. Corolla tubuiar-funnel-form or salver-form. Stamens equally or meqnally inserted. Cajsulde with solitary to umerons secls. - Mostly lierls with alternate leaves. ()ur species belongs to the Collomm, in which the flowers anc capitate-glomerate and foliose-braeted or seattered, stamens nnequally inserted in the narrow tube of the salver-form corolla, wules solitary, and leaves sessile and entire; ammals. (Derlicaterl to Philiy (iil, a Npanish botanist.)

1. G. lineàlis, Cray. Brunching and in age spreading, 6-18' high; leaves linear- or oblong-lanceolate; calyx-lobes triangular-lanceolate, acute; corolla $6^{\prime \prime}$ long, from lilac-purple to nearly white, very slender, with small nimb. (Collomia linearis. Nutt.) - From Minn. west to the Pacific.

\section{POIEM O N I UM, Toum. Flink TAlemix.}

Calyx bell-shaped, herbaceons. Stamens equally inserted at the summit of the very short tube of the open-bell-shaped or shit fumel-form corolla; filauncuts slender, declined, hairy-appentagerl at the hase. Capsule few-severalscolded. - Perennials, with alternate pinmate leaves, the npper leaflets sometines confluent; the (l,lue or white) corymbuse fluwers nearly bractless. (An

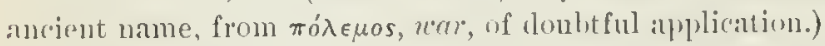

1. P. réptans, I. Smootlı thronghout or slightly pulescent; stems

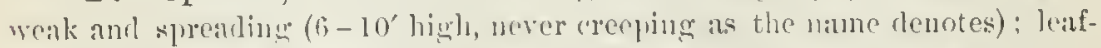

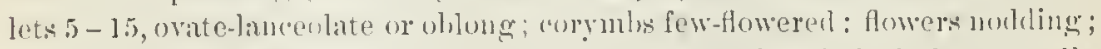
(al y'x-lobes ovate, shorter than the tuhe; slumens and style inclules; corvolla light hlue, about $\frac{1}{2}$ wide; cripsules about 3-seeded. - Wools, S. Y. to Minu., sonutl to Sla. aurl Mu. May, June. 
2. P. cæruleum, L. (JACos's L.ıDEkn.) Stem erect $\left(1-3^{\circ}\right.$ higlı) teallets $9-21$, linear-lanceolate, oblong- or orate-lanceolate, mostly crowded, Howers unnerous, in a thyrsus or contracted pauicle; lubes of the calyx longer than the tube ; stumens and style mostly exserted beyond the bright blue corolla, which is nearly $l^{\prime}$ broad; capsule several-seeded. - Rare in our range, occurring in swamps and on mountains in N. H., N. Y., N.J., and Mu., but common in the westeru mountains and far northward.

\section{()rder 71. HYDROPHYLIACEAE. (WATELLAF Fanil\%)}

Ilerbs, commonly hairy, will mostly allernale leares, regular 5̃-merous and 5-rtndrous fowers, in aspect between the foregoing and the next orter: but the orary entire and 1-celled with 2 parietal 4-many-ovuled placente, or rurely 2-celled by the union of the plucenta in the axis; style 2-cleft, or 2 separate styles: finit a 2-zalced 1 -many-scederl cupsule. _ sceds mostly reticulated or pitted. Embryo small in copions albumen. - Flowers chiefly blue or white, in one-siderl eymes or false racemes, which are mostly bractless and eoiled from the apex when young, as in the Boracre Family. I small orter of plants of no marked properties; some cultirated for ornament.

Tribe I. HYDROPHYLLEA. Uviry ant ean'sule l-celled. Seeds pitted or reticn-

lated ; allninen eartiligiuous. Leaves cut-toothed, lobed $m^{2}$ pinnate. Style 2-cleft.

* Ovary lined with the dilated and Heshy placentre, which enclose the ovules and seeds (in our plants only 4) like an inner pericarp.

1. Ifydrophyllum. Stamens exserted; anthers linear. Calyx un hanger ill fruit.

2. Nemophila. Stumens included; anthers short. Calyx with appentages at the sinuses.

a. Nulisia. stanens inchuded. Calyx lestitute of appendares, enlarger in fruit.

* Ovary with narrow parietal placente, in fruit projecting inward more or less.

4. Phacelia. Conolla-lobes imbrieatel in the bud. Calyx destitute of aptendages.

Tribe II. II DROLEA. Ovary and capsule q-celled, the plicentwe often projecting from the axis far into the cells. Albumen fleshy Leaves entire. Styles 2.

5. IIydrolea. Corolla hetwetn whed-shaped alld bell shaped

\section{HY D R O P H ÝL L U, 'ToMm. Waterleaf.}

Calyx 5-parted, sumetimes with a small apperudage in ench sinus, early open in the lut. Corolla bell-slatered, 5-cleft: the lobes convolute in the bud; the tube fumisled with 5 longituliual linear appendiges (1) plusito the lobes, which (a)lere by their midlle, while their eflges are folded inward, forming a nectariferons arores. Stamens and sty.le mostly exserted: filments more or lese heareled ; anthers linear. ()vary bristly-hairy (as is llsual in the family); the 2 fleshy platenta expanderl so as to line the cell ant noarly fill the cavity, soon free from the walls except at the top and bottom, each bearing a pair of ovules on the inner face. Capsule ripening $1-4$ secels, spherical. - l'eremials, with petioled ample leaves, and white or pale blue cymose-clustered flowers. (Name

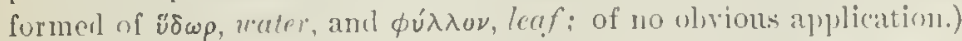

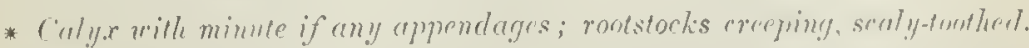

1. H. macrophýllum, Nutt. Ponegh-hairy; leares whlome, primute und jinnutifid; the dirisions $9-13$, matr, ohtuse, coarsely cut-toothed ; root-leaves 
$1^{\circ} \mathrm{long} ;$ peduncle shorter than the petivle; calyx-lobes lanecolate-pointed from a1 broan base, very hairy ; Howers ( 6 " long) crowded in a globular cluster ; anthers short-oblong, - Rich woods, Ohio to Va. and Mla, west to the Mississippi. July.

2. H. Virgínicum, L. Smoothish $\left(1-2^{\circ}\right.$ ligh); leaves pinnately divided; the dirisions 5-7, orate-lunceolate or oblong, pointed, sharply cut-toothed, the lowest mostly 2-parted, the uppermost eonfluent; peduncles longer than the petiales of the upper leaves, forked; calyx-lobes narrowly linear, bristly-ciliate; Howers $3^{\prime \prime}$ long; autliers oblong-linear. - Rich woods. June-Ang.

3. H. Canadénse, L. Nearly smooth (10 liggli); leares $\left(3-5^{\prime}\right.$ broad) palmately 5-7-loled, rounded, heart-shaped at hase, muequally tuothed, those from the rout sometimes with $2-3$ small and scattered lateral leaflets; peduncles mostly shorter than the petiolen, forked, the nearly white flowers on very short pedicels; ('alyx-lobes linear-awl-shaped, nearly sulootl, often with minute teeth in the sinlses. - Damp rich woods, K. Eng. to the momitains of Ira., and west to the Mississippi. June - Aug. - Rootstocks thickened and very strongly toothed in 2 rows by the persistent bases of the stont petioles.

* Calyx uith " small reflexed lobe in each simus; stamens little exserted.

4. H. appendiculàtum, Michx. Hairy; stem-leaves palmately 5-lohed, rounded, the lolies toothed and pointed, the lowest pinnately divided, eymes rather loosely Howered; filiform pedicels and calyx bristly-hairy - Damp woods, Ont. to mountains of N. C., west to Minn., Iowa, and Mo. Jnne, July.

\section{NEMOPHILA, Nint.}

Calyx 5-parted, with a reflexed appendage in eneh sinus, more or less enlarged in fruit. Corolla bell-shaped or alnust wheel-shaped; the lobes convolnte in the bud; the tmbe mostly with 10 smill folls or scales insile. Stamens included; anthers orvid or heart-shaperl. I'lacentac (bearing each $2-12$ ormles), capsule and seets as in Hydroplyllnum. - Diffuse and fragile anumals, with opposite or partly alteruate pinnatifil or lobed leaves, and one-flowered pertuncles; the corolla white, blue, or marked with purple. (Name composed of vémos, "grove, and $\phi ı \epsilon^{\prime} \omega$, to love.) Some linulsome sjecies are garden annuals.

1. N. microcalyx, Fisch. \& Merer. Sulll, ronghisl-puliescent; stems diffuscly sprearling ( $2-S^{\prime}$ long) ; leaves parted or deeply aleft into $3-5$ roumelish or wedge-obovate sparingly cut-lobed divisions, the mper leaves all alternate; peduncles opposite the leares, shorter than the long petioles; flowers minute; corolla white, longer than the calyx; plasenta each 2-ovuled; eapsule 1 - 2-seeded. - Moist woods, Va. to Fla., west to $\Lambda$ rk. and Tex. $\Lambda$ pril-Jnne.

\section{ELIÍSIA, l.}

Calyx 5-parted, withont appendages, enlarged and foliaeeons in fruit. Corolla bell-shit]erl or 'ylindraeeons, not longer than the ealyx, 5-lobed above; the lobes imbricated or conrolnte in the bud, the tube with 5 minute appenlages within. Stamens includerl. l'lacente (each 2-ovuled), frnit, and seels nuch as in IIydroplyyllmm. - I)elicate and hranching annuals, with lobed or divided leares, the lower opposite, and small whitish flowers. (Named for John Ellis, a distinguishen naturalist, an linglish corresponlent of Linnaws.) 
1. E. Nyctèlea, I. Minutely or sparingly roughish-hairy, divergently branched $\left(6-12^{\prime}\right.$ ligh $\left.h_{1}\right)$; leaves pinnately parted into $7-13$ lanceolate or linensohlong sparingly eut-tonthed divisions ; perluncles solitary in the forks or opposite the leaves, 1 -flowered ; caly-x-lubes lanceolate, pointed, abont the length of the cylinlraceons (whitish) corolla (in fruit ovate-lanceolate, nearly $\frac{1}{2}$ long), eapsule pendulous. (E. ambigua, Null.; merrly a slender form.) - Sliady damp plaees, N. J. to Va., west to Minu. and Mo. May-July.

\section{PHACELIA, Juss.}

Calyx 5-parted; the sinuses naked. Corolla open-bell-sliajer, 5-lobed; the lubes imbrieater in the bud. Filaments slender, often (with the 2-cleft style) exsertel ; anthers ovoid or obloug. () sary with 2 narrow linear placente alherent to the walls, in fruit usually projecting inwarel more or less, the two often forming an imperfect partition in the oroid 4 -many seederl capsule. (Ovules 2-30 on ealch placenta.) - l'erennial or mostly anmual herls, with simple, lobed, or diviled leaves, anil often lanulsome (bine, purple, or white)

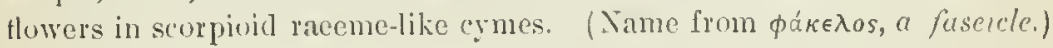

\$1. PILACELIA proper. Serds and orutes omly 4 (two on each placenta); rorolla rempanulute, with narrow folds or apjendayes withm, the lohes entre.

1. P. bipinnatifida, Michx. Biennial; stem upright, hairy (1 - $2^{\circ}$ high), leaves long-petioled, pinnately 3-5-dividel, the divisions or leaftets ovate or oblong-ovate, acute, coarsely and often sparingly cut-lobed or pin natificl, racemes elougated, lonsely many-flowered, glaudular-pubescent ; perlicels abont the lengtl of the caly: sprealing or recurverl. - Shaled hanks, in rich soil, Ohio to Ill. and sonthwarl. May, June - Corolla bright hlue, 6" brad, with 5 pairs of longitulinal ciliate folds, eorering as many externally keeled deep grooves. Stamens bearded below and with the style exserted.

\$2. COSMANTHUS. Ovules and seeds as in \$1; corolla almost rotate, wuth fimbiate lobes, and no appendages within: filumom/s willous-bearded, rarely exserterl; leaves pimatifid, the upper elasping.

2. P. Púrshii, l3nekley. Sparsely hairy; stem erect or ascending, brancher $\left(8-12^{\prime}\right.$ high $)$; lobes of the stem-lecues $5-9$, oblong or lanreolate, acule; raceme many-fonered: culy.r-loles lunce-linear: corolla light lue, rarying to white (about $\frac{1}{2}$ in lianeter). - Moist wooded banks, W' P'enn. to Minn., and sontlwarcl. $\Delta$ pril - June.

3. P. fimbriàta, Michx. Slightly hairy, slender: stems spreadiug or ascenling (5-8' lomg), few-leaved; lowest leaves 3 - 5-divided into rommlish lea f lets; the upjer 5 - 7 -cleft or cut-toothed, the /obes obituse: raceme 3 - 10 -flowered caly $x$-lobes linear-ablong, obtutse, hecoming spatulate; cordla wlute (3- t" broad). - Woorls, high mountains of Ya. to Mla. May.

\$ 3. COSHLNTIIOLDES. Orwes and seeds 2-8 on each plurenu, corolla rotate or eampanulate, with entire inbes and no appeudreys.s.

4. P. parviflòa, Pursh. Somewlat hairy, slender, diffusly spreaciug

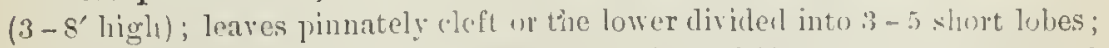
racemes solitary, loosely 5-l.s-flowered; peclicels filiform, at leneth several times longer than the oblong calyx-lobes; corolla open-eampanulate, luluish- 
white (4-6" broad); filaments hairy; capsule globular, 6-12-seeded, a half shorter than the calyx. - Shaded banks, l'eun. and Ohio to Mo., south to S' C. and Tex. April-June.

Var hirsuta, Gray. More lirsute and the stems less slender, apparently growing in more open dry soil; corolla larger, $5-7$ " in diameter; seeds $4-8$. - I'rairies and barrens, S. W. Mo. to E. 'T'ex.; also Va. and Ga.

5. P. Covíllei, Watson. Like the last; rucenes 2-5-Howered; calyxlobes linear, in fruit $3^{\prime \prime}$ long or more; corvlla tubular-("ampanulate with erect Imb , filaments glabrous; capsule depressed-globose; seeds 4, large. - Lark

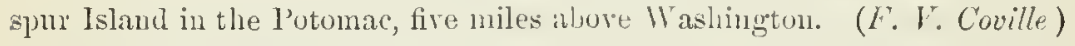

\$ 4. EUTTOCA. Ovules and seeds numerous on each placenta; corolla rotate. campanulate, with 10 vertical lamella witlin.

6. P. Franklínii, Gray. Soft-hairy; stem erect $\left(6-15^{\prime}\right.$ high $)$, rather stout; leaves pinnately parted into nany lanceolate or obloug-linear lobes, wheh are crowled and often cut-toothed or piunatifil ; racemes short, deuse, crowlet nuto an oblong spike; caly- x-lubes linear; corolla blue. - Shores of $\mathrm{L}$ superior, thence north and westward.

\section{HY D R Ò E A, I.}

Calyx 5-partel. Corolla short-campanulate or almost wheel-slaped, 5-cleft. Filaments dilated at base. Styles 2, listinct. Capsule globular, 2-celled, with very large and fleshy many-seeded placenta, thin-walled, 2-4-ralved or burst ing irregularly. Secls miunte, striate-ribled.-1Ierbs or scarcely slurubly. growing in water or wet places (whence the uane, from viow, water), with entire leaves, often laving spines in their axils, and clustered hlue Howers.

1. H. affinis, Gray. Glabrous throughout; stem ascending from a creeping hase, armed with small axillary spines; leaves lanceolate, tapering to a rery short petiole; flowers in small axillary leafy-lirated clusters; tlivisions of the calyx lance-orate, equalling the corolla and the irregularly-bursting globose capsule. - Banlis of streanis, s. Ill. to Tex.

\section{Order 7:. BORHAGINACEAE. (Borage Famü.)}

Chiefly rough-luiry herls, with allernate entire leaves, and symmetrical flowers with a 5 -purted calyr, "regulur s-loberl corolla (except in Echium), 5) stamens inserted on its tube, "single style and a usully deeply 4-lobed mory ( $u$ in I Iabiata ${ }^{2}$ ), forming in fruil 4 seed-lile 1-seeded nutlets, or sepuruting into tro a-sechled or four 1-seeded nutlots. Albumen none. Cotyletons plino-convex; rallicle pointing to the apex of the fruit. Stigmas 1 or 2. Calyx ralvate, the corolla imbricated (in Myosotis convolute) in the but. lilowers mostly on one sick of the branches of a relured 'yme. initating a spike or raceme, which is rolled up from the

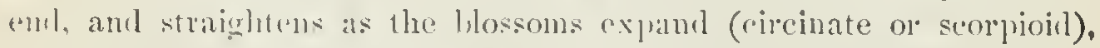
often bractless. (A ratler hare family of innocent, mucilaginous, and Alghtly bitter plants; the roots of some species yiclding a red clye.)

Trilw I. HELIOTJOOPIEX. Orary not lobed; fruit separating into $2-4$ nutlets

1 Meliotropium. Combla sulveroform. Stamens included. Nutipts 1 - werelled. 
Tulue II. BORRAGINEAL. Ovary deeply t-parted, forming as many separate 1. soeded nutlets in firuit; style rising from the centre letween then.

* Corolla and stamens regular.

- Nutlets arned, attaclied laterally ; coirolla sliort, closed by 5 scales.

2. Cynoglossun. Nutlets horizontally radiate, much produeed downward, covered wicl barbed prickles.

3. Lchinospermum. Nutlets erect or ascending, the margin or back armed with barbed pricliles.

$$
\text { + + Nutlets not armed, attaelied more or less laterally. }
$$

4. Krynitzkia. Corolla short, white, with closed throat. Futlets attaehed along the inuel angle.

5. Mertensia. Corolla trumpet-shaped with open thront, usually blue. Nutlets fleshy, attachel just above the base.

+ + + Nutlets unarned, attached by the very base, ovold, mostly smooth and shining. ++ Scar hat, small. Racentes leafy-bracterte, except in n. 6.

i. Myosotis. Corulla short salver-form, its lobes rounded, and throat erested.

7. Lithompermum. Corolla salver-form to funnel-form, its rounded lobes spreading; the throat either naked or with low crests.

s. Onosmodium. Corolla tubular, mappendaged, its erect lobes acute. +++ sear large anl excarated.

9. Sympliytum. Curolla oblong-tubular, onlarged above and elosed lyy 5 scales. * Conolla irregular, limb and throat oblique and lobes mequal.

10. Lycopsis. Cololla-tube curved, closed with hispid seales. Stanens included.

11. Echimm. Dilated throat of corolli mappendaged. Stamens unequal, exserted.

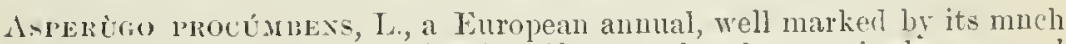
cularged membranaceons and reiny frnctiferous calyx, has sparingly appeared in waste gronnds about Kew York and I'hiladelphia, and at P'ipestone, Linu.

\section{H E L I T RO PI U M, Toum. Toursole, Helotrope}

Corolla silver-form or funnel-form, mappendaged, more or less phated in the bud. Anthers nearly scssile. Style short; stigma conical or capitate. Fruit 2-4-lohed, separating into 2 ind linated 2-celled and 2-sceded closed carpels, or more commonly into 4 one-sceded nutlets. - IIerlss or low slirubly plauts; leaves entire; 1. in summer, white (in our speeies). (The ancient

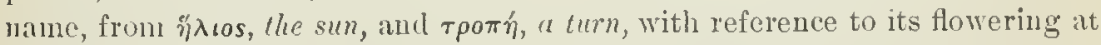
the snmmer solstice.)

$\$ 1$. HELIOTROPIUM proper. Fruit 4-lobed, separating into four 1-celled 1-seeded mullets. Siyle short.

* Hlowers in bractless one-sided scorpioid spites.

H. Euroritux, L. Frect annual (6-18' higlı), hoary-pubeseent; leares oval, Iong-petioled; lateral spikes single, the terninal in pairs; calyx spreading in fruit, hairy, - Waste places, sonthwanl; scaree. (Adv, from Eu.)

1. H. Curassávicum, I. Apmarenty annal, olatrous; stems ascentnng; leaves lance-linenr or spritulate, thickish, pale, almost veinless; spikes in pairs. - Sandy seashore, Ya. ; saline soils, $\$$. Ill., and south and westward.

$$
\text { * Inflorescence not ut ull scorproiel; flowers scattered. }
$$

2. H. tenéllum, Torr. A spiun to a foot high, pauiculately branchel, slcurler, stringse-"anescent; leaves narrowly linear, with rerolute margins;

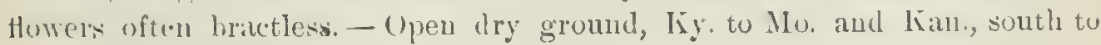
\lia. and 'Yex. 
\$2. HÜPLCA. Frut didymous, the 2 carpels each splitting into two 1-seeded nutlets: style elongated; flowers scuttered, large.

3. H. convolvulàceum, Gray. Low annual, strigose-hirsute and hoary, much brauched; leaves lanceolate, or ovate or eveu linear, shortpetioled; Howers "pposite the leares and terminal; corolla 6" broad, the strigose-hirsute tube about twice as long as the linear sepals. - Sandy plains, Neb. to IV. Tex. A showy plant, with sweet-scented flowers.

\$3. TIARÍDIUM. Fruit -lobed, separating mto two -eelled 2-seeded earpels, with sometimes a pair of empty fulse eells; style very short; flowers in bractless scorpioid spikes.

H. Ixmcux, I. Erect and lairy annual; leaves petioled, ovate or oral and somewhat heart-shaped; spikes single; fruit 2-cleft, mitre-sliaped, with an empty false cell before each seed-bearing cell. (Heliophytum Indieum, $D C$.$) - Waste places, aloug the great rivers, from S. Ind. to IIo., and south-$ ward. (Adv. from India.)

\section{CY NOGLÓ S S U M, Touru. IIound's-Toxgue.}

Corolla funnel-form, the tube about equalling the 5-parted ealyx, and throat closed witl 5 obtuse scales; lobes romded. Stamens included. Nutlets deIressed or eonvex, oblique, fixed near the apex to the base of the style, roughened all orer with short barbed or hooked prickles. - Coarse herbs, with a strong seent and petioled lower leares; the mostly panicled (so-ealled) raeemes llaked above, usially bracted at base. Fl. all summer. (Name from kúw a $a$ dog, and $\gamma \lambda \hat{\omega} \sigma \sigma \alpha$, fongue: from the shippe and texture of the leares.)

C. officistè, I. (Comox Ilotsos-Toxgrk.) Biennial; clothed will short soft hatrs, leffy, panicled above; upper leaves lanceolate, closely sessile by a rounder or slightly heart-shaped lase; laccunes nearly-bractless; corollu reddish-pmple (narely white); nutlets flat on the hroal upjer face, somewhat margined. - Waste ground and pastures; a familiar and tronblesome weed; the large nutlets alliering to the flece of sheep, ctc. (Nat. from Eu.)

1. C. Virgínicum, L. (Wnı, Comfrer.) T'erenuial; rouglesist with spreading bristly livirs; stem simple, feu-leuced (2-3० lighl); stem-leares lanceolate-oblong. clasping by a cleep heartshliuped base; racenes feu and "orymbed, raised on lony naked pedumles, bractless; rorolla pale blue: nutlets strongly convex. - Open wools, Ont. and Sask. to Fliı. and La.

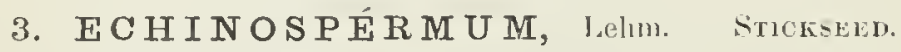

Corolla salver-form, short, imbrieated in the lut, the throat elosed with 5 short scales. Stamens iucluded. Nutlets ercet, ficerl laterally to the base of the style or centril column, triangular or eoupresserl, the hack armed all orer (1) with $1-3$ marginal rows of prickles which are harben at the apex, otherwise naker. - Rough-lairy and grayish herbs, with small blue to whitish flowers in raeemes or spikes; ours annuals or biemuials, flowering all summer. (Name compoumded of $\dot{\epsilon} \chi \hat{i \nu} o s$, a ledgehog, aud $\sigma \pi \hat{\epsilon} \rho \mu a$, sord.)

* Raeemes punicled, leafy-uraeteate at base: slender pedirels recurved or deflexed in fruit; calyx-lobes stont, at length reflered; biennial, not lispid.

1. E. Virgínicum, Lehm. (BErant's Lıce.) Stem 2-40 high; radical leares round-orate or curlate, slendor-petiolest; ranline $\left(3-8^{\prime}\right.$ long) orate- 
oblong to oblong-lanceolate, acmminate at both ends; loosely paniculate racemes divaricate; pedicel and flower each a line long; nutlets of the globose finit equally short-ylochidiate over the whole back. (Cynoglossmm Morisoni, I C $)$ - Borders of woods and thickets, N. Eng. to Minn., south to Va. and La.

2. E. defléxum, Lehm., var Americànum, Gray. I)iffusely branched, about $1^{\circ}$ highl, leaves oblong to lanceulate; racemes lax, loosely paniculate; flowers small; mutlets of the globular-pyrumidal fint only maryinally glochidiate. - Iowa, Minn., and northwarl

3. E. floribúndum, Lehnn liather strict, $2^{\circ}$ high or more; leaves ollong- to linear-lanceolate, the lowest tapering into margined petioles; rar cenes nmmerons, eommonly geminate and in fruit rather strict; corolla larger (blue, sometimes white), 2-3" in diameter; nutlets scabrous and margined with a close row of flat subulate prickles - Mim aurl kask., and westward.

* Racemes leafy-bructeate. stoul pedicels not deflexed; calyx becoming foliaceous; leaves lnear, lanceolute, or the lower sputulate: hspud annuals.

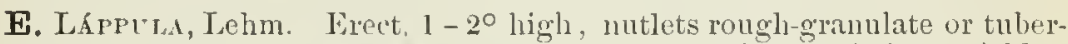
culate on the back, the margins with a double row of slencler distinct prickles, or these irregular over most of the back - Waste and cultivated grounds, from Canada to the Mislde Atlantic States. (Nat. from En.)

4. E. Redówskii, Lelın., var occidentàle, Watson. Frect, 1-20 ligh, at length diffuse: nutlets irregularly and minutely sharp-tuberculate, the margins armed witls a single row of stont flattened prickles sometimes confluent at base. - Minn. to Tex., and westward.

\section{KRYNÍTZKIA, Fisclı. \& Meyer.}

Calyx 5-parted or deeply cleft, erect or little sprearling in fruit. Corolla short, usually with more or less fornicate throat. Nutlets erect and straight, unarmed, attachel to the axis either at imner edge of base or ventrally from the base upward. - Ours are very hispid annuals or biemnials, with small white flowers in scorpioid spikes. I large western genus. (Dedicated to Prof.J. Krynitzki, of Cracow.)

1. K. crassisépala, Gray. Anutal, diffusely much brauched, a span high, very rough-hispid; leaves ollanceolate and linear-spatulate; flowers very small, short-pedicelled, mostly bracteate; lobes of the persistent caly $x$ closed weer the fruit, the midrib below becoming much thichened and indurated; nutlets uvate, acute, dissimiler, 3 of them muricate-graunlate aurl 1 larger and smooth, uttached from the buse to the middle. - I'lains, Sask. to Kan, Tex. and N. Mex.

\section{MERTÉNSIA, Roth. LuNGWon.}

Corolla trumpet-shaperl or bell-funnel-shaped, longer than the deeply 5-cleft or 5-parted calys, 11aked, or with 5 small glandular folcts or appendages in the open throat. Anthers oblong or arrow-shaped. Style long and thread-form. Nutlets oroid, fleshy when fresh, smooth or winkled, ohliquely attacherl next. the base by a prominent interual angle, the sear small. - Sinouth or softhairy perennial herhs, with pale and entire leaves, and hamlsnme purplish-blue (rarely white) flowers, in loose and short panicled ur cormbed raceme-like clusters, only the lower one leafy-bracted; pedicels slemler. (Named for P'of: Francis Churles Mertens, a German botanist.) 
* Corolla trumpet-shaped, with spreading nearly entire lumb and naked throat; filuments slender, exserted; hypogynous disk 2-lobed.

1. M. Virgínica, DC. (Virginian Cowslip. Lungwort. Blue Bells.) Very smooth, pale, erect $(1-20 \mathrm{high})$; leares oborate, veiny', those at the root $\left(4-6^{\prime}\right.$ long $)$ petiolerl; colvila trumpet-shaped, $1^{\prime}$ long, mainy times exceeding the calyx, rich purple-blne, rarely white; nutlets dnll and roughish. - Allnrial banks, N. Y. to Mimu., S. C, and Ark. May. Cnltivated for ornament.

* Corolla with conspicuously 5-lobed limb, and crested throat.

+ Filaments broad and short; nutlets dull, winkled or roughish when dry.

2 M. paniculàta, Don. Ronghish ani inore or less hairy, erect $\left(1-2^{\circ}\right.$ high), loosely branched, leaves orute and orale-lanceolute, taper-pointed, ribbed, thin; corolla ( $6^{\prime \prime}$ long) somewhat funnel-form, $3-4$ times the length of the lance-linear acute dirisions of the ealyx, filaments broader and shorter than the anthers. - Shore of L. Superior and north and westward. July and $\perp u g$

3. M. lanceolàta, I)C. Glabrous or hirsute, pale, 10 high or less, sinple or branched, leares spatulate-oblong to Innccoluteduear, smaller (1 - 2'long), neurly reinless, obtuse or acule; corolla-tube somewhat longer than the lanceolate calyx-lobes; flaments generclly longer than the anthers. - The Dakotas to N. Mex. and westward.

++ Filaments longer and narrower than the anthers; nutlets shining, utricular.

4. M. maritima, Don. (SE⿺ Luxowort.) Sprearling or decumbent, smooth, glaucous; leares fleshy, orate or oborate or spatulate, the upper suxface becoming papillose; corolla white, bell-fumel-form ( $3^{\prime \prime}$ long), twice the length of the calyx. - Sea-coast, on rocks and sand, Cape Cod to Maine and northward; scarce. June-Aug.

\section{MYOSÒTIS, Dill. Scorpion-firtss. Forget-Me-rot.}

Corolla salver-form, the tube about the length of the 5-toothed or 5-cleft calyx, the throat with 5 small and hhunt arching appendages oplusite the romuled lobes; the latter convolnte in the furl! Stamens includerl, on rely short filaments. Nintlets smoth, compresserl, fixerl at the base; the scar ninute. - Low and mustly softhairy herls, with entire leaves, those of the stem sessile, and with surall flowers in nakel racemes, which are entirely hractless, or occasionally with one or two small leaves next the hase, prolongerl and straightened in frnit. Flowering through the season. (Tame composed of

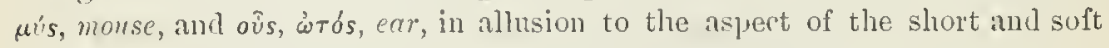
leaves in some sjecies; one popular name is M(o[sE-EAR.)

* Calyx open in fruit, its hairs apmessed, none of them hooked or glandular.

M. Palústris, Withering. (TrLE Foriat-Mf-xot.) Perennial; stems ascenling from an oblipule ("reeping base $\left(9-20^{\prime}\right.$ high), loosely branchect,

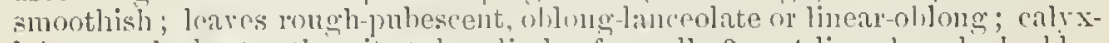
lobes mush shorter than its tube; limb of corolla 3 or 4 lines broal, sky-biue with a yellow oye. - In wet ground, prohahly only escaped from cultivation. (Nat. fiom liu.)

1. M. láxa, Lehm. Perennial from filiform subterranean shoots; stems very slender, lecumbent; pubescence all appresserl leares lanceolate-oblong 
or somewhat spatulate; calyx-lubes as long as its tube; limb of corolla 2 or 3 " broal, paler blue. (M. palustris, var. laxa, Gray.) - Iu water and wet groumd, Newf. to N. Y. (Eu.)

* C'alyx closing or the lobes evect in fruit, clothed with spreading hairs, some minuely hooked or gland-tipped; corolla small; annual or biennial.

2. M. arvénsis, IIoffm. IIirsute with spreading liairs, ereet or aseending $\left(6-15^{\prime}\right.$ lig $\left.g_{1}\right)$; leaves oblong-lanceolate, acutislı; rucemes naked at the base and stullied; corolla blue, rarely white; pedicels spreading in fiuil and longer than the 5-cleft equal calyx. - Fields, etc.; not rery common. (Eu.)

3. M. vérna, Nutt. Bristly-lirsute, branched from the base, erect (4$12^{\prime}$ high); lectes obtuse, linear-oblong, or the lower spatulate-oblong; racemes leafy at the buse; corolla very small, white, with a short liml, ; pedicels in fruit erect and coppressed at the base, usually abruptly bent ontward near the apex, rather shorter than the deeply 5-clefi unequal (somewhat 2-lipped) rery hispid culy.x. - Dry ground, rather common. May - July.

M. VEnsfunon, Pers. Hore slender than the last, simple at base; raeemes loose, mostly naked at hase; flowers almost sessile; corolla pale yellow changing to bhe ov violet; calyx deeply and equally 5-cleft. - Fields, Del. (Nat. from Eu.)

\section{Lithos Pfrim UM, Tomm. Gromwel. Puccoon.}

Corolla funuel-form, or sometimes salver-shaped; the open throat naked, or with a more or less erident transverse fold or scale-like appendage opposite each lobe; the spreading limb 5-cleft, its lobes rounded. Authers oblong, almost sessile, ineluded. Nutlets ovate, smooth ol roughened, mostly bony o. stony, fixed loy the base; scar nearly flat. - Herhs, with dhiclish and eommonly red roots and sessile leares; flowers solitary ancl as if axillary, or spiked and leafy-bracted, sometines dimorphous as to iusertion of stamens and length of style. (Nane formed of $\lambda \hat{\theta}$ os, stone, and $\sigma \pi \operatorname{p}^{\prime} \mu \alpha$, sced, from the liard nutlets.)

\$ 1. Nutlets inlereled or rough-urinkled and pitted, gray and dull, throat of the (nearly white) corollu destitule of any erident folds or appendages.

L. ARvéxsle, L. (CoRN Grourelu.) Minutely rough-hoary, annual or biemial; stems ereet $\left(6-12^{\prime}\right.$ higl $\left.h_{1}\right)$; leaves lanceolate or linear, veinless; corolla searcely longer than the calyx. - Sauly banlis and roadsides. MayAug. (Nat. from Lu.)

\$2. Nullets smooth and shining, white lite irory; corollu greenish-uhite or paleyellou, small, with 5 distinct pubescent scales in the throat; perennial.

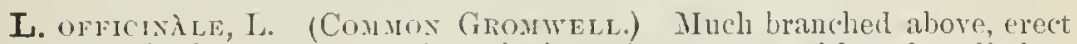
(1-20 high); leares thinnish, brondly lanreolate, arute, with a few distinct veins, rough alwore, soft-puluescent beneath; corolla exceeding the calyx.Roalsides, N. Ling. to Minn. (Nat, from Hu.)

1. L. latifolium, Miclux. Stem loosely branelıed, erect $\left(2-3^{\circ}\right.$ high), rongly; leares ovate und orate-lanceulate, mostly tuper-pointed (even the floral ones 2-4' long), ribbed-2eined, roughish abore, fulely soft-pubeseent beneath, the root-leares large and rounderl; corolla shorter than the calyx. - Open ground and borders of woorls, W. New York to Minm., south to Va. and Ark.

\$3. BATSCI11ג. Nutlets white, smooth and sliming; rorolla large, salver.

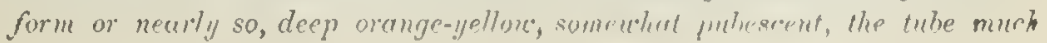


exceeding the calyx, and the throat appenduged. (Roots perennial, long and deep, yielding a red dye.)

* Corolla-tube one lerilf to twire longer than the coly.x, not much longer than the ample limb, the lobs entire; "ppenduges little if at all projectimy.

2. L. hírtum, Lelın. Hispial with hristly hairs $\left(1-2^{\circ}\right.$ highl); stenleaves lanceolate or linear, those of the flowering hanches ovate-oblong, nistly-ciliate; corolla uoolly-beurded at the buse inside (limb 8-12" hroall);

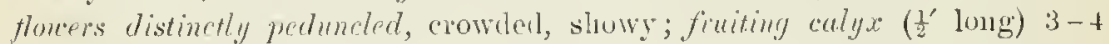
times longer than the nutlets. - l'ine barrens, ete., N. Y. to Minn., soutl aut westward. I pril-June.

3. L. canéscens, lehm. (Procoox of the ludians.) stofly hairy and nore or less houry ( $6-15$ high); lentes obtuse, linearoblong, or the upper orate-obloug, more or less druny beneath and roughish with close appressed hairs above; flowers sessile; corolla nated at the luse within; finiting caly. $x$. $\left(3^{\prime \prime}\right.$ long) barely twice the length of the milets. - Plains and open woods, iu sandy soil, Out. to Va., Ala., and westward. May.

* Corolla-tube in uell-developed flowers 2-4 times the length of the caly $x$ and of its erose-toothed lobes, and the appendages ronspicuous and arehing; later flowers small, cleistogenous.

4. L. angustifolium, Michx. Erect or diffusely branched from the base, $6-18^{\prime}$ high, minutely rongl-strigose and houry; leaves linear; flowers pedicelled, leafy-bracterl, of two surts; the earlier large and shwy (corollattube $8-18^{\prime \prime}$ long), the later and those of more diffusely branching plants, with inconspicuous or small aud pale corollas, withont crests, and the pedicels commonly recurved in fruit; mutlets usually punctate. (L. longiflormm, Spreng.; the long-flowered form.) - Dry and sterile or sandy soil, Ind. and Mich. to the Dakotas and Tex, and westward.

\section{ONOSM O D U M, Michx. False Gromwel.}

Calyx 5-parterl; the divisions linear and erect. Corolla tubular, or tubularfunnel-form, not crested (tho sinnses minutely hooded-inflexel), the 5 acute lobes converging or barely sprealing. Anthers oblong-linear or arrowshapel, mucronate, inserted in tho throat. Style threal-form, much exserted. Nutlets lomy, ovoid, smonth, erect, fixed hy the bise; tho scar minute, not hollowed out. - Chictly peremial herls, coarse and hispid, with obloug aud sessile ribled-roned leaves and white, greenish, or gellowish flowers, in at length elongated and rrect leafy raceme-like rlusters; in sum-

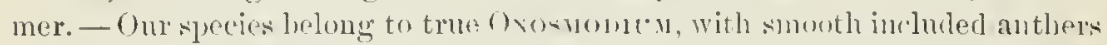
on very short filanents; the corolla rarely twice the length of the calyx. (Named from the likeness to the genus Omosmu, which name neans uss-smell.)

1. O. Virginiànum, 1)C. "Yothed wll mere with hersh and rigid (1)-

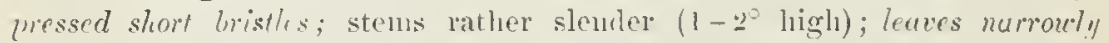

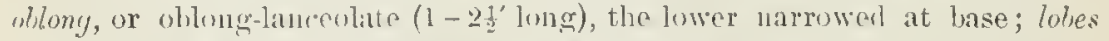

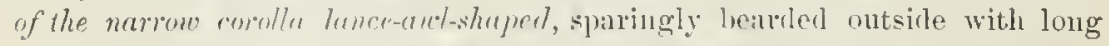
bristles. - Banks anl lıillsiles, N. Eug. to Fla.., Mo., and La.

2. O. Caroliniànum, DC. Sheyg!y all orer with long and spreading bristly hairs; stem stunt, upright $\left(2-4^{\circ}\right.$ highl): lectres orate-lanceolate or 
oblong-lanceolate, aeute; lobes of the rather broad corolla vicate-triangular or triangular-lanceolate, thickly hirsute outside - Alluvial grounds, W. New York to Minu., south to Ga. and Tex.

Var. mólle, Gray. Pubescence shorter and less spreading or appressed, $1-2^{\circ}$ luigh; leaves mustly smaller ( $2^{\prime}$ long), when young softly strigose-eanescent beneath. (O. molle, Michx.) - 1ll. to Minn., Tex., and westward.

\section{SÝ M P H Y T U M, Tourn. ComFrer,}

Corolla oblong-tubulin', inflated above, 5-toothed, the short teeth spreading; the throat closed with 5 chn erging linear-aw-sliaped scales. Stamens included; anther's elongated. Style thread-form. Nutlets smouth, orate, erect, fixed by the large hollowed base, which is fmely touthed on its margin. - Coarse peremnial herbs, with thickened hitterish mucilaginous roots; the notding racene-like clusters either single or in pairs. (Ancient Greek name from $\sigma u \mu \phi \varepsilon i v, 10$ grve toyether, probably for its rejuted lealing virtues.)

S. ofrumis: lo (Commox Commar.) lairy, branched, winged above by the decurrent leaves; the lower leaves wate-lanceolate, tapering into a petiole, the upper narrower; corolla yellowish-white, rarely purplish. - Noist places; escaped from gardens, June, (Adv, from Eu.)

\section{L Y CÓ P S I S, L. Butibow.}

Corolla fumel-shaped, with curves tule and slightly unaqual limb; the throat closed with 5 eonvex obtuse bristly scales opjosite the lobes. Stamens and strle included. Nutlets rough-wrinkled, erect, fixed by a hollowed-out

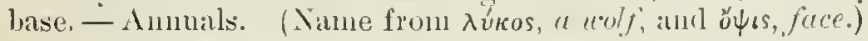

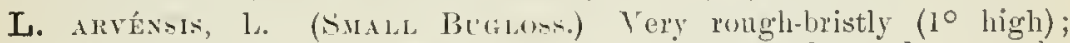
leares lanceolate; Howers in leafy raceme-like clusters; calyx as long as the tube of the small blue corvlla. - Dry or sandy fields, New Eng. to Ya.; scarce, (Adv, from Eu.)

\section{1. É CHI UM, Tourn. Vipkr's Bugloss.}

Corolla with a rylindraceous or funnel-form tube, and a more or less unequal spreatling 5-lobed border; lobes rounderl, the expranded throat naker. stamens mostly exserted, unequal. Style theaulform. Nutlets ronghened or wrinkled, fised by a that base. (A nanie of l)iuscorilles, from éxts, a riper.)

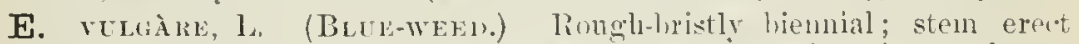
(20 high), mostly simple; stem-leaves linear-linceolate, sessile; Howers slowy in short hateral clusters, disposed in a long and nartow thyrsus; corolla reddish-purple cllanging to britliant blue (rarely pale). - Roadsides and mearlows of the Mildle Atlantie States. June, (Nat. from Ein.)

\section{Order 73. CONVOLVULACEAe. (Convolvulus Famly.)}

Chiefly twining or trailing herhs, often with some milky juice, with alternate leaves (or scales) and regular 5 -androus flowers; a calyx of 5 imbrieated sepals, "5-plaiterl or 5-lobed corolla emvolute or twisted in the bud (imbricnte in 11. 6): "2 celled (rurely 3-celled) orary (or in one tribe 2 separate pistils), with a pair of erect orules in each cell, the cells sometimes doubled by a fulse partition bctween the seeds, so beeoining 4-celled; the embryo large, curcen or coiled in mucilaginous albumen. Truit a globular 2-6-seeden capsule. Flowers nostly slowy, on axil-

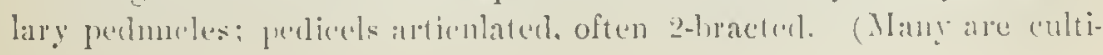


vated for ornament, and one, the Sweet Putato, for its edible farinaceous roots; those of several species are catliartie; e. g. Jalap.)

Tribe I. DICHONOREA. Cappls 2 or 4 , distinct or nearly so; styles 2, basilar, Creeping herbs.

1. Dichondra. Corolla deefly 5-cleft. Pistils 2, one-seeded.

Tribe II. CONVOLV ULEA. Ovary entive. Leafy plants, mostly twiners.

2. Ipomœa. Style unclivided, with stigma cayitate or 2-3-ylobose.

3. Convolvulus. Style undivided or 2-cleft only at alex; stigrms 2, linear-filiform to suluate or ovate.

4. Horeveria. style 2-cleft or 2-parted; the divisions simple; stigmas capitate.

5. Evolvulus. Styles 2, each 2-cleft; stigmas linear-filiforn. Not twining.

Tribe III. CUSCUTEZE. Ovary entire. Leafless parasitic twining herbs, never green. Embro filiforn, coiled, without cotyledons.

6. Cuscuta. The only genus of the group.

\section{DICHÓNDRA, Forst.}

Calyx 5-parted. Corolla broally hell-shaped, 5-cleft. Stamens ineluded. Styles, oraries, and utricular 1-2-serled capsules 2, distinet. Stigmas thick. - Small and ereeping perennial herhs, soft-pulicscent, with kirhey-shaped entire leares, and axillary I-flowered bractless peduncles. Corolla sinall, yel-

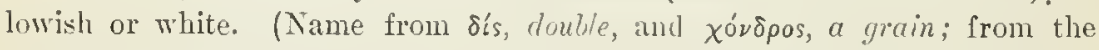
fruit.)

1. D. rèpens, Forst. Leaves round-kidney-shaped, pubescent, green both sides; corolla not exceeding the calyx (1-1 $\frac{1}{2}{ }^{\prime \prime}$ long). - Wet ground. Va. to Tex., near the coast.

\section{IPOMLĖA, L. Mormixg Glory}

Calyx not bracteate at base, but the onter sepals commonly largur. Corolla salver-form or funnel-form to nearly campaunlate; the limb entive or slightlylobed. Style undivided, terminated by a single capitate or 2 -3-globose stigma. Capsule globular, 4-6 (by aluortion fewer)-scerled, 2-4-valverl. (Name,

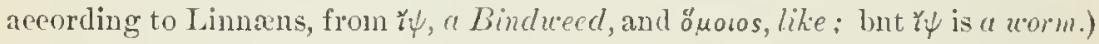

\$ 1. QUAMIOCIIT. Corolla salver-form, or with somewhat fumel-form but urrrow tube; stomens and style exserted; fourrs red. Anmual twiners

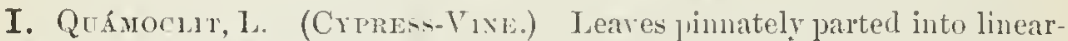
thread-shaped delieate parallel lobes; peduncles 1-flowered; corolla narrow. scarlet-red, or sometimes white. (Quanoclit vulgaris, Choisy.) - S paringly s]untaneons soutliwarl. ('Trop). Amer., etc.)

I. coccfxes, I. Leaves heart-shaped, acmminate, entire or angled; separls aw11-pointed; corolla light scarlet ( $\mathrm{l}^{\prime}$ long). (Quamoclit coecinea, . Hoenr/h.) River-banks, etc., ()hio to Ill., Va., and sunthward. (I'pobably indigenous in N. Mex. and Arizona.)

\$. IPOMIEA proper. Corolla fumm-form no nearly campanulate, contorted in the lund: stamens and style not exserted.

* (Momsixi; Guotiv) Lotes of stigma and refls 3 ; sepals iong and namoun,

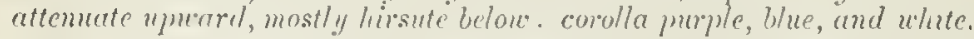

I. HEIfRACli, Jacq. Stems letrorsely hairy, leares leart-shaped, 3-lohed, the lobes acute or acmminate; pednucles short, or rather long, I-3-flowered;

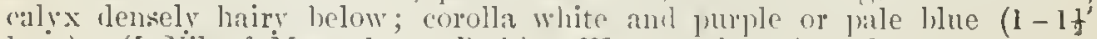
luig). (I. Nil. of IIanual, not Roth.) - Waste an! ("ultivited gromud, Penn. (1) lili, and La. (Trop. Amer.) 


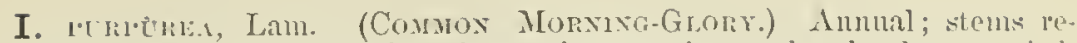
trorsely hairy ; leaves heart-shaped, acumimute, entire; peduncles long, umberlately 3-5-fluwered; calyx bristly-hairy beluw; corolla funne!-form (2’ loug) purple, varying to white. - Escaped in cultivated grounds. ('Trop. Amer.)

* Stigma 2-lobed m entire; cells 2, each 2-seeded; sepuls brouder, imbricated.

- Leares cordate, acuminate.

1. I. panduràta, Meyer. (Milud Pora To-vine. Max-of-the-E.trth.; Perennial, smooth u nearly so when old, trailing or sometimes twining; leaves occasionally contracted at the sides so as to be fillle-sliaped; peduncles longer than the petiolss, 1-5-flowered; sepals smooth, acate-ablong, rery olutuse; (orolla open-funnelform ( $3^{\prime}$ long), white witl purple in the tube.- Dry gromud, Comm. tw Micli., south to Fla. and Tex. June-Aug. Stems long and stout, from a litge root, which often weighs $10-20$ pounds.

2. I. lacunòsa, L. Anunal; rather smooth; stem twıing and creeping, slender; leaves entire or angled-lobed; peduncles short, 1-3-flowered; sepuls lance-ollong, pointed, bristly-ciliate or hairy, lialf the length of the sharply 5-lobed (white, $\frac{1}{2}-\frac{1^{\prime}}{3}$ long) corolla. - River-banks and luw grounds, Penn. to Ill., soutl to S. C. and Tex.

\section{+ + Leuces linear; not tuining.}

3. I. leptophýlla, Torr. Peremial, very glalurus; stems erect $\boldsymbol{l}^{\circ}$ ssocuding (2-40 high), with slender recuring branches, from an inmense root (weighing 10-100 pounds) ; leaves 2-4' long, 2-3" wille, short-petioled, acute; perlumcles short, 1-2-flowered; sepals broally orate, rery obtuse, onter ones shorter; corolla pink-purple, funmel-form, about $3^{\prime}$ lung. - Plains of Seb. to central Kau., Tex., and westwarl.

\section{CON V ÓL V U LUS, Tourn. Bindwed.}

Corolla fumnel-form to campanulate. Stamens included. Style undivided or 2-cleft ouly at the apex: stigmas 2, limear-filiform to subulate or ovate. Capsule globose, a-celled, or imperfectly 4-celled by spuriuns partitions between the 2 seels, or by abortion l-celled, mostly 2 -4-valved. - Ilerbs or somewhat shrubby plants, either twining, erect, or prostrate. (Name from convolvo, to entwiue.)

\$1. CALISTEGIA. Stigmas oval to whlong; calyx enclosed in 2 broad leafy bracts.

1. C. spithamæus, I. Douny; stem low and mostly simple, upright or ascendiny $\left(6-12^{\prime}\right.$ long) ; leaves ol)long, with or without a heart-shaped $01^{\circ}$ auricled base ; corolla white ( $2^{\prime}$ loug) ; stigmas oral. (Calystegia spithamaa, Prush.) - Iry and sandy or rucky suil; not rare.

2. C. sèpium, I. (Hewae Brxpweito.) Glabous, or more or less pubescent; stem turing or sometimes trailing extensively; leaves triutugularhalberd-shaped or arrow-shapen, acnte or pointed, the hasal lobes obliquely truncate and often somewhat toothed or sinnate-lohed; peduncles 4 -angled; bracts conmonly acnte: corolla white or tinged with rose-color ( $1 \frac{1}{2}-2^{\prime}$ long). (Calystegia sepium, R. Br.) - Moist allurial soil, or along streams; $\mathbf{X}$. Atlan. tic States and westward. (Eu., etc.)

Var. Americànus, sims. Glalıous; corolla pink or rose-purple; bracts obtuse. (C.sepium of $\mathrm{Am}$. autluors mainly.) - Common, across the continent. 
Var. rèpens, Giry. More or less pubescent; sterile and sometimes flowering stems cxtensively prostrate; leaves moro narrowly sagittate or collate, the basal lobes eommonly ohtuse or rounded and entire; eorolla from almost white to rose-eolor; bracts very nltuse or acute. (Calystegia sepium, var. puhescens, Groy.) - Common.

\section{\$2. Sigmas fliform; no bructs at on near the base of the calyx.}

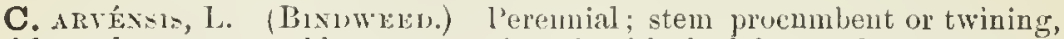
and low ; leaves ovate-oblong, arrow-shaped, with the lobes at the lase acute; peduncles mostly l-Howered; bracts minute, romote; eorolla (9" long) white or tinged with reddislı. - Oli fielı, N. Atlantic States. (Eu.)

\section{BREW E RIA, R. Br.}

Styles 2, or rarely 3, simple and distinct, or else united into one below; stigmas depressed-capitate. ()therwise as Convolvulus and Evolvulus. Perennial prostrate or diffusely sprealing lesths; Howers small; in summer; corolla more or less hairy or silky ontsicle. (Nimed for sammel Brewer, an English botanist or anateur of the 18 th (century.)

1. B. humistràta, Gray. spursely hury or nearly smooth; leares varying from oblong with a somewhat heart-slaped base to linear, mucronate or emarginate; peduncles 1 -7-flowered; luacts shorter than the pedicels; sepuls pointed, ylabrons or nearly so; corollu white; filaments hairy; styles united at base. (Junania lnmistrata, Gray.) - Dry pine barrens, Va. to La.

2. B. aquática, Gray. Minutely sofi downy and somewhat hoary; pe. duncles 1-3-flowered; sepals silk $y$; corolla pink or purple; filaments smooth; styles relmost distinet; otherwise nearly as n. 1. (Bonania aquatica, Gray.) Wet pine barrens and margins of ponds, N. C. to 'Tex., extending into Mo.

3. B. Pickeríngii, Gray. Soft-pmlescent or smouthish; leaves rery murrouly linear on the lowest lincar-spatnlate, tiljering to the base, nenrly sessile; peduncles 1 - 3-flowered ; brots resembling the leaves, mostly exeeding the flowers; sepuls hairy: filaments (scarcely hairy) and styles (united for above the middle) erserted from the open whe corolla. (Bonamia Piekeringii, Gray.) - I)ry pine harrens and prairies, N.J. and southward; also W. 111.

\section{EVÓLVULUS, L.}

Calyx of 5 sejals, naked at base. Corolla ppen funnel-form or almost rotate. Styles 2, carll 2-cleft; stigmas obtuse. ('apsnle 2-eelled; the cells 2-seeded. - Low and sulall lierbs or suffirutescent plants, mostly diff nse, never twining (hence the name, from evoleo, to unroll, in contrast with Convolvulus).

1. E. argénteus, P’ursh. Many-stemmed frum a somewhat woody baste, dwarf, silky-i illons all over; lcaves crowled, luoilly lancolate, sessile, or the

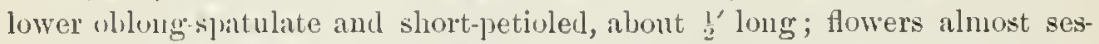
sile in the axils; corolla purple, $3^{\prime \prime}$ hroal. - Sterile plains and prairies, the Dakutis and Neb. to Mo. and Tex.

\section{C ÚSCUTA, Tourn. Donder.}

Calyx 5-(1arely t-) rleft, or of 5 sepals. Corolla globular-urn-shaped, bell-haped, or short-tuhular, the sprealing lurder 5- (rurely +-) eleft, imbricate. Stamens with a scale-like often fringed appendiage at hase. (3vary 2-celled 
f-ornled; styles distinct, or rarely united. Capsule mostly 4-seeded. Embryo thread-shaped, spirally coiled in the rather fleshy allumen, destitute of cotyledons, sometimes with a few alternate scales (helongiug to the plumule); germination occurring in the soil. - Leafless annual lierbs, with thread-like yellowish or reddish stems, bearing a few minute scales in place of leaves: on rising from the grom becoming entirely parasitic on the bark of herbs and shrubs on which they twine, and to which they adhere by means of suchers leveloped on the surface in contact. Flowers small, cymose-clustered, mostly white; usually produced late in summer and in autumn. (Name suj)posed to be of Arabic derivation.)

\section{\$ 1. Stigmas elongaterl; capsule circumscissile.}

C. Híluxu, Weilie. (Frax Donur.) Stems very slender, low; flowers globular, sessile in dense scattered lieals; corolla 5-purted, short-cylindrical, searcely exceeding the broally ovate acute divisions of the calyx, persistent ilround the capsule; stamens included; scales short, lruad, cronulate, shorter than the glohose ovary - Hlax-fields; in Furope very injurious; sparingly introdnced with fax-seed into the Northern States. June.

C. Eurrmyum, Mlur. Stems very slender; Howers capitate; corolla-lobes sprending, the cylindrical tube longer than the suberect acute sepals; scales large, contignous, touthed; stamens exserted. - Uccasionally found in cloverfielils. (Int. from Lu.)

\$2. Stigmas cupitate; capsule indehiscent.

* Calyx gamosepalous ; ovary and capsule depressed-globose.

- Flowers in dense or globular clusters; corolla with short and wide tube, per sistent at the base of the capsule; styles mosily shorter than the ovary.

1. C. chlorocárpa, Ingelun. Stems course, orange-colored; flower: white $\left(1-1 \frac{1}{4}\right.$ long); lohes of calyx und corollu (mostly 4) acute, often longer than the tube; scales small, 2-cleft, often reduced to a few teeth; the thin capsnle pale greenish-yellow. - Wet places, from Wisc. and Minn. to Ark.; also in l'enn. and Del., often on P'olygonum.

2. C. arvénsis, Beyrich. Stems pale and stender, low; flowers smaller. (harlly $1^{\prime \prime}$ long); calyx-lobes (5) obtuse, mostly very bruad; those of the corolla acmuinate, longer than the tube, with inflexed joints; scales large, deeply fringed. - Rather dry soil on various low plants, X. Y. to Fla, west to the Jacific. Very variable.

+ + Flowers in panicled oflen compound cymes; styles slender, mostly longer. than the ovary; corolla withering on the summit of the large capsule.

3. C. tenuifòra, Engelm. Stems coarse and yellow, usually rather highrlimling; flowers ( 1 "long or less) on short thick perlicels, often 4-merous; loles of calyx and corolla oblong, obtuse, the latter mostly shorter than the stender deeply campanulate tulon; scales shorter than the tube, fringed. - On tall herbs and shrubs in wet places, l'em. to Minn., and south to Tex.

* Calyx gamosepalous; ovury and capsule pointed, the latter envcloped or capped by the marccscent corolla; flowers in loosc paniclcd cymes.

+ Acute tips of the corolla-lobes inflexcd.

4. C. decora, Engelm. Stens coarse; flowers fleshy and more or less papillnse; caly-lobes triangular, acute; those of the broarly campanulate 
corolla ovate-lanceolate, minutely crenulate, spreading; scales large, deeply fiinged; capsule enveloped by remains of corolla. (C. indecora, Choisy.) - Var. PULChériud, Engelm. The larger form, with coarser stems, and conspicuous flowers $1 \frac{1}{2}-2 \frac{1}{2}$ long and wide; anthers and stigmas yellow or deep purple. - Wet prairies, on herbs and low slurtls (principally Leguminose and Composite), from Ill. to Fla. and Tex., and westward.

5. C. infléxa, Engelm. Similar to the preceding; flowers of the same structure, but smaller (only $1^{\prime \prime}$ long), generally 4-merous; corolla deeper, with erect lobes, finally capping the capsule; scules reduced to a few teeth. - Open woods and dry prairies, on shruls (hazels, etc.) or coarse herbs, sonthem $\mathrm{N}$. Eng. to Neb. and Ark.

\section{+ + Corolla-lobes obtuse, spreading.}

6. C. Gronòvii, Willd. Stems coarse, ofteu climbing high; corollalobes mostly shorter than the deeply campanulate tube; scales copionsly fringed; capsule globose, umbonute. - Wet shady places, Canala to Minn., sonth to Fla. and 'Tex. The commonest of our species. Flowers very rariable in size and compactuess of clusters. - Var. LATIFtòna, Engelm., is a form with flowers of more delicate texture, and shorter tube and longer lobes to the corolla. Common northward.

7. C. rostràta, Shuttleworth. Similar to the preceding; flowers larger $\left(2-3^{\prime \prime}\right.$ long $)$, more delicate and whiter; lobes of corolla and calyx shorter than its tube; slender styles longer; orary bottle-shaped; capsule long-pointed. - Shady valleys in the Alleghanies, from MId. and Va, sontliward; on tall herbs, rarely shrubs.

* * * Sepals 5, distinct, surrounded by 2 or more similar bracts; styles capillary; scales large, deeply fringed; capsule capped by the marcescent corolla.

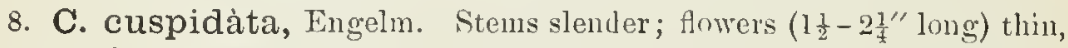
on tracteolate pedicels in loose prenieles; the ovate-orbicular bracts and sepals and the oblong corollatobes cuspidate or mucronate, rarely obtuse, shorter thau the cylindrical tule; styles many times longer than the ovary, at length exserted. - Wet or dry prairies, on Ambrosia, Ira, some Leguminosæ, etc., Neb. to Tex., occasionally down the Missouri as far as St. Lonis.

9. C. compácta, Juss. Stems coarse; flowers closely sessile in densely compart clusters; bracts $(3-5)$ and sepals orbicular, concare, slightly crenate, appressed, nearly equalling or much shorter than the cylindrical tuhe of the corolla; stamens shorter than the oblong olituse spreadling lobes of the latter. $-A$ long the west side of the Alleghanies from (Ont. to Ala., West to Mo. and Tex. In damp wouls, almost always on shrubs.

10. C. glomeràta, Choisy. Flowers rery densely clustercd, forming kuotty masses closely encircling the stem of the foster plant, much imbricateil with scarions oblong bracts, thcir tips recureed-spreading; sepals ncarly similar. shorter than the oblong-eylindrical tule of the corolla ; stamens nearly as long as the oblomg-lanceolate obtuse spreading or reflexed corolla-lobes; style several times longer than the orary. - Wet prairies, Ohio to Minn., Kin., and Tex., mostly on tall Compositx. The repe-like twists ( $\frac{1}{2}-\frac{z^{\prime}}{4}$ thick), of white flowers with golden yellow antliers imbelded in a mass of curly bracts, have a singnlar appe:trance. 


\section{Order 74. SOLANACLAE. (Nightshade Fanily.)}

Herbs (or rarely shrubs), with colorless juice and alternate leares, regular 5-merous and 5-androus flowers, on lractless pellicels; the corolla imoricale or valcute in the bud, and mostly plaited: the fruit a 2-celled (rarely 3-5-celled) many-seeded capsule or berry. - Seeds campylotropous or amphitropous. Embryo mostly slender and curved in fleshy allumen. Calyx usually persistent. Stamens mostly equal, inserted on the corolla. Style and stigma single. Placente in the axis, often projecting far into the cells. (Foliage rank-scented, and with the fruits mostly narcotic, often very poisonous, while some are edible.) - A large family in the tropics, but very few indigenous in our district. It shades off into Serophulariacea, from which the plaited regular eorolia and 5 equal stamens gencrally distinguish it.

* Corolla whecl-slraped, 5-parted or 5-lobed; the lobes valvate and their margins usually turned iuward in the bud. Anthers connivent. Fruit a berry.

1. Solanum. Authers opening by pores or chinks at the tip.

* Corolla various, not whecl-shaped, uor valvate in the bud. Anthers separate.

- Fruit a ber'y, closely invested by an herbaceous (not angled) calyx.

2. Chamasaracha. Corolla plicate, 5-angulate. Pedicels solitary, recurved in finit. - Fruit a ber'y, enclosed in the bladdery-inflated ealyx. Corolla widely expranding.

3. Physalis. Calyx 5-eleft. Corolla 5-lobed or nearly entire. Berry juicy, 2-celled.

4. Nicandra. Calyx 5-parted. Corolla nealy entive. Bery dry, 3-5-celled.

+++ Fruit a berry with the unaltered calyx persistent at its base.

5. Lycium. Corolla funnel-form or tubular, not plaited. Berry small, 2-celled. +++ Fruit a capsule.

6. Hyoscyamus. Calyx urn-shaper, enclosing the smonth 2-cclled capsnle, which opens by the tol falling off as a lid. Corolla and stanens somewhat irregular.

7. Dntura. Calyx prismatic, 5-tootlied. Capsule prichly, naked, more or less 4-celled, 4-valvell. Corolla funuel-for'tn.

S. Nicotiana. Calyx tubnlar-bell-shaped, 5-cleft. Capsule enclosed in tlie calyx, 2-celled.

\section{SOL À N U M, Toum. Nightsindid.}

Calyx and wheel-shaped corolla 5-parted or 5-cleft (rarely 4-10-parted), the latter plaited in the bud, and valvate or induplicate. Stamens exserted ; filaments rery short; anthers converging around the style, opening at the tip ly two pores or chinks. Berry usually 2-eelled. - IIerbs, or shruhs in warm climates, the larger leaves often aecompanied by a smaller lateral (rameal) one; the peduncles also mostly lateral and extra-axillary. $-A$ rast genus, chiefly in warmer regions, including the Potato (S. Tubrosta) and the

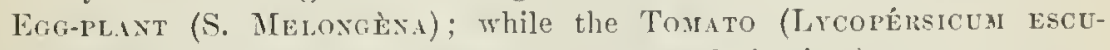
LExT(M) is closely related. (Name of unkwown derivation.)

* Not prickly; anthers blunt; flowers and globose naked bemies smoll.

- Perennial, climbing or twining.

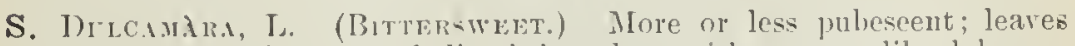
ovate-lieart shaped. the npper liallorel shaped, or with two ear-like loles or leatlets at lanse; flowers (purple or blue) in suall eymes; herries uval, rel. Moist lanks anil around dwellings. Jume-Sept. (Nat. from Lu.) 
+ + Simpleteared annuals.

1. S. triflorum, Nutt. Low, sprealing, slightly lairy or nearly glabrous, leaves oblong, pinnutifid ( 7 -9-lobed) with rounded sinnses; perluncles $1-3$. flowered; corolla white; beries green, as large as a small cherry-Central Kan., and westward; chiefly a weerl near dwellings.

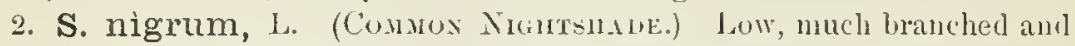
ofteu sjreading, nearly glabrous, rough on the angles; leaces orule, uruy. toothed; flovers white, in small umbel-like lateral clustcrs, drooping; caly.r. spreading; filaments hairy; herries globular, Uluek, - Shaded grounds and Felds; common, appearing as if intruluced, lint a cosmopolite. July-Sept.

V'ar. vuloosen, Mill. Low, somewlat viscill-puhescent or villous; leaves small, eonspicuusly angular-dentite; tilameuts ghalnous; berries yellow. Established near Philinlelplia, from hallast. (Alik. from Eu.)

S. Glícnle, Link. Cinereuns-puluserent or pulleculent, rather tall $\left(2-3^{3}\right.$

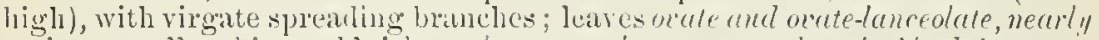

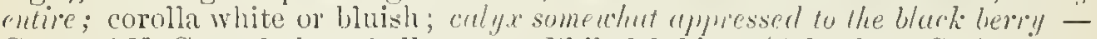
Coast of N. C., and ahout ballast near l'hiladelphiat. (All. from S Am.)

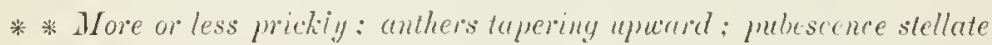

+ Perennial; fruit naked; unthers equal; corolla volet, rareiy while.

3. S. Carolinénse, L. (Honsk-Netruk.) Hirsute or roughsh-pubescent with 4-8rayed huirs; mickles stout, yellowish, copions (rarely scauty); leares oblong ur ovate, ubtusely sinuate-toothed or lobed ur sinuate-pinnatifid, ra cemes sinple, swon lateral; calyx-lobes acumnale; berries about $6^{\prime \prime}$ broud.-Sandy soil and waste gromuds, Conn. to Iowa, sontly to Fla and Tex.

4. S. elæagnifolium, Car. Silvery-canescent wh dense scurf like pn hescence of many-rayed hairs; prickles small, slender, more or less copious or wanting; leaces luncolule to oblong and linear, sinuate-repand or entire culyx-lobes slender; berry seldom $6^{\prime \prime}$ in chameter. - l'rairies and plinins. E kian. to Tex., and westwart.

5. S. Torrèyi, Gray. Cinereous whth a someuhut close pubescence of alunt "yutly 3-12-ruyed huirs: mickles small and stout, scanty or nearly wanting; lecures ocale with truncate or slightly cordate base, sinuately $5-7$-lobed $(+-6)$ long); calyx-lobes short-ovate, whrutly long acuminute; berry 1' in dumeter. I'rairics, etc., E. Kinl. and Tex.

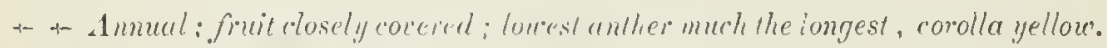

6. S. rostratum, Dunal Very prickly, somewhat hoary or yellowish with a copious wholly stellate pubescence ( $1-20$ high) leares $1-2$ pinuatifid. (allyx densely prickly ; stanens and style much declined. - Plaius of Neb. to 'Tex; spreading eastwarl to 1$]$ and Temn

\section{CHA M Æ}

Calyx herhaceme, closely investing the glohose herry (or most of it), obscurcly if at all veiny. Corolla rotate, 5-angulate, plicate in the lucl. Fila. ments filiform; antliers separate, olleng - Perennials, with mostly narrow entire or pinnatifid leares talpering into margined petioles, and filiform naked perlicels solitaly in the axils, refracted or recurvel in frnit. (saracha is a

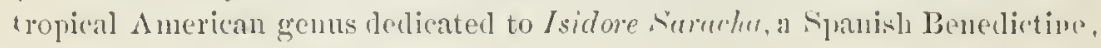
the jurefix zamai, on the !romull.) 
1. C. sórdida, Gray. Mneh branched from root or hasc, somewhat einereous with short viscid pubescenee; leaves obovate-spatulate or cuneate-oblong to oblanceolate, repaul to incisely pinnatifid ; calyx when young villons-riseid; corolla pale yellow or violet-purple (6" broad); berry as large as a pea. - Dry or elayey soil, central and W. Kían. to Tex. and Arizona.

\section{PHÝSALIS, I. GRouxd Chérir.}

Calyx 5-cleft, reticulated aud enlarging after Howering, at length mueh inflated ant enclosing the 2-celled globular (edible) herry. Corolla between wheet-shaped and funnel-form, the very short tube marked with 5 eoucave spots at the hase; the plaited border somewhat 5-lobed or barely 5 - 10 -toothed. Stamens 5, erect; anthers separate, "pening lengthwise - Herbs (in this country), with the leares often meyually in pairs, and the l-flowered nodding peduncles extra-axillary; Howering through the summer. (Name $\phi v \sigma a \lambda i s, ~ "$ bladder, from the inflated calyx.)

* Corolla large, white or tinged with blue, without dark centre, with almost entire border; jubescence simple.

1. P. grandiflòra, Hook. Climmy-pubescent, erect; leares lance-ovate, pointed, entire or nearly so; corolla $1-2^{\prime}$ wide when expanded, aud with a woolly ring in the throat; fruiting calyx glolmlar, apparently nearly filled by the berr. S. shore of L. Superior to Sask. : Providence Fslaud, L. Champlain (Perkins).

* Corolla lurid greenish-white or yellow, mostly with dark centre, 3-10" broad. - Annuals, glabrous or pubescence mimute; anthers riolet.

2. P. Philadélphica, Lam. Leaves ovate or oblong-ovate, oblique at hase, entire, repand, or very spuringly angulate-toothed; corolla brownish-or riolet-spotted in the centre, $7-10^{\prime \prime}$ broad; calyx at maturity glohose and completely filled by the large reddish or purple herry and open at the moutl. lu fertile soil, P'enn, to Minu. and T'ex.

3. P. angulàta, L. Much brauched; leaves ovate or ovate-oblong, sharply and inegularly laciniate-toothed; peduncles filiform; corolla unspotted, rery small $\left(3-6^{\prime \prime}\right.$ broad when expanded); fruiting calyx conical-ovate with a truncate or sunken hase, 10 -angled, loosely intiated, at leugth well filled by the greenish-yellow berry. - Open rich grounds, Peun. to Minm., and sonthwart.

+ - Strong-scented, villous or pubescent with viscid or glandnlur simple hairs; fruiting ralyx ovate-pyramidal, carinately 5-ungled, closed, loosely enveloping the yrun wo yellow berry; leates ovate or cordate.

4. P. pubéscens, L. Ammul, diffusely much brauched or at length decumbent; leares angulate- or repand-toothed or nearly entire; corolla spotted with brown purple in the centre, 5-6" broud when expauded, obscurely 5-10trothed; unthers violet. - Low grounds, X. Y. to Minn., south to Fla. and 'Tex, and westwarl. - A very doubtful form, found at Independence, Mo. (B. F. Bush), has the small corolla (2" hroad) yellow, without a brown ceutre, the anther's yellow, the fruting calyx smaller, and the ber'y viscid.

๖. P. Virginiàna, Mill. Peremial, liffusely much lranched and widely suratiug, or at timt erect; leaves sometimes oblong, repand or olituscly toutherl,

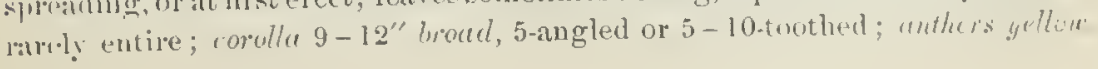


(P. viscosa, Gray, Man., not L.) - Light or sandy soils, Ont. and Minn. to Fla. and 'Tex. - Var. AlB BfGA, Gray, is a coarse and very villous form with violet anthers. Wisc, and westward.

+++ Perennials, mostly low, not viscid; mulescence stellate or simple or nearly none; anthers almost aluays yellow.

6. P. viscòsa, L. Cinereous or uhen young almost canescent with short stellate or 2-3-forked pubescence; stems ascending or sprearling from slender creeping subterranean shoots; leaves orate or oval, varying to oblong and obovate, entire or undulate; corolla greenish-ycllow, with a more or less flark eye ; fruiting calyx globose-ovate; berry yellow or orange. - In sands on and near the coast, Va. to N. C. and Fla.

7. P. lanceolàta, Michx. More or less hirsute-pubescent with short stiff mostly simple huirs, varying to nearly glalnous; stems from rather stout subterranean shoots, angled, somewhat rigid; leaves oblong-ouate to nurrowly lanceolate, sparingly angulate-toothed to undulate or entire; corolla ochrolencous, with a more or less dark eye; calyx commonly hirsute, in fruit pyramidal-ocate ( $1-1 \frac{1}{2}$ 'long); berry reddish. (P. I'eunsylvanica, Gray, Man., in part; not L.) - Dry open ground, Penw. to Ill., Mimu., and south and westward.

Var. læevigàta, Gray. Glabrous or almost so throughout, or with some very short hairs on young parts. - Neb. to Tex., and westward.

Var. hírta, Gray. A remarkable ambiguous form, with much of the hir sute-pubescence of the leares $2-3$-forked, ats also are some of the abundant villous-hispid hairs of the stem. - Wet woods, Tex. to Mo., and E. Kan.

\section{N I C Á N D R A, Adaus. Apple of Peru.}

Calyx 5-parted, 5-angled, the divisions rather arrow-shaped, enlarged and blarder-like in fruit, enclosing the 3-5-celled glubular dry berry. Corolla with borter nearly entire. (Otherwise much like Physalis. - An anumal smooth herb $\left(2-3^{\circ}\right.$ high), with wate simate tootherl or angled leaves, and solitary pale blue flowers on axillary and terminal peduncles. (Named after the poet Nicander of Colophon.)

N. PIISAloìnes, Gaertn. - Waste grounds, near dwelliugs and old gardens. (Aclv. from l'eru.)

\section{LÝ $\mathrm{Y}$ U M, L. Matrinoni-Vine.}

Calyx 3-5-toothed or -cleft, not enlarging. persistent at the hase of the berry. Corolla funnel-form or salver-shaped, 5-lolved, the lobes imbricated and not plaiterl in the bud. Stamens 5 ; anthers opening lengthwise. Style slenler; stigna capitate. Berry small, 2-cellel. Slnobhy, often sping jlants, witl alternate and entire small leaves, and mustly axillary small fluwers. (Named from the country, Lycia.)

L. vilodie, D)ual. (Commox M.) Shrub with long samentose recurveldrooping branches, smooth, sparingly if at all spiny ; leaves oblong- or spatulate-lanceulate, often fascieled, narrowel into a slut petiole; flowers on slencle perluncles fascicled in the axils; (orolla short funnel-form, greenisli-purple; style and slender filaments equalling its lnbes; berry woil, orange-led. - $A$ bout divellings, and escaped into waste grounds in l'enu., ete. (Achr. from Eu.)

\section{H Y O C Y A M U S, Tourn. Mribaxk.}

Calyx bell-shaperl or uru-shaped, 5-lobed. Corolla funuel-form, oblique, with

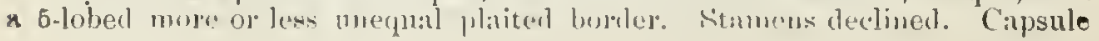


enclused in the persistent ealyx, 2-celled, opening transiersely all round near the apex, which falls off like it licl. - Clanmy-pubescent, fetid, narcotic lierbs with lurid flowers in the axils of angled or tootherl leaves. (Name composed uf ús, íos, a hor, and rúapos, a beun; siarl to be proisonous to swine.)

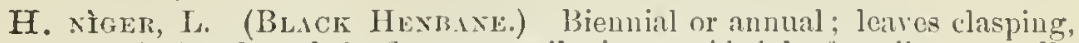
sinnate-toothed and angled; fluwers sessile, in one-sided leafy spikes; corulla dull yellowish, strongly reticulated with purple veins. - Escaped from gardens to roadsides. (Adv. from liu.)

\section{D A T Ù R A, L. Jamestowi-Weed. Thorn- $\Lambda$ pple.}

Calyx prismatic, 5-toothed, separating transversely above the base in fruit, the upper part falling away. Corolla funnel-form, with a large and spreading 5-10-toothed plaited border. Stigma 2-lipped. Capsule globular, prickly, 4-valverl, 2-celled, with 2 thick placentie projected from the axis into the niddile of thr cells, and connected with the walls by an imperfect false partition, so that the capsule is t-celled except near the top, the placentx as if on the mrddle of these false partitions. Seeds rather large, flat. - liank weeds, narcoticpoisonons, with ovate leaves, and large showy flowers on short peduncles in the forks of the branching stem; prodnced all summer and antumn. (Altered from the Arabic name, Tutomel.)

D. Stramonem, 1, (Common Stramoxium or Thorn Aple.) Annual, glabrous; leaves orate, siumate-tuothed or angled; stem green; corolla white ( $3^{\prime}$ long), the lowler with 5 teeth; lower prickles of the capsule mostly shorter. - Waste grouncls; a well-kuown ill-scented weel. ( $\mathrm{Aciv}$. from $\Lambda$ sia? )

D. 'Títula, L. (P'vis'L: 'T') Mostly taller'; stem pu'ple; corolla pale violet-purple; prickles of the capsule nearly equal. - Waste grounds, in the Atlantic States. (Alv. from trop. Amer.)

\section{N I C O TI À N A, Tonrn. Tовассо.}

Calyx tubular-bell-shaped, 5-cleft. Corolla funmel-form or salver-form, usually witl a long tube; the plaited border 5-lobed. Stigma capitate. Capsule 2-celled, 2-4-vitled from the ipex. Seeds minute- - Rank acrid-narcotic herbs, mostly climmy-pubescent, with ample entire leaves, and racemed or panicled flowers. (Named after John Nicot, who was thought to lave introduced Tobacco (N. 'Tasicum, 1.) into Europe.)

N. rústic , T. (Who Tonacco.) Amunal; leaves ovate, petioled; tube of the dull greenish-yellow corolla cylindrical, two thirds longer than the calyx. the lobes rounded. - ()li fields, from N. I. Westward and sonthward; a relic of cultivation by the Inclians. (Of unknown nativity.)

\section{Order 75. SCROPHULARIACEAE. (Figwort Famly.)}

Chiefly herls (rarely trees), with didynamous stamens (or perfect stamens ffien only 2, rarely 5) inserted on the tube of the 2-lipped or more or less irregular cornlla, the lobes of which are imbricated in the but; fruit a 2 celled and uswally many-seeded capsule, with the placentce in the axis: seeds anatropous, or amplitropous, with a small embryo in copious allumen. - Style single; stigma entire or 2-lobed. I, caves and mflesence various; but the flowers not terminal in any genuine representatives of the order. A large order of bitterish plants, some of them nareotic-poisonous.

I. ANTIRR11NIIDE.E. [Pper lipur lobes of the corolla coveriug the luwer in the bull (witl occasional exceptions in Minulus, etc.) Capsule usually septicidal. 
Tribe I. VEIBASCEA. Corolla rotate. Flowers racemose. Leaves alternate.

1. Verbascum. Stamens 5, all with anthers, and 3 or all with bearded filanents.

Tribe II. ANTIRRIINEA. Comolla tubular, with a spur or sae at the base below, the throat usually with a pralite. Cinsule opening by clinks or holes. Flowers in sinple racemes or axillary. Lower leaves usually opposite or whorled, stamens 4.

2. Linaria. Cormlla spurred at base; the jalate seldon closing the tliroat.

3. Antirrhinum. Corolla merely silceate at base; the palate clusing the throat.

Trlbe III. CHELONEA. Corolli tubnlar, or 2-lipued, not spurred uor saecate below Capsule 2-4-vilverl Leaves olyusite Inflorescence usually eompound, of small axillary spiked or racened ur unbel-like chisters or eymes, or when redueed to a singli. flower the perluncle mostly 2-bracterte. Stamens 4 , and usually a rudiment of tlie fiftls

4 Scrophularia. Corolla inflated, globular or oblong, with four erect lobes and one spreading one Rudiment of the sterile stamen a scale on the upper lip.

5 Coliinsia. Corolla 2-eleft, the short tube saceate on the upper side; the middle lobe of the lower lip silc-lilie and enelosing the declined stannens.

13. Chelone. Corolla tubular inffated above. Sterile stanten shorter than the others. dnther's very woolly. Seeds winged.

7 Pentstemon. Corvlla tubular. Sterile stauen about as long as the rest. Seeds wingless.

Tribe IV. GRATIOLEA. Corulla tubular, not saceate nor spurted, Capsule 2valved Flowers solitary iu the axils of braets or leaves: peduncles naked (or 2-bracteolate in $\mathrm{n}, 12$ ). Leaves all or the lower ones opposite. No traee of a fiftl stamen

* Stamens 4, all anther-bearing and similar.

\& Mimulns. Calyx prisinatie, 5-angled, 5-toothed. Corulla elongated.

؛. Conobea. Calyx 5-parted, the divisions equal. Corolla short.

10. Herpestis. Calyx 5-parted, mequal, the upper division largest. Corolla short.

11 Limosella. Calyx 5-toothed, Corolla open licll-shnierl, 5-cleft, nearly regular. Leares alternate or faseieled, fleshy, Dwarf aquatie or marsh plant.

* * Auther-bearing stamens 2 ; usually also a pair of sterile lilaments.

12. Gratiola. Calyx 5-parted, stanens included, the sterile pair short or uone.

13 Ilysanthes Calyx 5-prarted, stamens included, the sterile filaments protruded.

14. Micrantiremum. Flower's minute. Calyx 4-touthed or eleft. Upper lip of corolla short or none. Filuments with an appendage : sterile pair uone Dwarf aquatic.

II. RHINANTHIDE $\mathrm{E}$. Under lip or the lateral lobes of the corolla covering the upper in the bud. Capsule commonly locuticidal.

Tribe V. DIGITILEAE. Curulla whech-shaped, salver-shaped, or bell-sliaped, Stamens 2 or 4, not approaelting in prairs nor strongly didynamons; anthers 2-celled.

15. Synthyris. Cally 4-parted. Corolla bell-slaped, 2-4-loled, irregular Stamens 2 ni1. Leives alternate. Howers raemed,

16. Veronica Calyx 4-(rarely $3-5-)$ 1nuted, Corolli wheel-shaped or salver-sliaped, aimost regular stamens 2, Leaves chiefly oplosite nl whorler. Flowers racemed.

Tribe VI. GERARDIEAE. Corolla with a spreating and slightly mequal 5-lobet limb stanens 4, approximate in pairs, Leaves olposite, or the uppermost alternate.

* Corolla salver-shajed. Anthers 1-celled. Flowers in a spitic.

17. Buchnera. Calyx tubular, 5 -toothed. Limb of the elongated corolla 5-cleft.

* Corolla bell-sliaped to fummel-form: anthers 2-celled.

15. Seymeria. Stamens nearly equal. Tube of the eorolla broul, not longer than the lobes.

19. Gerardla. Stanens stronirly unequal, included.

Trlbe VII. FUPIIRASIEA. Corolla tubular, olwiously 2-lippea ; the upper lip nar. row, erect or arched, enclosing the 4 usually strongly didynamons stamens.

* Anther-colls unequal and separated Capsule miny-seerlecl.

20. Castilleia. Calyx tubular, cleft down the lower, and often also on the uprer, side.

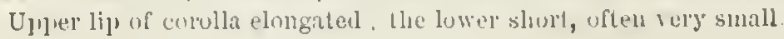


21. Orthocarpus. Calyx tubulir-eampanulate, 4-eleft. Upper lip of corolla little longer and usually mich narrower than the inflated lower one.

* Anther-cells equal. Capsule many-several-seeded.

22. Schwalbea. Calyx 5-tnothed, very oblique, the "lyel fouth much the smallest.

2:3. Euplnasia. Calyx 4-eleft. Ulyer lip of the comlla Capsule ollong.

24. Bartsia. Calyx 4-clett. Ulyer lip of cololli entire and sides not folded bauk.

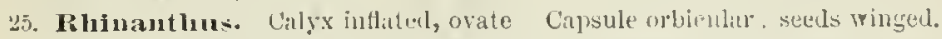

26. Pedicularis. Chlyx not intated. Calsule ovate or sworl-shapul : seeds wingless.

* * Anthor-cells equal. Cirjsule l - t-seperled

27. Melampyrum. Cilyx t-eleft. Ovily 2-eclled, t-oruled, Cupsule flat, oblique.

\section{VERBÁ S U M, 1. MI Llêr.}

Calyx 5-parted. Corolla 5-lohed, open or concave, wheel-shaped; the lobes broad and rounded, a little meunal. Stamens 5, all the filanents, or the 3 upper, woolly. Style flattenerl at the apex. Capsule globular, many-seeded. - lall and nsually woolly biemial heris, with alternate leaves, those of the sten sessile or decurrent. "Flowers in large terminal spikes or racemes, ephemcrial; in summer. (T'le ancient Latin name, altered from Burluscum.)

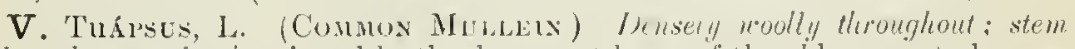
mll and stout, simple, wiuged by the decurrent bases of the oblong acute leaves: flowers (yellow, very rarely white) in a polunged and very dense aylindrubl spike; lower stamens usually beardless. - Fields, a common weed. (Nat. trom En.)

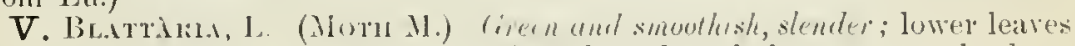
petioled, oblong, doubly seluate, sonctimes lye-shaped, the uprer partly clasping; raceme loose; tilaments all bearled with violet wool. - lioadsides, throngh vit our lange. Cordla either yellow, or white with a tinge of purple. (Nat. from Eu.)

V. Licnxims, I. (Write M.) Clothed with thin powdery woolliness; stem and branches angled above; leaves ovate, acute, not decurrent, greenish above; flowers (yellow, rarely white) in a prramidal panicle; filaments with whitish wool. - Ficlds, N. Atluntic States, rather rare. (Adr. from Lu.)

\section{L I N À RIA, Tourn. Tùd-Frax.}

Calyx 5-parted. Corolla persmate, with the prominent palate often nearly closing the throat, spurrenl at hase on the lower side. Stamens 4. Capsule thin, oprening below the summit hy one or two pores or chinks. Seeds many. - Ilerls, witl at least all the upper leaves alternate (in ours), f. in summer. (Name from Linum, the Flax, which the leares of some speeies resemble.)

* Slender glabrous unnual or hiemial; leates linear, entire and altemate (or smaller, whomg, and opposite on procumbent shoots), small blue fowers in a naked trminul raceme.

1. L. Canadénsis, Dumont. Flowering stems nearly simple $\left(6-30^{\prime}\right.$ nigh); leaves flat ( $1-2^{\prime \prime}$ wide); pedicels erect, not longer than the filiform curved spur of the corolla. - Samly soil, common.

* Pcremial, ereat ( 1 - $3^{\circ}$ high), glaturous, whth nurrou entire and alternate pale leaves, and yellow flowers in a termmal raceme.

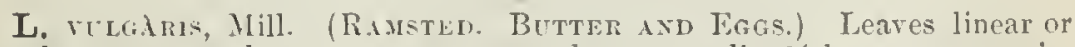
nearly so, extremely ummerous; raceme dense; corolla l' long or more, in

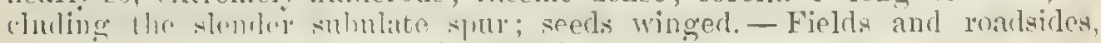

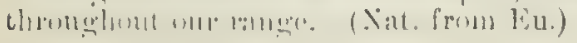


L. GEvistuotuls, Mill. Glaucous, paniculately branched; leaves lancen. late, acute; flowers smaller and more scattered; seeds wingless. - Sparingly naturalized near New lourk. (Nat. from lis.)

* * Anmual, prommbent, much branched, with broad petioled veiny alternate leaves, and small purplish and yellow flowers from their axils.

L. Eustixk, Mill. Spreading uvel the ground, slender, latiry ; leaves luastate or the lower ovate, much surpassed by the filiform peluncles; calyx-lobes lanceolate, acute; corolla 3-4" long, inclnding the sulinlate spur. - Sandy lauks and shores, Canada tu N. C., rather rare. (Nat. fom liu.)

L. Nơna, Mill. Like the preceding, but with romalish or ('ordate leaves aud ovate or cordate calyx-lobes. - Ocoasionally occurs on hallist or waste grounds near cities. (Nat. from Lu.)

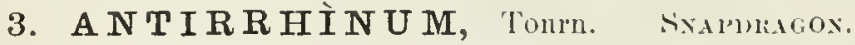

Corolla saceate at the base, the throat closed lw the large bearled palate. seeds oblong-truncate. Otherwise nearly as Liniria. - Corolla commonly showy, resembling the face of an animal ol a mask; whence the mane (from

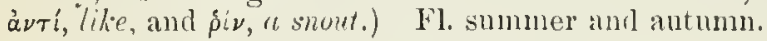

A. (1Róxтum, L. A small-flowered ammal or biennial, low, erect; leaves lance-linear; spike loose, leafy: sepals lunger than the purplish or white corolla. - About gardens and old fields in Atlautic States. (. Irlv. from Iiu.)

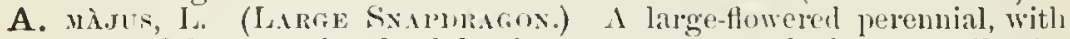

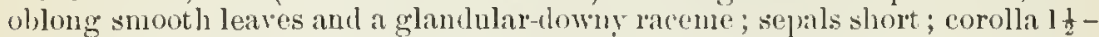

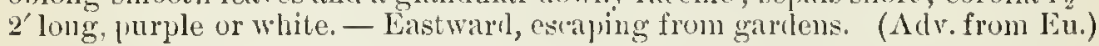

\section{SCROPHULARIA, Tourn. Figwort.}

Calyx deeply 5-cleft. Corolla witl a somewhat glolular tube; the 4 npper lobes of the short burder erect (the two upper longer), the lower spreading. Stamens 4, declined, with the anther-cells transverse and confluent into one; the fifth stamen a scale-like ruliment at the snmmit of the tube of the corolla. Capsule many-seeded. - Rank leros, witl mostly opposite leaves, and small greenisln-purple or luril flowers in loose cymes, forming a terminal narow. panicle. (Sio called liecause a reputerl remedy for smofula.)

1. S. nodosa, I.., var. Marilándica, Gray. Simootl perennial (3-50 high), stem 4-sicled; leaves oviate, ollonger or the upper lanceolate, aeminate, cut-serrate, romuled or rarely heart-shilped at hase. - I)amp grounds, N. Eng. to Fla., west to the Rocky Mts. (Fu., Asia, the type.)

\section{COLLÍNSIA, Nutt.}

Calyx deeply 5-cleft. Corolla declined, with the tulse saccate or bulging at the hase on the upper side, deeply 2-lipperl; the upper lip 2-cleft, its lobes jartly turmed loakward, the lower 3-cleft, its mirlle lobe keeled and sac-like, enclosing the 4 declined stamens and style. Fifth stamen a gland-like rudi. ment. Capsule 4-many-seeded - Slender branching annuals or biennials, with olprosite leaves, and handsome party-rolored Howers in umbel-like clusters, appearing whorled in the axils of the upper leaves. (Dedicated to the late Zurechens Collens, of Plhilaulelphia, an arcenrate botanist.)

1. C. vérna, Nintt. Slender $\left(6-20^{\prime}\right.$ ligh $)$, lower leaves ovate, the upper ovate-lanceolate, clasping by the heart-slaped base, tootherl; uhors about 6 flowered. flowers long-peduncled; corollu (blue and white) twice the length of the ralyx. - Moist soil. Western N. Yr. to W. Va., Wisc. and Ky. May, June. 
2. C. parviflora, Dougl. Small; luwer leares ovate or rounded, the upper obloug-lauceolate, mostly entire; whols 2-6-flowered; flowers shortpeduncled; the small (blue) corolla scarcely exceeding the calyx. - Shore of I. Superior, N. Mich., and westward.

\section{CHELÒN E, Toum. Turthe-hball. Sxakr-hean.}

Calyx of 5 distinct imbricated sepals. Corolla inflated-tnlular, with the moutl a little open; npper lip broad and areled, keelerl in the middle, notched at the apex; the lower woolly-bearded in the throat, 3 -lobed at the apex, the midille lobe smallest. Stamens 4, with woolly filaments and very woolly heart-shaped anthers, and a fifth sterile filament smaller than the others. Seeds many, wing-margined. - Smooth perennials, with upright branching stems, opposite serrate leaves, aud large white or purple flowers, which are nearly sessile in spikes or clusters, and closely imbricated with round-ovate roncave bracts and bractlets. (Name from $\chi \notin \lambda \omega \omega \eta$, a tortoise, the corolla resembling in shape the head of a reptile.)

1. C. glàbra, I. A foot or two (or even 6-70) ligh; leaves namouly to rother boully lunreolate (4-5' $\mathrm{long}, 4-12^{\prime \prime}$ wicle), gracually acuminate, serrate with sharp appressed tceth, narrowed at base usually into a very short petiole; brarts not riliate; corolla white, or burely tinged with rose. - Wet places, Newf. to Minn., south to Fla, and Tex.

2. C. obliqua, I. Less strict or with spreading branches, $1-2^{\circ}$ high ; leares broudly lancedate to oblong (2-5' long), sometimes laciniately serrate, more veiny and duller, acnte or obtuse at base, mostly short-petioled; bracts ciliolute; corolla deep and bright rose-color. - s. Ill. to Va. aud Fla.

\section{PENTSTE MON, Mitchell. BEARU-TONGUE.}

Calyx 5-parted. Corolla tulunlar and more or less inflated, or bell-shaped, either decidedly or slightly 2-lipper; the upper lip 2-lobed, aud the lower 3-cleft. Stamens 4, declined at the base, ascenuing above, and a fifth sterile tilament usmally as long as the others, either uaked or bearderl. Seeds numerous, wingless. - Pereunials, brauched from the base, simple above, with opposite leaves, the upper sessile and mostly clasping. Ilowers mostly showy,

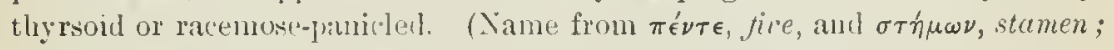
the fifth stamen being prestent and (couspicuous, although sterilc.)

* Iiscud or glandular above, nore or less pubescent or glabrous below; leaves often torthed or denticulate.

- Thyrse somewhat open; leares acute-lanceolate to linear; corolla $9-12^{\prime \prime}$ long, the lower lip usually bearded within.

1. P. pubéscens, Solanrler. Titem $1-20$ high, viscid-pubescent (at least the inflorescence); latees whomg lo lanceulate (2-4' long), the lowest and radical ovate or olslong, usually denticulate; thyrse narrow; corolla dull violet or purple (or partly whitish), erery morlerutely dilaterl, the throat nearly closed by a villous-beurded julate; sterile filmment densrly bearded. - Dry or rocky grounds, S. Maine (Miss Furlish) to Minn., soutlı to Fla. and 'Tex.

2. P. lævigàtus, Sulantrir. Silcm $2-4^{\circ}$ high, mostly glalmous except the influresceuce; leares firmer, sumewhat glussy, the culline veate-or ublong. 
lanceolate with subcurdate clasping base (2-5' long); thyrse broader; corolla white (commonly tinged with purple), abruptly and broadly inflated, the throut widely open; sterile filament thinly bectided above. - Moist or rieh soil, Penn. to Fla. and westward, where the common form is

Var. Digitàlis, Gray. Stem sometimes $5^{\circ}$ high ; corolla larger and more abruptly inflated, white. (P. Digitalis, Nutt.) - Penn. to Iowa, Mo., Ark., etc.

3. P. grácilis, Nutt. Glabrous or juberulent, riscid-pubeseent above, $1^{\circ}$ high or less; stem-leares mostly linear-lanceolate, the radieal spatnlate or oblong; corolla tubulin-fumel-form or nearly cylindrical with open throat, lilac-purple or whitish. - Minn. to Mo., and westward.

\section{+ + Thyrse raceme-like. All extreme vestern.}

4. P. Cobæa, Nutt. Soft-puberulent, $1^{\circ}$ high; leares ovate or oblong, or the lower broally lanceolate and the upper cordate-clasping, mostly sharply toothed; thyrse short; corolle 2 'long, broudly ventricose, dull purple or whitisls. - Prairies, Kan. to Tex.

5. P. tubiflòrus, Nutt. Wholly glabrous excepting the viscid ovate sepals, 2-3० high; leares oblong or ovate-lancelate, elitive or sparsely toothed, the floral shorter than the remote dense clusters of the rirgate thyrse; corolla 9 "long, the narrow tube yradually dilated unurerd, white or whitish. Low prairies, Kan. and $\lambda$ rk.

6. P. álbidus, Nutt. Viscid-pubescent, 6-10' high; leares obloug-lanceolate or narrow, entire or sparsely toothed; clusters of the strict thyrse fewHowered, approrimute; sepals lanceolate, densely pubescent; corolla 9" long, with shorter tube and more dilated throat. - Plains, Neb. to S. Dak. and Tex.

* * Clabrous throuthout and glunrous; lenves sessile, entire; thyrse raceme-like.

7. P. grandiflorus, Nutt. Stem $2-4^{\circ}$ high; leares thichish, the upper and floral rounded, all but the obovate radical ones clasping or perfoliute; pedicels short; rorolla $2^{\prime}$ long, oblong-campanulute, nearly regular, lilae or lavenderbue ; sterile filannent looked and minutely bearded at the apex. - Prairies, from Ill. and IVise, to the 1)akotats, Neb., and Kan.

8. P. glàber, l'ursh. Stems $1-2^{\circ}$ high; leaves mostly oblong-lanreulute or the upper wrete-tancedale: thyrse elongated, the peduncles and pedicels very

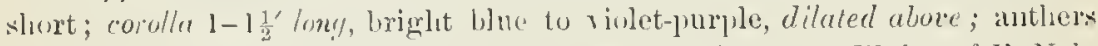
and apex of sterile filanent glahrons or sparsely hirsnte. - Plains of E. Nel. to S. Dak., and westward.

9. P. acuminatus, Dugl. Stem $6-20^{\prime}$ high, stont; leares thick, the

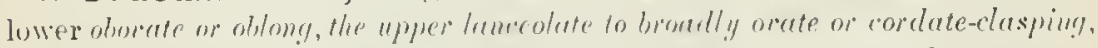
ande or armuinate; thyrse leafy below, very narrow; rorolla 9" long, lilac or siolet; sterile filament mostly bearded ahore. - Kan. to Minn., and westwarl.

\section{MÍM U L U S, L. MONET-FLower.}

Calyx prismatic, 5-ingled, 5-toothed, the upper tooth largest. Corulla tubulin; upper lip erect or reflexed-spreading, 2-lobed; the lower sprealing, 3lobed. Stamens 4. Stigma 2-loled, the lobes orate. Sceds numerons. Ilerlss, with opposite leaves, and mostly hanelsome fluwers on sulitary axillary and bractless peduncles. (Diminntive of mimus, a buffoon, from the grinning corollia.) 
* Erect from a perennial root, glabrous; leaves ferther-veined: coivlla vialetjurple.

1. M. ríngens, I. Stem square $\left(1-2^{\circ}\right.$ high $)$; leuces oblong or lanceolrite, pointed, clasping by a lieart-shaped base, serrate; peduncles longer than the Hower; calyx-teeth taper-pointed, nearly equal; corolla personate. - Wet places, N. Lng. to Minn., and sonthward; eommon. July-Sept. - Flower $1-1 \frac{T^{\prime}}{2}$ long, rarely white.

2. M. alatus, $\lambda$ it. Stem somewlat winged at the angles; leares oblongocute, tupering into a petiole; peduncles shorter than the calyx, which has very slurt abruptly pointed teeth; otherwise like the last. - Wet places, western N. Eug. to 111., south to N. C. and 'lex.

* * Leaves several-nerved and veiny, dentate, the upper sessile und clasping; culyx oblique, the upper tooth longest: corollu yellonc, the louer lip bearded.

3. M. Jamèsii, Torr. Diffusely sprearting, smootlı or smoothish; stems (reepiug at base; stem-leaves romndish or kichey'-shajed, nearly sessile, equalling the peduncles; ealyx ovate, inflated in fruit; throat of corolla broad and open. - In water or wet places, usually in springs, N. Mich. and Minn. to Ill., Kian., and westward.

M. LÙTEUs, L. Erect or with later branches spreading; leaves orate to ronudish or subeordate; corolla deep yellow, with brown-purple dots or blotches, often large. - Wet mearlows, Norfolk, Ct. (Adv. from Calif.)

\section{CON Ò B A, Aublet.}

Calyx 5-parted, equal. Cpper lip of corolla 2-lobed, the lower 3-parted. itamens 4, fertile; anthers approximate. Stigma 2-lobed, the lobes wedgeform. Seeds numerous - Low hranching herls, with opposite leaves, and small solitary flowers on axillary perluncles. (Name unexplained.)

1. C. multífida, Benth. Anumal, diffuscly spreading, much branched, minutely pubescent; leaves petioled, pinnately parted, chvisions linear-wedgeshaped; perluncles naked; corolla (greenish-white) scarecly longer than the calyx, - Along streans and shores, ()hio to III., Ark., and Tex.; also adr. below Philarlelphia. July-Sept.

\section{HERPESTIS, Gaertn. f.}

Calyx 5-parted ; the upper division broadest, the innermost often very uarrow. [ ' pper lip of the eorolla entire, notched or 2 -cleft, and the lower 3 -lobed, or the liml, nearly equally 5-lohed. Stamens 4 , all fertile. Sityle dilated or 2-lober at the apex. Seeds numerous. - Low herbs, with opposite leaves, and solitury axillary fluwers; in summer; ours rather sncenlent perenuials. (Name from $\dot{e} \rho \pi n \sigma \tau \eta \dot{s}$, "arfping thing, the species being chicfly procumbent.)

* Corolla plainly bilabiate, the 2 upper lobes united to form the upper lip; leaves many-nerved.

1. H. nigréscens, Bentl. Erect or ascending, very leafy, glabrous; leaves piunately reined, oblong to euneate-lanceolate ( $1-2^{\prime}$ long), serrate; pedicels equalling and the upper surpassing the leaves; eorolla whitish or purplish. - Wet places, Mrl aml N. C. to Tex, along and near the eoast. 
2. H. rotundifolia, Pursh. Nearly smooth, creeping; leaves round obovate, half-clusping ( $\frac{1}{2}-1^{\prime}$ long), entire, basally nerved; pediencles twice or thrce the length of the calyx; upper sepal ovate; corolla white or pale blue. - Margins of ponds, Ill. to Minn., Mo., anr. sonthward.

3. H. amplexicaulis, Purslı. Stems hairy, creeping at base; leaves onte, clasping, entire, basally nerved; peduncles shorter than the caly.r: upper sepal heart-shaped; corolla blue. - Margin of pine-barren ponds, N. J. and Md. to La. - Aromatic when bruised.

* * Corolla obscurely bilabiate, the limb subequally 5tubed; stamens utmost equal.

4. H. Monnièra, HBK. Glabrous, prostrate and creeping; leaves spatulate to obovate-enneate, entire or somewhat toothed, nearly nerveless, sessile; corolla pale blne. - River-banks and shores near the sea, MId. to Tex.

\section{LIMOSÉLIA, L. Мunort.}

Calyx bell-shaped, 5-toothed. Corolla short, widely bell-shaped, 5-cleft, nearly regular. Stamens 4 ; authers confluently l-celled. Style short, clnbshaped. Capsnle globular, many-seeded; the partition thin and vanishing.Small annuals, growing in mnd, usually near the sea-shore, crecping by slender runuer's, without ascending stems; the entire fleshy leares in dense clns. ters around the simple 1-flowered naked peduncles. Flowers small, white or ourplish. (Name from limus, mud, and sella, seat.)

1. L. aquática, L., var. tenuifòlia, Hoffm. Leares (with no blade distinct from the petiole) awl-shaped or thread-form. - Brackish river-banks and shores, Lab. to N. J., and far north and west. (Eu., Asia, etc.)

\section{GR A TİOLA, L. HEDGE-Hrssop.}

Calyx 5-parted, the narrow divisions nearly equal. Upper lip of corolla entire or 2-cleft, the lower 3-cleft. Fertile stamens 2, included, posterior; the anterior mere sterile filaments, or wanting. Style dilated or 2-lipped at the apex. Capsnle 4-ralred, many-seeded. — Low herbs, mostly peremials, some apparently ammals, with opposite sessile leaves, and axillary 1-flowered peduncles, usmally with 2 bractlets at the base of the calyx. Flowering all summer; all inhabiting wet or damp places. (Name from gratiu, grace or favor, on account of supposed excellent medicinal properties.)

$\$ 1$. Anthers uith a broad connective, the cells transrerse; stems mostly diffusely branched, or creeping at base, soft viscid-pubsscont or smooth; corollas 4-6" long; bractlets foliaceous, equalling the calyj.x.

* Sterile filaments minute or none; corolla whitish, with the tube yellowish.

1. G. Virginiàna, L. Stem clammy-pulerulent above $\left(1-6^{\prime}\right.$ high); leaves laneeolate with narrow base, acute, entire or sparingly toothed; pedincles almost equalling the leaves ( $\left(\frac{1}{2}-\mathrm{l}^{\prime} \mathrm{long}\right)$; pod ovoid (2" long). - Very eommon.

2. G. sphærocárpa, Ell. Smooth, rather stont (5-10' high); leaves lauce-grate or oblong to oval-obovate $\left(1-2^{\prime} l o n g\right)$, tootherl ; peduncles scarcely longer than the calyx and the large (:3") grubular pod $-\mathrm{N}$. J. and MId. to Jil., couth to Fla. and Tex. 
* Sterile filaments slender, tipped with a little head; leaves short ( $\frac{1}{2}-1^{\prime}$ long).

3. G. viscosa, sichwein. Clammy-pubescent or ylandular; leares ovate. lanceolate or oblony, acute, tuothed, mostly shorter than the peluncles; corolla whitish, yellow within. - Ky. to N. C. aud Ga.

4. G. aùrea, Muhl. Neurly glabrous; leaves lanceolute or oblong-linear, entire, equalling the peduncles; corolla golden-yellow ( $\frac{1}{2}$ long). - Sandy swanps, Vt. aud N. H. to Ohio, and south to Fla.

\$2. Anthers with no broad connective, the cells vertical; sterile filaments tipped with a head; hairy apparently annual plants, with erect rigid and mort simple stems.

5. G. pilosa, Michx. Leaves ovate or oblong, sparingly toothed, sessile ( $\frac{1}{2}^{\prime}$ long); Howers nearly sessile; curolla white, $3-4^{\prime \prime}$ loug, scarcely exeeding the ealyx. - Luw ground, N. J. to Fla. and 'Tex.

\section{I I Y SÁNTHES, Raf.}

Calyx 5-parterl, nearly equal. Upper lip of eorolla short, erect, 2-lobed; the lower larger and spreading, 3-cleft. Fertile stamens 2, included, posterior; the anterior pair sterile, inserted in the throat, 2-lobed, withont anthers; une of the lobes glandnlar, the otler smoth, usually shurt aud tooth-like. Stigna 2-lobed. Capsule orate or oblong, many-seederl. - Small and smooth annuals, with opposite leaves, and small axillary (jurplish) flowers, on filiform uaked pedicels, or the upper racemed, proilnced all summer. (Name from i ixus, mud, or mire, and aै $\nu$ or flover.)

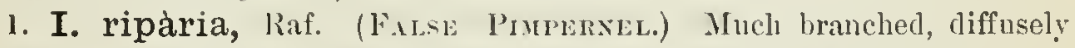
spreading (4-8' high), or at first simple and erect, leaf $y$; leaves ovate, rounded, or oblong, spariugly toothed or entire, the upper lartly clasping; corolla $3^{\prime \prime}$ loug. (I. gratioloides, Benih.) - IVet places ; commun.

\section{MICRÁ NTHEMUM, Michx.}

Calyx 4-lobed or 4- (rarely 5-) parted. Corolla slort, 2-lipped, with the upper lip considerably shorter than the lower, or 1-lipped, the npper lip ohsolete; lower lip 3-cleft, the middle lohe longest. Stamens 2, anterior, the short filaments with a glandular (mostly basal) appendage; anthers 2-celled, didymons; no sterile filaments. Style short; the stigma 2-lohed. Capsule globular, thin, with a very delicate or eranescent partition, sereral-many-sceded. - Small, smonth, depressed and tufted or creeping ammals, in mud or shallow water, with opposite aur entire ronnded or spatulate sessile leaves, anl minute white or purplish flowers solitary in the axils of some of the midcle lears: (usually

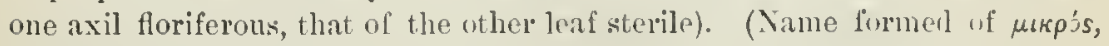
small, and $\not \dot{\alpha} \nu \theta \epsilon$, flower.)

1. M. Nuttàllii, Gray. Branches ascenling, $1-2^{\prime}$ high ; leaves obovatespatulate or vral; peduncles at length recurvel, ahout the length of the calyx, which is bell-shaped, 4-toothed and usually split down on one side, in fruit becoming pear-shaped; midlle lobe of the corolla lineal-oblong, nearly twice the length of the laternl ones; inpendage of the stamen nearly as loug as the filament itself; stigmas subulate. - Tiral mul of rivers, N. J. to Fla. Aug. Oct. 


\section{SÝ NTHYRIS, Benth.}

Calyx 4-parted. Corolla somewhat bell-shaped, rariously $2-4$-lobed or cleft. Stamens 2, inserted just below the upper sinuses, occasionally with another yair from the other sinuses, exserterl; anther-cells not confluent. Style slender; stigma simple. Capsule flattened, rounded, obtuse or notehed, 2-celled (rarely 3-lobed and 3-celled), mauy-sceded, loculicidal; the valves cohering below with the axis. - Perennial lerbs, with the simple stems beset with partly clasping bract-like alternate leares, the root-leaves rounded and petioled, crenate. Flowers in a raceme or spike, bracteate. (Name from oúv, toyrflere, and evois, a little door; in allusion to the closed ralres of the pod.)

1. S. Houghtoniàna, Beutl. Hairy; root-leaves orate, heart-shaperl; spike dense (5-12' long); corolla (greenish-white or yellowish) not longer than the ealyx, usually 2-3-parted. - Oak-harrens and prairies, Mich. to Minn., south to Ind., Ill., and Iowa.

\section{VERÓ N I C A, T. SPEEDWlel.}

Calyx 4- (rarely 3-5-) parted. Corolla wheel-shaped or salver-shaped, the border 4-parted (rarely 5-parted); the lateral lobes or the lower one commonly narrower than the others. Stamens 2, one each side of the upper lobe of the corolla, exserted; anther-cells confluent at the apex. Style entire; stigma single. Capsule flattened, obtuse or notelied at the apex, 2-celled, few-manyseeded. - Chiefly herbs; leaves mostly opposite or whorled; Howers blue, fleshcolor, ar white. (Derivation doubtful; perhaps the flower of St. Veronica.)

\$1. LEPTÁNDRA. Tall peremials, with mostly whorled leaves; racemes terminal, dense, spiked; bracts very small; tube of the corolla longer than its limb and muth longer than the culyx; both sometimes 5-clejt.

1. V. Virgínica, I. (Curver's-root. Culver's Pirsic.) Smouth or rather downy ; stem simple, straight $\left(2-6^{\circ}\right.$ high $)$; leaves whorled in fours to screus, short-petioled, lanceolate, pointed, funcly seruate; spikes panicled; corolla small, nearly white; stanens mnch cxselted; capsule oblong-ovate, not notched, opening by 4 tecth at the apex, masy-sechled. - Rich woods, Vt. to Minn., E. Kanı., and southward. July, Ang.

\$ 2. VERONICA proper. Cornlla wheel-shaped; consule more or less notched, strongly fattened exrept in $\mathrm{n} .2$ and 3 ; low herbs.

* Perennials, stoloniferous or rooting at base, with opposite usually serrate leaves: racemes axillary, mostly opposite; corolla pale blue.

+ Capsule turgid, orbicular, many-seeded.

2. V. Anagállis, I. (WAter SPeEnwel..) Smooth, creeping and rcoting at base, then erect; leaves sessite, most of thern clasping by a lieart-shaped luse, orule-lumeenlate, acute, serrate or entire $\left(2-33^{\prime}\right.$ long) ; pedicels spreading; corolla pale blue witl pruple stripes; (apsule sliglitly notcherl. - Brooks and ditches, N. Eug. to N. T., west to the liocky Mts. June-Aug. (Lu., Asia.)

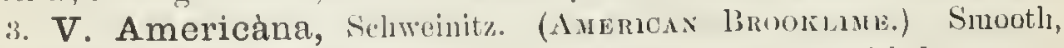
decumbent at hase, then crect $\left(8-15^{\prime}\right.$ ligh $)$; lenves mostly petioled, ovate or uldomy, serrate, thickish, trmucate or slightly leart-shaped at base; the slemlor pedicels spreatling. - Broshs aud ditches, common. June- Aug. 


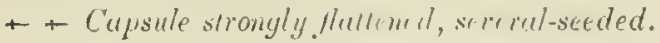

4. V. scutellàta, L. (Malsu Sipkswkic.) Smooll, slender and weak

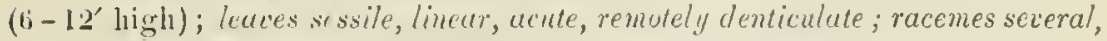
very shomer and zigzag; floners's finc and scattered, on elongated spreading or retlexed pedicels; capsule rey flat, much broader than long, notched at hoth ends or didymons. - Bogs, common. June-Ang. (Eu., Asia.)

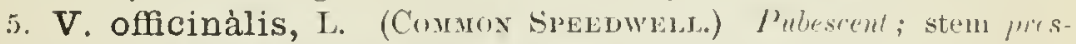

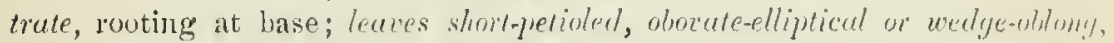
obtuse, seriute; racemes densely muny-flomered; pedicels shorter than the caly : capsule olovate-triangular, broally notched. - 1)ry hills and open woods, $\lambda$. Eug. to Mich., and southward. July. (Kit., Asia.)

V. Ciranduns, I. Stem jubeserm, at least in two lines, ascending from a creeping base; lomes subsessile, oreto or cordate, incisely crenate; racemes lowsely-flowered; perlicels little longer than calyx; capsule triangular-ohcorlate. - Sparingly introduced into Canata, N. Y., and l'sun. (Adv. from Eu.)

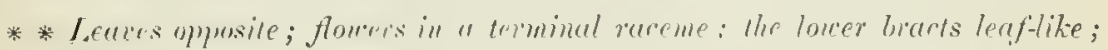
capsules flut, serpral-serded. Perennials (moslly turning Llackish in drying).

6. V. alpina, I. Stem hranched from the base, erect, simple (2-12' high); leaves elliptical, or the luwest rounded, cutire or tootherl, nearly sessile; rareme hairy, fru-fowered, cronded; capsule obovate, notched. - Alpine summits of the White Mts. (Fu., Asia.)

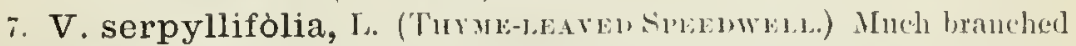
at the ("resping base, neally smooth ; branches ascending and simple (2- - t' high) ; leners mente or oblong, ohscurely crenate, the lowest pelinted and rombled, the mper passing into lanceolate hracts; raceme loose; corolla whitish, or pale hine, with derper stripes; capsule rounded, broader than long, obtusely noteher. - Roadsides and fidils, common; introdueed and indigenous. May-July (Eu., Asia.)

* * Ammals; floral leaves like those of the stum (or sumewhat reduced), the flowers appearing to be r.rillary and solitury, mostly alternate; corolla shorter. than the culyx.

- Flowers short-pedicelled; flural leures reduced; corolla shorter than the calyx.

8. V. peregrina, L. (Nickwen. Prrstaxis Spemwir.) Glanllular-puberulent or neurly smouth, erect (4-9' lighli), branched ; Incest leaves prided, oculoblong, toothed, thickish, the other's scssile, ol,tus; the upper ahlong-linear and entire, longer than the alnost sessile (whitish) Howers; crppsule orliculur, slightly notched, many-seeled. - Waste anth cultivated gromuch, in damp soil; throughout U. s., and slmost cosmopolite. A pril- June.

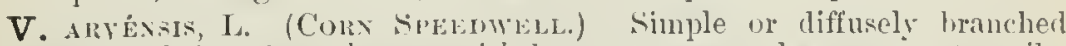
(3-8' high), hairy; loner leates petioled, orate, crenute; the upperinost sessile, lineeolate, entire; cupsule inmersely heurt-shapd, the lobes romuled. - ('ultivated grounds, $\Lambda$ tlantic states to 'Tex, rather rare. (Nat. from Ku.)

++ Flowers long-pradicelled in axils of ordmary leares; seeds cup-shuped.

V. Agréstis, L. (FIflin SPEEDwell.) Leaves round or ovate, crenatetwothed, the floral somew hat similar; calyx-lobes oblung; flower small; ordiy

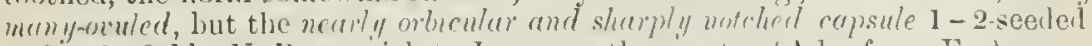
- Sandy fields, N. Brunswick to La., near the (oast. (Niv. from Eu.)

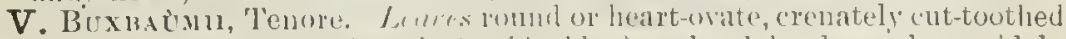

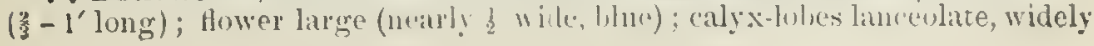


spreading in finit; capsule obcordate-triangular, broadly notched, 16-24-seeded, - IVaste grounds, rare in Atlantic States. (Adv. from Eu.)

V. HEDER-EHLIA, L. (IVY-LAVED SPEEHWLL.) Leares rounded or heart-shaped, 3-7-toothed or lobed; calyx-lubes somewhat heart-shaped; flow. ers small; capsule turgid, 2-lobed, 2-4-seeded. - Shaded places, N. J., Penu., ete. April-June. (Adv. from Lix.)

\section{BÚ CH N ERA, L. Blue-Hearts.}

Calyx tubular, obscurely nerverl, 5-toothed. Corolla salver-form, with a straight or curved tube and an alinost equally 5-cleft limb, the lobes oblong or wedge-obovate, flat. Stamens 4, included, approximate in pairs; anthers one-celled (the other cell wanting). Style club-shaped and entire. Capsule 2-valved, many-seeded. - l'eremnial rough-hairy herlss (doubtless root-parasitic), turning blackish in drying, with opposite leares, or the uppermost alternate; the flowers opjusite in a terminal sjike, bracted and with 2 bractlets. (Named

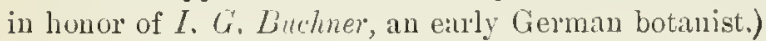

1. B. Americàna, I. Rough-hairy; stem wand-like (I-20 high); lower leares obovate-oblong, the other's ovate-oblong to linear-lanceolate, sjaringly and coarsely toothed, veiny; spike interrupted; calyx longer than the bracts, one third the lengtl of the deep-purple corolla ( $\mathrm{I}^{\prime}$ long). - Moist sandy ground, western N. Y. to Minn., and sonthward. June- $\Lambda$ ug.

\section{SEYM ERIA, Pnrsh.}

Calyx bell-shaped, deeply 5-cleft. Corolla with a short and broad tube, not longer than the 5 rate or oblong nearly equal and spreading lobes. Stamens 4, somewhat equal; anthers alproximate by pairs, ohlong, 2-celled; the cells equal and pointless. Cajsule many-seeded. - Erect branching herbs, with the general aspect and character of Gerardia ; leaves mostly opposite and dissected or pinnatifid, the uppermost alteriate and bract-like. Fowers yellow, interruptedly racemed or spiked. (Named for Hemry Seymer, an English naturalist.)

1. S. macrophylla, Nutt. (Mublix-Hoxalove.) Rather pubescent $\left(4-5^{\circ}\right.$ high); lewes large, the lower pinnately divided, with the lnoully lanceolate divisions pimmatifit and incised, the npper lincentate; tube of the corolla incurved, rery woolly insile, as are the filments except at the apex; style short, clilated and notched at the point; capsnle urate, pointed. - Shady riverbanks, Ohio to lowa, south to Tex. July.

\section{GERÁ R DIA, I.}

Calya bell-shaped, 5-toothed or 5-cleft. Corolla campannlate-funnel-form, or somewhat tubular, swelling above, with 5 more or less mequal spreading lobes, the I mper usually rather subller and more mited. Stamens 4, strongly didynanous, inchuled, lairy; anthers apuruaching by pairs, 2-celled, the cells parillel, often pointed at base. Sityle elongated, mostly enlarged and fattened at the apex. Capsule globular or orate, pointed, many-seeded. - Erect hranch. nug herbs (unore or less root-parasitic); stenteaves opposite, or the upjer alternate, the mpermost reduced to hracts and subtending 1 flowered peduncles, which often form a racene or spike Fluwers showy, pmrple or yellow; in late summor and antumm. (1)edicated to the celebrated herhalist, John Germde.) 
§1. DASYSTOMA. Corolla yellow, the tube woolly inside, as well as the an thers and filaments; anthers alihe, awn-pointed at base; leaves rather largo, more or less incised or pinnatifid.

* Pubescence partly glandulur and viscid; corolla pubescent outside.

1. G. pediculària, L. Anunal or biennial, smoothish or pubescent, much branchel ( $2-3^{\circ}$ high), rery leafy; leaves orate-lanceolate, pinnatifil, and the loles cut and tootlied; pedicels longer than the laairy mostly serrate calyx-lobes. - Dry copses; $N$. Ling. to Minn., south to Fla. aud Ark.

* * No glandulur pubescence; corolla glalwous outside; perennial.

2. G. grandiflòra, Benth. Minutely downy; stem much branched (2$4^{\circ}$ high); leaves oeute-lancelate, coursely toothed or cut, the lower pinnatifid: pedicels rather shorter than the calyx; corolla $\left(2^{\prime}\right.$ long + times the length of the broadly lanceolate entire or toothed calyx-loves, - Oak openings, Wisc. and Minn. to Tenn. and Tex.

3. G. flàva, I. (Dowxir Fasse Foxrinu.) Puhescent wilh a fine close down; stem (3-4 high) mostly simple; lecress orate-lanceolate or obling, obtuse, entive, or the lower usually sinuate-loothed or prnatifid; pedicels eery short; calyx-lohes oblong, ol,tuse, rather shorter than the tuhe, corolla $1 \frac{1}{2}^{\prime}$ long. - Open woods, $\mathrm{N}$. Ling, to Wisc, and Iowa, south to Ga, and A I'k.

4. G. quercifòlia, l'ursh. (Smootí False foxglove.) Smooth and ylaucous $\left(3-6^{\circ}\right.$ ligh $)$, usually branching; lower leaves commonly twice-pinnatifid: the "pper oblung-lanceolate, pinnatifid or entre; pedicels neavly as long as: the calyx; calyx-lubes lance-linear, acute, as long as the at length inflateil tube; corolla 2' long. - Dry woods, N. Eng. to Minn., south to Fla. and Ill.

5. G. lævigàta, Raf. Simoolh, not glancous ; stem (1-2 $2^{\circ}$ high $)$ mostly simple; leaces lanceolute, acute, entire, or the lowest obscurely toothed; pedicels shorter then the caly.x-ube: corolla $\mathrm{l}^{\prime}$ long. (G. integrifolia, Gray.) Oak-barrens, etc, Penn, to Mich. and Ill, soutlı in the mountains to Ga.

§ 2. OTOPIIÝLis. Corolle prerple (rarely white), naked within, as well as the very unerual jilaments: anther's disstmilur, pointless, ylabrous or sparingly hairy.

6. G. auriculàta, Michx, Rough-hairy; stem erect, nearly simple (9-20' high); leares lanceolute or orrte-lanceulate, sessile, the lower entire, the others with an oblong-lanceolate lobe on each side at the base; flowers nearly sessile in the axils (1' long). - Low grounds and prairies, Mr. Menn. to Minn., south to N. C. ani Mo.

7. G. densiflòra, Benth. Mor hispid and rough, very leafy: leave's rigid, pinnately parted into 3-7 nurromly linear acute dirisions, those subtending the densely spricate flouers similar and cromiled; corolla orer l' long. - Praries, F. Iran, to Tex.

\$3. GERARDIA proper. Corolla murple or rose-color (rarely uhite); calyxteeth short; anthers alike, ncurly pointless, pubesceni; cauline leares linear or narrower, culire.

* Perennial; leaves erret, very narrou; pedicels evect, as long us, Anral leares.

8. G. linifolia, Nutt. Glabrous, $2-3^{\circ}$ high, sparingly nr pranulately hranched; leaves flat, thickish, l" wide; calyx-teeth minute; corolla l' long. 
miuntely pubescent outside, villons within and lobes ciliate; anthers and fila uents very villous. - Low pine barrens, I)el. to Fla.

* Anmuals; herbuye blaclish in drying (except n. 13).

+ Pedicels little if ut all longer than the calyx ant copsule.

9. G. áspera, I ougl. Sparingly hranched ( $1-2^{\circ}$ lighlı); leates long aud linear, rongh; predicels (most of them alternate) equalling or morlerately exceeding the cally, which bas triungulur-luncedute ucute lobes about half us long as the tube; corolla orer l' long. - Plains and prairies, Mich. and IV. Ind. to the Dakotas and W. Ark.

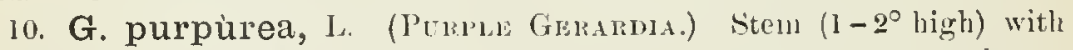
long and rigid widely spreading lranches; leaces linear, acute, rough-maryined: flowers large ( $1^{\prime}$ long), lright punple, often downy; pedirels slinter

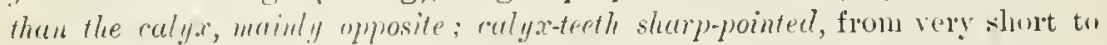
about half as long as the tube. - low grounds, mainly near the coast and in

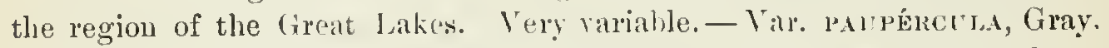
simonther, more simple; corolla usually only !' long, lighter rose-purple. N. Eng. to I'enu., N. Hll., Minn., and northwarl.

11. G. maritima, Raf. (SEA-suL G.) low (t-12' high), with slourter hranches; leaves and short broud culyx-tecth ruller fleshy and obtuse; pedicels alwut as long as the calyx; corolla ?2 long. - Salt marshes along the coast. + + Pedicels usually exceeding the conollat: "coolly anthers ruspidate at base

12. G. tenuifolia, Vahl. (SLexver G.) Leares narouly linear, acute, the floral ones mostly like the other's; calyx-teeth very short, acute; capsinte ylobular, not exceding the culy $x$; corolla about d' long. - Low or dry ground, common. - Var. uAchophÝlı.., Benth. Stouter; larger leaves $1 \frac{1}{2}-2^{\prime}$ long and almost 2 " wide, scabrous; pedicels ascending; calyx-teeth larger; corvolla little vere $\frac{1}{2}$ long. W. Iowa to W. Ia. and Col. - Vill. Aspéculd, Gray. leaves all nearly filiform and upper face hispidulons-seabrous; intlorescence more paniculate; corolla small, the expandel limb only $6^{\prime \prime}$ in diameter. Irry bare hills, Mich. and N. Ind. to Minn. ancl Mu.

13. G. Skinneriàna, Wood. Leuces bristleshred, ats are the branchlets, or the lower linear; capsule orute, mostly lonyer than the calyx, whieh has short setaceons teeth; corolla $4-6^{\prime \prime}$ long. ((x. setacea, Grun, Man., not of W'alt.) - Sandy low ground, Mass. to Minn., soutl to Fla. and La.

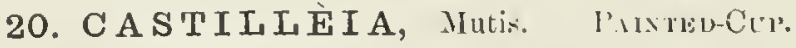

Calyx tubulin, flatteued, cleft at the summit on the anterior, and usually on the posterior side also; the divisions entire or 2-lobst. Tube of the corollat included in the calyx; its upper lij) (galea) long and narmow, arched ant keeled, flattened laterally, enclosing the + unequal stanens. lower lip short. 3-lobed. Anther-cells olylong-linear, unequal, the onter fixed by the middle, the inner pendulons. Capsule many-seeded. - Ilerbs (root-parasitic), witl alternate entire or cut-lobed leaves; the floral ones usually dilated, colored, and more showy than the yellow or purplish spiked flowers. (Dedicated to Castillejo, a Spanish botanist.)

1. C. coccínea, Spreng. (Scarnet Panten-Crt.) llairy biennial or annuil; stem simple; root-leares chustered, mostly entire, oborate or 
whlung; those of the stem incised; the Horal 3-5-cleft, bright scarlet toward the summit (rarely yellow); calyx about the length of the pale yellow corolla, equally cleft boll sirles, the lobes quadrate-oblong, tutire or retuse. - Low sandy ground, Maine to Minn., south to N. J., Tenu, anrl Tex.

2. C. pállida, Kunth, var. septentrionàlis, Gray. Perennial, smooth or sparingly hairy, at the summit woolly; leares mainly entire, the lower linear, upper broaler"; the floral oblong or obovate, greenish-white, varying to yel-

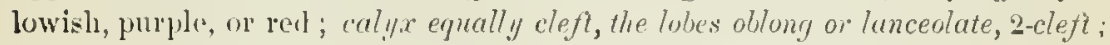
corolia $\frac{1}{2}-1$ 'long, the galea decidedly shorter than the tube, not over 2 or 3 times as long as the lip. - Alpine smmints of $\mathrm{X}$. Eng., X. shore of I. Superior, west and northwarl.

3. C. sessiliflòra, P'ursh. l'arenuial, $b^{\circ}-8^{\prime}$ high, rery leafy', cinereonspulsescent; leaves nustly 3-5-('le[t, with narow divelging sometimes eleft

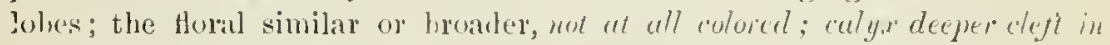
fiont, the narrow lobes deep!y. 2-cleft ; corolla 2' long, the short galea but twice as long as the slender-lobed lip. - Prairies, Wisc. and Ill. to N. Dak. and Tex.

\section{ORTH OCÁRPUS, Nutt}

Corolla with the upper lij (yalea) little longer and asually much narower than the inthated 1-3-saccate fower one. Utherwise nearly as Castilleia.

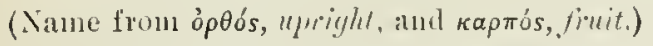

1. O. lùteus, Nutt. Anuual, pubescent and linsute, sometines viscich, erect, $1^{\circ}$ ligh; leaves linear to lanceulate, ocmsionally 3 -cleft; spike dense; iracts broader, mostly 3-cleft, about equalling the Howers, not colored; (co. rulla golden-yellow, not 6 " long, $2-3$ times as long as the calyx. - Plains, N. Minn. to Col., and westwarkl.

\section{SCH W Ál B E A, Gronov. Chaff-serd.}

Calyx oblique, tubular, 10-12-ribbed, 5-tootherl; the posterior tooth much the smaller, the 2 anterior mited higher than the others. L 'puer lip of the corolla arched, oblong, entire; the lower little shorter, erect, 2-plaiterl, with :3 very short and broal obtuse lobes. Stamens 4, included in the uper lip; anther-cells efunal and parallel. Capsule ovate, many-seeded. Seeds linear, with a loose chaff-like coat. $-\Lambda$ perennial minutely pubescent upright her's $\left(1-2^{\circ}\right.$ ligh), with leafy simple stems, terminater by a loose spike of wather large dull purplish-yellow Howers; leaves altemate, sessile, 3-nervel, cutire, "wate or obloug, the upper gradnally rerluced to narrow loracts; perlicels icry short, witl 2 luactlets unrler the calyx. (I)erlicated to $C$. Cr. Schucellip, an obscure German lotanist.)

1. S. Americàna, I. - Wet sandy soil, Mass. to La, near the cuatst. May-Jialy.

\section{EUPHR ÀSIA, Tourn. FYeBRIGIT.}

Calyx tubular or hell-shaperl, 4-cleft. Upper lip of the corolla erect, searcely arched, 2-lobed, and the sides folled back; lower lip spreading, 3-eleft, the lobes olituse or notchel. Stimens 4 , unler the npun liy; ant her. cells equal, printed at the base. Capsule oblong, flattenel. Sienls numer- 
nus. - Ilorls, with luanching stems, and opposite toothed or cut leaves.

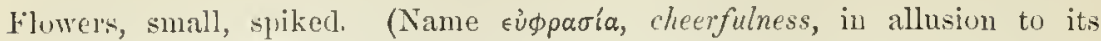
reputed inerlicinal properties.)

1. E. officinàlis, L. Low annual; leaves orate or lanceolate, the luwest crenate, the floral bristly-toothed; lubes of the lower lip of the (whitjsh, yellowish, or hluish) corolla notched. - Coast of Maine and Lower Canala; perhaps introduced from Eu. - Var. Tıт́́ıcA, Benth., a low form with small flowers $\left(2-3^{\prime \prime}\right.$ long), and mostly rounded leaves. - Alpine region of N. H., shore of L. Superior, and fitr northward.

\section{4. В Á R T S I A, L.}

Calyx equally 4-cleft. Curulla with upper lip entire and sides not folderl back. (Itherwise much as Luphrasia. - Ilerhs, with opposite sessile leaves, and subsessite fluwers, in the upper axils and in a terminal leafy spike.

B. 1)Doxtìce, Huds. A span or two high from an annual root, hatching, scabrons-pubescent; leaves oblong-lanceolate, contsely and remotely serrate; spikes elongated, loosely-flowered ; corolla small, rose-red. - Coast of Maine and N. Scotia. (Nat. from Lu.)

\section{RHINÁNTH US, L. Yellow-RatTle.}

Calyx memhrauaceous, flattened, mueh inflated in fruit, 4-toothed. Upper lip of corolla arched, ovate, obtuse, flattened, entire at the summit, hut with a minnte tooth on each side below the apex; lower lip 3-lobed. Finnens 4 , uncler the upper lip; anthers approximate, hairy, transterse; the cells equal, pointless Caysule orbicular, flattened, Seeds many, orbicular, wiugred. Annual upright herhs, with opposite leares; the yellow flowers crowded in a

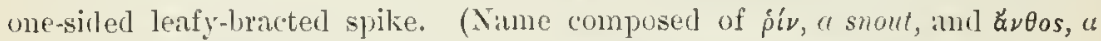
flowe, from the beaked upper lip in some speeies formerly of this genus.)

1. R. Crista-gálli, $\mathrm{L}_{\text {. }}$ Leares marrowly oblong to lanceulate, cuarsely serrate, the floral bracts more incised with bristle-tipued teeth; corolla 6 " long; seeds broadly winged (when ripe they rattle in the inflated calyx, whence the popular name.) - Coast of $\mathrm{N}$. Eug. aud aljune region of $\mathrm{N}$. Il, to $\mathbf{L}$. Superior, and northrard. (Eu, Asia.)

\section{PEDI C L I RIS, Tourn. Lousewort.}

Calyx various. Corolla strongly 2-lipped; the upper lip arched, flattened, often beaked at the apex; the lower erect at base, 2-crested abore, 3-luled; lobes commonly spreading, the lateral ones rounded and langer. Stamens 4 , under the "ipper lip; anthers trinsverse; the cells equal, pointless. Capsule ovate or lanceolate, mostly ollique, sereral-seeded. - I'eremial herbs, with chiefly pinnatificl leaves, the floral loractlike, and rather large flowers in at spike. (Name from pediculus, a louse; of no obvious application.)

1. P. Canadénsis, L. (Commox Lolsewoliz. W'oon Betoxy.)

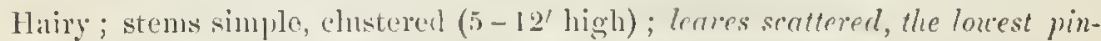
nately parted, the others lalf-prmatifid; spilie short and dense; caly.x split in front, otherwise almost ontme, oblirue; upper lip of the (tull greenish-yellow and $\mu_{10} u_{i s h}$ ) rorolla hooded, inrured, 2-toothed under the apex; capsule flut, somenhat swerd-shriped. - Copses and bauks, commou. May-July. 
2. P. lanceolàta, Michx. Stem upright (1-3o hight), neary simple, mostly smooth; laces purtly opposite, wblong-lancerlate, doubly cut-toothed; spike crowded; culy.x 2-tubed, leafy-crested; upred lip of the (Jale yellow) corolla incured atuel bearing a slort truncate leals at the apex, the lower erect, so as wearly to close the throat; capsule oecute, scarcely longro than the cal,f..- Siwamps, Conns, to Va., ()hio, and Minn.

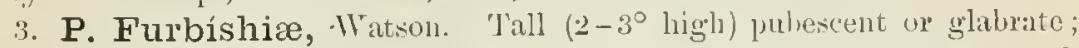
leaves laucolate, pimutely purted und the short oblong dicisions pimutifidinrised, or the npper simply pinnatifil and tho lobes serrate; bracts orate, laciniate-dentate; coly.x-lobes 5, rather unequal, linear-lanceolate, entire w toothed; upper lip of curolla straight and beakless, the truncate apex bicuspidate, the lower erect, truncately 3-lohed; cupsule brocully ovate. - Banks of the st. John's, Aroostook Co., Maine (.Miss Lute Furbish), and adjacent N. Brunswick.

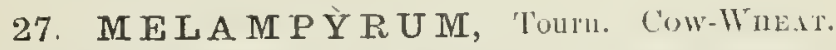

Caly $x$ bell-shaperl, $4-1$ left; the taper lobes slarppointed. Tube of corvolla "ylindrical, enlanging above; upper lip arched, compressed, straight in front; the lower erect-sprearling, biconvex, 3-lobed at the apex. Stamens 4, nnder the mper lip; anthers alproxinate, oblong, nearly vertical, lairy ; the equal cells minutely pointed at hase. (Mary with 2 owules in each cell. Capsule flattened, oblique. I-4-seeded. - Erect branching amuls, with opposite leares, the lower entire, the upyer mostly tontherl at hase. Fluwer's sulitary

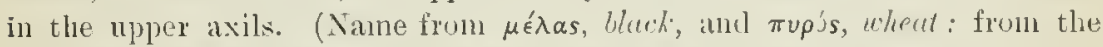
color of the semls of solne species ats they appear mixed with grain.)

1. M. Americanum, Michx, leaves lancolinte, short-petioled, the floral ones like the lower, or truncate at bise and heset with a few bristy teeth; calyx-teeth linear-awl-shaped, nut lalli the length of the sleucler tube of the pale greenish-yellow corolla $\left(5^{\prime \prime} \mathrm{lomg}\right)$. - ( ) pen wools; common, from the Atlautic to Minu. and Iowa, especially eastwanl. June - Sept.

\section{ORDER 76. OROBANCHACNAE. (BRONM-RAPH FAMUY.)}

IIerbs destitute of green foliage (root-parasiles), monopetalous, didynamous, the ovary one-celled with 2 or 4 parietal placentre: porl rery manyseeded; seeds minule, with allumen and a very minule embryo. - Calyx persistent, 4-5-tootled or parterl. Corolla tubular. more or less zlipped, ringent, persistent and withering; npper lip entire or 2-lober, the lower 3-lobed. Stamens 4, cliclyamous, inserterl on the tube of the rolla; anthers 2-eelled, persistent. Ovary free, oroil. pointed with a l mo style; stigma laroge. Capsule 1-relled, L-valverl; each valve hearing on its faee one placenta or a prair. Secers very numerous. minute. - I ow. thick or fleshy herbs, bearing scales in place of leares, lurid yellowish or urownish throughout. Flowers solitary or spikert.

* Flowers of two sorts, scattered along slencler maricled branclies.

1. Epiphegus. Upuel flowers sturile, with is tubnlal andla ; the lower fertile, with the corolla minute aud not cxpanding. Bracts inconspicuous. 
** Fluwers all alike and prerfect; stems mostly simple.

2. Conopholis. Flowers deusely spicate. Calyx deeply cleft in front. Corolla 2-ljpped Stanens exsciterl.

3. Aphylon. l'hwers pedicellate, sometimes subsessile and thyrsoid-spicate. Calyx regularly 5-cleft. Corolla somewhat 2-lipped. Stanens included.

4. Orobanclie. Flowers sessile, spicate. Calyx cleft before and belind almost to the base. Cimolla 2-lipped, Stanens included.

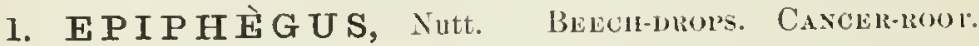

Hlowers racemose or spilied, scattered on the branches; the upper sterile, with a long tubulu corolla aud long filaments and style; the lower fertile, with a very short corolla which seldom opens, but is forced off from the base by the growth of the pod; stameus and style very short. Calyx 5-toothed. Stigma capitate, a little 2-loberl. Capsule 2-valverl at the apex, with 2 aprproximate placente on cach valve. - Herlss slembre, purplish or yellowishhown, mach branchen, with small scattered scales, 6-12' high. (Name from $\varepsilon \pi i$, upon, aud $\phi \eta \gamma$ 's, the Letrol, because it grows on the roots of that tree.)

1. E. Virginiàna, Bart. Corolla of the upper (sterile) flowers whitish and purple, 6-8" loug, curverl, 4-toothed. - Common under Beecli-trees, paria sitic on their rosts; X. Brunswick to Wisc., sonth to Fla. and $\triangle$ rk. $\$$ ug. - (let.

\section{CONÓPHOLIS, Wallrotl. Siguw-root. Cascer-koor.}

Flowers in al thick sealy spike, perfect, with 2 buctlets at the hase of the irregularly 4-5-toothed calyx; its tulse split down on the lower sille. Curolla tulular, swollen at base, strongry 2-lipped; upjer lip arched, notched at the smmlnit, the lower shorter, 3-parted, spreanling. Stanens pootruclesl. Stigma lepresserl. Capsule with 4 placente, a pair on the nicldle of ench valve.Ilpler scales forming hracts to the Howers, regularly indricate, not unlike

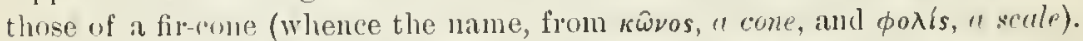

1. C. Americàna, Wallroth. - Oak wooks, growing in clusters anong fallen leaves; X. Eng to Mleh., south to Fla. and Tem. May, June. - I singolar plant, chestnut-coloted or vellowish thronghout, as thick as a man's thuml, 3-6' lighl, covered with fleshy stales, which beeme lly amd hard.

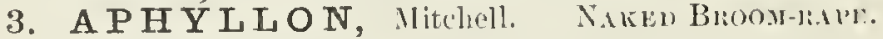

Fhowers perfect, pedicellate, sometimes sulsessile and thychoid-sificate. ('ilyx 5-cleft, regular. Corolla somewhat o-lipped; the upper lip more or loss sprealing and 2-lobed, the lower spresting. 3-lobed. Stanens inclnderl.

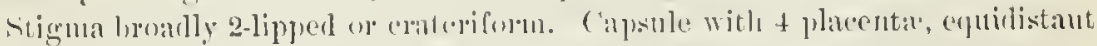

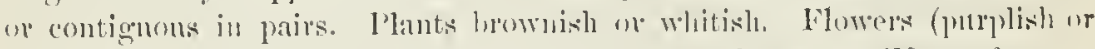

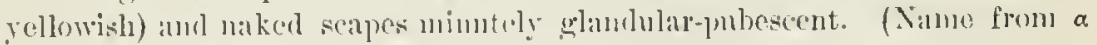
privative and $\phi \dot{u} \lambda \lambda \omega \nu$, foliugr, allurling to the nuked stalks.)

* Flourers solitary on long nuled scupes or peduncles, without bractlets; corolla with a long surved tube and spreading 5 -lobed limb.

1. A. uniflorum, Gray. (ONw-Fowerer, Caxek-koot.) Stem subterrancan or nearly so, very slont, sealy, often hranchesl, each hranch sending ир 1 - 3 slenter one-flowered scapes $\left(3-5^{\prime}\right.$ high): theisions the the colyx lance-

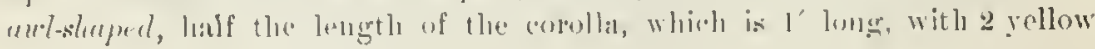


bearded folels in the throat, and obovate lobes. - 1)amp woorlauds, Newf. to Va. and Tex., and west to the I'acific. April-July.

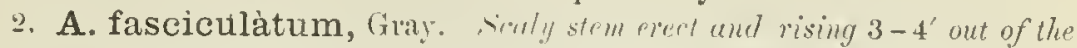
yround, mostly longer than the cruwded pednucles; divisions of the calyx tri"myular, very much shorter thun the corollu, which las rounded short lobes. Simly ground, L. Michigan to Minn., southward west of the Mississippi, and westward. On drtenisia, Fuingonm, ete. May.

* * Canlescent; flowers densely sprime, with 1-2 bractlets ut base of calyx; corolla 2-lipped, the uppor lip. less or not at all 2-cleft.

3. A. Ludoviciànum, Gray. Glandular-pulsescent, branched (3-12' high); corolla somewhat curver, twice the length of the narrow lanceolate (alyx-lobes; the lips equal in length. (Ihelipara Ludoviciana, Wa/p). Minn. to Ill, and 'Tex., and westward.

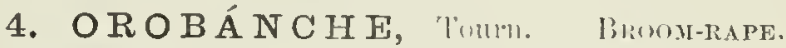

Flowers shicate, sessile. Calyx cleft hefore and behind almost or quite to the hase, the livisions nstully 2 -cleft. Corolla 2-lipped; upper lip elect, 2 lobed or enlarginate, the lower spreading, buvadly 3-lobed. Stamens includer. - ()ld World parasites, on luots of various plants.

O. Mixol, L. A span to a loot high, puhescent, pale yellowish-brown, ol with purplish-tinged Hower's in a lather loose spike; "orolla 6" long. - Par"asitic on clover, X.J. to Va. Sparingly and probil)] recently introdnced.

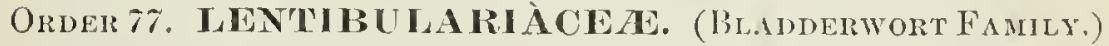

Small herbs (growing in water or wel places), with a -lipped calyx, and a 2-lipped personate corolla, 2 stamens with (confluently) one-celled anthers, and a one-celled owary with a fiee central placentr. bearing several anatropous seeds, with a thick struight embryo, and no albumen. - Corolla deeply. 2-lipped, the lower lip larger, 3-lobed and with a prominent palate. spurred at the base in front: the palate usually bearded, Orary free: style very short or none; stigma 1 - 2-lipped. Capsule often burstiner irregularly. Scapes 1 - few-flowered. -- The following are the two principal genera.

I Utricularia. Calyx-lobes mostly entire. Upper lip of eorolla ereet. Filaments strongly ineurved. Foliage dissected; lialder-bearing.

2Pinguicula. Calyx with upper lip deeply 3-and lower 2-eleft. Corolla-lobes spreading Filaments straighter. Terrestial, with entire rosulate leaves next the groumb.

\section{UTRICULÀRIA, I. BLADDERWORT.}

Lips of the 2-parted calyx entire, or nearly so. Corolla personate, the palate on the lower lip projecting, often closing the throat; npper lip erect Anthers convergent. - Aquatic and immersed, with capillary dissected leares. liearing little bladters, which float the plant at the time of flowering; or rooting in the mud, and sometimes with few or no leaves or bladders. Scapes 1 few-flowered; usually flowering all summer. Bladders furnished with a valru. lar lid and usually with a few bristles at the orifice. (Name from utriculus, a little bladder.) 
* Upper leaves in a whorl on the otherwise naked scape, floating by mean v! large bladders formed of the influted petioles; the lower leaves dissec ed and capillar:y, bearing small bladders; rootlets few or none.

1. U. inflàta, Walt. Swimming free; bladder-like petioles olıng, pointed at the ends and branchen near the apex, bearing fine thread-rike divisions; flowers 3-10 (large, yellow); the appressed spur half the length of the corolla; style distinct. - In still water, Maine to Tex., near the coalst.

* * Scupes naked (except some small scaly bracts), fiom immersed branching stems, which commonly swim free, bearing capillury dissected leares with small bladilers on their lobes; roots few and not affixed, or none. (Mostly perennial, propagated from year to year by tuber-lilie buds.)

+ Cleistoyumons, florrers alony the submersed copionsly bladder-bearing stems.

2. U. clandestina, Nurt. Leaves numerons ou the slender immersel stems, several times forkert, (apillary; scapes stenter (3-5' high); lijs of the yellow corolla nearly equal in length, the lower broader and b-lobed, somewhat longer than the approximate thick and bInnt spur. - Pouds, from N. Brmnswick and N. kng. to N. J., near the coast.

+ No cleistogramous floucers.

+ Pedicels recurced in finit; corollu yellow.

3. U. vulgàris, l. (Greatmi Blanderwort.) Iminersed stems $\left(1-3^{\circ}\right.$ longy) crowded will 2-3-pinnately many-puted copillur!l leaves, bearing many bdudders ; scapes 5 - 12-flowered ( $6-12^{\prime}$ long); rorollu closed ( $6-9^{\prime \prime}$ broad), the siles reflexed; spur conical, rather shorter than the lower lip, thick and blust in the European and the high northern plant; in the common American plint less thick and rather acute. - Common in ponds and slow streans, Newf. to Mimm, sonth to Via. and Tex, and westward. (Ln., Lsia.)

4. U. minor, L. (SMraLer B.) Lentes scuttered on the thread-like irnmersed stems, $2-4$ times forlied, short; scapes weak, 2-8-flowered (3-7' high); upper lip of the gaping corollu not longer thun the depressed palate; spur rery short and blunt, or almost none. - Shallow water, L. Mass. to Minn., sonth to N. J. and Ark, and westward. (Eu.)

++ ++ Pedicels erect in fruit, fro and slender; corolla yellow.

5. U. gíbba, 1. Scape (1-3' high) 1-2-flowed, at base furuished with very slender short brancles, bearing sparingly tlisected capillary rontlike leaves and scattered hladters: corolla $3-4$ " linoul, the lips broad and rounded, nearly equal; the loute with the sides retlexest, crocting and "1pmoxinate to the very thick and blunt conical gibbous spur. - Shallow witere, Mlass. to Mich., sonth to Vit. and 111.; Mt. Desert (F. M/. Day).

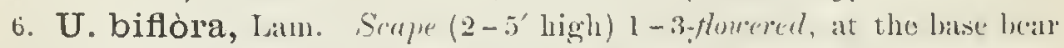
ing somewhat elongaterl submersed hamches with apillany root-like leaves and numerous bladdlers; corvlla $4-66^{\prime \prime}$ licoul, the spur oblong, equalling the lower lip; seeds scale-shaped. - Ponds and shallow waters, S. Ill. and Iowa to T'ex.; also S. Va. (?), and Barnstable, Miss. (IT. Deune).

7. U. fibrosa, Walt. Leates crowded or whorled on the small immersci stems, several times forked, capillury; the bladders borne mainly along the stems; flowers $2-6$ ( $6^{\prime \prime}$ broad); lips uearly erqual, broal and expauterl, the 
upper undulate, concave, plaited-striate in the middle; spur nearly linear, obtuse, approaching and almost equalling the lower lip. (U. striata, Le Conte.) -Shallow pools in pine barrens, L. Island and N. J. to Fla. and Ala.

8. U. intermedia, Hayne. Leares crowled on the inmersed stems, 2-runked, 4-5 times forked, riyid, the divisions linear-awl-shaped, minntely bristle-tootherl along the margins; the bladders borne on sopurate lenfless branches; upper lip of corolla much longer than the palate; spur coniralsubulate, acute, appressed to the very broud $\left(6-8^{\prime \prime}\right)$ louer lip and mearly as long as it. - Shallow pools, Newf. to N. J., west to Iowa, Minn., and northward (Eu., Asia.)

$$
+++ \text { Pedicels erect in fruit, rather long; corolla violet-purple. }
$$

9. U. purpurea, Walt. Leaver whorled along the loug immersed free flouting stens, petioled, decompound, capillary, bearing many bluklers; flowers 2-4 (6" wide); spur appressed to the 3-lober 2-saccate lower lip of the corolla aud about half its lengtlı. - Ponds, Maine and $\mathrm{X}$. L'enn. to Fla, mainly near the coast; also Lake Co., Ind.

* * Scape solitary, slender and nuked, or with a few small scales, the base rooting in the mud or soil; leaves small, awl-shaped or grass-tike, often raised out of the uuter, commonly feu or fugacious; air-bladder's fen on the leaves or rootlets, or commorly none.

- Hlover purple, solitury; leaves bearing a few delicate lobes.

10. U. resupinàta, B. I). Greene. Scape (2-8' high) 2-bracterl above; leaves threal-like, on delicate creeping branches; corolla $\left(4-5^{\prime \prime}\right.$ long $)$ deeply -parted; spur oblong-conical, very obtuse, shorter than the clilated lower lip and remote from it, both ascending, the flower resting transversely on the summit of the scape. - Sandy margins of ponds, E. Maine to R. I., near the coast; also N. New York and Presque Isle, L. Erie.

+ + Flowers 2-10, (chiefly) ycllow; leaves entire, rarely seen.

11. U. subulàta, L. Stem capillary $\left(3-5^{\prime}\right.$ high); pedicels capillary: lourer lip of the corolla fat or with its margins recurved, equally 3-lobed, mnch larger than the ovate upper one; spur oblong, acute, straight, uppressed to the lower lip, which it nearly equals in length. - Sandy swamps, aucl pine-batrrens, Nautncket, Mass., to X. J., Fla., and 'T'ex., near the coast.

Var. cleistógama, Gray. Only 1 -2' high, bearing 1 or 2 evidently cleistogamous purplish Howers, not larger than a pin's heat ; capsule becoming $1^{\prime \prime}$ long. (The unnamed Utricularia in the Man., p. 320). - With the ordinary form; Barnstable and Nantucket, Mass., pine-barrens of N. J., and soutlwward.

12. U. cornùta, Michx. Stem strict $\left(3^{\prime}-1^{\circ}\right.$ high $)$, 1-5-flowered; pedicels not longer than the caly. $x$; corolla 1 ' long, the loner lip large and helmetshaped, its centre very convex and projecting, while the silles are strongly reflexed; upper lip oborate and mnch smaller; spur aul-shoped, turned down. ward and untward, abont as long as the lower lip. - Peat-bogs, or sandy swanps, Newf. to Minn., south to Fla. and Tex.; common.

\section{PINGUÍCULA, Tonrn. Bl"Tterwort.}

Upper lip of tho calyx 3-cleft, the lower 2-cleft. Corolla with an open hairg or spotted palate, the lohes spreadiug. - Sinall and stomless perennials, frow. 
ing on damp rocks, with l-flowered scapes, and broal and entire leaves, all clustered at the root, soft-fieshy, mostly greasy to the toncll (whence the name, from pinguis, fat).

1. P. vulgảris, L. Leaves ovate or elliptical; scape and calyx a little pubesecut; lips of the violet corolla very unequal, the tube fumel-form; spur straightish. - Wet rocks, northern N. Eng. and N. Y. to Minu., and far nortlwird. (Eu., Asia.)

\section{Order 78. BIGNONIÀCEAE. (Bignomia Famir.)}

Woody plants, monopetalous, dilynumous or diandrous, with the ourary commonly 2-celled by the meeting of the two parietal placentce or of a projection from them, many-ovuled; fruit a dry capsule, the large flat wingeri seerls with a flat embryo and no albumen, the broarl and leaf-like cotyledous: notched at both ends. - Calyx 2-lipped, 5-cleft, o1 entire. Corolla tubular or bell-shaperl, 5-lobed, somewhat irregular or 2-lipped, deciduous; the lower lobe largest. Stanens inserted on the corolla; the fifth or posterior one, and sometimes the shorter pair also, sterile or rudimentary: anthers of 2 diverging cells. Orary free, bearing a long style, with at z-lipped stigma. - Teares compound or simple, opposite, rarely alternate. Flowers large and show y. - Chietly a tropical family.

1. Bignonia l'ud flattencd parallel with the partition. Luaves compound, tendril-bentins

2. Tecoma. Pod thattish contrary to the partition. Leaves compound, without temirils.

3. Catalpa. Pod terete. Fertile stamens only2. Trees : lenves simple.

\section{BI G N O N I A, 'Touru.}

Calyx truneate, or slightly 5-tootherl. Curolla somewhat bell-shaped, 5-lubed and rather 2-lipped. Stameus 4, often showing a rudiment of the fiftl. Capsule linear, 2-cellerl, flattened parallel with the valves and partition. Seeus transversely winged. - Woody climbers, with chictly compunud leaves, ter minating in a teudril. (Named for the Ilbé Bignon.)

1. B. capreolàta, I. (Cross-rise.) Smootl ; leaves of 2 orate or ul.. long leaflets and a branched tendril, often with a pair of aecessory leaves in the axil resembling stipules; peduncles few and clustered, I-flowered ; corolla

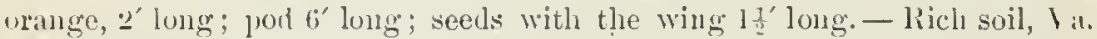
10 .. Ill. and soutl to Flat. and La. April. Climbing tall trees; a transiveries section of the wood slowing a eross.

\section{TÉ COM A, JISS. TRUMPET-LOWER.}

Calyx hell-shaped, 5-toothed. Corolla funnel-form, 5-loherl, a little irregular Stamens 4. Capsule 2-relled, with the partition at right angles to the convex valves. Siceds transicrsely winged. - Woody, with compound leaves, clinling by aerial rootlets. (Abrilged from the Mexicas name.)

1. T. radicans, Juss. ('Trumplit Cheerer.) Leaves pinnae; leatlets $9-11$, orate, pointed, toothed; Howers corymbed; stanens not protruded he-

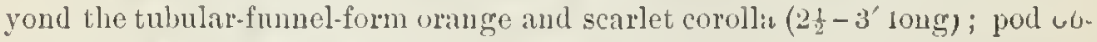
janceolate, 4-5' long. - Moist soil, l'enn. to Ill., sonth to Fla. and 'l'ex. ('on* non in cultivation fartler nortl. 


\section{CatálipA, siop., Walt. Catalpa. Indian Bean.}

Calyx deeply 2-lipped. Corvlla bell-shaped, swelling; the undulate 5-lobed spreading border irregular and 2-lipped. Fertile stanens 2, or sometimes t; the 1 or 3 others sterile and rudinnentary. Capsule very long and slender, nearly cylindrical, 2-celled, the partition at right angles to the valves. Seeds winged on each side, the wings cut into a fringe. - Trees, with orate or cordate and mainly opposite leaves. (The aboriginal name.)

1. C. speciósa, Warter. A large and tall tree, with thick bark; leaves ample, heart-shaperl, lung-acuminatc; corolla '2' long, nearly white, inconspicuously sprotted, with obconical tube and slightly oblique linb, the lower lobe emarginate; capsule thick. - Low rich woodlands, S. Ind. to Tenn., Mo., and Ark. Mas.

C. BIGxoxtollis, Walt, of Ga, Ala. and Miss., very widely cultivated, and formerly including the abore species, is a low much branched tree, with thin hark, smaller ( 1 ? long) thickly spotten corolla (with oblique limb and lower lobe entire), and a much thinier capsule.

\section{ORDER 79. PLDALIÀCEA.}

Herbs, with chiefly opposite simple leaves, and flowers as of the preeding Order, excrpl in structure of otary and fruit, the former being 1-eelled, the latter flestly-h,upaeeous, with wingless seeds and thich entire eotyledons. - Ovary (in ours) 1-celled, with 2 parietal intruded placenta expanded into 2 broad lanellac or united into a central columella.

\section{MARTÝ I A, I. Uñcorn-rlixt.}

Calyx 5-cleft, mostly unequal. Corolla gibbons, bell-shaperl, 5-lobed and sumewhat 2-lipperl. Fertile stamens 4 , or only 2. Fruit fleshy, the flesh at length falling away in 2 valves; the inner part woorly, terminated by a beak, which at length splits into 2 hooked horns, and opens at the apex between the hrus, imperfectly 5-celled, owing to the divergence of the two plates of eack liaccuta, leaving a space in the ccutre, while by reaching and colnering with the walls of the fruit they form 4 other cclls. Seeds several, wingless, with a thick roughened coat. - Low branching amunak, clanmy-puhescent, exhalmg a heay odor; stems thickish; leaves simple, rounded; flowers racemed, large. (1)edicated to Prof. Ioln Martyn, of Cambridge, Fugland.)

I. M. proboscídea, flox. Leaves leart-sluper, oblique, entire or umInlate, the upper alternate; corolla dull white or purplish, or spotter with yellow and purple; entocarp of the fruit crested on one side, long-heaked.lianks of the Mississippi and its lower tribntaries, from S. Ind., Ill., and Iowa, to northern Mexico. Nlso cultivated and naturalized farther north.

\section{Order 80. ACanthàceAe. (Acaxthus Famis.)}

Chiefly herls, with opposite simple leaves, dirtynamous or diandrous sta. mens, inserted on the tube of the more or less 2-lipped eorolla, the lobes of whieh are convolute or imbricated in the bud; fruil a 2-celled and few- (4-12.) sperled capsule: seerls anutropous, without albumen. usually flat and 
supported by hooked projections of the placente (retinacula). - Flowers ('ommonly much bracted. Calyx 5-eleft. Style threarl-form; stigma simple or 2-eleft. Pod loenlieidal, usually flattened eontrary to the valres and partition. Cotyledons broad and flat. - Mueilaginous and slightly bitter, not noxious. A large family in the warmer parts of the world; represented in gardens by Tncxblisia, whieh differs from the rest by the grobular pod and seeds, the latter not on hooks.

* Corolla not obvionsly hilubiate, the 5 lubes l,road and roundish, sureading; stamens 4.

1. Calophanes. Calyx-lobes long-filiform. Capsule 2-4-sceded.

2 Ruellia. Calyx-lobes mostly linear or lanceolate. Capsule 6-20-seeded.

* Corolia bilabiate, upper lip erect and concave, lower spreading; stamens 2.

3. Dianthera. Capsule oborate, flattened, t-seeder.

\section{C A LÓ PHA NES, Don.}

Calyx deeply 5-cleft or parted; its lobes elongated setaceous-acuminate or aristiform. Corolla funnel-form, with ample limb, convolute in the bud. Stamens 4 , the anthers nucronate or sonetimes aristate at base. Ovules a single pair in each cell. Capsule oblong-linear, 2-4-seeded. - Low branching peremnials, pubescent or hirsute, with proportionally large axillary nearly sessile

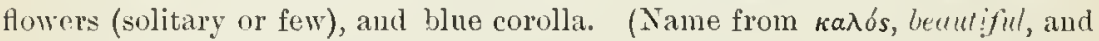
paiv $\omega$, to appeur.)

1. C. oblongifolia, Don. Stems usually erect and simple, $\frac{1}{2}-1^{\circ}$ high ; leaves from narrowly obloug to oval, very obtuse, sessile ( $l^{\prime}$ long or less); (orolla blue, sometimes purple-lottel or mottled, seldom l' long; calyx-lobes nearly distinct, filiform-setaceous, hirsute. - Pine-barreus, S. Va. to Fla.

\section{RUÉLIIA, Plumier.}

Calyx 5-parted. Corolla funnel-form, with spreading ample border, convoInte in the bud. Stamens 4, the cells of the somewliat arrow-shaperl anthers parallel and nearly equal. Capsule narrow, in our species somewhat flattened, contracted and seedless at the base, abore 8-12-seeded. Seeds with a mucilaginons coat, when wet exhibiting nnder the nicroscope innumerable talpering short bristles, their walls marked with rings or spirals. - Jerennials, with rather large and showy blue or pnrple flowers, mostly in axillary clusters, sometimes also with small flowers precociously close-fertilized in the bud. Ca lyx often 2-bracteolate. (Named for the early herbalist, John Ruelle.)

1. R. ciliòsa, l'ursh, IIirsute with soft whitish hairs $\left(1-3^{\circ}\right.$ high); learps nearly sessile, orvl or orate-ohlong $\left(1-2^{\prime}\right.$ long); flowers $1-3$ and almost sessile in the axils; tube of the corollu $\left(1-1 \frac{1^{\prime}}{2} \operatorname{long}\right)$ fully twice the length of the setuceous calyx-lobss; the throat short. - 1)ry ground, Mich. to Minn., south to Fla. and Ta. Jnne-Sept. - Var. wufat , Gray. Sparingly hirsnte-pubescent or glabrate; leaves orate-ollong, usually slort-petioled, larger; tube of corolla little exceding the harlly hirsute calyx. - Va and Fy. to $\Lambda$ la. $\Lambda$ ppearing like a hyloril with the next.

2. R. strèpens, I. Glabrous or spuringly mbescent $\left(1-4^{\circ}\right.$ high) ; leaves narroued at buse imo a petiole, ovate, obovate, or mostly ollong (2t-5' longl, tube of the corolla (about $I^{\prime}$ long) little longer than the dilated portion, shigntly 
xreerling the lanemble or lineur calyx-lobes. - Rich soil, l'enn. to Wisc., sontil to Fla. and'lex. July-sept. - I'ar. cleistáxtu, liay. Leaves conunonly harrower and olslong; flowers for most of the season cleistogamous. - Common with the ordinary form.

\section{DIA N TH E R A, Gronov. WATER-WrLlow.}

Calyx 5-parted. Corolla deeply 2-lipped; the upper lip erect, notched; the lower spreading, 3-parted, external in the bud. Stamens 2; anthers 2-celled, the cells separated and somewliat nnequal. Capsule oborate, flatteued, contracted at base into a short stalk, t-seedel. - P'erennial herls, growing iu water or wet places, with entire leares, and purplish flowers in axillary pe. duncled spikes or heads. (Name formed of sís, double, and àvenpá, anther, the separated cells giving the appearance of two anthers on each filament.)

1. D. Americàna, I. Stem $1-3^{\circ}$ higlı; leares linear-lanceolate, elongated; spikes oblong, dense, long-peduncled; corolla 4-5" long. - In water, N. W. Vt. to Wise, south to S. C. and Tex. July-Sept.

\section{Order 81. VERBENACEAE. (Tervary Famil.)}

ITerbs or shrubs, with opposite leares, more or less 2-lipped or irregular corolla, and didynamous stamens, the 2-4-celled (in Phryma 1-celled) fiuit dry or drupaceous, usually splitting when ripe into as many 1-seeded inteliscent nutlets; differing from the following order in the ovary not lxing 4-lobed, the style therefore terminal, and the plants seldom aromatic or furnisling a rolatile oil. - Seeds with a straight embryo and little or no albumen. - A large ordes in the warmer parts of the world, sparingly represented in cool regions.

Tribe I. VEIBENEA. Ovary :-4-celled, with an erect anatropous ovnle in each cell.

1. Verbena. Flowers in spikes or heals. Calyx tnbnlar. Fruit splitting into 4 untlets.

". Lippia. Flowers in spikes or heads. Calyx short, 2-cleft. Fruit s]litting into ?uutlets.

3. Callicarpa. Flowers in axillary eymes. Calyx short. Frnit berry-like, witle +1 utlets.

Tribe II. PHRYMEA. Ovary 1-celled; ovule crect, orthotropous.

4. Phryma. Flowers in slender spikes. Calyx cyliulrieal, 2-lin)ed. Fruit an achene.

\section{VERBE NA, Tourn. Vervain.}

Calyx tuhular, 5-toothed, one of the teetl often shorter than the others. Comblia tubular, uften curvel, salver-form; the border somewhat mesually jrleft. Stanens inchled; the upper pair oceasionally withont anthers. Sityle slender; stigna mostly 2-luhed. Fruit splitting into 4 seed-like nutlets.Flowers sessile, in single or often panicled spikes, bracterl; prodncerl all summer. (The latin name for any sacred herb; (derivation ohsenre.) - The spe(ies present numerous spontaneous hybrids.

\$ 1. Anthers not appendaged: flowers small, in namow spikes.

* Spikes filiform, with flowers or at least fruits scattered, naked, the inconspicuous bracts shorter than the caly.x.

V. officisals, L. (European V.) Annual, glabrous or nearly so, loosely branched (1-30 high); leares pinnatifid or is-cleft, ollonq-lancrolate, 
sessile, smouth abonce, the lobes cut and toothed; spikes panicled; flouers purplish, very small. - Roadsides and old fields, N. J. to Minn., south to 'Tex., and westward. (Nat. from Eu.)

1. V. urticæfòlia, I. (Wurs V.) Perennial, from minutely pubescent to almost glabrous, rather tall $\left(3-5^{\circ}\right.$ high); lenes orul or oblong-orate, ucule, coursely serrute, petioled; spikes at length much elongated, loosely panicled; flowers very small, white. - Waste or open grounds. (Trop. Am.)

* * Spikes thicker or densely flowered; the fruits crovded, mostly orerlapping each other; bracts inconspicuous, not exeeding the flowers; perennial.

2. V. angustifolia, Michx. Low $\left(6-18^{\prime}\right.$ high), often simple; leuves nurrouly lanceolate, tapering to the base, sessile, roughish, slightly toothed; spikes few or single; the purple flowers crowded, larger than in the next. 1)ry or sandy ground, Mass. to Miml., south to Fla. and Ark.

3. V. hastàta, I. (BLuE VErisix.) Tall $\left(4-6^{\circ}\right.$ high); leaves luneeolate ne chlung-lanecolute, taper-pointed, cut-serrate, petioled, the lower often lobed and somptimes halberl-shaped at lase; spikes linear, ereet, corymbed or panicled; flowers blue. - Waste grounds anıl roarlsides; eommon.

4. V. stricta, Vent. (Honn I.) Junny with soft whitish hairs, erect, simple or brancherl (1-20 high); lenes scssile, obovate or oblong, serrate; spikes thich, somewhat clustered, hitiry; flowers rather large, purple. - Barrens and prairies, Olio to S. Dak., sonth to Tex. and N. Mex.

$$
\text { * * sprikes thich, sessite and leafy-bracted; anmal. }
$$

5. V. bracteòsa, Michx. Widlely spreading or procumbent, hairy ; leares werge-lanceolate, cut-pinnatifil or 3-cleft, slort-petioled; spikes single, renotely flowered ; bracts lirge, the lower pinnatifid, longer than the small purple flowers. - Prairies anrl waste grounds, (Jhio to Minn., south and westward.

$\$ 2$. Anthers of the ionger stumens glandular-tipped; flowers showy, from depressed-capitate beeoming spicate.

c. V. bipinnatífiàn, Nutt. Ilispid-lirsule, $\frac{1}{2}-10$ high; leares $\left(1 \frac{1}{2}-4^{\prime}\right.$ long) bipinnately parted, or 3-parted into more or less bipinnatifid divisions, the lobes eommonly linear or broaler; bracts mostly surpassing the calyx; limb of bluish-purple or lilae eorolla $4-5$ " broad. - Plains and prairies, Kan. to Ark. and Tex., and westward.

7. V. Aublètia, I. Slender, $1^{\circ}$ high or less, soft-pubescent or glubrate; leares $\left(1-2^{\prime}\right.$ long) ownte ox ove-ohtong in outline, with a wedge-shaped base, incisely lobed and torthed, often more ieeply 3-rleft; brarts shorter than or equal ling the ealyx; limb of redtish-purple or lilac (rarely white) eorolla $6-8^{\prime \prime}$ broad. - Open woods and prairies, Ind. and IIl. to Fla., Ark., and N. Mex.

\section{L I P P I A, Houst.}

Calyx short, often flattened, 2-4-toothed, or 2-lipped. Corolla 2-lippred. nppor lip notched, the lower much larger, 3-lobed. Stamens included. Style slunder; stigma obliquely capitate. Fruit 2-celled, 2-seeded. (Dedicated w) L uyustus Lippi, an It:lian maturalist and traveller.)

1. L. lanceolàta, Michx. (Fog-niır.) Creeping extensively, roushish,

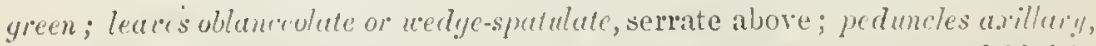
slender, exceeding the lences, beariug solitary closely lnacted heads of bluish. 
white flowers; bructs mucronate or pointless. - River-banks, E. Penn, to Minn., south to Fla. and Tex. July-Sept.

2. L. cuneifolia, Stend. Diffusely branched from a woody base, procnmbent (not crecping), minutely canescent throughout; leaves rigid, cuncute linear, incisely 2 -6-touthed above the middle; peduncles axillary, mostly shorter than the leaves; bracts rigid, broadly cuneate, abruptly acuminate; corolla white (?). - Plains, W. Neb. to central Kan. and Arizona.

\section{CALLICÁRPA, L.}

Calyx 4-5-toothed, short. Corolla tubular-bell-shaped, 4-5-lobed, nearly regnliur. Stanels 4, nearly equal, exscrted; anthers opening at the apex. Style slenler, thickened npward. Fruit a small berry-like drupe, with 4 nutlets. shrubs, with scurfy puhescence, and small flowers in axillary eymes. (Name

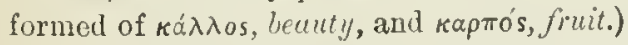

1. C. Americána, L. (Fliexcir Mulberlir.) Leaves ovate-oblong with a tapering base, acuminate, tootherl, whitish beneath; eymes many-flowered; calyx obsenrely 4-toothed; corolla bluish; fruit violet-color. - Rich soíl, Va. to 'Tex., thence north to Mo. May-Jnly.

\section{PHR Y MIA, L。 LopseED.}

Calyx cylindrical, 2-lipped; the upper lip of 3 bristle-awl-shapel teeth; the lower shorter, 2-toothed. Corolla 2-lipped; ulper lip notched; the lower much larger, 3-lobed. Stamens included. Style slender; stigna 2-lobel. Fruit dry, in the botton of the enlyx, oblong, 1-celled and 1-sceded. Seed orthotropous. Cotyledons convolute ronnd their axis. - I perennial herb, with slender branching stems, and cuarscly toothed ovate leaves, the lower long-petioled; the small upposite flowers in elongated and slender terminal spikes, strictly reflexed in fruit. Corolla purplish or rose-color. (Derivation of the nane unknown.)

1. P. Leptostàchya, I. Plant $2-3^{\circ}$ high ; leaves $3-5^{\prime}$ long, thin; calyx strongly ribbed and closed in fruit, the long slender teeth hooked at the tip.- Moist and open woorls, common. (E. Asia.)

\section{Order 82. LABIÀtae. (Mint Family.)}

Chiefly herbs, with square stems, opposite aromatic leaves, more or less 2lipped corolla, didymamous or diandrous stamens, and a deeply 4-lobed ovary, which forms in finit 4 litlle seed-like nutlets or achenes, surrounding the base of the single style in the bottom of the persistent calyx, each filled with a single erect seed. - Nutlets smooth or barely roughish and fixed by their base, exccpt in the first tribe. Albumen inostly none. Embryo straight (except in Scutellaria); radicle at the base of the fruit. Ipper lip of the eorolla 2-lobel or sometimes entire; the lower 3-lobed. Stamens inserted on the tube of the corolla. Style 2-lobed at the apes. Flowers axillary, chicfly in cymose clusters, these of ten agregatcd in terminal spikes or racemes. Foliage mostly dotted with small glands containiug a volatile oil, upon which depends the warmth and aroma of the plants of this larere and well-known family. 
I. Nutlets rugose-reticulated, attached obliquely or ventrally; ovary merely t-lober.

Tribe I. AJUGOIDEA. Stamens 4, ascending and parallel, mostly exserted from the upper side of the corolla, Calyx 5 - 10-nerved.

* Linut of corolla merely oblique, of 5 nearly equal and similar lobes,

1. Trichostena. Corolla-lobes all dechined. Calyx oblique, Stanens exserted.

2. Isantlius. Calyx bell-shaped. Corolla small, the lobes spreading. Stanens included.

* * Limb of corolla irregular, seemingly unilaliate, the npler lip being either split dows or very short; stamens exserted from the eleft.

3. Teucrium. Corolla deeply eleft between the 2 small lobes of the upper lip.

4. Ajuga. Corolla with a very short anil as if trumcate upper lip.

II. Nutlets smooth or granulate; scar basal, small; orary deeply 4-parted.

Tribe II. SATURFINEE. Upper pair of stanens shorter or wanting; anthers 2celled. Upler lip of corolla not galeate or concave.

* Flowers in loose temuinal pauicled racemes; calyx 2-lipped, enlarcerl and declined in fruit.

5. Collinsonia. Lower lobe of corolla fimloriate, much the largest. Stamens 2.

t. Ferilla. Curolla short, the lower lobe little larger. Stamens 4, included.

* * Plowers in more or less crowded clusters or whorls, axillary or sjicate.

+ Corolla not evidently 2-lipued, but almost equally 4 -lobed, small. Stamens crect, distant.

7. Mentha. Fertile stamens 4, nearly equal.

8. Lycopus. Fertile stanens 2, and often 2 sterile fitaments without anthers.

+ + orolla more or less 2-lipped.

+ Stamens distant and straiglit, often divergent, never convergent nor eurved.

$=$ Strmens 2, with or without rudiments of the upper pair.

9. Cunila. Calyx very hairy in the throat, equally 5-toothed. Corolla small. $==$ Stamens 4 ; ealyx $10-13$-nerved, and hairy in the thront (exeept. n. 10).

10. IIyssopus. Calyx tubular, 15-nervecl, equally 5-toothed. Stamens exserted.

11. Pyenanthemum. Calyx ovate or short-tubular, equally 5-toother or somewinat 2. liliped. llowers in dense heads or ('llisters.

12. Origauum. Calyx ovate-bell-shapeel, 5-tontled. Spilies with large colored bracts.

13. Thymus. Culyx ovate, noulding in fruit, 2-lîpred. Bracts minute; leaves very small.

++ ++ Stancus (often 2 ouly in n. 16) ascending or areuate, often more or less converging (or ascending parallel under the reet upler lip, in 11,14 and 15 ).

14. Satureia. Calyx hell-shaped, 10-nerved, naked in the throat, equally 5-tootled.

15. Calamintlia. Calyx tubular, ofteu hairy in the throat, 13-nerved, 2-lipued. Tube of corolla straight.

16. Melissa. Calyx tubular-bell-shaped, flattish on the upper side. Corolla cmrved npward,

17. Hedeona. Calyx gibbons on the lower side, hairy in the throat. Flowers loose.

Tribe III. MIONA I: DEEX. Stumens 2, ascending ind parallel; anthers apparently ou really 1 -riellet. Corolla strongly 2 -lipred.

18. Salvia. Calyx 2-lipped. Anthers with a long connective astride the filament, bearina a linenr cell at the upper end, and nome or an imperfect cell on the lower.

19. Monarda. Calyx tubular and clongatel, equally 5-tontliel. Intliers of 2 cells con fluent into one, the connective inconspicuons.

20. Blephilia. Calyx ovate-tubular, 2-lipineul. Anther's as in the last.

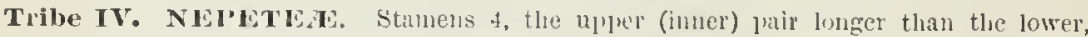

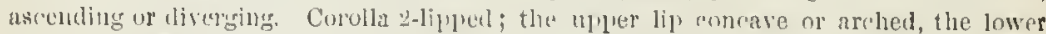
spreading. Calyx mostly 15 -nerved.

* Anthers not approximate in pairs: their cells parallel or nearly so.

21. Lophanthus. stamens divergent, exserted : "1] per pair deelined, lower ascending.

2: Codrontella. Stanems all ascending, not excedinge the lip of the curolla 
* Arthers more ol less alproximate in pairs; tleir cells divaricate or divergent; flaments ascending, not exserted.

23. Nepeta. Calyx more or less curved, equally j-toothed.

24. Dracocephalum. Calyx straight, the upper tooth much the larger.

Tribe V. SCUTELLA RINEAE. Stamens 4, ascending and parallel. Calyx bilabiate, elosed in fruit; the rounded liys entire. Corolla bilabiate, the upper lip arehed.

25. Scutellaria. Calyx with a helnet-like projection on the upper side.

Tribe VI. STACHYDEA. Stamens 4, parallel and ascendiug under the galeate or concave "ly's lip, the lower (outer) pair longer (except in n. 31, 32). Calyx 5-10nerved, not :-liphed (exeept in 11. 26).

* Calyx reticulate-veiny, clecrly bilabiatc, closed in fruit.

26. I3runella. Calyx nerved and veiny; upucr lip fiat, 3-toothed, the lowel 2 -cleft.

* *alyx thin, inflated in fruit, obsenrely nerved, 3-5-lobed, open.

27. Physostegia. Calyx 5-toothed or 5-lobed. Anther-cells parallel.

28. Synandra. Calyx almost equally 4-lohed! Anther-cells widcly divergent.

*** Caly $x$ of firmer texture, distinctly 5-10-nerved or striate, 5-10-toothed.

- Stanens included in the short eorolla-tube, its upper lip merely coneave.

29. Marrubium. Calyx tubular, 5-10-nerved, and with 5 or 10 awl-shaped teeth.

+ + Stamens ascending uuder the galeate upper lip of the eorolla.

+* Stamens not deflexed after anthesis ; naturalized froin the Old World.

30. Ballota. Calyx somewhat funnel-form, expanding above into a spreading 5-toothed border. Nutlets roundisl at top. Upper lip of the corolla erect.

31. Phlomis. Calyx tubular, the 5 teetl abruptly awned. Ulyer lip of the eorolla arehed.

32. Leonurus. Calyx top-sllaled, the rigid spiny-pointed tecth soon spreading. Nutlets truneate and acutely 3 -angled at top. Leares eleft or incised.

33. Lamium. Calyx-teetl not spiny-pointed. Nutlets sharply 3-angled, truncate.

94. Galeopsis. Calyx tubular-bell-shaped; the 5 teeth spiny-pointed. Antliers transversely 2-valved, the smaller valve eiliate.

+* Stamens often deflexed or contorted after authesis.

55. Stachys. Caly $x$ tubular-bell-shaped, equally 5 -toothed or the 2 upper teeth united into one. Nutlets rounded at tol).

\section{TRICH OSTEMA， I. Blue Curls.}

Calyx bell-shaped, oblique, deeply 5-cleft; the 3 upper teeth elongated and partly united, the 2 lower very short. Corolla 5-lobed; the lohes narrowly oblong, declined, nearly equal in length; the 3 lnwer more or less nnited. Stamens 4, with very long capillary filaments, exsertert much beyond the corolla, curver]; anther-cells clivergent and at length confluent. - Low annuals, somewhat clammy-glandular and balsamic, brancherl, with entire leaves, and mostly solitary I-flowered pedicels terminating the branehes, hecoming lateral hy the prouluction of axillary branchlets, and the flower appearing to be reversel, namely, the short teeth of the calyx upward, ete. Corolla blue, rarying to pink, rarely white, small; in summer anrl antumn. (Name composed of $\theta p(\xi$, hair, and $\sigma \tau \hat{\eta} \mu \alpha$, stamen, from the capillary filaments.)

1. T. dichótomum, L. (Bastari) Pesxrrovat.) Viscirl with rather minute pubescence; leaves lance-oblong or rhombic-lanceolute, rarely lance-linear, short-petioled. - Sandy' fields, E. Mass. to Ky., soutl to Fla. and 'Tex.

2. T. lineàre, Nutt. Puberulent, more slender and less forked; leares linear, nearly smooth. - Conn. to La., near the coast; in sandy ground. 


\section{IS Á NTHUS, Michi:. False Pexiyrotal.}

Calyx bell-shaped, 5-lobed, equal, enlarged in fruit. Corolla little longer than the calyx; the border bell-shnpecl, with 5 nearly equal and obovate spreading lobes. Stameus 4, slightly didynanous, iuculved-ascending, scatcely exceeding the corolla. - A low, much branched annual, clanmy-pubescent, with nearly entire lance-oblong 3-nerved leaves, and small pale blne flowers ou

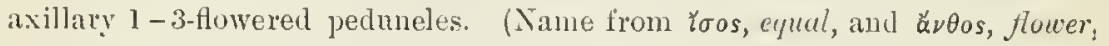
refurring to the almost regular corolla.)

1. I. cærủleus, Michx. Corolla $2-3^{\prime \prime}$ long, little exceeding the calyx. - Dry or sterile gromel, Maine to Ill., Minn., and sonthward. July, August.

\section{TE U C R I U M, Tourn. Gemander.}

Calyx 5-toothed. Corolla with the 4 upper lobes nearly equal, oblung, tumed forward, so that there seems to be no upper lip; the lower lohe much larger. stamens 4, exserted from the deep cleft between the 2 upper lobes of the corolla; anther-cells confluent. (Named for Teucer, king of 'Troy.)

1. T. Canadénse, L. (Americax Germammer. Wood Śage) Perennial, downy, erect $\left(1-3^{\circ}\right.$ high) ; leares ovate-lancenlate, serrate, rounded at base, slurt-petioled, hoary underneatl, the flolal scarcely longer than the oblique unequally-toothed calyx; whorls abont 6-fluwered, crowded in a long and simple wand-like spike; caly $x$ canescent, the 3 upper lobes very obtuse or the unidule one acutisli; corolla purple, rose, or sometines cream-color (6" long). - Low grounds; not rare. July-Sept.

2. T. occidentàle, Gray. Loostly puvescent; culyx villous with viscid huirs, the upper lobes acute or middle one acuminate; corolla 4-5" long; otherwise like the last. $-\Lambda$ western form, from Neb. sonthwestward, and extending enstward (Ont., and near Philadelphia).

\section{4. ÁJ UGA, L.}

Calyx 5-toothed. Corolla with rely short and as if truneate upper lip; the large and spreadiug lower lip with the middle lohe emarginate or 2-cleft. Stamens as in 'Teucrimm, but antler-cells less confluent. (From $\alpha$-privative, and (vyov (Latin juyum), yole, from the seeming absence of a roke-fellow to the lower lip of the corolla.)

A. réptaxs, I. Perennial, alont $1^{\circ}$ ligh, with copious creeping stolons; leares oborate or spatulate, sometimes sinmate, the cauline sessile, the floral alproximate, subtenling sereral sessile blue flowers. - Naturalized near Saeo, Mlaine, Montreal, etc. (Eı., N. Asia.)

\section{COLIINSÒNIA, L. Horse-B.iL.}

Calyx orate, enlarged and declined in fruit, 2-lipped; upper lip trumcate and Aattened, 3-tootlied, the lower 2-eleft. Curolla elungated, expanded at the throat, somewlint 2-lippes, the tube witl a bearded ring witlin; the + upper lobes

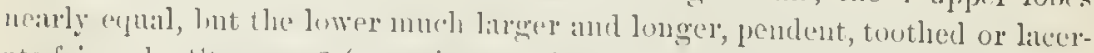

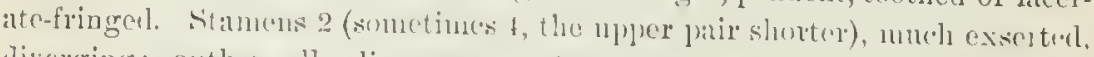

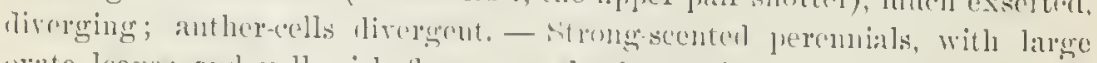

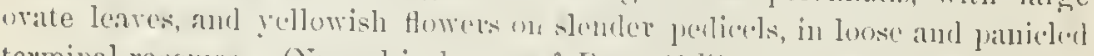

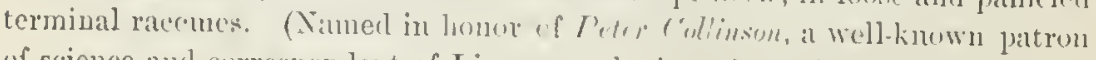
of science aud correspondent of Linueus, who introduced it into Lugliurl.) 
1. C. Canadénsis, L. (Rich-Wlib. Stoxk-Ruot.) Nearly smooth ( $1-3^{\circ}$ high); leaves serrate, pointed, petioled (3-6' long); pauiele loose; corolla 8-9" long, lemou-seented; stamens 2. - Ricl moist woods, N. Brunswick to Wisc, south to Fla. and Mo. July-Sept.

\section{PERÍLLA, L.}

Calyx as in Collinsonia. Corolla-tube included, the limb 5-cleft; lower lobe a little larger. Stamens 4, included, erect, distant. - Coarse aromatie annual, witl small towers in panicled and axillary raeemes. ( $A$ Greek and Latin proper name.)

P. ocrmoines, I, Erect, branching, 2-30 high; leaves urate, cuarsely toothed; flower's white. - A bout dwellings and roadsides, S. Ill. (Schneck.) (Adv, from Li. Asia.)

\section{MÉ N T H A, Tourn. Мisт.}

Calyx bell-shaped or tubular, 5-toothed, equal or wearly so. Corolla with a slort included tube; the bell-shaped border somewlat equally 4 -cleft; the upper lohe broadest, entire or notched. Stamens 4, equal, erect, distant. - Odorous perennial herlss; the small flowers mostly in close clusters, forming axillary capitate whorls, sometimes approximated in interupted spikes, produced in summer, of two sorts as to the fertility of thestamens in must species. Corollit pale purple or whitish. Sjeeies mostly adventive or naturalized from Europe, witl many hybrids. (Mívon of Theophrastus, from a Ximph of that name, fahled to have been changed into Mint by I'roserpine.)

* Spikes narrow and leafless, densely crouded; leares sessile or nearly so.

M. sruvestris, 1. (Horse Mist of Eur.) Finely pubescent or canesrent: leuves orute-oblong to oblong-tunceolute, acute, sharply serrate, often glabrous above; spikes rather slenter, cunescenlly pubescent. - Roalsiles, etc., l'enn.Var, Aloptcenotnes, Baker. Leaves larger, more nearly sessile, broadly wal and obtuse, often sul,cordate, coarsely serrate, more veiny, but not ruguse; aproaehing the next. - l'enu, and $\mathrm{N}$.J.

M. Rotuxdróla, L. Fintheriry or downy; lenes broadly elliptical to romi-orute and somewhat heart shaped, myose, crenate-toothed; spikes slender, not ronescent. - Atlantic states, at a few stations, Maine to Tex.

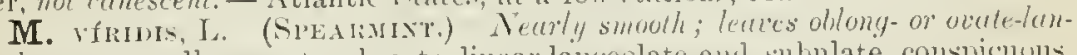
reolule, unequally serrate; luracts linear-lanceolate ann subnlate, conspicuuns. - Wet places; in all cultivated ilistricts.

* Flowers perdicellate, less rrouded, in intemuted liafless spikes, or some in the upper arils: leares petioled.

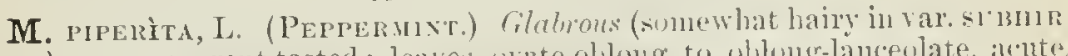
- irt), very pungent-tasted; leaves wate-ohlong to ohlong-lanceolate, aleutes - harply serrate; spikes nurow, lows. - Along lowolis, escajed everywhere.

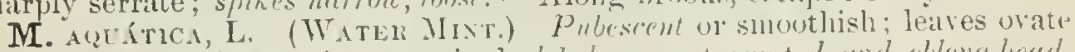
wr round-orate; flowers in a terminal plobulur or mermpted and oblong head, witen with one or more clusters in the axils of the upper lenves; calyx and

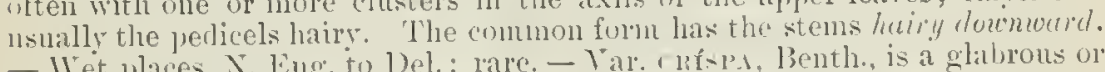

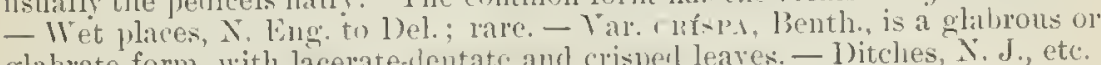
glabrate form, with lacerate-dentate and crisperl leaves. - l)itches, $\mathbf{X}$. J., ete.

* * Flouers in globular whorls or rlustors, all in the axils of the leares, the uppermost axils not flower-bearing: lentrs move or less petinled, toothed.

M. sıtria, L. (Whorlan Mist.) sem hairy donmurd; leaves ovate sharply serrate; calyx oblong-cylindrical with ri!l slender heth. - Waste damp places, Mass, to l'enn.; not common. l'atsos intu the next. 
M. Arvésis, L. (CORx Mint.) Lower and smaller-leaved than the last; leaves obtusely serrate; calyx bell-shaped, the teeth short and broader. - Moist fielus, N. Ling., ete.; rare.

1. M. Canadénsis, L. (WiL, Mist.) Leares varying from orateohlong to lauceolate, tapering to both ends; calyx oblong-bell-shaped, the teeth rather short; hairs on the stem not conspicnonsly reflexed. The commoner form is more or less laairy, and has nearly the odor of Pemnyroyal. - Wet places, through the northern U. States across the continent, and northward.

Var. glabràta, Benth. Leaves and stems alınost glabrons, the former sometimes very short-petioled; scent sweeter, as of Monarda. - Similar range.

\section{L Ý C O PUS, 'lourn. Watese Hokehouñ.}

Calyx bell-shaped, 4-5-toothed, naked in the throat. Corolla bell-shaped, scarcely longer than the calyx, nearly equally 4-lohed. Stamens 2, ristant; the npper pair either sterile rndinents or wanting. Nintlets with thickened margins. - J'eremnial low herbs, glabrous or puberulent, resembling Mints, witl sharply toothed or pimatifid leaves, the floral ones similar and much longer than the dense axillary whorls of small mostly white flowers; in sum-

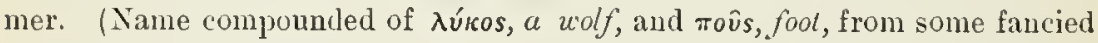
likeness in the leaves.)

* Stoloniferous, the long filiform runners often tuberiferous; leaves only serrate.

- Calyx-teeth usually 4, barely acutish, shorter lian the mature nutlets.

1. L. Virgínicus, I. (Bugle-ween.) Stem obtnsely 4-angled $\left(6^{\prime}-2^{\circ}\right.$ high); leaves oblong or orate-lanceolate, toothed, entire toward the base, acn ininate at both ends, short-petioled; calyx-teeth orate. - Shady moist places. Lab. to Fla., Mo, and northwestward across the continent.

++ Calyx-teell usually 5, very acute, longer llian the mullets.

+ Bracts minute; corolla lwice as long as the calyx.

2. L. Sessilifolius, Gray. Stem rather acutely 4 -angled; leares closely sessile, ovate or lanceulate-ollong ( $1-2^{\prime}$ long), sparsely sharply serrate; caly.r. leeth subulate, rigid. (L. Europrens, var. sessilifolius, Gray, Man.) - Pine hurens of N. J. to Cape Cod, Mass. (Deane).

3. L. rubéllus, Moench. Stem ratler obtusely 4-angled; leaves futioled, ovate-oblong or ollong-lanceolate, sharply serrate in the midlle, rltomute-acuminate at both ends ( $3^{\prime}$ long); calyx-teeth triangular-sululate, not rigid-pointed. (1. Juropeus, var. integrifolins, Gruy.) - Penn. to Minn., and sonthward.

+- Outer bracts conspicuous; corolla lardly exceeding the calyx.

4. L. lùcidus, Turez., rar. Americànus, Gray. Stem strict, stout, $2-30$ lighl, leaves lanceolate and oblong-lanceolate $\left(2-4^{\prime}\right.$ long $)$, acute or acnminate, very sharply and coansely scrate, sessile or nearly so; calyx-teeth attennate-subulate. - Sask. and Minn. to Kían., thence west to Calif.

* * Not stoloniferons; lectes incised or pinnatifid.

5. I. sinuàtus, Ell. Stem erect, $1-3^{\circ}$ high, acutely 4-angled; leaves

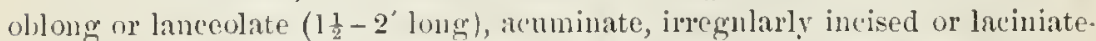
pimatifil, or some of the upper merely sinuate, tajering to a slender petiole: (a!r'x-teeth slurt-cuspidate; sterile filaments slender, conspicnons, with giob.

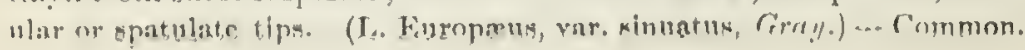




\section{CUN亡LA, L. DitTaNY.}

Calyx ovate-tubular, equally 5-toothed, very hairy in the throat. Corolla 2. iipped; upper lip erect, Hattish, mostly notched; the lower spreading, 3-cleft. Stamens 2, erect, exserted, distiut; sterile filaments short, minute. - I'eren nials, with small white or jurplish flowers, in corymbed cymes or eluster's. (An ancient luatin name, of $111 \mathrm{kn}$ wm origin.)

1. C. Mariàna, L. (Cumun Drтraxı.) Stems tufted, corymlosely much branched ( $1^{\circ}$ ligh); leares smooth, ovate, serrate, rounded or heart shaped at base, nearly scssile, dutted ( $l^{\prime}$ long); cymes peduncled; calyx stri. ate.-Dry hills, southern N. Y. to S. Ind., soutlı to Ga. and Ark.

\section{H Y S S Ò P U S, Tourn. Hrssor.}

Calyx tubular, 15-nerved, equally 5-tootherl, naked in the throat. Corolla short, 2-lipperl; upper lip erect, flat, olsseurely noteherl, the lower 3-cleft, with the middle lohe larger and 2-cleft. Stanens" 4, exserted, diverging. - l'erennial herb, with wand-like sinple branches, lanceulate or linear entire leaves, and blue-purple flowers in small (lnsters, crowded in aspike. (The ancient name.)

H. officisis, L. - Roadsides, ete, sparingly escaped from garlens. (Adr.from Eu.)

\section{P Y C N Á N T H M U M, Miclix. Mountaix Mint. Basil.}

Calyx ovate-oblong or tubular, abont 13-nerved, equally 5-toothed, or the three upper teeth more or less nnitel, naked in the throat. Corslla short, more or less 2-lipped; the upper lip straight, nearly flat, entire or sliglitly notched; the lower 3-cleft, its lobes all ovate and obtuse. Stamens 4, distant, the lower pair rather longer; anther-cells parallel. - V'eremial upright lierbs, with a pungent mint-like flavor, corymbosely luanched above, the floral leaves often whitenced the nany-flowered whorls dense. crowded with bracts, and nsublly forming terminal hearls or close ermes. Corolla whitish or purplish, the lips nostly dotted witl pu'ple. Fl. summer and early antumn. - Varies, like the Mints, with the stanems exserted or included in different flowers. (Name composed of $\pi \nu \kappa \nu o ́ s$, dense, and ă $\theta \varepsilon \mu \nu \nu$, a blossom, from the dense influrescence.)

* Bracts and equal calyx-teeth awn-tipped, rigid, naked, as long us the corolla: flowers in rather dense inostly terminal heads; leaves rigid, slightly petioled.

1. P. aristàtum, Michx. Minutely hoary-puberulent ( $1-2^{\circ}$ high); leaves uvate-oblong and oblong-lanceolate, acute, sparingly denticulate-serrate ( $1-2^{\prime}$ long $)$, roundish at the base. - l'ine barrens, N. J. to Fla. and Lat.

Var. hyssopifolium, Cray. Leaves narrowly oblong or broadly liuear, aearly entire and obtuse. - Va. to Fila.

* * Bructs and equal and similar culyx-teeth not au'ned.

- Leaves linear or lanceolate, nearly sessile, entire, very numerous ; capitate glomerules sinall and numerous, densely eymose, imbricated with many short repressised rigid brects.

2. P. lanceolàtum, Pursh. Simoothish or minuely pubessent ( $2^{\circ}$ high); fences lanceulute or lance-lineur, obtuse at hase; herds downy; bracts ovate or lanceolate; culyx-tecth short and triungular. - Dry tlickets, Mass. to the Dakotas, south to Git. and Ark. 
3. P. linifolium, Pursh. Smouther and leares narrouer and heads less downy than in the last; the navower bracts and lanee-aul-shaped ealyx-teeth pungently pointed. - Dry gronnd, Mass. to Minn., sonth to Fla. and Tex.

+- + Leaves lanceolate to oxate, sessile or nearly so, dentieulate or entire; herrls: larger and fewer, with fewer and looser brats.

4. P. mùticum, Pers. Minutely horry throughout, or becoming almost snooth, corrmbosely much branclied ( 1 - 210 ligh); leaves ovate or broadly scate-laneeolate, varying to lancenlate, rather rigid, ueute, rounded or slightly heart-shaped at base, mostly sesile and minutely shitip-toothed, prominently veiued, green when old; the floral ones, short bracts, and triangular or orate calyx-tceth, hoary with a fine close down: fower-clusters very dense. - Maine to S. Ill., south to Fla. and Ark.

Var. pilòsum, Gray. Hoary with luose pubescence; leaves thinner, oblonglanceolate, mustly acute or acutish at base; bracts and especially the narrower (often somewhat unequal) calyx-teetl ofteu villous-jubescent. (P. pilosum, Nutt.) - Ohio to Iowa, Kian, and $\Delta \mathrm{rk}$.

5. P. léptodon, Gray. Soft-pubescent, or glabrate below, loosely branched; leaves membranaecuus, green ( $1 \frac{1}{2}-2^{\prime}$ long), lanceolate or oblong-laneeolate, subsessile; clusters larger and looser, canescent-lirsute; long-acuminate braets and ralyx-teeth slender-subulate, villous-hirsule. - S. Mo. to northwestern N. C.

++ + Leaves linear- or oblong-lanceulate, short-petioled, not at all hoary; flowers in mostly terminal dense capitate clusters : calyx hoary-pubeseent.

6. P. Torrèyi, Bentl. Puberulen: stem strict and nearly simple (2$3^{\circ}$ high); leaves thin, linear-laneeolate, tapering to both ends (mostly $2^{\prime}$ long and $2-3$ " wicle), nearly entire; heals small ; awl-shaped calyx-teetl and mostly appressed bracts canescent. - Dry soil, southern N. Y. to Penn, ant Del.

7. P. clinopodioides, Gray. Pubescent; leaves broadly or ublong-lanrevlute, shurply denticulate (sometiues entire) ; heads fewer and larger; loract. luose. - I ry soil, southern N. Y. to E. Penu.

* * Calyx bilabiate (3 upper teeth united), the teeth and the tips of the loose bracts not rigid: Howers in dense flattened glomerate cymes: leares thin, mostly serrate, petioled, the uppermost more or less canesrent.

8. P. Túllia, Benth. Leares greener and lowely soft-domy, only the floral ones whitened, otherwise resembling those of the next; romes dense; mots nueh surpassing the flowers, their long awn-like points and the arnpointer ealyx-teeth bearden with long loose hairs. - S. Va. and N. C. to Tenn. ind Ga.

9. P. incànum, Michx. Leaves orate-oblong, acute, remotely toothed, coun!y above und mostly horr!y with whitish wool undemeath, the uprermost whitrned both sides; rymes open; bracts linear-awl-shaped and, with the calyx-teeth, more or less awn-pointed. - N. Eng. to Ont. and Ind., sontli to Fla. and 'Tex. **** Calyx equally 5-toothed; hearls fiu, large and globose (terminal and in the "1]m" urils of the thin petioled leaves); bracts loose, eiliate-bearded.

10. P. montanum, Michx. Stem $\left(1-3^{\circ}\right.$ ligh $)$ and ovate-or oblonglanceolate scruate leaves glabrous; hracts very acnte or awl-pointed, the sutermost orate and leaf-like, the inner linear; teeth of the tubular calyx slort and

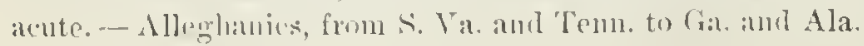




\section{ORÍGA N U M, 'Tourn. WiLd Marjoray.}

Calyx orate-lyell-shaped, hairy in the throat, striate, j-toothed. Tube of the rorolla about the length of the calyx, 2 -lipped; the "yper lip rather erect and slightly notched, the luwer longer, of 3 nearly equal spreatling lobes. Stamens 4, exsertecl, direrging. - l'erennials, with nearly entire leaves, aud purplish flowers crowderl in cylindri'al or oblung spikes, inbricated with colored loracts. (An ancient (ireek name, composed uf upos, "monntrin, and gávos, delight.)

O. vectinl, L. Cpright, hairy, corymbuse at the summit; leares petioler, round-orate; Lracts orate, oltuse, purplish. - Roadsides, Atlantic States. June-Oct. (Nat. from Eu.)

\section{TH Y M U S, 'Tourı. 'ThYмe.}

Calyx ovate, 2-lipper, 13-nerved, hairy in the throat; the upper lip 3-toothed, spreading; the luwer 2-cleft, with the awl-slaned divisions ciliate. Corolla short, slightly 2-lipped; the "1’er lip straight and flattish, notched at the apex, the lower 3-cleft. Stamens + , straiglit and distant, nsually exserted. - Low perPnnials, witl small and entire strongly-veined leaves, and purplish or whitish Howers. ('T'he ancient Greek name of the Tlyyme, probably from $\theta \dot{v} \omega$, to burn perfume, beeanse it was used for incense.)

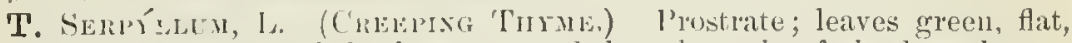
ovate, entire, short-petioled; flowers erowled at the ends of the branelies. (1) fields, E. Jiss. to Penu. (Adr. from Eur.)

\section{SATUREIA, Tom'll. Sivorr.}

Calyx bell-shaped, 10 nerv col, "rpally-5-toothed, naked in the throat. Corolla a-lipped; the upper lip erect, Hat, nearly entire, the lower 3 -eleft. Stamens 4 , somewhat ascending. - Iromatic plants, with narrow entire leaves, often clustered, and somewhat spiked purplish Howers. (The aucient Latin namo.)

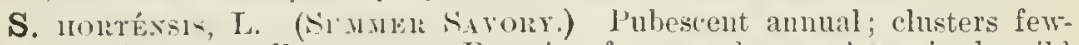
Howered; bracts small or none. - Escaping from gartens and sparingly wild in ()hio to 11l, ete. (Adv. from En.)

\section{CaId i íntha, Tourn. Calamint,}

Calyx tubular, 13-neverl, mostly lairy in the throat, 2-lipped; the upper lip 3-rleft, the lower 2-cleft. Corolla with a straight tube anrl an inflated throat, distinctly 2-lipped; the upper lip crect, Hattisli, entire or notehed; the Iower sprealing, 3-parterl, the midcle lube usually lingest. Stamens +, mostly ascending; the anthers lusully approximate in pairs. - l'erennials, with mostly furplish or whitish flower's, prorluced all summer: inforeseence rarious.

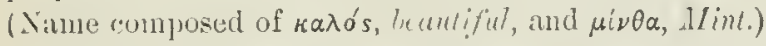

$\$ 1$. Flowers loose, without lony-subulate bracts; caly $x$ villous in the throut.

* Pubescent; peduncles short but mostly distinct; bracts minute.

C. Néreta, Link. (B.sil-TuymL) Soft-hairy; stem ascending ( $1-3^{\circ}$ liimli) ; leaves petioled, broally orate, oltuse, crenate ; corolla (3" long) twice the length of the calyx. - Dry waste grounds, Md, to Ark. (Nat. from Eu.)

* Glabrous or nearly so; common peduncles lardly any; pedicels $\mathbf{1 - 5}$, slender, the conspicuous uracts subulate-acuminatc; on ret limestone river-lank.s.

1. C. glabélla, Benth. Smonth; stems diffüs ar sprending (1-20 long); leaves slightly petioled, oblong or bhlong-linear, narrowed at hase ( $\Sigma^{\prime \prime}-2^{\prime}$ long), sparingly toothed or nearly entire: (dusters $3-5$ Howered: (mollit (purplish, $6-6^{\prime \prime}$ long) fully twice the length of the calyx-s. low , lir., and Tenn 
2. C. Nuttàllii, Gray. Smaller; the flowering stems more upright (5-9' high), with narrower mostly entive leaves and fewer-fowerent lusters, while sterile runners from the base bear ovate thickish leares only 2-5" long. (C. glabella, var. Nuttallii, Gray.) - Niagara Falls to Mimu., suth to Mo. and 'T'ex.

\$2. Flowers in sessile dense many-fowered clusters, and involucrate with conspicuous setuceous-subulute rigid lracts; culyx neurly nuked in the throut.

3. C. Clinopodium, Benth. (B.sir.) Ilairy, erect $\left(1-2^{\circ}\right.$ lighh); leares orate, petioled, nearly entire; flowers (pale purple) in gluhular clusters; hairy hracts as long as the calyx. - Border's of thickets and fields, naturalized exteusively, but indigenous from the Great Lalkes to the liocky Mts. (Lu., Asia.)

\section{MELISSA, L. Ван\}.}

Calyx with the upper lip flattenerl and 3-toothed, the lower 2-cleft. Corolla with a recurver-ascending tube. Ntamens 4, curved and conniving under the upper lip. (Itherwise nearly as Calamintha. - ('lusters few-flowered, lonse, une-sided, with few and mostly ovate buacts resembling the leaves. (Name from $\mu \epsilon \operatorname{c} \sigma \sigma \alpha$, a ber: the flower's yelling abuudance of honey.)

M. offcixiss, L. (Commox lidsu.) Upright, brancling, peremnial, pubeseent; leaves hroadly orate, crenate-toothed, lemon-scented; corolla nearly white. - Sparingly escaped from gardens. (Nat. from Eu.)

\section{H E DEÒMA, Pers. Mock Pinnyroyal.}

Calyx ovoid or tubular, giblons on the lower side near the base, 13-nerved, hearded in the throat, 2-lipped; upper lip 3-toothed, the lower 2-cleft. (o. rolla 2-lipped ; upper lip erect, flat, notched at the apex, the lower spreading, 3-cleft. Fertile stamens 2; the upper pair reduced to sterile filaments or wanting. - Low, odorons ammals, with small leaves, and loose axilary clusters of flowers (in summer), often forming teminal leafy racemes. (Altered fron $\dot{\eta} \delta v o ́ \sigma \mu o \nu$, an ancient name of Mint, from its sweet scent.)

* Sterile filaments manifest; leaves oblong-ovate, petioled, somewhat serrate.

1. H. pulegioides, Pers. (Americix Pexwreral.) Erect, branching, laairy; whorls few-flowered; upper calyx-tenth triangular, the lower setaceots-subulate; corolla (bluish, pubescent) scarcoly exiserted ( $2-3^{\prime \prime}$ long); taste and odor nearly of the true Pennyroyal (Neutha I'ulegium) of Europe.Common from N. Lug. to the Dakotas, and sonthward.

* * Sterile filuments mimute or obsolrte; Irates norrou, entire, sessile or neurly su.

2. H. híspida, Pursh. Mostly low; leures linere, crouded, almost gher-

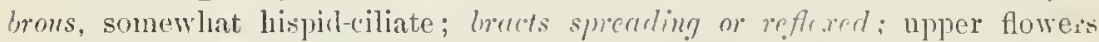
rather crowded ; culy,r-fefle all sululute, crualling the hluish corolla. - l'lains, Minn. and Dak. to W. Tll. and La.

3. H. Drummóndi, Bentlı. Pubeseent or pulerulı', a span or two lighl]; leares oblong to linear; bracts mosily erect; calyx hilsute or hispid, its teeth at length comnivent, the louer nearly twice as long as the upper. - Central Neb. and Kinl. to 'Tex., and westward.

\section{SÁ LVIA, L. SAGE.}

Calyx 2-lipperl; upper lip s-tontled w. entire, the lower 2-cleft. Corolla

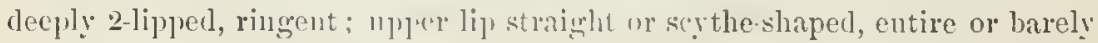


notched, the lower spreading or pendent, 3-lobed, its middle lobe larger. Stamens 2, on short filaments, juinted witl the clungated transverse eomnective, wre end of which, ascending under the upper lip, Lears a linear l-celled (half-) anther, the other, usually descending, bear's an imperfect or deformed (half-) anther or none at all. - Flower's mostly large ind showy, in spiked, racemerl, ur panicled whorls, produced in summer. (Nane from saleo, to save, in allusion to the reputed healing qualities of Sage.)

* Both anther-cells pollinifurous ; lenees mostly lyrately lobed or pinnatifid.

1. S. lyràta, L. (LYRE-LEAven S.LGL) Low peremial (10-20' high), somewhat hairy; stem nearly simple and nakel ; loot-leares lyre-shaped or sinuatc-pimatifil, smutimes almost entire; those of the stem mostly a single pair, smaller and narower; the floral oblong-linear, not longer than the calyx; whorls loose and distant, forming an interupted raceme; upper lip of the blue-puryle pubescent corolla (nnarly I' lomg') short, straight, not vaulted.

- Woodlands and meadows, N. J. to Ill., sonth to Fla. and Tex.

* Lower anther-cell wanting; the sterile cnds of the connertires mostly united.

t- Caly $x$ obscurely bilubiate; corolla 8 - 12"long, with mominently exserted tulie.

2. S. azùrea, Lam., var. grandiflòra, Benth. Cinereous-puberulent, $1-5^{\circ}$ higll; lower leaves lanceulate or ublung, obtuse, lenticulate or serrate, tapering to a short petiole; njper narrower, often linear, entire; inflorescence spike-like, tomentuluse-sericeous ; calyx-teeth short, the hroal npyer lip entire; eorolla deep blue (varying to white). - L. Neh. to Miss., 'Tex., and Col. $4-+$ Calyx deeply bilabiute; corolla $4-6$ "long, the tube hardly at all exserted.

3. S. lanceolàta, Willd. Puberulent or nearly glabrous, 5-12' high; leaves lanceolate or linear-oliony, irregnlarly serrate or nearly entire, tapering to a slender petiole; inflorescenee rirgate-spiciforn, interupted; upper lip of calyx entire, lower 2-cleft; corolla blue, $4^{\prime \prime}$ long, litle exserfed; style glabrous or nearly so. - l'lains, Iowa and Neb. to 'T'ex. and Ariz.

4. S. urticifòlia, I. I'illous-pulescent and someuhat viscid, or glabratc, 1-2o high; leures conrsely serrate, orate, with truncate or cuneate buse decurrent into a winged petiole; inflorescence racemosc-spieate, of mumerous listant clusters; calyx-lips divergent, the upper 3-toothed, lower 2-cleft; corolla blue and white, $5-6$ " long, twice the length of the culy.x; style strongly bearded. Woodlands, Md. to ky., south to Ga. and La.

S. Scldies, L. (Ch.lix.) Villous pubescent, riscid, stout, $2-30$ high ; leaves ample, long-petioled, ovate and cordate, crenate, rugose; the floral forming hracts of the spike, tinged with white and rose-color; corolla white and bluish, lather linge, the lung npper lip falcate and compressed. - Es(apel from gardens, P'enn. (Nat. from En.)

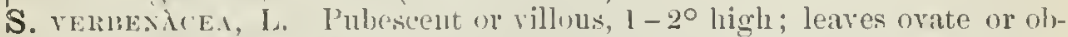
loner often enrlate at base, mustly simate-incised or moderately pinnatifid, the lobes crenate-tootherl, rusose; the few canline mostly sessile, the flom

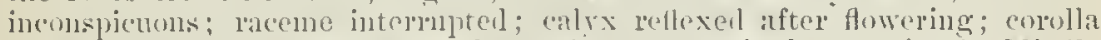
hluish, small, the upper lip neally straight. - Sparingly seen in the Midhle States. (Niat. from lin)

\section{MONÁR D A, L. HoRsh-Jist.}

Calyx tuhular, elongated, 15 neved, nearly equally 5-toothed, usually hairy in the thront. Corolla elungatod, with a slimbtly expanded throat, and a 
strongly 2-lipped limb; lips liuear or oblong, somewhat equal, the upper erect, entire or slightly uotched, the lower spreading, 3 lobed at the apex, its lateral lobes ovate aud obtuse, the middle oue narrower and slightly notched. Stamens 2, elougated, ascending, inserted in the throat of the corulla; anthers linear (the diraricate cells confluent at the junctiou). - Odorons erect herbs, with entire or toothed leares, and pretty large flowers in a few whorled hearls. closely surrounded with bracts. (1)edicated to Nicoles Monardes, autlor of many tracts upon medicinal and other useful plants, especially those of the New World, in the latter half of the 16 th century.)

* Stamens and style exserted beyond the linear straight acute upper lip of the corolla; heads solitary and terminal or sometimes 2 or 3 ; leuces acutely more or less serrate; perennials.

+ Leares petioled; caly $x$-teeth scurcely longer than the width of the tube.

1. M. dídyma, I. (1)swego TEA. Bee-Batr.) Somewhat hairy (20 high), acutely 4-angled; leaves orate-lanceolate, acumiuate, the florcl ones und the large outer bracts tinged with red; calyx smooth, incurced, nearly nuked in the throut; corolla smooth (2' long), bright red, slowy. - Moist wuods by streams, N. Eug. to Mich., south to Ga. in the mountaius. July-Aug.

2. M. clinopódia, L. Neatly glabrous to villous-pubesceut; leaves orate-lauceolate aud ovate; bructs whitish; calyx moderately hirsute in the throat; corolla slightly pubescent (1'long), dull white or flesh-colored. - Shady places, ravines, etc., Ont. to Ill., and along the mountains to Ga.

3. M. fistulosa, I. (WiLn Benganor.) Smoothish or downy, 2-50 high; leares orate-lancoulate, the uppermost and outer bracts somewhat colored (whitish or purplish); rulys slightly curved, erry hairy in the threat: rorolla ( $\mathrm{l}^{\prime}$ long or more) purple or purplish clotted, smooth or hairy - 1)ry soil, Vt. and E. Mass. to Fla., and far westward. Very rariable; the following are the more markel forms. - Var. Rùnsa, Gray, Corolla bright crimson or rose-red; habit of $n .1$, but npper lip of corolla villons-bearded on the back at tip; throat of calyx with the outer bristly hairs widely sprearling. In moist ground, Alleghany Mts. - Var. xìmL, Gray. Corolla deep purlute. Alleghany Mts. - Yar. sócurs, Benth. Corolla flesh-color to lilac, glanchular, its npper lip lairy outside or more bearded at the tip ; leares paller, softmbescent beneatlı; throat of calyx mostly filled with rlemse hearl, with sometimes au outer row of bristles. Fxtends to Miuu. and westrart.

+ + Leaves nearly sessile; calyr-teeth elongated, lax: houd sulitury.

4. M. Bradburiàna, Beck. Leaves clothed with long soft liairs, er." "ially underneatli; the floral and the outer hracts somewlat herit-shaperl, purplish; raly smoothish, contracted ahore, vely hairy in the throat, with awl-shaped awned teeth; corolla smonthish, hearded at the tip of the nperer lip, searcely twice the length of the calyx, pale-purplish, the lower lip rlotted " ith pnrple. - Thickets, Jur. to 'Tenu. and Kaus.

* Stamens not exceeding the jalcute upper lip of the short rorolla ; leads aritlary or interrupled sprirate: leaves lancealute or oblong, spursely serrate. lupering into the putiols.

5. M. punctàta, I. (Ilonsk-Mist.) Peremial, minntely dowuy

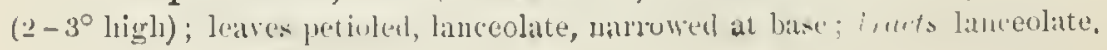


blunt, obtuse at hase, sessile, yellowisl and purple; teeth of the downy calyx short and armless, rigirl, soon spreading; corollat nearly smooth, yfllorish, the uper lip spotted with pur/le, notched at the apex, the tuhe scarcely exceeding the calyx. - Sandy gromnd, X. Y. to Minu., south to Fla. and Tex.

6. M. citriodora, Cerv. Innuel, $1-3^{\circ}$ ligh; bracts narrowly oblong, their slender utwed tipss spreading or recurving; calyx-teeth slender, at length usually sprealing; corolla white or pinkish, not spolted. - Veb. to Tex.

\section{BLEPHÍLIA, Raf.}

Calyx oroid-tubular, 13-nerved, 2-lipped, naked in the throat; upper lip with 3 awned teetl, the luwer with 2 nearly awnless teeth. Corolla inflaterl in the throat, strongly aud nearly equally 2-lipped ; upper lip erect, entire, the luw er spreading, 3-cleft, its lateral lobes ovite and rounded, larger than the oblong and notched midtle one. Stamens 2, ascending, exserted (the upper pair minute or none); anthers, ete., as in Monarka. - Perennial lierbs, with nearly the foliage, etc., of Monarlat the small pale blnisli purple flowers crowlect in axillary anl teruninal globose whorls; in summer. (Name from $\beta \lambda € \phi \alpha \rho / s$, the ryslash, in relerence to the hairy-fringed bracts and calyx-tecth.)

1. B. ciliàta, liaf. Somewhat downy $\left(1-2^{\circ}\right.$ high $)$; leaters almost sessile, ollong-ocate, narrouced at base, whitish-downy underneath; ontel bracts oratr, acute, eolored, eiliate, ans long as the ealyx; corolla lairy. - Dry open places, Mass. to Minn., sontlı to (ia. and lian.

2. B. hirsuta, Bentl. 'I'aller', hairy throughout; leaves long-petioled, orutr, prointed, rounded or heart-shaped at base; the lower floral ones similar, the npermost ant the birrts linedi-aul-shaped, shorter than the long-liaired calyx; eorolla smoothish, pale, with (larker pulple spots. - Muist sharly places, It. to Mlinn., soutl to Ga. and E. 'Tex.

\section{L O PHÁNTH US, Benth. Girnt IIrssop.}

Calyx tubular-bell-shaped, 15-11erved, oblique, 5-toothed, the upper teeth mather longer than the others. Corolla 2-lipperl; upper lip nearly erect, 2 loher, the lowel sonewhat sperealing, 3-cleft, with the micklle lobe crenate.

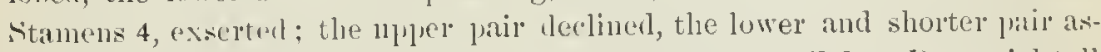
centing, so that the patins rosis; anther-eells nearly parallel. - l'ereminil tall lerls, with petioled serate leaves, and small flwers crowled in interupted

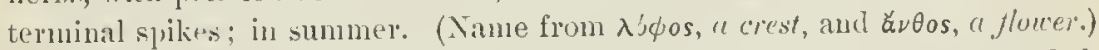

1. L. nepetoides, Bentl. Sitem stont, $2 \frac{1}{2}-6^{\circ}$ high, slın'ply 4-ingled, smooth, or nearly so) ; leaves urate, somewhat pointed, coarsely crenate-touthed $\left(2-4^{\prime}\right.$ long $)$; spikes $2-6^{\prime}$ long, eruwded with the orate pointed braets; caly.xtreth orute, vother obtuse, lithle shorter thren the pale greenish-yellow corolla. Burlers of wools, Vt. to Minn., sonth to $\mathrm{X}$. C. and Tex.

2. L. scrophulariæfólius, Benth. Stem (obtusely 4 -angled) and lower surfaee of the ovate or sonewhat lieat-shiped acute leaves more or less pubes cent ; caly:x-terth lancenlate, arute, shorter than the purplish corolla (spikes 4-15' long); otherwise like the last. - Sane range.

3. L. anisàtus, Bentlı. Smooth, but the orate aente leares glaucous white undcrneath with ninute down; relly retelh lancenlute, acute. - Plains, Wisc. to Minn., Neb., and westwarl. - Foliage with the scent of anise. 


\section{CEDRONÉLLA, Moench.}

Calyx rather ohliquely 5-tootherl, many-nerved. Corolla ample, expanded at the throat, 2-lipped; the upper lip flattish or concare, 2-lobed, the lower 3cleft, spreading, the midlle lobe largest. Stanens t, ascending, the lower pair shorter; anther-cells parallel. — Sweet-secnted perenululs, with pale purplish flowers. (Name a diminutive of cedrus, the cedir-tree, from the aromatic leaves of C. triphylla, the Bulm-of-Gileud of English garilens.)

1. C. cordàta, Benth Low, with slender rumers, hairy; leaves brondly heart-shaped, crenate, petioled, the floral shorter thau the calyx; whorls fewHowered, at the sumnit of short ascending stems; corolla hairy iuside (1 $\frac{1}{2}$ long); stamens shorter than the upper lip. - Moist shady bauks, W. P'eun. to Ky., south to the mountains of N. C. and Tenn.

\section{NÉPETA, L. CAT-MiNT.}

Calyx tubular, often incurved, olliquely 5-toothed. Corolla dilater in the throat, 2-lipped; the upper lip erect, rather concover, notched or 2-cleft; the lower spreading, 3-cleft, the midhlle lohe largest, either 2-lobed or entire. Stamens 4 , ascending nuder the upper lip, the lower pair shorter; anthers alpproximate in pairs, the cells divergent. - l'eremial licrls. (The Latin name, thought to be derived from Nepote, as Ltrurian city.)

$\S 1$. Cymose clusters rather dense and many-forcered, forming intorrupted spikes or racemes; upper ford leares small and bract-like.

N. Cataria, L. (Catxip.) Jowny, crect, linuehed; leares leeart-shaped, whlong, deeply erenate, whitish-downy undelnenth; comolla whitish, dotter with purple. - Near dwellings; a veiy common weed. July-sept. (Nat. from Lu.)

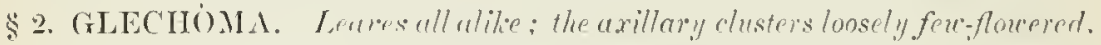

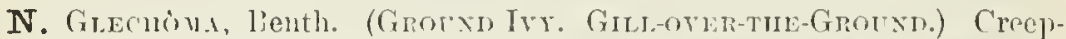
ing and trailing; leaves pretioled, rnund kidner-shaped, crenate, grech both sides: corolla thriee the length of the calyx, light linc. - Dimn or shady" places, common. (Nat, fron lỉn.)

\section{DRACOCEP H I U MT, 'T'ourn. DRAGON-HLAv.}

Calyx tubular, 13-15-11ered, straight, 5-toothed; the mpper tooth nsually mnch the largest. Corolla 2-lipjed: the upper lipslighty archerl and notched; the lower spreading, 3-cleft, with its millle lobe largest and 2-cleft or notcherl at the end. Stamens 4 , ascending moler the npper lip, the lower jrair shorter. anthers approximate by pairs, the cells divergent. - Whorls many-floweret, mostly spiked or capitate, and with awn-toothed or fringed leafy bract: (Name from $\delta \rho \alpha \kappa^{\prime} \omega$, a dragon, and $\kappa \in \phi a \lambda \eta^{\prime}$, herd, alluding to the form of the corolla in the original species.)

1. D. parviflorum, Nutt. Annual or biennial; stem erect, leafy ( 8 20' high); leares orate-laneeolate, sharply ent-tonthed, jetioled; whorls rrowded in a terminal head or spike; npper tooth of the ealyx ovate, nearly equalling the bluish small slencler corolla - Rocky or gravelly soil, northern N. Y. to Iowa and Minu., and westward.

\section{SCUTEILARIA， I. Skullap.}

Calyx bell-shaped in flower, 2-lipped; the lips entire, clnsed in fruit, the up

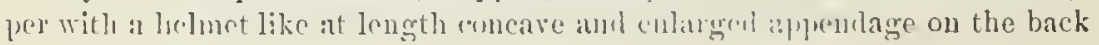


(the upper sepal); calyx splitting to the base at maturity, the upper lip usu. ally falling away. Corolla with an elungated curved ascendir:g tube, dilated at the throat, 2-lipped; the upper lip arched, entire or barely notched, the lateral lobes mostly connected with the upper rather than the lower lip; the lower lobe or lip sprealing and convex, uotcherl at the apex. Stamens 4, ascending under the njper lip); inther's approximate in pairs, (iliate or bearled, those of the lower stamens 1-celled (halved), of the uprer a-celled and heart-shaped. Bitter perential herbs, not aromatic, the slort peduncles or pedicels chiefly oplosite, l-Howerel, often I-sided, axillary or spiked or racemel; in summer. (Name from scutella, a dish, in allusiou to the appenclage to the fruiting calyx.)

\$ 1. Nutlets wingless, mostly marginless, on "low yynobase.

* Flouces snall ( $3^{\prime \prime}$ long), in axillury and sometimes terminal 1-sided racemes.

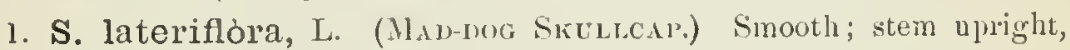
much branched ( $1-2^{\circ}$ high) ; leaves lanceolate-orate or vrate-oblong, jointed, coarsely serrite, rounded at base, petioled $\left(2-3^{\prime}\right.$ lung), the lower Horal ones similar; flowers lilue, rarely white. - Wet shaded places, common.

* Flowers larger (6-12" long) in terminal single or panicled racemes, the floral leaves yradually reduced to bracts.

- Stem-leaves all cordute, crenute-tuothed, slender-petioled; lateral lobes of the corolla almost equalling the short upper lip.

2. S. versícolor, Nutt. Soft hairy, the hairs of the inflorescence, ete., partly viscid-glandular; stem mostly erect $\left(1-3^{\circ}\right.$ high $)$; leures ocate or roundorate, very reiuy, rugose, the flural relucel to broadly vrate entire bracts about equalling the glanchular-hairy calyx; racemes mostly simple; eorolla bright blue with lower side and lip whitish. - Banks of streams, I'enn. to Wisc, Miun, and sonthward. - Var. sìxor, Chapm. Low, slender, and thin-leaved; flural leares small. - Monntains of Va., ete.

3. S. saxátilis, Ridlell. Cilabrous or slightly hairy; stem weak, ascending $\left(6-18^{\prime}\right.$ long $)$, often prodncing runner's, branched; leares ovate or orateuhlung (1-2' long), thin, obtuse; upper lnats obloug or ovate, small, entire; raceme simple, louse. - Moist sharled banks, Del. to Uhio, sonth in the mountains to Via. and 'Tems.

- + Stem-leares crenate-dentate or serrate (or nearly entire in 11.7 ), only the lowest if an! cordate at base, more or less petioled; laterul lobes of the blue corolla shorter than the galoute upper lip.

4. S. Serràta, Andrews. Green and nearly glabrous: stem rather simple (1-30 high $)$, with single loosely flowered racemes; leaves serrate, acuminate al bolle ends, wrate or orate-oblong; ealyx, etc., somewhat hairy; corolla $1^{\prime}$ long, nurvor, its lips equul in length. - Woors, I'enn. to Ill. and $\mathrm{N}$. C.

5. S. canéscens, Nutt. Sitem branched abuve $\left(2-4^{\circ}\right.$ ligh $)$, with the funicled muny-flowered rureme's, flowers, and the lower surface of the orate or lunce-orate acute (at the base achte, obtuse, or cordate) crenute leaves whitish with fine soft doum, often becoming rather glalorous; bracts oblong or lanceolate; corolla 8-9' long. - River-banks, Ont. and L'eun. to the mountains of N.C. and N. Ala., west to Kan. and Ark.

6. S. pilosa, Michx. Pubescent with spreading hairs; stem nearly simplo $\left(1-3^{\circ}\right.$ ligrh); lates rather distunt, crenate, ablong-orate, obuse vaving to 
romulish-orate, the lower abrupt or heart-shaped at base and long-petioled. the upper on short margined petioles, veiny; bracts oblong-spatulate; racennes short, often branched ; corolla $6^{\prime \prime}$ luny, mher narrow, the lower lip a little shorter. - Dry or sterile ground, southern N. Y. to Mich., sonth to Fla. and 'lex.

Var. hirsuta, Gray, is a large form (sometimes $3^{\circ}$ high), more hirsute, with larger very coarsely crenate leaves (2-3' long). - licher soil, liy.

Var. ovalifolia, Benth., is a form with shorter and finer pubescence, and narrower less veiny leaves. - N. J. to Va.

7. S. integrifolia, L. Downy all over with a minute hoariuess; steni commonly simple (1-2 high); leaves oblong-lanceolute or linear, mostly entire, obtuse, very short-petioled; corolla $\mathbf{l}^{\prime}$ long, much enlurged above, the ample lips pqual in length. - Dry ground, N. Eng. to Fla. and 'Tex.

* * Flourers solitary in the axils of the upper mostly sessile lenres, which resemble the lower ones but are occasionally reduced.

8. S. Wrightii, Gray, Firm and woody at hase, not stoloniferous no. tuleriferous, low, mauy-stemmed in a tuft, minutely cinereous-pubcruleut,

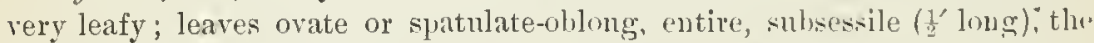
upper floral shorter than the flowers; corolla pubescent ( $\frac{1^{\prime}}{2}$ long), usually vinlet. - Kan. to Tex.

9. S. párvula, Michx. Herlaceous; subtermean stolons monilifo:mtulwifurous; minutely downy, dwarf $\left(3-6^{\prime}\right.$ high), branched and spreading: all lout the lower leares sessile and entire, the lowest round-orate, the other: urate or lance-ovate, slightly heart-sliaped $\left(6-8^{\prime \prime} \mathrm{long}\right)$; curolla $2-4^{\prime \prime}$ long. Sandy banks, IW. New Eng. to Minn., south to Fla. and 'lex. - Var. nóts. Gray, is more spreading, softly pubescent thronghout, with larger less firm leaves. - Sandy hanks, S. Ill. to Kan.

10. S. galericulàta, I. /lerbuceous; subterranean stolons not tuberif: erous; smooth or a little downy, erect $\left(1-2^{\circ}\right.$ ligh $)$, simple; leares oratelanceolate, acnte, serrate, roundish and slightly heart-shaperl at base $\left(l-Q^{\prime}\right.$ loug); corolla violet-blue, $s-9^{\prime \prime} \operatorname{long}$, with slender tube, the large lower lip' nearly erect. - Wet slady places; common especially northward. (Fu.)

\$2. Nutlets conspicuously winged, ench rised on a slender bus".

11. S. nervòsa, l'ursh. Simonth, simple or branched, slender, 10-20' high; lower leaves roundish, the midlle ovate, tootherl, somewhat heart-shaped ( $1^{\prime}$ long), the foral ovate-lanceolate, entire; nervo-like reins prominent heineath; corolla bluish, $t^{\prime \prime}$ long, the lower lip exceeling the concave upler one -Moist thickets, N. Y. to Ind, south to Va. and Mo.

\section{BRUNÉLIA, Tonrn. SELF-HEAl.}

Calyx tubular-bell-shaped, somewhat 10-nerver and reticulated-reiny, flattened on the upper side, naked in the throat, closed in fruit, 2-lipped; upper lip broad and Hat, truncate, with 3 short teeth, the lower 2-'left. Corolla ascendling, sliglitly contricted at the throat and lilated at the lower sile just beneatl it, 2-lipperl; upper lip erect, arched, entire; the lower reflexedsprealing, 3-cleft, its lateral lobes oblong, the milllle one romded, concave, denticulate. Stamens 4, ascending nuder the upper lip; filaments 2-toothed at the apex, the lowre tonth hearing the anther; anthers approxinate in pairs, 
tleir cells diverging. - low pereunials, with nearly simple stems, and \$-flowthol clusters of flowers sessile in the axils of round aul brut-like menbritnacoons floral leaves, imbricated in a close spike or hend. (Name sail to bo frum the German brume, a disease of the throat, for which this plant was a reputed remedy.)

1. B. vulgàris, L. (Commox SELF-IIEAL or IIEAL-ALL.) Leaves ovateablong, entire or tootlusl, petioled, hairy or smoothish; corolla (violet or fleshcolor, rarely white) not twice the length of the puxplish caly. fields, Newf. to Fla, Westward across the continent. June-Sept. (Eu.)

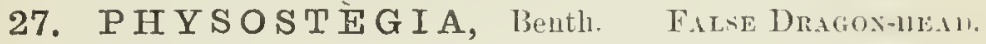

Calyx nearly rpully 5-toothed, obscnely 10-nerved, short-tubnlar or beellslaperl, more or less cularger and slightly inflated in fruit. Corolla funnelform, with a much inflated thruat, 2-lipperl; npper lip erect, nearly entire; the lower 3-parted, spreading, small, its middle lohe latrere, broud and rounded, notrlud. Stamens 4 , ascending muler the npper lip; anthers aplowimate; the eclls parallel - Smooth peremials, with unight wand-like stems, and sessile lanceolate no ololong mosty surrate leaves. Flowers large and slowy, rose or flesh-color variegated with purple, opposite, crowded in simple or

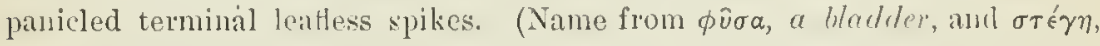
"s corering.)

1. P. Virginiàna, Bentl. Stem $1-4^{\circ}$ high, tcrminatel hy a simple virgate or several panicled spikes; leaves thickisls; caly $x^{\prime}$ fumlur-crmpomblute, as teeth half the lemplh of the tube; corolla l' long. - Wet gromuls, from N. Vt. west and sonthward. Varics greatly. - Var, Morrcilita, Gray. Slender and commouly low, with crenulate-denticulate or obscurely serrate leares, and slender or loosely-flowned spikes. - Midlle Atlantic States.

2. P. intermedia, Gray. Slender, 1-3 high, remotely leaved; leaves linear-lanceolate, repand-denticnlate; spikes filifor n, ratler remotely flowered; ralyx short and broadly campanulate, its teeth about as long as the tube; corolla $5-6 "$ long, much dilated upurard. - Burrens, W. Ky. and Ark. to La. and Tex.

\section{SY NÁ NDRA, Nutt.}

Calyx bell-shaper, inflated, membranaceous, irrogularly veiuy, almost equally 4-toother! Corolla with a long tube, much expanderl above and at the throat; the njper lip slightly arched, entire, the lower spreading and 3-cleft, with ovat loles, the milulle one broadest and notched at the end. Sitamens 4, ascencling tilaments hairy; anthers approximate in pairs uncler the upper lip; the two upler each with one fertile and one smaller sterile cell, the latter colls colsering together (whence the name; from $\sigma u \dot{v}$, together, ancl àvíp, for (inther).

1. S. grandiflora, Nutt. Hairy biennial, $1^{\circ}$ light ; lower leares longpetioled, hroadly orate, heart-shaped, crenate, thin, the floral sessile, gralually reduccl to bracts, cach with a single sessile flowcr' ; corolla $l_{\frac{1}{2}}^{\prime}$ long, yellowishwhite.-Shady bauks of streams, S. Ohio to Ill, and Tenn. In spring.

\section{M A R R Ù B I U M, 'Tourn. Horenow's}

Calyx tubular, 5-10-nerved, nearly equally $5-10$-tootled, the teetl more or less spiny-pointed and spreading at maturity. Upper lip of the corolla erect. 
notched, the lower spreading, 3-cleft, its middle lolse broadest. Stamens 4 , included in the tube of the corolla. - Whitish-woolly bitter-aromatic perennials, branched at the base, with rugose and crenate or cut leaves, and many-flowered axillary wholds. ( $\Lambda$ name of l'liny, from the Hebrew marob, a bitter juice.)

M. vulgane, L. (Common Iloremorxd.) Stems ascending; leaves romul-ovate, petioled, crenate-toothed; whorls capitate; calyx witl 10 recurved teeth, the alternate oues shorter; corolla small, white.- Escaped from gardeus into waste paces. (Nat. from En.)

\section{B A LL ÒT A, L. Fetid Horeiound.}

Calyx nearly funnel-form; the 10-ribbed tube expanded above into a sprearling regular border, with $5-10$ teetl. Anthers exserted beyond the tnbe of the corolla, approximate in pairs. Otherwise much as in IIarnbium. (The Greek name, of uncertain origin.)

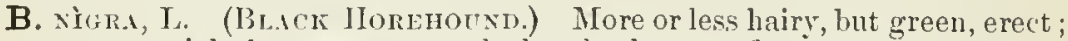
the root peremial; leaves ovate, toothed; whorls nany-flowered, clense; calvi. teeth 5, longer than the tube of the purplish corolla. - Waste places, N. Iing., Penn., ete. (Nat. from Lu.)

\section{PHI Ò IS, Tourn. Jerusaley Sigk.}

Calyx tuhular, 5-10-nerrerl, truncate or equally 5-tootherl. Lpper lip of the corolla arched; the lower sprealing, 3-cleft. Stamens 4, ascending and approximate in pairs under the npper lip; the filaments of the upper jair longer then the others in L'. tuberosa, with an anl-shaped appendage at base; anthercells divergent and confluent. - Lenves ruguse. Whorls dense and man-flowered, axillary, remotc, liracted. (An old Greek name of a woolly plant.)

P. Timkloss, I\% Tall perennial (3-5o high), nearly smontl : leares orateheart-shaped, crenate, petioled, the Horal oblong-lanceolate; bracts awl-shaped, hairy ; npper lip of the purple corolla densely bearded with white hairs on the insicle. - S. shore of Lake Untario, N. I. June, Jnl\% (Nat. from Lu.)

\section{LEON U R U S, L. Motherwort.}

Calyx top-shaped, 5-nerved, with 5 nearly equal teeth which are awl-shaped, and when old rather spiny-pointed and spreading. Luper lip of the corolla oblong and eutire, sonew hat arched ; the lower sprearling, 3-lobed, its midcle lobe larger, narrowly oblong-obovate, entire, the lateral ones oblong. Stamens 4 , ascending under the upper lip; anther's approximate in pairs, the valves naked. Nintlets truncate and sharply 3-angled. - Upright lerhs, with cut-lobed leaves, and close whorls of flower's in their axils; in sunmer. (Name from $\lambda \epsilon ́ \omega \nu$, a lion, :mil oủpá, tail, i. e. Lion's-tail.)

I. Cardiaca, L. (Commox Motmerwort.) Tall percmial; leares long. petioled, the lower rounded, palmately lobed, the floral wedge-shined at hase, :3-cleft, the lobes lanceolate; upper lip of the pale purple corolla bearded. IViste places, around dwellings. (Nat. from Lu.)

L. Markubúsıur, J. Tall biemial, with elongated branches; sten:laves oblong-ovate, conrsely toothed ; corolla (whitish) shorter than the caly'xteeth, the tube naked withia; lower lip ratler erect. - Roalsides, N. J. to I iel., and soutliward. ( $\Lambda$ dr. from Eu.)

L. Sinúlices, l. Tall biennial; leaves 3-parted, the divisions 2-5-cleft, or dceply 3-7-cleft and incised ; corolla (purplish) twice as long as the caly'x, the upper lip fornicate, the lower little surealing. - Waste grounds, l'enin.;

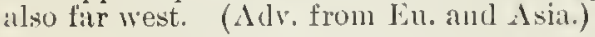

\section{I $\dot{A} \mathbf{M} I U \mathbf{M}$, L. I)EAD-NETTLE.}

Calvx tubular-hell-shaped, about 5-nerverl, with 5 ncarly equal awl-pointed

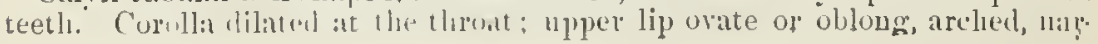


rowed at the base; the middle lobe of the spreading lower lip broarl, notehed at the apex, contracted as if stalked at the lase, the lateral ones small, at the margin of the throat. Stamens 4 , ascending under the upper lip; anthers approximate in pairs, 2-cellerl, the cells divergent. Nutlets truncite. - Deeumbent lierlos, the lowest leaves small and longr-petioled, the michle heart-shaped and doubly toothed, the floral subtenling the whorled Hower-chuster; spring to autumn. (Name from $\lambda a b$ ós, throat, in allusion to the ringent eorolla.)

* Annuals or biennials, lou ; flowers small, purple, in few whorls or heads.

L. AMPLEXICA ÙLE, I. Leaves rounded, deeply crenate-toothed or ent, the upper ones clasping; corolla elongated, upper lip bearded, the lower spotted lateral lobes truncate, - Rather common. (Nat. from Eu.)

L. PUnureum, I. Leares roundish or oblong, heart-shaped, erenate toothed, all petioled. - N. Ing. and Penn. (Nat. from Eu.)

$$
\text { * Perennial, taller ; flowers larger, in several axillary whorts. }
$$

L. Ámur, I. Haily ; leaves ovate, heart-shaped, petioled; calyx-teetl very slender, sprealing; corolla white, the tube curved upward, olliquely contracted near the base, where there is a ring of lairs inside; lateral lobes of lower lip bearing a long slendel touth, - E. New Eng. (Nat. from Eu.)

L. MACuLAтr 1 , L. Like the last, but leares more frequently marked with a white spot on the upper face, and flowers purplish, with the ring of hairs transverse instead of oblique. - Sparingly eseaped. (Adv, from liu.)

\section{GALEópsis, L. llemp-Nettee.}

Calyx tubular-bell-shaped, about 5-nerved, with 5 somewhat equal and spinytipped teetl. Cololla lilated at the throat; upper lip ovate, arched, entire; the lower 3-cleft, sprealing, the lateral lobes orate, the millle one inverselyheart-shaped; palate with 2 teeth at the simuses. Stamens 4 , ascending umler the upper lip; anther-cells transeersely 2-icaled; the imner valve of each cell hristly-fringed, the outer one larger and naked. - Anmuls, with spreading branches, and several - many-flowered whorls in the axils of foral leaves which

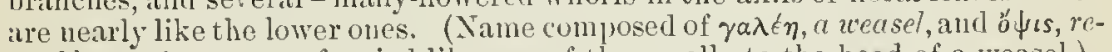
semblance, from some fancied likeness of the corolla to the head of a weasel.)

G. Tetramt, I. (Commox Hemp-Nettre.) Stem swollen below the joints. bristly-hairy: leaves ovate, coarsely serrate; eorolla purplish or variegated, abont twice the length of the calyx; or, in var. GRANDIFLòn, $3-4$ times the length of the calyx, often yellowish with a purple spot on the lower lip. Waste places, common. Aug., Sept. (Nat. from Eu.)

G. LÁnivi, I. (RED II.) Stem smooth or pubescent; leaves oblong-lanrevate, more or less downy; corolla red or rose-color (often spotted with yellow), much exceeding the calyx. - E. New Eng, rare. Aug. (Adv, from Eu.)

\section{STACHYS, Toum. Hiede-NetTle.}

Calyx tubular-bell-slaped, 5-10-nerverl, equally 5-toothed, or the upper teeth united to form an upper lip. (Corolla not lilated at the throat; upper lip) "rec or rather sprealing, olten arched, entire or nearly so; the lower usually longer and sprearling, 3-lohed, with the michlle lobe largest and nearly entire. Stameus 4 , asceurling under the upper lip (often reflexed on the throat after flowering); antlers approximate in pairs. Nutlets obtuse, not truneate.Whorls 2-many-flowered, approximate in a terminal raceme or spike (whence the name, from $\sigma \tau a ́ \chi v s$, a spike). Flowers purple or rose-red, in summer.

\section{* Root annual; stems decumbent, low.}

S. drrixsis, I. (Wornmont.) Hairy; leaves petioled, curlate-ovate, obtuse, crenate; whor]s $4-6$-flowered, distant; corolla (purplish) scarcel! longer thitu the Mnamed calyx. - Waste plaees, L. Mass. ( WW. frum Eu.) 
* Root perennial; stem erect.

+ Leaves obscurely or not at all cordate, sessile or short-petioled.

I. S. hyssopifolia, Michx, simooth and glutrons, or the nodes hirsute; stems slender $\left(1^{\circ}\right.$ lighh); leaves linear-oblong or nurrouly linear, sessile, ol, scurely toothed towarl the apex; whorls 4 -6-fowered, rather distant; corolla glabrous, twice or thrice the length of the triangular-awl-shaped spreading calyx-teeth, - Wet sandy places, Mass, to Mich., south to Fla. and MIo. - Tar. AMBfOCA, Gray, is stunter $\left(1-2^{\circ}\right.$ high $)$, sonetimes with scattered retrorse bristles on the angles of the stem, ancl with broader $\left(3-6^{\prime \prime}\right)$ serrulate leaves. - Ill, and Ky. to Gir.

2. S. palústris, l, Stem 4-angled $\left(2-3^{\circ}\right.$ liggh $)$, leafy, hirsute with spreading or reflexed hairs, especially on the angles; leares sessile, or the lower short-pecioled, oblong- or ovate-lenceolate, crenately serrate, rounded at hase, downy or hairy-pubescent, obtusish $\left(2-4^{\prime}\right.$ long), the upper floral ones shorter than the vearly sessile calyx; whorls 6 - 10-flowered, the upper crow - erl into an intermpte a spike; calyx lispirl; the lance-subulate teeth somewhat spiny, half the length of the corolla, direrging in fruit; upper lip of corolla pubesceut. - Wet ground, Newf. to l'enn., westward across the continent.

3. S. áspera, Michx. Taller; stem more commonly smooth on the sides, the angles beset with stiff reflexed lristlcs; leaves hairy or smoothishl, as in the last, but nearly all distinctly' petio'ed, the lower floral as long as the flowers: spike often slenler and more interrupted; culyx mostly glabrous, the tube rather narrower and the teeth more awl-shaped and spiny; corolla gluthons thronghout. (S. palustris, var. aspera, Groy.) - Wet ground, commun.

Var. glàbra, Cray. MIore slendes, smooth and ylabrous throughout, or with few bristly hairs; leares taper-puinted, more sharply toothed, mostly rounded or truncate at the base, all more conspicuously petioled. (S. palustris. var. glabra, Groly.) - Western N. Y. to Ill, and southward

$$
++ \text { Nearly all the leaves long-petioled and cordate. }
$$

4. S. cordàta, Riddell. Rather weak, hirsute, $2-3^{\circ}$ high; leares all (wate- or oblong-cor'late, acuminate, crenate $\left(2-5^{\prime}\right.$ long $)$, the floral mostlyminnte; spikes slenter, of ummerous few-flowered clusters; calyx only 2" long; corolla glabrous throughout (or nearly so), barely 5" long. (s. palustris, rall. cordata, Gray.) - Thickets, S. Ohio to lowa, south to Va., 'Temm. and Mo.

\section{()rder 83. I'LANTAGINACEAE. ('llaNtair Family.)}

Chiefly stemless herbs, with regular 4-merous spiked flowers, the stamens inserted on the tube of the dry and membranuceous reinless monopetalous corolla, alternate with its lobes; - chiefly represented ly the two following genera.

\section{PIANTAGO, Tourn. Plantaln. Ribwort.}

Calyx of 4 imbricated persistent sepals, mostly with dry membranaceous margins. Corolla salver-form or rotate, withering on the pod, the border 4 parted. Stamens 4, or rarely 2 , in all or some flowers with long and weak 
exserted filaments, and fugaciuus 2-celled inthers. Ovary 2- (or in 11 . 5 filsty $3-4$-) celled, with 1 - several orules in each cell. Style aud long hairy stigna -ingle, filiform. C'ipsule 2-celled, 2 -several-seeded, opening trausversely, su that the top falls off like a lid and the louse partition (which bears the peltate seeds) falls away. Embryo straight, in fleshy allumen. - Leaves ribberl. l'lowers whitish, small, in a bracted spike or head, raised un a naked seape. ('he Latin name.)

\$1. Stamens 4; flower's all perfect; curolla not closed orer the fruit.

* Flowers proterogynous, the style first projecting fiom the unopened corolla, the

anthers long-exserted after the corolla has opened: seeds nut hollowed on the face (except in P. lanceolata).

- Corolla glabrous; leates strongly ribbed; perenuial

+ribs of the broad leaces rising fiom the midrib.

1. P. cordàta, Lann. Tall, glabrons; leares heart-shaped or round-ovate (3-8' loug), long-petioled; spike at lengtlı loosely flowered; bracts rounclurate, flesly; ; apsule $2-4$-seeded. - llong streans, X. Y. to Minn., and sontlowarel.

++ Ribs of the leaf free to the contracted base.

2. P. major, L. (Commox Plaxtax.) smooth ol rather hairy, rarely l'onghish; lenes orate, oblong, ovel, or slightly hourtshaperl, often tootherl, abruptly uarowed into a chanuelled petiole; spike dense, oluzse; sepals round-

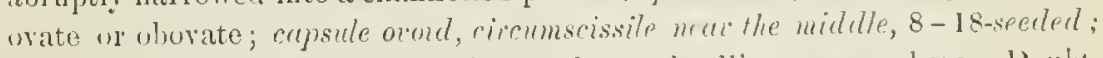
seeds amyled, retirulated. - Waysiles and near dwellings everywhere. Donht. lass introflucel from Eu., but native from I. Superiol and X. STinn., nurthward.

3. P. Rugélii, Decaisne. Teaves as in the last, but paler aud thimure; spritirs lomg and thin, attenuate at the upex: sepals oblong, acutely carinate; rapsules rylindraceous-oblong, circumscissile much beton the middle, 4 -9-seeded: serds oud-ollong, not reliculated. (P. Kamtschatica, Giru, Man., not Cham.) - Vt. to Minu., soutl to Ga. and 'Tex.

4 P. eriopoda, Torr. Usually a mass of yelloneish rool at the base: lenes thirkish, oblanceolute to oboute, with short stont petioles; spike dense or loose; sepuls and bract more or less scarions but not eariunte: cajsule orvid, weet weer 4-sceded. - Woist and saline soil; Reel River valley, Minn., and Westwald ; also on the Lower st. Lawrence.

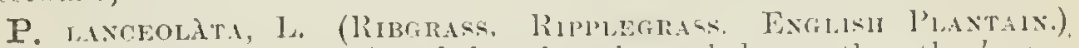
Mustly lairy; scape grooved-angled, at length much lomger than the lancer-

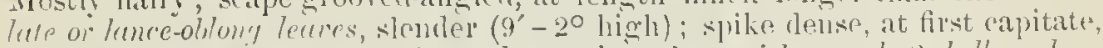
in age cylinducal; hract and sepuls scarions, bownish; secels 2, hollowed on 1h. fure. - Very common. (Nitt. from Eill.)

- Iniollutulie externally puliescent; leates linear or filform, fleshy, indistinctly ribbed: seeds 2-4; maritime, flten wooll!y at buse.

5. P. decipiens, Barneond. Annual, or sometimes biemulal with a stout

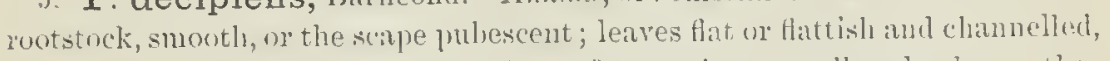
rect, nearly as loug as the scape $(5-12)$, acmminate; spike slender, rather !oose. (l’, maritima, rar. juncoides, Groy, Mau.) - silt mankhes, Itlautic

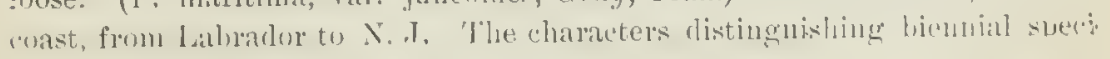
mede of this from the next are ubscure. 
6. P. maritima, L. Peremial; spikes dense-Coast of Mass.; Gulf of St. Lawrence to Lab. and Greenland. (Eu.)

* * Flowers of 2 sorts (as respects length of anthers and filaments) on different plants, mostly cleistogamous; coroll a-tobes broad, rounded, persistently spreading; seeds 2, boat-shaped; inflorescence and narrow leaves silky-pubescent or woolly; annual.

7. P. Patagónica, Jacq., var. gnaphalioides, Gray. White with silky wool; leaves 1-3-nerved, rarying from oblong-linear to filiform; spike very dense ( $\frac{1}{4}-4^{\prime}$ long), woolly; bracts not exceeding the calyx; sepals very obtuse, scarions, with a thick centre. - P'rairies and dry plains, Miun. to Ind., Ky., and Tex., westward to the Pacific. Very variable. - Var. xìn, Gray. with sparse and loose pmbescence, green and soon glabrate rigid leaves, and short bracts. - Var. sixuloss, Gray; a canescent form with aristately prolonged and rigid bracts. - Var. Anśrits, Gray; loosely haily and green, or becoming glabrous, with narrowly linear bracts $2-3$ times the length of the Howers. (Nat. on Martha's Vineyard, and about Boston.)

\$2. Flowers subdivecions or polygamo-cleistogumous; the corolla in the fertile (or mainly fertile) plant closed over the maturing capsule and forming a kind of beak, and anthers not exserted; sterile flowers with spreading corolla and long-exserter filaments; seerls mostly flat; small annuals or biennial.

* Leaves comparatively broud, short-petioled or sulsessile; stamens 4 .

8. P. Virgínica, L. Hairy or hoary-pubescent $\left(2-9^{\prime}\right.$ high); leaves ublong, varying to obovate and spatulate-lanceolate, 3-5-neved, slightly ou ('oarsely and sparingly toothed; spikes mostly deuse $\left(1-2^{\prime}\right.$ long); seeds usually 2. - Sandy grounds, s. New Eng. to S. Ill., sonth to Fla. and Ariz.

* * Cerres linerr or filiform; fowers rery small; stamens 2 ; spite slender.

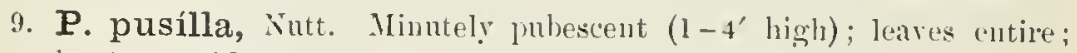
rolpsule short-ocoid, 4-seeded, little exceeding the calyx and bract. - silutly soil, sontheru N. Y. to Ya., west to the Rocky Mts. A pr.-Aug.

10. P. heterophýlla, Nutt. Leaves lather flesily, acute, entile, ur some of them helow 2-4twherl or tuotherl; cupsule oldong-conoidal, 10-28-seeded, nearly twice the length of the calyx and lract. - Low saurly gromul, l'enu to Fla. aud Tex. Apr.-.June.

\section{LITTORÉLLA, I.}

Flowers monocions; the male sulitary on a mostly simple naked seape, (aly 4 -parted, longer than the rylindraceous f-cleft cololla; stamens exserted on rery long capillary filanents. Female flowers usually 2 , sosite at thu base of the scape; caly of 3 wr + mucpulal sepals; conolla un-shapent, with a $3-4-$ touthel orifice. Ovaly with a single coll anct ovule, tipled with a long later. :lly stignatie style, matuling as an achene. (Name fromlitus or hitus, shore. from the plare of erowth.)

I. L. lacústris, I. Stoloniferous lut otluevise stemless; leaves terete.

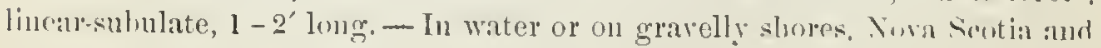
N. Banuswick, to J. Champlain (Promgle) aur Out. 


\section{DIVISION III. APETALOUS DICOTYLEDONOUS PLANTS.}

Corolla none; the floral envelopes in a single series (calyx), ol sometimes wanting altogether.

\section{Order 84. NYCTAGTNÀCEA'. (Fouri-o'clock Famltr.)}

Herbs (or in the tropics often slerubs or trees), with mostly opposite and entire leaves, stems tumid at the joints, a delicate tubular or funnel-form calyx which is colored like a corolle, its persistent base constricted above the 1-celled 1-seeded ovary, and indurated into a sort of nut-like pericarp; the stamens few, slender, and hypogynous; the embryo coiled around the outside of mealy albumen, with broar foliaceous cotyledons (in Abronia monocotyledonous by abortion). - Represented in our gardens by the Fourc'clock, or Marvei of Peru (Mirábilis Jalápa), in which the calyx is commonly mistaken for a corolla, the enp-like involucre of each flower exactly imitating a calyx.

1. Oxybaphus. Involucre of united bracts. Fruit wingless. Caiyx bell-slapled.

2. Abronia. Involucre of distinct bracts. Fruit 5-winged, Calyx salver-form.

\section{OXÝ BAPHUS, Vahl.}

Flowers $3-5$ in the same 5 -lobed nembranaceous broad and open inrolucre, which enlarges and is thin and reticulated in fruit. Calyx with a very short tube and a bell-shaped (rose or purple) decidnous limb, plated in the hut. Stamens mostly $3(3-5)$, hypogynous. Style filiform; stigma capitate. Fruit achene-like, several-ribbed or angled (pubescent in ours). - Herlss, ahounding on the westeru plains, with rery large and thick perennial poots, op posite leaves, and mostly clusterell small flowers. (Name ózvBáqov, a vinegur-saucer, or small shallow vessel; from the shatpe of the involucre.)

1. O. nyctagíneus, sweet. Nearly smouth; stem becoming repentelly forked, $1-3^{\circ}$ high; leaves all petioled (except the uppermost rerlurerl mies), from broadly orate to lanrelute, rounded or cordate or cuneate al luss ; intlorescence loose and hut slightly pubescent, the peduncles slencler (at first solitary in the axils); fru it ollong-oborate, 2" long, ratler acutely angled. — Miun. and Wise. to Tex. and La.; rare escape from garlens in L. Mass. and R. I.

2. O. hirsùtus, sweet. More or less glandular-lirsute, especially about the nodes aud the usually contraeted inflorescence, $1-3^{\circ}$ high ; leaves lanreo. late to linear-luncrolute, srssile and cuneate at base or narowerl to a short petiole; stamens often 5; fruit with thickened obtuse angles. - J'lains of the Sask. to Wisc., Iowa., N'eb., and 'Tex.

3. O. angustifolius, sweet. Often tall, glabons except the more or less hirsute peduncles and involucres; lenves lineur, thick and gulancons, often elougated (2-6' long); frut as in the last. - Nim. to 'Tex., anl westward.

\section{A B R Ò N I A, Juss.}

Involucre of $5-15$ distinct linets, enclosing numerous sessile flewers. Caly $x$ wher-form, with obcurlate lobes. Stamens 5), included, aluate to the (aly: $x$ -

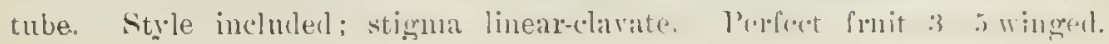


Fimbryo monocotyledonous. - Low herbs, with thiek opposite petioled unequal leaves, axillary or terminal peduncles, and showy flowers in solitary

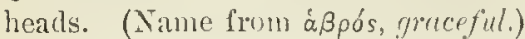

1. A. fràgrans, Nutt. More or less viscjl-pubescent, from a perennial rnot; leaves oblong or wate, truncate or cuneate at hase; involuere conspicnous, of lnoal orate white and scarious hracts; flowers white, fragrant, 4-10" long; fruit coriaceus, olpyramidal, with narrow undulate coarsely retieulated wings - From TV. lowa to Utah and N. Mex.

\section{Ordek 85. ILLECHBRACEAE. (KNotwokT FamLY.)}

Therts, with mostly opposite and entire leaces, sccrious stipules (except in Scleranthus), a $4-5$-loothed or -parted herbuceous or coriaceous persistent calyx. no petals, stamens borne on the calyx, as many as the lobes and opposite them or fewer, styles 2 and often uniterl, and fruit a 1-seeded utricle. Seud upon a basal funicle, the embryo (in ours) surroundiner the mealy albumen. -- Small diffure or tufted herbs, with small greenish or whitish flowers in elusters or dichotomous rymes.

1. Anychia. Stanens on the base of the 5-jarted awnless calyx. Styles barlly any.

"2. I'anyehia. Stanens on the base of the 5-parted calyx; the sepals hooded at the summit and bristle-pointed. Style 1, 2-cleft at the top-

3. Scleranthus. Stamens bome on the throat of the indurated 5 -c"left and pointless calyx. stylesi 2. stipules none.

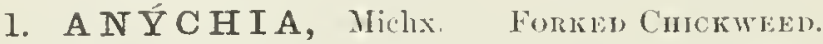

Sepals 5, scarcaly concave, inlistinetly muronate on the back, greenish. Sitamens 2-3, rarely 5. Stigmas 2, sessile. Ttricle larger than the ealyx. Radicle tumed downwall. - Small, many times forked annuals, with small stipules, ant minute Howers in the forks, produced all summer. (Wime deri vation as the next. genus.)

1. A. dichótoma, Michx. More or less pubescrm, short-jomled. lou and spreading; leares somewhat petioled, mostly very narrowly lanceolite or oblancenlate; flowers nearly sessile and somewhat clustered. - Mostly in ogen places, N. Eng. to Fla., west to Mimm. aur Ark.

2. A. capillàcea, DC. Sinooth, longer-juinted, slender and erect: leaces

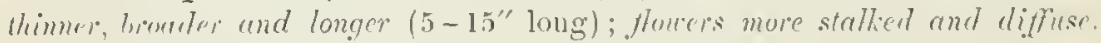
(A. riclotoma, var. capillacea, Torr.) - Dry worllands, same range as the last, but more abundant northward.

\section{PA RONÝCHIA, 'Tomm. W'mtLow-WorT.}

Sepals 5, lincar or oblong, concave, awner at the apex. Petals (or stannnodia) Indistle-form, or minute teetl, or nome. Situmens 5 . Sty.le 2-cleft at the apex. Utricle enclosed in the calyx. Riulicle ascending. - Tufted herlss (ours purnuil), with dry and silvery stipules, anl whstered flowers. (Crapk name for a whilow, ancl for a plant thought to cure it.)

1. P. argyrócoma, Nutt. liorning hroarl lufts, banched, sprcuding:

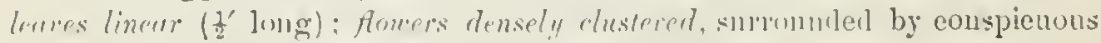

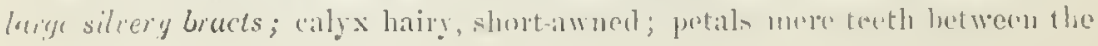


stamens. - Bare mountain slopes of the White Its., and in the Allegrlanies from Va. to Gat.; also coast of Maine and neal Newburyport, Mass. July

2. P. dichótoma, Nutt. Smooth, tufted; stems $\left(6-12^{\prime}\right.$ high) ascending

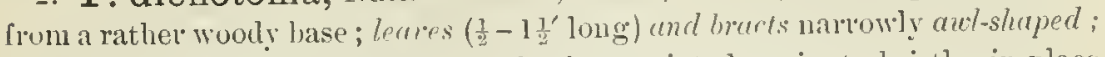
"ymes open, many-times forked; sepals short-pointed; minute lristles in place of petals. - liucks, IId. to N. C. and Tex. July-Sept.

3. P. Jamèsii, 'Torr. \& Gray. Subcespitose, mueh lranched from the smmewhat woody base, minutely pulierulent; leaves filifurm-subulate, ohtuse 11\% mucronate; forked crmes rather close; calyx narow-ampannlate with turbinate base. - Central Kan. to Wr. Neb., Col., and Tex.

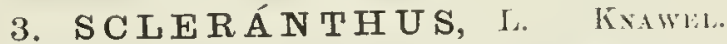

Sepals 5, mnited below in an indurated cup, enclusing the utricle. Stamens: 10 or 5. Sityles 2, distinct. - Homely little weerls, witl awl-shaped laves, obscure greeuish clustered Howers, and no stipuless. (Name from $\sigma \kappa \lambda \eta \rho^{\prime}$, hord, and \&utos, flouer, from the harlened ealys-tube.)

S. Áxuts, L. Muel branched, spreading $\left(3-5^{\prime}\right.$ high $)$; flowers seswile in the forks; caly:x-lobes scarcely margined. - Waste places. (Nat. from Fu.)

\section{Order 86. AMARAN'IACAA. (AMARANTH FAMII)}

Weedy herbs, with nearly the characters of the next family, but the flower: mostly inbricated with dry and scurious persistent bracts; these ofien colored, rommonly 3 in number; the 1-celled ovary in our genera 1-ovuled. ('The yreater part of the order tiopical.)

* Antlicro 2-cellecia ; flowers unisexual; leaves alternate.

1. Amarantus. Flower's monocious or polyganous, all with a ealyx of 3 or 5 distinct erect sepals, not falling wil' with the fruit.

$\therefore$ Acnida. Flowers diceions. Calgx none in the fertile flowers.

* * Intherr 1-rellent; flowers perfect; leaves opposite.

3. Iresine. Calyx of 5 sephls. Filanents mited helow into a eup. Flowers pauiculate.

Froelichia. Cillyx jecleft. Filiments united into it tules. Flowers spicate.

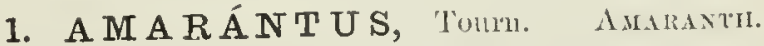

Flowers monacious or polyganums, 3-bratert. Calyx of 5 , ur sometimes 3 , frual ereet sepals, glabrous. Stanens 5 , rarely 2 or 3 , separate; anthers 2celled. Stignas 2 or 3 . Fruit an ovoid 1-seeded ntricle, $2-3$-beaked at the apex, mostly longer than the calyx, opening thansversely ur sometines burst-

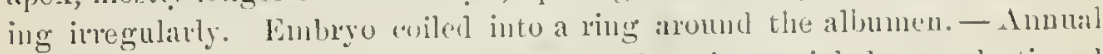
lleeds, of coarse aspect, with alternate aud cutive petiolol sutosely tipjerl leitres, ant suall green or purplish flowers in axillary or tominal spiked

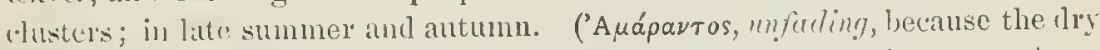
calyx and bracts do not wither. The Romans, like the Greerk, wrote Anurautus, which the early butanists incorrectly altered to 1 moromllus.)

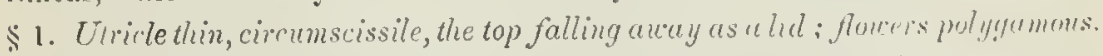
* loners in terminul and axillary simple or mostly panirled spilies: stem prow $\left(1-6^{\circ}\right.$ high $)$; leates long-petioled: stumens and sepuls :5.

- Ren Amariviss. Flowers and often leaves tinged with rimsm or purple.

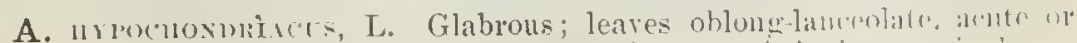

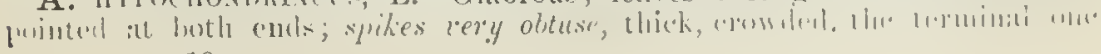


elongated and interrupted; bracts lony-auned; fruit $2-3-c l e j t$ wi the upex, longer than the calyx. - Rarely spontaneons about gardens. (Ad. from Trop. Amer.)

A. vixiculdus, L. Stem mostly pubeseent; leaves oblong-ovate or orate. lanceolate; sprikes mumerous and slender, punicled, erect or sprealing; lnucts "un-pointed; flowers small, green tinger with red, or sometimes crimson ; fruit $2-3$-toothed at the apex, longer than the ealyx. - livadsides, ete. (Adr. from 'Trop. Amer.)

\section{+ - Greex Amarantus, Pigwenn. Flowers green, rarely a litle reddish.}

A. RETroftéxrs, I. Ronghish and more or less pubescent; leaves dul green, loug-petioled, orate or rhombic-orate, unchlate: the thick spikes crowded in a stiff or glomerate panicle; lracts awn-pointed, rigid, exceeling the acute or obtnse sejals. - Cultivated grounds, common; indigenous southwestward. (Arlv, from Trop. Amer.)

A. culoróstachrs, Willd. Very similar, but smoother and decper green, with more slender, linear-cylindric, more or less thexnous spikes, the lat tral ones spreading or divaricate, aid the sepals more frequently acute or ancunate. (A. retroflexus, var. chlorostaclys, (bay.) - Cultivated grounds; alparentlyalso inligenous sonthwestwarl. - Var. nismuts, Watson, is sintar, but smooth aud still more loosely panicled. (A. retroflexins, var. lỵbridus, Ciray.) (Adv. from Trop. $\Lambda$ mer.)

* Flowers rrouded in close and small axillary clusters; stems lox, spreading or ascending; stamens and sepals 3, or the former only 2.

1. A. álbus, L. (Tumbl Wén.) Smooth, pale green; stems uhitish, erect or ascending, diffusely branched; leaves small, oborate and spatulateoblong, very obtuse or retuse; flowers greenish; sepals acuminate, lalf the length of the rugose fiut, much shorter than the suinlute rigid pnengently pointed bracts; secd small, gr" broud. - Wraste grounls, common.

2. A. blitoides, Watson. Iike the last, but prostrute or decumbent: spikelets usually contracted; brarts orate-oblomg, shorlly acuminale; sepals ol)tuse or acute; finit not rugose; seed uhout l" broud. - From Minn. to MIs. and 'Tex., and westward, and introducel catstwarl ats fill as western $\mathrm{N}$. I'.

A. Buìtum, L., resembles the linst, hut is usmally erect, with shorter and more scarions hratets, and a smaller seed more notclied at the hilum. - Near N. Y. City and Bostum. (Adr. from Eur.)

§2. Utricle thinnish, busting or imprevertly rimmscissite; fouers nonacious.

A. sıxoses, I. (Tumex Auskixm.) sumoth, Jushy-hianched; stem rechlish, leaves rhombicovate or ovate-lanceolate, full green, a par of spimes

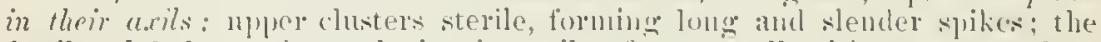
fertile grlubular and nustly in the axils: fowners yollowish-green, small. -

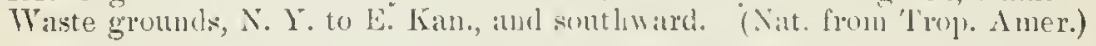

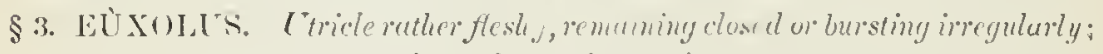
no spines; bracts incomsjucuous.

3. A. pùmilus, Raf. Low or luostrate; leaves fleshy and oborate, enarginate, strongly newed; flower-elusters small and axillary; stamens and seprls 5, the latter half the length of the whenerely 5-ribbed fruit. - Sambly beaches, R. I. tu Va.

A. 'tufup's, bram. Very slender, procumbent, pubesent; leaves small, light grecu, rhombic-ovate to -lancelate, acute, the marmin (risporl and undulate; flowers in small axillary clusters; luatets and sepals searums, ohlancen-

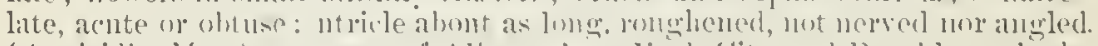

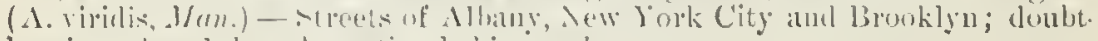
less introduced, but the native habitat unknown. 


\section{A CNİ D A, Mitch. Water-Hemp.}

Characters of Amarautus, except that the flowers are completely diœcious and the pistillate oues without ealyx. Bracts $1-3$, unequal. Staminate calyx of 5 thin oblong mucronate-tipped sepals, longer than the bracts; stamens 5 , the auther-cells united only at the niddle. Stigmas 2-5, often loug and plumose-hispit. Fruit somewhat coriaceous and inclehiscnt, or a thin membran. wns utricle dehiscing irregulary (rarely circumscissile), usually 3 -5-angled. (Name from a- privative, and $\kappa \nu$ í $\eta$, « nettle.)

\$1. ACNIDA proper. Fruit indehiscent, with firm and close pericarp.

1. A. cannábina, I. Lsually stout, $2-6^{\circ}$ high or more, grabrous; leaves lancenlate to linear-lanceslate, acmminate, long-petioled ; sepals of sterile flowers ovate-oblong, obtuse or acntish; bracts uslahly thin and lax, much

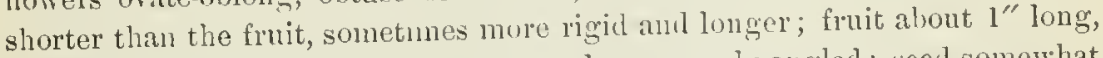
oborate, the pericarp rather thin, more or less rugusely angled; seed somewhat turgid, not angled, usually less than 1" loug, shiuing.- Salt or brackish marshes, coast of $\mathrm{N}$. Eug. to Fla.

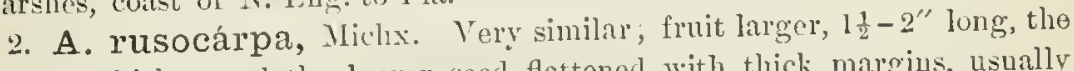
pericarp thicker, and the larger seed flattened with thick margius, usually thickest ou the cotyledouar side. - N. Y. (?) and Pem. to S. Car.; apparently much ress common than the last, though it is often difficult to positively distinguish the species from the immature fruit.

\$2. MONTELIL. Fruit dohiscing irregularly, the pericarp thin, loose and usually roughened; not salt-marsh plants.

3. A. tuberculàta, Mloq. Tall and erect, or sometimes low and decumbent; leaves lanceolate, acute or acutish or sometimes obtuse; sepals of sterile flowers lanceolate, acute or acuminate; pistillate flower's closely clusterel in more or less ilense naked or leafy axillary and terminal spikes (or the axillary: (apitate); hracts rather rigid, acumiuate, equalling or excecling the fruit: utricle about $\frac{1}{2}$ " long; seel slining, $\frac{1}{2}-\frac{1}{3}$ " in diancter. (Montelia tamariscina, Gray, in part.) - Uhio to S. Dak, Mo., Ala, and La.

Var. subnuda, Watson. Erect or often prostrate, the lower elusters at least of pistillate fluwers nore or less cy mose and often in glolonse heads; bracts thinner, narrow and lax, shorter than the fruit. (M. tamariscina, val. concatenata, Cray, in part.) - IV. Vt. (Oukes); Ont. to Minn., and sontluaril. Often appeariug quite distiuct from the type, but intermediate forms are not rare.

\section{I RES I N E, 1. Browne.}

Flowers nostly polyganous or diocious, 3-bracted. Calyx of 5 sepals. Stamens mostly 5; filaments slender, united into a short cup at base; anthers 1-celled, orate. Fruit a globular utricle, uot opening. - Herbs, with opposite petioled leaves, and minute scarious-white flowers, crowden into clusters or spiked and hranching panicles; the calyx, ete, often bearing long wool (wheuce

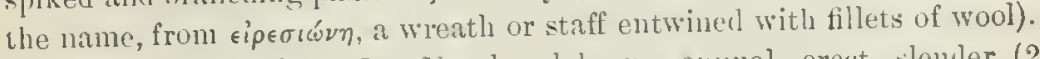

1. I. celosioides, L. Nearly glalıuus, ammal, erect, slender $\left(2-4^{2}\right.$ ligh); ieaves orate lanceolite; pancles very slender, often loroal and diffuse, naked; bracts and calyx silvery. white, the fertile calyx twice longer than the 
broad bracts and densely silky-s illous at base. - Dry banks, Ohio to Kan., and far southward. Sept.

\section{FROELÍCHIA, Monch.}

Flowers perfect, 3-bractel. Caly tululat, 5-clef at the summit, luelow $2-5$ crested lengthwise, w tulereled amb indurated in fruit, enclusing the indehiscent thin ntricle. Filaments unitet into a tube, bealling 5 oblong 1-celled anthers, and as many sterile strap-shaped appendages. - llairy or woolly herth with opposite sessile leaves, and spiked simous-brated fowers. (Named for . A. Froelich, a (ieman butiusist of the last century.)

1. F. Floridàna, Hoyuin, lioot annual; stem leatlens above $\left(1-3^{\circ}\right.$ light); leaves lancolate, silky-thwny beneath; spikelets ('worderl into an in-

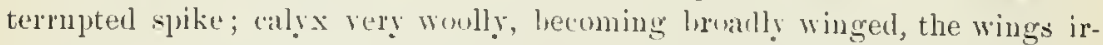
regularly tuothed. - Dry sauly places, s. Minn. to Ill., Col., Tex, and Flit.

2. F. grácilis, Moq. Nure slencler, with narrow leaves, the spikelets smaller, and the crests of the matured calyx of nearly distinct rigid processes. - Col. to Tex., and is reported from Kansas.

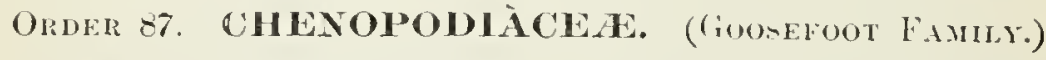

Chiegly herbs, of homely aspeet, more or less succulent, with maslly alternate leaves und no stipules nor srowious bracts, minute grewish flowers, wh the free calyx imbriculed in the lud, the stamens as many as ils lobes, or. occusionally fewer, and inserted opposite them or on their base; the 1-celled ovary becoming a 1-sceded thin utriclc or rurely an achene. Embryo coiled into a ring around the mealy albumen, when there is any, or else condupte cate, or spiral. - Calyx persistent, mostly enclosing the fruit. Styles or stigmas 2, rarely $3-5$. (Mostly inert or innow' wht, weedy plants: sereral are pot-herbs, such as Spinach and Beet.)

* Eubryo coiled into a ring about usually copions central allmmen. Leaves flat, not spiny. Stem not jointerl.

- Fowers perliect (or stumens only occasionally wanting), clustered or panicled; calyx

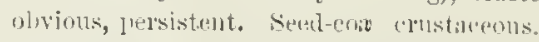

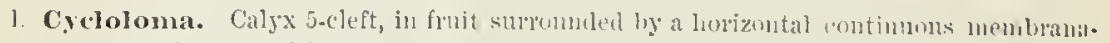
reous wing. Sem horizontal, crustacents, Lenves simuate-tootlexl.

2. Fischia. Like n, 1, but wing 5-lulen] and seed-coat memlnanaceous. Leaves entire.

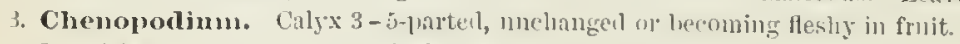

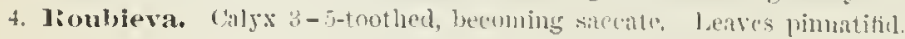

+ + Flowers monecions or diocions: the staminate melusters, mostly sprikenl : the pistil-

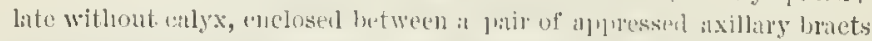

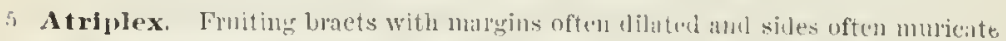

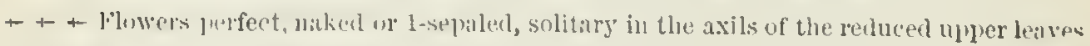

6. Coxispermum. l'ericurp oval, fattenel, nellepent to the vertical seed. Leaves linear.

* Emhrye nurowly horsesloe-slaped or conduplicate no albumen. Stem flesliy, jointed;

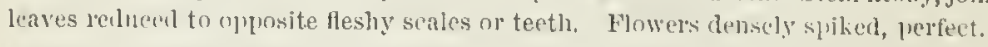

7. Salicornja. Flowers sumle in lollows of the axis of the fleshy spilie. Calyd utriele-lilie.

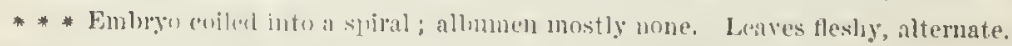

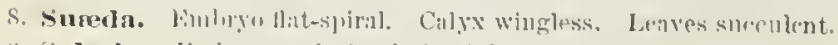

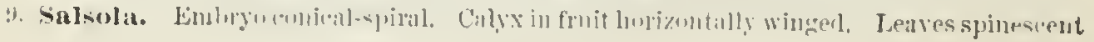




\section{CYCLOLÒMA, Juquin. Wisged Pigwed.}

Flowers perfect or pistillate, buactless. Calyx 5-cleft, with the cuncave lubes strongly keeled, enclosing the depressed fruit, at length appendaged with a broal and continums horizontal searions wing. Stamens 5 . Sityles 3 (rancly 2). Sced horizuntal, flat; cuats crustaceons. Embryo cheircling the mealy albumen. - An amnual and much-branched coarse herb, with alternate sinuite-tonthed petioled learce, and very small scattered sessile flowers in open

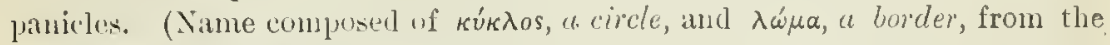
encircling wing of the (all $x_{\text {. }}$ )

1. C. platyphýllum, Ilopuin. - Diffuse $\left(6-15^{\prime}\right.$ high), more or lesis arachoid-pubescent or glabrate, light green or often deep purple. - Sandy soil, Minn. to W. 11l, S. Ind., Ark., and westward across the plains.

\section{KÒCHIA, Rotlı.}

Chamacters nearly ats in Cycloloma, lut the seed-coat membranaceuns and the all unmen wanting. - Anmals or suff miticuse peremnials, with Hat or more nsually linear and terete leaves. (Nimed for W. D. I. Kinh, a (ierman lotaluist.)

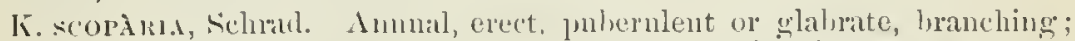
leaves narrowly lanceulate to linear; Huwers in small ixillary chusters, sessile, each sepal developing a thick wing. - Fiparingly introduced; V't., Out., and 11l. (Nat. from Lu.)

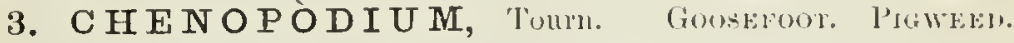

Elowers perfect, all bratless. Calyx 5-(rarely t-) parted or lobed, nuchanged in frnit or hecoming succulent and berry-like, more or less enveloping the depresserl fruit. Stamens nustly 5 ; filaments filiform. Styles 2, rarely 3. Seeel hurizontal or vertical, lenticular; the cuat crustaceous; embryo coiled latrty wr fully round the mealy illumen. - Weeds, usially with a white maliness, or glimelular. Flowers sensile in small cluster's collected in spiked

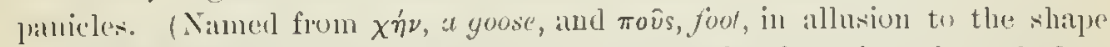
of the learves.) - (bur species are mostly anumals, fluwering thrumgh late summer an! antunı, growing around dwellings, in manted soil, cultivated gromnds, and waste places.

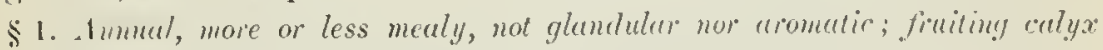
dry; seed horizontal; embryo a complete ring.

* Pericarp cery easily separuted from the seed; lentes entire or rartly sinuatedentate.

1. C. Bosciànum, Mloq. Erect, slender (20 lighly), lousely lranched,

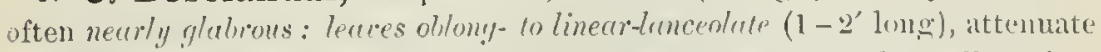
into a slender pride, acute, the lower sinuate-dentate or often all entire: flowers small, solitary or in small clusters npon the slender branchlets; culy. not strongly retrinute. (C. album, var. Busciaum, Gircey, Maunal.) - N. I. to Ninu, soutls to X. C. and Tex.

2. C. leptophỳllum, Nutt. Densely mealy or rarely nearly glabrons

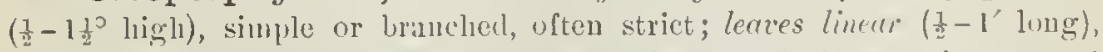
cutire, ruther shortly petiolch; fluwers clusely clustered, in dense or interrupted

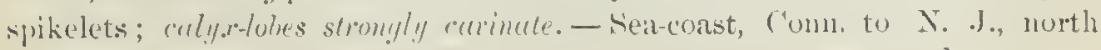
slure of L. Frie, and from s. l)ik, to Col, X. Mex, and westwarl. 
* Pericarp persistent upon the smooth seed; leaves more or less sinuateden. tate (except in C. polyspermum).

C. POLYspermun, I. Low, often spreading, green and wholly destitute of mealimess; leares all entire, oblong or uvate and on slender petioles; flowers very small, in slenter panicles in all the axils, the thin lobes of the calyx very incompletely enclosing the fruit; seerl obtuse-edgerl. - Sparingly naturalized in the Eastern States. (.1 lr. from En.)

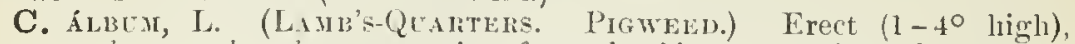
more or less mealy; leaves umying from rhombic-ounte to lanceolate or the uppermost even linear, acute, all or only the louer more or less angulute-toothed:

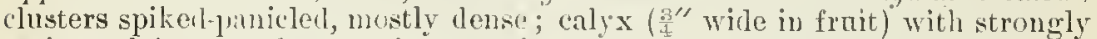
carinate lobes, uearly or quite covering the seed. - Introduccrl everywhere. (Nat, from Eu.) - Vir. Vínue, Moq., more common eastward, is less mealy and with less dense inforescence.

C. úrbicum, L. Rather pale or dull green, nearly destitute of mealiness, with ereet branches $\left(1-3^{\circ}\right.$ high); lecies triangular, acute, cortrsely and shuply many-toothed; spities cicet, wouded in a long and narrou rucemose punicle; calyx-lobes not keeled; sut with rounded maryins. - Ipparently throughont our range. (Nat. from Eu.)

C. mundL: L. Resembles the preceding, but less erect, loosely branched (1-2 $2^{\circ}$ high); leures rhomboid-rine, acute, coursely and shurply unernally torthed, thin, bright green; spikes or racemes diverying, somenturit corymbed: calyx-lobes searcely keeled; seed shorp-enlyet. - From N. Eng. to Mich. and Mo. (Adv. from lisu.)

3. C. hýbridum, I. (MAPL-LEAved Gooswfoot.) Bright green throughout; stem widely much branched (2-40 high); leares thin $\left(2-6^{\prime}\right.$ long), somewhat triamgular and heart-shaped, taper-pointed, simuate-angled, the angles extending into a fere large and pointed teeth; racemes diffusely and loosely panieled, leafless; calyx not fully covering the fruit, its lobes lieeled. - Indigenous from western N. Y. and liy., westward across the contiuent; introdueed eastwark.

\$2. Annual or peremial herbs, sonenhat mealy, not glandular-pubescent: fruiting culyx dry; seed lange, subglobose, vertical, exserted; embryo n complete ring.

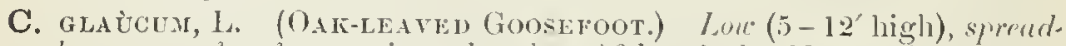
ing, glancous-mealy; leaces sinuately pinnatifid-tathed, oblong, olituse, pale green above; clusters in axillary spikes, small ; seed sharp-edged. - 'Throughcut our range and westward (Nat. from Er.)

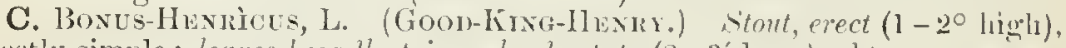
mostly simple; leaves broadly triangular-hastate (2-3' long), obtuse or acute, subsinute or entive; flowers somenhat dersely pumiculate? spiked; sepd with uhtuse edges. (Blitum Bonus-Henricus, Reichenb.) - Nparingly introlneerl. ( $\Lambda \mathrm{dv}$. from Eu.)

\$3. Annual, glabrous; calyx more or loss fleshy in finit and often colored, enclosing the utricle; seed mostly certical; embryo a complete ring; flowrrs in crowded chesters, axillary or in spikes.

4. C. rubrum, l. (Cosśr Burre) Stem angled, much branehed; leares thickish, triangular-lanceolate, tapering below into a wedge-slaped base and above into a slender point, sparingly and coarsely toothed, the upper linem-lanceolate; clusters scattered in axillary leaty spikes; culy $x$-lobes $2-4$, ruther fleshy; stamens 1-2 ; seed shining, the margin acute. (Blitum maritimum, Vutt.) - Sratcoast of Northern States, and in suline plaees to Minn. (En.)

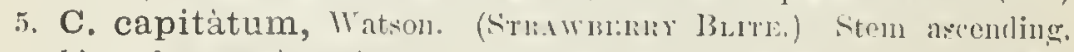
loraching; leaves triangulin and somewhat halberd-shaped, sinuate-toothed: 
slusters simple (large), interruptedly spiked, the upper leafless; stamens 1-5; culyx berry-like in fruit; seed oroid, flattish, smooth, with a very narrow margin. (Blitum (apitatum, $\left.L_{.}\right)$- Dry rich ground, along the Great Lakes, northward and westward. The calyx becomes pulpy and briglat red in fruit, when the large clusters look like strawberies. (Eu.)

\$. Annual, not mealy, but more or less glundular-pubescent, aromatic; calyx 2-3-parted, dry in fruit; seed often vertical; embryo not a complete ring.

C. Bòtrys, L. (Jerushlem Oak. Featmer Geranium.) Glandularpubescent and viscid; leares slender-petioled, oblong, obtuse, sinuate-pinnatifid; ruremes rymoss-rliverying, lonse, leafless; fruit not perfectly enclused. Widely introflucell. (Nat. from En.)

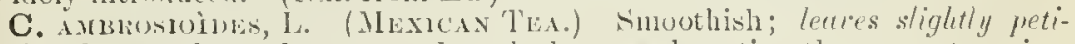
ded, oblong or lanceslate, repand-toothed or nearly entire, the upper tapering to both enits; spikes denvely flourered, leuf $\%$, or intermixed with leaves; frnit perfectly enclosed in the calyx. - Waste places, common throughout our range, especially southwarl. (Nat. from 'Trop. Amer.)

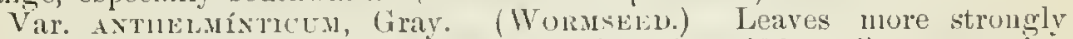
tootled, the lower sometimes almost laciniate-pinnatifil; spikes more elougated, moslly leafless. - From Long Island and sonthward, west to Wisc. and 'Tex. (Nat. from 'Trop. Amer.)

\section{ROUBIEVA, Moquin.}

Flowers minute, perfect or pistillate, solitary or $2-3$ together in the axils. Calyx urceolate, 3 -5-touthed, leconning enlarged and saccate, contracted at the apex and enclusing the fruit. Stancus 5, included; styles 3 , exserterl. Fruit membranaceuns, conly ressed, glandular-lutterl. Seed vertical. Embryo ammular. - P'ereunial glandular lerh, with alternate pimnatific leaves.

R. MLtTílDA, Moq. Prustrite or ascending, branching and leafy; leares lauceolate to linear $\left(\frac{1}{2}-1 \frac{1}{2}\right.$ long $)$, deeply pinnatifid with narrow lobes ; fruiting calyx obovate. (Cheuropolinns multificum, L.) - Sparingly iutroduced in the Arlantic States. (Adv. from $s$. Amer.)

\section{5. Á TRIPLEX, Tourn. Oracie.}

Flowers monocious or diccions; the staminate like the flowers of Chenopodinm, lut sterile ly the abortion of the pistil; the fertile consisting simply of a naked pistil enclosed hetween a pair of alpressed foliaceons bracts, which are enlarged in fruit, and sometimes united. Seed vertical. Embryo coiled into a ring around the allumen. In one section, including the Garden Orache, there are some fertile flowers with a calyx, like the staminate, but withont stameus, and with horizontal seeds. - Herbs (ours annuals) usnally mealy $w{ }^{\circ}$ seurfy with bran-like scales, with spiked-clustered flowers; in summer and sutumn. ('The ancient Latin name, a corruption of the Greek, ảrpápał̌s.)

A. rósern, I. Hoary-mealy; leares short-petioled or the upper sessile, rlombic-ovate or ohlung with a wedge-shaped base, coarsely sinnate-tuotherl; fertile flowers mostly clustered in the axils; fruiting bracts broad, olten chttoothed and warty. - Sparingly introduced at the east. (Adv. from kin.)

1. A. pátulum, L. Erect or prostrate $\left(1-4^{\circ}\right.$ lighl $)$, dlark green ancl glahrons or somewhat scurfy; leares narrowly lanceolate-hastate $\left(1-4^{\prime}\right.$ long), the lower sometimes opposite, entire or sparingly sinuate-lentate, petioled, the upper lanceulate to linear; flowers clustered in rather slender spikes, the two kinds tugether or separate; fruiting lowets ovate-triangular or rhombicbastate, entire or toutled, often muricate on the lack, mited to near the 
midclle. - Very variable. The typuical form scarcely occurs except as naturalized from Euroue.- Var, ustritru, Gray. Erect or spreading, stout, at luast the lower leaves broally triangular-hastate, often coarsely and irregularly toothed. Salt and brackish places, on the coast from Can. to Ya., along the Great Lakes, aud far Wesiwad. - Var. sirrondıe, Gray. Slender; leares linear-lanceolate to linear, rarely subhastate or toothed. Canada to X. J., and westwarl alomg the Great Lakes. - Var. susspcitr. Watson. A low erect and often simple form ( $3-12^{\prime}$ high), usmally quite s'urfy: leaves

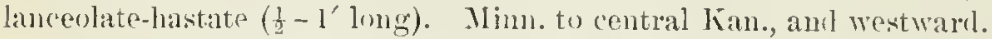

2. A. arenàrium, Nutt. Siliery-menly, diffusely sprending; leaves ol)long, marrwed at base, nearly sessilte: fruting bracts broadly werlge-shipherl, inited, 3-nerved, 2-5-toothed at the summit, and usually strongly muricate anc reticulate on the siles. - Sandy heaches, along the coast, Mass. to Fla.

3. A. argénteum, Nutt. I'sually low, much brancherl, gray-ecurfy, leafy; leaves deltoid or subhombic, often subhastate; staminate flowers in terminal spikes; froting bracts rombl-xhmbic, indurated, mited, the free margins more or less dilater and decply towthenl, the silles varionsly appendaged.-Red River Valley, Mimn., sonth and westwarl.

\section{CORISPÉR M U M, A. Jus. Bug-sen.}

Flowers perfect, single aut sessile in the axils of the upper leaves reduced to hracts, usuatly foming a spike. Calyx of a single delieate sepal on the inner side. Stamens 1 or 2, rarely 5. Styles 2. Fruit wal, Hat, with the whter face lather couvex and the imner concave, sharp-margined, a caryopsis, i. e, the thin pericarp adherent to the vertical seed. linbryo slender, coiled aromd a central alhumen. - I fow lumehing amuals, with marow linear alternate l-nerved leaves. (Nane furmed of kópıs, "lmy, and $\sigma \pi \varepsilon \dot{p} \mu \alpha$, sred.)

1. C. hyssopifolium, I. Somewhat hairy when young, pale; Horal leaves or hracts awl-shaped from a dilated lase or the upper ovate and pointed, scarious-margined; fruit wing-margined. - Sandy beaches along the Great Lakes, centual Yelo, Tex., and westward, - Leaves msnally pmugent.

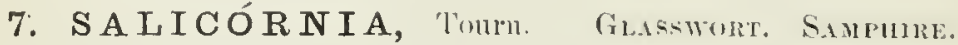

Flowers perfect, 3 togrether immersed in each hollow of the thickened "prer joints, forming a spike; the two lateral sometimes sterile. Calyx small aul bladder-like, with a toothed or torn margin, at length spongy and narrowly wing-lordered, enclosing the flattened thin utricle. Stanems 1 or 2. Styles 2 , nnited at base. Seed rertical, withont albumen. Embryo thick, the cotyletons incumbent upon the radicle. - Low saline plants, with sncenlent leafles. jointed stems, and opposite branches; the flower-benring branchlets forming the spikes. (Naune composed of sal, salt, and comm, a horn; silline plants with horn-like hranches.)

1. S. mucronàta, Bigel. Anmual, erect, stont, naked below (2-12' high), (uning rol in age; spikes thick, closely jointed; sedes mucronate-pointed ans :onspricums, uspecially when try; middle flower hulf higher than the lateral ones or less, wrulying nearly the whole length of the joint; fruit pulsescent; seed $\frac{1}{3}-z^{\prime \prime}$ long. (S. Virginiea, Groy, Manmal; nut l..) - Sea-coast from N. Scotia to Va. 


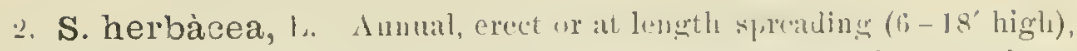

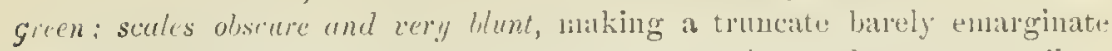
tormination of the longer joints of the stem or clonguled narouer spikes; mirklle flower much highel than the lateral ones, slighty shorter than the joint; fruit pubescent; seed $\frac{2}{3}-1$ "long. - Salt marshes of the coast aut interior salt springs, anul alkaline localities.

3. S. ambigua, Michx. Numerous tuftell stens (3-12 lung) decum. bent or ascending from a hard and rather woody creepiny luse or rootstock, grveenish, tuming leal-colored; spikes slender, shmt-jointed, the scules short, antish or ucute: flowers neurly equal in height and equalling the joint; seed pubescent, $\frac{1}{3} "$ lug. (S. fruticusi, var. ambigua, Gouy, Mlanual.) - Sea-coast, Mass, to Fla. and 'Tex.

\section{SU 市D A, Forskal. SEA 13LITl.}

Flowers perfect, sessile in the axils of leafy hracts. Calyx 5-parted, Heshy, enclosing the fruit (utricle) and often rarinte or crested, Stamens 5. Nitigmas 22 or 3. Sced vertical or horizontal, with a flat-spiral embryo, divirling the scanty allumen (when there is any) into two portions. - Fleshy waline plants, witl alternate nearly terete linear leares. (An Aralic name.)

1. S. lineàris, Noq. Ammal, prostrate or usually erect, l-20 high, branched; leates narrou at base, $\frac{1}{2}-2^{\prime}$ long, acute; foral bracts acmuninate, on slender branchlets; sepals very thick; anther's exserted; seed horizontal, rounl-oral, black, $\frac{1}{2}$ "broarl. (S. maritima, Gray; not Dumort.) - Sea-coast, N. Sootia to Fla. - A loubtful form of L. Mass. has the bracts and shorter leaves obtuse, larger flowers un less slender branchlets, ancl rechlish seeds nearly" l" hroal.

2. S. depréssa, Watson. Ammal, decumbent or erect, branching from the base ; lentes broudest at buse, the cauline 3-12" long, the flom lanceolate to orate; one or more of the calyx-lobes very strongly carinate or rrested. Saline soil, lied River Valley, Minn., to Col., and westward.

\section{SÁLSOLA, I. SALTWRT.}

Flowers perfect, with 2 bractlets. Calyx 5-parted, persistent and enclosing the depressed fruit in its base; its divisions at length horizontally winged on the back, the wings forming a broal and circular scarions border. Stamens mostly 5. Styles 2. Seed horizontal, without albumen, filled by the embryo, which is coiled in a conical spiral (cochleate). - Herbs or slightly shrubby hranching plants of the sea-shore, with fleshy and rather terete or awl-shaped leaves, anl sessile axillary flowers. (1)iminutive of salsus, salty.)

1. S. Kàli, 1. (Comuox SALTwort.) Annual, diffusely branching, bushy, rough or smoothish; leaves all altermate, awl-shaperl, pricky-pointed; flowers single; calyx witl the conrerging lobes forming a surt of beak over the fruit, the large rose or flo sh-colored wiugs nearly orlownlar and sprearling. - Sandy seatshore, X. Eug. to Fial. Aug. (Eu.)

\section{Order 88. PHYTOTA CCÁCAE. (POKEwEed FAMH.)}

Plants with allemate entire lewes and perfecl flowers, having the general characters of Clienopodiaces, bit usually a several-celled ovary composed of as many corpels whited in a ring, and forming a berry in fiut. 


\section{PHYTOLÁ C C A, Tourn. Pokeweed.}

Calyx of 5 roumded and petal-like sepals. Stamens 5-30. Orary of 5-12 earpels, united in a ring, with as many short separate styles, in fruit forming a depressed-globose 5-12-celled berry, with a single verticul seed in each cell. Embryo curved in a ring around the allmuen. - Thall and stout perennial Lerbs, with large petioled leaves, and terminal mones whieh become lateral and opposite the leaves. (Name compounder of фutón, plant, and the French lac, lake, in allusion to the crimson coloring matter which the berries yiell.)

1. P. decándra, L. (Commox l’oke or Sonk. Garget. l’utesox. Berrr.) Stamens and styles 10. - Low grounds. July-Sept. - I smooth plant, with a rather unpleasant olor, and a rery large poisomous rout, often 4-6' in diameter, sending up stont stalks at length $6-9^{\circ}$ high ; calyx white; ovary green; berries in long racemes, dark-purple and tilled with crinsun juice. ripe in autumu.

\section{Order 89. POLYGONACEA. (BCckwheat Famly.)}

Herbs, with alternate entive leares, and stipules in the form of sheaths (ocrear, these sometimes obsolete) abore the stoollen joints of the stem; the flowers moslly perfect, with a more or less persistent calyx, a 1-celled ovary bearing 2 or 3 styles or stignnas, and a single erect orthotropous seed. Fruit usually an achene, compressert or 3-4-angled ol -winged. Embryo curved or straightish, on the outside of the albumen, or rarely in its centre. Stamens $4-12$, inserted on the base of the 3 -6-cleft calyx. (Juce often aerid, sometimes agreably acid, as in Sorrel; the roots, as in Rhubarb, sometimes catluartic.)

* Flowers involucrate; stamens 9 ; stjpules none.

1. Eriogonum. Involncre severnl-flowered, with flowers exserted. Calyx 6-cleft.

* Flowers without imvoluere; staniens 4 to S.

- Stipular sheaths manifest; ovule ereet from the base of the cell.

+ Seprals 4 or 6 , the outer low reflexed, the inner erect and enlarging in fruit.

2. Oxyria. Sepals 4. Stignas 2. Aclenc orbienlar-winged. Leaves reniform.

3. Rumex. Sepuls 6. Stigmas 3. Achene 3-angled.

++ Sepals 5 (sometimes 4), equal and erect in fruit. Achene triangular or lenticular.

4. Polygonum. Eubryo slender, enred around one side of the albumen. Pealieels mostly fascieled.

5. Fagopyrum. Embryo in the allumen, its rely broad eotyledons twistel-plaiterl.

6. Polygonella. Enbrjo slender, nearly straight. Pedicels solitary. Leaves jointen at base.

- + Stipules obsolete; ovule hanging fron the npex of a slender stalk.

7. Brunnichia. Calyx 5-parted, in fruit witb a wing decurent on the pelicel. Tendri] clinber.

\section{ERIÓ GON UM, Miehx.}

Flowers perfect, involnerate; involncre 4-8-toothed or lobed, usmally manyfowered; the more or less exserted perlicels intermixed with narrow sealicus: buacts. Calyx 6-parted or -cleft, colored, persistent about the achene. Stat mens 9, upon the lase of the calyx. Styles 3; stigmas capitate. Acheve 
triangular. Embryo straight aud axile, with foliaceous cotyledous. - Annuals or perennials, with rulical or alternate or whorled entire leares, without stipules. (Name from є̌ptov, ưol, and yóvo, hnee.)

1. E. ánnuum, Nutt. Inmual, erect, lealfy, naked above, $2^{\circ}$ high, whitefoccuse-tomentose throughout; leares ohlong-lanceolate, acute at botl ends, short-petiolate, flat; bracts small, triangular; involucres nmmeroms in terminal eymes, turbinate, shortly perlicelled, $1-1 \frac{1}{2}$ " long, very tomentose; flowers white, the outer scpalls oblong-obovate, $1^{\prime \prime}$ long or less. - Central Kan. to Col., aud southward.

\section{OXÝRIA, Hill. Mountain SORRei.}

(alyx herbaceous, of 4 sepals; the outer smaller and spreading, the inner broaler and erect (but unclanged) in fruit. Stamens 6. Stigmas 2, sessile, tufterl. Achene lenticular, thin, flat, much larger than the calyx, surrounded by a hroal veiny wing. Seed fattened contray to the wing. Embryo straight, in the centre of the albumen, slcnder. - Low alpine perenuial, with roundkidney-form and long-petioled leaves chiefy from the root, oblipuely truncate sheaths, and small greenish flowers chustered in panicled racemes on a slenter scape. (Name from ózús, som, in allusion to the acid leaves.)

1. O. digyna, llill. Lcives all roumd-kiclney-form, nsmally notched at the end; fruit orbieular. - Alpine region of the White Mts, and far north and westward. (1iu.)

\section{R U M EX, I. Dock. Sorrel.}

Calyx of 6 sepals; the 3 outer herbaceons, sometimes united at base, spreadmg in fruit; the 3 inner larger, somewhat colored, enlarged after flowering (in frut called ralees) and comrergent orer the 3-angled achene, veiny, often bearing a grain-like tubercle on the back. Stamens 6 . Styles 3 ; stigmas tufter. binhryoslightly curver, lying along one sicle of the albunen, slender. - Coarse herls, with small and homely (mostly green) flowers, whicli are (rowled and commonly whorled in panicled racemes; the petioles somewhat sheatling at base. (The ancient Latin name; of unknown etymology.)

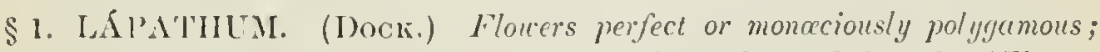
herbuge not sorr or sarcely so; none of the leaves haberd-shaped. (Flouering through the summer.)

* I'erennials, $1-7^{\circ}$ high, mostly with fusiform roots; valves not bearing hristles.

- Talies (large, $3^{\prime \prime}$ broad or more, thin) all naked or one with at small grain.

R. Patrentid, Id. (Patrexce Dork.) A rery tall species, with ovatewhlong ancl lanceolate leaves (loralest alowe the laise), those from the root $2-$ $33^{\circ}$ long, aud one of the heart-shapel nearly or guite entire valves ( $3^{\prime \prime}$ broarl) bearing a sunll grain, or its mielrib thickened at base. - N. Eng. and N. Y'. (Akl from Eu.)

1. R. venòsus, Pursh. Sitems from running rontstocks, erect (1 ${ }^{\circ}$ lighl or less), with conspicuous dilated stipnles; leaves on short hut rather slender petioles, orate or oblong to lanceolate $\left(3-\delta^{\prime}\right.$ longr), acute or acmunintc, only the lowest ohtuse at hase; panicle nearly sessile, short, dense in frut ; valves entire, glamlless, hroally corlate with a deep sints, 9-12" in clinucter, luright rose-color. - Sark. to central Mo. and Kan., ancl westward. 
- Tralces smaller; one or more of them conspicuously yrain-bearing.

++ Indigenurs; leaces not uary, none heart-shaped, except the lowest of 11.5 .

2. R. Británnica, L. (Gikat WATEk-1)ock.) 'l'all and stont $\left(5-6^{\circ}\right.$ high) ; leaves ohlong -lanceolate, lather acute at hoth ends, transversely veined, and with obscurely erose-crenulate margins (the lowest, including the petiole, $1-2^{\circ}$ long, the midlle rarely truncate or obsculely cordate at base); racenuce upright in a large compound pa iche, nearly leathess; whorls crowded; pedicels capillary, nodding, ubout wice the lenyth of the firmiting culy, $x$; the rulces orbirulut or round-ovate, rery ulutuse, obsemely heart-slaped at bise, finely ifticulaled. entire or repaul-ilenticulate ( $2-3$ " broal), all grain-bearing. (R. orbiculatns, Gro.y.) - Wet places, N. Eng. to N. J., west to Minu. and Kian.

3. R. altissimus, Wood. (HALE Dock.) liather tall (2-6 liggli); leaves ovate-or oblong-lanceolute, aeute, pale, thickish, obscmely veiny (the canline 3-6' long, contracted at base into a short petiole); racemes spike-like and panicled, nearly leafless; whonls crowded; pedicels wodding, shorler than

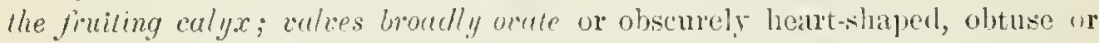
acntish, entire, loosely reticulated (about 2" broad), one with a conspicuons grain, the others witl a thickened millrib or naked. (12. Britannical, Ciray; not L.) - Moist grounds, X. Y. and X. J. to Miun. and Kian.

4. R. salicifòlius, Weimmann. (W Wнте 1)ock.) Rather low (1-30 ligh); root white; lates narromly or linear-lancelale, or the lowest oblong;

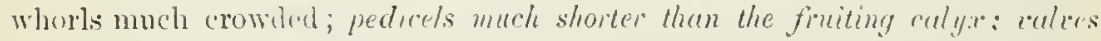
deltord-nede, obtusish (or acutish (about $1 \frac{1}{2} "$ long), one, two or smetines all with a cons]senous often very large grain; otherwise nearly as 11, 3. - Salt marshes, from Nowf. to X. Eng., abont the Great Lakes, and far westward.

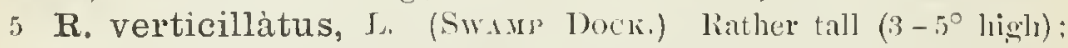
leaves lancenlate or oblong-lanceolate, rather obtuse, thickish palo-green, the lowest often lieart-shajerl at hase; racemes nearly leafless, elongated, Iouse, the whorls crumen or the lower ones distant; fruit-bearing pedicels slender, alub-

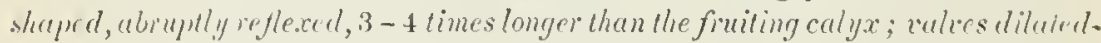
rhomboil, obtusely someutut prointed, strongly rugose-retirulated, each bearing a very large grain. - Wet swampss, common.

- Taturulized Eimopreun ureeds; lower lentes mosily heart-shaped at buse.

R. crissus, T, (Curied Dock.) Smooth (3-4o high); Icreses wilh slrongly newy-curled margins, lancrolale, acute, the lower trmeate or scarecly

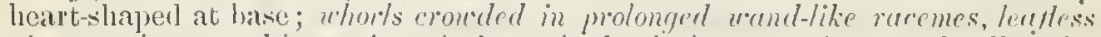

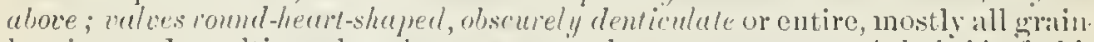
bearing. - In coltivated and waste ground, very common, A hylivid of this with the next is reporten from Mlass., N. Y., and Ml.

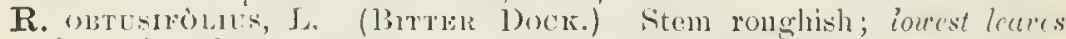
mete-lieurt-sheyed, obluse, rather duwny on the reins beneath, somewhat wary-

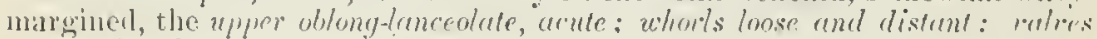
meate-halberd-shaped, with some sharp arel-shaped terlh at base, strongly roticulaterl, one of them principally grain-heanium. - Fichls, ete., common.

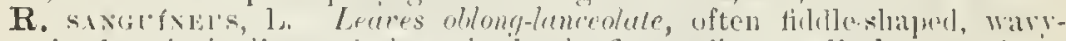

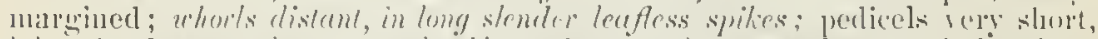

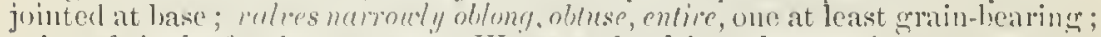
veins of the leaf red, or erren, - Waste and enltivated ground.

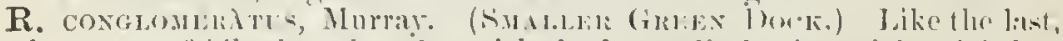

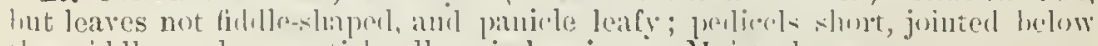

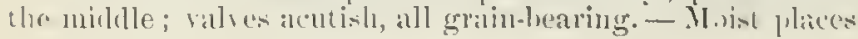


* A Amuals, low; valves bearing lony awns or bristles.

6. R. maritimus, L. (GoLdis Dock.) Minutely pubercent, diffusely branclied, 6-12' high; leaves lance-linear, wavy-nargined, the lower anricled or heart-shaped at base; whorls excessively crowded in leafy and companct or interrupted spikes; valves rhombic-oblong, lance-pointed, each bearing $2-3$ long awn-like hristles on each side, and a large grain on the back. - Sea-shore, Mlass, to N. C.; also from Ill. to Minn., and westward.

\$2. ACETOSA. (Sorrel.) Flowers dicecious, small, in a leminal naked panicle; herbage sour; some leares haberd-shaped; smooth perennials, spreading by ruming rootstocks, floweriny in spriny.

7. R. hastátulus, Baldw. Stem simple, $1-2^{\circ}$ high ; leaves nearly as in the next; perlicels jointerl at or below the midlle; ralres of the frmiting calyx ronnd-heurt-shoryd, thin, finely reticulated, naked, mony times lurger thun the aclene. (R. Engelmanni, Ledeb.) - S. W. IH. to L. Kan., 'lex, and Fla.; Riverhead, long' lstand (Yomg).

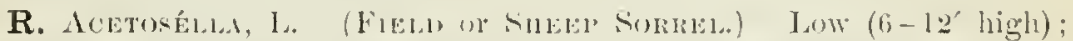

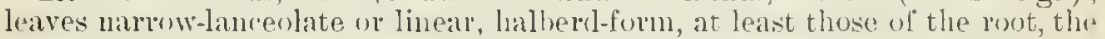

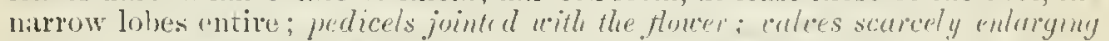
in firuit, oruh, naked. - Abundant everywhere. (Nat. from kin.)

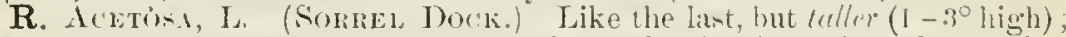
leaves oblong or hroally lanceolate; molres puluming in fint and mhimblur, the outer reflexerl. - ' 'huirlotte, Vt., aul P'enn lau, N. I. (Nat. from liu.)

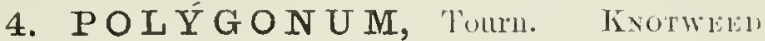

Calyx mustly 5-parted ; the divisions often petal-like, all erect in fruit, withering or persistent. Stamens $4-9$. Styles or stigmas 2 or 3 ; achene accortingly lenticular or 3-angular. Embryo placed in a groore on the outside of the albumen and curvel half-way arome it; the radicle and usually the cutyledons slender. - l'edicels juinted. Ours all herlacems, with fibrous roots (except u. 19), flowering lhough late summer and early antumm. (Name

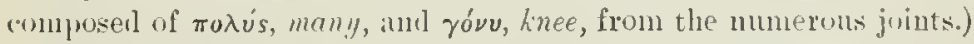

\$. POLYGONLM proper. Flowers in axillary fuscirles on spicute with foliaceous bruets; leaves and bracts jointed upon a rery short petiole adnule to the short shcuth of the 2-lobed or lacerate scarious stimules: stems striate: caly.x 5-6-parted, usually more or less herbuceous; stumens 3-8, the 3 inner filaments brout at buse; styles 3 ; cotyledons incumbent; albumen horny; glabrous commals, exeept n. 1. (\$ Aricularia, Meesn.)

\section{* Leafy throughout.}

1. P. marítimum, L. Perennial, at length woody at hise (or sometimes anmal), prustrate, glaucous, the stout stems very shortly juinted ; lences thich, wal to linear-oblong $\left(3-10^{\prime \prime}\right.$ long), exceeding the nodes; stipules rery couspicums; sepals petaloid; stamens 8; achene smooth and shining, exserted.Searcoast from Mass. to Ga, (Eu.)

2. P. aviculàre, L. Sleuder, mostly prostrate or uscending, blush-green; leaves oblung to linceolate (3-10" long), usually acute or acutish; sepuls lumell! 1" lony, green with linkish margins; stamens 8 (rarely 5); achene dull anl minutely iramular, mostly included. - Common everywlere in yards, natste plates, rete. (Litl, Asia.) 
3. P. eréstum, I. Stonter, ereet or ascending $\left(1-2^{\circ}\right.$ high), yellouish;

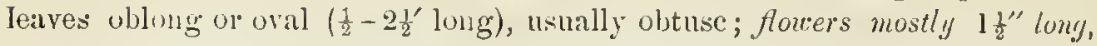
often yellowish, on more or less exserted pedicels; stamens 5-6; achene dull, included. (P. aviculare, var. erectum, lioth.) - Common, by waysides, etc.

* Leares much reduced above and bract-like.

4. P. ramosissimum, Michx. Frect or ascending $\left(2-4^{\circ} \mathrm{high}\right)$, yellowish-green; leaves lanceolate to linear ( $1-2 \frac{y^{\prime}}{2}$ long), acute; flour's and achene as in 1 . 3, but sepals more frequently 6 , the strmens $3-6$, and the achene mostly smooth and shining. - Saudy shores and banks of streams, E. Mass. to N. Y., west to Minn., Ark., Tex., and far westwarl.

5. P. ténue, Michx. Stem angled, erect ( $\frac{1}{2}-1 \frac{1}{2} 0$ high), glabrous, or slightly scabrous at the nodes; leures narowly linear to Ianceolate $\left(1-2^{\prime}\right.$ long), 3-neried, acute at each end and often cuspiclate, the margins somewhat scabrous and at length revolute; flower's often solitary, nearly sessile; stamens 8 ; achene included, (lull black. - Mry soil, N. Eng. to S. C., west to Mlimn., Mo., and 'Tex.

6. P. campòrum, Meisn. Stem terete, erect or ascending $\left(2-3^{\circ}\right.$ high), glabrous; lecres deciduous, linear to oblong, usually short; palimels slemert, exserted fiom the scarious sheaths; stamens 8. - E. Kan. to Tex.

\$2. PERSICARIA. Flowers in dense spikes, with small scarious bracts: leaves not jointed on the petiole; sheaths cylindrical, truncate, entire, nated or ciliate-fringed or murgined; calyx colored, 5-parted, appressed to the fruit; stamens 4-8; filaments filiform; cotyledons accumbent.

* Shenths and brarts not cilute or finged; sepals not punctate; style 2-cleft.

7. P. lapathifòlium, I. Anuual, branching, $1-4^{\circ}$ high, glahıous or the peduncles often minutely glamlular; leaves lanceolate, attenuatc upward from near the cuneate base and acuminate, somewhat scabrous with short appressed hairs on the midrib and uargin, or rarely foccose-tomentose heneath; sheatlis and bucts rarely somewhat ciliolate; spikes oblong to linear $\left(\frac{1}{2}-2^{\prime}\right.$ lomg), lense, erect or nearly so; flowers white or pale rose-color; stamens 6 ; achene ovate, rarely I" broad. (I'. nodosum, Pers. P'. incarnatum, l/un., in part.) - Wet places; N. Eng. anil Can. to 111., Wisc., and far westward. Very variable. (Eu.)

Var. incarnàtum, Watson. Ieares often large $\left(6-12^{\prime}\right.$ long, $1-3^{\prime}$ wille); spikes more slender and elongater $\left(2-f^{\prime}\right.$ long), nodding. (P. incanatum, Ell.) - Pem. to Ill., Mo., and sonthwarel.

Var. incànum, Koch. Low $\left(6-12^{\prime}\right.$ high $)$; leaves small, obtusish, more or less loary beneath with flocose tomentum; spikes short. - Cayuga Lake, N. Y., Out., shores of I. Superior, and northwestwirl (Eu.)

8. P. Pennsylvánicum, L. A similar species, but the brancles abur und esprecially the peduncles beset with sliphitale glands; flowers larger and of ten bright rose-color, in slort erect spikes, often on exserted perliccls; stanens nsually 8 ; achene ncarly orbicular, over l" broal. - Moist soil, in open waste places, common.

9. P. amphibium, L. I'erennial, aquatic or rooting in the mud, stout and glabrous or nearly so, not hranching above the ronting lase; lenres usuully flocling, thick, smooth and shiniug shese. mastly long-pretioled, ellipticul 
(1) whlong or sometines lanceolate, arutish, cumcate or erorlate at base (2-5)

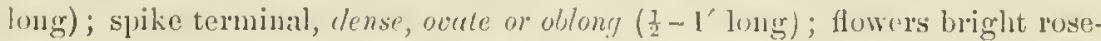
color $\left(1 \frac{1}{2}-3^{\prime \prime}\right.$ long); the 5 stamens and 2-eleft sty le exserted. - Widely distributed and rather common. (Vil., Asia.)

10. P. Muhlenbérgii, Watson. Peremial, in muddy or dry places, vecumbent or suberect, sculbrus with short approssed or glunduhr hairs; leaves

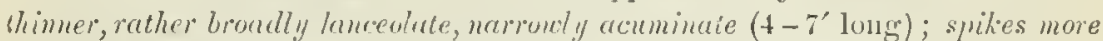
plongated ( $1-3^{\prime}$ longr), often in pairs; flowers and fruit nearly as in the last. (1'. an1 hilbinn, vall. terrestre, Cimy, Manual; not Leers.) - N. Engr. to Fla., "Nestward across the continent.

* * Sheaths and lnacts bristly riliate or the sheaths foliaceously maringed.

+- Sepuls not pumutute; slyle 2-rlofi; acliene someutut flutcned.

11. P. Hartwrightii, (iray. Peremiul, very closely alliod to 11.9 , growing usually in mul, the ascenling stems rooting at base and very leafy, more or less rongh-huiry, at least on the sheatls and bracts, the former ciliate

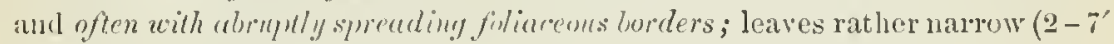
long), on very short petioles; flowers rnd fint as in $11.9 .-\mathrm{N}$. ling. and X. Y., to Minn., Iowa, and far westwarl. When growing in water the floating leaves are thicker and ghlibrous.

12. P. Càreyi, (lney. Annual, erect, the stem (3-50 liing -r and perhncles ylundulu-bristly: leares nurrouly lanceolule, attenuate to both ends, roughish; sheaths ciliate or sometimes margined; spikes slender, loose and nodding; flowers purplish; stamens mostly 5. - Shady swamps, S. Maine and N. H. to Penn. and Ont.

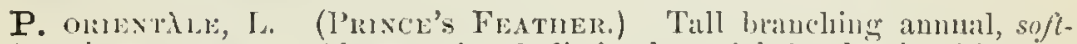
harioy; leares arele or oblong, pointed, distinctly jetioled; sheulls ciliate or sfon will an abrupt sprealing bonder: flowers large, liright roso-color, in donse "glindrical nodding spikes; stumens 7. - Sparingly escirpud from gardens into waste gromols. (Arlv, from India.)

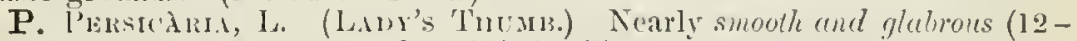
$18^{\prime}$ ligglı); sheatlis more or less bristly-ciliate; leares lanceolate, pointed, ronghish, often nuakel witl a clark triangular or lum spot near the midclle; spilies ovevil or oblung, dense, evert, on smooth (or at loalst not glandular) pedmniles; stamens mustly 6 ; styles half 2-3-cleft; achene gibhous-flattened or sometimes triangular, smooth and sliniug. - Waste and damp places, very Lummon. (Nat. from liu.)

+o Sepals conspicuously dotted and leaves puntate (except 11. 13), will "acrio juce; style mostly 3-parted, und achene trangulur; sheaths bristle-fringed.

13. P. hydropiperoides, Michx. (Mitd Wateri-Piplin.) Peren rial, not acrid; stem smooth $\left(1-3^{\circ}\right.$ high), branching; the namow slicatho iairy: leaves narrowly laneeolate, sometimes oblong; spikes erect, slender. annetimes filiform, often interrupterl at base $\left(1-2 \frac{1^{\prime}}{2} \mathrm{long}\right)$; flowers small, fleshwlor or nearly white; sepals not dotled; stumens 8; achene sharply triangular, smooth and shining. - Wet places and in shallow water; common, especially susthward.

14. P. Hydrópiper, I. (Common Smartweno or WAter-Puiperr.)

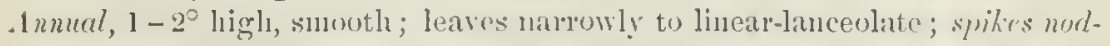
dimy, usually sliort or intermpterl ; flowers mostly greenish; sfumens 6; stylo 2-3 partend arhene dull, minutely stritte. Moist or wet gronnels; aljarrently introluced castwand, but inligenons nonth and westward.

(Eu.) 


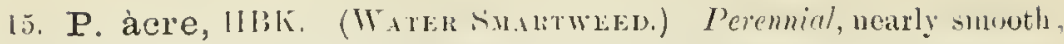
stems rooting at the decumbent base, $2-5^{\circ}$ high; leaves larger and longrer than in the last, taper-pointerl; spikes erect; flowers whitish, sometimes Heshcolor; stamens 8; style mostly 3-jurted; achene smooth and shining. - Wret places; commou, especially southwatrol.

\$3. BISTÓRTA. Gilabrous ulpine perennials, with thick creeping rootstock and simple stems; flowers in "spilietitie raceme; calyx colored, deeplys cleft; stumens 8; styles 3 , lony.

16. P. vivíparum, L. Snomth, dwarf $\left(4-8^{\prime}\right.$ high), bearing a linear arect spike of Hesh-colored flowers (ur alten little red lmllhets in their place); 'eaves lanceolate. - Alpine smmmits of X. Lng., shores of L. Superior, and sorthward. (Eu.)

\$. TOVARA. L'erennuls; flowers in loose nalied long and slender spikes; calyx rather herbucous (greenish), unequally 4-parted; stamens 5; styles 2, distinct, rigid and persistent on the smoth lenticular arliene.

17. P. Virginianum, L. Almost smooth; stem terete, upriglit (2-40 high) ; sheaths cylindrical, hairy and fringed; leaves orate, or the llyer wratslanceolate, taper-pointed, rounded at the base, short-petioled, rougli-ciliate (36' loug); flowers $1-3$ from each bract, sumewhat ("urved, the styles deflexed in fruit, minutely looket. - T'liekets in rich soil, common. (Asia.)

\$5. TINIARIA. Ammals or peremials, mostly turiming w elimbing, and with petioled cordate or sagitate leates; Alneers in luose panicles or racemes or in terminul or axillary chusters; calyr green with colored margins, 5- (ravely 4-) parted; stamens mostly 8; styles wr stigmess 3 (2) in 11. 18).

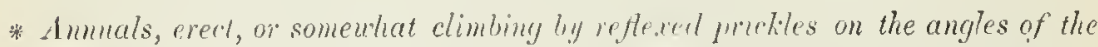
stem and putioles; sepuls (pale rose-color or whir) wol keeled; bracts chutf-litie.

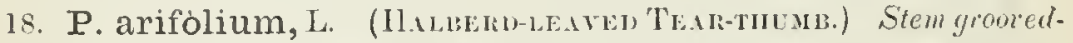
angled ; leares halberd-shruped, taper-pointed, lony-pretided; flowers somewhiat racened (few); poluncles glaulular-hristly; calyx often 4-parted ; stumens 6 ; slyles 2, very short; urhene lenticulur (large). - Isow grounds. (Asia.)

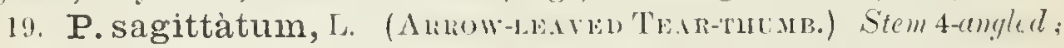

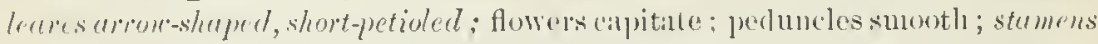

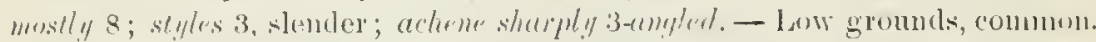
- slender, smunth except the angles of the stemin and midrib beneath, whir.h

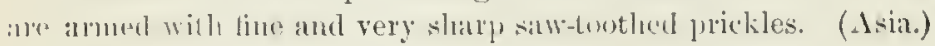

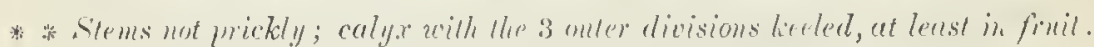
flowers in loose panicled raremes: hraets short-sheathing.

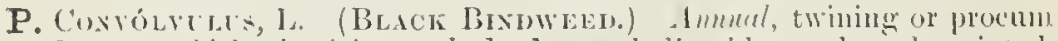
bout, low; romglish, the joints naked; leaves halberi-heart-shinged, pointed;

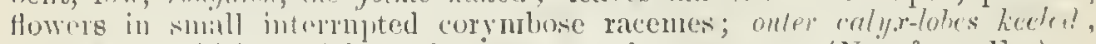
achene smonthish. - ('ult. and wiste grounds, common. (Nat. inom liu.)

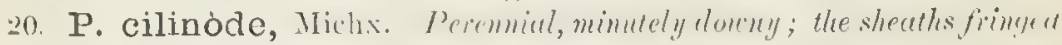
at the hase with roflexed bristles; leares heart-shaped and slighthly hallewer

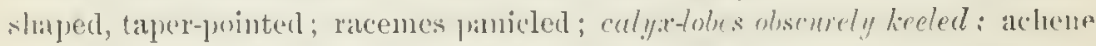

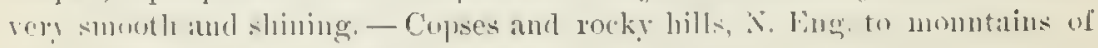
N. (', west to . Mieht and Mimm. C'limbing is - $9^{\circ}$ higght. 
21. P. dumetòrum, L., var scándens, Gray. (ClimbixG Falsk BuскшиE.r.) Peremual, smouth; sheulhs naked; leaves heart-shaped or slightly halberd-shaped, pointed; racemes interrupted, leafy; the 3 outer calyx. lobes strongly keeled und in finit uinged; achene snooth and shiniug. - Moist thickets, common. 'Wwining 8-120 high over bushes.

P. cuspluAtru, sich, \& Zuce. Peremial, elect, stout and tall, glabrous except the loose axillary prinicled lacents; leaves round-ovate, shortly acnniuate, truncate or cordate at base; outer sepals broadly winged in frinit. ()ecasionally escaped from gurdens. (Japan.)

\section{F A G O P Y R U M, 'Tourn. BUCkwnet.}

Calyx petal-like, equally 5-parted, withering and nearly unchanged in fruit Stamens 8. Styles 3 ; stigmas capitate. Achene 3-sided, longer than the calyx. Embryo large, in the centre of the albumen, which it divides into 2 parts, with rery hoad and foliaceons phated and twisted cotyledons. - Glabrons anmals, with triangular-heart-shaped or halberd-shaped leaves, semicylindrical sheaths, and corymbose racemes or panicles of white flowers, often tinged with green on ruse-color. (Name from fugues, the beech, and $\pi$ upós, wheut, from the resemblance of the grain to the beech-nnt; so the English name Inckwheat, from the German buche, beech.)

F. esculéxtu, Moench. (Bickwnit.) Sunothish; flower with \& honey-bearing yellow-glands interposed between the stamens; achenc acute and entire, smootl and shining. - Old fields, remaining as a weed after cultration, and escaping into copses. June-Sept. (\$d\%. from EH.)

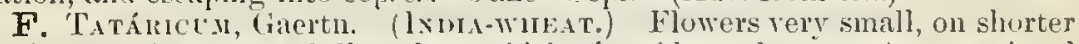
pedicels; achene rery dull and roughish, the sides sulcate. $-\Lambda$ occasional escape from enltivation. ( $\Lambda$ dr. from $A$ sia.)

\section{POLYGONÉLLA, Michx.}

F'luwers perfect ol polygamons-dicecions. Calyx 5-parted, petaloid, lousely persistent about the achene, the 3 inner divisions often enlarging in frnit, in which case the outer are usially spreading. Stamens 8. Sityles 3 , and achene 3-ingular Embryo slender, straight or nearly so, toward one side of the albumen. - Slender glabrous anuals we perennals, with alternate mostly linear leares jointed at thw lase, and rather rigid truncate or oblique naked sheaths and hracts. Flowers on solitary jointed pedicels (nodding in fruit) in slender flutcled racenes. (Diminutive of P'olygonmu.)

1. P. articulàta, Meisu. Annual, erect, branching, glaucous, 4-12' high; leaves linear-filiform, decidnous; flowers rose-color, nodling, in very slender racemes, the calyx a little enl:rged in fruit ; 3 inner filaments dilated at hase; achone exserted, smooth. (I'olygonum articulatum, Gray.) - Dry: sandy soil; on the coast from Maine to N. J., and along the Great Lakes.

\section{BRUN NICHIA, Banks.}

Calyx 5-parted; the divisions somewhat petal-like, oblong, connivent ami coriaceous in fruit, the base and almost the whole length of the pedicel wuscel un one side. Stamens 8; filanents capillary. Styles 3, slender; stigmas cle. pressed-capitate. Ovule pendulous on a slender erect funculus; seed erect. b-grooved. Achene obtusely triangular, partly 3-celled, enclused in the indu. rated calyx. Eubryo in one of the angles of the unealy alummen, sonew ha rurved. - Somewhat shubby with grooved stems, climbing by tendrils Ir u the concis of the branches. ( Samed for $F$. Brunuch, a l)anish naturalist 
1. B. cirrhòsa, Banks. Giabrous; leaves uvate or heart-shaped, pointed, entire; petioles dilated at base and partly clasping, but with no distinct slieath or stipules; flowcrs greenish, $2-5$ in a fascicle from the axil of an awl-shaped bract, these crowded in axillary and terminal racemes; pedicel jointed near the base; fruiting calyx with the wing $\mathbf{l}^{\prime}$ long. - S. Ill. to S. C. and Fla.

\section{Order 90. PODOStemàceze. (River-weed family.)}

Aquatics, growing on stones in running water, some with the aspect of Sea-weeds, or others of Mosses or Liverworts; the minute nated flowers bursting from a spathe-like involucre as in Liverworts, producing a 2-3. celled many-seeded ribbed capsule; - represented in North America by

\section{PODOSTEMON, Michx. River-weed.}

Flowers solitary, nearly sessile in a tubular sac-like involucre, destitute of floral envelopes. Stamens 2, borne on one sidc of the stalk of the ovary, with their long filaments united into one for more than half their length, and 2 slort sterilc filaments, one on each side; anthers 2-celled. Stigmas 2, awl-shapecl. Capsule pedicellate, oval, 8-ribbed, 2-ccllerl, 2-valved. Seeds minute, very numerous on a thick persistent central placenta, destitute of albumen. - Leares 2-ranked. (Name from $\pi 0 \hat{\nu} s$, foot, and $\sigma \tau \eta \dot{\eta} \mu \nu$, stumen; the two stamens being apparently raised on a stalk by the side of the ovary.)

1. P. ceratophýllus, Michx. Leares rigicl or horny, dilated into a shcathing base, above mostly forked into thread-like or lincar lobes. - Not rare in shallow streams, E. Mass. to Minn., and sonthward. July-Sept. A small olive-green plant, of firm texture, resembling a Seaweed, tenaciously attached to loose stones by fleshy disks or processes in place of roots.

\section{Ordek 91. ARISTOLOChIÁCEAe. (Bhthwort Faml\%.)}

Twining sleruls, or low horls, with perfect flowers, the conspicuous hurid calyx valvate in bud and coherent (at least ut base) with the 6-celled ovary, which forms a many-seeded 6-celled capsulc or berry in fruit. Stamens i12, more or less united with the style; anthers atnate, extrorse. - Leaves petioled, mostly heart-shaped and entire. Seeds antropous, with a large fleshy rhaphe, and a minute embryo in fleslyy albumen. A small family of bitter-tonic or stimulant, sometimes aromatic plants.

1. A sarum. Stemless herbs. Stanens 12, with more or less distinct filaments.

2. Aristolochia. Caulescent herbs or twining shrubs. Stumons 6 , the sessile anther: adnate to the stigma.

\section{1. Ás ARU M, 'Tourm. Asarabacca. Wint Gisger.}

Calyx regular'; the limb 3-cleft or parted. Stamens 12, with more or less distinct filanents, their tips usually continued heyoud the anther into a point. Capsule rather fleslyy, globular, bursting irregularly or leculicidal. Seeds large, thick. - Stemless perennial herbs, with aromatic-pungent creeping rootstocks bearing 2 or:3 scales, thicn one or two kilner-sliapect or heart-shaped leaves un long petioles, and a slort-pedunderl flower close to the gronnd in the lower axil; in spring. (1n anclent name, of obscure terivation.) 
$\$ 1$ Calyx-tube wholly adnate to the ovary, the tips inflexed in lud; filaments slender, much longer than the short anthers; style barely 6-lobed at the summit, with 6 radiuting thich stigmas; leaves a single pair, unspotted.

1. A. Canadénse, I. Soft-pubescent; leares membranaceous, kidneyshaped, more or less pointed (4-5' wicle when full grown); caly'x bell-shaped, the upper part of the short-pointed lobes wilely and abruptly spreading, brown-purple inside. - Hillsides in rich woods; ' 'mmmon, especially northward,

\$2. Calyx-tube inflated bell-shaped, somewhat contracted ut the throat, its base adnate to the lower half of the ovary; limb 3-cleft, short; anthers sessile or neurly so, oblong-linear; styles 6, fleshy, diverging, 2-cleft, bearing a thick extrorse stigma below the cleft; leaves thickish, persistent, usually only one each year, often uhitish-mottled; peduncle very short; rootstocks clustered, ascenting.

2. A. Virgínicum, L. Nearly glabrous; leuves round-heurt-shaped (about $2^{\prime}$ wide); ealyx short, retienlated within; authers pointless. - Va. to Ga., in and near the mountains.

3. A. alifollium, Miehx. Leaveshalberd-heart-shaped (2-4'long); caly x oblong-tubular, with very short and blunt lobes; anthers obtusely short-pointed. - Va. to Fla.

\section{ARISTOLOCHIA, 'Tourn. Brrmwort.}

Caly $x$ tubular' ; the tube variously intlated above the ovary, mostly contracterl at the throat. Stamens 6 , the sessile anther's wholly aduate to the short and flesly 3-6-lobed or angled style. Capsule naked, septicidally 6-valved. Seeds very flat._- 'lwining, elinbing, or sonetimes upright perennial herbs or shrubs, with alternate leaves and lateral or axillary greenish or lurid-purple flowers (Named from reputed medieinal properties.)

$\$ 1$. Calyx-tube bent like the letter $S$, enlarged at the two ends, the small limb ob. tusely 3-loled; anthers contiguous in pairs (making 4 cells in a row under sach of the three truncate lobes of the stigma); low herbs.

1. A. Serpentària, L. (Virginia Sxakeroo'r.) Stems (8-15' high) branched at base, pulbescent; leaves ovate or oblong (or narrower) from a heartshaped base or halberd-form, mostly acute or pointell flowers all next the root, short-perluncled. - Rieh woods, Conn. to Fla., west to Mich., Mo., and La. July. - The fibrous, aromatie-stimulant root is well known in medicine.

\$. Calyx-tube stiongly curved like a Dutch pipe, contracted at the mouth, the short limb obscurely 3-lobed; anthers contiguous in pairs under each of the 3 short and thick loles of the stigma; very tall twining shrubs; flowers from one or tuo of the superposed accessory axillary buds.

2 A. Sipho, L'Her. (l'ipe-Vine. Dutchman's Pipe.) Nearly glabrous; leares rounl-kidney-shaped (sometimes $8-12$ broad); pecluneles with a ('lasping bract; (aly $\times$ ( $1 \frac{1}{2}$ long) with a brown-purple abrupt flat border. - Rieh Wurls, Penn. to Ga., West to Minn. and Kan. May.

3. A. tomentósa, sims. Douny or soft-hairy; lectes round-heart-shaped, very veiny $\left(3-5^{\prime} \operatorname{lon} g\right)$; culyr yellowish, with an oblizne cark purple closed or ifire and a ruyose reflexed limb. - Rich woods, mountains \& T. C. to Fla., west to.s. Ill. and Mo. June. 
\$3. Calyx-tube straight, open, with ample 6-lobed limb, the lobes appendaged. anthers equidistant; erect herbs; flowers in axillary cymose fascicles.

A. CLEMATrtis, L., with long-petioled cordate leaves, from Europe, is said to have permanently escaped near Ithaca, N. Y. (Dudley).

\section{Order 92. PIPERACEA. (P'EPRR Family.)}

Herbs, with jointed stems, allernate entire leates, and perfect flowers in spitits, entirely destitute of fimul chrelopes, and with $3-5$ more or less sepurate or united viaries. - Ovules few, orthotropous. Embryo heartshaped, minute, contained in a litte sac at the apes of the albumen.The characters are those of the 'Tribe Saumien. the Piperace proper (wholly tropical) differing in having a 1-celled and 1-ovuled orary.

\section{SA U R U RUS, I. Lizaru's-tall.}

Stamens mostly 6 or 7 , hypogynons, with distinct filaments. Fruit some what fleshy, wrinkled, of $3-4$ indehiscent "mpels miter at base. Stigmas recured. Seets usually solitary, ascending. - l'erennial marsh herls, with hent-shaped converging-ribbed putioled leaves, withont distinct stipules; flowers (each with a small bract alluate to or horne on the pediccl) crowded in a slencler wanl-like and naked peduncled teminal spike or raceme (its appearance griving rise to the name, from oavipos, a lisurd. and oùpá, tuil).

1. S. cérnuus, L. Flowers white, fragrant; spike nodling at the end: hract lanceolate; tilaments long and capillary. - Swamps, Conn. to (Int., Minn. Mo, and sonthwarl. June- - Ing.

\section{()rdir 9:3. LAURACEAe. (Taurei Fayiry.)}

Lromatic trees or shrubs, with alternate simple leares mosll! marked with minute pellucid slots, and flowers with a regular calyx of $t$ or 6 coloreri sepals, imbrieated in 2 rous in the but, free from the 1-celled and 1-orule orury, and mostly feuer than the stamens: anthers opening by 2004 uplified

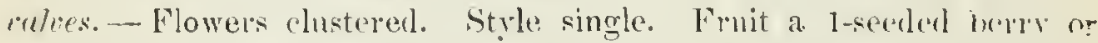
drupe. Sred antropous, suspended, witl no allumen, filled br the larg: almonil-like embryo.

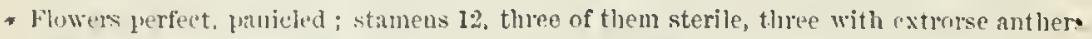

1. Persea. Cinlyx insistent. Anthers t-eellek. Evergreen.

* Flowers cliorious, oj nearly so ; stumens in the steríle flowers 9 Leares decidunus.

2. Sassafras. Flowers in eoryub-or umbel-like racemes. Antliers t-inelled, 4-valva

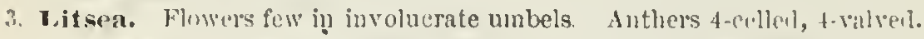

4 Inulfera. Flowers in umbel-like clusters. Anthers 2-cellul, 2-valved.

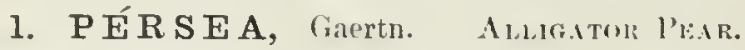

Flowers perfect, witl a 6-parted calyx. persistent at the halso of the fre-ry-like fruit. Stamens 12, in four rows, the 3 of the innermost row sterile and gland. like, the rest bondug f-eedled anther's (i. e. with each proper cell divided trans vers(l) into lwo), opreniug by as many uplifted valves: the anthers of a stamens turned ontwarl, the ot hers intrurse. - Trees, with persistent entire learus, and small panicled Howers. (An ancient name of some (Jriental tree.) 
1. P. Calolinènsis, Nees. (Rep Bar.) Hoary with at tile down, at leist when young; leaves obloug, pale, soon smootl above; perluncle lrestring fen flowers in a close cluster; sepals clowny, the outcr shorter; berries lark hlue, on a rel stalk. - Swamps, s. Del. to Fla. and Tex. May. A small tree.

\section{SA S S A RAS, Nees.}

Flowers diccions, with a 6 -parted spreading calyx; the sterile kind with 9 stancus inserted on the lase of the caly $\mathrm{x}$ in $3 \mathrm{rows}$, the 3 inner with a pair of stalked granls at the hase of each; anther's t-celled, t-valved ; fertile flowers "ith 6 short rudiments of stanens aud an ovoid ovary. Drupe oroid (blue), smpjorted on a club-shaped and rather fleshy reddish pedicel. - Trees, with spicy-aromatic hark, and very mucilaginous twigs and foliage; leaves decichous, often lobed. Flowers greenisllyellow, naked, in clustered ant peduncled corymbed racemes, appearing with the leaves, involucrate witl scaly" loricts. Jeaf-burs scaly. (The popular natue, applied by the early french settlers in Floriclit.)

1. S. Officinale, Nees. 'Tres $15-125^{\circ}$ high, with yellowish-green twigs; leares urate, entire, or sume of them 3-lubed, soon glabrons. - Rich woods, E. Mass. to S. Ont., Mich., E. Iowa aud lian, and south to the Ginlf. April.

\section{LIT S E A, Lam.}

Flowers diecions, with a 6-parted teciduons ealyx; the sterile witls 9 stamens in 3 rows; their anthers all introrse, t-celled, t-valved; fertile flowers with 12 or more rullinents of stanens and a globular ovary. Drupe globular. - Sibruhs or trees, with entire leaves, ant suall flowers in axillary clustered umbels. (Name of ('hinese origin.)

1. L. geniculàta, Benth. \& IJouk. (Jow sincl.) Flowers (yellow) appearing before the leciduous oblong leaves, which are hairy on the midrits beneath; blanches forked and divaricate, the branchlets zigzag; iuvolucres $2-4$-leacd, 2-t-fluwered; fruit red. ('letrantlera geniculata, Nees.) Siwanps, Vit. to Fla. April.

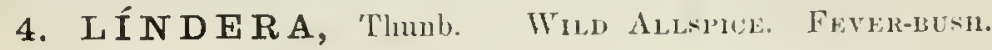

Flower's polyganuus-dioetous, with a 6 -parted open calyx; the sterile with 9 stamens in 3 rows, the imer filments 1 - 2-lobed and whlam-baring at hase; iuthers 2-celled and 2-valved ; fertile flowers with 15 - 18 ruclinents of stamens in 2 forms, and a glohnlar vory. Drupe oboroid, red, the stalk wot thickenerl. - Shrubs, with deciduous leaves, and honey-yellow Howers in almost sessio lintrial umbel-like clnsters, appearing before the leares (in our species) : the r.lusters composed of smaller clusters or umbels, each of +-6 flowers and surromiled hy an involucre of t deciluons scales. Leaf-l)uls scaly. (Named for John Lincier, a Swedish hotanist of the early part of the 18th century.)

1. L. Benzòn, Blume. (Spice-Busn. Bexdarimusu.) Neurly smooth (6-15 lighli); leutes oblong-obocute, pale underueath. - Damp woods, N. Fing. to Ont., Mlich., E. Kill, and southward. March, April.

2. L. melissæfolia, Plune. Young branches and buds pubresent; leutes

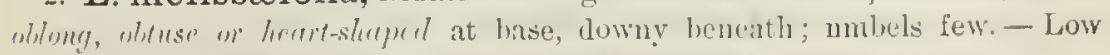
arominds, X. C. to Flis., west to S. Ill, and Mo. A pril. 


\section{Order 94. THYMEL $\boldsymbol{A}$ i CEA. (Mezereum Famly.)}

Shrubs, with acrid and very tough (not aromatic) bark, entire leaves, and perfect flowers with a regular and simple colored calyx, bearing usually twice as many stamens as its lobes, free from the 1-celled and 1-ovuled ovary, which forms a berry-like drupe in fruit, with a single suspended anatropous seed. Embryo large; albuuneu little or none.

1. Dirca. Calyx tubular, without spreading lobes. Stamens and style exserted.

2. Daphne. Calyx-lobes (4) spreading. Stamens included. Style very short or none.

\section{DíRCA, L. Leathlirmood. Moosewood.}

Calyx petal-like, tulbular-funuel-shaped, truncate, the border wavy or obscurely about 4-toothed. Stamens 8, long and slender, inserted ou the calyx above the middle, protruded, the alterinte ones longer. Style thread-form; stigma capitate. Drupe oval (redlish). - A much-branched bnsh, with jointer branchlets, oval-obovate alternate leaves, at length smooth, deciduous, ou very short petioles, the bases of which conceal the buds of the next seasou. Flowers light yellow, preceding the leaves, 3 or 4 iu a cluster from a bud of as many dark-hairy scales, forming an involncre, from which soou after proceeds a leafy branch. (Name of uncertain derivation.)

1. D. palústris, L. Shrub $2-5^{\circ}$ high; the wood white. soft, and rery brittle; but the trbrous bark renarkably tough (used ly the Indians for thongs, whence the popular uames). - Damp rich woods, N. Bruuswick to Miuu. and Mo., south to the Gulf. A pril.

\section{DÁ P H N E, Linn. Mezereur.}

Calyx salver-silaperl or somewhat fammel-slraped, the border spreadiug and 4-lobed. Stamens 8, included : the anthers nearly sessile on the calyx-tube. Styie very short or nue; stirma capitate. Drupe rel. - Harly low shrub. (Mythological name of the nymph transformed by 1 pollo into a Laurel.)

D. Mezèreta, L. Shrub $1-3^{\circ}$ high, with pulple-pose-colorel (rarely white) flower's, in liateral clusters on shouts of the preceding rear, hefore the linceolate very smooth green leaves; licries red. - Fscaped from eultivation in Canala, Mass., and N. Y. Early spring. (Nat. from Eu.)

\section{Order 95. ELAeAGNàCEAe. (Oleaster Family.)}

Slerubs or small trees, with silvery-scuify lenves and perfect or dixcious fowers; further rlistinguisher from the Mezerem Family by the crect or ascending alluminous seed, and the ealyx-tube becoming pulpy and berry-like in fruit, strietly enclosing the achenc.

1. Elacagnus. Flowers perfect. Stanens 4. Leaves alternate.

2. Shepherdia. Flowers diocions. Stamens 8 Leaves opposite.

\section{EL无 ÁG I U, Tourn.}

Flowers perfect. Calyx cylindric-campanulate above the persistent oblong or glohose base, the limb valvately 4 -cleft, deciduons. Stanens 4 , in the thruat. Style linear, stirrmatic on one side. Fruit drupe-like, with an ohlong, 8-striate stoue. - Leaves alternate, eutire and petivled, and flowers axillary and pedi- 


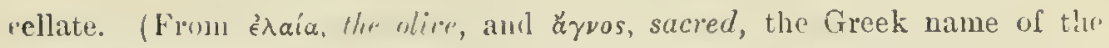
('haste-tree, liter. linus-eosuss.)

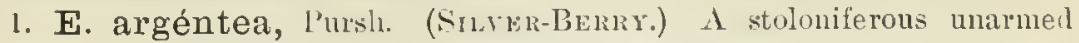
shrub $\left(6-12^{\circ}\right.$ high), the younger branches covered with fermginous seales: leaves elliptir to lanceolate, unlulate, silvery-scurfy anl more or less ferrugi. nous; flowers numerous, deflexed, silvery without, pale yellow witlin, fratgrant; fruit scurfy, round-ovoid, lly and mealy, edible, $4-5$ " long. - N. W'. Mimn. to Ltah and Montana.

\section{SHEPHÉRDIA, Nutt.}

Flowers dinecious; the sterile with a t-parted caly: (valvate in the bud) and 8 stamens, alternating with as many proresses of the thick disk; the fertile with an mon-shaped t-eleft ealyx, enclosing the ovary (the urifice closed by the teetl of the disk), and becoming berry-like iu fruit. Style slender; stigma 1-sided. - Leaves opposite, entire, decihous: the small Howers nearly sessile in their axils on the branches, clustered, or the fertile solitary. (Named for John sihejher, formerly curatur of the biverpool Botauic (virden.)

1. S. Canadénsis, Nutt. Leaves plliptical (1) orate, neilly naked aud green above, silvery"-downy and scurfy with rusty scales beneath; fruit yel-

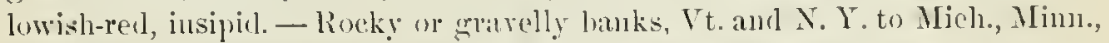
and north and westwarl. Mly - Slirub $3-60^{\circ}$ ligh, the branchlets, yonug leaves, yellowish Howers, etce, covered with rusty scales.

2. S. argéntea, Nutt. (Btrrulo-BERrY.) Somewhat thorny, 5-18 ligh; leares cuneate-obleng, silvery on hoth sides; fruit oroid, searlet, aeid and edible.- . Minn. to Col., and westward.

\section{Order 96. MoRANTHACEA. (Mistletoe Family.)}

Shrubby p/ants with coriacenus yreenish foliage, parasitic on trees, represented in the northern temperate zone chiefly by the Mistletoe and its near allies; distinguished from the next family more by the parasitie growth and habit, and by the more reduced llowers, than by essential charaeters.

1. Phoradendron. Anthers 2-celled. Berry globose, pulpy. Leaves foliaceons.

2. A rceuthobium. Anthers a single orbicular cell. Berry compressed, fleshy. Lenves seale-like, connate.

\section{PHORADÉndRON, Nint. False Mistletor.}

Flowers diceious, in short catkin-like jointer spikes, usually several to each short fleshy bract or seale, and sunk in the joint. Calyx glohular, 3- (rarely 2-4-) lobed; in the staminate flowers a sessile anther is borue on the base of each lobe, transversely 2-celled, each cell opening by a pore or slit; in the fertile flowers the ealyx-tube alleres to the orary; stigma sessile, obtuse. Berry l-seeded, pnlpy. Embryosmali, half imberded in the summit of mneilaginous albumen. - Yellowish-green woody parasites on the branches of trees, with jointed much-hranched stems, thick and firm persistent leaves (or only seales in their place), and axillary small spikes of flowers. (Name eomposed of $\phi \omega ́ p, a$ thief, and $\delta \notin \nu \delta \rho o v$, tiee; from the parasitie habit.) 
1. P. flavéscens, Nutt. (Ankricax Mistetor.) Leaves oborate or oval, somewhat petioled, longer than the spikes, yellowish; berries white. On various decidnous trees, N. J. to S. Ind, Mo, and southward.

\section{ARCEUTHÒBIUM, Bieb.}

Flowers axillary or teminal, solitary or several from the same axil. Calyx mostly compressed; the staminate usually 3-parted, the pistillate 2-toothed. Anthers a single orbicular cell, opening by a circular slit. Berry conpresserl, fleshy, on a short recurved perlicel. - Parasitic on Conifers, glabrous, with rectangular branches and connate scalle-like leaves; flowers often crowded in apparent spikes or panicles, opening in summer or antumu and maturing fruit

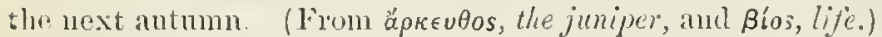

1. A. pusíllum, l’eck. Very dwarf, the slender scattered or chisteml stems 3-10" high, ustally simple, olive-green to chestnut; scales ubtus"; flowers sulitary in most of the axils; fruit narrowly oblong, l" long. - (1) Ilies migra; N. New Tork; Hanover, N. II. (Jesup).; Pocono Mt., Penn.

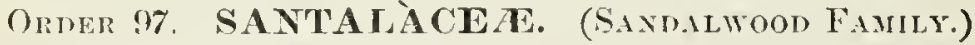

Ilerbs, slmuls, or trees, with entire leaves; the 4 -5-cleft calyx valvate in the bud, its tube colerent with the 1-celled orary, which contains $2-4$ orules suspender from the apex of a stalk-like fiee central placenta which rises from. the base of the cell, but the (indeliscent) fruit always 1-seteded. Seed destitute of any proper seed-eoat. Emlnyo small, at the apex of copions albmen; radicle directed upward; cotyledons eylindrieal. Sitamens equal in number to the lobes of the ealyx, and inserterl opposite then into the elge of the fleshy disk at their base. Style 1. A small order, the greater part belonging to warm regions.

1. Comandra. Fown's perfect, in umbel-like clusters. Low lerbacenus perennials.

2. Prularia, Flowers dicecions or polyganons, in short spilies or racemes, shrub.

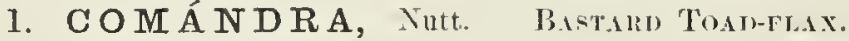

Flowers perfect. Calyx bell-shaped or sonn mu-shaped, lined above the wary with an atherent disk which has a s-lobed free border. Stanens inserted on the erlge of the disk hetween its lobes, oplosite the lohes of the ealyx, to the midhlle of which the anthers are connected hy a tuft of threarl-like hairs. Fruit drupe-like or unt-like, crowned hy the persistent calyx-lobes, the eavity filled ly the grlobular seel. - Low and smooth (sometimes parasitic) peremials, with leerbiloms stems from a rather worly hase or root, alternate and alnust sessile leaves, and greenish-white flowers in terminal or axillary small

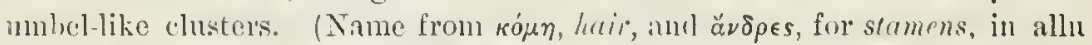
sim to the hairs on the caly-xhes which are attached to the anthers.)

1. C. umbellàta, Nutt. Sten $8-10^{\prime}$ high, hranched, rery leafy; leavex

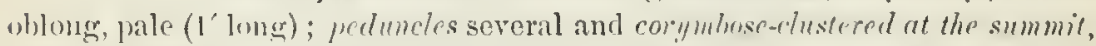
sereml-floureed: (alyx-tube conspicuously continued as a neck to the dry globular-arn-sherpud finit; the lobes oblong; style slemlen. - Dry ground, ennmon. May, Jume. liont forming parasitic attaclunents to the roots of trees.

2. C. pállida, A. DC. Lenes mrouer, more gluurous and acufer, lineur fo narrouly lanceolute (or those upon the main stem oblong), all acute or sone. 
What euspidate; fruil ovoid, larger (3-4" lung), sessile ur on short stunt peclicels. - IV. Minn. to S. Wr. Kan., and westward.

3. C. lívida, Richardson. Peduncles slender, axillary, 3-5-fouced, shorter than the oval leares; calyx-tube not eontinued beyond the orary, the lnbes ovate; style short; fruit pulpy when ripe, red. - Newi., N. Vt., sandy shores of L. Superior, and northward.

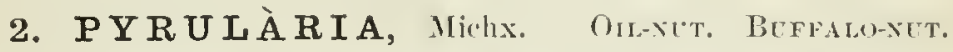

Flowers dicecions or polygamous. Calyx 4-5-cleft, the lobes recurverl, hairy-tufted at base in the male flowers. Stamens 4 or 5 , on rery short filat ments, altermate with as many rounded glands. Fertile flower's with a pearshaped orary invester by the alherent tube of the calyx, nakerl at the flat summit; disk with 5 glands; sy le short and thick; stigna capitate-Hattencel. Fruit fleshy and drupe-like, pear slaped; the globose enlecarp thin. Embryo small; albumen very oily. - Sllumls or trees, with alteruate short-petiolred and leciluons leaves; the sinall greenish flowers in slort and simplu spikis on racemes. (Name a diminntive of Pyrus, from the shaje of the fruit.)

1. P. pủbera, Miclix. Ślirub straggling (3- l.20 lighli), minutely (luwny when young, at length nearly glabrous; leares obovate-oblong, acute or pointed at botll ends, soft, very reiny, minntely pellncid-punctate; spike small and few-flowered, terminal; calyx 5-cleft; fruit 1' long. (I'. oleifera, ('iuy.) - Rich woods, monntains of l'enn. to Ga. Whole plant, especially the frnit, imbued with an acrid oil.

\section{ORDER 98. EUPHORBIACLA. (SPLRGE FAMLY.)}

Plants usually with a milly acrid juice, and monxecious on dicecious flouers, mostly apetalous, sometimes achlamydeous (occusionally polypetalous or monopetalous); the ovary fire and usually 3-celled, with a single or sometimes a pair of ovules hanging from the summit of each cell; stigmas or Tranches of the style as many or wice as many as the cells; fiut commonly a s-lobed capsule, the lobes or carpels separating elastically from a persistent aris and elastically 2-ralved; seed anatropous; emlvryo straight, almost as long as and the flat cotyledons mostlu as wille as the fleshy or aily allumen. Stipules often present. - A vast $f$, fily in the warmer parts of the world; most numerously ropesented in northern countries by the genus lis phorbia, which has very reduced flowers within a calyx-like involuere.

* Fluwers all without enlyx, included in a eup-shaped calyx-lite involuere, - the whole liable to be mistalien for a single flower.

1. Euphorbia. Involucre surounding many staminate flowers (each of a single naked stamen) and one pistillate flower (a 3-lobed pistil).

* Flowers with a ealyx, without invulucre.

- Seerls and ovules 2 in each cell ; flowers monnecions.

2. Pachyandra. Flowers in basal spikes, Calyx 4 -parterl. Stanens 4, distinct.

3. Phyllanthus. Flowers axillary. Stamens 3, mited.

+ - Secds and ovules 1 in cacl cell.

u. Flowers a jetalous, in eymose janieles (2-3-chotomous); stnnens 10, crect in the bud.

f. Jatropha. Calyx rorolla-like, the staninate sislwerom; armed with stinging hairs. 
b. Flowers in terminal lacemes or spikes. Stantus iuflexed in tlue bud. Stellate-downy or seurfy, or hriry and glaunlar; leaves mostly enture.

5. Croton. Flowers spikel or glomerate. Uraly and fruit 3- (rarely 2 - 4-) cellerl.

6. Crotonopsis. Flowers scatterel on the branclilets. Ovary aud fruit 1-celled.

c. Flowers in axillary spilies or racenes (excent n. 9), apetalous (except n. 7). Stamens $S$ or more; antlers crect in the but.

7. Argythamnia. Petals and sejals 5. stamens 10-15, united. Styles bifid, linear.

8. Acalypha. Calyx 4-(3-5-) parted. Stanens mostly 8. Fertile flowers in the axils of leafy bracts. Stigmas tinely disserted.

9. Rlcinus. Racemes teminal, subjaicled. Calyx 3-5-parted. Stamens very numer ous; the filaments repeatedly brancher. Styles 2-parted.

0. Flowers apetalous, iu racemes or spikes pistillate at base. Stamens 2 or 3 . Styles simple

10. Tragia. Flowers racenuse. Calyx-lobes valvate in bud. Hirsute or pubcscent.

11. Stillingia. Flowers spieate. Calyx-lobes imbricate in bul. Fertile bracts glandu liferuus. Glabrous.

\section{EUPHÓRBIA, L. SPurge.}

Flowers monocions, included in a cup-shaped $4-5$-lobed inrolucre (fou of older authors) resembling a ealyx or corolla, and nsually bearing large thick glands (with or without petal-like margins) at its sinuses. Sterile Aowers numerous and lining tle base of the involucre, each from the axil of a Jittle hract, and consisting nelely of a single stanen jointed on a perlicel like the filament; anther-cells globular, separate. Fertile flower solitary in the midlle of the involucre, soun protrules on a long perlicel, consisting of a 3-lolved and 3-celled ovary with no calyx, or a mere restige. Styles 3, each 2-cleft; the stigmas thelefore 6. l'od separating into 3 1-seeded carpels, which split elastically into 2 valres. Sced often caruncled (ours only in $\$ \$ 5$ and 6). - Plants (hrors in the United States), with a milky acrid juice. Peduncles teminal, often umbellate-clustered; in the first section mostly alpearing lateral, but not leally axillary. (Named after Enphorbus, physician to King Juba.)

A. Glands of the imolncre uith petal-lite, wsually white or rose-colored, maryins or appendages: these almost obsolete in n. 1.

\$ I ANISOPHÝrLUUI. Leness all opposite, shomt-petioled, small, oblique at luse; stipulds awt-shaped or sraly and oflen fringed, persistent; stems murle lranched, spreading or nsully mocumbent; inrolucres solitary in the forks or in terminal or psendo-dateral clusters, small, mith 4 glands; seeds ashcolored (exrept in 11. 10); ammuls.

* Sireds smooth and even; lenes entire; uchole plant glabrons.

I. F. polygonifolia, L. I'rostrate-spreading; leaves oblong-linear, ontuse, mueromate, slightly cordate ar ohtnse at hase $\left(4-8^{\prime \prime}\right.$ long $)$; stipules setaceously divided; peduncles in the forks, as long as the petioles; lobes of the involucre longer than the minute not appenduged glands; pods obtusely" angled ; secrls ovate (orer $l^{\prime \prime}$ long, the largust of this sertion). - Sandy shores of the Atlantic ant of the Great Lakes.

2. E. Géyeri, lingelm. I'rucumbent; lences oblong-orete, obtuse, slightly muncrunte, nustly acntish at lase, lowermost eordate $\left(3-6^{\prime \prime}\right.$ longr); stipules setaceously dividerl; peduneles as long as the jetioles, at length in loose foliacmons lateral clnsters; glands with murou whe or red appendages; pods 
acutely angled; seerls orate, acute at one eud ( $\frac{1}{2}{ }^{\prime \prime}$ long $)$. - Surdy soil, 111. to Wisce, Minn., and lín.

3. E. petaloidea, Fugelu. Resembling the last, but lalf-erect aud spreacling; leaces longer, nurrourer, retuse or emarginute; ped uncles longer than the petioles; involucres larger, the broudly crmpamelate appendages murh larger and conspicuous: por obtusely angled ; seeds nearly l" long. - From lowa and Mo., westward.

4. E. sérpens, llBK. Stems filiform, prostrate, and often looting; /erues roumd-ovate, obtuse or cordate at bise (only $\frac{1}{2}-1 \frac{1}{2}{ }^{\prime \prime} \operatorname{long}$ ); slipules memhounceous, triangular: peduncles much louger than the petioles, at length in loose foliaceous lateral clustex's; glands of the rely small involucre with mimte

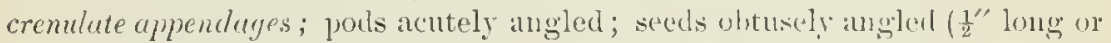
less). - Rich soil, Hll. and lowa to Kan., and sonthward. Riarely alel. eastward.

* * Seeds mimutely roughened or transcersely winkled or pitted; leaves more or less sermale, smooth or often huiry.

5. E. serpyllifolia, l'ers. Glabrous, prostuate-spreacling ; leuces wboruteoblong, narrowerl at the very obligne hase, sharply serrulate toward the obtuse apex $\left(3-6^{\prime \prime}\right.$ long, often with a red spoc); stipules lanceolate, finlmiate; peduncles as long as or longer than the petioles, at length in loose foliaceous lateral clusters; glands of the small involucre with narmw somewhat tootherl

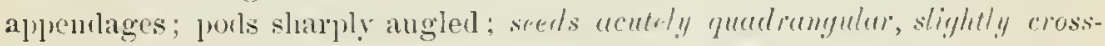
urinkled, often pitted (nearly"

6. E. glyptospérma, Engeln. (ilabrous (or very rarely puberulent), erect-sprealing; leaces lineur-oblony, nustly filcate, very nuequal at base,

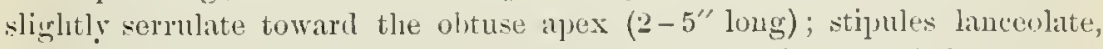
setacenusly divided; peduncles as long as the petioles, in dense foliacens lateral clusters; grlands of the rery sluall involuche with narow crenulate appendages; pork sharply angled; sceds sharply 4 -ringled and with 5 or 6 shaip

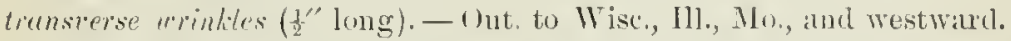

․ E. maculàta, I. I'rostrate; stens pulurulent or hainy ; lences oblong-

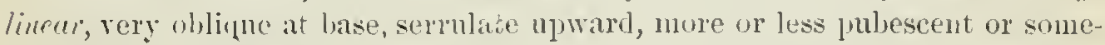
tines smoothish (4-6" long), nstlally with a brown-red spot in the centre; stipules lanceulate, fiubriate; peluncles as loug as the petioles, in dense foliaceous lateril chusters; glands of the small iuvolucle ninute, with narrow slighty crenite (usually red) appendages; pols acutely angled, puberulent;

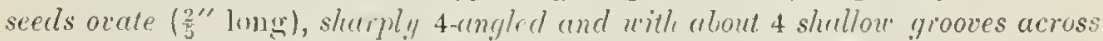
the concrue sides. - Open pliters, puakirles, etce, common.

8. E. humistràta, Engolu. I'rumlent. puberulent or laxiy ; leaces sliptical or ovorate, very ohlisue at hase, serrulate towat the apex, sparsely hairy underneath ( $t-9$ " long, sometines witl a brow spot above); stipules lanceolate, finloriate; pecluncles ratler shorter than the petioles, in dense scarcely foliaceuss lateral clusters; ineolucre cleft on the buck, its (red or white) appendages truncate or" crenate; pods sliarply angled. pubermleut; secls orate,

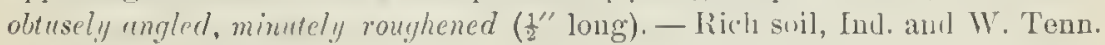
to Minn. anıl kan.

9. E. Préslii, Guss. Simouth or with scattered lain's, ascenting or erect $\left(1-2^{\circ}\right.$ higli); leaves ol)ligne at the obtuse or slighty (urdate hase, orate-oblong or obloug-linear, sometimes falcate, serrate ( $\frac{1}{2}-1 \frac{f^{\prime}}{2}$ long), often with a 
red spot or red margins; stipules triangular; peduncles longer than the petioles, cullected in loose leafy terminal cymes; aprenduges entire, larger and white, ox smaller and sonctimes red ; pod glabrous, obtusely anyled; seeds woule,

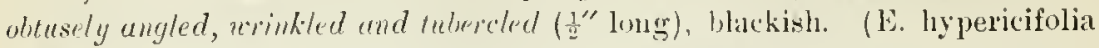
of Mun., not L.) - Common thruughout the U. S. eatst of the plains.

\$2. ZYGOPHYLIÍDIUM. Lene's opposite, on short petioles, not whligue, uith stipulur ylueds; stems dichotomously branched, areet; cymes terminal; incolureres uith 5 glands; seeds tubereukte.

10. E. hexágona, Nutt. Sumewhat hairy (1 ${ }^{\circ}$ highl or more); branche: striate-angled; leares linear-lanceolate, entire; involucre hairy without and whthin; glands with green orate-trianghlar appendages twice their length; capsuie smooth; seek orate. - Iowa to 'lex., west to Col. and Mlontana.

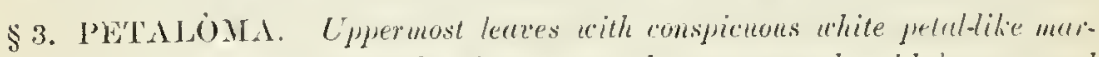

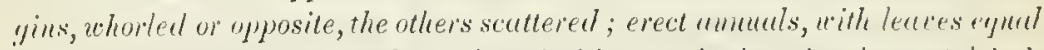
al base and entive, and with lanceolute decidnous stipules; incolucres 5 -loberl, in an umbel-lilie inflorescence.

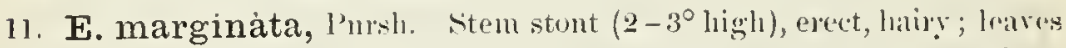
sessile, ovate or oblong, acute; unbel with 3 dichotomolis rays; glands of the involuce with broad white appendiges. - Minu. to Mo., west to (ol., also spereling eastwird to Ohio, and frequently escaperl from gardens, where it is often cultivater for its slowy broally white-nargined lhomal leares.

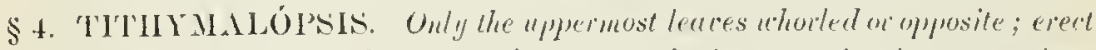
perennials, will entice leaces eqnal at buse; stipules none; incolacres mastl! I islobed, in the jorks of the beandes and triminal; inflorescence umbellifiorn.

12. E. corollàta, L. (ilahrous or sometines spatingly hairy $\left(2-33^{\circ}\right.$ high); leaves wate, lanceolate, or lincar, entire, olstuse; umbel 5- $; 3-7-$ forked, and the forks again 2-3- (or rarely 5-) forked; iurolucres long-pednuled, with showy white appendages (appenting like petals), the bobes miunte int incurvel; pod slemper-preticelled, surooth; seels thick (1" long or

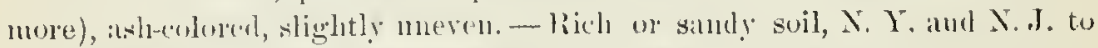
Fla., West to Mimu, and Lal., also alventive in Mass. July-Oct.

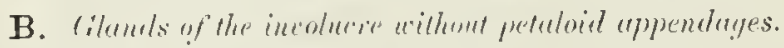

\$5. POINSETRTA. Throlures in terminal clusters, 4-5-lobed, wilh few (or often solitury) cup-shuped glunds; crect annuls, with cariable, entire, den. tate, or simutr lereres, all or only the upper ones apposite: the uppermos, often colorerl, aspecially ul berse: stipules smull rued glandulur.

13. E. dentàta, Michx. Erect or ascending. laairy (10 high); leaves ovate, lancenlate, or linear. pretinled, coarsely tonthed (1-2' long), only the lowest altemute, the mper often paler at base; involucres almost sessile, with 5 oblong dentite lobes, and one or sometimes more short-stalked glands; reeds orate-grlohnlan, shightly tulereled. — Rich soil, Penn. to 'Tenn., Iowa. I\%. Lian., and southwart. July - sept.

14. E. heterophýlla, $\dot{\mathrm{I}}_{2}$. Erect $\left(1-3^{\circ} \text { high }\right)_{1}$, glabrons: luctes alterme, petioled, orate-fichle-shaped and simuatc-tonthed, "1. lancenlite or linear

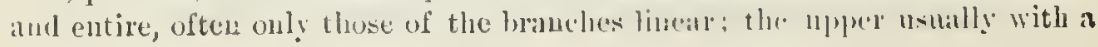


red lase; involncres alout the length of the peluncle, with 5 orate incised lobes and at single or few and almost sessile glands; seeds nearly globular, tubercled. - Slopes and rocky soil, Minn, to WV. [ll., Iowa and Mo.

$\$ 6$. 'TITHIENALUS. Inolucres in a terminal dichotomous of commonly umbelliform inflorescence, 5- or usually 4-lubed, with as many flut or concer entire or crescem-shaped glands; seeds curnonculate (except 11. 15); mirs ascending or erect, and mostly glabrous, without stipnles.

* Perenniuls wilh entire leavs, all or only the upper opposite; imolucres longpedumeterl in a dichotomons infloressence, mostly with 5 tianstersely oblong ylands; sceds wilhout rarmele.

15. E. Ipecacuánhre, 1. Nitems many from a very long jerpendicular rent, erect or diffusely sprealing (j-10' long), forking from near the batse: lowes varging fom obure ur oblong to narowly lineal, almost ressile,

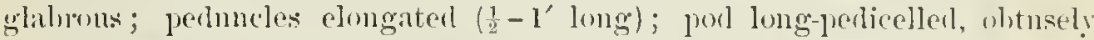
angled, nearly smonth; seel orate, white, sparsely marked with impreswel clots. - Sandy soil, near the const; Conn. to Fla.; also barrens of S. Ind.

* * Leures scuttered, only the floral in the umbelliform inflorescener mhorled or opposite and of a differeut shape; glands mostly 4.

+ Leaves servulate or rarely rntive; glunds transiersely oval, obluse.

+ Seeds smooth and eren; pod uarty or rough.

16. E. Darlingtònii, Gray. 'Tall peremial (2-4 high); lrotes entire, minutely domm, benealh; those of the stem lanceolate-nhlong from a narrow lise ; the floral oval, very obtuse; the upper roundish-rlilated with at truncate hase; mubel 5-8-rayed, then simply forked; pod mimudy "rorty: large glol11 lar seet with a small carmucle. - Copses, N. Y. and l'emu, to the momutains of X.C. July - Sept.

17. E. obtusàta, Pursh. Lirect ammul (1-20 high); leres wblong-spurulate, minntely serrnlate, smooth, all obtuse; mpper mes omelate at base; Horal mes ovate, dilated, barely mucromate; muled once or twice divided into 3 rars, then into 2; imenlure with nuled lolies and small stipitate glauds; styles des. timel. lenger than the orary, erect, 2-cleft to the middle: port heset with longe warts. - Danp woods, Va.to S. C., west to lowa amd Kan. May-July.

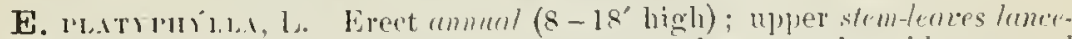

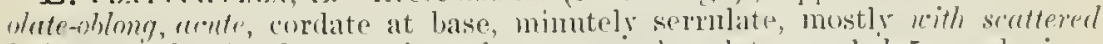

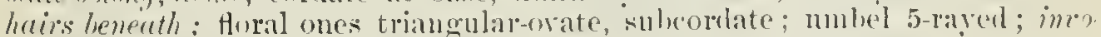

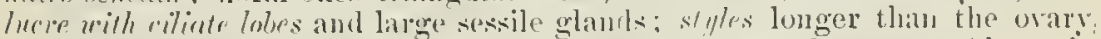
united at besse, slighlly; 2-eleft: pol covered with depressed watts. - Ilong the

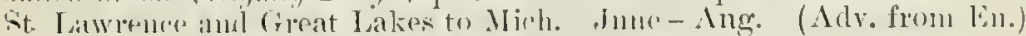

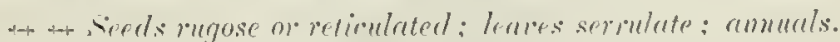

18. E. dictyospérma, Fischer \& Meyer. Stem ereet $(8-18$ higlo); leurs uhlong- or ohorate-spatulate, smooth, all olotuse aud whusely serrate: upper ones rordate at base; foral ones romdishorate or oliscurely heartshaped, slightly mucronate; mmhels once or twice 3-lorked, then 2-forked; involucre with nearly naked lobes and small whost sfssile glonds: sty]les

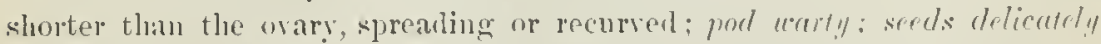
reticulated.- Praidies and roadsides, Md. to Mim., Mla., and Westward May - July. 
E. Ilezioscòrı, L. Stems ascending (6-12' highl), stout; leares all oborate and very romnled or retuse at the end, finely serrate, smooth or a little hairy, those of the stem wedge-shaped; umbel clivided into 5 rays, theu into 3, or at length simply forked; glomels orlicular, stulked: pods smooth and ev+re: seeds with course honeycomb-lile jeticulutions. - Waste places, eastward and along the Great lakes to Mich. July-Sept. (Nat, from Eu.)

+ + Lenes entire; glands crescent-shaped or 2-horned.

+ seeds smorth und durk-colored; perennials, arith rumning rootstochs.

E. Fsuca, L. Stems clustered $\left(1^{\circ}\right.$ high); lenres lanceolate or linear, the floral (yellowish) broedly heart-shaped, mucronate; unlsel divided into many iays, then forking; glands short-lorned (brown); jouls smoothish and granular. - Mass., western N. Y., anl Mich.; rare (Nh. from Ku.)

E. Cipskísins, I. Stems alensely elustered $\left(6-10^{\prime}\right.$ high); stem-lences

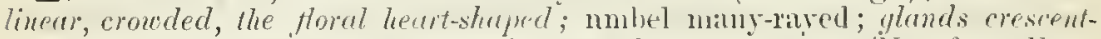
sheped; pouls granular. - Escaped from gardens, common. (Nat. from Eus.)

E. NIC.éxiss, All. Stout and tall ghabrous perennial ; leares oblong of oblong-lanceolate, the Horal broadly heart-shaped, mucromate; terminal unnel many-rayed, the lays forking; glands short-horned; pods finely wrinliled. A rare escape; Binghampton, N. Y. (Adr, from Eu.)

++ Seeds smilptured, ash-colored; pod smonth; ammuals or biennials.

E. PérLus, T. Exect or ascending $\left(5-10^{\prime}\right.$ lighh); leares petioled, thin, round-obovate, the upper floral ones orate; unbel 3-rayed, then forking; glinds long-horned; lobes of the poul 2-rimi-rested on the back; sceds $2-1$ promed on the inner fuce, pitted on the bark (scarcely orev $\frac{1}{2}$ long). - Waste julices, N. Eng. to N. J. and western N. Y. (Milv. from Eu.)

19. E. commutàta, Engeln. Stems hranclied from a commonly de('mulucut base (6-12' ligh); leares obovate, whtuse; the upper all sessile, the upper floral ones roundish-dilated, broaler than long; nmbel 3-forked; glands with slenter horns; copsule obtusely angled ; seeds ovate, pitted all oier (1" Iong). - Along streans ant shady slopes, Md. to Fli., Minn., aud Mo.

* * Cilabrom anmul or biennial with entire opposite and decussale leares, an nmbelliform inflorescenre, and short-linrued glands.

E. LÁtmlis, I. Sitem stout $\left(2-3^{\circ}\right.$ high $)$; leaves thick, liuear or oblong, the Horal ublong-ovate and heart-shaped; mubel 4-raved, then forking. sparingly escaped from gardens, N. king. to N. C. (Arlv, from lia.)

\section{PACH Y S Á N D R A, Michx.}

Flower's monacions, in naked spikes. Calyx 4-5-parted. l'etals none. sitr. Fl. Stamens t, separate; filaments long-exserted, thick and flat; an. thers oblong-linear. Fert. Fl. Wvary 3-elled; styles 3, thick, awl-shaped. recurved, stigmatic down their whole length insicle. Ovules a pair in each cell, suspented, with the rhaphe dorsal (turned away from the placenta). Capsule decply 3-horned, 3-eclled, splitting into 3 at length 2-valved 2-seeded carpels. - Nearly gobrons, low and procumbent perenial herbs, witls matted creeping rowtstocks, am alternate, wate or olovate. coarsely toothed leaves, narrowed at hase into a petiole. Flowers each 1 - 3-hrated, the uper staminte, a few fertile unes at bast, unpleasintly seented ; sejals greenish or purplish; filancents white (their sime and thicknosis giving the namme, from

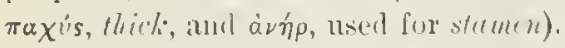

1. P. procúmbens, Nichx. Sitems $\left(6-9^{\prime}\right.$ long) hearing sererul al, froximate lates at the summit on slender petioles, and a few many-Huwered 
spikes along the hase; the intervening portion walied, or with a few small scales. - Woorls, numutains of Ky., W. Val, and southwar. March-May.

\section{PHYLLÁNTHUS, L.}

Flowers munucious, axillary. Calyx usually 5-6-parted, imbricated in the bud. Petals none. Stamens mostly 3 , erect in the bud, often united. (1)ules 2 in each cell of the ovary. Capsnle depresserl; each carpel 2-ralved, 2-seerlerl. Seerls not curnuculate. - Jeaves alternate, 2-ranket, with sulall stipnles.

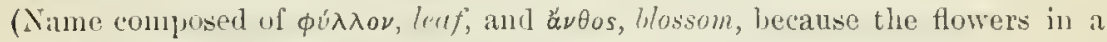
few species are horne upon leaf-like dilated brunches.)

1. P. Carolinénsis, Walt. Annual, low and sleuder, bunclied; leaves nhuvate or oval, short-petioled; flowers commonly 2 in each axil, almost sessile, one staminate, the other fertile; caly $\mathrm{x}$-parted; stamens 3 ; styles 3 , each 2-cleft; glands of the disk in the fertile flower's united in a cnp. - Gravelly hanks, L. L'en11. to Fla, west to S. Ind. and Ill. July-Sept.

\section{JÁ TROPHA, ‘...}

Flowers monocious, rarely diacious, in a terminal open forking cyme; the fertile ones nsually in the lower forks. Calyx corolla-like, in the staninate Howers often salver-shaped, 5-lobel; in the pistillate, 5-parterl, imbris'ated or convolute in the bur. Corolla of 5 distinct or apparently united petals, or none. Glands of the disk opposite the calyx-lobes. Stanens 10-30, in 2 or nore whorls; filanents monalel phous at base. Ovary mostly 3-celled ; styles 3, unitel below, their smmmits once or twice forkerl. Capsule 3-celled, 3-seeder, separating into 3 two-valvel carpels. Seed carunculate. - Perennial herbaccous or shrubly plants, chicfly tropical, with alternate nustly long-petioled palnately-reined leares, and stipules. - our species is of the section Cxibóscolds, with apetalous Howels, the staminate corolla salverform, and the plants mostly alued with stinging bristles. (Nane said by

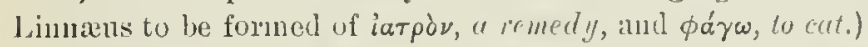

1. J. stimulósa, Michx. (Triad-softr. Spurge-Nettre.) 1lerbaceous, from a loug perennial root, branching $\left(6^{\prime}-2^{\circ}\right.$ high $)$; leaves rounclishheart-shaped, 3-5-lobed nearly to the base, on long petioles; the divisions entire or acutely tontled, cut, or even pinmatifid, often discolored; flowers white, fragrant, $9^{\prime \prime}$ long or more; filaments 10 , monadelphous only at the woolly base, or the outer set almost distinct. (J, mrens, var. stimulusa. I. Vuell.) - Dry sandy soil, Va. to Fla. and La. June-sept.

\section{CRÒTON, L.}

Flower's monocious, ratrely dinc(ints. mostly in terminal spike-like racemes or spikes. Sler. Fl. Calyx 5-(rurely 4-f-) parter ; the divisions lightly imbricated or neatr! valvite in the but. Potals nsmally present, as many,

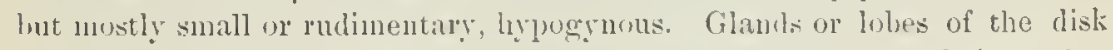
as many as and altemate with the petals. Receptacle nsually hairy. Stamens 5 or nore; filanents witl the anther's inflexed in the bud. Fert. F\%. Calyx 5-10-cleft or parted, nearly as in the staminate fowers; lut petals none or minute ludiments. (bary 3- (rarely 2-4-) cellerl, with a single orule in cach cell : styles ats many, from unce to thrice 2-cleft. (apsule separating 
into as may 2-valved 1-seeded carpels. Seeds carunculate. - Stellate (low y, or scurfy, or hairy and glandular plants, mostly strong-scented; the fertile flowers nsually at the base of the sterile spike or chaster. Leaves alteruate,

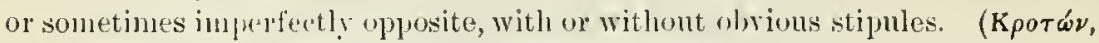
the Greek name of the (anstor-oil l'lant, of this family.)

* Sterile flowers with t-purtud coly.x, us many petuls, "4-rayged disk, and 8 stamens; fertile flowers with 5-parted caly.x, very minute rudimentary jutals, and the 3 styles 2-eleft.

1. C. glandulòsus, L. Annual, ronghthairy and glandular $\left(1-2^{\circ}\right.$ high), somewhat umbellately luanched; leaves oblong or linear-ollong, obtusely toothed, the base with a sancer-shaped gland on each side; fertile fowers capitate-clustered at the base of the sterile spike, sessile in the forks and terminal. - Open waste places, Va. to Iowa, E. Kan. and sonthwarl.

* * Sterile flowers with 5-parted collyx, as many glands alternating with the petals, and 10-14 stamens; fertile flowers with $7-12-p a r t e d ~ c a l y . r$, wo petals, and the 3 styles twice or thrice 2-p'irted.

2. C. capitatus, Michx. Anunal, deusely soft-woully and romewhat nhlandular $\left(1-2^{\circ}\right.$ ligglu), branched; leaves loug-petioled, lauce-oblong or elongrated-ollong, rounderl at base, entire; petals obovate-lauceolate, deusely fimbriate; fertile flowers several, capitate-crowderl at the lase of the slowt. terminal sterile spike. - Barrens, N. J. to Ga., west to S. Ind., Iowa, and F. Kitı. July - Sept.

** * Sterile flowers with unequally 3-5-parted calyx, as many petals and scale-fike glands, and 3-8 stamens; fertile flowers with equally 5-parted calyx, no petals, 5 glands, and 2 sessile 2-parted stigmas.

3. C. monanthógynus, Miclix. Annual, whitisl-stellate-puljescent and rustr-glanelular; stems $(1-20$ high $)$ slender, crect, below often nubellately 3-4-forked, then repeatedly 2-3-forked or alternately branched; leares (1) long-ovate or nurrowly oblong, entire, often acutish (6-12" long, about wice the length of the petioles); flowers in the forks, the sterile few on the summit of a short and erect peduncle, the fertile few and clnstered or inostly (w)litary on short recurved pednucles; ovary 2-celled ; fruit often by abortion 1-celled and 1-secded; the seed broadly oval. - Barrens and dry prairies, $\therefore$. Ind. to N. C. and Flit, west to E. Kian. June-Sept.

**** Diecions; craly.c equally 5-parted; petuls none; stamens 10 or more, styles trice or thrice dichotomously a-parited.

4. C. Texénsis, Muell. Ammal, covered with a cluse cinescént stellate pulnescence, dichotomously lwanched ur spreading $\left(1-2^{\circ}\right.$ high $)$; leaves narmwly oblong-lanceolate to linear; staminate spikes or racemes very slort, uften sessile; capsule stellate-tomentose and somewhat muricate. - Mo. and Kan. to Ala., Tex, and westwarl.

\section{CROTONÓPSIS, Michx.}

Flowers monoeivus, in very small terminal or latcral spikes or clusters, the lower fertile. Ster. Fl. Calyx equally 5-parterl. l'etals is, spatulate. Stamens 5, opposite the petals; filanents distinet, inflexel in the luul, enlarged 
at the apex. Fert. I\% Calyx unequally 3-5-parted, Petals none. Glauds (petal-like scales) 5, opposite the sepals. Orary l-celled, simple, l-oruled, hearing a twice or thice forked style. Fruit dry and indeliscent, small, l-secterl. Seed without carmucle. -1 slender low ammal, with alternate or opposite short-petioled linear or elliptical-lanceolate leares, which alle green and smootilisll above, but silvery loan with stary hairs and sculfy with blownish scales

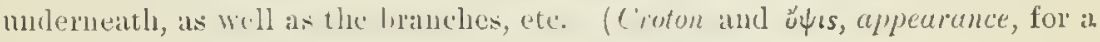
plant with the asjeret and generial cliaracter of Croton.)

1. C. lineàris, Miclux.-1)ry sandy suil, N.J. to Flia, west to Ill, aud lían. Jnly - Sept. - Fruil about I" long.

\section{A R G Y THÁ IM N I A, l'. Browne.}

Flowers monocions. Caly 5 -prated, valvate in the staminate flowers, inbricate in the gistillate. l'otals alternate with the caly'x-lobes and with the grominent lobes of the glandular disk. Stimens 5-15, mited into a central column in I-3 whorls. Styles 1-3-clult. Cipsule depressed, 3-lohed. Siech

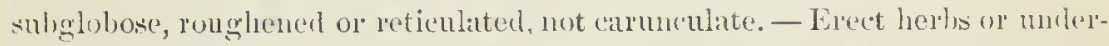
slunks, with jurplish juice, and alternate usually stipulate leares. (Nome from

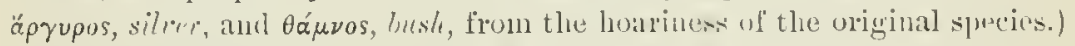

1. A. mercurialina, Muell. Stem erect, neary simple (1-20 ligh), seri(eouls; leates sessile, ohlung orate to lanceolate, entire, pubercent with al)

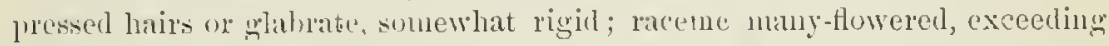

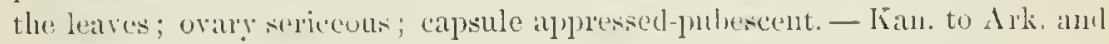
rex.

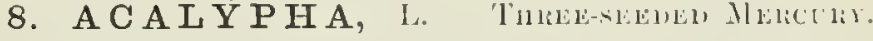

Flowers nonocious; the sterile very small, chustered in spikes, with the few or solitary fertile flowers at their base, ox sometimes in separate spikes. Calyx of the sterile flowers 4-parted aud valvate in buel; of the fertile, 3-5-parterl. (ivollal nune. Stamens -16 ; filanients short, monadelphous at hase; anthercells separate, long, often worm-shaped, langing from the apex of the filament. Sityles 3, the upper face or stignuls cut-fringed (usually red). Capsule sepallating into 3 globular 2-ralved carpels, rarely of only one carpel - llerbs four's anmals), or in the tropies often shrubs, resembling Nettles or Amaranths; the leares alteruate, petioled, with stipules. Clusters of sterile flowers with a minute bract; the fertile surromnled ly" a large and leaf-like cut-lobed persistent

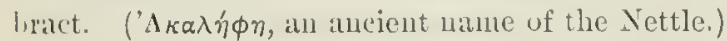

- Finit smooth or meril!l methesent; seeds neurly smooth.

1. A. Virgínica, L. Simothish or hairy (1 - 20 highl ), often turning purple; leaves urate or uhlong-orate, obtusely and sparsely serrate, long-petinled; sterile spilie rather few-flowered, mostly shorter than the large leat-like bilnately 5-9-cleft fruiting hracts; fertile Howers $1-3$ in each axil. - Fields and open places, N. Eug. to Ont. and Minu., south to the Gull. July- Sept.

V'ar. grácilens, Muell. Leaves lanceolate or even lincar, less tootled and s'rorter-petiolerl; the slender sterile spike often I' long, and much surpassing the less ele ft or few toothed fruiting bracts. - Simedy dry soil, li. I. aud Conu. to lila., west to 111., L. Kan. and Tex. 
* * Fruit echinute with soft bristly green projections; sceds rough-wrinkled.

2. A. Caroliniana, Ell. Leaves thin, orate-cordate, sharply and elosely serrate-toothed, abruptly acuminate, long-petioled; sterile spikes short, axillary; the fertile ones mostly terminal and elongated, their bracts deeply cut into many linear lobes. - N. J. to Fla., west to Ohio, Kan., and Tex.

\section{RÍCINUS, lim. Castoh-onl Plaxt.}

Flowers in racemose or panicled clunters, the fertile ahove, the staminate below. Calyx 5-parterl. Stamens very mmerous, with repeatedly branching filaments. Styles 3, united at base, each bifid, red. Capsule large, 3-lobed, with 3 large seeds. A I tall stately amual, with very large alteruate peltate
and palmately $7-11$-cleft leaves (often $1-2 \circ$ broad). (Ihe aneient Romau name of the plant.)

R. consùns, L. - Cultivated extensively for ornament, and sparingly es. caped in Md., Mo., and southward. Very variable.

\section{TR A G I A, P'lumier.}

Flowers monacious, in racemes, aletalous. Ster. $1 \%$ Calyx 3-5- (eliefly 3-) parted, valvate in the bud. Stamens 2 or 3 ; filaments short; antler-cell. united. Fert. Fl. Calyx 3-8-parted, persistent. Style 3-cleft or 3-parted; the brimches 3, simple. Capsule 3-celled, 3-lobed, lristly, separating into three 2-valved 1-seerled carpels. Seeds not carunculate. - Lrect or climbing plants (1) remial herbs in U.S.), pubescent on hispid, sometimes stinging, with mostly alternate stipulate leares; the small-flowered racemes terminal or opposite the leaves; the sterile flowers above, the few fortile at the base, all with small bracts. (Named for the early herbalist Bock, latinired Tragns.)

1. T. innócua, Walt. Frect, paniculate-branched, softly hairy-pubescent $\left(6-12^{\prime}\right.$ high $)$; leaves varying from olovate-oblong to narrowly linear, acute at base, obtusely or siunately few-tootled or lobed, sometimes entire, short-petioled or sessile, paler beneath ; sterile calyx usually 4-parted; stamens 2. (T', urens, L.) - Dry sandy soil, E. Va. to Fla. aud La. Mlay - Aug. - Not stinging.

2. 'T. nepetæfolia, Cav. lirect or reclining or slightly twining, hirsute with stingring hairs; leaves urate-innceulate or triangulur-luncelate, or the lowerovate, all somewhat curdute or truncute at buse, conrsely cut-toothed, short-petioled; sterile coly: usually 3-parted and stamens 3. (T. urticafolia, V/ch.x.) -Virginia (Pursh), and common sonthward to Fla, and Tex., Mu., Lau., and restward. - T. stridni-, Muell., of the sonthwest, which is reporterl from Kinl., may he distinguished by its $4-5-$ parted sterile calyx, $4-5$ stamens, and alongateel styles.

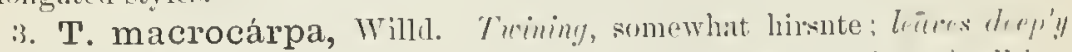
cordate, ovate, mostly narrowly alcuminate, shamply serrate $\left(3-5^{\prime}\right.$ long), all lint

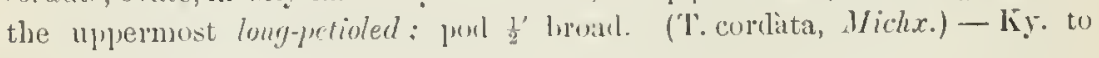
Ga., Fla., and La.

\section{STILIINGIA, Farden.}

Flowers monocions, aggregated in a terninal spike. Petals and glants of the disk noue. Calyx 2-3eleft or parted; the div isions inllricated in the bunl. staneus 2 or 3 ; inthers alnate, turned outward. Style thick; stigmils :3, 
diverging, simple. Cajpsule 3-celled, 3-lober, 3-seeded. Seed carunculate.sinvoth upright plants, with the alternate leaves mostly 2-glaudular at base; the fertile flowers few at the base of the dense sterile spike (rarely separate); the bract for each cluster with a large gland on each side. (Named for Li: B. Stillingfeet.)

1. S. sylvática, L. Herbacenus $\left(1-3^{\circ}\right.$ ligh $)$; leaves almost sessile, ob. long-lanceulate, serrulate; glants of the spike sancer-shaped. - Sandy and dry soil, Va. to Fla., west to kian. aud 'Tex. June-Sept.

\section{OrDER 99. UIRTICÀCEAE. (NeTtLE FAMLY.)}

Plants with stipules, and monxeious or diocions or rarely (in the Ehr Family) perfect flowers, fumishal with a regular caly. fiee from the 1 celled (rarely 2-celled) ovary which forms a 1-seeded fiuil: the embryo in the albumen when there is any, its radicle pointing upacurd; stamens a* many as the lobes of the calyx and opposite them, or sometimes ferer. Cotyledons usually broad. Stipules often deciduous. - A large order (far the greater part tropical).

Tribe I. ULMEX: Flowers mostly polygamous, upon the last jear's branches. An. thers erect in the bul, extrorse. Styles or stiginas 2 . Fruit a winged samara or nutlike. Seed suspended. Eimbryo straight. - I'rees, with altemate serrate pinnately reined leaves anrl fingacious stipules.

1. U1mus. Flowers preceding the leaves Ovary $1-2$-ovuled. Fruit winged all arouncl.

¿. Planera. Flowers alplearing with the leaves. Ovule one. Fruit wingless, nut-like.

Tribe Ir. CELTIDEA. Is in Trihe I., but the diceious-polygamous flowers urom branches of the sane year; anthers introrse; liruit a druje: embryo curved.

3 Celtis. Ovary l-oruled. Flowers appearing with the leaves. Leaves 3-nerved at base.

Tribe III. CANNA BINEA. Flowers dicecious; the sterile racemed or panicled; the lertile in cluster's or eatisius, the calyx of one sejal embracing the ovary. Filanents short, erert in the bud. Stigmas 2, elongated. Ovary l-celled, with a pendulous ovule, forming a small grlinfular aelsene in fruit. Enbryo curved or eoiled. - Erect or elinbing lierbs, with watery juice, mostly opposite lobed or divided leaves, persistent stipmles, and a filrous inner bark.

4 Cannabis. Furtile fuwers spikcul-clustered. Leaves 5-7-divided. Erert.

j Humulus. Fertile flowers in a short spilie forming a menbranacens catlin in fruit. Leaves $3-5$-loberl. Climbiug.

Tribe IV. MOREX. Flowers unisexnal, racemose, spicate or eapitate; ealyx becoming fleshy or juiey in fruit. Anthers inflexed in the bud. Style undivided or 2-parted. fliform: ovule pendulous; fruit an aeliene, embryo eurres. - Trees or shrubs, with milky juice, alternate leaves, and fugaeious stipules.

6. Maclura. Steril flowers in lonse racemes; fertile in glohose heads. Leaves entire.

7. Morus. Fertile and sterile flowers in separate spikes. Ieaves ilntate, 3-nerved.

Trihe V. URTICLA. Furvers unisexual. Filaments intiexen in the burl. style or sticmin simple. Wrary 1-elled, with an ereet ovnle, forning an arhene in Iruit. Enbryo straight. - Heris with watery juice, tough fibrous bark, and olnosite or alternate leaves; often arnecl with stinging hairs.

* Calyx in the fertile flowers of $2-5$ separate or nearly separate sepals.

- Plant beset with stinging bristles.

s. Urtica. Supuls + in luth fertile and sterile fuwers. Mrene strainht and erect, en chosecl by the a inner and larger sepals. Stigma capitate-tufted. Leaves opposite. 
9. Laportea. Sepals 5 in the sterile tlowers, 4 in the fertile, or aplationtly only 2 . Stigu: long-subulate, Aeheue very oblique, defiexed, nearly naked. Leaves alternate.

+ + Plant wholly destitute of stinging bristles. Leaves olposite

10. Pilea. Sepals 3 or 4 , those of the fertile Howers unequal, all or all but one small. Acliene partly uaked, straight and erect. Stigma pencil-tulted. Smooth and shining.

* Fertile enlyx tubular or cup-shaped, enclosing the achene. Unarmed.

11. Buhneria. Flower-clusters spiked, not involuerate. Style lung aud tliread-shaped, stirnatic down one side. Leaves opposite, serrate.

12. Parietaria. Flowers in involucrate-bracted colusters. Stigma tufted. Leaves alternate, entire.

\section{1. Ú L M U S, I. ELM.}

Calyx bell-slaped, 4-9-cleft. Stamens $4-9$, with long and slender filaments. Ovary 1 -2-celled, with a single anatropons ornle suspended from the snumit of each cell; styles 2 , short, diverging, stignutic along the immer elige Fruit a 1-celled and l-seeded memluranaceons samara, wiuged all aromul. Albumen none; emlnyo straight; the cotylulons linge. - Flower's polygitmons, purplish or yellowish, in lateral clusters, in our species preceding the leares, which are strongly straight-reined, short-petioled, and oblique or unequally somewliat heart-shaped at base, stipules small, carlucons. (T'le classical Latin nane.)

* Flurers nermly sessile: fruit orbicular, not ciliate: lenves rery rough above.

1. U. fúlva, Michx. (Suppery or Rev Elx.) lßuds before expansion soft-down witli msty hairs (large) ; leaves ovate-oblong, taper-pointed, doubly serrate $\left(4-8^{\prime}\right.$ long, sweet-scented in dryoing $)$, soft-downy beneatl or slightly rougle downward; branchlets downy; calyx-lobes and stamens $5-9$; fruit $\left(8-9^{\prime \prime}\right.$ wide) with the cell pubescent. - Rich soil, N. Eng. to the 1)akotas, and

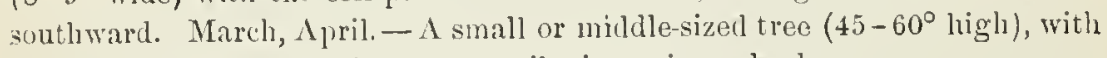
toug! , rediish wood, and a very mucilaginous iuner bark.

* * Fluners on slender drooping pedirels, which are jointed above the middle: fmit mente or oval, fringed-ciliute; leaces smooth above, or nearly so.

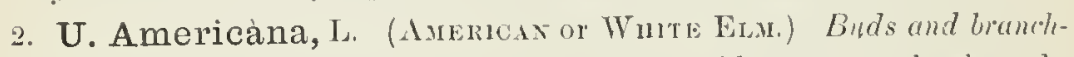
lets glabrous; brunches not corky: leaves obovate-oblong ur oral, abruptly pointed, sharply and often donbly serrate (2-t'long), soft-pubescent beneath, or som glabuous; floures in close fuscicles; calyx with 7 - 9 ronndish lobes;

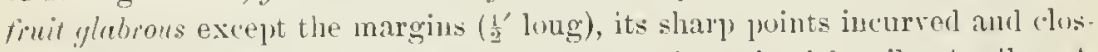
ing the notch. - Nloist wouls, especially along rivers, in rich soil. A $\Lambda_{\text {pril. }}-\Lambda$ large and well-known ornamental tree, variahle in hahit, nsinally with spreading branches and lrooping branchlets.

3. U. racemòsa, 'l'lumas. (Cork or Rock Eux.) Bud-sentes dounyriliute and somewhat pmbescent, as are the young bumchlets; brunches often with corky ridyes; leaves nearly as in the last, but with reins more simple and stritglit; fouces racemed; fruit uuch as in the last, but ratler larger. - Riverbanks, s. IV. Vt. to Ont. and central Minn., sontl to Mo. and Ky. A large ancl very valuable tree.

4. U. alàta, Michx. (Wanoo or WINGed El3.) Bud-scules and bramrhlets nearly glabours: branches rorky-winged, at least some of them; leaves

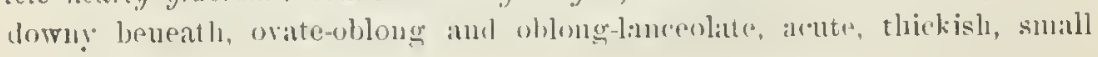


(1-2 $\frac{1^{\prime}}{2}$ long); calyx-lobes obovate; fruit lowny on the face at least when young. - Va. to S. Ind., S. Mo, aud southward. Marel. A small tree.

\section{PLÁ N E R A, Gmelin. Plaver-tree.}

Flowers monociously polygamous. Caly $4-5$-cleft. Stamens $4-5$, Uvary wroid, 1-celled, 1-ovuled, cruwned with 2 spleading styles which are stigmatuse down the inner side, in fruit beconingr corlaceons and nut-like, not winger. Albumen none; embryo straight. - Trees with small leaves, like those of Elms, the flowers appearing with them, in small axillary clusters. (Named for J.J. Planer, a German botanist.)

1. P. aquática, Gmel. Nearly glabrous; leares ovate-oblong, small, fruit stalked in the calyx, beset with irregular rough projections. - W'et banks, N. C. to Kíy., S. Ill., and southward. April. A rather small tree.

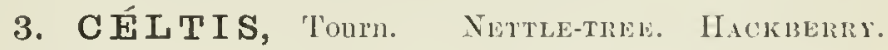

Flowers monœciously polygamous, Calyx 5-6-parted, persistent. Stanens $5-6$. Ovary 1-celled, with a single suspended orule; stigmas 2, loug aur pointed, recurved. Fruit a globular drupe. Embryo curved, nearly enclosing a little gelatinous albumen ; cotyledons folded and crumpled. - Leaves pointed, petioled, inequilateral. Stipules calucous. Flowers greenish, axillary, the fortile solitary or in pairs, pednucled, appearing with the leaves, the lower unally staninate only, fascicled or racemose along the base of the branches (If the season. ( $A$ name of Pliny's for an $\Lambda$ frican species of Lotus.)

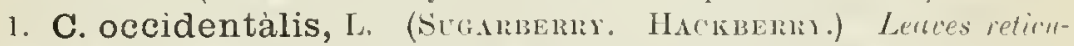
lefed, ovate, cordate-ovate and orate-lanceolate, taper-pointed, usually conspicuously and sharply so, more or less oblique at base, shurply surute, sometimes sparingly so or only toward the apex, scabrous but mostly glabrous above, usially soft-pubescent beneath, at least when young; fruit rechlish or yellowisli, turning dark purple at maturity, its perluncle once or twice the length of slie petiole. - Woods and river-hanks, N. Eng. to Minn., and southwarl. April, May. - A small or sometimes large tree, with the anject of an Fin, bearing sweet and edible fruits as large as bird-cherries, at first obnvate, ripe in autumn; the flesl thin. Very variable in the form, texture, ete, of the leaves. - Var. PưmLd, Gray. Low and striggling $\left(4-10^{\circ}\right.$ high); leaves thin when mature, and smooth, slightly acuminute. River-banks, on rocks, from Maryland southward.

2. C. Mississippiénsis, Bosc. Lenves entire ("arely few-toothed), very long taper-pointed, rounted at base, mostly oblique, thin, and smooth; fruit small. - Ill. to 'Tenn, and southwarl. A small tree with warty bark.

\section{CÁ N N A B I S, Tourı. HЕмr.}

Flowers dicecious: the sterile in axillary compound l'acemes or panicles, with 5 sepals and 5 dropping stamens. Fertile flowers spiked-clustered, I-hracted: the ealyx of a single sepal enlarging at the base and fulderl round the ovary. Achene crustaceous. Embryo simply curverl. - A tall roughish amual, with rligitate leaves of $5-7$ linear-lanceolate coalsely tontherl leaflets, the upper alternate; the inner bark of very tough fibres. "The ancient Greek name, of obscure etymology.)

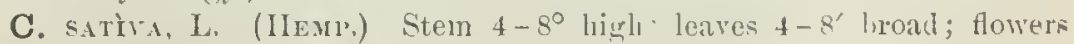
green. - IV iste and eultivated gromul. (Adv. fiom Eu.) 


\section{H U M ULUS, L. Hor.}

Flowers dioeions; the sterile in loose axillary panieles, with 5 sepals and 5 ereet stamens. Fertile flowers in short axillary and solitary spikes or catkins; braets foliaeeons, imbricated, each 2-flowered, in fruit forming a sort of membranaceons strolile. Calyx of a single sepal, embracing the ovary. Achene invested with the cnlarged seale-like calyx. Embryo coiled in a flat spiral. 'Jwining rough perennials, with stens almost prickly dowmard, and mostly opposite heart-shaped and palmately 3-7-lobed leaves, with persistent orate stipules between the petioles. (A late Latin name, of Tentonic origin.)

1. H. Lùpulus, I. (Commox IIor.) Leaves mostly 3-5-lobed, connonly louger than the petioles; brats, ete., smoothisls; the fruiting cal yx, achene, ete., sprinkled with yellow resinous grains, which give the bitterness and aroma to the hop. - Alluvial banks, N. Eng. to western N. Y., the Great Lakes and westward, aud south in the mountains to Ga. July. (En., Asia.)

\section{M A C L ƯR A, Nutt. Osage Oranga. Bon b'Ane.}

Hlowers dinecious; the staminate in loose short racenes, with + -parted calyx, and 4 stamens inflexerl in the loud ; the pistillate in a dense glohose loeal, with at 4-cleft calyx enclosing the ovary. Style filiform, loug-exserted; ornle pen. dnlous. Fruit an achene, buried in the greatly enlared fleshy alyx. Nlbumen nowe. Embryo recurved. - Trees with milky juice, altemate entire pimnately reined leaves, cadneous stipules, axillary peduncles, and stont axillary spines. (Named for the early American geolugist, II illiam Machme)

l. M. aurantiaca, Nutt. A tree $30-50^{\circ}$ high ; leaves ovate to oblonglanceolate, printed, mostly rounded at base, green and shining; syncil' glo. hose, yellowish green, 2-3' in dianeter. - E. Kan. and Mo. to N. Tex.: extensively used for helges. Wood bright urange.

\section{MORUS, Tourn. MÜm:m}

Flowers monoerions or dicecious; the two kinds in separate axillary and "atkin-like spikes. Calyx 4-partel ; lobes orate. Nitamens f; tilaments clastically expanding. ()vary 2-celled, one of the cells smaller and disilpuenring; styles 2, thread-form, stigmatic down the inside. Achene orate, compressed, covered by the succulent herry-like culyx, the whole spike this becoming a thickened oblong and juicy (edible) agrengate fruit. - 'lress witl milky juice aud broal leaves; sterile spikes rather slender. (T'le chissical latin name.)

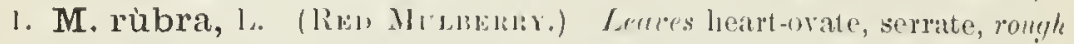

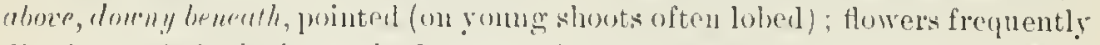
direcious; fimil dur fmiple, loug. - Rich wouls, W. Now Eng. to s. Ont., the Dakotas, E. Kan., and southward. May. - Large tree, ripening its blackbrry-like fruit in July.

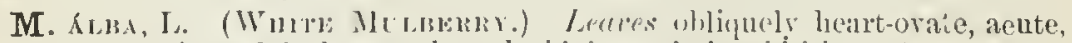
serrate, sometinc's loherl, smooth and shining; frmit whitish. - Spontaneons near houses. (Alv. from Eu.)

\section{URTì C A, 'Tourn. Nettul:}

Flowers monucious, or mrely dinecions, clnstered, the clusters mostly in ra. (emes, spikes, or loose heads. ster. $1 \%$. Sepals 4 . Stannens 4 , inserted around 
the cup-shaped rudiment of a pistil. Fert. Fl. Sepals 4, in pairs; the $20 n$ tre smaller and sprearling; the 2 inner flat or concave, in fruit membranaceous and enclusing the straight and erect ovate flattened achene. Stigmiı sessile, a.pitate and pencil-tufterl. — llerls, armed with stinging hairs. Leaves opposite; stipules in our species distinct. Flowers greenish; in summer. (The classical Latin name; from uro, to buru.)

* Perennials; flowr-rolusters in branching prenicled spikes, often dincious.

1. U. grácilis, Ait. Sparingly bristly, slender $\left(2-6^{\circ}\right.$ high $)$; leares ovuleInceolate, pointed, scrmate, 3-5-nerved from the romded or scarcely heartshaped base, almost glabrous, the elonguted slender pretioles sprringly bristly: spikes slender and loosely panicled. - Fence-rows and moist ground, common. stings few.

U. Drorcs, L. Tery bristly and stinging (2-30 high); leures ocute, heurt shaped, pointed, very deeply serrate, downy beneath as well as the upper part of the stem; spikes much branched. - Waste places and roadsides, rather rare. Canada and X. Eng. to S. C., West to Minn. and Mo. (Nat. from Eur.)

* Annuals; flocer-cluster's rhiegly axillary and shorter than the petiole, androgynous.

U. Ùrex, J. Leaves ellipticul or oute, very coarsely and deeply serrate with long sprearling teeth, the terminal teeth not longer than the lateral ones; fover-chusters 2 in ench axil, smull and loose. - Waste yromnds, near dwellings, castwarl ; scarce. Plant 8-12' high, with sparse stings. (Nat. from lin.)

2. U. chamædryoides, Pursh. Leuces arate and mostly heurt-shaped, the upper orate-lanceolate, coarsely scrate-toothed; flower-clusters globular, $1-2$ in each axil, and spiked at the summit. - Allurial shaded soil, from Ky. to the Gulf States. Slender, 6-30' high, sparsely leset witl stings.

\section{I A Pó RTEA, Gandichand. Woon-Netté.}

Flowers moncecious or diœcious, clustered, in loose cymes; the upper widely spreading and chiefly or entirely fertile; the lower mostly sterile. Ster. F\%. Sepals and stamens 5 , with a rudinent of an ovary. Fert. Fl. Calyx of 4 sepals, the two outer or one of them nsually minute, and the two inner much larger. Stigna elongated awl-shaped, hairy down one side, persistent. Achene ovate, flat, extremely oblique, retlexel on the winged or margined pedicel, nearly niked. - Pereunial herbs, with stinging hairs, large alteruate serrato leaves, and axillary stipules. (Named for $1 /$. Litporte.)

1. L. Canadénsis, Gaudichaud. Stem 2-3 high; leares ovate, pointed, strongly fenther-reiued ( $3-7^{\prime}$ long), long-petioled; fertile cymes divergent; stipule single, 2-cleft. - Moist rich woods. July-Sept.

\section{PÍLt A, Lindl. Richweed. Clearweed.}

Flowers moncecious or dinecious. Ster. F\%. Sepals and stamens 3-4. Fert. F\%. Sepals 3, oblong, more or less nnequal; a rurliment of a stamen conı. monly before eacli in the form of a hooded scale. Stimma sessile, pencil-tufted. Achene orate, compressed, rect, partly or nearly naked. - Stingless, mostly glabroms and low herbs, with oplosite leaves and uniterl stipules; the staminate flowers often mixel with the fertile. (Nimed from the slape of the larger sepal of the fertile flower in the origiual species, which partl! covers shr achene, like the pileus, or felt cap. of the Romaus.) 


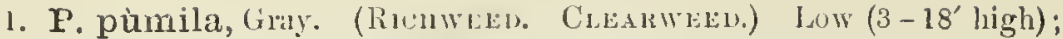
stems smooth and shining, pellueil; leaves ovate, consely toothed, pointed, 3-ribbed aud veiny; flower-clusters mnch shorter than the petioles; sepals of the fertile flowers lanceolate, scarcely unequal. - Cool and moist staded plaees. July - Sept.

\section{B $\mathrm{E}$ H M E $\mathbf{E} \mathbf{A}$, Jaeq. False Nettle.}

Flowers monœcions or diceions, elnstered; the sterile much as in Irtica the fertile with a tubular or uru-shaped entire or 2-4-toothed calyx enclosini the ovary. Style elongated awl-shaped, stigmatic and papillose clown on side. Aehene elliptieal, closely invested by the dry and persistent compresse! ("aly. - No stings. (Named after Cr. R. Boelimer, Professor at Wittuberpe in the last eentury.)

1. B. cylindrica, Willd. ['eremial, smoothish or fulescent ind mure or less seabrous; stem $\left(1-3^{\circ}\right.$ high) simple; leaves chiefly upposite (larely all alteruate), ovate to ovate- or oblong-lamceolate, pointel, serrate, 3-nervol ; sti 1ules distinct; petioles short or elongated ; flowers diocious, or the two kincls intermixed, the small clusters densely aggregated in simple and elongated axillary spikes, the sterile interrupted, the fertile often eontinuous, frequently leaf-hearing at the apex. - Moist or shady ground, eommon. Very variable.

\section{PARIETÀ I A, Toum. Plititor.}

Flowers monucionsly polygamous; the staminate, pistillate, and perfect intermixed in the same involucrate-hraeted cymose axillary elusters; the sterile much as in the last; the fertile with a tulular or hell-shaped t-lobed and nerverl calyx, enelosing the ovary and the oroirl arhene. Style slender or none; stigma pencil-tufted. - Homely, diffuse or tufted herbs, not stinging, with alternate entire 3-ribbed leaves, and no stipmles. (The ancient Latiu name, becanse growing on old walls.)

1. P. Pennsylvánica, Muhl. Low, anmual, simple or sparingly liraneher, minutely downy; leaves oblong-laneeolate, thin, reiny, ronghish with oparge dots; flowers shorter thau the involuere; stigma sessile. - Sharled roeky banks, E. Mass. and V't. to Minn., and soutluwad. June-Aug.

\section{Order 100. PLATANAClad. (Phaxe-tree Famir.)}

Trees, with watery juice, alternate palmately-lobed leaces, sheathing stipules, rund moncecious. fowers in separate and nated spherical heads, deslimte of calyx or corolla: the fruit merely club-shaped 1-seederl nutlets. furmished with " ring of bristly hairs about the lase? consists only of the following renus (of uncertain relationship).

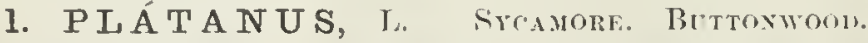

Siterile flowers of numerous stamens, witl clul-sluped little seales intermixel; filaments very short. Fertilo flowers in separate catkins, consisting of inversely pramial ovaries mixed with little soules. Sityle rather lateral, awl-shaped on threat-like, simple. Nutlets coriareons, small, tawny-laniry below, containing a single orthotropous pentuloms seed. Fmbry in the axis of 
thin albumen. - Large trees, with the bark deciduous in broal thiu brittle plates; dilated base of the petiole enclosing the bud of the next season. (The ancient name, from $\pi \lambda \alpha \tau$ v́s, broad.)

1. P. occidentàlis, L. Leaves mostly truneate at base, angularly sinuate-lobed or toothel, the short lobes sharp-pointed; fertile heads solitary. hanging on a long pelunele. - Alluvial banks, S. Maine to N. T't., Ont., S. E. Minn., E. Kan., and sonthward, Our largest tree, often $90-130^{\circ} \mathrm{high}$, with a trunk $6-1 t^{\circ}$ in lianeter.

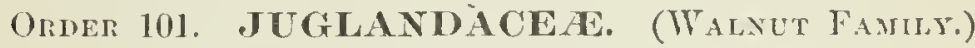

'Trees, with altemate pinnate leaves, and no stipules; flovers monocious, the sterile in cathins (aments) with an irregular calyx adnate to the bract: the fertile solitary or in a small cluster or spilie, with a regular 3-5-lobed ralyx adlerent to the incompletely 2-4-celled but only 1-omuled orary. Fruit a timel of lry drupe, with a crustaceous or bony nut-shell. containing "lrige 4-lobed orthotropous seed. Albumen none. Cotyledons fleshy and oily, sinuous or corrugated, 2-loluel ; radiche short, superior. Petals sometimes present in the fertile flowers. - I small fanily of inportant trees, consisting chiefly of the two following genera.

\section{J Ù G L A N S, I. WaINuT.}

Sterile flowers in long and simple lateral catkins from the wood of the prereding year; the culy adherent to the entire bracts or seales, mequally $3-6$ ('left. Stanens 12-40; filaments free, very short. Fertile Howers solitary or several together on a peduncle at the end of the hrauches, with a 4 -toother ("alyx, bearing 4 small petals at the sinuses. Strles 2 , very short ; stigmas ", somewhat club-shaped and fringed. Fruit with a filnous-fleshy indehisecut cpicarp, and a mostly rough irregularly furrowed endocarp or mut-shell. 'lrees, with strong-scented or resinons-aromatic latk, few-sealed or almost naked buds ( 3 or 4 superposed, and the uppermost far above the axil), odd-pinunte leaves of many serrate leaflets, and the embryo sweet and edible. Pith in plates. (Name contracter from Joris glum, the nut of Jupiter.)

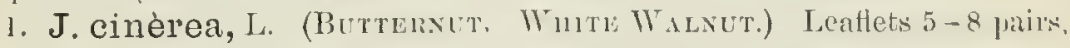
(b)long-lanceolate, pointed, rounded at base, downy, especially beneath, the petioles and brancliets douny with clemmy hairs: fruil oblong, clammy, pointed the nut deeply seulptured and rough with ragged ridges, 2-celled at the base. - Rich woorls, X. Ling. to the momntains of Gia., west to Minn., F. Kan., and Ark. Tree 50-750 high, with gray bark, widely spreading branches, and lighter brown wood than in the next.

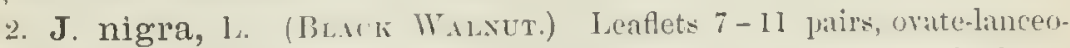
late, taper-pointed, sumewhat heart-shaped or unequal at hase, smesoth alove, the lower surface and the petivles minutely domng; finit spluevicul, roughly lotted, the nut corrugaterl, 4-celled at top and bottom. - Rich wouls, Wr. Mlass. and Conn. to Fla., west to Mimn., E. Neb., F. Kan., and sulthward. $\Lambda$ large and handsome tree (often $90-150^{\circ}$ high), with rough brown lark, and valuable purplish-hrown wood turniug liackish with age. 


\section{CÁRY Y, Nutt. Нickorr.}

Sterile flowers in slender lateral and clustered eatkins; enlyx naked, adhe. rent to the bract, unequally $2-3$-parterl. Stamens $3-10$; filaments short or uone, free. Fertile flower's $2-5$ in a rluster or slunt sjuke, on a peduncle ter. minating the sluot of the seasun; alyx 4-tootherl petals none. Stigmis sessile, 2 or 4 , large, papillose, persistent. Fruit with a 4 -ralred, firm and at length dry exocarp (involucre), falling away from the smooth aul crustacous or bony entocarp or unt-shell, which is incompletely 2-celled, and at the base mostly 4-celled. - Fine timber-trees, with hard and very tough wood, and scaly bnds, from which in spring are put forth nsually both kinds of flowers, the sterile below and the fertile above the leaves. Nuts ripen and fall in Oetoher. (Kapúa, an ancient name of the Wahut.)

\$1. Sterile cathins fascicled (no com mon peduncle or sumetimes a very short one) from separate lateral scaly buds mar the summit of shoots of the preceding year; bud-scales few; fruit elonguted-oblong; the thin-shelled nut 2-celled below; seed suet; leaflets short-stulled, numerous.

1. C. olivæiórmis, Nutt. (I’LCAN-sut.) Minntely downy, becoming nearly smooth; leallets $13-15$, ollong-lanceolate, tipering gradually to a slender point, falcate, servate; nut olive-shaped. - River bottoms, S. Ind., S. Ill., and Iowa, to La. and 'Tex. A large tree $\left(90-160^{\circ}\right.$ ligh $)$, witl delicious nuts.

\$2. Sterile callins in threes (rarely more) on a common pedincle fiom the axit of the immer serales of the common hud, therefore at the base of the shoot of the seuson, which, then bearing 3 or 4 leares, is terminated by the fertile flowers; fruit glubular or ocul: nut 4-celled at buse; leaflets sessile or nearly so.

* Bud-scules numerous, about 10, successively enurapping, the inner ones acres cent, becoming thin and membranaceous and rather tardily deciduous; hush of the finit splitting promptly into 4 mre or less thick and when dry hard or woody valces; seed sireet and delicious. (The hickory muts of the market.)

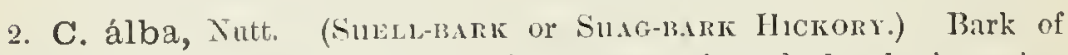
trunk shaggy, exfoliating in rough strips or plates; inuer bud-scales becoming large and couspicuous, persistent till the flowers are fully developed; leaflets $5-7$, when young ninutely downy beneath, fuely serrate, the three "lper ohovate-lanceslate, the lower pair much smaller and olnlong-lauceolate, all taperpointed; fruit glolular or depressed; mut uthe, flattisl-glubular, barely mu(ronate, the shell thinnish. - N. ling. to N. shore of I. Frie and S. E. Minn., suntli to Fla, li. Kan., and Tex. Iarge and hambsome tree $\left(70-90^{\circ}\right.$ high, ol nore), of great cconomic value. The principal lickory-nut of the markets.

3. C. sulcàta, Nutt. (Bu; Siltu-вakк. Kixi-sit.) Bark, ete, as in 11.1 ; lenflets $7-9$, more downy beneath; fruit oeul or orate, 4-ribber above the midtle, the lusk very thick; nut lurge $\left(1 \frac{1}{4}-2^{\prime}\right.$ long) and usually augular, sull uhile or yellowish, thirls-rorlled, usuchlly strongly pointed at both ends. Central N. Y. and Peun. to S. Ind., E. Kan., and Ind. Terr. 'Tree $70-90^{\circ}$ ligh, or mole, in rich soil of bottom lands.

4. C. tomentòsa, Nutt. (Mockin-set. White-henit IIIckori.) Burk close, mugli, lut not slagrey and exfoliatiug on oll truulss; catkius, shoots, and lower surface of dle leares tomentose when young, resinous scented. 
leafets 7-9, lance-obovate or the lower oblong-lancculate, pointerl; fruil glub. ular or ovoid, with a very thick and hard husk; nut globuler, not compresserl, 4-ridged toward the slightly pointed summit, brounish, very thiek-shelled, l' in dianeter or smaller. - N. Eng. to $\mathrm{N}$. shore of L. Firie, E. Neb., and south to the Gulf. 'Tree $70-100^{\circ}$ high, usnally un rich upland hillsides.

5. C. microcárpa, Nutt. With rough close bark, small orate tuds, and the glabrous foliage, ete., of 11. 6 ; fruit small, subglobose, witl rather thin husk; nut thin-shelled, not angled. - N. Y. to Del., west to Mich. and 111.

* * Bud-scales numerous or feu'; husk of the fruit thin and rather friable at maturity, 4-valved only to the middle or tardily to near the base; seed more or less bitter; bark of old trunk not exfoliating.

6. C. porcina, Nutt. (PIG-NtT or Broom II.) Bud-scales nearly as iu 11. 4, but smaller, caducous; shoots, catkins, and leaves glubrons or nearly so; leaflets 5-7, oblong- or obovate-lanceolate and taper-pointed, sernate; fruit

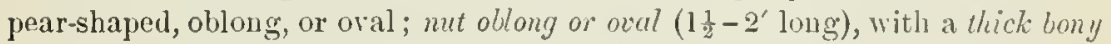
shell; the oily seed at first sweet in taste, then bitterish. - - . Maine to Fla., west to Minn., L. Neb., and 'T'ex. 'Tree $70-90^{\circ}$ high (rarely 120 ), on dry hills and uplands.

7. C. amàra, Nutt. (BıtTer-xut or Swam H.) Scales of the small yellowish bnds about 6 , valvate in pairs, cadueous in leafing; catkins and young herbage more or less pubescent, soon beeoming alnost glabrous; leuflets 7-11, lanceolate or oblong-lanceolate; fruit globular, narrowly 6-ridged; nut globular, short-pointed, white (harely l' long), thin-walled; sect at first sweettasted, soon extremely bitter. - Moist soil, N. Lng. to Fla., west to Minn., E. Neb., and Tex. 'Tree 50-750 higll; husk and nut-shell thinner aud less hard than in other species.

\section{ORDER 102. MYRICACIAZE. (SWERT-Gale FamLX.)}

Monocious or diacious shrubs. with both linels of flowers in short scaly catkins, and resinous-dotted often framrant leares, - differing from the Birches chiefly in the 1-celled ovary with a single erect orthotropous ovule, and the drupe-like nut. Involure and perianth none.

\section{MYRİ $\mathbf{A}$, S. BAYrenr. iVAX-Mrrte.}

'The only genns. - Flowers solitary under a scale-like bract and with a pair' of bractlets, the sterile in oblong ar eylindrical, the fertile in ovoid or globular catkins, from axillary scoly lurls; stamens $2-8$; filments somewhat united below; anthers 2-celled. () vary with 2-8 scales at its hase, and 2 threal-like stignas. Fruit a smill globular or oblong nut, or diey dinpe, coated witl resinons grmins ol wax. (Mupikn, the ancient name of the Tanarisk or some other shrub; perlajss (rom $\mu$ pi $\zeta \omega$, to perfume.)

* Mostly diacious; fertile cathins onord; orary will 2-4 scales at base; nut globular; leaves entire or somexhut serrate.

1. M. Gàle, I. (Swriet Guv.) Shrub 3-50 high; leaves vedge-lanceolate, sermate toward the apex, prele, later than the flowers; sterile cathims closely clustered; nuts in inbricated heads, 2-winger by the two thick ovate 


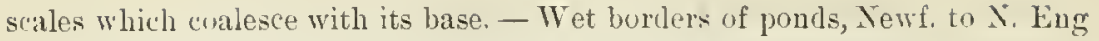
ancl along the Great Lakes to Miun, south in the mountains to Va.

2. M. cerífera, I. (Bayberry, WAX-Mrrtue.) Leaves oblong-lun: reolute, narrowed at the base, entire or wavy-toothed toward the apex, shinin! and resinous-dotted both sides, somewhat preceding the flowers, fragrant; sterile cutkins scattered, oblong; scales wedge-shaped at the lase; nuts scattered and naked, bony, and incrusted with white wax. - Sandy soil near the coast, from Nova Scotia to Fla. and Ala.; also on L. Erie. Shrub $3-8^{\circ}$ high, but sometimes a tree $35^{\circ}$ ligh ; fruit sometimes persistent for 2 or 3 years.

* Frequently moncecious; fertile catlins globular: ovary surrounded by 8 long linear-awl-shaped persistent scales; mut oroid-oblong; Icares pimatifid with many rounded lobes.

3. M. asplenifolia, Eudl. Slunb 1-20 high, with sweet-scenterl ferulike linear-lanceolate leaves; stipules half leart-shaperl; scales of the sterile ('atkins kidney-heart-shaped, pointed. (Comptonia asplenifolia, Ait.) — Sterile hills, N. Eng. to N. C, west to Minu, and Ind. Known as Sweet Fern.

\section{ORder 103. CUPUTIFERAE. (OAK FAMLY.)}

Monacious trees or shrubs, with alternate simple straigh-ieined leures, leciduous stipules, the strile flowers in catlins for capitate-clustered in ile Beech), the fertile solitary, clustered, spikerl, or in sculy cullins, the 1 -celled and 1-seeled nut with or without an involucre. Ovary morc or less 2-7-celled, with 1 or 2 jendulous anatropous ovules in each cell : but all the cells and ovules except one disappearing in the fruit. Seed with no allumen. filled with the embryo.

Tribe I. BETULEAE. Flowers in sealy catkins, 2 or 3 to each bract, Sterile catkius penclulous. Stamens $2-4$, and calyx usurlly 2 - t-parted. Fertile fowers with no calyx, and no involuere to the compressed and often winged small nut. Ovary 2-celled, 2-oruled.

1. Betula. Stanens 2, lifid. Fertile scules thin, 3-lobed, deciduons with the nuts.

2. Alnus. Stamens 4. Fertile scales thick, entire, persisting after the nuts have fallen.

Tribe II. CORYLEAE. Sterile catlins pendulous, witl no calyx; stumens 3 or more to each bract and more or less adnate to it, the flaments often forked (anthers 1-celled). Fertile flowers in a sliort ament or heal, 2 to encli bract, and each with one or more bractlets which form a foliaceous involure to the unt. Ovary 2-celled, "-oviled.

* Bract of staninate flurel furnished with a pair of bratlets insile: fertile Howers few

3. Corylus. Involucre leafy-coriacenus, melosing the latge bony nut.

* Bract of stuminate flower simple ; fertile flowers in short catkins ; nut snull, aclienc-like

4. Ostrya. Each ovary and nut included in a bladdery and closed bag.

5. Carpinus. Eauh nut subtended by an enlarged leafy bractlet.

Tribe III. OUEIRCINEAE. Sterile flower's with 4-7-lohed calyx and stanems meleti. nite $(3-20)$. Fertile flower's 1 or few, enclosed in a cupule consisting of consuliclaterl bracts, which becomes induriteil (scaly or fritkly) and surrounds or encloses the nut.

* Sterile flowers in slender catlins.

6. Quercus. Cupule 1-flowered, scaly aml entire: nut hard and terete.

7. Castanea. Cupule 2 -t-flowered, forming a prickly lard bur, 2-4-valved when ripe. * Sterile fluwers in a small hear.

8. Fagus. Cupule E-flowered, t-valved, eontaining \& slarply triangular nuts. 


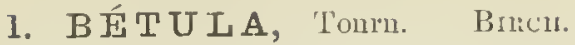

Sterile flowers 3, and bractlets 2, to each shield-shaped scale or bract of the catkins, consisting each of a caly $\mathrm{x}$ of one scale beariug 4 slort filaments with l-celled anthers (or strictly of two 2-jartcel filaments, each division bearing an anther-cell). Fertile Howers 2 or 3 to each 3-lubed lract, without bractlets or calyx, each of a naked ovary, becoming a broadly winged and scale-like nutlet (or small samara) crowned with the two sprealing stigmas. - Outer bark usually separable in sheets, that of the branchlets dotted. 'Twigs and leaves often spicy-alomatic. Foliage mostly thin and light. Buds scssile, sealy. Sterile catkins long and llooping, terminal and lateral, sessile, formed in smmmer, remaining naked through the succeeding winter, and expanding their golden flowers in early spring, with or preccling the leares; fertile catkius oblong or cylindrical, peluucled, usually terminating rery short 2-leaved early lateral branches of the seasun. (The ancient Latin name, of Celtic origin.)

* Trees, uith broun or yellow-inuy bark, supet-aromatic as well as the twigs, membranaceous and straightiveined Hornbeam-like leaves heart-shaped or rounded at base, on short petioles, and sessile very thick fiuiting cathins; their scales about equally 3-cleft, rather persistent; wing of fruit not broader than the seed-berwing body.

1. B. lénta, L. (Cuenry B. Sweet or Blacr Bırcu.) Bark of trunk durk broun, wlose (outer layers scarcely laminate), very sweet-aromatic; leares ovate or oblong-ovate from a more or less heart-shaped base, acuminate, slarply. and finely dloubly serrate all round, when mature shining or bright green above and glabrous except on the veins bencatls; fruiting cathins oblong-cylindrical

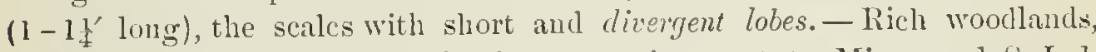
Newf. to N. Del., and south in the mountains, west to Minn., and S. Ind. 'Tree $50-75^{\circ}$ high, with reddish bronze-colored spray; wood rose-colored, finegrained, valuable for cabinet-rork.

2. B. lutea, Michx. f. (YLLıw or Gray Braci.) Bark of trunk yellowish-or silvery-gray, detuching in very thin flmy layers, within and the twigs much less aromatic; lcaves $\left(3-5^{\prime} \mathrm{long}\right)$ slightly or not at all heart-shaper and often narowish toward the base, duller-green above and usually more downy on the reins bcneath ; fruiting catkins oblong-oroid ( $1^{\prime}$ or less in length, $6-9^{\prime \prime}$ thick), the thinnel scales $\left(5-6^{\prime \prime}\right.$ long) twice as large as in 1.1 , and with narlower harely spreading lolies. - Rich moist woollands, Canada and N. Eng. to Del, west to Minn.; also along ligh peaks to Temu, and X. C. Often $60-90^{\circ}$ high at the north; rood whiter and less valuable.

* Trees, with chalhy-uhite bark separable in thin shects, orate or triangular leaves of firmer texture, on long slender petioles; fruiting cuthins cylindrical, usually hanging on rather slender peduncles; their scules glabrous, with short diverging lolses, freply deriduous ; wing of the finit much broader than its body.

3. B. populifolia, lit. ( \ubrican White Burch. Gray Birch.) Trunk usually ascending $\left(15-30^{\circ}\right.$ high); leaves trimugulur (deltoil), very taper. pointed (usually aloruptly), trmeate or nearly so at the broal base, smooth and shining both sides, execent the lesiurne glimls when young. (B. alba, var. 
populifulia, Spach.) - Poor sandy soils, N. Brunswick to Del., west to I. Untario. Barls much less separable than the next; leaves on slender petioles, tremulous as those of the aspen.

4. B. papyrifera, Marshall. (Paper or Caxoe Burch. White: Brisur.) Leares orule, tuper-pointed, heart-shaped or alurupt (or rarely wedgeshapecl) at base, smowth and green abore, pale, glindular-lutted, and a little lrairy on the veins beneath, sharply and unequally doulbly serrate, $3-4$ times the length of the petiole. (B. papyracea, Ait.) - Rich woodlands and streambanks, N. Eng. to N. I'emm., N. Ill, and Mlinn., and far north and westward. 'T'ree $50-75^{\circ}$ high, with bark freely spllitting into paper-like layers, $-V^{r}$ ar. mxon, Tuckerman, is a dwarf form of the alpine region of the Withe MIts.

* * Tree, with greenish-brown bark, somewhat leminate, and reddish twigs, ovate leaves whitish beneath, and soft-downy peduncled finiting catkins.

5. B. nigra, L. (liven or Ren Brrcn.) Leaves rhombic-ovate, acutish at both ends, irregularly doubly serrate, whitish and (until old) downy underneath; petivles and peeduncle of nearly the same length $\left(3-\tau^{\prime \prime}\right)$ and with the whlong catkin tomentose; the bracts with oblong-linear nearly equal lobes; fruit broadly winged. - Banks of streams, Mass. to Fla., west to Minn., L. Kan., and Tex. Tree $50-75^{\circ}$ high, with lighth-colored wood and somewhat Aller-like leaves.

* * * * Shrubs, with brounish bark, rounded or wedge-shaped crenate and mostly small leaves of thichish or coriaceous texture, and oblong or cylindrical glabrous and mostly erect catkins, on short peduncles.

6. B. pùmila, L. (Low Burcis) Stems ( $2-8^{\circ}$ high) erect or ascending, not glandulur; young luranches and lower face of young leaves mostly soft-downy; leares oborate, roundish, or orbicular (6-16"long), pale beneath, reinlets on both faces, funely reticulated; wing of the fruit mostly narrower thiu the hody, - Bogs, W. ('onn. and X. J. to Ind. and Minn., and nort hward througllsut Canada. Leares nolully not at all resiniferons or glandular-dotted.

7. B. glandulósa, Michx. (1) Wa BrF Bırcir.) Stems erect or mostly sprcading $\left(1-4^{\circ}\right.$ high), wr when alpine procumbent; branchlets glabrons, conspicuously dotted with resinous wart-like glunds; leaves roundish wedge-obovate or sometimes orbicular $\left(6-9^{\prime \prime}\right.$ long), green and glabrous both sides, less reticnlated; fruiting catkins mostly shorter amel oblong or 'wal ; wing of the fruit nirrower than or sometimes equalling the looly, - High mountains of $\mathrm{N}$. Lug. and N. Y., to L. superior, and far northward.

\section{2. Á L N U S, 'Turn. Almik.}

Sterile catkins elongated and drooping, with 4 or 5 bractlets and 3 (rarely 6) flower's uyon each short-stalked shield-shaped scale; each flower nstally. with a 3-5-parter cally and als many stamens; filanents slort aud simple; anthers 2-celled. Fertile catkins wroid or ublong; the fleshy seales each 2-3. flowered, with a calyx of 4 little scales adherent to the scales or bracts of the cattin, which are thick and wooxly in fruit, wedge olowate, truncate, or 3-5loherl, and persistent. - Sluruhs or sullall trees, with few-scaled leaf-luds, and solitary or often racenose-clustered catkins, terminating leafless branchlets or pedurcles. (The ancient Latin name.) 
\$ 1. Flourers deceloped in spring with the leares; the sterile from cuthus which have remained nuked over winter; while the fertile have been enclosed in a sculy bud; firuit with a conspicuous thin wing, as in Birch.

1. A. víridis, DC. (GreEx or Molext1x Aldir.) Slıub $3-8^{\circ}$ high ; leaves round-oval, orate, or slightly lieart-shaped, glutirous and smootl or' softly downy beneath, irregularly serrulate or biserulate with very sliarp and closely set teeth, sometimes sinmate-toothed and serrulate (vall. slvidta Regel), on young shoots often cut-tootherl; fertile catkius slender-stalked, clustered, ovoid $\left(6-8^{\prime \prime}\right.$ long $) .-O n$ mountains and mountain streams, Newf. to W. Mass., X. Y., I. Superior, and far north and west; also iu the Alleglianies to N. C. (Eu., Asia.)

\$2. Hourers developed in earliest spring, before the leaves, from mastly clustered catkins which (of both sorts) were formed the foregoing summer und have remained waked ocer winter; fruit wingless or with an wrou coriaceous margin.

2. A. incàna, Willl. (Spkckexn or Hoxk 1.) Leaves broadly ozal or ovate, rounded at base, sharply and often doubly serrate, uhitenerl and mostly douny beneath; stipules obloug-lanceolate; fruit orbicnlar. - Borders of streams and swamps, Newf. to Mass., E. Neb., Minn., and westward. Shrub or tree 8-20 lighl; the common Alder northward. (Eu., Asia.)

3. A. serrulàta, Willd. (Snootu A.) Lences uluerne, acule at base, sharply serrate with minute teeth, thickish, green loik sicles, smooth or often rowny beneath; stipules oral ; fruit orate. - Burders of streans and swamps, ilass. to Fliı., west to S. E. Minn. and Tex.; common. Shrub forming dense thickets, or sometimes at the south a small tree $6-35^{\circ}$ high.

\$3. Flowers in autumn (Sept.) from cathins of the season; the fertile mostly solitary in the axils of the leares, ripening the fruit a year later; fruit wingless.

4. A. marítima, Mull. (SE.-SIDE A.) Cilabrons; leaves oblong, orate, or oborate with a wed ge-shaped base, slender-petioled, sliarply serrulate, bright green, or rather rusty beneath; fruiting catkins large, ovoid or ohlong (9-12' long, 6" thick). - Borders of streams and swamps. S. Del. and E. Md., near the coast. Small tree $15-25^{\circ}$ high. (E. Asia.)

\section{Có RYLUS, Tomm. HAzEL-Nit. Filbert.}

Sterile flowers in dromping crelindrical catkins, consisting of 8 (lıalf-) stunens with l-celled anthers, their short filaments and pajr of scaly hractlets collering more or less with the imer face of the scale of the catkin. Fertile fluwers several in a scaly bud, each a single ovary in the axil of a scalc or bract, and accompauiel by a pair of lateral bractlets; orary tippel with a slort limb of the alherent calyx, incompletely 2-celled, with 2 pendulons orules, one of then sterile; style short; stigmas 2, elongated and slender. Nint uroid or oblong, hony, enclosed in a leafy or partly coriaceus cup or intolncle, consisting of the two bractlets enlargen and often grown together, lacerated at the border. Cotrledons rery thick (raisen to the surface in germination), colille; the short radicle included. - Slirubs or small trees, with thindisl douhly-tuothed leaves, lolded lengthwise in the bud, flowering iu early spring; sterile cathins single (1) lascicled from sealy buds of the axils of the preceding rear, the fertile ter- 
minating early leafy shoots. ('The classical nane, probably from kófus, $a$ telmet, from the involucre.)

1. C. Americàna, Walt. (WH, HAzLL-NiT.) Leaves roundish-heartsiaped, pointed; involucre open above down to the globose 11ut, of 2 broad foliureous cut-toothed almost distinct bracts, their base coriaceons and downy, or with glantular bristles intermixed. - Thickets, N. Eng. to Ont. and the Dakotas, and sunthward. Twigs and petioles often glandular-bristly.

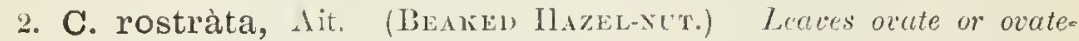
Mhong, somewhat henr-shaped, pointed; incolucre of united bracts, much pro'mnged above the ovoid nut into a nurow tubulur beak, densely bristly. $-\mathrm{N}$. rcotia to nortler'n X. J., Mich., Minn., and westward, and south in the moun trins to Ga. Shruh $2-6^{\circ}$ ligh.

\section{4. ÓSTRY A, Micheli. Hop-Horxina. Ilox-Woon.}

Siterile flowers in drooping eylindrical catkins, consisting of several stamens in the axil of each bract; filaments slort, often forked, hearing l-celled (lalf-) :nthers; their tips hairy. Fertile flowers in short catkins; a pair to each deriduous bract, each of an incompletely 2-celled 2-uruled ovary, crowned with the short bearded borler of the adherent ealyx, tipped with 2 long-linear stigmas, and enclosed in a tubular fractlet, which in fruit becomes a closed blarlIery obloug bag, rery much larger thin the small and smooth nut; these inflated involucres loosely imbricated to form a sort of strobile, in aypeallance like that of the Hop. - Sleuder trees, with rery hard wood, brownish furrowed l,alk, and fuliage resembling that of Birch; leares open and concare in the lud, nore or less plaited on the straight veins. Fluwers in splng, appearing with the leaves; the sterile catkins $1-3$ together from scaly huds at the tip of the branches of the preceding year; the lertile single, terminating short leafy sloots of the scason. (The classical name.)

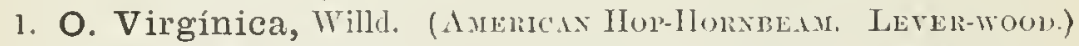
Leares oblong-orate, taper-pointed, ver! sharply doubly serate, downy beneath, with $11-15$ principal reins; buls acute; involucral sacs bristly-hairy at the base. - Rich wouls, common, from tle Atlantic to N. Mimm, Neb., F. Kían., and sonthward. Tree $25-45^{\circ}$ hight ; lop-litie stroliles full-grown in Aug.

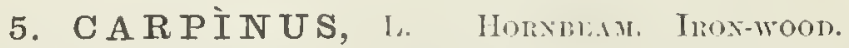

siterile flowers in drooping eylindrical catlins, consisting of several stamens in the axil of a simple and entire scale-like hrat; filanents very short, mostly -forked, the forks bearing l-celled (half-) anthers with hairy tips. Fertile Howers several, spiked in a sort of loose terminal eatkin, with small deciduons luacts, each subtending a pair of flowers, as in Ostrya; lut the single involucrelike bractlet is open, cnlarged in fruit and foliacenus, merely snlitending the -mall orate sêveral-nerved nut. - Trees or tall shrubs, with smooth elose gray lark, in this and in the slender lnds and straight-veined leaves resembling the Beech; lea f-buds and inflorescence as in Ostrya. (The early Latin name.)

1. C. Caroliniana, Walter. (Americax Horsmen. Bue or Water Pi:kcu.) Lcaves ovate-olslong, pointerl, sharply doubly sermate, soon nearly'

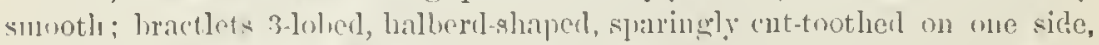

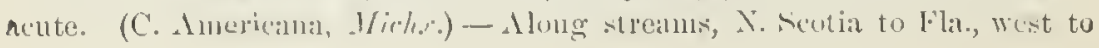




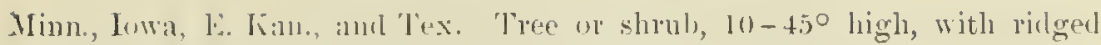
trunk, and rery hatrl woul.

\section{QUERCUS, I. (AK.}

Sterile Howers in slender uaked catkins; hrats calucous; ealyx 2-8-parted

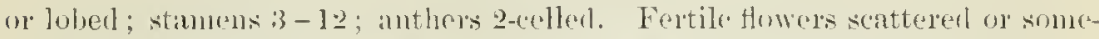

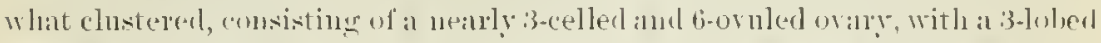
stigna, enelosed by a sealy hul-like involucre which becomes an iudnuted env ('npmle) aromul the base of the pounded nut or acorn. Cotyledons remining :molergromul in gernination; radicle very short, included. - Flowers greenish an yellowish. Niterile catkins single or often several from the sane lateral scaly lmol, filiform and hanging in all our species. (The classical Latin nume.) All Hower in spring, and sherl their nuts in Oet. of the sinus or the next rear.

\$. LELCOIBALANLS. Bark pule, often scaly: leaces and their lobes or terth altusp, neer bristle-pointed; stamens $6-8$; senles of the cnp more or

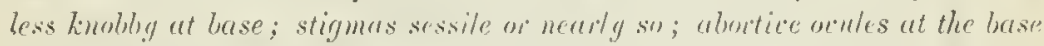
of the perfert seed; immer surface of mut glabrons; frnit maturing the first

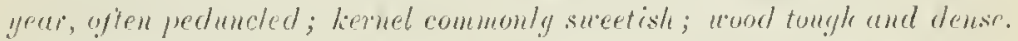

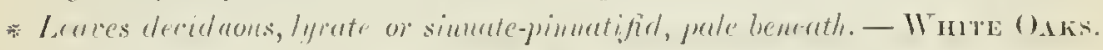

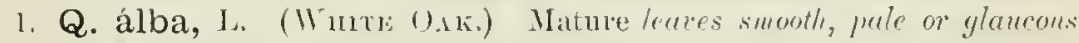
medrencuth, bright garen abore, whosate-oblong, oblirquely cut into $3-9$ obloner

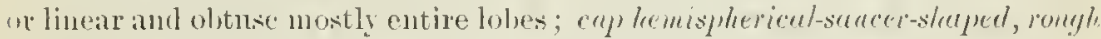

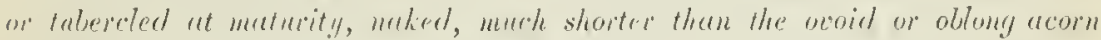
(I'longr). - All soils, Maine to S. E. Minn., E. Kan., aud sonth to the (inlf. A linge and vilubible tree; lobes of the leaves short and broad (3-5), or deep ilnd ninrow (.)- 3$)$.

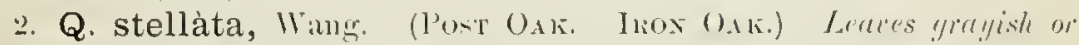

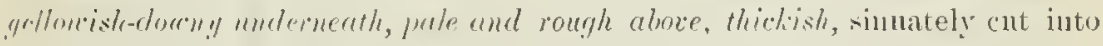
$5-7$ rounder divergent lobes, the upier ones inuch larger and often $1-3$.

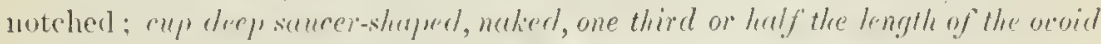

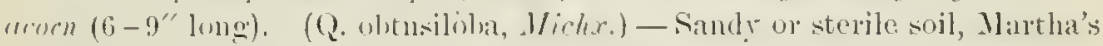

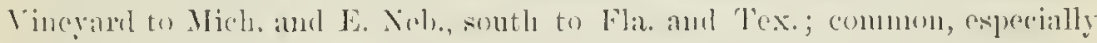
withwillel. A suall tree with rery dnulsle wond.

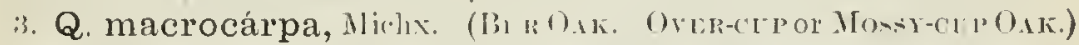

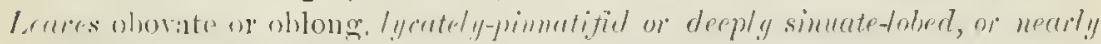
jerted. senetines noarly entire, irregular, downy or pale beneath; the lobes "jaringly and obtusely tootherl, or the smaller ones entile ; "lyp deep, thick anr?

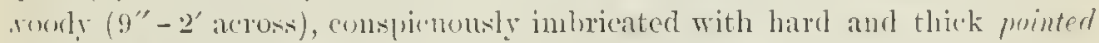

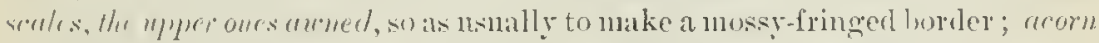

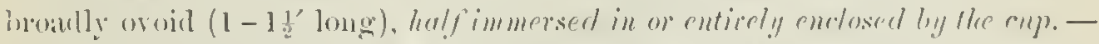

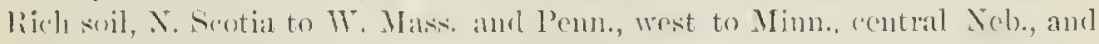
lian. I larese and valuable tree; extremely vatrable in the sime and fringe of

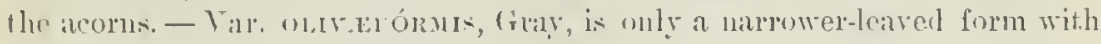
111 usually sumall olshog acorns.

4. Q. lyràta, Walt. (Over-cty OAк. Swap PO-t O.к.) Leaves crow ded at the (anf of the branchlets, ohovate-ohlong, acute at liase, more ne les: speply 7 - -9-mbed, white-tomentose beneath or at longth smonthish, the holes tran-

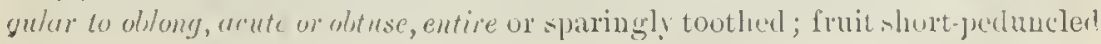


"r sessile; cup round-ovate, thim, with rugged scales, ulmost coverng the depressted.

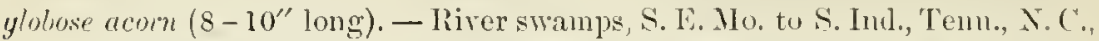
and southward. $-\Lambda$ large tree, with flaky bark; intermediate bekween n. 3 and n. 5.

* * Leaves codisely simute-toothed, lin not lobed (except slightly in n. 5), whitish

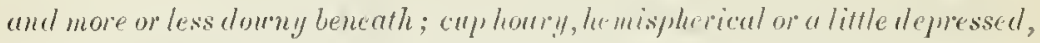

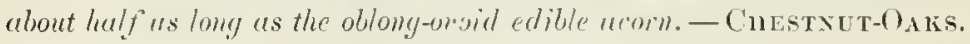

5. Q. bícolor, Willd. (NWAMP WMTE ()Al.) Leaves obovate or ohlong-obovate, wedye-shaped at buse, coursely simme-crenatr and often rather pinnutifid than toothed, usually soft-rloun!y and white-hour!y beneatl, the main primary reins $6-8$ pairs, lax and little prominent; fruiting peduncle much longer than the petiole; upper scales of the eup awn-pointed, smetines forming a mossr-fringed margin; acorn scareely $I^{\prime}$ long. - Borders of streanis and swamps, S. Maine to Ont., Mimn., and E. Kin., and south in the nunutains to N. Ga. $-\Lambda$ large tree, with flaky bark.

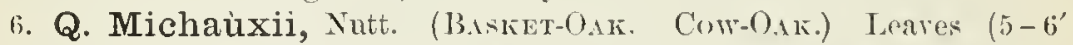
long) oval or obovate, acute, obtuse ur eren cordute ut buse, regularly dentate (commonly not deeply), rather rigid, usurlly rery tomentose beneath; stemorus usurlly 10; fruit short-peduncled; (anj, shillow, tulerenlate with hard and stout acute scales, witlout fringe; acorn $1_{\frac{1}{2}}^{y^{\prime}}$ long. (Q. Prinus, var Micl:ancii, Chapm.) - Borders of streans and swamps, Del. to Fla., and in the west from S. Ind. to $\perp I$ o., and sonth to the Gulf. $-\Lambda$ large and valuahle tree, witl gray flaky bark and large sweet edihle acoms. Intermediate forms anpear to counect with n. 5, of which Dr. Engehmann considered it at sulbspecies.

7. Q. Prinus, L. (Chesstert-OAn.) Leares thick, valying, obovate or 1)long to lanceolate, sometimes acminate, with an obtuse or acule base, undnintely crenate-toothed, pele and mimutely downy bencath, the main primary rits $10-16$ pairs, straight, prominent beneath; fruiting pectumcles shorter then the petioles, offen revey short; cup thick (6-12" wide), nostly tuhereulate with harel and stout scales; acom liurge (sometimes 1-1 l' long). (Lurl. var. monticola, Mich.r.) - Rocky hanks and hillsides, E. Mass. to X. Y. and Ont., and sonth iu the mountains to N. Ala. A large tree, with thick and deeply furrowed bark, ricls in tamnin.

8. Q. Muhlenbérgii, Engelm. (Ýllow Onк. Cunstrut-OAк.)

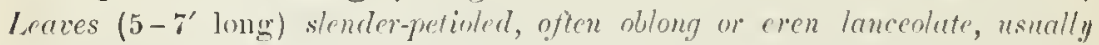
urute or pointed, mostly ubtuse or roundisls ut hase, almost equably and rathe? sharphly toothed; ('up) sulsessile, shallow, thin, of small appresserl seales, $5-7^{\prime \prime}$ bread; acom globose or whorate, $7-9 "$ "lugg. ((2. P'rinus, var. acumiuata,

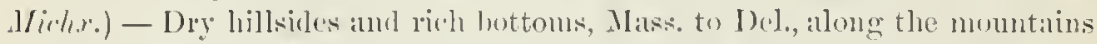
to X. Ala., west to Minn., li. Neh., and Tex. - Leatres more like those of the ('hestnut than any other; the prinlary reins rery straiglt, impresserl above proninent hencath. A tall tree, with thin faky bark.

9. Q. prinoides, Willı. Like bhe list, lut of low stuture (usually $2-4^{\circ}$ liggh), with smallen more undulate leaves on shorter petioles (3-6" long), and deepere cups with more tumid scules. (Q. l'rinus, var. humilis, M/arsh.) - Sann?

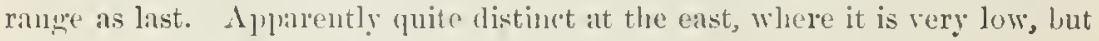
running into Q. Muhlenbergii at the far west. 


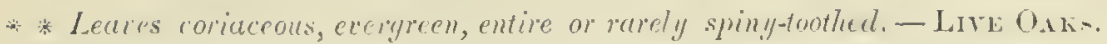

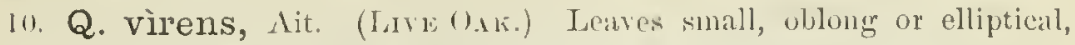
loary bencath as well as the hranchlets; peduncle nsually conspicuous, 1 - 3fruited; cup top-shaped; acoun oblong; cotyledons emmpletely mited into one mass. - Alung the coast from Vra. to Fla. and Tex. I3ecoming a large tree at the sonth, and formerly extensively used in ship-bnilding.

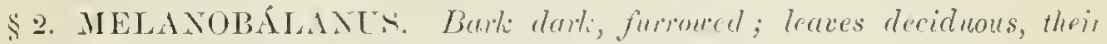
lobes and teeth arute and bristle-prointed (ut least in youth); stumens mostly 4-6; cup-scales mombramaceous; styles long and spreading; abritive orule: near the top of the perfect sred; inner surfuce of nut tomentose; finit muturing the second year, sfssile or on steont thick preduncles; wool porous and brittle. Веаск OAKS.

* Leaves pinmatifid or lobed, slender-petioled, not coriaceons, the lobes or teeth conspicuously bristle-poimted.

+ Mature leares glabrous on both sides or newrly so, oechl, oblony or somewhat obovate in outline, from moderately simute-primatifid to deeply pimatifid, turning vurions shades of red or crimson in late antumn; large trees, with reddish coarse-grainad wood; spresios closely reluted and apprerently readily hybridizing.

11. Q. rubra, L. (Ren OnK.) Ciu sucuces-shuped or Aat, with a narrow

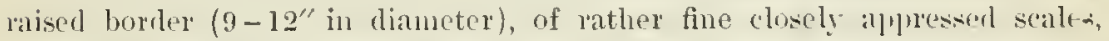
sessile or on a rery short and abrupt narrow stalk or neck, ecry much sherter thrm the oblong-ovoid on ellipsovidul acom, whịch is l' or less in length; leares rather thin, turning dark reel after frost, moterately (rarely very deeply) pimatifid, the lobes acmuninate from a broad hase, witl a few coarse teeth; lark of trmuk dark gray, smoothish. - Common both in rich and poor soil,

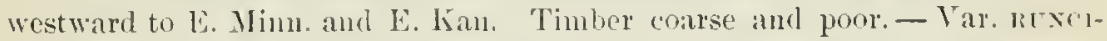
хiтA, A. DC., is a form with regular nearly entire lobes and the frutit nearly "hatf smaller ; fomul near st. Louis.

12. Q. coccínea, Wang. (Scondet ()Ak.) ('up top-shuped, or hemispherical will "conimel. buse ( $7-9$ " broad), coarsely scaly, covering laalf or more of the broudly or globulur-aroirl ucom, the scales somewhat appressed and mlahrate, or in western localities yellowish-canescent and squarrose as in rax. tincturia; leaves in the orlinary furus, at least on full-grown trees, bright sreen, shining above, tuming red in antumn, deeply pinnatifir, the slender lobes divergent and sparingly (ut-tonthed; lnds small; acorns 6-9" long: bark of the trunk glay, the interior redilish. - Moist or dry soil; eommon. from s. Maine to I) M., Minn., $\mathrm{T}$. Mo, and sonth in the mountains.

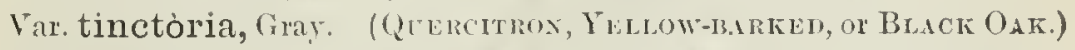
Leaves with broaler nndivided lobes, commonly paler and somewhat pubescent beneath, turning brownish, orange, or dull red in autumu; cup-seales large and lnosely imbrieated or sumare when dry, yellowish gray, pubeseent; bark of trunk darker-eolored and romglier on the surface, thicker, and internally or:uge, mncl more valnable for the tammer and lyer ; buls longer and more pointed; ('n) sometimes less top shaped. (Q. tiuctoria, Burtum.) - Dry or gravelly uplaucls, S. Naine to S. Minn, W. Nob, and Tex. Intermediato forms comnect this with the types Tho bark is largoly used in tanning. 
Var. ambígua, Gray. (Gis O.ı.) Founel along onr northeastern bor. ders to Lake Champlain and northward, fignred and briefly characterized by Michaux as with the foliage of $\mathrm{Q}$. rubra and the frnit of $\mathrm{Q}$. coecilien. It was consistered by Dr. Engelmaun as a form of Q. rubra with cups hemispherieal or evell turbinate.

13. Q. palústris, Du Roi. (Swamp Spanish or Pis Onis.) Cuj flul suucer-shuped, sumetimes contracted into a short scaly base or stalk, fine-scaled (5-" " broad), very much shomer then the usually giobose or depressed acom, which is $5-7$ "long; leaves deeply pinnatifid with divergent lobes and broad rounded sinuses. - Low grounds; rather common, from Mass, to Del. and MId, west to Minn., l. liann, and Ark.

+- . Muture laves sojt-douny bencuth; cup suncer-shuped, with a somerchut

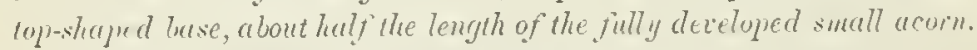

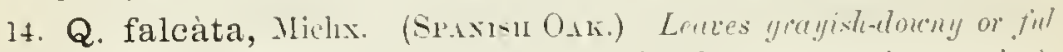
rous undermeuth, obtuse or rounded at base, 3 -5-lobed ubore (oometimes entire); the lobes jrolonged, mosily narrow and moie or less scyllerstuped, especially the terminal one, entire or sparingly cut-toothed; acorn globose, $4-5$ " long. 1) ry or sandy soil, Long Island to Flar, aud from $s$. Int. to Mfo, aud 'Tex. A brge or small tree, extremely variable in foliage; bark excellent for tanuing.

15. Q. ilicifolia, Wang. (Ben or Black Scrtb-OAK.) Duarf (3-

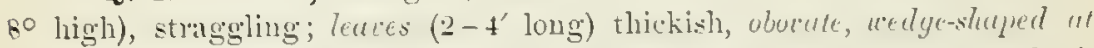
bnse, angularly about 5- (3-i-) lobed, white-tlowny benewth: bobes short and triamgular, spreading; acorn oroji, glohular, 5- 6" long. - Sandy barrens im rocky litls, X. Eng. to Ohio and Ky.

* * Lates entire or wath a fiv teuth (or somerthat 3-5-lobed at the summit), crinceous, commonly bristle-ponted; acorns globular, small (not over 6"long).

- Leures thick, widening or often much diluted upuard and more or less sinuule or somenthat 3-5-labed: acorns globulur-oroid.

16. Q. aquática, Walter. (Water-OAK.) Leares glabrous and slining, oborut-sputulute or surrouly wedy-form, wilk a long tupering base ant an often obscurely 3-lobed sunnit, varying to oblanceolate; cup sancer-shaped or hemispherical. - Wet grounds, around ponds, etc., Del. to the Gulf, and from ky. and Mo. to Tex. - Tree $30-40^{\circ}$ high ; running into nuny rarieties, especially southwarl; the leaves on seedlings aud stroug shouts often incised or sinuatepinuatifid; then mostly" bristle-pointed.

17. Q. nigra, L. (BLAckJAck or BARRex OAK.) Leaces broadly uedige shaped, but sometimes rounder or obscurely cordate at the base, uidely diluted and somewhat 3-lobed (rarely 5-lobed) at the summit, occasionally with one $0_{1}$ iwo lateral conspicuonsly bristle-tippeel lobes or teeth, rusty-pubescent heneath, shining above, large (t-9' loug); cup top-shuped, coarse-scaly; acorn shortorvid. - Dry sandy barreus, or heary clay soil, Long Island to S. Minn., L.. Nobl, and sontluwarl. A small tree (sometimes $30-40^{\circ}$ high), of little valune.

+ + Leares not ditnted upurerd, generally entire; acorn globuse.

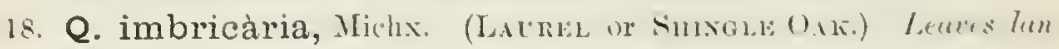

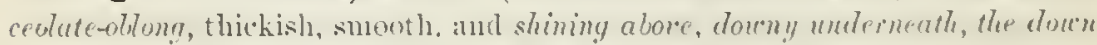
rummonly persistent: "up between salucer-slinped and top-shlapped. - Rich woodlauds, l'eun. to Gia., west to S. Wisc., low:a, li. Neh., and X. Ark.- 
'Tree $30-90^{\circ}$ higl. The specific name is in allusion to its early nse for slingles.

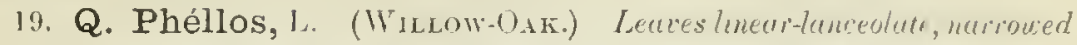
to both ends, soun glubous, light green (3-4' long); cup santer-shaped. Bottoin lauds or riele sandy uplands, Staten Island to N. Fla., west to S. Ky., 1lo., and 'Tex.

In addition to the above, the following ly brick lawe been recoguized :-

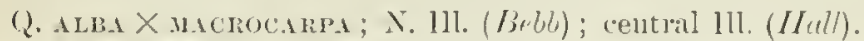

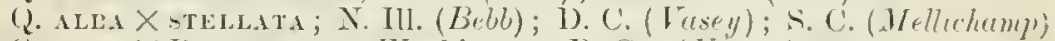

Q. ALEA X I'rixts; near Washington, D. C. (I Us'y.)

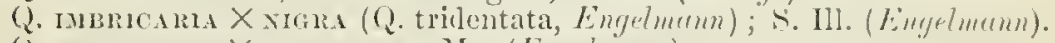

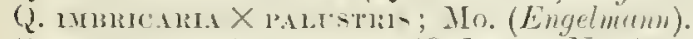

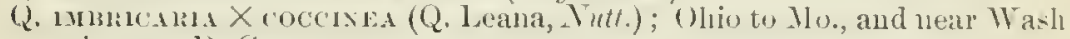
ingtou, 1). C.

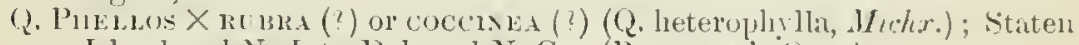
Islind and N. I. to 1)el. and N. C. (B.AlTRAM's O.AK.)

(2. P'uelus X sigla (Q. Rudkini, Britt.); N. J. (Rudkin).

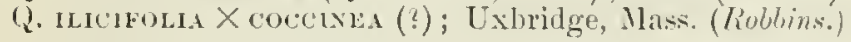

\section{CASTÀ NEA, 'Гони. Cиestrit.}

Sterile fluwers interuptedly clustered in loug and naked cylindrical catkins, calyx mostly 6-parted; stamens 8-20; filaments slender; anthers 2-creller]. lertile Howers few, usually 3 together in an oroid scaly prickly involucre; calyx with a 6-lobed border crowning the 3-7-cellerl 6-14-ovuled ovary; abortive stanens 5-12; styles linear, exserted, as many as the cells of the oran ; stin. mits small. Nuts coriacens, oroil, enclosed $2-3$ together or solitary in the lark and thick rery prickly t-ralved involucre. Cotylectons rery thick, simewhat plaited, colsering together, remaining undergromul in gemination. lanves strongly straight-yeined, undivicled. Flowers appenting later than tle* l'ares, crean-color; the catkins axillary near the end of the lumcles, wholly sterile or the upper ones androgrnous with the fertile flowers at the hase. ('The classical name, from that of a town in 'l'hessaly.)

1. C. Sativa, Mill., var. Americàna. (Chestsit.) Al large tree.

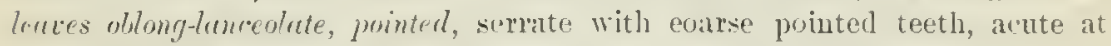
base, when mature smonth and green both sides; nuts 2 or 3 in each involucre. therefore fiattened on one or both sides, very sweet. (C. vesca, var, of the Manmal.) - liock! woods nud hillsides, S. Maine to D)., along the momntains to N. Ala., and west to S. Mlich., S. Ind., and 'Teun.

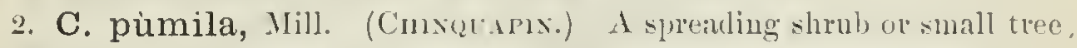
Lraces oblom, arme", serrate with pointed teetl, whitned-doun! beneath; invo. 'ucres small, often spiked; the ovoid pointerl nut scarcely laalf as linge as a common chestunt, rery sweet, solitary. not flattened. - Rich hillsides and borders of swamps, S. Pell1. to Flin, west to s. Ind. and Tex.

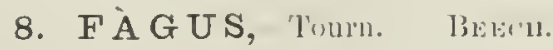

Sterile flowers in small hears on drooping pectuncles, with decidnous scalelike bracts; calyx l,ell-slinjed, 5-7-cleft; stinnens $8-16$; filaments slenrler, anthers 2-celled, Fertile flowren nsually in pitios alt the apex of a short pe-

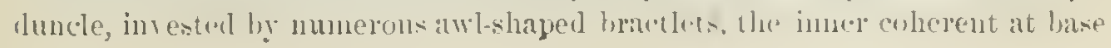


to form the 4-lobed involucre; calyx-lobes 6, awl-shaped; orary 3-celled with 2 ovules in each cell; styles 3 , thread-like, stigmatic along the inner side. Nuts sharply 3 -sided, nsually 2 in each nrn-shaped and soft-prickly coriaceous involu. are, which divides to below the middle into 4 valves. Cotyledons thick, folded and somewhat united ; hut rising and expanding in germination. - 'l'rees, with a close and smooth ash-gray bark, a light horizontal splay, and nudivided strongly straight-reined leaves, which are open and convex in tle tapering hul and plaited on the reins. Flowers appearing with the leaves, the yellowish staminate flowers from the lower, the pistillate from the upper axils of the leaves of the season. (The classical Latin name, from $\phi a ́ \gamma \omega$, to eut, in allusion to the esculent nuts.)

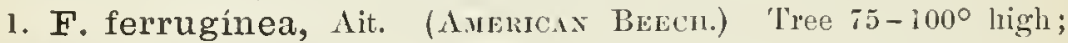
leaves ohlong-ovate, taper-pointed, distinctly and ofteu coursely toothed; petiales and midrib sown nearly naked; prickles of the fluit mostly recurred or spreading. - N. Scotia to Fla., west to Wisc., E. Ill., Mo., and Tex.

\section{Order 104. SALTCACEAE. (Wrllow Family.)}

Diwcious trees or shrubs, with both linds of flowers in catkins, one to each bract, without perianth; the fruit a 1-celled and 2-4-talvod iod, with 2-4 parietal or basal placentce, bearing numerous seerls furnished with long silky down. - Style usually short or none; stigmas 2, often 2-lobed. Seeds ascending, anatropous, without albumen. Cotyledons flattened. Jeaves alternate, undivided, with swalc-like and deciduons, or else leaflike and persistent, stipules. Nood soft and light; bark bitter.

1. Salix. Bracts entirc. Flowers witl small glands; dislis none. Stamens few. Stignas short. Buds with a single scale.

2. Populus. Bracts lacerate. Flowers with a broad or cur-sliaped disk. Stamens numerous. Stigmas elongated. Buds scaly.

\section{S À L I X, 'Tourn. Willaw. Osier, (By M. S. Biebr, Esq.)}

Bracts (scules) of the catkins entire. Sterile flovers of $3-10$, mostly 2 , distinct or united stamens, accompanied by 1 or 2 small glands. Fertile Howers also with a small flat glanıl at the base of the orary; stigmas rlort. - írees "1 shruls, generally growing along streans, with tercte and lithe branches. Leaves mostly long and pointed, entire or glandularly toothed. 13urls corered ly a single scale, with an inner atherent membrane (separating in 11. 14). Catkins appearing hefore or with the leaves. (The cliswiral Latin name.)

\$ 1. A ments borne un short lateral leufy branchlets; srules yellourish, fulling be fors the cupsules mature; fllaments huiry belour, all fires; st jle wry short or ouso lete; stigmas thich, notched. Trees or large shruls: leares luper-pointed.

* Leaces closely serrate with inflexed teeth; capsules glabrous.

- Stamens 3-5 or more.

+r Trees $15-50^{\circ}$ high, with rough bark and slender turigs; no peliolar glands; sterile aments chungated, narrouly cylinirical; fluwers somewhat remolely subverticillute; srales entire, short and rounded, rrispr-villons on the inside.

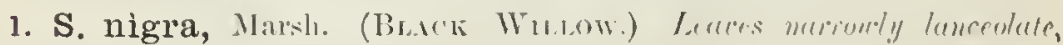

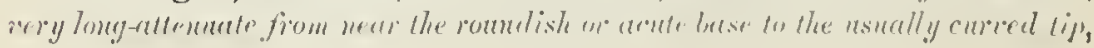


often downy when young, at length green and glabrous except the petiole and midrib; stipules liuge, semicordatc, pointed and persistent, or small, ovoid and deciduns; fruitiug aments $\left(1 \frac{1}{2}-3^{\prime}\right.$ long) more or less dense; capsules ovate eonieal, sliortly pedicelled. - Banks of streams aud lakes, bending over the water; commolr. - Var. FAccits, Torr. Leaves narrower and scytheshapcd. - Var. W W 1811, Bebb. Leares broader, often 1'wide, glancons and veined bencatlı; stipules large, round-reniform; ancnts long, looscly flowered; capsules globosc-conical, long-pclicelled. Rocky islands of the Potomac ( I $\mathrm{Fard)}$; Falls of the ()hio (short); Mo. The leaves alone are easily mistaken for those of $n .14 .-A$ lybrid of this specics with S. alba, rar. vitellina, is found in Mayne Co., N. Y. (E. L. Thankenson).

2. S. amygdaloides, Ander's. Leaves lanceolute or ovate-lanceolate, $2-4^{\prime}$ long, attenuate-euspidate, pule or glaucous beneath; petioles long and slender; stipules minutc, very early deciduous; fertile aments becoming very loose in fiuit from the lengthening of the slcnder pedicels. - Central N. I. (Dudley) to Mo.; common westward.

++ A shrub or small bushy tree, $6-15^{\circ}$ high, with smooth bark and rather stout poliched twigs; petioles glandular; sterile aments thick, oblong-cylindrical, densely flouered; stamens commonly 5 ; scales dentate, hairy at base, smooth above.

3. S. lùcida, Muhl. (Smrng WV.) Lcares orate-lanceolate or narrower, tapering to a very lng achminate point, at leugth coriaceous, smooth and shining both sides; stipules small, oblong; fruiting aments oftcn persistent, the capsules bccoming rigid and polished, as in the nearly allied S. pentandra of Europe. - Banks of streams, N. Eng. to Penn., west and northward. A beantiful spccies on account of its slowy staminate aments and large glossy leares.

\section{- - Stamens mostly 2; capsules subsessile or very shortly pedicelled; leaves lanccolate, long-acuminate.}

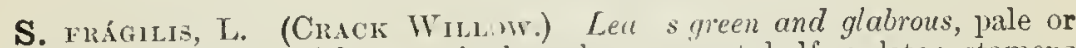
gliucous heneath, $3-6^{\prime}$ long; stipules when l'rescnt lialf-eorlate; stamens rarely 3-4; cupsule long-conical, chotly pedicell d. - A tall and handsome

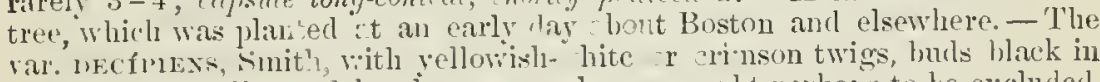
winter, and smaller and lorghiter gre n 'ears, ought perhajs to he excluded, the plant so named ly, lbinnte, etc., $b$ ing nue of the hylrids mentioned below (Adv. from Eur.)

S. ALBA, L. (WH1T: W.) Leaves ushy-gray or silky-nthile on both sides,

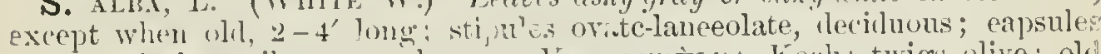

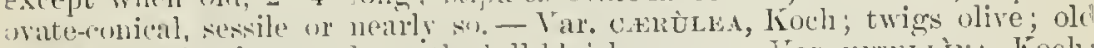

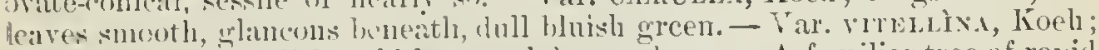
wigs yellow or redelish; old l ares glabrous abowc. $-\Lambda$ familiar tree of rapid growth, attaining a height $u\left[50-0^{\circ}\right.$. The tyopical form, with olive twigs and old leaves silky on both sides, is ramely fomm with us, but the var. virrusind

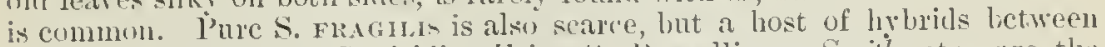
the two, representing S. virilis, Fries, S. Russelliana, Smih, etce, are the commonest of introlnced willows. These forms are rendered almost inextri(able by a further cruss, by no means rare, with on native s. lncilla. (Aclv. from Enl)

S. Babrioxica, Tourn. (WExprag W.) Extensively planted for orna. ment, and in some places wilely spread along river-hạ!ks am! lake-shores by

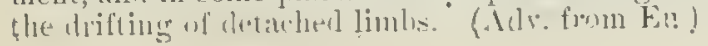


* Lentes renotely denticulute with projecting teeth; stumens 2 ; cupsule glabrous or silky.

4. S. longifòlia, Muhl. Leaves linear-lanceolate, 2-4' long, tapering at each end, nearly sessile, more or less silky when young, at length smooth and green hoth sides; stipules small, lanceolate, deciduous; aments linear: cylindric, ofteu clustered at the ends of the branchlets; capsule shortly perli celled; stigmas large, sessile. - Found sparingly along the $\Lambda$ tlantic coast from: Iaine to the Potomac; common westward. A shrub, rooting extensively in alluvial deposits and forming dense clumps. This species is a peculiar $\Lambda$ mericau type, aud exceedingly variable; the earliest leaves after germination pinuately lobed.

\$2. Aments lateral or terminal, with or without bracts; scales persistent, colored at the tip; stamens 2 (usually 1 in $\mathrm{n} .19$ ), with glabrous filaments (united and hairy in $\mathrm{S}$. purpurea); shrubs or small trees.

\section{* Cupsules tomentose.}

- Pedicels 3-6 times the long'h of the gland; style medium or none.

- Large slrubs or small trees (8-150 high); leaves oborate or elliptic-lanceo. late, $2-4^{\prime}$ long, acute or acuminate, more or less obscurely and irregularl, serrate, thin becoming rigid, glancous beneath; fertile aments oblouy-cyliurliti. $2-3^{\prime}$ long, loosely, flowered.

5. S. rostràta, Richardson. Leaves dull green und donny above, stoutly veined and softhairy bencath, serrate, crenate or subentire; stipules when present semi-cordate, tonthed, acute; aments appearing with the leaves, the steril. narrowed at base, pale yellow; capsules tapering to a very long slender beak; pedicels threat-like, much exceeding the pule, rosi-tipped, hinear, thinly villous scules; style scarcoly any; stigma-lohes entire or deeply parted. (S. livilit,

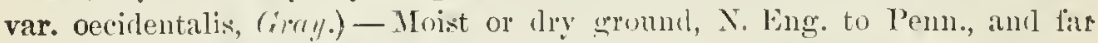
west and northwarl. N $t$ : preading $\mathrm{f}^{\prime} \mathrm{rm}^{\mathrm{m}}$ the root but having rather the hal it of a small tree, with it distinct trunk.

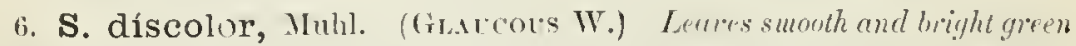
nbore, swm smouth line the irregularly ercnate-simate, the serratures remote at lase, closer, finm and hecoming uholete toward the point ; stipules $\frac{1}{2}$ ' long or more, and shlarply toothed, w small and nearly entire; uments closcty sessile, thich, oblong-rylindrical, I' long or more, appeuriug before the leaces in earliest spring; s. ales durk reat or beown, heerming black, ropionsty clothed with long

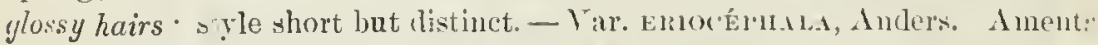
more densely flowered and mor silvery silky; leas sometimes retaining : serrugin'us pulescence beneath even when fully grown. - Var. l'msoinsw, Anlers. Aments more lo. sely fowered, less silky; (apsules more thinly tomentuse; style longer: stigma-lobes laciniate; leaves narrower. (A. prinoides, Pursh.) Includes narrow-leaved forms of the type, and others which are probably lyohrids with S. cordata. - Low meadows and river-hanks, common. The just expanding leaves are often overspread with evanescent fermginous hairirs.

- Cpland grayish shmbs, I-8 high; leaves oblanceolate, pointed, the louest whture, drumy abore beroming glabrate, beneath glaucous, rugose-veined and soflly tomm nituse, the margin revolute, undulate-entire; aments oroid or 
oblony, closely sessile, appearing bejore the leaces, maked ut base; capsules wather shortly pedicelled, greenish or reddish, spreading; scales durk red or broumish; style distinct; stigmas bifid.

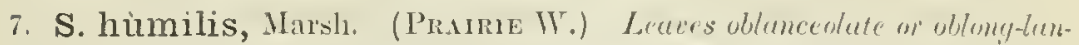
ceolate, the lowest oborate; stipules medinm-sized, semi-ovate, entire or oftener

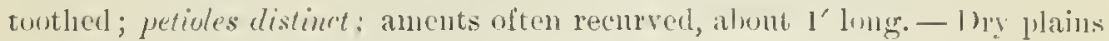
anrl harrens, cominom. A shruh, $3-8^{\circ}$ high, varving onuch in the sive and whape of the leaves. Hybricls with n. b have equally broad and large but dullex green leaves, wiftly tomentose beneath and with shorter petioles, the ament: orpully thick hut usually recurved, and the calpsules un shorter pedicels. Fmall forns alparently pass into the next.

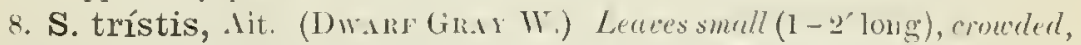

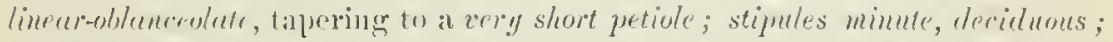
aments rery snali, alohula ol oval, abont $\frac{1}{2}$ lomg in fruit. - Sindy plains or

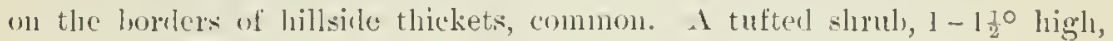
rising from a strong large root.

+++++ Lou shruls, i3 - $10^{\circ}$ high, of cold swemps, with slender yellowish or reddish twigs: lences lanceolute, smooth abme, glancous beneath and cotered when young with appressed silerery-silhy hairs; aments (especially the fertile) with a feu lorify bracts at base; rapsule pedicelled, silvery-silly; stigmas bifirl.

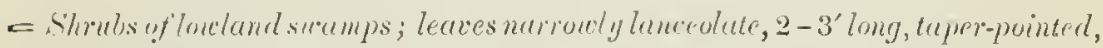
finely mul cevenly serrate; stipules linear or semi-cordate, deciduous; aments sessile or in fint slightly preduncled ; style ver.y short.

9. S. serícea, Marsh. (Silk IV.) I.eaves at first (principally beneath) very silky, tuming black in drying; ancnts narowly cylindricai, the fertile densely Howererl; capsule short-pedicellerl, ovate-ohlong, rather ohtuse. - Com. mon, hut more prevalent from the region of the cireat Lakes castwarl.

10. S. petiolàris, Smith. Leaves unly slightly silky when young, soon smontl, with lesstendency to blacken in drying; fertile aments oroid-erlindric, in fruit broal and loose from the lengthening of the pedicels; eapsule rostrate from an wate base, rather acute - Var, wisicrus, Anders, has extremely lowe ments, and lery long-pediceller attenute-rostrate capsules, - Common, but more prevalent from the Great Lakes westwarel. 'This species, like tho preceling, lỵludirlizs frecly with S. cordata.

$==1$ 1pine shrub; leares 1-2'long, repand-crenate; stipules minmie, fugacious; aments leafy-peduncled; style distinct.

11. S. argyrocárpa, Anders. Teaves tipering evenly to both mais, acute, or the calliest obovate and oltuse, at length rigid, the margin slightly revolute; petiole short; fruiting ament short (alout l' longr), loosely Howrerel; (apsule taperine, fleusely silky-silvery; gland of the staminate flower varously" donblerl. - Moist alpine ravines in a few limited localities on or near Mt. Washington, X. II. ; also in Lower Canada aun Lab. A lushy branched shrub, ereet or depressed at hase, $1-20$ high, growing in wide dense patehes. 1 ly-

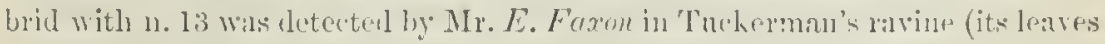
collected by Dr. Gray as carly as 1842 !), appearing like a large formu of the speciez :pith the aruents of $\rightarrow$. pleylicifulia. 
+- I'odirels twice the lenyth of the glend; style chomgrted.

12. S. cándida, W'illd. (SAcie W. Hosky W.) Leaves lanceolate or linear-lanceolate, 2-4' long, taper-pointerl or the lowest olituse, rather rigirl, downy above, becoming glahrate, brmuth covered with a dense whte tomentum, the rerolute margin sulsentire; stipules laneolute, abont as long as the petivles; aments eylindrical, densely flowered, $2^{\prime}$ long in frutit; anthers red; the dark gland elongated; capsule densely white-roully; style dark red ; stigmas short. spreading, notched. - Cold bogs, N. ling. and $\mathrm{X}$. J. to Iowa, and nortluward. -A hoary shrub $2-5^{\circ}$ ligh ; jomg shoots white-woolly, the older red. 'lwo beautiful hybrids, with n. 10 and n. 14, have been found near Flint, Mich. (Dr. Clarke).

13. S. phylicifólia, L. Leaves lameeolate, ovate-lanceolate or elliptie, somewhat equally pointed or obtuse at both ends, remotely and minutely repandtoothed, 2-3' long, very smooth on both sides, dark green and shining above, glaucous beneath, at length coriaccous; stipules obsolete; aments sessile with a few small bracts at base, $I^{\prime}$ long, lather densely flowered, oblong-eylindric, the fertile somewhat stipitate, becoming $2^{\prime}$ long in fruit; scales dark, silkyvillous; capsule conic-rostrate from an oroid base; stigmas bifid or entire, yellow drying black. (S. chlorophylla, of Lan.; S. chlorophylla, var. denn(lata, Anders.) - Moist ravines on alpine smmmits of the IThite Mountains, and of Mt. Mansfield, Vt. $-A$ divaricately mnch lianched shrub $1-100$ high; twigs glabrous, sometines covered with a glaucous hloom. (En.)

S. Vumpals, I., tho Osisk Wiluow of Enrope, is occasionally planted, but soon dies out. Some of its lỵlmils, as S. Summux., Willd, ete., stand our climate better, lint cammot le regarded as adrentive.

+++ Capsules sessile; flaments and often the reddish anthers unitrd so as to (1) prear as one.

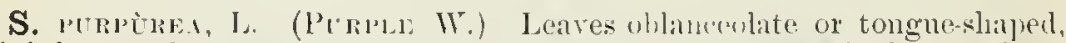
slightly serulate, very sumotl, glancescent, subupusite; stipules olsolete:

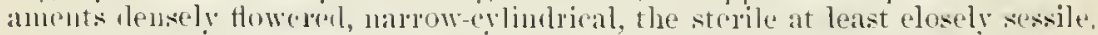
witl only very small lomets at bise; seale small, round, crisp-villous, tipped with dark puiple; capsules grarish-tomentose, vrate-conical, obust. - Lum gremuls; commonly eultivated for hasket-jorls. (Adr. from Lu.)

$$
\text { * C'apsules glubrous. }
$$

+ Tall shmbs, 4-10 high : leares lanreolate or orate-lanceolate, 2-4' long, acute or acuminute (on rigurums shoots rounded, truncute on cordate at base), serrate; sterile aments very silk!, with "feu bracts ut base, l' long or more, the fertile leafy-peduncled, in frnit $2^{\prime}$ long or more; capsules tupering, pointed.

++ Leaves soon smooth; capsules long-pedicelled; style medium.

14. S. cordàta, Muhl. (HE.nT-LEAvEd $\mathrm{W}^{\mathrm{r}}$ ) Leaves oblong-lunceolate or narrouer, on the flowering branclies often tapering at base, sharply serrate, funcly denticulate or subentire, green both sides or scarcely paler beneath, the young often silky or downy, especially on the midril, not turning black in Ilring; stipules reniform or orate, serrate, usually lurge and conspicuous; anents ruther stender; capsules greenish or rufescent, 2-3" long. (S. rigidin, Mull.) - Var. Axarstat, Anders. Leaves narrower, grarlually acuminate, finely serrate - In wet places and along streams, ete; our most widely dis-

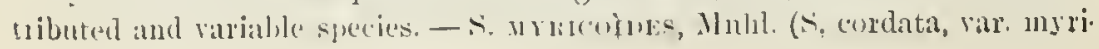


coides, Darl., Fl. Cestr., 3 ed.), is a hylyrid between this species and S. sericea, liaving the lcaves, evcn those of the most vigorous shoots, tapering and rather acute at bave, glaucous or glancescent beneath and sparsely appressed-hairy; stipules small, orate, pointed; capsules more or less silky when young, becoming glabrate, shortly pedicelled; twigs brittle at base. A hybrid with the European S. incana (surprising on account of the rarity of the cnltivated parent) is found at Ithaca, N. Y. (Dudley).

15. S. glaucophýlla, Bebb. Leaves varying from ovate with a broadly rounded base to oblong-lanceolate and equally pointed at both ends (3-4' long, nearly 2 ' wide), glandular-serrate, subcoriaceous, glabrous throughout, dark green and shining above, glaueous beneuth, the young drying black; stipules large, earshaped, dentate; aments thiek, oblong-cylindrical, in size and silkiness resembling n. 6 ; capsules attenuate-rostrate, 3-5' long, greenish, chying brown. Var. waustrfòlı, Bebb; leares narower ( $3^{\prime}$ long, $8^{\prime}$ wide), pointed at both ends. (S. angustata, of ed. 2, in part.) - Var. BRevrfólı, Bebb; leaves uborate, about $\mathrm{l}^{\prime}$ long, strongly veined. - Common on the sand Iunes of Lake Miehigan, and occasionally found away from the lake-shore in N. Ill. and Wisc.

16. S. balsamífera, Barratt. Leares broadly rounded and usually subeordate at base, at first very thin, sulpellucid and of a rich reddish color, at length vigid, dark green ubove, pulr or glaurous and prommently retreulate-veined beneath, slightly glandular-serrulate; petioles long and slender; stipules obso. lete; fertile aments becoming very lax in fruit, the long slender pedicels $6-8$ times the length of the gland; style short. (S. pyrifolia, Anders.) - In open swamps along our northeru boundary, Maine to Minn., and northward; White Viountains of N. I. (Litlle, 1823 ; rcdiscurered by Pringle, and C. E. and $E$. Faxon). A much branched shrub, growing in clumps; reeent twigs shiningchestnut on the sumuy side.

*+ Leaves elothed, even when fully grown, with a long silk!y tomentum on both sides, whieh is finally derichous; capsule sulsessite; style elongated.

17. S. adenophýlla, Hook. Leares orite or very broadly lanceolate, (uspidate-acuninate ( $1-2^{\prime}$ long), dull green both sides, very closely serrate with fine projecting gland-tipped teeth; stipules conspicuous, orate-cordate, glandular-serrate, exceeding the slort stont petioles, which are dilated at base and embrace the obtuse silky buls; aments leafy-peduncled, the fertile wot mrely becoming $4^{\prime}$ long, densely flowered. — Shores of the Great Lakes, rooting extensively in the sand-lnnes. A large straggling shrub, witl stont to nentose twigs and crowled leares. Hybriclizes with S. cordata.

- Low erect shrub, 1 - $3^{\circ}$ high : leares small, entire; capsules oblong-cylindric; stiymas sessile or nerrly so.

18. S. myrtilloides, L. Leaves elliptic-ohorate, about 1' long, obtuso or somewhat pointed, entire, smooth on loth sides, somewhat coriaceons when matnre, revolute, reticulated, pale or glancous heneath; fertile aments oblong, loosely few-flowerchl, horne on long leafy perluncles; capsules redlish green; perlicels slcnder, twice the length of the nearly smonth grexuish yellow scale.

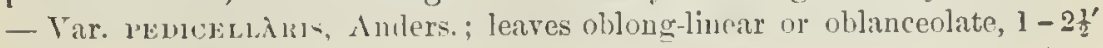

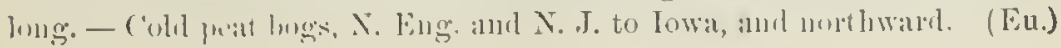


++ Prostrale or creeping and matted alpine slrubs.

19. S. Uva-úrsi, P’ursh. (BEarberre W.) Leares elliptical anch pointed, or obovate and obtuse, less than l' loug, $3-4$ " wide, tapering at liase, slightly toothed, strongly veined, smooth and shining alove, pale and rather glineous beneatls; aments borne on slender lateral leufy peduncles, oblong-rylimibic, $6-9^{\prime \prime}$ long, the fertile lengthening to $2^{\prime}$ and narrowly cylindric, densely flowered above, often loose below; scrles obovate, rose-red at the tip, corered with long silky hairs; stamens rarely 2 ; capsule ovate-conical, brownish at maturity; pedicel scarcely excecling the glind; style distinet. (S. Cutleri, Tuckerm.) - Abundant orer all the alpine summits of N. New Eng. and N. Y. Closely prostrate, spreading from a stout central root over an area $1-2^{\circ}$ il diameter.

20. S. herbàcea, L. Leares roundish oral, heart-shaped, obtuse or retuse, less than $1^{\prime}$ long, serrate, smooth and shining, reticulately veined; amonts terminuting 2-leaved branchlets, small, ovoid, 4-10-flowerd; scales concave, oburate, obtuse, glubrous or slightly pubescent; cupsule snbsessile. - Ilpine summits of the White Mountains, and far northward. A very small herb-like species, the latf-underground stems ereeping and rooting to a considerable extent, the hrawehes seldom rising abore $1-2^{\prime}$ from the ground. (Eu.)

\section{PÓ PU L U S, Tourn. Porlak. Msper.}

Brats (scules) of the eatkins irregularly eut-lobed at the apex. Flowers from a cup sliaped disk which is obliquely lengthenerl in front. Stamens $8-30$, or more; filaments distinct. Stigmas 2-4, elongated. Cilpsules 2-4-valreul. Trees, with broad and more or less heart-shaped or ovate toothed leaves, aud often angular branches. Buds scaly, covered with resinous vanish. Cathins long and irooping, appearing before the leares. (The classical Iatiu name, of uncertain origin.)

\$1. Styles 2, with 2-3 narrou or filiform lobes: capsules thin, oblong-conical, 2-ealied: seeds very smull; leures orate.

* Petioles laterally flattened; bracts silly: stumens 6-20; capsules mumerous, small, on very shont pedicels.

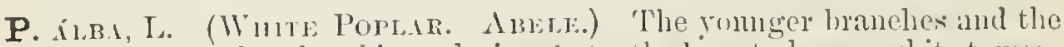
muler surface of the rhombic-oval sinuate-tonthedl alcute leaves white-tomentrise: s'ales cremate, fringed. - Frequently anlivated for shade, sprealing miclely ly the rot, ind oceasionally spontineons. (Adv. from Eu.)

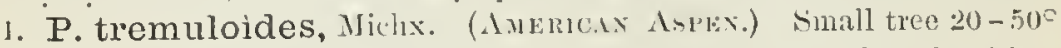
high with smooth greenish-white hark; lenes roumlish-heret-shaped, with a

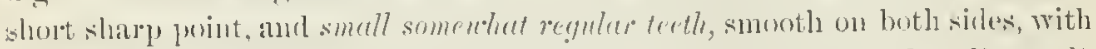
downy margins, on long slender petioles; scoles sut into 3-4 dopplinecu divisions, fringed with long hairs. - Maine to the momtains of P'emn., N. liy., Minn., ancl fin nortl and westwark.

9. P. grandidentàta, Michx. (I, IRGE-Tootmen) Aspex.) Tree 607,50 high, with smothish gray hark; lecues ronendish-ovate, with large and ir. regular simute terth, when young densely covered with white silky wool, at length smooth both sides; scales eut imfo 5 - 6 unequel small divisions, slightly" fringed. - Rich woorls and borders of streinus, X. Scotia to the momutians of X. C., west to X. Minn. and 'T'enn. 
* * L'etiules teicte; brarts nut silky: stumens $12-60$.

3. P. heterophýlla, L. (Dowxix Polltu.) Tree $40-80^{\circ}$ higll; leaves uvate with a somewhat truncate or cordate base, ol,tuse, crenate, white-woully when roung, at length nearly smootl, except on the elevated veins loneath; fertile cathius few-flowered; capsules $\frac{1}{2}$ long, equalling the pedicels. - Borders of river swanps, Comn. to Ga., and in the west from S. Ind. and Ill. to Ark. and W. La.

\$2. Styles 2-4, with dilated lobes; cupsules large, often thick, subylobiose to arate-oblong, 2-4-calied : bructs mostly glubrous; seeds 1-2" luny.

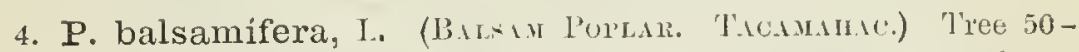
$75^{\circ}$ highl, the large buls vamislurl with a copisus fraglant resin; leaves

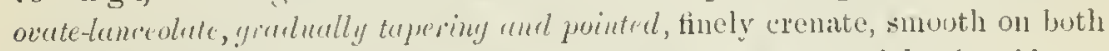
siles, whitish and reticnlately reined beneath, on terete petioles -2 ' long: scales dilaterl, slightly hairy; shumens 20-30; caysule ovate, 2-calred. - Burders of rivers and swamp, $\mathrm{X}$. New Kng. to Mich. and Minn., and far north

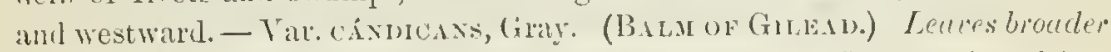
and more or less heart-shaped; petiole commonly hariry. Common in cultivat tion, but rare or unkuowu in a wild state.

5. P. monilifera, dit. (Corrox-woon. Necklace Poptals.) Tree $75-150^{\circ}$ high; feucs broudly deltoid, with numerous crenate serratures and narrow ver! acute acomination, sonretines orate, rarely cordate, on clongater flattenerl pretiules; scales lacerate-fringed, not hairy; stumens 60 or more; capsules on sleuder pedicels ( $4-5$ "long) in long catkins, oblong-ovate, $3-4$-raleed. (Incl. P'. angulata, Lit.) - Borders of streams, western N. Eng. to Fla., west to the Rucky Mts.

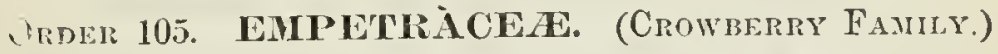

Low shrubly evergreens, with the foliage, aspect, and compound pollen of IIeaths, and the drupaceous firuit of irctostaphylus, but the divided or laciniate stigmas, ete, of some Euphorbiacea; - probably only an apetalous and polymunous or dicecious degenerate for'm of Ericacede, - conprising three genera, two of which occur within the linuts of this work, and the third farther south.

1. Smpetrum. Flowers scattered and solitary in the axils. Sepals 3 , somewhat petallike.

2. Corema. Flowers collected in terminal heads. Calys none.

\section{1. ÉmPETRU M, 'Tourn. Crowbrry.}

Flowers polygamous, scattered and solitary in the axils of the leaves (inconspicuous), scaly-bracted. (alyx of 3 spreading and somewhat petal-like sepals. Stamens 3. Style vert short; stigma 6-9-1ayed. Fruit a berry-like drupe, with fi-9 secd-like nutlets, each containing an erect anatrupous seed. Fimbryo terete, in the axis of copious albumen, with a slender inferior radicle and very

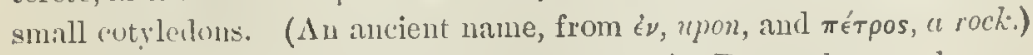

1. E. nigrum, T. (Buдck Cuowrprry.) Procunluent and spreading; leaves linkillohlme, scattered; fruit hlack. - Newf., Munnt Desert and 
adjacent coast of Maine, alpine summits in N. Eng. and N. Y., L. Superior, and northward. (En.)

\section{C O R È M A, Don. Broom-Crowberry.}

Flowers diocious or polygamons, collected in terminal heads, each in the axil of a scaly bract, and with 5 or 6 thin and scarions imbricated bractlets, but no proper calyx. Stamens 3, rarely 4, with long filaments. Style slender, 3- (or rarely 4-5-) cleft; stigmas narrow, often toothed. Drupe small, with 3 (rarely 4-5) nutlets. Seed, etc., as in the last. - Diffusely muchbranched little shrubs, with seattered ol' nearly whorles narrowly linear heath-

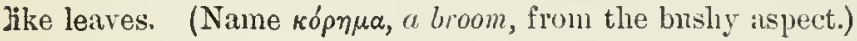

1. C. Conrádii, 'Torr. Shrub $6^{\prime}-2^{\circ}$ high, diffusely branched, nearly smooth; drupe very small, dry and juiceless when ripe. - Saudy pine barrens and dry rocky places, N. J. and L. Island (?), Sllawangunk MIts., N. Y., coast of S. E. Mass. and Maine, to Newf. The sterile plant is landsome in flower, on account of the tufted purple filanents and brown-purple anthers.

\section{Order 106. CERATOPHyLCÀCEAs. (Hornwort Family.)}

Aquatic herbs, with whorled finely dissected leaves, and minuie axillary and sessile monceious flowers without floral envelopes, but with an 8-12cleft involucre in place of a calyx, the fertile a simple 1-celled ovary, with a suspended orthotropous ovule; seed filled by a highly dereloped embriyn with a very short radicle, thich oval cotyleslons, and a plumule consisting of several nodes and leaves. - Consists only of the genus

\section{CERATOPHÝLLUM. L. Honxwort.}

Sterile flowers of 10-20 stanens, with large sessile anthers. Fruit an achene, beakerl with the slender persistent style. - Herbs growing under water, in ponds or slow-flowing streams; the sessile leaves cut into thriceforked thread-like rigid divisions (whence the name from képas, a hom, and $\phi \dot{u} \lambda \lambda a \nu$, leuf).

1. C. demérsum, 1. Fruit smooth, marginless, beakerl with a long persistent style, and with a short spine or tubercle at the base on each sille. - Var. echixdtux, Gray, has the fruit mostly larger ( $3^{\prime \prime}$ long), rongh-pim. plect on the sides, the narrowly winged margin spiny-tonthed. - Sluw streans and ponds, acruss the continent. (Eul., etc.) 


\section{SubClass II. GYMNOSPÉRMA.}

Pistil represented hy an open scale or leaf, or else entirely wanting; the ovtules and seeds therefore nalied (withont a peri(arp), and fertilized by the direct application of the pollen. Cotyledons often more than two.

\section{Ornet: 10\%. CONÍFERAL. (l'INe Family.)}

Thees or slunbs, with resinous juice, moslly aul-shaped or needle-shaped sutive leates, and monecious or rarely dieccious fluners in cathins or solitary, destitute of calyx or corollu. Ownles orthotropons or inverted. Embryo in the axis of the alhumen, nearly its length. (Wood destitute of dnets. (mmposed chiefly of a lomogeneons lange woody filore which is markend with eircular diskn on two sirles.)

Subornek I. Pinacear. Fertile flowers in scaly aments becoming conn's or hery-like. Ovule's 2 or more at the base of each scale. Instly noncecions and evergreen.

Tribe 1. ABIETIXAd. (l'is: Fandy proper.) Fertile fowers in catkins, consist-

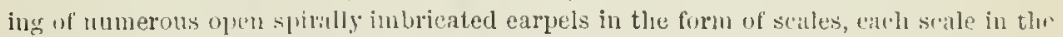
axil of a thin persistent bract; in fruit forming a strobile or cone. ovales 2 , allierent to the base of each scale, inverted. Sceds winged. cotyledons :3-16, Anthers spirally arranged "1pon the stamineal enlumn, which is sultender hy involncrul seales. Jurls scaly. Lenves scattered (or fiscicled in 2.1 and 5 ), linear to needle-shaped.

* Cones maturing the second year, their seules hecoming thickencd and corky.

1. Pinus. Leaves $2-5$ in il cluster, surnounded by a sheath of scarious bnd-seales. * Cones maturingr the first, year, their scales remaining thin.

- Cones pendulous, their scales persistent; bracts sinaller than the scales; leaves jointed upon a juninent persistent hase, solitary.

2. I'icea. leaves sessile, keeled on both sicles (tetragonal!

3 Tsuga. I.enves petiolerl, llit.

+ + Cones erect; bricts lomer than the scales; leaf-sears not srominent.

4. Abies. Seales of the lirgo anc leciluous. Leaves persistent, solitary, kecled beneath.

5. Larix. Scales of the small cone jersistent. Leaves mostly fascieled, flat, deriduous

Tribe II. TAXUDIE.A. Fertile aments of several spirally arranged imbrieated seales,

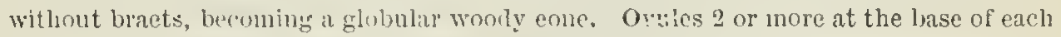
scale, erect. Leares lincal, alteralto; leat-buls not sealy.

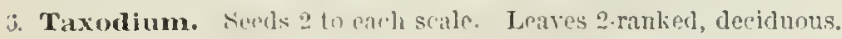

Tribe III. CUPIESSINEA. Scales of the fertile ament few, decussately opposite

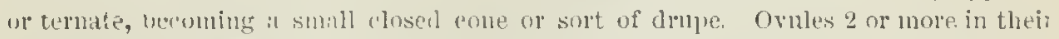
axils, erect. Cotylerons 2 (rarely mur) leares derussitely ollosite or ternate, usu. ally seale-like anul aluate, the parlier flee and sulmlatr; louf-huds unt sualy.

* Momecions ; fruit a small come; leares mposite anu fulinge nore or' less 2-ranked.

7 Chanacyparis. Cone glubose; senles peltate. Seels 1 or 2 , narowly winged.

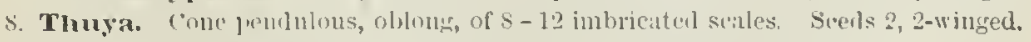

* Hineions. Fruit luery-like, with bony ovate seris.

gunipervis. Fruit-seales 3 - 6 , coulescent. foliage not 2-ranked. 


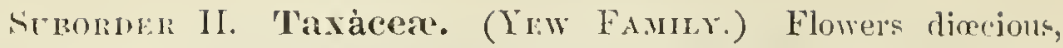
axillary and solitary, the fertile consisting of a naked erect ovule which heeomes a bony-coaterl seed more or less surrounded or enclosed by the enlarged fleshy disk (or scale).

10. Taxus. Leaves linear, seatturd. Secd sumbunder by a red berry-like cup.

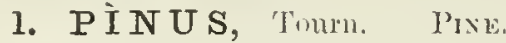

Sterile flower at the base of the shoot of the same spring, involucrate by a anearly definite mumber of scales, consisting of mumerous stumens spirally in serted on the axis, with very short filanents and a scale-like commective; anther-cells 2, opening lengthwise. I'ollen of 3 mited cells, the 2 lateral mes cmpty. Fertile catkins solitary or aggregated immediately below the terminal bud, or lateral on the young shoot, consisting of imlricated canpelsury scales, each in the axil of a persistent hract, hearing a pain of inverter wrules at the base. Frint a cone formed of the imbicaten wooly carpellary s(ales, which are thickenen at the apex (except in White l'ines), persistent, s]mealing when ripe and iry ; the 2 nut-like seeds part.." sunk in excavatims. at the base of the scale; in separating carrying away a part vi its lining as a thin fragile wing. Cotyledons 3-12, linear. - P'rimary leares thin and chafflike, merely bul-seates; from their axils immediately proced the secondary needle-shaperl evergreen leaves, in fascicles of 2 to 5 , from slender buds, some thin scurioms lmu-scales sheathing the have of the cluster. Leaves when in pair's semicylindrical, hecoming channelled: when more than ? triangulan; their wges in our species serrulate. Blnswms levelopel in spring; the cones maturing in the seconl antmun. ('The classical Latin mame.)

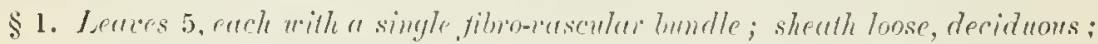

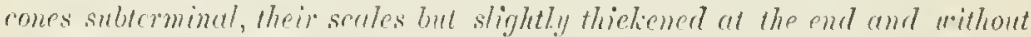
priclite or proint: burk smonth execpt on nld trunks.

1. P. Stróbus, L. (Whits P'sw.) 'Tree $85-160^{\circ}$ highi leaves very

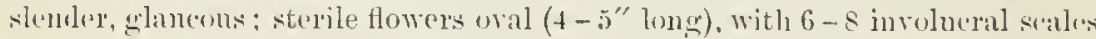
at lasse: fertile "atkins long-stallied, crlindrieal; cones narrow, cylindrical,

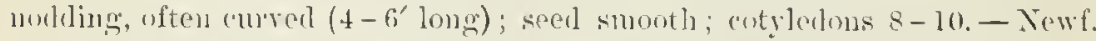

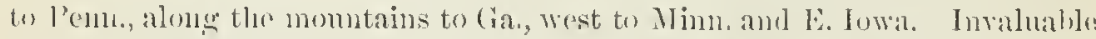
for its solt, light, white or yellowish wood, in lange trees nearly free from resil.

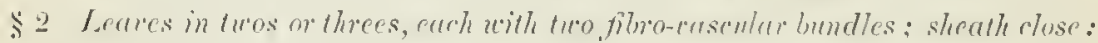
uroody seates of the cones thirkeurd at the end and usually spimy-tippert.

* Cones lateral: their seates much thickened al the end: leares rigud.

- Lemers in thress (rurerly in licos in 11. 2).

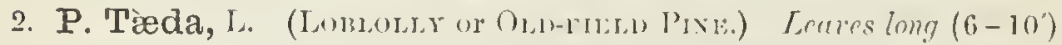

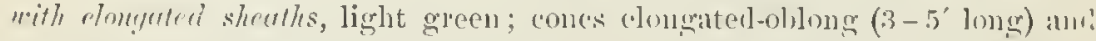

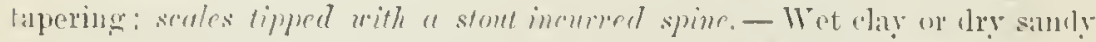

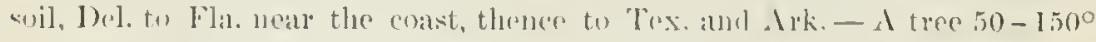
high, staminate ftuwers slenter, $2^{\prime} l o n g$, w itl listully $10-13$ involucral scales: seeds with 3 stromgrongh ridges on the nuler side.

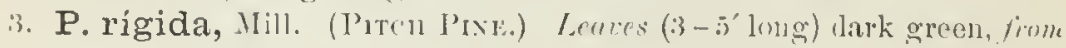

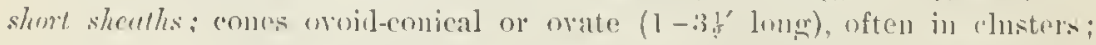

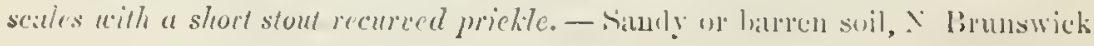




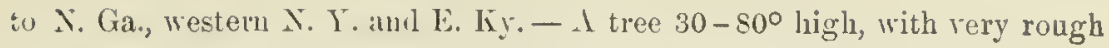
clark bark and hard resinous wood; sterile flowers shorter; scales 6-8.

t- t- Leaves in twos (some in threes in $\mathbf{n . 4} 4$ and 7 ).

4. P. púngens, Michx.f. (TamLe Mourtaix Pixe.) Leqress stout, short (1 $\frac{1}{4}-2 \frac{1}{2}$ ' long), crowded, bluish, the sheath short (very shor't on old foliage);

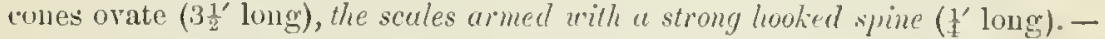
Alleghany Mts., I'emn., to N. C. and Teun. $-\Lambda$ rather small tree $\left(20-60^{\circ}\right.$ high); cones long-persistent.

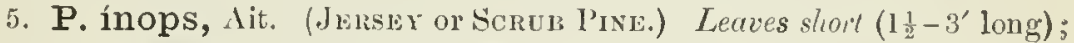
grones ublong-cunical, sometimes curved (2-3' long), the sentes tipped with a struight or recurved aw -shaped prichle. - Barrens and sterile hills, Long Island to S. C., mostly near the coast, west through Ky. to S. Int. - I straggling tree at the east, $15-40^{\circ}$ high, witlı spreading or drooping branchlets; large westward. Young shoots with a purplish glaucous bloom.

6. P. Banksiàna, Lambert. (Gral or Nontulix Scrum Pive.) Leaves short ( 1 ' long), oblique, divergent; cones conical, olblong, usually curved ( $1 \frac{1}{2}-2^{\prime}$ long), smooth, the scules pointless. - Barren sandy soil, S. Maine and N. Vt. to S. Mich., central Minn., and northward. Straggling shrub or low tree.

7. P. mitis, Michx. (Yellow l'sxe.) Leares sometimes in threes, from long sliculls, slender (3-5' long); cones orate- or oblong conical (brarely $2^{\prime}$ Iong), the srales with a minute weak prickle. - Usually dry or sandy soil, Staten Isliud to Fla., S. Ind., S. L. Kan. and Tex. - I straight tree, $50-100^{\circ}$ high, with dark green leaves more soft and slender than the preceding. 'The western form has more rigid leares and more tuberculate and spiny cones.

* Cones lerminal; leaves long and stender, in twos or threes.

8. P. resinòsa, Ait. (REu PIxe.) Leaves in twos from loug sheaths, "longated (5-6'lony), dark green; cones vrate-conical, smooth (uboul 2' long), their scules slighlly thichencd, pointless: sterile flowers oblong-linear (6-9" long), subtended hy about 6 involncral scales which are early deciduous by :ur articulation above the base. - Dry wools, Mass. to N. Penlı., Mich., and Mlinı, and nortlward. $-\Lambda$ tall tree, with reddish, rather smooth bark and liard wood, not rely resinous.

9. P. palústris, Mill. (Toxg-Ledrip, Ylalow, or Georgid Prye.) Leaves in threes loom long sheathis, rery long $(10-15)$, crowded at the summit of very scaly lumulies: strule flowers $2 \frac{1}{2}-3^{\prime}$ long, rose-purple; cones large, (ylindrical or conical-oblong $\left(6-10^{\prime}\right.$ long), the thick scales armed with a show recurved spine. (I'. anstralis, Mh hh. ) - Sandy soil, S. Va. to Fla. and Tex. A large tree, with thin-scaled bark and exceedingly hard and resinous wood.

\section{PİEA, Link. SPrứe.}

Sterile flowers axillury (or sometines terminal) on branchlets of the preceriug year; anthers tipperl witl a ronnded recmred alpendige, their cells open ing lengthwise. Fertile catkins and cones terminal; cones maturing the first year, pendulous: their scales thin, not thickened nor prickly-tipued, persistent. Leaves scattered, needle-shaped and lieeled above and bolow (t-sided), pointing every way. Otlemwise nealy as in l'inus. ('The classicul lutin mane.)

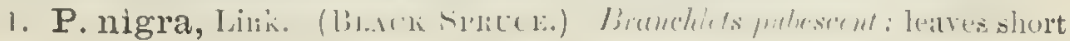

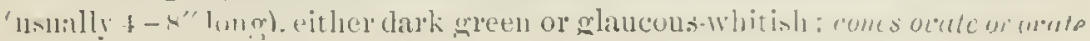


Dblong (10 - 20" long), mostly, recurved, persistent, the rigid scales with a thin dentieulate edge. (Alies nigra, Poir.) - Swamps and cold mountain woods, New Eng. to Penn., eentral Mich., Minn, and northward, and south in the nountains to Ga. $\Lambda$ tree $40-70^{\circ}$ high. - Var, rùbra, Engelm. Leaves larger and darker; cones larger, bright red-brown, more realily deciduous.

2. P. álba, Link. (W111 Tre SPruce.) Branchlets gicabrous; leaves more slender, pale or glancous; cones nodding, cylindricai (about 2 ' loug), pale, deciduons, the thimner scales with an entire edge. (Alies alba, Mich $x$.) Northern New Eng, and N. Y. to L. Superior, and northward. $-\Lambda$ handsomer tree than n. $1,50-150^{\circ}$ high, in aspect more like a Balsam Fir.

\section{TS Ù G A, Carrière. Hesloock.}

Sterile flowers a subglobose eluster of stameus, from the axils of last year's leaves, the long stipe surrounded by numerous bud-scales; anthers tipped with a short spur or knob, their eonfluent eells opening transversely; jollen-grains simple. Fertile eatkins and eones on the end of last year's branchlets; cones maturing the first yenr, pendulons; their scales thin, persistent. Leares scattered, flat, whitened leneatl, appearing 2-rauket. (The Japazese name of one of the species.)

1. T. Canadénsis, Carr. Teares petioled, short-linear, obtuse ( $\frac{1}{2}$ longr); cones oval $\left(6-8^{\prime \prime}\right.$ long), of few thin scales much longer than the bracts. (Abies Canalensis, Ifich.x.) - Mostly hilly or rocky woods, N. Scotia to Del., and along the mountains to $\mathrm{Ala}$., west to Mich. and Minn. $-\Lambda$ tall tree, with ligglit and spreading spray and clelicate foliage, bright green above, silvery beneatl.

\section{4. À BIES, Link. Fur.}

Sterile flower's from the axils of last year's leares; anthers tipped with a knob, their cells hursting transtersely; pollen as in I'inus. Fertile catkins and cones erect on the upper side of sprealing l,ranches; cones maturing the first year; their thin scales and mostly exserted bracts decilnous at maturity Seeds and hark with balsan-lbearing vesicles. Leaves scattered, scrsile, flat, with the midrib prominent on the whitened lower surface, on horizontal branches aplearing 2-ranked. (The classical Latin name.)

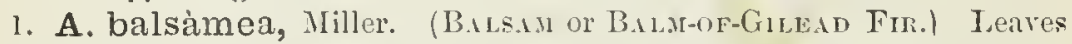
narrowly linear ( $6-10^{\prime \prime}$ long); concs cylindrical ( $2-4^{\prime}$ long, $\mathrm{I}^{\prime}$ thick), violetcolored; the bracts ohorwe, serrulate, tipped with an abmpt slender point, shorter than the srules. - Damp woods and mountain swamps, Newf. to Pell11., along the mountains to Vra, west to Minn., and northwarl, A slender tree or at high elevations a low or prostrate shrub.

\section{L À R I X, Tourn, Larcir.}

Catkins lateral, terminating short spurs on branches of a year's growth or more, short or clolnlar, dereloped in carly spring; the sterile from leafless buts; the fertile mostly with leares below. Anther cells opening transrersely Pollen-grains simple, globular, Cones as in Spruce, the scales persistent.-Leaves needle-shinged, soft, deciduous, all folineons, very many in a fascicle dereloped in carly spring from lateral sealy and glubular lunls, and seatterenl

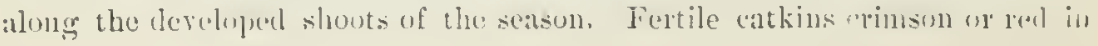
Anwer. (The ancient namo.) 
1. L. Americàna, Michx. (Americax or Buck Larch. Tamarack. llickmatack.) Leaves short; cones ovoid $\left(6-9^{\prime \prime}\right.$ long), of fell rumuled scales, arranged in $\frac{2}{5}$ order. - Chiefly in cold swamps, N. l'enn. to N. Iud. and rentral Minn., and far northward. I slender tree, $30-100^{\circ}$ high, with hard aud very resinous wood.

\section{TAXODIUM, Richard. Bald Crpress.}

Flowers monocious, the two kinds on the same luanches. Sterile flowers spiked-panicled, of few stamens; filaments seale-like, shield shaped, bearing 2-5 anther-cells. Fertile catkius oroid, in small clusters, scaly, with a pair of ovules at the base of each scale. Cone globular, clused, composed of very thick and angular somewhat shield-shaped scales, bearing 2 angled seeds at the base. Cotyledous 6-9. - Trees, with narrow linear 2-ranked light and deciduons leaves; a part of the slender leafy lianchlets of the season also de-

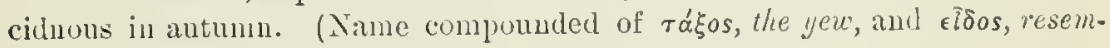
blance, the leaves beiug Yew-like.)

1. T. distichum, licharl. (AMerrca. Bald Crpress.) Leaves liuear and spreadiug; also some anl-shaped and imlicated on flowering branchlets. - Swanls, s. Jel. to s. Jll. and Mo, and sonthware, where it is a very large and valuable tree. Mareh, $\Lambda$ pril.

\section{CHA M 死 CÝPARIS, Spacli. Wmte Cedar. Crpress.}

Flowers monocious on lifferent branches, in terminal small catkius. Sterile flowers composed of shield-shaped scale-like filaments beariug $2-4$ anther-cells under the lower margin. Fertile catlins globular, of shield-shaped scales clecussate in pairs, hearing few $(1-4)$ erect bottle-shaped orules at base. Cone globular, firmly closed, but opening at maturity; the scales thick, pointed or hossed in the midlle; the few angled or somewliat winged seeds attaehed to their contracted hase or stalk. Cotyledons 2 or 3. - Strong-scented evergreen trees, with very small and scale-like or some awl-shaped closely appressedimbricated leaves, distichums Inanchlets, and exceedingly durable wood. (From

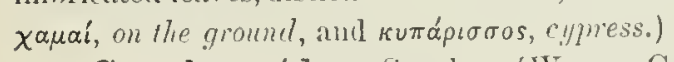

1. C. sphæroidea, Sirach. (Winte CrDar.) Leaves minute, pale, orate or triangular-awl-shaped, often with a small gland on the lack, closely imbricated in 4 rows; anther-cells 2 under each scale; cones small $\left(3-5^{\prime \prime}\right.$ in diameter) of alout 3 pairs of scules: seels slightly wiuged. (Cupressns thyoides, L.) - Swamps, S. Maine to Fla. and Miss. A tree 30-90 high, the wood and fibrons shrelly bark, as well as foliage, much as in Arbor Vitæ.

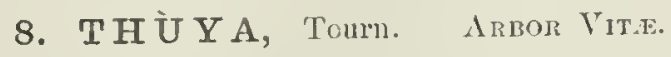

Flowers mostly monecious on different branches, in very small terminal ovoid catkius. Stamens with a scale-like filament or comnective, bearing 4 authel-cells. Fertile catkius of few imbricaterl scales, fixed by the base, each bearing 2 erect ovules, dry and spreading at matnrity. Cotyledons 2. - small evergheen trees, with rery Hat 2 -rallked spray, and clusely inbricater, small, appressed, persistent leaves these of two solts, on linferent or successirn

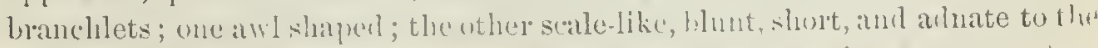

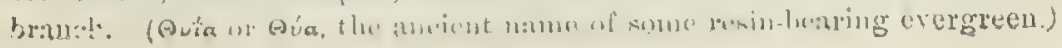




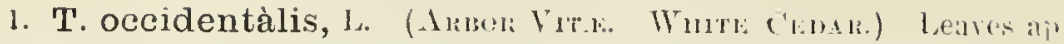
presserl-imhricated in 4 rows on the 2-elged blanchlets; scirles of the col, pointless; seeds broully winged all round. - swamps and aod rocky lankis N. Brumswick to P'enu, atong the monutains to $\mathrm{X}$. C., West to Minn. A true 20-50 high, with jale shredly lark, and light, soft, but very durable vood.

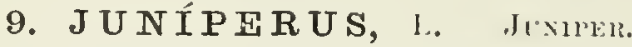

Flowers dicecions, or occusionally monœcious, in rery small lateral catkin: Anther-cells 3-6, attached to the lower edge of the shichl-shaped scale. Fis tile catkins oroil, of 3-6 fleshy coalescent scales, each l-t)`uled, in fruit form. ing a sort of berry, which is scaly-bracted mulerneath, l,hish-black with white bloom. Seeds 1-3, ovate, wingless, bony. Cotyleclons 2. - Evergreen trees or shrubs, with awl-shaped or scale-like rigit leaves, often of two shapes in $\$ 2$. (The clissical name.)

\$1. OXYCÉDRUS. Aments axillary; leaves in whor of 3 , free and jointed at base, linear-subulute, michly-pointerl, rhamelled and white ylaurous abore.

1. J. commùnis, I. (Commox .Juxpler.) S'llrub or small tree, with spreading or pendulons branches; leaves rigil, more or less sprealing (5-9" long); berry dirk blue ( $3^{\prime \prime}$ or more in clianeter). - l)ry sterile hills, common.

Var. alpina, Gaul, is a decumbent or prostrate form, with shorter ( $2-4$ " long) less spreading leaves. - Maine to Minn., and northwarl.

§2. SABINA. Aments terminal; leares moslly "pnositu, of tu०o forms, i. c., aul-shaped and loose, and scale-shaped, appressed-mmbriculed and crouded, the latter with a resiniferous gland on the hack.

2. J. Sabina, Id, var. procúmbens, Pursl. 1 procumbent, prostrute or sometimes rreeping shrub; scale-like leaves acute; herry on short recurved pedmules, 3-5" in diameter. - Rocky lanks, borlers of swamps, ete., N. Enug. to N. Mimn., aurl northwari.

3. J. Virginiàna, 1. (RED Cwest or sirix.) From a shrub to a tree 60-90 high, prramilal in form; scale-like leaves obtuse or acutish, entire; berries on straight perlumcles, about $3^{\prime \prime}$ in diameter. - I ry hills or deep swamps, common. Bark shredly, and hent-wool red and aromatie.

\section{TÁXU S, 'Tonru. Yrw.}

Flowers mostly ılioreious, or sometimes monocious, axillary from sealy buds; the sterile small and globular, formed of a few maked stamens; antlier-cells 3-8 muler a shirll-like somewhat lohed commetive. Fertile flowers solitary, scaly-hrated at hase, consisting merely of an erect sessile ornhe, with an annu Iar lisk, which becomes cup-shaped aromul its base and at length julpy and berry-like, globular and real, nearly enclosing the nut-like secl. Cotrleclous 2.

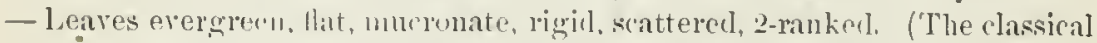

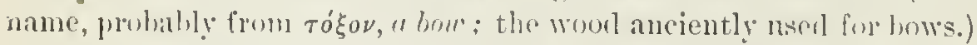

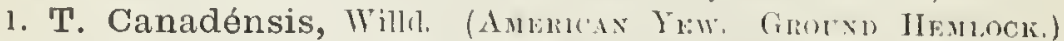
A low stragrling lush, the stems diffusely sprearling; leaves linear, green butl silles. ('T. haceata, var. Cimblensis, Willd.) - J hist hanks and hills, especially unler evergreens; Newf. to N. J., Iowa, Mim., and northward. 


\section{Class II. MONOCOTYLEDONOUS OR ENDOGENOUS PLANTS.}

Stenls with no manifest distinction into bark, wood, and pith, bnt the woody fibre and vessels in bundles or tlireads which are irregularly imberled in the cellular tissue; perennial trunks destitute of anmual layers. Leaves mostly parallelveined (nerved) and sheathing at the base, seldom separating by an articulation, alnost always alternate or scattered and not toothed. Parts of the llower commonly in threes. Embryo with a single cotyledon, and the leaves of the plumule alternate.

\section{OHDER 105. HYDROCHARIDACEAE. (Frog't-HIT FAMU.)}

Aquatic herls, with diacious or polyyumons regulur floneers, sessile or on scape-lilie puluncles from a spalle, and simple or double floral encelopes, which in the fertile floweis are united into a lube and coherent will the 1 3-celled ovary. Stamens $3-12$, distinct or monadelphous; anther's-celled. Stirmats 3 or fo. Fruit ripening under water, indehiscent, many-sceded. Seeds ascendiug, without albuneu; embryo straight.

Tribe I. II YDRILLEA. Stem blonguted, subnerged, leafy. Sprathes small, sessile.

1. Eloclea. Lenves verticillite (rarely olprosite). Perianth-tuhe long-filiforn.

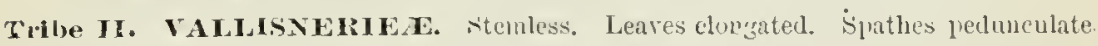

2. Vallisneria. Sulmerged; grass-like. Fertile flower solitury on a very long scape.

Tribe II . STRATIOTEX. Stem very short, with crowder leares. Sprathes peilunculate. Ovary 6-9-eelled.

3. Limmobium. Stemless, foating; broad leares long-petioled.

\section{ELOD E A, Michix. Water-Whe.}

Fluwers polygamo-diocious, solitary and sessile from a sessile tubular 2-eleft axillary spathe. Sterile flower's smill or minute, with 3 sepals barely mited at base, ancl usmally 3 similar or narrower petals; filaments short and miter at hase, or none; anthers 3-9, oval. Fertile flowers pistillate or appluentl:" perfect; perianth exteuderl into an extremely loug capillary tube; the limb B-parterl; the small lobes oborate, sureating. Stamens $3-9$, often with inperfect authers or none. () rary l-celled, with 3 pririetal placenta, each bearing a few orthotrupuns ormles; the capillang style coherent with the tube of the perituth; stiguas 3, large, 2-lobed or notched, exserted. Frnit oblomg,

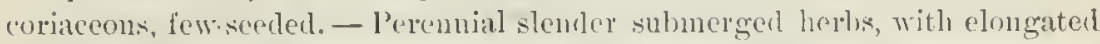
branching stems, thickly heset with pellucid and veinless, l-nerved, sessile, whorlet or opposite loars. The stanimate flowers (rarely seen) commonly break off, as in I'allisneria, and ficat on the surface, where they expand and shed their pollen around the stignats of the fertile flowers, raised to the surface 
by the prolonged calyx-tube, which varies in length according to the depth of the water. (Name from $\varepsilon^{\prime} \lambda \omega^{\prime} \delta \eta$ s, marshy.)

1. E. Canadénsis, Mielux. Leaves in "3's or 4's, or the lower opposite, varying from linear to oval-oblong, minutely serrulate; stamens 9 in the sterile flowers, 3 or 6 almost sessile anthers in the fertile. (Anaeharis Canadensis, Planchon.) - Slow streans and ponds, eommon. July.

\section{VAILISNERIA, L. Tape-grass. Eel-grass.}

Flowers strictly dicecious; the sterile numerous and crnwled in a head on a conical reccptacle, enclosed in an orate at length 3 -ralved spathe which is borne on a very short scape; stamens mostly 3 . Fertile flowers solitary ant sessile in a tubular spathe upon an exceedingly lengthened scape. l'erianth (caly'x) 3-parted in the sterile flowers; in the fertile with a linear tube coherent with the 1-celled ovary, but not extended beyond it, 3-lobed (the lobes obovate); also 3 linear small petals. Stigmas 3, large, nearly sessile, 2-lobecl. Ovules very numerous, scattered over the walls, orthotropons. Fruit elongated, cylindrical, berry-like. - Stemless plants, with long linear grass-like leaves, wholly submerged. The staninate clusters heing confinen to the bottom by the shortness of the scape, the flower-burls themselves loreak from their short peclicels and float on the surface, where they shed their pollen around the fertile flowers, which are raised to the surface by sudden growth at the same time; afterwards the thread-form scapes ( $2-4$ feet long) coil up spirally, drawing the fruit muler water to ripen. (Named for Ant. Fullisneri, an early Italian botanist.)

1. V. spiràlis, L. Leares line:lr, thin, loug aud ribbon-like $\left(1-6^{\circ}\right.$ long $)$, obscurely servulate, obtuse, somewhat nerred and netted-reined. - Common in slow waters, N. Eng. to Fla., west to Minu. and Tex.

\section{L I M N O B I U M, lichard. American Frog's-iit.}

Flowers diøcions, (or monœcious?) from sessile or somewhat peduncled spathes; the sterile spathe 1-leaved, producing abont 3 long-pedicelled flowers; the fertile 2-leared, with a single short-penlicelled flower. Calyx 3-partch or cleft; sepals oblong-oval. I'etals 3, oblong-linen: Filanents entirely united in a eentral solid column, bearing 6-12 linear anthers at unequal heights; there are $3-6$ awl shaped rndiments of stamens in the fertile flowers. Ovary 6 - 9-celled, with as many placente in the axis, forming an ovoid nany-seeded herry in fruit; stigmas as many as the cells, but 2-parted, awl-shaped. $-\Lambda$ stemless peremial hero, floating in stignant water, proliferous ly mumers, with long-petioled and round-heart-shinped leares, which are spongy-reticulated and purplish underneath; rootlets slender, hairy. Silerile flowers rather small; the fertile larger; pertuncle notdling in fruit. Petals white? (Name from

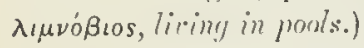

1. L. Spóngia, Richanıl. Lenve's l-2’ long, faintly 5-nerved; peeluncle of sterile flower abont $3^{\prime}$ long and tiliform, of the fertile only $l^{\prime}$ long and stout. - Stagniant water, N. J. to Fla.; also L. Ontario, 1ll., and Mo.

\section{Order 109. BurdianNícede. (Bumaxia Famig.)}

Small amunal herbls, often with mimule and sorate-tike leares, or those at the ront grass-lite; the floucrs perfect, with a b-cleft comblla-litie perianth. the 
tute of which allieres to the 1-celled or 3-celled ovary; strmens 3 and aisinct, opposite the inner divisions of the perianth; copsule many-seeded, the seeds very minute. - A small, chiefly tropical family.

\section{B U R M Á N N I A, L.}

Ovary 3 -celled, with the thick placentie in the axis. Filaments 3 , very short. Style slender; stigma capitate-3-lubed. Capsule uften 3-winged. (Named for J. Burmunn, an early Dutch botanist.)

1. B. biflòra, I. Stem low and slender $\left(2-4^{\prime}\right.$ high), 2 flowered at the summit, or soon several-flowered; perianth (2-3" long) bright blue, 3-winged. - Peaty bogs, Va. tu Fla.

\section{Order 110. ORCHIDÀCEA. (Orchis Famly.)}

Herbs, clearly distinguished by the ir perfect irveyula. flowers, with 6-merous perianth adnate to the 1-celled ovary, with immmerable arules on 3 parietal placenta, and with eilher one or two gynamlrous stanens, the pollen coherin! in masses. Fruit a 1-celled s-ralved eapsule, with innmuerable minute seeds, appearing like fine saw-dust. Periantl of 6 divisions in 2 sets; the ; outer (sepals) mostly of the sume petal like texture and appeanance as tle 3 inner (petals). One of the inner set differs more or less in figure, lirection, ete., from the rest, and is caller the lip; only the other two taking the name of petals in the following leseriptions. The lip is really the upper petal, i. e. the one next to the axis, but by a twist of the ovary of half a turn it is more commonly directed forward and brought next the mact. Before the lip, in the axis of the flower, is the column, eonposer of a single stamen, or in Cypripedium of two stamens and a rulliment of a third, variously colement with or borne on the style or thick fleshy stigma; antler "2-celled; eacle cell containiug one or more masses of pollen (pollinia) or the pollen granular (in Cypripelium). Stigna a broad glıtinous surface, except in $\mathrm{C}_{2} \mathrm{p}^{\mathrm{x}} \mathrm{i}$ ed dium. - Perennials, often tuber-bearing or tuberous-rooted; some epiphytes. Leaves parallel-nerved, all alternate. Flowers often showy, commonly singular in slape, solitary, racemed, or spiked, each subtended by a bract, - in all arruged for fertilization by the aid of insects, very few capalsle of unaided self-fertilization.

Tribe I. EPIDENDREAE. Anther teminnl, erect or inclined, opereulite. Pollinic smooth anil waxy, 4 or $\$$ (2 or 4 in each eell), distinct, or those in each cell (or all in 13. and 7 ) united at hase. (Pollinia $S$ only in $\mathrm{n} .7$ of onr genera.)

* Green-foliaged plants, from solid bulbs, with 1 or 2 leaves.

- Colunn very short; leaf solitary.

1. Microstylis. Flowers raeemose, minute, greenish. Petals filiform.

+ - Column elougated : lenves ralical.

+* Whole plant (except the flowers) green.

2. Liparic. Leaves 2. Raceme few-flowered. Jilu flat, entire.

3. Calypser. I caf solitary. Fluwer larce, solitary. Lip saceute.

+t+ i single green autumnal leaf; otlerwise matuly brownish or purplish.

4. Tipularia. Racene many-flowered; flowers small, greenisla; lij, 3-lobed.

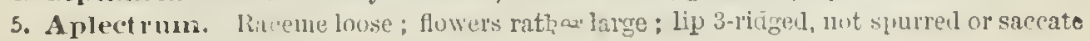


* Loifless, witl colnlloid roots; whole plant brownish or J"ullowish; flowers racemose.

6. Corallurlıza. Lullinia 4, in 2 pairs. Flower gibbous or somewhat spmren, and lip witl 1 -3 ritiges; sepals and petals 1 - 3-uerved.

7. Hexulectris. Polliuil s, united. Flower not gibbous; sepals am petals severalnurver : lip witli 5 -li riclges.

Fribe 11. NEOTIEA. Inthers erect npon the back of the colmun at the summit,

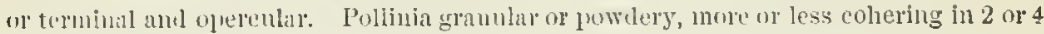
delicate misses, and attached at the apex to the beak of the stigmit.

* Authers without olereulum, ereet upon the back of the short column, Flowers small, in spilies or ricemes.

S. Listera. Stem from a fibrons root, 2-foliate. Lip flat, 2-lobed.

9. Spirantlues. Stenis lenfy below, from tuberous-fascicled ronts. Flower's 1-3-ranked in a twisted spike. Lip embracing tho column below, with 2 cullosities at base.

10. Goodyera. Leaves radical, white-reticulated. Lip entire, free from the column. siceate, without callosities.

* Anther npereulate, crect and jointed unun the shrot colnum. Stem stont, very leafy.

11. Epipactis. Flowers lacemose; perianth sluealing; lip lilated above.

* * Anther terminal, opereulate, incumbent; colum elongrated. Stem scapose or fewleaverl flowers large, nolitary or few.

12. Arethusa. Leaf and flower solitary. Lip bearded, its hase arlherent to the linen. collumn. Pollinia 4.

13. Calopogon. Leaf solitary, grass-lilic. Lip bearded, stalled, fice. Column winged at the alyex, Polliniat 4.

14. Pogonia. More ar loss leafg. Lip erested, free. Colum clarate. Polliniz 2.

Tribe III. OPHIXYEAs. Anthe withont operenlum, the cells adnate to the top wi the eolmum nul often continuous with the beak of the stigna. Pollinia 2, of conse" gains unitul by an clastie web, each atiahed at hase ly a stalk to a riscid gland

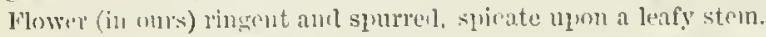

15. Orelnis. The two glunds or viseid disks enclosed in a comnon ponch.

16. Halmenaria. 'the two ghlunds nakel, either alyoximate widely separated.

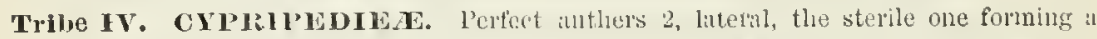

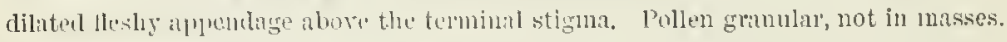

17. Cypripedium. Stoms more or less leafy. Perinuth spreading ; lip an inflated sar.

\section{MICRÓSTY I I, Nutt. Amer's-Mortu.}

Sepals oblong, spreading. Petuls tlueatlike or linear, spreading. Lip auricled or wate at base, not tuberled, entire or nearly so. Column very small, terete, witl 2 tecoth or anricles at the smmmit and the erect anther between thenl. Pollen-nubsics t, in one row (2 in each cell). collering by pairs at the

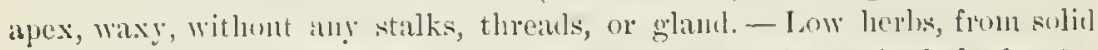
bulbs, prociucing simple stems, which bear in our species a single leaf and a

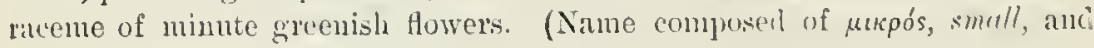

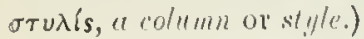

l. M. monophýllos, Lindl. Slender $\left(4-6^{\prime}\right.$ lighh); leuf sheathing the base of the stem, ovate elliptical; racemes spritid, long and stender; pedirels not longer then the flowers; lip long-pointed. — Coll] wet swanps, N. New Eng to Penu., X. Ind., Mlim., and northwintl. July. (Ku.)

2. M. ophioglossoides, Nutt. Leaf near the midllle of the stem,

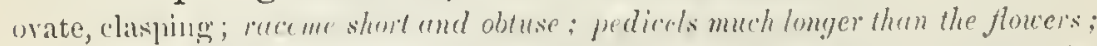

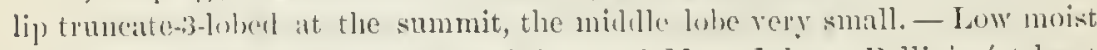

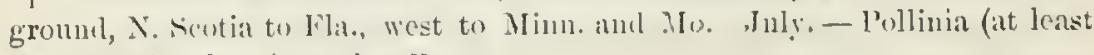
sometimes) only 1 in cach cell. 


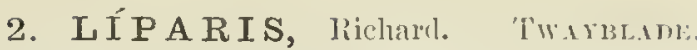

Sepals and petals nearly equal, linear, or the latter threatlike, spreading. Lip Hat, entire, often bearing 2 tubercles alove the bise. Colunu elongated, incurved, margined at the apex. Anther lirtlike, terninil; pullen-masses t, in one row (2 to earh (ell), slightly mited in pairs, withont stalk, threals, (1) grland. - sinall, low herlss, with solid hulbs, producing 2 mot-leaves and a low scape, which bears a raceme of few purjlish or greenish Howers. (Name frent $\lambda$ imapós, fut or shiming, in allusion to the smooth or unctuous leaves.)

I L. liliifolia, Richard. Leares ovate; petals tluead-like, retlexed; lif

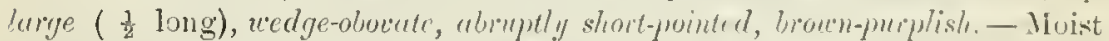
woodlands, N. Eng. to Ga, west to Minn. and Mo. Jume.

2. L. Lœsèlii, Richard. Leaves elliptic-lanceolate or oblong, keclesl; lip obovate or oblong (2" iong), mucronate, yellowistegreen, shorter than the linear unequal petals and sepals. - Bogs, X. Scotia to Ma., S. Ill., and Minu. (En.)

\section{CA LÝ PSO, Salisl).}

Sepals and petals nearly similar, ascending, spreuling, lanceolate, pointed. lip larger than the rest of the Hower, sac-shaped, inflated $\left(9^{\prime \prime} \operatorname{long}\right)$, 2-pointed unlermeath the apex. Column hroarly winged and petal-like, ovate, bearing the lirlike anther just below the apex; pollen-misses waxy, 2, each 2-parterl, all sessile our a styure gland, - A little bog-herl, the solid bulbs producing " single orite or slightly heart-shaperl thin leaf, as in 1 plectrum, aurl a short (3-5' higli) seape, sheathed lielow, bearing a large and slowy (variegated ymple, pink, and yellow) Hower. (Name from the gorldess Cedlypsu.)

1. C. boreàlis, Nalisb. - Colil bogs and wet woods, the luths resting in moss, with a coralloid root heneath; Maine and Vt. to Mich. and Minno, and northwarl. Misy - A very local ancl heantiful plant. Lip somewhat resembling that of a Lady's Slipper, woolly-hairy insisle. (Eu.)

\section{TIPUIÀ R I A, Nutt. CriNe-rur Orcris.}

Sepals and petals sprendiug, ohlong; the latter lather narrower. Lip profonged beneath into a threarlike ascending spur twice or thrice the length of the flower (9-12" long), 3-loherl; the michle lolse linear, a little wavy, as long as the petals, the side lobes short aud triaugular. Colnmn narrow anci wingless. Anther lid-like, terminil; pollen-masses 2, waxy, each 2-parted, comneted lỵ a linear stalk with the transverse small gland. - II erb with large solid bulbs conmected horizontally, on a distinct pedicel, produring in antmm a single ovate nerved and phated leaf on a slender petiole, purplish beneath, aud in summer a long slender scape, with 1 or 2 sleaths at hase, learing a mome of many small greenish Howers timsed with purple. (Name from a fancied resemblance of the flowers to insects of thas genns Tijulu.)

1. T. díscolor, Nutt. Scape 10-18' highl ; lip hlunt at the tip. - Sandy woods, It. to N..J. and Fla, west to Aitch.; very scallece.

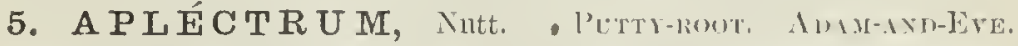

l'eriantl neither giblons mo with any trace of a spur or sac at the base. lip free, the palate 3-ridged. Otherwise the finwers and s'ape (invested be- 
low with 3 greenish sheatls) as in Curallorhiza; but, instearl of a coral like root, a slender naked rootstock produces each year a thick, globular, soiid bulb or corm, often $\mathrm{l}^{\prime}$ in cliameter (filled with exceedingly glutiuons matter), which seucls up late in summer a large, oral, many-nerverl and plaited, petioled, greeu leaf, lasting throngh the winter, and early in the succeedling summer its stape is terminated by a loose raceme of ding! rather large fluwers. (The name composed of a-privative aud $\pi \lambda \bar{n} \kappa \tau$ pov, a spur, from the total want of the latter.)

1. A. hiemále, Nutt. Stem $1^{\circ}$ hich or more; perianth greenish-hrown! or the lip whitish, and somewhat speckled with purple, 5-6" long. - Woorls, in rich mould; rather rare or local, X. Eng. to Ga., west to Minn. and Mo. Each corm lasts 2 or 3 years before it shrivels, so that 3 or 4 are found horizontally connected.

\section{CORALLORHİZA, Haller. Coral-root.}

Perianth somewhat ringent, oblique aud gibbous or olscurely spurred at hase; the oblong or lanceolate sepals aurl petals nearlv alike, 1 -3-nerved, the upper arching; the lateral sepals ascencliag, their bises witl that of the lip forming the gibbosity or short spur which is nostly arluate to the summit of the orary ; lip slightly arlherent to the base of the 2-erlged straightisl column, bearing a pair of projecting ridges on the face beluw, sprealing wrecurver at the apex. Anther terminal, lid-like. l'ollen-masses 4 , obliquely incumbent, soft-waxy, free. - Brownish or yellowish herbs, destitute of green foliage, with much-hranched and toothed coral-like root stocks (probal,y root-parasitical), sending up a simple scape, with sheaths in place of leaves and bearing a raceme of rather small dull-colored fluwers; fruit reflexed. (Name composed of

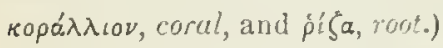

$\S 1$. Sinull spur or sac adnate to the summit of the ovary; flowers small; lip uhitish or purplish, often molled with crimson.

1. C. innàta, R. Browu. I'lant slenvler, light brownish or yelluwish (39' high), 5-12-flowererl; perlicels very short; periantl 2 - 21." long; lip sompwhat hastately 3-bohed alowe the brise, the lanellæ thick and rather short; spur a very small protuberance; capsnle os"al or ellijtical (3-4" long). - Swamps and damp wools, X. Eug. to northern N. J., Ohio, Mich., Minn., and nurthward, and south in the mountains to Ga. May, June. (Eu.)

2. C. odontorhiza, Nntt. Plant light bruwn or furplish; stem rather slender, bulbous-tlickened at base ( $f-16$ ' highl), 6-20-fluwered; peclicels rather slender; perianth abuut $3^{\prime \prime}$ long; lip entire or nerely denticulate, thin, broally orate or obovate, abruptly contracted into a clum-like buse, the lanellae a pair of short projections; the spur represented hy a sull cavity wholly arlnate to the sunmit of the ovary; capsule at first very acute at base, at lengtl short-oral (4" long). - Rich wools, E. Mass. (Mitchings) and Vt. to X. J. and Fla., west to Mich. and Mo. May - July.

3. C. multiflòra, Nutt. Plant purplish, rather stont $\left(9-18^{\prime}\right.$ high $), 10$ 30-floweral - jerianth $2 \frac{1}{3}-4^{\prime \prime}$ long; lip repply 3-lobed, with a short narrowerl hase aurl with prominent lamella, suur nuafert and protuberaut; cajsule whiong (6-9" long), short-pedicelled. - J)ry wouls, N. Eing. to Ma., west to

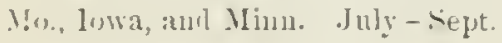


\$2. Spur none; the broadly gibbons somewhat saccate base wholly fiee fiom the ovary; flowers large for the genus, purple, unspotted, more exprnding.

4. C. striàta, Lindl. I'laut purplish, stout $\left(6-16^{\prime}\right.$ high $)$, learing $15-25$ large flowers in a crowded spilie, on very short pedicels; perianth 6-7" long; lip oval or obovate, perfectly entire, concave, barely narrowed at the hase, where it bears $1-3$ short lamellac; all the parts of the perianth narked with 3 darker nerres; pod oblong (y" long). (C. Macrei, Gray.) - Woods, from L. Erie westward along the Great Lakes and to the Pacifie.

\section{HEXALÉCTRIS, Raf.}

Sepals and petals nearly rpual, somewliat spreading, several-uerved, not gillons uor spurrerl at base, free. Lip olsorate, witls 5-6 prominent rilges down the mildle, 3-lobel above, the mildle lobe somewhat eoncave, Pollenmasses 8, unitel into a single fascole. Otherwise as in Corallorhiza. (Name

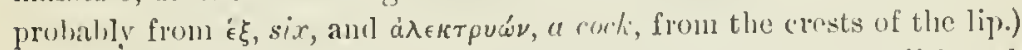

1. H. aphýllus, Raf. Stem $1-2^{\circ}$ high, heset with pulplish scales, the lower sheathing; flowers racencol, bracteate, brownish-purple, 6-8" long. (Bletia aphylla, Vutt.) - Rich wooks, Liy. and Mo. to Fla, and Mex.

\section{LísteRA, R. Brown. Twaybank.}

Sepals and petals nearly alike, spreuting or deflexed. Lip mostly droopiug, longer than the sepals, 2-lobel or 2-cleft, Column wingless; stigna with a romider heak, Nnther borne on the hack of the column at the smmmit, erect, ovate; pollen powdery, in 2 masses, joined to a minute gland. - lioots filsous. Stem hearing a pair of oppmite sessile laves in the midlle, and a spike or raceme of greenish or brownish forplo suall flowers. (Dedicated to Marlin Lister, an early and celelsated British naturalist.)

* Column very short; sejuls orme, reflexed; plants delicate, $4-8$ ' high.

1. L. cordàta, R. Browu. Leaves rouncl-ovate, somewhat lieart-slaped $\left(\frac{1}{2}-1\right.$ 'long); ratcene smooth ; flouerss minute, rrouded, on pedicels not longer llan the onary; lip linear, twice as long as the sepals, l-toothed each side at base, 2-cle/t. - Coll wourls, X..J. to Mich., Mlinn., and northwark. June. (Lu.)

2. L. austràlis, Lindl. Leaves orate; receme loose and slender ; flowers rery small, on mimutel. glandulur-pulsescent pedicels lwire the lemglh of the ovary; lip linear, 3-4 times the length of the sopals, 2-parled, the divisions linearsetuceous. - l amp thickets, Oswego Co., N. Y., and from N. J. to Iila. Jume.

* * Column longer, arching or straightish.

3. L. convallarioides, Nutt. l'lant 4-9' higlı; leaves oval or rounrlish, and sometines a little heart-shaperl $\left(1-1 \frac{1}{2}{ }^{\prime}\right.$ long $)$; racene louse, pubescent; perlicels slender, lip wedge-oblong, 2-lobed at the dilatred apex, and ltoothed on e:tels sile at the hake, nenrly twice the lonerth of the narrowly

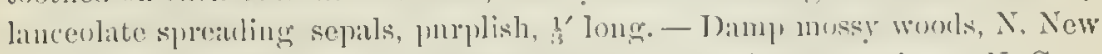
Eng. to Nlich., Minn., and northward, and sonth in the monntains to N. C.

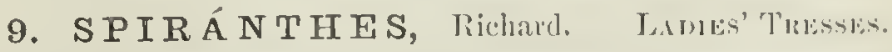

l'eriunth sommolat ringent, oblipue on the owary ; the sepals and protals all uarrow, mustly erect or commirent, the three mper pieces sticking hogether 
more or less, the two lower coveriug the base of the lip. Lip oblong, short. stalkel or sessile, the lower part involute around the colnmm, and with a callous protulerance on each sirte of the base; the somewhat dilated summit sprearling or recurved, crisped, wary, or rarely toothed or lobed. Colmmu short, ohlique, hearing the orate stigma on the front, and the sessile or short. stalked (mostly icnte or pointed) 2-celled ereet antlier on the back. Pollenmasses 2 (one in each cell), marrowly whorate, each 2-cleft, ars split into thin and tender plates of granular pollen united by elastic threads, and soon adhering at base to the narrow boat-shaped viscil gland, which is set in the slender or tapering thin beak terminating the colmm. After the remoral of the glaud, the beak is left as a 2-toothed or 2-forker tip. - Roots clusteredtuberous; stem more or less waked ahove, leaf-bearing helow or at the base. Fluwers small (ours all white or greenish-white), hent horizontally, I - 3-rankerl in a spike, which is commonly more or less spirally twisted (whence the name,

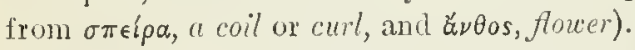

* Flowers in 3 ranks, crouded in a close spike: leares at the root and base of the stem mesent at the flourering season.

1. S. latifòlia, 'Torr. Low; waked stem or sane $4-9^{\prime}$ (rarely 12') high, smooth; leaves all next the base, oblong or lance-oblong ( $1-4^{\prime}$ long. $3-9^{\prime \prime}$ wicle), 3-5-nerved, contracted into a sheathing lase; spike narrow (1-3' long) ; flocers small $\left(2-3^{\prime \prime}\right.$ longr $)$; lip quadrate-oblong, yellowish on the face, not contlated in the midlle, thin, wary-crisped at the very obtuse or truncite apex, the small callosities at the base oblong, marginal and admate for thei whole length; gland and beak of the stigma short. - Moist banks, V't. aud IV. Mass. to Mich. and Minu, south to Mel. and Mil.

2. S. Romanzoffiàna, Cham. Stem leafy below and leafiy-bracted alore $\left(5-15^{\prime}\right.$ high); leaves rarying from oblong-laweeolate to grassy-linear; spilie dense, oblong or cylindrical $\left(\mathrm{f}-4^{\prime}\right.$ long); perianth curved and the sumnit munifestly ringonf, pure white ( $t^{\prime \prime}$ long), the sepals and petals all comivent in the upper purtion or galea; the lip ocate-oblong, contracted below the rounded uncly-cronulute much recured summit, otherwise cutire, the callosities at base globular and smooth; gland oblong-linear and the 2-horned beak of the stigmu shurt.- High and cool hogs, X. New Eug. to Mieh. and Mimn., and nortlwark; Norfolk, Comm. (Berhou'); eentral N. Y. July, Aug. (Ireland.)

3. S. cérnua, lichard. Stem lewf! below and leafy-lnacted abore $\left(6-20^{\prime}\right.$ ligh); leares lineur-lunceulutr, the lowest elongated ( $4-12^{\prime} \operatorname{long}, 2-9^{\prime \prime}$ wide); spike crlindrieal, rather dense ( $2-5$ long) and with the white fragrant flowcrs eitler pubescent or nearly smooth; periantl horizontal or recurving (4$5 "$ long), the loner seprels not ipturned or comnivent with the npper; lip oblong and rery olstuse when outspread, but conduplicate or the margins much incurved, wavycrisperl alove the midlle, especially at the flattislo and recurver sproding apex, the callusities at the base prominent, nipple-shaped, somewhat hairy; glancl of the stigna linein, in a long and reny slemele beak. - Common in wet places, cspecially castwand and sonthwarl. Sept., Oct. Very radialle in size and foliage, often nearly losing its root-leavs at flowering time. - I

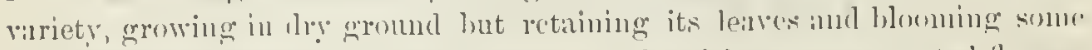
what later, has greenish rean-colured or yellowish strunger-scented fouts l.. Mass aud Del. 
* *lovers in one straight or spirally twisted rank.

\section{- Stem bearing elongated leares at and toward the base, whirh mostly persist during the flowering season.}

4. S. pràcox, Watson. Root of fleshy or tuberous-tlickened fibres; stem $9^{\prime}-2^{\circ}$ high; lower and root-leaves linean or lance-linear $\left(3-8^{\prime}\right.$ long, $2-$ 4 " wide) gradually tapering to the base, the upjer" redueed to slreathing bracts; spike linear, dense (2-5' long), usually much twisted, the axis, oraries, etc., downy-pubescent; bracts wate and gradually, or rhombic-orate and aluruptly taper-pointed, surpassing the orary, the nargins broally hyaline; perianth $3^{\text {pr }}$ long; lip ovate-oblong when outspread, witl ratler small callosities at base, crisped at the romuled slightly recurved apex; anther and heal of the stigma very acute. (S. graminea, lar. Wa!teri, G'oy.) - Wot, grassy places, Mass. to N. J. and Fla.

+t- Srape rery slender, merely bructed; the leaves with a blade all in a cluster "t the ground, otate or oblong, abruptly contracted into a petiole, commonly withering away at or before flowering; fovers small, and whole plant glabrons or nearly so; bracts small, sharp-pointed, not longer than the cupsule.

5. S. grácilis, Bigelow. Ronts clustered, tuberous-thickened: scapre s-1s high, bearing a slender many-fluwered one-sided or twisted spilie; perianth barely $1 \frac{1}{2}-2$ " long; lip or al when ontsprearl, narrowly oblong in natural form. thickish and green above with thin white margins, the recurved obtuse or aeutish apex wavy-erisped, the eallosities at the base nipple-shaped. - Hilly wonds aurd saudy plains, eommon. July- Oet.

6. S. símplex, Gray. Root a solitary oblong or spindle-shaped tuber; no leaves at flowering time; senpe $5-9^{\prime}$ high, bearing a small narrow (rarely 1. sided) spike (1-3' long) of very short flowers (perianth 1-1 1" long); lip thin, white, oborute-oblong, the apex eroded and crisperl, the callosities at the base slender. - Dry sanrly soil, İ. Mass. to N. J., Del., and Mrr. Aug., Sept.

\section{GOODYERA, 13. Br. Rutrhesale-Plastain.}

Lip sae-shaped, sessile, entire, and without callosities at hase. Otherwise as Spiranthes. - Root of thick fibres, from a somewliat fleshy creeping rootstock, bearing a tuft of thickish petioled leares, ustially reticulated with white veining. Scape, spike, and the greenish-white small Howers usually glandulardowny. (Dedieated to John (roodyerr, an early. Finglish botanist.)

\$ 1. Lip strongly saccate-inflated and with a short spreading or recurved tip; anther short, horne on a distinct flament attached to the back of the short columm, blunt; gland-bearing tip or beak of the stigna rery shont.

1. G. rèpens, R. Br. Small $\left(5-8^{\prime}\right.$ high $)$ and slender; leaves ovate, inore or less white-reticulaterl (about l' long); flowers several, in a loos l-siderl spike; lip with an orate recurved tip; sepals arate. - Woods, under evergreens, common northwarl and through the Alleglanies. July. (Eu.)

2. G. pubéscens, R. Br. Larger; leares strongly wlite-reticulated : scape 6-12' high, the numerous crowded flowers not one-sided: tip of the yloluler lip ver!l short: otherwise like the preceding, and too near to it Rich wods. Newf. to Fla., wost to Miclt, ancl Minn. 
\$2. Lip barcly saccute belou, tapering and its sides incolute abore: anther orates long-pointed, borne on the buse of the rer.y short column, which is continued above the stigma ixo a conspicuous tapering awl-shaped gland-bearing beak.

3. G. Menzièsii, Lindl. Leaves ovate-oblong, acute $\left(2-3^{\prime}\right.$ long), le'ss white-reticulated than the preceding, some not at all so; scape $9-12^{\prime}$ high ; flowers rather numerous in a looser often 1-sided spike; Hower-buds less pubescent, elongated-orate and pointed; lip with the saccate-conduplicate lumer portion gradually tapering into the narrow barely spreading summit. - Woods, Gaspe and Tadonsac, L. Can. (./. A. Allen, Goodule); Crawford, N. H. (Miss Minns); western N. Y. to Minn., and westward. July.

\section{EPIPÁCTIS, Haller.}

Sepals and petals nearly equal, spreading. Iip free, deeply concare at base, narrowly constrieted and somewhat jointed in the midde, the nper portion dilated and petaloid. Columu short, ereet. Anther sessile behind the broad truncate stigma, on a slender-jointed base; pollen-masses coarsely gramular, becoming attached to the gland capping the small rounded beak of the stigma. - Stem leafy, with racemed flowers, conspicnous bracts, and ovaries reflexed at maturity. (The aneient Greek name of a plant.)

1. E. Helleborine, Crantz. Stems $1-2^{\circ}$ high ; leaves broadly orate $(2-$ $3^{\prime}$ long), pointed, plicate, the upper narrower; raceme pubescent, 30-50-flowered, 1-sided ; flowers varying from light greenish-yello'v to dark purple; sepals ovate-lauceolate, $3-4$ " long; petals rather smaller; lip orate, pointerl abore, with a dark centre. (E. latifolia, 1 ll.) - Near Syracuse and Buffalo, N. Y.; the only known stations. (Eu.)

\section{A R E THÜSA, Gronov.}

Flower ringent; the lanceolate sepals and petals nearly alike, united at base; ascending and arching over the column. Lip dilated and recurres-spreading toward the summit; very slightly gibbous at hase. Column adherent to the lip below, petal-like, dilated at the apex. Anther lid-like, terminal, of 2 approximate cells; pollen-masses powiery-granular, 2 in each cell. - Beautiful low herbs, consisting of a sheathed scape from a globular solid bnlb, terminaterl usually by a single laryo rose-purple flower. I, seaf solitary, linear, nerved, hiden in the sheaths of the scape, protruding after flowering. (Dedicated to the nymph Arethusa.)

1. A. bulbósa, I. Flower single (rarely 2), erect $\left(1-2^{\prime} \operatorname{lomg}\right.$ ), with an ontire lip recurvel at the apex and hearlest-crested down the face. - Bogs, Newf. to the mumtains of N. C., west to Ind. and Minn.

\section{CALOPOGON, li. Br.}

Flower with the ovary or stalk not twisting, therefore presenting its lip on the upper or inner sicle. Sepals ancl petals nearly alike, lance-ovate, spreacliug, distinct. Lip sprealing, distant from the column, laised on a narrowed base ur stalk, dilated at the summit, strongly bearded along the npper side. Column free, slender, winged at the apex. Anther termiunl aud lid-like, sessile; pullenmases 4 (two in each rell), of soft powdery grains, lightly connected by deli. 
cate threads. - Scape from a small sulic bulb, sheathed below by the base of the grass-like leaf, naked above, bearing sercrul large flowers. Bracts minute.

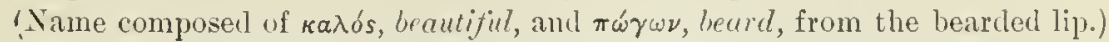

1. C. pulchéllus, R. Br. Leaf linear; scape about $1^{\circ}$ high, 2-6-flow: ered; flowers I' broal, junk-purple; lip as if hinged at the iusertion, beautifully bearded toward the dilated summit with white, yellow, and purple club-shaped !airs. - Bogs, Newf. to Fla, west to Miun, and Mo.

\section{POG ON I A, Juss.}

Flower irregular, the sepals and petals separate. Lip crested or 3-lohea column free, elongated, chub-shaped, wingless. Anther terminal and lid-like,

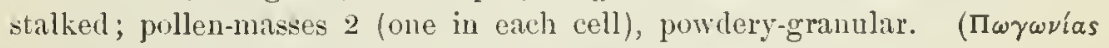
bearded, from the lip of some of the original species.)

$\$$ 1. Sepals and petals nearly equal and alike, pale rose-color, sometimes white.

1. P. ophioglossoides, Nutt. Root of tlick fibres; stem $\left(6-9^{\prime}\right.$ high $)$ bearing a singte oval or lance-oblung leaf near the uniclle and a smaller one or bract near the terminal Hower, rarely one or two others witl a flower in the axil; flower I' long, sweet-scented; lip spatulate, apjrressed below to the columm, beard-crested and fringed. - Bogs, Newf. to Fla., west to N. Ind. and Minn. June, July. (Japan.)

2. P. péndula, Lindl. Stem $\left(3-8^{\prime} \text { high }\right]_{3}$ from oblong tubers, bearing 3 to 7 alternate ovate-clasping very small $\left(3-6^{\prime \prime}\right)$ leaves, the upper $1-4$ with Irooping flowers in their axils on slender pelicels; perianth $\frac{1}{2}$ long, narrow; lip spatulate, somewhat 3-lobed, roughish or crispect above, crestless. - Damp woods, N. Eng. to Fla., west to Wisc. and Mo.

\$2. Sepals linear, ding!y or broumish, longer and much narrover than the erect or comment petrls; lip 3-lobed at the apex, crested dou'n the middle, beardless; flouers solitary (or rarely a pair), terminal; root a cluster of fibres.

3. $\mathbf{P}$. divaricàta, R. Br. Stem $\left(1-2^{\circ}\right.$ high h) hearing a lanceolate leaf in the middle, and a lenfy brart next the flower, which is recurved on the ovary; but the sepals ascending or direrging, spatulate-linear, longer than the lanceolate-spatnlate pointed and flesh-colored petals, these about $1-1 \frac{1^{\prime}}{2}$ long. Wet pine-barrens, N. J. to Fla, June, July.

4. P. verticillàta, Nutt. Stem $\left(6-12^{\prime}\right.$ ligh $)$ naker, except some small seales at the base and a whorl of mostly 5 oborate or olmate-oblong sessile leaves at the summit; flover dusk purplish, on a pedumcle longer than the ovary and crpsule; sepals more than turee the length of the petals, narrowly linear, spreading from a mostly erect hase (1 $1 \frac{1}{2}-2^{\prime}$ long); lip with a nal'ow crest down the midlle. - Low wools, N. Eng. to Fla., west to Tul, and Wisc.; ratler rare, especially eastrard. May, Jume. Glaucous when young. Fruit-stalk erect, about $1 \frac{1}{2}^{\prime}$ long, more than lialf the length of the leares.

5. P. affinis, Austin. Somewhat smaller than the precerling; leaves paler and rather narrower; flowers (not rarely in pairs) yelluwish or greenish ;

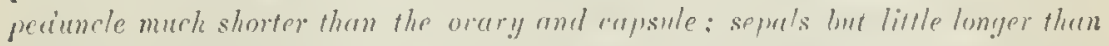
the petals, tapering to the hase; lip crested urer the whole face and on tho midile of the lobes. - Low woods, S. IF. Comn., S. New lork, and N. New Jersey ; rare. 


\section{5. Ó R C H I S, L.}

Flower ringent; the sepals and petals nearly equal. Lip turned dowuwari, coalescing with the base of the colnmu, spurred below. Anther-cells contignous and parallel. Pollen collering in munerons coarse waxy grains, which are collected on a cobneb-like elastic tiswe into 2 large masses (one filling each anther-enll) borne on a slender stalk, the base of which is attached to a gland or sticky disk of the stignal, the two ghlmols contained in a common little ponel: or howled fold, plated just abore the orifice of the spur. Flowers showy, in a spike. - (hur species with low seape-like stems, with 1 or 2 leares at hase, from

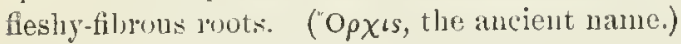

1. O. spectábilis, L. (Know ()rcms.) Root of thick fleshy filsres, producing 2 oblmu-oboute shining lences (3-6' long), and a few-flowerer + angled scape ( $4-7^{\prime}$ high); hracts leaf-like, lanceolate; sepals and petals all lighty uniterl to form the vanlted galea or upper lip, pink-purple, the ovate undivided lip white. - Ric.l wools, N. Brunswick to Ga., west to Mlinn. and Mo. May.

2. O. rotundifolia, Pursl. Stem nakerl above, 1-leared at base (5-9' high), fron a slencler creeping rootstock; leaf rarying from almost orbicular to oblong $\left(1 \frac{1}{2}-3^{\prime}\right.$ long $)$; Hower's rose-purple, the lip white and spotterl with jurphe, 3-lobed, and the larger middle lobe dilated and 2-lobed or strongiy nutched at the sumnit $\left(4-6^{\prime \prime}\right.$ long), exceeding the orate-oblong petals and sejals, and the slender depending spur. (Habenaria rotundifolia, Richord. son.) - Dann, womls and logs, N. Maine to Vt., N. Y., Minn., and northward.

\section{H A B E N À I A, Willd. Rerx-Orcus.}

Glands or viscid disks (to which the pollen-masses are attached) naked and exposed, sejarate, sometimes wirlely so (becoming attached, some to the proboscis, others to the face or lical of insects feeding upon the nectar of the spur, the pollen thus (:Irried from one blusison to another); otherwise nearly is in true( )relis ; the latcral sepals, loweres, mostly sprealing. (Name from hulene, a thong or rein, in :llusion to the slape of the lip or spur of some species.)

1. GIIXIISXIA. Cells of the anther parallel and approximate, ther glands therefore contignous. (11yendages of the stigma in our species lio we there and much developed, oblong or cheb-shajed.)

1. H. tridentàta, Hook. Fiten slencler $\left(6-12^{\prime} \operatorname{ligh}_{1}\right)$, witl a single of

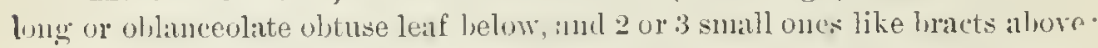
Flike 6-12-flowered, oblong; floneers greenish or whitish, zee"y small: hip wedue whent, froncute, and with 3 shont teeth at the apex: the slender and shighty club. shapeel spur curved upward, longer than the orary. - Wet wods, X. Eugr. to Minn. anul Ind, and sontlı in the mountains to x. C. June, July. - Rout of few fleslyy filmes. Anpendages of the stigma three, ohlong-chub-shaped, one outside cacle orbicular ghand and one between them, rising as ligh as the anther-cell, their cellutar viscisl sumnits receiving pollen in the unopened Hower, and penctited hy pollen-tubes!

2. H. integra, sureng. lioot of very flesly fibres (ur some of them

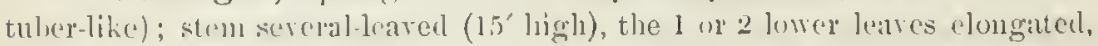

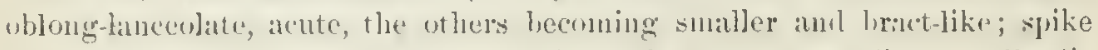

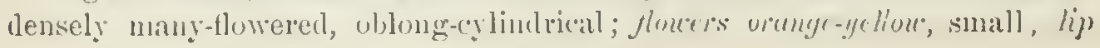


weate, entive or slightly crenulate or wavy, shorter than the aw-shaped descending spur. - Wet pine-barrens, N. J. to Fla. July. - Appendages of the stigna two, lateral, oblong, fleslyy; heak or mickle appendage uarror.

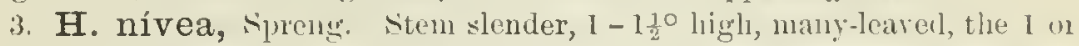
2 luwer leaves lancelinear and $4-8^{\prime} \mathrm{long}$, the others small and bract-like; spike eylindrical, lousely many-Howered; flowers white, small: jetals and entivo fip limearoblong: spur threal-shaped, ascending, as long as the white orary which is not twistech. - P'ine-birren swamps, s. Del. to Flit. Illg.

3 2. PERULARLA. Cells of the anther narly parallet, the ealces uf rach extended ut base so as to form the sides of a deep oblong groove or cavit!, which is lined by the dilated orbieular and incured ylaud. (Flourers smull, greenish, slender-syurred.)

4. H. viréscens, Sjureugr. Leaves orate-oblong or oblong-lanceolate, the uppermost linear-lanceolate and pointed, passing into the bracts of the rlongated raceme; petals orate; flowers dull green; lip fmmisher with a tooth un each side and a strong nasal protuberance in the midrle of the hasc, olilong, Iruncate-obtuse, abont the leugth of the sepals, lialf the length of the slcnder ('lub-shaped spur. - Wet places, common; N. Eng. to I'lat, West to Minm. and Mo. June, July. - Stem 10-20' high ; the spilie at finst ilense, with the brartis longer than the flowers, at length elongated and often lonse, the npper bractis shorter than the flowers, which are quite small, ancl with scarcely a tinge of yollow, drying brownish.

S3. PLATANTIlEliA. Calls of the anther sometimes purallel, more commonly dicergent, so that thea tupering bases and the exposed glands are more or less distant. (liout a eluster of fleshy fibres, or tuberous-thicliened.)

* Houers grecnish ar whe, small, mmerous in a close spike; spmer not conger than the entice or morely notched narrow hip; anther-cells almost parallel, wholly aduate; stem learig.

+ - Spur short and sac-lilir: the 3 sepuls and 2 marrou petals eveet; glonds small, ruller widely sepmated.

5. H. bracteata, R. Br. Stem 6-I2' high; lower leaves ohorate, the

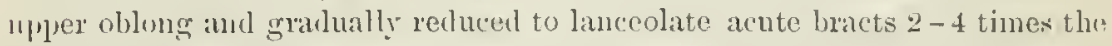
length of the green flowers; spike $10-30$-flowered; lip (b)long-linear or slightly spatulate, truncate and $2-3$-trothel or lobed at the tip, more than twice the: length of the white spur. (11. viridis, var. bracteata, Rruchenb.) - Damp wools and meadows, N. Eng. to Nlinn., Iowa, Inl., sonth in the mountains to N. C., and fir northward.

-. Spur slender, incured, ubont equalling the ent ire lip; lateral sepals spreading.

6. H. hyperbòrea, li. Br. Stem rery lcafy (6'-20 hich ); Icrms lanepolate, erect; spike lense $\left(2-15^{\prime}\right.$ long); lower bracts lancenlite, longer than tho (greenish) jlowers; lip and petuls lumeolate, somerthat equal, the latter spreading from the base; anther somewhat orerhanging the transwcrsely dilated stigna ; glends orbieular: stalk of the pollen-masses rery slender and weak. - I'eat bogs and wet cold wools, N. Eng. to X. Y., S. Ill., Iowa, and, northward. Tuue, July: (Fu.)

7. H. dilatàta, Gring. Resembles n. 6, but usually unre nitnder, with

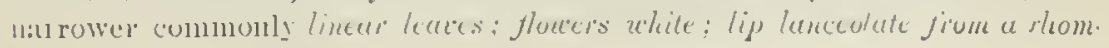


boidul-diluted base, entire, its base with the bases of the petals and sepals erect. onuivent, above spreading; anther-cells almost parallel; glaneds approximede. lurge und strup-shaped, rcotical, nearly as long as the pollen-mass and its short flat stalk together; stigma narrow; a trowel-shaped conspicuons beak betwees the bases of the anther-cells. - Cold bogs, Conn. to N. Y., Mich., Minn., and northward.

* Flouers greenish or ulute, 5-15 in a loose sprike, rather large for the size of the plant; scape or stem naked above, 1-leared at base (5-9' high); spur not longer than the lip; anther-cells wholly adnate, arcuate and widely separated.

8. H. obtusàta, Richardson. Leaf obovate or spatnlate-oblong; upper sepal very broad and rounded, the others and the petals lance-oblong; lip entire, linear or lanceolate, deflexed ( $3^{\prime \prime}$ long), about the length of the tapering and curving spur. - Cold peat bogs, Maine and N. New Eng. (Mt. Wachusett, ilass.), to Minn. and northward. (En.)

* * Flowers white or greenish, numerous in a loose spike, on a naked scape, 2leaved at base; spur longer than the narrou entive lip; anther-cells widely diverging, their narrowed beak-like bases mojecting forward; stalk of the pollen-mass laterally affixed to the back of the orbicular gland, the viscous face of which looks obliquely inuard.

9. H. Hoókeri, Torr. Leaves orbicular, sprealling $\left(3-4^{\prime}\right.$ broad); scape mostly naked ( $\frac{1}{2}-1^{\circ}$ high), bearing $10-20$ upright sessile yellowish-yreen flowers in a struct spike; sepals orate-lanceolate; lip linceolate, pointed, ineurved, longer than the lance-aul-shoped petals; spur slender, acule, abont the length of the ovary (nearly $\mathbf{l}^{\prime}$ long). - Damp woods and borders of swamps, N. Scotia to N.J. west to Minn. and Iowa. - Var. obloxgmòla, Paine, has oblong leaves $\left(3-5^{\prime}\right.$ by $\left.1 \frac{1}{2}-2^{\prime}\right)$. N. Y. and Can.

10. H. orbiculàta, Tol'r. Teaves rery large $\left(4-8^{\prime}\right.$ wide), orlicular, spreading flat on the ground, shining above, silvery beneath; seape bracted (1-2 high), hearing many spreading greonish-uhle floners in a lonse raceme:

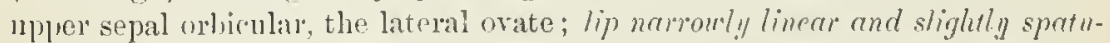
lote, olfuse, drooping, nearly thrice the length of the oblong-lanceolate and

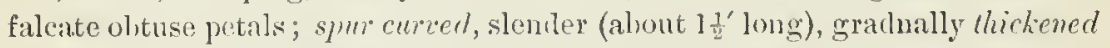
towarl the blunt ajex, fwice the length of the ovory; anther-cells strongly projecting at the free beak-like base (the glands nearly $\frac{1}{6}$ apart). - Rieh wouls (especially coniferous), Newf. to Pem. and in the monntains to N. C., west to Mich. and Minn.

* * * * (Frisgun Orcinis.) Flowers several ar many in an open spike, witl. mostly foliacrous bracts; stem (rather tall) lienfy; sputr thead-shaped or scarcely club-shaped, longer than the fringed, rleft, or dissected lip; amthercells widely separated and usually direrging, their narmo bentitike bases, supported by the arms of the stigma, strongly projerting forward or partly upueard.

- Lip prectinutely fringed but undivided; flowers golden yellow or while; anther. cells midlely divergemt, the orbicular glands as if raised on a tentacle mojert. ing far forwerd or slightly imured ; orany long, tapering to the summit.

11. H. cristàta, R. Br. Iown leaves lanceolate, elongated the upper

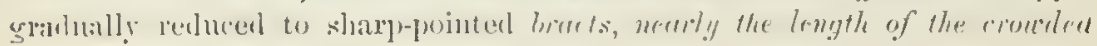


(yellow) flowers; spike oblong or cylindrical ; petals rounded, crenate; lip orate, with a lacerale-fringed margin, scurcely shorter than the slender obtuse incurved spur, which is not half the length of the ovary. - Iogss, N. J. to Fla. July. Flowers very much smaller than in the next.

12. H. ciliàris, R. Br. (Yellow Friveded-Orcins.) Stem $1 \frac{1}{2}-2^{\circ}$ high ; leaves oblong or lanceolate; the upper passing into prointed lracts, which are shorter than the ovaries; spike oblong, rather closely many-flowered; flowers bright orunge-yellow; lateral sepal rounded, reflexed; petals linear, cut-fringed at the apex; lip oblong (6"long), about half the length of the spur, fumished with a very lony and ropious capillary fringe. - Wet sandy places, N. Eng. to Fla. and Tex., west to Mich. and Ind. Our most handsome species.

13. H. blephariglóttis, Torr. (Wure Frmani-Orcins.) Stem $10 / 1 / 2$ high ; leaves, etc., as in the last; forcers uhife, rather smaller; petals spatulate, usually slightly cut or toothed at the apex; lip ovate- or lanceolate-oblong, with the irregtlar capillary fringe of the margins usnally shorter than its disk, one third the length of the spur. - Peat bogs and horders of ponds, Newf. to N. J., west to Mich. and Minu. July, - Var, nolopétalA, Torr, has narrower petals with the toothing obsolete, and the lip, less fringed.

+ - (Grimisn Frivged-Orcins.) Lip 3-parted aboen the stalk-like base, the divistons cut into capillary fringes: flouers gremish-or yellowish-white; anther-colls not very divergent, the beaked buses projecting forward; the large glands neal or lanceolate, nearly facing ench other; ovary shorttupering above; spurs long, clarate.

14. H. leucophæa, Gray. Stem $2-4^{\circ}$ high; leares ollong-lanceolate; the bracts similar, rather shorter than the (large, fragrant) flowers; spike commonly elongated, loose; petals obovate, minutely cut-toothed; divisions of the lip $\left(7-10^{\prime \prime}\right.$ long) broadly wedge-shaped or fon-shaped, many-cleft to the middle into a copions thread-like fringe; spur longer than the ovary $\left(1-1 \frac{1}{2}\right.$ long) ; glands transversely oral. - Moist meadows, western N. Y. to Ky., Mo, aud Minn. July.

15. H. lácera, Ri. Br. (RaGged Frisged-Orcuis.) Leaves obloug or l:unceolate; raceme loosely many-flowered; petals oblong-linear, entire; divisims of the lip narrow, deeply parted into a few loun nearly capillary lobes; spur abont the length of the ovary ; glands oblong-lincer, as long as the stalk of the pollen-mass. - Bogss and muist thickets, N. Scotia tu N. C. and Ga., west to Minn. and Mo. ; common. July.

to + (Purpue Frivged-Orcuis.) Lip fan-shaped, 3-parted above the stalklike base, the divisions erosely fringed; flowers purple; anther-cells widely separated, little divergent, the orbicular glands oblique; ovary contracted only at the summit; the long cureing spur somewhat clavate.

16. H. psycodes, Gray. Leaves ohlong or liunceolate, the uppermost passing into linear-lauceolate brats; raceme cylindrical, densely many-fou-

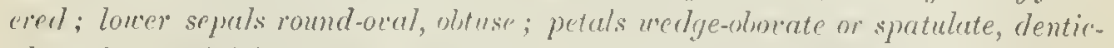
ulute above; divisions of the spreadug iip broadly wedge-shaped, many-cleft into a short fringe. - Wet meadows and bogs, common; Newf. to N. C., west to Ind. and Ninn. July, Ang. - Vlowers short-perlicellerl, crowrled in a spike of $4-10^{\prime}$ in longth, kmall, lut sery haul-inle, fragrant; lip sbent-etalkewl, 
barely $\frac{1}{2}$ broad and not so long; the middle lobe broadest and nore closely friuged, but not so decply eleft as the lateral ones.

17. H. fimbriàta, R. Br. Lower leaves oval or oblong, the upper few, passing into lanceolate bracts; syike or raceme ollong, lonsely-flowered; lower sequals ocate, acule; petals oblong, truthed dom the sides: divisions of the pendent large lip $\left(\frac{8}{4}-l^{\prime}\right.$ broad) fan-shaped, nore fringerl. - Wet meadms, $\mathrm{X}$. seotia to N.J. and N. C., west to Mich. June. - Flowers fewer (litac-purple), $3 \mathrm{or}^{4} 4$ times larger than those of the preverling.

18. H. peramona, Gray. Luwer lenves oblong-ovate, the mper lancen late; spike oblung or cylindrical, tensely dlowered; lower sepals romul-ovate: petals roumlerloburate, raised on a claw; dicisions' of the large lip rery brondly wedye-shuped, irregularly cioded-toothed at the broally dilated summit, the lat erat bues truncute, the middle one 2-lobed. - Moist meadows and banks, l'enu. and N. J. to Ill., ant south in the mountains. Ang. - Flowers lange and showy (violet-purple); the lip paler and $8-10^{\prime \prime} \operatorname{long}$, variably toothesl, but not fringed.

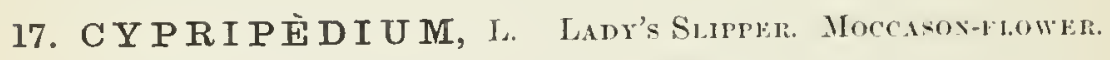

Scpals spreading: all three distinct, or in most cases two of them muited into one muler the lip. P'etals spreating, resembling the sepals lut lisually man rower. Lip a latge intlated sac. Column declined; on wath side a fertile stamen, with its sbort filament hearing a 2 -celled anthor; the pollon lowse and pulyy or powdery-granular; on the mper sille al dilated-triangulan, petal-like but thickish boly, which answers to the fertile stamen of other (Thehich, and rovers the summit of the style; stigma terminal, boal, obscurely :3-loberl, moist and ronghish (not smooth and viseid as in the rest of the oricr). P'olleu in most of onr species, pspecially in 11 . 6, exposed by the conversion of the face of the anther into a riscinl, varuish-like filn, which adheres to whatever tunches it, earrying away some of the pollen. - lioot of many tufted fibres. Leares large, many-nerved and plaited, sheathing at the hase. Flowers sulitary or

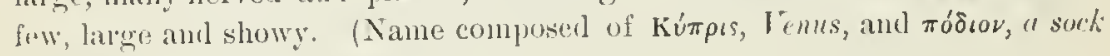
or Instin, i. e. Venus's slipper.)

\section{\$1. The thre sepuls separate; stem lenfy; flower solitary, drooping.}

1. C. arietinum, R. Br. (R.M's-11Esd L.) Stem slender $\left(6-10^{\prime}\right.$ high); npper sepal wite-lanceolate, pointed; the 2 lower and the prtals lisear and

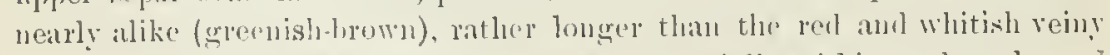
tip ( $6^{\prime \prime}$ lung), which is somewhat jnherent, aspecially within, and prolonged

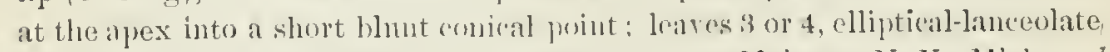
nearly smooth. - Colıl swamps and damp wools, Mane to X. Y., Mich. and Mimi, aud northwarl.

\section{\$2. Turo uf the sepals mnited into one meder the lip.}

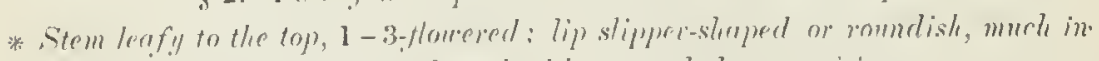
Anted, herizontal, and will a roumded open orifire.

+ Sepals mal limear waty-twisted peals mou'nish, minted, longer than the lip.

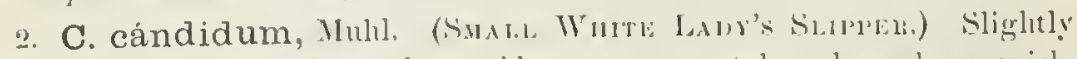

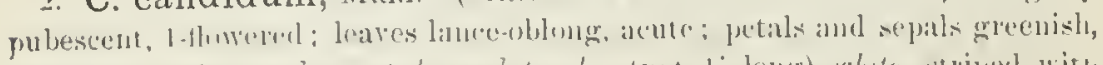

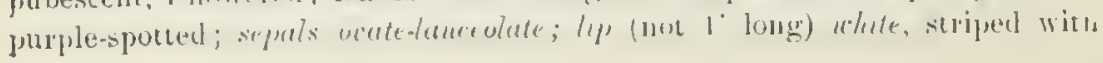


purple inside, fattish laterally, convex above; sterile stumen fumrolute. Bugs, N. Y. aud I'enn. to Minn., Mo., and Ky.; rare. May, , June.

3. C. parviflòum, Salish. (SunLLeli Yellow L.) Sitem l-20 high leaves oval, pointed; sepals orute or orute-lancenlate: lip flufrish firm abore, bright yellowe (1' long or less); sterile stamen triangular. - Bongs and low woods, Newf. to Ga., west to Minn. and F. Kim. May, Jule. - Flowers fragrant; sepals and petals uore brown-jurple than in the next, into which it seems to pass.

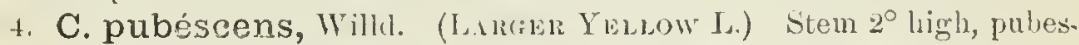
cent, as are the broadly oral acute leares; sepuls elonguted-lumrolate; lip fattrned laterally, very convex and gibbous above, $1 \frac{1}{2}-\underline{y}^{\prime}$ long, fule yellow. Bogs and low wools; same lange as the last.

+ + sepals and petals plune, romded, white, not longer than the lip.

5. C. spectábile, Salisb. (Snowr L.) Downy, $2^{\circ}$ high; leaves uvate, pointed; sepals lond-ovate or orbicular, rattler longer than the oflong petals;

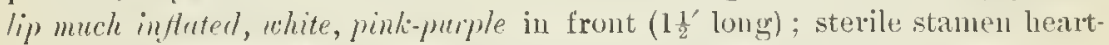
ovate. - l'eat-hogrs, Maine and IV. New Eng. to Mimm, and Mo., and south in the mountaius to X. C. July. - The most beautiful of the genus.

* Scupe naked, z-leaced at base, 1-flowered: sepuls and prtals greemish. shorter than the drooping lip, which has a closed fissure town its whole length in fiont.

6. C. acaùle, Ait. (Srmaness I.) Downy; leaves oblong; scape 8-12' high, with a green bract at top; sepals oblong-lanceolate, printed, nearly as long as the linear petals; lip obovoid or oblong, l'ose-purple (rarely white), nearly 2' long, reiny; sterile stamen rhombuil. - l)y or moist woods; Newl. to N. C., west to N. Int., Mich., and Minn. May, June.

\section{ORDE: 111. BROMLLIACEAA. (PINAPPLE HAMLY)}

Herbs (or scarrerly woorly plunts, neurly all tropical), the grealer part epiphytes, with persistent dry or fleshy and chrmelled croweled leaves, shealhing at the brtse, usuchly covered with scurf; 6-cmelrous; the 6-cleft perianth adherent to the ovary in the PINE-APPLE, ete., or free from it in

\section{TII LÁ N D S A, L. Low: Moess.}

Periantl plainly louble, 6-parted; the 3 onter divisions (sepals) nembranaceous; the 3 inner (petals) colored; all connivent below into : tuhe, sprealing ahove, lanceulate. Stamens 6 , hypgrnous 1 ol the alternate ones cohering with the lase of the petals; anthers introrse. (Wary fres ; style thear-s.apen; stigmas :3. Capsule cintilaginous, 3-celled, loculicirlally 3-valved; the ralves splitting into an inncr and an onter layer. S'seels several or many in each cell, anatropous, club-shaped, puinted, raised on a long laniry-tufted stalk, like a coma. Lubryo small, at the base of copions albumen. - Scurfy-laded epiplyytes. (Named for Prof. Tillands of Abo.)

1. T. usneoides, I. (Commox Loxg Moss or BLACK Moss.) Stems

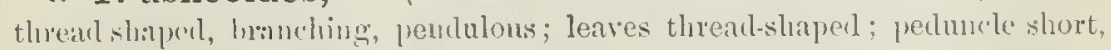
I-flowrenl; Hower yellow, - East Sihore, Va., sonth to Fha, and westward; growing on the branches of trees, forming long hanging tuits. 


\section{Order 112. HAEMODORACEA. (Bloonwort FaniLy.)}

Herbs, with fibrous roots, usually equitant leaves, and perfect 3-6-androus regular flowers, which are woolly or scurfy outside; the tube of the 6-loberl perianth coherent with the whole surface, or with merely the loucer part, of the 3-celled ovary. - Anthers introrse. Style single, sometimes 3-partible; the 3 stigmas alternate with the cells of the orary. Capsule crowned or 'nclosed by the persistent perianth, 3-celled, loenlicidal, 3-many-seeded. Embryo small, in hard or flesly albumen. A small family; chiefly of the southern hemisphere.

* Ovary wholly arlherent to the ealyx-tube ; style filiform ; seeds peltate. antuitropous.

1. Lachnanthes. Stamens 3 , exserted ; anthers versatile. Leaves equitant.

* Ovary free except at the base ; style 3-partible; seeds anatropous.

2. Lopliola. Stamens 6 , on the base of the woolly 6-eleft periantl. Leaves equitant.

3. Aletris. Stamens 6 , in the throat of the warty-roughened and tubular 6-toothed perianth. Leaves flat, spreading.

\section{L A CH N ÁN THES, L. Rep-root.}

Perianth woolly outside, 6-parted lown to the adherent ovary. Stamens 3. opposite the 3 larger or inuer divisions; filaments long, exserted; anther's linear, fixed by the middle. Style thread-like, exserted, declined. Capsule glohular. Seeds few on each fleshy placenta, flat and rounded, fixed by the middle. - Herb, with a red filıons perennial root, equitant sword-shaped leares, clustered at the base and scattered on the stem, which is hairy at the top and terminated by a dense compound cyme of dingy yellow and loosely woolly fluwers (whence the name, from $\lambda \alpha^{\prime} \chi^{\nu \eta}, u$, uol, and á $\nu 00 s, b l o s s o m$ ).

1. I. tinctoria, Ell. - Suudy swamps, near the coast, S. E. Mass., R. I., and N. J. to Fla. July-Sept,

\section{LOPHİOA, Ker.}

Perianth densely woolly, deeply 6-cleft; the divisions nearly equal, spreading, longer than the 6 stamens, which are inserted at their base. Anthers fixed by the hase. Capsule ovate, free from the perimth except at the base, pointer with the awl-shaped style, whieh fually splits into 3 divisions, one terminating each valve. Seerls numerous, oblong. ribben, anatropous. $-\Lambda$ slender perennial herb, with creeping rootstocks and filurous roots, linear and nearly smooth efpitant leaves; the stem leafless and whitened with soft matted wool toward the smmmit, as also the crowled or panicles cyme. Perianth dingy yellow inside; the lobes naked ouly towarl the tip, cach clothed with a woolly tuft

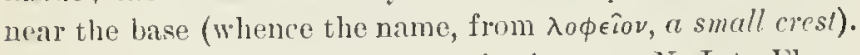

1. L. aùrea, Ker.-Boggy pine-barrens, N. J. to F'la. Juue- $\Lambda$ ug.

\section{3. átetiris, i. Colic-root. Star-grass.}

Perianth cylindrical, not woolly, but wrinkled and rougliened outside by thickly-set points which look like scurfy mealiness, the tube cohering below with the base only of the ovary, 6-cleft at the summit. Stamens 6 , inserted at the lase of the loles; filanents and anthers short, inchulel. Style awl-shaped. 3-cleft at the apex; stigmas minutely 2-lobel. Cansule oratr. enclosed in the 
roughened perianth; the dehiscence, seeds, etc, nearly as in Lophiola. - I'r. remial and smooth stemless herbs, very bitter, with filorous roots, and a sprealing cluster of thin and flat lanceolate leaves; the small flowers in a wand-like spiked laceme, terminating a naked slender scape (2-30 highl). Bracts awlshaped, minute. ('A $\lambda \in \tau \rho$ is, a female slare who griuds corn; the uane applied to these plants in allusion to the apparent mealiness dusted orex the hlossons.)

1. A. farinosa, L. Flowers oblong-tubular, white; Jobes lanceolateoblong. - Grassy or sandy moods, Mass. to Fla., Ill, aud Minu. July, Aug.

2. A. aùrea, Walt. Hlowers bell-shaped, yellow (fewer and shorter); lohes short-ovate. - Barrens, N. J. to Fla. July,

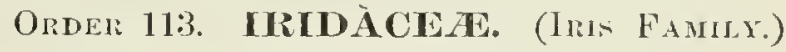

Herbs, with equitant 2-ranlied leaves, and regular or irregular perfect Howers; the divisions of the 6-cleft petal-litie perianth convolute in the bud in 2 sets, the tube coherent with the 3-celied ovary, and :" lisfinct or monadelphous stamens, alternate with the inner divisions of the perianth, with extrorse anthers. - Flower's from a spatlec of 2 or more leaves or bracts, usually howy. Style single, msually 3-cleft; stigmas 3, opposite the. cells of the ovary, or 6 by the parting of the style-branches. Capsule. 3-celled, loculicidal, many-seeder. Seeds anatropous; embryo straight in fleshy albumen. Rootstocks, tubers, or conns mostly aerid.

* Branches of the style (or stignas) onpusite the anthers.

1. Iris. Outer divisions of the perianth recurved, the inuer erect; stigmas petal-like.

* * Branches of the style alternate with the anther's. Perianth regular.

2. Nemastylis. Stem from a coated bulb. Filaments united. Style-branches 2-cleft.

3. Belameanda. Stems from a creeping rhizome. Filaments distinct. Stigmas dilated.

t. Sisyrinchium. Root fibrous. Filinents united. Stigmas thrend-like.

\section{1. İRIS, Tourn. Flower-De-Lece.}

Perianth 6-cleft; the tube more or less prolonged bevond the orary ; the 3 onter livisions spreading or reflexed, the 3 inner suller, rrect. Sitamens distinct; the oblong or lineir anthers sheltered uncler the overarching petallike stigmas (or rather branches of the style, benring the true stigna in the forn of a thin lip or plate uncer the apex); most of the style commate with the tube of the perianth. Capsule 3-6-augled, coriaceons. Seerls depresserlflattened, usually in 2 rows in each cell. - Perennials, with sworl-xhluped ur. grassy leaves, and large showy flowers; ours with creeping and more or lesis tuberous rootstoclis. ("Ioss, the rainbou', anciently applierl to this genus in account of its bright and raried colors.)

* stems leafy and rather tall ( $1-3^{\circ}$ high), from thicliened rootstocks, often branching; mbe of the perianth shorter than the divisions, which are beardless and crestless, the erect inuer ones (petats) much smaller than the outer.

- Howers violel-blue, variegaled wilh green, yellow or white, and purple-reined.

1. I. versícolor, L. (LARGER BLUE FLAG.) Stem stont, angled on one side; leaves surord-shaped (影 wille); orary obtusely triangular with the sirles flat; flowers $\left(2 \frac{1}{2}-3^{\prime} \mathrm{loug}\right)$ short-jeduncled, the funnel-form tube shorter 
than the ovary; capsule oblong, turgit, with romuled angles. - Wet places. Newf, to Fla., west to Minn. aud Ark. May, June.

2. I. prismática, Pnrsh. (Scexulu Buve Flici.) Stem very slender, terete; lcures narrouly lineur (2-3" wide); flowers slender-peduncled (1 $\frac{1}{2}-2^{\prime}$ long), the tube extremely short; ovary 3 -angled, each side 2 -groored ; capsule sharply triangular. (I. Virginica, Man.; not L.) - Marshes near the coast, Maine to N. C. June.

I. Cumounixi, Watson, resembling n. 1, but with longer laxer and greencr leaves, and the very large seets in one row in each cell, probably oceurs ins. Va.

+ +- Flowers comper-colored or Inll reddish-broun; petals wiclely spreading.

:3. I. fúlva, lier. Stem and leaves as 11.1 ; tube of the perianth cylindri'al, as long as the 6-angled ovary; style-branches narrow. (1. cnpreal, Pursh.) - Nmamps, S. Ill. and Mo. to La. and Git. May.

* Stems low (3-6' high), from lufted and creeping slender (or here and there tuberous-thichened) rootstucks, 1-3-flowered; tube of the perianth long and slender; the vialotblue divisions normly equal.

4. I. vérna, I. (Dwinf InIs.) Leaves linear, grass-like, rather glancons; the thread-like tube of the perianth abont the length of the divisions, which are oblong-obovate and on slender clumes, the outer ones slightly hairy down the orange-yellow base, crestless; capsule oltusely triangular. - Wooded lillsicles, Lancaster Co., Peun., to S. C., west to Ky. and Ala. April. - Flowers sometimes white with vellowish centre.

5. I. cristàta, Ait. (Cresten) Dwarf Iris.) Leuves lanceolute (3-5' long when grown); those of the spathe ovate-lanceolute, shorter than the threadlike tube of the promuth, which is $2^{\prime}$ long and murh longer than the light blue obruatr short-clawed divisions, the outer ones rrested but bearlless; capsulte sharply triangnlau. - In the monutaius from Ml. to N. C.; Trumbull Cu., (Hiv (Inyroham); kuobs of S. Incl. May.-Flowers fragrant.

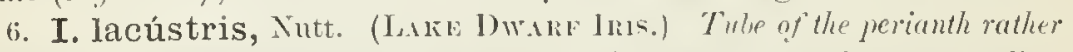
shorter than the dirisions (velluwish, $\frac{1}{2}-\frac{3{ }^{\prime}}{4}$ long), diluted upucard, not exeeeding the spathe; otlerwise as in the last, and toe near it. - Gravelly shores of lakes Huron aud Michigan. Mạ.

I. P'seudicolus, 1., the Yixum las of European mashes, with rery lomg linear leaves and lnight yellow bearlless flowers, is reported as having lurnme established in Mass. and N. Y.

\section{NEMÁSTYLIS, Nintt.}

P'erianth spreading, the segments similar and nearly equal. Filanents more or less united intu a tube. Style short, its slemler 2-partel branches alteruate witl the antlers incl exserted between them; stimmas minute, terminal. Cay-

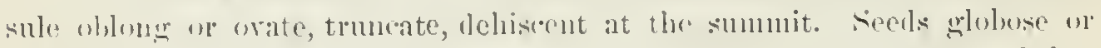

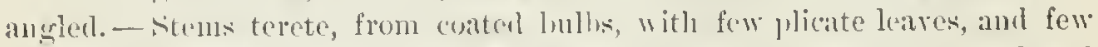

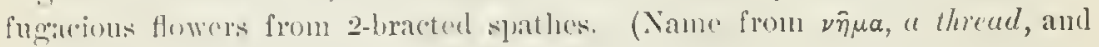

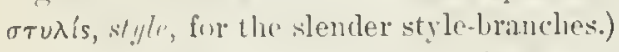

1. N. geminiflora, Nutt. Steul 1 - 20 higll; spatles 2-fowered; peri-

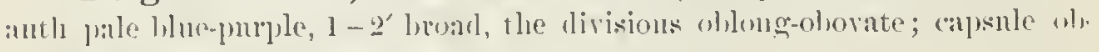
orilte, to loner. - F. Kan. to Tex. 


\section{BELA M C Á N D A, dians. Blackberri-Lily.}

Perianth 6-parted almost to the ovary; the divisions widely and equally spreading, all nearly alike, oblong with a uarrowed base, uaked. Stamens nomadelphons only at lase; anthers oblong. Style club-shaped, 3-cleft, the narrow divisions fipperl with a sullill dilateil stigma. Capsule pear-shaped; the valves at length falling away, luaving the central column covererl with the globose black and fleshy-coateil seeds, inititing a blackherry (whence thes popular name). - Yerenuial, with routstucks, foliage, ete, of an Iris; the

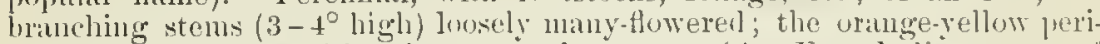
anth mottled ahove witl crimson-pirple spots. ( $\$$ nI bast Indian name of the species.)

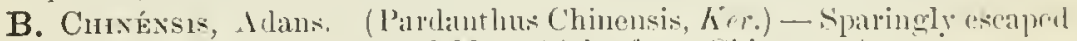
from gardens, Mla to S. Intl and Mo. (Adv. from China, ete.)

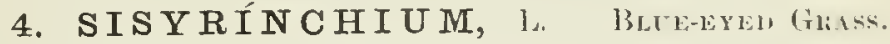

l'erianth 6-parted; the divisions alike, spreading Stamens momalolphons

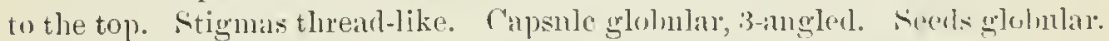
- low slender peremials, witl filnous roots, grassy or lancenlate leares, mostly

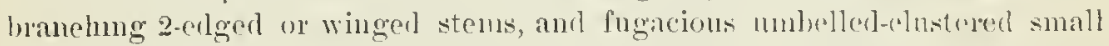
Howers from a 2-leaved spathe. (A meaningless name, of (rrek rrigin.)

1. S. angustifòlium, Mlill. Scape (t-12' high) wingrerl or wingless, simple, the sputhe solikuly and terminal, its onter bract more or less elongated; Howers deliente blue, thanging to purplish (rarely white), the divisions of the perianth more or less notcherl, bristle-pointed and ciliate; nature serls glolost",

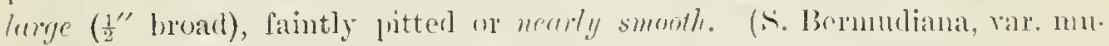
(ronatum, Corny, excl. descre) - Moist nealows, ete., among glass; (oummon werywhere. June-Aug.

2. S. ánceps, Cav. Scape $\left(6-18^{\prime}\right.$ higlı) usually branching and bearingr 2 แr more peduneled spathes; seerls more ovate, mnch smaller, deeply pitted (s. Bermudiana, var. auceps, (ivay, excl. des(r.) - similar localities; common

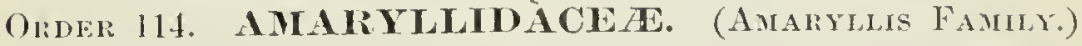

Chiefly bulbous and scape-bearing herbs, not scurfy or woolly, with linew fat root-leates, and regular (or nearly so) and perfect b-androus flowers, the tube of the corolline 6-parted perianth coherent with the 3-celled ovary; the labs imbricated in the bud. - Anthers introrse. Style single. Capsule 3-celled, several - many-seeded. Seeds anatropous or nearly so, with a straight embryo in the axis of fleshy albumen. - An orrler representur in our crardens by the Narcisus, Daffodil, Snowerlop, etc., but with rery few indigenons representatives in this country. Bulbs acrid. I)iffers from Liliarea chiefly in the inferior ovary.

* Capsule 3-valved, lorulieidal: anthers versatile; rerianth fumnel-slaned; glabrous.

1. Zephyanthes. Flowel naked in the throat; the tube sliort or none. Bulbs coated.

2. Hymenocallis. Flowel with a slouder tube and narrow reurved lobes : a cul-shaperl Nown cunnecting the stanens, Bullos coated.

3. Agave. Flower equally 6-cleft, persistent, 110 erown. Fleshy-leaved, not bulbous. * Capsule indehiseent; anthers sigittate ; villous.

4. Hypoxis. Perianth Gumed nearly down to the nury, persistent. Buth snlid. 


\section{ZEPHYRÁNTHES, 【erl.}

Perianth fumnel-form, from a tulnlal lase; the 6 divisions petal-like and similar, spreading above; the 6 stane versatile. I'od membranaceous, 3-lober. - Leaves and low scape from a coated

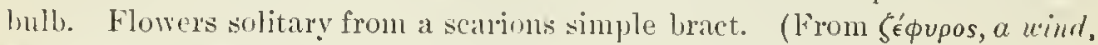
and ă $\nu 00$, flucere.)

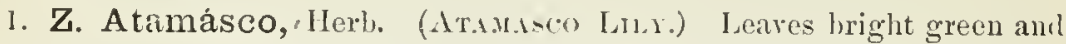
shinilg, very narow, chamucled, the margins acnte; scape 6-12' high; peiluncle short; spathe 2 deft at the apex; perianth white and pink, 3' long; stamons and style dexlined. - Penn. to Vat, and Flis. June.

\section{H Y M E N O C ÁLIIS, Salisb.}

Perianth with a long and slender tuhe, and an eqnal 6-parted limb; lobes long and narrow, recurved; the throat bearing a tulular or cup-shaped corollike delicate crowu, which commects the bases of the 6 cascrted stamens. Anthers linear, resatile. C'apsule thin, 2-3-loherl; sechls nsually 2 in each rell, hasal, fleshy, often like bulblets. - Scapes aud lears from a coated bulb. Flowers white, fragrant, large and showy, sessile $i n$ an unbel-like head or "luster, subtended by 2 or more scarions bracts. (Nane composed of $i \mu \eta \dot{v}, \alpha$

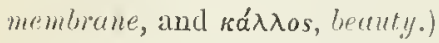

1. H. oceidentàlis, Kunth. Leaves strap-shaperl, glaucous, $1-1 \frac{1}{2}^{\circ}$ long,

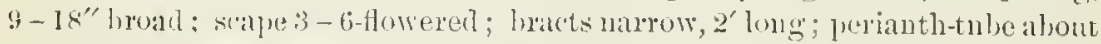
$2 \frac{1}{2}-4^{\prime}$ long, the linean segments scarcely shorter; the crown $12-15^{\prime \prime}$ long. rubular below, broally funelform athore, the unigin deltoid and entire, or -2-toothed and erose, between the white filaments, whicls are twice longer; anthers yellow; style green. - Marshy hanks of streams, s. 11l. to N. Ga. and Ala. - Apparently distinet from II. Iacera, Salisb. (Pancratium rotatnm, (ier), of the southern coast.

\section{A G $\mathbf{A}$ V E, I. AmerichN Aloe.}

P'erianth tubular-funnel-form, persistent, 6-parted ; the divisions nearly equal, narrow, Stamens 6 ; anthers linear, rersatile. Calsule coriaceons, nuanyseched. Seeds flattened. - Leaves thick and fleslyy, often with cartilaginoms or sping teeth, chusterel at the hase of the many-fluwered scape, from a thick fihrons pouted cown. (Name from ágauń, noble, - not inapluropriate as applied to A. Awels

1. A. Virgínica, I. (F.Ls: Arov.) llerbacens; leaves entire a* denticulate; seape $3-6^{\circ}$ high; flowers scattered in a louse wand-like spike, greenish-ycllow, fugrant, the perianth 9-12" Inng, its narrow tube twice longer than the erect lobes. - Dry or lok ky banks, Mul. and Va. to Fla., West to S. Ind., Mo., and Tex.

\section{HYPÓXIS, I. St. SAli-frass.}

Perianth persistent, 6-parterl, spreading; the 3 outer divisions a little herba. ceons outside. Stanens 6 ; anthers sagittate, erect. Capsule crowned with the withered or closenl periantl, not opening lyg ralves. Seeds glohnlan, with a crustareons coat, asconding, imperfoctly anatropons, the rhaphe not adhereut 
quite down to the micropyle, the persistent seed-stalk thus forming a sort of lateral beak. Radicle inferior! - Stemless small lerbs, with grassy and hairgo linear leares and slender few-flowered sempes, from a solirl bulb. (An old name for a plant having sumpish leaves, from üroģus, sul-acid.)

1. H. erécta, L. Leares linear, grass-like, longer than the mulsellately 1 -4-flowered scape; divisions of the perianth hairy and greenish outside, yellow within, - Meadows and open woods, N. Eng. to Fla., west to Minn., E. Kan., and Tex.

\section{Order 115. DIOSCOREACTAE. (YaM Family.)}

Plants with twining stems from large tuberous roots or hnollerl rootstoeks, and ribbed and netled-veined petioled leaces, small diocinus G-androus and regular flowers, with the 6-cleft calyx-like periumlh allerent in lhe fertile plent to the 3-celled otary. Siyles 3, distinct. - Ovules 1 or 2 in wath cell, anatropous. Fruit usually a membranarcous 3-angled or wingred capsule. Secels with a minute embryo in hard albumen.

\section{DIOSCOREA, l'lumier. YAx.}

Flowers rery small, in axillary panicles or meenes. Stamens b; at the batse of the divisions of the 6-parter perianth. Capsule 3-celled, 3-winged, locnli. vidally 3.valved ly splitting throngh the winged angles. Sieeds 1 or $2 \mathrm{in}$ eacls cell, flat, with a membranaceous wiug. (Dedicated to the fireek naturalist, Hiosruridrs.)

1. D. villosa, I. (Wı́ Y̌u-koo'r) Herbaceous. Sitems slender, frum knotty and matted rootstocks, twining over bushes; leaves mostly alternate, sumetimes nearly opposite or in fours, more or less down beneatl, lieartslapped, (onspicumsly pointed, 9-11-ribbed; flowers pale greenish-yellow, the: sterile in droophug panicles, the fertile in choopiug simple racemes; capsules S-10" loug, - Thickets, S. New ling, to Fla., west to Mim., Kau., and Tex.

\section{()RDER 116. LILIACFAE. (LIMY FaMIHY.)}

Herbs, or rarely wood! plants, with repgular cuml symmetrical almost aluays G-androus flowers; the perianll unt glumacenus. fice from the cliegly 3 celled oxary; the stamens one before ench of is theisions or lobes (i. c. 6, in

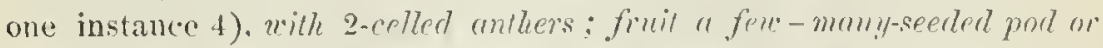
herry; the small embryo rnclusel in copions ritumen. Sects anatropous or amplitropous (orthotropous in smilax). Flowers not from a spathe, except in Allium; the outer and inner ranks of the prorianth colored alike (or nearly so) and generally similar, cxcept in Trillium.

Srborden I. Similaceac. Shrubly or rany herlacens, the petiole of the :3 - 9-nerved netterl-reined leaves often tendril-learing. Flowers (in ours) diuceious, in axillaly umbels, small, witl regular (i-plarted decirnous periantl, Anthers apparently 1-celled. Stigmas 3, sessile, Fruit a 3-celled berry, with $1-2$ pendulous orthotropous secds in each cell. Embryo minute in horny albumen.

1. Smilax. (haracters als alusite. 
Suborder II. Liliacea proper. Never climbing by tendrils. Very rarely diceious. Seeds anatropous or amphitropous.

Series A. Floral bracts scurious. Stamens perigynous ou the usually withering-persistent nerved periunth; inthers introrse. Style undivided, mostly persistent. Fruit a loculiciclal eapsule or a berry. Leaves trims. versely veined.

Scale froul a coated bulb; fruit cal psular; le:tves linear.

- Flowers umbellate; segnents 1-nerver : pedicels not jointed.

2. Allium. Perianth 6-parted. Capsule decply lobed, often crestecl; cells 1 -2-seeched. Very allixeons.

3. Nothoscordum. Perianth 6-parted. Seeds sereral in each cell. Not alliacenus.

4. Androstephimm. Perianth tubular-fumel-foru. Filaments in the throat, united into a crown

+ + Flowers racemose, b-pruted, the segments is - seremal-uerved.

5. Canassial. Fluwers light biue, long-racemose. Filanents filiform.

6. Ornitlogalum. Flowers grecnish wlite, sub-corynbose. Filaments dilated.

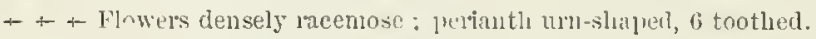

7. MLuscari. Fhwers deer blue, small. stamens included.

* S Sten or scaje not from a bulb, sercril-flowered; eapsule many-seeded.

S. Hemerocallis. Siape from a flesly-fibrous root. Flowers few, large, jellow, tubulur-fumel-form: limb 6-parted. Stamens and long style rlecliner. Needs glolonse.

9. Yucca. Stem wouly, lcafy. Flowers white, campanulate, G-parterl. Stignas sessile, Seeuls flat.

* * Leafy stems (seape in n. 10) fiom rumning rootstocks ; fruit a berry ; leaves cordate to lanceolate (exce 1 t 11.13$)$; Howers white; pealicels jointed

+ Periunth gamopliyllous, b-lobed.

10. Convallaria. Teares sheathing the seaje. Flowers racenose; ferianth bell-shaped.

11. Polygonatum. Stem leafy. Flowers axillurg; perianth cylimbical + + Perianth-segments distinrt, small, sprenuing, persistent.

12. Asparagus. Stems wanehing. the alunent leaves thead-like. Flowers axillary

13. Smilacina. Steur simlele, leafy. Flowers j-parted. meemose or prouiculate.

14. Maiantlenum. Sten low, g-lentel. plowers t-merous, lacenose.

SETres 13. Floral liracts nome or foliacents. Stamens lypogrnous or at the base of the distinct segments of the leciduons perianth (persistent in n. 23); anthels extrorse or dehiscent laterally. Style undivided, decid uous (stigmas sesile and persistent in n. 23). Firuit a loculicidal capsule or a berry. Veinlets anastomosing (transverse in $11.15,17-19$ ).

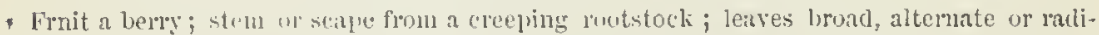
ral : flowers nutrowly compantulate

15. Streptopus. stem leafy. Flowers axilluy, on bont pediecls. Anthers sagittate. acute: filanents deltoicl ur subulate.

16. Disponnm. Stem leafy. Flowers few, in terminal unbels. Anthersobloug, obtuse: filaments sleuler. Veiulets anastomosing.

17. Clintomia. Finwers umbellate on a seape, few or many.

* * Fruit at cipsule.

+ Stems leafy, from a short or cree ling routstock ; flowers few, solitary, pendulous; capsule few-secded.

1r. Uvularia. Stem terete. Leares perfoliate. Flowers terminal. Capsule truncate, 3-lnbed.

19. Oakesia. Sten anglerl. Leaves sessile. Flowers olposite the leares. Capsulo arutely :-wingerl. 
- + Stcm or seape from a bulb or corm; calisule many-seeled.

n. Erythronium. Scape from a solid bulb, with a pair of leaves. Flower solitary Seeds angled, obovoid.

21. Lllium. Stem leafy from a sealy bulb. Seeds lıorizontal, flattened.

* * Fruit a berry; stem from a tuber-like rootstock, bcaring 1 or 2 whorls of leaves; flowers terminal ; stignas sessile.

…. Medeola. Leaves in 2 whorls. Flowers unbellate. Periantli-segments similar, eolored, deciduous.

23. Trillimm. Lenves (3) in a terminal whorl. Flower solitary; onter sejals leaf-like, jer'sistent.

Sinzies C. Floral bracts green or greenish (rarely scarious), or none. Stamens at the base of the distinct 1 - several-nerved persistent perianth-segments; anthers small, versatile. Styles or sessile stigmas distinct. Capr sule mostly septieidal. Feeds with a louse testa or appendaged. Leaves with transverse reinlets (except in 11.24 and 25).

- Stems leafy or bracteate, from a thick tuberous rootstock; flowers racemose; antliels --celled; stigmas linear.

24. Helonias. Lenves radical, oblanceolate. Flowers perfect. Cajsule broully obovite, many'seeded.

25. Chamalirium. Sten very leafy. Ilowers dioceious, Capsule oblons, llimy-seederl,

26. Xerophyllum. Stem very leafy; leaves very narrow. Flowers perfect. Capsule few-seeded.

* * Stems disticlously equitant-leafy, from a creeping rootstock; flowers on bracteolate leclirels, ricemose: anthers 2-celled; stigmas small, terminal; seeds often aplyenuaged,

2-. Tofieldia. Bractlets 3, verticillate. Styles sliort. Seels liorizontal.

„x. Narthecinm. Bractlet linear. Stigma slightly lobal. Seeds ascending.

* * Antivers heart- or kidney-shaped, eonfluently I-celled, and peltate after opcning: stignus terminal; capsule 3-beaked by the persistent styles: seeds angled or flatteucd and uargined.

- Stens tall, leafy, fron a thick rootstock, pubescent above; flowers polygamous, ranemose-paniculate; seeds flat, winged.

29. Melnuthimm. Sepals free from the ovary, their long claws bearing the filanents.

: 3 . Veratrum. Sejals witlout elaws, slightly adnate to the orary. Laves strongly n rrent ind liliente.

+ + thont mostly bulbous ; glabrous ; Howers raeenose or paniclerl; seeds narrow, angled; leaves linear.

31. Stenanthium. Sepals lanceolate, acuninate, withont glands.

:2. Zygadenus. Sepals oblong to orate, ghandulur towarl the basc.

i:3. Aluianthium. Flowers in a dense racenc. Seprals ovate-oblong, glandless, freo from the ovary. Cells of the capsiste widely divergent, $1-2$-seeded.

\section{S Mild A X, Tourn. Greenprier, Cat-ibrier.}

Fluwers diocious in umbels or axillary peduneles, small, greenish or yellow. ish, regular, the perianth-segments distinct, deeiduons. Filaments linear, inserted on the very base, the introrse anthers linear or oblong, fixed hy the hase, apparently l-celleil. Ovary of fertile flower's 3-celled (l-cellerl, with single stigma, in 1. 11); stigmas thick and spreatling, almost sessile; ovules 1 or 2 in each cell, pendulons, orthotropous ; fruit a small berry, - Shrul)y or rarely lerbaceous, usually climbing or supported by a jain of trullils wn the petiole of the ribhed and netted-veined simple leaves. (l'he anciont direek name, ul' obscure meaning.) 
\$1. Stems herbaceous, not priekly; flowers carrion-seented; ovules 2 in each cell ; leaves membranous, mucronate-tipped; berries bluish-black with a bloom.

1. S. herbàcea, I. (CARriox-Frower.) Stem climbing, 3-150 high ; leaves ovate or rounded, mostly heurt-shaped or truncate at base, abrnptly aente to short-acumiuate, 7 -9-nerved, smooth; petioles $\frac{1}{2}-\mathrm{l}^{\prime} \mathrm{long}$; perluncles elon-

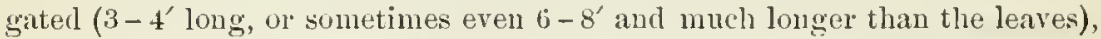
20-40-fluwered; seeds 6. - Moist meallows and river-banks: common, from the Atlantic to Minn., Mo., and Tex. June. Very variable.-Var. Pulvervif́nta, Gray, has the leaves more or less soft-downy beneath.

2. S. tamnifolia, Michx. Stem upright or climbing; leaves mostly 5 . nerved, smooth, broadly ovate to lanceolate, truncate or cordate at base, al)ruptly acute to aeuminate, some of them lastate with broad rounded lobes; peduncles longer than the petioles; berry smaller, 2-3-seeded. - Pine-barrens, N.J. to s. C.

3. S. ecirrhàta, Watson. Erect, $\frac{1}{2}-3^{\circ}$ high, without tendrils (or only the uppermost petioles tendril-bearing), glabrous; lower leaves reduced to narrow scale-like bracts, the rest thin, 5-7-nerved, braally orate-elliptical to roundish, aeute, mostly cordate at base, 2-5' loug, sometines verticillate, sparsely pubescent beneath; perluncles about equalling the petioles ( $1-2 \frac{1^{\prime}}{2}$ long $)$, on the lower part of the stem; umbels 10 -20-Howered; berry 3-seeded. - Md. to S. C., west to Mich. and Mo. May, June.

\$2. Stems woody, often prickly; ovules solitary; glabrous throughout.

* Leares ovule or roumdish, ete., most of them rounded or heart-shaped at buse, and 5-9-nerved, the three middle nerres or ribs stronger and more eonspicuous.

+ Pechuncles shorter or scareely longer than the petioles (2-6"), flattened; leares thickish, green both sides.

4. S. Wálteri, l'ursh. Stem low, somewhat angled, prickly near the base or unarmed; leaves oute to ovate-lanceolate or oblong, someuhat heurt-shuped or romnded at base (3-4' long); borries coral-red. - H'ine barrens, X. J. to Fla.

5. S. rotundifólia, I\% (Common Greenbrier. Horsi-brier.) Stem armed with scattered prickles, as well as the terete branches; branchlets more or less 4-angular ; leness mute or round-onate, often broules than long, slightly

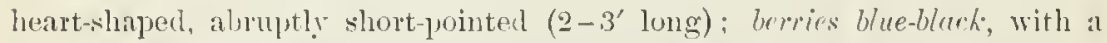
hloom. - Moist thickets, N. Eng. to (ial., west to Minn. and Tex. Very vari-

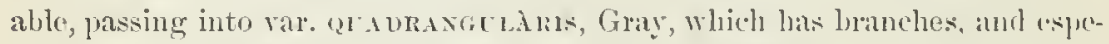
cially loranchlets, 4-ingular, and is more common west.

+- + Peduncle longer than but seldom twice the length of the short petiole, flat tened; lones: fardily deciduous or partly persistent; berrirs black, with a bloom.

6. S. glaùca, Walt. Terete hanches and somewhat 4-angulat hranclilets armed with scittred stont prickles, or naked; lenes orute, rarely subcurdate, glancous benerth and sometines also alyove, as well as the branchlets when young (ahout $2^{\prime}$ long), almuptly mucronate, the edges sumoth and naked. - bry thickets, E. Mass. to Fline, west to S. Ind., Mlo, and Tex.

7. S. bòna-nox, I. Branches anel the angular (often syuare) lianchlets spansely armed with short ligid prickles; leares varying from round-heartshaped and slightly contracted above the dilated base to fickle-shaped and halherd-shaped or 3-loled, green and shining both sides, cuspidate-pointed, tha 
margins often somewhat bristly-eiliate or spinulose. (s. tamnoides, Mfon.; probably not L.) —'Thiekets; Nantucket, Mass. (L. L. Dume); N. J. to Fla., went to Ill., Mo., and 'Tex.

++ - Peduncle 2-4 times the length of the petiole; leures ample $(3-5$ ' long), thin or thimnish, green hoth sides; berries blach; stem terete and branchles: nearly so.

8. S. híspida, Muhl. Rootstock cylinchical, clongated; stem (climling high) below clensely beset with lony and weak blackish mistly mickles, the flowcring branchlets mostly naked; leaves orate and the larger heart-shajped, pointed, slightly rough-margined, membranaceous and deciduous; peduncles $1 \frac{1}{2}-2^{\prime}$ long; sepals laneeolate, almost $3^{\prime \prime}$ long. - Moist thickets, Conn, to Va., west to Minn. and Tex. June.

9. S. Pseudo-China, J. Rootstock tuberous; stems and branches unammed, or with very few weak priekles; leares orate-heart-shaped, or on the lranchlets ovate-oblong, euspidate-pointed, often rough-ciliate, heeoming firm in texture; perluncles flat $\left(2-3^{\prime}\right.$ long). - Dry or sindy soil, N. J. to Fla., west to S. Ind, and Mo. JuIr.

* Leares curying fiom oblong-lanceolute to lineur, numoned at base into a short petiole, 3-5-nerved, shining abour, paler or glaucous beneath, many without tendrils; peduncles short, scldom exceeding the petioles, terete; the umbels sometimes panived; branches terete, unarmed.

10. S. lanceolàta, 1. Leares thinnish, rather deeiduons, ovate-lanceolate or lanee-oblong; stigmas 3 ; berries dull red. - Riel wovds and margins of swamps, Va. to Fla., west to Ark. and Tex. June.

11. S. Iaurifòlia, I. Lences thick and coriuceuns, evergreen, varying from

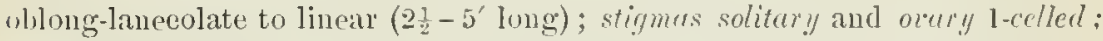
berries black when ripe, l-seeded, maturing in the second year. - Pine-barrens, N. J. to Fla, west to Ark. and La. July, Aug.

\section{2. ÁLLIU M, L. Oxiox. Garlic.}

Perianth of 6 entirely eolored sepals, which are distinct, or united at the rery base, l-nerved, often becoming dry and searious and more or less persistent; the 6 filaments awl-shaped or rlilated at base. Sty-le persistent, but jointerl upon the very short axis of the orary, thread-like; stigma simple. Capsule loberl, loculieidal, 3-ralred, witl 1 -2 orold-kidney-shaped amphitropous or (atupylytropous hlack seeds in eacl ecll. — Strung-scented and pungent stemless lierls: the leares and seape from a coaterl lulb; flowers in a simple umbel, some of tlem frequently elanged to bullolets: spathe searious, 1-2-ralved. (Thie aucient latin name of the Garlic.)

\$. Bulls cespitose, narrowly olinng and crowning a rlizome; coats membranous. * Leaces (2 or 3) clliphic-lancolate; ovules solitary in each cell.

1. A. tricóccum, Ait. (Wrın LeEæ.) Seapenaked (4-12' high from ('lustered pointed bulbs, ' 2 long), bearing an ereet many-flowered unbel; leares 5) $-9^{\prime}$ long, 1-2' wide: sepals oblong (greenish white), equalling the nearly listinet filanents; capsule strongly 3-lobed. - Rich woods, WV. N. Eng. to Minu. and Inwa, sonth in the monntains to $\mathcal{N}$. C. Leaves appearing in early spring ancl dying before the flowers are developed. 
* Leaves linear; ovules a pair in each cell.

2. A. Schœnóprasum, I. (Curves.) Scape naked or leafy at base $\left(6-12^{\prime}\right.$ high), bearing a glolular cupitute umbel of many rose-jurple flowers; sepals lanceolate, prointed, longex than the simple downally dilated filaments; lectes aul-shaped, hollow: capsule not crested. - From X. Brunswick and the Great Lakes to the I'acific. (Eu., Asia.)

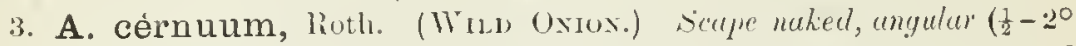
ligh), nodding at the apex, hearing a loose or drooping few-many-fowered nimbel; leuves lineur, flutened, sharoly heeled ( $1^{\circ}$ loug); sepals oblong-ovate, acute (rose-culor), shorter thin the slender filaments and style; cupsule 6rrested. - In the Alleghanies to S. C., West to Minl., Mo., 'Tex., and Westward.

\$2. Bulbs moslly solitary, not Mizomatous; couts gjon jibrous; leaces nurrowly linew, flat or chemuelled (tercte in $\mathrm{A}$. vineale).

4. A. stellàtum, Fras. scape terete $\left(6-18^{\prime}\right.$ ligh $)$, slender, bearing an srect umbel; bulb-coats membranons; sopals broad, acute; stamens and st.gle exserted; capsule prominently 6-crested. - Rochy slopes, Mium. to WV. Ill. and Mo., and westwart.

5. A. reticulátum, Frasel. Scraje $3-8$ ' hight ; bulbs densely and coursel!y fibrons-couted; spathe 2-ralved; nmbel darely bulbiferons; sepals ovate-tu nartowly lanceolate, thin and lax in fruit, a third longer then the stamens: cupsule crested. - Silsk. to Iowa and N. Mex.

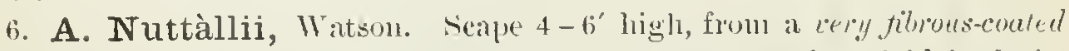
lull); spathe nstlilly" 3-valved; sepals usually broader, ruther rigid in fruit; reprosule not rersted. - Central hin. to 'lex., and westward.

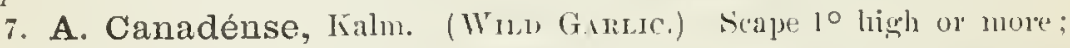
bulb-coats somewlat fibrous; nmbel densely bulbiforom or lew-flowered; sepals narrowly lanceolate, obtusish, eipualling ou exceeding the stamens ; capsule mot

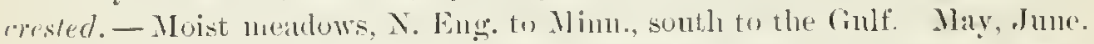

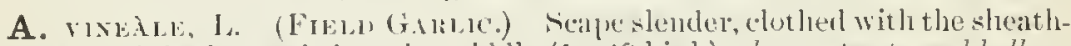

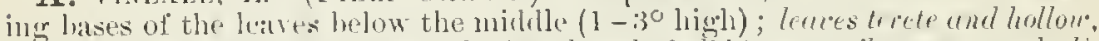

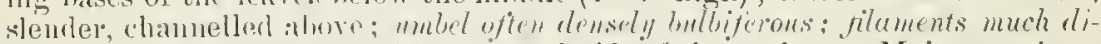

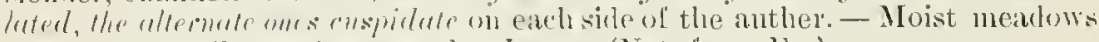
and fields; a vile werel castwark. June. (Nat. from Bu.)

\section{NOTHÓSCORDUM, liuntı.}

Fluwers greenish ol yellowish white. Capsule oblung-oborate, somewhat lubed, obtuse, with the style olscurely jointed on the smmit ; colls severat urnled and -secied. Filaments filiform, distinet, anlute at hase. Bub tmi.

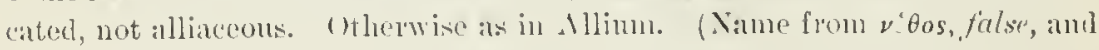
$\sigma \kappa o ́ \rho \delta ı \nu, ~ g a r l i c$.

1. N. striàtum, huth. Sump 10 high or lass; hulb small, often lmhiferous at base; leaves narowly linear; flowers few, on slenter policels, th. verments narrowly olulong. 4-6" long; ovmles 4-7 in each cell. (Allium striatum, Jacq.) - Prairies and ppen woods, Va. to Ind., Neb., and southward.

\section{A N DROSTÉPHIUM, 'Torr.}

P'eriant funnel-form, the eyludrieal tube entulling the somew hat spreating

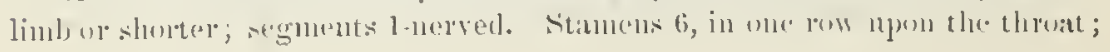


the filanents united to form an elect tubnlar crown, with bifid lobes alternate witl the oblong rersatile anthers. Capsule sessile, subglobose-triquetrour, bealked by the stont persistent style; seculs large, few to several in cull cell.

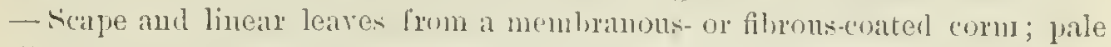
lilac Howers unbellate; pelicels not jointed; insolucral bracts several. (Name

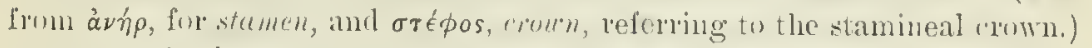

1. A. violàceum, 'Turr. Reipe 2-6' liggh; Hower's - I2' lung or more,

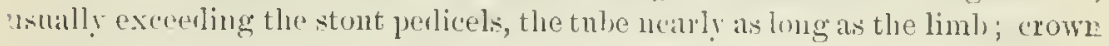
scarcely shorter than the liml, - Lan, to 'Tex.

\section{C A M Á S S I A, Lindl.}

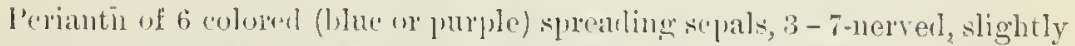
irregular, mostly recillums; the filiform tilaments it their hase. Style thearl-

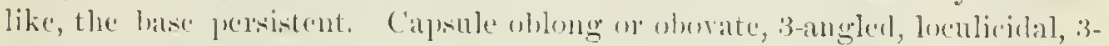

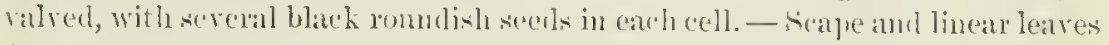
from a coated balb; the flowers in a simple ralcene, mostly linated, on jointed forlicels. (From the native Indian nature gunemesh or commensi)

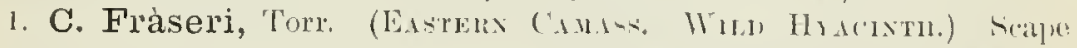
$1^{\circ}$ high or Inore: leaves keeled; raceme elongated; hracts longer thau the:

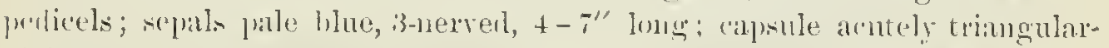

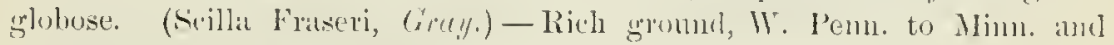
L. Lim, and in the monntains to Ga.

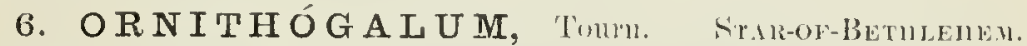

l'eriantle of if colured (white) sprealing $3-7$-nerverl sepals. Filanents 6 , flattenerl-aw l-slaped. Style 3-sided; stignua 3-angled. C'ap:ulo membranous, roumlish-ingmbar, with few dark and roundish seerls in earlo cell, loculicidil.

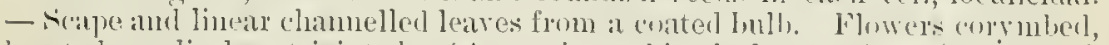
loketed; pedicels not jointed. (An ancient whimsical name from öpves, a bird, anıl $\gamma a \dot{\lambda} \alpha \alpha$, milli.)

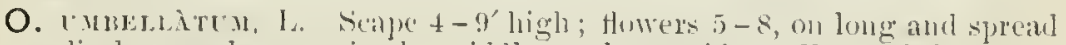
ing perlicels; sepals green in the midlle on the outside. - Escaped from garHells. (Nitt. form Kin.)

O. Nitris. L. Scape $1^{\circ}$ high on more; flowers 5 or 6 , large (I' long), nort-

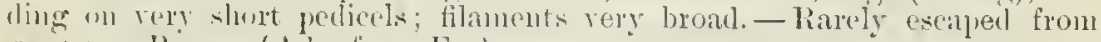

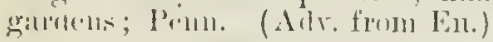

\section{M U S C À R I, 'Tumu. Grape-HYACiN'n.}

l'eriantl globular or woil, minutely 6-toothed (blue). Stamens 6, ineluded: anthers short, introrse. Sty le short. "(apsule loculicidal, witl 2 black angular

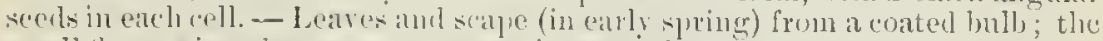
small flower's in a rense raceme, sumetimes misk-seenterl (whence the name).

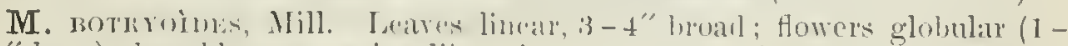

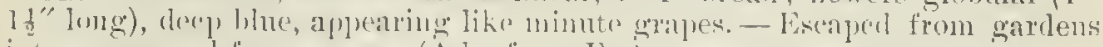

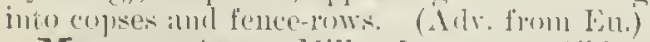

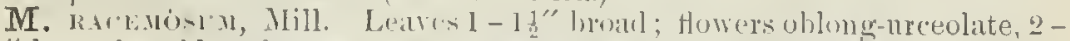
$2 \frac{1}{2}$ "long, deep blue, fragrant. - Rare escaje, Mi. and l'enu. (Adiv. from Eü.)

\section{HEIEROCÁLIIS, L. DAr-LIL.}

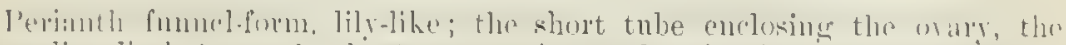
sprealing limbl tiparted; the bstamens inserted on its throat. Anthers as in 
Lilium, but iutrorse. Filaments and style long and threan-like, declined and ascending; stigma simple. Capsule (at first rather fleshy) 3-angled, loculicidally 3-valved, with several black spherical seeds in each cell. _ - Whowr perenuials, with fleshy-fibrous roots; the long and linear keeled leaves 2-ranked at the base of the tall scapes, which bear at the summit several bracted and large rellow flowers; these collapse and decay after expanding for a single

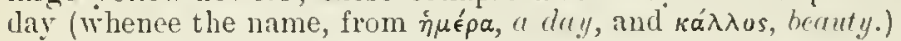

H. FÚLA, L. (Comsox DAY-LiLr.) Inner divisions (petals) of the tawy orange perianth way and obtuse, - Roadsides, escaped from gardens. (Adr. from Eur.)

\section{YÚCCA, L. Bear-Grass. Spaxish Bayoxet.}

lerianth of 6 petal-like (white or greenish) wral or oblong and acute flat sepals, withering-persistent, the 3 inner broader, lunger than the 6 stanens. Stigmas 3, sessile. Capsule ollong, somewhat 6-sided, 3-celled, or inperfectly 6-celled by a partition from the baek, fleshy, at length loeulicidally 3-ralred from the apex. Scels very many in each cell, flattened. - Stems woody, either very short or rising into thick and colnmmar palm-like trunks, hearing persistent rigid linear ol strord-shaped leaves, and an often anple compound panicle or branehed raceme of showy flowers. (The native Iatytian nime for the rout of the Cassavin-plant.)

1. Y. angustifölia, l'ursh. Camblex nume rery shont ; learestraight

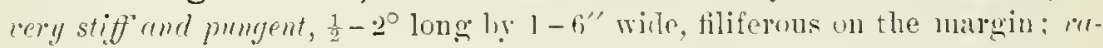
reme mostly simple, neurly sessile $\left(1-t^{\circ}\right.$ long); Howrers $1 \frac{1}{2}-2 \frac{1}{2}^{\prime}$ wide ; stigntir green, shorter than the orary; eapsule 6-sidenl ( $3^{\prime}$ long); seeds 5-6" broad. -s. Dak. to Iowa, Kau., and N. Mex. May, June.

2. Y. filamentòsa, I. (Aлn's NeEurk) ('audex $1^{\circ}$ ligrt or less, from a running routstouk ; leaves numerous, couracenns, more or less tallering to a short point, romgh on the back, $1 \frac{1}{2}-2^{\circ} \operatorname{long}$ hy $1-3^{\prime}$ wide, filiferous on

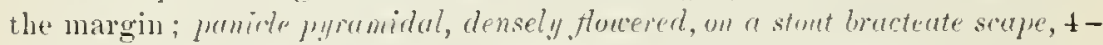

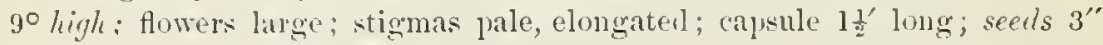
broad. - Fear the coast, Mul to Fla. and Ja. July. Very variable.

\section{CON VALLÁRIA, L. hily of the VAlles.}

l'eriantlı hell-slaped (white), 6-lobed, decidnons; the lobes recurred. Stamens 6 , includerl, inserted ou the base of the perianth: anthers introrse. Uvary 3-celled, tapering iuto a stout style; stigma triangular. Orules $4-6$ in each (cell. Berry few-seederl (red) $-\Lambda$ low perennial herb, glabms, stemless, witl: slender ruming rootstoeks, sending up from a scaly-sheathing bud 2 oblong leaves, with their long sleathing petioles enrolled one within the other sols to alpear like a stalk, and an augled scape bearing a wus-sirled raceme of pretty and sweet-scented nodding flowers. (Alterul from fillum concallium, the juyular name.)

I. C. majàlis, L. - High mountains of Vit. tos. C. Apparently identical with the European Las of THE VALAL of the gardens.

\section{POLYGONATU M, Tourn. Soromox's SEA..}

l'erianth cylindrical-oblong, 6-lobed at the summit; the 6 stamens inserterl on or above the midlle of the tube, included; antlers introrse. ()varr 3-celled. 
with 2-6 orules in cach cell; style slender, decidnous by a joint; stigma obtuse or eapitate, obscurely 3-lobed. Berry globular, black or blue; the cells 1-2-seederl. - Peremial herhs, with simple erect or eurving stems, from creeping thick and knotted rootstocks, naked below, above bearing nearly sessile or half-clasping nerved leaves, and axillary nodding greenish flowers; perlicels jointed near the flower. (The aneient mane, composed of moגús, many, and róvu, knce, alluling to the numerous joints of the rootstock and stem.) () urs are alternate-leared sjeeies, the stem terete or scareely angled when fresh.

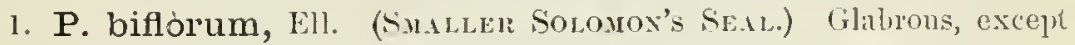
the ovate-oblong or lance-oblong nearly sessite leares, which are commonly minutely pubescent us uell as pale or glarcous underncath; sten slender (1-3 $3^{\circ}$ high); peduncles 1 -3- but mostly -2-flowered; perianth 4-6" long; filanents papillose-roughened, inserted tuward the summit of the perianth. - Wooder hillsiles, N. Brunswick to Fli., west to Minn., E. Kan., and Tex.

2. P. gigantèm, Dietrich. (GREAT S.) Glabrous throughout; stem stont and mostly till (2-70 high), terete; leaves ovate, partly claspring $\left(3-8^{\prime}\right.$ long), or the upjer oblong and nerrly sessile, many-nerved; peductes severat. (2-8-) flowered, jointed below the flower; flowers 5-9" long; fituments smooth and naked, or nearly so, inserted on the midhle of the tube. - Meadows and river-banks, N. Eng. to Va., west to the Roeky Mts. June.

\section{A S P ÁRAGU S, Tourn. Asparagus.}

Perianth 6-parted, sprealing above; the 6 staneus on its base; anthers introrse. Style shurt; stimna 3-lobed. Berry spherical, 3-celled; the cells 2-seederl. - I'eremials, with much-branched stems from thick and matter rootstocks, and small greenish-yellow axillary flowers on jointed pedicels. 'The narrow, commonly thread-like, so-called leaves are really brinchlets, acting as lcaves, clustered in the axils of little scales which are the true leares ('The ancient Greek name.)

A. oricinals, L. (Gardex Asparigus.) Ilerhaeeous, tall, bushybrancherl leares thread-like. - A frequent eseape from garrlens. June (Adv. from Eu.)

\section{S M I L A C I N A, Desf. False Solomor's Seal.}

Perianth 6-parted, spreading, vithering-persistent (white). Stamens 6, inserted at the hase of the divisions; filaments slender, anthers short, introrse, Ovary 3-celled, with 2 orules in each cell; style short aud thick, stigma ob. seurely 3-lobed. Berry globular, 1-2-seeded. - Perennial herbs, with simple stems from ereeping or thickish rootstoeks, alternate nerverl mostly sessile leaves, and white, sometimes fragrant flowers in a terminal and simple or compound raeeme. (Name a diminutive of Smilax, to which, however, these plints bear little resemblance.)

* Flourers on very short pedircls in a terminal racemose panicle: stamens exceeding the small (1"long) segments; outles collateral; rootstork stout, fleshy.

1. S. racemósa, Desf. (False Sprexard.) Minutely downy $\left(1-3^{0}\right.$ high); leaves numerous, oblong or oval-laneeolate, taper-pointerl, ciliate, alr ruptly somewhat petioled ; beries pale red, speekled witl purple, aromatic.-Mrint copues, X. Brunswick to S. C., west to Mina., F.. Kan, and Ark. 
* Flowers larger (2-3" lony), un solitury pedicts in a simple feu-floupred raceme; stumens included; ovules not culluteral; rootstock raller slender.

2. S. stellàta, Desf. Plant $\left(1^{\circ}\right.$ high or less) nerrly ghabrons, or the 7 12 ablony-lemecalue lenes minutely downy beneatly when yomg, slightly dasping; racene sessile or nearly so; bervies bluckish. - Moist banks, I all. to X. J., west to K. Kan., Nlinn, illd westward. (lin.)

3. S. trifolia, besf. Glabrous, deuf $\left(2-6^{\prime}\right.$ lighl) : lrures 3 (sometimes 2 or 4), oblong, tapering to a shouthing buse; raneme pulluncled; berries red - Cold bogs, Lab. to N. Eng., West to Mich. and Min. (Sib.)

\section{M A I Á N T HE M U M, Wiggu.}

leriauth f-parted, witl as mauy stamens. () May 2-colled; stigma 2-lohed.

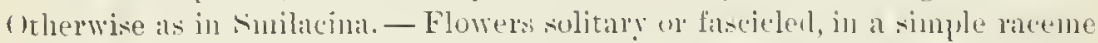
upon a luw 2-3-leaved stem. Leares vaite- to lanceulate-cordate. (Xame from Huils, Mar, am! ă $\nu \theta \in \mu o \nu$, " Houres:)

1. M. Canadénse, J)est. P'ubercent or ghlubrous $(3-5$ highl); leares lanceolate to orite, cordinte at base with a very narrow sinns, sessile or rery sloutly petioled; perianth-segments $1^{\prime \prime}$ long. (Similacina hifolia, vilr. C'allatlensis, (iray.) - Moint wouls, Lab. to N. C., West to Mimn. anel Lowa. Ma!:

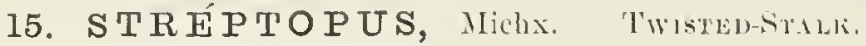

I'erianth recurved-spreating from a bell-shaped base, decidnoths; the 6 dis-

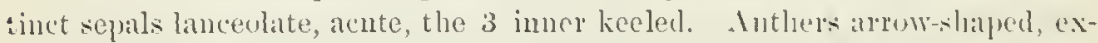
trorse, fixed near the hase to the short Hattened filanents, tapering abure to a slencler entire or e-cleft point. Urary with many ovules in each coll ; style and sometimes the stigmas one. Berry red, roundish-oroid, many-seded.llerbs, with rather stont stems from a creeping rootstock, forking and avergent branches, ovate and taper-pointed romuled-clisping membranaceous leaves, and small (extra-) axillary flowers, either sulitary or in pairs, on slemier thread-like peluncles, which are abruptly bent or conturted near the midlle (whence the natme, from $\sigma \tau \rho \in \pi \tau o$ s, turisted, and moves, yoot or stulk).

1. S. amplexifólius, DC. Stem $2-3^{\circ}$ ligh, glabrous; leaves ren"y smooth, ghumens undermenh, strongly chasping; forcer greenish-xhite ( $4-6$ " long) on a long abruptly bent peluncle; anthers tapering to a slenler entire

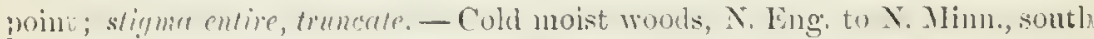
to ()hio, l'enu, and in the momntains to X. C. June. (En.)

2. S. roseus, Michx. Lomerlemes green buth sides, finely cillute, and the

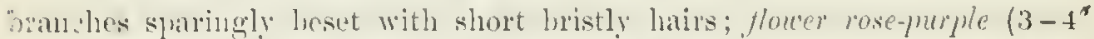
lung), more than half the length of the slighty bent peduncle; anthers 2 lornerl; stigma 3-eleft. - Cold damp) woosls, X. Fug. to X. Minn., and south in the momntaius to Ga. May.

\section{DI S POR U M, Salisb.}

l'erianth narrowly hell-shaped, the 6 sepals lanerolate or linear, decidnons. Filanents threal-like, much longer than the linear-oblong blunt anthers. which are fixed ly a puint alwo the base and extrolse. (Jary with 2 ovules (in our species) suspended from the smmmit of each cell; style une; stigma: 
short, rechred-spreading, or sometimes united into one! I3erry ovoid or ols. ling, pointed, 3-6-seeded, red. - Downy low lerls, with creeping rootstocks, "rect stems sparingly hranched albore, with elosely sessile ovate thin and transtersely veined learen, aud greenish-yellow drooping flowers, on slender terminal pertuncles, solituy or few in an umbel. (Name from $\delta i s$, domble, and $\sigma \pi \circ \alpha^{2}$, secd, in allusion to tle 2 orules in e:telı cell.)

1. D. lanugiròsum, Bentl. \& Ilook. Leaves ovate-1)lumg, taperminted, rombled or slightly heart-slaped at base, closely semsile, downy be-

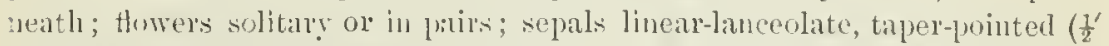
long), soon slueading, twiec th length of the stamens, greenish; style smooth: stigmas 3. (I'rusartes launginosi, Don.) - Rich woods, Western X. Y. to Va. and Ga, west to $\mathrm{Ky}$, and 'Teun. May.

\section{CLINTÒ I A, liaf.}

Perianth of is separate sepals, hil haped, lily-like, deciduons: the 6 stamers inserted at their base. Filaments long and thread-like; anthers linear or oblong, extrorsely fixed by a point above the bise, the cells oponing down the margins. (Wary ovodl-oblong, 2-3-celled; style long; stigmas 2 or 3, or in oirs muterl into one. Berry few - many-seeded. - Short-stemmed perennials, with slencler 'reeping rootstocks, bearing a naked perhunde slutherl at the base by the stalks of $2-4$ large oliong or oval ciliate leaves; fowers rather large, mmbelled, rawely single. (Dedicated to De Iritt rlintom.)

1. C. boreàlis, Raf. Scape aul leaves 5-8' long; umlef 3 -ti-flureped; periantl greenisle-yellow, snmewhat downy ontside $\left(3-4^{\prime \prime} \operatorname{long}\right)$; berry oroid, lilue; mewles $20 \mathrm{~m}$ more. - Cold moist woorls, Lal). to N. C., went to Minul.

2. C. umbellàta, 'Tor'r. Flower's half the size of the last, white, speckled with green or purplish dots; mbel many-flomered; berry glolular, black; wules 2 in each cell. - Rich wools, in the Alleghanies from N. Y. to Ga.

\section{U V U L À R I A, L. Bellwort.}

Perianth narrowly bell-slaper, lily-like, decidnous; the 6 distinct sepuls sipatulite-linceolate, acuminate, obtnsely gibtous at base, with a deep lourybeatring groove within borderer on ench sile by a callus-like ridge. Sitamens much shorier, harely adherent to tledr hase; anthers linear, much longer thiu the filanents, adnate and oxtrorse, lnt the long narow cells opening laterally. Style deeply 3-cleft; the divisions stigmatic along the inne sicle Capsulc

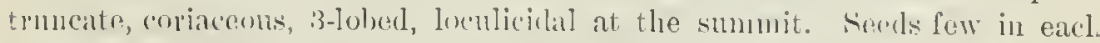
:all, olorviı, witl a thin white aril. - Stems rather low, turete, from a short "ootstock witl Hesly pouts, laked or sealy at base, forking alowe, heariug oblong perfoliate flat and nembranaceous leaves witlı smoreth malroins, aur

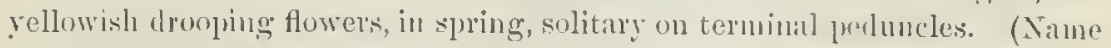
"froun the fluwers langing like the uvula, or palate.")

1. U. perfoliata, I. Filucous throughont, $\frac{1}{2}-11^{\circ}$ high, with $1-3$ leavea below the fork ; iecress glulurous, oblong- to ovate-lanceolate, acute; periumlisegments gromulur-pubesent within (8-16" long); stumens shorterthren the styles;

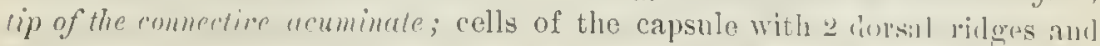
2-beaked at the anex. - lich woorls, N. Eng. to the l)akitas, and sonthward. 
2. U. grandiflora, Snith. Yellowish-green, not glaucous; stem naked or with a single leaf below the fork; leaves whitish-pubescent beneath, usualls sonewhat acuminate; periunth-segments smooth within or nearly so $\left(12-18^{\prime \prime}\right.$ loug); stumens exceeding the styles, nltusely tipped; capsule obtusely lobed (U. flava, simith.) - Rich woods, Canada to Ga., west to Minu. and Mo.

\section{O A K ESIA, Watson.}

Flowers resembling those of Urmlaria, hut the segments olstuse or acutish carinately giblous and withont ridges within. Capsule membranous, elliptical, acutish at each end or shortly stipitate, triquetrons and acutely winged, very tarlily dehiscent. Seeds globose, with a very tumid spongy rhaphe.Sten acutely angled, from a slender creeping rootstock, with sessile clisping leares scahrons on the margin, and 1 or 2 flowers teminal on slender peduncles hat soon appearing opposite to the leaves by the growth of the branches. (Dedicated to Irillium Oukes.)

1. O. sessilifòlia, Watson. I,eaves lance-oblong, acute at eath "eud, pale, glaucons leneath, sessile or partly clasping; sepals $;$ - 12" loug; anthers bhtuse; capsule shurt-stipitate, $6-10$ "long. (Crularia sessilifolia, L.) - Low woots, N. Brumswick to Fla., west to Mimm., Neb. and A trk.

2. O. pubérula, Watson. Slightly pulberulent; leaves bright green both sidtes and shining, wal, mostly rounten at base, with rougher edges; stylen separate to near the base, not exceeding the acute anthers; capsule not stipitate, 10-12" long. (Uvularia puberula, Michx.) - MLountaius, Ýa. to S. C.

\section{ER Y T H R Ò N I M, L. Dog N-Tooth Violet.}

l'erianth lily-like, of 6 distinct lanceolate sepals, recurvel or spreading ahore, lecidnons, the 3 inner usually with a callous tooth on each sile of the ureect base, and a groore in the middle. Filaments 6 , awl-slaped; anthers chlong-linear, continuing erect. Style elongated. Capsule oborate, (ontracted at hase, 3-ralved, loculicidal. Seeds rather numerous, orojil, witl a loose membranaceous tip. - Neally stemless herbs, with two smooth and shining flat leaves tapering into petioles and sheathing the base of the commonly one-flowered scape, rising from a deep solid-scally bulb. Fluwers rather larere, nordling, in spring. (The Greek name for the purple-flowered Europeall species, from épuepós, rerl.)

1. E. Americànum, Kier. (Yellow Ahner's-tonict.) Seape $6-9^{\circ}$ ligh; leaves elliptical-lanceolate, pale green, mottled with purplish and whitish and conmonly minutely dotted; periunth light yellon, often spotterl near the lase $\left(10-20^{\prime \prime}\right.$ long); style club-shaped; stigmes united. - Rich gromnd, N. Brunswick to Flito, west to Minm, and $\lambda$ rk.

2. E. álbidum, Nutt. (W'nte Don's-тооти Vıolet.) Leaves elliptical-lanceolate, less or not at all spotted; perianth pinkish-ulhite: inner divisions toothless; style more slender except at the apex, hearing 3 short spreading stigmes. - lich ground, N. Y. to N. J., west tu Minn. and Kan.

3. E. propúllans, Gray. Offilont arising from the stem, near the middle: leaves smaller and more acuminate; fomers bright ross-entor, vellowish at hase $\left(6^{\prime \prime} \mathrm{long}\right)$; style slender: stigmas united. - In rich ssil, Minul. and Ont. 


\section{LI I U M, L. LILI.}

Perianth funmel-form or bell-shaped, colored, of 6 distinct sepals, spreading or recurved above, with a honey-bearing furow at the base, decicluous; the 6 stamens somewhat arhering to their lases. Anthers linear, extrorsely attached near the middle to the tapering apes of the long filament, which is at first included, at length versatile; the cells dehisceut by a lateral or slightly introrse line. Style elongated, somewhat club-shaped; stigma 3-lobed. Capsule oblong, containing wamerous flat and horizontal (derressed) soft-coated seeds densely packed in E rows in each cell. Bulbs scaly, producing simple stems, with numerous alternate-scattered or whorled narrow sessile leaves, and from one to several large and showy flowers; in summer. (The classical Latin name, from the Greek $\lambda \in l \rho เ o \nu$.

* Flovers erect, the sepals nurroured below into claus; bulbs not thizomatons.

1. L. Philadélphicum, I. (Wild Oraxie-Ren Lily. Woon Lrur.) Stem 2-30 high ; lrures lincui-lunceolute, whorled or scattered; flowers (2-4' long) 1-3, open-bell-shaped, roldish-oiange spotted with purplish inside; the lanceolate sepals not recurved at the summit; bulb of thick fleshy jointed scales. - Dry or sandy ground, N. Ling. to N. C., west to Minn. and Mo.

2. L. Catesbàei, Walt. (Sortuerx REs Inx.) Leares linear-lanceolute, scuttered; flower solitary, open-bell-shaped, the long-clawed sepals wary on the margin and recurved at the summit, scartet, spotted with clark purple and yellow inside; bulb-scales thin, narow ind leaf-bearing. - Pine-barrens, N. C. to Fla., west to Ky. and Mo.

* Flacers nordeling, the sepuls sessile; bulbs rhizomatous.

3. I. supérbum, L. ('TunK's-CAP LiLr.) Stem 3-70 high; lower leaves whorled, lanceulate, pointerl, 3-nerved, smooth; flowers (3' long) often many $(3-20$ or 40) in a prramidal raceme; sepols strongly recolute, bright orange, with numerous dark pmrple spots inside. - Rich low gromuls, $x$. Brunswick to Ga., west to Minm. and Mo.

4. L. Canadénse, I. (WIn, Yellow Lilr.) Stem 2-70 high; leaves • remotely wholed, lanceolate, strongly 3-nerved, the margins and nerves rough; flowers fow $\left(2-3^{\prime}\right.$ long $)$, long-pedmeled, oblong-bell-shaped, the soprls repcrired-spreading abore, yellow or orange, msually spotted with brown. - Moint meadows and bogs, N. Brunswiek w Ga., west to Minn. and Mo.

5. L. Gràyi, Watson. Stems $2-3^{\circ}$ high; leaves in whorls of $4-8$, lan ceolate, acute or slightly acuminate, smooth; flouers 1 or 2 , nearly horizon 'al, the sepuls ( $1 \frac{1}{2}-2 \frac{1}{2}$ ' long) but little spreading above the ruther broad base. ather abruptly acute, deep reddish orange, thickly spotted within. - Peaks of otter, Ya, and southward in the mountains to N. C.

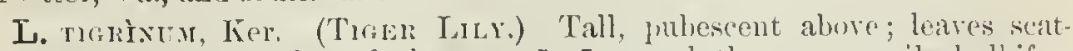
terei, narmwly lanceolate, latk green, 5-7-nervel, the upper axils bulbifer" ous; flowerin linge, resembling those of L. superbun. - An escape from gardens. (Irl. from F. Lsia.)

\section{M E D E L A, fronor. Indax Cucturer-root.}

Perianth recurverl, the 3 sepals and 3 petals oblong and alike (pale greenishrellow), deciduons. Stamens 6 ; anther's shorter than the slender filmments,

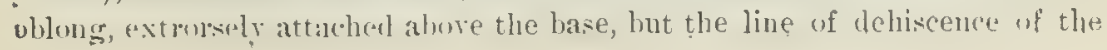


closely contignous parallel cells lateral or slightly introrse. Stignas, or styles, stignatic dom the npper sille, recurved-cliverging from the glubose orary, long and thead-fom, flecihous. Berry globose (dark purple), 3-celled, fewsceded. - I peremial herb, with a simple slender stem ( $1-3^{\circ}$ high, elothei with floceulent and deeiduons wol), rising from a horizontal aud tuberons white rootstoek (which las the taste of (ucmmber), bearing near the miclile a whorl of 5-9 oborate-lanceolate and pointed, sessile, lightly parallel-ribbed and netted-reiny, thin leaves; also mother of 3 (rarely 4 or 5 ) much smallez wrate ones at the top, subtending a sessile umbel of small reenred Howers (Namel after the sorceress 1/edea, for its supposed great medicinal virtues.)

1. M. Virginiàna, L. - Rich damp woods, N. Eng. to Minn., Ind., and southward. June.

\section{TRÍILI U M, L, YTAKe Robin. Birtiroot.}

Sepals 3, lanceolate, spreading, herbaceous, persistent. Petals 3, larger, withering in age. Stamens 6 ; anthers linear, on short filaments, aduate, nsually introrse; the eells opening down the margins. Stigmas sessile, aw shaped or slender, spreading or recurved above, persistent, stigmatic down the inner side. Orary 3-6-angled. Berry orate, nsually 6-angled or -winged, 3-celled (purple or red). Seeds orate, horizontal, sereral in each eell. - I.ow peremint heros, with a stont and simple stem rising from a short and pratmorse tuber-like rootstock, naked, bearing at the summit a whorl of 3 anple, commonly broadly orate, more or less ribhed but netted-reined leaves, and a terminal large flower; in spring. (Name from triplum, triple; all the parts being in threes.) - Monstrosities are not rare with the ealyx and sonnctincs letals clanged to leares, or the parts of the flower increased in numbet.

\section{* Oeary and finit 6-angled and more or less winged.}

+ Flower sessile; the rery broad comective produced beyond the anther-rells.

1. T. séssile, I. Leares sessile, orote or rhomboidal, ar'nte, often blotched - or spotted; sepals spreading; sessile peluls erect-spmeding, narrowly lancer(ulate or oblaneeolate, dark and dull purple, varying to greenish, fruit grlobose, 6" long. - Moist woods, P'enn. to. Filı, west to Mimn. and Mrk.

2. T. recurvàtum, Beck. Lecues contructed ut the buse into " petiole,

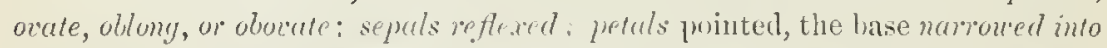
a clace, whloug-lanceolate to wrate, dink purle; fruit ovate, strongiy winger ahore, 9" long. - lichl worls, Ohio and Ind. to Minn. and Ark.

+ + Floner pedicelled; ronmediere nurrou", not produced; leares subsessile.

+ + Pedicul longer than the flower; filtment shorter than the anther.

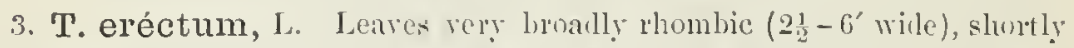
acuminate; pedicel (1-3' longr) urually more or less inclined or declinato;

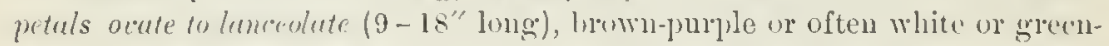
ish or pinkish; stances cyualling or dxceeding the slont distinct spreartmy or recureel sfigmus: frut ovate, 1' long, redlish. - lich woods, N. Scotia to N. C., West to Minn. ind Mo. Flowers ill-scented.

4. 'T. grandiflorum, Silisl), leares less broarlly rlombie-orate (1 $1 \frac{1}{2}-4$ '

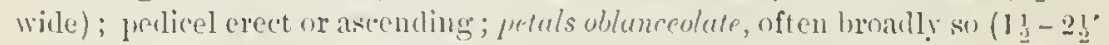
long), white turning rose-color or marked with green; stanens with sumt 
filanents (persistently green about the fruit) and anthers, exceeding the cory siender erect or sulwert and someulut cohrome stigmas; frnit globose, $\frac{1}{2}-1$ " long. - Rich wouds, I't. to X. C., West to Mimm. and Mo.

$+1+$ Pedicel short, recured or strongly declinate; filuments slender, alout equalling the anther.

5. T. cérnuurn, L. Leaves very broally rhombic-ovate (2-4' broad); petals white or pink, ovate- to oblong-lancenlate $(6-12$ "long), wav', recurvedspreading; stamens with short antlers, sherter than the stout rec'nred dis. tinct stigmas; fruit orate. - Moist woods, N. Eng. to Minn., sontl to Ga. and Mo.

* * Oeary and fruit 3-lobed or angled, not winged; filaments stender, about equalling the anthers; pedicel erect or inclined; leaves petiolate.

6. T. nivàle, Rirklell. (1) Wлиғ Wnite 'T.) śmall (2-4' high); leaces mal or orute, oltuse $\left(1-2^{\prime}\right.$ long); prtals oblong, obtuse $\left.(6-15)^{\prime \prime}(1) 1 \mathrm{~g}\right)$, white, scarcely wary, spreatling from an erect base, equalling the peduncle; styles

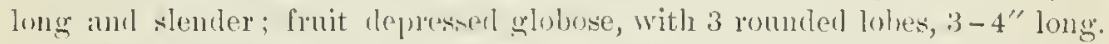
- Rich woods, W'. l'mon. antl liy. to Minn. and Iowia.

7. T. erythrocárpum, Mielix. ('АIxTED 'T.) Leuces orule, tuper.

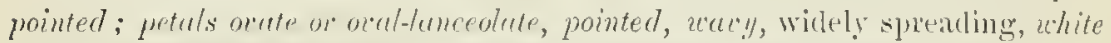
fuinted with purple stripes at the buse, shortex than the peduncle; fruit broal wate, obtuse, $7-9$ "long. - Cohl damp wouds aud logs, X. Brunswick to Ga. west to Wisc. and Mo.

\section{H E L Ò N I A S, I.}

Flowers perfect. l'eriumth of 6 spratulate-oblung purple sepals, persistent,

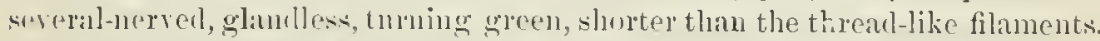
Anthers 2-celled, rommlish-uval, hlue, extronse. Sityles revolute, stimnatio

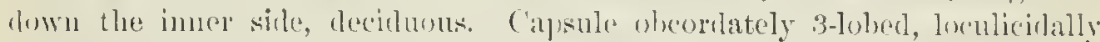
3-valved ; the valves divergently 2-lohed. Serds many in each ('oll, linear, with a tipering appendige at buth endk. - A smonth pelennial, with many oblongr-

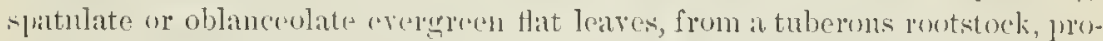
luring in early spring a stont loblow sparsely bracteate scape (1 - 20 high 1 ), sheathed with broal bracts at the hase, and terminated by a simple and shont dense raceme. Bracts obsolete: pedicels shorter than the flowers. (Name

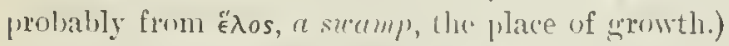

1. H. bullata, I. - Wet places, I'en11, and N. J. to V'a. ; rare and low.al.

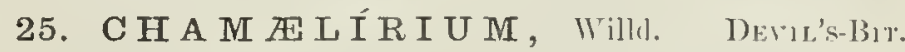

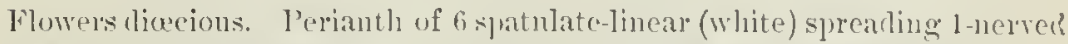
sepals, withering-persistent. Filaments and (white) anthers, as in llelonias; fertile flowers with rudimentary stamens. Styles linear-hul,-slapeel, stigmatic alomg the inner sille. Capsule orofil-oblong, not loberl, of at thin tex-

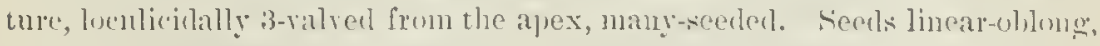

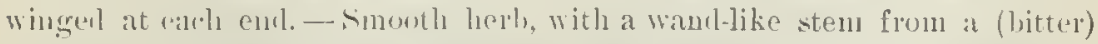
thick ans! alompt tuherom romstoxk, terminated by a long wanl-like spiked

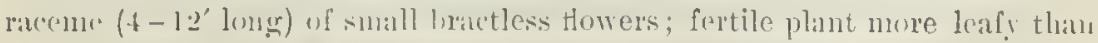
the staninate. leaves llat, lincenlate, the lowest spatulate, tapering intu a 


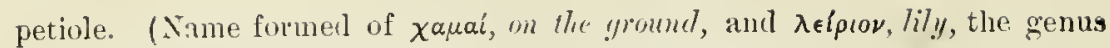
having heen founded on a dwarf undeveloped specimen.)

i. C. Caroliniànum, Willd. (BLAzixG-írı.) sitem 1-40 high. (C. lutemm, (iray.) - Low grounds, N. Fing. to Gil., west to Neb. and Ark. Jnne.

\section{X ER O P II Ý L L U M, Nielx.}

Flowers perfeet. I'erianth willely sprealing; sepals petal-like (white), oval. distinct, without glands or claws, 5-7-nerved, at length withering, about the length of the awl-shaped filaments. Inthers 2-eelled, short, extrorse. Styles thread-iike, stigmatic down the inner side, persistent. Capsule globnlar, 3-lobed, obtuse (small), locnlieilal; the valves bearing the partitions. Seeds 2 in each cell, collateral, 3-angled, not margined. - Herb with the stem simple, $\mathrm{l}-4^{2}$ high, from a thick tuberous rootstock, bearing a simple dense bracteate racene of showy flowers, and thickly beset witl neelle-shaped leaves, the upper recluced to bristle-like braets; those from the root rery many in a dense tuft, reclined, a foot long or more, $\mathrm{l}^{\prime \prime}$ wide below, rough on the margin, re-

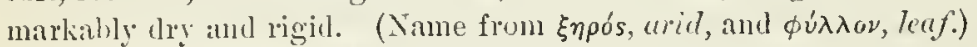

1. X. setifòlium, Michx. Stem $1-t^{\circ}$ high. (X. asphodeloides, Nutı.) - I’ine-barrens, N. J. to Ga. Juue.

\section{TOF I E L D I A, Juđson. Fuse Aspionet.}

Flowers perfect, usually with a little 3-bracted involucre muderneath. Per anth more or less sureading, persistent; the sepals (white or greenish) eoncave, ollong or oborate, without claws, 3-nerved. Filaments awl-shaped; anthers short, inuate or somewhat introrse, 2-eelled. Styles awl-shaped; stigmas terminal. ('ipsule 3-angular, 3-partible or septicilal ; cells manyseeded. Seeds oblong, horizontal. - Slender pelennials, mostly tufted, witl short or ereeping rhizomes, aud simple stems leafy only at the base, bearing small flowers in a cluse laceme or spike. leares -ranked, equitant, linear, grass-like. (Nomed for Mr. Tofield, an English botanist of the last century.) * Clabrons; perlicels solilury, in a short rareme or head; seeds not appendaged.

1. T. palústris, 11 uson. Seape leafless or nearly so $\left(2-6^{\prime}\right.$ high $)$, slen der, hearing a glohnlar or ollong heal or short raceme of whitish flowers; leares tufted, $\frac{1}{2}-1 y_{3}^{\prime}$ long. - L. Superior, and northward. (Lu.)

* Stem and inforeserme pulvescent; pedirels fascicled in threes; seeds candate

2. T. glutinòsa, Willıl. Stem $\left(6-16^{\prime}\right.$ highlı) and pedicels very glulinus, with dar glands; leaves linadly linear, short; jeriantl not becoming rigirl; capsule thin; seeds witlı a contorted tail at each end. - Moist grounds, Maine to Nlim, and northwarl: also sonth in the Alleghamies. June.

3. T. pùbens, $\Lambda$ it. Stem $\left(1-3^{\circ}\right.$ higrh $)$ and pedicels romglemed with mimute glunds; leaves longer and numowel' ; perianth rigid alout the firm capsule; seeds with a slurt white appendage at earh cud. - l’ne-harrens, N. J. to Fla. and Ala. July.

\section{N A R T H E I U M, Moehring. BoG-Aspilodis..}

Sepals 6, linen-lanceolate, !ellowish, persistent. Filaments 6, woolly ; anthers linear, introrse. Capsule cylindrieal-oblong, attennate npward aud bearing 
the slightly loherl sessile stigma, loeulieidal, many-seeded. Seeds ascending, appenclager at each end with a long bristle-form tail. - Rontstock creeping, hearing linear equitant leaves, and a simple stem or seape, terminatel by a simple dense bracteate raeeme; pedieels bearing a linear bractlet. (Nane an anagram of $A$ thericum, from à $\nu \theta \dot{\epsilon}$ peros, supposed to have heen the $A$ sphodel.)

1. N. Americànum, Ker. Stem $1^{\circ}$ high or more; leaves $1^{\text {" wide, }}$ 7 -9-nerved; raeeme dense $\left(1-2^{\prime}\right.$ long); perianth-segments narrowly linear $\left(2-21^{\prime \prime}\right.$ long), seareely exceeding the stamens. (N. ossifragum, var. Ameri; canum, Gray.) - Sandy bogs, piue-barrens of N. J. June, July.

\section{MELÁ NTHIU M, Lim.}

Flowers moncecionsly polygamous. Perianth of 6 separate and free widely spreading somewhat heart-shaped or oblong and halberd-shaped or oblanceolate sepals, raised on slender claws, crean-colored or greenish, the base marked with 2 approximate or eonfluent glands, or glandless, turning greenish brown and persistent. Filaments shorter than the sepals, alhering to their claws often to near the summit, persistent. Anthers heart-shaped or kidner-shaped, confluently 1-eelled, shield-shaped after opening, extrorse. Styles 3, awl-shaped, rliverging, tipped with simple stignas. Cipsule ov vid-conieal, 3-lobel, of 3 inflater membranaeeous earpels unitel in the axis, separating when ripe, and splitting down the inner edge, several-seerled. Seeds flat, hroadly winged. Stems tall and leafy, from a thiek rootstock, roughish-downy above, as well as the open and ample pyramiltal panicle (composed chiefly of sinple racenes), the terminal part mostly fertile. Leaves linear to oblaneeolate or oval, not

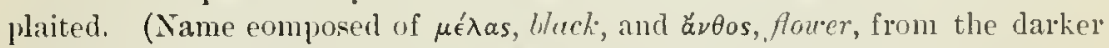
color whieh the persistent perianth assumes after blossoming.)

* Sepals with a conspirnous doulle-ylund at the summit of the clau.

1. M. Virgínicum, I. (B1'm-1.Lowr.) Stem 3-50 high, leafy, rather slender; leaves linear ( $4-10^{\prime \prime}$ wide); sepals flat, orate to uhlong or

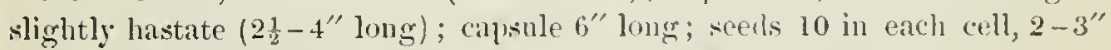
long. - Wet meadows, N. Ling. to N. C., west to Ihinn. aud 'Tex.

2. MI. latifolium, Desrouss. Leaves more oblancedate, often ' 2 broal; sepals mndulate (2-3" long), the rery narow claw nearly efpualling the orbichlar or orate blacle; capsule $6-8^{\prime \prime} \operatorname{long}$; styles more slencler ; seerts $4-8$ in each cell, $3-4^{\prime \prime}$ long. (M. xacemosum, Michx.) - WT. Conn. to s. C.

$$
\text { * * Seprils uhlurecolate, without glands. }
$$

3. M. parviflórum, Watson. Stem rather slender $\left(2-5^{\circ}\right.$ high $)$, sparingly leafy, naked above; leares oval to oblaneeolate (2-4' wide), on loug petioles; sepals $2-3^{\prime \prime}$ long, oblanceolate or spatulate, those of the sterile flowers on claws; stamens very slort ; eapsule 6" long; seeds $4-6$ in each eell, 4 " long. (Veratrum parviflorum, Mich.x.) - lı the Alleghanies. Va. to s. C.

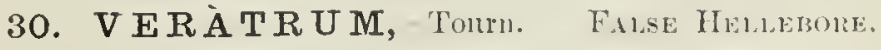

Flowers monceiously polygamous. Perianth of 6 spreating and separate obovate-oblomg (sreenish or brownish) sepnls, more or less contracter at the hase (but not clawed), nearly free from the orary, not gland-bearing. Filaments free from the sepals and shorter than they, reenring. Anthers, pistils. 
frnit, ete, near.y as in Mfelanthium. - Somewhat pulescen peremnials, with simple stems from a thickened base producing coarse filrous roots (very poisonous), 3-ranked, plaited and strongly veined leares, and ratemed-panicled dull or dingy flowers; in summer. (Name from rere, truly, and ater, llack.)

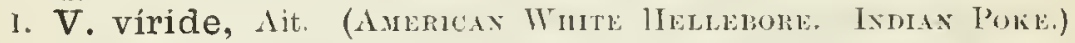
Stem stont, cery leafy to the top $\left(2-7^{\circ}\right.$ lighli); leures broudly ocal, printed, sheuth-rlasping; panicle pyramidul, the dense spike-like rucentes sprealing: periunth yellowish-green, moderately spreating, the segments cillute-servilate ovary glabrous; eapsule many-seeded. - Swanps and low grumds, common.

2. V. Woódii, lobbins. Stem stender, sparingly leufy ( $2-5^{\circ}$ ligh $)$; leures sblanceolute, only the lowest sheathing; punicle rety nurvou; periunth greenishpurple, with entire seyments; orary tomentosi, soon glabrate; capsule few-seeded. - Woods and hilly barrens, S. Ind. to Mo.

\section{STENÁNTHIUM, Gray.}

Flowers polygamons. Perianth spreading; the sejals narrowly lanceolate, tapering to a point from the lroaler hase, where they are united and colerent with the base of the orary, not gland-hearing, persistent, much longer than the short stamens. Anthers, capsules, ete, nearly as in V'elatrum. Feeds nearly wingless. - Smooth, with a wand-like leafy' stem from a bullous hase, long and gralss-like comrluplicate-keeled leaves, anrl numerons sull flowers in conpumul racemes, forming a long terminal panicle; in summer. (Name composed of

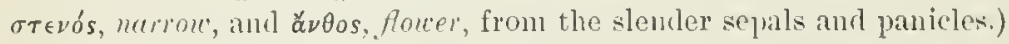

1. S. angustifolium, Gray. Stem leafy $\left(3-4^{\circ}\right.$ high), rery slender; leners $2-3$ " broad: pancle elongated, nearly simple, very open, with sleuler flexuons lorarches; flowers nearly sessile or the fortilo on short pedicels; sejalls lincalplancenlate (white), 2-3" "lomg; crtpinle strongly reftexed, warrowly ulilong-orate, with spreading beaks. - In the Alleghanios from Vat to s. C.

2. S. robústum, Watson. Ristrulling the last; stem stent, leafy, erect (3-50 high); lenres $4-10^{\prime \prime}$ broud ; panicle or racemo often 20 long, freguently

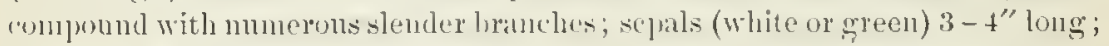
cupsule erert, orate, with recurred beaks. - l'enn. tos.. C., (l)ho and 'Tenu.

\section{ZYGADE N U S, Michx.}

Flowers perfect or polygamous, l'erianth withering-persistent, spreading; the petal-like whlomg or orate sepals I - 2-glamlular near the more or less nar rweel but not unguiculate lase, which is either free, or united and coheren. vith the base of the ority. Stamens free from the sepals and alout their length. Anthers, styles, and calpule nearly as in Mclauthimu. Seets augled, mucly at all margined. - Very smouth and somewlat gliducolls perennials, with simple stems from creeping rootstocks or coated bulhs, linear leaves, and rather lange

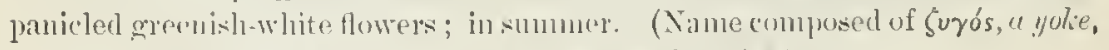

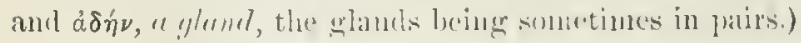

* Cilunds on the prinuth comspicuous.

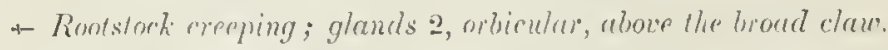

1 Z. glabérrimus, Michx. Stemls $1-30$ high : leaves grass-like, (hannelled, conspicnonsly nerved, clongated, tapering to a peint ; panicle preramidal, 


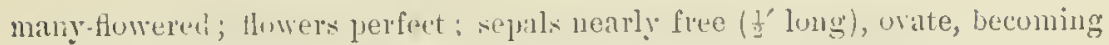
lance-ovate, with a short claw. - Cirissy low grounds, Fa. to Fla. and Ala.

+- + Rout bulbous; glands cocering the base of the sepuls.

2. Z. élegans, l'ursh. Stem $1-3^{\circ}$ high; leaves flat, cariuate; raceme sinple or sparingly branched and few-flowered; bracts vate-lanceolate; base of the periatlu colerent with the lase of the owary, the thin ovate or obovate sejals matred with a large obcordate gland, the inner abruptly contracted to 8 . bluad claw. (\%. glatcus, \utt.) - N. Fug. to N. Ill, Miun., and westward.

3. Z. Nuttallii, Gray. Like the list; raceme rather lensely flowered, witlı narrow bracts; periantl free; sepals with an ill-(iefined gland at base, nut at a!l claned; seeds larger (3" long). - Kam. to 'Tex. and Col.

* G Gunds of the periunth obcure ; perianth small, rotate; bull somewhat fibrous.

4. Z. leimanthoides, Grạ. Sitem $1-4^{\circ}$ lighl, slenler; leaves narrowly linear ; Huwers small ( 4 " in dianeter) and unnerous, in a few 'romded panieled racemes; only a yellowish spot on the contracted base of the divisions of the free periantl. - Luw grumbls, pine-barrens of X. J., to Ga.

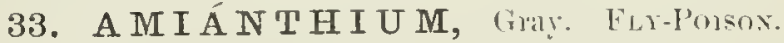

Flowers perfect. l'eriuntl willely spreadiug; the distinct and free petal-like (white) sepals oval or oburate, without claws or glands, persintent. Filaments rapillary, equalling or exceeling the pretiantl. Anther's, capsules, eté, nearly als in Melauthinn. Sityles thread-like. Seels wingless, blulung or linear, with a loose (oat, $1-4$ in eacn cell. - Glalirons, with simple stems from a bulbous base or conted lull, scape-like, few-leared, terminated by a simple dense raceme of hand some flown's, turning greenish with age. Icares linear, lieeled, grass like.

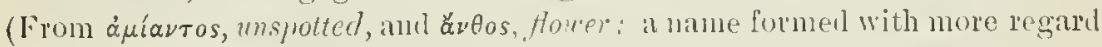
to euphony than to good construction, alluding to the glandless perianth.)

1. A. muscæetóxicum, Glạ: (Fur-l'nisox, Leares broully linear,

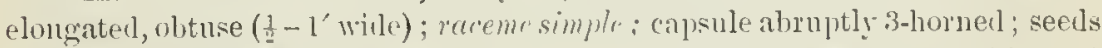
ublong, with a Heshy red coat. - (1)pen works, X. J. to Fla., west to Ky. and Alk. Inne, only.

\section{ORDER 11\%. PONTEDERI I CEAS. (PICKRRL-WEED FAMITY)}

A quatic herbs, with perfect more or less invegular flowers fiom a spathe: the petal-like 6-merous perianth, free from the 3-relled orary: the 3 or 6 mostly unequal or dissimilar stemens inserted in ils throat. -. Perianth witl He 6 divisions colored alike. imbricrled in 2 rows in the hud, the whole together sometimes revolute-coiled after llowering, then withering awa!, or the base thickened-persistent and enclosing the fruit. Inthers introwse. Ovules anatropous. Style 1 ; stigma 3-lober no 6-toothel. Fruit a perfectly or incompletely 3-celled many-serded capsule, or a 1-celled l-secded ntricle. Embryo slender, in floury albumen.

1. Pontederia. Thike numy-fowerel. Perianth 2-lipper, its Anshy jelsistent base en. Chosing the 1-sidedert utricle. Stamens 6.

2. Heteranthera. Fpatle 1 -few-fluwered. Perianth salver-shapet. Stanems 3 . Cap sule nans'-scelted. 


\section{PONTEDER A, L. Pickerel-wed.}

Perianth fumnel-form, 2-lipped; the 3 upper divisions united to form the 3 . lobed upper lip; the 3 lower spreading, and their claws, which form the Iower part of the curving tube, more or less separate or separable to the base; after Howering the tube is revolnte-coiled from the apex downward, and its fleshythickened persistent lase encloses the fruit. Stamens 6 ; the 3 anterior longexserted; the 3 posterior (often sterile or imperfect) with very short filaments, unequally inserted lower down; anthers versatile, oval, blue. Ovary 3-celled; two of the cells empty, the other with a single suspended ovule. Utricle 1. celled, filled with the single seed. - Stont herbs, growing in shallow water, with thick creeping rootstocks, producing erect long-petioled mostly leartshaped leares, and a l-leaved stem, bearing a spike of violet-blue ephemeral flowers. Root-leaves with a sheathing stipule within the petiole. (Dedicater to Pontedera, Professor at Padua at the beginning of the last century.)

1. P. cordàta, L. Leaves arrow-heart-shaped, blunt, or sometimes triangular-elongated and tapering and scarcely cordate (var. AxGUSTIFòliA, Torr.) ; spike dense, from a spathe-like bract; upper lobe of perianth marked with a pair of yellow spots (rarely all white); caly $x$-tube in fruit crested witl 6 touthed ridges. - N. Scotia to Ela., west to Miun. and Tex. July-Sept.

\section{HETEANTHER A, Rniz \& Pav. Mud-Plaxtaix.}

Perianth salver-form with a slender tube; the limb somewhat equally 6 . parted, ephemeral. Stamens 3 , in the throat, usually unequal; anthers erect. Capsule 1-celled or incompletely 3-celled by intrusion of the placenta, manyseeted. - Creeping, floating or submerged low herbs, in mud or shallow water, with a 1 -few-flowered spathe bursting from the sheathing side or base of a

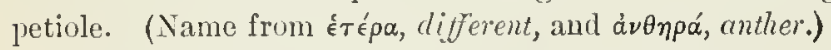

* Stamens unequal; 2 posterior filaments with ovate yellow anthers; the other longer, with a larger oblong or sagittate yreenish anther; capsule incompletely 3-celled ; lcares rounded, long-petioled; creeping or floating plants.

1. H. renifórmis, Ruiz\& Par. Leaves round-kidney-shaped to cordate and acute; spathe 3-5-flowered ; flowers white or pale blue. - Conn. to X..J., west to 111. and K. Kinn., and southward. (S. An.)

2. H. limòsa, Valıl. Leaves ohlong or lauce-oblong, obtuse at both ends; spathe I-flowered; Howers larger, blne. - Va. to MIn. ...id La. (S. Am.)

* Stamens alike, with sagiltate anthers; capsule 1-celled, with 3 parietal pla. centu, leaves lineur, translucrnt, sessile; submerged grass-like herbs, with only the flowers reaching the surfuce.

3. H. graminea, Vahl. The slender branching stems clothert with leaves and bearing a terminal 1 -flowered spathe (hecoming lateral); flowers small, pale yellow, with a very long thread-like tube. (Schollera graminifulia. Willd.) - N. Eng. to N. C., west to Minn. and E. Kian.

\section{Order 118. XYRIDÀCeAe. (Yeldow-eyederass Family.)}

Rush-tike lierts, with equitant leaves shealhing the breve of a nuked scape, which in teminated by a head of perfect B-rmilions flowers, with extrorso 
unthers, gumaceous caly.x. und a regular colored corolla; the 3-valied moslly 1-celled rapsule conlaining several or many orthotropous seeds with "minute embryo at the aper of fleshy albumen.

\section{XYRIS, Gronor. Yhlow-eyen Grass.}

Flowers single in the axils of coriacents sale-like luacts, which are densely inbricated in a head. Siepals 3 ; the 2 laterat ghumelike, boat-shaped or keeled ant persistent; the anteriol one latger and memblanacens, enwarlphing the corolla in the bucl and decistuous with it. J'etals 3 , with claws, which cohere more or less. Fertile stancus :3, with linear anthers, inserted on the claws of the petals, alternating with 3 sterile filaments, which are cleft and in our spe('ies plumose or bearded at the apex. Style 3-cleft. Capsule oblong, free, 1celled, with 3 parietal more or less projecting placente, 3-valved, many-seedled. - Florrers yellow, producerl all stmmer. Onrs apparently all perennials.

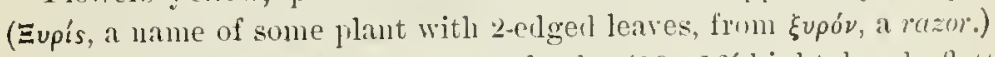

1. X. flexuosa, Inhl. Ficape slenter $\left(10-16^{\prime}\right.$ ligh $)$, barely flattened at the summit, often from a hulhous base, rery smooth, much longer than tho narrowly linear leaves, both commonly twisted with age; heal roundish-ovoid $(3-4$ "long); laterul sepuls oblong-lanceolate, fincly ciliute-scrurions on the wurrou wingless kerl, 1t:ually with a minute bearlerl tuft at the apex, shorter than the bract. - Sandly or peaty bogs, Mass. to Fla., west to Minn. and Mo.

Var. pusilla, Cray. Sinall anl very slencle seldom twisted, $2-9^{\prime}$ high, the base not bulbous; heal 2-3" long. - White Mts. to l'enn., west to L. superior.

2. X. tórta, Smith. Scape terete, with one sharp edge, slender, $9-20^{\prime}$ high, from a lark hullous base, and with the linear-filiform rigid leares becoming spirally twisted ; hearl owoil, hecoming spindle-shapert, ol obloug and acute $(5-9 "$ long); sepals exceeding the lmact; luteral sopuls umgerl on the heel and finged above the middle. - Pine batrens, in dry sind, N. J. to Flit., 'Tex. and Ark.

3. X. Caroliniàna, Walt. Scape flattish, 1-angled below, 2-erlgerl at the summit, smooth, $\frac{1}{2}-2^{\circ}$ high, the base hardly luthlbuts; lerares linear-sucord. shaped, flut, 2-4" broad; hearl glubular-ovoid (5-7"long); luteral sepals otscurely lacerate-finged above on the ninged leel, rather shorter than the bract. - Sandy swamps, near the coast, Mass. to Fla.

4. X. fimbriàta, lill. Sicupe somerhat angled, 2-erlged alore. rough

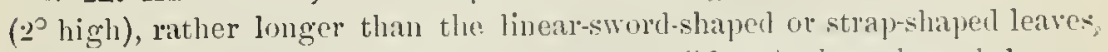
the base not buthous; heal ohong-ovate $\left(6-10^{\prime \prime}\right.$ long); lateral sepuls lancert. late-linear, nearly tuice the lenyth of the bract, above the middle conspiruously jiinged on the wing-margined keel, and eren plumose at the srmmit. - Pine-bur. reus, N. J. to Fla. and Tex.

\section{Order 119. MAYACEAE. (MATAC. Famm.)}

Moss-like aquatic plants, lensely leafy, with narromly-linear sessile pellucid leaves, axillary nalien perluncles terminated by a solitary perfect 3 . androus flower, herbaceous calyx, white coroila, and a 3-valved 1-celled several-sceled capsule. 
1. M A Y À CA, Aublet.

The only geuns. Perianth persisteut, of 3 herbaceous lanceolate sepain, and 3 ohorate petals. Stanens alternate with the petals. Ovary with 3 pari. etal few-ornled placentar style filiform; stigma simple. - Creeping or float. ing in shallow water; the leaves I-nerved, entire, notched at the apex; the perluncle solitary, sheathed at base. (1n aboriginal name.)

1. M. Michauxii, schott \& Endl. Peduncles not mucl exceeding tho Teaver, norlding in fruit. - Ya. to Fla. and 'Tex.

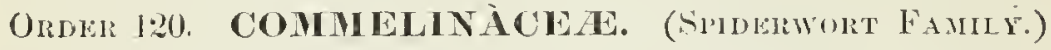

Merbs, with fitrous or sonetimes thickened roots, jointed and often liranch. ingleufy stems, and chieply perfect and 6-androus, often irregular flowers, with the periunh free from the 2 -3-celled ocury, and having a distinct culye cent corolle; viz., 3 persistent commonly herbaceous sepals, and : petals, ephemeral, deenying or deciluous. Stanens hypogyncus, kome of them often sterile; anthers with 2 separated eells. Style 1; stigna unclivided. Capsule 2-3-celled, 2-3-ralved, loculicidal, 3 -severalseeded. Seeds orthotropous. Embryo small, pulley-shaped, partly sunk in a shallow depresion at the apex of the albumen. Leaves ovate, linceolate or linear, parallel-veined, hat, sheathed at base; the upper. most often dissimilar and forming a kind of spathe. - Chiefly tropical.

.. Commelina. Cyule sessile within a corlate or connate briet (spatle). Petals un equal. Perfect stanens 3 ; filaments nialied.

2. Tradescantia. Bracts leaf-like or small and scarious. I'tals equal. Perfect staucns 6 ; tilaments betrded.

\section{COM MELİ N A, Dill. DNYHLWER.}

Flowers irregular. Sepals somewhat colned, unequal; the 2 lateral partlyunited by their contignous margin. 'Two lateral petals rounded or kidneyshined, on long elaws, the ond one smaller. Stamens unequal, 3 of them fertite, one of whieh is bent inwart; 3 of them sterile and smaller, with imperfort 'ross-shaped antleers; filments nakel. Capsule 3-celled, two of the colls :2secded, the other 1-seeded or abortive. - Stems luranching, often proemulnent and rontiug at the joints. Leares contracten at hase into sheathing petioles: the flomal one heart-shaperl and "lasping, folled tongether or hooded, forming ispathe enclowing the flowers, which expruml for a single morning and are ('urvel on their pedicel before and afterwards. l'etals blue. Flowering all :munner. Ours all with perennial roots, or yropagating by striking root from the joints. (1)elicinted to the early Dutch botanists .J. and G. Commelin.)

* Ientrul cells 2-oruled (usually 2-seeded), the dorsal 1-oruled.

1. C. nudiflora, I. Slender and creeping, glabrous; leares lanecolate, small (1-2' loug); sprathe cordate, acute, with margins not united: seeds res liculated. (C. Cayennensis, Richurd.) - Alluvial banks, Del. to Fla, west to loncl., Mo. and Tex

2. C. hirtélla, Vahl. Fouf, fret (2-40 highli); leaves large, lancenlate,

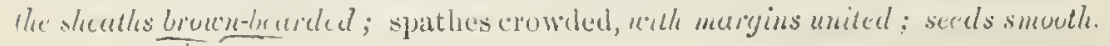


(C. ereeta, Gray, Man., not L.) - River-banks, Penu. to Fla., west to Mo. and 'Tex.

* Cells 1-ovuled,1-seeded: seeds smooth; spathe cucullate; roots sub-tuberous.

3. C. erécta, L. Slender, often low; leares linear; cells all delinstent. Pelln. to Fla.

4. C. Virgínica, I. Silendcr, usually tall; leaves lanceolate to linear; dorsal cell indehisrent, scubrous. - Danp riell woods and banks, southern X. I. to Fla., west to Mich., Iowa, and Mu.

\section{TRADESCÁ N T I A, L. SPIDERWort.}

Flowers regular. Sepals herbaceous. P'etals all alike, orate, sessile. Sta incus all fertile; filaments bearderl. Capsule 2-3-eellerl, the cells I-2-seedell. - l'eremials. Stems mucilaginous, mostly upright, nealy simple, leafy. Ienves keelel. Flowers ephemeral, in mublled colusters, axillary and terminal, produeen through the smmmer; floral leares nearly like the others. (Named for the eller Tradescum, gardener to Charles the First of England.) * Umbels terminal or sometimes luteral, sessile, sublended by 1 or 2 leaf-like bracts; leaves linear to narrorly lanceolate: flowers blue.

1. T. Virgínica, J. (Commox SPminwort) Roots flesly-fibrous, smonth or only slightly villous, $1 n^{\prime}$ or $^{\circ}$ less glaucous, often tall and slendor and with linear leares, rather rurely with 1 or 2 long lateral perduncles, luacts nstlally a pair. - lkich ground, N. Y. to Fla., west to Minu., 'Tex., and the liocky Mts. Very rariable - Var. vlloosa, Watson. Often dwarf, more or less villous throughont as well as pubeseent. Mississippi valley and Gulf Stites. - Var. Flvivosi, Wratson. Stout and dark green, with large linearlanceolate pubeseent leares, the stem usually flexuous, and with several short lateral branehes ol sessile axillary heads. ('T flexuosa, Raf.) - Uhio to Ky: and Ga. 'T. pilosa, Lelhm., is an internediate form.

* * Limbel perlunculate, subtended b., small subscarious bracts; flowers small, rosc-rolor.

2. T. rosea, lent. Small, simler $\left(6-10^{\prime}\right.$ ligh $)$, smooth, erect from a running routstoek; leaves rery naromy linear, grass-like. _ sandy woods, Mel. to Fla, west to Ky. and Mo.

\section{Order 121. JUNCiCe}

Grass-like or mush-like herls, with small flowers, a regular and hypogynous persistent perianth of 6 stmilar glumaceous sepals, 6 or rarely 3 stamens with 2-celled anthers, a single short style, 3 filiform hairy stigmas, and an ovary ciller 3-celled or 1-celled with 3 parietal plucenta, forming a loculicidal 3-iculved cripsule. Seets anatropous, with a minute embryo enclosed at the lase of the fesly albumen. - Flowers liliaceous in structure, but sedge. like in aspect and texture.

1. Juncus. Capsule 3-celled (or imperfectly so), many-seeded. Plants never hairy, in moist ground or water.

2. Luzula. Caysule 1-celled, 3-seeded. Plants often hairy, in dry ground 


\section{J Ú N C U S, Tourn. Rush. Bog-Rush.}

Capsule many-seeded, 3-eelled, or 1-celled by the placenta not reaching the axis. Stamens when 3 opposite the 3 outer sepals. - Chiefly perenuials, and in wet soit or water, witl pithy or hollow and simple (rarely branching) stems, and panicled or chustered smatl (greenish or brownish) tlowers, chiefly in summer. Plant never hairy. ('The classical nane, from jungo, to join, alluding to the use of the stems for bands.)

$\$ 1$. Stems lenfless and scape-fike, from matted ruming rootstorkis, sheuthed at base; the sheaths sometimes bearing terete linutless leat'es like the scape; flowers in sessile apparently laterut punicles, the involucral leaf being similar to and continning the scape. - Juxcre proper.

* Flowers solitary on the pedicels or ultimate ramifications of the panicle.

- Sheaths at base of the stem leafless.

++ Stumens 3.

1. J. effúsus, L. (Commox or Soft Rísu.) Scape soft and pliant (2$4^{\circ}$ high); inner sleaths awned; panicle difnsely much branched, nauy-flowered; flowers small ( 1 1" long $^{\prime \prime}$ ), greenish; sepals lauceolate, very acute, as loug as the narow trimgular-oborate retuse and pointless greenish-brown capsule: anthers as long is the filanents; style very sholt; seeds small (about $\frac{1}{4}$ long), with short pule points. - Marshy gromnd, very (")mmon. (En.) - Var. coxalonekirs, Fingelm. Scape more distinctly striate; panicle closely crowded; capsule short-pointed. In sphagnous swamps.

++ Stamens 6 .

2. J. filifórmis, I. Scape very slender ( $1-2^{\circ}$ high $)$, pliant; panicle fewflowered, almost simple; flowers $1 \frac{1}{2}$ " long; sepals lanceolate, the inner a little shorter and loss acnte, longer than the broally orate ohtuse but mucronate greenish capsule; anthers shorter than the filanents; style rery short; seed (less than $\frac{1}{3}$ " long) short-pointed at both ends, indistinctly reticnlated. $-\lambda$. Eng. to Miclu., Neb., and nortluward. (En.)

3. J. Smithii, Engelm. Seape ruther slenter $\left(2-3^{\circ}\right.$ ligh $)$; pancle fer. Acwered, nearly simple; flowers hrown (1 l" longs ); unter sepals lanceolate, acute, the immer a little shorter, ohtusish, shorter than the broally owate rather triangular acute deep chestunt-browu capsule: anthers as loug as the filauents; style short; seels large ( $f^{\prime \prime}$ long or nore), olotuse, sluret-appeuchared at both curls, many-pibbed and leticnlatet. - Splagnons swanps, on Broal Mt. and in Lebanon Co., l'ent.

4. J. Bálticus, 1)ethard, var. littoràlis, Fingelm. Scape rigid (2-3 lighl1); panicse loose; flowers larer (2" long), chestnnt-frown witl green; sepals orate-nanceolate, the onter shinp-pointed, the imer obtusish, as lung as the elliptical ratler triangular obtuse and mucronate deep lorow us capsule; anthers mnch louger tlian the broal filanents; style about the leugth of the

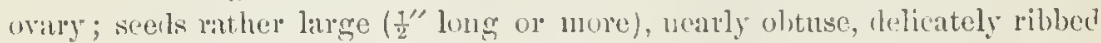
anr! rouss-lined. - Nimily shores, Newf. to Mass., west to Penn., along the firoat lakes, and westward. - Var. moxrdxus, Engelun. Sepals neatly equal ;

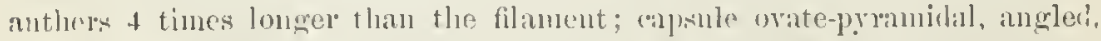

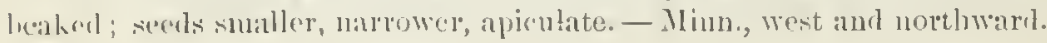


+ + Innermost sheulhs lerif-louring: stamens 6.

5. J. setàceus, Rostlinvins. Scape slender (1-3 high); panicle loose, rather few-flowerel; flowers grenish (2" long); sepals lanceolate, sharppointed, especially the 3 shining exterior ones, spreading in fruit, as long as the nearly globose beak-pointerl greenish or light-bruwn capsule; anthers as long as the filaments; style conspicums; seeds ( $\frac{1 \text { " }}{3}$ long) almost globose, ribued and cruss-lined. - Va. to Fla., west to MIo. and La.

* Flowers in chesters, 6-androus; imnermost sheaths at base of stem leaf-bearing.

6. J. Rœmeriànus, Scleele. Scape stont and rigicl $\left(2-3^{\circ}\right.$ high), its apex as well as the leaves pungent; panicle compound, open and sprealing, lirown; 3-6 greenish or light-lurown flowers ( $1 \frac{1}{2}$ " long) in a cluster; outer seprals lancenlate, sharp-pointed, longer than the obtusish inner ones, as long as the elliptical rather triangular obtuse mucronate brown capsule; anthers much longer than the broul filanents; styles shorter than the ovary; seeds ( $\frac{1}{3}$ "long) oval, oltuse, very telicately ribued. - Brackish marshes, N. J. to Fla. and 'Iex.

7. J. maritimus, L. Resembling the last, but with a rigid contracted green panicle, an ovary attenuated inte a style of nearly its own length, a greenish acute capsule which usually exeeets the acute sepals, and seeds with ristinct tails aud stronger ribs. - Known in this country only from Coney lsland, N. Y., where it is apparently indigenous. (Eu.)

\$ 2. Stems simple (rarely brunched), leafy ut base or throughout; leaves flat, or somewhot terete or setaceous and channelled, never knotted; panicle or head terminal. - GRASSY-LEAVLD JUACI.

* Floucrs in close heuds (produced in late summer).

- Leaves thread-like, hollow; stamens 6; seeds few, large and caudate; the single head (sometimes 2) 1-4-flowered.

8. J. stýgius, I. Stems slencler $\left(6-16^{\prime}\right.$ high) from slender branching rootstocks, 1-3-leaved below, naked above; heals 1 or rarely 2, of 3-4-flowers, abont the length of the sheathing suarions awl-pointed braet; flowers pale and recklish ( $2 \frac{1}{2}-3^{\prime \prime}$ loug); sepals lanceolate, the iuner obtusish. $\frac{8}{4}$ the length of the oblong acuminate capsule, as long as the slencler stameus; filaments mauy tines longer than the oblong antlier's ; recurved stigmas shorter than the style; seeds oblong, with a rery louse coat prolonged at both ends (1 $\frac{1}{2}{ }^{\prime \prime}$ long). - Peatbogs, Newf. to northern N. I., west to Mich. and X. Minn. (Eu.)

9. J. trífidus, I. Strons densely tuftel from matted creeping rootstoeks, erect $\left(5-10^{\prime}\right.$ high $\left.l_{1}\right)$, sheathed and nustly leafless at base, 2-3-leaved at the summit, the upper threal-like leaves subtending the sessile head; flowers brown $\left(1 \frac{1}{2}-2^{\prime \prime}\right.$ long): sepals ovate-lanceolate, acute, equalling or rather shorter than the ovate beak-pointed de+p lorown capsule; anthers mueh longer than the tilaments ; seeds few, oblong, angled ( $1^{\prime \prime} \log g$ ), short-tailed. - Alpine summit, of X. Engr. ant X. Y, ant fall northward; also in N. J. (Eu.)

+ + Lenres flat and grass-like; stamens 3 ; stems flattened, simple, leafy.

10. J. repers, Michx. Stems ascending $\left(4-6^{\prime}\right.$ high $)$ from a filroms an nual root, at length creeping or floating; leaves short, livear, those of the stem searly opposite and fascicled: leats few in a lonse leafy panicle, 3-12-flow 
ered; flowers green (3" long); sepatls rigil, lince-sululate, slender-pointed, the 3 outer as long as the linear trimgalar ubtuse capsule, the imer muelt longer; stanens as long as the outer sepals; filanents many times longer than the oblong anthers; seeds small ( $\overline{1}_{\bar{\prime}}^{\prime \prime}$ long), oborate, slightly pointed, very delicately ribbed and cross-lined. - Miry bauks, Md. to Fla. and La.

11. J. marginàtus, Rostk. Stem erect, from a bulbous and stoloniferous balse $\left(1-3^{\circ}\right.$ high $)$; leares Iong-linear; heatls $3-8$-flowered, panicled; flower: jurplish with green (1 $\left.\frac{1}{2} " \mathrm{long}\right)$; sepals oblong, the 3 onter aeute and slightly: awned, the inner longer, mostlyo obtuse, ats long as the almost gobular scarcely mucronate capsule; stamens exceeding the outerseplals; purple anthers shorter than the filaments; style very short; seeds ( $1-\frac{1}{3}$ "long) slender, pointed at both ends and strongly ribbel. - Moist sandy places, S. New Eng. to Fla., went.

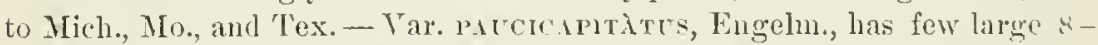
15-flowered lieals; and var. Brwiònt's, Lingelm., has numerons small 2--3: flowered leads in much-brancherl panicles.

$$
\text { * * Flovers solitury, punicled; stamens } 6 \text {. }
$$

+ Stems slender, simple, tufted, leafy below; root peremial (fl.early in summer). +r Seeds tril-pointed at both ends.

12. J. Vàseyi, lingelm. Stems rigid ( $1-2 y_{3}^{\circ}$ high); leaves nearly terete, very slightly chammelled on the immer side; panicle longer than the inroluctal leaf, loose; flowexs few, often one-siden, greenish or light brown (2" long ur more); sepals lanceolate, acnte, anpresserl, shorter than the oblong and reture green-brown capsule; anthers as long as the filanents; style very short ; seeds

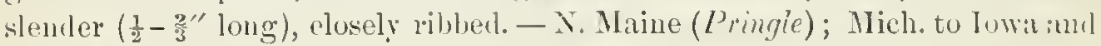
westward.

13. J. Greénii, (a)kes \& Tuckerm. Stems rigid $\left(1-2^{\circ}\right.$ ligh $)$; laves nearly terete, very deeply chanmelled (almost involute) on the immer side; panicle nsually muclu shorter than the prineipal erect involucral leaf, tense, the numerens Howers often one-xider (13" long); sepals lanceolate, acute, light greenish-brown, appressed, shorter than the oroid-ohlong obtuse greenish-hro:s n ("al)sule; anthers as long as the filaments; style very short; seets orvid $\left(\frac{1}{3}-\frac{z^{\prime}}{3}\right.$ long), ribued and eclicately cross-lined. - Sandy coast of N. Eng, N. Y., am N. J., and alwent the head of Lake Mlichigan.

$$
\text { + + Seeds merely apiculate at both ends. }
$$

14. J. ténuis, Willd. Stem wiry $(9-18$ highli); leaves flat or chamelled panicle shorter than the involucral leaves, lonse, "1r rarely arowed f flower: freen (2" long or more); sepals lanceolate, very acute, sprealing in frnir ionger than the ovoil retuse scarcely pointed green (alpsule; anthers we: 14 !y

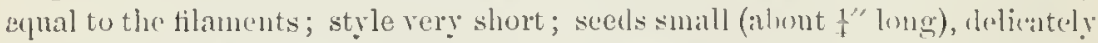
ribbed and cross-lined. - Fields and roadsiles, wery common. (Eus.) - Vilr. stcúxnus, Engelm.; fowers smaller, secund along the incurval buthes.

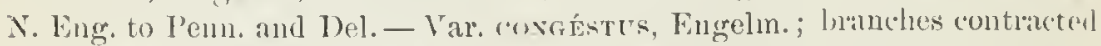
into a head aud the fowers darker-colorerl. Minn. and westward.

15. J. dichótomus, Ell. Sitems rigicl $\left(1 \frac{1}{2}-20\right.$ high) froul a tmunicl hase; Inaves filiform, nearly terete. slighltly grooved on the imner side; paniele loose. often with l-sided forked heanches, mostly longer than the involneral leaf;

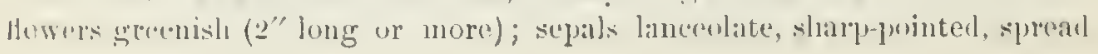


iag in iruit, as long as the globular beaked lighlit mahogany-colored caljsule,

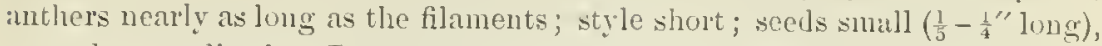
coarsely cross-lined. - Low sandy grounds, N. J, to Fli.

16. J. Gerárdi, Loiscl. (Buack-Gras.). Stems scarcely flattened, rigid $\left(\mathrm{I}-2^{\circ}\right.$ high $)$; panicle contracted, usually longer than the bracteal leaf; fow-

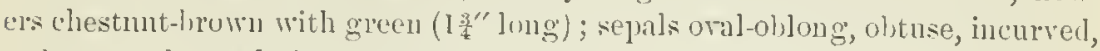
as long as the ovil ultuse and mucronate capsule; anthers mnch longer than the short filaments; style as long as the orary; seeds (nearly $\frac{1}{3}$ " long) obo wate, delicately ribbed and cross-linced, - Salt marshes; common along the coast and in W. New York: rare ahout the Great Lakes. (E)u.)

+ + Stems brenched, difjuse, leafy; root annul, fibrous.

17. J. bufònius, L. Stems low and slender $\left(3-9^{\prime}\right.$ ligh $\left.\mathrm{h}_{1}\right)$, leafr, often hrincherl from the bise; panicle s]reading, mustly with one-sided ilichnto

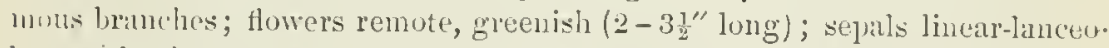
litte, atil-pointed, the 3 outer much exceeding the imner and the oblong obtuse capsinle; stamens short; filaments scarecly longer than the anthers, seets ellijtical, obtuse $\left(\frac{1}{5}-\frac{1}{6} "\right.$ loug). - Low grounds, by roadsides; common. (En.)

S3. Stems leafy; lentes terete or luterally futtened, more or less distinctly knot. ted by intermal transverse partitions; panicle terminal, with flou'er's chiefly in heads. - KNOTTY-LEAVED JUSCI.

* Seeds burely pointed, not caudate.

- Floverss solitary or 2 logether, panicled; slamens 6 .

18. J. pelocárpus, li. Meyer. Stems slender and erect from a sleuder running l'notstrek ( $6-1 \mathrm{~S}^{\prime}$ high), hearing few thread-like slightly linotted leares, branching ahove into a conjound sprealing pancle, locaring the flowers in the forks and along one side of the branches; often with the fluwers m. in place of them are tufts of leaves; flowers small $\left(1-1\right.$ f lomg $^{\prime}$, greenish with rell; sepals whlong, ol,tuse, the 3 inner ones longer, but slorter thin the (n)long taler-locked, I-celled capsule; anthers monch longer than the filaments; style slenler; seeds ( $f^{\prime \prime}$ long) whorate, short-pointed. - Sandy, wet or swampy" plices, Newf. to Fla., west along the Great Lalies to Mimm. 'The proliferons? plints are nsually sterile and moch larger, with langer diffuse panicles. -

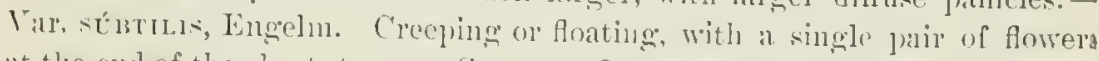
at the end of the slort stems. - Somewet Co., Naine (C. F. - imith); Canada.

++ Ileuds numerous, of $3-12$-fourers (farely more); in eurly summer ++ Stamens 6.

19. J. articulàtus, $\mathrm{Y}$. Stems ascenling or srect $\left(9-15^{\prime}\right.$ higlı), tuftec irom a short creeping rontstock, with 1 or 2 slemler leaves; panicle short, sprealing, the crowded hents 3 -s-fowered; flowers brown, rarely jale ( $1 \frac{1}{t}-$

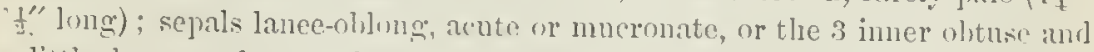
a little longer, shorter than the wate oblong acute or abruptly mucromate.

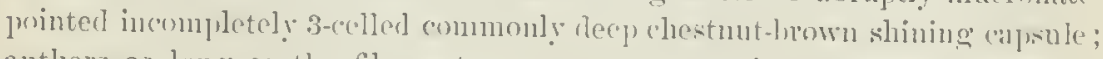
antlers as long as the filaments; orary attenuate intor a short style; seeds

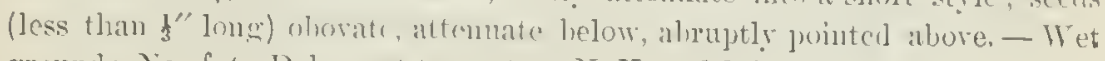
grounds, Newf. to Del., we.t to westem X. Y. aud Micl. (En.) 
20. J. alpinus, Villars, var. insignis, Fries. Stems ereet $\left(9-18^{\prime}\right.$ hlgh) from a creeping rootstock, with 1 or 2 slender leaves; pauicle meagre, with erect branehes bearing distant greenislı or light-hrowu heals, each of $3-6$ flowers ( $11-1 \frac{1}{2}$ " long $)$; sejals ollong, whtuse, the ontur mucrouate or cuspidate and usnally longer than the rounded inner ones, als long as or shorter than the obtnse short-pointed incompletely 3-celled lighth-irown eapsule; anther's as long as the filaments; style short; sceds ( $3^{\prime \prime}$ or more in lengtly) spindle-shaped. - Wet sandy banks, I. Chanplain, Cayuga Lake, aloug the Great Lakes, and far west and northwarl. (Eu.)

21. J. militaris, Bigel. Stcm stout $\left(2-4^{\circ}\right.$ high) from a thick creeping rowtstock, bearing a solitary stout erect leaf $\left(\frac{1}{2}-3 \frac{10}{2}\right.$ long) below the midelle, which overtops the crowded and rather contracted panicle; heads numerons, 5-12- (rarely 25-) flowered; flowers brownish (1 $\frac{1}{2}{ }^{\prime \prime}$ long) ; sepals lanceulate, the outer awl-pointed, as long as the ovate-oblongr triangular taper-beatied 1-celled capsule; anthers longer than the filanents; ovary attculate into a slender style; seeds $\left(\frac{1}{4}-\frac{1}{3}\right.$ " long) globose-obovate, obtuse, aluruptly puiluted._In bogs and streanns, Maine to Md. Sometimes producing, in Howing water, numberless capillary submersed leaves, $2-3^{\circ}$ loug, from the rootstock.

\section{+ Stumens 3.}

22. J. acuminàtus, Michx. Stems tufted, erect, slender $\left(1-2^{\circ}\right.$ long $)$, bearing about 2 leaves and a very lonse sprealing pancle; heads rather fow and large, 5-many-flowered, greenisli, at length straw-colored or darker; sepals lance-awh-shaped, sharp-pointed, equal (1 1 - 2" long), as long as the triaugular-prismatic short-pointed 1-celled straw-colored or light brown capsule; anthers a little shorter than the filaments; style alınost noue, seeds suill $\left(\frac{1}{5}-1^{\prime \prime}\right.$ long), acnte at both ends, ribher-reticulatel. - N. Eng. to Ga., Minn. and Tex. May, June. Very variahle. IJeads often proliferons in antumn.

Var. débilis, Fugelm. Stens slender $\left(9-18^{\prime}\right.$ ligh $)$; lieads green, 3-6flowered, in a loose panicle; flowers smaller $\left(1 \frac{1}{-1}-1 \frac{1}{2}\right.$ long); cajstule longer than the sepals. - Wet sandy soil, N. J. to s.. C., west to Ohio, Mo., and Miss. Stem sometimes decumbent and rooting.

Var. robústus, lingelnz. Stens stout, tall (2-40 highl), hearing numerous 5-8-flowered light-brown heads in a large much-hranched panicle; flowers small ( $1-1 \frac{1}{5}$ " long); oroid cajsule scircely louger than the sepals. - Deep swamps, Ill. to Mro. and La.

$$
\text { to + + Meads fon, crowded, of numcrous flowers. }
$$

+ Stamens 3; stem rigit from a thick white horizontal rootstock.

23. J. brachycárpus, Engelm. Stem rrect (1-210 himgh), hearing abont 2 leaves and 2-10 densely flowered spherical heals (4-5) wide) in a slightly spreading crowded panicle nuch exceding the involneral leaf; flowers pale green (2"long); sepals lance-linenr, anw-pointed, the 3 outer mich longer than the inner, and the ovoid printed 1-celled capsule rather shorter;

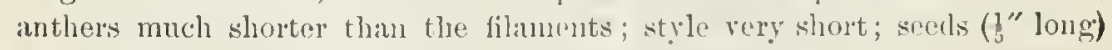
abruptly apiculate. - Moist places in open wools and prairies, Ohio and Miclo to Mo., Miss., and 'lex.

24. J. scirpoldes, Lann. Stem erect $\left(1-3^{\circ}\right.$ highl $)$, rather slenler, leatring about 2o terete leares with widle and open sheatlos, and a panicle of fen or 
many densely-flowered pale-green spherical heals, much longer than the inroJucral leaf, its branches erect and often elougated; heals (3- $t^{\prime \prime}$ wicle) 15-40fluwered; flowers 1 t $-1{ }^{1}$ " long; sepals rigid, awl-shaped and (especially tlie outer) bristly pointed, at length pungent, as long as the staneus and nearly equalling the oblong-triangular taper-pointed 1-celled capsule; authers very small; style elongated or rery short; seels ovoid, abruptly pointed at each encl ( $t^{\prime \prime}$ long). - Wet sandy soil, Mass. to N. J. aud S. C., west to Ind., Mo., and 'lex.

Var. echinatus, Fngelı. Stouter; leares terete; branches of the compact panicle short; heads larger (5-6" wide), 40 - 80 -flowered ; flowers $1 \frac{3}{4}-2^{\prime \prime}$ ?ong); sepals narrower and more sharply pointed, the outer a little longer than the inner; stamens shorter and anthers longer than in the preceding, and seeds ratler smallej and nore slender. - Mrl, to l'la.

Var. polycéphalus, Engelm. Much stouter; leaves laterally Hattened $\left(3-6^{\prime \prime}\right.$ wide); panicle sporeathg, branched, beariug many distant heads as large as in the last; flowel's $2-2 \frac{1}{2}$ "long; the 3 outer sepals the longer; anthers about as long an the filaneuts; seels larger (1" long). — s. Va, to Fla, west to Mo. and 'l'ex.

$$
+ \text { Stamens } 6 \text {. }
$$

25. J. nodòsus, I. Stem erect $\left(6-15^{\prime}\right.$ or $2^{\circ}$ high $)$, slender from a creeping threar-like and tuber-bearing rootstock, mostly witl 2 or 3 slender leaves; healls few or serer'al, rarely" single, 8 - 20-flowered (3t-4" wide), overtoppeá

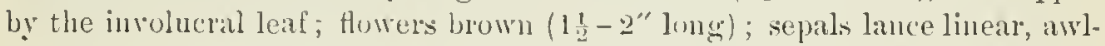
pointed (the 3 outer mostly a little shorter), nearly as long as the slender triangular taper-pointed l-celled capsule; anthers olsloug, shorter than the filuments; style rery short; seeds (about $l^{\prime \prime}$ long) obovate, abruptly inneronate. - Swamps and gravelly banks, N. J. and Penu. to N. Ind. and Iowa, and

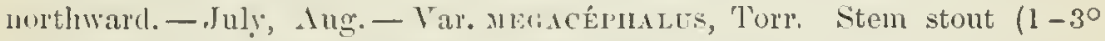
high), with thick leaves; leatls few and large (6-8" wide), 30-80-flowered; flowers pale green ( $\left.21-23_{4}^{\prime \prime} l o n g \circ\right)$; outer sepals longest; anthers linear, shorter thau the filanents. - Mestern N. Y. to Minn. and Mo., and westward.

* Seeds caudate.

- Stumens 3.

26. J. Canadénsis, J. Gay. 'l'ufted stems erect, terete, smooth, bearing 2-3 leave; houls few-or many-fowered, paniculate; sepals lineeolate, the :3 onter shorter than the inure, nut muxh longer than the stamens, equal to or shorter than tlue triangulan-furismatie almost l-celled usually short-pointed (at)sule; style mostly slunt; scesk more or less distinctly tail-pointed, delipately many ribhed. - Conmon almost everywhere. Iug, Sept. Easily disEinguisled by its late flowering from the similar 11.22. Very variable.

Var. longicaudàtus, Engehm. Ntem stont and rigid $\left(1 \frac{1}{2}-3^{\circ}\right.$ high), bearing in a decomponul sumewhat sprealing panicle the mmerous 5-50fhwered heads; flowers greenish or light luw (1! -2" long); sepals awlprinted, mostly shorter than the ahruptly short-pointed eapsule; seerls slender $\left(\frac{2}{3}-1 "\right.$ long), conspieuously tail-pointed. - Maine to S. C., west to Minn and La. The inust (*omm1ni form.

Tar. subcaudàtus, Eugrelm. Stem slender, often decumbent $(1-20$ hight), hearing in simpler spreating panicles fewer 8-20-flowenel luaks: 
Hower's greenish, as lutge ats in the lint; sepals awl-shaped, but not so rigid;

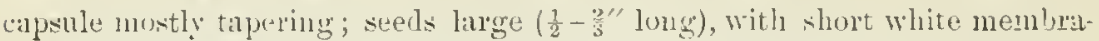
nous appentages, nut reticulated. - Comn. to I'emn. mul Ga.

Tar. brachycéphalus, Engelm. Stem slender (l $\frac{1}{2}-2 \frac{1}{2}^{\circ}$ high), bearing nnmerous small 3 -5-fluwered heals in a large spreading panicle; fluwers greenish or light brown $\left(1 \frac{1}{4}-1 \frac{1}{2}\right.$ " long'); sepals mostly obtuse, shorter than the brown aloruptly short-pointel capsule; style louger than in other forms: seeds smaller ( $\frac{1}{4}-\frac{1}{3}$ " long), slender, with rather short appendages. - l'ens. and western N. Y., to Wisc. and Ill.

Var. coarctàtus, Engelm. S'tem slender, shorter ( $8-1 \Omega^{\prime}$ high), bearing fewer deep-brown 3-5-flowered heals in a somewhat erect contracted panicle; Howers as large as in the last; sepals acute, or rarely obtusish, much shorter than the prisnatic abruptly pointed deep-lown eapsule; seeds as in the last. -. N. Eng. to N. J., N. Minn., and westwarkl.

t- t- stumens 6.

27. J. ásper, Engelm. Stems tnfterl, rrect $\left(2-3^{\circ}\right.$ high), terete, stout, rigid, and with the ligid leaves mugh; panicle with rigid slighty spreading lnimehes, bearing seattered few- (2-6-) Howered heals; flowers greenish with bown (2t" long) : sepals orate-linembate, awl-pointerl, rigiul and strongly nerved, the outer much shorter than the inner, these a little shorter than the triangular-orvil beaked incompletely 3-celled brown calpsule; orary tapering into a conspicuons style; seeds large, ublong, with white or often redulish appeudages (1 1" long). - Sphagnous swamps, X. J. دlug.

\section{L ÜZULA, DC. Woor-Resir.}

Capsule 1-celled, 3-seeded, one seel to each parietil placenta. - l'eremnials, often hairy, usmally iu dry gromul, with flat and solt usally hairy leaves, and spiked-crowden or umbelled Howers. (From Girmen Luzulu, or Lanculu, thin. of lux, light, - a name given to one of the speries from its shining with (lew.)

* Pedicels 1-flouered, an "loose compound cymr or imbel.

1. L. vernàlis, 1) C. Plant 6-9' high; leaves lancelinear, hairy; umbel mostly simple; repals pointed, shorter than the obtuse capsule; seels with at curved appenlage. (L. pilosa, Irilld.) - Wools and lranks, Newf. to the uucuntiuns of $\mathrm{N}$. C., west to Mim. (En.)

2. L. spadícea, DC., var. melanocárpa, Meyer. Nearly smooth (1 $3^{\circ}$ high) ; leaves broadly linear ; rorymb decomponnd, loose ; pedirels elrooping. sepals pninterl, straw-color, about the length of the minutely pointed and hrown atpsule; seels not appendaged. (L. parvifora, var. melanorarpa, (froy)-

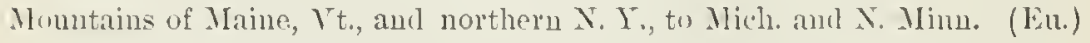

* * Flavers rmorded in spikes or close clusters. (Plants 6-12' high.)

3. L. campéstris, DC. Leares fal, linerr: spikes 4-12, somenlirt um belled, oroil, straw-color, some of them long-peduncled, others nearly sexsile; sepals bristle-pointed, longer than the oltuse capsules; seeds with a conical appendage at hase. - I ry fields and wools, common. May. (Eu.)

4. L. arcuàta, Meyer. Lcuws chumnelled, linear; spikes 3-5, on unequrl often recurid pedmeles, ovod, chestnut-brown; brats ciliate-fringed; sepals 
taljer-pointed, longre than tle obtusc capsule; seeds not alpuenulaged. - Alpine sumnits of the White Mts. and fir northward, (En.)

5. L. spicàta, Desraux. Leaves channelled, warrowly linear; flowers in sessice clustris, forming a nodding internuted spiked panicle, brown; sepals bristle-pointed, scarcely als loug as the abruptly short-pointed capsule; seeds: merely witl a romudish projection at base. - With the last, and more comunou. (Eu.)

\section{ORHe: 120. TYPHÄCEAE. (CAT-TAIL FAMLY.)}

Marsh or aquaticherbs, with neread and linerr sessile leures, and monocious flowers on uspadix on in heads, destilute of proper flurul encelopes. Ovary 1 - 2-celled, with as many jersistent styles and (usually elongated) 1-sided stigmas; cells 1-ovuled. F'vut nut-like when ripe, 1-soeded, rarely 2-seceded. Seed suspenderl, anatropous; embryo straight in copious albumen. líout jerennial.

1. Typha. Fluwers in a cylindrical compat teminal spike: spathe-like bract deciduous

2. Sparganiun. Flowers in glounlar hends with folliceous bract.s.

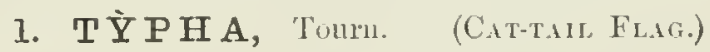

Flowers in a long and very dense cylindrical s]ike terminating the stem; the upper part consisting of stanens only, insertexl lirectly wn the axis, and intermixed with loug lails; the luwer pant consisting of stipitate l-celled orarixs, the stipes bearing club-shaped bristles, which form the conjuns down of the frnit. Nutlets minute, rery long-stilked. - S jathes merely decilnons

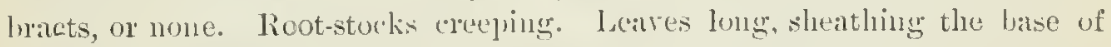
thro simple jointless stems, ereet, thickish. Flowering in summer. (Tú $\eta$, the old (ireek name.)

1. T. latifòlia, L. (Comaо C.xт-Tall.) Stont and tall $\left(t-6^{\circ}\right.$ high), the flat sheathing leares $3-10^{\prime \prime}$ hroal, exceeling the stem ; the staminate and lark hown pistillate parts of the spike (each $3-6^{\prime}$ long or more) usually contuguous, the latter at leugtlı !' in diameter; pustillate flowers without bractlets; stigmu rhombir-lanceolur ; pollen-gmains in fours. - In marshes, throngh. ont N. Ain. (Eu.)

2. T. angustifòlia, T. Leaves narrower (3-6" broarl), taller, sumewhat convex on the lack; pistillare and staminate inflonescence nsually separated ly a short interval, the light brown spike beeoning $5-6$ " in diameter; pollen. yrains simple; pistillate flawers with a linear stigme and "hair-like bracthe slightly dilated at tle smmmit. - N. Eug. to N. J., west to Mieh, and Mo.; less frequent, and mainly near the const. (Eu.)

\section{S P A R G À I I U M, Tonm. BrR-TREE,}

Flowers collecterl in separate dense am splerical leafy-luraterl heads, which are scattered aloug the smmmit of the stcm; the upjer sterile, consisting merely of stamens, with minute scales imegularly interposul; the lower or fertile larmer, consisting of numerons sessile l - o-elled pistils, enll surrounded by 3-6 scales much like a calyx. Fruit werge-shaljert or clul-shlalped, more or less corky tuwarl the sumuit, the hard endoenry perforated at the apex.- 
Rootstocks creeping and stoloniferons; roots fibrous. Stems simple or branching, sheathed beluw by the base of the linear leaves. Flumering through the summer. (Name from $\sigma \pi \alpha$ a javov, a fillet, from the ribbon-like leares.)

* Finit sessile, broad and truncate, ofien 2-seeded; stigmas often 2, elongated; scales rigid, nearly equalling the finit; erect, with branched inflorescence

1. S. eurycárpum, Engelm. Stems stout, erect $\left(2-1^{\circ}\right.$ high); leaves mostly flat and merely keeled; pistil atteuuate into a slıort style bcaring 1 or 2 elongated stigmas; fruit-heads $2-6$ or more, $\mathbf{l}^{\prime}$ wide; fruit many-angled ( $3 \frac{1}{2}-4^{\prime \prime}$ long) when mature, with a broad and depressed or retuse summit ab. ruptly tipped iu the centre. - Borders of pouds, lakes, and rivers, N. Eng. to Va., west to the Pacific.

* Fruit comparatively narrow, and mostly someuthat stipitate, 1-celled, longer than the scales.

2. S. simplex, Huls. Stems slenter, erect $\left(\frac{1}{2}-2^{\circ}\right.$ high $)$; leares more or less triquetrous $\left(2 \frac{1}{2}-4^{\prime \prime}\right.$ wide) ; fertile heads $(1-4)$ of the usually simple inflorescence often above the axils, sessilc or peruncled, $6-8^{\prime \prime}$ wide in fruit; stigma linear, equalling the rather slencler style or shorter; nutlcts pale, fusiform or uarrowly oblong (about $2^{\prime \prime}$ long), more or less contracted in the middle. - $\mathrm{N}$. Eug. to N. J., West to Mich., Minn., and northwark. (Eu.)

Var. andrócladum, Engelm. Stouter (l $\frac{1}{2}-3^{\circ}$ high), with usuall! brouder leaves $\left(4-9^{\prime \prime}\right)$ and branching inflorescence, the head or pednncles axillary or nearly so; fruiting heads $(1-7)$ often larger ( $6-12^{\prime \prime}$ broad), the nutlet: 2-3" loug. (S. androcladum, Morong.) - In bogs or shallow water, common; N. Fing. to Fla., west to Minn. and Mo.

Var. angustifólium, Engelm. Very slender; leaves floating, long and narrow ( $\frac{1}{2}-2 \frac{1}{2}$ " wide), flat; inflorescence simple; heads $\left(t-6^{\prime \prime}\right.$ broad) and nutlets smaller. - Momtain lakes and slow streams, N. Y., N. Eng., and northward; sometimes nearly out of wate $\tilde{i}$, lwarf and witl shorter erect leares.

Tar. flùtans, Engelm. Floating in deep watcr, with long slender stems and flat uarrow leaves; inflorescence usually short, spariugly branched; style stout with a short oval stigma; fruiting heads $t-6$ " hroad; nutlets dark, as large as iu the type. (S. androcladum, var. fluctuans, Jorong.; not S. Huitan, Fries.) - Ponds, l'enu., Wr. Conn., White Mts., N. Minu., and northward.

3. S. minimum, Fries. Usuclly.foating, with rer"! slender stems and thin fat narrow leares: fertile heads 1 or 2 , axillary, sessile or peoluncled (4-5" widc); stigma oral, about as long as the short style, scarcely surprassing the wal or oborate denticulate scales; fimit ollong-uborate (1 - 2" long), pointed, somewhat triangular, the stipe very' short or nonc. - N. Fig. to l'enn., N. Inl., Minn., north and westward. - Stems 3-6' high when growiug ont of water, much longer wheu submerged. (Eu.)

\section{Order 123. Ariceze. (Arum Family.)}

Plants with acrit or pungent juice, simple or componnd oflen veiny leaves, and flowers crowded on a spatix, which is usully surrounded by a spathe. - Floral envelopes none, or of 4-6 sepals. Fruit usually a berry. seeds with fleshy albumen, or none, but filled with the large Meshy en. 
bryo. A large family, ehiefly tropical. Herbage abounding in slender rhaphides. - The genuine Araces have no floral envelopes, and are almost all monæcious or diucious; but the genera of the second section, with more highly developed flowers, are not to be separated.

* Spathe surroundiug or subtending the spadix; flowers naked, i. e. without perianth.

1. Arisaema. Flowers monocious or dioeious, covering only the base of the spadix.

D. Peltandra. Flowers monocious, covering the spadix; anthers above, ovaries below.

3. Calla. Flowers perfect (at least the lower ones), coveriug the whole of the short spadix. Slathe open and slreading.

* * Spathe surrounding the spadix in n. 4, none or imperfect in the rest; flowers with $\varepsilon$. calyx or perianth and perfect, covering the whole spadix.

4. Symplocarpus. Spadix globular, in a fleshy shell-shaped spathe. Stemless.

5. Oxontium. Spadix narrow, naked, terminating the terete scape.

6. A corus. Spadix eslindrical, vorne on the side of a leaf-like scape.

\section{A R I S À MA, Martins. Ixnia Turip. Dragon Arum.}

Spathe convolute below and mostly arched above. Flowers monccions or hy abortion dicecious, covering only the base of the spadix, which is elongated and naked abore. Floral envelopes nowe. Sterile flowers above the fertile, each of a cluster of almost sessile $2-4$-celled anthers, opening by pores or chinks at the top. Fertile flowers consisting each of a 1-celled orary, tipped with a depressed stigma, and containing 5 or 6 orthotropons orules erect from the base of the cell; in frnit a 1 -few-seeded scarlet berry. Enbryo in the axis of albumen. - Low perennial herbs, with a tuberous rootstock or corm, sending up a simple scapc sheathed with the petioles of the simple or componnd veiny leaves. (Name from ápis, a kind of arum, and $\alpha \hat{i} \mu a, b l o o d$, from the spotted leaves of some species.)

1. A. triphýllum, Torr. (Ixordx Turxip.) Leares mostly 2, divided into 3 ellipticulorate pointed leuflets; spadix mostly diacious, club-shaped, obtnse, much shorter than the spathe, which is flattened and incurved-hooded at the ovate-lanceolate, pointed summit. - Rich woods, $\mathbf{X}$. Scotia to Fla., west to Minn. and E. Kan. May-Corm turnip-shaped, wrinkled, farinaceons, with an intensely acrid juice; spathe with the petioles and sheaths green, or often variegated with dark purple and whitish stripes or spots.

2. A. Dracóntium, schott. (Grees Dragox. Dragox-root.) Leaf usually solitury, pedately divided into 7 - I I oblong-lanceolate pointed leaflets; spadix often undrogynous, tupering to a long and slender point beyond the oblong and convolute pointed greenish spathe. - Low grounds, N. Eng. to Fla., west to Minu., E. Kan., and 'Tex. Jme. - Corms clustered; petiole $1-2^{\circ}$ long, much longer than the perluncle.

\section{PELTÁNDRA, Raf. ARrow ArEm.}

Spathe elongated, convolute throughont or with a dilated blade above. Flowers monocions, thickly corering the long and tapering spadix throughout (or only its apex naked). Floral envelopes none. Anther-masses sessile, naked, covering all the upper part of the spadix, each of $4-6$ pairs of cells imbedted in the margin of a thick and shield-shaped connective, opening hy terminal pores. Wrires at the base of the spadix, each survumber by $4-5$ listinct, scilc-like, white staminulia, 1-elled, bearing $1-f(\cdot w$ amphitropons 
ornles at the base; stigma truneate. Fruit a leathery or fleshy berry, $1-3$. sended. Sieed obovate, surromded by tenacions jelly, the base empty, the "upper part filled with a large fleshy spherical embryo; no albunen. - Stemless herls, with arrow-shaped or hastate leaves, palmately 3-nerved aud piumatels reined, and simple seapes from a thick-filnous or subtuleroms poot. Fruit in a globose cluster, enelosed lyy the persistent fleshy lise of the spithe. (Name from $\pi \dot{\varepsilon} \lambda \tau \eta$, a target, and ävíp, for stamen, from the shape of the latter:)

1. P. undulàta, Raf. Root of thick tufted fih'es; s(ape $1-1 \frac{1}{2} \mathrm{~h}$ high, abous agualling the leaves; hasal lobes of the leaves rather long and often acutish; s) at he conrolute throughont, way on the margin, mostly green, $4-7^{\prime}$ long; sterile portion of the sparlix several times longer than the pistillate; ornles several; frtit green; seeds l-3. (l'. Virginica, Kwnth, and most author's.) Whallow water, New Eng. to Fla., west to Mich. aur lucl. Jume.

2 P. álba, Raf. liootstock tuberous, coverel with thiek-fleshy roots aul propagating by offshoots; lobes of the leaves mostly short and broal, obtuse; s]atlie :3-4' long, the hlade hronder, acuminate, somewhat expanded, white; sterile part of the sparlix searcely longer than the pistillate; ovules and seeds solitary ; berry scarlet, $5-6^{\prime \prime}$ long. (P. Tirginea, schot. Nanthosona sagittifolia, Chrym., not Schott. Calidinm glaueum, Ell. Arum Virginirum, L., in part?) - Marshes, S. Va. (?) and X. C. to Fla.

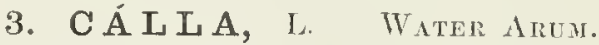

Spathe open and spreading, ovate (abruptly pointed, the upper surface white), persistent. Spadix oblong, entirely eorered with flowers; the lower perfeet and 6-androus; the upper often of stamens only. Floral envelopes none. Filaments slender; anthers 2-celled, opening lengthwise. Orary 1eeilerl, with 5-9 erect matropons orules; stigma almost sessile. lerries (red) distinct, few-sederl. Seeds with a consphemous rhaphe and an embryo nearly the lengtl of the hard allumen. - A low perennial herl, growing in eolil bogs, with a long creeping rootstock, beining heart-shaperl long-petioled leaves, and solitary seapes. (An ancieut name, of mknown meaning.)

1. C. palústris, 1.-Cold bogs, N. heotin to N. .J., west to Mieh. and Minn., and northwaxl. June. - Seeds surrounded with jelly, (En.)

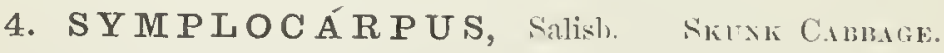

Sinathe hooded-shell-form, pointerl, rery thek and fleshy, rleenying in fruit. Spalix globular, slort-stalked, entirely and densely eovered with perfect

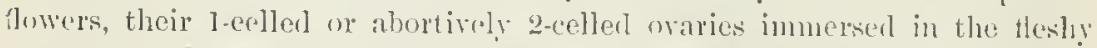
receptarle. Sepals t, hooled. Stamens t, opposite the sepals, with at length

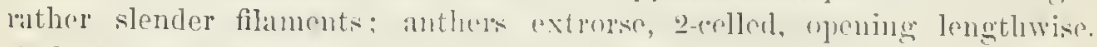

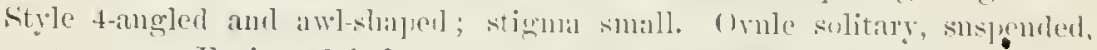
anatropous. Fruit a glolmlar or ural nuas, composed of the enlarged and spongy spalix, onclosing the spherienl secels just heneath the surface, which is

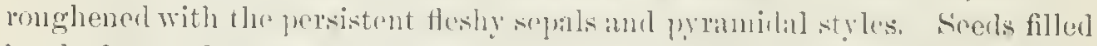
by the large globular am fleshy corm-like emlnryo, which lwats one or several plumules at the end next the base of the orary; allonnon none. - Peremial lerl, with a strong orlor like that of the skunk, and alio somewhat allialeous:

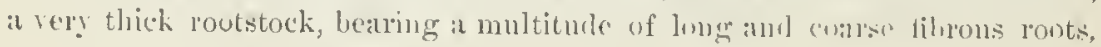


and a cluster of very large and broad entire veiny leaves, preceded in earliest spring by the nearly sessile spathes, which barely rise out of the ground.

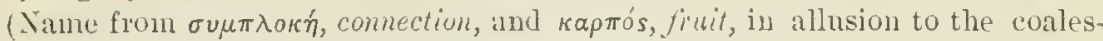
(esuce of the ovaries into a compousd fruit.)

1. S. fòtidus, valisb. Leares ovate, corclate, lecoming $1-2^{\circ}$ long, shortpetioled; spathe spotted and striped with purple and yellowish-green, ovate, incurverl; fruit (in autunn) 22-3' in dian., in decay shedding the bull,let-like seeds, which are $4-6^{\prime \prime}$ loug. - Bogs aud moist grounds, N. Fcotia to N. C. west to Mium. and Iowa.

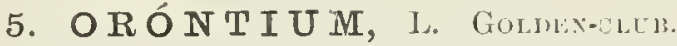

Spatle incomplete aul distant, merely a leaf-slueatl investing the lower part of the slender sealex, and bearing a small and inperfect bract-like blade. Flowers crowled all wer the narow spadix, perfect; the lower with 6 con ("ave sepals and 6 stanneus; the upjer ones with 4 . Filanents Hattened; anthers 2-celled, opening ollignely lengthwise. Ovary 1-celled, witl an anatropous "rule; stigna sessile, entire. Fruit a green utricke. Seed withont albumen. Emluro thick and Heshy, "with a large concenled carity at the sumnit, the plumule eureel in a groove on the ontside." ( $\Gamma\left(m^{2} r^{\circ}\right)$ - In aquatic perennial, with a decplowstock, long-petioled and entire bhlong and nerved Hoating leares, and the spulix terminating the elongated sciupe; its rather chub-shaped "mersed apex as thick as the spadix. (Origin of the name obsemre.)

1. O. aquáticum, L. - Pouds, Mass. to Fla. May.

\section{6. Á C O R U S, L. Sweet Flag. Calahus.}

Siadix eylinluical, lateral, sessile, emerging from the side of a simple 2-edged s:al) which resembles the leares, densely corcred witl perfect Howers. Sejals 6, concave. Stamens 6; filaments linear; antlers kiuney-sliajed, l-celled, "puniug accoss. Ovary 2-3-celled, witl several peudulous ortlotropous ovules in calcll cell: stigna minnte. Fruit at lesgth dry, golatinous inside, l-fewsereded. Enthryo in the axis of albumen. - l'ungent aromatic plants, espe(ially the thick (reeping rootstocks (calamus of the slops), which send up) 2 mlycul sworl-like leares, and scapes somewhat like them, bearing the spadix on

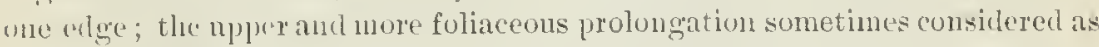
a kind of open sjuthe. ("A kopas, the ancient name, of no known meaning.)

1. A. Cálamus, L. Sicape leaf-like and prolonged far leyoud the (yellowislt-grerne sparlix. - Margins of rivulets, swamps, etc., N. Scotia to Fla. best to Minn., Iowa, and L. Lian.

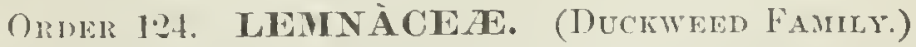

Mimute stemless plants, flouting free on the uater, destitute of distinat :tr $m$ and foliage. leing merely a frond, producing one or few monocious. lowers fiom the edge or upper surface, and commonly hanging roots fiom underneath: neules rising from the base of the cell. Fruit a 1 - 7-seeded utricle. Sterd large; the apex or radicular extremity of the sect-coat sepamble us an oprerculum or lid (as in Cabomba, etc.). Emluryostraight, surremuled hy, flestly or somprimes ipr! scanty albumen. - The simplest, and 
some of them the smallest of flowering plants, propragating hy the prolit. erons growth of a new individual from a cleft in the edge or base of the parent frond, remaining conneeter for some time or separating, also by autumnal fronds in the form of minute bulblets, which sink to the bottom of the water, but rise and regetate in spring; the flowers (in summer) and fruit searce, in some species hardly ever seen. Frond more or less cavernous; the upper surfaee funished with stomata. - These plants may be regarded as very simplified Araeer.

1. Spirodela. Frond 7-11-nerved, with sereral rootlets.

2. Lemna. Frond $1-5$-nerved, with a single rootlet.

\& Wolfia. Frond thick, very minute $\left(\frac{1}{6}-\frac{z^{\prime}}{3}\right.$ broad), without rootlets.

\section{S PIRODELA, Schleiden.}

Anther-cells biloeellate by a vertical partition and longitudiually dehiscentr Ovules 2. Fronl 7-11-nerved or mole; rootlets serelal, with axile rasenlar tissue. Otherwise as Lemua. (From $\sigma \pi \epsilon \hat{\imath} \rho \alpha$, " cmel, and $\delta \hat{\eta} \lambda o s$, evident.)

1. S. polyrrhiza, Siclleil. Fronds round-obovate $(2-4$ " long), thick, purple and rather convex beucath, lark greeu above, palmately (urustly i-) nerved. (Lemna polyrrhiza, L.) - Very common in pouds and pools, througinout N. Am., but very rarely found in flower or fruit. (Eu.)

\section{LÉ MNA, L. DUCKWEED. DUCK's-Mist.}

Flowers produced from a cleft in the margin of the frond, usually three together surrounded by a spathe; two of them staninate, consisting of a stamen only; the other pistillate, of a simple pistil; the whole therefore imitating a single diandrous flower. Stcr. F\%. Filament slencler; anther 2- celled, disly. mons; the cells dehiscent transircrsely; pollen-grains large, spherical, muriate. Fert. Fi. Ovary l-celled; style and truncate or fumel khajed stigma simple. Orules and seeds I - 7. - Fronds 1 - 5-nerved, producing a single rootlet beneath (whieh is lestitute of vascular tissue), proliferous from a cleft in the margin toward the base, and at length stipitate; the tissue abomoling with bundles of rhaphides. ( $\mathrm{nn}$ old Greek name of uncertain meaning.)

* Orule solitury, orthotropous or neurly so; frond 1-3-ncreed, thin.

- Fronds oblong, stulked ut base, remaining connected.

1. L. trisúlca, I. Fronds ollong to oblong-lanceolate $\left(6-9^{\prime \prime}\right.$ long), attenmate at base into a slenler stalk, lenticulate at the tip, very olscurely 3 nerved, often without rootlets, usually sereral series of offshoots remaining comected; spathe silk-like; scerls wate, amphitropous, with small round operculum, - Ponds and springy places, N. Scotia to N. .J., west to the l'acific. (Fu.)

-. + Fronds oblong to elliptical or round-orate, sessile, soom sepurating.

2. L. Valdiviàna, Philippi. Fronds elliphic-oblong, small (about $1^{\prime \prime}$ long), rather thick, nsnally somewhat fakute, obscurely 1-mered; spathe broud-reni. form; ntricle longrovate, pointed by the long style; seed orthotropous, oblong; with a prominent acute operculum. (L. 'Torreyi, Alstim.) - I'ools, N. J. and sonthward, westwinl across the continent. (S. $\Lambda$ m.)

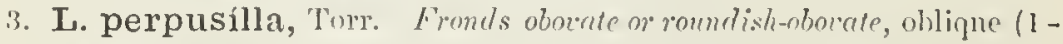
11" long), obsurely i-narped; utricle orate; style rather Iong; sud orthotro 
grous, wrate or oval, olstuse, with scarcel!/ apiculute operculum. - X. I. and N. J., west to Mich. and Wisc. - Var. Trixílzis, Austiu, las larger, distinctly 3. served fronds, and an ineynally cordate seed.

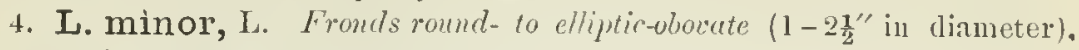
rather thick, ery obscurely 3-nerved; spathe sac-like; utricle sliort-nrn-shaped, tipjed with a short style; seed oblong-obovate, amphitropous, with prominent rounded operculum. - Stagnaut waters, throughout N. Am. (Eu.)

* Ovules $2-7$, anatropous; fronds very thick and spongy, flat above, very

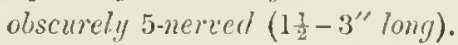

5. L. gíbba, I. Fronds obovate-elliptic to nearly orbicular, almost hemispherical, soon separating; bract sac-like. - Mo. (?) to Ariz. and Calif.

\section{W Ó LFFIA, Horkel.}

Flowers central, bursting through the upper surfice of the globular (or in sone foreign ones flat) and loosely cellular frond, only 2 ; one consisting of at si:ngle stanen with a l-celled 2-valved anther; the other of a globular ovary, tipjed with a very short style and a depressed stigna. Ovule orthotropous, rather ollipne in the cell. [triele splierical. Albumen thin. - Frouls rootless, prolif(rous from a cleft or fumel-shaped opening at the hase, the offspring soou detached; no rlisplides. - The simplest and suallest of flowering plauts, from $\frac{1}{4}-\frac{2}{3}$ " Iong (an $A$ frien and Cnban species much latrger), foating as little grains on the water. (Named for .John Fred. II olff, who wrote on Lemna in 1801.)

1. W. Columbiàna, Karsten. Glohose or globular, $\frac{1}{3}-\frac{2}{3}$ " long, very Lowely cellular, light green all orer, not dotterl; stomata $1-6$; the opening at the base cir'nlar inul with a thin borler. - Floating rather beneath the surface of stagnant water, Conn. to X. J., west to Minn. and La.

2. W. Brasiliénsis, Wedlell. ()hlong, smaller and more densely cellnlar, thattish and decp grecn with nany stomata above, tumid and pale below, brown-dotted all orer, anteriur "elge slarp, opening at base circular. - Growing with the last, lunt floating on the snrface.

\section{Order 125. Alismiceze. (Water-Plantaix Family.)}

Marsh herls, with scape-like stems, sheathing leaves, and perfect or monocious or diocious fomers; perianth of 3 herbaceous persistent sepals and as many (often conspricuons) white deciduous pelals, which are imbricate or incolute in bul; slamens 6 or more, inchuled; ocaries numerous, distinct, 1-celled and moslly 1-nvulerl, becoming achenes in fruit (in our genera) ; seeds erece; camp?lotropous. - Roots fibrous; leaves radical, petiolate and strongly nerved with transwerse reinlets, the earlier sometimes withont blade; fowers long-perlicellate, mostly verticillate, in a loose racene or panicle, with lanceolate scarions bracts slightly connate at base.

1. Alisma. Flowers perfect, nsually G-androus Carpels flattened, in one whorl.

2. Sagittaria. Flowers mostly unisexutl. Stauleus rarcly few. Carpels flattener, in derse heals, winget.

8. Echinodorus. Wlowers perfect. Stamens 6 or more. Carpels capitate, turgil and ribbed, often beaked. 


\section{ALÍSM A, L. WATERPhatan.}

Fluwers perfect. l'etals involute in the bud. Simmens definite, nostly 6 Graries many in a sinple circle on a flattened receptacle, forming flattened corbacous achenes, which are dilated and 2 -3-keeled on the back. - lioots fibrons. Leares all firon the luot, several-riblyed, with comnecterl reinlets. scape witl whorled paricled lumeles. Flowers smatl, white or pale rosecolor. (The Greek nume; of uncertain clerivation.)

1. A. Plantàgo, l. l'eremuial by a stunt proliferous corm ; leares long petioled, orate, olynng, or lanceolate or even linear, awte, mostly rounded or heart-shaped at hase, :3-9-1served; panicle loose, compound, many-flowered $\left(1-2^{\circ}\right.$ loug); (arpels obliquely obovate, forming an ohtusely triangular whorl

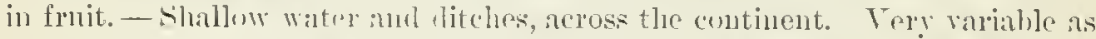
to foliage, but the leaves lsually more luroadly cordate-ovate thau iu old

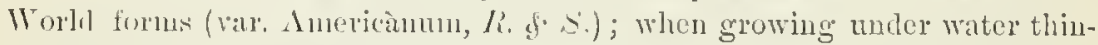
неr and narrowly lanceulate. (Fu, etc.)

\section{SAGITTÁRIA, L. ARROW-HEAI.}

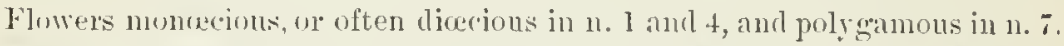
Petals imbricaterl in the hurl. Stameus indefuite, larely few. Ovaries many,

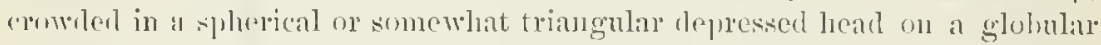

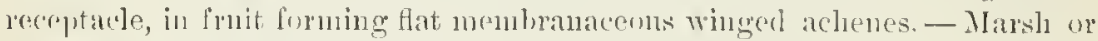
appatie, mustly permulal, stoloniferms hexls, with milky juice and tibons

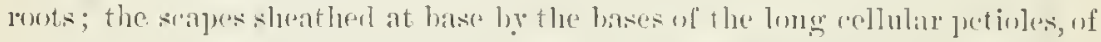

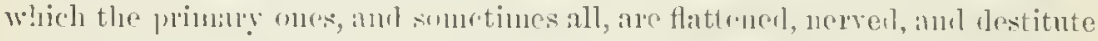
of any proper hlarle (i. e. are phylloclia); when present the blate is arrow-

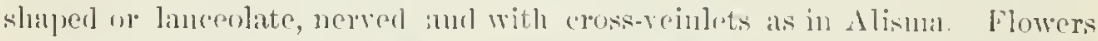

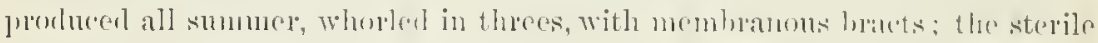

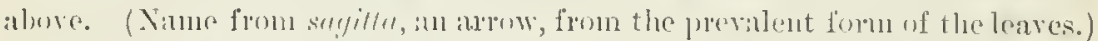

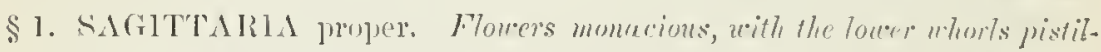

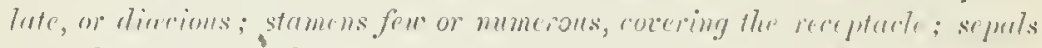
sperenting or ingexed in finit.

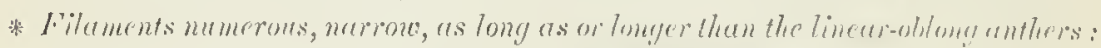
bracts 3, distimet; finiting hereds lurger.

1. S. variábilis, Engehu. Scape $\left(1-4^{\circ}\right.$ ligh a angle with me m more of the lower whorls fertile; leaves very varoms, almost alwars sigittute; luacts mostly guinted; perlicels of the fertile flowers at leatst half the langth "f thes sterilo ones; jetals wholly white; filanents grlabons, nrirly twice the bangth of thr authers; achenes obovate (alont l" long), winged on lonth mangins, witl a long curvel or usually lorizontal luak $1-1$ its lengtl. (s. silgit-

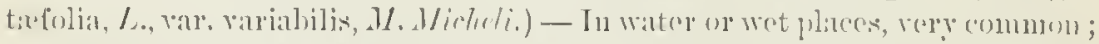

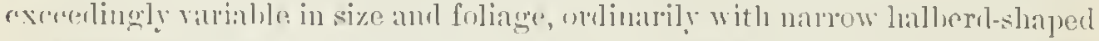

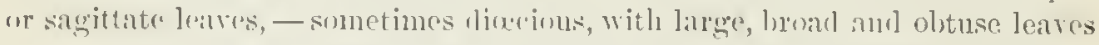

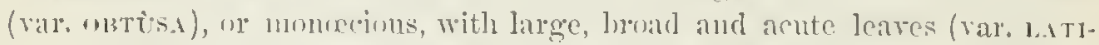

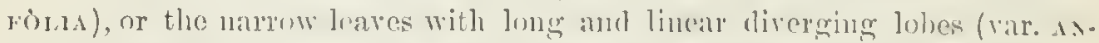

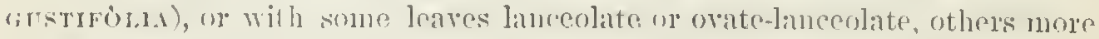

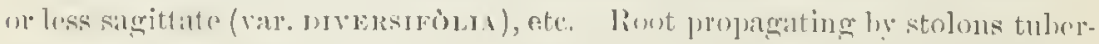
ifrems at the atremity. - The ruropean species lats the fertile perliecls ouly 
$\frac{1}{3}$ or $\frac{1}{4}$ the length of the sterile; claws of the petals purple-tinger; filaments nut longer than the anther's ; and achenes almost orbicular, rery hroally winged and with a short strilight leak.

Var, pubéscens, lingelm. ['pper part of petiole aud scape and especially the orhicular-orate obtuse bracts and sepals pubescent or woolly; beak of fruit horizontal. - N. J. and Y'enn. to Ga.

Var. (?) grácilis, Engelm. Lohes of the silgittate leaves very narowly

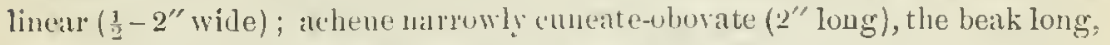
stont, and strongly recurved, the sides usially strongly 1-3-crested. (S. cristata, Eingelun.!) - Mass. tu western X. I. ; Inwa.

2. S. lancifolia, L. Salpe $2-5^{2}$ high, with several of the lower whorts fertile; learss lanceolate or lance-oblung, rarely linear, all with a tapering bise, thick or coriaceous (6-18' long and on a long and stont petiole, never sagittate), the nerves mostly alising from the very thick midrib; bracts orate, acute or atuminate; pedicels slender, the fertile scalcely shorter than the sterile ones; filaments pulescent; achenes falcate, winged on the back, pointed with in incurvel beak. - Siramps, Ml. to Ky. Mlo, and southwari. ( IT. Ind.)

* * Fituments very short, with enlaryed mostly glandulur base; anthers veute or short-oblong; fruiting heads small: uracts more or less connate; leaves very raraly sagittate.

3. S. heterophýlla, Pursh. Shape weil (3'-2o high), at lengtl procumbent: leaves lancolate or lance-nyal, entire, or with one or two narrow basal sagittate applunlages; hrarts roundish, obtuse; flowers of the lowest whorl fertile and ulmost sessile; the sterile on long pedicels; filaments glan-

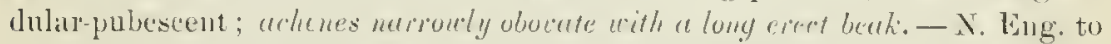
Flan, west to Minn, and Mo. Varies as to foliage, the leaves being loroar

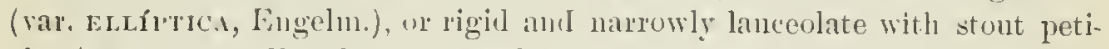

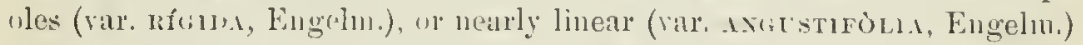

4. S. gramínea, Michx. Sheape $3^{\prime}-2^{\circ}$ ligls; phyllodir flut, mostly lnoudly lineur, aruminuts: laves orate-lanceolate to linear, on long slender petioles, sometintes rednced to the petiole nerely; bracts rather obluse; whorls of Howers often few, all staminate or the luwer fertile; pedicels slender, spread-

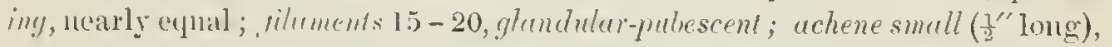
latrowly obnrate, almost beakless, minged on the buck, fut and scarcely costate on the sides. - N. Kang. to Mimn, sunth to the Gulf; very varialle.

5. S. tères, Watson. Mhyllorlin lerete, very ucutely attennute nymard, 3:2’ long, very rarely hearing a narow hlade; scape $\frac{1}{2}-1 \frac{1}{2} 0$ higlt; luacts connate at base; pedirels in I -3 wholls, all very slender and spreading, 1 or 2 fruiting, f-1' long; filaments 12, lilited, pubescent; whene olovate, l" lon/, whith an ered beak, the margins and sides crenately several-crested. - In shallow water, s. New ling. to N. J. (IIYanuis, Mass, Derur; Wading liver, L. I., Miller: barrens of X. .J., Torey.) I'hyllodia nsually very trumgly nodose.

6. S. nàtans, Michx. vir. loràta, Chapm. Usually dwatr; leures lin. ert, strup-shaped, obtuse w" arutish, 1-6' long, equalling or shorter than the scape, very rarely with a narow blade; perlicels in $1-3$ wlonls, only 1 or 2 fruiting, stouter and rerumed: brasts connate or sputhe-like: filimrints $6-8$,

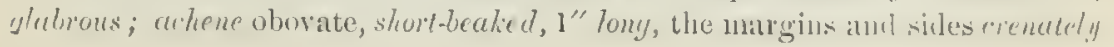


crested. (S. pusilla, Pursh.) - In mud or shallow water, near the coast; N. Y. to Fla.

Var. (?) gracíllima, Watson. Scape aud the almost or wholly bladeless leaves very slender aud greatly elongated (2-40 long, $1^{\prime \prime}$ wide); pelicels all elongated, in usually distant whorls, the lower pistillate, slender and spread-

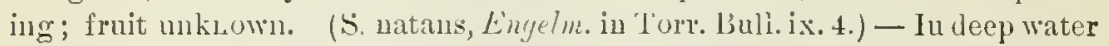
of streams in E. Mass. (Hitchings, Boutt, C'. E. F'aron, etc.) Wholly submerged, only 1 or 2 flowers appearing at a time, floating ou the surface. The fruit, maturing under water, has not yet beeu collected.

§2. LOPHIOCARPLS. Fertile flowers perfect; stamens 9-15, at the base of the receptacle; sepuls erect and embracing the fruit.

7. S. calycina, Engelm. Scape weak $\left(3-9^{\prime}\right.$ ligl 1$)$, at leugth mostly procunbeut; usually vuly the lowest whorl fertile, with pecticels as long as thuse of the sterile flowers, rec: rred in fruit ; bracts orbicular, olutuse or rarely pointed ; filaments sligh' $y$ rough, as long as the auther's; achenes obovate with a short horizuntal style; leaves brually halberd-shaped, obtuse or acutish, with wide spreading lubes, often wiler than loug, or lanceulate or sometimes reduced to linear phyllodia. - Maine to 1)el., west to Wisc., Mo., and 'lex. Quite variable, several forms being enumerated, as var. spox(rosis, with spongy texture and blacleless submerged leaves, eastward; aud westward, var. FLùraxs, with lauce-linear fluatiug leares.

\section{ECHINÓDORUS, Richard.}

Flowers perfect. Petals imbricuterl in the bur. Stamens 6-21 or more. Ovaries several or many, imbricated in a liead, forming thick and ribhed achenes in fruit, often beakerl with a projecting persistent style. - Mostly anmuals, with the babit of Sagittaria, the naked stems sparingly branched or simple, aud the flowers on rather short perlicels, in whorls of $3-6$ or more.

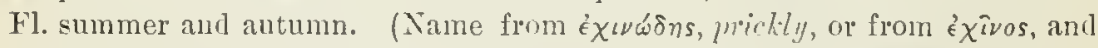
Sopós, a leathern bollle, applied to the ovary, which is in most species armed with the persistent style, so as to form a solt of prickly head of fruit.)

1. E. párvulus, Engelın. Scapes $1-3^{\prime}$ highh; shoots often creeping and

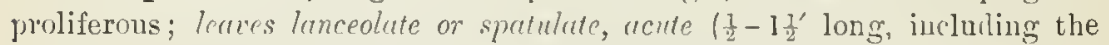
petiole); umbel single, 2-8-flowered; peditels reflexed iu fruit; flowel $3^{\prime \prime}$ broad; stamens 9 ; styles much shorter than the ourry: achenes beakless, obtusely few-ribberl. - In mud, Mass. to Mich. aud E. Miuu., sonth to Fla. and Tex. (S. Am.)

2. E. rostràtus, Engelm. Scape erect, $3^{\prime}-2^{\circ}$ high, longer thau the leaves; lemes broully ovate, cordate or truncate at busp, obtuse (the blade I - $3^{\prime}$ (oug) ; tmbel proliferous, in a branched panicle; flower 5" broad; stumens 12; styles longer than the ovary; achenes beaked, acutely many-ribbecl. - Swamps and ditches, Ill to Fla., Mo., and Tex. - 1 low form (var. Laxceodites, Engelm.) has the leaves lanceolate with an acute base. Ill., Mo.

3. E. radicans, Eugelm. Stems or srape mostrate, creeping $\left(2-4^{\circ} \mathrm{long}\right)$, proliferuus, hearing many whorls of flowers; leaves somewhat truncately hroadly heart-shiped, obtuse (2-8' 1)road), long-petioled ; flowers $6-9^{\prime \prime}$ broatl;

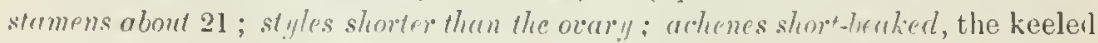
inck cleuticulate. - Swamps, Ill. to N. C. and Fla., West to Mo. and Tex. 


\section{Order 1:0. NaIADACEAE. (PoxdweEd FaMily.)}

Marsh or mostly immersed aquatic herls, will stems jointerl and lenfy or (in 'T'iglochin) waked and scupe-like, leaves sheathing at buse or stipulate, and flowers perfect or unisexual, often spathaceous, with periunth of 4 or 6 herbaceous distinct valvate segments, or memliranous and tubular or cupshaped, or none. Stamens 1, 2, 4 or 6, with extrorse anthers. Ovaries 1-6, clistinct or more or less coherent, 1-eelled, usually 1-ovuled, in fruit follicular or eapsular or an indehiscent berry or utricle.

Subondir I. Juncaginca. Narsh plants, with terete 1)ladeless leaves; flowers perfect, spicate or racemose, with herbaceous 6- (rarely 3-) lobed periantly; carpels 3 o. 6 , more or less united, separating at maturity. Seeds anatropous; embryo straight.

1. Triglnchin. Uvalies $3-6$, united until naturity. Leaves radieal. Flowers braetless, in a splike-like racene teruinuting a jointless senje.

2. Scheuchzeria. Oviries 3, nearly distinet, at lengtlı divergent. Flowers braeteate in a loose racone unon a leaty stem.

Suborder II. Naiadlea. Immersed aquaties, with flat leaves; oyaries solitary or distinet, 1-ovuled.

- Flowers perfect, spilied or clustered; anthers 4 or 2, sessile; leaves alternate.

3. Potamogeton. Spike pedumeled. Seprals 4, herbaceous. Anthers 4. Ovaries 4, sessile.

4. Ruppia. Flowers on an enclosed spadix, at length long-exserted, without perianth. Anther-eells 4, distinct. Ovaries 4, becoming stipitate.

+ Flowers monceious or diceious, axillary, naked, monandrous; leaves opposite (alternate in $\mathrm{n}, 6)$.

s. Zannichellia. Monceions. Pistils (2-5) from a cup-shaperl involucre or slieath.

6. Zostera. Pistils anl stamens alteruate in 2 vertieal row's on the imer side of a leaf-like anclosml spulix. Stimmas, linenr. Stcm ereeping.

7. Vaias. Direcions: pistil solitary, naked. Stanen enelosed in a membranous spatbe. Stems floating, with oplosite or ternate leaves.

\section{TRIGLÒCHI N, L. Arrow-grass.}

Sepals and petals nearly alike (greenish), ovate, eoncave, deciduous. Stamens $3-6$; anthers oval, on very short filaments. P'istils united into a $3-6$ rellel eomponnd ovary; stignasis sessile; orules solitary. Capsule splitting when ripe into $3-6$ carpels, which separate from a persistent central axis. Jerennials, with rnsh-like, fleshy leaves, below sheathing the base of the wandlike nakerl and jointless scape. Flowers small, in a spiked raeeme, bractless. (Name composed of $\tau \rho \in \hat{\imath}$, thre, and $\gamma \lambda \omega \chi \boldsymbol{i}$, point, from the three points of the ripe fruit in $\mathrm{n}$. I when dehiscent.)

$$
\text { * Fruit of } 3 \text { carpels. }
$$

1. T. palústris, T. Seape $\left(6-18^{\prime}\right.$ high) and leares slender; sepais and stumens o; finil limeru-clul-shuped; carpels when ripe separating from helow upward, leaving a triangular axis, axi-pointed at base. - Marshes, western X. Y. to Ill., Minn, anci westward. Aug. (Fin., Asia, ete.)

2. T. striáta, liuiz \& Pav. Scape $\left(6-12^{\prime}\right.$ high) and leaves slender; flow. ers very small; s'puls and stamens 3 ; fruit globose-tringular, or when iry 3-lobel. ('I. trimulra, Wich.r.) - Sea-shore, Md. to Fla. (S. Am., etc.) 
* Fruit of 6 carpels (rarely 5).

3. T. marítima, L. Scape $\left(1-3^{\circ}\right.$ high $)$ and leaves thickish, fleslyy; fruit orate or oblong, acutish; carpels rounded at base and slightly grooved on the back, the edgres acute. - Salt-marklies along the coast, Lab. to N. J., and in saline, loggy or wet places across the continent. (Eu., Asia, ete.)

\section{SCHEUCHZERIA, L.}

Sepals and petals oblong, spreuling, nearly alike (greenisl-yellow), but the latter narrower, persistent. Stamens 6 ; anthers linear. () paries 3 , globular, slightly united at base, 2-3-ovuled, learing flat sessile stigmas, in fruit forming 3 diverging and inflated 1 - 2-seeded pods, opening along the inside. $-\mathbf{A}$ low bog-lierh, with a creeping jointed rootstock, tapering into the ascending simple stem, which is righag, partly sheatlued by the bases of the grass-like conduplicate leaves, aurl terminated by al loose raceme of a few flowers, with sheathing hracts; leaves tubulan at the apex. (Namer for John and Jolm Jucob Scheuchapr, distinguished Swiss botanists early in the 18 th century.)

1. S. palústris, L. - Peat-logs, N. Brunswick to N. J., westward aeross the eontinent. June. (Eu., Asia.)

\section{POTAMOGETON, Tourn. Pondwen.}

Flowers perfort. Sepals 4, romnled, valvate in the bud. Stanens 4, opposite the sepals; anthers nearly sessile, 2-celled. (Vvaries + (rarely only one), with an ascending campylotropous nvule; stigma sessile or on a short style. Frnit drupe-like when fresh, more or less compresserl; endocarp (nutlet) erustaceous. Embryo houked, ammular, or cochleate, the radicular end pointing downward. - Herls of fresl, or one in brackislı, ponds and streams, with jointed mostly rooting stems, and 2-ranked leaves, whircl are usually alternate or imperfectly uppusite; the submersed ones pellucid, the floating ones often diliten and of a firmer texture. Stipules memlnanons, more or less united aml sheathing. Spikes sheathed by the stipules in the bul, mostly laised on it perluncle to the surface of the water. ( $\Lambda_{11}$ ancient name, composed of

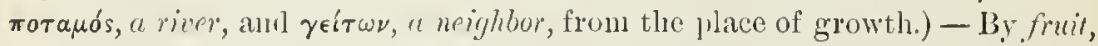
the full-grown fresl or maceraterl fruit is intended; ly nulet, tlat with the fleshy onter portion or epicar p remored. All except n. 19 flower in smmmer: the month mentioned indicates the time of ripening of the fruit.

$\$ 1$. Leaves of two sorts; floating ones more or less roriureons, with a dilated petioled bade, different in form from the thinn sulmersed ones.

* Submersed lecues sedured to narrowly grass-like of filiform sessile phyllodiu.

+ Stems ruther stout: stipules fiee: spilifs all smersed, cylindrical and densely finited: fincits fleshy and migirl, oblignely obovare.

1. P. nàtans, 1. Sitem simple or spumingly bromched: Aoating leares all long-petioled, elliptical or orate, somewhat cordate at bise, obtnse but with a blunt point, 2I-29-11erved; nper submersed leaves lanceslate, early perislling, the lowel (later in the season) very slenter (3- '’ lung, harely l" wide); upper stipules rery long, acute; peduncle ubut thr thrkiness of the stem: spikes 1 -2' long; siles of the turgid mule with a small deep impression in tha middle; 
embryo coiled into an incomplete elliptical riug. - Ponls am ditches, N. Scotia to Va., westward across the continent. In leeper or flowing water the ilant becomes more slender and often wlolly submersed (var. Plotixus, Кinch).- Aug., Sept. (Eu., Asia.)

2. P. Oakesiànus, Robbins. Stem more slender, much manched; Hoating leaves smaller ( $1-1 \frac{1}{2}$ long), wate- or oblong-elliptical, olstuse, fewer(17-23-) nerved; lowest subnersen ones almost capillary (unly $\frac{1}{1}-\frac{1}{2}$ "wide),

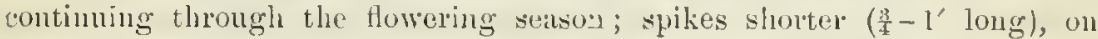
peduncles murh thicher thun the stem; fruit smaller and more acute; sides of the turyid mullet not at all impressed: curvature of the emilryo nearly circular, its apex clirected to a point above its base. - londs, and especially pools and stagnaut ditches, Mass, to N. J. ; also Anticosti. $\backslash u$ ge.

3. P. Pennsylvánicus, C'han. sitems cumpressed, often simple from the creeping routstocks; floating leaves chiefly opposite $\left(1-3\right.$ fong $^{\prime}$ long), $11-17$ nerved, oblong, tapering into a short petiole, the lower gradually narowing and passing into the submersed ones, which are very mumerous and approximate, 2-ranked, linear $\left(2-5^{\prime}\right.$ long", and $1-21^{\prime \prime}$ wile), $5-7$-neved, the lateral nerves slender and nearly marginal, the space within the inner nerves rousely cellular-reticulated; stipules very obtuse; sjukes munerous, abont the length of the thickened peduncle; fruit romel-obornte, fattisln, 3-keeled when dre; mutlet distinctly impressed on the sides; curvature of the enthyo transiersely oral. (I’. Claytonii, T'uckerm.) - Still or Howing water, N. Brunswick to s.. C., West to N. lud. and Minı. July, Aug.

+ + Like the precrding section, but ull the purts small, slender and delicate, only the fertile plants produciny flouting leuves; spikes iery sumbll and fewflowered; propaguled by aulumn buds.

4. P. Vaseyi, Robbins. Very delicate; stem alunost alpillary' flouting lences obocale $\left(3-5^{\prime \prime}\right.$ long) and abont the length of their filifun petioles, with 5 nerves deeply inpressed beneath, eross-reins distinct; sulunerserl leaves filiform-linear, very attenute (1-2' long, $\frac{1}{x}-1$ " wile) and achte: stipules not aduate, scarious, long, acute; spikes all emersed, few, interrupterl-ohlong,

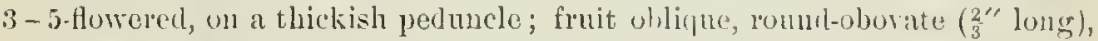
rompressed, slightly sharp-margined, tipped witl a distinet rechlreed style, the sides impressed and face acute; upper portion of the embryo circularly incurverl, its apex transverse to the fruit. - Canda and N. Eng.; also Ill. 'Tlue fruiting form, with thating leaves, rare; the submerged form allyarently murlo more abundait.

5. P. lateràlis, Moroug. Stem filiform, branching; flouting leutes ellipicul (4-6" long ly 2" wide), with $5-7$ nerves deeply impresserl leneatl, tapering at base into a somewhat dilated petiole slorter thau the blade; submersed leaves linert, acute ( $1-3^{\prime} \operatorname{long}$ by $\frac{1}{+}-\frac{1}{2}{ }^{\prime \prime}$ wide), 1 -3-nerved, the mirlnerve with fine veins or cellular reticulations on each side, bi-glaudular at loase; stipules short: pedunch with a very peruliur lateral appearance, widely sluealing at maturity, sometimes eren recurvel, often thicker than the stem; spikes often interupted (2-4-flowered) ; fruit ulliquely ohowate (hardly $1^{\prime \prime}$ lung), the back much curved, witl two fine grooves upon it; embryo ovil iu

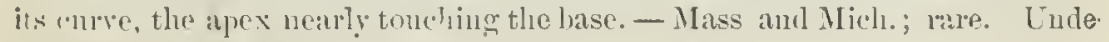
r(e)ped specintens resemble I'. jusillus. 


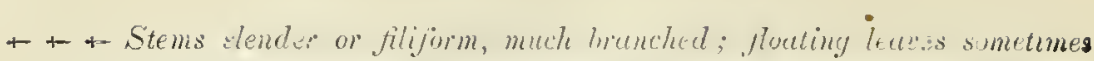
wanting; stipules adnate to the base of the leaj; spikes of two hinds, one emersed, rylindrical and many-flowered, on a chub-shaped peduncle, the other submersed, globular and few-flowered; fruit fat, cochleate, with thin or scarcely any flesh and a thin nutlet; embryo spiral.

6. P. Spiríllus, Tuekerm. Floating leaves oval to lanee-oblong and lanceolate (the largest 10" long, $4^{\prime \prime}$ wile), usually obtuse, about equalling the ruther dilated petioles, with 5 - many nerves beneath deeply impressed; upper submersed leaves either with or without a lance-oblong or broad-linear proper blade; the numerous lower ones narror-linear, tapering toward the obtuse apex $\left(\frac{3}{1}-1 \frac{1^{\prime}}{2}\right.$ long, $\frac{1}{4}-\frac{2^{\prime \prime}}{3}$ wide); stipnles early lacerate; submersed flumers usuclly so'itury on rery short erect peduncles; fruit with the back either minged and with 4-5 distinct teeth or vingless and entire; embryo coiled 1 $1 \frac{3}{4}$ turns. Rivers, and even far up small streams, N. Eng. to Va., west to Mieh. and Mo. June-Aug. - Stem less stender than in the next.

7. P. hýbridus, Michx. Floating leaves oval to lance-oblong (the largest $10^{\prime \prime}$ long, $6^{\prime \prime}$ wile), often aente, longer than the filiform petioles, with ahout $5-7$ nerves beneath deeply impresserl; submersed leares very numerons, atmost setaceuns ( $1-3^{\prime}$ long, very rarely $\frac{1}{2}$ " wide); stipules obtuse; chersed spikes 4-7"long; submersed spikes 1-4-flowered, their peduncles (of their own length) frequently recurved; fruit mimute, about 8-toothed on the nargin; embryo cuiled $1 \frac{1}{2}$ turns. - Shallow stagnant waters, N. Brunswick to Fla, west to Mich., Mo., and N. Mex. June-Aug.

* * Submersed leaves lanceolute, rarely oval or linear, membranuccous; spities dense, many-flowered, on stout pedincles.

8. P. ruféscens, Schrad. Stem simple; floating leaves (often wanting) $2-5^{\prime}$ long, rather thin, wedge-oblanceolate, narroved into a short petiule, $11-$ 17-nerved; submersed leares almost sessile, lanceolate and lance-oblong, smooth on the margin, fever-neved; stipules broad, hyaline, obtuse, upper vnes :teminate; spike 1-2' long, often somewhat coupound; fruit oborate, lenticular, pitted when immature, with an acute margin and pointed with tho rather long style; embryo incompletely annul:tr. - In streams or ponds, $\mathrm{N}$. Brnnswick to N. J., west to Minn. and 'Tex. Ang., sept. (Eu.)

9. P. flùitans, Roth. Stem of ten branching below; floating leaves thin. nish, lance-oblong or long-elliptical, often aeute, long-petioled, 17-23-nerred; submersed leaves very long (3-12', by 2-12" wide), lanceolate and lunce-linear, 7-1.5-nervel, coarsely retienulated; peduneles somewhat thickened upward; frnit obliquely obovate, ohseurely 3-keeled when fresh, and distinctly so when dry, the middle one winged above and sometimes with $3-5$ shallow indentations; the rounded slightly curved fice surmounted by the short style; nutlet with the sides scarcely impressed; upper part of the embryo circularly in curved. (P. lonchites, Tuckerm.) - In streams or rarely in ponds, N. Brunswick to X. J., west to Mimn. and Lowa. Jug., Scpt. (Eu.)

10. P. púlcher, Tuckerm. Stem simple, b!ack-spottcd; leares of three linds; floating ones becoming very large ( $4 \frac{1}{2}$ by $\left.3 \frac{x^{\prime}}{2}\right)$, roundish-ovate and cordate or ovate-oblong, 25-37-nerved, all alternate: upper submersed ones (3-5) usually loncesdule, acnte at hase and very long-acuminate, 10-15-nerved, very thin, cellular eacls side of the midrib, undulate, short-petioled; lourst (2-i 
urar the base of the stem) thicher, plane, oval or oblong with a rounded base, or spatulate-oblong, on longer petioles; stipules rather short and obiuse; peduncles thicker than the stem; fruit with a rounded back and angular face, pointed, distinctly 3-keeled when fresh, sharply so when dry ; nutlet with two deep dorsal furrows, and a siuns below the angle in front; sides flat; enbryo eireularly much ineurved above. - P'onds, Vt. to Ga. and Mo. July, $\Lambda u g$.

11. P. amplifolius, 'Tuckerm. Stems simple, of very variable lengtlı; flonting leaves (sometimes wanting) large, oblong or lance-ovate, sometimes slightly cordate at base, aloruptly acutish, 30-50-nerved, ou rather long petiles; submersed leaves often very large (reaching $\gamma^{\prime}$ by $2^{\prime}$ ), laneeulate or oral, acnte at each end, usnally much recurved, undulate, mostly on short petioles; stipules very long and tapering to a point, soon becoming loose; peduncles thickened "pward, in deep water mueh elongated f fruit very large (wer 2" long), rather obliquely obovate, 3-keeled, with a broat stout leak; nutlet slightly impressed on the sides; upper part of the embryo curver into a ring. - I'onds and rivers, X. Eng. to N. J., west to Minn. and Kan. Ang., Sept.

12. P. Illinoénsis, Morong. Stem stout, brencling towards the snmmit; floating leaves opposite, oral or orate $\left(2-5^{\prime}\right.$ long by $1 \frac{1}{2}-2^{\prime}$ broad), 19 25-nerved, romuled or subeorlate at base, with a short blunt point at apex, on short petioles; submersed leares ruther few, oblong-elliplical, acute at each end, usually ample (langest 8' by $1 \frac{7}{2}$ ); stipules corrse, obtuse, strongly bicarinate ( $2^{\prime}$ long); perluncles ofteu clnstered at the summit $\left(2-4^{\prime}\right.$ long), thickening

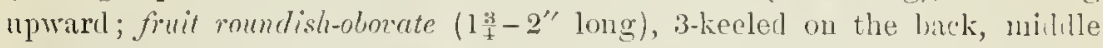
keel prominent; mutlet flattened and slightly impressed on the silles, olituse or pointerl at hase; apex of embryo directed transtersely inward. - Streams anl ditclies, western N. Y. to III., Iowa, anl Mlim. Very near the last.

13. P. heterophýllus, rinhel. stem slender, very branching below; fluatian leares mostly thin, variable, but with a short blunt point, 9-15-nerved, usially $1-2^{\prime}$ long and $6-9^{\prime \prime}$ wirle; submersed unes usually lancevlate or linearlanerolate, acuninate or cuspidate, narowed towarl the base, about i-nerved on the stem and 3-nerved ou the brunches; upper ones petioled, lower sessile; stipules obtnse, loose; peduncles somewhat thickened upward; fruit small, roundish, eompressed, scarcely keeled; embryo anuulur aluve. (l'. granineus, Fries.) - Still or flowing water, commou. Varies exceedingly in its submersed leaves, peduncles, etc.; the var. GRamisifólus (Fries), growing in rapid streams, with stems much elongated and less branched, and the flaccicl submersed leaves 2-7' long by $2-10^{\prime \prime}$ wide.

Var. (?) myriophýllus, Robbins. Sending up from ruming rootstocis many short repeatedly dichotomons and densely leafy stems; fertile stenss very slender; Hoating leaves small, delicate, lance-oblong, on long filiform petioles; submersed stem-leaves larger, early perishing; those of the branclics

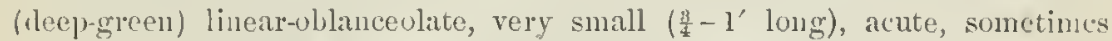
minutely serrulate; spike slender, loosely-flowerech, nuch shorter than the thickened peduncle. - Apponaug I'ond, R. I., without frnit.

13?. P. Zízii, Mert. \& Koch. liesembling 1'. lucens, but smaller, much branched at base: upper leaves coriuceous or subcoricucous, long-petioled and somethmes emersed, the others subsessile, all usually numerous, uudulate and shining: pedıucle elongated. (P'. lncens, var. minor, Nolle. Also l'. gramineus, var. (?) spathulaformis, Robbirs; I'. spathæformis, Tuckerm.; "1. vari" 
ans, Morong.") - N. Eng. to Fla., and westward. Connecting with the next section. (Eu.)

\$2. Leaves all submersed and similar, mustly sessile, membranaceuns and di-

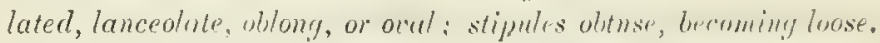

14. P. lúcens, I. Stem thick, lonanching, sometince vely large; leores more or less petioled, oval or lutuceolate, murronote, of ten rougli scrulate, fiegruently shining; peduncles often elongated; frmit rombish and compressed,

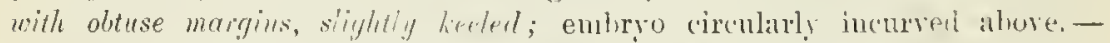
Pouds, N. Eug. to Fla., west to the Pacific. Aug, Sept. (Fn.)

Var. (?) Connecticuténsis, Robhins. Stem flexuous; leores all sulmersed, nearly sessile, lanceolate, acmminute, rrisped, not shining nor somblute: finit larger, distinetly keeled; nutlet thick and hard. - Lake Saltonstall, East Haven, Conn.

1.j. P. pralóngus, Wrulf. Stem rery long, hrunching, Hexuns; lenres lance-oblong or lanceolite (sometines i long), half'rlusphing, whens with a buatshriped cavity at the extreuity, thence splitting on pressure; stipulessurimus, very ohtnse; spikes mather louse-llowered; polmoles wry lomy (sometimes reakling 20'); fint obliquely whovate, compunessed, shorply keeled when dry ; style terminating the nearly sulught face; curve of the enthyo wal and longritudinal. - Ponds and large rivers, $\mathrm{X}$. Scotia to Mass, west to Minn. and lowa. Sept., Oct. - Stem white; foliage hright green. (ku.)

16. P. perfoliàtus, L. Stem hancling; lences wbiculur, ovate or lanceolate from a inrluterlasping base, usually obtuse and often minutely serrnlate; peduncles slort, cylindrieal; firmit irregulnrly olwate, obtusely maryined; embryo incurved in an wal. - Pouds and slow streams, common. N. Scotia to Fla., west to Minm. and Iowa. Siept., Oet. (lin.)

Var. lanceolàtus, Robbius. langer; leares bong-lanceolate from a cor-

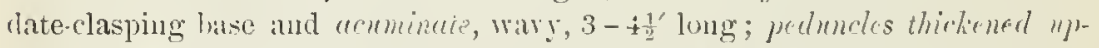
word. - Same lange as the species, anct extending west to the P'acific.

17. Y. críspus, L. Stem rompressed; leute limen-oblony, lalf-clasping,

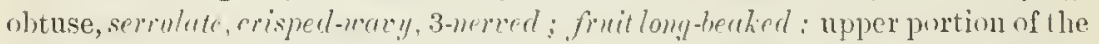
embryo incurved in a large circle. - Flowing and stagnant waters, Mass. to N. J. and Ya, west to western N. Y. June, July. (Liu.)

18. P. Mýsticus, Morong. Stem very stenter and irregularly branching,

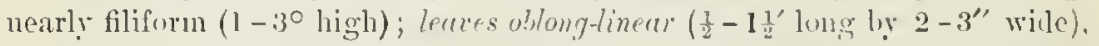
5 - 7-nerved, jimely molulate and entire, oltuse or bhonlly jointed, abruptly narrowing at brise, srssite or purtly daspring; spikes few, capitate ( $1-6$-flowered). on erect peiluneles $\left(1-2^{\prime}\right.$ long $)$; fruit (immature) olowate, sulall (harily $\frac{8}{4}$ long), obsrumely 3-lineted on tho buck, a little beaked ly the slender recnival style. - Mystic J'mul, Medforl, Minss.

\$3. Leaces all submersed und similne, mostly mombranaceous and sessile, linear or sitareous.

* Stipules free from the slicuthing buse of the leaf.

19. P. zosterafólius, schum. Stem branching, wing-fluttened; leaves linear and grass-like (conmonly $t^{\prime}$ by $1 \frac{1}{2}{ }^{\prime \prime}$ ), alumptly pointed, with many fine and 3 larger nores; stipules (seen young) ol,long, very obtuse; spikes cylindrical, 12-15-flowerel, not half as long as the peduncle; fruit obliquely ohovate, somewhat liecled and with slight teeth on the back, the sides not impressed. 
the face areluing and terminated by the slurt style; summit of the larye embryo lyiny trunserse to the firut. (P. eompressus, Fies; not L.?) - Still and slow. flowing waters, N. Lug. to N. J., Iowa, and Mlinu. Aug., Sept, (Eu.)

20. P. Híllii, Jorong. Stem slender, urdely branchiny, fluttish; leaves linear, acute ( $1-2 \frac{1}{2}$ long by $\frac{1}{2}-1 \frac{1}{4}$ " wide), 3-nemod, the lateral nerves delicate and near the margin; stipules whitish, striate, obtuse $\left(3-5^{\prime \prime}\right.$ long); sprikes capitate (3-6-fruited), on slunt spreading or recured peduncles; frnit as in the last. - Mich, and western N. Y.

21. P. obtusifolius, Mertens \& Kioeh. Stem flattened, very brancliniy. leares linear, tapering toward the base, olstne and mucronate or very acute, 3- (ravely 5-) nerved; stipules clangrted, rery whtuse; spite ovate, continuons, 5-8-flowered, about the lenyth of the peduncle; fruit oval, apiculate with the style, not keeled when fresh, umper portion of embryo eoiled inwart and lying trunsverse to the fint. - slow streams and ponds, Canada and N. Eng. to western N. Y. and Mieh. Sept., Oct. (Eu.)

22. P. pauciflorus, l'ursh. Sitem, filiform, fluttish and very branching; lrares nurrouly linear $\left(1-2^{\prime} \operatorname{long}\right.$ and seldom $\frac{y^{\prime \prime}}{2}$ wide), aente, obscurely :3mereel; stipules obtuse; spikes capitate, 1-4-(usually 2-) fluwered, on short (-Inl)-shaped peduncles; fruit romdish icuticulu?: the buck more or less rrested; nyer portion of the enbryo incured in a circle. - Still or stagnant wates, N. Brunswick to Ga., Iowa, Minl1., and westward.

Var. Niagarénsis, Gray. Stem often longer $\left(1-3^{\circ}\right)$; leaves larger $\left(1 \frac{1}{2}-\right.$ $3 y^{\prime} \operatorname{long}$ by $\mathrm{l}^{\prime \prime}$ wirle or less), 3-5-nerred at hase, very acute aud mncronate, nitrowed to the subpetiolate base. (1'. Niangensis, Tuckerm.) - Riuming water, Great Lakes to S. C.; also in Cal.

23. P. pusíllus, L. Stem slender, flattish or neally cylindrical, often very branching; leares narrou- or setaceous-lineur, alcuminate, acule or sulucute, I 3-nered, furnished with translucent glends on each sicle at the base; stipules at first obtuse; spikes intermuterl or capitate, 2-8-tlowered, on rather long peAuncles; fimit ubliquely elliptical, srmpely lifeled; upr.x of embryo ineurved and directed obliquely dounurd. - Pools and ditches, N. Seotia to N. J., west to Minn. and XIo., and westwal. - leares sumetines almost setaceous frar. temuissimus, $\operatorname{Ror}($ ).

Var. polyphýllus, Mıฯm. Dwarf form (3-5' high), divaricately branehing from the base, very lealy thumghont; laves very obtuse, not cuspidate, 3-nerved ; non-flowering but aluundantly provides with propagating buds which are formed on the thickened and hitriened ends of the bramches and closely investerl by imbricated leaves. - In a shallow pool, S. Natick, Mass.

24. P. mucronatus, Finrar. Resembling 1'. pusillns, bnt stem less branching ; leaves brouder (alnost 1" wile), often s-neved; spites interrupted. (1'. pusillus, var. major, Fries.) - N. Brunswick to western N. Y., Mich., and Minn. July. (En.)

25. P. gemmípalus, hobhins. Stem filifurm, branching, terete, varying greatly in lecight; lecers larir-lilie, sometimes not as broad as the stem, often with no apparent midrib, trpering to the finest frim (1 - 3' long), bi-glandular at base; stipules $\frac{1}{2}-1^{\prime}$ long; spikes few (3-6-Howeren), intermpted, on long filiform peduneles; propagating buds iery mumeme; fruit like that of l'. pusillus, very rare. (P. pusillus, rar.? gemmiparus, Rubbins.) - Slow-noring st reams and still water, Mass. Iug., Sept. 
26. P. Tuckermàni, Robbins. Very slender aud delicate from a creeping rootstuck, of a fiue light green; stem filiform with several short and repeatedly dichotomous leaf-bearing branches; lenes thin and that, but setaceous and tapering to near the fineness of a lair $\left(1-t^{\prime} l o n g\right.$ and $y^{\prime \prime}$ extreme width), ubscurely 1-3-nerved, with a few coarse reticulations; stipules rather persistent below; $\frac{1}{3}$ 'loug, obtuse; peduncle solitarly, very long, rather thickenel upward; spike 48-flowered, in fruit continuous, oblong; fruit thick-lenticular, obscurely 3-keeled; nutlet slightly impressed on the sides; shell thick and hard; embryo nearly annular. - Cold ponds, White Mountains of N. II., N. Y., aud N. J.

* * Stipules united with the sheathing buse of the leaf.

27. P. pectinàtus, L. stem filiform, repeatedly dichotomous; leaves very narrowly linear, attemate to the apex, l-ncrved with a few transverse veins; spikes interrupted, on long filiform peduncles; fruit obliquely broad-oborate, compressed, bluntly lieeled; shell of untlet very thick; emlryo spirally incurved. - N. Brunswick to Fla., westward across the continent. Aug. - Oct. (Fin.)

28. P. marinus, I. Resembling uarrow-leaved forms of the last species, low and very leafy; peduncles much elongated; fruit much smaller (1"long) and thinuer, round-obovate, not keeled upou the rounded back, tipped with the hroad sessile stigma ; embryo cmmulur. - IVesteru N. Y., IIl., Mich., and soutlward. Probahly the range of this species is much mure extensive than indi('ated, as it has heen comfounderl with P'. pectinatus.

29. P. Robbínsii, Oakes. Stem ascending from a creeping base, rigid, very hranching, incested by the bases of the leaves and stipules; leaves crowded in tuo ranks, recurest-spreading, narrow-lanceolate or linear (3-5' long and 2$3^{\prime \prime}$ wide), acuminate, cilicte-serrilate with trauslucent tecth, many-nervell; stipules obtuse when young, their nerves soon becoming bristles; spikes numerous, loosely few-flowered, on short peduncles; fruit oblong-obovate ( 2 "long), keeled with a broadish wing, acntely beaked; embryo stont, orally annular. In ponds and slow streams, N. Bruuswick to N. J., the N. shore of L. Superior, and far westwarl.

\section{R Ú P PIA, I. Ditchi-grass.}

Flowers perfect, 2 or more approximated on a slender spadix, which is at first cnclosed in the sheathing spathe-like lase of a leaf, entirely destitute of floral envelopes, consisting of 2 sessile stamens, each with 2 large and separate auther-cells, and 4 small sessile oraries, with solitary camprylotropons suspended ovules; stigma sessile, depressed. Fruit small ohliquely ovate pointed drupes, each raiset on a slender stalk which appears after flowering; the spadix itself also then raised on an elongated threarl-f(n)m pednncle. Embryo ovoid, with a short and pointed plumule from the upler end, by the side of the short cotyledun. - Narine herbs, growing under water, with long and thread-like forking stems, and slender almost capillary alteruate leaves, sheathing at the base. Flowers rising to the surface at the time of expansion. (Derliented to $I I . B$. Rinppins, a German lotanical anthor of the early" part of the 18th century.)

1. R. marítima, l. Leaves linear-eapillar!' ; nut orate, obliquely erect, 1." long; fruiting pethucles capillary (3-6' long); stipes 1-12" long. Shallow bays, along the entire coast; also occasioually in saline places in the interior. (Eu., Asia, etc.) 


\section{ZA N N I H ÉLIA, Micheli. Horned Pondwed.}

Flowers monceious, sessile, naked, usually huth kincls from the same axil; the sterile consisting of a single stanen, with a slencler filament bearing a $2-$ 4 eelled anther; the fertile of $2-5$ (nsually 4 ) sessile pistils in the same cupshaped involucre, forming obliquely ohlong mutlets in fruit, beaked with a short style, which is tipped by an ohligurely disk-shaped or sonewhat 2-lobed stigma. Seed orthotropous, suspended, straight. Cotyledon tilper, bent and coiled. Slender branching herbs, growing under water, with nostly opposite loug and linear thread-form entire leaves, and sheathing nembranous stipules. (Named in honor of Zamnichelli, a Venetian botanist.)

1. Z. palústris, I. Style at least half as long as the fruit, which is flattish, somewhat incurved, even, or vecasionally nore or less tootled on the back (not wing-margined in our plant), nearly sessile; or, in rar. peduxculats, both the cluster and the separite fruits evidently peduncled. - l'onds and slow streams, thronghout N. America, lut not common. July. (liu, Asia.)

\section{ZOSTERA, I. Grass-wrack. Eel-Grass.}

Flowers moncerions; the two kinds naked and sessile and alternately arranged in two rows on the midrib of oue sicle of a linear leaf-like spadix, which is hidden in a long and sheatll-like base of a leaf (spathe); the sterile fluwers consisting of single ovate or oval l-celled sessile anthers, as large as the ovaries, and contaning a tuft of threads in place of ordinary pollen; the fertile of single ovate-oblong ovaries attached near their apex, tapering mpward into an awlshaped style, and containing a pendnlous orthutrupons orule; stigmas 2 , long and bristle-form, deciluons. Ltricle bursting irregularly, cnclosing an oblong longitudinally ribbed seed (or mutlet). Emblyo slupt aud thick (proper cotyledon almost obsolete), with an open chink or cleft its whole length, from which protrudes a doubly eurved slender plumule. - Griss like marine herbs, growing wholly under water, from a jointed creeping stem or rootstock, sheathed by the bases of the very long and linear, oltuse, entire, grass-like, ribbon-shaped leaves (whenee the name, from (worńp, a band).

1. Z. marina, I. Leaves ulscenrely 3-5-nerved. - Common in shoal water of bays along the eoast, from Newf. to Fla. (Eu.)

\section{N A I A S, I. NAIAD.}

Flowers dioceious or monnecions, axillary, solitary and sessile; the sterile consisting of a single stamen encluserl in a little membranons spathe; anther at first nearly sessile, the filament at length elongated. Fertile flowers eonsisting of a single ovary tapering into a short style; stigmas $2-4$, awl-shaped; orule erect, anatropous. Fruit a little seed-like nutlet, enclosed in a loose and separable membranous epicarp. Embryo straight, the ralicular end downward.Slender lranchiug herbs, growing under wher, with opposite aurl linear leaves, somewhat crowded into whorls. spimnlose-toothed, sessile aur dilated at hase. Flowers very small, solitary, hut often clnstered with the branch-leaves in the axils; in summer. (Naís, a water-numph.)

1. N. martna, I, Stem rofher stont and often ar med with brond mickles: leares brondly linear (3-18" long), roressely and sharply toothed, the dilated base

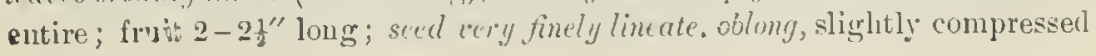


(X. major, All.) - Marshes and salt-springs of westeru X. Y. aud Mich. 'Teetl of one or more brownish cells upon a many-cellerl hase. (Eu.)

Var. grácilis, Horongr. lnternodes long $\left(1-3^{\prime}\right)$ ancl nearly naked, with mly a few teeth above; lanes very narrow, the dilated base also toothed; fruit smaller. - Canoga mishes, wosteru N. Y.; also in Flat.

Var. recurvàta, Nulley: Stens slont, inclined to be dichotonousing branched, reeurved-spreading; leaves msmally recurvel, the teetl prominent, the dilater base with a projecting tooth each side. - ('aynga marshes, N. Y.

2. N. Héxilis, Rostk. \& Schmidt. Stems usuully very stender; leures

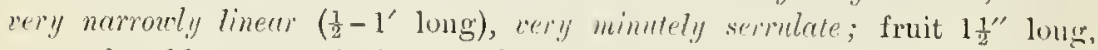
narrowly oblong; seeds lance-oval, smooth and shiming. - Ponds and sluw streans, N. Scotia to S. C., Iowa and Mim. Teeth on the margins of the leares 1-celled. (Eu.) - T'ar. Rouúst., Morong. Stem stunt, few-leaved, sparsely brauehing, elougated ; leares flat, abmuttly acute. - E. Mass., Mich., and 'Tex.

3. N. Índica, Cham., var. gracíllima, 1. Br. Branches alternate; leaves very narrowly linear, nearly copillury, straight, servate, the roundcd lobes of the sheathim, buse spimuloseritiute; fruit linear, impressed-dotted between the numerous ribs. - Mass. to Peun, west to Ind. and Mo. 'Teetl of 3 cells eaeh.

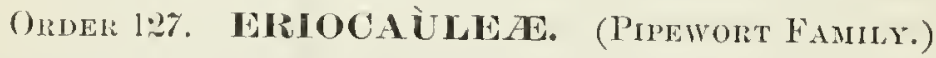

Aqualic or murith herls, stemless or short-slemmed, with a tuft of fibrous roots, a chuster of linear and often loosely cellular grass-like leates, and nuked scapes sheathed al the base, bearing dense heads of monocious or rorely divecious small 2-:3-merous. flowers. each in the axil of a scarious bract; the periunth double or rurely simple, cluffig; anthers introrse; thu: fruit a 2-3-celled 2 -3-sected capsule; seeds pendnlons, orthotropnoss: embryo at the apex of mealy albumen. - Chiefly tropical plants, a few in northern temperate regions.

1. EriocauIon. Periantli (louble, the inmer (crolla) tubular-funnel-form in the staminate Howers; stamens twice as many as its lobes (4). Anthers s-celled.

2. I'a palanthus. Perituth us in the last: stanens only as many as the cololla-lobes (3). Authers 2-eclled.

3. Lachnocaulon. Periantlı simple, of 3 sepnals. Stanens 3, monadelphous below. Anthers 1-cellecl.

\section{ERIOCA ULLON, T. PMEWORT.}

Flowers monocions and andlogynous, i. e. hotlı kincls in the same heal, either intermixed, or the central unes sterile and the exterior fortile, raxely diocions. Sier. Fl. Calyx of 2 or 3 liceled or boat-shapeel sejals, usually spatulate or dilated npwarl. Corolla tuhulau', 2-3-lohed, each of the lobes bearing a hiack grland or spot. Stamens twice as many, one inserted at the base of each lole and one in each sinus; anthers 2-celled. I'istils rudinentary. Fert. Fl. Calyx as in the sterile fluwers, often remote from the rest of the flower (therefore perlapps to be viewerl as a pair of bratetets). Corolla of 2 or 3 separate marrow petals. Stamens none. (Tary often stalked, 2-3-lohed, 2-3-celled; stylo 1; stigmas 2 or 3 , slemler. ('apsule memhanacens, loculicidal. — Leaves inostly slunoth, loosely cellular and pellucid, that or concare above. Scapes or perlun. 
les rerminated by a siugle head, involucrate by some outer empty bracts. Flowers, also the tips of the bracts, ete, nsually white-learded or woolly(Name compoumderl of Éprov, rool, and kaudós, te stalk, from the wool at the base of the scape.) - our species are all stemless, wholly glabrous excepting at the base and the Howers, with a depressed head and dimerous Hower's.

1. E. decangulàre, L. Leares obtuse, varying from linear-lanceolate to linear-awl-shiped, rather rigid; seapes $10-12$-ribbed $\left(1-3^{\circ}\right.$ high); head hemispherical, hroming globular (2-7" wide); scales of the involucre autish, straw-color ol light brown; chaff (bracts among the Howers) printed. - l'inebarren swanps, N. I. to Fla. July-sept.

2. E. gnaphalòdes, Michx. Lecures spreating (2-5' long), grassiy-awlslurped, rigit, or when snbunerserl thin and pellucid, tapering gradually to a shar" point, mostly shorter thiu the sheath of the 10-ribbed scape: scales of the involucre very obtuse, turning leal-colur; chuff obtuse. - l'ine-barren swamps, N. .J. to I"la.

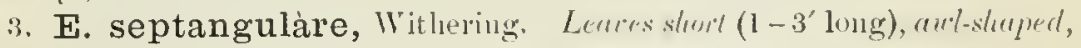
mollucid, soft and very cellular; srofe $4-7$-striute, slender, $2-6$ ' ligh, or when silbmerserl becoming $1-6^{\circ} \mathrm{long}$, accorrling to the depth of the water; chuff mutish; head $2-3$ " broul; the lracts, chaft, etc, learl-culor, except the white corme beard. - In pomds or along their borders, Yewf. to N. J., west to Ind., Mirh., anl Mim, July, Ang. (Eu.)

\section{P开PALÁ NTHUS, Martius.}

Stamens as many as the (often involute) lobes of the fumnel-form corolla of the sterile flowers, and opposite them, commonly 3, and the flower temary thronghout. ()therwise nearly as in Eriocanlon. (Nime from $\pi a \iota \pi a ́ \lambda \eta$, dust

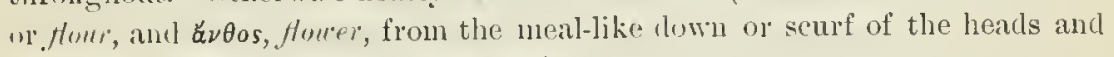
Howers of many Sonth American species.)

1. P. flavídulus, Kinuth. 'Tufted, stemless; leaves hristle-awl-shaperl (1' long); seapes very slender, simple, minutely pulsescent ( $6-12^{\prime}$ high $)$, 5angled; bracts of the involucre oblong, pale straw-color, those among the flowe's mostly obsolete; periath glabruss; sepals and petals of the fertile flowers linear-lancelate, scarions-white. - I, nw pine-barrens, s. Va. to Fla.

\section{L A CH NOCA Ù LON, líntl. IIatry Pipewort,}

Flowers moncerions, etc, as in Eriocaulon. Calyx of 3 sepals. Corolla none! Ster, Fl. Stamens:3 ; filaments below coalescent into a elub-shaperl tube around the rudiment of a pistil, above separate and elongated; anthers l-celled! Fent Fl. Ovary 3-celled, surrounded by 3 tufts of hairs (in place of a corolla). Stig-

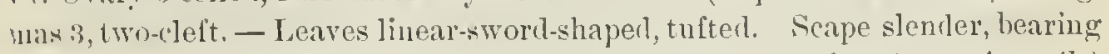

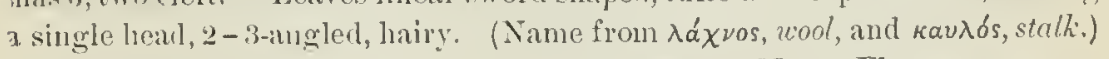

I. L. Michaùi, Kuntl. - Low pine-larrens, Va. to Fla.

\section{Order lar. CYPEIRACAE. (ShDGE FAMILy.)}

Grass-like or rusth-like herbs, with fibrous roots, mostly solid stems (culms),

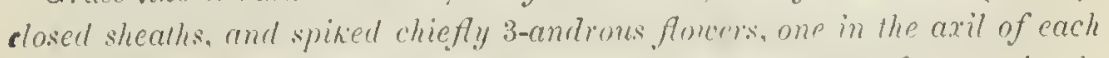
of the ghume-like imbricated bracts (scales. glumes). If stitute of any perianth, 
or with hypogynous bristles or scales in its place; the 1-celled ovary with a single erect unatropous ovule, in fiuit forming an achene. Style g-cleft with the fruit fattened or lenticular, or 3-cleft and fruit 3-angular. Embryo minute at the base of the somewhat floury albumen. Stem-leaves when present 3-ranked. - A large, widely diffused family.

I. Flowers all perfect, rarely some of them with stamens or pistil abortive: spikes all of one sort.

Tribe I. SCIRPEA. Spikelets mostly utany-lluwered, with only 1 (rarely 2) of the lower scales emlyty.

* Stales of the spikelet strietly 2-ranked, conduplicate and keeled.

+ Flowers destitute of bristles and of heak to the achene; inflorescence terminal.

1. Cyperus. Spikelets few-many-flowered, usually elongated or slender.

2. Kyllinga. Spikelets I-fluwered (but of 3 or 4 seules), glonerate in a sessile head.

+- + Flower furnished with bristles ; achene beaked; infloreseence axillary.

3. Dulichinun. Spikelets 6-10-fluwered, slender, clustered on an axillary pedunele.

* * Scules of the several - many-flowered spikelet imbricated all round (subdisticlous in n. 5).

- Achene crowned with the bulbous persistent base of the style (usually deciduous in n. 7) ; flowers without inner seales (bractlets).

++ Hypogynous bristles (perianth) generally present; culm naked.

4. Eleocharis. Spikelet solitary, terminating the culn. Stamens 3.

++ +t Bristles always none; culm leafy.

5. Dichromena. Spikelets crowded into a leafy-involuerate head, laterally flattened, the scales more or less conduplicate and keeled. Many of the flowers injertect or abortive.

6. Psilocarya. Spikelets in broad open rymes. Style almost wholly persistent.

7. Fimbristylis. spikelets ju au involucrate umbel. Culn leafy at base, style usually wholly deciduous.

+ + Style not bulbous at base.

++ Flowers without inner scales, but bristles generally present.

8. Scirpus. Spikelets solitary or clustered, or in a compound unlel, the stem often leafy at base and infloreseence involucrate. Barbed bristles $3-8$ or nume. Stanens mostly 3.

9. Erioplorum. As Scirpus, but the bristles naked, exserted and ofteu silky in fruit. Stamens $1-3$.

++ ++ Flower with one or more inner seales.

10. Fuirena. Scales of the spikelet awnod below the apex. Flower surrounded by 3 stalked petal-like scales altcrnating with 3 bristles.

11. Hemicarpha. Flower with a single very minute hyaline seale next the axis of the spikelet: bristles none.

12. Lipocarpha. Flower enclosed by 2 inner seales, onc next the axis, the other in front of the achene; bristles none.

Tribe II. RHYNCHOSPOREA. Strikelets mostly 1-2-floweled, with 2 - many $0_{+}$ the lower seales empty.

13. Thynchospora. Spikelets terete or fattisll; seales convex, either lonsely enwrajping or regnlarly inbricatul. Achene erownel with a persistent tubercle or beak, and commonly surrounded by bristles.

14. Cladium. Spikelets terete, few-flowered, the seales, ete, as in the preeding. Acher-9 destitute of tubercle. No bristles.

\section{Flowers nnisexual.}

Tribe II. SCLEIIFA. Flowers monocious; the staminate and pistillate in the same or in different chustered spikes. Aeliene uaked, bony or crustaeeous, supported on a hardened disk.

Ti. Scleria. Spikes few-flowered; lower scales empty. No bristles or inner seales. 
Tribe IV. CARICEA. Flowers monocious in the sane (androgynous) or in separate spikes, or sometines diucious. Achene enclosed il a sac (perigynium).

16. Carex. Hypogynous bristle shott and enclosed in the jerigynium or none.

\section{C Y P E R US, 'Tomn. Galivale. (I'l. 1.)}

Spikelets many-few-flowered, mostly flat, varionsly arranged, mostly in clusters or heads, which are commonly disposed in a sinple or compound terminal nnbel. Scales 2-ranked, conluplicate ant keeled (their decurrent hase below often forming margins or wings to the hollow of the joint of the axis next below), deciluous when old. Stamens 1-3. No bristles or inner scales. Sityle 2-3-cleft, deciluots. Achene lenticular or triaugular, naked at the apex.Culms mostly triaugular, simple, leafy at base, and with one or nore leaves at the summit, forming an involucre to the nmbel or head. I'erluncles or rays unequal, sheatlied at base. All flowering in late snmmer or autumn. (Kúteıpos, the ancient name.)

§1. PYCRELS. Achene lenticular, the edge turned to the rhachis; spithelet Rattened, muny-flowered; rhachis narrow, not winged. Anmuals.

* Cinbel simple or copitale, rarely slighlly compaund.

1. C. flavéscens, L. Culms 4-10' high ; spilielets 5-8" long; involucre 3-leaved, very unequal; sjikelets becoming lincar, obtuse, clustered on the 2-4 very short rays (perluncles); scules obtuse, straw-yellow; stamens 3 ; achene shining, orbicular, its superficial cells obloug. - Low grounds, N. Eng. to Mich., Ill., and sontlıward. (Eu., etc.)

2. C. diándrus, Torr. (Pl. 1, fig. 1-4.) Sipikelets lance-oblong (3-9"), scattered or clustered on the $2-5$ very sliort or unequal rays ; scules rather obluse, purple-trown on the margins or nearly all over; slumens 2, or sometimes 3; achene dull, ollong-oborale; otherwise much like the last. - Low grouuds, common from the Atlantic to Minn., Ark., and N. Mex. - Var. CAsrixeus, 'Torr. Seales more firn and hrowner; with the type.

3. C. Nuttàllii, Torr. Culuns 4-12’ lighlı; spikelets lance-linear, acnte and very flat ( $\frac{1}{2}-l^{\prime}$ long), crowded on the few usually very short (or some of them distinct) rays; scules oblong, yellowish.brown, rather loose; stamens 2; achere oblong-ahorale, wry blunt, dull. - Mostly in salt or brackish marshes, along the coast, from Mass. to the Gulf.

4. C. polystàchyus, liotth., var. leptostàchyus, Boeckl. Culms sery slender, 6 - 15 " ligh ; leaves and elongated involucre very narrow; sjikelets few to many on the 4-8 rays, linear, acute, 2-9" long; scales thin, ovule, cule, closely imlricaled, pule brown; stamens 2; achene linear-oblong or clarale, short-pointed, yraysish and mimulely pilterl. (C. microdontns, Torr.) - Margins of ponds aud streans, Va. to Fla. and Tex.

$$
\text { * Timlsel compound. }
$$

5. C. flavicomus, Villl. Cnlm stout $\left(1-3^{\circ}\right.$ high $)$; leaves of the invoIncre $3-5$, very long; spikelets linear $\left(t-9^{\prime \prime}\right.$ long), spiked and crowded on the whole length of the hranches of the several-rayed unlyel, sprealing; srales oval, ver!y obtuse, yellowish and bromish, broudly srarions-(whitsh-) morgined; stamens 3; achene obovale, mucronate, blackish. - Low grounls, Va. to Fla. 
\$2. CIPERL's proper. Achene triangulur; spikelets usually many-fowered, more or less futtened, with carinate scales, the rhachis marginless or nearly so (uinged in $\mathrm{n} .12$ ).

* Stamen 1 ; spikelets short und small $\left(1 \frac{1}{2}-5\right.$ "long) in ylobulur heads, orate or linear-oblony, many-flowered; achene oblong-obovate to linear.

+Lou immals; involucre 2-3-leaved; heads few; scales pointed.

6. C. aristàtus, Rottb. 1)warf $\left(1-5^{\prime}\right.$ high); spikelets chestmut-brown, blong beroming linear, 7 - 13-Huwered, in $1-5$ ovate heads (sessile ant clussered, or short-peduncled) ; scales nerced, tapering to a long recurced point; achene uhlong-obuvate, obtuse. (C. inflexus, M/hl.) - Sandy wet shores; common. Fiwet-scented in drying.

7. C. acuminàtus, Torr. Slenter (3-12' ligh); spikelets oirate, becominy obluny, 16-30-tluwered, pule; scules abseurly 3-nerced, short-tipped; achene oblung, pointed at buth euds. - Low ground, Ill. and sunthwestrard.

+ + Tull perennial $\left(1-4^{\circ}\right.$ high); heads many, greenish; scales pointless.

8. C. calcaràtus, Nees. C'ulu ubtusely triangular; leaves and iuvolucre

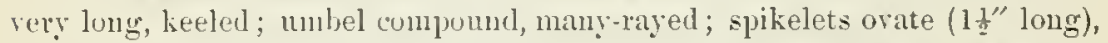
in numerous suah heads achenes pale, linear, on a slender stipe; scales uarrow, acutish, obscurely 3-nerved. (C. virens, Grun, in part; not Michx. C. I.uzula, var. umbellatus, Brift.) - W' to places, Deı. to Fla. and Tex.

* * Stumens 3 ( 2 in C. fuscus) ; spilielcts chustered on the rays of a simple umbel (or in a single sessile heal); scules mostly green or greenish and many-nerred, abruptly sharp-pointed; achene obovite, sharply triangular.

- Lou unnuls.

9. C. compréssus, L. Culms 3-9' high, witl a simple sessile ur a few umbellate chuster's of oblung to linear spikelets (15-30-floweres aul $3-8^{\prime \prime}$ long) with crowdel strongly keclech and rery acute pale scales. - Sterile fields along the coast, Md. to Fla. and Tex, ; also adventive near Philadelphia.

C. FÉcL, L. (If similar labit; spikelets much smaller (2-4" long), the thin bown scales (greenish only on the keol) barely acutish and rory faintly nervel. - Revere Beach, Mlass. (Yonng); on lallast at I'hiladelphia. (.111: from En.)

t- I- Ierminil, propayating frum hard clustered corms or bulb-like tubers.

10. C. Schweinitzii, Torl. C"nlm rongl on the angles $\left(1-2^{\circ} h \mathrm{gh}\right)$; $1 \mathrm{~m}$ hel 4-8-rayed, rays very unequal, erect; spikelets loosely or someuhat remotel;

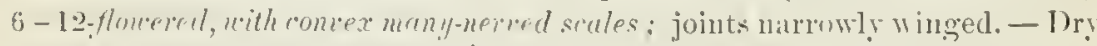
:anly shores and rilges, western $\mathrm{X}$. Y. and Penu. to Minn. and Kan.

11. C. filicúlmis, Yahl. Culm slexlex. wiry, oftureclined (8-15"

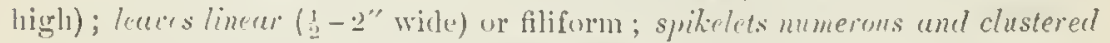
In one sessile densw head, or in 1 - i additional looser hearls on spreading rays of an irregular umbel; joints of the aris naked: seales bunt, greenish. - Dry stcrile soil ; (r)mmon, especially southwarl.

12. C. Gràyii, Torl. Culun threal-form, wiry $\left(6-12^{\prime}\right.$ high); lectes al. most bristle-shuped, chamelled; umbel simple, 4-6-rayed: spitios 5- 10 in a inse head, spreading; joints of the uxis winged: scules raller olunse, grecnishhhostunt-color. - Barren sands, llymouth, Mass, to X. J., near the coast. 
§ 3. PAPỲRUS. Style 3-cleft; achene triangular ; stamens 3 ; spitielets manyflowered, flattened, the carinate scules decurvent upon the rhachis as scurious wings; spikes in simple or compound umbels.

* Wings of the rhachis soon separating to the base as a pair of fiee scales; armual.

13. C. erythrorhizos, Muhl. (Pl. 1, fig.5-8.) Culm obtusely triangular $\left(3^{\prime}-3^{\circ}\right.$ highl); umbel many-rayed; involucre $t-5$-leavel, very long; involucels bristle-form; spikelets very nmmerons, crowled in ublong or cylin(Irical nearly sessile heads or spikes, sprealing horizontally, linear, flattish (3 $6^{\prime \prime}$ long), bright chestnut-colored ; scales lanceolate, nucronulate. - Nlluvia! bauks, L. I. to P'enn., Mich., Mimn., and sonthward; also adventive in N. Ling.

* Wings of the rhachis persistently attached; perennial by slender running rootstocks.

+ Acliene round-obovate; scales mucronate or acute, fiee or spreading.

14. C. Háspan, I. Cnlms sharply angled (1-1 $\frac{1}{2}^{\circ}$ high); leaves linear, "fftur reduced to meubrunous sheaths; umbel spreading, the filiform rays mostly Iomyer than the 2-leaved involucre; spikelets narrowly linear ; scales light redhishlown, oblong, mucronate, 3-nerved. - Ponds and ditches, Va. to Fla. and Tex.

15. C. dentàtus, Torr. (Pl. 1, fig. 9.) Cnlms slender ( $1^{\circ}$ liglı); leaves rigirl and keeled; umbel erect, shorter than the 3 -4-leaved inducre; scales reddish-brown, with qreen keel, orate, ucute, T-nerverl. - Sandy swanps, N. Eng. and northern X. Y. to S. C. and IT. Ya. Spikes often abortive and changed into leafy tults.

+ + Achene linur to oblony; scules appressed, pointless or nearly so. ++ Perennial by tuberiferous stolons.

16. C. rotúndus, I. (Nut-Grass.) Culn slender $\left(\frac{1}{2}-11^{\circ}{ }^{\circ}\right.$ high), Jonger than the leaves; umbel simple or slightly compound, about equalling the involncre; the few rays each hearing $4-9$ dark clestnut-purple In-40-flowered reute spikelets $\left(4-9^{\prime \prime}\right.$ long); sroles orte, closely apmessed, nerveless except on the keel._Sandy fiells, Vit. w Flit. and 'Tex.; also adventive near Philadelphia and New York riby. (kit.)

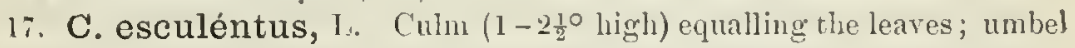
uften counpound, +-7 -rayed, much shorter than the long involucre; spikelets mumerous, light clestnul or stracioblor, aculish, 12-30-flowered ( $4-7^{\prime \prime}$ long) ; scales ovate or orate-oblong nariouly scarions-margined, nered, the acutish tips rrther loose: achene oblong-uhorate. (C. phymatodes, Mull.) - Low grounds, along rivers, etc, N. Brunswick to Fla., west to Miun. and Tex.; spreading exunsively by its smill nut-like tuhers and becoming a pest in cultivated grounds. + + Perennial, propagatiny by corm-like lubers from the base; spikelets numou, acuminate, often tertish; scales oblong-lanceolate; achene linear-oblong.

18. C. strigósus, L. Culm mostly stout ( $1-3^{\circ}$ high); most of the rays of the umbel elongated $\left(1-5^{\prime}\right)$, their sheaths 2-bristled; spikelets 5 - 25-flowered, spreading; scales several-nerved, wuch longer than the achene. - Damp or fertile soil, Canada to Fla., west to Minn., Tex., and the Pacific. Very variable in the number and leugth of the rays of the simple or compound umbel, and in the size of the spikelats ( $2 \frac{1}{2}-6$ or even $12^{\prime \prime}$ long), more or less lensely crowded un the axis. 
\$4. IICLIDIUM. S'tyle 3-cleft; spikelets narrow, terete or nearly so, fewmany-flowered, the scales closely appressed and the broad wings of the jointed rhachis enclosing the triangulur achene.

19. C. speciòsus, Vahl. Culm stout, mostly low (5-20' high); rays of the simple or conpound umbel nostly all short and crouded; spilielets 10-20-

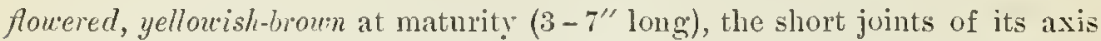
winged with very lroal scaly margins which elnbrace the arate triangular achene; the scales orcte, obtusish, inturicately overhpping. (C. Michauxianus, Gray, Manual; not Schultes.) - Low grounds and sandy lanks, N. Eung. to Fla., west to Minn. and Tex.

20. C. Engelmánni, Steud. Resembles u. 19; but the spikelets more slender and terete, someribat remotely 5 -15-foucred, the zigzag joints of the axis slender and narrowly winged, and the oblong or oral broadly scarious scales proportionully shorter, so as to expose a part of the axis of each joint, the successive scales not renching the base of the one above on the same side; achene oblonglinear, very sinall. - Low grounds, Mass. to Wisc. and soutlward.

$\$ 5$. MARISCUS. Spikelets 1-4-flowered, subterete, usually in dense heads; scales appressed, severul-nerved, the loccer empty and often persistent after the fall of the rest of the spikelet; joints of the rharhes uinged, enclosing the triangular achene. Perennial.

* Spikelets slender and acuminute, more or less refracted in usuully close um. belled spikes. - Connecting with $\S 4$.

21. C. Lancastriénsis, P'urter. Culm (1-20 high) triangular; leaves rether broadly lineur; umbel of 6 - 9 mostly elongated rays; spikelets rery numerous in short-oblong close herels, swon reflexed, of $3-6$ narrow scales, the upper and lower empty, twice the length of the lineal-oblong achene, which is nearly $\mathbf{l}^{\prime \prime}$ long. - Rich soil, l'ent. ant N. J. to Ala.

22. C. retrofráctus, 'Torr. Culm and leaves nsually mimtely downy and rongh on the obtusish angles ( $1-3^{\circ}$ higl $)$; unbel many-rared; spikelets sleuder-aul-shiped, very numerons in obovate or chlong heads terminating the

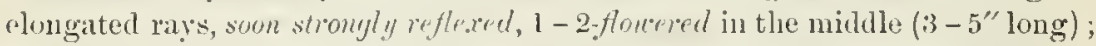
scales nsually 4 or 5 , the two lwwest ovate and empty, the fertile lanceolate and pointed, the nppermost involnte-awl-shaped ; achene linear, 1 1 " long. Sandy fields, N. J. to Fla. and 'Tex.

23. C. l'efráctus, Engelm. Culm 1-20 lrigli; rays usually more or les: dongated; spikelets very slenter, in rather loose leads, divaricate or more or less reflexed, 2-4-Howered; acliene linear, 1." long. - N. J. to N. C. and Mo. * * sipikelets very short, blunt, in densely compracted globose or cylindrical heads

24. C. ovulàris, Torr. Culm sharply triangular $\left(6^{\prime}-2^{\circ}\right.$ ligh $)$; unbel

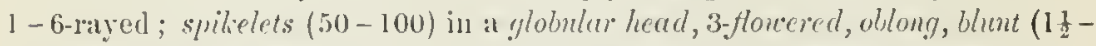
2" long) ; scales orate, oltuse, a little longer than the ovate-oblong achene. Sindy dry soil, sontheru I. Y. to Flin, west to Ill., Ark., and Tex. - Var. ronústrs, Bueckl., is a form with large heads ( $4-8^{\prime \prime}$ long), the spikelets 34-fiowered. (C. Wolfii, $W^{5}$ mol.) - Ill. to Ark, and sonthward.

25. C. Torrèyi, Britton. Like the last, but the hads cylindrical or oblong, spilketets usuelly 2-flockered, and uchene lincar-oblong. - L. Island to Fla.. west to Tex. 


\section{KYLLÍ N G A, Rotthoell. (P'l. 1.)}

Spikelets of 3 or 4 two-ranker scales, 1 - $1 \frac{1}{2}$-flowered; the 2 lower scales minute and empty, as in Cyperus, $\$ 4$, lut style oftener 2-rleft and achene lenticular; spikes densely aggregated iu solitary or triple sessile heads. Culms leafy at base; involucre 3-leaved. (Named after Peter Kylling, a Danish botanist of the 17 th century.)

1. K. pùmila, Michx. Amnutl; culns 2-9' liggh; head globular or 3-loberl, whitish-grecu (alwut 4" broal), spikelets strictly 1-flowered; upper scales orate, pointed, rough on the keel; stancus aud styles 2; leaves liuear - Low grounds, Ohio to 11l., soutle to Fla. and 'l'ex. $\Lambda$ ug.

\section{DU LÍ CHIU M, l'ers. (P'l. 1.)}

Spikelets many- $(6-10-)$ flowered, linear, flattenerl, sessile in 2 ranks on axillary solitary peluncles emorging from the shraths of the leares; scales 2 lanked, lanceolate, ilecurrent, forming flat wing-like margins on the joint below. l'erianth of $6-9$ dlowwardly barbed bristles. Stanens 3. Style 2-cleft abure. Achene flattened, linear-oblong, beaked with the loug persistent style. - A peremial herl), with a terete simple hollow culm (1-20 high), juinted anul leafy to the sunmit; leaves short and flat, livear, 3-ranked. (An alteratwu of Dulcichinum, an old name for a species of (yperus.)

1. D. spathàceum, P'rs. Borlers of pouds, N. Scotia to Fla., west tis Minn. and 'Tex. July-Sept.

\section{ELEÓCHARIS, R. Br. Srmk-Rush. (I’. 3.)}

Spikelet single, terminating the nakerl culm, many-several-flowered. Scales inbricated all ronud in many (ralely in 2 or 3 ) ranks. I'eriantl of $3-12$ (contmonly 6) bristles, usually rongle or barbed dowuwarl, rarely obsolete. Stamens 2-3. Style 2-3-cleft, its bulbous base persistent as a tubercle jointer upon the apex of the lenticular or triangular achene. - Leafless, chiefly perennial, with tufted culms sleathed at the lrase, from matted or crepping root-

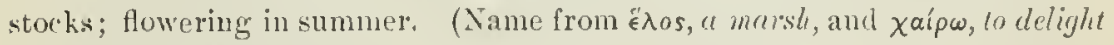
in: being marsh plants.)

\$. S. Spitielet terete, hurdly if at all thicker than the spongy-cellulur culm; scules jirmly persistent; style mostl! 3-cleft; bristles 6 (rurely 7 ), firm or rigid, mostly barlied donnerarl, ryulling or surpassing the triangular or lenticular achene.

* Spikelet linear or lanceolnte-aul-shuperl, feu-flowered; scales (only 3-9) few. ranlied, convolute-clasping the long fattened joints of the uxis, lanceolate, herbaceous (green) and sereral-nerved on the burk, and with thin scarimes margins.

1. E. Robbínsii, Oakes. Floner-beuring culms eauctly triungulur, ratler stout, erect $\left(8^{\prime}-2^{\circ}\right.$ ligh), also jurluling tufts of (apillary abortive stens or

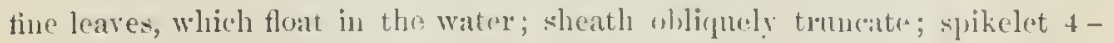
$10^{\prime \prime}$ long; acleue oblong-obovate, triangoular, minutely reticoulated, about laalf the length of the bristles, tipped with a fattencel aw l-shaper? tuluercle. - Shal l.w. water, N. Fug. to Fla. 
* * Spikelet cylindrical, many-fluwered, l-2'lony; seales in several mnks, firm. coriaceous with scarious maryin, pale, nerceless or jainlly striate; culms large and stout $\left(2-4^{\circ}\right.$ high); basul sheaths often leaf-bearing.

2. E. equisetoides, Torr. Culm terete, linatted us if jointed by many cross-partitions; urhene smooth (the minute reticulation transversely linearrectangular), with a conical-heaked tubercle. - Shallow water, R. I. to Fla., west to Mich. and Tex.

3. E. quadrangulata, Ii. [31. (1'1.33, .ig. 6-9.) Culm continuous and sherply 4-anyled; achene jinely refineluted, with : conlcal flattened distinct tubercle, - Shallow water, central $X$. Y. to Mich., and sonthward; raro.

\$2. Sprikelet lerete uml turgid-ome, much thicler thun the very slender culm; scules thin-coriareous or firm-membranaceons, persistent, ovate; style 3-clefi; bristles stomt, barbed donmuar (or sommimes upuard), as long as the striate and pitted-reticnlated trimgular arhene and its tmbercle; culms tuffed firm filvous ruots, 1 - 20 high.

4. E. tuberculòsa, IR. I31. (P'l.3, fig. 10.) Cinluts flattish, striate; spikelet 3-6" long, many-flowered ; mbercle fattish-cap-shaped, as larye rs the bod!y of the arhene. - Wet sauly soil, from Mass. along the coast tu Flat.

5. E. tórtilis, s'chult. Culms sharply triangular, capillary, twisting when

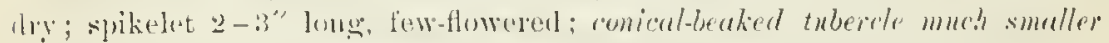

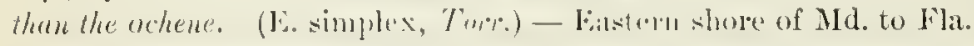

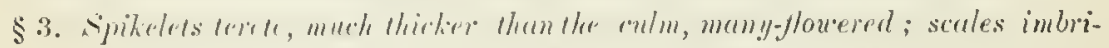
cated in many or more than 3 ranks, thin-membranaceons or scarions, with a thicker midrib, nsually lronnisñ or jurghlish, sometimes decidnous.

* Style 2-cleft (ofien 3-cleft in 11. T and 10) and the smooth achene lenticular: culms slender or thread-form, terete or compressed.

+ Anmuls ; rulms infted, from jibrons roots.

6. E. capitata, R. Br. Culns terete, $1-8^{\prime}$ higle or more; spikelets mente 10 oblong (1-3" long), ol,tuse, 15-40-flowered; scules thickish, round-ovate, whluse, brown or brownish with green lieel and paler margins; stamens 2 ; achene

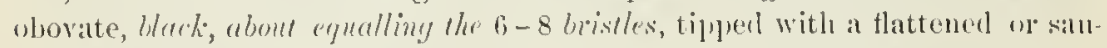

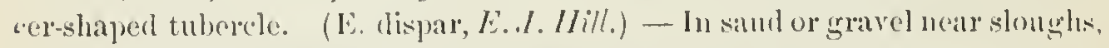

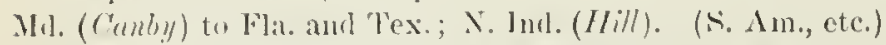

7. E. ovàta, li. Br. Culms noirly terete, 8-14' high; sjuikelet globos.

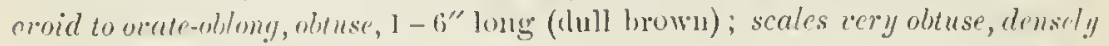

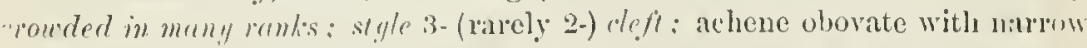
inse, pale-brownish, shining, shorter than the $6-8$ hristles, bronder them the

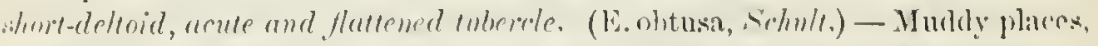
X. Brunswrick to Miun., sonth aud westwarl. Variable as to the lengthol' it: luistles. A low form, with smaller and more narrowly ohovate achenes, aul

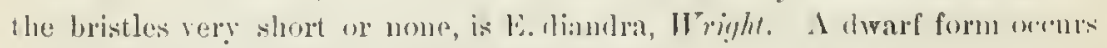
with verys small and frw-floweroll heals. (Eu.)

8. E. Engelmánni, Steml. Like the last; spikelets usnaliy namowly eylindrical and acute on antish, $2-8$ " long; achene broad and truncate, the tubercle covering the snmmit: lristles not exceding the achene. (F. obtusa. var. detousi, (iray.) - Mass. to P'enu. and Mo. 
++ Peremials, with ruming roolstorks.

9. E. olivàcea, 'Torr. (I'l. 2, fig. 1 -5.) Culms flattisl, groured, dif.

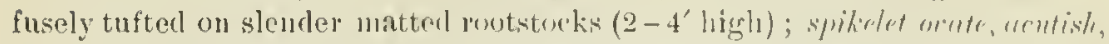

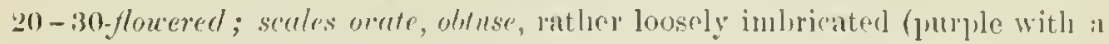

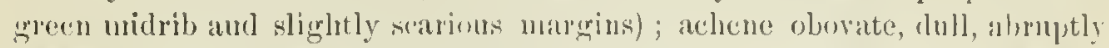
heaked with a narrow tuliewle, shorter than the $6-8$ bristles. - Wet, satudy soil, Mass. to N. C., anul western X. Y.

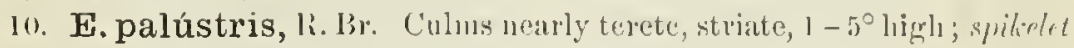

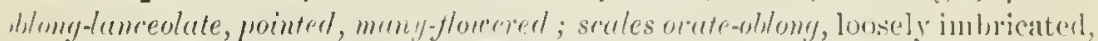
rolvlish-brown with a hroal and translncent whitisls nulgen and a grecnish lin'l, the upper acutish, the lowest lombled and often ("nlatreng ; achene rathen. narrowly obovate, somewhat slining, crower with a short ovate or orate-tri-

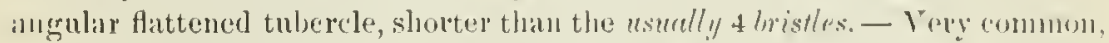
rither in water, when it is pretty stont and tall, or in wet grassy gumbur.

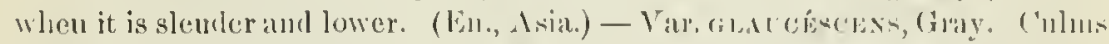

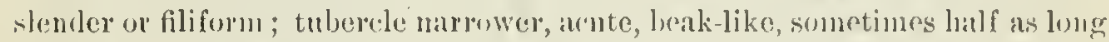

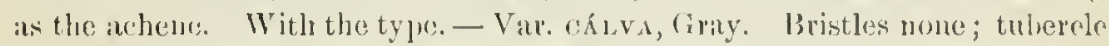
short, lont narmwer than in the type. - Var. visixs, I. II. Batiley. Culns wry stout, rigial; aclone more broally obovoid. Lake Champlinin and aloug the Great lalies to Mimn.

$$
\text { * Arhene tricmgular or turgirl; style 3-rleft }
$$

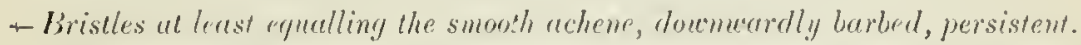

11. E. rostellàta, 'l'orr. Ciulms flatlened and striate-grooved, wiry, elect

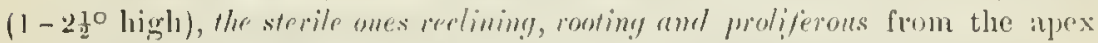

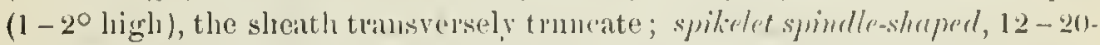
Howererl ; seales ovate, ohtnse (lienht-hown); acliene obovate-triangnlar, nat-

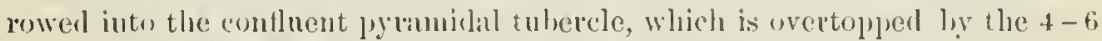
bristles. - Mnurshes, N. Eng. to S. 1'., west to Micl. and Ky.

12. E. intermedia, Selutlts. Culms crullary, wiry, striate-groovel,

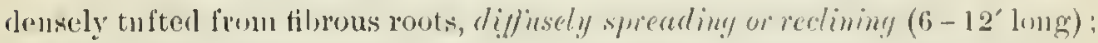
spikelet chlong-oecute, acutish, lonsely $10-20$-flowered (2-3" longr); rables oblong, obtne, green-keeled, the sides juplish-hown: achene obovoll with a nal-

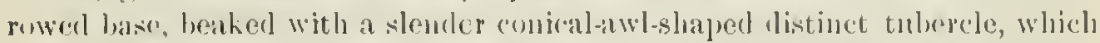
nearly eruals the 6 bristles. - W'at slopes, l'enn, to lowa, nortle to Canarla.

13. E. Torreyàna, Boeckl. Like the preceding, lut more capillary and lewals smaller (1 $1-2^{\prime \prime}$ loug), somrtimes praliferons, the one or more slowt new

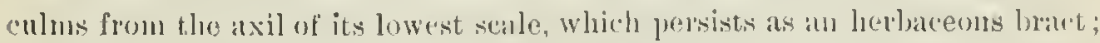

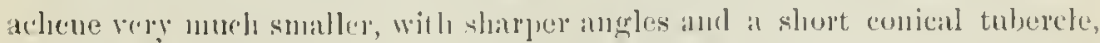

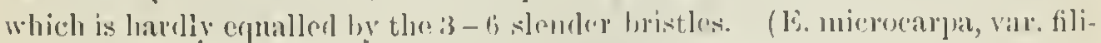

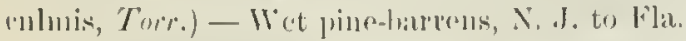

+- Bristles 2-4, sherter than the achene, slender and fragile, or nome.

14. E. ténuis, hécultes. Culms almost mpillary, crect frour rumning rout-

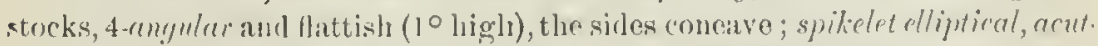

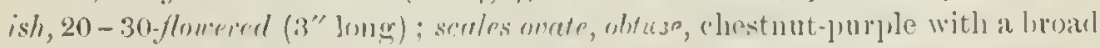

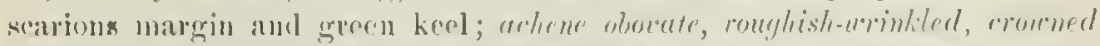
rrith a smoll depressed tuluerele, gersistent after the fall of the stalcs; loristless

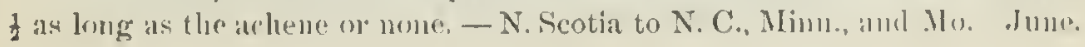


15. E. compréssa, Sullirant. Culms, fut, striate, tufted, erect $\left(1 \cdots 2^{\text {s }}\right.$ ligh); spikelet ovate-oblong, or at length lancenlate, $20-30$-flowered (4-7" long!; scales lanceolate-ovate, acute, lark purple with lroad white pellucil margins and summit; achene yellowish, whorate-pear-shrped, obtusely triangular, wrinkled, crouned wilh a small romical and pointed tubercle; bristles 1-4, rery slender, fragile, shorter than or equalling the achene (sometimes none or a single rudiment). - Wet places, X. Y. and Ont. to Minn. and MLo.

16. E. melanocárpa, Torr. Culms flutrmed, grooved, wiry, erect (9$18^{\prime}$ high); spikelct cylindrical-oroid or oblong, thirk, obtuse, densely many-flow. ered $\left(3-6^{\prime \prime}\right.$ long $)$; scales closely many-rankerl, roundish-orate, very obtuse, hrownish with broad scarions margins; arhene smooth, obocate-top-shaped, obtusely triangular, the broad summit entrely coeced like a lid by the flat dejressed lulercle, which is raised in the centre into a short abrupt triangular point; bristles often obsolete; achene som blackish. - Met sand, Mass. to Fla.

17. E. tricostàta, Torr. Culms fluttish $\left(1-2^{\circ}\right.$ high $)$; spikelet soon cylimdricul, densely many-flowered $\left(6-9^{\prime \prime}\right.$ long $)$, thickishs; scales ovate, very obtuse, rusty brown, with broad scarions margins; achene olovute, with 3 prominent thickened angles, minulely rough-wrinkled, wowned with a short-conical acule ubercle; bristles none. - N. J. to Fla.

18. E. Wólfii, Gray. Culms slenler ( $1^{\circ}$ high $)$, from very small creepingr rhizomes, 2-pdgerl: spikelet orate-oblong, acute; scales ovate-oblong, obtuse, scarious, pale purple; achene pyriform, shining, with 9 nearly equidistunt obtuse ribs and transverse winkles between them; lubercle depressed, truncate, more or less apiculate; bristles not seen. - Wet prairies, N. Iowa and S. Minn.

$\S 4$. Spikelet more or less flattened, thicker than the slender or capillary culm, few-many-flowered; the thin membranaceous scules somewhat 2-3-ranked; style 3-cleft; bristles of the perianth 3-6, fiagile or fugacions. Small or delicate species, differing fiom the lust division chiefly in the flattish spikelets.

* Tubercle contracted at its junction with the achene.

19. E. aciculàris, R. Br. Culms finely capillary $\left(2-8^{\prime}\right.$ long), more or losis 4-rmyulur; spikelet 3-9-flowered; scales orate-oblong, ratler obtuse (greenish with purple sides); achene obovate-oblong, with 3-ribbed angles and $2-3$ time as many smaller intermediate rils, also transversely striate, longer than the $3-+$ very fngacious bristles; tubercle conical-triangular. - Muddy shores, across the continent. (Eu., Asia.)

20. E. pygmàea, Torr. Culms bristle like, flattened and grooved (1-2 l,igh); spikelet ovate, 3 -8-flowered; scales orate (greenish), the upper rather acute; achenc ovoid, acutely triangular, smooth and shining, fipped with a mi nute tubercle; bristles mostly longer than the fruit, sometimes wanting.Brackish marshes, from N. Brumswick to Fla.

* Tubercle continuous with the nullet und not contracted ut base.

21. E. pauciflora, Link. Culıns striate-angled, rery slender (3-9' high), scarcely tufted, on slender running rootstocks, with a short truncate sheath at hase; scales of the ovate spikelet eviclently 2-ranked, chestnut-brown, pointless, all flower-bearing, the two lower larger; hristles 3-6, alout as long as the conspicuously leaked triangular acliene. (Scirpus pauciflorus, ligllfoot.) Wet places, N. Y. to N. Ill. aud Minn., north and westward. (Eu, Asia.) 


\section{DI CHR Ò M E A, Richarıl. (Pl. 4.)}

Spikelets aggregated in a terminal leafy-inrolucrate head, more or less compresserl, few-flowered, all but 3 or 4 of the flowers usually imperfect or abortive. Sicales imbricated sonewhat in 2 ranks, more or less conduplicate or boat-shaped, keeled, white or whitish. Stamens 3. Sityle 2-cleft I'erianth, bristles, etc., none. Aclene lenticular, wrinkled transiersely, crowned with the persistent and hroad tubercled base of the style. - Culms leafy, from creeping perennial rootstocks; the leaves of the involucre mostly white at the base (whence the name, from sis, double, and $\chi \rho \bar{\omega} \mu \alpha$, color).

1. D. leucocéphala, Hichx. Culm triangular $\left(1-2^{\circ}\right.$ high); leaves narrow; those of the involucre 4-7; achene truncate, not margined. - l)anu pine-barrens, N. J. to Fla. Aug., Sept.

2. D. latifòlia, Balkwin. (Pl. 4, fig. 1-5.) Culm stouter, nearly terete; leaves broadly linear, those of the involucre 8 or 9 , tapering from base to apex; achene round-oborate, faintly wrinkled, the tuherele decurreut on its edges. - Low pine-barrens, Yia. to Fla.

\section{PSILOCÁR Y A, 'Torr. BALD-Rush. (P.4.)}

Spikelets ovoid, terete, the numerous scales all alike and regularly imbricated, each with a perfect flower. I'erianth (bristles) wholly wanting. Stamens mostly 2. Sityle 2-cleft, its base or the greater part of it enlarging and hardening to form the beak of the lenticular or tumid more or less wrinkled achene. - Annuals, with leafy ('ulms, the spikelets in terminal and axillary cymes. (Name from $\psi$ ìós, muled, and kapúa, nut.)

1. P. scirpoides, Torr. Innual ( $t-10^{\prime}$ high $)$, leafy; leares flat; spikelets 20-30-flowerel; scales oblong-ovate, acnte, chestunt-colured; achene somewhat nurgined, beaked with a sword-sluaped almost wholly persistent style. (Rhynchospora scirpoides, (rory.) - Inmndated places, S. N. Eng.

\section{FIMBRÍSTYLIS, Vahl. (Pl. 3.)}

Spikelets several-many-flowererl, terete; scales all floriferons, regularly imbricated in several ranks. Periantl (bristles, etc.) none. Stamens $1-3$. Style 2-3-cleft, often with a dilated or tumid hase, which is decidnons (except in n. 4) from the apex of the naker lenticular or triangular achene. (Jtherwise as in Scirpns. - Culms leafy at hase. Spikelets in our specios unbellerl, and the involucre 2-3-leaverl. (Xame componnded of fimbric, a fringe, ant stylus, style, which is fringed with hairs in the gemnine species.)

* Style 2-cleft, Hattened aud riliur : achene lenticular: tubercle soon deciduous. spikelets muny-flowered.

1. F. spadicea, Vahl, var. castànea, Gray. Culms (1-210 high ) tufted from a perennial root, rigid, as are the thread-form convolute-channelled leaves, smooth; spikelets ovate-oblong beconing cylinclrical, dark chestnutcolor (2" thick); stamens 2 or 3 ; achene very mimutrly striute and reticulated. - Salt marshes along the coast, N. Y. and N. J. to Fla. July-Sept. — Sicales lighter colored than in the tropical form.

2. F. láxa, Yahl. (I'l. 3, fig. 1-5.) Culms slenıler (ֵ-12’ high) from

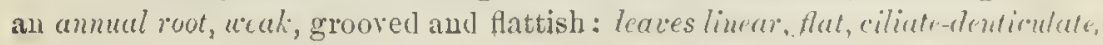


glaucous, sometimes hairy; spikelets ovate, acute (3"long); stamen 1 ; achene conspicuously 6-8-ribher on each side, and with fine; cross-lines. — Low ground, Penn. to Fla, west to Ill. and La. July-Sept.

* Style 3-cleft and achene triangular; tubercle soon deciduous; spikielets smaller and fewer-forered.

3. F. autumnàlis, Roem. \& Schult. (Pl. 3, fig. 6-9.) Ammual (3$166^{\prime}$ high), in tnfts; culms flat, slender, diffuse or erect; leaves flat, acnte; umbel componnd; spikelets oblong, acute ( $1-2^{\prime \prime}$ long), single or $2-3$ in a cluster; scales orate-lanceolate, mncronate; stamens 1-3. - Low grounds, Maine to Fla., west to Ill. and La.

*** Style 3-cleft, filiform and not ciliate; achene acutely triangular; tubercle more or less persistent.

4. F. capillàris, Gray. Low annual, dcnsely tnfted (3-9' lighlı); culm and leaves nearly canillary, the latter short; umbel componnd or panicled; spikelets ( 2 " long) oroid-oblong; stamens 2; achene minutely wrinkled, very whtnse. - Sandy fields, N. Eng. to Fla., west to Minn., Tex., and the Pacific.

F. VánLr, Link (F. congesta, Torr.), a diminntive southern species, with long filiform lcares, sessile capitate spikelets, narrow acuminate scales, and the style 2-cleft and not ciliate, has been found in hallast-sand along the nortl-. eril coast.

\section{SCÍR P S, Tourn. Bulrusir or Curb-Rusir. (Pl. 3.)}

sjpikelets several - many-flowered, solitary or in a terminal cluster which is subtended by a 1 -screral-leaver involucre (this when simple often appearing like a contimation of the culm), terete, the scales being legularly inbricated all romul in many or several lanks, or rarely somewhat compressed and the fower scales inclining to be 2-ranked. Flowel's to all the scales, or to all hut onc or two of the lowest, all perfect. l'erianth of 3-6 mostly retrorsely harber (11 riliate hristles (not elongated), or sometimes wanting. Stamens mostly :3. Sityle 2-3-cleft, simple, not bulbons at base, wholly decidnons, or sometimes leaving a tip or point to the lenticular or triangular achene, - Culms sheathed it hase; the slieaths usually leaf-hearing. Mostly peremials; flowering in summer. (The Latin name of the Bullush.)

* Spritelets solitary, few-floresed, small, apten flullish: arhene triangular, smooth

+ Imolurre a short and-shaped bract: "ulms luftod (3-12' high), filiform.

1. S. caespitósus, I. Culms leme, wiry, densely sheathed at base, iı compart turfy tufts; the uper sheath hearing a very shont aul-shuped leuf; spikelet woid, lusty-colon' involucrul bract a rigirl-pointed seale, resembling the lowest purope scale of the spikelet and scarcely surpassing it; bristles 6 , smorlh, longer thiu the abruptly short-pointed achene. - Coast of Maine, alpine sumnits of X. Ling., swamps of northern N. Y., N. I1l., Mlinn., and northward; also un Roan Mt., N. C. (Eu.)

2. S. Clintónii, Gray. Culms acutely triangular, almost bristle-like. sheaths at the huse hearing a rery slender almost bristle-shuped leaf shorter (usually very much shorter) than the culn, involucral hract aw -shaped, mostly shorter than the chestnut-colored orate spikelet, which has puintess sortes: utherwise as the uext. - Rather dry plains, N. I. June. 
3. S. planifolius, Muhl. Culms triungnlar, lerify at base; leaves lineur: flul, as long as the culm, and like it rough-ergerl; involucral bract a bristletipped scale usually orertopling the ovate or oblong ehestuut-colored spikelet, the green midrils of the scules extended into shurp points; bristles uprardly harry, as long as the pointless achene. - Dry or moist gromud, N. Fing. to 1).., west to western N. Y. and Penn.; IT. Mo (B. F. Bush.).

+ + One-leaved inzolucre more conspicuous, and as if contiming the rulm.

4. S. subterminàlis, Torr. Apnatic; culms ( $1-3^{\circ}$ long, thickish-fili form) p rtly and the shorter filiforu leares wholly submensed, cellular; thr. filiform green bract $6-12$ " long, much surpassing the ublong spilselet; scales somewhat pointed; bristles 6 , bearded downwad, rather slorter than the ahruptly-pointed achene. - Slow streams and pouds, X. Eng. to N. J., west to Mich, and X. Ind. - Var. TERréstus, l'ane; less tall, with firmer stem and leaves, and fruiting spike more turgid. Growing chiefty enerserl; lleckine (")., N. Y.

* * Spikelets clustered (rurely only one), appearing lateral, the one-tenced impohucre ressmbling and sreming to be a continuation of the natied rulm.

- Culm sharply triangulai, stont, chiefly from ruming rootstorkis; spikelets mar:yflowered, rust." brown, closely sessile in one cluster; sheaths at base more ur less lory-leeuring.

5. S. púngens, Vahl. Runuing rootstocks longrg and stout; culm shary/y 3-angled throughont $\left(1-4^{\circ}\right.$ high) with concave sides; Irrers $1-3$, elonguted (4-10' long), keeled and channelled ; spikelets l-6, capitate, ovoil, nsually. long, overtopperl by the pointed involueral leaf; seales ovate, sparingly viliate, L-cleft at the apex and awn-pointed from between the acute loles; anthers tipped with un an\%-shaped minutely finuged uppendage; style 2-cleft (rarely :3-cleft); hristles $2-6$, shorter than the oborite plino-convex and mucronate smoth ichene. - Borders of salt and fresh ponds and streans, throughont ‥ Am. (Ein., S. Am.)

6. S. Torrèi, Olney. Rootstocks slenter if any (so that the plant is readily pulled n], form the mnd); culm 3-tungled, with enneave sides, ratlier slender $\left(2-4^{\circ}\right.$ high $)$, leriy at bast: leares $20 r 3$, more than half the length af the culm, triangular-ehannelled, slenden; spitelets $1-4$, oblong or spindle-shaped, urute, distimet, pale chestuut-color, long orertopper by the slender ereet involucral leaf; scales ovate, smooth, entire, barely mucronate; style 3-rleft: Iristhes longer than the unequally triangular-oborate very smonth lomy-pointed achene. - Borders of ponds, lnackisll and frest, X. Eng. to Penn., Mich., and Mim.

- S. Olnèyi, Ciray. Culm 3-nimg-angled, with decply excrleated sides, stont (2-7० high), the upper sheath bearing a short triangular leaf or nowe: spikelets 6-12, (olosely capitate. oroirl, obtuse, overtopped by the slort involucial loaf; seales orloimlar, smootli, the ineonspienons mueronate point shorter than the scarions apex; anthers wilh a ver!l short and hunt mimutly bearded tip: style 2-cleft: luristles 6, scarcely eclualling the narrowly obovate plano-convex and mneronate achene. - Salt marshes, s. New ling. to Flit, west to the Pacifie.

S. morroxitus, I. Resembling the last, $1-3^{\circ}$ high ; spikelets numerons

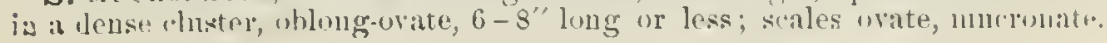


firm, searcely at all scariuns; style 3-cleft; achene smaller, broally obovate - In a single locality in Delaware Co., Yenu. ; probably iutruluced from s. Europe.

+- +- Culm triangular, tall and stout, from slender running rootstocks; spikelets many-flowered, loosely umbellute or corymbed, involucellate-bracted.

8. S. Cánbyi, Gray. Culm (3-5 ligh) 3-angled, usually sharply sn above, obtusely below, the sheath at base extended into a lung slender triangular and channelled leaf $\left(2-4^{\circ} \mathrm{long}\right)$; inrolucral leaf similar $\left(4-8^{\prime}\right.$ long), contimuing the culm; spikelets oblong $(4-6$ " long), single or sometimes purliferously 2 or 3 together, nodding on the apes of the 5-9 long filiform and Hattened pednucles or lays of the dichotomous umbel like corymb, or the central one nearly sessile; scales loosely imbricated, oblong-ovate, acute, pale, thin and scarions, with a greenish nerved back; bistles 6, firm, furnished abore with spreading hairs rather than barbs, equalling the slender abrupt

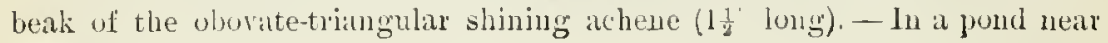
Salisbury, Mil.

+++ Culm trote, rery tall and stout, from a deep ruming rootstock, leafless or very nearly so; spikelets numerous, chustered in a one-sided comprom umbel-like panicle lonyer than the incolural leaf; incolucellate bracts small, scale-like and rusty-scarious; scales of the spiticlets rusty or chestmut-broutn, scarious, the midrib extended into a mucronate point.

9. S. lacústris, ls. (Great Bullesir.) Cuhn 3-9 high, $\frac{1}{2}-1^{\prime}$ thick at base ; spikelets orate-oblong ( $3-t^{\prime \prime}$ long) ; scales mostly a little down on the back and ciliate; style 2-cleft; achene pale and dull, oborate with a narrowed base, plano-eonvex, mucronate-pointed, usnall! wertopped ly the $4-6$ slender downwardly barbed bristles. (si. validus, lith.) - Common everywhere in still fresh water. (Eu., Asia, etr.)

++++ Culms slender from an annual root, terete, plano-runcex or obtusely trangular, naked; the sheaths rurely bearing a short leaf; spikelets few or several in a sessile chuster, sometimes solitury, much acertopped by the incolucral leaf; bristles often few or uanting.

10. S. débilis, P’ursh. (1’.3, fig. 1-5.) Culms obtusely triangulur, with "omewhat hollowert silles. 1 - 20 high, yellowish-green, shining; spikelets : 12 , capitate, ovate-oblong, ubtuse (3-t" ling), elestnut-brown; involneral leaf often lorizontal at maturity; scales rounlisls; stancens 3 ; style 2-3 Neft; brisiles 6, sfout, downwardly barbed, ecpnalling or two surpasing the ob ovate turgilly plano-convex (or hluntly 3-sided) airnptly mucronate-pointer? smonthish achene. - Siwamy, Mlass. to S. C., Minn. and Neb. Aug., kept.

11. S. Smithii, Gray. Culms terete, slender, 3-12' high, often leafbearing from the upper sheath, dull green as are the $1-3$ oblong-ovate acute spikelets; iuvolueral leaf always crect; scales oblong-oval; style 2-cleft; bristles 1 or 2 minute moliments or none; achene smmechat lenticular, smouth. deeiduons with the seales. - Wet shores, Delaware Bay to L. Ontario, Mich., N. Incl, and 1tl. July.

12. S. supinus, L., var. Hállii, Gray. Culms filifurm, 5-12' hight; upper sheath rarely distinctly leaf-bearing; spiliclets $1-7$ in a sessile or some. times geminately proliferous cluster, ovate-oblong becoming cylinchical, green 
"ish; scales ovate, strongly keeled, mucronate-pointed; stamens 2 or 3 ; stylo L-cleft; bristles none; achene vbrute-orbicular, mucronate, plano-eonvex, strongly urinkled transversely. - Wet shores, Ill. to 'Tex.; also found in E. Mass. (Ititchings). (Eu.)

* * Spilielets in simple or mustly compound umbellate or cymose-panicled clusters, many-flowered, terete ; involucre of mostly several fat leares: culm tall, from tufled or running rootslocks, triungular, leafy, sedge-like: leares ruugh on the maryin; style mostly 3-cleft.

- Spikelets large $\left(6-15^{\prime \prime} / o n g\right)$; midrib of the scules extended beyond the mostly lacerate or tuo-cleft apex into a distinct aun.

13 S. marítimus, L. (SEA Chub-Rirar.) l.eares flat, liuear, as long as the stont culn $\left(1-3^{\circ}\right.$ ligh $)$, those of the inrolucte $1-4$, very morqual; spikelets few-sereral in a sessile cluster, and often also with $1-4$ unequal lays bearing 1-7 orate or oblongeylindrical (rusty-browu) spilielets; awns of the sciles soon recurred; achene aboede-arbichlar, compressed, flat on one side, convex or obtuse-angled on the other, mimutely pointed, shininy, shorter than the 1-6 unequal and deciduous (sometimes olsolete) bristles. - Silline loealities, on the coast from $\mathbf{N}$. Scotia to Fla., and in the intevior nowss the continent. (Eu.) - Var, macrosticuros, Michx, ; larger, with very thick oblongcylindrical heads ( $1-1 \frac{1}{2}$ long), and longer involncul leaf (often $1^{\circ} \mathrm{lomg}$ ).

14. S. fluviátilis, Gray. (Rrver C.) Culn very stont, 3-5口 ligh : ieares flat, hroally linear ( $\frac{1}{2}$ wide or more), tapering gralually to a point, the upper and those of the very long involucre very mueh exceeding the comprund umbel; rays 5-9, elongated, recurved-spreading, calch bearing $1-5$ wate or oblong-cylindrical aeute paler heads; scales less lacerate and awn less recurved; uchene obovate, sharply and exuctly triangular, conspicuously pointed, oparpe, searcely equalling the 6 rigid bristles. - Borlers of lakes and large streams, W. Vt. to Com. and Peun., west to Miun. and lowa.

+ + Sprikelels very numerous, small $\left(1-3^{\prime \prime}\right.$ long); scales mucronate-pomted or blunt: umbel-like cymose panirle irregular, compound or decompound; $\mathrm{culm}$ $2-5^{\circ}$ high, unusually leafy; leares broadly linear, green and rather soft: bristles very slender, often more or less tortuous and naked below.

15. S. sylváticus, I. Spikelets lead-rolored, chstered 3-10 together at the end of the mostly slender ntimute divisions of the open decomponnd panicle, ovoid or lauee-orate, 2" long; scales bluntish; hristles 6, downwarlly barher! thronghout, mather exceeding the triangular short-pointed athene; style 3-cleft. -Along brookis, E. Nhas. to N. Y. and E. Peun.

Var. dígynus, Bueckl. Sityle 2-eleft :und the achene not at all angled on the back; stamens 2, and bristles 4., (S. mierocarpus, Presl.) - N. Seutia aul N. Fng, to Minu, and westwird.

16. S. atròvirens, Mhull. Teaves somewhat more rigid; spikclets dull greenish-broun, densely comylomerute (10-30 toyether) into close hends, these also usinally densely clustered in a less compoum panicle; scales pointed; brisths sparsely and strongly dommardly barbed abore the millle, nothel below, nearly. straight, as long as the eouspienously pointed and obviate-oblong triangular achene. - Wet meadows and bogs, N. Scotia and N. kng., wesc to Minn., Lan. aud the Pacific. 
1\%. S. polyphýllus, Vathl. Culm usually more leafy; spikelets yellow bruch, ovate, becoming cylindrical, chustered :3-8 toyrther in small heads on the. short ultimate divisions of the open decompound umbel: seales mucronate; brisIles 6, usually twire bent, soft-barbed tomrarl the summit anly, about twice tho length of the achene. - Swamps and borders of poncls, western N. Eng. to N. C, west to Minu. and Ark.

\section{ERIÓPHORU M, I. Cotroxitgkiss. (Pl. 3.)}

Bristles naked, unally very munerons, often silky and becoming greatly

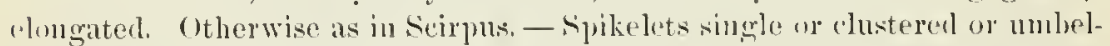
late, nsually iurolncrate with erect scalle-like bratse, upon a leafy or naked stem; scales membranacens, l - is-nerved. Stỵle very slenter and elongatted, B-cleft. Achene acutely triangular. (Name composed of éptov, uool or cottm, ancl popós, beuring.)

* Bristles 6, rust-colored, beroming tortuons and entungled; ; rntm rery leafy, hearing numerous spithelets in un inrolucrote decomponnd "ymose-panicled umbel.

1. E. lineàtum, Benth. \& Ilook. ('nlm triangular, leafy (1-30 high); leaves linear, flat, rather broul, rongh on the margins; umbels terminal and sometimes axillary, loose, drooping, the terminal with a 1-3-leatres inceluce

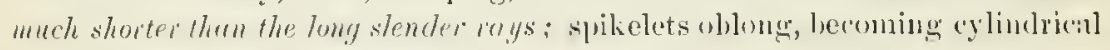
(2-4" Iong), on thread-like drooping predicels; bristles "t motnrity scatcely exceding the orate green-keeled printed scales; achene slarp-pointed. (Scir-

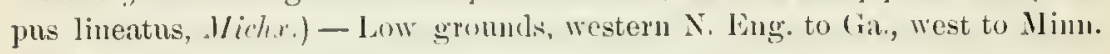
and Mo.

2. E. cyperinum, L. (I']. 3, fig. 6-10, mrier Scirpms.) (Wool-(Mr.ss.) Culm nearly terete (2-50 high) ; leaves narrowly linear, long, rigid, thase of

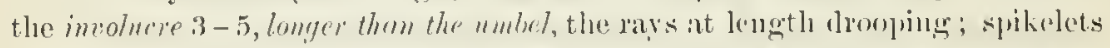
exceedingly munerous, orate, clustered, or the lateral peedicelled, woolly at maturity ( $1 ! 2-33^{\prime \prime}$ longs); the rust-colored lwistles much longer them the pointles.s

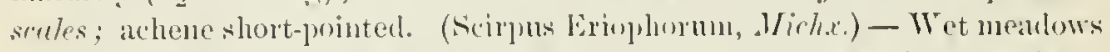
and swamp, Newf to Fla, west to Minn. anrl Iow: Exceclingly valdiable in the chatracter and size of the mulnel, the typical form having the spikelets

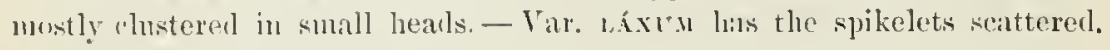
the lateral lomgerpedicelled.

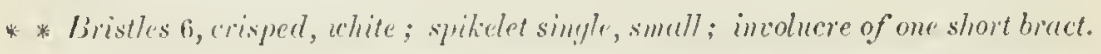

3. E. alpinum, I. (Pl, 3, lig. 1-6.) Culns slender, many in a row from a ruming rootstock ( $6-10^{\prime}$ ligh 1$)$, scalorons, naked; sheaths at the base

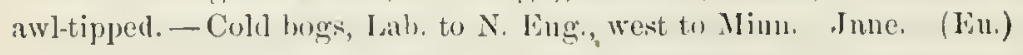

* * Bristles very memerous, not "risped, forming dense cottony heads in finit.

+ Cutm bearing a single spikelet: involuere none.

4. E. vaginatum, L. Culms in close tufts $\left(1^{\circ}\right.$ lighl $)$, leafy only at the hase, above with 2 inflated leafless sheaths; root-leaves long and thread-furm, triangular-channelled; scales of the orate spikelet long-pointed, leat-color at maturity, - Cold and high peat-bogs, N. Fing. to P'emn., Mich., Minm, and unrthw:arl. May, June, (Fu.) 


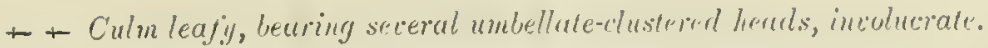

5. E. Virgínicum, L. Culn rigid $\left(2-t^{2}\right.$ highl $)$; leares very uarrowly linear, elougated, Hat; spilielets neurly sessilr, "roneded in "dense cluster or head; uool rusty or copper-color, only thrice the lungth of the scale; stamen 1. - Bogs and low meadows, Newf. to Fla., West to Minu. and Neb. July, Aug. - Var. Alucu, Gray, las the woul white. X. New Jork.

6. E. polystáchyon, I. Culn rigirl (1 - 20 liggh), olscurely triangular;

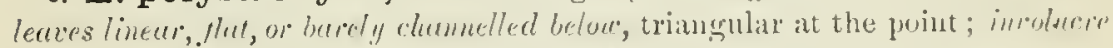
2-3-leured; spikelets several $(4-12)$, on smooth molding peluncles, some of

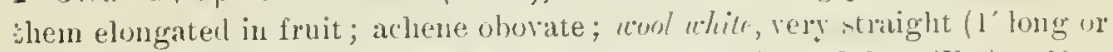

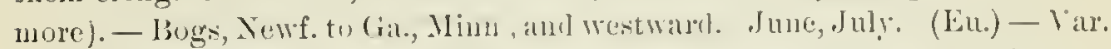

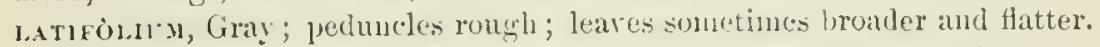

7. E. grácile, liveh. Culus sleuder (1-2) lighli), rather triangular; lenres slfuder, chamnelled-triunnular, rough on the angles; involncre shot and scale-tike, mostly l-leaced; perluncles rough or roughish-pubescent; spikelets $3-7$, small, when mature the copious white wool $6-9$ "long; achene ellipticallinear. - Cold hogss, Newf. to N.J., west to Minn. aud Mo. Scales in omr plant mustly light chestnut aud about 3-nerved. Jume- $\Delta$ ug. (Eu.)

\section{FUIRE N A, liottboell. LuBrELld-Grass. (Pl. 2.)}

Sprikuets many-flowered, terete, clustered or solitary, axillary aud teminal. Seales inbricated in many ranks, awned below the apex, all Horiferous. l'erir antl of :3 ovate or heart-slaped petaloid scales, mostly on claws, and nsually with as man! alternating small bristles. Stamens 3. Atyle 3-cleft. Achene triangular, jointed with the persistent base of the style. ('ulus from a perennial root, olstusely triangular. (Naned fol ( $\therefore$. Firen, a Manish botanist.)

1. F. squarrosa, Michx., val. híspida, Clıpm. (1'l. 2, fig. 1-7.) Dtem ( $1-3^{\circ}$ higl $)$ leafy ; leaves aul slseaths usually hensely hairy; spikelets urvid-ohlong ( $4-6$ " long), clustered in leals, hristly with the spreading aw wh of the soles; perianth-scales rhombic or deltoilt-ovate, with a short thick awn or point, the interposed mostly larbed bristles shorter than the achene. Saudy wet places. X. . . to lia., west to Ky: and 'Tex.

Var. pủmila, Torr. ['sually low ( $1-6$ ' high or more $)$, with 1 - 6 spike-

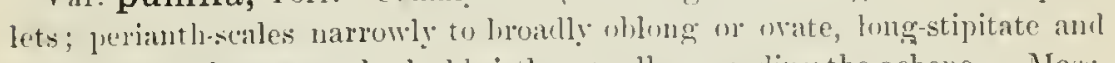
attenuate to a loug awn; barbed bristles usually excerding the acheue. - Mass. to X. F., Flis., aurl La.; Mich. 'The commonest form.

\section{HEMICÁ R P H A, Nés. (Pl. 2.)}

Spikelet, thwers, etc., as in Scirpus, except that there is a minnte translucent scale (rearlily overlooked) between the fuwer aud the axis of the spikelret. Stanen only one. Style 2-cleft. Bristles or uther yeriantlu uoue, (Name from

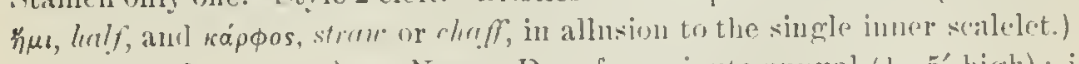

1. H. subsquarrosa, Nees. Dwarf or minnte anmal (1-5' hight); involncre i-loaves, as if a contimation of the bristle-like culm, and nsually with another minute leaf; spikelets $2-3$ (barel! 2" long); s'ales l,row"u, tipped will a short recurved point. - Sand! borders of ponds and rivers, $N$ Eng. to Fla, west to the Pacific. 


\section{LIPOCÁR P H A, R. Br. (Pl. 2.)}

Spikelets terete, many-flowered, in a terminal close cluster involucrate by leafy bracts. Scales spatulate, regularly imbricated all round in many ranks, awnless, decidnons, a few of the lowest empty. Innel scales (braetlets) 2 to each flower, thin, one between the scale of the spikelet and the flower, one between the latter and the axis of the spikelet. Bristles or other perianth none. Stamens I or 2. Style 2-3-cleft. Achene flattisl or triangular, naked at the

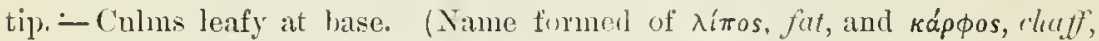
from the thickness of the inner scales of some suecies.)

1. L. maculàta, 'Torr. Annual; culn ( $4-8^{\prime}$ lighl $)$ much longer than the linear concave leares; spikelets ( $1-2^{\prime \prime}$ long) greeu and dark-spotted; inner scales delicate; stamen one; achene oblung with a contracted base. springy or miry places, Va. to Fla.; near Philadelphia, probably adventive.

\section{RHYNCHÓSPORA, Vahl. Beak-Rush. (Pl. 4.)}

Spikelets panicled or varionsly clustered, ovate, glol,ular, or spindle-shaped, terete, or sometimes flattish; but the scales open or larely concave (uot buatshaped nor keeled); the lower commonly loosely inbricated and empty, the uppermost often subtending imperfect flower's. I'erianth in the form of bristles (mostly 6). Stamens mostly 3. Achene lenticular, globular, or flat, crowned with a conspicuons tubercle or beak consisting of the persistent inclurated base ur even of the greater part of the style. - Chiefly perennials, witl more or less triangular and leafy culms; the spikelets in terminal and axillary clusters; flowering in summer. (Name composed of ṕv $\gamma \chi \alpha s, a$ suout, and $\sigma$ tropá, a seed, from the beaked achene.)

§1. RHYNCHOSPORA proper. Spikelets terete or biconvex, few-manyflowerted; style conspicuously 2-cleft, its buse only forming the tubercle of the mostly lenticular achene; bristles usually present, morely rough or barbedatenticulate (not plumose).

* Achene trunsiersely urinkled; bristles mostly 6, upuardly denticulate.

1. R. cymòsa, Nutt. Culm triangular; leares linear (1' wide); eymes corymbose, the spikelets crowded and clustered; achene round-oborate, twice the length of the hristles, fomr times the length of the depressed-conical tuberrle. - Low grounds, l'enn. and N. J4 to Fla., west to N. Ind. and Ill.

2. R. Torreyàna, Gray. (I'l. 4, figs. 1-5.) C'ulm nearly terete, slender: leaves bristle-form; cymes pauicled, somewhat loose, the spikelets mostly pedirelled; achene oblong-aborate, longer than the bristles, thrice the length of the broarl compresser-conical tubercle. - Swanps; pine-barrens of N. J. to S. C.

3. R. inexpánsa, Vahl. Culm trimumlar, slender; leaves nurowly lin.. enr: spikelets spimble-shaped, mostly perlicelled, in drooping panicles; achene udom, half the length of the slender bristles, twice the length of the triangularsubulate tubercle. - Low groums, Vi. to Ga.

* Achone smooth and even.

+- Bristles 6, long and conspicuous, unwarlly denticulate.

4. R. fúsca, Roem. \& Schultes. Culm 6-12' highl ; lenres bristle furin

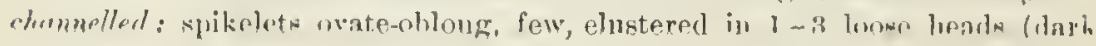


('hestnut-color); achene obovate, ha!f the lenyth of the bristles, equalling the triangular-sword-shaped acute tuberce, which is rough-sermlite ou the margius. - Low gromuls, N. Brunswick to N. J., west to I. Superior. (Eu.)

5. R. gracilénta, Gray. Culns very slender, 1-2o ligh; leures narrouly linear; spikelets ovoil, in $2-4$ small clusters, the lateral long-peduncled; achene ovoid, ruther shorter than the bristles, about the length of the flat awlshaped tubercle. - Low groumb, sunthern N. Y. and N. J. to Fla.

6. R. oligántha, Gray. Cnlm and leaves filiform, 6-12' high; spikelets very few $(1-4)$, wrate-ohlong; hristles plunose brlow the middle; achene oburate-oblong, bearing a conical tuluercle $\frac{1}{3}$ its lengtl. - Del. (Canby) to Fla.

+ + Bristles none, or $1-3$ and mimule; spikelets pale, 1-flowered.

7. R. pállida, M. A. Curtis. Culn (1-20 high) acutely triangular; leaves and spikelets as in the next species, but ouly a terminal dense cluster, which is less white or turus pale reddish-tawuy; achene oborate-leuticular, tipped with a minute depressed and apiculate tubercle; the delicate bristles 4-5 times shorter or obsolete. - liogs in pine-harens of $\mathrm{N}$. J. and N. C.

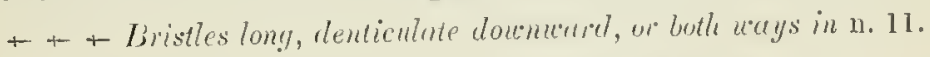

+ Spikelets white or whitish, becoming tawny with age, perfecting only a single florer; stamens usuully 2; bristles 9-12, or even 20.

8. R. álba, valıl. Cuhu sleud(r (1-20 high), triaugular above; leaves narrowly linear or almost bristle-form; spikelets lanceolate, deusely crowderl in a hearlike ternimal corymb aud ustally one or two lateral ones; achene obloug-oborate with a narrowed lase, scarcely longer than the flattened-awlshaped tubercle, shorter than the bristles. - Bogs, Newf. to Fla., west to N. Ind., Mimr., and oregon. (Eu.)

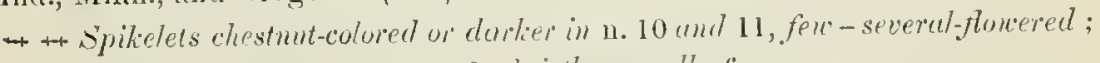
stanens 3 ; brisilles usually 6.

9. R. capillàcea, 'Torr. CuIn 6-9' high, slender; lemes bristle-form: spilielets $3-6$ in a terminal chuster, and commonly I or 2 on in lemote axillary peduncle, oblong-lanceolate (1 ale chestunt-color, 3 " loug); achene oblong-oivoid, stipitate, very obscurely wrinklerl, albont hrolf the length of the (6, rarely 12 ) stont bristles, and twice the length of the lanceolate-heaked tubercle. - Bogs and rocky river-banks, N. Vt. to P'(nul., west to western $\mathrm{X}$. Y. and Minn. - Vall. 1.visèt., Ilill. Bristles perlectly smootl. N. WT. Ind.

10. R. Knieskérnii, Carey. Culn 6-18' high, slender; leares nurrouly linear, sluot ; spikelets mumeroms, croveded in 4-6 distant clusters, oblong.

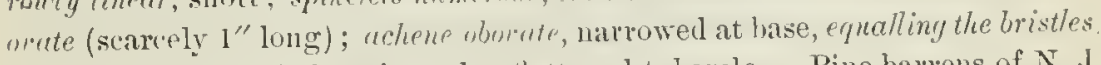
twice the length of the triangular Hattened tubercle. - Pine-barrens of $\mathrm{N}$. J. (on log iron ore exclusively) to $\mathrm{V}^{\mathrm{a}} \mathrm{a}$; rare.

11. J. glomeràta, Vahl. Cnlm $1-3^{\circ}$ high; lenves linear, flat; spikelets numcrous in distunt clusters me herls (often in pairs from the same sheath), woid-oblong; achene obovate, margined, narrowed at base, as long as the lanceawl-shaped flattened tubercle, which equals the always downwardly barbed bristles. - Low grounds, N. Eng. to Fla., west to Mich. and N. Ind.

12. R. cephalántha, Gray. Culm stout $\left(2-3^{\circ}\right.$ high $)$; leaves narrouly limer, flat, kepled; spikelets very nummons, rrourded in 2 or 3 or more dense Jolulur hends which are distant (and often in pairs). oblong-lancenlate, dark 
Hrown; achene orbicular-obovate, margined, narrowed at base, about as loug as the awl-shaped beak; bristles twice longer, stout, barbed dounuerd and sometimes also upurarl. - Sandy swamps, long Islind to N. J. and Fla.

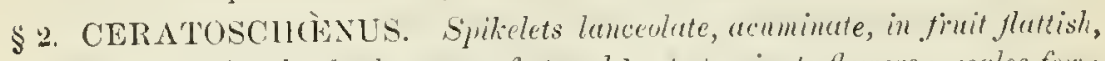
cymose-panicled, of only one prefect and $1-4$ stamimate flowers; scales few; bristles rigil, minutely scubrous upuard: styl. simple or barely 2-toothed, filiform and yradually thichened downural, in finit persistent as an exserted, slender-awl-shaped, "pwourdly runghened beak, several times longer than the smouth flat obovate achene: coarse perennials; spiliclets in flower $4^{\prime \prime}$, in fruit including the projecting berk about I' lony.

13. R. corniculàta, Gray. (Ilonxeu lísu.) Culu3-60 high; leares about 6" wide; "ymes decompound, diffinse; brisiles aut-shoped, stout, unequal, shorter than the achene. - Wet places, Penn. to Fla., west to s. Ind. and Mo.

14. R. macrostàchya, 'T'orr. (1'l. 4, tig. 1-4.) Cymes decompomul, or in the northern form somewhat simple and sumller, and the spikelets usually more clustered; Wristles cupillary, twice the length of the achene. - Borders of ponds, Mass. to $\mathrm{X}$. J. and Fla.; rave.

\section{C L À DIU M, I'. Browne. 'Twig-Resr. (Pl. 5.)}

Spikelets oroid or oblong, of sereral lousely imbricated scales; the lower empty, one or two above bearing a stminate or imperfect flower; the terminal Hower perfect and fertile. Perianth none. Stamens. Style 2-3-cleft, decilluons. Achene oroid or globular, somewhat corky at the summit, or pointed, without any tulerele, in which it differs from lihynchosporia. (Diminutive of $\kappa \lambda \alpha$ sos, a brunch, from the repeatedly branched (yme of the original species.)

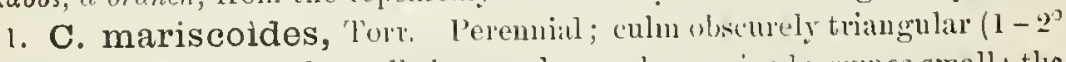
high); learcs nanrow, chamnelled, scurcely longhthatginel; cymes small; thr spikelets clustered in heads $3-8$ together on $2-4$ juluncles; style 3-cleft. Bogs, N. Scotia to Del., west to $\$$. Minm and Lowa. July.

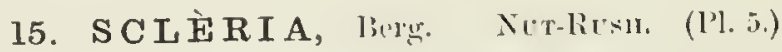

Flower's munceions; the fertile spikelets 1-Howered, usually intermixed with clusters of few-flomered stauinate spiknets. Scales loosely imbricated, the lower emptr. Stamens 1-3. Sityle 3-eleft. Aclene globular, stony, bony, or cummel-like in texture. Bristles, etce, mone. Perennials, with triangular leafy culms, mostly from creeping rextstexks; Howering in smmmer; all in luw ground or swampls. Inflowesene, in one spectes, ol terminal and axillary

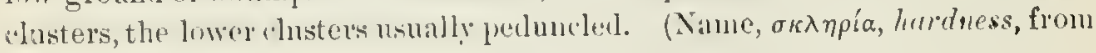
the imbrinted iruit.)

\section{* Achene smooth.}

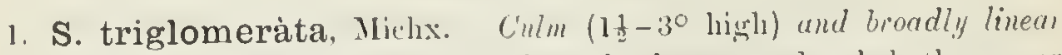
leaves roughish; fascicles of spikelets few, the lowest jedmucled, the upper somewhat in threes; achene ovate-glubose or depressut, on an obscure crusta. ceons disk, - Mass. and Yt. to Fla, west to Mim. and 'Tex. - Var. Grdcilis. Britton. Culms slender $\left(1-2^{\circ}\right.$ long); fascicles few-flowered, the lower ( 2 :3-flowered) on very long filiform poduncles; achene not more than half as large, acutish. - N. J. 
2. S. oligántha, Ell. C'ulns slender, $2^{\circ}$ high, the angles somewhat winged ; leares lineur (2" wille), smouth except the scabrous apex; lateral fascicles 1 or 2, usually on long exserted peduneles; achene ocate, on a tuberculate disk. - Va. to Fla. and Tex.

$$
\text { * * ichene papillose or vaity. }
$$

3. S. pauciflòra, Muhl. Smootlish or luiry; culın slender (9-24' high): leaves marrowly linear; fascicles few-flowered, the lateral pedunculate, sessile, o1 wanting; bracts ciliate; acheue globose-ovate; the disk a narrow ring bearing 3 pairs of minute tubercles. - N. H. to Ohio, sunth to Fla. and Tex.

* * Achene reticulated or urinkled.

4. S. reticulàris, Michix. (l’l. 5, fig. 6-10.) Culms slender, erect, scabrous $\left(1-2 \frac{1}{2}^{\circ} \operatorname{ligh}\right)$; leaves lineal ( $1-1 \frac{1}{2}^{\prime \prime}$ wide), smooth; lateral fascicles $1-3$, loose, remote, nearly erect, on short often influded pedmucles: bracts glabrous; achene globuse, regulum y reticuluted und pitted, not hairy, resting upon a double greenish conspicuonsly 3-lobed disk, the inner appressed to and de-

- ciluous with the achene.- E. Mass. to Fla. - Var. Punbeves, Britton. Fidges of reticnlations more or less hairy, especially toward the apex; lateral faseicles generally on longer peduneles. Pine-barrens of N. J. tu Fla. - Var. onscìr., Britton. Achene buny, its surface with very olscure reticnlations, nearly smooth at the summit. R. I. and K. C.

5. S. Torreyàna, Walpers. Culms weak, diffuse, slightly scabrous or smooth; leives linear ( $2-4^{\prime \prime}$ wide), smooth; lateral fascicles loose, on more or les's elongated und dropping filiform pedundes: achene irregnlusly pitted-reticulored or pitted-rnyose with the ridges somewhat spriblly arranged and more or less hairy (sometimes smooth); otherwise as in the list. (N. laxa, Turr.) l'ine-barrens, N.J. to Fla. and 'Tex.

6. S. verticillàta, Mulıl. Sinooth; culus sinuple, slender ( $4-2 t^{\prime}$ ligh); loures narowly linear; fuscicles 3-9-tluwered, $4-6$, sessile in un intermpted

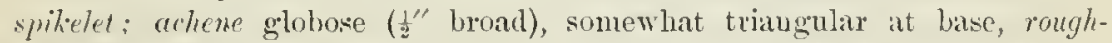
wrinkled with short elemed ridyes; disk ubsolete. - E. Mass. to Ont., Minn., and south to the Giulf.

\section{C À R EX, Ruppius. SEnGL. (By L. H. BAILY.)}

Flowers misexual, destitute of floral enrelopes, disposed in spikes; the stamiuate consisting of three stamens, in the axil of a bract, or scale; the pistillate comprising a single pistil with a bifid or trifid style, forming in fruit n hard lenticular or triangular achene, whieh is enclosed in a sac (perigymum) furmed by the complete union of the borders of a bractlet or of connate bractlets and bornc in the axil of a hract, or scale. Staninate and pistillate flowr.s horne in different parts of the spike (spike androyymous), or in separate spities on the same culm, or rarely the plant dincinus - Perenuial grass-likf lierbs with mostly triangular eulms, 3-ranked luaves, nsually with rough margrius and keel, and spikes in the axils of leafy or seale-like bracts, often aggregated into heads. An exceediugly critıcal genus, the study of which should he attempted only with eomplete and fllly mature specimens. (The elassieal Latin name, of obscure signification; derived by some from keipw, to rut, on aecount of the sharp leaves - as the English name Shear-grass.) (Pl.5 and 6.) 


\section{Synopsis of Sections and Groups.}

§1. CAREX proper. Staniuate flowers forming one or more terminal lineal or club-slaped spikes (often jistillate at base or apcx). Pistillate Howers usually in distiuet and sim. ple mostly peduneled siskes. Cross-section of perigyniun circular, obtusely anglec, or prominently triangular in outline. Style moslly 3 parted and aeheue triangular or triquetrous.

* 1. Physocarpae. Perigynium mostly straw-eolored at uaturity, papery in texture, usually more or less inflated, smootlı (sonetimes hairy in 11.6 ), nerved, tapering iuto a beak as loug as or longer than the body; spikes few to many, distinct, eompactly flowered . stigmas 2 (2 in n. J0).

+ 1. Puncifiore. Perigynium greenisl, linear-lanceolate or almost needle slaped, not inflated, strongly deflexed at maturity, several times longer than the inconspieunus scale: spike androgynous, the pistillate fluwers at base, few. - Sp. 1.

+2. Lupuine. Perigynium gleen or greenish-tawny or sumetimes yellow, more or less inflated (except in $1.2-4)$, long, nsually very turgid at base, mostly ereet or nearly so, very gralnally attennate to it long slenderly toothed beak exceeding the scale; spikes 3 ol more, the staminate inostly 1 and stalked, the pistillate of ten sessile, usually short and thick, often becoming dark onlorel in drying. - Sp. $2-5$.

- 3. Vesicarior. Perigynium suooth and shining, much inflated, at maturity straw-eolore or sometimes purple, loeaked and conslicuously" short-toothed (entire in n. 10), usually prominently few-1served, mucls shorter thitu in +2 ; staminate spikes eoumouly 2 or more; nistillate spilies as a rule long and densely cylinilical. - Sp. $9-16$.

- 4. Pseudocyperce. Perigynium less inflet, more conspicnously nerved or evell costate, and with more or less setaceous or awned teeth; scale usually awned; spilies mostly nodding or spreading, connose in ippearauce, greeuish, grecnish-yellow, or ochroleucous -Sp. $17-19$.

+5. Squarsosce. Perigynium obconie or obovoid, squarrose in exceedingly dense short spikes. - Sp. 20, 21.

* 2. Trachychlanae. Perigyuium mostly thick and hard in texture, often scabrous or hirsute, straight-beaked; pistillate spilics compactly flowered, mostly large, erect or nearly so: staminate spikes 1 or uore; stigmas 3. Gencrally large aud eoarse.

- 1. Shortiance. Terminal spike androsynons, staminate below; perigynium small, seabrous, nenly beakless, entire. - Sp. 22.

- 2. Anomalie. Terminal spike all staminate; pistillate spikes long and ejliudrieal, nostly dense; yerigynium broad and short, short-beaked, the orifice very slightly notehed or entire, mostly granulate. - Sp. 23.

-3. Hirtce. A heterogeneous gronp, distinguished from -2 by the longer and more deeply eut beak (slightly toothed in 11.24 ), and hy the hairy perigyoninn (smooth in n. 25). Sp. $24-27$.

+- 4. Palulose. Staminate spikes 2 or more, long-stalled; the pistillate 2 -several, usually all pednuclecl, long and heavy, loose-Howered, erect or nodding; perigynium large, thick in texture, strongly nerved, mostly smocth, nsually (onnspienonsly beaked. Coarst species. - \$1. 28, 29

* 3. Microrhynchae. Parallel witl * 2; distingnished in general by the much smalles and nearly or entirely beakless and mostly entire-nonthed perigynium, whieh is much thimner in texture: stigmas 2 or 3 . Paludose and alpune species, of various habit, mostly with colnutsl spikes, often in dense tnfts or tussocks.

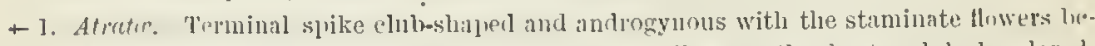
low (very ritely all staminate in 11. 32); pistillate sjikes mostly short and dark-colored, erect or drooping; stigmas $3 .-\mathrm{S}$ 1. $30-32$.

+ 2. Rigidue. Mostly stiff, with short erect closely flowered spilikes, an entirely staminate terminal spike, dark colored scales, and bracts with purple or black aurieles at base; stigmas 2 or $3 .-$ Sp. 33.

-3. Acutre. Mostly larger and more slender, ustally paludnse, with sreen or light-enlored large and long spikes; stigmas 2 ( 3 in n. 39$)$. Distinguished from -2 mainly by latit. -\$p. $34-89$. 
- 4. Cryptocamne. Large, witl noddingr or lnooping linge spikes, their dark seales very long and con:jieuons; stigmas $2,-5 \mathrm{p} .10,41$.

—5. Pendulince. Distinguished from +4 by the smaller size, smaller spikes, sheatiless braets, and whitish, nore or less granulated, nearly poiutless perigynum ; stigmas 3 . Sp. $42-45$.

* 4. Hymenochlan:e. I'erigynum mostly light green or whitish, nsually thin and unembranous, often soncwliat intlated or loosely investing the arlienc, eommonly smooth and shining (luary in 11.46 , sometines in n. 17 ), slender or oblong, attemute to a distinct or lonir minntely toothen straight beak (or heakless or nearly so in -1 and 11.55 ); pistillate spilies several or many, mostly loosely flowered and on filiform nodelug ur

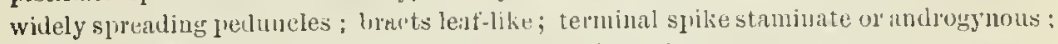
stigmas 3. Mostly mather tall ind slenter uplaud speeies.

- 1. Virescentes. Termiual spilie pistillate at top ; pistillate spikes oblong or eylimlrieal, dense, erect; lerigyniun orate or obovate, marly w' 'luite heakless, often hairy. - SI. 46,47 .

- 2. Sylvaticr. Terminal spike all staminate; pistillate spikes mostly long-exserted, slender; perigynim few-nerved, comtracted into a eyludrical beak whel is longer than the body. - sp. 48.

-3. Flexiles, Terminal spike all staminate; pistillite spikes rather thick (very small in u. 50), more or less drooping; perigyniun beaked, few-rerved or nerveless, tawny or whitish.-\$1), 49, 50.

-4. Debiles. Terminal spilie all stanimate (oecasionally pistillate above iu 11. 5j3); pistillate spikes very nirrow and slender, long-exsertel and noddiug, mostly very loosely flowered; lerigyniun rather suall, not turgid, prouninently beaked. - \$1). 51-53.

- 5. Gracillima. Terminal spilie pistillate at top ; pistillate spikes habitually thieker than in + 4; perigynium ovate-oblong, more or less turgid; the beak short or noue. - sp. $54-57$.

-6. Grisea. Termiual spuke staminate; perigynim more or less turgid or plump, often

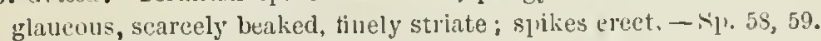

* 5. Spirostachye. Perigynium smooth or mimntely granulated or rarely sounewliat ser. rate ou the margins, frominently nerved, mostly yellowish, squarose, mostly beakerl (entirely beakless in $n .63$ ), the orifice entire ; staujute spike mostly single : pistillate spikes $2-5$, short (usually $l^{\prime}$ long or less), yellow or fuseous, eompactly flowered; stigmas 3, - Mediun-sized speejes, growing in meadurs and grassy swales.

- I. Granulares. Sjikes senttered, crindrioal, the lowest long-stalked ; braets ereet, long and leafy; slieatlus short or neirly obsolete. - Sp. 60, 61.

- 2. Extenst. Spikes mostly approximate or aggregied at the top of the culn (beeoming remote in C extensil), the lowest I or a subtencled by a Iong and leafy mostly abruptiy spreading and nearly or entilely sheatlless bract. Teruinal spike sometines andro. gynous. - Sp. 62.

-3. Pallescentes. Spikes glnhnlar or short-nhlonu, obtuse, sessile or short-pedımoled, approximate at the top of the eulul ; bracts slort, leaf-like, sheatlless : perigynium eutire at the nrifice, the beak none or very short and stont. $-\mathrm{Sp}$. 63, 64.

* 6. Dactylostachya. Perigyuium minstly slint aud triangular, unostly with a short and straight or eurved beak, green or greenisli, smareely iuflaterl; scales of the pistillate spikes mostly whitish (sometimes dark-rolored in the Digitcerp), often small ; staninate spike mostly one: pistillate spilies short (selılom exceeling 1'), comunnly rather loosely flowered and slenter (spike single and plant dieesous in n. 83): britets sheathing, the sheatis of en conspicuous aml colored. - Low and lax or slendel species inlabiting mealows and copses.

- 1. Oligocarpe. Slender and narrow-leaved, with leafy brats and inconspiennus green sheatlıs; periggnimm muncled ou the angles, finely many-striate, often somewliat pune. tulate as in n. 58, to which the group forms a trincition. - sp. $65-67$.

-2. Laxiflorr. Slender and more or less hroacl-lenverl, witl inustly lenfy hracts, green or purple sheaths, and lonsely fowered spikes: perigynium mostly colisplieuousiy three angled, with a more al less enred beak. - Sj. $68-74$. 
- 3. Panicee. Mustly stouter and narrow-leaved, with thimer spikes; perigynium often strongly nerved, not eonspieuously triangular, nften somewhat turgid: braets and sheaths various, $-\mathrm{Sp} .75-78$.

- 4 Bicolores Small species witl a beakless, more or less round or pyriform perigynium, whieh is eommonly glaueous; terminal spike androgynous or all staminate; stigmas mostly 2.-Sp. 79.

- 5. Digitate. Low speeles; sheaths memlranaceous or lyyaline and eolored, either not prolonged into a bract or the braet very short and not foliaceous; perigynium more or less three-angled, often hairy, the beak straight or nearly so. $-\$ p, s 0-\$ 3$.

- T. Sphreridiophora. Perigynium mostly short and rounded, three-angled in the Triquetrae, tirm on lard in texture, not inflated, hairy or scabrous, the beak straight and usually bifid; staminate spike one : pistillate spikes short ( $1^{\prime}$ long or less), usually glob. ular or short-oblong, more or less sessile and approximate or the longer ones radical (spike single in $\mathrm{n} .84$ ) : braets sheathless, short, or obsolete ; stigmas rarely two. - Low species of dry gromnd, with leaves all radical.

- 1. Scirpince. Spike one, unisexual; plant dicecions. - Sp. 84.

-2. Montance. Spikes two to several, the lowest oecasionally long-peduneled and radient: perigynimu roumled, eontraeted above aud below, mostly bearing two prominent ribs, more or less hairy. - Low speeies of dry soils. - Sp. 85-91.

- 3. Triquetro. Taller; sjikes mostly approximate at the top of the culu, oblong or cylindrieal ; perigynium conspienously 3-angled. - Sp. 92.

- 8. Phyllostachyre. Perigynimm mueh as in the Montanc; spike one, staminate above: pistillate flowers few, often remote, usually on a more or less zigzag rhachis; seales pro longed aud leaf-like. $-\mathrm{S}$. $.93-95$

* 9. Leptocephale. Perigynium thin in texture, grees, oblong or laueeolate or linear in general outline, beakless: spike one, staminate above, thin and slender; stigmas mostly three. - Sinall, slender and grass-like. - Sp. 96.

* 10. Physocephalie. Spike one, globular or slıort-oblong, staminate at the alex; perigynium straw-eolored, paper-like, more or less inflated; stignas three. Leaves remarkably broarl in our speeles. $-\mathrm{Sp}$. 97.

§2. VIGNEA. Staminate flowers few and ineonspieunus, borne at the base or apex of the pistillate spikes. Pistillate flowers in short sessile spikes (or spike single in some cases), which are eommonly mole or less agoregnted into heads or even panieled. Perigynium plimn-convex. Styles two and achene lenticular. - The spikes, especially the uppermost, 11snally have eontracted bases when the staminate fiowers are bome below the pistillate ones, and empty seales at the top when the staminate flowers are borne at the summit.

-11. Acroarrhense. Staminate flowers borne at the top of the spikes (or, m the Multiflorce and Arcurrier, spikes often wholly staminate and the plants oceasionally dioceious).

+1. Fatidre. Spikes tawny or hrown, not elongated, very densely aggregated into a eontinuous glohose somewhat elaffy liend; lerigynium orate or orite-lanceolate, nerveless or nearly so, mostly thin in texture, - - $\mathrm{Sp}, .98,99$.

- 2. Vupinip. Spjikes mostly yellow or tawny when mature, densely aggregated or sometimes somewhat scattered below or even panicled : perigyniun thiek in texture, spongy at base, mostly stipitate, bearing very ennplicnous nerves, whieh converge below aud are espeeially prominent on the onter side. $-51,100-102$.

-3. Multiflorr. Hearls varions, mostly loosely flowered, sometimes a panicle, fellow or tawny; spikes short (rarely longer than broad), staminate flowers sometines oeeupying whole spikes in tlue niddle or at the apex of the head ; perigsninm mostly small and short and nearly nerveless, or in some species heconing nearly lanceolate and mort or less prominently nerved, firm in textmre, usually numerous. - Sp. 10.3-108.

4. Arencrirn. Spikes longer than in the last seetion, linear or nearly so, aggregated into short, almost globose heads: perigynimu laneeolate or ovite-laneeolate, mnstly lurger and more delieate in textnle: s'sles awn-pointed or very aeute. Staninate flowery variously situated, - (C. arenaria.) 
- 5. Wuhlenberfance. Spikes green or nearly so wlien mature, asgresated or scatterecl, never in compound heads; perigynimu mostly short-ovate, staminate flowers always at the top of the spike, - Sp, $109-114$.

- 6. Dioice. Spike commonly one, small: whuts sinall and slender, often diceious. - Sn $115-117$.

* 12. Hyparrhence. Staminte flowers borne at the base of the spikes (or in n. 124 and 125 variously situated).

- 1. Elongate. Spikes silvery green or sumctines tawny when mature, distiuct, Inostly smull; perigyniun not wilg-margined nur eonspienously broadened, inostly nearly flat ont the imer surface, - S1, $118-124$.

- 2. Ovales. Splikes tawny or dark, ratluel lamge, sometimes erowded ; perigynium with it more or less thin or winged margin, whieh is mostly iueurved at maturity, renclering the perigynium concave inside. - Sp. 125-132.

- 3, Cyperoidec. Spikes green, oblong, densely erowded into it short head snbtended by two or three leafy bracts which are erect and prolonged from six inches to a foot; perigynium linear-laneeolate, seareely marginel. - sl 1, 133.

\section{Artificial Key.}

Spike 1, staninute at top; scales of pistillate Howers leaf-like . . . S Sp.93-95 Spike 1, seales not leaf-like.

Usually direious; stigma 2 . . . . . . . . . . . . 115-117

Stigmas 3, - Perigyuium densely laairy , . . . . . . . . . 84

Spike stamiuate at base ; perioryia squarrose . . . . . 21

Spike staminate at top, - Globose ; leaves broad . . . • m

Perigyniun nearly lineur, beakless _ . 96

Perigynium long, spindle-shaped . . 1

Spikes several or numerous, sessile, spieate or capitate; stigmas 2.

All in a globose or ovoid uninterrupted head.

All stauniuate above. - Usually green at maturity . . . . . . 112, 114

Usually jollow or tawny or brown . . . 98,99, 104, 105

All staninate below, - Leafy-bracteate . . . . . . . . . . 133

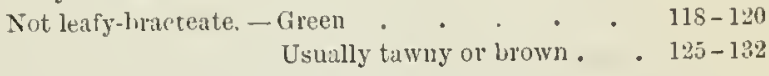

Some or all of the spikes distinet or the luad interrupted.

Staminate and pistillate flower's variously disposed, some of the spilies often muisexual.

Head large and long . . . . . . . . . 10S, C. arenaria,

llead short or linear . . . . . . . . . . . . 124,125

Spikes staminate ahove . . . . . . . . . . $100-114$

Spikes staninate below , . . , , . . , , . 11S-133

spikes ustually more or less pedicelled, the wliolly or partially staminate spikes uppermost.

Terminal spike (rarely the 2 or 3 uplerinost) staminate only at base.

Stigmas 2 .

Stigmas 3 : spilies erect,

Short aud squarrose. . . . . . . . . . . . 20,21

Not squarose . . . . . . . . . 22,30,32,46,47, 54, 79

Stigmas 3; spikes more or less drooping . . . . . . 31,51-53,55-57

Terminal spilie or spikes staninate.

Stigmas 2. - Spikes spreading or pendulous . . . . . . . 34, 37, 40,41

Spikes erect or nearly so . . . . . 9-16, $34-41,85-91,79$

Stigmas 3 : splikes spreading or dropling.

Perigyulum juminently 3 -angled . . . . . . . . 65-7t

Perigynim large, thin, mush inflated . . . . . . . . . 9-16

Perigyuium firmer, not inflated.

Bealiless . . . . . . . . . . . 42-4

Beaked or prominently pointed. - Teeth long, stiff and sliarp , . . 17-1.

Teeth sliort and thin, or none $30,31,39,45-\%$ : 
Stigmas s ; spikes erect or ascending.

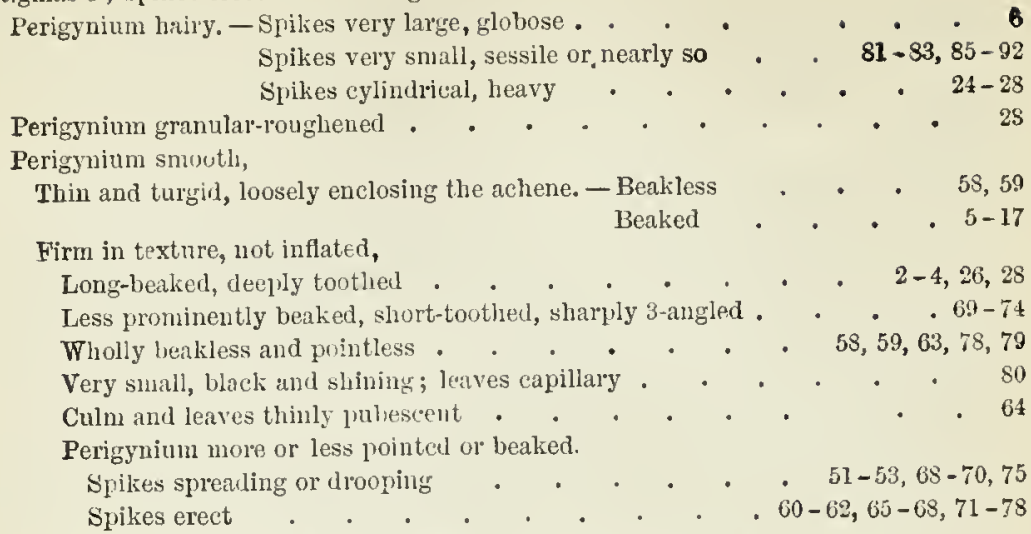

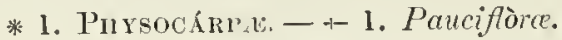

1. C. pauciflora, Lightf. (1'l. 5, fig. 1-16.) Very slender but erect, 6-18' high ; leaves very marrow, uncl shorter than the culm; staminate and pistillate flowers $2-5$; perigynium at maturity easily detached. - Cold spluagnum swamps, New Eng. to N. Penn. and Minn.; local. (Eu.)

$$
\text { * 1. - +2. Luputinue. }
$$

-Teeth of the perigynium strongly reflexed.

2. C. subulàta, Michx. Green, very sleuder lnt erect, $6^{\prime}-2^{\circ}$ high; leares narrow, somewhat shorter than the culur; bracts leafy, sheathing; pistillate spikes 2-t, seattered, 2-6-Howered; perigyninm deflexed.-Deep sphagnum swamps, R. I. to L. I'enn., and southward; rery local.

$$
++ \text { Teeth erect or spreuling. }
$$

\section{$=$ Whole plunt yellowish; perigynium lithe or not ut all inflated.}

3. C. Michauxiàna, Bocekl. Slender but stiff aud ereet, 1-2 $2^{\circ}$ high : leaves narrow :mb firm, shorter than the culus: spikes 2-3, the lowest usually remote and slort-peilnnelol, the remainder ageregaterl and sessile; staninate spike small, wholly sessile; perigynimu not intlated, erect or sprearling, twice longer than the blunt seale. (C. rostlata, M/ch.r.) - Bogs and lakeborders, mountains of $\mathrm{N}$. H. and N. Y., and westwarl to I. Superior; local.

4. C. folliculàta, I. Stont, 2-30 liggle: leaves rely broat and flat, lax; pistillate sprikes $3-4$, scattered, all but the npermust prominently pecluneled ; staninate spike short-peduneled; periengum langer, inflated, the seale awnerl and nearly as long. — Cold swanps, New ling. to N. J. and Penu., and west to Mich.; rather local.

$$
==\text { Plant green : perigynium much inflated. }
$$

5. C. intuméscens, Rudge. Sleuder, 18-30' high; lenves narrow; pistillate spikes two, loosely 1-8-fluweresl, the perigrninm erectsprealing, not prominently manyervel. - Wret pastures and swamps; common.

6. C. Gràyii, carey. I arger and stouter ; leabes bread and flat, 3-4" wide; pistillate suikes 1 or 2 , the lowest often perhuclerl, perfectly globnlar aud compactly 12-30-foweresl, the perigntum spmealing or deflexed

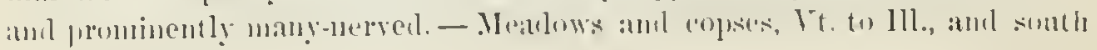


to Ga. ; rare eastward. - In var. HIspfDULd, Gray, the perigynium is sparsely hispidillous.

7. C. lupulina, Muhl. Very stout aud leafy; leaves rather broad and 'oose ; pistillate spikes 2-6, approximate at the top of the culm, all closely sessile or the lower sometimes short-jeduncled, oblong or short-cylintrical, very heavy and densely tlowered; staminate spike small and sessile; perigynium large and rather soft, erect or hut slightly spreading, giving the spike a hop-like aspect (whence the name). (C.lurida, Builey.) - Simamps and wet pastures; frequent.

Var. pedunculàta, Dewey. Sprikes more or less seattererl, some or all prominently peduncled; staminate spike usually conspicuons, often longpeduncled, very variable in size; perignnium more spreading. (C. gigantea, Rudye.) - With the species, hut mure common.

Var. polystàchya, Schwein. \& Torr. Stouter, the leaves rery broad (oiten $\frac{f^{\prime}}{2}$ ); bracts broad and far exceeding the culm; pistillate spikes $4-6$, all long $\left(3-4^{\prime}\right)$ and (ylindrical, more wr less short-peduncled, somewliat seattered, becoming yellow; perigynium very large, ascending. (C. lupuliformis, S'tertu.) - N. Y. and N. J.; not common.

C. LuPclìa X retrórsi, Dudley. Distinguished from C. lupulina by its straw-colored perigynium, which is less inflated and more spreading, standing at nearly right angles to the axis of the spilie; scales acnte to short-awned, rongh. (C. lurida $\times$ retrorsa, Bailey). - Ithaca, N. Y. (Dudley), aud Lausing, Mich. (Bailey). Resembles n. I6.

8. C. grándis, Bailey. Distiugnished from C. lupulina, var. polystachya, by its much more scattered and mostly slurter slim spikes, which are comparatively loosely flowered; perigynium swollen below but very abruptly contracted into a slenter beak $3-4$ times as long as the body, spreading at right angles or nearly so, never becoming yellow; scales narrow, smooth. (C. gigantea of previons editions.) - Swamps, Ky., Del., and southward; local.

$$
\text { * 1. - + 3. Tesicàrice. }
$$

- Spikes very small, glohular or shoit-oblong.

9. C. oligospérma, Michx. Tery slender, but stiff, 18-30' high ; reaves and bract: very nirrow, becoming involnte; staminate spike single, peduncled; pistillate spikes 1 or 2 , sessile or the lowest very short-peduncled, 3-8-flowered; perigrnium turgil, short-ovoid, gralually contracted into i very short aud minutely tootlerl beak, prominently few-nerved, yellow, nearly twice longer than the blunt scale. - Deep swamps and borters of lakes, $\mathrm{A}$. ling. to P'enn. and Minn.; frequent.

10. C. miliàris, Michs. Culm rery slender but erect, 12-18' high, sinooth, or slightly rough above on the angles; leaves almost filiform, mostly shorter than the crlm; staminate spikes $1-2$, excredingly narrow, cleviter an inch or two; pistillate spikes $1-3$, the nppe one sessile and the lowest

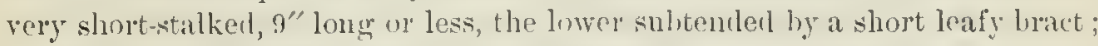
perigrnimu very small, broal- or romul-ovate or ovate-ohlong, thin but firm,

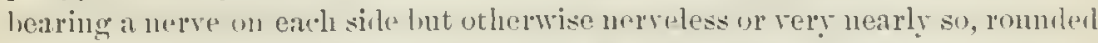
into a very short terete entire or somewhat erose lieak; scales lirown, lan'sovate, white tipped, ahout as long as the perigynium. (C. rotuudata! of list eil.) - Ontlet of Moosehearl I.ake, Maine. anil northward. 
Var. major, Bailey. Culn much stouter (often over $2^{\circ}$ high), thick and very sharply angled; leaves stont and clannelled or involute; staminate spikes short-stalked; the pistillate 1-5, darker, nostly longer and larger; scale varying from wholly obtuse to acutish. - Outlet of Moosehead Lake (Porter), and northward.

Var. (?) aurea, Bailey. Taller and mostly stonter than the type; pistillate spikes one or two, often staminate at top, yellow or stramineous; pericrinim longer, gradually produced into a eonspicnous and more or less wother beak, prominently few-nerved, yellow, broaler and usually longer than the blunt scale. (C. pulla, and rar. miliaris, last ed.) - Outlet of Moosehead Take (Smith), and northward.

+ Spikes much larger, cylindrical.

$=$ Scales all, or all. but the very lowest, smooth.

11. C. utriculàta, Boott. Very stont and robust, $3-4^{\circ}$ high; leaves broad $\left(4-6^{\prime \prime}\right)$ and flat, very prominently norlulose, particularly below; spikes $3-4,3-6^{\prime}$ long, very thick and dense above but usually more or less attenuate below, erect or ncarly so, all but the lowest sessile or very short-stalked; perigynium orate, only moderately inflatel, rather abruptly contracted into a short toothed beak, at maturity usually squarrose, rather prominently fewnerved, the upper longer than the sharp scale, the lower shorter than or only erpualling the sharper or awned scile. (C. rostrata, Bailey, ete) - Swanps, everywhere; common. Passes imperectibly into var. sìnon, Boott, which is distinguished by its much smaller size, spikes $21^{\prime}$ long or less, smaller perigroum, blunt scales, and narrower and little molnlose leaves. With the type.

12. C. monile, Tuckerm. Rather slencler but erect, $2-3^{\circ}$ high, the culm sharply angled aud usually rough above; pistillate spikes $2-3$, the lowest me (1) two short-stalked, erect or sprealing, 1-3' long, narrowly eylindrical: perigrnium turgirl, prominently beaked, alout 10-nerved, ascending, longre. than the rery sharp seale. (C. Vaseyi, Dewe\%) - Mcatuws and swales; common, - In rat. nosstioss, Bailey, the plant is very slender thronghout, and the teminal spike more or less pistillate, while the remaining spikes are reducer to one or tro which are very small and loosely flowered and usmally un very long filiform perluncles. I.. Mass. (Sinn).

13. C. Tuckermàni, Jewey. I)iffer's from the last ehicfly in the comparatively shorter $\left(1-\underline{2}^{\prime}\right.$ long) spikes, which are much thicker (usually $\frac{1}{2}$ or uore) ; jerigynimm greatly inflated and very thin and papery, the body broades than long (alont 3 " thick); scale thin and nalrow, acute, all but the very lowest less thin hall the length of the porigrnium. - Swamps, W. New Fun. to X. J., and west to Minn.; frequent.

14. C. bullàta, sehkulı. (I’l. 6, fig. 15-20.) Slender, I-20 higlı; culu very sharply and rumghly angled, thin lut stiff; leaves narrow, rongl-erlget. stiff; spikes 1 or 2 , romote, shout and thick (1'arely $11^{\prime}$ long), sessile or the lower

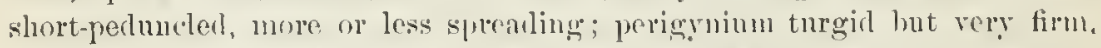
lnll straw eolored and shining as if varnished, prominently few-nerved, the long beak usually mimtely romghened; scale membrauaceous and l)hnt, albut !l as long as the perigyninm. - Swamps from E. Mass. to X.J. and E. l'eun., and southwarl; frequent. 
C. BCllata X Itricurata, Bailey. Perigyum considerably smaller and more sprealling, less shining; scales longer and sharper. (C. Olneyi, Boott.) - Providence, R. I. (Olney).

15. C. retrórsa, Schweiu. Stont, $2-3^{\circ}$ high ; culm obtusely angled aud smooth or nearly so; leaves broad aud soft, roughish, much longer tban the culm; spikes 3-5, approximate near the top of the culm or the lowest renute, all but the lowest 1 or 2 sessile, $1-2^{\prime} \operatorname{long}$ and rery compactly flowered, erect or spreading; perigynium very thin and papery, nuch inflaterl, prominently nerved, strongly reflexed; scale very short aud small. — Swamps, from Penll. northward, common. - In rar. Ilírti, Gray, a common monstrons form, the spikes are more or less scattered and peduncled, loosely flowered, and the perigynimm less reflexed or spreading.

$$
==\text { Scules all rough-auned. }
$$

16. C. lùricia, Wahl. Tariable in size, mostly ranging from $1 \frac{1}{2}-3^{\circ}$ ligh, stont; cul 11 rather olıtnsely angled and smootlı; leaves long and loose, rough; spikes $2-4$, varionsly disposerl, the 1 or 2 npler sessile, nearly erect or often drooping, very densely flowered; perigynimm thin and turgid, often somewhat shining, rather lightly ahont 10-nerved, very long and slenderly leaked, ascending; staminate spike single, scales linear, half as long as the perigyninom or more. (C.tentaculata, Muh.) - Swamps, N. Eug. to S. Ill., and southwarl; alunilant eastwarl. Very variable. - Var. ciścils, Bailey. l'lant more slender; spikes $2-3$, very small and marrowly cylindrical (1' Inug or less, and $3^{\prime \prime}$ broarl or less). Mts. of V't., Penn., and Tenn.

Var. fláccida, Bailey. Lower, scarcely exceeding 12-15' in height; spikes 2-4, all sessile and approximate at the top of the culm, small and straight (l' long or less), dull brown or reddish-lnown, loosely flowered and entirely lacking the rlense and comose appearance of the type; periggnium rery thin and mucl inflated, the body usually larger than in the type and nore gradually contracted into the beak. - N. Y. to N. .J.; apparently searce.

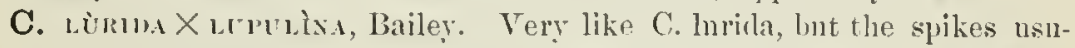
ally all approximate or only the lowest separated, erect or sprealing, all sessile, green or greenish, often curved; perigyninm very long-beaked and ascenting; staminate spike one, sessile or very nearly so, strongly resembling that of $\mathrm{C}$. Iupmlina. (C. tentaculata, var, altion, Bontt.) - Mass., Conn., and N. Y.; little known. C. lopulina $\times$ retronsa is clistinguisher from this by its yellow or straw-colorel more scatterel spikes which are shorter and always straight, and the loose, larger and more inflated perigynia.

\section{* 1.-+ 4. Pseurlocypèrre. \\ + Sprikes all erect or ascending.}

17. C. Schweinítzil, Dewey. Soft but erect, $1-2^{\circ}$ high, stoloniferous, vellowish-green and becoming straw-colored in drying; culm flattish and "mooth; leaves broad $\left(3-t^{\prime \prime}\right)$, the radical longer than the culm, the others mostly short; spikes $3-4$, the lower one or two short-pedumcled, narrowly long-cylindrical ( $1 \frac{1}{3}-3^{\prime}$ long, $t^{\prime \prime}$ brond); perigynum thin and somerlat inflated, prominently few-nerverl, the long beak short-toothed, ascending; scalo awned and commonly rough at the tip, a little shorter than the perigyninm. - Swanıps, W. Now Kug.to . .. J., and west to . Iich.; local. 


\section{++ ++ Spikes widely spreading or diooping.}

18. C. hystricina, Muhl. Slender but erect, I-2o high; culm very sharply angled anl rough, at least above; leaves louther narrow, roughish; spikes $1-3$, borne near the top of the culm, the uprer onc often sessile, the remainder on more or less filiform stalkis, sliort (rancly 1! long) and compactly flowered; perigrnium greenish, very strongly $15-20$-nerverl, the very slender beak strongly tootherl; scale linear and rungh-awned, nearly or quite as long as the perigrurim. - Swales, throughont; frequent. Often confonded with n. 16.

Var. Dudlèyi, Bailey. 'Taller'; spikes larger ant slinnner ( $1 \frac{1}{2}-2 \frac{y^{\prime}}{2}$ long), light straw-colored, all secund and widely divareate or nodding; perigrnium stronger toothed ; seales usually more prominent, - Swales, Conn. (Irright), Ithaca, X. Y. (Duelley), Wrise. (Lapherm).

19. C. Pseùdo-Cypèrus, I. 'Jall and stout, 2-30 high; culm thick and rery sharply triangnlar, rough throughout; leaves very loug, rough-margined; spikes $3-5$, all slenderl: perluncled and more or less drooping, all somewhat contiguous, loug (mostly 2-3') and narowly cylindrieal, very eompactly flowered; perigyium elliptic-lanceolate, more or less 2-edged, manycostiate, the beak shorter than the body, with erect short teeth, strongly reflexed ; scale very rough-awned, about the length of the perigyium. - Swamps and lake-borders, N. Fing. to Penn., and Mich.; rare. (kin.)

Var. Americàna, Ilochst. Mostl, stouter, the leares broaler (abont $\frac{1}{4}$ ); spikes thicker and commonly more drooping; perigyniun longer, the beak mostly longer than the body and the teeth long and prominently spreading. (C. comosa, Booll.) - Swamps; common.

\section{* 1. - + 5. Squarròsie.}

20. C. stenólepis, 'Torr. Stout aud rery leafy, $1-2^{\circ}$ hight ; culm obtusely anglerl, very smooth; leares about $3^{\prime \prime}$ hroal, rongh on the nerves, the upper and the bracts very much longer than the eulm; terminal spike often pistillate at top; other spikes $3-5$, the uppermost sessile on the zigzag rhachis. short ( $1-1 \frac{1^{\prime}}{2}$ or less) and evenly cylindrical, often staminate at top; perigyuium very abruptly contractel into a short but slender twothed beak, shorter than the long-linear and rough scale. - Swamps and meadows, central Penn., to N. Ohio, west and southward ; frequent.

21. C. squarrósa, L. Cespitose, $2-3^{\circ}$ high ; eulu sharply angled, more or less rough ahove; leaves brond and weak, roughish, exceediug the culm; bracts much less prominent than in the last; spikes $1-3$, thick, the terminal always two-thirds pistillate or nore, the remainder more or less stalked, erect or slightly nolding, glohnlar or ollong-(rylinlric, lorown, exceedingly densely flowered; perigynum larger, the beak rough ; seale short and usually invis. ible. - Bogs, throughout; infrequent.

\section{* 2. Traciuculax.e. - 1. Shortiäne.}

22. C. Shortiàna, Dewey. 'Tall ancl slenler hut strict, in small clumps, $2-3^{\circ}$ high; leaves about $\frac{1}{4}$ broal, flat, rough on the nerves; spikes $3-5$, somewhat approximate near the top of the cnlm, the lowest 2 or 3 short-peduneled, erect, small ( $1^{\prime}$ long or less, and 2" wide), evenly cylindrical, exeectingly flensely" fowererl; preriggnium small, rireular or ronnd-ovate, Aat. 
sharp-edged, nerveless, the orifice entire, perfectly squarrose; scale thin and blunt, about the length of the perigynium. - Wet meadows, S. Penn. and Va. to Ill. ; rare eastward.

\section{* 2. - 2 . Anómalce.}

23. C. scabràta, Schwein. Tall and rather stout, very leafy, $1-3^{\circ}$ high, culm slarply and very roughly angled; leaves broal and flat, very rough; spikes $3-5$, scattered, the upper 1 or 2 sessile, the remainder often long-peluncled and sometimes nodding, $1-2^{\prime}$ long, narrowly cylindrical and compactly flowered; perigynium broadly ovate, prominently few-nerved, rough, the beak nearly as long as the body aud slightly toothed; scale acute and rough-tipped, green-nerved, aljout as long as the body of the perigynium. Wet meadows and glades, as far west as Mich.; common eastward.

$$
\text { * 2. }-+3 \text {. Hirtce. }
$$

24. C. vestita, Willd. Stout and stiff, $2-3^{\circ}$ high; culm sharply an. gled, smooth or somewhat rough; leaves narrow and rather short, roughish; staminate spike I, rarely 2, sessile or nearly so; pistillate spikes $2-5$, approximate and sessile, or rarely the lowest sub-radical, often staninate at top, oblong or short-cylindric (rarely l' long), compactly flowered; perigyuium ovate, nerved, stiffy hairy, short-beaked, the beak often purple, and whitehyaline at the orifice, which becomes more or less split with age; scale thin and blunt or acute, shorter than the perigrnium. - Tufted in sandy soils, from N. Eng. to N. Y., and sonthward; freqnent.

25. C. striàta, Miclıx., var. brèvis, Bailey. Stiff, $1 \frac{1}{2}-21^{\circ}$ high ; culm sharply anglerl, snooth or slightly rongli ahove, mostly exceeding the leaves, leaves narrow and stiff, beconing involute; spikes 1 - 2, mostly closely sessile, considerably separated when two, slort (rarely 1 1 $\frac{1}{2}$ long) and rather thick, erect; perigrninu hroad-ovate with impressed nerves, smooth, ascending, shortbeaked and very short-toothed; scale thin, ol,tuse or acutish, mostly about $\frac{1}{2}$ as long as the perigyium. - P'ine-hareen swamps, N.J., and southward; local.

26. C. Houghtònii, 'Torr, Stiff, $1-2^{\circ}$ high, extensively creeping; culm rather sharply angled, rongl, exceeling the leaves; leaves flat and rery sharp-pointed; spikes 1-3, sessile or the lowest short-stalked, erect, varying from nearly globular tu cylindric ( $1 \frac{1^{\prime}}{2}$ long), complact ; perigynium short-ovate, stifly pubescent, proninently nervel and toothed ; scile thin-margined, acute or awned, shorter than the perigrnium. - Sandy knolls and lanks from MIaine to Minn. along our northern borders, and northwestward; rather local.

27. C. filifórmis, L. 'Tall and very slender bnt erect, $2-3^{\circ}$ high ; culn: obtuse, smooth; leaves very long, involute-filiform, rongh; spikes 1 - 3 , sessile, somewhat scittered, erect, short and thick (rarely over l' long); perigy"linm very short-ovate, the teeth very short, the few nerves ohscured br the clense stiff hairs; scale thin and blunt, about as lung as the perigynium. Bogs, throughout, north of Penu. ; frequent. (Eu.)

Var. latifolia, Boeckl. Culın mostly rough above; leaves fat, 1-2" broad; spikes usually somewlat slimmer ant scales often sharper and longer (C. lanuginosa, Mirh.x.) - Swales and low mealows, throughout; common.

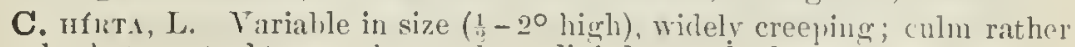
slender but erect, obtne aurl smooth or sliglitly rough above; leares soft aul? 
that, generally sparsely hairy and the shcathis very hirsute, rarely smooth: spikes $2-3$, distant, möre or less shortly-pertuncled, erect wr nearly so, $1 \frac{1}{2}$ loni or less and rather loose; periggnimu long-ovate, nerverl, soft-hairy, the prominent beak slenderly toothed; scale thin and green-nerved, awned, mostly a little shorter. - E. Mass. to central N. Y. and Pem. (Nat. from Eu.)

$$
\text { * 2. - + 4. Puludoste. }
$$

++ Teeth slender, mostly spreading.

28. C. trichocárpa, Muhl. Stout and tall, $2-3^{\circ}$ high ; eulm sharply angled, rough aborc; leaves very numerous, flat and very rough, but not hairy, much exeeeding the culm; spikes 2-5, seattered, the lower stalked and more or less spreading, long and heary $\left(1-t^{\prime}\right)$ but loosely flowered at base; perigyaim long-ovate, many-eostate, spalrsely short-hairy, about twice as long as the mulubuniceous, acute or acuminate scale. - Marshes: frequent.

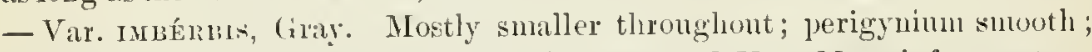
scales usually sharper and longer. Drier places, N. Y. to Mo.; infrequont.

Var. Dewèyi, Bailey. leaves narrower, often lecoming somewhat invo

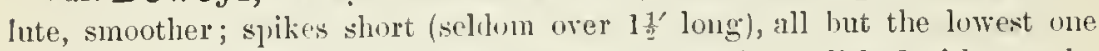
sessile; perigy uiun smooth, thick in texture, becoming polished with age, the nerves impressed; scales sharp, mostly a little slouter than the periggnim. - Dakota (Sfymom), and northwestward. Resembles small forms of 11. 2 ?.

Var. aristàta, Bailey. Mostly stonter; leaves more or less hairy on the under surface and sheaths; perigrnimu usmally longer. smooth, the tecth longer and more spreading. (C. aristata, $R$. Br.) - N. Eng. to Minn. ; rare eastward.

$$
\text { +o Teeth short, erect or rery nearly so. }
$$

29. C. ripária, W. Curtis. Very linge and stont, $2-4^{\circ}$ high, stoloniferous; leaves mostly broad, flat, rough, whucous, much longer than the sharply angled culm; spilies 2-4, scattered and all more or less peduncled, the lowest often very long-stalked, varying from almost globular in starved plants to 3 $f^{\prime}$ long, erect or the lower somewhat dropjing, lonsely. Howered lelow; peri. gyminm orate-lanceolate, coriaceous, rather lightly many-nerved, beeoming polished, the beak short and thick; scale varying from blunt to awned, shorter ur longer than the perigynum. - Swales; common. (Eu.)

C. ACUTúnliss, Fhrh. Stout, $2-3^{\circ}$ hight; culm thick and sharp, mostly smooth; leaves loroud, fiat and glaucous, much prolonged; spikes $3-5$, all brit: the uppermost pechucled, spreadiug on dropping, nadrowly cylindric $\left(2-33^{\prime}\right.$ loug), loosely Howered below; perigrnimm oxate, wry strongly many-nerved, the short heik slightly tootherl; sabe rongli-awnen and longer than the perigynim. (C. paludusa, Cowlen.) - swales, Dorhester, and New Bedford Riass (Nat, from Eu.) The former station has been recently destroyed.

\section{* 3. Microniricha.- - Atiate.}

\section{+ Alpine; plant small.}

30. C. alpina, Swartz. Small and slenter, $\frac{1}{2}-2^{\circ}$ high; eulm thin aud olstuse, smooth or ronghish, naked above; lenves narrow and flat, shorter than the culm; spikes commonly 3, sometimes 2014 , aggregated, glolular and very small, all closely sessile or rarely the lowest exceclingly short-stalked; perigyninm orbicular or oborate, nerveless or nearl! so, the slort beak slightly notcherl, a little longer than the ovate and black mostly obtuse scale. - Islo Royale, T. Superior. (Fu.) 
31. C. atràta, I., var. ovàta, Butt. Very slenler but erect, 1 - $2^{\circ}$ high ; rulm rather sharp, roughish above; leaves narrow but flat, shorter than the culn; spikes $3-5$, all bnt the terminal one on slender stalks $\frac{1}{2}-2^{\prime}$ long, drooping when mature, $1^{\prime}$ long or less, ovate-oblong or short-cylindric, reddish. brown; perigrnimm broally wate, thin and puncticulate, very short-beaked, the orifice slightly notched; scale blunt, thin-margined, about as long as the perigrnium. (C. atrata, M(m.) - White Mountains, N. H., Smugglers' Notch, Vt. (Broinerd), and nort liwarl.

+ Paludose: plant larger.

32. C. fúsca, AII. liather slender but stiff, l-3० higll; culm sharp

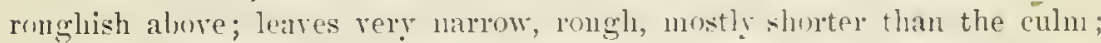
spikes $2-4$, the terminal rarely all staminate, all sessile and approximate or the lowest sometimes very shortstalked, varying from globular to narrowly cylindric (often becoming $1 \frac{1}{3}$ long), dark lorme or variegated; perigynim elliptic and leakloss, whitish and grannlar, nearly nerveless, the orifice entire; staninate scales very long-lanceolate, the pistillate lance-orate and rery sharp, conspicnonsly longer than the gerigrnium. (C. Buxbaumii, Wahl.) - Bogs, thronghont; frequent. (Eus.)

$$
\text { * 3. - + 2. Rigide. }
$$

33. C. vulgàris, Fries. Low anrl stiff, alwout $1^{\circ}$ or sometimes $18^{\prime}$ ligh : confm sharp, smooth or rather rough above; leaves marow and stiff, shorter than the colm, glaucous Line; staninate spike sessile or nealy so; spikes 2 4 , all seswile or rarely the lowest rery sholt-stalked, short and erect (l' long $\mathrm{m}^{\circ}$ less), rery densely fowered or sometimes beconing loose below, the lowest snbtended ly a hact $1-3^{\prime}$ long; periggniun apuressed, oval or round-ovate, mostly fincly striate towarl the base, the beak cntire or very nearly so, bright green until orer-mature; seale orate and rery ol,tuse, puple with a faint white nerve, conspicuously narrowre and shorter than the perigynim, thus causing the spike in the growing flant to assme a characteristic green-and-black appearance. - Swales and low mearlows along, the sea-board, from Mass. nortlward; crmmon. (liu.)

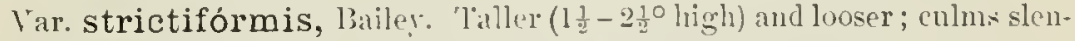
ler; leaves long and narow, lix, scarcely glatucons; staminate spike longer perluncled; pistillate spikes looser and often longer, mostly brown or tawnygreen. (C. limmla, M(an.) - Swales from F. Penn. northward, near the sealoarl; frequent. Often confonnled with $n .3+$, but easily distinguished by the. ann-cespitose habit, sheaths unt filuillose, and the short scales very obtuse.

Var. hyperbòrea, Buntt. Šmmewhat stoloniferous, low, often smallel than the type; spikes shurter and mostly loosely Howered, often becming very thin; scales generally longer, giving the spikes a darker color; stigmis often 3. (C. rigila, var. (!) Bigelovii, Tucherm.) - .lpine summits of $\mathrm{X}$. $\mathrm{H}$. Yt., and N. Y. (Eir.)

$$
\text { * 3. }-+3 \text {. Aciulu. }
$$

- Stipmas 2; srules not ranspicuously acule, or if so, divaricate.

$=$ Spites erect, or rarely spreading in n. 34 .

34. C. strícta, Lam. 'Tall and slender but erect. $2-4^{\circ}$ highl, generall!

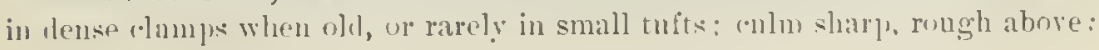


leares long and uarrow, rough on the eflges, the lowest sheatlis nsually heeoming prominently fibrillose; 1 or 2 lowest bracts leafy and equalling the enlm; spilies 3-5, variable in size and shape, scattered, the lowest usually more or less peluncled and clawate and the others sessile, erect or slreading, oblong or cylindric ( $\frac{1}{2}-2^{\prime} \operatorname{long}$ and $2-3^{\prime \prime}$ broad), all eompaetly flowered above but often attenuate at base (or rarely alternate-flowerer throughont), the upper mostly staminate at top, all greenish-purple or pallid; perigrnium ovate and small, tawny, mostly lightly few-nerved anl somewhat grunular, the beak very short and commonly entire; scale obtuse to nearly acute, alsont equalling the perigy nium or a little slorter. - Swales, throughout; abnuciant and variable.

Var. angustàta. Stricter'; spikes longer and nar'rower $\left(3-t^{\prime}\right.$ longr and about $1 \frac{1}{2}$ " broal), never clavate, nore approximate and always erect, the staminate portion usually much longer (often $1-2^{\prime}$ ), rust-colored; scales narrower and sharper, mostly longer than the jerigynimn. (C. augustata, Boott, in part.) - Same range as the type, but less common.

Var. decora, Bailey. Lsually smaller; lisal sheaths rarely fibrillose; spikes shorter (seldtom over $1^{\prime}$ long), sessile or very nearly so, rarely attemuate at base, spreading, the terminal staminate flowers few, rust-colored; bract: more spreading; scales very shar 1 ant spreading, longer than the periggnimum. (C. aperta, M(u.) - N. Eng. to Wisc.; rather rare.

C. strícta $X$ promónis. Leaves and culns very slender; spikes short (1 long or less), sessile and compact, the upper 1 or 2 searcely lracted, pallid; periggnimm small, smooth. - Kewrenaw Co., Vich. (Farwell.) Exactly intermediate between the two species.

35. C. aquátilis, Wahl. Large and stout, glancous, $2-4^{\circ}$ high ; culın very obtuse and smooth; leaves exceedingly long, broader than in the last, the bracts broad and prolonged far heyoud the culn ; spikes 3-5, 1-2' long, very compact or the lowest sometimes attemate below, ereet, thick ( $3^{\prime \prime}$ broad or less); perigynium ronnd-ovite or broally. "Hliptic, nerveless, greenish, imbricater; scale obtuse and much slorter and narrower than the perigynium. - Swamps and lake-margins, N. ling, to Minn.; not common. (En.)

36. C. lenticulàris, Michx. Rather slender but ereet, pale tliroughout, $1-2^{\circ}$ high; culm slarp, usually slightly rough albove; leaves very narrow, numerous, much surpassing the enlm; spikes $3-6$, more or less aggregated or the lowest remote, the terminal androgynons or staminate, mostly sessile, erect; perigynium ovate, minntely graunlar, brownerved, the tip empty and entire; scale pale and obuse, ahout $\frac{1}{3}$ the length of the perigrninu. - Gravelly borders of ponds and lakes, northern N. Eng to Minn.; mostly local.

$$
==\text { Spikes widely spreading or drooping. }
$$

37. C. tórta, 13oott. Slender but erect, $1 \frac{1}{2}-210 \mathrm{~h}$ high, in elumps, with exeealingly tough and corl-like roots; eulm rather sliarp, smootl or roughish above; leaves that and rather soft, those of the culn very short; spikes $3-5$, mostly somew hat aplroximate or the lower remote, the ry per sessile and ascending lout the others drooping, long and slender (often $3^{\prime}$ long, 2" broul or less); perigy'nim lance-ovite, thin and green, nerveless, the slim upper half empty ancl more or less tortuous, the heak entire or erose; scale purple-margined and very ohtuse, slorter than the perigynimn. - Colul banks and swamps, V't. to N. C. ; infreqlient. 


\section{+. Stigmus 2; scales long-acute and ascending.}

38. C. salina, Wahl, var. cuspidàta, Wahl. Rather stout, 1-2 $\frac{1}{2}$ high; culm rather sharp, smooth; leaves narow but flat; spikes $2-4$, somewhat approximate, the lowest 1 or 2 very short-stalked, erect, short ( 1 or or less) and rather thick, the lower sultemled by leaf-like bracts 3 - $4^{\prime}$ long; perigyninm elliptic, somewhat gramular, marked with 2 or 3 nerves or nerveless, the nimnte beak entre; scale brown-mangined, produced into a lighter and rongl: awn much exceeling the perigynim. (C.salina, l/(m.) - Salt marshes, Mass. and along the coast northward; rare in the United States. (Fu.) Anomalons forms, which appear to be hỵbrids, luve been separated as

C. strícta $\times$ silisd, Bailey. Spikes thimner and morescattered, more inclined to be peduucled; scales blunt or slort-awned, litte exceeding the nerigynium. - Near Boston, Mass., Wr. Boott, Morong.

$$
++++ \text { Stigmas } 3 .
$$

39. C. prasina, Wahl. Slender, somewhat flexuose, $1 \frac{1}{2}-2 \frac{10}{2}$ highl ; culm rather slarp, smooth; leaves very narow, soft and that, rongh; spikes 2-3, peduncled and spreading or drooping, sonewhat approxinate, green, $1-2$ long, narrow and loosely flowered ; perigynim pale, uarrowly triangular-ovate, thin, nearly nerveless, produced into a short but slender entire or minutely tootherl beak; scale very thiu and acute, neally colorless, shorter than the perigynimm. (C. miliacea, Muhl.) - Meadows aud bogs, V't. to Mich., aud suuthwarl ; infrequent.

$$
\text { * 3.- - 4. Crylotocárur. }
$$

40. C. marítima, O. F. Mueller. Mostly stout, $1-22^{\circ}$ high ; culm sharp, smooth or rough above; spikes $2-6$, scattered, all or all but the upper one on very long weak stalks and pendulous, $1-3$ ' long and thick and bushy, usually staninate at top; perigyniun nearly orbicular, pale, few-nerved or nerveless, the beak very short and entire or nearly so; scale produced into a greenish rough awn $3-8$ times als long as the perigynium. - Salt marshes of the coast, Mass., Maine, anl northward; not common. Leares smooth, broad aud flat. (Lu.)

41. C. crinita, Lam. Rolust and mostly stont, 2-40 high ; culm sharp and rough or sometimes smouth; leaves about $3^{\prime \prime}$ broad, flat, nlore or less rough on the nerves and margins ; spikes $3-6$, somewhat scattered, all variously pertuncled, mostly secund, ('urved and drooping (or in sinall forms rarely near?y erect), 1-4' long, narrowly and evenly ç̣linilric, compact or attenuate below, often staninate at top; perigyniun orate, thin and puncticulate, obscurely uerved, the minute point entire; scale greenish-lown and rongh-awned, 2 - 3 times as long as the perigymum. (C. gyumdra, Schucin.) - Swales; conmon. - Var, mìvol, Boott. Much smaller in all its parts, 10-18' ligh; leaves narrow; spikes $3-4,1 \frac{1}{2}{ }^{\prime}$ long or less, less llooping; scales less prominent. Maine to $\mathrm{X} . \mathrm{Y}$.; searce. Somewhat resembles 11,39 .

C. ckisita $\times$ tónd, Bailey. Nore slender than C. crinita, the leaves nalrower; spikes nearly as slender as those of $\mathrm{C}$. torta ; scales hlunt or simply acute and little longer than the perigyninu, (1) sometimes very short-awned. - Moist mealows near the Glen IIouse, White Mts. (Brainerd). Might be mistaken for drooping-spiked forms of 11.34 . 


\section{* 3. - 5. Pendulino.}

+ Spikes narrowly cylindrical.

42. C. littoràlis, Sehwein. Somewhat slender but erect, $1-2^{\circ}$ high ; leaves narrow and rather stiff, flat, glaucous, shorter thau the sharp and nearly smouth culm; staminate spikes $1-3$, dark purple, $1 \frac{1}{2}$ long or less, the scales obtuse; pistillate spikes $2-4$, somewhat approximate, on thread-like pedun. cles, $1-2^{\prime}$ long, usually staminate at top; perigynium lance-oral, faintly nerved, the minute beak entire, mostly longer than the obtuse purple seale; bracts prominently purple-auricled. (C. Barrattii, Schwein. \& Torr.) Marshes near the coast, N. J. and sonthward; rare.

$$
+ \text { Spikes glo ulur or oblong. }
$$

$=$ Scales very sharp, prominently longer than the perigynium.

43. C. Magellánica, Lam. Slender but ereet, $8-18^{\prime}$ high; leares flat and lax, somewhat shorter thau the culm; lowest bract as wile as the leares or nearly so and exceeding the eulm; spikes $2-3$, approximate, all sleuderly stalked and drooping; perigyuium orbicular or broad-orate, nerved in the eeutre, $\frac{1}{2}-\frac{2}{3}$ the length of the seale. (C. irrigua, Smith.)-Deep swamps, throughout, nortlı of l'enn.; loeal. (Eu.)

$$
==\text { Scales blunt, little exceeding the perigynium. }
$$

44. C. rariflòra, Smith. Very small but stiff, $4-10^{\prime}$ lighl, somewhat stoloniferous; culn obtuse and very smooth; leaves very narrow, becoming involute, shorter than the culn; spikes 1-2, only 3-10-flowered, lrooping, borne in the axil of a minute awl-like and purple-auricled bract; perigynium ovate, nearly pointless, olscurely nerved, mostly a little shorter than the enveluping scale. - Mt. Katahdin, Maine (Goodule). (Eu.)

45. C. limòsa, L. Slender but rather stiff, $1-2^{\circ}$ high, stoloniferous; culun sharp, rougl above; leaves very narrow, strongly keeled or involute; spikes 1-2, nodding on slourt stalks or the upper one erect, oblong, springing from the axil of a very uarrow bract which is nearly always shorter than the ('ulm; perigynium very short-pointed, about the leugth of the broad scale.Deep swamps, througlout, north of Penu, ; local. (Eu.)

\section{* 4. Hrmexochlisase - - I, Virescéntes.}

46. C. viréscens, Mull, Slender, ereet or spreadiug, $1-1 \frac{1}{2}{ }^{\circ}$ liggh: leaves very narrow, more or less hairy; spikes $3-5$, green, short-oblong, all somewhat stalked and often spreading, compact (1 ${ }^{\prime \prime}$ thick or less); perigrninm orate and costate, very hairy, longer than the thin and white acute scale. - Var. costata, Dewey, usmally the commoner form, is taller (often reach. ing $\left.2 \frac{1}{2}^{\circ}\right)$, with spikes long-cylindrie, $\frac{1}{8}-2^{\prime}$ loug, and a stronger ribled periggninm. - Banks and copses, N. Eng, to Mich., aud sonthward ; common eastward.

47. C. trìceps, Michx., var. hirsùta, Bailey. Usually stiffer; leares hairy; spikes $2-4$ (11sually 3), all contiguous or oceasionally the lowest somewhat removed, sessile, short-oblong or globular, green or brown (2-3" thick); perigynium hroad-ovate, flattish, very obtuse, often sparsely hirsute when young but smooth at maturity; staminate scales very sharp; pistillate seales arute or short-awned, about the length of or shorter than the perigyninm. Dry copses and fields, N. Eng. to Mo., anl sonthwird; rare northwarl, - Var. 
Suf́rnn, Porter. 'Till, slenrler, olive-green, the leaves very long, rery nearly.

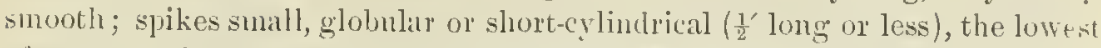
wten somewhat remote, all nore inclined to be peduncled; perigrnium globular and turgirl, forown, squarrose, giving the spike a characteristic plump apr learance. - Fields and wooklands, sonthern N. J., E. P'enu, and southward; alsin in Ark, f frequent.

$$
\text { * 4.- - 2. sylucútrce. }
$$

4. C. longiróstris, 'Torr. Very slender but erect, $1 \frac{1}{2}-3^{\circ}$ highly, growing 1.1 stools; leaves narrow, flat, loose; spilses 3-5, 1-2' long, loosely flowered, Armping; perigynim thiu, slightly inflated, green, nearly nerveless, sprearing, the beak longer than the body, about the length of the awned scale. Shatly hanks from $N$. Eng. to Neb., aud northwarl; frequent. - Var. nisok, Boott. Smallu and sleuterer; spikes 9" long or less, very narrow and rery" sonerely or even alternately fow-Howered; perigynium smaller. Neb. and westwarlu.

$$
\text { * 4. - + 3. Fléxiles. }
$$

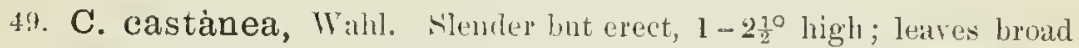
and flat, hairy, much shorter thun the rough culm; spikes $2-4$, approximate, widely spreating or lrouping on filiform stalks, l' loug or less, rather deuse, bawny; periggnimu hruard-lancesslate, grarlnally narrowed into a beak $\frac{1}{2}$ as long as the hody, thin, with a nerve on each side, longer than the light brown or whitish acute thin scale. (C. Hexilis, Rudge.) - Banks, Conn, to Minn.; local.

C. Arotita X ustases, Bailey. Leares mostly uarmwer, less hairy or smootlı; spikes very slenter and loosely flowered (searcely over l" wile), erect ur hoophing, chestunt color; perigninim thin, long-ovate, shorter-lieaked, lightly nervel, mostly surpassing the pointed whitish s(ule. (C. Knieskernii,

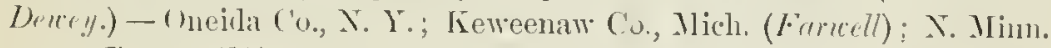

50. C. capillàris, L. V'ery slenter but erect, 2-12' high ; culn surootll, longer thin the numur flat or at length involute leaves; spikes 2-4, cither scatteresl or il'proxinate, all nure or loss long-perluncled and chonping, horne in the axils of consticuous sheathing hracts, rery small (3-12-flowerer]); peri-

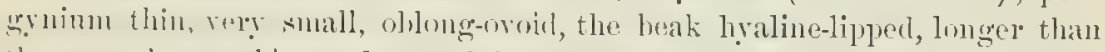
the rely whtur white scale. - Alpine smmits of the White Mts.; Cortland, X. Y., Alconil C'o., Mich., and l'int de' 'Tonr', L. Iluron. (Eu.)

$$
\text { * 4.- - 4. Débiles. }
$$

I'r rigynium thin, rarcly with more than tuw prominent nerces.

51. C. alctàta, Boott. Slender, erect, $1-2^{\circ}$ high; radical leaves $\cdots$, d:h shorter than the culm and rery hroal $\left(2 \frac{1}{2}-5^{\prime \prime}\right)$, flat; bracts loreal and slourt, long-sheathing; spikes $3-5$, all wirlely spteading or drooping on filiform stalks, 1 - $3^{\prime}$ loug anl exceediugly slender; perigyniun short (2" long or less), abruptly and conspicussly stipitate and abruptly contricted into a beak, 3-cornered, promineutly nerved, green, mostly spreading, searcely longer thau the very sharp or cuspilate sculle, - Wookls ind copses, N. Engr. to l'enn. and Minn.; common.

Var. Faxòni, 13ailey. Spikes shorter and usually short-perlunclerl, erect or uearly su, much more deusely flowered, part of then common]! ('untignous at the top of the culn, rendering the shorter staminate spike inconspiantoms. 
perigynium usnally larger. - Lisbon, X. II. (Faxm); Keweenaw Co., Mich (Furuell); extreme northern Minn. (Bailey); also in Canada.

52. C. débilis, Michx., var. Rủdgei, Bailey. Very slender and diffuse, $1-2 \frac{1}{2} 0$ high (or rarely reduced to $3-t^{\prime}$ !) ; leaves narrow and lax, longer than the cnln; spikes mostly heavier than in the last; perigrnium mneh longer, very gradnally narrowed at each end, scarcely angled and not prominently nervel, rusty when ripe, erect, twice longer than the obtuse or acntisli scale (C. debilis, of last ed.) - Copses, N. Fing. to N. Mich., and sonthward; frequent east and sonthwarl. - Var. stifetor, Bailey. Usually taller, strict; leaves broaler (abont $2^{\prime \prime}$ wide) and firmer; spikes stiffer, simply sprending or even ereet; perigyninm mostly shorter and greener, often little exceeding the scale. White Mts. (Faron). - Var. pủbe, Gray. Perigyninm usually more slender, more nerved and minutely pubescent. Center and Lancaster Counties, Penn. (Porter, Lumsden), and Bedford Co, Va. (Curtiss).

C. nébulis X vunéscexs, Bailey. I'lant slender and very green; leaves flat, rough, mosty longer than the culm, spikes 2-3, 2' long, thin and slender, ereet or nearly so, the terminal one bearing a few pistillate flowers at top; perigynimn exactly intermediate between the two species, lance-ovate, nerved and shighty hairy, short-beaked, thin, twice Ionger than the scale. - lievere, near Boston, Mass. (Faxon).

+ + Perigynium firm, mominently many-nerred.

53. C. venústa, Dewey, var. minor, Boeckl. Silencler but strict, $1 \frac{1}{2}-$ $2^{\circ}$ ligh; leaves narrow and strict, abont as long as the culm; spikes $1-2^{\prime}$ long, scattered, the upper usually ascenling, the terminal one sometimes staminate at top; perigynimm ascending, the very short and stunt beak prominenty toothed, thrice longer than the rusty narow scale. (C. glabra, Boott.) - Spliagnous swamps, Oncida Co., N. Y., N. J., and sonthward ; local.

$$
\text { * 4. - + 5. Giaćllime. }
$$

\section{+Perigynium small, scarcely turyid.}

54. C. restivalis, M. A. Curtis. Slender lut erect, 1-1:0 high; leaves very narrow, flat, shorter than the culm, the sheaths pubescent; spikes $3-4$, erect or sprealing, l-2' Iong : and rery loosely flowered, all but the lowest short-stalked; perigynimm very small, ovate, scarcely pointed and the orifice entire, few-nervel, about twice longer than the olituse seale - Saldle Moun. tain, W. Mlass., and sonthwarl in the momntains to X. C.; rare.

55. C. gracillima, Schwein. Tall and slculer, sometimes diffuse, i $\frac{1}{2}-$ $3^{\circ}$ high; leaves broal and flat (the laulical ahont $3^{\prime \prime}$ wirle), very dark anc. might green; spikes $3-4$, scattered, the trminal rarely staminate, densely Howered except at base, perluncled anc druphing, (w)en; perigyninm ovate, thin aud slightly swollen, nerved, obtuse, wrife entire, twice longer than the very obtuse seale. - Wondlands and low moalows, thronghont; common. In poorer soil and stuny places, it rums into var. nummus, Balley, and is then smaller, has much narrower leaves and very small erect spikes (2-12-flowererl), aus mostly smaller perigynia.

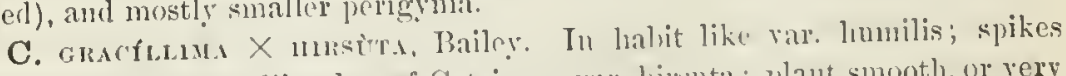

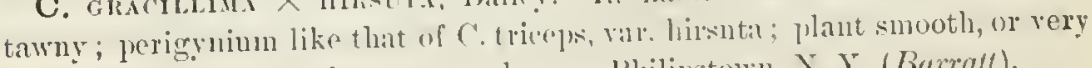
minutely pubescent under a strong leus. - L'hilipstown, X. I. (Barrall). 
C. GRacíllima $\times$ rebéschas, Bailey. Tall and erect; lentes uarrowel than in the last, usually slightly hairy; spikes slender, erect or slightly sprearling, often staminate at top; perigrnimm exacty intermediate between the two species, orate, obscurely nerved, sparsely hairy, beaked, about the length of the orate ciliate rough-awuel scale. (C. Sullivantii, Boott.) - Colunbus, (Ohio (Sullivant); Yonkers, X. Y. (L. C. Houe); Stanton, Del. (Commons).

\section{- + Perigynium large, prominently inflated.}

56. C. formòsa, Dewey. Slender, erect, $1-2 \frac{1}{2} \circ$ ligh; leares flat, mostly wather broat, those of the culn very short: :pikes $3-5$, scattered, oblong or short-cylindrical ( $l^{\prime}$ long or less), compact, all flexuose or drooping; perigy'n. imn orate, puncticulate, obscurely nerved, short-beaked with a slightly notched orifice, all but the lowest one or two twice longer than the blunt or cuspidate scale. - Wouds aud copses, I't. to Mich.; local.

57. C. Davísii, Schwein. \& Torl. Aways taller; spikes heavier; perigynium more inflaterl, strongly nerved aud prominently tootled, no longer or shorter than the conspicnously awned and spreading scale. - Wet meadows, W. Mass. to S. Minn., and soutluward; rare east and northward.

* 4. -+6 . Trizsce.

58. C. grísea, Wahl. Stout, $1-2^{\circ}$ ligh ; leaves broad $\left(2-3^{\prime \prime}\right)$ and slightily glancous; bracts broad ant leaf-like, diverging, very much exceeding the culm; staninate spikc sniall and sessile; pistillate spilies $3-4$, short ( $1^{\prime}$ long or less), thr' highest two nwally contiguous to the stanimate spike and sessile, the others somewhat remote and peduncled, all erect, compact; perigynium oblong, pointless, narked with impressed nerves, tnrgid and crlindric, all but the lowest longer thim the narrow, cuspidate or hilunt, nerved scale. - Moist grounds, throughout, except along our northem borlers; conmon, - Var. Axrrstr. FónA, Boott. Much more slender; leaves scarcely lalf su wide, the bracts, especially, much narrower and shorter and more erect; spikes slender; perigrnium scarcely inflated, triangular-oblong, bearing a sharp lieak-like point, 2-ranked; scale nerveless, long-iwnet and spreading. N. J. to S. Olio, and southward; comnon. - Var. (i Losós.s, Bàiley. Low, 3 - 12' high, often sprending; spikes few-fluwered, often witlı but 2 or 3 perigynia; perigyuinn short, inflated, very biunt, nearly globose or obovate; scale short, not proninently cuspidate or the upler ones wholly blunt. No., Kan., and southward.

Var. (?) rígida, Bailey; liigid; leaves rather narrow, long and erect; stanimate spike prominently peduncled; pistillate spikes scattered, all more or less stalked, conspicuously" 2-ranked ; perigyninn triangular-oblong, hard, longer than the cuspidate ascending sealc. - Sellersrille, Penn., and Del.

59. C. glancodèa, Tuckem. Lax or somewhat striet $\left(6-18^{\prime}\right.$ high $)$, denscly glancons; leaves flat, varial,le in width; spikes as in $\mathrm{n} .58$; perigynium firm, not inflated, prominently imprensert-nerved, glancous, longer than the short-cuspilate or blunt thin inul appressed siale. (C. flaccosperma, last ed.) - Meardows and swamps, Mass. to S. 111, anıl sonthwart; local.

\section{* 5. Sprostichy. - - irunulares.}

60. C. granulàris, Mluhl. Erect or spreading, $8^{\prime}-2^{\circ}$ high, somewhat glaucons; lenves flat, varions; bracts broad and long, mnch exceedling the $* n l m$; spikes $3-\downarrow$, scattered, all but the upper peluncled, erect or ascending 
compact, short-oblong to cylindrie, never exceeding l' in lengtl ; staminate spike small and usually sessile; perigynium ovoid, very strongly nervel, the nearly entire short beak usually bent; scale thin and pointed, about $\frac{1}{2}$ the lengtl of the perigrnium. - Moist grassy places; common. - Var IIsLis.i. I'orter. Ilabitually lower and more slender; radical leaves very broad $\left(3-4^{\prime \prime}\right)$ and more glaucons; pistillate spikes $\frac{1}{2}$ loug or less, thinner; periggnium a laalf smaller, narower. Wrisc. to Vit, infrequent.

61. C. Cràwei, Dewey. Luw, strict, stoloniferous (4-12' high); loaves narrow; bracts scarcly exceeding the culm ; spikes 2-4, seattered, the lunest radieal or nearly so, shurt-pednucled on the upper sessile, erect, eomparct, $9^{\prime \prime}$ long or less; staminate spike gencrally peluncled ; periggnium orate, usually resinous-dotted, obsemrely or few-nerved, very short-pointed, longer than the obtuse or short-pointed scale. - Moist places, N. Y. to 11l. and Minu; locul, especially eastward.

$$
\text { * 5. - - 2. Eirténse. }
$$

C. kxtéss, Gooden. Hender but strict, 1-20 high; leares iurolute, spikes abont 3 , the lowest remote and short-peduncled, the remainder approxinate and sessile, slort (about $\frac{1^{\prime}}{2}$ long) and compact; perigynimu orate, very strongly nerved, ascending, the short stout heak sharply toothed, longer than

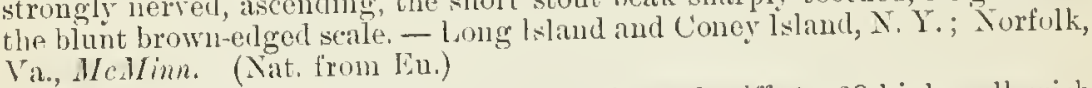

62. C. flàva, I. Very slencer hut strict aud stiff, 1-20 highl, yellowish throughout; leaves flat hut narruw, mostly shorter than the culm; staninate spike sessile or nearly so, usually ullique; pistillate spikes $2-4$, all continnous or rarely the lowest one remote, all bat the lowest sessile, short-ohtong "10 globular, densely Howered, the lowest subtended by a long divaricate hract; perigynium ovate, produced into a deflexed beak as long as the boly, strongly nerved, thrice longer than the blunt scale, - swales and wet meadows, N. Eng. to L. Superior; rare westward. (En.) - Var. GRÁmsis, Bailey. Smaller ant green, 6-12' high; leaves mostly longer than the culm; bracts erect; perigynium straight or nearly so, the heak often rough. Grassy places, probably common aud generally distributed.

Var. viridula, Bailey. Small and slender, very strict, green or greenishwhite; leaves narrow, equalling or exceeding the culm; bracts long ancl strietly erect; spikes very small or sometimes hecoming cylindric, nore clusely aggregated; perigruim conspicnously smaller, the beak very short and straight. (C. Edleri, last ed.) - Cold bogs, N. Fing. to Penu., and northwestward; loeal.

\section{* 5. - + 3. Pullescéntes. \\ +Perigynium uholly beakless.}

63. C. palléscens, L. Slemler, erect, $4^{\prime}-2^{\circ}$ liggll. tuftel ; leaves nar row, flat, the lower slightly pubescent, particularly on the sheaths; spikes $2-$ t, $\frac{1}{2}$ long or less, densely flowered, all but the nuer one very shintly perluncled, erect or sprealing; perig!nim glohular-oblong, thin and rery nearly nerveless, about the length of the cuspulate scale. - Glails and moinlowis, I ling to Penu., Wise. and I, Simperior ; rate Westwalul. (L.u.)

- Perigynium rery stout-traked.

64. C. Torrèyi, Tnckeln. Stiff, $1-1 z^{\circ}$ high; culnu and loaves thinly pubescent; spikes all sessile, very slont; perigynium obovate, very strongly 
many-nerved, retuse, the beak short and straight, equalling or exceeding the Inostly cuspidate scale. - Supposed to have been collected, a half-century ago, in N. Y. by 'Torrey, and in Penn. by Schweinitz. It occurs in the Rocky Mountain region, and high northward.

$$
\begin{aligned}
& \text { * 6. Dactruostàchia - + } 1 \text {. Oligocárpe. } \\
& \text { + Sheaths smooth. }
\end{aligned}
$$

65. C. conoidea, Schlkuhr. Slender but strict, $1-1 \frac{1}{2}^{\circ}$ high; staminate spike long-peduncled or rarely nealy sessile; spikes $2-3$, scattered, shortstalked or the upper one sessile (the lowest frequently very long-stalked), ol). long (rarely l' long) and rather loosely flowered, erect; periggnimm oblongconical, impressed-nerved, gradually narrowed to a proint, the orifice eutire; seale loosely spreading and rough-amed, eyualling or exceeling the perigynimn. - Modst grassy places, N. Eug. to Ill, aud sonthward; rave westwarl.

66. C. oligocárpa, schkluhr. Diffuse, 10-18' high; lracts flat anl spreading; staminate spike sessile or stalkerl spilies 2-4, scattered, stalkel or the upperuost sessile, lousely 2-8-flowered, erect; perigynium smail, harel, fincly implessed-nerved, abruptly contracted into a conspicnons mostly oblirne loak, the orifice entire; scale very loosely spreading and rongh-awned, longer than the perigynitum. - Dry woods and copses, W. New Eug. to Mo., and sonthward; rare westward. Often confommled with small forms of n. 58.

$$
\text { tot +n. Sheuths pubescent. }
$$

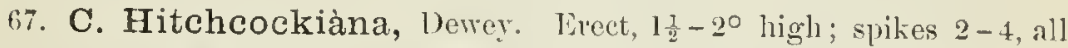
more or less peluncled, rery loosely few-flowered, erect; perigynium triangular-orate, many-striate, the stroug beak prominently oblique, shorter than the rough-iwned scale. - Rich woods, W. New Eng. to Ill., and southward w l'enu. and Kíy.; freqnent.

$$
\text { * 6. - + 2. Laxiftòre. }
$$

+o Sheaths green.

$=$ Perig!mium moslly obscurely triangular, the beak very imominent.

68. C. laxiflora, Lan. Slender but mostly erect, 1-20 high; leaves rarely over "2" ride, ratler suft: stuminate spike peduncled or at least conspicuous: pistillate spikes $2-4$, seattererl, peduscled or the npper one sessile, forsely flowered, cylimblic or sometimes reduced to short-obloug, erect or thes lower loosely spreading; perigrnium obovate, conspicuously nerved, the short

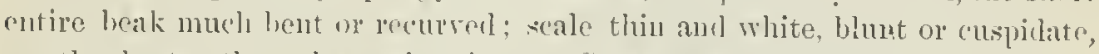
mostly shorter thiun the perigrnium. - Grass: places, throughut common.

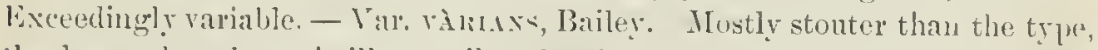
the leaves inoarler; pistillate spikes $\frac{1}{2}-l^{\prime}$ long, the two upper more or les: contiguous to the staminate spike and sessile ur nearly so; luncts leafy and frolongetl. - C'opses ancl grissy places, throughout; conmon. Conuterfeit, var. patulifolia. - Var. smítı́., Carey. Diffuse; pistiłlate spikes rarely over $\frac{I^{\prime}}{2}$ long, the mper sessild and aggregated ahout the inconspicnons staninate spike, the lowest usnally long-xserted. Crassy places, throughout; very

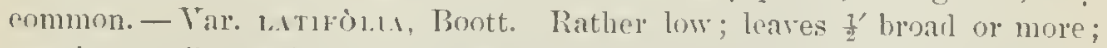
staminate spike sessile or very nearly so: pistillate spikes cylincleic and loose,

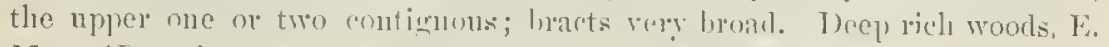
IIass. (Deune) to Penn. and Mich.; common westward. - Var. p'dtulffólte, 
Carey. Glancons; leaves 3 " broal or more ; staminate slike prominent, mostly stalked; pistillate spikes long and alternately flowered, scattered and pedu1. cled; perigyninm (as in the following varieties) elliptic, attenuate at buth ends, mostly less prominently nerved, and the heak not strongly recnrved. Open places, N. Eng. to Mich., and soutlwward; frequent. - Var. 1Hvsucdts, Bailey. Tall and stout; leaves narrower; staminate spike large and stalled; pistillate spikes scattered, all but the upper one promisuently peducled, long; perigyuium very large, divaricate, triangular, contracted into a stipe-like base at least half as long as the body. Near Washingtou, Yasey. - Var. struoFuxi, Boott. Tery weak and slemler; leaves 2 "wide or less; staminate spike usually peducled; pistillate $2-3$, scattered, few-flowererl, lowest drooping; perigynimn very long-pointed. S. E. Penn., and southward; frequent. $==$ Perigynium sharply triangular, short, and mostly not prominently beaked.

a. Spities diooping or flexwose.

69. C. digitàlis, Willd. Very slender, bright green, tufter, 6 - $18^{\prime}$ ligh ; leaves rery narrow ( $1-2$ " wide); staninate spike short stalked; pistillate spikes 2-4, all on filifor'n stalks and all but the upper widely spreading or drooping, linear, alternately flowered; perigrninu very snall, impresserlnerved, longer than the acute whitish scale. - Dryish woods and glacles, $N$. Fug. to Mich., and southwarl ; frequent. - Var. ('orludt, Balley. Leaves nuch broader, and the cnlms weak and reclined; spilies heavier and mostly shorter; perigyniun larger, very shap. Rich woods, central Mich., and probably elsewliele westwarl.

70. C. laxicúlmis, schlleiu. Differs from the variety of 11.69 chiefly in its more cespituse labit, its leusely glancons-blue covering, very slender culm, and very long and filiform peduncles. (C. retrocurva, Dewey.) - Glades, N. Eng. to Mich. and Va.; rare westward.

\section{b. Spikes erect.}

71. C. ptychocárpa, Steudel. Low, glaucous, $3-10^{\prime}$ high ; leares flat and rather broud ( $2^{\prime \prime}$ or more), mucl exceeling the culm; bracts leafy and much prolongerl; staminate spike very small and sessile, mostly orertopperl by the npper pistillate spike; pistillate spikes $2-3$, sessile or short-xtalkerl or rarely the lowest long-perhucled, erect; periggnimn tawn, much as in 11.69 , twice longer than the rery thin ubtuse scale. - Low grounds or swamps, E Mass., N. J., Del., and sontlward; local.

72. C. platyphýlla, Carey. Low, sprealiug, glaucous, 6-12' high . leaves $\frac{1}{2}$ broal or more, mostly shorter than the culms: hracts with thin and sharp-pointed leaf-like tips $1-2$ ' long; stamiuate spike stalkerl; pistillate spikes 2-3, scattered, all more m less peduncled, alternately 2-10-Howered: perigrninm short, strongly many-striate, about the length of the acute or cuspirlate scale. - kich sharly wools and hanks, N. Wng. to Mlich., aur suttlwarrl to Va.; nostly local.

73. C. Careyàna, 'Torr'. Tall and slender', mostly erect, $1-2^{\circ}$ lighl, leaves bright green, firm, $3-4^{\prime \prime}$ wide or more, shorter than the long culm; bructs leafy, longer than in the last; staminate spike heary and stalked; pistillate spikes $2-3$ (mostly 2), the upper msnally near the terminal spike, and nearly sessile, the other remote and long-peduncled, loosely 2 -8-tlowered; 
perigynium very large and very sharply angled, the beak obliqne, finely many. nerved, twice louger than the sharp seale. - Rich woods, N. Eng. to Mieh., and southward to Wishington; rare.

$$
++ \text { Sheuths usually purple. }
$$

74. C. plantagínea, Lan. Slender but erect, $1-2^{\circ}$ high; leaves $\frac{1}{2}-1^{\prime}$ broad, very firm, appearing after the Howers and persisting over winter, shorter than the culm; staninate spike purple and clavate, stalked; pistillate spikes $3-4$, scattered, loosely few-fluwered, crect, the peduncles included in the leafless sheatlss; perigynim smaller thin in 1.73 , prominently beaked, about as long as the sharp seale. - Rich woods, N. Eng. to IVise., and sonthward; local.

$$
\text { * 6. - + 3. Peníces. }
$$

+ Beuli cylindrical and prominent; plant not gluucous.

75. C. Saltuénsis, Bailey. Vcry slencler anıl more or less cliffuse, strongiy stoloniferons, $1-1 \frac{1}{2} 0$ high; leaves narrow and soft, shorter than the culni spikes 2-3, scattered, all pelunclerl and more or less spreading, loosely 3-10Howered; perigyninm small, nearly nerveless, thin, the beak straight and sharply toothed; seale loose, acute, shorter thin the perigynium. (C. vaginata, last ed.) - Deep swamps, Vt. to Mimm.; loeal.

76. C. polymórpha, Mnhl. Stout, 1-2o lighl ; leaves lather broar. short; spikes I - 2, short-stalkel, erect, compact or rarely loose, usually stiminate at the apex, 1 1' long or less; perigynium long-orate, obscurely nerved; the very long and neaty straight beak oblinge or lipped at the oritive; scale reldish-hrown, obtuse, shorter than the perigyninn. - Moist ineadows, Mass, to N. C.; local.

\section{+ Beak short or none; plant often glaucous. $=$ Plants of ordinary habit.}

77. C. tetánica, Schkuhr. Rather slencler, rarely glaucous, somewhat stoloniferous; culn scabrous, at least above; spikes all pednncled, the upper one rery slortly so, pale, all more or less attenuate below, the lower borne $\vdots$ u the axils of bracts $3^{\prime}$ long or more; periggnium not turgicl, greenish, prominently many-nerverl, the beak strongly bent; scale obtuse or abrnptly inucronate, all except the lowest mostly shorter than the perigynim. - Meadows and borders of ponds from W. Mass. westward; common westward. - Var. Woòn, 13ailey. Very slender and strongly stoloniferons; leaves narrow, very long and lax; spikes mostly alternately flowered thronghont; seales often sharper. (C. Woodii, Dewey.) Rich wools, N. Y. to Mich., and south to Washington; frerpent. - Var. Middu, Bailey. Stiffer; leaves mostly broaler and stricter; spikes thick and densely foweresl, not attenuate at base, the upper one often sessile; perigynium larger. (C. Meadii, Derey.) R. I. to Neb., and southward; rare eastward. - Var. Caxnrx, Porter. Stout and stiff; leaves still hroader (abont $2^{\prime \prime}$ wide) and flat; spikes thick, often wile; werigynium long, straight or very nearly so; scale large, nearly equalling or exceeding the perigynum. F. I'enn. (Cunby); 11l. and Wisc.; little known.

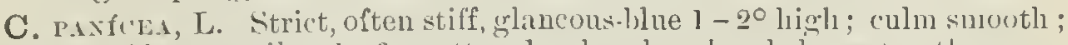
brarts $1-2^{\prime}$ long; spikes $1-3$, scattered, eolored, perluncled, erect, rather compact or lonse helow, seldom l' long; perigynium ovid, yellow or purple, somewhit turgid, scarcely nerved, the point nstually curved, mostly longer than the

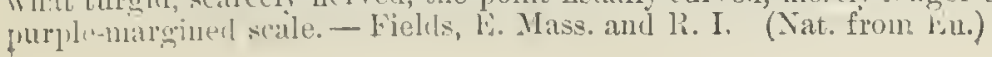




$$
==\text { Tery strict, densely gluenrous. }
$$

78. C. lívida, Willd. Culms $18^{\prime}$ ligh or less; leaves narrow, often beeom ing involute; spikes 1 or 2 and aggregatted or approximate, or rarely a third nearly radieat, sessile (r nearly so, erect, narrow; perigrnium ovoid-oblong, nerved, grauular, beakless, the point straight or nearly so, orifice entire; scale obtuse, mostly a little shorter than the perigynimm. - Pine-barrens of $\mathrm{X}$. J., and sphagnum swamps northward to X. Eng. and L. Superior; loeal. (Lu.)

$$
\text { * 6. - + 4. Bicolòres. }
$$

79. C. aurea, Nntt. Low and slender, $1^{\circ}$ high or less; bracts exceeling the culm; spikes 2-4, all but the lowest usually approximate, peduneled or the upper one or two sessile, erect, loosely few-flowered or sometimes becoming ${ }_{4}^{3} \mathrm{long}$, at maturity yellow or brown, the terninal one frequently pistillate above; perigrnimm Heshy at maturity, nerved, longer than the blunt scale.Wet meadows and springy banks, throughout; rather cummon.

$$
\begin{aligned}
& \text { * 6. }-+5 \text {. Digitàla. } \\
& + \text { Spilies two or more. }
\end{aligned}
$$

80. C. ebúrnea, Boott. Exceedingly slender and capillary, erect, 4-12' high, stoloniferous; leaves shorter than the culm; staminate spike very small and very short-peduncled, orertopped by the two upper pistillate spikes ; pistillite spikes 2-4, ilproximate or the lowest remote, all stalked. erect, 2-6-thow('rox ; perigrnium very small, almost nerveless, smontl and hecoming black anul shining at full maturity ; scale white and thin, obtuse, shorter than the perigrnium. - Tufted in sandy or light soils from X. Eng. to K. Y. and Neb.; frequent.

81. C. Richardsòni, R. 13r. Rather stiff, 4-9' high, stoloniferons; sheatlss short, purple or brown; staminate spike stout and mostly short-peduncher p pistillate spikes $1-2$, approximate, the very short stalks included, erect, compact, less thim $\frac{1}{2}$ in length; perigynimm obovoid, firm, hairy, the very short beak entire or erose; scale brown with a conspicuous white-lyaline margin, ohtuse or pointless, and longer than the periggnium. - I)ry gromd, western N. I. to Ill, anll northwestward; lare.

82. C. pedunculàta, Muhl. Low and diffuse, 3-10' high, forming mits; leares alumlant, rery green, flat and firm, longer than the weak culms; staminate spike rery small, with the mpermost pistillate spike susile at its laise; pistillate spikes $2-4$ on each culm, scattered and long-perluncled from green sheatls, ercet or spreading, many other spikes nearly or quite radical and very long-stalked, all 3-8-flowered ; periggnimm triugular-oborate, smosth or very sligltily pubescent above, the short and nearly entire heak somewhat olligue; scalle green or purple, truncate and cnspidate, mostly a little longer than the perigrnimu. - Dry woods aud hanks, N. Eng. to Va. (Kemedy) and Minn.; frequent northward.

+++ Sprilie one or ravely a rudiment of a second; plant dixcious.

83. C. pícta, Steurlel. Rather weak, 10 high or less; leaves flat and firm, persisting through the winter, at least twiee longer than the culm; a sheatling purplescale at the base of the spike; staminate spike alout $l^{\prime}$ long, clavato in anthesis, the purple scales ending in a very short and blunt whitislı tip: pistillate spike uturower and mostly longer, the scales more abruptly cont rintw! 
iuto a colured cusp and at leugth deciduous; perigynium oborate, mnch conIruted below into a stipe-like base, very strongly nerved, entirely pointless, hairy above, covered by the scale. (C. Boottiana, Benth.) - In a wooderl ravine with Hepatica and Lpigxa, near Bloomington, Ind. (Dudley); also \& la. and La.

* 7. Spilzeridiómiore. - t- 1. Scirpince.

84. C. scirpoidea, Michx. Strict, the pistillate plant mostly stiff, $6-18$ high; leaves flat, shorter than the culm; spike $l^{\prime}$ long or less, densely crliudrical, very rarely with a rudimentary second spike at its base; perigrnium ovate, short-pointed, very hairy, about the length of the ciliate purple scale. Mountains of $\mathrm{X}$. New Eug.; Drummond's Island, L. Hurou. (Norway.)

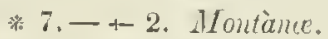

+t Some or all of the culms longer than the leares (or in the type of $\mathrm{n} .85$ ficquently shorter).

$=$ Staminate spike minute, wholly or partially concealed in the head; leaves always very narrow; radical spikes often present.

85. C. defléza Horuen. Diffuse and low, tufted; culnns $1-6^{\prime}$ high, setaceous, more wr lest curvel or spreading, little exceeding or shorter than the leaves; staminate spike exceediugly minte and nearly always entirely invisiblo in the head; pistillate spikes $2-3,2-5$-Howered, grecu, or green aud brown, all aggregated into a head, the lowest one always more or less sliortpeduncler aurl subtended by a leafy bract $\frac{1}{2}$ long or less; radical spikes few; jorigyinm rery small aud much contracted helow, sparsely hairy or ncarly. smooth, the beak fit and rery short, mostly longer than the acutish scale. (C. Nova-Anglix, last el., mostly.) - High monutains of $\mathrm{N}$. H. and Vt.

Var. Deanei, Bailey. 'Taller' and lax, the cnlns 6-12' high and some or all prominently longer than the longer and loose leares; staminate spike much larger (2 - 3" loug), erect or ol,ligue, sessile; pistillate spikes larger ( $4-$ 8-flowered), less agregregated or the lowest usually separated, though rarely more than I' apart; radical spikes usually munerous; bract mostly longer. - Swales ur dry ish places, high or suhalpine regions, Mt. Desert, Maine (Rand); Essex, Mass.; N. II., I't., and N. I.; searce. In aspect like n. 86.

Var. media, Bailey. Rather stiff, 4-12' high, in leuse tufts ; most of the spikes equalling or exceeding the leaves, the staminate prominent, erect (35 " loug), sessile or very short-peduncled; pistillate spikes 2-3, all scattered, the uppermust at or near the base of the staminate spike, the lowest usmally very proninently peduncled and subtended by a conspicuous bract which surpasses the culn, all rather compactly 3 - 8-flowered, green, or brown and green ; radical spiks several; perigynium larger, much like that of short-beaked forms of n. 90. - licweeniw Co., Mich. (Farwell); also far westward.

86. C. vària, Muhl. Erect, mostly strict, 6-15' high h, tufted and somewhat stoloniferuns; culms rariable in length, often twice longer than the leaves; staninate spike $3^{\prime \prime}$ long or less; pistillate spilies cluscly aggregated, (1) lurely somewhat loosely" disposed but never scattered, all strictly sessile, green; radical spikes none; lower bract usually present; perigynium longerpointer than in the last, abont the length of the slump scalc. (C. Emmonsii, Deney.) - Banks and dry woods; frequent. - In var. Colondta, Bailey, the acales are purple. Mostly southward. 
$==$ Staminate spike very prominent (or in the variety of $\mathbf{n} .89$ very small, but the leaves broad); radical spities none.

a. Scales smooth.

87. C. Nòvæ-Ángliæ, Schwein. Very slender and soft, erect, stoloniferons, $6-8^{\prime}$ high; culuns little longer than the very narrow leaves; staminate spike exeeerlingly narrow ( $3-8^{\prime \prime} \operatorname{long}$ ly about $\frac{1}{2}^{\prime \prime}$ wide), mostly minutely peduncled; pistillate spikes 2 , or rarely 3 , the upper one near the base of the staminate spike, the lower very short-peduncled and removed $\frac{1}{2}-l^{\prime}$ and subtended by a leafy bract whieh nearly or quite equals the culn, both rather loosely 3-6-flowered; perigynim very narrow, often nearly oblanceolate, small, very thinly hairy, the beak sharp and prominent; stigmas often 2. Mountain swamps of $1 \mathrm{I}^{r}$. Mass., and Mt. Desert, Maine (Rund); rare.

88. C. Pennsylvánica, Lam, I foot high or less, ereet, strongly stoloniferous, forming lirge patches ; leares narrow and more or less involnte, dark or dull green, mostly nearly as long as the enlm ; staminate spilie $\frac{1^{\prime}}{2}$ (rarely $\frac{g^{\prime}}{4}$ ) long, usually dull brown or brown-purple, sessile or very nearly so; pistillate spikes $1-3$, contignous or the two lower rarely $\frac{1}{2}$ apart, all sessile and usually cark-eolored, the lowest bract rery short or at least rarely prominent; perigyuium short- or rount-orate, hairy. - Dry fields; unr commonest species.

89. C. communis, Bailey. Ilabitually tallex and stricter, 8-18' high, in small tufts, never stoloniferous; leares proportionately shorter, broad (about $2^{\prime \prime}$ ), flat and pale; staminate spilie mostly longer, often short-peduncled and usmally paler; pistillate spikes $2-4$, scattered on the upper part of the culm, green or tawy the lowest one or two sometimes preduncled and often with prominent leafy bracts. (C. raria, last ed.) - Dry hill-sides; common.

Var. Wheèleri, Bailey. Mostly greener, $3-1 t^{\prime}$ high ; leaves soft and flat and much shorter than the culm; staminate spike long or less, very narrow, sessile and oblique; pistillate spikes mostly ('loser together. - Knolls in woods, Ionia Co., Mich. (WTheeler), and Alcona Co. (Bailey); Middletown, Conn. (Barratt), and Cheshire Co., N. II. It has much the aspect of 11.86 , but is readily distinguisherl by the brual leares and more scattered spikes.

\section{b. Scceles rought-ruspidate.}

C. Iritox, Jacl. Rather stiff, the culm sometimes curved, 3-10' hign, leaves flat, slorter than the culm; stuminate spike prominently clavate, mostly. sessile; pistillate spikes $2-3$, all contignnus, sessile or the lowest very shortpeduncled and suhtemled by a bract strecely an long as itself, all ohlong or short-eylindric, the lowest about 6" long: perigrnium triangular-obovoil, the very short beak entire or erose, thinly hispid-hirsute, alwut the length of the scale. - Fields, li. Nass. (Nat. from Eu. ealy in the century.)

- +ait or usually all of the culms murle shmpt than the leaves.

90. C. umbellàta, Schkulu. (1'l.6, fig. $11-14$.$) Low, growing in small$ and dense mats ( $1-3^{\prime}$ across) ; leares short and often stiff $\left(2-6^{\prime}\right.$ long), flat, the earliest very narow lout the later "ften 2" broal; spilies all on separate scapes which rarely exceed $1-2$ in lengtl (or ratrely one vr two short true ellms), usmally densely agrgregated at the surfice of the gronden and hilden ly the leares, the pistillate spikes green or tammy and ruther loosely few-flowered;

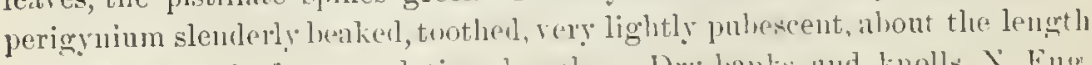

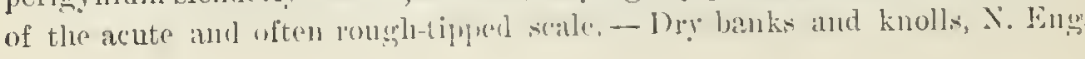


to N.J. and N. Y., and perhaps farther westward; infrequent. - Var. vfCINA, Dewey. 'Tufts looser' and larger; leaves longer (often $1^{\circ}$ or more) and laxer, sometimes broaler; some pistillate spikes borne near the base of the staminate on a true culm which is $3-8^{\prime}$ high, one or two on each culm. With the species and farther westward; infrequent.

91. C. nigro-marginàta, Schwein. Lenves mostly stiffer than in n. 90, often broader, and some of the culms prolonged; perigynimm smooth or nearly so, shorter beaked; scales purlle-nurgined, giving the spikes a very dark or rariegated appearance, considerably larger and longer than in the last. - Dry hillsides, N. J., and southward; local.

$$
\text { * 7. - + 3. Triquétrece. }
$$

92. C. pubéscens, Muhl. Strict, $1-2^{\circ}$ high, pubescent throughout; leares flat and soft, shorter thum the culm; spikes 2-4, the lower 1 or 2 short. peduncled, and about $\frac{y^{\prime}}{2}$ long, loosely flowered, erect; perigynim very hairy, conspicnonsly beaked and minntely toothed, straight, about the length of the truncate and rougl-cuspidate thin scale.-Copses and moist meadows, $N$. Eng. to Ky., and westward ; frequent.

* 8. PUI LLOSTÁCHY.E.

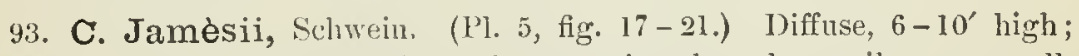
leaves very marow ( $l^{\prime \prime}$ or less), much surpassing the culm; spike very small, the staminate portion inconspicuons, the pistillate flowers $1-3$ and loosely disposed; perigynium globular, prorluced into a very long and roughened rearly entire beak; scale narrow, the lowest often $1-2^{\prime}$ long, the upper often shorter than the periggyniun. (C. Steudelii, Kunth.) - Woods, N. Y. to Ill., and southward ; frequent.

94. C. Willdenòvii, Schkulır. Lower, stiffer, the leaves broader and pale; spike larger, the piatillate flowers $3-9$, compact; perigynium bearing a prominent two-edged rely rough beak; scales chaffy, nerved, as broal as and somewhat longer than the perigrnium, or the lowest rarely overtopping the spike.-Copses, Mass. to Michl, and sunthward; rare.

95. C. Báckii, Boott. Forming dense nuts; leaves still broaler ( $2^{\prime \prime}$ or unore), very abmudaut; staminate flowers about 3 ; pistillate $2-5$; perigynium more gradually beakel, smooth throughout; scales rery broad and leaf-like, all exceerling the culm and entirely enveloping the spike. - W. Mass. to Ohio, and far westward; local and rare, especially castwarl.

\section{* 9. InPtoć́pint.z.}

96. C. polytrichoides, Mulıt. Capillary, erect or slightly diffuse, 6 $18^{\prime}$ high; leares mostly slorter than the culm; spike $2-4$ "long, linear, the staminate portion very small: perigy nim thin and green, nerved, about twice longer than the obtuse calneous scale. - Bogs; common.

\section{* 10. PHysocépliLte.}

97. C. Fràseri, Andrews. Cespitose; culm 6-15' high, naked or the lower portion includer in loosely shenthing abortive leares, smooth and stiff; leares $I^{\prime}$ broal or more, destitute of midrib, very thick and persistent, pale, I $-2^{\circ}$ long; spike whitish; perigynim ovoid, faintly nerved, much longer than the scale. - Ricl monutain woods, Va. and sontluward; very local and mare. A must remarkable plant. 


\section{§ 2. VÍGNEA. - * 11. Acroarnut̀xt. - + 1. Fótide}

98. C. chordorhiza, Ehrl. Very extensively stoloniferous; culn mostly erect, $1-1 \frac{10}{2}$ long; leaves involute, shorter than the culm; perigrnium globular, very strongly nerved, short-pointen and entire, abont the longth of the acute scale. - Cold bogs and soft lake-borders, I't. to Iowa, and northward; infrequent. (Eu.)

99. C. stenophylla, Wahl. Stiff, $3-8^{\prime}$ hight ; leaves involute and shorter than the culm; perigynim uvate, flat on the inner facc, lightly nervel, grate kally contracted into a short and entire rough-edged beak, tightly enclosing the achene, at maturity longer than the hyaline acutish scale. - 1)ry grounds, Thayer Co., Neb. (Bessey); Emmet Co., Iowa (Crotly), and westurud. (Eu.)

$$
\text { * 11. - + 2. Vulpìnce. }
$$

+ Beak shorter than or about as long as the body of the perigynium.

100. C. conjúncta, Boott. Strict but rather weak, $1 \frac{1}{2}-3 \frac{1}{2} 0$ higlı; culm suft and sharply triangular or nearly wing-angled, becoming perfectly flat when pressed ; leaves soft, about $3^{\prime \prime}$ hrond; head $1-3^{\prime}$ long, interrupted, often nearly green, infrequently bearing a few setaceous hracts; perigrninn lanceorate, light colored, whitish and thickened below, the beak lightly notched and roughish, aboat equalling or a little cxceeling the cuspidate scale.Siwales and glades, N. J., Ky., and westward; usually rare.

$$
\text { Beak twire the length of the body of the perigynium or longer. }
$$

I01. C. stipàta, Mulıl. Stout, I-3० high, in clumps; cnlm ratleer suft, rery sharp; head $1-3^{\prime}$ long, rarely somewhat componnd at base, iuterrupted, the lowest spikes often $\frac{1}{2}$ ' long; periggrnium lanceolate, brown-neverl, the bak tuothed and roughish, abont twice the length of the body, and much longer than the scale. - Swales; common and variable.

102. C. crus-córvi, Shuttlew. Stont, glancons, 2-30 lighlı; rulnt rough, at least above; leaves fiat and very wile; head moll branched ami (')mpouml, $3-6$ ' long; perigynium long-lanceolate, the short hase rery thick and disk-like, the roughish and rery slcnder henk thrice the length of the body or more, 3-4 times the length of the inconspicuons scalc. - Swanps, $\mathrm{S}$. Minn to Neb. and Ky., and southward; rare northward.

$$
\begin{aligned}
& \text { * 11. - + 3. Multiflorre. } \\
& \text { +t Spities conspinously pamicled. }
\end{aligned}
$$

103. C. decompósita, Mnlıl. Nitout, exceclingly deep green, 11-:30 limh, in stools; culm rery olitnsely angled, almost terete below; leaves firm,

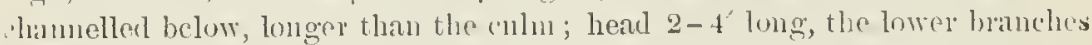

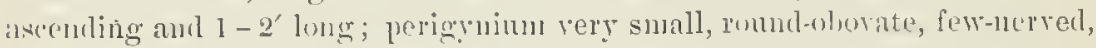
inul aud at matmity shiniug, the abrupt short heak entire or rery nearly so; scale acnte, ahout the length of the periggnimu. - Swamps, X. I. to Mich. and southwarl; local.

\section{+ Spikes in a simple or nearly simple head.}

$=$ Leaves rery nurme ( $I^{\prime \prime}$ broud or less), becoming more or less involute.

104. C. teretiúscula, Gonden. Siender but mostly erect, $1 \frac{1}{2}-210$ high, in loose stools; culm rather obtuse, rough at the toje, mostly longer thin the beares; head $1-2^{\prime}$ long, compact or somewhat intermpted, narrow ( $l^{\prime}$ willo or 
less); perigyium very small, ovate and truneate below, bearing a few ineouspicuons short nerves on the onter side, stipitate, firm and at maturity biackish and shining, the short beak lighter colored; scale chaffy and acute, about the l. $1 \mathrm{gth}$ l. of the perigyium. - Swales, N. Eng. to l'eun., aud westward; conmon. (1iu.) - Var. lisuós, Boott. More slender; liead mostly longer, the upper purtion often somewhat nodding, the spikes scattered and the lowest ones often slightly compound. N. Y., aud westward; common.

$==$ Leaves broader and flut (occusionully involute in $\mathrm{n.}$. 106).

a. Scales very sharp, mostly rough-tipped.

1. Perigynium large (2" long or more), nerveless on the iuner face.

105 C. alopecoidea, Tuckerm. Stout but rather solt, 2-30 ligh; culn rather sharp, thick and soft in texture; leaves $2-3$ " wide, about the length of the culm, very green; heal $l_{\frac{1}{2}}^{\prime}$ long or less, sometimes green, and recasionally a little compound, the spikes many awl conplactly or somewhat loosely disposed or the lowest often separate and all mostly short-oblong; jerigyium ovate, tapering into a rough beak, rery proninently stipitate, witl a few brown nerves on the outer face, ascending, about equalling or a little execeding the scale. - (1) pen swales, X. Y., P'enn., and Mich.; local. In aspect like 11. 101 .

Var. sparsispicata, l)ewey. Weak, the leares much nurower and lax; head $1-3^{\prime}$ long and linear or hearly so, the spikes smaller and separated or scattered. - S. L. Mich. (Cooley, Clark); little known.

106. C. grávida, Bailey. Lower and the culm thinner and more sharply angled, l - 20 high: leaves rather narower and firmer, slovter than the culn; heal short, always simple, globular or short-ohlong, the lowest spikes larely listinct ; spikes few (4- $\mathbf{i}$ ), globular, or broader than hng ; perigynium broadly orate, nearly twice linger, sessile, plump and somewhat polisherl at maturity,

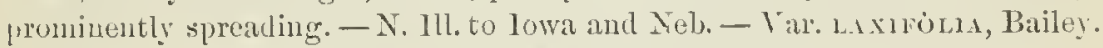
Much larger, $2-3 \frac{10}{2}$ high; leares broader (about $1^{\prime}$ ) and lax ; luead large aud dense, ovoil or ol,long, searcely interrupted. X. 1tl. to S. Dak.

\section{Perigynium very small, mostly nerved on the imer. face.}

107. C. vulpinoídea, Michx. Mostly rathej stiff, 1-210 high; culm rery rougl, at least ahove; leaves varions, mostly Hat and longer than the culm; heal l-t' long, usually much intermuter and frequently somewhat rompound, varying from chull brown to almost green at maturity, commonly providerl with many very setaceous short bracts; spilies very nnmerous, aszending and densely' flowerel ; perigynium ovate or lance-ovate, mostly ascencling. - Low places, variable ; very abundant, especially nortluwarl.

1. Sicules bint, smoolh and lyuline-tipped.

108. C. Sartwéllii, Dewey. Stiff and strict, $1 \frac{1}{2}-2 \frac{1}{2}{ }^{\circ}$ high ${ }^{\circ}$; leaves produced into a long slender point, mostly shorter than the culm; staminate flowers rarionsly disposed, frequently whole spikes being sterile; head $1-3$ ' long and rather narrow, the individual spikes usually clearly defined, or occasionally the heal iutermpted below, tawny-bown; perigyum elliptic or lauce-elliptic, nerved on both sides, very gratually contricted into a short beak; seale about the length of tho primpinm. (C'. risticha, last ed.) liogs, eentral N. I., west and northward; frequent. 
* 11. - + 4. Arenàrice.

C. ARENAria, Linn. Extensively crecping, $1^{\circ}$ high or less; leaves very narrow and very long-pointed, shorter thin the culum; head about l' long, dense or sometiucs intermuted, ovoid or oblong; spilin's few to many, those at the apex of the hoal usually staminate, the interoncoliate ones staminate at the summit, the lowest entirely pistillate and subtenched hy a bract abont 1' long; perigninm very strongly nerved on both faces, wing-margined above, sharply long-tootlied, about the length of the sinhtr. - Kea-beaches near Norfolk, la. (Bcl/imn). (Adv, from lu.)

\section{* 11. - + 5. Muhlenbergianur.}

+- Heads narrow, the spikes scuttered (or often agyreguted in C. muricata.) $=$ Perigyminu almost levite.

109. C. tenélla, Schkuhr. Lxceedingly slendler, $6^{\prime}-2^{\circ}$ high, in tufts; leavos flat, soft, and weak, mostly shorter than the culnu; spilies 1-3-flowered, or the termiual 4-6-flowered, all distinct and scattered on the upper part of the culm, the bracts olsolete or the lowest present anr rery short; jerigynium elliptic-ovate, very plump, fincly nerved, the minute beak entire, longer than the white scale, usually at length splitting and exposing the blackish acheie. - Cold swamps, N. Eug. to l'emm, ant far westwirl; common. (Eu.)

$$
==\text { Perigynium flattisll. }
$$

110. C. ròsea, Schkuhr. Alwiys slenter anl weak, erect, $1-2 \frac{10}{2}$ high, exeedling the natrow leaves; spilies $5-8,6-14$-fiowered, the upper $3-4$ aggregated, the others $3-9^{\prime \prime}$ ayart, the lowest nsually with a setuceous bract; perigynum lance-ovate, thin and shining nerveless, scarely marginel, rough on the edges above, perfectly sfuarrose, very green, abont twice longer than the translucent white scalc. - Kich woods, N. Eng. to Minn. and Neh, ; fre'puent. - Var. Ranits, Dewey, Lower and much more slenter, the culms sumetimes almost capillary; spikes $2-5$, scattered, $2-4$-flowereul ; 1erigy nium nustly uarrower and more ascending. ()/en places and dricr wonds; (communon.

Var. Texénsis, Torr. Tery slemlel hut strict, $1^{\circ}$ high or less; spikes $3-4$, all contignous or the lower mus appruximate, $2-6$-flowered; perigyuium linceolate, the base prominently sponge, smonth or nearly so, conspicuously

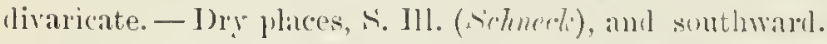

Var. retrofléxa, 'lorr. Often luther stiff, $1-1 \frac{1}{2}^{\circ}$ high; spikes $4-8$, the

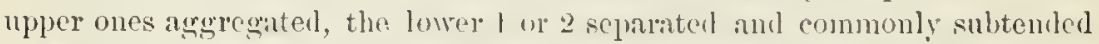
hy a conspicuons hract, often bownish: perigrnim orate, smooth throughont, very prominently corky and swollen at the lases, which is frequently contracted almost to a stipe, at maturity unally willy spreading or reflexed; scale brownish and sharp, at length decilams. (C. lotroflexa, Muhl.) - Copses, throughont; rure northwarl.

111. C. sparganioldes, Mulıl. Stunter, stiff; 'ulm 2-30 high; leaves very broad (usmally f' or move) and flat, their sheaths conspicuously chothing

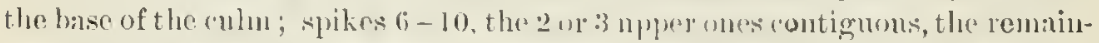

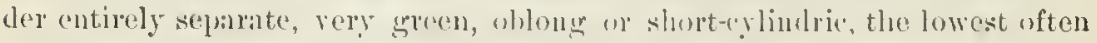

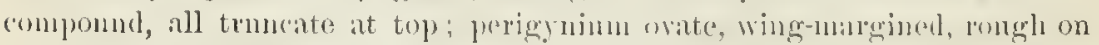
the short beak, often obscurely nerved on the onter fate, considerably longer than the rough-pointerl scale. - lich wooks; frepucut.

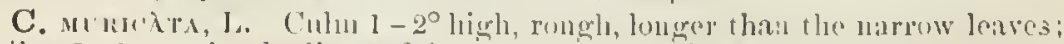
spikes 5-10, varionsly dispmed, hit usially some of them scattered, frequently 
all aggregated, rarely tawuy; perigynium heary, ovate, thin aud sliuing, nerveless, the long beak minutely rongh, sprealding, a little louger than the sharp green or brownish seale. - Dry fields, L. Mass., where it is common, and sparingly south aurl westward to Ya aud (Hio. (Nat, from Eu.)

+ Heads short-oblong or globular, the spikes all aggreguted, or only the lowest one or two sepurate.

$=$ Plant very stiff throughout.

112. C. Muhlenbérgii, Schkulı1. Pale, growiug in small tufts, $1-2 \frac{1}{2}^{\circ}$ high; culns mucl prolonged bejond the few narrow and at length involute 'eaves; heal $\frac{g^{\prime}}{4}$ long or less, the individual spikes elearly defined; spikes g-lolular, 4-8; perigynim nearly circular, rery strongly nerved on both fices, broader than the rough-cuspiclate scale and about as long. - Open sterile suils; frequent. - Var. Lxéris, l3oott. Perigynium nearly or entirely

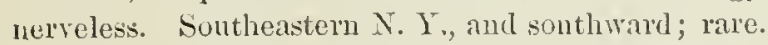

$$
==\text { Plant strict but not stiff. }
$$

113. C. cephaloídea, Dewey. Lax, very green, $2-3^{\circ}$ highl ; leaves broad $\left(2-3^{\prime \prime}\right)$ and thin, slorter than the long culm; head rather loose, $\frac{g^{\prime}}{x^{\prime}}$ long or more, all but the rery uppermost spikes denty definer ; perigynum ovate, cutirely noreless, long rough-pointed, spreading, twice louger than the rery thin scale or more. - sharly bankis, IV. Misss, to Mich. ; frequent.

114. C. cephalóphora, Mulı. MLstly smaller aud stricter, pale; leaves half as wile or less; head small, ravely $\frac{1}{2}$ long, glolular or vely short-oblong, never interupted, the lower 1 or 2 spikes usnally bearing a rery setaceons short bract; perigynium twice smaller than in tle last, scarcely longer than the rough-r'nspiclate scale. - I)ry and mostly sterile knolls; eommon.

Var. angustifolia, Boott. Low, s' high or less; leaves very narrow; head smaller, usually tawny; perigynimu mostly broader, - West and soutlwward; rare.

$$
\text { * 11. - + 6. Livice. }
$$

+ Perigynium nerceless or very nearly so.

15. C. capitàta, L. Rigid, $3^{\prime}-1^{\circ}$ high ; leaves filiform, shorter than the culm; hearl glohular, uniformly staminate ahove, lrown, very small; perigynim hroally ovate, very thin, whitisl, prominently beaked, ereet and appressel, longer than the ver! thin and olituse scale. - Alpine summits of the White Momitains. (Eu.)

\section{++ ++ Porigynium prominently nerved.}

116. C. gynòcrates, Trormsk. Stiff but very slender, $3-6^{\prime}$ high, dice ions; leaves filiform and setacents, ahout the length of the eulm; spike ob long, 2-4" long; perigynim elliptic-ovate, nearly terete, stipitate, widely. spreading or reflexed at maturity, $10 \% 2$ sumetimes horne at the base of the staminate spike. - Cold spliagnum swamps, ['enn., north and westward; loeal, particularly sonthwarl.

117. C. exilis, Dewey. Very stiff, slender, 1-2 high; leaves involutefiliform ancl very stiff, shorter than the eulm; spike varying from almost gholular to cylinclicil (frequently $l^{\prime}$ long), either unisexual or the sexes variwnly placed, rery raply a supplementary spike at hase; perigyium ellipticurate, thattisli, stipitate and somewhat cordate at base, strongly brown-nerved 
on the vuter fice, lather faintly nerved on the inner, rough-edged abuve, sharyly toothed, spreading, a little longer than the seale. - Cold swamps aud lake-borters, N. Eag. and eastern N. Y. to N. J.; rare.

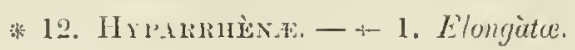

+ Perigyniun very shary-margined, firm, often thachened at base, spreading in open und at maturity stellate spilies.

118. C. echinàta, Muray, rar. cephalántha, Bailey, Rather stiff but slender, $1-2^{\circ}$ ligh ; leaves very narrow and involute, abont the length of the culm; spilies 5-8, approximate or even aggregaterl into a heal, groen, compactly 15 -30-flowered, short-oblong or nearly globulir'; perigynim ovateIanceolate, rough on the nimgins above, nerved on both faces, spreading or reflexed at maturity, the beak long and prominent, longer than the sharp white scale. (C. stellulatia, last el.) - E. Peum. (Porter) to Mass. (Jorong), : mol westward to L. Nuperior; rare. - Var. cosferr , Bailey. V'cry stiff; spikes contiguous or scattered, spreading; short-oblong or globulin, dense; frerigrnium broadly orate or eren nearly round-orate, very strongly nerved, reflexerl or widely sprealing. Near the seatconst; mcommon. The perigyia resemble those of 11.112. - Vax. w1cóstrils, Boeckl. Mostly very sender; spilies frw, 3-10-flowered, usually tawny ; perigynium small, lancewate, nerved on the unter face but usnally nereless on the inner, erect or sprealiug, the beak rather long or proninent. (C. scirpoides, Selkuhr. C. sterilis, Willl.) Swale, thoughont; very common and variable. - Var. Axatsrits, Bailey. Exwerdingly slenter; spikes few ant very few-flowered, mostly all contiguns; perighnium lanceulate or lincin-lancenlate, twice the length of the scale or more. N. Y., Vt., and northwart; rate.

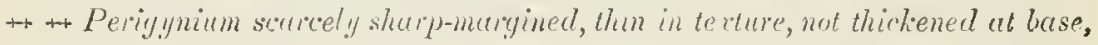
mostly in closely flowered and rounded wi ublong spities.

= Perigynimm ocute or nearly so, the beak short or none.

a. Biracts not molomged.

119. C. canéscens, I. Stiff and rather stout, $1-2 \frac{1}{2}^{\circ}$ lighl, glatuous and

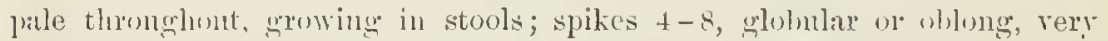

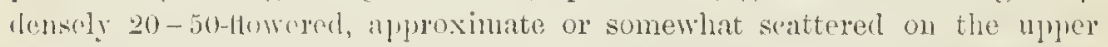
part of the culn, misally fumnently contracted bolow with the staninate flowers; perigryinu short-mate, silvery-mhite and minntely punctienlate,

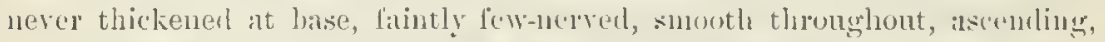
the leak very slurt and cutire; seale obtuse or acntish, abont the length of the perigynum. - Cool swamps and bogrs, N. ling. to l'enn., west and north. ward; fregnent northward. (En.)

l'ar. vulgàris, bililey. Very slender, lower, not gelancous, in small and loure Lnfts; spihes smiller and ustally fewer, loosely fowered; perigynim mostly more heaked, pominently spmending. - Mustly in drier places; rery

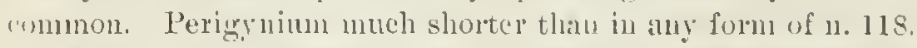

Var. alpícola, Wahl. Low and stiff, or at luwer altitudes liecoming some. what slender, selfom much over $1^{\circ}$ in height; spikess small, glolular or nearly M, dense, well defined and lorow or tawy, perigninm as in the type, ascent.

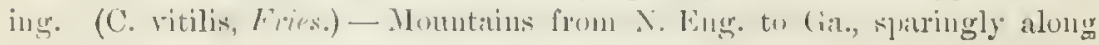
wr northern bundary, and far westward. (liu.) 
Var. polys tàchya, Boott. Erect and mostly strict, not glaucous, $1 \frac{1}{2}-2 \frac{1}{2}$ high, scarcely tufted; leares rery lax and exceeding the culn1; spikes oblong, more or less aggregated in an oblong interupted head, the lowest 1 or 2 subtended by short scale-like lracts; perigrnium somewhat spreading. (C. arcta, Boott.) Low woods, N. New lug. to N. Mimn.; rale. Resembles C. echinata, var. cephalantha.

I20. C. Norvégica, Willd. Luw and stiff, bnt rather slender, $1^{\circ}$ high or less; leaves rery narrow, nostly shorter than the culn; sprikes $3-5$, somewhat scattered, brown, globular or oblong, compactly man-flowered, the terminal one long-contracted below witl the staminate Howers; perigynimm very short-ovate, thick, the beak rough, a little longer thau the very obtuse s'ale. - Salt marshes, Maine, and northwad, lane. (lia.)

121. C. tenuiflòa, Walll. Tery slender and diffuse, $1-1 \frac{1}{2}^{\circ}$ high, in tufts; leaves very narrow and lax, slorter than the filiform eulm; spikes 2 4 , all loosely few-flowered :und silvery-green, and aggregated into a small globular head; perigynium elliptic, olssurely ner'ved, smootl, beakless, spreal. ing, abont the lengtl of the white thin scale--Bogs, N. New Eug. to N. Mim.; local. (Eu.)

\section{b. Bracts much prolonged, the lowest 2-3' long.}

122. C. trispérma, Dewey. (1'.6, fig. 1-5.) Exceedingly slender, in small and loose tufts, the weak reclining culms $1-2^{\circ}$ long; leaves soft and narrow, shorter than the culn; spikes $2-3,1-3$ ' aprart, silvery-green, $2-3$ flowered; perigyniun rery thin, finely nerved, the beak entire or nearly so; scale acute, very thin, nsnally shorter than the perigynium. - Cold bogs. thronghont; common nortlıaril.

$$
==\text { Perigynim ovate-lanceolate to linear-lanceolate. }
$$

123. C. Deweyàna, Schwein. Weak, $1-1 \frac{10}{2}$ hight ; leaves flat aud soft, shorter than the culm, yellowisli-green; spikes $3-6$, most? oblong or sometimes but 2-3-flowerel, loose, the upler ones contignons but the lower 1 or 2 usually considerably separated on the zigzag rhachis and mostly sulbtended hy a lract, all silvery-green; perigynimm ovate-lanceolate or narrower, very thin in texture, nerveless, smmewhat thickenel lielow on the onter face, the iong heak rough; siale very thin, acute or cuspiclate, about the length of the jerigynium. - lny woorls; rommon.

124. C. bromoides, Sehkuhr. Iax, 1-20 high, in dense stools; leaves very warrow, ahout as lume as the culn! ; staminate flowers varionsly situated in the head, sometimes a few spikes wholly sterile, rarely the plants diaecious; spikes $3-6$, whlong or short-cylinheic, erect, silvery-tawn or brown; perigynimm linear-lancolitr, firm especially at thr hase, prominently nerved, the long and ronghentrl heak twothed; scale shanp, shorter than the perigyuium. -Opeu bogs; comnunon.

$$
\text { + Perigynium ovute-lancolate, with winged margins. }
$$

125. C. siccàta, Dewey. Fxtensirely creeping, $1-2^{\circ}$ high, erect; leaves firm, narrow, about the iength of the culm; stamillate flowers varionsly situated, usually some of the spikes wholly sterile; spikes $3-5$, agregated or separated, urvid or slivit-ublong, silvery-browu; hriggnium fin, herved on 
both faces, the long beak rough and toothed, the margins prominent or some times very narrow; scale acute, about the length of the perigynium. - Sandy fields and banks, N. Eng. to Ohio, west and northward; frequent.

th+ Perigynium ovate-lanceolate or narrouer, scale-like, with little distinction between bodly and margin.

126. C. Muskinguménsis, Schwein. Robust, erect, $2-3^{\circ}$ high; leares many and lax, loosely sheathing, those on the sterile shoots crowled near the top, all flat and long-pointed; spikes 6-12, contiguons, erect, narrowly cylindric (often $\mathrm{l}^{\prime}$ long), becoming light brown and presenting a dried appearance, very densely flowered; perigyuium linear-lanceolate ( $3^{\prime \prime}$ long), prominently nerved, ciliate on the white margins above, appressed, twice the length of the scale or more. (C. arida, Sckwein. S. Torr.) - Woods and copses, Mich. and Ohio to Ill, and Wisc.; local.

127. C. tribuloides, Wahl. Stout and erect, $2-3^{\circ}$ high; leaves nar. rower than in the last, loosely sheathing; spikes 6-15, aggregated into an oblong or somewhat interrupted heary head, short-ollong or sometimes nearly globular, green or tawny-green, compact, not marrored above; periagraiuu linear-lanceolate ( $3^{\prime \prime}$ long), obscurely nervel, erect but the points conspicnous, rough-margined, nearly twice the length of the scale. (C. lagopodioides, Schkulr.) - Open swales; frequent. - Tar, turnàm, Bailey. Culm softer and often iax; the lenves broader; spikes more loosely disposed, forming a heal $1-2^{\prime}$ long, which is slender and more or less interrupted but always erect, green, becoming tawny, if at all, only when the perigynia legin to fall, oborateoblong ( to rarely $\frac{1}{2}$ long), contractet below; perigyinum ascending and more appressed, the points therefore not cons\}icuous. Woods, throughout; rare. - Var. Redúcta, Bailey. Very sleuter, l-20 high, the culm prujecting beyond the leaves; spikes 2-10, small and nearly globular (usually less than 3" broad), all usually distinct, the lowest separated, hrown, especially at maturity, the head often flexuose; perigyninm small, the points spreading and conspicuous. Copses, N. Eng. to the Dakotas; infrequent.

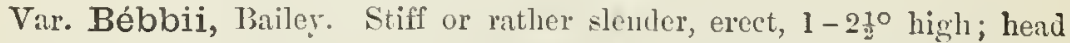
dense, oroid or oblong ( $\frac{1}{4}-\frac{g^{\prime}}{4}$ or very selitom $l^{\prime}$ long), the lowest spike only rarely distinet, straw-colored; spikes small ( $3^{\prime \prime}$ long or less), their axes ascend. ing; bracts at the hase of the hearl small or none; points of the small perigynium conspicuons. (C. Bebhii, Olney.) - Dry low gronnds, thronghout; common.

Var. cristàta, Bailey. Stout and stiff, $1 \frac{1}{2}-3^{\circ} \operatorname{ligh}$; heat more or less open or at least the lower 1 or 2 spikes commonly distinct, $l^{\prime}$ long or more, green; spikes larger than in the last and almost exactly globulan, their axes more divergent or fully horizontal; bracts usually conspicuous, sometimes one of them foliaccous; perigynium sprending, the points more conspicuous. (C. cristata, Schwein.) - Moist ground, throughout from Penn. northward; common.

128. C. scopària, Schkuhr. Rather slender but erect, $1-2 z_{2}^{\circ}$ high ; leares very narrow, shorter than the culm; head short and conparatirely thick, always tawny or brown, bractless or nearly so; spikes $3-8$, all contignous or hunched, ovate-oblong, always prominently narrowed or cone-shaped abore, ascending: perigynium as in 11. 127, but erect or ascending. - Open swales, thrcughiour: common eastward. 
Var. minor, boott. Much smaller, 6-10' ligh, the leaves very narrow; hearl very smill and darlier browu; spikes very small (2 -4 "long). - Roeky and sterile places, northward; frequent.

+++ Perigynium ovate or brouder, thichened in the middle, wing.margined (in n. 129 marginless).

$=$ Head silvery-broun, silvery-yreen, or silvery-whitish.

129. C. adústa, Boott. Very stiff aud stout, $1 \frac{1}{2}-2 \frac{1}{2}^{\circ}$ high, in dense tufts; head very heavy, erect, varying from globular to oblong, silvery-brown; spikes 5-10, globular and heavy, all aggregated or sometimes distinct, the lowest 1 or 2 subtended by a short and very broad-based, nerved and pointed bract; perigynium broadly ovate, wingless or very nealy so, plump, shining, nerved on the outer face but nerveless on the inuer, filled ly the large achene; scale acute, about the length of the perigynum. (C. pinguis, Builey.) - Dry and mostly hard soils, Mt. Desert, Maine (Greenlenf"), and nortluwrol, and Crawford Co., Mich. (Imiley), to X. Miun., aud far northwestward; local.

130. C. fœenea, Will. Slender, erect or the top of the culm flexuose, $1-2^{\circ}$ high; head long and weak, often nodding; spilies $5-8$, small, nearly globular and much contracted below, silvery-green, altcruately disposed; perigyuium varying from ovate to long-ovate, very thin, much longer than the sinall achene, prominently rough-margined, strongly many-nerved on both faces, especially on the small imner face; bracts entirely wanting or ineonspieuous. (C. arlusta, last ed.) - Dryish copses, N. Eng. to Penn. and Minn.; not common. - Var. PERPĹ́xa, Bailey. Mostly taller and stouter ; spikes larger and less attenuated or even truncate below, apjroximate or even aggregated, the head erect or nearly so and the lowest bract occasionally prominent; perigrniun thickcr and firmer in texture. N. Eng. to Mimn.; infrequent.

131. C. silicea, Olney. Stiff, $1-2^{\circ} \mathrm{high}$, in clumps; leaves very narrow, becoming involute, not exceeling the culm; head $1-3^{\prime}$ long, nsually flexnose or nodlling alove the middle ai maturity; spikes $5-8$, silvcry-white or silverytawny at full maturity, all more or less separated, ovate, couspicuously contracted below and cone-sliajed alove, erect on the culm; perigyuinm very broarl-ovate and rery thin, obscurely nerved, appressed, about as long as the acute colorless scale. (C. fouca, var. sabulonun, last ed.; C. straminea, var. moniliformis, Tuckerm.) - Sands of the sea-shore, Maine to N. J.; frequent. $==$ Ilead dull brown or green (usually somevhat silvery in var. foenea of $\mathrm{n} .132$ ).

132. C. stramínea, Milld. Very slender, crect, lut the top of the culm often flexuose, I - $3^{\circ}$ ligh ; lcaves nalrow and long-pointed, stiff, shorter than the culux ; spikes $3-8$, tawn, very small ( $2-3$ " lroal), globular or sometimes a little tapering below from the presence of many staminate flowers, usually all entirely distinct on the very slender, often zighag or flexuose rhachis; bracts none, or only the luwst cunspicuous; perigrnium small and orate, nerved on both faces bit never unusually prominently nerverl on the inner face (as is the perigyinum of 11 . 130), the points spreading and rather conspicuous; scalc acute, about the length of the perigynum. (C. straminea, var. tenera, last (4.) - Dryish (o)pses and ficlds; common. Inmensely variable.

Var. mirábilis, Tuckern. Culn long and mostly weak, often $4^{\circ}$ lim. much longer than she lonse leaver; spikes $4-8$, larger, usually : all contignums 
or occasionally the lowest 1 or 2 separrate, spreading, loosely Howered, tawn: or frequently greenish; perigynium narrowly orate, thin, longer than the scale, the points mule spreading and rery comspicuous. (C. mirabilis, Deuey.) - Shady places, throughout; frequent.

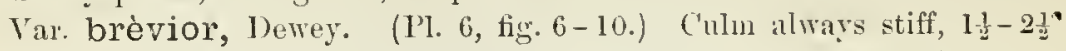
high, longer than the stiff long-pointed leaves; spikes $3-8$, all distinct, contignous or more or less separated, large $\left(3-5^{\prime \prime}\right.$ broad), globular, the head always short and erect; perigynium orhienlar or ovate-orbicular, often cordate at base, mostly very broally winged. (C. straninea, and vars. typica, hyalina, and Mearlii, last (d.) - Dry suils, throughont; common.

Var. apérta, Buott. Culm slender but strict helow tle head, $1-2^{\circ}$ high, growing in dense tufts; leaves very narrow, usually much shorter than the cuIm; spikes 4-6, large, heary, muel contracted below, usually all separated, becoming iusty, disposed in a weak or nodding head; perigynium narrowly ovate - Bogs, throughout; rare westward. Transition to n. 128, from which the ovate perigynia distinguish it.

Var. invisa, W. Boott. Culm very slender, weak above; leaves very nar. row with exceedingly long thin points, abont the length of the cuhn; spikes small ( 3 " broad or less), ovate, variously disposed in dense or open heads or sometimes the lowest remote or even subralical, rusty, the lower ones subtended by filiform lracts $2-5^{\prime}$ long. - Swales near the sen-board, Maine to Del.; infrequent. A pt to be confounded with 11.128 .

Var. alata, Bailey. CuIn very stiff, $1 \frac{1}{2}-3^{\circ}$ high, longer than the stiff leaves; spikes very large, oblong or couical, always pointed, usually all contignous, green or sometimes becoming tawı ; perigynum orbicular or orbieular-obovate, rery abruptly contracted into a slort beak which is prominent in the spike. (C. alata, Torr.) - Swales, MIass. to Ill., and southward; rare and uncharacteristic far iuland.

Yar. cumulàta, Bailey. Culm very stiff, $2-3^{\circ}$ high, greatly exceeding the firm leaves; spikes 5 - 30, all iggregated or deusely eapitate, green, widely divergent, pointed above, very alorupty contracted or even truncate at base, very densely flowered; perigrnim small, hroal, very obscurely nerved, the points incouspicuous.-Dry grounds, l'em. to N. Lug, and northward; rare.

Var. fònea, 'Torr. CuIm very stiff, longel than the leaves, $1-2^{\circ}$ high ; spikes 4-8, contiguous or separated, nerer densely aggregated, prominently contracted hoth above and below, very densely fluwered, green, or often silrerygreen. (C. f(xuea, last erl., excl. vals.; not Willd.) - Near the sea-coast: frepuent.

C. Lepolìxs, I. Distinguished from $\mathrm{C}$. straminea, var. hrevior, as follows: - Isually lower ; spikes rusty-hrown, ovoid or ollong, erest or apluressed, more or less contracted both ahore aud helow, contiguous in an intermpted head l' long or less; perigynimm lance-orate, thiu, very narowly margined, ereet and appressed, obscurely nerved. - Ibout Boston (11. Boolt, Morong). (Adr. from Eu.)

$$
\text { * 12. }-+3 . \text { Cyperoider }
$$

133. C. sychnocéphala, Carey. Erect, $3-18^{\prime}$ high, leafy; head $\frac{1}{2}-1^{\prime}$ long; perigyuinm very slenler, fiuntly nerved, $5-6$ times longer than the exceedingly small achene, mostly a little longer than the sharp seale. - Glades. central T. Y. to Minn., and far westward; rare. 


\section{Order 129. Gratíneze. (Grass Family.)}

Grasses, with usually hollow stems (culns) closed at the joints, alternate 2-ranked leaves, their sheaths split or open on the side opposite the blade; the hypogynous flowers solitary in the axils of imbricuted 2-ranked glumes, forming a 1 -many-flowered spikelet; the lower glumes (1 or usually 2) cunpty, the succeeding foucering glumes enclosing each a somewhat smaller and usually thinner seale (called the palet) and 2 or 3 very minute lyaline seales (lorlicules) at the base of the tlower. Stamens $1-6$, commonly 3: anthers versatile, 2-celled, the cells distinct. Styles mostly 2 or 2-parted; rtigmas hiairy or feathery. Ovary 1-cellerd, 1-oruled, forming a seed-like grain (curyopsis) in fruit. Embryo small, on the outsirle and at the base of the floury albumen. - Roots fibrous. Sheath of the leaves usually more or less extendect above the base of the blade into a scarious appendage (ligule). Spikelets panieled or spiked. Palet nsually 2-nerved or 2-keeted, enclosed or partly rovered by the oflume. Grain sometimes free from. sometimes permancutly allerent to, the palet. - A vast anıl most important family, as it furnisles the cereal grains, and the principal food of eattle, etc. 'The terns flowering giume and palet are now allopted in place of the outer and inner palets of previous editions, while for convenience the ter'm flower is often retained for the flower proper together with the enclosing flowering grlume. (See Plates 7 - 15.)

Srries A. Spikelets jointed upon the pedicel below the glunes, of one ter. minal perfect flower (sometines a Iower staminate or neutral flower in n. 5), or some or all of the 1-flowered spikelets unisexual in n. 10-12. Glumes 4 (rarely only 2 or 3).

Tribe I. PANICE.E. sprikelets of one perfeut Huwer, in spikes or panicles. Flowering glunie awnless, in linit more rigid thau the empty glumes.

* Spikelets iu 2-4 ranks on a more or less flattened vharhis. - See also n. 5 (\$ Digitaria).

- Rhachis produced beyund the upjur spilielet; glumes 3.

1. Spartina. Spikelets much flattened laterally in 2 elose rauks.

- + Rhachis not produced above the upper s]ikelet (rarely in n. 3).

2. Beckmannia. Spikelets oborate, in 2 close l"ws. Gluues 3 (or 4), strungly concave, viriliate.

3. I’axpalum. Spikelets plano-convex, sessile or nearly so. Glumes s (rarely 2).

t Erlochloa. Apikelets jlano-convex, laneeolate, witl a basal callus, slort-pedicelled. * Spikelets irregularly paniculate or spicate.

i I'unicum. Spikelets ovate, not involucrate nor the pelicels bristly. Glumes 4 , the luwest nsuilly small or miuute.

(i. Setaria. Splikelets iu densc cyludrical spikes or mancles, the pedicels bristle-bearing.

; Cenchrus. Spikichets $(1-j)$ enclosed iu a globulin spiny bur-like involucre.

8. Amplifearpun. Spitielets of 2 kinds, one in a terminal paricle, the other subter ranean on ralical perluncles.

Tribe II. ORIZLA. Silielets unisexual or perfect, in loose panities, with only glumes (in our getucla) and jalc: none. Stamens often 6 .

๑. Leersia. Flowers jerfect. Spilielets much dattened. Glumes carinate.

10. Zizania. Spikelets unisexual. Glumes convex, narow. 
Tribe III. MAXDEAE. Spikelets of a single perfect or unisexual or rudinentary flower, in jointed spikes, in pairs at each joint, mostly inbedrled in the thick rhachis.

11. Tripsacum. Spikelets monocious, the staminate abore in the spilie.

12. Rottbollia. One spibelet of each pair sterile and shortly pedicelled, the other fertile, sessile and sunk in the rlachis.

Tribe IV. ANDROPOGONEE. Spikelets in pairs or threes on the (usually jointed and bearded) rhaclis of a spike or branches of a panicle, one sessile aud fertile, the lateral pedicelled and often sterile or rudimentary; 2 upper ghmes smaller and hyaline, that of the fertile flower mostly awned.

13. Erianthus. Sjikelcts in pairs, spieate, all alike fertile, involucrate with a silly tuft.

14. Andropogon. Spikelets spicate, in pairs, the pericellate sterile or rudimentary; thachis bearded.

15. Chrysopogon. Spikelets in open panicles, in pairs or threes, only the sessile fertile,

Swnes B, Rhachis of the spikelet usually jointed abore the persistent lower glumes (jointed below the glnmes only in n. 19,31, and 36). Spikelets 1 - many-flowered, the uppermost flowers often imperfect or rudimentary.

Tribe V. PHALARIDEAE. Glumes 5, only the uppermost fertile, the 2 middle ones rudimentary or empty or staminate; palct 1-nerred. Pauicle mostly contracted and spike-like.

16. Phalaris. Middle glumes mere rudiments each side of the shining triand rous flower.

17 Anthoxanthum. Middle glumes empty, awned on the bick. Stamens 2.

18. Hierochloe. Middle glumes triaulrous. Fertile flower diandrous.

Tribe VI. AGROSTIDE $\mathbb{E}$. Glimes 3 ; flower solitary, perfect (rarely a rudimeutary or perfect second flower in n. 23 and $32-34$ ) ; palet $2-n e r v e d$,

- Flowering glume with a terminal awn (none in n. 22), closely embracing the grain in fruit, spilielets in panicles or loose spikes, the rhaclis not produced beyond the flower (except in n. 24 and a single species of n. 23). - STтPEג.

+ Fruiting glume firm and indurated, with a callus at base (none in 11,22 ).

19. A ristida. Awn 3-fid, the branches divaricate. Callus acute.

20. Stipa. Awn simple, twisted. Callus mostly acute.

21. Oryzopsis. Awn simple, striiglit, deciduous. Flnwer oblong; callus short, obtuse.

22. Milium. Awn noue. Flower small, oroid, withont callus.

+ + Fruiting glume thin and membranous; onter glume smaller or minute.

23. Mulhlenbergia. Flower mostly hairy at base, the glume mucronate or awned.

24. Brachyelytrum. Rhachis produced into a bristle above, Outer glunes very small, the flowering one loug-awned. Stimens 2.

* * lowering glume awnless or short-awned, loosely cmbracing the grain, thin, the lower glumes complicate-cariuate; spikiclets in deuse spike-like panicles, the rlachis not produced. - PHLEOIDEF.

25. Heleochloa. Awns none. Spikes short and scarcely exserted.

26. Phleum. Glumes somewhat tmneate, mneronate or slort-awned, Spike cylindric.

27. Alopecurns, Lower glumes united at base, the flowering awned on the back. Palet nuue. Spike cylindric.

* * Glumes membranous, the lower rarcly strongly complicate, the flowering with a dor sal awn or awnless; spilielets varously panicled. - AGROSTE.

+ Flowcring glune 1- (rarely 3-) nererl, awnless; grain loosely enclosed or naked.

28. Sporobolus. Culnis wiry or rigid, Leaves involute.

- + Flowering giume 3-5-nerred, mostly awned; grain enclosed.

++ Rhnehis not roduced above the single flower.

29. Agrostis. Spilied is in an open paricle.

30. Polypogon. Enuty glumes long-awned. Panicle slike-lin

31. Cinna. Sfikelets flattencd, in at Inose panicle. Pulet l-nerved. Stamen a 
++ Rhachis bearing a rudimentary second flower or short bristle (except in species of 11. 33).

32. Apera. Flowering glume bifid, awued. Panicle very loose and delicate.

33. Calamagrostis. Flowers hairy-tufted at base. Glumes membranaceous. Palet thin.

34. Ammopliila. Spilelets large. Flowers hairy-tufted at base. Glumes and palet chartaceous.

Tribe VII. AVENEA. Spilselets 2-several-flowered, panicled, the rlachis or base of the flower's oftel bearded; upper flower imperfect or rudimentary (exeept in n. 37 ). Flowering glume bearing a twisted, bent or straight awn on its back or below the apex.

* One of the flowers staminate only.

35. A rrhenatherum. Lower flower stainiuate, long-awned : middle flower perfect, nearly awnless; the upper mrimentary.

36. ILolcus. Flowers :, the lower perfect, awnless, the upper staminate, awned. * * Flowers all perfect or the ippermost usually rudinentary.

37. Aira. Spikelets very small, in a diffuse frauicle. Flowers 2, perfect, awned toward the base.

3s. Deschampsia. Spikelets 2-flowerel, with a hairy rudiment. Glumes thin-scarious, the flowering one erose-truneate, awned near the middle.

39. Trisetum. Suikelets 2 -several-fowerel. Flowering glune thin, compressed, carinate, 2-toothed, awned above by the exeurrent mid-nerve.

40. Avena. Spilielets 2 -severil-flowered. Flowering glume liard and firm, rounded on the back, 5-9-nerred, the mid-nerve lons-exeurrent at or below the 3-tnothed apex.

41 Danthonia. As Avella, lut the 3 middle nerves of the floweriug glume running into a flattish twister awn from betweeu the teeth.

Trihe VIII. CHLORIDEA. Spikelets 2-several-flowercd with one or more of the upper flowers imperfect (Hower 1 and perfect in n. 45), arranged in 2 rows upon the rhachis of a 1 -sided spike.

* Spikelets with one perfect flower.

42. Cynodon. Spikes $3-5$, slender, digitate. Flower and the rudiment awnless.

43. Cteniun. Sinike solitary, terminal. Flowers $4-6$, the midrle one perfect.

44. Gynmopogon. Spikes filiform, raccuose. Spikclets remote, of a perfect flower and an awned rudiment.

45. Schedomnardus. Spikes 3-9, slender, seattered, distant. Spikelets small, 1-flowered, allinless.

46. Boutcloua. Spikes scattered (rarely 1 and terminal), dense. Glume of perfect flower i-toothed. Rudimentary flowers 1-3-awned.

* Spikelets with two or more perfect flowers; awns none.

47. Elensine. Spikes digitate, dense.

48. Leptochloa. Spikes raeenose, slender. Spikelets small, alternate.

* * Spikelets diœcious; spikes small, very dissimilar.

49. Buchloe. Pistillatc spikes capitate, sessile, the sprikelets 1-flowered; staminate spikes (2 or 3 ) on a perluuele, the spikelets 2-3-flowered.

Tribe IX. FESTUCEA. Spikelets few - many. flowered, panieled, the uppermost flowers often imperfect or abortive. Glumes pointicss or the flowering ones tipned witl a straiglat awn or bristle.

* Flowering glume 1-3-nerved, 2-3-toothed. Rhachis short-bearded or glabrous.

50. Triodia. Rliaclis of the spikelet hearded. Nerves of the flowering glume 3, villons, at least the midile one more or less excurrent.

51. Diplachne. Rinchis glabrous. Glume 1-3-nerved, with 2 small teeth, and a short awn in the cleft.

* Glume 3-11erved, entire or 2-toothed and mucrnnate between the teeth. Rhaehis and flowers long-villous. Tall reeds with ample panieles.

52. Pluragmites. Spikelets 3-7-flowered lowest florer naked, staminate or neutrat Glume entire.

53. A rundo. As n. 52, hut flowers all perfect. Glume biffd. 
* * Glume 3-nerved, the nerves (at least the mid-nerve) exeurrent; spikelets few, in tlis axils of floral leaves.

54. MIunroa. Low or prostrate nucli-branelied annual.

* * * Glume 3- (rarely 1-) nerved, obtuse or aente, awuless ; rlaclis and fluwer unlieu.

55. Koleria. Paniele contraeted. Spikelets 2-4-flowered. Cilumes eompressed-keeled, acute or mueronate.

56. Eatouia. Paniele slender, more or less dense, Spikelets 2-Howered. Glumes very dissimilar, usually obtuse, the upper empty one euclosing the flowers.

57. Eragrostis. Spilielets flattened, 2-nuny-flowered, Glunes acute or aentish. Palet persistent.

*****Glume 3-5-nerved, obtuse or abmul-euspidate; spilielet 3-5-flowered ; upper sterile flowers convolute around each other.

58. Melica. Glumes 5-nerved or more, searious, obtuse. Panicle simple or nearly so.

50. Diar riena. Glunes 3-nerved, coriaceous, the flowering one ahruptly cuspidate. Pan. icle loosely ferw-flowered.

***** Flowering glume 5-nerved or more (sometimes (ulsiruly so), Only the ter minal flower abortive, or none.

+ Glumes more or less strongly eomuressed and arinate (rentrieose in 11,63 ).

60. Uniola. Spikelets broad, flat anl a-edger, in usnally loose panieles. Glumes coriaceons, acute, the $3-6$ lower viles empty

61. Distichlis. Diceious. Spikelets large, flattened, in a r.lose planicle, Empty glumes 2 , acuie.

62. Dactylis. I'anicle eontracted in 1-silled clusters. Glumes herbaceous, awn-pointed, rough-ciliate on the keel.

6:3. Briza. Sprikelets heart-shaped, in lax panicles. Glumes ronndish, rentrieose, seariousmaryined.

64. Poa. Sprilielets small, flattened, ovate to lamee-orate, in a loose pauicle. Flowering glumes membranous and scarious-marghed, pointless, ustally webly or pubescent toward the base.

65. Grapheplorum. Spikelets eompressed, in a loose pauicle, the hriby jointed rlachis prodnced into a hairy pedieed. Glumes thin-menuluanous, faintly nerved, entire.

+- Glumes eonvex un the back, not earinate (or somewl , t so in n. $7(0)$,

66. Scolochloa. Spilielets subterete, in a lax panicle, the r. chis villons at the base of the flowers, ending in a naked fredicel. Glumes cori.ceons, prominently 7-nerved, toothed at the apex. In water.

67. Glyceria. Spilielets terete or flat tislı. Flowering glumes scarions at the nsually blunt stumit, prominently 5-7-nerved.

68. Puccinellia. Mainly as Glyeeria, but the glumes obsoletely 5-1erved.

69. Festnea. Spikelets terete or flattislı. Flowering gl!nme acute, puinted or awned at the tip, fen-nerved. Styles terminal.

70. Bromus. Glume ronnded or keeled on the baek, mostly awner below the 2-eleft tip, 5 -9-nerved. Styles searcely terninal.

Tribe X. HORIDEA. Spikelets 1 -sereral-flowered, sessile on opposite sides of a zig. zag jointerl elumnelled rhaehis, forming a spike. Empty ghmes sometiues abortive or wanting. Ulipermost flower imperfeet or abortive.

* Sjikelets single at cacl joint of the solitary splke.

71. Lolium. Spikelets many-flowered, plinced edgewise nut the rhaelis of the spoike, with one eujity glume.

72. Agropyrum, Spikelets 3-several-flowered, placerl flatwise on the rlıelis, Empty glinnes 2, right and left.

73. Lepturus. Spilielets small, 1-2-flowered; empty glumes 1 or 2. Spiko very slender.

* Spilielets : m more at eaeh joint of the solitary spike ; the empty glumes side hy side in front of the spikelets (none or rudimentary in $n .76$. )

M. Hordeun. Silielets 1-flowered, 3 at each joint, the lateral ones nsually sterile. 
ic Elymus. Filikelets 1 - seteral-Howered, all perfect and similar.

it Asprella. Sprikelets few-flowered, somewhat pedicelled, $l-3$ at each joint. Gilurues none or small and decichous.

Tribe XI. BAMBUSEA. Tall woody reeds, the flat leares with a short petiole jointed upon the sheatl. Spilielets few-many-flowerm, that tened, in panicles or racenes.

77. Arumdinaria. Flowering glumes roundel on the bacls, nany-nered, acuminate or bristle-pointecl ; empty glumes very small.

1. SPARTI N A, Schreher. Comor Marsu Grass. (l'l. ?.)

Spikelets 1-Howered, very nuch Hattened laterally, jointed and sessile in 3 ranks on the outer sicle of a triangnlar rhachis. Cihnues 3, nnepual, lanceolate, strongly (compressed-kee led, acnte or bristle-pointed, mostly romgh-bristly on the keel; palet thin, ('fulling () longer than the flowering glume. Stameus 3. Sityles long, more or less united. - l'erannials, with simple and rigid often

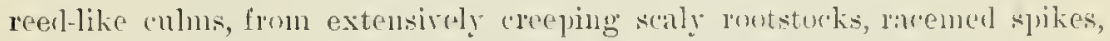
very smooth sheatls, and long tough leaves (whence the name, fom $\sigma \pi \alpha \rho$ rivis. a rord, sneh as was made from the hark of the symefimm or Brooul).

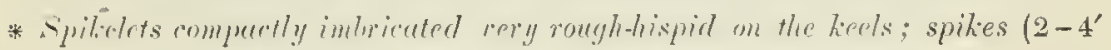
long) mope or tess pulnuded: culm and elonguted leares rigid.

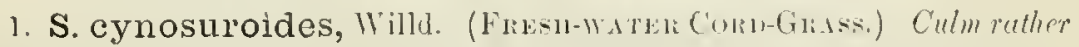
slender $\left(2-6^{\circ}\right.$ high $)$. leaces nurom: $\left(2-4^{\circ}\right.$ long, 2' wirle below or less), tapering to a very slenler point, keeled, Hat, but quickly involute in drying, smooth

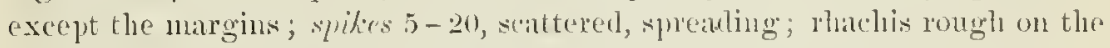
margins; ylumes armepointed, especially the mirllle une (its awu ahout $\frac{1}{1}$ long), strongly serdulate-hisipl on the keel, the lower equalling the upper, whose strong mitrib abruptly terminates below the membranous apex. - Banks of rivers and lakes, "1 in rich soil, especially northwar. Ing.

․ S. polystàchya, Willd. (Sil.T livest-Gris.) ('ulm tull and stout $\left(4-9^{\circ}\right.$ liggh, often $l^{\prime}$ in diameter near the hase); lenes brord $\left(1-l^{\prime}\right)$, roughish underneuth, as well as the margins; spikes 20-50, forming a donse oblong ra-

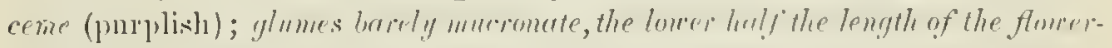
ing ome, of which the rongh-lispiel mirtrib reaches to the apex. - Sald or brak ish mashes, within tile-water, especially southward.

3. S. júncea, Willd. (Resir SAlt-Gisss.) C'ulms lou (1 - 20 high) and slender; leates narrou and rush-like, strongly imelute, rer"y smooth; spikes $1-5$, on very short peduncles, the rhachis smooth; glumes urute, the lower scarcely half the length of the middle one, not half the length of the upper. - Salt marsles and sea-beaches. Iug. (Fu.)

* Epitiplets looscly imbricatod, or somewliat remote and alternute, the keels only slightly hairy or roughish under a lens; spilies sessile and erect, soft; leares, rhaclis, etc. very smonth; culm ruther succulent.

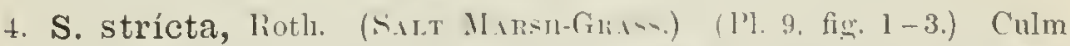
$1-4^{\circ}$ high, laty to the top) f leaves snon combohte, matrow; spikes few $(2-4)$, the rhathis slightly projecting heroud the crowlen or imbricaterl sprikelets; glumes achte, very mequil, the larger I-nerved, a little longer than the Hower. - S'alt narshes, Penn., ete.-- Odor strung and raucił. (En.)

lau. glàbra, Ciray. Culn and leaves longer ; spikes 5-12 (2-3’ long): spikelets inbricate-crowded. - Common on the coast. 
Var. alterniflòn, Gray. Spikes more sleuder $\left(3-5^{\prime}\right.$ long), and the spike. lets remotish, barely overlapping, the rhachis eontinuel into a nore conspicnous bract-like appendage; larger glume indistinctly 5-nerved; otherwise as in the preceding form, into which it passes. - Cummon with the last; also Onondaga Lake, J. A. Paine.

\section{B E C K M Á N N I A, Host. (J'l. 15.)}

Spikelets jointed upon the pedicels, 1 -2-flowerel (only one ferile), obovate and laterally compressed, imbricated in 2 rows npom one sille of the angled rhachis of a spilie. Glumes 3 or 4, the 2 lower strungly concave and carinate, obtuse or acutish, the 1 or 2 flowering glumes narrower, lanceolate, acute or acmminate and a little exserted, beconing lather rigid and with the thin palet enclosing the oblong grain, $-\Lambda$ stont crect subaruatic peremial, with the short spikes erect and simply spicate or in a strict narrow panicle. (Named for . Ioln Beclimann, professor of botany at Goettingen.)

1. B. erucæfórmis, Host, var. uniflòra, Scribn. Glumes 3 and spikelets 1-flowered; spikes ( $6^{\prime \prime}$ long or less) panicled. - N. W. Iowa, W. Miun., and westward. 'The Old World form, which also is found in the far northwest, has 2-flowered spikelets.

\section{PÁ S P A L U M, L. (Pl. 13.)}

Spikelets spiked or somewhat racemed, in 2-4 rows on one side of a flattened or filiform continuous rhachis, jointed upon very short pedicels, planoeonvex, awuless, 1-flowered. Glnmes 3 (rarely only 2), the terminal one flowering. Flower coriaceons, mostly orbicular or ovate, flat on the imer side, convex on the onter. Stamens 3. Spikes one or nore, at or toward the snmmit of an elongated peduncle, (П $\alpha \sigma \pi a ́ \lambda o s, a$ Greek name for Millet.)

* Spities with a $\left(\mathrm{I}^{\prime \prime}\right)$ broad and thin membranaceous or foliaceous and keeled rhachis, the incurved margins partly enelosing the small two-rowed spitielets. (Smooth, aquatic, or nearly so, decumbent or floating.)

1. P. flutitans, Funth. Anmual; leaves lanceolute, flat $\left(3-8^{\prime \prime}\right)$, broad; spikes numerous in a raceme, the rhachis somewhat projecting beyoud the minute and slightly pubesecnt spikelets into a tapering point, scabrous on the back. - River-swamps, Va. to S. Ill., Mo, and sonthward. Sept., Oct.

2. P. Walteriànum, Sehultes. Perennial; leaves linear, short; spikes $3-7$, the lowest partly included in the sheath of the uppermost leaf, the rhachis blunt; spikelets glabrons. - Low or wet grounds, N. J. (Cape May, Siutull), Del., and southward.

* * Spikes with a narron wingless rhachis ; perennials, or mostly so. + Spitelets very obtuse, orbirular; spities one terminal and often 1 - 5 lateral.

3. P. setàceum, Michx. Cnlm asecnding or deeumbent $\left(1-2^{\circ}\right.$ long): slender; leares (2" wide, flat) and sheatlis clothed with soft spreading hairs; spikes very slender (2-4' long), smooth, mostly solitury on a long peduncle, and usually one from the sheaths of cuch of the upper leures on shont peduncles or in-

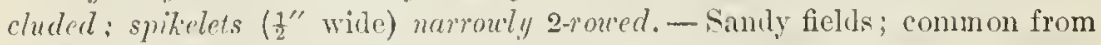
L. Mass, to Ill., and southwarl. Aug.

4. P. læve, Michx, (I'1. 13, fig. 1-3.) Iright green, sparingly villous, vather stout; stems somewhat decumbent; leares and spikes widely spreacl. 
ing; spikes $(2-4)$ approximate, $2-4^{\prime}$ long, smooth or nearly so; spikelets about $1^{\prime \prime}$ wide, 2-rowed. - Moist suil, s. New Fug. to Ky, and southward.

5. P. Floridànum, Michx. Stout, erect, $3-6^{\circ}$ high, glaucous ; sheaths aud leaves more or less villons, the latter aud the spikes erect or ascending; spikes $(2-5)$ broader, $2-5$ long, the smooth spikelets nearly $2^{\prime \prime}$ broad, in 2 rows. - Moist soil; Del. to Fla., Alk, and Tex.

$$
\text { + + Spikelets acute; spities sereral, racemose. }
$$

6. P. dilatàtum, Poir. Stont, erect, $2-5^{\circ}$ higl, villous at the top of the 3heath; spikes few on a naked peduncle, erect, $2-3^{\prime}$ long; spikelets $1^{\prime \prime}$ long or more, the lower glume suft-rillons on the margin, - Va, to Tex.

+- + Spikelets acute; spikes always a puir at the summit of the naked peduncle.

7. P. dístichum, L. (Jonт-Grass.) Nearly glalıous, rather glancous; culms asceulling (about $1^{\circ}$ high) from a long creeping base; leaves linearlanceolate ( $2-3^{\prime}$ long); peduncle usually short ; spikes short and closely-flowered ( $9^{\prime \prime}-2^{\prime}$ long), often slightly separated ; rhachis flat ou the back; spitielets orcute, slightly pointed (barely $1 \frac{1}{2}$ "long), approximute on one side of the rhachis. - Wet fields, ria. and southward. July-sept.

8. P. Ellióttii, Watson. Culns ascending ( $\left.1-21^{\circ} \mathrm{high}\right)$ from a creeping hase; leaves lanceolate $\left(3-6^{\prime}\right.$ loug, $4-6^{\prime \prime}$ wile) ; spites slender, rather sparsely flowered (1-4' long), both sessile upon the long slender peduncle; spitielets oute-lanceolate (2' $2^{\prime \prime} \mathrm{log}$ ), on neurly opposite sides of the rhachis. (Milium paspalòdes, Ell. P. Digitaria, Chapm, ; not Puir.) - Va. and southward.

\section{ERIÓCHLOA, 11BḰ. (Pl. 15.)}

Spikelets ovate, subsessile or shortly perlicellerl upon one side of the rhachis of a spike, with a callus at base and jointed on the pedicel, 1-flowered. Glumes 3 , the 2 empty ones slightly unequal, membranaceous, acute, the flowering one shorter, inclurated, olstuse, enclosing the free grain, - Coarse tufted grasses, with flat leaves, the spikes more or less scattered along a common perluncle, and the pedicels and riachis of the spike nsually pubescent or hairy (hence

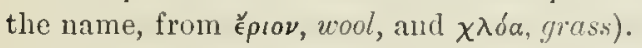

1. E. polystàchya, IHK. Culms erect or decumbent, $2^{\circ}$ high ; spikes 6-12, erect or ascending, $1-2^{\prime}$ long, forming a compound spike $3-6^{\prime}$ long; spikelets glabrous, very shortly pedicelled, oblong-lanceolate, nearly $2^{\prime \prime}$ long. -S. Kan. to Tex. and Mex.

\section{Pá N I C U M, I. Panic-Grass. (Pl. 13.)}

Spikelets jointed upon the pedicels, orate, panicled, racemed, or sometimes spiked, not involucrate, with one perfect and sometimes a second lower rudimentary or staminate flower. Glumes 4, but tle lower one nsually short or minute (rarely even wanting), and the thirl enpty or sterile, membranaceoherbaceous, I'pper flower perfect, clused, coriareous or cartilaginous, usually flattish parallel with the glumes, awnless (cxcept in \$3), enclosing the free aul grooreless grain. Stamens 3. Stigmas phumse, usually purple. (An ancient I atin name of the Italian Millet, I'. Italicum (now Setaria Italica), of uncertain origin and meaning.) 
\$1. DIGITARIA. Spitelets crouded 2-3 together in simple and mostly $\mathrm{I}$. sided clustered spities or spitietike racemes, wholly aunless and pointless, I-flowered; lower ylume minute or obsolete or wunting; amnual, often purplish.

* Spikes erect; the thachis filiform and nearly terete.

1. P. filifórme, L. Culus very slender $\left(1-2^{\circ}\right.$ high $)$, upright; lower sheaths hairy; spikes $2-8$, alternate, approximate, filiform; spikelets ollong,

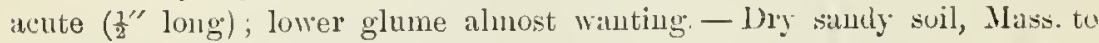
N. J. along the cuast, to Iowa, Neb., and southward. Lug.

$$
\text { ** sipikes spreading; the thuchis ful and thin. }
$$

P. caldbrus, Gaudin. Culms spreading, prostrate, or sometimes crect (5-12' long), glahrons; spikes 2-6, widely dicerying, nearly digitate; spikelets oroid (abont $\mathrm{I}^{\prime \prime}$ long); upper empty glume equalling the floceer, the lnuer almost wanting. - Cultivated grourls auil waste places; common, especially soutluvard; sometimes appearing incligenous. Ang., sept. (Nat. from Eu.)

P. Sangunale, J. (Common Crab- or Fingiri-Grass.) (P'l. 13, fig. 1-3.) Culms ereet or spreading $\left(1-2^{\circ}\right.$ high); leares and sheaths glabrous (1) hairy; spikes $4-15$, spreading, digitate; spikelets oblong ( $1 \frac{1}{2}$ "long); second glume half the length of the flower, the lower one small. - Cultivated and waste grounds. Aug.-Oct. (Nat. from En.)

§2. PANICUM proper. Spikelets scattered, in panicles, awnless.

* Panicle elongated und racemose, wand-like or pyramidal; the numerous and usually pointed spikelets short-pedicelled, excepting n. 3 and 4 .

+ Sterile flourer none; loicer ylume short; spikelets $\frac{1}{3}-1 \frac{1}{3}$ "long; annuals except n. 4 ; lerwes flat; sheaths flattened.

- Glabrous and smooth throughout; spikelets appressed, short-pedicelled.

2. P. proliferum, Lam. Culms usually thiekish and rather sueeulent, branehed, geniculate and ascending from a procumbent hase; sheatlis flat. tened; ligule ciliate; panicles terminal and laterel, compound, pramidal, the slenter primary branches at length sprealing; spikelets pale green, rarely purplish ; lower giume lnoad, $\frac{1}{3}$ to ${ }_{1}^{1}$ the length of the upper, which is little longer than the How ering one. - Marshy river-banks and shores, especially if brackish, but also in the interior, from Mass, to Iown, and sontluwarl. Aug. +* Hispid or hairy on the sheuths, at lenst the foner; spikelets mostly scattered on slenter pedicels in an ample, loose, at lenyth cory effuse panicle; culins mostly brasched from the buse, erect an ascending $\left(10-20^{\prime}\right.$ high $)$.

3. P. capillàre, $I_{\text {. }}$ (OL.1-witen Gris.) (Pl. 13, fig. 4, 5.) All the sheaths and usually the leares ropiously huing or hispid; panicle mostly very compound, the branches diraricate when old ; spikelets from oroid to narrowly ohlong, pointerl; lourer glume half the length of the upper ampty one, whicl is longer than the elliptical obtuse perfert flomer. - Sandy soil and cultivated fields ererywhere. Aug. - Oet. - Varies extremely in size and appearance. the culms erect aul simple, or clecumbent, genicnlate and hranched ; in te-

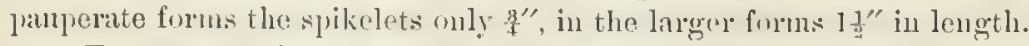

4. P. autumnàle, 13ose. Root peremial (?), lower sheaths and margins of the small narrow leaves more or less hairy, otherwise glabrous, except some bristly hairs in the main axils of the very effuse rupillary panicle, its murh efongater divisions sparingly lranched, or eren simple and terminated with

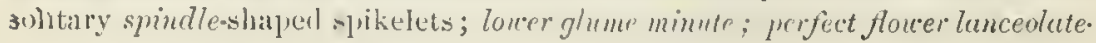


oblong and pointed. nearly equalling the lance-oblong ubtusish empty glumes. —Saud-hills, Ill. to Minn., Mo., and southward.

+ + Sterile flower rudimcnury (stuminute in n. 7), its glume fully twice the

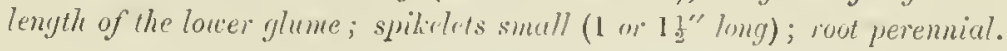

5. P. ánceps, Michx. C'ulms flut, upright (2-4 high); leaves rather boadly linear ( $1-2^{\circ}$ long, $4-5^{\prime \prime}$ wide), smonth; pinicle contikted-prramidal; spikelets ovcule-lunceulute, pointert, a little curved; second glume 5-7. nerved; nentral flower one third longer than the perfect one. - Wet sandy soil, N. J. and l'enn, to S. Ill., and sonthward. Ang. - sipikelets larger and branches of the panicle louger and nitrower thin in the next.

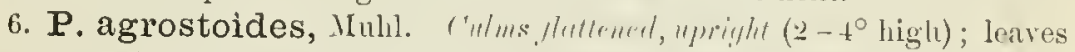

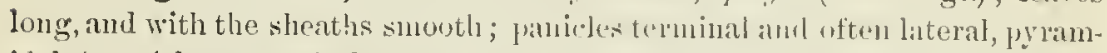

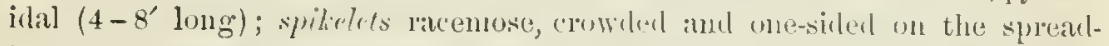
jug loranches, ovate-ollong, amule (purplish); second ylume 5-neived, longer than the nentral fower; perfect Hower shorter, hearded at the apex. - Wet meatows and stures, li. Mass. to Mium., Neis, and common sonthwart. Ang.

7. P. Curtísii, Chipın. Culus stout, $3-4^{\circ}$ high, often rooting below; mostly glabrous; panicle slencler, simple, spike-like $\left(6-8^{\prime}\right.$ long $)$, the spikes ily'essect; spikelets lanceolate, acute; lower glnme half the length of the 5-nerved second one.- Ponds, I)el. to H. and 'l'ex.

- + + sicrile Howor staminute; lones glume more lhan half the length of the

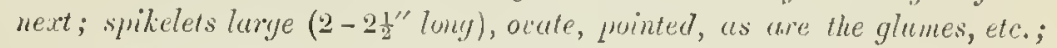
peremials, glabrous, with tall or stout and rigid upright culms.

8. P. virgàtum, L. (l'l. 13, fig. 8, 9.) 'I'all (3 - 50 higll) ; leaves very long, flat; lignle silky-bearded; branches of the componnd loose and large panire $\left(9^{\prime}-2 \circ\right.$ long) at length spreading or drwopiny; spikelets scattered, usually purplish. - Moist sancir soil; common. Lng.

9. P. amàrum, Ell. Culms ( $1 \frac{10}{2}$ ligh or more) sheathed to the top; lentes involute, glancous, corinceous, the uppermost exreding the contracted panirle, the simple racemore hranches of which ale appressed; spikelets pale. Simcly shores, Comu. V Va., and southwarl. Iug., sept. - The northern form (var. Mìus, Vasey \& Seribn.) somewhat smaller than the sonthern.

* *amirle short or smull, lonsely spreading or diffuse; perennials. t- storile fourer nome: spikelets unorty roughenerl.

10. P. verrucosum, Muhl. Smooth; culms hranching and spreading, very sleuder $\left(1-2^{\circ}\right.$ long), naked above; leaves linear-lanceolate $\left(2-3^{\prime \prime}\right.$ wide), shining; branches of the diffuse panicle capillary, few-flowered; spikelet. dark green, oval, acute, $\frac{3{ }^{\prime \prime}}{4}$ long; Inver glume $\frac{1}{4}$ as long as the faintly nerved second. - Saudy swamps, N. Eng. to Va., near the coast, and sonthward.

- + Lover (sterile) flout nemtral, or in $\mathrm{n} .12$ and sometimes in n. 11 staminate, the palet scarious and sometimes small and inconspicuous.

- Culm-leaves broadly lanceolate or wider, with 9-15 principal nerves (obscurs or none in $\mathrm{n.} \mathrm{17).}$

$$
=\text { Spikelets 1-1 } 1 \text { "l long. }
$$

11. P. xanthophysum, Gray. Culn simple, or at leagth branched near the base $\left(9-15^{\prime}\right.$ high) ; sheaths hairy; lerurs luncevilute, cery acule $\left(4-6^{\prime}\right.$ 
loug by $\frac{1^{\prime}}{2}$ wirle), not liluted at the cilliate-bearded clasping base, sinoth except the margins, strongly 9-11-nerped; punicle lonj-pedunded, very simple, the appressed branches bcaring a few roundisk-obotute spiticlets (abont $1 \frac{1{ }^{\prime \prime}}{2} \mathrm{long}$ ); lower glume orate, acutish, $\frac{1}{3}-\frac{1}{2}$ the length of the 9-nerved second. - Dry sandy soil, Maine to l'enu., W'isc, lowa, and northward; rare. June. - Y'ellowish-green; spikelets uinutely downy; sterile flower sometimes staminate.

12. P. latifolium, L. Culm $\left(1-2^{\circ}\right.$ high $)$ smooth; the joiuts and the throat or margins of the otherwise smooth sheuths often bearded with soft woolly hairs; leaves broadly oblong-lanceolate from a heait-clasping base (often $\mathrm{I}^{\prime}$ wide), taper-poiuted, il - 15-nerved, smooth, or s]ningly downy-hairy; panicle more or less exserted ( $2-3^{\prime}$ long), usually long-peduncled, the brauches spreading; spikelets obovate, $1 \frac{1}{2}$ "lony, downy; lower glume orate, not half the length of the many-nerved second; sterile flower often (not always) witl 3 stamens. Moist thickets; common. June-Aug.

13. P. clandestinum, L. (Pl. 13, fig. 6, 7.) Culn rigid (1-3 high), very leafy to the top, at length producing appressel hrauches, the joints naked; sheaths rough with papille bearing very stiff and spreading bristly hairs; leaves oblong-lanceolate from a heart-clasping base, very taper-pointed; lateral and usually also the terminal panicle more or less enclosed in the sheaths, or with the terminal oue at length long-peduncled; - otherwise resembling n. 12; but the spikelets more ovoid, often smooth; the lower flower (always?) nentral. - Low thickets and river-banks, N. Eng. to Mich., Mo., and sonthward. Juue-Sept.

14. P. víscidum, Ell. Culms stout, upright or ascending, at length much branched, leafy to the top, densely relvety-douny all orer, as also the sheaths, with reflexed soft and often clammy hairs, except a ring below each

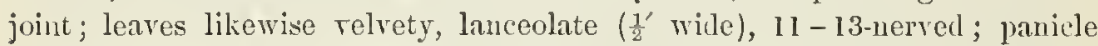
spreading, the lateral ones included; spikelets obovate, 1 or $1 \frac{1}{2}$ "long, downy; the romutish lower glume scarcely one fourth the length of the 7 -nerved second one. - Damp soil, X. J. to Va., and southward. Ang.

15. P. scopàrium, Lam. Culms upright, at length much hranched and reclining $\left(1-2^{\circ}\right.$ long), roughish; leaves lanceolute $\left(3-5^{\prime}\right.$ long by $\frac{7}{8}-\frac{1^{\prime}}{2}$ wide), rather faintly 9-nerved, hairy or smooth, fringed on the whole inargin or next the base with long and stiff spreading hairs, the sheaths bristly throughout with similar hairs; panicle open, nearly simple, bearing few tumil-obovate hairy or smoothish spikelets about $1 \frac{1}{2}$ "long; lower glume romudish, abont laalf or a quarter of the length of the upper one. (1'. panciflorum, Ell.) - W'et meadwws anl copses, E. Mass. to Minn., west and southward. June, July.

16. P. commutàtum, Schnltes. Rather slender, erect, $1-2^{\circ}$ ligh, nerely glabrons: leaves lanceolate, acuninate (3- $6^{\prime}$ long), the margins to. warl the base and the sheaths sparscly ciliate; panicle spreading, ofteu shortpednucled; spikelets scattered, glabrous, oblong, ucutish, little nore than $\mathbf{I}^{\prime \prime}$ long; lover glume orate, often acnte. $-\mathbf{N}$. Y. to Fla. $-\Lambda$ frequent variety with smaller spikelets (not $I^{\prime \prime}$ long) alpronches the next, and has also been confused with l'. dichotomum. - Ont. to Va. and southward.

$$
==\text { Spikelets less than } \mathbf{I}^{\prime \prime} \text { long. }
$$

17. P. nitidum, Michx. (Lam.?) Resemlies the last, leaves rather thick and the priveipal nerves very obscure or none excent at the base; pau 


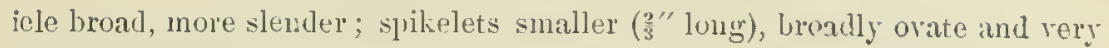
ultuse; lower glume rery obtuse. (I. sphiurocarpon, Eil.) - X. I. to Ga, and westward.

18. P. microcárpon, Muhl. Like the last; the broadly lanceolate leaves nearly similar; but nisully longer ( $8^{\prime}$ long or less), distinctly nerred; panicle soon exserted on a slender peduncle, ratler narower, with numerous slender branchos and very many-thwered ( $3-7^{\prime}$ long); spikelets about $\frac{7^{\prime \prime}}{2}$ long, ovoid, smooth or smoothish; lower glume orlicular and very small. 1)ry or moist thickets, l'enn. to Mich., Neb., and sonthward. July-sept.

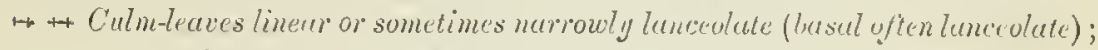
primary nerves often indistinct or none; spilielets small.

19. P. depauperàtum, Mulıl. Culnıs simple or blanclied from the fare, forming close tufts $\left(6-12^{\prime}\right.$ ligh $)$, terminated by a simple and few-flowcred contracted panicle, often much orertoplped by the narrowly linear and elongated $\left(4-7^{\prime}\right)$ npper leares; spikelets $\frac{8}{4}-11^{\prime \prime}$ long, oval-olorate, commonly pointed when young; lwer glume orate. - Varies, with the leaves involute, at least when dry (P. involntmu, Torr.), and with the sheaths eithel beset with long latirs or nearly smooth; the pranicle either partly included, or on a long and slenter peduncle. - 1)ry wools and hills; rather common. June.

20. P. consanguíneum, Kuntl. Culns slender, $1-2^{\circ}$ high, often decumbent aud rooting below; nearly glabrons or the sheaths and leaves somewhat pubescent or rillous; paniche small, witl rather few spreading fow-

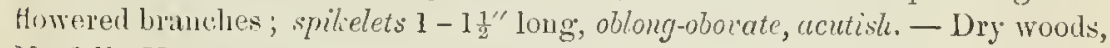
Norfolk, Va., aud south to Fl. and Tex.

21. P. dichótomum, L.! Culns $\left(8^{\prime}-2^{\circ}\right.$ high $)$ at first mostly simple, learing a more or less exsorterl sprealing compound panicle ( $1-3^{\prime}$ Iong), and linear to linear-lanceolate fat leaves (those tufted at the root usually oratelanceolate and rery short, thickish); but commonly branching later in the season, the branches often clustered, and bearing nearly simple and ineluded small panicles; spiticlets $\frac{1}{2}-\frac{2}{3} "$ long, elliptirnl, obtuse, downy or sunooth; lower glume romdish. - Common evergwhere. Very rariable both in labit anl in the amount of villosity (depending upon the soil, exposure, season, cte.), so that it is difficult to specify any well defined rarietios. The more eonspienous forms are ( 1 ) commune, with simple eulns erect or ascenling, and leaves suberect, nsiall! laale green - (b) fasciculàtum, with chusteren leafy branches and slort peluncles, a common antmmnal state - ant (c) gracile, the enlms lax, very slenler and elongated, with rather distant spreading leaves (nsually bright green), and mostly loug-pecinculate pinicles.

22. P. laxiflorum, Lan.! Closely resembling the last speeies, in its several forms; distinguishod ly the larger acutisl spikelets (nearly or quite I"long). - Common.

\& 3. ECHINOCHILOA. Spilietets imbricated-spited on the branches of the simple or compound raceme or panicle, usually rongh with appressed stiff hairs; louer pulet of the sterile flawer uw-pointed or auned.

P. Cres-gíld, I. (Barryard-Grass.) Root annual; culms stont, bramiling from the base ( $1-4^{\circ}$ high); leaves lanceulate ( $\frac{1}{2}$ 'vicle or more), rongh-magined. otherwise with the sheaths snouth; splies alternate $\left(1-3^{\prime}\right.$ long), erowded in a dense paniele; glumes ovate, abruptly pointed; glune 
of the neutral flower bearing a rough awn of variable length. - V'aries greatly; sometimes awnless or nearly so; sometimes long-ancucd, especially in the rar. HisplDEy, a very large anil coarse form with the sheaths of the leaves rery bristly. - Moist, chiety manured soil; the rariety in clitches, espe cially of brackisli water; possibly" indigenons. Iug. -Uct. (Nat. from En.)

\section{Setàni A, Beauy. Bristly Foxtall Grass. (Pl. 13.)}

Spikelets altogether as in Panicm proper, and awnless, but with the short reduncles bearing below the joint of the spikelet solitary or clustered bristles resembling awns (but not forming an involucre). Intluresence a densespiked panicle, or apparently a eylindrieal spike. - Inmals, in cultivated or manured grounds, witl linear or lanceolate flat leares. (Name from stu, a bristle.)

\section{* Bristles single or in pairs, roughened or bubed docnumel.}

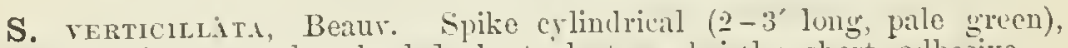
composed of apparently whorlert short chusters; bristles short, achesive. Near dwellings. (Adr. from Eu.)

\section{* Bristles in clusters, roughened or burbed upuard.}

S. rlatid, Benur. (Foxtan. Pigeox-Gliss.) (Pl. 13, fig. 1, 2.) spitie cylindrical, dense, tauny yellow $\left(2-4^{\prime}\right.$ long); bristles $6-11$ in a cluster, much linger than the spikelets; perfect flower trunsiersely winkled. - Very conmon, in stubble, etc. (Adr. from Eu.)

S. vírids, Beanr. (Greex Foxtall. Bottle-(rian...) Spike nemly "ylindrical, more or less compound, green: uristles fert, lnnger than the spikelets;

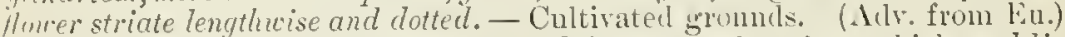

S. IrÁlica, Konth. Epike compound, interupted at hase, thick, molding; (6-9' long), yellowish or purplish; bristles 2 or 3 in at chestre, eithel much longer or else shorter than the spikelets. - Cultirated unker the nane of Ilnkt: or Huxgariax or l3kagal Grass; rarely spontaneons. (Aly. from lin.)

\section{CÉNCHRUS, I. HEDGEHOG- Or Bir-Girass. (Pl. 14.)}

Spikelets as in Panicum, awnless, but enclosed 1 to 5 together in a glohulinr and bristly or spiny involucre, whieh becomes coriaceous and forms a deciduwus hard and rigrid bur; the involueres sessile in a terminal spike. Styles nuited below. (An ancient Greek name of Setricis Italica.)

1. C. tribuloides, I. Annual; culms branched and ascending ( $1^{\circ}$ higlı or less); leaves flat; spike oblong, of 8 - 20 spherieal heats; involucre prickly all wer with spreading and barbed short spines, more or less downy, enelosing 22 or 3 spikiclets. - Sandy soil, on river banks, etc. Ang. - I vile weed.

\section{A M PHICÁ R P U M, Kiunth. (Pl. 13.)}

Sijkelets jointed upon the pedicels, l-flowered, oblung or woil, of twe binds; one kind in a terminal panicle, deciduous from the juint witlont fruit although the flower is perfect; the other kind solitary at the extremity of slender rumer-like radical perluncles (more or less sheatherl towirl the base), much larger than the others, perfect and fertile, subterromean, fertilized in the hurl. Glumes 3, nearly efpual, 5-11ervel in the panicle, man nerved in the fertile spikelets; palet a little slorter; all becoming induratel aul euclosing the very large grain. Stimens 3 (small in the radical flowers). Sitigmats plumose,

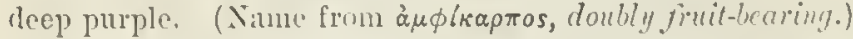

1. A. Púrshii, kunth. Inmula or biemial(!), ereet, I-to high ; leares lanceolate, copious on the lower part of the culm, hispirl, especially on the 
sheaths; panicle strict, naked; grain ovoid or oblong ( $2-3^{\prime \prime}$ long), terete. Moist sandy pine-barrens, N. J. to Fla. Sept.

\section{LEERSIA, Swatz. W'HTE Grass. (l’.7.)}

Fluwers erowder in one-sided panicled spikes or racemes, perfect, but those in the open panicles usnally sterile by the abortion of the ovary, those enclowerl in the sheatls of the leares close-fertilized in the bud and prolific. Sipikelet. 1-flowererl, flat, more or less inbricated over each other, jointed upon the shor" pedicels. Glumes 2, chartaeeous, strongly fattened laterally or conduplicate, awnless, bristly-ciliate on the keels, closed, nearly equal in length, but the lower much broader, enclosing the flat grain. Palet none. Stamens $1-6$ Stigmas feathery, the hair's branching. - I'erennial malsh grasses; the flat lurves, sheaths, etc, rough upward, being elothed with very minute hooked mickles. (Named after John Daniel Leers, a German botanist.)

* Spitelets narrowly oblong, rather loosely crowded.

1. L. Virgínica, Willd. (Wuite Griss.) Panicle simple; the spitielets rosely appressed on the slender branches, around which they are partly curvel ( $1 \frac{1}{2}$ "long) ; stameus 2 (a third imperfect or wating); glumes sparing! ciliate (greenish-white). - Wet woods; Maine to Minn., ancl sonthwad. $\Lambda$ ug.

2. L. oryzoides, Nwartz. (Rıce Cut-Gkss..) (I'l. 7, fig. I-3.) I'unicle

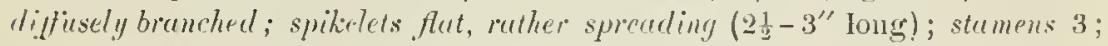
glumes strongly bristly-ciliate (whitish). - Yrery wet places; Mass. to Minn., :mul soutlwarif; eonumon. Lug. (Eu.)

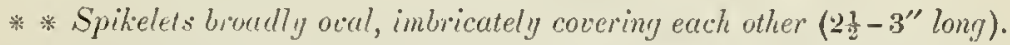

3. L. lenticulàis, Michx. (САтсн-FуY Gusss) Smoothish; panicle simple; glnnes rery hat, strongly bristly-ciliate (said to elose and catch flies); stimens 2; otherwise like the preeeding. - Low grounds, Va., Ill., aud southward.

\section{ZIZÀ N I A, Gronov. Water or Ixdian Rice. (Pl. 7.)}

Flowers monocions; the stmminate and pistillate both in 1-flowererl spike. lots in the same panicle. Glumes 2, subtenterl by a small eartilaginous ring, lorlaren-memhanarous, (m) res, awnless in the sterile, the lower one tipped with it strairlit illu in the fertile spikelets. Palet none. Stamens 6. StigI1:s pencil-form. - Targe, often reed-like water-grasses. Fikelets jointed "pon the ('lub-shaped pedicels, very deciduous. (Adopted from şávov, the ancient name of some wild grain.)

1 Z. aquática, I. (INmAx lims. WATkr OATs.) (Pl. 7, fig. 1-4.) Annual; culns $3-9^{\circ}$ high; leaves Hat, $2-3^{\circ}$ long, linear-lanceulate; louer heunches of the anple pyramidal punicle stuminute, spreading; the upper ertet, pristillate; loxer glume long-aured, rough; styles distinct; grain linear, slender, 6" long. - Swanpy borders of streams and in shallow water; common, expecially northwestward. A $\mathrm{ug}$.

2. Z. miliàcea, Michx. P'eremial; panicle diffuse, ample, the staminate unl pistillure fowers intermixed; awns short; styles united; grain ovate.P'rul. (?), Ohio, and southward. Aug - Leaves involnte. 


\section{T R I P A C U M, L. Gama-Ghass, Sesaue-Grass. (Pl. 14.)}

spikelets munxecious, in jointed unilateral spikes, staninate above and fertile below. Stmininte spikelets in pairs, sessile at each triangular joint of the narrow rhachis, both ilike, 2-fluwered, louger than the joints; glumes 4, coriaceons, the lower (unter) one nerverl, the second boat-shajed, the upper with the palets very thin and inembranaceuns, awnless; anthers opening by 2 pores at the apex. l'istillate spikelets 2-Howered (the lower flower neutral), single and deeply inbedded in each oblong joint of the cartilaginums thickened rhachis, vccupying a boat-shaped recess which is closed by the polished and eartilaginons orate outer glume, the inner glume mucls thimer and pointed, the npper with the palets very thin and scarious, pointless. Styles united; stig. mas rery long (purple), hispid. Grain oroid, free. - Culns stout and tall, solid, from very thick creeping rootstocks. Leaves lıvad and flat. Spikes axillary and terminal, separating spontaneously into joints at maturity. (Nane from $\tau \rho t \beta \omega$, to $m b$, perluaps in allusion to the polisher fertile spiko.)

1. T. dactyloides, L. Spikes $\left(4-8^{\prime}\right.$ long) $2-3$ together at the summit (when their eontignous sides are more or less Hattened), and also solitary from some of the upper sheaths (when the fertile part is cylindrical); in var. uovostacmum, the terminal spike alsu sulitary. - Hoist soil, from Conn. to Penn. and Fla., near the eoast, and from Ill. southwart. Aug. - Culn 4-7 hight ; leaves like those of Indian Corn. This is one of our largest and most remarkable Grasses; sometimes used for fodder at the South.

\section{ROTTB́́fLLIA， L. f. (Pl. 15.)}

Spikelets in pairs at each joint of a terete slender spike, awnless; one inperfect or rudimentary on a short and thick appressed perlicel; the other sessile and imbedded in an excaration of the joint of the rhachis, 1-flowered or warely with a second staminate flower. Glumes 4, obtuse, the outer hard and cartilaginous, witl a transerse depression next the base, the inner one boatshaped and membranaceons, the 2 upper thin and delicate. Stamens 3. Styles 2. - Tall or coar'se perenuials, with rigid stens, and single cartilaginons spikes terminating the stem and axillury branches, chiefty sultropical. (Naned for Prof. C. F. Rothoell, an excellent I)anish butanist, who wrote much upon (ivanines, Cyperaces, ete.)

1. R. rugosa, Nutt. Culn flattish, 2-40 highl ;eaves lineal ; spikes $1-2^{\prime}$ long, the lateral ones on short clnstered manehes in the axils, often partly inchuled in the sheaths of the leaves; sterilc flower nentral; lower glume transversely rugose. - Low pine-barrens, from S. Del. (W. M. Canby) sonthwarl near the eoast. Sept. - Oct.

\section{ERIÁ NTHUS, Miehx. Woolix Bliro-Grass. (I'l. 14.)}

Spikelets spiked, in pairs npon each joint of the slender rhachis, one sessile, tho other perlicelled, both 1-flowered, alike. Glumes 4, the 2 lower nearly equal, one 4-j-nered, the other many-nerved; the 2 upper lyaline, one empty, the npper awuer from the tip. Stamens 3. Grain free. - Tall and stont reed-like perennials, with the spikes crowded in a panicle, and clotherd with long silky hairs, especially in a tuft aromel the base of each spikelet

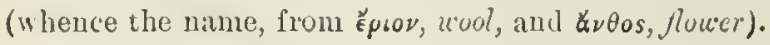


¿. E. saccharoides, Michx. (PI. 14, fig. 1, 2.) Culn (4-6 high) woolly-bearded at the joints; panicle contructed; the silky hairs longer than the sprikelets, shorter than the awn; stamens 2. (L. alopecuroides, 1:ll.) - Wet piue-barrens, from N.J. aud 111. sonthward; rare. Siept., Oct.

2. E. brevibárbis, Michx. Culn (2 $-5^{\circ}$ high), somewhat bearded at the upper joints; panicle rather open; silky hairs shorter than the spikelets. Low grounds, Va., and southward.

\section{A N D R O POG O N, liogen. Bealu-Grass. (1'l. 14.)}

Spikelets in pairs upon cacl joint of the slender rhachis, spiked or racemed, une of them pedicelled and sterile (staninate, pistillate or neutral), often a mere vestige, the other sessile, l-flowered and fertile; lower glume the larger; roliacons and nerved, blunt, the secoud carinate and acute, the 2 upper hyalin', the flowering glume avned from the tip. Stamens 1 - 3. Grain free.Coarse, mostly rigid perennials, mostly iu sterile or sandy soil; witl lateral or terminal spikes commouly clustered or digitate; the rhachis hairy or plunose-hearled, and often the sterile or staminate flowers also (wlience the name, composed of ávń $\rho$, man, aud $\pi \dot{\omega} \gamma \omega \nu$, beard).

* Synikes digitate, thickish, short-bearded, the sterile spikelet stuminute; stamens 3.

1. A. furcàtus, Muhl. (Pl. 14, fig. 1-3.) Tall, 3-40 high, rigill, the naked summit of the culm (and usually some lateral branchess) terminated by $2-5$ rigid spikes; spikelets approxinrate, appressed; lrairs at the base of the fertile spikelet, on the rhachis atud on the stunt pedicel of the awnless stamiwate spikelet short and rather sparse; awn of fertile flower long and beut; leaves Hat, ronghish, the lower ones long. ("ג. proviucialis, Lum.") - Common in dry sterile soil. Aug. - Oct.

$$
\text { * * Spikes with slender often zigzag rhachis, silky-villous, }
$$

- Single and scattered along the branches, with the silky hairs shorter than the forcers; sterile spilielet conspicuons but mostly neutral; the fertile triandrous.

2. A. Scopàrius, Michx. Culms slenter $\left(1-3^{\circ}\right.$ high), with numerons panieulate hranches; lower sheaths and narrow leaves hairy; spikes slender, scattererl, mostly perluncled ( $1-2^{\prime}$ long), rery loose, wften purplish, silky with lax dull-white hairs; sterile spikelet awn-pointed or awnless; the lertile about half the length of its twisted or bent awn.- Dry ground. Jnly-Sept.

3. A. marítimus, Chapun. Smooth aud glaucous; culms aseending from creeping rootstocks, $1-12^{\circ}$ high; leaves rather rigid, divarieate, their compressed sheaths imbricated; panicle short; peduncles included withim the conspicuous bracts; rhachis and pedicels copionsly eiliate with sprearling hairs; glumes larger, 3-4" long. - Simty sea-coast; Cape May, aud south to Fla.

+ + In pairs or clustered; the copious soft-silky laairs much longer than the flow:ers: sterile spikelet a small nentiol rudiment (in 11.4 and 5), or altogether wanting on the very plumose-hairy pedicel; fertite flower monandrous, its awn capillary; leaves narrow, the lower or their sheuths often rather hairy.

4. A. argénteus, Ell. Smontlı; anlms rather slender (I - 30 higrli);

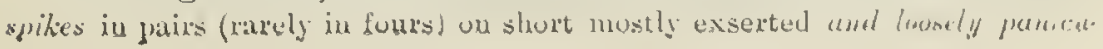


late peduncles, densely) floncered (1 - 2' long), very silky with long bright whit huirs. (A. argyraeus, Schultes.) - Md. to Va., near the coast, and southward.

5. A. Ellióttii, Chapm. Closely resembling the last; sheaths and leaves villons; upper nodes of the branches densely bearded. - Md. to Fla. and Tex.

6. A. Virgínicus, L. Cnlm flattish below, slender $\left(2-3^{\circ}\right.$ high $)$, sparingly short-branched alwre, sheaths smooth; spikes 2 or 3 together in distant apmessed cluster:s, shonter thun their sheathing loracts, weak (1'long), the spikelets loose on the filiform rhachis, the soft hairs dull white. (A, dissitiflorus, Wichx. A. vagrinatus, Ell, a form with larger and inflated sheaths.) - Sandy anil, E. Mass. to Va., Ill., and sonthward. Sept., Oct.

7. A. macroùrus, Michx. C'nlm stont $\left(2-3^{\circ}\right.$ high $)$, bushy-branched at the summit, Tourled with very numerons spikes forming thick leafy clusters; sheaths rougl, the uppermost hairy; flowers nearly as in the preeeding; the sterile spikelet of each pair wholly wanting, its pedicel slender and very phr. mose. - Low and samly grounds, N. Y. to Var, near the coast, and sonthwarrl.

8. A. laguroides, I) C. Cnlms slender, tall, the elongated pedunce hearing numerous sessile spikes in a spike-like panicle $2-4^{\prime}$ long; spikes : Hender, I'lnug or more, rery silky; spikelets glabrous, the sterile a narrm. convolute empty glume. - Central Kan. to Tex. and Mex.

to +t Symikes digitute-rlustered, very sitky; sterile spikelet larger than the? fertile one.

9. A. Hàllii, Irackel. Culm stout, $2-3^{\circ}$ high; lateral peduneles fer, searcely exserted from the sheaths; spikes $2-5,1-3^{\prime}$ long, dense; spikelets $3-4$ " long. - Central Kan, to Dak, and westward.

\section{CHRYSOPÒGON, Trim. (Pl. 14.)}

Spikelets in pairs on the ramifications of an open panicle (those at the ends of the branches in threes), the latcral ones pedicellate, sterile or often rednced mercly to their perlicels; only the sessile middle or terminal one fertilc, its ghmes coriaceons or indurated, sometimes awnless; otherwise nearly as in Ludropogun. Stamens 3. (Name composed of $\chi \rho v \sigma o ́ s$, gold, and $\pi \dot{\omega} \gamma \omega \nu$, beard.)

1. C. nùtans, Benth. (1Noman Grass. Woon-Grass.) Root peremuial; 'nlm simple $\left(3-5^{\circ} \mathrm{high}\right)$, terete; leaves linear-lanceolate, glancous; sheatlis surosth; panicte narrowly oblong, crowded or loose $\left(6-12^{\prime}\right.$ long $)$; the perfect spikclets at length drooping (yellowish or russet-hrown and shining), elotheu especially twward the base with fawn-colored hairs, lanceolate, shorter than the twisterl awn; sterile spikelets small and imperfect, decidnons, or redueed to a mere plomose-lairy pedicel. (Andropogon arenacens, Michx. Sorghum lutams, (row.) - I) ry sil ; common, especially southward.

\section{PHálaris, I. Canart-Grass. (Pl. 13.)}

Spikelets (rowrled in a clustered or spiked pan:-ies 1-flowered. Glumes 5, the thiri aud fourth redneed to mere rudiments (a scale or a pedicel), one on eacli side, at the hase of the flowering ghume and palet, whieh are flattish, awnless and shining, shorter than the equal boat-shaped and keeled persistcnt empty glnmes, finally coriaeeous or cartilaginons, and closely enclosing the flattenci free and smooth grain. Stanens 3. - Leares broad, mostly flat

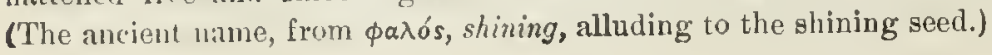


§ 1. PHALARIS proper. Panicle very dense, spike-like; ylumes wing-keeled.

P. Caxaménsis, L. (Cañax-Grass.) Amual, $1-2^{\circ}$ high; spike "ral enpty glumes white witl green reins, the rudimentary ones small lanceolate scales. - Waste places and roadsides; rare. ( $\Lambda$ wr. from Eu.)

\$2. DIGRAPHIS. Panicle branched, the clusters open in unthesis; glumes not uinged on the back.

1. P. arundinàcea, L. (RELd C.) (P1. 13, fig. 1, 2.) Perenuial, $2-4^{\circ}$ high; leaves that $(3-5)^{\prime \prime}$ wicle); glumes open at flowering, 3-nerved, thrice the length of the fertile flower; ruclimentary glumes reduced to a minute hairy scale or peclicel. - Wet grounds; common, especially northward. June, July - Var. pfora, the leaves striped with white, is the familiar Ris. Box-Grass of the gardens. (Eu.)

\section{ANThoXánthum, I. Sweet Vernal-Grass.}

(P1. 13.)

Spikelets spiked-panicled, 1-flowered. Glumes 5, the third and fourth empty, liairy, 2-lobed and awned on the back, the flowering glume and palet smail, hyaline aud obtuse; basal glumes persistent, very thin, acute, keeled, the lower half as long as the upper. Syuamula none. Stamens 2. Grain ovate,

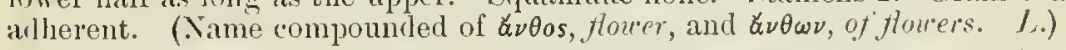

A. onoldтr. I. Spikelets (brownish or tinged with green) sprealing at fowering-time; one midlle glume bearing a bent awn from near its base, the other short-awned below the tip. - Meadows, pastures, etc. Low slender perennial; rery sweet-scented in drying. May-July. (Nat. from Eu.)

\section{H I E RÓ CH LOE, Gmelin. Holy Grass. (Pl. 13.)}

Spikelets 3-flowerer, open-panicled, the two lower (lateral) flowers staninate only, 3-androus, sessile, the carinate glumes often awned on the micldle of the back or near the tip, the uppermust fluwer perfect, sliort-pedicelled, scarcely as long as the others, 2-indrous, awnless. Basal glumes persistent, carinate, acnte, somewhat 3 -nerved, eqnalling or exceeling the spikelet. - Perennials; leaves flat. (Name composed of ifp's, sucred, and $\chi$ 入ón, grass; these sweetscented grasses being strewn before the church-doors on saints' days, in the North of Europe.)

1. H. boreàlis, Ruem. \& Schultes. (Yaxilla or Sexeca Grass.) (Pl. 13, fig. 1, 2.) Panicle somewhat one-sided, pyranidal (2-5' long); peduncles smooth; staninate Howers with the glume mncronate or bristle-pointerl at or near the tip; rootstock creeping. - Moist mealows, chiefly northward near the coast and along the Great Lakes. May. - Culu $1-2^{\circ}$ high, with short, lanceolate leaves. Spikelets chestnut-color; the staninate flowers strongly hairy-fringed on the margins, and the fertile one at the tip. (Eu.)

2. H. alpina, Ruem. \& Schultes. Panicle contracted (1-2’ long) ; one of the staminate flowers with its glnme barely pointed or short-awned near the tip, the other long-awned from below tho middle; lowest leaves very narrow. - Alpine mountain-tops, N. Eng., N. Y., and northwart. July. (Eu.)

\section{ARÍstid A, L. Triple-Awned Grass. (Pl. 8.)}

Spikelets 1-flowered, not jointed on the pedicels. Onter glumes unequal, wf(en bristle-pointed; the flowering glume tipped with three awns; clie palet unch smaller. Otlerwise much as in Stipa- - Culms loranching; leaves nar- 
row, often involute. Spikelets in simple or panicled reemes or spikes. Grain linear. All grow in sterile, dry soil, and all ours lave the awns paked and persistent, and Hower late. (Name from arista, a beard or awn.)

* A uns separate to the base, not jointed witle the glume.

+ Axns very unequal; the much shorter or minute lateral ones erect, the elongated middle one horizontal or turned downeurd; low $\left(5-18^{\prime}\right.$ ligh) and branching, mostly tufted anmuals, and the spikelets in neurly simple spikes.

+ Middle awn more or less coiled.

1. A. ramosíssima, Engelm. Culms much branched; spikes loose, ursually exserted; lower glumes $6-10^{\prime \prime}$ long, exceeding the upper, nsually rather strongly 3-5-nerved; middle awn $\mathrm{I}^{\prime}$ long, soon abruptly hooked-recurved, the lateral ones $1-3^{\prime \prime}$ long, - Dry prairies of 1ll., Ky., and Mo.Also var. Unisuistita, Engelm., with the latelal awnis wanting.

2. A. basiràmea, Engelm. Spikes closer, nostly enclosed at base, at all the lower nodes (even to the base of the culm) very short and sessile; lower glumes $4-8$ "long, nostly thin and I-nerved or rather faintly 3-nerved; middle awn rery sleuder, 6 " long, the lateral $2^{\prime \prime}$ long, - Ill. to Neb. and Minn.

3. A. dichótoma, Miclux. (Povertr Grass.) Culms luw, very slender, mueh branched throughout, as'ending; spikelets in narrow strict simple or compound spikes; lower glumes nearly equal ( $3-4^{\prime \prime}$ long), longer than the flowering glune and fully equalling its minute lateral awros (or unequal and slorter, in var. Curtissn, Gray), the soon reflexed mildle awn about an long. - Dry, sandy or gravelly fields; common, Maine to Ill., and southward.

++ Middle aun nearly straight (not coiled).

4. A. grácilis, Ell. Culms slender, erect $\left(6-18^{\prime}\right.$ high), naked above and terminating in a slender raceme- or spike-like virgate pauicle; lower glumes I-nerved, about the length of the upper, the exserter lateral awus varying from one third to fully half the lengtly of the horizontally bent middle one: or in var. neparperita, from one fifth to one third its length. - Sandy soil, eonst of Mass, ant from Ill. sonthwarl. - Middle awn 3-9" long in the ordinary forms, but not rarely shorter, and very variable often on the same plant.

+ - Awns all diverging and alite, or the laterul ones moderately shorter, rarely at all coilert.

+ Glumes equal or the middle one longer.

5. A. stricta, Michx. Culms $\left(2-3^{\circ}\right.$ high) ilensely tufted from a peren. zichl root, bearing a $\left(1^{\circ}\right)$ long spiliced panicle; leares involute-thread-form, long, rigill, sometimes dlowny; awns abont the length of the glnmes $\left(6^{\prime \prime}\right)$ or the lateral one third shorter. - Va. and sonthward.

6. A. oligántha, Jichx. Culms $(6-20$ highl $)$ tufted from an amual root, bearing a loosely, feu-flocered rucrme; leaves short, somewhat involuta

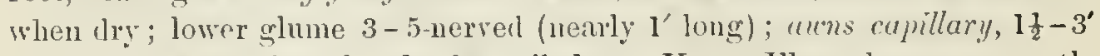
long, much exceeding the slender spikelet. - Va. to Ill, and common southwestiward.

7. A. purpùrea, Nutt. Perenuial; culms ( $1^{\circ}$ high or less) densely tnfterl, sprealing; leaves rerolute and filiform, short; panicle loose, of rather few sleuder-pedicellate spikelets; lower glumes thin, i-nerved, loose, the outer 
abont half the length of the imer, which is $8-10^{\prime \prime}$ long; awus $2-4^{\prime \prime}$ long. Minn. and the Dakutas to Tex. - Very variable.

++ Middle ghume shorter thun the loneer; perenmials, simple-stemmed, $2-4^{\circ}$ high.

8. A. purpuráscens, l'oir. (PI. 8.) Glolurous: leaver long, rathe1 involute; spikelets in a (10-18') long spiked panicle; lower glumes i-nerved; anes much longes then the spilielet, the midule une about l' long. - Mass. to Mich., Mimn., and southward; conmun.

9. A. lanàta, Poir. T'all aul stont; leares tarlily involute, rough above, rigidl shenths "rolly; panicle ( 1 - 20 long) suike-like or more compound and open; glmes 1-neved, 6-8" long; middle awu I' long. - Del. to Fla.

* * I uns mitrd below into one, jointed with the apex of the glume; root cmmul.

10. A. tuberculòsa, Nutt. Cnlm branched below (6-18' high), tumid at the joints; panicles rigid, loose, the branches in pairs, one of them short and about 2-flowered, the other elongated and sereral-fowered; lower golumes (l' long, including their slender-awned tips) longer than the upper, which is tipjed with the eommon stalk (abont its own length) of the 3 equal divergently-bent awns ( $1 \frac{1}{2}-2^{\prime}$ long) twisting togetlee at the base. - Sandy soil, $\mathrm{L}^{-}$. Mass. to N. J.; also Wisc., Minn., and southward.

\section{STİPA, L. Featmer-Grass. (Pl. 8.)}

Spikelets 1-flowered, terete; the fower falling away at maturity (with the conspicnous obconical bearded aud often sharp-pointerl callus) from the mem. branaceous persistent lower glumes. Fertile glmmes coriaceous, cylindricalinvolute and closely embracing the smaller palet and the cylindrical grain, having a long and twisted or tortums simple awn jointed with its apex. Stamens mostly 3. Stigmas pinnose. - Perennials, with nawow involute laves and a loose panicle. (Name from $\sigma \tau u ́ \pi \eta$, ton, in allusion to the flaxen appearance of the feathery awns of the original species. In our species the awn is naked.)

* Callus or base of the flower short and bhut; lower glumes pointless.

1. S. Richardsònii, Link. Culn $\left(1 \frac{1}{2}-2^{\circ}\right.$ higil $)$ and leaves slender; panicle loose $\left(4-5^{\prime}\right.$ long), witl slender few-flowered branches; lower ghtumes nearly equal, oblong, acutisl $\left(2 \frac{1}{2}-4^{\prime \prime}\right.$ long), about equalling the pubescent linear-oblong fertile one, which beass a tortuous awn 6-9" Inng. - l'leasant Mountain, near Sebago Lake, Maine, Mt. Marcy, N. I., north shore of L Superior, Mont., and northward.

* Callus pungently pointed, at maturity villons-bearded; flowering glume slen. der and minutely bearded at the tip; empty glumes taper-pointed.

2. S. avenàcea, L. (BLAck OAx-GRAss.) (Pl. 8.) Culm slender (1$2^{\circ}$ high); leares almost bristle-form; panicle open; fertile glume blackish, nearly as long as the lower ones (abont 4 "long); the awn bent above, twisted below (2-3' long). - Dry woods, S. New Eng, to Wisc., aud sonthward.

3. S. spártea, Trin. (Porcurine Grass.) Culu ratler stout ( $1 \frac{1}{2}-3^{\circ}$ high); panicle contracted; fertile glume linear, $\frac{8}{4}-1^{\prime}$ long (including the long (allus), pubescent below, shorter than the lanceolate slender subulate-pointer 


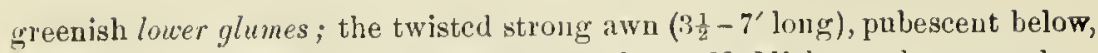
jough above. - Plains and prairies, from IIl. and N. Mich. northwestward.

4. S. virídula, Trin. Culns clusteren, 1-30 high or more; janicle narrow and usually dense, 6-18' long; glumes very thin, 3-4" long; fertile glume usually somewhat silky, with a short callus; awn l' loug, slender, glabrous or a little pubescent below.-W. Minn., the Iakotas, aud southwestward.

\section{ORYZÓPSIS, Michx. Mouxtax Rice. (P'l. 8.)}

Spikclets l-flowered, nearly terete. Lower glumes herbaceous or thin-mcmbranaceous, several-nerved, nearly equal, commonly rather longer than the oblong flower, which is decirhons at matnrity, and with a very slort olstuse callus or sear-like base. Flowering glune coriaceous, at lengtl involute so as closely to criclose the equal palet and the oblong grain; a simple nntwister and decidnous awn jointed on its apex. Stamens 3 . S'quamula 2 or 3, conspicuons. Stignas plumose. - Perennials, with rigid leaves and a narrow raceme or panirle. Sipikclets greenish, rather large. (Name composed of

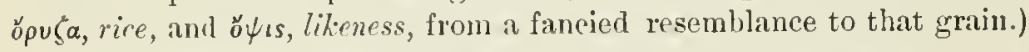

* Styles distinct, short; culm leafy to the summit; leaves broad and flat.

1. O. melanocárpa, Mulıl. Leaves lanceolate, taper-pointed; sheaths bearderl in the throat; panicle simple or sparingly branched; awn thrice the longth of the blackish glume (nearly 1' long). - Rocky woods, N. Eng. to Yenn., Minn., Mo., and westwarl. Ang. - Culm 2-3 high.

* Styles united below, slender; culms tufted, nalied; leaves concave or involute.

2. O. asperifolia, Miclıx. (Pl. 8, fig. 1, 2.) Culms $\left(9-18^{\prime}\right.$ high), with sheaths bcaring a merc rudimentary blade, overtopped by the long and rigid lineur leaf from the buse; very simple panicle or raceme few-flowered; "un 2-3 times the length of the rather hairy whitish glume. - Hillsides, ete., in rich woods; common, N. Ling. to Minn, and northwarl. May. - Leaves without kecks, rough-edged, pale bencath, lasting through the winter. Squamnlat lanceolate, almost as long as tho palet!

3. O. Canadénsis, 'Torr. Culus sleurler $(6-15$ ' high $)$, the lowest theaths leaf-bearing; leaves involute-thread-shraped; panicle contracted (1-2' long), the brancles usually in pairs; glume jullescent, whitish; aun shorf and cery decilunus, or wrenting. - locky hills and dry pluins, Maine to W. New Fing, the mountaius of I'eun., W'isc., Minn., ancl northward; rare. May.Cilumes 1-2" long, sometimes purplish.

\section{MÍI I M, 'lourn. Mump-Grass. ('ll 13.)}

Sipikelets 1-flowered, diffusely paniclen, not jointed with their perlicels, con. misting of 2 equal nembranaceous convex and awrless persistent glnmes, with a coriacenus awnlws flowering glume and narrow palet. Stamens 3. Stigunas branchel-plumuse. Crain not grooverl, enclosel in its glume and palet, all deciolums tomgether. (The ancient Latin name of the Millet, which however belongs to a lifferent gems, of uncertain menting.)

1. M. effùsum, I. Smooth perennial, $3-6^{\circ}$ high; leaves broad and flat, thin; panicle spreating $\left(6-9^{\prime}\right.$ long); flower ovoirl-oblong. - Cold damp wools and inountain incadows, N. Eng. to Ill., and nortlıwarl. June. (Eu) 
23. MUHLENBÉRGIA, Schreber. Drop-seed G. (Pl.8.)

Spikelets 1-flowered, in contraeted or rarely in open panicles. Empty ghmes mostly acute or bristle-pointed, persistent, usually thin; the lower rather smaller or minnte. Flower very short-stalked or sessile, the glume and palet tsually minutely bearded at base, herbaeeons, deciduons with the enelosed grain, often equal, the glume 3-nerved, mucronate or awned at the apex. Stamens 3. (Dedieated to the Rev. Di. Itenry Wuhlentery, a distinguisher? Ameriean botanist of the early part of this century.)

§ 1. MUHLENBEliGIA proper. I'unicles contracted or glomerate, on branch. ing rigid culms from scaly creeping rootstucks; leaces short and nurrow.

* Florering glume burely mucronate or slurp-pointed.

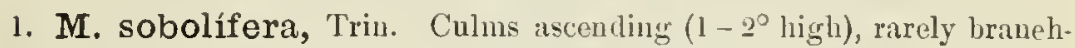
ing; the simple contracted panicle very slender or filifurm ; lower glumes barely pointed, almost equal, one third shorter than the floner; Howering glume abruptly short-mueronate, equalling the palet. - " pen locky woods, Mass. to Mieh., Minu., and sonthward. Aug. - Spikelets less than I" long.

2. M. glomeràta, Triu. Culms upright ( $1-3^{\circ}$ high $)$, sparingly branched or simple; panicle (2-3' long) oblong-lineur, contrurted into an intermupter glomerate spike, long-perluneled, the branches sessile; ylumes auned, nearly: equal, and (with the bristle-like awn) about twiee the length of the unequal very acute Howering glume and palet. - Bogs aud wet rocks, rommon, especially northward. Ang. - Var. lisuon, Tasey. A stont strict mueh-branched leafy form, the lower glumes but little longer than the flower. Ill. to S. Iak.

3. M. Mexicàna, Triı. Culnss ascending, much branched $\left(2-33^{\circ}\right.$ high $\left.{ }_{1}\right)$; panicles lateral and terminal, often ineluded at the base, contracted, the brom densely spiked-chustered, linear (green and purplish); lower glumes aunles:, sharp-pointed, unequal, the uprer about the length of the very acnte flowering one.-Low grounds; common. Ang. Varies with more slender panieles.

* Flowering glume bristle-awned from the tip; flowers short-pedicelled.

- Lower glumes long and bristle-pointed.

4. M. sylvática, Torr. \& Gray. (Pl. 8, fig. 1, 2.) Culms aseending, much branehed and diffusely sprearling $\left(2-4^{\circ}\right.$ long); contracted promicles densely many-flowered; lower glumes almost equal, bristle-pointed, nearly as long as the flowering one, whicl bears an awn twice or thriee the length of the spikelet. - Inw or roeky woods; common. Alt., Sept.

5. M. ambígua, Torr. Culms ascending, clustered and branching, 10 high; panicles eontraeted, densely many-flowered; spikclet 2-flowered, the upper flower like the lower and perfeet, or more frequently redueerl to a mere awn at the hase of the lower flower; lower glumes nearly equal, long-pointerl florering glume villous, as long as the lower and equalling the palet, its awn nearly twice longer. - Minn. (shore of Elysian Lake, Waseca Co., Geyer). A remarkable species, approalhing Brachyelytrum in the structure of the spikelet, but with wholly the habit of Muhlenbergia.

$$
\text { + + Lower glumes short or minute, not or serrely pointed. }
$$

6. M. Willdenòvii, Trin. Cnlms upright ( $3^{\circ} \mathrm{high}$ ), slender, simple or sparingl! hranched ; contracted ponicle slendrr, loosely flowered; loner glumts 
s'ightly unequal, shmt-printed, hu!f the length of the foucering one, which hears an awn 3-4 times the longtl of the spikelet. - Rocky woorls; rather com mon. Aug.

7. M. diffúsa, Schreher. (1) Morked. Nrmble Wrll.) (Pl. 8, fig. 3-5.) Culns diffusely much branched (8-18' high); contracted panicles slender, rather loosely mauy-flowered, terminal ancl lateral; empty glumes extremely minute, the louer absolete, the upper truncate; awn once or twice longer than the flowering glume. - Jry hills ind woods, from 5 . New Eng to Mich., lowa, and southward. Aug., Sept. - spikelets only $1^{\prime \prime}$ long.

§. TRICHÓCHLOA. Punirle rery loose und open, the long branches and pedicels eupillar!y; leaves narrou, often convolute-bristle-form.

8. M. capillàris, Knnth. (Hım-Gruss) Culm simple, "pright (2 high) from a tihous root; pauicle capillary, expanting (6-20' long, pnrple); empty glumes unequal, the lower nostly pointless, the upper more or less bristle-pointed, one third or half the lesgth of the long-awned flowering ghme. - Sandy soil, W. New Eng. to N. I., Ky., Mu., and sonthward. Sept I'edicels $1-2^{\prime}$ loug, scarceiy thicker than the awns, which are about $\mathbf{l}^{\prime}$ long.

\section{B R A C H Y É L Y T R U M, Beauv.}

Spikelets 1-flowered, with a conspicuoms filiform pedicel of an abortive sec. ond flower about half its length, nearly terete, few, in a simple appressed racemed panicle. Lower glumes mecfual, persistent, usually minute, or the lower one almost obsolcte. Flowering glume and palet charticev-herbaceous, involute, enclosing the linear-ohlong grain, somewhat equal, rongh with scattered short bristles, the first 5-nerved, extended into a long stritight am, the palet 2-pointed; the awn-like sterile pelicel partly lodged in the groove on its back. Stamens 2; anthers and stigmas very long. - l'eremnial, with simple ('ulms $\left(1-3^{\circ}\right.$ high) from creeping rootstocks, dowy sheaths, broul and flat lanceolate pointed leares, and spikelets $\frac{y^{\prime}}{2} \ln g$ withont the awn. (Namecomjosed of $\beta \rho \alpha \chi$ is, short, and Ěx $v \tau \rho o \nu$, hisk, from the minute glumes.)

1. B. aristàtum, Beaur. Rocky woods; common. June. - Vill. Ex(iBLM $\Lambda$ NNI, Gray, is a western form, with the sccoul glume awn-pointed, nearly half the length of the flowering one.

\section{HELEÓCHLOA, Host. (Pl. 7.)}

Spikelets 1-flowered, crowled in a dense spike ur spike-like panicle. Lower glumes persistent, membranaceons, ante, ciliate-curuate, awnless ; flowering glume similar, a little longer, ancl a little exceeding the palet. Stamens 3.Iow cespitose anmals; spike often scarcely exserted from the nl]per sheath.

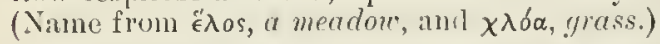

H. scuncioines, Host. Isually nearly prostrate and tufted; leaves rather rigirl, tapering to a slarp point; spike oblong, thick, $7-20^{\prime \prime}$ long. (Crypsis s('hoenoiles, Lam.) - Waste places, N. J. to Del. (Nat. from Lu.)

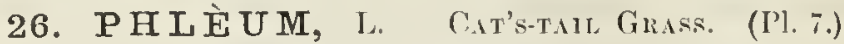

Spikelets 1-Howered, in a very dense cylindrical spike-like pandele. Iower glumes persistent, membranaceons, folled-carinate, snlot runcate, muronate or short-awned; flowering glume hyaline, shorter, trumcate. Stamens i3. Sityles distinct. - l'eremials. (From $\phi \lambda \epsilon^{\prime} \omega s$, a Greek mame for a kind of peed.) 
P. phatesse, L. (Thothy. Heris's-Grass in New Eng. and N. Y.) 'Tall; spike long-cylintricul; lower glmmes ciliate on the back, tipped with $a$ short bristle. - Meadows, commonly cultivated for hay. (Nat. from Eu.)

1. P. alpinum, L. Low; spilie orote-ollong; lower glmmes strongly ciliate on the back, tipped with a rongh awn about their own length. - Alpine tops of the White Mountains, N. 11., :url high northward. (En.)

\section{A L OPECŨRUS, L. Foxtale Grass. (Pl. 7.)}

Spikelets 1-flowered, jointed on the pedieel. Lower glumes boat-slapeds strongly compressed and keeled, nealy equal, mniterl at hase, equalling or exceeding the flowering glume, which is awned on the hack below the midlle; palet mostly wanting! Stamens 3. Styles mostly united. Stigmas long and feathered. - Clnsters contracted into a cylinlrical and soft dense spike; perennial. (Name from $\dot{a} \lambda \dot{\omega} \pi \eta \xi$, for, and oúpá,fail, from the shape of the spike.)

A. prateisis, L. (Meanow Foxtall.) ('ulm ujuright, smonth (20 high);

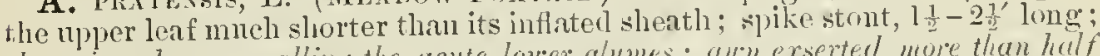
flowering glume equalling the acute lover glumes: and erserted more than half its length, twi d. - Meaduws and pastures, eastward. May. (Nat. from En.)

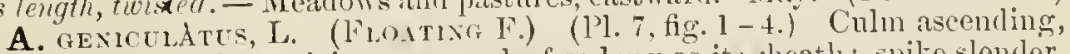
often bent at the lower joints; uper leaf as long as its sheatlı; spike slender, $1-2^{\prime}$ long; flowering ylume rather shorter than the obtuse lomer y/umes, the an'n fiom near its buse and projecting from half to treire its length bejond it. - Moist mealows, eastwarl. June-Aing. (Nat. from En.)

Var. aristulàtus, Torr. The awn very slender and scarcely exserted. (1. aristulatus, Michx.) - In water and wet places; common. June-Aug.

\section{SPORÓBOLUS, R. Br. Drop-Seen Grass. Rusir-Grass. (Pl. 7.)}

Spikelets small, 1- (rarely 2-) flowered, in an opeu or contracted or spiked panicle. Lower glumes persistent, 1-3-nerved, not awned or pointed, the lower smaller; flowering glume of the same textnre as the lower ones (membranaceo-chartaceons) and nsually longer than they, naked, awnless and mostly pointless, 1-nerved (rarely somewhat 3-nered) ; palet similar, 2-nerver. Stamens chiefly 3. Stigmas simply feathery. Grain glolular to oblong or cylindrical, deciduous, often very thin, containing the loose seed. - Culns wiry or rigil. Leares involnte, the throat usually bearded, and sheaths often

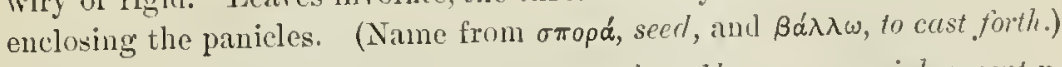

* Panicle contracted, often simple; grain ocal or oblong: perennial, except n. 2.

1. S. ásper, Kinntlı. ('nlms tufted $\left(2-4^{\circ}\right.$ high); lowest leaves very long, rigil, rough on the elges, tapering to a long involute and threal-like point, the nper short, involute; sheaths partly or at first wholly enclusing the contracted panicle; flower murh longer then the nnequal louer glumes; grain oral or oblong. (Vilfa astern, Beaur.) - Sandy fields and dry hills, especially sonthwart. Sept. - Spikelets 2-3" long. Flowering glnme and palet rough above. smooth or hairy helow, the palet tapering upward, acnte, anil one half to twice longer than the glume, or else obtuse and equalled or even considerably exceelerl by the glume!

2. S. vaginæflorus, Tasey. (I'l. 7, fig. 4, 5.) Culms slender (6-12' high), ascencliug; leaves involute-awl shapel $\left(1-4^{\prime} \mathrm{long}\right)$; panicles simple and spiked, the lateral and often the terminal concealed in the sheaths; flower. 
ing glume and palrt somewhut equal, acute, about the length of the nearly equat. lower glumes, wnly $\frac{1}{3}$ longer thau the oval grain. (Vilfa vaginaflora, Torr.) - Barren and sindy diy ficlis; common, especially sontlwarc. Sept.

3. S. cuspidàtus, 'lorr. Frect cuhns and appressed leaves more slender than in the precerling; punicle exsmpd, very simple and narrow; spikelets smaller, the lower glumes acuminute, little shorter than the euspilate upper une. (Vilfa cuspilata, Torr.) - Manine (on the St. Jolm's River, G. L. Good (1)e) ; also Iowa, Minn., aud common westward.

4. S. depauperatus, Vasey. liesembling n. 3, but the culms decum bent at base and matted, the leaves short and nsually widely spreading, and the lower glumes barely acute, not hall the length of the upper one. - W. Minn. to Kin., and sonthwestward.

5. S. Virgínicus, linnth. Culms tufterl, slender (5-12' long), often procumbent, bumbed; leaves convolute, rigil ; jalets rather shorter than the nearly equal acute glmmes. (Vilfa Virginica, Beane.) - Sandy seashore, Virginla (Cheyton) and sonthward. - Spikelets much smaller and more numerous than in the others.

6. S. minor, Varsey. Culms tufted, rery slender, geniculate and ascent. ing, sinple, $1^{\circ}$ high; leaves short and namow ; peduncles little exserted from?

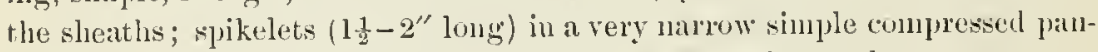
icle ( 1 - 2' long), not crowded: mhmes and palet ncally equal, acute or sone What acuminate. - Va. to Y. C., 'T'enn, and 'T'es.

S. frumcts, R. Br. Cnhns stout, erect, 2-30 hight leaves elongated, attenthate; panicle very narow, $6-18^{\prime}$ long, the densely crowdenl spikelets $\frac{1}{2}$ " long. - On ballast, and naturalized sonthward. (From Trop. $\Lambda \mathrm{m}$.)

* Panicle pyramidul, open; glumes rery mequal; grain globose, utricular, pereminils.

7. S. júnceus, Kunth. Lenees incolute, marrow, rigid, the lorest elon-

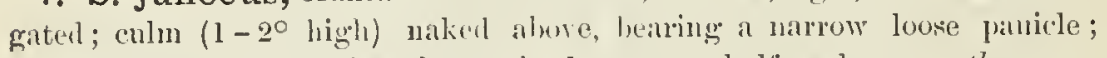
empty glumes ovute, ruther obtuse, the lower one lalf as long as, the upper

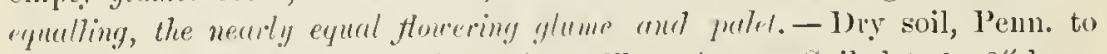

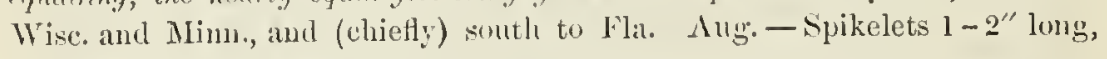
shining.

8. S. heterólepis, Grạ. Leures incululo-lhered-form, rigid, the luwest as long ats the culm $\left(1-2^{\circ}\right)$ which is naked alowe; lanicle rery lowse; ennpty ghumes rery unequal; the loure aul-shuyed for bristle-pointed from a hroal liase) and somewhat shorter, the "lyper orate-ublung and tenper-pointed and honger,

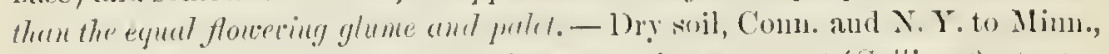
Nob, and I,Io. Aug. - l'lant exhaling an unpleasant scent (Sullirent), stouter thin the last, the spikelets thrice larger. Itricle $I^{\prime \prime}$ in dimeter, shining, thick and coriacenus!

9. S. cryptándrus, Grạ: (Pl. 7, fig. 1-3.) Culm 2-3 high; leares fut, pale (2" wide); the pyrimidal learl-colored panicle bursting from the up. fur sheath which usuilly encluses its base, its spreadiug hranches hairy in the axils; spikelets 1" loug; "pper empty glume lancolate, rather acute, twite the Twyth of the lower one, as long as the nearly equal Howering glume and pilet; shuatlis strongly hearded at the thruat. - Sindy slores, coast of New ling. and of the Gresit Takes, Mim. to kim., ant westward. Aug., Sept. 
10. S. airoides, 'Torr. Culnu tufterl, ofte'n stont, erect, $\frac{1}{2}-3^{\circ}$ high; leares strongly revolute and attennate, rather rigicl ; panicle open and diffuse, broadly pyranidal, glabrous; spikelets solitary un slender pedicels, I" long; lower glumes unequal, lather olstuse. - Veb. Lo'l'ex, and westward.

S. Aslperifóches, Thurh, a sinilat hut smallur species, with thimer and shorter leaves very rough on the margin, the inflorescence scabrous, and spikelets smaller, with the glumes nearly crual, is iery common westwarl, and probably occurs within our limits - as also $x$. coxfites, Vasey ( anthors, not $\left.K^{*} u n t h\right)$, a low slendre anmal, with very short enlums and a delicate diffuse paniele, the very small spikelets ( $\frac{1}{2}$ " $\mathrm{long}$ ) on filiform-clavate jeclicels.

* * Empty glumes almost equnl: panicle rucemose-clongated, open, the predicels rupillar!y; sheaths wated at the throat; spilielets not unfiequently turoflovered: peremial.

11. S. compréssus, kinnth. Very smooth, leafy to the top); (alms luffed, stout, cery. flat: sheaths flattened, nuch longer than the internodes; irmes erect, uar'row, conduplicate-channelled; empty ghmes acutish, abont one third shorter than the obtuse flowering onr. - Bogs, on long Island and in the pine-harrens of X... Sept. - Forming strong tussocks, $1-2^{\circ}$ high. Panicle $8-12$ loug; spikelets 1" long, purplisl.

12. S. serótinus, Gray. Smooth; culms very slender, fluttish (8-15' high), fir-leared; leares very slenter, chanuelled; panicle soon much exserted, the diffuse capillary branches scattered; glumes orate, obtuse, abont half the lengrth of the flower. - Saudy wet places, Maine to N. J. and Mich. Sept. A very delicate grass; the spikelets half a line long.

\section{A GRóstis, I. Buxt-Grass. (Pl. 7.)}

Spikelets 1-flowered, in an open paniele. Empty glumes somewhat equal, or the lower rather longer, nsually. longer than the flowering one, pointless. Flowering glume and palet very thin, pointless, nalied; the first 3-5-nerver, frequently awned on the back; the palet often minute or none. Stamens chiefly 3. Crain (earyopsis) free. - Culms usually tufted, slender; root rom. monly perennial. (Name from àyós, a field, the place of growth.)

\$1. AGROSTIS proper. Palet manifest, but shorter than the glume.

A. Aldid, L. (Fiorix or Wrmte Bext-Grass.) Rootstocks ereeping or stoluniferons; culms $1-2^{\circ}$ high, often decommlent at base; leaves short, Hat, the lignle long and acnte; panicle contracted after flowering, greenish purplish or brownish, the branches slightly rough; flowering gome nearly equalling the empty ones, 3-nerved, rarely short-awned, the palet about lablf as long. - Meadows and fields, a valuable grass; naturalized from En. and conItivated, aud perhaps native north and westward.

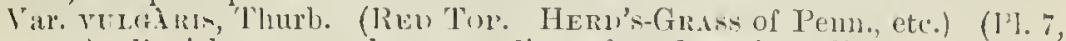
fir. 1, 2.) l'anicle more or less spreading after floweriug; lignle short and truneate. (A. vulgaris, With.) - Low meadows and pastures; nat. from Eu. and cultivated, also perhaps indigenous.

1. A. arachnoides, Ell. Culms ( $1^{\circ}$ high) and leaves very slender; panicle open, weak and drooping; glumes nearly equal, loughish on the keel and margins, the flowering glume shorter, with 2 mimte bristles at the trun. eate apex and a long exceelingly delicate awn on the back above the middle palet uninute. - Mo, to Ky., Tonn., and S. Car. 
2. A. exaràta, Trin. Culms ereet, 1-20 high; leaves mostly ereet; panicle narrow, erowded, greeuish, the rays mostly flower-liearing to the base; spikelets $1 \frac{1}{2}-2^{\prime \prime}$ long; glnmes nearly equal, acnte, the floweriug ones shorter, sometimes awned above the middle. - Wisc. (Vasey) to Sask., and far westward.

\section{§2. TRICHÒDIUM. Palet abortive, minute, or none.}

3. A. elàta, 'Trin. Culms firm or stout $\left(2-3^{\circ}\right.$ high $)$; leaves flat $\left(1-2^{\prime \prime}\right.$ wide); upper ligules elongated ( $\left.2-3^{\prime \prime} \mathrm{long}\right)$; spikelets crouded on the branches

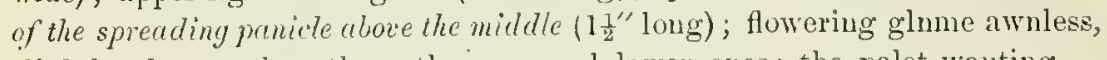
slightly shorter than the rather unequal lower ones; the palet wanting. Swamps, N. J. and southward. Oct.

4. A. perénnans, Tuckem. (Tnis-Grass.) Culms slender, ereet from a lleetmbent base $\left(1-2^{\circ}\right.$ bigh) ; leaves flat (the upper $4-6^{\prime}$ long, $1-2^{\prime \prime}$ wide); panicle at length diffisely spreading, pule green; the branches short, divided and flower-beuring from or below the middle; flowering glume aunless (rarely short-awned), shorter than the unequal lower ones; the palet ninute or obsolete. - Damp shaded places. July, $A$ ug. - spikelets, ete., as in n. 5, into which it seems to vary.

5. A. scàbra, Willd. (Han-Griss.) (1'l. 7, fig. 3.) Cutms very slen$d r$, ereet $\left(\mathrm{l}-2^{\circ} \mathrm{high}\right)$; leaves short and narrow, the lower soon involnte (the upper 1-3' long, less than $\mathbf{l}^{\prime \prime}$ wide); panicle very loose and dirergent, purflish, the long capillary branches flower-bearing at and near the apex; flowering glume aunless or occasionally short-umed on the back, shorter than the rather unequal very acute empty ones; the palet minute or olsolete ; root biennial! - Exsiceated places; eommon. June-Aug. - Remarkable for the long and divergent capillary branches of the extremely loose panicle; these are whorled, rough with very minute bristles (under a lens), as also the keel of the glumes. Spikelets $\mathrm{I}^{\prime \prime}$ loug. A chwarf momtain form oceurs, growing in tufts in lollows of rocks, ete. - A variety (?) from abont the White Mountains, ete. (rar. mont:nil, Tucherm.), has a more or less exserted awn.

6. A. canina, L. (Browr Brit-Grass.) Culms 8'-2o ligh; root leaves involute-lristle-form, those of the eulm flat and broarer; panicle loose; lower glumes slightly unequal, ovate-lanceolate, very acute, the flowering one exserlly auned on the buck at or below the middle; spikelets brownish or porplish, rarely pale or greenish ( 1 - 1 1" long). - Meadows, sparingly naturalized eastward. $A$ mountain form with shorter and more spreading panicle $(\Lambda$. Pickeríngii \& 1 . eoncinna, Tuckerm., A. canina, var, alpina, Oches, \& El. 2;

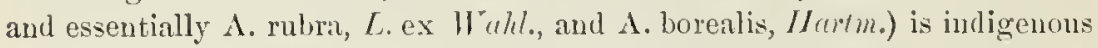
on mountain-tops, Maine to N. Y.; also an ampler form in the Alleglutuies of Penn. and southward (A. rupéstris, Chupman, etc.). July-Aug. (Eu.)

\section{P L L y $\mathrm{P}$ G O N, Desf. Bearn-Grass. (Pl. 8.)}

Sipikelets I-flowered, in a contracted, mostly spike-like panicle. Empty glumes nearly equal, loug-awned, much longer than the membranaceons flowering one which is commonly short-awned below the alx.x. Stamens 3. Grain free. (Namle composed of $\pi$ o $\lambda \dot{v}$, much, and $\pi \omega \gamma \omega \dot{\nu}$, bermel.)

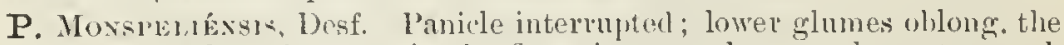
awn from a notch at the summit, the flowering one also awnel ; rost anmul - Inles of firoals (Rohbins), biallatst heaps, and soutliwad. (Nit. from Eu.) 


\section{1, Cí N N A, L. Woon Reev-Grass. (Pl. 8.)}

Spikelets 1-flowered, much flattened, erowded in an open flaccid paniclo. Empty glumes persistent, lanceolate, acute, strongly keeled, rough-serrulate on the keel; the lower rather snaller, the npper a little exeeeding the flower, which is manifestly stalked, smooth and naked; flowering glmme much like the lower, longer than the palet, nsually slort-awned or inneronate on the lack below the pointless apex. Stanen one, opposite the l-nerved palet! Grain linear-unlong, free. -1 perennial, rather sweet-scented grass, with simple aud upright somewhat reed-like culms $\left(2-7^{\circ}\right.$ high), bearing au anple componnd terminal panicle, its branches in fours or fives; the broadly linear-lanceolate flat leaves ( $4-6^{\prime \prime}$ wide) witl conspicuous ligules. Spikelets green, often purplish-tingel. (From kívva, a name in Dioseorides for a kind of grass.)

1. C. arundinàcea, L. (Pl. 8, fig. 1, 2.) Paniele 6-15' long, rather desse, the brunches and pedicels sprearling in flower, afterward erect; spikelets $2 \frac{1}{2}-3^{\prime \prime}$ long; a wn of the glume cither olsolete or manifest. - Moist woods and shaded swanjs; rather common. July, Ang.

2. C. péndula, Trin. Panicle lonse and more slender, the branches nearly capillary and drooping in flower; peelicels rery rougli; glnmes thimer, the lower less meqnal; spikelets $1 \frac{1}{2}-2^{\prime \prime}$ long; palet obtuse. (C. armndinacea, var. pendula, Gray.) - beep damp woods, N. New Lng. to Lake Snperior and northward, and on monntains sonthward. (Eu.)

\section{A P E R A, Adans.}

With the eharacters of $A$ grostis; distinguished by the presence of a secoud mudimentary flower in the form of a short bristle, and by the 2-toothed palet little shorter than the flowering lificl ghnme, which is dorsally awned. - A rather late munal, with narrow flat leaves, and a contracted or spreading panicle with numerous filiform branches and rery numerous small slining spikelets. (Nane fron ámipos, unmuimed; applicition olscenre.)

A. SpìcA-réxtr, lieaur. Spikelets $\frac{1}{2}-I^{\prime \prime}$ long, - Sparingly naturalized (Nat. from Eu.)

\section{CALA M A GRóstis, Adins. Reen Bext-G. (I’l. 8.)}

Spikelets 1-flowered, and (in omr rpecies) often with a pedieel or rudiment of a second abortive flower (rarely 2-flowered), in an open or spiked panicle. Lower glumes nostly membanaceous, keelerl or boat-shaped, often il'nte eommonly nearly equal, and excecting the flower, whieh hears at the basc copious white hristly lairs; Howering glume thin, bearing a slender awn on he hack or below the tip, or sometimes awnless; the palet mostly slorter. stamens 3. Grain free.-Perennials, with rumning rootstoeks, and mostly tall and sinple rigid culms. (Name eompounded of kádauss, a reed, and

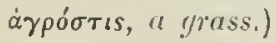

\$. DEYEUXIA. Rudiment of a second flower present in the form of a phmose or huiry small pedicel behind the palet (eery rarely more developed and having a glume or eren stamens); glumes membranciceous, or the flowering one thin and delirute, the latter 3-5-nerved and ann-bearing.

* Panicle luriser and opene even after flowering; the mostly purple-tinged or lead colored strigusenscabrous glumes not clusing in fruit; copious hairs of the 
rhachis abont equaling the flowering glume, not surpassed by those of tho rudiment; awn delicate, stiught.

1. C. Canadénsis, Beauv. (Bute-Jurve Griss.) (P1. 8, fig. 1, 2.) Culm tall $\left(3-5^{\circ}\right.$ ligh); leaves flat when fresh, glancons; panicle oblong; glumes ovate-lanceolate, acute, $1 \frac{1}{4}-1 \frac{1}{2}$ "long; aun from near the midlle of the npper glume, not exceeding and scurcely stouter than the basal hairs. (Deyeuxia Canadensis, Howk. $f_{\text {.) }}$ - Wet grounds; common northward. July.

2. C. Langsdórffii, 'Trin. Sjuikelets larger, $2 \frac{1}{2}-3$ " long; glumes lancer. late or oblony-lanceolate and gradually taper-poimted; awn stonter; otherwise like the preceding. (Deyeuxia Laugstorflii, Kunth.) - Mountains of N. New Eug., L. Superior, and nortliward. (Eu.)

* Panicle strict, its short branches appressed or erect after flowering, and the glumes mostly closed: floueviug glume less deticute, roughish, sometimes of as firan texture as the lower; aun stoutel.

+ Leaves narrou, inclined to be involute; aun straight.

3. C. stricta, 'Trin. P'anicle glomerate and lobed, strict, 2-4' long; glumes $1 \frac{1}{2}-2^{\prime \prime}$ long, orite-oblong, not aemninate; hairs searcely or little shorter than the flower, and as long as those of the rudiment; awn from the middle of the thin flowering glume or lower, and harely exceeding it. (Deyenxia neglecta, Kunth?) - Monntains of $\mathbf{X}$. New Eng., Lake Superior, aud north and westward. (Eu.)

4. C. Lappónica, 'Trin. Culm and rootstockis stunter' than in C. stricta, the narrow panicle less dense, and jurplish spikelets larger ; glumes fully 2" lung, taperiug to a point; awn from nuch below the midlle of the glune, stont. (Deyeuxia Iapponica, Kinth.) - lsle lioyale, Lake superior, to Lab., north and westward. Ang. (Eu.)

$4+$ + Leaves broader, flut; awn stonter, bent, diceryent, or turisted when dry.

5. C. confinis, Nutt. 'Tall ; panicle elongated $(t-6$ '), its ratleer slender branehes spreadiuy at flowering-time, afterward appressed; glumes lanceoblong, very acute, 2" long, pale; huirs of the floner ropions, cqual, slightly or one third slorter thin the thin flowering glume and than those of the rudiment; awn lorne much helow the midlle of the glnme, somewhat surpassing it; grain glabrous. (Deyeuxia confinis, Kunth.) - Swamps, N. and W. New Tork (especially I'enu Yan, Sartwe/l) anl Penn.; Mlinu., and wostward. July.

6. C. Nuttalliàna, Steurl. Culn stout $\left(3-5^{\circ}\right.$ ligh $)$; panicle contrureri and spike-like; glumes lanceolate and tapering into slender awl-slaped tips, 3" long; hairs wu the lower side seanty and luvely half the length of the firm and heeled flowering glume, on the other side longer and eyualling the eopions inft on the sumnit of the rudinent; awn burnc half-way between the middle and the taperiug tip of the glune, stout, not twisted; grain bearled at the to]" (Deyeuxia Nuttalliaua, Iasey.) - Moist grounds, li. New Eug. to Penu., Via.. and southward. $\Delta u g$.

7. C. Pórteri, Gray. Cuhn sleucler (2-40 high); a woolly-bearded ring at the junction of the broadly linear leaves with the sheath; panicle long and morrom, with the branches appressed; glumes lanceolate, acute, pale, $2-2 \frac{1^{\prime \prime}}{2}$ longr lirtis of the flower aul of the short rudiment scanty, and both reaehing ahout (1) the middle of the flower behiud the palet, but very short or none at the 
base of the firm-membranucuus fonering glume, whicls hears near its base " fwisted aun of its own length. (Deyeuxia Porteri, lase.) - Iny woods, I’ulpit Rocks and vicinity, IIuntingdon Co., Penn., Proj, T. C. Porter.

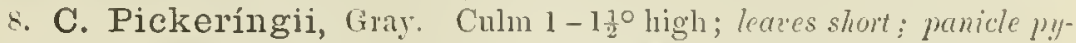
ramidat, purplish; glumes ovate-oblong, bluntisll or bluntly pointed (1 $\frac{1}{2}-2^{\prime \prime}$ long) ; hairs both of the flouer and of the rudiment rery short and scanty, one fourth or fifth the length of the flower, none belind the obtuse flowering glume, which hears betweeu its middle and base a slort stout (straight or bent, not swisted) awn. (Deyeuxia Pickeringii, T'asey.) - White Mts, in the alpine -egion of Mt. Waslington, and a more luxuriant form with smaller spikelets at Echo Lakie, Franconia; Andover, Mass. (.I. Robinsem); Cape Breton.

\$2. CALAMIOTÍLA. liudimut of second flower wonting; ylumes and palet rathes chartarous, compressed-keeled: flowering ghume 1-nerced, entirely auntess; putet strongly b-liecled ; punicle at length open and loosie.

9. C. brevipilis, Gray. Branches of the diffuse lyramidal panicle capilliry (purplish); empty glumes orte, mucronate; the upper sliglitly, the lower nearly one half shorter than the flowering glume and palet, which are more than twise the length of the heriss and bistly-bearded along the herels. (Ammophila breripilis, Benth.) - Saudy swamps, pine-barrens of N. J.; rare. siept. - Culm 2- to ligh ; leaves nearly Hat; spikelets 2" loug.

10. C. longifòlia, Hook. Culm $\left(1-4^{\circ}\right.$ hish $)$ stont, from thick running motstocks; leness rigid, clonguted, involufs alowe and tapering into a long threal-like point; panicle at first close, heenning open and pyranical, the

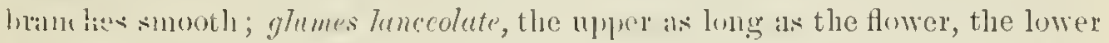

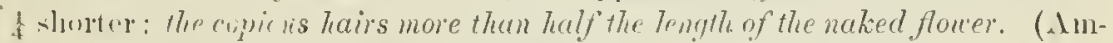
nophilia longifolia, Benth.) - Sands, along the npuer Great Lakes, from 11. and Wich. to the Dakotas, Kan., and westward. Ang. - Spikelets $2 \frac{1}{2}-3^{\prime \prime}$ long.

\section{A M M O PHILA, Host. (1'l. 15.)}

spikelets large, in ib entracted spike-like panicle, 1-flowerel, with a pedicellike rueliment of a second flow' (plumose alove), the flower hairy-tufted at bise:. Empty glumes scarious-chartaceous, linceolate, compresser-keeled, nearly erpal; flowering glume and palet similar, a little shorter, the glume j-nerved, slightly mucromate or obsenrely awned near the tip, the paiet 2 kecled. - A coarse perennial maritine species, with running rootstocks.

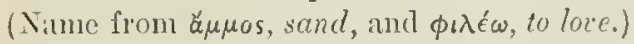

1. A. alundinàcea, Ilost. (SE.t Sixd-ReEn.) Culn stunt and rigic $2-3^{\circ}$ high) from firm rumuing rootstocks ; leaves long, soon involute; panicle ontracted into a lense crlindrical spike $\left(5-9^{\prime}\right.$ loug) ; spikelets $5-6^{\prime \prime}$ long; hairs only one thipd of the length of the flower. (Calanampstis arenariat, lioth.) - Sandy beaches, N. J. to Maine and northward, and on the Great Lakes. Aug. (Eu.)

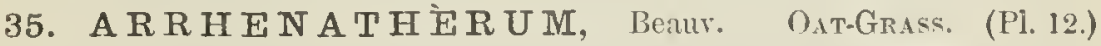

Spikelets open-pranicled, 2-flowered, with the rurliment of a thited flower: the middle flow perfect, its glume larcly hristle-pointed from near the tip; the lnwest fluwer staminite only, benring a long hent awn lexlow the middle of

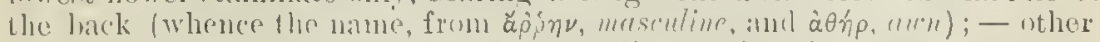

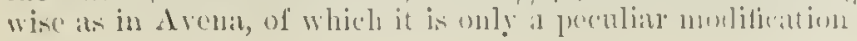


A. Avenácum, Beanv. Root perenuial; culn $2-4^{\circ}$ high; leaves broad, flat; panicle elumgated; glumes scarious, very unequal. - Meadows and lots; absurdly called Gruss of the Andes. May-July. (Nat from En.)

36. HÓLCUS, I. (partly). Meadow Soft-Grass. (Pl. 12.)

spikelets crowded in an open panicle, 2-flowered; the boat-shaped nnembranaceons glumes suclosing and much exceeding the remotish flowers. Lower flower perfect, its papery or thin-coriaccons glume awnless and pointless; the mpper flower staminate, otherwise similar, bit bearing a stout bent awn below the apex. Stanens 3. Styles plumose to the base. Graiu free. (A name in Pliny for a kind of grass, from ox rós, atticetice, of oluscure application.)

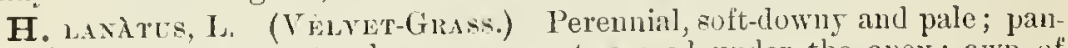
icle oblong; upper empty glume mucioncte-awned nurler the apex; awn of the staninate flower curved. - Moist meadows. Junc. (Nat. from Liu.)

\section{A I R A, L. ILair-Grass.}

Spikelets very small, in an open diffu: 3 pauicle, of 2 perfect contignous flowcrs. Glumes thin-membramacous, the two lower persistent, nearly equal, acute,

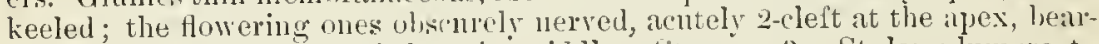
ing a slender twisterl awn below the mislle. Simmens 3. Styles plumose to the base. Grain ol,long, adnate. - Low annuals, with short setaceons leaves (An ancient Greek wame for Darmel.)

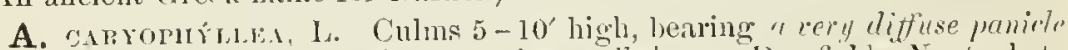
of purplish and at lengtl silvery semions spilopets, - Dry fields, Nantucket; also Newcastle, Del., W. IF. (Mnty. (Nat. from Eu.)

A. Pritcox, I. Culms tufted, $3-4^{\prime}$ lighl ; limehes of the small and dense punicle appressed; awn from below the middle of the glume. - Sandy fields, N. J. to Va.; rare. (Nat. from Eur.)

\section{DESCHÁMPSI A, 13eauv. (P1. 12.)}

Spikelets small, pauicled, of 2 perfect flowers and the hairy pedicel or rudi ment of a thirel (rarely staminate); rhachis hairy. Empty glumes persistent, membranaccons and shining, carinate, acute, nearly equal; flowering glumes toothed or erose-denticulate at the truncate summit, nsually delicately $3-5$ nerved, with a slender twisted awn near on lelow the middle. Grain oblong. free. - Root peremnial. (Namerl fur Loiselem-Deslongchamps, a Frenel botanist.)

$$
\text { * Empty glumes somewhat shorter than the flovers. }
$$

1. D. flexuòsa, Triı. (Cомыох Hım-Glsss.) (Pl. 12, fig. 1-3.) Culms slemier, nearly naker $\left(1-3^{\circ}\right.$ high) ahove the small tufts of ineolute bristle-form ront-leares ( $1-6^{\prime}$ loug); loranches of the small spreading paniele sapillary; awn longer than the protet, al length bent and twisted. (Aira flexunsat t.) - Dry places; common. June. (Kiu.)

2. D. caspitósa, Buanr. ('ulu tufterl (2-10 high); leutes fu', lineur:

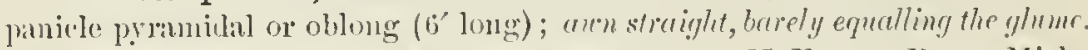
( Aira (axpitus: L.) - Shores of likes and streans; N. Eng. to P'enn., Mich., and northwarl. June, July. (lin.)

$$
\text { * * Enpty glumes longer then the Alowers, } 2-2 \frac{1}{3} \text { " long. }
$$

3. D. atropurpùrea, sichcele. Culıss 8-15' high, weak; leaves Hat, rather wide; panicle of few spending hranches; awn stont, twice longer than

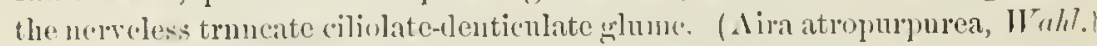
- Aprine summits of X. H. anl X. Y., to Lab. and northward. Ang. (En.) 


\section{TR IS ET U M, I'ersoun.}

(PI. 12.)

Spikelets 2-several-flowered, often in a contracted panicle; the flowering glume compressed-keeled, of about the same thiu-membrauaceous texture as the entpty glumes, bearing a lient or flexuous (rarely twisterl) awn at or below the sharply 2-toothed or 2-pointed apex (whence the nance, from tris, three, and seta, a bristle); otherwise nearly as in Avena. Ours are perenuials.

1. T. subspicàtum, Bcauv., rar. mólle, Gray. (Pl. 12, fig. 1, 2.) Winutely soft-douny; panicle dense, much contracted, oblong or linear (2-3' long); glumes abont the length of th= 2-3 smooth flowers; awn dorsal, diverging, much exserted. - Monntains and rocky river-banks, N. New Eng: to L. Superior, and northward. July. $-\Lambda$ bout $1^{\circ}$ high; leaves flat, short. (En.)

2. T. palústre, Torr. Smooth; panicle rather long and narrow (5' long), loose, the branches capillary; spikelets fat ( $3^{\prime \prime}$ long); lower glumes shorter than the two smooth lanceolate Howers; the upper flower on a slightly hairy joint of the rhachis, with a slender spreading or bent arr next the slort 2pointed tip, the lower commonly aumless or only mucronate-pointed. - Low gromuls, sonthern N. Y. to Ill, and sonthward. June.-Culm sleuder, 2-3 high; leaves lat, short; spikelets yellowish-white, tinged witl green.

\section{A V 亡 $\mathbf{E} \mathbf{A}$, 'Tonm. OAT. (Pl. 12.)}

Spikelets 2-many-flowered, panicled; the flowers lerbaceo-chartaceous, or becoming harder, of firmer texture than the large and mostly nnequal empty glumes; the uppermost fower imperfect; rhachis and base of the flower often bearded. Flowering glume routed on the back, mostly 5-11-nerved, bearing a long ustally bent or twisted awn on the back or between the two acute teetl at the apex, proceeding from the mid-nerve only, Stamens 3. Grain oblong-linear, groored on one side, usually hairy, at least at the top, free, but invested by the palet. (The classical Latiu name.)

$$
\text { * Spikelets large (1'long); annual. }
$$

A. FÁtus, L. Resembling the common oat (.1. sativa), the few spikelets in a loose panicle, mostly pendulous; flowering glunes covered with long hrownish hairs and bearing a bent awn 1-2' long. - Wisc., Minm. (Nat. from Lin.)

$$
\text { * * Smaller-fourered perennials. }
$$

1. A. striàta, Michx. (Pl. 12, fig. 1, 2.) Gilabrons and smonth throughont, slender (1 - 20 high) ; leaves narow; ligule slort, truncate; panicle simple, loose; spikelets ( $\left.6^{\prime \prime} \mathrm{long}\right)$ on capillary pedicels, 3-6-flowered, muclo exceeding the scarious-marginer purple acute empty glumes; lower glume 1"uper 3-nerved; rhichis smooth; flowers short-bearded at base; flowering glume "-nerved, much longer than the ciliate-fringed palet ( 4 "long), mostly shorter than its soon bent or dirergent awn, which rises just helow the tapering very slarply cuspirlate 2-cleft tip. - Rocky, sharled hills, N. New Eug., N. Y., and northwestwird, fune.

2. A. Smíthii, Portel. Taller $\left(2 \frac{1}{2}-4 \frac{1}{2} \circ\right.$ high), rather stout; leares broadly linear $\left(3-f^{\prime \prime}\right.$ wide) aud taper-pointed, flat, and with the sheaths and culn in. irorsely scalrous; ligule elongated, acute; panicle larger $\left(6-12^{\prime}\right.$ long), the few branches at length sprealing; empty glumes slightly purplish, the lower 3-nopred, the upper 5-nerved, scabrons on the nerves; rharlis minntry hispirl, 
flowers $(3-5)$ nuked at base; awn straight, $\frac{1}{3}$ - $\frac{1}{2}$ the length of the 7 -nerved glume.- X. Mich, and Isle Royale, L. S'uperior. A pril, May.

\section{DANTHONIA, DC. WILD OAT-GRAss. (Pl. 12.)}

Flowering glume (oblong or orate, rounded-cylindraceous, 7 -9-nerved) bearing between the sharp-pointed or awn-like teeth of the tip an awn usually commosed of the 3 middle nerres, which is thattish and spirally twisting at lose; otherwise nearly as in Arena. Empty glumes longer than the imbricater? Howers. Oms perennials, $1-2^{\circ}$ high, with narow and soon involute leaves. hairy sheaths bearded at the throat, aud a smill simple panicle or raceme of about 7 -flowered spikelets. (Named for Dunthoine, a French botinist.)

1. D. spicata, Beaur. (Pl. 12, fig. 1-3.) Culms tufted, low; leaves short, rery narow; spikelets few; 3-5" loug, subspicate; flowering glume loosely hairy, its tecth short and pointless. - Dry ant sterile or rocky soil.

2. D. serícea, Nutt. Culms taller and not tufted $\left(1-3^{\circ}\right.$ high), terete: leares larger, at letst the sheaths si7lyy-rillous; spikelets more numerons and panicled, 6-9" long; flowering ghume revy silloy-ritlous, tipped with slender u'n-pointed teeth. - Dry or moist sandy' soil, sonthern Mass., N. J., and sonthward; rure. June.

3. D. compréssa, Aust. Culms slender, $2^{\circ}$ high, somewhat compresserl, paler and subaniculate on the narower side; leaves elougated, rery narow, villous only at the summit of the sheath ; spikelets $6-12$, loosely panicled, 5" long; flowering glume loosely hiliry or pubescent, the teeth rery long-awued. - Dry banks; Yt. (Pingle) ; F. Mass., N. Y., I'enu, and mountains of X. C.

\section{C Ý NODO N, Richard. Berutud or secten-Gras.s. (Pl. 9.)}

Śpikelets 1-Howered, with a mere naked short-pedicelled rudiment of a second Hower, inblnicate-spiked on cne side of a flattish rhachis; the spikes usually digitate at the naked snmmit of the flowering culms. Empty glumes keeled, pointless, rather meqnal; tlowering glume and palet pointless and awnless, the glume larger, boat-shaped. Stamess 3. - Low diffnsely luanched aur extensively creeping perennials, with short Hattisli leares. (Name composed of kúw, a doy, and ósoús, a tom/h.)

C. Díctulox, l'ers. Spikes 3-5; flowering glume smooth, longer thau the blunt rudiment. - Penn., and southward, where it is cultirated for pasturage. (Nat. from Eu.)

\section{C TÉ N I U M, Panzer. 'Гоотисne-Grıss. (Pl. 9.)}

spikelets densely imbricated in two rows on one side of the flat curved rla shis of the sulitary terminal spike. Clumes persistent; the lower (interior) much smaller; the oher concave below, hearing a stout reenreal ann, like a arm, on the midlle of the back. Flowers $t-6$, all but one neutral; the one ur tw lower consisting of empty anned glumes, and the one or two uppermost of (anpty awnless glumes; the perfect Hower intermediate, its glmue memlura. nareons, anned or mucronate helow the apex and densely ciliate toward the linse, 3-nerver. Stimens 3. Stigmas plumose. (Tame kteviov, a small comb. from the pectinate appearance of the spike.)

1. C. Americànum, slreng. Culm (3-40 high from a perennial root) simple, pubescent or roughish; latrer glume warty-glandnlar outside, cou. spicunsly awned. - Wet pine-barrens, s. Va. and southward. - Taste ver! litilgrent 


\section{GY M N P P GON, Beaur.}

Spikelets of one perfect Hower, aud the rindiment of a second (consisting of an awn-like pedicel mostly learing a maked lristle), sessile aud renotely alternate on long filiform rays or spikes, which form a crowded naked racene. Glumes lance-iwl-slinger, keeled, almost equal, rather longer than the nembranaceous Howering glune, which is cylindrical-involute, with the midrib produced from just below the 2-cleft apex into a straight and slender bristle like awn; palet nearly as long, with the abortive rudinent at jts base. Sita mens 3. Stigmas pencil-form, prple. - Root perenuial. Leaves short and Hat, thickish, I-3' long. (Xime compused of $\gamma \nu \mu \nu o ́ s, ~ n a k e d$, and $\pi \dot{\omega} \gamma \omega \nu, u$ beard, alluding to the reduction of the abritive finver to a bare awn.)

1. G. racemòsus, Beanv. (P'l. 9, fig. 1, 2.) Culns cinstered from a short rootstock $\left(1^{\circ}\right.$ likgli), wiry, leafy; leaves ohlong-lancolate; spities flowerbearing to the base (5-8' long), soon divergent; awn of the abortive flower shorter than its stalk, equalling the pointerl glumes, not more than laalf the length of the awn of the fertile Hower. - Samdy pine-lumens, N. J. to Via, and sonthward, Aug., sept.

2. G. brevifoblius, Trin. Filiform spiles lonn-peduncled, i.e. fourerhearing only above tle millile; flowering glume ciliate near the base, shortawned; awn of the abontive flower obsolcte or minute; glumes acute. - Sussex Co., Del., and sonthward.

\section{SCHEDON NÁRDUS, Stcul. (11. 11.)}

Spikelets small, acuminate, 1-floweren, appressed-sessile and suttered along oue side of the slenrle rlachis of the distant seswile and diraricately spreading spikes. Enpty ghunes persistent, marow, acuninate, more or less muepual, the longer usually a little shorter than the rather rigid acuminate flowering oue. Famens 3. Styles fistinct. Cimin linear. - I low slenles amual, brancling from the base, with short maruw leares. (Name from $\sigma \chi \in \delta$ ó $\nu$, near, amıl Tridus, from its resenblance to tlat gemus.)

1. S. Texánus, Steud. Stem $\left(6-20^{\prime}\right.$ long $)$ naked and curred above,

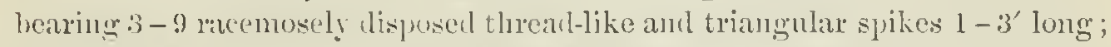
spikelets $12_{2}^{\prime \prime}$ long. (Lepturus paniculatus, Nutt.) - Open grounds and saltlicks, IIl. to Mlont., Col., and 'l'ix. Ang.

\section{BOUTELO U̇A, Lagasca. Mrskft-Griss. (PI. 9.)}

Spikelets crowded and cluscly sessile in 2 lows on one sile of a flattened Thachis, conyrixing one perfert fluwer below and one ur nore sterile (mostly acutral) or luhimentary Huwers. Gilumes convex-keder, the lower one shorter P'erecet flower with the 3-nerved ghlune 3-toutled or eleft at the apex, the :uerved palet 2-toothed; the tceth, at least of tho former, pointer or subulateawned. Stamens 3; anthers orunge-colored ol rel. - Rudinentary fowers mostly 1-3-awned. Spuikes sulitary, racemerl or spikerl; the rhachis somewhat cxtended heyomd the spikelets. (Named for Cluudius Boutrou, a Spanisls witer upon fioriculture and agriculture.)

\$1. CHONDROSIIM. Spikes pectinate, of very many spikelets, oblong or linear, wery dense, solitary and terminal or far in a raceme; sterile fower: $1-3$ on a short puied, neutral, consisting of $1-3$ scales and awns. 
1. B. oligostàchya, Torr. Glabrous, peremial $\left(6-12^{\prime}\right.$ high); leaves very narrow; spikes $1-5$, the rhachis glabrons; glumes all sparingly soft-hairy, the lobes awl-pointed; sterile flower copiously cillous-tufted at the summit of the naked peclicel, its 3 awns equalling the larger glume. $-\mathbf{N}$. W. Wise, to N. Mak., and south to Tex. and Mex. - Glumes obsenrely if at all papillose along the keel, the middle lobe of the flowering one 2-cleft at the tip. Sterile flowers often 2, the seeond mostly a large awnless seale, beeoming hood-iike and coriaceous.

2. B. hirsùta, Lag. 'Tufted $\left(8-20^{\prime}\right.$ high $)$, perennial; lenves flat, lance. linear, papillose-lairy or glabrons; spikes 1-4; upper emply glune hisprid with strong bristles from dark worty glunds; flowering glume pubescent, 3-cleft into awl-pointed lohes; sterile flocer und its predirel glubrous, the 3 awns longer than the glumes and fertile flower. - Saudy plains, Ill., Wise., Minu., and southwestward to Mex.

§2. ATIEROPȮGON. Spikes short, mumerous in a long and virgate one. sided spike or raceme, spreading or reflexed, each of few (4-12) spikelets; sterile flower's neutral, rudimentary.

3. B. racemòsa, Lag. (Pl. 9, fig. 1, 2.) Cnlns tufted from perennial ruotstocks $\left(1-3^{\circ}\right.$ ligh $)$; sheatls often hairy; leaves narrow; spikes $\frac{1}{2}$ or less in length, nearly sessile, $20-60$ in number in a loose general spike (8-15' long); flowers scabrous; glune of the fertile with 3 short awl-pointed teeth; sterile flower reduced to a single sinall awn, or mostly to 3 awns shorter than the fertile flower, and 1 or 2 small or minute scales. (B. curtipendula, Ciruy.) -1)ry hills and plains, southern N. Y. to Minn., and south to 'Tex. and Mex. July-Sept. - Passes by transitions into var. A mistoss, with spikes shorter; sterile flower of a large saceate glnme, awned at the 2-cleft tip and from the lateral nerves, the middle awn exserted, and with a rndiment of a palet. - Ill. (lieyer), and southward.

\section{ELEUSìn E, Gaertn. Crab-Grass. Yard-Grass. (Pl. 9.)}

Spikelets 2-6-flowered, with a terminal imperfect flower or naked rudiment, closely intricate-spiked on one side of a Hattish rhachis; the spikes ligitate. Glumes membranaceons, shorter than the flowers; flowering glume anil palet awnless, the glume ovate, keeled, langer than the palet. Stmmens 3. Pericarp (utricle) containing a lonse wrinkled sced. - Low anutuls, with flat

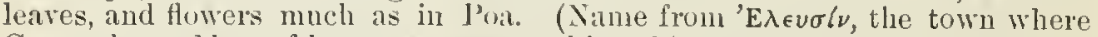
Ceres, the gouldess of harvests, was worshipped.)

E. Frimcs, Gierth. (1)og's-tall or Wrke Grass.) (1'l. 9, fig. 1-6.) Culms ascending, thattened; spikes $2-5$ (about 2' long, greenish); glumes pointless; terminal flower a mere rudiment. - Yards, etc., chiefly southward. (Nat. from Ind.?)

E. Egriticג, Pers. (Pl. 9, fig. 1-4, as 1)actyloctenimu.) Culms often ereeping at base ; leaves ciliate at hase; spikes $4-\overline{5}$; lower grlnme awned and the flowering one pointed. (1)aetyluetenimm Egytiacun, II illd.) - Culti-

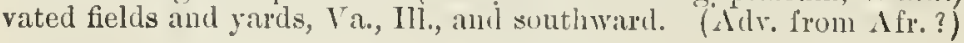

\section{IEPTÓCH L O A, Benur.}

Spikelets 3 - many-flowered (the uppermost flower imperfect), loosely spiked on one side of a long filiform thachis; the spikes racemed. Glumes memhrantaeeous, keeled, rarely awned, uearly equal; fluwering glume 3-nerved 
sometimes simply alwuel, larger thau the palet. Stamens 2 or 3 . Seed closely enclosed. - Our's anumals. Leaves flat. (Name composed of $\lambda \in \pi$ rós, slender, and $\chi \lambda \delta \alpha, g r a s s$, from the long attenuated spikes.)

1. I. mucronàta, Kunth. Wheaths hairy; spikes numerous (20-40, $2-4^{\prime}$ in length), in a long pauicle-like racene; spilielets sulall; glumes more or less mncronate, nearly equalling or exceeding the :3-4 awnless flowers. Fields, Va. to Ill., Mo., and southward. \ug.

\section{B Ù C H L O Ë, Lingelm. Buff.llo Griss. (P'l. 15.)}

Spikelets diøcious (rarely nuncecious), very unlike; the staninate $2-3$. Aowered, sessile in 2 rows in slort 1-sided spikes, the empty ghumes blunt, 1-nerved, very unequal, the flowering linger, is-nerved, a little exceeding the 2-nerved palet; fertile spikelets 1-flowererl, ill a contricted, capitave, l-sirled spike, the large onter ghumes indurated, 3-fid at the apex, united at base and resembling an involucle, the inner (lower) nuch smaller and membranaceous, or in the lowest spikelet resenulung the onter ; Howering glune narrow, hyaline, bifid or nearly entire, enclusing the 2-nerved palet. Styles distinct. Grain orate, free. - I perennial, "reping or stoloniferons, with narrow flat leaves; staninate spikes $(2-3)$ in a pedunculate spike, the pistillate pair sessile in the lroald sheaths of the upper leares. (Name a contraction of Bubalochlö̈, from $\beta$ oú $\beta a \lambda o s, b u f f i l o$, and $\chi^{\lambda} \dot{\eta} \eta$, gruss.)

1. B. dactyloides, Engelm. Low $\left(3-8^{\prime}\right.$ high) and hroadly tufted; sterile spikes $3-6^{\prime \prime}$ long, the fertile liearls $3^{\prime \prime}$ long. - Plains of the Sask. to Minn., Kan., and 'Tex. One of the most ralnable grasses of the plains.

\section{TRIÒDIA， R. Br. (Pl. 10.)}

Spikelets 3-12-flowered, somewhat terete, the rhachis with bearded joints; terninal flower abortive. limpty glumes unefual ; Howeriug glumes membranaeeons or somewhat chartaceons, much larger than the 2-tootherl palet, convex, 2-3-tonther or cleft at the apex, conspicnously hairy-hearderl or villous on the 3 strong nerves, of which the lateral are marginal or nearly so and usually excurrent, as is the mid-nerve especially, into a short cusp or awn. Stamens 3. Stigmas lark purple, plumose. Grain ollong, nearly giblous. Leaves taper-pointed; sheaths hearded at the throat. I'anicle simple or compound; the spikelets often lacemose, purplish. (Name from $\tau \rho t$, three, and oboús, a tooth, alluding to the flowering g'lume.)

\$1. TRIODTA proper. Glumes shorter than the roneded flowers, the flowering one 3-cuspidate by the mojection of the nerves, and usually with intermediate. membranuerous tecth; palet naked.

1. T. cùprea, Jacq. (T.ı. RnD-тов.) Perenual ; culm uyught $\left(3-5^{\circ}\right.$ high), very smooth, as are the Hat loaves: panicle larne and compound, the rigil capillary branches spreading, naked below; spikclets very numerons, 5 - F-flowereil, shining, purple ( $t^{\prime \prime}$ lomg $)$; the Howeling ghunes hairy toward the base, their points almost ennal, scarcely exceeding the intermediate teeth, thus appearing 5-toothel. ('Tricuspis seslerioides, Torr.) - Jry or saudy fields, sonthern N. Y. to Mo., and sonthward. Ang. - A showy grass, with the sprealing panicle sometimes 10 wide. 
\$2. TRIPLASIS. Cinmes much shorter than the sumewhat remote flowers, flocering flume and palet strongly finge-hearded, the glume z-cleft at the summit, its mid-nerve produced into an uwn between the truncte or awn. pointed divisions.

2. T. purpùrea, Hack. (Sivi)-(rkiss.) ('nlms many in a thit fiom the sinne anumal lont, ascending $\left(6-12^{\prime}\right.$ high), with nnmerons learled joints; loaves involute-awl shaped, mostly short; paurcles rery simple, bearing fov 2-5-Howerer spikelots, the terminal me usmally exserted, the axillury one: incluted in the commonly latiry sheaths; arre murh shorter then the ghume,

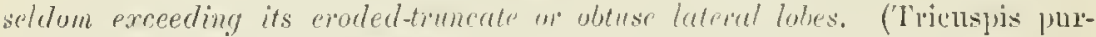
purea, Gray.) - In sand, Mass. to l'a. along the coilst, and sonthward; also I. Lire, near Buffalo, and Ill. Ing., Sept. - Plint acicl to the tiste.

\section{D I P L Á C H N E, Beaur.}

Syikelets several-Howered, narrow, crect ancl scattererl along the slender rhachis of the long spicate spikes; frowers all perfect or the uppermost staminatr. Empty glumes membranareons, carinate, alcute, mequal; flowering glumur sliglitly longer, 1 - 3-11erved, 2-toothed, anct mncronate or shontly awned lotwerell the teetly. Stamens:3. Strles clistinct. Ginin free - Conse grasses,

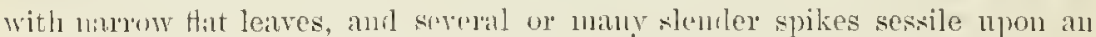

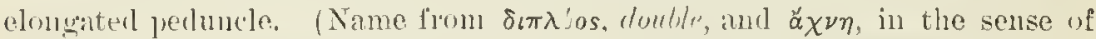
rhaffi, with reference to the 2-lobel ghume.)

1. D. fasciculàris, lieanv. Smooth; latrs longer than the genicnlaterecombent and branching colms, the nlper sheathing the hase of the paniche like sprike, which is composed of mamy strict spikes (3-5' longr); spikelets slightly perlicelled, 7-11-Howered, mueh longer thin the lanceolate glumes; dowers hairy-mangined toward the base, the glnme with somall lateral teetl and a short awn in the eleft of the apex. (Leptorhlus fascicularis, (iruy) Brackish mealows, from R. I. southward along the const, and froun Ill. southwarl on the Mississippi. Aug. - Sept.

\section{PH RA G M I TES, T'rin. Rev. (I'l. 11.)}

Spikelets 3-7-flowered ; the flowers rather listant, silky-rillous at base, and with a conspichous silky-hearderl rhachis, all perfect aurl 3-aurlums, except the lowext, which is either nentual or with $1-3$ stanens, and naked. Glumes memhanaeenu, shorter than the flowers, lancenlate, keeled, sharprointed, very unequal ; flowering glume and palet membrauacous, slencler, the grlume narmoly awk shaped, thrice the length of the palet. Squamule 2, largo.

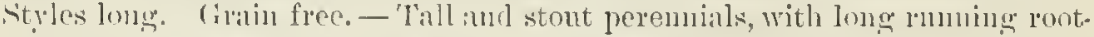

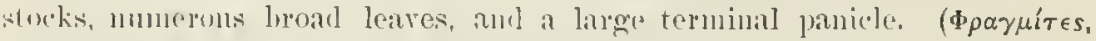
flaveing in leedyrs, which thes aquatic grass (loes not.)

1. P. commùnis, Trin. I'anicle loose, jodlling; spikelets 3 -5-fowerel ; Hower's equalling the bearl. - Eilges of ponds. Sept. - Looks like Brooul. Corn at a listance, 5-120 high; leares 2' wile. (Eu.)

\section{A R Ü N D O, I.}

Flowers all perfect; flowering glume lifirl, sluolt-awned between the teeth Otherwise as l'luagmites. ('Tlie Latin mame of the species.) 
A. Dóxax, L. Very tall $\left(10-18^{\circ}\right)$; spikelets 3-4-flowered.-Clusely resembling Phragmites communis. Cultiratel for ormament, and naturalized in Bedford Co., Va. (A. H. C'urtiss.) (Nat. from Eu.)

\section{MÚ $\mathrm{NROA}$, T'or.}

Spikelets usnally 3-flowered, few $(2-4)$ and nearly sessile in the axils of floral leaves; flowers perfect, or the uppermost abortive. Empty grlumer lanceolate, acute, lyaline and l-nerved; flowering glumes larger, 3-nurved. ather rigid, the mid-nerve stout, exeurrent, the lateral ones scarcely so.-Low or prostrate many-stemmed anu uals, fasciculately buanched, with erowder. short flat rigid or pungent leares, the short sheaths strongly striate. (Named for the English agrostologist, Maj-Gen. ITillium M/mmo.)

1. M. squarrosa, Torr. Glaucour, smewhat pubescent and villous at the nodes or glabrons; leaves $3-12^{\prime \prime} \operatorname{long}$. - Dry plains, central lian. to the lakotas, west to Mont., I'tah, and New Mex.

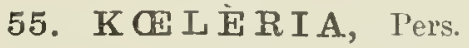

Spikelets 3-7-flowerer, crowled in a dense anrl narow spiko-like panicle. Glumes membranacous, compressed-keded, obscurely 3-nerverl, barely aente, or the flowering glume often mucronate or hristle-puinted; the empity ones - noderately unequal, nearly as long as the spikelet. Stamens 3. Grain free. - Tufted with simple upright eulns, the slicatls often downy; allied to Dactylis and Poa. (Nimed for l'rof. (i.L. Kineler, an early writer on Grasses.)

1. K. cristàta, l'ers. Culns $1-20$ high ; leaves flat, the lower sparingly lairy or ciliate; lanicle narrowly spikexl, interrupted or lobed at base; spikelets 2-4-Howered; flowering glune acute or mncronate. - Var. GrícILIs, Giay, with a loug and narrow spike, the flowers usually barely acute. - Dry lills, Penu. to Ill. and Kian., thence north and westward. (Eu.)

\section{EATÒNIA, liaf.}

Spikelets usually 2-flowered, with an abortive rudinent or pedicel, numer. ons, in a eontrated or slender panicle, very smootl. Enyty glumes some. what equal in length, but very dissimilar, a little shorter than the flowers; the lower narrowly linear, keeled, l-newed; the upper broally obovate, folder ronut the flowers, 3-nered on the back, not keeled, scarions-margined. Floweriug glume oblong, ohtuse, compressed-boat-shaped, naked, chartaceous; the wet very thin and hyaline. Stamens 3. Grain linear-oblong, not grooverl - l'erennial, tall and slender grasses, with simple tnfted eulms, and ofter farsely clowny sheaths, flat lower leaves, and smill greenish (ravely purplish) spikelets. Named for Prof, Imos Eaton, author of a popular Manual of the Butany of the United States, which was for a long time the only general work available for stndents in this eountry, and of other polulitr treatises.) * Lipper empty glume rounded-obovate and very obfuse; panirle nsurily dense.

1. E. obtusàta, Gray. (Pl. 10.) Panicle dense and contracterl, somewhat interrupted, rarely slender; the spikelets erowded on the slont crect branches; upper glume roug! on the lack; flowers lance-oblong. - -1)y soil, N. I'enu. to Ha., Mich, and air westward. June, JuL. 
* Glume narrower, sometimes acutish; panicle more loose and slender.

2. E. Pennsylvánica, Gray. Leaves mostly $3-6^{\prime}$ long; panicle long and slender, loose, the raccmose branclies lax and somewhat elongated; glnmes thin and broadly scarious, the lowest half the length of the flower, very narrow, the upper obtnse or bluntly somewhat pointed; the 2 (rarely 3) flowers lanceolate, with pointed glumes. - Varies, witl a fuller pauicle, $6-8^{\prime}$ long, with the aspect of Cinna (var. MAson, Torr.); and, rarely, witl the lower palet minutely micronate-pointed! - Moist woods and meadows; common.

3. F. Dudlèi, Vasey. Culms very slender; leaves shorter, $1-2^{\prime}$ long; panicle very sleuder, the branches few, short anl mustly appressed; empty glumes nearly equal, the lower oblong, the upper hroadly elliptical, apiculate; flowering glumes shorter than in n. 2, acutish. - Loug Island to central N. Y., sonth to S. C.

\section{ERAGRÓ S TIS, Beauv.}

(Pl. 10.)

Spikelets 2-70-flowered, nearly as in Poa, except that the flowering glume is but 3- (rarely 1-) nerved, not wellby-haired at the base, and is decidnons; palet persistent on the rhachis after the rest of the flower has fallen. - Culms often branching. Leares linear, frequently involute, and the ligule or throat of the sheath bearded with long villous hairs. Panicle various. (Name from sip, spring, and ă $\gamma p 0 \sigma \tau t s$, a grass.)

* Prostrate and creeping, much branched; root annunl; spikelets fat, imperfectly direcions, clustered, almost sessile, in the more fertile plant rlmost capitate.

1. E. réptans, Nees. Spikelets linear-lauceolate, 10-30-flowered; flowers lance-orate, acute; leaves short, almost awl-shaped. - Gravelly riverborders; common. Ang. - Flowering branches 2-5' high.

* * Diffusely spreadiny, or the flovering culms ussfuding, low (6-15' high), annual; spilelets often large, flut, forming a narrow crouded panicle.

E. mìnon, Host. Slleaths often hairy; leaves flat, snooth; spikelets shortperlicelled, lance- or oblong-linear, 8-20-flowered, leat-colored (2-5" long); flowers ovate, obtuse, the lateral nerves becoming evident, and keel smooth. (1). poxoides, Becuw.) - Sandy waste places, eastward; rare. (Nat. from Eu.)

E. MAлоR, llost. Sheatlıs mostly glabrous; spikelets larger (3-10" long), becoming linear, whitish when old,"10-50-flowered ; flowers more spreatling, their glimes larger, with very strong lateral nerves and rongh on the keel. (K. poreoides, var. megastachya, Gru!. ) - Similar situations, and more common. Ang. - Euits a sharp, nupleasant orlor. (Nat. from Eu.)

** * Erect, or in yroup + diffusely spreading and ascending; panicle open, its branches capillary; spikelets proportionally small, sometimes mimite. (Number of flowers in the spikelet rery rariable, according to age, etc.)

- Annual: culms slender, branching and dernmbent or spreading at base; leaves narrow, flat, soft; branches of the narrowe panicle rather short and thicklyflowered, not bearded in the axils, or sometines the lowest sparingly.

E. PILósı, Beanv. (Pl. 10, fig. 1-4.) l'anicle elongated-oblong, with rather erect buanches (except at flowering-time); spitelets 5-12-flowered (24" long. purplistl-lead-color), becoming linear, atout equalling their pedicels: empty glumes (small) and flowering ones ubfuse, the hatter hroadly ovate, 1-nerowd (lateral nerves obsolete). - Sandy or gravelly waste placess, S. New Eug. to Ill., and sunthwaril. Ang. - I'lant 6-12' high." (Nat. from Eu.) 
2. E. Fránkii, Meyer. Iluch branched and diffuse $\left(3-8^{\prime}\right.$ high $h_{1}$; panicle orate-oblong, rather dense, spreading; spiliclets $2-5$-jlowered (1- $1 \frac{1}{2}$ "long $)$, on slender pedicels; glumes iery acute; the flouering one orate, acnte, rather obscurely 3-nerved. - Low or sandy ground, s. Pem. to Kan., and southwestward. Aug.

3. E. Púrshii, Schrader. Sparingly branched at the decumbent base, then erect $\left(\frac{1}{2}-2^{2}\right.$ high); panicle elongated, the bianches widely sprcading, very loose ; spikelets $5-18$-flox cred, oblong-lanceolate, at length linear $\left(2-4 \frac{1}{2}\right.$ " long), mostly much shorter than their capillar!y pedicels; ghumes all ovate anc. acutc, or the flowering ones acutish, 3-nerved. - Sandy or sterile open grounds. P'ell1. to Mo., and southwestward; also introcluced northward.

+ + Culus sinple, or branching only at the very base, firm, erect, mostly forming thich tufts; lcaves very long; panicle very large, compund, often longer than the cu/m, with clongated loosely-flowered branches, their axils often beardal. (Donbtfiul perennials, or n. 5 armual.)

4. E. ténuis, Gray. Panicle virgately elonguted ( $1-2 \frac{1}{2} \circ$ long), rery loose, the spreading branches bearded in some of the lower axils, their remote divisions and long diverging pedicels capillary; spikelets 2-6- (sometimes 7 - 12-) flowered, pale or greenish; lourer glumes lanceolute or auc-shaped, very acute (1 $\frac{1}{2}-$ 2 "long), membranaceous, as are the oblong-lancedate acutc flowers ; flowering ylume distinctly 3-nerved; the npper ciliate-scabrous. - Sandy soil, Ohio to Ill., lian., and southward. Aug.-Uct. - Leaves rather rigid, $1 \frac{1}{2}-20$ long, glalirous or sparingly hairy; the sheaths hairy or glabrous; the throat strongly bearded ; flowers much larger than in the next, fully $1_{2}^{1 / 2}$ long.

5. F. capillàris, Nees. Panicle widely expanding, usually mnch longer than the culm, its spreading branches (mostly naked in the axils) and long diverying pedicels capillary; spikelets rather teretc, very small, 2-4-flowered, greenish or purplish; glumes and flowers ovate, ncute (less than I" long); flouering glume obscurely 3-nered, scarcely keeled : the palet rough-ciliate. - Sandy dry soil and fields; common, especially southward. Aug., Sept. - Leaves and sheaths very hairy, or nearly glabrous; the former about $1^{\circ}$ loug, not rigicl; panicie $1-2^{\circ}$ long, soon diffuse.

6. E. pectinàcea, Gray. Punicle uidely diffuse, its rigid divergent main branches bearded in the axils; the cupillary pedicels more ar less appressed on the secontary luanches; spitielets flut, 5-15-flowered, hecoming linear, purple or purplish; glumes and Howers orate or oblong-ovate, acutish; flowering glume strongly 3-nerved ; pulct hirsute-ciliute. - Leaves long, rigid, mostly hairy. the sheaths especially so; plint $1-3^{\circ}$ high; spikelets $2-3^{\prime \prime} \operatorname{lomg}, 1^{\prime \prime}$ wille; closely fluwered. - Yar. s'Ectábrus, Gray. Leaves and shoaths nustly erlahrous; branches of the panicle (the lower reflesed with ago) anul jedicels shorter; spikelets rather larger. - Sandy dry ground, from K. Mass. near the coast, and from Ohio and Ill., southwarl. Aug. - Oct.

7. F. campéstris, Trin. Glabrous or the sheaths villous at the throat; culm short, bearing an elongated and very open panicle with divaricate branches bearded at base; spikelets linear, flat, 8-12-flowered, sessile or nearly so along the branchlets; glumes very acute or acuminate, 3-nerved, ronghish on the keel ; palet minutely ciliate. (E. pectinacea, rar. refracta, Chrom. Poa refracta, Ell.) - Del. and Md. to Fla. and Mla. 


\section{M ÉLICA, L. Melic-(imass. (Pl. 10.)}

Spikelets 2-8-flowered; the $1-3$ upjer flowers imperfect and dissimilar, convolute around each other, and enwapped by the upper fertile flower. Enpty glumes usually large, scarious-margined, convex, obtuse; the upper $\mathbf{7}$-9nerved. Flowering glume papery-membranaeens, dry and sorretimes indurating with age, romeled or flattish on the back, 5-many-nervel, scarions at the entire blunt summit. Stamens 3. - Perennials with soft flat leaves. Panicle simple or sparingly branched; the rather large spikelets racenose-onesided. (An old Italian name for Sorglum, from mel, lioney.)

1. M. mùtica, Walt. (I'1. 10.) slender, with usually narrow leaves, the panicle often relucerl to a simple racene; lower glumes nearly equal and almost equalling the spikelet; fertile flowers usmally 2; flowering grlumes broat, smootl, ol,tuse. - Rich soil, l'enn. to Fla., west to Wisc., Iowa, aml 'l'ex.

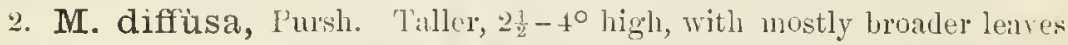
:mb a more usually compound and many-flowered panicle; lower glmmes more unequal, the onter rery broul; fertile flowers msually 3 ; flowering ghumes somewhat sealmons anl more acute. (M. mutica, var. diffusa, Gouy.) - Penn. to Ill., and southwilit.

\section{DI A R R H N A, Raf. (l'l. 10.)}

Spikelets several-flowered, smootl and shining, une on two of the uppermost fowers sterile. Emyty ghmes orate, much shorter than the flowers, coriarons; the lower mull smaller; Howering glnme ovate, courex on the hack, ligidly coriaceons, its 3 nerves terminating in a strong and abrupt enspidate or awl-shaped tip. Siquamula orate, viliate. Stamens ?. Grain very large, ohliquely oroil, obtusely juinterl, rather longer that the glume, the cartilaginons shining pericarp not adherent to the seed. $-\Lambda$ nearly smooth peremial, with rmung gotstocks, froducing simple culns $\left(2-3^{\circ}\right.$ highl $)$ with long linearlanceolate flat leares toward the lase, naked above, lsearing a few sloort-pedicelled spikelets $\left(2-33^{\prime \prime}\right.$ long) in a rery simple panicle. (Name composed of $\delta i s, t c^{\circ} 0$, and $\alpha \alpha^{\prime} \rho \eta \nu, m u n$, from the two stamens.)

1. D. Americàna, Beaur, siluded river-lanks and woods, Ohio to Ilk., and southward. Aug.

\section{U N İ O L A, L. SPIKE-Ghiss. (11. 11.)}

spikelets clusely many-flowered, very Hat and 2-erged ; 3-6 of the lowest glumes empty, lanceolate, compressed-kecled; flowering glume coriaceo memhranaceons, strongly laterally compressed and kecled, striate-nervel, usually rente or pointed, entire, enclusing the much smaller compressed 2-keeled palet and the free laterally fiattened smonth grisir. Stamen $\mathbf{l}$ (or in $\mathbf{U}$. pinieulatat 3). - Upright smooth perenuials, growing in tufts from stroug creeping ruotstocks, with broal leaves and linge spikelets in an open or spiked panicle. (Ancient uame of some plant, a diminutive of unio, unity.)

* Spilelets large $\left(\frac{1}{2}-2^{\prime}(\right.$ ong) $)$, weate or oblong, 9-30-flowered; panicle open.

1. U. paniculata, I. (Swa OATs.) Culm anl panicle elongated (4$8^{\circ}$ high); leares nurow, when dry comvolnte; spritelels viute, stort-pedicelled; fhlmes glahroms, linntisli, several of the lower sterle; stamens 3. - Sand-hills wil the sein sliure, $S$. Ya. and sunthward. 
2. U. latifolia, Miclıx. (1'l. 11, fig. 1-3) Culni $2-4^{\circ}$ high; panicle 'oose; leaves broud and flat (nearly 1' wide); sprikelets at lengtl oblong, hanging un long perlicels: glumes acnte, ciliate on the keel, all but the lovest witl perfect monaudrons flowers. - Sliaded slopes,. . l'enn. to Ill., and southward.

* * Apilelets small: panicle contrueted, und-lilie; perfect flowers long-pointed.

3. U. grácilis, Michx. Cuhn $3^{\circ}$ high, slender; spikelets short-pedicelled $\left(2-33^{\prime \prime}\right.$ long), hroally werlge-slaped, acute at hase, 4-8-forcered; glumes oratc and divergently healied, long, the 3 lowest empty - Sandy soil, from long Island to lra, near the coast, and sonthward. Ang.

\section{DISTÍCHLIS, liaf. Spike-Grass. (Pl, 10.)}

Spikelets and numerous flowers compressem, crowrted in a densely spiked or capitate panicle. (ilumes herbaceons or membanacous, the lower faintly many-nervel ; flowering glumes walher coriaceous, laterally much flattened, faintly many-nered, acute. Wvary stalked. - I'lowers dicecions, rather large.

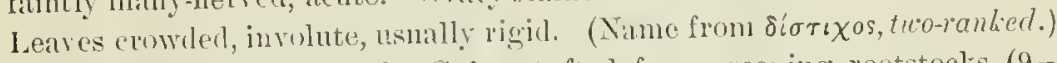

1. D. maritima, Raf. Culns tufted from creeping rootstocks $\left(9-18^{\prime}\right.$ high); spike ohlong, flattenel (l' long); spikelets ovate or olhong, 5-10-flowpred; glunes smooth and naked; grain pointed. (Brizopyrum spicatum, llook.) - Silt marshes aurl slonres. Aug. - (ilumes of the pistillate flowers more rigid and almost keeled: stignas very long, plumose; the staminate glumes smaller and somewliat lounded on the back.

\section{DÁCTYLIS, I. Orchari) Grass. (Pl. 10.)}

spikelets several flowered, crowled in me-xiled clusters, forming a branching dense paniele. Glumes all herbaceous, kexled, awn-pointed, rough-ciliate on the keel; the flowering one 5-nerwed, the npper nust commonly sumaller amd thimer. Stannens 3. Grain lance-olsong, acute, free.-- Stunt tiffed per-

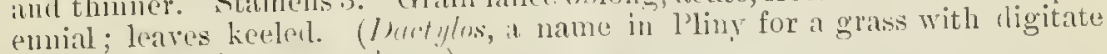
spikes, from $\delta a ́ k \tau v \lambda o s, ~ " f i n g()^{\circ}$.)

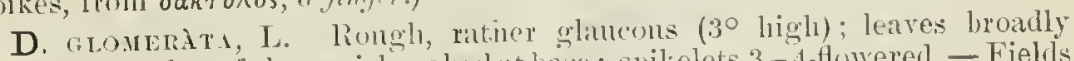
linear ; bunches of the panicle naked at base: spikelets 3 -4-fluwered. — Fields and yarks, especially in shate. June. (Nat, from lin.)

\section{BRİZA, L. Qrakisct (imass. (I'l. 10.)}

spikelets many-fluwered, wate or heart-shaped, fluttish-tunid; the flowers clesely imbricatol. Glumes romelish, uneplusl, pmrplish, very concave of ventricose, 3-5-nerved; the fluwering rentriose on the hatch, lieart-shaped at the lase, papery-nembranacens and becoming dry, scarions-margined, of

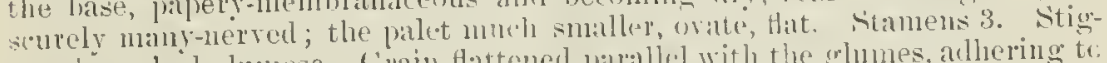
mits hancheil-plumose. Grain flattened parallel with the ghlmmes, adhering to the palet, - Leaves flat; pancle lonse, diffus", with linge show spikelets often

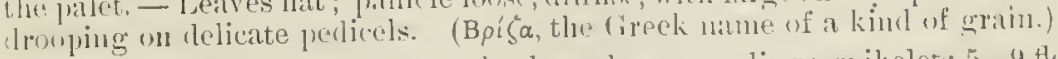

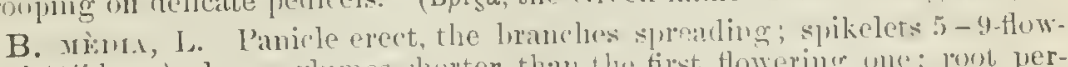
ared ( $3^{\prime \prime}$ long $)$; luwel glumes shorter than the first flowering wne; low peremuial. - l'astures; sparingl, "astwatld. June. (Alv. from Eu.)

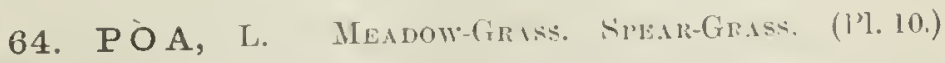

spikelets ovate or lance-ovate, laterally mupressell, sereral (2) - lo-) flow.

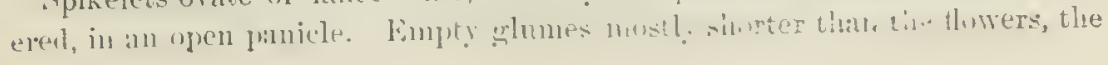


lower smaller; flowering glume membranaceo-herlaceots, with a delicate scarious margin, conpresset-keelerl, pointless, 5-nerved (the intermediate nerres more obscure or ohsolete), the principal nerves commonly clothed with soto hairs at and toward the often cobwebby base; palet membranaceous, 2-tootheu. Stamens 2 or 3. Stigmas simply plumose. Grain oblong, free. C Culms tufted, from perennial roots, except n. 1 . Leaves smooth, usually flat anc soft. (П'ó $\alpha$, an ancient Greek name for grass or fodder.)

* Low and spreading $\left(3-6^{\prime}\right.$ high) from an anmul or biennial root, flaccid; branches of the short panirle single or in pairs.

P. Axxua, L. (Low Srenti-Grass.) Culms flattened; panicle often $\mathbf{l}$. sided, usually short and prramiclal, sometimes more slender (P, cristata Chapm.); spikelets crow(ed, rely short-pedicelled, 3-7-flowered. - Culti vated and waste gromnds, everywhere. A pril-Oct. (Nat. from Eu.)

* Low; the culms $\left(6-20^{\prime}\right.$ long) geniculate-ascending from a running rootstoch: rigid, vory much futtened; panicle simple and contractch.

P. conpréssi, I. (Wire-Griss. Exglisn Blue-Grass.) (l'l. 10, fig. 1-4.) Pale, as if glaneous; leaves short; panicle dense and narrow, somewhat one-sided ( $1-3^{\prime}$ long), the shor't branches mostly in pairs; spikelets almost sessile, 3-10-flowered, flat. - Dry, mostly sterile soil, in waste places; rarely in woods. (Nat. from Eu.)

* * Low alpine or alpestrine species, crect, in perennial tufts.

- Soft and fuccid, smooth or mearly so, even to the branches of the panicle; leaves short and fat, short-pointed; liqule elongated.

1. P. alpina, L. Culms rather stout $\left(8-14^{\prime}\right.$ ligh $)$; leavcs broadly linear, especially those of the $\mathrm{cu}$ ) $\mathrm{m}$ ( $1 \frac{1}{2}-2^{\prime}$ long, $1 \frac{1}{2}-3^{\prime \prime}$ wille); panicle short and broad ; spikelets broadly ovate, $3-9$-flowered (about $3^{\prime \prime}$ long); flowering glume villous on the midrib and margins. - N. Maine (?), Isle hoyale and north shore of Lake Superior, and northward. (Eu.)

2. P. Iáxa, llaenke. Culms slender (4-9' high); leaves narow; panielc somewhat raccme-lilie, narrow, often one-sided and nodling; spikelets 2-4-flowered, one lualf smaller. - Mlpine urountain-tops of Maine, N. II, and N. New York, and high northward. (Eu.)

+ + More strict and rigid, roughish, espccially the panicle; ligule short.

3. P. nemoràlis, L. Culms $6-20^{\prime}$ high ; leaves narrow, slort, soon in volute; linanches of the panicle $2-5$ tugether, very scabous ; spikelets purplist (or sometines pale), 2-5-flowered; lower glumes ovale-lunceolate and taper. pointerl, the fowering lanceolate, somewhat webby at hase, villous on the kee? and nargins below the miklle, its uerres obscure. (l'. cesia, Smith.) - 'The more common form las a usually narrow somewhat nodding panicle, with slort ascending lrancles, the small pale or purplish spikelets 2-flowerect. 1_al), to N. Maine and N. Vt.; Iake Champlain (Pringle); N. slore of L. Superion to N. Lowa, and westward. $-\Lambda$ form with sonewhat stouter aud stricter habit, the darker on often pale spikelets 3-5-fowered (P. casia, var. strictior, (imy), corresponds nearly" to the European l', casia. High mountains of N. II. and Vt., and Gardner's Island, L. Champlain (C. E. Foron), lsle Royale and $\mathbf{N}$. shore of L. Superior, and westward. $-\Lambda$ lso a form witl the branches of the short panicle broadly divaricate; N, Wise. (Lapham). (Eu.) 
**** Talier $\left(1-3^{\circ}\right)$ meadow or woodland grasses; panicle open.

- Spikelets mostly very numerous and crowded on the rather short rough branches (usually in fives) of the oblong or pyramidal panicle, green, or sometimes violet-tinged; flowers acute; crouded, more or less webbed at base.

4. P. serótina, Ehrluart. (False Red-Top. Fowl Mranow-Grass.) Culms tufted without ruming rootstocks; leaves marrowly lincar, soft anr smooth; ligules elonguted; spikelets $2-4$ - (rimely 5-) Howered ( $1-2^{\prime \prime}$ long), alc short-pedicelled in an elongated panicle, often tinged with dull purple; flowers and glumes narrow; flowering glume very obscurely nerved. - Wet meadows and low banks of streams; common, especially northward. Jnly, Ang. $-\Lambda$ good grass for moist meadows. (Eu,)

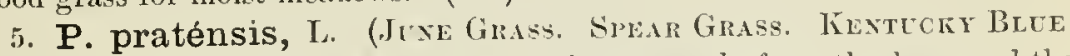
Grass.) Culms scuding off copious ruming rootstocks from the base, and the sheaths smooth : lignle short and blunt; panicle short-pyramidal; spikelets 3-5flowered, crowded, and mostly almost sessile on the hranches, orate-lauccolate or ovate; flowering glume 5-nerverl, hairy on the muryins as well as keel, - Common in dry soil; imported for pastures and mcadows. Indigenous in mountain regions fromi N. Penn. to New Lng., and northward. May-July. (Eu.)

P. Trivials, L. (Rovgunsm Meatow-Griss.) ('ulmserect from a some what decumbent hase, but no distinct ruming rootstocks; sheaths and leares more or less rough: ligule oblong, acute; panicle longer or with the branches more distant; spikelets mostly 3 -flowered, broader upward; floxering glume prominently 5-nered, naked at the morgins; otherwise nearly as in the preced. ing. - Moist meadows, ete. July. (Nat. from Eu.)

+ + Spikelets fewer and more scattered, on slender pedicels; plants soft and smooth, flocering early. (No mmning rootstocks, except in n. 10.)

-+ Spitelets small $\left(1-2^{\prime \prime}\right.$ long), pale green, rather loosely 2-4-flowered: Howers oblong, obtuse; flowering ylume scarcely scarious-tipped; culm-leaces lancelinear, acute, 1 - $3^{\prime}$ long.

6. P. sylvéstris, Gray. Ch'. fattish, erect; branches of the oblonglyramidal panicle snort, numerous, in fives or more; flowering glunces villoms on the leel its whole length, and on the maryins below the middle, sparingiy webberl at base. - Rocky wook and meadows, western N. Y. to Wisc., Kan., :mil sonthward. June.

7. P. débilis, Torr. Culms terete, weak; branches of the small panicle few and slender (the lower $1 \frac{1}{2}-2$ ' long to the few spikelets), in pair's and threcs; foucers very obtuse, smooth and glabrons, except a sparing weh at hase. - Rocky woodlands, R. I. to Penn. and Wisc. May.

++ Spikelets 2" long, light green; oblong-lunceolate flowers and ghumes acnte.

8. P. alsodes, Gray. Leaves rather narrowly linear, acute, the upyernost $\left(2 \frac{1}{2}-4^{\prime}\right.$ long) often sleathing the base of the narrow and loose panicle. the capillary branches appressed when young. mostly in threes or fours; Huw ering glume very obscurcly nerved, rillous on the keel beluw, and with a narrow cobwebby tuft at base, otherwise glalorous. - Woods, on hillsiles, N. Eng. to Penn. and Va., west to Wisc. May, June.

+++ Spikelets larger $\left(3-4^{\prime \prime}\right.$ lony). pale green, ruely purple-tinged, few and scattered at the ends of the long capillary bramitics (mostly in pairs or threes) of the very diffuse punicle; floners 3-6, luose, oblong and obtuse, as 
is the larger glume; flowering glume conspicnously scarious at the apex, villous below the middle on the keel and maryins; culms flattish, smooth.

9. F. flexuosa, Muhl. (not of Wahl.) Culns $1-3^{\circ}$ high, tufter!, its leaves all lincar $\left(2-5^{\prime}\right.$ long), frodually taper-prointed; panicle rory effuse (its branches 2-4' long to tlie 4-6-flowered spilielets or first ramification) ; flowering glume prominently nerved, no web at the base. - I)ry wools, I'eun. aud Del, to Ky., and soutliward. Feb. - May, - Near the list.

10. P. brevifolia, Muhl. Culms $1-1 \frac{1}{2}^{\circ}$ high from running rootstocks,

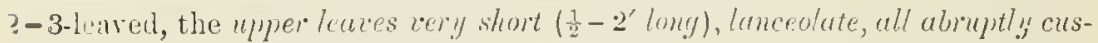
pillute-tuped; branches of the slort panicle nustly in pairs; spikelets 3-4Howered; flowering "llume ruther absurely nored, robrebly at base. - Rocky or hilly woodlands, Penn., Va., and sparingly westwarl to Ky, and Ill. April, May. - Culm scarcely snpassing the long root-leares.

\section{GRAPHFPHORUM, Desr.}

Sipikelets 2-4-flowerel, compressed, the rhachis pilose on one side, jointed, produced above the flowers into a hairy pedicel. Enuty glumes thin-membranaceons, acute, carinnte, mostly nearly equalling the remote flowers; flowering glume thin and membranceous or scarions, convex, scarcely keeled, faintly nerved, entire, pointless and awuless. Stameus 3. Stigmas plumose. Orar! glitrons. - Perennial, with linear flat leares, their sheaths clusel at base, the

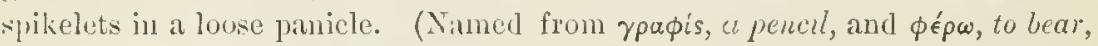
from the terminal hairy pedicel.)

1. G. melicoídeum, Dest. Culn 1-20 higlı; leaves ronghish; panicle open; glumes mucqual, lanceolite, their midrib and the pedicels rongl. N. Maine, N. Vt, Lpper Mich., and northward; rare. - Var. nàss, Gray, is a luxmiant form, 2-30 high, with ampler panicle; borders of a swamp, Macomb Ca., Micl. Aug.

\section{SCOLÓCHटOA, Link. (Pl. 15.)}

spikelets 2-4-flowered, sulbteretc. Riachis hary at the base of the flowers, enlling in a naked perlicel. Eumpty glumes concarr, memlinuaceots, mequal,

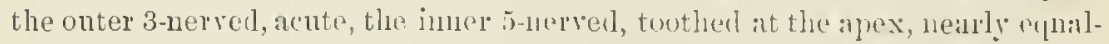
ling the flowers; flowering glune mon ligid, proninently i-nerverl, tontleat

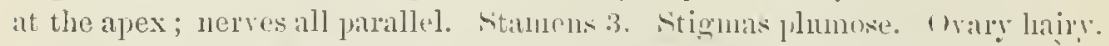
- Tall perennials, growing in water, with lousely sherthing leawes, and spike

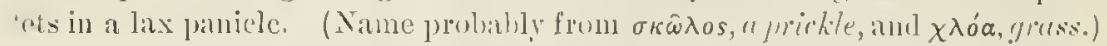

1. S. festucàcea, link. Stout, $3-4^{\circ}$ liggl, smooth; leaves rough the margins; panicle suluerect; spikclets $3-4$ " loug. (Festuca borealis, Mook.) - Emmet Co., Iowa (Cratty), ant northward.

\section{GL Y C E R I A, R. Br. Manna-Grass. (Pl. 10.)}

Spikelets terete an flattish, several-many-fowered; the flowers mostly early Heciluons hy the brealing up of the rhichis into joints, leaving the short and mequal 1-3-110\%el nembranavous lower ghume lehind. Flowering glume :ur l jalet uaked, of a ratler firm texture, nearly equal: the grlume roumderl on

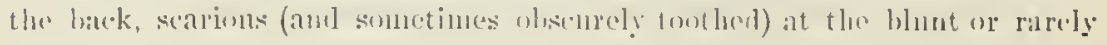


acute summit, glabisus, prominently 5-7-nerver, the nerves parallel and separate. Siquanulic fleshy and truneate, or none. Stamens conmonly 2. Sityles present; stignils compoundly plumosc. Orary smootl. Grain oblong, free, the furrow very narrow or none, - Pereminl smooth marsh grasses, mostly with creeping bases or rootstoeks; spikelets panicled. (Name from rivkepós, suret, in allnsion to the taste of the grain.)

* Spiliclets oecate, oblong, or linear-ablong, $1-3$ "in length,

+ At length nodding in an open panicle, futtish laterally but turgid.

1. G. Canadénsis, 'Irin. (Ratteessake-Grass.) Culm stout, $2-3^{\circ}$ high; leaves long, ronghish; paniele oblong-pyramidal, at length drooping; spikelets ovate, at length very broad and tumid, Briza-like, 2" long, pale, witl furplish glumes; flowering glume aente or blnnt-pointed, firm, with not very prominent nerves, longer than the rounded palet. - Bogs and wet places; common from P'enn. to K. Kan., and northward. July.

++ Erect in a nurrow contracted panicle, someutut fluttened and turgid.

2. G. obtùsa, 'I'rin. Culı stout, $1-2^{\circ}$ hight, very leafy; leaves long, smooth; penicle nurrouly oblon!, dense $\left(3-5^{\prime} \operatorname{long}\right)$; spikelets 3 - 7 -flowered, $2-3$ " long; flowering glnme obtuse. - Bogs, E. New Eng. to Penu. and souihward, ne:ar the coast.

3. G. elongàta, Trin. Leaves very long ( $\mathrm{l}^{\circ}$ or more), rongh; panicle nurowly racemose, elongated $\left(1^{\circ} \mathrm{long}\right)$, recurving; the branches and 3 -4-flowered spikelets appressed: flowering rolume obtuse. - Wet woods, N. Eng. to Mich., Minn., and northward; Roan Mt., X. C. (Scribner). July-Aug.

+++ Diffuse; flower-glume truncute-obtuse, strongly 7-nerved; palet 2-toothed.

4. G. nervàta, Trin. (Fow Mradow-Grass.) (Pl, 10, fig, 1-3.) Culm erect, $1-3^{\circ}$ high ; leaves rather long; bruches of the loose panicle capillary, at length drooping, the numerous small spikelets ( $1-2^{\prime \prime} l o n g$, eommonly purplisli) orate-oblong, 3-7-tlowered. - Moist meadows; common. June.

5. G. pállida, Trin. Cnlms slender, l $-3^{\circ} \mathrm{long}$, aseending from a ereeping hase; leares short, sharp-pointed, pale; brunches of the ruther simple punicle slender, evert-spreadiny, rouglt; the spikelets usually feu, someuhut appressed, whlong-linear, 5-9-flowered (pale, 2-3" long); flowering glume minutely 5tonthed; the palet laneeolate, eonspienously 2-toothed. - Shallow water; Maine to Vta., west to Ky., Ind., and Mieh.; common, especially northward. July.

6. G. grándis, Watson. (ReED Meanow-Grana.) Culn stout, nplight, $3-5^{\circ}$ high ; leaves large $\left(1-2^{\circ}\right.$ long, $\frac{1}{3}-\frac{1}{2}$ wide) ; panicle much branched, ample (8-15' long), the mumerous branches ascending, spreading with aye; spikeicts oblong or linerct-oblong, 3-6-flowered (usually purplish, 2-3" long); flowpring glume entive. (G. aquatica of Amer. authors) - IVet grounds; N. Eng. to western N. Y., Mielı., Minn., and westward.

* Spikelets linear $\left(\frac{1}{2}-1^{\prime}\right.$ long), pale, appressed on the branches of the long narrow racemose panicle, terete except during anthesis; palets minutely roughish, the upper 2-toothed; squamulce unilateral or united; ligule long; culm flattened ( $1-5^{\circ}$ high), ascending from a rooting buse. (Glyecria, R. Br.)

7. G. fluitans, R. Br. Panicle $1^{\circ}$ long; the simple brauches appressed. fually spreatius lecluw ; leaves short and ratler hroul, lory smouth; spikelets 
7-13-flowered; flowering glume oblong, obtuse, or the scarious tip aeutish, eutire or obscurely 3 -lobed, usually rather longer than the bluut palet. - Slatlow water; common. June-Ang.

8. G. acutiflora, Torr. Spikelets 5-12-flowered, few and seattered; flowering glume oblong-lanceolate, acute, shorter than the long tapering point of the pulet. - Wet places, Penn. to Maine; rather rare. Juue. - Resembles the last; but the ereet leaves smaller, the separate Howers twice the length ( $4^{\prime \prime}$ long), and less nerved.

\section{PUCCINELIIA, Parl.}

Characters as iu Glyeeria, but the flowering glunes inconspicuously or obsoletely 5-nerved; squamula thin and distinct; stigmas sessile and simply plumose; grain conpressed, often broadly furrowed. Mostly saline specres; perennial. (Named for Prof. Benedetto Puccinelli, an Italiau botanist.)

1. P. marítima, Parl. (Goose-Grass. Sea Spear-Grass.) Root stoloniferous; culns erect, $1-1 \frac{1}{2} \mathrm{ligh}$; leaves involute, acute or pungent; lower branches of the narrow panicle often solitary or in pars, appressed or more or less spreading; spikelets $3-6^{\prime \prime}$ loug, oblong or linear, 4-9-flowered ; flowering ginmes rounded at the summit, $1 \frac{1}{2}$ " long. (Glyceria maritima, Wahl. Atropis maritima, Griseb.) - Marshes along the coast; not rare, and somewhat variable in the form of the pauicle and size of the glumes. (Fu.)

Var. (?) minor, Watson. Culms low and slender, from very slender (reeping rootstocks; leaves very narrow and involute; ligule long: panicle short and very uarow; spikelets 2-4-flowered, the flowers $1^{\prime \prime}$ long or less. Shore of Mt. Desert Island (E. L. Rend); Labrador (J. A. L//en). - Probably rather a form of the western P. airoides (Poa airoilles, $N$ utt.).

2. P. dístans, Parl. Not stoiloniferous; culms rather stout, geniculate helow; leaves mostly fat, short; ligule short; lower branches of the panicle in fours or fives, usually more or less naked at hase, soon spreading aud at length deflexed; spikelets 2-3" long, 3-6-floweres ; flowering glume truu(ate-obtuse, $\frac{1}{2}-1$ " long. (Glyeeria distaus, Wrahl. Atropis distans, Griseb.) - Salt marshes along the coast and on ballast; apparently much rarer than the last, and perhaps not native. (Fu.)

\section{FEST Ù C A, I. Fescte-Grass. (P'l. 10.)}

Spikelets 3-many-flowered, panicled or racemose; the Howers not webby at base. Iower glumes mequal, mustly keelel. Flowering glunes charta ceous or almost coriaceons, romdish (not keeled) on the back, nore or less 3-5-nervel, acute, pointed, or often liristle awned from the tip, rarely blunt; the palet mostly adhering at naturity to the enclosed grain. Sitmens $1-3$. - llowers, and often the leaves, rather dry and harsh. ( $\Lambda$ u ancieut Latiu name of some kind of grass, of uncertain nieaniug.)

* Flowers awt-shaped, bristle-pninted or awned from the tip; panicle contractea.

- Annuals or biemials, slender, 5-18' high; lenes convolute-bristle-form.

F. Mrthrs, I. Pauicle spike-like, one siled; sprikelets almut 5-flowered; lower glumes very unequal; rmm mmoh lomper them the flomering ghime, fully 6" in lenertls; stimen 1.- I)ry fields, Niutncket, Miss., to Del., and sonthward. July, (Nat. from Eu.) 
1. F. tenélla, Willd. Panicle spike-like, one-sider, or more compound aril open; spikelets 7-13-flowered; arn 1-3"long or more, usually shorter than or cbout equalling the glume: stamens 2. - Dry sterile soil, especially soutliward. June, July.

$$
\text { +t + Perennial, tufted, 6-24' high; stamens } 3 .
$$

2. F. ovina, L. (SneEr's Flscl'l\%) Glaneons, $\frac{1}{2}-2^{\circ}$ high; leaves mostly radieal, very narrow and convolute; panicle somewhat one-sided, short, usually more or less compound, open in Howering; spikelets 3-8-flowered; awn not more than half the length of the flower, often mueh shorter or alnost wanting. - Indigenous in vorthern New Lng., about Lake Superior, and northwarl; naturalized farther soutl as a pasture grass. June. - Valics greatly. - Var. virfens, L. (which with us has running rootstoeks), a state with the spikelets partially eonverted into leafy shoots, is found on the alpine summits of the White Mits., and high northwarl. - Var. Dukiúseula, Koch, is a tall form, with spikelets rather larger, nsually in a more compound panirle; culm-leaves often flat or less couvolute, and the lower with their sheaths pither smootl or hairy. New Eug. to Va, and westward, as a naturalized plant, and indigenons northward. A native form of this variety with a lax panicle, 2-4-flowered spikelets, and slender awns nearly as long as the glume (var. rubra, of last ed.), is found on lieweenaw l'eninsula (hobbins) and Isle liogale, L. Simperior (Gilmun). (Eu.)

* * Fourers oblong or lanceolate, awnless or nearly so $\left(1 \frac{1}{2}-4\right.$ " lomg); grain often free! (Root perennial; culms mostly tall; leaves flat.)

3. F. nùtans, Willd. Culm $2-4^{\circ}$ high, naked above; leaves broally linear, taper-pointed, dark green, often rather hairy; panicle of several long und slender spreading bronches, mostly in pairs, drooping when old, rough, naked below, bearing near their extremity a few orate $3-5$-flowered spikelets $\left(3^{\prime \prime}\right.$ loug) on pretty loug perlicels; flucers ovute-oblung, rather obtuse, cluse lugether, eoriaceous, smooth, very obscurely 5-nerved. - Roeky woods and eopses. July. - A eommon form with the panicle more or less eontrated and somuwhat erect has been distiuguished as F. Shortii.

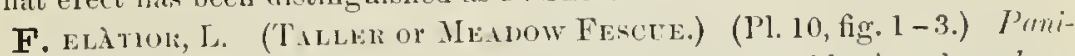
cle narrow, contraeted before aud after flowering, erect, with short branches: spilielets crowled, 5-10-flowererl; flowers rather remote, oblong-lanceolute: Howering glume 5-nerved, scurious-margined, blunt, acute, or rarely with a distinct but very slort awn. - The type is large, $3-4^{\circ}$ high; spikelets about 6" long, in an ample and compound panicle. Rich grass-lincl. - Var. prisTexsls, Gray (F. pratensis, IIuds.), is lower ( $1-3^{\circ}$ high $)$, with a simpler or close panicle of smaller or narrower spikelets, and abounds in grass-lands. June-Aug. (Nat. from En.)

F. gigavi:A, Vill. Erect, glahrous, $3-4^{\circ}$ high; leaves bright green, $3-6^{\prime \prime}$ 1) roar; panicle very loose, nohling; spikelets $3-6$-fluwered; flowering glumes 3 " long, with a sleuder awn of twice the leugth. - Of rare occurrence near the coast. (Nat. from Eu.)

\section{B R Ò US, I. Brome-Grass. (Pl. 10.)}

Spikelets 5-many-fowered, panicled. Glumes uneqnal, membrauaceous, the lower 1-5-, the upper 3-9-nerved, Flowering glume either eonvex on 
the back or eompressed-keeled, 5-9-nerved, awner or bristle-pointed from below the mostly 2-cleft tip; palet at length arlhering to the groove of the oblong or linear grain. Stamens 3. Styles attached below the apex of the ovary. - Coarse grasses, with large spikelets, at lengtl drooping, on pedicels thiekener at the apex. (An ancient name for the Oat, from Bpópos, food.)

\$1. Flowering glume oblong, turgid, and convex on the back; the flowers imbricated over one another before expansion; lower empty glume distinctly 3-5nerved, the upper 5-9-nerved.

* Perennial; indigcnous. Lower glume strongly 3-ncrved, the upper 5-nerved.

1. B. Kálmii, Gray. (Wrus Curss.) Culm slender $\left(1 \frac{1}{2}-3^{\circ}\right.$ high); leaves and sheaths conspicuonsly or sparingly hairy; panicle simple, small $\left(3-4^{\prime} \mathrm{long}\right)$; spikelets drooping on capillary peduncles, closely 7 - 12-thowered, densely silky all over; awn only one third the length of the lance-oblong Aower; flowering glume 7-9-nerved, much longer and larger than the palet. - Dry grounl, N. Eng. to Penn., Mo., Mimn., and northward. June, July.

* Annuals or biennials, introluced info ymain-jields, wre rely in waste grounds.

B. secálines, L. (Cheat or Cnems.) (1’l. 10, fig. 1, 2.) Panicle spread. ing, even in firit, the drooping peduncles little bratched; spikelets oblongwode, turyid, smooth, of 8-10 rather distant fluwers; glume rather longer than the palet, short-awned or awnless; sheaths nearly glabrous. - 'oo common in wheat-fields. June, July. (Ailv. frum Lu.)

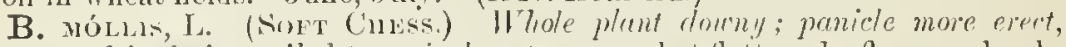
contracted in finit: spiliclets comiral-ovate, somewhat flattened ; flowers closely imbricated; glume reute, equalling the awn. - Wheat-fields, N. Y. to Va.; scarce. June. ( $\Lambda$ dv. from Lu.)

B. lincruoses, J. (Upingre Cinss.) Very similar to the last, bnt nearly glalirous or the sheaths sometimes hairy; ghumes glabrous and shining. (Arlv. from Eu.)

$\$ 2$. Flovering ghume somexhat convex, but heeled and laterally more or less compressed, at leust alove, flowers soon separating from each othcr ; lower empty glume !-nerred, the upper 3-nerved, or with an obscurc additional pair.

* Peremial, tall $\left(3-5^{\circ}\right.$ high); flowers oblong or lancrolate.

2. B. ciliàtus, I. Panicle compound, very loose, the elongated hranehes at length divergent, drooping; spikelets 7-12-flowered; flowering gltume tipperl with an awn $\frac{1}{2}-\frac{8}{4}$ its length, silky with appressed hairs near the margins, at least loclow (or rarely naked), smooth or smoothish on the back; ur, in var. rúncis:, Gray, clothed all over with short and fine appressed hairs. - liver-hanks and moist woodlands; common. July, Aug. - Culm "unl large leaves $(3-6$ " wide) smooth or somewhit hairy; the sheaths in the larger forms often hairy or densely downy near the top. Variable, eomprising severnl forms.

B. K:1.1: I. Culm slender and panicle smaller; spikelets 5 -9-flowered: glume linear-lanceolate, scarcely keelel, hairy near the margins, rather longer than the awn; sheaths and lower leaves haily or downy.-N lirunswick to Mieh. and liy. (Nat. from lin.)

* * Amuel or bienninl; flowers slender; palet pertinate-cilute on the nereres.

B. stínuls, I. Culm glahrons; leaves rather downy pranicle open:

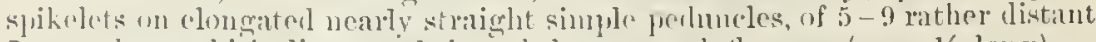

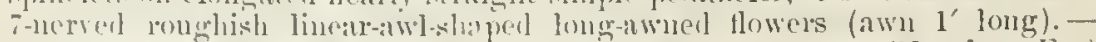

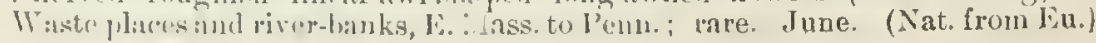


B. тесто̀น, L. I.eaves short; panicle las, somewhat 1-sided, the more numerons pubeseent spikelets on very slender curving pedicels. - More common, N. Ling, to I'enn. and N. Y. (Aclv, from Eu.)

\section{L ÒI I U M, L. DARNEL. (Pl. 11.)}

Sipikelets miny-flowered, solit:ury on each joint of the continuous rhachis, placed edgewise; empty glumes, except in the terminal spikelet, only one (the nlyer) and exterual. (therwise nearly as in $\Lambda$ gropyrum. (Ancient Latin llatue.)

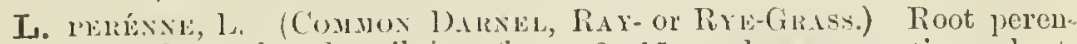
nial; glume shorter than the spilictet; floceers 8-15, awnlcsis or sometimes shortawned. - Ficlds and lots; eastward. June. (Nat. from liu.)

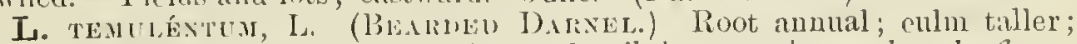
unter glame filliy runalling the 5-7-Howered spilielet; awn longer than the flower

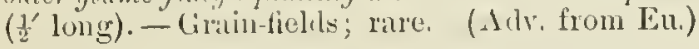

\section{A G ROPY்RUM, Gaertn. (Pl. 11.)}

Spikelets 3-many-flowererl, compressed, 2-ranked, alternate on opposite sides of a solitary terminal spike, single at each joint (the lowermost, or all, rarely in pairs) aud sessile with the side against the axis. Glumes transrerse (i. e. right and left), nearly equal and opposite, laneeolate, herbaccous, nerved. Flowering glumes rigid, convex on the back, 5-7-nerved, pointed (1) awnel from the tip; palet flattened, bristly-cilinte on the nerves, adherent to the grvove of the grain. Stamens 3.- - ) ur species rather coarse perennials, of clifficult defiuition. (Name from àypós, a field, and rvpós, wheat.)

* Multiplying ly tong muning rootstocks; ann shorter than the flower or none.

1. A. rèpens, Benur. (Corcu-, Qutcit-, or Qúr-Giass.) Spitelets 4-8-flowerrl, glubous or uearly so; glumes 3-7-nerved; rlachis glabrous, lut rough on the orlges; awus when present straight; leaves flat and often roughish or pubcscent above. ('Triticum repens, $L_{\text {. }}$ ) - Nat. from Europe in cultivated grounds, ficlds, ete., and very troublesome; indigenous in some of its forms nortliwestwird aud on the coast. - Varies greatly. The ordinary form las a narrow spike, with :3-5-flowered spikelets, the glumes mercly acute and rigicl-cuspichate, or acuminate, or short-awued. A tall form, rather bright green, bears awis nuirly as long as the glumes. Other forms abound, especially on or 11 all the cosst. A maritine variety, much resembling var. frlancum, Boiss. (A. glancum, R. S. S.), with large erowded 5-10-flowered spikelets and glumes very blunt or mucronate, glancous and the leaves rather rigid and jungent, oceurs on the coast of Nanine (Cape Elizabetl, Thekermon). In the more nsual form of this varioty, with the large spikes iften elougated $\left(3-9^{\prime}\right)$ and the laves less rigil, the grlumes are acuminate (1) rarely short-awned. The rlachis or the whole inflorescence and the lower sheatlss are sometiues very pulesent. The glahrous state, or a very sinilar rrlabrous variety, is also alumdant in the western region, from lian. and Neb. to the l)akotas, and westwarl, where it is known as Blue-joint or Blue-stem. (Eu.)

2. A. dasystàchyum, Vascy. Ristemhling the last; glaucous; lenves narrow ant often involute; the 5-9-fluwered sprikelets densely douny-hairy all wer; glumes thimuer with s('illious margins, mostly long-aeuninate. ('Triti-

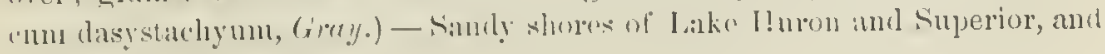
northward. Sug. 
* No obvious munning rootstocks, glubrous, or the flat and roughish leaves some times hairy aboce; glumes as well as flowers mostly awned or aicn-pointed.

3. A. violàceum, Lange. Spite short, dense, strict and rigid, usually tinged with violet or purple; spikelets $3-5$-flowered ; glumes conspicuously 5nerved, rather abruptly narrowed into a cusp or short aun. (Triticum violaceum, Hornem.) - Alpine region of the White Mts., I. Superior, north and westward. (Eu.) - Passing into a vauety with longer usually pale narrow spikes and atteuuate often long-awned glumes, which sometimes approaches A. caninum. N. Brunswick, White Mts., N. II., Penu. (Porter), L. superior, and westward.

4. A. caninum, R.\& S. (AwNed Wheat-Grass.) Spike usually more o' less nodding, at least in fruit, rather dense $\left(3-6^{\prime}\right.$ long); spikelets $3-5$ flowered; glumes 3-5-nerved; auns straight or somewhut bent or spreading, fully twice the length of the palet. (Triticum caninum, L.) - Sparingly naturalized in cultivated ground and meadows. Indigenous along our northern borders, and westwaril. (Eu.)

5. A. ténerum, Vasey. Culms $1-3^{\circ}$ high; leaves narrow; spike very narrow, 2- $\boldsymbol{\gamma}^{\prime}$ long; spikelets $3-5$-flowered; glumes short-acumiuate. - Minu. to Kan., and very common westward.

\section{LEPT Ù U S, R. Br.}

Spikelets 1-2-flowered, solitary and alternate "pon the opposite sides of a narrow spike, sessile and appressed in the concave joints. Eulpty golumes transverse, narrow, rigicl, 5-nervel, the flowering much shorter, thin and lyaline. - Low ammals, luranching at the basc, with narrow leares and rigill often curved spikes. (Name from $\lambda \in \pi \tau$ ós, murrom, and oupá, tail, or spike.)

L. Ixcenvires, Triu. Much hanched, decumbent, 6 ' high or less; spikes terminal and lateral, 1-4' long, the base included in the broad sheath. Borders of brackislı marshes, Mil. to S. Va., and on hallast northward. (Natfrom Eu.)

\section{HÓ R DEU M, Touru. B.ırıer. (Pl. 11.)}

Spikclets 1-flowered, with an awl-shaped rudinent on the inner side, three at each joint of the rhachis of a terminal spike, bnt the latcral ones nsually imperfect or albortive, and slort-stalked. Empty glumes side by sicle in front of the spikelets, 6 in number, forming a kind of involuce, slencler ancl awnpointed or bristle-form. Flowering glume aud jalet herbaceous, the former (anterior) convex, long-awncl from the apex. Stanens 3. Grain oblong, commonly alherent. - Spike often separating into joints. Ours amuals or biemials, or scarecly peremial. ('The ancient Latin name.)

1. H. jubàtum, I. (Sormine-Tall Grias.) (I'l. 11, fig. 1, 2.) Low; lateral flowers abortive, on a slort perlicel, short-awned; the perfect flower bearing a capillary awn (2' long) alont equalling the similar capillary glumes, all sprcading. - Sanrly sea-shore, upper Great Lakes, and wcstwirl. June.

2. H. praténse, Iluts. Inw $\left(6-18^{\prime}\right.$ highl); latcral flowers imperfect or ncutral, awnless m. nerely pointerl; perfect flower with awn as long as those of the glumes $\left(3-6^{\prime \prime}\right)$; spike lineat, $1-2^{\prime}$ long. - I'lains, esperially in saline snil, Olio to 111. and westwald ; also sparingly introdnerd, Va., aud southwatrel alonge the romst. Maty, Jute. (En.) 


\section{5. ÉLY M U S, L. LYuE-GRASS. WILD RTE. (Pl. 11.)}

Spikelets 2-4 at each joint of the rhachis of a terminal spike, all fertile and alike, sussile, each 1-7-Howered. Glumes conspicnons, nearly side by side in front of the spikelets, 2 for each spikelet, forming an involucre to the cluster. Flower coriaceons; the glume rounded on the back, acute or awned at the apex. Grain adherent to the involving glnme (whence the name, an ancient one for some grain, from $\dot{\epsilon} \lambda \dot{u} \omega$, to roll up).

* Glumes and flowers firm or rigid, all or only the latter awned; spikelets $1-5$ flowered; slender perennials, with rather harsh and broad flat leaves.

\section{+ Spike large and stont.}

1. E. Virgínicus, L. (Pl. 11, fig. 1-3.) Culm stout, 2-3 high; spike rigidly upright, dense (2-3' long, $6^{\prime \prime}$ thick), the short preduncle usually inrluded in the sheath; spikelets 2-3 together, 2-3-flowered, smouth, rather shortawned, about the length of the thickened strongly-nerved and bristle-pointed lanceolate glumes. - Rirer-banks; common. Ang.

2. E. Canadénsis, L. Spike soon nodding (5-9' long), on an exserted peduncle; spikelets mostly in pairs, of 3-5 long-awned rough or rough-hairy Howers; the aul-shaped glumes tipped with shorter auns. - Var. Ginccufócius, Gray, is pale or glancous throughout, the flower's with more spreading awns ( $1 \frac{1}{2}^{\prime}$ long). - Yar. 1xTenuènus, Y'asey, has the awns scarcely longer than the glumes. - River-banks; common.

\section{+- Spike and culm more slender.}

3. E. striàtus, WVilld. More or less pubescent; spitie dense and thickish (2-4' long), upright or slightly nodding; spikelets mostly in pairs, 1-2- (or rarely 3-) flowered, minutely bristly-hairy; glumes awl-shaped, mistle-auned, 1-3-nerved, abont thrice the length of the flowers, which are only $3^{\prime \prime}$ long exclusive of the capillary awn ( $1^{\prime}$ long). - Var. villosus, Gray, has very hairy Howers and glumes, and villous sheaths. - Rocky woods and banks. Jnly, Aug.

4. E. Sibíricus, L., var. Americànus. Glabrous; spike u'and-like $\left(2-6^{\prime}\right.$ long, 2-3" thick), often somewhat nodding; spikelets in pairs, $3-6$ flowered; glumes linear-lanceolate, 3-5-nerved, acnminate and smooth or often scabrous on the nerves, shortauned, shorter than the flowers, which hear an erect awn of once or twice their length. - Marquette, Mich. (Porter), N. Minn.s and westward.

* Chlumes and palet awnless and soft in texture; red-like perennals.

5. E. móllis, 'Trin. Culm ( $3^{\circ}$ high) velvety at top; spike thick, erect (8 $8^{\prime}$ long); spikelets 2 or 3 at each joint, 5 -8-flowered: the lanceolate pointed 5 -7-nerved glumes ( $\mathbf{l}^{\prime}$ long) and the pointed flowers soft-villous; rhachis of the spikelets separating into joints. - Shore of the Great Lakes, Maine, and northward. (Near E. arenarius.)

* * Empty glumes very narrou, and all ver!y long-auned; spike disarticulating at maturity.

6. E. Sitànion, Schnltes. Low $\left(\frac{1}{2}-2^{\circ}\right.$ high $)$, stout; spike $1-4^{\prime}$ long, the peduncie slightly exserted; the spreading scabrous awns 2-3' long. - Central Minu. to kau., antl westrard. 
76. A S PRELLA, Willd. Bottle-Brusir Grass. (Pl. 11.)

Spikelets 2-3 or sometimes solitary on each joint of the rhaehis of a ter minal spike, raised on a very short callons pedicel, loosely 2 -4-flowererl (when solitary flatwise on the rhachis). Glumes none! or sinall, awn-like, and deciduous. Otherwise nearly as in Elymus. (Name a diminutive of asper, rough or prickly.)

I. A. Hýstrix, Willd. Perennial; eulms $3-4^{\circ}$ high; leaves and sheatls smoothish; spike loose $\left(3-6^{\prime}\right.$ long $)$; the spreading spikelets $2-3$ together, early deeiduous; Howers smoothish or often rough-hairy, tipped with an awn thrice their longth (I' loug). (Gymnostichum Hystrix, Schreb.) - Moist woodlands. July, Aug.

\section{'7. A RU N DI N ÀRIA, Michx. CAxe. (Pl. 11.)}

Spikelets flattened, 5-14-flowered; the flowers somewhat separated on the jointed rhachis. Empty glumes very small, membranaceous, the upper one larger. Flowering glumes aud palet herbaceons or somewhat membranaceous. the glume convex on the back, many-nerved, tapering into a mucronate point or liristle. Sipumula 3, longer than the ovary. Stamens 3. Grain oblong, free. - Arborescent or shrubly grasses, simple or with fascicled branclies, and with large spilielets in pauicles or racemes; blate of the leaf jointed upon the sheath; Howers polyganons. (Name from arundo, a reed.)

1. A. macrospérma, Michx. (LARge Caxi.) (11. 11, fig. 1, 2.) Culms arlorescent, $10-40^{\circ}$ high and $\frac{1}{2}-3^{\prime}$ thick at base, rigil, simple the first year, branching the second, afterwards at indefinite periods fruiting, and soon after (leeaying; leaves lanceolate ( $1-2^{\prime}$ wide), smoothish or pubescent, the sheath ciliate on one margin, stoutly fimbriate each side of the base of the leaf; panicle lateral, composed of few simple racemes; spikelets $1-3^{\prime}$ long, purplisl or pale, erect; flowering glume lanceolate, acnte or acuminate, glabrous or pubescent, fringed (5-I2" long). - River-banks, S. Va. (?), Ky., and sonthward, forming cane-brakes. April.

Var. suffiuticosa, Mumo. (Swren CAxe. Smıl CAxe.) Trower and more slender $\left(2-10^{\circ}\right.$ high 1$)$, often growing in water; leaves $4^{\prime \prime}-\mathrm{I}^{\prime}$ broad; spikelets solitary or in a simple raceme at the summit of the branches, or frequently on leafless radieal culms. (A. tecta, Mhhl.) - Swamps and moist soil, Md., S. Ind. to S. K. Mo., and southward. Sometimes fruiting severu years in sueeession. 


\section{SERIES II.}

\section{CRYPTOGAMOUS OR FLOWERLESS PLANTS.}

Vegetabes destitute of proper flowers (i. e. having no stamens nor pistils), and producing instead of seeds minute one-eelled germinating boclies ealled spores, in which there is no embryo or rudimentary plantlet.

\section{Class III. ACROGENS.}

Cryptogamous plants with a distinet axis or stem, growing from the apex, and commonly not with later increase in diameter, usually furuished with distinet leares; reproduetion by antheridia and arehegonia, sometimes also by gemmation.

\section{SUbClass I. VASCULAR ACROGENS, or PTERI- DOPIYTES. ${ }^{1}$}

Stems containing woorly fibre and vessels (especially sealariform or spiral ducts). Antheridia or archegonia, or both, formed on a minute prothallus which is developed from the spore on germination, the archegonium containing a nucleus, which after fertilization becomes an oöspore and at length grows into the conspicuous spore-bearing plant.

ORder 130. EQUISETACEAE. (IIOlisetait. Family.)

Rush-like, often branching plants, with jointed and mostly hollow stems from running rootstocks, having sheaths al the joints, and, when fertile, terminated by the conical or spike-like fructification composed of shieldshaped stalked scales bearing the spore-case's beneath. - I single genus.

1 The orders of this Subchass have been elaborated anew for this edition by Prof. Daxiel C. Eaton of Tale Lnirersity. 


\section{EQUISETUM, L. Horsetall. Scouning Rusir. (Pl. 21.)}

Spore-cases (sporungia, thece) 6 or 7 , adhering to the under side of the angled shield-shaped scales of the spike, I-eelled, opening down the inuer side and discharging the mumerous loose spores. To the base of each spore are attached 4 threiul-like aud chb-shaped elastic filanents, which roll up closely around the spore when moist, and wucoil when lry. - Rootstorks peremial, wide-creeping, hard and blackish, jointel, often branched aucl sometimes lear. ing small tubers. Stens erect, ç lindrical, lwllow, jointed; the surface striated or groured witl altermate ridges and fincuws, the cuticle in most species con. taining silica in the form of minute granules, rusettes, or tubercles; the joints containing hesicles the central air-carity a circle of smaller hollows beneatlo the furrows and a set of still smaller unes beneath the rilges; the nodes closed ancl solin, each hearing instear of leaves a sheatlo which is divided into teeth corresponding in nunber and prsition to the principal ridges of the stem; stomata in the furows, each with two pairs of gnard-cells, of which the onter pair is marked with raliatiug lines of silica. Branches, when present, in whorls from the lase of the sheatl, like the sten, lut without the central air. (avity. P'rothallus green, formerl npon the gronud, often varimely loberl, msually dioecious. (The ancient name, from cyuss, lorse, and setu, lristle.)

\$1. Anmul-stemmed, not surviving the winter.

* Fruting in spring firom snft and ruther sucuteut pule or brounish fertile stems.

- the sterile stems on buches aperting later, herbaceous and very difjerent.

- Fertile stems unbranched, destitute of chlorophyll and soon perishiny; tho sterile brenrling appiously.

3. F. arvénse, T. (Commos II.) Fertilestems $\left(t-10^{\prime}\right.$ high) with looso and usually distant aljout $8-12$-tootled sheaths; the sterile slender (at lengtn $1-2^{\circ}$ high), 10 - 14-furrowed, producing long and simple or sparingly brancliei 4-angular branehes, their teeth 4, lierbaceous, lanecolate. - Moist, especially gravelly soil; very eommon. March-May. Rootstoeks often bearing little tuhers. - Var. campéstre, Milde, is a not uneommon state, in whieh the sterile stem bears a small fruiting spike at the summit. (Eu.)

+ + Fertile stems when older produciny herbaceous 3-sided branches, and lasting through the summer, except the nutied top which perishes after fructificution.

2. E. praténse, Ėhrl. Sterile and finally also the fertile stems produeing simple struight branches; sheaths of the stem with orate-laneeolate short teeth. those of the lranches 3-toothed; stems more slender and the branches slorter than in the last. - Mieh. to Mimn., and northward. April, May. (Eu.)

3. E. sylváticum, L. Sterile and fertile stems (alout 12-furrowed) producing compond racemed branches; sheaths Ioose, with 8-14 ratler blunt teeth, those of the branches bearing 4 or 5 , of the branchlets 3 , lance-pointed divergent teeth. - Wet sliad! places; eommon northwari. May. (Eu.)

* * Fruting in summer; stems all of one kind, or the fertile contemporaneous with and like the sterile, equally herbuceous, producing mostly simple branches, or sometimes nearly nalied.

4. E. palústre, I. Stems $\left(10-18^{\prime}\right.$ high) slender, very deeply 5-9.

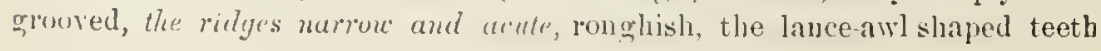


whitish-margined; branches always hollow, $4-7$-angled, ratlier few in a whorl. - Wet places, Niagara River (Clinton), Wisc. (A ustm), and northward. Jume. (Eir.)

5. E. littoràle, Kühlewein. Stems (8-1 $8^{\prime}$ high) slender, deeply 6-16grooved, the ridges rouncled, the teeth shorter than in the last, narrowly whitemargined; branches often solid, 3-4-angled, 2-6 in a whorl. - Wet sandy shores, Yt. and N. Y., and northward. - Spores always abortive, whence the plant has heen considered a lybrid, perhaps of $\mathrm{E}$. arvense and E. limosum July. (Lu.)

6. E. limòsum, L. (Pl. 21, fig. 1-5.) Stems $\left(2-5^{\circ}\right.$ high) slightlymanyfurrowed, smooth, sometimes continuing unbranched, bnt usually producing ascending branches after frnctification; sheaths appressed, with $10-22$ (commonly about 18) dark-brown and acute rigid short teeth. - In shallow water; rather common. - $\Delta$ ir-cavities none under the grooves, but small ones under the ridges. $\Lambda$ form in which the branches bear numerous small spikes is var. POLISTÀnu M, Brickner. June, July. (Eu.)

\$2. Stems all alike, evergreen, unbrunched, or produerng a few slender ereet branehes; fruiting in summer. Contral aureavity of the stem very large.

* Stems tall and stout $\left(1 \frac{1}{2}-4^{\circ}\right.$ or even $6^{\circ}$ hrgh), simple, or casually branched, evenly many-grooved; sheaths appressed.

7. E. hyemàle, I. (Scourrxig-Rusif. Smate-Grass.) Stems $1 \frac{1}{2}-4^{\circ}$ high, 8-34 grooved, the ridges rougliened by two more or less distinct lines of tubereles; sheaths elongated, with a black girdle above the base and a llack limb; ridges of the sheatlis obscurely 4-carinate, the teetl blackish, membranaceous, soon falling off. - Wet banks; common northward. Formerly in common use for polishing wood and metal. (lin.)

8. E. robústum, Braun Stems tall and stout (sometimes $8-10^{\circ}$ high and nearly an inch thick), 20-48-grooved, the rdges roughened with one line of transversely oblong tubereles; sheaths rather short, with a black girdle at base and a black limb; ridges of the sheaths tricarinate, the blackish teeth soon falling off. - River-banks, Ohio and westward.

9. E. lævigàtum, Braun. Stems $1-4^{\circ}$ high, rather slender, pale green, 14-30-groored, the ridges almost smooth; sheath slightly enlarged upward, with a black girlle at the hase of the mostly deciduous white-margined teeth, and rarely also at the hase of the sheath; rilges of the sheath with ore keel, or sometimes olscurely tricarinate. - By streams and in clayey places, Ohio to Minn., and westward.

* Stems slender, in tufts, 5-10-grooved: sheaths looser.

10. E. variegàtum, Schleicher. Stems ascending (6-18' long), nsually simple from a branched base, 5 -10-rrooced; sheatlis green variegated with black above, the $5-10$ teeth tipperl with a deciduous bristle. - Shores or riverbanks, N. II. (Bellows Falls, Carey) and Niagara to Minu, and northward; rare. (Eu.)

11. E. scirpoides, Michx. Stems very numerous in a tuft, fliform $\left(3-6^{\prime}\right.$ ligh), flemous and cmring, mostly 6-grooved, with acute ridges; sheaths 3. toothed, the bristle-puinted teeth more persistent; contril air-cavity wanting. - Wooderl hillsides. ‥ Fing. to l'enn., Minn., and northward. (Eu.) 


\section{Order 131. FíldCes. (Ferisi,)}

Leafy plants, with the leaves (fronds) usually raised on a stalk or petiole (stipe), rising firom a (sumetimes greatly elongated) rootstock, sepu. rately rolled up (circinate) in the bud, and bearing on the under surface or ulong the margin small reticulated sporangia, which at length split opren and discharge the numerous minute spores. Prothallus green, above ground, normally moncecious.

Suborder I. Polypodiànceac. Sporangia collected in dots, lines, or variously shajed clusters (sori or fruit-llots) on the back or margins of the frond or its divisions, cellular-1eticulaterl, stalkecl, the stalk running into a vertical incomplete many-jointed ring, which by straightening at maturity roptures the sporangimn transversely on the inner sicle, discharging the spores. Fruit-rlots often covered (at least when young) by a membrane ealled the indusium (or less properly the involuere), growing either from the back or the margin of the froncl. (Plates 16-19.)

Tribe I. POLYPODIEAE. Fructification on the butk of the frond, in round or loundish fruit-dots (sori) placed on the reins or at the ends of the reins, without indusium of any lind. Stipes articulated to the rootstock, leaving a distinct scar when separated. Veins free (not reticulated) in our species.

1. Polypodium. Sori romin, in one or inore rows, on each side of the midrib or of the seguments of the frond.

Tribe II. GIRAMMIITIDIA. Sori more or less elongated, without indusium, placed on the back of the frond, ustally along the reins or near their extrenities, Veins free in our species.

2. Notholana. Sort short, of few rither larese sporangia, placed near the tips of the veins; miler surfice of the froml usully either clufly, woolly, or jowdery.

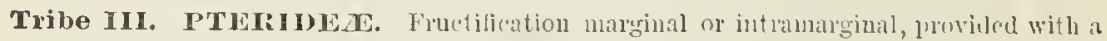
general indusium formed of the (eithes altered or unchanged) num orin of the frond. Stipes not articulated to the rootstuck. Veins free in all our speejes.

* Sporangia at the ends of the vciss, on a reflexed portion of the margin of the fromd.

3. Adiantum. Miurib of the pimules marginal or none. Stije black and polished.

* Sporangia borne on a continous marginal vein-like deceptacle, conneeting tlie apices of the veins, and covered by a delicate whitish indusinm formen of the reflexed margin.

4. Pteris. Midrib ol the pinuules central. Stipe light-colored.

* * Sporangia at or near the ends of the nuconnected veins, borne on the under surface of the fromd: inclusinn various.

5. Cheilanthes. Sori minnte, at the enls of the vins; indusimm continuous or interrupted. Fonds mostly chafly, woully, or julvernlent, rancly smoutl.

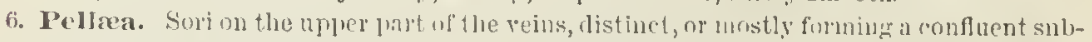

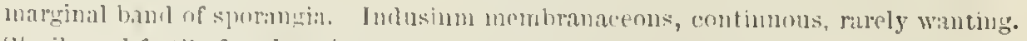
Sterile anul fertile fromls uot very mulike : stipes dark-tolored; fronds smooth.

7. Cryptogramuce. Sori roundislı or elongatel and extencling far down the free veins, at first covereel by the very brond continuous inclusiun, at lengtl exposed and confluent. Strile aml fortile frunds very liflerent; stipes linliteculureul : fronds smooth.

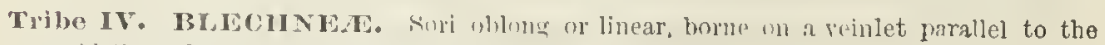

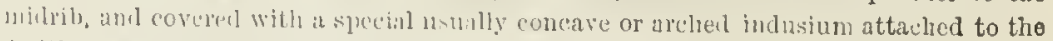
fruting veinlet, and opening along thes imer side.

S. Woodwardia. Sori forming a chain-like low each side of the midrib or central vein. Veíns reticulated. 
Tribe V. ASPLENIEA. Sori more or less elongated, oceupying one or butl sides of oblique veins, envered by a special indusium which is attached by one side to the fertile veiu, and is free on the other: stipes not articulated.

9. Asplenium. Sori on the upper side or rarely on botl sides of a veinlet. Veins free in all sur species.

10. Scolopendrium. Sori linear, confluent in pairs, each pair appearing like a single sorus with a double indusium opeuing lown the middle. Veins free.

11. Camptosorus. Sori oblong, variously eurved, or some of them in opposite pairs. Veins reticulated.

Tribe VI. ASPIDIEAE. Sori round or roundish, on the back or rarely at the alpex of the vein, with a special indusium, rarely naker. Stipes not articulated to the rootstork.

* Indusium obsolete or none.

12. Pliegopteris. Sori round, rather suall, Veins free in our species.

* Indusium evident, round or rouudish, covering the sporangia, at lcast when young. Sterile and fertile fronds not very unlike. Veins free in our species.

13. Aspidium. Indusum flat or slightly convex, orbicular or round-reniform, fixed by the contre, opening all round the margin.

14. Cystopteris. Indusiun convex, fixed by a broal base partly under the sorus, cominonly reflexert as the sporangia ripen.

* * Indusiur obsenre, irregularly semicircular. Fertile fronds much contracted and very unlike the sterile ones.

15. Onoclea. Sporangia on an elevated receptacle; divisions of the fertile frond pod-like or berty-likic.

Tribe VI. WOODSIEAc. Sori lonnd, borne on the reins; indusinm fixed under the sorns, livided into segments or into slender filanents.

16. Woodsia. Small ferus with free veins. Indusium very delicate.

Tribe VII. DICKSONIEA. Ľori roundish, marginal or submarginal. lndusiun cup-shaped or two-valved, the outer lortion composed of a reflexerl lobule of the frond, or more or less united to it.

17. Dicksonia. Indusium in our species small, membranaceous, nearly globular. Frond elongated, decomponnd.

Suborder II. Hymenophylliceae. Sporangia sessile on $\Omega$ bristle-like reeptacle within a eup-shaper or hivalvular involuere, the ring transverse and complete. Fronds delicately membranaeeous.

18. Trichomanes. livolneres funnel-form or cup-sliaped.

Suborber lit. Schizà̀ceae. Sporangia ovate, sessile, having a complote transverse artieulated ring at the apex, and opening by a longitudinal slit. (Pl. 19.)

19. Schizaca. Spningia naked, fixerl in a double row to the midrib of the warrow fertile segunuts. Simile fronds rigit, simple or lichntomously brancher.

20. Lygodiun. Sporangia borne in a flouble row on morow fertile secments, each spo rangium seaterl on a separate veinlet, and providen with a special seale-like inulusium. Fronils leafy, climbing.

Suborder IT. Osmundicear. Sporangia naked, globose, mostly pedicelled, reticulated, with no ring or mere traees of one near the apex. opening into two valves by a longitudinal slit. Stipes winged at base and almost stipulate! (Pl. 19.)

21. Osmunda. lertile piunx or fronds very mucli contrneter, bearing the abundant and large sporangia upon the margins of the rery nintow sngments. Veins free. 


\section{POLYPÒ DIUM, L. Polryonr. (PI. 16.)}

Fruit-duts round, naked, arranged on the back of the frond in one or mure rows each side of the midrib or central vein, or irregnlarly scattered, each borne in our species on the end of a free reinlet. Rootstocks creeping, branched, often covered with chaffy scales, hearing scattered roumdish knols, to which the stipes are attached by a distiuct articulation. (Name from modis, many, and $\pi$ ovs, foot, alluding to the branching routstock.)

1. P. vulgàre, L. (I'l. 16, fig. 1-3.) Fronds evergreen, oblong, smooth both sides, 4-10' high, simple and deeply pinnatifid; the divisions linear-ohlong, obtuse or somewhat acnte, remotely and olsscurely toothed; reins once or twice forked; fruit-dots large, midua!y betwren the midril and the maryin.Rocks; common. July. (En.)

2. P. incànum, Swartz. Fronds evergreen and coriaceous, oblong, 2-6' high, grayish and very scurfy underneuth with peltate scales, simply pinnatifid; the divisions oblong-linear, olituse; fintit-dots rather small, neur the margin; veins forking, free in the N. American plant!-Roeks and trunks of trees, Va. and Ohio to Ill, and southward. Ang.

\section{NOTHOL is NA, R. Brown. Clodk-FerN.}

Fruit-dots roundisk or ablong, placed near the ents of the veins, soon more or less conflnent into an irregular marginal band, with no proper involucre. Veins always free. Fronds of small size, 1 - 4-pinnate, the luwer surface almost always either hairy, tomentose, chaffy, or covered with a fine waxy white or

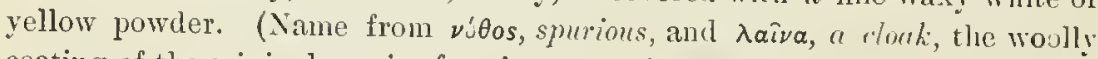
coating of the original species forming a spurious covering to the sporangia.)

1. N. dealbàta, Kunze. Fronds triaugular-ovate, $1-3^{\prime}$ long, 3-4-pinnate; rhachis and branches straight, blaek and shining; ultinate pimmles scarcely a line long, white and powdery on the lower surface. - Clefts of calcareous rocks, Mo., Kan., and sonthwestward. July-Aug.

\section{A D I Á N TU M, I. Maidexinar. (Pl. 17.)}

Fruit-dots marginal, short, borne on the under side of a transverscly oblong, erescent-shaped or romdish, more or less altered margin or smmuit of a lobe or tooth of the frond reftexed to form an indusium; the sporangia attacled to the approximated tips of the free forking veins. - Main rib (costa) of the pinmnles none (in cur specis:s), or at the lower margin. Stipes black and polished. ('The ancient name, from a privative and saivw, meaning unneffed, the smootl folinge repelling rain-1 hops.)

1. A. pedàtum, I. (PI. 17, fig. 1-3.) Frond forked at the summit of the upright slender stalk $\left(9-155^{\prime}\right.$ high), the recurved liranches hearing on one side several slender sprealing pinnate divisions; pinmles numerous, shortstanked and whlipnely triangular-ohlong, entire on the lower margin, from which the veius all frowed, and cleft and fruit-hearing on the other. - Rich, moist woods, Inly. - A delicate aud must graceful Fern.

2. A. Capíllus-Véneris, L. Fronds with a contimous main rhuchis, orrte-tencmolale, $9-18^{\prime}$ long, often penclent, 2-3-pinuate at the base, the upper third or half simply" pimate; pimmles werge obovate or rlombond, $6-12$ " long, deeply and irregularly incised; veinlets flabcllately forling from the 
Lise; inrolncres lnuulate or transversely oblong. - Moist rocky plaees, Va to Mo., and southward. (En.)

\section{PTERIS, L. Brake or BRackex. (P1. 17.)}

Sporangia in a continuous slender line of fructification, occupying the entire margin of the fertile frond, and covered by its reflexed narrow edge which forms a contintuus memlranaceous indusium, attached to an uninterrupted transverse vein-like receptacle connecting the tips of the forkech free reins. Fronds 1-3-pimate or decomponnd. (The ancient Greek name of Ferus, from $\pi \tau \in \rho^{\prime} \nu$, a wing, on acconnt of the prevalent pinnate or feathery fronds.)

1. P. aquilina, I. (Commox BRaks.) Frond dull green ( $2-3^{\circ}$ wide), termate at the summit of an erect stout stalk ( $1-2^{\circ}$ ligh), the widely sprearing braneles twice pinnate; pinnules oblong-lanceolate; the upper undivided; the lower more or less pinuatificl, with oblong obtuse lobes, margined all round with the indusiun, which is really double in this species. - Var. CACDÀTA, with the lobes very narrow and revolute, the terminal ones much elongated, is a sonthern form, which extends in a modified condition as far north as New Jersey. - 'Thickets and hillsiles, common. Aug. (En.)

\section{CHEILÁNTHES, Swartz. Lip-Ferx. (PI. 17.)}

Sporangia borne on the thickened encls of free veinlets, forming small and roundish distinct or nearly contiguous marginal fruit-dots, covered by a mostly whitish and nembranaceous, sometimes herbaccons, common indnsium, formerl of the reflesed margin of separate lohes or of the whole pinnule. - Low, nostly with 2-3-pinnate and hairy or chaffy, rarely smooth fronds, the sterile and fertile nearly alike, the divisions with the principal rein central. Some species with continuous inclusium connect this genus very closely with the next. (Name composed of $\chi \epsilon \hat{\imath} \lambda o s$, "lip, and ávCos. flouer, from the shape of the indusinm.)

$$
\text { * Fronds smooth, or at most hairy. }
$$

1. C. Alabaménsis, Kiumze. Fronds smooth, cluartaceous (2-8'long), ovate-lanceolate, bipinuate; pinne numerous, oblong-lanceolate; pinnules triangular-oblong, rather acute, often auriculate or lohed; indusium continuous, ruther broad, pule, and of firm consistence. - On rocks, mountains of Va. to ky., and sonthwarl.

2. C. vestita, Swartz. (P1. 17, fig. 1, 2.) Fronds $\left(6-15^{\prime}\right.$ high), lauceolite-oblong, hirsute, as are the brown and shining stipes, with straightish promi rently erticulated rusty hairs, twice pinuate; pinna rather distant, triangularwate; pimmles oblong, "rowded ( $2-4$ " long $)$, more or less incised, the ends

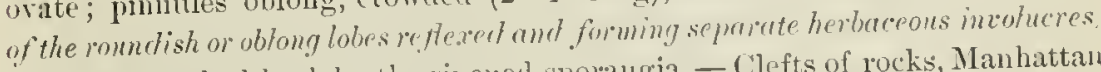
which are pushed back by the ripened sporangia. - Clefts of rocks, Man hattau Island ( $\mathrm{H}^{r}$. Wr. Denslow) and X. J. to lll., anl soutluward.

$$
\text { * Fronds woolly or tomentose. }
$$

3. C. tomentòsa, Liuk. Fronds (12-20 high) lanceolate-oblong, densely tomentose with slender and entumgled whitish obscurely articulated hairs, thrice pinuate; prinary and secondary pinne oblong or ovate-oblong; pimmies ais-

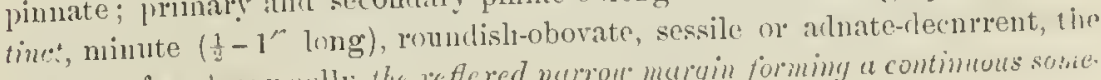
upper surface less wolly, the reflexed nurron muryin forming a contimuas soste. 
what membrunaceons indusium. - Monntains of Va. and Ky.; thence west and sontluward. - Stipe aud rhachis rather stout, brown, covered with narrow chaffy scales and whitish lairs.

4. C. lanuginòsa, Nutt. Stipes slender, at first hairy, black or brown, shining; fronds $\left(3-\sigma^{\prime}\right.$ high) orate-lanceolate, woolly with soft uhitish distinctly articulated flattened lavirs, becoming smoother above, twice or thrice pinnate; pinnæ (5-6" long) ovate, the lowest distant, the others contignous; pinnules crenately pimatifid, or mostly divided into minute and ronndish densely

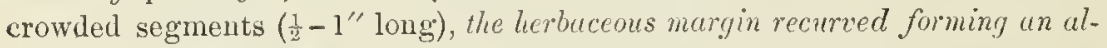
most continuous indusium. - In dense tufts, on dry rocks and eliffs, Ill. to Minn, thenee west and southward.

\section{PEII, ì A, Link. Cliff-Brake. (Pl. 16.)}

Sporangia in roundish or elongated clusters on the upper part of the free veins, distinct, or confluent laterally" so as to imitate the marginal eontinuous line of frnctification of Pteris, commonly covered by a lroad membranaceous and continuous (rarely interrupted) general indusimm, which consists of the reflexed and altered margin of the fertile pinmule or division. Small ferns, with 1-3-pimate fronds, the fertile ones with namower divisions than the sterile, but otherwise similar. Stipes generally dark-colored, smooth and shining. (Name from $\pi \in \lambda \lambda$ ós, clushy, alluding to the stipe.)

1. P. grácilis, Ilook. (Pl. 16.) Fronds smooth $\left(3-6^{\prime}\right.$ high), delicately membranaceons and slender, of few pinna, the lower ones once or twice pinnately parted into $3-5$ decurrent divisions, those of the fertile frond oblong or linear-oblong, entire or spariugly incised; of the sterile ovate or oborate, crenate or incised; reins of the fertile fronds mostly only once forked. Shanded calcareons rocks, Mass, to Minn., mul northward; rare. July. Rootstock very slender, creeping; stipes polished, brownish, darker and sparingly chaffy at hase.

2. P. atropurpùrea, Link. Smooth, except sone bristly-chaffy hairs on the midribs and especially on the drul purple and pulished stulk aud rhachis, 6-15' high; frond coriuceous, pale, once or below twice prinnate; the divisions lroadly linear or ublung, or the stcrile sometimes oval, chiefly entire, somewhat heart-shaped or else truncate at the stalked hase; reins ahout twice forked. - Dry calcareous rocks; not common, bnt of widle range. July.Rootstock short and stout; stipes clustered.

\section{CRYPTOGRÁ M M E, R. Brown. Rock-Brake.}

Fruit-dots roundish or elongated and extending far down on the free forkins veins. 'True involucre or indusiun nune, the herbucous margins of the fertile segments at first reflexed and meeting at the millib, at length opening out flat and exposing the confluent sporangia. - Low ferns, with smooth, 2 - 3-pinnate fronds, the fertile ones taller than the sterile, and with much narrower divis-

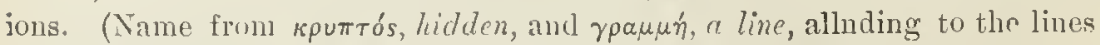
of sporangia at first concealed by the reflexed matgin.)

1. U. acrostichoides, R. Brown. Stipes densely tufted, straw-colored ; fronds 2-3-pinnate ( $\left(-10^{\prime}\right.$ high $)$; frotile segments stalked, linear or linearoblong $\left(3-5^{\prime \prime}\right.$ long), the spurangia in lins extending down the reins almost 
to the midrib, confluent when ripe and covering the under surfaee of the now fully opened segments; sterile fronds on much shurter stipes, with ovate or oburate decmrent and cremately toothed or incisel segments. (Allosorus acrostichoides, sprengel.) - ( )n roeks, from L. Superior westward and northward. - Very near C. erispa of Eu.

\section{WOODW ÁRDIA, Smith. Chain-Ferx. (Pl. 17.)}

Fruit-dots oblong or linear, arranged in one or more chain-like rows on transverse anatomosing veinlets frarallel and near to the midrib. Indusinm fixed by its outer margin to the frnitful veinlet, free and opening on the sicle next the midrib. Veins more or less reticulated, free toward the margin of the iroud. - Large ferns, with pinnatifil or pinnate fronds. (Named for Thomas .I. Woodward, an English botanist.)

\$1. ANCHISTEA. Sterile and fertile fronds alike; veins forming only one row of meshes (areoles).

1. W. Virgínica, Smith. (Pl. 17, fig. 4, 5.) Fronds $\left(2-3^{\circ}\right.$ high) pinnate, with numerous lanceulate pimatifid piund; segments oblong; veins forming a row of narrow areoles along the midrib both of the pinna and of the lobes, the outer reinlets iree; fruit-lots oblong, one to each areole, eonfluent when ripe. - Wet swamps, Maiue to Ark., and southward. Rootstoeks reeping, often $6-8^{\circ}$ long! July.

§.. LORINSERIA. Sterile and fertile fronds unlike; veins of the sterile fronds forming many rows of meshes.

2. W. angustifòlia, Smith. (P1. 17, fig. 1-3.) Fronds pinnatifid; sterile ones (12-18' ligh) with laneeolate serrulate divisions united by a broad wing; fertile fronds taller, with narrowly linear almost discomected clivisions, the areoles and fruit-rluts $(4-5)^{\prime \prime}$ long) in a single row each side of the secondary midribs; routstocks (reeping. - Wet woods, New Eng., near the coast, to Ark., and southward; rare. Aug., Sept.

\section{A S P L E N I M, I. SPLEenworT. (Pl. 18.)}

Fruit-dots oblong or linear, ollique, separate; the straight, or mely curved, indusiun fixed lengthwise ly one erge to the upper (inner) sicle of the fertile rein; - in some species a part of the fruit-lots are double, the fertile vein bearing two indusia placed back to back. Veins free in all our species. (Nane from a privative aul $\sigma \pi \lambda \eta \nu$, the spleen, for supposerl remectial propertios.)

\$1. ASPLINTIMI proper. Indusium struight or stightly curved, attached to the uplue side of the rein, rarely double.

* Small sereryren ferns; fronds pimatifir, or pimate only near the base.

1. A. pinnatífidum, Nutt. Fronds $\left(3-6^{\prime} \mathrm{long}\right)$ lanceolate, pinnatifid, or pinnate belou, tupering uboce into a slenter prolongution, "the apex sometintes ruoting"; lobes roundish-orate, obtuse, or the lonest pair long-acuminate; fruitlots irregular, those next the mirlrih uften donble, even the slencler prolongation fertile. - On cliffs and rocks, l'em. to Mo., and sonthward; very rare. July. - Resembles the Walking-Leaf (Camptosorus), lut the veins are free Stipes brownish, becoming green above, and so passing into the broad pale greon midrit). 
2. A. ebenoides, R. R. Scott. Fronds (4-9' long) broadly laneeolate pinnatifid, below pinnate, the apex prolonged and slender; divisions lanceolate from a l.oad base, the lower ones shorter, often proliferous, as is the apex of the frond; fruit-dots much as in the last; stipes blach und polished, as is the lower part of the midrib, especially beneath. - Limestone cliffs, Conn. and Penn., and southward; very rare, usually growing with Camptosorus and Aspleuium ebeneum, of which Rev. MI. G. Berkeley considered it a probable hybrid.

* * Sinall evergreen ferns; the narrour fronds simply pinnate with numerous pinno. - Pinne not auricled.

3. A. víride, Hudsou. Fronds $\left(2-5^{\prime} \mathrm{long}\right)$ tufted, linear in ontline, pale green, softly herbacents; pinnce roundisth-orate or orate-rhomboid, short-stalked, erenately toothed $\left(2-4^{\prime \prime}\right.$ long), the midvein indistinct and forking; the slender stipe brownish and passing into a green herbaceous rhachis. - Shaded cliffs; northern New Eng., west and northward; rare. (Eu.)

4. A. 'Trichómanes, L. Fronds $\left(3-8^{\prime}\right.$ long $)$ in densc spreading tufts, linear in outline, durh green and nore rigid ; pinner raundish-oblon:j or ovul (3-4" long), entire or crenulate, rarcly incised, unequal-sided, obliquely wedge-truncate at base, attached by a narrow point, the midvein forking and evanesceut; the thread-like stipe and rhachis purple-brown and shining. - Shaded eliffs; eommon. July. (Eu.)

\section{++ Pinna more or less auricled.}

5. A. párvulum, Mart. \& Gal. Fronds upright $\left(t-10^{\prime}\right.$ highl $)$, narrowly linear-oblanceolate; pinnce $\left(2-6^{\prime \prime}\right.$ long) rigid and thich ish, mostly opposite, nearly sessile, somewhat deflexed, oblong, obtuse, entire or crenulate, auricled on the upper or both sites; suri rather few, as near the margin as the continuous midvein; stipe and rluachis black and shining. - Mountains of Va. to Mo, and sonthward. - Nearly intermediate between the last and the next.

6. A. ebèneum, Ait. Fronds upright $\left(9-18^{\prime}\right.$ ligh), linear-oblanceolate in outline, fertile ones much the taller; pinne $\left(6-18^{\prime \prime} l o n g^{\circ}\right)$ firmly membranaceous, mostly alternate, sessile, spreading, oblong or oblong-linear, finely serrate or even incised, the base auricled on the upper or both sides; sori many, nearer the elongated midvein than the margin; stipe and rhachis blackishpurple and shining. - Rocky, open woods; rather common.

* * Small evergreen forns; the broader fionds 1-3-pimnate; pimne incised.

7. A. Bradlèyi, D. C. Faton. Fronds oblong-lunccolute, $4-7$ 'long, hesides the blackish and sonewhat shining stipe, membranaceons, pinnate; pinns rather numerous, the lower ones no lurger than the middle ones, all sliort stalked, oblong-ovate, obtuse, incised or pimnatifid into oblong toothed lobes. - ()n rocks, ky. and soutliward; rare. $\Lambda$ single plant lias been gathered uear Newburg, N. Y. - Intermediate between $\Lambda$. ebeneum and $\Lambda$. montanum.

8. A. montànum, Willd. Fronds orate-lanceolute from a liroad buse (2 5' long), subcoriaceons, pinnate; pinnie ovate-oblong, the lowest pinnately cleft into oblong or ovate cut-toothed lobes, the uprev gralually simpler; rhachis green, broud and flut; stipe brown at buse. - Cliffs and rocks, from Conn. and l'eun. to Ky, and sontluward. July.

9. A. Rùta-murària, L. Fronds deltoid-ovate $\left(1-2 \frac{1}{2}\right.$ long), subcuriaceous, laxly 2-3-pinnate at base, the pinua alteruate; ultimate segments few, 
stalked (2-5"long), from narrowly muncate to roundish-obvate, toothed or incised at the apex; veins forking; sori $2-4$ on a segment. - Limestone cliffs, Vt. to Mich., and southward; scarce. July. (Eu.)

***** Tall ferns $\left(2-4^{\circ}\right.$ high), not evergreen: fronds pinnate or sub-bipinnate.

10. A. angustifolium, Michx. Fronds thin, simply pimate; pinnce numerous, short-stalked, lineur-lanceolate, aeuminute, entire or cremnlate (3-4' long), those of the fertile frond narrower; fruit-lots linear, 20-40 each sile of the milvein; indusia slightly convex. - Rich woods, W. New Eng. to Wise., and southward along the monntains. Sept.

11. A. thelypteroides, Michx. (Yl. 18, fig. 1, 2.) Fronds $\left(2-3^{\circ}\right.$ ligh) pinnate; pinne deep/y pinnatifid, linear-lanceolate $\left(3-5^{\prime}\right.$ long); the lobes oblong, obtnse, minutely toother, crowded, each bearing $3-6$ pairs of oblong fruit-dots, some of them double. - Rich woods; not rare. July - Sept.

\$2. ATHÝRIUM. Indusium delieate, eurved, often crossing the vein, and attached to both sides of it, thus becoming reniform, or shaped like a horseshoe.

12. A. Filix-fœémina, Bernh. Fronds $\left(1-3^{\circ}\right.$ high $)$ ovate-oblong or broally lanceolate, twice pimnate; pinna lanceolate, numerous; pinnules confluent on the secondary rhachis hy a narrow margin, oblong and doubly serrate, or elongated and pinmately incised with cnt-toothed segments; fruit-rlots short, varionsly curved, at length confluent. - Moist woods; common and presenting many varying forms. July. (Eu.)

\section{SCOLOPENDRIU M, Smith. Hart's-Tongue. (Pl. 18.)}

Fruit-dots linear, elongated, almost at right angles to the midrib, contiguous by twos, one on the upper" side of one veinlet, and the next on the lower side of the next smperior veinlet, thus appearing to have a double indusium opening along the middle. (The ancient Greek name, so called liecanse the unmerons parallel lines of frnit resemble the feet of the centipede, or Seolopendra.)

1. S. vulgàre, Smith. Frond ollong-lanceolate from an auricled-heartsliaped base, entire or wary-margived $\left(7-18^{\prime}\right.$ long, $1-2^{\prime}$ wide), bright green. - Shaded ravines and under limestone cliffs; central N. Y.; also in Canada and 'T'enn.; very rare. Aug. (Eu.)

\section{CA M P Tosòr U S, Link. Walking-Leaf. (Pl. 18.)}

Fruit-dots oblong or linear, as in Asplením, but irregularly scattered on either side of the reticulated veins of the simple frond, those next the midrib single, the outer ones inclined to approximate in pairs (so that their two indusia open face to face), or to become confluent at their ends, thus forming crooked

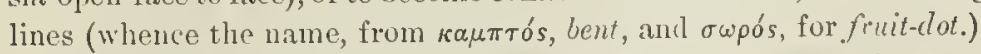

1. C. rhizophýllus, Link. Fronds evergreen, sub-coriaceous, growing in tufts, sprealing or procmmbent $\left(4-12^{\prime}\right.$ long), gradually narrowed from a cordate or anricled base to a long and slender acumination, which often roots at the curl and forms a new plant. - Shated rocks, especially calcareous rocks, N. Eng. to Minn., and southward to Kan. and $\Lambda$ la. - The auricles are sometimes greatly elongated, and even rooting; in anotler form they are lacking, as in the thinner leavel ( Sibiricus. July. 


\section{PhEGópteris, Fée. Befch Ferv.}

Fruit-dots small, round, naked (no indusinm), borne on the back of the veins below the apex. Sitipe continuous with the rootstock. - Our species have free reins and bright green memhranaceous fronts, decaying in early autumn. (Name composed of $\phi \eta \gamma o ́ s$, an octi or leech, and $\pi \tau \epsilon p i s$, fern.)

* Fronds tucice pimatifid; pimme all sessile, adnate to the winged rhachis.

1. P. polypodioides, Fée. Fronds triangular, longer than broad $\left(4-\mathbf{9}^{\text {- }}\right.$ long), hairy on the reins, especially benenth; pinna lincar-lanceolate, the louest pair defexed and shonling forwarl : their divisions oblong, obtuse, entire. the basal deeurrent upon the main rhachis; fruit-rots all near the margin. 1)amp woods; common northwarl. July- Rootstock slentler, creeping, bear ing a few distant slender stalks, rather longer than the fronds. (En.)

2. P. hexagonóptera, Fée. Fronds triangular, usually brouder than long (7-12' broal), slightly pubescent and often finely glandular beneath; pinnæ lanceolate; upper segments oblong, ohtuse, toothed or entire, those of the very large louest pinne elongated and pinmately lobed, hasal ones very mucis decurrent and forming a coutinuons many-angled wing along the main rhachis; fruit-dots near the margin; some also between the sinus and the mic. rib. - Rather open woods, New Eng. to Minn., and sonthwart: common. July. - Larger and broaker than the list, which it often clusely resembles.

* Fronds ternate, the three divisions petioled; rhachis wingless.

3. P. Dryópteris, Fée. Fronds smooth, broally triangular ( $4-6^{\prime}$ wide), the three triangular primary divisions all widely smeading, 1 - 2-pinuate; segments oblong, obtuse, eutire or toothed; fruit-dots near the margin. - Rocky woods; common northward. July. (Eu.)

4. P. calcàrea, Fée. Fronds mimity glandular and somewhat rigid, the lateral divisions ascending; lowest inferior pinne of the lateral divisions smaller in proportion than in the last species, which it otherwise closely resembles. - Iowa and Minn.; rare. July. (Fu.)

\section{A S P Íd I M, Swartz. Shiein Fenx. Wood Ferv. (Pl. 19.)}

Frnit-dots round, borne ou the back or rarely at the apex of the veins. Indnsium covering the sporangia, flat or flattish, scarions, orbicular and peltate at the centre, or round-kidney-shaped and fixed either centrally or by the sinus, opening all round the margin. Stipe eoutinnous (not artieulated) with the rootstock. - Our species have free veins and 1-3-pinnate frouds. (Nane. $\dot{a} \sigma \pi i \delta$ เov, a small shield, from the shape of the indusium.)

§ 1. DRYÓPTERIS. Indusium reniform, or orbirular with a narrow sinus. * Teins simple or simply forked and straight; fronds anmual, decaying in au. tumn, the stalks and slender creeping rootstocks nearly naked.

1. A. Thelýpteris, Swart\%. Fronds pinnate, lauceolate in outline; pinna horizontal or slightly recurved, linear-laueeolate, deeply pinnatifid, the louest pairs scarcely smaller; lobes oblong, entire, obtuse or appearing acute when iu fruit from the strongly rerolute margins ; reins mostly forked, bearing the (soon eonfluent) fruit-dots near their midlle; indusium minute, smooth and naked - Marshes; common. Aug. - Stalk $1^{\circ}$ long or more, usually longer than the frond, which is of thicker texture than the next, and slightly downy. (Eu.) 
2. A. Noveboracénse, Sivartz. Fronds pinnate, lanceolate in outline, rapering both ways from the middle; pinux lanceolate, the lowest 2 or more pairs graduclly shorter and deflexed; lobes flat, oblong, basal ones often enlarged and incised; veins simple, or forkel in the basal lobes; fruit-dots distinct, near the margin; indusium miuute, the margin glanduliferous. - Swamps and moist thickets; common. July. - Frond pale green, delicate and mem. branaceous, hairy beneath along the midribs aud veius.

* Veins, at least the lowest, more than once forked or somewhat pinnately branching; fruit-bearing veinlets often obscure or vanishing above the fruitdot; fronds, at least the sterile ones, often evergreen; stalks and apex of the thickened rootstock scaly or chaffy, and often the main rliachis also.

+ Fronds small, pinnate; pinnce pinnatifid; indusia very large, persistent.

3. A. fràgrans, Swartz. Fronds $\left(4-12^{\prime}\right.$ high) glandular and aromatic, narrowly lanceolate, with liuear-oblong pinuately-parted pinnæ; their crowded divisions ( 2 "long) oblong, obtuse, toothed or nearly entire, nearly covered beneath with the very large thin imbricated iudusia, which are orbicular with a narrow sinns, the margin sparingly glauduliferons and often ragged. - On rocks, especially near waterfalls, mountains of uorthern New Eng., west and northwarl. - Rootstock stout, nearly erect, densely chaffy, as are the crowded stipes and rhachis. (Asia, and barely reaching S. E. Eu.)

+ + Large (1 - 210 high), the fronds mostly twice pimnate with variously toothed and incised pinuules; indusia rather small, strivelled in age, or deciduous.

4. A. spinulòsum, Swartz. Stipes with a few pale-broun deciduous scales; frond ovate-lanceolate, twice pinuate; pinnce oblique to the rhachis, elongated-triangular, the lower pairs broadly triangular; pinnules set obliquely on the midribs, connected by a very narrow wing, oblong, acute, incisely serrite or pinnatifid with spinulosely-toothed lobes; indusium smooth and without marginal glands. - Iu damp woods, New Eng. to Ky., aud northward. July. - The commou Enropean type, rare in North America. (Eu.)

Var. intermedium, D. C. Eaton. Scales of the stipe few, brown with a darker centre; frond broadly obloug-ovate, twice or often thrice pinnate; pinne spreading, oblong-lanceolate, the lower mecually triangular-orate; pinnules crowded, orate-obloug, spreading, pimately divided; the oblong lobes spinnlose-toothed at the apex; morgin of the indusium denticulate and beset with minute stalked glands. - Woods, everywhere.

Var. dilatàtum, Hook. Scales of the stipe large, broun with a dark centre; frond broader, orute or triangular-arate in ontline, oftenest thrice pinnate; pinnules lance-oblong, the lowest uften much elongated; indusium (in the North American plant) smooth and naked. $-\Lambda$ dwarf state, fruiting when only $5-8^{\prime}$ ligh, answers to var. dumetorum. - N. New Eng. to Minn., chiefly in inountain woods, and northward. (Én.)

5. A. Boottii, 'Tuckerman. Scales of the stipe pale-broun; fronds $\left(1-2 \frac{1}{2}^{\circ}\right.$ long) elongated-lauceolate in outline, somewhat narrowed at hase ; lowest pinnæe triangular-orate, the upper longer aud narrower; pinnules oblong-ovate, sharply spinulose-servate or the lower pinnatifid; indusium minutely glandular. (A. spinulosum, var. Boottii, of last el. A. cristatum, var. uliginosum, Milde.) - Wet thickets and ahout ponds, New Eng. to Del. and Minu. July. - Sterile fronds much smaller and simpler than the fertile. (Eu.) 
+ + + Large (2-40 high); fionds once pimate and the pinnce deeply pinnati. fid, or nearly twice pinnate; fruit-dots not very near the margin; the indu. sium large, thinnish and flat, persistent.

6. A. cristàtum, Swartz. Frond linear-oblong or lanceolate in outline ( $1-2^{\circ}$ long) ; pinne short $\left(2-3^{\prime}\right.$ long), triangulur-oblong, or the lowest ucarly triangular-ovate, from a somewhat heart-shaped base, acute, deeply pinnatifid; the divisions $(6-10$ pairs) oblong, very obtuse, finely serrate or cut-toothed, the lowest pinnatificl-lobed; fruit-dots as near the midrein as the margin; indusium round-reniform, the sinus mostly shallow, smooth and naked. - Swamps, ete.; common. July. - Stipes and the stout creeping rootstock bearing broad aud deciduous chaffy scales. (Eu.)

Var. Clintoniànum. Frond in every way much larger $\left(2 \frac{1}{2}-4^{\circ} \mathrm{loug}\right)$, pinne oblong-lanceolate, broadest at base $\left(4-6^{\prime}\right.$ long, $1-2^{\prime}$ broad), deeply pinnatifid; the divisions ( $8-16$ pairs) crowded or distant, linear-oblong, obtuse, obscurely serrate or cut-toothed, the basal sometimes piunately lobed; reius pinnately forkiug, the lowest anterior veiulets beariug the fruit-lots near the midvein; indusium orbicular with a shallow sinus, smooth aud uaked. Swampy woods, New Eng. to N. J., N. Y. (G. W. Clinton, etc.), and westward. July. - Rootstock stout, creeping, chaffy (like the stipes) with large bright-brown scales. A showy ferm, unlike any European form of A. cristatum, and often mistaken for A. Goldiaum.

7. A. Goldiànum, Hook. Frond broadly ovate, or the fertile orateoblong in outline $\left(2-3^{\circ}\right.$ long); pinne $\left(6-9^{\prime}\right.$ long), oblong-lanccolate, broadest in the middle, pinnately parted ; the divisions (about 20 pairs) oblong-linear, slightly scythe-shaped (9-15" long), serrate with appressed teeth; reins pinnately forking and bearing the fiuit-dots very near the midvein; indusium very large, orbicular with a deep narrow sinus, smooth and without margiual glands. - Rich aud moist woods, from Coun. to Ky., and northward. July. - A stately fern, often $4^{\circ}$ high, the fronds growing in a circle from a stout ascending chaffy rootstock, and lecaying in autumn. Indusium with the sides of the sinus ofteu overlapping, thus appearing to be round and entire as in $\$$ Polystichum.

++++ Large $\left(1-3^{\circ}\right.$ high); stipes very chaffy at base; fionds twice pinnate, but the upper pinnules confluent, some of the lower pinnatifid-toothed; fruitdots rather large; indusium convex, without marginal glands, persistent.

8. A. Filiz-mas, Swartz. Frond lauceolate in outline $\left(1-3^{\circ}\right.$ high $)$; pinnx linear-lanceolate, tapering from base to apex; pinuules oblong, very obtuse, serrate at the apex and obscurely so at the sides, the basal incisely lobed, distinct, thc upper confluent; fruit-dots uearer the nidrein than the margin, and usually confined to the lower half of cach fertile pinnule.liocky woods, N. Mich. to the Dakotas and Col. - Frond thickish but not sur. viving the winter. (Eu.)

9. A. marginàle, Swartz. (I'l. 19, fig. 1, 2.) Frond evergreen, smootl, thickish and almost coriaceous, ovatc-oblong in outline $\left(1-2^{\circ}\right.$ long); ninnæ lanceolate, acuminate, slightly broadest ahove the hase; pinnules oblong or oblong-scythe-slaped, crowded, obtuse or pointed, cntire or crenately-trotherl; fruit-rlots close to the margin. - Rocky hillsides in rich woods; common, 3 pecially uorthward. Aug. 
§2. POLÝSTICIUM. Indusium orbicular and entire, peltute, fixed by the depressed centre; fronds rigid und coriaceous, evergreen, very chaffy on the rhachis, etc.; pinnce or pinnules auricled at base on the upper side, crowded, the teeth or lobes bristle-tipped.

\section{* Fronds simply pinnate.}

10. A. acrostichoides. Swartz. (Cukistmas Fers.) (Pl. 19, fig. 3, 4.) Frond lanceolate ( $1-2 \frac{1}{2}$ ligh), stulked; pinnce linear-lanceolate, somewhat scythe-shaped, lalf-halberd-shaped at the slightly stalked base, scrrulate with ajpressed bristly teeth; the fertile (upper) coniracted and smaller, bearing contiguous fruit-dots nea the nidrib, which are confluent with age, covering the surface. - Var. Incìsu is a state with cut-lobed pinnx, a not unfrequent case in the sterile fronds; sometimes witl all the tips fertile. - Common in rocky woods, especially northwarl. July.

11. A. Lonchitis, swartz. Frond linear-lanceolate $\left(9-20^{\prime}\right.$ high $)$, scarcely stalked, very rigid; pinme broadly lanceolate-scythe-shaped, or the lowest tranyular, strongly auricled on the upper side, and wedge-truncate on the lower, densely spinulose-toothed ( $\mathrm{l}^{\prime}$ or less in length), copiously fruit-bearing; fruitdots contiguous and near the margins. - Woods, sunthern shore of Lake Superior, and northward. (Eu.)

$$
\text { * Fronds bipinnate. }
$$

12. A. aculeàtum, Swartz, var. Braunii, Koch. Fronds spreading $\left(1 \frac{1}{2}-2^{\circ}\right.$ long), oblong-lanceolate in outline, with a tapering base, the lower of the nany pairs of oblong-lanceolate pinns gradually reduced in size and obtuse; pinnules ovate or oblong, obtuse, truncate and alnost rectangular at base, short-stalked, or the upper confluent, sharply toothed, beset with long and soft as well as chaffy hairs. - Deep woods, mountains of New Eng., N. Y., and Penu., and northward. (Eu.)

\section{CYSTÓ PTERIS, Bernhardi. Bladner Ferx. (Pl. 19.)}

Fruit-dots roundish, horne on the back of a straight fork of the free reins; the delicate indusium hood-like or arehed, attached by a broad base on the inner side (toward the midrib) partly mucler the fruit-dot, early opening free at the other side, which looks toward the apex of the lobe, and is somewhat jagged, soon thrown back or withering away.-Tufted ferus witl slender and delicate 2-3-pinnate fronds; the lohes cnt-toothed. (Name composed of $\kappa \dot{u} \sigma \tau \iota s, a$ bladder, and $\pi \tau \epsilon \rho l s$, fern, from the inflated indusium.)

1. C. bulbifera, Bernl. (Pl. 19, fig. 1-3.) Frond lancelate, elongated ( $1-2^{\circ}$ long), 2- pinnate; the pinnx lanceolate-oblong, pointed, horizontal (1 $2^{\prime}$ long); the rhachis and pinno often bearing bulblets underncath, winglcss; jinnules crowded, oblong, obtuse, toothed or pinnatifid ; indusium short, truncate on the free side. - Shaded ravines, not rare from X. Eng. to Ark., commoner on calcareous rocks. July. - Specimens from 'Tenn. and Ark. havo sometimes shorter froncls and few or no lulblets, indicating an approach to the next species.

2. C. frágilis, Bernh. Frond oblongtanceolate $\left(4-8^{\prime}\right.$ long, besides the bittle stalk which is fully as long), $2-3$-pinnate; the pinnse and pinnules orate or lanceolate in outline, irregularlv vinnatifid or cut-toother, mostly acute, 
decurren. on the margined or winged rhachis; indusium tapering or acute at the free end. - Slraded cliffs and rocky wools; common and greatly varying in the shape aud entting of tho pinnules. July. (Eu.)

\section{O N OCLEA， L. (I'1. 16 and 19.)}

Sporangia borne on elevated receptacles, forming ronndish sori imperfectly sovered by very delicate hoorl-shaped indusia attached to the base of the receptacles. Fertile fronds erect, rigid, with contracted pod-like or berry-like divisions at first completely concealing the sporangia, and at last, when dry and indurated, cracking open and allowing the spores to escape. Sterile fronds foliaceous. Rootstocks creeping and constantly forming new plauts (Name apparently from önos, " ressel, and $k \lambda \epsilon i \omega$, to close, from the singularly rolled up fruetification.)

\$1. ONOCLEA proper. Strrile frond with unastomosing veins.

1. O. sensíbilis, L. (Sensituvi Ferin.) (1'l. 19, fig. 1, 2.) Fronds scattered; the sterile ones long-stalked $\left(2-15^{\prime}\right.$ long $)$, triangular-orate, pinnatifid into a few ollong-lanceolate sinnately lohed or nearly entire segments; veins reticnlated witls fine meshes; fertile fronds contracted, closely lipinnate, the pinnules rolled up into borry-like hodies. - Noist meadows and thickets, very common and variable. July. - Imperfectly fertile fronds sometimes occur, with the still foliaceous pimn cut into obovate segments with free veins and abortive sori; the so-called rar. oвтusuroustr.

\section{§2. STRUTMOPPTERIS. Sterile frond with fiee veins.}

2. O. Struthiópteris, IIoffmam. (Pl. 16, tig. I-5.) Fronds growing in a erowu; sterile ones short-stalked $\left(2-10^{\circ}\right.$ ligh $)$, broadly lanceolate, narrowed toward the hase, pinnate with many linear-linceslate, pinnatificl pinnar; veins free, the veinlets simple; fertile frond shorter, pinnate with pod-like or somewhat necklace-slaped pimas. (Struthiopteris Germanica, Willd.) Alluvial soil, common northwarl. July. - The rootstock sends out slender underground stolons, which bear fromls the next year. (En.)

\section{W O Ó D I A, R. lirown.}

Fruit-dots round, borne on the hack of sinply-forked free reins; the very thin and often evanescent indusium attached hy its base all around the receptaele, under the sporangia, either small and open, or else early bursting at the top into irregular pisees on lobes. - Simall and tufterl pinnately-livided ferns. (Dedicated to Joseph Wonds, an Finglish hotanist.)

* Stalks obscurely articulated some distamce from the base; fronds chaffy or smooth, never glandular; indusium divided netrly to the crntre into slenter hairs which are curled over the sporangia.

1. W. Ilvénsis, R. Brown. Frond oblong-lanceulate (2-6' long by 12$18^{\prime \prime}$ wide), smoothish and green above, thickly clothed underneoth as well us the stulk with rusty bristle-like chaff, pinnate; the pinnia crowded, oblong, obtuse, sessile, pimatrly parted, the numerons cronded segments oblong, obtuse, obseurely crenate; the fruit-dots near the margin, somewhat confluent when old. - Exposed rocks; common, especially nortliward, and southward in the Alleghanies. June. (Fin.) 
2. W. hyperborea, R. Brown. Frond narrowly oblong-lanceolate (2$6^{\prime}$ long by $8-12^{\prime \prime}$ wide), smooth above, sparingly paleaceous-hirsute beneath, piunate; the pinnæ triangular-ovate, obtuse, pinnately lobed, the lobes few and nearly eutire; fruit-lots rarely eonfluent. - Monntain ravines, northern Yt. and N. Y., and northwarl; rare. (En.)

3. W. glabélla, R. Brown. (I'l. 19, fig. 1-3.) smouth and naked throughout; frond linear and very delicate ( $2-5^{\prime}$ high), pinuate; pinne roundish-orute, the lower ones rather remote ( $2-t^{\prime \prime}$ long), obtuse, crenately lobed; fruit-lots seanty; the hairs of the indusium fewer than in the last two species. - On moist nussy rocks, mountains of northern New Eng., north aud westward. First found at Little Falls, N. Y., ly Dr. V'asey. (Eu.)

* Stalks not articulated; fronds never chaffy, often glandular-pubescent.

- Indusium of a few broad segments, at first covering the sorus completely.

4. W. obtùsa, Torr. (P1. 19, fig. 4, 5.) Firoud broadly lanceolate, minutely glandular-hairy $\left(6-12^{\prime}\right.$ high $)$, piunate, or nearly twice pinnate; pinnæe rather remote, triangular-ovate or oblong $\left(1-2^{\prime}\right.$ long), lluntish, pinnately parted ; segments oblong, obtuse, crenately toothed, the lower pinnatifid with toothed lobes; veins forked, and bearing the fruit-dots on or below the minutely toother lobes; indusium at length splitting into several spreading jagged lobes. - Rocky banks and cliffs; not rare.

+ + Indusium entirely concraled bmecuth the sorus, divided into very narrow segments or rednced to minute hairs.

5. W. Oregàna, D. C. Eaton. Suooth, with fronds $\left(2-8^{\prime}\right.$ high, $8-12^{\prime \prime}$ wide) elliptical-lanceslate, pimnate, the fertile ones tallest; pinnx triangularoblong, obtuse, pinnatifil; segments cblong or ovate, obtuse, finely toothed, and in larger fronds incised; fruit-dots near the margin; inchsium very small, divided alnost to the centre into a few necklace-like-jointed cilia. - Crevices of roeks, south shore of Lake Superior (Roblins), and westwarl.

6. W. scopulina, 1). C. Eaton. Much like the last, but the rather larger fronds puberulent beneath with minute jointed hairs and stalked glands; indusium deeply eleft into narrow segments ending in jointed hairs. - Roeky places, Minn., southward and westward.

\section{D I C K S Ò N I A, I’’Her.}

(Pl. 18.)

Fruit-dots small, globular, marginal, eaeh placed on the apex of a free vein or fork; the sporangia borne on au elevated globular receptacle, enclosed in a memlranaceous enp-shaped indusinm which is open at the top, and on the outer side partly adherent to a reflexed toothlet of the frond. (Named for James Dirkson, au English Cryptogamic hotanist.)

1. D. pilosiúscula, Willd. Fronds minutely glandular and hairy $\left(2-3^{\circ}\right.$ high), ovate-lanceolate and acminate in outline, pale green, very thin, with strong ehaffless stalks rising from stender extensively creeping naked routstocks, mostly bipimate: primary pinne laneeolate, pointed, the secontary pinnatifil into oblong and obtuse cut-toothed lobes; fruit-lots minute, each on a recurverl toothlet, usually one at the upper margin of each lobe. (D. punctifhlula, Kmap.) - ('ommon in moist and shady places, from New Eng. to Mlinu. - Frond swert-scented in drying. 


\section{TR I CHÓMA N ES, L. Filuy FerN.}

Sporangia with a transverse entire ring, sessile on a cylindrical receptacle which is produced from the end of a rein and enclosed in a funnel-form or cup-shaped involucre of the sime substance with the frond. Fronds very thin and pellucid, often eonsisting of a single layer of cells. ( $\mathrm{Au}$ ancient Greek name for some feru.)

1. T. radicans, Swartz. Frouds very delicato, oblong-lanceolate in out. line (4-8' long, 6-18' wide), bipinnatifid; rhachis uarrowly wiuged; pinnx triangular-ovate, the divisions toothed or again lobed; involucres tubular. funnel-shaped, margined, the moutl truncate; receptacle often much exserted. - On moist and dripping sandstone cliffs, Ky., and sonthward; rare. - 'Thongh the fronds are so very delicate, yet they survive for several years; they begin to fruit the second or third year, and thereafter the receptacle continues to grow and to produce uew sporangia at its base. (Eu.)

\section{S C H I Z 良 A, Smith.}

Sporangia large, ovoid, striate-rayed at the apex, opening by a longitudinal cleft, naked, vertically sessile in a double row along the single veiu of the narrow divisions of the pinnate (or radiate) fertile appendages to the slender and simply linear, or (in foreign species) fan-shaped or dichotomously many-cleft fronds (wheuce the name, from $\sigma \chi i \zeta \omega$, to split).

1. S. pusílla, I'ursh. Sterile fronds linear, very slender, flattened and tortuous; the fertile oues equally slender ( $x^{\prime \prime}$ wide), but taller $\left(3-4^{\prime}\right.$ highl $)$, and bearing at the top the fertile appendage, consisting of about 5 pairs of crowded pinna (each $1-1 \frac{1}{2}$ " long), - Low grounds, pine barrens of $\mathrm{N}$. J.; very local. Sept. (Mlso in Nova Scotia and Newf.)

\section{L Y Gò I I M, Swartz. Chmbige Ferx. (Pl. 20.)}

Fronds twiniug or climbing, bearing stalked and variously lobed (or compound) divisions in pairs, with mostly free veins; the fructification ou separate contracted divisions or spike-like lobes, one sille of which is eovered with a donble row of imbricated hooded scale-like indusia, fixed by a broad hase to short oblique veinlets. Sporangia much as in Schizea, but oblique, fixer to the veinlet by the inner side next the base, one or rarely two covered ly each inclusium. (Name from $\lambda v \gamma \omega \dot{\delta} \eta s_{\text {s, flexille.) }}$

1. L. palmàtum, Swartz. Very smooth; stalks slender, flexile and twining $\left(1-3^{\circ}\right.$ long), from slender running rootstocks; the short alterinte liranches or petioles 2-forked; each fork bearing a round-heart-sliajed palmately 4-7-lobed frondlet; fertile frondlets above, eontracted and screral times forked, forming a terminal panicle. - I cow moist thickets and open woods, Mass. to Va., Ky., and sparingly southward; rare. Sept.

\section{O S M Ú N D A, L. Flowering Fern. (P1. 20.)}

Fertile fronds or fertile portions of the frond destitute of chlorophyll, very mnch contracted, and hearing on the margins of the narrow rhachis like divis. inns short-pedicelled and naked sporangia; these are glolular, thin and reticulated, large, opening ly a longitndinal cleft into two valves, and bearing near 
the apex a small pateh of thiekened oblong cells, the rudiment of a transverse ring. - Fronds tall and upright, growing in large crowns from thickened rootstocks, once or twice pinnate; veins forking and free. Spores green. (Osmunder, a Saxon name of the Celtic divinity, 'Thor.)

\section{* Sterile fronds truly bipinnate.}

1. O. regàlis, L. (Flowkrivg FERx.) Very smooth, pale green (2$5^{\circ}$ high); sterile pinules $13-25$, varying from oblong-ovai to lance-oblong, finely seriulate, espeeially toward the apex, otherwise entire, or crenately lobed toward the rounded, oblique and truncate, or even cordate and semi-auriculate base, sessile or short-stalked $\left(1-2^{\prime}\right.$ long $)$; the fertile racenose-punicled at the summit of the frond. - Swamps and wet woods; common. The cordate pinnules sometimes fond here are commoner in Europe. Maj, June. (Eu.)

* Sterile fronds once pinnate; pinnce deeply pimatifid; the lobes entire.

2. O. Claytoniàna, L. (I'l. 20, fig. 1-3.) Clothed with loose wool when young, soon smooth; fertile fronds taller thron the sterile $\left(2-4^{\circ}\right.$ high); pinne oblonglanceolate, with oblong obtuse divisions; some $(2-5$ pairs $)$ of the middle pinnce fertile, these entirely pinnate; sporangia greenish, turning brown. - Low grounds, common. May. - Iruiting as it unfolds.

3. O. cinnamómea, L. (Cirnamor Fers.) Clothed with rusty wool when young; sterile fronds tallest (at length $3-5^{\circ}$ high), smooth when full grown, the lanceolate pinna pimnatifid into broadly oblong obtuse divisions; fertile fronds separate, appearing earlier from the same rootstock and soon withering $\left(1-2^{\circ}\right.$ high), eontracted, twice pinnate, covered with the cinnamoncolored sporangia. - Var. Fliox Doss is a rare occusional state, in whieh some of the fronds are sterile below and more sparsely fertile at their summit, or rarely in the niddle. - Swamps and low copses, everywhere. May.

\section{Order 132. OPHHOGLOSSÁCEA. (AdDer's-Tongue FAMiLr.)}

Leafy and often somewhat flesly plants; the leaves (fronds) simple or branchel, often fern-like in appearance, erect in vernation, developed from underground buls formed cither inside the base of the old stalk or by the side of it, and bearing in special spikes or panicles rather large subeoriaceous biralvular sporangia formed from the main tissue of the fruiting branches. Prothallus underground, not green, monecious. - A small order, separated from Ferns on account of the different nature of the sporangia, the ereet vernation, ete.

1. Botrychium. Sporangin in pinnate or compound spikes, distinet. Veins free.

2. Ophioglossum. Sporangil cohering in a simple splike. Veins reticulated.

\section{BOTRÝCHIU M, Swartz, Moowwort. (P1. 20.)}

Rootstock very short, erect, with clustered fieshy roots (which are full of starcl, in very minute, irregular granules?); the hase of the maked stalk containing the ind for the neat year's frond; frond with an anterior fertile and a posterior sterile segment; the former mostly 1-3-pinmate, the contracted divisions bearing a double row of sessile nakerl sporangia; these are distinet, rather coriaceous, not reticulated, globular, without a ring, and open trans. 
versely into two valves. Sterile segment of the frond ternately or pinnately divided or compound; veins all free. Spores copions, sulphur-eolor. (Name a diminntive of Bótpvs, a cluster of grapes, from the appearanee of the frnctification.)

\$ 1. BOTRYCHIUAI proper. Base of the stalk containing the bud completely closed; sterile segment more or less fleshy; the cells of the epidermis straight.

* Sterile portion of the frond sessile or nearly so at or above the middle of the plant. Plants small.

1. B. Lunària, Swartz. Sterile segment nearly sessile, borne near the middle of the plaut, oblong, simply-pinnate with 5-15 lunate or fan-shaped very obtnse erenate, incised or nearly entire, fleshy divisions, more or less excised at the hase on the lower or on both sides, the veins radiating from the base aurl repeatedly forking; fertile segment panieled, $2-3$-pinnate. $-\mathrm{N}$. Ling. to Lake superior, and nortliward ; rare. - Very tleshy, $4-10^{\prime}$ ligh. (En.)

2. B. símplex, Ilitehcock. Fronds small ( $2-4^{\prime}$, rarely $5-6^{\prime}$ high), the sterile segment short-petioled from near the middle of the plant, thich ish and fleshy, simple and ronudish, or pinnately 3 - 7-lobed ; the lobes roundish-obovate, nearly entire, deenrrent on the broald and flat indeterminate rhachis; the veins all forking from the base; fertile segment simple or 1-2-pinnate. - Maine to N. Y., Minn., and northward; rare. (13in.)

3. B. lanceolàtum, Angstroem. Frunds sulall (3-10' high); the sterile segment closely sessile ut the toj of the long and slender common stalk, scarcely Heshy, triangular, temately tuice pinnatifid; the arute lubes lanceolate, incised or toothed; reinlets forking from a continuous mide in; fertile part 2-3-pinnate. - N. Eng. and N. J. to Ohio and lake Superior. Jnly - Ang. (Eu.)

4. B. matricariafolium, Brann. Fronds small (3-10' lighli); the sterile segment nearly sissile at the top of the long and slenter common stalk, moderately fleshy, orate or triangulur, varying from pinate to bipinnatifid; the lobes oblong-orrte and obtuse; midrein dissipated into forking reinlets; fer. tile part 2-3.pinnate. - Same range as the last. Jnne, July. (Eu.)

* * Strrile portion of the frond long-stulked; the common stulk short in moportion to the size of the plant. Plunts" usitally lurger.

5. B. ternàtum, Swartz. (P']. 20.) Plunt rery fleshy (4-16' high), sparsely hairy; sterile seyment lony-prtioled from near the base of the plant, broadly triangular, temute und curiously decompound with stulked divisions; ultimate segments varying fron roundish-reniform :ud sub-entire to oratelanceolate and donbly incised; fertile segment erect, 2-4-pinnate. - The fullowing varieties pass into eachother: - Valr. Alsthi $1 \mathrm{k}$; frond ample; nltimate segments rhomboil-orate with it denticulate margin. - Var. INTERMènIry; fronl of moderate size; nltimate segments as in var. anstrale. (B. Innarioides, of last ell.) - V'ar. rut.zólita ; froud small; ultimate segments few, orate and semicordate. - Var. Lr x. niol̀nss; frond sulull ; nltimate segments roundisll-reniform. - Vatr. on Lìve u ; froul moderate; ultimate segments ohliquely lanceolate, denticulate or toothed. - Var. DIsséctur; segments dissected into imumerable narrow lohes or teetlo, - lastures and hillsides, sometimes in dry woods, rather common, ceppecially vars. intermedinn and obliqumu, — Var. rutixfuliun uccurs in Europe. 
\$2. OSMITNDOPTERIS. Base of the stult containing the bud open along one side: sterite segment membranaceous; the colls of the epidermis flexuous.

6. B. Virginiànum, Swartz. Fronds tall and ample; sterile segment sessile above the middle of the plant, broadly triangular, thin and membranaceous, ternate; the short-stalked primary divisions once or tuice pimate, and then once or twice piunatificl the oblong lobes cnt-toothed toward the apex; reins forking from a midrein: fertile part 2-3-pinnate. - Rich woods; common. - l'lant $1-2^{\circ}$ high, or often reluced to a few inches, in which case it is 13. gracile, Pursh. .Jume, July. (Eu.)

\section{OPHIOGLÓS S U M, I. Adner's-Toxge. (Pl. 20.)}

Rootstock erect, fleshy anl sometines tuberous, with slender fleshy roots which are sometimes proliferons; Ind placed by the side of the lase of the stalk; frouds with anterior and posterior segments as in Botryehinm, but the coriaceous sporangia connate and coherent in two ranks on the edges of a simple spike. Sterile segment fleshy, simple in our species; the veins reticulated. Spores copious, sulphur-yellow. (Name from ơ $\phi$ s, a serpent, and $\gamma \lambda \hat{\omega} \sigma \sigma \alpha$, tongue.)

1. O. vulgàtum, L. Fronds from a slender rootstock (2-12' high), mostly solitary ; sterile segment sessile near the middle of the plant, orate or elliptical $\left(1-3^{\prime} \mathrm{long}\right)$; midvein indistinct or none; veins forming small meshes enclosed in larger ones. - Bogs and pastures; not common. July. (Eu.)

\section{Order 133. LYCOPODTÀCEA. (Club-Moss Family.)}

Low plants, usually of inoss-like aspeet, with elongated and often mueh branehed stems eovered with small lanceolate or subulate, rarely oblong or rounded, persistent entire leaves; the sporangia 1-3-celled, solitary in the axils of the lcares, or on their upper surfaee, when ripe opening into two or three valves, and shedding the numerous yellow spores, whieh are all of one kind. - 'The Order, as here defined, eonsists mainly of the large genus

\section{I Y COPÒ DIU M, L. Cier-Moss. (Pl. 21.)}

Spore-cases coriaceous, flattened, usually kidney-shaped, 1-celled, 2-valved, mostly by a transverse line round the margiu, disclarging the subtile spores in the form of a copions sulphmr-colored inflammable powiler. - l'erennials, with evergreen one-nerved leaves, imbricated or crowded in 4-16 ranks. (Name

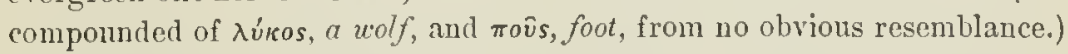

\$ 1. Spoie-cases in the axils of the ordinary (dark green and shining, rigid, lanceolate, about 8-ranked) leares.

1. L. Selàgo, I. Stems erect and rigid, dichotomous, forming a leveltopped cluster ( $3-6^{\prime}$ high) ; leaves uniform, crowded, ascending, glossy, pointed, entire or denticnlate; sporangia in the axils of maltered leares. - Mountaintops, Maine to Lake Superior, and northward. - The leaves of this and the next species often bear little gemme, with the lower bracts pointed, and the 2-3 uppermost broadly ohovate and fleshy, as figured in 1768 by Dillenius. These gemma fall to the ground and their axis grows into the stem of a new plant. 
as speeimens collected in 1854 show very plainly. (For their true nature see Sachs' Lehrbuch, Engl. trans., p. 411.)

2. L. lucidulum, Michx. Stems assurgent, less rigid, dichotomons (6 * $12^{\prime}$ long); leaves pointed, toothed, at first spreading, then deflexed, arranged in alternate zones of shorter and longer leaves, the shorter leaves more frequently bearing sporangia in their axils; proliferons gemmæ usually abundant. - Cold, danp woods; common northward. $\Lambda$ ug.

\$2. Spore-cases only in the axils of the upper (bracteal) leavcs, thus forming a spike.

* Leaves of the creeping sterile and of the upright fertile stems or branches and those of the simple spike nearly al.kc, nany-ranked.

3. L. inundàtum, L. Dwarf; creeping sterile stems forking, flaccid; the fertile solitary $\left(1-4^{\prime}\right.$ high), bearing a short thick spike; leaves lanceolate or lance-awl-shaped, acute, soft, spreading, mostly entirc, those of the prostrate stems curving upward. - Var. BrGELovn, Tnckerm., has fertile stems $5-7^{\prime}$ high, its leaves more awl-shaped and pointed, sparser and more ppright, often somewhat teeth-bearing. - Sandy bogs, northward, not common; the var., eastern New Eng. to N. J., and southward. Ang. (En.)

4. I. alopecuroides, L. Sicms stout, very densely leafy throughont; the sterile branches recurved-procumbent and creeping; the fertile of the same thickness, 6-20' high; leaves narrouly linear-awl-shaped, spinulose-pointed, sprcading, conspicuously bristle-toothed below the middle; those of the cylindrical spike with long setaceous tips. - Pine-barren swamps, N. J. to Va., and southward. Ang., Sept. - Stems, including the dense leaves, $\frac{1^{\prime}}{2}$ thick; the comose spike, with its longer spreading leaves, $8-1^{\prime}$ thick.

* Leaves (bracts) of the catkin-like spikc scale-like, imbricated, yellowish, ovate or heart-shaped, very different from those of the sterile stems and branches.

- Spikes scssilc (i. e. branches equally leafy to the top), single.

5. I. annótinum, L. Much branched; stcms prostrate and creeping (1 $4^{\circ}$ long); the asccnding branches similar (5-8' high), sparingly forked, the sterile ones making yearly growths from the summit; learcs equai, spreading, in about 5 ranks, rigil, lanceolate, pointed, minutely serrulate (pale green); spike solitary, oblong-cylindrical, thick. - Var. PÚNGLNs, Spring, is a rednced sub-alpine or mountain form, with shorter and more rigid-pointed erectish leaves. - Woods; common northward; the var. on the White Mountains, with intermediate forms around the base. July. (Eu.)

6. I. obscùum, L. Rootstock cord-like, subterranean, bearing scattered, erect, tree-like stems diviling at the summit into several densely dichotoinous spreading branches; leaves linear-lanceolate, decurrent, entire, acnte, G-ranked, those of the two upper and two lower ranks smaller and appresised, the lateral ones incurved-spreading; spikes $1-10$, erect, mostly sessile; bracts scarious-margined, broadly ovate, abruptly apiculate. - Var. DENDRofDEUM (L. dendroideum, Michx.) has all the leaves alike and incurved spreading. Molst woods. Aug. - Remarkable for its tree-like appearance.

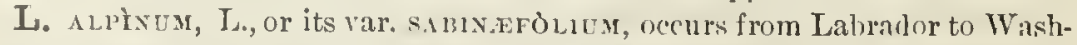
ington, and is to he expected in northern Maine and Minn. It has slender branches with ligid neariy appressed leaves. 
$\therefore+$ Spikes peduncled, i. e. the leaves minute on the fertile branches. +- Leaves homogeneous and equal, many-ranked; stems terete.

7. L. clavàtum, L. (Connon Cucb-Mloss.) Stems creeping exten sively, with similar ascending short and very leafy branches; the fertile terminated by a slender peduncle $\left(4-6^{\prime}\right.$ long), bearing about $2-3$ (rarely 1 or 4 ) linear-cylindrical spikes; leaves lineal-awl-shaped, incurved-spreading (light green), tipped, as also the bracts, with a fine bristle. - Dry woods; eommon espeeially northward. July. (Eu.)

+- Leaves of two forms, few-ranked; stems or branches flattened.

8. L. Caroliniànum, L. (1'l. 21.) Sterile stems and their few short iranches entirely creeping (leafless and rooting on the under side), thickly elothed with broadly lanceolate acute and somewhat oblique l-nerved luteral leaves widely spreading in 2 runks, anl a shorter intermediate row appressed on the upper side; also sending up a stender simple pedunele $\left(2-4^{\prime}\right.$ high, clothed merely with small bract-like and appressed awl-shaped leaves), bearing a single cylindrical spite. - Wet pine-barreus, N. J. to Va., and southward.

9. L. complanàtum, L. (Grudxd-1'1Ne.) Stems extensively creeping (often subterranean), the erect or asrending branches several times forked above; bnshy brunchlets crowded, flattened, fan-like and spreading, all clothed with minute imbricated-ripmessed awl-shaped leares in 4 ranks, with deenrrentunited hases, the lateral rows with somewhat spreading tooth-like tips, those of the upper and under rows smaller, narrower, wholly appressed; peduncle slender, bearing 2-4 cylindrical spikes. - Var. Cunuscrparf́seds has narrower, more erect and bushy branches, ant the leares less distinctly dimorphous. - Woods and thickets; common, especially northward. (Eu.)

\section{Order 134. SELAGINELTACEZE.}

Leafy plants, terrestrial or rooted in mul, never very large; the stems luranching or short and eorm-like; the leaves small and 4-6-rowed, or subulate and elongated; sporangia one-eelled, solitary; axillary or borne on the upper surface of the leaf at its base and enwrapped in its margins, some eontaining large spores (macrospores) and others small spores (microspores). The macrospores are in the shape of a low triangular pyramid with a hemispherical base, and markerl with elevated ribs along the angles. In germination they develop a minute prothallus which bears archegonia to be fertilized by antherozoids developed from the microspores.

1. Selaginella. Terrestrial ; stems slender; leaves small ; sporangia minute and axillary.

3. Isoetes. Aquatie or growing in mud: stems corm-like: leaves elmgated and rush-like, sporangia very large, enwripped by the dihated bases of the leaves.

\section{SELA GINÉLLA, Beauv. (l. 21.)}

Fructification of two kinds, namely, of minute and oblong or globular sporeeases, containing reddish or olange-colored powdery microspores; and of mostly 2-valved tumid larger ones, filled by 3 or 4 (rarely 1-6) much larger globose angular macrospores; the former usually in the upper and the latter in the lower ixils of the leafy 4 -ranked sessile spike, but sometimes the two kinds 
are on opposite sides all along the spike. (Name a diminutive of Selago, an ancient name of a Lycopodium, from which this gemms is separated, and which the plants greatly resemble in habit and foliage.)

* Leaves all alike and uniformly imbricated; those of the spitie similar.

I. S. spinosa, Beauv. Sterile stems prostrute or ereeping, small and slender; the fertile thicker, ascending, simple ( $1-3^{\prime}$ high); leaves lanceolate, acute, spreading, sparsely spinulose-ciliate. (S. selaginoides, Link.) - Wet places, N. H. (Pursh), Mich., Lake Superior, Colorado, and northward; rare. - Leaves larger on the fertile stems, yellowish-green. (En.)

2. S. rupéstris, spring. (1'1. 21, fig. 1-4.) Much branched in close tufis (1-3' high); leaves densely apmessed-imbricated, linear-lanceolate, convex and with a groored keel, minutely ciliate, bristle-tipped; those of the strongly quadrangular spike rather broader. - Dry and exposed rocks; rery common. - Grayish-green in aspect, resembling a rigid Moss. Very variable farther west and south. (Ev.)

* * Leaves shorter above and below, stipule-like; the lateral larger, 2-ranked

3. S. àpus, Spring. Stems tufted and prostrate, creeping, mneh branehed, flaeeid; leaves pellucid-membranaceons, the larger spreading horizontally, ovate, obliqne, mostly obtuse, the smaller appressed, taper-pointed; those of the short spikes nearly similar; larger spore-cases copions at the lower part of the spike. - Low, shady places; not rare, especially sonthward. $-\Lambda$ delicate little plant, resembling a Moss or Jungermannia.

\section{Is ÒETES, L. QunLwort. (Pl. 21.)}

Stem or trunk a fleshy more or less depressed corm, rooting just abore its 2 . lobed (or in many foreign species 3-lobed) base, above covered with the dilated and imbricated hases of the awl-shaped or linear somewhat quadrangular leaves, which inclnde four air-tules, intercepted by cross partitions. Sporangia pretty large, orbicnlar or ovoit, plano-convex, very thin, sessile in the axils of the leaves, and mited at the hack with their exeavated bases (the thin edges of the excavation folding round partly cover them, forming the relum), travursed internally ly transverse threads; those of the onter leaves filled with large spherical macrosipores, their whitish crustaceous integument marked by one cirenlar, and on the npper snrface by three radiating elevated lines (cireumscribing a lower lemisphere, and three upper segments which open valve-like in germination); those of the inner leaves filled with very minute and pow dery grayish microspores; these are always obliquely oblong and triangular - Mostly small aquatics, grass-like or rnsh-like in aspeet, some always sub. merged, others amphibious, a few living in merely moist soil, ntaturing their fruit in late summer and early antunn, except n. 7 and some forms of $n .6$.

This genus is left essentially as it was elaborated for the 5th edition by the late Dr. Geongl: Kingeluans. The present editor has added to the range of a few species, and given var. robusta of n. 3 .

* Growing under water, only accidentally or in very dry seasons out of water; leaves without stomutu (exrept in forms of $\mathrm{n}$. 3) and peripherical bast-bundles.

1. I. lacústris, I. (1'l. 21, fig. 1-5.) Leaves (10-25 in number, 2-6́ ing) dark green, rigid ; sporanginn woid or circular, the upper third, or less, 
cotered by the velum, the free part pale and unspotted; both kinds of spores the largest of our species; maerospores $\left(0.32-0.38^{\prime \prime}\right.$ wide) covered with short and twisted crested ridges, whieh often anastomoso; nicrospores $\left(0.017-0.020^{\prime \prime}\right.$ long) smooth. - Mountain likes, l'enn., N. Y., and New Eng. to Lake Superior, and nortlwward, often with 11.3. (En.)

2. I. Tuckermàni, Braun. Leaves $\left(10-30,2-3^{\prime}\right.$ long) very slender, awl-shaped, olive-grecn, the onter recurved; sporaugium ovoid or cireular, the npper third covered by the velum, the free part sometimes browish-spotted; macrospores $\left(0.22-0.28^{\prime \prime}\right.$ wide) on the upper segments covered with parallel and anastomosing ridges, the lower half reticulated; microspores (0.013$0.015^{\prime \prime}$ long) smooth or very delicately pipillose. - Nystic and other ponds near Boston, together with the next (Tuckerman, $W$. Boott).

3. I. echinóspora, Duricu. Leaves slender, awl-shaped; sporangium ovoid or circular ; macrospores $(0.20-0.25$ " wide) beset all over with small entire and obtuse or slightly forked spinules. (En.) - In this European form, the leaves are very slenderly attenuated ( $3-t^{\prime}$ long), the upper margin of the sporangium only is covered with the narrow velum, the free part is unspotted, and the slightly papillose microspores are larger $\left(0.015-0.016^{\prime \prime}\right.$ long).

Var. Braùnid, Engelın. I.eaves (15-30 in number, 3-6' long) dark and often olive-green, straight or commonly recurred, half or two thirds of the sporangium covered l,y the velum, the free part often with light brown syots; macrospores as in the type; microspores smaller $\left(0.013-0.014^{\prime \prime}\right.$ long $)$, smooth. (I. Bramii, Durieu.) - Ponds and lakes, New Eng. to N. I., I'emn., Mieh., and northward, often with the two preceling. - Frequently with a few stomata, especially in Niagara specimens.

Var. robústa, Engelm. Stouter; leaves (25-70,5-8 long') witl abuıdant stomata all over their surfaee; velum eovering about one half of the large spotted sporangium; macrospores $0.18-0.27^{\prime \prime}$ wide. - Lake Champlain, north enil of Isle La Motte (Pringle).

Var. muricàta, Engelm. Leaves $\left(15-30,6-10^{\prime}\right.$ long) straight or flaccid, bright green; ahont one half of the almost circular sporangium covered by the velum, unspotted; maerospores (0.22-0.27" wide) with shorter and blunter spinules; microspores as in the last variaty, or rarely spinulose. (I. muricata Durieu.) - In some ponds north of Boston ( $\mathrm{H}^{\mathrm{r}}$. Boott).

Var. Boóttii, Engolm. Leaves (12-20,4-5' ligh) awl-shaped, stifty erect, bright green, with stomata; sporangium as in the list; macrospores as in the type, but a little smaller and with very slender spinules. (I. Boottii, Braun, in litt.) - Pond in Woburn, ncar Boston, partly out of water (W'. Boott). * * Growing purtly out of uater, either by the pond drying up or by the receding of the ebb tide; leaves with stomata, and in $\mathrm{n} .6$ and 7 with four or more peripherical bast-bundles.

4. I. saccharàta, Engelm. Leaves $\left(10-15,2-3^{\prime}\right.$ long) slender, olivegreen, curved; sporangium small, ovoid, only the upper edge covered by the relum, nearly unspotted; macrospores $\left(0.20-0.22^{\prime \prime}\right.$ wide) minutely tuberculate; microspores (0.012" long) papillose. - On Wicomico and Nanticoke livers, eastern shore of Maryland, between high and low tide (Canby).

5. I. riparia, Engelm. Leaves $\left(15-30,4-8^{\prime}\right.$ long slender, deep green, erect; aporangium mostly oblong, upper margin to one third cusered by the 
velum, the free part spotted; macrospores very variable in size $\left(0.22-0.30^{-1}\right.$ wilc), the upper segments covered by short crested ridges, which on the lower hemisphere run tugether forming a network; microspores larger than in any other species except 11, $1\left(0.013-0.016^{\prime \prime}\right.$ long), mostly somewliat tuberculated, - Gravelly banks of the Delaware, from above 1'hiladelphia to Wilmington, between flood and elb tide; margins of ponds, Lake Saltonstall, Conn. (Setchell), and northward. - 1)istinguished from the nearly allied I. lacustris by the stomata of the leaves, the spotted sporauginm, the smaller size of the macrospores and their reticulation on the lower half.

6. I. Engelmánni, Braun. Leaves long (25-100, 9-20’ long), light green, erect or at last prostrate, flat on the upper sicle; sporanginm mostly oblong, unsputted, the relum very narrow; macrospores $\left(0.19-0.24^{\prime \prime}\right.$ wide) covered all over with a cuarse honeycomb-like network; microspores 10.012 $0.014^{\prime \prime}$ long) mostly sinooth. - Shallow pouds and ditches, from Mass. (near Boston, W. Boott, M. Munn) and Meriden, Conu. (F. W. Hall), to Peun, and 1)el. and (probably through the Middle States) to Mo. - By far the largest of our species, often mature in July.

Yar. grácilis, Engelm. Jeaves few $(8-12$ only, 9-12' long) and rery slender; both kinds of spores nearly as in the type. - Southern New Eng. (Westrille, Comn., Setchell) and N. J. (Ennis) ; entirely submersed!

Var. válida, Engelm. 'Trunk large and stont (often 1-2' wide); leaves (50-100, even 200, 18-25' long) with an elerated ridge on the upper side; sporanginm oblong or linear-ollong $\left(4-9^{\prime \prime}\right.$ long), $\frac{1}{3}-\frac{1}{2}$ or more covered by the velum; spores very small; macrospores $0.16-0.22^{\prime \prime}$ wide; mierospores $0.011-0.013^{\prime \prime}$ long, spiuulose. - Del. (C'unby) and Penu. (Porter). Sept.

7. I. melanópoda, J. Gay. Leaves $\left(15-50,6-10^{\prime}\right.$ long) very slender, keeled on the back, straight, bright green, usually with dark brown or black shining bases; sporangium inostly oblong, with a very narrow relum, brown or spotted; macrospores rery small $\left(0.14-0.18^{\prime \prime}\right.$ wirle), smoothish, or with faiut tubercles or ridges; microspores (0.010-0.012" long) spinulose. - Shallow ponds, and wet prairies and fields, central and northern 11l. (E. Hull, Vusey), and westward. June, and sometimes again in Nov. - 'lrumk more spherical and more deeply 2-lohed, and both kinds of spores smaller than in any other of onr species; leaves disappearing during the summer heat. ('losely approaehing the completely terrestrial species of the Mediterranean region.

\section{ORDER 1:35, MIRSILIACEAE.}

Perennial plants rooted in mul, laving a slender creeping rhizome and either filiform or 4-prarterl long-petioled leaves; the somewhat crustaceous several-eclled sporocarps ljorne on peduncles which rise from the rhizome near the leaf-stalks, or are more or less consolidated with the latter, and eontain both macrospores and microspores.

\section{M A R SİLI A, 1. (Pl. 25.)}

Submersed or emersed aquatic plants, with slender creeping rootstocks, Bending up elongaterl petioles, which bear at the apex a whorl of four nervoseveined leaflets, and at or near their base, or sometimes on the rootstock, one 
or more ovoid sporoearps. 'These sporocarps or fruit usually have two teetl near the base, and are 2-eelled vertically, with mauy transverse partitions, and split or burst into 2 valves at maturity. The sporocarps have a ring along the edges of the valves, which at length swells up and hears the sausageshaped compartments from their places. The compartments contain macrosporangia and microsporangia intermixed. (Named for Aloysius Marsili, an early Italian naturalist.)

1. M. quadrifólia, L. Leaflets broally obovate-enneate, glabrous ; sporoearps usually 2 or 3 on a short perluncle from near the lase of the petioles, pedicelled, glabrous or somewhat lairy, the basal teeth small, obtuse, or the ajper one acute. - In water, the leaflets commonly floating on the surface; Bantam Lake, Litelifield, Conn., and now introduced in many places. (Eu.)

2. M. vestita, Hook. \& Grev. Leaflets broadly cuneate, usually hairy, cutire (2-7" long and broad); petioles $1-4^{\prime}$ long; peduncles free from the petiole; sporoearps solitary, short-peduncled (about 2" long), very hairy when young; upper basal tootl of sporocarp longest, acute, straight or curved, lower tooth aeute, the sinus between them rounded. (M. mucronata, Braun.) - In swamps whieh beeome try in summer; lowa and southwestward.

\section{OHDER 136. SALVINIÀCEAE.}

Floating plants of small size, having a morc or less elongated and somctimes branching axis, bearing apparcntly distichous leaves; sporocarps or conceptacles very soft and thin-walled, two or more on a common stalk, one-celled and having a central, oftcn branched receptacle which bears either macrosporangia containing solitary macrospores, or microsporangia with numerous microspores.

\section{A zó I I A, Lam. (Pl. 21.)}

Small moss-like plants, the stems pinnately braneled, eovered witl minute 2-lobed inbricated leaves, and emitting rootlets on the under side. Conceptacles in pairs beneath the stem; the smaller ones acorn-shaped, containing at the base a single maerospore with a few corpuscles of monown character above it; the larger ones glolose, and having a basal placenta which bears many pedicellate microsporangia which contain masses of microspores.

1. A. Caroliniàna, Willu. Plants somewliat deltoid in ontline $\left(4-12^{\prime \prime}\right.$ broad), much branclied; leaves with orate loles, the lower lobe reddish, the upper one green witl a reddish burder'; macrospores with three attendant corpuscles, its surface minutely granulate; masses of microspores gloehidiate. Floating on quiet waters, from Lake Ontario westward and southward, - ap. pearing like a reldish hepatic moss.

Salvinia NAtaxe, I., was sail by Pursh to grow floating on the surface of small lakes in Westeri New York, and has more reeently been said to oceur in Missouri. It has ohlong-oval fioating leaves $4-6$ " long, closely pinnately. reined, which bear coneeptaeles and branching plumose fibres on their under surface. 


\section{Subclass II. CELLULAR ACROGENS, or}

\section{BRYOPHYTES.}

Plants composed of cellular tissue only. Antheridia or archegonia, or both, formed upon the stem or branches of the plant itself, which is developed from the germinating spore usually with the intervention of a filiform or conferva-like prothallus. - Divided into the Mrusci, or Mosses, and the He. paticee.

\section{Division I. HEPÁtiC.̇. ${ }^{1}$ (Liveriworts.)}

Plants usually procumbent, consisting of a simple thallus, a thalloid stem, or a leafy axis; leaves when present 2-ranked, with uniform leaf-cells and no midvein; thalloid forms witl or without a midvein, smooth or scurfy or scaly beneath and usually with numcrous rootlets. Sexual reproduction by antheridia and archegonia, which are immorsed in the thallus, or sessile or pedicelled upon it, or bornc on a peduncled receptacle. The fcrtilized archegonium develops into a capsule (sporogonium) closely invested by a calyptra, which ruptures above as the ripencel capsule (containing numerons spores and usually elaters) pushes upward. It is also commonly surrounded by a usually double involucre, the inner (often called perianth) more or less tubular, the outer tubnlar or more often foliaceous, sometimes wholly wanting. l'ropagation is also effected by offshoots (innovations), rumers (flagella), or by gemmoe, which appear at the margin of the leaves or on the surface of the thallus, often in special receptacles.

\section{Order 13\%. JUNGERMANNIÀCEAE. Scale-Mosses.}

P'lant-body a leafy axis or rarely thallose. Capsule borne on a slender often elongated pedicel, splitting at maturity into 4 valves. Elaters mixed with the spores, mostly hispiral (unispiral in n. $1-3,32$, and 33 , $1-3$-spiral in n. 5 and 28). Antheridia and archegonia ritxeious or monœeious, in the latter ease either mingled in the same infloreseence, or separated upon the same braneh, with the antherilia naked in the axils of the lower leaves, or on separate parts of the same plant. Leaves

1 Elaborated for this edition by Prof. L. M. Underwoon, of Syracuse. N. Y 
2-ranked, incubous (i. e. the apex of each leaf lying on the base of the next above), or suceubous (i. e. the apex of each leaf lying under the base of the next above), or sometimes transverse, with frequently a third row of rudimentary leaves beneath the stem.

\section{Artificial Key to the Genera.}

§. Plaut-body a leafy axis.

* Leaves eomplicate-bilobed (i. e. folded together) or with a smal: basal lobe.

+ Lower lobe smaller than the upper.

+* Root-hairs borne on the stems or underleaves.

1. Frullania. Lower lobe mostly saeeate, nore or less remote from the stem. Branehes intra-axillary, the leaves on either side free.

2. Jubula. Lower lobe saeeate; branehes lateral, a basal leaf borne partly on the stem, partly on the braneh.

3. Lejeunca. Lower lobe incurved, more ur less inflated.

5. Porella. Lower lobe ligulate. Periunth triangulitr, the third or odd augle ventral.

$$
\text { +. + Root-hail's rising from the lower lobes. }
$$

4. Radula. Perianth eompressed. Underleaves none.

+ - Upier lobe smaller than the lower, or the two sonnewhat equa!.

++ Leaves sueeubous as to their lower lobes.

15. Scapania. Involueral leaves 2 ; perianth dorsally eompressed, the mouth truneate, bilabiate, decturved.

16. Diploplyylum. Involneral leaves few; periantl erect, round, the moutl dentieulate. + + Leaves transterse.

25. Mrarsupella. Periantlı tubular or somewlat eompressed. (Compare also Junger mamnia $\$$ Splienololius.)

* Leares palmately 3-4-(1) many-) cleft.

+ Divisions numerous, capillary. Plants large, usually in eonspieuous mants.

6. Itilidium. Leaves palınatifid with eiliate margins.

7. Trichocolea. Leaves setreeously multifill.

+ + Leaves 3-4-eleft or liarted; plants small, nostly ineonspicuous.

10. Lepidozia. Laf-divisions two cells wide or more.

11. Blepharostoma. Leaf-divisions only one cell wide.

** * Leaves entire, emarginate, or 2 -3-toothed or -lobed.

- Leaves elosely inbrieate on short julaceons stems.

27. Gymmomitrium. Involuere double, the immer shorter.

$$
++ \text { Leaves deeply bilobed. }
$$

8. Herberta. Underleaves large. Periantl fusiform on an elongated braneh.

12. Ceplnalozia. Underleaves mostly wanting; periauth mostly triangular on a short branch.

$$
++ \text { + Leaves ineubous, mostly plane or depressed. }
$$

9. Bazzania. Leares mostly $2-3$-toothed. Perianth fusiform on a short braneh.

14. Kantia. Leaves mostly entire. Perianth fleshy, pendulous, subtertanean.

$$
+++ \text { Leaves sueeubnus or transverse. }
$$

+ Underleaves entire or nearly so.

13. Odontoschisma. Inrolncral leaves numerous, small, ineised, those of the stem rounded or retuse.

21. Mylia. Involucrai leaves?, comate at hase. Large.

22. Harpanthus. luvolucitl leaves few, smaller than the semi-vertical emarginate atem. leaves. Sinall. 
24. Jungermannia. Involucral leaves few, mostly larger than the entire or bidentate stem-leares, Medium-sized or large.

+ +t Underleaves 2-4-eleft, -parted, or -clivided.

17. Geocalyx. Involucre fleshy, saceatc, pendent. Leaves bilentate; underleaves 2-cleft.

18. Lophocolea. Fruit terminal on the main stem or a primary branch. Involucral leaves distinet.

39. Chiloscyphus. Fuit on a short lateral brancl. Involucral leaves distinct. (Seo 2lso Jungernaunia.)

+++++ Uuderleaves nostly wanting.

a. Leaves entire or barely retuse.

23. LiochIana. Involucral leaves distinct, like those of the stem; perianth truncato. depressed at the aluex.

26. Nardia. Involucral leaves connate at basc and adnate to the perianth.

b. Leaves bidentate or bilobed, rarely 3-loled.

12. Cephalozia. Branches all from bencath. Periantl on a slort branch, mostly trigonal with the odd angle beneatl.

24. Jungermannia. Simple or branching laterally. Perianth terminal, mostly laterally compressed.

c. Leaves mostly spioulose or dentate.

20. Plagiochila. Involncral leaves large ; perianth laterally compressed.

§ 2. Plant-body pseudo.folinceous with succubous leaf.like lobes.

28. Fossombronia. Perianth large, cimpanulate.

§3. P'lant-iody a tliallus.

* Thallus with a distinct costa.

29. Pallaricinia. Thallus $3-6$ " wide, mostly simple, the margins sinuate or undulate. l'e.iuti tubular, at length dorsal.

30. Blasia. Thallus $3-6^{\prime \prime}$ wille, lobed, dichotomous, or radiate, the margins pinnatifidsiluate.

32. Metzgeria. Tlallus narrow $\left(1-2^{\prime \prime}\right)$, ciliate at the margins or on one or both sides,

* Thallus vitl an inconspicuous costa or none.

33. A neura. Thallus rather narrow, mostly palmatcly or pinnately lobed. Sporogonium rismg from the under side wear the margin.

31. Pellia. Thallus wider, uostly simple or forked. Sporogonium rising from the upper surface.

\section{F $\mathrm{R} U \mathrm{~L} L \overline{\mathrm{A}} \mathrm{N} I \mathrm{~A}$, Faddi. (Pl. 24.)}

Leaves incubous, complicate-lilobed, the lower lobe usually inflated, helmetor club-shaped; underleaves bifil, rarely cutire, with basal rootlets. INiceious or monccions. Fruit terminal on the branches. Involncral leaves 2 or 4 , larger than the stem-leaves; perianth 3-4-angled, mucronate. Calyptra pyriform, fleshy. Capsule globose, the lower third solit. Elaters truncate at each end, unispiral, adherent to the valyes. Spores large, reddish, minutely muricate. Antherilia most often on a short branch, globose-oblong or cylindric. Archegonia 2-4, long-styled. (Named for Lconardo Frulluni, an Italian Minister of Sitate.)

§ 1. TRACIIYCOLLA. Periant: triangular in section, rough with tubercles or scales, or villons ; louer leaf-lohe helmet-shaped, Iruncate at base.

* Lmer lonftobe about three fourths the size of the upper.

3. F. Oakesıàna, Anst. Stems widely branching; fertile branches short, leaves obliquely orbicular, loosely imbricate, the lower lolie rotund, contiguous to the stem; underleaves ovate-rotund or subobovate, little wider than the 
stem, bifil; involucral leaves more or less connate, equally bilobed, the lobes entire, obtuse; perianth small, subobovate-pyriform, smooth or $1-7$-nerved or alate both sides. - Mrite Mts., on stunted spluce and virch trees.

$$
\text { * Lower leaf-lobe much smuller than the upper. }
$$

- Inderleaves scarcely wider than the stem, ovate, bifil, the divisions entire, acute; perianth 1-carinate or smooth, except in $\mathrm{n.} 2$; stems crepping.

2. F. Virginica, Lelm. Stems short, irregularly branching; leaves crowded, ovate, entire, somewhat concave, the lower lobes sometimes expanderl into a lancenlate lanina; underleaves ronnd-ovate, bifid, twice the wilth of the stem; perianth compressed-pyriform, tuberculatc, 2-4-carinate dorsally, 4-carinate ventrally. - On bark of trees, rarely on rocks; common.

3. F. Eboracénsis, Lehm. Buanches clustered; lcaves loose, imbricate on the branches, rounl-ovate, cntire; perianth prriform, slightly compressed and repand, smonth, ohscurely carinate beneath and giblous toward the apex. (F. saxatilis, lindenl.) - On trees and rocks; conmon northward.

4. F. Pennsylvánica, Stepl. Stems dichotonons; leaves imbricate, flat, ovate, murnute or rarely olsuse, entire; lower lobe marginal, large, round-cucnllate; underleaves hroally orate, deeply parted, the divisions long. acuminate ; diocious; antherishal spikes on short lateral branches, elongated; lobes of the involucral leaves acuminate, much narrowed at base, and the large unlerleaves carinate-concave, deeply parted, their apiculate divisions entire or toothed. - Sharled rucks, Stouy Creek, Carbon Co., P'enu. (Licu). Known only from the original description.

5. F. saxícola, Aust. Stems mmerous, widely branching; leaves orbicular, scarcely oblique, flat; lower lobe near the stem, small, or rarely larger and round-galcate; underleares scarcely wider than the stem, subovate, bificl perianth broadly oblong, howl-shaped with very short mouth, papillose, abruptly broad-carinate beneath, 1-mauy-nerved each sile of the keel, 2-angled. Sloping dry trap rocks, Closter, N. J. (. Iustin).

+ + Underlerues 2-3 times wider than the stem, roumd or subquadrate, bifid, the divisions blunt or truncate.

++ Leaves lax, rather distunt; lower lobe mostly expanded, ovate-tanceolute.

6. F. æolòtis, Nees. Procunbent, irregularly luanched or subpinnate; lcaves semi-vertical, subsfunarose, obliquely cordate, the lower lobe expanded; unclerleaves ovate, acutely bifid, the upper margin angular-dentate or entire; sporogonium unknowu. - On trees and rocks, chiefly in mountain regions.

++ Leaves close-imbricate; lower lobe galeate, seldom expanded except on terminal leaves.

7. F. squarrósa, Nees, 1)cumbent, pinnately branching, the short fertile branch lateral; leaves sulvertical, suborbiculiu, obtuse, entire; lower lobe obovate-cucullate or galeate, subappressed ; underleares cordate or rounder, simute-subdentate, slightly bifid; perianth oblong, trifnetrous, convex dorsally, strongly keeled ventrally. - On rocks and trees, N. Y. to Ohio, and southward; rather common.

8. F. plàna, Sulliv. Procumbent, widely branching or subpinnate; leaves orbicular, subinbricate; lower lobe very small, as luond as long, close to the stem; underleaves rather large, flat, rounded, slightly lifid; mono. 
cious; periantls ohlong-oval or snbolborate, triquetrous, dorsally suleate, acutely keeled ventrally; antheridial spikes globose. - Shaded rocks, N. Y. and N. J. to E. Tenn.

9. F. dilatàta, Nees. Loosely and widely pinnate; leaves round, entire, opaque; lower lobe subrounded, encullate, elose to the stem; underleaves subquadrate, toothed at the anterior angles; involneral leaves with 2 or 3 entire lobes; perianth tuberculate, retuse. - Rocks and trunks of trees; rather eommon. (Eur.)

§2. THYOPSIÉLLA. Perianth smooth; leaves semicordate at base (marked by a central moniliform row of cells, on sometimes in $\mathrm{n} .12$ by a few scattered large cells); lower lobe near the stem (except in 11.11 ), cylindric-saccate, mostly erect; underleaves rounl-oval, the margin entire, recurved; diacious.

\section{* Leaves orbiculur.}

10. F. Asagrayàna, Mont. (1'l. 24.) (Tecping, simply pinuate; leaves concave, obtuse, deeurved; lower lobe oblong-clarate, emarginate at base; underleaves oblomg, that, 2-eleft, the sinus obtuse; involneral leaves unequally 2-cleft, the dorsal segment oblong, pointed, nearly entire, the ventral snbulate; perianth pyriform, 3-sidel, obtuscly keeled beneatl. . (F. Grayana of authors.) - Rocks and bark of coniferons trecs; frequent.

11. F. Tamarísci, Nees. Bipinuately branching, somewhat rigid; leares obtuse, mucromately acute or subacuminate, decurved, entire; lower lobe distant from the stem, oral or oblong; underleares cunarlrate-orate or oborate, emarginate, the margin revolute; inrolucral leaves bifid, sermlate; perianth oblong, suleate dorsally, obtusely keeled rentrally, - N. Eng. and southward; rare. (En.)

$$
\text { * Leaves oblong from a narroued base. }
$$

12. F. fragilifolia, Tayl. l'roembent, sulpimate, the alternate flattened branches subremote; leaves subimbrieate, ascenting, recnrved, entire; lower lohe oblong-galeate; underleaves round-ohorate, flat, appressed, bifid, the margins entire or angled; perianth obovate-eordate, coneare dorsally, keeled ventrally; involneral leares suhequally lohed, obtusely few-toothed. (F. polysticta, Mont. F. Snllivantia, Aust.) - On trees in a cedar swamp, Urbana, Ohio (Sullivant). (En.)

\section{J Ù B U L A, Dnmort. (PI. 25.)}

Charaeters mearly as in Frullania. Leaves large and flat, an axillary one at the hase of each branch without a lower lohe. Calyptian turnip-slaped, abruptly glohose above. Monoecions, with 2 antlecidia in each leaf of a spikelike braneh, and the archegnnia mostly solitary. (Name from juba, a mane, allucling to the persistent elaters.)

1. J. Hutchínsiæ, Dumort., rar. Sullivántii, Sprnee. Snbdichoto. mously hranching: leaves dark olive-green, sulimbricate, olliquely ovate, acute, entire or snbrepand; lower lobe saccate, rather remote from the stem, not spurred as in the European form ; underleaves ronndish, serrate or entire; inrolucral leaves hifid, serrate; perianth triangular-nhpyriform. (Frullania Hutchinsiæ, Nees, in part.) - Wet rocks, N. Eng. to S. C.; moro eommon in the mountains. 


\section{L E J E Ù N E A, Libert. (1' 24.)}

Leaves deeurrent at the folds, the lower lobe ineurved and ventricose; underleaves usually present, entire or bifid. Archegonium with a slender persistent style, solitary on a usually very short branch; the perianth free from the involucral leaves, oval or ohlong, terete or angular, varionsly carinate, cristate, or ciliate. Capsule grobose, 4 -cleft to the midlle, the valves recurved. Spores large $(40-50 \mu$ hroall), globose or oblong, tuberculate. Antherirlia at the bise of ordinary leaves or in the axils of the leaves of a spike-like brancl. otherwise as Frullania. (Named for A.-L.-S. Lejeme, a French botanist.)

* Underleares mitire.

1. L. clypeàta, Sulliv. (Pl. 24.) Stems procumbent, somewhat pinnately branched, $\frac{8}{4}-1^{\prime}$ long; leaves whitisl-green, round-orate, cellular-crenulite, deflexed ; lower lobe flat, oblong-rnadrate; underleares round-quadrate; monucious; involucral leares larger than those of the stem, the perianth round-obovate, 2-3-carinate dorsally, I-carinate ventrally, the kecls rough. (I. ealyeulata, Tayl.) - On rocks and trees; common south and westrard.

* * Underlenves bifid; leuces entire.

2. L. serpyllifolia, Libert, var. Americàna, Iindb. Stems long, somewhat branching, pale, pellncid and fragile; leaves rather remote, flat, opening from a basilar sac, scarcely decurved, oblignely roundish-ovate, obtuse, often slightly repand; underleaves ahout half as large, rounl-oral with a broal obtuse sinus and acute lobes; monocious; the obovate-clarate perianth on a lateral branch. (I. cavifolia, Lust.) - (on cerlars, etc., Catskill Mts. (Cleve), Belleville, Ont. (Mucoun), aurl southwart; rather common.

3. L. lùcens, Tayl. Whitish, filiform, pinnately brancherl; leares jemote, rarely subimbrieate, obliquely orate-triangular, roinlerl or ol,tuse, semi-cordate at base; lower lobe ovoid, acute or apiculate; underleares $\frac{1}{2}$ as large as tho lateral, round-oval, deeply bifi, the lobes broad-sululate; diocious ; involncral leaves ratler longer, with lanceolate lobes; perianth scarcely emersed, broadly pyriform, 5-carinate. (L. cuenllata, Sullir.; not Nees.)-Near Cincinnati; moist rocks, Alleghany Mts. and sonthward (Sullivant). Minute and flaccid.

* * Underleares obsolete: leaves murimlatedenticulate.

4. I. calcàrea, Libert. Yery mimte; stems slenter, loosely branching; leaves orate, falcate-decurverl, sinuate-complicate at hase; nonocious; involneral leaves bifid, the divisious entire; perianth on a very short lateral hranch, pyriform-clavate, acutely 5-angled, the margin echinate-nuriculate. (I. echinata, $T a y l$.$) - On rocks and roots of trees; rather common. (Eu.)$

\section{R Á D U L A, Dumort. (I’. 24.)}

I.eaves large, complicate-biloberl, incubous; lower luhe small, beariug roothairs; underleaves none. Dicecions, rarely moncecions. Fruit nsually terminal. Involncral leares 2 , slightly smaller than the canline, 2-loherl; perianth tubluar, compressed or nearly terete, truncate, entire or crenate. Calyptra pyriform, persistent. Capsule oval-eylindric. Elaters slender, free. Spores large, globose, minntely tuberculate. Antheridia in the rentricose bases of 
spicate leaves. (Radula, a scraper or spatula, in allusion to tlie form of the periauth.)

* Lover lobe subquadrate, barely incumbent on the stem.

1. R. complanàta, Dumort. Creeping, widely subpinnately lranching; leaves imbricate, spreading, rounderl, the lower lobe obtuse or acute; moncecious; perianth obconic, compressed, the mouth entire, truncate; anthe. ridia in the bases of 2-3 pairs of strongly imbricate tumid leares. - On rocks and roots of trees; common. (Lit.)

2. R. obcónica, Sulliv. (l'l. 24.) Smaller, indetcrminately branched; leaves somewhat remote, rouud-obovate, convex; unonecious; jerimnth clavate obconic, obliçuely truncate; autheridia axillary on short lateral branches rising near the termiual involucre. - On trees iu cedar swamps, N. J. to Chio.

* Lover lobe small, rounded, more or less transversely adnate.

3. R. tènax, Lindb. Stems brownish-green, rigid, tenacious; lcaves remote, scarcely decurrent, obliquely elliptic-ovate, opaque, the cells round and strongly chlorophyllose; diocious; the anthcridial spike lateral below the keel of a leaf, long, linear, somewhat obtnse. (R. pallens, sullir.; not Gottsche.) - On rotten trunks, in the Catskill Mts., and southward, especially in the mountains.

\section{PORÉLLA, Dill.}

Leaves largc, incubous, complicate-bilobed; lower lobe ligulate, suberect; underleaves similar, decurrent at base, the apex eutire. Diœcions. Fruit on a short lateral brancl.. Involucral leares usually 4, 2-lobed, the margin ciliate or denticulate; perianth somewlat oval, compressed, bilabiate, incised or cutire. Caly ptra glolose, persistent. Capsule globuse, reddisl, short-stalked. Elaters very numerous, 2-3-spiral, free. Spores large, rough. Antleridia solitary in the saccate bases of leaves, crowded in short spikcs. (Name a diminutive of porus, an opening.)

* Leaves more or less remote; stcms bipinnate.

1. P. pinnata, I. Stems irregularly piunate, fastigiate at the ends; leaves scarcely incubous, ovate-oblong, the rounderl apex sometimes slightly decurved; lower lobe minute, flat, ol,long, obtuse, as long but not half as wide as the flat, entire, ovate-rectangular, scarcely decurrcnt underleaves. (Madotheca Porella, Nees.) - On rocks aud trees sulject to inumdation; common. (Eur.)

* * Leaves mostly closely imbricate; stems mostly simply pimate (or bipinnaté in 11.2 ).

2. P. platyphýlla, Lindb. (Pl. 24.) Ycllowish or fuscous-green; stems irregularly pimate, ofteu fastigiate at the ends: learcs obliqucly ovate, more or less concave at base and the rounded upper margin curvel upward and undulate, mostly entire; lower lobe obliquely ovate, the margin strongly recurved, with an acute tooth at base; underleaves senicircular, with strongly reflexed margins. (Madotheca platyphylla, Dumort.) - On rocks and trees; cominon eastward. (Eul.)

3. P. Thùja, Lindb. Finscous-green or hlackish, somewhat regularly pinnate; leaves convex, closely appressed, obliquely ronnd-orate, the ronnded 
apex decurved, more or less denticulate; lower lobe oblong, obtuse, with an acute tooth at base, longer but narrower than the quadrate underleaves, both with strougly recurved sparsely denticnlate margins. (Marlotheca 'Thnja, Dumort.) - On rocks and trees; more common westwarl. (Eu.)

4. P. dentàta, Lindb. Mostly fuscous-green, irregularly pinuate or sub. dichotomous; leaves more remote on the branches, ohliquely romud-ovate, the ronnded summit slightly decurved, more or less denticulate; lower lobe decurrent, twisted, obliquely orate, acute, with recurved undulate denticulate margin and a large acute tooth at base; underleaves twice as wide as the lower lobes, quadrate-oval, the undulate reflexed margin dentate, especially near the base. (Madotheca rivularis, Nees.) - Sladed rocks, Yellow Springs, Olio (Sullivant). (lin.)

5. P. Sullivántii, Underw. Stems strongly decurved at the enrls in drying; leaves suberect, the straiglit ventral margin strongly involute toward the apex; cells large, puuctate-stelliform; perianth lnoadly keeled beneath, the keel 2-angled. (Madotheca sullivantii, A ust.) - Alleghany MIts. (Sullivant); rare.

\section{PTILIDIU, Nees.}

Leaves incubous, complicate-bilohed, each lole divided and lacerately ciliate; underleares 4-5-lobed, ciliate. Dioecious. Frnit terminating short branches. Involucral leaves $2-4$, 4 -cleft ; perianth terete, obovate, the mouth comnivent, plicate, denticulate. Calyptra pyriform, coriaceous. Capsule ovate. Spores globose. Antheridia in the base of closely inbricated leaves. (Name a (liminutive of $\pi \tau$ ínov, a feuther, from the fringed foliage.)

1. P. ciliare, Nees. Stems crowded, subpinnate; fringes of the foliage long-setaceous. (13lepharozia ciliaris, Lumort.) - On rotten logs and stumps; coinmon. (Liu.)

\section{TRICHOCÓLEA, Dumort. (Pl. 24.)}

Ieaves succubous, 4-5-divided, and with the underleares setaceously fringed. Diœcions. Fruit terminal, or axillary from the growtl of imno. vations. Involucral leaves coalescent into an oblong truncate lairy tube, blenked in onr species with the calyptra; perianth none. Capsule ol,long, its pedicel bulbous at base. Elaters free. Anthericlia large, in the axils of leaves on terminal branches. Name from $\theta \rho i \xi$, hair, and koגeós, a sheath, from the hairy involucre.)

1. T. tomentélla, Dumort. Stems pinnately decompound, densely tufted, glaucons, 2-6' long; leaves nesıly uniform; underleaves subquadrate, as wide as the stem. - $\lambda$ mung mosses in swanpls; common. (En.)

T. Bunndecond, Aust., rery imperfectly described from specimens collected in Irbana, Ohio, is said to be simply and rather distantly pinnate.

\section{HERBÉRTA, S. F. Gray. (1'l. 24.)}

Leaves large, incubous or nearly trausterse, narrow, 3-ranked, the underleaves being scarcely smaller, rleft to or below the midrle, the lobes acute. Dicecions. Fruit terminal on a long branch. Involucral leaves numerous, equitant; perianth orate-subulate or narrowly fusiform, 3-augled, deeply 6-8. 
lobed. Calyptra sinall, obovate, deeply trifid. Capsule large, globose. Elaters frec. Spores large, muricnlate. Antheridia in the bases of leaves of a short terminal spike. (Named for William Herbert, an English botanist.)

I. H. adúnca, S. I'. Gray. Stems long and slender, erect, browuisl, nearly simple; leares and underleaves almost alike, curved and one-sided, the lobes ianceolate. (Sendtnera juniperina, Sullir.; not Nets.) - On rocks, Greenwood Mts., N. J., Catskill Mts., N. Y., and probably northward. (En.)

\section{B A Z Z À N I A, S. F. Gray. (Pl. 24.)}

Leaves incubous, oblique, decurved, mostly truncate-tridentate ; underleaves wider than the stem, mostly $3-4$-tuothed or crenate. Diocions. Frnit on a short branch from the axil of an nnderleaf. Involucral leaves nuch imbricate, concave, orbicular or ovate, incised at the apex; perianth orate-subulate or fnsiform, somewhat 3-keeled. Calyptra pyriform or cyliudric-oblong. Capsule oblong. Antheridial spikes from the axils of underleaves. (Named for M. Bazzani, an Italian I'rofessor of Anatomy.)

1. B. trilobàta, S. F. Gray. (Pl. 24.) Creeping, dichotomons, proliferous; leaves ovate, the broad apex acutely 3 -tootled; underleares roundishquadrangnlar, spreading, 4-6-toothed above; perianth curved, cylindric, plicate at the narrow apex and 3-toothed. (Mastigobrym trilohatum, Nees. M. tridenticnlatum, Lindenb.) - Ravines, wet woods and swamps; common and variable. (En.)

2. B. defléxa, Underw. Stems forked or alternately branched; leaves strongly deflexed, cordate-ovate or ovate-oblong, falcate, the upper margin arcuate, the narrow apex 2-3-toothed or entire; underleaves roundish-quadrate, the upper margin bifid, (renate, or entire; perianth cylindric, arcuate, plicate above and denticnlate. (Mastjgobrymn deflexmm, Nees.) - On rocks in the higher mountains eastward. (Eu.)

\section{IEPIDOZIA, I)unort.}

Leaves small, incubous, palmately -2-4-cleft or -parted; underleaves sim1Inr, often smaller. Dicecious or rarely monocions. Frnit terminal on short lranclies from the under side of the stem. Involncral leaves small, appressed, concave, 2-4-cleft; perianth elongated, wate-snbnlate or narrowly fusiform, ubtusely triangnlar above, entire or denticnlate. Calyptra included, pyriform or oblong. Capsule oblong-eylindric. Spores ninute, smooth or roughish. Antlieridia large, pedicelled, solitary in the axils of 2-cleft spicate leaves.' (Name from $\lambda \in \pi i s, a$ scale, and ógos, "shoot, for tho scale-like foliage.)

l. L. réptans, Dumort. (1'l. 24.) Creeping, pinnately componnd, the hranches often flagellate; leares decurved, subquadrate, $3-4$-cleft; inrolucral leaves ovate, truncate, unequally 4-toothed; periantl incmed, dentate. - On the gronnd and retten wood, N. J., and common nortlward. (Eu.)

2. L. setàcea, Mitt. Leaves deeply 2-3-cleft or -parted, incurved, the lobes subulate, formed of a somewhat donble series of cells; underleaves sim.

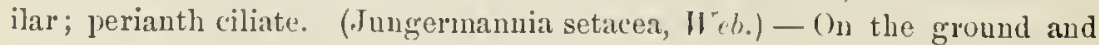
rotten wood; common. liesembling the uext in its leaves, but smaller and browrish. (Eu.) 


\section{BLEPHARÓSTOMA, Dnmort.}

(Pl. 25.)

Leaves transverse or sliglt tly incubous, $3-4$-parted, the divisions capillary; underleaves smaller, mostly 2-3-parted. Diøcious or monacious. Fruit terminal. Involucral leares numerous, verticillate, deeply 4-cleft; perianth exserted, pyriform-cylindric, laciniate. Calyptra short, oblong, bilaliate. Capsule cylindric-oblong. Elaters large, very obtuse. Spores large, smooth. Antheridia solitary in the axils of leaf-like bracts. (Name from $\beta \lambda \epsilon$ épopov, an eyelid, and $\sigma \tau o \dot{\mu} \alpha$, month, in allnsion to the fringed orifice of the perianth.)

1. B. trichophýllum, Dumort. Flaccid, branched, creeping; leafdivisions straight, spreading, cach comprosed of a single row of cells; periantls ovate-cylindric. (Jungcrmannia trichophylla, L.) - On the ground and rotten wood. Minute, light green. (Fu.)

\section{CEPHALÒZIA, Dumort. (Pl. 23.)}

Leaves mostly succubous, chiefly 2-lobed, the margins nuiformly plane or subincurved; underlcares smaller, often wanting except on fruiting branches. Branches from the under sile of the stem. Honocious or diøcions. Involucral leares mmerons, capitatc, 3-rankerl, nsually 2-lohed; perianth long, triangular-prismatic, the constricted month varionsly dentate. Calyptra small. Capsule somewhat oblong. Elaters free. Spores minute. Antheridia in the hase of inflated spicate leaves. (Name from $\kappa є \phi \alpha \lambda \dot{\eta}$, head, and üsos, bud, for the capitate involncre.)

\$1. CEPIIALOZLA proper. Periunith more or less 3-angled or 3-carinate; leaf-cells large (mostly $25-50 \mu$ brord) ; plants mostly medlum-sized.

* Itnderlenres rarely present except on fruiting branches.

1. C. Virginiàna, spruce. Withont runers, usually pale; leares small, bbliquely round-ovate, acutely 2-lobed nearly to the middle; cells quadratehexagonal, opaque; diøcious, rarely monœcious; involucral leaves round'Inadrate, with slender acmminate lobes; pcrianth large, widest above the mildle, unequally ciliolate; capsule large, long-exserted; antheridial spike long. (C. catennlata of authors; not $/$ huchn.) - On rotten wood or swampy ground, N. Eng. to Ya., and sonthward.

2. C. multiflòra, Spruce. (1'1. 23.) Often sulppinnate, withont runners, pale green; leares small, rouud-rhombic, decurrent, bifil $\frac{1}{3}$ their length ; cells yuadrate-hexagonal, pellncid; diøcions; imner involucral leares $3-4$ times as long as the onter; perianth linear-fusiform, 3-plaited when young, triangular only abore when matnre, ciliate or toother, fleshy; calyptra fleshy, oval-globose; capsnje rather short-pedicelled; spores cinnamon-color. - On the gromnd and rotten wood; common. (Eu.)

3. C. pléniceps, Underw. Stems rery short, branching, densely cespitose, pale green or whitish; leaves thick, orbicular, strongly concare, subclasping but not decurrent, bifid t their length, the acutc lobes incurvei and strongly connivent; involucral leares oblong, palnately "2-4-cleft, the rentral like the underleares; perianth large, oblong-cylindrie, oltuscly angled, the plicate month denticulate. (Jungermannia pleniceps, $A u$ st.) $-A$ mong Sphagnum in the White Mts. (Oahes). 
4. C. bicuspidàta, Dumort. Prostrate or assurgent, cespitose, nsually greenish or reddish, with runuers; lower leaves small and distant, the upper larger, ronud-ovate, cleft nearly to the middle, the lobes ovate-lanceolate and acute, the lower lobe narrower and acuminate; cells large, pellucid; monœcious; involucral leaves about 3 pairs, the imiermost uearly three times as loug as the onter, cleft $\frac{1}{2}$ their length ; perianth four times as long as the leares, linear-prismatic or fusiform, thin, denticulate or ciliate; capsule cylindricoblong; spores purple. (Jungermannia bicuspi(ata, L.) - On the ground, monutains of N. Eng., N. Y., and N. J. (Eu.)

5. C. curvifòlia, Dumort. Slender, rarely forked, withont runuers, greeuish, reddish, or often purple; leaves imbricate, ascending, obovate, concare, semicordate at base, lunately bifid below the middle, the lobes incurvea or hooked; cells small, quadrate; monœcions or dicecious; involucral leaves complicate, the lobes suborate, spinulose-leuticulate; perianth large, rosepurple, triquetrous, the wide mouth ciliate; calyptra thin; capsule oblongglobose. (Jungermannia curvifolia, Dicks.) - On rotten logs in swamps, etc.; common. (En.)

$$
\text { * Underleaves usually present; leaves rarely subimbricate. }
$$

6. C. flùitans, Spruce. Stems $2-3^{\prime}$ long, loosely creeping, with short thick runners; leaves large, ovate-oblong, lobed to near the middle, the lower lobc larger, lauceolate, obtnse; cells large, mostly hexagonal; underleares linear, appressed; diøecious; involucral leares cleft to the middle; periauth oral-cylindric, nearly entire; calyptra short, pyriform; capsule oblong; spores small, minutely tuberenlate; antheridia globose, pedicelled, solitary in the axils. - In bogs, on mosses or partly floating; rare. (Eu.)

\$2. CEPHALOZIELLA. Perianth 3-6-angled; leaf-cells small $(14-20 \mu$ uroad); plants small, often minute; underleares present in 11.9 .

7. C. divaricàta, Dumort. Sparingly branched, without ruuners; leaves very small, cuneate or round-quadrate, the orate-triangular lobes acute; cells pellncid or subopaque; involncral leaves larger, the lobes acute, denticulate; perianth linear or narrowly fusiform, prismatic, denticulate or subeutire; (apsule ohlong-globose, long-exsertel. (Jungermamia divaricata, Smith.) Dry rocks and sand, pine barrens of $\mathrm{N}$. J., and northwart. (En.)

8. C. Macoùnii, Aust. Slender, much branchet, dark green; leaves scarcely broader than the stem, wide-spreading, hifil with a broal or lnnate sinus, the broad-sulmlate lobes mostly acute; cells sulquadrate, somewhat pel. lucid; diocions; involncral leaves appressed, 2-3-lobed, irregnlarly spinulose; perianth small, whitish, oborate or orate-fusiform, oltusely 3-angled, setulose or ciliate. - Rotten logs, mountains of N. Fing., and northward (Austin, Macoun).

9. C. Sullivántii, Anst. Stems $3-6^{\prime \prime}$ long, fleshỵ, rootlets numerous; fertile branches suberect, clavate; leaves inbricate, ofteu narrower than the stem, subqualrate-oratc, more or less serrate, the sims and lobes subacute; diwecious; inrolncral leares 3, erect, free; perianth lroadly oral or suboborate, olitusely and sparingly angled, the apex slightly plicate, the moutl connivent, dentate, sometimes narrowly scarious; capsule oral. - On rotten wood, N. J., (Thin, and Ill.; rare. Our smallest species. 


\section{ODONTOSCHÍsMA, Dumort. (Pl. 24.)}

Leaves succubons, orate or romdish, entire or retuse, rarely bidentate, underleares minute, sometimes ubscure or wanting. Diocious or sometimes monocious. Fruit terminal on a short branch from the lover sicle of the stem. Invohcral leaves few, 3-ranked, bifil or rarely 3-4-cleft; periantl large, trialngular-fusiform, ciliate or dentate. Calyptra membranous. Capsule cylindricoblong. Anthericlia in small whitish spikes on the under sirle of the siem. (Name from ósoús, a touth, and $\sigma \chi^{\prime} \sigma \mu \alpha$, " cleft, alluding to th" perianth.)

1. O. Sphágni, Inunort. (1’l. 24.) Leives sprealing or ascendiug, orate, rounded or oblong; entire or retuse, subconcave; underleaves inostly wanting; perianth $3-6$ times longer than the leares, subulate-fusiform, la(ciniate or ciliate. (Splatgnucetis communis, N'ees.) - Among mosses, N. J. to 111., and southward. (Eu.)

2. O. denudàta, Lindb. Stems densely rooting, somewliat leafless at buse, flagellate, hanching above; leares sprealing, broally ovate, entire; mulerleaves hroally oral, entire or sublenticulate; perianth close-connivent above, at length lumsting imegularly. - On rotten wood, Canada to Olio, and soutl aloug the mountains. (Eu.)

\section{KÁ N TIA, s. li. Gray. (Pl. 24.)}

Leaves large, incubous, flat or conrex, entire or retuse; underleavas small, roundish, the apex entire, retuse or hifil. Dicecions or monacious. Involucre pendulous, subterranean, clavate or subcylinclric, fleslyy, hairy, attached to the stem by one side of its moutl. Calyptra nembranous, partly adnate to the involucre. Capsule cylindric, the valves spirally twisted. Spores minute, roughish. Antherilia solitary in the reduced leaves of short lateral branches. (Name from J. Kavel, a plysician at 'The llagne.)

1. K. Trichómanis, S. F. Gray. (Pl. 24.) Creeping; withont rentral runners; leaves pale green, imbricate, spreading, romulish-ovate, obtuse. (Calypogeia Trichomatis, Corda.) - ( 11 the ground and rotten logs; rery common. (Ru.) - Var. RWULARIs, Anst. Leaves dusky green or blackish, more scattered, flaccid; cells large. X. J. (Austin.) - Var. TÉxurs, Aust. Very slender, innovate-luanching; leaves smaller, especially above, dimidiateorate or subfalcate, sublecurent. Southem N. J. (dustin).

2. K. Sullivántii, Tnulerw. T'rostrate, with ventral runuers; leaves flat, subcontiguous or imbricate, obliquely rounrl-ovate, minutely 2-toothed with a lunulate sinus, abruptly decurrent; cells large, miforn ; underleaves minute, the upper orbicular, bifid, the lower twice 2-lobed, the prinary lobes round-quadrate, divaricate, the secondary ovate or subulate. (Calypogeia Sullivantii, Aust.) - Delaware Water Gap, X. J. (Austin).

\section{S C A P À N I A, Dumort. (P'l. 24.)}

Leaves complicate-bilobed, the upper lobe smaller, the lower succubous; margins entire or dentate or ciliate; underleaves none. Diocious. Iruit terminal. luvolncral leaves like the cauline but more equally lobed; perianth obovate, clorsally conpresserl, bilahiate, the month truncate, entire ur toothed, decurved. Ciusule ovate. Elaters long, attached to the middle of 
the valves. Antheridia $3-20$, in the axils of small saccate leares, which are scarcely imbricate or crowded into terminal heads. (Name from okatávıov, a shovel, from the form of the perianth.)

\section{* Leaflobes somewhat equal.}

1. S. subalpina, Dnmort. Leaves equidistant, imbricate, cleft nearly to the middle, the roundish obtuse lobes denticulate on the onter margin; perianth much exceeling the involucral leaves, obovate from a narrow base, denticulate. - Mountains of N. ling. (Oakes, Austin); L. Snperior (Gillman, Macoun). (Eur.)

2. S. glaucocéphala, Aust. Stems short, cespitose, creeping or assending, subsimple, with numerous offshoots; leaf-lobes broadly ovate, entire, mostly obtuse and apicnlate; involncral lcaves sometimes denticulate; perianth small, subcuneate, entirc. (Jungermannia glaucocephala, Tayl.; S. Peckii, Aust.) - On rotten wood, N. Eng. to N. Y. and Canada.

* * Lower lobe about twice the size of the upper, except near the susnmit. - Leaves broader than long; upper lobes rounded or blunt.

3. S. undulàta, Dumort. (P1. 24.) Ascending or erect, slightly branched; leaves lax, spreading, entire or ciliate-denticulate, the lobes round-trapezoidal, equal at the summit of the stem; perianth oblong-incurred, nearly entire, twice as long as the outcr involucre. - In woods, dimp meadows, and rills; conmon, cspecially in mountain districts. - Var. pUrpỦres, Nees; a form with long lax stens and rose-colored or purplish leares. (En.)

4. S. irrígua, Dumort Creeping; leaves somewlat rigid, repaud, deeply lohed; lobes rounded, submucronate, the lower appressed, the upper convex with incurved apex; perianth ovate, denticulate. (S. compacta, var. irrigua, Aust.) - Wet places, N. J., Catskill MIts., mountains of N. Eng., and nortle. ward. (Eu.)

\section{- + Leaves longer than broad; upper lobes more or less acute.}

5. S. nemoròsa, Dumort. Rather stont, flexnose, (reeping at base, luaves rather distant, decurrent on both sides, ciliate-dentate, the lower lobe whorate, obtuse, slightly convex, the upper corlatte, acute, concave; perianth W.uscly ciliate; capsule large, roundish-ovate, redlish-brown. (s. breviflora, $T(a, l$.$) - On rocks, etc., in swamps and rills; common and variable. (Eu.)$

6. S. Oakèsii, Aust. Leaves obovate, somewhat spreading, often deflexcl, closely complicate, convex, the lower lobe coarsely dentate, and with deep purple spur-like tccth on the kecl, the upper roundish and less dentate yerianth usually dentate. - White Mts. (Oales, Austin).

$$
\text { * * Lower lobes 3-4 times the size of the upper. }
$$

7. S. exsécta, $\Lambda$ nst. $\Lambda$ scending; leaves subcomplicate, entire, tha iowe. lobe orate, acute or bidentate, concave, the upper small and tooth-like; involucral leares 3-5-cleft; perianth ollung, obtuse, plicate. (Jungermannia ex. secta, Schmidel.) - lligh mountains, far northward; rare. - P'erhaps better retained in Juugermannia. (Eu.)

8. S. umbròsa, Dumort. Stems short, decumbent, slightly branched; leaf-lobes ovate, acute, serrate; perianth incurved, naked at the mouth. I' hite Mts.; rare. -The tips of the shoots are frequently covered with a lark mass of gemma. (Eu.) 


\section{D I P L O P H Ý L L U M, Dumort.}

Leaves rather uarrow, complicate-lilobed, the lobes subeqnal or the upper maller, the luwer sucmbous; underleares none. Fnit terminal. Involurall leares few: Periantl cylindrical, scarcely or not at all compuressed, pluri-

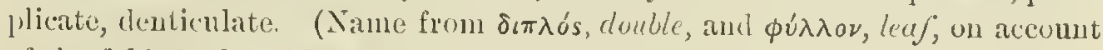
of the folder 2-luhed leaves.)

1. D. álbicans, Innnort., vilr. taxifolium, Nees, Stens ascending, almust rootless; leaves closely folded, suldenticnlate, with a rudimentary fellucid line near the have or noue, the lobes obtuse or antish, the lower

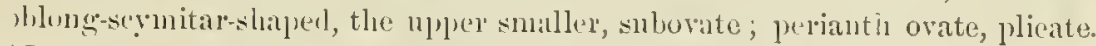
(.Jumgermannia allicans and J. obtusifolia of Sullic.; not of $\mathrm{L}$. and / / ook.) Inder rocks in muntain ravines and on the ground. (Eu.) - The typhal form veeurs in $\mathrm{N}$. Scotial, distinguished by a broad pellueid mediun line i. botll lobes.

\section{GEÓCALYX, Nees.}

I.eares sneculous, bidentate; underleaves 2-cleft, with linear divisions. Fruit lateral, pendent. Involucre simple, fleslyy, saccate, oblong, truncate, attaclied to the stem by one side of the montl. Calyptra membranons, lartly idnate to the involucre. ('il]sule ollong. Elaters free. Antleridiat in the axils of small leaves on spike-like lateral hranches. (Nanne from géa,

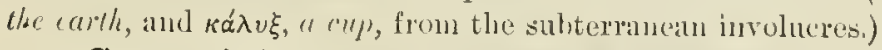

1. G. gravèolens, Nees. Leares ovate-flnadrate, 2-toothed, lighlit green; molexleaves oral-lanceolate, clelt to the middle. - On the ground, and rotteu $\operatorname{logs}$; not rare. (Eu.)

\section{LOPHOCÓLEA, Dumort.}

I.eares suecubous, dorsilly derellrent, olliquely urate-oblong, broadly trunale or bidentate; underleaves smaller, more or less quadrate, bifid or with $4-8$ eapillang lobes, Biweions or monceions. Fruit terminal on the main stem or primary lnanches. Involuchal leaves 2-4, large, often spinulose; lerianth triangular-prismatic, 3-loherl, wiliate or laciniate. Calyptra short, shovate, at lingth lacerate alowe. ('alsule ohlong-globose. Antherilia mostly solitary in or near the base of orlinaly leaves. (Name from $\lambda$ ódos,

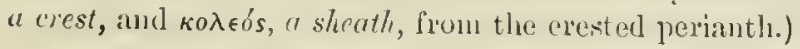

* Underleners moslly bifid (or 3-4-cleft in n, 1); divisions mostly entire.

1. L. bidentàta, Dunort. Stems 1-2' longr, procumbent, sparsely branching; leaves pale green, orate-triangular, acutely 2-tonthed, the teeth shlique withi a lunulate sinus; moncecinns; periantl oblung-triangular, laeiniate; antheridia $2-3$ in a cluster, axillitry. - ( ) lo locks in shitly rills; not com111). (Fu.)

2. L. Austini, Liulls. Creeping; leares uniformly deeply lobed, the lobes and nsually the sims actute; mulerleaves comparatively smail, the lobes Fubulate; eells sulall; monuevous; antheridia sulitary in the upper axils. (L. minur, Lust.; nut Nes.) - On roots of trees in woods (.1ustin). Imperfectly known.

3. L. Macoiunii, Anst. Stems very short, prostrate, ascendiug at the apex, densels bialiculuse; leares suberect, orate-subquadrate, 2-lobed with ob. 
tuse lobes and siuus, or retuse or ofteu eutire; miderleaves light piuk, deeply bifid, the setaceous lobes spreading-incurved; monocions; involucral leaves somewhat oblong, repaudly 2-4-toothed at the ilpex; perianth suboborate, slightly angletl. - On logs, Little Falls, $\mathrm{Y}$. Y. (Austiu); Ont. (1/acoun).

4. L. minor, Nees. Diffusely branching; leares 1ale green, wal-subquadrate, expanded, courex, sliglitly rigid, equally aud acutely bifid with a luuate sinus; underleaves $\frac{1}{3}$ as large, deeply bifid, the lanceolate lolos acumi, nate; diocious; iuvolucral leaves like the cauline; perianth obtusely triau. gular-plicate at the apex. (L. crocata, Aust; not Tees.) - On the ground und dry rocks in limestone regious (Austin). (Eu.)

* Divisions of the underleaves more or less dentate.

5. L. heterophýlla, Nees. (Pl. 23.) Stems shurt, creeping or aseend. ing, much brauched; leares orate-subquadrate, entire, retnse and bideutate on the same stem; underleares large, 2 - 3-cleft; iurolucral leares lobed and dentate; perianth terminal, the mouth crested - On the ground and rotteu logs in woods and swanls; ; rery common. (Eu.)

6. L. Hàllii, Aust. Creeping, rery slightly rooting; leares subvertical, obloug, cleft nearly to the middle with obtnse sints aud erect mostly obtuse lobes; lower underleares small, suberually 2-parted with au obtuse sinus, the upper ones larger, with a single tooth on each site or palmately 3-4-parted. the apical sublanceolate and narruwly bifid. - On the ground, 11l. (Hall).

\section{CHIL OSCYPHUS, Curla. (Pl. 23.)}

Leares succubous, dorsally decurrent, mostly rounded and entire; under. leares rooting at the base, usuilly deeply 2-cleft. Fruit terminal ou a very short lateral branch. Involucral Jeaves $2-6$, the outer smaller, the inuer variously cut; perianth small, obconic or campannlate, 3-angled and 3-lobed only at the apex, the lobes usually spinose. Caly ptral fleshy, subglobuse or clarate Capsule oblongr-globose. Antherilia in the saccate bases of stem-leares. (Name from $\chi \epsilon \hat{\imath} \lambda o s$, alip, and $\sigma \kappa u ́ \phi o s, ~ a ~ b o w l$, from the form of the periauth.) * Underleaves 4-parted.

1. C. ascéndens, Hook. \& Wils. (Pl. 23.) Prostrate; leares large, pale green, ascending, roundish-oblong, slightly emarginate; involucral leares two, 2-cleft; perianth 2-3-lohed, the lobes long and irregularly lacerate. toothed. - On rotten logs; rather commou.

\section{** Underleaies bifid.}

2. C. palléscens, Dunort. Procumbent, creeping; leaves flattened, srate-subquadrate, ol,tuse or retuse; underleaves orate, distant, free; inrolucral leares two, 2-toothell; periantlı deeply trifil, the lohes spinose-dentate, mostly shorter than the concipicuous calyptra. - Nountains of X. Eng. (Oukes).

3. C. polyánthos, Corda. l'rocumbent, creeping; leares subasceuding, wrate-subquidrate, truncate or subretnse; underleaves or ate-oblong, distant, free; involucral leaves 2, slightly 2-toothed; perianth 3-lobed, the sliort lobes nearly entire, shorter than the ealyptra. - Var. Krwctints, Nees. Larger, more branching, succulent; leares mostly rounded alove: nurlerleares often dirided in halves or wanting. - On the gromul amnong mosses or on rotten logs, commou; the variety in shaded rills or still zmuls. (Eu.). 


\section{PLAGIOCHİLA, Dnmort. (H1. 24.)}

Leaves large, snecubous, rounded or truncate ahove, dentate or spinose or rarely entire, the clorsal margin reflexel ; underleaves usually none. Diocious or monœcions. Fruit terminal, or axillary by the growth of offshoots. Involucral leaves larger than the canline; perianth latcrally compressed, erect or decurred, obliquely truncate and bilaliate, the lobes cntire or ciliate-dentate. Capsule thick, oval. Elaters attached to the middle of the valves. Antheridia oval, $2-3$ in the axils of spicate learcs. (Name from $\pi \lambda \alpha$ ' $\gamma$ เos, oblique, and $\chi \in \hat{\epsilon} \lambda$ os, lip, from the form of the perianth.)

* Underleaves 2-3-cleft, fugacious.

1. P. porelloides, Lindenb. Branches ascending; leaves subimbricate, convex-gibbous, round-obovate, the uppermost repand-denticulate, the rest entire, the dorsal margin reflexed; perianth terminal, oblong-ovate, the mouth compresserl, denticulate. - Among mosses in swamps and river-bottoms; common.

2. P. interrúpta, Dumort. (Pl. 24.) Prostrate, horizontally branched, copiously rooting; leares imbricate, horizontal, oval, entire or slightly repand; underleares lanceolate; perianth terminal, broadly obconic, the mouth compressed, repand-crenulate. (1'. macrostoma, Sulliv.) - Moist banks and decay ed logs, N. Eng., Ohio, and northward. (Eu.)

$$
\text { * Underleares unting. }
$$

3. P. spinulosa, Dumort. Creeping, branches ascendiug; leaves remote, obliquely sprealing, oborate-cuneate, the dorsal margin reflexed, entire, the ventral and apex spinulose-toothed; perianth rounded, at length oblong, the month spinnlose. - Shaded rocks in mountain regions; rare. (Fu.)

4. P. asplenoides, Inmort. Branched, creeping or ascending; leares subimbricate, obliquely spreading, round-obovate, cntire or denticulate, the dorsal margin reflexed; perianth much exceeling the inrolncral leares, oblong, dilated at the trnncate or ciliate apex. - In rocky rivulets; eommon. (Eu.)

\section{M Ý LI A, S. F. Gray. (I'l. 25.)}

Leaves succubons, semi-rertical, circular, or ovate and pointed; underleaves subulate. Dicecious. Fruit terminal or pseulaxillary. Involucral leaves 2, clasping; perianth ovate-oblong, laterally compressed above a subterete base, the apex at length bilabiate, denticulate. Capsule ovate, coriaceous. Elaters free. Antheridia 2 in the axils of bracts clnstered near the apex of distinct branches. (Name from Mrylius, an early hotanist.)

1. M. Taylòri, S.F. Gray. Stems erect, nearly simple, radicn lose; leaves large, convex, orbicular, entire, purplish ; colls large; unlerleares lance-subuhate, entire or subdentate; perianth terminal, oval; calyptra finally longuxserted. (Jungermamia Taylori, Hook.) - Wet rocks, high mountains of N. Fing. and N. Y. (Eu.)

\section{HARPÁNTHUS, Nees. (P1. 23.)}

Leares succubons, semi-rertical, ovate, emarginate; underleaves connate with the learcs, ovate or lanceolate, l-toothed at hase Dinecions. Fruit on short shopts from the axils of the unjerleares, finally sublateral. Involucrad 
leaves 2 or 4 . l'eriantl terete, the luwer half thickened. Cal! ptra fleshy, con. fluent with the perianth for $\frac{2}{3}$ its length. Capsule oral. Anthericlia 1 or 2 in the axils of bracts terminal on slender hranches. (Name from äp $p \eta$, a sickle, and aेvos, flower.)

1. H. scutatus, Spruce, Stems filiform, lecumbent, nsually simple; leaves smaller at the hase and apex of the stems, roundish-orate, concave, sharply bifentatr, the apex lnnate or acnte; underleaves large, aemminate molncral lesves two, 2-3ecleft, the upper adnate to the perianth; periantl oratr, becoming obovate, olscurely $3-4$-plicate, splitting above on one sills; (apsule deep brown. (Jungernamia scutata, I' eber) - On rotten logs in alanı places; common, (Eu.)

H. Flotoriars, Nees. (11. 23.) Stems flexuns, procumbent, mosty unbranched ; leaves orate-urhicular, horizontal, the ajex contuated and emargmate with a shallow sims; morleares large, write or lanceslate, obliquely inserted, entire or more often touther on one or hoth sifles near the mirllla; liucious; perianth subcylindric, slightly sickleshaped, the month pointed at first, notehed on one side and finally cremulate; antheridial elliptic, single in the base of swollen leares. (Pleuranthe olivacea, T'ayl.) - "North America" (Linmmond), but not cullecter recently; certainly extralinitial.

\section{LIO C H L 罡 N A , Ners. (P1. 2.5.)}

I. araes succuhous, ovate-nhloug, entire or slightly retuse; underleares none. l)incious or monucious. Involucral leaves 2 or 4 , like the cunline; perianth frrifum, becoming cylimlice, incured, abmptly rombles at the summit, the mimnte orifies proninently ciliolate. Capsule ohlong, long-exserted. Lilatrers attacherl to the midhle of the valves. Sipores nimute, globose. An theridia in the axils of ordiuny leaves. Archegonia j-12. (Name from

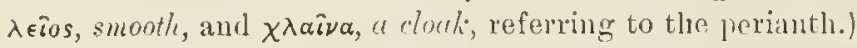

1. I. lanceolàta, Nees. Closel! creeping, hrauched; leaves nometimes decurrent; involueral leaves vertical; perianth at right angles with the stem;

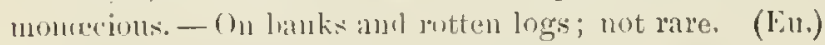

\section{J U N G E R M Á N N I A, Mi»leli.}

Leaves succubons, rarely subtransverse, entire, loberl or dentate, the margins never recurved; underlenves present or nome. Direcious or monnecions. Fruit terminal. Involucral leaves $40 \mathrm{r}^{\circ}$ fewer, like the cumline or more ineised, free ; periantl laterilly (ompureserl or terete, nsually:3-l0-carinate, the nsually suall uouth eutire or tontlonl. Calyptra oval-pyriform. Capsule globose or oblong, rarely cyliulric. Sipures mimnte, smootl or roughislı. Archegonia

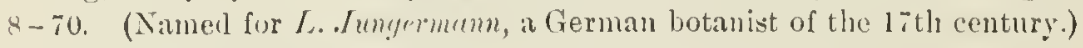
§. JUNGEIIIANNLA proper. Leaves orbicular or ovate, pntire wr barely refuse : underoleres none (very smull in n. 1).

1. J. Schràderi, Martius. (P1, 25.) Creepind, Hexnons; leaves roundMliptic, entire, iscrulines: underleaves broally subulate, unt apparent on old stems; involur'sil lewrs large, elongated, the inner smaller and more or less liciniate; periantl oval-obovate, ascending. - On the gronucl and rotten logs; common. (Erl.)

2. J. sphrerocárpa, Ionk, Stems creeping, the tips ascentling, sul,simple, greenislı: leaves semi-vertical, rather rigil, orlicular, ollipucly spread. 
ing, decurrent dorwally, pale green; inwlucral leaves sepurats; jerianth exserted, oborate-obloug, the mouth 4-cleft; capsule globuse. - Mountains of N. Ling. (Austin); rare. (Eu.)

3. J. pumila, With. Stems creeping, the tips somewhat ascendiug, sulsinte, routing, pale; leaves ascending, ovate, obtuse, concave, entire; involucral leaves like the cauline, erect; periauth terninal, fusiform, plicate ahwe and denticulate; calsule oval. - On shaded rocks along rivulets, Clon ter, N. J. (Austin). (È.u.)

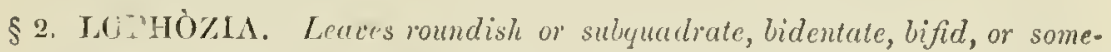
times 3-5-cleft; underleaves none, or small and mosily 2-parted; perianth usually strongly plieate.

\section{* Underleaves mesent. \\ - Leaves bifial or 2-lobed.}

4. J. Gillmàni, Aust. Stens slort, leusely cespitose, prostrate, strongly raliculuse; leaves vertical, round-ovate, subconcave, bifid, the lower leaves with nsually acute sinus and lobes, the upper much latger with rounded lobes and obtuse sinns; underleaves entire or the broader bifir; perianth without involueral leaves, dorsal, sessile, obovate, subgibbous, ciliate, at length mucl inciked. - In a sandstone cave, 'Traine Island, I. Superios" (Gillman).

5. J. Wattiana, Aust. Stems rather thick, 2-4" long, fragile, subflexnosr, strongly radiculose; leaves subvertical or sprealing, subovate, concare, pntuginatcly 2-lobed, the lobes aente or the upper obtuse; underleaves sonnwhat obsulete, ladir-like or subulate, incurved; involucral leaves little lirger, less deeply lobed ; periantl terminal, small, ovate-gourd-slaped, whitish, ciliate. - On the ground, northern shore of 1 . Superior (1/acoun).

$$
\text { +- + Lerues 3-5-eleft. }
$$

6. J. barbàta, Schrel. (I'l. 25.) Procumbent, sparingly branclied; leaves roundish-quadrate, with obtnse, acute, or nucronulate lobes aud obtuse mudulate sinuses; underleaves lirvad, eutire or 2-tootled, sometines obsolete; periantl ovate, plicate-angled towad the apex, denticulate.-On rocks in mountain regions; eommou. (Eu.)

Var. attenuáta, Martius. Ascending, witl numerous offshouts; stenleaves semi-rertical, oblicuely spreacling, rommish, acntely 2 -t-toothed, those of the slowts closely inbricate, premorscly 2-4-denticulate; involucral lenes two, 3-tootlerl; perianth oblong. - In similiu localities. (Eu.)

7. J. setifórmis, Elurh. lipect or iscending, dichotonons; leaves touthed at hase, 3-4-cleft, the lolos ovate-oblong, acute, channelled; under. caves eiliate-(lentatc at base, deeply bifis, the divisions lanceolate, acuminate; involucral leaves more tuothel than the canline; periantl terninal, oval, plicate. - Alpine smmmits of N. Il. (Oales). (Eu.)

\section{* Underleares unting.}

\section{- Letres 2-toothed; involucral leaves 2-4-clef.}

8. J. alpéstris, Si.hleih. Stems creping, erowded, bifid-brauching, the ends aseending; leaves smi-rerticul, ovate-subyualrate, ol)liquely tootherl, the teeth unequal, acute or mucronulate, listant; involucral leaves wider, 2-3-cleft; perianth twice as long, oblong, smooth, the north complicate; capsule oval. Alpine region of $\mathrm{N}$. $\mathrm{H}$. (Oakes). (Lu.) 
9. J. ventricósa, Dicks. Stems dense, close-creeping, branching from leneath; leares semi-rertical, subuturlıate, mostly flat, broadly and acutely emarginate-bidentate, often bearing globules; involucral leaves larger, round, ercet-spreading, 3-4-cleft, subdentate; perianth orate, inflated, narrowly conplicate above; capsule oral. - On the gromed and rotten wood in the mountains, and far northward; connmon. (En.)

10. J. Wallrothiảna, Nees. Minute, blackish; stens creeping, strougly ronting, subsimple; leaves clasping, semi-rcrtical, closely imbricate, ovatequindrate, concive, obtusely bideutate with an obtuse sinus, or al'ute in the upper leaves; involneral leaves linger, ereed, commate at l,ase, 3-tootlued, wavyplicate; perianth oral-cylindric, plicate and sublentate, pellncirl, reddish below. - Ou coarse sand in the White Mts. (Oales). (Eu.)

+ + Leaves bifid or 2-lobed, the rentral lobe often inflexed or subcomplicate; involucral leaves merely toothed, excejt in 11.11 .

11. J. láxa, Lindb. Widely creeping, mostly simple, usually purplishblack; leaves imbricate, or distant un the erect fertile stems, 2-3-lobed, the lobes obtuse, wary; cells rery large, lax; involucral leaves 2, wide, short, cristate-undulate, ohtnsely many-lohed; perianth exserted, long-clarite, snbplicate above, minutely ciliate, (J. polita, Lust. : not Nees.) - Anumg s.juagnum uear Closter, N. J. (Austin).

12. J. excisa, Dirks. Stems closely creeping, slort, suhsimple, rather rigid; leaves semi-rertical, erect-spreadiug, pellucid, romelish, with straight acute lubes and decp obtuse sinns; involncral leaves erect, quadrate, usmally 4-5-toothed; perianth erect, oblong, pale, hauded and spotted with pink, plicate above, irregularly denticnlate. - Sterile grounds in open wools; conmoll. (En.)

Var. críspa, Hook. Leares romul-puarlrate, closely imbricute, deeply and obtusely 2-3-cleft; involucral leaves 3-4-clelt, comate at base, subserrate. (J.intermedia, Lindenl.) - In crevices of rocks, X. Y. and X.J. (Austin). (Eu.)

13. J. incisa, Schrad. Stems thick, routing, closely creeping or alscending; leares crowded, semi-rertical, complicate, subynadrate, 2-6-cleft, the acnte lobes unequal, more or less spinulosedeutate; involucral leares sinilar, more plicate and dentate, free; perianth short, oral or obovate, plicate above, denticulate. - On rotten wood in the montaius, and northward. (Eu.)

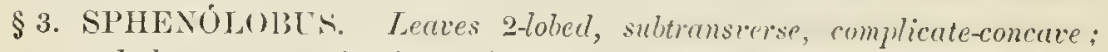
underleaves none; involueral leares 2-3-cleft. (Verging toward Marsu. pella on one side and Diploplyyllum on the other.)

14. J. Michauxii, Weber. Stems ascending, flexuous by repeated inmovations below the summit; leaves crowded, subvertical, erect-spreading, subsaccate at base, subquallate, bifid with strainht acute lobes and a narrow sims; involneral leares similar, the outer serrulate, the inuer smallel*; perianth orate-subclarate, ol,tuse, plicate above, fringed. - Falleu trunks, nountains of N. Y. and N. Eng.; ; common. (En.)

15. J. minuta, Crantz, Rootless; leaves cleft $1-\frac{1}{2}$ their length, the lobes ovate, snlequal, acnte or obtuse, entirc, or gemmiparous ones subdentate; involucral leaves trifiel; perianth oval-oblong or subcylindric, - On rocks in high momutain regions, and nortlwward. (Eu.) 
16. J. Helleriàna, Nees. (P'l.25.) Creeping, entangled; leaves spread. ing, subascending, cleft $\frac{1}{3}-\frac{1}{2}$ their length, the lobes equal, acute, entire or serrate; involueral leaves $2-3$-cleft, sj,inulose-serrate; periauth ovate, the nuth contraeted. - On rotten wood, N. Y., N. Eng., and northward. (Eu.)

\$. GYMNOCOLLA. Leares 2-lotwl: underleures none; imolucral leaves like the cunline; periunth pronculate, dentimulate.

17. J. inflàta, Iluds. (1'1. 25.) l'uruunhent or ascending, loosely radiculose, branching; leaves seni-rertical, roundish-elliptic, inequilateral, the sinus and unequal lobes olotuse; periuth terminal ur at length dorsal, oral or pyriform, smooth, the moutl connivent; capsule oblong. - On sterile ground and rocks, N. J. (Austin), and northward in the nountains. (Eu.)

\section{MARSUPELLA, Dınort.}

Stems dorsally (')mpuressed, with rotlets at the base and often producing somewhat leatless rumers. I feares transerse, complicate-bilobed; involucral leaves 2 or 4, connate with the periantl. I'erianth tubular or oval, subcompressed parallel to the base of the leaves. Elaters free. Spores round, rufous (in our species). Antleridia mostly terminal. (Name a diminutive of marsupium, a pouch, from the form of the perianth.)

1. M. sphacelàta, Dumort. Stems erect, snbflexuous, pale brown; leaves rather distant, concave, oburate to obcorlate, somewhat clasping, the sinus narrow; dicecions; involneral leaves larger than the eanline, cordate; perianth free at the apex, with $4-5$ loroal acute teeth; antheridia $1-3$, in short terminal spikes. - Wret rocks, nountains of $\mathrm{X}$. Jing. to $\mathrm{X}$. J., and sonthwarl. (Eu.)

2. M. emarginàta, J)unort. (I'l. 23.) Stens simple or inmovating at the sumunit, rigril, somewhat thickened uprarl; leaves usually broader than long, rouml-cordate or subquadrate, lobes olutuse or mueronate, sinus aente; dicecious; imolucral leaves 4-s, usually lirger, more deeply and aeutely emarginate; perianth wreolite, the closel apr splitting into $4-5$ triangular lohes; antherilia 2-3, onal, axillary in terminal spikes. (Sarcoscyphus Ehrharti, Cordu.) - On wet rocks, chiefly in montain rivulets, $Y$. Y. and $\mathrm{X}$. Fing. Floating forms are longer with distant leares. (Fu.)

3. M. adústa, siruce. Stems minute, clavate; leaves (5-8 pairs) imbricate, round in broadly orate from a sheathing base, acutely lobed with angular sinus; monoecious ; perianth included, campanulate, crenate becoming irregularly loberl; spres punctate; antheridia 1 or 2 , oral, in the axils of tle lower involncral leares. (Gymnomitrinm adustum, XTees.) - Alpine region of the White Mts. (Oules, Hustin). (Fin.)

\section{NÁRDIA, S. F. Gray. (PI. 25.)}

Stems laterally compressel, usually without runners. Leaves suecubous, subeoneave or flat, the apex romuled, rarely retuse or birlentate; underleares none (in our species). Monacious or dipcious. Involucral leares $2-4$ pairs, connate at base. Perimutl subcompressed Interally, connate with the involu. cral leares. Antleridia terminal on somewhat spike-likestems. Named for S. Nardi, an Italian abbot.) 
\$1. EUCALYX. Perianth comate at base with the inner involucral leaves. somerhat surpassing them, 3-8-curinate, the mouth constricted.

1. N. hyalina, Carring. Creeping, witl ascending tips, the branches diehotomous-fastigiate, with elaret-colored rootlets; Jeaves lousely imbricate, decurrent, roundish, repand-mululate; monorious or rlicecions; inrolueral leaves broader, appressed, one comnate with the lower third of the perianth, whieh is somewhat exserted, olwuate, plicate witl acute rough angles, loostellate, at length 4-cleft; capsule round-orate. (Jungermamia hyalina, Lyell.) - On banks in woods, Closter, N.J. (Austin), Ohio (Lesquerenx). (Eu.)

2. N. crenulàta, Lindb. (Pl. 25.) Prostrate, lrancling; leaves orbieular, entire, larger toward the inwluere aud with large marginal cells; diorious; involucral leaves 2 , rarely 3 , alnate to the hase of the perianth, whieh is flattened or terete, morc or less regularly 4-5-jlieate, the augles sinooth: mouth much contracted, tootled. (Jungermamial (crenulata, smith.) - On the ground in old fields, N. Y. and sonthward. (Eu.)

3. N. crenulifórmis, Lindl. Densely eespitose; fertile stems creeping, thickened upward, with mmerons puple rootlet, the sterile subscending, attenuate upward; lcaves sublecurreut, obliqnely sprealiug, orluicular, eoncare, entire or nearly so; periunth small, snbobovate, nore or less connate with the involueral leaves, not exserted or slightly so, rooting at hasc, triquetrous aluwe, beeoming 4-7-plicate; calyptra often violet-purple; eapsule oral-gobost. (.) ungermamia (renuliformis, 1 ust.) - On rocks in rivulets, Closter, N. I. (Anstin), Coshoctun Co., Ohio (Sullirent).

4. N. bitórmis, lindb. I) nsely cespitose, much branched, innorating from beucath; rootlets mumerous; leares searcely imbricate, alteruate, sureading, obliquely senicireular or broally orate, retusc or entire, deeurent dursally: eells large, hyaline; branch-leares half as large, ovate or obovate, scarcely deeurrent; dioccions; antherilia solitiry; fruit unknown. (Jungernannia liformis, Aust.) - On steep wet rucks, Delaware Water Gap, N. J. (Austin). \$2. CHASCÓSTOMA. Periunth exserted, subampanulate and opon, deeply lacinute, connute with the involncrul leures.

5. N. fossombronioides, lindl). Stems densely eespitose, ascending; rootlets numerous, purple; leaves 2-ranked, subrertical, spreading-subrecurved, rooting, elosely imbricate, orbicular, elasping ly a slightly corlate bass, subrentrieose, mulnlate-repand, the apex uniplicate and slightly emarginate; monneeious; perianth very large, 6 - 10-plicate, the lobes entire; calyptra violet; capsule short-oral. (Jungermannia fossombronioides, Aust.)-On rocks in a rivulet, Closter, X.J. (.1ustin), anl southward.

\section{GY M NOMÍTRIUM, Corla.}

Leaves elosely inlricated, 2-rauked on faseicled ascending julaceous stems, rmarginate-bidentate; nnderleaves none. Diocions. Imolucre dunble, the imner shorter, of $201^{*}$ uwre dentate and deeply cleft leaves. Calyptra short. "ampanulate. Cajsule slobose, the valves at length reflexed. Fiaters eadı" (ous. Antleridia in the axils of leaves, oval, stipitate. (Name from rouvbs,

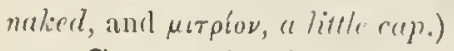

1. G. concinnàtum, Corda. Stems simple nr imblicately branching, thiekened at the alpex; leaves ovate, bifil, with a narrow scarious margin. 
(Cesia concinnata, S. F. Gray.) - Alpine regions of the White Mts. (Oukes). - Gravish or silvery-olive. (Eu.)

\section{FOS SOMBRO NIA, liarldi.}

Stems tlalloid, with large subpualrate sncenbous leaves; underleaves none. Diocious or monaciols. Frnit teminal or ly innuration dorsal on the nuain stem. Involueral leaves 5-6 (in wr specics), small, subulate, adnate. Periantl open-campanulate or onjyraniclal, crenate-lobed. Calyptra free, subgrobose. Capsule short-pedicelled, gluhose, irregularly valved. Llaters very short, 1-3- (mostly 2-) spiral, free. Spores large, very rongh. Antheridia $2-3$, short pedicellerl, naked. Perfect archegronia 2-3. (Named for $T^{r}$. Fossombroni, an Italian Minister of State.)

\section{* Plunt lurge or of medium size; stems mostly simple.}

1. F. pusílla, Dumort. (I'l. 23.) Sitens 6-10" long; leaves retuse, entire or irregularly indented; perianth obcunic, dentate; platers short and thick; spores brown, depressed-glohose-tetrahedral, to $\mu$ hroarl, crested, thes slender crests pellucid, rarely hecoming contuent. - ()n lamp ground. Its occurence in America is douthtul. (lin.)

2. F. Dumortièri, Limulh. (espitose, greenish or lrownisl-yellow; stems :3-6" loug, I" wide, shortly lifureate; rootlets copions, purple; leaves numerous, smaller toward each end of the stem; inonocions; perianth large, broadly olpyramidal; calyptra nearly as long; eliters scanty ; spores globusetetrahedral yellowish-brown, regularly pitted. - White Mits. (Furlow), N. J. (Austin), and perhaps elsewliere; confused with 11.

3. F. angulosa, haddi. Stems narrowly forkerl at the apex; leaves horizontal, subquallrate, the upper undulate-lubect; dicecions; periantl dilatedconie, crenate; spores lrownish-yelluw, globose-tetrahedral, not depressed, $30 \mu$ broal, deejly reticulated, the retieulations large, 5-6-angled. - Brackish menlows, eommon; fruiting in early spring. (Lu.)

* Plrunt minute; stems forked or fastigiately divided.

4. F. crístula, Anst. Stems 1-2" long; leaves whitish, qualrate or round-obovate, subentire, strongly crisped-undulate; ripsule immersed on a short pedicel; elaters short, nore or less diverse, with a single narrow annular and spiral fibre; spores pale fuscons, nore or less tuberculate.-1)n moist sand in unfrequented path:; Batsto, X. J. (Awstin).

\section{2ย. PALLAVICÍNIA, S. F. Gray.}

'I'hallus with a distinct eosta. Frnit arising from the costa, at first terminal hecoming lorsal. Dicecious. Involucre cup-slutped, short-laverate. Periantl long-tubular, denticulate. Calyptra iregularly lacerate. ('apsule slendercylindric. laters slender, free. Spores minute. Antherilia dorsal, covered with minute finliriate scales. (Named for $L$. Prollovicini, Archbishop of Genoa.)

1. P. Lyéllii, S. F. ixay. Thallus thin, $1-4$ long, $3-5$ " wide, simple or bifid, the margin entire, slighlity "renate or serrate; cells large, oblongr-hexagonal ; perianth erect, fleshy (5) (olls thick heluw), the sumewhat constricted inouth lobate-ciliolate; perlicel long, exceding the thallus: capsule cylindrie. 
five times as long as broad. (Steetzia Lyellii, Lehm.) - Among mosses in swamps and on dripping rocks; common, especially southward. (Eu.)

\section{BLÀSIA, Micheli. (Pl. 23.)}

Thallus simple or forked or stellate, with sinuous margins Diocious. Fruit from an oval carity in the costa. Involucre mostly none. Calyptra obovate. Capsule oval-globose. Antheridia immersed in the thallns, covered with dentate scales. Gemmæ globose, issuing ly a slender ascending tube from large flask-shaped receptacles which are immersed in the thallus. (Named for Blasius Biagi, a monk of Valombrosa aud companion of Micheli.)

1. B. pusilla, I. Thallus $\frac{8}{4}-1 \frac{1}{2}^{\prime}$ long, $2-3^{\prime \prime}$ wide, narrowly obovate, the margins piunatifid-sinuous. - Wet banks; eommon. (En.)

\section{PÉLLIA, Raddi. (1'l. 23.)}

Thallus with a broarl indeterminate costa. Monnecious or diceious. Fructification dorsal near the end of the thallus. Involucre short, cup-shaped, lacerate-dentate. Calyptra menbranous, oval, longer or shorter than the involucre. Capsule globose. Elaters loug, free. Antheridia globose, immersed in the costa. (Named for A. L. Pelli, an Italian botanist.)

\section{* Vomocions.}

1. P. epiphýlla, Raddi. (1'. 23.) Thallus oblong, lobed and sinuate, somewhat flesly, much thickeued in the middle; capsule exserted. - On the ground in wet places; not uncommon eastward. (Eu.)

* Diacious.

2. P. endiviæfolia, Dumort. Thallus flat, green or purplish, broadly linear, dichotomous, the margin mostly undulate or crisped. - On the gromnd aud in ditches; conmon, but often coufused with u. I. (Eu.)

3. P. calycina, Nees. Thallus dichotomous, proliferous, the early divisions linear-oblong, the margins ascending and remotely sinuate, the later divisions linear-palmatifid, coarsely nerved; cells large, hexagonal; involucre eiliate-fringed or lacerate: calyptra smooth, included. - Wet limestones and shales. (Eu.)

\section{METZGËIA, Raddi. (Pl. 23.)}

Thallus linear, dichotomons, with well defined eosta. Diœcions. Frnctifi eation arising from the under side of the costa. Involuere l-leaved, scale-like, at length ventricose. Calyptra clavate or pyriform, fleshy. Capsule shortperlicelled. Elaters unispiral, some remaining attached to the tips of the valves. Spores minute, mostly smooth. Autheridia globose, cnclosed in a scale on the under surface of the costa. (Named for J. Metzger, a German botanist.) .

\section{* Densely villous throughout.}

1. M. pubéscens, Raddi. Thallus $1-2^{\prime}$ long, $\mathbf{l}^{\prime \prime}$ wide, alternately pinnate or somewhat decompound, the short linear branches of uniform width, flat, the margin undulate; hairs longer beneath, single or in twos and threes near the margin, irregularly curved; midril, nearly without cortical layer, with $6-10$ (nostly 8 ) rows of very uniform peripheral cells; diøecions. - In nountain regions, eastward. (Eu.) 
* Hairy on the margins and midrib beneath, smooth above; diccious (n. 4 monocious).

2. M. myriópoda, Lindb. Thallns elongated (2' long, z" wide), dichotomons, the long linear branches of nniform width, convex above, the reflexed margins not undulate; midrib densely pilose beneath; hairs rather long, straight or nodding, the nuarginal mostly in clnsters of $3-6$, some with diseoid tips; midrib covered above with 2 rows of enlarged cells, and beneatl with $3-r$ (usually $4-6$ ) rows of smaller cells, lax and often indistinct. (M. furcata, Sullic., in part; not Nees.) - Shaded rocks and trees in the Alleghanies (Sullivent), and sontliward.

3. M. hamàta, Lindb. Like the last; thallus muclı elougated $\left(4^{\prime}\right.$ loug. $1-1 \frac{1}{2}$ "wide); hairs very long, divaricate and hooked-deflexed, the marginal in twos, rarely with discoid tips; midrib covered alove and below witl two rows of enlarged lax cells. (M. furcata, Sulliv, in part.) - Alleghany Mits. (Sullivant).

4. M. conjugàta, Lindb. 'Thallus $1 \frac{1}{2}$ ' long, $\frac{1}{2}-1$ " wide, usnally dichotounous, the short branches irregular in widtl, convex above, the margins nore or less undulate; laairs rather long, straight, divaricate, the marginal usually in twos, very often disk-bearing; midribs corered above with 2 , below witl $3-6$ rows of enlarged lax cells. - On shaded rocks and trunks of trees, central N. Y., and southward. (Eu.)

\section{A N E Ù R A, Dumort. (11. 23.)}

Tliallus fleshy, prostrate or assurgent from a creeping base; costa obscure. 1)iœcions or monceious. Fructification arising from the under side near the margin. Involucre cup-shaped, short and lacerate, or none. Calyptra large, fleshy, more or less clavate. Capsule large, oblong-cylindric. Elaters unispiral, in part acllerent to the tips of the valves. Spores minute, smooth or minutely roughened. Antherilia immersed in the surface of receptacles proceeding from the margin of the thallus. (Name from $\alpha$-privative, and $\nu \in \hat{\nu} \rho o \nu$, a nerve.)

\section{* Thallus narrow (about 1" wide), palmately divided.}

1. A. látifrons, Lindb. Thallus cespitose, ascending or erect, usnally dark green, 6-9" long, mostly pellucid; branches linear, ol,use and emarginate, plano-convex; cells large, oblong-rhombic; monecious; archegonia $3-$ 10 , short, conie; calyptra white, verncose, pyriform-clavate; capsule oval. brown; spores $12 \frac{1}{3}-14 \frac{1}{2} \mu$ broad, globose, minutely and densely papillose; antheridia globose. (A. palmata of authors; not Dumort.) - On rotten logs; conımon.

$$
\text { * * Thallus narrow (about 1" uide), pinnate or bipinnate. }
$$

2. A. multífida, Dumort. Thallus prostrate, brownish-green, pinnately divided, the primary portion biconvex, somew hat rigid, the branches horizontal, pectinately pinnate with narrow linear divisions; moncecions; fructification rising from the primary part or from the branches; involucre fleslyy; calyptra tuberculate. - Var. MaJon, Nees. Primary portion and branches thick, the branches interruptedly pinnate with short obtuse divisions. - On decayed wood and moss in swamps, N. J. (Austin). and south in the mountains. (En.) 
3. A. pinnatífida, Nees. 'Thallus pinnately divited or subsimple, flat or srmewhat chamelled; branches horizontal, the broaler pimatifid or dentate, obtuse; calyptra somewhat smooth.-On dripjing rocks, Hokukus, N. J. (Austin), N. Haven, Conn. (Laton). (Eu.)

* * Thallus wider (2" ur moie), simple ur irregularly lobed.

4. A. séssilis, sjreng. 'T'hallus decmubent, irregularly loberl, 1-2' long: $3-5$ " wide; involuere none; perlicel $\frac{3}{4}-1^{\prime}$ long, sometines fohled njon itself and remaining within the calyptra, the capsule thus appearing sessile; antheridia on elongaterl receptacles. - Wooded swamps. Lilongater floating forms, 5-6' lory, have been fouml in the White Mts. (Farlow, Fraton).

5. A. pínguis, Dumort. 'Thallus $1-2$ ' long, lecumbent wr ascenting. fleshy, linear-ohlong, simple or slightly lubed, the nargin sinuate; dicecions; involucre short, lacerate; calyptria cyliudric, smouth; eapsule brownish, fur rumed; autheridia in 2-lobed receptacles. - Wet bauks, N. J. to ()hio, aud sonthward. (Eu.)

\section{ORDER 138. AN'THOCHROTACEAS. (HORNED LIVETWORTS.)}

Plant-body a thitlus, irregularly branching. Handel, without epirlermis or pores, and more or less vosiculuse. Huvolucre single, tubular. Calyptrar rupturing ealy near the hase, and borme on the apex of the capsule. Capsule dorsal, porl-like, erect or curved ontward, more or less perfectly 2-valred, usually stomatose, lapering into a pechecl or often sessile with a bullous base. Columella filiform. Elaters with or without spiral filores. Spores flattish, more or less conrex-prisuatic, yapillo:e or smooth.

1. Anthoceros. Celpsule narrowly linear, existety pedicelled, 2-19alvel. Ehaters present.

2. Notothylas. linpsule very short, st'ssile, not ralven below the michle. Elaters not olivions.

\section{A NTHÓCEROS, Micholi. (1'l. 22.)}

'l'hallus dark greeu or blackish, ustally ikeprosed, rarionsly lohed, with large chlorophyll-grains, frequenty glanchlar-thickened at the apex or in lines along the middle so as to atpear nervet. Mromecinns or diocions. Capsule lincar, 2-valved, exsertly perlicelled. Elaters simple: or hrinched, often geniculate, more or less leterunorphons, the fibres wanting or indistinct.

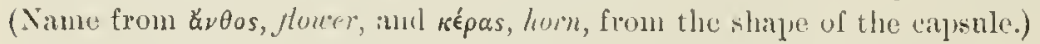

1. A. làvis, L. (1'l. 2.2.) 'l'hallus smooth, nearly flat aluve; dixcluus; involucre 1-2" long, trumpet-shaperl when ory, repand-tootherl; capsule pale brown or yellowish, 1 - I $\frac{1}{2}$ long; elatess rather short, vellowish; spores rellow, nearly smooth, ingular. - Wet clay hamks, from ('anada sonth and westwark. (Eu.)

2. A. punctàtus, 1. 'T'hiallu's small, depresserl, or often cespitose and erect, more or less glaudular; monucious: involnere rather short, oblonglinear, slightly repand, sometimes sourions at the month; capsule l' high, black; elaters fuseous, flattish, grenicnlate; spores black, strongly inuriculate. warply angled. - Wet bauks, Canala to Mo., and southward. (Eu.) 


\section{NOTOTH Y I A S, Silliv.}

'Thallus orbicular, tender, laciniate and undnlate or crisped, papilluse-reticulate. Monocious. Involncre sessile, continuons with the thallus, opening irregularly alowe. Capsule rery slort, chlongr-gholose or ovate-rylindric, perli(elled from a thickened bull, 2-ralverl to the middle or rupturing irregularly. likter's none, or fragmentary aud inconspienons. spures subghohose, smooth. ish. Antherilia elliptic-globose, immersed in the thallus. (Nimne from $\nu \hat{\omega} \tau o s$, the buck, and $\theta u \lambda a$ s, a bug, from the shape and position of the involucre.)

1. N. orbiculáris, Sulliv. (I'l. 22.2) 'Tlatllns:3-8" wide; capsules 1 2" long, erect or decurved, wholly included or slightly exserted, of thin and jwose textme, with a suture on rach side; slumes light yellowish-brewn. (Indulling N. valrata, simllir.) - Wret places, Camada to the (inlf.

2. N. melanóspora, fulliv. Thallus small, depessel or sometimes respitose, of lax texture; capsule uften without sutures; spores rlark brown,

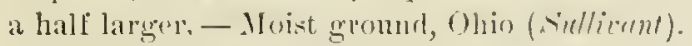

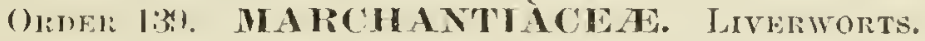

Plant-hody a thallus, dichotomous or subpalnately branching, usually innovating from the apex or beneath it. more or less thickenerl in the middle, and bearing numbens rootlets beneath and usually colored or imbricating seales. Fyprlemis nsually more or less distinct and strongly porose alove. Capsules glohose, l'urcly oval, opening irregularly, pendent from the under sile of a perluneled disk-like receptacle (carpocephalum). Elaters presunt, mostly z-spiral.

* T'hallus platuly costate, distinetly porose exeept in $n, 6$.

+ Genma mosent on sterile stems.

1. Marchantia. Gemme in enll-shaped reseptucles. Fertile recentacle 7 - 11 -rayed.

8. Lunularia. Gemme in rescent-shaped receptacles. Fertile recentacle cruciform.

$$
+ \text { - Gemule wanting. }
$$

* Receptarle conic-hemispherieal, 2-4-loturd; perianth lobed or fringed.

23. Preiasia. Rereptarle 2-4-kober, with as many alteruate rily-like rays. Perianth 4-5Inberl.

3. Finbriaria. Receptacle 4-lobed. Perianth conspienous, split into 8 - 16 fringe-like sergurnelits.

++ + Receptacle more ar less eonical; perianth none.

4. Conocephalus. Thallus very large, strongly ateolate. Reeptacle conical, membranous.

Grimaldia. Thallus small. Perlumele elatly at lase and apex. Receptacle coniclomispluerie, truneately 3-4-lobed.

; Astella. Thallus plorose. Recptacle conic-hemispheric, hecoming flattened, acutely 4- (1- 6-) lober.

* Thallis thir, ecostate or harcly costate.

- Dumortiera, Receptarle convex, 2-S-lobed. Perisutli none.

\section{M A R C H Á N T A, Marchant f.}

Thallus large, forking, areolate, porose, with broal diffusel midrib; gemma in a cup-shaped receptacle. Dixecious. Frrtile pereptacle perluneled from au apical simus of the thallus, radiately lobed. Inwulues alteruate with the rays, nembranous, larerate, enclosing 3-6 l-fruited cleft peritutlis, Calyptra per. 
sistent. Capsule globose, exserted, pendulous, dehiseing by several revolute segments. Elaters long, attenuate to each end. Spores snooth. Antheridia immersed in a peduneled disk-like radiate or lobed reeeptacle. (Named for Vicholas Marchant, a French botanist.)

1. M. polymórpha, L. 'Tliallus $2-5^{\prime}$ loug, $\frac{1}{2}-1 \frac{1^{\prime}}{2}$ wide, numeronsly porose, renulose; reeeptacle divided into usually 9 terete rays; peduncles 1 $3^{\prime}$ high; antheridial disk crenately or palmately 2-8-lobed, on a peduucle l' $^{\prime}$ ligh or less. - Everywhere common. (Eu.)

\section{PREİSSIA, Nees. (I'l. 22.)}

Thallns obcordate, sparingly forked, increasing by joints; pores conspieuous; gemmæ none. Diœeious or monœeions. Fertile receptaele hemispheric, 1-4-lobed, with as many alternating shorter rib-like rays. Onter involncres attached beneath the lobes, 1-3-fruited, opening outward by an irregular line; perianth oheonic-campanulate, angular, unequally 4-5-lobed. Calyptra persistent. Capsule large, distinctly pedicelled, dehiseing by $4-\varepsilon$ revolute segments. Elaters short. Spores coarsely tubereulate. (Named for L.Preiss, a (German botanist.)

1. P. commutàta, Nees. Thallns $1-2^{\prime}$ long, with conspienous white pores above, and dark purple scales beneatlı; nsually monœcions; peduncle $\frac{1}{2}-I^{\prime}$ high ; eapsules eonspicuous, dark purple; antheridia in a peduncled disklike receptacle. (P'. hemisphwrica, Cogn.) - On slaty and limestone roeks, from X. J. north and westward. (Eu.)

\section{FIMBRIÀRIA, Nees. (Pl. 22.)}

Thallns thiekened in the mildle by a keeled costa, usually conspieuously porose, with dark pnrple seales beneatl, gemma none. Monœeions. Reeeptacle rising from the apex, conic or hemispheric, concave beneath and expanded into usually 4 large eampanulate 1 -frnited involueres. Periantl oblong-oval or subennic, exserted half its length and eleft into 8-16 fringe-like segments. Calyptra with a long style, fugacions. Capsule nearly sessile, irregularly circumseissile. Elaters rather short, 1 -4-spiral. Spores angular, subreticulated. Antheridia immersed in the thallus. (Name from fimbria, a fringe, alluding to the perianth.)

1. F. tenélla, Nees. Thallns of one or more long-wedge-shaped emarginate divisions about $6-9^{\prime \prime}$ long, grayish-green and porose abore, purple on the margins; peduncle $l^{\prime}$ high or more, usually purple; receptacle obtusely conic; perianth white, 8-eleft. - On damp ground in sandy fields or on roeks, cential N. Y. to Mn., and sontliwarl.

\section{CONOCÉPHALUS, Neck. (Pl. 22.)}

'Thallus diclintomons, copiously reticnlate and porose, with a narrow costa; gemmæ none. Receptacle conic-mitriform, menbranous. Involucres 5-8, tubular, 1-fruited, suspented from the apex of the peduncle; perianth none. Calyptra jersistent, campannlate, $2-4$-lobed at the apex. Capsnle pedicelled, ohlong-pyriform, dehiscing by $5-8$ revulute segnents. Elaters sliort, thick. spores muriculate. Antheridia imbeduled in an oval disk sessile near the apex uf the thallus. (Name from $\kappa \hat{\omega} \nu o s, a$ cone, and $\kappa \in \phi a \lambda \eta_{1}$ a head.) 
1. C. cónicus, Dumort. 'Thallns $2-6$ ' long, $\frac{1}{2}-\frac{3}{1}$ wide; receptacle conic, striate, crenate. (Fegatella eonica, Corda.) - Shady banks; common. (Eu.)

\section{G RI M Á LI A, Raddi. (Pl. 23.)}

Thallus thick, more or less channelled, dichotomous, inmorating from the apex, with thick epidermis, closely areolate and porose-scabrons alove, purple and more or less scaly beneatlı; gemme none. Monocions or liwcious. Receptacle perluncled, hemispherical or eonoirlal, 3-4-lobed. Involucres as many, 1-fruited, each a distention of the lobe. Capsule filling the involncre, cireumseissile in the midelle, the calyptra persistent at its base. Antheridia in an oval or obeordate disk immersed in the apex of the thallus. (Named for $L$ ). Grimaldi, an Italian botanist.)

1. G. bárbifrons, Biseh. (1'l, 23.) 'Thallus linear-olecuneate, 3-6" long, $1-2$ " wide, 2 -lohed at the apex, pale green with nsually distinet whitish pores, the scales beneatl often extending far beyond the ungin and beconing whitish; peduncle profnsely ehaffy at hase and alpex, sometimes much reduced; antherielial disks obcordate. (Including (i. sessilis, Gulliv.) - Thin soll on rocks, Comm. and N. J. to Iowa; rare or local. (Eu.)

2. G. rupéstris, Lindenb. 'Thallus $3-6^{\prime \prime}$ long, 1-3" wide, witl nenbranons margins; reeptacle small, hemispherical, I-4-fruterl, the pedunele abont l' high, sparingly scaly at hase, harbulate at the apex; involuere short, ('remulate; spores tuberonlate. (Duralia rupestris, Ters.) - In ealcareous or shaly rocks, $\mathrm{X}$. Y. and Ohiu. (liu.)

\section{A S TER ÉLA, Beau. (I'l. 22.)}

Thallus rigid, very indistinctly porose, the midrib broud, strong and distinct. Receptacle conie-hemispheric, becoming thattencl, 1-6- (nsually 4-) lolied. Monecions. Involneres coherent with the lobes, I-fruited, 2-valved. Calyptra minute, lacerate, persistent at the base uf the eapsule. Capsule greenish, rupturing by imegular narrow teeth or hy a fromentary operoulum. Elaters noderately long, mosty 2-spiral. Sporestulerenlate. Anthericlia in sessile luuate disks. (Diminutive of aster, a stur, from the form of the receptaele.)

1. A. hemisphierica, Beanr. 'Thalhus forking and increasing by joints, pale green, purple beneath; receptacle papillose on the snmmit (less so at maturity); peduncle bearded at bise and ilpex, ${ }_{4}^{8}-1^{\prime}$ long, often $2-3$ times longer after maturity. (Reboulia hemispherica, licedi.) - Shaded banks, chiefly along streams; more common southwarl. - I smaller form or perhaps rariety (Reboulia mieroephiala, Nees: R. Sullivantii, relum.) occurs in Penn., Ohio, and southwart. (En.)

\section{DUMORTIERA, Nees. (1']. 22.)}

Thallus large, thin, soft, with a slight costa, dichutomous, usually with seattered hair-like rootlets beneath; gemma none. Receptacle convex, 2-8-lobed. Involueres 1 -fruited, conuate with the loles beneath, lorizontal, opening by a vertical terminal slit. C'apsule distinetly pedicelled, obloug-rylobose, dehiscing by 4-6 irregular valves. Elaters $2-3$-spiral, parietal, very long, straight, attenuate both ways. Spores muriculate. Antheridia in a short peduncled rlisk paleaceous beuentl. (Named for B.C. Dumortier, a Belgiau hotanist.) 
1. D. hirsùta, Nees. 'Thallus $2-5$ ' long, $6-9$ " wide, deep greeu, be. soming blackish, entire on the margins, naked above or with a delicate appressed pubescence; diocions; receptacle may-fruited, the margin closely hairy; permole rather long, chaffy at the apex. - On moist calcareous rocks, Gaston, I'enn. (Purfer), and soutliward.

\section{LUNULÀRIA, Micleeli.}

'Thaths oblong with romiled lobes, distinctly areolate and porose, with imIricate sublnuate seales beneath; gemma in arscent-shaped receptacles. Dinecions. Fertile receptacle usuilly cruciately divided into 4 horizontal secrments or involucres, which are tnbular, vertically bilabiate aur 1 -fruiterl. Calyptra included, persistent. Capsule exserted, 4-8-ralved. Ealaters shout. we slender, mostly free. Spores nearle smooth. Antherirlia borne in the apieal simus of the thallus. (Nime from lumula, a little moon.)

L. wodidus, Raddi. 'Thallus 1-2' long, forker, innovating frou the

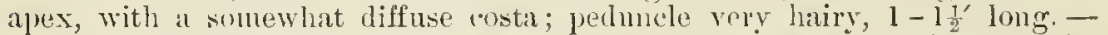
lutrolncerl into greenhouses; always sterile, hut eisily recognized by the characteristic receptacles. (I. eruciata, Dumo\%.) (Int, from En.)

\section{ORIER: 140. RICGIACIAS.}

Plant-boty a dichotomously branching thallus, terestrial or aquatic. Capsules short-judicelled, or sessile on the thallus, or immersed in its substance, free or comnate with the calyptra, globose, at lengtli ruptur'ing irregularly. Calyptra crownel with a more or less deciluous print. Elaters none. Spores usually augular, reticulate or muriculate. Anheridia ovate, immersed in the thallus in flask-shaped cavitics with protruding, orifices (astiotes).

1. Riccia. Capsule immersed in the thallis. Involuere none.

2. Spharocarpus. Calsule sessile on the thallus. Involucre inflated-pyriform.

\section{R I C C I A, Micheli. (I'1. 22.)}

Thallus at first radiately divided, the centle often son decaying; the divisions bifid ur di-tri-chotonons, flat. or depressed or ehamelled above, msually (onvex and uaked or squamulose bencath; margins naked or spinulose-ciliate:

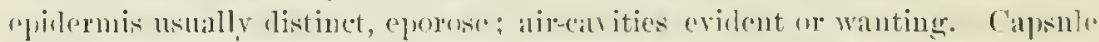
inmersed, sesile. Calyptra with a persistent style. Spres alveolate or murionlate, nsually Hattened and angmlar. (Named for P. F. Riceci, an Italian nobleman, jatron of Micheli.)

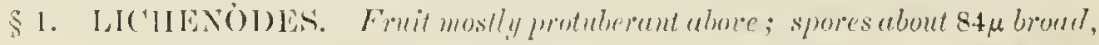

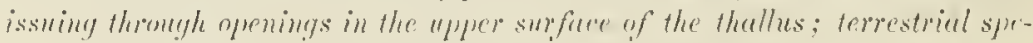

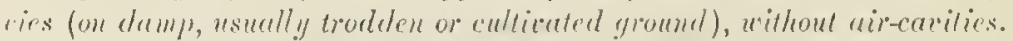

* Thallus neked, wilhout cilia or scales.

1. R. Fróstii, Aust. 'I'lullus orlicular, 6-12" hroad, thiunish, grayishgrreu, the apex and narowly membramous matgius sometimes purplish, miuntely pitterl; divisions linear or subspatulate, subtruncate and sliglitly enurginate; routlets smooth or olsoletely lapillose within; eapsules very proninent bencath; spores barely $50 \mu$ broal, nearly round, somewhat mar. gined, with rlepressed sides when dry, fuscons. - Ohio, Ill, and westward. 
** Thallus with white scales benerth (durk purple in n, 4), the margin naked.

2. R. solocálpa, Bisch. Thallus 3-8" in diameter, pale green beculling whitisli, finely reticulate, subradiately or dichotonously divided, the whlong-linear segments subacute, depply sulcate, witls a few inconspicuous scalcs towad the apex not extending beyond the margin ; margins erect when dry; spures issning through clink early appearing aloug the groore above. 'l'lin rocky soil and rultivated fields, (loster, N. J. (Austin), westeru N. I. (Clinton), incl lll. (Hall). (Eu.)

3. R. lamellosa, liaidi. Thallus pale grecu, elegantly reticulated, sulradiately dividce, the divisions ohovate or obcordate, bifid or 2-lobed, 2-5" long, clannelles at the alex, with menlsanous ascending margius, and furnished beneath with transverse scales which extend cousiderably beyond the: margin; spores much as in 11. 2. - 'llin rocky soil, Cluster, N. T. (Austiin).

4. R. nigrélla, 1)(. Thiallus diclotonously divíled, tho divisious linear, chamelled, with entire narrowly membranons margins, green above, dark purple bencatl aud fumished with transverse semicircular scales uot axraeding the margin. - liocky ground, X. Y. (Turrey), and Chest(r, l'mull. (Porter). (Eu.)

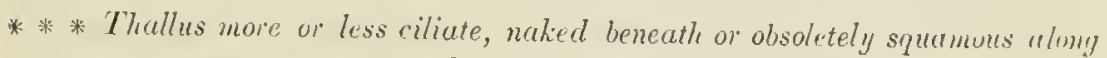
the extreme edge.

5. R. arvénsis, Lust. Thallus mueh divided, $3-9^{\prime \prime}$ broad, papilloseroticulate, dull green both sides, becoming fuscous above, the flat margins at l':1gth furple; divisions sulcate, dichotomous, the linear-elliptic or subspatulitte luhes acutisle and obsoletely emarginate; cilia whitish, very slort and inconslinous or nealy wanting; capsules aggrogated toward the apex; spures $71-8+\mu$ lroat, dark fuscous, reticulate, with pollucid margiu. - Var.

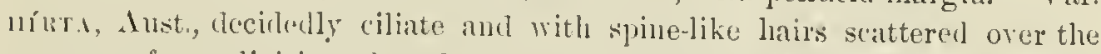
up (r) surface; divisions lroader, nore obtuse; spores nearly black, larger $(8+-101 \mu)$ and smoother. - Cultivated fields and (the ral.) rocky places, ('luster, N.J. (Austim).

6. R. Lescuriàna, Aust. Stellately or subcruciately divided, the obcorlatc or cuneate-linear divisions 2-6" long, punctate-reticulate, suliglancous or asly-grcen lotlı sirles or becoming purple beneatl, the slightly coucave lubes emarginate, closely ciliate witl short olstusc spine-like white liairs; ("ipsules scattered, clicfly near the base of the divisions; spores $71-83 \mu$ broul, lark brown, reticulate, not margined. - Cultivated fields and rocky grounds, N. J. to Ill., and soutliward.

\$2. SPONGODES. Thallus with large air-eavities usually opening by pits through the upper surface, and with slight depressions over the capsules which are prominent beneath; spores $41-51 \mu$ broad, obtusely angular or globose; terrestrial.

․ R. crystállina, I. Orbicular, 6-9" broad, the obcordate or cumeate divisions lufil or 2-tuhed, flat above and the surface much broken up into pits, the margins sulcrenate; capsules scattered; spores issuing through the upper surface. - On mul flats, J1. (Holl), wrest and sonthward. (Ku.)

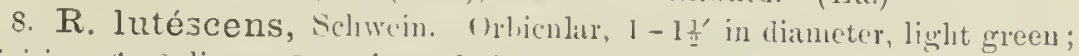
divisions $6-8$, linear, $2-3$ times forked, narrowly clanuelled, olsordate aud 
thickened at the apex, with delicate whitish obliquely otate appressed scales; rootlets wanting beneath abore the mildle; frniting plant unknown. - Drierl up pools and ditches, Canada to Mo., and southward. An analogous form has been developed by Lindberg from R. nataus.

9. R. ténuis, Aust. Thallus thin, olive or yellowish-green, shining, the $2-4$ divisions roundish-obovate, $2-4$ " long, flat, with sinuate inargins, green beneath with a slender eosta and few rootlets; eapsule very delicate, closely adherent to the substance of the thallus, minutely apiculate; spores round or short-oval, conspicnously depressed at one end when dry. - Wet ground in open woods, Closter and Lawrence, N. J. (Austin), and Mo. (Hull).

\$3. RICCIÉLLA. Thullus lincur, dichotomous, floating or rarely terrestrial; capsule protuberant from the lower surface.

10. R. flùitans, L. Thallus often in extended patches, thin, green, radiately expanling, the often intricate divisions $\frac{1}{2}-1 \frac{1}{2}$ " wide, parallel-nerred, Hat, without rootlets, cal ernous only toward the slightly dilated rery obtuse or subtruncate apex; capsules present only in some terrestrial forms, very prominent below, rupturing beneath the apex. - Very variable. The nost not-

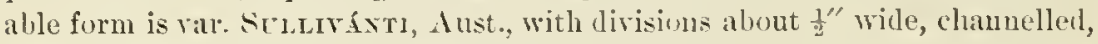
eavernous throngliout, the margins crisped-crenulate, and rootlets numerous on the costa tumid with abundant capsules, which are tipped with a long funnel-mouthed point; spores olscurely angled, reticulate and margined. (1i. Sullivanti, . 1ust.) - In ponds or ditches or growing in wet places upon the grounl; the variety often in cultivated fields. (En.)

\$ 4. RICCIOCARPLS. Thellus ubcordule, flouting or rarely terrestrial; cap. sules not protruding, at length exposed by a cleft in the centrel grooce.

11. R. nàtans, L. (1'1. 22.2.) Divisions obcordate or cuneate, broally emarginats, 3-6" long, purplish, very narrowly channelled, witl numerous nuiform air-earities beneath the phitlermis, ronting toward the base and at lengtlı witl diark purple stales treneatl the ajex: ("apsules in 1 or 2 rows beneath the groore; spores blatk, ingular, strongly papilluse. - Canada to the Gulf. (Eu.)

\section{SPH届 ROCÁRPUS, Micheli.}

(Pl. 22.)

'Thallus lohed, withont costil or epidermis. Involueres sessile, obconic or prriform, perforated at the alpex, continnons with the thallns at lase. CaIyptrat closely investing the single gloluse indehiscent cajsule, crowned with a deciduous point. Spores globme, muriculite, remaining mited in al coecus. Antheridia bome in folliculan holies on the surface of al separate thallns. An anomaluns genus, perhaps more closely related to the Jungermanniacese.

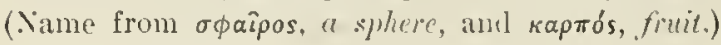

1. S. terréstris, simitl. "Thalluş orbicular, $3-6^{\prime \prime}$ broad, corered by the clustered intlated "involncres, which are nenly $\mathrm{l}^{\prime \prime}$ long, $3-4$ times the length of the capsule; coccus $102-127 \mu$ wille, indistinctly lobed. (S. Michelii, Bellardi.) - In cultivated tields, mostly southern. (Lu.) 


\section{ADDITIONS AND CORRECTIONS.}

Page 59. - Arganoxe Mexicaxa. Colleeted at Merodosia, Ill., with white flowers, by A. B. Seymour.

\section{l'age 75. - Insert after Cleome integrifolia -}

C. spixoss, I. Viscirl-pulescent, 3-40 ligh; a pair of short stipular spines under the petiole of each leaf ; leaflets $5-7$, oblong-lanceolate; flowers lauge, rose-purple to white; stamens $2-3^{\prime}$ long; stipe of the linear porl about '2' Jong. (C. pungens, Willd.) - An escape from cultivation, near Mt. Carmel, III. (Schneck), and in waste gromels sonthward; also on ballast. (Int. from 'l'ro]). Amer.)

Page 86. - Arenaria Grœenlandica. Found on Mt. Desert Island, Maine (liund).

Inge 87. - Stellaria borealis. In the mountaius of northern N. J.

S. humifusa. 'This species lias also heen found on Cranberry Islaud, near Mt. Desert, Maine, ly J. II. Redjield.

Page 91. - Under Talinum teretifolium add the character - style erpalling the stamens. - Insert

2. T. calycinum, Engelm. Leaves somewhat broader; flowers ant capsules larger; stamens 30 or more; style twice longer than the stamens, leclinerl. - Central Kan. to W. Tex.

Under Claytonia insert -

3. C. Chamissonis, Esch. Weak, procumbent or ascending, rooting below and pereninil ly lateril and terminal filiform runners; leaves several pairs, ohlong-spatulate, 1-2' long; inflorescence racemosely 1-9-flowered ; petals pale rose-color; cipsule surall, l-3-seeded. - In a colı ravine, Winoua Co., Minn.; in the mountains from Colorado north and westward.

Page 211. - Hydrocotyle Americana. Add - propagating by filiform tuberiferous stolous.

1'age 230. - Insertafter the genus I)ipsaens -

2. SCA B I O S A, Tomrn. Scamioug.

Characters of Dipsacns, lut the green leaves of the involucre and involueels not rigid nor spimescent. (Name from srubies, the itcll, from its use as a remerly.)

S. Arstrils, Wulf. Terenial, sparsely luanelied, nearly glabrons, $1 \frac{1}{2}-$ $3^{\circ}$ high; faves narrowly lancenlate to lineal, the luwer ohlanceolate, slightly tootleel or entire; heads shont-oblong; calyx olotusely short-lobed; corollat pale blue.- Central N. Y. anil l'em.; raro. (Adv. from Ein.) 
Sige 395. - After Onowixim: mrom insert-

O. RAMosA, L. Often branehel, 6' high or less, of a pale straw-eolor ; flowers 3-bracteate, the lateral braets small; ealyx 4-toothed, split at the baek; corvlla pale blne, $6-8^{\prime \prime}$ long. - On the roots of hemp and tobaeco; Kiy. (Int. from Eu.)

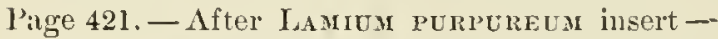

L. ixternèdu, Fries, hesembling $I_{*}, p u r p u r e m$, but the ealyx-teetl !onger than the tube, the rather narrower eorolla withont a hairy ring within iear the base, and the nutlet longer ( 3 times as long as broad). - Cultivated fielis near Hinglam, Mass. (C.J. Sprague). (Adr. from En.)

l'age 427. - Insert in the generic key-

5 Cladothrix. Flowers perfect, minute, axillary. Densely white-tomentose.

l'age 430. - Insert after the genus Frelichia -

\section{C LA D Ó THRIX, Nutt.}

Flowers perfect, 3-bractel. Sepals 5, ereet, rigid-searions, somewhat pilose. Stamens 5, the filaments mitel at base; anthers large, 1-celled. Stigma large, eapitate, 2-loberl. Utriele globose, inlehiscent. - Densely stellate. tomentose low herls or woody at base, with opposite petiolate leares and rery sumall flowers solitary or few in the axils. (Name from $\kappa \lambda a ́ \delta o s, ~ " h r u c h$, and $\theta \rho i \xi$, hair, for the branching tomentum.)

1. C. lanuginòsa, Nutt. J'ostrate or ascending, much branched; leaves round-obovate to rlombonidal, $3-10^{\prime \prime}$ long. - Central Kan. (Mechan) and sonthwestwarl.

J'age 435. - Salsola Kali. This species has heen found in Emmet Co. Iowa (Cratty), at Yankton, S. Dak. (Bruhin), and in river-bottoms in N. W. Neb. and eentral part of the l)akotas.

\section{l'age 437. - Aftel Eriogonum annuum insert -}

2. E. Allèni, Watson. Perennial, white-tomentose thronghont, the tall sape-like stem repeatedly dichotomous above; radical leaves lanceolate, longpetiolate, the upper in whorls of 4 or 5 , orate to oblong-ovate, very shorty petiolate, much redneed ahore; involucres mostly sessile; flowers glabrous, yellow, the segruents elliptical. - Near White sulphur Springs, WV. In (T.F. Allen).

Page 445. - Asarum Canadense. In this species there are mdinentary subnlate petali, alteruate with the ealyx-lobes.

Page 463. - Celtis Mississippiensis. ('ummon in low river-bottom. of W. Mo. ( $F, B u s h)$; lescribed as laving a very smooth trumk, like a sycamone, and soft yellowish britte wool, not eoarse-grained as in (Y accilentalis.

I'age 491. - Lnuler Pinus arli -

10. P. ponderosa, Dougl., rar. scopulòrum, Engelm. Leaves in twos or usually threes from long shenths, $3-6^{\prime}$ long, rather rigicl; staminate flowers $1^{\prime}$ lnug; cones subterminal, 2 $2-3$ ' long, oval, often $3-5$ together, the prominent summit of the thiek soules learing a stout straight or incurved priekle. - Central Neb. and westward in the Rocky Mountains. $-\Delta$ large tree with very thiek bark. 
l'age 514. - After Iris Caroliniayd insert -

$2^{\mathrm{a}}$. I. hexágona, Walt. Stems flexuous, often low and sleuder $\left(1-3^{\circ}\right.$ high), leafy; leaves much exceeding the stem, $6-12^{\prime \prime}$ broad; flowers solitary and sessile in the axils, large, deep blue, variegated with yellow; purple, and white; tube $\frac{1^{\prime}}{2}$ long; segmeuts about $3^{\prime}$ long, the inner narrow; capsule ol)long cylindrie, 6-angled, 2’ long. - Prairies, Ky. (Short) to W. Mo. (Bush), aud on the coast from S. Car. southward.

l'age 515. - S. angustifolium. What appears to be a form of this speeies

with pale yellow flowers is fuund uear Independence, Mo. (Bush).

lage 516 - Under Zephyranthes Atamasco insert the synouym (Amaryllis Atamaseo, L.).

Page 555. - S. teres has been collected also at Brewster, Mass. (Farlow).

I'age 575. - $\Lambda$ fter E. Torreyana insert -

$13^{\mathrm{a}}$. E. álbida, Torr. Like n. 12 and 13 in habit, somewhat stouter; spikelet dense, ellipsoidal or oblong, 1-4" long, acutish, with pale obtuse scales; acliene very small, triangular-obovate, very snooth, witl a broadly triangular tubercle upon a narrow base, shorter than or exeeeding the reddish bristles. - Salt marshes, Northampton Co., Va. (Canby), and sonth to Fla. and Tex.

Page 653. - T. subspicatum, rar. molle, is reported from Roan MIt., $\mathrm{N}$ C. (Scribner), and probably occurs on the higher Alleghanies northward. l'age 662. - After M. diffusa iusert -

3. M. Pórteri, Scribn. Tall and sleuder; panicle very uarrow, the slender branches erect or the lower slightly divergent; pedicels flexuous or rerurved, puhescent; glumes very unequal and shorter than the spikelet; fertile flowers 3-5, the glumes seabrous. - Mountains of Col. and sonthwarl ; reported froul Cass Co., Neb. (J. G. Smith).

Page 663. - D. maritima. On alkaline soil in Neb., and very conmon in similar localities west and southwestward; chiefly the var. stríctA, 'Tlurl, with setaceonsly convolute leaves, the many- $(10-20$-) flowered spikelets in a loose panicle.

Page 5. - Under * 1 real - (sometimes opposite or whorled, stipulate in Magnoliace:e and rarely in Ramunculace: $)$.

Pağe 8. - Inder Ilicineæ real - and usually deciduous stipules.

l'age 38. - A. Pennsylvanica. Reported from Aroostook Co., Naiue (J. C. Parlin).

l'age 40. - M. minimus. Reported from Accomac Co, Va., (E. Mears).

l'age $41,-\mathbf{R}$. ambigens. An earlier name is $R$. laxicaulis, Darby.

l'age 44. - Adl - 2. C. nàtans, Pall. Stem prostrate or flontiug; leares cremulate or entire; sepals oval, $2-3^{\prime \prime}$ long, white or pinkislı. - I'ower, Minn $(F . . / . / l / l)$, and northwart. 
Page 73. - L. Runerale. Reported at Buckfield and Orono, Maine (Parlin).

Page 75. - P. graveolens. Sail to rauge to the Chesajeake (I'orter).

Add at Lotton - R. ín, l. Leaves punuate, undulate, glaucous; flow. ers white; sepals and petals 5 or 6 , the latter all i-fid - Inftalo, N. Y. (Clinton); Youngstown, Uhio (Ingraham). (Adr. from Eu.)

l'age 83. - D. wetronnes. licad-glabrons or roughish. - On the dowrs, Martha's Vineyard (Edith Wutson).

Page 84 - S. antirrhina. A very slender form with much smaller apeta lons flowers, anl capsules only $2^{\prime \prime}$ loug, occurs at liockford, Ill.

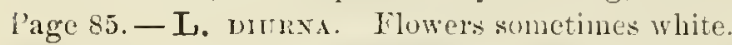

Page 87. - Tuder S. uliginosa real - reiny, often ciliate at hase.

Page 89. - S. procumbens. I Leares linear-lanceolate to narrowly linear - Champion Mline, Marquette Co., Mivol. (E. . M Mill).

Page 95. - Luder geus 3 retul - with small nsually rather close clnsters.

Page 99-M. angustum. is lio founl in IV. Ill. along the Mississippi. Under S. Napxa reul - aloug and near the Alleghanies.

Page 107. - Lnder (Orins 25) insert - Stipules small or minute, usma!ly soon decidnous. - Akl - 'the dquifinden of previous editions.

Page 108. - I. mollis. ('ominon on the l'ocono platean, Penn. (Porter).

Page 127.-C. scoralill's. At (isterrille, Mass. (Miss S. Minns).

Page 140.-D. sessilifolium. Also at Norwach, Conn. (Graves), and in Plymouth Co., Mass. (Boott).

lage 152. - P. spriosa. The garden Plum, a thumless derivative from rar. insititia, larely occurs as an estape. - Mil- P. irium, l., the Bird Cherry, with drooping puleserit acutely serrate feaves on hong petioles, lax

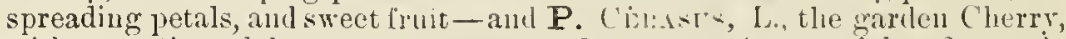
with spreading glabrous clenatescrinte leaves on short petioles, firm sub-

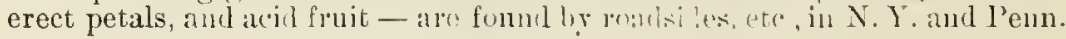

Page 155. - To R. Canadensis arl - Var roribzccus, Bailey. Leaflets triangular-ovate, unequally aud sharply doulby selrate, often nearly lobed; peduncles longer and straighter, orertupping the leares; flowers very large, $1-2^{\prime}$ broad, the sepals foliaeeons and incised; fruit large. W. Va., aud probably sonthward. Cnltirated as the Lucretia Dewbery.

Page 159. - After P. Pennsylvanica insert-P. Récts, I. A tall herbaceous perenuiai, sparsely villous and glandular-puberulent, with digitate 5 - 7 -foliolate leaves, incisely pinuatifid leaflets, and large yellow flowers in a broal cyme. - Central N. Y. (lutrod. from Eu.)

Page 164. - Add - R. cinsamosea, L. (Cixsmos liose) With hrownish-red hark, some straiglitish prickles, pale leaves downy beneath, and small double pale red flowers. - An escape about old gardens and by roadsides. N. Eng, N. Y., etc.

Insert - P. MAı's, L., the Apple. and much more rarely the Pear, $\mathbf{P}$. commùnis, L., occur self-sown in pastures, etc.

Page 176. - R. rubrum. 'The garden form sometimes occurs as an escape. l'age 177. - In the last line read - from western N. I. to Ga. and S. Ind. Page 181. - M. scabratum. Keweenaw Co., Mich. (O. A. F(trell).

Page 185. - Under A. coccinea read - west to S. Ind., N. 111., Kan., etc. Add - 2. A. auriculàta, Willd. Flowers smaller, in loose peduncled axillary cymes; capsule $\mathbf{l}^{\prime \prime}$ in cliamcter. ( $\Lambda$. Wriglitii, Gray.) - Fillmore Co., Neb. (Kev. J. H. Wibbe). A Texan species, perhaps introdueed. Under I. SALICARIA add-and central N. Y. 
Page 201. - D. Carota. Flowers oceasionally purple or reddish.

Puge 207. - Under B. angustifolia read - Mass. (?), Mich., N. Ill., aur westward.

Page 214. - C. circinata. Calyx-teeth minute; stone globular, not furrowed. - C. sericea. Stone large, more or less acnte at base, oblique and irregularly sharp-ridged. - C. asperifolia. Stone nearly globular or somewhat oblique, smooth or slightly furrowed. - C. stolonifera. Stone very variable, oblique, flattened or scarcely so, more or less furrowel. - C. stricta. Stone small, nearly globular, smootl. This species aplpears to include $C$. paniculata. C. cundidissima, Marsh., is a little earlier name, but the ideutification is somewhat doubtful. $-\Lambda d d-$

5a. C. Bàileyi, Coult. \& Erans. Intermcdiate betreen nos. 5 and 6 in foliage and pubescence; brauches reddish-brown: fruit white; stone compressed, truncate, furrowed on the prominent edges, broader than high. About the Great Lakes (Erie to Superior) and westward. Perhaps a hybrid. Page 215. $-\Lambda$ dd $1^{a}$. N. biflora, Walt. Leares smaller than is usnal in u. 1 ( 1 - $3^{\prime}$ long); fertile flowers $1-3$; stone dcciledly flattened and more strongly furrowed. - N. J. to Fla., Tenn. and southward.

Page 226. - G. Moldgao. Occurs in eastern N. Fng. - Flowers in this species loosely panicled, in G. rerta densely so.

Page 233. - Enter - $43^{\mathrm{n}}$. Franseria. As A mbrosia, but fruit 1-4-celled, 1 -4-beaked.

I'age 250. - S. neglecta, rar. linoides. At Turner, Maine (J.A. Allen). T'age 252. - S. Ohioensis. Rear - central $\mathbf{X}$. Y, and from Ohio to Wisc. l'age 269. - G. purpureum. At Youngstown, Ohio (R. II. Ingraham). Page 273. - Add-43". FRA NSERIA, Cav.

Resembling Ambrosia, but the fortile involucre enclosing $1-4$ flowers, the fruit 1-4-celled aurl 1-4-heaked, more or less bur-like with scattered prickles. (Named for A. Fronser, a sianisin botanist.)

1. F. tomentosa, Gray. Lnw, erect and rather stout, densely silkytomentose; leaves very white beneath, more or less pinnately cleft or nearly entire. - Hacplierson, Kan. (Kellemon), and southwestward.

lage 275. - H. scabra. liepurted from ()xord Co., Maine (Parlin).

Page 284. - B. connata, rar. comoss. Reported from central N. Y. (Dudley).

Page 297 . - Inder C. xirs read - black or brown pectiuately-ciliate fringe: rays usually wanting.

Page 302. - P. altissima. Glahrous or somewhat hispidulous.

Page 320. - Inder R. nudiflorum read — swamps and open woods.

l’age 329. - Undcr D. Meadia add - Var. Frénchii, Vasey. Often dwarf, glabrous or pubescent above; leaves orate or orate-elliptical, sometimes corlate at hase. - l'enn. to S. 11l. and Ark.

Page 35t.- L. trachyspermum. Reported from sonthern N. J. (Britton). Page 361. - Aspentro procumbexs. At New Bedford, Mass. (Hervey).

Page 378. - Enter - 7a. Paulownia. Corolla tubular with spreading limb. Sterile stamen none. Seeds winged. A Catalpa-like tree.

Page 382. - P. albidus. Reported from S. Mr, Minn. (Mc.Millan). 


\section{Add - $\quad 7^{\text {? }}$. PAULÒWNIA, sieb. \& Znce.}

Calyx deeply 5-ceft, woolly. Corrolla dectined, fumelform, with 5 rounded oblipuely spreading lobes. Sitanens 4 , inclubled. I'oul turgid, thick, loculi. cidal. Seeds small, wingerl. - A trec with large opposite cordate entire on 3-lobed pulsescent leaves, and large teminal panicles of showy violet Howers. (Named for Ima Panlowne, dang'hter of Czar l'aul I.)

P. 1mpenir.s, Sieb. \& Znee. A handsome tree resembling the Catalpa; cult. from Japan. - Growing wild in N. J. and Del.

Page 388. - B. Americana. Also found in S. E. Penn. and southwart.

Page 391. - Add $-1^{\circledR}$. C. indivisa, Engelm. Winter-annual; leaves limear-lanceolate, entire or with 2 or 3 slender lateral lobes; bracts anl calyxloles oborate, bright red. - Shannon Co., Mo. (S. M. Tracy). May-Jume. Iage 395.- U. clandestina. Reported from mountain bogs, centrai P'enn. (I'viler).

Page 397. - U. resupinata. Reported from Lake Co., Ind. (Hill), and lonia Co., Mich.

Page 401. - Add - 3. R. pedunculàta, Torr. Slightly puberulent; leares orate-oblong, short-petioler ; peluucles axillary, about as long as the leaf, 1-3-flowered, bracteate; calyx-lobes about equalling the narrow corolla-tube. - Jefferson Co., Mo. (Hasse), and south to La.

Page 405. - T. dichotomum. Western Maine (Parlin).

lage 419. - P. Virginiana. At Hanover, Maine ('arlin).

l'age 426 - P. algyrocoma. Whitecap Mt., Oxford Co, Maine (Parlin). lage 487 . - P. heterophylla. This has 3-valved capsules and large seeds, and probably dilated styles - and should therefore be placed in $\$ 2$.

Page 502. - S. Romanzoffiana. Reported from N. W. Penn. (Porter).

Page 505. - P. affinis. Also reportell from E. Penn. (Porter).

Page 525. - Under genus 13 reac - ; cells 1 - 2-seeded.

Page 529. - Under I. Canadense read - flowers 1-16, usually few.

lage 543. - J. pelocarpus, var. strutiss. Iake Ilopatcong, N. J.

l'age 544. - J. acuminatus, var. debilis. It Rumford, Maine (I'arlin).

l'age 545, - Under J. scirpoides read - Mich., Ind, Mo., and Tex.

l'age 563. - Under P. Hillii read - Mich., northern Ohio, and western

N. I. - P. obtusifolius. lieported from Tower, Minn. (I/ll).

l'age 564. - P. Tuckermani. Reported from eastem and central Penu.

(Porter). P. confervoides, Reichenh, appears to he an earlier name.P. Robbinsii. Reported from Take Co., Ind., Marquette Co, Mich., and Chesago Lake, F. Minm. (llill).

Page 574. - Under E. Engelmanni, for E. obtusa, read E. Engelmanui. Page 577. - F. spadicea. Nko in Kankakee, Ilenderson and St. Clair Cos., 111. (FFill).

Page 589. - Under + 4. Cryptocripe real - stigmas 2 or 3.

I’age 590. - Under * 7 add $-+1^{\mathrm{n}}$. Filifolice. Spike one, androgynous.

Page 599. - For C. vulgaris, Fries, read-C. rígida, Goolen., var. Goodenóvii, Bailey - and at end insert - (C. rnlgaris, Fries.). - For Var. hyperborea, Boott, real - Var. Bigelovii, Tuckerm., - and at end substitnte the synonym - iC. vulgaris, var, lyyperborea, Boott.).

I’age 601.-Add - 41"a. C. verrucosa, Mull. Glaneons, stont and stiff, $2 \sim 4^{\circ}$ high ; leares long, rongli-angled, becoming revolute; spikes $3-10$, 
stout, scattered to loosely aggregated, then erect or ascel iing, usually somewhat staminate above, variously peluncled ; scales thiu, brown, emarginate, shorter than the broadly ovate or horate strongly few-nerved glaucous perigynimm, but the hispid awn from 2-3 times longer to nearly obsolete; beak short, entire; stigmas 3. (C. glaucescens, Ell.) - Swamps and ponds; extreme southern Va., Mo., and southward.

Page 606. - C. Torreyi. Found in Henne jin Co., Minn. (Sandberg).

Page 611.- Add - * 7. - + $1^{2}$. Filifolie.

84 ${ }^{\mathrm{a}}$. C. filifòlia, Nutt. Culm slender, oltusely angled, smooth, 3-12' high; leares filifuru, rigid; perigynim lroally triangular-obovoid, thin, with a short white-hyaline entire lieak, usually about equalling the lroad lyalinemargined clasping scale. - Ft. lincoln, N. 1)ak. (Hete(t)d), and westwarl. l'age 626. - Under 69. Festuca read - tip (rarely blunt), few-ncrved.

l'age 635. - L. olyzoides. Reported as conmon in Oxford Co., Maine (Purlin). - Z. miliacea. Reported at Poconoke City, Mcl. (E. Mears). Page 646. - S. heterolepis. Reported from S. E. L'enn. (Porter). Page 650. - C. Porteri. Reporterl from Tompkins Co., N. Y. (Dudley). Page 651. - A. arundinacea. Reporterl at ()ean City, Mrl. (1/ears). Page 652. - Under genus 37 read - in a contracted or open. - A. caryophyllea. Lower fowers sometines awnless. Accomac Co., Va. (1Mears). Page 653. - A. striata. licported from N. Pem. (Porter). - T. palustre. Occurs in southern ('oum.

Page 657. - T. cuprea. Oceurs in southern Conn.

l'age 658. - D. fascicularis. In saline loc:alities in central N. Y. (Dudley).

Page 659. - E. obtusata. Real-eential N. Y. to Fla., ete.

Page 677. - E. littorale. Banks of the Susqueliann, P'enn.

Page 682. - P. gracilis. Fonnd in Lycoming and Sullivan Cos., Penu, and in Iowa.

Page 683. - W. angustifolia. Reporter from \$. Haven, Mich. (Bailey). Page 694. - B. simplex. Reported from Pocono Mt., Penn. (Porter), and Ellicott's Mills, M(l. (J. B. Egerton).

I’age 695. - L. Selago. Add - and suth in the mountains to Ga.

l'age 698. - Substitute - * * Leares in 4 ranks, tew buteral and spreading, and two above, which wre smaller and ascending.

Page 700. - Var. valida. On Salt Pond Mt., Va., in wet ground (Canlyy).

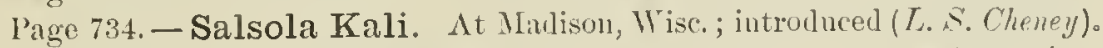
In the Index add - A quFordaCEA, $107-A$ simiua, 50 - Franseria, $735^{\mathrm{b}}-$ Pastinaea, $202-$ Paulownia, $735^{\circ}-$ Prunts, 151.

Notw. - "Western New York," as used throughnut the Manmal, is to be muderstool as including the lake-regrion of central New York.

Several additional species are reporter as rarely escaped or as growing wild in eemeteries, about old gardens or lleserted homestearls, etc., - as Lumariu biennis, Moench, Honesty or Satin-flower - Lychnis Coronaria, L., Mnllein Pink - Levisticum officinale, Koch, Lovage-Lonicera Nylosteum, I., aud L. Tatarica, L., Honeysuckles - Taleriana officinalis, I., Valeriau - 1 : temisia Abrotanum, L., Sonthernwood - Vinca minor, L., Periwinkle, etc. 


\section{LIST OF ORDERS,}

\section{WITH THE NUMBER OF GENERA AND SPECIES, NATIVE AND INTRODUCED.}

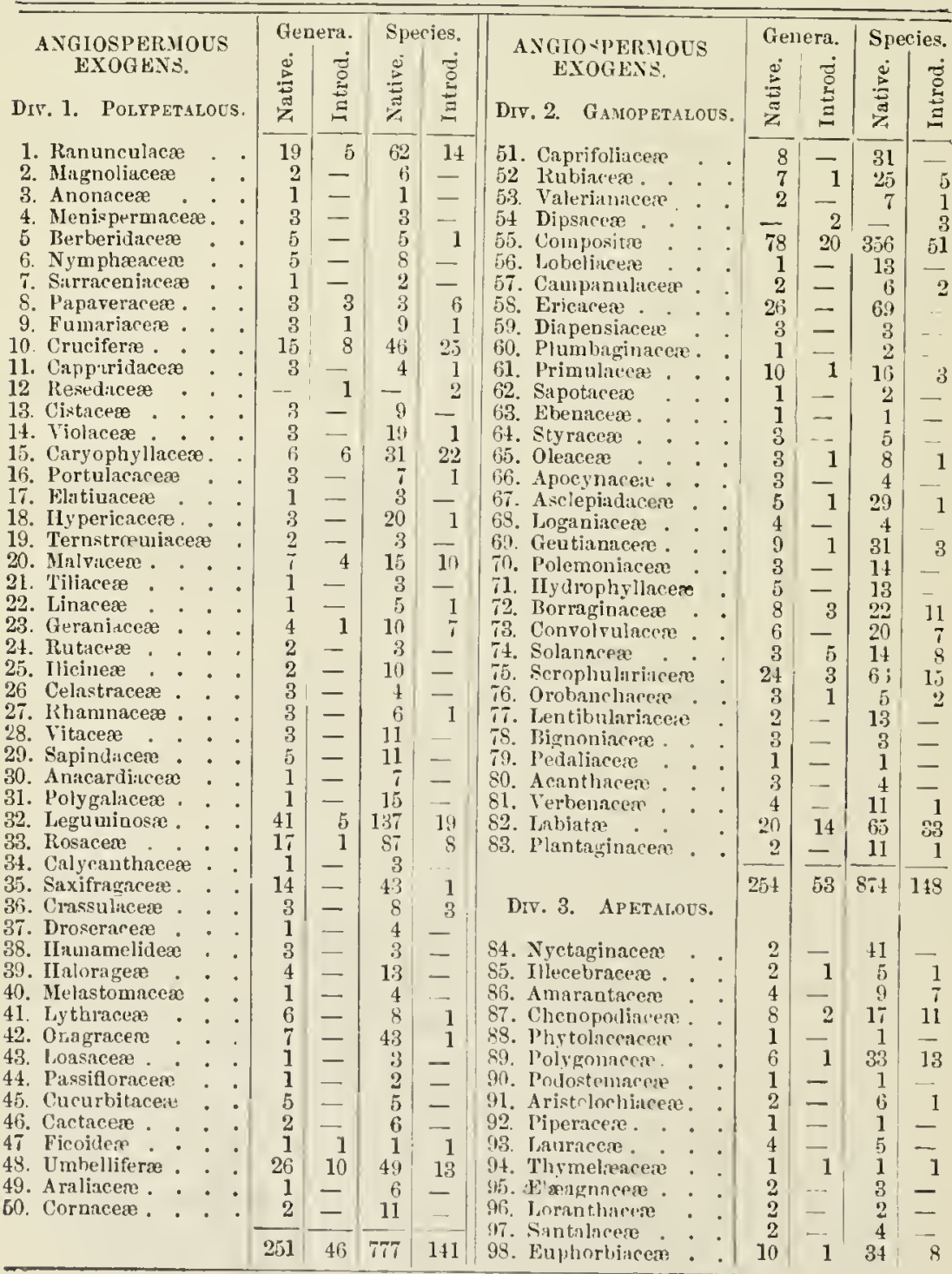




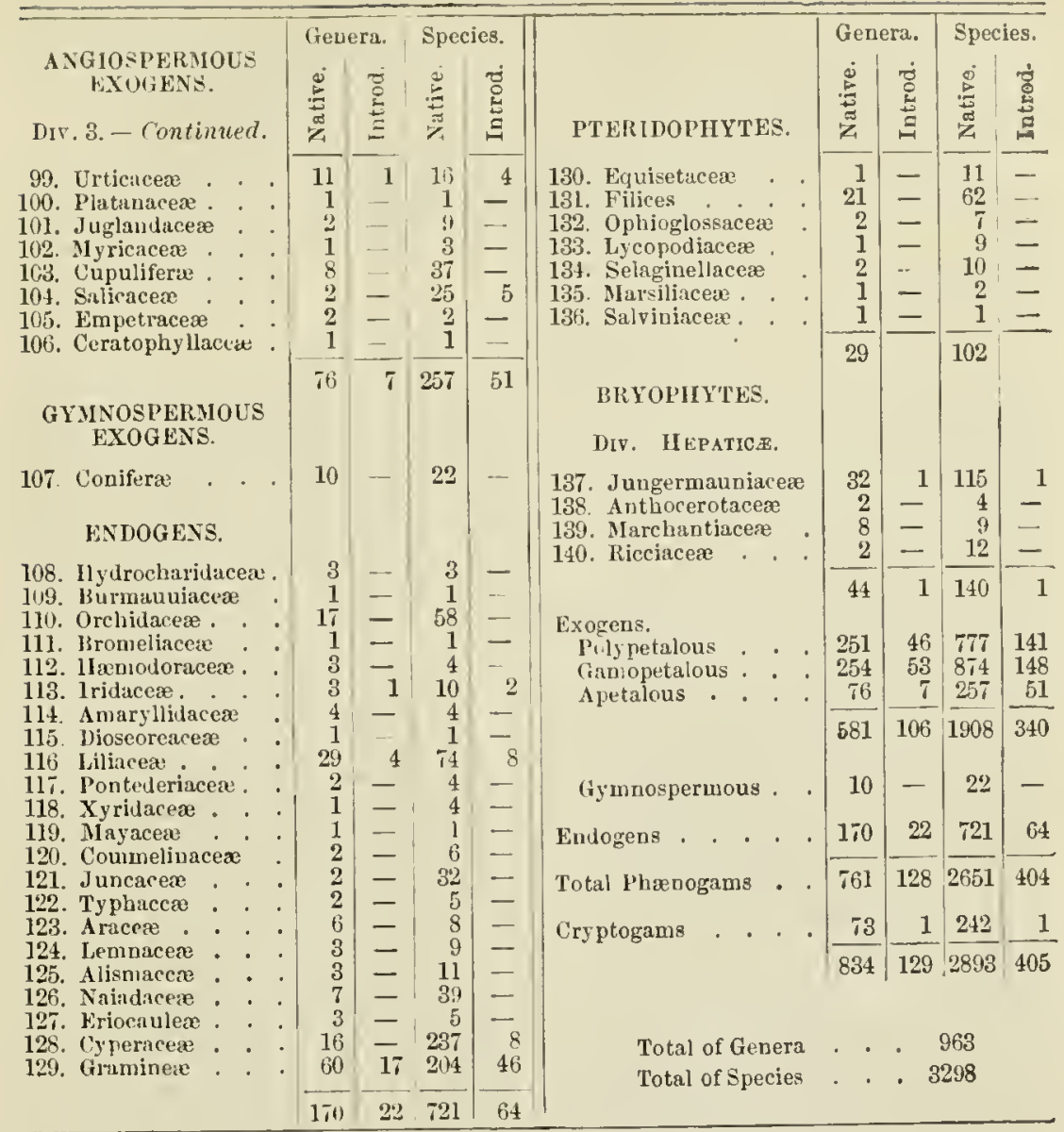




\section{GL O S A R Y.}

Abnormal, Differing from the normal or usual strneture.

Abortion. Imperfect development or nondevelopment of an organ.

Abortive. Defective or buren.

deculescent. Stemless or apparently so.

Accumbent (cotyledon). Hitring the "dges against the radicle.

Acerb. Sour and astringent.

Arhene. A smill, dry and hard, 1-eelled, 1seeded, indeliscent fruit.

Allamycleous. Withont ealyx or corolla.

fcicular. Slender needle-shaped.

fongenous. Growing from the apex by a terninal bud or by the apical cell ouly.

drulerte. Prickly; beset with priekles.

fculeolate. Beset with diminutive priekles.

scuminate. Tapering at the end.

Acute. Terminating with a sharp or welldetined angle.

Estiration. The arrangement of the parts of the perianth in the bud.

Adnate. United, as the inferior ovary with the ealyx-tube. Adnate anther, one attached for its whole length to the inner or outer face of the filament.

Allentice. liecently or imperfeetly naturulized.

Alote. Winged.

Allumin. Any deposit of nutritive material nccomplunying the embryo.

Alhumiuons. II sving albumen.

Alliacenus. Having the smell or taste of garlic.

Alternate. Not opposite to encls other, as repals and petals, or as leaves upon il stum. lleevtrete. Howeyenmbed; laving augulitr depressions separated by thin partitions.

isment. A eatkin, or peculiar scaly unisexual spike.

Amphitropmus (ovnle or seed). Inilf-inverted and straight, with the hilum lateral.

Amplexicurl. Clasping the stem.

Anustomosing. Connecting by cross-veins and forming a network.

Anatropons (ovule). Inverted and straight, with the nicropyle next the hilum and the ladicle conscrquently inforior.

Analronglnous (inflorescence), Composent uf iotle stumbate and pistillate fowers. -androus. In compositiou, having stamens. Angiospermous. Having the seeds borne within a pericarp.

Anmual. Ot only oue year's duration. Winter ammal, a plant from antumn-sow seed whieh blooms and fruits in the following spring

Anmular. In the form of in ring.

Anterior. On the tront side of a flower and next the bract, rewote trour the axis of inHorescenee; equivalent to inferior and (less properly) exterior.

Allther. 'The polliniferous part of a stamen. Sutherilium, In Cryptogrum, the organ corresponding to an anther.

Autheriferous. Antber-bearing.

Altherizoid. One of the minute organs developed in an antheridiun, corresponding to pollen-graius.

Anlhesis. 'The time of expansion of a flower. ipetalous. II Ining no petals.

Apical. Situated at the apex ol tip.

Apiculate. Linding iu a short pointed tip

Appressed. Lying close and llat against.

Aquatic. Growing in water.

Aruchnoid. C'ubwebby; of slender entuu gled lavirs.

Archegonium. The organ eorresponding to a pistil in the higher Cryptogams.

Arruale. Inderately eurved.

Arevlufer. lisuked out into suall spaces, reticulate.

A il. An anjenluge froming at or about the hilum of a secul.

Arillate. Having an aril.

Articulate. Tointed; luving a nole or joint. Aserming. Rising somewlat obliquely, or curving upward. Ascemling orule. one that is attached above the base of the orary and is direeted 11 wward.

tssurgent. Ascending

Atemunte. Slenderly tapering; beeoming Fery numrow

Auricle. An inr shaped appendage.

furiculute. Furnished witls anricles.

Alu-sheped. Narrowri upwril from the

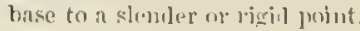

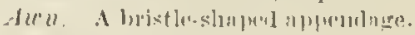

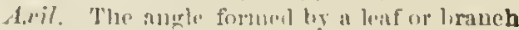
will the stıut 
Axlle. Situated iu the axis.

Axil'ary. Situated in an axil.

Lxis. Whe ceutral line of nuy organ or support of a gromp of organs; a stem, etc.

Baccate. Berry-like; pulpy throughout.

Barbed. Furnished with rigid points or short bristles, usually reflexcd like the barb of a fish-hook.

Barbellate. Finely barbed.

Burbulate. Finely bearded.

Basal, Basilar. At or pertainiug to the base.

Basificel. Attached by the base.

Bealied. Lnding in a beak or prolonged tip.

Bearled. Bearing a long a w 11 , or furuished with long or stitf luir's.

Berry. A fruit the whole pericarp of which is fleshy or pulpy.

Bi- or Bis-. A Latin prefix siguifying two, twice, or doubly.

Billentate. Having two teeth.

Biennial. Of two years' duration.

lifita. 'Two-cleft.

bilaliate. 'rwo-lipped.

Bilocellate. Haviug two secondary cells.

Bilocular. 'Two-cellut.

Biserual. Ilaring both staueus and pistils.

Bladlery. Thin and iuflated.

Blade. The limb or expanded portion of a leaf, ete.

liract. A more or less inculified leaf suliteruling a flower or belonging to au iufloreseence, or sometimes cauline.

Brectecte. Ilaving braets.

Bracteolute. Having biactlets.

lirecteose. With nunerous or couspicuous braets.

Wretlet. A secondary bract, as one upon the pedicel of a Hower.

Iristle. A stiff hair or any similar outgrow th.

lind. The rudiuneutary state of a stem or brauch; au unexpanded flower.

Bull. A subterranean leaf-bud with fieshy scales or eoats.

Rulbiferous. Bearing bulbs.

Fulblet. A small bull, especislly one borne upon the stem.

Bulbous. IIaving the elaracter of a bulb.

Crulucouts. Falling off very curly.

Calcarate. Produced into or having a spur.

Callus. A hard protuberanee or eallosity.

Crlyculate. Maring bracts around the ealy $\mathrm{x}$ imitating an outer caly $x$.

Calyptro. The menbranous hood or covering of the capsulc in Hepatice and Hosses.

Caly.r. The outer perianth of the fower.

rampromilate. Bell-shaped; eup-shaped with a broad oase.

rampylospermous. Iraving seeds with hogitudinally involute margins, as in some Uinhelliferie.

Cimpylotropous (ovule ox secd). So eurved as to bring the apex and base uearly tugether.

Canaliculate. Lougitudinally ehannelled.

Canescent. Hoary with gruy pubescence.

Capitate. Shaped like a head; collected into a Lead or dense cluster.

C'apitellate. Collected into a small head.

C'apsular. Belonging to or of the muture of a eapsule.

Capsule. A dry dehiscent fruit composed of more than one carpel; the spore-case of Ilepatice, etc.

Capsuliferous. Capsule-bearing.

farincte. Having a keel or a projeeting lon. gitudinal nedid ine ou the lower surfitet.

f'uplel. A simple pistil, or one member of a compouud pistil.

Cortilarginouss. of the texture of cartilage ; firm aud tough.

Curuncle. An excreseeuce or appendage at or about the bilum of a seed.

curunculate. Having a caruncle.

C'aryopsis. A giadn, as of grasses; a seedlike firuit with a thiu pericarp aduate to the contained seed.

Costemeous. of a chestuut eolor; browu.

catlin. An ameut.

Cruclate. Having a slender tail-like appeudage.

Cauclex. The persistent base of au otherwise annual lierbaceous steus.

c'ulescent. II uviug a manifest stem.

crucline. Belonging to the steus.

Cnemous Hollow; full of air-cavities.

(' $t$ ll. One of the uninute vesieles, of very rarious forus, of which plants are formed. Any structure eontaiuing a carity, as the cells of an auther, ovary, ete.

Cellular (tissne). Composed of short transpareut thiu-walled cells, in distinction from fibrous or vascular.

respitose. Growing in tufts; forming wats or turf.

Chrff. A small thin scale or braet, becoming dry and menbranous.

Chaffy. IIaving or resembling chaff.

Channelled. Deeply groover longitudinally, like a gutter.

Chartacenus. IIaving the texture of writing paper.

Chlornply!l. The green grains within the colls of plants.

Chlovoplyllose. Containing chlorophyll.

Cilinte. Marginally fringed with hairs.

rilinlate. Minutely rillate.

Cimerems Ash-color.

rircincte. Coiled from the top downward, as the young frond of $\mathrm{a}$ fern.

Circumscissile. Dehiscing by a regular transverse cireular lime of dirision.

Clamte. Club-shnjed; gradually thickened upward.

Cleistogrmons. Fertilized in the bud, withnut the opening of the flower. 
Cleft. Cut about to the middle.

Climbing. Ascending by laying hold of surrounding objects for support

Cluster. Any assemblage of flowers on a plant.

Clustered. Collected in a bunch of any sort.

Coalescence. The union of parts or organs of the same kiud.

Coccus (pl. Cocci), One of the parts into which a lobed fruit with 1 -seeded cells splits.

Cochleate. Spiral, like a snail-shell.

cohesion. The union of one organ with nnother.

Columella. The persistent axis of some capsules, spore-cases, etc.

Columnar, Like a colunn.

Commissure. 'The surface by which one carpel joins another, as in the Umbelliferse.

Comose. Furnished with a coma or tuft of hairs.

Complicate. Folded upon itself.

Compound. Couposed of 2 or more similar parts united into ove whole. Compound leaf, one divided into separate leaflets.

Compressed. Flattened laterally.

Conceptacle. In some Cryptogams a case or receptacle contrining the organs of fructification.

Conduplicate. Folded together lcngth wise.

confluent. Running into each other; blended into one.

Coniferous. Cone-bearing.

Connate. United congenitally.

Connective. The portion of a stamen which conneets the two cells of the anther.

connivent. Coming into contact; converging.

Conoidal. Nearly conical.

Convergent. Approaching each other.

Convolute. Rolled up longitudinally.

Cordate. Heart-shaped with the point upward.

Coriaceous. Leathery in texture.

Corm. The enlarged fleshy base of a stem, bulb-like but solid.

Corolla. The inner perianth, of distinct or connate petals.

Coroniform. Shaped like a erown.

Comegate. Wrinkled or in folds.

Corymb. A flat-topped or convex open flowercluster, in the stricter use of the word equiva lent to a contracted raceme and progressing in its flowering from the margin inward.

Corymbose. In corymbs, or corymb-like.

Cosmopolite. Found in most parts of the globe (of plants).

Costa. A rib; a midrib or mid-nerve.

Costate. Ribbed; haviug one or more lougitudinal ribs or nerves.

Cotylertons. The foliar portion or first leaves (one, two, or more) of the embryo ns found in the seed.

rrateriform. In the slape of a saucer or cup, bemlspherical or uiore shallow.
Creepiny. Running along or under the ground and rooting.

cremale. Deutate with the teeth much rounded.

Cremuate. Finely crenate.

Crested, cristate. Bearing an elevated appendage resembliug a crest.

Crown. An iutuer appendage to a petal, or to the throat of a corolla.

Cruciate. Cross-shaped.

Crustaceous. Ot hard and brittle texture.

Cucullate. Ilooded or hood-shaped; cowled.

Culm. The peculiar stem of sedges and grasses.

Cuneate. Wodge-shaped; triangular with the acute angle downward.

Cuspiclute. Tipped with a cusp, or sharp and rigid point.

Cylindraceous. Somewhat or nearly cylindrical.

Cyme. A usually broad and fattish determinate iufloresceuce, i. e. with its central or terminal flowers blooning earliest.

Cymose. Bearing cymes or cyne-like.

Deciduous. Not persistent; not evergreen.

becompound. More than once compound or diviled.

Decumbent. Reclining, but with the summit ascending.

Decurrent (leaf). Extending down the steu below the iusertion.

Decureel. Curred downward.

Decussate. Alternating in pairs at right angles, or in threes.

Definite. Of a constant number, not excecling tweuty.

Deflexed. Bent or turned abruptly downward.

Dehiscent. Opening regularly by ralves, slits, etc, as a capsule or antber.

Deltoid. Shaped like the Gireek letter $\Delta$.

Dentate. Toothed, usually with the teeth directed outward.

Denticulate. Minutely dentate.

Depressed. Sonewhat tattenel from above.

Di-, Dis-. A Greek prufix siguifying two or twice.

Diadelphous (stamens). Combined in two scts.

Jiandronts. Having two stamens.

licarpellary. Composed of two carpels.

Jichotomous. Forking regularly by pairs.

Dicotyledonous. IIaving two coty ledons.

Didymous. T'win; found in pairs.

Didynanous (stamens). In two pairs of un equal length.

Diffuse. Willely or loosely spreading.

Digitate. Compound, with the nembers borne in a whorl at the apex of the support.

Dimerous (flower). ILaviug all the parts in twos.

Dimidinte. In halves, as if oue hnlf $t+1$ wanting. 
Dimorphous. Occurring in two forms.

Diccious. Unisexual, with the two kinds of flowers on separate plants.

Jiscoid. Reseubliug a disk. Jiscoid head, in Composita, one without ray-flowers.

Disk. A developmeut of the recepticle at or around the base of the pistil. In Compositie, the tubular flowers of the head as distinct from the ray.

Dissected. Cut or divided into numerous seguents.

Dissepincnt. A partition in an ovary or fruit.

Distichous. In two vertical ranks.

Distinct. Separate; uot united; evident.

vivaricate, Widely divergent.

Jivergent. Inclioed away from each other.

Divided. Lobed to the base.

Dorsal. Upon or relatiug to the back or outer surface of an organ.

brupaceous. Reseubling or of the uature of a urupe.

Drupc. A fleshy or pulpy fruit with the inner portion of the pericarp (1-celled and 1 . seeded, or sometimes several-celled) hard or stony.

Dirupelet. A dinioutive drupe.

$E$ - or $E x-$ A Latin prefix having often a privative signification, as ebracteate, without bracts.

Echinate. Beset with prickles.

Effuse. Very loosely spreading.

Elater. A usually spirally marked threit found in the caysules of uost Hepatica.

Ellipsoidal. Nearly elliptical; of solids, elliptical in outline.

Elliptical. Iu the form of au ellipse; oval.

Emarginate. Having a shallow notch at the extremity.

Fimbryo. The rudimentary plautlet within the soed.

Endocarp. The inner layer of a yericarp.

Encloyenous. Growing throughout the substance of the stem, iustead of by superficial layers.

Entire. Without toothing or division.

Fphemeral. Isatiug only for one day.

Epidermis. The cuticle or thin nembrane covering the outer surface.

Epigynous. Growiug on the summit of the ovary, or apparently so.

lipiphyte. A plint growing attached to atnother plant, but not parasitie; an ail-plant.

Ejorose. Without pores.

Equitant. Astride, used of conluplinate leaves which enfold each other in two runks, as i:l Iris.

Erect. Vertical; upright as respects the plane of tie base.

Erose. As if gnawed.

Firculuminous. Withont albumen.

Excurent. Running out, as a nerve of a leaf projeeting beyond the margin.
Exfoliating. Cleaving off in thin layers.

Exogenones. Growiug by aunutar layers uear the surface; belonging to the Exogens.

Exserted. Plojerting beyond au envelope, as stameus from a corolla.

Extrorse. Facing outward.

Falcate. Scythe-sliaped; curved and flat, tapering gradually.

Farinaceous. Coutaining starch; starchlike.

Farinose. Covered with a meal-like powder.

Fiscicle. A close bundle or cluster.

Fnstigiate (branches). Erect and near together.

Ferruginous. Rust-color.

Fertile. Capable of producing fruit, or pro. duetive, as a flower having a pistil, or an nuther with pollen.

Fibrillose. Furnished or abounding with fine fibres.

Filnous. Composed of or resembling fibres. ribrous tissue, a tissue formed of elongated thick-walled eells.

Fibro-vascular. Composed of woody fibres and ducts.

Filctment. The part of a stamen which supports the anther; any threal-like body.

Filamentous. Composed of threads.

Filiferous. Thread-bearing.

Filiform. Threal-shaped ; long, slender, and terete.

Fimbriate. Fringed.

Fimbrillate. IIaving a ninute fringe.

Fingered. Digitate.

Fistular: IIollow and cylindrical.

filaccid. Without rigidity; lax and weak.

Fleshy. Succulent; juicy; of the consistence of flesh.

Flexuous. Zigzag; bending alternately in opposite directions.

Floccose. Clothed with locks of soft hair or wool.

Foliaccous. Leaf-hike in texture or appearance.

-folicte. Having leaves.

-foliolate. IIaving lenflets.

Follicle. A fruit consisting of a single carpel, dehiscing hy the ventral suture.

Follicular. Like a follicle.

Forkel. Dirided into uearly equal branehes

Fomicute. Arehed over, as the eorona of sone Borraginaces. elosing the throat.

l. ree. Not aduate to other organs.

Frirlble. Eisily crumbled.

Finnd. The leaf of Feris and some other C'ryptogams; also in some Phænogama, as in Lemnace, where it serves for stem as well as foliage.

Finit. The seed-liearing product of a plant, siniple, compouud, or aggregated, of whatever form.

Fugracious. Falliag or fuding very early.

Funicle. The free stalk of an ovule or seed 
Fuscous. Grayish-brown.

Fissiform. Spindle-shaped; swollen in the uiddle and narrowing toward each ond

Galea, A hooded or helmet-shaped portion of a periantl, as the upper sepal of Aconitum, and the upper lip of some bilabiate eorollas.

Galeate. Irehnet-shaped; having a galea.

Gamopelalous. Inaving the petals of the eorolla more or less united.

Gimoplyllous. Composed of coilescent leaves, sepals, or petals.

Gemma. A bud cr body analogots to a bud by which a plant propagates itself.

Gemmiparous. Produeing genme.

Geniculate. Beut abrupty, like a knee.

ribbous. Protuberant or swollen on one side.

flabrate. Somewhat glubrous, or becoming glabrous.

Vlabrous. Smootl, not rough, jubesenent, or hajry.

Gland. A secreting surfuce or strueture; any protuverance or appeudage hasing the appearanee of such an organ.

Glandular. Betring glands or of the nature of a gland.

Glaucous. Covered or whiteued with a bloom.

Glolose, Globular. Spherieal or nearly so.

Glochidiate. Barbel at the tip.

Glomerute. Compatiy clustered.

Glumaceous. Furnished with or resembling glumes.

Glume, One of the ehaffy bracts of the in. floreseence of Grasses.

Gromular, Composed of small grains.

Gregarious, (irowing in gooups or clunters.

(I) mnospermous. Bearing nakel sueds. without an ovary.

Gimanflous. IItving the stauens horno: upon the pistil, as in Orchidacere.

Gymoluese. An enlizgement or prolungention of the receptacle bearing the oviry.

Hrbit. The goneral appenance of a plitut.

Halluerd-shupext. The same as llitstatte.

IItstate. Like an surow-hend, but will tlue basal lobes pointing outward neally at right angles.

Ihecul. A dense eluster of sessile or noarly scssile tlowers on a very alort axis or ie. cepitucis.

IIecert-sherperl. Ovato with a siuns il bitse.

Ilerb. A plant with no persistent woody stem above grouud.

Irerbaceous. Having the charnotors of au lerb; leat-like in color and texture.

Hoteronarpous. Producing urore tlian one kind of fruit.

Neteragamous. bearing two kinds of flowers,
IItum. The sear or point of attarhmeut of the seed.

Ifirsute. Pubeseent with rat?us course or stiff hairs.

Hispid, Beset with rigid or brintly h.jo is with bristlus.

IIspidlulous. Minutely hispill.

IVoary. Grayisl-white with a tise $\because(1)$ pubesceuce.

Il-mogemols. Bearing lut oue kis.! w? flowers,

Hooderl. Shaped like a hool or cowl

Ilyaline. 'J'ransparent or transluevent.

IIybrit. A cross-bred of two species.

IIy) neath the oviry aud free from it and from the ealyx; haviug the petals and stamens so situnted.

Intricate. Overlapping, vither vertieally or spirully, where the lower piece covers tho base of the next ligher, or laterally, as it. the astivatiou of a calyx or corolla, where: at least one pieee must be wlolly exterinil aud one iuternal.

Immersed. Growing wholly unlel witur: wholly eovered by the involucrial leares, its sometiues the capsule in liepaticax.

Inciscel. Cut sharply and ineyulitly, mane or less decply.

Inclueded. Not at all protiuded frous thesirrounding envelope.

Incubons (leaf). Having the tip or mpur margin overlapping the how'l marail of the leaf above.

Incumbent (cotyledons). Lying with the back of one against the radiclie.

Inrlyinite (stamens). Tnenustar in number. or very momerous.

Indelissent. Not opening by valves, ete, ; reusuining porsistently ilosel.

Indignenous. Nitive and ariginal to the country.

Indurated. llardened.

Indusium. 'The proper often shichl-shapel covering of the sorus or finit-slut in kerms.

Inreguilateral. Uuequal-cillewl.

figrivion. Loweror below; outer or auterior. Inferion or ory, one that is alriate to the ealyx.

Intluted. Bladdery.

Inforescence. The flowering part of a plans, aud espocially the mote of its armugenent.

fufire. In composition. helow; us intw. axillary, helow tlue ixil.

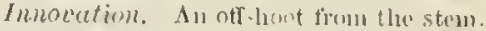

Inserted. Attachel to ur growing out of.

Inter- or intrar. In composition, lutwern.

Interfoliaceous, Butwen the leaves of a pair, th the stipules of mum liulineses.

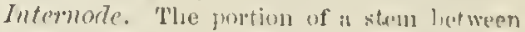
two nodos,

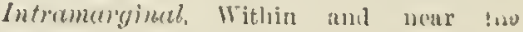
walgh. 
Introrse. Turned inward or toward the axis.

Involucel. A sicondary involucre, as that of an umbellet in Unbelliferw.

lnvolucellate. Laving au involucel.

Ineolucral. Belonging to an involuere.

Involucrate. Haviug an involucre.

[nvolucre. A circle or collection of bracts surrounding a flower cluster or head, or a siugle tlower.

Involute, Rolled inward.

Irregular (Hower). Showing inequality in the size, form, or uvion of its similar parts.

Julaceous, Resembling a catkin iu appearance.

Keel. A central dorsal ridge, like the keel of a boat; the two anterior united petals of a papilionaceous flower.

Kidney-shaped. Crescentic with the ends broad and rounded; reniform.

Labiate. Lipped; belongiug to the Labiata.

Lacerate. Irrcgularly eleft as if torn.

Laciniate. Slashed; cut into narrow pointed lobes.

Lamella. A thin flat plate or laterally flattened riage.

Lanccolate. Shaped like a lance-head, broadest above the base and narrowed to the apex.

Lateral. Belonging to or borve on the side.

Lax. Loose and slender.

Leaflet. A single division of a compound leaf.

Legume. The fruit of the Leguminosx, formed of a simple pistil and usually dehiscent by both sutures.

Leguminous. Pertaining to a legume or to the Jeguminose.

Lenticular. Ientil-shaped; of the shape of a doublc-convex lens.

Lepiclote. Beset with small scurfy scales.

Ligulate. Furnished with a ligulc.

Ligule. A strap-shaped corolla, as in the ray-flowers of Coupositx; a tbin scarious projection from the summit of the slieath in Grasses.

Liliaceous. Lily-like; belonging to the Liliacer.

Limb. The expanded portion of a gamopetalous corolla, above the throat; the expanded portion of any petal, or of a leaf.

Linear. Long and uarrow, with parallel margius.

Lip. Finch of the upper and lower divisions of a bilabiate corolla or calyx; the peculiar upper petal in Orchicls.

zobe. Any segment of an organ, especially if rounded.

Lobed. Divided into or bearing lobes.

- levelar. In composition, having cells.

Lmulicidal. Dehiscent into the eavity of a celt through the dorsal suture
Lunate. Of the shape of a half-moon or crescent.

Lunulate. Diminutive of Lunate.

Lyrate. linnatifid with a large and rounded terninal lobe, and the lower lobes small.

Macrospore. The larger kind of spore in Selagiuellacea, ete.

Marcescent. Withering but persistent.

Marginal. Along or near the edge.

Marginate. Furnished witb a border peculiar in texture or appearance.

Mealy. Fininaceous.

Membranaceous, Membranous. Thin and rather soft and more or less translucent.

Meniscoill. Concavo-convex.

Mericarp. One of the achene-like carpels of Umbelliferæ.

-merous. In composition, having parts, as 2. merous, having two parts of each kind.

Micropyle. The point upon the seed at which was the orifice of the ovule.

Microspore. The smaller kind of spore in Selaginellacer, etc.

Milril. The central or main rib of a leaf.

Mitriform. Shaped like a mitre or cap.

Monadelphons (stamens). United by their filaments into a tube or column.

Noniliform. Rescmbling a string of beads; cyliuds ieal with contractions at intervals.

Monocotyledonous. IIaving but one cotyledon.

Monacious. Witl stamens and pistils in separate flowers on the sane plant.

Mucilaginous. Slimy; containing mucilage. Iucro. A short and small abrupt tip.

Mucronate. Tipped with a mucro,

Multifid. Cleft into many lobes or segments. Muricate. Rough with short hard points.

Muriculate. Very finely muricate.

Naked. Bare; without the usual covering or appendages.

Nectary. Any place or organ where nectar is secreted.

Nectariferous. Producing nectar.

Nerve. A simple or unbranched vein or slender rib.

Noile. The place upon is stem which normally bears a lcuf or whorl of leaves.

Nodose. Finotty or knobby.

Nucleus. The germ-cell of the ovule, which by fertilization becomes the sced; tbe ker. nel of a seed.

Numerous. Indefinite in number.

Nut, A hard indehiscent 1.celled and 1sceded fruit, though usually resulting from a compound ovary.

Nutlet. A diminutive nut.

$O b$-. A Latin prefix, usually carrying the ilea of inversion.

Oheompressed. Compressed dorso rentrally instead of laterally. 
Obconically. Inversely conical, having the attachment at the apex.

Obcorlate. Iuverted heart-shaped.

oblanceolate. Lanceolate with the hroadest part toward the apex

Oblique. Unequal-sided or slanting.

oblong. Considerahly longer than hroad and with nearly paralle; sides.

obovate. Inverted urate.

Obovoid. Having the form of an inverted egg.

Ubsolete. Not evident; rudimentary.

Obtuse. Blunt or rounded at the end.

Ocrea. A leggin-shaped or tubular stipule.

Ocreate. Having sheathing stipules.

Ochroleucous. Yellowish-white.

Officinal. Of the shops; used in medicine or the arts.

Oospore. The fertilized nucleus or germ-rell of the arehegonium in Cryptogams, fron which the new plant is direetly developed.

Opaque. Dull; not smooth and shining.

Operculate. Furuished with a lid.

Operculum. A lid; the upper portion of a circumscissile capsule.

Orbicular. Circular.

Orthotropous (ovule or seed). Erect, with the orifice or micropyle at the apex.

Oval. Broadly elliptical.

Ovary. The part of the pistil that contains the ovules.

Ovate. Egg-shaped; having an outline like that of an egg, with the hroader end downward.

Ovoid. A solid with an oval outline.

Ovule. The holy which after fertilization becomes the seed.

Ovuliferous. Bearing orules.

Palate. A rounded projection of the lower lip of a personate corolla, closing the throat.

Paleaceous. Chaffy.

Palet. The upper thin chaffy or hyaline bract which with the glume encloses the flower in Grasses.

Palmate (leaf). Radiately lohed or divided.

Palmately. In a paimate manner.

Panicle. A loose irreguiarly conpound in. florescence wlth pedicellate flowers.

Panicled, Paniculate. Borne in a panicle; resembling a panicle.

Papilionaceons (corolia). Kaving a standard, wings, and keel, as in the peculiar corolla of many Leguninosre.

Papillose. Bearing minute nipple-shaped projections.

Pappus. The modificd calyx-limh in Compositæ, forming a crown of very various character at the summit of the achene.

Parasitic. Growing on and deriving nourishment from another plant.

Parictal. Borne on or pertaining to the wall or inner surface of a capsule

Parted. Cleft nearly hut not quite to the hase.
Partial. of secondary rank.

Pectinate. Pinnatifid with narrow closely set segments ; consh-like.

Pedate. Palmately divided or parted, with the latcral segments 2-cleft.

Pedicel. The support of a single flowcr.

Pedicellute. Borne on a pedicel.

Perluncle. A primary flower-stalk, supporting either a cluster or a solitary flower.

Pedunculate. Borne upon a peduncie.

Peltate. Shield-formed and atrached to the support by the lower surface.

Penclulous. More or less hanging or declined. Purlulous ovule, one that hangs from the side of the cell.

Perennial. Lasting year after year.

Perfect (flower). Having hoth pistil and stamens.

Perfoliate (leaf). Having the stem apparently passing through it.

l'erianth. The floral envelope, consisting of the calyx and corolla (when present), whatever their foru ; in Hepatica, the inner usually sac-like involucre of the archegonium.

Pericarp. The matured ovary.

Perigynium. The iuflated sac which encloses the ovary in Carex.

Perigynous. Adnate to the periunth, and therefore around the ovary and not at its hase.

Persistent. Long-continuous, as a calyx upon the fruit, leaves through winter, etc.

Personate (corolla). Bilahiate, and the throat closed hy a prominent palate.

Petal. A division of the corolla.

Petaloirl. Colored and resemhling a petal.

Petiolate. IIaving a petiole.

Petiole. The footstalk of a leaf.

Phrenogamons. Having flowers with stamens and pistils and producing sceds.

Phyllolium. A somewhat dilated petiole having the form of and serving as a leafblade.

Pilose: Hairy, especially.with soft hairs.

Pinna (pl. Pinna). One of the primary divisions of a pinnate or compoundly pinnate frond or leaf.

Pinnate (leaf). Compound, with the leaflets arranged on each side of a common petiole

Pinnatifid. Pinnately cleft.

Pinmule. A secondary pinna; one of the pin nately disposed divisions of a pinna.

Pistil. The seed-hearing organ of the flower, consisting of the ovary, stigma, and style when present.

Pistillate. Provided with p̣istils, and, in lts more proper sense, without stamens.

Pitted. Marked with small depressions or pits.

Placenta. Any part of the interior of the ovary which bears ovules.

Plane. Flat; with a flat aurface or surfaces.

Plicate. Folded into plaits, usually lengthwise. 
Plumose. Having fine hairs on each side, like the plume of a feather, as the pappus. bristles of Thistles.

Plumule. The bud or growing point of the embryo.

Pod. Any dry and dehiscent truit

Pointed. Acuminute.

Pollen. The fecundating grains contained in the anther.

Polliniferous. Bearing pollen.

Pollinium (pl. Pollinia). A mass of waxy pollen or of coherent pollen-grains, as in Asclepias and Orchids.

Polypetalous. Having separatc petals.

Pome. A kind of fleshy fruit of which the apple is the type.

Porose. Pierced with small holes or pores.

Posterior In an axillary flower, on the side ncarcst to the axis of inflorescence.

Posticous. On the posterior side; extrorse.

Prcemorse. Appearing as if bitten off.

Prickle. A small spine or more or less slender sharp outgrowth from the bark or rind.

Prismatic. Of the shape of a prisn, angular, with flat sides, and of nearly uniform size throughout.

Procumbent. Lying on the ground.

Proliferous. Producing offshnots.

Prostrate. Lying flat upon the ground.

Proterogynous. Having the stigma ripe for the pollen before the maturity of the anthers of the same tower.

Prothallus. A cellular usually flat and thallus like growth, resulting from the germination of a spore, upon which are developed sexual organs or new plants.

Pseudixillary. Terminal but becoming appirently axillary by the growth of a latexai branch.

Pseudo-costate. Falso-ribbed, as where a marginal vein or rib is formed by the confluence of the true veins.

Pteridophytes. Fern-plants; Ferns and their allies.

Puberulent. Minutely pubescent.

Pubescent. Covered with hairs, especially if short, soft and downy.

Punctate. Dotted with depressions or with translucent internal glands or colored dots.

Puncticulate. Minutely punctate.

Pungent. Terminating in a rigid sharp point; acrid.

Putamen. The shell of a nut; the bony part of a stone-fruit.

Quadrate. Nearly equare in form.

Raceme. A simple inflorescence of pedlcelled flowers upon a common more or iess elongated axis.

Racemose. In racemes; or resembling a raceme.
Radiate. Spreading from or arranged around a common centre; bearing ray-flowers.

Radical. Belonging to or proceeding from the root or base of the stem ncar the ground.

Radicle. The portion of the embryo below the cotyledons, more properly called th: caudicle.

Radiculose. Bearing rootlets.

Rameal. Belonging to a branch.

Ramification. Branching.

Ray. The branch of an untel ; the margin: flowers of an inflorescence when distinct from the disk

Receptacle. The more or less expanded or produced portion of an axis which vears the organs of a flower (the torus) or the collected flowers of a head ; any similar struc. ture in Cryptogarns.

Recurved. Curved downward or backward.

Reflexed. Abruptly bent or turned downward.

Regular. Uniform in shape or structure.

Reniform. Kidney-shaped.

Repand. With a slightly uneven and somewhat sinuate margin.

Resiniferous. Producing resin.

Reticulate. In the form of network; netveined.

Fetrorse. Directed back or downward.

Retuse. With a shallow notch at a rounded apex.

Revolute. Rolled backward from the mal gins or apex.

Rhachis. The axis of a spike or of a com. pound leaf.

Rhaphe. The ridge or adnate funicle which in an anatropous ovule connects the two ends.

Rhizome. Any prostrate or subterranean stem, usually ronting at the nodes and becoming erect at the apex. Very variable in character, and including morphologically the tuber, corm, bulb, etc.

Rhombic, Rhomboidal. Somewhat lozengeshaped; obliquely four-sided.

Rib. A primary or prominent vein of a leaf. Ringent. Gaplng, as the mouth of an open bilabiate corolla.

Root. The underground part of a plant which supplies it with nourishment.

Rootstock. Same as Rhizome.

Rostrate. Having a beak or spnr.

Rosulate. In the form of a rosette.

Rotate (corolla). Wheel-shaped; flat and circular in outline.

Rotund. Rounded in outline.

Rudiment. A very partially developed or gan; a vestige.

Rudimentary. But slightly developed.

Rufous. Reddish brown.

Iragose. Wrinkled.

Runcinate. Sharply incised, with the seg ments directed back ward.

Runner A tiform or very slender stolon 
Saccate. Sac-shaped.

Sagittate. Shaped like an arrow-head, the basal lobes directed downward.

Salver-shaped (corolla). Ilaving a slender tube abruptly expanded into a flat linb.

Samara. An indehiscent winged fruit.

Scabrous. Rough to the touch.

Scalariform (vessels). Having transverse markings like the rounds of 8 ladder.

Scape. A peduncle rising from the ground, naked or without proper foliage.

Scapose. Bearing or resembling a scape.

Scarious. Thin, dry, and membranaceous, not green.

Scorpioid (inflorescence). Circinately coiled while in bud.

Scurf. Small bran-like scales on the epidermis.

Scymitar-shaped (leaf). Curved with a Hattriangular section, the straighter edgc the thickest.

Seed. The ripened ovule, consisting of the embryo and its proper coats.

Segment. One of the parts of a leaf or other like organ that is cleft or divided.

Sepat. A division of a caly $\mathbf{x}$.

Septicidal (capsule). Dehiscing through the partitions and between the cells.

Septum. Any kind of partition.

Serrate. Having teeth pointing forward.

Serrulate. Finely serrate.

Sessile. Without footstalk of any kind.

Setaceous. Bristle-like.

Setose. Beset with bristles.

Setulose. Having minute bristles.

Sheath. A tubular envelope, as the lower part of the leaf in Grasses.

Sheathing. Enclosing as by a sheath.

Shrub. A woody perennial, smaller than a tree.

Silicle. A short silique.

Silique. The pcculiar pod of Cruciferæ.

Silky. Covered with cloke-pressed soft and straight pubescence.

Simple. Of one piece; not compound.

Sinuate. With the outline of the margin strongly wavy.

Sinus. The cleft or recess between two lobes.

Smooth. Without roughness or pubescence.

Somus (pl. Sori). A heap or cluster, applicd to the fruit-dots of Ferns.

Spadix. A spike with a fleshy axis.

Spathe. A large bract or pair of bracts enclosing an inflorescence.

Spatulate. Gradually uarrowed downward from a rounded summit.

Spicate. Arranged in or resembling a spike Spiciform. Spike-like.

Spike. A form of simple infloresccuce with the flowers sessile or nearly so upon a more or less elongated common axis.

Spikelet. A small or secondary spike.

spindle-shaped. Sanie as Fusiform.
Spine. A sharp woody or rigid outgrowth from the stem.

Spinose. Spine-like, or haring spines.

Sporangium. $\Lambda$ spore-case.

Spore. The reproductive organ in Cryptogams which corresponds to a sced.

Sporocarp. The fruit-cases of certain Cryptogams containing sporangia or spores.

Spur. A hollow sac-like or tubular extension of some part of a blossom, usually nectariferous.

Squamula. A reduced scale, as the bypogynous scales in Grasses.

Squarrose. IIaving fpreading and projecting processes, such as the tips of involucral scales.

Squarmulose. Diminutirely squarrose.

Stamen. Oue of the pollen-bearing or fertilizing organs of the flcwer.

Staminodium. A sterile stamen, or any structure without anther corresponding to a stamen.

Standard. The upper dilated petal of $\mathbf{a}$ papilionaceous corolla.

Stellate, Stelliform. Star-shaped.

Stem. The main asceuding axis of a plant.

Sterile. Unproductive, as a flower without pistil, or stanen without an anther.

Stigme. That part of a pistil through which fertilization by the pollen is of fected.

Stigmatic. Belonging to or characteristic of the stigma.

Stipe. The stalk-like support of a pistil: the leaf-stalk of a Fern.

Stipitate. Ilaving a stipe.

Stipular. Belonging to stipules.

Stipulate. Ilaring stipules.

Stipule. An appendage at the base of a pet1oie or on each side of its insertion.

Stolon. A runner, or any basal branch that is disposed to root.

Stoloniferous. Producing stolons.

Stoma (pl. Stomata). Au orifice in the epidermis of a leaf communicating with internal air-cavities.

S/riate. Marked with fine longitudinal llnes or ridges.

Strict. Very straight and upright.

Strignse. Beset with appressed sharp straight and stiff hairs.

Strobile. $\Lambda \mathrm{n}$ inflorescence marked by imbricated bracts or scales, as in the Hop and Pinte-cone.

Strophiole. An appendage at the hilum of certain seeds.

Style. The usually attenuated portion of the pistil connecting the stigma and ovary.

Stylopodium. $\Lambda$ disk-like expansion at the base of a style, as in Umbelliferæ.

Sub-. A Latin prefix, usuaily signifying somewhat or slightly.

Subulate. Awl-shaped.

Succubous (lenves). Haring the upper mur 
gIn of a leaf covered by the base of the one above.

Succulent. Juicy ; fleshy.

Suffrutescent. Slightly or obscurely shrubby.

Suffruticose. Very low and woody; dimiuutively shrubby.

Sulcate. Grooved or furrowed.

Superior (ovary). Free from the eaiyx.

Susperuled (ovule). Hanging from the apex of the cell.

Suture. A line of dehiscence.

Symmetrical (flowcr). Regular as to the number of its parts ; having tbe same number of parts in each circle.

Synonym. A superseded or unused name.

Tail. Any slender terminal prolongation.

Terete. Having a circular transversc section.

Terminal. At or bclonging to the apex.

Temary. Consisting of three.

Temate. In thrces.

Tetradynamous. IIaving four long and two shorter stanicns.

Tetragona'. Four-angled.

Thalamiflorous. Having the parts of the flower hypogynous.

Thalloid, Thallose. Resembling a tballus.

Thallus. In Cryptogans. A cellular expansion taking the place of stem aud folinge.

Throat. Tbe orifice of a gamopetalous corolla or calyx; tbe part betwcen the proper tube and the linb.

Thyrse. A contracted or ovate and usually compact panicle.

Thyrsoid. Resembling a thyrse.

Tomentose. Densely pubescent with matted wool.

Tooth. Any smali marginal lobe.

Torose. Cylindrical with contractions at in. tervals.

Torulose. Dininutive of Torose.

Torus. The receptacle of a flower.

Transverse. Across; in a right and left direction.

Tri-. In composition, three or tbrice.

Triandrous. Having tbree stamens.

Trifoliolate. Having three leatlets.

Trigonous. Threc-angled.

Trimorphons. Occurring under three forms.

Triquetrous. IIaving three salient angles, tbe sides concave or channelled.

Truncate. Ending abruptly, as if cut off transrersely .

Tuber. A thickened and short subterranean branch having numerons buds or eyes.

Tubercle. A small tuber or tuber-like body.

Tuberiferous. Bcaring tubers.

Tuberous. IInving the cbaracter of a tuber ; tuber-like in appearance.

T'umid. Swollen

l'unicated. Having concentric coats, as an onion
Turbinate. Top-shaped; Inversely conicul. Twining. Winding spirally about a support.

Umbel. An inflorescence in which a cluster of peduncles or pedicels spring from the same point.

Umbellate. In or like an umbel.

Tmbellet. A secondary nubel.

Umbonate. Bearing a stout projection in the centre; boseed.

Underleaves. Tbe small accessory leaves or stipules on the under side of the stem iu Hepaticæ.

Uululate. With a wavy surface; repaud.

Unguiculate. Contracted at base into \& claw.

Uni-. In composition, one.

Unisexual. Of one sex, either staminate or pistillate only.

Urceolate. Jlollow and cylindrical or ovoid, and contracted at or below the moutb, like an urn.

Utricle. A small bladdery 1-seeded fruit; any small bladder-like body.

Talvate. Opening by valves, as a capsule; in astivation, meeting by the edges without overlapping

Valve. Oue of the pieces into which a capsule splits.

Vascular. Furnished with vessels or ducts.

Veins. Tbreads of fibro-vascular tissue in a leaf or other organ, especially those which branch (as distinguished from nerves).

Irentral. Belonging to the anterior or inner face of an organ; tbe opposite of dorsal.

Ventricose. Swelling unequally, or inflated on one side.

Vernation. The arrangement of leaves in the bud.

Verricose. Covered with wart-like elevations.

Versatile (anther). Attached near the mid dle and turning freely on its support.

Vertical. Perpendicular to the horizon; longitudinal.

Verticillate. Disposed in a whorl.

Vesicle. A small bladder or air-cavity

Vesicular, Vesiculose. Composed of or covcred with vesicles.

Tillous. Bearing long and soft hairs.

Virgate. Wand-shaped; slender, straight and erect.

I'iscid. Glutinous; sticky.

Whorl. An arrangement of leaves, etc., in a circle round the $\mathrm{stem}$.

Wing. Any membranous or thin expansion bordering or surrounding an organ; the lateral petal of a papilionaceous corolla.

IFoolly. Clothed witb long and tortuous or matted hairs. 



\section{N D EX.}

\section{[SYNoNyMS IN ITALICs.]}

Abele
Ables
Abronia
Abutilon
Acacia, Rose
Acalypha
Acarraders
Accr
Aceratcs
Achillea
Acnida
Aconitum (Aconite)
Winter
Acorus
Actiea
Actinella
Actinoneris
Adam-and-Eve
Adan's Necdlc
Adder's-mouth
Adder's-tongue
Yellow

Adeucaulon

Adiantum

Adlumia

Adonis

Aloxa

Agnpodium

玉anynomene

Esculus

Ethusa

Agave

Agrimonia (Agrimony)

Agropy ruin

Ayrostemna

Agrostis

Ailanthus

Aira

Ajuga

Alchemilla

Alder

Black

Aletris

Alfalfa

Alisma

Alishacese

Alligator Pear

Allium

Allosorus

Allspice, Carolins Wild

Alnus

Aloe, Amcrican

$$
\text { False }
$$

$181,185,185$
651,651

60 Andropogon

40 Androsice

216 Androstephium

208 Anemone

137 Rue

115 Anemonella

205 A neura

516 Angelica

161 Augelica-tree

671 A.rosics.s

85 Antennaria

647 Anthemis

${ }_{107}$ Anthoceros

652, 652 A.TTHOCERot.ce

406 Anthoxanthum

161 Anthriscus

472 Antirrbinum

109 . Inychia

322 A per:

512 A phanostephus

139 Aphyllon

554 Apiastrum

553 A pios

446 Apium

521, 522 Aplectrum

683 Aplopappus

167 APOCYNACEx

447. A pocynum

472 Apple

516. Bnlsam

616. Crab
645

17

$\begin{array}{r}171 \\ 68 \\ +27 \\ \hline\end{array}$

427

527

735

273

166

535

131

115

243

146

63

337

118

496

331

316

637,63

$\begin{array}{r}539 \\ \hline\end{array}$

Apple, May
Thorn
57

Apple-of-Peru $\quad 376$

Aquileria $\quad 65,71,72$

A E.ACE E $\quad 65,71,748$

Aralia $\quad 212$

Ar.hliace

Arhor-vitie 493

Arbutus, Trailing 315

Arceuthohium $\quad 450$

Archangelica 201, 202, 205

Archemora 202

Arctiunl
Arctostaphylos

Arenaria $\quad 85,733$

Arethusa 504

Argemone 59,733

Argythamnia $\quad 459$

Arisama $\quad 649$

Aristida 639

Aristolochia 445

ARISTOLOCHIACEA

A rnic: $\quad 292$

Arrhenatherum 651

522 Arrow-griss

36 Arrow-wood 217

39 Artemisia 290

38 Artichoke, Jerusalem 277

725 Arum 550

201 A rrow 549

210 Jragon 549

50 Water 550

26., 268 Arundinaria 674

288 Aruado 658

726 A carabacea 444

726 Asarum 414, 734

639 A SCLEPLADACER 338

206 Asclepias 339

390 Asclepiodora 339

426 Ascyrum 92

335

253 Mountain 164

391 Prickly 106

209 Asimina 50

114 Asparagus 525

$20 y$ Aspen 486

493 Asperugo 361

245 Asphodel, Bog 632

337 False 532

338 Aspidium 686

164 Aaplenium 683

195 Asprella 674

164 A sicer 255

acuminatus 264 


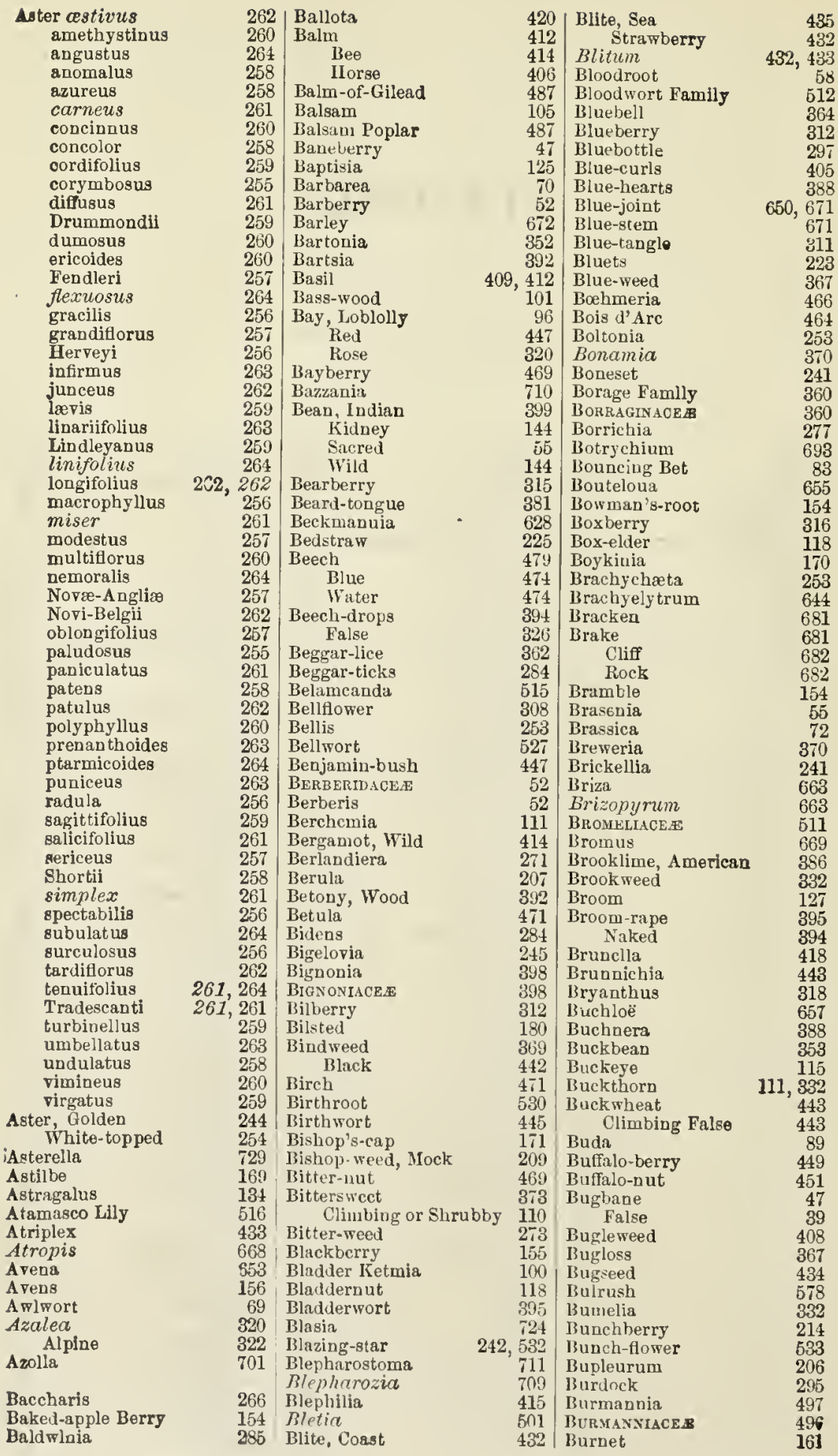




Burning-bush
Bur-reed
Butter-and-eggs
Buttercup
Butterfy-wced
Butternut
Butterweed
Butterwort
Button-bush
Buttonweed
Buttonwood

Cabbage, Skunk

Caboniba

Cacalia

Cactacex

Cactus Family

Cakile

Caladium

Calamagrostis

Calamint

Calamintha

Calamus

Calico-bush

Calla

Callicarpa

Callirrhoë

Callitriche

Calluna

Calophanes

Calopogon

Caltha

Calycanthaceas

Calycanthus

Calycocarpum

Calypogeia

Calypso

Calystegia

Camassia

Camelina

Camellia Family

Campanula

Cakpanulacese

Campion

Camptosorus

Cancer-root

Cane

Cannabis

Caper Family

Capparidace

Caprifoliaces

Capsella

Caraway

Cardamine

Cardinal-flower

Carduus

Carex

acutiformis

adusta

astivalis

alata

slopecoidea

alpina

angustata

aperia

aquatilis

arcta

arctata

arenaria

arida

aristata

atrata

surea

Backil

Barratti

Bebbii

Boottiana
110

Cares bromoides

547 bullata

379 Buxbrumic

40 canescens

340 capillaris.

467 capitata

265,293

$39 \pi$

224

Caresaua

castanea

cephaloidea

cephalophora

chordorhiza

collnumus

comosre

conjuncta

conoidea

Crawei

crinita

cristate

Crus-corvi

Davisii

debilis

decomposita

deflexa

Deweyana

dicritalis

disticha

ehurnca

echinata

Emmonsii

exilis

extensa

filiformis

thaccosperma

flin it

Hexilis

foenea

folliculata

369,370

formosa

Fraseri

fusca

gigautca

glabra

glaucodea

gracillima

grandis

granularis

gravidia

Grayii

grisea

gynandra

gynocrutes

hirta

Hitchcockiana

Hough tonii

hystricina

intumescens

irrigica

Jamesii

Knieskernii

lagopodioides

lanuginosa

laxiculmis

laxiflora

lenticularis

leporina

limosa

limula

littoralis

livida

longirostris

lupuliformis

lupulina

lurida

610

613

Mngellanica

maritima

620

Mearlii

Michauxiana
619 Carex miliacea 601

594 miliaris 593

599 mimbilis $62^{\prime 2}$

618 monile 59

603 Muhlenbergii 617

617 muricata 616

608 Muskingumensis 62

603 nigro-narginata 613

617 Norvegica 619

617 Nova-Anglia 611,612

614 (Ederi 606

612 oligocarpa 607

596 oligosperma 593

614 Oineyi 595

607 pallesccus $600^{\circ}$

606 paludosa 598

601 panicea 609

620 pancitlora 592

61t pelunculata 610

$605 \quad$ Pennsylvanica 612

604, 607 picta 610

614 jinguis 621

611 plantaginea 609

619 platyphylla 608

608 polymorpha 609

615 polytrichoides 613

610 pracox 612

618 prasina 601

611 Pseudo-Cyperus 596

617 ptychocarpa 608

606 pubescens 613

$597 \quad$ pulla 594

605 rariflora 602

606 retrocurva 608

603 retroflexa 616

$621,622 \quad$ retrorsa 598

Richardsoni $\quad 610$

rigida 599

riparia $\quad 598$

rosea 616

rostrata 592

rotundata 598

saling 601

Siltuensis 609

Surtwellii 615

scabrata $\quad 597$

Schweinitzii $\quad 595$

scilpoidea $\quad 611$

scirpoides $\quad 618$

scoparia 620

shortiana $\quad 596$

siccata 619

silicea 621

sparganioides $\quad 616$

squirrosa $\quad 596$

stellulata $\quad 618$

stenolepis $\quad 596$

stenophylla $\quad 614$

Steudelii 613

stipata 614

straminea $\quad 621$

striata $\quad 597$

stricta

subulata

Sullivantii 605

sychnocephala $\quad 622$

tersella. $\quad 616$

tentaculata

tenuiflora 619

tcretiuscula

tetanica $\quad 6(19$

Torreyi 606

torta 600

tribuloides $\quad 620$

tricels $\quad 6(12)$

triclioarpa $\quad 598$

trisperma 619 


\begin{tabular}{|c|c|c|c|c|c|c|}
\hline Carex Tuckermani & 594 & Cherry, Ground & 875 & Compass-plant & & \\
\hline $\begin{array}{l}\text { umbellata } \\
\text { utrienlata }\end{array}$ & $\begin{array}{l}612 \\
594\end{array}$ & $\begin{array}{l}\text { Sand } \\
\text { Chervil }\end{array}$ & 152 & Composite & & \\
\hline vaginata & 609 & Chess & $\begin{array}{l}206 \\
670\end{array}$ & $\begin{array}{l}\text { Comptona } \\
\text { Cone-flower }\end{array}$ & & O \\
\hline varia & 611,612 & Chestnut & 479 & Purple & & \\
\hline Vaseyi & 594 & Horse & 115 & CONIFER & & \\
\hline venusta & 604 & Chiek weed & 86 & Conioselinum & & \\
\hline vestita & 597 & Forked & 426 & Conium & & \\
\hline virescens & 602 & Indian & 198 & Conobea & & \\
\hline vitilis. & 618 & Jagged & 87 & Conoeephalus & & \\
\hline vulgaris & 599 & Mouse-ear & 88 & Conopholis & & \\
\hline vulpinoidea & 615 & Chieory & 298 & Convallaria & & \\
\hline Willdeuovii & 613 & Chiloseyphus & 716 & CONVOLVULACES & & \\
\hline Woodii & 639 & Chimaphila & 322 & Convolvulus & & \\
\hline Carnation & 83 & Chinquapin & 479 & Coptis & & \\
\hline Carpetweed & 198 & Water & 55 & Coral-berry & & \\
\hline Carpinus & $47 t$ & Chiogenes & 314 & Coral-root & & \\
\hline Carrion-flower & 520 & Chionanthus & 337 & Corallorhiza & & \\
\hline Carrot & 201 & Chives & 522 & Corema & & \\
\hline Carum & 208 & Chokeberry & 164 & Coreopsis & & \\
\hline Carya & 468 & Chondrilla & 303 & Corispermum & & \\
\hline CARYOPHYLLACEE & 82 & Chrysanthemum & 289 & CORNACEF & & \\
\hline Casbew Fimily & 118 & Chrysogonum & 271 & Cornel & & \\
\hline Cassandru & 317 & Chrysopogon & 638 & Corn-salad & & \\
\hline Cassena & 108 & Chrysopsis & 244 & Cornus & & \\
\hline Cassia & 147 & Chrysosplenium & 172 & Coronilla & & \\
\hline Cassiope & 318 & Cichorium & 298 & Corpse-plant & & \\
\hline Castanea & 479 & Cicuta & 208 & Corydalis & & \\
\hline Castilleia & 390 & Cimicifuga & 47 & Corylus & & \\
\hline Castor-oil Plant & 460 & Cinna & 649 & Cottonwood & & \\
\hline Catalpa & 399 & Cinquefoil & 158 & Cowberry & & \\
\hline Cat-brier & 519 & Cirerea & 193 & Cowslip & & \\
\hline Catehfy & 83 & Cirsintm & 295,296 & Ameriean & & \\
\hline Catgut & 133 & Cissus & 114 & Virginian & & \\
\hline Catmint & 416 & CIST ICE & 76 & Cow-wheat & & \\
\hline Catnip & 416 & Cladium & 586 & Crab-apple & & \\
\hline Cat-tail Flag & 547 & Cladothrix & 734 & Cranberry & & 12,3 \\
\hline Cauealis & 201 & Cladrastis & 126 & Cranberry-tree & & \\
\hline Caulophyllum & 52 & Clary & 413 & Cranesbill & & \\
\hline Ceanothus & 112 & Claytonia & 91,733 & Crantzis & & \\
\hline Cedar, Red & 494 & Clear-weed & 465 & CrassulaCEE & & \\
\hline White & 493,494 & Cleavers & 225 & Crateg & & \\
\hline Cedronella & 416 & Clematis & 35 & Cress, Bitter & & \\
\hline Celaudine & & Cleome & 75,733 & Mouse-ear & & \\
\hline Cetastrace. & 109 & Cleomella & 75 & Penny & & \\
\hline Celastrus & 110 & Clethra & 322 & Rock & & \\
\hline Celtis & 463,734 & Clintonia & 527 & Spring & & \\
\hline Cenehrus & 634 & Clitoria & 145 & Swine & & \\
\hline Centaurea & 297 & Clotbur & 274 & Water & & \\
\hline Centaury & 347 & Cloudberry & 154 & Finter & & \\
\hline Centr & 14 & Clover & 128 & Crepis & & \\
\hline Cent & & Bush & 141 & Cross-vine & & \\
\hline Cephalan & 22 & Prairie & 132 & laria & & \\
\hline Cephalozia & 711 & Sweet & 129 & Croton & & \\
\hline Cerastiuin & 88 & Club-moss & 695,697 & Crotonopsis & & \\
\hline Ceratopayllace. & 488 & Cnieus & 295,297 & Crowberry & & \\
\hline Ceratophyllum & & Coeeulus & 51 & Broom & & \\
\hline Cercis & 147 & Cochlearia & 70 & Crowfoot & & \\
\hline Cesia & & & 85 & Crown-beard & & \\
\hline Chærophyllum & 206,209 & Coeklebur & 274 & CRUCIFERE & & \\
\hline Chretopappa & 253 & Coclopleurum & 205 & ('rypsis & & \\
\hline Chat & 39 & Coffe & 219 & Cryptogramm & & \\
\hline Chaffweed & & Coffee-tree, Kentucky & 148 & Cryptotænia & & \\
\hline Chamæey paris & 49 & Cohosh & 47,52 & Ctenium & & \\
\hline Cham & 531 & Colie-root & 512 & Cuekoo-flower & & \\
\hline Clam & 374 & & 380 & Cueumber & & \\
\hline Chame & 288 & & 406 & Bur & & \\
\hline & 289 & Collomia & 356 & Cueumber-root & Indian & \\
\hline Charlock & 72,74 & Coltsfoot & 291 & Cucumber-tree & & \\
\hline & & & 292 & Cueurbita & & \\
\hline erberry & 81 & Colum & 45 & CUCURBITACKA & & \\
\hline Cheilanthes & 681 & Columbo, American & 852 & Cudweed & & \\
\hline Chelidonium & 58 & Comandra & 450 & Culver's-physic & & \\
\hline Chelone & 381 & Comfrey & $86 \pi$ & Culver's-root & & \\
\hline Cas: & 430 & Wild & $36 i 2$ & Cunila & & \\
\hline Cheruopodium & 431 & Commelina & 538 & Cuphea & & \\
\hline Cherry & 151 & COMMELINACEM & 628 & Cup-plant & & \\
\hline
\end{tabular}


INDEX.

\begin{tabular}{|c|c|c|c|c|c|c|}
\hline Cupressus & 493 & Disporum & 526 & ERIOCAULEB & & 566 \\
\hline Cupseed & 51 & Distichlis & 3,735 & Eriocaulon & & 566 \\
\hline CUPUllfere & 470 & Dittany & 409 & Eriochloa & & $62 y$ \\
\hline Currant & 174 & Dock & 437 & Eriogonum & 436 &, 734 \\
\hline Iudian & 220 & Prairie & 270 & Eriophorum & & 582 \\
\hline Cuscuta & 369 & Spatter & 56 & Erodium & & 104 \\
\hline Custard-apple Eamily & 50 & Dockmackie & 218 & Eryngium & & 211 \\
\hline Cyclanthera & 196 & Doduer & 370 & Eryngo & & 211 \\
\hline Cycloloma & 431 & Dodecatheou & 328 & Erysimum & & 71 \\
\hline Cymopterus & 203 & Dogbanc & 338 & Erythrae & & 347 \\
\hline Cynodon & 654 & Dogirood & 214 & Erythrouium & & 523 \\
\hline Cynoglossum & 362,363 & Draba & 67 & Eulophus & & 206 \\
\hline Cynthia & 298 & Dracocephalum & 416 & Euonymus & & 110 \\
\hline CXPERACEA & 567 & Dragon-head & 416 & Eupatorium & & 239 \\
\hline Cyperus & 569 & False & 419 & Euphorbia & & 452 \\
\hline Cypress & 493 & Dragon-root & 543 & EUPHORBIACEA & & 451 \\
\hline Cyprcss-vine & 368 & Drosera & 178 & Euphrasia & & 391 \\
\hline Cypripedium & 510 & Droseracea & 178 & Eustoma & & 349 \\
\hline Cystopteris & 689 & Dryas & 157 & Evax & & 267 \\
\hline \multirow[t]{2}{*}{ Cytisus } & 127 & Duck's-meat & 552 & Evening Primrose & Family & 186 \\
\hline & & Duckwced & 552 & Everlasting & $26^{\circ}$ & 268 \\
\hline Dactylis & 663 & Dulichium & 573 & Evolvulus & & 370 \\
\hline Dactyloctenium & 656 & Dumortiera & 729 & Ey ebright & & 391 \\
\hline Dehoon Holly & 108 & Dutchman's-breeches & 60 & & & \\
\hline Daisy & 253 & Dutchman's-pipe & 445 & Fagopyrum & & 443 \\
\hline Ox-eye & 289 & Duvalia & 729 & Fagus & & 79 \\
\hline White & 289 & Dyer's-weed & 75 & Falsc-mermaid & & 104 \\
\hline Dalea & 132 & Dysodia & 285 & Farlileberry & & 312 \\
\hline Dalibarda & 156 & & & Featherfoil & & 328 \\
\hline Dame's-violet & 71 & Eatonia & 659 & Fedia & & 229 \\
\hline Dandeliou & 303 & EBENACE. & 323 & Fegatella & & 29 \\
\hline Dwarf & 297 & Ebony Family & 333 & Fennel & & 205 \\
\hline Fall & 299 & Echinacea & $2 \overline{75}$ & Dog & & 239 \\
\hline False & 303 & Echinocystis & 195 & Fennel-Hower & & 48 \\
\hline Dangleberry & 311 & Echinodorus & 556 & Fern, Beecli & & 686 \\
\hline Danthonia & 654 & Echinospermum & 362 & Bladuer & & 689 \\
\hline Daphne & 448 & Echium & 367 & Chain & & 683 \\
\hline Darnel & 671 & Eclipta & 274 & Christmas & & 689 \\
\hline Datura & $37 \pi$ & Eel-grass & 6,565 & Cinnamon & & 93 \\
\hline Daucus & 201 & Eglantine & 164 & Climbing & & 92 \\
\hline Day-flower & 538 & ELAAGNaCEA & 448 & Cloak & & 680 \\
\hline Dead-nettle & 420 & Elaggu us & 448 & Filmy & & 692 \\
\hline Decodon & 186 & ELATIXACEA & 91 & Flowering & & 693 \\
\hline Decumaria & 173 & Elatine & 91 & Lip & & 681 \\
\hline Deerberry & 312 & Eluer & 217 & Sensitive & & 690 \\
\hline Delphinium & 46 & Box & 118 & Shield & & 686 \\
\hline Dentaria & 64 & Marsh & 272 & Wood & & 686 \\
\hline Deschampsia & 652 & Wild & 213 & Ferns & & 678 \\
\hline Dcsmanthus & 149 & Elecanpane & 269 & Fescue & & 668 \\
\hline Desmodium & 138 & Eleocharis & 3,735 & Sheep's & & 669 \\
\hline Devil's-bit & 531 & Elcphantopus & 237 & Festuca & 666 , & 668 \\
\hline Dewberry & 155 & Elephant's-foot & 237 & Fever-bush & & 447 \\
\hline Deyeuxia & 650 & Eleusine & 656 & Feverfew & & 289 \\
\hline Dianthera & 401 & Ellisia & 358 & Feverwort & & 219 \\
\hline Dianthus & 83 & Elm & 462 & FrCOIDE.E & & 198 \\
\hline Diapensia & 326 & Elodea & 495 & Fig, Indian & & 197 \\
\hline DIAPENBIACEB & 326 & Elodes & 95 & Figwort & & 380 \\
\hline Diarrhena & 662 & Elymus & 673 & Filago & & 267 \\
\hline Dicentra & 60 & EMPETRACEAS & 487 & Filbert & & 473 \\
\hline Dichondra & 368 & Empetrum & 487 & Fillices & & 678 \\
\hline Dichromens & 577 & Enchanter's Nightshade & 193 & Fimbriaria & & 728 \\
\hline Dicksonia & 691 & Engelmannia & 272 & Fimbristylis & & 577 \\
\hline Didiplis & 184 & Enslenia & 343 & Fiorin & & $64 i$ \\
\hline Diervilla & 222 & Epigaa & 315 & Fir & & 492 \\
\hline Diodia & 225 & Epilobium & 188 & Fire-weed & 188, & 294 \\
\hline Dionaea & 179 & Epipactis & 504 & Five-finger & & 158 \\
\hline Dioscorea & 517 & Fpiphegus & 394 & Flag & & 513 \\
\hline Droscoreaces & 517 & EQUTSETAOzB & 675 & Cat-tail & & 547 \\
\hline Diospy ros & 333 & Equisctum & 676 & Sweet & & 551 \\
\hline Diphylleia & 53 & Eragrostis & 660 & Flax & & 101 \\
\hline Diplachne & 658 & Eranthis & 45 & Fleabane & & 264 \\
\hline Miplopappus & 263 & Erechtites & 294 & Marsh & & 266 \\
\hline Diplophyllum & 715 & Erianthus & 636 & Floating-heart & & 353 \\
\hline DIPSAGE $A B$ & 229 & Erica & 318 & Floerkea & & 104 \\
\hline Dipsacus & 229 & ERICACEs & 309 & Elower-de-luce & & 513 \\
\hline Dircs & 448 & Erigenis & 210 & Fly-poison & & 35 \\
\hline Disoopleurs & 209 & Erigeron & 264 & Foniculum & & \\
\hline
\end{tabular}




\begin{tabular}{|c|c|c|c|c|c|c|}
\hline $\begin{array}{l}\text { Fog-fruit } \\
\text { Forestiera }\end{array}$ & 402 & Goodyera & & 503 & Grass, Ripple & \\
\hline $\begin{array}{l}\text { Forestiera } \\
\text { Forget-me-not }\end{array}$ & 836 & Gooseberry & & 174 & Rush & \\
\hline Forsteronia & $\begin{array}{l}364 \\
338\end{array}$ & $\begin{array}{l}\text { Goosefoot } \\
\text { Gordouia }\end{array}$ & & 431 & Rye & 671,6 \\
\hline Fossombronia & 723 & Gourd Family & & $\begin{array}{r}96 \\
194\end{array}$ & $\begin{array}{l}\text { Salt } \\
\text { Sand }\end{array}$ & \\
\hline Fothergilla & 179 & Gout-weed & & 208 & $\begin{array}{l}\text { Sand } \\
\text { Scorpion }\end{array}$ & \\
\hline Four-o'clock & 425 & GRAMINEA & & 623 & Scurvy & \\
\hline Foxberry & 314 & Grape & & 113 & Scutch & \\
\hline Foxglove, False & $3 \$ 9$ & Grape Hyacinth & & 523 & Seneca & \\
\hline Inullein & 358 & Graphephorum & & 666 & Sesame & \\
\hline $\begin{array}{l}\text { Foxtail } \\
\text { Fragaria }\end{array}$ & 634 & Grass Family & & 623 & Shave & \\
\hline $\begin{array}{l}\text { Fragaria } \\
\text { Frangula }\end{array}$ & 158 & Grass, Barnyard & & 683 & Soft & \\
\hline $\begin{array}{l}\text { Frangula } \\
\text { Frasera }\end{array}$ & 112 & Beak & & 584 & & 63,665 , \\
\hline Eraxinus & $\begin{array}{l}352 \\
335\end{array}$ & Bear & & 524 & Spike & 662 \\
\hline Fringe-tree & $\begin{array}{l}335 \\
337\end{array}$ & Beard & 636,687, & 648 & Squirrel-tail & \\
\hline Froelichia & 430 & $\begin{array}{l}\text { Bengal } \\
\text { Bent }\end{array}$ & $647,648,6$ & $\begin{array}{l}634 \\
649\end{array}$ & $\begin{array}{l}\text { Star } \\
\text { Sweet Vernal }\end{array}$ & \\
\hline Frog's-bit, American & 496 & Bermuda & & 654 & Tape & \\
\hline Frost-weed & 76 & Biue, Englis & $\operatorname{sh}$ & 664 & Thin & \\
\hline Frullania & 704,706 & Blue, Kentu & acky & 665 & othy & \\
\hline Fuircua & 583 & Blue-eyed & & 515 & Toothache & \\
\hline Fumaria & 61 & Blue-joint & 650,6 & 671 & e-awned & \\
\hline TUMARLACEE & 59 & Blue-stem & & 671 & Umbre & \\
\hline Fumitory & 61 & Bottie & & 634 & Vanil & \\
\hline Climbing & 66 & Bottle-brush & & 674 & Velvet & \\
\hline Gaillardia & 288 & $\begin{array}{l}\text { Brome } \\
\text { Buffalo }\end{array}$ & & 669 & Wheat, A wned & $33+2$ \\
\hline tia & 146 & Bur & & $63 \pm$ & & 67,6 \\
\hline lax = & 327 & Canary & & 638 & $W_{i}$ & 656,66 \\
\hline ale, Sweet & 469 & Catch fly & & 636 & Wo & \\
\hline is & 421 & Cat's-tail & & 644 & Wo & \\
\hline & 569 & Cord & & 627 & $\mathrm{Yal}$ & \\
\hline oga & 234,286 & Cotton & & 582 & Yellow-eyed & 53 \\
\hline Galium & 225 & Couch & & 671 & Grass-of-Parne & 17 \\
\hline Gall-of-the-earth & 301 & Crab & 630,6 & & Grass-wrack & \\
\hline$t$ & & Cut, lice & & 636 & Gratio & \\
\hline & 5 & Deer & & 183 & Greenl & \\
\hline heria & 315 & Ditch & & 564 & Gre & \\
\hline sacia & 192 & Dog's-tail & & 656 & yer's & \\
\hline sacia & & Drop-seed & 643,6 & & Gri & \\
\hline ium & 34 & Eel & 496,5 & & Gri & \\
\hline enis & 127 & Feather & & 641 & Gromwe & 36 \\
\hline hentia & & & & & & \\
\hline & & & & 330 & Grour & 144,21 \\
\hline Spurred & 35 & Foxtail & 634,6 & & & \\
\hline entiana & 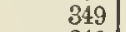 & Gan & & 635 & -tree & \\
\hline NTIANACEE & 346 & & 226,6 & & Guela & \\
\hline oe: & & $\mathrm{Ha}$ & $644,648,6$ & 562 & Gum-t & \\
\hline$E \mathbb{E}$ & ic & gehog & & 634 & & \\
\hline eran & 10 & IIerds & 645,6 & & Guti & \\
\hline & & Holy & & 339 & & \\
\hline rardia & & garian & & & Gyn & 721,72 \\
\hline & & Ind & & & & \\
\hline $\operatorname{um}$ & & Joil & & & Gymnostichum & 67 \\
\hline in & & Jun & & & Gy'psophila & \\
\hline $\begin{array}{l}\text { Sille- } \\
\text { Sill-o }\end{array}$ & & & & & & \\
\hline ding & & 18 & & & $\begin{array}{l}\text { Ilabe } \\
\text { Hack }\end{array}$ & 506,50 \\
\hline & & Meadow & $663,665,6$ & & $\begin{array}{l}\text { Hac } \\
\text { Hac }\end{array}$ & \\
\hline & & & & 662 & $\mathrm{CB}$ & \\
\hline acium & & & & & & 85 \\
\hline & & & & & & \\
\hline & & Oat & $641,651,6$ & 654 & $\mathrm{II}_{\mathrm{A}}$ & \\
\hline or & & Old-witch & & 630 & $\mathrm{II}_{\mathrm{A}}$ & \\
\hline & 666,668 & & & & & \\
\hline & & & & & Har & \\
\hline & & Pani & & & & \\
\hline at's- & 163,2 & Pige & & & & \\
\hline & & & & & IIar & \\
\hline at's-1 & & & & & Hart's & 68 \\
\hline & & Qulck, or Qu & aitch & 671 & Haw & \\
\hline Idet & & Rattlesnake & & & $\mathrm{Bl}$ & \\
\hline & & & & & Haw & \\
\hline less & & & $647,657,6$ & & $119 w$ & 2 \\
\hline ld $t$ & & & 627,6 & 349 & Hawt & \\
\hline . & & & & & Hazel, witch & \\
\hline & & Ribbon & & 33 & Inzelnut & \\
\hline
\end{tabular}


INDEX.

Heul-all

Heart's-eas*

Hcather

Heath Family

Hedeoma

IIedysarum

IIelenium

IIeleochloa

II elianthemum

II elianthus

Heliophytum

II eliopsis

II eliotropium (Heliotrope)

Hellebore False

IIelleborus

IIelonias

IIemerocallis

¿Iemicarpha

IIemlock

Ground

Water

IIEMODORACES

Ifemp

Indian

Water

Ilenbane

IIepatica

HEPATIC R

ITeracleum

Herb-Robert

Herba-impia

Herberta

IIereules' Clu.

Herpestis

II esperis

IIeterantliera

Heterotheea

IIeuehera

II exalectris

IIibiseus

IH ickory

IJ ieraeium

II ieroehloë

High-water Shrub

IIippuris

Hobble-bush

I Ioffmansergia

Hogweed

Holeus

IIolly

Dahoon

Mountain

IIolosteum

Honew ort

Honeysuekle Bush

Honkenya

Hop

II op-tree

IIordeum

Horehonnd

Black

Fetid

Water

Hornbeam IIop

Hornwort

Horse-brier

Jorse-chestnut

IIorseradish

Horse-sugar

IIorsetai]

Uorse-wecd

Hosaekia

Hottonia

Hound's-tongue
419 Houstonla

78,81 Huckleberry

818

309

412

133

287

644

$2 \frac{76}{7}$

362

275

45

533

45

531

523

683

209,492

494

208

512

463
463

338

429

37

34,38

702

202

103

267
709

709
213

383

71
536

244

171

501

468

299

639

182

182
148

273

652

108

108

87

207

220

86

464 Jaeob's-ladder

107 Jamestown-weed

672

419

420

420

408

474

474

488

520

115

70

335
676

676

130
328

328 Juniperus (Juniper)

362 JussiaA

Hudsonia

Humulns

uutsman's-eup wild

Iydrangea

ydrastis

Hydrolen

IIYDROPHYLLACEA

ydrophyllum

Hymenopappus

Hyoseyamns

ERTCACEA

1 Iy poxis

Hyssopus (Hyssop)

Ilex

ILLECEBRAOEA

ysanthes

Indiau-physie

ndian-pipe

Indian-poke

Indigo

Ealse

Wild

Indigofera

Inkberry

Inula

onidium

IRIDACE $A$

ron-wood

Isanthus

soetes

Isopyrum

Iva

$v y$, American

Ground

Poison

atropha

Jessaminc, Yeilow

Jewel-weed

Joe-Pye Weed

Jubula

Judas-tree

JUGLANDACERE

Juglans

JUNCACE $P$

uneus

uneberry

222 Kalmfa

311 Kantia

312 Ketmia, Bladuer

ermannia 710-712, 714 $715,717,718,718,722$

66 King-nut

464 Kriunikinnik

57 Knapwecd

523 Kuawel

523 Kuotwecd

173 Knotwort Family

48 Kochia

495 Koelcria

210, 733 Kosteletzkya

360 Krigia

$3 \tilde{j}$ Krynitzkia

357 Kuhnia

516 Kyllinga

286

376

92 LaBiate

92 Lachnanthes

516 Laehnoeaulon

409 Lactuea

415 Lady's-mantle

$38 \pm$ Lally's-slipper

Lady's-thuub

Lady's-tresses

107

107

426
385

385

105
154

534

133

125,13

Lamib's-quarters

Lamium

Lampsana

Laportea

Larch

Larix

Larkspur

Lathyrus

195 LAURACEA

133 Laurel

109

2.23

223
269

81

154

368

429
513

513, ชือ̄

238
474

406

698

44
174

174

115

416

416
119

119

357

377

45

53

345
105

105
239

239

706
147
467

467
467

467
539

539

166

urel

Ameriean

Ground

Laurestinns

Lavender, Sea

Lead-plant

Leadwort Eamily

Leaf-eup

Lenther-flower

Leather-leaf

Lentherwood

Leavenworthia

Leeliea 
Liatris

Ligusticum

Ligustrum

LILIACEAS

Lilium

Lily

Atamasce

Blackberry

Day

Pond

Water

Lily -of-the-valley

Limnanthemum

Limnobium

Limosella

LINACEA

Linaria

Linden

Lindera

ling

Linnæea

Linum

Liochlæna

Lion's-foot

Liparis

Lipocarpha

Lippia

Liquidambar

Liquorice wild

Liriodendron

Listera.

Lithospermum

Litsea

Littorella

Live-forever

Liver-leaf

hiverworts

Lizard's-tail

LOASACEA

Lobelia

LOBELIACEA

Loblolly-bay

Locust

Iloney

Water

Loganiacea

Loiseleuria

Lolium

Lonicera

Loosestrife

False

Swamp

Lophanthus

Lophiola

Lophocolea

Lopseed

LORANTHACE, $B$

Lousewort

Lovage

Lucerne

Ludwigia

Lungwort

Lunularia

Lupinus (Lupine)

Luzula

Lychnis

Lycium

Lycopsis

LYOOPODIAOEE

Lycopodium

Lycopus

Lygodesmis

Ly godium

Lysimachis

LYTHRAOEA

Iothrum

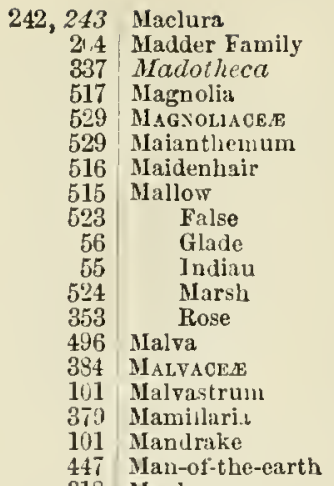

318 Maple

219 Ash-leaved

101 Marchantix

718 MARCHANTIACEA

301 Mire's-tail

499 Marigold, Bur

584 Fetid

402 Marsh

179, 180 Water 137 Marjorum, Wild

226 Marrubium

50 Marshallia

501 Marsilia

365 Marsiliacese

447 Marsupella

424 Jartynia

178 Marvel-of-Poru

33 Mastigobryum

702 Matricaria

446 Matrimuny-vine

193 Mayaca

305 MAYACE

305 May -apple

96 Mayflower

134 May-weed

148 Meadow-bcauty

149 Meadow-sweet

345 Medeola

32 Medicino

671 Medick

220 Melampyrum

185, 330 Melanthium

187 Melastomace

186 Melica

415 Melilotus (Melilot)

512 Melissa

715 Melothria

403 Mexisperma eex

449 Menispermum

39' Ientha

205 Mentzelia

129 Menyauthes

187 Menziesia

363 Mercury, Three-seeded

730 Mernaid-weed

128 Mertensin

546 Metzoria

85 Mezereum

376 Micranthemum

367 Microstylis

695 Mignonette

695 Mikania

408 Milfoil

302

692

Wilfoil

Milium

330, 330 Milkweed

Green

185 Milkwort

\begin{tabular}{|c|c|c|}
\hline 464 & Milkwort, Sea & 331 \\
\hline 222 & Millet & 642 \\
\hline 708,709 & Mimulus & 382 \\
\hline 49 & Mint & 407 \\
\hline 49 & Cat & 416 \\
\hline 526 & Horse & 413 \\
\hline 680 & Mountain & 409 \\
\hline 97 & Pepper & 407 \\
\hline 98 & Spear & 407 \\
\hline 98 & Mirabilis & 425 \\
\hline 99 & Mist-flower & 241 \\
\hline 97 & Mistletoe & 450 \\
\hline 100 & False & 449 \\
\hline 97 & Mitehella & 224 \\
\hline 96 & Mitella & 171 \\
\hline 98 & Mitreola & 346 \\
\hline $19 \pi$ & Nitrewort & 171,346 \\
\hline 53 & False & 171 \\
\hline 369 & Moccasor-flower & 510 \\
\hline 117 & Mocker-1.ut & 468 \\
\hline 118 & Modiola & 100 \\
\hline 727 & Mollugo & 198 \\
\hline 727 & Monarda & 413 \\
\hline 182 & Moneses & 323 \\
\hline 284 & Moneywort & 831 \\
\hline 288 & Monkey-fiower & 382 \\
\hline 44 & Monkshood & \\
\hline 285 & Monotropa & 325 \\
\hline 411 & Montelia & 429 \\
\hline 419 & Moonseed & \\
\hline 286 & Moonwort & \\
\hline 700 & Mooserood & 44 \\
\hline 700 & Moruing-glory & \\
\hline 721 & Morus & \\
\hline 399 & Moschatel & \\
\hline & & \\
\hline
\end{tabular}

171

510

100

198

413

331

382

325

429

61

443

464

511 , Black, or Long Flowering

Hotherwort

Mouse-tail

Mudwort

Mugwort

Mublenbergia

Mulberry

$$
\text { French }
$$

Iulgedium

Mullein

Munroa

Muscari

Mustard

$$
\begin{aligned}
& \text { Hedge } \\
& \text { Tansy }
\end{aligned}
$$

Tower

Treacle

Wormseed

695,697

420

40

384

291

643

464

403

304, 305

379

659
623

72

71, 72

66

71

Mylia

Myosotis

Myosurus

IIy rica

MYrICACEA

Myriophyllum

Myrtle, Saud

$$
\text { Wax }
$$

Nabalus

Naind

NAIADACEE

385 Naias

498 Napea

75 Nardia

239 Nariosmia

289 Narthecium

181 Nesturtium

642 Neckweed

339 Negundo

843 Nelumbium

120 Nelumbo 
Nemastylis

Neuropanthes

Nemophila

Nepeta

Nescar

Nettle

Dead

False

IIedge

11 c1i, p

IIorse

Spu:-pe

Wood

lettl:-1. e.

Nicundra

Nicotiana

Nigella

Nightshade Enchauter's

Ninble-Will

Ninebark

Nipplewort

Nonesuch

Nutholæus

Notboscordum

Notothylas

Nuphar

NrCtaginace, R

Nymphaea

NYMPHËACE,E

Ny8sa

Oak

Jerusalem

Poison

Oakesia

Oat

Sea

Wuter

wild.

Obolaria

Odontoschisma

Euothera

Oil-nut

Oldeulandia

Oleace e

Oleaster Family

Olive Family

ONAGRACEÁ

Onion

Onoelea

Onopordon

Onosmodium

OpiIIoglossaCEA

Ophioglossum

Opuntia

Orache

Orange, Mock Osage

Orangc-root

ORCamaCeE

Orchis

Crane fly

Rein

Showy

Origanum

Ornithogalum

OROBANCHACEA

Orobanche

Orontium

Orpine

Orthocarpus

Oryzopsis

Osier

Osmorrhiza

Osmunda
$514 \mid$ Ostrys

109 Oxalis

358 Ox-eye

416 Sea

186 Oxybaphus

464 Oxydendrum

420 Oxyria

466 Oxytropis

421 Oyster-plant

421

374 Pachysaudra

457 Pachystims

465 Prpalanthus

463 Painted-cup

376 Pallavicinia

37̄ Pencratilum

48 Panicum

373 Pansy

193 Papaver

644 Papitericea

153 Papaw

$29 \bar{i}$ Pappoose-root

130 Parlanthus

680 Parietaria

522 Parnassia

727 Paronychia

56 Parsley Fanily

425 Parsley, Fool's

55 Hemlock

54 Parsley-piert

215 Parsnip Cow

475 Weadow

433 Parthenium

119 Partriclyc berry

528 Paspalum

653 Pasque-flower

$66^{\circ}$ Passiflora

$636^{\circ}$ Passifloraces

654 Passion-flower

353 Pastinaca

713 Pea, Besch

190 Butterfy

451 Everlasting

221 IIoary

335 Milk

448 Partridge

335 Peinut, Hog

186 Pear

521 Alligator

690 Prickly

297 Pearlwort

166 Vecan-nut

693 Pedaliace

695 P'edicularis

197 Pellita

433 Pellia

174 Pellitory

464 Peltandra

48 Pennycress

497 Pennyroyal, American

498,50

506 False

506 Pennywort, Water

411 Penthorum

523 Pentstemon

393 Pepper Famlly

895, 734 Pepper, Water

551 Pepper-bush

177 Peppergrass

391 Pepperidge

642 Peppermint

480 Pepper-root

210 Pepperwort

692 Perilla

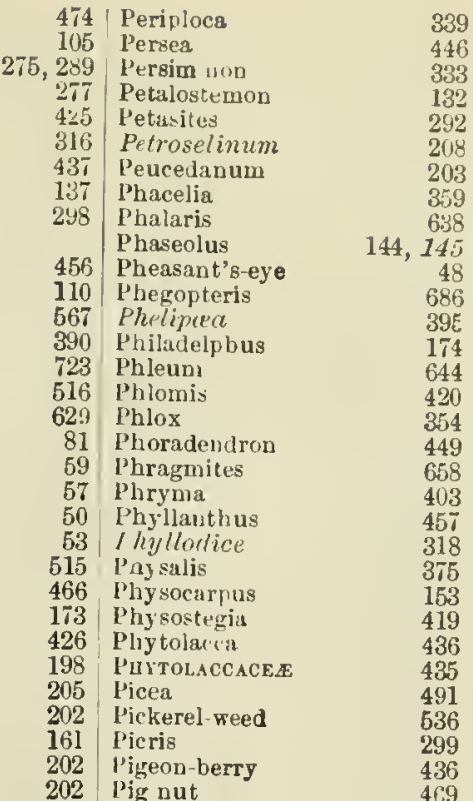

428,431

431

465

331

385

332

206

490

697

511

325

325

83,84

84

346

490,734

77
320

446

445

566

567

322

57

466

463

422

422

422

204

536

503

266

554

466

466

718

340

352

266

151
833 
Plum, Ground Red

P'LUMBAGINACEAE

Poa

Podophyllum

Podostemaced

Pollostemon

Pogouia

Pokeweed

Polauisia

Polemoniaced

Polemonium

Polygala

Polygatace.

Polygonace

l'olygouatum

Polygonella

Polygonum

Polymnia

Polypodium

Poly pody

Polypogon

Polypremum

Poly tæuia

Pomme-blanche

Pond-spice

Pondweed

IIorned

Pontederia

Pont ederiace

Poplar

Poppy White

Celandine

Corn

Horn

Mexican

Prickly

Populus

Porella

Portulaca

Portulacace

Potanogeton

Potato vine, Wild

Potentilla

Poterium

Preissia

Prenanthes

Prim

Primrose

Prinuula Evening

Primulacea

Prince's-feut.ter

Prince's-piue

Prosartes

Psilocarya

Psoralea

Ptelea

p'teris

Pterospora

Ptilidium

Puccinellia

Puecoou Yellow

Pulse Family

Purslune

Sea

Water

Putty-root

Pycnautbemun

Pyrola

Pyrrhopappu:

Pyrularia

Pyrus

Pyxil intbera

Pyxie
135 Onamoclit

151 Queen-of-the-prairie

327 Quercus

663 Quillwort

53

444 Radish

444 Radula

505 Ragged-Robin

436 Ragweed

74 liagrort

354 lRamsted

356 RaNONCUlaCEE

120 Ranuuculus

120 Rape, Droom

436 Raphauus

524 Raspberry

443 Rattlebox

439, 413 Rattlesnake-master

269 Rattlesnake-root

680 Rattlesnake-weed

680 Reboulia

648 Redbud

345 Red-root

203 Redtop

131 False

447 Tall

558 Reed

565 Bur

536 Reseda

535 RESEDACEA

486 RHAMNACEE

50 Rhamnus

59 liheuuatism-root

58 Rbexis

59 Rhinanthus

58 Rhododendron

59 Rhodora

59 Rhus

486 Rhynchosia

708 Rhyncliospora

40 libes

90 Ribgrass

558 Ribwort

369 Riccia

158 IIICCIACE A

161 Rice, lndian

728 Water

300 Rich weed

337 Ricinus

329 Riverweed

190 Robinia

329 Rocket

328 Dyer's

441 Sea

323 Yellow

527 Rock.rose

577 Rosa

130 Rosaces:

107 Rose

681 Cotton

325 Gnelder

709 Ruck

668 Rosebay

365 Rosemary, Marsh

48 Rosiu-weed

123 Rotala

90 Rottbollia

193 Roubieva

184, I88 RuBLACE

499 Rubus

409 Rudbcckia

323 Rue Family

303 Rue, Neudow

451 Ruellia

164 Rumex

323 Ruppia

323 Rush

\begin{tabular}{r|ll}
368 & Rush, Bald & 57 \\
153 & Bog & 54 \\
475 & Club & 57 \\
698 & Horned & 58 \\
& Nut & 58 \\
$\mathbf{7 4}$ & Scouring & 67 \\
707 & Spike & 57 \\
85 & Twig & 58 \\
273 & Wood & 54 \\
293 & RuTACE. & $\mathbf{1 0}$ \\
379 & Rye, Wild & 67 \\
34 & & \\
40 & Srbbatia & 34
\end{tabular}

578

586

586

676

573

586

$5 \pm 6$
106

673

347

412

420

406

Wood

554,735

Sagittaria

St. Andrew's-cross

St. John's-wort

Marsh

St. Peter's-wort

, 5

112 ,

512 Salicace

647 Salicornia

665 Salix

667 Salmon-berry

658 Salsify

547 Salsola

75 Saltwort

75 Salvia

111 Salvinia

111 SALVINIACFA

53 Sumbueus

183 Samolus

392 Samphire

3:0 Sandal-wood Family

321 Sandweed, Sea

118 Sandwort

147 Sanguinaria

577,584 Sanicula (Sanicle)

174 Sixtalace.s

423 SAPINDACEA

432 Sapindus

730

730

635

407,465

460

441

134

i1

75

70

76
162

150

150

267

218
76

76
320

327

270

184

636

433

222

154

276

106
39

400

437

564

540

Saponaria

SAPOTACEE

Sarcoscyphus

Sarracenia

Sarraceniace

Sarsaparilla

Sassafras

Satureia

Saururus

Savin

Sivory

Saxifraga

SAXIPRAGACE $B$

Saxifrage Golden

Scabiosa (Scabious)

Scale-mosses

Scapania

Schedonnardus

Schenchzeria

Sclizæa

Schollera

Sehrankia

schwalbea

Schrreinitzia

Scilla

Scirpus

Scleranthus

Sclerin

Sclerolepis

Seolochioa

Scolopendrium

Scrophularia

116

Sapodila Family 332 
INDEX.

\begin{tabular}{|c|c|c|c|c|c|}
\hline SOROPBOLARIACEAB & 377 & Solidago Drummondi & 252 & Sporobolus & 645 \\
\hline Scutellaria & 416 & Eliottii & 250 & Spring-beauty & 91 \\
\hline Sedge & 587 & elliptica & 250 & Spruce & 491 \\
\hline Sedge Family & 567 & gigantea & $\begin{array}{l}251 \\
252\end{array}$ & Spurge & $\begin{array}{r}452 \\
90\end{array}$ \\
\hline $\begin{array}{l}\text { Sedum } \\
\text { Seed-bor }\end{array}$ & $\begin{array}{l}17 \\
187\end{array}$ & $\begin{array}{l}\text { Houghtonii } \\
\text { numilis }\end{array}$ & $\begin{array}{l}202 \\
248\end{array}$ & $\begin{array}{l}\text { Spurrey } \\
\text { Sand }\end{array}$ & $\begin{array}{l}90 \\
89\end{array}$ \\
\hline $\begin{array}{l}\text { Seed-box } \\
\text { Selaginella }\end{array}$ & 697 & $\begin{array}{l}\text { numilis } \\
\text { juncea }\end{array}$ & $\begin{array}{l}240 \\
250\end{array}$ & Squatr-root & 394 \\
\hline SELAGLNELLACEAB & 697 & lanceolata & 252 & Squaw-weed & 293 \\
\hline Selenia & 63 & latifolia & 247 & Squirrel-corn & 60 \\
\hline Self-heal & 418 & Liadheimeriana & 247 & Stachys & 421 \\
\hline Sendtnera & 710 & linoides & 250 & Staff-trec & 110 \\
\hline Senebiera & 74 & macrophylla & $24 i$ & Stagger-bush & 316 \\
\hline Sencrio & 292 & Missouriensis & 251 & Staphylea & 118 \\
\hline Scana & 147 & nonticola & 247 & Star-Hower & 329 \\
\hline Seusitive-brier & 149 & Muhlenbergii & 250 & Star-grass & 512,516 \\
\hline Sensitive-plant, Wild & 148 & neglecta & 250 & Star-of-bethlehem & 523 \\
\hline Sericocarpus & 254 & nemoralis & $25 \mathrm{~L}$ & Starwort & 86,255 \\
\hline Service-berry & 166 & odora & 249 & Water & 182 \\
\hline Sesuvium & 198 & Ohioensis & 252 & Statice & 327 \\
\hline Setaria & 634 & patula & $2+9$ & Steeple-bush & 153 \\
\hline Seyuleria & 388 & petiolaris & 246 & Steetzia & 724 \\
\hline Shad-bush & 166 & pilosa & 249 & Steironema & 330 \\
\hline Sbecp-berry & 219 & puberula & 248 & Steliaria & 86,733 \\
\hline Shepherdlis & 449 & radula & 251 & Stenanthium & 534 \\
\hline Shepherd's-purso & 73 & Riddellii & 252 & Stenosiphon & $19 ?$ \\
\hline Sherardia & 227 & rigida & 252 & Stickseted & $36 \div$ \\
\hline Shin-leaf & 323 & rugosa. & 249 & Sticktıght & 284 \\
\hline Shooting-star & $3 \% 9$ & rupestris & 251 & Stilliugia & 460 \\
\hline Sibbaldia & 161 & sempervirens & 248 & Stipa & 641 \\
\hline Sickle-pod & 66 & serotiua & 251,251 & Stitchwort & 87 \\
\hline Sicyos & 195 & Shortii & 251 & Stonecrop & 177 \\
\hline Sida & 99 & speciosa & 249 & Diteh & 176 \\
\hline Side-saddle Flower & 57 & squarrosa & 246 & Stone-root & 107 \\
\hline Sileue & 83 & stricta & 248,219 & Storitx & 333 \\
\hline Silkweed & 339 & tenuifolia & 252 & Storksbill & 04 \\
\hline Silphium & 270 & thyrsoidea & 248 & Stranionium & $3 i t$ \\
\hline Silver-bell Tree & 334 & tortifolia & $24 y$ & Strawberry & 158 \\
\hline Silver-berry & 449 & nliginosa & 249 & Barren & 58 \\
\hline Silver-weed & 160 & ulmifolia & 250 & Strawberry - busn & 10 \\
\hline Sinapis & 72 & virgata & 248 & Streptopus & 326 \\
\hline Sisynubrium & 71 & Virguurea & 248 & Strophosty les & 145 \\
\hline Bisyrinchium & 515,735 & Solomion's-seal & $52+$ & Struthiopteris & 390 \\
\hline Sium & 207,207 & Fulso & 525 & Stuartia & 96 \\
\hline Bkulicap & 416 & Sonchus & 305 & Sty lophorum & 58 \\
\hline Sk unk-cabbage & 550 & Sophora & 127 & Stylosanthes & 142 \\
\hline Bloe & 152 & Sorrel & $43 i$ & STYRACACER & 333 \\
\hline Smartweed & 441 & Mountain & $43 i$ & Sty rux & 334 \\
\hline Smilacina & 525,526 & Wood & 105 & Sureda & 434 \\
\hline Bmilax & 519 & Sorrel-tree & 316 & Subularia & 69 \\
\hline Snake-bead & 381 & Sour-gum & 215 & Succory & 298 \\
\hline Snake-root & 47 & Sour-wood & 316 & Sugar-berry & 463 \\
\hline Black & 212 & Spanish-bayonet & 524 & Sullivantia & 171 \\
\hline Button & $211, \overline{242}$ & Spanish-ncedles & 285 & Sumach & 118 \\
\hline Seneca & 120 & Sparganium & 647 & Sundew & 178 \\
\hline Virginia & 445 & Spartina & 627 & Sunflower & $2 \pi$ \\
\hline Whitc & 241 & spatter-dock & 56 & Supple-Jack & 111 \\
\hline Snapdragon & 380 & Spcarmint & 407 & Sweetbrier & 164 \\
\hline Sneezeweed & 287 & Spearwort & 41 & Sweet-cicely & 210 \\
\hline Sneezewort & 289 & Spceularia & 308 & Swcet-Hag & 551 \\
\hline Snowball-tres & 218 & Speedwell & 396 & Sweet-gale & 469 \\
\hline Snowberry & 220 & Spergula & 90 & Sweet-gum & 180 \\
\hline Creeping & 314 & Spergularia & 89 & Sweet-leaf & 34 \\
\hline Snowdrop & 334 & Spermacoce & 225 & Sweet-scented shrub & 167 \\
\hline Sospberry & 116 & Spheralcea & 99 & Sweet-William & \\
\hline Soapwort & 83 & Spharocarpus & 732 & Wild & 354 \\
\hline Solanaczes & 373 & Sphagnocetis & 713 & Sycamore & 466 \\
\hline Solanum & 373 & Spice-busb & 447 & Symplioricurpos & 0 \\
\hline Solea & 81 & Spiderwort & 639 & Sympliytum & 7 \\
\hline Solidago & 246 & Spigelia & 346 & Symplocarpus & \\
\hline altissima & 249 & Spikenard & 213 & Symploros & 4 \\
\hline arguta & 250,250 & False & 525 & Synandra & 9 \\
\hline bicolor & $24 i$ & Spindle-tree & 110 & Synthyris & \\
\hline Bigelovii & 247 & Spirae & $153,15.3$ & Syringa & 2 \\
\hline Boottii & 250 & Spiranthes & 5 & & \\
\hline схена & 247 & Spirodela & $5 i 2$ & Tacamnhac & \\
\hline Canadensis & $\begin{array}{l}251 \\
247\end{array}$ & Spleenwort & $6 \subseteq 3$ & Talinum & . $-91,7399$ \\
\hline Curtisii & 247 & Spoonnood & & Tamarack & \\
\hline
\end{tabular}




\begin{tabular}{|c|c|c|c|c|c|}
\hline $\begin{array}{l}\text { Tanacetnm } \\
\text { Tansy }\end{array}$ & $\begin{array}{l}290 \\
290\end{array}$ & & $\begin{array}{r}405 \\
657,658\end{array}$ & $\begin{array}{l}\text { Yolet, Dame's } \\
\text { Dog's-tooth }\end{array}$ & \\
\hline Tarasacum & 303 & $\begin{array}{l}\text { Tricuspis } \\
\text { Trientalis }\end{array}$ & 657,6558 & $\begin{array}{l}\text { Dog's-tooth } \\
\text { Green }\end{array}$ & \\
\hline Tare & 142 & Trifolium & 128 & Water & \\
\hline Taxodium & 493 & Triglochin & 657 & Virginian-creeper & \\
\hline Tarus & 494 & Trilisa & 243 & Virgin's-bower & \\
\hline Tea-berry & 316 & Trillium & 530 & VITACES & \\
\hline Tea Family & 95 & Triodia & 657 & Vitis & 113,11 \\
\hline Tea, Labrador & 321 & Triosteum & 219 & & \\
\hline Mexican & 433 & 'I'ripsacum & 636 & Waahoo & \\
\hline New Jersey & 112 & Trisetum & 653,735 & Wake-robin & \\
\hline Oswego & 414 & Triticum & 671,672 & Waldsteinia & \\
\hline Tear-thumb & 442 & Trollius & 45 & Walking-lear & \\
\hline Teasel & 229 & Troximon & 302 & Walltlower, Western & \\
\hline Tecoms & 398 & Trumpet-creeper & 398 & Walnut & \\
\hline Tephrosia & 133 & Trumpet-Hlower & 398 & Watercress & \\
\hline TERastreminces & 95 & Trumpets & 57 & Waterleaf & \\
\hline Tetragonotheca & 274 & Trumpet-weed & 239 & Water-nymph & \\
\hline Tetranthera & 447 & Tsuga & 492 & Water-shield & \\
\hline Toucrium & 406 & Tulip-tree & 50 & Waterweed & \\
\hline Thalictrum & 39,39 & Tumbleweed & 428 & Waterwort & \\
\hline Thaspium & 204,208 & Tupelo & 215 & Wax-work & \\
\hline Thelesperma & 285 & Turnip, Indian & 549 & Way faring-tree & \\
\hline Thely podium & 72 & Turnsole & 361 & Weigela & 2 \\
\hline Theruiopsis & 126 & Turtlehead & 381 & Weld & \\
\hline Thimbleberry & 155 & Tussilago & 291 & Wheat, Cor & \\
\hline 'Thistle & 295 & Twayblade & 499,501 & India & \\
\hline Canada & 296 & Twin-flower & 219 & Whin & \\
\hline Cotton & 297 & Twin-lear & 53 & Whiteweed & \\
\hline Plunieless & 296 & Twisted-stalk & 526 & Whitlow-wort & \\
\hline Scoteh & 297 & Typha & 547 & Wicky & \\
\hline Sow & 305 & TYPHACE $B$ & 547 & Willow & \\
\hline Star & 297 & & & Willow-herb & 18 \\
\hline Thlaspi & 73 & Ulmus & 462 & Wind-flower & 36, \\
\hline Thorn & 165 & UMB & 198 & Winterb & \\
\hline Black & & Unbr & 53 & Wintergreen & 815,3 \\
\hline White & 165 & Uulbr & 49,50 & Aromatic & \\
\hline Thoroughwax & 206 & Unicorn-plant & 399 & Chickweed & \\
\hline Thoroughwort & 239 & Uniola & 662 & Creeping & \\
\hline Thuya & 493 & Urtica & 464 & Spotted & \\
\hline Thyme & 411 & ACER & 461 & Wistaria & \\
\hline Basil & 411 & Utricularia & $3: 5$ & Witch hazel & \\
\hline Creeping & 411 & Uvularia & 527,528 & Wolf-berry & 2 \\
\hline Tarmedachers & 448 & & & Wolfsbane & \\
\hline Thymus & 411 & Vaccaria & 83 & Wood & 116,2 \\
\hline Tiarella & & Vacrinjum & 312 & Wood & \\
\hline Tickseed & & Valeriuna (Valerian) & 228 & Wood & \\
\hline Tiedemannia & 202 & Greek & 356 & Wood & \\
\hline Tilia & 101 & VALERIA: & 228 & Worms & \\
\hline T'uiaces & 101 & Yale & 228 & Worm & \\
\hline Tillex & & Vallis & 496 & Komen & 27 \\
\hline ndsis & 511 & Vanill & 243 & & \\
\hline & & Velve & 99 & Xanthiam & \\
\hline r's-weed & & Venus s Fly-trap & 179 & $\mathrm{X}$ al & \\
\hline Tipularia & 499 & .. Looking-glass & 308 & & 55 \\
\hline & 89 & Feratrum & 533,533 & $\bar{X}$ ant & \\
\hline Toadflax & 379 & Verbascuin & 379 & Xero & \\
\hline Bastard & & Verbena & 401 & XYRIDA & \\
\hline Tobacco & & ICES & 401 & Xyris & 53 \\
\hline Indian & & Verbe & 280 & & \\
\hline Tofieldia & 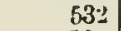 & Vernc & 238 & $\mathrm{Ya}$ & \\
\hline Toothache-tree & 106 & & 386 & & \\
\hline Toot & 64 & Verv & $4 \cup 1$ & Yaupon & \\
\hline Touch-me-not & 10 & Vesicaria & 69 & Yellow-es & \\
\hline Townsendia & & Vetch & 142 & Yesi & \\
\hline & & Joint, Sensitive & 137 & Yellow-ro & \\
\hline Trad & & Mi & & Yellow-wood & 120 \\
\hline Tragia & & Vetchling & 143 & lew & 494 \\
\hline Tragopogon & 298 & Viburnum & 217 & Yucea & 52 \\
\hline & 39 & Vicia & & & \\
\hline & 45 & Vilfa & 645,646 & Zannichellin & \\
\hline P-heared & & Vincetoxicum & 344 & Tephyrantlies & 516,73 \\
\hline Trefoil & 128 & Vine Family & $\$ 12$ & Zizania & \\
\hline Shrubbs & 107 & Yinla & 78 & Zizi & 206,20 \\
\hline Tirk & 139 & Viot.ACER & 78 & Zostera & 66 \\
\hline $\begin{array}{l}\text { Tilchocolea } \\
\text { Irtchomanes }\end{array}$ & $\begin{array}{l}719 \\
692\end{array}$ & Violet & 78 & Zygadenns & \\
\hline & & & & & \\
\hline
\end{tabular}




\section{The Botanist's Microscope}

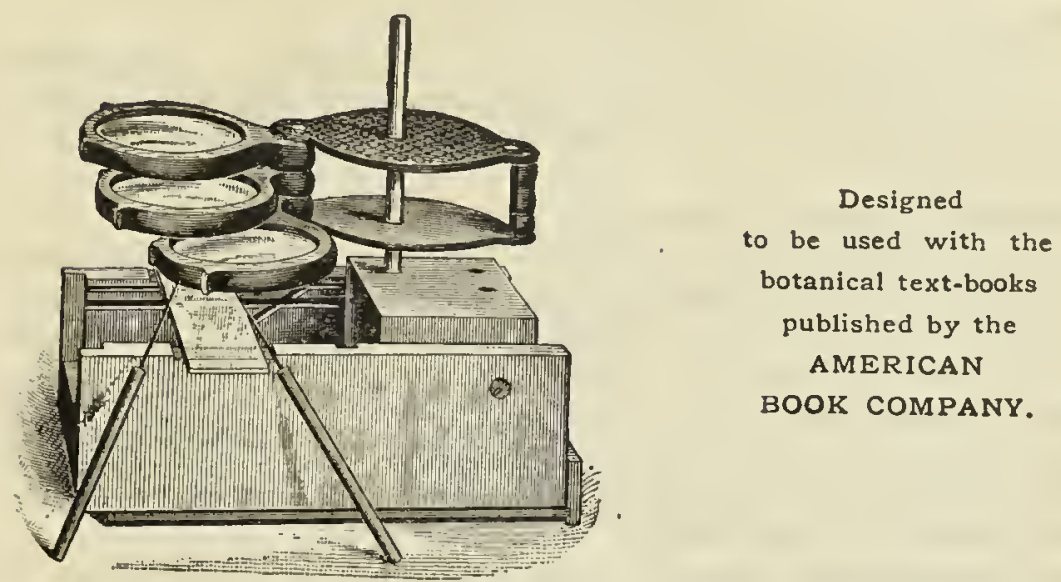

This convenient instrument, devised and manufactured first for the use of the students in Harvard University, has given so great satisfaction there, and elsewhere, that we have made arrangements by which we are able to offer it to students in all parts of the country at a very reasonable price.

A thousand things about forest, field, or garden afford objects of intense interest for daily study, and a good Microscope furnishes the best means for unlocking their secrets. Of this Microscope the late Dr. Gray said: "I do not think anything better can be made for the money."

This Microscope is attached to a box, one and a half inches high and less than four inches long, into which it is neatly folded when not in use. The needles are used for dissecting flowers or other objects too small to be otherwise handled for analysis.

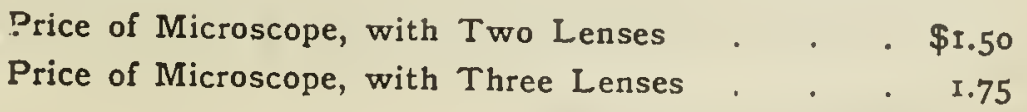

These Microscopes will be sent, prepaid, to any address on receipt of the price, by the

\section{AMERICAN BOOK COMPANY}




\section{Zoölogy and Natural History}

\section{Burnet's Zoölogy}

By Margaretta Burnet, Cloth, I2mo. 216 pages . . 75 cents

A new text-book for high schools and academies, by a practical teacher; sufficiently elementary for beginners and full enough for the usual course in Natural History.

\section{Needham's Elementary Lessons in Zoölogy}

By James G. Needham. Cloth, I 2 mo. 302 pages

An elementary text-book for high schools, academies, normal schools and preparatory college classes. Special attention is given to the study by scientific methods, laboratory practice, microscopic study and practical zoötomy.

Cooper's Animal Life

By Sarah Cooper. Cloth, I2mo. 427 pages . . . \$1.25

An attractive book for young people. Admirably adapted for supplementary readings in Natural History.

\section{Holders' Elementary Zoölogy}

By C. F. Holder, and J. B. Holder, M.D. Cloth, I2mo. 40 I pp. \$1.20

A text-book for high school classes and other schools of secondary grade.

\section{Hooker's Natural History}

By Worthington Hooker, M.D. Cloth, I2mo. 394 pages 90 cents

Designed either for the use of schools or for the general reader.

\section{Morse's First Book in Zoölogy}

By Edward S. Morse, Ph.D. Boards, I2mo. 204 pages . 87 cents

For the first study of animal life. The examples presented are such as are common and familiar.

\section{Nicholson's Text-Book of Zoölogy}

By H. A. Nicholson, M.D. Cloth, i2mo. 421 pages . $\$ 1.38$

Revised edition. Adapted for advanced grades of high schools or academies and for first work in college classes.

\section{Steele's Popular Zoölogy}

By J. Dorman Steele and J. W. P. Jenks. Cloth, i2mo, 369 pp. \$1.20

For academies, preparatory schools and general reading. This popular work is marked by the same clearness of method and simplicity of statement that characterize all Prof. Steele's text-books in the Natural Sciences.

\section{Tenneys' Natural History of Animals}

By Sanborn Tenney and Abbey A. Tenney. Revised Edition.

Cloth, I2mo. 28I pages.

This new edition has been entirely reset and thoroughly revised, the recent changes in classification introduced, and the book in all respects brought up to date.

\section{Treat's Home Studies in Nature}

By Mrs. MARY Treat. Cloth, I2mo. 244 pages 90 cents

An interesting and instructive addition to the works on Natural History.

Copies of any of the above books will be sent, prepaid, to any address on receipt of the price by the Publishers:

\section{American Book Company}

New York 


\section{Aids to Field and Laboratory Work in Botany}

Apgar's Plant Analysis. By E. A. and A. C. Apgar.

Cloth, small 4 to. I 24 pages . . . . . 55 cents

A book of blank schedules, adapted to Gray's Botanies, for pupils' use in writing and preserving brief systematic descriptions of the plants analyzed by them in field or class work. Space is allowed for descriptions of about one hundred and twenty-four plants with an alphabetical index.

An analytical arrangement of botanical terms is provided, in which the words defined are illustrated by small wood cuts, which show at a glance the characteristics named in the definition.

By using the Plant Analysis, pupils will become faniliar with the meaning of botanical terms, and will learn how to apply these terms in botanical descriptions.

\section{Apgar's Trees of the Northern United States.}

Their Study, Description, and Determination. For the use of

Schools and Private Students. By Austin C. Apgar

Cloth, I2mo. 224 pages. Copiously Illustrated. \$I.00

This work has been prepared as an accessory to the study of Botany, and to assist and encourage teachers in introducing. into their classes instruction in Nature Study. The trees of our forests, lawns, yards, orchards, streets, borders and parks afford a most farorable and fruitful field for the purposes of such stucly. They are real objects of nature, easily accessible, and of such a character as to admit of being studied at all seasons and in all localities. Besides, the subject is one of general and increasing interest and one that can be taught successfully by those who have had no regular scientific training.

Copies of either of the above books will be sent, prepaid, to any address on receipt of the price by the Publishers:

\section{AMERICAN BOOK COMPANY}

New York

Cincinnati

Chicago 



\section{P L A T E S}

\section{WITH EXPLANATIONS.}




\section{RXPLANATION OF PLATE $\mathbb{l}$.}

CYI'ERUS. - (1) Small plant of C. dianclrus; (2) a spikelet magnified ; (3) a piece of the rhachis with one scale enclosing its flower; (4) a separate flower more magnified. - (5) C. erythrorlizos, a spikelet magnifiel ; the lower scales and flowers have fallen, showing the small internal scales of the section Papyrus, formed of the winged margins of the joints of the rhachis detacherl; (6) a separate one, more enlargerl ; 7 ) a flower; (8) an achene, cut in two. - (9) C. dentatus, a piece of the rhachis of a spike with the lower part of one scale, showing how it is decurrent on the joint beneath (cut acruss) to form scale-like wings.

DULICHIUM. - (1) L pper part of a plant of I). spathaceum ; (2) part of a spikelet somewhat enlarged; (3) piece of rhachis, and one scale decurrent on the joint beneath; (4) maguified flower.

KYLLINGA. - (1) l'lant of Ki. pumila; (2) one-flowered spikelet on a piece of the rhachis, enlarged; (3) the same, more enlarged and open; (4) achene; and (5) section of same magnitied. 
Genera uf Dуретеcem Plate 1

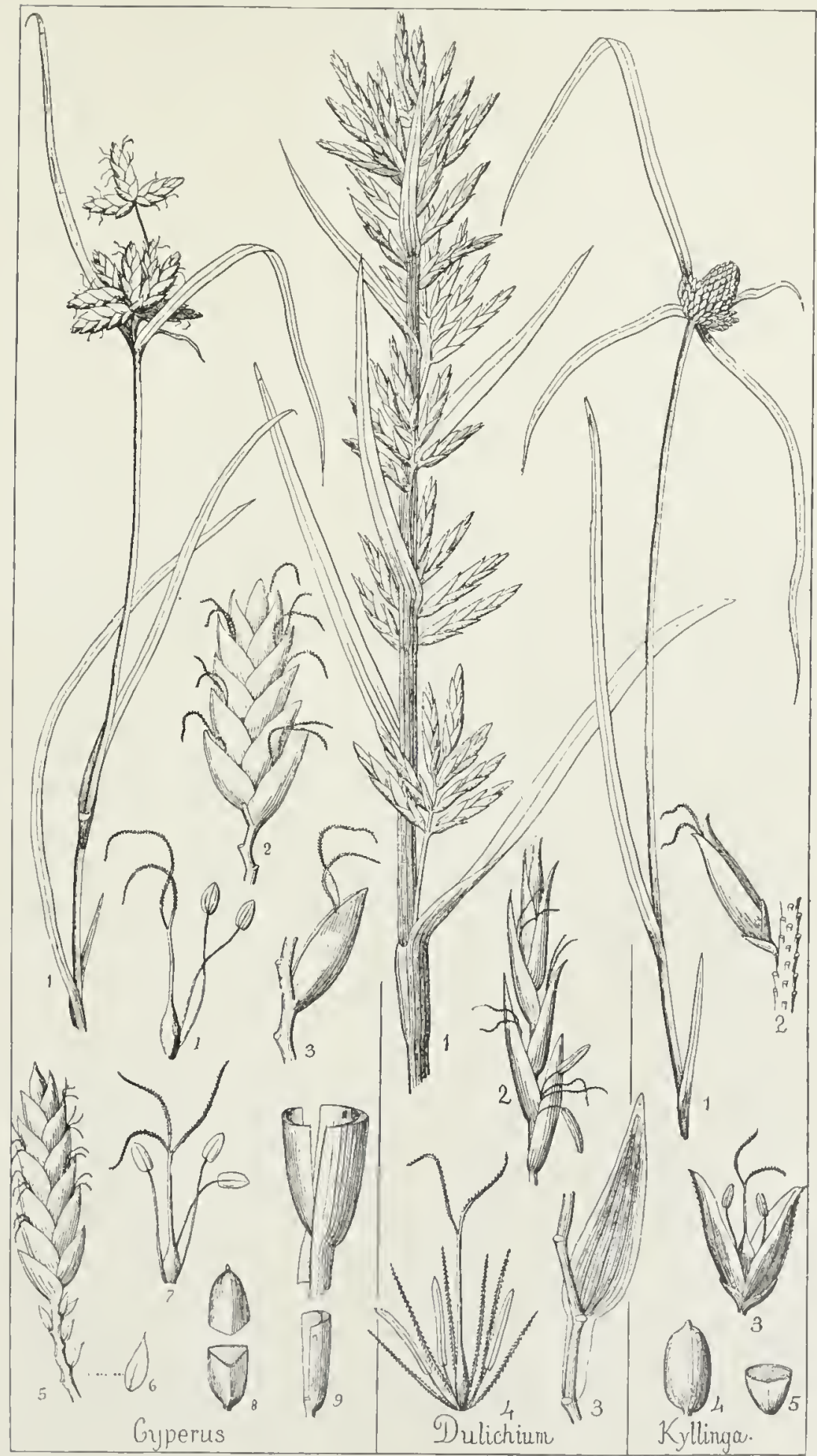




\section{EXPLANATION OF PLATE II.}

IEMICARPHA.- (1) Plant of H. subsquarrosa, uatural size; (2) a spikelet enlarged, with its bract; (3) magnified scale of the same; (5) a flower, with its single stanen and minute internal scale, magnified; (6) achene, magnified.

LIPOCARPIA - (1) Upper part of plants of I. nuaculata, with spikelets; (2) diagram of a flower, representing the ovary between the two internal scales, a single stamen, the scale of the spikelet on one side, and the axis of the spikelet on the other; (3) scale of spikiclet detached; $(1)$ a flower with its two inner seales; (5) achene, magnified.

FUIRENA. - (1) Ipper portion of plant of F. squarrosa, var. pumila; (2) scale of spike enclosing a fluwer; (3) open scale of same; (4) flower; (5) one of the scales and one of the bristles of the perianth; (6) achene, and ( 7 ) section of same. 


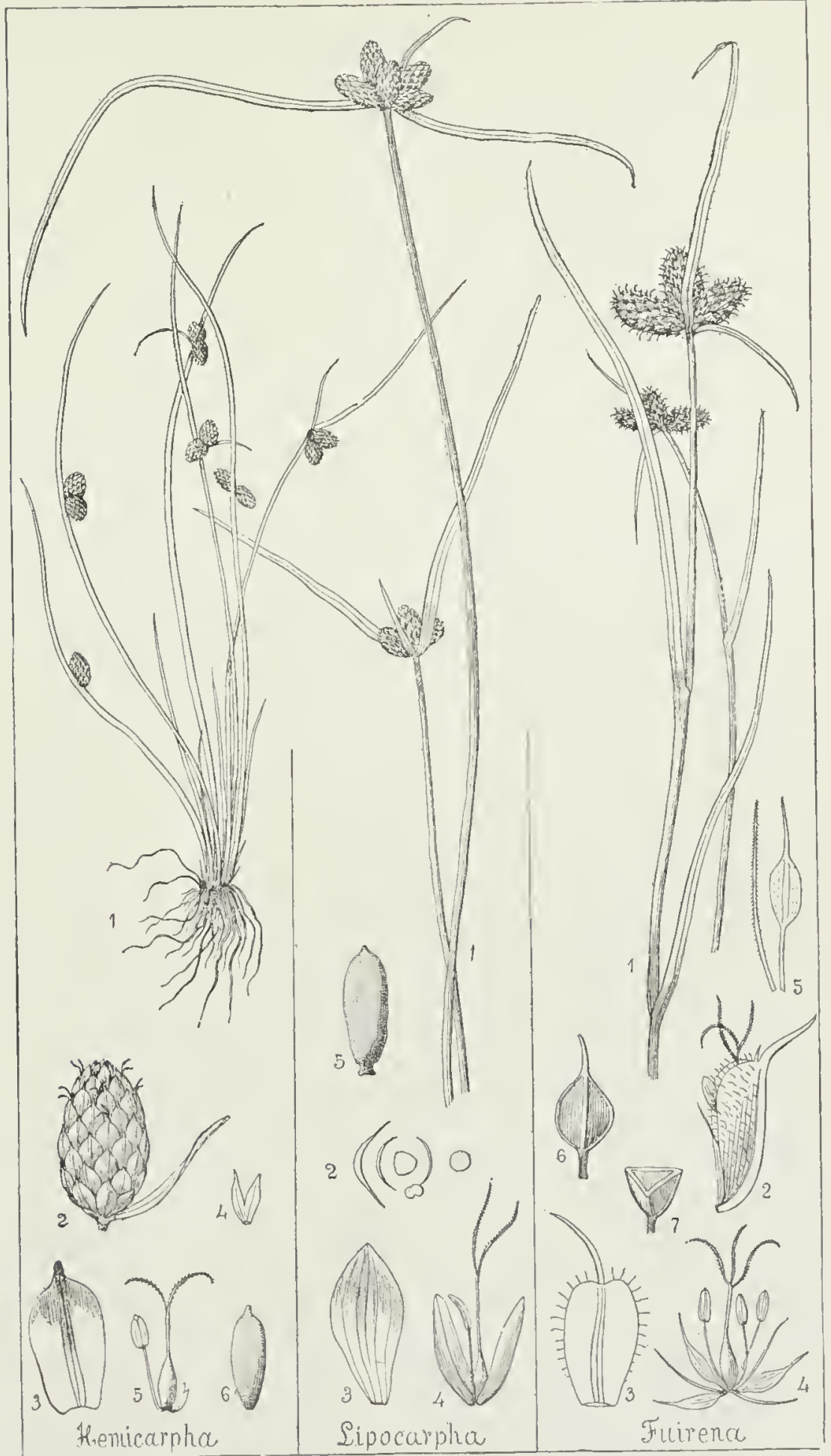




\section{EXPLANATION OF PLATE III.}

ELEOCHARIS. - (1) Sinall plaut of E. olivacea; (2) the spikelet enlarged;

(3) detached scale; (t) flower; (5) achene aud bristles. - (6) $\mathrm{L}$. quadrangulata, spikelet; (7) a scale; (8) Hower; (9) achene and lristles. (10) E. tuberculosa; the achene with its great tubercle, and bristles.

SCIRPUS. - (1) Summit of plant of small S. clebilis; (2) a spikelet; (3) a scale of the same, and (4) flower; (5) achene with its lisistes.

ERIOPIORUM. - (1) Small plant of E. alpinum, in Hower; (2) spikelet; (3) a scale, and (4) a flower from the same; (5) the spikelet, in fonit, the bristles forming a cottony tuft; (6) achene and its bristles. - (6, uncler Scirpus) a small portion of the inflorescence of $\mathbf{E}$. cyperinum; (7) a flower; (8) a spikelet in fuit; (9) athene from the same, with the tortnons bristles; (10) section of the acliene.

EIMIBRISTYLIS. - (1) Summit of a small flowering stem of F. laxa; (2) a spikelet of the same; (3) a detached scale, ant (4) a flower of the same; (5) achene. - F. antumualis; (6), a spikelet, enlarged; (7) fluwer; (8) achene, and (9) section of the same. 


\section{Genera af Гyperaceg Plate III}

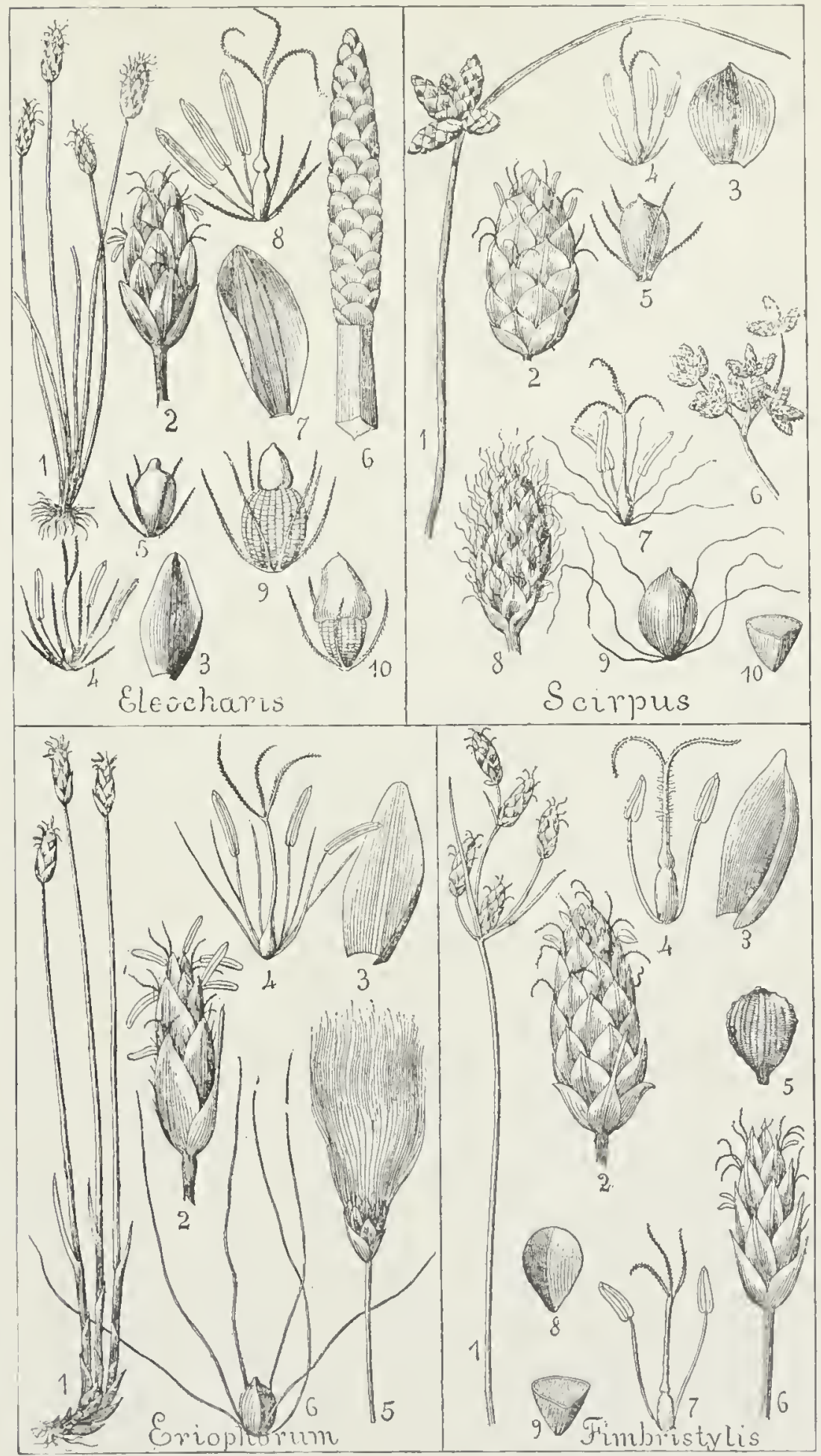




\section{EXPLANATION OF PLATE IV.}

DICMROMENA. - (1) Heal and inrolucre of D. latifolia; (2) a scale from one of the spikelets, and (3) the same cut across; (4) a fluwer; (5) achene with its tubercle.

PSILOCARYA. - (1) l'art of plant, (2) enlarged spikelet, (3) detached scale, (4) Hower, and (5) achene with its beak, of l'. scirroiles.

RHYNCIOSPORA. - (1) L puer part of flowering stem of R. Torreyana; (2) a spikelet; (3) detached Hower; (4) achene, with short bristles at its base; (5) one of these bristles more magnified.

R. (\$ CERATOSCIICNUS). - (1) Lpper part of fruiting plant, (2) detached spikelet, (3) flower, and (4) beaked achene, with its bristles, of $\mathbf{R}$. macrostachya. 


$$
\text { Genere af Cyperacem Flate IV }
$$

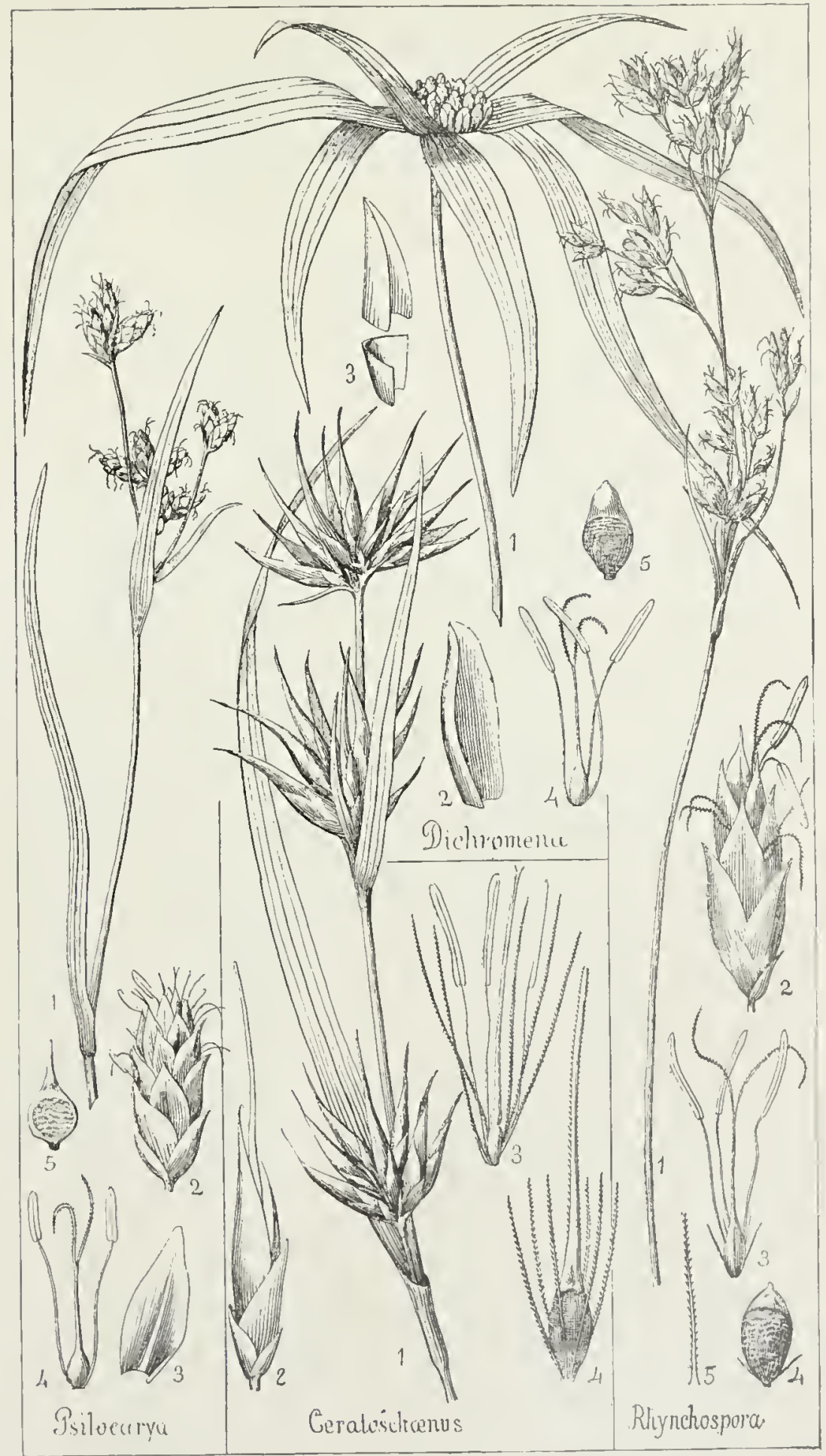




\section{EXPLANATION OF PLATE V.}

CLADIUM. - (1) Summit of a plant of C. mariscoides; (2) detached spikelet; (3) same, open, showing a staminate and a perfect flower; (4) the nut-like achene, and (5) the longitudinal section of the same.

SCLERIA. - (6) Summit of a flowering stem of S. reticularis; (7) three spikelets from a chuster, the midile one pistillate, the lateral oncs staniuate; (8) staminate spiliclet displaying fomr male flowers, the flaments of two of them laving lust their anthers; (9) pistillate spikelet displaying a single pistillate flower; (10) achene with the 3-lobed doulle cup underueatl.

CAREX. - (11) l'lant of C. pancifora; (12) a staninate flower with its scale; (13) scale, and (14) mature pistillate flower, in its perigynimm; (15) cross-section of perigynium and of the contaned achene; (16) achene

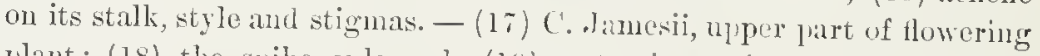
plant; (18) the spike enlarged; (19) a staminate thower and its scale; (20) pistillate flower in its perigynum; (21) the same with half the perigynium cut away to show the contained achene and style. 
Genera of Cyperaceas Plate I

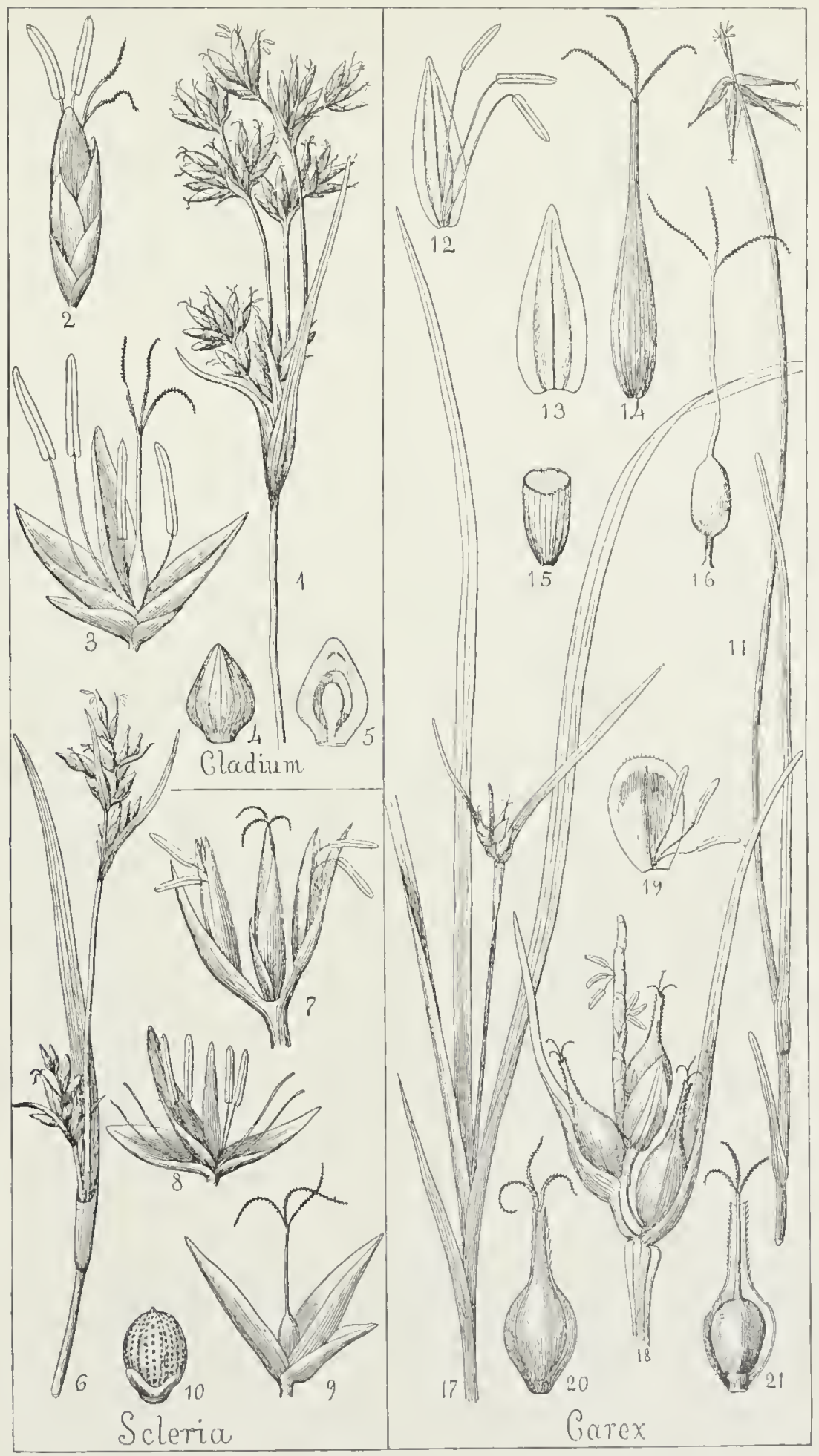




\section{EXPLANATION OF PLATE VI.}

CAREX. - (1) C. trisperma, upper part of a stem in fruit; (2) enlarged spike displayed, with three staminate and two pistillate flowers; $(3)$ a scale, and (4) a ripe perigyniun, of the latter; with (5) a section of the perigynium near the base, and of the contained achene. - (6) C. straminea, var. brevior, summit of a fruiting plant; (7) a spike enlarged; (8) scale of a pistillate flower; (9) the winged perigynimm and the contained achene cut across; (10) detached achene with persistent style and stigmas. - (11) C. umbellata, whole plant; (12) a perigynium and its scale; (13) cross-section toward the base of perigynium and its contained achene; (14) detached achene with its persistent style and stigmas. - C. bullata; (15) upper part of plant in fruit, witl one pistillate and two staminate spikes; (16) one of its staminate flowers with the scale; (17) a pistillate scale, and (18) mature perigsnium; (19) longitulinal section of the latter, showing the achene and its style, and (20) cross section of the same. 
Gengra af Гурегеzem Plate II

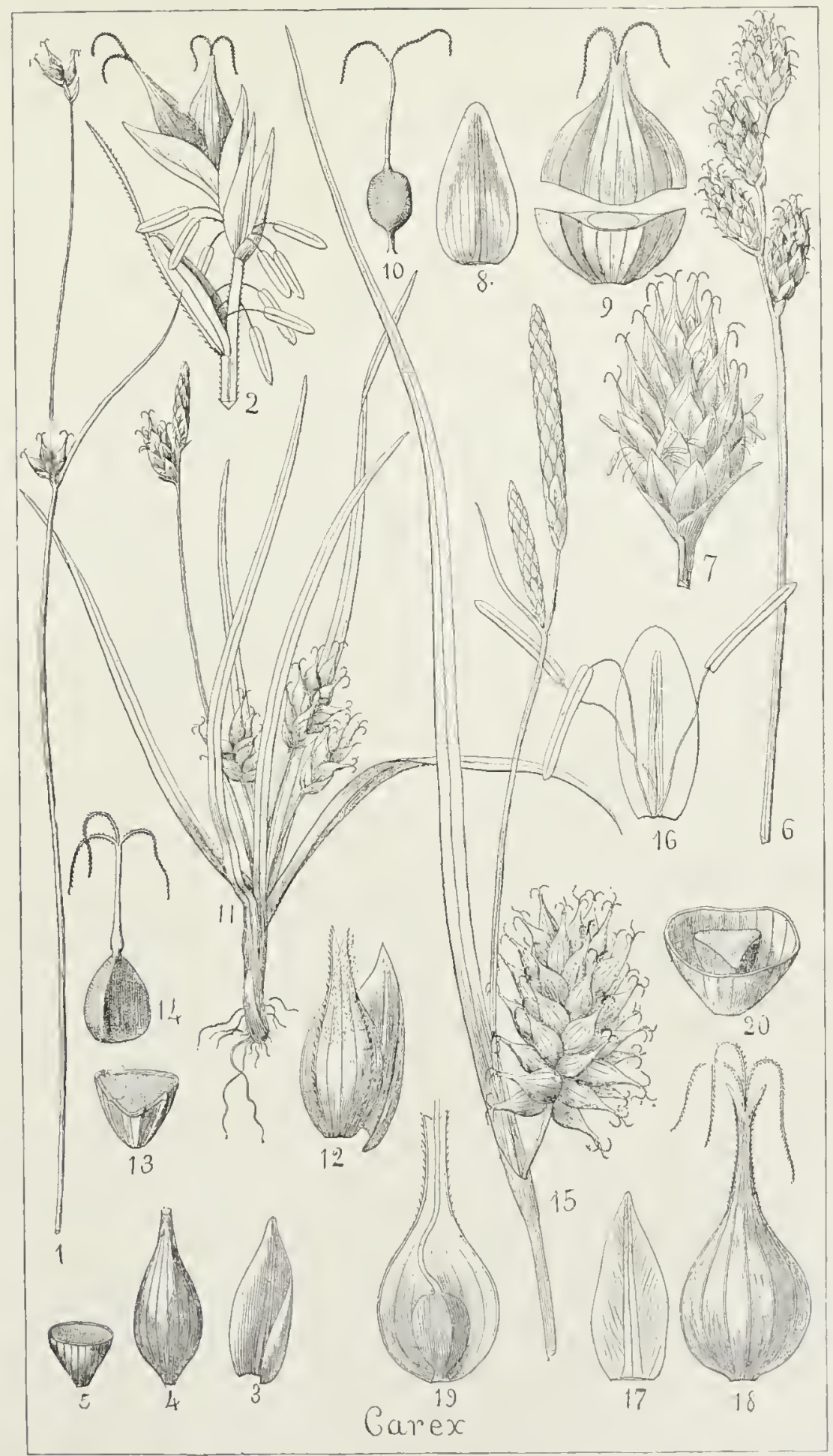




\section{EXPLANATION OF PLATE VII.}

LEERSIA. - (1) Panicle of L. oryzoides, reduced in size ; (2) a branchlet of the same, with its spikelets, of the natural size; and (3) an open spikelet in flower, enlarged.

ZIZANIA. - (1) A staminate, and (2) a pistillate flower or spikelet of $Z$. aquatica; (3) a magnified pistil with a pair of squanule or hypogynous scales; (4) a grain, aud a magnified longitudinal section of the lower part of the same, showing the embryo at the ontsicle of the base of the allomen.

ALOPECURUS. - (1) Part of a plant of $A$. geniculatus, in flower ; (2) a few spikelets from the spike-like inforescence, moderately magnifiel; (3) an open spikelet in flower, more magnified, and (t) the single flowering glume detached.

PHLEU II. - $\Lambda$ detached spikelet of P. pratense, having the flower with its glume and palet raised above the empty glnmes, magnified.

HELEOCHL() A. - (1) Inflorescence of H. scuanoides; (2) a separate enlarged spikelet; and (3) the same open, in flower.

SPOROB()LUS. - (1) A spikelet of S. cryptandrus, magnified; (2) the same, with the flower open, raised alore the entyty glumes; and (3) the fruit, more magnified, showing the seerl loose in the pericarl) (utricle). - (4) An enlarged spikelet of li. vagintufora; and (5) the same displayed.

AGROSTls. - (1) Panjele of $\lambda$. allat, var. vulgaris, with (2) in enlarged open spikelet of the same; also (3) the rongl perlicel and glumes of A. scabra, with the flower separated, the latter having no palet. 


\section{Eenera uf Grasses Plate VII}

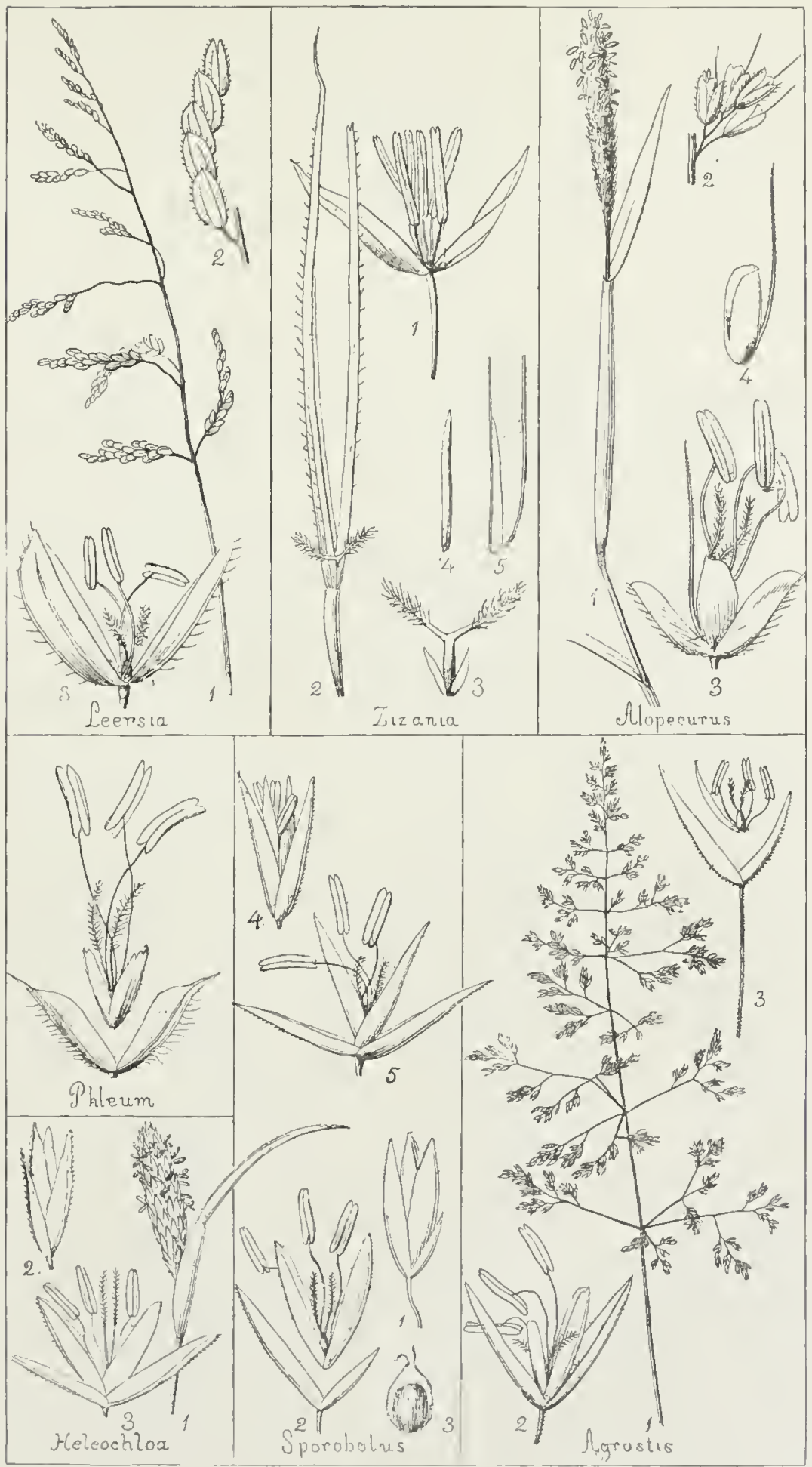




\section{EXPLANATION OF PIATE VIII.}

POLYPOGON. - (1) Spike-like contracted panicle of P. Monspeliensis; (2) an enlarged detached spikelet, showing the long awns to the empity glumes; (3) the same open in flower; and (4) a separate flower without the empty glumes.

CINNA. - (I) A magnified spikelet of C. arundinacen; and (2) the same open, displaying the flowering glume and palet, the single stamen, and the pistil.

MUHLENBERGIA. - (1) A magnified closed spikelet of M. sylvatica; (2) the same with the open fluwer ratised ont of the empty ghumes. - (3) A magnified spikelet of $M I$. diffnial ; ( + ) its minute and unerinal empty glumes more magnified; aud (5) an open spikelet of the sane.

BRACHYLLYTRUM.- (1) A spikelet of B, aristatum enlarged; (2) the same displayed.

CALAMAGROATTS. - (1) An open spikelet of C. Cauadensis, enlarged, displaying all the parts; (2) the same with the flower raised out of the empty glumes, showing the hairy ruliment hehind the palet.

ORYZOISIS. - (1) An open magnified spikelet of (1. asperifolia; and (2) the flower of the same remoreil from the enpty glumes. Notice the remarkably long squamula or hypogyous scales, which here nearly equal the glume in length.

STIPA. - Empty glumes and flower (a little separated) of $s$, arenacea, enlarged.

$\Lambda$ RISTID A. $-\Lambda$ spikelet of $A$. purpurascens, enlarged. 


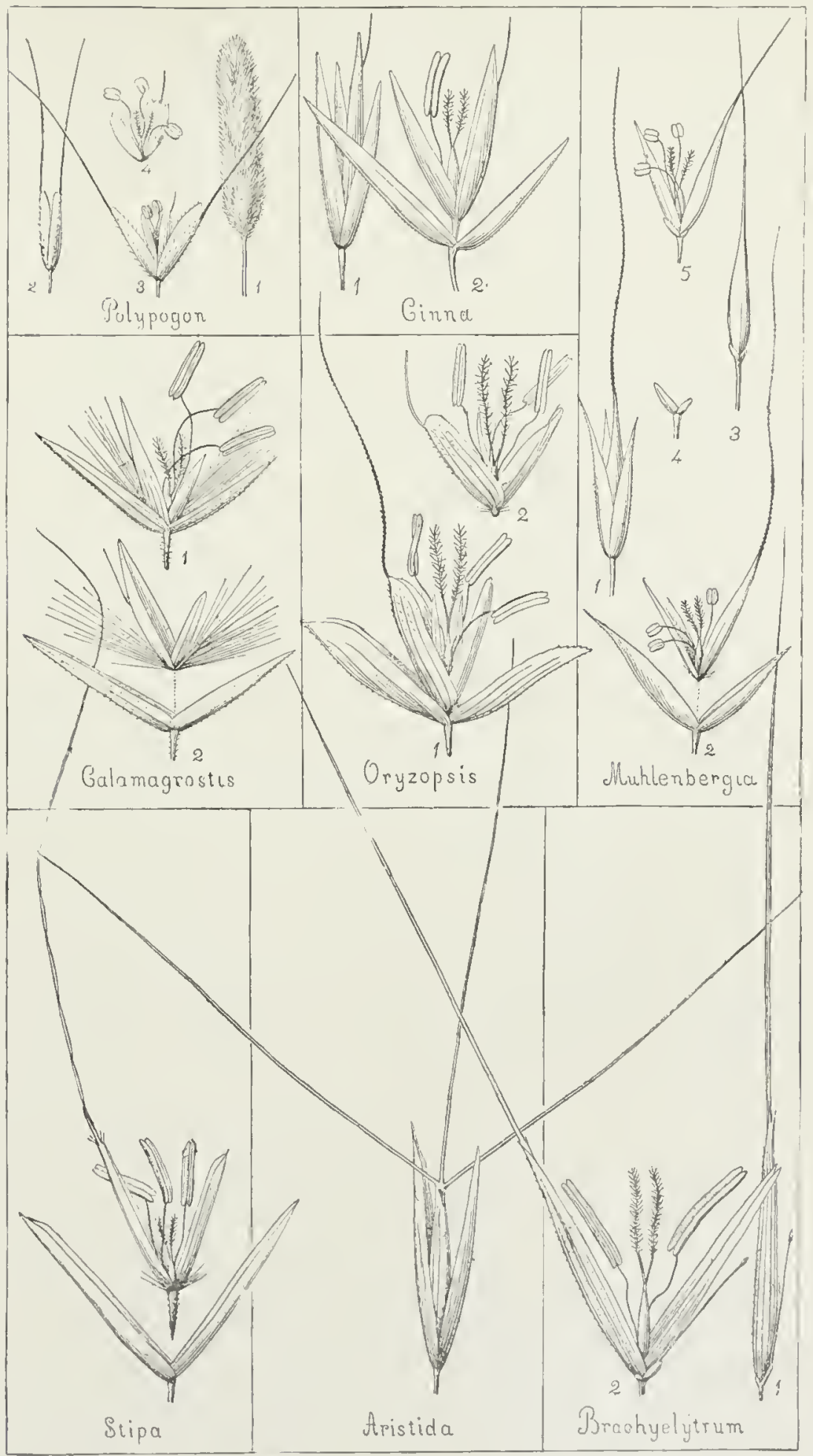




\section{EXPLANATION OF PLATE IX.}

SPARTINA. - (1) P'ortion of the intlurescence of S. stricta, of the natural size; (2) a spikelet enlarged; and (3) the same displayed, the flower raised above the empty glumes.

C'TENIUM. - (1) spike of C. Americanum; (2) a single spikelet magnified; and (3) the sime displayed, the empty glumes separated.

BOUTELOLA. - (1) A portion of the compound spike of B. racemosa, of the natural size; and (2) a spikelet displayed and magnified, the flowers raised ont of the empty glunes.

GYMNOPOGON. - (1) Influrescence of G. racemosus, reduced in size; and (2) a magnified spikelet with the parts displayed.

CYNODON. - (1) Inforescence of ('. 1)actylun, of digitate spikes; (2) a spikelet magnilied and displayed, showing a perfect flower and a rudinent.

ELEUSINE. - (1) ()ne of the spilies from the digitate influrescence of $\mathrm{E}$. Indica; (2) a magnified sprikelet; (3) the sanne with the flewers more displayed; (4) a flower from the last, showing its parts; (5) the fruit magnified, showing the seed loose in the utricle; and (6) the wrinkled

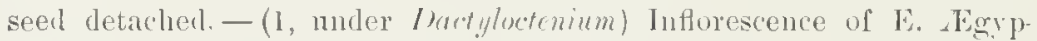
tiaca, of cligitate spikes; (2) one of the spikelets nagnified; (3) the frnit magnified, showing the seed loose in the thin perican (utricle); and (4) the wrinkled seed more magnified.

DIPLACIINE. - (1) small prortion of the inforcsence of $\mathrm{D}$. fascicularis; (2) one of its spiliclets displayed and magnified; (3) an open llower of the same. 


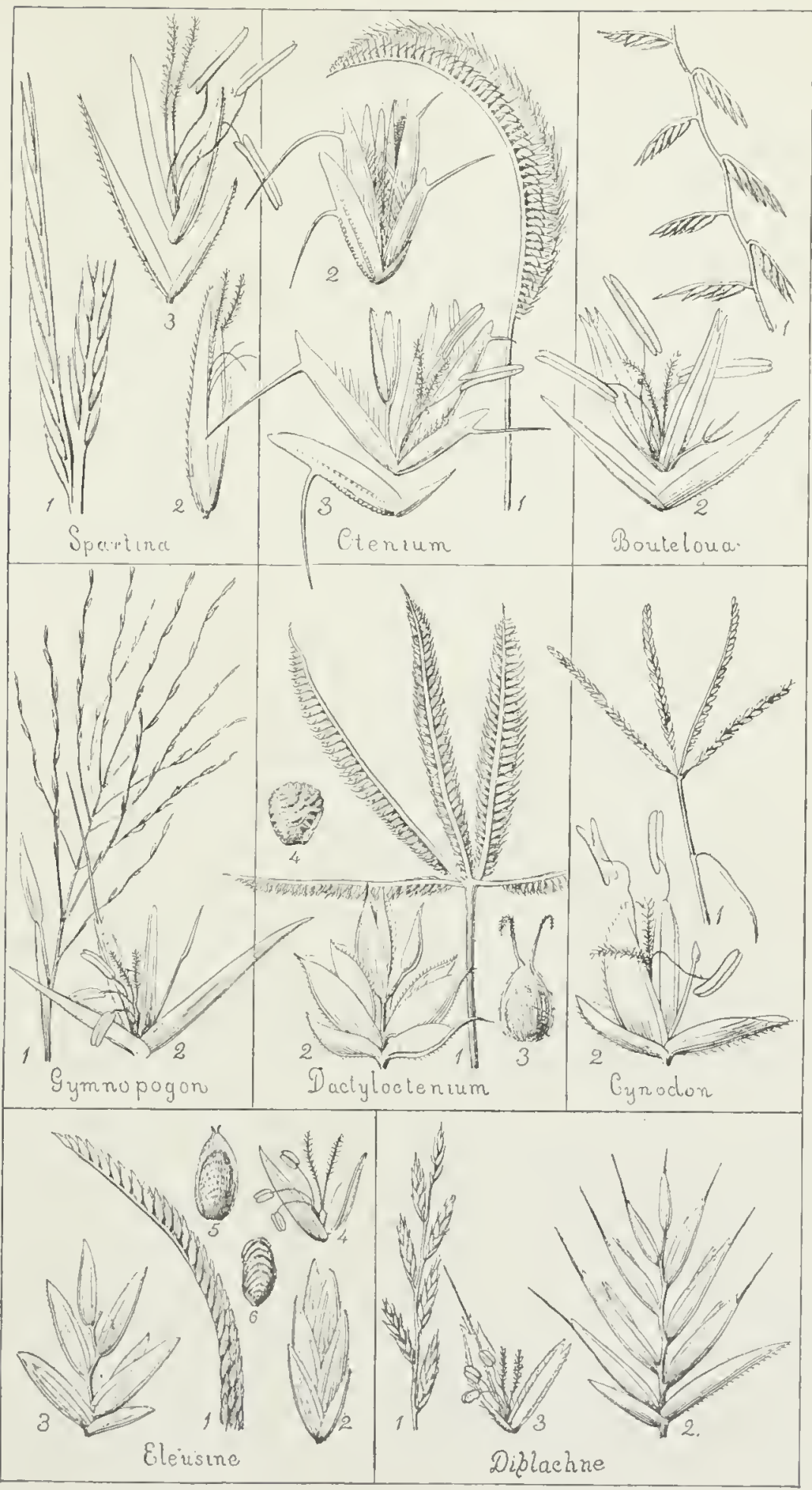




\section{EXPLANATION OF PLATE X.}

TRIODIA. - (1) Magnified spikelet of T. seslerioides; (2) the same displayed and the lowest flower open; (3) back view of the flowering glume spread out.

GRAPHEPHORUM. - (1) A magnified spikelet of C. melicoides, lisplayed; (2) a part of the hairy rhachis and one flower of the same.

DIARRHENA. - (1) A spikelet of 1). Americana, enlarged; (2) the grain in its glume and palet.

DACTYLIS. - A spikelet of D. glomerata magnified and displayed.

KCELERIA.- (1) A magnified spikelet of Ki. cristata, expanded, showing the empty glumes, the three flowers, and a rudiment; (2) lowel half of a flowering glume, partly spread open; it is moln more folderl and keeled in its natural condition.

EA'TUNIA. - $\Lambda$ magnified spikelet of E. obtusata, expanded, showing the empty glumes, the two flowers, and a rudiment.

MELICA. - A magnified spikelet of II. mutica, expanded, showing the enpty glumes, two perfect fowers, and an abortive one.

GLYCERLA. - (1) A magnified spikelet of (r.nervata ; (2) a separate flower with one joint of the rhachis; and (3) the lower half of a flowering glume, showing its form (rounrled on the back, not keeled).

DIS'TICIILIS. - (1) A pistillate spikelet of I). maritima, enlarged; (2) a flower from the same; and (3) a flower from a staminate spikelet.

POA. - (1) Panicle of 1'. compressa, rerlucel in size; (2) a magnifich spikelet; (3) a separate flower more magnified; (4) a flowering glume cut across and somewhat ontspread.

ERAGROSTIS. - (1) A spikelet of F. pilosa, enlarged; (2) the same, from which the glumes and all of six lower flowers cxcopt the palcts have fallen away ; (3) a magnified flower, open ; (4) the flowering glume of the same outsprearl.

BRIZA. - (1) A spikelet of 13. media, enlanged; (2) a separate flower.

FES'TUCA. - (1) A spikelet of F. elation, enlarged; (2) a seprarate flower; (3) lower part of a fluwering ghime, ontspread.

I3ROMUS.- (1) A spikelet of 13. secaliuus, or Chess; and (2) a separz:o flower, enlarged. 
Genera af Grasses Plate $X$

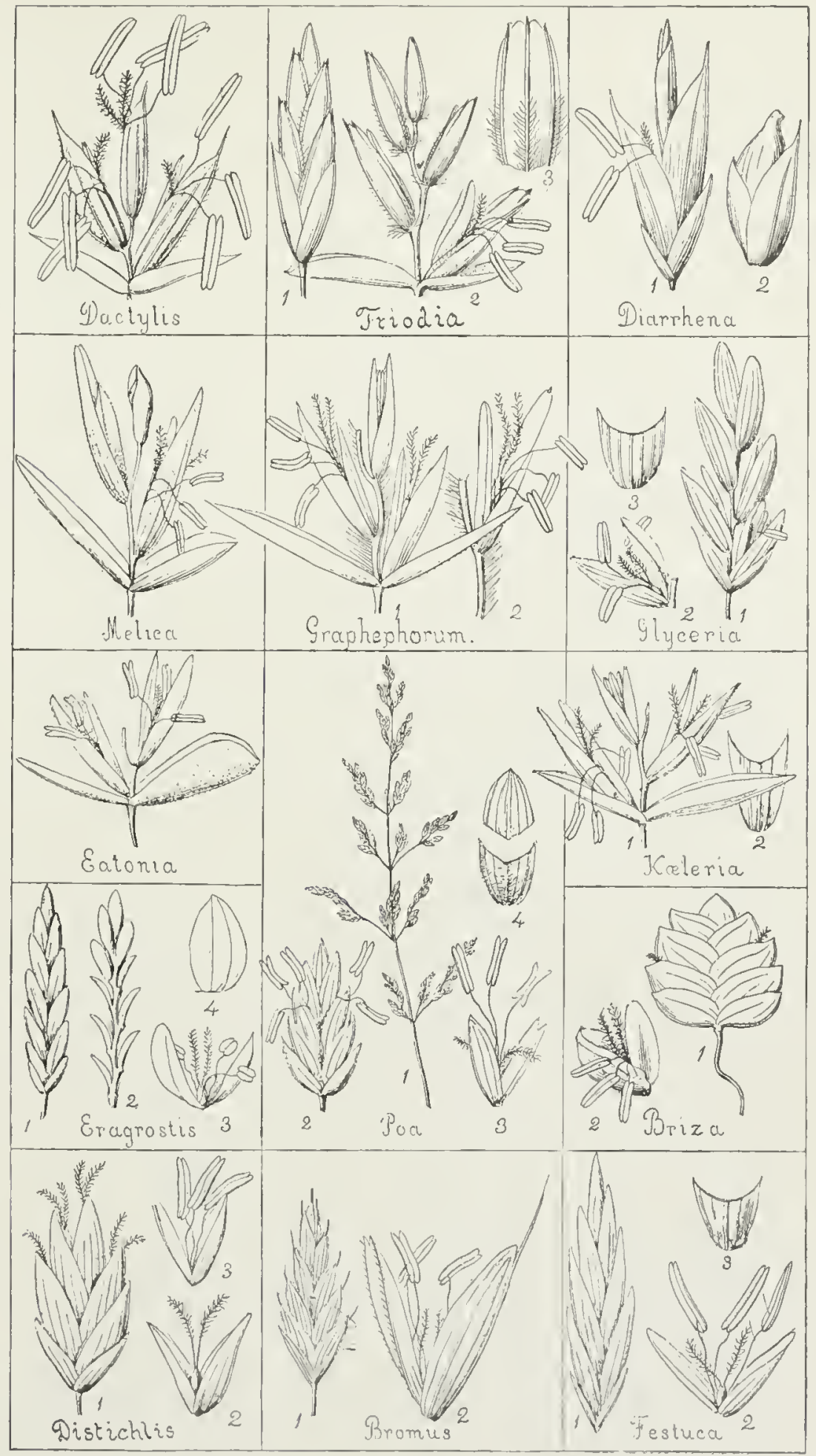




\section{EXPLANATION OF PLATE XI.}

UNIOI,A.-(1) $\Lambda$ spikelet of U. latifolia, of alout the natural size; (2) a flower, enlarged; (3) empty flowering ghmo of the lowest (sterilo) flower. PIIRAGMITES. - (1) I spikelet of l'. commmuis, (nlatreat; (2) one of the perfect flowers, enlarged; and (3) the lowest Hower, which has stanens 011 ly:

ARTNI)INARIA. - (1) A spikelet of A. macrosperma; and (2) a separate flower, magnified.

SCHLIONNARDLS. - (1) Portion of the spike of S. T'exanus, enlitrets and (2) a flower, magnificd.

LOLIIT. - (1) Portion of the spike of L. temulentmon; and (2) a seprante flower, magnified.

AGROP'Y LUM. - (1) Portion of the spike of A. repens, or Conch-Grass, of alout the natural size; (2) a flower, magnified.

IIORIDELM. - (1) The three one-floweres spikelets from one joint of the spike of H. juhatum, with their awm-like empty glumes, the lateral flowers alortive and nentral, the middle one alone perfect; (2) this perfuct flower (with an awn-like rudinent) open and culargenl.

ELY IILS. - (1) The two spikelets of one joint of the spike of E. Virginicus, alout the natural size; (2) the empty ghmes and the Howers of one wpithe. let, cularged and displayed; and (3) an open flower, more magnified.

ASPRELTA. - (1) A spikelet of A. Hystrix; and (2) an expanded fower magnified. 
Genera of Grasses Plate X.]

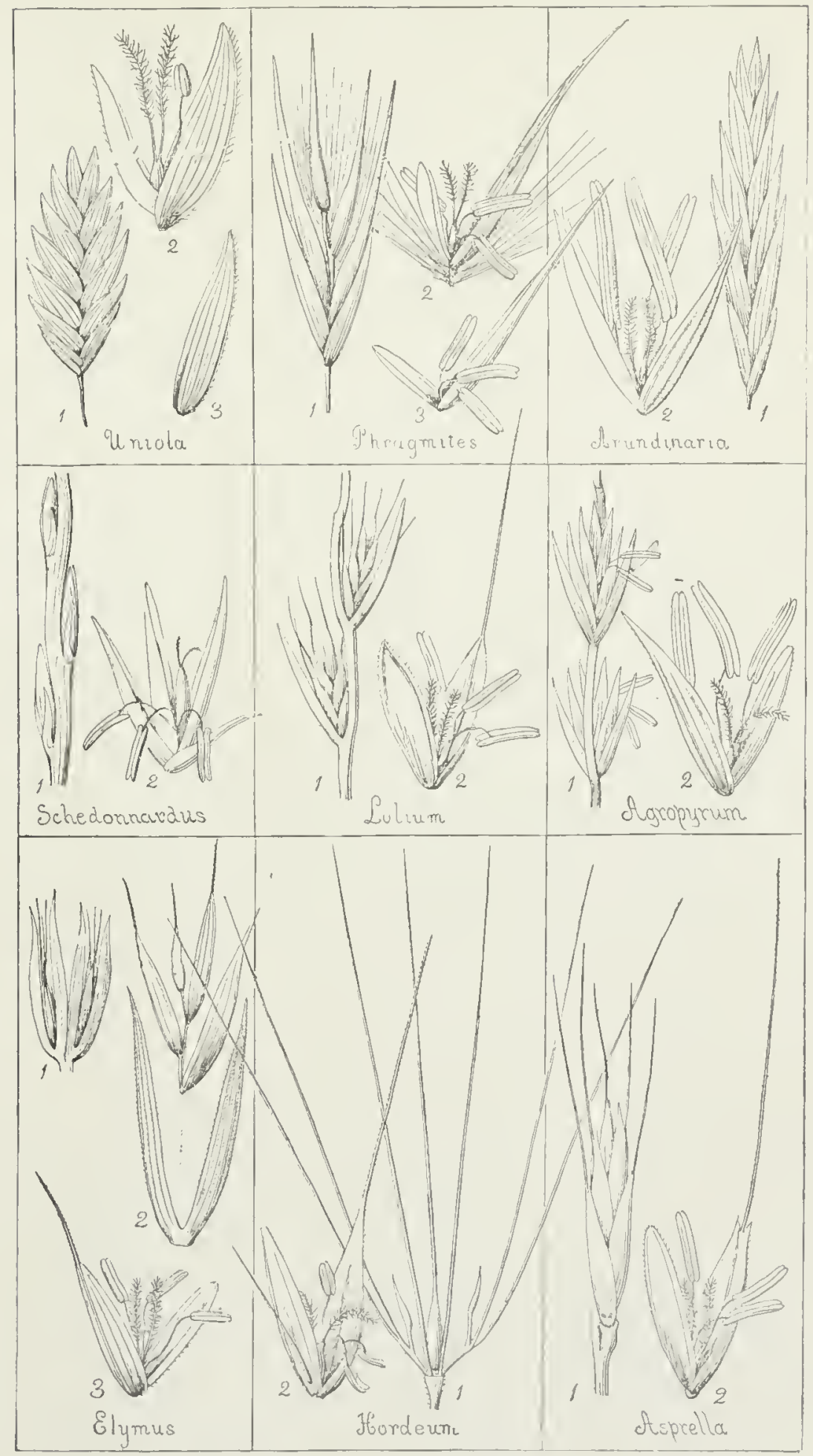




\section{EXPLANATION OF PLATE XIT.}

PLSCHAMPSIA. - (1) Panicle of 1). flexnosa; (2) a spikelet, magnified, the parts displayed; and (3) one of the flowers detached and open.

DAN'THONIA. - (1) Paniclo of D. spicata; (2) a spikelet enlarged; and (3) a separate flower from the same.

TRISITUM. - (1) $\Lambda$ spikelet of 'T. sulspicatum, var. molle, expanded and magnified; and (2) a separate open flower.

AVENA. - (1) A spikelet of A. striata, displayed and magnified; and (2) a separate flower.

ARRHENATHERUM. - A spikelet of $A$. avenaceum, displayed and magnified; (1) the empty glumes; (2) the fluwers, the lower one staminate only, the next perfect, and the third a rudiment.

HOLCUS. - (1) A spikelet of II. lauatus, magnified; (2) the same displayed to show the two flowers, the lower perfect and awnless, the apper staminate and awned. 
Genera af Grasses Plate XII

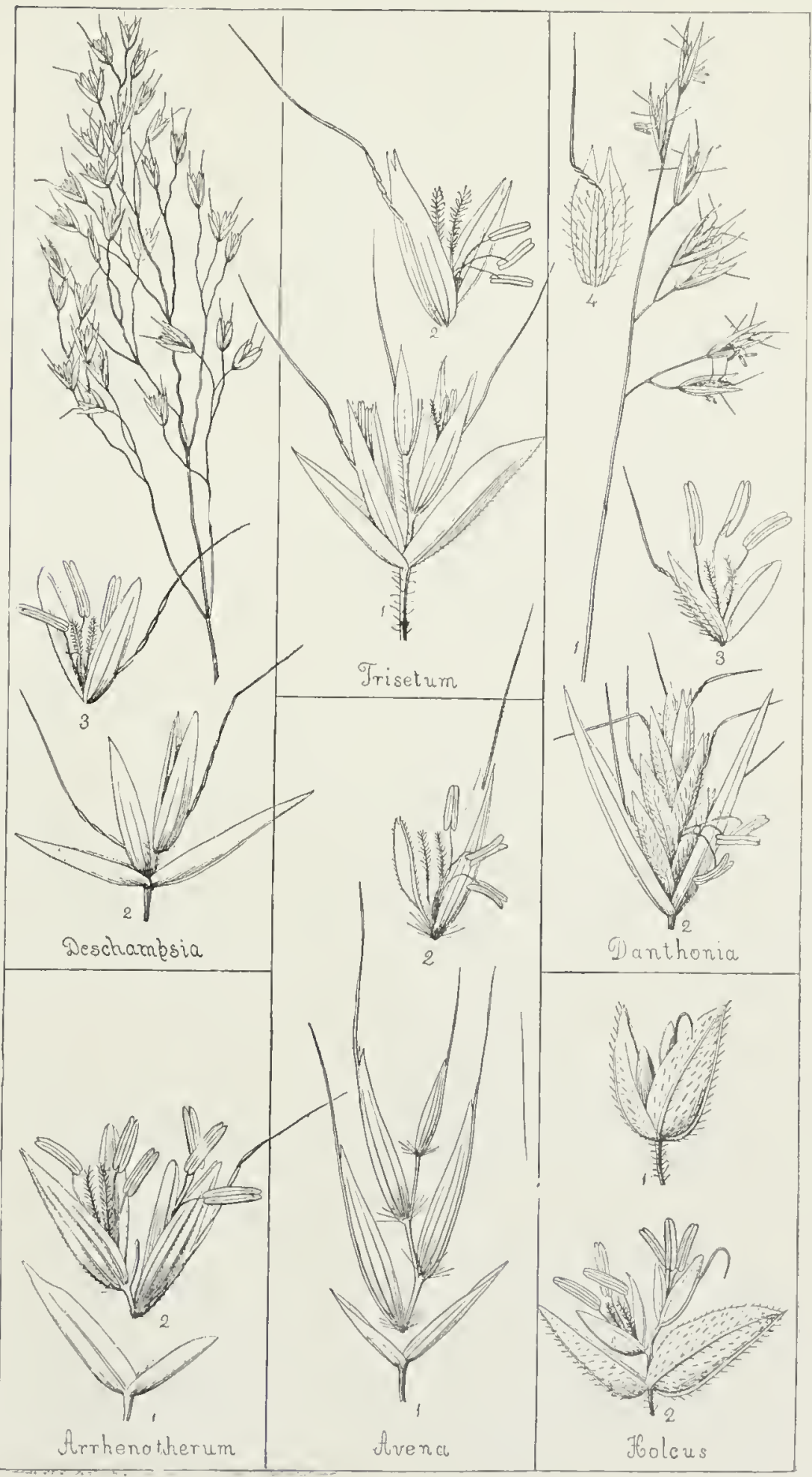




\section{EXPLANATION OF PLATE XII.}

HIEROCHLOE. - (1) A spikelet of Il, borealis, enlarged; (2) the same displayed, the flowers separated from the empty glumes, the two lateral ones with 3 stamens and no pistil, the middle or terminal one with a jistil and only 2 stanens.

ANTIIOXANTILUM. - (1) The spike-like inflorescence of $\Lambda$ voloratnm; (2) a spikelet magnified; (3) another with the puts displayed, the flowers raised from the lower empty glumes, the lateral glumes empty and awned, the terminal Hower perfect and diandrous.

PIIALARIS.- (1) A spikelet of I'. armelinacen, enlirged, (2) the enjty golumes, aul a prerfect flower with a hairy ruliment un each sicle of it.

MILIUM. - (1) Portion of the panicle of M. effusnu; (2) a closed spikelet, magnified ; and (3) the same displayer.

AMI'lIICARPUII, - (1) A spikelet from the panicle of A. Purshii, magnifierl; (2) the same, with the parts displayed; and (3) a ralical (fertile) spikelet, enlarged.

PASPALUMI. - (1) Inflorescence of l'. lave; (2) a closed spikelet, enlarged; (3) the same with the parts displayed.

PANICUM. - (1) l'art of a spike of l'. sangninale; (2) one of its spikelets, magnified; (3) the same with its parts displayed, the three lower glumes empty, - (4) A spilielet of P. capillare, magnified ; (5) the same displayed,

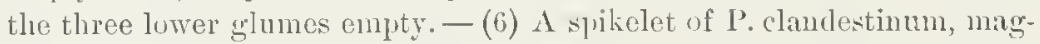
nified; (7) the same displayed, the lower flower represented by a glume and palet only. - (8) A spikelet of I'. virgatum, magnified; (9) the same displayed, the lower tower staminate.

SETARLA. - (1) A magnified spikclet of S. glauca, with the accompanying clnster of bristles; (2) the spilielet displayed, showing the uentral lower flower, of a grlune and palet only, and the perfect flower. 


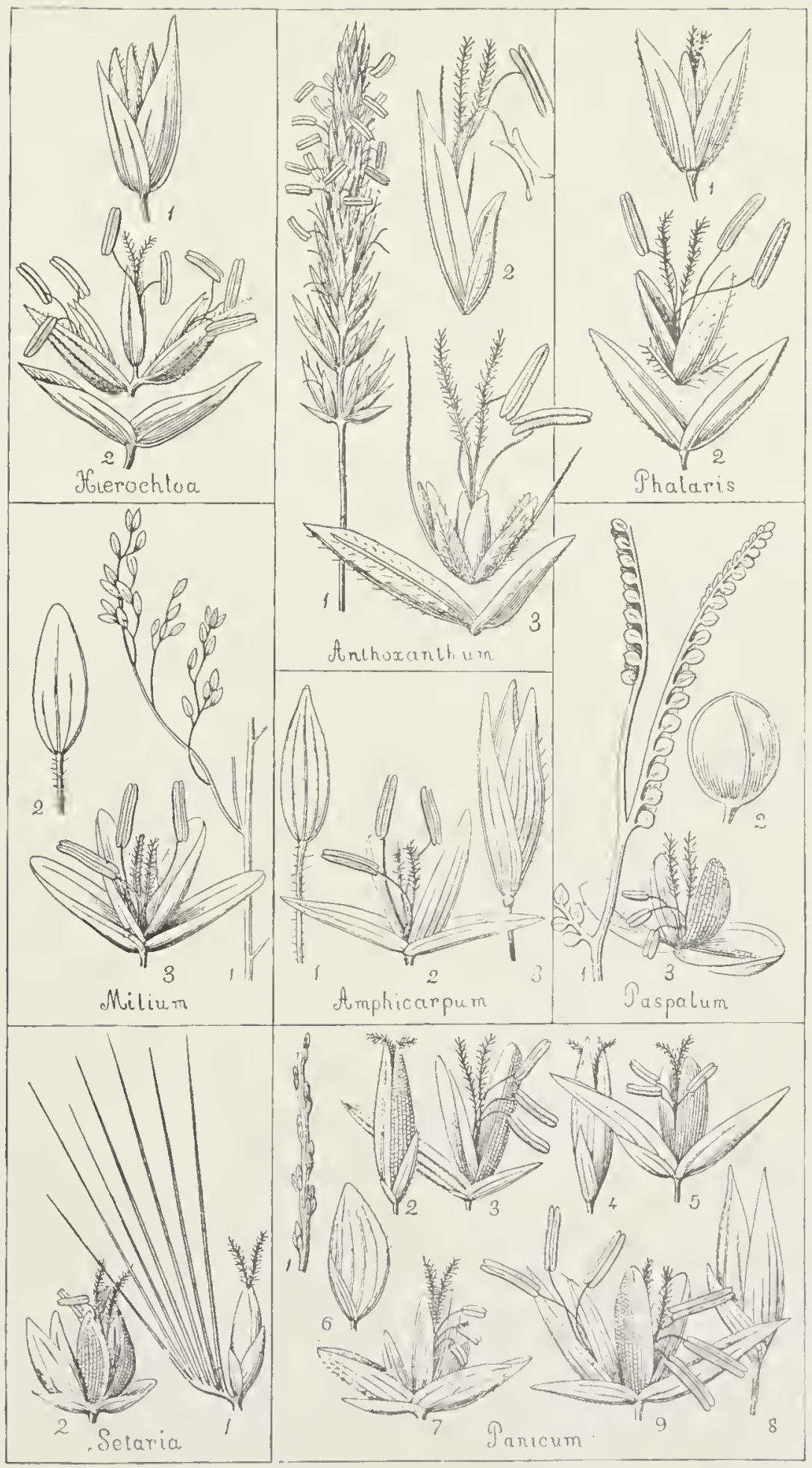




\section{EXPLANATION OF PLATE XIV.}

CENCHRUS. - (1) Involucre of C. tribuloides, in flower, enlarged; (2) longitudinal section of the same; (3) a spikelet displayed (the stigmas should belong to the right-hand flower; the left-hand or lower flower is only staminate).

TRII'S LCUM. - (1) Piece of the spike (of the natural size), pistillate below, staminate above; (2) a longitudinal section of one of the pistillate spikelets; (3) a pistillate spikelet with its parts clisplayed; (4) a staninate (two-flowered) spikelet, with its parts displayed.

ERIANTHUS. - (1) Part of the hairy inflorescence witl two spilielets of E. saccharoides, enlarged; (2) one of the spikelets clisplayed.

ANDROPOGON. - (1) Small portion of the spike of $\Lambda$. furcatus, enlarged, with one fertile and awned spikelet, and one staninate and awnless spikelet; (2) the fertile spikelet, and (3) the staminate spikelet, displayed.

CHRISOPOGON. - (1) A fertile suikelet of C. nutius, enlarged, with a sterile pedicel on each side; (2) the spikelet displayed. 


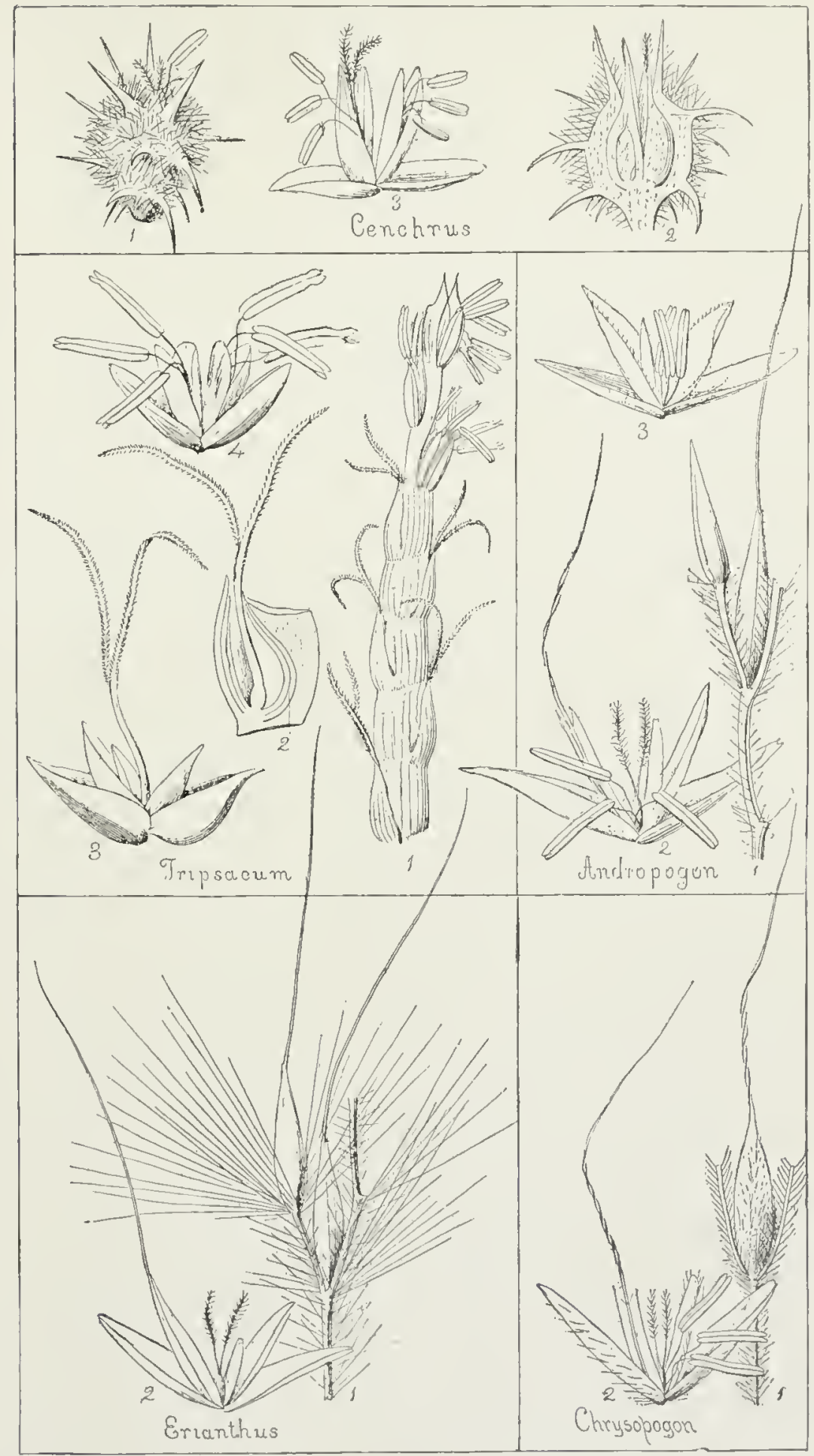




\section{EXPLANATION OF PLATE XV.}

BECKMANNTA. - (1) Tuforescence of B. erucaformis, var, reduced in size ; (2) a spike, enlarged; (3) a spikelet, and ( 4 ) the same opened; (5) the flower.

ERIOCIILOA. - (1) Inflorescence of E. polystacliya, rednced ; (2) a spikelet, enlirged, and (3) the same opened; (4) the Hower opened.

RO'T'TBCELILI. - (1) I'ortion of the spilie of R. rugosi, somewlat reduced, aud (2) a portion enlarged, with (3) the fertile spikelet and (4) the pedicelled sterile spikelet of the miklle joint displaced; (5) the fertile spikelet opened; (6) the third empty glume, and (7) the flower.

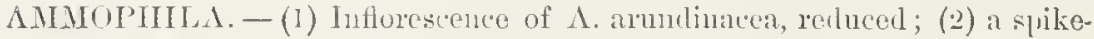
let, enlarged, and (3) the flower, with a hairy rudiment at the base of the palet.

LEP'TOCHLOA. - (1) Inflorescence of I. mucronata, reduced; (2) portion of rhachis of a spike, bearing two spikelets; (3) a s-tlowered spikelut; and (t) a flower removel.

BUCIILOE: - (1) Staninate and (2) pistillate inforescence of B. dactyloides; (3) a staminate splikelet, and (t) onc of its flower's removerl ; (5) a pistillate spikelet, (nilarged; (6) rertical section of same; and (7) the outer empty glume remored.

MUNROA.- (1) Infforescence of M. suluarosa; (2) a spikelet, enlarged; and (3) a flower, (y)med.

SCOLOCilLOA. - (1) Inforescence of S. festucacea, rednced; (2) a spikelet, enlarged; and (3) a flower.

PUCCTNEI,LLA. - (1) Inforescence of 1'. maritima, reduced; (2) a spikelet, eularged; aud (3) a Hower. 
Fenera ut Gresses Plate XI

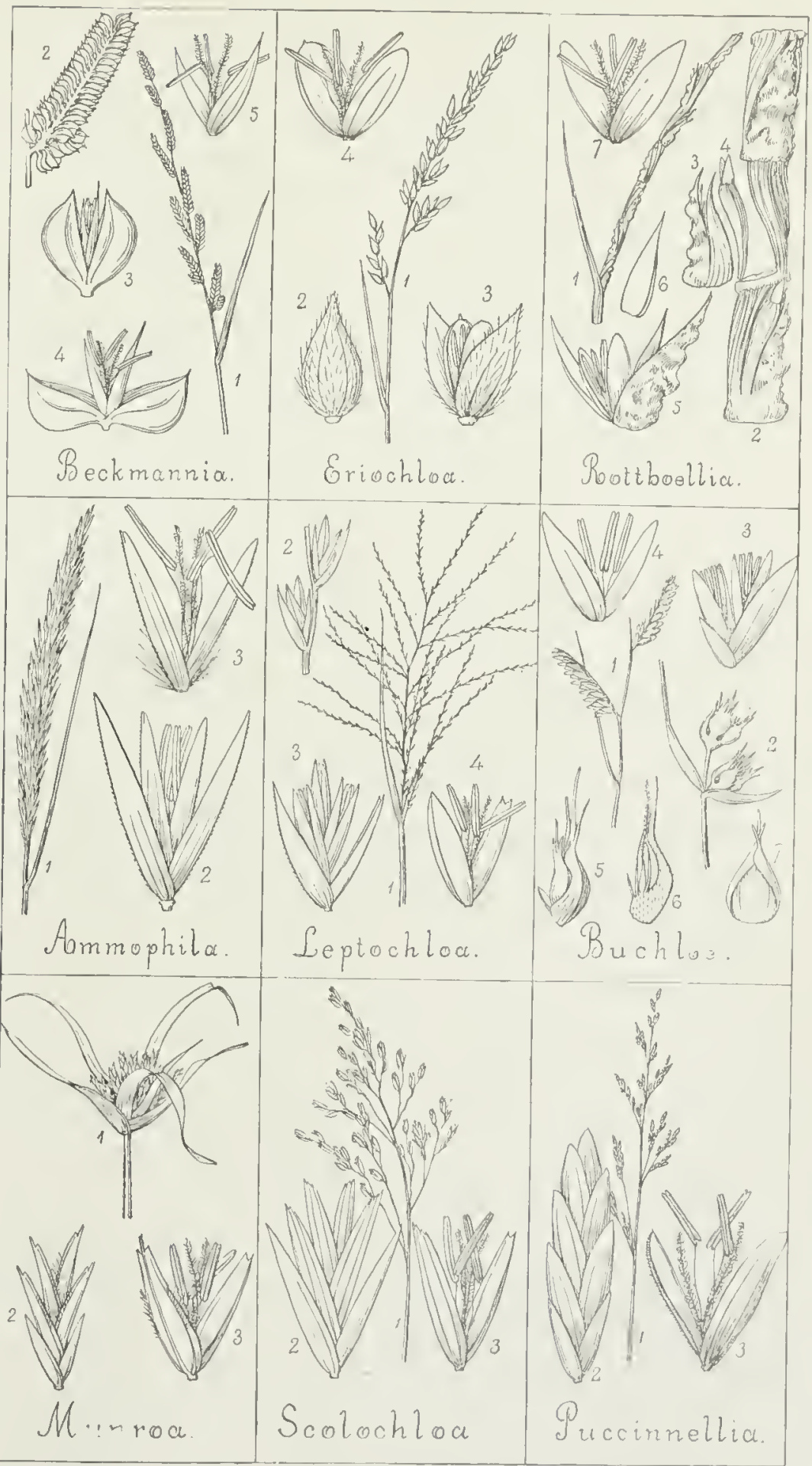




\section{EXPLANATION OF PLATE XVI.}

POLYPODIUM. - Plant of P. vulgare; piece of the frond; a magnified sporangium with its stalk, and another bursting and discharging spores.

ONUCLEA. - (1) I'in11a of the sterile froud of 0. Struthiopteris; (2) portion of a fertile frons ; (3) a piece of one pinna cut off to show the mamer in which it is rolled $u p$; and (4) a portion of the last, magnified, with one side molled; toward the base the sporangia all remored, to show how the fruit-dots are borne each on the middle of a rein.

PELLA.A. - Sterile and fertile plants of P. gracilis, and (1) a portion of the fertile frond enlarged, with a piece of the marginal indusinm turned back to display the fruit; the sporangia are all removed from the fruit-bearing tips of the two forks of the lower vein. 
Gemere af Filices Plate XII

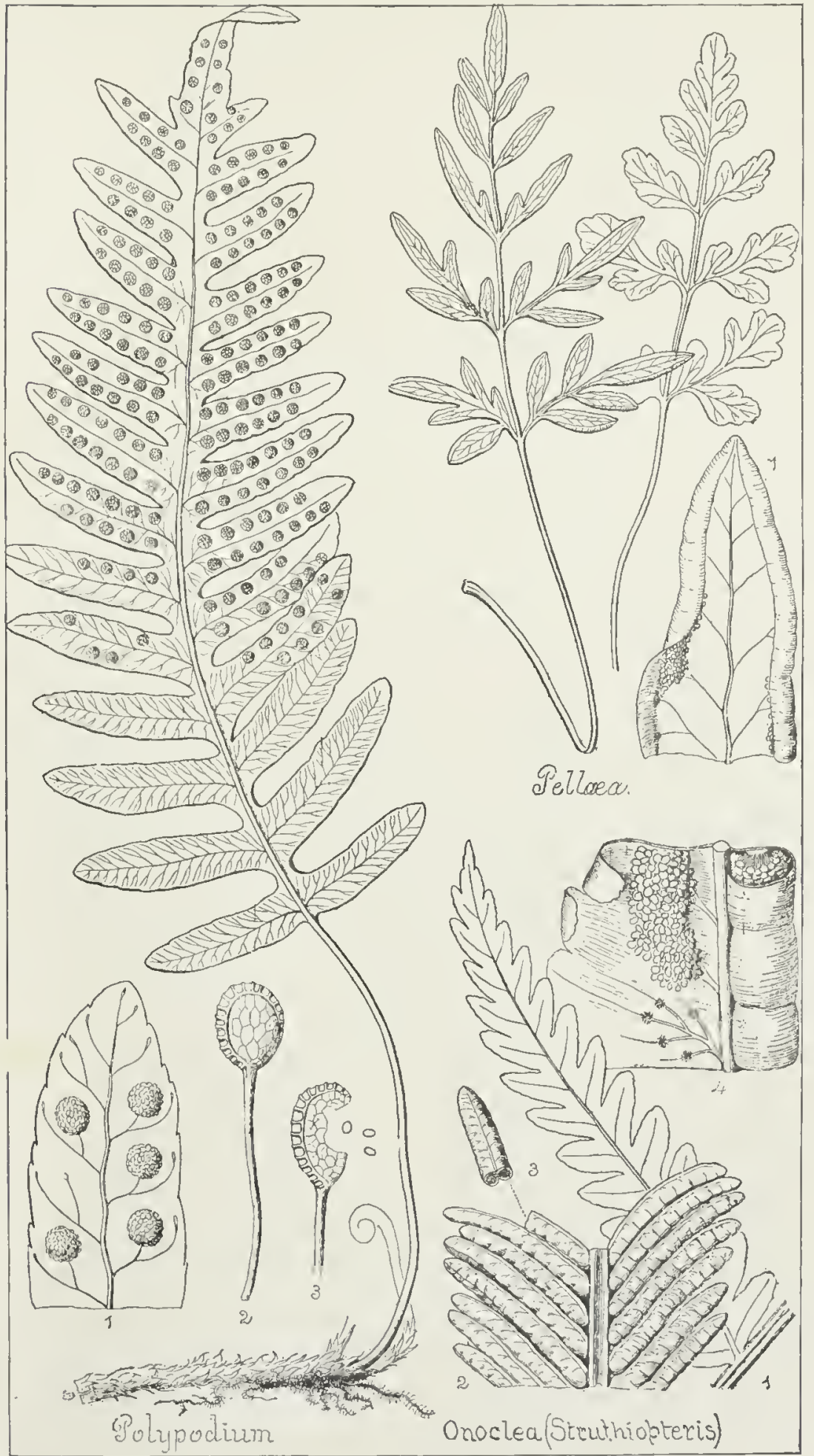




\section{EXPLANATION OF PLATE XYII.}

PTERIS. - A pinnule of P. aquilina, and (2) a piece of one of the lobes, enlarged, the marginal indnsinm rolled back on one sicle, displaying the fruit; the sporangia all removed from the lower part to show the receptacle that bears them, viz. a cross-line connecting the tips of the veins.

ADIANTUM. - (1) l'iece of the frond of $A$. pedatum; (2) a pinnule somewhat enlargerl; and (3) a piece of one more enlarged, with the indusium of one fruit-rlot turned back to show the attachment of the fruit.

CHEILANTHES. - (1) Small plant of C. vestita; and (2) a fruit-bearing pinnule, enlarged.

WOODIVARDIA. - (1) Portion of the sterile and (2) of the fertile frond of W.angustifolia; (3) a piece of the latter, enlarged ; (4) piece of the frond of W. Virginica; and (5) part of a fruiting lobe, enlarged. 


\section{Genera af Filices Flate X VII}

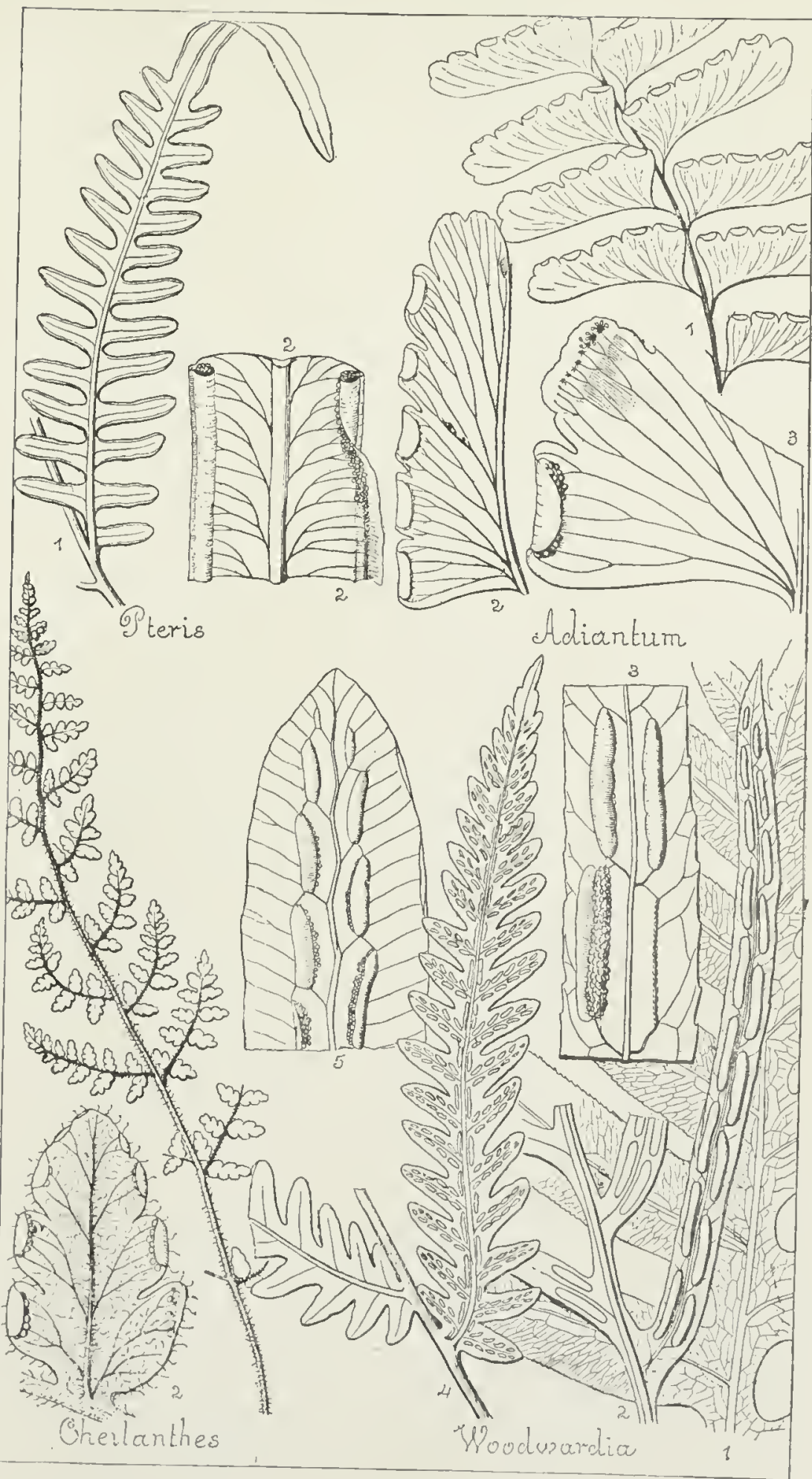




\section{EXPLANATION OF PLATE XTIII.}

CAMPTOSORUS. - Plant of C. rhizophyllus, and (1) a portion of a frond, with fruit-dots, enlarged.

SCOLOPENDRIUM. - Tip of a fertile frond of S. vulgare; and (2) a piece enlarged, with two fruit-clots.

ASPLENIUM. - (1) A pinna of A. thelypteroides; and (2) part of a lobe in fruit, enlarged.

DICKSt)NIA. - (1) P'inna of D. pilosiuscula; (2) portion of a pimule, enlarged; and (3) a fruit-dot in its cup-shaped indusium. 
Eenera of Filices Plate XIIIII

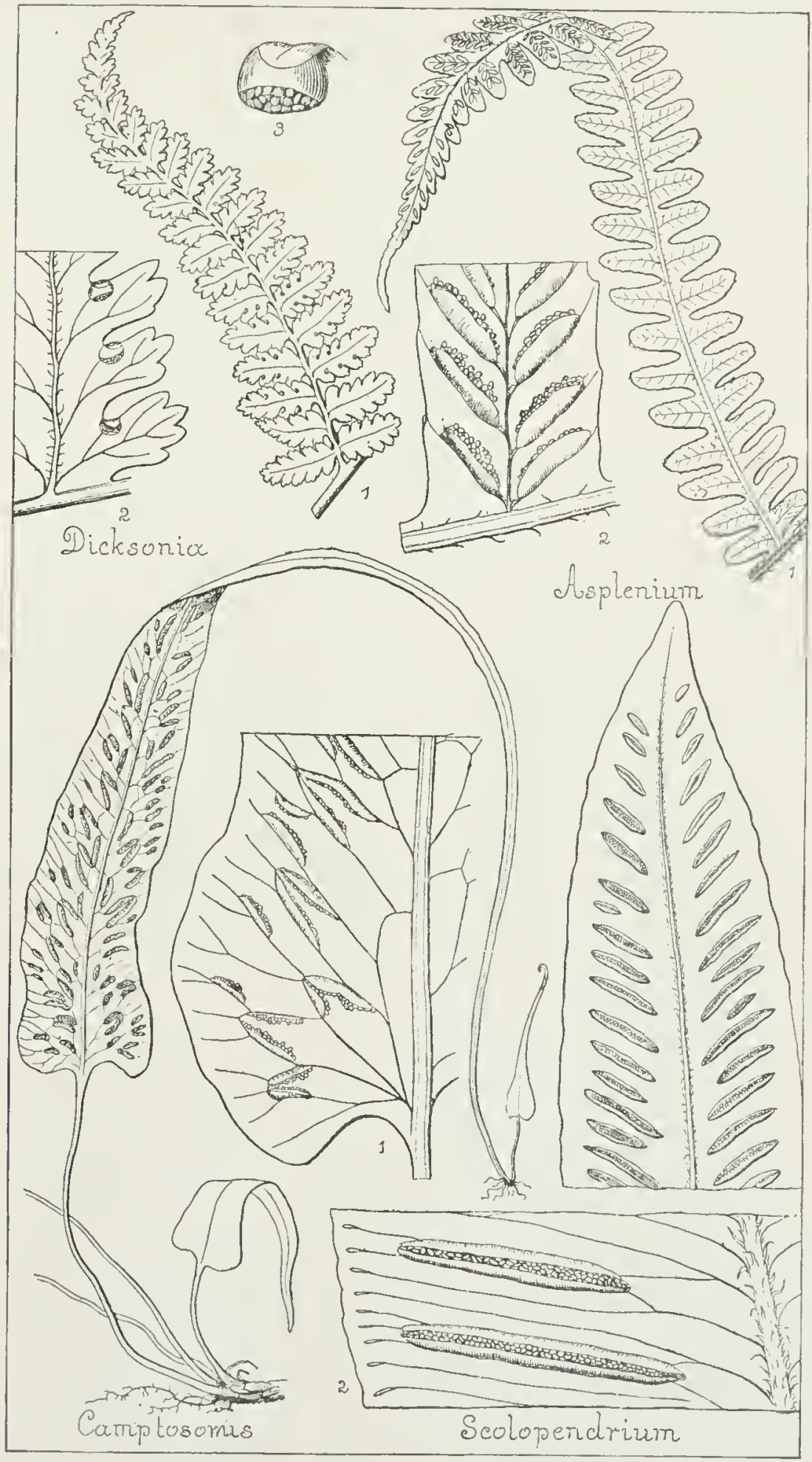




\section{IXPLANATION OF PLATE XIX.}

CYSTOP'TERIS. - (1) Pieee of the frond of C. bulbifera; (2) a lobe in fruit, enlarged; and (3) a small portion mole magnifiel, bearing a fruit-dot with its indusium throwu back.

WOODSIA. - (1) Small frond of W. glabella; (2) a part of a fruiting pinna of the same, magnified; and (3) a separate indusium, more magnified; (4) a pieee of a fruitful pinnule of W. obtusa, enlarged; and (5) a fruit with the opened indusium beneath, more magnifierl.

ASPIDIUM. - (1) I'inna of A. (Dryopteris) marginale; and (2) a magnified fruitiug portion; (3) piece of $\Lambda$. (l'olystichum) acrostichoides; and (4) a small fruiting portion, magnified.

ONOCLEA. - Sterile and fertile froud of O. sensibilis; (1) front view of a fruiting eontracted pinnule, enlarged; and (2) the same laid open and viewed from the other side; on one lobe the sporangia are removed from the veins 
Gemera af Filices Plate XIX

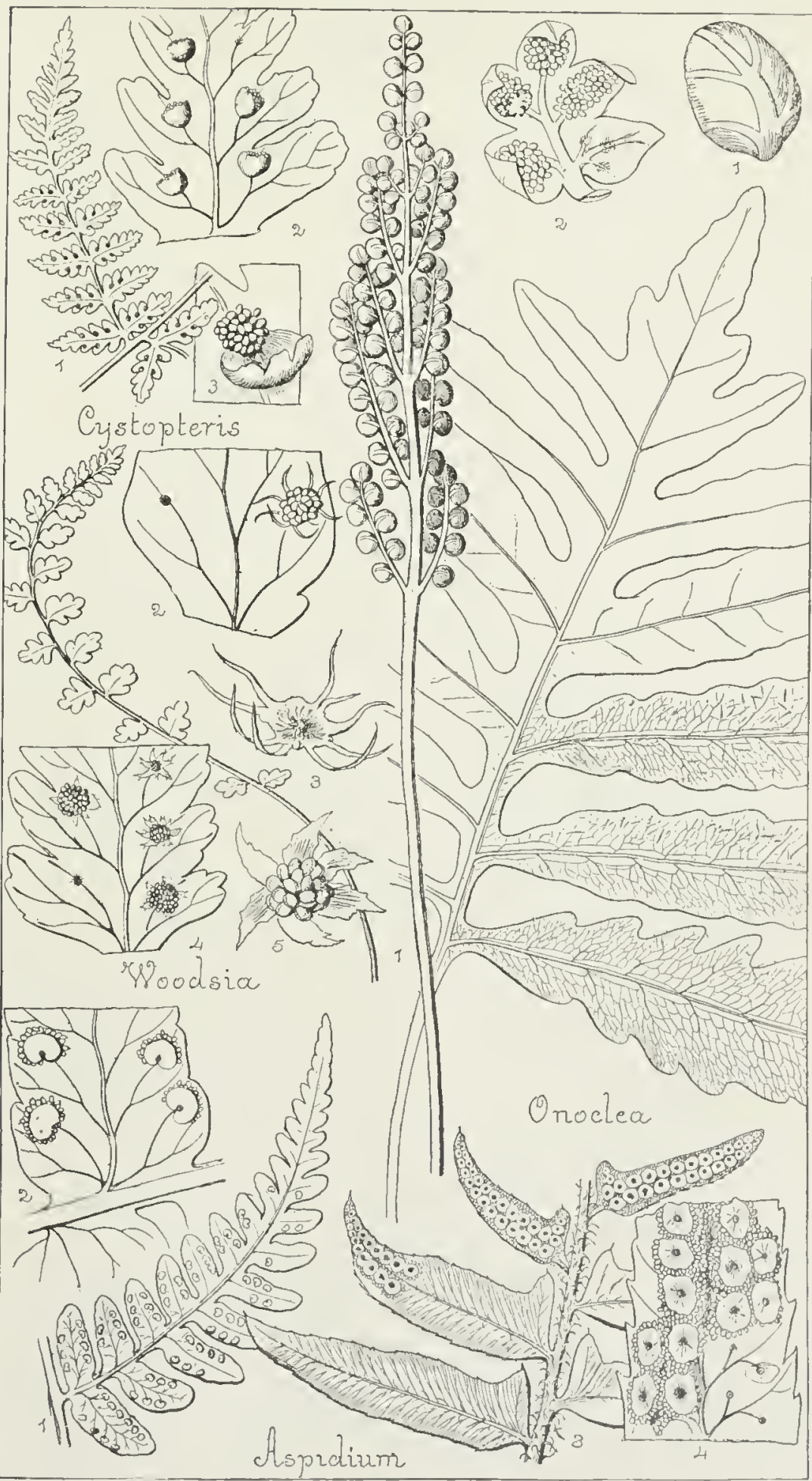




\section{EXPLANATION OF PLATE XX.}

SCHIZ FA. - Plant of S. pusilla, of the natural size; (1) a fertile pinna with eleven sporangia, magnified; and (2) a separate spurangium, nure magnified.

LYGODIUM. - (1) Summit of frond of I. palmatnm, with fertile and sterile divisions; (2) a fruiting lobe enlarged, with two of the lower scales, or indusia, remored, displaying a sporaugium under each; and (3) a sporangium more magnified.

OSMUNDA. - (1) Small piece of the frond of O. Claytoniana, with a fertile and a sterile pinna ; (2) a portion of the fruit magnified; and (3) one sporangium more magnified.

BOTRYCHIUM. - l'lant of B. ternatum, and (1) a portion of the fruit, with six sporangia, magnified.

OPHIOGLOSSUM. - Frond of $O$. vulgatum, and (1) a portion of the fruiting spike enlarged. 


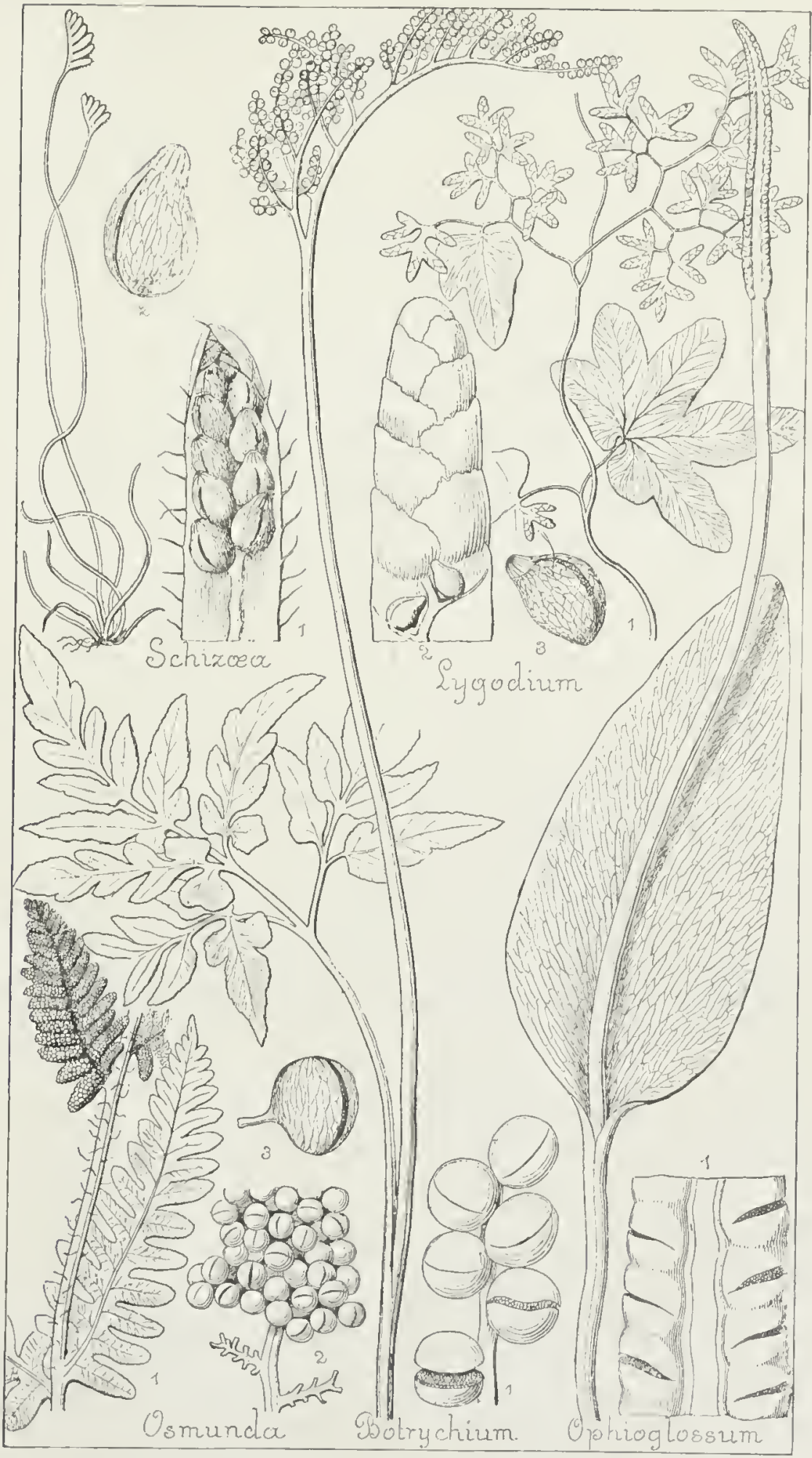




\section{EXPLANATION OF PLATE XXI.}

EQUISETUM. - (1) Upper part of fertile plant of I. limosum; (2) one of the shield-shaped scales or receptaeles of the spike, with the six sporangia unclemeath, enlarged; (3) same seen from below, discharging the spores; (4) a magnified spore with the club-shaped filaments spreading; and (5) the same with the filaments coiled up.

LYCOPODIUML - Plant of L. Carolinianum, and (1) a magnified seale of the spike removed, with the sporanginm in its axil, discharging powdery spores.

SELAGINELLA. - Plant of S. rupestris; (1) part of a fertile spike, enlarged; (2) scale from the upper part of it, with its sporangium, containing inuu. merable powtery spores; (3) seale from the base, with its sporangium containing few large spores; and (4) three large spores.

ISOETES. - (1) I'lant of I. lacustris; (2) sporocarp containing the minute spores, ent across, enlarged; (5) same divided lengtliwise; (3) sporocarp with the large spores, divided lengthwise; and (4) three large spores more magnified.

AZOLLA. - (1) Ilant; (2) a portion mannified, with conceptacles of both kinds; (3) the maerosporic one, more magnified; (4) the microsporic one, more magnified; (5) the same burst open, showing the stalked microsporangia; (6) one of the latter more magnified; (7) another bursting; and (8) three masses of microspores beset with glochidiate or barbed bristles. 


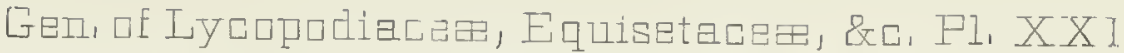

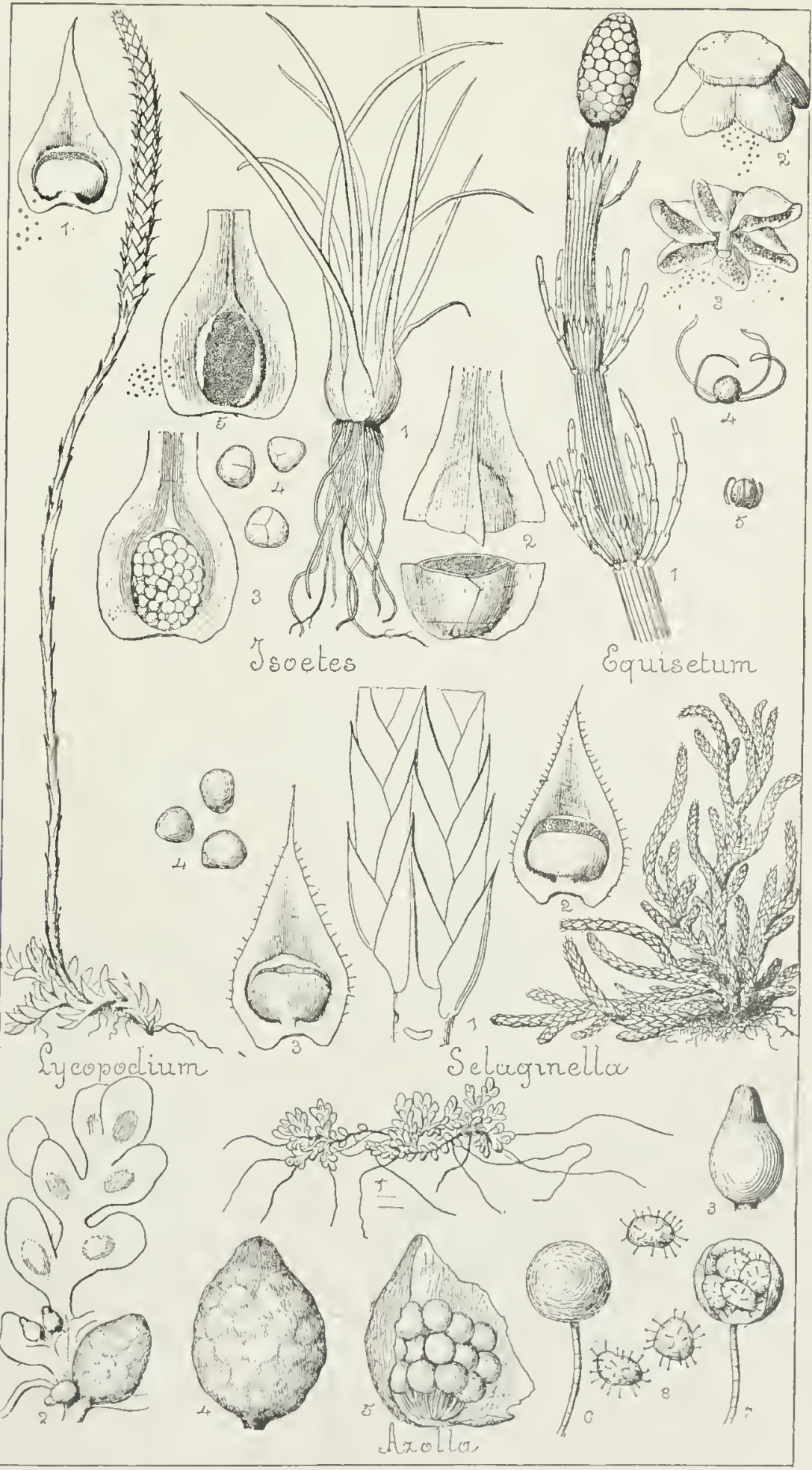




\section{EXPLANATION OF PLATE XXII.}

RICCIA. - Plant of R. natans; section of thallus, showing two imbedded capsules and numerous air-eavities; spores enclosed in a mother-eell; three free spores; and ealyptra with style.

ANTIIUCEROS. - I'lant of A. laevis; portion of the columella and ralves of the eapsule, with spores and elaters; two spores and two elaters.

NO'TO'TII LAS. - Plants of N. orbicularis; section of the thallus through the involucre; apex of protruding capsule; lower half of capsule showing the columella; npjer half of capsnle; a gemma; an antheridinm; twelve free spores, aul two clusters of spores ( 4 in eaeh).

ASTELELLA - Ilant of A. hemisplawien; \& receptacle riewed from above; the same from below; capsule dehiscing, witl remains of calyptra at base; section of $\delta$ disk; an elater, a portion of sane, and spores.

SPHAROC $\triangle R P U S$ - l'lant of S. terrestris; cluster of five involucres; involucre enclosing a capsule; capsule filled with spores; and three spores.

DUMORTIERA. - P'ortions of $\delta$ and $q$ plints of 1 ). hilsuta; $q$ receptacle showing three involucres, two with capsules; capsule with calyptra; see. tion of $\delta$ disk; elater and portion of simue; spores.

AITONIA. - Plint of $\Lambda$. Wrightii; upler view of $q$ receptacle with three involucres; sicle view of same; involucre partly cut away showing cap. sule and remains of calyptra; a capsule closed, and deliscent; an elater, a piece of same, and spores.

CONOCEPHALUS. - P'arts of $\delta$ and $q$ plants of C. conicus; section of $q$ receptacle, slowing two involucres and capsules; capsule witll ruptured calyptra; section of $\delta$ clisk; elaters, a portion of me, and spores.

PREISSIA. - Parts of $\delta$ and $q$ plants of $P$. commutata; section of $q$ receptaele; periantlı opened showing calyptra aud calsule; section of part of $\delta$ disk; elaters, a part of one, and spores.

MARCIIANTIA. - l'arts of $\delta$ and $\&$ pliuts of M. polynorplat section of receptacle; periantl, calyptra, and causule; section of part of $\delta$ disk; an elater, part of sime, and sjores.

FIMBRLARIA. - l'lant of $\mathrm{F}$. tenella; $q$ receptacle, and section of same; capsule dehiscing; claters and spores.

PALLA VICINIA. - I'lant of I'. Lyellii; part of thallıs witl involuere, perianth, and calyptra; periantle cut away showing young calyptra; capsule closed, and dehiscent; antheridiun enclosed in a leaf; elater and spores. 


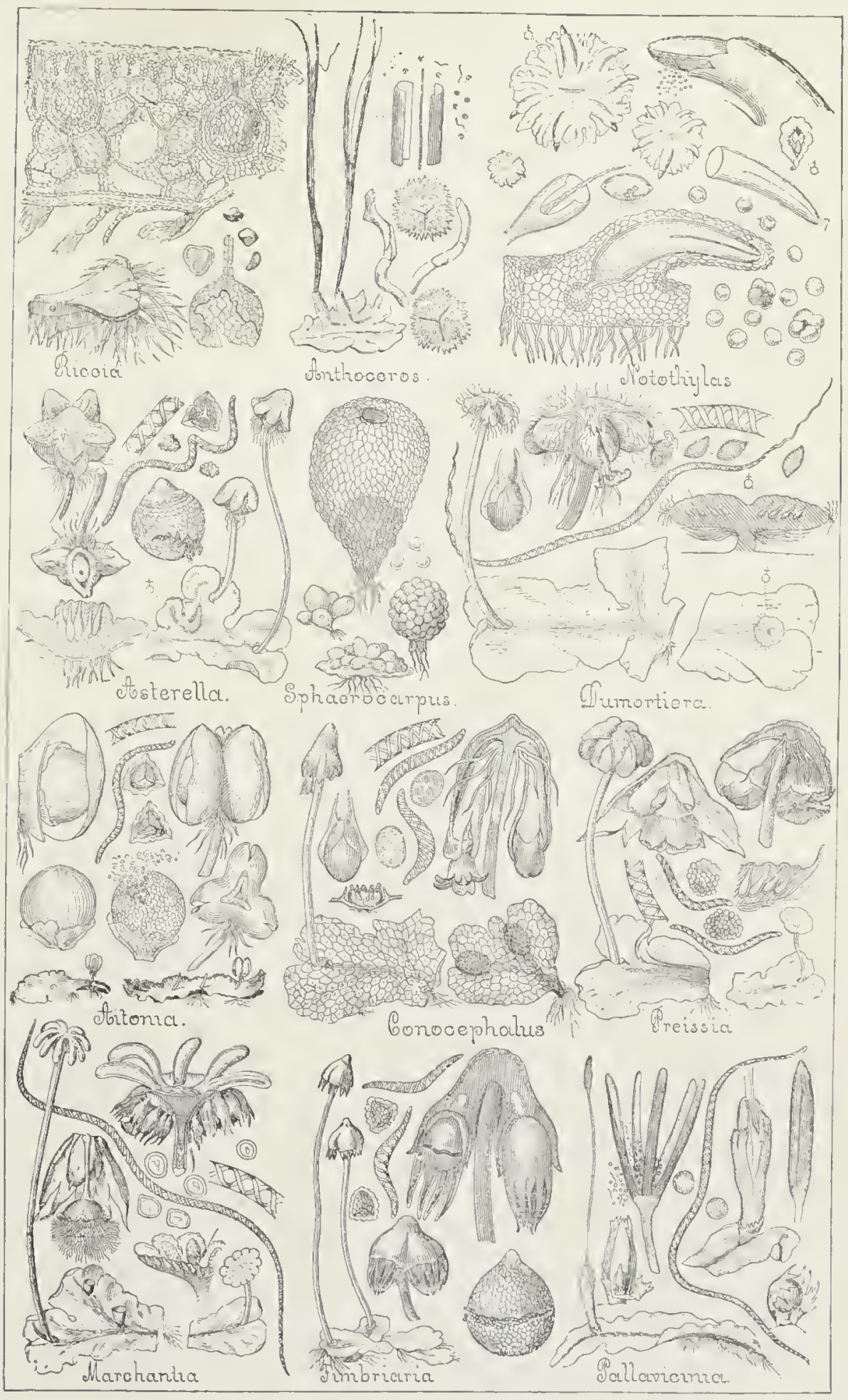




\section{EXPLANATION OF PLATE XXIII.}

PELLIA. - Plant of P. epiphylla ; calyptra with base of pedieel ; capsule ; an elater, part of same, two spores, and two antheridia.

BLASIA. - Plants of B. pusilla; section of cavity at the end of the midrib showing young perianth and calyptra; end of thallus with calyptra and protruding capsule; capsule dehiscing; elaters and spores; part of elater and two spores; of thallus with two antheridia; genuniparous thallus with two receptacles; section of a receptacle showing enclused gemmæ and the protruded orifice.

METZGERIA. - l'lauts ( $\delta$, $\&$, and gemmiparous) of M. furcata, and parts of same enlarged; hispid perianth with 2-lobed involucral leaf and base of pedicel; a gemma; an antheridium; elaters and spores.

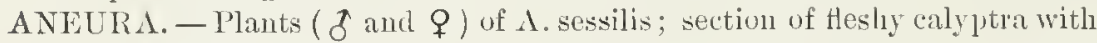
base of pedicel; dehiscing capsule hearded by jersistent elaters; elater, part of same, and spores; part of thallus with long deflexed o receptacles, and one cut transversely showing antheridia.

FOSSOMBRONIA. - Plant of F. pusilla, and a part entarged ; capsule dehiscing, with perianth and involueral leaves; part of sten with two leaves and dorsal antheridia; an antheridium, elaters, and spores.

GEOCALXX. - I'lant of G. graveolens; two pairs of leaves with underleatres; part of stem with an underleaf; section of involucre showing calyptra and base of pedicel; lehiscent capsule; elaters and spores.

GRIMLALIIA. - Parts of $\delta$ and $q$ plants of $G$, barbifrons; section of $\delta$ disk; 9 receptacle and section of same; dehiscent capsule; elaters and spores.

CHILOSCYPHUS. - l'lant of C. ascendens; a leaf with nuderleaf; a pair of leaves with antheridia; a part of sten with involucral leaves, perianth, and ealyptra; deliscent capsule; claters and spores.

HARPANTIIUS. - I'lant of H. Flotoviaus, and same enlarged ; a pair of leaves with underleaf; perianth with involucral leaves, and section showing calyptra; elaters, a part of ome, and spores.

LOPIOCOLEA. - I'lant of L. heterophylla ; a part enlarged with involncral leaves and periantl ; cross-section of perianth; three pairs of leaves with nuderleares; a leaf and antherilium; an underlenf; an elater aurl spores.

CEPIIAL(OZIA. - Plant of C. multiflora; two pairs of leaves; periantl with involucral leaves; an involucral leaf; calyptra ; capsule closed, and clehiscent; an elater and siores.

GYMNOMITRIUM. - l'lants of G. eoncinuatum; thee pairs of leaves; : ipex of stem with involucral leaves and dehiscent capsule; two involucral leaves; calyptra.

MARSUI'ELLA. - I'laut of M. enarginata; part of sane with involucral leaves; involucre and perianth opened showing calyptra and base of pedicel; capsule; clater and spores. 
Genera uf Hepaticae Plate XXIII

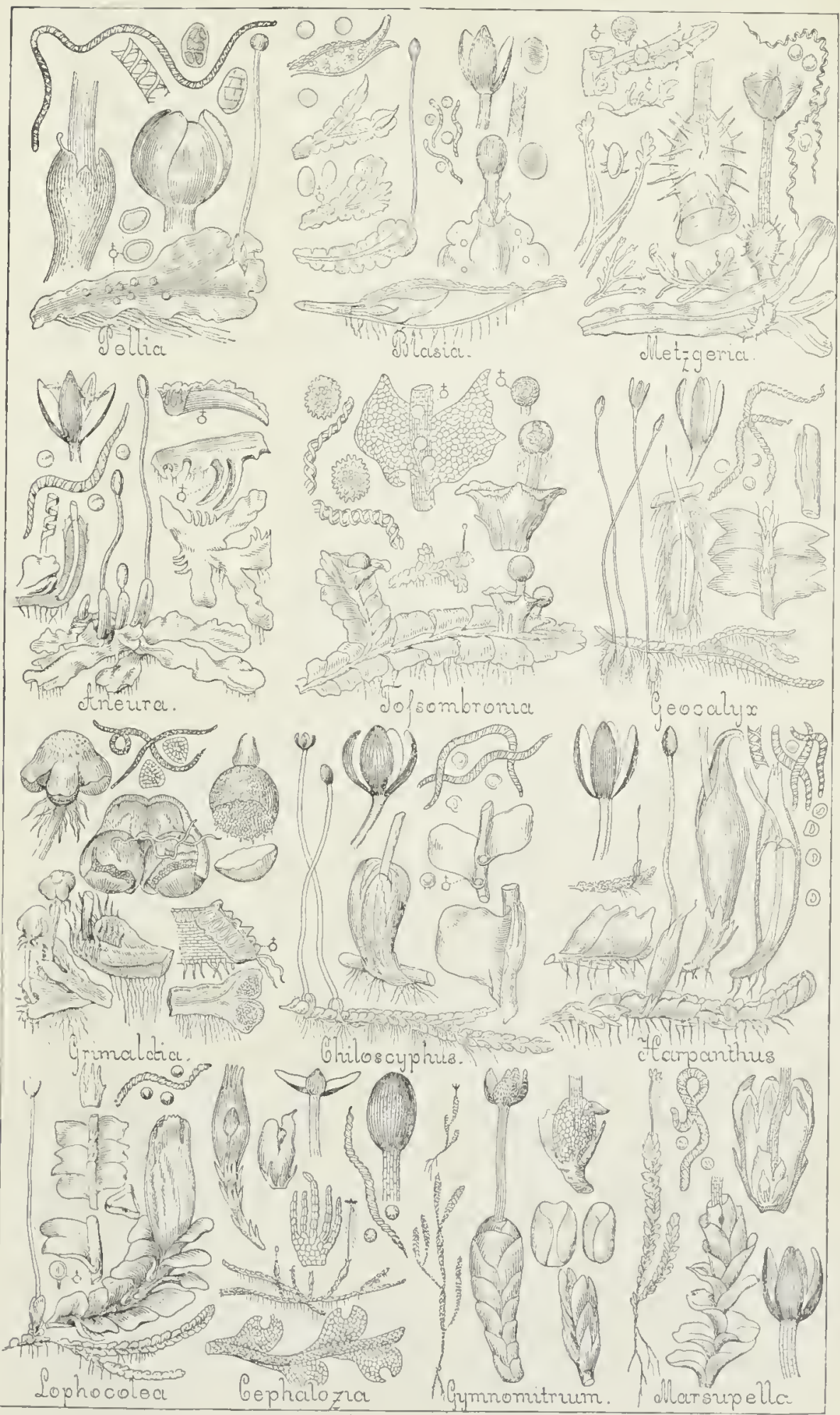




\section{EXPLANATION OF PLATE XXIV.}

SCAPANIA. - I'lant of S. undulata; apex of stem with involucral leaves and periantl enclosing calyptric; three pairs of leares, a capsule, elater, and spores.

PLAliOCHLA. - I'lant of P. interrupta; five leaves; an underleaf; periantlı enclosing calyptra; antheridia, capsule, elaters, and spores.

ODONTOSCHISHA. - I'lant of (). Splagui; parts of stems, one learing gemma, the other a perianth with involucral leaves; an involucral leaf; a capsule, claters, and spores.

LEJEUNEL1. - l'lant of L. clypeata; perianth with capsnle and involueral leaves; cross section of periantls; part of stem with of branch; leaves with molerleaves; claters and spores.

FRULLdNAd. - I'lant of F. Asagrayana; two pairs of Ieaves seen from above, and from below with unlerleaves and rentral lobes; periantl witl involucral leaves; cross-section of perianth; involucral leaf; capsule, elaters, aud spores.

PORLLLA. - I'laut of I'. platyphylla; a pair of leaves with unlerleares; lant of stem with \& spikcs; an antheridinm in its leaf; perianth with involucral leaves ancl ansule; an elater, and spores.

RA1)(LA. - Plant of R. obconica ; end of branch with periauth and capsule and lateral of hranches; a $\delta$ hanch; an antheridium; leaves seen from ahore ant below; a capsule, elater, and spores.

PTILIDIUM. - l'lant of l'. ciliare; a pair of leaves; un underleaf; perianth with involucral leaves; capsule, elater, aul spores.

BAYKANIA. - Plant of P. trilobata; two pairs of leaves with mulerleaves and $\delta$ spike; portion of $\delta$ spike, and antheridium; capsule, elates, and spores.

TRICIOCOLlis. - Plant of 'T. tomentella; leaf and underleaf; capsnle; elater and spores.

IERBERTA. - l'lant of II. adunea; purtion with leaves and mnderleaves; perianth; calsules; elater amb spores.

LEPII)(XIA. - l'lant of L. reptans; portion with leaves and underleaves; antherilium in its leaf and free; periuntl with involncre; capsule, chater, and spores.

K $\Lambda$ NTIA. - l'lant of K. Trichomanis; leaves and muderleaves; hairy involucre, ancl section showing calyptra; capsule witl spiral valves; elater and spores. 


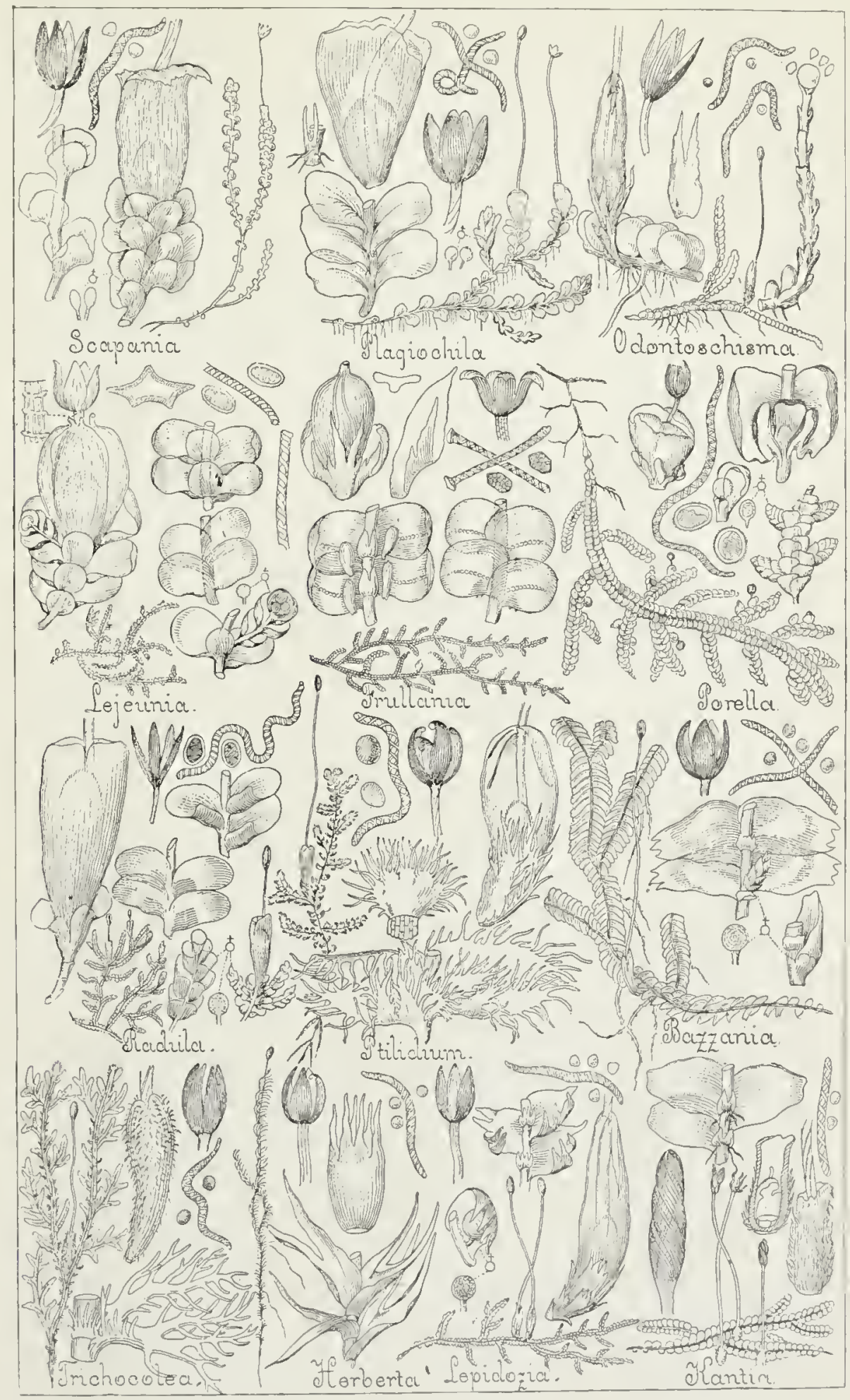




\section{EXPLANATION OF PLATE XXV.}

JUBULA... Plant of typical J. Hntchinsiv, enlarged; two pairs of leaves seen from below; a lower lobe separate and divided; a perianth with its outer involucre and the dehiscent capsule; an elater.

BLEPIIAROSTOMA. - Plant of B. trichophylla, and same enlarged; periantl with the oiter involucre, rentrul side ; two cross-sections of perianth; portion of the margin of its urifice, expanded.

LIUCHLANNA. - I'lunt of L. lanceolata; eud of fertile lranch, with two leaves, two iuvolucral leaves, aud young periunts; summit of periauth; perianth and involucre, the capsule protruding; calpsule on its pedicel, with remains of ealyptra; capsule dehiscent.

MYLIA. - Plants of M. Taylori, colarged; portion of stem, seen from beseath; a cauline leaf (below); an underleaf; an involucral leaf (above); perianth partly cut away, showing the calyptra and exserted deliscent capsule.

DHPLOPHYLLUNI. - I'lant of typical D. alhicans, enlarged ; a folded leaf; a leaf with the npper lobe expanded to show the nerve; an involueral leaf seen from withont, and from within; perianth, cut longitudinally: calyptra.

NARDIA. - I'lant of N. crenulata (a slender small-leaved form), enlarged; portion of upere stem with leaves; perianth; calystra; elater and spores.

JUNGERMANNLA.— \$ 1. I lants of .J. Schraderi, natnral size and enlarged; two leaves; two underleares; involncre; summit of perianth. — \$2. Plant of J. larbata, enlarged; jortion of stem with leaves and underleares; perianth with involucre; involncre. $-\$ 3$. L'lant of J. Hellcriana, enlarged; summit of stem with leares, involucre, and perianth; involncral leaves; margin of perianth unfolded. $-\$ 4$. Plants of J. iuflata, natural size and enlarged; cauline leaves; involneral leaf.

LUNULARIA, - Sterile and fruiting plauts of L. vulgaris, enlarged ; section of involucre, showing calyptra and capsule; lunate receptacle of sterile plant, witl genmex.

MALSIJA.- Portion of plant of M. (quallifolia ; a sporocarp ; sporocarp burst in water and extruling the gelatinums ring with compraments attached. 
Eenera af Hepaticae Plete XXI

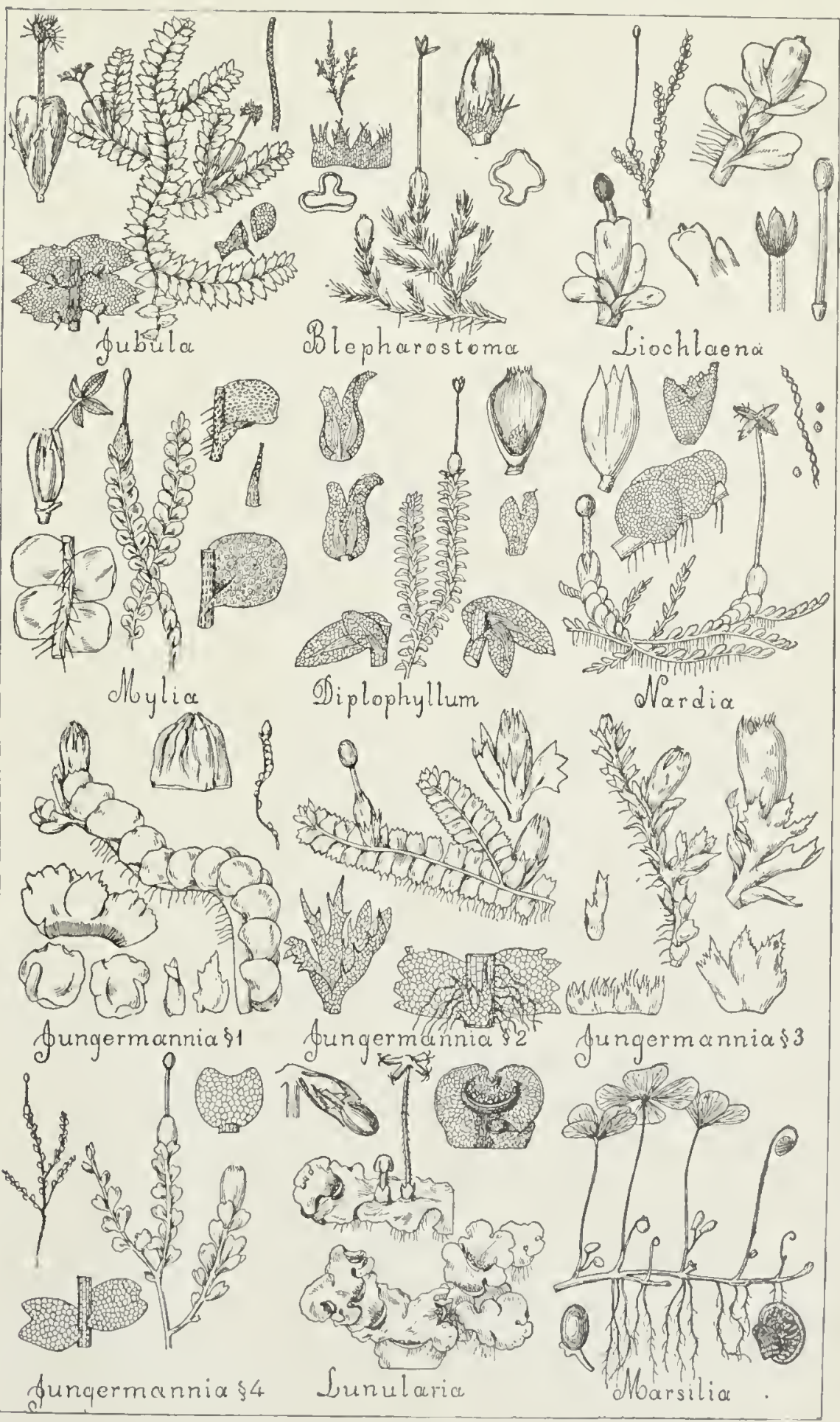








\section{Date Due}

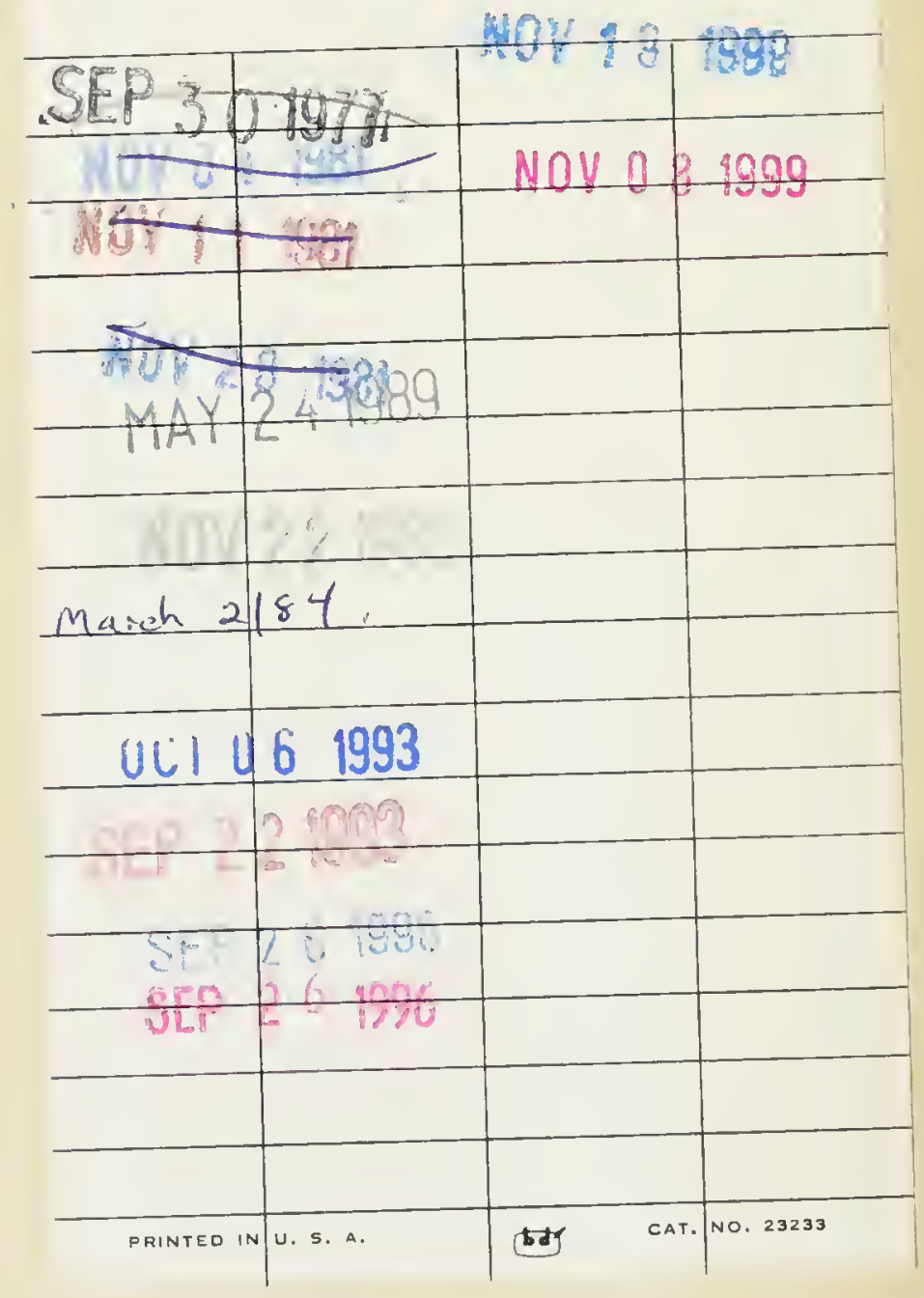



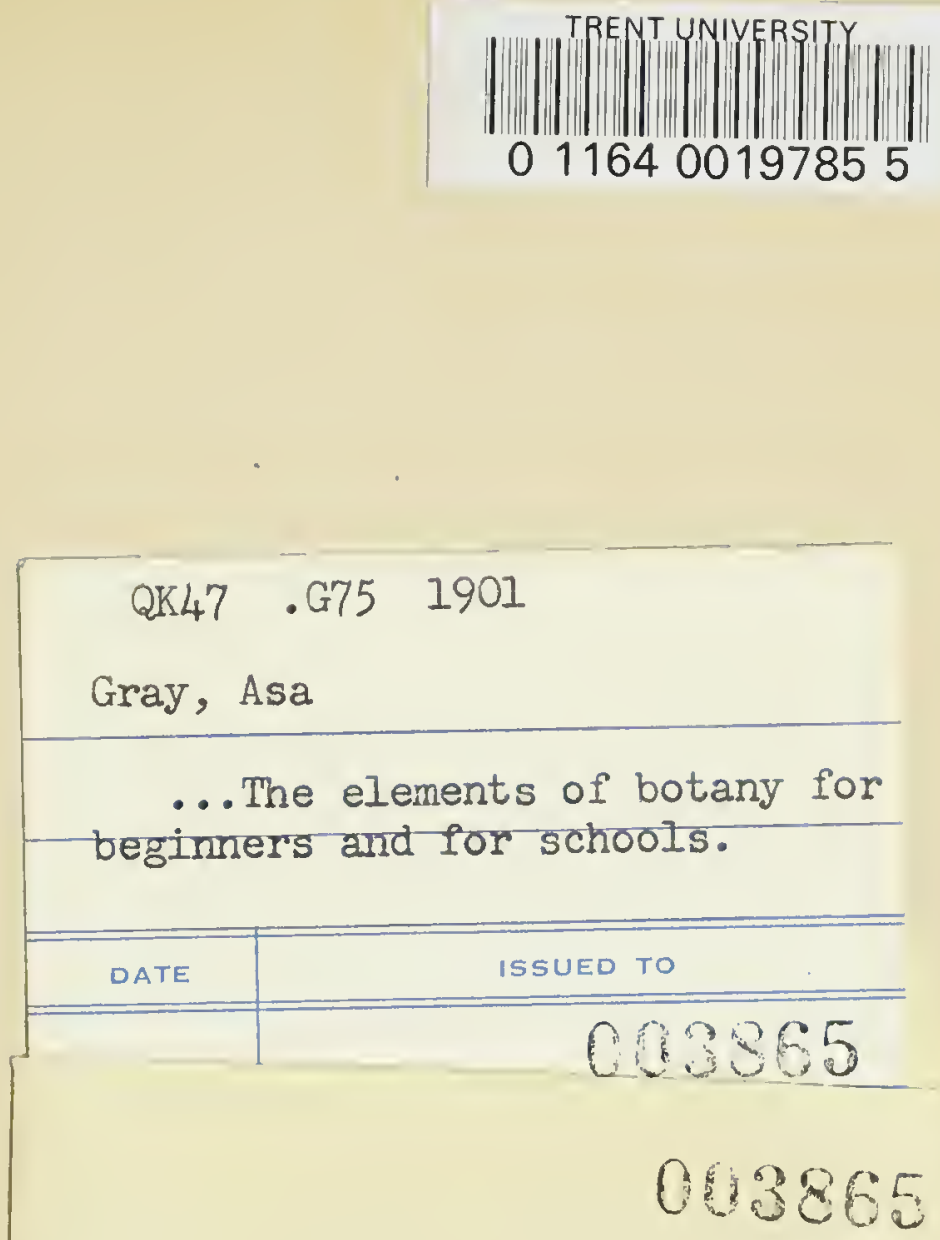


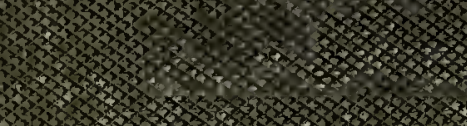
33 35 3 35 